

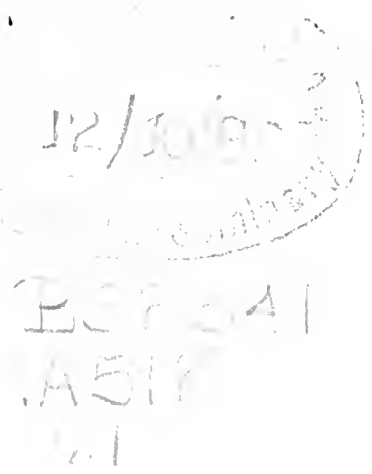




$$
\text { . }
$$





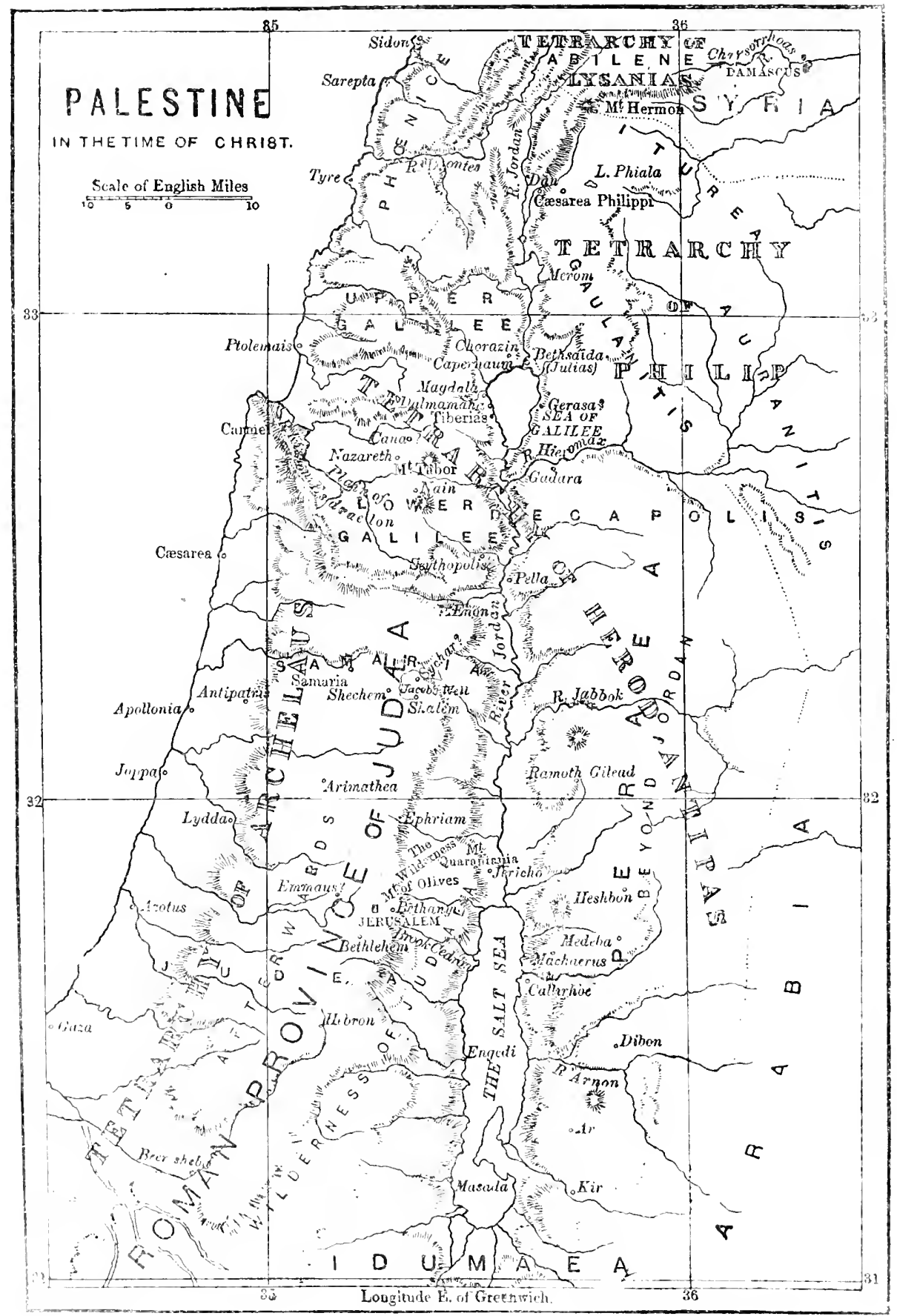




\section{AMERICAN COMNENTARY}

ox the

\section{NEW TESTAMHNT.}

EITTED BY

AIVAH HOVEY, D.D., LL.D.

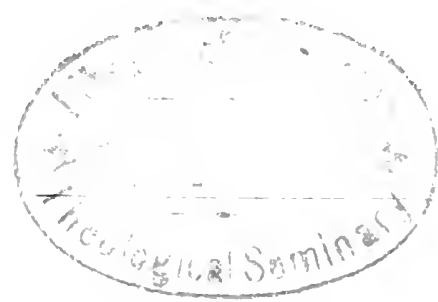

PIIJAISEIJIIA:

AMERICAN BAPTIST PIRACATION ROCHET, 1420 ('HESTNTT STHERT. 


\section{COMMENTARY}

ON THF:

GOSPELOEMATTHEII.

BY

JOHN A. BROADUS, D. D., LL. I).

PIIILADEIPIIL:

AMERICAN BAPTIST PLBLICATION SOCIETY.

I 420 Chestnut Street. 


\section{AN AMERICAN COMMENTARY}

\section{ox \\ THE NEW TESTAMENT.}

The following volumes of this series, formerly ealled the Complete Commentary on the New Testament, have already been published. The remainder are all in preparation, and will be issued, probably, two volumes per year until completed:

The Gospel of Mattinew, by John A. Broadus, I). D., LL. D.

The Gospel of MArk, by W. N. Clarke, D. D.

The (iospel of Luke, by George R. Bliss, I). D).

Tue Gospel of John, by Alvah Hovey, D. D., LL. D.

Tine Aits of the A postles, by Horatio B. IIackett, D. D.

Tile Revelaten, by Justin A. Smith, I. D., in consultation

with James Robinson Boise, Ph. D., D. I., LL. D.

\section{STEREOTYPED BY GARDNER COLBY.}

The stereotype plates of this volume lave been paid for out of the legacy of the late Gardner Colby. And for this reason the book, though containing 664 pages, is sold at the low price of $\$ 2.25$.

Entered according to Act of Congress, in the year 1886, by the AMERICAN BAPTIST PUBLICATION SOCIETY,

In the Office of the Librarian of Congress, at Washington. 


\title{
GENERAL INTRODLCTION
}

\section{TO THE NEW TESTAMIENT.}

\author{
BY AITAII IIOVEY. D. W., LL. D.
}

I.

\section{THE CANON OF THE NEW TESTAMET.}

For the purposes of this Introduction it is munecessily to grive a history of the word "eanon," or evon a list of the significations whirh it has in andent literatere. As applied to the New Testament, it means" "the collection of benks which constitute the original written rute of the ('hristian faith" (Wexteotl). If there is any. standard of religions faith and practice recognized hy (hori-tians of erery lame as authoritative, it is this collection of books which are sllplensed to have heen written by the immediate disciples of ('hrist and their associaltes.

It is true that christians do mot all agree in hoblinge these books to be the omly authoritative rule of fith and practice in matters of religion, but the all ancere in holding them to be an wrignal and authoritative rule, even though, as some suppose, their teaching must be supplemented lye erelesiastional tradition. It is

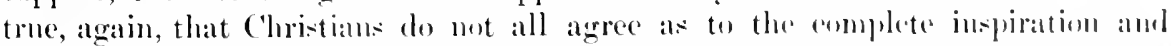
final authority of these bouks, but they all conede to them rery high authority at the only original doements of the (hiristian religion mow extant. It is also true that Christians do net all angee in their interpretation of these books, or in their theory as to the persons who are pralified to interporet them, but they all admit the high importance of their teachimg, whenever it is ascertained.

\section{How was the Canon of the New Testament established?}

In secking an answele to this question it will be temml that the ways of ( are not like our ways; for hmman wislom womble dombtess, hase dermed it ex-

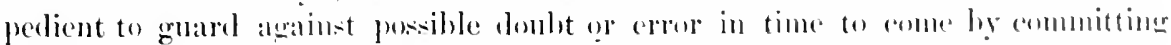

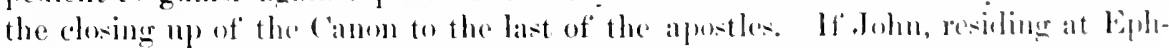
esus in his old age, hat inserted in his last hook a list of the inspired writing of his contemporaries, with such a sketeh of their contents as wemlal make it asy to identify them; if he hat testifies that the number of such writiugs was then com-

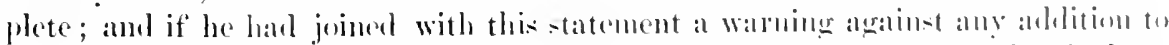
or subtraction foun the number or the teaching of these booke like that in liev. $22: 18,19)$,-this, it may le thement, womld have fixed the ('amen of the New

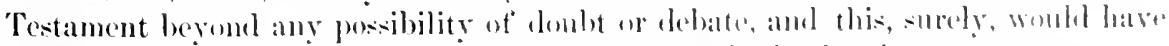

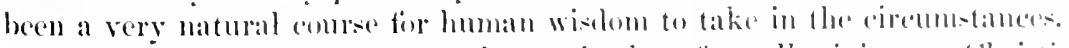

But it might have proved to be a mistake after all, griving to christians less 
stable grounts for confidence than they now have. Would it not have led then to overlook" all other evidence, and to depend exclusively on the witness of this apostle? Would it not have exciterl in critieal minds suspicions of human ealculation or fear, and demand for impossilde jroof that John himself wrote the book containing the list described, or at least the paragraph in which the list was found? Would it not have provoked the alscertion that such a proceeding was unexampled and malled for by the ciremimstances of ('hristians at that time, since they must have known who were the writers of the Govpels and Epistles which they had received? These and similar criticisms would certainly have been male if the conrse suggested had been taken, even thongh that course was the safest and best possible in the eyes of human wisdom.

But it was not taken. The Spirit of God, who is wiser than men, and who presided over the work of the apostles, chose another way of establishing the Canon, another way of making known to Chritians the authoritative documents of their religion in distinction from other books pertaining to it. And the way chosen by the Spirit was perfectly obvious and natural. It was to make use of the prudence and piety of the churches in accomplishing this work, by committing to them the writings of men who were known to be inspired teachers of Christian truth. For the prudence and piety of the churches would be morally certain to preserve these writings as a sacred trust, and to hand them down, with the names of their authors, from generation to generation as authoritative expositions of their religion.

If, for example, the churches of Philippi and Corinth received from Paul letters that were instinct with the spirit of love, wistom, and authority-letters that pritised their virtues, reproved their sins, corrected their errors, relieved their perplexities, scattered their duults, and brightenes their hopes-they would not fail to preserve these letters with the utmost care, or to leave them as precious treasures to their sncessors in the chureh. While they would be very willing to have them read and copied by dirciples of Christ from other churches, they would lo likely to insist upon retaining them in their own custody. Ant sine the letters directed to a single chunch were few in number (rarely if ever more than two), there would never be the slightest danger of mistake as to their author:hip.

Thus, hy a natural process, under the control of good sense and right feeling, would nearly all the writings of "apostles" and "apostolic men" (Tertulliun) be kept distinct from the writings of these who eould not dechare the will of ('hrist with exual authority. For example, the Epistles of Paul to the Corinthian: would never for a moment be put on a level with the epistle which they reecived, a third of a century later, from the church in Rome, and which was written by Clement, Bishop of that church. Even if the latter were sometimes real in the chureh at corinth, or were copieal into the same manueript with the former, there would be no danger of confision. For if we look merely at the gencral contentof the two Epistles of P'anl to "the chureh of Com in Corinth," and of the first epistle of (lement to that chureh, it is manifestly alhourl to ascribe them all to the same auther, or to arcribe the camonical epistles to Clement and the ecelesiatical episte to P'aul. Besiles, the former prurport to be firm the apostle, while 
the latter purports to be from the ehureh in Rome. There may have beren rases

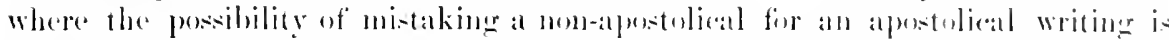

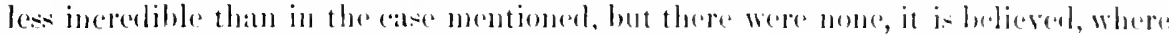
such a mistake can he regalmbel ats probable.

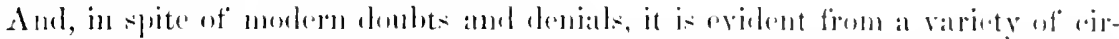

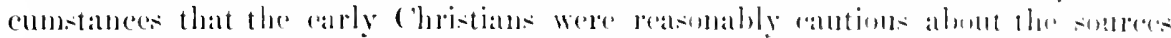

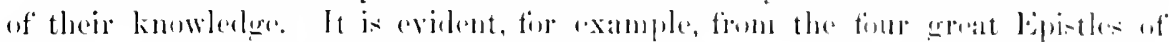

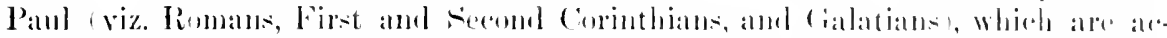

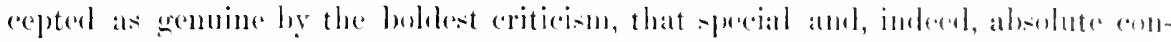

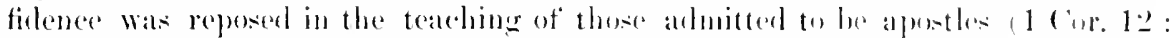

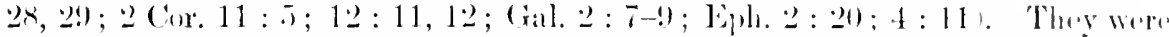

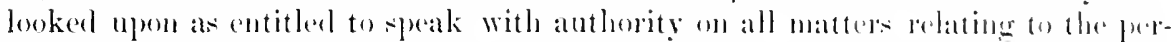
son and work of christ or the duty of his forllowers. Naturally, therefore, the ia

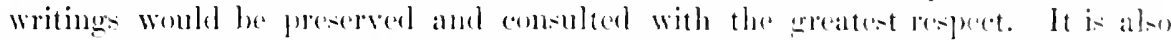

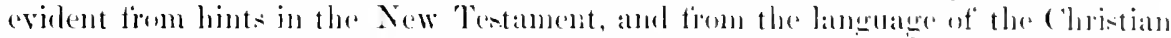
Fathers, that alony with the teaching of the apostes was phaced the toalehing of

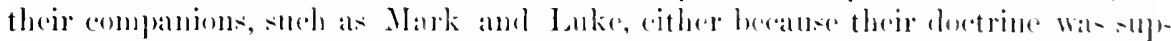

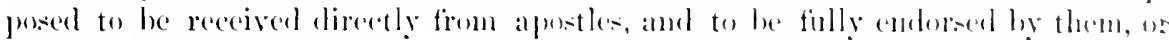
heeatse, in aldelition to their intimacy with apestles, they were hedieved to have a special grift of inspiration to pualify them for their work.

lf, now, as history appreas to show, the formation of the Xow Teatament

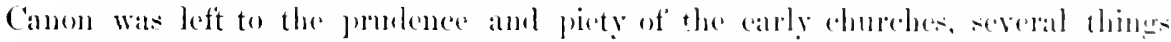

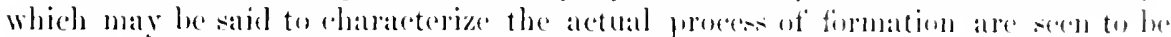
natural, if not inevitable. A few of these may be nament in this platere

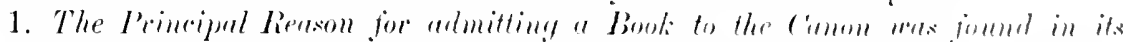

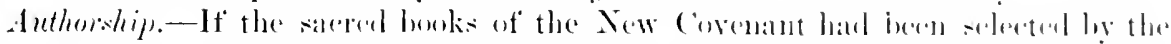
apestle fohn, the names and relations of their writers mieht have been a mattele

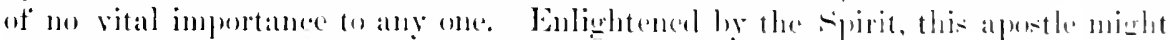

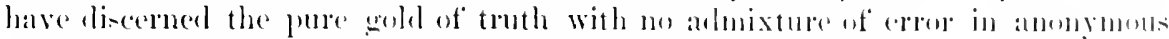

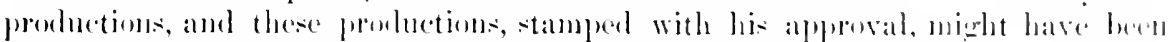

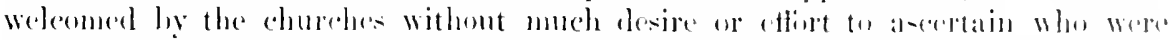

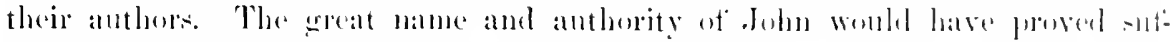

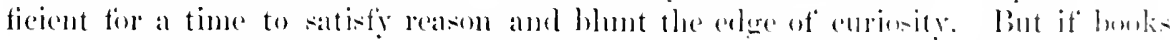

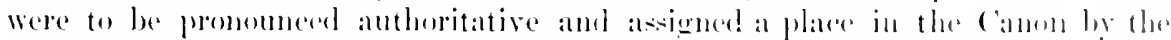

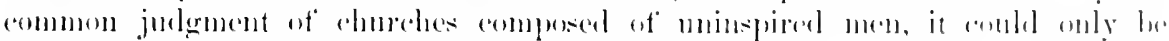

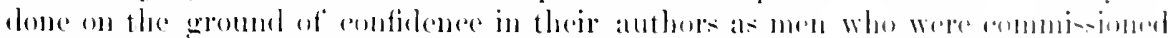

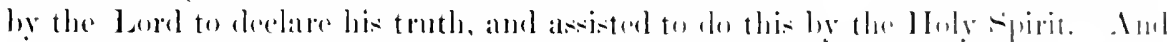

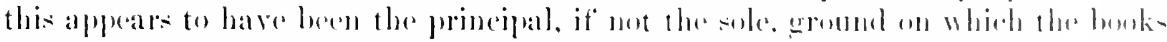

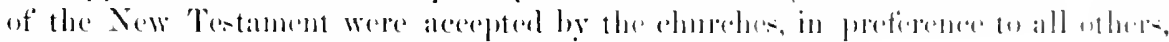
as anthentice statements of tiuet, of dectrine, and ut duts.

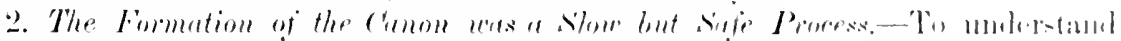
this, the reader mest pireture to himself the comelition of the ehomelue when the

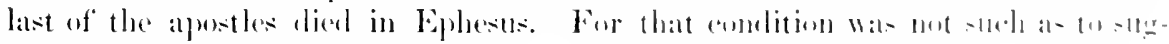

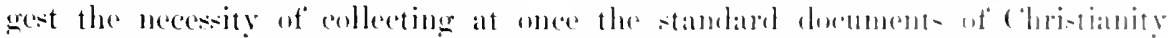
into a single volume. Ind John ever directed them to collecet those decument-? 
Were they not doing their appointed work, each in its separate form and appropriate sphere, as thry had been doing it, some for a long period already? While the apostle was living there had been no lack of anthoritative instruction, and now, though be had fillon atelej, there were many still alive who had heard the gespel fiom his lips a thousand times, and who had perhaps enjoyed his personal frimelsi]): could these ever forget his doctrine or manner of life? Moreover, they were all familiar, it may be presmed, with one or more of the synoptic Grospels, as well as with that of John, and with some of the Epistles-every onte witten on a separate pardument, comvenient for use and not too expensive for ownership. Was not this the best form in which to preserve and circulate them still? Besides, the Epistles in almost every instance were written to the Christians of a particular province or chureh, or to an individual saint, and must therefore have been specially arkapted to the spiritual wants of those athressed: were they then equally important to others? Might it not still be wise to cireulate particular books fior the most part where they were most needed, some in one province and some in another, even as the apostles sent them originally, some to one purince and some to another?

Such may have heen the reflections of devout men at the elose of the first century, if inteed the subject of' a New 'Testament Canon engaged their attention at all. But this is very duuhtful. For the perils of the times, and their own probable frectom fiom toubts as to the origin of standard Christian writings, may have prevented the thought of forming a New Testament Canon from entering thejr minds. And as the rears flew by, whether red with blom or white with peace, and their struggle with Pagmisin and erol was incessunt, it is clear that there could have been little oppertunity for united comsel until the reign of Constantine. Then, for the first time, would the question of making a full collection of the Sacond Seriptures of the New Covenant be likely to receive due consideration. And then it lid receive suitalile attention. Then the claims of certain writings that had not heen received as sacent in every part of Christendom were ambarcel, and the full collection of hooks that ought to be esteened canonieal was ascertained to the satisfaction of the churches.

3. L'urtial Collections preceded the Full and Fimal Collection.-That this shonld be the case was incritable. Consider, first, the Gentile churehes founded ly Paul. Is it not certain that they would feel a special interest in the Epostles written by

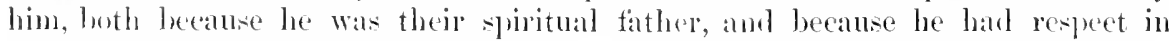
what he wrote to their peculiar training and comdition? And along with his Ejotles they would surely be anxious to posses the four Gospels and the $A$ ets of the Apostles-the former, heeause they would earnestly desire to know all that could he known of their Iord's earthy life; and the latter, because they would maturally wish to talee the fontsteps of Paul in loringing the gospel to the (ientiles. To these might be adked in many of the churehes a few other houks; for example, the First Epristle of Peter amel the First of John. But it need not be -mpposed that these proluctions were all bound up in the same manuseript volune, even though they were believed to be of ergul and ultimate authority.'

I Says S. P. Tregelles: "In the reign of Trajan-i.e. atmost immediately after the death of 


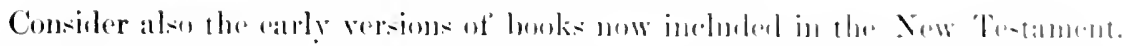

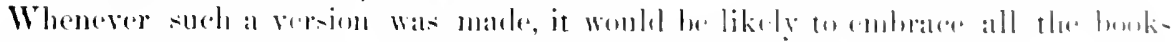

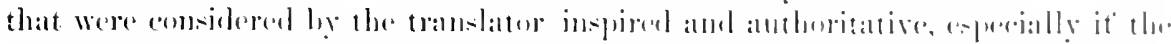

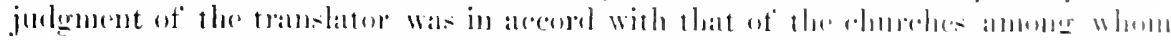

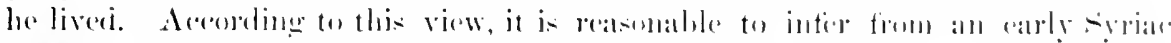

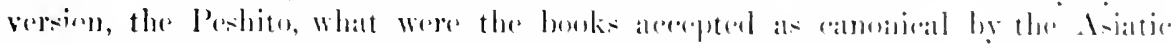

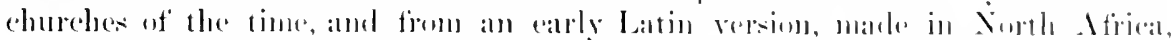

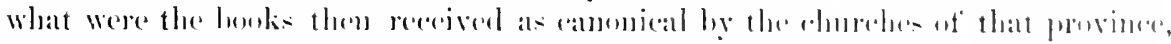

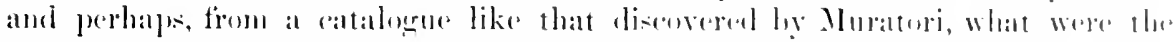

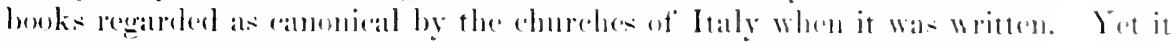

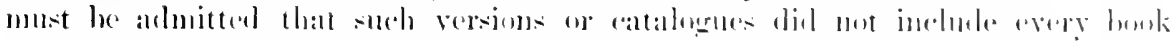

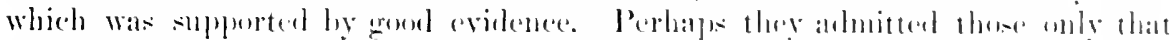

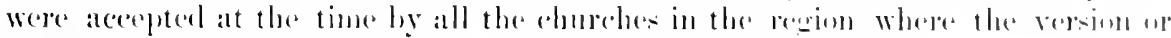

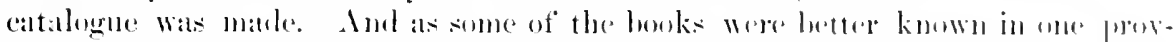

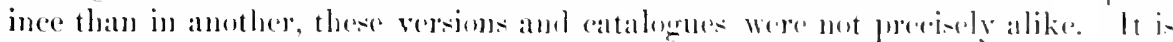

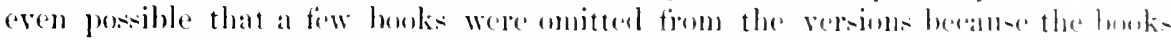

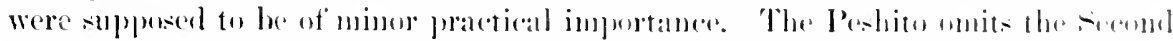

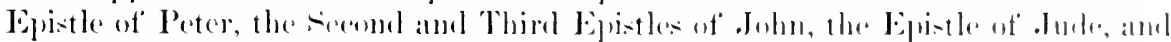

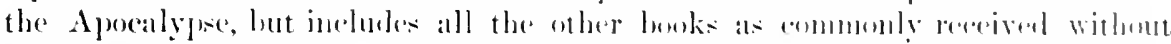

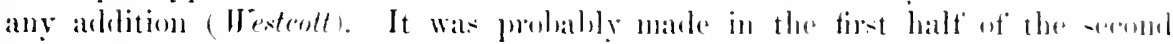

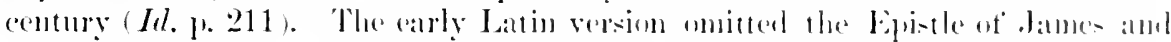

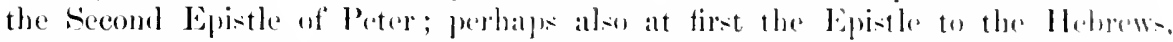

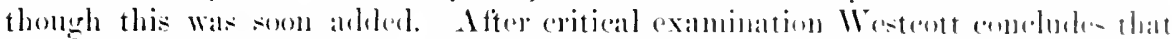

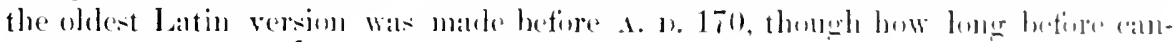

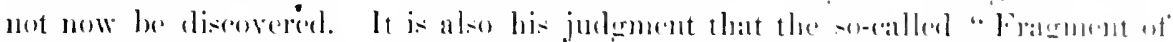

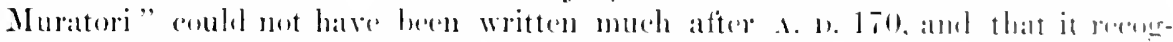

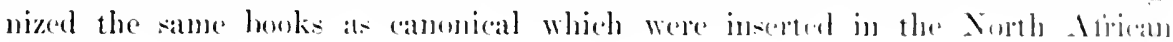
versions.

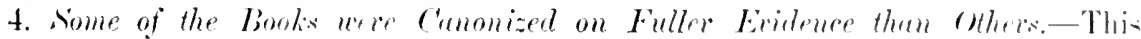

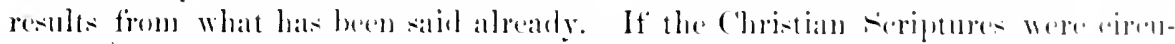

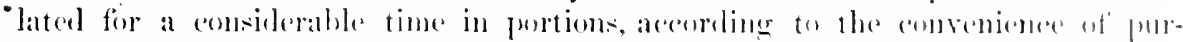

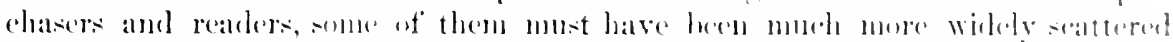
and generally kmown than others. Merely jersonal letters. like the somol and

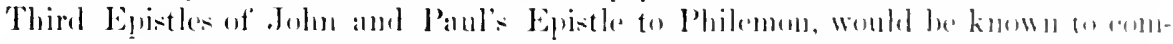

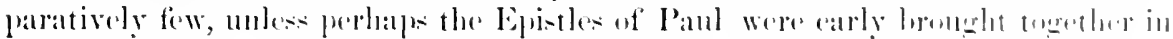

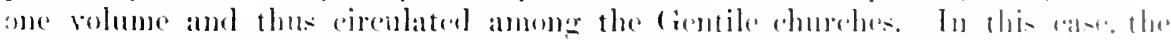

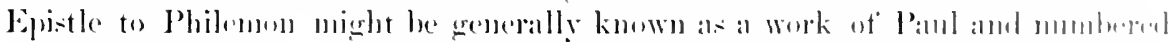

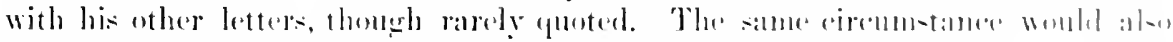

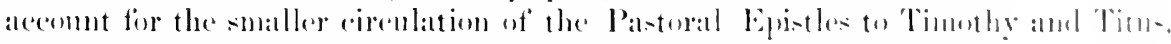

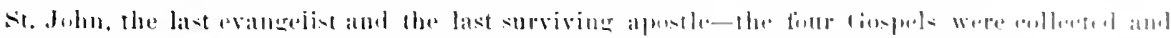

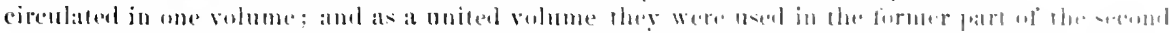

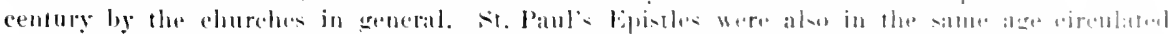

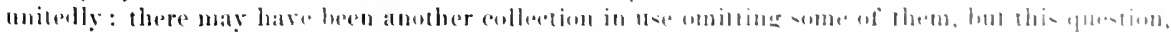

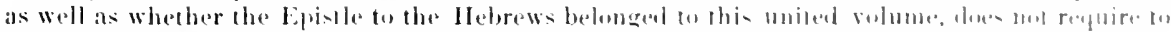

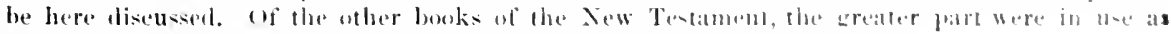
separate books," ete. (Ilorne's Introd. to the Holy scriptures, vol. ir. I. 25.) 
thongh these would be somght ly the ministry for a special reason, the instruction which they give as to the plalifications and duties of pastors. Again, such a book

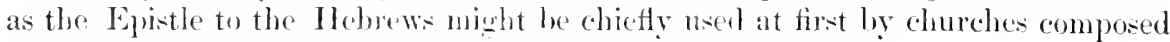
of Jewish comverts, for whose sperial benefit it was writen.

still firther: local ol temprerary enthusiam for a certain doctrine might lead to a more extensive and diligent noe of the book in which it was smpposerl to be taught than was malle of wher bukx no less interesting to-day, while local or temporary dislike of certain doetrines might lear first to neglect, and then to ignorance, of the books supposerl to teach them. This was probahty true of the anctrine of Chiliasm as atferting the use or neglect of the Aprocalype.

For these reasons it is plain that the evidence fin the canonicity of certain books of' the New 'Trotament would appear to be less compulsory in the fourth century than that for the canomicity of others. A nuiform and universal tradition would commend a lane part of these seriptures to the conficlence of every upright inquirer, but other portions wonld be supported by testimony from certain quarters and perioks ouly.

From this general survey of the mocess by which the New Testament Canon was establisher in the early church it is now proper to turn to a consideration of the question-

\section{Why should this Canon of the New Testament be accepted as Trustworthy?}

The first and most obvions reasom for this is our conficlence in the good sense and piety of those who mitel their voices in adopting it. But if their pepute for intelligence and faimess of mind were less than it is, there are two circmustances in their favor: the matter to be determined was not likely, on the whole, to enkindle partisan strife, and the evidence on which to foumd their decision was much more abmoknt then than it is now ; for, as the writings of Euschius elearly prove, a lare part of that evidence has disippeared with the numerous rolumes in which it was found.

In the light of these statements, the conchsions adopted hy elutrehes and commoils in the latter lant of the fourth century, even though they were but a ratification or declaration of the views of ('hristians in different palls of the empire, are presmmalily eorrent, and should be beceived with confidence mules they ean be proved emoneons. The " hurdan of proof" rests upon those who reject any portions of the New 'Testannent as moworthy of a place in the canon of IIoly

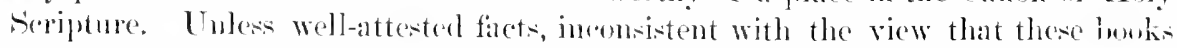
were witten by "apostles" of "apostolic mon," and were rereived with veneration by those to whom they were first sent, ang lie produced, the books are cutitled to rotain the high position which was then aceorded to them. This state of the case should be borne in mind by arely ane who mulertakes to review the anguments

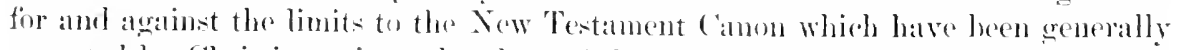

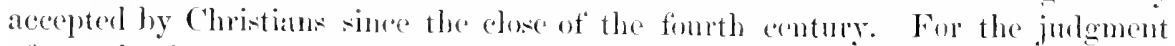
of men having much evidenes since lost must not be set aside as of no value. To restate our position: Since the churches and conneils of the fourth century fixed 


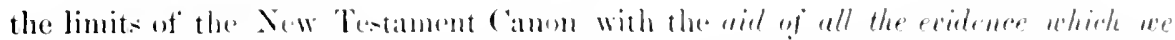

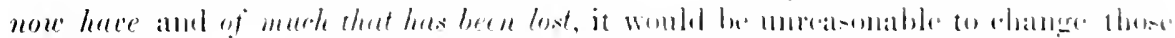

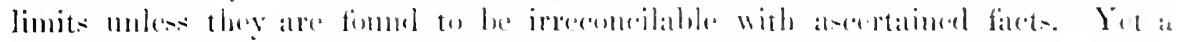

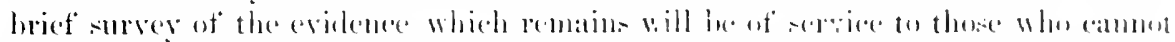

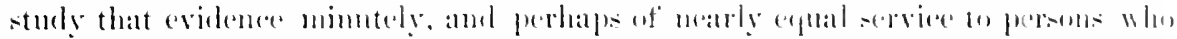

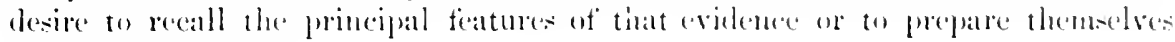
for the sturly of it.

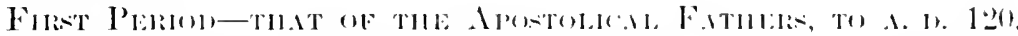

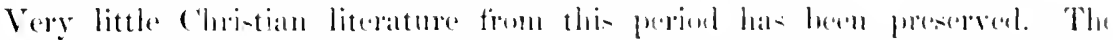

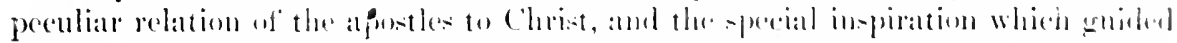

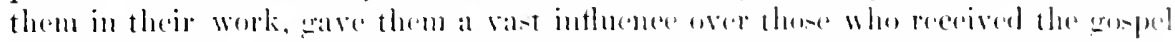

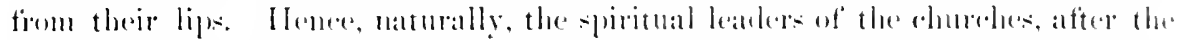

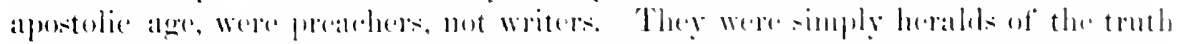

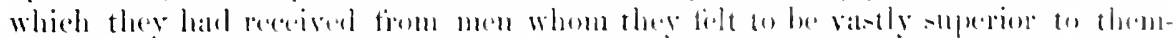

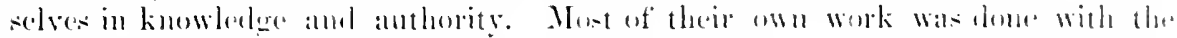

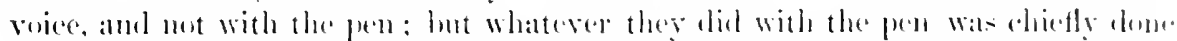

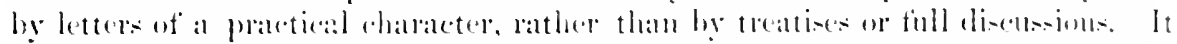

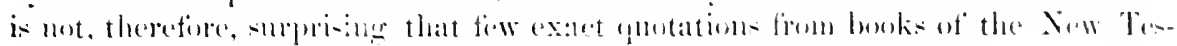

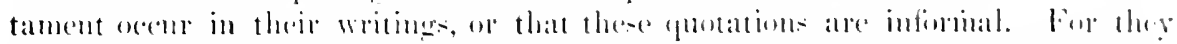

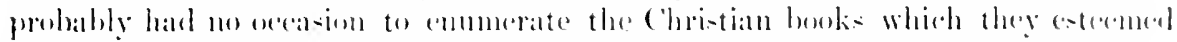

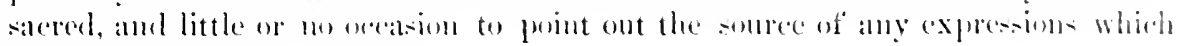
they drew trom those buskis.

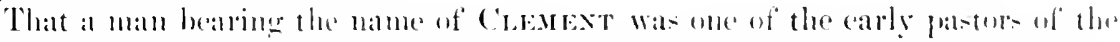

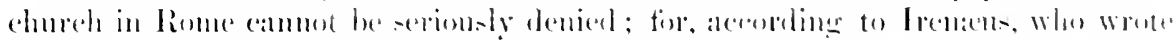

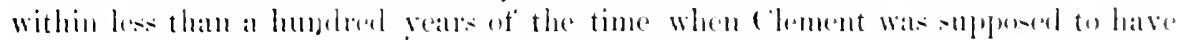

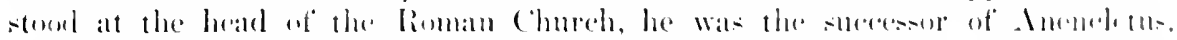

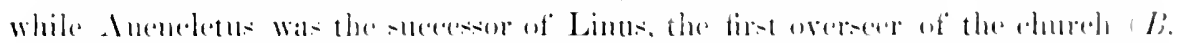

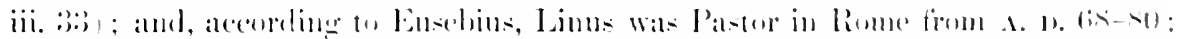

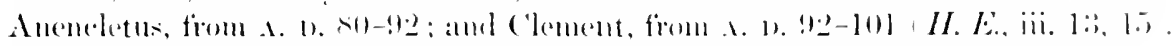

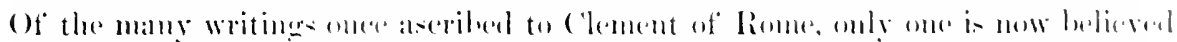

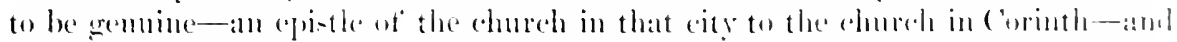

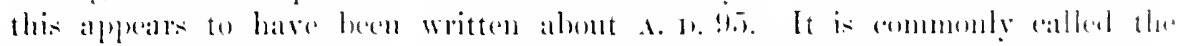

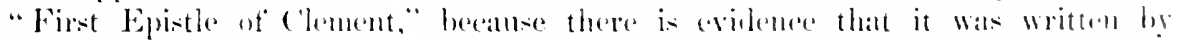

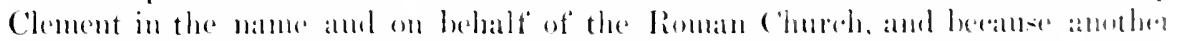

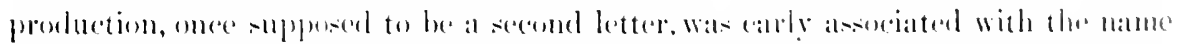

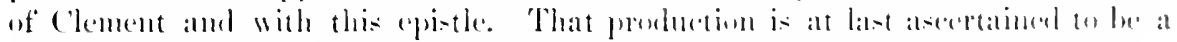

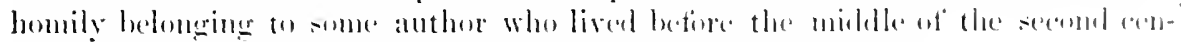
tury. It is therefere probably the oblus christian hamily extant.

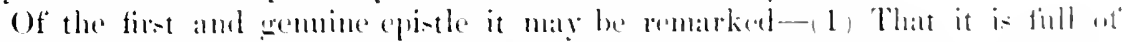

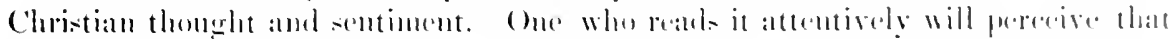

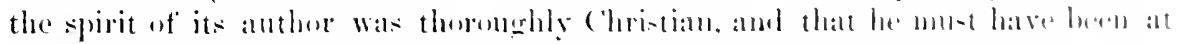

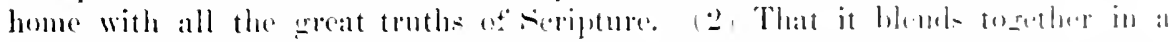

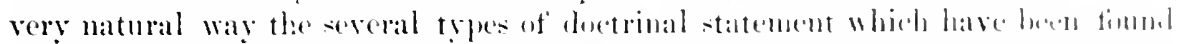

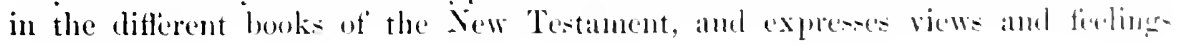


which womld he promed in a candirl mind by perusing with reverence all these bowks. So munifiest is this that, in the language of the epistle, we seen to hear again, as it were, thomgh in tianter tomes, the voices of Christ and of Peter, of

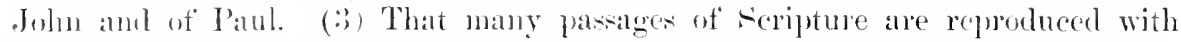

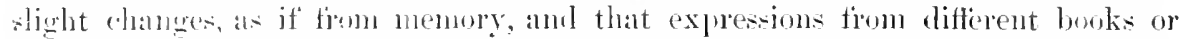
chapters are blemled together in puotation, as if they belonged to the same para-

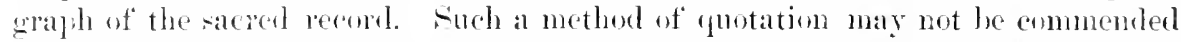
as acholaly or critical, but it was certainly rery natural, esjecially if the writer

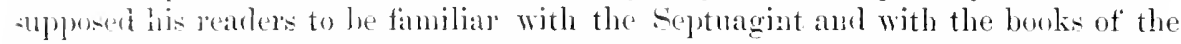
Few 'Tutament. (4) That it refers particularly to Paul's First Epistle to the

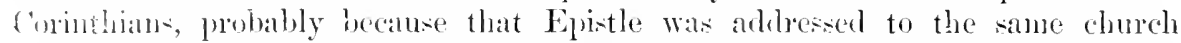
when it was in somewhat similar cireumstances; but the author appears to have been "well acoualuted with the writings of Paul" (Domaldson). Important extracts are male fiom the Epistle to the Helrews, thomgh without describing the -nule from which they were derived. (5) 'That the contents and language of this epistle are acounted for by supposing that its writer knew and revernced the Scriptures of the OHl amd the New Textament, while they camnot easily be alecomted for if he was igmonent of any considerable part of the latter rolume."

The brief references in carly (hristian writers to Isxates wartant the belief that he was for a comsiderable time Bishop of Antioch, and that, either about A. 1) 107 or about A. D. 116, he was sent as a comdemned Christian to Rome, where he suffered matyrelom. The epistes ascribed to him are preserved in three forms, the longest of which may be ponouncer quite morothy of confidence. But of the other two forms it je difficult to say which has the best claim to be regateder genuine. The temlency of eriticism seems, howerer, to be just now more finvorable to the seven epistles of the shorter reconson in Greak than to the three epistles in Syria, the latter boing regarded as marle up of extracts from three of the former. Without molertaling to decile betwees the elaims of these two forms of the Ignatian letters, and without affioning positively that Ignatius wrote even the three in the form published by ('uretom, it may be remarker (1) that the seven contain many more references to the New Testanest than the three. But even the tentimony af the seren as to the New 'Testament will be foumd to be indirect instead of direct, and implied instead of expresed. For they do not formally alploal to the sacoed books of the New (ovenant, but prouppose their existence by the use of workls, sentences, and thomglats which those looks contain. (2) The author of these epistles must have been well acouainted with the witings of Paul and of John, and by no mean; ignorant of other. New Testament seriptures. Charteris reeog-

1 "We must remember that the ancient writer has not a small, compact reference lible at his sile, but, when he wishul to verify a reference, would have to take an mwieldy roll out of its case, and then womld sot find it divibed into eldapter and verse, like our modern bonks, but would have only the columns, and those not numbered, to groide him. We must remember, too, that the memory was much more protised and relied upon in ancient times, expecially amomg the Jews."

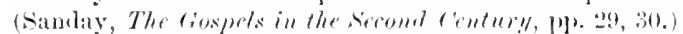

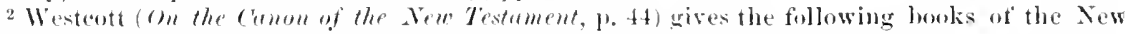
Testament as certainly or posibly refered to hy clement: Romans, Ephesians, First Timothy (?), Titus (?), I tebrews, James. 


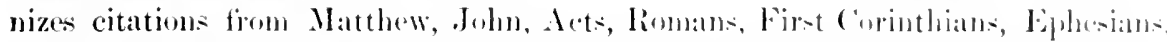

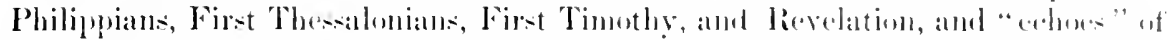

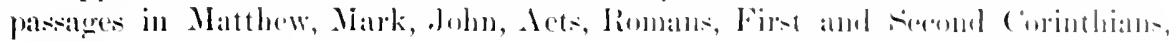

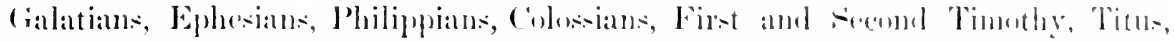

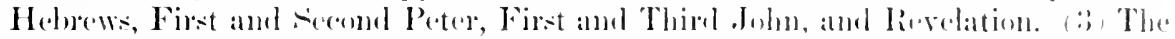

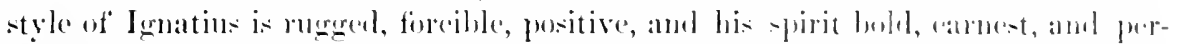

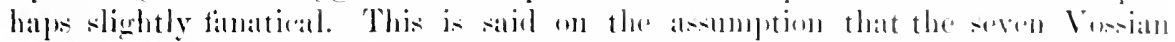

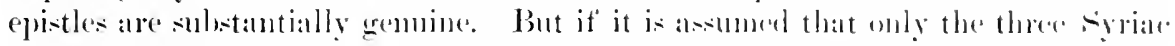
epistles are genume, the references to the New Testament ane tiew, though the spirit

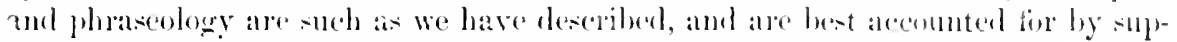
pesing Ignatius familial with the writings of l'aul amel of .John.

Poscane was the living link between the apuste-copedally John-and Irenaens, a well-known hishop and writer who flutri-hed in (ianl during the last

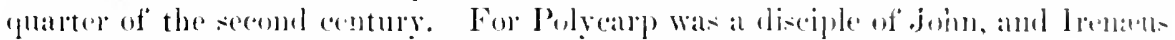

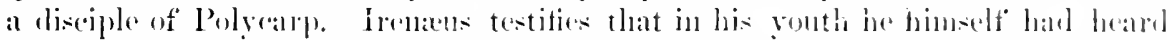

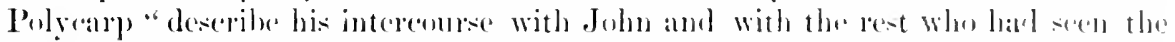

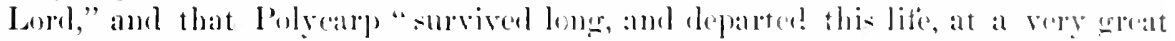

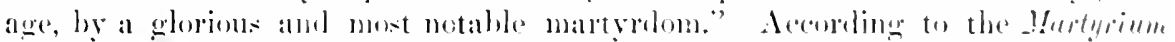

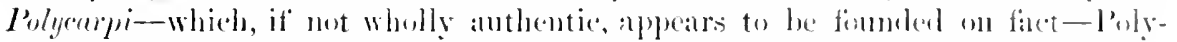

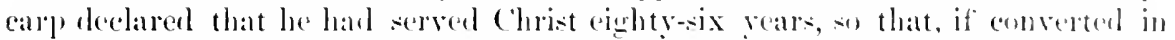
ehildhool, he was joubaluly more tham nimety years ald at the time of his death. But scholats are not anded as to the date of his death, some plateing it alumt A. 1) 15is, and others about 1. I. 166j, eleven years later. It the firmere date bu

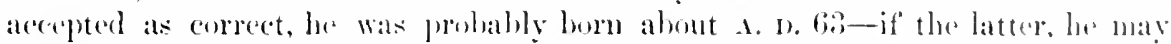

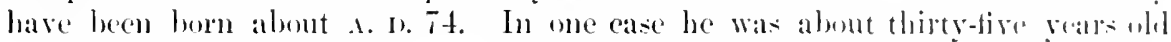

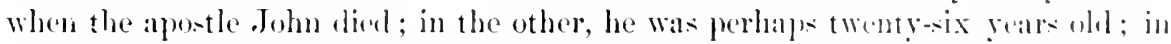

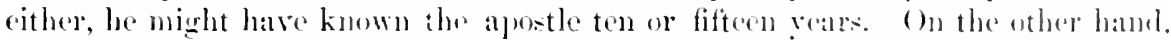

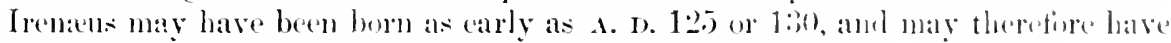

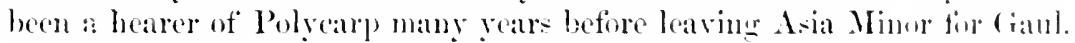

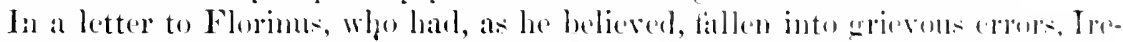

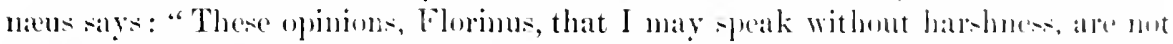

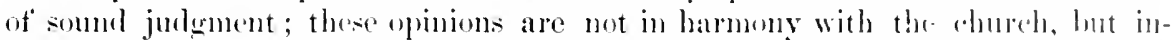
volve those alopting them in the greatest inpiety ; these opinions aven the heretic: outside the pale of the church have never ventured to broble ; these oprinions the

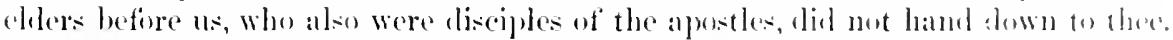

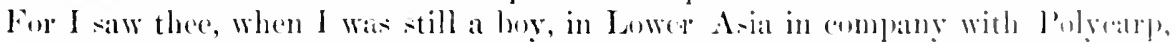

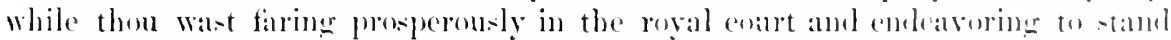
well with him. For I distinetly remember the incidents of that time lueter than

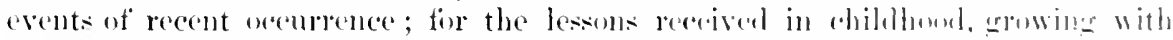

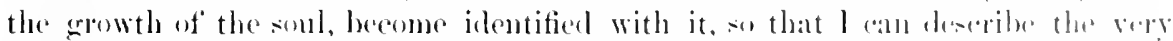
place in which the blesed Polyearp nsed to sit when he liseomsed, and his anders

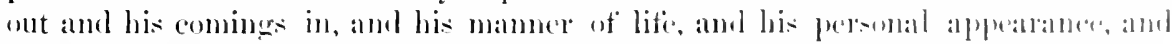
his intereourse with John and with the rest who hanl seren the Iand, and luw ho

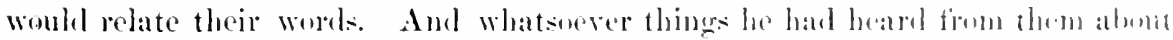
the Lord, and about his miracles, and about his teaching. Polỵalph a having ro- 
ceived them from eye-witneses of the life of the Worl, would relate altogether in accorlance with the seriptures. To these [discouses] I used to listen at the time with attention hy Goul's merey, which was bestowerl npon me, noting them down, not on paper, lunt in my heart; and by the garae of God I constantly ruminate upon them firithfully."

Moreover, in his work Against Iteresies, Ireneus refers to him again, after speaking of the succesion of Roman bishops through whom the true actrine laal been handed down to his own times: "And Polycarp also-who not only was tanght by apostles, and livel in familiar intercourse with many that had seen Christ, but also received his appointment for Asta by apostles in the church that is in smyrua, an overseer, whom also we have seen in the hegimning of our life, for he remaind a long time, and at an excedingly old age, having lorne his testimony gloriouly and most notably, departed this life-always tamght these things, which also he leamed from the apostes, which also he gave to the chmech, and which alone are true. To these doctrines testimony is also borne loy all the churches througlout Asia, and by those who have been up till this time the successors of Polycarp), who was a much more trustworthy and secme witness of the iruth than Valentinus and Marcion and the rest, who helel wieked opinions. Moreover, there is an epistle of Polycarp addresced to the Philippians, which is most adequate, and from which both his manner of life and his preathing of the truth may be learnt by those who desire to lean amel are anxious for their own salvation" ( B. iii. 3).

To the genumeness of this letter several abjections have been urged, but these objections are greatly outweighed by the evidence in its faror; so that, whatever may be thought of ch. 13, the rest of the epistle must he acepted at the work of Polycarp. Indeed, it would be difficult to name any ameient writing which is better authentioated than this. It may therefore be used without fear as a fair sample of Christian counsel and exhortation soon after the begimming of the second "entury. And it is specially noticeable (1) that the tone of the letter accords with the testimony of Irenceus that its anthor had listened to the venemble apostle John and to others who had seen the Lord. For this experience, whether in routh or carly manhood, would he likely to make a deep impression on a susceptible mind, and would be mfirorable to originality of thought or expresion. (2) That the pluaseolory of the letter acrees with the alleged circumstaneces of the writer. For if Polycalp was Bishop of the chureh in sinyrna and a disciple of Joln, it is extremely polnble that he was familiar with the writings of Peter, Paul, and John, all of whom hat been commecterl, more or less closely, with the chmrehes of $\mathrm{A}$-ial Minor. And the mind of the write of this epristle evidently moved in the thonghts and language of these apostes and of Christ. (3) That a rery consielerable part of the lotter is conched in sentences borrowed from the New Testament. These sentences are not generally quoted with an express refercnce to sumese, but they are naturally appropriated and mate the vehicle of expresion, as if the writer were perfectly fimiliar with them, and could comnt upon their being recognized by his reaters. Especially marked is his use of the Pastoral Epistles and of the First Epistle of Peter. Charteris finds in the letter of 


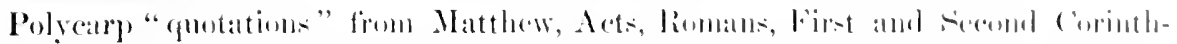

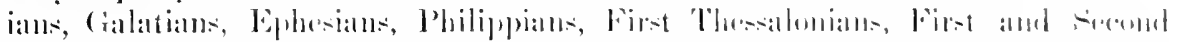

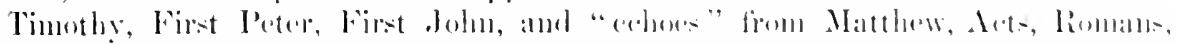

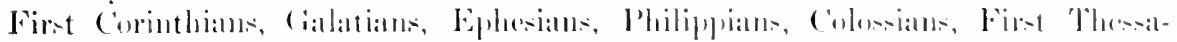

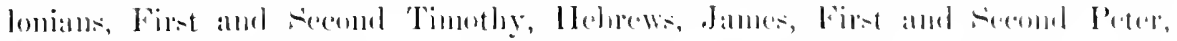
First John, Jurle.

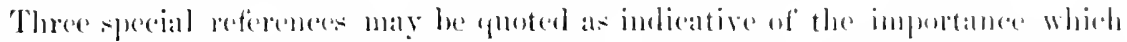

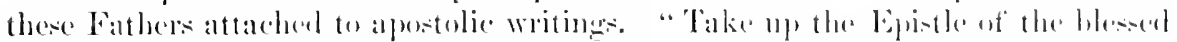

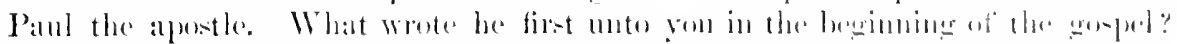

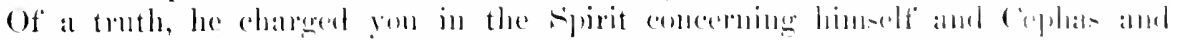

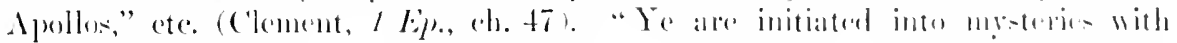

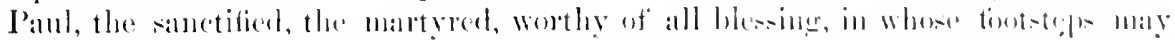

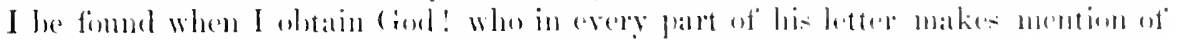

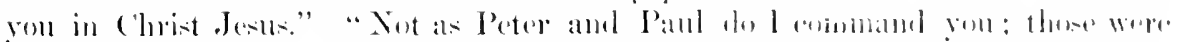

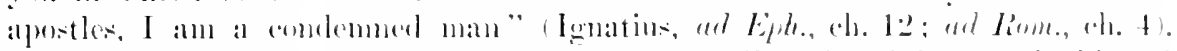

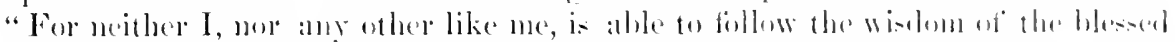

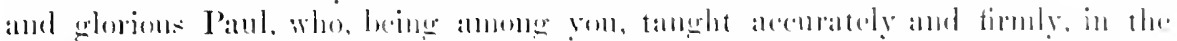

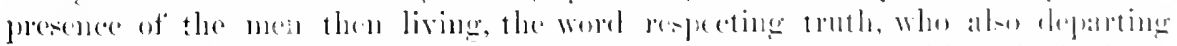

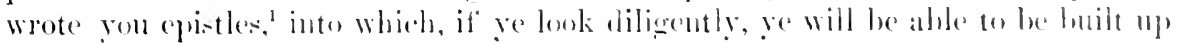

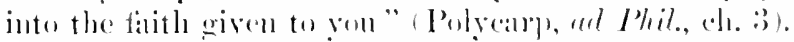

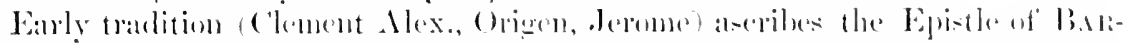

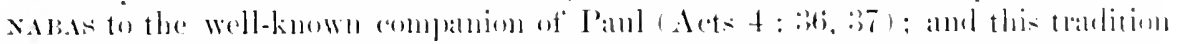

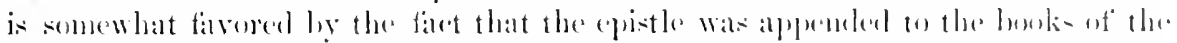

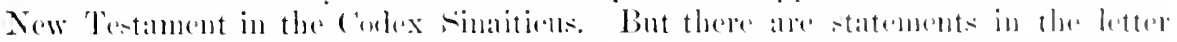

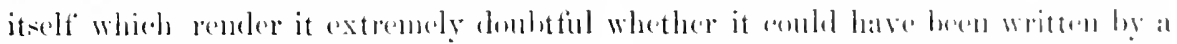

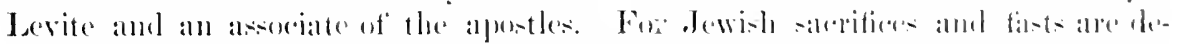

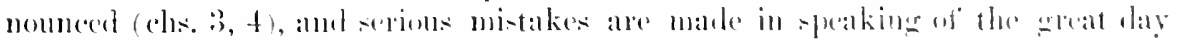

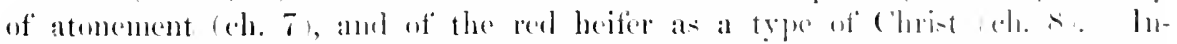

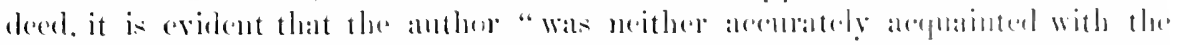

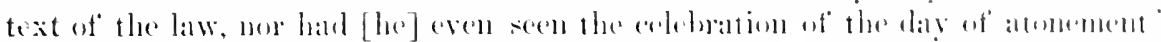

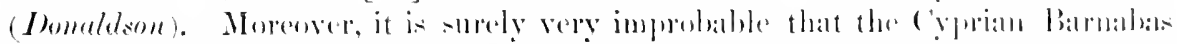

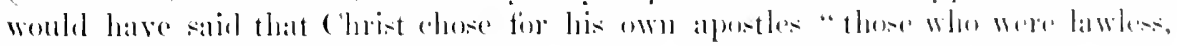

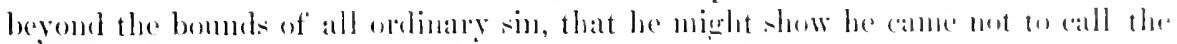
righteons, lut simers" (ch. 万).

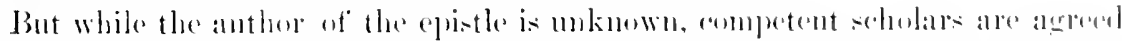

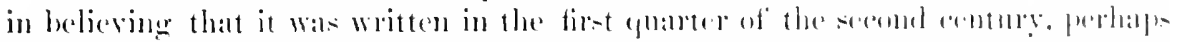

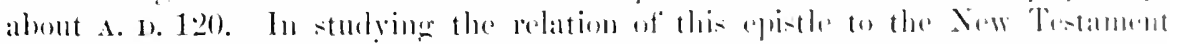

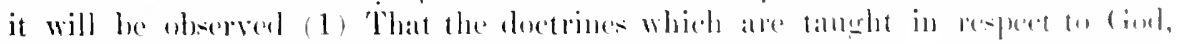

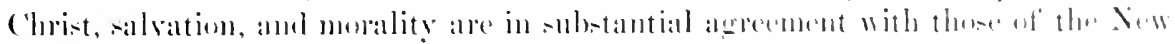

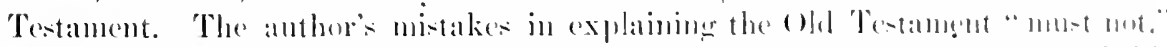

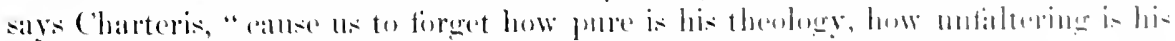

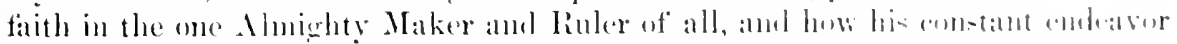

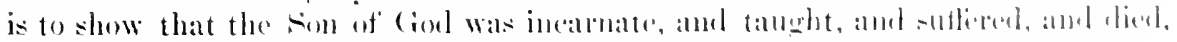


and rose, and revived, that he might be Lomd of both the dead and living." That in ductrine this epistle represents exchisively neither Paul nor Peter nor John, hut rather all of them. Hilgenfeld maintains that his teaching is Pauline, though tending to Gnosticism. Dornes says that "with the fundamental thoughts of Peter he combats Julaism within Christianity." Ant Charteris remarks, "Not only the Bamalas regard Christ's incarnation in the same way as John does, but the farcts of christ's life as recorded by John recun to be the indispensable basis of his theolngy." All are doulhtless correct; and this fact is best accontuted for by supmonge that Barmabas was fimiliar with the writings of all these alpostles. (3) That this epistle first quotes a palsage from the New Testament with the bihlical formula, "It is written" (ch. 4 ; cf. Matt. 22:14). There is also no sufficient reason for cloubting that it uses the words of Matt. 9: 13 in eh. 5: ["In order that he might show that] he came not to call the righteon, but simners." Several pretty distinct reminiscences of the language of the Fourth Gospel maty aloo be traced.

Of the writer of this epistle Donaldson says: "However weak and misdirected his intellectual powers may be, and howerer light his head may occasionally seem, his heart always heats right. There is not one expresion contrary to the somment morality, and mach that staids out in magniticent contrast to the morality of his age, even of its highest plitosophers."

\section{Tine Arie of Greer Apologists-a. D. 120-A. D. 170.}

The eireumstances of Chritians in this period led them to write a considerable number of howks, treating a great valriety of topics. But of these books many, and inced those of the greatert value, perished in the early ages. Among these were the Diatessaron of Tatian, the Expositions of Papias, the Ecelesiatical History of Hegesippos, and the works of Melito and Apollinaris, which, it is sail, ranged oxer the wille domain of theology, interpretation, morals, apologetices, and church polity, and which must have been much richer in materiats for ascertaining what books of the New Teatament were deemed authoritative than most of the works that have come down firm about the mildde of the second ecntury.

But nearly all these writings were in the hands of Ensehins, and it is therefore a matter of importance to know the principles which guinled him in lis use of them. Fortunately, Bishop Lightioot has diseorered those principles by a careful interpretation of his "prefatory statenents" and a thorough verification of the meaning assigned to then. He has thus proved "that the main object of Ensebius was to give such information as night assint in forming correct views respecting the Canon of scripture," that he "was therefore indifferent to any quotations or references in early "Christian writings which went toward establishing the canonicity of these books which hat never been disputed in the ehureh; "and "that to" this class belonged the finr (rospels, the Acts, and thirteen Epistles of Paul."

Hence it is claimed that "the silence of Eusebins respecting early witnesses to the Fourth Gospel is an evidenee in its faror. Its apostolic authorship has never been questioned by any church-writer from the beginning, so far as Eusebius was 


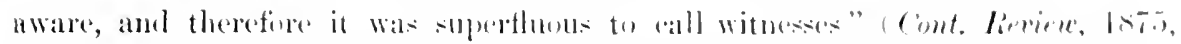

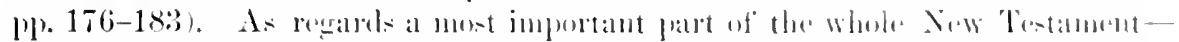

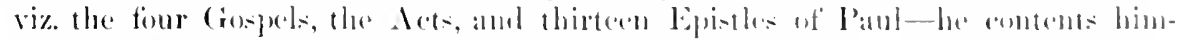

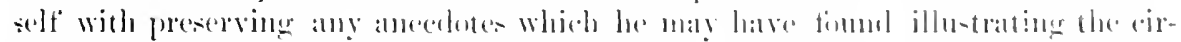

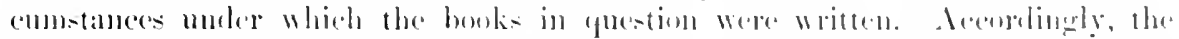

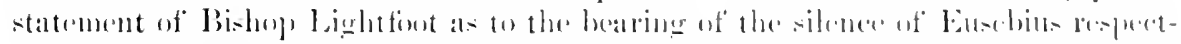

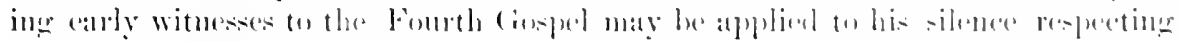

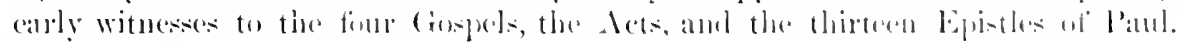

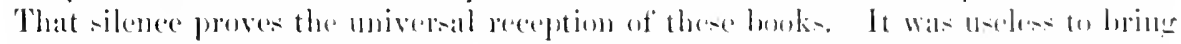

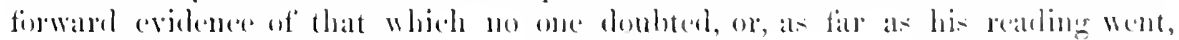
hasl ever dombterl.

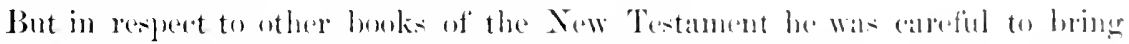

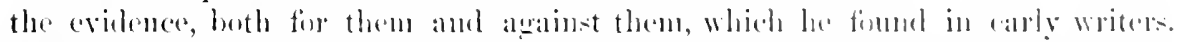

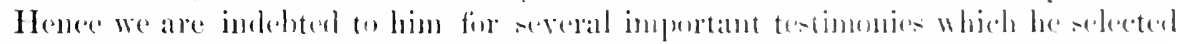

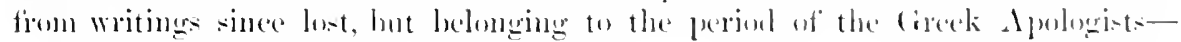
i.e. .. 1). 1.20-.1. 1). 170.

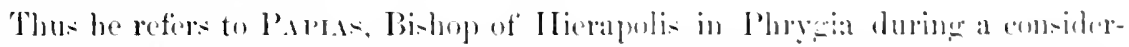

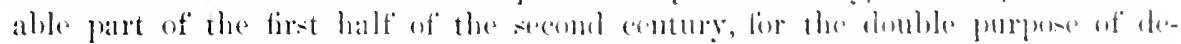
charing that he mamb use of cortain lumbs as autheritative which were mot

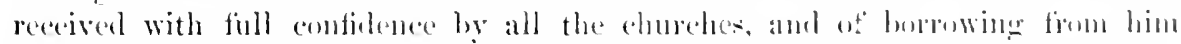

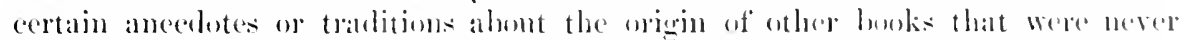

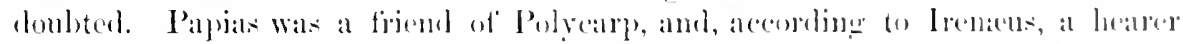

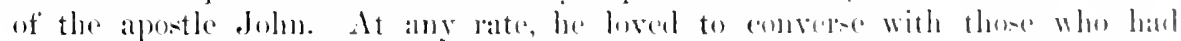

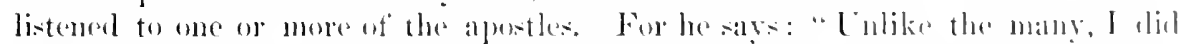

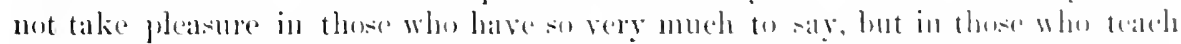

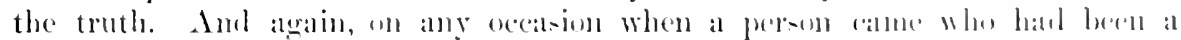

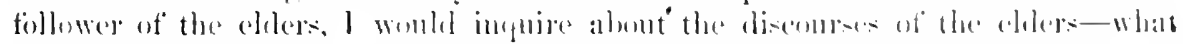

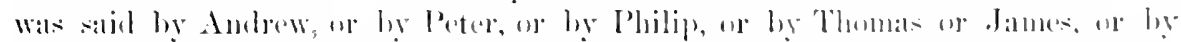

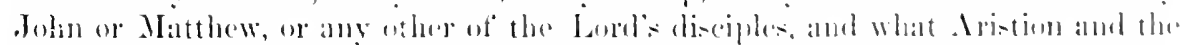

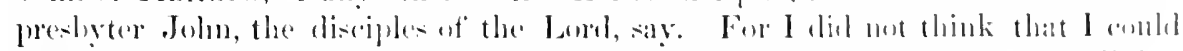

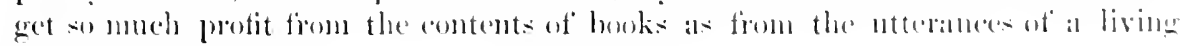
and ahiline vojer."

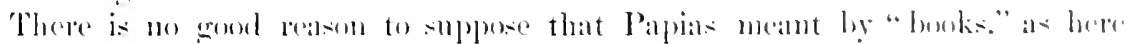

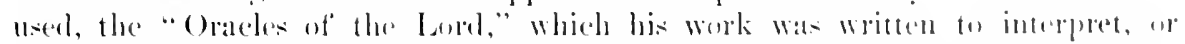
inderel any apostolieal writimes. It is far muse pubbahle that he hand in miml

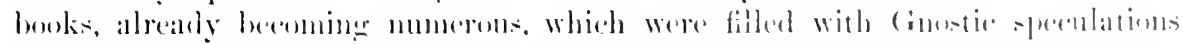

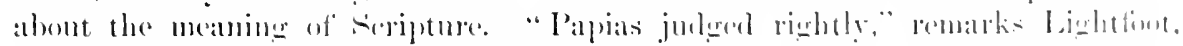

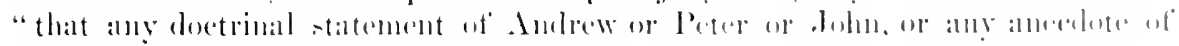

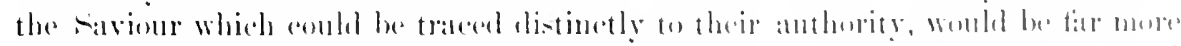

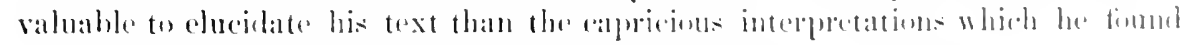

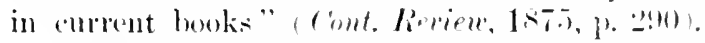

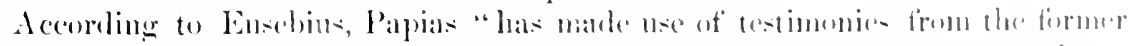

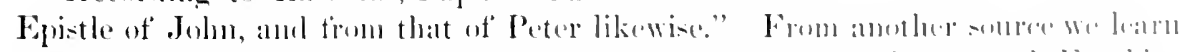

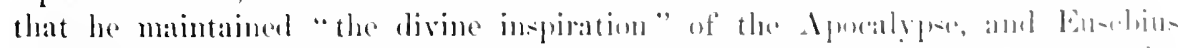

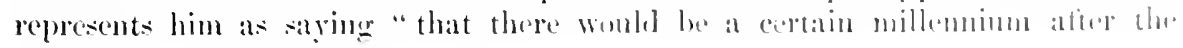


resurpection, and that there woukl be a corporeal reign of christ on this rery earth; which things he appears to have inagined, as if they were anthorized by

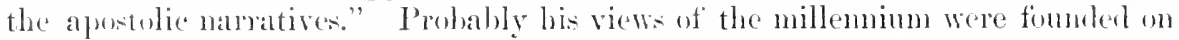
what he smplosel to be the meanimg of ('hrist's lamguage in the twenty-fourth

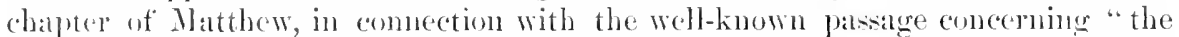
thousant rean's" in Revelation, twenticth chapter. By "the former Epistle of" Joln" Eincelous doubtless meant his First Epristle; for he testifies in allerious chapter that "besides the Gospel of" John, his First Episte is acknowledged without dispute, both by thase of the present day and also by the ancients. The other two dipistes, howerer, are disputed" (II. E., iii. 24).

Eusebiuk also, acourling to his plan, yuotes fiom Papias certain areounts

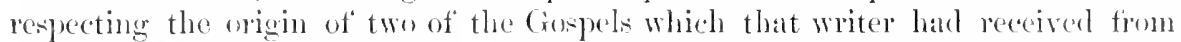
the elders Aristion and John. Thus: "So then Matthew composed the ( Pracles in the Hobrew language, and carch one interpreted them as he was alole." This declaration ohrionsly refers to a period that was already past when P'aljias wote his "Expositions," and there is no reaton to suppese that the "Oracles" compresel by Matthew were known to Palpias in their Ifelorew form. His knowledere of their existence in that firm was derived from "the elelers." Nor is ther" any grood reason to helieve that the word "Oracles" was not need of historical als weil

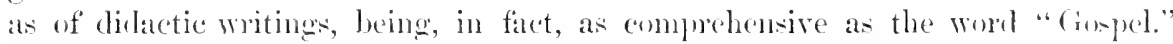

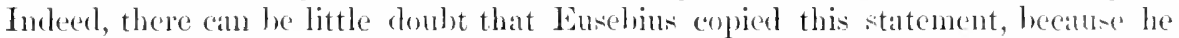
understort it to refer to the first chaft and original form of the camonical Guret of Mattlew. Hence the Aramaic "Oracles" must have been supersederl by the Greek "Gonel" hefore the close of the first century; and it is diffienlt to believe that they contained anything escentially different from what is found in that Giosiel.

Again, Eusebius quotes from Papias the following aceount of Mark: "And John the Elder satil also this: Mark, having hecome the interpureter of Peter, wrote down acenrately everything that he remembered, without, howerer, recoreling in oreler what was either said or done by Chrint. For neither did he hear the

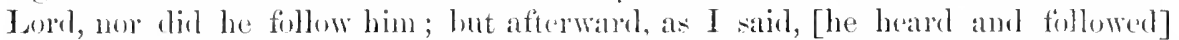
Peter, who adapted his instruetions to the necols [of his hearers], hut had no design of giving a comnected aleconnt of the Lord's Oracles (or discourses). So then Mark mate no mistake while he thus wrote lown some things als he remembered them; fior be male it his care not to omit anything that he heard, or to set down any filke statement therein."

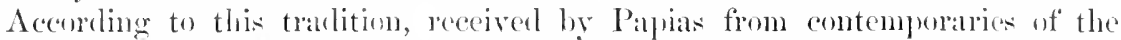
alpostes, the work of Mark here refered to wat al careful memoriter recond of what

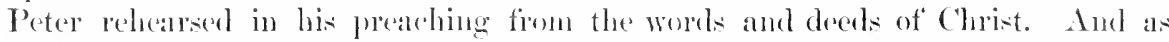

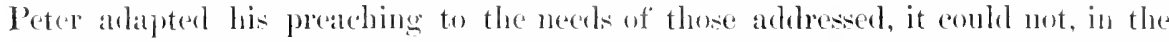
batture of the ease, fimmish a complete or chromological narrative of christ"s life. Are we then justified in supuosing that the work of Mark, retered to in this extralct, was the second of om four Gospels:?

(1) That Gospel is the hrictest of the four. It gives no genealogr, no aceomt of the hirth of John the Baptist or of Jesus the Christ, no outline of the longer 
same in his Dislogne with Trypho ( Westcott); if his use of the Gospels is quite as frepuant as their use in later Apologies (e.g. that of Tertullian); and if his lan.

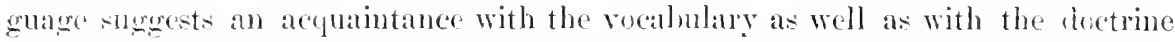
of Paul, -it is as much as any thoughtful seholar ought to expect on the ar:amption that Justin knew and homores the writings of the apostles as sacred. And juit these thingss are finnd to be true of his two $A$ pologies and of his Dialogue with Trypho, a Jew.

Justin in his first Apology refers three times to the Memorabilin of the Apostles, stating in one place that in then were "taught all things concerning our Silvimer, Jesus ('hrist" (I. 393), in another", that they were read, together with the writing:s of the prophets, in the weekly meetings of ('hristians (I. 67), and in another, that they "were called Cospels" (I. 66). In the Dialogue with Trypho he quetes them ten times as the Memomabilin of the Apostles and five times as the Memorrbilir. An intereting passage of the Dialogue contains these words: "In the Memorabilia, which I say were composed by the apostles and those who fillowed them, [it is written] that swent as drops strectmed down as he was pratying and saying, Let this cup, if it be possible, pass anomy from me" (ef. Luke '22: 44). A, he was making a quotation from Luke, it seemerl proper to call attention to the faret that the Apostolic Memornbilia were not all written by apostles, but rather by the apostles and their followers.

With this statement should he compared the language of Tertullian: "We lay down, in the first place, that the Evangelic Instrument has apostles for its authors, on whom this charge of publishing the gospel was laid by the Lord himelf; if aloo anstolic men, yet not these alone, but with apostles, and after apostles. . . . In fine, of the apostles, John and Matthew implant faith in us-of their followers, Luke and Mark refieda it." As the form of Justin's explanation agrees so perfectly with the general statement of Tertullian, it eannot reakonably be denied that the interpretation of his own statement by Tertullian is a just interpretation of Justin's language also. And if so, Justin knew and received the same four Gospels which Ireneus and his eontemporaries, forty years later, received, and which Tertullian and his contemporaries, fifty or sixty years later, receiverl. It is also to be eonsidered that . Justin must have been for a long time (aty twenty-five years at least) a contemperary of Polycarp, and Irencens for the first twenty on thinty years of his lile a contemporary of both Justin and Polycarp, and Ter tullian for als long a time a entemporary of Ireneus. Whether Irenteus ever met Justin Martyr we lave no means of knowing, but they lived in the same period long conough to transmit the traditions of that periorl to the next; so that we eannot aswme the ocenrence of any great and sulden change in the written sourees of Christian knowledge which left no trace of itself in their works.

It is manifestly imposible to bring within the limits of an Introduction the critical processes by which the Memorabilia of Justin are shown to be ielentieal with our four Goseds. But the rearler will find a good illustration of them in Dr. Ezra Abbot's recent work on The Anthorship of the Fourth Gospel. IJe atfirms that "Justin wwhere expressy quotes the "Memoirs' for anything which is not substantially found in our Gospels; and there is nothing in his deviations 
from exact correspondence with them, as resants matters of firet of the repurt of

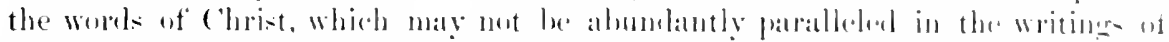

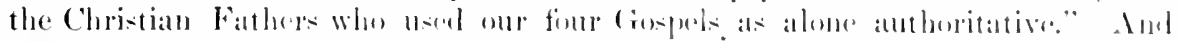

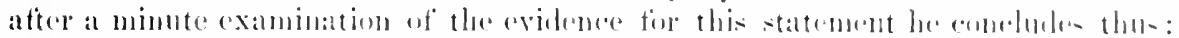

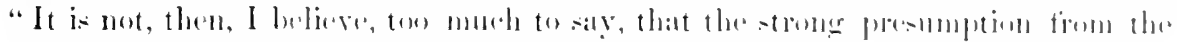

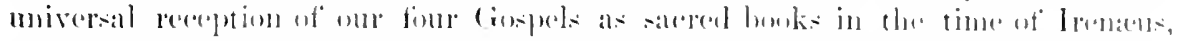

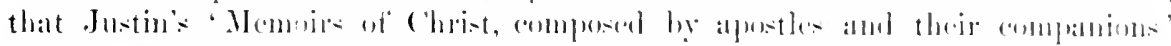

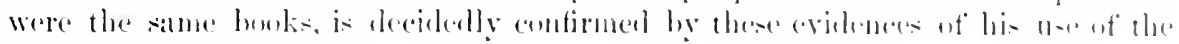

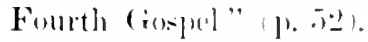

In a valuable work by I)r. Samblay, on The Fond (rospels in the serond rentury

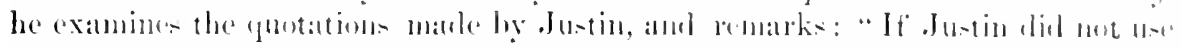

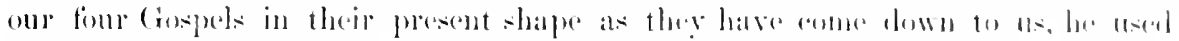

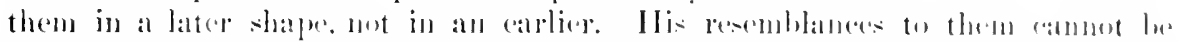

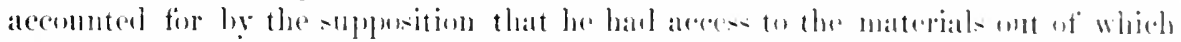

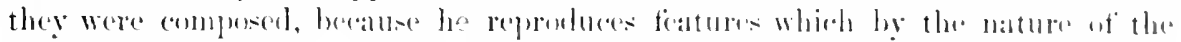

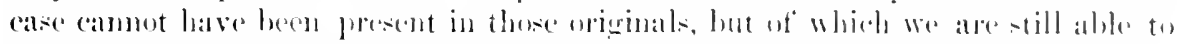

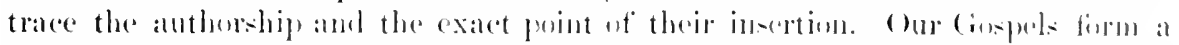
secombary stage in the histury of the trxt-. Justin's funtations, a teletials. In order to reated the state in which it [the text] is fomml in Justin, the rosul lin:

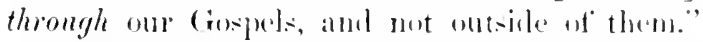

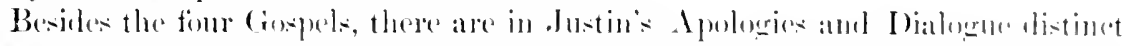

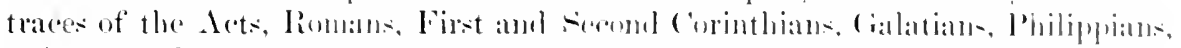

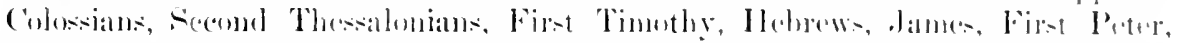

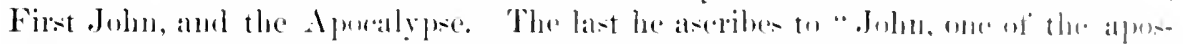

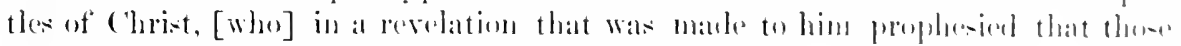

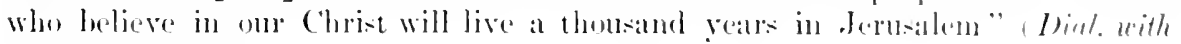
Trypho, (ch. s1).

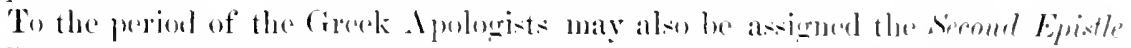
of Clement a homily), which makes use of Matthew and Inke toreother with the

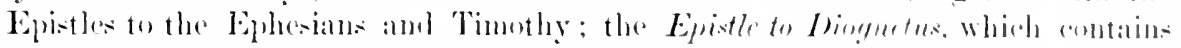

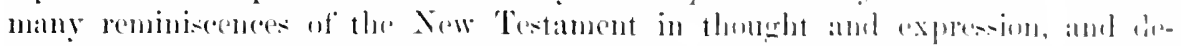

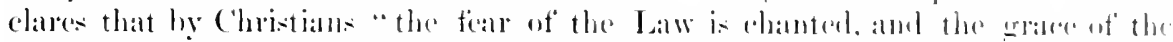

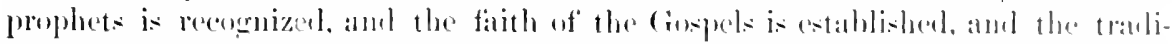

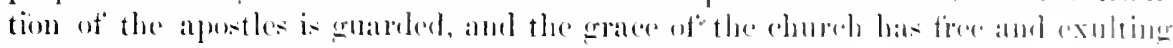

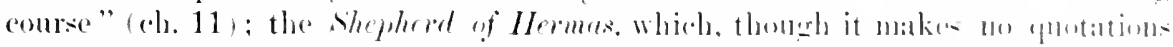

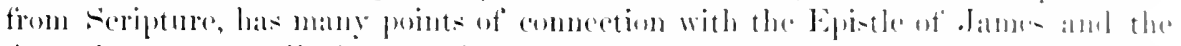

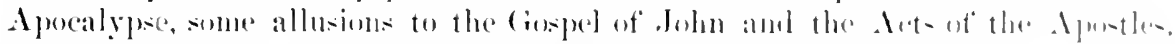

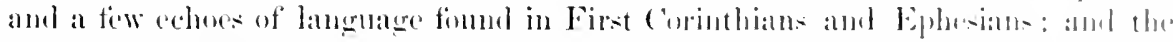

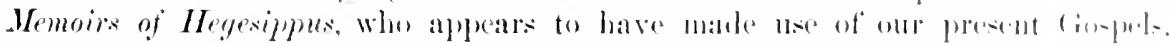
while he took certain thinge from "the Gespel to the Hobrews." of which reme little is known.

To the same periul should probably be asigned the Muratorian Fratument an the Camom, the Latin version of the Sew Teatament in North Afriat, and the earliest siriac version.

(1) The Fragment on the Cunon, di-eoverer by Muratori, begrins now with the 
last words of a sentence which prohably referred to the Cospel of Mark. It then proeeds to speak of the Thirl Gospel as written by Luke the phrsician, who not sere the Lorel; of the Fourth Grespel as written by John, a disciple of the Lombl, at the retuest of his fellow-diseiples and his clelers, with a reference also to his Epistles, and a quotation fiom the First; of the Aets of the Apostles as componed ly Iske; of the Epistles of Paul-to the corinthians the first, th the Ephesins the secomd, to the Philippians the thirt, to the Colosians the fourth, to the (Xalatians the fifth, to the Thessalonians the sixth, to the Romans the serentle; also to the Corinthians and Thessabons a second each, to Philemon one, to Titus ome, anf to Timothy two, on aceount of love and affection (thirteen in ald). It then speaks of two spurious Epristes that were aseribed to Panl-one to the Lanoliceans and another to the Alexandrians-and adds that one Fpistle of Jude and two superseribed of Jobn are recejved hy catholic chustians. Finally, that "we receive alos only the Rerelations of .John and Peter, which [latter] some of us are mwilling to have reat in the chunch." There is, moreover, a reference to "Wiskom, written by the friends of solomon in his honom," which Westeott thinks mat imply a lest clause mentioning the Epistle to the Hebrews as written by a friend of Paul. The same soholar discovers indications of two braks in the Fragment where the Epistles of James, First and fecomel Peter, and Hohrews may have heen named in the original Greck list. This is of coure conjecture. but there are several peenliarities of the list as it now stanch which seem to render it in a certain measure probable. At any rate, this list appears to cmbrace the four (rospels, the Acts, thirteen Epistles of Paul, two of . Joln, one of Jude, and the Revelation of . John. And if the two Epistles of John refered to near the ent of the list are the Sceond and the 'Thiml, Bishon Lightfort's conjecture that the First Epistle of John was then connected with his Crospel is ex-

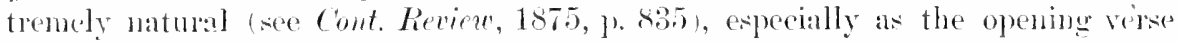
of that Epistle is quoted ly the Fragnent in giving an aceount of the oregin of the ringel. Moreover, in view of the other testimonies of this perion, it is dithrult to lindieve that the First Epristle of Peter coulel have been onitted firm the list; and it is surely more likely that there was a referenee, by way of com-

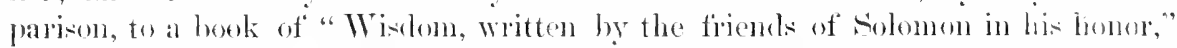
than to suppose that a book with that title was reckoned among the Clnistian Seriptures.

(2) The eurliest Lutin version of the Now Testament was prepared before

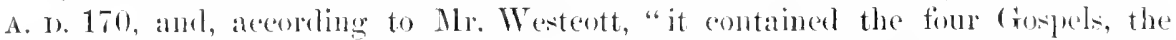
Arts, thinteen Epistles of St. Paul, the three ('atholic Epistles of St. John, the First Epistle of St. Teter, the Epistle of St. Tulle, and the Apuealype. To thes

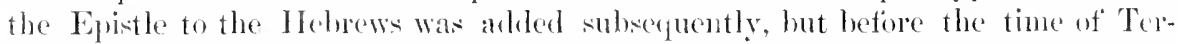
tullian, and without the anthor's name. There is no external evidence to show that the Epistle of St. Janes on the Second Epostle of Ft. Peter was included in the V'etus I atima" (Un the ('anom of the X. T., p. 22.5).

(i) The early syriac ersion, called the Peshito, is commonly supposed to have heen male in the first half of the secomel century, and may sately be assumed to have been in use before A. 5. 170. It has all the bouks of the New Testament 


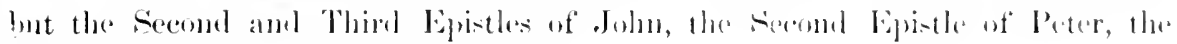

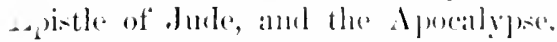

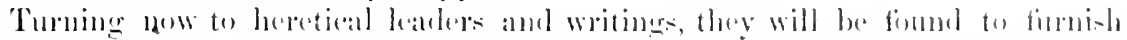

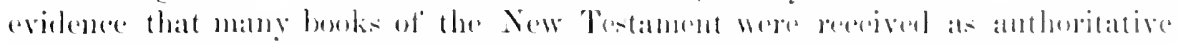

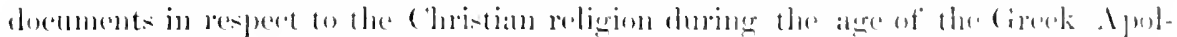

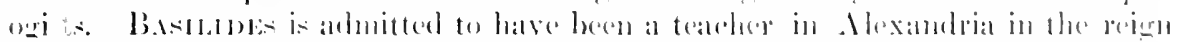

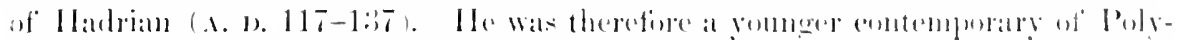

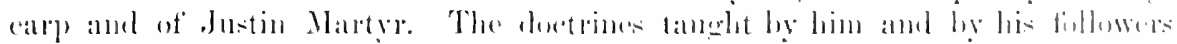

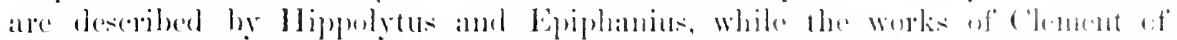

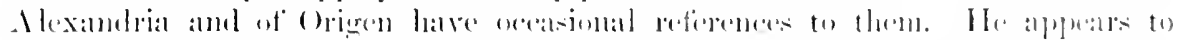

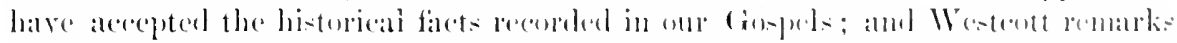

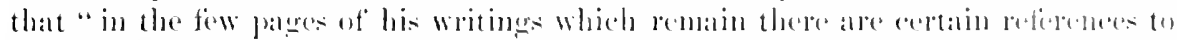

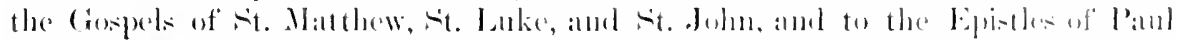

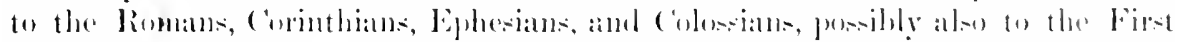

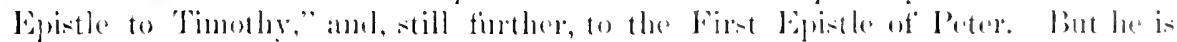

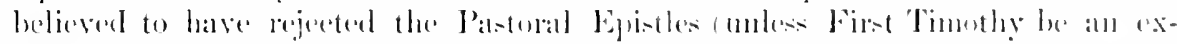

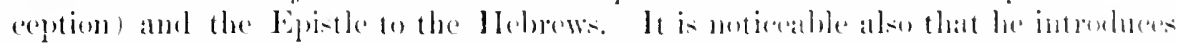

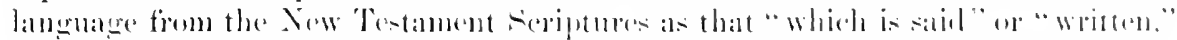

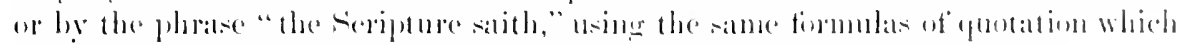

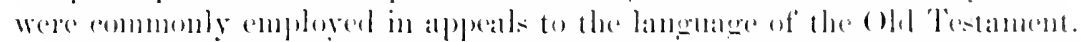

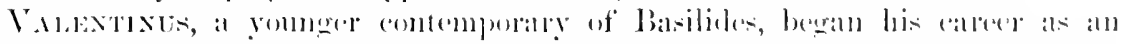

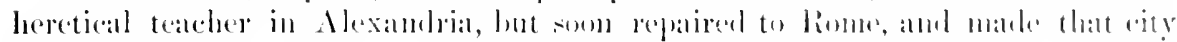

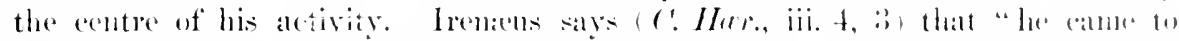

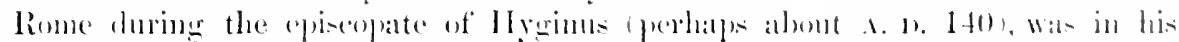

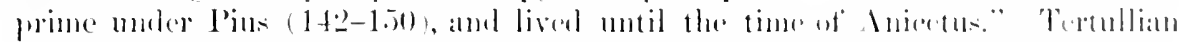

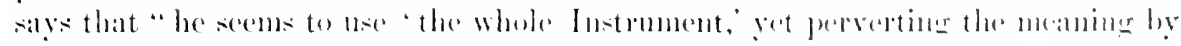
his methend of interpretation." In this way he was thought to be a mene crafty"

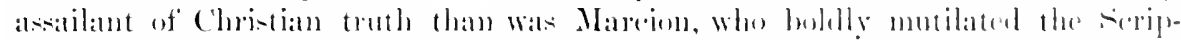

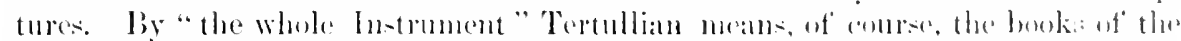

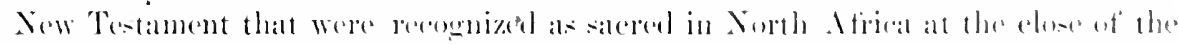

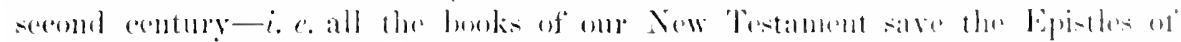

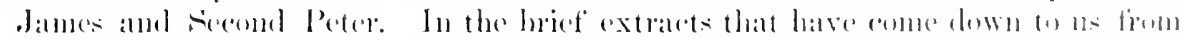

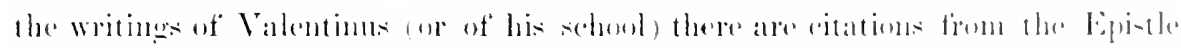

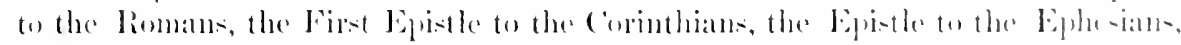

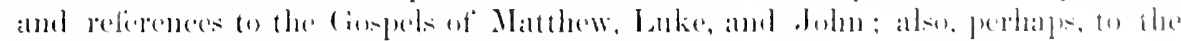

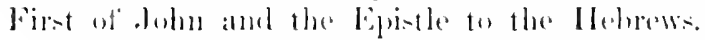

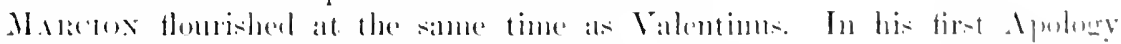

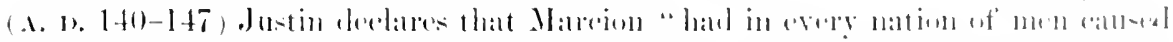

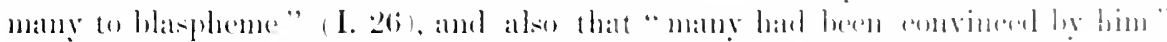

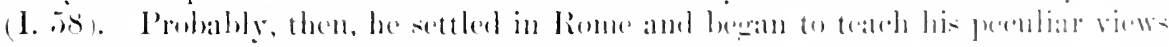

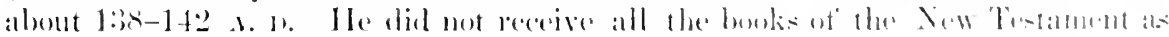

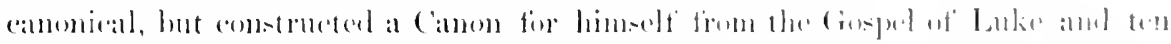

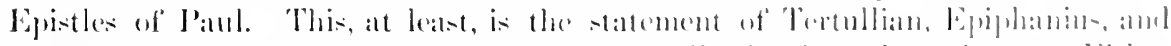

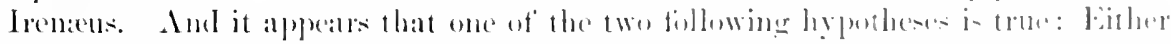

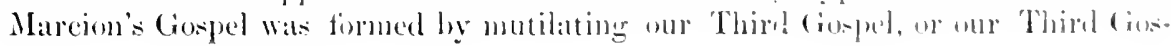


pel was formed by interpolating that of Marcion. After comparing the two, Dr. sanday says: "The frospel [of Mareion] stands to our synoptic entirey in the relation of defect. We may say 'entirely' for the additions are so insignificantsome thirty words in all, and those for the nust pant supported by other anthority -that for practical purposes they need not be reckoned. With the execption of these thity work inserted, and some, also slight, alterations of phrase, Mancion's Gospel presents simply an abridgment of our St. Luke." Again: "In Germany it scems to be agreed at the present time that the lypothesis of a mutilated Luke suits the dognatic argument leetter than that of later Jukaing interpolations." Once more, after a carefinl analysis of the language of Luke s Gospel, Dr. Anulay remalks: "The total result may he smmmarized thus: Aceepting the schene of Marcion's Gospel given some pages back, which is sulstantially that of" "Supermatural Religion, Nareion will have omitted a total of three hundred and nine verses. In those vores there are found one humbed and eleven distinct pernliarities of St. Luke's style, numberiug in all one humber and eighty-five soparate instances; there are also found one hundred and thirty-ejght words peculiar to or specially characteristic of the third evangelist, with two hundred and twenty-four instances. In othor work, the verified peculiarities of St. Luke's style amol diction (and how marked many of these are will have been seen from the examples above) are fomm in the portions of the Gospel omitted by Marcion in a proportion averaging consideralbly mure than one to each verse." It is therefore evident that the three hunded and nine verses were written by Luke, and were stricken fiom his Conpel by Mareion; for an interpolator conld not have imitated the style and vocabulary of Luke so perfectly as it is represented in these verses.

But was Lnke's Gospel a new production when it was adopted by Marcion about $\Lambda$. I. 140? Or does the text which he uses pove upon examination to be one that had been corrupted more or less hy transcription? In answer to this question Dr. Sanday, in a work distinguished for caution and moderation of statement, affirms that the textual phonomena "show that Marcion's Gospel, so far" fiom being an orignal document, has behind it a deep historical backgromnd, and stands at the hrad of a scries of copies which have already passed through a number of hank, and heen exposed to a proportionate amomit of corruption." Again: "I think it is a safe proposition to assert that, in orler to bring the text of Marcion's Gospel into the state in which we find it, there must have been a long previons history, and the manuseripts through which it was conveyed must have partel far from the parent stem."

It may be added that Marcion appears to have treated the ten Episties of Panl which he accepted in the same way as he treated the Gospel of Luks; that in, as far as he accepted the Epistles at all, he accepted the text as he fomul it, withont making any changes; but from the Epistles, as from the Gospel, he omitted such verses or parateraphs as did not agree with his doctrinal opinions. (See the enclusive argument by Sanday, Pl) 204-237.)

To this period also must probably he assigned the so-called "Homiles of

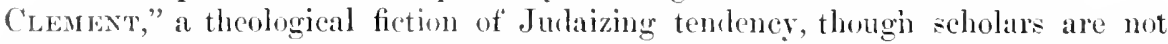
yet agreed as to the time when it was written. Those who have given the subject 


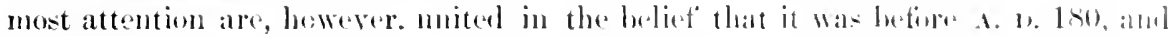

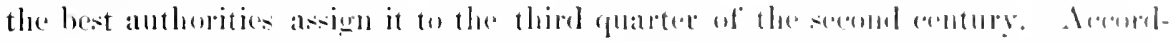

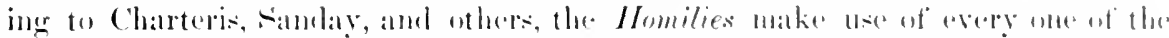

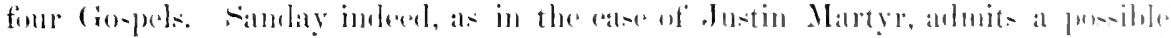

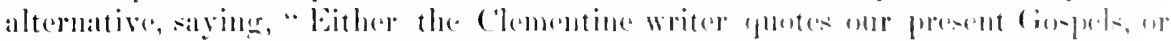

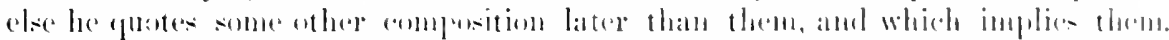

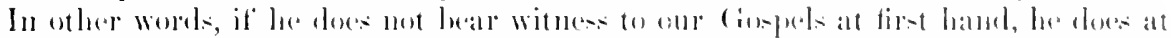

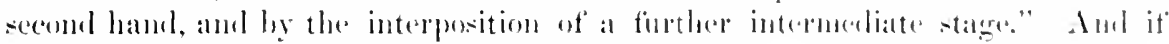

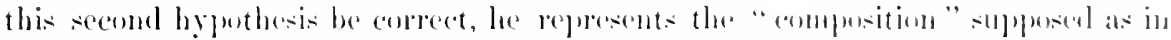

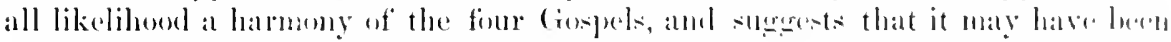

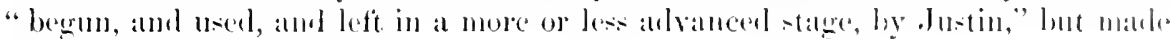
public afterwarel by 'Tatian.

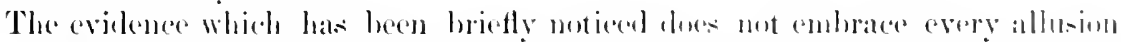

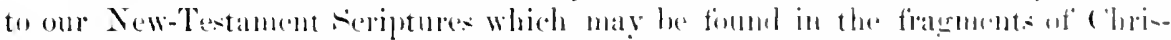

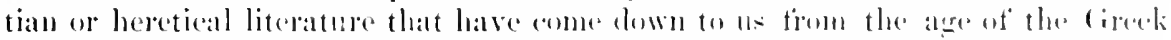

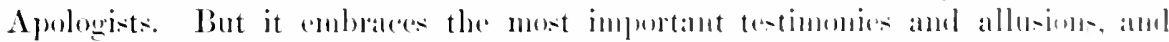

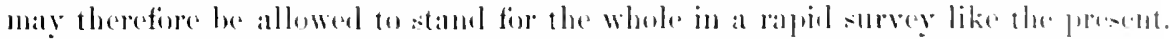

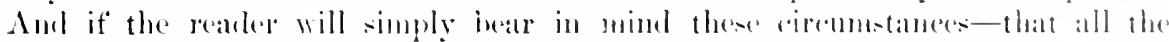

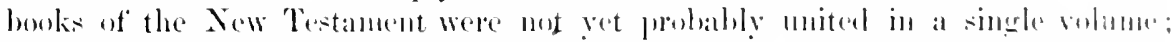

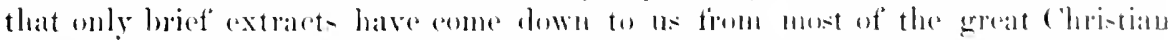

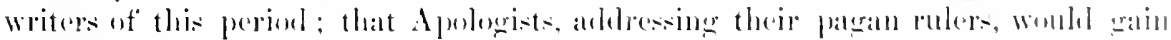

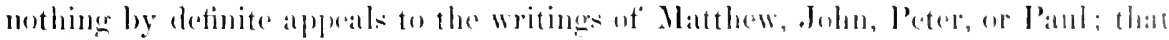
it was ton carly for tho existence of many thanslations, esperially of the whole Xiew

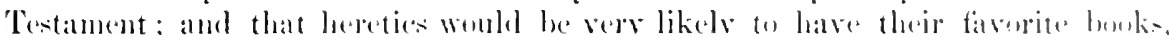
rejecting or neglecting others-he will perhaps ine gratitiol at the atmount and

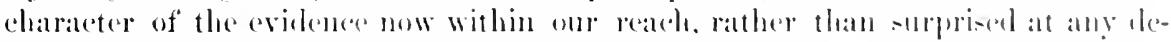
fects in the same whinh arities maly be able to distersere.

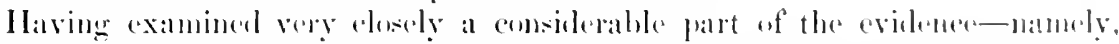

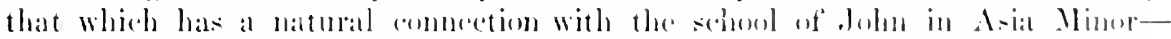

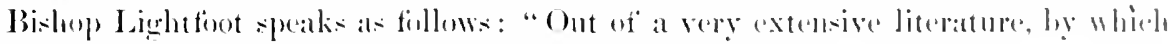

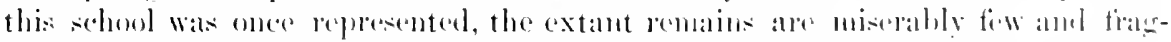

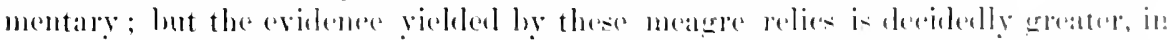
propertion to their extent, than we hald any right to expert. As resalel- the

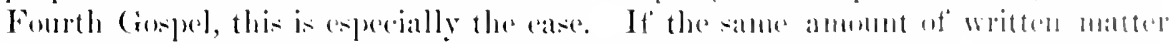

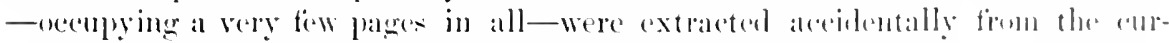

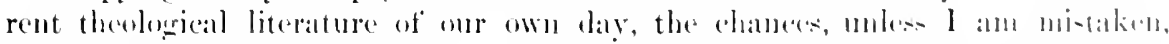
would be strongly agaimst omr finding so many indieations of the $11-1$ a this (iospel."

\section{Fla) A. 1). $17(1)-1.1), 4(1)$.}

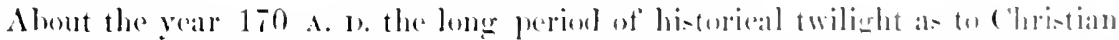

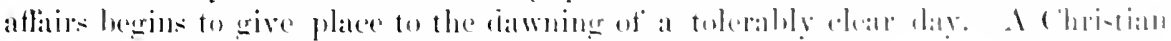

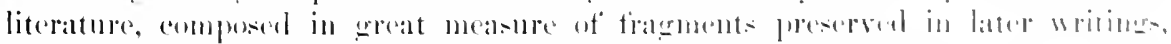

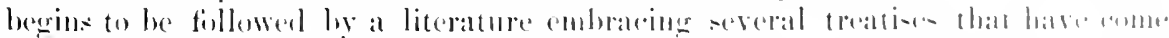

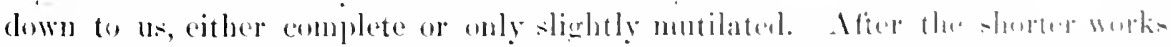
of Tatian (so far als preserved), Athenagoras, and 'Thenphilus of' Antioch we pats 
to the more extended produetions of Ireneus, Clement of Alexandria, Tertullian, and Origen, fimling eonclusive evilence that many looks of the New Testament were received ly all the churehe in Europe, Asia, and Africa as indisputably apostolic. These were the forr (xospels, the Acts of the Apostles, thinteen tivthes of Paul, and the First Epistles of Peter and John. No competent seholar will deny that from this time onward these writing were esteemed sacred ambl athoritative by the whole christian world, just as truly as they were so extecmed at the begiming of the unesent eentury. They were nowhere questioned, but everywhere aceepted as palsts of the Camom. Of the remaining books, some were received here, and others there, with alsolute confidence, while none of them were received without doubt everywhere and by all. From this time forward our attention will therefore he directed more and more to the doubtfinl books. Set it will be instrmetive to notiee the mannes in which the molisputed hooks, and expecially the four Gospens, as well as the disputed books, are characterized by the leading witers.

In the following passage I Rex wo sets forth his estimate of apostolic teaclingan estimate which was shared, without clould, by the erreat borly of christians in his day: "For we have leaned to know the ecomony of our salvation thomeln no others lut those by whom the gospel eame to us; whieh gospel they then proalued, but afterward by the will of crod deliveren to us in seriptures, that it might lee at ground and pillar of our faith. For it is not right to say that they firealded before they had a perfect knowlerlge, as some dase to aftim, boating that they are correctors of the apostles. For after ouj Lord rose again from the dearl they indeed were clothed with pories from on high, thromgh the Iloly syingt coming upon them-were filled with the spirit for all duties and had perfect knowledge; they went forth to the end of the earth, preaching good news of blesings to us from God, and annomucing edestial peace to men, because they all and eateh had the gospel of God" ( $(?$ Har., iii. 1$)$.

Of the authosship of the four Gospels he thus speaks: "Matthew indeed among the Ilehrews in their own language pulblished a witten Gospel, while Peter and Paul in Rome were preaching the govel and fonmeling the chureh. And after their departure Mark himself, the rliceiple amd interpreter of Peter, delivered to us in writing that which was preached hy Peter. Noreover, Luke, the follower of Paul, put down in a book the cospel that was preached by him. Afterwarl, Joln, the disciple of the Lom, who also leaned back on his hosme, himself published the Grospel while he was residing at Ephens in Asia" (ibirl.).

Of the general recognition of these Gospels even by hedeties he bears witness

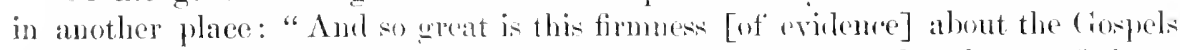
that even the hereties themselves bear testimony to them, and aleh one of them, by starting from the same, is compenterl to confirm their teaching. For the Ehionites, nsing only the (iospel aromeling to Matthew, are proved ly that to make false smppositions concerning the I Lord. But Nareion, though mutilating the (iospel acooreling to Isuke, is shown hy those portions which are still preserved by him to be a hasphemed anainst the only existing God. Moreover, those who sepanate Jesus from the Christ, and say that Christ renained inpassible, but Jeus only 


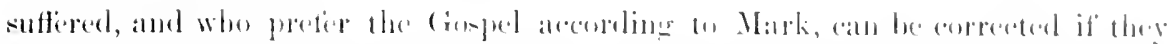

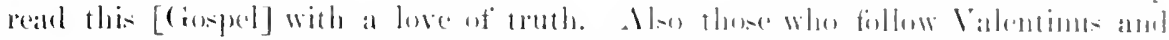

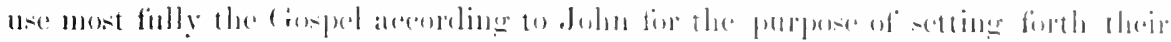

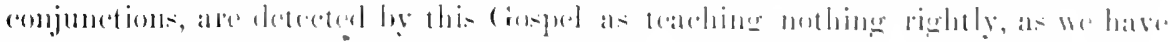

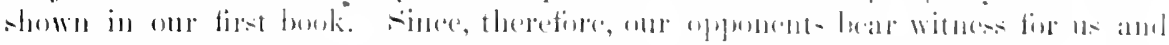

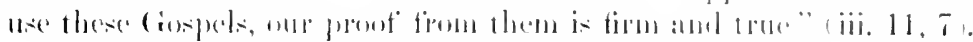

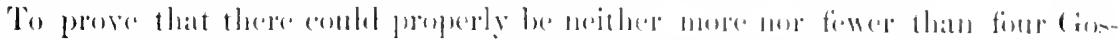

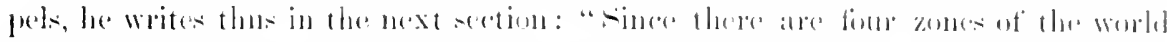

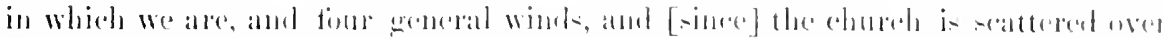

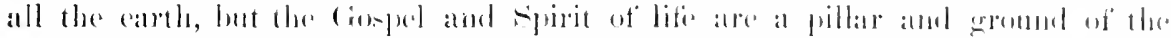

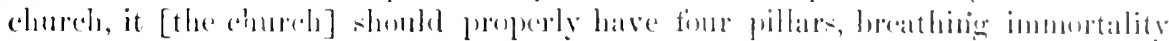

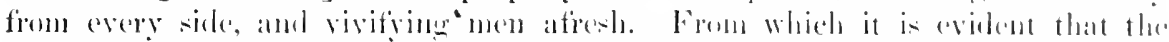

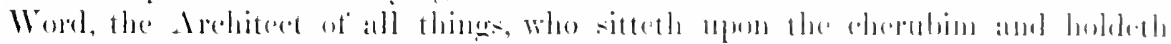

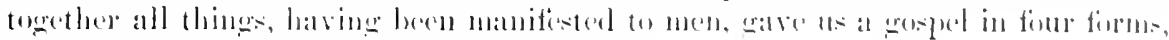

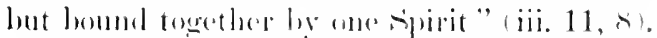

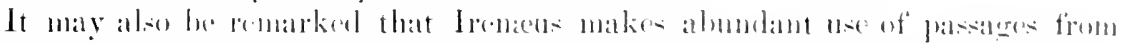

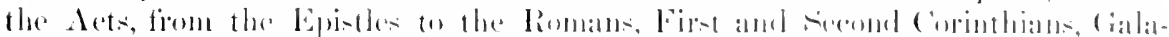

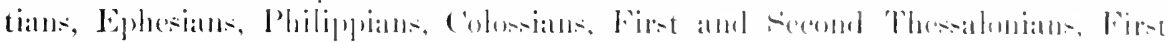

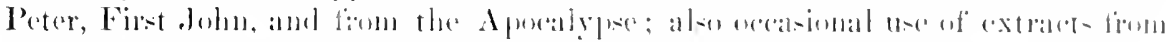

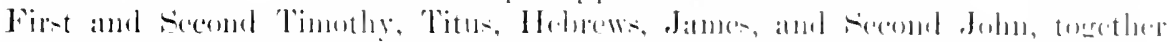

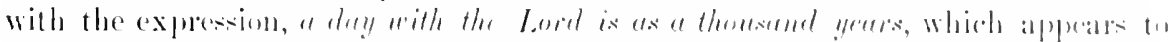

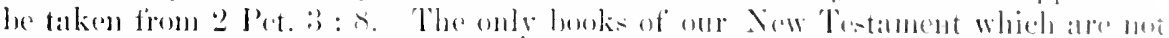

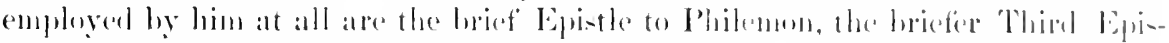

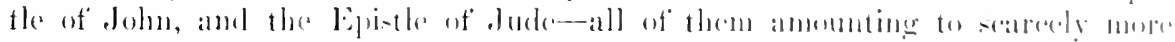

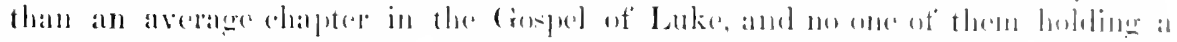

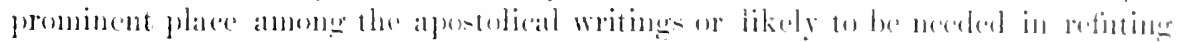

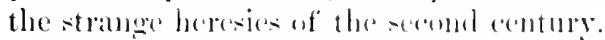

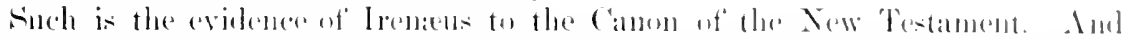

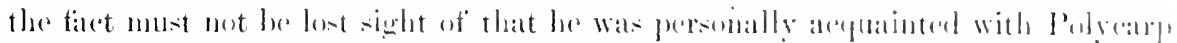

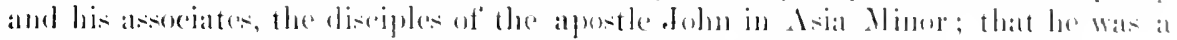

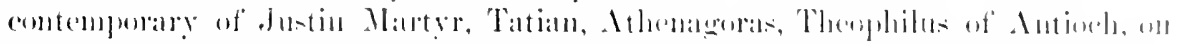

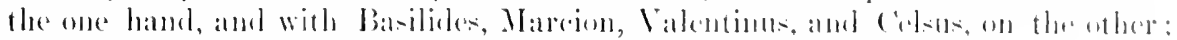

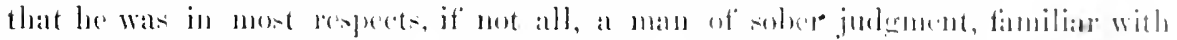

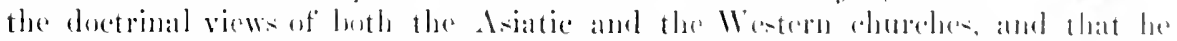

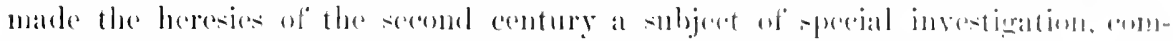

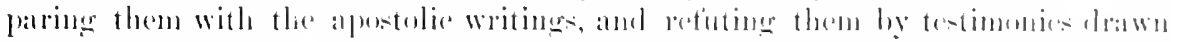

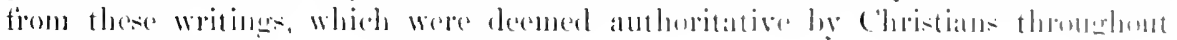
the known worlel.

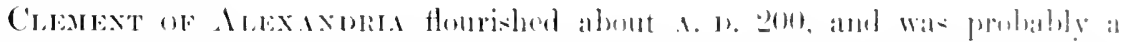

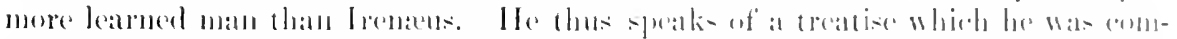

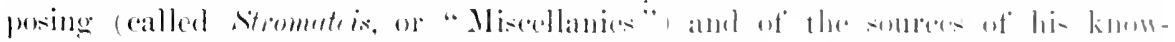

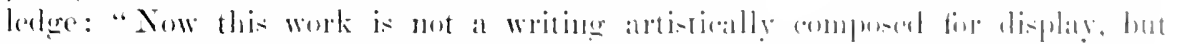

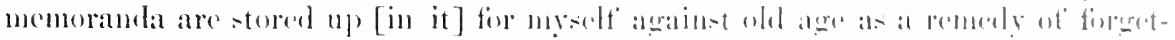

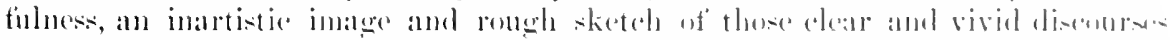
which I was thought wortly to hear, and of blesed and truly remarkable men. 
Of these, one, the Ionian, was in frecee, and others in Marna Cruecia. One of them was of ('wle-sylia, another fiom Egypt, anl sthers in [or through] the East. ()f this rexion that of Assria was one, and another in Pallestine, a Hebrew by dexcent. Whon l met with the last (he was first in ability), having hunted him

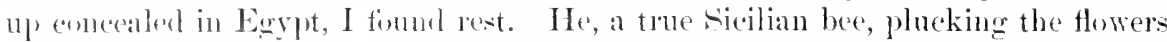
of buth the prophetic and the apostolic meatow, bewat in the souls of his heares a pure substance of knowlerlere. Sut they, preserving the veritable tradition of

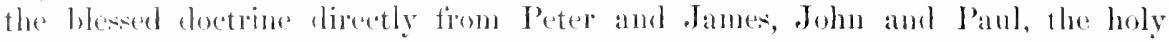
apostles, son leceiving it firm fither (but few are they who are like their fathers), same imberel hy the will of (rom to tepesit in us also those aneestral and apostolic seerk: and well I know that they will rejoice, not, I mean, as being pleased with this description, but with the mere prevervation of truth as it was noted alown" (Misell., i. 1, 11). It is generally anhitted that the perom whom Clement here calls his last and ablest teather was Jantenus, head of the catechetical school in Alexantria. Plotius reperents Pantemes as a hearer of the apostles, and, as far as age is comerlned, he might posibly have been so. At any late, he appears to have been a diligent stulent of the prophetic and apostolic Scriptures, and, as Wresteott has sald, "there is not the slightest gromnd for assuning any oromic (change in the doxtrine of the Alexandrian (hurch between the age of the apretles and Pantixus," the teacher and predecesor of Clement. The latter was at the

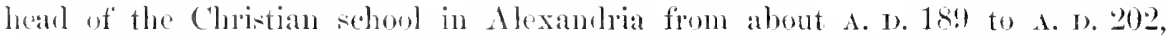
when he was compelled to kave the city by the persention under serems.

Clement makes we of the four (ropels, the Acts of the Apostles, the Epristles to the Jomans, the (orinthians ( First and Secomb), the (ialatians, the Ephesians, the (obsisins, the Philippians, the Thessolonians (First and Second), Timothy (Fijet and Second), Titus, Philemon, Hohrews, the Finst Ejistle of Peter, the Finst of . John, the Epistle of Jude, and the book of Revelation; but he appears to have no quotations from the Epristles of James, Second Peter, and Third John. Eurebius tertifies that "in the work allow Hypotoposes, Clement has given us eoncise explanations of the whole canonical solipture, without omitting the lisputed borks: I mean the Epistle of Jute and the remaining (atholic Epistles, as well as the Ejpistle of Barnabas and the soralled Revelation of Peter. Moreorer, he says that the Ejistle to the Inobews is Panl's, but that it was witten to the Hobrews in the IJebrew language, and that Iake, having arefully translated it, published

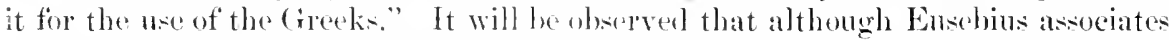
the Catholic Epistles with the Epistle of Banahas and the sorealled Fevelation of Peter, he yet distinguishes the formed fon the latter, making thereby in some seme two classes of "disputed bonks." Very noteworthy is the lamenare of Clement in respect to the Epistle to the IIthrews, thengh there are strong objections to his view that our (ireek lipistle is a tramslation.

'To the testimeny of ('lement may be suljoinerl that of Orares, his suceesor' after a time in the Alexambian schomb, and the most learned hiblical eritic of the Ante-Nicene Church. If perfect reliance enuld be placed on the translation of Rufinus, the following pastage firom his ITomilies on Joshua (vii. 2) wonlal be conclusive as to his view of the New Testament C'anon: "So too om Lorl Jesus 


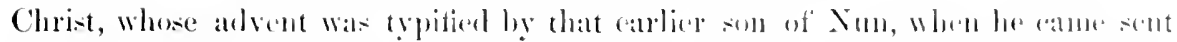

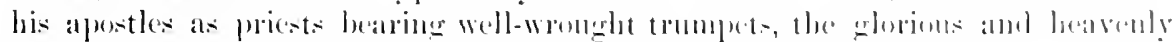

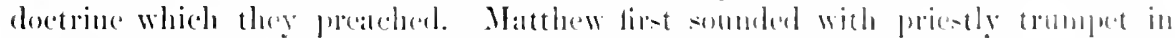

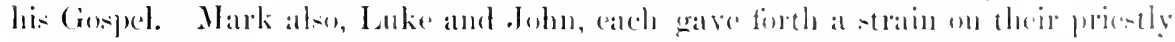

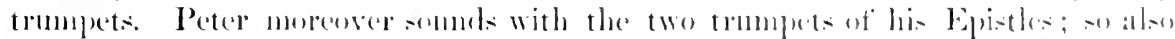

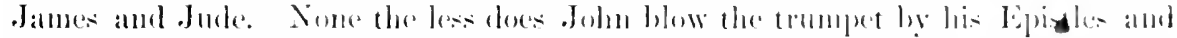

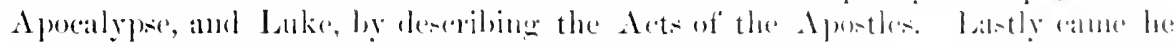

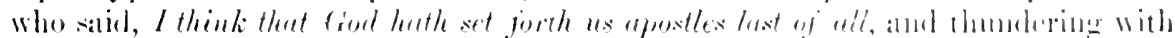

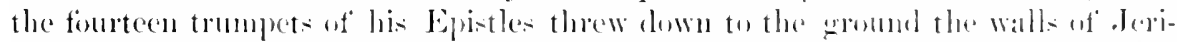

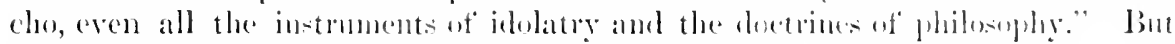

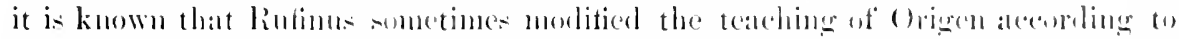
his: own belief of what was true, and therefore it is pesilhe that he hat dene so in this place. Yet there is ample evidene to be fomml in the motranslated writings

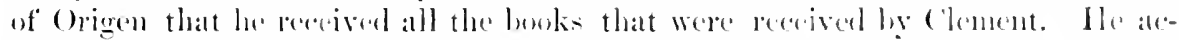

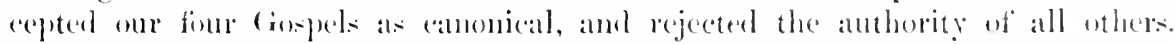

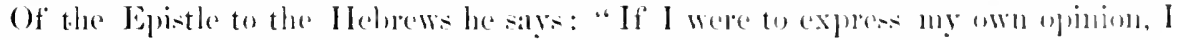

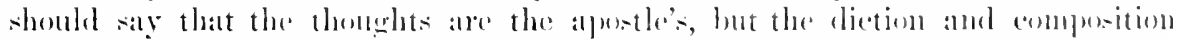
that of some one who reconded frem memory the apontles teatehing, and, ate it were,

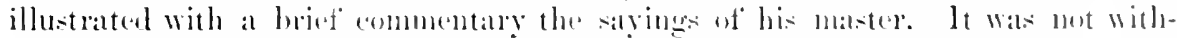
ont geod reasen that the men of wh time have hamber it down als l'alul's. But

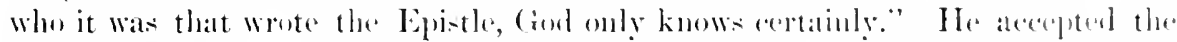

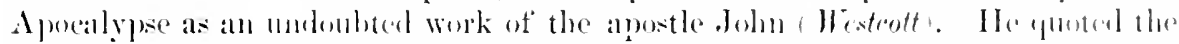

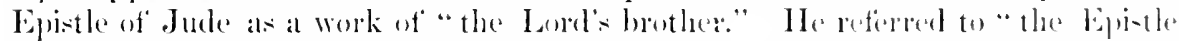

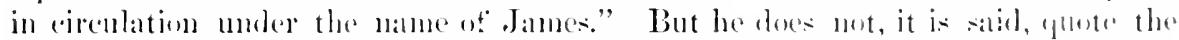

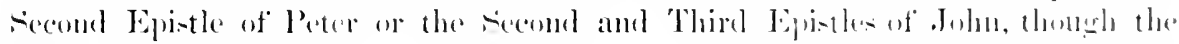

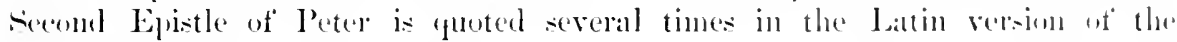
Homilies.

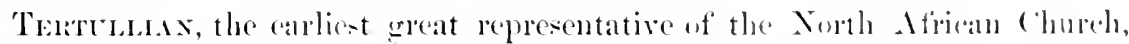
was probably born in ('arthatge about A. I. 160, and wals therefine a contempurary

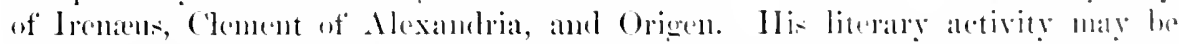

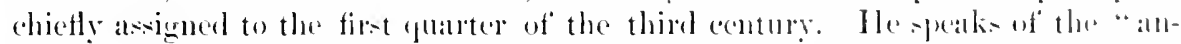

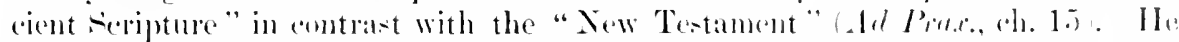

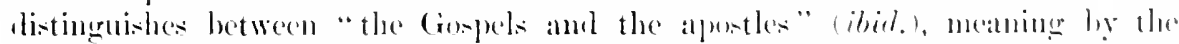

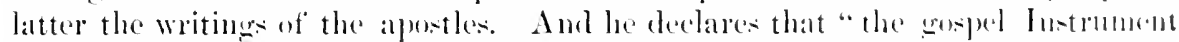

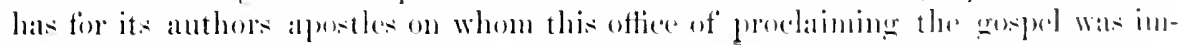

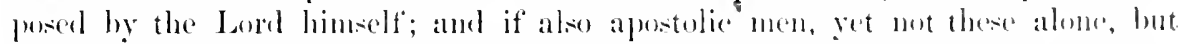

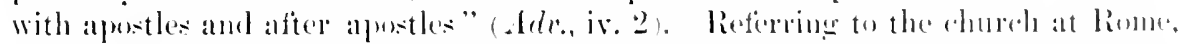

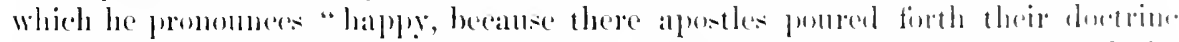
with their blowel," he declates that "she mites in one volume the law and the

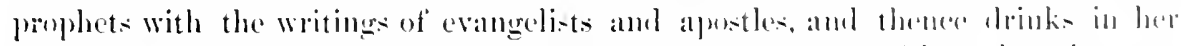

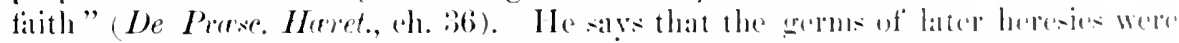

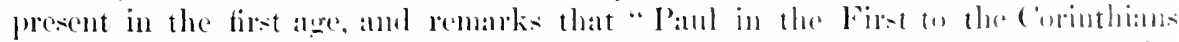

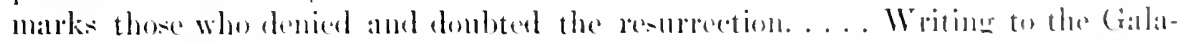
tians, he assails thowe who pratetise and defend eirenumeison and the latw. Instrueting Timothy, he also eondemus such als "forbicl to malry" (1 Tim. t: : 
Equally does he smite snch as said that 'the resurrection was already past' (2 Tim. 2:3).... When he mentions 'endless genealogies' (1 Tim. 1:4) Valentinus is reengnizel," ete. . . A Agan, "John in the Apocalype is conimanded to chative those "who eat things offered to idols and commit fornication" (Rer. 2:20). But in the Epistle he calls those antichrists in a special semere who deny that ('hrist has come in the flesh, and who do not think that Jesus is the son

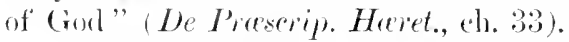

Tertullian recognizes in his writings the fou Gospels, the Acts of the Apostles, thirteen Ejistles of Paul, First Peter, First John, Jule, the A prealypec, and (though as written by Barmabas and of second-rate authority) the Epristle to the Hehrews-i.e. all the books of our New Testament except the Epistles of James, second P'eter, and second and Third John (Chateris).

It is important to bear in mind the localities with which these great writers must have been familiar. Irenaus, comected with Polycarp, with Pothinus. and with some of the hishops of Rome, may be saicl to reflect the belief of Asia Minor, Caul, and Italy; Clement of Alexandria, the pupil of Pantenus, and Origen, the distinguished scholar who was at home both in Egypt and in Palestine, may le said to reflect the belief' of Christians in Egylt, Paletine, and crecce; and 'Tertulliam, the fiery and powerful teacher at Carthige, mist be presumed to reflect the belief of the churehes of North Afriea, with which he was well actuminted, and of the churches in and about Rome, where many of the herctice, whom he ansailed with resistless torrents of argument and denunciation, resiled. Thes: these writers refresent, if they do not thably or trebly represent, the several great provinees where Christians harl become numerous and powerful.

Noticeahle also is the high authority which these writers attribute to the OHd and New Testaments. Ireneus affirms that "the Serijtures are inteed perfect, because they' were spoken by the Word of Gorl and his Spirit" (C. Herr., ii. 28, 2). Clement proposes to show that "the seriptures which wo have believed were ratified by Ommipotent Authority," and "to show fiom them to all the heresies that there is me Gorl and Lord Omnipotent, who has been truly preached by the law and the prophets, and in addition to these by the blesed gonelel " (Miscell., iv. 1). Tertullian, ly a variety of testimonies, ats well as by the use which he makes of the New Testament, proves that for him its teaching is ultimate and divine. With no less reverence does Origen treat the Seriptures of the New Tetament.

A few rematis may mow be mate in respeet to the seven disputed bouks of the New 'iestament-viz the Epistle to the Hobrews, the book of lievelation, and the Epristes of James, Julle, Seeomd and Third John, and Fecond Peter.

(1) The Epistle to the Ilelorews was generally received in Alexamdria and the East, while it was doulhterl or rejected for a long time in North Africal and the West. It is found in the Peshito, but not in the Fagment of Murateri on the ('anm, or in the carliest form of the Latin version. Origen ascribes it hahitually to Paul, though he appears to have believed that the thoughts only were the aposthe's, while the composition was by some other person. Tertullian aseribes it to Barnabas, the companion of Paul, and claims for it no more than secontary 


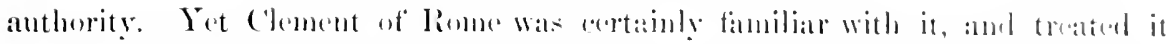

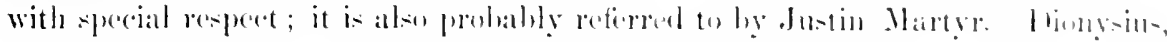

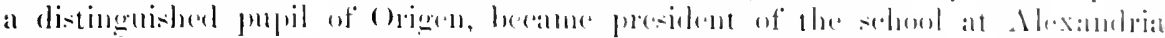

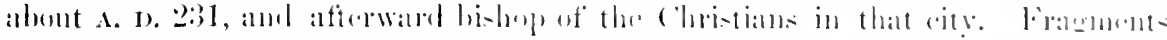

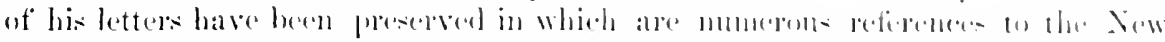

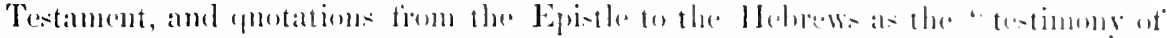

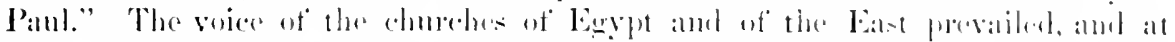

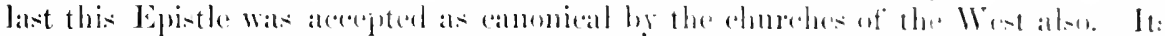

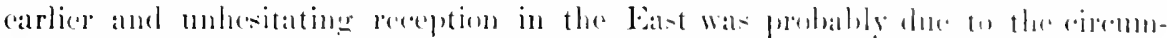

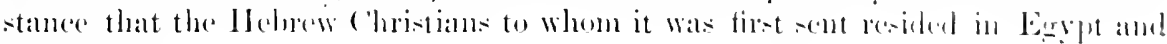
the liats

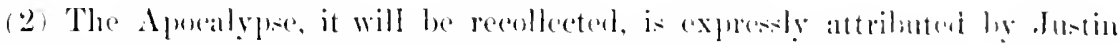

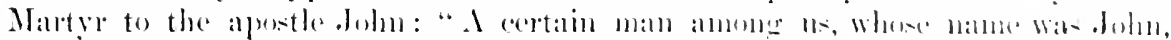

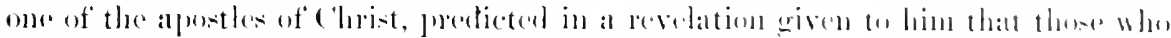

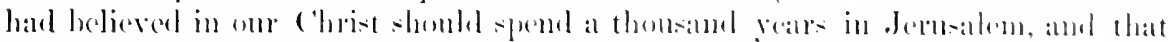

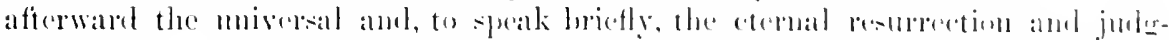

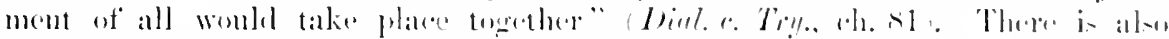

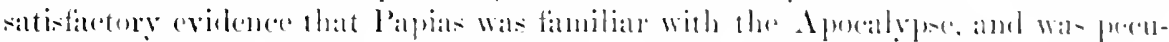

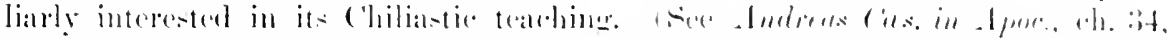

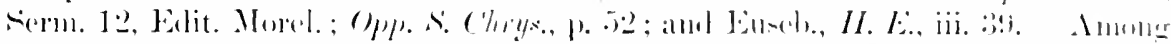

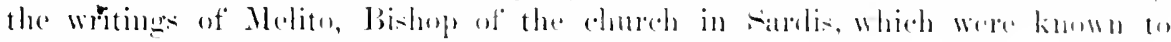

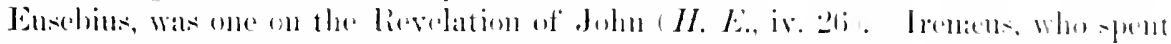

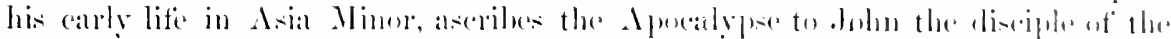

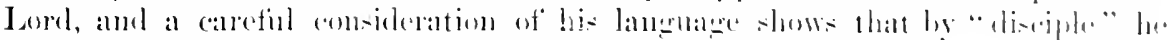

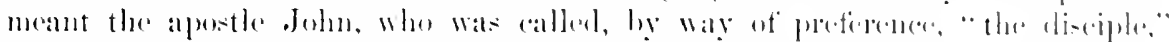

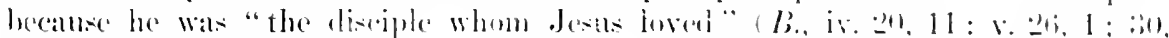

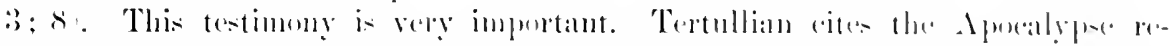

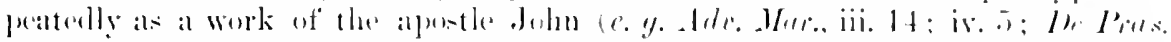

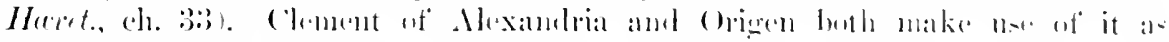

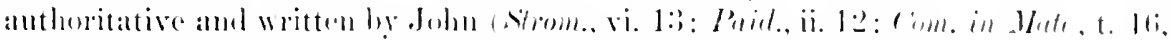
tom. iii. ]. 711; (

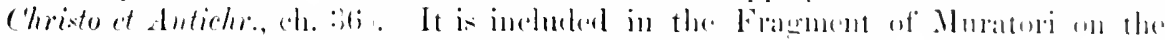

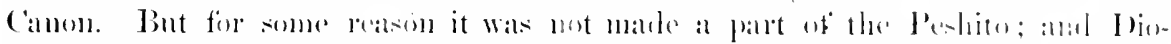

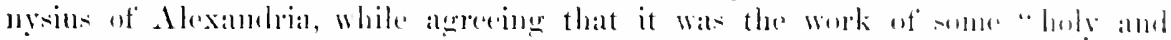

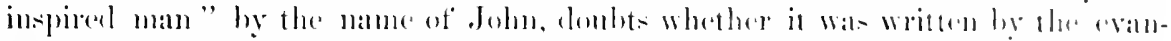

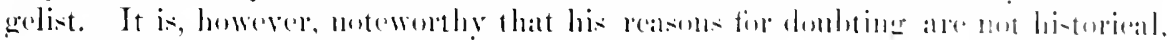

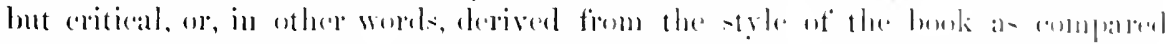

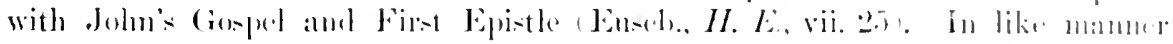

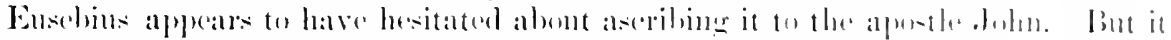

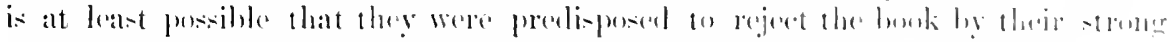

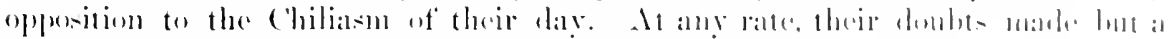

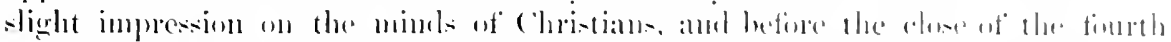

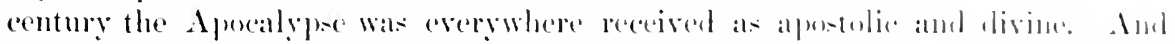

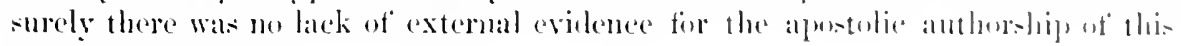
remarkable book. 
(3) The Elistle of James, like that to the Hebrews, was addressed to believing Inraclites who dil not reside in Palestine; and this cireumstance aceounts for the non-miveral reception of the Epirtle in the early church. "It was meant only fir dewish believeris, and was not likely, therefiore, to eireulate wirlely among Gentile ('hristians" (S'mith's Isict. of the Bible, p. 1208). Hence, too, it was inchuded in the P'enito, but not in the Huratorian C'anom or in most of the Mss. of the early Latin rersion. As might have been expected, it was received als camonieal in Alexamllia. Thus Origen says: "For if there may be something called faith, but exinting without works, such a faith is dead, als we have rearl in the current Epistle of James" ( ('om. in Jorn., F. 19)). Again: "As also James the apostle alys, Every gond gift and every perfect gift is from above, coming down from the Father of lights" (Com. in Ep. arl Rom., ix.). "Eusebius tells as a matter of fact that some comnter it spurious, and that there was a lack of early testimony to it; but he himself quotes it als apostolic" ("'herteris). Athamisius, a yomnger contemporary of Eusebius, accepted it as inspired and eanonieal (Ath. Opp., tom. p. 38). The oljections to the letter derived from its contents ane of no forece, and there appears to be no gowd reason to dould that the churches and their teachers were guided ly sufficient evidence in assigning to this Epistle a place in the (amon of - saripture.

(4) The Epistle of Jule purports to have been written by "the hrother of James," who must therefore have been well known to ('hristians. This James is generally betieved to have been "the Lord's brother," speken of in Gal. 1:19, the writer of the Epistle motiend above, and for many years the Bishop of the church at Jerusilem. The Muratorian Canon numbers the Epistle of Jule with the sacred books of the New Tentament. It was also in the Old Latin repsion, though not in the syriac. ('Fement of Alexamlia appeals to it in both the Paidegorgos and the Stromuteis (Prid., iii. 44; Str., iii. 11); noreover, the Latin Adumbrationes found in the editions of Clement eontain notes written by him on this Epistle, ate well ats on the First Epistle of Peter and the first two Epistles of John (Westertt, 1']. 310, 811). Origen agrees with (lement in the use of Jude as a falt of the New Testament ( ( 6 m. in .Watt., t. 10, eh. 17, and others). Tertullian speaks of the apostle Jule an bearing testimony to Enoch or the book of Enoch (Ie cultu femin, i.:?). Eurebius, while placing it with the disputed books, says that the Catholic Eplistles, incluling .Jule, are publicly used with the rest in most of the churehes (II. E., ii. (h. 2.9). It is eonsidered anthoritative and eanonical by Athanasins, ly the Lamdienan Comeil (about A. D. 364-Charteris), and by (yril of Jerusalem (Cuteches., iv. p. 36, sq.).

(5 and 6) It is difficult to see why the Seeond and Third Epistles of John should have been called " catholic" or "general," for they are manife-tly brief lettere to individuals, of no more interest to the churehes than was the letter to Plibemon, and of much less general significane than the Epistles to Timothy amel Titus. Charteris says that they "were at an early date supposed to be general, the "elect laty' and "Gails' being supposed to demote the Christian chureh." But the fact that they are brief personal letters aceounts for their being so little known to the great body of the early Christians. The writer designates himself 
or associates of apostles, and were therefore authentic statements of the original fucts and doctrines of the Christian religion.

Meanwhile, other books, with which many Chistians were particularly pleased,

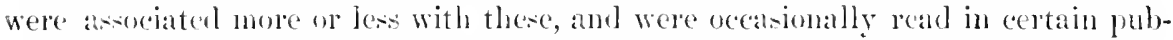
lie meetings of some of the churches. The First Epistle of Clement to the Corinthians, the so-called Epistle of Iannabas, and the Shepherd of Hermas, are perhaps the most important of these. But they seem never to have been considererl of equal authority with apostolie and inspired scripture, and they were all in due time assigned without hesitation to their true place outside the Canon.

\section{II.}

\section{ORDER OF BOOKS IN THE CANON.}

Turs has not always been the same. By the presunt arrangement the Historical part holds the first place, the Inoctrinal part the second, and the Prophetical part the third. And to this general order there secms to be no good oljection. The life and work of Jesus Christ are the logical foundation and starting-point of Christianity; hence the evangelical narratives ought to prececte everything elise in the Christian Camon. But the early work of the apostlesuntil the gowpel had gained a secure foothold anoug both Jews and Gireck- - was inseparably connected with the preaching of $\mathrm{J}$ cons and with the beginnings of the Christian religion; aceordingly, hy common consent, the story of the Acts of the Apestles is mate to follow the (rospels. With equal propriety do the Epistles, which set forth the doetrines of (chriatianity for the edifieation of believers, instructing, adnonishing, and encomaging the disciples of the lord Jesus in their confliet with evil, follow the historieal bonks, thengh it is not quite so obrions what is gained hy discegarding chromology in the arrangement of Paul's Epistles or by placing the Catholie Epistles after those of Paul. And as to the Aprocalypec, it takes the position of a final look, partly becaluse of its relation to the future, and partly hecause of the time when it was supposed to have becu written -that is, near the close of the first eentury, and after nearly or quite all the other books of the New Testanient had been griven to the churches.

This is the natural airder, ret in some of the manuseripts, as well as in the Complutemsian elition of the New Tostanent (1514), the Epirtles of I'anl precerle the Acts. In one manuseript the order is saisl to be this: the Acts, the Patuline Epistles, the Catholic Epistles, the (xorpels. In another the Apucalype

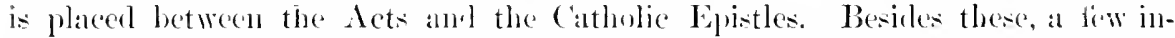
stances are mentioned by serivener (Introd. to the Crit. of the $N . T$. . p. 67) in which the three great divisions of the New Testanent do not stand in their natural order. But there instances are stricly execptional. The general orler is the following: the Gorpels, the Acts, the Catholic Epistles, the Pandine Epistles, the Aprealypese.

But when we turn our attention firom this general order to the arrangenent of books under the first and second divisions, a eertain variety alpears. The four 
as well as by the trained scholar. The letters to the Thessalonians, the Corinthians, the Galatians, the Romans, which were composed before his first imprisonment in Rome, and while lie was pushing forward his misionary work in every direction pusible, would be perecived to differ in a perfectly natural way from the letters to the Philippians, the Colosians, the Ephesians, and Philemon, which were written during his first imprisonment in Rome, and after his two years' confinement at Cesarea, while the letters to Timothy and Titus would be found in harmeny with a still later perion of life. Without being conficlent as to the mode of it: production, we are, on the whole, inclined to connect the Ejistle to the Hebrews with the mind of Paul as its primary sonree, and to assign it to the period of his confinement in Cexarea and Rome (A. 1).59-(i⿱口) ).

If the Catholic Epistles retain their present place between the writings of Paul and the book of Revelation, there might be some slight advantage in putting the three Epirtles of John after the Epistle of Jurle-thus: James, Peter, Jurle, John. And if it were a rettled result of biblical criticism that Jude was written hefore Second Peter, it might be still better to make the order James, Jude, Peter, John. For then the really general Epistles by James, Jude, and Peter woukd follow the general Epistle to the Hebrews, the order of succession in the Testament would agree with the true relation between Jude and Second Peter, and the Epistles and Apocalype of John would appear together as a final group. But, biblica scholars are by no means certain that Jude was written before Second Peter, and therefore its appropriate situation remains at present in doubt.

\section{III.}

\section{GREEK WEXT OF THE NEW TESTAMENT.}

Axy commentary worthy of the name must take account of the Greek text of the New Testament. It may expound for the most part a current version of that text, but it can never do this in a safe and satisfactory manner without comparing it with the Greek original. But that original, as it came from the hands of the apostles and their aswociates, is no longer in existence. How, then, ean we ascertain as nearly posible what it was? If the autographs have all perisher, how can we learn what they combined?

(1) From Mrouscripts of an carly age or from copies of manuscripts that were made in an early age. A few of these mannseripts, distinguished fir their antiquity and importance, are written in eapital letters, and are therefore ealled $\mathrm{wn}$ cials. It is not incredible that some of the inspired antographs were in the hands of those who prepared the oldest existing manuscripts, yet there is no evidence a'd hut little probability, of this. A great majority of knower manoscripts are written in small letters commected with one another, and are therefore called cursives.

(2) From Versions of an early age. Only those that were made during the first three centuries are of much account in establishing the original text; and , the early versions the most literal are the most useful in this respect. A fre 
paraphratic transation, however truly or ieliomatically it may express the sense of the original, is of little service in revealinge the inspired text.

(i) From (enotutions mate by the early ('luristian whiters. These quetations differ in value for textual criticion aceorling to the ane in which a griven writer

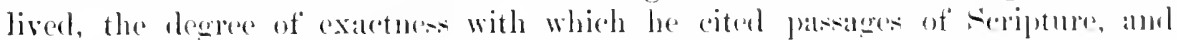

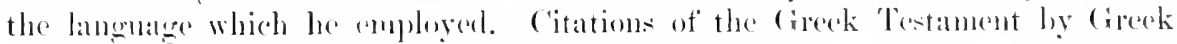

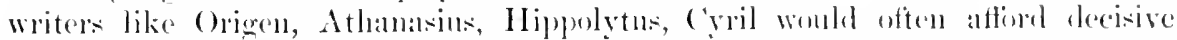
evilenee of the rext as fomm in the manmseripts usea hy them, while eitations in Latin by Tertullian or Gyprian or Augustinc would be less decisive in their evidence.

(4) From Citionl Ellitions of the New Tratament fimmlen on a careful exami mation of the precelines somres. If all the best erlitors agree in a proticular realing, there is strong reason to believe it gemune. If they differ, there is presumably some gromml for dombt, and at all conts a commentator is compelled to look

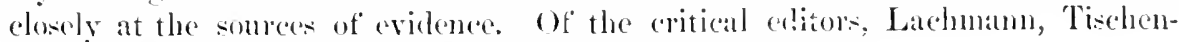
dorf, Treendies, Westeott and Hort, deserve special attention.

Retuming to the subjoet of mamuseripts, it may be observed that all the oldest Cireek eopies of the $N$ ow Testament are written in mucial (or eapital) letters. This form previled until alout the tenth eentury. But in the ninth or tenth century cursire lotters began to be used, and, with various ligatures and contractions, contimuel to be employed until the introduction of printing. By reason of their ane, thedefore, the uncial manuscripts ale, as a chas, of pre-eninent value; but are there any marks by which the earlier mantseripts of this class ean be lis-

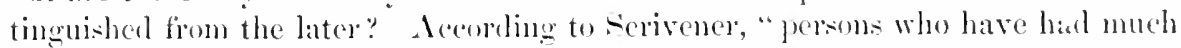
experience in the study of manu-cripts are able to distinguish [them] fiom one another in respect of stro amb eharacter so that the exact period at which each

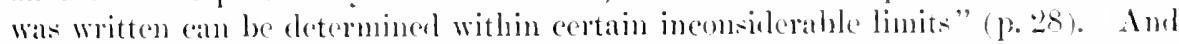
after printing rut as critically as posible, by means of fac-similes and rerbal notes, the changes which took plase in various uncial letters of the alphabet, he sums up

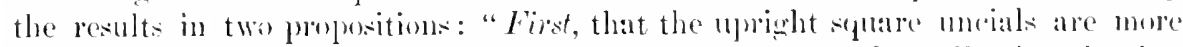
ancient than those which are narrow, oblong, or leming. Serombly, that the simpler amb less elaborate the style of writinge, the more remete its probable date" (p. 38). Of these popositions there can be no reasomble doubt, but the changes fiom century to century must le traced with peeuliar exactucss, and none but experts can spak with the highest enfidence resecting them. Fortumater, however, the mumber of experts in this branch of leaming is not likely to diminish, but to increase.

Morener, the oldest manuscripts of the New Testament ane written upuin vellum-i.e., speaking strictly, the delicate skins of young alves; or upen farchment-i.e. the skins of sheep or of goats. Indeed, the oldest are sald hy serivener to be "almost invariably inseribed on the thimest and whitest vellmm. that could be procured, while mamiscripts of later ages are usually commosed of parch ment, thick, discolored, and coarsely grained." Tet pupyrus was a cheaper mate. rial, very generally used instead of vellum or parchment at the time when the New-Testament Scriptures were written, and "its fiail and brittle quality" may 
perhaps accomnt for the finct that no miginal mamuceript of any book of the New Tetament is known to be in existence.

In form the mantraripts commonly resemble printed books. A few only are foliss, more are octavos, but the greater part are quatos, their height slightly excecling their brealth. Many copies have two (rreek colmmns on a page, hut the comex latiram has three, and the Corlex Sinaticas fomr. In the carly mucial mannsuipt: there is no space between the different words: an unbroken snceesion of letter: nul be separated by the reader into worls as his eye passes along the mintorn line. But "the sinaitic and Vatican mannecripts have a single point here and there on a level with the top of the letters, and occasionally a very small loreak in the continu us uncials, with or without the point, to denote a pance in the sonse" (Novicner). Abhreviated words are somewhat frequent, but they larely occasion any ambignity, since they are almost never resorted to muless the

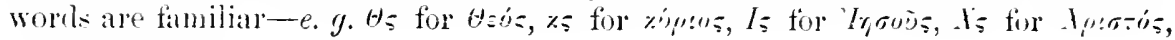

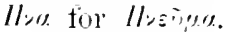

The following manuscripts must be frequently named in the Commentary, and should therefore he briefly described:

(1) The Codex Sinaiticus (or $\mathbf{x}$ ) is now in St. Petersurg, and is the property of the Rusian emperor. "It is made of the finest skins of antelopes, and its leaves are $; 0$ lange that a single aninal would funish only two" (col. Fied.-

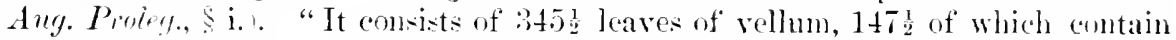
the whole Xow Tostament, the Epiotle of Bamalis, amb a fiagment of the Shepherl of Hemus. Each page contains four eolumn, with 48 lines in a column." It is supposed to have heen written about the midule of the fourth century-i. $e$.

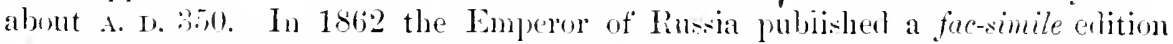
of three humber copies, edited by Tischendorf, who discovered the manuscrint in the Convent of St. Catharine, at the forst of Mount Finai, in 1844.

(2) The Corler Alexundrims (or A) is in the British Musenm. It is written on vellum in modal letters. Each page has two columns of 50 lines each. The fomth volume, of 134 leaves, contains most of the New Testament, also the First Eppistle of clement of Rome, a smatl part of the so-ealled Secomel Ejistle, and three beantiful ('luritian hymns. Matthew's Gospel is wanting form the beginning to 25: 0 : Johns, from $6: 50$ to $8: 52$ (two leaves); and Second curinthians, fion $4: 1: 3$ to $12: 6$ thee laves). All the other books of the New Testament are complete. The Catholic Epistles follow the Acts, and the Pastoral Epristles that to the Hebrews. This manuscript is ascribed on good gromeds to the beginnines or at the latest the midelle, of the fifth century, A. D. $4(00-450$. It is believer to have been taken firom $A$ lexambia to Constantinople by the patriaroh (yril Lucas, who sent it to Charles I., King of England, though the English ambassarlor, sir Thomas Roe, about 1628.

(:) The (oder lieticenus (or B) is in the Vatican Library at Rome. "All who have in-preted the colex are lour in their praises of the fine, thin vellum, the clear and clegant hand of the first penman, and the simplieity of the whole

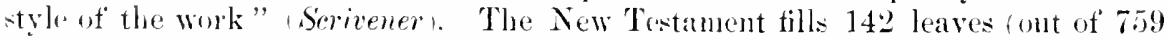
for the whole Bible). Each of the three columns on a page has 42 lines, with 16 
or 18 letters in a line-the letters being somewhat smaller than there of coulex 1 , and comsiderably smaller than those of corlex s. There are no interval- hetween

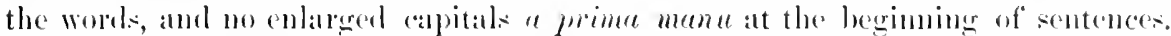
It contains the New Testament complete to Ileb. : : 14 by the original copyist, while the rest of Hebrews, the fon Pastoral Epistles, and the Aprealypere are sald to lave been supplied in the fifterenth eentury from a manureript belonging to

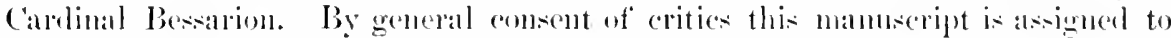

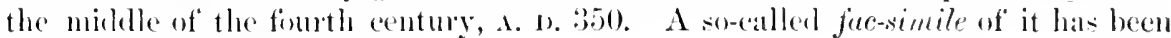
published be the lomman (inria.

(4) The Codex Ejheremi (or (') is in the Lenyal Lihrary of Pallis. It is a

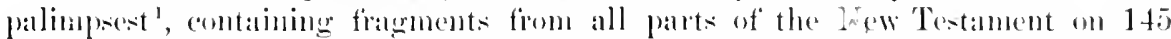
leaves, hut amoming in all to lese than two-thirik of the volume. About 85

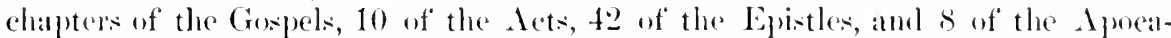
lypse have perished. It is written on vellum, very good, but not so fine als that of Codex $A$ amel some others. It has but one columm on a plage, with firom 40 to th lines in the eolumn. The letters are a little larger and more elaborate than those of $A$ or B. The writing is entinumine, with but a single point for punetuation, and this point eommonly, but mot always, put on al level with the top of the preceling letter. This mantecript belongs to the fifth eentury (about A. D. 4.50), amel is of "firstrate importanee" als fill als it geoes.

(5) The (odex Bezre (or I) of the (ionels and Aets) is in the Library of Cambridge (England), to which Lniversity it was presented by Theodore Bezal in 1581. It is a vellum manueript, thmog the material is not quite as fine as that of $x, A$, or B. The Cireek text on the left of each page is aceompanied by a Latin version on the right - line being ats nearly epperite and paralled to line as posible. The letters are of the same size as in Codex C. Both Davidson and serivener say of this manuseript that "its singularly eorrupt text, nu comection with its great antiputy, is a "mrious problem which eamot ealiiy be solved." "The best julgment of the "yge of this MIS. appears to be that which asigns it to the sixth century" "Taking the peculialrities of this ML. into eonridcration, it

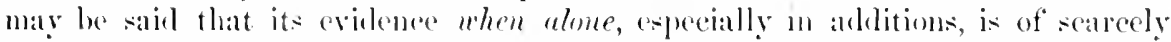
any value as to the gemuine text, but of the very greatest when corroborated by other very ancient anthority" (Tregelles).

(6) The Coder Regies (on L, is in the Royal Library of Paris. It (onsists of

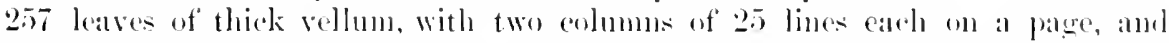

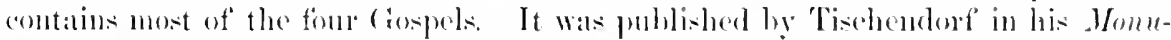
mentu Suera Ineditu, 1st6. Written in the eighth or ninth eentury, it beals at strone resemblanee in its text to ('olex $B$, to the quotations of Origerin, and to the

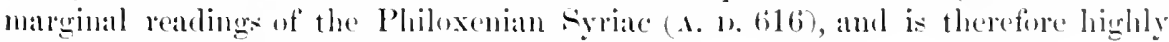
esteemed by the best critics.

The following remarks of Westeott merit attention: (1) "That B desceres the first place as an authority ; (2) That $x$ and I) have much in eommon, and a text of very high antipuity, lating from the end of the secoml century; (3) That the

I. $\epsilon$. a Colex Reseriptus, the original writing being partially obluterated and a second treatise written over it. 
(hamateristic readings of $\mathrm{C}$ and $\mathrm{L}$ indicate and and gammatical revision; (4) That in the Gospels A gives a revised text, the basis of the later Alexandrine text; (5) That the characteristic realings of $\mathrm{B}$, of $\mathbf{s}, \mathrm{I}$, and of $\mathrm{C} \mathrm{L}$, lave all more or less support in the Ante-Nicene age ; and (6) That very few reatlings in the Gospels will stand the test which are not supported by $x$ or B or D."

Mure than fiftcen hunded cursice manuscripts of the whole or of parts of the $\mathrm{New}$ Testament are known to he in existence-all of them written since A. D. 900. But only a few of this great number have been thoronghly "collatea." Some of these leserve notice in this place:

1. The Corlex Basiliensis is an illuminated mamseript at Basle, ascribed to the tenth century. It has been collated by Wetetein, C. L. Roth, and Tregelles. "In the Gospels the text is very remarkable, adhering pretty closely to the meials B L and others of that class" (Scrivener).

13. The Codex Regins .50 of the twelfth eentury is regarded (together with 69 , 124 , aml 346 ) as a transeript from a manuecript whese text was substantially the same as that of the mocial D.

33. The Coder Regius 14 is a folio of the twelfth contury, containing all the Now Testanent but the Apocalypse. The text is very valuable, isembling Corlices B, D, I, more than does that of any other cursives. "After Lalroque, Wetstein, Grieshach, Begtrup, and Scholz, it was most laboriously collated by Tregelles in 1850" (Scrivener).

157. The Codex Urbino-Iatienus of the twelfth century, pronomneed by Birch the most imprortant MS. of the New Testanent in the Vatican, after B. Among the cursives it stands next in value to Corlex 39.

20.5 and 209, belonging to the Library of St. Mark's, Venice, supposed by Burgon to be copies from the sane archetype, have a text much like that of $B$, at least in the Gospels. They are asigned respectively to the fifteenth and to the twalfth centuries.

For a more detailed account of the manuscripts of the New Testament the reader is referred to the finuth vol. of Inome's Introduction to the critical sfudy ... of the ILoly Seriptures, new alition (1866), this volume being written by S. P. Tregelles; to Scrivener's Introduction to the C'riticism of the New Testament, second edition; to The story of the Mlomeserints, by Rer. Geo. E. Merrill; and to The Critical IItundbook, by E. C. Mitehell, D. D.

Passing now to a consideration of early verwions as affording covidence in respect to the Greek text at the time when they were marle, we camot so better than to quote the following remanks of Tregalles: "The value of the testimony of versions to the genuine ancient text is conviderable; for although they have been suljected to the same easualties of transeription as has the text of the original Greek, and though at times they have been remodelled in some sort of conformity to the Greek coples then corrent, yet in general they are representatives of the Greek text from which they were firmed. The easualties of transmission would rarely, if ever, affect locuments in different languages in a way precisely similar, and we may in this manner account for not a few divergences in the versions as they have come down to us; yet when we find an avewedly aneient trans- 


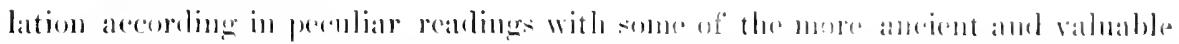

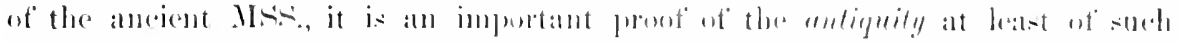

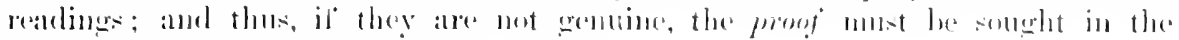

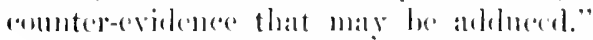

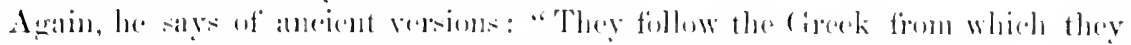

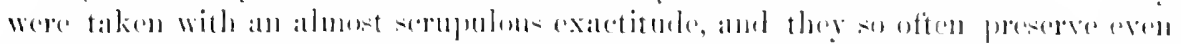

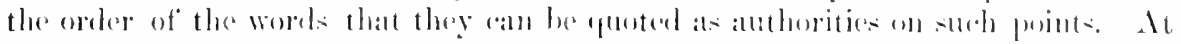

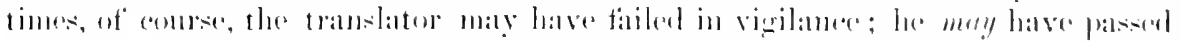

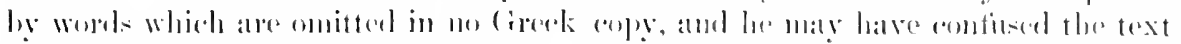

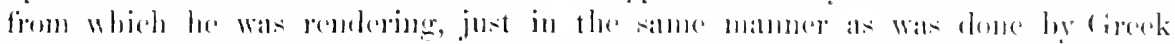

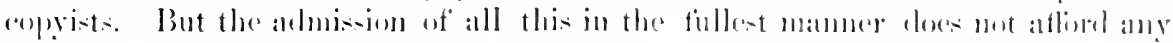

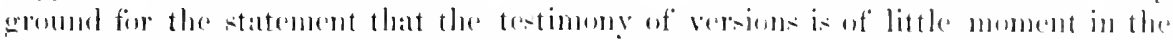

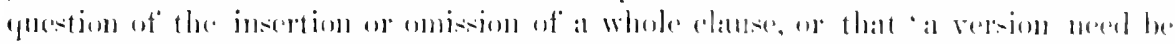

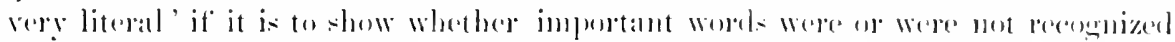

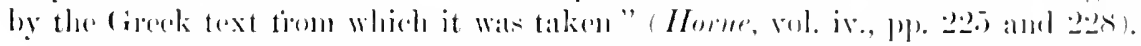

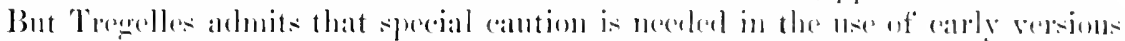

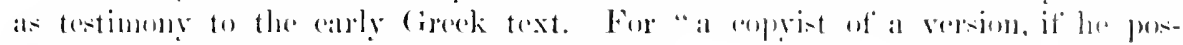

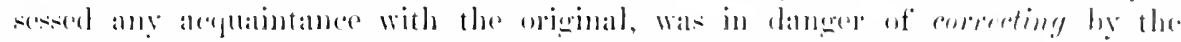

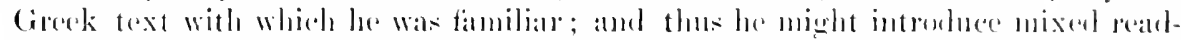

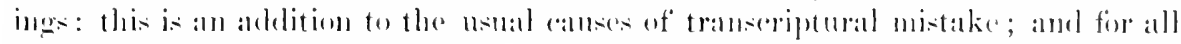

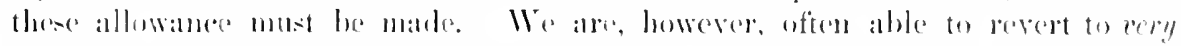

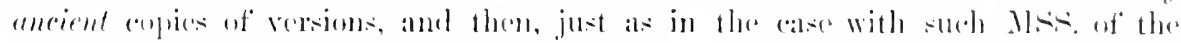

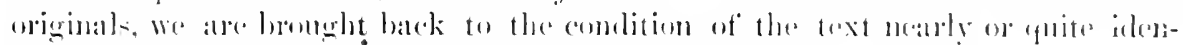

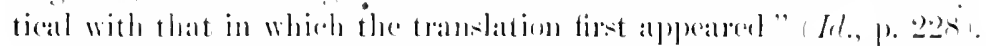

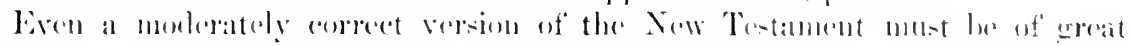

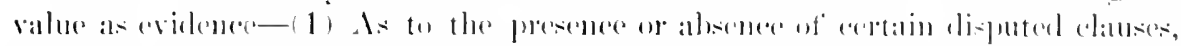

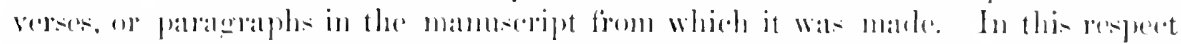

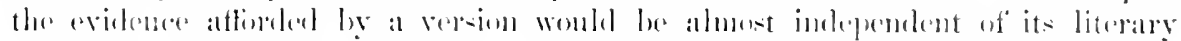

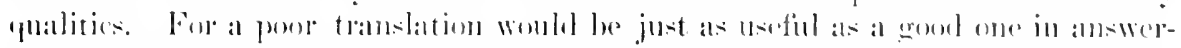

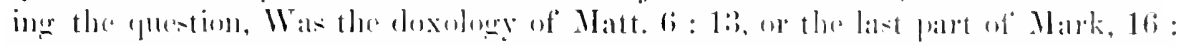

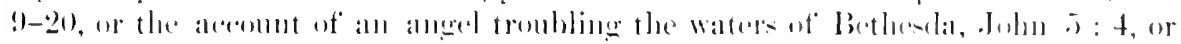

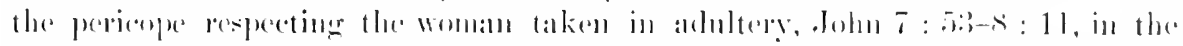

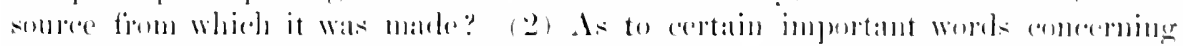

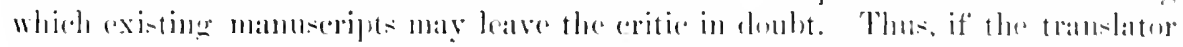

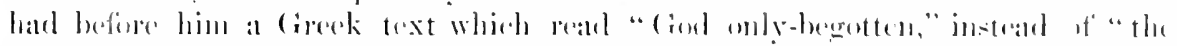

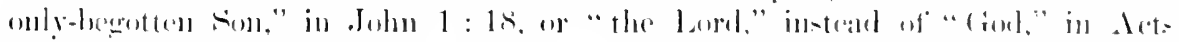

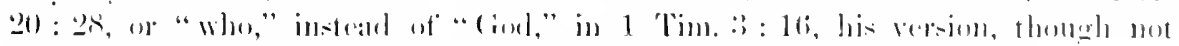

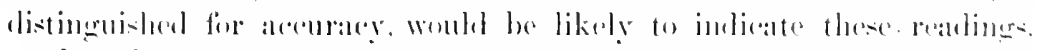

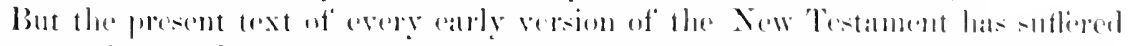

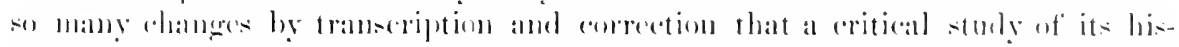

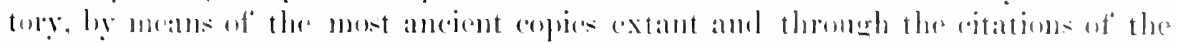

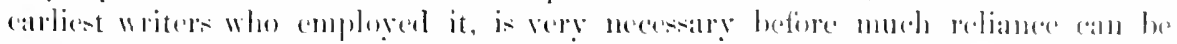

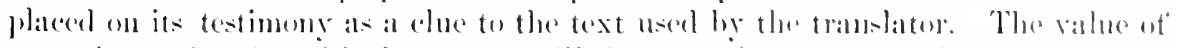

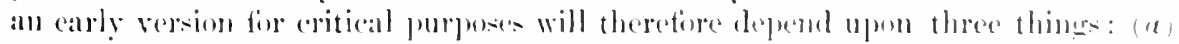
Upon the time when it was made; (b) Cpon the literall exalctues with which it 
reproduced the original; and (e) Upon the certainty with which its own primary text ean now be made ont. Julged by these testr, it is believed that the most important versions for critical purposes are-(1) The Old Latin and the Syriac (Peshito :und (uretonian); (2) The Coptic (Memphitic and Thebac), the Latin Vulgate, the Harelean syriac, and perhaps the Gothie.

As we have ahearly observesl, the first Latin version was male in North Africa, and is now fitly called the Old Latin Verion. It can be traced in several manncripts, especially a, b, $c$, and the framents of $i$, compared with quotations from the Now Tertament found in the writings of the Fathers who lived in North Africa-e.g. 'Tertullian, Cyprian, Arnobius, Lactantius, Augustine, and in the ancient Latin verwon of Irenans Against Heresies. On these and similar authorities Tregelles remarks: "In one respect the testimmy of the early Latin copiess can hardly be extimated too highly. The translators adhered so closely to the Erced text from which the voriom was formed that they practically made it their rule to follow as far as they could even the order of the Crreek words" Home, ir., p. 2565). But he distinctly concerdes that "the Veswo Vetus, as maltered, contains both readlings and corruptions which are more ancient than the time of .Jerome" -readings sustained by paramount early evidence, and defeets which were removed by the recension of Jerome. The (Hal Latin Version was probably in existence as early as the year 170, and perhaps much earlier. And scrivener asserts that "although the testimony of verwoms is peculiarly liable to doubt and error, the Peshito Srriale and Old Latin translations of the Greek Testament stand with a few of the mot ancient mannecripts of the original in the very first rank as anthorities and airs for the critical revision of the text."

There has been some elifference of opinion among scholars as to the eritical value of the Syriac Tersion of portions of the Now Testament, publisheal by Dr. Cureton in 18 is, as eomplared with the critical value of the Pewhito. Dean Alford spoke of the former as "perhaps the earliest and most important of all the versions," and Tregelles atfirms that "the reallings" [of this translation alre] "in far ereater accordance with the oldest authorities of varions kinds than is the case in the previously-known Pehito. . . . Probably this ohler form of syriac text was known to the tranklator of the Peshito Gorecks, and from it he took much that would suit his purpose," etc. On the other hand, Scrivener uses this lan-

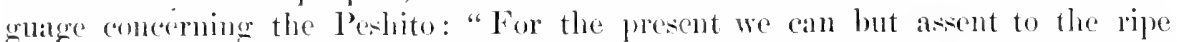

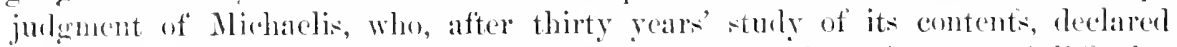
that he could (onsult no translation with so much confidence in eases of clifficulty and doubt. While remarkathle for its ease and frechom, it very seldom becomes loose or paraphratie. The Peshito has well heen called "the queen of versoms" of Ifoly Writ, for it is at once the oldest and one of the most excellent of those wherehy cool's providence has blessed and edified the church" (p. 280). Westeott clasifies the Srriac Versions thus: "The Ole (Curetonian) Syriac, the Vulgrate Srriac (Peshito), the Ilarelean Srriac," showing that he agrees with Tregelles and curetom as to the comparative ane of the two versions.

For the two Eggptian or Coptic versions, the Memplitic and the Thebaic, we may asoume a very early origin. They mathave been made before the close of 
the second century. This is admitted by Lightfout, who also remarks that, "with

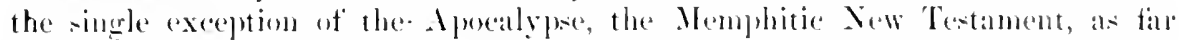

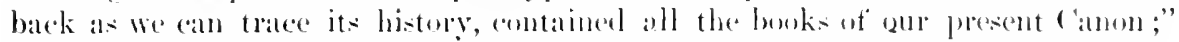

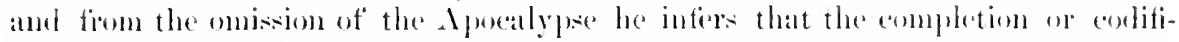
cation of this version was effiected about the midelle of the thirel entury, when,

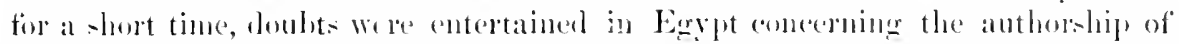

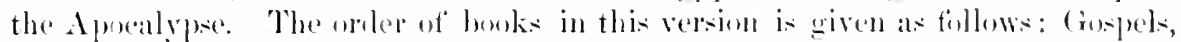

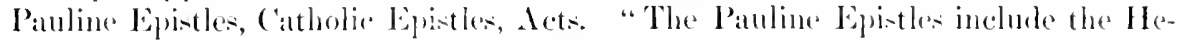
bews, which is placed after First and second Thessalonians and before First and

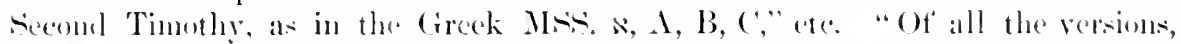
the Memplatie is perhape the most important for the textmal eritie. In puint of" antiquity it must vield the palm to the ()ld syras and the ()he latin; but, mulike them, it pueserves the best text as emrent amomer the Mlexambian Fathers,

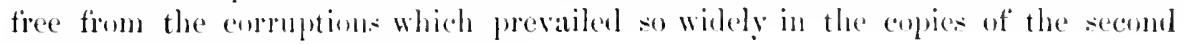

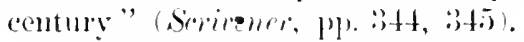

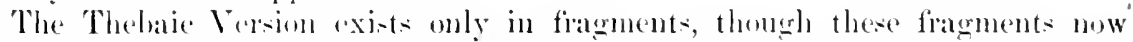
embrace a hare part of the Now Festament. In this verione as well as in the

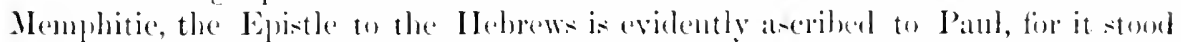

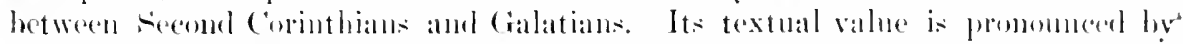
Lightiont only second to that of the Memphitie Version, of which it is wholly, inclepentent.

These are the most important of the arly versions in the matter of textmal

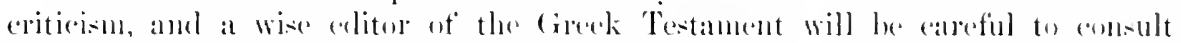
them. Others are of less value, though not unworthy of attention in the stuly of lonhtfiul palisigers.

latsty, some use may be mate in textual critieism of the mumerous quetertions: which are foumd in the writies of the Christian lathers. But these foutations are of far less servoe in estahlishing the true text than they are in proving the existence of the New-Textment seriptares at an early day, the respect which was paid to them by christians, and their substantial anerenent with the bouks we now have. In these latter lesperts their testimeny is of the highest value: in the former respert, it mont be used with very great antion, for the following reasoms: (1) The quetations of the Fathers were often mate foum memery. This is aldmitted by those most familiar with andy christian literature. Fur is it at all smprising. For if those writers were sire of the substatee of a palssige which

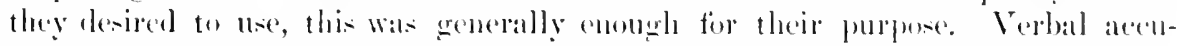
racy eould only he attaines by ansulting the manuseript in almust erery in-

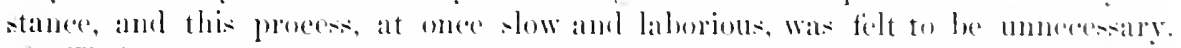
(2) Theor quotations were in many eases male up of expres-ions fiom disterent parts of seripture, lonsely put together, and giving no mole from the sereral palssages than suited their immediate object. Citations thus made an be of hut little serviee in shewing what was the realing of any passage from which a particular

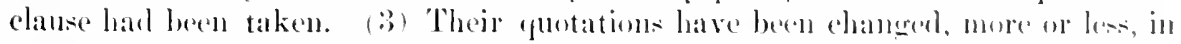
many instanees, ly (o)pyists or editors. Perhaps the ciremuntanee that they were loosely made has seemed to eopyists and editors a reason for changing them in the 
interest of accuracy; but if, in doing this, they have been guiled by the readlings femml in mameripts of their own times, they have injured the citations for purposes of textmal iriticism.

Neverthelesw, it is certanly possible to molervate the innortance of Patristic quetatims as a guile to the original text of the New Testament. For there are places, though few, where the Fathers alpeal to the corlices of their own early daly as reading thus and so, or where they discriminate between codices, salying that many of thom have a particular reading, and implying that others have it not. There are places ato where they show, by expesition or by arement, what most have been the reading accepted by theme though it is doubtful to ms. Fspecially valuable in this respect are the commentaries of Greek writers; and it is not $t(x)$ much to say that the works of Origen and of some others may be profitably studied with referenee to ancertaining the original text of the New Testament. Yet mutil the writings of the Christian Fathers have been edited with pecoliar care, and with the use of the earlict manuerijts preserved, they onght to be alprealeal to with the utmost caution.

In the light of these facts as to the sonrees of evilence respecting the original text of the New Testament, it is manifest that intermeters are called upon to decile for themselves what that erielence regnires, at leant in cases where the critical entitor's disagree; and the writers of this Commentary have sometimes dome this. It will be ohserved, howerer, that they have proceseded in this matter with rery great cantion, ramely faroring a change of the text from which the Common Version was mate unlese that change is adepted by some of the best extitols and required by ably and weighty eridence. In other language, they have labored ditigently to discover the pure wort of ( and an it was delivered to early cluristians by inspired men, and on lese diligent? to ascertain the precise meaning of that word, amd to plate that meaning in the clearest manner posible before the rearler's mind.

As an alid to the aceomplishment of this purpose it has been thenght desirable to print the Revised Version (1881) side by side with the Common Version (1611) at the tope of the palge. For, to saly nothing of improvenents in transiation, the

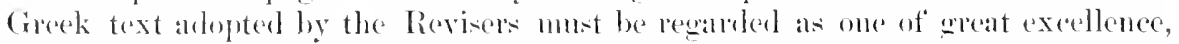
approaching more nearly perhaps than any one yet prepared to that which existed

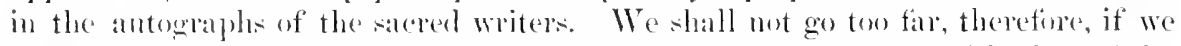

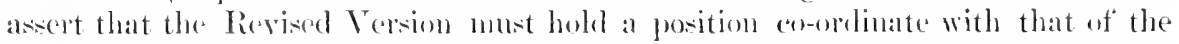
Common Verson-first, heeane it represents in per-pienous English a remarkably pure text of the original; and secomdly, beeanse it is likely to be in the hands of a vast majority of those who rearl the New Testament at all.

With these remarke this Introrhetion might be clowed. But it may not be improper to add a ferr words of explanation. (1) Special introuluetions to the several bocks of the Now Testament will be given by the writers upou these

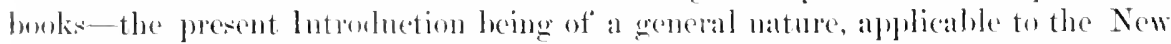
Tetament as a collection of alcoed writinge, but mot aining to give all the evidesure for" the authorship and antherity of particular books. (2) The molersigned is only responsible for the selectim of the writers who prepare this Commentary, 
and for the eneneral chatracter of the Commentary itself, but not for the details of interpretation in particular pasiages. Yet he hat in a few instances inserted hrief

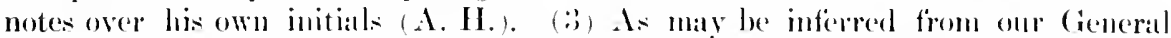
Introduetion, due regard is patid ly the writers of this ('ommentary to the results

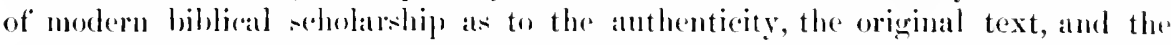
true meaning of the New-Testament soriptures. (4) Yot the results of earefiul and critical study are presented in the clatrest tems possible. Cireck words are very raroly introluced; indeed, never, muless they are deemed necessary to justify the interpretation given: and, when introkect, they are carefully translatedthe object of the writers being elistinetly this, to render the Commentary useful to

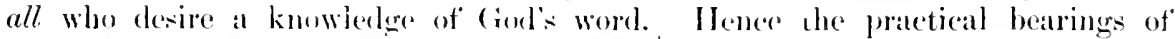
divine truth are often insisten upon 13 the Commentary.

Notb.--The remaining volumes of the ('ommentary will be publisherl as rapidly as eircum. staneses will permit. The work on many of them is far achanced, and it is confidently expected that two or nore rolmmes will be publisled yearly, until the series (probably consisting of twelve volmmes) is complete.

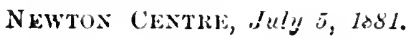




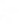


TO THE PHERISHED MEMOHS UF

\section{GESSNER IIARISON, M. D.,}

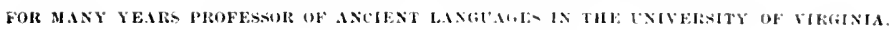

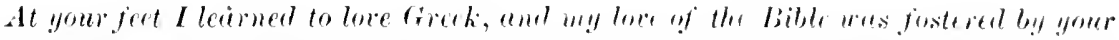

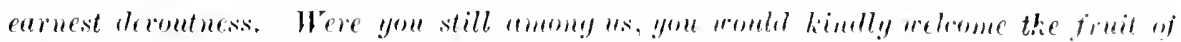

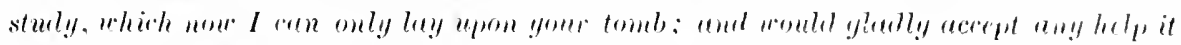

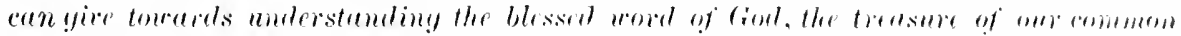

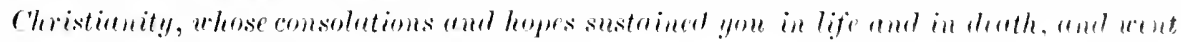
ecith you into the unsen und aternal.

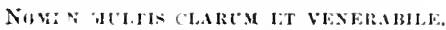

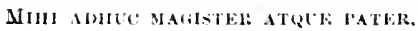

J. A. B. 


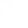

. 


\section{PREFACE.}

Turm Commentary is designed primarily for persons who have no knowled of Greek. But the effint has been made to add, in foot-notes, some matters interesting to scholars, in regard to Greek Grammar, and expecially to 'Text-('riticism. These will not embarrass the general reader, being entirely detached and printed in sutaller type.

The batsis of the work is of comrse my personal study of the Greek, mantaned throngh many years of teaching as Professor of the Interpretation of the New Textament, and renewed for this task with the help of lexiens, grammars, and concordanees. I have been far from seeking novel interpretations for their own sake but it is believed that some now light has been thrown upon a good many points.

At the same time. help has been eonstantly songht from ancient versions and Christian "Fathers." as well as from a wide range of later commentators. The early versions constanty employed were the Pesho syriac, the Memphitic (Cop)lic), the Old Latin in varions forms and Latin Vulgate, and the (ionhice.

The Fathers found mont heipfil have been Origen. Jerome, and (hrysustem, with the latter"s fathful followers, Theophylact and Buthymins and Augustime. Numerous others have of conrse been eonsulted on particular pasanger or guestions: and on two or three palsiges some eontribution has been male to the history of interpretation.

Copions materials of illustration have been derived from the Jewish writings. As regards .Josephos and Philo, the apoeryphal and apocalyptic berks, and the Mishna (chiefly in the Latin of Surenhusins). I have commonly quoted them after personal examination. For the Talmod of Jerusalem I have used sehwabs French transiation so far as it has appeared. The Talmul of babylon. the Talrerums.

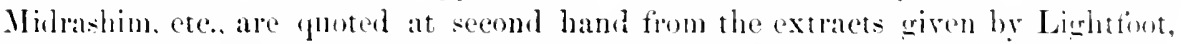
sichoetgen, Wetstein. (rill, and others, ineluding especially the reecent works of Wünshe and Eilersheim. Who have furnished nany valuable additions and correce-

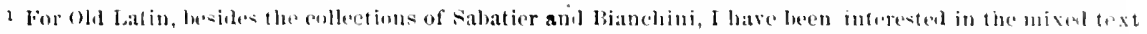

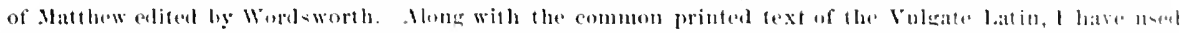

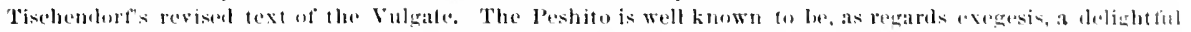

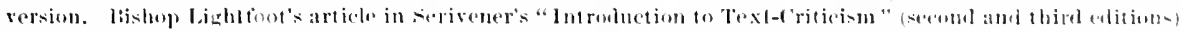

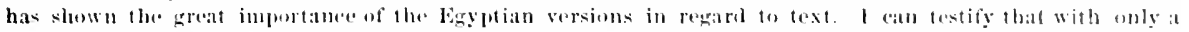

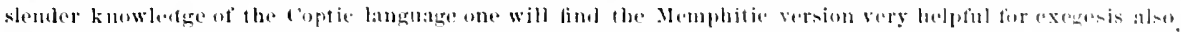

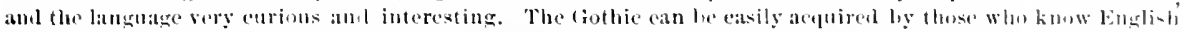

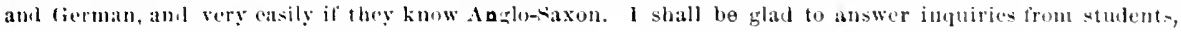
concerning books for learning Coptic and Gothic. 
tions. It is hoped that the frequent references to Josephus may lead some persons to make themselves f:tmiliar with his writings, which many now un wisely neglect. The references to the Old Testament Apocrypha are not intended to treat those writings as in any sense a part of the Bible, but they are used, like the other Jewish works, to show Jewish opinion or custom, or to exemplify certain uses of language.

Miny of the illustrative quotations from Greek and Latin classics are from Wetstein, others drawn from varions sources.

Of all these studies the commentary aims to present only the results, and everinuthere, it is hoped, in a form intelligible to the Englisli reader.

Among modern commentators, I am of course most indebted to Meyer. Lifelong study of his works, and the early adoption of similar lexico-grammatical methods of exegesis, render it difficult to determine what may have been originally due to him; special acknowledgment has been male wherever there was conscious indebtedness, and this general acknowledgment is added. I have also long found the commentaries of Bishop Ellicott a highly profitable discipline in crrammatical, and those of Bishop Lightfouot in historical interpretation ; and the various works of Camon Westeot have been of great assistance. Except in the case of Merer and Alexander, I have, in preparing this work, usually taken versions, Fathers, and later commentaries in chronological order. Thus before examining recent writers I had commonly been over the same ground. The result would naturally be frequent coincidence of opinion, and sometimes included curious resemblance of expressions. Wherever any explanation or remark has been derived from older or more recent works, there is express acknowledgment. The writings of Calvin, Maldonatus, Bengel, Keim, Weiss, Lutteroth, Plumptre, Morison, and Edersheim have been very often helpful, and others that cannot be particularly named.

As to the sources of the material common to Matthew and other Gospels, no theory has been adopted. Those who hold that Matthew and Luke were built on Mark, or the like, can render this view plausible by examples selected for the purpose. But go steadily througl, observing, for example, the attempts of Keim to show at every point that Mark has drawn from Matthew. and of Weiss to show that Matthew has built on Mark, and one can searcely fail to perceive that both hypotheses break down, notwithstanding that Keim and Weis are men of rare ability, the finest scholarship, curious ingenuity, and unhesitating freedom in manipulating the materials. Nor have the recent publications of E. A. Abbott and Rushbrooke made any very important advance upon the similar work of Ewald. As to the apparent contradictions, or "discrepancies." between Matthew and the other Gospels, I have offered such explanations as seemed reasonable, without encouraging a nervous solicitude to explain everything, where our information is limited, and the points of disagreement are such as must always arise in different reports of the same event or discourse, though each thoroughly correct.

In all such cases of uncertainty about the Greek text, as would affect the transiation or interpretation, I have intended to state the preferable reading with a 
confidence varving ateonding to the evidences and in all that are of comsiderable

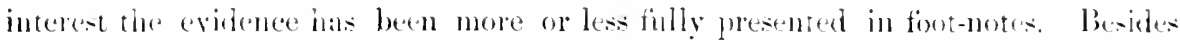
persols: alequanted with text-eriticism, other reaters who feel euriosity in reatud to the subjere will be likely to examine these foot-notes; and I have endeavored to

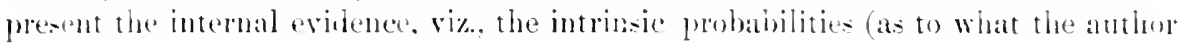
wrobe), and the transeriprional probabilities (as to changes likely to have been mate by well-neaning students or colyists), in such tems as mitht be inteiligible to the general reater. As it is momlly much easice to state transerintional than intrinsic probabilities, I may seem to hare attached a greater relative imporlance to the formel than was intended. In a good many cases the foot-note grives a tolerably

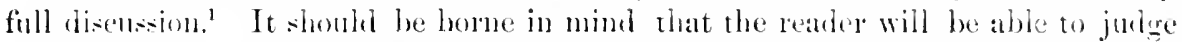
more safely of such questions in proportion as he has gainerlexperience.-Che solicitole, and even alarm, which some persons feel in rearal to the encroachntents of text-eriticism, must be rearaled as without canse. Instead of shaking falib in Seripture. these researches will ultimately strengthen fath. When the shock of abaudoning a familial expression has pased. one almosi invariably beerins to see that ihe true text is best. The general teachings of the New Testament as to doetrine and duty are now known to be established independently of all pas-onese that eontain donbtful readingrs. And why shomld we wonder it it is sontetimes difficult to determine the true text? There is well known to be a similar uneertainty as to the translation and interpretation of some passages. This excites no alam or anxiety, nor should we fech disturbed about occasional uncertainty of text. And the damerer of sulujective bias in judgring as to the text. is no greater than in regard to intermetation and traisistation.

The commentary is bised on the Common English Version, a printed lis the American Bible society, hut wih comstant comparison of the recent Aneln- Imeriean Revison. This resisom in its English form oririnally eonstituted the basis; the eommon rersion was substituted in the office of mblieation. in ories that the

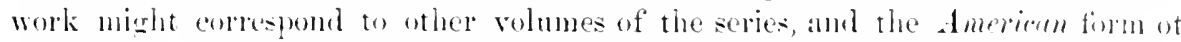
the revi-ion was printed instead of the Euglish. These aldptations were carefully made ly a competent hand, and will not embarrass or mislead the realer miles it be in one respect. The Revised Version seems otten to be presented as a merp alromative rembering; while $I$ am fully persualed that it is almust unitombly superior to the Common Version, and often gratuly superior. Wherever its render-

1 The general contributions to textacritioism male by Wecteott and llort are invaluahle, and most of their

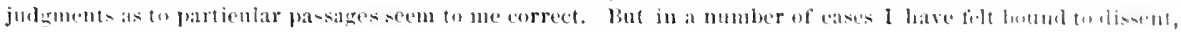

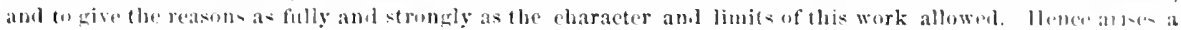

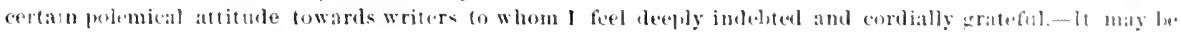

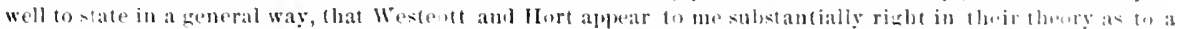

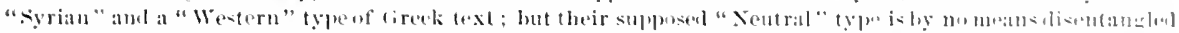

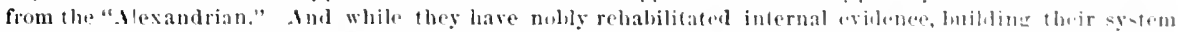

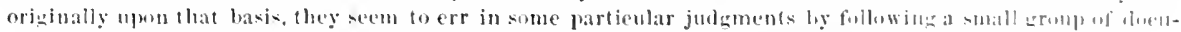

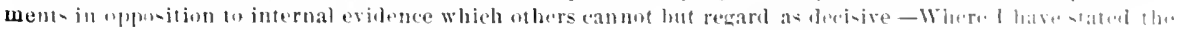

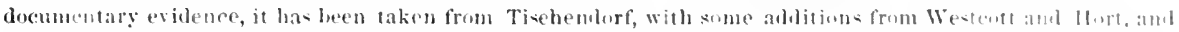
a few from my uw realing. In particular, l have added, where it seemed desirable, the readings of the newy found Codex Rossaneusis $(\mathbf{\Sigma})$. 
ings seem of questionable pronriety, the fact is distinctly brought out in the commentary. The marginal renderings of the Common and the Revised Version are nsually noticed. The early English transtations are mentioned, when bikely to mofit the general reader, omitting points of merely phiknlogical or literary interest. These verwoms have been quoted from Batgster's English Hexalpha, and where "arly English versions" in general are refered to, only these given in that collection are meant unless the contrary is stated. Certain recent English transhations are also frequenty eited, particularly those of the American Bible Union, Noyes, Darby, and Davirion.

The references to all parts of the Bible are the result of painstabing examination, and the minister or Sunday-sehool teacher who desirts to make careful study of a particular passage will find his reward in searching out all that are given. The frequent cross-references may require justification. Commentaries are chiefly used, not in the way of continums reading, but in the sturly of partienlar sentences or parauraphs. Sis that case it becomes highty convenient to find references to other fralts of the work, in which a word or phrase may be found specially explained, or a kindred topic more fully discused.

The rescriptions of places and sketehes of personal history are given for the sake of numerous readers who have no Bible Dictionary, and becanse others who would not hunt ap the book of reference might rean the brief aceount here given. These articles are constructed with a special view to the illustration of the Gospels. The materials of description are drawn from many sonrces. notably from Robinson's "Biblical Researches," and Thonson's "Land and Book," in its earlier and its later forms; also from the recent cxplontions of the English and Americun societies, particularly as renresented by the writings of Warren. Wibon, and Conder, and of Nerrill. I have of eourse been aided in the use of these materials by my own visit to Palestine: extracts from my jumbal are given in some places where the matter appeared to be interesting, and has not been found elsewhere.

Quntations from the Old Totament need special attention, for they are very numeron: in this Gosbel, and some of them presen: serious difficuly. The form of the quntation has been carefully compared with the Hebrew and the Septuarint, amd the differences of language stated and so far as possible accomted for ; the meanimg hats been still more carefully examined, so as to see how fitr we ear pereeive the ground for asserting a prophetic relation. Creat pains have been taken, in these paratres and everywhere, to state nothing as certain that is only mobable, and fi:nkly to recognize all difficulties.

The phrase "Homiletical and Pratical" became familiar to me when translatfing and rditing the protion thus designated of Lange (Erdmann) on 1 and 2 Simuel. There are some advantages in giving homiletical and practical remarks unon an cutire paragra!h, rather than upon successive verses. Tet the line cannot he sharbly drawn, and much in the way of general discusion and practieal ohservation will he found in immediate connection with the explanations. Besides detached statements of truth and suggestions of duty and consolation, I have under 
this head very often given schemes of thomght, hoping that these would be mone

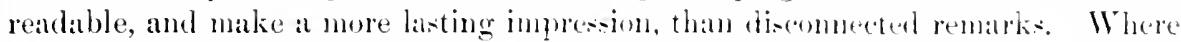
such sehemes amount to phans of semoms. they may sugerest to ministers the prate-

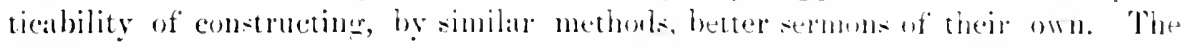

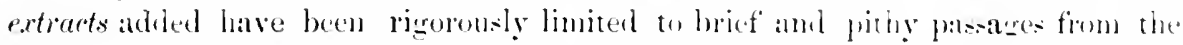
Greek and Latin Fathers, from Lather and Calvin, form . Jormy Taylor. Bishop' Hall, and Matthew Hemry, with some fiom mi-cellanents somress partionhuly on chap. 5-7. At the outsit, a good many extrates were make from the exceilent homiletical works of D. Thomas, Joseph Parker, and Bishop ligle; but as the bonk was growing too large for its design, and as these works are corrent and not costly. it was thought best, in the final revision, to strike out most of what han ixen drawn fiom these somees. The cxtracts have sometimes been condensed, or otindrise slightly altererl.

This commentary does not profess to be undenominational. Matters upois which our religrious bodies differ have been disensed with entire fiankness. but also. it is hoped, with true Christian respect and regard. After all, there are but few passages of the Gospel in regard to which evangelical opinion is seriously at variance.

The better class of Sumlay-sehool teachers have, in preparing these expositions, been eonstanty before my mind. It has been interesting to observe in the las revision, how very often ay paragraphe agree with the lesons of the luternational Series upon this Gospel, which will extend from July 1, 185t to July 1. 1sxs. The teacher who is hurried will find it easy to practice, in regard to oceasional prolomend diseussions, what a high literary authon ity has called "judiedous skiplpinge" ; for as the pertions explaned are printed in blackfaced type, the ere will quickly pats firm one word or phrase to another. Some teachers will derive usefirl pratienal instruetion for their pmpils fiom the paragraphs headed "Homiletic.n and Pratetical."

This work has been on hand more than twenty years. having been pushed forward at different periods, and for several years past with rarely interrubted application. Considerạble portions have been twice or thrice rawitten. I have labored to make a clear, sound, and useful eommentary, and I shall be rery gral and thankful it it proves accoptable and helpful to earnest reakers of the bible.

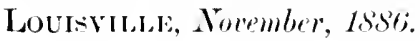

J. A. B.

For varions reasons, no Introduetion to Jathew has beren prepard. The author's views as to the origin and authority of this Gospel would be substantially the sane as may be foumd in Salmon's " Introdurtion to the Now 'Testament "; Hover's "General Introduction"; the works of Westcott and charteris on the " (amon of the New 'Testament," ete.

At the elose of the volume will be foumd an Index of the writers quoted, with explanation of abbreviatal names, and some elementary information as to the authors and their works: and a second Index of terms and topics, persons and places, of which some general aceomnt is given is the commentary upon the palssages indicated. 



\title{
THE GOSPEL ACCORIDING TO NITTHHEW.
}

\section{I P'TEIR I.}

Julk book of the generation of Jesus christ, line son of lowid, the sou nt dbraham.

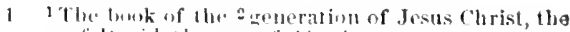

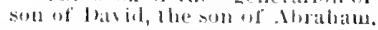

\author{
I Gr. The gonralogy of Jesus thrist ...2 Or, birth, a-iu ver, I ,
}

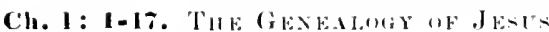
Cinkist.

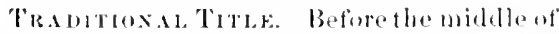
the second century, we lind the name conpel alreads applied to dhe narratives of our silk-

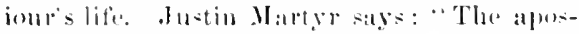
thes, in the memoirs matr by them, which are

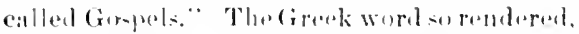

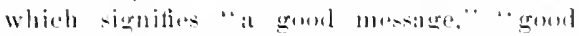

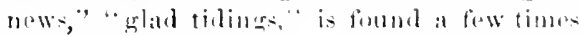

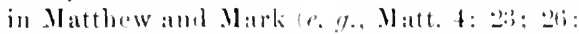

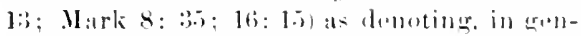

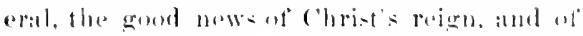

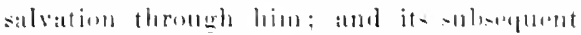
application to our four natratives of ('hriat": life and toachinge was natural and appropriate, The bertearly antheritian for the trext give the title in the simple form, Cospel aceording to batthew, some of them hasing only. Aceordiner to Matthew," wherethe word "(xispel" is implied, thengh not ax-

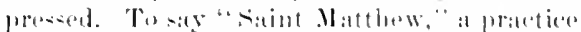
which many persens retain from Romanist

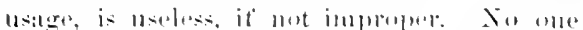

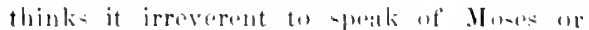

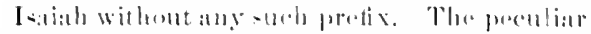

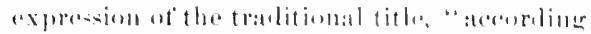

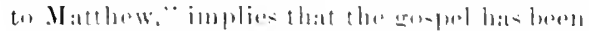

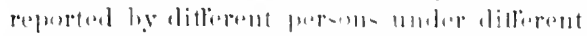
a-pects. and this is the w:I! in which Natthew

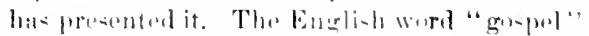

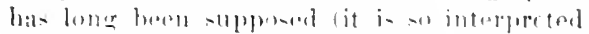
aren in the alesenth antury to be derived

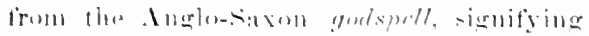

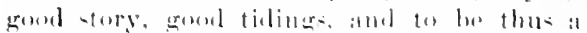
literal trandation of the direnk. But recent

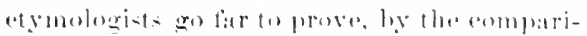

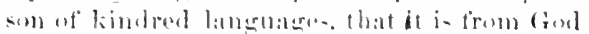
and spell, meaning a naprative of (ioml, and sol

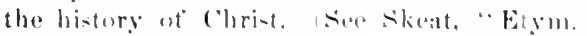
Dict. and supplement."

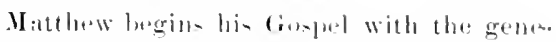
alogy of mor Lord. be-igning lo prove,

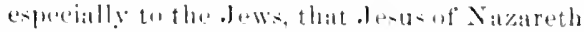

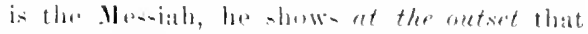

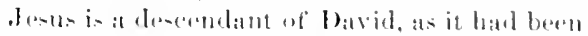

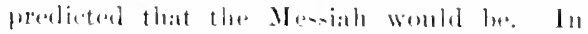

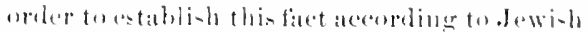
latw it mu-t bes shown that the legal tather of

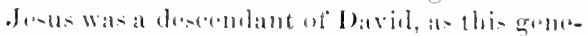
alogy deses and to give the aremourent grater

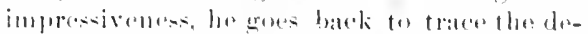
seent from $A$ brahatm, the father of the dewi-h

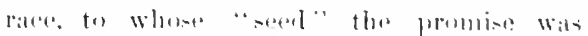

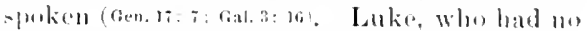

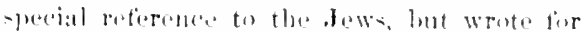

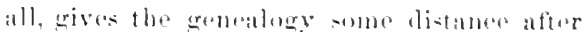
the begioning of life lowk (tonke $3: a 3$ ), and (allowe it ule to Alam, tho fathor of all

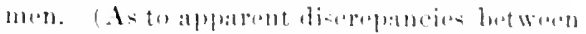

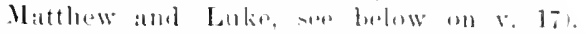
Mark, in bis short narrative given no gene-

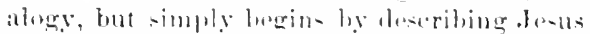

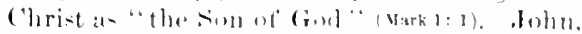

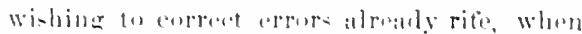
he wrote: as to hoth the hum:ta and the divine?

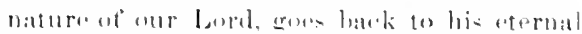
presexistence ats the Wrerl, his divinity and creatur-hip. and then statte hi- incartation.

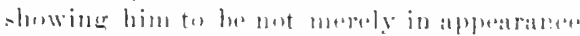

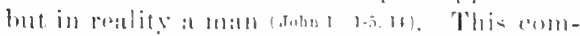
parion make it plate that Vatthew - tir-t

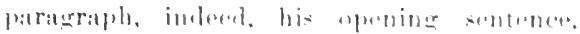

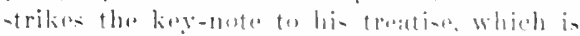

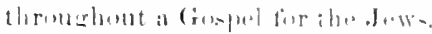

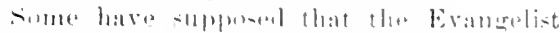

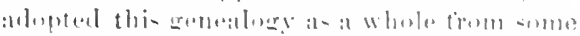

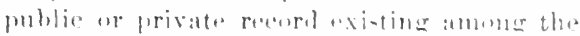

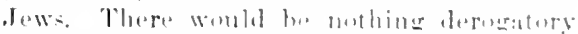

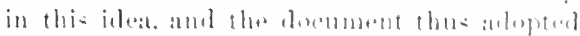

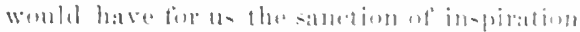
ats to its correctness; but it secms more naturab 
to think that Matthew framed the list himself trom the old Testament and the Jewish records. Some of its peculiarities, $e . g$., the incidental mention of certain females (sce below), are best explained as having been introluced by him, with a special design. That the Jews did, in the first century, still possess genealogical records, at leatst of important families, is shown by varions fincts. Thus Paul asserted without reserve that he was of the tribe of Beıjamin (Rom. 11: 1; Phil. 3:5). Josephus ("Life" " 1 ) gives his own priestly and roykdescent for several generations, and adds: "I present the deseent of our family as $I$ found it recorded in the publie tablets, and to those who try to slander us I wish much joy." This unquestionable evidence made him teel perfectly secure. And in the book against Apion (i. T) lie describes the pains taken by priests residing in Egypt, Babylon, and other toreign comtries, to send to Jerusalem properly certified statements as to marriages and births in their families; and dechares that after any great war, such as that which had reeently occurred, the surviving pritsts prepared new copies from the old records. The story told by Julius Africanus (Euseb. "IIist." I. 7, 13) that IIerod burnt the genealogies of the Jews, in order to prevent his own inferiority as an Idumsean from being manifest, conflicts with these and all the other statements on the subject, and cortainly cammot be true in its full extent. We are told that Rabbi Hillel, a contemporary of Jesus, proved from a genealogical table at Jerusalem that he was a descendant of David. ("Bereshith Rabba," f. 98, quoted by Godet, "Com. on Luke," 3: 23.) There is also a story that Domitian (A. D. 81-916) oretered all descendints of bavid to be slain, and certain hereties acensed as such the descendants of Jude, a lirother of the Saviour, who being summoned bofore the emperor acknowledged that they wore desornded from David, but stated that they lived by tilling their little farms, and showed their hands hard with toil, (from which we see, with Weise, that the family of Jesus were still pour), so that the emperor dismsised them as persons not likely to excite revolution. (Hegesippus in Euseb. "Hist." jii. 19, 20.) (On the other hand, all this is changed at the present day. The Jewish reeords have long since completely perished, and no Jew conld now prove himself' a descendant of Davill. If' one claiming to be the Messiah shomld now arise, als some Jews still expect, no such evidence could be furmished as that with which IIathew here begins.

1. The opening words signify either, Book of the generation, i. e., descent-book, pedigree, gencalogy, thus referring only to v. 2-17 (eomp. Gen. 5: 1; 11: 27), or, Book upon the birth, referring to the whole account of the birth of Jesus in eh. 1 and 2 . (Compare the use of the same term in $v .18$, there rendered 'birth'). The choice botween these two meanings of the filrase must romain a matter of doubt, and is of no real importance. The view of some that "book of the generation" hre denotes a history in general (at perhaps in Gen. 25: 19; $37: 2$ ), must protty certainly be rejeeted. Jesns, the sume as Joshua (see on v. 21), is our Lord's privite or personal name; Christ is his official rame, being a translation into Greek of the IIobrew word 'Mesiah,' which signifies 'anointed' and with the article, 'the anointed one.' (Comp. 1 Sam. 24: 6, 10; Psa. 2: 2; 10:; : 15; 1sa. 45:1; D:เn. 9: 25, 26; Jolun $1: 20,25,41$; 4: 25, 29; Acts 4: 26). It appears in the Gospels as a proper name only here, together with v. 16,18 , and probably 16 : 21 (comp. also $r$. 16, and 27: 17); Nark 1: 1; John 1: 17; 17: 3. Everywhere else in the Gonprels it denotes the promised Messiah or anointed one, semetimes without reference to J esus at all, but usually applied to him aither by direct asiortion or by implication. When not a proper name it commonly las the article, 'the Christ,' which is often omitted in Common English Version isere on 2: 4). In John 1: 41; 4: 25, we find Mresias, a Greek form of Mesiah. Whother Jesus was the Messiah, was during lis ministry an open question, and the Evangelists do lint, in their history of him, asime it as then settled. But after his ascension the apoetles would naturally take this for granted in their expresions, and accordingly 'Christ' or 'Jesus christ,' is very otten used in the Acts and Epistles as a propur name. It like manner Matthew, Mark, and John, in writing their Goipls we the same nuw fitmiliar expression in the introduction, though in the berly of their marrative they speak acenrding to the state of the question when the events 
2 Alraham begal Isaae: and lsata begat dacob; a and Jacob legeat Julas and his lorelbren:

3) Ind Judas begat l'hares alld Katrat of Thamar ; and

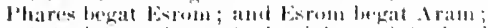

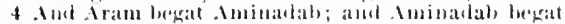

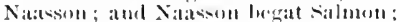

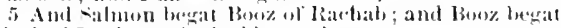

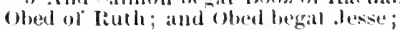

2 Nhraham legat Isatac; and Isate lexpit Jacob: and

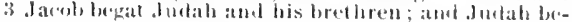

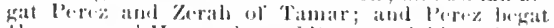

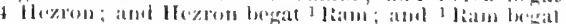

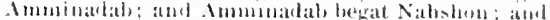

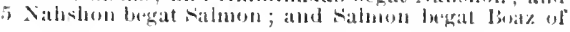

oecurred. In 16: 21 we may see a special reason, as there pointed ont. And so Jusus himself, in John 17: 3, when protying in the presonece of his disciples at the elose of his ministry, speaks as taking his Messiahship tor granted; as in Mark 9: 41 , 'beause ye are Christ's, he is anticipating the future conviction of his followers. Son of Abrahnu maty be in appesition rither with 'David' or with 'Jesus Christ,' the Greek being ambiguone, like the English. But either sense involves what the otluer would exprese, and so both amount to the same thing: in Jesus were fulfilloul the propheeies that the Messiah should descent from David and from Abraham.

2. Among the sons of Jacob, Judas, or Juduh, is singled out, breatro he is the one from whom David and desus wore desended; but his brethren arealso mentioned hy the Evangelist, perhaps simply becaune it was common to speak of the twelve patriarchs and the twelve tribes all togerthor (.tets $\left.7: y_{1} 9\right)$; or, it maly be, with the denign of reminding his peaters that all the other tribes were of the same descent as Judah, and thus all were interested in the Ilesiall.

Nany of the names in this list are, in the Common English Version. more or lese different in form from the eorrespunding names in our version of the Olal Tomtament, and thromehout the New Testament the same thing frepuently oreme. The Now Tratamont writers have usually employed that form of a name which was alreacile familiar to their reatlers, who were ganerally aceustomed, Jews a well at Gentiles, to reat, not the original Hebrew of the (1)d Testamsentfor the Ilenrew proper wat then little used in eonversation (the Aramaic having larerely supplanted it)-but the Greek translation konwu as the septuagint. The atuthors of that trabialation often fated to express the IJehrow names in Groek as oxactly as they might have dune. Besilhe, th. tamek lan- guage is in some respecto lens able to express Holues word than the English is, particalarly in resperet to the letter he which abounds in Ilalorew mames, and which the (ireek cannot represent at all exeept at the begimiagen of a word. or in the combinations ch, the phe Aceorlingly. Noah wats written Noe (24, 3i), Korals written ('ore (Juten), and Elisha be-

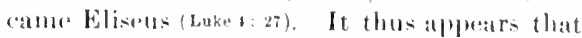
not only have the names in our version of the Tru Testame:-t undergono a two-foll ehamere, -presenting u- the English form of the enonmon Creek form of the Helwew words-hut the ditlerence in increased by the fient that in (nur version of the old Testament, remelered direetly from the Ilobres, we have the name often more exactly axpresed than could be done in Grens. The writers of the New Terstament gave their readers the furm of the names that they wore all familiar with in realling the Soptuagint; so that they bad tho sume form in beth Testaments. And this result will be secureal for English readlers if in the Now Testament we -hould put inte English leters mot the (iroek form of the name as there given, hut the Hobrew form as it aecurs in the (0)d Tostament. Then the reader of on vereion, like the reitler in the apostle's days, will find the name in the anme form throughout his Bible, and wibl thus feet that it is the same name. There must be at few exceptions; as, for cosmonle, it would hardly be proper to write our saloburs name Iorbita, thengla we shosuld thas be much more vividly reminderl of the orierin and atsomiat-

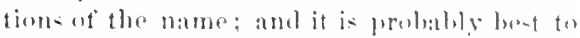
retain the fireek form, Judase for the tratur

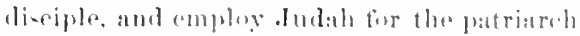
and others and Jude for the writer of the

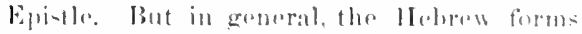

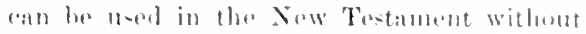
ditliculty or imprepriety.

3-5. Commentature have al ways noticed

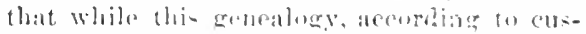
tom, gives only the names of tibe men, it 
6 And Jesse begat David the king; and David the kiug berat solomon of her thit hed been the wife of Urias;

7 And solomon begat lioboam; and loboam begat Abia; ant Abia begat lsis;

$x$ Aml Asa begat Josaphiat and Josaphat begat Joram ; sud Jorim iregat ()ziar;

y And Gzias begat Joatham; and Joathan begat Achaz: ind Achaz breat lizekias;

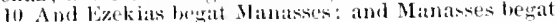
Amous ; and Anum hegat Josiats;

1t Aibl.losias bewat fechunias and his brethren, about the time they were earried away to liat ylom:

12. And alter they were browght to Babylon, Jechonias begat salathiel; and salathed lecat Zoribahel;
6 Tahah: and boaz begat obed of Ruth: and Olsed begat denese; and Jess. begat loavid lhe king.

Ant lar id begat solomonn of ber that hat been the

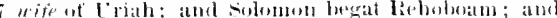
Relwhosm hegat Abijoth; and Nbijah begat Isar; 8 aml A-at begat Tehoshaphat and Jehushiphol be-

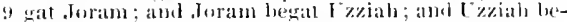

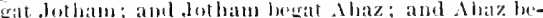
10 gat Ilezekiah; and Ilezekiah hegat Mauanseh; and Alanasoh begat 2 Anon; and 2 Amon begat Josiah; 11 and Josiah tegat ferhoniah abl his bredhren, al the time of the "arrying aw wy to bahelon.

12 And after tha searring away to l'ithlon, Jechoniah begat 4 shealtiel; and shealteil begat Ze-

1 Or, Asaph....2 Gr. Amos....3 orr, removal to Babylon..... Gr. Salathiel.

turns aside to make incidental mention of four women-Thamar, Rahab, Ruth, and the wife of Uriah-of" whom three were polluted by shameful wickedness, and the fourth was by birth a beathen. This appears to have been done simply becaluse anch of the four became a mother of the Mrssianic line in an irregular and extraordinary way, as in recounting a long list of names one is very apt to mention anything unowal that attaches to this or that indivilual. The anystical meanings which some find in the introduction of these names, cannot be accepted by a sober judgment; and the notion (Lange) that Tamar, for example, really acted under the impulse of a fonatieal faith, "being resolved at all bazards to beome one of the mothers of God's ehosen mee," is a partieularly wild fancy.-The introduction of leth Phares and Zara, while throughout the l'st only one person is usually given, is probably due to the fact that Tamar their mother has been mentioned (comp. 1 (hron. 2: 4), and that we bore them both at one birth. - There is ne suffirient reason to question that the Rahab here mentioned is the fimoms womin of Joricho; nor that she hat pursued the disgrameful alling eommonly stupued.- The lengtla of time botween Salmon and David makes it likely that some nambes hase lwen loreornitted (as also in liuth 4: 21 f., and 1

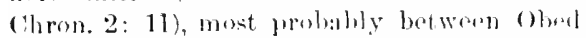
and Jesse; but this is not certain, ats the treneral

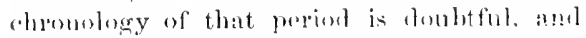
the parents in some aseses maty lacre been antvanced in years when the chiblen were lurn.

6. David the ling is thas signalized, probably as being the first of this line who attained that dignity, and he to whom the ponnise wats marde of a seed that shomld pering forever. In the seeond sentence of this verse, "the' fing' in the common text is a mere addition from the first sentence, wanting in several of the best early douments.

8. Between Jornm and Uzziah, three names are omitted, Ahaziah, Joa-h, and Amazial (2 Kinge 8:24; 1 Chmn. $3: 11 ; 2$ Chron. 22:1,11;24:27). This wits probably done to sceure symmetry, by bringing the number of names in each discourse to fourteen (see on v. 17); and these particular persons might naturally be selected for omiscion, beause they wort mmediate descendants of $A$ hab and Jezebel.

11, 12. Here also a name has been omittod, that of Jehoiakim, who was the son of Josiah, and father of Jeholachin, or Jeeoniah ( 2 kings 23: 34:24:6). As in v. 8, we may suppose one llame to have been purposely omitted by the Frangelist, and this partieular person to bave bern thosen heciluse in lis raign occurred the aront- which led to the captivity. As to the further diffichlty on which some have insisted, that while we reat here of Jechonias and his brethrea, in 1 Chron. 9 : 16 , but one brother of his is mentionad,--it is enough to recall the fumiliar facet that genealugieal lists such as that very often onit some of a man's children, mentioning mly those which belongerl to the line of strocesion, or which there was some speceial reason for incluting; and so there mieht very woll have lesen other brothers known from genosalogies existing in Matthew's time, but whom the compler of chronides had no oreasion to include in his li-t.-The expression, the time they were carried away to babylon-or, the remerel, mar. of Rev. Ver., -is of course not to be presed as involving an exaret enincidenee of the woevents, lut to be munderstood in the more semeral way, which is natural in sueh casses. Josiah died some years before the removil to Babylon (2 chrou. i6). This great event was 


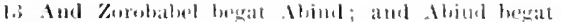
Eliakim; aml liakim begall Izol;

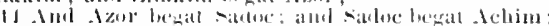
and drhim begat liliud:

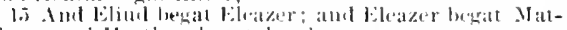

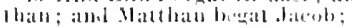

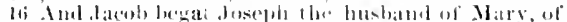

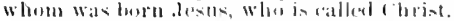

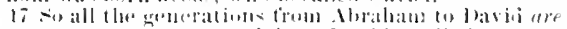

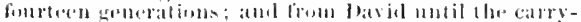

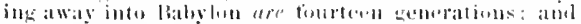

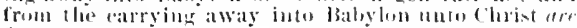
forterten genciations.

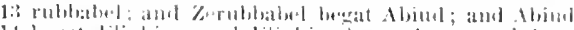

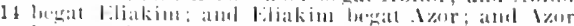

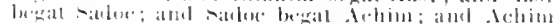

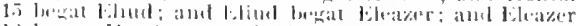

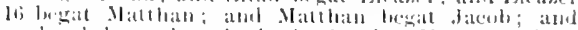

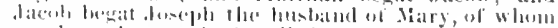

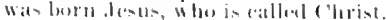

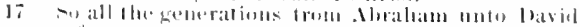

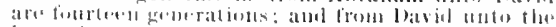

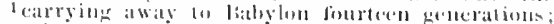

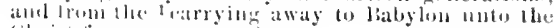
Christ fourteren menerifions.

I Or. Rt novat to Bitbylen.

really a foreibletran-portation, but the Evangali-t uses the miller term 'rement' or

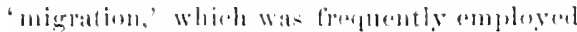

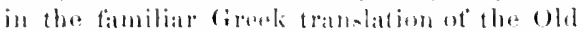
Tetalment, and would he less painful to the

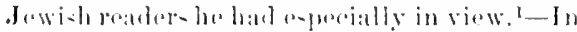

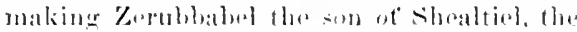

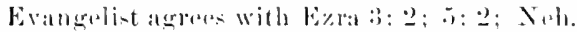

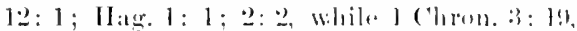

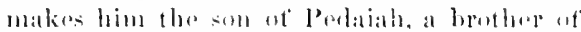

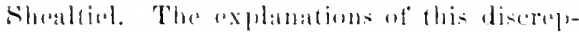

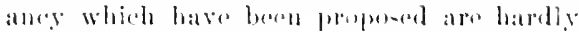
sittistatery. It is met surprising that there

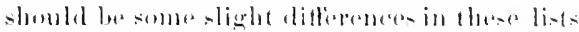

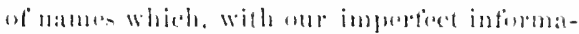
tion, wo are now manlila to raplain. I nervous solicitude to roplatio at all hatzalels, is uncalled for and unberoming.

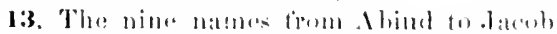

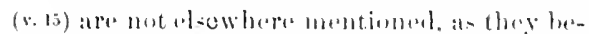

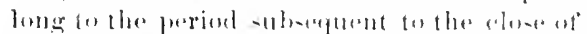

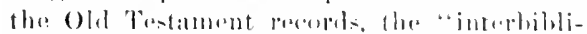

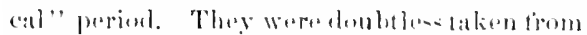

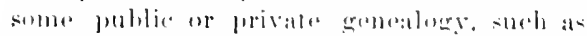

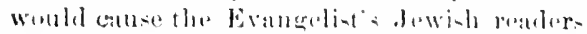
to receive them without erain-ayiner. Tha

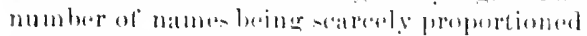

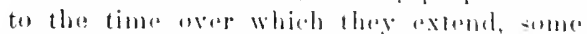
have thouerhe that herealen a fiew names mal have beren ondeted, as in r. s, 11 .

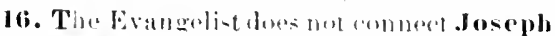

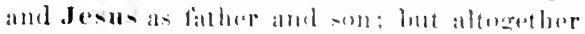

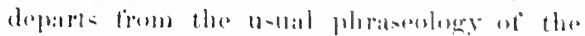

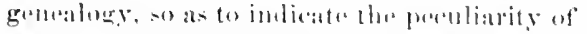

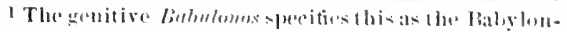

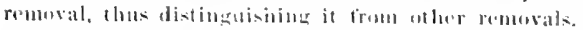

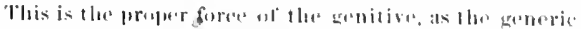

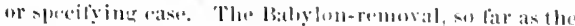
mera lorm of the expresion genes, might meat the re-

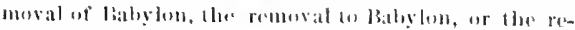
moval from latuylon: hul lar woll-known histurical facts let wo dinlu as lo the real meaning. Sere similar uses of the gentive in $4: 1.5 ; 10: 5 ;$ John $7: 35 ; 10: 7$.
}

the savinur's hireh. The nane Jesus (i. to

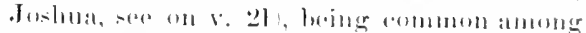

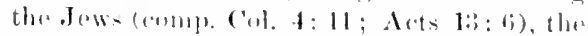

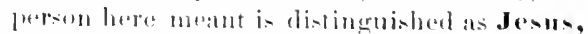
who is-or, the om-called christ, so jul

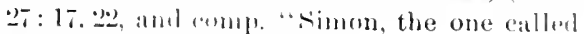
Petrer, in 4: 18; 10; 2.)

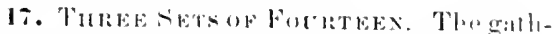
reing of this lomer list of manes intu throw

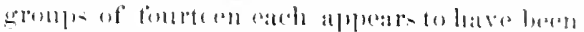

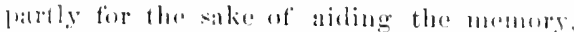
atul party in ordere to indiate the thresereat

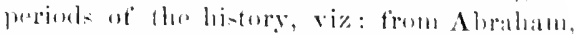
the lither ot the mation, to " lowid the kinge.

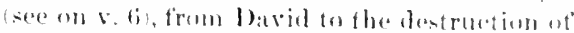
the monatedey at the ramoval tor bahelon, amb

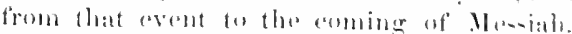

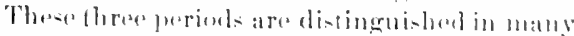
ways: amome athers by the form at exorerth-

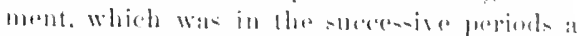

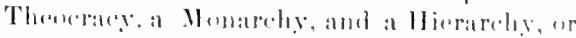
goverument be the prients, this beiner for lhe must part tho form atteg the reture frout the alptivits. Finding that the names from

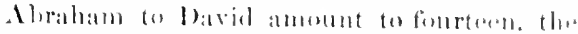

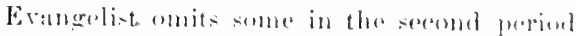

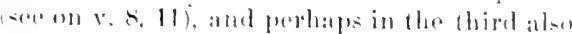

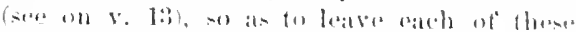
furiod the samm mumber as the tir-t. 'This

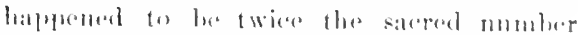
seron, an that the whole tiet of mannes is di

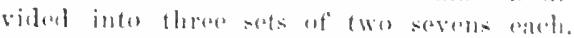
sinularly a Rahblinical writer sals: "From

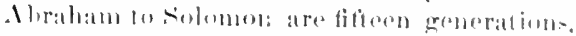
and then the mown was at the lull; forns sul-

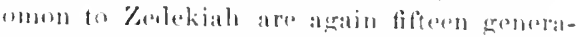

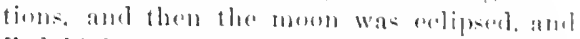

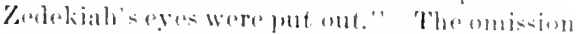
of somm names jeresents me diffenlty, beine

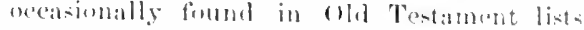
likewise. "It was a combunn prative with the J Jws to distribute genealogies inte divine 
jons, each containing some favorite or mystiail number, and in order to this, generations were either repeated or left out. Thus in Philo the generations from Adam to Muses are divided juto two decats (sets of ten), and one liebdomad (set of seven), by the repetition of Abrabam. But in a Samaritan poem the very sane series is divided into two decads only, by the omission of six of the least important names." (Smith's "Dict.," Art. "Genealogy of Jesus.") We are told that the Arabians now abbreviate their ganealogies in the same manner, and give the destent by a few prominent names. So, in fatet, otten do the English, or any other people; the object being, in such cases, not to furnish a complete list of one's ancestors, but simply to establish the doscent from a certain line. Where such omissions are made in the seripture genealogies, the usual term "begot" (or, as in Luke, "son of" ) is retained, and nust of course be then understood not literally, but as denoting progenitorship or desernt in general, a sense very common in the language of soripture, and eommon throughout the East, both in ancient and modern times. (Comp. v. 1). Iatthew's three fourteens have been variously made out by expositors. It seems best rither to eount from Abraham to Divid, from Daviel again to Josiah, and from .Jechoniah to Jesus, or, from Abralian to David, from solomon to Jachonial, as representing the tine of the removal, and from Jechoniah again to Jesus. The fact that either of these modes of reckoning (and, indeed, one or two others) may be plausibly supported, emours with the omission of some names to show that the Fvangelist did not design this division to be pressed with literal exactness, but only to be taken in a certain general way, for purposes such as those above suggestred.

'THE GENEALOGIES OF MATTHEW AND Luks. There is an obvious diserepaney botwern the two genoalogies, (oompl. Lake 3: 2;) ff.), which has always altraeted attention, and to explain whieh, we fiud various thenrics suggested. Most scholars at the present day are divided between two of these, and aither of them is sufficianty probable to sot aside objertion to the erudibility of the Evangelists on the gromel of the diserepancy. The two genealogies diverge attor David, Matthrow's passing down through solomon, and
Luke's (which is stated in the opposite order), through Nathan, and they do not afterwards agree, unless it may possibly be in the case of Shealtiel and Zerubbabel, as these two names occur together in both lists.

1. One explanation supposes that, while Natthew gives the genealogy of Josepls, the reputed and legal father of Jesus, Luke really gives that of Mary, but simply puts her husband's name instead of liers, because it was not customary for a woman' - mame to appear in a genealogy, but that of her husband instead. This is a mere supposition, of course, but it is a perfectly posible and reasonable one, and it las the great advantage of showing that Jesus was not only a descendant of David legally, through his reputed father, but also atetually, through his mother. There is good reason besides to believe (Luke $1: 32$; Acts 2:30; Rom. 1:3; 2 Tim. $2: x)$, that II: $y$ was herself a descendant of I)avid, as beld by Justin Martyr. Irenaus, Tertullian, and other Fathers. The fact that Elisabuth, the wite of a priest, was Mary's "kinswoman," (Luke 1. 36 , the term denotes relationshi]), but without indicating its degree), is no proof that Mary was not of the tribe of" Judali, sinee persons of the different tribes sometimes intermarried; indeed the earliest known Elisabeth, Aaron's wife, appears to have been of the tribe of .Judah. (Ex.6:23; Numb. 2:3.) This theory would? aecord with the special characteristics and manifest design of the two Gospels. Matthew, who wrote especially for Jews, gives the legal. Aescent of Jesus from David, through Joseph, it being a rule of the Rabbins that "the deseent on the father's side only shall becalled a deseent; the descent by the mother is not ealled any descent." Juke, who wrote without any special reforence to the Jews, for general cireulation, gives the real descelit from David. In like manner Mattlow mantions the angelic appearance to Joneph; Luke that to IIary. This axplanation jo adepted substantially, by Luther, Lightfout, Bengel. Olslansern, Elirard, Wieseler, Bleek (in part), Lange, Robinson, Alexander, Godat, Weiss. Andrews hesitate: (nee a valuable disens-

1 If we simply suppose that Justin adopted this theory of the genealogits, viz: that lukw gives that uf Mary, there will be none of that eonflict, between his statements on this subjeet and our fiospels, upon whieh the author of "superuatural fieligion" so much iusists. 
sion by Warficld in the "Presb. Review," Vol. I1, 1. :388-:397).

2. Ifot of the Fathere, and many recent writurs (an Winer, Meyer), hold that both

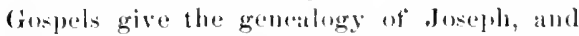
then attempt in varions ways to renove the discrepancy, or pass it by as irrecencilable. The lest "xplanation upen this riew is that recently offered by hord linerey, vize: the hypothesis that llatthere gives the line of suceession to the throne, and that upon a falure of the direct line, Joreph became the next hoir; while halie gives Joseph's private

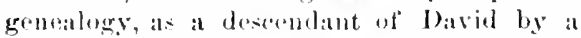
younger line. which at this point supplied the failure in the older branch, and furnished the beir to the throne. This thoury is ably advocated in Lort llervey's volume on the Gerealogies, and his artiele in siniths "1)ict.," "Gescatogy of J Je-ns ('hrist," and is mow ipuite popular with English writers, as Mill, Altorel, Workworth, Ellientt, Westeott, Fatrbairn, Farrar. It is altegether perible, and when presented in detail has several striking points; yot the former explathation is leelieved to be in seme respects preferible. We are little eomcerned to show whieh of them is best, and under noobligation to prove that eitherot them is certainly correet; fin we are not attempting to establish from the Genesilogies the eredibility of Ilatthew's (inelen. When the object is simply to refute an whjection to that eredibility, founded on an apparent discrepaney between two statements, it is sulticisut topresent any hypothetial axplatuation of the dithenlty which is presilhe. If the axplanattion be altogether reasonalle and probablile, so much the better. And if there be two, or several, possible explatnations, these reinfores each other in remoring the gromnd for objecetim, and it is not neeessary to elomose between them.

The mames shenltiel and Zerublabel in the genealogies need not be supponed to represent the sume persons. There are various instanees in the (Old Tostament lists, of a striking similarity betwen several natues in lines that are nuquestionably distinet.

HOSILETIALAXI PUATIRIL.

Besides the value of this generalogy, to the Jews and to ns, in showing that, Jesese was at descemblant of David, as it hat been predicted that the Meswiah would be,-the apparontly barren list of mames might suggest mueh thomght to a mind fanilial with the (O)d Thestament. Buring all this long period, the prose ielential arrangentent- were going an, which preparent fer the coming at the "seed" promised to Alrahatn. Virery person in this greme alogy-the wieked as well as the derout, aven the woman of atainel chatracter-firmed a link in the ebain et povidenees. Thorengh all the trombled enturin, threugh all the nattional changer, whether reigning in splendor, or dethroned and in ealptivity, or alterwards subsiding into insignilianere number the rule of the high prient or of Il Inerl, the apponinted line was preserved; mutil anomg the rules population of atl olscoure village, are foumd the harl-working arpenter and the poor maiden, who arre chosele to rear the seed of Abraham, the soll of lonvid.

r. 1. (Mrist, at 1) the son of Abraluan (tint 3: 16), 2) the son of l)avid. The Jews alde the only race of mankinel that can trace their origin in anthentic history to al single ances-

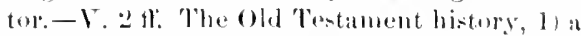
history of Providence, 2) a history of Redemption; earh fonding its climax and consummation in christ. $-V$. 8-5. The divine sovereignty and (endereension, in enusing the Saviour to spring from a line eontaining seme? pressens so unwortly of the hemor. and who reflected so littlo erodit on their desendant. And a rebulie to that exeen-ive pride of ancestry, to which the law wereso prome, alm which js st commonn anong mankind in general. Chrys.: "Me teadies ats also bereby, never to hideour face at our forefat beres' wiekedness, but to serele aftur ome thing alome. oven

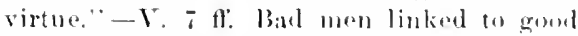
men, 1) als desermolants of the good, 2) ats allcestors of the enoul.-V. 11. Thr removal to Babylou, as a step in the preparation for Mus siah.-V. 1: The three great proriendsof dowish histery betore chriete as all preparing in rarious ways fiur his eoming and his work.

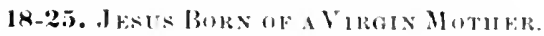

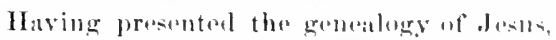
the inspired writer commenees the narrative proper with matters pertaining to Jestse himt and infancy. (1:k,to:2:3) The passalgrs now

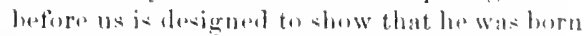
of a virerin mother. Mattlew deres mot moll tion the annumedation to Mary, wor the birth of the forerumer (lake1), but begins at thes 
Is Now the birth of Jesus ('hrist was on this wise: 1 When as his mother llary was epoused lo Joseph, befire they ame together, she was tomat with ehitd of the Holy host.
8 Now the lbirth 20 Jests Christ was w this wist: Whon his molher Mary had been betrothen to Joseph, bofore they came together sle was found

1 Or. Generation: an in ver. 1...2 Sotse aucient :uthurities reat, of the Ghrist.

time when it becane apparent that Mary vas with child, which would besoun after her retum from the visit to Elisabeth (Lase $1: 56$ ).

18. 'The birth' of Jesus Christ was on this wise. It has already been intimated (v.16) that he was not in the ordinary way the son of .Joseph; and this point is now distinetly stated. II mother Mary. It is no doubt wisely provided that we know very littlecoucerning the personal history of" "Mary the mother of Jesus." (Aets 1:14.) The traditions relating to her, so highly prized by Romanints, are of no value. She wat probably (see on 1 : 17) a descendant of David. We know nothing of her parents, or of any brothers; there is allusion to a sister (John 15: 2j), who is by some identified with " Mary the wife of clopas," mentioned just after, and who upon tinat supposition must have borne tlo same name (see on 13:55). We are informod that Elisabeth was her kinswoman (Lnke]: 36 ), so that Jesus and his forermuner were remote relatives. Mary'searly homeaplearsto have been Nazareth, and the probably lived a life of poverty and toil. As to her eharactur, we are someswat better informed. In Lake's narrative she appears before us as a dexply pions maiden, jroment to believe what fod revaled (luke $1: 34,45$ ), and anxions to have all Hiffenlties in the way of her faith removed (wake 1: as); as humbly rejoicing in tha high privilegesecoured to brer hy the divine promiot (Luke 1 : 46.55$)$, and through the years which followed thoughtfully pondering the thing which necurred in connection with her ehild.

1 The moreot text of the Greek is ymesis, "origin,' and so hirth, rather than gemmess, prob. derived from egemethe in v. 16. A few very early versions and bathers here omit 'Jesus,' readines simply 'the birth of the ('hrist, and this is aldepted by Trege, W H., amd Mackellan. The question is quite interesting, for the principhes involved, to stultents of text-rilioism fere

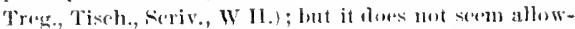

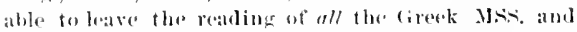
most versions. The practient dithrenee is nut very im-

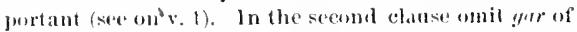
the common freek text, leaving the simple genitive aboohte. Hatthew quite frequently employs this construction (Wciss).
(Luke 2: 19.) The familiarity with seriptur. manitented by her soug of thankisgivinu (Luke 1. 46 ff,), shows how lovingly she had beril accustomed to dwell on the word of God. Mary was of coulse not faultess, but her character was worthy of her high providential position, and she deserves our admiration and gratitude. Above all the "mothers of the wise and good" may we cail her 'happy" (Luke 1: 4x), and cherish her memory. The utterly unseriptural, absurd, and blasphe. mons extreme to which the Romanists latve gradually carried their venoration of Mary, must not drive us into the oplusite extreme. The name 'Mary' is the same as Miriam, and is often written Mariam in the Grek, partieularly when applied to the mother of our Lurd $(r . q ., v .20)$. Its original moaning of rebellionsness was quite suitable for the sister of Moses.

Of' Joseph likewise but little is known. Though of the old royal fanily, he apyears to bave been quite poror, and to have firllowed the lowly calling of woud-workmatn, plobably what we call a carpenter (complon 18 : 55). Ile is here dectared (v. 19, Rev. ver.) to be a 'righteous' man, and we shall proxently find him faithfully attentive to his precioms charge (en.2); hut beyoud this the seriptures give us no information (comp) at end of (ch. :2).

Espouscd, Rev. Ver. gives betiothel. So Wye., Tyn., Gen. The Com. Tir. tollowed Rhoins in giving "eponsed," which formelly maint betrothed. It appears to bava been a custom among the Jews for a botrothed majden to remain still for some time in hes fither's house, bofore the marriage was comsummated; and before they came together, mobably reters to their coming to live in the same home, though it may be taken in the other semse, which is obvioms (commp. 1 (or. 7 : 5). She was fonnd, does not imply an attempl at (a)meralment. but merely sates that it was then ascertained. The expression is comsistent with the viow that sho herself diseovered the fart, and then, through information conveyed in some suitable way, it was ascertained ly Joseph. The narrative is 


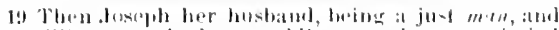

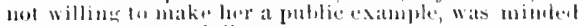
(1) jut hor atway privily.

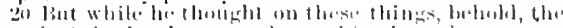

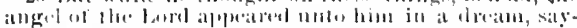

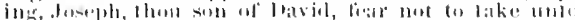

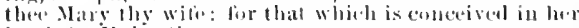
is of the Jloly lihost.

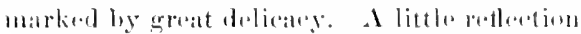
will suggeret reatens why a divine peretarion

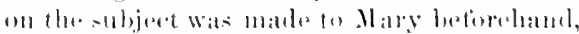

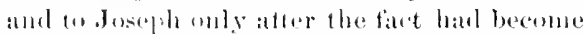
apparent. I difliment course with regard 10 either of them would hase orearioned addi-

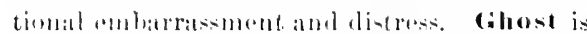

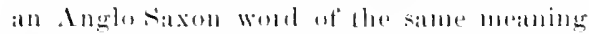
ats th. Lattin 'splitit, and having the satue

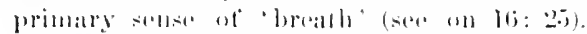
It hat in mulem limes given wily to the Lattin

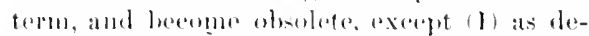
noting a spirit of a deand prer-ons antpused to

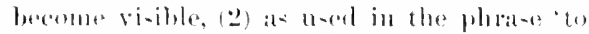

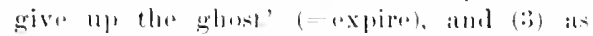
alphlend to the thirl prosen of the Trinity.

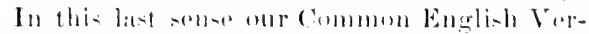
sint Now 'lestament in which 'holy' is prefixed,

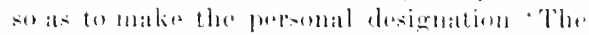
Iloly Ghost'; and rmpleys it in all slleh

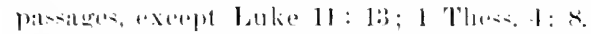
When mad withont 'holy' in the New 'Tem-

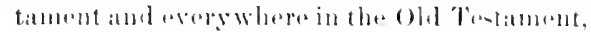
the word is 'splirit. (Comple al to 'hatlow,

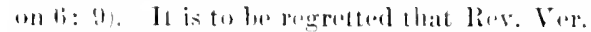

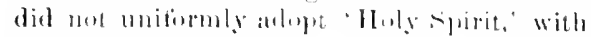

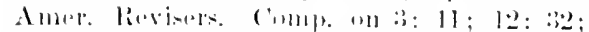
2. 191. Of the lloly Ghost, bliterally ont of. matking the Holy sipirit at the sturee o.

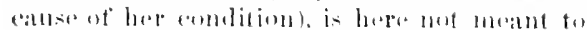
be molderesent at at part ut the di-cosery, but is a faret appended he the natrilur. - I noter

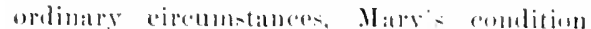
would hatre incolved a crime which, by the

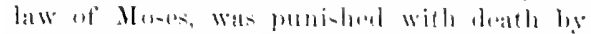

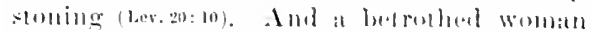

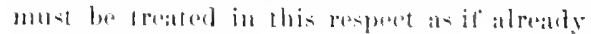
mitried (Bent, $22: 23$ r.).

19. From the time of belpothal the parties

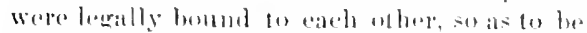

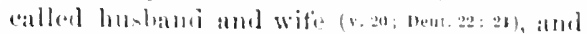
so) that monhatity in eillore wombl be adule

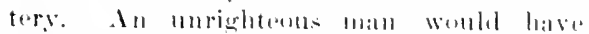
cherished it pas-inate ander. and solluht bo

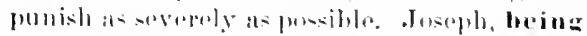
a just (Rev. Ver. righteums), man, (comp). I

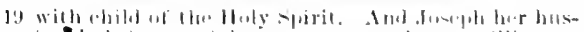

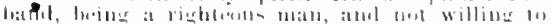

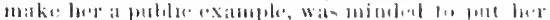

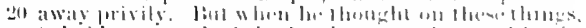

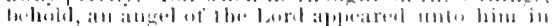

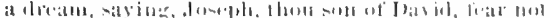
w tatke nulo the Iary thy wile: for that which is

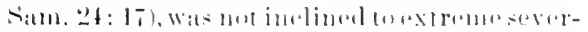

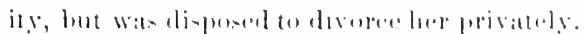
(s) Blecek, (irimm, (remer) or it maly

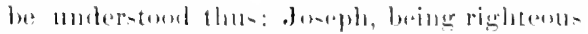
(and therefore forting that in - lech ciremon-

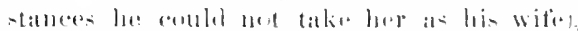
and yet non willing to tapued her publicls.?

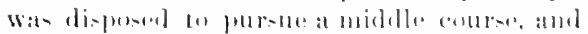

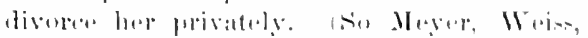

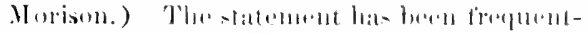

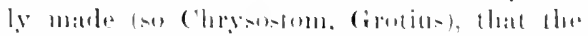
Comek word rendered rightoms' maty sig-

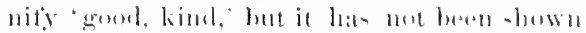
to hate that meaning angwhere in the Now

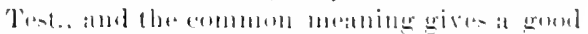

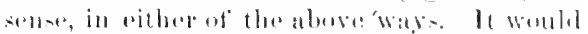

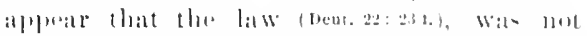

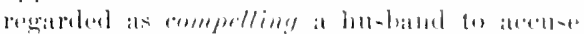

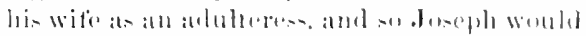
not be violating the lat il he should arodid the extreme contres, atul divoree bur, atul this withent stating his reason in the " writing of

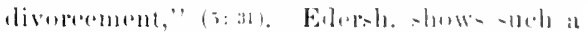
course to alecord with ell-tom and liabhinieal (1pinion.

20. The angel, mure probibly an angel, althougl the croek might be contep-

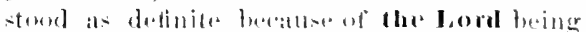

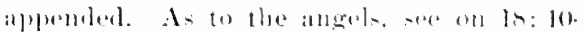

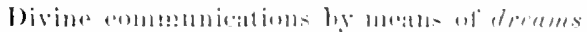

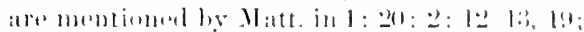
- דיel

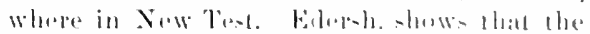

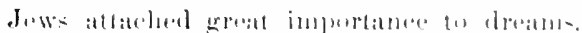

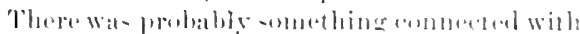

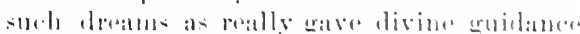

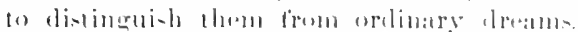

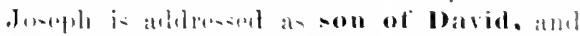

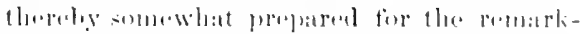

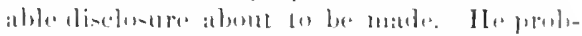
ably knew that hi- wate a leatine hram h of the

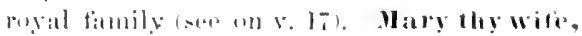

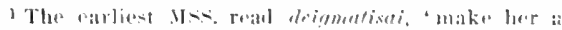

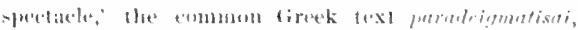

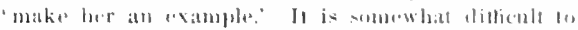

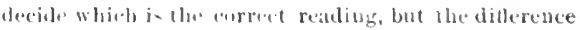
iu meaniugt is unimgortant. 
21 And she shall bring forth a son, and thou shalt. call lig wance JEs s : tor he shall save his jeople trom iheir silus.
21 leonceived in her is of the Iloly spirit. And she shall bring forth a son; and thou shale call his wane Jesus; for it is he that shall save his geople from

$161^{\circ}$, begotten.

the luetrothed woman being frequently spoken of ax at wite. (Deut. 22:24.) sio as to "Joseph her lukband; in v. 19. Of the Holy Ghost. Accordingly in v. 21 it is not, shall bring forth a son 'unto thee, as was said to Zacharias, (Luke 1: 13.)

21. Jesus is the same name as Joshual, a contration of Jehoshtuh (Num. $13: 16 ; 1 \mathrm{ebr} .7: 27$ ), signifying in Hebrew 'Jehovah is helper, or 'Help of Jehovah.' In the later books, (e. g., Neh. 7: 7; 8: 17; Ezra 2: 2, ete.), it sumetimes takes the firm Jeshua (Jeshuab), and this the Greek translators of the Old Testament expressed (comp. on v. 2) by Jesus. (In the Jewish buoks subsoquent to Cluristianity it is foequently Jeshu). The name Jushua is everywhere in the septuagint found in this form, Jesus, and so in the two passages of the New Testament in which Joshua is mentioned (Acts 7: 45; IIeb. 4: 8). As applied to our Lord there is of comse a certain modifieation of the idea conveyed by the name, but the leading thought is the sime, viz., deliverance, salvation, and that springing tiom Jehovah. Like Joshua, who led Isract into thr promised land, Jasus was to be the leader and rules" of his pemple, the "captain of their salvation" (Ireb, 2: 10), under whose guidance they would be delivered from all dangers and brouglit safe to the rest that remaineth (Heh.4: 9). Like the high-priest Joshua, who was associated with Zerubbabel in loringing the Jews back from the captivity (Eza 2: 2: Zech. $3: 1 \mathrm{ff}$ ), Jesns was to be the higli-priest of his people. He thus answerel at the same time to the civil and religious rulers of the mation, at once King and Priest. Comp. "he shall be a priest upon his throne," satid of .Joshua in Zich. (i: 15. - Iary had also been told (Luke 1. 31 f.) that the child must le namod .Jesus, but without the ruson for it hore given. For he shall save. In lievised Tersion, it is

Jother persons named . Toshua or Jesus are tombl in

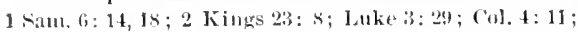
Jeclus. Prologue aud $50: 27$; Josephus, "Ant." vi. 6, 6; xi. 7,1 ; xii. 5,1 ; xv. 3, 1. See al so Bar-Jesus, Ar.ts 1:3: 6. Jason, in Aets 17:5; Rom. 96 : 21 is the same name altered into a form sommling better in freek, as dews anong us often give their names a more Linglish shape. he that shall sare. The word 'he' is here pretty chearly emphatie in the Greek, he himself, be and no other, though Revised Version rather exaggerates the emplasis.' The word rendered 'save' signifios primarily to 'preserve, secondarily to 'deliver,' and it often convers buth ideas at the same time. It is applied to physieal dangers (8:25), death (24:2\%; $27: 40,42)$, disease $(9: 21,22 ;$ James $5: 15)$, and to $\sin$ and its consequences, which is the common use. From their sins, from both the consequences and the dominion, both the penalty and the pouer of their sins. Messiah did not come, as the Jews eommonly supposed he would, :inply to save his people from the dominion of foreigners; it was something deeper an l higher, tusave them from theirsins. And not to save them in their sins, but from their sins. His people would to Joseph naturally mean Ispael. It may have been meant to denote the spiritual Israel, including some of the nation, though not all (Rom. 9:6, 27, 31: 11:7), and some Gentiles. (Rom. 9: 25, 26, 30.) Or the angel may have meant simply the people of Israel, $i$. e., the truly pious anong them, not intending to exclude the Gentiles from being saved by Jests, but confining the view at present to the salvation of the Jews. So the angel announces to the shepherds "great joy, which shall be to all the people." (Lake 2: 10, Re. vised version.) Eectus. 46: 1 says of Joshua, "Who according to bis mane became great for the salvation of his eleet" (Gool's elect), which shows that the meaning of the name would be readily apprehended, and the connection in Eeclus, clurly cunfines the "elect" to Israce. Comp. the restriction of our Lerd's ministry, and the temporary lestriction of the ministry of the Twelve, to "the lost sheep ot"

1 Winer, Fritzelte, Meyer, and oblhers, bohd that autos iu Nom. is always emphatic. I3ut the New Testament lats some examples (see Buttmann, p. 107, firimm 11. 2) in which it eannot without great violence be so understrod, and we seem eompelled to admit that it is oceasionally only an uncmphat ie 'he, ete. (Jatio $i s$ ). It is freely so usyl in modern (iveek (Mullach), and there is a partly similar use of ipse in late Latin (Ronsch). Comp. Eillieott on Col. 1: 17; Moulton's note to Winer, 1. $18 \overline{\%}$ 
22 Now all this was done, that it might be fultilled which was spoken of the lord by the prophed, saying,
:2 their sius. Now all this is come lo pass, that it

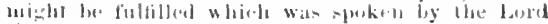
through the propher, sityilig, the house of Israte." $(5: 24$; $10: 5,6$.$) The sume$ question as in this case arises in Acts 5 : : 31 , lievi-al Version, "to grive repentance to Isracl, and remisoion of sins."

2:2. All this was done, ote. The statemont and guotation in v. 2.2 $f^{\circ}$. lats been 111 derstond by some axpostors (Chryse, Alexamblor), ats a part of the workls of the angel. They render: 'And all this has taken place, that it may be fulfilled,' ete., and the languagre, su far as that gues, warrants their interpretation. In 2ti: Sti, the same form of expresion is commonly reforred to the speaker of what preacelles, and not to the Evange!ist (eomp. IIark 14: 14); in 21 : 4, the conneretion will anlmit nf ather view foes nute theres). In the present aine, howerer, we should have to sllpuse the angel to beanticipating whon lae says: "All this has taken place," for most of the erents to which he refers were yet future; and in 2]: 4, no lnat of the event in yuestion has taken place whan the savionr speaks. Jlatthew has not plstowhere than in these threa passages the precise expression, "all this bas taken plater in

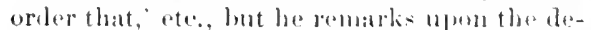

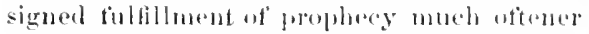
than the other Evandulists, so that it is quite natural to rofor this -tatement tu him; which

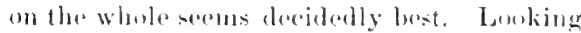
back upouthe events, Matthew anneet- them with the time at which he is writing, and thus vory maturally says: "All this hats tuken place that it might be fulfillerl, fto. ${ }^{2}$

Fullelled is the tram-lation of a Greak worl signitying to 'make full,' t, 'fill up.' (sothe English till full or fintill). It is often used in New Textament, botli literally, ats to filla salley, boat, ete. and tiguratively, as to fill with gladness, knowledge, ete. In a derivativerense it signifies to 'pertion fully, 'aceomplish,

The word rendered in the $60 \mathrm{~mm}$ n linglish Version

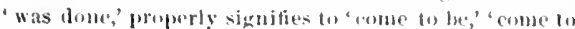
pass,' 'happen,' rec., atul this monning is rery impurtant for the exact exposition of many pateiges in the New Testament. The slulent slould lowk out for lhis word, and mot be conlent to remler it loostly.

2The peculiar illiom of the cireck wakes it monally proper to remler 'that it may, or 'that it might, according to the commecticn. being applied to a worli ar a duty, anel to prom dietions, as here. This last very important use, tufultill (at prediction), is fomend forequently

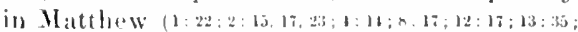

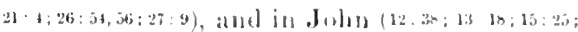
17:12:16:9,3;19, 23:36); seroral times in Lute

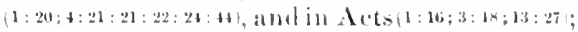

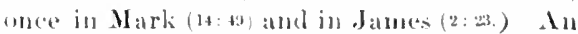

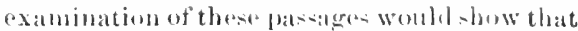
in erencral they will adonit only the strict sernse of filtill, inulying a real prediction, and that no and of thene reptrires the guite different meanime attatehed to the term lyy somes expmejers, yiz.: that while there wats no real

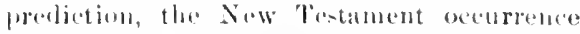
reminded the Evanemet of the (old 'Tota-

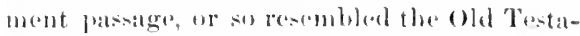

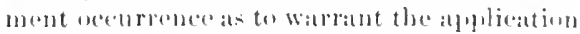

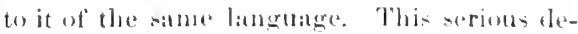
farture from the etymulegy and regular note ut the worel is supuned by such expesiturs to bo required by a tiew pansages in which it is difficult for es to sere that there raists the strict relation of prediction and fulfillmont. [But smelt passages, it wil] be fomnd, all aldmit

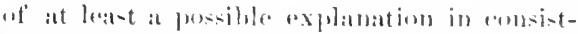
"ney with the izisos af a real tullillmunt (ste

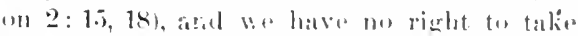
this or any other mord in a sense aldien te its

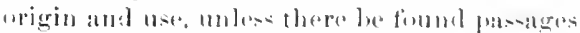
in which it cammet pessibly latse the $11=11$ inl meaniner. The strict application of this rule af interpretation is hore a matter ot impurt-

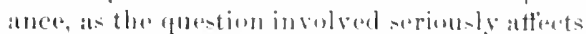

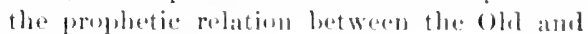
the New 'lestanent.

But two thines are to be abserved. (1) The Xaw 'Te-tament writers sumestimes fluete ()]d

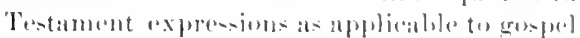
thets or truths, without saloing that they atre prophereies te. a., liom 10: 181, and in some arase it is doubthul how they intend the epmotittion to he regardel. (2) It is often munecessary, and sometimes impossible, to suppume that the prophet him-elt hat in mind that which the New Tostanent writer eallo a tulfilluent of his prodiction. Sume prodictions were feven insoluntary, ns that of caiaphas.

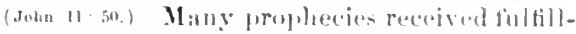
ments which the prophet does not appear to 
23 Behold, a virgin shall be with ehild, and shall 23 bring forth a som, and they shall call his name liwmanuel, which being interpreted is, forl with us.
Fehold, the virgin shall be with child, and shall bring forth al soll,

And they shall eall his name 1 Inmanuel;

1 Gr. Emmenuel

have at all contemplated. But as God"s poridence often brought about the fuifilnent though the human actor. were beedless or even ignorant of the predictions they fultilled $(e \cdot g$. , John 19: 24), so God's spiric often contemplated fulfillments of which the prophet had un conception, but which the Evangelist makes known. And it is of a piece with the general development of revelation that the later in-piration should explain the records of earlier inspiration, and that only after events have occurred should the early predictions of them be fully understond.

Some still insist that the phrase that it might be fulfilled should be renclered, or at any rate should be understood as denoting, 'so that it was fultiled,' expressing only the result; but the best scholars are now very nearly unanimous in maintaining that we must hold tast, in this and all similar passages, to the established nueaning of the phrase. The design expressed is often not merely, and in mme eases not at all, that of the loman agents, hut the design of God in his providence. It is probaloly the fatilure to note this simple distinction-while it was elearly perecived that in some parsages no such derign as that stated can have been entelatined hy the actors thouselve-that has led numerents earlier intrepreters, inchuding some of tho Greck Fathers, to accept the sense of result; and the disposition to do so has douluthes been strug ghoned in some minds by dislike to the idea of divine predestination. Notice that the torm which luero procedes does not axactly signify "was dome" (which would direct our thoughts to the human actors), but, as above explained, 'has aecurred,' 'has taken place, i. c., in the course of providence. (Comp. (m) 2: 17 , and $6: 10$ ).

23. The quotation is from Isa. 7: 14. Proposing to give $A$ haz a sign of speedy deliverance from his enenies, Ephlanim and Syria. the prophet speaks as here quoted, adding (Aloxander's verion): "Curds and homey shall he eat antil he shall know (loow) to reject the evil and choose the good; for before the child shall kuow (luow) to reject the evil and chouse the good, the land of whose two kings thou art afraid shall be forsaken." A eertain womaln (to us unknown), then a virgin, would bear a son; and before he should arrive at the early age indicated, $i$. e., in the course of a few years, Ahaz would be delivered from the dreaded kings of Syria and Isl'tel by the coming of the Assyrians, who would lay those countries waste. Then Judah would posper, and the growing child would have other foud than merely eurds and honey. It is not necessary to maintain that Isaiah limself saw anything further in the prediction. But as "spoken by" the Lord, through the prophet, we learn from Matthew that it also pointed forward to the birth from the more notable virgin, of one who should be not menely a pledge of divine deliveranee, but himself the Deliverer: who should not simply give tolien by his name of God's presence to protect, but should himselt be the fresent and manifest Deity. We need not subpuse that Mathew would in argument with a Jew have appealed to this passage as hy itself proving to the Jew that Jesus was the Messial-for we bave no information that the Jews understood it as a Messianie fassage -but it is one of many predictions, some more and some less plain, which all combined would fornish conclusive proof. And we, who might never have perceived such a reference in the prophet's words, accept it on the autlority of the Evangelist, and do so without Aifficulty, because we see how fully the proplotic books are provaded by the Messianic idia. (Acs $10: 43$.$) "To him all the prophets$ bear witness.' Some expositors of Isaiah (as Hengstenberg, Alexander) understand an exclusior reference to the hirth of Jesus; but bow could that possibly beeone a sign to $A$ inaz of his speedy deliveranee from syria and Eplirain? The Hebrew is. liternlly, "Behold, the maiden conceiving and bringing forth a sol, and ealling" ate. As the calling is future, it is matural to take the other participles an future also (Toy.) The last Helorew verb

1 For the principal actur old Enslish commonly said "ol" (same word as Latin $a b$, (ireck $a p o$ ); in modern English it is 'by.' The intermediary we now most clearly express by ' 1 hrough.' 


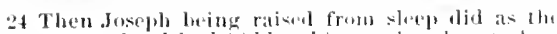

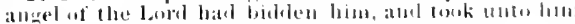
his wile:

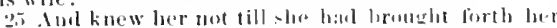

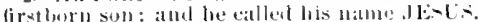

21 which is, lobing interputed, firml with ls: Ant

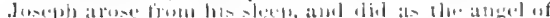

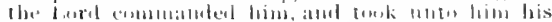

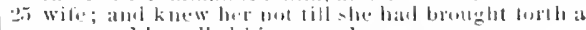

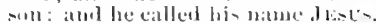

might mean 'then shalt 'all,' and is the sept.

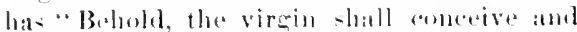
bring forth a con, and thon shalt "all," atce. Matthew has substantially the sime as the Septe (which he commonly fillows, anmp. on

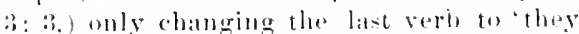
stall call,' $i$. e., people thall rall-he shall be

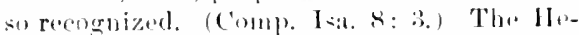
braw substantive simnities "malden." No rase hav been found in which it mest meatl a married womm ; the only examples adtuced by

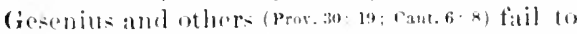
prove the point. The singt. here transtates 'virein, Matthew contirms that by his anthority, and all the offorts have falded to show that it is wrong. 1 mmanus. ()ne of the firms of the principal Hoirew woml for (iod is $\mathrm{fl}^{\text {; }}$ and immennusignifies 'with 11.' While this was to be the actual name of the child burn in the time of that, it was fer . Teras not a mame actually bortse but only a drecription of his elatractor and position. ('omp. the name Jedidiah, 'belovent of' J abovah,' which Nathan gave to solomon at his birth (2 sam. 12:251, hut which was not actually borme by

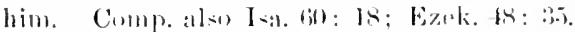

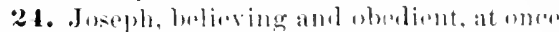
married his betrothed, with all the ell-tomary copemonice, taking hor to his hollas, whane she would have his protection and tembler

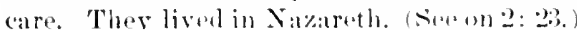

25. Till she brought forth her firstborn son. The Revised Version properly omit. the phrise, "her firsthorn." 2 Though not said

This Ilelvew worl is almah. Another word, bethuah. generally means virgin, but in. Juel 1 : s is clearly spplid to a young wife. If such an in-tanes had lesen foumt for almoh, it would lave been daimed as trimmilant proof that 'viruin' is mot bere' a proper translation. The otber fireek translations of Isaiah rend or by nemis, a young woman; but it must bes res

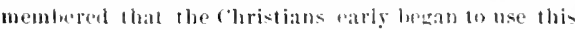
passage agatu-t the . Tews, and that of the three translators Apuila was a Jew, Theoblotion a Jew or a beretie, Eymmabus an Ebonite (Judaizer, which makes their renderine suspieinus. Buxtorf and hevy give no Aramaie (chalulen) examplos in whieh almoh must mean a marriel woman. The result sesusto be that almah does net certainly prove a virgin birh here, it is said in Luke2: 7, that he was "her fir-tborn. 'This Horate of Luke, amb Matthew"s "till, naturally sugera-t that. Mary afterwarls bure other children, but do not certatinly prove it. The worel "till' is somere times comployed wherethe state of thinge dets not changere after the time indicated. Fet the examples adduced the best art, perhape, P's.

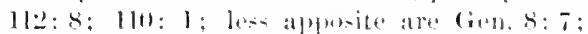

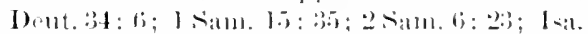

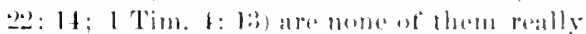
similar to the one before ns. The word will inevitably sugget that afterwards it was otherwine, unles there los something in the connection or the nature of the ease to forlud such a eonelusion. In like manture the dedication of the firsburn son (Fxodus 1.3- 1.5 ) gitue at sort at teehnical sense to the term fir-lburn, which might calle it to be applied fo all only ehild. Still, this would be very unatural for lolke. writing bong aflerwarels, and purfectly knowing that there wat no other uffepering, if such was the ease. (imbine these sipatrille strong probabilities finrnisher by "till' and

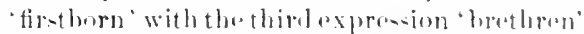
op 'brothers and even 'sistere' (sere and b: i.i), and the result is a very -trong arement to the efteret that Mary bure alher children. The Romanists hold marriage lo be a lowe holy state than colibitey, and so they - at ande all these expresions without liesitation. When some Protentatut = (at Alexamler), on gromuls of vague sentiment. olijeret to the inlea that Mary was really a wife, and menat-

buf fully alluits of that surses, which Mathew confirms

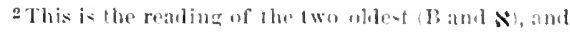

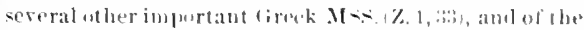

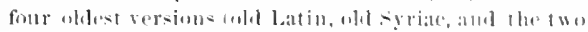
Ezyptian.) The allitional worls, 'be firslura, are

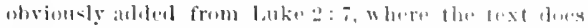

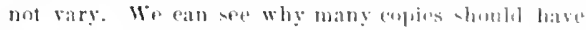
inserted them here, to maki Mathluen -imilar fo Juke.

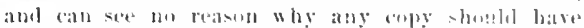

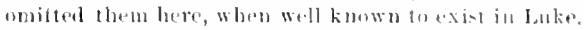
Oheervation shows that asimitation of paralled passates was alunst always eflected log insertion in the shurter, and the probalile reanon is that it would bave

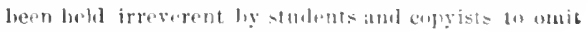
anything from the longer text. 


\section{CH A P T E R I I.}

Now when Jesus was lorn in Bechlchem of Judea 1 in the days of Herod the king, belold, there came wise uen froui the eas to Jerusalem,

1 Now when Jesus was born in Bethlehem of Judxa in the days of Herod the hing, bebold, 1 wise men

I Gr. Kugi. Compare Esther 1: 13; Dan. $2:$ I3.

edly a mother, they ought to perceive that the Evangelists had no such feeling, or they would certainly have avoided using so many expresions which naturally suggest the contrary.

It was inevitable that Jesus should be commonly regarded as the son of Joseph (13:55; John 1:46), for the divine comnunications to Joseph and Mary cumld not ai present be made known. Accordingly even Mary says, 'thy father and I,' and even Luke 'his parents'. (Luke $2: 41,43,4 x_{6}$ )

\section{HOMILETICAL AND PRACTICAL.}

V. 18 f. The most 'highly-favored' of all women has to bear for a time the deepest reproach a woman can suffer. (Edersh.: "The first sharp pang of the sword which was topierce her soul.") But it proves only a step in the progress to everlasting lonor.-V. $19 \mathrm{t}$. Divine guidance in perplexity. (1) A perplexity here of the most cruelly painful sort. (2) The perplexed man is unselfishly anxious to do right. (3) He takes time and reflects. (4) The Lord directs him. Personal righteousness and prayerful reflection will often carry us through; and the result may be the highest joy. JER. TAYLOR: "In all our doubts we shall have a resolution from heaven, or some of its ministers, if we have recourse thither for a guide, and be not hasty in our discourses, or inconsiderate in our purposes, or rash in judgunent." -V.20. Jesusamb the Moly spirit. (1) Hishumanity due to the Holy Spirit. (2) His whole life entrolled by the Holy Spirit (4: 1; 12: 28; John 3: 34; Heb. 9: 14). (3) His mission vindicated and commended by the Holy Spirit. (1 Tim. 3: 16; John 16: 8-11.) (t) His work continued by the Holy Spirit (John 14: 16; 16: 13; Acts 16: 7; "the Spirit of Christ, Ron. 8: 9.)-V. 21. The three Joshuss. - Our Saviour. I. What he is. (1) God with us. (2) Born of a Woman. (3) Tlus the God-man. II. What he does. (1) He will save. (2) He will save his people. (3) He will save his people from their sins.-The gospel not merely gives us religions instruction, hnt makes known a pel'sonal Saviour. Its power does not reside in propositions, but in a person. $-T$. 22. Providencefulfilling prophecy.-V.21-23. Nicoll: "Jesus Christ was, (1) The child of the Holy Ghost, who bad existed from eternity, and now entered into the sphere of sense and time: (2) Born into the world with a distinct mission -his name was called Jesus, because he was to save." - V. 23. Mary. (1) The Mary of propheey. (2) The Mary of history. (3) The Mary of modern fancy. See Milton's "Hymn on the Nativity," and Mrs. Browning's noble poem, "The Virgin Mary to the Child Jesus." LorimER: "Such a nother must have exerted a marked influence on the character of her child. To question it would be to question the reality of his humanity."

The Incarnation, as to its nature, is of necessity unfathomably mysterious; but as a fact, it is unspeakably glorious, and, with the Atomement and Intercession, it furnishes a divinely simple and beatifnl solution of the otherwise insoluble problem of human salvation. Many things the world accepts and uses as vitally important facts, concerning the nature of which there may yet be questions it is impossible to answer.

Ch. 2: 1-12. Tile Visit of The Magi. Having spoken of the birth of Jesus (comp. on 1: 18, ) the Evangelist now adds (ch.2) two incidents of his infancy, viz., the visit of the Magi (v.1-12), and closely connected therewith the flight into Egypt and return. (v.13-23) The first tends to show that Jesus was the Messiah, and to honor him, in bringing out the signal respect paid him by distinguished Gentiles, as often predicted of the Messiab, e. g., Isa. 60: 3, ) and in stating the appearance of $n$ star in connection with his birth; the second incident exhibits God's special care of the child. Bothare connected with extrandinary divine communications (v,12,13, 19), lesigned for his protection, and with the fulfillment of prophecies conrerning the Messinh, such as the birth at Buthlebem (5), the calling ont of Egypt (15), the.disconsolate mourners (18), and the residence at Namareth (28). Comparing this section with Luke, ch. 2, we see 
that Mitthew records slebh inceilents of the intaney ats turnish prontes that Justs is the

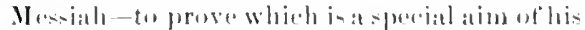

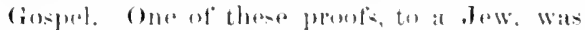

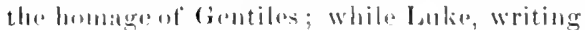
more lop cientiles, who know that the majority of the Jews hatel rejected o Je-us as their Mosiall, montions the loougnition of the child by the eom-pitumsly devout dews, simeon and II:mnal.

1. The narrative goes right on. The precoling sentences enderl with the name Jesus, and this begins: Now when Jesns was born, ete. Litrally, the of sus, the one just mentioned; "this Ju- wo " would be too strong a rembring, but it mat help to show the clase connection.

Bellobeen is a very ancient but always small village, prettily situated on a hill about fire miles solth of Jurusalinu. Its originat namm was Ephrath or Wybratah (ien, 35: 16, 19 48:7), probubly applied to the surrounding country, as well as to tho town. The Isatel-

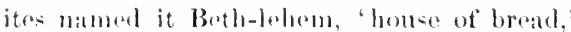
or, ats wa hould sily, 'broald-town,' which the Arabse retain ats But-lalum. This name was

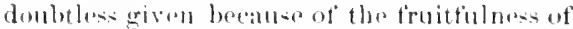
its fiolds, which is still remathahle. It was called Bathlehom Ephratah, or Bothlohom Ju-

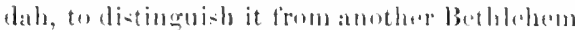

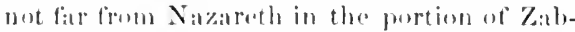

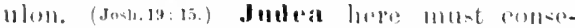
quently be maderstemel. not at denoting the whole (a) a narmorer semoe, Jumba as di-tinguisherl

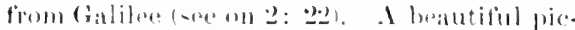
tore al lite at Bethlohom is fommo in the Busk of Ruth. It Was the birthplatere of Dovid, but he did methiner to inerealse its importance; nur did the "sing of Datid, Whe was born

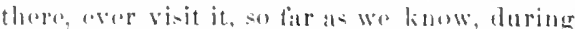

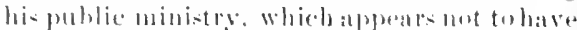
extemeled south of Jerusilem. In like manner the prosent popmlation is anly about 4, (km),

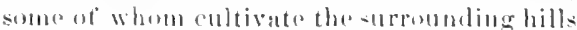

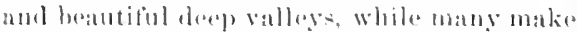
their living by manutionturing trinkets to soll to pilerims and travelers. In itself, Bothle. heoll was firom dir-t to last "little to be amoner

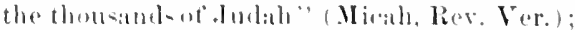
yet in moral importane it was "in no wise least" among them (Matt., Rev. Vor.), for from it canne forth the Messinh. The tradi- tional Inotition of partionlar saremel events

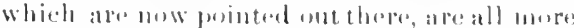

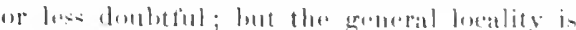
besomel fumetion that neir to which , la(n)t

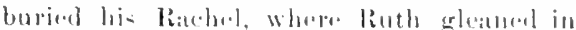
the rich whote tiolds, and l)atid showet hio youthful valur in protereting his flocki, and wherevalley and hill--iele shone with colestial light and echowel thr allgels solng when "he silviolur wats burn.

Matthew hero tirst montions a place. Ile deres not refore to a provions residence of

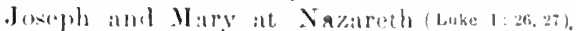
lut certainly towe not in the loust exclude it; and in fatet his way ot introlucing Bubla-

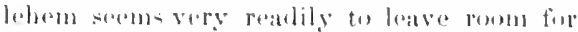
what we learn elsowhere, vim, that the enents lie has al roatly uarrated (1. In-2s) diel not ocener at that blater.

IItrobl the ling wombl be well knomb, by this simple deseription, to Mattlerw's ti lost reatere, who knew that the other ros:al

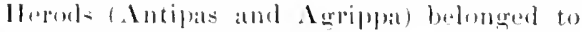
¿t later periol. (latie aloo, 1: 5, plateres the

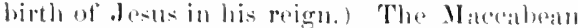
or Hasmoneanl line of rulers, who had made? the second contury B. C., olue of the mont glorions periols in the mational history, had rapidly degenerated. and atter the siltail

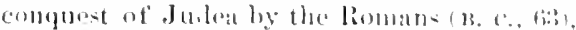
an Idumean namol Antipater attainat, he Rollan filvor, a gratually interasing fowr

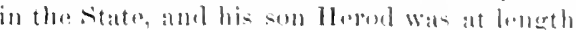

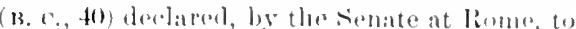
be king of the fows. Aidad be the Rombun

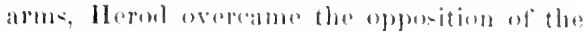

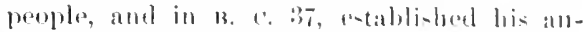
thority, which ho sollerht to remblor bess anpojulat by marying the beatutitul Mariander, the heiress of the Mateab atu line. Aelroit

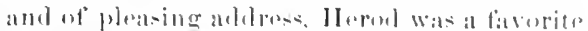

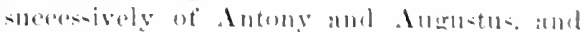
aven the fiscinating Cloupat rat wats nnablo to

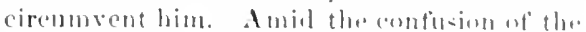

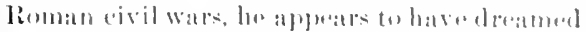

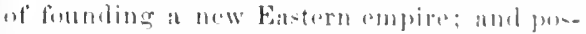
sibly with this view he mald eostly pronents

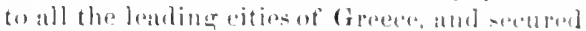
the alyouintmont of President of the () lympric Fimes. Mesutime ho strove to plutas his

I They were enlled Inceabean from Jodas Maccabens. and Hasmonean or Asamonean from ('hisuon, one of Lis aucestors. 
own people, while also gratifying his personal astes, liy ereeting many splendid buildings in varions cities of his duminions; among athers rebuilaing the Temple in a style ot unrivaled magnificence. That he could command means for such lavish expense at lome and ahroul, at the same time courting popularity ly various remissions of taxes, shows that his subjects were numerous and wealthy, and his adminiatration vigorous. But besides being a usurper,-not of the Davidie nor of the IIaccallean line-supported by the hated Romans, and a favorer of foreign ideas and customs, and even of idolatry, he was extremely arbitrary and cruel, especially in his declining yenrs. Mariamne herself, whom he loved with mad fondness, and several of lis sons, with many other pelsons, fell vietims to his jealousy and suspicion. Bitterly hated by the great mass of the Jews, and afraid to trust even his own family, the unhappy old tyrant was constantly on the watch for attempty to destroy him, or to dispose of the succession otherwise than he wished. These facts strikingly accord with the perturbation at hearing of one 'born king of the Jews,' and the hypucrisy, emning, and eruelty, which appear in comnection with the visit of the Magi. (See on r. 20, 20, and read the copions history of Herod in .Josephus, "Antiquities [Ancient History] of the Jews," Book XIV.XVIII., a history which throws mueh light on the New Testament times.)

The wise men, or Magi (see margin Rev. Ver.), were originally the priestly tribe or caste among the Medes, and afterwards the Medo-Persians, being the reeognized teachers of religion and of seience. In the great Persian Empire they wielded tho highent influenceand power. Astoscience, they cultivated astronomy , especially in the form of astrolugy, with medicine, and every form of divination and ineantation. Their name gradually eame to be applied to persons of similar pusition and pursuits in othernations, especially todiviners, enchanters. It is used in the Greek translation of Dan. 1:20; 2: 27; $5: 7,11,15$, to render a word signifying 'diviner,' ete. So in the New Testament it is employed to describe Barjesus (Acts 13: 6, 8, translated "sorcerer'), and worls derived from it applied to Simon at Samaria (Acts $8: 9,11$, 'soreeries'), who is commonly spoken of as simon Magus (comp. also Wisdom 17: T); and from it come our words magic, magician, ete. It is however probable that these magi from the East were not mere ordinary astrologers or diviners, but belonged to the old Persian class, many members of which still maintained a high position and an revated character. (Comp. Upham.) so it is likely, but of comroe not certain, that they eane from Persia or from Bibylonia;" in the latter region .Jews were now very numerous and influential, and in Persia also they had been regarded with special interest. as far back as the time of Cyrus. However this may be, the visit and homage of ' magi from the East' would be piterencel by the Jews, and was in fact, a most improssive tribute to the infant IIessiah. The tradition that they were lings, found as early as Tertullian, doubtless grew out of the supposed propheey that kings should do homage to Messiah (Psa. 68: 29,31; $2: 10) ;^{3}$ and the traditional
1 The word is clearly Indu-European. The Old Persian (Zebd) language has a root mut $=$ groat ness, evideutly the same ront as Lat in mag-nus, Sansk rit mah-at, ireek meg-a(1)s, (inthic mik-ils, Scuteh mick-le, mueke. English much. As in Latin mar-ister is 'superior,' aml bence 'instructor' (which we borlow as master, schothlolater), so fron mag-at came mag-arash (found in the Zend Aresta), or contracted mag-ush (fouml in

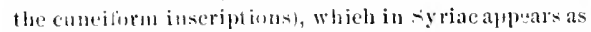
merrloh, and in cireek tomk the form of magos; just as kurush was writen Kuros, ('yrus. (fomp. Curtitus (ir. Etym., llaug in liham, keil, Rawlinson.) Similarly the llubew rat, rabli, rabhuni, signifes superior, and hence teacher, it is still a question whether Rab-mag (Jer. 39: :3, 13) is connected with maros (see Gesen.) ; if sn, it woull eonstine the shemitie with the Indo-Europeau term for 'great one, or it might mean the 'ruling । magus,' The use of mages in the Greek of liantel dors not at all show lbat this word was emploged anong the Bitylonians themselves. The argument of Zockler (llerog, ed. 2) that the magi existed anong the early Acealians of Babylonia, is far from eonclusive

2 'East' is in the Greek here phural, 'astern regions'; but it does not differ substantially (C pham wrong) from the singular (sces: $11 ; 24: 27$; Luke $13: 29$.

3 Matthew can hardly have resaried their coming as the fulfillment of any particular proplsecy, or acording to his custom he would have been apt to mation it. Weiss: "The erities who maintain that he uodificd facts and perverted prestielions in urider to find raried fulfilment of Messianic prophecy, ought to aceount for this neglect of such motable passiges as those just quoted trom the I'salus." 
2 saying, Where is be that is lorn King of the Jews?

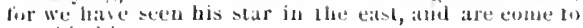
worshipbim.

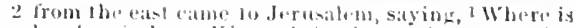

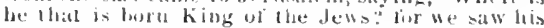

$10 \mathrm{r}$, Where is the King of the Jeth's that is born.

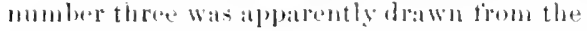
mumber af their gifts. These, with the trati-

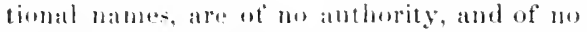

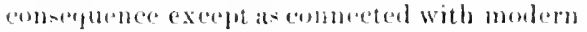
Christian art.-Wise men from the East. The freak is ambigunus, but more probably meats this than "wise men eatme from the East." To Jerusalem, the apital of the comntry, thes: strangers would naturally eome, as there ther could most readily obtain infermation coneroming the new-born king.

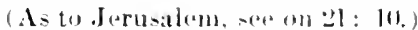

2. His star. 'Two num--mpermatural explanations have b(n+l) otlesed. (1) One was first suggested by the astromomer lípler (d. 16i30), and is well prosentod lig Altord llant al.). In the year 747 of liome there were three different eonjunctions (in the comstellation Pisers of the planets . Iupiter and situru, in May, October, anel November. The astrolugg-loving $\mathrm{I}$ agi nay have somelow (onmeded this eonjenction with the birth of a Jewish king; aven as the . Jewish witer, Abarbanel (A. I. 145:3), thought that Mesiah wats at latud in his day beatuse here laad been

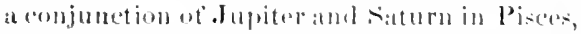
a conjunetion of which planets tradition rep-

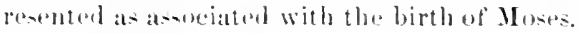
It is supposed that alter the Maty conjumetion the Magi set out, and in Jarusalem saw the

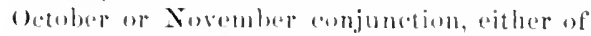
which at cortain hours would have been in flar diroetion af Bethlehrem. But the Greeli word is aster, star,' and mot astion, which is nsod for a group of stars. The two planets

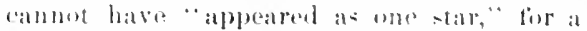
recent English atromomer shows (ximitls: "Dire.", that they were nowel moarer each other than one degree, which ja about double the apparent diameter of the mones. Simpe loblet that 'star" must heres be taken in at general semete denotines a group: but the

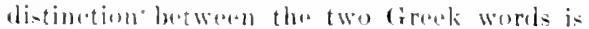
uniformly obersod. It is al-o ohjected to this theory that wher tata tor the time of Christ's birth would place it at least two yeatrs later than $A$. I. r., 7t7, thomeh the concluxion from those ditat is not certain. Edersh. rather lavors this thenry, and adduces for the first time at basage from a minum Midra-lo about

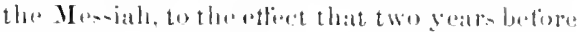
his coming "the star shall shine terth in the atat, and this i, thastar oft the Messiah." liut these minor lialbinical troatises alre of uneertatin date, and theres would be much rom for suspecting that the statement in puretion Wats imitated from Matthew. (2) Simlte “'va-

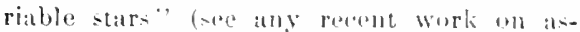
tromomy rary so willoly ats at timbe fol becolne invisible and atterwatererappreatr and it has bearl supposeal (Letteroth) thate such it

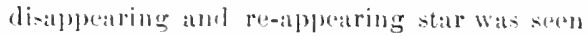
by the Masi.-Either of these theories is in

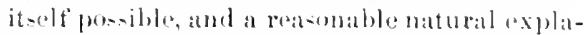
mation would obvinusy le better than the unnecessury introduction of the miraculous. But it is extremely diflicult to reconcile theos: theories with the latuguage of $v$. !, the star - . Went bofore them, till it came and stood wor where the young child was. If at beavenly body be considered ats moving forward in atranes of them from deru-alem, it womld the equally in advanees when they arrived at liethlohem. and in 110 sonas stancling over that plater. Talimen Matthew's latugruage according to its obrions impurt, we have to set asida the alwere explatuations, alud

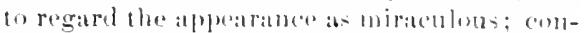
jecture as to its mature will then be to no protit. The supermatural is antily atdmithol beres, since there wereso many mirateles o(n)nected with the silvionrs bipth, and the vi-it of the Magi was all went of greatt moral siornificance, fit to be the oceasion at a miralele.

Why did they eall it his stat? Ipom

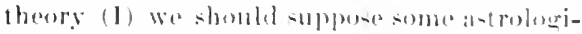

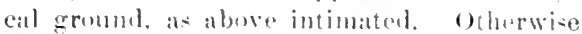

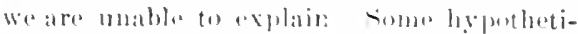

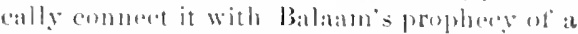
stal out of oncob) (xum. 26. 17), Which all the

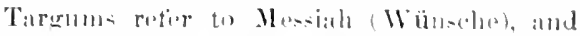

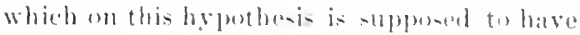

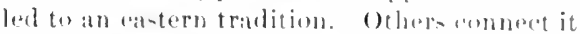

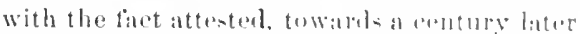

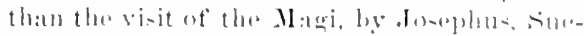
tomius. and Takitus, that it hatel long lean believer throughout the Eatet that furanom

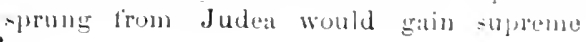


3 When Herod the king hat heard these things, be was troubled, amb all Jerusalem witb him.

4 And when be had gathered all the chief priests and seribes of the people togerber, be demanded of them where Christ sbotila be born.
3 star int he east, and are come to 1 worship him. And when flerod the king heard it, be was tronbled, and 4 all Jerusalem with him. And gathering together all the chief priests and seribes of the perple, he inquired of then where the Christ should be born.

I The Greek wouls denotes an act of reverence, whether pail to man (ree ch. 18: 26), or to God (ree ch. $f: 10$ ).

power (Jos. "War," vi. 6, 4; Suet. "Vesp." " 4; Tae. "Hist." v. 13) ; but there is in those writers nothing of a star,' and Suetonius and Tacitus appear to have merely borrowed from Josephus.

In the cast might here mean 'at its rising'; but v. 9 leaves no doubt. Worship. But do homage is mueh more probably the correct rendering bere (the Greek word meaning either), because there is no reason to believe that they regarded the new born king as in any sense divine, though they apparently expected his reign to influence other nations.

3. Herod was troubled at the idea of a rival. (see on v. 1); and while many dependants of Herod would really share his feelings, being interested in the permanence of his govemment, all the people would be disturbed at the same time, through fear of new tyrannies and eruelties as the effect of his jealous fears.

4. As the question to be asked was a religious-potitical one, the king assembled all the leading students of the law to answer it. The chief priests and scribes might mean the Sanhedrin, as in 20:18, the elders being here omitted, as in $27: 1$ the scribes are onitted. But the word all, with the additional phrase of the pcople, makes it more natural to understand a general assemblage of teachers, including many seribes who did not belong to the Sanbelrin. This would accorl with the idea of great uneasiness on his part; comp. the similar conrse of Nebuebalnezzar and Belshazzar. (Dan. 2;2;5: i.) The "chief priests' comprised the high priest at the time, any persons who had previously oceupied that office (as IIerod and the Romans made frequent changes), and probably also the heads of the twenty-four courses of priests (Luke 1:8), for the language of Josephus ("Ant." xx. 8, 8; "W: "Wr," iv. 3, 9) implies that the number of "high priests' was considerable. The term 'scribes' (in the Old Testament meaning military sec-

1 The prostion of autou, 'liss, does not neeessarily sbow enmphas, the star that signifies him and 110 other (Meyer, Weiss), for these genitive pronouns are often pat befure their noun, without empbasis, where retaries had now for several centuries denoted those who supervised the copying of the suriptures, which Jewish feeling required to be performed with the most scrupulous care. Their minute acquaintance with the text of Seripture would naturally lend to their beis.g consulted as to its meaning; and in the timo of our Lord they were by eommon consent regarded as authorized expounders of the law (hence called 'lawyers,' 22: 35), and besides answering the inquiries of individuals as to questions of trutlis and duty, many of them gave public instruction on such subjects, (hence called 'doctors-or teachers-of' the law,' Luke 5: 17), particularly at the schools in the temple courts. Their instructions and prictical decisions were at this time seldom the result of their own thinking, but consisted of sayings landed down from earlier teachers, or traditional decisions of tribunals in former times. (Comp. on $7:$ 29.) Those scribes who acted as teachers were among the persons called Rabbi. Altogether, they possessed very great influence and distinction, and some of their number were united with the 'chief priests' and the 'elders' to form the sanhedrin (see on 26:55, 59). Filled with ambition and vanity, they exposed themselves to the severe censure of our Lorl, who gives a vivid picture of them in Lulie 20): 46. Some of the scribes were saduluces, but most of them Pharisees; and hence we frequently find the 'seribes and Pharinees' mentioned together, since the policy and the speeial faults which characterized the scribe extended also to all the rest of the great Pharisaie party.

Christ, literally, the Christ. The article should by all means be retained in the. English. It is proper to use in translation the Greek word 'Christ'; but we may often see more clearly how such expression presented themselves to the original Jewish hearers, by substituting 'the Messiah.' (Try this, e.g., in sonue strong word precedes on whieh they may lean -the matter being regulated by nere taste as to the halmonious suceession of words. (see Winer, p. $155[193]$. 
5 And they said uno him, In Bothlehem of Jublea : for thas it is wroten by the propher,

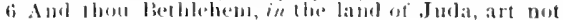

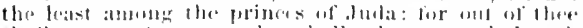

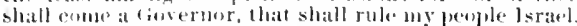

7 Then lletoul, when he had privily callent the wise men, inguireal of them diligently what time the stat alpeareal.
5 And they said unto him, In Bethinhem of Judiea: for thos it is writen llorough the prophes,

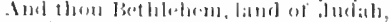

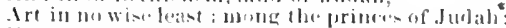

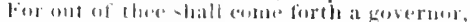

Who slfall la shepheril ol my people Isratel.

7 Then Herent privily catled the I wise men, and learued of then rarefilly " what time the star alp

I Gr. maqt......2 Ur, the time of the star that appeared.

22: 42; 24:5, 23; Mark 12: 35; Luke 24: 24;. 46; Juln $7: 27,31,41,42 ; A(1,17:: 3 ; 10: 28$. As to the maning of 'Christ, soe un 1: 1 . shomb be horm, viz., aceording to tho pro. phets, or any other maths ot knowing; where is the appointed o $\mathrm{r}$ axpected plate of Messiah's hirth. 1

5, 6. They could answer without hesitattion, in Bethlehem of Jucleat, for thus (to this ctlocet, viz., that the Messiall is to be born there) it is written hats been written, and stands now written, is on reorel) by (properly theough, ser an 1: 2.2) the prophet, viz.. Mieah 5: 2. The application of this prediction to the birth of the Mesiah at Bethlehem is obvinus and gomerally arlmitted, and was familiar in the times of our

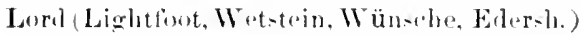
It is here quoted with some ebangesol phrateology whiel may be roadily axphained. Micali, a, is alten done in poetry, $w^{2}$ an an antique name-Bethlehem Ejularatah (Gon 4s: 7 ; see on v. l); Matthew talies the (emmoun ()], Testament form, Bethlehem-Jutah (Ruth ) 1. ete.), though not the purely Greck form .Ju-

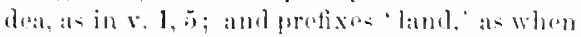

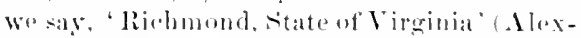
ander). Mieah says, "Thun art little to he amomer the thomsands of .Jadith, (yet) aut of there, rete., (Reve. Ver.), meanimg that it is al small and insignificant place (sere an ve 1). searecely wortly to be numbered among the towns of Judal- -yet out of it would comes. ete. while Matthew's mind turns towarls the moral importance of l3ethlobom ats derived from this very fact, and so he puts it, "art in no wise tho leat among the leachers an Judali, for out of these" liev. Ver. "Thousands' was an antiqua designation ot the grreat families into which the tribes wore smblivided

It is not likely that Mathew intended angthing more than variety in using two words for 'born, $v .1$, 4 , and $x, 2$.

2The Inglish verb 'to shepherd' is mucls wanted here aud iu varims other passages (f. $9 .$, John $21: 16$; Aets $20: 28 ; 1$ Peter $5: 2 ;$ liev. $7: 17$ ). It is given as a
(Juig. 6. 15, margin: I Sam. 10: 19: 23: 23), an1 Wat a\}plierl ly Mirals to a town as the resielence of surllatamily; while Matthew uses the more familiar term, "gevermors or "frimese, nusalling those who he toirtle stood at the hoarl of the greal families, and might the petiore represent them or their abode. (0) Matthew's Hebrew text may, perhaps, latve had a slighty difforent word whinl signities bleaders.) Shall rule. This is a grencral term used by Mical, but Matthaw unes the spereific mord sherpleme, who shall shepherd my people, which includes both governing, protecting, and foeding-a form of expresion apluliod

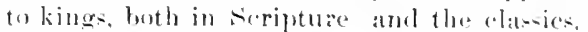
and rapeatedly used in Mesalanice propherenes The ather slight differences recpuire no asplatation. It thus appears that the clianges in ploracondogy which II atthew here malios in puoting da not introluce any jolest foreign to the original, lut lering out more plainly its actual moaning; and the samo thing i true in many ofluer New Testament fuentations from the (1) Testament. It Was eomemon among the Jows of that age to interprest in quoting (see Ellor-h.. ch. S). Wu ste from Joln 7 : 42 that the Jows meler-tood this passale of Mieah as Masianie a and in like manner the Targum (Toy) puts it, "()ut of theo shall come forth before me the Masiath."

7 f. 'Then is a falvorite word of trancition with Mitthew (2:16:3.13: 1 1,ete) Privily, or prientely. In jublic. II rom duubtless affert-

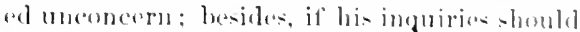
beeome known, tho parties atlected nierlet

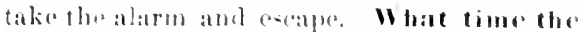
star appeared. This would sivesume indi(attion as tuthe age of the child. Hothere-

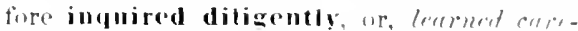

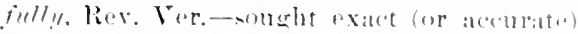

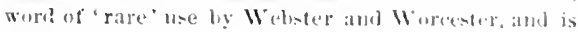

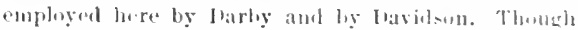
nol so familiar as to suit a poptutar vession, it may, perhaps, he allowalib as a strict rens]cring. lick. Ver., 'which shall be shejherd of my people.' 
8 And he sent them to Bethlehem, and said, fo and search diligently for the young child; and when ye lave found him, bring me word again, that I may conse and worship lim also.

g Whos they had heard the king, they departed; and, lo, the stir, which they saw in the east, went before them, till it came and stood over where the young chilt] wils.

10 When they saw the star, they rejoieed with exceeding great joy.

11 And when they were come into the house, they satw the voung ehild with Mlary his mother, and fell down, and worshipped hin: and when they had opened their treasures, they presented unto him gilts; gold, and trankincense, and myrrh.

knowledge on that point. 'Diligently' in Com. Ver. was drawn from the Vulgate Latin. It is likely that when the Magi first came he had inquired why they believed the star to signify that a king of the Jews was horn. And now, having learned the place and age, he takes steps to learn the person. Go and search liligently, or investigate accurately, the expression in v. 8 being fuller and stronger than in v. 7. Ile treats the matter as highly important, and he is a man who never leaves any stome unturned.

9, 10. The Magi were not well nequainted with Herod's eharacter, and appear not to have suspected his real design; so they set about carrying out his direetions. It has always been quite common in the East to travel at night. And lo, a phrase to call attention. The Greek word is used very often by $\mathbf{M}$ att. (1: 20,$23 ; 2: 1,9,13,19$, etc.), and Luke, rarely by Mark or John. It was long ago that they saw the star in the East, and here it is again. Went before them, literally, led them forward, and the Greek has the imperfect, naturally suggesting that as they moved forwal it moved also. (Comp. on v. 2). It appears to have indicated to them not merely the tow -showing that the scribes were right-but the quarter of the town, if not the very house. (v.11.) Notice the strong expression of v. 10, as to their joy.

11. The house, $i$. e., the partieular house in which he was, as referred to in v. 9, or perhaps the house over which the star stood. We are not to think here of the place in which the shepherds had fornal the child, on the morning after his hirth. (lnke $2: 16$.) It had in all probability been some time since
8 peared. And he sent them to Bethlehen, and said, fio and seareh wat eareftully concernitg the young chila; and when ye have found hime, loring ane wori,

9 that I also may come and worship hin. Amol they, having heard the king, went their way; and lo, the star, which they saw in the east, went betore them, till it came and stond wer where the young chilh 10 was. Anel when they saw the star, they rejuied 11 with exceding great joy. And they came intuthe house and saw the young child with Mary his mother; and they beli down and worshipled hin and opening their treasures they offered unto him

then: the presentation in the temple, forty days after the birth (Luke $2: 22$; Lev. 12: 1-4), must have taken place before this visit which trumbled all Jerusalem, and which was immadiately followed by the flight into Egypt. There had posibly also been a journey to Nazaleth (Luke 2: 39), and Joseph seems to have besen now making Bothlehem his lome. (Comp. on v. 23.) 1 'To speak of a little child with his mother is so natural that no stress should be haid on the omission of Joseph, who is mentioned by Luke (2:16) in describing the previous visits of the shepherds. Observe that it is the child with Mary his mother. (Comp. v. 13.) Our modern Romanists would bave been sure to say, "the blessed Virgin with her ehild." Fell down and worshipped, or, did homage. See on v. 2.-Presented. Offred, as in all Euglish Versions before King James, is the literat and common rendering, and more expressive of rospect than "iresented." The word rendered treasures here more probably means treasure-chests, or the like, $i$. e., the vessels or packages eontaining the treasures. The refinements and spiritualizings of numerous ancient and modem expositors as to the number and signifiance of the gifts presinted, are wholly unwaranted. It was, and still is, an Oriental eustom and regarded as of great importanee, that one nust ne visit a superior, especially a king, without some gift (comp. Gen. 4:3: 11; 1 sam. 9: 7, 8; 1 Kings 10: 2; Psalm 72: 10); and nothing fould be more appropriate, or was more customary, than gold and eostly spices. Frankinceuse (English name from its giving forth its odor freely) is a glittering, bitter, and
IIn here realing they saw, Com. Ver, rimhtly forsakes the text of both Stephens and Ibeza (who read 'found, eomp. Lnke 2: 16), being guided by stephens' blatement of authorities and Beza's note. It shows the same unusual independence in 10: 10 'staves'-though wrongly there-and in a few passaces of other hooks. (See Westott and Abbott in suith's Dict., im. ed., p. 213: note). 
12 And heine warned of fiod ju a lleam that they

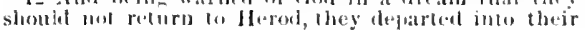
own coundry allollier way.

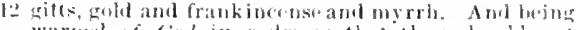

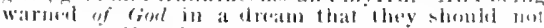

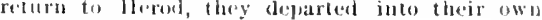
country anofler waty. olorens gum, abtained by incisions inter the bark of a poeuliar trene. The ancients procored it chiofly from Iribia, the moderns bring it frum the Eats Indies. Myrrh is the gum filniliar to 11 , which asudes form a troe found in Alabia and Aby-sinia. It was much

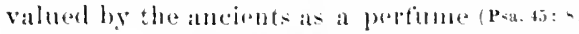
song of sol.3: 6), alos at a splice, a lledicine, atud a means of embalminge. (Johu 19: 3:s).

12. Warned of ciod, or, decinely instrected. The Groek word demotes the reception of a response or commonnteation, as firoun an oracle, and in the serjetures from God, thouerh the name of (iond is not mentioned.

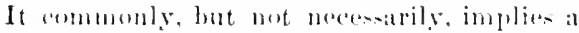
previoms prager ar application for dipection. which may or maty mot have benth mate in thiscats. In a dream. Sise on l: 201)-Departed, more exactly, retierel, withlewe, at in v. 1:, ]t, 2... The the the exelltion of

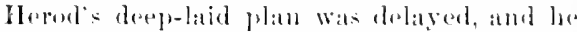
was prevented torm knowing propiaty what ehild his jealousy should striko; whits the well-meaning Magi oscaperl all complieatiun with his further sehemes. Their route of return m:a have beon toward: the nuthernend

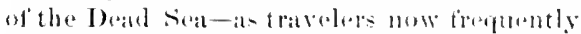
go, leaving . Jerusalem sonse miles to the left -or around its suthorn end, which womld carry them far away from 11 roud in a fow hulls.

\section{HOMILETHOAL INI PR.TITIL.}

1. These Magi from the Eiat will, Jilio the Queen of the south and the ment ot Xineveh (12: 4, 42), rior up in the judemont and comdemin all who have had clearele light eoncerniner the Mesials thath they hade, and have re-

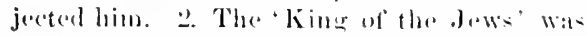
destined to becomes aloo Kiner of the Gentiles

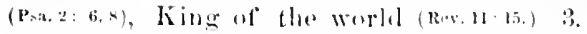
There were these that did not want the existing situation disturbed, even to introduce the Ilesianie reign. The mont benefiecut and indi-pensoble ehanges will be opposed, and often by well-mesuing people. 4 Horod inguires the teachings of seripture anly that he may work against thenn. By politieal cratt and might he will make even divine prodietions serve his own selfish purpose. Otiten now do political tricksters appeal tor rolierious trablires te promote mere secoular ands, and sonetimes even at the expens of rolierion. -) "It is written." Net muly haverevelations beron malde to men in the past, but many of them stamel on recerd, "a possension forever."

Leterher: "Nover mind the seribes; what sath the sicripture?" 'The scribes should be a warning to all poligious teachers, in the pulpit, thesunday-seluoul, the family ; they told others where to find the siaviour, but did not

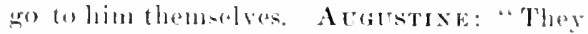
were like milestomes; they pointed ont sompthing to travelers, but themselves rematisidel stolid and motionless." b. That which is na:1terially little' may be morally "ly an mean, least. An in-ignificant spent has often leoen the -eene of "vents posessing the groutert innpritance and the highest moral grandeur. Sis with our little rarth as the seene of reclemption. 7, 8. More soerot than diplomater. derper than the insestigations of the wisen and mightier than all kingly puwer, is the prosidemee of (xod. - 1 also.' The boary hypo-

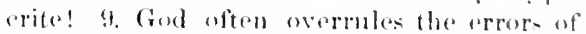

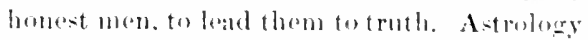
promoted the study of atmomomy, alehomy

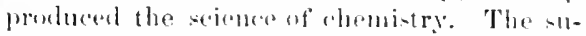
peretition of the Magi had part in their timb. ing the Mesiale. 11. The joy of beloblding that which we bave travoled far to tims? II ALL: "The alst saw that which Buthlehem might have sexu; ofteimes those which are nearest in place are furthest off in aflecetions." LETIER: "The star stomel oxere the land of the Jews and over their heads, and they saw it not: so ever sinere as to the light of the gense pel. The only momated who ever deservent that man sloutel fill down brofore him was a ehild of proverty. Whose life was spent in feachione, and who died an imnominions. death." Observe that they did homatere to the ehild, not fo his mother. Gifts wereottiorad to an Oriental king, not a- meded by him. but as the natural expression at reveremes andi love; so with onr gifts to (iod. 12. The slight(st touch of the supermatural may thwart thes protoumlest human sagaleity. 11 A LL: "Thase sages made a happy vogage; for mom they 
13 And when they were departed, bebold, the angel

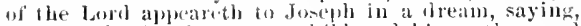
Arise, and take the young thild and his mother, and

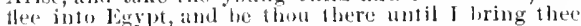
word: tor Ilerod will seck the young child to destroy lim.

14 When he arose, he took the young child and his mother by night, and deprarted info ligypt:

15) And was there mutil the death of Iferod: that it
13 Now when they were departed, behold, an angel of the hord appeareth to Jontph in a drean, say iug, Arise, and take the younte child and his mother, and Ace into lirypt, ami he thou there until I tell thes: for llerod will seck the young child to destroy him. 14 And be aro-r and lowk the young olijd aind his 15 mother by night, ant eeparted into Egylt and was there unil the death of llerol: that it ninht be Gulfilled whith was spoken ly the hord through grew into further aequaintanee with God.' LuTunR: We see here how Christ has three kinds of disciples. 1. 'The priests and seribes, who know the seripture and teach it to everybody, and do not come up to it thomselves. 2. Herod, who believes the seripture, that Christ is now born; and yet goes right against it, trying to prevent what it says from being done. :). The pious Magi, who left euntry and house and home, and made it their one concern to find Christ.

What a vast horizon opens with the beginning of the Gospels. The genealogies point back to Abraham and to Adam, and John's preface points back to eternity. The eensus, by order of Casar Augustus, reminds us of iuperial Rome and all her history. The Magi, probably of Aryan descent, and full of the oldest Chaldiann learning, remund us of the hoary East. All the previous history of Western Asia and of Somthem Europe stand in relation to this lube in Bethlehem. Mroreover. 'the eity of Darid,' and 'Mesiah tho Lord,' recall the long-eherished Messianic hape. And the angelic song treats this lowly birth as an oceasion of praise in hearen and peace on wirth.

13-18. The Fliat into Egypt.

13. Departed, withdrawn, same word as in v. 12, 14, 22. It is also employed in describing another rapid sories of withdrawals, 14: 13; 15:21.-The-rather an-angel, the Greek laving luere no artiele. Appeareth in a dream, sep on 1: 20.--Take, more exactly, take along, take with you, as in $26: 37$. - Egypt was at this time a well-governed Roman purince, and beyond the jurisdiction of Jerod. A jomrney of someseventy-fise miles soutliwast, would bring Joseph to the borler, towartsthe isthmus, and a hundrod miles more woula take him into the heart of the enuntry. Besides being thus rasy of aceess, and having in arlier days been a place of refuge for fugitives from Judea (1 kiogs 11: 41); Jer. 43: 7), 1 Egypt was now thronged with Jowish residents. Alexander the Great, in laying out his new eity of Alexandria, arigued a pilace to the Jews, granting them equal privi. leges with the Marodonians. The early Ptolemies pursued a similar course, transtorring some from Palestine by forec, and encouraging the inmigration of others. In Egypt was made the greater part, probably the whole, of the famous translation of the Old Testament from IIebrew into Greek, (wmmonly called the septuagint. About 150 B. '., a separate temple was built for the Jews in Egypt, at once evineing and tending to ineruac their importance. Sonewhat earlier began the sueeession of Jewish Alexandrine philonoleres, the mon-t remarkable of whom, Philo, was now twenty to thirty gears old. In a treatine witten abont A. D. 40, he says the Jews in Egypt numbered near a million. These facts afford reasons for doseph's being directed to flee into Egypt. At the same time all was providentially arranged with a view to the fulfillment of fuphecy (v. 15). A late tradition names the village of IIataea, near Lewntopolis, the site of the Jawish temple, as the residence of the "holy family." Iate apoeryphal writings have many marvefons sories of the flight and sojourn, and of the jufaney of Jesus in general, which have pased freely into Christian art, but areotherwise unimportant. Memay conjecture that the gifts of the Magi atded in thesupport of the refugees; a capenter dwelling as a foreigner in a coroded country, was nut likely at onee to find adequate employment.

1. Ho aroce at onee, and sot ont by night. The ohild is named first, as the mome import ant pereon, and the one endangered; and the whole expresion (here and in v. 19 ) reminds us that Joseplo was not rally his father

15. That it might be hilfilled... of

The writer was told in Siguthern Palestinc, in 1sil, of a man who had incurred the wrab of the Turkish ufliciuls, and fled to Egypl. 
might fe fultitled which was spoken of the doril ly the

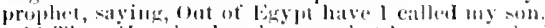

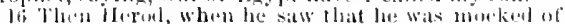
the wisc men, was exceeding wroth, aturl sont forth, and slew all the children blat were in bethlehem, and in all

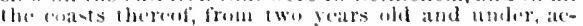
curcling to the time which he had diligently inctuibal of the wise men. the prophet, saying, out of liggpt alid I eall my

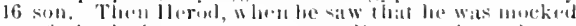

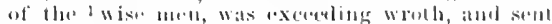
firth, and slew all bly male ehilalen that were in

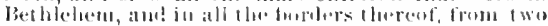
years old and under, aceording to the time which

I Gr. Magi.

the Lord by. On "ot" and "by, sece on l: 2.2. Have I eallede Did I eall, is a literal tramslation of the tiresk, and aremialy better suits the stallomont of a romote event. 'The prediction quoted is from Ilos. 11: 1. In form it follow the Molnew axatly, while the

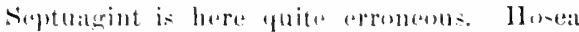
clearly refers to the alling of loriel out of

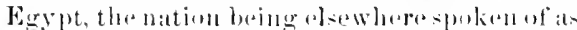

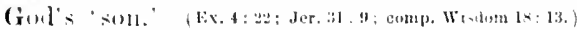
But theme is an evident typical relation bo-

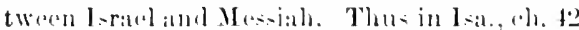
to si. the "orevant ut Johuvals is primarily the aation, but lhe predietions have betes more complenely fullilled in chri-t, who emberded and am-anmated the miseion at

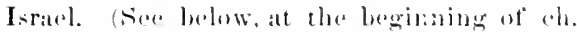

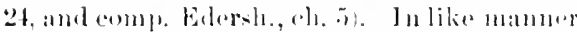
here. Is I-racel in the elolihhoul of the nat-

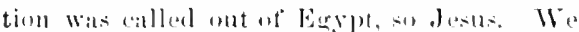
may even find resemblance in minute details ;

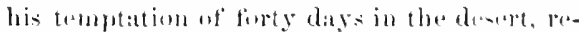

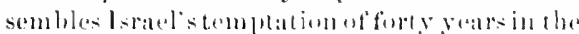
deselt, which it-elf arremponded to the tiorty

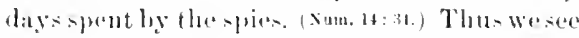

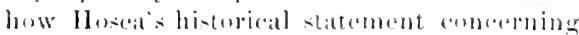

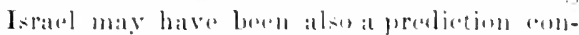

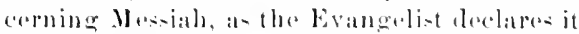
was. It is not necessilly to stlphese that thi-

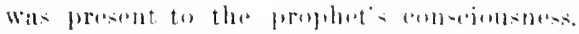
lixaled ly inspiratiou, a proplate may wall have said thimgs having dewper meanimg-l han he was dinlinelly awareat, amel which om a a

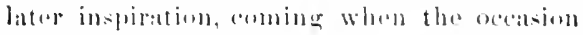

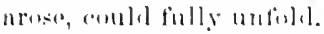

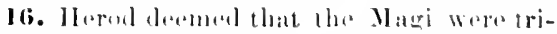
fling with him Thry gol from him line in-

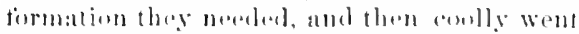

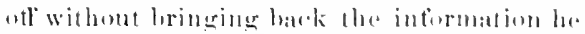

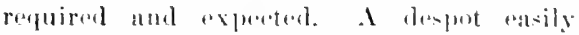

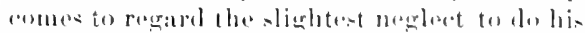
bidling as a grose in-ult. Alpanly. nu

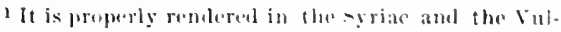
gate, in the lieneva and thu liheims, and by Bezat. But Wychf, through translating Ilu. Vulgate, las simply 'clithren,' and so 'Tynitale, and Crantuer, and also dombt, denierninger to malke way with thas child, the king was mow ereatly incensed at this in-

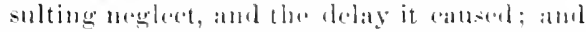

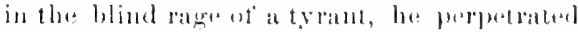
an act which may sem to lls mot merely

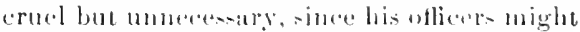
atasly have fomml wat tha chibl whieh the Masi latel visited, and also ill--suited (1) his design, siner in an indiserininate masaleres the elibl sought might ascapes. Such blind cruelty is, umederall the cirenmstances, matural

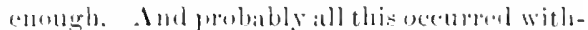

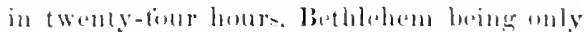
five miles ott. 'lihe Magi went at nighlatil, amd being warmal in a elreatm, departed during the night. As they diel not return mest disy,

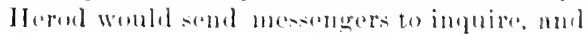

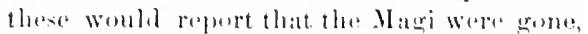
and the child mi--ing. Jaron might andolude that the chibl was -infuly concealed in the

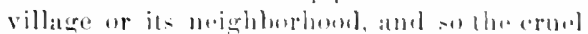

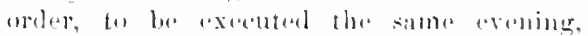

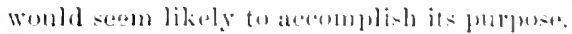

All the children. Propuely, all the mele children, as in Res. Ver., the original marliing the enencles. The bomers. Tha Enerlish word enots formerly siendital lumbrs

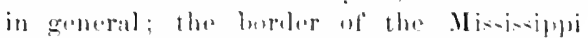

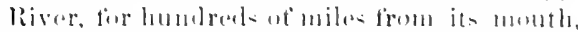

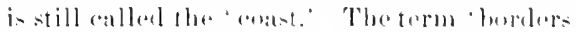
is aften nated for the territery they inclesen,

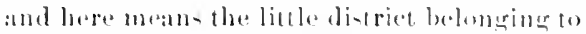
the town. From two years old and moler,

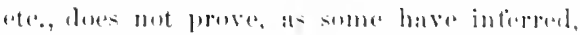

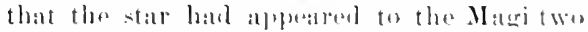

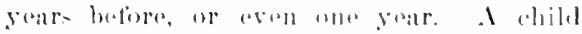

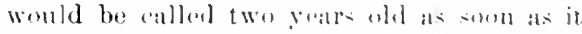

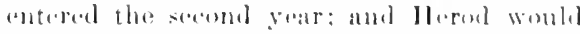

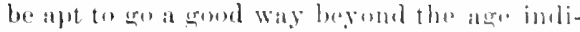
catcel by the time of its appearamer, in wroler tu maliestros.

licelesiastioal tratition making it fimrtont

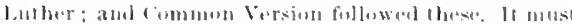

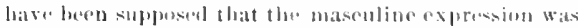

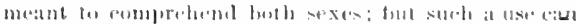
never be assuned unless the connection rejuires ic. 
17 Then was fulfilled that whieh was spoken by Jereny the prophet, saying,

1s In liana was there a voiee heard, lamentation aud weeping, and great nourning, Rachil weeping/18 for her children, and would not be comtorted, because they are not.
17 he bat earefully tearned of the 1 wis. mon. Then was fultillet that which was spoken through Jeremiah the frophet, saying,

$A$ voice was heard in Lamah,

Weeping aud sreat mourning,

liaclsel wesping for her chiklen:

And she would oot be comtorted, beeanse they are not.

I Gr. Magi.

thousand), and modern poputar opinion bave greatly exaggerated the number of children slain, which by any just calculation from the probable population of the little town and its distriet must have been very smatl, say fifteen, or twenty. We can thus see how little foundation there is for the objection taken by certain critice to the authenticity of this incident, on the ground that it is not mentioned by Josephus. Amid the numerous and aggravated cruelties which marked the closing period of Herod's life, the massacre of a fow children in an obsenre village might have been eatsily orerlooked by the historian. And when it is said that the connection of this massatere with a person supposed to be Messiab made it a prominent tiact, we may reply that, supprosing this connection known to Josephus (who was not born till some forty yeats afterwards), it would have made him atl the more dispused to omit the incident, seeing that he has the impudenese to represent the Messianic hopes of the nation as fulfilled in his patron, Tespasian. In like manner, when proffessing to state the teachings of John the Baptist, he makes no allusion to John's announcement of the coming of Messiah. (See on $3: 2.)^{2}$

17, 18. Then was fillilled. Sis in $27: 9$.

1 Besides the details given by Josephus, olserve the folkwing general statement ("Ant.," 17, f, 1): "Alud despairing of surviving he grow utterly savage, aeting with morestrained anger and bitferness towards all; and the cumse was lis helief that he was despised, and that the nation took pleasure in his misforlunes."

2 Tlu Latin writer, Maerolijus, an offietal under flue Christian omperor Theodosius (5th century), among various witty sayings of the first Angustus, gives the following: "llearing that anong the torys mbler two years old, whom llerod, King of the Iews, oriteled to he killed, his own soll also was slain, Augustus saiu, "Befler be II trod's pigr than his son." (In troek, which Anguslus habitually spoke, "lietter he llerol's hyn than his hyom.") The tratition associated with the jest, has obviously mingled the killing of Antipater, Herod's grown son, with the story of the childron at Bethlehem. It is not at all likcly that the two inci-
Everywhere else Iathew says, "that it might be fulfilled.' In these two cases he probabiy felt an instinctive reluctance, in which we can sympathize, to associate directly the divine purpose with a deed of enormous wickedness. He says, in these instances, as in the others, that the event 'fulfilled' a prediction; but avoids saying, what is true in a just sense, but would seem to require explanation, that the erent was provielentially brought about for that purpose. By-or, throughfollowing the correct text. ${ }^{3}$ For the meaning of the prepsition, comp. on 1 : 2.2 . The quotation is from .Jer. $81: 15$. The words lamentation and are here not genuine.

This quotation presents serious difliculty. When Nebuchadnezaar ordered that the people should be carried into captivity, the persons selected were asembled, previous to setting out, at Ramah, which may have been Ramal in the tribe of Benjamin, about five miles north of Jerusalem (and ten miles from Bethlehem), or else some place of that name near Bethlehem. (Thomson II., 28). This cal)tivity seemed to threaten the complete destruction of the nation, with all their national hopes; and the bitter grief of the peoples is poetically dencribed by representing Rachel, one of the mothers of the nation-the mother

dents were originally connected ly Augustus, whoknew all alout the dath of Autipaler and his brothers. The confusion is manitenly dueto a later time, and lhe story of the loys under two gears most probably eame from Christian sourees, thongh that question caunot be determined.

3 Sume stmdents or eopyists doubtless eonsidered it an error of previous eopyists, olserving that 'the lord' is not bere mentioned, as in $1: 22 ; 2: 15$, aul iommonly, and so altered it to 'by.' ( $A$ fow Mss. have a similar ehange to 'hy' in v. 23.) similarly in :": 3 .

4 They were no doult inserted by some, beeause foumd in the original of the prophet. Few forms of alteration in the New Testament text are more eommon than surh assimilation of quotations lo the Old Testament, it being erroneots ly taken for granted that the New Testament writers always fuoted with verbal exactuess. 
1! bit when 11 erod was deat, betweld, an atugel of the

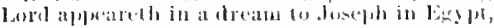

at that tribe in whone territory the axiles wart

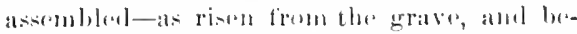

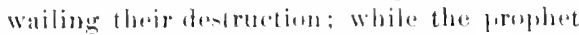
combirts has with the as-surance that there is hope fur the future, for the people will be lesstored. Now, when this furetical pasitgre is said by Mathlow lo he 'fultilled' in the atso of the massare at Bathlohem, how are we to

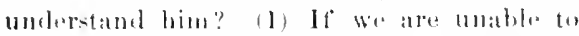

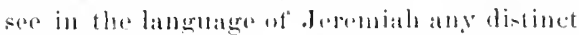
reforence to this masarese it will not follow that the Evangelist bas meroly male an apd quotation. Ile and his Jewi-h reators hat

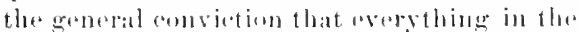
history of their nation was saberel and -igniti-

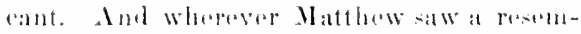
blanes between an eront in the history of A-low and an event in the lite of Mresiah,

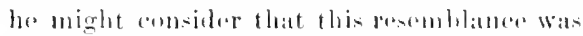
divinoly elesierned, and wish his reateles to

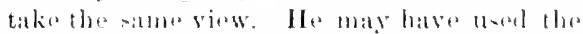
worel 'fultill' in this sense, net intending to

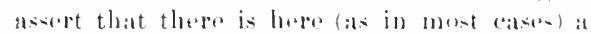
dofinite prenlietion, distincety fultillad, lsut

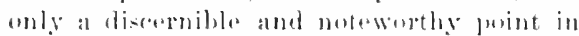

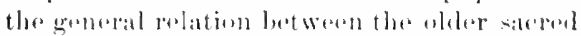
bistury and the new. Thus anderstemet, the

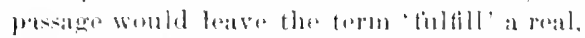

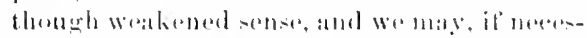
sily, penarel it as similarly a-ed in varimas

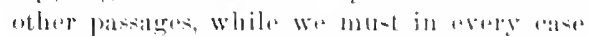
inguipe whether there is mot in fultilluent in

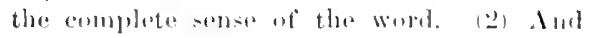
maly we not bere trane somb indiations of

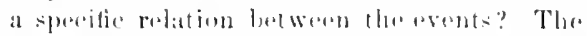

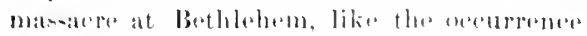

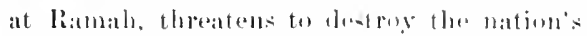

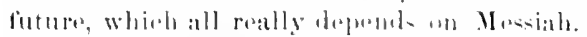

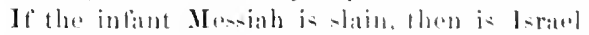
ruinder. Ninpuse anty that sumb at Buhle-

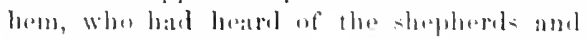

19

But when lTerod wat dead, beholel, an angel of the

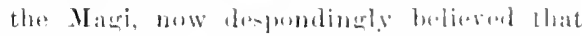
the naw-lurn liner was sabin, and their

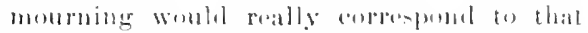

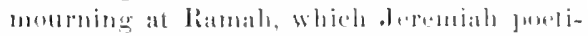

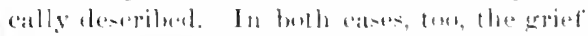

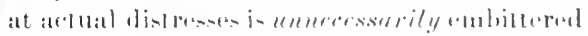

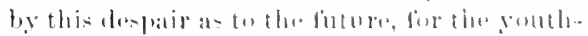

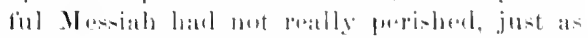

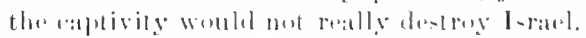

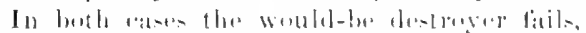
and blesinge are in sore for the preple of

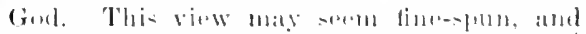

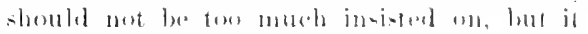

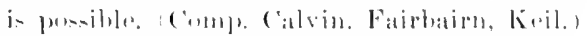

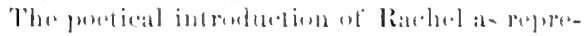

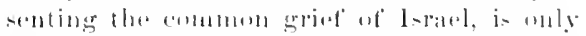
a -1 burdinate and incidental thing, and wa

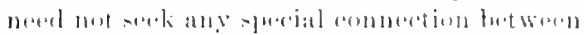

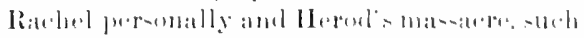

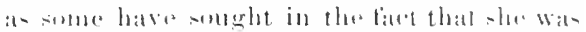

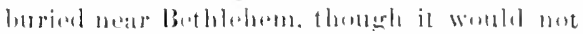

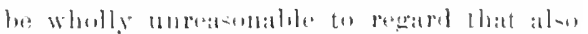
as signitioum. The tomb ut liatebel is still

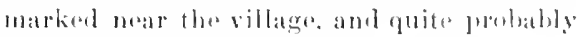
at the real jolines.

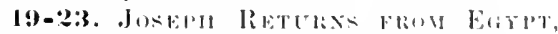

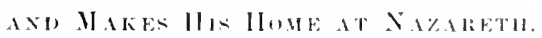

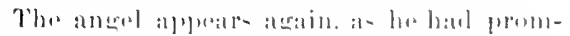

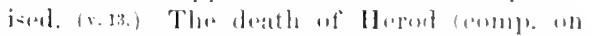

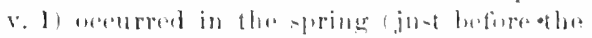

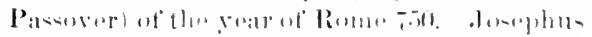

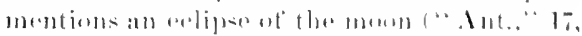

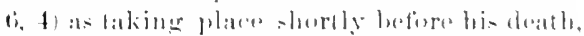

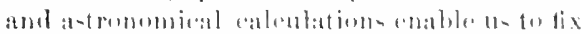

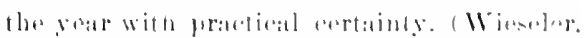

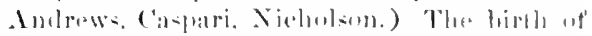

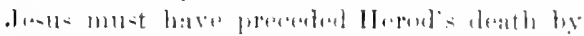

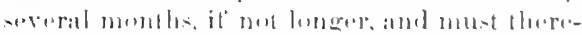

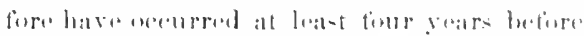

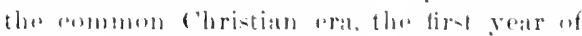

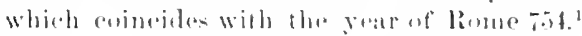

faml death. Is he was, when he h."gan his ministry.

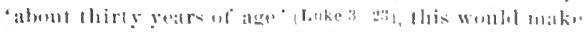

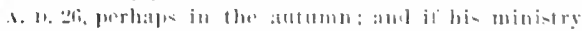

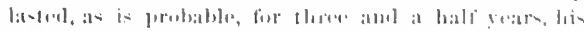

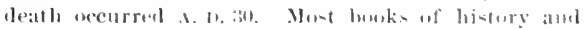

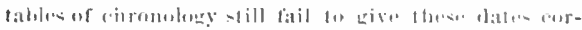

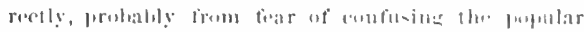

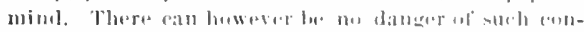
fusinn, if the simple dated, as just staled, receive the shirbter attentiun. 
20) Sayins, Arise, and take the young child and his mother, and an into the lawl of larael: for they are dead which soushl the young child's bite.
20 Lord appeareth in a drean to Joseph in Egrju, saying, Arise aml take the gommehild and his unther, and go into the land of israel: for they are dead
The poos old tyrant died of a no-t loathome and torturing disease (see oom. "Ant.," 17, b, 5), in the seventieth year of his lite, and the thirty-serenth of his nominal, or thirtyfourth of his actual reign. (Jos. "War," 1 , $3: 8 ;$; “Ant.," $17,8,1$.)

20. 'Talie the child and go, not now" 'flee,' as betore (v. 13). They are dead. The expresion was probably suggested by Ex. 4: 19, "For all atre dead that sought thy life" (Sept.), and so it talies a general form. There are nome now that seek the child's lite-all such are dead. This might be satid the expression heing borrowed) without specific reference to any death but that of Herorl. (S'o Bengel, Bleek, Keil.) It is also possible to understand the plural as a mere general statement of a partieular finct, such as is common in all languages, and without any reference to Ex. 4: 19. (Mever). The idea (Euthym., Clark, Lutteroth) that Antipater is included, who wat slain a few days before IIere."s death, ansllumes that he hat shatred his lather's hostility to the child, an as a tion unsupperterl and improbable. - To seft the life of any one is a IIobrew icliom, Rom. $11:: 3 ;$ J 1 r. 4: 30 ; Ex. 4: 19. The land of Israel was said partly, perhaps, in contrast to the heathen land in which they had been

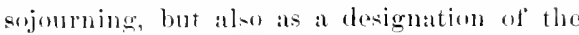
whole country, the term 'Judea' being prese ently appliod (v. 2.2) to a purticular district. "Land of I.ratel' is not elsewhere found in the New Tortament, lut ace 'cities of' Isranl. in $10: 2 ?$. But when he heard. 'Notwithstanding,' in ('om. Ver., is culte toustrong for the Greek connective. Judea, always in Mathlew, Mark, and John, and sometimes in Luke and Acts, means the sonthorn distriet. as distinguished from Galilee, Samaria, and Prora. Elsewhore in Lukr and lets, and always in the Elistles, it denotes the whole comintry. In v. 2.) the only fact of import-

\footnotetext{
Tho name 'Pulestine ' means lawd of the P'hilistines, the form beine a litth changed in passine throngh the cimek. (In Comb. Ver. of Old Testament, "Palestina' and 'flhilintia.' As the Philistines aceupied the maritme plan, the direcks and komans, first visiting the towns nota the eoast, afterwarts extemelel the name of the eoast to the adjacent region iuland, as
}

ance to Joseph is that Archelatus reigns over Judea, where he hos intended to live; and we need not suppose that 'Judea' here ineludes Simaria, which was also under Arelelaus' dominion. 1 After many ehanges of his will, IIerod at the last moment divided his chminions among three of his sons (Jos. "Ant.," 18, 8-11). (1) Herod Antipas was made Tetrareh of Galike and Perea. (The Greek word 'tetrarch' signified originally the ruier of the fourth part of a province or distriet, as in Galatia; but was applied by the Romans in the time of our Lord to the ruler of any considerable part of' a province or people.) He is the Herod who alpuars in comnection with John the Baptist and the public ministry of our Lord (14: $1 \mathrm{ff}$ ). (2) IIcrod Philip, Tetrareh of Iturea, 'Prachonitis, and some adjacent districts, is not mentioned in the Gonel history, extept in Luke 3: 1 . It was another Herod Philip, one left in a private station, that marriel their niece IIerodias, and was forsaken by her for Antipas; the danghter of this other Philipand llerodias was Salome, the dancer, whosubequently matried Philip the Tetrareh. Among the ten wives and numerous children of II erod the Great, the same names fretiuently recur. Philije the Tetrareh is dascribed by Josephus as a worthy nean, and a just ruler; apparently the best man of the Herod family. Our Lord, towards the else of his ministry in Galilee, repeatedly retires from the dominions of the weak and ('unning Antipas to those of Philip (14: 13); 1.): :2); 16: 13). (3) To Arehelatus were given Indea (with Idumea) and Samaria, making at least one hall' of his father's kingdom, and vielding twiee as much revenue as both the tetrarchies combined (Jos. "Ant.," 17,11, t). Iterod assigned him the title of "king, and he was saluted as such after his father's death, and so pegarded in Juden for a emsiderableperiod (Jos. "Ant.," 17, 8, 1f, and ch.

they did in many other eares, and thus Palestine heeami a common name for the whole conntry, being so llsed sometiures aven by l'bilo and Jusephus. Thomgl not fomnd in $\mathrm{N}^{+}$(a) lestanuent, it has comtinued to mal tha nane? Judea to the prescut day. The rodoubtable l'bilistines still live in grography. 
2I Aml he arose, and took the yound chill abl his mother, and cathe ingo the lant at lsatel.

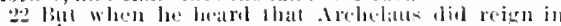
Judea in the rom of his fith her Jleroet, he was atiat

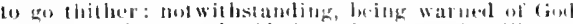

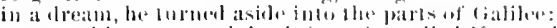

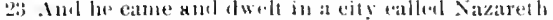
that it might lo follilled which was spotecte by the froplets, Ile shall be callerl a Xazarebe.

9. 1-5), thenght the Empuror Aurantu- finally allowed him only the title of athotreh ruler of a nation or people, a rather more homorable tithe thatu tetrarels), with the promine.

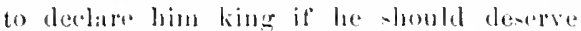
it. The expression did reion, or wers reigning, i. e., was kinge, is thus minutely eorrect for the greriod immediatmy fillowine Ilerol's death. It may, howesere, be understend as used lowede junt as "kinge is applieel to any ruler, from the Romatu Eunpreror (1 Petre ": 13) to Herod Antipas the

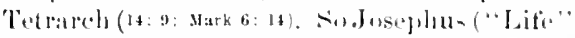
3) says his own fiather was bom "while Arebelatu wat roigning the tenth year." Joseph is strpurised and disappesinted at learuing that drobelatus in appointerl king of Judea, fore it land beent molerstoud that Antijnas was to sucereed his tither in the whelle kingedom, and Herod makl the dhange ju-l before his death (.Ius. "Ant.," $17,6,1 ; 8,1$; (4, 4

On warmed and turued aside, or withdrew, see on $x$. l:. The parts of dialilece. thase parts at the comntry which were coms-

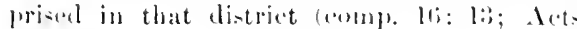
2(1: 2).

23. The town of Natareth is mot ment-

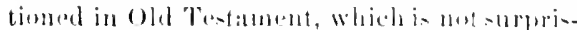

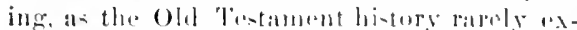

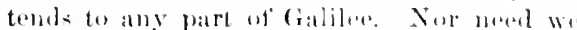
womler that Josephus deres not nature it, an it was a suall texw remote from the prineipal

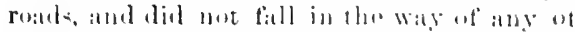
the military aperations which lan ateserilus. It wis situated about fifte-five miles morth of Jerusalem, in an elevated lateins stand its is frequently tound in simutrit and cialilen.

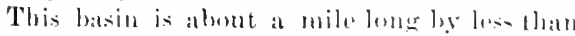
lablf a mile widle, opening sonthward by at narrow and wibling pass inte the great platu

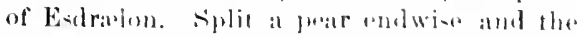
lower lialt, with the arobiel stem, will giwn the shape of the valley of Nazareth. The

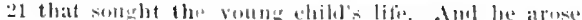

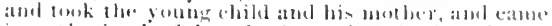

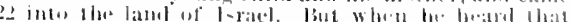

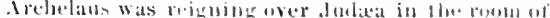

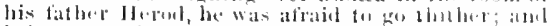

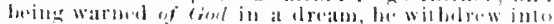

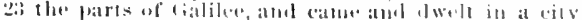
called folzaresh: Alat it might be tultilled whith was

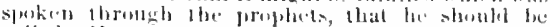
called a Namarene.

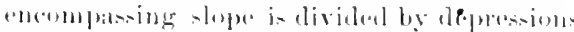

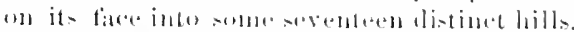

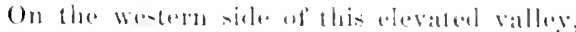
atul sloping a lithle way ur the western hill,

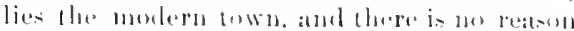
(1) thiuli the site hite materially elotugand.

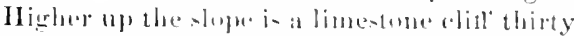
ur forty teat high. which (or one of the sind

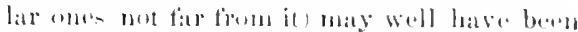
the "hrow of the hill wheren their eity wat huilt," from which the mole proprosed le catet

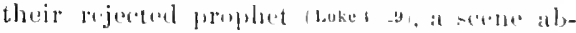
- ardly located he monkinh tradition at a pre-

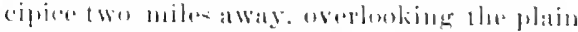

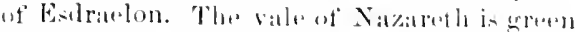
and rery fertile, with many truit trese and at

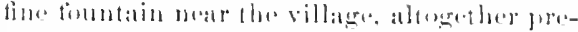
senting a leatutitul areme : and from the high

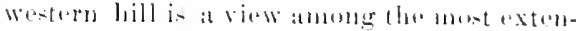

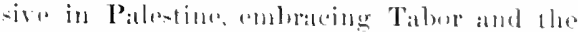
ereat plain, Carmel and the Whe Maliterra-

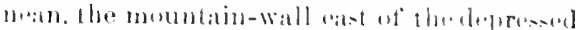

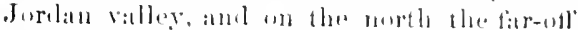

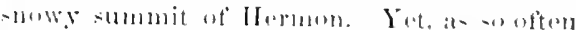
happerse, the dwollers amid all then betaluties of nature were rute siolent, ame of exil re

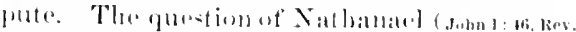

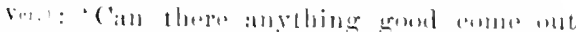

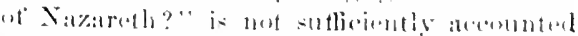

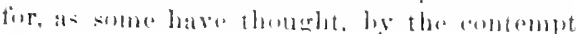

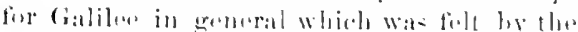

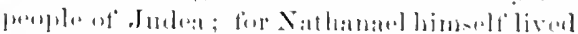

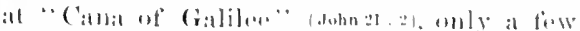

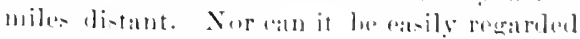

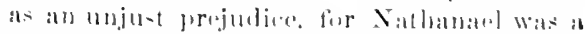

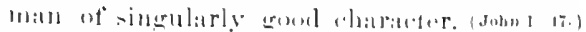

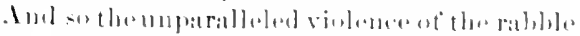

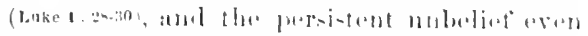

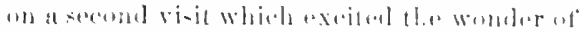

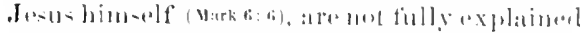

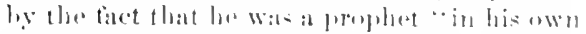

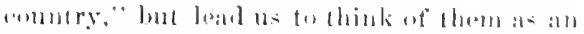

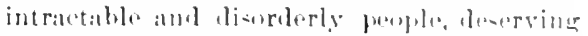
their bind rejulation. But here liven the

The original Aramate form of the name was problably Nazala (sec lieim). 
righteous foseph, and the ineek, devout Mary ; and here "increased in wisdom and stature, and in fivor with God and man" (Luke 2: 52), the child, the boy, the youth, the man, who was in due time to eome forth from this obscure village as the eonsolation of I'sracl, at the savions of the world. Here he wrouglat (Mark $6: 3$ ) at the humble and laborious (alling of his reputed father (see on $13:$ : 5) ; here he worshipped every subbath, with such worship ats only the prerfect eould pay, in the synagogne from which he wats afterwards to be rudely thrust forth; and often, no doubt, le would climb this western hill as the sun was sinking in the ILediterranean, and look down with pure pleasure upon the boatiful valley, or far away over the magnificent prospect, and, as his human mind gradually unfolded to comprelend his mision, would think great thoughts of the kingrlom that should till the whole earth and should have no end. (Seecopions and plusing deseriptions in Renan and Geikies.

That he should be called, is as matural a transation of the Greek as He shall be called, and better suits the most probable interpretation of this passage. The words, 'He shall be called a Nazerene, are not found in the old Testament. The difficulty thus presented has been variously explained. (1) Chrys., IIanna, and some others, suppose a last prophery. But this is a mere make-shift. The term 'the prophets' in New Testament, everywhe means the eanonieal prophets. (Mieyer.) Ewald's suggestion that it may be from an apoeryphal luok, is likewioe a makeshift. (2) Jerome, Calvin, and others, comneet it with thr law as to the Nazirites. But Nazareth and Nazalesue are almont certainly not derivel from mezir, 'eonsorated,' Mint from netwer, 'branch.' 'shoot,' ats show by the Sirriac and the liabbinieal forms of the werd Nazarend linbiuson, Erang. and Mishna); or eje from some kindred word formed on the same root. (Grimm.1 Morenver, fesue was in no spuce a Nazirite, being quite ditferent, as he himself decelares (11:1x, 19), from Jollen the Baptict. Oheerve that Reve. Ter. in Num. 6: 2; Judg. 13: 5, ote... spolls not Naza-

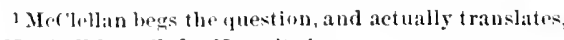
'He shall be called a Nazarite.'

2 It has beeu remarked that Plutareh frequently quotes rite, but Nazirite, according to the Hebrew nazir. (3) Fritzsehe, Meyer, Bleek, Weiss, Edersh., and others, suppose a reference to Isa. 11: 1, where Messiah is called a 'branch,' Hobrew netzer. An equivalent though different llebrew word is applied to him in Jer. $23: 5 ; 33: 15$; Zech. $3 ; 8 ; 6: 12$. From the passige in Isaiah, reinforeed by the others, it may have become common (Bleek supposes) to eall the Messiah simply netzer, 'branch,' as is perhaps implied in Zeeh. $3: 8$. So the predietion of the 'prophets' led to IIessiah's being 'called' Net\%r, and as a resilnent at Netzer on Natzara, Jesus was called Nazalrence This is ingenious and may be true, though it seems tar-fetched. (4) Olslatusen, Lange, Westeott (Int.), and others, understand it as referring to the various predietions (e.g., Psa. 22; Isal. 53), that Mersiah would be despined and reviled, as was done when he was 'called' a Nazarene. Had he been called Jesus the Bethlehemite. it would have semed honorable; but to be called Josus the Nazarene, would at once awaken the eontempt of the Jews, and would be a prima facie argument against his claims to be regarded as Messial, the son of Darid; and we know that such an argument was once actually used. (Johu 7 : 41.) ${ }^{2}$ Asthus understood, the passage is best translated as in Rev. Ter. This seems, upon the whole, to be deeidedly the best view. The MLhammedans in Palestine, now commonly eall Christians Nazalenes. (Thomson, II., 316.) (i) Hengstenberg, Alexander, Ellicott. Keil, combine (B) and (4), nnderstanding [silah 11:1 to represent Mlessiah as " a shoot from the prostrate trunk or stem of' Inse, i. e., as from the royal family of . Iudah in its bumble and reduced estate." (Alex.). But this mode of comneting the two theories appears artificial. It is better to be entent with one or the other, as either of then is quite possibly eorrect. (6) Intteroth hats a new axplanation: Joseph saw that a life in Bethlehem would be perilous for the child, and in order that he might live, and the propheeies coneerning him as Mrssial might be fulfillefl, Joseph took him to dwell in Nazaroth, "becanse be would be ealled a Naza-

Plato as saying something which tannot be found in Plato's works in so miny words, but is substantially containal in various pasiages. Indecd the same thing is done by many writers, aud is perfectly natural. 
LutuEn represents the Magi in their own country as the first New Testament preachers, and the murdered innoents as the first martyrs.

V. I9 (and 18). If we wait and wateh for the guidance whieh God has promised, it will comes, and at the right time. V.20. He that 'fled' in alarm (v.13) now 'goes' in safety. Alas! for the human bejug whose death brings a focling of relicef to the imnocent and the gord. V.22. Like fither, like som.

$\mathrm{V}^{+}$. 23, The truest greatness usually grows up in rotirement, often in obscurity; and the grates peromage in history was not an exeretion to this rule. In our day of hot haste, and especially of gouthful impatience to be at work, it is well to remember that he who linew his ministry could last but a few years, spent thirty years in the most quict preparattion.

\section{THE YOUTH OF JESUS,}

As to flue Saviour's life, from the point now reached to his laptism $(3: 13)$, we have no information in Matthew, and none in the other Gosjuls, sive the interesting and instructive incident of Lnke 2: 41-5.2. Thare we find him at the age of fwelve, highly intelligent and frusted by his parents; devoted to the study of the fieriptures, showing a wonderfinl arequantance with them (amp). Josplums. "Life," \%), and asking questoms in the enger desipe to know more; begimning to pelearo that frol is in some penuliar sense his 'Father, "and fond of' attendaneo at his "Father's lonse'; slorinking alreary trom the sensation he probures, rotiring into obseurity and subjeet to his pitrents; and "memeing in wislom as he grows instibture (tor a a o). It is a bright

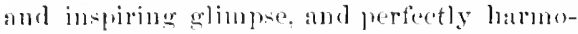
nious with lis eharater and life as a public teulluer.

To meet the curiokity always felt as to his chilahood and youth, a varioty of marvelous stories wore inventod during the arly centuries, which were recoreled in symergphal Gospus or pasend into tradition. Though many of these are sonetioned hy the Romish Chereh, they are often alowerl, amd sometimes blasfhomeme; and the receital of them would be fo me profit, moless it were in the way of illustratine lig contrast the simplicity, the reserve, the porfect sood taste, of the inspirad narrative.
The external conditions mnder which Jesus grew ul, are known to us from genelal sources of information. His development must have been influenced by such outwald rircumstances as the following: (1) Hone. (2) $\mathrm{Na-}$ ture (see as to Nazaroth, on v. 23). His deep love of maturealpear. repeatedly in his public ministry. (3) The sicriptures. (4) The synagegue. (j) Labor; he was a worker in wouca (ara 6:3), and it is stated in a very carly tradition that he made "ploughs and yokes" (Justin Martyr, "Trypluo," 88). It is not improbable that after.Joseph's aleath (eomp. helow), the growiog youth's labur aided ju the support of that lised mother for whom ho took patins to provide when he was alout to die (John 19:26.23.) That he spent much time in reflection, and in prayertul communion with his Father, is naturally inferred from his course at a later period. (On this paragraph, comp. Keim and Edershoim).

A wong the outward events of these twentyeight or twenty-nime years, a few at least ought to be here recalled.

When J Jeus was about ten years old, A. D. R, such serious complaints against Arebelaus were made at liome, that he was deposed from the ethrarchate of . Fudea and samaria, and banisled to Vienua, in Gaul. (.Jos. "Ant.," 17, 13,2.) At that time the callier history of Arohelaus (see on v. 2*2) would be much talked about, and thus becoming fimiliar to Jests, might have afterwards sugrested the Parable of the Pounds. (Lubers: an.) For there is a striking remomblance in many laading points: (1) Areholaus went away to Rome to receive loyal power, and return to exereise it, and left his supporters in charge of his atlinir. 2, The Jews hated him, and sent an embissy of fifty persons to Rome to say that they did not want Arrelelan as their king. ("Ant." 17, 11, 1f.) (3) When Archelaus returned, though Augustus hid enjoined noderation, he punished with great severity. $(17,13,2$.$) After the banishment of Arche-$ laus, his dominions were made a Roman province, Many of the Jows bat desired this at the death of II Iext. and now antroated that it be dome, being weary of their weak nativo rulers, and expecting eqronter quiet and better protection for property and business under a Roman goveruor. Exactly similar changes, and for similar reasons, now often oexur in British India, and under the Russian rule in 


\section{CIIA P'TE li III.}

$I^{N}$ those days came John the Baptist, preaching in the widderness of durleat,
1 And inthondayseometh John the latetist, preach-

Contral d-ia, and were then taking place in)

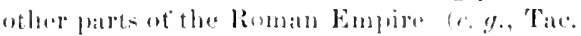

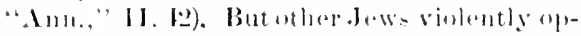
puseal sereh at rbatuge, alinging to the bare

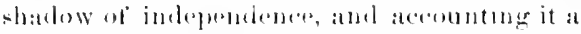

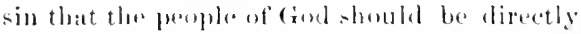

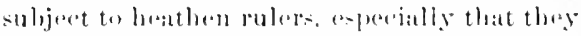
should fay them taxes. A pertion of these broke ont into rebullion mulde .Julats, the

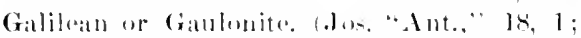
Lets 5: :3.) Jhiomevement, and other similat insurrections in fisllewing years, were ratsily quelled by the hemands, but tho sentiment which proslucerl them remained. (Comp). a secetion ofthe fiemalu Anabaptiots, the Fifth Monarchy mon in England, at(.) From it camo the furetion, " ls it lawful to reire tribute to

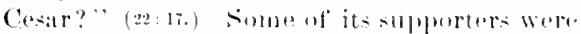
subsefurntly atsoliated als Cananites or Zelotale, includiug Fimun, who beame one of the twelle apostles. (10.t.) Denemeration ly degrees into mere robluers, the men af this opinionstill anmmanded popmlat stmpittis. as was perhapes shown in the rasent Barabbats. (27: เ6.) The stme smonlulerines sentinuent

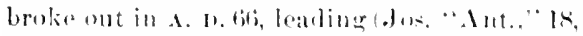
1, 6) to the war which ental in the restruetim of Jerusalem, and in which the \%ouluts took a frominent part. Thto Roman Gov-

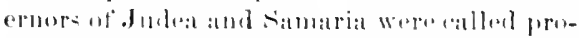
curaturs, tho sixtle ut whom, Pontius Pilatus (27: 2), mbled from A. I). 24 whon the mintstry

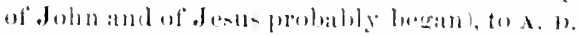

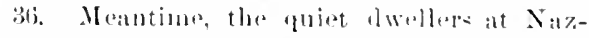
areth were mot directly comenemed in these chatuges anel commotions, rematining moder

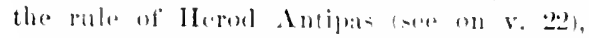
which comtimurel to A, 1) :39.

The youthtul carpenter wat probably in his nimetenth year (A. b. If when the great

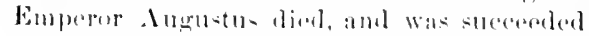

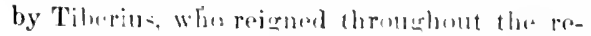

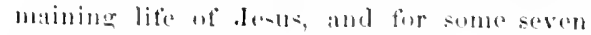
years longer (.1. 1). 37 ).

The Greek has a particle of transilion, de, which we often roncler 'and,' 'laut,' begin more naturally without any conjunetion. It is est to render it here, because the narrative seems to
It sems natrly artain that Joseth died at

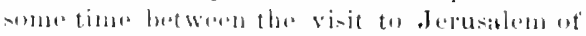

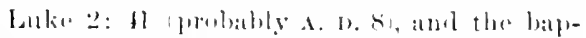

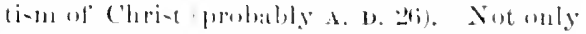
in he merel mentioned in the history at mo

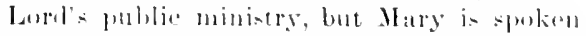
of in - lleh ways an-sem to imply that she was then a widum. That several sull- and daugli-

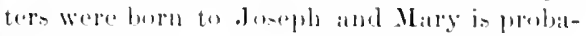
ble, but not certain. (Comp. on I : 2.5, and l:i: (5i).

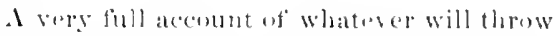
light on this prerol in the liteot christ, in-

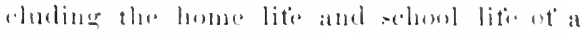
Jewish child, the secial intluences, fublic Worehije, and religious sentiments at the time, thr political chatuges, and the growing and

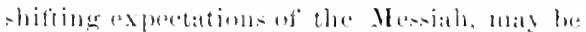

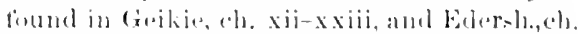

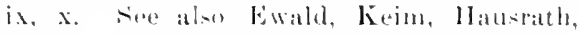
Edorsheim's "siletehes of Jewish sierial life," and uther witers.

\section{('h. 3: 1-12. MIN⿴囗十 OF Jйу тиЕ} B.⿻

The seremel grate division of this crospel

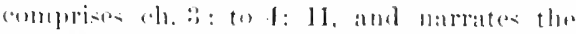

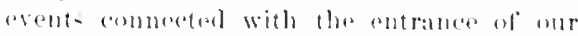
Lomel upun his publice work, including tho

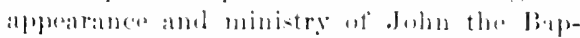
tist (3:1-12), the bitptisn. of .J (n-1): 1:-17) and his temptation. (t r.11,) llure tion the tirst

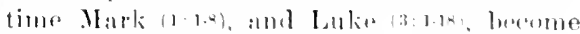

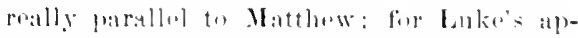
parently paralle] mattor beretutiole has luen entipely diatinet for m Mattlew.

1. In those daỵs. The lixe. Tor. has,

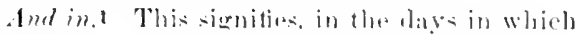
Juseph and hi- family dwalt at Sizaroth,

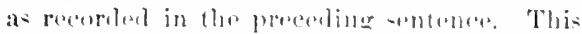

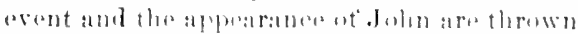
together as belonging to thes siture periuel. nut

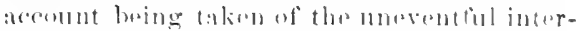
reniner time, which, in this resser. Was nour

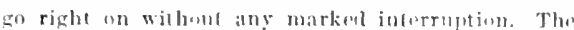

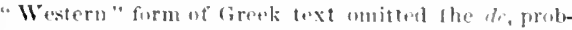
ably because it was thought there unght to be a jause. 
thirty years. (loke:3:23) So Ex. 2: 11, “in those digs," ba-ses over the whole tinue tron Mnses early youth, when his mother returned him to Pliarabli's daughter, until le was finty years oid. (Acts $i: 23$.) In other tases the expression is equally indefinite, thomgh the time passed over is shorter (e. g., Isal. :8: 1; IIark 1: 9; Aets 1: 15). The same lase at the plirase is found in classic writers also, where nothing is aimet at but a general dexignation of the time. Luke (3:1) here gives the date of John's appearance with great particularity. Pontius Pilate becante procurator a. D. 25-6. The fiteenth rear of Tiberius is probably to be eonnted from the time when he was associated with Augustus (two years before the latter's deathi, which would be A. D. 12. There camont be much doubt that Joln appeared in A. D. 20ij. Came, or rather, arrices, presents himself. The word is several times used to denote the arrival or public appearance of an official personage (toml). 1 Mate. 4: $41 ;$; 11 b. 9 : 11 ; and below, v. 13); ant it may be intended luere to denote Johu's appearance in his ofticial character. The Greek las liere the present tense, preeisely as in v. 13.

John the Baptist.-The mo-t probable date for the beginning of the Baptist s ministry is A. n. 26, say in the spring. (Comp. on 2: 19.) The Hatate.John (Johaman = Jehovah graciomsly gavel had become common since the time of the popular ruler Joltu II yreanus (died B. (1) 10i): thirteen persons of that name are montioned in Josephur and in the New Testament, besides the Baptist amd the Evangulint, wo meet with John Mark (Aotsw: 12), and Jalun af the high-priesty family. (Acts 4:6.) John the lorerunner was well known to Matthew's fir-t readers as the 'Baptist, or Baptizer (compl. 14: 2, 8); we fint Josephos also ("Ant.," 18, 5, 2) mentiming him as "John, whe was surnamed Bapti-t." This name, the baptizer. Was of enurse given him in consequrene af the remarkable rite he perfirmed, whieh attraced universal attention, and wa ropeatedy used as the characteristic peprenentalive of his whole work lsere on 21: 25).-The circumstatures connected with Juhn's birth are given mly hy Luke. Ot his history siones ehilhhond we anly know that he 'was $\vdots \mathrm{t}+\mathrm{l}$ : deserts till the daty of his shewing unto Isratel. (Lukel: o.) Hi= fiatlier would be anxious to give to the ehilel of sueh hopes the best priestly edueation, and it is probable that lo retired $t$, 'the eleserts' after the death ot his parents, who were of advanted age at the time af lid-birth. Such a step would be natural only when grown, or nearly so. In the wild region between Jerusalen and the Dead Sea (see below), he probably spent lis time in religious meditation, rijening for his great mission. Fot that he knew human nature, and observed the men of his own time, appears from Luke : 10-14. In this same wild region twelt the Escenes (see on v. T), and here also Joseplats ("Lifie," 2) locates the teaclier Banus, with whom he spent three years in sechusion, at a perial about thirty years later than Johu's public appearance. It had been appointed (Luke : 15) that from the beginning of John's lite he should not 'drink wine or strong drink, i. e., should live as a Nazirite (Num.6: 1-21), implying extraortinary and lifelong consecration to Gods service. A chilal of the momutains, and living a temperate life in the open air, he probably beeame surong in body, as well as 'grew strong in suirit. (Luke 1. so.) Comp. an v. 4. It is probable see on v. 13) that he hegan his ministry when about thirty years old. "This protracted period of private disciplinte and preparation in the lite both of Christ and his forerumner, is in striking contrast with our own impatience even under the most hurried sipenticial processes of education." (Alexander). - That a priest -lould becalled to be a propliet was met strange; compl. Jeremiah and Ezckiel.-For a fiurtier areount of John, see throughout this ehajuter, and o1 4: 12; 9: $14 \mathrm{ti}, ; 11: 2-19 ; 14: 1-13$; $17: 10-1: 3: 21: 25,32 . \quad$ Köhle, : "Though the historical information is very limited, there are few persolns of wheme we call form so elear and lively a comeeption. . . An imposing figure, ju wlose posture and trats of eommtemance were depicted jron will, and deep, hely arnestuess, yet without passing into luatuese. In entencral, Jubn may he called at "lassieal "xample of the manitestation of love in the garh at soverity. We canmet lanbt

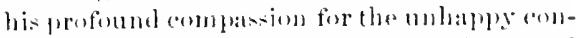
dition of his people. sunken in sin and expused to jurtgrient, althomghit womld hard!y oceur to us terenerive of him as weeping, likr the Lord Jesus, over the coming fate of Jerusalem." 
2 And saying, Repent ye: for the kingilomol heaven is at haud.

2 ing in the wolderuess of Jublta, saying, litpent ge

Preaching. See on 4: 17. The word wilderness is used both in Oid Fentanent and Now Testament to denote a region not regularly luilt up and cultivated, portioms of which were quitesturile, while other jwertions might be not destitute of herloage and other spontanerou- produetions. Finch a fract was commonly usol for palsturiage (Psa. tis, 12; Joel 2 : 22; Luke 15:1), and sometiunes (antainel watchtowers (20ron.26:10), settlexl inhabitants (Juises 1:16), and even cities. (Josh 15:6! ; 1 a. 1:: 11.) Tho 'wilderness of Judea' was a region of' no very well marked boundaries, lying weot of the Doal sea, and of the "xtrome suthern part of the Jordan, oceupying alout onethirel of the territury of Judah (Koim), and extemeling up into that of Banjamin. The narrow plain of the Jurdan, from the sian of Galilese to the Drabl seat is alio callad by

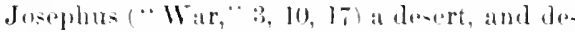
scribed by him as parched, mohealthy, and destitute of water, "x(o)t tho riser. (sis al-o Thomson, Il. J.jof.) Now Juke $(3: 2,3)$ says: "The word of Gonl eame unto, Jolus, in the wilderness, and lie came into all the country about Jurdan preaching, and Juln (1.24) speak-ot him a- engateral in baptizing. a little later than this, at Bethang, heyome Jordan. We thus comclude that II attholv, as in many other eases, contents himself with the general statement that fohns proaching and hap-

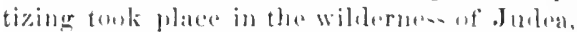
which included the lower batrt of tha Jurdan valley, and being without dofinits boumelaries, diel not need to lre earefiully di-tingui-hed

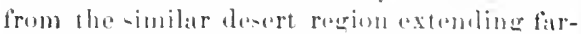
ther uptheriver, into whith as we grather from

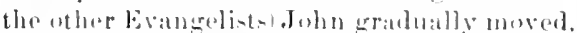

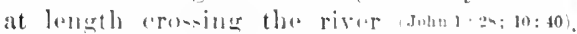

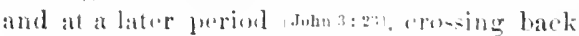
nud removing to Enom, which wat ertatinly Hestef the ondand There is thus no oecit-

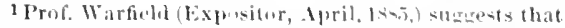
the bethany of John I: 24, was burth of the sea of

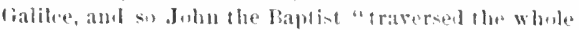
length of Palestine, preaching reptutume." But the eribence of a sits called bothany in that vieing is very" slender, amb his argument from John's narrative is far from salisfletury. Jesus might eavily enemuter sereral persons from listbatida, and whe from Cana, among the great crowds allending John's baptism, no sion for inferring, as some do, from Lake's

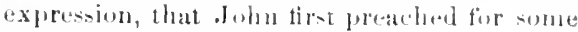
tinte in the willeprorse at at listance from the Jordan, amb atterwardis rane to the river. It shoulal be observol that revents dencribed an aecurring in 'the willarmess, or the wilder-

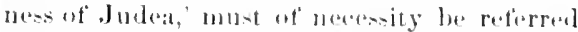
to diffirent part at that puite astemsive dintriot. John had probably livod \{loke 1 : wh in the southwesterm part, Lward, Habron; the scene of his baptizing wa in the northeastern

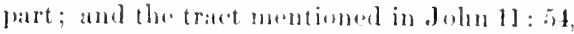
aperarently formonl the northwatern jart. I. (1) the secolle af the templation, see on $4: 1$. The same fireck word is nowed in all the late siges of New Testament in which the (inn. Ver. has 'wildermess' or 'Iterert. (sinet

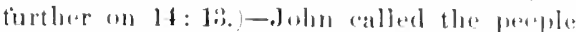
awat from the seats of grovernment and of fixed social influences, inte the wilder recrions,

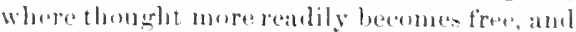
where the mind is at one drawn ont towards God, and triven in mpen itselt. (Koins.) In

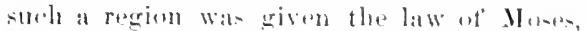
and protenders to a jopphotie mi-sind, aftor wor Lurd's time, lapuatedly drew erowds intu

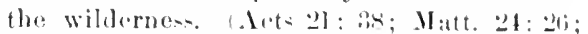
Jos. "Int.," $2(1,5,1$; " Wir,"

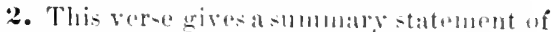
the sulstance of Jolus s preatehing. IRepent. Tounderstaud the presiots New Tustament unse of this highly inpurtant term, we must di-tingutsh betwen the Grenk worel. tha English

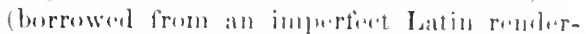

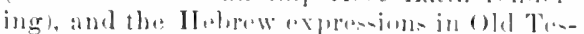

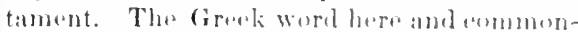

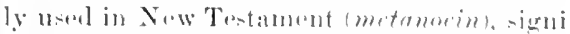

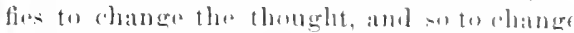
the opinion or purpues. This inner ahasege

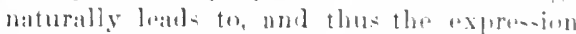

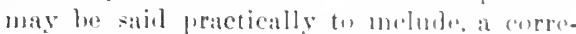

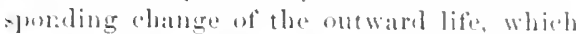

mater where it was: for the peopleceme frem all partsof

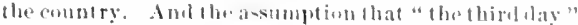

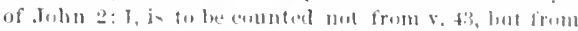

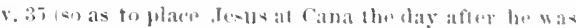
with Juhn), is arbilrary, wnnatural, and in tact, when

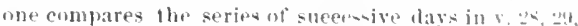

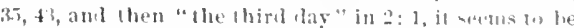
ont of th" question. We can serem reasun to believe that the baptist ever reached balitee. 
we usually deseribe by the word 'reform.' A change of thought does not neeessarily involve grief; and the word is sometimes used by Greek writers for a mere change of opinion or judgment, where there was no occasion for regret. But in all moral uses of the term there will of course be grief at the previous wrong course that one now determines to abandon. Whenever this Greek word is employed in New Testament (unless we exeept Heb. 12:17), the reference is to changing the mind, purpose, from sin to holiness, and no one will do this who does not feel deep sorrow for the sin he has already committed. Sorrow is thus not expressed by the word itself, but in New Testament use is always suggested from the wature of the ease, and thus becomes asseciated with the word. To repent, then, as a religious term of New Testament, is to change the mind, thought, purpose, as regards sin and the service of God-a change naturally accompanied by deep sorrow for past sin, and naturally leading to a change of the outward life. A different Greek word (metamelesthai), signifying to change the feeling of care or concern, to regret, is employed in $21: 29(80)$, $32 ; 27: 3$, and in Rom. $11: 29 ; 2$ Cor. $7: 8,10$ ('repented of');Heb. $7: 21$. This regret might of course lead to change of purpose and eonduct, but the term does not denote any sueh change, though the circumstances sometimes suggest it. It is only the first Greek word that New Testament uss to denote repenting of sin. The distinction between the two must, however, not be too strongly pressed, as shown by their use in the Septuagint (see below). A changed feeling might imply, or at least suggest, a ehanger purpose, and a changed purpose at ehanged feeling, so that both would sometimes yield substantially the same sense.

The Hebrew word for 'repent' denotes pain, grief, and sometimes suggests ehange of thought and purpose: the Septuagint translate it sometimes by the seeond and sometimes by

This Hebrew term is repeatedly applied to fod, as grieving over something he had done (the sept. using both (rreek words). The people are said to 'repent' (Sept. metumelesthai) in Ex. 13:17; Jud. 21:6, 15, and in Joh 42:6; (in these the Sept. mistranslates). As applied to grieving over sin, it is foum in Jer. 8: 6: 'No man repenteth of his wiekedness,' and $31: 19$ : 'After my turning, I repent,' (in both passages the Sept. has metunoein). Comp. Ecclus. 48:11. The other passages of Old Testament in which English Version the first of the above-mentioned Greek words. ${ }^{1}$ It is noticeable that the prophets now here exhort men to 'repent' ( $t$ liough telling them to mourn and weep over their sins), but use the simple and practical word 'turn.' The New Testument also frequeutly employs this general and practicul term, variously translated into English by 'turn,' 'return,' 'be converted'; and in Aets $3: 19 ; 26: 20$, both are combined, 'repent and turn' (eomp. Aets 11: 21, 'believed and turned'). It thus appenis that the New Testament exhortation is substantially the same as that of the prophets (e. g., Joel 2: 12, 13; Isa. 55: 7 ; Ezek. 38 : 11, 15; Zech. 1:3,4); but the New T'estament term (metanoein) rendered 'repent' is more specifie, and strictly denotes the inward change, leaving the outward elange to be inferred as a consequenee, or sometimes distinetly expressing it by adding the word 'turn.' In both the Old Testament and the New Testament exhortation the element of griff for sin is left in the background, neither word directly expressing grief at all, though it must in the nature of things always be present.

But great difficulty has been found in translating this Greek work into other languages. The Syriac versions, unable to give the precise meaning, fall back upon 'turn,' the same word as in Hebrew. The Latin versions give 'exereise penitence' (pcenitentiam agere). But this Latin word, penitence, apparently conneeted by etymology with pain, signifies grief or distress, and is rarely extended to a change of purpose, thus corresponding to the Hebrew word which we render 'repent,' but not corresponding to the terms employed in old Testament and New Testament exhortations. II nee a subtle and pernicious error, pervading the whole sphere of Latin Christianity, by which the exhortation of New Testament is understood to be an exhortation to grief over sin, as the primary and principal idea of the term. One step further, and penitence was

represents men as repenting, have is the original 'turn'(1 Kings 8: 47; Ezek. 14:6; 18:30). But in the Apocrypha, Eeelus. 17: 24 exhorts men to turn to the Lord and forsake their sins, and says, "Luto those that repent (metanoein) he grants return to him.' Wisdon 11: 24, "Thou overlookest men's sins that they may repent.' Comp. Wisdom 12: 10, 19. Ecelus. 44: 16 speaks of Enoch as "a pattern of repentance (metanoia) to the generations.' Comp. also Wisdow 5: 3 . 
contracted into penance, and associated with medieval ideas muknown to New Testament, and the English Versions made by liomanists, now represont John. and Jesus, and leter, as saying (pronitrntime agite), 'du penance.' From a late Latin compound (repenitere) eomes our English word "respent, which inharits the fiult of the Latin, making grief the prominent element, and change of purpose secondary, if expressed at all. Thus our English word corresponds exactly to the second Greek word (metamelesthai), and to the llebrew word rendered' repent, but sadly fails to translate the exhortation of the New Testament. It is therefore necessary constantly to repeat the expianation that the New Testmment worl in itself tenotes simply change of purpose as to sin, leaving us to understand from the nature ot things, the accompanying grief and the consequent reformation.'

But while John's exhortation is substantially the same as that of the prophets, it is enforeed by a new and strong motive, the near approach of the longexpeeted Mesianiereign. Is at hand, or more literally, has come near. (So 4: 17; 10: 7.) This is here montioned by Matthew alone, who writes esperially tor Jews. They continually spoke of Messiah as 'the coming one' (11:3), of' the Mrssianic period as 'the coming nge' (neb.6:5), and John tells them that Messialis reign has drawn near. Hodoes not say, Reperit, and su the reign will draw near, but Repent, fur it has drawn near (Calvin). The werd basilfia, which everywhere in English Version is rendered kingdom, mans (1) lingohip, the possession of royal authority, e.g., Rev. 11: 15; 'the lingship (sovereignty) over the world is become our Lord's and his Christ's' ; comp. Rev. 17: 18; Mitt. 16: 28; I's. 22: 28. (2) 'reigu,' the exereise of royil power, or the periold during which it is exorcised; (3) "kingdom.' the subjects, the organization (12:25), or the territory. ( $1 \otimes)$ In the sense of the territory it is not used in Now Testament coneerning Mosiah's kinghom, and probably not in

1 A pamplitet, by Trealwell Walden, entiled "An Undeveloper Chapter in the life of (hrist" (New York, Whittaker, lse-n), is devoted to the worl metonoin. It presents forcibly the grievous ineorrotness of the translation 'repentance, but dors not show what linglish worl or phrase could now be substituted in a popth- the sense of organization. Of the renderings: king-hip, roign, and kingalom, two would frequently be neeesary, and sometines all three at once, to express the full sense of the original term. As we have to choose one, the word 'reign' is in this and many other passages a more nearly adequate rendering than 'kingdom,' and less likely to mislead. The kingdom (reign) of heaven is an expression used more than thirty times by Matthew, though he sometimes (12.28;19:24;21:31,43) uses the one always found in the other Evangelists, 'kingdom (reign) of God.' 'Heaven' is in this phrase ulay's plural in the Grevk, "the heavelss, an imitation of the plural (dual) form, which the word alway has in IIebrew, and not diftering in meaning from the singular. lleaven, regarded as the special residence of God, is sometimes very naturally used to represent frod himself (e.g., I)an. 4: 24; 1 Mace. 3: (1); Luke 15: 18, 21), just as we say; "heaven grant,' etc.. and so 'kingdom of heaven' is rquivalent to 'kinglom of God.' 'The Jows, serupulous about using tla name of God, frequently substituted 'lueaven' (,$g ., 1$ Mace. 8: $5(1,60 ; 4: 55)$, and the Talmud otten has the plurase 'kingdom of heaven.' It was natural that Matthew, writing especially for Jews, should respeet their feeling, and commonly use this expression.

The New Testament idea of the "kinglom (reign) of crod has its roots in the proplestic writings. In Jsiah (ch. 1: 39t! and Mienh, it is declared that God will raise up a rigliteous king. who shall deliver his people and give them prosperity (ค. \%. 1sa. 9: 6, 7; 11: 1-10; Micalh 4: 1-8). This hope is prosented with modifieations hy. Jeromial and hisentutomporaries (c. q. Jor. 23) 5, f; Ezok. $37: 2 t)$, pointiug now unt to an individual king, lut to a Davidie dynaty (eomp. 2 ('hron. 1:R: s), guiding the missinn of the chosen prople. But in Daniel, when lsracl is fallen low, there is given assurance that "the God of hearon" will establish a universal monarehy. will "one likeason of man" as the king. Han." at 7: 13,14.) This ideat must have termenterdin the lar version. The diseussion is interesting am prefitable. Jut we think the author exagerates the inturtanee of lis theme, as momographs are apt $10 \mathrm{~d} n$, and is quite mistaken in supmoing that the word oxpresech simply an intellectual change, a transfigured theory of moral truth. 
3 For this is he that was spoken of by the prophet Esaias, saying, The voice of one crying in the wilder-
3 for the kingdom of heaven is at hand. For this is he

minds of at least some Jews, till it took the form we find in the Gospels, when devout persons are not only "waiting for the consolation of Israel," and "for the redemption of Jerusalem" (Luke 2:25, 38), but "waiting for the kingdom of God" (Lure 23:51; 17:20); the B:lptist says, "the kingdom of heaven (God) has drawn near," as something which all will understand. The Jews of that period had many fanciful confused, and sometimes fanatieal notions in regard to the character of this expeeted divine reign, as shown by the book of Enoch, the Targums, and the Talmud, (seet Lightfoot, Wetstein, Gill, and Drummond, "The Jewish Messiah"), but the New Testament is of eourse responsible only for its own use of the phrase. We see also that the statement in Daniel has, before the New Testament times, led to the belief that a "son of man," called also the Messiah, will reign in God's promised kingdom, for this is expresily asserted in the book of Enoch, (much of which was pretty certuinly written before the Christian era), and the Talmud abounds in referenees to "King Messiab." This persuasion our Lord confirms in $13: 41 ; 25: 31,34 ; \mathrm{John}$ 18: 36. It was one great object of Matthew's Gospel to show how Jesus corrected the Jewish errors as regards the nature of the expected Messianic reign. Much error has diffused itself through the Christian world from eonfounding "the kingrom" with what is popmLarly called "the chureh." Edersh. "W must dismiss the notion that the expresion Kingdom of Heaven refers to the church. whether visible (aceording to the Roman Catholir view) or invisible (aceording to certain Protestant writers)." Comp. below on $13: 37 \mathrm{ft}^{\circ}$.

The statement of Josephus ("Ant.," 18, 5, 2) eoncerning John's teachings and baption, is marked hy his nsual affectation of a philusophical tone, and his usual omission of all Messianic references: "John, who was surnamed Baptist a gesed man, and one who bade the Jews in the exereise of virtue, and in the pratetice of righteousness towards one another and piety towards God, to come to baptism; for that so would the baptism also appear acceptable to him, if they used it, not for the forgiveness of certain sins, but for the purification of the body, it being supposed that the soul atso had previously been eleansed by righteousness." Josephus adds that the people were greatly excited by John's preaching, and that Herod imprisoned and slew him because he feared revolution-a statement which perhaps points to John's proclamation in regard to the near approath of the kingdom of God. It was natural that Josephus should onit all distinct reference to this Messianic reign, for he had kng before committed himself to the essentially absurd but politic statement that the Messianie hope of Israel was fulfilled in his patron Vespasian ("War," 6, $5,4)$. Both. Jews and heathen constantly inelined to think that ablution was itself the means of eleansing the soul from sin; and against this notion Josephus declares that John's baptiom was not expected to bring forgiveness of sins, but that the soul must have been previously eleansed by turning from sin to righteouness. Comp. Tertullian: "We ate not washer that we may cease to sin, but because we have ceased: since we have already been bathed in heart.'

3. This is by some expositors taken as the words of John, who cert:inly did on one occasion apply the prophecs to himself (John : :23); but here the reference is much more naturilly understood as made by the Evangelist-the present tense is expressing the general fact that John is the prenticted forerumer. For gives the reason why John appeared in the wikderness and badte the porple prepare for the Memianie reign, viz., because John is the peron spoken of by-through - the prophet ('through,' see on 2:17), as destined to do so. The voice of one erying, 1 ete., Isa, 40: 3. In the Hebrew the accents inticate, and the

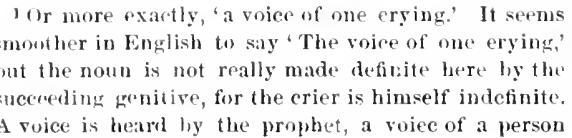

erying. (An Lheims, Davidson.) Darby, 'Voice of him that 'riuth,'errs in making the latter elause definite, for 'him that erieth' would require the article before the fireck participle. 
ness, l'repare ye the way of the Lord, make his falls viraights.

f Ind the simme John had his rament of camed's hatr, and a leathern girdle abuat his loins; aud his meat was loeusts and wild boney.

parallelism proves, that "in the wilderness belongs to 'prepare'; andso hev. Ver., Isaiah. Matthew (as also Markand luke) folluws the septuagint in connecting that phritse with 'crying, and in omitting the parallel phratse 'in the desert' from the next chathe. This changedoes not atlect the sulsotantial meaning, and it malies cleatrer the real eorrespondence between the prediction and the fultilhent, 'preatehing in the wilderme-s' (v. 1), 'erying in the wildernes' (v. B). It might withunt improprety be sulpused that Matthew himself altered the phrasenlegy to bring ont this correspondence, lut in many similar cases it is plain that he has simply followed the fat miliar seputuagint. P'repare ye. Make ye realy, was here subtituted by Rev. Ver. for "prepare, becaluse in the parallel passage of Mark ( 1 : 3), the salms worl is tram-litted 'mako ge reaty, in order to kiespl it dietinct from anotleer Greele word rendered "prepare" in Mark 1:2. Susch painto to render the sume Greek word eserywhere by the same English word will prove very usetul in eoncordanor work, and all minute: study, but it strikes the castal reauler as unelens alteration uf the translation.-The inmediate referenese of the prophecy in lsaiah is probably to Johuvalu, as

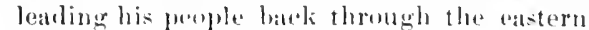
desert from their eantivity in Babylan: the

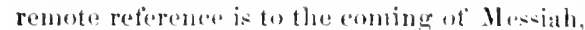
and ppiritu:al deliverances. Jlere, as often in the prophet-(see on 2): 15), there is a trpical relation between the biatery ol h ratel and that of $\mathbf{M}$ essiah.-Cireat public roule were ratre in

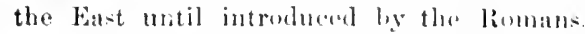
When an Oriental monareh was designing to journey into at certain recrion, lie sent mesengers in atvance to rengire that a grated road shemld be prepared. Honce the intage, hore denoting spiritual proparation. Notice that in Isa. 40: 4, evory pitrt of the process of grading is mentionuil.

4. And the snme John had, or, 'Aml he, John, had.' 'The difference in menning between these renderings is unimpmrtant. Atter remarking npon the prodiction fultiled in John, the Erangelist proceeds to speak that was smben of through Isaiah the prophel, saying,

'The soire of one crying in the willerness, Wake ye realy the way of the lored,

Make his pathis strablit.

4 Now John himbell had his rament of camel"s hair and a leathern groble aloout his boins; and his find

further of John himself. The clothing of camel's hair was a conrse cloth mate by weaving eamel's hatr, amd such cloth is still often worn in the Eatat by the poor. There is no evidence that garments of camel-skin, like these male of sheep-skins and goat-skins (nteb. 11:37) have evor bean worn in the Eant (an imagined by the painters, and by Fritziche and smith, "Dict.," art. (amel); and the "xpression here elistinctly forlids such a notion, being liturally 'ot' camel's hairs' (so the (ireck ot Mark 1: 1, 'catiol's hairs'). So M(ryer, Bleck, Weirs. A girdle was a necessaly and almost universal part of an Oriental's dress (eomp. 10: !), marg. of hev. Ver. ; Acts 21: 11), being required to bind the long, loese robe (see on $5: 40$ ), in order to active labor, or rapid lecomotion, and it was often very eastly and -howy (comp. Rev. I: 13). John's girkle was mate of leather, cheal and rude, as was Elijabs. (zkines 1:s.) Noat, or food. The worel "mrat' is need in Com. Ver. te tramslate several Gresti words, but all of them signity fond, mutriment, stotentumes. This world sometime include ftesh, to which, in modern English, the term meat is exclusively applienl. (Compl. 1 cor. 8: 13, "It' food makes my brother sin. I will at no more flest.' liii. En. Vur.) The lalw uf Moses (Lev.11:22) alllowed loensts, at leit-t of eertain kinds, to be eaten; and a tratise in the Talmud copions y discusens the matros hy which "elean locmets might be distinguished. To cat these is still common in the East among the puor. The heads, legs, and wings being removed, they are boilod, stewed, or ronsted, and sometimice dresed with lutter. They are eatem luth fresh, and drietl, or salted. They are very different from what we cull locusts. Tile notion that John ate the fruit of the tree whieh we eall lonust, is utterly unwarranterl. and forbililen by the Gresk worl. The wild honey is thomght by some able writers (as Fritzsche, Robinson, Meyor, Bleck, Grimm. Weiss) to have been the grum ('xuling from a tree, but on very slemder groumds (emmp. Keil). Mueh more probably it was, an (a)tinmonly supposed, the honey of wild bees, de- 
5 Then went out to him Jerusalem, and all Judea, and all the region round about Jordan,
5 was locusts and wild honey. Then went out unto him Jerusalem, and all Judæa, and all the region posited in trees, rocks, etc., such as is mentioned in Old Testament (Judg. 14:8 f.; 1 sam. 14: 25 ff.; Ps, 81:16), and found at the present day also in the wild regions in which John lived. This was very abundant, and considered cheap and poor food (comp. Isa. 7: 15). Eustathius says (Wet.) that Pythagoras lived very poorly, often contenting himself with honey alone.

It lad been predicted (Mal. $4: 5 \mathrm{f}$ ) that Elijah the prophet should be sent before the advent of Messiah to prepare the people for his coming. This was explained by the angel (Luke $1: 17$ ) as to be fultilled in $J$ ohn, who would go before the Lord 'in the spirit and power of Elijah,' and was also declared by Jesus to have been fulfilled in John (see on 11: 14; 17: 10-13) The ministry of each consisted mainly in severe reproof and exliortation to amendment, and there was something appropriate to such a work in seclusion of life, with rude fare and coarse clothing, and in austerity of manner. "Even his appearance called men to repentance." (Theophylact). This was hardly personal asceticism, but appears to have been designed, like the numerous symbolical acts employed by other prophets, to attract attention, and give greater impressiveness, to the reformer's rebukes of a luxurious and worldly minded generation. It was what we call an "object-lesson." We may imagine the effect when Elijah suddenly issued from his retrents, and, arrayed like some Bedouin or savage Dervish of to-day, stood before a weak and self-indulgent king, witl stern look and tone, and harsh words of merited reproof. And similar nust have been the effect of John's ajpearance and known mode of life. (Comp. on 11: 8.) Elijah is described as 'an hairy man' (2 Kings 1:8), literally 'a possessor of hair,' and this is best understood as menning that he wore a garment made of hair (margin Rev. Ver.), especially as his girdle is mentioned immediately after. This characteristic dress of Elijah appears to have been imitated by succeeding prophets; for we find in Zecl. 13: 4 the prediction of a time when the false prophets would bocome ashaned of their impostures, and would not "wear a garment of" hair to deceive.' On the part of John, these peculiarities were not a mere imitation of his prototype, for they had the same appropriateness and significance in both cases.-There is little propriety in the notion of some artists and writers that John was attenuated through much fasting. Doubtless he did fast (see on 9: 14), but so did many Jews, and not necessarily to attenuation. His out-door life and homely food might (see on v. 2) even promote bodily health (compare Elijah), and physical foreeseems naturally implied in his preaching to great crowds in the open air, and boldly facing the most jealous and powerful. John was also like Elijali in that he was not a writing prophet, but left his work to be recorded by others. (Pressensé).

5. After a general account (v. 1-4) of John's public appearance and preaching, with the fact that in him a prophecy was fulfiled, and after a description of his peculiar dress and manner of life, we have now (v. $5 \mathrm{f}$.) a general statement that the people went forth to him in large numbers and were baptized, and this is followed (v. 7-12) by a specimen of his preaching, given more in detail.

Then, Matthew's favorite term of transition. resumes the time of v. 1. 2. Not only Jerusalem, but the entire district of Judea, and all the region round about,-or, the circuit of the-Jordan, only part of which was included in Judea, came forth. The Hebrew plirase, 'round of the Jordan' or, 'circuit of the Jordan,' $i$. e., the country about the river, is inadequately rendered in Com. Ver. by 'plain' (Gen. 13: 10, 11; margin Rev. Ter. 'circle'; 1 Kings $7: 46 ; 2$ Chron. 4: 17). The cases of its accurrence in Old Testament refer particularly, as here, to the lower part of the river, towards the Dead Sea. All, is of course, to be understood as an hyperbole, strongly expressing the fnct that very many of the people came forth. (Comp. 8: 34.) Similar hyperbolical expressions abound in all languages and periods. We learn from John (1:35-45; 21:2), that some came from Galilee ulso, but this was perbaps at a later period, when John was baptizing higher "1p the river. The year to which John's early ministry probably belongs, A. D. 26, was a Subbatical year (Wieseler), when the people 

their sins.

6 round about Jordan; and they were biplized of him

who strictly observed the law would have more than ordinary leisure.

It was centuries since a prophet had appoarefl, and the Jews had often longed for prophetie guidance. Thus Judas Mareabeus and his followers laid away the stones of the desererated altar" "until a jrophet should appear to answer eonesming them" (1 Bace.4:46); and the woman of Simaria, als soon as she perceivel that here was a prophet, asked him to settle the long-di-puted question eoucerning the proper place to worship. (Jount:19f.) In the time of Christ, some were expecting the personal re-ilppearance of Jeremiah (below, 16: 14), and many that of Elijan (John 1; 21; Luke 9:8: Matt. 16:14:17:10;27:19); while others were looking for the prophet like unto Moses. (Jom 1: 21 ; beut. 14: 15, 18.) Ant now the report spreat far and wide, that at last a prophet laad come. Who in dress and place of abode resembled the great Elijah, who might be Mossiah, or at least a forerunner of Mesciah, for he declared that the Mesianie reign was near, who performed a very striking rite, and spoko severe rebukes and earuest exhortations to turn from evil ways, such as had been spoken by all the prophets, sueh as will always arrent the attention of mankind. No womler the Jews, from all the country adjacent to the seene of his ministry, and tor many montls, continually poured torth to sees and hear him, and, more or less, impressed by !is announcement of the Mesianie reigu and his enll to repentanee, eonfessed their sins and suburted to his baptism.

6. Baptized. The Greek word baptizo, which we borrow. was of very eammon use, th is seen in every period of Greek literature,

1 Bupto, 'dip,' had the root bqph, akitt to bath in bathus, 'deep' (c'urtius), just as dip aml deep, German tamfen aud tief have the same root. From betute, eame the verhal aljective bapkos, 'diph,' and from this was male the rerl bapt-izo, as if in linglisll we should say dipt-ize, viz., to put into a dipt condilion. The usual way of bringing one into a dipt condition would be to dip him. But sometimes it mighl be otherwise conceired; as e. ?., land overfowed ly warer might he described as baplizel, being now in, within the water, just as an objeet dipt woulel be wilhin it. There is in lansuage a gemeral tendency to use strouger derivative or eompound words (e. \%., verbs compoundet) will prepr ositions) in place of the original and simpler word, and was applied to a great variety of matters, including the most fautiar atets of erery-day lite. It was thus a word which every Greckspealing hearer and reader in apostolie times would at once and elearly understand. It meant what we express by 'immerse' and kindred terms, and no one conld then have thought of attributing to it a wholly ditterent sense, such as 'sprinkle, 'or 'jomr' without distinct explanation to that e+tect. The pereple who speak Greek at the present day. wholly reject and ridienle the idea of u-ing this ( reek word in any other than it: awn detinite and well-known sellse; and the Greek Chureh still holds nothing to be baptisn but inmersion. But the newly diecovered treatise called the Didache, or "Teaching," writton snue time in the second century, probibly in the latter half of the century, shows that in some region of the Christian world there was a disposition to allow a substitute when water was scarce. Thus ch. 7, "Batptize . . in living water (i. e. of a stream, fountain, or poral, ats (pposed to standing or deal water). And if thou have no living watter, baptize in uther water; and if thon eanst not in cold, then in warm. And if thon have neither. pour water upon the head thrice." Hero it is crident that baptize moans only immeros. but if water be searee, pouring may be substituted for baprizing. In like mamer we find in the Wrest, towards the midlle of the third eenturs, that in ense of sovere sickness some allowed pouring, and after a while some thonght sprinkling sufficient, and these more conventient sub-titutes grewine reasingly common, though often condemned by the edele-iatical authurities, mutil in the thirteenth century their

until finally the compound or derivative is no stronger in many uses than the simple wort. Thus ramt-izo meansexactly the same as refin' 'sprinkle'; compl, statizo and histemi, kaumalizo and kaiu, and many similar eases. Now baptizo did not beesme exactly aml uniformly equivalent to bapto. The sense "lye" is confinest to lylyto, and there are various uses uf haptizo, 'diptize' in which bopto, 'dip,' womk be inadequat": but in many eges they are substant ially equivalent, like rontizo and roino. The often repealed stalement that baptizo is frequentative, signifying 'dip frequenty, is erroneus, and would never have been male but for a failure to perceive the etymology of the word as above given. 
general use was sanctioned by the poje. Luther and Calvin (16th cent.) both explicitly declared that the primitive baptism was inmersion, and the former said it ought to be restored; but they allowed the existing practice to remain undisturbed. In the course of time many Protestants came to perceive that it was very awkward to rest their practice in this respect on the authority of the Church of lione, and being accustomed and attached to the practice they very naturally somght countenance for it in Scripture. Such are the unavoidable defects of language, that strongly biased and ingenious ninds can always cast sone apparent doubt over the meaning of the plainest words; as laas been done, for example, with respect to words teaching the divinity of Christ, the atonement, and eternal punishment. It is therefore not surprising that a good many able and conscientious men in Great Britain and America (very few in Germany ) have succeeded in persuading themselves that perhaps, or even quite probably, baptizo might be understood as meaning pour or sprinkle, or purify in general, or something that womld sanction the practice handed down from revered fathers; and that a few very bold spirits should even venture to cut the knot and assert, that not only sprinkling uay be baptism, but nothing else ean be. These considerations should promote charity, and may serve to explain the rise, in modern times, of so much controversy about a very plain word.

This controversy has led to a wide examination of Greek literature with reference to this term, and in all the instanees of its use that have been found, whether literal or figurative, its fundamental meaning (whatever may be the farticular rendering nost suitable to the connection and to English idiom) is always 'inmerse, that being in the great nuss of cases the only possible sense, and in all cases appropriate and natural. (See a full list of "lassified examples in Conant "On Baptizein," Philadelphia.) So it is lefined and explained in most Grek Lexicons that are of any authority (.$g$. in Liddell and Scott, Grimm, Sophoeles" Greek Lex. of the Romin and Byzantine periods, Boston), without a hint of any other meaning; and so it is interpreted ly almost all commentators in Germany, the land of scholars, and by very many in the
Church of England. But some good Lexicoms of classical Greek (as Rost and Pahm) add such meanings as 'moisten,' 'drench, 'overwhelm,' justufying then only by certain figurative uses of the word, in which drunkards are called 'the baptized,' or men are said to be baptized in (or with) debts, nismistortunes, ete; some Lexicons of New Testament Greek (as Robinson) urge that in certain passages of New Testament and Septuagint (e. g., Mark 7: 4; Luke 11: 88 ; Acts 2: 41; 10: 48; 16: 33; Judith 12: 7), the circumstances make it, in the Jexicographer's judgment, unlikely that an immersion was performed; and some others (as Cremer, comp. Stephen's "Thesaurus"), suppose that the Jews came to use the Hobrew trabl 'dip,' and thelefore used baptizo, as a genoral term for religious washing, which might then be sometimes performed in other ways. Tet all the lexicographers who thus present an additional meaning give 'immerse' as the primary and general meaning of the word. Now it is a most important principle in the interpretation of language, without the observance of which all interpretation becomes uncertain and unreliable, that whatever is the common and regular meaning of a word, as shown by its origin and general use, must be held to be its meaning everywhere, until there shall be found some passage in which it camot have that sense. Upon this principle, whether formally recognized or not, scholars are constantly working. But no passage has been pointed out in which this word must have some other than its ordinary meaning; indeed, none in which that meaning is not both possible and appropriate. Thus the classical expressions solely relied on by Rost and Paln for another meaning, are given by Liddeil and Sicott (6th and 7th ed.) as examples of the primary sense 'to dip in or under water,' and compared with the English phra-es 'soaked in wine,' 'over head and ears in debt,' such expressions being obviously figurative in both languages. In the passages cited by Robinson, nothing more can be claimed than that in those cases immersion would have been inconvenient or ditticult, and is therefore thouglit unlikely; while a due consideration of Jewish scrupulosity and known customs makes immersion not only possible in such cases, but natural enough-nnd these 
by Maimonides, was an immersion), and then sacrifice, in which he publicly acted as a Jew. After the temple was destroyed, the sacrifice became impossible, and then the purification became the closing, and in the case of women, the only act performed; and so it naturally attracted greater attention, and by the fitth century had come to be regarded as distinct from all other purific ions, and as possessing a very high importance, equal, if not superior, to that of circumcision. This view takes away all force from the otherwise plausible argument that the so-called proselyte-baptism must have been ancient, on the ground that the Jews would never have adopted it from the hated Christians; for we see that it was not so adopted at all, but was simply one of their own purifications, which from the force of circumstances canse, in the course of some centuries after the destruction of the temple, to be regarded as a peculiar initiatory rite. And if later Jewish writers assert that it was ancient, even that it originated at Mount Sinai, they make the same clain for every usage existing among them, however unquestionably late in its origin; and besides, we have seen that the essence of this practice was ancient, though it afterwards assumed its peculiar character and consequence. $^{1}$

There isthus no reason for supposing that John's baptism was a mere modification of some existing rite. Our Lord distinctly intimated (21:25) that the baptism of John was "from heaven." The forerunner himself testified that God "sent" bim "to baptize in water." (John 1:33.) Föhler: "So the baptism of John is a highly significant and expressive rite, which in its grand simplicity bears the distinct stamp of a divine ordering."

In Jordan. The expression thus translated affords a strong, though in itself not an absolute proof, that the action of baptizing was

\footnotetext{
1 The explanation of its rise was first given by Sehneekenburger, whose cxeellent little work " How Old is the Jewish Proselyte-Baptism" (1828), has not been translated from the German. The nost complete and satisfaetory diseussion of the subjeet is by Toy, in Bapt ist Quarterly, 1872, p. 301 if. See also among many writers, (ill, "Works," Vol. II. pp. 760-799, and Leyrer (and Delitzseh) in 1Herzog. Reent leading writers generally eoncur in Sehneckenburger's view, e. g.. Winer, Meyer, Ewall, Bleck, Cremer, Keim, Keil, Godet; on the other band, Edersb. (App. xii.) urges that "previous
}

performed within the limits of the stream. This is the natural and regular meaning of the phrase, and must be everywhere adhered to unless there is something in the connection to forbid it. But the Greek preposition en is used in some connections not found in English; as, for example, we cannot say, "a city was situated in the Euxine Sea," "an ambush was laid in a river," but the Greek has these expressions, meaning that the sea or river was in a certain general sense the locality in which the eity or ambush was situated, though not in the strict sense which our 'in' would indicate, seeing that such a sense is in those instances not possible from the nature of the case. So in English we say 'the man is in the mountain,' meaning not the earth composing it, but the mountain in a more general sense. Now if the action of baptizing were one which could not be performed in the river in the strict sense, we might understand 'in the Jordan' as meaning only in that general locality (comp. Mark 4: 1, 'in the sea'). But until it is shown that the signification of the term baptize is incompatible with the idea of its being performed strictly in the river, $i . e$, in the water, we are bound to take the preposition in its proper and ordinary sense. Now even those who maintain that 'baptizo' is at times used with a certain latitude, generally agree that its regular and usual sense is one which does not forbid, but entirely accords with, the idea of its being performed in the water. We have therefore the natural and "lmost uniform use of 'in' concurring with the established meaning of the verb, and reinforcing the argument by which that meaning is established. (Comp. 'in water' v. 11, Rev. Ver., margin). The Rev. Ver, reads, the river Jordan. ${ }^{2}$ The word Jurlan, always with the article in the Hebrew and the Groek, signifies 'the descender,' and was so named from its rapid descent in a long and deep valley or

to Christ, the haptism of proselytes was eustomary" ; lut he gives neither evidence nor argument for anything else than the above-mentioned purifieation be. fort sacrifices, whieh was a matter of course. schurer also alvoeates the same opinion, but presents nothing new.

'The word 'river' (as in Mark $1: 5$ ) is here given by B, ‥ C. M. $\Delta . \mathbf{s}$, and more than thirty eursive MSS and by all the early versions except the Latin, and is adoptel by Lach., Treg., Tiseh., Alf., Weiss, W H. Yet while Mark would uaturally tell his Gentile readers 
fissure. The highest of jts three principal fountains on the slopes of Hermon is seventeen hundred feet above the level of the Mediterrancan; the first lake it forms, llûleh, has its surtice only one hundred and twenty feet above the Mediteranean, while the second, the Laki of Galilee, is six hundred and eightytwo fiet (Comcler) betow the level, and the thiral Lake, the Dead sea, is twelve hundred and ninety-two fiet below the level of the Mediterranean, besides being itself some thirteen linulred feet deep. The tissure or valley varies in wilth, south of the lake of Gatilee, from two to six miles, and nearer the Dead siea it beeomses forurteen miles wide (Conder). Windingabout in this long, narrow valley is another depressed valley forty to one hundred aud tifty feet deeper), of several hundred rards in width; and within this the actual bed of the river sinks deeper still. The distance in a straight line from its highest source to the southern end of the Dead sea is about one hundred and sixty miles, or exclutjug the Dead Sea, about ane hundred and titteen miles. But so extremely crooked is the winding river that Iynch estimates it to be near two bundred miles between the Lake of Galilee and its mouth (which is sixty-tivemiles in a straight line), and though less erooked higher up, jts whole length nunt be at least two hundred and seventy-five miles, not ineluding the Dead siea. The width and depth of eourse vary at different sasons, as it is swollen in February and March by the rains, and in May, the "time of latrvest" (Josh. 3:15), by the melting snows of Hermon. Above Lake IItêle it is some forty feet wide, and is deep and repid, but foriable alumet everywhere. Towards the Lakeot Galiles it is about sixty feet, and easily formal at several places. For some miles below the lake Lynele foumd it about seventy-five feet widr, and at points

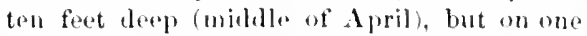
of the numerous rapids only eight inches deep. About tive miles below the lake an in.

that the Jordan was a river dike many other explanations he gives, this was quite merlless for Matt., and contrary to his usige in similar cases. Translators and copyists in foreign comntries would, however, think the word necessary here, evell as $\mathbf{N}$ and Olt syriat have insertel it in John 1: 28. Wa thus see that Matt. is not likely to have written it and copyists would be likely to insert it. This strong union of intrinsic and Iranseriptional evidence might eren outweigh the very strong fortant tributary enters from the east, and below this the usual deptl varies frous two and ons half to six fect (litter). About half way from the Lake of Galilee to the salt ( Dead) Sea, the lijver . Iabbok enters trom the east, and smaller streans come in at various neighboring points on both sides. It here leecomes from eighty to one hundred and titty fert wide, and trom tive to twelve teet derp (MeClintock and C'rooks, "(ye."). Nearthe mouth it widens to smo five homelred and fifty feet, and the depth diminishes to two or three teet (Ifinch). The principal forels are not many (though Conder collected the nanes of about tiorty in all). (1) About two miles above the mouth (Fish). Several miles higher up is the traditional place ot our Lord's laptisu, nearly oppusite Jerichu, and somewhat above this is (2) a ford ureal at some seasons. At the traditional place the river is, in spring (when nost travelers visit it), both tou dece and too swift for fording. Fet just before katerseveral thousand Greek and oriental pilgrims (ju the Midalle Aeses there were sometimes 1(k),(kK) go to this place-men, women, and chillron-and immere themselves as a sacred bath, mang of themelianging their garments amid the dinse thirkets of shrubbery which extend for sone distance from the stream; and almost every year, in the vast tanatical throng, crowding in together, sume are drowned. Several puiles above this place is now a forry-boat (compl. 2 siam. 19: 18), which is handled with ditliculty, the eurrent being in Mareh exersively strong. (8) Ten miles below the mouth of the . lablok is a ford now mach used ju going trom $\mathrm{N}_{\text {al }}$ molus to Es-salt ( Van de Velde). (t) Abuse the Iabbok is the ford of sillecoth, where.Jacob crosised with his tiumily and flocks (Gen. 32: 10, 22.) (5) Near Beisan is a ford, which Robinson (III., 325) crossed with diffiunty, but Which, on March 24, 18:1, the Modîn of Beisan suid womld muly reach the horses betlies. In this neighburhoud Conder, in April,

documentary evidence in favor of the word, but for the faet that I) and some copies of (1)] latin omil "river' in Mark 1: $\bar{b}$, as well as here, which indieales that the " Wrestern" text was hostile to the worl, and thus accounts for ils omission in many copies of Matt. This worl must therefore lie aceepted as a part of Mat thew"s text, yel not withoul sume lingering doubt. The question has obvionsly no praclical importance, however interestiug (u) the textual critie. 
7 But when he saw many of the Pharisees and sidducees eome to his baytisu, he sajd unto them, o generation ot vipers, who hath waroed you to flee fiom the wrath to cume?
7 in the river Jordau, confessing their sins. But when he saw many of the Pharisees and sadducets couning ${ }^{1}$ wo his bapdism, he said unto them, le offspring of vipers, who warned you to flee from the wrath to

$10 \mathrm{r}$, for buptism.

found twenty-one possible fords within seven miles. About ten miles above Beisan is a Saracenic bridge the only one now crossing the river), upon the road from Nabulus to Damaseus, and above it are said to be several difficult and little-used fords. (6) Not far bekw the Lake of Galike is an important ford, which the Jews of our Lord's time must have constantly used in going from Galilee through Perea to Jerusalem. At this, on March 25 , 1871, the water eame nearly to the root of a horse's tail. - But in summer the river falls much lower, and must be easily fordable at many points. - The outer and prineipal part of the Jordan valley is nearly all entirely unproductive without irrigation, justifying the statement of Josephus that the Jordan flows through a desert ("War," $3,10,7)$. But the banks of the river are everywhere fringed with trees (willow, balsam, ete.), amid which the birds sing, and in whose pleasant shade the multitudes could gather to hear the voice of the new prophet. Is to the seene of the baptism of Jesus, see on v. 13 .

The purple reecived this solemn rite coufessing their sins. The Seriptures promise forgiveness on eondition of confession (Prov. 2s: 13; 1 Jotn 1:9), though of course this is not the meritorious ground of forgiveness. It was required by the MIstic Lotw (Lev. 5:5; 16:21; 26:40; Num. 5: 7), and is often reorded as practiced by the penitent (e. g, 2 Chron. 30: 22; Psa. 82: 5; Neh. 9: 2, 3; Dan. 9: 20; Acts 19: 18). The term here used appears to denote an attually spokin confessiom, and the present fartieiple shows that it was made in immediate connection with the aret of bajtism. MIat probably the confussion was not made to the multitude, but simply to Juhn, and was not uniform, but variod aceording to every man's calling, charactor, ete., (comp). John's specific exhortations to different classes, Inke 3: 10. 14. The act of submitting to baptism was itself also (Köhl(r) a oonfession of taith. namely, of faith in the good news of the kinglom. (Nark 1: 15; Aets $19 ; 4$,)
We have now (v. 7-12) a specimen of John's teachings given more in detail.

7. The Pharisees and sadducees were the two great parties, at once religious and political, among the Jews at the time of Christ. The date of their origin is unknown, and they no doubt arose gradually. In the colluries immediately following the return from the Captivity there must have been various divisions of public sentiment. Some insisted on eonforming to all decisions of tribumals and opinions of leading teaclers, others thought it enough to observe the original directions of the law; some busied thensulves in developing many raal or supposed germs of truth contained in the law and the prophets, others said they wanted no religious taaching but that of the sacred books, especially the Pentateuch; some were extremely zealuts for thair religion, and ready to die in its defence, others were more ready to suit their action to changing cireumstances; some cherished a bitter hatred to foreigners, others were friendly to them, ete. such divergencies of opinion on many questions of truth and duty would gradually associate themselves, by sympathy or antagonism, with sone one leading division, so as to form two listinct, though at first not well defined, partifs. Then when any new religious or political issue arose (the religious and political being always more or less blended, from the nature of the Jowish institutions), the mere fact that one party took one side of the question would alecide the opposite purty to title the other side. Thus by degrees the parties became sharply defined, compact, antagonizing at all points.l Josephus hejd that the Pharisees and Sadducees were distinct parties in 13. C. 145. ("Ant.," 1\%, 5, 9.) ('ertninly in the later years of John Hyounus (died B. r. 106), they were politically antagonistic. ("Ant.," 13, 10,5.) By the time of our Jurd's ministry, the division had dombtless become more pronounced. The bistory of their hostility was known to run back to

1 The alwe was written before the appearance of fying support in his elaborate thiseussion. (Book iii. Edersheim's work, and the view presented finds grati- ebap. 2.) 
the Maccabean struggle, the Pharisons now representing the patrints of that time, amel it had incluled many tieree politienl contlicts and wars under the suceessore of John $11 \mathrm{yr}$ canus ("Ant.," 1:3, 15,5; 13, 16,5), whith left a bitter and lating latred. At the time of Christ, the sadducees were comparatively tow in number, but enbraced a large proportion of wralthy and intluential men ("Ant.." 18 , 1, 4), including many members of the sunbedrin (Act 5: 17), and were more likiely to have the sympatlye of the Roman rulers. But the Pharisese were far more numerous, and on aceonit of the patriotie record and pions reputation of the party, ponesecent the sympathies and support of the perple at large. Yot, while political antagonism hat callesel bitterness, the ehiet diftierences between the two parties hat always been religions. The Pharisees hald to many traditional interpret-

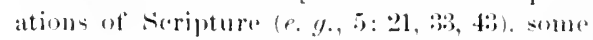
of them not merely aroments, but subverswe of it great trutlis, and also to matny traditional rukes for the conduct of liti, piationlarly as to externals, some of these likewine tending to set nille the teachings of Gord's word. (15:2 a.) These they claimed, as must Jews have erer since done, to be of almost equal authority wilh the law; indeed. they were called the "oral law," and heod to have been giren orally to Moses at Mount sinat, and handed down from him. Alwent two eenturies alter Christ many of these trallitions were written down, and form what is called the Mishma, or 'secomd,' $i$. p., the soeond law. All these tratitional interpretations and rules the saddulens rejected, acknowledging no anthority but the seriptures. and especially 'the law, i. P., the five books aseribed to Moses. But the interpretations of the later centuries befores

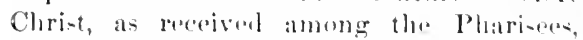
had alicited from the seriptures varions

\footnotetext{
1 Commentaries upun the Vishna (with supplenentary tratitions also) were afterwards witten, and knewn as ciemara, "enmpletion," lineanse they completed the Mishua. The derusalem fiemarat was writen in the fourth century after e'hrist, and that of ballyglos in the fifth century. Tha Minhas, with une or the onher of thest, is emmonly meant ly the term Talmud "instruetion').
}

2 so, if an Eggutian toucherd a swine, he went to the river and 'dipped himself trom it' (bapto), eluthes and all (Her. I1. 4 i). true and important doctrines, as that of the separate existence of spirits, and a certain approach to the christian dextrine of the resurrection from the dead (antup. on 22: 23); while the Sidluceses, in arojoling traditionalism, went to the oppueite axtrome of rationalism, and wholly rejaend these docetrines, atud even the beliet in angels Aete 23. 8), though this last is so plainly and repeatedly taught in old Textament. The Pharieses, in their fimatical zail fore the law of puritiontions, and the numerous rules which tradition had added, shrank from all akstedation with "sinners," i. e. perseme who notoriou-ly. violated the law (Luke $8: 39$ ), and thought it in-

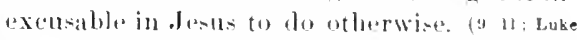
15:2.) Thus, when they came form marliet, where they might posibly have tour hed some persen or thing that was ceremonially 'unclean, they ware wont te perform a complete purification, 'immerad thimsolves,' betore they would eat. (Mark 7: 4.) 2 This scrupulosity in separating thembelles probably leal to the name Pharinezes, soparat ters.' The name sadducees most likely mant 'rightenus, as denoting that they contented themselves with being simply rightrous men, and diel not care for newfangled belieds and strait-laced wherrances. ${ }^{3}$ Our Saviour less fropuenty refierrent to the ermors of the sathlueses, great as they were, doubtless becalle the people in gemeral were

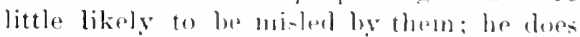
however antion his disciplen antinst their locetrine (and that of the Phatr) in 16: 11 . They apprate 'temptisg' him in lli: 1, and

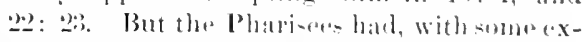
creptions foreh a Ticolemus, (ramaliel, Paul), lost the true patriotiom amol espencially the true piots which had gationd their party so much popular favor, and were striving by

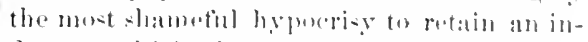
fluenere which they on longer dentreal, and

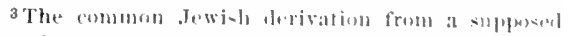
fombler named Zambet is nuw almost universally ro-

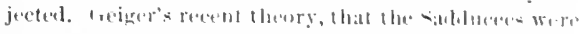

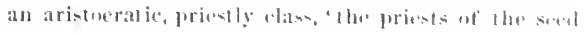

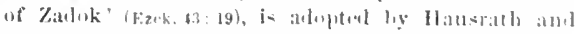

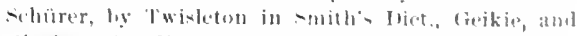
tim-burg in kitto, lnt is extremely far-fetelod, and does net explatio the facts. See in mplusition to it. Edersh. Vol. 1. 1. 32.2. Th. luest recent tratises are those of Wellbausen and Montet. (see ludex.) 
which they abused to the worst ends; and our Lord rebuked their liypoerisy on various occasions, and unsparingly exposed it in the last public discourse ot his ministry, ch. 23 . The continued rivalry between Pharisees and Sadducees was the providential means of securing freedom from persecution for several years after the ascension of Christ (Act: ch.4.6), and was made useful even at a later time by Paul. (Acts 23:6.) Nowritings of Sadducees remain to $1 \mathrm{~s}$, and we know them, besides the few references in New Testament, only from writers who were Plarisees, viz., Josephus and the Talmud, and who may have done them scant justice. They seem to have ceased to exist soon after the destruction of the Jewish State, which was the natural fate of a rationalistic party, having little devout earnestness, and whose standing had bcen social and political rather than religious.

The term 'sect' applied in Eng. Ver. to the Pharisees and the Sadducees (Acts 5:17;15:5;26:5) does not, according to its present use, correctly render the Greek word nor correctly represent the facts of the case; they were parties, with the peculiarity above mentioned, that they were at the same time religious and political parties. But there was a 'sect,' in our sense, then existing among the Jews, called the Essenes, who had a strictly exclusive organization and worship, and indeed lived in seclusion, much like the monks of later times. They were few in number, having small conmunities scattered over Palestine, and the largest on the western shore of the Dead Sea. They were probably an off hoot of the Pharisees, whose leading views they shared. Their comparative insignificance, their never attending the temple-worship, and this apparent relation to the Pharisees, will account for the fact that they are never mentioned in N. T., nor in the Talmud, being known to us only through the writings of Philo, Josephus, and Pliny. All attempts to show that some ideas or practices were derived from them by John the Baptist or by Jesus, have proved a failure; but their teachings do throw light on the heresy Paul attacked at Colosse (see an admirable essay in Lightfoot on Colossians). Josepluus says ("Ant.," 13:5.9) that the Essenes were utter fatalists, the Sadducees held to extreme views of free-will, substantially reject- ing providence, while the Pharisees occupied a middle ground, recognizing both human freedom and responsibility, and divine control.

Come-or, coming-to his baptism, that is, coming to be baptized by him." The expression many of the Pharisees and sadducees, with only one article, throws the two parties together as both needing sharp rebuke. (Comp. 16: 6, 11, 12.) - Wlat is here given as addressed to them, really applied, more or less, to the people at large, and was intended to apply to all it fitted, and Luke (3: 7) gives it as addressed to 'the crowds that came forth to be baptized by him.' So in Matthew, the people at large are evidently addressed in what immediately follows, v. 9 ff. Perhaps also Matthew here refers to a particular case, while Luke states a general fact, as his tenses (in the Greek) may imply.- IVe learn from Luke 7 : $29 \mathrm{f}$., that the Pliarisees and lawyers who on a certain oceasion in Galilee heard the teachings of Jesus concerning John, had not been baptized by John, as the people present and the publicans had been; but this ought not to be relied on as proving that no Pharisees had been baptized by John. Only a portion of them were at all disposed to seek his baptism, and some of these were doubtless repelled by John's stern rebuke and rigorous requirements. (Comp. on 21: 32.)

O generation, or, Ie offspring-of vipers, merely a plirase of reproach, describing them as noxious and odious, and perhaps also as insidious. (Comp. 12: 34; 23: 33; Isa. 14: 29; 59: 5; Psa. 58:4.) Classic writers present similar expressions. The idea that they are meant to be described as children of the devil, the old serpent, seems funciful. Warned, is stronger than the original, which signifies to show secretly or partially, and thus to intimate, suggest, indicate, or more generally, to make known. To flee from, may either mean 'to escape,' as in 23: 33, or to 'avoid,' 'shun,' as in 1 Cor. 10:14. With the former meaning it would be, "Who intimated to you that you would escape the coming wrath?' viz., when there was so little reason to believe they would escape; with the latter: "Who suggested to you to flee from,' etc., the surprise being that any one should take the trouble, with so little pros- 
8 Bring forth therefore froits meet for a repentance: 9 And lhink nut to say wilhin yourselves, $1 \mathrm{H}^{*}$ have Alraban to our fialuer: for I say cuto you, that fiol is able of these stores to raje up children unto . Hhahitu,

10 Ant now also the ax is haid unlo the root of the trees: therefore every tree which lingeth not forlh good fruit is bewn down, and casl inlo lhe fire.
8 eome? Bring forth therefore fruil worthy of trevent9 ance: and think nol to say wilhin yoursulves, 11 e have Abraham lo on father: for l say lint, volu, llat fiod is able of these stones to raine up childron unto

10 Abrabam. Ald even now the axe bioth al the root of the tries: evary tree therefore that bringeth bot forth gool fruit is hewn down, and cast intolbe lire.

a Or, ansuerable to amendment of life.-1 Or, your repentance.

peet of any good result. The latter is the more natural sense. The wrath to comeor, coming wrath. It was expected among the Jews (as the book of Enoch shows), that in connection with Messiah's appearanee there would be an outburst of God's wrath

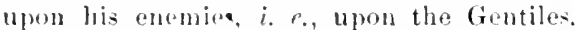
But John, in acoordanee with the whole tenor of his tritehing, deseribes 'the aming wrath' as threatening all Gud's enomies, including impenitent Jews; and this was alroaly implied in Mal., ch. 3 and t. Similarly Paul in 1 Thess. $1: 10$.

8. Fruits, fruit (singular), is the correct reading.' Bring forth, literally, make. The rendering 'bring forth,' eommon from 'Tyndale down, mixes the metaphore. 'Produce, though not pleasing, would be allowable, and suits exactly in v. 10 . Therefore, presents the exhortation as the cunsequence of what preedes, or is naturally supplied. "As you profess repentance and wish to be baptimed, therefore produce frut wrothy of repentance, and thus prove that you really do repent." This exlortation he might naturally address to all (buke $3:$ ), while it wats espeeially appropriate to the Pharisees aul satduceses. It is not probable that lae required them to go off and prove their repentance before be enuld baptize them; he only gave them a special eharge.

9. $A$ great hindrance to a true repentance on their part, was the idea generally entertained among the Jews, that all the deseendants of Abraham must certainly eseaje wrath, would assuredly lie savel (see .John 8: 33, 3!1). John proceeds therefore to correct this error. Think not to say, is an exact imitation of the Greek, and signifies either 'do not think yourselves at liberty to say,' 'warranted in saying,' (comp. Phil. 3: 4), or more probably, "do not think you will say.' 'du not propose to yourselves to say" (comp. Luke's 'Ao not begin to say'). 'To say within yourselves, corresponds to a well-known IIrbrew expression, "to say in his heart' (2t: 14; Psa, 4 1; 10:6;14:1), and is tused also in 9: 21; Luke 7: 89, 49; Rev. 18: 7. We huve Abraham to-or, for-our father, with emphusic on 'fatber, 'as shww in Greek by the order of the words. Decended at they were from Abraham, they thought themselves perfeetly sate from the Mesiande wath, and in little meel of reprotanee. One Rabbi in a Midrash even says (Wet.), "In the age to come Alralban sits be-ille the gates of (iehemna, and sutferes no cireumeised Israelite to go down"; though the Rabbi does make ingenions provision for an exception in the catse of those whohavesinned exeesively. Edersh: "No principle was more fully atablished in the popular eomvietimn, than that all [-ratel had part in the world to come, and this speeifically becillse of their connection with Abraham. This appears not only from the New Tost., from Philu, and Josifhers, but from many Rabluinie pasiages." I say unto yon, calls attention to what he is alumt to say, as being important. (Comp. on 5: 18). Of, ur, out of, as the material (tram-lated "out of

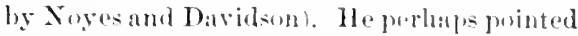
to the loose stones lyiug on tha river-bank. The fact that Gond enuld with surh perfect ease raise up chilelen to Ahriliam, and so was not dependent on them for the euntiountion of Abraham's posterity, would suggest that they might readily be set aside from enjoying the blessing promised to d braham's descondants. So Goul once threatened to Moses that he would destroy the nation, and raise up an new people from him.-This represintation that the Messianic blessings would not necesarily be enjoyed by all Jews as such, alcorels with that of John 1: 2r, that they would not be limited to Jews, but that Mesiah takes awny the sin of the world.' Comp. nlan Paul's argument in Gal. 3: 7, and liom. 4: 11\%.

10. Now also, or, alpeady. Nint only is there a coning Messianic wrath, but alreitly

\footnotetext{
I Not only is the singular best supported, but we ean see how the plural wight be introduced in assimilation to Luke $3: 8$.
} 
11 I indeed baptize you with water unto repentance: but he that eometh alior me is mightior than I, whose shoes I am not worthy to bear: he shall baptize you with the Ifoly Ghost, wind with tire:
11 I indeed baptize you 1 in water unto repentance: but he that conelh after me is mightier than I, whose shoes I an not 2 worthy to bear: he sluall baptize you

$1 \mathrm{Or}$, with...2 Gr, sufficient.

there is beginning a Messianic discrimination among the descendants of Abraham. It is thereforelighlime to repent (Weiss). 'Also' must be omitted; it was doubtless inserted from Luke 3: 9. Even now translates 'now' in its emphatic position. Is laid unto, or, lies at, the root. Noyes. The verb is exactly 'lies.' The Greek preposition leads many to render 'is laid to the root,' $i$. e., applied to it in actual eutting; and timber being very searce in Palestine, it is now common to eut down a tree at the ground (Thomson, ii., 291). But the meaning more probably is that it has been brought to the tree and lies there ready for use. Therefore, i. e., since such is the design with which the axe has been placed there. Bringeth not forth good fruit, is the same inage as in r. 8; but instead of the specific iclea of fruit appropriate to repentance, we have here the more genoral idea of good fruit. Hewn down, literally 'cut out,' viz., out of its place in the vineyard. (So Davidson). The present tenses, 'is cut out' and 'is cast,' deseribe the action as actually going on; the discrimination is already beginning, "even now.' In 7: 19, the present tense denotes what is eustomary in the ease of all such trees. Every, the most honored and priviJeged ot the nation (r. i) not exeepted. There was leginning a sovere serutiny of all, and the unworthy would be utterly axeluded from that share in Mossiah's kingdom which the persins addressed so confidently anticipated.

At this point Luke mentions various elasses as infuiring' of the pratacher, "What are we to do then?" viz., by way of producing good fruit, fruit worthy of repentanee; and gives some piguant and highly suggestive replies. (Luke $3:$ :10-14.)

11. The idea of $v$. 10 is nuw (r.ur.) brought out by Jaln more explieitly by contrasting with his own work that of the grently superior personate who is coming atter him, whose work will be far more discriminating and thormeh. The most striking and charateri-tie thing about his own ministry being the bantism he administered (conno, on 21: 25), he employs that in stating the contrast. And it could be very naturally thus employed, since immersion in water furnished an apt and exprosive inage for representing the soul as being as it were immersed in, batled in, brumglit complotely under the influence of, thoroughly affacted by, the operations of the Holy spirit. The rison Saviour afterwards used the same image, and made the same contrast with John's bajtism, in promising to the diseiples the Holy spirit's influences, to be given after his ascension. (Actsu: s.) The eontrast here is certainly not, as some have imagined, between John's bajutism and that actually performed by Jesus, through his diseiples (Johu $3: 22 ; 4: 2$ ), for that was as much a "waterbaptism" as John's. Nor does it seem proper to confine the view in any respect to the prersonal ministry of Josus, but to understand a reference to the entire work of the coming Messiah, ineluding what followed hispersonal ascension. This work of Messiah would diffor from, and be superior to, the merely introductory work of the forerunner in the vay stated.

Indeed here represents a very peeuiar Greak particke (men) which denotes that to the clause in which it stands there will presently be opposed or contrasted some other statement (commonly introduced by 'luat'). We have nothing exactly like this in English, and have to say 'indeed,' 'truly,' "to be sure, etc., and often we use no word, and express the idea by a mere emphasis: "I baptize in water... but he that is roming,' ete. (Comp. especially men, truly, on 9: 3i.) With-rather, in watcr (as given in Amer. App.), is the proper rendering of the preposition and case here employed. In a few expressions the Grok has en, 'in' (with its ease), to denote merely the instrument or means, not merely in phrases which we ean initate, as 'In what slall it he salted?' (5:13), 'In what measure ye measure' $(7: 2)$, but also, in imitation of a Hebrew use, in connections wheré the English idiom could not employ 'in,' as 'Trample them witl (in) their feet' ( $7: 6$, see note), 'Smite with (in) the sword.' 
(Lakeg: w.) Here the alction was origimally comeroived as in a cortain sense located in

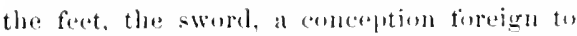
our idions. But it mu-t be obrerved that thisnse of the preporition i- ratre and it cammot

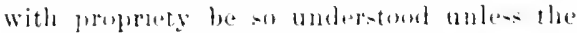
connestion is such as allogether to exclucle the (a)monom and naturai meaning. Sinws,

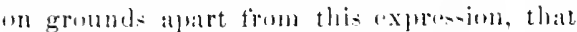
balptizinge from the nature at the actiom, callnot have been grertiormed 'in water' in the strict lonl sensta and it will be lawful to interpret the propurition (with its cane) as

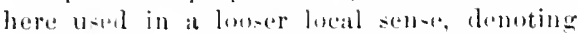
the instrument or means. But here the common and natural semse of the preperition exatly agrees with the natume of the: action. (Comp. an 5 . 6, and alat coun). l Corr. 10: 2. "in the clomd and in the sta," ambl 2 Kings s: 10, 14.) so here Meyer, Wei-s, IIC(yellatn, ate.

But we are told by some that while John (1:26, 31, 33) hats this sime 'in woter, Lulie, in the paralled flatsigen to this $13: 16)$, and also in Aets (1: i, repreated in Aets 11: lii), uses the simple ans of the momn without any prome sition (and so probably in Marli 1: 8, 1 and that thi- certainly" matu- 'with water,' denoting merely an in-trument, which makes it more likely that the silume was meant in Mathew and John. 'Phen it is aremed that an instrument is always wideled, and "rpplied to tha ohject athereted by the action, and so that "haputize with Water" cannut demote an jumar-ion. But these positums are unternalile. The simple Grock case may italf mean 'in water.' that is, it may be nut the

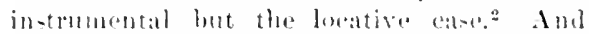
granting it to bu the inatrumbnt, an in-tru-

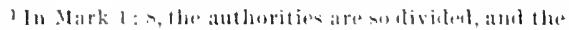

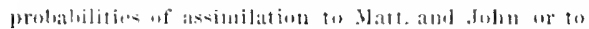

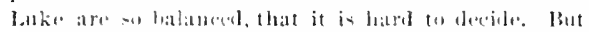

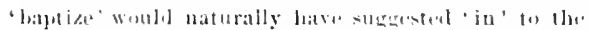

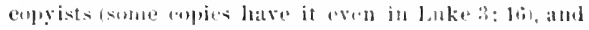
this maties it more likely that the wriginal text of . lark wats like that of Luke (II H. In Matt, and Juhn,

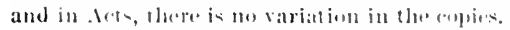

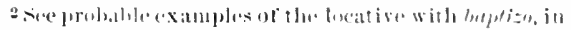

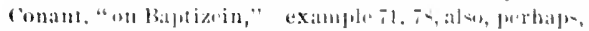

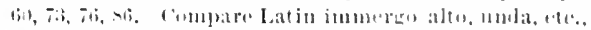
where the caln is mecesarily location and not instrunetutal.

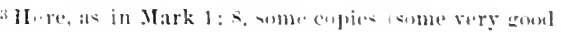

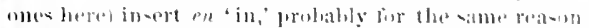
as there, that the circumstances sthestested it. John 21 :

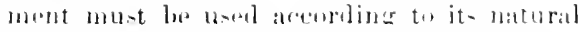
relation to the action. Tlarese is a corious

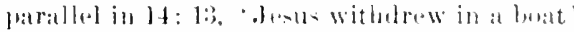

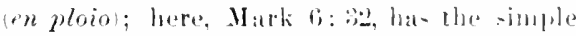

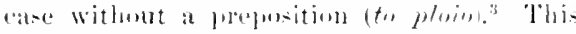
also may mean 'in the buat, but grant that it is instrumantal, the way to make a lust the instrument of groing across the lake is to put

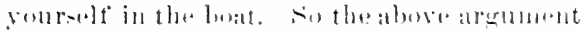

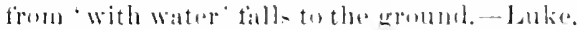

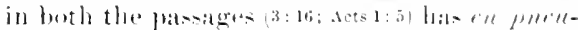

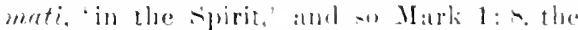

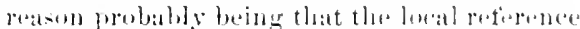

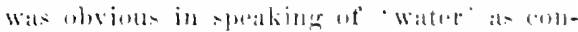

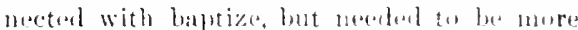
distinctly lowerht unt in shaking uf the IIoly sperit, that the figme of immerson in

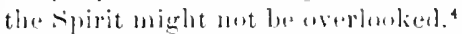

cuto repentance. The must matural waty to umbler-tand this propusition with it - atus,

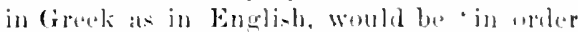
that your may repent." Sothe same expre.

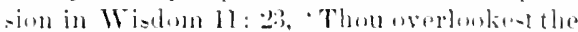
sins of mon unto repentanee.' 'The disticulty

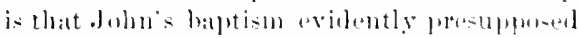

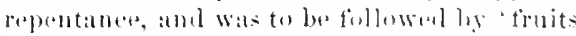
wortly of repentateres. Aecordinerly, some

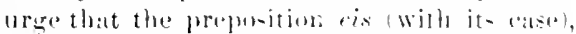

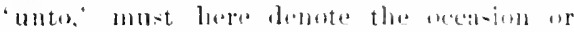
gromud of the hatptizing. a moanime which it clearly has in 12: 41 , and which i-ancribed to it

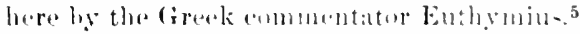
This, howerer, is a rery umusul amol ditheult

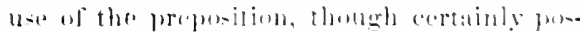
sible. Otherstake it tomean erencellly. With

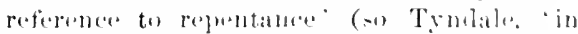
token af"). Fuch a meaning the prepu-ition

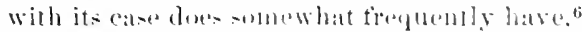

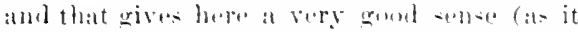

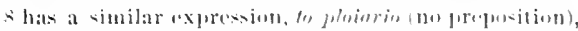

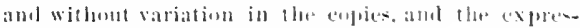

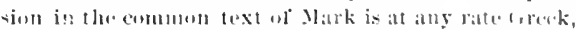
if it he not the tron text.

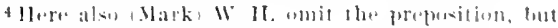

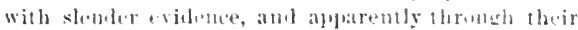
arions ilevorion to b.

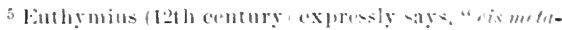

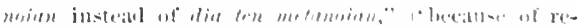

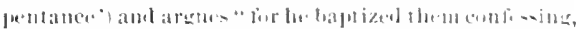

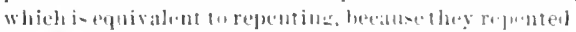

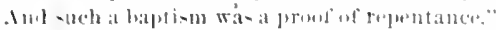

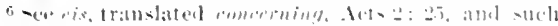

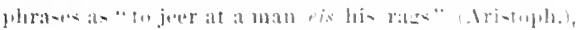

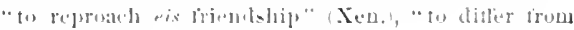
whe ris sirtue " (1'lat.). 
would also in Luke 3: 3; Mark 1: 4, "unto remission of sins'). But it is best to adhere if possible to the common and most natural sense 'in order to.' And it may perhaps be bo understood if we revert (Crener) to $\mathrm{v}$. 7,8 , the special occasion of what $\mathbf{J o h n}$ is saying. Those whom he baptized all professed repentance, but concerning some it was very doubtful whether there was a real change of thought and purpose (see on v. 2), and he exhorts them to show by the appropriate fruits that such was the case. He might therefore saly, "I baptize you in order that you may really repent," including in the one view and one expression, the primary change of purpose and the subsequent results and proof thereof. This makes the design that of John in baptizing (so Hofmann in Keil), and not exactly the design of the baptism itself (as Meyer, and many). In the parallel pasages of Mark and Luke (Mark $1: 8$; Luke $3: 16$ ), this phrase, 'unto repentance,' is not given, probably because each of them had just before spoken of it as a 'bat)tism of repentance.' That expression (Mark 4; Luke $3: 3$; also Acts $13: 24 ; 19: 4$ ) is still more indefinite than the other; by it the baptism is simply distinguished from other baptisms, characterized as a repentance-baptism (comp. 'Babylon-removal' $1: 11$ ), and we are left to determine, from the nature of the ease and the known cireumstances, what precise relation existed between the baptism and repentance.

Ife that cometh after me. Literally, the (one) coming bchind me. The expression implies that they lad heard of this couning peromage before. And we know from the Tilmud that the Jews frequently spoke of Nessiah as IIabba, "the coming (one;') (compr. 11:3; 21: 9), perhaps originally deriving it from such expressions as Zech. 9: 9; Mal. 3: 1; Psal. 118: 26. Mark and Luke, not writing espeeially for Jews, do not here use this Jewish phrase. (Mark 1: 7; Luke 3: 16.) Mightier than I, not only superior in position, but more powerful, able to accomplish what he could not. Not worthy to bear, or, more exicctly, in colloquial phrase, 'not tit to earry.' The word rendered shoes (or, sandals) signifies "what is bound under, and denotes the sole of leather, raw hide, or wood which they wore under the foot, and which, fastened to the foot by a thong or strap, constituted its entire covering. A Bedouin from beyond Jordan may be seen to-day with just such sandals of untanned sheepskin. It was the office of the lowest menial among all the slaves of a household, to carry his master's sandals, as when he went to the bath, or to untie and remove them when he entered the house; this last being the expression given by Mark and Luke as used here or on a similar occasion. Somewhat similar among us would be the task of removing muddy overshoes. A like menial service was that of washing the feet after removing the sandals. (Luke 7: 4; John 13:3 ff.) We learn from Luke 3: 15 that the poople were beginning to meditate whether John himself might be the Messiah, and it was partly to meet this that John told them he was so immensely inferior to the Coming One. In general, John is singularly free from self-assertion. Whileboldly rebuking the most influential classes (v. 7 ), and braving the wrath of Herod Antipas (14:4), he speaks of himself only in the way of declaring the imeomparable superiority of the Coming One (comp. John $3: 28 \mathrm{ff}$.). Great force of eharacter, mited with great humility and modesty, must eommand hearty admiration.

He, emplatie, as in 1: 21. With the Holy Ghost and with fire. Better, in the IIoly Spirit and fire. Rev. Ver. The original has no article, and some propose to render "in lloly spirit,' $i$. e, in holy spiritual influences. But the phrase 1loly spirit was so definite by reason of its common use, as to he for Matthew's readers virtually a proper name, so that, like other proper names, it conld be used with or without the article; and it is used without the article in numerous instanees, particularly when in eonnection with a prepoposition, as here. English idiom requires the article, as in many other eases where the Greek may omit it. Comp. 'holy eovenant' in 1 Mrec. 1: 15, and 'all Seripture' in 2 Tim. 3: 16. As to 'Ghrist,' aud 'Spirit.' see on 1: 18. Observe how helpful it would be to have the same word 'Spirit' here as in $8: 16$, and 4: 1. This statement of John's is plainly a figure, as in v. 10, 12. To say that John' baptism was only in water, and Christian baptism is both in water and the Spirit, is curiously to mix the inage and that which it signifies. But such mixing need not surprise us, 
for much enfusion las arisen in ('hristian thought from the wide-spread motion of bapltismal regeneration. John here satys that while he immerned men in water, the symber of a new and fure life, the mighties Coming One would (se to spestk) immorere them in the Hely spirit, who really produe's - weh a lite. Josus did not literally immeres men in the spirit, any more than he literally smote men

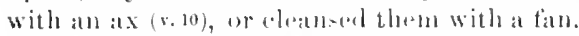
(v.12.) I'lemptie: "As learel and understomel at the time, the baption with the lloly Gihos would imply that the souls thus baptized would he plunged, as it were, in that ereative and informing sperit whinh was the souree af lite and holiness and wirdent." It is likewion

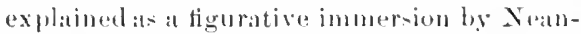
der, II yor, Bleck. This tigurativeuse of the term rexpubles such expressions of protiane writers at 'immer-al in iermoranede, 'in sorrow, 'in lebts, as also our saviour's description of his own drealtul suffirings as at baptism. (Lake 12:50.) In Euglish tor we are constantly saying, 'immorasel in business,' 'plunged in de-pair," 'bathed in delight, ete.

but what is moant hy tian additional words, and fire? Oberve that in the preading verse the fire receives the antruit tul trees, and in the next verse the tire (a) V. 11 evielently teaches the same geromal lesson, and it would thorefore be matural to understaml the fire which ends eath of the three parallel semfersers in essentially the satue way ats a fire which ann-luntes the wieked. And

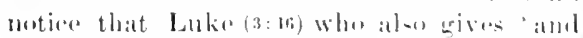
fire, hats the other indares ot lenruing the nufruitful troes and the thatl ( lake:s:s, bi), whild, in Mark 1: 8; Johu 1: an; and lets l: i) 11: 16, where the other intages atre met mentioned, moither are the words "and

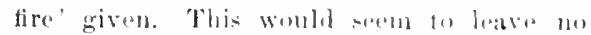
doubt at to the meaning of then words. The objextion is that in the othor images (v.10.12) two elasese are di-tingui-hed, and the denting of cach is seluarately stated: while leres it is simply "sluall baptize your, olle class at persolls, "in the lloly sporit and fire, withont even repeating the joremeition

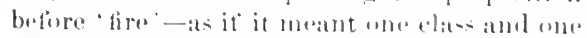

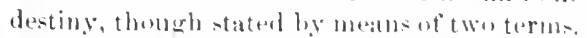

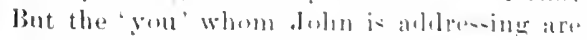
not simply the ledieving and pentent, but the dows in getueral, with special reference at

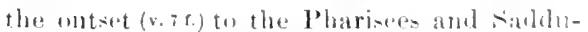
exes. Now it hatel been prerlicted ly Malachi

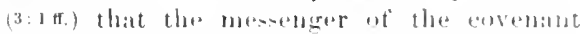
would come and purify the nation e-peratly

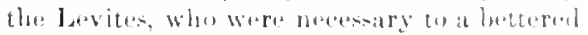
worship and national lifel, as slyer i- purified in a furnate; and this dores not simply mean that loe would furity individuals by ansuming what was fialuly in them, frut II Il 4: l-; slows it to mean that he would prority the nation by consuming the wiekrel individuals like "stublule, atad then the truly" righteous ot" the nation would rejoice and proper. The nation would be, as it were, flerewn inte a fur-

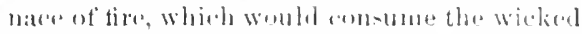
ankung them, and leave a puritied nation. In like manner, Juhn says, the mierley Coming One will 'jlunge you, tho Jus whom lir.

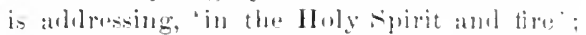

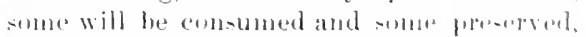

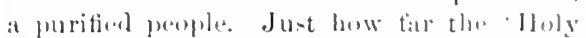
spirit in John"s mouth dittirs fmon the (). T. and approatehes the S. T. ide'at it Wentat

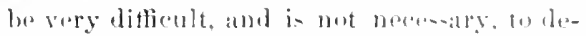

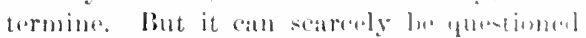
that .Iohnes thenght is commoneted with that of Malachi, and it so, the explanation ju-t offerod is in all probability correct. (atul].

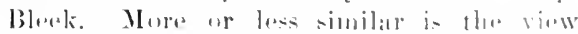

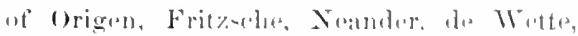

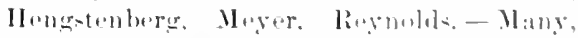
bowerer, sllppose that the "July spirit" $i=t a$

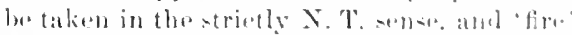

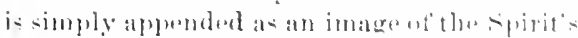
purifyine work 10 mon the individusl, moll-1111-

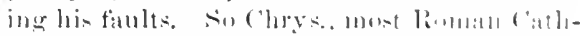

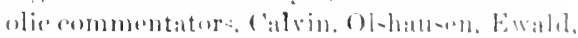

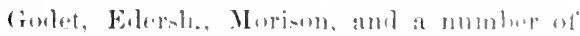
others. Somo of these think we hatre a simi-

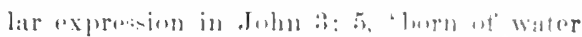

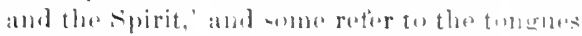

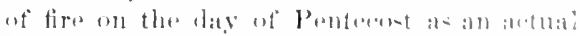

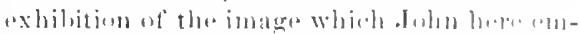

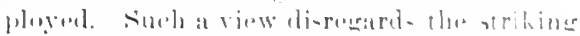

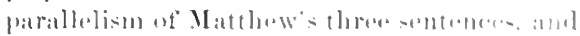

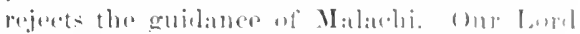

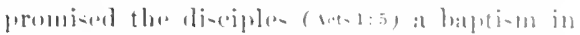

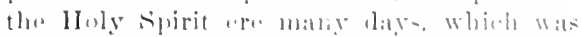

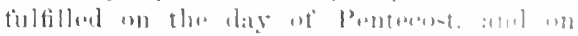

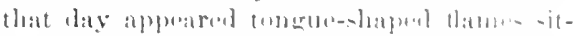

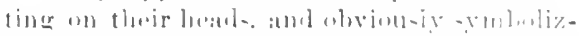

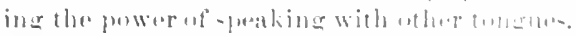
Aml it is maintained that thi- in whit buhn 
12 Whose fan is in bi, hami, and he will thoroughly purer his tlour, and git ber his wheal inte the garner; but he will bur's up the chatf with unquenchable fire.
121 in the Holy sipirit and in fire: whose fan is in his hamk, ant lie whll horoughly cheanse his threshingflow; and he will gallher his wheat into the garner, but the chatl he will buru up with unquenchabte tire.

1 Or, with

ment. But Jesus did not in his promise ad 'and fire, and there is no mention of fiery tomgues in the case of Cornelius and his hou-uhold, when Peter expresty reognized (Acts 11:16) a fulfilment of the suriour's promise. Nay, the forerumner meant something drepere and broader than the pwwer of spealiinc with tongues; he was describing the great work of diserimination, by which some would se d-troyed and the rest purified.

That difficulty was long ago felt as to the meaning of "fire, aprears trum its being omittred liere by many late MIs:. and a few late versions and Fatherm; sot none of them omit it in Luke 3: 16. Wyalif and Rheins have "in the Iloly Ghost and fire." Tyndale introluced "with the Inoly Ghost and with fire, (altering the preposition and repeating it, followed by the other early Protestant versions, and now by Alford and Darby. 'In the Holy spirit and fire' is the rendering of Bible Tnion Revinion, of Noyes ('in firo') and Davidson, and Aner. Apl. to Rev. Ter.

1:. A thipl inage for the work of scruting and separation, and bore expresty referred, as in ror. 11, to Mesiah. Fau, more exactly a wimmeing-shorl; with this the Jewsthrew 11] their whont aguinst the wind, which would

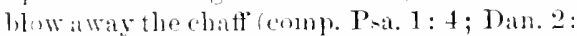
:5: II s. 13:8), while the grain fell in a heal). The 'threshing-flour,' a cireulat space of luston atheth, wa then elennet up, and the

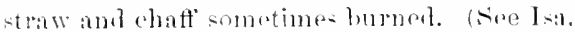
5: 24. Thoromghly purece or, clember. The axmination and diccrimination will be womplete. The saruer, or granars, barn, liturally, plate for pontting amay. The owes

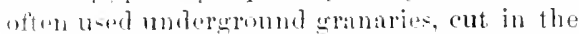
solid rext, like rinterns, or vaulted and cenumterl. In these arain comld be kipt for veirs. The term ponderent chati includes also jits of -traw, hroken by the trateling. With unducuchable fire. "It $\mathrm{I}^{+}$mat here render "With hre' instrumental, or 'in fire, locative, ju-t an in v. 11 and 1: : 40. Comp. 'intofire, ․ 10, and Mark!1: 4\%, By saying unguenohnoble tive, be turns attention away from the literalities of the image to the eternal things represinted. So with 'eternal tabernacles' in Luke 16: 9. Pev. Ver.

Luke adds ( $:$ : 18, B. U. Ver.) that 'with miny other cxhortations he published the good tidings to the people, varying his practical exhortations while adhoring to the same general good news that the reign of heaven was near at hand. This statement, as shown by what folluws in Luke, is designed to cover the whole perind of John's ministry. In Jolun 1: 26 f., we have two in-tances at te-timony to Jesus after luis bajtism, somewhat similar to that of v. 10-12, borne hefore the event.

\section{HOMILETICAL AND PRACTICAL,}

The personal eharactor of John the Baptist. (1) II is courageous severity, v. 7; 14: 4. (2) His practical wisdom, Luke $3: 10-14$. (3) $\mathrm{II}$ is humility and unselfishess, $\vee$. 11; John 3 : $27-30 .-$ Religious benefits of solitude, as illustrated by the case of .Jun.-The ministry of John. (1) Its suljects and spirit. (2) Its relation to the ministry of Jesus. (3) The grent effects it produced, r. 5; 11: 11.-Jer. 'TA YLOR: "John wa-like the morning star, or the blushings springing form the winchows of the east, foretelling the approach of the sun of righteru-ness." Jutier: "Now things. 1) A new prophrot:-2) A new ceremony ; 3) A new prenching; 4) A new king." - T. 2. The alls to repentance, (1) By the prophets, (2) liy Juhn, (3) By Jesus, (4) By the apuntles.'The old exhortation, 'pejent,' and the new motive, 'for the reign,' etc-linsir: "True proitents have other thomghts of God and Christ. and sin and holiness, and this world and the other, than they have had, and stand otherwise affected toward them. The ehange of the miml produces a ehange of the way." T. 3. Prevaration for Christ's reign: (1) In what it consists-unfesing and forsaking sins. (2) $110 w^{-i t}$ is exhibited, (a) by baptism, v. 6, (b) by fruit, v.8. (:) IIow nun are induced (1) make it-by the rojec ot on. erying.-ED.

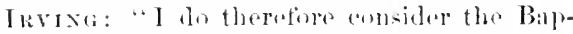
tist as our pattorn and permi-eion to take strung weapons of argument and terrible de- 
13 Then confelh Jesus from Galilee to Jordan. unto 13 John, to be baptized ot him.

nunciation, wherewith to clear away obstructions, and make a highway for the desedent of nur Lerrl. Chri-t cante not until the Baptist latal enlur. The gonel of salvation combeth not until the four of comelemuation and ruin hath seized us. The Batptist rested his lever upon the in-tant comine of Christ, and from that fulcrum tomk his purchase upon the present." Curveronu: "The Prophet and the Baptiot go upm the same ideas; the Prophet says, "Prepate ye the way of the Lord," the Baptist. 'Pruduce fruits worthy of repentance." $\mathrm{V}$. 4. The first Elijah and the second Elijalı (compl 11: 14). Bexart: "Even Juhn's foud and raiment preached." -JER. Tarour: "The prouchers life is his best sermon." -ED. Irviga: " And what is there goud that cometh not out of - utlering? and what is theregrat that cometh mot out of selfdenial? what is there new, in knowledge or in virtue, that cometh nut out of solitary thought? and what is there moble and lasting in purpuse that (oundoth not wut of long unr-ing and strengthening in the sereret chamburs of the mind?" - H.AL, : "Surre wil] Chri-t come into that soul, where the herald of repentanee hath not been befure him."

V. R. Relations lwewern contesion of sin and biptisul. $V$. 7 . The wrath to enue. (1) There is still a wrath to amone (2) Wo ought to flee from it. :3) Wa wuglit to indure others to floe. (4) Mere alarm will not secure escape.-Coming to baption unworthily: (1) With suberticial views and impressims, v. 7 . (2) With promd self-res liance, $v$. !. (3) With no intontion to live nceordingly, v. 8. E1). JRvixa: "But romgher fiar than hairy raimont or rocky wild wats that ungentle voice which wats rung among the thumsude of Israce. Such a salutation as he oponed with porhaps never smote the priele of any asambly, 'C generation of" vipers! It was bitterly, it wats monturtly, but oh, it was truly said." V.8. TukopuyLACT: "W, mus not wnly fleweril. but also produce fruits of virtue." - Christianity is positive. - I. I Human pride loumbled by remembering divine soverugnts-Folly of relying on a pious alleestry, when wat pious ourselves. Christianity dues not propose to save mon by nations or by races, but individually.

T. 10-12. Chriotianty discriminates: / Th" rightents and the wicked living toredter

(2) How christianity discriminates betwent

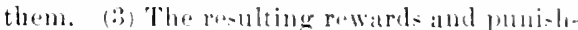

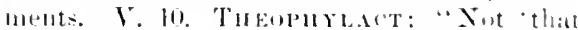

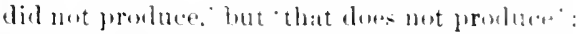
fis we must be al way- bearing fimit. It' you

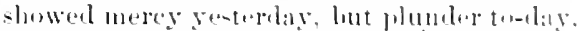

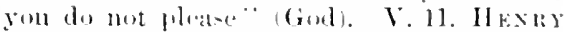

“It is a groat comblort to faithful mini-ter. to: think that Ju- ('hrist is mighter than ther. can hethat for then. and that bythem, which

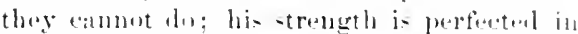
their wealine.. . . Those whum Giml put homor mono are therely made very humblo.

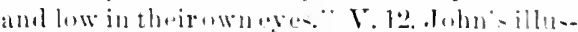

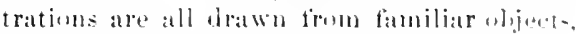
and mainly rumal-from fruit-trats, cutting with an ax, thre-hing and winnowing errain, stones that lie aromud, a sorvant carryine hio mater's samelal- the baptism he is furturan. ing. the ell-tom- as to marriage. (John 3,2$)+\cdots$

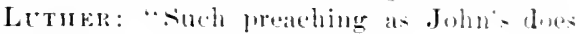
not pass awaty withumt fruits."

\section{3-17.-BAPTIA OF JEStS}

The bilptisn of .Jo-n-firms the tran-ition from the mini-try at John to that at'.J.himsert: It i- lese fully dereribed ly Mark

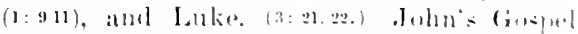

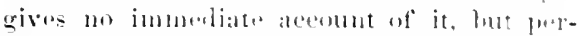
haps aliubles to it aftorwards. John 3: wh.

13. Then is a emmective froquently and-

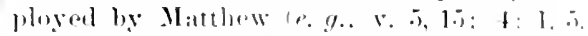

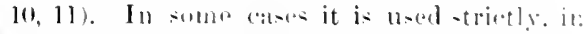
others lomely, devignating a period ot andsiderable extent. like the phrase 'in then days in v. 1, which is here noed by Mals (1:9.) Jatthew dere not here moin that .I w-ll alpeareel at the numbet When Juhn Wa

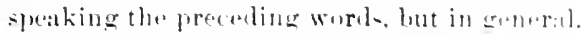
at the time when .Juhn was angagenl in lialltiziug and prealubing. as ju-t dencribel. W" have no means ot anertaining how lolur he

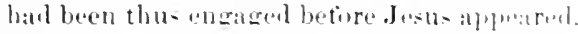
We learn irum Luke (a: 3 , Rev. Ver.). llat

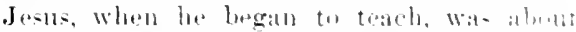
thirty ycars of age; and sulpusing that . Juhn 
14 But John forbate him, saring. I have need to be baptized of there, and comest thou lo me? 1t unto John, to be haptized of Lim. But John would have hindered him, saying, I have need to be bap- began at the same age, his ministry had already been exercised some six months. (cuke 1:26.) But it is a mistake to say that John must have begun at the age of thirty, for the age fixed by the law as to Levites (Num. 4:3,33), was shortly afterwards lowered to twenty-five (Num. 8:24), and by David was for a special reason turther reduced to twenty (1 chros. 23: 2t-2i); and so continued under Hezekiah (2 Chrou. $31: 17$ ), and atter the eaptivity (Eza 3: 8), and most likely in the time of Christ, when David's courses of priests were certuinly maintained, and probably also his general arrangement as to Levites. Luke says it was 'when all the people were baptized' (of courso a general expression, not strictly universal), which implies the lapse of at least several nonths, it we consider the journeys necessary. As Galilee is not mentioned in v. 5, we may smppose that the people of Galilee in general came later than those of Judea, and we should thus have an external reason also for. Jesus' late arrival, besides his internal reasons, (Keim). Others from Galilee are som after mentioned (John 1: 35-4i) as disciples of John. The traditional day of our Lord's baptism is 6.January ('Epiphany, manifestation), but that is unlikely. More probably John began in spring, and Jesus was baptized the following autumn, of A. D. 266; but no exact detromination is made.

Cometh, arrives, makes his appearance, as in v. 1. From Galilee, $i . e$., Nazaleth ( $2: 22$ f.), a Mark here expressly states. At Nazareth, Jesns has been living since his infancy (see aloove at close of chap. 2). As to Galilee, see an 4: 12. To Jordan. The traditional place is nurly opposite Jericho. (See on v.6.) But the place cannot be deternined. John's testimony to Jesus, apparently a few weeks later, was given at Bethany beyond Jordan (.ohn 1:28. Bethabara is a false reading), but we lo not know where this Bethany was, besides that John may have moved in the meantime, as he certainly moved once (John $3: 23)$, and probably more than once. (Joho 10:40.) Conder and Geikie (comp. Stanley) think the place of onr Lord's baptism was far up the river, near Bethleh m, where Conder found a ford now called Abarah, 'crossing.' This locality would suit the circumstances, but the reading Bethabara, must unquestionably be rejeeted. Bethany might (Köhler) very well mean 'slip-town' (aniyreh, 'ship'), as Bethabara means 'forl-town' or 'ferry town.' A village supported by boating on the river might perish after the desolation of the country by the Romans, and so Origen could not hear of it, and avowedly elanged Bethany to Bethabara. The similar name of the village near Jerusalem probably signified 'date-town,' or "poor-town." To be baptized. The construction of the original distinctly implies, what the connection also would indicate, that he came with that design. Of him, where modern English would say 'by.' (See on $1: 2 * 2$.

$11 \mathrm{f}$. The reluctance of John to baptize Jesus, with what was said by them on the subject, is recorded by Matthew alone. ${ }^{\mathbf{1}}$

But John forbade-literally, was hindering him. The imperfect tense is occasionally thus used to denote an attempted action, since some actions, if engaged in but not completed, must be afterwards regarded as only attempted. This sense, in all cuses, grows out of the nature of the action and the circumstances, the tense itsolf having the ame maning as elsewhore. ${ }^{2}$ The verb rendered 'hinder' is compounded with a preposition, which increases its force, "was completely hindering,' 'earnestly sumght to hinder.' In the next clause, all the pronouns are emphatic: "I have need to be baptized by thee, and thou comest to me!' or, 'and conlest thou to me?' an expression of surprise,
${ }^{1} \mathrm{~B}, \boldsymbol{N}$ and the Sahidie rersion, followed ly Tiseh. and W II., omit 'John,' and then the ('sreek signifies 'but he.' It is pasier to explain this subsequent insertion of 'Juhn' than its omission, and su the shorter reading is very likely correet; lut the question can hardly be settlad, and is practieally unimportant.

a The rendering of liev. Ver., 'would have bindered him,' gives the idea with tolerable sueeens. But to call this (B]. Lightfoot on Revision) a "eonditional sense of the imperfeet" is quite unwarranted and unwise, for it is merely earrying back into the creek a conception suggested by the approximate trinslation into English. It is instruetive to observe how often able grammarians fall into this mistake of tirst translatiug, and then sumposing the original to entain the same forws of enception as the coujectural translation. 
whether it be understoud as an exclanation (Euthym.), or as a question. (Comp. Johm 13: 6.) In like manner, John's nother had felt moworthy at a visit from the mother of her Lorrl. (Lake 1: 43.) It maty be (Juteroth) that as John received the contemion of others, and achinistered to them the symbol ot puritication, ha often remembered that ho too had sins to contiss and turn uway from, and therefore felt on this accision that lo would grtadly recoive baption trom his recoumbed superior. There is no suttiejent around for supposing that he distinetly expected to receive this, hut be folt the "neerl' uf eonfession, repentance, nul symbolieal purification. And the idea of . Jexus administuring baptism would not be strange, for hedilatierwatris baptize many, by the hands of his disciples. (John3:22; 1:I f.) The nution af solne Fathers (as Chrys.) that Johu Was afterwarel-atetually haptized by Jesus, is nut only without warrint, hut serms rexeluded by tho laneruage ot . John :3: 206-28; tor .Julun's followers would in that wate have axpresesel no surplise, and lohin world have settled the matter at once. (.1 Lapide). Tor muleretand John as lecre indicating the expectation that Justes will baptize him in the Inly spirit (Gill, uthers), is strangely to confinurl the literal and the fierurative, as wild allegrorizing often leads man te do. Sufter it to be so now, or, frerbajs, 'suller me now' as indicaterl by the last clatuse, 'then hestller- hime.' suffer nowe that I take the porition of infieriority to the by reseiving baptism at thy

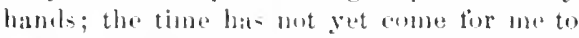
us-unte my destimal position. Brecometh us. sonue understind 'us' of' Jesus alone, but ngain-t all probability, sincer in the proceding verse both perouns wore mate emphatie, and sine the reforence to Juhn as well ats himselt suits the comnection. John thought it would be prosumption in hion, and unworthy combescostason in this smperior person-

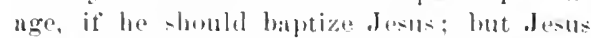
aleclares it fuite appopriate, bexomines, firr them both-putting the deelatration, however, in the form of a genteral statinentelt: fin thus it becometh us to lintil all righteousuess,

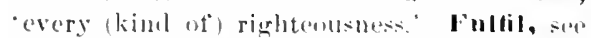
an 1: 20, luere signitios to pertorm fully. Baptism Was divinely (ommanaded (sor 21 : 25), nud though coupled with the eorfinstion of $\sin$ and arowal of repentance, wats at the same time the expression of a rablinen to

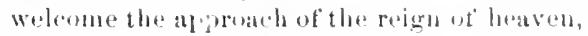
and ot a desire to share therejn. It was therefore right fior all good men to be baptizenl; and Jusus, as a man, was under obligations to do whatever was incumberet an other gend men. The pemarliable relation which he and . Juhn sustained to each wether and to the kingromot heaven, did not prevent its being [ropere tur "atch of them fully tu furform everything that was rightente; and so in this cate thel nut prevent its being proper that he should bo haptized, and that John should baptize him. (C'mnp. Gill). Such seems to bet the olwious and simple meaning of this expresionn.

But many thempes latve beren fresented as to the significance and poppriety obt our Lard's baptisn. (1) Simne loold that Jeans wats baptized as a consecration to the office and work of Wrasiah. But was purifieation a enosererattion? It was sometimes preliminary to (a) $)$ secration, but the latter was effieded by latying on the altats. And it the Mensiah, "the anointed, was to he comsererated loy any ceremony, it would maturally have been hey anointing. (2) Others say that in louptism he was eomsererated at prient. But Jesum wats not literally a priest. Ho had no condecetion whatever with the priestly lines and he dial not do the work at" it Jowish priest. A. " i

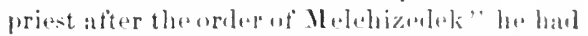
nothing to do with eoremonies. (3) Many bave adopted the view given already hy . Instin Martyr ("Tryph."

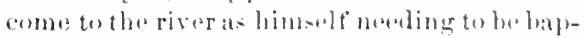

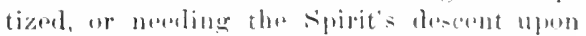
him; but just as hu was burn and e.ruejtied not as neweling them but for the benedit at the humall ralce, so"... While men thuneht of him as a carpenter. "the IInly sirit for the" sake of mankind thew down upon hisn in the form of a duve," and a voice dectared lim

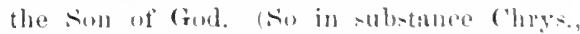
Euthym). This views as develuped and ax-

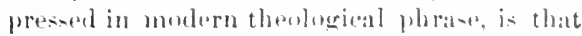

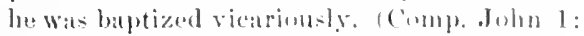

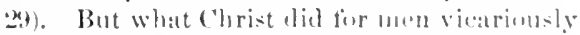

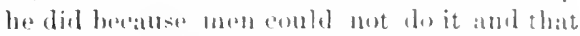
they might encrue the penalty of their tialure: Was that in any sanse trua of bajtisul Justials statement is in a gemeral sulletrue, but the vicarious theory cinnot be sustained. In 
15 And Jesus answering said unto him, Suffer it to be $80110 \mathrm{w}$ : for llus it becometh ns to fultil all righteousness. 'Then he suffered him.

16 And Jests, when hewas baptized, went up straightway oul of the water: and, lo, the heavens were opened unto him, and ho saw the suirit of fiod deseending like a dove, and lighting upou him:
15 tized of thee, and comest thou to me? Bnt Jesus answering salid unto him, sutfer 1 if 110 w: for 1 hus it becometh us to thifil all righteousuess. Then he 6 suffereth him. And Jesus, when he was hapized, weat up straghlway trom the water: and bo, the hearens were opened 2 undo him, and he saw the spirit of cod descending as a dove, and eoming upon

l Or, me....2 Some aucient autborities omit unto him.

generit, we ought to beware of forcing the ideas of vicarious action and imputed righteousness upon those portions of seripture which do not elearly present them. (4) A recent writer (Kirtley on "Design of Baptism") says that the chief object of the baptisn of Jesus was to symbolize at the beginning the erowning acts of his work; that our Lord 'did 'fulfil all righteousness,' actually in his work, symbolically in his baptism"; and that he "associates his followers with himself" in this matter," saying, "In this ordinance it is fitting that $I$ and my followers should fulfil all righteousness." This faney is ingenious but fir-fetehed, and the latter part quite baseless. (5) The simple and natural view, for all who do not insist on tarrying back the Patuline doetrine of imputed righteousness, is the one already stated. It was proper for all devout Jews to be baptized ; therefore it was proper for Jesus. It one so deeply, though hitherto quietly devout, had staped awat from the ministry and baption of the new prophet, it would have been setting a very bad example, unless explained; and explanation of his future position and work eould not then be given, even if it was then entirely plain to his own mind. Notwithstunding the peculiar mission of John and Jesus, it was becoming that they should fully perform everything righteots. (so in substance, Meyer, Ewald, Bleek, Farrar, Geikie, Edessh.; Grotius already, and comp. Calvin. Davidson translates 'every duty.' Hase, Keim, and others, regurd baptism in the case of Jesus as simply a vow of devotion to the approaching Messianie reign, which is part of the truth). A somewhat similar ease vecurs in 17: $24 \mathrm{fr}$. Jesus there intimates that he might, as the Son of God, claim exemption from the payment of the templecontributions, but that the rulers might make his refiual an excuse for rejecting him, and so he will do ats all devout Jews do, and pay it.

16. Straightway, or, immediately. The stress laid on his going up immediately might possibly be understood as meaning that whereas in that warm elimate the newly baptized often stood some time in the river, witing till others had been baptized and many could ascend together, Jesus was alone in this matter and ancended without delay. Euthymius mentions the view that others were detained ly John in the water till they eonfesed their sins, and Jesus went nu inmediately because he had no sins to confess; but it would seen mueb more likely that the confession was made before than after the baptism. The true explanation seems to be furnished by Mark, who says (1:10), "and straightway, eoming 11 , out of the water, he saw the heavens opened.' This makes it likely that in Matthew also the real thought is that the opening of the heavens and descent of the dove followed immediately upon the baptism. Events followed each other quicklybaptized, ascended, saw. (Keim.) The senso is brought out by putting only a comma atter 'water,' and reading right on. Luke 3: 21 has not the word 'immediately', but what he says is to the same effect. Ont of, or, from. This preposition does not in itself show whother he had beon in the water. The correct text in Mark 1: 10 is 'out of,' and does show that he had been in the water; and so in Acts $8: 39$. When we say that a person has just come 'from the house,' 'from the town,' we regard. the house or town, sofar as this expression is eoncerned, as the point of departure; the eireumstances will nsually indieate whether he was in the house or town before coming; (r.g., A tets $13: 13 ; 16: 11 ; 25: 1)$. So the same aetion is frequently described by 'from' and 'out of,' the latter expressly stating what the former leaves to be understood. Thus in $7: 4$, Rev. Ver.: 'Let me east out the mote from thine eye,' (most MSS.); and in $v$. 5, 'out of thine eye.' In 17: 18, departed, or came forth from him, while Mark 9: 25) has 'out of him.' Comp. on 24: 1 . so in Tobit 6:3. "A fish leaped up from the river, and wished to devour the lad.' 


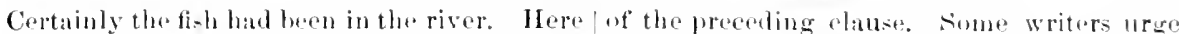
in Matthew the connection and rimenmstances that John is the subject of the freeceding

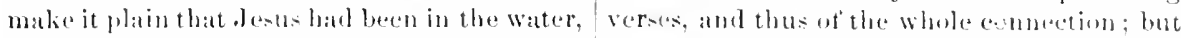

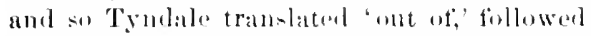
by other English varsins down to the connmon verion. Even the liheins, abandoning Wyclif"s "tro.' and taling liberties with the Vulgate de, renders 'out of:' The correct translation in Matthew is however "from," and $\Leftrightarrow$ all recent versions. But the rendering of the older versions shows that they phainly saw what the falets wore. (Tyudale and his followers rember similarly in 14: 1:3 and Luke 12: 54. Tert. Rece) It to the cxitct forre of tho explession "ont of' ( Mark and Acts) in such a ase, comp. below on 17: a, literally, 'out of the momntain.' Thismons that they hadl bean in, within, the limits represented by the mountain, though not moler its soil. And so it is comerejuhle that "out of the rieer, it that were the explession here, might under peeculiar aremmstamees be nseal where one hat only beon amid the reods on the

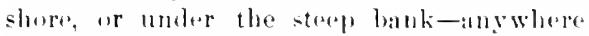
within the space denoted by the riser (compl.

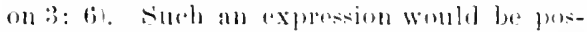
sible in such a sense, howerer mulikely to lue usel. But 'out of the reter' must signify that the person hate besu within the limits denoted by the water: and the hank, themgla in some sense a jart of the river, is in no semse a part of the watel. Of conter these (*xpresions do not of themselses slowe that tha person has heren enveleperl in the water we may sporak ot a man as "in the water" when he is simply standiug in it. It would thus be possible-however improbable and annatural -if we hat no guide here but the preposition 'out of" in Mark and tho cireumstances in Matthew, to molerstand that .Jesus merely stoud in the strotm and hat water put mpon his head. But when these expressions stand in eomnection with baptizn, which arerghoty agrees primarily and commonly meant 'immerse, then the inforences is inevitable.

The heavens were opened unto him,t not meroly signitying so that he eould see into the hearens, lut for him, for his bemefit, so as to affect ur concern him. 'IIim' is naturally' understoml as referring to. Jesus, the subject

I'Ento him' is wanting in seseral of the earliest and best auluorities, and not fouml in luke $3: 21$. It might bave seemed to some copyists and translators out of

v. 16j introlues a distinet subdivi-ion ot tho narrative-luke mentions (3:21) that J $(4+1)$ Was at the time praying. The opening ot the heavens was deubtlens an actual miracolons apyearance, stach as is trequenty mentioned elsowhere. (Ezek, 1: 1; 1sa. 64: 1; Aets ; : 5t; kev. 4:1,) Mark, in his vivial way has, literally. ho saw the heavens splitting, in the act ot pating asunder. Aub he saw, $i$,,., lends saw.

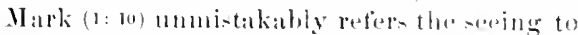
Je-lls, and it is natural se to under-iand here. Some saty that, it'so, 'him' at the rout at' the sentence womld have to be 'himselt.' but this is a mintak" (Miner, 151 [18!1]. Comp). Juhn 1: 48). We le:tru from Juhn 1: :32 that the Baptizer alou maw, as it had been promionel le should. Lulie merely states the olijective fitet that the haswen opened and the sipirit

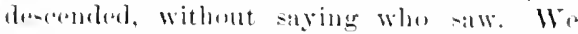
anumot decile whether any one alse than

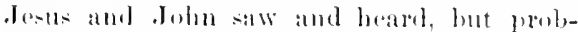
ably not. On the aceasion spolind of in Jutn 12: 28 tl:, the prouple hearel at solmol fom heaven, which they thomert was thumder, but diel not distinguish words. It the

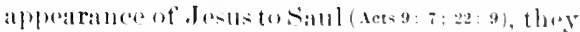
that were with him saw the light and hearl a sommd, but did not distinguish the woreds. Sis probably here. Trur, tha tatimony ats given by Matthew, 'This is, etc.., Wat adelpessed to some other than . Jasles himself, lute it is enomgh to muderstand that it was adelesend to Jolnu, as in 17: 5 to but a lew persuls. John

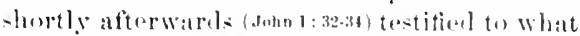
he hatl sepol. Deserdidiug like a dove, lit-

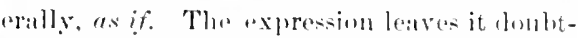
ful whether the eromprison is with the form

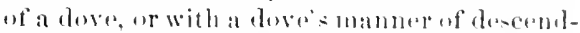

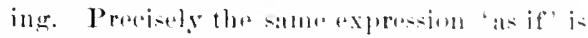
cmployed hy Mark, Isukes and .tohn. (1:3:.)

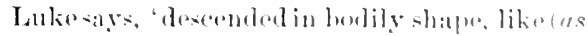

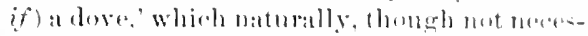
sarily, indieates that it was in the - balpe at it dove. Expositers are here ereatly divided. But it is certain that some bodily form was assumerl. That of the [xentle and guiledes dove (comp. 10: 11i) would be natural amb

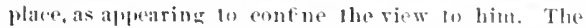
question is ditlicult, ant unimporlant, bul the expression is most probably germuine. 
17 And 10 a voice from heaven, saying, This is my 17 him; and lo, a voice out of the heavens, saying, ${ }^{1}$ This beloved Son, in whom I am well pleased. is my beloved son, in whom I an: well pleased.

$10 \mathrm{r}$, This is my Son; my beloved in whom I am well pleased. See ch. xii. 18.

suggestive, while a dove's manner of descending is hapdly so peculiar and striking that a mere resemblance te it in movement would have been carefully recorded by each of the Evangelists. It seems therefore reasonable to adbere to the ancient opinion (Justin Martyr, Origen, Chrys., and others), that the spirit descended in the torm of a dove. It has been often repeated that a labbinical interpretation of Gen. 1:2, likens the spirit of God 'brooling upon the face of the waters' to a dove. But Edersh., Vol. I., p. 287, quite explains this away, and also states that the Targum on Song 2: 12, which declares 'the voice of the turtle' to be the voice of the Holy Spirit, dates considerably later than the Talmud. Su there seems to be no ground for the Jewish clam, that this appearance of a dove has earlier Rabbinical parallels. Yet if the claim were well supported, it would not be surprising. We recognize it as one of the excellencies of the seriptures, that the form of the revelation is constantly in accordance with the modes of conception natural to man, and even sometimes conformed to the peculiar way's of thinking of the people chosen to recrive it. Comp. on 7: 3-5. Morison quotes Yarenius as saying, "It was not as an eagle, but as a dove; an animal corresponding among hirds to the lamb among beasts." And lighting, or coming, npon him. It was inle to translate the plain 'coming' by 'lighting.' The Baptizer afterwards testified (Jobn $1: 32$ ) that it 'abode,' or 'remained, on him,' $i$. $e_{\text {. }}$ probably for some tine, thus symbolizing the great firct that the Mediatur was to be henceforth permanently and preculiarly in union with and under the influence of the $\mathrm{Holy}$ Spirit. Acordingly we find immediately atter $(t: 1)$ that Jesus is said to be 'led up by the spirit,' etc. (Comp. Johm ?: 34.) The coming of the Spirit apon our Lord was so very peculiar in its relation to his office, that we are scarcely warranted in taking it as the ground of a petition that the spirit would bless any ordinary baptismal oecasion. Such a blessíng should be fervently sought, but hardly on this grousd. heaven-rather, the heavens, plural, as in the preceding verse (see on v. 2). So Mark, while Luke uses the singular. We atso often say 'beaven' and 'the heavens' indifferently. The Talmud has many stories of a voice from heaven, coming to decide questions, to commend certain teachers, ete., and calks it Bath kol, 'daughter of a voice,' perhaps meaning a faint sound as if coming from a great distance. See Lf., Gill, Wünsche. Edersh. insists that there is no real analogy between the Bath kol and this voice from heaven. There is no intrinsic objection to the idea of a resemblance. Here also, as in v. 16, we see that revelation adapts its choice of a form to the popular mind. Other instances of a voice from heaven, see in John 12: 28; and to a certain extent in Matthew $17: 5$; Acts 9 : 4; Rev. 1: 10. Comp. Acts 2: 2. This is. Mark 1: 11 (according to the best authorities for the text) and Luke 3: 22, have 'Thou art my betoved son, in thee, etc. Of course, it eanuot be that both of these are the words actually spoken. As to the authenticity of the narrative, such slight and wholly unimportant variations really confirm it, being precisely such as always oceur in the independent testimony of different witnesses. As to the cmmplete inspiration of the Seriptures, we must accept it as one of the facts of the case that the inspired writers not unfrequently repurt merely the substance of what was said, without aiming to give the exact words. So, for example, at the institution of the Supper (26:26 ff.), in Gethsemane (26:39 ff.), in the inscription on the cross (27:37), etc. In some instances of such variation we may suppose that the exact expressions given by the different writers were all employed in the connection, but in other eases that hypothesis is unwarranted. While such facts is these should make us eautious in theorizing as to verbal inspiration, they do not require us to lay aside the belief that the inspiration of Scripture is complete, that the inspired writers have every where told us just what God would have us know.

The words spoken are the same that were 
uttered on the Mount of Transiguration. (17:5;2Pet.1:17.) The rerson reterred to was known in that case by the transtigured appearance, and here by the descent of the dove upon him. The Greek is more emplatic: 'this is my son, the beloved. -There is no propriety in saying, with some expositors, that 'beloved' signifies 'only leggotten.' As ajrplied to our Loril, the two terms are to a certain extent equivalent, and they are sometimes confounded by the sept. trarslators, but there is of courec, al diatinction betwern them. In whom I am-or, was-well pleased, or, 'in whom I delighted.' The tense of the verb may be understomel ats denoting what took place at some indefinite past time, and from the nature ot the case still holds good; as in 2:3: 2, liturally, "The seribes and the Pharisers sat down in Mloses seat,' and so are sitting thare now-where in English we should say, 'have sat down.' (si) Winer, 2-8 [347], Buttm., 198.) It this view be atopted, the rendering of the Common $V^{\top}$ arsion expresses the subatantial moaning pretty well. Bat the Greek tense more naturally denotes some pant time, to be determined from the connection, fiom the nature of the case, or from other teablings of seripture. The time here referral to might be that indicated by Ps. ㄹ: 7; by Isal. 4:2: 1 (which is perhaps alluderl to here, and is quoted below in 12: 18); also by Juhn 17: 24; Eph. 1:4. In the depths of eternity, betore crostion hagan, Gorl loved, delighted in, his Eterual sion; and now at the baptism and the tram-tigurattjou, he bears witness to him, alluding to sueh declarations as the above, and saybar: "This is my som, the boloved, in whom my sonl delighted.' 'This latter "xplanation is perhaps preterable, hut it is harrl to docide: and both agree as to the main rentting sena. that the Father elelights in him now. This declaration might make mores real to the human mind of Jesus that peouliar sonship to God at which he had in thildhood alrealy. indicated consciousness. (Luke2: ta.) such a view connects itself (Calvin) with the fact that he was fraying (Luke $3: 21,22$ ) whon the voice came. It was also a commendation of him to .John, who soon atter bore witums before all (John1:34) "that this is the sim of God'; just at at the transfiguration the voice came to the three disciples also, who were to testify at the pouper time. (17:9.) - A poeryjual writers in the second and thirel asturies make fanciful adelitions to this aceount, as that a great light slone round the platere, that a fire was kindled in tho. Jorelan f perhate a fancy wrought out of $" 3:$ 11), and that the voice added. 'I to-day have begotten thee.'

\section{HOMILETIOAL ANI PRAOTIOAL.}

Kens: "The baptisn of Jesus the culmination of John's mini-try, and the begiming of

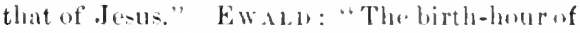
Christianity." ["uknuwn in Aquinas: "As when the morning star has risen, the sum does not wat tor tbat -tar to set, but rising as it goes forward, erralually obscures its brightness; so Christ Waited not for Jolli to linish his course, but appeared while he ret taught."

V. 13. Importance af Baption: Not as carrying with it regeneration, or procuring renision, but 1 ) an imitation of Christ's ('xatmple; 2) an act of Chriats own appointment $28: 19$; 3) an outh of allegiance to Christ, "in the name ; t) a symbol of purification from sin through ('htiot, Acts :2: 16 ; 5) a symbol of burial and resurrection in union with Cluriat. Ponn. 6: 1. V. 14. How utten are well-meant but utterl:- mistaken effort = made to discuade prersuls trom what is entirely right. Such effortis frequently proceed, as here, from the misapplixation of something that is true.- John's twotuld diffienlty (com) Lange) ; 1 to baptize the Phariones and siadducoes, who were unwortly of his bajtisll; 2) To bajtize Jous, of whom his baptism was unworthy.-Jolun's lajutisu highly homored:

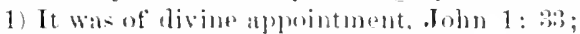
2) It gaver name to his whole work, "the baptism of John' (21:25). Julun the Bat)tizer: 3 , It was received by grat multitulas; 4) Evon the saviour submitud to it; 5) Jesus bitutizerl on like (onditions, Juln $3:$ :2, 4: 1, 2; Mark $1: 14$.

V. 15. Here for the firet timo in this Gospel our Lord presents an eromple to us. Lut us be carefol in all that fillows to seck his fortseps and learn to walk in them. (1 Pet. 2: 21: 1 John 2:6: 1 Cor. 11:1.) - I regard for what is becoming requires us not merely to consider the cpinions ot mankimel, lut our own real "hatracter and relations. To consider in this high sense what becomos us, i- an exalted and inspiring view of lite. Comp. Ileb. 2: 10. - 


\section{CHA PTER I V.}

THEN was Jesus led up of the Spirit into the wilderness to be temprod of the devil.
Our Lord's baptiom at an example: 1) It is right for those who wish to take part in the Messiah's reign to be baptized. (Jesus regarcled this as a part of righteonsness.) 2) The most extruordinary character and circumatances do not make it beeming to neglect this duty. 3) The mistaken opposition of devout triends should not prevent our performing it. 4) Loving obedience is apt to be followed by an approving testimony. HENRY: "They who are of greatest attatinments in gifts and graces should yet in their place bear their testimony to instituted ordinances by a humble and diligent attendance on them, that they maty give a good example to others." AuBrose: "Also like a wise mater inculcating his doctrines as much by his own practice as by word of mouth, he did that which be emmmanded his disciples to do. The Roman Cato said, "Submit to the law which thou thyself hast enacted.'"

V. 16. Griffitin: "Iust as the "veil of the temple was rent in twain" to symbolize the perfect aecess of all men to God (neb. 10: 19, 20), so here the heavens are "rent asunder' (same Greek word), to show how near Got is to Jesus and Jesus is to God. So in John 1: 51, Rev. Yer., 'Te shall see heaven opened, and the angels ascending and descending' (to and frobetween me and God), that is, You shatl see that $I$ am living in uninterrupted commmunication with the Father." - Lutner: "Highest things. 1) The hightent preacher, God. 2) The highest pulpit, the hearens. 3) The highest sermon: "This is my beloved Son, in whom I an well pleased.'"

\section{Ch. 1: 1-11. The Tenptiton.}

The Temptation concludes Matthew's accomnt of events connected with our Lord's entrance upon his public work (see on $3: 1$, 13). That work was now about to begin, and he was doubtless meditating upon it. Some recent crities go to great lengthe in speenlating upon the "phlau" of Jesus, at this and subse-

1 The meaning of this 'up' was obscured to early and later translators hy their ignorance of the geography of Palestine. The Latin versions and the Pesh. Syriac quent periods. There is little or no indication of any plan, and such unsupported speculattions seem unprofitable and unwise. But his meditations in beginning his work would furnish the natural occasion for such speeial temptations as are here depicted. These are also reeorded by Luke (1:1-13), and briefly mentioned by Mark. (1:12 f.)

1. Then see on 3: 18), viz., when be hatd been baptized. Luke implies, and Mark states, that it was 'immediately' after the baptism. Led np, $i$. $e$, from the ralles of the Jurdan (see on 8: 6) into the higher land. Into the widderness (see on $3: 1$ ). Some recent writers (Stanley, Plumptre) make it east of the Jordan, but the general use of the term in the $\mathrm{N}$. $\mathrm{T}$. favors the common view that it was on the west. Luke's 'returned' (t:1) also favors this view, but does not settle the question, for Jesus may have crosed below the Lake of Galilee, and come through Perea to be baptized, at the Galileans often took this ronte to.Jerusalem. The motion that it was the wilderness of sinai is founded only on the fact that there occurred the furty das fist of Moses and of Elijah. - It was certininly a very retired and wild part of the "wilderness,' for Mark says, with one of his rivid descriptive touches, "and he was with the wild beasts.' A tralition which appears first in the time of the Crusales places it in a mountain just west of Jericho, hence called Quarantania, (al place of forty days; eomp. querantine, a torty days' detention). This mountain is six or eiglit miles from the traditional place of the baptism, and rises some fifteen humbred feet almont perpendicularly from the platin of the Jordan, which is here at its widest part. In the rocky face of the mountain are the openings of numerous artificial caves, made by monks of the Crusading period, perhaps some of them by old Jewish Erenites. But to our modcrn fueling it seems unlikely that wur Lord withelew tor a cave, and probilile that he went further away from the populous plain of Jericho. Some think (s'chatf) that Quar-

have simply 'was led.' Tyndale gave 'ledd awaye, and was followed by Cranmer and Genera. 
antania may lawe been the place of the thice temptation, if not of those precoeling, which is quite posible. After all, it may bu that a fpecial providence caured the precers locality of thin and many otber "vents in our Lord's

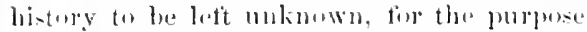
of retraining superstion. 'The spirit, vi\%, the sipit of God, well known and just mentioned. (3:16.) Luke says low was full of the Holy spirit.' From the time ot his bapti-m (seen an: : 16) we lind freppent statements that the (ion-man, the Moliatol, was specially and powertully under the intluence of the Ifoly

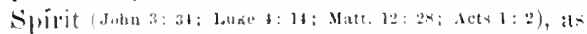

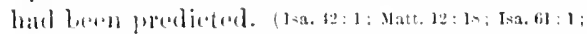

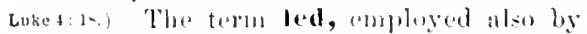
Luke, appears to denoteronly an intermal intpulse wrenght lye the sipirit. Mark (1:12) exprenesthe same idea by a stoung figure, literaliy, "the spirit asts him forth inte the wildernes." "This is the langlatgre of the prophet-paroxy-m, sajzed with an irresistible impule: so the boly men ot old wero im-

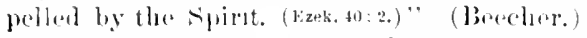

'ro be tempted. The (ireek word signitio to try, or make trial of, to test. The motive of such teling or trial mat be gond or bat. (1) The object may be to aserertain eharaceter, to deverop and make manifest its axeedlencies, or to expose its fiulde. that thery may

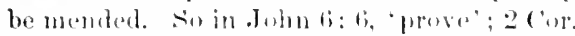

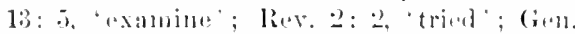

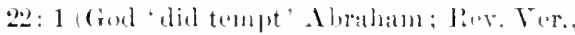

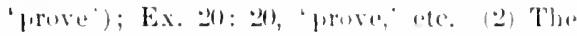
object may be unfrimelly. lial. (at) Man 'tempt' God, trot him, in some impropers

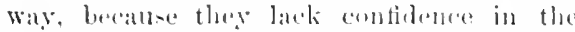
fultillmost of his promian ar threats. Sil

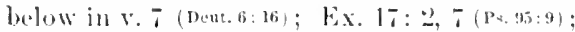

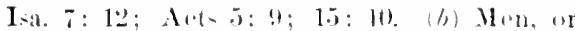
Satan and his subordinates, "tompte men, test them, with a view to draw ant aril temelencies, and entice inter sin. So lowe and in 1 (ur. 7:5; 1 These. 3: 5, ete. (This sense deses not oecur in the O. T.) I In all cases there is a testing, trying, and the ditlerenter lies in the nature and design of it. ()ur Enerlish word. 'tempt,' was formoryly used in all these senses. but is now restrieted to the hat sense; and

I. Alforel remark that the direek word here employed, peirazo, dues nol have this sense in the classics. True; but the simpler and more common form, peiruo, is repeatedy so used. some confuaim arion, fint examples in the translation of Janue 1 : 20-15, whore thare is a tran-ition tions the amol to tha batefions 'trials" to 'tomptations. Or the

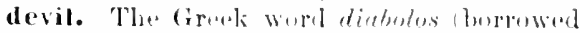

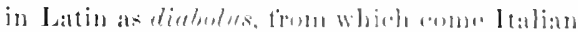

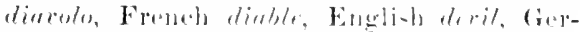

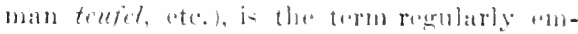

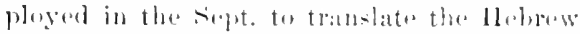

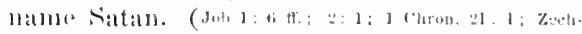

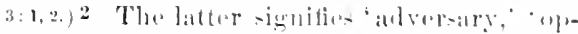
peser," while diabeles strictly signities "san-

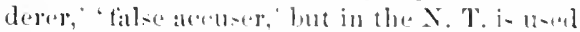
as practically copuivalent to fiatan. Sir Mark 1: 1:) has "templed by satan, ambl seo below,

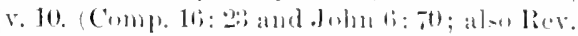
12: \%.) The torm devil in the X. T' is

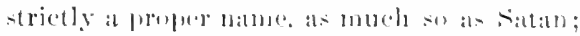
his suberdinates slomld be called themens.

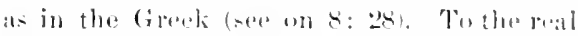
exiatence and perentality of the deril the serijutures are fully eommitted. Ite is reprecented at the claiet at the fallen angels (25: 41; compl. 9: :34), and thoough there be is able, thomel not ammipresent, to be carrying on the tomptation of many persons at the somp time. Ho $\mathrm{j}=$, of conlos, limited in knowledge, though inneasurably sllperior (1) matu.

How could . Tesus be temptial? Was it pussible for him to sin? It this was in nus sellete posible, then be was met leally tempeted. arertainly wot "like as wo are" (11+b.+13.) lint low (an it have been pestille for him to -in? If we think of his human nature in itselt, apart from the co-linked divinity, and aburt from the Joly spirit that tilled and lon him, then we must say that, like delan in his state of purity, like the alugels and every uther

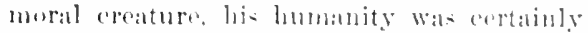
in itself capalble at' simninge and thus thes

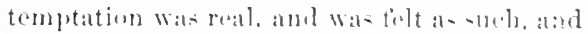

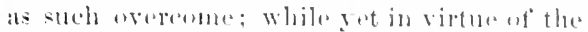
union with tho divine nature, and wit the power of the Moly spirit that tilled him. it

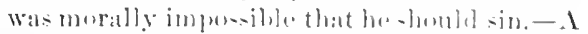
substantially -imilar view is werl stated ly Fdersheim.-J(4) was temptal an other

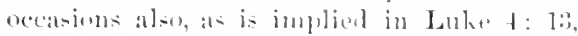

aldumpre erromeonsly states lhat the lireek ward io diflerent in Zech. 3: 1, 2. In using all enmmentaries, incluling the present one, realers will tind it worth while to "verify the references." 
2 And when he had fasted forty days and fort y nights, he was afterwaril an hungered.
2 ness to be tempted of the devil. And when he had fasted forty days and forty nights, he afterward and atfirmed in Luke 22: 28, and Heb. 4: 15 . It lias been remarked (Ullmann) that there are in the nature of things two great elasses of temptations, the one to commit positive evil, and the other to shlink from what is right. In the former way Jesus was tempted here, and when the people wanted him to be king (John 6: 15); in the latter way he was tempted iu Gethsemane, and when Peter tried to dissurde him. (16:22, 23.)

Why should Jesus be tempted? We can see some of the reasons. (1) It gave proof of his true humanity, proof that he possessed a real human soul. (2) It was part of his example to us. (3) It formed part of his personal diseipline (Heh.5:7-9); and (4) of his preparation to be a sympathizing intercessor. (Heb. 2:18; 4: 15.) (5) It formed a part of that great conflict in which the "seed of the woman" was to "bruise the serpent's head." (Gen.3: 15.) In this first great struggle of the confliet the destined conqueror came off completely victorious.

During the forty days (Luke $4: 2$ ), and at other times, our Lord was doubtless tempted by suggestion to his mind, as we are; but in the three sigual and final temptations here deseribed, it seems to be distinctly declared that Satan appeared in bodily form and with actually spoken words, and this fitted the seene for distinet and impressive description. To malse it a mere vision, is without the slightest warrant. And while it is possible to regard the history as merely a vivid deseription of a series of iuternal temptations, it does no small violence to the language and the entire color of the narrative. Note especially the correspondence of the two expressions, "the devil leaves him. . . angels came and ministered to him,' where few who believe the Bible at all will question that the angels appeared in bodily form, as on so many othor ofeasions. The desire of many commentators to reduce the seene to internal suggestion, apparently arises from two causes. (1) Some wish to lessen the diffienties of the narrative. But those who are repelled by the idea of satan's personal appearance will be equally reluetant to admit his personality ; so that there is nothing gained, and the difficulties of the subject are in fact inherent and have to be aceepted. (2) Others wish to assimilate the Saviour's temptations to our own. (Heb. 4: 15.) But this desire is amply net by considering his temptations during the forty days and throughout his career. (See above.) Every point connected with this series of temptations has oceasioned a vast amount of speculation, often of the wildest character. Yet the subject from its very nature calls for guarded interpretation, great moderation in conjecture, and willingrness to remain ignorant where we have no means of knowing; and it requires to be diseussed in a spirit of profound reverence and humility. Familiar as we have grown with the simple narrative, it presents one of the most wonderful, mysterious, awful seenes of the world's history. O dark and drealful enemy, ever plotting our ruin and exulting in our woe, here thou wast completely conquered on earth, eonquered by a man, and in the strength of that Spirit whose help is offered to us all.

2. It is best to understand the fasting as entire abstinenee from food. The word does not necessarily mean this, nor does cren the strong expression of Luke, the did not eat anything in those days,' for Lulie uses equally strong language of Paul's companions in Acts $27: 3 \%$, where he ean only mean that they had taken very irregular and inadequate fond, as it were nothing at all. (Comp. below 11: 18.) Still, the literal meaning is preferable here, becanse there is here nothing to forbid it, beeause also in the eorresponding cases of Moses and Elijah the fusting is usually understond to have been entire, and hecanse we thus best see the force of the statement, 'afterwarls he was hungry, or, as Luke, 'and when they (the forty days) were emmpleted he was lungry, leading us to suppose that during the forty days he was not hungry, but supernaturally sustained. The time was the same as in the case of Moses (Ex, 34: $2 *)$, and Elijah (1 kings 19:x), and was perhaps typieally related also to the forty years spent by Israel in the wilderness. (See on 2: 15). We do not know what originally caused the adoption of forty as a saered or sulenun number. (Gen. 7:12; Deut. 9:25; 10:10; Ezek. 4:6; Acts $7: 23$, snd often.) "Jesus had forty days before his public 
3 And when the templer ame to him, he sajd, If thon be line fon of God, command that these slones be made liread.
3 humgered. And the trntuler eame and said unto him, it thou art the son of God. command that apearance; forty days, ns if for preparation, beforebisascension. ( $10 t \times 1: 3$.)" (Bengel). And forty nights, added (by Matt. alone) perhaps because the Jews were aceustomed to spreak of the niglat and day as together eonstitutingene period (see on 12: Hi), or beraluse they frequently tasted during the day and then ate at night (2sam. 1:12), while here it was day and night, as in Estir. 4: 16. The design of the spirit that he should be tempted was probaby not the sole design of this retirenent; our Lord, thus sechuded and supermaturally sustainea, doubtless spent his time in prayerful communion with his Father, as often afterwards (Luke6:12; John 6: 15), and probally also (soe on v. 1) in meditation upon the great work he was about to enmmence. So Musas and Elijah, as lawgiver and retormor. Our Lord's fasting was not an act of selt-mortification, if he was preternaturally sustained, and is not an example tous. Tomake it the authority for a regular anmual "tist " of torty days by all Christians ("Lent") is wholly unwarranted, and very strange. (Comp. Ilexander.)

3. Came to him-we cannot tell in what form. If thou be-art-the son of God. The form ot expression in Greek is most maturaliy understood as assuming that the supposition is fact, as slortly before declared. (3: 17.) Wyclif' art '; 'Tydate to K. Jaunes 'lue,' Tha Greek is not subjunctive but indicative. The tempter puts the matter in this form in oreler to invite. Jesus to establish the faet by a miracle, and in order to intimate that he certainly has the right thus to sat ist"y his hunger. "Soul' is by its position in the fresk emphatic. God's ordinary creatures may sutler, they eannot belp it; but if thou art his son, it is unworthy at thee thus to sutlier, and unneressary-"speak, that these stomes may beeome loaves. It does not follow, on this riow, that Satan fully understood what was involved in Jesus' being God's Som; ant this ignorance will necount fior an attempt otherwise not only audacious hut absurd. Those who prefer the view that he really doubted whether.Jesus was God's Son, are at liberty so to interpret the phrase, "if thou art' ete., though it is a less natural and less common use. Command, ete.,-or, speak that . . may become. (Comp. the same construction in 20: 21. ') Luke (1:3) has "speak to this stone, that it mav become a loat,' as if pointing to a particular one. (Comp. 3: 9; $7:$ :1). 'Become' is the litural and exact translation. 'These stones, lying around, as in $3:$ !. The Enghish word 'hreat' being only used collectively, wa have to introduce 'loatt,' 'loavos' to give the exace idea.

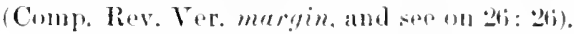

This first temptation thus apjears to be twofold (and so of the others); he is t(moted to satisty lumger, and in such a way as will prove him to be the sion of Gut. Our botily appetites form the oceasion of many of our sererest temptations. Yet these appetites are not sintul in themselves; the sin eonsists in seeling excessive or essentially improper gratificatior of them, or in seeking lawtul gratifieation by improper means. Ju-us was tempted to work a mirale in order to relievo his hunger. We could not say boforehand whother this would be right, but we seo throughout his history that he never performed miracies merely for his own benetit; they were all wrought to do good to uthers, and to attest his divine mission.- Ind this attestation was never given to those who akkent it trom improper motives. (12:3*f.:16:1 ff.) He paid no heod to the taunt $(27: 40)$ : "It' then be-or art-the son of frod, coms down trom the eross" the first ratuse being precisely the same as here). Anel so he takes no mutice. in replying to the tempter, af the propusition that he should by the miracle prose himsele

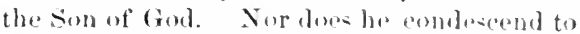
refer to the attesting voice from ho: voll. (3:17.) We have no reason to bulieve flat aur Land had ever wrought a miracle upto this time, the 'beginning of his miracles' (auhn 2: 11) taking place shertly atter. He would not beerin till his 'hour' hate 'emme.' (John: 'The miracles of his ehilaboud, so numeroms in some apocryphal gospels, are without hi-turical foundation, and mont of them quite unworthy of him, as child or man. 
4 But he answerel and salid, lt is written, Man shall not live by hreat alone, bet hy every word that proceedeth ont an the month at ciod.

5 lone the levil taked him up into the holy city, and setteth him on a pinuacle of the temple,
4 these stones become l bread. But he answered and saicl, It is written, Man shall not live by hread alone, but by every worid that ponceedet hum ot ine mouth of 5 fiod. The'n the devil taketh him into the holy city:

1 Gr. loaves.

1. It is writen, perfect tense, it stands written fso in 2: 5, and below in r. $7,7,10$, and eftum). (on Lord meets every temptation by a quatation fiom seriputure. 'The Father's word was to him thesword with which he ennquered the great spiritual enemy. (Eph. 6: 17.) This quotation is from Deut 8: 3 , and the two below are from the same book, which is ricls in spiritual amb levotional matter. Notice, too, that all the passages he thus alpulice to bimselt are fom procepts given to Isracl in the wilderness, at the opening of the national career -tbere being a typical relation between Israel and the Mentialy (see on 2 : 15). Possibly (rodet) be had, during his retirement, been specially meditating on the aceumt of Israel's forty years in the wilderness. This quotation agrees witl the sept., and ditfers from the Hebrew only in inserting 'word,' where the Hebrow has simply 'all that goes forth trom the nonth at the Lord.' And this is really the meaning of the Greek, 'every word that goes ${ }^{1}$ forth, ete., $i$. e., whatever lue says that man ball live on. There is nu propriety in understanding here a reference to the spiritual lite as sumatined by God's word, viz., by the Scriptures; the Hebrew phrase and the conneation in Jomberonmm quite forbid suble an idea. God fed Israte with manma, a thing unknown to them and their fatbers, "that be might malia thee know that man shall not live on linad only, but on all that goes forth form the mouth ot the Lord shall man live" - that the sulpurt of life is nut absolutely dependent on ordinary fond, but it may be surtained on xhatever (ind shall chose to say, te apjoint. And so, Tums will not worle tho miracle to obtain orelinary foud, hecause God can, if loe

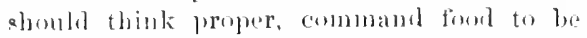
sllplied him in an extrandinary way. And thinappoars to have been done, througrlo angels (soe oll v. 11). To insist on making the passace, in prite of the connection in J)enterolumy, and here, alphly also to suritual foom, as so many do, jo unreasomable, and disluomoringtotlus Bible, whicls is not a loonk of riddles,

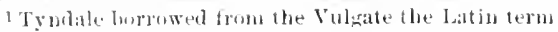
'proceds,' and most English rersions have followed but given for practical instruction, and must be interpreted on principles of common sense, or it camot be interpreted at all. -Man shall not. Thus he identifies himself with humanity, applying as a matter of course to himselt what is true of mankind. And lue conquers temptation not as God, but a- man, by the power of the sipirit and of the lessons that are 'written.' Shall not live, viz., such is the dirine plan or appointment. By-or, upon-bread, as that on which life rests for support. So, 'upon every word,' etc., or according to another reading 'in every word,' $i$. e., in the use of, which amounts to the same thing. Ont of is luere literally 'through.'

5. Then, comp. on v. 1. Lulie (4:5) simply comnects by 'and,' and gives the two remaining temptations in the reverse order, seeming ( $B(n) g(c)$, otluers) to follow the matural order of topography-first the desert, then a high mountain in the desert, then Jerusatlem. Mattlew"s is the natural topjeal orler, the second temptation being ju-t the pposite of the first, and the third forming the climax. It seems natural also that the severe rebulie of v. 10, slrould put an end to satan's attempts, and accordingly Lulie, in the correct trixt, does not give it. (Nee alou bolow, on v. 8.) Talieth him-literally, takes him with him, or 'along with him,' dues not prove that he was carriad involumtarily or supermaturally (see the sime word in 17: 1; Mark 4: 36, ete.), nor durs Luke's term 'Jed' prove the comtrary. We lave no means of determining the manner of going, and are left to suppose that ofosus went as men u-ually gro, and so that the devil did likewise. The word up, Tyn. to King.James, is not here in the Greek. The holy city, i. e., Jemalem, regarderl as holy hecause the seat ot the temple and its worship. (omp). Isit. 48: 2; I): (3): 24; Neh. 11: 1; Matt. 27: 58. Seme . Howish coins were inseribed (Gill, otbers), 'Jeru-alem the holy'; old Jewish prayers alon have "the holy eity" (IVuncehe), and the Arals now eall Jerusalen El-Kuls, "the holy. (As

him, but the simple and exact English rendering is 'goes forth.' 
6 And snith tums him, If thou be the fon of fiud cast thysclf duwn: for it is wilten, lle shall give his angels eharge encerning thee: and in lheif hanls they shall bear llees up, lest al any time thou dash thy guot arainst a stont.
6 and he set him on the loinnacte of the lemple, and

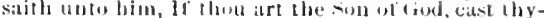
self down: lor it is written,

He shall give his angels charge enncernine thee :

Aud on their havds lley shall hear thee up,

lest haply thou dash thy fint againut a sloue.

1 Gr. wing.

to Jerusalem, sce on 21: 10.) And setteth. Rev. Ter., And he set. The correct toxt has the past tense, but the meaning is substantially thesame. A pinnacle of the temple. Our Lorre, who did not belong to the priesthood, is nowhere said to have entered thes naos, but only went into the hieron, $i$. e., into the courts, as other laws did. On the innel side of the wall enchosing the great outer court ran a long portico or eolomnale, the root of which also covered the top of the wall, and sometimes was built up above the wall to a great height. The auter battlement of such a roof, rising above the outer wall, is probabiy what is here called "pinnacle,' and 'the pinnacle' suggests some well-known or remarliable pinnacle. It is doubthal whether this was "the portico that is calleal Solomon's' (John 10:2:1; Acts: 3 11), on the east sille of the temple enclosure, and described by Josephus ("Ant.," 20, 4, 7) as of great height; more probably it was what he calls "the royal portice" (ot llerod), on the south side, and which he represents ("Ant.," $15,11,5)$ as "one of the nuost remirkable works under the sun." Below the wall enchosing the temple court, there was an inmense substruction extending up trom the buttom ot the ravine, and so deep that one could not see to the foot of it (probably the soutlueast corner); "on this aroses the vast heiglit of the portico, so that il one should look down from the summit of its roof', putting tonether the depths, he would grow diz\%s, the siglit not reaching ints the? unmeasured abyss." This high-wrought ate-

The N. T. has two tireek words transtated 'temple.' The one (hitront), signifying 'saeret (plater), dunotes the whole saered enclosure, eomprising the several courts (see on $21: 12$ ), as well as the salered house itself. This last, the saered louse, into which none but the priests antered, is designated by the other wort (amos, rendered 'sanetuary' in 2:3: 35, and $27: 5$, liev. Ver.), found in luke 1: 9, 21, 22; Mall. 23: 16-35; 26: fil (Mark 14:5s); 27: 5, 40 (Mark 15:29); 27: 51; (M:15k 15:34; Luke :3: 45): John 2: 19-21; Acts $17: 24 ; 19: 24$ ('shrines'); and in every passage of the Epislles and Revelation in seription at least presents us with a seene very suitable to the temptation in guestion.

6. This temptation, like the tir-t, apyears to have beentwofold, afpeatiog to a watural feeling and also to Messianic aspiration. Many persons when looking down from a dizzy height feet a strong disjosition torthrow thenrselves down; with sonne, the feoling is intense and almont irrosistible; and it is mot unrotsomable, and not elerogatory to aur saviour, to suppose that here also siatan tried to take advantage of a natural leeling, as he had before done with hunger. Let him throw himself lown, and see if God woukd not protect him; and thus descending in so public a place and supernaturally protecterl, he would be observed, and at once hatiled by the populace as 'he that should come.' This litst saems to have born part of the idea presinted; for otherwise why take him to the temple (Ijightfoot, Luteroth)? A precipien in the wilderness would have sufficed for the mere temptation to throw hinzidf down; the arefilly ehosen place molicates that the ida was also te "xhibit himself in public. Keim: "At the sime time a test of the protection Goul would extend to his ambassalor, and a miracle of display by which the fath of Israel might be won for Gud's messenger." Is Joslls had in the former case lortitied himself by quoting Scripture, so the temperer supports his suggas tion hy quoting a promise of protection amid

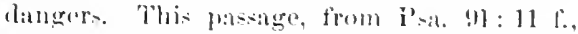
"pplics to any on" who trusts in forl, and by eminemase to Jestls. The quotation tollowi sept. and lleb., with the onsision al a chase

which Gom. Fing. Ver. has 'temple', exorpt 1 ('or. 9: 13 (which has hieront) Hieron is lhe word ustal in

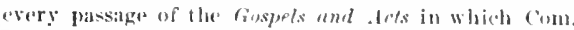
Eng. Ver. lats 'femple, except thuse jusl named and Luku.11:51, (literally' humke.')

The tireek word mar from its use in lh" sipt., be reatily unterstuol en mean battement, parapet, or the like. (irimm, Bloek), The passage in Eus, "Ilist.", ii., 23, relied on loy Bible Comm., and others, fo sloww that as pinmacte of the naos was here meant, is confused, and proves nothing 
7 Jesus said unto him, It is written again, Thou shalt not tempt the Lord thy ciod.

8 Agan, the devil taketh him up into an exceeding high mountain, aud sheweth him all the kingdous of the world, and the glory of them;
7 Jesus said unto him, Again it is written, Thou shalt 8 not try the Lord thy (xod. Again, the devil laketh him unto an exceeding.high mountain, aud sheweth him all the kingdoms of the world, and the glory of not important to the application ("to keep thee in all thy ways'), such an omission (Toy) as the New Test. writers often make. It is therefore not proper to say, as is often said, that Satan misquoted; it was a misinterpretation and misapplication. The expression, in their hands they shall bear thee up, as a mother or a nurse supports a child (Num.11:12; Deut. 1:31; 1sa. 49:22; Acts 13:18, margiu; 1 Thess. 2:7), is of course figurative, referring to providential protection. Satan treats it as if we were authorized to expect its literal and supernatural fulfillnent; and while there are of course limitations to such a promise (see below), he takes no account of these. Observe that the plural 'angels' renders it improper to quote this passage in support of the Jewish fancy of a guardian angel attending ench individual: The passage corresponds to Heb. 1: 14, where the angels are said to minister to God for the benefit of' his people. 'Lest haply' is nore probably the meaning bere, than 'lest at any time.'

7. It is written again. What Satan had quoted is indeed found, but in another place is written that which forbids what be suggests and is seeking to justify. There is hore an illustration of two important rules of interpretation: that a figurative expression must not be so understood as to bring it in conflict with unfigurative passages; and that an unlimited promise or statement must not be appliad to arses forlidden by other teachings of Seripture.-This quotation is from Deut. 6: 16. It follows sept., and differs from IIeb. only in using singular instead of plural ("Ye shall not," ete.), thus rendering more pointed the application to an individual.-The Grek word here rendered 'tempt' is a compound of that ordinarily used (see on v. 1), and has a somewhat more emplatie moaning; but we can harlly express the difference in a translation. To 'tempt God' is to test, or put him to the trial, in order to see whether he can and will fulfill his promisos. The App. of the Amer. Revisers would here render 'make trial of.' This Ahaz (1sa.7:12) with affected humility dechined to do. Deut. 6: 16, refers to the ase in which the Israclites tempted Jehovah at Mussah ('temptation'), by requir- ing a supply of water to prove that he would fulfill his promise to take care of them. (Ex. 17: 2, 7. Comp. Pra. 78; 1s; 95:8,9; 1 Cor. 10:9; Heb. 3:9.) Ananias and Sapphira (Acts:9) tempted the Spirit of the Lord, by virtually putting him to the test whether be would know and reveal their villany. Peter declared (Acts 15:10) that it would be tempting God to act as if they wanted further proof of his will that the Gentiles should not be required to bear the yoke of the ceremonial law. And so Jests intimates that it would be tempting God to plunge voluntarily into danger, as if to make trial whether he would fulfill his promise of protection. These cases show the nature of the sin in question. Its source is in all cases unbelief. This was understood by the author of Wisdom, 1: 2: "He is found by those who do not tempt him, and he manifests himselt to those who do not distrust him." -It is unwarrantable to say (Alexander, others) that the passage as quoted by our Saviour has a double application, so as at the samedime to rebuke Satan for tempting him. Such "duable applications" of Scripture are almost always fauciful, save in the case of prophecies and types. - Throughout his ministry our loord acted on the principle here involved. He never went voluntarily into danger, and always prudently turned away from the wrath of his enemies, save when some duty called.

8. In the third temptation Satan no longer says 'If thou art God's Son,' no longer attempts to incite. Jesus to prove his Somship; or Messiahship by miracle; and as if conceding that he is Messiah and will found a kingdom, he proposes to aid him in making it a splendid earthly kinglom, in subordination to himsclf. That Mussiah would have a magnificent carthly kinglom was the genoral expectation of such Jews as were now expecting Messiah at all; and the cisciples elung tenacionsly to this notion throughout our Lord's ministry. The tempter hopes to work upon such a conception in Jasus. Neander: "Herein was the temptation, that the Messiah should not develop his kingdom gradually, and in its pure spiritunlity from within, but should establish 
9 And saith untw him, All these things will I give thee, il thou wilt lalt down and worstiplue.

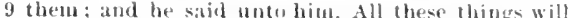
I give thet, if thon wilt lall down and worship lote. it at onee, as an outwarel dominion; and that although this could not be accousplished without the use of an evil agene'y, the end would sanctify the means." Mang a man, before and since, has with satan's secret help surveyed the glittering spectacle of bumblless Aominion, and so burnod with the fieree longingentianbition that lue wats reaty for anything that would bring sucerss. Alits! how neally was this idea ot"a world-wide kingdom, leeld in allegiance to siatan, fultilled by sume in the Middle lges who boustod the title of Vicar ot Chri-t.

Here also, as in the former eases, the temptation of Jestls seedns to bave been twofold, appealing to a natural ferling-the love of power, the dosile to rule wer others-and at the same time suggesting a way in which his I essianie mission might be expeditionsly carried through.

Talietl him-or, talies lim along with him, asinv. 5. Luke (4:5) silys, "led him uj," Rev. Ver. What the oxceediug high monntain was, it is quite in porsible to judge. Is the highe-t momntain on earth would mo noure have sufticed fior a literal view of all the kingdoms of the warle than the highest near to Jerusalem, there is nothing gatimed by gaing far away in our (enjereture. Trablition names a mountail near Jelicho (sote an v. 1). but with mo great probability. Shemeth him all the lingdoms of the world. Some underetanel a litural viow of all tha districts of Palo-tine. But thome is no prout that theterm renderod 'world' (Kistmes) was aver used to

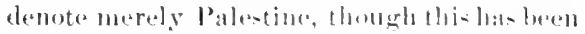
aften asererted; and the distrints ot Paldetiate would at that time harelly have heren ealled lingloms; besilles that the signiticancent the temptation is much elearer and more -triking on the other view, la is best to umberstand a sort of viaions. It may artuinly he ennerived

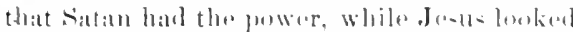

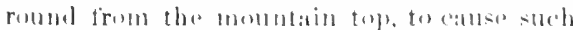

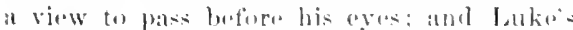

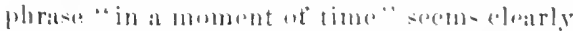
to indiento that it wa-superuatural. Alford:

'Literalls. "if thou fall down," Thissubunctive was natural in early buelish (s) Wyelifi, and is baroly pussible still. To siy if lhou wilt fall down (Tymllite and all since) is ambiguous, serming lo introluce the
"If it be objected that in that case there wats mo need for the aseent of the molutain. I answer, that such matural acessosies aro made use of frepuently in supernatural revelations; secepereially Rev. 21: 10." Bengel: "siluows -to the ays what the horizon enobraced ; the

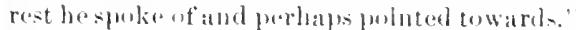
Feil: "In the case of buth Jens and sitan experionces are posible which are intumsible for mero man. Which we cammot aclepuately. represent wanr minds, anel latre no rierht to deny." We may very wall take "all the kingroms" as an hyperbole (comple. E⿰ral 1 : 2), esperially as matny lats of the earth would present litele that was glorious, or attractivetowordly ambition. And the glory of them, is added heatuse their glory was esperially paraled before his view, But Jesus would fork bencath the glittering surface, and see lobllowness, clegradation, sutfieringr, ruin. Douletless his ardent desire to save mon wat not weakened hy this panorama, but greatly strengthened. Throughout his subsefuent minietry the idea of al glurious and all-ennbracing earthly kingdom was often fremenel apon him by the multitule, and comstintly chorishad liy his elowent tolluwers, hut re jeted ly him. IIоw much more truly glomuns the "kingalom not of this world ' Jotum to whireh has did formed; and low bluseded a thing it will ho when "the kimgelom of the world is

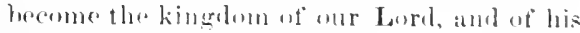
Christ.' (Rev. 11: 15. Rev. Ver.)

9. All these things, the Greek placing the empluasis nol so mueh on all, ats om "there thines. "Thre elairm which sittan here implies, and in lallif t: di. expremly amorets,

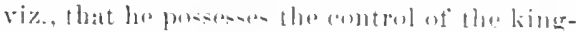
domit at the world and llooir erlory, is mot

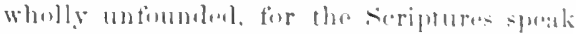
of lim at the prinew or wanl af this world.

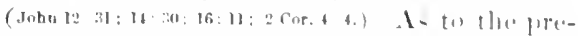
ense nature and limitations of this puwer we

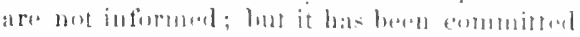
to him (totket: a), and the lixvelation of . Inlu fraches that it shall and hay he withdrawn.

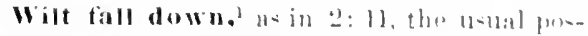

element of willineruess, whinh is mel in the original. Yet it makes a -mombluer Fag. phrase, and sy is lusi in a pupular rersion. 
10 Then saith. Jesus unto him, Get thee hence, Satan; for it is written, I'hon slalt worship the Lord thy crod, and hin only shalt thou serve.

11 Then the devil leavetin him, and, behold, angels cante and ministered unto him.
10 Then saith Jesus unto him, Get thee bence, satan: for it is written, Thou shalt worship the lard thy

11 God, and him ouly shal thon serve. Then the theril leaveth him; and behold, angels canne and ministered unto him. ture in the East, whether for adoration or for homage. Worship. See on $2: 2$. Therehas been difference of opinion as to whether it here signifies idolatrous worship (eomp. 1 Cor. 10: 20; Rev. 9: 20), or only homage as to a civil superior; but the latter, paid to Satan, wouk neeessarily lead to the former. The tempter proposes that Jesus shall recognize the worldly power which Satan is allowed to exercise, and shall eonform his Messianic reign to existing conditions by acknowledging Satan's sovereignty. Jesus was in fact to reigu over this world, yet not as suceessor or subordinate to Satan, but by utterly overthrowing his dominion. (Comp. 12: 25, 28).

10. Get thee hence,' 'begone,' or, 'away with thee,' here said in abhorrence or disgust, though sometimes in kindness (as 8: 13). Satan, see on v. 1 . It is written, see on v. 4 . The quotation here is from Deut. 6: 13, and follows Sept. It diflers from Hebrew in introducing 'only' or 'alone,' which merely expresses what is indicated in the Hebrew by the emphasis; and also in substituting for the general term 'fear' the more speeifie term 'worship,' which makes more manifest the affiliation of the passage to the matter in hand. (See on 2: 6.)

11. Leaveth him. An example of what was afterwards tallght by James (4: 7), "Resist the devil, and he will flee from you.' Luke (4:13) says, 'for a season.' Doubtless his temptations were frequently renewed throughont the Saviour's ministry (comp. on v. 1), and espeeially when it was about to close. (John 1t:30.) Benyel: "This temptation is a speeimen of Christ's whole state of humiliation, and an epitome of all the temptations, not only moral but spiritual, which the devil contrived from the heginning." Angels came; came near to him (same term an in v. 3). Ministered, or, were ministering-unto him. This word signifies to attend as a servant, wait on, etc., often with particular reference to supplying food (comp, 8: 15; 25:44; 27:55; Luke 8: 3; $10: 40$ 'serve'; 12 : 37 ; Acts $6: 2$ 'serve'). And so apparently here. They waited on him as human friends might have waited on one whom they found hungry, weary, lonely. To Elijah (1 kings 19:6, i) an angel brought food before the forty days' fast; to Jesus at its elose. He had refused to relieve his hunger by turning the stones into loaves of bread, referring to the case of Israel, to whom God supplied food in an extraordinary way; and now God makes an extraordinary provision for him. He lad refused to try an experiment upon a promise of angelic help (v. b), and now angelie help comes unsought. The term employed. 'were ministering to him,' not simply narrates the fact, but vividly deseribes it as going on. And so, with the baffled tempter withdrawn, and angels engaged in ministering to him, this wonderful and iffecting scene comes to a close.

Our Lord is now fully prepared for his work as Messiah. At his baptism the Father gave him an extraordinary recognition and greeting. During the forty days he has doubtless reflected upon the need and the character of that saving work which he has come inte the world to do. And now the tempter's proposals have familiarized his mind with the thought of three principal wrong courses which will often during his ministry be proposed to him, and whicli he will always instantly reject as he has done here-he will never use his supernatural powers to relieve his own natural wants, nor to make a display before man, and be will utterly avoid the favorite Jewish notion of a brilliant worldly kingdom, obtained by worldy means and used for worldly purposes. ${ }^{2}$
1 Many MSs, and versions (some that are early) add 'bohind me, manifestly an assinilation to $16: 23$, where there is no variation in the realing.

"The legendary temptation of sakhya Muni (afterwarks Bualdha) has somotimes been likened to the temptation of 'hrist. Edwin Armold, in "The Light of Asia," has borrowed phrases and ideas from the Gos- pel, so as to give a false appearanee of resemblance. When these are removed, and details which he omils are restored, the two accounts have no resemblance beyout the hare fact of a person being speeially tempted when meditating a great work for the good of mankind, which is doubtless, in one shape or other, a universal experience. See Kellogg, "The Light of Asia 


\section{HOMLETHEL ANH PRACTIAL.}

V. 1. The oecurrence of this special season of temptation immediately atter our Leord's baptisn and when he was about to enter on his ministry, while nut wholly analogous to the ase of his disciples, yet corresponds with "not infrequent experience-Ecelus. 2) 1 : "My son, if thon art coming near to serve the Lord, prepare thy sonl for temptation." - EUTirM. : "That thou also alter baptism mayst no longer lead thyself, but rather be led by the spirit, and that if atter baptism then tallest into temptations thon mayest not be confonnded." -Gill: "And so it often is, that aftersweet eommonion with God in his ordimances, alter large disenseries of his lose and jutcrest in hims, follow sore temptations, trials, and exercises." - food olten brings his people into temptation (6: 13), and so lete brought the Captain of theirsalvation. (Heb. 2: 10),-MILToN (Pir. Rog.) :

\section{But first I mean}

To exereise him in the wihleruess;

There he shall tirst lay down the rudiments of his greal warfare, cre l seml him torth

To eonquer sin aul death, the twa graud foes, By bumiliation ant strong sutferance.

somemen have fancied that they would earape temptation by flecing to solitude-and others by sealing soriety ; behold, Jesus is tempted both in th. wilderness and in the Ifoly City. There is here 1) a discipline to the tempted Redeoner; 2) all example to his tompted followers, and ii) a losen of failure to the tempter. Throe distinet practical evils are prevalent as to the dovil, achele which mast help him. (a) some deny his existence, i. e.. either his personality or his agency-whieh gives him an admibable opportunity to carry on his work unsuspoeted. (b) I forl persons nsocelate him with the sublimw enceptiens of Paradise Lost, and thus ferel a diminished nbhorrence. (a) The great mas asomedate bim with all that is ridiculans. The instinctive desire to shake ofl horrible thoughts has hed to this, as men joke in a disoneting-room, and it has grown custumary, and gamed strengrth from prevaling skepticism. The practice of applying ludierous desiglations to the devil, and maling him the point of anusing storits and jests, as well as the grotesque nuriery deseriptions and stories, can never tail to be vory hurtful, and should be avoided and dis-

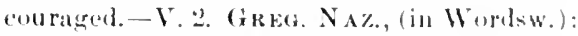
"Christ hungerod as man, and fed the hungry as God. 11, was hungry as math, and yet he is the Bread "1f lifo. Ilo was athirst as man, and yet he says, leot him that is athirst combe to me and drink. He was weary, and is our Rest. . . II" hass tribute, and is a King; ho is called a devil, an.l catets out devils; prays, and hatars prayer; weeps, and driesour tears; is sold firr thirty piecos of silver, ant relexens the world; is led as a sheere to the slatuglater, and is the crool shepherd." - Eueksul. "Moses failed after his forty days fast, whes in indignation lo arist the talles of the law from him; Elijah failed beforehis forty days' fast; Jesus was assalled for forty days, and endured the trial."

V. 3. 'libe demand for special prouts of the divine mission of christ is often made in a wrong spirit, by persoms whom those very proufs would not convince; as Satan atherwards wituesed numerous miracles wromglet by Jesus, but without effect. - iElkIt: "No temptation is more difficult to rosist tlan the prompting to de what soams nexelful tor seltpreservation, when abundant means are in our hands." - Mokssox: "The prine tomptation of millions, thengh they oflen roalize it mot, is to nso improper means of making their hread." T. 4. Onr Lard was "tempted lilit" as we are, and he resisted like ns we must. If he had wrought a miracle for his won rolief. that would lave lesen no examplo for us ; but it was an (xample that he slomulet in trying rirenm-lanees trust in fod and wailand that he should be guidad and su-tainew by what "is written. It we womld imitate this example, let ns beomente thomghriully inbued with the principles of seripture (Ps. 119: 11), and familiar with its preacels ambl examples, so that they may he naturally suggested to tle mind, or readily reatled, just

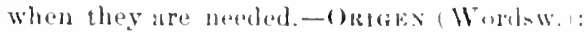
"He ronts the tempter by whate all may" wield, the sword of the spirit, which is 
the word of God. (Fph.6:17.) Hence learn the value of Seripture, and the impotence of Satan against it." -s'TIER: "As Eve in the beginning rightly opposed the tempter with crod has said! but alas, did not persist therein-eren so now the Lord; but he hoids firn." - Ligntaoot: "Observe (1) That the first word spoken by Christ in his ministerial oflice is an assertion of the authority of scripture. (2) That he opposeth the word of God as the properest ineounterer against the words of the devil. (3) That he alledgeth suripture as a thing undeniable and uneontrollable by the devil himself. (4) That he maketh the scripture his rule, though he had the fullness of the spirit above measure." - HENRY: "As in our greatest abundance we must not think to live without God, so in our greatest straits we must learn to live upon God." There is a common saying, "Necessity knows no law.' But it ought to know the law of duty.

V. 5. HeNrY: "Pinnacles of the temple are places of temptation. (1) High places in the world are so. (2) High places in the church are in a special manner dangerous." V. 6. Hexry : "We must aroid going from one extreme to another-from despair to presumption, from prodigality to covetousness," etc.-LANGE: "The holiest thing may be perverted to become the most vile temptition. (1) A stuy in the holy city. (2) The prospect from the pinnacle of the temple. (3) The promise contained in an inspired Psalno." One of the subtlest and sometimes mightiest forms of temptation to a devout mind is the misaplication of Scripture, so as to give apparent warant for doing what we incline to. We need not only to know the language of Scripture, but to undertand the real meaning and legitimate applieation. A great aid in this is to compare other passages, as our Lord here does-BexaEL: "Scripture must through scripture be interpreted and reconeiled."-Wordsworth: "The devil may tempt us to fall, but he cannot make us fall; he may persuade us to east ourselves down, but he cannot cast us down." $-V$. 7. True faith never tries expuriments upon the pronises, being satisfied that they will be fulfilled as oecasion nay urise. We have no right to create danger, and expect Providence to shield us from it. The love of ndventure, curiosity as to the places and procedures of vice, the spirit of speculation in business, the profits of some calling attended by moral perils, -often lead men to tempt God. It is a common form of sin. (Sre Chalmers' Sermons on the Temptations.) Griffith: "W violate the organic conditions of health, and then expect some miracle of restoration. IV e devote ourselves to seeming luty, labor on in what we fancy must be saintly self-sacrifice, till the brain is fevered, the strength is a $\mathrm{x}$ hausted, and imbecility and death come in to punish the presumption of testing the Lord our God." "-Jesus did afterwards work miracles equivalent to those proposed in the first and second temptations, when he multiplied food, and when he wallied on the water; but in these ases he was using his supernatural power for the benefit of others.

V. 8. See Milton's deseription in Par. Regained, Book iii. V. 9. How often are measures adopted by preacher or church that are unworthy of Christianity, and defended only by urging that they take, that they succed. But Christ would not rule over the world by Satan's help, and we must not seek to advance the kingdom w' holiness by unboly means.Theophylar't: "Now also he says to the covetous that the world is his, so that they gain it who worship him." -SCHAFF : "Satan's greatest weapous are his half-truths, his perversions of the truth." V. 10. Often the only proper way to deal with the tempter is to bid him begone. Augustine: "It is the devil's part to suggest, it is ours not to consent."-JER. TAYLOR: "The Lamb of God could by no means endure it when tempted to a direct dishonoring of God. Our own injuries are opportunities of patience; but when the glory of God and his inmodiate honor is the question, then is the occasion for the flames of a clear shining and unconsuming zeal." I. 11. Grotius: "Formerly conqueror of our firstparents and long conqueror of the human race, but now conquered by Christ, and to be conquered by Christians. (1 John 5:18.)"

GRIFFITI: "The successive temptations may be ranked as temptations to under-confidence, wer-confidence, and other eonfidence. The first, to take things impatiently into our hands; the seeond, to throw things presumptuously on God's bands; the third, to trunsfer things disloyally into other hands than God's." 
- LoRInER: "The spirit of evil takes things that are right in themselves and porverts them to our undoing; as here, the intinct of sellprecervation, the feeling of self-coutidence, the hope of self-aggrandizenent." We am see in these temptations a progression. (a) The tempter appeals to, (1) a bodily appetite, (2) an obscure nervous feeling, (3) ambition, which is wholly of the mind. (b) II proposes (1) a useful miracle, (2) a useles miracle, (3) al uross sin. (c) He seeks to excite, (1) listrust of God, (2) presunputuous reliance on God, (3) worldly-minded abandonment of (jod.

12-25. Beglavisg of ouk Lord's IIXISTRY IX GALILEE.

The third and prineipal division of the Gospel of Inatthew, from $4: 12$ to the and of chap. 18, gives an account of our Lord's ministry in Galilee. A goneral introduction to that alcount is given in $4: 12-2.5$.

II atving deseribed the events annected with the entrance of Jesus npon his public work, it is natural that the narrative should pase to the work itself. So far at we learn from Mitt., Mark (1: 11) and Luke (1: 16), this begall aftel John the Baptist: labors were closed by his imprisonment, aul it; seene was Galilee and adjacent distriets, until sbortly before our L.r.l's death. Nor fo they intimate that any long time intervened between the temptation and this ministry in Galilee. The Gorpel of John, on the other hand, recorls a number of intervening events, embracing the teatimony of . John the Baptist to Josus, atter his baptiam, and apparently after hi-temptation: the gaining of di-ciples, the marriage at Canat, and the brief residence at Canpernatum (Johul: 19, 102:12); the first Pasover of our Lord's public ministry, with the expulion of the trallers and the conversation with Nicodernus (John 2: 13. to 3: 21); the teaching and batptizing in Judea before John the Baptist s imprisonment, and the oecurrences at sychar when Jusus was on the way to Gatlilee. (John $3: 22$ to 4 : 2.) But there is here no real contruliction between John and the other Erangelists. None of them could record the whole of Jesus' publie life, and eich mont solect according to his particular deign Where events are omitted in a brief narrative. we eannot expect to find $n$ wide break as if to invite their insertion from some other souree; for this would destroy the continuify of the narrative, and greatly imparir its interest and impresiveness. The story must (go) rightit on, but must not contain such expressions ats would exclude the event- it emit-. This inthe course which Matthew, Maris, and Luke have here pursued. They make no allusion to labors of our Lord betwern the temptation and John's imprianment, hut do not at all affirm that there were on intervening labor:; and various facts mentioned by them (e.g. Lake 10: 381 , really imply that our Lord had been preatehing in Judea before the ricit which ended in his death. What were the reason. for omitting one thing and inserting another, we may not in all cases be able to pereetre. But the concourence of the three first Evangeli-t - in beginning their account of Chriat's public ministry juat after that of the firerunner clowed, suggesto (Ewald, Alexander), that the work ot Chrint then assumed in -nome semse a ditlerent charater; the early preateding and baptizing of our Lord while the forermuner work still went ou (Joha 3.22 I.; 4:1 r.) Wa- introductory, and his ministry now takes in souse sense al higher position. The transition from the old Dispenation to the New wa in many respects gratual. Even uftrer the a-cension of Christ and the spectal eoming of the spirit, the Jewish Chri-tians long comtinued to observe the cormonims of tho law. continued it apparently until providentially stopped by the destruetion of the temple. And no the forerunner continued his preaching and baptizing side by -ide with that of Jo-uc until providentially stopled hy his impriamment. It is likely that thro oral narratives commommly given by the apu-the foryar afturthe aseension were accustomed to beerin their accomnt of the Lord's ministry, as we find the three first (yopels doine. With this brint at whigeh his ministry stomel out apart from that of the

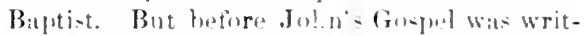
ton. some pursons wero mantaining that the Baptist's work was designed to he premanent, and ought to be contimued by hi-dieciples: it may have bran partly to correct thi-error that John natrates the aarlier ministry of Jesus, showing that he wa- not at mer sucepssur of the Bapti-t, but began to preatel before the wher comad, and that the formunnor dintinctly and repeatedly acknowledered his nwn inferiority and anerted that hi-work was designed to be temporary. (Joho $1: 23-37$; 3.26 ff.) 
12 Now when Jesus had hearl that John was ' east 12 Now when he heard that John was delivered up, iuto prison, he departeá in to (ialilee;

$10 \mathrm{r}$, delivered up.

If we adopt the common and probable reekoning that our Lord's publie ministry oceupied about three years and a half, putting bis baptisn some montlis before the Passover at which Nicodemus visited him, then the habors in Galilee and vicinity reeorded by Matthew (and Mark and Luke) begin during the seeond year of his ministry (reckoning from Passover to Passover, beeause at the Passover he died), and probably in the latter part of that year; thus leaving rather less than two years for this "ministry in Galilee," which ended six months before the crueifixion.

It is evident that Matthew does not in this part of his work propose to himself a ehronologieal aceount of events and discourses. He sets out with the general statement that our Lord withdrew (from Judea) into Galilee, and making Capernaum his residence and the centre of his operations, began to preach. ( $\mathbf{v}$. 12-17.) Then comes the fact of his ealling certain persons to follow him, and unite with him in these labors. ( eral account of his going about all Galilee, preaching and healing, while his fame spread c fur and wide, and he was followed by erowds from all the adjacent regions. ( $v$. 23.25.) The present section thus carries us into the heart of the ministry in Galilee. Afterwards we shall find that great disconrse (ch, 5-7), in which our Lord set forth eertain principles of the kingd:m or reign he came to proclaim and establish; and then a number of miracles and diseourses, such as were calculated to prove the fact that Jesus is the Messiah, and to exhibit the true nature of the Messianic reignthe twofold object of Matthew's Gospel. In all this there is no attempt at chronological order, but a grouping of the topies which is more effective for the sacred writer's object. (Comp. on 8: 1; 9:35;11:2;12:1;14:1.)

12. Now when Jesus had heard, or, and herering. The narrative goes right on. ${ }^{1}$ Cast

1'.Jesus' does not belong to the true text. It was probably inserted in publie reading for perspicuity (as also in v. 18, 23), and so erept into the text. Some codal. of Vulgatc give it even in $5: 1$.

2Tyndale, following Wyclif, here gave 'taken,' a very poor trauslation of the Vulgate. Beza's note, into prison, or, delivered up,-literally, passed on, 'givel from haud to hand.' It is a word often used in the Gospels and the Acts, sometimes correctly translated by 'deliver,' 2 often ineorrectly by 'betray.' 1 atthew here contents himself with this general expression, without stating the cireumstances of John's imprisonment, because they were familiar to his readers. Afterwards, when telling of John's death (1t:3ff), he states the cause of his imprisonment. Aecording to the chronolugical estimates above mentioned, the imprisonment took place over twelve months after the baptism of Jesus, and thus John's preaching and baptizing continued in all about a year and a half. Henceforth, until his death, about a year hater, we are to think of him as a prisoner in the Castle of Machaerus, some niles east of the northern part of the Dead Sea. (See on 14:6.) Departed, withdrew, or, 'retired,' 3 as above in 2: $12,13,14,22$, and below in $12: 15 ; 14: 13$, ete. The word does not necessarily imply danger. (See Acts $23: 16 ; 26: 31$.) Yet the circumstances here suggest that our Lord withdrew to avoid inconvenient consequences which might follow if he remained in Judea. And this is explained by John. The Plarisees at Jerusallem had been watching the Baptist (Johu 1: $19 \mathrm{ff}$ ), and were doubtless jealons of his influence. But of late they had heard that Jesus was making and baptizing more diseiples than John (John 4:1), and now that John was inprisoned they would be likely to turn their jealous attention to Jesus, who therefore withdrew from Judea into the remoter Galiles. It is a strange mistake to say that he wished to aroid Herod, for Judea (Johu 4:3) was not in Herod's dominions, and Galilee was. Similar withdrawals by our Lord we shall find below, in $12: 15 ; 14: 13 ; 15: 21$. (Comp. on $8: 4$.)

Galilee, the scene of the greater part of our Lord's ministry, is wrongly conceived by

"i. e., had been thrown into prison," appears to hare been followed by the Common Version.

3 so the Latin version and Rheims ('retiled'), the Syriac ('removed'), Davidson, ctc. 'Departcd' comes from Tyndaic. 
13 Anl leaving Nazareth, ho came and dwelt in cafernatum, which is upon the sea coast, in the horders of Zabulon and Sephlinalim:

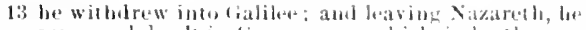
cante and dwelt in fiperuante, which is by the soa, many as a pour country, witl a degraded popmation. It has always been much more fertile and beantiful than Judea, ant in the time of Cbrist had an immense population, brave, energotic, and wealthy. (Comp. below on $v$. 23.) The nathe appeats to have comse from the Galil or 'eimenit' uf twenty cities given by solomon to lliram, king of Tyre (Josh. 20: 7 ; l kitg:9: 11:2 king* 15:29), and was gradually extemeled to elemote the northern part of the lloly lamel in gencrat. From its proximity to and commection with Pheniein this district womld be largely occupred by (rentiles, and so was (allel by Isatah, literally (:0:1) ceircuit of the Gentilos.' Doring and after the eaptivity the Gentiles became predominant. In 13. 6. 16t, the Jews in Galike were so few that the Mateabees carried them all away to Juelea tor sitety. (1 Mace 5: 23.) In the time of Christ the vant pojpulation ware chiefly .Jows, though steveral cities are axpresily said (oosephus, sitrabu) to have contained many Gentiles and they were doubtlens numerous elsewhare. These probably sometimes beard Jisus, who may have sometimes spokan in firesk, but there is mothing to wareant the faney that he was a "Fureign Missionary." as habitually preaching to the leathen; and it is guite forbilden by 10: 5, and 15: 24. The ennstant ussociation with Gentiles, as well as the di-tance from ocrusalem, maty have softerest the religions projulices of the (Galilean , dews, and rendered them more aceessible to the new teachings. The Galikan prommuncerl Arat maic with some provincial peenliarities hy whied the perejle af Joru-alem comble recongnize them (26: 3 ), but this lose not show them to bave bean ignorant. Galilew axhibited an intense aetivity in agrionlture, fisheries, manufacturing, and trade. Buides local husiness,

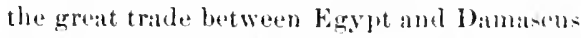
passed through this region. Jem lakbred anong an intelligent amd actively busy pande. The district comprised the immonsty fintile plain of Ealraclon on the south: the broad, rolling uplands of the entre, rich in grass

This proceds upon the view that the risit to Nazareth in $13: 54$ (Mark $6: 1$ ) is distinct from that of Juke 4: 16 , a view not ecrainly, bu probally, correct.- ieveral Mss. read in this place Nazara, and that is prob- and wheat, in bright thwers and shaty treas and the higher hills and mountaino of the nerth, which, inter-pererel with dexpralley. presunted the greates variety at prolucetion

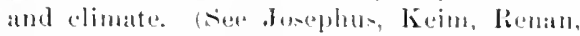
Nembauer, and enpecially Merrills " tialilee in the Tine of vor leml," trome "Biblieth. siace" for 1874.) T'liree times we tind our Lord heseribed a makiug extem-ive journeys

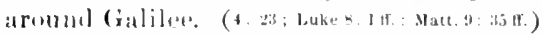

I:3 fl. He diel mot make this changere immes diately upun reaching Galilue, but first revisited Cana (Johns: li), and beram leaching in Galilere with grat aceptance ; buket 1.5), (anlling promently to Nazareth. (bubet bits.) Being there rejected und his lifie attempletel, he list (Luke 4: $: 1$ ), and went down to ('apernamm. llere lar would not only be more tres from popular violence, but would eome in contart with a much barger and more active-minderl frepulatios. Su Paul Jabured experially at

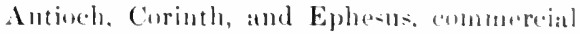
centres, in which men's mind- were atetive and ready to grasp new ideas, and from which the news would spreat in prery dipection, and excursions ande be reaiily made. came and dwelt in, as in 2 : 2). Capermanm was aur Lerd's home, the centre af hi- laburs amel jourmeys, for probably neaty two gatrs. (Cimp. on v. 12.) (On the weterts shore th the Latio af Galiles (nee an v. 18) thropex-

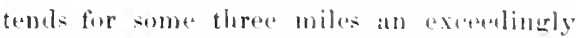
fortile plain, callod the "Ilain of (rennesaret." (see on 14: :34.) In this plain, or a little morth of it, Capernatum was- -ituatul; but the mole highly exalted city has been cian down into sueh ilestruction (11:23), thite we tatunet

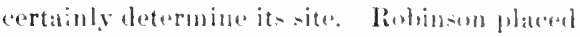
it at Khan Mingeh, wh the nombern edere at the plain. and is till folluwed by kein and Comder. (Roman and Godet doutitul.) But the great majority of recent explurers protor the view that it was at Tel Hum. two miles further up the shore. The ealliet Msts. and versions give the name as Capharnaum, and the siviategive Capharnahum. As Cal-

ahy the original form of the wort Keim, firimm, But mann). But as Nazaret, or Nazareth, or Nazarain ocenrs in must fissages, it setems useless to dejort from the common form here. 
14 That it might be fulfilled which was spoken by Esaias the profliet, sayirg,

15 'The land ot 'Zabulon, and the land of Nephthalim, by the way of the sea, bejond Jordan, Galilee of Ihe 1 Gentiles:
14 in the borders of Zebulun and Naphtali: that it might be fultilled which was spoken through Isaiah the prophet, saying,

15 Plie land of Zéulun and the land of Naphtali, I Toward the sea, beyond Jordan, Galilee of the ".ienliles,

I Gr. The way of the sea....2 Gr. nations: aud so elsewhere.

phar in Hebrew means 'village,' Capharnalsum means 'village of Nahum,' or perhaps 'village of consolation' (Origen). In modern Arabic the word Tel denotes a hill covered with ruins, and thus Tel Hum might well be the modern form of village of $\mathrm{Na}$ hum (so Ewald, Delitzsch, and others). Moreover, the ruins at Tel ffum contain much black basaltie rock, which is very hard to work, and must have been brought from the country S. E. of the lake, so that its free use indicates a wealthy city, the most important in the neighborhood. Now Capernaum evidently had such pre-eminence among the cities on the northern shores of the lake, and so it seems highly probable that Tel Hum is the site of Calpernamm. ${ }^{1}$ At Tel Hum are the ruins of a beatiful synagogue, the finest of which we have any remains in all Palestine, and this may well have been 'the synagogue' built by the centurion. (Luke $7: 5$.) Originally but a 'village' (Caphar), and so not mentioned in $\mathrm{O}$. T., it had in $\mathrm{N}$. T. times become a 'city.' (Luke 4: 31.) It probably lad a large fistuing business (the fish were put up in salt and transported to the interior), and general trade on the lake, while very near it passed the principal road from Damaseus to Ptolemais, earrying the trade with Egypt, It had a custom-house (9:9), and a garrison of Roman soldiers. (8:9.) Our Lord had at a former period remained hare for a short time (John 2:12), perhaps sojourning with Peter, whom we afterwards find living at Capernaum. (8:14: Mark 1:29; 2:1.) In the synagrgue at (ape rnam he delivered the great diseourse of John, ch, 6 (see John 6: 59). It was a convenient starting point for his journeys into Galilee or Deeapolis, towards Tyre or Cesarea Philippi, to Perea or Judea; and was the home to which he constantly returned.

Borders, ats in $2: 16$. The burders of $\boldsymbol{Z}$ abulon and Nephthalim means the borders common to the two, the boundary between

${ }^{1}$ This view, favored lyy Ewald, Delitzsch, Ritter, Hausrath, Thomson, "Reevery of Jerusalem," Farrar, schatf, Geikie, and others, is particularly well argued them. For the peculiar forms of the names, Zabulon and Nephthalim, see on 1: 2. The Evangelist takes pains to describe the situation of Capernaum, as beside the sea (lake), and on the boundary between these two tribes, in order to show the minute correspondence to the prediction he is about to quote. Matthew often introduces Messianic prophecies as fulfilled in Jesus $(1: 22 ; 2: 6,15,17$, 23: $3: 3$ ), this being an evidence of his Messiahship.

14. For that it might be fulfilled by, or, through, see on 1: 22; and for the form of the names Esalats or Isaiah, on 1:2. A providential design of Jesus going to reside in this region was that the prophecy might be fulfilled; there might of course be other designs at the same time.

$15 \mathrm{f}$. The Sept. translation of this passage (Isa. $9: \mathbf{I}$ f.), is quite incorrect, and Matt. does not follow the sept., as he commonly does where it is suffieiently accurate for his purpose. The original Hebrew contains some expressions which would be intelligib'e only by consulting the connection, and these Matt. has omitted, but without affecting the meaning of the passage, as applying to our Lord's settlement at Capernaum. He even begins in the middle of a sentence, taking only what was appropriate to the matter in hand. The prophet has spoken of great afflictions which would befall the people at the hands of the Assyrians and others, but which would be followed by great blessings, to be enjoyed espeeially by the tribes mentioned, they having been most aflicted; and the Evangelist shows us a remoter reference in this to the blessings connected with the work of the Messiah, to whom Isaiah immediately afterwards $(9: 6 \mathrm{f}$.) makes a distinet reference. By the way of the sea, omit 'by.' This might menn rond" to the seat, or simply sea-road (Meyer, Weiss); or road by the sea, meaning the great caravin route which passed near the sea, $i$. e., the Lake,

by liartlett. None of them present the argument from the masses of black rock, which are not found in any. other ruiss in the neighborhood. 
16 "The people whieh sat in darkness saw great light ; 10 and to them which sat in the region and shatow of deatlo light is sprung up.

17 From that line lesus hegan to preach, and to say, Repent: for the kingdum of beaven is at haud.
The pople that sat in larkness

Saw a great light.

Ard to them that sat in the region and shadow of desth.

Tor them thid light spring up.

17 From that time lrepan Jesus to preach, and to say, Repent ye; for the kiugdom of heaven is at hamd. of Galilee (see on v. 18) ; or road from the sea, viz., the Mediterranean (Keim). The English 'sea-road'l would be equally ambiguous. The most probable meaning is the second, 'roal by the seat, designating the rogions adjacent to the lake. Beyoud Jordan (seer. ves) in 0. 'T. usmally means east of the Jordan, but in some falssagrs west of it (see Num. :32: 19; [)(2ut. 1]:30; Jush. 5: 1; 22: 7), reminding us that Ismal (ame first to the region rast of the river. It of course depends on the writer's point of view in each case. Isaials, having reforred to the calanitios which would be inflicted by the Eastern nations, might naturally for the moment speak from their point of view, and thus 'beyomel Jordan' would mean west of the Jordan, and would denote the same region as the other expressions. This fits the connection. which has a sorires of parallel phrases. 'Tluose who profter tha nore eommon 0 . ' $\mathrm{T}$. sense of 'beyond Jordan' understand Decapolis, east of the lake, or Pereal, east of the lower dortan fees on v. 25. They then either hold that this denotes a region distinct from (xalilene, or supepose that Galilee sombtimes includer Docapolis, ete. Galilee of the Gentiles (see onv $v$ 12). The worl rentered Gentiles signifies simply 'nations' (see margin of liev. Ver.). The I-raelites called all others 'the nutions,' in distinetion from themstres, who were the chosen people.

16. In this verse is an instanee of that "ynrallalism" which is the peouliarity" in the" structure of Hobrow poetry, and eonsequently nbounds in $\mathrm{O}$. T. There are two principal variotion of it: $(a)$ the sreond chanse simply repeats, in diflerent phraseology, the thomert of the tirst; and (b) the second stands in contrust with the first. The present example belongs to $(a)$, the seeond clanse repeating first, but in stronger terms. (hee other examples in $7: 6 ; 12: 30$ ) shadow of death,

1 The Greek genitive is often most exaetly rendered Into English by means of a eompoumd substantive (comp, on $1: 11$ ).

2Literally, "and to those sitting. . . . light arose to or, death-shade, is simply a figure for the densest darkness. (Complo Jer. 10: 16; Anus 5: 8; Ps. 107: 10; 2:?: 4, seomaruin Rev. Ter. "drep darliness'; ween .Job 10: 21.) The region and shadow' may be molerstoml as equivalent by what grammarians call hendiadys to 'region of the shadow' (which is thes meaning of the Hab. ), or as simply expatuling the inlea, region of death and sharlow te dasth. Is sprung up, ar, arose; the Greak tarm is often used of sunris" nur? dawn. ${ }^{2}$ plot image seems to be that of gersons who had lost their way in the denso darliness, and upon whom arose the gratat light af the morning. The Heb. hats "walled. . . sat,' while Matt. says 'sat' in both cases, which with reference to the figure is an equivalent axpression. Here, ats solten in Seripture, darkness and light represent igmorancer, sin, misery, as opposed to knowledge, holiness, lappriness.Alexander: "The vasese in its original endnection has replect lo the dagrateles and opepressed state ot the Galilana, arising from their sifuation on the frontior, their expone to attack form without, and their actoal anixture with the Grotiles." Malt. shows us in this languages a further roference to the spiritual darkuess of the Galikans of our Lorles time. All the Jows were in spiritual darkness, und the Galileans ware inferiur in res ligious privileges to the Judeans, and despied hy them. (John $7: 41$, a. 52.) Theres is no prow that they were morally more arerrent than the

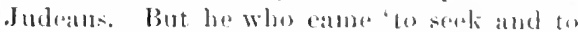
savethat which is lost, fixed in this romoles and despisad soction of the II ly Lamd the contre of his babors, and here ahose most of the apostlos who were to earry his teachings to Julea and Samaria, and the prods of the atuth. (acts $1: x$ )

17. Establishing himself in Capernamm, our Lord began to preach. From that time began that public miniatry which Jathew proposes to duscribe. (Compo on ve I2.)

them.' This repetition of the prononn after the vorh is a Ilowew illom, natural to the Evangelist, though awkward in (ireek and English. 
18 And Jesus, walking by the sta of Galilee, saw 1 wo 18 brethren, simon called P'eter, and Audrew his brolher, casting a netinto he sea: for they were fishers.
And walking by the sea of fialilee, be saw two brethren, simon, wbo is called Peter, and Andrew bis brother, casting a wet into the sea; for they
The English word preach is derived (through the French) from the Latin predico, which signifies to proclaim, publish, declare. The Greek word here used (kerusso) has the same sense, to proclaim as a crier or herald does, and in general to proclain, publish, declare. This is the word always used by Matthew where the Common English Version has 'preach,' except in 11: 5, and elsewhere in N. T. it is always rendered 'preach,' except in Luke 12: 3 ; Rev. $5: 2$, 'proelaju,' and in Mark 1:45;5:20;7:36;13:10: Luke 8: 39 'publish.' But it will not do to infer that 'to preach' is always in N. T. an official funetion, as these facts have led some to do, beeause the English word is also used (in other N. T. books) to translate various other words, which carry no suggestion of a herald or other official. Thus euangelizomai, to bear a good message, bring good news (comp. euangelion, 'gospel,' introductory note to $1: 1$ ), used once by Matt. (11:5), and not at all by Mark or John, is a favorite word with Luke and Paul, and often rendered in Com. Ver. by 'preach,' or 'preach the gospel.' Lalto, to talk, spoak, a very eommon word in that sense, is rendered 'preach' in Mark 2: 2; Acts $8: 25 ; 11: 19 ; 13: 42 ; 14: 25 ; 16: 6.2$

Repent, ete. See on 3: 2. Our Lurd begins this ministry after the imprisonment of John, with precisely the same exlortation and announcement that had been made by Juhn. We naturally infor that his previous preatehing in Judea had been to the same effect. Yet he by no mans confined himself to the announcement and exhortation, but already in Judea had strongly stated to Niendemus and to the woman of Samaria the spiritual nature of the Messianic reign. To the woman he hard also declared himself the M essiah (Jobn 4: 26; comp. Johu 1: 46-51), but it did not accord with his purpose publicly to declare this in Gatilee. From Mark 1: 15 we see that along with the exhortation to repent he called on the people to 'believe in the gospel,' or good news, viz.. in the good news he was announcing; just as the Baptist bade them 'believe on the (one) coming after him.' (Acts 19:4.) 'Thus not only repentanee, but faith in the Messiah, was preached before as well as after the day of Pentecost. Then, as in the ease of Abrabam (Rom. 4: 11) and always, belief in God's word was the root of piety. And if the baytism of John, and that administered by Jesus through his disciples (Johu 4:1r.), was conditioned on faith in the Messiah as well ts repentance, what essential difference was there between it and Christian baptism?

18. In v. 18-22 we have an aceount of the call of certain disciples, Simon and Andrew, James and John. The first two of these, and in all probability John also, had attached themselves to .Jesus on the Jordan, soon after his temptation, as had also Philip and Nathanael (John 1: $35 \mathrm{fr}$ ) From that time we find him constantly attended by persous known as "lis disciples,' at Cana (John2:2,11), at Cajernatum, (John 2:12), at Jerusalem (John2: 17, 22), in his labors in Judea (Johu $3: 22 ; 4: 2$ ), and at Sychar. (John $4: 8 ; 27.33$.) Supposing, as there seems reason to do, that these included some or all of the five persons above named, we conclude that upon returning to Galilee they had left Jesus, gone to their own homes, and resumed their former oecupations, it being probable that he had never yet told them they were to forsake all and follow him without intermission. And it was natural enough that they should return to fishing after being so long with .Jesus, even as some of them sought food in that way after his resurrection. (John2l: 1.) The training of the disciples for their work was very gradual see on $10: 1$ ). Cn the present oceasion, finding the two pairs of brothers engaged in their oecupation as fishermen, Josus ealls on them to attend him in his ministry, which they seem to have constantly done from this time forward. Their inmediate compliance with his demand $(v, 20,22)$ ceases to be strange when we remember their former connection with him; and this is one of the eases in which Matthew, Mark, and

I Dialegomai, to converse, discuss, etc., diungello, katangello, to bear a message, make known, etc, parresiuzomat, to speak withont reserve, speak boldly, and plero to completc (Rom. 15: 19), are also oceasionally rendered

'preach,' besides being frequently used in their common meanings. The worls rendered 'preacher' and 'preaehing, are always from kerusso, except in 1 Cor. 1: 18 ('word,' logos.) 
Luke, make statenents which sexem to imply a previous ministry such as was afterwarels deacribed by Jolin. We see also trom the fuller aceount of the ciremmstaneses given by Luke (5: 1 ff.)-for it is very unwise to as-omme two diflorent calls, ats Clark and others dithat a miracle was wrought which mande a great impresiom on Petor and the rest.-Omit 'Jesus, as in v. 12.

The sea of (talilee has been well said to be "the most salered sheet of water in the world," for it is intimately associated with many of the most interesting events in the life of our Loral. It is called in O. T. "thesea of Chinnereth, or "Chinneroth" (Num.34:11; Josh.12:3), perhaps from a town of that mame on its batuks. (Jo+h, 19: 35.) In N. T. times it wals (and)monly called "Lake of Gemmesaret" (Luke 5: 1, Josephus, Nitrabo, ote.), as already in 1 Mace. 11: 67, "water of Gemnesar," the name being probahly derived from the platin on its northwestern shore (see on $14: ; 4)$. We also find in John (21:1:6:1) the name "sea of Tiberias," from the city which lJerod Antipats built on the southwestern shore, and named after the emperor Tiberius, and which is at the prosent alay the only town remaining near the lake. The name "sea of Galilue," here and in Mark $7: 31$; Jolun 6: 1, was abvious]y taken from the great district on the wert. In Ilebrew the term rendered seat was aloc) appliral to small borlies of water (ats mow in German a sea may be a small lake), and this unclassical use of the term is arbopted in fireeli by Matt., Mark, and Juhn. but non hy Isuke, who says 'lake.' It is important to observe this usatge ; for many persons think of the Sea of Galilee ats a large lubly ut water, when it is only asmall lake, twelveatsel a quarter miles long, anel six and three-fuarter miles in its greatest breatth. Its surfices is six hundred and eighty-two feet below the lewal of the Mediterramean (emmp. on $8:(j)$, so that form the bills on either side it seems sunken in at great ravine. The range of mountains which benuds the whole Jordan valley on the east, rise here just from the enstern shure of the Inke (except a bit of plain at the upper and lower extremities) to the height of nearly two thousand feet. They are deeply furrowed by ravines, and have a barren and desolnteajpenrance. The mountains an the west curve round so ns to give space for the lake, und be- sides leaving the bealutiful plain of Gemmesaret on the morthwest, prenest "an altermation of solt grissy shopes and roeky alitt-" 'Tlue warmth doe to the great alderesom, and the numerous and cophous of linge which breat out on the western side, produce a high logrea ot fertility, which attains its grantest rielumeso in the platin of Gennesaret. Downthe ratrines an this side, ats wall ats on the eas, colne rushing winds, which oftere lash the surfiare we the lalie to fury (sen (1) \&: 24) A pound nearly all the westem sicle lies a gontly sluping beach, which southwardi- roughly strewn with stones, but in the midelle amol nomthern part is af smooth sand. The water is fombel, as described by Joseplias, ta be remarliably elear, coonl, and swerot; and the lakes still abounds in choice tish, which doubless led to the name Bethsalia, house of tish, fishtown, for a town on the northeast and amotherom the northwest. Besides nine citier, some of them quite propulans, on the western shore, there were many villages on the hill-sides. IIamna: "It is perhatps not too much to saly that never did so small a sheed of watel seete so many keels cutting its suffuce, or so matuy human babitations cireling round and shatowing its waves, as did the Neat of Galilee in the days of Josus C'hrist." Our Larel was throwing himselt into the ruidst of the busy world (eompl. on v. 12 amel 1:3), where? great erowds wombleatily eollect to bear and see; while whenevar he wished to avoid them, he eould retire from the latie-shore to the adjacent lote hills, or erose the narrow lalke to the comparative solitudes beyond. On the present weasion we think of him as going furth from Caperuatum, and walling by the? sea, along the sloping and sandy beateh, until presently he sees ammong the busy fishermen those humble brothers whom he hat chosen ta follow him in labors destincad to malie tlie Sea of Galiloe fimmons forever.

How pleasant lo me thy deep blue wave, O) sia of tiallilene?

For the glorious one who eame to save IIath often stoml by thee.

Graceful aroumb thee the mountains meet, Thou calut reposing sea;

But alı! lat more, the beatififl feet of Jesus walked wier thee.

Tell me, re momblering fraguents, tell, Was lae sariour's cily here? 
19 And he saith unto them, Follow me, and I will make you fishers of men.

20 And they siraightway left their nets, and followed oim.

Lifted to hearen, has it sunk to hell, With none to shed a tear?

And was it beside this very sea The new-risen saviuur said,

Three times to simon, "Lovest thou me? My lambs and sheep, then leed."

O Saviour, gone to frod's right hand, But the same Saviour still,

Graved on thy heart is this lovely strand And every fragrant hill.

Oh: give me, Lord, hy this sacred wave, Threefuld thy love divine,

That I may leed, till I find my grare, Thy flock-both thine and mine.

M'CHEYNE.

On simon called Peter (as to the form of expression comp. 1: 16), and on Andrew, see on 10: 2. A net is in the original a different word from the more general term empleyed in v. $20 \mathrm{f}$., but without any substantial difference of meaning. The cireumstances show that it was a dip-net. (Comp). on 13: 47.) -The fact that our Lord chose 'fishermen' to receive and propagate his teachings, and not Ratbhis, shows that be relied on something better than mere human learning and worldly iiffluence, and the suecess of their labors is one eviduce of the divine power which attemls the preathing of the gospel. But this ide'a must not be carried too far. There is no reason at all to ronsider them weak inen, and their position and pursuits seemed in some respects to fit them for their work. They were perbape less prepossessed by the follies of Pharisaic tradition, and thus better prepared for receiving and transmitting now doctrine, and they were eminently wen of the peeple. "Working men" in the Eist (Kitto) are often marliedly intelligent, correct in language, and courteous, ant it has always been a matter of eourse there that some such men should rise to the highest station. And it has often been seen in Ameriea that such men, when they possess real force, have greater popular influence from their ready and wellrecognized sympathy with the eommon mind.

- There was afterwatrds addet to the number of the apostles a man of lofty intellect, filled with Jewish learning, and not ignorant of Greek literature, and it is he that was chosen
19 were fishers. And he saith unto them, Come $y$ 20 after me, and I will make you fishers of men. And they straightway left the nets, and followed him.

to be the ehief instrument of introducing the gospel among the eultivated Greeks, and to write such inspired treatises as the Epistle to the Romans, while at the same time le abhorred the idea of relying on human philosophy or rhetorie, when the excelleney of the power must be of Gorl, and not of men. In all this we see a rebuke to the presumption and exelusiveness both of learning and of ignorance. -It is not certain that any others of the twelve than the four here named were fishermen by profession. We know that Matthew was not, nor is it likely that Nathanael of Cana was. The incident in John $21: 1 \mathrm{ft}$. does not prove that to have been the proper calling of every one present. Still, it is probible that all the twelve were men in eomparatively humble life, and without the learning of the Rabbinical schools. (Comp. Acts 4: 13.)

19. Follow me. This was translated Come ye after me, by Wyclif and Rheims, followed by Davidson, Noyes, Alford, McClellan. The entire phrase was translated 'follow me' by Tyndale, and so eame into Common Version. The first term is literally 'hither.' $o r$ 'come hither,' as in 11: 28. With the addition 'after me' it implies that they were to come and follow him, viz., as his disciples (eomp. Luke $9: 23 ; 14: 27)$. The same idea is presently expressed ( $v .20,22)$ by the simple term 'fol. low'; and in 19: 21, both "hither' and 'follow, are combined. It was the pratetice of many of the Greek philosophers to have their pupils aceompany them wherever they went, instrueting them not only by elaborate disconrses, but also by conversations with them, or with others in their presence. So Elijath was for some years followed (1 kings 19:20 f.) by Elisha, his destined snecessor. It is eary to see the wistom of sueb a course, in these enses and in that of the Great Teacher. Similar languige is fount below in $9: 9 ; 16: 24$. Fishers of men, as he himself had just been oceupied with a thronging erowd. (Luke 5: 1.)

20-22. For explanation of their immediately obeying, see on v. 18 . So Elisha left at once his numerous oxen, and followed the proplet. Peter remembers long afterwards that they 'left all' and followed Jesus \{19:2r, Rer. Ver.) And going on, etc., or going forwurd. 
21 And guing on from thence, he saw other two brethren, fames the son of Zelsedec, and John his brothrr, in a ship with Zeleder lheir father, mending their nets; and he called them.

2': And the immediately left the ship and their father, and followed him.

23 And Jestr went alunt all trablee, teadsing in their synagogace, and preatehing the gospel of the kingdom, aind healing all manner of sickness and all mamner of discase amoug the people.
21 And going on from thence he saw other wo brath-

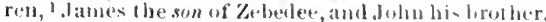
in the boal with Kebealee their tather, meludius their 22 nets; anl he called thent. And they stralghtway left the boal and their father, and folliowed him.

23 And 2 Irsus went about in all falilet, teaching in their symagornes, and presching the 3 inospel ot ilue kingdom, and healing all mauner of diseatse and all

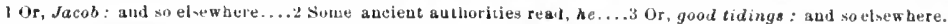

The eonnection in Luke (5:7) shows that it a was only a short distance, for Poter had beckoned to James and John when he found his boat so full, and they came and filled theirs also. Probably they then brought their boat to shore at a diflerent point, and to this J esus advanced, and addressed to them also his eall. -These two pairs of brothers, thus ealled at the same time, appear to have been peculiarty associated, forming the first of those quaternions, or eompanies of four, into which the twelve are in all the lists divided see on 10 : 2ff). The twelve probably eomprised also a third pair of brothers (buke a: 16), where 'brother' is more probably the meaning). In a ship, ar theboat, viz., the one thry kept and used. The article was duly translated, "in the ship.' by Tyudale and Crammer. The translaters of Common Version seen to have hat in general but little feeling for the artiele. 'Boat' (Noyes, MeClellan) is newessary in modern English to express the exact idea. The Greak word means something used for sailing, and is applied to veswets of various sizes, just at the English ship and skiff were originally the same word. On the Latke of Galilee these fishing-vessels were in all probability mere boats. We cannot tell whether or not they had sails, which are never montioned in the Gospels. With v. 22 compure Mark 1: 20, " nad leaving their fither Zobedee in the boat with the lifed sarvints,' Bil. Un. Ver., which indieates that this fimnily were not in graat poverty, and so the sons were not depriving their father of necessary ussistance (eomp. 10: 2).

23. In $v$. 2:-23 is given a general aceount of our Lord's making a clicut of GaldLEe, as be did alsu on two subsequent oceasions. (Luke 4: 1-3, and statc. 9: 35 to 11:1.) P'artieular ineidents of the circuit are postpuned by Matt. till after giving the Sermon on the Monnt (ch. 5-7), to which this paratgraph furnishes a sort of introduction.

Jesus went about. 'Jesus' should prob- ably be omitted, as in $v .18$, though the evidence is here not conclusive. "Wont about' is imperfect tense, continued or kept going: Christ's labors were ineessint. All Galilee, (comp. on r. 12) is also a strong expression. Galilee was a small district, saly seventy miles long and forty in greatest width; but Josephus dechares that it had two hundred and four cities and villages ("Life," ch, ,5, Whiston, wrongly, two bundred and forty), and elsewhere ("War.," $8,3,2$ ) says: "The rities are mumerous, and the multitude of villages everywhere erowded with ben, owing to the fecundity of the soil, so that the smallest of them contains above fifteen thousand inhabitants." This is obviously an exaggeration or loose statement, as there mu-t, in the n:1ture of things, have been many smaller villages. But Josephus had ample opportunity toknow, baviug been commanding general in Galilee in A. D. 66. Nearly all the people lived in cities, or villages, and (omitting thoe who did not) aleenrding to these two statoments of . Josephus there were in Galitee, thirty-five years (one generation) later than our Lord's ministry, more than three million inbabitants; an estimate which some other facts support. But few of the aities are named in the Gospels, yet quite a mumber in Josephus, whose military operations leatd him to speak of them. At any rate, thepe were over two bundred cities and considerable villages, and while we must not press the phrase 'in all Galilee,' we preceive that this circuit by our Lord was one of great labor. and roquiring much time, since to visit only half the towns at the rate of one every day, would have taken more than three months. These arithmetical estimates should however not be insisted on, save as helps to form a general conception of the labors of love our Lura performed, as he "went about doiner goud, and healing all that were oppresed of the devil.' (Aces 10:34.) Notice also the expres-ions which lere follow: 'all manner of sickness, 'all 
Syria,' 'all sick people.' Of partieular milacles and discourses in our Lord's ministry the Gospels give only a few oxamples; and it is verg important to dwell on these general statenu.nts, and expand the imagination orer this great extent of beneficent work. Day atter dis: weck after week, he goes from town to town, "twahing, healing. In scores of syllagrome lae speaks, hundreds and perhaps thousands ot pornons he heals; feeling tatigne like ang othor humau being (John 4:6; M:tt. 8: 24; Nark 6:31), he toils on. Teaching. The constant application of 'teach' and 'taacher' to our Luml reminds us that the gospel proposes to instruct and enlighten men, in their ignorance of spiritual things-giving both intormation as to the ficts of God's word and instruction in its principles.

symagogues. These were of great service to Jesus, and afterwards to his apostles, in fur. ni-hing congregations already assembled in a quiet place, as-ociated with nothing but worship. The Greek word which we borrow (sumagoge) signities a collection of objects, or persolss, and in the sept. is often used for the congregation al assembly of Israel (comp. on 16: 18), in N. T. only for a local assembly of Jews in a particular place to worship, or tor the place in which they assembled. The practice of holding such meetings probably originated during the Babylonian captivity, when the ponple were cut off from the temple worship, and having heen found pleasant and nseful, was continued afterward. In the time of Christ synagogues are referred to as a thing of collre in every town, not only in Palestine. lat wherever there were many Jews. After the destruction of Jerusalem, in A. w. 70, thw -ynagogues would naturally reeeire a further develument in organization and wolnip, and it should not be forgotten cllat the acomots of these furnished by the Jewish bunks (see Bihle Dictionaries) refar to this later time. In N. T. we find no proufsof complete organization and regular jurisliction, but there is mention of 'rulers' or 'elders, and of an 'attendant' (Iake t: 20); also) of expulsion (Johns:22;12:42; 16:2), by which it $i s$ sufhient to understand that they forbade the person to attend their meotings, which womld also atube him to he shumbed in soejety. The examples in Luke 4: 2l and Acts 13: 15 show how unr Lord and his apostles could turn the worship and Scripture reading to account. Philo says the reading and detailed exposition of Suripture was continued till late in the afternoon. Regular meetings were held in the synagogues on the sabbath and on festival-days; whether also on the second and fith dilys of the week, as at a later periot, we cannot determine (see Luke 18: 12). Nor are we informed whether extraordinary mectings eould be ealled on other days. us when Jesus arrived in a town and wished to be heard; and we know well that our Lord would speali wherever people could be assembled in quictness, as well in the open air as in a synagogue. Preaching, proclaiming (Kerusso), see on v. 17. Gospel (margin of Rev. Ver. 'good tidings') see note introductory to 1: 1. The gospel of the kingdon is the good news of that kingdom (or reign) of Messiah which was about to be established (see on 3: 2 and 6: 10). The propluets had associated ideas of joy with the eoming of Mrssiali's reign; and now Jesus proclaims the 'good news' that it is near. See an interesting specinen of his preaching at this period i) Luke $4: 18$. Healing. There were two great departments of his public work-to make known truth, and miraculously to relieve men's distresses. He was a Teacher and a Healer. All manner of sickness-or, every kind of disease; the word is so rendered in v. 24. Disease-this word differs from that above. It secms to denote infirmity, or such diseases as produce feebleness rather than positive suffering. The same two Greek words meaning 'disease' and 'infirmity,' are coupled in $9: 35$ and $10: 1$. The MIRACLEs of Jesus cannot posibly he separated from his history or his teaching, nor ean they he rejected without impeaching his character, or also declaring the Epistles of Paul. as weHl as the Grepels and Acts, to be so utterly untrustworthy that nothing whatever can be received upun their authority. Nay, if one denjes the possibility of miracles, he need anly be logi(al to deny the possibility of cruation. If we believe that God caused these physical fores to exist, ant to act according to the laws which molern science is so nobly bus in observing. where is the diffieulty in believing (upon suitrole tostimony) that God's own spiritunl influence has sometimes modified the aetion of these forces, without violating their nature? 


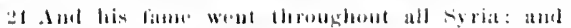

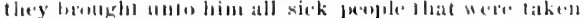

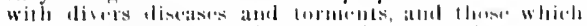

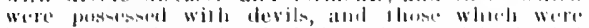

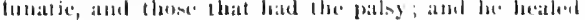
1 litill.

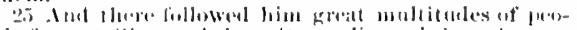

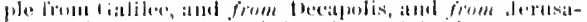

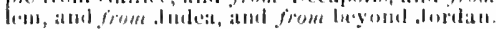

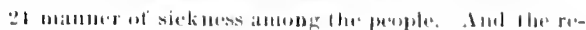

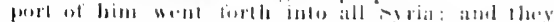

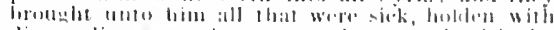

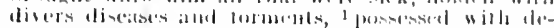

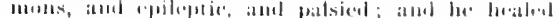

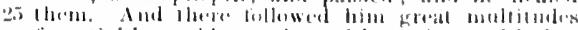

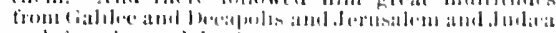
and frout leyollad Jordath.

1 Hr, drmoniars.

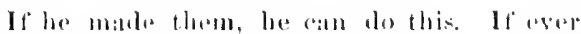

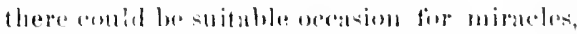

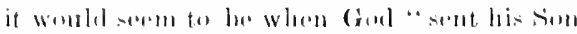
inle the worlal." Nor atu aluy nobler, wor-

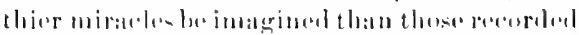

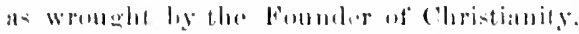

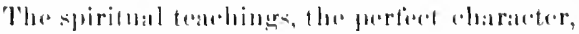
and the moble miracles af ('hrist, all support

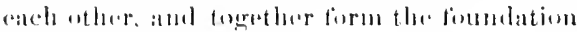

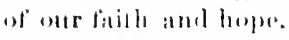

21. Ilis fame, linv. Vir., the report, lit"rally, hearill. Went throughout. 'Tyr-

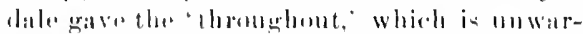

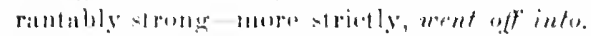

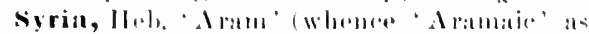

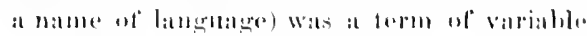
rxtent, denotion in semeral the eomotry atet

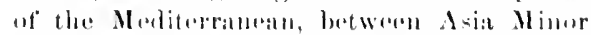

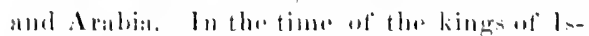
ratel it signilias l la kinglom of whirh loumas-

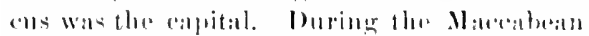

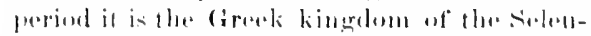
cides, with Intionels ats itscappital. At the times

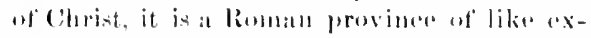

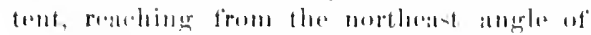

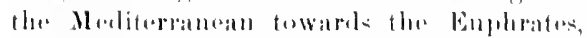

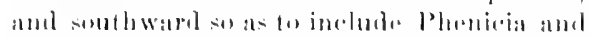

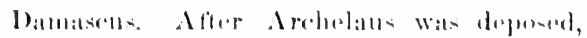

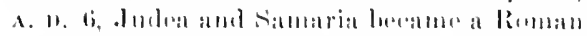

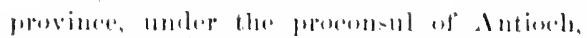

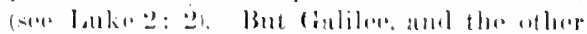
distriate enerermol by llorul Antipas amb

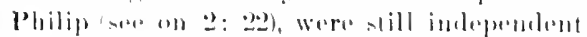

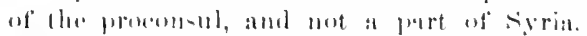

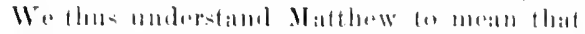

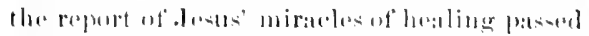

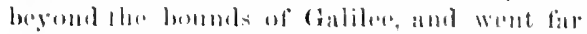
away intothe dietriets northwarl. It would be folly lo prose the 'into' and 'all' so as lo

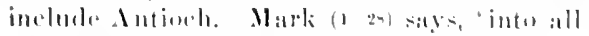

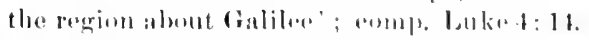
Alt siele people, litarally, these haring

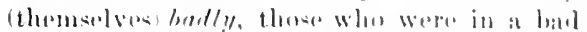

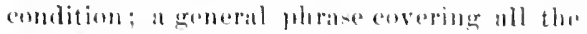
riases presently specified. Forments, or

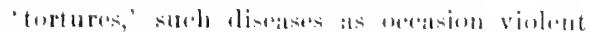

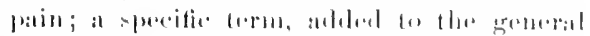

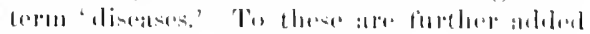

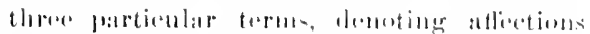

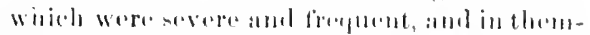

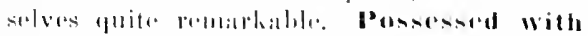

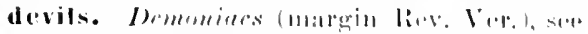

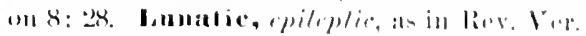

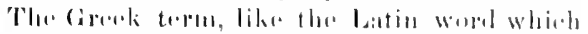

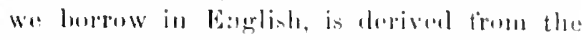
worel for momen, lut was applind not lo in-

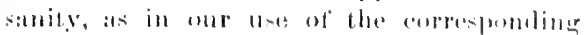

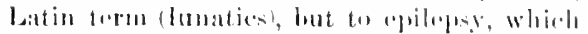

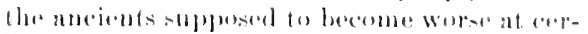

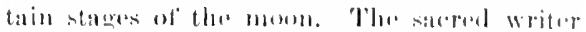
empleys the familiar term, ju-t its ho suralis

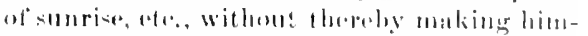

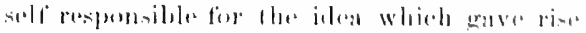
to it. This apilopy might ar might nut low

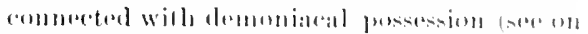

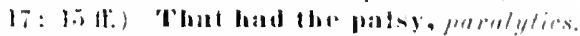

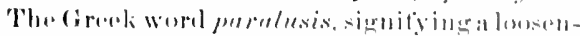

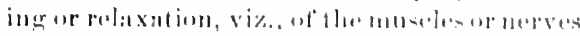

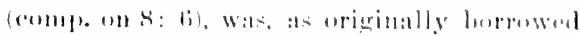

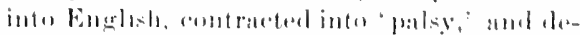
motes in sierijulure all that wa mow mand by

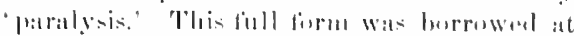

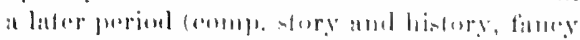

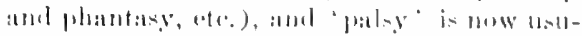

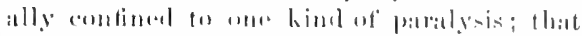
which prouluens an involuntary iremulams

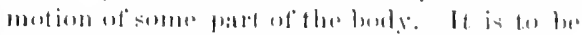

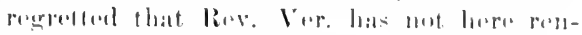

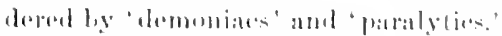

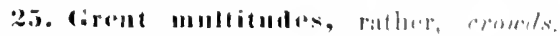

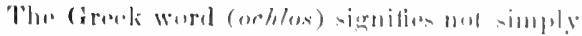

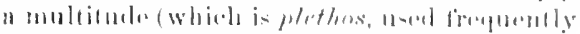

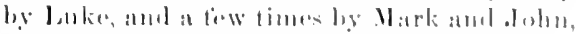

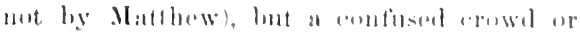

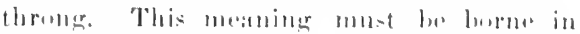

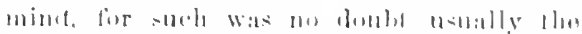

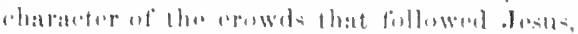

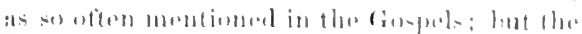

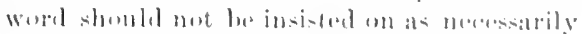
lanving this distinctive sonse in every case, for 
it can scarcely be so taken in Acts 1: 15. The crowds who thus followed Jesus were not all in any just sense his disciples. They came and went, attended him a longer or shorter time, to see his miracles and hear his teachings; sometimes many straggled away, and again they would throng around him to see some new wonder. So we must notice that follow means more or less in different cases. The term people was uselessly introduced bere by Tyndale and followers-Galilee. see on $v, 12$. The word from is in the original given only before Galilee, thus grouping all the other localities with it. Decapolis signifies a district containing ten eities (comp. Tripolis, Pentapolis), and bere designates a region of somewhat indefinite extent, lying mainly on the southeast of the Lake of Galilee, but including Scythopolis (Beth-shean) on the western bauk of the Jordan valley. After the Romans gained control of Palestine (beginning B. C. 63), these ten cities were allowed peeuliar privileges. Ancient writers differ at to what cities formed the ten, Pliny including Damaseus, which Josephus scems to exclude; perhaps the Romans made "hanges. One of them was Gadara, see on 8: 28. The popultion of these towns was very largely Gentile, and after the death of Herod the Great they were not governed by either of his sons, but belonged to the Roman province of Syria. (See Caspari.) JerusaIem, see on 21: 10; Judea, on 2: 1; beyond Jordau (Perea), on 19: 1.-Though Jesus had retired from Judea to Galilee, many came thence to attend him here. (Comp. on $15: 1$, )

\section{IIOMILETICAL AND PRACTICAL.}

V. 12. Cin roston: "Wherefire doth he depart? Again instructing us not to meet temptations, but to give place and withdraw ourselves."-V. 13. HENRY: "It is just with God to take the gospel and the means of grace from those that slight them. Christ will not stay hong whore he is not weleome." -Capernaum. 1) Greatly farored as the home of Jesus. 2) Severely tested by his teachings and miracles. 3) Utterly ruined for rejecting him. (11: 23.)-V. 15. The nost destitute field will sometimes prove most fruitful.- V. 16. Darkness and light. 1) The mianight darkness of sin, ignorance, and unbelief. 2) The morning sunlight of a present gospel. 3) The noondity brightness reached by following the path of the just. (Prov. 4: 18.) STARke (in Lange): "Many live under the full blaze of the gospel as if they still sat in the shadow of deatlu." -V. 17. The preaching of Jesus. 1) Its subjects, 2) Its spirit. 3) Itseffects. The call to repentince has been made by all God's messengers; e.g., by the prophets ('turn ye'), by John the Baptist, by Jesus hinself, ly the apustles after his ascension. (Acts $2: 38: 3: 19: 20: 21$.) HENRY: "The doctrine of repentance is right gospel-doctrine. Not only the au-tere Baptist, who was looked upon as a melancholy, morose man, but the sweet and gracious J Jesus, whose life dropped as a howey-comb, preached repentance; for it is an unspeakable privilege that room is lett for repentance."

V. 19. Fishers of men. 1) Humble workers, but a lofty work. 2) It requires tact, perseverance, patient endurance of frequent failure. 3) He who calls us to it promises that we shall not labor in vain. [Beware of the wild fancies of certain Fathers, comparing Christians to fishes, ete., whith some modern writers unwisely quote]. STARKE (in Lange): "Let none faney that he can suceed by himself; even Christ chose assistants." $-V .21$. Two pairs of brothers. Christ sanctifies and makes use of natural affections. $-V, 21$ t. 1) He saw, 2) IIe called, 3) They followed him. Calvin: "This shows (1) the energy of Christ's voice, (2) docility and prompt obededience in the disciples."-V. 22. We also should be ready if necessary to leave business and kindred, in order to follow Jesus. (Comp. Luke $9: 57-62$.) Whe eannot tread in his bodily footsteps; many did this with little or no profit; but by faith and loving imagination we may see him manifested (John 14:21-23); and in initating and obeying we shall in the best serse be following him.

V. 23. 'In their synagogues.' It may be proper to preach truth even in places where others preach much error. Jesus a Teacher and a Healer; and the relations between these functions. Sin was the prime cause of discise, and special sin is often the immediate cause of particular diseases. The mirncles of henling both relieved humin distress, and attested the divine authority of the tenching. IIENRY: "What we hear of Christ from others, should invite us to him." Currs.: "If we have any bodily nilment, we do und 


\section{A P T E R V.}

contrive everything to be rid of what pains us; but when our sout is indisposed, we delay, and draw back."-r. 25. It is well if crowds come to a preacher: he should then take great pains $(5: 1)$ to teach them the truth they need $(5: i)$; but they may admire his teachings as novel and striking (7:285.), and yet few of them beeome Christians; and the fault may sometimes be wholly their own.

\section{SERILON ON THE MOUNT.}

Chap. 5-7.

\section{GENERAL INTRODURTEON TO THE SERMON ON THE: MOUNT.}

The diseourse in ch. $5-7$ is well known by the traditional name of 'The Scrmon on the Mount. Several general questions in regard to it require to be answered.

(1) Unity of the discourse. Some contend that we caunot, or need not, suppose Jesus to have spoken on a single oecasion all that Matthew hero gives, but that he has grouped together things sid at different times, for the purpose of furnishing a comprehensive exhibition of our saviour's teachings. This they argue partly from the fact that many things eontained in the diseourse as givon hy Matthew are recorded by Luke, and even by Matthew himself, as sitid on other oceasions (see on 5: 13, 15, 18, 25, 29, 82; 6: 9, 22.2, 24, $25 ; 7: 2,7,17,23)$, and partly from the manifest design on Matthew's part to compese not so much a ehronologieal narrative as a historical argument, in which things are so arranged as to bring out the points he wishes to make prominent. But in grouping the miracles of els. 8 and a, loe does not at all saly that they acenred in that order, nor that the discourse of eh. 5-i preceded them all; while he does distinctly say that this diseourse wat delivered on a single necasion (eomp. $\delta: 1$. and 8: 1), and if the faets were othorwise his aceonnt of the matter would lue definitely orroneons, which enmut be almitterd uratil it is proven. And as to the oceurrenes of similar sayings elsewhere, why may wo not suppoe that our Lord would repent substantially the same sayings? It would laske lwen very unnatural had he not done that which is froms practiced by all traveling teachers and which. apart from any question as to the speaker's resources, is really demanded by the similarity in the condition and wants of diflerent audiences. And we have abundant evidence, from passages having no connection with the Sermon on the Monut, that he frequently mad: such repetitions, with greater or less variation of statement, anet particulaty in the case of brief", pithy sayings. such as would maturally be introduced in different connections, and of very important dretrines and exhortations, such as varions aneliences would alike need. E. g., "IIe that hath ars to hear, let him heatr," 11: 15; 13 : 9; "Except ye become ats little children," ete., 18; $3 ; 19$ : 14, and add the repeated inculcation of humility in other ways, 20: 20 ; Joln 13: 13 1t.; Luke 12: "2t ff. (Compl. also $23: 12$; Luke $14: 11 ; 18: 14$ ) "If ye have fitith as a grain of musturd seed," ete., 17: 20; 21: 21; Luke 17:6. "Whosoever thall confess me," ete., 10: 82:; Luke 12:8; 9: 20. "The servant is not greater than bis Lord," $10: 24$; Luke 6 : 40; John 13: 16; $15: 20$; in the last of which passages Jesus refers to his having told them the same thing betore, as he does alse in John 13: 33. (Comp. John 7 : :34 8: 21.) "He that finds his life shall lose it, and he that loses his life for my sake thall find it," 10: 38, 39); 16: 21 f.; Luke 17: 33 ; John 12: 25. See also the image of taling up the cross and following him, in 10: 38; 113: 24; Luko 14: 27; Mark 10: 21. With such facts hefore us, it is manifest that the resurrence in other connections of partienlar ideas and expressions which appear in this dis. course, is no proefe that it was not all deliverod on the oration before us. Thus luth the supposed reasuns fait, and we latre no ground for setting aside the view which an unprejuliced reader of 11 atthew would naturally aldept, that ho has recoreled what wisactually spoken by Jesus as hes sat on llee Mount. It is not sald that nothing olsw was spoken; and the suppration that 11 atthew"s report is somewhat condensed (ats onten in the (bospels), will aceount for the apparome latek of (xonnection in some places (sas on $7: 1-12$ ), and tor the rapial suecesion of -eplat rate porints. which some have thought Bleak! that at miscellanentse ont-door audience eould hardly fol- 
low or retain. Neander: "Tle discourse is made up of many sentrintious passages, caleulated separately to impress the memory of the hearers, and remain as fluitful germs in their hearts; but, on the other hand, bound together as parts of an organic whole.

(2) Is this the same discourse as that given by Luke, in 6: 20-49? They are held to be different diseourses by Augustine, atter him by nearly all writers till the Reformation Bleek), and by a tew writers since, as Erasmas, Dodaridge, Macknight, Alexander, Lange, G. W. Clark, Coleridge, Plumptre; some of these thinking the two were delivered on the same day, and others with a longer jnterval. They are taken as different reports of the same discourse by Origen and Chrys., by Calvin, and by almost all recent expositsrs. In favor of this view are the obvious facts that the two begin and end exactly alike, and nearly everything which Luke gives is also given by Mathew; and that both are inmediately followed by the record of the same events, viz., the entrance into Capernaum and the hoaling of the centurion's servant. The objections (well stated in Clark's Harm.) rest on supposed differentes of pluce, time, circumstances, and contents. (a) But Luke (6:17) does not say 'stood in the plain,' but 'stood on a level place, which might very naturally he a bit of level ground, or a narrow plain in the momntain region, exactly what is found at the traditional place (see on v. 1). (b) As to the timeand circumstances, Luke' - disconrse follows the choice of the Twelve. and Matthew's seems to eome earlier, som after the begiming of the ministry in tralibe. But Matthew's arrangement in ah. 8-1:) je olovionsly topical rather than chromolongieal, and so it is natural that without saying at what precise period of the ministry it was spoken, he sbould give at the outeot this erreat disemerse, which would set before his owish readers the relation of . Josus teateding to the law of Moses, and the true nature of the Messianic reign. (Nive the commontion trated on 4:12.) And if the events proesling the

1 The Greek worl pedinos is commonly used with reference to a plain as opposed to a mountain (a natural opposition), but sometimes for a plain or tlat valley among mountains, or a tlat plaet on a mountain. "Thus in Jer. 21: 13. Jernsilen is ealled rock of the plain, and in Isa. 13: 2 we have irs Sopt. "lilt up a sighal upon discourse seem different in Matthew, it suust be observed that he does not at all state just when the discourse was delivered. (c) As to contents, Luke omits the large portions (Matt. $5: 17-37$, and $6: 1-18$ ) which were specially inportant and interesting to Jews, but less so to the Gentile readers whom Luke had chiefly in view; and also omits some portions, probably because he gives substantially the same thing elsewhere, as said by our Lord on other occasions (e. g., Matt. 6: 9-13; Luke 11: 2-4; Iatt. 6: 25-34; Luke 12: 22-31.) WVe thus account for every omission of any great inportance. There are various other instances also (as in ch. 10, 11, 18, 25) in which Matthew has recorded an extensive disconrse of which Mark or Luke gives only a part. Some conchude from these examples that Matthew was quite in the habit of eollecting into one discourse many things said at different times; but the facts do not in any of the cases require this view, and therefore do not justity it, since we must take for granted, unless the eontrary has been proven, the in-pired apostles'aceuracy. At the same time we may suppose that Mathew has here given, at least in some places, omly a summary report of what was said, for he has several times omitted matters which Luke records (e. g., eomp. 5: 12 with Luke 6: $23-6 ; 5: 47$ with Luke 6: 30-35; $7: 12$ with Luke 6: 31-10.) In regard to the general fact that the Evangelists sometimes differ as to details in reprorting the sane saying, see on $\mathrm{D}: 17$.

(3) Design of the discourse. Our Lord had been proclaiming (4:17), as Jolun had done before hin, that the reign of heaven was near, and that therefore the people onght to repent. In this diseourse be sets forth che characteristies of those who are to be subjects of this reign and share the privileges connected with it, and urges upon them various duties. In particular, he clearly exhibits the relation of his teachings to the moril law, in order to correct any notion that he proposod to set the haw aside, or to relax its rigor, when, on the contrary he came to inculcate not merely an

al levol (flat) mountain' (ep' orous pedinou), Ifeb., ' upon a bare hill,' not eorerel with trees. This latter passage is obseure (see fiesen., Seblutus., and commentaries on Isaiah), but either this or the use in Jeremiab seems to furnish a parallel for the use in Luke. 
external but a deeply spiritual morality. It is a strange faney of some that Jesu- Was a revolutionary reformer, overturning exinting jdeats and institutions to sulntilute his own, when he himselt expresly declares the contrary (see on j: 17). Aeander: "The connected systen of truths nufolded in this diseourse was intencled to rxhibit to the preople the kingdom of (aod as the nim of the Old Dispensation; as the consummation for which that dispensation propared tho way. The sermon on the Mount, therefore, forms the point of transition firom the Law to the Gospel; Christianity is exhibited in it as oudaism spiritualized and transtigured." Iirgarded as

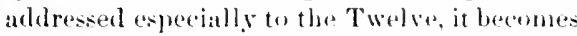
the great opening lecture in a enurse ot instruction by which they were to be fitted for their work ats his witueses and relpesentatives; just at the farewell disenurse ot Jolun 14-17 maly be called (Bermarel) the closing leeture. It is quite an rerror it men expect to find in the elisomrse an ejutome either af Christian deetrine or af C'hristian ethies. Many of the distiuguishing and fundanental dectrises of Christianity were never distinetly and fully tauglit by the saviour himselt, hocause men could not underetand them till ufter the grout facts on which they rest, his death, resurection, and aserension, hat taken place. Aud while he here teaches us many weighty and precious lesoms for the proper conduct of lifie they are by no means presented as a complete sy-tem of morals, lut seem to be introlueed ahietly as entrihuting to, or incidentally connerted with. the diseussion of his great theme, the nathere and requirements of the Menimuic roign. It is therefore vory unwise and pre-lamptuous to single out this one discourse and propuse to live by it, in discegard of the further taachings of Christ and his apostles. True, he here gives a siugle prece)te $(8: 12$, which he says "is the law and the prophets." But that ne nore warrants the neglect of ererything beyond this discourse, than the closing precept 'Fear Gud and kene his eommandunents, for this is the all of man, would warrant us in negleeting the old Testament for the one look of Ecelesiastes. Ile who spota the siermon on the Mount hits also said, "Fixerept it man be loorn again, he cannot seethe kingdom of fiod, and 'even so must the sion of man be lifted 11 , that whosoeser believeth in him shoulel not perish, but have eternal lifo," and he in devarting promised his alymtles the IIoly spririt to lead then into all the truth, and set them before the world as authoritative teachers of Christian doetrine and duty. It is not honoring the sermon on the Mount, or it Author, to represent this as all that mon need. seeing he has griven us much mere.

The unrivaled beauties of our lanrd's thought and style, the Iotty simplicity, the charming freshness and perfect naturalness, the familiar and vivid illustration, the pointed aud sometiues paradoxical and startling statement, which even when imperfectly understool could never be forgotten, the sublino elevation of sentiment. and the inimitable tome which marlis all his teachlings, shine conspicuous in this adelress, which is sweet te the heart of a child, and befure which the noblest intellects in every age have bowed in devout admiration. Well might Daniel Webstersay. in the inscription he loft for his tomb, "Mly beart has always asoured and re-asslured mes, that the gospel of .Jests ( 'hrist man be a divime rality. Thesiormon on the Mount cannot be a merely human production."

(4) Amalysis. The discouros, as given by Inthew, admits of being analyzed in varions ways, the connection bring less obrions in some platees, and the arrangement of the whole being very simple and inartiticial. The following analysis may be useful, thongh we. must take care mot to draw too broadly the lines of division between the difforent seetions.

I. Characteristics aud privileges of the subjerets of the Messianie reiern, $5: 3-12$.

II. Their influence and responsibility, 5: $13-16$.

III. Relation of Christ's mission to the Moral Law, is: $17-4 \times$.

1. 'This relation sated in genoral, 17-19.

2. Superiority of the morality lo enjoined to that taught and practiced by the seribere
1 Edersh. remarks that our Lord's use of phrases and modes of teaching curront at the lime, ronelers more striking the contrast between this di-course and the Jewish eontemporary leaching as to the whole spirit and tone. The supposed Rabhinic parallels are in general only superficially similar, and often exatrily opprosite in spirit. Ste examplt's in Edersh., Book iii., ch. 15 . 
AD seeing the multitudes, he went "p into a A mountain: and when he was set, his diseiples came unto him:
1 And seeing the multitudes, he went up into the uountain: and when he had sagniown, his disciples and Pharisees, $20-48$. Illustrated by reference to murder, ete. (21.26), adultery and divorce (27-32), onths (33-37), requital of injuries (38.42), love of enemies (4\$-48).

IV. Good works to be performed out of regard to God's approval rather than man's, 6: 1-18, e.g., alms-giving (2-4), prayer (5-15), iasting (16-1s.)

$V$. Single-hearted devotion to God, as opposed to worldly ains and anxieties, 6: $19-34$.

VI. Censoriousness must be avoided, 7 : 1-6.

VII. Encouragement to pray to God for strength to fulfill this and all the preceding requirements, $7: 7-11$.

VIII. General principle or rule, which sums up all the (moral) teachings of the discourse, and of the Old Testament, $7: 12$.

IX. Concluding exhortations to practice as well as hear and protess, 7: 13-27.

\section{Ch. 5 : 1-12. The Beatrutues.}

1. The multitudes-or', crowds-viz., the 'great crowds' spoken of in the preceding sentence (see on 4: 25.) The connection goes right on without any break, the paragrajh of 4: 23-25 forming a sort of introduction to the diseourse. (For the general comnetion, see on 4: 12.) On some oecusion, in the course of the labors just deseribed, oeeurred that which Matthew proceeds to narrate. He went up. Was it to avoid the crowds, as some think, or was it not rather that the presence of such erowds made it proper to adlress them in an extended discourse, setting forth the nature of that Messianic kinglom, or reign, which he had been declaring to he at hund? Into a-the -monntain. 'This more frobably means the momntain-region, just as persons among us who live near such it region familiarly speak of it as "the monntain" - "INeisu't at home, he's gone u\}) in the monntain." The word 'monntain' is used for a mountain-region in Gen. 19) 17, 19, 30, and elsewhere in $0 . \mathrm{T}$. The nost eommon secne of all this part of our Lorl's ministry was the lake-shore, and with this would

1 The artiele is leere discegarded by all the parly English translators, who learned cireek throwing the medium of the Latin, and so had little feeling for the easily contrast in the apostle's mind the adjacent mountain-region. So in 14: 29, "the mountain' is the mountain-region east of the lake, near where he had just fed the five thousand, and in 15: 29, the same region further south. That such is the meaning here becomes highly probable (it' we hold Luke's discourse to be the same) from Mark $3: 13$, where the same expression "he gous up into the mountain' occurs on the sane orasion, -viz., the choice of the twelve (Mark $3: 13 \cdot 19$ ), which Luke ( $5: 17)$ shows to have been immediately followed by the discourse-and the preceding connection (Mark $3: 7-9$ ) evidently makes it there mean that he goes up from the lake-shore juto the mountain-region. This also best fits in Luke 6:12. The phrise 'the mountain,' might mean the particular mountain near them at the time (Meyer), or the well-known mountain (De Wette), as one or the other is probably meant in Luke 9: 28, the Mount of the 'Transfiguration; though of this we know nothing. But the prejonderanee of usage and probubility is for thenther sense, the mountain-region. There is then nothing in the bistory to indicate what particular part of the adjacent mountain-region is meant. The connection in Mark, and the statement of Matt. ( $8: 5$ ) and Luke ( $7: 1$ ) that he afterwards went to Capernaum, show that it was on the west side of the lake; but the latter statement does not, as so often urged, sloow that it was near Capernaum. There is no inportant objection to the tradition plaeing it at the double-top mountain now called "IIorns of IIattin," which (Stanley) strikingly corresponds to the eircumstances, since J esus might well have spent the night un one of the two summits, and the next morning deceended to the that space between the two, and there delivered the discourse. But the tradition is unkuown to the Greek and Easteru writors, and among Latins first found in Brocardus, about A. D. 1283. (Robinson.) We can only say, therefore, that this may quite possibly have been the spot. When he was set, or, had sat down, sitting boing among the Jews

article, which they often omit or insert in a curiously arbitrary fashion. 
2 And he opened his mouth, and taught them, saying,

3. Blensed are the poor in spirit: for theirs is the kingdom of heaven.

the customary posture for one engagol in teaching. Luke's expression (6:17) 'stood,' does not conflict with this, for that denotes simply the end of the drescent, and not the posture in teaching. His disciples. The? Greek word rendered 'disciple, like the Latin discipulus, which we havo borrowed, signities a 'lenruer,' as opposed to a 'teacher,' and is nsed in that genrral sense in 10: "2t, literally, "A learner is not above his teacher, nor a save nbove his master.' 'The Greeks frepuently applied it to the pupils of a philosopher, as denoting those who received his instructions and were suppered to adopt his opinions. In a like sonse we read of the 'disciples of the Pharisores' (22:16i), and the 'disciples of .Joln ' (9:14:11:2: 11:12; M:ark 2 18, ete.); and similarly the disciples af Josus, in the present pasioge, and in ganeral, are those who habitually heard his teachings, and were supposed to recoive them ats true. But tha term, as there lued, wenlel have a mero lax and a more strict application, sometimes denoting the whole arowel of those who followed bin for a while, and alplarently believed his teachings (e.g., Jolnh fi: fili), but commonly used of those who really did believe, and submit themsolves to his authority as a teacher. In some passages (as 1t: 15it.) the connection shows that it means "the disciples' by excellener, riz., the Twelve. After our Lord's asemsion the application of the term was very naturally widened to embrace all who received ats true the teachings of the Christin religion, Clorist being in reality still thoir tealler, though he taught theough others. We cannert here understand the term as denoting all who werepresent and listened to his teachings, fur it is nowhere llsed in so loose a way; it munt mean his disciples, as distinguished from whers who were not sueh. This would ineludethe four mentioned in 4: 18 ti., but womld not be contined tothem. Matthew has not proviously had the word, but he employs it in that general sense with which all had become fimiliar at the time when he wrote. From Luke ij: 12-20 we learn that, butore delivering the discourse, Jesus had selected the Twelve who were to be his special attomlants ; but Luke alsu men-
2 came unto him: and he openel his mouth and latught them, siaying,

3 Blessed are the poor in spirit: for theirs is the kingdom of heiven.

tions (6: 17, literally), a "erowel of' his disciples" as present when it was spolien. Matthew does not refer to the Twelve as n body till he (o)mes to speak of their being sent forth two and two (10:1 f.), just as he gives an ancosunt of Jolnu's imprisonucut only in eonnection with the story of his death (eomp). on 4: 12: 14: 3). Came unto him, drew near attor loe hatd thus assuned the posture of a teacher. Or, canc near while the people at large stomd fitrther off.

2. This expanded statement is in acoordance with that cireunstantiality in description which is characteristic of the Hebraw language and adds beauty to the seripture narratives. It sorves, in a case like this, to fix attention upon the important diseome whicll follows. (comp. Job:3: 1; Acts 8: :5); 10: "). ) Taught is imperfect tenso, and deseribes the teaching as in progress-you seo it going on. The Euglish 'was teaching' or 'went to teaching, would here be tou strong. Them reters expecially to his disciples, who are especially astinguished in the proceding verso trom the erowds (eomp. Luke 6: 2011), and are appedally aldresserl in such passales of the diseourse as 5: 11, 1:-16, ete. ; but that the crowds also heard would be naturally suggested by the conncetion, and is affirmed in $7: 28 \mathrm{f}$.

3. In $v$ : :-12 anr Lord sets forth the chararteristices amd pririleges of the subjerts of the kingdom of hraven. These sentunces are commonly called the "leatitudes," from bectess, 'blesened' or "hisplyy, the word here employed in the Latin ver.jons, and ly some are called materisms, from the Grosk word Some writers eomplare with those the benedietions of Dent. 28; lut the cases are not similar. Others mark out an elaborate parallel to the giving of the Tren (ommanduments: but this is highly artilicial, and tends to divert attention frous our Lard's real design. It would be more appropriato to complare such passages as Psa. 1: 1; 31: 1 f.: 144: 15; Prov. 3: 13; Dan. 12: 12, where a character is tescribed as well as happiness dechred. The Jews axpected great fulicity under the reign of Messials: witnessthe suring of one of them (Luxe 1t: 15. Ht.). "Hatpy he who shall eat breal 
in the kingdom of God.' Our Lord, by telling who are the happy in the Messianic kingdom, gives at once a very distiset glimpe into the nature and requirenents of that kingdom. It is immediately sees to be quite the reverse of the carnal expectations eherished among the Jews. Not the rich, the rejoicing and proud, not conquering warriors nor popuiar fivorites, are the happy under the Messianic reign, but these - the poor, the mourning and meek, the peacemaker, the persecuted. Most of these sayings are therefore striking paradoxes, and the whole forms a singularly felicitous introduction to his discourse, touching a chord that vibrates in all human hearts -happy, luppy-instantly awakening the liveliest attontion, and also conveying important instruction as to the great theme. Luther: "Now that's a fine, sweet, friendly beginning of his teaching amb preaching. For he goes at it, not like Moses or a teacher of the law, with commands and threats, but in the very friendliest way, with nothing but attractions and allurements and hovely promises." It wats also a beautifully natural introduction (Weiss), because he came to preach the 'good news' of the kingdom ( $1: 23$ ), the fulfillment of all the Messianie hopes and promises.

Blessed. Happy more nearly expressos. the sense of the (ireek word than 'blessed.' It is rendered 'happy' in the common version of John 19: 17; Aets 26: 2; Rom. 14: 22; 1 Cor. $7: 40 ; 1$ Pet. $3: 14 ; 4: 14$, and the corresponding verb in Jomes $5: 11$; and this might lie used almost everywhere, leaving "blessed' to translate another term fomd in
$21: 9 ; 23: 39 ; 25: 34$, ete., and a kindred word in Mark 14: 61; Rom. 9: 5, ete. Our 'happy' could not, it is true, be applied to Gol, as in 1 Tim. 1: 11; 6: 15) (Bib. Un. Ver 'blisstul'), where 'blessed,' though familiar to $u s$, is really also inadequate. But more is gained than is lost by keeping the terms distinct, for the difference is often quite important. The shock which many persons foel at the introduction of 'happy' here, is partly at reproduction of the surprise felt by our Lurd's first hearers-happy the poor, happy the momeners, ete. - the paradox is really part of the meaning. 1 The sense is quito similat (and the same Greek word is used) in 16:17; Rom. 4: 6-8; 1 Cur. 7 : 40; James 1: 12; 1 Pet. 3: 14; Rev. 14: 13. The original has in this ease no verb-not 'haplyy are,' but simply 'happy the proor,' ete. So in the Greek of. Psil. 1: 1, ete. The poor. The Jews looked upon wealth, being one of the chief elements of worldly prosperity, as a sure proof that its possessor was the object of God's favor. an error which our Lord subsequently sought to correct in the parable of the rieh man and Lazarus. (Luke 16:19.) In like manuer they no doubt supposed that in Messiah's kingdom the rich, the "better elass," would enjoy the highest privileges. In striking opposition to these expectations, he says, 'Happy the pror, for theirs is the kingdom of heaven.' This is atl that Luke (6: 20, lit.) gives; and certainly the poor were wore likely to share the privileges of the Messianic reign than the rich, because more likely to be humble and looking for Messiah s coming. ${ }^{2}$ (Comp. 11:5; 19: 23;
1 The distinction between macorios and onlogeftes (and kindred terms) is matutaned throughout the sept. as it is in the llebrew works. The Pesh. Srriac rersion of $\mathrm{N}$. T. 1 ranslates 'happy' here and in 11:6; $12: 16$; 16: 17; 21: 26, and nses 'blessed' fur exlogemenos in 21 : 9, ete. The ciothie likewise maintans the distinction. But the latin versions used beatus for looth the (ireek worts, probably for two reasons; (a) beatus really means happy as well as besscd, (b) the other Latin word felir hal joblatrons associations, which would have made it ineongruous in seripture, somewhat as 'Aneky' would be now. But this confounding of the' two fruek words in the Latin versionshas eaused much monfusion in modern buropean versions, and great arbitrariness of rendering in lhe early English versions. Tyndal. used 'happy' in John 13: 17, ete, followed hy Cranmer, (ieneva, and King James; hut Tyndale also usted it in Mat1. 11:6; 16:17;21:46; (ial. 4: 15; James 1: 12,25 , followed by Cramuer or Geneva, or both, but not by King James. Neither rendering is in our passage entirely satisfactory, but 'halpy' hest conveysthe ilea.

2 Some (Gill, of hers) take the word ptorhos in its enmmon elassical sense of heggar, and understand those who come to God as beggors. Tertullian onee expresses that view: "Iraply the beggars-for so requires the meaning of the Greek word." But it is very unlikely that such is here the meaning. Plochos is in the N. T. the emmon word for poor, being found thirty-five times, while the other word penes is found only in '? (or. 9: 9 (from Sept.) and penichros in Luke 21: 2 . In the sept. prenes is usul nearly as often as ptochos, and for the most part to transtate the same lfobrew words. These facts forbid insisting on the distinetire elassical sonse of beggar in every $\mathrm{N}$. T. passage; and in the present ease it seems quite inappropriate to int roduce the notion that they beg. 
4 IBlessid wre they that mourn: for they shall be comforted.
4 I Blessed are they that mourn: for they shall be comitorterl.

1 some atuctent authorities trauspone ver, 4 and 5.

Lnke 4: 18; Isa. 61: 1; 66;: 2; James 2: 5; and below an v. 4,5.) But while men need not, they might misunderstand or misereresent this gemeral term (as well as 'hunger,' "weep, in Luke ti: 2l.) Thus the Emporor Julian mockingly said he wished to contiscate the provery of the Christians, in order that as porr mon they might enter the kinglom of hearen. Now Jatthew's acoomnt shows that our Lurd touk pains to detine more precisely what loneant, by saying the poor in spirit. Poverty, want, sorrow, do not of themselves sorure spiritual blessings; these are promisol to such as have the corresponding state of thought and fieling. The grammationl construction 'porr in the spirit' is the same as in 'pure in the latart.' (1.8.) The meaning may be (Bleek) (a) "porr in the (sphere of the) spirit,' in spiritual matters, or (b) 'poor in their spirit,' comsciomsly pour. Probably the tormer is hare meant liy the plorase, while the latere thomght is sugerested by the enenection. The poore, not antwarly only, but in the inner man; not in the tomporal but the spiritual sphere; and it is inrolved, in the mature of the case, that they are conseious of their spiritual destitution (comp. Isil. liti: 2, anel contrist Rav. 3: 17). Those who in the sploere of the spirit, in the spiritual lifie, are destiute, and tion their need. I gowl example is the publican of the parable. It is quite posible for a man rich in the temporal sphere to be at the same time poor in spirit. ' Ellersb. quotes firom the Mishna, "Lver be more and more lowly in spirit, since the expectaney of man is to beeome the foud of worms," and "alls it the

Barnabas 19: 2 has the same grammatioal eonstruetion: "Thou shall he simple in hears aucl rich in spirit." Many Fathers understoml our larrt to mean pour by free will, eontentedly or voluntarily pour, and some applied it, ats most Romanists now (h), to mumastie sows of poverty, and the like. But 'spirit' will not yield this (Maldom, in rain fuotes 26 : 11 ), and the able Romanist commentator Arnoldi calls it a manifestly artificial iuterpretation. 'Poor in intelfert,' weakminded, was amtler of Juhan's jests, and is gravely proposel hy Fritzsche and firmm, but seems to weel no refutation. Achelis makes it poor in the matter exact counterpart of' thi so sing. "marking not the optimian, bat the pensinism of liti"." For. It would bes a little moler axact to leop der "because' in all tho beatitudes (sea on $v$ 12). Theirs has in the original an empluatice position; it is theirs, they are preasely the

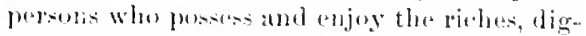

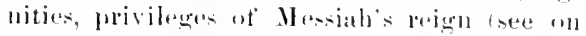

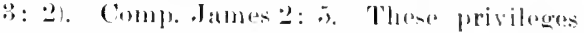
alreaty belong to them, and shall henceforth be enjoyed by them-notice the tutule temse in the following sentences. How dillerent is all this trom worldly kingranus. In Lule to: 24 , is recorrad the opposite of this fir-t beatitude, "Woe to you who ara rich, firr you have reorived your emolation," have all the comsolation you will get.

1. The regular gradation which somes andeaver to puint out in the several beatitudes is artificial, if not imagrinary. Thryale-imply eroupe I in a natural way, and the traturtion trom the pour to the mourners is natulal enough." (Bhserve (Tholuck) that the thre* tirst classes, pone, mourning. meek, aro all in the prediction af Isa. \$1: 1-:3, to which on Loral repeatedly roforreal as fultillal in his ministry (11: 5; Luke 4: 17-21).

Happy they that grieve, is a very striking paradox, suited fo awaken attention and iead to retlection. 'rhey that mourn, wrer any of the dis reses of life. temporal ar spiritual; but with the impliation that if over temporal distresses, they monrn in a rolierions spirit. Coder the reign of Maniah they shall be comforted-the kind of combtort corresponding of contes to the lind of dintmes, and suited to their highest good. The secund part

of the Holy -pirit, pour, and thus fropared to receive

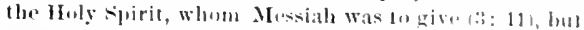

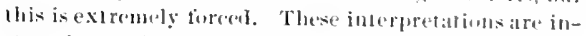
structive as showing that the expression is really ditfi. eult.

g Tivel. and others transpose r. 4 and 5, putting the meek firs, aceorling to I, Iatiu, (lal syriac, several Fathers. This group" uf "We'stern" atuborities is now well known bo entain many arbitriry allerations of the toxt. The design of the alterition here probably was to bave the meek come next to the pour in spirit, as an appropriate sequence. 
5 Blessed are the meck: for they shall inherit the earth.

of Isaials begins (40:1), with 'comfort ye my people,' and is pervaded throughout by that idea, it being distinetly declared (61:2) that Messiah is to comfort all that mourn. The later Jews caught this conception, and in the Talmul the Messials is sometimes called Mrmahem, 'comforter.' At the time of his birth some truly devout ones were "waiting fur the comsolation of Iorael.' (Luke 2: 25.) They is emphatic, and so in v. 5-8. In Luke 6: 25 is recorded the opposite of this beatitude.

5. The sayings of this varse, and of $v .7-10$, are wanting in Luke's brieter report. The explession here used is derived from Psa. 37 : 11. The Heb. word for meek and that for 'pow' are from the same root, and cortainly' meekness is akin to poverty of spirit. Our Iord declares that not the ambitious and arrogant, the irascible and violent, sueh as usually become prominent in tho outhreali of revolutions, are the happy under Messials's reign, but the meek. The term 'moek' is bard to define, in Heb., Greek, or Eug., but it includes freedon from pretension (1 Pet.3:4.15), gentleness (11:23; James $3: 13)$, and patient endurance of injury-where it is proper to endure. The Mosianie king himself is meek (21:5), and the meek shall be his hapuy subjects. Shall inherit the earth, or, land. ${ }^{1}$ It was promised to Abraham that he should "inlerit' the 'land' of Canamn. (Gen. 13: 15;15:7, etc) This was partly realized by Jis descendants under Joshual. (Judges $2:$ in in the lleb.) Their possession of it was always imperfeet and sumatimes interrupted, but still they ehe rished the promise made to $\mathrm{Abrah}$ bum, amd hoped for its complete fulfilment. The Psirnist distinguishes two classes in Isral, the wioked and the medk; those who amid all trials melily trust and serve (rod, and declares $\left(P^{2} \times 3,37: 9,11,29,29\right)$ that these shatl 'inherit the land.' Isalah promises (57:13:60:21, that after the captivity those who trust in crod shall 'inherit the land.' 'The apocryblat story of Tobit represents devont Jews during the ealptivity as cherishing tho hopre that the seed of the patriarels shall 'inherit the land.' (Tob. 4:12.) And just as the 'kinglon of heaven'
5 Blussed are the meek: for they shall iuherit the earll.

(v.3) takes in our Lord's discourses a higher and more spiritual meaning, so with this phrase. The meek shall be full eitizens in the Iessianie lingdom (like these holding real estate), enjoying all rights and privileges. This would of course men especially religious privileges (com). "inberit the kingdom,' in its full and perfected state, $25: 84 ; 1$ Cor. 6 : $10 ; 15: 50 ;$ Gal. $5: 21 ;$ Eph. $5: 5$, ete.) The explanation that Christians shall have as much of the earth as is really desirable for them is superficial, and the other, that Christianity is finally to take possession of the whole earth, is artificial. The $O$. T. and the N. T. usage seems to leave no doubt as to the meaning. The poor in spirit, the mourners. the meek, obviounly represent kindred traits of character, and should not be conceived of as three entirely distinct classes of persons. So as to the other beatitudes.

6. IInnger and thirst. A natural and strong expression for desire, common in all languages. Luke (6:21) gives only 'hunger,' the other term merely expanding the image (eomp. Psa. 6:8: 1) ; and does not say for what. (Comp. above on v. 3.) Righteousness here must not by any means be understood of imputed righteousness, but (ats even Luther adnits) of personal righteousness; the being and doing what is right, as in $3: 15 ; 5: 20$; Luke 1: 75, ete. The attempt (schatf' and others) to make it include both icleas, is futile. It is very doubtful whether the Pauline idea of imputed rigliteousness occurs anywhere in the Gospels, not even in John 16: 10. Filled. The original word is of frequent oceurrence, signifying to feed, to sittisfy with ford, originally used of feeding animals, in later Greek of feeding men. (Comp. in 14: 20; Luke 16: 21; James 2: 16; Phil. 4: 12; Rev. 19: 21.) They who hunger and thirst for righteousness shall, under Messiath's reign, be fed full, completely satisfied. It of course does not mean satisfied once for all, so as to have no desire any more. That is lere true which Wisdom say"s in sirach (Ecclus.) 24: 21, "They that (ait me shall still hunger, and they that drink me shall still thirst.' The Seriptures teach

1'Farth' all the carly Eng. versions except Rheins, and most of the recent versons. Rheims, Heclellan 'land,' Darby hesitates. 
6 blessed are they which do hunger and thirst after righteousness: tor they shall be tilled.

7 Blessed are the mereiful: fur they shall oblain merey.

8 lilesserl are the pure in heart: for they shall see Grol.

9 Blesseat are the peacemakers: for they shall be ealled the children of ciol.
6 Blesad are they that hunger and thirst aftor righleousucss: for they shall be tilled.

7 Blessed are the mereitul: for lbey shall obtain meres.

8 blessed are the gure in heart: for they shall see (ionl.

9 Bleswl are the peacemakers: for they shall he ealled soms ot God. that this satisfaction will be progressive in the present life, and become pertect as we enter upon the perteet world.-Observe (Tholucki) that after rightemsness there follow threa elements of righteousness, viz., pity, purity, pearee.

7. Mereiful. The originnl word includes also the iclea of eompassion, as in IIeb. 2: 17; Prov. 14: 21, and implies a desire to remove the evils which excite eompassion. It thus denotes not only merey to the guilty, but pity for the suffering, and help to the needy. See Luke :3: 11 ; Matt. 25: 37-40; James 2: 13. To be mereiful is not the ground of receiving merey liom God, but an oceasion and comdition t!lereot. (18:33 f.) Comp. the relation between forgioing and being forgiven, as axplained on 6: 12. Thes Jerusalem Talmud gives as a saying of (ramali(ol, "Whensoevor thou hast merey, God will haves merey uprom thee; if thou hast not merey, neither will Gind have mercy upon thee."

8. Pure iu hoart, as contrasted with mere extermal, bolily puritiotion, about which the Jews, and aspecially the Pharisees, wero very

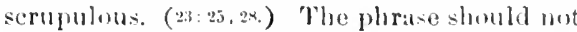
be limited to the absence of nneluate foelings, but includes froelom from all the defiling intluences ot sin upon the inmeg man. Origen: "Every sin stains the soul." The 'heart' in sieripture 11 se is the sout of' thought and will as well as of foeling. (Comp. on ti: 21.) We must shum defiling thoughts, purposes, and feelings. Calvin here understands especially freedom from triekry and cumning. Sio Jautes (t:k) says, "Purity your hearts, ye doublemincled.' A like hreath of meaning is implied in the eommoction of Psil. 24: 4. (omp. tor various applications of the phrase, Psil. 5l: 10; 75: 1; 1 Tim. 1:5;2 Tim. 2: 2.2. The meanimg is thus seon to be very compreluensive, a when wo spak at n pure character, pure motives, ete. There is nothing here said as to the way in which this purity is to be obtained; that was afterwards fully revealed through the apostles. Acts $15: 9 ;$ J Johu 1:7,9; Eptr.5:26:2 Cor.7:1.) Shall sce God. The expression is derived from the laseges of Oriontal courts, where kings live in great seclusiom, and it is a lare and distinguished privilege to be almited into the very presence of the monareh, and see him face to face. See 1 Kings 10: 8; Esther 1: 14; II t). 12: 14; Rev. 2y: : 4, and an equivalent expression in Matt. 18: 10. With lhe whole verse here compare l'sa. "2t: "3t.: "Who shall ascend intes the hill of the Lord? or whoslatl stand in his holy place? Ho that hath chean hands and a pore beart. - It is a kintred, but quite distinet thouglit that we find in 1 John 3: 2 , that of the immediate pereeption and thorengh knowledge of (rod in the future lite, as trunding to make us like him.

9. II we the contrat to worldly kingloms, which runsthrough the whole passigen, is particularly great. In them the highest honor and esteom are given to warriors, but under the Mesianic roigh to peacemakers, those whobring about peace between enemies. It may be taken for errauted that they will bo ponceable in their own dispesilion and contduet, will strive (o) maintain peace as woll as to restore it when disturbed; but that is not included in the mestuing at the word. Wor" isom: "This delightiul beatitude must have soumded like a elaput thumder over the heart= ot some of those who ware reveling in tha imagination that the time had arrivel when war to the bitter end was to be proclanimed arainst the surrounding prineipalities of the Gentiles." It is difficult to determinewhestuer they is here emphatie, as it is in v. 4-8.' The difference would here he slight. Called the children, or soms-of God, as boing like him ( $x$. 4.5), objects of his specind atlections, ete. They shall not only be sons of Gord, but
IThe extermal evilence for omitting antoi (and thos leaving "they" without emplasis) is strong, but mot eonclusive. It is more probable liat the word was inserted by enpyista (1) make this like the other beatitudes than that it was omitted. 
10 Blessed are they which are gerseculed for righteousnoss' sake: for 1 hoirs is llu kiugdion of heavell.

11 Blesed are ve when men shall revile you, and perseente you, and siall sily all mannel of evil arainst you 1 falsely, fur wy sake.

12. liejucer, and be "xcencling arlad: for great is your reward in heaval : for so persecuted they the prophets which wele before you.
10 lilussed are they that bave been perscuted for righteoustuess" sake: for theirs is the kingrom of 11 hoaven. Blissed are ye when men shall jeproach you, and proceute you, aud say all manuer of evil

12 arainst vou lalsely for ny sake. liejoice, and be exceeding glad: tor great is your roward in leaven: for so perseculed they the prophets that were liefore yoll.

I Gr. lying.

shall be called such, reeognized as sueh in his kingdom-not mereres sulpipects of the kingdom, but sons of the king. We need not wonder at this exalted promise to pencemakers, for theirs is a very difficult and very noble achievement. They must often be content to bear bitter emplaint from both sides, must axereise great selt-eontrol, unwestried pattience, and loving tact, and must be manifestly impartial and unselfish. There is no more Godlike work to be done in this world than peatermaking.

10. They which are-or, that have beenpersecuted, the form of expremion aceording with the fact that the chief rewards of such sufferers do not so much attend on the perseeution as follow it. The expression obvionsly points forwarl to the persecution of his followers, hut it is well to remember that at the probable time of his delivering this diseourse, Jows himself was alrealy beginning to be bitterly hated and reviled, and his life sought. (Luke 6: 7, 11; 3ark 3:6.) Persecution usually involved taking away one's possessions, leaving lim in powerty and want; and so theirs is the kingdom of heaven is here a manifextly appropriate form of blessing, as in $x$.?. Comp. Hob. 10: :4. (krys.: "Although he gives different names to the rewards, yot nothing ase but the kingdum deres be shatew ont by all these silvings." Aleramler: "Thus, by a beantilul reituration of his own exprossions, he comses back to the point from which he started, in declaring for whose sake his kingdom was to be croreted, or of whom it was to bo composed. Not the rich, the gay, the firee, the full, the running, the warlike, (1) the favorites of earthly rulers, were, as sueh, t; be distinguished in his kinglom; but the poor, the sorrowfil, the meek, the hungry, the sinere, the preacetul, and the persented, who endured all this for his sake, and who

I Nany authorities add rema, 'pery evil word' but this is protably not geunine. It makes no ditlerenee in the meaning. longed for spiritual no less than for secular relief." - An addition to the text, said by Clement of Alexandria to be made by some, suggests a pleasing thought: "Happy they that have been perseeuted for $m y$ sake, for they shall have a place where they will not be per-eented." V. $10 \mathrm{f}$. seem to be referred to in 1 Pet. 3:14; 4:14. Various sentiments of the Sermon on the Mount are apparently alluded to ly James, Paul, and Peter.

11. Here Luke (6: 22) again comes in, having onitted what we have above in v. 5 and 7-10. V. $11 \mathrm{f}$. contain an elaboration and express application to Christ's diseiples of the general dectinntion of $v, 10$. Here for the first time we have the socond person. Blessed, or, happy, are ye. But 'ye' is not exprened by a separate Greek word, and so is not emphatic. In Luke (6:20 fr.) all the beatitudes given are in the seeond person. When would be more literally whenever, $i . e$. , in all enses. They shall revile you, (no emphasis on (they'), is an impersonal expression, like the Eng. 'they say,' or, 'they tell me.' And shall say all manner of evil agaust you, same expression in Acts $28: 21$. Lulie (6: 26] strengthens the promise by pronomeing a woe upon them when universally well spoken of. Falsely is omitted from the text by some critics, ${ }^{2}$ but on insufficient authority ; and the idea it conveys would at any rate have to be supplied, from the very nature of the ease. (Comp. 1 Pet. 4: 1.5 t.) For my salie. Reproaches and cruel treatment endured on some other aecount, however unmerited, are not here in question.

12. Chesely eonneeted with the preceding. Rejoice, and be exceding glad. The tirst is the common word for 'rejoice'; the second a ritrer wovd, denoting great delight and axultation, which is used several times by Luke, John, and Peter. Both words are eom-

2 By T), and old Latin (many eopies), which make so many abitrary alterations; here probably followiug Luke (6: 2:2), as they do twice in $\mathrm{v} .12$. 
bined, as here, in 1 l'ot. 4: 1:3; Rov. 19: $\mathbf{\imath}$, and tongether comstitute a very stronge expres-

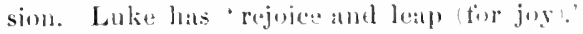
There is a bealliful instance of the anontlus rejoicing under persecution, in Aets 5: 41 . For great is your reward. The fier would be more exactly rendered 'beeatuse, as in all throuther beatitudes. In the next elatuse is the wort properly rentered 'forl.' The form of expresion, 'your reward, implios a dotinita rewart the (irook having an article). designed for them, and kept for them in heaven, literally, the hermes. (Cimus. 25: 34; Col. 1: 1.; ; i P.t. 1: 4; 11 (ub. $11: 20$.) As to the plural. "the hetavens, sere on :?: 2. For so they persecuted they, impersonal, at v. 11. Alfurd: "Fur intanee feremiah was

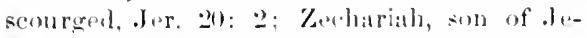

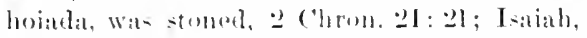
necopting to Jewi-h tradition, wats sawn atunler by Manatiolh." similar reference to prerections is male in Yeh. 9: 26 ; Ifatt.

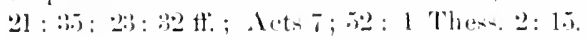
The finct that the prophets were persecuted in like mammer, furni-hes at ground for asouranee that the persils- addetered will be rewarded. They are following the finteteps of the frophete, and hatl, like theme, hate a great rewarl. Comp. 10: 41 : Jatues 5: 10. The rewald is however not merital by the peree-

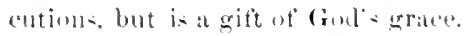

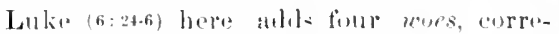
spending to the fourbeatitudes he has recordest. If it les thought that these woulel not enter naturally into Mattluew's connection, wo have to remember that each apparently gires only a sketch of what was satil. (See alwove, In)trot. to the discourse).

It will be ohatered that in IIatthew the word happy occurs nine times; but ate v. 11 is substantially it repetition of $x$. 10. We see that there are eight beationdeg (or matarionas. some exchuld from the entht that of $v$ ste as being ditferent in tone from the others-in order to make junt sopum, the sacred number. But this is utterly arbitrary. In fict the eight, although following eateh other in a sufficiently natural order, have no stibness of arrangement. Our Lord liere, and often elsewhere, speaks with a certain rhythmical movement such as is natural to elevated sentiment; but still ull is inatificial and simple.
HONILETHCAT, ANW PRACTICAL.

V. 1. Sermun and the llount: (1) The preatcher. (2) The heatrers. (:3) The strmm -its leadding thoughts. (H, The eflecet -titted, 7: 28.-PTtER: “All apertolical prowhing of the gonfel must begin wilh the grateinus eommencement ut thi- sermun, the enelu-

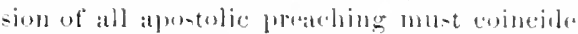
witls ito awtul andelusion: but intermediate lies all that progrendre teatehing atud exhortattion. whicls througl titith in it-fultiller estal)lishes the law in the believer.-Mnetr, amial the awfut splenders of Mount rinat. gave at law which condemns; Chri-t, on the quiet mentain in Galilee, a gu-pel which sares."

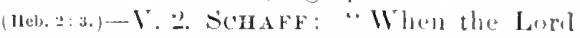

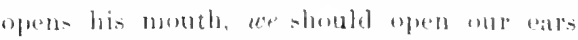
and hearts." - V. :?. In general, the beatitudes teateh that true happines in life depends un elsarated rather than cireumstances-bunsis:

$$
\begin{aligned}
& \text { It's mo' in titlus nor iu rank, } \\
& \text { It's no' in wealth like L, n'on bank, } \\
& \text { To jurediate peace and rest. } \\
& \text { If hajphitess hate nol her soat } \\
& \text { And centre in lae hrobs, } \\
& \text { We may he wise, or rich, or greal, } \\
& \text { But aeverem be hlst.- }
\end{aligned}
$$

A homiletieal chanifination of the beatitudes (many might of conrer be given):

The poor in pritit, the mumpers. the mesk. (2) The hutegring. ote. : and the pure in

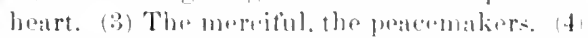

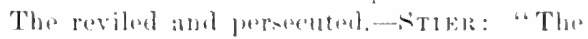
eight Beneetictions, with their comditions, are

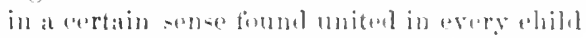
of (rokl and ne member of this womberful series mat be altowether wanting from the time that the first purerty of epirit hats ras epived the gift of grrace yet is there an actual and gradual srowth of ane ont of the other.

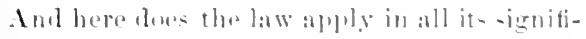
cances, that the gift recerved must be pressorved. exerciod, and incrabell : and that to bim only who ha- hall nure be griven in order to his havingabl."

Cors. a LApInE: "Thope are three surts of poor: (1) thow wto :tre se actually, as beggars; (2) in spirit, but nut alctually-as Abraham, who was rich in finct, joor in spirit: (3) both in fuct ame in spirit." Currs: "As pricle is the fommain of all wirkedne-s, so is humility the prineiple of all self-command." -ETIER: "Oh, that the riehly 
endowed and worldly blessed of our diay, to whom the beginning of the Sermon on the Mount muat come with the full forre of most direct contrast and contradietion, would only mecolkly hear it."

V. 4. Tukophy : "Thuse who mournalways, and not simply unce" (as if it were mourned). - T. 5. Tueorily : : "The meek are not those who are never at all angry, for such are insensible, but these who foeling anger control it, and who are angry when they ought to be. Meekness excludes revenge, irritability, morbid sensitiveness, but not selfdefence, or the quiet and steady maintenaise of rights." The Christian inheritance in the Messianie kingdom, is, like that of Israel (according to the divine plan), a gift directly from God, (Gen.17:x), and therefore (1) inalienable (1.ev. 25: 23); (2) imprerishable (1 Pet. 1:4).

V. 7. T'HeopliyL.: "Not by means of money only are you to be mereiful, but also by words; and eren if you have nothing, by tear's." - In this world of sin and sorrow, there is frequent, nay constant oceasion for being mereiful in one way or another. HENRY : "A man may be truly merciful, who has not wherewithal to be bomntiful or liberal." Cintrs. (eondensed in Aq.): "The reward bere seems at first to be only an equal return; but indeed it is much more; for human merey and divine merey are not to be put on an equality." Silak.:

Metrey .... is twice lblessed;

It blesseth lim that gives, and him that takes:

. . Aud earthly power duth then show likest forl's, When merey seasons justiee.-

-But not merey at the axpense of justice, as teo often in trial by jury- - V. 8. Not merely clean garments, elean person ("cleanliness is next to godliness"), hands clean from blood or pelt, but also cleamness of thought, motive, feceling.

V. 9. Peacemaking. I. Difficulties which the task involves: (1) In our own defects, (ㅁ) in the faults of the parties at variance, (B) in the forlish or wieked interterenes of others. II. Inducenents to undertake the tark. (1) Evils which flow from valiance and strife. (2) Blsused effects of reconciliation. (3) The work is (andlike, and will have God's speeial aid and reward.-While not expressing, this passage maturally suggests the fact that fod is in Christ, reconciling the world unto himself, and 'making peace' (cul, 1: 20, s:me word as bere); and that we also ought to be busy in reconciling our fellow-men to Goel. SHAK :

God's benison go with you, and with those That would make good of bad, and friends of foes.

Corx. a Lapide: "Father Gaspar so excelled in peacemaking, that the lawyers said they should die of hunger."

V. 10. The same persons who are pure in heart and peacemakers may be roviled, and that for the sake of him who was perfectly pure and the greatest of peacemakers.-V. 11. Luther (in Lange): "What comfort that the son of God himself calls us blessed, let whover may speak ill of us." (1 cor.4:3-5.) -Hexpy: "There is no evil so black and horrid, which at one time or another has not been said, falsely, of Christ's disciples and followers." Strer: "The daring disregard of truth witl which the world is wont audar ciously to calumniate the children of God, the Satanie cumning with which its lies are woven, would be altogether incredible, if it were not matter of fact." Plunptre: "The witnesses for unweleome truths lave never had, anywhere or at any time, a light or casy task." Griffiril : Violent outbursts, indeed, of ill-will are now but rare. Culture has softened manners, and made ferocity illbred. But the native dislike of falsehood to truth, of worldliness to godliness, of evil to good, still dwells in the heart; it oozes out in bitter, though quiet drops; it leaps forth sometimes in words which, though smoother than oil, are ver." swords." $-V$. 12. It is often a melancluoly consolation in time of sore trial or temptation to remember that no trial has taken you but such as is common to man (1 Cor. $10: 13$.)

13-16. Influente and Responshimat

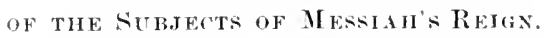

The influence and consequent responsibility of Christ's disciplos see Analysis in the Iutroduction to this discourso) are here exbibited by means of two figures, salt and light. The genoral thought is that they have a great work to do, and persecution (v. 10.12) must nut eause them to negleet it. Several of the charalcteristics just aseribed to them, as meek. preacemakers, porsecuted for righteonsuess' sake, pertain to their relation to others, and qualify for useful exertions and influence. 
13 St are the salt of the earth: but if the salt have lost his savour, wherewilh sliall it besalled" it is thenceforth gool for nolhing, but to becast oul, and lo be irodden uuiler foot of men.
13 Ve are the salt of the earlh: tut if the salt have lost ils savour, wherenith shall il lie satted? il is thenceforlt good for nothing, but lo be east oul and
13. As salt preserves things trom corruption and deealy, so it is the office of Christians to preserve the mass of mankind from utter moral corruption and ruin. Some bring in also the idea of salt is seasoning-that Christians are to save life from being stale and flat -lut this seems strained, and little in harmony with the general tome of the discourse. Othersay (Grimm) that salt of the earth must mean some saline fertilizing material, but this is forbidten by the next elatuse. - There is no propriety in restrieting the saying to ministers, as is done by some Fathers, by Romanists in general, and by Calvin, (xill, andother. Jesus meant the 'diseiples' (v.1) as distinguisled from the world in general, but not particularly the Twelve; ecrtainly Matthew amnot have so understoud, as he has not yet mentioned the Twelve; and nubody thinlis the Beatitudes were addresed to the Twelve more than other disciples notier the 'you' in v. 11, 12). A minister's calling gives him special inHuence, but so will another diecille's wealth, social or official position, talents, attaimments, ete. - Notice (Mey.) how the expressions used for mankind correspond to the intages; the salt of the earth, the mass of mankind to be penetrated and preserved; the light of the world, the expanse over which it is to shine. Ye is expressed in the Greek aml so is emphatie (in v. 14 also). You, the often poor, persecutind (v. 10-12), aro of great importance to the world, and must fullill your duty to it. Are. Alromly true of the disciples aldressed, and a prermanent fict as to Clirist's disciples in general.

But this high office of Christians is by no meats to become an occasion for spiriunal pride; rather does our Lord procend to show the evils of tailing to exert the salutary in fluence in question. Have lost his-rither its-savour, become tasteless. For 'its' instead of the old neuter pussessive 'his,' see on 24: 32. The sume idlut is expressed in Marli 9: 50, by 'lost his saltnes.' I If. Cnti] lately there was hardly satistactory evidence (schöttgen) that this ever actually happens, and commentators generally held the expression to be a more supposition. But Matundrell's statement (abut $A$. D. 1690) that be found south of the Dat sea maseres of salt that had beeome tatsteless, is now supported by Thomson: "It is a well-known tact that the salt of this country [Palestine], when in contact with the ground, or exposed to min and sun, does beeome insipid and useless. From the mamner in which it is gathered, much earth and other impurities are necessarily collected with it. Not a little of it is so impure that it camnot be used at all; and such salt som effloresces and turns to dustnot to fruitful soil, hwwever. It is not only good for mothing itolte, but it actually destroys all fertility wherever it is thrown; and this is the retson why it is east inte the street." "The sweeping out of the spoiled silt and easting it into the strect, are actions tamiliar to all men." soe more fully in vol. ii., p. 361-3. The case -upposed is thus seen to be one of actual and fropuent aecurrence. The application is obrious. Christians must perform their function, must really serve ats salt to mankind, or they will besorthlessandeontemptible, and that irreovarably. Some, (Luther, ete.), undertand wherewith 2 shall it be salted, impersmally, with what shall salting then be done; hut this is unsuitalle to the connection, for it would require the next words to declare that there is no substitute for salt. In the similar expresion of Mark (9:50) it is clearly peromial; "wherewith will you seasun-or, salt-it?' Maldonatus: "There
J Mathew's word (same in Luke 11: :34) means primarily fomake foolish (comp. v. 22) , and is suset in Rom. 1: 22; 1 (a)r. $1: 20$. A witty saying which loses the sult of wit beomes silly, and suty a renction in the figure salt is said to be made foolish ty losing its saltness. A Greek writer (Wet.) speaks of roots that are foolish, (i.e., insipid) to the taster. So the Latin fatus was sometimes used.
2 "Wherewith' is literally 'in.what, the action being eoneeired in such cases as locatel in that which is the material, means, etc. of performing it. such uses of 'in' are found rarely in linglish, oftener in classical Greek, and quite frequently in llebrew and Ifebraized Greek. Comp. on 3: 11. 
14 Ye are the light of the world. A city that is set on a hill cannot he lijil.

15 Neithar domen light a eandle, and put it under a a bushel, hut on a cuncilestick; aud it giveth light unto all that are in the butse.

16 Let your linht so shine hefore men, that they may see your good works, and ghorify your father which is in beaven.
14 troditen under foot of men. Te are the light of the 15 world. A cily set in a bill eanuot be bid. Neither domen light it lamp, and put it unler the lusbel, but on the stand; and it shineth unto all that are in

16 the house. Even so let your hight shine liefore men, that they may see your good works, and glorify your Father who is iu beaven.

a The word in the origrnal signiteth a measure containing about a pint less than a peck.

is no salt for salt." Luke (14:34) gives the same inage as n-ed in a different comneetion. Good for uothing, literally, has no force or effeacy. Thuse who employ our Lord's image here in suplurt of the idea that the regenerate may wholly "lose their religion," ought to abserve that it would also teach that they can never recovor it. In this case, as in others, a view of the mournful efferts which would follow utter apostasy, is employed as one means of prestrving from it. Our Lord's design is not negative but positive, to arouse his disciples to watchtul diligence and persevering devotion. Many of the Jews who protessed to be very religions, were orthodox and scrupulous without real piety, and the subjects of the Messianic reign must not be so.

14. The same idea is here presented by a second inage, which has a natural relation to the former. Pliny (Wet.): "To all bodies there is notlung more useful than salt and sun." Ve, emphatie, as in v. 13. Jesus (2]sewhere declares that he himself is the Light of the world. (Juhu 8:12;9:5;12:35;1, Jha 1:7 t.) WVe of coursa understand that the light whieh his people emit is really derived from lim. (Eph. 5: 2.) In Plill. 2: 15 they are eompared to the heavenly luminaries; in Jolnn 5) 8.5 the Baptist is called, literally, 'the burning and shining lamp'-which Jesus had probulbly saik before he spoke the Sermon on the Mount. IHere Christians are the light of the world, the source of spiritual light to it, as the sul [John 11:9) is of nitural light. They are the light by means of which the world, the maks of mankind, may see tho things of roligion, may see the truth about Gorl and his serviop. Comp. Wialon, 4: "2t. "The multitule of the wise is the salvation of the world." Ep. (1) Diogmetus, 6, "What soul is in body, this are Christians in the world." - Anything that givos light will be abserved, and Christians, as losing the light of the world, eannot escape abservation if they would. But this thought is presented more foreibly by ehanging the figure. A city that is set on a hill-or mountain-cannot be hid, being thus seen distinetly, on all sides, and from a distunce. Cities thus situated were not uneommon in Galilee-as in most other hily comntries in ancient times-and Jesus may perhaps have pointed to one while speaking; but it is jale to eonjecture which one. The houses were often built (as they are now) of a very white limestone, which would make the city more distinetly visible. The thought piainly is, that Christians acenpy of neeessity a conspienous position, and must be seen. To make it mean "the church," un Mount Zion (Stier, Keil, ete.), is utterly munatural. There is still probably some reference to the persecutions spoken of in v. $11 \mathrm{f}$., which might make the titint-hearted desire to withdraw from observation.

15. And Christians should not wish to avoid being observel, even if they eould. Such was not the divine design in making them sources of light. Neither do men-literally they, impersonalasinv. 11. A-the-bushel, i. e., the one kept in the house. The Greek worl (borrowed from Latin, as it was natural that Poman measures should beeome common in the provinces) denotes a measure containing about a peck; but it is better for us to retain the familiar term, the exact dimensions being of no importance to the idea, which is simply that of eoneealment, and is elsewhere expressed by putting the lamp urder the bed. (Mark 4:21.) 'Candle, and candlestick, are misleading, the thing meant being a lamp and a lamp-stand. Giveth light-or shines. The Greek word is the same as in the succeeling verse. Here, as often, the common version has obscured the connection ly munecessarily varying the terms. The fault began here with Tyndale, and was alopted hy all his early suceessors exeept Rheims-In Lnke 8: 16 and 11 : 30 we find the sane saying (slightly varied) used on other oecasions and with a different application.

16. Let your light so shine. As the lamp which is not hidden but set on the stand 
shines turall that are in the bouse, sol het your light shine betore men, that (in orrler that) I they noty sae, ete. The position of the worels in the Gresk (in which "so' is the firit word), shows the amplasis to be on 'so' and 'shine, aud so' signifies in the way suggestegl by the imstge of the preceding somtences. The incorrect ponition of" so' in Com. Ter. (trom Tymales) encourages the erromeous idea that it nuans in such a way that (at the result) mon may see, ote. Before. Not simply 'for men, for their benefit, as in the preceding clatuse, but betoremen,' in thrir presence.

rhat they may see.... and ghority. There is no propriety in saying that this is merely arpivalent to "that soring. . . they may glority. The passage taaches us to desire and design that mon maty see, bealuse thus the highar object will be secured, their gloritying (iml. (Comp. in i: 1, 3, 4.) Ostentation of gond works, which Jesus afterwards (b:1) so soveresly eondemms, womld be like llatuting the lamp at the dour, instead of simply atting it an its appropriate stand. The shining of the light (omsists in good works. (Comp. Titus is:s.) Junrlor thus to shime, the works must mot merely be morally goul (agntha, as Rom. 1:; :3), but also usorally beatutinl (kala, liere and in 1 Poter :2: 1:3), attracting the almiring attention of uthers. (Acledis.) He dows not say "may glorify you, tor the aroul works of finl's ehildron are all due to hin, and lenee the beholelers ought mot to pritice them, but to ghorify their Fathar. (Cimp. 9: 8; 1 Pater:2: 12.) Fur the phrasir rather. . in heaven, ste on $f:$ : Aleanele: "Thus the siavinur wimbs up this divisinn ot his great discourse, by leading his disciples throurh the lommeliost and most tiuniliar every-tay analugios at anmmon lite. to the sublime and final end of all existrince."

HOUILETHEAL ANI PRACTICAL.

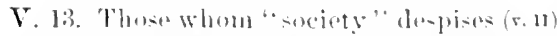
may yet he indispensible to its hiebost woltare. Contempt and reviling must not prevent them trom striving to axurt it wholesomen religinus influence. But if protesed christians be llseless, thwn aro they really despicable. Trimpled on, (a) undeservally (x.11),

IProbal,y nu one wouki now chim that hojes any. where denotes mere result or eflect, as Com. Ver. makes (b) leservedly. (s.13.)-Hr:xkr: "Let Ginl be gloritiol in the shame and rojection ot those by whome he has lisen reproatelesd, and who have made themsalyes tit tor mothing but to botrampled upmo." - T. 1t. Christiansa light to the world. I. What may thry show? (1) That Christianity is true. 12) That Cluristiar piety is practioabla. (a) That a life of piety is desiralole. II. How mal they show it? (1) By what they say-in public-private. (2) By what they do. gumel works. (v. 16.)-V. 1t-1t;. Piety shining. (1) I C'hristian eanmot encaune? observatim it lue womld-a rity on a hill. (2) A Christian should not wish to hide his piety the lature under the bushel. (3) is Christian shomlel show piety in natural and appropriate ways-the lampl on the lamp-otand. (1) A christian should lot his piety shime with no saltish aim. but for the good of man and the glory ut (iond.

Y. 15. ("HnYs. " "Nothing makes a man in illustrinus at the manifestation of virtmo: tir he shines as it (1)al with sumbeams." ('L,E.M. A LEx. Mret.) grives a tradition that Matthias the alpostle used to say that if a pioms

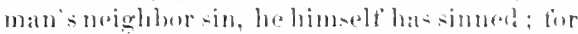

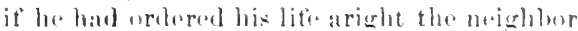
would have been retrainul hy his eximple. - V. 16. Wromeand right way-19 "xhibiting

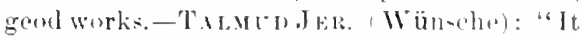
is not emongh to he innewent hefore God, ane must show his innoendee heforemen also." lf Christians alo ovil works, ngen will bo

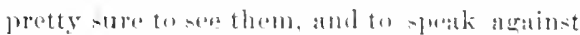

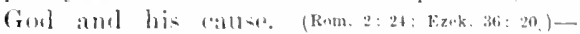
Rolsista (irithlo): "Ah! what an argamant agatust the moluliever is the life of the Christian! No, man is nut thes of himente; something more than lomman is roigning

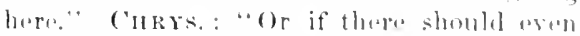
be some who speak evil ot thesesarch intu

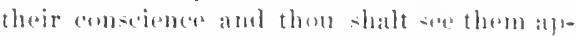
planding and almiring there." NTER: "Thas goud worel withomt the groml walk is of no

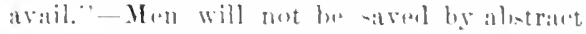
truth, but by trath imbuthed, 1 in a per-umal

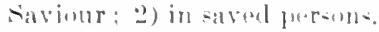

No Christian has a right to he regardlese of his reputation, fior not himseltalone is eoncormed. He may juateine it matere little for him what men may think, since frod knows

il, the meaning beimg purpuse or design. Anothur important example is in Luke 16: 26. 
17 Think not that I am come to destroy the law, or 17 the prophets: I am not come lo destroy, but to tulfil.

Think not that I came to destroy the law or the

his heart; but in su far as men do him injustice, they fail to renter that glory to God whith his good works ought to secure; and so, out of regard for the cause with which he is identified, be should not suffer himself to be misunderstood or misrepresented, where it can bearoided. - This passage, v. 13-16, should lead the Christian reader at once to tremble at his reponsibility and to rejoice at his privilege. How much harm we do by our ineonsistencies; how much good we may do, the least infuential among $1 \mathrm{~s}$, by simply being what we profess to be. TrREE ("The Living Epistle"): "Ot all moles of ineuleating Christianity, exenplifying it is the best. The best conmentary on the Bible the world has ever secon is a holy life. The most eloquent sermon in behalf of the gospel that the world bas ever heart is a uniform, active piety. The best version of the written truth that has ever been made is a consistent religious example. The Christian whose light thus shines not only correctly renters, but beautifies the sacred text.... While the truth is being road from the Bible, and proclaimed from the pulpit, lctall the menibers of our eburches second and enforce that truth by the silent eloquence of boly lives, and the world's conversion will move forward at home and abroad, with primitive speed."

17-26. Relation of Christ's Mission TO TIIE LAw.

Hore commences the main division of the discourse, in which our Lord shows the relation of his mission to the kaw of Moses; and asuerts that, so far from proposing to ralax its restraiuts or overtlirow its authorify, he tame to complete it. This portion, which is mut given by Luke, extends to 5: 48 (see Analysis in Int. to eli.5). The relation to what precedes, though uot distinctly indicater, is sufficiently plain. Having set forth eartain elar. acteristies of the suljeets of the Massianie reign (v.3.12), and their influence and roponsibility (13.16), he now procesels to show that the Messinnic reign will in important respects be different flom what was popularly expected.

17. Think not. (For the ('xpression conp. 10:34; 3: 9.) The Jows were very likely to think su. The introkaction of Massial's reign was in the view of many to be a great political revolution, such as is apt to be attended by a setting aside of many institutions and laws, and a diminished regard for the restraints of morality. And it appears from later.Jewish writers that some of them did in fact expeet that Messiah would abrogate the law, and supported the notion by their interpretation of Jer. 31: 31. Many might also begin to think that $J$ esus cherisled some such revolutionary design, from the fact that he had already (as we see from the order of Luke and Mark) called a publican to be one of his imnediate followers, and aten with publicans and sinners (Luke 5: 27.32), declared that he was introducing a new orler of things (Luke $5: 36.39$ ), and repeatedly disregarled the Jewish notions of the Sabbath. (Luke 6:1-11.) These things appeared to them revolutionary, though we know they were not contrary to the real spirit and design of the Old Test. I an conne, or, came, an expression frequently employed by Jesus, indicating that he had a mission (comp. 9: $13 ; 10: 34 ; 1$ Tim. 1: 15, etc.), and which naturally accords with the fact of his pre-existence; but it must not be relied on as a proof of his pre-existence, for the sume expression is applied to John (see 11: 18f.) To destroy. In the physical sense, the word signifies to loose, dissolve, pull to pieces (as a bridge, wall, house), and is applied to the temple in 26: 61 and $24: 2$ ('throw down'), to the body regarded as a house in 2 Cor. 5: 1, and is figuratively used in Rom. 14: 20 und Dets 5: $38 \mathrm{f}$. ('come to nought' and 'overcome'). So in Gal. 2: 18, Paul uses this word t" describe Peter as having (so to speak) pulled down an old building as useless, and now gone to building it mp again. In like manner here the inage is most probably that of a building. There is no other eximple in N. T. of this precise use-pulling down, abrogating, a law -but it is found in 2 Mace. 2: 20, and in the classies (Grimm). A less irtensive furm of the same verb is employed in v. 19 ('break'), where it is contrasted with 'do' and reters to the practical setting aside of the law in men's action, while here the reference is rather to the theoretical setting aside in our Lord's teaching.

The law or the prophets. This phrase was trequently employed to denote the entire 
Scriptures (i. p..theo. T.), the "law" beingthe tive books ot Mone, and the prophets' the remaimler. (Nere, e. \%, 7: 12; 11: 13; "2): f(); J,1 ke. 11;: 16; Jolnn 1: 45; Acts 13: 15; 28: 2:3; Rom. : : 21.) In Luke 24: 44 it is "the law, and the prophets, and the pathes, the last division probably ine'uding the other poetical bouks. In some other cases the

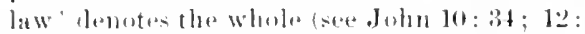
34; 15: 25; 1 (orr. 14:2l.) Observe it is "the law or the prophets.' Not merely were the requirements of Moses to eontimue in foree, (whieh sulne Jews regarded as mores silerod than the rest af the (). T.), but also all that was taught by the othor inspired writers, the prephets. Nopart of the existing seriptures was (1) be set asile. And we know from busephus and early Christian writers, that all Jews of aur lurd's time would umlerstant "theseriptures' or 'the litw and the prophetse" as meaning a well kmown and well defined colleretion of sacrod beoks, the sime as our Old Tretament.

To fulde. The word thus remlered lias besn explained on $1: 2.2$. It here signitios to

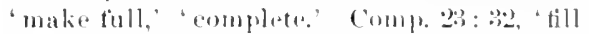
11p the meande of your finthers'; Phil. 2: 2,

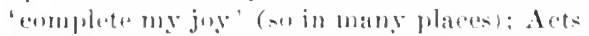
13: 25, "was complloting his courat" ; ('ol. 2):

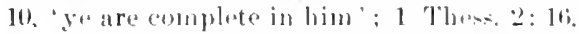
'fill up their sins"; aml so of' completing a mumber, a time, etc. The joleat stome to be that the law is regseded as provions ly inomplote, not thlly developul into all the hroulth

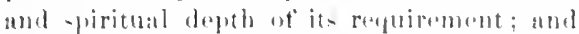
Chri-t eamen to make it eomplete. 'lobe majority of expusturs umblerstand tlas worel ate denoting totulfill is forforming what the law requirel (eomp), 3: 15; Rim). ]:3: 8), But does this suit the eomlowetion? (1) There is a markel contrast to "de-truy, whieh term pretty alearly refers to his teaching. (2) The in-tances whels follow throughout the chapter to illuntrate thin stying, are exprenty exmoples of his teaching and not of his action: smel while that whieh here immosliately fold lows relates to aretion, it is not his aletion, hut that which his tameliners repuire wt others. The thought is, them, not to jurtorm hy his lifi, but to romplete by bis teaching. Inther: "He speaks of that fulfilling which is aceomplished by teaching, just as by "Alastruy ha loes not mean acting comtrary to the law, but breaking with it by his teanhingr," Galvin "The puention hore is af fultilling by taaching. not hy his lifi." And it i- interploted in -lob-

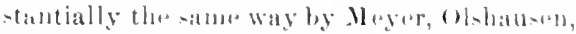
de Wettr, Ewalel, Theluck, Alfird, and ithers. 'The Latin, syriac, and Gothe versiuns, locke

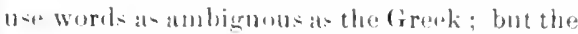
Constie worl alistinctly methe to pertect, complete. Origen, in punting this patsolge on l:3: to, take it tom meatu complete. Jeromedoubt:; Angustine, Themplyl., Euthym., nuder-tambl

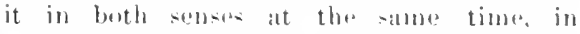
which they are tollowed hy varions nowheren writers (e. g., (iill, Plumpltre), and solne work ont quite a mumber of distimet semase ats includel (f. g., Chrys, Bletek, Wurl-W., ('lark, sichatl.) But such interplestation an-

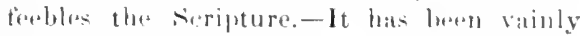
attempterl to bring this saving of Jents in andlict with what Paul teatrhes concelning the law. The latter troats of tho law not as a rule of lite, but ats a motals of justifieation; and he dectares, not only that the law cammot justify anw that Chri-t is comme. but that it never was able to ju-titis. and hente the necenoity for christ's wark. "The law of the Lurd is perferet," sajel the Psalmint, i. e., froe from teferet or blemili-h,

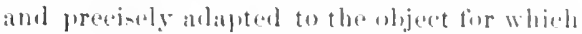
it was given; while vet firs a higher num more spiritual dispen-ation it- primeiples migle be devolopes into erouter eompleteness. This

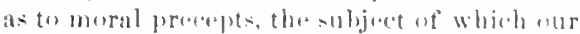

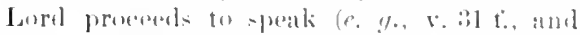
eomplo 19: s. As to typess and problictions. his tearlings and work completed them hy preasuting the full reality to which they re-

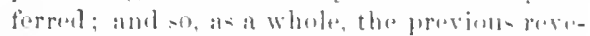

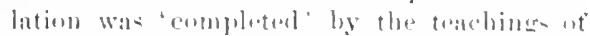
Chrint and his aym-the-.The illea still sulbu-

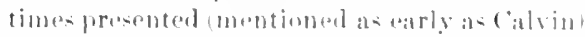
that ofesis was a revolutionary retiormer, wit-

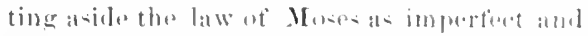
etfete, is contrary to tha whale spirit of thi-

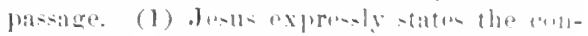
trary-be same nut to dertroy hut tu romeplete and enmpleting is very ditlerent f'roll

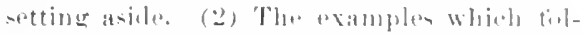
low in this chapter are mot examplen of

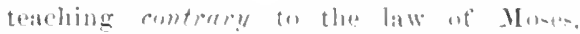
lust of going inether in the seme diteretion. The anly siving he comlenens is 'and hate thine enemy' (v.43), and this was. 
18 For verily I say unlo you, Till heaven and earth pass, one jot or ome tiute shall in no wise pass from the law, till all be fulfilled.
18 prophets: I came not to destroy, but to fulfil. For verily I say unto you, Till heaven and earth pass away, one jot or one tittle shall in no wise jass away not from the law, but a Rabbinical addition. In 1!: 8 is only an apparent exception (see note there). (thrys: "Let us now ask those who reject the law, Is 'be not angry' contrary to "do not kill'? or is not the one the pertecting and filling aut of the other? It is manifest that the one is a completion of the other, and is the greater for this reason. For he that is not earried away into anger, will mu(r) more abstain from mureler."

18. For, presenting what follows as a confirmation of what precoles. Verily is in the original 'annen,' a Heb. word signifying firm, fathtul, reliable (comp. Rev. $\because:$ 14), often employed in O. 'T. as an adverb, 'surely,' 'truly, and then usually placed at the end of a sentence, either as endursing its assertion ('so it is'), orexpressing the wish that it may prove true ("so be it"). When thus used at the end of a sentence, our Eng. versions both of 0 . T. and $\mathrm{N}$. $T$. retain the Heb. word Amen, and also in a few cases where with the same meaning it precedes the sentence. (Jer. $2 x: 6 ;$ Rev. $7: 12: 19: 4 ; 22: 20$.) Nutice particularly the responsive use in 1 Col. 14: 10; Rev. 5 : 14; comp. Deut. $27: 15 \mathrm{fl}$. Our Lord frejuently employs the term at the beginning of a sontence, in the literal sense of 'surely,' 'truly.' and in these cases Eng. versions tramslate it "verily" (i. e., truly). In Joln it is always doublod, hut single in the other Evangelists. Two molified forms of the Hob. work are similarly employed in Josh. 7 : 201; Job 19: 5. I say unto you, is a formula rery often employed by our Lord, with or without 'verily' if. 9., v. 20, 26; $0: 2,5$, 16. 24; 8: 10, 11, ete.), and serving to (all attention to what follows, as being important anl eortainly true, somewhat as in collorgual English wesay, "I tell you," "I asinge you,", "tr. In these cases ' $I$ ' is not separatoly "xpressod in the Greek, and eomsequently is not cmphatic; but it is separately expresede and therefore emphatic in v. 22, 28, 32, 34, 39, 44, where there is a contrast between his teachings and those of others.

rill heaven and earth pass away, is a proverbial expression which would popularly signify never, and is probably aesigned to be so understood bere, the true limit of the law's continuance being given in the other clause, till all be fulfilled. In $24: 35$, the same iklea is explessed only the more strongly by departing from the proverb- Hearen and earth shall pass away, but my words shall not fass away.' Comp. also Luke 16:17. In like manner the Midrash on Genesis (Wet.) says, "Everything has its end, heaven and warth have their end, one thing being excepted whicli bas no end, that is the law." Jot, in the Greek iota, signifies the Heb. latter iod (pronounced yōl), corresponding to the Eng. $i$. It is mueh smaller than the other Heb. letters, so that it is liable to be overlooked; and besides, in many words it can be either inserted or omitted without affecting the sound or the sense, somewhat like the " in favour of honour. The Midrash on Leviticus says (Edersh.) that the iod which was taken from the name Saraj was prefixed to that of Hoshea, making. Jehoshua, Joshua. No part of the law, not the most insignificant Tetter, was to be set aside. And this statement is further strengthened by adding titte, -in the Greek 'horn,'-denoting a very slight projection at the corner of certain Heb. letters, which distinguishes them from others that are rounded. ${ }^{1}$ Comp. Luke 16: 17. The word 'horn' in this sense would not be nuderstood among us, and so 'tittle' (a very small object) was wisely used by Wyclit, and retained by all subsequent trabslators. The whole expression has heen aptly compared to our Eug. saring, "Not the dut of an $i$ mor the cross of a $t . "$ We also frequently ("mploy in the same way the Greek ioto (same as iod), "Every iota of it." The Rabbis have similar "xprosions, but they quilble about the mere worls, while our Lord rofers to the meaning. In un wise, is, in the original, merely a domblud and thus strong negative, the same as in lohn ti: 35 . From the law. He does not add 'or firm the jrophets' ; and it is ot the law that he proceeds to speak in r. $19 \mathrm{f}$., and in the examples which follow; yet he had in v. 17 coually affirmed the permanence ot the 
19 Whosotser therefore shall hreak one of these leatst

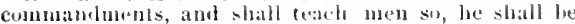

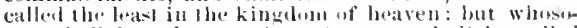
ever sliall do and hated th'm, the sallue shall be ealled great in lbe kingelent of heaven.

20 Fur I say unlo you, That cxeept your righteousness sball excecel the righteotsuess of the scribes and l'harises, ye shall in un ease enter into the kingdom of hearen.
19 from the law, till all thiuss bw accomplisined. Who-

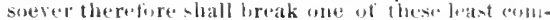

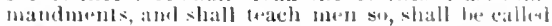
lowat in the kingdom of heaven: hut whonever -hall

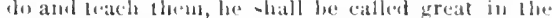
20 kimplom ot hoavesl. For 1 sily unto you, that exeept

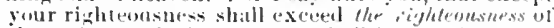

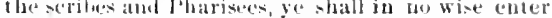
jute the kilgalon of heaven. prophets. and a reforence to them seems to be sugereted in the expression which here immethately fisllows. Till all be linlilledar, come to pass. This is not at all like the worel rendered fultil in $v .17$, but is the one remdered 'emme to pass' in 24: 1;, sese on 1: 2.2). Sot the smallent part of the law shall ba- away till werything i. e., everything it (ontains) shall (eome to pass. The things prodicted in the law must all oecur; the entire subsance foreshadwwed by ang ceremung or type must have come intorexi-tence; the avil regulationz for the. fewish sitate, atter lasting while it latets. nust continue to serve as the germ and basis of much Christian logislation; the moral (ethieal) precepts munt be obeyen by every new generation. Not till all this has taken place, shall the least particle of the Jaw be ammulled.

19. Therefore. As all rematins in undiminished force, it is a sin to violate, or to teach others to violate, one of its loast enmmandments. Break. It is a eompunnd ot the worl here used that is lemelered "destroy" in v. 17. 'This word signities to 'loose, atul as afplied to our atetion in rearal to a law, it would mean to lowse the obligation of the law, viz., by ateting antrary to it. whinh we in English call breating the law. In $ง .17$ it was to loose or pull down by teatehing ; lout here the "twath' is expresed sepatritely, and spoken of as correpomeling $\left({ }^{\circ} \leq 1^{\circ}\right)$ to the loming. (c)mp. Jubn I: 2:3; 10: 3,5.) One of these least commandments. The. Jews

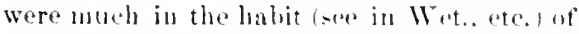
classitying the various commonambunents as greatrer and lese (22:36), sumetime comparing those whieh they reckoned leat to the smallest lettersot the alphabet. Surbali-tinetion was natural in regarel to external rites, even as

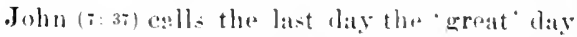
of the Farst of Tabernacles. And althongh they male unwarranted and artificial distinctionseven among moral duties, fot thesaviour dues here clatarly rocosuize some commandments as less impuatant than others, while expresily declaring then to be not unimprt-

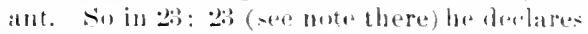
ethical duties to be "weightier" thau the duty" of tithing herh-. Aud shall teach men so. It is bad to de whong, but worse if in aclelition se teach others to do wrong. Called. Xot only shall be sueh, but slaall be sil called, $i$. e. declared, recongized to be sueh. (Comp. on 5: 9.) Least ... great, shatl have the lowest place, or a high plate, in Christ's kingelom, in point of dignity and privilege. (Comp. 11: $11 ; 18: 1,5$.

20. For. This sontence gives a pronf of the previous statement. You may readily se that he who tramegreses one of these leatist commandments shall have a low plate in the

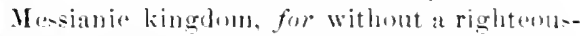
nexsurpaning the sicribes and Pharisees. Fun sall have no plate in it all. Comp. 18:4. I say unto you, serent v. 18. Except. Thless (Ditudarm, Darby) is better in modern English. IRighteousuess. Notimputerl. hut

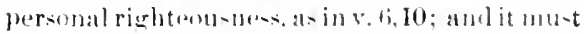

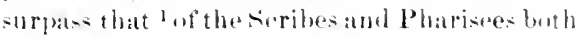
in aregree and in kimb, must be a more spirit11:1 and free (James I : 25), and a nore complote righteounness. ats illustrated at length in the

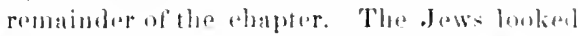
upon the sereribes and l'harisess as heing aminently righteous, and doubthes dill unt think it ineumbent on ordinary porple to bea-gand as they were: so moleh the more surprieise must have been this deelaration ot . Jusus. Fur the suribes, sce an 2: 4 ; for the Pbarienes.

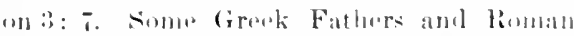
Catholic writers, with Seameler, Bleck, ate..

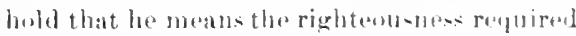
by the law ot Mares (ivbleb law the seribos and I'harisees kept). thus implying that the law did not refuire emough; but this is straimel and unuatural. In no case. luthe Greek simply a strong negative, as in v. In.

I Literally, 'shall "xceel the scrihes and Pharisees', but this is evidently a condensed expression for 'exoeed that of the s. and $l^{\prime}$ '. (Winer, $245[307]$, Butt. 168.) 
21 Ye have heard that it was said by them of old time, Thum slialt not kill; and whosoever shall $k i l l$ shall be in danger of i he juilgment:

2.) But 1 say unto you, That whosoever is angro with his brother without a eause shall be in danger of the judgruent: and whosoever shall say to his brother, Raea, shall be in danger of the collucil: but whosoever shall say, Thou fool, shall be in danger of hell fire.
21 Ye have hearl that it was sail to them of old time, Thou shahi not kill; and whosoever shall kill shall 22 be in dauger of the judguent: but I say unto you, that every one who is augry with his brother shall be in danger of the judgnent; and whosoever shall say to his brother, a Raca, shall be in danget of the eouncil; and whosoever shall say, 3 Thou foul,

1. Many ancieut authorities iusert without cause...2 An expression of contenut....3 Or, Moreh, a Hebrew expression of condemnatin.

Enter into the kingdom of heaven is a thrase often employed by our Lord (e.g., 7 : 21; 18:3; 19: 23; comp. 'enter into life', 18: 8; 'enter into the joy of thy Lord,' 25: 21), meaning to become subjects of the Messianic reign and share its full benefits.

21 tf. Our Lord now proceeds isee Anal. at the beginning of the ehap.) to illustrate the general statements of $v, 17-20$, by instancing various commandments of the law, with the interpretations which the Jewish teachers were atecustomed to put on them, and decharing in every case that he enjoined a still stricter and more invard and spiritual morality, not merely in condemning the prevalent errors, but in more fully earrying out the spirit of the commandments themselves than had been done by the law. This was completing the iaw (v. 17). giving it a deeper and more spiritual application. The revelation given through Moses and tho prophets, though perfectly adapted to its oljects, was in various resprets rudimentary, and now God's son (Heb. 1:2) would develop the whole into completoness. All that he teaches as to moral duties was really involved in the law, but be brought it out, so as to give a more distinct and complete exhibition of its requirments. of the six pxamplas thus presented, the first is the law of MURI)R. (v. 21-26, )

Ye have heard, espreially when listening to the reading of the law in the synagorurs, with the comments and explamations made by the teachers of former generations, whiels, as handed down by tradition, were thro repoated in connection, with the roading. (Com). John 12: 34; Rom. 2: 13.) That it was said by -rather to-them of old time, or the ancients. Every generation naturally rogards its own as modern times, and looks back to long past generations as "the ancients." The rendering 'said by' which Com. Ver. and some able commentators adopt (as Fritz., Olsh., Ewald, Keim), is possible according to general Greek usage, but is altogether opposed to the actual N. T. use (presented by Conant) of the terms and constructions which the original here employs; and the great mass of recent expositors bold to the other sense, "said to.' 1 This will then naturally mean, said by Moses in giving the law (Ex.20:13; Dent.5:17), but may also include the old teachers in their interpretations; and a traditional addition being here given, it seems necessary to consider them included. Some of these traditional nodifiations (see another in v. 43) had come down through several centuries, and might thus be sairl to have been spolien to the ancients. And our Lurd takes his examples from the law as in his day habitually beard and understond. The traditional addition in this case, and whosoever shall kill shall be in danger of the judguent, was jrobably designed by speeifying the proper tribunal to indieate the appropriate penalty. "The judgunent' is generally understood to mean a local Jewish court established in every important town, in accoldance with the command of Deut. 16: 18. (2 chr. 19:5.) It is said by Josephus ("Ant.," 4, 8, 15, comp. "War," 2, $20,5)$, to have consisted of seven persons, though the Pabbins say twenty-three. It inflicted punishment, for eapital crimes, by the sword.

2:2. But I say unto you. ' $I$ ' is here separately expressed in the Greek, nud is therefore emphatic, contrasting his tenchings with the law, and the traditional interpreta-

frintel by Sabatier and Bianehini. Ab antiykis is bere given in a, b, e; antiquis in d, f, If, Ambr. $1 n v, 33, a b$ antiquis in a, c; antignis in b, f, tr, gl, h, Cylu., Hil., Aug. 'This antiguis (whieh is also the reading of the Vulgate) is ambiguous like the (rreck, and so is the resh. Syriae. The hothie gives "to the aneients', and the Coptic what is unmistakably equivalent thereto.
'The rendering 'said by' is not in any ling. ver. before K. J., whioh here (as often) followed Beza, who gives "by," aml defends it at leigth in a note. Many commentators suppose this rentering to have originated with Beza, and Tholuck says it is first foumd in the Persian (Polyglott); it may therefore lse well to state the rendering of the leading old Latin eopies as 
tims. The same contrat recurs in every instance throughout the series, ( $v, 2 \times, 32,34,39,4$, and comg. wa s. 1. ) He "tatught them as one haviug muthority." (7:29.) 'Chat whosoever-literally, every we that-is angry with his brother. The expressinn is somewhat different from that of the preading verse and of the two following elanses in this ver-e, translatol 'whosoever', and lixes attention upun tha idra that the statement applies to every single inlivilual. 'The term 'brother' is probably drawn from the familiar orewish

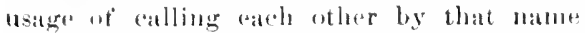
(e. g., in Tobit), but aplears to be meant in a brouder sense, as applying to any fellow-man, just at in Luke 10: 201, th. Jewish restriction of 'nuighbor' is eorrenterl. The lact that all moth are brothers. ageravates the guilt of that angar which our Lord eumlemos. Without cause, is omitted by some of tho oldest atuthoritios for the trext, and loy most of the recont erities. It was probably introduced by students and copyists trom a teeling that the endemnation of anger was too sweeping. But killing ton is sometimes necessury and lawiul, yet tho fommmandment does not say, Thou shalt not kill withunt eatuse. The exception is to be malle, in buth tates, as at matirr of enurse. Raca is an Iramaic wort, most probably signifying "unpty" (.Jurome), as if mes should atl another "moty heat," equivalent to aur blocklerel. Daridion and Noyes tratestate it "simpluaton. It secms to have been a rommon apresion of contenet among the Jews, being uftun so uned in tise Talmud. Fool, is thenglit loy many lats Meger, Grimm) to lue here usal, as in Psa. 14: 1, and other passages of O. T., to denote "wicked man-which would make this a greater repromelo than liacal. But there is no neesesity tor introlucing that ideat here; the satue word decurs, in its communn sell-e, in this diseourse. (7:26.) "F(n)l" is used as an exprowion of contempt in all languages, "evinuine prides of intaleot to be a universal passion." (.llemender.) The werd rendered council, sinnilies here, as enumonly in $\mathrm{V}$. T., the great senate and supreme Court of

10 inttel by+R. $\boldsymbol{x}$ and several eursives, and hy Vulg. and Ethinpie versions, and expresty declares loy severai Fathers to be wanting in "the aceuratte coples," or in "most of the ancient copies." It is fomml in ol, Latin, Oldsyriac, and Coptie, and is therefore a very the nation, which the Jaws (borrowing this (irewk word) called sanhedrin (ste on 20i:

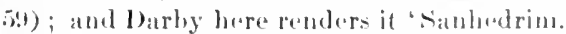
Before this liggluest tribumal Jerus wats tried. IIell-fire, litwrally, the Grhenne of fire. Gitlenna is from two llobrew words, Gri Hinnom, simnifying "valley of Himnon or 'valley of lamentation,' (in 2 lings 2:3: 10, 'valley ot the childrun-sons-ot' Ilimmom' or 'valley ot the soms of lamentation'). 'This name was applied to the valley lying immediately south of Jertastem, emploged by some of the bater kings for the wor-hip of the iolol Molueh. (2 Chrou.2n:3; 33.6; Jer. 7:31.) Nuch ub- ourity still liangs over the ehararter and worship of this horrid idol. Childruen were burned as sacrifices to him (Psas. 100: 3*: .ler. 7:31); but it is not cortain whether they were burmet alive or were tirst shin, the latter seaming tu

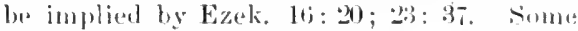
late Rabbinical writers say that IIolocls was made of brass and heated trom beneath, and in its outstretehed arms the infint was lad and barned to death; while drumse were beaten to drown its aries, lest they should "xcite its father'seomparsion-and laenoe, they say, eame the name Tophet (Jer. $7: 31,32$ ) alpplied to " place in this vallay, the II eb. Toph signifying a trum. But this story was rery likely ferived from a similar pratetice atmong the Cartlaginians, as related ly some of tha later Greek bistorian:-the improlubble jelan of the drum being added, marely to aceount for the namo Tophet. Yot whether performal in this way or not. the burning of children at : sacrities to Moloch-prohibited nlready in Lev. 18: 21; 200: 20 tf.-was a horrid almonillation; and when Josials alwhishoel it ha determined to defile the valley of Minnum (or lamentation) which had been its stene, hy

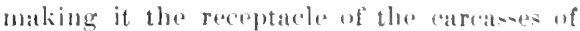
eriminals and other filth from the city $(2 \mathrm{king}$ 23: 10); and this pratetion continued till thotime of our Lurd. Kimehi, an enuinent Jowish - Mbular of the thirtementh conturg. says in his Commentary on the P'salms that tire was kejt constintly burning in Gehinnom to (1) $11-1$ une the tilth und carrasies-a stutenent which :u-

early addion, say by midllat of second rentury. Tyndale, following lirasmus" third fol., has mo such word. Cranmer introulucel it a few years later (1539). Ste plens gives il in 1550. 
counts for the phrase 'Gehen na of fire.' From these repulsive assoeiatious, Gehenna was very naturally employed among the Jews as a desiguation of the place of future torment; being sil used in v. 2y, 30; 10: 28; 23:15, 33; Mark 9: 49, 45; Luke 12:5; James $3: 6$; and 'Gehenma of fire' in 18: 9; Mark 9: 47. The idea of fire is one naturally and frequently associated with tuture torment (eomp. on 25 : 41), and in this ease may be regarded as suggested by the sacrificial fires in the worship of Moloch, if Kimeli's statement be eonsidered too late to be reliable. 'Cast into Gehenna,' (v. 29. etc.), was a phrase naturally suggested by the pratice of easting eareasses into the valley. The Greek is here literally "liable into the Gehenna of fire,' $i$. e., liable to be east into it. Winer, 213 [267].-Another word, Hades, whieh in Com. Ver. of N. T. is often translated 'hell,' will be explained on 11 : 23.

It has commonly been supposed that our Lord designed a climax in the three punishment-_leath by the sword, as inflicted by 'the judguent'; death by stoning, when condemned by the Saubedrin; and the Gobenua of fire.' As to the latter, some have fancied an allusion to some peculiarly ignominious punishment inflicted in the valley of Hinnom, while others understand the punishment of hell, according to the general N. T. use of the term Gehenna. But it is quite diffieult, indeed injussible, to make out any corresponding alimax in the three offences, espe(ailly to show that calling a man 'fool' is immensely worse than ealling him Raea ('simpleton'), as much worse as the difference between being stoned to death and suffering uternal perdition. ${ }^{1}$ These difficulties are avoided by "disearding the idea of a elimax altogether, and explaining the three elauses as substantially equivalent, though formally dissinilar expressions of the same idea, namely, that the law of God forbids not only murder but malignant anger, and it: oral manifestations." (Alerander.) Our Lord is showing that he enjoins a more inward and spiritual morality than they were aceustomed to; and he says that not merely is murder a crime, deserving the severe punishment which the lueal tribunals were wont to inflict, but that anger is a erime, and should be punished too (eomp. 1 John $3: 15$ ); and that the use of words of eontempt is an offence worthy to be punished by the highest tribuual, yea, worthy of eternal perdition. Edersh. represents the sages in the Talmud as decharing that to give an opprobrious by-uime. or to put another openly to shame, was one of those things which deserved Gehenmat. Of eourse all this supposes that the anger and the contemptuous expressions are unwarranted and involve malignant polings. A man may be justificd in being angry with anotber under eertain circumstances, as, under certain eircumstanees, he may be justified in killing another. In Mark 8 : 5, Revised Version, Jesus is said to have looked round upon the people "with anger, being grieved at the hardening of their hearts." (comp. Johu 2: 15); and the apostles tell us to "be angry and sin not" (E,h.4:26), and to be "slow to writh." (James I: 19.) Yet while feelings of indignation at wrong-doing are not necessarily sinful, they are very aly to become so, and need the most caleful guarhing. Especially is anger likely to become sinful if not quiekly repressed; and hence the injunetion, "Let not the sun go down upon your writh." (Eph.4:26.) Comp. Aristotle: "He that is angry for what he ought, and morenver as heought, and when and as long as he ought, is commended." - And so as to using expressions of eontempt. Our Lora calls the Seribes and Plarisees 'fools' in 23: 17, and uses equivalent terms in Luke 12: 20; 24: 25, one of which is also applied by Paml to the Galatiaus (Gas.3:1,3); and the word rendered 'vain' in .James 2: 20 is literally 'empty, and exactly correspouds to Raca. Jesus even used still more opprobrious terms, 'devil,' and 'Satan.' (16:23; John6:70.) It follows that the use of sueh terms of reproach is mot esentially and necessarily wrong, but it is very apt to spring from, or to lead to, wrong feelings, and may thus constitute a great sin; it should therefore be labitually avoided, and prateced only where it is eertainly deserved and would do good. On the

1 some fancy that more, 'fool,' though a familiar here in the Aramaic form, mora, like raka? And then (irrek word, is here really a Heb. word moreh, signify - this word is not greatly st rouger than 'fool,' and would ing 'rebel' or 'stubborn.' (See Tholnck, Alford, stan- not materially lessen the diticulty.

ley.) But would it not in that case bave been given. 
23 Therefore if thou bring thy gifl to the altar, and

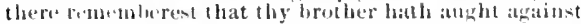
thet:

It beave there thy grif before the allar, and go thy way ; firt the renteiled to thy brother, and then cone and intier thy kitt.
23 shalt be in danger 1 of the 2 hell of tire. It therefore thou art ofleriag thy gifl al the altar, and thele re-

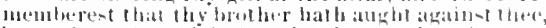

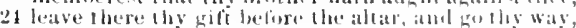
first be roconciled to thy brouher, athd then come and

1 Gr. unto ar into...2 Gir. Gehenna of gire.

other hand, we must remember that a man might scrupmlonsly avoid the use ot the purticular terns 'simpleton' and 'timl,' and still be trequently viulating the spirit of our Lorl's taaching. - Of course if such angry expresions as these are sinful, how antull more sintul is all cursing, a thing wroug in itselt, and for which men sometimes plead as an rexuse, that they were mneontrollybly anery-that is, the very sinful words are exensible beanuse they procesed trom a very sintul fereling.

2:3. Having thus deelared that aecording to his trachings, the principle of the law against murler applies to anger and insult (comple 1 John : : 15), he alde the injunction to becone reconciled to ono with whom we alre at rariane. This sundel bo done at onee, even it it refuides the interruption of a sacerifie (v.23 r.); should be dome while with a platintifl on the way, hefore reaching the court. (v.25f.) Notiee that here, ( $x .23 * 6)$, the singular is ased, "thou, whoreas the plural had been empluyed betore, and is afterwards resumeel. He thus takes an individual ase, as it were singling out one person and aldresing him. und thereby grives greater print to the precept, just as is sometimes dome by all fublic speakers. especially by pracherm. A similat change to the singulat may be seen in v. 29, 36, 3.4, and comp. on 4i: 5 .

Therefore if, presonting the injunction as an inforenee from, or result at, that which precerles. Since the probibition ju-t made extends mot merely to autwarl arts. but to words and forelings of anger and oonternpt, it followes that one unght to sork reconciliation.

Thou briug-or, art offering. This is the regular use of the term, as in v. 2t. Com. Ver. loro fullows Genera in remoloring by 'bring,' hut Tyndale, Cranmer, and Rhrins. had "offerest. Cift, ageneral term, including all kink of otlierings. The nltar, viz., the altar in the inner cont of the tample (soro on 21: 12). Iud there rememberest, therw, while engaged in the most solemn net of the Jewish worship. Brother, see on $v, 22$.
Aught-or, something-against thee. The expresion is no doubtio purpusely male goneral, so as to eovor all casts, everie tho slightest ; ho does not say, is at enmity with there, 'is angry with there, hut 'has suncuhing agaimst thes.' (Compl. Mark ll: 25.) Marly,

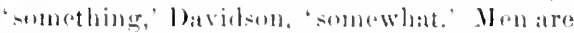
more disponed to remember that they have

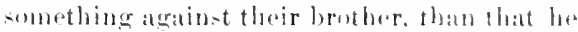
has something agrainst theme. The language implies that in the case supposed the persen adelessod is himself the otliondrel. But the

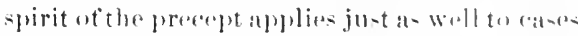
in which we know we have done nu worner. siball we morely be willing to be reseneiled

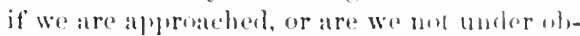

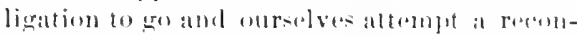
filiation? A man must not sareriflec his dignity, neither must he negreat his duty.

21. Leave there. I) not marely determine that you will go and be resemeilad as soon ats the grift has been offereal. It is forthparatively eats to reoble upon portiorming it

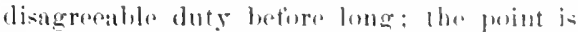
to fuertiom it at onere. Leave there thy gritt betore the altar, and go, first he recomeded to thy hrother, and then rome and atlere thy

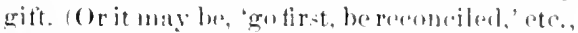
as Jeyer, Ewald, libeli-the (romek heingatubisuons, lut the meaniner in aither case substantially thesame. Alformder" "It ivevident that this is not sugerested as a case at all likely to aceor in real lite or even a a tormal rule to be observed if it shall mentur, hut rather it is a strong assuranee that it would be right and proper thus to act. if these ware no othar means of areomplishing the ond required." (comp on v. 2!!) (Boll wishod his people to show merey, rather than to otfire sacrition. Acts of wor-hip are vory imbertant, hut even an act of workhijemierlat properly be jostgoned that we may re-entabli-h frimally relations withone who has a complatint agatinst 11. It is an ulter misapprohension tortake this precegt as indicating that thore is a speral propriety inseling reconciliation hafore partaking of the Lurd's supper, witl the practi- 
25 Agree with thine adversary quickly, while thou art in the way with hin; lest at any time the alversary deliver thee to llie judge, and the judge deliver thee to the officer, and thou be cast into prison.

26 Verily I say unto thee, Thou shalt by no means eome wht thence, lill thou hast paid the utiermost larthing.
25 offer thy gift. Agree with thine adversary quiekly. while thou art with him in the way; lest haply tlie adversary deliver thee to the judge, and the judge 1 deliver thee to the offieer, and thou be easl into

26 prison. Verily I say unto tliee, Thou shalt by no means come out thence, till thou have paid the last farthing.

I Some anclent authorities omit deliver the.

cal inference often drawn that there is no great harm in postponing reeoneiliation unti? that solumnity is approaching. For (1) the reforence is to temple-worship, and the principle would apply ju-t as truly to any otlier act of public or private devotion as to the Lord's Supper. And (2) the point bere is not that eren though we should delay to seek reeonciliation at other times, we must be certain to seek it when engaging in solemn worship; but that so great is the importanee of being reconuiled at once, whenever the offence is committed or is realled, that even if one remembers the existence of such a personal difficulty when just engaging in worship, he would do well to suspend the most solemn service in order to go immediately and be reeneiled. All the more, then, is it our duty to seak reconciliation at other times. Still, it is of enurse natural that we should be more likely to think of the need of forgiving and being recomoiled when we engage in solemn worship, and so our Lord elsewhere says, (Mark 11: 25, Rer. ver.): "And whensoever yestand priying, forgive, if ye have aught against any one. We are not so much under greater obligation to forgive then than at other times, as more likely then to remember and realize tho obligation.

25, 26. For the connection, see on v. 23. Agree with. Litcrally, be iecll alisposed to (Grimm, Davidson), which sugge ats that we must seek to sooure gond will by showing gond will. Quickly, not after a while, some of these times, lout quickly. Anger is wrong. and angry diflieultios would be sattled at mes. The adversary at law, in the case here supposed, is a erulitor, as shown by $v$. 26. While thou art in the way with him, viz., on the way to the judge. Acerriling to the Roman law, the plaintiff comld carry the acoused with hin before the julge; the defenclant might settle the matter on any terms while they were on the way, but after the tribunal was reached the thing must go according to law. Lest at any time. (Perhaps, or simply 'lest,' as Tyudale and Genera, Noyes and Davidson.) Tou do not know but it will turn out as about to be deseribed, and had better guard against such a result. Deliver thee, hand thee over. And the judge . . to the officer, the intermediate process of trial and conviction being omitted, as a thing naturally understood. And, in that case, thou be cast into prison, an easy change of eonstruction (as in Luke 14: $8 \mathrm{f}$, and often.) Verily I say unto thee, see on v. 18. Thou shalt by no meaus, or, not, the same strong negation as in v. 18, 20 . Farthing ripresents a small Roman coin of brass, equal in value to about two-fiths of a cent, and thus double the 'mite' (Mark 12:42), which Luke has in the other instance of our Lord's employing this image. (Luke 12:59.) The Talmud refers to a similar counsel as proverbial: "There are men that say, while thou art in the way with thy adversary, be obedient." - Most commentators understand this Ianguage of our Lord as referring allegorically to the necessity of being reconciled to God, lest he cast us into the perpetual imprisonment of perdition; while Romanists make it a proof-text for purgatory, and some. Universalists for final restoration (viz., when the dabt has been paid); but the whole comnection (see on v. 23) seems elearly to require that we should take it in the simple, natural sense. (So Chrys., with Theophyl., and Euthym. Jerome, Zwingli, and Calvin, and even Gill, usually so given to allegorizing.) We miglit say that the pasage affords a good illustration of the spiritual truth in question, hut there is no sufficient indication that our Lord hore meant to teach that truth. Cer. tainly the duty of adjusting persmal difficultios, for which speeific directions nre afterwards given (18:15 f.), is one of such immense importance that we may well be content to

' 'Teliver thee, after judge, is wanting in sume of the earliest authorities, and is evidently an addition naturally made by copyists or students. 
regard that as all the saviour is here teaching.

\section{IIO.MILETIOAI, AXI PRACTICAL.}

V. 17, 18. The Old Testament. 1) Its teichings still instruetive, whether they be historical, mereptive, ceremonial, or predictive. 2) Its precepts still binding, with the necessary adaptations to a spiritual dispensation; and its moral requirements made more searel $1-$ ing ane spiritual by the N. T. Callow: "It is of no little avail for strengthening faith in the goipel to be told that it is nothing else than a complement of the law." - The U. T. and the N. T. are neceesary to each other, at parts of one whole. When men leegin by disparuging the 0 . T., they will end with like views of the N.T. Tineorure. "What the law sketehed, Chrint painted completely. The painter does not de-troy the sketch, but rather fills it up." Augustres: "The New Test. lies hidden in the Old; the Old Test. lies unfolded in the New." EvTurs.: "While the law forbids the ends of sins, Christ forbate also the beginnings. For mureler is a froit of sin; but the root of the sin is anger. And unless the root be removed, it will some time or other bear truit." WYkEs: "To the philosophic state:matn, and to the religious reformer of every generation, the best recommendation of what is new will always be that it comes. not to destroy the old, but to fulfill it; to understand its spirit, to realize its purjmes, to earry forwarel its work, and to make exery change an unfoldiog into higher power."

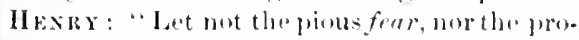
fane hope, that Christianity will destroy the luw."-V. 19. All shomlal both do anal teach. 1) The professed teacher must also be a doer. 2) The lumblest provite Christian must not be eoutent with doing, but also teach. Cusss.: "For on this aceount he limalf las set the doing before the traehing; to intimate that so most of all may one be able: to teately." - Lealet eommambluents. 1) Mlural precepts are more important than cerenumies. (Comp. 7: 12; 15: 11.) 21 some eeremonies are more important than others. 3) What ever Gorl has commanded is important. P. Аноти: "Bu attentive to a light precept ats to a grave, for thou knowest not the anigneel reward of precept.." (Comp. Eph. tj: 2f. with Deut. 22: : 7.) HExky: "It is a dangerous thing, in duetrine or practice, to disannul the loast of God's conmands; either to comtrat their "xtent, or to watken the obligation of them." - Mronsmetimessy, as torone print or another, "(Oh, this is a very unimpmetant mattere after all." but is it a eommanduluent of God's word? Then beware how bou rlisegarl it.-Y. 20. The sicribes and Phatrisedes led externally ablamelas life, eurrupt ats they were inwardly. Wo onght to eherish better principles and motives than they did, but surely we ought mot to tiall below them in ontward eomeluet. Shall grateful lose to our Saviour fail to make Christians as "eneful to maintain good worlis" (Tht. $3: x)$, as thone Jews were through estentation and andf-rierheonsnes? It entent to let it be ontherwire, hatve we reation to feed assured that we haverentered into. Mesolah's kingelom, that we are Chrint's people at all? -Our rightemsness should include, ant only outward atets. but alwe fere ings. See the examples which our Lond procecels to give.)

V. 21. II kxky: "The law was ancient, lout not antiquated."-Killing. 1) When it is lawful, and no sin. 2) When it is sinful to some rxtent. B) When it inone of the greatert posible sims. The evil of carrying concenaled weapons.-Dueling. -V. 22. Angrer. 1) Even when justifiable and righterns, always very aljt to become sintiul. 2) sometimes snch in character and degres at to share the gruilt of murder. 3) Contempt for otleres, a milder form of anger, is ofton bighly sinful. -T.usen (Wun.): "Whenever a man is anery, if" a wise man, wi-dom leaves him: if a prophet, the prophetic gift leatres him." -II kasky: "Anger is sinful. 1 When it is without any just provocation griven: 2) When it is whout any gond end aimed at ; 3) When it extereds

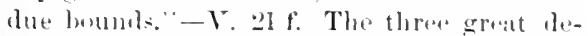
fartments of sin-sinful actions, sinful words, sinful terelings. -The sin of calling "hal names" ; e. ?. rationalist, heretice, infidel; or bigrot, persecutur, prenelytur, seretarian, Illeharitable, illiberal; or Pharime hyperita.

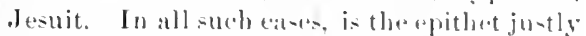
applicable, and are we applyong it with : right aim anel in a riglat spirit? Otherwise wesin. Josus catleel some men fimls, hypuerites, serpents, deril, satan, when -llely an epithet wa known to him to be deserval, and when gool would ande from npulying it.

V. 2.3. The high duty of seeking rexon- 
27 Ye have heard that il was said by them of old time, Thou shall wot commil awlulery:

28 But l say unto you, lhat wlosoever tooketh on a a woman to lust atier ber hath committed adultery wilh her already in his heart.
27 Ye have heard that it was said, Thou shalt not 2s commit adultery : but I say unto you, that every one that looketh on a woman to lust after her hath com- ciliation; thinking not merely whether you have something again-t others, butespecially when whers have something against you. To seek reconciliation is a higher duty than the mast solemn at of worslisp. Life is more important than extermal acts of worship, and a healthy life will make worship more aceeptable and protitable. Yet he does not say, Go and be reconciled instead of offering thy gitt, but then come and offer. Worship without charity, eharity without worship, worship am charity; love God and thy neighbor. GRIFFITII: "There is often as much mischief done to social harmony by a proud determination not to confess ourselves in the wrong, or not to make tro easy, submissi:e reparation for wrong, as by the actual doing of wrong." STIER: "Be reconciled, forgive or obtain forgiveness, do at least thy best, that so nothing may be set against thy aceount by the great Judge." -Rom. 12: 18, "If it be possible, so far as in you lies, live peaceably with all men." If otherwise, let it proceed from the othor side. $-\mathrm{V} .25 \mathrm{f}$. GRIfrith : "There is at now anse here. The first requirement (v. 23 f.) was, offer reparation spontaneously, before it is demancled of sou. This seeond is, Yield reparation ungrudgingly, when it is denanded of yon.' - Ntrive to stetle personal diffieulties in private, without waiting for the intervention of legal processes. (1 cor. 6:6-4.) In like manner it is best to settle difficulties withrut taking them before the charch. (18:15.)-It is molaucholy to see how many personal difficultirs arise amongmen, and even among the profismel followers of Christ, and how often both sides are proud and unbending, instead of acting as he herusolenmly enjoins. Christian, stop' a moment and think. Is there some one with whom you ars at variance? Then cosse reading at this line, and pravertully consiler whether you cannot do something towards reeoneiliation. Make an effort, even if you have before tried in vain, an honest and earnest effort, in the fear of God; and then return to read, with a meek and gentle spirit, these words of oul Saviour.

27-32. The LAw Concerning ADULTERY AND DIVORCE.

By this second example (see on v:21) our Lord further illustrates and applies the statement of v. 17-20 that he does not propuse to relax the requirements of the law, but enjoins a still stricter and more spiritual morality.

27. Ye have heard that it was said. See on v. 21. By-to-them of old time, is luere a spurious addition from v. 21. It may be noticed (Stier) that a eertain variety is observed in introducing this series of examples; the full phrase of $v .21$ is shortened in $v .27$ and still further in v. 31 ; and then in v. 33 the full phrase is resumed, to be again sbortened in v. 38 and 43 . Thou shalt not commit adultery. (Ex. 20: 14 : Deut. 5: 18.) This probibition of a particular species of unelastity may be regarded as carrying with it in principlelike others of the ten eommandments -the prohibition of unehastity in geveral. No addition to this commandment is said to have been made in the traditional teaching, as was done in the frmer case (v. 21); but we know that the Jewish teachers were disposed to limit the commandment to attual adultery. Jesus extends it so as to forbid dallying with the eorresponding desires. He thus 'completes' the law. (v.17.)

28. Int I say. The ' $I$ ' is emphatic; see on $v$. 22. To lust after her, $i$. $e$, with a view to lust after her, an intentional looking for the purpose of stimulating, and delighting in, impure desire. This, 'with a vitw to,' is the proper furce of the Greek phrase, the same that is used in $6: 1 ; 13: 30 ; 23: 5$. The English word 'lust' originally signified desire of any kind, good or bad (as in German now). In the Seriptures it is used only for evil desires, and at the present day is confined to one particular class of evil desires. The Greek word here used signifies 'desire' in general, and is used in a good sense in 13: 17;
It is wanting in most of the early authorities, and is manifestly an addilion by way of assimilation to $v, 21$, etc. Its presence in some old Latin codices (with the
Vulg.) and in the Old Syriac, shows that the addition was made early, by the middle of the second century, like many other corruptions of the text. 
29 Ind if thy right se offend thea, pluck it oul, and cast it lrom thee: lor it is profitable len thee that one ut thy menbors shomld perish, and not that thy whole body should be casl into bell.

Luke 2.2: 15, and some other pawages. Mure frequently it lats a bad semee, at in .Iark $4: 1 ! 1$, etc., flenoting evil desires in general (human desires being so often evil). Thr specitic sense of sexual desire is found (in the New Text.) only bere and in Rom. 1:24, thengh of course inciulad, along with other desires, in mot case, of the bad sense. Hath committed adultery with her already in his heart. The distinetion between our lurd's teachings and what they wrore aceustomed to, is exerentially the same as in $x$. 218 . Jesus eondems, not merely the outward act of sill, but the cheri-hing of sintul desire. stier: "He who experiences at a first glance this desire, and then in-toad of torning away and withdrawing from sin (2 Per. 2: 14), throws a seeond glance with lo-thul intent and in orler to retain and increas that impulse, commits the sin." $\mathrm{A}$. in $1 \mathrm{Joh}$ 3: 15 , "whesoever hateth his brother is a murderer,'so here, every one that cherishes lust by a look is an melulterer. Comp.

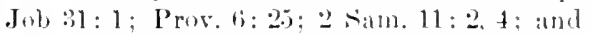
2 Pet. 2: 14, 'eyes full of atultery. The Greek and Roman and the Jewish writers Iave aloo many ayings tote in Wet., Gill. as to the sinfuluess of a lust ful look.

29 f. The vigorous self-restraint which is requisite in order to avoid the sin just forbidden, suggests the iflea that all our propensities must be eontrolled, and that the greateat possible salf-denial would be far better than that snffering in hell, whieh must be the reward of sinfil gratifieations. Thi- eorre-ponds tor the application made in $v .23$, and hore again the aldess is to an individual, 'thrm.'

Thy right eye, literally, thy oye, the right (eye); even an eye, even the best eye. mut in such a case be given up. Comp. Ex. 29: 20; 1 sam. 11:2; Zech. 11: 1\%. The 'eye' is doublews seleeted becanse suggested by the preending sentence $(r, 2 n)$, and also beeanse of it genral impurtance. Otfend thee, or, causes there to stumble, or 'to sin.' The Freek word is found in sept. and quite often in $\mathrm{N}$. T., though not found in motane Greek writers, and involves such difficulties as to justify a detailed explanation. Comp. Conant.
29 mined allullery wilh hor abready in his heart. Aml

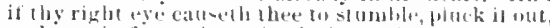
and cast it from thee: for it is protitable liog the

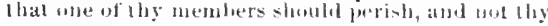

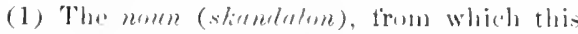
verb is lerivel, Aetustes primarily the trapetick or trigger of a net or trap, again-t which the game strikes and calleses the tray to fall]; and derivatively, anything against which me strika, wbetlure a stembling-block, is in Ler. 19: 14: "Thom shalt not put a stumblingblock before the blind, or more rarely, an whstacle set to binder the progresen af any one, as in the apocry phal bonk of Judith $(5: 1)$ it is satd the Istatites had put walls on the mountain-tups, and 'obstacles' (or 'obstructions') in the plains, to reaist the progress of the invaders. From these derivative sensens (onne several figurative llese, as to meral and religious objects: (a) A stumbling-block, ats eatusing one to fall into sin. (Matt. 13:41; 12: i: Luke 17:1; Rom. 14:13:1 J.h11: $: 10 ; \mathrm{kev}, 2: 14$ ) (b) An obstaple which mon strike against and stop. an oceasion of lisbelief. (Rom. 9:32 f.; 16:17; 1 Cor. 1:23; 1 Peter2:A.) (c) An ubject which one strikes again-t and is hurt or repelled, so as to be displeased with it. an "otlenee" in the present Engli-h sonse of that word. (Mnte.16: 23; Gal.5:11.) (By further derivation comes our English use of seandal, which word is borrowed from the Greek, but eonveys a meaning no where found in Greek ase.) In some cares two of thes sen-e may be united, as the second and third in 1 cor. $1: 23$. (In Rom. 11: 9, the reference in probably tunt tor a stumbling-block, but to the primary sense of a trap-stick or trigger, as a figure for a means of de-truction). (2) In like mannerthe uerb (skandulizo) is used fignratively in three corresponding senses: a Tomale one stmble and fill, to carese to sin. Matt. $5: 29$ f.; 1n: 6.9; Luke 17: 2; Rom. 11:21; 1 for. $8: 13 ; 2 \operatorname{Cor} .11: 29$.) (b) $\mathrm{T}$ ( obstruct one's path or make him stop, to cause one to dishelieve and reject or forsulie. (Man. 11: $6 ; 13: 21,57 ; 15: 12: 24 \cdot 11: 26: 31,33:$ Johu 16:1.) (c) T11 pain or disflease, to offend in our motern sense of the wo:d, (Matt. 17:27: John 6:61.) And from this by further derivation comes our peculiar Engli-b nae of the borrowel wort "scandalize.") Hure also, as with the numn, two or three senses may sometime: be fornd combined.

\footnotetext{
II has alwars been found diflicult to translate tle 'offend, which might have been dereloped intu all the worls into English. Tyndale introuluced the Latin senses of the Biblical Greek tern, but bas not been.
} 
30 And if thy right hand offend thee, eut it off, and cast it trom thee: lor it is protitable for thee that one of thy nembers should perish, and not that thy whole body should be cast into hell.

31 ll hath loen said, Whosoever shalt put away his wife, let him give her a writing of divorcement:
30 whole body be cast into 1 hell. And if thy right hand eauseth thee to stumble, cut it otf, and cast it fron thee: for it is protitable for thee that one of thy members should perish, and not thy whole borly go

31 into 1 hell. It was said also, Whosoever sluall put away his wile, bel him give her a wriling of divorcement:

l Ge. Gehenna.

Thus the idea is, if thy right eye causes thee to sin. The expression is obviously designed to teach a general lesson by "assuming all extreme case," a method quite "characteristic of our Lord's tealehings," (see Alexander, and comp. on v, 24 and v. 39). He is not presenting this as an actual case, or one likely to occur; but "if it slould occur, if the only alternative presented to a man were habitual transgression or the loss of his most valuable members," then he ought to "choose mutilation rather than a life of sin; and that choiee inclucles all miunr eases, as the whole includes the part, and as the greater comprehends the less."

For it is profitable for thee. The appeal is to a man's own higher interest, which is really promoted by all the self-sacrifice and self-denial required by the word of God. That one of thy members should perish, or simply 'that one of thy members perish,' the old English subjunctive. 1 Be cast, same term as in the preceding clause. Hetl, Gehenna, the place of torment. See on v. 22.

30. Another and entirely similar illustration of the principle in question. The repetition and reiteration of a thought, with only sliglit rhange of figure or phrase, is characteristic of the Scriptures; and it is not merely to be noted as a literary peculiarity, for the in-

The ('reat Bible's ' hrnder' was a failure. The Geneva tonk 'eanse to offend, and so Bible U'n., Noyes, and Iavidson, King James put this sometimes in the margin, and in the text initated Tyndale. But this rendering has long been a stumbling-block to the general remier, and an offence to scholars. The Rev. Ver has given perhape the best available renderings, but varions senses above deseribed require to be carefully distinulished by the realer. The syriac uses the same ront as one which in Ifelirew signifies to eause to totter, stumble, fall. The Coptic and the latin versions here transferred the Greek word scandalizo, and following the Vulgate the Rheins rersion says 'scandatize,' which to a modern English realer is even more misieating than 'offemd.' Wyclif's 'slander' is but another derivative (through the French) from the same scandalizo.

1 This use of hina, and the subjunctive, which is common in the Scpt, and extremely so In N. T., though spired writers, and the Great Teacher, employ this means of impressing upon men truths which are important and which they are unwilling to receive. So preachers are often compelled to do now; and thongh the fastidious may complain, as in the days of Isaiah, that they are treated too much like children (Isa. 28: 10), yet others, and perhaps the complainers themselves, often need amplification and repetition-while of course theses should not be used as an expedient to disguise porerty of thought, by hammering a very little gold into a very large surface. There is something excexdingly solemn and stately in the repetition here; and in 18: $8 \mathrm{f}$., where our Lord presents the same idea in a difforent connection, we find the foot also introluced, as a still further amplification (comp. on 7 : 9-11); it may also be notieed that there the eye is mentioned last (comp. Mark $9: 43$ ff.), while here it comes first, because of v. 28 . Be cast into hell, literally go off-or awayinto hell. This reading is required ly the best authorities for the Greek text; it was changed so as to be like v. 29.

31 f. The extreme facility of divore which existed among the Jews of our saviour's time, was the occasion, on a large scale, of the sin of adultery (v.32); and thus the transition is very natural from the topic of the preceding

very rare in chassic freek, should not be called subfinal or hypotelic, for it is not at all a weakening of the telic or final sense, but is entirely indejendent. The clanse introluced by hina is here really nominative to the verb ' is profitable' (the Greek having no equivalent for our 'it' in such expressions). So in $10: 25 ; 18: 6,14$. Sometimes it is accusutire, either of the direet object $(14: 36 ; 26: 63)$, or of general refercnee, 'as $t(1)(n: m)$; in faet the final use really belongs under this last liead. And sometimes it is appositional, whether to a nominative (Luke 1:43), an accusative (John 6:29), or a loeative (John 15:8). Whatever speeial itua may arise is due to the natural relations between the matters spoken of in each case, or to the counection of the stalement. Abundant examples may he found in Grimm, but wrongiy elassified ; nor are these uses at all satisfactorily treated by Winer, or Buttmann, or Jelf. (In the similar statement of $18: 8 \mathrm{f}$. we find not twina and subj., but the usual classical construction, the infinitive). 
32 but I say unto you, That whoserever shall pot away his wile, satring for the callse of formication, callseth luer (1) commit aduhery: and whosiever shall marry lier that is divored committella adultery.
32 but I say unte you, that every one that putedl

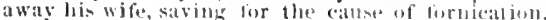
makidh hir an aluleress: anel whosenerer shall marry her when she is put away (v)mminteth adultery. verses to this, which is not to be emosidered a n.w and distinet exampla (see on v. 21), but another dingatment of the same subjeet. Ac"orlingly it is intromluend by a simpler form "10 "xpression than in the other ases; not, Y" have hearl that it was saje,' but simply, Ind it hath bean said.

Tha daw of Muses (treut 2t: 1) required that if a man determined to put away his wite, bo shombl give her a formal denoment to that "rllinet. The Jews in the time of Christ woro greatly at varianee as to the proper ause of dibore, but most of them held that it was buful for a man to dismiss hiv wife 'for every cauce' (soe on 1!: 3), and that there was no restrietion at all except that ho must grive her the doctument. Aecorilingly, in this case also our Lord is not setting aride the law (v. 17), nor at all eonfletiog with its true deign. The I-ractites, like wher Griental nations, had no doubt bom inclined tor great laxity in the matter of divoree, and Muses was not encouraging this, hut to some

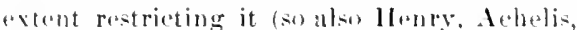
Riitsolit in Iterzog), by appointing that a man should not sond otl his wite with a mere oral dismissal, which he might al, in a fit of parion, hut should grive herat rogular writing ( Maimunides gives a form in $11-1$ : in his day, twalth contury, see in hightfiset or Gill.) This, esperially in the earliest prerionl, when fow conld write, womlel repuire a Levite to prepare it, anel thas give opportmity for raflection and advices, and womld hesides place tho rojeceted wife in a buttor porition for thes future, by showing that she hat been a lawtul

The freek term employed,prmin o whith primarily signifies 'harlongy, the primary signilieation of formieation atoon is not al ways confined to mehatity in unmarried persoms, but applied (1) the married also, as in 1 cor. $5: 1$ ff. ; funs $7:$ i 7 . The correspunding Hobrew worl is the one al ways empluyel tiguratively lo denote Jsratl's wnfaithfuluess to Jehosiah, her hu-band. Thus in Ezok. "23:5, tholuh (somaria), after "hearing solus anl datughters" to Jehovah (v. b), "played the barlot when she was mine," comp. Num. 5: $19 \mathrm{f}$. Sie 11 osea 3: 3, and liesen. on zmah. Diun (alss. says of the Empress II ssalina, kutiemoicheupto kui ejmrnenelo, "she both eommitted alultery and played the harlot.' "hrys. says bere: "Do sou see how this ayrees with what precedes"? wite. The dreument, ateorreling to the intention of the law, implied that she was innocent of adultery; tor it a wite was guilty of that erine the law reptuirel that sho should be put to drath, and thore wald in that cat-e be no neat of a divorea at all. Still, it was not comsidered obligatory to intlice this fenalty. ((.m) on 1: !!.) A further pestriction upon the fareility of divoree was made by the provision (Deut.24 2.4) that atter the termination, by divoree or death, of another marriage on the part of the Woman, the man whe formerly divoreed har could not then take her back, as this would shock the instinctive sense of propriety- It thus appears that Je-us is here carrying out the deign of the IIsenic enactmont by a still further restrietion in the same diroetion; is not abrogating the law, but eompleting it. (v.17.) - Aecording to the terms of the law, and the eommon usage of the Jews, only the hushand could divores: and so our Lord spoulis here omly of what the husband may do. But on a later aceatom (Mark 10-12), be mentions also the ease at at woman's putting away har hushanel. It is natural that Marli rather than Matthew should record this, as it was a ease mueh more likely to onerer amomg Gentiles than among . Jix

32. In this verse, instead of whosoever, the earrect toxt gives the slightly st ronger expresion, every ome who, as in Rev. Vor.,

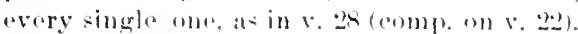
- Hut I say unto you. "I' omplatic, sow an

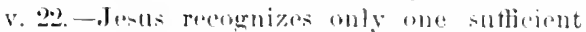
ground of hivorea. It is a part of the mys-

For ho that loce nut lowk at anoller nan's mife with

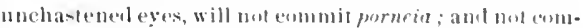

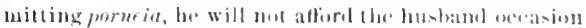
foeant out his wife." Chrys, errtainly kutw trenk, and ho distinetly applies lhis teron to the eas of a married woman. So Themphyl, amd Euthym. expressly, atul su (origen on t!): !. Apolinarius (in (ramer, says, "f'hrist allows one to put away her that has commitled fornieation, lecamse she dissolvenl the phssical moien." Jerome speaks of the wife as having "scparated herself from her hushand ly fornieation." The l'exhitu

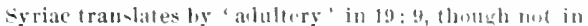
5: 3s, and tholgh distinguishing the ow ferms in 1.5: 19 and elsewhere. Almost all expositurs have under- 
tery of human nature that the connection between husband and wito produces $n$ strange

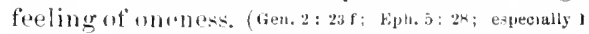
Cor.6: 15f.) And it is only when the sacred tie which thas hound them bas been broken, that either of them may lawfully form a marriage unim with anotler person. It is not said that in suly a cage the husband must put away the offerding wite, hut in saying that he must not racejt in that case, it is implied that then he may. Hovey: "This crime is one which inflicts so derp a wound on the innocent party, and violates so utterly and completely the substanew of conjugal duty, thut it is recognized loy foud as a valid ground for divaree, whonever this is sought by the unotfending husband "1" wife." But "there are many passages of: the Old Testament in which Goud addresses his people as an adulterous wife, whom, howerer, ho till reengnizes as his own, and strives to recover from idolatry" ; and the wromged husland or wife is at liberty to exercise like forbearance. - The same rule as bere is laid down at greater length in 19:3-9 (see motes), and rupeated on a third oecusion, Luke 16: 18. - The directions given by Paul in 1 Cor. $7: 10-16$ refer to a peculiar state of things, hut are in aeeordanee with our Lord's teachings, to which Paul expressly refers. Where only me of a heathen eouple had beeome a Christian, the apostle says it was best for them to emtinue together, since that wight result in the salvation of the wne not yet converted (1 for. $7: 10,16)$; but if the mbeliever insists on a separation, the heliever is, not 'under bomelage, 'enslaved' in such cases (v. เ5), not compalled to live with the unbeliver, whethur or no. (The worl is not simply 'buml,' lut 'enslaved,' and quite different from that rendered 'bound' in Rom. 7 : $2 \mathrm{f}$, which rofurs to the bomd of malriage.) Yet the partios thus separated, the apostle says, most remain unmarried, and the heliever must seak reconciliation. (v.11.)-Putting together that passage and aur Lord's teachings,

foom the word in this passige as signifying unehastity in grameral. Sue cirot., Mryer, Woiss. As the general trom it monla include the case of aldulery, amialsos that in which a wife was fond to haveluen unchaste before marriage, which latter easo the law treated as having the same guilt amb requiring the same punishment as adultery, (Deut, 22: $21 \mathrm{f}$ ) Dollinger urres that this last is in Ma1t. the sole meaning, but unsucesstully. Fet if the lerm 'adultery' had been here used, it would we learn that a husband and wife may for sufficient cause separate and live apart, but may not marry again unless the tie between them has been severed through the commission, by one or the other, of the erime our Lord mentions. If a man divoreed his wife for any other cause, Jesus deelares that he would be eausing her to commit adultery, $i . e$, if she should be married to another; and whosoever should marry her when divorced (or, "marry a divorcel [woman]'; it may mean either, and there is no important difference)-nnless, of rourse, the divoree were for the sufficient cause here mentioned-would be committing atultery, as she would still be, in the view of the divine law, the first busband's wife. (Comp. Hovey on The Scriptural Law of Divorce, Am. Bapt. Pub. Soc.) It has been well remarked that as the only ground of $\mathrm{di}-$ voree which our Lord admits is one pertaining to the essential nature of the marriage relation, no changes in the form of the outward anion, or of the outward divoree, can make any difference in this respeet.- It follows that all legislation which allows of divoree "from the bond of marriage," except for the eause here named, is eontrary to Christ's tenehing. It may be very well to legalize separation, with reference to questions of property, support, the control of children, ete. as is done in the so-called divoree "from bed and board" ; and in cases where the civil iaw does not provide for this, but permits a complete legal divorce, it may be allowable to seek such flivorce as an arrangement for separation; but still nejther larty has a moral right to re-marry. unless the religious union has been violated by the unehastity of one of them. In that case the imnoeent party has a right to full divoree and re-marriage; our Lord has said nothing as to tho question whether the guilty party has a moral right to marry again. This could be true only atter unquestionable repentance. Comp. the case of a man who has killed his wife. But for

have cxeluded this ease. We thus see a reason tor enploying the greneral term, bere and in 19: 9.- Maketh her an alulteress,' ( $v \cdot a 2)$, represents the correet cireck text. It means that if she is taken as wite hy anolber man, ber first husband has eaused her to be now an alulteress, by puttimur her away without proper ground; and the sceond hushand beeones an adulterer, fur she is still properly the wife of the otherman. The woman appears as passive. 
3.) Again, ye have hearil that il hath hecels sald by

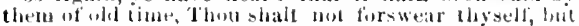

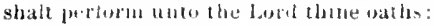

civil gurernment to refuse al begal divorce in cases where the Lerd distinctly andmits it, may be it grievens wrong to the innoent party, who is nuw absolved trom all moral obligation te) the othere and yot is not permited by the civil matement- to marry again, it dereired.The (irenk and other ()riental Churches, and mo-t I'rotestant Churchess bave always hold that in steh at case re-marriage is allowable. The ehurch of Roune tierbids it latse by spredial di-pensation), matintaining the prorpetual obligation of what it calls the "saterament" of marriage. The Germall P'rotestant Churclue are extremely lax as to divorenstarting from at wromg interpretation of l'aul's teatchinar, so as to make "drasertion" ( 1 cor. i: 15 a a ground of divoree-and that facet bar embarrabed many of the ablest German commentarim upun the present passige. In solue of the Enited States there hats aloe been al griesou facility of divoreer, again-t which a bealthy reaction is now in several thaters arising. The new law of England allow. legalizol soparation for various andases and divores proper for adultery. The state of South Carolina has no provision for lagal diveree. (1) n the history of divoree in anciont and molern times, se Woulacy on "Divoreer," Now York.)

\section{IIUMILETICAL AND PRACTICAL.}

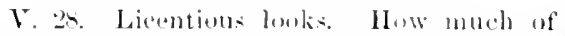
grievous in is eommited in thi- raspet before him who pertectly sees thr heart, and tow wom impurity in the heart is as real at an at wrom

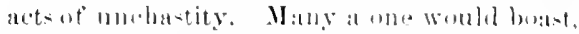
like the Phatrose in the parahle we beine ne

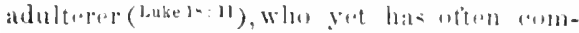
mitend aldultery in the hatert and fiom has

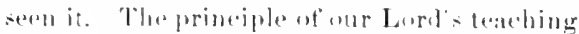

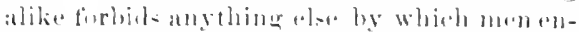

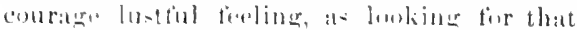
morpuese at work of art, indereent dancers,

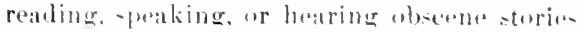
or obeceme jests, filthy imberinations, ete. Leteres: "You and prevent the devil from shouting arrows of evil thumahts inter your heart; but talie care that you do not lat such arrows stick fatet and grow there. Do ats a

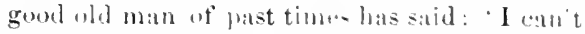
prevent a bird from tlying oreer my heat, but

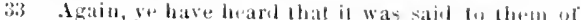

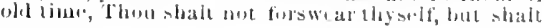

I can prevent him from matking a nas in my hair." -Remember that the great moans of keepling impropere thourhte out of our suimls,

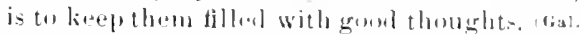

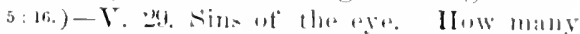
forms of sin are indicatud or exeited by lonk-

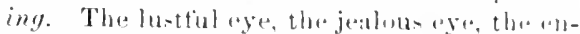

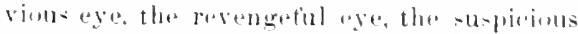

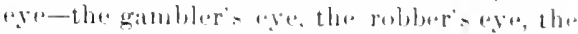
flatterer's ege. C'ukss: "Fur this were mot wat as one hating the eve, hat andue huing the rest of the budy. "- P'inte (in (irithth): "It reemo to mo that all who are mot entirely uninstrueted will rather blind them-1) gatze on thing which atre unseemly, and make them-edres deat than linton to hurtiul words, and eut out their tomgues than slerak what cheght unt to be speken." - Prutitible for these. Man bats a complex nature, and the Bible, which is divinely adapted to human nature alperals mot unly to comscience. the fest olligation to de right lecatuse it is righlt, but also te onr interest in the trua and hien selloe, our hopes and liatre for time and lor

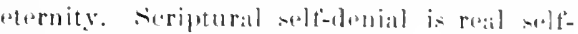
interest. - V. 80. sexerd (in firithth: "Whatever viens roml your heart. ciat them

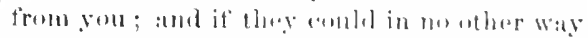

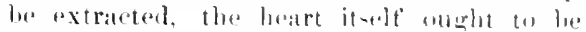
plucked out with them." DYkls: "Thos

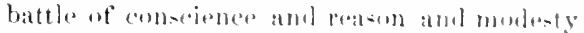
against sppetite. is to lw ingut within the heart of the templest man, and for it help, in-te

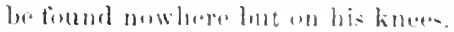

3:3-33. (0.1Tis.

The third aremple (ast on $\mathrm{x}$. 21), by which war Larel illa-trates the sujuriurity of the morality he enjoins, is the - $n$ bjeet of (baths. (r. 33-37.)

33. Again. With this trom of tran-ition

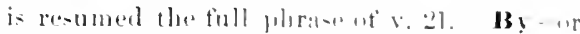

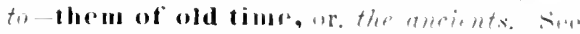

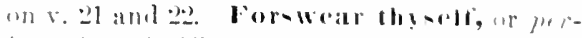

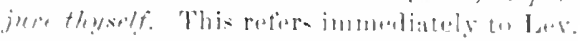
1!t: 1:. Then shale me s watr by my mant

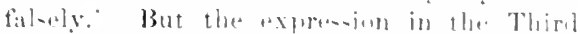

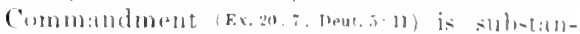
tially afuivalent, viz. lit+rally. "Then , hatt

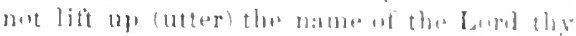

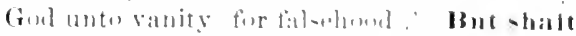


34 but I say unto you, Swear not at all; neither by heaven; for it is God's throme:
34 preform unto the Lord thine oaths: but I say unto you, swear not at all: neither by the lueaven, for it is is an ahlition which the Jewish teachers seem to have been aceustomed to make to the commandment, corresponding to these in v. 21 and $4 \%$, and was probably derived by them from 1)(nt. 23: 21; Num. 30: 8, where the referener is specially to vows. The verb bere rendered 'perform' is trinslated by 'pay' in v. 26 , and 18: 25-34; 'recompense' in $6: 4,6$, 18, Rev. Ver.; 'render' in 16: 27, Rev. Ver.; 21 : 41 ; $22: 21$; and signifies to give back, or to give in full, and hence to repay or to pay off. ${ }^{1}$ The idea here is that an oath becomes a debt to the Lord, and we must be sure to pay it. This conception is especially appropriate to a vow. (Same Greek term in Dent. 23: 21 ; Ecel. 5: 4 f.) Comp. the representation of sin in general as a dobt, in 6: 12. - The Jewish teachers correctly interpreted the law as prohibiting false swearing. Every assertion accompanied by an oath must be true; every promise accompanied by an oath must be kept. Bint this cannot be if men use many oaths; and they sought to evade the diffieulty in their usual fashion by a quibble of interpretation. The Third Commandment spoke of swearing in the name of .Jehovah; and the law elsewhere (Deut, 6:13) expressly required that they should "swear by his name," $i$. e., not lyy the mame of any false deity. So the Rabbis hald that the law made binding only those aatls which contained some name or peculiar attribute of God, or something else that was fminently sacred. (23:16 ff.) Othor watls, mot naming or diroetly suggesting (rod, they held to be not binding. The Talund exprossly declares that such oaths as "by heaven,' 'by the earth,' do not bind at all. And thumgh some teachers set themselves against this (sce on noxt verse), they were borne down by the majority. Aceordingly the dews were remarkalile for their frequent use of onths in ordinary conversation, swearing by the tample, hy tha altar, by the lamb, by the dishes, by the law, by Moses, liy the prophets, lyy the lifo of tho Rabhis, as well as the oaths here mentioned and rount]ess others, and reckoning such waths to be 'noth- ing.' (See on 23: $16 \mathrm{ff}$.) So common was the practice, that even among those who became Christians it continued as a great evil; and James, writing to Jewish Christians, condemns it with special emphasis: "But above all things, my brethren, 'swear not.'" (James 5: 12; emp. James 3:9f.) Many of the same forms of (oath are now used in Syria. (Thomson.)

34. But I say unto you. 'I' emphatic, see on $v .22$. Swear not at all. The true way to avoid false swearing is not to swear at all; the Rahbinical distinction would not bold, for even oaths which did not contain the divine name involved some sort of reference to God which made them solemn and obligatory -otherwise they would not be used as oaths. Strilie at the root of the matter; do not swear, and you will never swear falseiy. In this, as in the previous examples, our Lurd is enjoining, not merely an outward and literal obedience to the law, but that regard be had to the principle involved; and he will thus complete' the law. (v. 17.) The command not to swear falsely was a great restriction upon the familiar use of anths: Jesus does not abrogate that command, but goes farther in the same direction. - Yet as the prohibition of killing and of anger is not to be taken without any exception, it being lawful to kill and to be angry, upon sufficient occasion (sec on v. 22), so, we might conclude by parity of reasoning, must be the case here. And acoordingly we find our Lord himself consenting to speali when formally put upon oath before the supreme court (see on $26: 68$ ) ; and the Apostle Paul repeatedly using, where there was special ueasion, such expressions as 'God is my witness,' I call God for a witness upon my soul,' 'Before God I lie not,' (Rom.1: 9; 2 Cor. 1: 2:; Rer. Ver., Gal. 1: 20), which arestrong oaths; and the angel in Rov. 10: 6, swearing a very solemn oath. So in the O. T., men being aceustomed to swear 'As Jehora! liveth,' God himself is said to swear, 'As I live' (Fzek. 33: 11) ; and the Epistle to the Hebrews appeals to God's onth 'ly mysolf' (Gen, 22:16), as given to strengthen our coufidenee in the faithfuluess of his prom-
1 Tyndale's 'perform' is retained by all early and most later English Versions. MeClellan 'pay, and so Com. Ver. in Deut. 23:21; where Supt. has the word here used.-Tyndale and Genera have 'God' instead of 'the I.ord,' lint without authority, and their reason for intruducing it does not appear. 
35 Norby the earth; for it is his footstoul: neither 3a the throne of ciont; nur by the earth, for it is the by Jerusalem; for it is lle city of the frreat king.

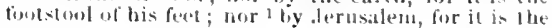

1 Or, toward.

ise. (Heb.6:13 6.) An outlu, therufore, is not inherently and neesesarily wrong, and thereare oceatsions which justify its une, at in judicial proceedings (our Lord's cxample, and where some very solumn asseveration in speech or writing is rerpuired by the eircumstances. (latul's example.) But as anger, even when legitimate, is i: great danger of leeoming sinbul (se on $v, 22$ ), so with batho, which are often administered in eourts of justice with such irreverence ats to be highly sinlul, and which in individual anertions or promises ought to be contined tu very rate and solemn oeeasions, and to be used, ats the apostle does, in the most reverential spirit. - The object of explating that, in this and the otherexamples treated by our Linrl, there mat be exceptions. to the absolute prohibition, is not to weaken those prohibitions, but partly to exhibit their aceordance with uther pasiages which might seem to be in eontliet with them. and partly to show that these are no unpractical and inpracticable theories, as so many superficially eomsider them, but when properly understood are rules for our aetual guldance in life. - The utter eondemmation of all oiths. which has been made by Waklensialls, Anabalptists, Mennonists, Quakers, ete., is foumd alpondy in Justin Martyr, Irenens, Origan, Clirys., Jerome, and other Fathers; ret oiths were sometimme employed hy the arly Christians. and gratually breame common, especially after the union ot Cinureh and state. Siee Surth: "Diel. ("hri-t. Autid.")

Neither by hearen, ete. Tho Jews unally maintained, als aboveshown, that ald oath was bet binding unless it contitiund the name of (renl, or mention of one of his attributes. But anyolhing used ats atu wath must havesome sort of relation to God, and this makes it bindinc, and so it ought not to bo used-i.e. need

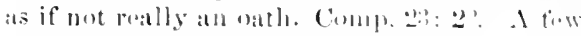
of the Jewish tenchers took a similar viow. one of them boing reeurded in thr. Tilmul

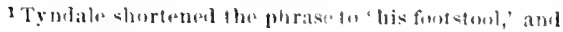
was follewed by cireat B., lemera, and com. Ver. There

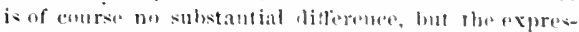

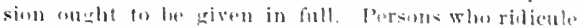

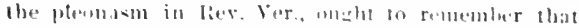
they are ridiculing the -actent writers. as saying, "If a person swears another by heaven and earth, does he mot al-oswear him by him to whom heatren and earth belongs?". But mon bed otherwise, as shown by Philo, the Talmud, amd II aimonicles (Light., Wet.). Philo states that some were in the habit of saying simply " By the," withent adding anything, of as to aroid making it distinctly all wath; : and he suggeet- that one might arld, "wot indeed the -luprene and revered Firs Cinse, but the earth, the sun, the stars, heiven, the universe." And Maimonides (twelth cent.l, commenting on the T'ilmual, geres still turther: "It" any one swears by heaven, by the earth, by the sun, ete., even though it be the intention of the swearer under these words to swear by him who created these things, yet this is not an oith." We were that here, as with reference to adultery and divoree, a few of the Jewish teachors were rigorous

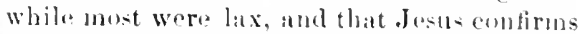
the view of the rigorous tew, and gous still farther. Some fancy that this is a reproateb to our Lord, as detrating from his corigrinality. But he did something better than to le ondiginal in ethice; for ly atuthoritatively sottling actual questulls of truth and duty, he sheweel that the tendency of his teathings is thoroughly practical. (Comp. on $7:$ :, 5 , and on $12: 10$.)

v. 3.5 f. These are further spromens, similat to that juat given, of waths which the Jews

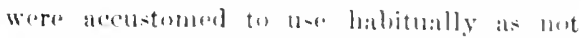
binding, and which on rord oxplatins to have rablly a sacred olement, sil that sueb une of them is wrong. II is foutstool, or, the funt-

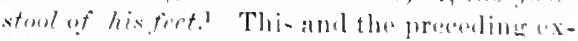
presion ate queted from Isil. bif: 1. The heaten is my thrmes and the earth is my

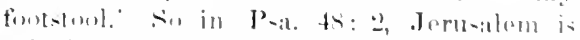

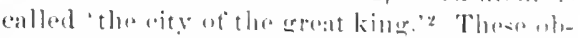

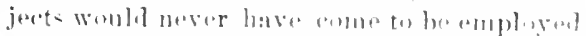

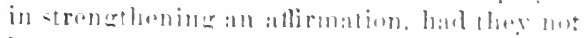

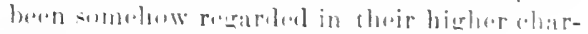

efn "liy Jerusalom, marein 'loward, liferally

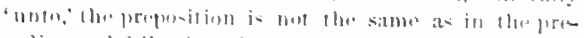
celingamb falluwing phrases, but thesulabandablutan ing does unt ditfer. 
36 Neither shalt thou swear by thy head, because thou canst not make une hair white or black.

37 but let your communication be, Yeal, yea; Nay, nay: for whatsever is nore than these comelh of evil.
39 city of the great King. Neither shalt thou swear by thy heat, for thou caust not make one hair white on $\therefore$ bhack. 'But let your speech be, Yea, yea ; Nay, nay ; and whatsover is more than these is of the evil one?

i Some ancient authorities read, but your speech shall be...2 Or, evil: as in ver $39 ; 6 ; 13$.

acter, as rebated to Gul; and though a man swearing liy them, particulaly atter the expression lats become trite, might not have such an idea distinctly present to his mind, yest it is rally and necessarily involved, when thwy are used in the way of an oath. Alexaviler: "He who swears by the eartls either swears by God, or does not swear at all."

36. Neither shalt thou swear. The form changing to the singular, as in v. 20 , thus making the application more personal and printed. By thy head. A very common wath among the Greaks and Romans, as woll at the Jews; probably founded on the idea that a man womld stake his head upon the assertion, would be willing to lose his lead if it should not prove true. But his life belongs to God and not to himself, and he is not able to change the color of a single hair of that head, which be so lightly angages to cast away. The reterence is of course to the change of color in growing ohl, which dependson the divinely dimeted course of nature (Weiss). Notice that the specimens mentioned deseend gradually to the lower kinds of oath, heaven, earth, Jerusialem, the head. In expression often heard amomg us, "by my life," or "my life on it," is sinful on the same principle as " by my heati."

37. IBut let your communieation-orspeech.' The term maturally suggesta that he is now roforring to the use of languagra in general, to orlinary conversation. The repetition, yea, yea; nay, nay, seems desigmod to indieate tlaat the proper mode of strengthening an asowtion is simply to repent the affirmation or nogation. Comp. our Lurels 'verily, verily.' lanl's expression (20or.1. 17) hats a riflerent bearing. The Rablis frequenoly dombleal these particles (Taldended), at wa de.

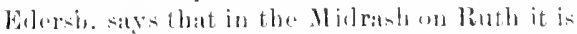

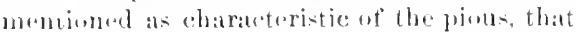
their you is yoat, ant their may nay. dambs

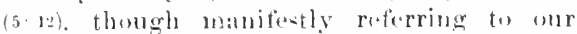

1'communication' is from Tyulale, folluwed by firest be, lisheva, and com. Ver. The levised Ver. rerains it in luke 26: 17 gret sete matrain), hut hats

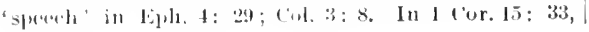

Lord's discourse, states the thing in a slightly different way. "Let your yeal be yea, and your nay, nay'; let the simple afliruation or negations suffice, without needing to be strengthened by aths. Maimonides, "Let the disciples of the wise be always truthiul and trustworthy; saying simply, yes, yes, and no, no," may bave really borrowed from the New Test.; for the Jewish writers adopted whatever they approved, from any souree. Cometh of evil-or, is of the evil one. The Greek is ambiguous, as in 6: 13, where see note. In this passage it is interpreted 'the evil (n) 'by Chrys. (and his followers Theoph. and Euthym.), Zwingli, Beza, Wetstein, Fritzsche, Ileyer, Kém, Grimm, Mansel, Plumetre; and 'evil' by Luther (though not in the first ed. of his trans.), Calvin, Bengel, Tholuck, De Wette, Ewald, Bleck, sitier, Weiss, Archelis, Keil. Taken in the former and somewhat more probable sense. the exprossion means, has its origin in Satan, as in 13: 19, 38. Taken in the other sense it means, is of evil origin. The general thought is in either case the same. The neeessity, real or supposed, for using waths, originates in evil, or in Satan; for it is due to the fact that men do not always faithfully keep their simple word. And like all the consequences of sin, this practice reacts to strengtben its source; for not only do men thereby bexome less earefill as to the truthfulness of assertions unattronded by an oath, but even aatho tend gradually to lose their solemen force by frequent, and popecially by beedless and irreverent repetition (comp. on 23: 16i). And so the abservance of anr Lord's prohibition would give to oatho a mach gratar balut in those eases in which they are really necossary and proper. Complo Mirrocles (Platonist ot the fifth cent.), "Revrremee an oath, and he not switt to use it, that soll may be accustomed to swear truly, from mut heing accustemed to swear." Adel ( Tet.) Philo: "Not to swear is highly heeoming

I'hilem, 6, the fireek is ditlient.-The authorities for 'shall he' (marin) are few ; the sense is substantially the sames. 
34 Ye have hearl that it hath been said, An eyo for an eye, and a toorb ror a looth: and advantageous, and is aceordant with a rutional uature, so instructed to speate truth on every aceasion that words are reckmmed oaths." Epictetus: "Avoid oaths, altugetlor if possible, but if mut, as far ats you calll." Quintilinn: "Toswear at all, unless whero it is necessary, is unbecoming a grave man.'

\section{HOMILETICAL ANU PRATICAL.}

V. 33. Perjury-its natur", tatlses, evil conrepuences, remedies. CHRYs.: "It' to sweitr is of the evil olle. how grat the pollatty which false sweariug will l,ring." $-V^{r}$. :34. Protanity-litlerent kinds, swouring, cursing, other kinds-evils of protanity, and ot all inreverence. - Cursing is always and essentially wrong, since no ome has a right to imprecate eternal ruin upou another. unless hy explicit divine direction, like the propluets. There is muels profine language which is

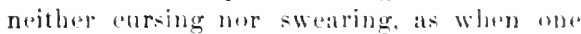
speaks in any wise irreserently of find, his worel, worship, wr angthing sitered. Promelers often speak of God tow fantialy, in molic. discourse and conversation. And there are phrases in which the name of Goul is either omitted or disguised, so that persoms timey they are not wrong, which get involve the

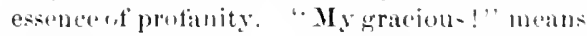
"My gracjum God." " Bless your smal," is "God bless yoursoul." "Zoumels" is "Grod"s wounds." One may plead that lie does nut mean this in using such phrises, hut so conld the Jews have said as to the expresioms which Jesus condenus; nay, the exemse of "not meaning anything by it" is aften given by persums who use profinely the most solemin oaths. Any ane who ohiserves fur a little while the language of those about him, or his own language, will be apt to eneomnter many phrases which, though not distinetly so designed, aro yet in direct violation of what our Lurd has hore taught, and should therefore be carefully eroiled. The charge of profanity also applies to all irreverent citations or lutierous applioutions of the language of Seripture, a very commom tault even in Christian soeicty. ((omp) on 12: $36 \mathrm{t}^{\circ}$ ) $-\mathrm{T} .37$. Self-respecting veracity will command respetet from others. What a eompliment when it is suid: llis word is as good as his bond.

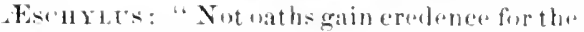

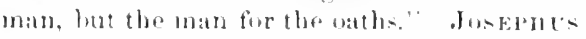

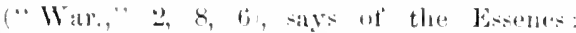
"Every worel they say is weightier than an wath, and swetring they shun, regarding it as Worse than perjury" - Inbitual ateuratey ut statement. a- nlpured to prevalent exaggerations. The pusitive degree maty really signtily more thati the =luperlative.

3K- IR. REQUTAL OF IXJURAR ANI LONE OF ENEMIES.

The forenth and fifth formmles (seteon v. 21), by whieh om Lam illustratus the superiority of hi-terchings, are the -nlyjets of Reyuital uf Injuries (v.34.42), and Lave of Enemies (ะ. 43.4. )

38. Ye have heard that it hath been said. Stur 111 r.21. An eye for an eye, the. Fin Ex. 21:24; beut. 19:21; Lev. 24: 20, in which patages these expressiens are complof with various similar ones, as "life for

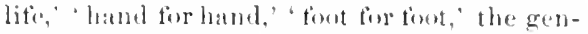
erall liw lering that of retaliation, or, "likefor like" - which was aloo the law of solon, and of the linnan Twelve Tables. This careful enunejation ly Moses of the law of retaliation, was doubtles desieneal partly to restrationen from going beyonel retaliation, as passiun often prompts one to intiet a far greater injury than he lats received. The Jews held that this law justifial pressual rotaliation we private wronga,

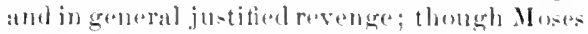
exprealy forbids revenge of private injurion in Lev. 1:t: 18: "Thule shalt not avellger, nor bear any grudge against the ehildren at thy perple, hut thou shat love thy reoghbur as thyself." In a rude state wi suedety, as in the early days of california, wery man talies in his ww hands the punishment of worngs leme. to him: and in the nost trivilized clari-tian commonity we are apt to find some indivilHals who glory in the faet that they protect mul avenge themselves. The Jews would defend sueh a prexedure on their part by misapplying to private ation what was given at public law. The teachings of enr Lord on this subject arethereform not in antagenism to the law of Mases, but serve to earry ont usure fully its spirit and design, to 'complete' the law (r.bi), as we have seen in all the previous instunces. 
39 But I say unto you, That ye resist not evi]: but whoswever shall smite lhee on thy right cheek, turn to him the other also.
39 and a tooth for a tooth: but I say unto you, Resist not lhim that is evil: but whosoever smiteth thee

1 Or, evil.

39. But I say unto you, see on v. 22. That ye resist not evil (the coil man). 'The Greek is ambignous (comp). on v. 37, and 6: 13). If inderstood as maseoline (Wyalif) it would not here mean 'the evil (one), Satan, as it would in v. 37 and 6: 13 -but the evil (man), the bad man who harms you, as in the ways that follow. If' understood as neuter (Tyudale and all other early Eng. versions), it would be evil in general. The resulting senses is substantially the same. The verb renclered 'resist' signifies to stand over against, withstand; and the idea seems to be to let evil have its course (or the evil man his course), and leave it for God to punish and control (see Rom. 12: 19 tt. ; 1 Thess. 5: 15; 1 Pet. 3: 9). Our Lumel says not merely that we must not revenge evil, but must not resist it. The explanation of his exact meaning can be better given aftor eomsidering one wf the examples he presents in illustration of this general principle. These examples are four, viz., personal violenee (v.39), vexatious litigation (v. 40), public exactions (v.41), and troublesone begging and borrowing (v. 42 ).

Shall smite, or, smites. Present tense in the better Greak text, which was reatily changed by copyists to the easicr future, fomd in v. 41. The Greek word meansto smite with rods, and to smite with the palm of the land (comp. 26: 67), colloquial Eng. 'slap.' Lule (6:29) has the general term 'strikes.'-The change to the singular number, 'ther,' is the sames that oceurs in v. 23 (seen note). It is here continued, as there, through theseveral particulars whirh follow (v. 40-42), and the plural is resumod witl the next subjeet. (v. 43.) smiting on the right cheek (literally jaw), is both at injury and a in insult (2 Cor. $11: 20)$, and yet to this the loving Rodemer was himself more than once subjected. (26:67; dohn $19: 3 \cdot)$ - Tho curions have observed that one naturally smites another's lott elueek first, while. Iestes tollows rather the general anstom of spraking, by which members of the right side are tirst mentionod (comply. ve:

1 The Russian novelist Count Tolstoi, in "My Rejigion," 1885 , futs torward this interpretalion with enthusiasm as a new discovery, and glories in the thought that
What are we to understand by the precept not to resist evil, or the evil man, with this and the following illustrations? There have always been some who maintained that these expressions are to be taken rigorously, as absolutely forbidding war, or any resistance to personal violence. In the early centuries some Christians positively refused to render military service, as being here forbidden. Many of the Anabaptists of Germany, in the age of the Reformation, condemned war, as did the Memonists of Holland. In America the view is now held by the Quakers (or Friends), the Tunkers (or Dunkers or Dunkards), and the Mennonists. 1 Berides those persons who conscientiously strove to arry out the supposed teachings of the passage, there have always been others who interpreted it in the same way, and have then made it a ground either of attack upon the morality of the gospel as fanciful and unwise, or of assault upon the current Christianity as inconsistent and confessedly immoral, or else of excuse for the total failure to attenpt obedience in any sense to commands which it seemed so impossible fully to carry out. On the other hand, most Christians have perceived that it eould not be meant to condemn war under all circumstanees, as various soldiers are referred to in the New Test., without any hint of their being required to cease to be soldiers, and as war is sometimes an ineritable necessity, to prevent yet greater evils. They have also perceived that the direction to turn the left cheek, eannot have been doxigned as a rule for general observanee, since it would oiten needlessly provolie greater wrong, and sering that our Lord himself did nut turn the other cheek when smitten, but mildly and yet firmly remonstrated (John 18:22 f.), while: Paul mot the suggestion to insult him in this way with a severe robuke (Act:23:3)-besides the fiact that Jesus ropeatedly took grat pains to avoid exposing himself to promal violence, hy withdrawing from places at which it was threatened. (Luke $4: 30 ;$ John $7: 1,10 ; 10: 39$ : Mark 9 ; 30. etc.)

the course thus indicated wouhl destroy society, which accurling to the Russian Nihilist view ought to be destroyed, at once and completely. 
10 Ind if any man will she ther at the latw, atud take away thy coat, let him have thy cloak also.
40 on thy right dheek, rurn to him the oller also. Aud if aluy math would gu lo law wilh thee, and take away
How then are we to interprot the language here (nmplored? It is not enough to say that aur Lord eamot have meant this as all ab-nlute and general rule, for while that is plain, the question recurs, what did he mean? It will not do to declare the lamguage merely digurative, for we have no warrant whatever firs calling phain statements tigurative-a pro(wess log which the most vital. doetrines and precepts of seripture might be explained away. Two renarlis will help to clear up the dillieulty. (1) Oursioviour's teachings in general aas well as the teachings of his apostles), are not simply didactic. but poleminal, aimed at exinting errors and evils; and while intended to be tumiversal in their applieation, they will be understond in thair exact bouring only when viewel in entrast to the woung opinion, festing, or practice lae was opecially designing in wah ease to eorrect. Many passiges of ficripture fail to be rightly interpreted beranse this principle is not apprehended or not borme in mind. In the prenent ease, J J aims to correct the revengeful pririt and pratetiee to which the Jews wore greatly addiceterl, mud which they justified by a loose anplication of the law of Mloses. (2) Our Lord liere, as we have observed in former instanees see on v. 2y, and compe the expres-ions in 6: 3 , (i). selects an extremenouse, in ordar to exhibit more vividly the principle by which we should be graided. Sis lar from velugetul resistance and retaliation being right, it would be bettere, if that werethe alternative, voluntarily to submit anrsolves to a yet greater wrong. Better to turn the ather chosk, to give up the other garment. to double the impressing offievers requisition, than to permit ourselves to practice that bas-ionate resistances and that revengerul retaliation to which we areall prone, and which the. Juwish teachers defondarl. The vase is an extreme ones and very unlikely to weeur; but it wern this would be right, rather than burevengeful, all the more is it ene duty to do thing lese difficult, sines. the greater includes the less. Dylies: "(of course, when an instance is selectod to illustrate a principle, the in-tature is 11:4ally an extremeser mext to impossible ane; botl becatese a principle is best sexu when pu-herl to its ultimate application, and also because there is less chance of people blindly copying the rx-

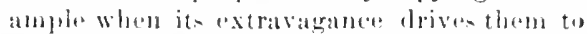
seareis for some imner meaning in it." On v. 24 we saw that if prompt reconseiliation is so importantas tomake it right to interrupt a saterifion in areler to settle a difliculty just then remembered, much nure is it our eluty, under all orelinary eilenumanees, to seek reeonciliation without delay. And so bere. It it woulel be proper, were that the altermative, even to expone ourselves volutatarily to the grosed atditional insult and wronge, such as is lore described, rather than be revengetul, then much nowe is it oms daty ta bear wromge and in-ult that havealrealy been intlicted, rathor thate exereine a spirit of revenges. 'Tn resist, to renent, to puniah, whether in national or individual attairs, is not necessarily and inberently sinful, but is usetul, when froperly regulated, to soejety, and even to the wrongdoer himnelf; and so it.is semetimes a duty to punish, evens when we should profer to do otherwise. but to resint or resent in a bistsionate and revongetul spirit is decply sintul. and $u$ sin to which men are se stromgly inclined that it mght to be guarded against with the utmost ware. And gret many profeseing Christians not only ant when excited. but deliberately and habituallyarow their intention to act, in the way which is here so prointedly condemned-more sumitive as to what the worid catle insult and dishomor, than to the teachings of infinite wislom, the sulemu commands of the Divine Rederemer. O, awardly andacity ! afraid to incur the world's petty frown, and not atraid to displease (borl.

10. Sue thee at-or, goto-law. Somonuderstand it to include private arbitration of diffieulties, as well as suits at law-and cortainly thes same term dees eover beth in 1 Cor. 6: 1, b-but the connection beresesmoto point diresetly and exolusively to a suit at law.

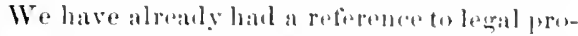
cesses in v. 25. There i-a Latin proverb which resembles this suynar. viz., "If antestes yell for the erg, aive him the ben also." coat. The Greak denotes the inner surment worn hy a Jew in those days, rosombling what the

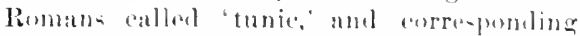
most nearly to a long shirt, which usmally" reached somewhat below the lines, but in tho 
41 And whosoever shall compel thee to go a mile, go" with him twain.

42 live to him that asketh there, and from him that would borrow of thee turn not thou away.
41 thy coat, let him have thy cloak also. And uhosoever shall lompel thee lo gor one mile, gor will him 42 1wail. live to him that asketh lhete, aul troul him laal would borrow of thee luru not linell away.

Gr. impress.

more degant article for dress occasions, reached abmost to the ground. It was sometimes worn loost, but commonly confined around the waist with a girdle. (3:4.) Insome casces two of these were worn (see on 10: 10), but in general only ane. It is this garment of our faviour which is sairl to bave been without seam. (John 19:23.) The other Greak worl, renderad cloak, is sometimes used to signify a garment in general, as in 9: 16; 17 : $2 ; 24: 18 ; 26: 65 ; 27: 31,35$. In other cases, as 9: 20, 21; 14: $36 ; 21: 7,8$, it denotes the onter garment, which appears (for our knowledge of Hebrew (lress is quite impertect) to have been for some persons a loose robe, and with others a large square piece of eloth, resembling a large shawl, wrapled aromud the person with more or less af taste and comsfort. In John 13:4, 12, there appear to have becon several garments; for Jesus would mot lay aside the inmont garment. But the outer and inner garment bere mentioned were commonly all, and the outer one was frequently usal by the por and travelers as a covering at night-just as shawls are used by travelers now. So the law of Moses provided (Ex. 22: 26) that if it were taken in pawn, it should be returned betore sunset. Such being the law, the Jewish tribunals would naturally allow the inner garment to be taken by judieial process rather than the outer one, and that will explain the order in which they are here mentioned. Lule $(6: 29)$ says mothing of a suit at law, but only speaks of taking away the garments, and henee mentions them in the order in which they would naturally be removed from the persin, the outer ginment first. - It is matter of common olserevation in all ages, that a man who is threatened with an unjust law-uit will show a peculiar animosity, and if be thinks himself nnjustly treated in the sentence, a peculiar rancor and revengefulness, declaring that he will yet make his atversary sullier for it. Rather than foel and act thus, our Leral says it would be better even voluntarily to give far more than the aggressor is awarded. (Comp. 1 Cor. 6: 7.) How evil than must be this raneorous spirit, and how carefully should Christinns avoid it.
41. Shall compel thee to go-or, impress thee for-a mile. "A" or One, is in the original emphatic by position. Impress. The Greek word was borrowed into Greet anel Latin from the Persian, to denote a Persiall practice continued by the Greek and Roman rulers who succeeded them in Western Asiat. It strictly signified to make one a pullic (ourier (fomp). Esther 8: 10, 14), and hence to make one temporarily perform a eourimr's work, or help a courier on his way, with horses or personal labors, ete.; and tinally it was applied to coercing or compelling any public service, as the Roman soldiers compelled or impressed simon to carry the tross. (27:32.) Such impressments were all the more odious to the Jews as being a subjugated people, suffering this harsh treatment from foreign rulers. During the great Maccalean struggle, one of the rival syrian kings sought to conciliate the Jews by promising many exemptions, inclueling this: "And I order that the beasts of burden of the Jews be not impressed" (same Greek worl, Jos. "Ant.." 13,2 , 3.) Impressment, like a lawsuit, is apt to produce very angry and revengeful feelings; and so this illustration is parallel to the foregoing.

42. The word rendered borrow would in classical Graek maturally suggest interest, but the Jews were forbidden (Ex, 22, 25: Lev. 25: 35: Deut. 23 : 19) to eharge interest against each other (see on 25: 27). Ruadiness to lend was strungly urged in Dont. 15: 7-11, and the idea repeated by subsequent inspired writers, as in Psa. 37 : 26 ; 112: 5. Henry: "Lending is sumetimes as great a piece of charity as giving, as it not mly relieves the present exigence, but obliges the borrower to providence, industry, and honesty." We aro here required to give, and to lend, not meroly where it is pleasant to do so, but where it is unpleasant, the latter being the jdea apparently suggested by the eonneetion with what precedss. But that the injunction is not intended to be absolute and without exception, is shown by the ease of God himselt, who promises, in terms as unlinited as these, to give whatever we ask in the manc of Jesus, and yet actually does give 
43 Ji" hav" hearl that it hath been said, Thou shalt

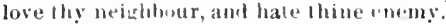

41 Bial I sily say unla you, hove your enemies, loltss them lhat "orse" you, do gored to them that hate you, anl pray [or them wheh despilelully use you and persecutte yill ;
43) Ye have hearl that it was sabl, Thum -hale los. It thy neighbunr, aul hate lhine antmy: but I sily milu you, love your eneluies, and pray lor theis only when he sees it to be proper. To give to those who "ask amiss" (James 4:3) would be no reit kindness to them-norinus. As in $v$. 45 and elswhore, Goul's example explains the meaning of his precepts.

43. Hore berins the fifth and lats example (see un v. 2l). viz., Loveor Faskues. This is clasely related to the proceding. (v. 3x-4*) Stier: "As this is tor eluse the distinctive roterence (1) the commandments, it is not wne of the individual emmmandments of the Decalingue which is introduced, as the first quotations had been; but the epitume of the whole secomd table, as . Mnsobarl al really spocifod it, viz., tile law af loce, of that onecentral disposition of mind, which hould evidence itselt in every good word and work."

'That it hath been said. Sce on r. 21. Thou shatt tove thy ueighbur, is trom Lur. 19: 18. But the Jewish teachers, with their customary efforts to explain away the rienroms repuirements of the law (comp. the catse ot onths, v. $830 \mathrm{tf}$.), here insisted ujom a strict and linited sense of the term 'noighbor.' The lawger whe catme to Jesus (Luke 10: 25 fo.), males it all turn upon this: I am to hovemy neighbor, but who is my neighbor? Our Lord's nuswer there shows, as he teaches here, that in thesense of the law even an enemy is ans neighbor. But the Jewish teachers held that an ememy was not a neighlour, and that the command to love the latter implied permission to withlould it from the former. Sin as they publicly repeated and expoumded the law, they would make the adrlition, "Thou shalt bove thy neighbor-and hate thine enemy." This they would probaps seek to justify by pointing to the sovere treatment of the Canandes which God enjoined upon Isracl; but that was an exoptional cace. The commandment to love thr neighbor wasextended in Lev. 19: 33,34 tostringers, yet that meant strangers sojourning in I-ratel. - With sueb trachings prevalent us Jesus here describes, we ean understand how the Jewseame to be charged by Tacitus with " hatreal to the human race." (See furthor on 22 : :34.)

44. But I say. See on $v$.21. The clauses onitted from this verse in Ruv. Vor. are wanting in the earliw-t manuscripts and rersions, and were mantiotly burrowed in later

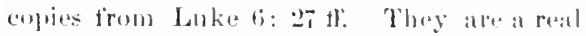
part of the disenurse, but not of Mitthes's report of it.-This injunction fimls no reat parallel anouner the teachinges of heathen sages. Those alleged have hean mi-modrorstond or ever-stated. The Empreror dulian (the "apostate"). while borrowing the iolaa firom the govpel he rejoctenel, felt thit it would

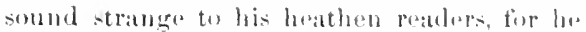
says in one ut his writings: "I would attirn, everly though it be a stringe thing to sily. that even to ane's enemies it womlel los right to erive elothing and foud." - Sume uree that the Olal and the New Testament- ars in contflict on this point, appeatiner. for exalluples, to the impreations and expreselums of hate which are found in the P-ilms. But the exanple of Gond himself shows that an abhorrence of confirmed wickedness and a desire for its punishment may co-exist with pityiner love and porsovering kincluess a and diffoult

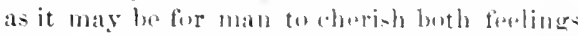
at onee, it is not more ditfirmlt thans somet other duties. And the (M)d Trest. ropeatedly teaches to show kimlnexs to atr (m) Ex. 23: 4f.; Lev. 14: 18; Prov. 24: 17, 2!;

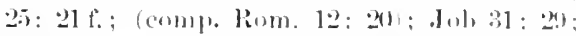
Psat 7: 4: 1 saln. 24: 5, while the Naw Test. has passages enrrespumbing to the improsaltions in tbe P'salms, as when P'atul formtorts thes Thessalomians with the thuterht that rod will torribly punish their persandurs (2 These 1: 6-10), or when the martyrial somis moler the altat

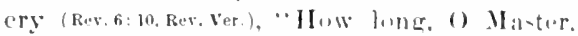
the holy and true, dost thou nat juetere and avenge our blond on them that dwell on the earth?" (Sopalion 1 (oor. 11: 2.2: Z Tim. 4: 14; Luke 18: 7.) The alitierenco is there fore of kind, and not af degrese; the latw speaks more of severits, the sanpel mors of kindness, thoum neither wholly lacks that which is most prominent in the othor. (Comp. on 5: 4.) sill, it is notably (baraceteristic of the go-pel that it enjoins not simply justice, but love. 
45 That ye may be the chiliren of your Fatluer which is in heaten: for he maketh his sun to rist on the evil inil on the good, and sendeth rain on lhe just and on the unjust,

46 lor jif ye bue them which love you, what reward have ye? do not eren the publicans the same?
45 that persecute you; that ye may be sons of your Father who is in heaven: for he maketh his sun to rise on the evil and the good, and sendeth rain on the 46 just and the unjust. For if ye love them that love you, what reward have $y e$ ? do not even the 1 publi-

I Thitt i, collectors or renters of Roman taxes: aud so tisewhere.

15. His sun, reminding us by the way that Goul puriesses and controls the sun. We commonly say "it rains," ete., but Jesus here rofires the arencies of mature directly to God. ${ }^{1}$ sendeth rain-literally-and rains. Sunshine amd rain are naturally chosen as anong the chief providential blessings. (Comp. Acts 14: 17.)-One element and proof of sonship is rosemhlance, as it is said (Eph.5:1), 'Be ye therefore followers (imitators) of God, ats dear ehildren,' and we are urged to love our emanies and treat them kindly, in order that we may be acting like onr Heavenly Father, for he loves his enemies, and sends natural blesings upon them as well ats upon his friends. Comp. Luke 6: 35, "for he is kind toward the unthankful and evil.'-'The same idea is presented by Seneca: "If you imitate the gods, give benefits even to the ungrateful; for eren to abandoned wretches the sun arises, athd to pirate the seas lie open." Sirach: "Be to orphans as a father. and instead of a hushand to their mother; and thou shalt be an a son of the Highest, and thy mother shall love thre more and more." The Talmed: "A thomsand thousand, and my riads are bound to praise thy mane for every drop of rain thou sendest down upon us, hecaluse thou rinderest good to the wieked." - But the hove of forl to his eneruies is not the same ats to his frionds, the one being a love of compassion and bemevolenee. the other a bue of complaconcy ; be bestows benofitis apon the wirked, he delights in the gond. And in like mannor we are not bidden to take admiring lolight in our enemies, but to cherish no lesvengeful and malignant foreling towards them, and to do anything we ean for their weltarethat is, of comsse, when it would not aid in the acemplishment of their evil designs against us. This is not inemsistent with restraning and even pmishing tinem; for Gox does so with his pnemirs.

16. Two other reasous for loving our encmies. (1) Otherwise what reward have ye?
It is implied that if we love our enemies, we have a religious reward (eomp. 1,12 and 6 : 1 ; and Luke 6: 32, 35). The scriptures do not leave men to the mere unaided sense of duty as a motive to do right, but appeal atso to their hopes and fears. Thus Moses (Heb.11: 26 , Rev. ver.), "looked unto the recompense of reward,' and even Jesus (Heb.12:2), 'for the joy that was set before him endured the cross, despising the shame.' (Comp. or 5: 29.) To say that this "vitiates morality" is to propose a philosophy of human conduct at variance with human nature. (2) Even the publicans. It is important to understand the odiun which attached among the Jews to the office of publiean. The Romans farmed out the privilege of collecting taxes, as is now dome in some Oriental eonntries. The right to collect a particular kind or kinds of revenue in a particular provinee was sold at Rome to some individual or joint-stoek eompany of the better clas of citizens (rquites), who were hence called "publicans," or collectoriof the public revenue. These parties sent out agents who employed as subordinates either Roman citizens of the lower class, or natives of the province. The subordinates were not in Roman usage called mublicani, but portitores. Yet as the same Greek word is applied to both, the Latin versions called both elasses publicans, and we do likewise. The tax-gatherers we meet in the Gospel history are doubtless all of the subordinate class, even Zaccheus being probably a chief of the portitores. (luke 19:2.) Tax-eollectors are in all comntries apt to be mpopular, and these men were espeeially so among the Jows. They eonstantly reminded the people of their subjugation to the Romans. and a promd poople, whose history told of Darid and solomen and the Maecabees, could never think of this without mortifeation. They often practiced extortion (Luke $3: 13 ; 19: *$ ), eltcouraged thereto by the fact that their employers patid the government a fixed sum, and kad all they conk get. No mative would take 
47 And if ye salule your hrethren only, what do ye

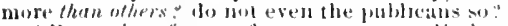

ty be ye the'refine perfect, even as your lather which is in hearen is perfecel.

such an office if he eared mueh for publie opinion, and those who did so were ustually renegades, or very lax as to ubservance of the law. Accorlingly, white the publicani at Rome, who really served the state, and sometimns advanced large sums to relieve the puhlie tinances are high!y commended by Cicero and others, we find that in all the provinees the subordinates were hated and shunne:l, and partieularly in Palestine. The Jews elassed them with heathen ( 0.47 and 19: 17) and with hatrlots $(21: 31)$, and one of the reproatches eatat on Jesus was that he was a "riend of publieans and inners.' (11: 19.) Matthew wats himself" at publican $(9: 9 ; 10: 3)$, though he may have been a man of better eharacter than was usual numg them. Mathew heard this discours", yet of $:$ is did not on that aceount use softened expressions about the clatse to which he had belongred. The later Jewish writers das then with rolders and murleters, and atfirm that they were not allowed to give testimony, and were excluded from the synagogues. Our Lorel is thus declaring that to love those who love us froves no higher grate of morality than that oceupied by the mont despiecd by publieatns and by heathen. (v. 45.) Lonkt 16:325.) usis the mure general term, 'simners.' In loving his friends a man may in a cortalin sense be lowing whly limself-a kind of expardect selfishness.

47. This repents, in another form, the thought of the precesling sentenen, such ann-

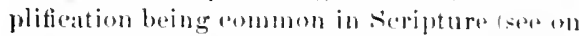
v. :30), and being very eflective in pepulatr disenurse. Publicans-rather, fientiles; the reading of the parliest Grenk manu-eripts and

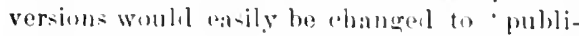
cans, to correspond with v. th. The Jaws: regarded wher nations with dielike and contempt, and so 'tlar nations. would sometimes be a term of contempt, which in English we express by 'Gentiles.' When Christianity beenuse prevalunt in the Roman Empire, the old Roman refigion still survived in many remote eountry distriets (pat!i, pragani), and so) its supporters were ealled "pagans." or in English 'heathen "living in the heatl or mocultivated country). Aecordingly the same Greek word is translated 'nations" in $21: 43$;
47 eans lhe same? And if ye salute your breldron onity what do ge more than oflers. do not avent the liteil-

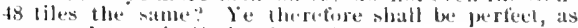
your heavenly pather is perlect.

24: $7,9,14 ; 25: 22 ; 28: 14$; and 'Rrutiles' in 4: $15 ; 5: 47$, Rev. Ver. ; $6: 232 ; 10: 5,18 ; 12$ : 18,$21 ; 20: 19,25$. A derivative was rendered in all the early Enerlish ver-ions by "heathen" in 6: 7; 18: 17, which gives the christion point of view, but the Reve. Vur. resteres the Jewish stand-point by lenderiug ' (ientiles.' (It dees the same in Acts 4: 25; 20 Corr. 11 : 26 ; Gal. 1: 16; 2): 1 ; $\left.3: 8_{0}\right)$-Tu silute a person is a stronger mark of kind foeliugs aceording to Oriental manners than among us, their salutations being unally elaborate, and theretore given only to express high respert. Juws did not generally salute Gentiles, and Mohammedius as a rula do not sillute Christians; and the Apustle Jobn (2 John es.) forbils not enly hospritality but 'gresting, (same word ats in Jame- 1: 1: Xets li): : :3) to teachers of thuse antichristian and gromsly immoral notions which prevalud. The expresis the importance of "sulute' in this verse, Tyndale and Geneval give a sort of jaratphrase, "if ge be friendly to vour brethren only, and fireat bible, "if' ye make muebof," ete.-Luke (6. 3a f) here gives some other expressions which sill further amplify the thoughts expressed in this ame the two preeeding versis. It is not difficult to nuelerstand that each Evameralint hats given only a part of what was spokon.

18. Be ge perfect. If sliall be (so Tyn-

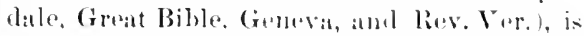
a literal translation of the Grove Future,

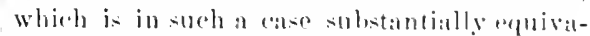
lent to an imperative. The ferm of expression may (arry an allusion to bout. Is: l:?. Ye is mplatice, meaning ('hrist's disciplen as enutrated with publicans and Goutilus. Therefore, presents this as a conclusion frome what preeceles: sinee ford ought to he at at hierher point of morality than publinatus aud] Gentiles, and ought to be like your Fither in heaven (comp. v. 4.5), theretiore youl slall be pertect. ete. Father which is in heaven. The realing Hervenly Fither of many carly manuseripts and versions, was easily changenl to the marecommon Fatber which is in heaven of $v$. 45; ti: 9, 14. The term rel:dered perfect is used in a varioty of conneetions, and its precise menning must al ways be 
determined by the partieular connection. Sometimes it is simply 'complete,' without any moral element, Heb. 9: 11, and perhaps James 1: 17. In other cases it means eomplete in crrowth ot body ol" mind, "fullgruwn.' (1 Cor. 14: 29; Eph. 4: 13; Heb. 5: 14:6:1;1 Cor. 2:6.) In yet others, complete morally, as Matt. 19: 21; Col. $1: 28 ; 4: 12$; James ] : 4, 25; $3:$ : And there are passages in which it serms to mean complete in both knowledge and momal exotlence, as Phil. $3: 15$, and jerhaps 1 Cor. 13: 10. Here, it is moral perfection in general, but with specifie reference to love-i. e., not loving friends only, whieh would be an imperfect love, but loving enemies alion, as our Heavenly Father does. Luke (6:36) gives only this specific thought, "mereitul.' But it does not seem propar to restriet Matthew's general term tothis thought alone. In all things, luve included, we ought to be prefect, even asour Heavenly Father is-to be lika him, and so prove ourselves to be his children. Our own minds demand a perfeet standard, such as the divine nature presents; and bowever far we may actually fall short of attaining it, yet he who is content with coming short gives no evidence that he is a ehild of Gor.

Thus ends the series of striking particulars (5. 21.48) in which our Lord compares his teachings with the law and the eurront explamations of it, so as to show that far from designing to relax the obligations of morality, his requilements were still more stringent, extending. not meroly to the ontward act, but to the motive and feeling; not merely to what the letter of the law required, but to all that it designal and involved. (See on v. 17.) $\mathrm{As}$ this portion of the Sermon on the Mount hats esperial roforenee to Jruish jdeas, Lalie, who wrote not for . Jews in particular (as Mattlow did), hat for eneral circulation, has given no report of it, exeept of what was said on the subjoct of love to enemies, and this he introduess as groural instruction, without any allusion to the. Jowish mianterpretations of the law and mistaken expectations, which with his design would have bren out of place.

\section{HOMILETICAL AND PRACTHCAL.}

V. 38-41. Four kinds of Retaliation. Natural passion says, Pequito tho like, and worse. (2) The law of Muses suys, Let the judge requite precisely the like. (3) Christ says, Do not (revengefully) requite the like at all-better receive the like a second time. (4) The apostle Peter says (1 Pet. 3:9), "Not rendering evil for evil, but contrariwise blessing." This is the Christian retaliation.-selfdefense, and pumislment in ways regulated by law, are not forbidden in forbidding laate and revenge. But do not "take the law in your own hands," and do not press the execution of the law in a revengeful spirit. CHRss. : "Nothing so restrains the wrong-doers, as when the injured benr what is done with gentleness. And it not only restrains them from rushing onward, but works upon them also to repent for what has gone hefore, and, in wonder at such furbearauce, to draw baek. And it makes them more our own, and eauses them to be slaves-not merely friends-instead of haters and enemies. Even as avengingoneself does just the contrary; for it disgraces each of the two, and makes them worse, and their anger it brightens into a greater flame; yea, often no less than death itself is the end of it, going on from bad to worse." STIER: "That heathenish law of honor, which will not accept the very slightest indignity, but even in the midst of unodern Christendom demants the duel itsalf. To this "point of homor' stands opposod the patient acceptance and endurance of insult, as the genuine Christian courige and knightly honor. Offer him the other also-that is, in thy heart, and in the dispusition of thy mind; ealmly and patient]y wait if he may strike thee another blow, and be ready to recoive that also-so fiar let thy spirit be from opposing. . . . The actual turning of the other cheek might be no other than a challenge to continued sin, consequently itself sinful, and opposed to the love of onr neighbor. There might even be a prond despite in it, or a mere hypoeritical affectation." DYkes: "By general consent, a blow on the face is the extreme of personal insults. . . But the spirit of our Turd's words is not open to the suspicion of being a eraven spirit. It is this suspieion, more, I faney, than any thing else, which is apt to diseredit the teaching of this text with generous men. Yethere, as always, it is sin, not love, that is the real cowart. He who best obeys the rule of Jesus will be the bravest man. To curb temper; to govern the spirit 


\section{CHAPTER VI.}

IAKl: heed that ve do not your almsa befiore men, to 1 leserll of lhem: oherwise ye have no reward of your lather which is in heaven.

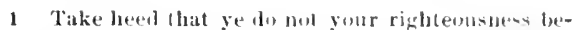

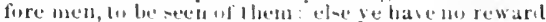
will your faller who is in heaveil.

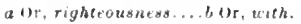

of revenge, even under insult; to place what is becter tan life, personal homor, under the control of a love which is patient and just becaluse it is strong-stronger than passion : this is true valor and true honor."

V. f.) Our duty to Begerars. I. Comensels. (1) We munt not refuse all bedaluse many are impontors. (2) We should striveto ascertain who are really neody and deserving, and to inform others. (3) We must not turn breggars nway simply becamie aftimaive or anmoyingthis would be a very petty solfisliness. (1) Whepe there is publie provision for beggars we -hould act in barmony with such arrangments, but cannot remit the matter whally to them. (s) To open some means of supporting themselves is far better than to suppurt them. II. Motimes. (1) Humanitythey have the same natureas atuselves, essentially the simme sonsitive foulings, patins and pleasures, momories and hopes amel desting. (2) Pirty. Grateful lowe to (ivel. Wre are begerars, to whom he gives liberally, and we must return to him by giving to tour followmen.--Burrowing and landing. It is mores blesidel to lond than to burrow. Cautions as to borrowing-encouragemtnts to lond. Compl. Lukiv li: 35.

V. H. CYRIL: "Int w loveour enemies, not as adulterers or murderers, hut as meno." -CHRYs.: "Hav" yell sern what steps ho has ascended, and how he hat placed as an the very summit of virtuo? leble at the surecssion from the heginning. The first-tel) is, not to begin injuring; the semed, atter injury has been begun, not to defend youraelf atganst the injurer loy like actions; the thirol, not to inflet an the wrong-rloer that which one has suffered, but to keep tyutet; the tourth, even to yield oneselt to suffer evil; the fifth, to yielel even more than le who dial the evil wishes; the sixth, not to hate him who does these things; the seventh, evento love him; the eighth, even to do him gami the ninth, even to pray to frot for him. IIate you seen the height of Claristian philosophy?" - Love your enemies. I. How? (1) Du not love what is wrong in ahem, but lave them notwithstanding the wromg. (2) Lane them in the same way that foul loves lise enemines. II.

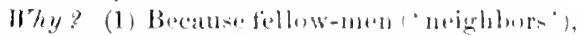
althougl enturies. (2) In arder to be like God, his children. I ERoure: "Mally say that to lose enemies is too much for lommatr nature; but bavid diel this to sianl and Ih-

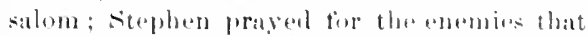
were soming him; dens both tameht and alid

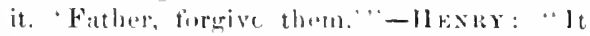
was satel at Archbinhop Crazuner, that the way (1) make him a friend wat to do him an ill turn; so many did he serve who had disobliged him."

V. 4.) Natural blessings, as sumshine and rain. The modern phrane is that they are caused by the "laws ot nature." Thry are caused by matural forcess. which we prereive to act regularly, and these regular mombonf acting we call laws. But wha alpuinterl the laws? Who ereated the furcess and mate them steh as to act in thesp recrular ways? The serifutures represtent the Creater as work-

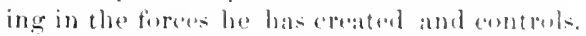
- Somohip to fod. (1) Shumn ly moral likenees to him. (2) In partiunlar, iy kinduess

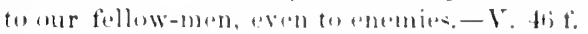
Natural kindness and Chrintian kinduess. Cisristians merht asomrebly to be better than men in general. V. 48. Imitatingr. (1, J), not indate the publicane and the (rontilas. (2)

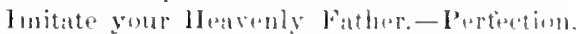
(1) We shomld wish to be juerteret-and patimed with our imperfections. (2) 11 e slumblets

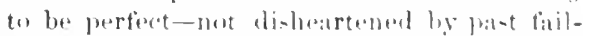
ures. (a) Wtomy hopeto be perfiect-ats we pase inte the pertinet wurlal.

Ch. 6: 1-1. (Rush) Witeks Witholt OsTENTATINY. I. ILMS-GIVIX.

Since $5: 17$ ate Analyeis at berinninger of ch. 5. our Lord has besti shoming that ha requires in the subjects of the M ....ianic rejunt, a ligher and more spiritual murality than that which was taught and practiced ly the scribes nnd Pharisues. This is continued in 
2 Therefore a whin thou doest thime alms, fo not som a trumbet hefore thete as low hyporites do in the synagourues and in the strests, that they may have folory of men. Verily 1 say unto you, They have 1 heir rewarel. abut when thou loest alms, let not thy lett hand know whal 1 hr gight hated doeth:

+ 'Hot thini ahos may be in secret: and thy Father which secthin secred himself shall reward hee ojenly.
2 When theretore thou doest alms, souml not a trumpet bofore thee, as the hypocritus do in the syllagunes and in the streets, llat they may have glory ot men. Verily l say unto you, They have 3 received their reward. But when thou doesi alms, let not thy jefi hand know what thy right hand 4 doeth: that thine alms may be in soeret: and iby liather who seeth in secret shall recompense thee.

a Or, cause not a trumpet to bo sounded.

6: 1-18; and a 5: 20 introduced the first main section, $(5: 20-48)$, so v. 1 introduces the second. (6:1.1\%.) In 5: 20 it is said that their righteousness must exceed the sicribes and Pharisees; accorlingly (Weiss, Lutteroth) $5:$ 20-18 gives examples from the teachings of the sicribes, and (i: 1-18 from the practice of the Pharisees. The general principle of verse 1 is illustrated by applying it to three exereises highly valued among the Jews (commended trogether in Tobit 12: 8), viz., almsgiving (v.2-4), prayer (5.15), and fasting. (16-18,) Each of these, he says, should be performed, not with a view to human approbation and rewald, but to that of God. Calvin: "A very necessary admonition; for in all virtues the entrance of ambition is to be avoided, and there is nowork so laudable as not to be in many instances corrupted and polluted by it."

1. Your righteonsmess, 1 i. e., righteous actions or good deeds (as in 5:6, 10, 20), including such as alms-giving, prayer, and fitsting. ${ }^{2}$ To do righteousness is a phrase of frequent oecurrence, as in Psa. 106: 3; Isa. 58: 2; 1 .John 2: 29; $7: 7,10$. To be seen of them. Mure fully rentered, "with a view to be louked at (or gazed at) by them'; the Groek construction is the same as in 5: 28; 23: 5, conveying distinetly the iden of jumpose, design; and the areek verb is a strong word (the ront from which comes thentre), and suguests the being gazed at as a spectacle. Sio 'hyporite' is originally 'actor, one who plays a part. This meaning of "to

${ }^{1}$ This (emmp. Comm. Ver. margin) is the reading of the three oldest uncials that eontain the passage ( $13 . \mathbf{N}$ 1.), of tha hatin vorsons (moarly all popies) and latin Fathers, and is alopted by lach., Tiseh., Treg., W II It might easily be alfered to the word meaning "alms, partly locease that is the subpeet of 5 . 2-t, and many did not see that v. 1 presented a distinet general prescept, and partly because the later lews otten used 'righteonsness' as moining alms, that heing in their view the foremost righteousness. (tomp. onr modern (miployuent of 'charity' to dinote simply alms-giving. This use is seen in the Talumd, and in the trepuent translations of the llebrew word lor righteousness by be seen,' is very strongly brought out hy Tyndale, Great Bible, and Geneva, "to the intent that,' etc. ; and for 'seen' Geneva says, 'looked at.' What our Lord forbids is therefore not publicity in performing good deeds. which is often necessary and therefore jooper. but ostentatious publicity, for the purpose of attracting attention and gaining aplaluse. This abviously does not conflict with $5: 10$, where the olject to be had in riew is that God may be glorified, not ourselves. (Sce on that passage.) No reward of-or, with (comp. margin of Com. Ver.), as if laid up in God's presence for you. Comp. 5: 12, $46 ; 1$ Pet. 1: 4.--The Greek and Roman philosophers and the Jewish writers have many maxins upon the importance of being unostentatious in virtue, especially in deeds of benevolence. A desire for the approbation of thr fellowmen is not in itself wrong, and not incomputible with piety, hut it should be completely subordinated to the desire that God may approve us, and that he may be glorified in us. This entire subordination is manifestly very dificult, and hence many think it easier to denounce ambition altogether, forgetting that ambition is an original principle of our nature, to destroy which would be as injurious as it is impossible. But while not inherontly sinful, ambition, like anger (see on $5: 20$ ), is exceedingly apt to become sinful, and hence the solenum warning hore given.

$2-1$. The tirst of the three subjects to which our Lurd applies the great principle of $r .1$ is

'alms' in the Sept, but is not tound in N. T., nor in the Ilebrew O. T.; for liesenius' examples, l'rus. 10 : :2; $11: 4$; 1'sa. 24:5; Nicah $6: 5$, do not at all require or justify such a sense. But this notion of righteousness as alms, spreading among Christians, might cause 'alms' to be written in the margin of $v .1$ as explaining the supposed meaning of righteousness, and then its substitution by eolyists. Notice that the Oriental versions grencrally read alms, as the usige just mentioned would he readily adopted in an Oriental language.

steveral early Mss. and versions insert de, 'But take heed, ete., which is atoptert by Tisch., and given in brackets by WII. The question of its genuineness is 
Alms-giving. (v.z) Therefore presents what follows as an inference foun what precedes, the specilic preept interred from the genoril. 'Thou, sate on 5: 25; ; 1 :5. When thon doest, appears to take lirr granfed that they will do so, as likewise in $v$.5 and 16. The Enelish word 'aluse' is an abridged form of the Cireek worl hore usod, plemesune (ommp. ouradjectiveolemesymary), gradually reducol to Germath almoron, Wyelit"s alus-

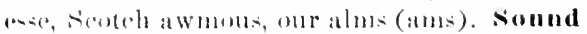
atrumpet, is by the Greck commentators and nearlyall recent writers under-tuml as merely n figurative expresinu, common to many languleses, for parade and aftiert to attract notice and applatuse. Thepe is 110 anthority for tha conjecture of Calvin forentioned ats early a Euthymius) and somouthres (including situr, that it was a practice annong tho Jew - fur an ostentutious alons-giver literally to somml a trumpet before him in pulolic platese to summon the moedy fommding it through anothor person, sae matrein of ('inm. Ver. I Lightf. somght long and marmestly for

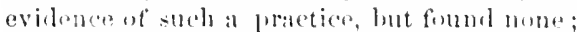
and it is very improbable that such a thing wamld have been promital "in the symagugues. We see much lonevolemes at the presint day so astentations that the griver might very naturally be tigurativaly dereribed as sombing a trumpet befors him. The notion of Edersheim, "The Tomple," p. 26, that tho "xpression refors for trumpet-shalped eontribution-luxes, in the tamples tratomy, appeatrs rextremaly falefotehed and fancifiul. IIy porites. The woral is lorrowed ly us from the fireck, and in elasice $11 \div-$-ignificed an actor, who wore a mask and played a pirt. This well illa-trates, as it naturally led to, the sense in which the wort is so ntem used in Seripture. Is tu symagames. sकu 4 : 2:? That they may have glory, ar, be glowifind of men, in eontrist to seoline the glury which foul gives. ( ('omp. Juhn 5) 44). Verily I say unt you, see on 5: 18. They have, or, hawe receivel. Sir Vulgate. Wyelif: and so Com. Tor. translates the same word in Luke f: 24. The Groek verb is a compound, sienifying to barentirely, havethe whole ot", lase in tull. The idea is that in being garod at and glorified by men they have all the: reward they will ever mbtain, for they must fail of the reward mentioned in v. l. (Compr. P's. 17: 14.) Siee thes satue word below in $b$. 5, I6. But when thou doest ans, the position of the words making 'thou' emplatice, in eontrat to the hypurites. I.et not thy loft hamd, ete. Hore, as in $v^{2} .2$, we have a tig-

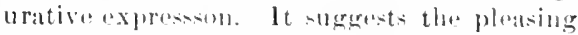
and striking image of a man passing one who is in need, and with lik- right hand griving alms inso quiet a way that, so to speak, even lis wwn left land does not know what is goning 0n. 'That, in v. 4, is not " so that' lunt 'in order that, explesing not simply the result, but the purpose; junt as ill v. 2, in 5: 15. ete. Of course this does not require that all benevolenes shall be literally secret, but that no henevolence shall be astentatious- ene on ․ 1). Sis far from trumpeting your almsgiving betore the public, do not aven let it be known to yourself. Which seeth in secret, not exactly whor rees what is dome in secrot, but who is present in serect and sees there. Comp. v. i, 18, "which is in secret.' relvin: "He silently glances at a kind ot tolly which prevalils everywhore thumg men, that they think they have lost their pain if there have not been many spectators of their virtues." Reward, refomponse, or, repey, is the word explained on to: $: 3,1$ and diflereut from the nomil rendered 'roward' in v. 1 l. Wo are? not told whon or low the reeompense will be givers, and may mulersand that it will be both in time amd in comernity, buth in clantaster and in folicity.

The.Jul hold almo-riving in the highest estimation. Thus Tolnit, I': $x$, says, "It is gond to do alme rather thath to tratare up gold. For alms delivers from deatle [a mi-iuterpretation of Prov. 10: 2; 11:4i, and this will purge awa every sin." Compr. sirach 29: 11 1t. The Talmud siye that almsgiving is "moro "xiollent than all wforings,", hard to deeile. If alopred, it womk seem to imply the expeetition that $5: 20$ and 12 womld stir in the persons ahldresod a desire to be rightemus, and so they would need the ration. "But take eare," ete.

I'Uimself' and 'openly' are onitted hy the earliest manuscripts and most of the early versious. We can see bor they may have been written on the margin, to briug out the implind cont rast, and then suppusel fo bu part of the text hecanse quite appropriate: while it present originally, we eannot inagint why any one shonk have wished oumit them. So they must be ro jected without hesitarion. 
is "erpual to the whole liww," will "deliver form the condemnation of hell," and makes a man "perfiectly righteous." In the Talmud of Babylun, Psa. 17: 15, is explained to mean, "I shall behold thy face on account of alms" [prownrly, in rigliteousness'], and the inference is llaw that "on aceount of one fartling given to the poor in alms, a nan becomes partaker of the beatifie vision." Maimonides lartirelarizes eight degrees of alns-giving, the merit being araded according to the circumstances. In like manner the Roman Catholics attah great value to gifts and other kinduenoes to the poor, believing that they atone for sins. Ifolding the books of Tobit and sirath to be anonical, they find in them prout-textefor this doctrine. Add to the above Siriall :3: :30, "alms will atome for sins." In this, as in various otluer cases, there is reason to feal that Protestants, by a natural reaction from Romich error, fitil to value an important Christian duty as they should do. See Prov. 19: 17, also the eup of cold water (Natt. 10:42), the jurlgrment scenes (25:35 ז.), also 2 Cor. 9: $6 \mathrm{ff}$; Phil. 4: 18 f:; 1 Tin. 6: 19; James 1: 27. That is a good saying of a Roman joust, "It is only the riches you give that you will ulway have." And see Tobit $4: 7 \mathrm{ff}$.

Some of the Jewish writers also enjoin seerecy in alms-giving. Talmud: "He that doesalons in secrot is greater than Moses." A Mohammedan proverb says: "Hast thou done a goud slael, cast it into the sea; if the fisl find it nut, yot will G.d see it." And among the trabliomal soyings of Johammed, we find, "In alum-griving, the lelt hand slould not know whit the right has given" -one of the nunerous instances in which Hohammed bonrowed from the seriptures, not only the Old butalos the New Testanent.

\section{IOUILETICAL AND PRACTICAL.}

T. 1. VIxET (in Lutteruth): "To be per-

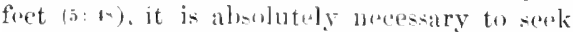
the notion and aim at the alloroval of a perfect bring." CHkYs.: "It may be, both that whe doingalms [he had the wrongtext] before men may not do it to be sesen of thems, and again that one not doing it before mon maty An it to beseen of them.... He (Chrict) defines both the penalty and reward not by the result of the action, but by the intention of the dis.r.- V. 1 and 5: 16. Goud Works in
Publie. 1) Wrong motive, that men may honor us. 2) Right motive, that men may glorify God.-Boakduax: "Distinguish between doing right in order to lielp others, as when one lights a beaeon in order to guide the sailor, and doing riglit in order to be praised by others, as when one stands in full blaze of a clandelier in order to display his own jewelry." Dykes: "The actions of piety, like its tones or its gaits, are so imitable, and the imitation is so hard of detection, that they become the invariable livery of the hypocrite. For the same reason, they seduce those who are not yet liy poerites into bocoming so. Whell a man would increase or preserve a reputation for piety which he bas once honestly enough obtained, it is fatally easy to perform pious acts, with this end in view, at little oftener or a little more ostentatiously than he would do were he only careful about serving God.'

V. 2-1. Two ways of doing good, and two kinds of reward. - What is the hypoerite's reward? Praise from some of his fellow-men, with the consciousness that he does not deserveit, a perpetual dread lest they find him out, and frequent fears of that coming time when the seerets of all hearts shall be revealed.-It is not necessarily wrong to employ example and emulation in persuading men to give. (2 Cor. 8 and 9.)-Hypoerisy. 1) Its nature. 2) Its unwilling tribute to trup piety -as counterfeit coin is abundant berause genuize coin is so valuable. 3) Its rewird. (a) the reward it may gain, (b) the rewarl it must miss. Rocuffoucauld : "Hypoerisy is a sort of homage that vice pays to virtue." HENRY: "The hypurite eatches at the shadow, but the upright man makes sure of thesubstance." Eece Howo: "But thireare subtler forms of hypucrisy, which Clurist does not denounee, probably because they have sprung since out of the corruption of a subtler creed . . . They would practice assiduously the rules by which Christ said heaven was to be won. They would patiently turn the left cheek, indefatigably walk the two miles, they wath bless with effusion those who cursed them, and pray fluently for those who used them spitefully. To love their enemies. to love any one, they would certainly find impossible, but the out warl signs of love might easily be learnt. And thus there would arise 
i And when thou prayest, thou shate not be as the hypocritus are: for they love to pray stanling in lho

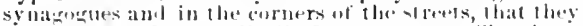
may be seen of men. Verily I saly unto you, lhey have theip rewarel.

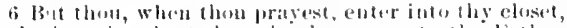
and when thou lase shet thy dour, pray to thy Jalloor which is in secret; and thy lather which seeth in seceret shatl reward the opendy.

- bat when ge praty, use mot vain repetitions, as the.

at new elass of actors, not like thowe whom C'hrist denounced .... hoping to impese by their dramatic talent upon their Father in heiveno." Lethek: "If we eatee our charitable dereds lecaune numb are ungratetul, that shows that we were not aiming to pleatse and honor (rowl."

j-15. (roud Works Wathout OStexta tron. II. P'RAYER.

5. The general principle of v. 1, that gond worke intust not be performed ostentationsty, is now applied to a sacond example (compitre all v. 2). And when thou prayest. The correet text is, and when ye may. It was atrly changerl in some copples into" thou prityest," to agrese with the singular verho which precede. But throughout this pasiage (x. 1-1x) thes plural is userl in the general injume(i.ms $(v, 1,5,16)$, and the singular in the pointed

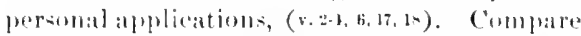

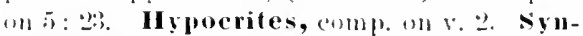

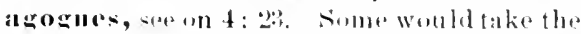
wor.l here in its elyoulogienal sense, ats denuting "gatlerings" anywhere, but there is no propriety in departing from the $11-11,1$ 1 meat1ine. It was not wronge to pray in the symagugues, which was a comment llsige; lut these hyperites prayed there rather thath in secret. and diet so fir the purpese of display. In the corners of the streets, they fonuld be seon from four slirections, and thes woulel be delightfully armspicuous. The word for "streets" is difle rent from that of $v$. 3, and demetes brond. spacious streets. To pray standius. Three postures in prayer atro

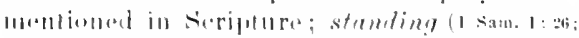

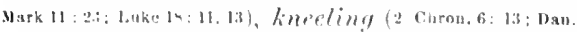

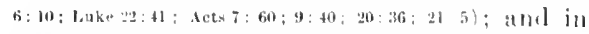
cases at peroliat awe or distress, prostration

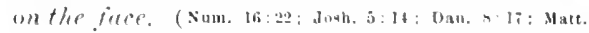

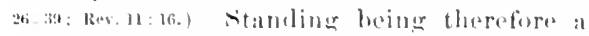
common persure, it is plain that this formed not part of the display, whith consistod in chousine the mo-t problic places to paracle their devotions. The Titinud of Babylon savs that persons would sometimes stand three
5 And when ye proty, ye shatl not be as the hypocrites: for they low lostamd and pray in the syuat

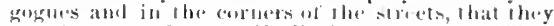

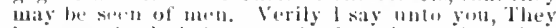

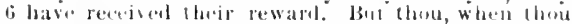

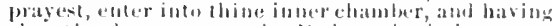
shut thy dowr, prity lot thy lather wios is in serel, and thy lather whin seeth in sieret shall recomplense

7 thete. And in praying lose mol vain repetitions, ats

loners in a public places and a praying persture (Lightf.). The exulase fior sach parade ot devotion wan fonmed in the dedea that when lhe hour of prayer arrived, ome must pray wherever be wats; so with the Mohammunatus now, who may often be seen proying in the most public places. The pratedien of imflo-

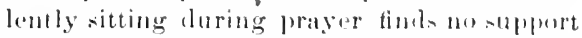
either in seripture procedent (untess : s:am. $7: 18$ be clamed ats sach), in the matural teeling of propriety, or in levout "x]pritence.

Verily I say moto you, see $1115: 5$ : 18. They have, have received-"have in fuil." see on s. 24 .

6. But thou, changing again to the silrgular number for puinted perenbal applieation

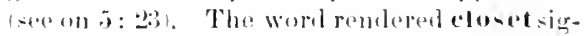
nifies originally a store-poum, and then any prisute or retired room. liav. Vor., "inner "hamber." It is frepuently applied in the:

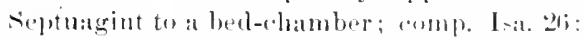
20, "Come, my pentle, enter thum intu thy" chambers, and shat thy disors albut these: hide thyeolt ats it were tor a little moment. until the inclignation be overpat." Comparo

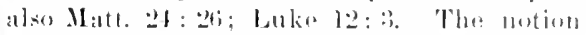
that ener Lurd dexigns to reter to al particulat

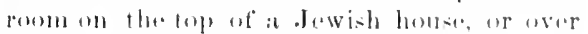
the main entranes of the building, is unwarratuted, and unneressarily rostriets the meatl-

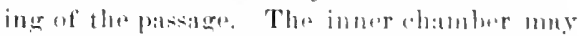

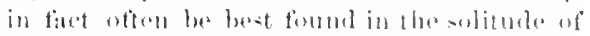

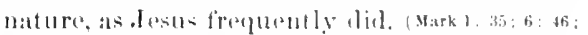
14.32.) Shont thy door, the word denterting that

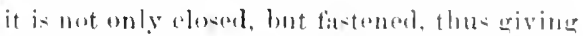
the julea of the most completeprisary. (comp.

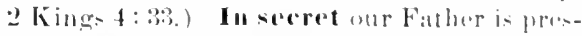
ent, in secrest he sees, and thongh men wili not recompense. he will. Comple Prore 1.j: :3. Openty is a spurions adlition. a in r. 4.)

if. Slightly dieresing in a very natural way from the precios line ot thought in $\mathrm{r}$. 1-18, and resuning the plural of general allarese, our Lord here appends a cellowre of another and kindrod titult in praper. in the injunction, use not vain repetitions. The 
heathen do: for they think that they shall be heard for their much speaking.

8 Be not yethetere like minte them: for your Father knoweth what things ye have need of , before ye ask him. the Gentiles do: for they think that they shall be 8 heard for their much speaking. Be not therefore like unto them: tor l your lab ber knoweth what

1 Sime ancient authorities read, God your Father.

Greek has a rare word formed so that its sound shall resemble the sense fonomatopoeia), and used to express stuttering, the indistinct speceh of little children, or any confused babble. This well represents the practice common in the public worship of some of the beathen, as when the priests of Batal continued from moming until noon to "ry: "O Batal, hear us!" (1 kings $15: 26$ ), and the multitude in the theatre at Ephesus for two hours shouted, "Great is Diana of the Ephesians." (Acts 19:34.) A great erowd continuing to repeat the same words, every one for himself, would make just the babbling noise which the Greek word expresses; and so would a single person, when, wearily and without interest, and as rapidly as possible, repeating the same word or phrase. Tyndale renderet "babble not much," followed by Great Bible and Genevi. The Com. Ver. rendering, "use not vain repetitions," was suggested by the commentary of Bezal, whose guidance that version frequently follows. It is possible that as a stutterer often repeats the same word, the Greek word came to be need to denote idle and unmeaning repetitions in general. The idea of the heathen was that for (in) their much speaking they would he lieard. Sit the Roman comic writer Terence makes one person tell another not to stun th" gods with thanksgivings, "unless rou jurlgo them to have no more sense than yourself, so as to think they do not understand anything mless it has been said a hundreal times" The Jews must have been inclining to the same practice, thinking that there was merit in saying over eertain words of prayer many times. In Talmud Bab., R. Hanin satys, "If prityer is prolonged, it will not be without effect." Another objerts that it may make one siek, and a third that it may anake him gloomy. (ompare Mark 12: 40 "And for a pretence make long prayers." Yet Feel. 5: 2 had winted ont the impropriety of much speaking in prayer, "Therefore let thy words be few," and the apocrywhal book of Sirach (Ecchss.) (7:14) said, "I)" not prittle in a multitude of elders, and do not repeat a word in thy prayer." So the Roman poet Plautus says, "Transact divine things in few words." The practice of praying a long time, as a fomai observance, would naturally lead to unmeaning repetition. The Buddhist monks at the present time, will for whole days together ery aloud the satered syllable Um; and some Mohammedans " turn about in a circle, and pronomnee the name of God until they drop down," After a $\mathbf{M}_{0-}$ hammedan funeral in some countries, devout men assemble, and repeat Allah el Allah, "God is God," three thousand times. A traveler in Persia tells of a man "whoprayed so loud and so long that he lost his voice, and then grouned out, in vojceless accents, the name of God fifty times." (Tholuck.) So in some prayers reeorded in the Avesta, and in the old Egyptian writings. M. IIuc tells of Buddhist students in Chinese Tartary, who will put a written prayer on a wheel, whieh is turned with a crank, or even by wind or water; and they believe that every revolution is a prayer, and adds to their merit. In like manner, Roman Catholies now think it very destut to repeat many times-often fifteen, and in some cases a hundred and fifty times-the $\Lambda$ ve Maria (Hail, Mary), and the Pater Noster (Our Father, i. $e_{\text {, }}$ the Lord's Prayer), and count the repetitions by slipping the beads of the rosary - thus employing (Tholuck) the very prayer our siviour set in eontrast to such notions and practices. This use of a rosary is a Buddhist fractice, which came throngh the Mohammedans to the spanish Chri-tians. - But our Father (see on v. 9l is not sluw to attend, as Elijah morkingly represented Baal to be, nor umable to understand unless it is said a hundred times; he knoweth what we need, not only as soon as we ask it once, but even before we ask it. Observe, however, two things: (1) God's knowing before we ask is no reason why we should not ask. We do not pray in order to give bim information, but to express our own desire, our feeling of need and dependence. Not that prayer, as many say, is designed simply to influence ourselves; 
men would pray very little if they really believed that to be all. We pray, as hoping therebs to induce Gind tu grant what we desire; and his: forelinowledge and even predestination of all thinge is no more an objection to praying than to acting. (2) Our siaviour cannot moan that long-continued proging is in itself improper, for he himeself osmetimes spent a whole night in prayer (tuke 6:2:2), and he spoke more than ane parable to emenurage perseveranee in prayer; nor is it neecesallily wrong to repreat the same words-at thing sometimesere vatural when we are deeply in earuest - for in Gethemane he "prayed a thirel time. saying again the same worls." (26: w.) The diffirence between these and the practice enondemmed is platin. Aughatine justly distinguishes between mueb spealing in prayer, and uruch prating.

9. After this manmer therefore pray ye, with a strong emphasis (as the Greek shows) on "ye." This injunction is presented as a cumsequence of" what precedes. Since it is unavitiling for us, and unworthy of onr hod, to pray as the heathen do (eomp. $v .7 ; .75$ ), therefore de ye priat thes. The special though of enure not exclucive desien with which the prayer that follows is here introluced is to fut in contrant with that of which he hat just been spesking ( $x$, i) a specinen of the right kind of praver. Ile thus teaches them "hy eximple ats well as hy freecept," to aroid the

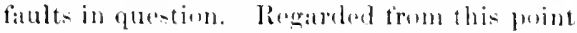
of view. We are struck with the anmprehensiveness and simplicity of the prityer. truly the rery opperite of "much speraking." of babbling repetitions and boisteroms pasion. Ilow vast its scope, how varied th applieations, louw simple its language. Tertudlian already observed that it is "as eophoms in meaning as it is endended in exprosoion." Yet with all this comprehensiveness, there is un propricty in gravely dofonding, as some do, and seeking to astabli-h by artiticial exposition, the mero rheturical hyperbule which Tertullian adds ("O) P'rayer." (hatp. 1), that "in this prayer is comprised at compend of the whole goipel."

Sulutantially the same prayer is recorted in Luke 11: 2-4 as a specimen or mokel of priyer in goneral, given in rospmse to it special requat from one of the disciples. Now we know that Jesus repeated many striking or impurtant sityings at diflerent

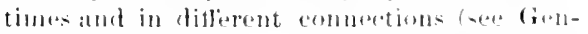
eral Introduction tu chatp. 5). There i- thuno difficulty in understanding that he gave this proyer on two ditlerent acca-jons. They whothink otherwion must either suppese that Matthew hat artificially com-trueted thin dis-

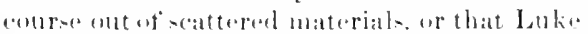
hats intreduced on atl unreal oreation (Luke $11: 1$ ) what actually berelenged to this dinenures and

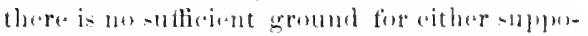
sition. Reerent studies in the harmeny at the

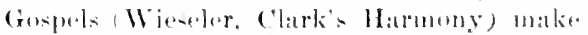
it highly probalile that the acea-ion on which Luke giver the prater wats long after the sermon on the IIount, during the latet tew

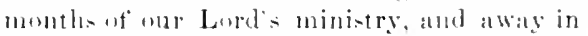

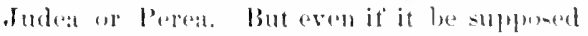
that the prityer wate given only unce, it wath remain true that the two Evamgelints have recorded it in very different term. Even in the enmmon Greek Text and the Commmon Fersion, there are severat ditferent expressions; and the muguestimably correct text griven in the Reviad Version makes the diflerences quite comsiderable.

\section{М. ТTHЕW 6: 9-13.}

our Father who art in heaven,

Halluwed on the name.

Thy kinglon come.

Thy will he lome, as in heaven, so on earth.

(iive us this lay our daily breat.

And forricie tes on dethts.

As we also have forgiven our debtors.

Ant bring us not into temptation,

but deliver un from the evil one.

Father,

L.LKE: 11: :-4.

llallowed be thy name.

Thy kinglum conne.

dive us day ly day our daily breat.

And forgive us unr sims;

For we nurstres also forgive every one that is intebterl to $11 \mathrm{~s}$

And bring as not into temptation.

If then our Lord gave the prayer on two

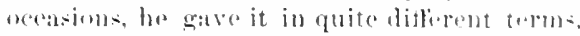
which shews, begond all question, that it wats not intemeles at a forme of prayere to han repreated in the some words. If, an the wher hand, it be supposed that he gave the prolyer only onee, then the Evangelist- certainly diat not understand it to be a form of pratyer. or they would not have recurled it in sheh different terms. There is no impurtant ditlerence 
in the substance of the two prarers; for the petition, "Jhy will be done," ete., only brings into specoul prominencesomething that is involved in "Fhy kingdom eome," and the petition, "But debi:er us from the evil one" only gives the other side of the foregoing, "And bring us not into temptation." There is no material difforence in the two prayers, but there is certainly a grent difference in form. It is entirely proper in praying, and indeed very desirable, to repeat any passage of serejure that seems specially appropriate. Fuw passages, if any, would be so often apmopriate for such a purpose as this prayer, beause it is so rich and sweet, and because the Saviour expressly gave it, on both oeeasions, as a model of praying. But in the face of the above facts, it eamnot for a moment be maintained that he has made it our duty to repeat this prayer whenever we pray, or to use these precise words from beginning to end whenever we feel moved to arlopt the prayer.

The common title "The Lurd's Prayer" hats been in use among Christians from an aurly period, being found alroaly in Cyprian, about A. D. 250, if in no earlier writer. 1 The prayer contains no allusion to the mediation of Christ, says nothing about asking in his mame, for which the disciples were not yet propared. (John 16:23 f.) like many other portions of Scripture, it was especially adapted to the precise times in which it was spoken, and the interpretation and applications of it must be made aceorilingly.

It is often asserted by modorn. Jews and rationalistie Christian writers that no portion of this prayer is original; for they say that all its petitions are fommal in the Talmul or in the litureses now used among the Jews, and supposad by them to be anciont. Jet us collect and consider the farts. They must be mainly stated at second hand; lut thes sources will be indicited.

"()ur Futher, who is in Iluaven," oceurs otten in the.Jewish lituraies. One ot the Jewi-h prayers ementins: "Lot us sometify thy nome in the world, as they sanctify it in the high heavens." Among the proyers the Kaddixh is especially valued, and has to bu ofton reeited: "Magnifiod and sametified be his great

1 In the fourth eentury wo fint it matutained th:t anly the baptized may repent this prare, some holding that the unbaptized could not properly say "Our mame in the world which, according to his good pleasure, he creatod, and may he spread abroad his reign in your days; and may his redemption blossom forth, and may M essiab be at hand and deliver his penple." (Wet.). And there are various other prasers that God's name may be sanctified. In the Talmud a Rabbi says: "Every prayer in which the name of Gud is not mentioned is no prayer." And anotlier says: "That prayer in which the kingdonn of God is not named, is no prayer." As a matter of enurse, the Jewish praycrs often include many petitions in regard to God's lingdom, though the exact jhrase, "Thy kinglom come," has not been cited, the nearest approach to it being, "Reveal the glory of thy kingdom upon us speedi]y." The Talmud of Bab. (Berach. f. 29 h) gives short prayers proper for time of peril, derived from several Rabbis, and among them this: "Rabbi Eliczer says, "Do thy will in heavon above, and give place to those that frar thee below; and do what thou pleasest.", The same treatise ( $f$. $60 \mathrm{~b}$ ), gives as a prayer before falling asleep: "Do not make us enter into the hand (power) of sin, nor into the hand of temptation, nor into the band of contempt." And again ( $\left.\mathrm{f}^{\prime} .16 \mathrm{~b}\right)$ : "Rabbi was wont tlus to pray" "Let it be thy good pleasure to deliver us from impudent men and impudenre. trom an evil man and trom an evil chance, from an evil aflection, from an evil companion, from an evil neighbor, from satan the destruyer, from a hard jurgment, and from a hard adrersary," [So Lightfoot, Wetstein, sejep, and Wünsche, in his German translation of Talmud Bat., V'al. I., A. D. 1886, Sehwalis French translation of Talmud .Jerusalem has "from a corrupter," instrad of "from Satan the destroger."]

It thus appears that mo parailel has been fommd to soveral impurtant alatuses of the praver, such as "Thy will be done, as in hearen, so on eathe," of the prayer for daily broal, to which nothing similar has been adrlueed save one of the short prayers in the Talmud, "The wauts of thy people Isracl are many, their thought is limited; may it please thee, o Loret our ford, to give each one what he noeds for nourishmont, and to every erea- 
9 After this manner flerefore tray ye: our lither which art in leatern, 11 allowed be ling nathe.
9 llimes ye have now of, before ye ask tim. Altor

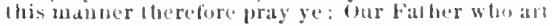

tule what it latelis" - which is really no parallet at all. Nor is aly praralled otfered to the petition that we may he teregiven as we forgrive,

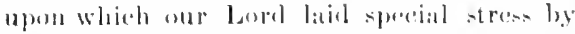
repesatiog its thomeght alter the elose of the

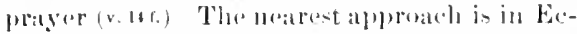
clus. 28: 2. (siae buluw an v. 1:2.)

Igain, the resemblatue in several castsis not very marked, as in "Thy kingelen eome," "D,oliver un from the evil ane." The omly racet patallels are to the addrens, "Our Fat ther who art in hearen," and to the petitions, "IIallowed he thy mane," and "Bring us not into templation."

In all these ases of resemblando the exprexion is ond most natural to be emploged. In regarel to ealling fiod our Fatleer, see beslow; and petitions as to find's name and lingdom, and as to temptations, must of

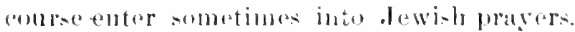
What then is the anount of the rhatrese that the prater is not orierinal? Some of its petitions have no parallel in Jewish literature, and otleers only partial patrallels. Ama ats the resemblances, exald or lantial, a little reflection shows that nothinge olse would bave

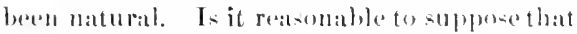

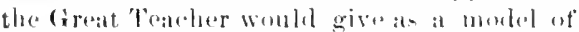
prayer to bis tolloweres a series ot petitions

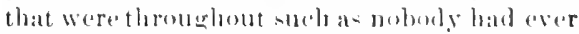

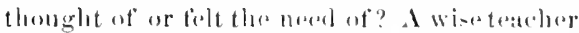
limlis new instruction to what is alrealy knownaref felt. And our Lomed sethical and devotional instruction- womld havo beselu really

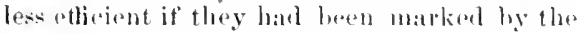
starting originality whiclt some have unwisoly rolimed fur thems. Grotims: "(our

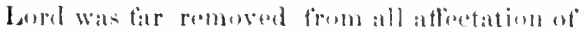
numbersity novelte." "Thwse, an the other hand, who have represoluted this prayer as entimly wating in orierinality are mofuted by the fisets; for Wo have sesen that several of the petitions arewithout parallal, and that the cases of rememblaturea are pertiently naturat;

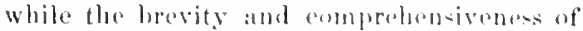
the prayor as a whold are wondertul in therextreme. It may be added, without treating it as an important ficet in the present rase, that some prayers in the .Jewioh litureries aro unquestionably more recent than the time of Christ, (see Margoliouth, Weiss, Ebrard in
Hermog), and that oven prayer and othere matero in the Talmud may hate been derived from the New Pestanont. The Rabbi-

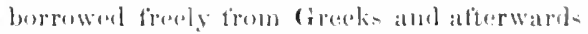
foom Irabians, and it is by no moans so cerletain as some madern ol ows imagime, that they did not alse borrow frem . I tles. But the explatuation of the materer be-

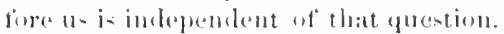

The prayer naturally falls into two divisioms, and it is an instrutive and imprestive fact that the tir-t petition-are thome which relate to (aod, his kingeloun and his grory, and

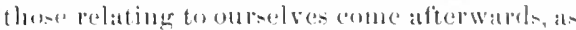

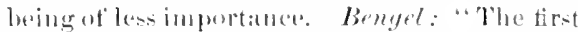
three are thy. thy, thy; the others, us, us,

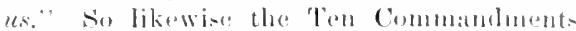
fall into two parts; the former setting forth mar duty to ciod, the latter to our neighbor. At the prosent day, the prevalent tendenery is to lergin with lomman mature amel watut amb to ask low Chriotianity suits itself to these: the Bible teaches us to think af (iod, and ask how we maysolit onrestresto his mature and will. As we areafterwards tatught to sele li kingroun first $(6: 31)$, su lare to fraty tiret that it may comere. Yeat the distinction in the prayer is not abolute, since the fullilluant al the first petitions will be alsofor foter gand, and the fultilluent of the others will bo also for

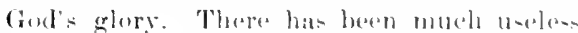
discusion in Gormang as to whether the prayer coutains avelu petitions (the Lutleran view, followion dugustine), or only aix tho Roformed or (Alvinian view, following Cliry. ostom). areording as we romsider verese l:3 to be ane petition ar two. Some writers try tw find in the several petitions sets of threses at if' illustrating the 'Trinity; but this is artificial and tancitul.

9. Our Father. The use of the plural. throughout the prayer. instand of chaturing to the singular, as $\mathrm{is}$ lume in v. 2, f, 17, r. $\mathrm{i}-$ aently present- this as a specimen ot soriol rather than serert propor; and so, insolves

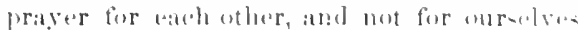
alome. (ompare 18: 19; Mal. 2) 10. Th. thought of (rod alsour Father is presented in

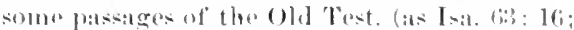
P.. 10:3: 1:3: I) Int. :3: : (i), and oftener in - nhsequent Jewish writings (Tobit 13: 4; Ecclus. 
23: $1 ; 51: 10$; Wisdom 2: 16; 14:3); and the later. Jews have several prayers in whith God is addressed as "our Father in beaven," an idea doubtless drawn by them from the Oid Test. The heathen, ton, were not wholly untamiliar with the thought. Mar . Hüller: "We have in the Veda the invoration Dyarespiter, the Greeli Zan pater, the Latin Jupiter; and that means in all the three languages what it meant betore these languages were torn asunder-it means beaven-Father." (Botrelman.) Plutareh says that the super-titious man recognizes only that which is sovereign in God, and not the fatherly ; and Seneca, that Gond has a tatherly mind towards good men. But it is Jesus who has rendered this ideat so elear and precious; distinctly comparing the teelings of human parents towards their children (i:11), and making the great thought faniliar by frequent repetition. In one sense God is the Fither ot all men, as in one sense alt men are brothrers; and so we ean fitly speak of the Fatherbood of God and the Brotherbood of man; and yet it is only believers in Christ who ean in the fullest sense call God Father (1 John $3: 1$; John $8: 42$ ), and eall ach other brethren. (1 John 3:14) In heaven. God, who is everywhere present, is constantly represented in seripture as maliing his special abule, and the special manifestation of the presence of his glory, in heraen. Aristetle noticed that this idea was common to all nations. But the beathen made heaven itwelf, varionsly peromified, an ohjest of worship; while in soripture, heaven is but the dwelling-place of (xoll. (Comp. Plumptre.)

IIallowed be thy name. Topray that his name, Jehovab, by whieh be is distinguished from all beathen deities, and marked nut as his poople's Goul, may be sonetified, ragarded and treated as holy (comp. Exod. 20): s; Lat. 202: 2, 32, Ezek. 36: 23; 1 Pet. 3: 15, and montrast "despine my name" Mal. 1: (b), involves the idea of praying that (xol, in all his character and dealings, may be reverenced and getorifiert. Complare such expressions ats "they that love thy name," "that know thy name" in the Old Test. and "grorify thy name" in John 12: 28; Rev. 15: 4. This illeat of taking the propor name an representing the person in his entire chatacter, is altenether natural, but was rendered peculiarly impres. ive to the Israelitish mind by their remark- able reverence for the name of Jehoval-a reverence which at length became superstitious, so that the later Jews would never pronounce that proper name at all, but uttered instead of it the word Adonat, which means Lord-and this led to the translation of $\mathrm{J} e-$ hovals in the septuagint by Kyrios, and in the English by Lord. The Anglo-saxon word "hallone," though often employed in the old Tentamnt, is used nowliere in the King James Version of the New Testament, except here and Luke $11: 2$. Ekewhere that verwion uses the Latin word sanctify. But in this familial and eherished prayer the old Anglosaxon word was retained (eomp. on 1: 18, as to the use of Holy Ghost). So likewise the Latin Vulgate, while translated anew fim the Hebriw, retained the old Latin Version of the Psalms as being so familiar that change would wot be tolerated; and the Engli-b Bonk of Common Prayer, though altered elsewhero to suit the King James Version, retains still the translation of the Psalms from the Great Bible, or Coverdale.

Thy kingdom come. Of the three words, kingship, reign, and kingdom, to which the Greek word here employed is equivalent (see on : : 2), it would be best in this and many passages to use the second term reign, sinee we can use only one. The roference is plainly to that Messianic reign which all devout Jews were exprecting (Mark 15: 43; Luke 23:51), and which John and Jesus bad been proclatiming as now neal at hand. (3:2:4:17.) The prayer that it might come would in the minds of uir Lerd shearers refer especially to the beginning of the reign, the introduction of the kingdom (Luke 17: $20 \mathrm{f}$.) ; but just as in the prophetie view the whote period from the leginning of Messiab's reign to its ultimate triumph, frequently appears as a print, so in the thll sense the coming of that reign or kinglom includes the idea of its complete establishment. It is therefore rerfectly legitimate for ns to use the petition with our minds specially directed towards the consummation of Chrit's reign, the complete establishment of his kingdom, his final glorious trinmpls, when the kingship (sovereignty) of the world, shall become our Lord's and his Christ's. (Rev, 11:15.) Thy will be done is more exactly thy will come to pass, 'take place, the same verb as in $1: 20$ (sos foot-note there), $5: 18 ; 24: 6,34$ (whore it is rendered come 


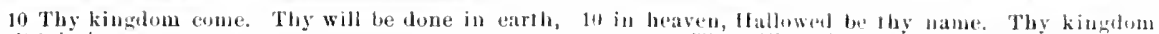
ay it is in heatert.

11 Give us this day our daily breal.

come. Thy will be olone, as in heavell, so on eitrth.

11 rive us this dity lour thatly bread. Alud forgive us

1 Gir. our bread for the coming day, wr. our needful brend.

to pass, in (omm. Ver.), and the same expros-

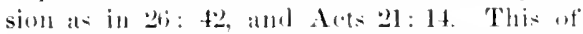

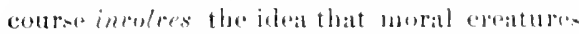
are to do his will, as in $7: 21 ; 12: 00$ (where the word * lo $^{*}$ is enspleyed), but it expresen a nore cosuprolensive thought. Theological writers distiuguish threes semses of the term will. Crod's will of purpose always cotnes (1) pass, in healeell, earth, and hell. But his will of desire does not yot always enme to palso on eartlo as it does in hestren. Ho wished Jorusalem tol bo silved (Luk. 13: 34), and thry would not. II" does not "wish that any shoulal perisls, lout that all should rome to repentance" (2Pet.3:9), and yet many refinos to repent, and prish. He wishes "all mall tobe

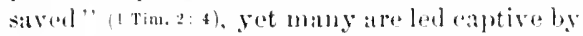

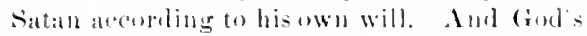
will of command, how oftend and how thitgrantly it is lisubeyed; how liow of his moral

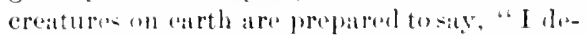

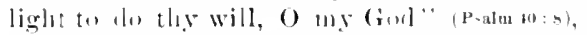

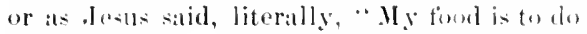
the will of him that sent me" (Jobnt:34); how few are joined to Christ by the fullmes of that tic, "Whosuevershall dothe will of my Father who is in lonoron, he is my lorother, and-inter, and usothar." (12:50.) In warth as it is in

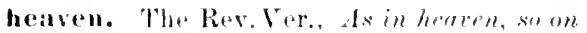
earth, gives theordor of the (iroveks atud makm

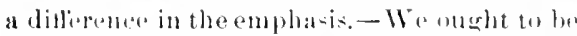
contimually praying this prayer. In lastrell, everethiner takes place as (rod wislase, everythime in perteetly pleasing in his sight. Als ? whell shall it be so on eallo? Whan mall hi-

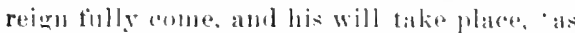

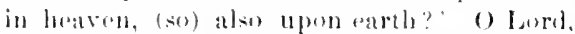
how long - This impresive petition is really involved in the foregoinge simply stating sol-

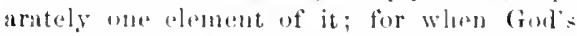
reign is fully come, his will must asmo to piss, atr. When therefore this is mutted from the prater an the socond oreasion (sobe

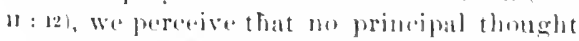
of the prayer is thus lo-t. Yot this is by no means a mere repetition or expansion, fir it brings into prominence one prictical clenent of God's reign, which we ought specially to dosire and aim to bring nbout. Sonne $e . g$.

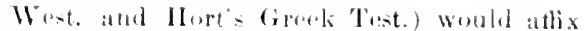
"as in lieaven. so al lon upun atarth," to all the

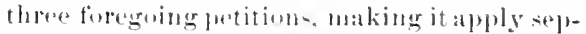
arately to call at" them. 'This is a prosible view, but not probible. (1) The worel= would not larmonize so well with "thy roign

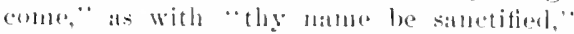
and "thy will cometo par.." (2) 'l'he omission of these word-in Luke $11: 2$ would tlum, be larder tis aceount firr.

11. Here becrins the seemend division of the prayer, that which contains petitions fou an selves (compare an v. 9). The grammational

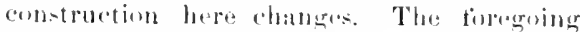

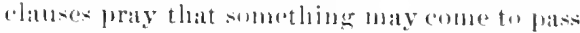

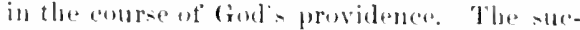

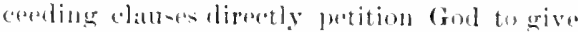
alld forgive. Daily bread. Bread naturally reprenents foud in general, all that is menessary (1) suppert life, of which breat is commonem stemened the most impurtant and indispentsable part. (Nark 3: :00:2 Thesa, 3: 12: Prov 30, - martio.) Theresesens to be no witriat for moleretanding the torm an hore ineluding spiritual mourishmont. It is altogether natural ant froper to draw the infereneerethat if we are bidelun to ask Gorl for bodily foud, we newel puite ats muclu to ask him fire that of the soul; hut inlerence is a ditlement thinge from interperetation. Comont: "Tlue beally and propriety of this sinerle potition for atothly gomd (restricted to that withent which life callnut subsint). has heen fielt in all ares of the elunrell."

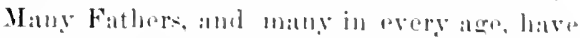
wrongly insistol upun "spiritualiziner" the patsage, an they have done with wall-ujegh averythine in seripture. Ierainst the arerAriven spirituality which allixets to boton iudifferent to atethly goud to think it worth

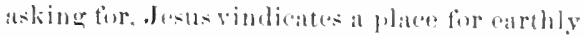
frowl in une prayers. In the prosent ateo, it is especially jmportant to uree that mint shall pray for tempural anod, ainces st mante think that the rocognamed prosenter at law in all temporal things puts them bevond the subere of prayer ; as it that would inot exelule from from his moveras: and ats if theres Were not law in spiritual thingsalss. Thu ward mpionsion) remelered daily, is extremely rare and 
obscure. Origen says, that it was not found in any Greek writer or in colloquial use, but seemed to have been coined by the Evangelists. Only three semses of the term have now any advocates: (1) ' (bread) for to-morrow, and so 'daily, Bishoy, Lightfoot, Meyer, Grimm, Wünsche, Nicholson, margin of' Rev. Test.; (2) 'neadful,' Godet, Keim, keil, Cremer, margin of liev. Test. (American Revisers); (3) 'supersubstantial,' Jorome in Matthew, and many lomanists. Etymological considerations strongly favor (1), and render (3) practically impossible. Bishop Lightfoot, "On a Fresh Revision of the New Test." App., has conclusively slown (and McClellan and Camon Cook vainly strive to meet his facts and arguments), how strongly (1) is supported by the early versions, being unifornly given by the Old Latin (and even .Jeronte retains it in Luke), by both the Egyptian versims, the Old Syriac, and the "Guspe] accurding to the Hebrews." Origen preferred (2), explaining it as meaning needful for the soul-a spiritualizing conception, which suited Origen's turn of mind and habitual methods of interprotation; and he gave this view great currency among the Greek Christians (see suicer) and the later syrians. Jerome, by an inpossible etymology, rendered it 'supersubstantial' in Matthew, though retaining in Luke the 'daily' of the old Latiu, and is followed in both passages by Wyclif and the Rheims version. Many Romanist writers have tried to use this rendering in Mattlew for the support of transubstantiation, though the Pomanist prayer-books have uniformly retained 'daily.' Plumptre strangely adopts Jeromes rendering, understanding it to mean "over and above material substance" (in which a material word is gratuitusly insarted), and thus entirely restricting the petition to spiritual bread. In (1) "Give us today our bread for to-morrow," would mean our daily bread, if we remember that one should not let the day chose without knowing how he is to lave fool for the next morning It is very difficult to see how (2) could ever have suggested the idea of daily, which is found in all the earlier versions, and often referred to by Greek Fathers (suicer). Moreover, the idea of $(2)$ could have been easily expessed by existing Greek words, while that of (1) would have required the coining of a Groek adjective (Origen.abwe). The objection to (1) is that it secms to conflict with v. 34, "Be not anxious for the morrow" ; but it is fairly answered that the $\mathbf{a} a y$ to prevent such anxirty is to pray that to-morrow's bread may be given us to-day, as in Phil. 4: 6, the remedy for anxiety is prayer; and if v. 34 probibits prayer for to-morrow's bread. then (Achelis) verse 31 would prohibit prayer for any ford. If we combine all the evidence, it would seem that (1) must be very decidedly ureferred. ${ }^{2}$ With this compare Janes $2: 15$, Rev. Ter., "And in lack of ditily foud": Prov. 30: 8, lit., "Feed me with my portion (or allowance) of bread"'; (Acts 6:1:2 kings 25:30); also the fact that the manna was given one day's supply at a time. This day, or simply 'to-day.' In Luke $11: 3$ it is day by day.' The phrase in Matthew is said by rarious $\mathbf{F}$ a-
1 Epromsios comes easily and naturally from he eqrousa, 'the oncoming (day), a very common expression for 'to-morrow' or 'next day' As to the possible etymology for (\%), and the etymological impossilility of (3), se the special treatises and the lexicons.

2 Mr. Paspati, a cireek gentleman of Constantinople, publishul (Athens, 18s.3), a leeture on the English lit:vised Version, in which he says (p. 14), that the word epiousios "is in general use among the Greeks. Mauy poor perple eomplain that they cannot gain their ppionsion breal. Epiousios means whatever can sustaiu or maintain." Mr. Sakellarios wriles from Athens (Fel). $1846)$, that the word "was and is used in the sense of neessary, food neeessary for suslenance." Now it is well known, ats alove slated, that this interpretation prevailed anomg the fireek Fathers, and so Mr. Constanline interprets, in his Greek eomm. on Matt. and Mark (Athens, 1878). So far as the word is $110 \mathrm{w}$ generally used among the Greeks in that sense, it is eridently a mere appropriation of a seripture term as eommonly understood. Mr. Iaspati remarks (p. 12) upon the frequent use ot sicriptural expressions among the Greeks, induding phrases relating in lilate and to Satan. There is here then wo independent testimony as to the meaning of the word.-It shouk be added that Ifr. Paspati's elueiclations in general show a lack of ac"fuaintance with seientific philolugy. - Warth ancl Jöckle, stud. $u$. Krit., 1sist, No. 4, argue that the phras. may mean to-day's bread, because epiousa, 'oneoming' (which commonly means to-morrow), is oceasionally used by a person speaking at or before dawn with refersnce to the then approaching dar. Thes suppose the prayer to have been designed as a morning prayer-and it womld have to be made very early, to render such a sense posable. This riew is highly ingenions, but ton fine suun to he probable in so simple and general a praçer. (Rejected by Cremer, ed. 4) Moreover how would this idea be expressed in Aramaic. 
12. And forgive us our dubs, as we forgive our 12 our debts, as we also hate forgiven our debtors. deblors.

thers (Wet.) to have leal to the daily repetition of this prayer, which is montioned as early as the boginning of the thirel century; but Lukn's phrase shows that at latast in the second anse nothing of the sort was eontemplatend.

12. Debts. This term is here usel for trausgressions, sins. In Aramaic, the native language of our Lord and the Evangelists, the word dobt (chob) is very often used for sin. See numerous examples from the Targums in Buxtort. Thisuse is perfectly natural in itselt, since an obligation to God which is not duly met lecomesto us a sin; complare the illustration of sin by a lelts in $16: 21,24$, 28. In like manuer the Engli-h word duty denotos that which is due, owed. (Plumptre) Acoorbingly in v. $14 \mathrm{t}$, the same idea is represcouted hy "tre-passes, tran-gressions. And in Lake (11 t. Rev. Ver.), the prayer rearls, "And forgive a- our sins; for we ourselves also for-

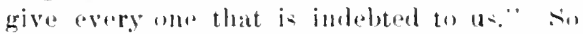
clear is it that debts lorere means sins that Tyudale translates in v. 12 by trespatses and trespasers: but this is anwarranted, and was not followed by any ather English tratslators. Observe that this petition is enmmecten with the foregoing by and. The litesustimed by daily bread is mot enough; we neesl also the forgiceness of sin (Weiss); complare 'Ind hring, $v, 1:$. As we forgive-or, as in Rov. Ver.-also have forgiven-our debtors. This does not preant our toreriventess of uthers ats the grouml of our being fingriven, nor as strietly the measure of Goll's formiveness towaris us fior he forgives perteetly, while everything in us is imperfect); but ly (e)mparing the forgrioness we supplicate with that we have slown, it states very improsively the idea, atturwards still furthrer amphasized in v. 1t t., that the usturgiving atumet bu torgiven. Obrerve that the Ravinal toxt (no (ioubt correct) makes it "liave forerion," ureacly before we seek forgiveness-mot at mere momentary affort at forgivenen, trumpul 11 ? for the nones. In Luke 1]: 4, it is, Fur wo ourselves alou forgive every one that is indehterl tous, which means not simply present but babitual forgiveness, as shown by the 'everyone, Inke's term 'for' might seom to make our forgiving the ground of our being fingiven; but it rather means that there is 110 unforgivingues on wer part to fistal an ob-tace to on being torgiven. Compare 5: 7; Lulie 2:3: :3t; 1 Tim. 1: :3, aml the batutiful illustration in the panable of 18 :

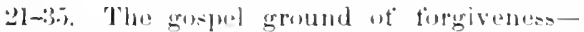
the atomenent and interession ot Christ-is of eoruse not herastated. The disciples could not have clearly understond a rotionence to it until atter christs death, resurrection, and ascension.

The Greaks and Romans admired shining instances of toreriveness, but did not venture to imeuleate or seem to experet it. A bawish

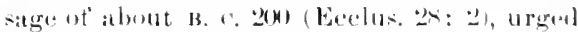
that men mu-t forgive it theg hoped to be formiren: "Forgive thy neighbur his wrotserdoing, and then when thon hast prayed, thy

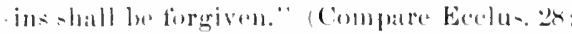
1-5.1 But it is Christianity that has mate this a thing actuat and fooked tar. Exese IIomo: "The forgiveness of" injuries, whinh was regardon in the andent world as a virtum indeml, but an alunost injrossibl. one, alprear to the morlerns in ordinary cases a plain luty . . . . a new virtur has been introlumal inta louman life. Not only hats it beon inculcaterl. but it has passed so completely inte the number of recenguized and indi-pensible virtues. that every ans in some dengere pratediens it, and that by not praticing it men incur adium and lose of charater. To the otluer great changes wronglit in men's minds by christ. this is now to be arlolol, the most signal and beneficent, if not the greatest of all," (Com-

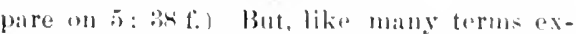
pessive ot Christian duts, the word forgive

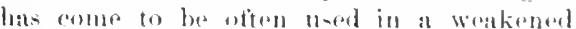
sense, amd many anxious minds are misled by its ambiguity. If forgive mans merely to

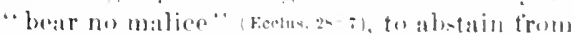

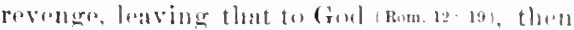

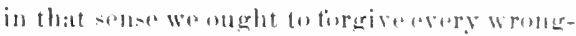
doer, even though impenitent, and still wur enemy. But this is not the seripture use wit thes worl torerve: and in the full sense withe term it is not anr duty, and not aven proper, to torgive one who has wrumered us until he

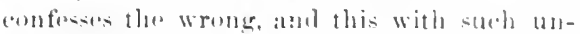
questioned sincerity unel gemuine chatuge of feeling and purpose as to show him worthy of 
1: And lead us not into temptation, but deliver us 13 And bring ns not into temptation, but deliver us from evil: for thine is the kinglom, and the power, and line glory, for ever. Amen.

being rest red to our confidence and regard. Thus (1ur Ler)d sily' (Lake 17:3, Rev. Ver.), "If thy brother sin, rebuke him; and if he repent, torgive him." IIere again the example of our IIeavinly Father illustrates the command to us. 11: sends rain and sumshine on the evil and the grod (emmp. on 5: 45 , but he does not forgive men, restoring them to his confidence and affection, until they sinceredy and thoromghly repent. In judging as to the sineerity and trustworthiness of those who profess repentince, our Lord inculcated great paticonce, and chatritable judgment. It a wrong firmiven is repeated a second or third time, we are apt to lone all pationce and refuse to forgive again; but be said, "It he sinagatinst thee seven times in the day, and seven times turn again to thee, saying, I repent; thou shalt furgive him." (Luke17:4. Rev. Ver.) Nay, in Matt. 18: '21 t", he makes it even "soventy timpseven" - not of eourse as an exact limit, but as a gencral and very strong injunetion of long-suffering and charitable judgment tow:lrds buman infirmity.

13. And lead-or, bring-us not into temptation. Hro again 'and,' because the forgiveness of pat sin is not ollongh; we need aleo preservation from sin in finture. All the andy Engli-h verwons bave 'lead,' doubtless influenced ly the Latin indueas. The Latin Fithers, Tertullian and Cyprian, explain it to mein 'Do not sutler us to be led,' and Augustime sitys (Wot.) that many so pray. and that it so reats in many (Latin) copies ; but that in the (xpok ho has never found anything lout: 'Do mot loring us.' This is the uniform reading and unduestionable meaning of the Gresk, and the difference is important. Men lead eatele othar inter temptation by otfering indueements to do wrong: but the thought heres is ot frodtes so ordering things in hiprovidenee as to bring us into trying cirenmstancese which would put our principlese and chatraters to the test. This prosidential aetion

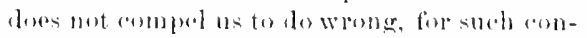
ditions berome to us the oreation of sin only when our own eris desires are the improlling (anse, (James 1:13.15.) The sameconditions proporly met would but manifest and strengthen one's piety, as when God "did prose Abrit- ham" (Gen. 22: 2, Rev. Ver.), or allowed Satan to test the fidelity and patience of Job. There is thus no contradiction between this petition and the preeept (James 1:2, Rev. ver.), "Count it all joy when ye tall into manifold temptatioms." One may be tested (see on 4:1 for the explanation of 'tempt'), rither with good or with evil intent. In the evil sense, God "temptetl no man." (J:mes 1:13.) The humble believer, self'-distrustful because comscions of remaining tendrneies to sin, and werkness in restraining them, prays that God will not bring him into temptation. (Comp. 26:41;1 Cor. 7: 5; Gal. 5: 7.) And yet, when God sees fit, notwithstanding his prayer and effort, to bring him into temptation, lie is then to rejoice (James 1:2), because when met in the strength of the Lord, it will certainly beoveremme (I cor. 10:13), because it will develop his Christian chatracter and thus prove a blessing (James:af.), and because it will secure for him an eternal reward. (5:12;

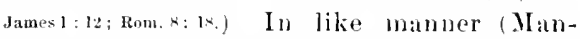
sel), wur Lord direeted the apostles to avoid persectition (10:23), though he hatd told them to rejoice when pursecuted. $(5: 10-12$.$) Bnt$ deliver us from evil, or, the evil one. This is not really a distinet petition from the foregoing, but further unfolds and separately states something involved therein. When therefore it was omitted on the second cecalsion (Luke11:4), no principal thought of the prayer was lont. (Comp. above on v. 10.) The Greck phrase rendered 'the evil one' is here ambigums, as in $5: 5,5$, and may equally well mean evil. The same expression is certainly masculine, and means Satan in 1:3: 19 , 38; Eph. 6: 16; 1 John 2: 18, 14; 3: 12; 5: 19 (comp. v. 18); it is clearly neuter, meaning avil in the abstract, in Luke 6: 45; Rom. 12: : ; 1 Thess. 5: : 20 and several examples of the nenter plural, 'evil things'); while the meaning is doubtful in Matt. is: $: 3,89 ; 6: 13$; John 17: 15; 2Thess. 3: 3. It is understond here as maseuline, meaningsitan, by Tert., Origen, Cyril (oterus., Grogery Nyse., Chrys., Theosphyl., Erasmus. Zwingli, Beza, Bungej, Fritz. Olsh., Elopard, Meyer, Grimm, Wordsworth, Renss, Plumptre. It is taken a-nouter, meaning evil in general, by Augustine, Luther, 
14 lior if ge forrive men their trespasses, your beavenly lather will also torgive you: 1f from the esil one. For if to forgife men their trespasats, your heavenly lablug will allat forgive

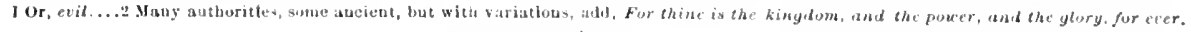
Amen.

Mesanchthon, Tholuck, Ewatd, Bleek, Stier,

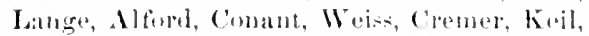
Achelis. Thone who object an vehemently to tranklating here by "the evil ane" are usually influeneed bargely by sentiment and labit, and sombtimes by skejeticism as to the real persornality of Satam. But the New Tes-

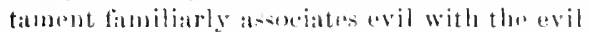
one, ats its lealiner embuliment and central

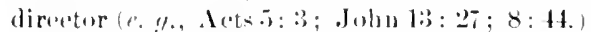
It is theretors quite imposible to escape from that idra, at we bedieve the Seriptures. It an never be certatioly dotormined whether the phrase is maseluline or uruter in this patasige and in Jobn 17: 15. But the more frequent oceurrence of the charly masculine use, with

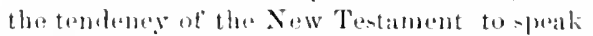
ratber ot evil persolls and evil atetions th:m at avil in the alstract, makes it more probable that the sense is masemlinu in each of these interesting passignes. 'Phe Revisurs haves brascely followerl the stromerer probability (puttiner avil' in the marein), thumel it wats

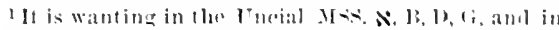
live eurives, and many uller enr-ives hatse marks in the text of meleson the marein, showille llat it is

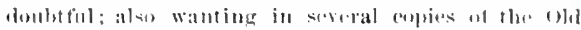
Jation, in the Vulgate, and the Menophitie. lispecially

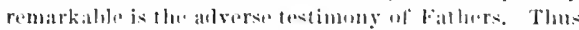
fertullian, in his interperetation of this prayer, atle

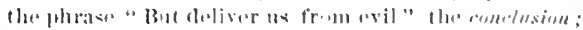

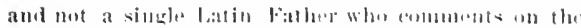

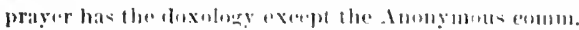

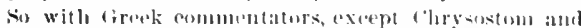
his followers, ly rif of In rusilem, in eoncluding his expo-ition, says: ". From the ayil one. And the nppesine desom is exil, from whom wo pray fo be de-

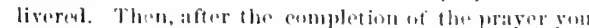

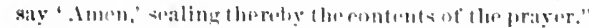
firesury uf Nyes: "From the evil one who in this

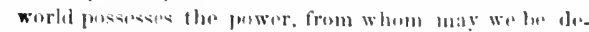

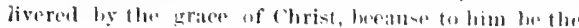
gower and the glory, fogether with the father an the

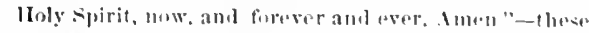
worls conoluling firenoryce expusition of the whole prayer. This and sereral similar T'at ristio comelusions show the origin of onr familiar doxelugy, natmely, in the ensfom of eoncluling a prayer with some form of doxology. Anil several early rersions apluar to "xhibit this dexology in the precese of gridual formation. "Thus the Mld syriac has, "Becumse thibe is the king- inevitable that theme wanld be at grait ontery.

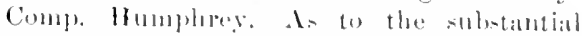

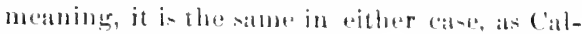
vin alrealy remarlis, and in tact either involves the other.

The dexulogry lo thi- praper in ('oln. Vore is begend all quasion spuriom, and rightly matted ly liev. Ver. IV may grisene the pleasing and tambliar worls with regret, but surnly it is more important to kissw what the Bible really emotains and rablly mentus, than (1) eling to semothing net really in the Bible,

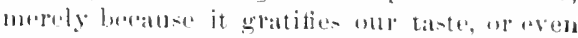
berallse it has fin us some preciens assediatiuns.

$11 \mathrm{t}$. The finct that this ahous of all the topices of the mayere in talien up a seromel time, and amplatied by stating it buth jomitivaly and

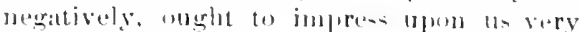
dexply the importance af torgiving il we wish to la forerivem. Comm. 18: 21-3is; Mark 11:

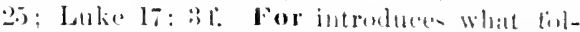
lowsas a confirmation ot'v. 12. Trespasocs,

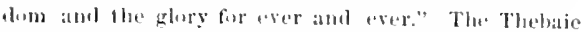
gives another indepentent form: "liecanse thine is the strength and the puwer for ever and ever." The

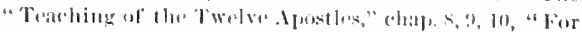

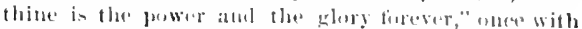
this prayer, ami then with tere aller pragersthere pro-

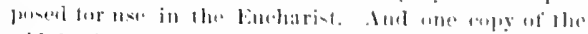

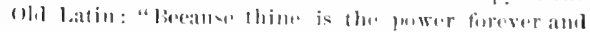

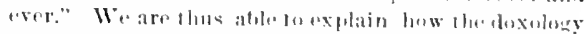
eane il: here, if originally wanting: whilo if orienally

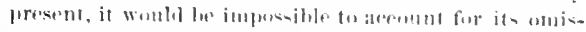

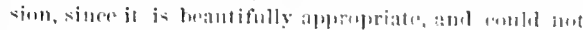

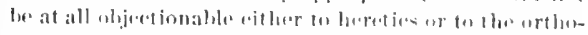
dox. Now renbmbering that it is wathing in several

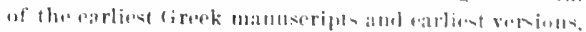
that there is no mention of it in an moluer uf hetailed Patristio exprestions af the prayer, and llat wo we it

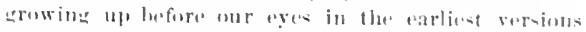

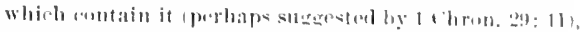

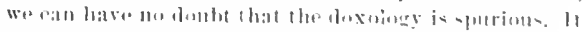

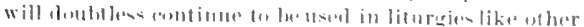

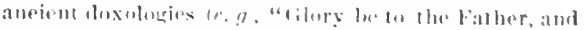

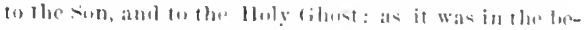
gioniug, is mow and ever shall le, worll without end. Amen"), hut it is nut a part of seriplur". Xor was it intruluenl intu the lionk of romume l'rayer until the time of charles II. 
more literally transgressions, interprets the word 'debts' in v. I: ; hence the practice of substituting this word in repeating the prayer.

HOMLETICAL ANU JRACTICAL

Y.5 t. Oriati: "The hyporites wearing the mask ot gondness, are actors in their own theatre, thesyngonges and the corners of the strerets." Hexkr: "Those who would not do as the hyporites do in their way and actions, munt not be as the hypoerites are in their frame and temper. As it is a terror to hypucrites, so it is a conntort to sincere Christians, that God sees in secret." -There might be astentation in a much lass public place that the symagogue or the street, and there might be true, unostentatious prayer elsewhere than in a private room. These places merely illustrate a principle, which is to be applied accoreling to circunstances. It is therefore a mistake to siplume that our Lord bere forbids individual prayerexcept when in solitude. The publican of the parable prayed openly, and aloud, with striking manifestations of griet, in the court of the temple, attracting the contemptums observation of the Pharisee, and no doubt of others; yet his prayer was acesptable. Jekus himself nometimes mate private prayer in the presenes of fis diseiples. (Luke 1]: 1.) still, literal privacy is best where it is attainable, and our Saviour frequently sought it in the open air, at early dawn. or at night. Solitude is fatorable to self-exanoination, and to individual communion with the Father.

$$
\begin{aligned}
& \text { JANDor: "Solitude is the antrohamber of God." } \\
& \text { Yousc; "O lost to reason, lost to lofty thought, }
\end{aligned}
$$

C'urys. "simme, even when their person is comcraled. make themsalves manifust to all by thrir soien."

One advantago of praying in solitude is that thron we noed feepl no hesitation in speaking aloud, which ereatly aid-in restraininge wandering thoughta, and attaining a doperer solemmity and puntion. Renularity in private pracer is indispensable to the attaimment and maintenance of a high order of pioty. It is well to lift the haset fo Gorl, oven for a monment, whomper wo foel spreial inclination or noed; ] lut at statod hours wa mu-t prave oven thougle we feel no inclination Thus may we combine the adrantages of regularity and inpulse.-How rich the reward of regular private dovotion. How it sootbes the perturbed spirit, strengthens for every trial, and sweetens every pleasure. Strange and sad that one who has known the blessedness of this privilege should ever permit himself to negleet it. CHRss. : "Let us not then make our prayer by the gesture of our body, nor by the loudness of un voice, lyut by the earnestness of our mind: neither with noise and clamor, and for display, so as even to disturb those that are noir us, but with all nodesty, and with contrition in the mind, and with inward tears." THEopiryl. "What, then, shall I not pray in ehurch? By all means, but with a right intention, and withont display, for it is not the place that hurts, but the manner and the aim. Many in fact, when praying in seeret, ar* doing it to please men." Eutily. : "If thou wishest spectators, thon hast, instead of all, God himself." Würt. Bribe (Lange): "Thuse brief ejaculatory prayers sent up to heaven in few words, and which may be uttered even while engaged in our daily labor, are by tar the richest and best." (15: 25.)-HexRy : "Secret prayer is to be performed in retirement, that we may be mobserved, and so may aroid ostentation; Indisturbed, and so may avoid distration; unheard. and so may use the greater treedonı."

V. T. Crpriax: "Fond hears not the voice, but the linart." Calvix: "In true prayer the tomgue does not go fiater than the heart; the grate of God is not attained by the empty utterance of words, but the pioms heart sends forth its affections like arrows to penetrate intu heaven." - To keep repeating the same thought in symomyms is a fault of the same nature as these vain repetitions, theugh less

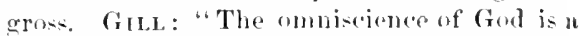
comsiderable argument, and a great eneouragement to prayer: he knows our persons and our wants boforeluand and as he is able to holp us, we have rason to bolieve he will."

V. 9. CYRHL: "Christ commands us to" pray hriofly, hecalle he kuow- our minds are easily lest off into wandering thoughts, espe(iilly in time of prayer." Qresxel (Lange): "A king who bimsolf draws up the petition which is to bo prosented must surely talie great pleasure in granting it." (Isa. 65: 24: John 
$16: 23$ ) BEDA (Blyth): "A prayerswertemate by the name of Father, makes me antiolunt of getting all I ask." MAldoxates: "The very name of father prays for us; becalloce it is the part of a father to provide things necesssary for his children." Elemys.: "Il, that lives a bad lite, amd ald]s fomd his Father, lias both arainst God and himaelf." C'mkrs.: "We mu-t thon pray stralightway, and lift our mind on wings and exalt it above the earth and attach it to tho heavens; for he (o) mands us tos:y, "tor Father who art in the

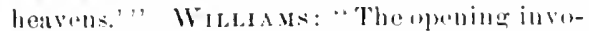
eation presents the Porenteng', "Our Father, the Brothorlemel, "Our Father"; amb the Home. '().r Father which art in hearen."

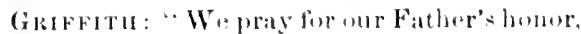
dominion, serviee; and then for our own pres-

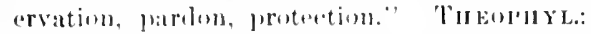
"For as fiod is blasphement for my salie, so also for my sake ho is sancetifiul, that is, glorified as holy."-If we wish and pray that God's mane may be hallowed, we onght enrselves nover to speak irreverently, oither of him, or of anything that is sacred trom it connection with him (eomp. on 5: :3:-3); ; and if" "actions speak loullor than words." it js still nowe important tor asoid ants which would profane anything that he hats male boly. Is it not polluting and bla-plubung

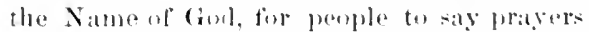
or sing praises to him when they are grom wicked, and hate nu presest intention to turn from their wicked ways? (compl liokliu.) No chureh wombermples a motoriolle drunliard, or adulteror, or all avelwel inlidel, to read the Bible in public wormhip. beamos of

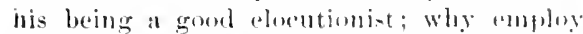
such a man to sing solos in pration of (xoml hocalse he is a good romalist? WEss: "The

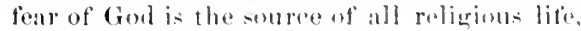
and the antecedent eomdition at all that is usked for in the progress of this prayel"."

V. 10. s'taxforn: "1)h, it ismoming! The reign of the Father is sure in lawe-nasur to show itsell, for no power can ever f'rustrate hi. purpose or fal-ify his worl." Wildams: "To pray for Clurist's kinglom is to pray tor the conversion of sinners and the edilication und sanctifieation of disciples. It is to ask the evangelization of the Gentiles and the restoration of the Jews. It is to implore that Antichrist may fall, and the idels perish from maler the whols heaven. It is to profieso sympatly with all that reliever and relatates and rofluachises man; and tor implore the remusal ot all that corrmpts and debases him, and tlast sells him, sml and bolly, to the service at the Evil Hue.

I)id we but lisew aright the neconstion of 1010 kiml, and the tratest, deepert wants ot enr "wn swuls, the hourly burebers of intercesson, from onr atets, and platur, and alus, and prayers, would still be. Let thy

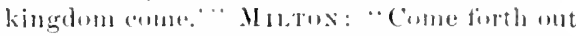
of thy royal ehamber, () Prince ot all the kings of the aarth! l'ut on the vinible robes of thy imperial majesty, take up that nulimited sceptre which thy Almighty Fathor

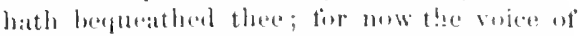
thy bride talls there, and all creatures sigh to be renewed."

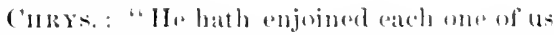

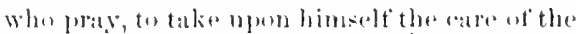
whole world. For he did nut at all may, "Thy

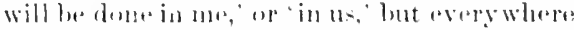
on the tarth; so that crror may he dentroyed, and truth implatuted, and all wiekialnose

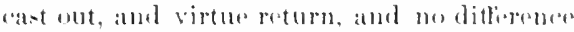
in this resperet be hemeretorth betweren heatren

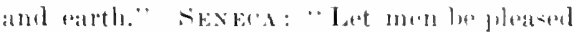

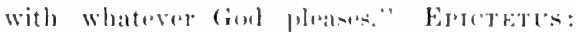

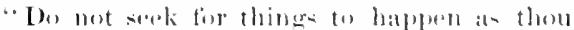

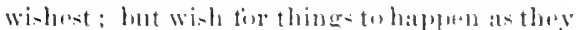

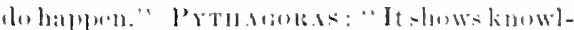

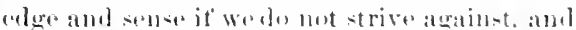
worry at, Divino Providence." -Thi- putition aneans not morely romiernation to trolls will When painful (26-12: tets al - 14): holt we pray that

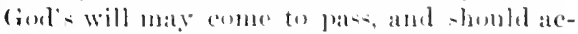
corlingly les striviner to bring to pas what"ver wo helinve ta lu his will.

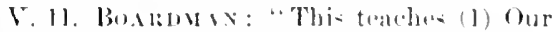

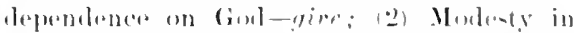

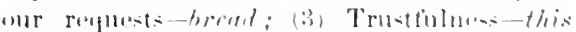
den!: (t) Bmotherhmol-us, whr." Ri-skix:

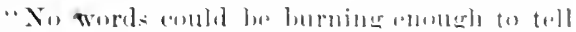

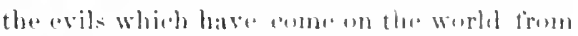

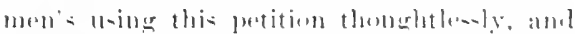

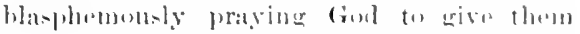

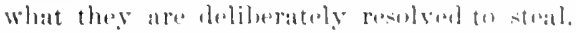
For the man who is mot, taly lis date doing work whide will arm his dimber, must be stealing his dinner."

r. H. We incur debt to (xud by -ins of omission, as truly as by sins uf commission. 
15 But if ye forgive not men their trespasses, neither will your Father forgive your trespasses.

It Moreover when ye fast, bo not, as the hypoerites, of a sul conntenance: for they disfigure their faces, that they tualy appear unto men to tist. Verily I say unto yon, Thicy hate their reward.
$15 \mathrm{you}$. But if ye forgive not men their trespasses, neither will your lather forgive your Irespasses.

I6 Moreover when ye fast, be not, as the hypoerites, of a sad countenanee: for they disfigure their faces, that they may be seen of men to fast. Verily I say
Comp. 25: 42. And as every wise business man takes dintinct accoment of all his pecuniary debts, so wo should think orer and deal with our moral debts. Boarduax: "This is the way in which our Hearenly Father forgives ns, for his tion's sake, our debts. We, finite, sinful mortaks, contracted the deht in the currency of earts; the sim of God paid the debt, so to speak, in the currency of hearen." Theoplly. "For Gord takes me as an exemplar; and what I do to another, he does to me." Euturar. "He makes us masters of the forciveness of our sins." BoARumav: "IJere is a man who has been bitterly wronged by amother; he says to him, "I formive you this, lunt I 'annot torget it.' He enters his cheset and prays: "Father, forgive me, as I have forgiven him! say to me in words that thou forgivest mes, but do not forget my offences! Blot them not out of the book of thy remembrance! Dotome as I do to him!' Ol, how often does this prayor, if oftered sincerely, mean a curse." SEXECA: "Let him easily pardon who needs pardon."

V. 1:. TinophyL. : "MI fore we must not fling ourselves into temptations; hut, if we have fallen into them, must pray that we may not be swa!lowed up." - We do very wrong when we expose servants or other dependents to temptation, by negligently griving them opportunity to deframl us, or by failing to pay them what they really need for support, or by showing them only the more forldidling aspects of our own life as professed Christians, thus inclining them to think ill of Christianity. LAxGF: "Thou who temptest others to sin, who exposest thyself wantonly to temptation, or who in temptation tienbest, yet not with the armor of God, why wilt thon mock frof by praying, "Lead us not into temptation?'(1 Pet. 5: 6; F.ph. 6:11.") Orifiex: "Let us pray that when struek by the fiery darts of the evil one we may not be kindled: and they are not kindled who with the shield of faith quench all the fiery darts which he sends against them." (Eph.6: 16.) liuskIN: "supposing we were first of all quite sure that we had prayed, honestly, the prayer against temptation, and that we would thankfully be refused anything we had set wur hearts upon, if indeed God saw that it would lead us into evil, might we mot have confidence afterwards that he .... would turn our hearts in the way that they should go?" BOARDMAN: "Well may this petition take its place as the conclusion of the Pattern Prayer. The evil it deprecates is the summary of all woe on man's part: the deliverance it eraves is the summary of all love on God's part."

The Lord's Prayer: I. That God may be glorified. 1. His name be hallowed. 2. His reign come. 3. His will come to pass, ete. II. That we may be blessed. 1. Temporal wants. 2. Spiritual wants: (a) Forgiven our sins; (b) Preserved from temptation, and delivered from satan.

We may imagine (Bengel) that in hearen all these petitions will be turned into praises. "God's nane is sanctified: his reign is come: his will comes to pass. He has forgiven us our sins: he has put an end to temptation: he has delivered us from Satan."

16-18. Good Works Without Ostentation. III. Fasting.

The third application of the general principle latd down in v. 1 is to Fasting. Compare on $\mathrm{v} .2$ and on $v, 5$. The reference liere is obviously not to general publie fists, but to voluntary individual fasting. This was common among the pious Jews, but the Pharisees had redneed it to a system (as formalists usually do with their religions observanees), fusting "twice in the week." (Luke 18:12.) The Tahmul informs us that they chose the second and fifth days of the week, because of the traclition that Moses went up Mount sinai on the fifth day, and came down on the seeond.

16. Be not, or more exactly, 'do not become, implying the assumption of such looks
1 Blyth on the Lord's Prayer, re-published ly James Pott, New York, contains an immense eolleetion of quotations from aneient and modern writers, one of whieh has been used abore. 
17 liut thu, when thon fastest, anoint thine head, 17 umo gou, They have reeeived their roward. But and wash thy fitce;

thou, when thou latstest, anoint thy head, and wask

for the time. Of a sad comutenance. It h.ul always been the custom among the Israclitus, as amomgr other Oriental nations, on areasions of sevore persomal of national aflietion, to manitest their grief and humiliation by wearing sackeloth, putting ashes on the hearl and talee, ete. (Connly. on 11: 21.) These the pharisate hypuerites appear to have achopter in their regular individual tasting, in oreler to make known the fatet and gain coedit for singular devoutuess. The Talmud of Bubylon says, "Whoever makes his tince? black (a commom expression in the Jewish writers for fasting) on aceount of the law in this workl, (rom will make his brightness to shine in the world to come." Verily I say unto you, see on 5: 18. 'They have receivel, more literally, have in full, bave all of.' Siee on v. 2. Instead of they may appear, ate., (the more literal rendering), May be sten of men (Tyudile, Gonevi), is preferrod, betause the former might suggert a mere appearance, which is not here intented. (So in v. 18.)

17. The Siviour refuires his disciple to dress on a day when he was fisting precisuly as on other days. So far from astentatiously exhibiting a voluntary act of a devotion, lac should even purposely eonceal it. But it is a gross misunderstanding to talie this as an injunction to dissimulation. Wre cannot ton often remind ourselves of the distinction between deception and comealment. Anoint thy head. This was an establishext enetom among the Jews from an early period. (Rum 3 : 3; 2 Sam.12:20; Psa. 2:3:5; 101-15; 133:2; Fecl, 9: 4; Matt. 26: i; Luke $z: 46$.$) Whan in great distross, they$ would omit this, as in 2 Sam. 14: 2; Dan. 10: 3 , and the Talmud enjoins a like course in connection with fasting. In ane passilge, however, we read of a man as " werping at home, hut when he went forth in public, lie batlual, anointed, ate, and drank. But why did he not do it openly? God answered, Although lue himself did not manifest the thing, yet I will manifest it." Bnt thon, the elange our Lord so frequently malies from the plural to the singular (comp. v. 2,6 , und secon $5: 2: 3)$. This shows that the refer-
Pnoe is to a case of private, inclivialual fanting, as in v. fi to private praying. Forthe varions phrases in v, 18, sea on similar phrases in $v$. 4 and 6 .

Is to the propriety of fasting on the part of Christians now, we see that Jush speakis as it taking for granted that his diseiples woukl fist. It might be sald that this was in the atrly patet of his ministry, when things werer in a transition stage. but in 9: 15, he likewise takes for granted that his disciples will fast after he shabl have laft them. Observa", however, that it is voluntary tiating ot which he is spealing, and there is mo trace in the Now Tost. of any appointment of at particular season for fastiug. Inderel, the ounly fast anjoined by the law of Moses wats that on the

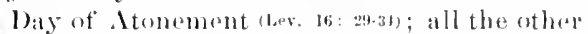
fasting mentional in the ()hd Test., whether national or individual, wat voluntary. In !) 15, the saviour clatrly teaclues that fasting is right only whon one's enolition malies it natural. In at time of joy, fasting would be umatural, and eoulal not experse a gonuine focling. But persons who aro in grout distress are naturally inclined to abstain from ataing. Now avery fepling is doplened by being in any natural way manifesterl ; and so a rincorer, though less strong foeling of listress, as an aandut of sin, may be strengthened by ab-tinence from foud. This may also ledpus for a tome in fixing an attention Mpm worship and devout meditation. Iet fasting is not in itself a meritorious action, but is preper only so far as it is natural under the ciremmetances. and useful in such ways as have boxn indicated. Whereverthisutility would beconterbulanced by injury to health, disqualifiotion: for active dutios, or other grave wils, then fasting ought not to be uracticel. Tha observaneo of national filsts would appose to be in like manner optional, and subject to the simes conditions. As to tasts appointod by some ecelesiastial authority for rogular samons of the week or vour, no seriptural authority can be clatmed fis making the injunction, and such regularly recurring fasts are axtranely apt to degenerate into formality (10m) Isa. ix: $3 \mathrm{ff}$.), or to encourage exessos at of her times

1 See the same Greek term in Luke 24: 17 (Rer. Text), and in the septuagint of Gen, 40: $7 ;$ Dan, $1: 10$. 
Is That thou appear not unto men to fast, lot unto 18 thy face; that thou be not seen of nen to fast, but thy lather which $1 \mathrm{~s}$ in secot: amel thy Father which seth in secret shall rowaril thece openly.

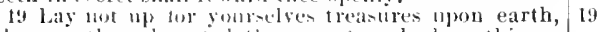
where buth and rusi loth corrupt, and where thieves break through and steal: of thy Fither who in in secret: and thy Father, who seetli in secrt, shall recompense thee.

19 Lay not 11 lor yoursetses treasures upon the earth, where moth and rust doth eomsume, and where thieves I lreak through and steal: but lay up for

1 Gr. dig through.

("Mardi Gras," ete. ', wr to be invested with an imaginary intrinsic meritorionsmess, opposed to the sprit of the gospel. The mortification of thr thend, which is smetimes megred as a benefit of regular fasting, "anu be leetter attained by habitual temperance than by occasinnal alotinenes." (Alereneler.) (Compare on 4: 2and on 9: 15.) But many (hristians of thr early eenturies had an exaggerated conoption of the importance of tasting fone of the many elementsof Judaism which they imported into (hristianity), and so the word tasting erept into numerous manuseripts and versinus in Mark !1: 24); Matt. 17: 21 (wbole verse spurious); Aets 10: $30 ; 1$ Cor. $7: 5$. (beo these passages in Rev. Test.) The word is part of the genuine text in Matt. 9: 15; Luke 2: $37 ; \operatorname{Acts} 13: 2 \mathrm{f} ; 14: 23$.

IIOMILETICAL ANU PRACTICAL.

Fasting. I. When? (1) On public oceasions, if we really feel grief, and roally desire to deepen it. (2) On private aceasions, if it would he natural in unr providential situation (9: 15), and would be profitable. (3) In either ase, only so far as compatible with heath and th" proper diseliargo of existing duties. I1. How? (1) Without the loast ostrontation. (v. 1,16.) (2) With sincere desire and earnest effort to commune with Gorl and gain spilitual profit. (v. 18.)-IIyporisy. 1. Mrethods. (1) Religions olservances-e. \%, alus-grjing, fasting, prayer. 2) Raligious pertesions, II. Rewards. (1) Glury of men (r.a), and even this nsually rery partial and very transient. (2) No rewaril from (roll. (s.l.) (B) Not fren the approval of ans's own conscience. (1) Igoravatul punishment in eloruity. (Mark 12: 40.) Commp. in general chap. 2e?.

('HRYs.: "And, wherous, in the matter of alunsquing . . . . aftrer saying. "Take hand

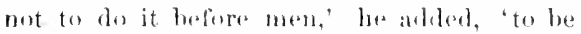
serall of them'; ret in lha matter of fasting and payer, ho made lou such limitation; why wathis? Because foralms-giving to bo altourathar concoaled is impossible, lut fur forarer and fasting, it is possible." VINes in Lut- teroth): "Fasting has no value save aceording to the dispositions by which it is aceommanied; it is good only in proportion as it is not the body alone, but the heart, that fasts."

19-34. SHNGLE-HEARTED DEVOTION TO God, as Opposed to Worldir Aiss AND Axxieties.

Having urged that good deeds should be performed, wut of regard, not for buman approbation and reward, but for that of God $(v, 1+18)$, our Lord now passes to the kindred topic of ineuleating, in general, an exclusive and entire devotion to God, as opposed to worldly aims and anxjeties. (v.19-34.) (Sce Analysis at the beginning of chapter 5.) 'This section of the great discourse naturally divides itself into four parts, viz., v. $19-21 ; v$. 22 f.; v. 24; v. 25-34. We can discern between these an internal, though not a formal connection. The sayings are gnomic in form, and only an internal eonnection eould be expected.

19-21. He begins with the thought that as the believer's heart ought to be in heaven (which is here taken for granted), and as the heart will be where the treasure is, therefore we should trasure to ourselves treasures in heaven, not on earth; and to this he eneourages by eont rasting the treasures of earth and heaven as respectively perishable and imperishable. The sama idea oceurs in Luke 12: $33 \mathrm{f}$, as used on a different occasion. The Jews of our sariour's age were very largely a trading people, possessing much the same characterintius at at present, and among them an uncommon love of momey. What is here said was therefore especially appropriate to them. but lully applies to men at all ages. It is also maturally understood as cxtending to all the other objects atter which men long and seek; in gencral, we are to have regard to, and strive to obtain, heavenly rather tham atrthly things (compare Col. $8: 1 \mathrm{ff}$ ), befause the leart will be fixed on that which we are laboring to possess.

Lay not up for yourselves-literally, $D_{0}$ not treasure to yourselves treasures. The 
20 But lay up for yoursetves treasures in heaven, where ncither unoh nor rist doth corrup, and where thieves do nut breat ibrungh nor steal :

gl lor where your I reasure is, there will pour leart be alsis.

2.' The lisht of the bonly is the ere: it thercotore thine cye be single, thy whole buly shall be fult of light.
20 yourselves treasures in lieaven, where noilon noth

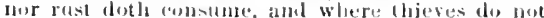
2 I lormak through nor steal: lior where oly treasure is,

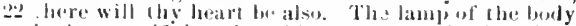
is tho cye: if iherefore thine egebe sinsle, iby whole

1 Gr. dig throtegh

English idiom is disinclined to this immediate repetition of the same word, and bence on popular versions express it atherwise. Jesus does not mean absolutely to forbiil the aceumulation ot wealth. It is a peruliarity of the lebrew style. often aceurring in sioripture, to make an ahoolute statement (esperially a prohibition), which i- dexigned to be understood relatively. See otleer instances in Lulie 14: 1:2; John 4: 21; 1 Pet. 3: : f. This makes the expresion more striking and improsive, like hyperbolieal phrases, etc., and such statements were not meant, or exprected to be taken literally and absolutoly, any more than hyperboles are so taken. This prineiple of interpretation is eapable of being abused, ats all others are; but it requires to be applied in stech passiges as the present. Versong is the "pposite of v. 19, axpandect for greater impressireness. Comp. v. 15. and see on 5: 30. 11 en lay up treatures in heaten by righteounness in general, beth in doing and suffiering for Chri-t'ssake(5:12, 46:6:6:2 Cor. 4:17); atnd : allumg wher things, by a right llse of eatrthly fur. sessions, als proposed to the rich young man 119: 21), and als taught in Luke 1:2: :3: and in the patrables of the unjust steward, (1.uke 16 1.) Remember also the "up of eold water (19. 42), the atvalrds of the judgument (25:40), and the. remarkable pasisge in 1 Tim. (6: 17-19; als.

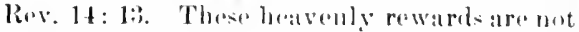
deserved loy onr goosd deods, being a gitt of

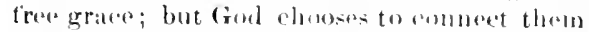
with. and proportion them to, onr deeds of kinduess to othere, and devotion to him.

Noth, rist. The girmonts of the Jews, us of othereriental nations, ellem chaned their tashom; and henee great stome of garments, problaps in part inherited, would often torm an important itom in one's pussessions.

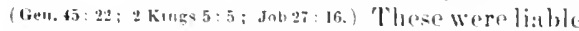
to be destroyed by moth. The term resuderent 'ru-t' ignilies 'eating,' and so consumption in whatever way. It maty be understencl here in the general sente of whatever comsumes or lestroys property ; or in the special sense of rist, just as we saly that rust eats. Compare James 5: 2 f., in which, als in various other pasiages, James arems to be referring to the Sermon on the Inount. The word rendered corrmpt-in lirv. Ver., consume-is literally 'calue to disappear,' and in v. lti is rondered distigure. 'Corrupt' dees net correctly express the idea. Thieves. As to the ither worel sometimes remdered "thief, but more

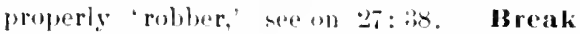
through is literally 'digthrough, as in margin of Rav. Vou, following Geneva and Rheims. It doubthes refors to the elay walls which many houmes hat (comp. Job 2t: lib). "The houses in Mexien are chiefly louilt of adebes (large sun-tried brieks), and in the attack on Monterey (184i), the Ameriean troms advanoed inte the heart of the city by digging occasionally through the walls of courts allel housese," Gith. D. II. IIVll. It is sometimes objected that the precions motals do not rust. But tley can be stolen. The heart is spoken of in sereripture, not aceording to our mokern view, as the seat of the aflece tions anly, but as the seat of all the powers of thas soul. both intelloret, sen-ibilities, alld will. (To sperak of the herre al the seat of intellect. is a thine muknown tothe Bilda.) Many pase sages of seripture are popularly minumerstoorl, from fitilure to keepthis usige in view. The conneretion in the present cato leads us to think of the aflintions as apectilly meant, but not exclusiroly. The thoughts, at well at feelings, will be where the trature is (anm). (al. 3: 2) ; and it is the power of linowing truth that is especially referresl to in the next twoverses. Your-R. V. thy-(twice) in s, 2l. The singular reprosents the correat Greek text, whieh was whanged to "your' by apyist who observed the plurals of $v$. $1: t$ if and dial not think of that impressive change to the singular which is so often made in this disconrse (eomp. v. 2, 6, 17; and exp un 5: 2:?

22 f. This passitge is in some ranpecte obseure, and has given commentaturs much trouble; but by remembering the connection, 
2: But if thine eye he evil, thy whole hody shat be full of alarkuess, li therelore the fight that is in the be dark ness, how great th that darkiness:
$2: 3$ boly shall the full of hight. But if thine ere be evil, thy whole buty shall be tull of darkness. lif therefire the light liat is in thre be datiliess, how great
And earetully noting the preeise mouning of the terms, the ditliculty mat les cleared mp. compire Lulie 11: 34-3t, nearly the sime passige. spoken on a ditlerentereasion. The light-literally, the lamp. The word is the sume as in 5: 15 , and demotes any portable light, The eye is the lamp of the boely beeause it is that part which gives the bedy light, by means of which the body sees. The worl sinsle, or, 'simple, represents the eye as giving one image of an object as opposed to: an eye which sees double, which gives dim, flickering images that displace one another, so that the objeet is not seen elestrly and steatily. This last is deseribed by a more general term at a bad" eye, the Greeli worel ermmonly expressing moral evil (and the phrase is so emplosed in 20: 15; Mark $7: 20$, but being sometimes foumd in the other, which is really its primary sense, as in the phrases 'bad eliet, 'bal health, 'bathess of eyes," all employed by l'ato. (some early expositors anderstond it to demotemeral esil here. and henee Tyndale. Great Bible. Geneva, and Darby translate "wieked.") Many" interpreters enolude" that "single" should be here understond as meaning a somme, healthy eye in general, as oppread to a bad. diseased one, which doesmot see well. But there is no stppurt in Greak usige tor such an interpretation of the word. and the Latin versions render it simplex, the Peshito gives the same sense, while the Momphitie borrows the Greek worl. It is very underirabie to abandon the specitic meaning if this word, which precisely suits the whole ent)neetion. and in eentrast with which the general termbat will naturally here take to itselt a corre-pmuling atplication. The 'single' age forms but one insce of its object, and dives not bleme that with the images of other objeets: the "bad "eye forms elittirent imatres of the stme thing, or blends different objects in its confused vision. So the single eye roully sees; while the bal ege practivally does nut see at all. If the eve be single, the whoto budy will be "full of light," thoroughly light: while it the eye be bal, the whole buly will be 'tull of darkness, thoroughly dark. The light that is in thee, the lamp ot the mind, or as Plato calls it, "the eye of the soul," would be onr inner power of perceiving truth and duty-what we commmly eall reason and ennscience: and would inelude both the natural light whioh these give, and their eapacity a receive the light of revelation. So philo says (following Aristotle): "For what the intelleet is in the soul, thit the eye is in the boly." Or wo might recall (Weiss) the tem 'hourt' trom v. 2l, which womld then represent the mind, and amount to the same thing. Now why is it that the gonel eye ot the illustration is spereitically deseribed as a "single' eye? The reason lies in that general truth with which the whole connection is dealing. viz., the propriety and necessity of exelusive regard to Gul. Just before, we are taught to store up havenly and not arthly treasure, that our hoarts may be in heaven, not on earth. Just after, that we cannot be the servants af both God and mammon, but must serve Ged alone; that we must not he moxious about temporal wants, but must seek his kingdom and the righteousness he requires, and trust his providence for the supply ot $1 \mathrm{~cm}^{\circ}$ poral nocessities. Anel so in the present passige. If the "hourt" (v.21), the "mind's "ree" the reasom and conseience, is fixed party on fied and partly on manmon, sometimes on heavenly and sumetines on atrthly things, then it resembles the bat eye, which mixes images of different ubjects, so that we really see nothing. Emictetus expresses a similar theught by n similar image: "If sou strive atter moral exeellence, and ret at the same time cluteh at power and pelt, you will most likely lose these last from havingan eyeto the former also; and most eertinly you will lose the turster." 'The g+neral thought is therefore of reason and enseiener dirliened, blinded - as by inheritance of taults, by misedueation, by budily excesses. by eovotonsmess, ambition, or other stromg p:soions-hut with special roterence hereto a re:son and emscience divided in aim and thus darkened. The heart must be directed with exolusive and stendy gaze toward= God, not distraeted by worldly aims and anxieties, or we shall be sadly lacking in clear pereeption of truth and duty. (Comp. Olsh., Alex., Plumptre.) How great is that 


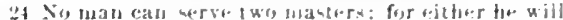

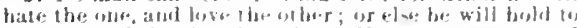

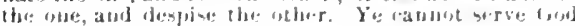
andl matumult.

(the) darkuess! "That in an indation of

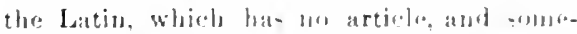

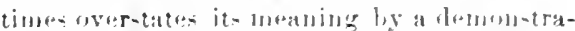

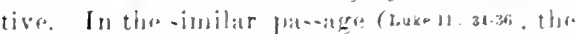
bright side of tho illu-tration is finally ubards prominurat, while here it in the rlark sidw.

21. A furtherand verv di-tinct illu-tration of the salmo grout truth, vi\%, the duts and

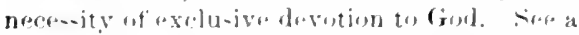

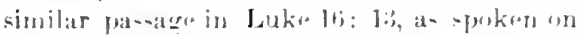

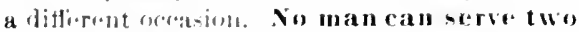
masters. All diffiralty or ravil about this statranent. on tlare groumd that there are reir-

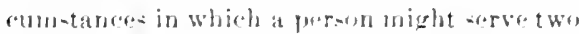

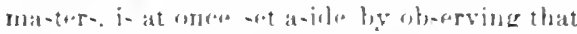

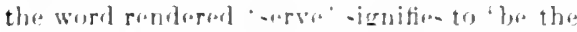
slave of, a rolation whish neresarily implias

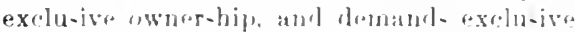

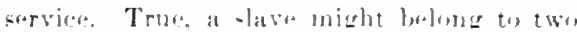

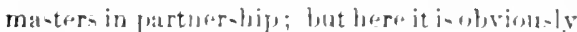
implied that the two are altogethor oldumed

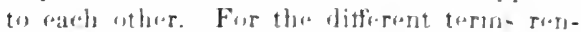

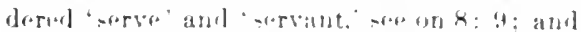

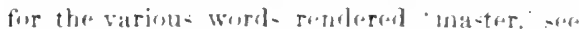
ron $x:$ 1!. The noxt word- are nort tatateleg-

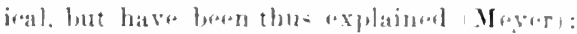

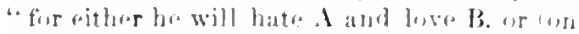

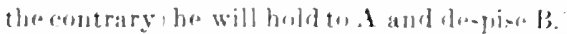

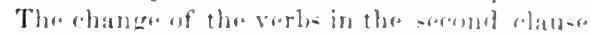
(in-tatal of -imply -aving, "will low a and

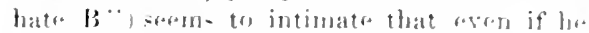

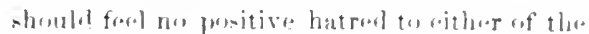

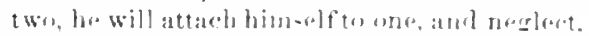

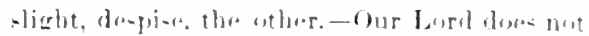
simply furnish the illu-tration. lanving it to bu

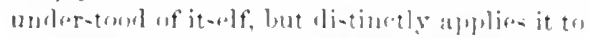
the -ubject in harrl. Ye cannot -rerse God and mammon. Thr worl taamoman is Aramaic, signifying walth, richw. It i-horm ger-

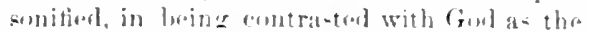
othor of two ina-ter-: but there i= nusufficiont

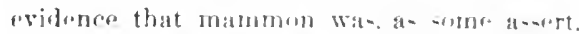
artually wor-higed as a cyrian divinity.

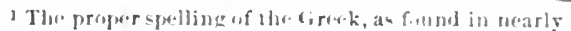

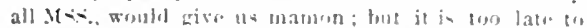
aller the lingliah furm. The abymology is most likwy, as uwaliy giren, from the Hilorew aman, foleaning that which progs, sujporte, or that which is relied on, trustel. Cerefirimm, Blerk, Thuluck, Bcholin. There

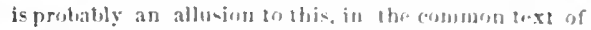
Mark 10: 24, B. C. Ver., "those why trust in riches" ;

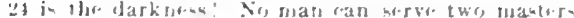

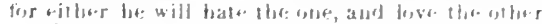

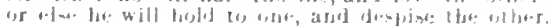

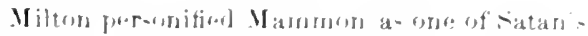

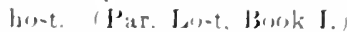

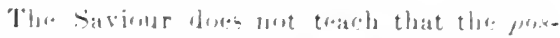

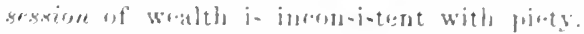

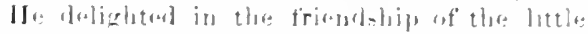

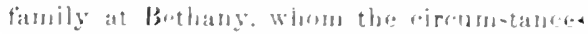

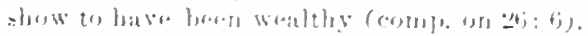

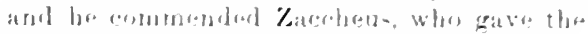

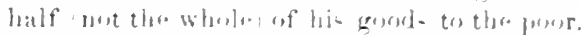

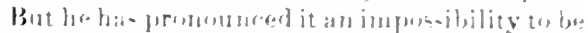

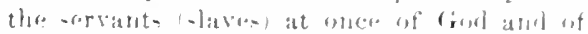

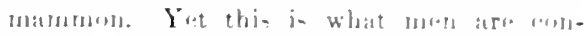
stantly attronpting to do, and Chrintians aro

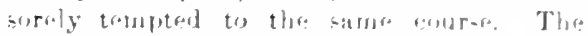
I-ratiten of Elijah" - tims dirl not averwedly

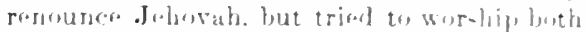

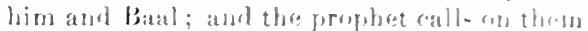

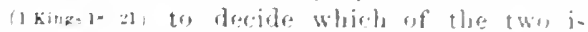

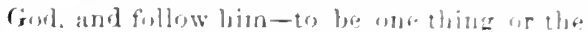

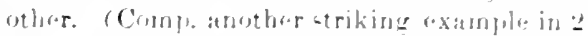

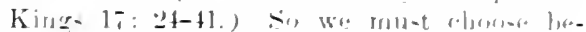

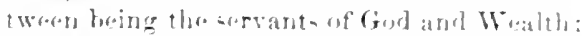
wo ratimet be brith. Whatevor reffort- Wo

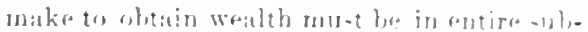

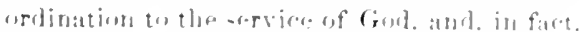
it part of that sorviofe: lis aleme moll-t las

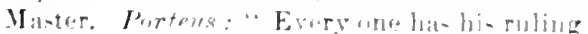

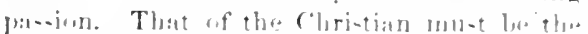

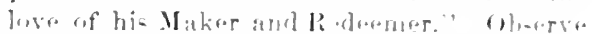

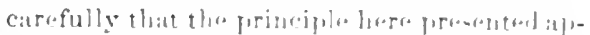

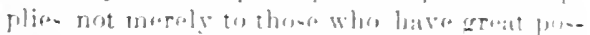

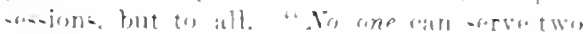

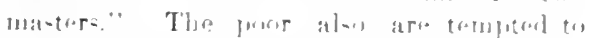
wake wealth a ma-tor and an idal rab?

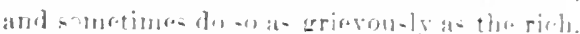

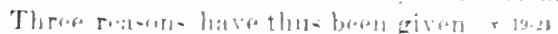

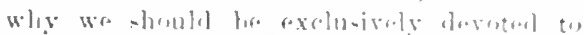

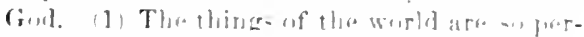

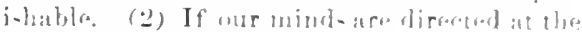
salure timf towards asthly and lantally

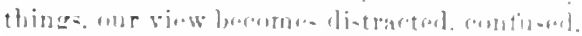

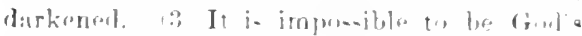

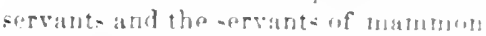

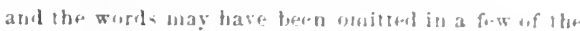

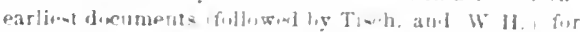

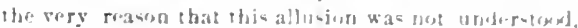

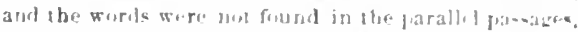

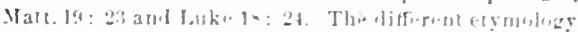

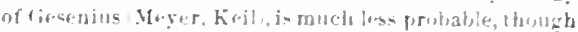
it yields the same meaning, riz., uealth. 
25 Therefore I say unto you, Take no thouglit for your life, what ye shall eat, or what ye shall driuk; nor yet tor your bisdy, what ye shall put on. Is not the life more than meat, and the boly than rament?
25 Ye eannot serve God and mammon. Therefore I say unto you, be not anxisus fier your life, what ye shall eall, or what ye shall drink: nor vet for your body, what ye shall put on. Is not the life more
25-34. Here the duty of entire and exelusive devotion to (rod (see on v. 1 and v. 19) is set in opposition to worldly anxieties, which are shown to be both unnecessary, unavailing, and unbeeoming; to spring from unbelief, and augment the ills of life; and it is added that by following the other course we shall gain, without anxiety, the very objects in question. The paragrapl is found in Luke 12 : 22-31, with slight variations, as on a later occusion repeated to the disciples in the hearing of a new audience. This passage "is one of the beanties of seripture. IIad it no other reeommendation than its felieity of illustration and its graess of eomposition, it would deserve our warm admiration; and indeed it has reeeived the tribute of admiration from men who were only in pursuit of iiterary beaties. But it has higher qualities of excellence than these; it spealis to the understanding, ard the heart, on themes of deep and universal importance."-John IIarris.

25. Therefore, viz., because of the truth he has been enforeing (in v. 1:1-24, but with special reference to $v$. 24, that single-hearted devotion to God is proper and needful. Consuming anxiety about the necessaries of life, instead of trusting Gord, betrays the same worldlyminded and ungorly feeling that is seen in the slave of mammon. Trust in God would prevont all such worldly anxieties. So the suffering Jebrew Christians, who had been plundered of their possessions (H'b. 10: 34 ), are urged to be free from the love of money, on the ground that God his promised never to fail nor forake his peoule. (new. 13:5t.) Food and (lothing alre the most urgent wants of our arthly eondition; and if we ought not to be anxims about these, much less should we be anxions alyout other things. Take nothought -or, be not amrious-lor your life-"Take no thonght' was a good rendering when King James' version was mate (so also in 1 sitm. 9: 5), for in Bacon, Shakspeare, and other writers of that period, 'thought' is towed as inchuding the jdea of anxiety, ats when al person is sairl (o) have died of thought. Tymbille and the

\footnotetext{
1 Some early authorities omit "or what yoshall irink, and W II. place these words in lorakets; hut the omission is readily expluined by desire to assimilate thet pas-
}

suceeding $\mathbf{E n g l i s h}$ versions translate 'be not careful' in this passage, but 'take thought' or 'take careful thought' in v. 27,31 , and 'eare,' in $v, 27,34$. The Greek verb used throughout this passage is also found (besides Luke 12: 2226) in 10: 19; Luke $10: 41$; 1 Cor. $7: 32$; Phil. $2: 20$ and $4: 6$, and a few other passages; and the eorresponding substantive in $13: 22 ; 2$ Cor. 11 : 28 (Rev. Ver.) "anxiety for all the ehurehes," 1 Pet. 5: I (Rev. Ver., "easting all your anxiety upon him, leeause he eareth for you" (where careth is a different verb); Ecelus. 30: 24, "anxiety bringsold age before the time." These pasages show that the word sometimes expresses a lawful feeling of intense eoneern, which is directed towards proper objects, kept within due bounds, and stimulates efforts to do our dity ; and that this feeling beemes wrong when misdireeted-or when existing in greater measure than is expended upon action, and so cating like an acid into the sonl-especially when it is a feeling which springs from lack of trust in God, this last being the idea of the present eonnection. The term care is used by us in a similar twofold sense, expressing sometimes a right and sometimes a wrong feeling. Our Lord of course does not mean that we are to exereise no forethought, and put forth no effort. Trust in God by no means implies the lack of these. Augustine refors to a soct in his time who called themselves Euchites, or Prayer-men, beeause they simply prayed for everything they wanted, without laboring to attain it. This grievous folly has been reproduced by some well-meaning persons in the present generation.

The first consideration hy which Josus seeks to restrain from the anxiety just forbidden is an argumont from the greater to the less. (v. :5.) If Goul bas given us the greater, viz., life, the body, is he likely to withhold the less, viz., the ford and the raiment? Life is the word which often denotes 'the soml,' but in many other cases, as here, simply the vital or animating principle (eomp. on 16: 25), to sustain which there is nom of food. ${ }^{1}$ Meat-lit. as in Pev. Ver., the fool. The worl 'meat'

sage to fuke 12: 22 (where also some early doenments insert the words by way of assimilation to MIatthew). 
2; Bebold the fowls of the air: for thes sow not, neith.r to they reate, aur gither intolarus; et your

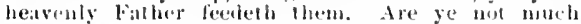
bitter than they:

27 llich ol yon by taking thought ean add one eubil unle hro stalure:
26) Ihan the food, and the body than the raiment? Bew hold the birds of the heavell, that they sow sot. neilber do lowy roap, nor gatber iuto barus; and your heavenly father lialedh them. Aro not ve ol

27 inteh more value thats lhey" Aud which of you by loeing anxious can ald one eubit unb liba

I (1) his stature.

formerly signified fuod, but is mow restricted to a particular kind of founl.

26. The secoud considerition is an argnment from the los to the greater, and this alpplicel first to finel (v, 26), and afterwards to elathiner. (v. $2 \times$ wo 30 ) Bebold the fowls of the air-orr, as in lioy. Ver., the bimls of the hearen, hird- that fly tree in the sly, and aser whirh mon exeroje no eare. (Comp) 8: 20; 13: :23; (ren. 1: 20;.) 'Fowl.' formerly signified birds in general, but is now restrieted to a errtain variely of amesticated birds. Instract of the gemeral term birds, the similar discourse in Luke 12: 22t, has the specific term 'ravens.' Aswwing, reaping, and gathering intobarns are the threcleading prosesses of areiculture, we thus luate it very strongly aflimol that the biris pertorm no part whatever of the work which men luse to pertogun

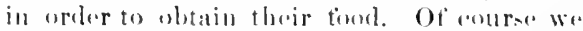
know that the birds exert themselses; Gud dors not feed them in idleness. But thery find their foud without ally of our alaborate proexeses. Tho inserted 'yet' in the Coms. Version onfocbles the simple and brantiful axpression. Are ye not, butlor. not ye; the "yes beinge expressel in the wrierinal, and thus shown to be emphatic. Inch better. of much more value, as (om). Vire. transiates the same cireseli plirase in lo: :31. The conclusion that museh more will Goul foed those who aro greatly more impurtant than the hirds, is hero left to be under-temel, but in the similar argumbut of 1 . : 0 is statul. The Mishnat says,

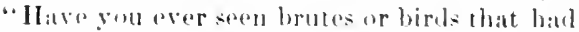
any trads? and yet they are moturished withont trumbla."

27. Butore masing to the argument as to raiment (v. 2a.30), our Lurul pause- to adil another remark to the reffecet that it is quite une araling for us to be anxinus abut foul. The general maning is plain, but the ablest

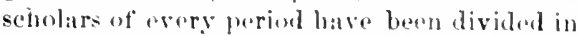
oprinion as to whather the leadiug term of the sentence here signitios stature or age. Its primary meaning and usual sense in forok writers is the latter (so in John 9: 2]; Heb.
11: 11); but it is sometimes nsed in the former serse (Luke 19: 3, and probably in Luke 2: 5.'; while Eph. 4: 13 may be undelstood either way.) The sieptuagint uses it soven times in the sense of age, and only anee. in that of stature. The "arly versions, Jatio. Peshito, Memploitic, Guthie, give "stature, and so do most of the Fathers, followed ly all the early English versions. Vet the American liveisers translate the meanure of his life, with 'stature' in the margin; and this sense of 'age' is more mppropriate to the comnection. The object of the senternce is to show that it is in vain to be anxious about food. (v.2. r.) Now few men aro anxious to obtain food that they may increase their stature, but all nom that they may proloner their life. This also best suits the expresion in Luke 12: "2f, "If" then ye are not able to do that which is least." since at cubit added to one's life would be very little. while a cobit (about nincteen inches) addul to the staturowould bo an emormous adilion. It is objected that 'cubit' is nowheroin serips ture found in this metaphorical application to the duration of life; but it is supported by the analogonserpression in P'sit. :3!): 5, "Thou bast made my days as hamd-breadths; and mine age is as nothing hefore thee" ; also by the exprewion of a Greek poet, "For u cubit"s time we enjuy the blom of onr youth": compare also (Achelis) Job 9: 25, and the Greek plirases "a -pan of lifo" and "a finererlong day." In this state of things it is mot -trange that the great mass of recent (1)inalentaturs profer the sense 'age. Morion urges that we cen add to our lifio by calofulness; "otherwise the medical profession is an absurdity." Bat our eflorts to do this aro fruitless withent God's blescing. He thinks the idea is that we cannot collarge courselves intu giants: but this overlooks Lulio l:2: 26. still, the other sense will yield the sime gemeral meaning for the passage. With all our anxiety about foud, we cannot (aport from Golls blesing) make the smallest addition to our life-or to our stature. 
28 And why take ye thought for raiment? Consider the lilies of iho field, bow they grow; they loil not, neither do they spin:

29 And yet I saty unto you, That even solomon in all his glory was bot arrayed like one of these.

30 Wheretore, if (ion so clotle the grass of the tield, which to day is, and lo morrow is cast into the wen, whill he not mueh more clothe you, o ye of little faith?

31 Therefore take no thought, saying, What shall we eat? or, What shall we drink? or, Wherewithal shall we be elothed":

28. In v. 28-80, the argument from the less to the greater is urged with reference to raiment. The lilies of the field, likt" "the birds of the heaven,' are those which grow wild without human eare, and thus all the more strikingly display the eare of God. We eannot determine the kind of lily meant, and the argumant holds for the plainest flower as well as the most gorgeous. The writer ubserved in Palestine lilies of a dark violet color, looking like violet velvet, and these might very naturally havostlggested a king in his rich purple robes. Solomon's song (5: 13) indicates colored lilies, and Dioseorides speaks of purple lilies (Nimith's Dict.). Tristram deseribes purple flowers, which he says would be popularly ealled lilies. The various attempts madr to "spiritualize" this reference to the lily, are, as usual, wholly unwarranted and out of place. They who are not satisfied with the simple beauty of our Lort's teaching, but must be seeking some mystical meaning which they think unore pleasing and instructive, are truly attempting "to gild refined gold, to paint tha lity."

29. Solomon in all his glory, does nut directly mean in glorious apparel, but in all the glory of his roval station, walth, and fume, which involved the use of beatitul garments.

30. If God so clothe-translate, flothesindicative mood, assuning it as a fact that he does. The grass of the field. The trim rendared grass includts weeds and flowers. All these wither very rapidly in the East, pspecially when a kot south wind is blowing (comp. Psa. (H): (i); and owing to the wearrity of fuel, this dried vegetation is still often usal to heat ovens for baking braul. The oven. This (Smith's Diet.) was a larie jar made ot clay, wider at the hottom. It was heated hy placing the fuel within, and the ashes bring removed through a bole at the bottom, tho flat cakes of bread were spread both on the inside
28 measure of his life? And why are ye anxious coneerning raiment? Consider the lilies of the held, bow they grow: they toil not, neither do they spin: 29 yet I say unto you, that even solomen in all his 30 glory was not arrayed like one of these. Hut if God doth so clolhe the grass of the field, whieh to-day is, and to-morrow is east into the oren, shalt he not 31 wuels more clothe you, a ye of little fitith? Be not therefore anxious, sayiug, What shall we eal? or, What shall we drink" or, Wherewithal shall we be

and the outside, and thus baked. Sometimes it was not a movable jar, but a fixture; and the primitive contrivance was probably a bole in the earth, with compacted sides. O ye of little faith, represents a single compound adjective, somewhat like little-beliering, used also in $8: 26 ; 14: 31 ; 16: 8$; in all eases with reference to distrust of God's protection, providential or miraculus. Enbelief is the root of the anxiety our Lord is here rebuking, at it is of every other sinful feeling; and thus we see one of the ways in which unbelief leads to unhappiness. In Talmud of Babylon, R. Eliezer says: "Whoever has a mouthful yet remaining in his basket, and says, "What shall I eat to-morrow, belongs to the number of those who have little faith."

31, 32. Therefore, viz., in view of the argument just adduced. On the ground of this, the prohibition of $\mathrm{v}$. 25 is reprated, and the suceeding verses append further considerations to the same effect. In v. $8: 2$ there seem to be two distinct reasons for avoiding this anxiety: (1) The Gentiles (1) heathen) seek after all these things, and it is unworthy of God's people to be like them (comp. on $5: 47$ ); (2) our Hearenly Father knows that we have need of all these things, and we may he sure he will not fail to supply our nord. Some think, however, that the seeond clatue furnishes the ground of the first; and explain by supplying a thought, thus: 'The hathen seek after these things, becalue ignorant that God knows and eares for their wants; but do not imitate them, for gour Heavenly Father knoweth, ete. (Comp. v. $7 \mathrm{f}$.) But it is rery rarely well to explain "for" by a supjosed ellipsis, and the former explantion seems preferable. Luke 12: 30 has 'but,' which gives the same ideat a little ditferently. The verb rendered seek is a compound of that in $x$. 38 , and denotes an over-intense or anxious seeking. Mll these things-all the things of the class to which these (food and rament? 
32 (For after all these things do the (ithliles seek:) for your heavenly faller knoweth laal ye have neced of all these things.

3is Hut seck ye tirst the kinglum of tioel, and his rightousness nul all these thiugs shall bet aded unto you.

it Take therefore no lhumght for the morrow: for the morrow shall lake lhomglil for the lhings of jtself. suthient unto lhe day is the evil therent.

belong, everything of this kind, i. e, all termporal wathts.

33. But seek ye, ete. Do nut, like the hathen, seek these things, but soek first his kingdome, and his righteonesnesss, and these things (emphasis bere on 'these things') shall all be adeled unto youe. Our Lord does nost simply enmmand us to avoid worldly anxiety, bat gives us something positive to do instead, ats a means of precluding it. So in l'hil. 4: ti, Rev. Ver.: "In nothing be anxious; but in everything ... . let your rengersts be made kumin unto (kind. And the peale of God . . . shall guard your hearts," ete. Solikeswise above in v. 20 wo are to lay up troi-ures in heaven, in-and of laying them up upon the earth. "llis kinglom.' This "vidently metus the kingdom of our Ileavenly Father, who is mentioned in the preceding senterlee. But the Groek phriace is not so entirely explicit as the Com. Version; so some one put the word gind in the margin, to explan what is meant, and it crept inte the text. 'so likewine in luke 10: :,1. seek firest his kingelom, and there will be no need of atterwards anxiously secking foud and raimant, ete., for they will be alded, not indeed without reoking, but without anxious secking; and so there will in this way be no aceation left for maxety about them. Wünsehs. quotes from the Talmud: "If" a man necupies himelt" alway's with the law, the Eternal supplies his wisher and needs." Gur Father's kinglom is heres the Me-

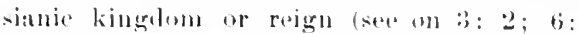
10). T'u seek this kingilom is to emdeaver to betome almited into it, and share the privilegos and duties of its subjerets. But not lenving as allogether to enr own endmelu<ions as the what is involved, the suviour here athls (not in Luke 12: 31) one point more specifically,

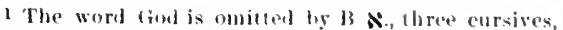
Bume copies of the old Latin, and of the Vulgate, the Memphitie and Ethiopic, and by one or two direek Fathers. We realily see how the word came in, and cannot imagine why any one sbould have wished to ex-
32. elothed? For after all thase things do llu ficuliles

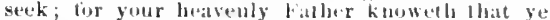

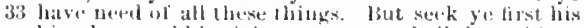

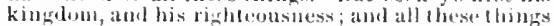

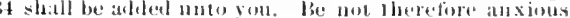
for lhe norrow: dir the nsorrow will be aluxious lor ilseli. Suffledet unto the day is the evil thereen.

and his righteonsness. This means that persollal righteonseness which our Fither requires in the subjects of the Nossianie reign, which they ought to bunger and thirst after (5:6); which onght to exceed that of the Seribes and Phariases (5:20), extending not merely to outward atets, but to the inner life of purpose and desire (5:21.4\%); whichenght to be practiced, not with a view to the praise of men, but to the approsal and rewards of the Fither in heaven. (6:1.1n.) We munt not introduce here the ielea of imputer righteosusness, which is foreign to the tone of this discourse, and does not distinctly alpear anywhere in the Gospels, being chietly set forth in Patul's Epistles to the Gillatians, Romatus, and Philippians. The great fiact of imputed righteonsness must have existed from the beginning of human repentance and for reviveness, but it does not follow that the idea was al ways revented.

This saying smms up the great principles of the whole patsage, $\vee .19-34$, vi\%, things spiritual first, and things temporal will follow. lle does not forbid anr desiring or souking temporal eroul; but salys it must always be held as secomditry and abordinate, to be wh. tained as a minor consorflemest of the pursuit of a higheraim. (Comp. Mark 10: 30; 1 king 3: 11-13.) In like manner the sayings in is: fsumd 7: 12 form, as it were, a summing up of what presecters them.

3.1. This section of the diseonrse nuw ends with n renewed injunction not to be anxious, tionded on the whole previous dicension (therefore), and directed especially to anxiety for to-morrow. It is coneerning the future that we are most likely los be anxims, and to-morrow is the nearest theture : and yet there is speceial reason for avoling this, sim.e to-morrow will have its own anxieties, and if

clude it. This consideration niakes lhe evidencesuti-

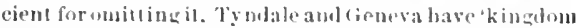
of hestren, which is here fouml only in me curave and three firet fatlers. Whenee did they derive it: 
we antieipate them, we uselessly add to the burden of to-day. Whether to-morrows anxieties will be proper or improper, is not here the fuestion; they will be felt then, and so shomlel not be borrowed to-day. The shall of Com. Version is somewhat misleating; the Greek is a simple future, and in this connection merely predicts. For the things, rte., better as Rev. Ver., for itself. 'For the things of itself" represents a very feebly supported reading of the Greek. Sufticient unto the day is the evil thereof. This mean not moral evil, the ordinary sense of the term, but natural evil, i. e., suffering, trouble, etc., as in Amos $8: 6$; Eecl. $7: 14$; 12: 1; Luke 16: 25; also in 1 Hace. $7: 23$; $10: 46$.

A Jewish writer (Wet.) says, "Be not anxjous about what is coming, before it takes place; for there is enough of vexation in its "wn hour." All men observe the folly of borrowing trouble from the future, and yet we continue to do it, and even to have a harge part of our distresses spring from the dread of future evil, which likely enough will never come. A French poverbsilys, "The worst misfortunes are those which never arrive" ; and a homely English proverb, "Never eross "bridge till you get to it." Anacreun: "I care for to-day; who knows to-morrow?" Horace: "What is to be on to-morrow avoid inquiring. Whatever sort of day fortune shall give, count it gain." But there is a broad distinction between our hidviour's teathing and such Epieurean emunsels. They mean that it is foolish to harass ourselves about an unknown and uncertain to-morrow, and so we must simply enjoy to-day; he, that we ought to trust in the protection and blessing of our Ifeavenly Father, and thus, while not heedless of the future, we may be free from anxiety about it. They say, "Tomorrow depends on chance; therefore try to forget it, and enjoy life to-day." II silys, "To-morrow and all its wats will bo porevided for by your Heavenly Father; therefore think of it withent anxiety, and try to du righ and please God to-day." On the other hand, our Lord's teaching is very diflepent from fatalism. Hedoes not say, the morrow is fixed by fitte, and you citnot belp yourself, but speaks of the personal (xod, our Father, who cares for us (1 Pet.5: T), and will supply our wants.

\section{HOMILETICAL AND PRACTICAL.}

V. 19-21. Laying up treasures in heaven. 1) Meaning. 2) Motives. (a) These treasures are imperishable; (b) Thus our heart will be in heaven. A Roman poet says: "A cunning thief will break your chest and earry off your money . . . . whatever is given to friends is beyond the reach of chance." A Jewish writer tells of a king, who was reproached for expending in time of famine the treasures of his fithers, aid who replied, "Iy fither's collected treasures on earth, but I in heaven." Augustrane: "Why do you lay up where your malose; and where, if you do not lose, you cannot always stay? There is another place to which I will remove you. Let what you bave go before, and fear not lest you lose it; I was the giver, I will be the guard." EuthyM. "That which is distributed among the poor, where is it treasured up? In heaven. How? The rewards of all this are there stored up and kejt safe." CaLVIN : "If honor is thought to be the summum bonum, then men's minds must be wholly possessed by ambition; if money, then avarice will at once become sovereign; if pleasure, then nothing an prevent men from degenerating intw brutal indulgence."

V. 22-20. Blindness. I. Limentable evils. (1) of bodily, (2) of spiritual blindness. II. Responsibility. (I) Blindness of the body is usually a misfortune. (2) Blindness of thr sonl always involves guilt. HI. Cure. (1) In physical blindness, cure seldom natural. (2) In blinduess of the soul, cure alway: supernatural. (3) Yot this (nire may be sought from Gorl, and means employed for promoting it. S'TIER: "In a certain sence and measure, indeed, must our eye, from the very beginning, be singly fixed upon God, his kinglom, and his righteonsness, upon the treasures in heaven; but is it not consummate holiness when this is perfectly ralized, nut there is no oblique or other regard?"

V. 24. The service of Mammon. I. Nature. (1) What it is not. (2) What it is. II. Temptations. (1) For personal gratitication-of appetite, taste, social and other ambition-love of posession-love of power. (2) For benefit of other-our families-the needy around us -the great good one bopes to do after a while. III. Some of the ways in whieh men try to serve Afammon and serve God also. IV. 
The two lopmlessy incompatible. Compare serving Jellovals aud Balal. (1 kings 1s: 21.) Whoneveretrying todu both, a man is, in faet, omly serving Mammun-not at all serving fod, and not in the highest sense benefiting himself. "Religion must be everything, or it is nothing.'.

A Roman writer speaks of one who did not own rieles, hat wasownod by riebes; by title a king, hut in mind a miserable saveof money.

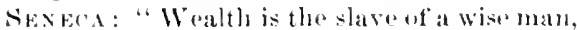

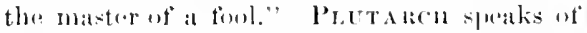
Pelopidas as relieving the needy, that he might nppear to bre truly mastereat wealth, not save. l't.eTe: "To prize watth, and at the same" tune lareng acouire wistom, is impossible, for a man mecessarily discerarels the ome or the

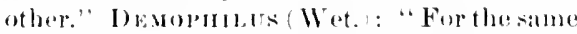
man to he a loser of riches and a lover of (xod, is impossible," Lutuks: "To have monery and property is not a sin, only you must not lat it lue gour master, hut you must be its

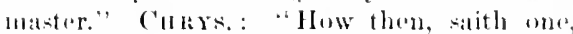
did Abralıam, how did Jol, obtain a goud roport? Tell me not of them that are rich, but of them that serve rielses. Since Jobalsu wats rieh, yet he sorvel not Mammon, lont possesced it and ruled orer it, and was a manter, nut a slave." drukiss: "The servant ot Mammon estimates persons and thingre ateoriling to their monery value; he regard- loss of momer as the highest loss, gain of momer at the bigluest gatio, and money as the highest nim of life." Litrenotu: "A man will obey the master he loves; forl, it he loves ford moro than money; money, it lae loses momey more that Goml."

V. 20-3). Anxiety about tompural wants.

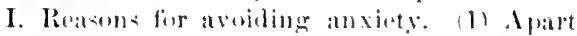
from Goul, it is futile, $v .27$. (2) Trusting in Goul, it is needless; (a) It loe cares torethe lito and the buty, he will aire tur the fiud and raiment, v. 2.); (b) It he fouls his hirls, he

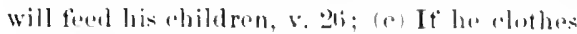

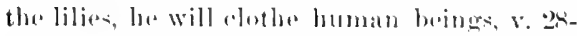
30. (:i) It malies ond's pouple no better thatu heathen, v. $31 \mathrm{t}^{\circ}$ (4) It is adilingeto-morrow"s evils to those of to-day, r. 3/. Il. Mratus of "roveling anxiety. (1) Remember that enr Jeavenly Father kmows our tomporal needs, r. 32. (2) seek spiritual good as suprome. and temporal good will, with due axprion on our part, but withunt anxioty. he amply supplied, $r .3 \%$. A lesson from the birds and

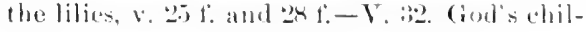
dronshomed be betere than the heathen.

lliy? (2) In what respect?

V. 25. ("111:y. : "Hethat formed the sle-h that is nourinheal, how will he not provide

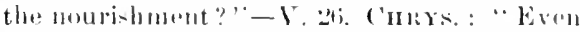
though it is theirs by nature, yet possilily we too may attain it by ehoser. For neither die.

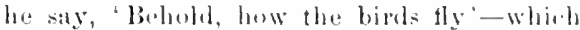

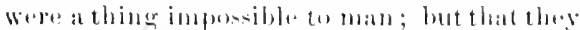
are fed withunt hering anxions, a kind of thing ass to beachioved by us also, it we will. Ant

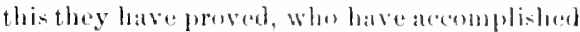
it in their actions." (gersere (in Latt.): " Yobody ever saw an "aldhly fittler fieal his hirds, and abandom his children, aml thall that be beliered of the II "avenly Fathere?" BExate: "Not thrie Father, but your

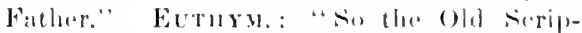
ture, when wishiner toi hit mest hard, sebds theres to the bese and the ant. . . What then? Must we not sow? II did not say, 'Do not sow; ; but, "I), not he anxinds.,"

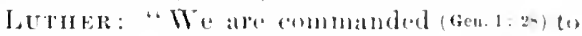
have dominion were all creatures, and yot we behave so shatuetully that a fochle sparrow must stamel in the gongel as doctor and proacher for the wixest of men, and daily

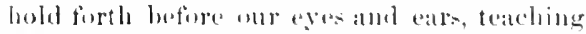
us to trust Goul, though we have the whole Bible and our reason to help us."-l. 28. ()ur Lorel's manner of toachiog is remarliable for the fropteney with which ho dlatwe illu-tra-

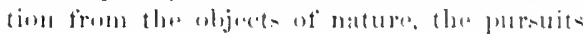

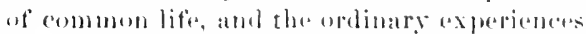
of mankind. Every preateler of the garepel, and roligions teacher of the gounge, should bet

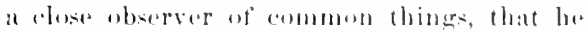
may bo better pualitiod to imitate thise ex-

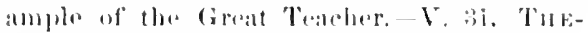

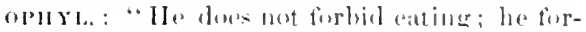

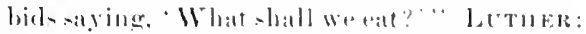

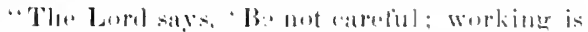

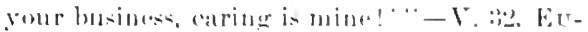

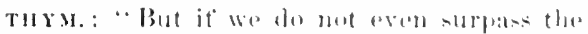

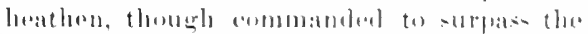
seribes and Platisus (3: 201, what pulak-hment shall we not dererve? . . . Sis the calllse of sour andioty allght to he the caluse at your frecelom teom anxioty. The more necessary thene things are, the more eberertul meght you to be. For what inther will andure not to supply his ahilelren's necescities?"

V. 3is. Which first, spiritual or temporal 


\section{CHA P T E R VII.}

TUIGE not, that ye be not judged.

- 2 bo wh whit judsment ye judge, ye shall be judged: atod wille what measure ye mete, it shall be nteastred to you agaiu.

gond? I. Suppose we seek the temporal first. (l) Wa shall be constantly less juclined to seek the spiritual. (2) We shall be eonstantly less prepared to find it. (B) Soon all temporal good must be abandoned, and for us there will be no spiritual good forever. II. Suppose we seek the spiritual first. (1) We shall not srek it in rain. (Comp. 7:7.) (2) $\mathrm{We}$ slall obtain temporal good also, not without seeking, but without anxious seeking. T. 34. To-murow. 1) Wre must not forget tounrrow, thinking ouly of to-day. The inportanee of to-day for eirilized man is fe.t to lie hargely in yesterday and to-morlow. 2) We must not presumben to-morrow, tor we know not what morrow a day may bring forth. (Prov. 27:1.) 3) We must not be anxious about to-morrow, but let fach day bear its own sufficient burden. 4) We shall best provide tor to-morlow, by faithfully performing the dutios of to-day. 5) Trusting God firr to-day, why ean we not trust him for tomorrow?-V. 3is. Euturu.: "For we have not cone intu existence that we may at and drink and wear, but that we may please God, and enjoy everlasting blessings." TukopurL. "It is amough for thee that thou art afliceted for torday; but if thou shalt be anxious for tomorrow, when wilt thom have leisnre for God?" Tammo (Wünsche): $\because$ Be not anxions for to-morrow, for thou knowest not what to-day brings forth; perhips to-morlow will not find thee, and so thou hast troubled thyself about a world which does not pertain to thee." AxTonINos: "Cast the future upmo Providence, and direct sumr present care solely towards piety and justiee." HexRY: "The andusion of this whole mattor thon is, that it is the will and eommand of the Lori .Jesis, that lis disciples should not be their own tormentors, nor make their passage through this world more dark and unpleasant by their apprehensions ot troubles, than God has made it by the troubles themselves." ("urst. "Let ns not suppose his injunctions ane imposible; for there are many who duly perform them."

Oh, sweet, sustaining trust in God, that ean
1, 2 Judge not, that ye be not judged. For with what judgment ye judge, ye shall be judged: and with what measure ye mete, it shall be measured unto you.

enable us to bear present ills without repining, and to look at the unknown future without fear; that can reconcile contentment with aspiration, and blend activity with repose; that can diseern everywhere in nature and providence the proots that all things are indeed working together for our good! Lord, inerease our faith.

7: 1-12. REBUKE OF CENSORIOTSNESS; Encouragement to Prayer; and The Golden Rule.

It has been thought by some writers that there is no connection between the early part of this ehapter and the preeding topies. But as we have found comnection throughout all the previous portion of the discourse, and as v. 13-27 obviously form a eonclusion to the whole, it seems most probable that v. 1-12 also stand in some natural relation to the remainder. That such a relation does exist, would appear to be shown by the following view: In the whole diseussion of $5: 20-48$ and $6: 1-18$, our Lord is contrasting the morality he enjoins upon the subjeets of the Messianic reigu with the teaching and practice of the Seribes and Pharisees. Various errors and evils common among the Jews, and eonspicuous in their sanetimonious teachers, are there noticed and rebuked, not with the formal order of a methodical discourse, but still with the sane generil design manifestly pursued throughout. But the great prineiple stated and applipd in 6: 1-18, viz., that good works should be performed (not ostentatimsly, as the hyparrites alid, but) out of regard for God only, admitted of a more extensive and varied application, which he proceeds to make in $r$. 19-84. From this partial digression, he now returns to rebuke another fault often committed among the Jews, partieularly the formalistic Pharisees (Luke 18:11), and to which all mu are sally liable, viz., that of lassing luash judguent upon others. $(7: 1-5$.$) \quad As it is$ lypocrisy $(6: 2,5,16)$ to make a display of rightenusness, so (Weiss) it is hypocrisy (i: a) to assume the right to judge others. and correct theirfaults. Then in $v$. 6 our Lord adds a 
caution against the opposite extreue. Now to avoid both extremes in this respect, and in all respets to contorm to those gemuibe and spiritual prineiples of morality which have been laid down throughout the disenurse, is a task more diffieult than we ean in our own strength pertorm. Accordingly, with leference not only to the immediately preceding injunctions, but to the whole discourse, he adds (v. 7-11) an encouragenent to pray to Goel. At the same time the expressions are put inte the most general form, so als not to be eonfined to the idea of praying for strength to pertorm the duties enjoined in this discourse, but to encourage to prayer in general. (Comp. the relation of James 1:5 to what precedes it.) Finally, he sums up all that he had been teaching throughout the diseourse eneeruing duties to other men, compresing all into the one general precept of v. 12, which is declared to embody the essence of the entire seriptures (o)d Test.).

If this view be correct, it is not strange that we find no conjunction at the hegianing of $v$. 1 and v. 7 , sinee in mell eave, whilethere is an internal connection betweren the tepic introduend and the previnus purtions of the discomrse, these is nostrong extermal connection with what immediately preaedes, steds as would require to be stated by a eonjunction. See similar cases at $5: 12,17 ; 1 ;: 19 ; 7: 13$. In v. b wemight expect a conjunterou, horaluse of its elose relation ter the preterling varsos; but observe that the expesions here astume the form of apuphtherms, which are usually stated (e. g., in the book ot l'roverbs) without connectives, louving it to the ratuler to diserern their internal relation. So at $6: 2,2,24$. Is to 'therefore' in v. I2, see bolow.

1, 2. The word remlered judge has sombtimes the stronger meaniug af" "oondemn, and many would so translate here. But that ciraly does not suit v. 2, and w. must rotain the rendering 'julge, while at the same tiune pereeiving that the and ection and the nature

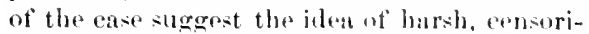
ous judgment. Ien are not likely to err in judging too favorably, nor to be lastrainol by the prospect of being tou fiworubly judged themselves. In the report of the diseourse given by Luke (6: 3i) the idea of condemnation is distinctly stated, but by an additional word.
The juaging thus forbidelen manifestly dises not refer to oflicial judgments in eourts, any more than 'swear not' prohibits waths in eourt (see wn: 34); nor to the formation ot opinions concerming the eluariteter and conduet of others, which is always a right, where we bave the means ot julgring, and enmmonly a duty, provided westrive to "judge rigliteous juelguent." (John i: 2s.) Toludelstand that we are nover, under any circumstances, to express or to fiorm an mpinion conemerning others, womld contliet with v. 11;, 20 below, alld mumerous other patsinges (f. g., 1 Thess. o): 2l), and with the example ot our siviour and the apmotles, in continually exposing and reproving eroor and evil. The applieation otten made of this saying, hy persons who de not wish their ruinous heresies or flagrant erimes to be condemanel, is thus seen to be unwarrinted. The reterence is to the sally commonn practice of officiously and fresumptuous!y undertaking to pass julgemont upou ot hers, a judgruent so utten untounded, unjust, or unkiud. Persons most inclined to hypreritical tisplay, like the Phatrises, would he most likely to judge others severely (louke 18: 9-11), hut all milnkind

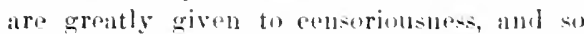
there is no need for the supposition ot some writers that our Lord here aldelresed himsalf directly to certain Phariones, -llpposed to have attracted attention at this joint of the dis-

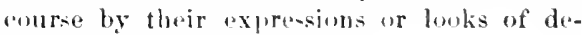
rision (as in Lulie 1b: 14).

Some explain that ye be not judged ( $v$. 1) and ye shall be judged (v. 2), as retiorring to the judgunent which our follow-men

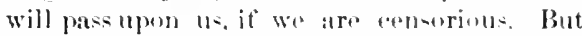
if $s$, we might with impunity (Actrelis) jutlge very pious pouple, who wanld nut judles us in the sane way. To moder-tand it of God's judgment arreos with the view at the whole discourse. which teateles us in everything to have regard to that renfuital of reward or punishment which we are to experet from God; and the ideathat Gud will deal with us as we deal with uthers, aecords with the santiment of 5: 7, B. IT. Ver., "IIajuy aro the mereiful, for they shall whtain murey," and of

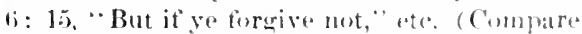
18: 35.) The inpersonal form at the expression, not telling who will thus judge, hut letilIng it to the conscience to say for itselt who 
3 And why beloldest thou the mote that is in thy brother's eve, but considerest nol the beam that is in thine ow neye"

4 Or how wilt thou ay to thy hrother, Let me pull out the mote ont of thine eye; and, behold, a beam is in thine own eye :

5 Thou hypercite, first cast out the beam out of thinc

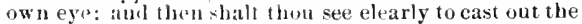
mote wat of thy brother's eye.

that Judge will be, heightens the solemnity of the paragese. Ot contres it is not meant that the mero abence of judging will of itself alone prevent our being judged by God on other grounds (comp. on 6: 12). This passage seems to be alluded to ly James (2: $13 ; 4: 12)$, who repeatedly makes allusion to this discourse. The phrases, with what judgment, and with what measure, are jiterally 'in what judgment' and 'in what measure, see on :⿱): 11. The 'again' of Com. Ver. represents a feebly-supported reading of the Greek. 'The saying. "With what measure ye measure it shall be measured to you, is also found in Mark 4: 24, as used on a different oecasion. It must have beon a proverbial saying at that time, for it reeurs very often in the 'Talmud. As to our Lord's use of current sayings, see on v. 3-5. For other passages whieh forbid harsh judging, see Gal. (i: 1-5; Rom. 2: 1-3; 14: 3f ; 1 Cor. 13: 7. This sin grows in evil times, for instance, during a war or a pestilence, as rapidly as olfishness dues. Everybody is busy finding fault, and few take time to notice the deeds that are praticeworthy. The practice is mot only sinful in itself, but promotes otleer sons; for many a man will expend so much conscientioneness upon the severe condemnation of others' faults, that he has not anough left for his own; nay, will even think that having pasesed merited comlemnation nown wromgdoing in others, be is thereby more at liberty to dowronghinself. Weonght to jurlge onrolves strietly, and judgeothers leniontly. A Roman writer states it well: "I think him best and most faulteses, who pardons others as if he himself sinnerl every day, yot abstains from sins as if he pardomed no one."

Lake (6: 3-40) gives some additional salyings here, which Matthew mits; ach has given only a sketeh of the discourse. See Introduction to chitr. 5.

1 The lireek text followed in the (om. Version ought to have leen translaled 'from' in $v .4$, the preposition being apo in v. 4, while it is ek loth times in r.5. ('omp. on 3: 16. liecent crities read $e k$ in $v, 4$, on the au-
3 Ant why beholdest thou the mote that is in thy brother's eye, hut considerest not the beam that is

4 in thine own eye? Or how wilt thou say to thy brother, Let me cast out the mote out of thine eye 5 and lo, the beam is in thine ow eye? Thou hypocrite, east ant first the bean out of thine own eye and then shalt thon see clearly to cast out the note out of thy brother's eye.

3-5. Another instance of that ehange to the singular number by which the ald ress is made more personal and pointed, see on 5:23 and 6: 6. The word rendered mote denotes any dry twig, splinter, bit of straw, or other trash, being applied by a classic writer to the materials of which birds build their nests. This, which is the sort of thing likely to get into the eye, naturally suggested a beam as the contrasted term. The latter expression is of course eminently lyperbolical, resembling those in 19: 24; 23: 24; John 21: 25; Rom. 9: 8, ete. In the present case, no one has any difficulty; but in some others, many stumble at the hyperbole, from the failure to consider that such expressions are eonstantly and natulally employed in the language of common life, especially among the Orientals. Considerest not, does not sef the mind on, think about. The ground of censure is not that one sees another's fault, howerer small, but that while seeing that, he does not think about his own fault, even though great. Or how wilt thou say, viz., with what sort of face will you say it, how fuel at liberty to say it? Comp. John 6: 42; 8: 33. In Luke 6: 42 it is a still stronger expresion, "Or how caust thou say." ete. Brother was used hy Jews as it is by Christians, in addressing one another; this is a seemingly kind, fraternal proposal. Pull -or cast-out represents the same Greek word throughout v. 4 and 5 . The Com. Version has here indulged its passion for varying the translation. See on $25: 46$. The beam, the definite beam that is assumed to be in his eye. The word hypocrite (v. 5.), has been cxplained on 6: 2. Its use here indicates that the person thus acting is esteemed as not simfly self-deceived, really unaware of the beam in his own eve, but as pretending to be free from fault; and with this aceords the "con. sidrrest not' in v. 3. Indeed, self-deception

thority of $\mathfrak{N}$ and several eursives. But it is rery likely that apo was changed to ek by way of assimilation to v. 5. Of course there is no substantial difference. 
five mot that which is holy unto the loggs, mither

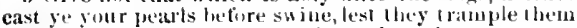
under their feet, and turn agaiu and rend sou.

rarely, if ever, exists, without some measure of by porerisy, mel rice eersa. Sec elearly, is in the Greek a compound of the verb remdered 'beholdest' in $r .3$. The jelea is that correcting our own faults will not only render it less unsuitable tor us to correct those of others, but will put us in better condition to doso, Ministers are by their calling repecially required to "reprove and rebuke," and hence a special robas why they should seek to be blameless themselves. but of course it is not me:unt that no 11 an must ever point out amother"s fault, or attempt to aid him in eorrecting it, until he has fully sueceded in correcting every similar fault of his own. This would prevent all effierts of the kind, since the truly humble Chri-tian will never make sure that he is wholly free from any wne fault whatsoever.

A remarkable instance of eondemning tle miseondenet of others, while igmering similar and tar ereater misenduet of our own, is seen in the history of David. (2s:me 1z.) Thitendeney of human mature is so obvinus, that it must have atrated attention in all ages and nations. Horace: "While you see your own taults with eyes blestred and unanointed. why is it that in the faults of your frimds, your rision is as harpl as an ateles's?" Seneca: "You observe the pimples ot others. when yourselves orergrewn with a vat number of uleers." The illustration alle Lurd uses is found several times in the Talmund; e. g., "I wonder whether there is any" one in this generation who is willing to receive reprouf.' Say, if one says to amother. '(ast out the splinter from thine eye. he will reply, "Cast wht the beam from thim" tye." The same image oecurs (Gesen. in Arabie poetry. It is therefore probable that thi- Was a prove erb already corrent among the Jaws when aur saviour used it. The same thing he apepears to tase done in $5.2 .6,12$; in $13: 57$. (comp. John 4: 4t); Acts 26; 14; amb arowedly in Luke 4: 2:). (Compl) ats th the use of parables, on 1:: :.) The admirable wiskons with which he derived his beantiful illustrations from the most familiar object in uature und relations of life, is here further seen in
6 Give not that which is boly mulo the dors, neither

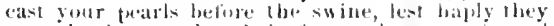

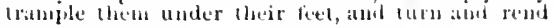
yol1.

his using current popular sayings, which all would understand and feol the firrecent. Sis

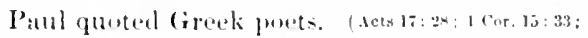
Titus 1: 1...) Our Lurel Was thus ateting out his own subafuent direction, bringing forth ont of liis treasure things mew and whe (13:52.) Originality is often a great sullew ot juwer, but more gond catn sometimes be doun, at decener pratetical impression produced, by adopting jelcas and expresions which are already familiar. (Cimp). on li: !.)

6. This presents, in the form of an apophthegm, and so withme any oxtermal mark of connection with what presedes (-ee at the beginning of this elinpter), a caution anotinst the aplusite oxtreme to what he han ju-t been rebuling. Whe must nut juelge uthers, but we must not beedlesty expuse sacred thing; (1) persons wholly wanting in appreciation, and sure to roject them. These two extremes of unwiot action ofters neet (schatl); those who juelge nwost har-hly aro often ma-t asily inpused on, Dogs havealways been renarded in the Fast with great abhorremer, mot bring 11-lably kept at home, and so not evineing the strong atsebment to owrers which so interests us, but running wild in trompls about the streets, where they devour andeaseses and offal. II whling and fighting ower their horrid

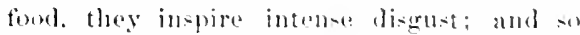
they aro gemerally asomedated in serejpture with ideas of reproach, contempte tre loathing. (1 s:m. 17:43; 24: 14: 1 Kinga 1t 11:21 19:2 Kinzs 13: Joh

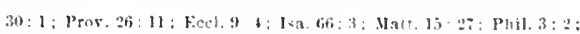
Eev. 22:15.) $\rightarrow$ the Mobammeditns now call christians dogs. 'That which is holy, coprectly ronders tho general and aletract exprosion of the original. This walle include the shew-bread, or any form of fimel which bad been otlered on the altar. hut eppecially suggests the flesh of survition (at) (a) "holy flosh" in IIar. 2: J"2: Jur. 11: 15), which it would have bepo a great profianation to throw tor the degs. like thesh torn by wild beststs. (F.x.22:31.) Neither cast your pearlo. In the Talmud (Wünsehe) a goud thunelat is otten called a pearl. (Comp. 1:3: 4i) i.) Before swine, or, the swine, with the article. like 'the dogs,' meaning the chass of ereatures. 
7 Ask, and it shatl be given you; seek, and ye shall find ; knck and it shall be opened uoto you:

8 for every one that asketh receiveth; and be that seeketh findeth; and to him that knocketh it shall be openetr.

As the two linds of animals were regarded with like foclings (comp. 2 Peter 2: 202), it is best to understand here a mere repetition under another inage, after the manner of the Hebrew parallelism. (See on $4: 15$.) The distinction sonte make between the dogs and the th swine, as representing essentially different kinds of peroons, is seareely warranted. And so the notion of some (even Achelis) that the th trampling applies to the swine, and the turning and reuding to the dogs, is now commonly rejected, as making the sentence exeessively artificial, and as requiring 'or turn.' Better talke botl as refurring to the swine, conceived at wild and savage. It was not necessary to explain to Jews that giving any sacred thing to the dogs would be a horrid profanation.

What, then, do we learn from this saying? It is a warning against mistaken zeal in trying to make converts, or to correct men's fiults. We must not judge (v. 1-5), but we must deal with men aceording to their character. Eftorts to convert a drunken man, "r one wlon las just been pouring out foul obscenity, would come noder this head. Some persons do harm by expressing, in mixed society, those intimate feelings of personal Christian experience with which only the devout can sympathize. Porhaps this last is intimated by the expression your pearls, those precions truths which have become yours. But esperially may we eonnect this verse with v. 5 , and learn that in undertaking to correct men's faults, we must exereise discretion, lest we do harm rather than good (eomp. Prov. 9: 8). Yat this precept, like those which precode. must not be pushed too fiar. Porsons from whom a lasty julgment might least expeet it, sumetimes weleome gospel truth, as did publicans and sinners, and the robber on the cross. Often our only mpans of deciding wisely is to make the trial, and then continue our labors or not, aceording to the results and prospects. (10:12.14; Acts 13:46.) Ryle: "We are most of us far more likely to err on the side of over-eantion than of over-zeal. We are generally far more dispused to remember the 'time to be silent' than the "time to speak." Espreeially must we not be too sulicitous to
7 Ask, and it shall be given you; seek, and ye shall 8 find; knock, and it shall be opened unto yoll: for every one that asketh receiveth; and hethal seeketh tindeth; and to him that knocketb it shall be opeued.

avoid injury to ourselves, which is a matter of minor importance compared with insult to the sacred and precious truth we present. Here again (see on v. 3-5), our Lord has probably adopted a proverbial saying, since we find in the Talmud, "Do not cast pearls to swine, nor deliver wisdom to him who does not know its worth." Still, there can be little doltbt that the Rabbis of later centuries borrowed striking sayings from the $\mathrm{New}$ Test., as they had long dono from the Greeks, and afterwards did from the Arabians.

7, 8. To avoid both the extremes pointed out in v. $1-5$ and v. 6 , is a difficult task. We must all find it very hard to be at once charitable an $\therefore$ watchful, hoping for the best, yet on our guard against the worst, judging no one, yet knowing men's characters and dealing with them aceordingly. Well may we rejoice to find that the next words are a most uffecting encouragement to prayer. Thus may we be enabled to perform these difficult duties and all the others enjoined in the discourse. Indeed, the language is so general as to hold good of prayer under all eireumstances and for all objects. Similar examples of a passage specifically applying to what precedes, but having also a muel wider general application, may be found in $5: 48 ; 6: 9 ; 7: 12 ;$ in James $1: 5$, where he means especially wi:dom to bear trials, but not that exelusively ; also in Gall. 6: 7, and many other passages of Paul's Epistles.

Knowing that men find it hard to pray in reality and with faith, Jesus condescends to enenurage us by much repetition. Ask, seek, knock, are here practically equivalent, the repetition being made for the salie of inpressiveness; all refined distinctions between them are out of place. Afterwarls $(v, s)$ the threefold promise is repeated by thrice asserting the general fact that so it always is. Ind still further eneouragement is given in the succeeding verses. What pains the saviour takes to make us pray! And his word is (rowded with gracious invitations and precions promises, such as ought to eonquer all our unbelief, nud fill us with joyful trust in coming to God. Of course these unqualified promise 
9 (or whal man is lnore of you, whom if his soll ask breal, will he give linl a slobe"

fli in is low at a fish, will he give him a serpent"

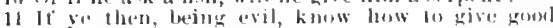

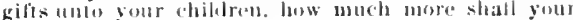

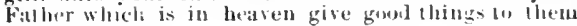
llial ask him:
9 or what man is lbure of you, who, if his son shall

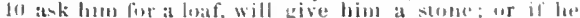
1) shall ask fior at tish, wall give him a sorpenl? II ye

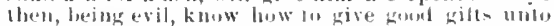
ront childrun, low much mor shall your lather ivbo is in heaven give goonl things fo them llat ank are subject to condition=, such as are elsewhere laid down; we most ask for proper purpunises (James : 3 ), according to Gud's will (1 Jola 5:14); see below un v. 11. In r. 8, it shalt be opened, is in some of the oldest anthoritites 'it is openud.' Wo canmest easily decide, since the present may have been changed into the future to he likev. T, or the future inte the prexent to be like otho other verlus in $r$, 8; fortunately there is no substantial difference of meining. The same thonerhts here given in $v .7-11$ ar found in Luke 11 : 9-13, as repreated on another accilsinll.

9-11. For the connection, sce on v. 7,8. Or propuses to regard the matter in another way. to introbue a different aremment. ()$r$, if the preasliug considerations do not fully con-

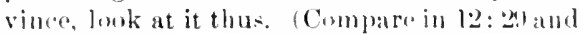
20: 15.) Or what man is there uf you. which does not mealu, as some explain, it lye is so much us a man, and nut a lorute; lut, thomer he is only a man. With ail tho imperforetion and evil which beloner to human nallar, e*en a man will be willing to wive to his som, and will have some jud rument in giving. The expression thus temde lo prepare the mind for the application mald in v. 11.

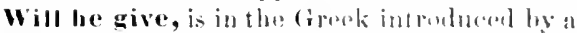
particle denoting that the answer must lleceesiarily be negative; and the brokencentruetion of the sentence remelers the copression more striking. " $1 V^{\circ}$ ho is there of ven, a man, of whom his son will ask a lout-will he give him a stone? Or alou he will ask a fishwill ho give him a serpert"? Bread. "The word maths ather 'breidl' (so) all the carly

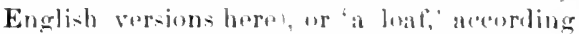
tu the demandsof anch partionluremnection; aud the latter seoms to tit best here. (Comp). on 20 : 20 (i) The rommel, flat cakes of bread. than and nuw emmmon in Paldints. resimbled flat stones (amp. on $4: 3)$. $\therefore$ in $n$ serpent somewhat resombles a lish. Broul and fioh were the ordinary find of those who dwelt by the Lakenf Galiles. On the subsequent rearsion lanke $11 \cdot 12$, all egy is adrled. to which a sorploin coiled might not be greatly assimilar. Now the puestion is nut whether the filther will refusc hin soll s refles-t, lout whether, illtead at the thing a-ked he will give him somothingsimilar that is uneless (a-tone) or hurtful

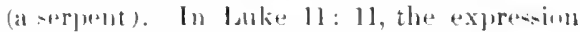

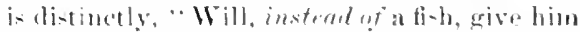
ascruxlat?" (Bib. Cn. Ver. Even an earthly parent will mot be ignorant enough to make

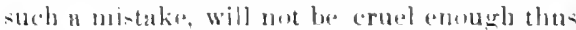
to mork his chilel's requtest. Being evil, in entrat with the huly God. Kinow how to give, (lus mot simply monare willingtugive, but underatand how to give judiciously and kindly, so that the grits aro really arood sitts. Compare such expresions as, "The Lurd knowerh how to deliser the godly out ut tempration" (2Pet. 2: 91; "I know both how to bes abaced, -or in humble cirenemstumers.,-alld I know bow to abound," i. e. withut heing unduly depresiml ar elatral (Pull t: 12); "It a man (ang one) kinw not how to rule his awn

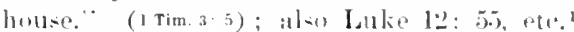
Thes statement involves a di-pusition to give, and the torm denotes julgmont in giving ; and

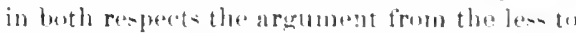
the greatur hold- gaml, how muel more will the Fatherom high, who is "too wise to err.tow gund to be wokind," grive what is really gombl. It is a nitural axtellsion of the silme areument to say, that if we ask for smonthing which wa think to lu gumbl, lunt which he knows to be evil, he will withbuld it. aven at= any judiejous human parent mulet iflen dus. It is really a part of the privilecese of prayer. that frod will withhold, il lus spes best. Ware

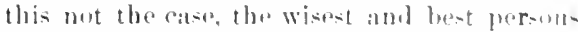
miglit often be shwest to a-k, for they know how often their judement as to what was brot has proved orroments. Bul as it is, wo maly ask without apprehension tor whataver we think is best. and anr pertiectly wi-n and perfeetly kind Father will give that, or sombe

1 Tyndale and the succeding Finglish versions ren"ter 'can give, doubtless following Lutber. The Cow.

Ver. wisely fulbus klheims in reudering ' $k$ und how to give." 
12 Therefore all things whatsoever ve would that men should doto you, do ge even so to them: for this is the law and the propheis.

thing which be sees to be better. On the second occasion (Labe 11: 13), our Lord substitutes fortlue ganeral expression 'good things,' the specinc blessing the Holy Spirit,' which is the best of all good gifts. "In this change we may sce evidence, not, as has been said, of 'a later form of Cliristian tradition,' but probably of a later and more spiritual teaching, addrosied to more adraneed diseiples." (Bib. Comm.) As to the frequeney with which Jesus speaks ol God as our Father, see (o) 6 : 9.

1:. Our Lord now gives one single precept for the regulation of our conduct, a sinple working rule, which is not merely a summary statement of all that he has been teaching on that subject throughout the discourse, but is expressily declared to eover the entire ground of what is required by "the law and the prophets," i. e., the whole of the then existing revelation (see on 5: 17). This precept is an application of the principle, "Thou shat love thy noighbor as thyself,' and on that, in conjunction with "Thou shalt love the Lord thy God with all thy heart,' Jesus afterwards declares that the whole law and the prophets hang. $(22: 40$.$) It is plain therefore that he$ does not here mean to say that the whole requirements of the Suriptures as to all duties are summed up in this rule, but their whole repuirements as to duties to our fellow-men. (Comp. Gill. 5: 14.) It is a great-mistake to suppose that nothing is involvod in love to Gud beyond love to aur neighbor. Therefore, ats an inforence from what precedes. The worl itself does not dotermine how far back its roforeneegoes. The rule that follows is apparently given as a sort of general consequence, or recapitulatory interence, from all that he has boon teaching eonecrning the righteonsmess repuireal of his pooplo (5:20:6: I, 33), so tiar, of eourse, as pertained to their tratamont of their fellow-n en. Ile did not eone to destroy the law and the prophets, but to dovelop and lexpen and braten them (ses (n11 5: 17) ; and so (Woiss) he lats here given onts simplo rube, which earries thoir whole contents in a emmpet form, ready for pompt and variod application. Luther: "With
12 hins?

things therefore whatsoever ve would that men should do unto you, even so do ye also uuto them: for this is the law and the prophets.

these words he eloses up the teachings of these three chapters, and ties them all up in a little bundle." See a somewhat similar use of 'therefore' in 6: 34 , and as to the connection here, see at the beginning of chap. 7.1

This simple and beantiful precent is now commonly called, from its excellence, the "Golden Rule," just as James (2: y) ealls the preeept, "Thou shalt love thy neighbor as thyself," the 'royal law.' The Jewish teachers endeavored to have a special rule for every exigeney of life, and have filled the Talmud with nice distinetions and wearisome details, without at last touching half the questions which must arise. The Great Teacher has furnished many particulars by way of illustration and example, but he delights to give comprobensive rules. Harris: "Like the few imaginary eireles by which geography circumseribes the earth, he has, by a few sentences, described and distributed into sections the whole globe of duty; so that wherever we maly be on it, we find ourselves encompassed by some comprohensive maxim; and in whatever direetion we may move, we have only to reflect, in order to pereeive that we are receding from, or appraching to, some line of morality." It is lere taken fol granted, that what one wishes others to do to him is something right, such a thing as he ought to wish. Otherwise the rule would lead to folly and crime. If a man should become a criminal, he would probably wish the judge to acquit him, though guilty; it does not follow that it the samo man is a judge, he ought to let the guilty ga free. When a child, one did not wish his father to restrain him; it does not tollow that be must now let his "wn son go unrestrainod. II ats, then, the savionr's rule failed here? No, it is takon for granted that the wish of onr own to which be bids us conform in our treatment of others, is, or would be, a right wish under all the ciremmstances. I do not wish now to be trated as a child, for mine is not the character or condition of a child; bat if I were a child, and had just views and right teelings, I should wish my fatleer not to make me my own master when unfit for it, but to restrain and discipline me, 
in the way that woukd be for my real good; and thus I ought to act toward- my child.

Here again, als in $5.2,: 3,1$, we timel that our Lorl has emplosed a form of statoment puite similar to smone siryengs then alrealy in ex-

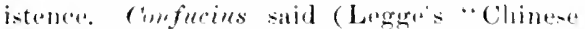

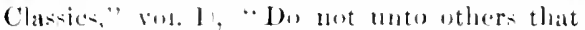
which you weruld not thoy should do antos you." Isocrates said, " What you are angry at when indleted on rou by othors, this do not do to others." I freseli biogratplor of Aristetle rabates that, being asked how we

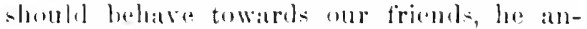
swered. "Is we should wish them to bellave toward us." The apueryphal bouk of Tubit (1: 15) hat: " What then hatest, do te mone." Of the erreat Rablit IIillel, who was probably stiil living at the birth of Clurist, the "lalumud relates, as showing that he was kind, and not irritable and headlone like shanmmai, "There is a story of a certain (ientile, whe caune to Slanmmai and said, Malie a proselyto ot me on this condition, that yon teath me the whole law while I stand on one fout. Je trow him aw:y with a lomg statl which ho hold in his hamol. The man eamo to II Illel, and he mate a prosulyte of him, sayingr, "What is hatefiul to thee, do not duto muother. This is the wholo law; the rat is explanation ot it." Philn, whu was an old man in A. 1). f1, says, "Oncemast not himselt" dowhat ho hates to have done to hins." senere who died $\mathrm{A}$. n. (ii), says that the best way to conter a benefit is "to grive als we should wi-h to reneive." $1 \mathrm{t}$ will be ohereded that the sayines of ('onfucius, lsorrates, and the three lewish teichers

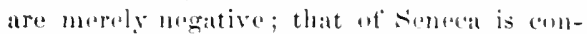
fined to griving, and that af . Aristetle to the treatment of friends. Our Lurd makes it a rule for proitive action, and towatrats all men; and dieclares. as Ilillel hall dome, that it is a summary of the entire sieriptures. It is a bart of his windone that he frefuedutly alupt: moles of thought and expressions already well known among men, or which had ecenrred to sume thoughtlul mind; whilo in many eases, at here, he gives them a new or a wider application. (Comp. on r. j, and apecially (b) 6: !1.) The real novelty of Christian
Ethies lies in the fatet that christianity offers not only instruction in anoral duty, but suritual laclp in acting ateordingly-lu Lake (6:33), this precente is given in a diflisent patet uf the sirmom on the Monnt. Luke's brief

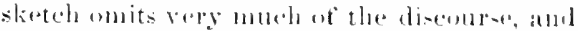
(1) prevent what he gives trom being a mere

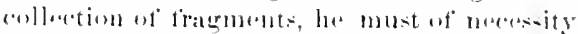
commect passages which havesome natural relation. Areurdinerly, this saying there tilllows the injumetion, "Give to every om" that anceth then," etce The phrase, for this is the law and the proplets, is onitual by

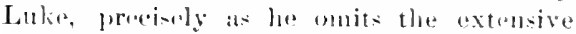

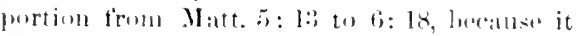

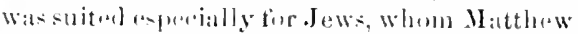
latu peralialy in view, but Lulie had not. (siee Int. ta e th:1]) 5.)

\section{IIONILETIAL, ANI PRATICAL.}

V. 1 i: Mutual misjudermonts: 1) Botween new comverts and ald diseiples. 2) Butweren

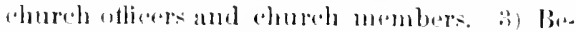

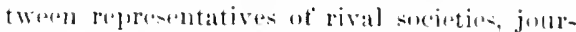

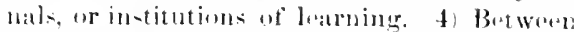

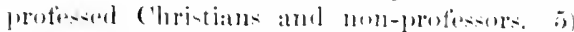

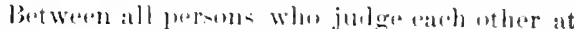

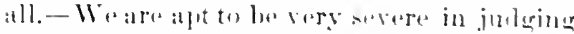

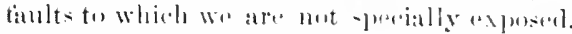
The drunkard is har-hly andelumed liv a man

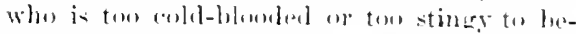
come a drumkard; tingines is harshly anddemoned ly onse who tinds it rasier to be lavish than ce(o)monical.

\section{" ('ompunut for sins they are indined to,}

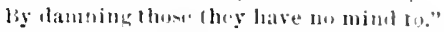

A preacher is alyet to illustateomly ly aceounts

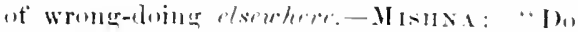
not judge pour neighbor till you have put

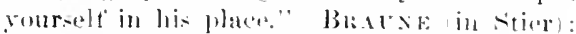
"Inelering uthers is the fuul stain ut' sucial life." Arofiss: "This jullering rests upon two evil tacters, the want at lowe to athers. and the asumption of (Eod's prorugative."

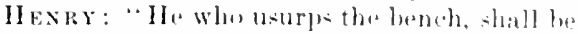

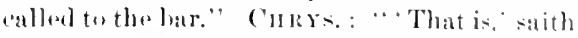
Christ, "it i= not the whther that thom andomm-

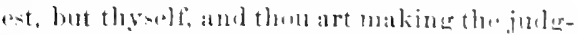

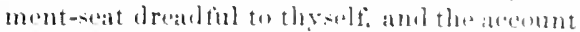

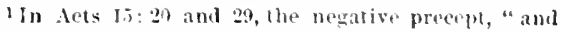
whatever gou do not wish lo happen Io gon, do not do in anuller," is interpotaled ly 1 , s'reral cursives, Thebaic, Ethiopic, Jrenaus (Latin), and in the second

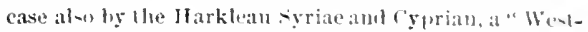
"ro" interpulation. Th" socalled "Tutuhige of the* Apustles" gives the samo feh. 1), followed ly the som called "Constilutions of the Aposlles," rii. 2. 
strict.' . . . He is not overthrowing reproof nor eorrection, but forbidding men to neglect their own faults, and exult over those of other men." DYKes: "To take one's self for a Clristian, and yet be ignorant of the extent of one's own guilt and evil-heartedness, is to be exactly in that state of blind conceit which qualities a man for the role of a heartless and reckless, and utterly unrighterous judge. .... We have to live with one another; and the kindly thoughts of others about ourselves is as the breath of life to us.... . There are some penth who always suspect base reasons for whatever looks generous, and exult in exposing them to view; but we are not apt to conclude that such men's own notives are the purest, or their own life the swretest in the worll." Plunptre: "Briefly we may say, (1) Indge no man unless it be a duty to do so. (2) A. fiar as may be, judge the offence, and not the offender. (3) Confine your judgment to the "arthly side of fanlts, and leave their relation to God, to him who sees the heart. (4) Nevor judge at all withut remembering your own sinfulness, and the ignorance and intimities which matextenuate the sinfulness of others."

T. , r. The mote and the beam. 1) We unst by no means let both remain. 2) We camnot really cast out either, if wholly careless almut the other. 3) Casting out the beam will make us more clear-sighted, more sympalthetic, and more skillful, in casting ont the mote, (not simply seeing the mote, v. 3; lout seeing to cant it out, v. 5). 4) For help in catting out both, ask, and it shall be given You, v. 7.-V. 1-5. Effinrts to erorrect the faults of our lorethren. 1) With no harsh, moliscriminating judement of their faults. 2) With no real or apparent assumption of being without fault onrolves. 3) With dear perception, heiglitenel by experience in correcting onr own faults. 4) With sympathetie and fraternal kindness.-V. 3. What we need here is not "to see oursels as others see us," but to soe ourselves as we see others. $-V .4$. Cr'ero: "It is the part of folly to see other people's fulults and forget our own." EUT.r.M. : "The healer onglit to he healthy." - Propusing to cast out the mote without thinking of the heam, is (DYk ks), 1) a blunder, 2) an hypoerisy. RADER (in Cor. a Lal). 1: "A crooked measuring-rule makes even straight things appear erooked."
V. 6. New converts are especially prone, in their inexperienced zeal, to cast pearls before swine. In religious teaching we must avoit those who 1) will despise the holy and precious truth, and 2) will damage the teachers. Such are pretended converts, who "join the church" in order to get trade or to impose on charity; cases often encountered in forejign and home missions, and in all large cities. Weiss: "Gospel truth is 1) 'holy,' as coming from God, 2) precious (pearls, comp. 13: 45)." Dykes: "We often stultify our attempts to reform the vicious and brutal by plans which look charitable, but are simply rhildish, winking at the darker facts of human character. . To select the fit occasion and discover the wise method; to adapt truth to the evil state of the hearer, and win for it a willing ear; to be cautious without being timid, and faithful but not indiscreet; this asks for a certain nice tact. . . a wisdom into which there enter several elements, but of which one element usually is a spiritual gift from the Father of lights." - We have frequent occasion to remember the proverb, "Speech is silvern, but silence is golden."

V. 7-11. To avoid censoriousness, and yet not cast pearls before swine, ask, and it shall be given you. To refrain from worldly anxieties, because trusting in God (6:19-34), ask, and it slall be given you. To esehew ostentation and all self-seeking in good works (6: 1.18), ask, and it shall be given you. To attain the profound spiritual righterusness which Jesus teathes and requires $(5: 17-4)$, ask, and it shall be given you. To be indeed the salt of the earth and the light of the world (5:13.16), ask, and it shall be given you. To find blessing in the trials of life (5:3-12), ask, and it shall be given you. If we do inot possess God's spiritual blessings, it must be because we do not ask. One may be a truly industrious man, and yet poor in temporal things; but one cannot be a truly praying man, and yet poor in spiritual things. ChrYs.: "And if thou dost not reeeive straightway, do not even thus despair. For to this end he said, linock, to signify that even if be shoukl not straiglutiway open the door, we are to continue there." Lutuen: "Hast thom here the consoling promise and rich assurance he gives, as showing that prayer has something in it, and is preciolli in Grod's sight, since Jexus so earnestly exhorts to it, so kindly invites, and 
13 Enter ye in at the strat gate: for wide is the gate, and loriad is the way, that leadeih lo dentraction, and matny thete lee whith gu in thereat:

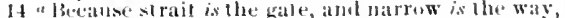

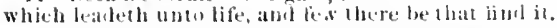

13 Linler ye in lin the narrow gate: for wide lis the

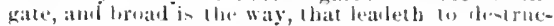

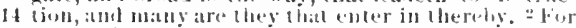

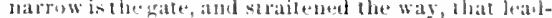
elo thlo life, ant tew are they that tind il.

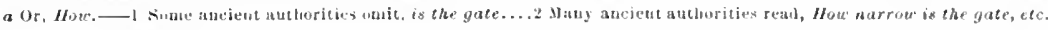

asuros us that we shall not ats in vatu; even it we hat moother ground or inducesuent that thi- rieh and loving word, it onght to be enough (1) (lraw us and drive as to prayer." - V. ! I-1].

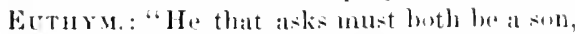
and munt and what it beronues the father to give, and i-profitable for the sem to recenve."

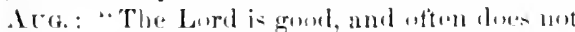
give what we slunkl wish, in order that he may grive what we should winh still more." Achlels: "If the som anks fire a stome or serpent, thinking it to loe al loat" or tish, the fathers love will give the real gorul. P'alul a*ked thries that the therm mieght la removed. and afterward- learued that the Master had dome for him somethinge fitr botter. (2) Cor. 12. *, 10.") Drkes: "Ilere, in these simple, homely, human words of Joils, we have surely all the philowphy of prager which Christian hearts require. . . all genume interesure betwixt ehild and perent must have two silles: while it is on the child s side, the frex-t and mest unlimiterl axpresion of - $110 \mathrm{ch}$ thinestatchilds lateat can lonether, or atehilet:

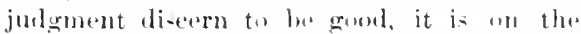
promt's side the freest and unot voluntary determination to give only what a riper juderment knows to be luest, and all that a larger heart yearm-to bestow."

V. J.丷. IInw to treat otlares. J) Worldly pride and homer will saly, Treat them ans they hatre treated us-return a kindures, pevenge an injury. 2) Je-us says, Treat them at we slumlal wish them te treat us-forrive, firluear, make the best of the pat, heme fior the bus in future. - To earry ont thi- rulu restuires imate nation, srmpathy, unseltishness.--liYus: "The (iolden Rulesettles a houndrod diffirult points. whieh in a worle like thi are eontinnally ari-ing between man amel man. lt prevents the neeresity of latying down endless little. rules for cour comelnet in spereitio eases. It swere the whole debatable ground with one mighty prineiple." - LA'THER: "All the tenehings ot these chapter he here tios up in a little hit of a bundle, that exery one may place in his bosm. Ant certainly it is a tine thing that Christ sets before us precisely our- selpes for an example. Thou thyself art thy manter, dector, amel preacher."

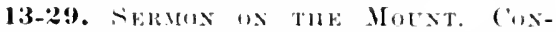

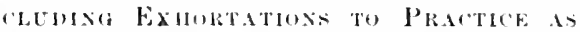
Well AS IlEAR AND PROFESS. EFFET ProDECED.

The sermen on the Iount is now drawing to a cloce. Its leading thumght- have beten presented, and there hal been a geenerall entcouragenent to seck holp from Gind, and a general rule for regulating our enoluduet, whick cover the whole sromind of the eliscourse. It

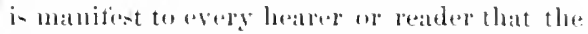
requirements which have been made are very ligoreus, in their protiond sprituality and rast complats. Gur lared deses not soften this rigor at all, but genes on to declare that the waty printed ont ly him is indeed mo hard to fime and follow, and that there is great danger

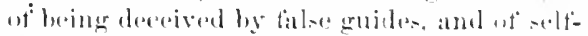

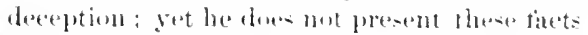

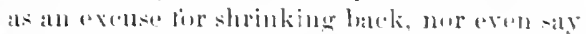
that in spite of there thing- we mont math the

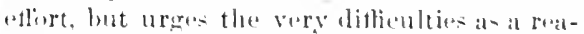

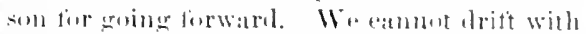

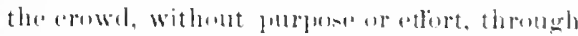
the narrow gate; to alet thus wonld latul thromgh the wide gate to de-sruetion. Ilocelfully and diligently we nunt gne in thromeh the narrow gate, along the stratemenl and

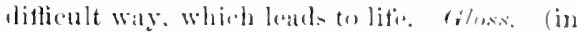
Aquinas: "Theoerh it be hard to do (o) another what youl would have defle to your-olte yet so must we den, thit we may entor the strait gare."

We may mark, asontaining datinet flongh

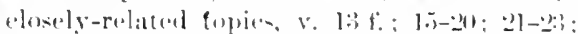

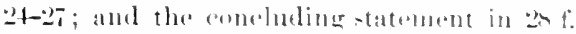
The apephthemantieal form of expresion, which we have al ready notienel at $v, 1$, h. 7 . is

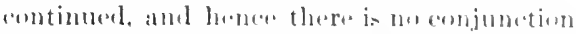
andecting 8 . 13 with what presedes, while the general relation of the theoghts is obrious, as just pointed ont.

13, 11. Inter ye in, viz, intolifi+ v. 1t),

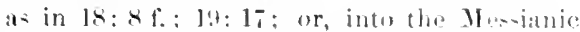
kinglum, as in $5: 201 ; 7: 21 ; 18: 3 ; 1: 4: 2 \mathrm{f}$. The comparison of 19 : 17 with 19: 2:3 shows 
that the two expressions are equivalent. See also 25: 21-23. It the strait-or through the nurvou-gate. The English word strat ' is derived (through the French) from the Latin strictum, and is thus a different word from traight, which is an old torm of stretched. The two are popularly confouncled in quoting this passage, "The straight and narrow way," although it is not at all said that the way is straight. The worl 'strait' is now little used except in Geography, and in such phrases as strait-laced and stratjacliet. For wide is the sate. It is quite pessible that 'the gate' should here be omittel (ats in maruin Rev. Vel.). ${ }^{1}$ There would be nothing lost from the substantial meaning (see below). The word rendered broad is at peculiar and stroner term, brond-spaced, 'spacious, describing the way as having plunty of room in it. Destruction. 'The Greek word is trinslated (Rev. Ver.) prerdition' in John 17: 12; Phil. 1: 28; 3: 19; 1 Tins. 6: 9; Heb. 10: 39; Rev. 17:8, 11; 'destruction' in Rom. 9: 22, 22 Pet. 2: 1, 3, Rev. Ver.; 3: 16. Go in-or-enter in, same Greck word as at the beginning of the sentence. 'Fhereat, literally, 'thlough it, would more naturally make us think of passing through the gate, but would also apply to the way or road, as in "pass alomg through that roarl.' (x: $\left.2 x^{\circ}\right)$ Fustead of because (v.14), there is much authority for a reacling which would nestn 'hew,' (ti instead of' hoti) making it all exclamation, "Hew narrow is the gate! It is extromely diffeult to decide. which is the correct rabling. ${ }^{2}$ As to the sense, 'beranse' would make this a reason why many enter the broal road, and an additimal roason (eomp. 'for,'v. 18) for the opening in-

1 The omission inv. 13 is supportel by $x$ and the 0 lal Latin, ant "mm!n freek amu latin Fathers, early and late"; in v. It the evilunee tiol umitting is watker. The st:te of the evidences is reality explatined by the supposition that 'the gate' is genuins in v. 14 anul spurious in v. 13 , aml is mot easily explatum otherwise. W II. allut this view in text and dppemelix. Tiseh. lorackotal in buth plikess.

"The evilence for hoti being $\mathbf{B} \mathrm{X}$, many cursives, a few latin copies, beyptian, and origan, is comsidared

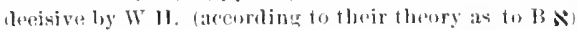
so that they do met even mention the other reating. Yot the latfer, bostes the support of all ol her uneialo (C: and D) are letre wating), numerous (ourkives, mearly all (1) Libtin and the Vulgate, OH s.yr., Pesh. am Harklean, otlee versions and various Fathers, has junction to enter in by the narrow gate. The rendering in the Common Version 'because (the Greek word in the text followed being the same ats in 'for:' v. 13) obscures the fatet that these are two paralled reasons fior the injunction. The reading 'how' does not present this formally as a reason, but states solemmly and impressively the fact, which he designs to aet as a motive for entering in by the narrow gate. An impassioned exclamittion would here be less strange than it might at first sight alppear, beeause the fact that so few are saved might well awaken profound enution in the saviour's bnsom. ${ }^{3}$ The word rendered narrow, or in Rev. Ver. straitened, signities pressed, pressed tugether, anmped; a Greek writer uses it when he deseribes one as occuping "a stratened cell"; so it innplies not merely that the road is marrow, but, as it wers, cramped, eonfined, so that there is difficulty in pussing along it. This word is thus the precise opposite of the term "spacious, applied to tho other road. In the one, men can wander heellesily, and roam about at pleasure in the broad spaces; the other requires to be pursued with great care and exactness. Mife is here first used, as meaning spiritual and eternal life, in our Lord's Galilean ministry; but previumsly in his early Judean ministry. (John $3 ; 15 \mathrm{f}: 4: 14,36$. Leadeth is literilly leadeth away, perluaps implying a long course. Though the exnressions in v. 1tare precisely parallel to those in v. 13, there is a striking excoption at the are; he dues nat say. "few are those that "nter in the angh it,' lut 'f $\mathrm{e}^{+} \mathrm{w}$ are those that find it. Onl attention is thus strongly called to the fact that this narrow gate and way is likely to be overholied, and so it should be

strongly in its favor the internal cvilence. If $t i$ was the original realing, it was quite unusual in such at cunnection and louked st range, and so might very (asily bave bes'n changed into the familiar hoti. but wly

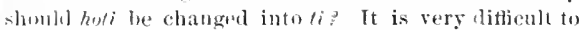
suppose the whange acelitental. The repetition ot hert

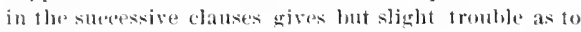
the sense: and eron it there was trouble, it would be at muengreatly increased by changing toli, which would lure have so rare and strange a use. In the presint state of "Text-criticism, the question ean hardly be stettled.

3' $\$$ ow' would be a very unusual meaning of $t i$, but not uneximplud, see Grimm, and Munltun in Winer, p. 5it?; a corresponding INebrew word is repeatedly employed in that sense. 
earefully seareled for and diligently entered.

In the marrow gate at the beximning of the way or at the end of it? Many have taken the tormer view, under-tanding by the gate eonversion, or the beginning of the Christian life, and by the waty its sulesectuent prosecution. (so Bunyan, in P'ilerion's Progren..) 1 larger number of expesiturs urges that it is more naturial to eoncerive of a manl leatling to at gate, by which we enter the eity ; and they forote ( W ret.) as similar in exprese

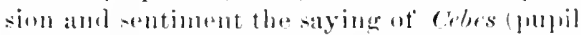
of Soerates): "Do you see a certatin little dome, and a certain rond beture the dome, which is not mush crowded, but very tew are journeying on it?. . . This is the rond that lead-tetrue instructinn." But it is also tatsy enungh to conceive of a gatte opentuge into at sparcions aromuse and at smaller one inte at narrow path, whieh conduets to the mansion.

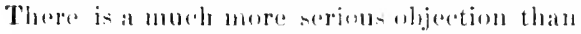
this to the common virw. It plassing through the narrow gate is conversion, to what does pasing through the wide gate correspund? There is no marked tran-ition mate by all

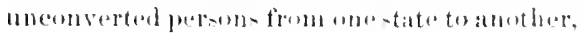

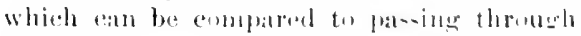
at Gater inter a new ruald. It, an the other hamd we undrestatul the gate as at the emel of

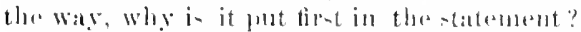

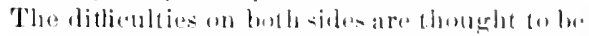
obriated hy the folluwing axplanation: ()ur

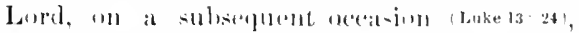

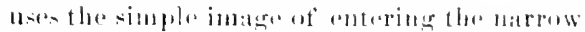
gatte. expressions sintilar to which aro antumon in Jewish and elas-ional writers. But here he expatuds the imatere reperesenting not anly a narrow gate, bat a narrow and dithoult roal,

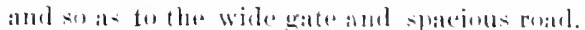
Wo have thus no orea-ion atarefully to mark ofl' the gatte, ats lying aither at the beraming

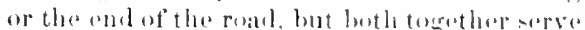
to set forth morestrongly than the simple ideal of a gate would do, the comparative ata-e of reaching perdition, and the ditfindty of reacelsing lise. (sin, in substanee. (Mrye. Jorome, Tholuek, Weiss, kioil.) And aneordingly "enter in through it" (v. 13.) and 'find it' (v. is) neest not be speecially atifinued to the sate or the wity being applicable to pither. and thus to buth. It" "the gate" be amitted atter 'wide' in v. 13 (see above), there will, aceord- inge to this view, be nothing lont of the substantial nuraning. Anlelis takes 'tiond it' an meaning timelite, which is grammaticalle fum-ible. bat dere not - uit the connection ; and to find at road is, in itoelf, a muele more natural "xperenown than to lomblife. It is misleading interpretation the saly (Plumptre) that Christ himselt is here the way and the gatte, betallas of John 11: 6 ; 10:7. Mnst at faniliar imatres be -llppored to have averywhere in the Bulde the sathe alluliertion?

The eomplarative atse and diffictulty of the

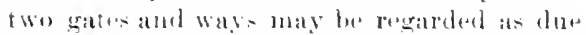

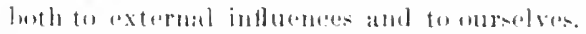
Iten in general da not intermet our propeses to destruetion, but much of their inflemes tencls to makr it ratsier; the crowd are groiner that way, and mankind have a deplerable. temblency to tollow the arowed. Comple Ex. 2:): 2.. At the same time, our sinful propensities are numbers and puwertul, and incline us in that same direction. On theother hatud, the way to lite is fenced in on either side by

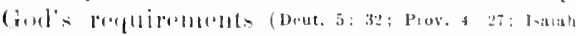
30:21), while sometimes persecutions (1.patet 18f.), and al witys the then-atud forms of temptatton, unite with our own sintul reluetance to de right, and make the gate very narrow, the way" "xenedingly stratemed. None the less is it true that Christ's pereple are the

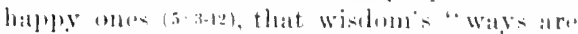
ways of plensantuese" (Prow 3: 17), and that

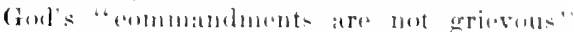

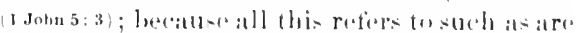

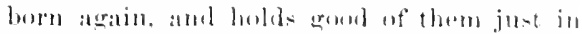

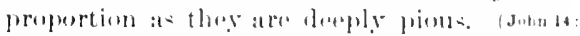

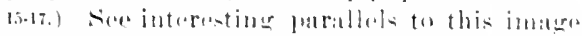
of the gate and the way in Eeclus. 21: 10: 2-

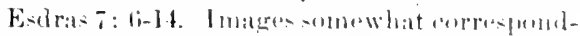
ing arre also quated trom Hesiod: "Evil wo

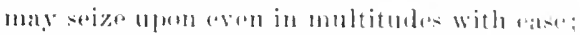
fler way to it is smooth, and it lims bury mar. But the immortal grols have plated sweat at the entrance to virtue. and longer and straightat is the path to it, and rough at first; but wheri

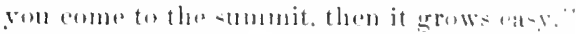
P'ythaterers (curn. a Lail].) satid " that at tirst the gath of virture is narrow and ontinel. but afterwarel- it beeomese wisler by dongrees: the way of pleatsure. on the other hamel, is not wille at the berginning. but afterwards it hecomes more and nore stritened." Philo: "A ruad worn by men and beasts, and suited 
15 Beware of false prophets, which cone to you in sheep's cluthing, but inwardly they are ravening wolves.

for riding horses and driving chariots, is very similar to pleasure; while the ways of prudence and temprance, and the other virtues, even if not impassable, are yet wholly unworn, for small is the number of those who walk on them."

15. Beware of false prophets. In your effirts to find and enter the narrow gate, the straitened way, beware of those who would mislead you. Alas! it is not enough that we have personally so much difficulty in finding the way to life, and that so many set us a bad example; there are others who deliberately altempt to lead us astray. For the term "prophets,' see on v. 22. There were already false teachers among the Jews, sanctimonious $(6: 2)$ and hypocritical. (Johu 10:1, 10.) And our Lurd may be referring immediately to these (Weiss); but he is also preparing for the future, as he will do still further near the (close of his ministry. $(24 ; 11,: 4$. $)$ so we find Paul spoaking of hypocritical false teachers as early as A. D. 50 (Gal. 2:4), warning the Ephesian ehlers in A. D. 58 against grievous Wolves (Acts $20: 28.31$ ), and a few years later giving many such warnings in the Pastoral Eppistless as Peter and Joln also do in their Fypistles. Few things are sumainful to the teacher of truth as to know that others will be busily teaching the same'persons ruinous error. In sheep's clothing means, of eourse, clothed like sheep, looking like sheep, just as in Eopls fable of the wolf in sheep's chothing. The idea of some that it means clothed in woolen garments, resembling a supposed stylo of garment worn by jrophets, is unfounded, and very nearly ridicollous. Ravening, rapacious, snatching at everything to devour it. (John 10:12.) Henry: "Every hypocrite is a gout in sheep's clothing, but a false prophet is a wolf in sheep's elothing; not only not a sheep, but the worst enemy the sheep have, that comes not but to tear and devour, to seatter the sheep, to drive them from God and from one another into erooked path.."

16-20. Our furd here shows how these false teachers may be detected, viz., by their fruits. Know is in the Greek a compound, meaning reognize, or fully know. Ye shall know (in Greek simply the future tense) is
15 Beware of false prophets, that come to you in sheep's clothing, but inwardy are ravening wolves.

bere not a command, but an assurance. Do men gather, literally, they, precisely like our impersonal expression, " they say," ete. (Comp. on 5: 10.) The Greek introduces the question by a particle which strongly implies that the answer must be negative. James (3:12) uses the same inage, probably haring this passage in mind; for, as already remarked, he often refers to the sermon on the Mount. Even so (v. 1i), i. e., as we do not gather one kind of fruits from another kind of tree, so it is also true that fruits are good or bad according as the tree is sound or unsount. Here, and in v. 18 , the original is plural, 'good fruits,' 'bad fruits' ; in v. 19 it is singular-mere variations for the sake of variety. Corrupt is, literally, decayed, rotten, and then unsound in general-a tree in a decayed or unhealthy condition, such that its sap is diseased, and it cannot produce good fruits. V. 17 states the actual fact of nature; v. 18 , that it cannot be otherwise, from the emetitution of things; $\because 19$ that men are accustomed to act acenralingly; $v .20$ is a repetition of what was said in v. 16, made for the sake of greater impressiveness, and presented as a conclusion from what has been said in v. 1619. A good many copies of the Greek introduce v. 19 by 'therefore,' and v. 15 by 'but' -from not perceiving the apophthegmatical character of the style. With v. 18 eomp. 12: 33 , where the same image is employed by our Lurd in another connection; with v. $19 \mathrm{com}$ pare the words of John the Baptist in $3: 10$, which many present had probably heard him speak. Hewn down (v.19) is literilly, cut out, i. e., from its place in the orchard. It is a matter of common observation that men do actually cut out and burn trees that do not produce good fruit.

There has been much discussion as to whether the 'fruits' by which we are to judge, represent the life or the teachings of the teachers in question. The latter riew provaled widely until Bengel, and the passage was freely nsed as authority for punishing hereties. By eomparing the whole comnection, especially the phrases, 'doeth the will' (v.21), 'workiniquity' (v. 23), "doeth them" (v. 24), we see the applieation here is to their works, their life. On the 


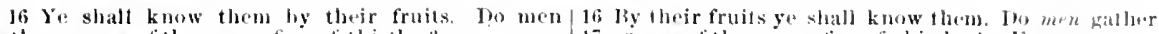
gather grajes of thorus, or figs ul thistles:"

17 Eiven su every gond irce liringeth forth good fruit: but a corrupe tree loringall torth ivil fruit.

Ix 1 good trea eammol bring forth evil fruit, neither

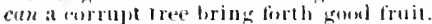

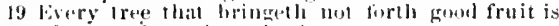
hewle dowin and east into the fire.

20 IVhurefore ly their frotis ye slatl know thrm.

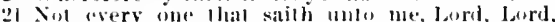
hball rnter into the kinglom of heaven; Iut he lhal doeth the will of my lather whieh is in liearen.

other hand, in Luke's sketch of the discourse (1.uke 6: 43), the special application is to the iclen that at a good tree protuces goonl truits, ete., so a good man will put forth good teachings, and these will have a gorsed eflect $110 \mathrm{~m}$ his pupils, and a barl man the reverse; and similar is the applieation whon our Lord uses the image again. (12:33.) II:y it not be that he here indicated an application both to their lite and the character and eflect of their teachings; and that II atthew's incomplete sketeh grives prominenere to the one, Luke's to the other? (There seem to be several such cases in the two reports of this diseourse.) In both respects false prophets would pretend to be mombers of the llock; making great pretence buth to a boly lifie amb to somb tatehing. But is their lif boly, is their tenching souml, and does it make their pupils wisel and bettor? Those tests will show what thry are inwardly and really. Jement: "For it behowes the servants of (rod that both their works should be approved by their taiching, and their teaching by their works." It is not meant that every separate item of false teriehing will be attended by some distinet evil practice; their evil conduet in general will show them to be bad men, and so to be unsafe teachers. When some teithers at ruinous heresy are men of scrupulons eonduct and plusing general character, and aren very devout, this may usually be aseribed to their religrous alucation and en rly habits, or to the religious atmosphere they breathe, or to a reat piety which their theories cambot destroy in then, however lut fiul to athere.

21. The test of false prophets, their fruits (v. 16. 20). naturally leals to the kindred thought that the followers of the tron prophet, the Saviour himself, will be known not by their professions of devotion to him, but by their fruits, their doing the will of his Fatlaer. That this is true in general is strikingly shown by declaring (v.228.) that even many

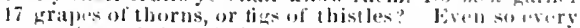

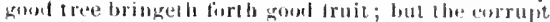

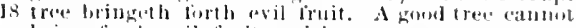
bring torih avil froit, neither can a corrujel trees 19 brime forth gord froit. Every tree that bringalli

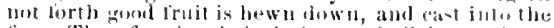
20) fire. Therefore hy lheir fruits ye shall know lhem.

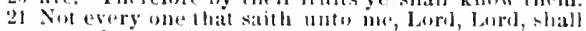
enter into ldo kingdom of heaven; but be thal doets
\end{abstract}

who have prophesid and wrought miracles by his name, will be fillally rejected at having never really benll his penplu. Mnch more, then, is that prosible and likely in the case of such as latue given less evidence of really being his followers. This palsinge (v. 21.23) is thus seen to be naturilly suggested by the preceding warning against talee prophets, but to be widoned into a solenm admonition to all, as to the dianger of self-dreception; and this again will naturally lend to the andelusion inv. 24-27. Not every one, but only some of them, omly those of them who do the will of God. (Comp. Luke 9: 5!, 61.) Lord, Lord, tha repetition expressing earmedoluten in aldressing him, which might, of conrse, lwe either real ur n-wmed. Similarly in v. 20; 25: 11, and compare "Misker, Mister" in Luke 8: 24. For the exact meaning of' 'Lard' soe on 8: 19. It anuegs tho jalena of rightial master, ruler, soreroign. If we call .l sus 'Lord,' and do not what he silys (Luke 6: 4i), or, what is the satue thing, do not the will of God, it is a flagrant incomsisteney-to pretend that he is our Master, and yet not obey him. Enter into the kingdom of heaven, see on 5: 20. The kingdom of hearen is here anderstond with reforence to its aonslummation. its elermal, glorions rewirds. (sise on :i: :-) IIe that doeth the will of my Futher. This is the first time in the Galilean ministry that Jesus speaks of God ats lais Father. It is

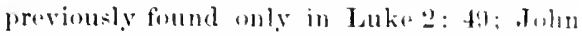
2: 16. Conup. as to "life, in v. 14. "Will' is here expecially what Gerd requires; and to 'do' the will of (ronl is to obey his enmmands.

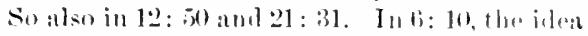
is quite ditlerent, viz., literally, ' bet thy will (desire. wish) eome to piss.' In l ('or. 12: :?, Rev. Ver., Paul declare that "mo man speaking in the spirit of (rod sath, Iosus is mathema: and no man ean say, Justs in Loril, but in the IIoly spirit." If evinlenty sapposes the utterance to be a sincere one, 
22 Many will say to me in that day, Lord, Lord, bave we not prophesied in thy name? and in thy name have casl out devils? and in thy nase done many wonderful works?

23 Ant then will I profess untothem, I never knew you: depart from me, ye lhat work iniquily.
2 the will of my Father who is in heaven. Many will say to me in that day, Lord, Lord, did we not prophesy by thy uame, and by thy name cits oul denons, and by thy natre do many lliting works"? 23 And then will I profess unto them, I never knew

$1 \mathrm{Gr}$. powers.

while the Saviour is here speaking of persons with whom it is all talk and outside. Distinct from buth these eases is the future universal it confession of Phit. 2: 11.

2:2, 23. For the connection see on v. 21, at the beginuing. In that day, the wellknown day, often spoken of, and familiar to the minds of all. It is a phrase frequently employed by the $\mathrm{O}$. T. prophets to designate the time of Messiah in general; as used in the N. T., it looks espeeially to the consummation of Messiah's kingdom (eomp. on 6: 10), and thu-denotes the day of judgment (see Luke $10: 12 ; 2$ Thess. $1: 10 ; 2$ Tim. $1: 12,18 ; 4$ : 8; Rev. 16: 14). Our Lord here begins to edueate his hearers to that coneeption, as in like manner he thus early intimates that he is to be the Judge, an idea brought out more fully in John 5: 22, 27; Matt. 25: $31 \mathrm{ff}$. Throughout the discourse it is evidently assumed that he is the Massiah, though not expressly so dechared, and it is therefire mot strange that be shoutd assume to be the final judge. Similar is the Lord, Lord, as atddressed to him; for this cannot be here the mere polite form of address (8:6; Acts $16: 30)$, since (Achelis) no one eould imagine that he would be saved for morely speaking politely to Jesus. Here is a touch of the "authority" which so impressed his hearers. (v. 24.) Have we not prophesied. The Hebrew word which we render 'prophet' signifies one who speaks under a divine influence, speatis as be is moved to speak by a divine power, and so is the ambassador of God tomen, the revealer and interpreter of his will. To foretell thing. future was thus only a part of the prophet's office; he was the inspired and authoritative religious instruetor of the people, whether as to things past, present, or future. The Greek word prophetes which we borrow, is now explainod at meaning not one who foretells, but (Lidlell \& Scott) one who for-teils, who

1 This eonstruetion is not elsewhere found with this worl in the New Test. (Mark 9: 38 has a preposition in the correet text), and appears to have heen hurrowed from Jer. $27: 15$. The Gothic takes pains to express it speaks for God, or (Grimm, Cremer) one who speaks openly, an interpreter (of the Deity); it thus correspond closely to the Hebrew word. To prophesy in the New Test., is always to speak by divine inspiration, though not always concerning the future. It is a mistake to say that it sometimes signifies merely to teach. Even in 1 Cor. 14: $1 \mathrm{ff}$., the apostle is not contrasting the gift of tongues with ordinary teaching, but with inspired teaching in the common language. In the present passage it is evident that to prophesy is regarded as a remarkable thing. In-or by -thy name, is the simple instrumental (wrongly called aative) case of the noun without a preposition." 'Thy' is emplatic in the original. It was by means of his name that they performed these wonders, and this is repeated three times; surely then he would not reject them. Comp. Acts $8: 16 ; 19: 13$; which last shows that the name of Jesus was sometimes aetually ealled out. For the seripture use of the word 'name' see on 28: 19 ; as to easting out demons, see on 8: 28. Wonderful works. Mighty works is better. Tyn. has 'miraeles,' followed by Great Bible, Gen., Rheims. It would be better to render this word (powers) uniformly by 'miracles,' as Com. Ver. nearly always does in the Aets and Epistles. Comp. on 12 : 38. Profess, see on 10: 32. They were professing to bave been his followers, and he will, on the contrary, protes-openly and plainly declare-that such they never really were. The Rev. Ver. here rightly retains 'profess' (instead of 'confess'), as also in Titus 1: 16; might it not better have done likewise in $\mathrm{Heb}$. $4: 14 ; 10: 23$ ? (Compare below, on 14:7). I never knew you. The word rentered 'never' is very strong, not even at any time. nearly equivalent to our "never, never." 'Kuew, i. e., as mine, as my people. So in 25: 12, where the bridegrom says to the fool- bere like the Greek, without a preposition, whieh it regularly employs where the Greek does. The Latin has inserted 'in.' 


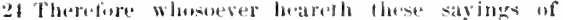

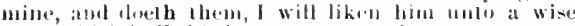
mat, which built his heuses npon at rock:
24 yots: thepart from nu", ye that work iniquity. Jivery

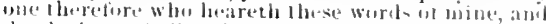
doeth lhem, shall be likened unlo at wine mats, wh i-h riguins, 'I know yoll not'; Juhn 10: 1:, Rer. Vor.. I know mine own, and mine own know ma" ; (ial. 4:4, Rev. Ver., "To know

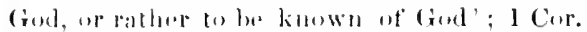
8: 3, Rar. Ver., If ant man loveth Goel, the

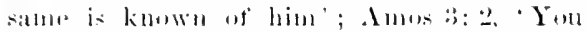
only did I know, out of all the familis of the

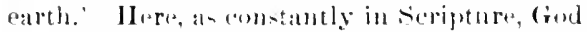
is spelion of in language derived trosu men. 1 man knows semer fersoms, and does mot know others: and only the former cat enjuy any privileges which may putatin to his acfuaintances suppose a pringes to bave formerly sojourmol in a distant provineer, and now

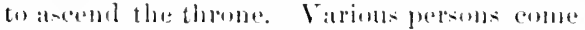
from that provinese chaiming to have been his acepuaintanewe, and hoping to anjoy the ad-

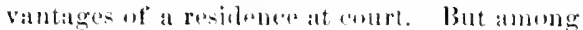

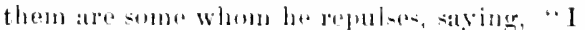
mever knew you." 'llaey maly iusist upon arious things as showing that they were his ateflationeres, and romdered him important

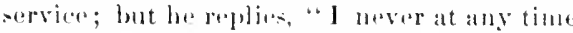

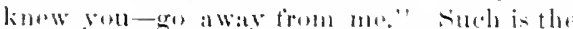

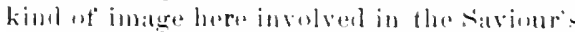

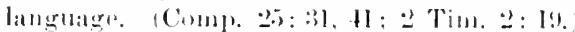

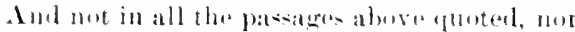

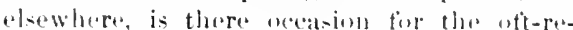
peated arbitrary notion loriven from the Fathers, that "know' anderge the anditional

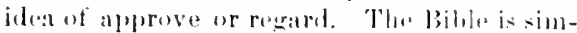

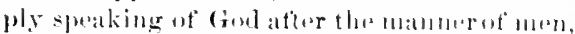

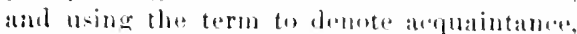

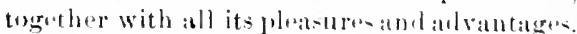

Depart from me, eomp. 25: H ; Lake l: : 24. Ie that work iniquity, i- funted from

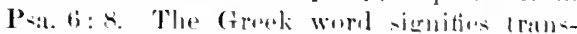

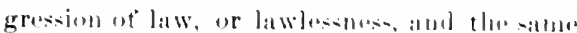

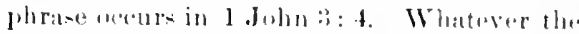
talk ut these men, their doings were wieked : they dial not do thewill of God ( v.21), did not bring forth good fruits (veln), alil not work

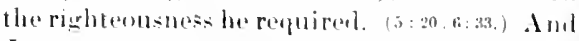
Jesus not mble dees nut know thesu now, he neser did know them, not even whon working miractes by his name. Some tramsiate, "Baeatse I never linew you, depart from me, ete. The Greek will hat this rembring, but less maturilly, nor does it suit so well the ennecetion and the general tone of the passage.
It need loot stopprise 11 so find that man

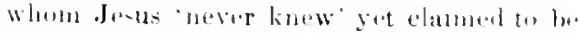

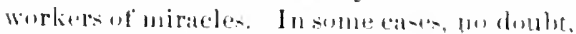
the clation was without fontudition. But

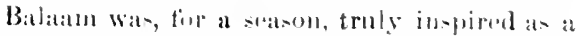
prophet, thoserh he was very weked, aml died in hisiniquity. Iudas dombtlen wrought miracles, as well a- his asonelates, when lhes Were serte wut to preateh and heal. (10:4.0.)

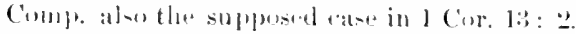
It is harilly probable: that the juenom - juken

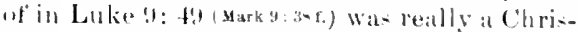
tiall, thumer he was helping the siaviumr: calus. Jet lelum, in 17 : 1!1, the failure ot the dieciples to work a miracle in ascribed to

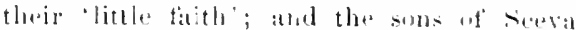

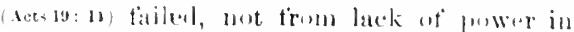

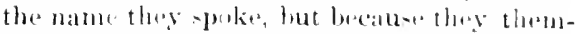

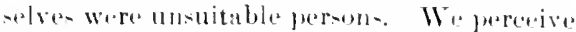

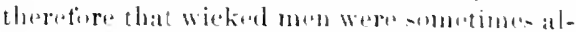

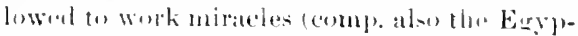

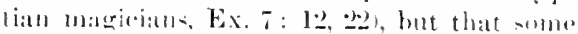

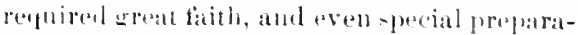

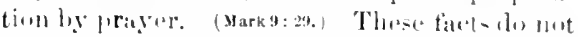
take away tlas evidentiary power ot puirates.

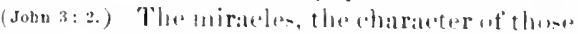
who wromglit tham, and thr nature at theip

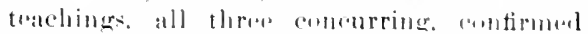
each ather. But if mon eombl sumli hy in-piration and work mirasles withunt bing truly

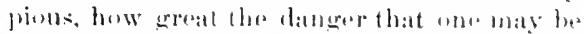

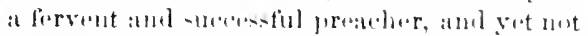
a Christian. Many taku suceess as a divinu atteratition to theom and their work: hut it is

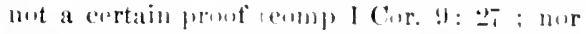

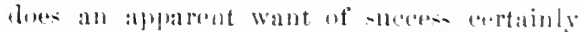

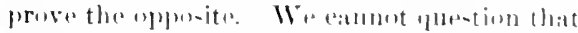

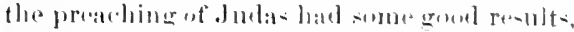

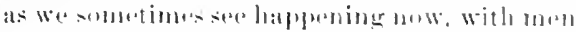
who afterwarels show that they naver wore

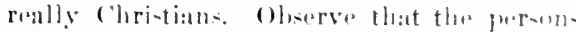

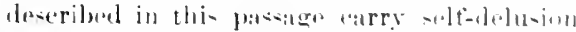
inter the "ther worla, "ven to the l)aty of Judgutut. Sin ints: 41.

21. Wr have mas (v.24.27), in the shapent an inforence trom what has bern said, a general cenelusion to the wholdedisenurse. Since profesions will be of no avail. nulas mo does the will of (foll (5.21.2s), theretore whoever hears these worls and dees them, will be a 
25 And the rain descended, and the floods came, and the winds bew, and heat upon that house: and it fell not: for it was finduded upren a rock.

26) Aml avery on that heareth the'se sayings of mine, and dowth them not, shatl he likened unto a toolish sall, "hich boilt his house upon the salul.

27 And the rain desernded, and the Hoods eame, and

prudent man, and whoever negleets the doing will be a foul. Jesus knows that many will treart him as Ezekiel was treated. (Ezek. 33:31 f.) These sayings of mine refers immediately to the Sermon on the Mount, but of course the same holds true of his other sayings (eomp. Luke 6: 47.) And doeth them, comp. 'doeth the will' in v. 21, 'work iniquity' in v. 2\%, and 'fruits' in v. 16. James refers to this passage in lis Epistle. (1:22-25.) The Misluna, Aloth: "To learn is not the main thing, but t" practice." I will liken, etc., or, he shall be likened. It is hard to decide between this reating of the Greek, and that of the Com. Vrer. There is of course no substantial difference. It does not mean, as some explain, that hre will be made like at the Day of Judgment (comp. the futures in v. 2.2 fo), but either 'will be like' in eharileter (as in ij: 8), or, will be eompared in the tenehing of Jesus, and in the estimation of those who learn his teaching; comp. Luke 6: $4 \bar{i}$, "I will show you to whom he is like'; eompe also Matt. 11: 16; Matrk 4: 30; Luke 13: 18; L:Im. 2: 13. Wise is more exactly 'sensible, 'prudent,' as in $10: 16 ; 2.5$ : 2; Lnke 16: 18. Upon a rock. Rather, the rock, as in v. 26, 'upon the sand.' In a limestone country like Galilee, it is anly neceswary to dig some distance, and you are apt to find a stratum of solid rock. It is very eommon in that region now to dig down to the rock, and lay the foundation of a houseon it. Comp. the expressions in Lake's sketch of the discourse, 'dug, and wont deepr, and haid a finundation upon the roek' (iake 6: 4*); eomple also Eph. 8: 18, literally, 'ronted and foundationed in lover.' It is idhe to saly that 'the ruek' here metus Christ, because he is elsewhere often called a roek. Must the image of a rock al ways me:m the salue thing? The themeght here obviously is that a man rests his salvation on a good foundation by atetual obedience, and not

1 For 'shall he likened,' B. א Z, a dozen or morw cursives, the Vulsate, Sabilic, Armenian, some Fathers. Thi old Latin enpies and the two beryptian rersions are divited. All the Syriac versions agree with (. L. and tbe other uncials, must eursives, alud some Fathers, in sulporting ' 1 will liken him.' it is muelt more prob-
25 built bis bouse upon the roek: and the rain deiscenled, and the thoods eame, and the winds blew, and beat noon that house; and it tell not: for it was 26 tounded upon the rock. And every one that heareth these words of mine, and doeth them not shall be likened unto a foolish man whobuilt his house upon 27 the sand: and the rain descended, and the floods

mere profession; by not simply hearing the Saviour's teaching, but aeting it out in character and life.-Observe that this passage is really a parable. Comp. on 13: 10.

2.5. Throughout verses 24-27 tho srmmetrieal strieture of sentence, and the exact correspondence butween the two comparisons, give a solemn dignity and impressiveness to this striking conclusion. Many writers distinguish the rain as affecting the roof, the floods the bottom, and the winds the sides of the house; but it emnot be that these are meant as distinct assaults upon it, for the power of the roof to resist rain would not depend on the solidity of the foundation. We must understand this as simply a detailed description of the overthrow. The rain descended, and (in consequence thereot) the rivers cane (mountain torrents, rushing down the ravines, and swelling up to the site of the house), and these washed around the building, and would have washed the earth from under its foundations, had they rested mainly on the loose surface of the ground, and then the winds would have blown it down; but this house did not fall, for its foundation wats latid upon the rock. Beat upon is, literally, 'fell upon' or 'fell against,' as when a man hurls himself headlong against something." There may be (MeClallan) a play upon the words, 'fell upon that house, and it fell not.' Founded, was derived by Com. Ver. from the Romish versions, and is better than the 'grounded' of Tyudale and his successors. The exact meaning would be expressed by 'foundationed,' if we had strch a word. Some elements of the illustration our Lord here employs, may be found in Prov. 12: 7 ; Isa. 28: 11; f.; Ezek. 13: 10-16.

$\mathbf{2 6}, \mathbf{2 7}$. Here the phraseology exactly eorresponds to v. 24, 25, except beat literally, smote upon, which is a mere rat-

able that this was changed into the other to suit r. 2i, than entrariwise to suit $11: 16$ and lake 6: 47 . Thus internal evidence is here again opposed to the authority of $13 . N$, and others.

2 Comp. the same Greek word in Mark 3: 11. 
the wimlihew, and beat upon that huase; and if fell: and grabt was the fill of it.

25 . lul il cambeto pass, when lesus bal ended thest sayiugs, the people were astonished at his doetrine: eame, and the winds hlow, atud smote upun that

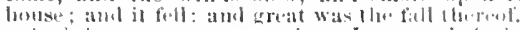

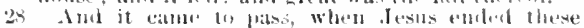
worls, the moltitudes were astominlued at his tearth- riation of the expresion, without substatutial diffirenee. The saud retiols to the lowe surtice of the gromnt, or perhapes to the same neenmulated in some part of a mountain rovius, which looks sumuth and firm, lout is liable to bes swept away ly the naxt flomed. Great. The finudation bring swept away, the whols houce woubl fall in one mighty cranh and commplote wreke.

This beantiful illustration makes itsown impresion: he whe hears the work of Christ, nom dorstlom, is stiongatust all the evil influenees of the world, satie forever; he who

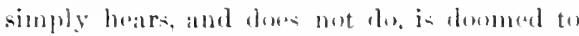
fail at silvation, and be aru-bed in utter destruction. To tind some sperial spiritual meaning in erery fartionlar, as "the rain ot temptation," "the tlomb of persecution," "the wionl of divers and strange doetriun.s," is pure fancy-wopk. The Minhua, Abuth, has a sommwhat similar illu-tlation: " I man who bas goud works, and lourusthe law much, to what is ho like? 'T'u at man that bulls with stomes bolow, and afterwarels with hrichs; and though many waters enome and status at thedi

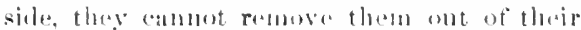
plate. But a man who bato no eroud worlis. and learne the law, to what is he like? 'Tua man that bulds with hricli- tir-t, and after-

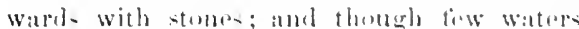
enme, they immatiately aserturn thems."

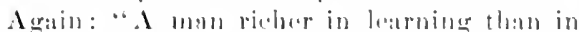
goud worlss is lilie a tree with many bramohos and tow routs-the tiret wiml werthrows it: but a man whose acetions are grealler than his loarmine is like a trea with tim hromeluse and many routs-all the winds of tho world may storm against it, hut eanmot mown it fom its

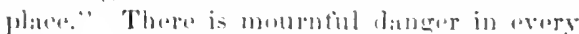
age. that mon will haar chrint's servants prould, and will themalves reat in his written woril, and stop at that, withont daing acecording to what they roul or hosir. Is the

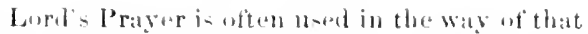
"bian repetition" to which it wate griven at a colstrat and corretive, so this closing illustration is oftan erroatly admired by persons who hear and (d) mot. It is a most momentous

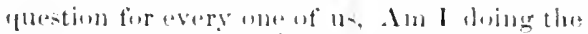

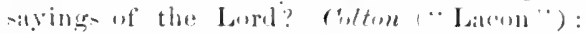
" Ilen will wrangle for religion; write for it; tight for it; die for it; angthing but-live for it."

28 f: Comeluding remarks of tho Evangelint as to the erlicet of this great discomber.

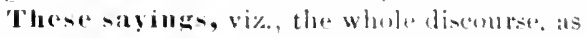
in 6.2 t-26. The people, murexatly, the cromels, the salne term at in $\overline{5}: 1$, and naturally leading the mind batk tuthe -tateof things

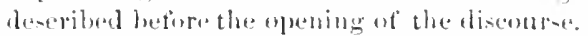
Com. Ver. obsenres this link of ennuection in

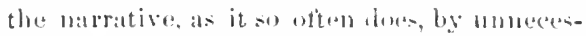
saly variation of the redulering where the

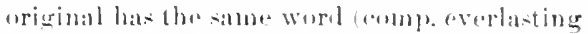

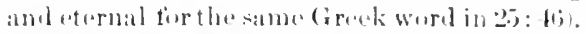

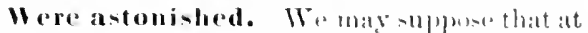

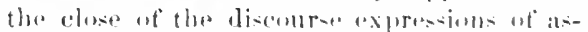
tonishoment brokio forth anumer the hitherte -ilint crowd. stier: "But, allat the more "wore astonjshem in which the whole termiNated with resarel to most, tramemits to 11 it

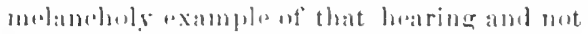
loiner. with warniner anainst which the sale-

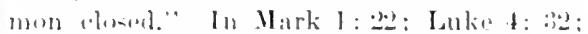

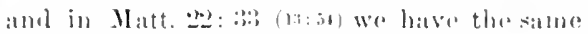

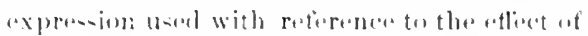

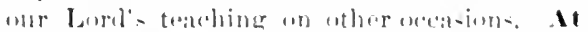
his dactrine-or. tenchime. The Euglinh word "Anetrine" anght to he still a correct rendering hare. bat in preant use it -uererests

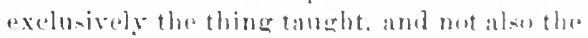

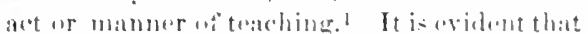

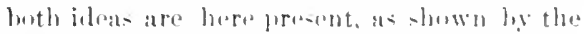
reason for atomi-hnest griven in the mext verse. Benefl: "Yom wemhl wamler why, in

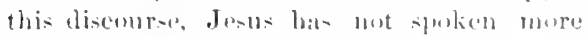

Houmphrey says the liev. Ver. has pulearoret to rondter didnche uriformly hy "Iraching' and dialds-

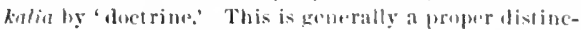
tion, but the Rev. Ver. has not heen able be carry it throngh, for in 12om, 16: 17 and 1 l'ins. $4: 13$ the remlerings are interchanged; and in fact the distinction is not

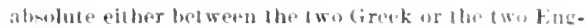
lish worts. In this fassage teaching is mun kuthr, fuemuse it jucludes londs the manuer and the mather,

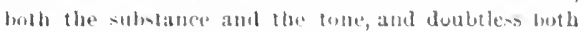
contributerl to the astonishment. 
29 For he taught them as one having authority, and not as the scribes.
29 ing : for he taught them as one having authority, and not as their scribes. elearly conterning his own person. But (1) he has so excellently sat forth the teaching itself, that they womld thence form an estimate of the excellence of the teacher. (2) His person was now sufficiently manifest. (3) In the discourse itarlf, he sufficiently intimates who he is, viz., 'the eoming one,' the Son of God, the .Judgrof all." (5:11, 17, 22; $7: 21$ 6.) raught. The imperfect tense of the Greek does not hore denote habitual teaching, but simply describes him as engaged in teaching. Anthority is the proper meaning of the wor!. In some cases atuthority carries with it the neeessary power; but the term does not directly mean power. The same word will meet us in $8: 9 ; 9: 4,8 ; 10: 1 ; 21: 23,24,27 ; 28: 18$. In all these Rev. Ver. properly translates by 'authority, except $9: 6,8$, and there places it in the margin. The Scribes. Their Seribes is the correct reading; and the expression resembles 'Sieribes of the people' in 2: 4 . The Seribes (see on 2:4) made it thoir business simply to state, to explain, and to apply the teachings of the Old lestament, together with the decisions of Jewish tribunals, and the sayings of famous tachers in past generations, as handed down by tradition. Seeing that for several renturies no prophet had appeared, it was rery proper that they shomld confine their roligions idess to the authority of the Old Test. ; lut, in aldition to this, they tied themsulves to past teachers, and insteat of forming their own opinions as to the meaning of Sieripture, were always quoting some Rabhi of former generations. All this appears plainly from the Talmud; $r . g .$, "R. Eliezer lowated that he had never said anything which he had not heard from lij: teacher." Thus the seribescould not speak as instinct with the convetion of aseertained truth, could not speak with the dignity and strength of asiared personal knowledge. t)ur saviour spoke as no other toacher would have a right to do, as hinself possessing 'atuthority' to deelare, on his own responsibility, what was true and right. Fven the prophets usually prefixed to their utterances. "Thus saith the Lerd"; while the worlsot" Jesus are, "Turily I say to yeur." (Soe on 5: 18, 22.) And he quintly ascerts the tremendens fact that men's future destiny will depend on their relation to hin (v.23), on their doing his words. (v. 24.) Hi- mole of teaching leing thus in contrast with that proper for uninspired men, and even with that of the prophots, the contrast must have bern all the more striking when it was comparal with such teaching as the multitades were acenstomed to hear from "their scribes.' Many per-oms are fomnd now who teach precisely as these seribes did, not merely going batek to Seripture as the final authority tor all religious truth-whieh is what they ought to do-but going back to "the Fathers," or to some great taachar or convocation of the last three or four centuries, as authority for the correct interpretation and just application of seriyture. It is the part of wisdom, as well as of modesty, to give nu small weight to the opinions of men whose abilities, learning, and piety have made them illustrions; but it a man is not aceustomed to come for himselt to the Bible, and form his own judgment of its meaning, his tachings, whntever else they may jossess, will have little of living power to sway men's souls.

\section{HONILETISAL AND PRACTICAL}

V. $13 \mathrm{f}$. The broad road: 1) Men are in it without finding or antering; 2) They pursue it without difficulty or effort; 3) They have plenty of complany ; 4) But it leads them to perolition. - Lutien: "What makes the way sonarrow? Nothing but the world, the flesh, and the devil." SillafF: "Contrasts: The narrow and wide gates; the stratened and broad ways; the goon and corrlipt trees, with their truit; saving and doine; active in Christ's name, yet working iniquity ; the ruck and the sand; standing the storm, and fallong in the storna; taching with atuthority, and traching as theirscribes." Cinks. : Furthe way is stratit, and the gate narrow, hut not the city. Thereforemust une neither look tor rest lere, nor there expect any more anght that is painful." N'TIER: "The narmw way to life is hroad enough for men who earofully, steadily walk in it. That is the consulation, which even this rigorous saying contains. What more is wanting than a way wheroin I may have room, and a gate that will let me through?" Drkes: "Amid the endlessvarieties to be found in life's broad road, there 
is but this single mark ly which to recounize

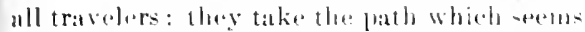

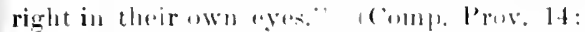
12.) IIt:ser: "Vin man, in his wit, would

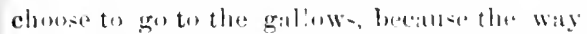
to it is -mosth and pleasant, nur rutune the

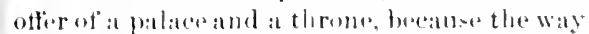

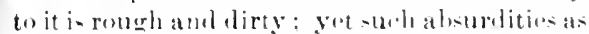
these aremen guilty ist in the concerment the ir souls." ('Alvix: "Mhrowe esmore it that men knowingly and willingly rush hemallong to ruin with a fosling of -

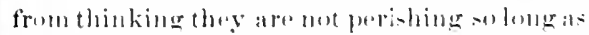

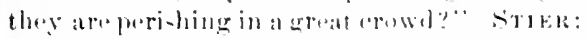
"The fooli-h world, indorel, lowsthe wiele:and the loreat, and the numbers-delights in the majoritim." Tumoss: " Man will tollow the multitules as the tiden follew the mone. The social fores of numbers lats ever becoll anain-t holintes in the worle." Drkes: "The mass

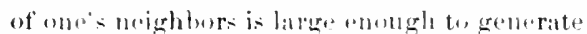
a publie npinion again-t which it is latme to eonterml. Among the crowels whos atficet nos Chri-tian isolation or perelliarity, there arese

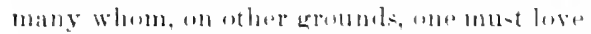

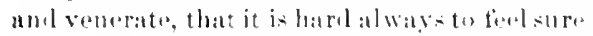
that who i r reght, and they all wroteg . . . To sen-itive natures with a hroall humanity, there. is aven a tixal pain in heing profindully ant af harmony, with the hulk at their tolluw-ment ... The indation of the trua C'lari-tian is. in sur atere, mores an inwarl than an whtwarl isolation." - sume may like to illu-trate the two ways by the well-kmown story of the Choice at Horeulin.

V. 15-2). 'Two metheds of tweting a ro-

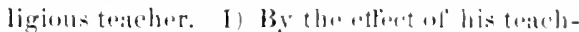
ings upon his own chatrater ambl life; 2 by the efferet of his teaching 11 pall thase who

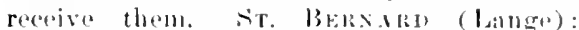

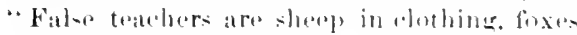
in cumning, Wolves in rmolty." Corrs.: "leit us not be trombled whing we seo matny heretics and hyperiten avellaw. Xay, fir this tow ebri-t foretold from the begriming."

IYkes: "When the path he lands in is liocovered to be so stratit ame serep, it presently begins to he satel, or imstrined. that lifie may be hal on ansior terms. The original guseal of the King undergoes some moditieation. Teachers who profess to teach still in the name of Jesus point men to a path which looks deceptively like the narrow way, and appears to combluet to a simbilar issure; only it is not so

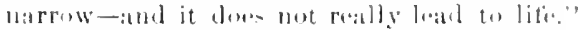

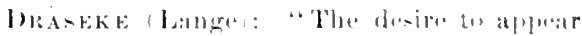
(a)ml: 1) It- nature; 2) Its origin; :i) Its

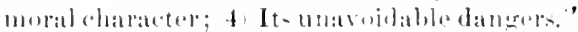

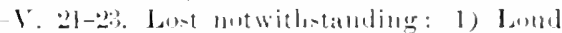

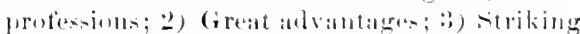

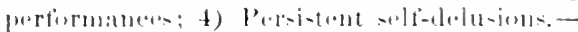

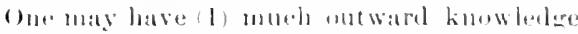

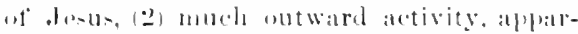
ently, in his soviere, (i3) yet late nu interior relation to him at all, and \& be be late ignu-

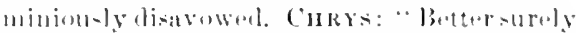
to radure a thourand thondertults. thatu tos

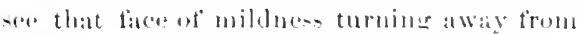
un, aml that ege of peace mot enduring to lowk 11 porn 10 s.

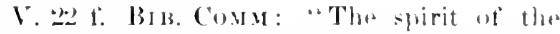
warning extemblis far beyond the extramelinary cases actually mantioned, and applies to all those in all ages who, whethor teachers or

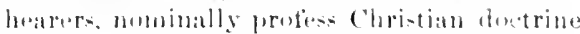

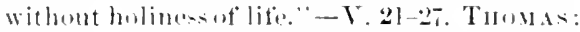
"Four kinels af religion: (1) The religione ot profeniun, v.2l. (2) The religion ut merit.

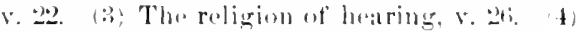
Tlac religion of loing. $r .24$.

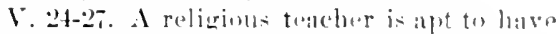
two ereat callses of griet: that st many will unt hear him at all, and that on many who larar, and perlape admire. will mut do. (imm).

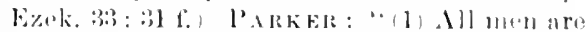

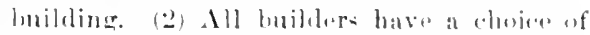
temmlations. (3) All toumblims will be triml. (H) (Only one fombration will stand,

brkes: "The wholo drift and movenenent of this loner diseourso has carrienl us formarel with it to ond Inot weiehty pratetial andelusim-that, after all, he only is a christian

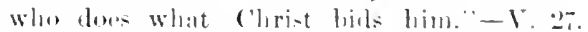
llark to the mighty era-lo in avery ate and

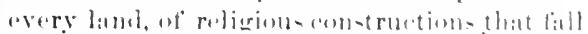

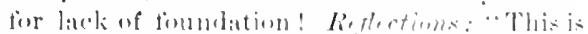
the eomelusion of the sermon an the Wolsut. amel we are lott with an impre-ejoll if fiear ;

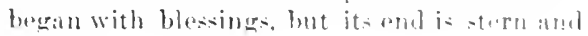
sivere."

V. 28 f. The moral teachiners uf , T, mas,

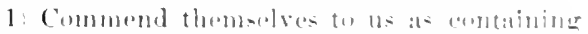
the highest human wialmm - surjitwing

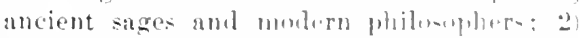
Come to us with supurbuman anthority-that of him who is the son of God (v,21), and will 


\section{CH A P TER VIII.}

WIIFN he was eome down from the mountain, great nultitures followed him.

2 And, helold, there came a leper and worshipped him, saying, Lord, if thon wilt, thou eanst make the cle:tu.

be our judge (v. 22); 3) Are embodied in an actual character-the peerless character of the 'Teacher himselt; 4) Bring with them the offer of hely in living up to them-that of the Holy spiric. (Luke 11:13.)-Distinguishing features of Christ's ministry. (1) Those whieh tannot be initated-his originality, miracleworking, authority. (2) Those which must not be initated-his positiveness, self-assurance, self-representation. (3) Those which should be initated-his naturahess, variety, suggestiveness, catholieity, spirituality, tendelness, faithfulness, devoutmess.

In our devotional study ot this great discourse, we should not be thinking too much ot its special adaptation to the Jews, but should read it as addressed to ourselves. Inagine that you stand anid the crowd and listron, and ever and anon his mild eye falls ufon you. Hear him telling you who are the haply under his reign, and how great, if you are onc of his, is your responsibility as the salt of the earth and the light of the world. Hear him explaining how spiritual and rigorous is that morality which he requires of you, in all your relations and duties; enjoining that your deeds of righteousness shall not be proformed ostentatiously, but with supreme regard to God, and that, serving God and trusting his eare, you meed mot be anxious about the things of this life. Listen elosely, and humbly, while he rebukes rensoriousness, whilw he oncourages to prayer, while he urges the danger lest you fail to bu saved, and looking rom solemnly in the face declares that you must not meraly hear these words of his, but do them. And then turn thoughtfully away, with the "Golden Rule" hid in your heart, and the graeious assurance ever somming in your ear, "Ask, and it shatl be given you."

Ch. 8: 1-17. A Group of Mirarles.

In rhap. 8: 1 to $9: 34$, we find a gromp of remarkable miracles. Having completed his sketrh of the Sermon on the Mount, the Evangelist returns to the state of things described before its introduction. (1:23-25.) Our
And when he was colue down from the mountain, 2 great multitudes followed him. And behold, there e.tme to him a leper and worshipped him, saying,

Lord was making a circuit of Galilee, followed by "great inultitudes" (4:25); on some recasion during the journey, moved by the presence of such (rowds $(5: 1)$, he went up into the mountain, and addressed to the disciples and them a long discourse (chap. 5 to 7 ), desigrned to set forth the nature of the Messianic reign, and corract many Jewish errors concerring it. When he had finished this and descended, "great multitudes" still followed him. And now having given this great specimen of our Lord's teaching, the Evangolist proceeds ( $)$ : 1 , tn $9: 34)$ to group some striking examples of his miracles, which show that if he taught as one luaving authority ( $7: 29)$, he actsd in like manner; and which threw light on the nature of his work as Messiah. In comnection with these miracles, Matthew also gives an account $(9: 9 \cdot 17)$ of his own call to firlow Jesus. When we compare the Gospels of $\mathbf{M}$ ark and Luke, we find several of these miracles, and the attendant sayings, introduced there in such comnections as to show that they did not oceur in the precise order in which they are lere mentioned. Some of them appear to have taken place hefore the delivery of the Sermon on the Mount, though during this journey about Galilee (see on 5: 1), and others at rarious subsequent times in the course of our Lord's labors in Galilee. They are gromped by Matthew without any particular regard to the chronological order, but in such a way as to promote the special design of his historical argument. Following upon these examples of our Jord's teaching (chap. 5-7), and his miracles (chap. 8, 9), we shall fiud (chap. 10), an account of his sending forth the Twelve, that they likewise may teach and work mirackes. (Nee on 9: 85).

The three first miracles here grouped involve the healing of very grievous diseasesleprosy, paralysis, severe fever.

I. 2-4. Henlixg of a LePER; alsogiven, with some additional particulars, in Mark 1: 40-45; Luke 5: 12-16.

2. And, behold. This expression by no means necessitates the supposition that the in- 
3 Ind Jens put forth his hand, and touchenl him, saying, 1 will; be thou elean. And immedialely his heprosy" was cleansed.
3 burd, if thon wilt, thon causl nako no dean. And he strelelued fordh his hatur, and lonelud him, stying, l will; ln: thou made cleath. And strathowiy cident aceurreel ju-t after the elose of the Sermon in the IIomnt. From the enmection in Jlark and Luke, it sorous very likely, thomgh not eertain, that it preceded the delivery of that disenurse. As to the locality, Lulie tolls us that it was 'in one of the cities,' $i$. e. uf (ialilee. There eame to him. The word: 'to him' represent a slight correction of the eammon Graek text. A leper. The lurrible disease of le leosy aplears to lave been partionlarly common among the Egyptians and the I-raclites. The elimate of Egypt Wassuited to agrarate the diso:ses, and it may be that the Istaclites there aequired a contitutional temleney to it, as supposal by strabo and Taritus. Tarions que-tions conererning loprosy still remain quite unsettled. The Greek worel (lepref). from which our worel is borrowol. Was derived from lepis, "a seale, thus signifying the sealy disease. Among the many kinds ot leprosy whieh seem to have existed in ancient and in molern times, that of the Bible appears to lane been not the elephantiasis, or knotty lepro-y, now often sorn in $\mathrm{I}_{\mathrm{al}} \mathrm{lestine.} \mathrm{but} \mathrm{the} \mathrm{"white} \mathrm{leprey."} \mathrm{It}$ began wit! a small spot, seah, or swolling. lying lower than the surfiee at the -kin, amel tho hair within it turning white. This would spread, and raw desh would appear. In bad eases, laresesortions, and sometimes the whole of the buly wombl astume a rhalky whiteness; the nails, and sometimes the hair, foll off, and in somo varietios the semose luseame blunterl, and hishly oftensive pus arathered on the hair and flowed from the nose. But it is not eertain that all these symptoms pertained to the bible leprosy. It deses sem nearly cortain that, while herelitary, ofton tor several gonorations, it wns not a contugious disense, at least not ju ordinary eaces. The law of Mones treaterl it (Les, eb.13antit) as an rxtrente form of erremonial defilement. When the disome spread aver the whole person. the sutlitrer was promouncod dean (Lev. 13:12.17), and conbl freely asonciate with others; which apponrs to be conelusive proof that it was not entarious. The rogulations requiring a leper to keepaway from others, to ery "Unoluan, nuelemn," ete.. simply meant that one who tomehed a beper would heeome ceremonially unclean, as if he hadl tonehed a doad borly, or a person having a romning ioste. (1.ev, 15:5.) All these things were to be rogarked as symbolically teaching the dreadiul pollution of sin, and the nexel of purification; and wn such symbel could be more impressive than at discares so hideros. Ihe peritieations when a leper had recovered (Lev. il) were quite similar to those preseribed for other kinds of erave ceremonial defilement. Leprosy was incurable by any kinwow remedies, hut would sometimen wear itself ant in the cour-e th time, in the individual, or in his dencentiants.

Worshipped. ('omp. on 2: 2. He eannot have meant worship as of (iod, but a deeply reverential silutation. Luke (5:12) says he "fell on his fice and besught him." Matthew's inprerfeet tense depoicts him as engaged inthis reveruntial aet. In likemanner, Lord, the worel userl in the sept. for Jehoviali, which in the Epistles (ommmonly means Joms and appears there to reognize his divinity, was aloo nand in (ireck (and still je) as a common form of aldress, and is properly

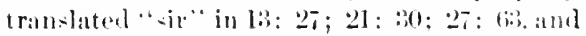
often. What precise amount of respecet it is to be mulur-toml as axpres-ing in any rase, mont

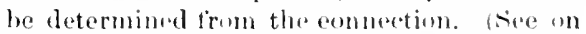
r. 19.) If thon witt, thou canst malie me clcan. He called the healing a eletnsing, beeanse the disease hat the alpearance of at defilement, amd mate ane ceromonially unelann. II. did not say, "It" thou const," like the despairing fathre vark : : at); hismly question was as to the Lord' willingues. (Comp. below, 9: 28.) Ilis language will expresw wat is often folt hy persums asking spirimul blessings; yot as to these we meght to latre no douht, either of the sioriour"s power or his willinguess.

\section{Put-ur stretched-forth his haul,} the eicomstances minutely detailed, atior the characteristio Hebrow style (eomp. on is: 2 . 'Put forth, 'Tymdale, etro is two feelble; Rheims alreaty has stretehed forth.' The word 'Itesus' is wanting in soveral of the earliost MSs. and versions, and obvindr-ly was mledel in athers to romove an apparent obseurity. So alsis in $r, 5,7$. Ind touched him. This must lave startled the be- 
4 And Jests sath unto him, see thom tell noman; but go thy way, slew thyself lo the priest, and otter the gift lliat Muses comminaded, for a testimong untu them.

jo And when frosts was entered into fapernaum, there came unto him at enturion, besteching him,

holkers, fir lis seemed to be incurring coremonial delilement; vet Jesus by touching did nut recoive defilement, but imprated reansing. I will, be thon elean. "A ready echo io the leper's mature faith. His uकn saring contained the words of the desired ropoun-" (Bengel.) Every other worker of miracles in the ()ld or the New Test. constantly ascribes the power and the glory to another; Jesus alone uses -uch expressions as ' $I$ will, he thou clean,' 'I charge thee, enme ont of him.' 'I say unto thee, arise.' (Comp. on 5: 2.2.) Thre has been much diseusion upon the futetion whether all who received bodily healing from Jesus, also reeeived spiritual blessings. It seems plain that in many instances such was not the ease; in others, the circumstances naturally lead us to think that the fath in his power to work miracles was also attencled by faith in his rower to forgive sins (complo on $4: 2)$. Whether that was true of the leper here mentioned, we have no means of deciling.

4. Sce thon tell no mar. Why this prohibition? Partly, perhaps, (as some think), in prea that the man might hasten to Jerusal $\rightarrow m$, and let the priests declare him healed before thes should hear of the miracle, as otherwise they might, through jealousy of Jesus, fretend that the eure was not real and complete. But similar prohibitions are found iu 1 : :30; 12: 16; 16: 20; 17: 9, ete, and there must have been some general reason. There was danger that the people would be("ome geratly +xoited, upon learing of hi. miracles, with the idea that lie was about to set up a splendid atarthly kingatom, aceording to their aprouents butions of Messiali's work (mohu6:116.), and would thus arouse tluts hoslility of the luwish rulors and that of the Rorman anthoritese, and intertere with his free-

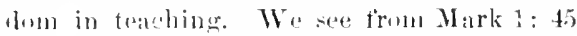
(loke 5:15) that by failing to rogard this prohibition the cleansed leper actually causud a serious interruption of our Lord's labors. The cxerptional case of Mark 5: 19; Luke 8: 39. proves llee rule. Jesus there specialiy hids a man to publinh what had been done for him:
4 his leprosf was cleaused. Aud Jesus saith unto him, set ihm tell m, man; but go, shew ibystelt to the priest, and onter the grit hal Tloses commanded, for a testibung untorlien.

5 And when be was entered into Capernaum, there

but there was in that region (southeast of the lake no danger of a great popular excitenent in tavor of making him a king, but on the antrary a vory unfavorable sentiment towardis him, which it was desirable to emrect. At a later periol we find our Lord making a series of distant juurneys, for the same purpose of preventing excitoment among the people, as wall as tor other rasons (see on 14: 13 , and comp. on $4: 12)$. Wh also see from 12: 16-21, that his mostentatious and quiet course of aetion was predicted. Shew thyself, with emphasis on 'thyselt,' as seen from its position in the Gleek (comp. Mark 1: 44); no mere report could envince a priest-the man nust show himsalt. For a testimony unto them. This is commerted nut with Moses commanded, but with whit precedes. 'Them' cannot refer to the priests. for they must decide that the man was healed befiure be could offer the gift. It must rofor to the preople in general, as suggested by "toll no man, and implied in the whole comnection. Such uses of' 'then,' denoting persons or things only implied in the connection, are eommon in N. T. Greek (Buttm., P. 14t6), and indeed in the colloquial usage of all languages. The sacrifice, mate after the jegular examination by the priest (Ler. 14), would be a testimony to the popple that the leper was thoromghly healed. and thus that the miracle was real; perhaps also a testimony (Chrys) that Jesus observed the law of Moses, which they were al ready logiuning to aceuse him wi disregaroling. (Comp. 'tor a testimony.' in 10 : 18; 24: 14, Rev. Ter.) For general remarks on the mirates, ser on $4: 24$.

II. 5-13. HeAlisg THE Cexterion's SErvant deseribed also in Luke 7 : 1-10, The language of Luke $7: 1$ makes it plain that this oceured shortly atter the delivery uf the Sermon on the Mount.

And when Jesus, -or, when he, onnitting the worcl 'Jesus,' as also in v. 3. Into Capermanm, now his place of residence. sue (n) 4: 13. I ecutmrion. This was the titlo of one of the officers of a Roman legion, who commanded a hundred men, but had a more 
6 And saying, Jord, my servant lieth at home sick of the palsy, grieviasly tormented.

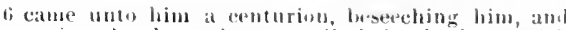
sayiug, lord, my iservant lieth in the lones sick

1 Ur, boy.

responsible and dignified position than our captitin. It cannot be determined whether this centurion was in the service of Herod Antipas, Tetrareh of Galilee (sece un 2: 20), who would doubtles liave his forees urganizod after the Roman fashion, and sometimes

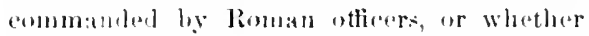
he was commeted with a Roman garrionn of Capernatum, sueh as the liomans frepuently maintaineal in mominally imderendent districts. II was a heathen, but a lover of the Jews, and had shown it ly lubliling the synagongue in which they then worshipel (Luke 7:5); probibly that large synagugue the foundations of which are now secell at Te] IIun. (sice on 4: 13.) There wore numerons, instances of intelligent and right-minded loathen who, when bronght in contact with the Jews, folt the superiority of their religion; e g., Cornedius. (acts In: 1.) This ('enturion at Caperuatum had probably known of the healing of the nobleman's son (Jahu $6:$ afr.), which tomk place theresome time befores, and t! is with other accounts of .Jests. Jatd I d to the full belief that he could heal his s'rvalut. There came nuto him. Luke (z:3:5.) siys that he sint the olders of the ofews, and afterwards some frients. Mattllew omits theste letails. and represents the centurion as doing himsolf what he did through others. Jn like

Iseven dillerent fircek worcls are in lle $\mathrm{N}$. T. rendered 'servatut, as follows: (1) Jiakomes, an atteulatut, water, as at table (John $2: 5.9$, amd somet imesasurant in Feneral: rembered'servant' in $22: 13 ; 2: 3: 11$ : 'minister' (originally a lanin word of eorrespunling signilieation)

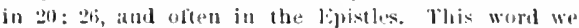
lave borrowal as didron, just as wo burrow hishon from

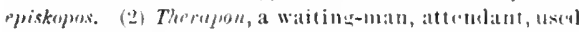
in Ilel, 3: 5, ensup. eommon text of Matt, 21: 45. (:3) IIupereles, a rower, saibor, and ill getueral a haml, au undarling, atent, attendant, inferior wheer, ete; romberol

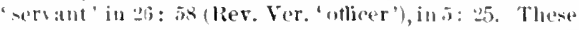
thres torme mierht be applies ejther to a slave or

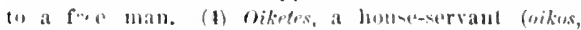
"house"), domestic; used in Luke 16: 13; I lever 2: 1s, ete. Theste mighe be slave or lree, hut were usteally slaves. (i) Pois, a chili, lny or girl, and alsu s'rvait, as above explatined; renslered 'servant' in v. 6, $x, 13$, also in 12: 18; 14: 2, and 'child' in 2: 16; 17: 1s, (Rev. Ver. "boy ") ; $21:$ 15. As applied lo servauts this teru spems to lave always meant slawes; 1t: 2 may be comp:tits with 1:: 3 . (6) Doulos, bomluan, slare. manner Mark (19:35) represents Janes and John at presenting to Jesus their anbitinte reques, whlunt any mention of their mother, whom Matthew (20.20) declares to have eome with them and acted ns spokesman. In Jolun

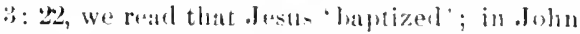
4: $1 \mathrm{f}$, this is axplatined to meatu that his diso eiples haptized. Sho in Jolnn 1!1: 1, it is said that Pilate took Jesus and acourend him, which of conter he did mot do with his - ww hands, but throngh his attendants. (omple.

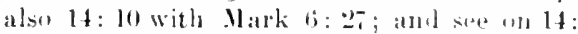
1!1. Similar forms of statement are commum anong us, both in literature and in the language of common life; and thepe in a tamilat law maxim, Que facit per alieur, facit pere se: he who dues a thing through another does it himselt:

6. Lord (see un v. 2), simply a very respeetful address. My servant is, in Greek, (d)atrly detinite, and may mean pither the

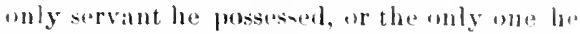
had with him at Caprernatum, or the ome that wa- doen exolusively ocoloping his mind. "Sirviut ( pales) is literally" lony, which term

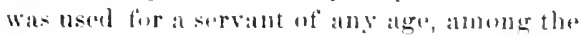

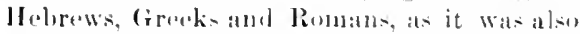
used in the slave silates of this entuntry; comp. the French garent. Ase turther an 12: 18.) The Rheim- ver-ion here translates

This always means at slave, though often useel fignratively, as 'slases of (renl,' 'slaves of .Jesus christ.' It is rendereel 'mond' or 'lwhiluan' in 1 (our. 12: $13 ;$; rabl.

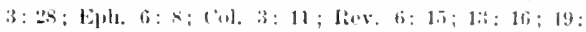

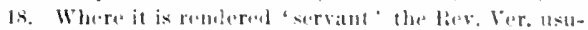
ally puts "hond-servant" in the margin, (7) Wisthios and Misthotos, a hirelint, hired natu, rendered 'hired servants' in Yark 1: 20: luke 1.5: 17, 19, and] "hire-

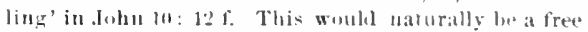
man. The English woril sersant is herrowed from the

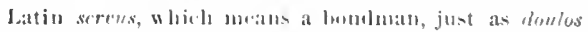
dues. But it has contur in linglislo to hatre it muth wiler use, denoting either bomben or hired attomatants.

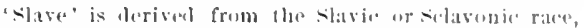
many of whom were redued to siervitule in the soulh-

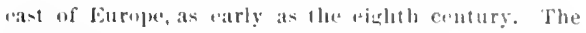
strong dislike to slavery at the present day has associated degrading ideas with this term, so that we enthid hardly anploy it now for the figurative ones of thelos;

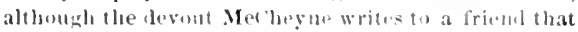
"it is sweet to llink of ourselves as the slaves of Cbrist." 
7 And Jesus saith unto him, I will come and beal him.

8 The eenturion answered and said, Lori, I am not worthy that thou shouldest emue under my roof: but sjeak ihe word only, and my servant shall be healed.

9 For 1 am a main under authority, having soldier. under me: and I say to this man, io, and he goeth and to another, (ome, and he comseth; and to my servant, Inthis, and he doeth it.

10 When Jesus heard it, he marvelled, and sajd to them that followed, Verily I wy unto you, I have not fould so great fith, no, not in Israel.
7 of the palsy, grievously tormented. And he sajt 8 unto him, i will come and heal him. And the eenturion answered and saik, I,ord, I am not l wortly that thou shouldest come under my roof: lut only say 2 the worl, and my 3 servant shall be healed. 9 For I also an a man muder authority, having under mystif soldiers: and I say to this one, tio, and he groth: and to another, Come, and he eometh

10 and to my 5 servant, to this, and he doeth it. And when lesus heard $i t$, he marvelled, and said to then that followed, Verily I say unto you, 6I have not

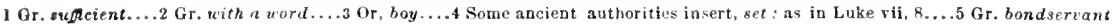
6 Many ancient auihorities read. With no man in Istael have I found so great faith.

'boy'; Wyc. supposed it to mean 'child,' as all the early English versions wromgly supposed in Aets 3: 13,$26 ; 4: 27,30$. Luke (7:2) has the term doulos, 'slave,' which is also used by Mattlew in v. 9. It is idle for Weiss to take pais as here meaning 'son,' from his mere passion for multiplying discrepancies.

Luke says (7:2) 'who was dear unto him.' Jos(2)luns tells us that the Roman soldiers were followed by many servants, who "in peace eonstantly ongaged in the warlike exereises of their masters, and in war shared their dangers." So a "Confederate" offieer and the slave who attended him in camp would often risk their lives for each other, while his other slaves at home usually took the most faithful eare of his wife and children. My servant-boy-lieth, literally, is prostrate, "bed ridden.' sick of the palsy-a paralytic (see on 4: 24). Grievously tormented, or, 'terribly tortured.' Some disoases then classed as paralysis produce violent pain. Compare the are in 1 Mace. 9:5.) f. Luke adds (7:2 B. U.) that he was 'about to die.

7-9. Jesus saith, or, he says, Jesus omitted, as in v. 3,5 . I will come, with some emphasis on 'I.' This proposition, boing reported to the centurion, brought out his humility and fath. A similar effect was produced on the Syro-J Paenician mother by refusal. (15;26.) Worthy, literally, not fit for ther to enter, t ete. II' may have meant (Edersh.) that he was Levitioally unfit, that to entor his home would render a .Jew ceremonically unclean; but the additional and stronger expression in Luke $7: 7$ leaves no doubt that he was also humbly thinking of his moral unworthiness. Speak the word, or, more exactly, speak 'with a word' (Rev. Ter. margin). So the nobleman's son there at Capernaum had been healed with a word when at a distance. (John 4:50.) The ernturion proceeds to illustrate the power of a word of command, by referring to his own experience as an officer and a master. For I also am a man? under anthority - . - and I say, ete. It is plain that 'under authority' is opprsed to 'having under myself soldiers' (Rev. Ier.)notice the 'myself.' He is a subordinate ennmander, aceu-tomed botb to obey and to be obeyed, and he is confident that in like nanner one word of eommand trom Jesus will cure disease. There is involved a sort of personification of the disease, as in Luke 4 : 39 , 'he rebuked the fever.' But what is the force of 'also'? (Com. Ver. followed Genera in neglecting 'also,' which was given ly Tyn., (rreat Bible, Rheins). The centurion rvidently moans that his case is like that of .lesus in regard to the word of eommand. Some think (Humphrey) that he regarded Josus as under divine anthority, while having power over disease. Or it may be that 'also' rofers to the latter part of the statement: for I alsc am a (subordinate) commandor, and my word of command is obeyed. To my servat, slave (see on v. 6). We cannot tell whether he meant the partieular servant that was sick, or the servant to whom he spokr in any case.

10. Marvelled-or-wondered. Hore he
1 For this nonfinal use of the tireek partiele that follows, ser on 5:29. Comp. the elassical eoustruction with 'tit' (viz., the infinitive) in I cor. 15: 9.

2 The margin of Rev. Yer. here follows W H. in mentioning that some ancient authorities ( $\boldsymbol{N}$ and some others) insert 'set.' But this cridently is an interpolation from Luke $7: 8$, and so should not luave been men- tioned. If genuine here, what ground can be suggested for its omission by ahmost all documents? It is wrong to follow $\mathbf{B}$ and $\mathbf{N}$ against the clearest internaleridence, espeeially when with internalevidence began the whole line of argument ly which W H. have established the great general excellence of their text. 
11 And I say unto you, That many shall come from the cast and west, and shilf sit fown with Mloraliam, and lsate; and lacob, jn the kingdow of heasell.
11 fouml so great faith, no, not in loratl. And I saly unto you, hoal many shall come fromb lhe east amb] Ilo west, and shatl sil down with Alirahim, and lsate,

1 Gr. recline.

wondered ut fich on another ocearion (Mark:6). at unleliet. Wre need not sperulate about his womblering, nor woalion the statement by attenpted explanations. Jasus wondered as a man, while as God nothing eould be wondertil to him. It is only the same difficulty that we moet with in such facts ats lis growing in wislont, and his not knowing the lity and hemr. Verily say unto you, serou $5: 18$. I have not found su great faith,' no, not in Israel. A similiar ease of ereat fath on the part of a heathen is fommel in 15: 22 tollowing. We foel sure that a porson with such beautiful humility and sucb faith in the power of Jesus to work mirateles, must have possessed, or would som eomo to possess, faith in his power to forgive sins also. (Compr. on v. 3.) What our Lordthus strongly eommends is not his humility, but that firith which is the root of every thing spiritual. ((ou) 15: 28; Lake 18: 8.) Ohservethat he does not rxpress surprise at finding so great fath in a soldier. There is no warrant in seripture for the notion of incompatibility between piety and the soldiers lifi.

11. And I say unto you (soe $\ldots 1,5:$ 18), releating the solemn athruation of the procoling sentence, basaun lar was abunt to say what the bews would be slow to believe, and what was of the greatent importance. From the east and west (comple. Isal, fis): (i), from the farthest parts of the earth in avery direstion, from the remotest Gentile nations. IJ Ire is alruady an intimation that Christianity will epread to all nations. And shull sit down, literally recline (see margin Rev. Ver.), i. e.. at table. The retotom of the l'ersians, which spread to the Gropk and limmans, lad also been adopted by the Jows, vize, to lie om a eoucle while eating. Thi was placed beside the table, and on it the peroun reclined lataning on his lett allow, so as to take furd from the table with his right hand, while the feet extemded oblifuely fot the ant sile of the cour h. Thus the teret enald be wasled while one was reclining (Luke $7: 38$; John 13:4r.); a m:L could leau his head back upen the breast, or lie "in the bosone "ot ane who reclined behind him. (John 13:23,25;1: 1 K; Luke 16:23.) This. luxurious mode of rating had not been the usage of their ancestors (so Gen. $27: 19 ;$ Judges 19 : i; 1 Sinu. 211: 21 f., whure the Hebrew de termines it to have beran really sitting); and the propluet Anos $(6: 4,7)$, robukes it as a part of the wicked luxury of" the poople, that they stretcheal themalyes at their banquets. But in the tiue of our Lerrel it land become the minversal custom, fortainly at all formal moals, and to dontherwise would have seomed singulur. Whorever in the N. T. 'sit,' 'sit down,' ete. are used with roference to enting, or where the plirase is 'sit at meat, etc.. the Greak always has some word denoting "tu recline'; and it is to be regretted that Rev. Vor. did nert place this in the text rather than in the marein. Wye. 'Tyu., and Great Bib. had 'rest, (ioneva and Rheims 'sit down.' With Ibraluam, Isaac, and Jacob. The Jews ansidered that their deseent from these patriarels made it certain that they would share with them the blessinge of the Messianie roiern; amb the Rabbinieal writings show that splonlid entretaimments, enjoyed with thr patriarehs, helonged to their cunception of the Mresianic felicity. IIere, as so often, our Savionr alapted hinselt to the common modes of expression. Sare tle same image in Luke

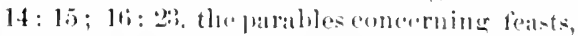
ar.d in Rev. 1!: 4. It was spereially appropriate in tlee present case; the . Jows would not at all eat with cirntiles; yet it is lore droclared that matug Goutiles from every direse tion will recline ut table with lhe great patriarehs, whilo, lews themselves shall be cant wut. This had been toreshadowed by the prophets but Jsmel was tom blind now to see it. The Talmud says (seberetter(on): "In the future world I will spreal for you a groat table, which the Gontiles will soe and be ashamoul." Luke doos not give this suying of anr Lord with roference to the eroturiou, hut in 1:3: $: 39$ he gives the same image as introduced on a

\footnotetext{
The marginal realing of Rev. Ver, has considerable tionat probibility : llere would he no sub-lantial dif-
} support, especially in rersions, and some trabserip-l ference in meaning. 
12. But the children of the kingdom shall be cast out into outer darkness: there shall be weeping and gnashing ot teelh.

1: And Jesus said unto the centurion, fiothy way and as thon hast helieved, so he it done unto thee. And his servart was healed in the selfsame hour.

14 And when lesus was come into Peler's house, he saw bis wite's mother lajd, and sick of a fever.
12 and Jaeob, in the kingdom of heaven: but the sons of the kingdom shall be east forth into the outer darkness: there shall be the weeping and gnaslung 13 of teeth. And Jesus said unto the centurion, fio thy way; as thou hast believed, so he it lone nnto thee. And the l servant was healed in that hour.

14 And when Jesus was cone into Peter's house, he

I Or, boy.

different neeasion. As to the phrase, kingdom of heaven, see on $3: 2$. It must here refer to the future state.

12. But the children-sons-of the kiugdom. By a IIebrew idiom a variety of ideas of intimate relation or close connection are expressed by the use of' 'son' or 'child'; $e . g$., in Old Test. 'sons of Belial (wiekedness)', as it were bom of wickedness, leriving thenr very nature from wickedness. So with "children of disobedience' (Epb.2:2, Rev. Ver.), and 'ehildren of obedience.' (1 Pet. 1:14, kev. ver.) In 'children of wrath' (Eph.2:3), 'ehildren of cursing (2 Pet. 2: 14, Rev. Ver.), we have a very strong exprossion of tho idea that these persons are by their very nature objects of wrath, of a curse.

'The sons of this world' (l,nke $16: x$, Rev. ver.) are wholly devoted to this world, as it were with a filial devotion. (See also un $4: 15 ; 11: 19$; 12: $38 ; 23: 15$, and comp. 1 Macc. 4: 2.) 'The surus of the resurrection' (1,uke $20: 36$, Rev. Ver.) are those who partake of it. And so' the sons of the kingdom here are the persoms who are "unsidered as having a right to its privileges by reason of their birth. Our Lord tells the Jews that strangirs to the kingdom would cone and enjoy its privileges, while its own sons would be east out. Into (the) onter darkness. The inage is derivel from a brightly lightest mansion during an evoning entertainment. Persoms expelled from the homse would find themalves in the darkness without. Sis in 2:3: 13; 25: 30, and enmp. "the blackuess of darkness forryer' in .Iude 12; 2 Pet. 2: 17. There shall be (the) weening and (the) gnashing of teeth, while within is the teast of thr soml, and the song of the blest. Why 'the weeping'" Probably the inlea of these as belonging to the punishment of Gohenma was tamiliar to our Lord's hearers. The same expression merolls six timesin Matthew (see $13: 42,50 ; 2,2: 13$; 24: $51 ; 25$ : 201 , and in Luke 13: 28; alway with the artiele, and always assonelated with the jdea of future punishment. (Comp. Buttm., p. 88.) Bungol understands it to be the weeping by eminence, and adds: "In this lite sorrow is not yet sorrow."

13. Go thy way, go along (eomp. v. 4), said here in kindness and encouragement; quite otherwise in 4: 10. So be it done unto thee, more litcrally, so let it happen to thee, 'come to pass for thee,' the torm explained on $(j: 10$. His faith was great, and so should the blessing be. Our Lorl frequently (not always) required faith in ordor to the reception of his miracles of hating, where there was a person capable of exereising it. But the healing cannot with any show of propriety be considered the effect of imagination, exeited by credulous faith, as in some apparent cures at the present day, for in this and various other cases it was not the sufferer that belicved, but some other person-and sometimes a person at a distanee. (15:28; John 4:53.) Moreover our Lold wrought miracles upon the dead, and upon inamimate nature, where such an explanation would be out of the question. In the selfsame-or, in that -hour, with some emphasis on 'that.'

I1I. 14-17. HEALING OF PETER's MUTHER-Ix-LAw, and of many others. From the parallel aecounts iu Mark $1: 29-34$; Lulie 4: 38-41, it appears that this took place before the delivery of the Sermon on the Mount, and upon a Sabbath-day, after leaving the syuagogue in Capernaum. Matthew groups these miracles with little coneern for exact time ant place. (See on v. 1.) Peter's house, at Capernaum, see Mark 1:21, 29. Andrew livet with his brother, and James and John accompanied Jesus on a visit to them. Perter and Andrew were natives of bethsaida , John 1:44), but had removed to Capernaum. (Nee the town deseribed on 4: 13.) It seems strange that Romanists ean so insist on the celibies of the elergy, when Peter himself, of whom the Pope is imagined to be the successor, was a married man, and not only at this time but long after, when at the height of' his apostolie labors; and 'the rest of the apostles' were likewise, except Paul. 


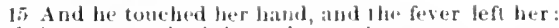
and she arose, and ministered hinto them.

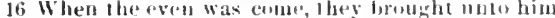
many lhat wero proserent with devils: and ho cast out the spirits with his word, alde healed all that were sick :

17 That it minht la fidflled which was spoten by Esaias the proplet, sayiug, Ilimsedi touk ear intirmities, and bare ont rickinesses.
1.5 saw his wife's mother lying sick of a ferer. And ho lenched her hamel, and the fiver left le'r: and she

16 arose, and ministered unte hims dud witer ever

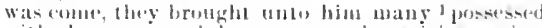

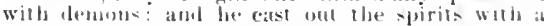

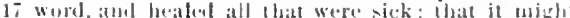
be fulfillol which was spokel through lsaiah libe propliet, sying, llimacli touk our intirnities, and bare our distalses.

1 Or. demuniacs.

(1 ror.9:5.) Sirli of a feser. Malarial fevers arecommon, fiomthemar-hes near the mouth of the Jorian. (Thomson, Geikie.)

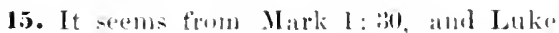

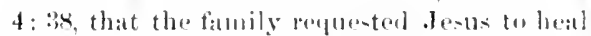
her. And he touched her hand. Our Lurd several times wrollelit miracles withont touching, and evenat a distanee. at: in the habling of tho centurims slate in the preeneling veroes; but be undally perfurmed some art, such ats touching the preson, taking him by the hatud, ete., which would make it evilent te all comcernod that he wats the canse at the miraneluns enle. Aud ministered unto themlitorally, ats in lient texts, werted on him. The verb is explained on 4: 11, and the fipeck

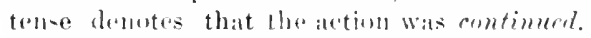
'Them," found in some wry documents, is "manifest asimilation to Mark and Iouke, where companions af . Irests are mentioned.

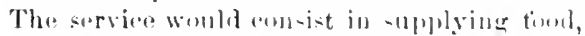
and any uther mexeled attumtions-il natural Way tor a womatn in her hume lo expres laer erratitude. Jeveme: "That hatmil ministereal, which had been temelod, amd hralded." (comp. Isuke 10: 41, where the simme werel is remderal "merving.') A severe timer Luke $1: 3 \mathrm{~m}$

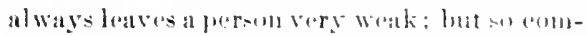

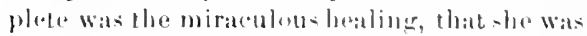
at ance prepared for acetivenextion. Hordsworth: "Tu the cave of l'hri-t's miracles, it was with disusesas with the ata. Itter the sorm there is a swall. before the siat sinlis inte a calm. But Christ reduced the fury of the sala by a word lo prertoet falm, as he did

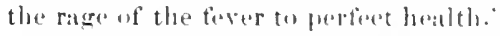

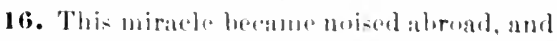
only deremened the impres-jon frombered by the easting wut of the une iesus spirit that same day in the synagugue. (Mark ] 21.za.) Sis that all the people became anxions to bring their demoniac or diseased trimels to seok like miraculous reliet. But the Jews were turs serupulous to do this on the sithluath day. When the even was come (eomp. 14: 15).
Luke get more detinitely, "when thes sun was setline.' 'Tho . lewish day was rechoned at: bregimine and endiug at sunset; so they came

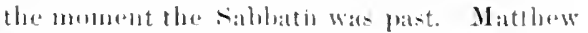
-igs mothing to show why they waited till evenine; be is simply throwing together n number ut miracles witheut griving all the

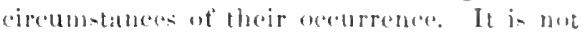
to be inforred that Jusle himself shared these seruples about healing on the sabbath, at thing which low had just dome (Mark and L,ulie). and ropeatedly did aftrowards. Possesend with devils, much leettere, demonires las in margin Rev. V(•r.), sre on v. 28 and $4: 21$. 'The Evangeli-t has alroaly mentioned in gerletral (4:a) that Je-lls healed all the demoniace that were brought to him during this riretut of Galidere. With his (a) word, just as he ball "with a word houled the eanturion's slave. (v. s.) All that were siek, ll gemeral expren

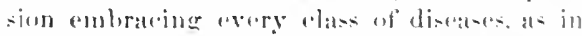
4: 24. Kitto: "The - Mu which hat sot upmo an expectant arowel at miserable creatures. arose unxt murning upun a city from which discase had flod." Our loord's miracles were very mumerome. Thaseparticularly descriled

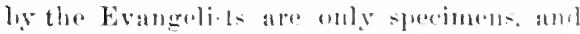
wa are repeatally told in passing. of hi- healing very mally jersolss and of usaluy disman. simply to read the statemento in $1: 24 ; 0: 2: 5:$

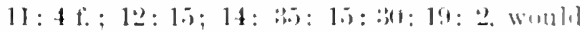
lua apt groally to andarge antes ideat of the ax-

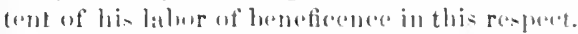

1\%. What it might be fulfiled. Thi naturally means that the events in quentiun bad luen actually predieted in the prophesy queted. and had taken place in the arrituse-

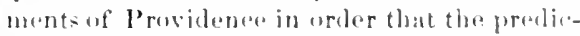
tion might he fulfilled. Siee on 1 : 20, the the particle rendered 'that' is not the samo howe

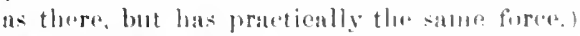
By Esaias.-Mure exutely throm!h, its in

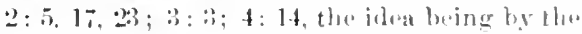
Lord thromeh the prophet. as fully expreased in $1: 22$; 2: 15. 'Isainh, instend of 'Esaia-' 
see on $1: 2$. It is only Matthew that here refers to the fulfilluent of a prediction, this being the sixth proplecy which he eites as being fultilled in J esus. (Comp. 1:23; 2:5, 15,$23 ; 4: 14$.) Himself took our infirmities and bare our sicknesses. The quotation is from Isia. 5is: 4, rendered in Com. Eng. Ver., "He hath borne our griefs and carried our sorrows.' The whole passage in Isaiah (52:13 to $33: 12)$ unquestionably refers to Christ's suffering for men as their substitute. (Comp. 1 Pet. 2:24.) There is thus ditticulty in perceiving the ground of the Evangelist's application of this prophecy to our Lord's healing diseases. The original of Istiah literally means 'Our diseases he took, and our pains he bore,' with slight emphasis both times on 'our' and 'he,' the word 'pains' comprising both bodily and mental distresses. As to the words, Matthew has thus exactly followed the Ifebrew (the hypothesis of his following an oral A ramic version is believed to be without adequate support), departing from the Sept., which here renders, "He bears our sins, and is pained about us." But how as to the meaning? Christ took upon himself, and thus took away from us, sin and all the distresses produced by sin. These distresses were divinely appointed punishments of sin, and we may suppose that but for Christ's atoning work, God's justice would not have allowed them to cease. For believers in Christ, diseates and various mental sufferings do indeed still continne, yet not as punishments, but to discipline them for theirgood. What our saviour suffired, in his life of humiliation and his death of agony, was not, as the prophet says men woukd think it was, the penalty uf wrongdoing on his nwn part, but was the taking on limself of our sin, and all our consequent woo. Of comrse he did not endure the precise and identienl sufferings, temporal or eterusl, which wo should othorwise have borne, but what he suffered in our stend inade it right that we shonld be rolined, to some extent even in this life, and eompletely in eternity, of all the consequences of our sins. His taking a way bollily diseases was thus not only a symbol (Meyer), but in some sonse a prat of his taking away sin. The matter may also be viewed ats Plumptre does: "He himself 'took' and 'bore' the suffirings which lhe removed. He suffered with those he saw sutler.
The power to heal was intinately connceted with the intensity of his sympatlyy, and so was followed (as analogous works of love are followed, in those who are most Christ-like in their lives), by weariness and physical exbaustion. What is related by St. Mark and St. Luke of our Lord's seeking out the refuge of solitude at the earliest dawn of the day that followed, is entirely in harmony with the view thus suggested."

\section{IIOMIETICAL AND PRACTICAL.}

V. $2 \mathrm{f}$. This suggests by analogy the need and the means of spiritual healing. Four questions as to our salvation : 1) Is Jesus ablè to save? 2) Is Jesus willing to save? 3) Do we need to be saved? 4) Do wo wish to be saved? Only the last question is really doubtful, and that depends on ourselves. $-V$. 4. Do not make loud professions of what christ has done tor you, but prove it by acting according to God's law. Schati remarks that it is possibie to make too much of the miracles-" "a kind of materialism, no less than the denial of the possibility ot such miracles."

V. $5 \mathrm{fr}$. The centurion. 1) His munificent gift to the people of (rod. (Luse $7: 5$. ) 2) His affectionate kinduess to a servint. (v. $6 ;$ Luke $7:$ :.) 8) II is poor opinion of himself. (v.8.) 4/ His great faith in Jesus. $(v .8,10$.$) 5) The exart and$ immediate answer to his petition. (v. :s.) - The three believing centurions. 1) This centurion at Capernam. 2) The centurion who had charge of the crucitixion (2t:54) 3) The centurion Cormelius. (Aets 10: 1.) - 1 deeply pions soldicr. HALL: "Even the bloody trade of war yieleded worthy cients to Christ."-Kinduess to : servant. HALL: "Had the master bcen sick, the faithful'st servant could have done no more. He is unworthy to be well served, thit will not sometimes wait upon his followers. Coneeits of inferiority may not breed in us a neglect of charitable offices. So must we look down upon our servant here on earth, as that we must still look up to our Master which is in haven." -V. 7. Developing faith. By refinsingall that was asked (15:24); 2) By offering more than was asked; 3) By granting just what was asked.-V. 8. It was no feigned humility with which the centurion spoke. He deeply folt himself unworthy of the presence and suciety of the Great Teacher. Yet the Jewish elders thought him worthy. (Luke 7 : 4.) 
is Now when Jesus saw greal nultitudes aboul him,

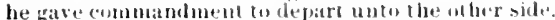

19 Ind a certain scrite e:tluc, and said ullu lim, Ifaster, I will follow thee whithersoever thon goest.

I i ir. ous acrithe..
19 Now when lesus saw great multitudes about him,

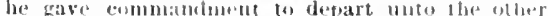
10 side. And there eatue d a seribe, atrl said unto him,

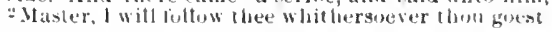

They who mo-t deserve the anteem of uthers are apt to have the humblest opinion of themolves; not because igmorant of ally excelleneies they may have attaind, but becatles more alecustomod to dwell an their faults, and more absorberl in the desire tor corsreet them. A man maly be comscinus of his puwers and attainments. may rejoice in his achicerements, may be pleased that men praise him, and at the same time be truly loumble, and full of gratitude to him who lats given it all. This is difficult for human weakluess, but so much the nure earnestly and prayerfully must it be solught. "What is thr fir-t thing in roligion? Humility. And what is the serent thing in religion? IImmility. And what is the thirt thing in religion? Homility."-HALL: "Nany a unc, it he hatel been in the centurion's anat, wouhl have thought woll of it; a captain, a man of gowel ability and command, a fomder of a sylligugles, a patron of religion; yet he orerlooks all thrse, and when he casts his aye upun the divino worth of Christ and his owo weakne-s, he silys, 'I am not worthy.' While be confesed himself unworthy of any faror, he atprowel himself" worthy of all." Enersileal: "Here was ane who was in the state leseribet in the first elallses of the Beatituthe and to whom eame the promise of the serend clanses; becallo Christ is the eommeting link between the. two." Gukrs.: "Forbecan-hemallohimwelf out unworthy esen to reseive Christ inte his house. he became worthy buth of a kingelom, and of nttaining unto these goul things which

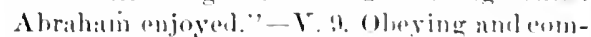
manding. 'It ite: "Ohthat l teruld be but such a servant to mine Heatiesaly Mater! Alas! every whe of his eommandis say. 'D, this,' and I do it not; every one of his inhibitions say, "Do it not, and I de it. He says, ' (io) from the world,' I run to it: he says, "Come to me.' I run from him. Wo is me! this is not service, but enmity." - Y. 10. Iest1: wonJering: 1) At the great faith of a beathen: 2) At the unbelief of his follow-townsmen. (Mark 6: 6.) Believing beathen still often shame those reared in Chrislian lands.

V. 15. What can we do for Jesus, who has dome so much for tls? We cannot now minister to him in the way of personal attention. hut 1) Weatn bring others to be his followers (John 1:41); 2) We ('sh mmister to his sulliering lirethren (25:w); :3) In general, we can show our love by keeping lis communlunents. (Johu 14: 15.)-V. 17. ATEAsM EY ER: "As a parable shows on arthly groumb the retiex of a higher truth, in order to serve at a means of explatung the latter, so a miracla which relieves an earthly puin is tha $-y$ mblol of the half within reach for a deeper need. Our Lorel eures the sick of the pralsy; but the first words of the narrative point most express y to a higher region. He gives sight to him that was lorn blime; Gut the concluding words of the history exclude the thought of a mere deest of compunsion."

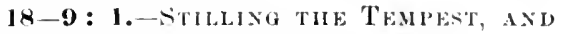

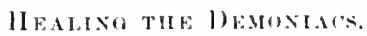

To tho miracles alreaty alduced see on $r$. 1). Matt. now adls two which are very remarkable. It is avident from Mark 4: and Lukes: 2.2 tt. . that they oceurred after the delivery of the farables in ehap. 18, and anparently in the evening of the same day on which these parables were deliveret. IItt. is giving a group of miracles in wap. 8 and 1.

18. Cireat multitudes, literally, many cromeds, as in 4: 2.; $8: 1$. ete. Unto the other side, $i$. r., of the Lake of (ralilee; literally, into the beyent. The region asst ot the lake and of the luwer Jordan wits commmonly ealled ly the Jews "Thes Perea, i. e., 'The Beyord (region), see on $4: 25$ and 19 : 1 . We cannot suplowe he sought eseape from personal annoyaneser discomfert. The fanatial axcitement of the people (chap. 12 and l: was ri-ing tow high (eomp. on 8: 4); them wis less upuortunity to du real gowd by his teachings when the erowl heame so grent at to pronluce confusion and disturbance; and in general, it was his plan te diftuse his labors throughout the country. Mark's phrase t: $35 \%$ "when the even was eome (onmp. Mult. Q: 16i). might imelude the lates afternoon (owe on 14 1.). It is thus not certain, though probshlo. that tho stormy pasesge was attor nightolill.

19. While they were preparing tw cruss the 
20 And Jesus sailh unto him, The fuxes have holes, and the birds of the air have nests; but the Son of wan hath not where to lay his head.
20 And Jesus saith unto him, 'The foxes have holes, and the birds of the heaven have nests; but the son

I Gr. Lodging-places.

lake, there oceurred the conversation mentioned in v. 19-22. Mark has no mention of this. Luke (9:57 fr) gives sinilar conversation as taking place at a much later period, on the final jumney from Galilee to Jerusalen, six months before the erucitixion. (see below, on 19: 1.) Perhaps our Lord Jepented these sayings, as he often did. (See Introduction to (hatp. 5.) Or it may be supposed that either Matthew or Luke has transposed these sayings from another time, as neither gives any distinct expression of connection. Aud a certain scribe came; literally, 'one seribe' (margin Rev. Ver.), perhaps designed to iutimate that, while most of Jesus' followers were men of private station and in humble life, here was one of the teachers, a Rabbi. But in many languages the numeral 'one' came at length to be used as what grammarians all the indetinite article; e. g., German ein; English an, a, from Angla-Saxon an, Scoteh ane; Freneh $m$, from Latin mus: and so in modern Greek; and it may be that we ought so to understand here (see Winer, p. $117[145]$ ), and in $19: 16 ; 21: 19$. There is a similar quention as to a few uses of the Ilebrew word for 'one.' As to the Scribes, see m 2: 4. Whithersoever thon goest, (comp). Rev. 14:4), not merely now, across the lake, but always and everywhere. This seribe was already in a broad, general sense, a 'diseiple" of Jesus-as is implied by 'another' in v. 21 -but wished to be one of his constant followers.

The varions words which the Common Tersion renders master are as follows: Furios, usually rendered 'Lurd,' whether as applied to God, to the master of a slave, or to any person in respectful address, equal te "Nir. (SHoe on v. 2.) It is rendered "master' in 6: $24 ; 15: 27$; and really signifies master in several passiges in which it is rendered 'I Iord, as in 18: 25 ff.; 24: $45 \mathrm{ff}$; 25: 18. Dexpotes, strictly the master of a slave, and rendered by that term in 1 Tin. $6: 1 \mathrm{f}$, etc., is not found in the Gospels. Rabbi, origimally signifying a superior ( $r a b$, 'gruat,' like magister from mag-nes.), was the common .Jewish word for a teacher. It was primarily my rab, 'ny teacher,' used only in adalressing him, but afterwards also in speaking of him, like Monsieur, Momsignore. A strongthened form was labboni, expressing the profoundest respect. (Mark $10: 51$; Jobn $20: 16$.) It is frequently retained witbout translation, but is by Com. Ter. rendered 'master' in 24: 25, 49. (Rev. Ter., Rabbi.) Epistates, literally, 'one set over,' variously used in the classies, in New Test. always a teacher, and found only in Luke. (5:5,etc) Huthegetes, leader, guide, instruetor, only in $23:$ 10. Dirlastatos, literally and strictly teacher, is so rendered in John 3: 2, and wherever it is used in Aets and the Epistles (except James 3: 1, 'masters'), and rendered 'doctor' (a Litin worl, meaning teaber) in Luke 2: 46. Everywhere else in the Gospels the Com. Ver. renders it 'master,' used like schoolmaster. In the Gospels 'master' always represents some word denoting a 'teacher,' excejt in 6: 24; 15: 27; Mark 13: 35; Luke 14: 21; 16: 13. In like manner our missionaries among the heathen are constantly addressed by the people as "Teacher."

20. 'The birds of the air, or heaven, as in 6: 26. Nests should be habitations or 'haunts,' the word meaning simply a dwelling-place (Rev. Ver., margin); and nests being actually oecupied only during incubation. The birds that fly froe and wide in the hearen have some rogular place to which they come to spend the night. A kindred verl, in 13: 22 is rendered 'lodge.' Various Fathers wildly allegorize the foxes and the birds (see Aquinas, Cat. Aur.). Hath not where to Iny his head, $i$. e., no fixed habitation. It does not so nuch dinote extreme poverty and discomfort, as the fact that his life was a wandering one. He had friends, at whose houses he was always welcome, and bospitality was often tenderud him by others. But frecuently journeying far aud wide over the eountry, even as now he was abont to cross the lake into a wild, inhospitable region, his life was che of peenliar trial and selt-denying toil. and if the scribe proposed to follow him wherever he went, he must make up his mind to follow a homeless wanderer, and so to 
21 Aml another of his disciples said unts him, ford, suff.r we first lo go and bury my laller.

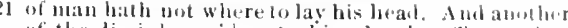
of the disciples stidl unto him, logrl, sutler me lirat andure many latalships. Euthymins (ammp.

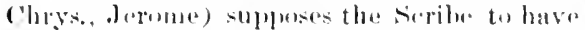
thought that larese bay was recetivel fior the miralles ut healing, which we know that Jesus told the Twelve they mu-t purform gratis. $(10 ; 8$.$) More likely the seribre wats$ thinling of a temporal Mes-ianie rejgn, with which the touchor was somehow combected, and which would hring its sulgject- jowere and walth. We on from this incident how eareful anr lerel was to warn men betoleleband what they wereto expect in entoringupun his

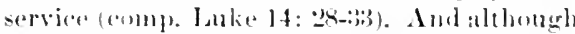
it is mot now the duty of all his followersets spend their lives in wanderiner labors, it is still the duty of every une to "renounce himsett", and take up his crose," and in the highest stense to "fillow" Jesus. II" alle not intormetl whether the seribe determined, notwithetandinge the warning he had recoived, thut lac would still follow the Talcher: alle would hope that ho did, and would rather infor so from the Erangelist s silonere soroing

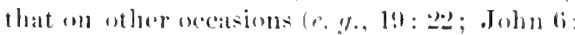
(ifi) the turuing bate of various apparent diseiples is distinctly conorded; also from tho aserebiation with the peren next mentioned. Expestors have perliaps beren severe in their judemont, in taking it for gramted that the feribes motives wore mereenary, and that

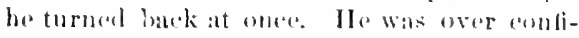
dent, and the kind Fenelere warned him to enunt the enst. The son of mum. This remarkable expression was no denlet fommeled on I):n. i: li, " I saw in tho night visions, and bohold, there ame with the elomels of heaven one like unte a soll of mun," Rave. Vere, a pasage which the .Jowish writors ngree in roferring to the Masiah. The socalled "Bomk of Enoch" frequently spreaks of the coming Me-iab ats the sion of man. We learn from. John les: is that the Jews understemel thispler:ase tomoan the Mesiah a and

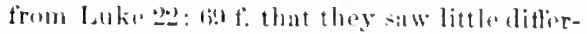
ence betweren olling bim the sion of man and the som af fiod. ()ur Lord's freffuent us of the phraso (more than seventy times) anstitutes an oft-ropeatud claim to be the Mesial)

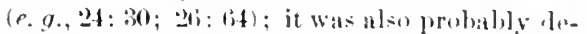
signed to render prominent the great fuet that ho was genuincly and thoroughly a mmn, a fact which belingers in his divinity sometimen fiul

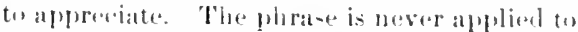
him hy any other than himselt, except m. Ict 7: iti, nul perhates in Rev. 1: 1:3; 14: 14. 1. the Ilaterew phrase ariginally sugeresed humatu foahlantos and frailty (ats ill l'sa. 8: 4 ;

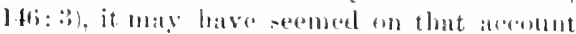
less apyrupriate to the now exalted atol glorjfied licelemer. The many attemptstorexpian

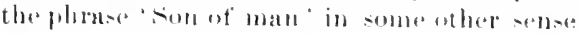
than as dunuting the Mesials, ure well stated and briefly retiuted in Mteyes.

21. And another of his disciples. Buth he and the sicribe mu-t hate been diseiples anly in the wider sense at the term (astent) a) 1). Tyodale and Geneva trans-late " amother that was ane of his tisciples," thus axchuling the sirerbe, but that is a firened rendering. Theres is a tradition (clem. Alex.) that this second man was the aposte Philip, but we have no means of deciding. Comjere

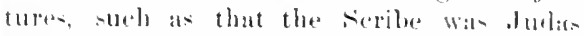
Iscalliot and the uther Thomas (Lamen). or that they Wore Thomats and Fimon Kalutes (Keim). are-imply ille. Why will ammen-

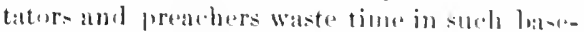

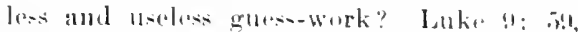

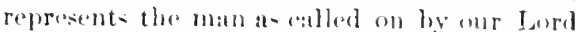
w follow him, and replying with tha repuest that he might tirst go and bury his father: Matthew does not mentions such a call. The mans serguest pertained to a matter which tha

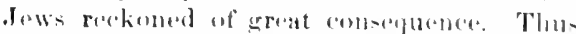
in Tobit di: 1.j, Tobias laars that he will dia and be thre deatle at his patents, and sils. "thry have no whlor som to lury torem." It is natural to suppose, that this matrs father was already dead, and it was the allstum to bury tho dead very smon; lut it was also alle-

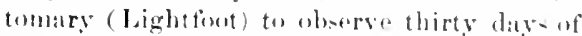

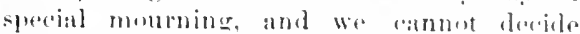
whather the man meant to include that time. Elishas somewhat similar reopuet ut Elijab was not druicul (1 Kings 19:20): and tho Inath might well have thunght himself ju-tifiol in asking loave to go home first. Yiet a higllpriest or a Nizirita was required by the law to

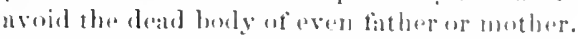
(Lev. 21:11: Num.6.68) : and one at the lat to. Jewisly commentaries says (IV (ot.) that "when the study of the law and the necessity of burying 
22 But Jesus sairl unto him, Follow me; and let the deal bury their dean.

20 Ant when he was entered into a shiph, his diseiples followed him.

24 And, bholit, there arose a great tempest in the sea, insomuch that the ship was covered with the waves: but be was asleep.

the dead eonflict, care of the dead takes precedence ; hut that if there is at sufficient number of prerons in attendance, the student must not lealve the law." $r$. 22. Let the dead bury, or, as in Rev. Ver., Leave the dead to bury (s) Darby, Davirlson), the Greek being stronger than let the lead bury.' To bury their (own) dead. This camnot nean let the dead bury eath other, $i$. e., let them remain unburied, for that is a forced explanation and an idea unworthy of our Lord. We must understand the dead spritually and the dead literally, ats in Rev. 3: 1. (Comp. John 11: 25 f.) Such a play upon worls is natural and platang to the Oriental mind, and different forms of it oceur frequently in seripture, including many jassages where it cannot be prearved in translation. (Comp. on 16: 25.) The idea bere is that there were enough of those who were spiritually dead to pertorm all the offices ot atfection to the dead, and so Chrint's followers were at liberty to devote themselves to their own far higher work. ('omp. 10:87.) In Luke's aceount (9:60, rib. ('u. ver.), we have the addition, 'but go thou and announce the kingdom of God.' It does not follow that Jesus would require all his followers, undor all cireumstances, to neglect the hurial of their dead, in order that they might work exelusively at spreading the gos$\mathrm{fe}^{\mathrm{e}}$; any more than he extends to every one the command latid upon the rich young ruler, to sell all he had and give to the poor. (19:21.) But we can eavily eneeive of circumstances now, in which it would be propere to hold in aleyance the stromerest promptings of natural aflection, in order to do our duty to Jesuls; ju-t as a soldier may see his bother fall at his side in at charge, and yot sometimes camot paluse to are for him, but must ru-h on. Their own dead. In Gen. 23: 4, 6 we have the expressions 'my dead, 'thy dead,' and similar expressions are enmmon now. So Jrous means toray that the dead in such a ease
22 to go and loury my father. But Jenus saith unto him, Follow me; ind leave the dead to bury their owin dead.

23 And when he was entered into a hoat, his disciples 24 followed him. And hebold, there arose a great tempest in the sea, insomueh that the boat was

are not yours, but belong to the spiritually dead, and should be buried by them. Here, as in v. 20, we are not inforned whether the man at once followed Jesus, but it would seem probable that he did. Luke 9: $60 \mathrm{f}$, adds a third ease.

23. Miracle of śtilling the Thupest (v. 23-25.) Comp. Mark 4: 36 ff.; Lulie 8: 22 ff. Into a ship 1-or, the boat, probably a boat suited to fishing, and without sails (sere on 4 : 21). It is called 'the boat,' must likely an being the one prepared in pursuance of his order to go ateruss (v. 18); perhaps it was at boit kept fir their regular use. We ought to translate 'boat' and not 'ship.' See on 4: 21. IIis disciples followed him, some in the same boat, and others in additional boats mentioned by Iark. ( $4: 36$.$) These little fishing craft were$ very numerous on the lake. (John6:23f.) The 'dieciples' arr most naturally understood here at ineluding not merely the Twelve (who as shown by the order of Mark and Luke had been selected lefore this time but others of his followers, who could be ealled discijles in the wore general sense of the term. (Nee on $5: 1$.

24. And, behold, an expresion much used by Matthew in calling attention to what follows as wonderful. Tempest. The word in the original denutes a sluking or shock, and is usually applied to an earthruatke, both in the classical writers and in the New Test. (e.g., $24: 7 ; 27: 54 ; 28: 2$ ), but liere used for a mighty storm, such as would shake men's dwellings, and seem to make the very earth tremble. Luke $(8: 23)$ tells us yet more distinctly, "and there came down a storm (another and more common word) of wind "1pon the lake,' riz., down the ravines on its sides, as often hapuens see description ot the lake ou 4:18). Bartlett witnessed a precisely similar oecurrence: "All the day there had uot been a breath of air, the sultry heat had been that of a furnace; but now a cool breeze 


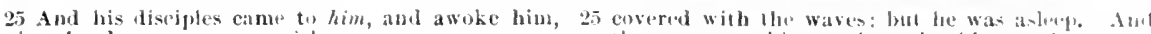
saying, loril, save us: We jerish.

26 And he sath und them, Why are ve learlul, ofe

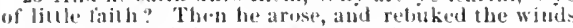
and the sea; and there was a great ealu.

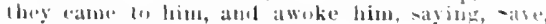

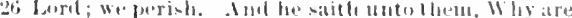

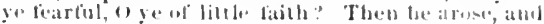
rebuked lihe wimls and the seap and lliere was a

eane off thi: table land, and ru-hing down the ravines that leseend to the lake, begate to rufle its placid busem. Is it gresw darker,

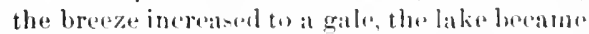
a sheet of foum, and the white-healed breakers darbal promlly on the rugged bealeh; it: genthe murmur has now elounged intu the wild and mournful sound of the whistling wind and the agitatial waters. Afar otl was dimly sorell a little barque strugerliner with the waves, and then lint sight of amidet the mity rack." 1 the lake is far beluw the level of the Mediterranean, the air i., often wreatly herated and ascends rapilly: and inte the vaeuum eome: rushing down the end at from the eatern nad we-tern table lands. - Thomson.) The ship-bont-was covered, or, 'was becoming coverell.' the form of the Greek verbdenotine an action in progress: so nlso in Mark (4:37), atud Lulie (8:23.) lBnt he was asleep-serping-the (ireek indicating some emphasis an 'be,' i. r. he, for hi-part. Mark. Whosonten gives pinpant detail- adds "on the eushion," $i$. e. the one they bat in the boat, at a part ot the enduch in the stern on which he wat lying. This makes a pieture: I esus seeping with his heal on the cushion, while the storn howled. the boat was tosicel to and fro, the billows brokeoverand were rapilly filling it-soundly and quietly sleeping. The uder of Mark and Lake make it appear that this was on the evening which forlowed the bla-phemens atecusation of chapter l: athd the erreat errolup of

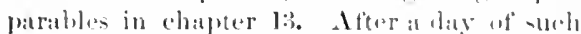

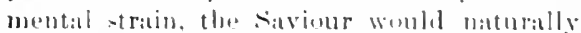
be exhatu-ted. P'rubably alst it wits nights. (bive (1) v. 18.)

25. 'The disciples-or, they-eame. "IIis disciples' wats an unberensary andition of the copyists. So with us : read sole, lourd, we perish. Mark (t:3*) has literally. "Tomeher" (dideskalos); Lake (8:24) hats "Mn-ter, matuter" (epistates), see en $x$. 1!1. It is often prident that the Evangelists have" not undertaken to give the exict words used. (stee on :3: 17.) The peril must have been really very grent: "for these men exereised to the sea inany of them from their routh, and familiar with all the ehathgen of that lake, would not latve benen teritient by the mere shadow ot a dinger." -

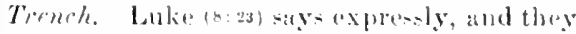
"wore in jonparely." "sive" here of couret means save our lives, not referring to the salvation of the soul. If the language is by us applied to the latter, it is very approprate. but anch alpulication is made on onr own autlurity.

26. Why are ye feartinl, mure exatetly, coneratly, which axpresens the force of the Greek term acourding to it wee in the elaseies and in the septangint. In the New Test. it is fouml ouly here includine Mark t: fol aml in Rev. 21 : 8, or limdred form in 2.Tim, 1:

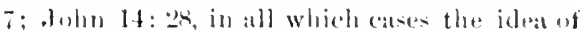
unworthy and discreditable fentr is appropriate. O ye of little tath, sece on ti: Fath, makes men entragents, and the disriphe weredi-comlitally timid, cowardly, be-

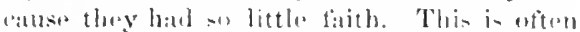

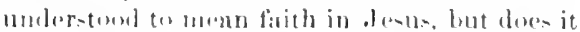
nut rather meatl at lack of faith in the providence of God their llancenly Futher, as in ti: :3? Then he ingere and robuled. Il, fir-t reblied the disciples while till lying on tha couth, and afterwards aren abul rebulad the winds and the seat. This expres-ion in-

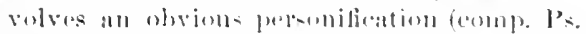

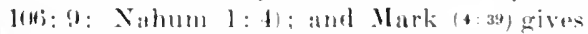

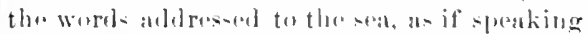
(1) a dereron, or tor work might be rendered Be silant. hush'; but the latter word is literally" la mazzled, applieables to a furion- beatet. A great calu,

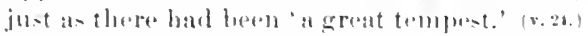
Herewas "a greater than oluald." (12 41.) Hew perfordy wa the saviour's humanty maniferted exen when he expreised more than buman power. Weariand, in berly and in mind, by his babure during the day ane on 18: 1), he is sleeping on the roshion: the next moment he rises, and sponks to the winds and the watres with the volope of thejr Creatur. Sir he wept in human rympathy with the sisters of Latzarus, ju-t buthe he spoke the word that brought him to life. 
27 But the men marvelled, saying, What manner of uan is this, that even the winds and the sea obey him!

2x And when he was enme to the other side into the cruntry of the liergesenes, there met hin two possessed with devils, coming ont of the tombs, exceteling fierce, so that no man might pass by that way.
27 great ealiu. And the men marvelled, saying, What manner of man is this, that even the winds and the sea obey him?

28 And when he was come to the other side into the country of the traditenes, there met him two l possessed with demons, conning forth out of the tombs, exeeteling tierce, so that no man could yass by that

1 Or, demoniacs

27. And the men marvelled. "The men' is a general term for tle persons present, ineluding such as were disciples (comp. 14: 39), and also very possibly some men employed in the boats. (Mark $4: 36$.) That even the winds and the sea obey him, a thing they had not previously witnessed, which would thereforesesm so them nore remarkable than that diseases obuyed him. Doubtless also this would epecially strike men whose lives had been spent as salors and fishermen, and who had sontten seen exhibited the terrible power of the storny sea. Sticr: "This empire over" nature is a new thing which Matthew has to record concerning Jesus. His narrative of selected mirales in chapters eight and nine rises through a gradation of importance; +leansing of the leper (a great thing even to begin with)-healing ata distance by his word, 'Be it lone'-commanding the wind and the sea-saying to the devils 'gu'-forgiving the sins of the paralytic (more indeed than saying arise! or, go hence! more than ruling the sea -finally giving life to the dead."

28. Healing of the two demoniacs. (8: 2x 109:1.) Comp. Mark 5: 1-21; Luke 8: 26-40. If the preceding miracle shows our Lord's command of the forees of mature, that which follows exhibits his power over avil spirits. Trench: "And Christ will do here a yot mightier work than that which he accomplished there; he will prove himselt here also the Prince of paree, the bringer back of the lost harmony; he will speak, and at his potent word this madder strite, this blinder rage which is in the heart of men, will allay it-elf; and hero also there shall be a gratit ":1m." Theophyl.: "While the men in the boat are douloting what manner of manthis is, that "von the winds and the sea wey him, the demons come to tell them."

ro the other side, viz., of the lake, as in

1 This suggestion is supported by tho statement of Thomson (part II, ch, 25) that when he anked the bedwin for Gergesa, lhey invariably satit it was at fiesal (or Khersa), seeming to pronounce the words alike. v. 18. The point reached was below the middle of the lake; and as they bad probably come from the vieinity of Capernaum, the voyage would be eight or ten miles. Into the country of the Gergesenes. The text of this and the parallel passages (Mark 5: 1; Tube $8: 26)$ is greatly confund, some documents for each of the three passages reading each of the three wurds, Gadarenus, Gerasenes, Gergesenes. The best doemments, however, give Gadarenes in Matthew, and Gerasenes in Mark and Luke. Thomson, Vol. I I. P. 9,5-5, fomnd a village alled Gersa, about the middle of the astern shore, with aneient trmbs in the adjacent mountain, and near the village found a steep place exactly suiting the story of the swine. So also Wilson, MrGarvey, and Merrill. We thus aceonnt for the name Gepasenes (ntirely apart from the large city of Gerasa, which was some thirty miles away. Gadara was a well-known city lying a few miles southeast of the lake, the ruins of which are still extensive and striking. Thecountryimmediately around a city usually belonged to it, and was called by its name; we lave ouly to make the very natural supuosition that the village of Gerasa (Khersa) belonged to the territory of Gadara, and we see how the people may be called both Gerasenes and Gadarenes. The name Gergesenes, which might be introduced by students or copyists, is thouglit by some to have arisen from the Girgashites. (Geo. 10: 16; Deut. $7: 1$; Joshu: 3:10) Origen says there was a city ealled Gergesa near the lake, and Euseb. ("Onom.") says the same, but may" have derivel it from Origen. The form Gergesa may pussibly have been merely a different promounciation of Gerasa, the $r$ of the latter taking a ratting, guttural sound like that of the strong Ayin, which in modern Arabie sounts much like our rg. ${ }^{\prime}$ But lowever that may ba, the genuine names Gadarenes nnd

But Thomson omits this statement in ed. 2. Experts in Arabie visiting the lake ought to determine bow the Bedwin really promounee the name of the ruins. Eusebius ("Onom." ed. Lagarde, p. 242) remarks that Ger- 
employing popular phraseology without en- sions are to be received as a reality. And thus dorsing it; as when Sicripture writers speak regarded they are not only wonderful, but inof the sun as rising, standing still, ete. And if Jesus addreses the spirit, bidding it come out, ete., he is supposed to be merely humoring the funcy of the deranged person in order to cure him. But if the belief in demoniacal posesnions was erroneons, how far-reaching was that error, and how important, especially in that age of great superstition. As to humoring, ete, the wisest authorities upon the treatment of the insane now saly that that is not the best conrse; they do not eontraliet so as to (xasperate, but neither do they eonfirm in delunive fancies-they try to divert attention. Thus we should have Jesus adopting a very questionable mode of treatment, which would encourage a most injurious error, when he was able to heal in any way he pleaserl. Sien too (Treneh), how distinctly false his sayings would become. We speak of lunatics, using the popular term without meaning to endorse the idea in which it had its origin, that such persons are powerfully affected by the moon (in Latin luna); but suppore one addressing the moon, bidding it cease troubling the man, ete., that would be fillwhood ; and in our Lord's case such gratuitous deception is incredible. (3) Why should these poswessions occur only about the time of our Lord's sojourn upon the earth? It is not alsolutely cortain that they do not always exist; and mare uneertainty on that point de-troys the force of the objection, as an objection. But we can see a resson why they should oecur only then; or should then be mercially manifesterl and recongized. The Eternal Word was then manifesting himself in the flesh; and thus tha great st ruggle whieh is always going on was brought out into visible appearance, so ac to exhibit in a visible and striking way the ahoolute powerlessness of the evil spirits to enntend against God. (Comp. at the begiuning of chap. 4, as to the appearance of satan in bolily form.) (4) The thing itself is so hard to understand. But this might be expeeted in such as subject. And ean wo understand the union of the divine and human nature in the person of . Jesus; the action of the Holy spirit on the human spirit; or the conncetion of our own mind and body? Yet nome the lese are all those facts.

It alpears then that the demoniaeal possesstructive. The expulsion of the evil spirits by Jesus and his apostles, was a signal exhibition of the beneficent character of the gospel and of the Saviour; a striking proof of his divine mission; and an impressive manifestation of that victory over Satan by our Lord, which is real already, and shall in lue time be complete. Finally, we thus vindicate as correct the plain, obvious meaning of Seripture statements, which, seeing that the Scriptures were written for the people, is a matter of great inportance. - The Gospel of John does not mention the casting out of demons by Jesus (thongh it refers to the popular belief in temoniacal possessions, John 7: 20; 8: 48-52; 10 : 20 f.). But we must remember that $J o h n$ mentions very few incidents of our siviour's ministry, usually such only as formed the oecasion of some remarkable discourse. Demoniacal possessions are not mentioned in the Olat Test. nor the Apocrypha, nor (Edersheim) in the Mishna, yet are repeatedly mentioned in Josephus ("Ant.," 6, 8, 2; 6, 11, 3; 8, 2.5; "War," 7, 6, 3). But the popular Jewish vipws were quite different from those of the New Test. (Edersh. App. XVI.) (As to 'devil' and 'demon,' see below on v. 31.)

Coming ont of the tombs. Driven from the town by the fears of the people or by their own frenzy, the poor demoniaes would find the caves, or chambers hewn in the rock, and appropriated to the dead, a convenient and perhaps congenial abode; though no Jew in his right mind would dwell in a tomb, which would make him in the ceremonial sense perpetually unclean. Such rocky tombs still abound in the mountains lying east of the southern part of the lake. Luke (s:27) seems in Com. Ver. to contradict Matthew s statement, saying, "There met him out of the city a certain man.' but the correct rendering of Luke is, "there met him a rertain man out of the city,' viz., a man who was a citizen of the eity. So that no man might pass by that way, viz., along the road that passed near the tombs, and led from the place at which the boat had landed towards the city. The unfortunate men had first rushed forth to meet Jesus and his followers, precisely as they had often done to others who eame along the road. Mark and Luke give many addi- 


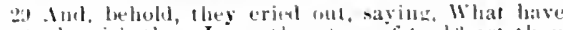

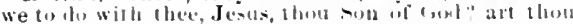

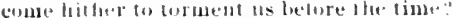

(3) Allithere was a geond way oull trom the'ma a berd of tuatuy switte leceding.

31 - in late derils leevought him, saving, If thou cast us out, sutfer us to gu away inte the berd of swinc.
29 way. And liehold, they friod ant. saying. What

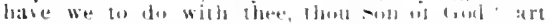

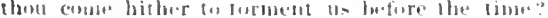
30 Xow there wav aliar ont frobs them a heral of many

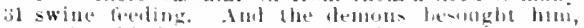

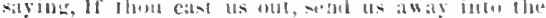
3:2 heril of swile. Amal he satid unte them, in. And timal particular conernine the more con-

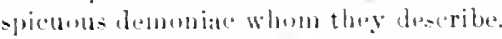

29. And, behold, calling spereial attention, a- in v. 24. :3. :34, and very wifen in Matthew. What have we to do with thee, literally, "What is theres to us and thep, a phrase findud in IItorew, Gresk, and Latin (Buttur., l. 23s), and which obsinusly means, what have we in contumbll what have we to do with eateh uller? It woull express arererebuke

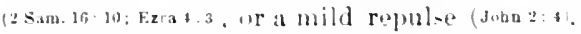
aceorling to the cireunstanees. the relation of the parties. and the latanter of utterance. Yhou son of cod. Tha name lexus was wromgly inserted here in many ducuments, by way ot asinilation to Mark and Luke. It is evilent that the men spoke what the evil spirit-thought and tislt. We canmont determine just how mueh these dark being did feel. It is likely that they very imperfectly under-tunl what was involved in calling Jrsu- the sinl of fiod; and the same was probably trae ot sotan, their chibet (comble on 4:3). Mark (3:11: decelares this ta-timuny (1) have benes griven in all anses. but he may be rofierring only to a particular periond of our lord - ministry. To torment us before the lime. The warl rendered 'time" means 'oceasion," stuson," ete. (see un 11 : 2.) The evil spirits wore persuatid that a wirse torment thatu they had ever amdured awated them at some future preriml, and they shrank from the thumght that the son of Gol might be about to intliet such alererabed torment by antieifation. We are toid in Jucle of that this future aceatsion is "the julgment of the great day." after which time sitaln and his anents "shall be tormented diy nod night tirroger and ever." (Rev 20:10.1-There aro-triking cuntralietions in the comduct of the demmiats: they came

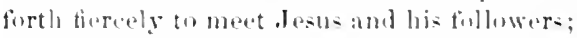
as they drew near they ran and wornhipped him" ( $\mathrm{x}, \mathrm{rk} 5: 6)$; and now they speat words of dreat and dislike. Sueh self-untralietions. such sudden changes ot feeling. Would seem pertiocty natural for one posaend by an evil spirit: at one moment he exprases his own feeling of distres and meed, at amother he - peaks fir the treadtul being who oceupies and contrul- him.

30. A good-long-way from them, the -ime Grock term as in latie 1.): 20 and Aets 2.3: 2.l. Thendd Latin and the Vul, ate, folhwed af course by Myelit and Rheims. have

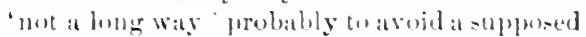
condlet with II:ark s: 11) and Luke - 32 , who say 'there wal there a loud, ete. Tyndale and his followers, aceostomed to reacl the Vulgate, seen to have had the sume tear, so that while following the Grete in omitting 'not' they get softened the expresion into 'a good way. but "a long way" is olwinu-ly a relative exprenion, signifying a greater ir less distance aceurdiner as eireumstances. Matthew apparently wi-lod to show that the lierd was tom far utf to be frightened liy the dumuniacs. Absuml as such a fincy might seem thre have not been wating "rationalists " of recent timestaraly that the "maniales" ran in among the herd, and terrified them into at stampede (sose even Ewaldi: or that the comvalsims and eries attemelant upmetheir healing had that etfoet. Mark and Luke simply tall us that the hard was there. without saying that it was mear or fitr awal ; and Murk, aceoreling to his en-tum of griving descriptive detail- alds " near the mombtatin." that is, the mountain range which runs along near the eaternste of the lake. Sea an 4 : 18.) A herd of many swine. Mark says they were about two themsind."

31. And the devils demomst besonght him. The word devil' (a+e ont: 1 ) is a romtraction of diabulos. the Greseli natume ot lijm who is in the 1Jubrow called sitall. This Groek word is applited in sereipture only to satan. neverto hi-saburdinates. whe are described by daimon. from whieh we derive demon. demoniac, ete. or daimumion. a diminutive form with equivalent meaning. The term 'Alevil' has heome tomiliarta English $\|$ age as denoting aither sitan or we we his-ubrominates. and the English R+uinersent 1Sil were unwilling to abandon it: while the American lievers preferred 'demon,' which 
32 And he said unto then, Go. And when they were eome unt, lhey went into the herd of swise: and, lehold, the whine lerd ol swine ran violently down a stee place jutn the sea, and perished in llat waters.

3if And they that kept them flod, and went their ways into the eily, and tohe every thing, and what was belallen lo the posessed ot the devils.

i3 And, bethold, the whole city eame out to meet they cane out, and went into the swine: and behold the whole lied rushed down the steep into the seat 3i) and perished in the waters. Aud they that ted them fled, and went away into the eit $y$, and told trery thing, and what was betallen to them that $3 t$ were ${ }^{1}$ possessed with demons. And helold, all the eity eame out to meet Jesus: and when they saw

I Ur, demoniacs.

is cortainly much better; for sometimes it is impurtant to distinguish between the two words. Matthew speaks of the demons withmut intimating whether there weresimply two, one in each possessed person, or more. Mark and Luka saly that the more comspicuous person declared himself possessed hy a legion of demons, and the full Roman legion of that fay amounted to six thousand men. The correct reading here is not suffer us to go away, restmbling Luke 8: 82 , but send us away, resembling Mark 5: 12.

3:2. Go-or, go along-'away with you,' the sanne word as in $4: 10 ; 5: 24,41 ; 8: 4,13$. The whole herd. Some copyists made the useless addition 'of swine.' A steep place, literally, the precipice-i. e., the one leading froth the jlain on which they were feeding, into the sait. And perished. The word is really 'died' (so Geneva, Rheims, Darby, Davidson), and there was never anything gained by substituting Tyndale's 'perished.' Swine are extromely averse to entering deep water, and require to be fureed into it; so there could be no mistake here as to the eause. The fact that irrational animals were thus possessed by the evil spirits shows that the possession of man eamnot have been merely a matter of imagrination or insanity. (See on v. 28.)

The question has often been raived, IIow was it riglut for our Lord to destroy so mueh valuable property? We need not have recourse to the supposition that the owners were Jews, whom the law forbade to a sat swine and the sicribe forlade to keep them, and that so their property was conficated. It is enough to saly that the saviour was acting in the "xpreise of Thivine Soreroignty. Stier: "The question why our Lard fremitted the demons to (nter tho swine, is alrealy answered loy another quastion - Why had the Lord permitted them to enter the men?" Godet: "It is one of those cates in which the purer, by its very nature, guarantees the riglit." All the other miracles of Jesus, save this, and the destruction of the fig-tree (see on 21: 19), were purely beneficent in their character and tendeney. Moreover the important lessons we may learn from this extraordinary oceurrence, the light it sheds on the reality of demoniacal possessions, will amply aecount for the destruction of property.

It has also been inquired why the demons, after earnestly begging permission to take refuge in the swine, should immediately cause them to destroy themselves. It may be supposed that in their malignity they took delight in doing any harm, even destroying property. Theoplyylact and Euthymius think they wished to destroy the swine for the purpose of prejudicing the owners against Jesus-a result which actually followed.

33. And they that kept-i.e., fed-them. The word is rendered 'feed' in the parallel passages of Mark and Luke, and evorywere c]se in the New Test., and it was very little worth while fur the King James Version, in its passion firr variety (and following Great Bible) to employ here another word, 'kept.' Went their ways into the city, viz., Gerasa (Khersa, see on v. 28.) And tuld crery thiug, and what was befallell, pic. -litelally, and the (things) of the demomized, what hat happened to them. The first thing reluetantly told would be the less of the swine, the rest being secondary in the view of the swine-herds.

34. And, behold, for this too was wollderful. (Comp. צ. 24, 29,82.) The whole city, an olvious and natural hyperbula, such as we frequantly employ. (Comp. or, 3:5.) Luke $(8: 34,3 i)$ adds that the swine-herds had carried the news, not only inte the city, but into the fouds, and that all the multiude of the surroumding country of the Girasenes came forth. That he would depart ${ }^{1}$ out

1 This is a nonfinal use of hopos, corresunding to a common New Test. use of hina (see on 5 : 29 , and found in Homer (Coodwin's "Moods and Tenses.") 
Iesus: and when they saw lim, they besought him thar he winld depart ont of their colasts.

Nol he thlered into a ohip, and passed over, and 1 came into his own eity.

w their coasts. 'From' and not 'out "it," sece oll 3: 16. "Burders' rither than

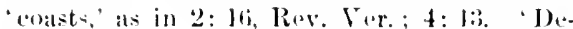
gart' is not the word eommonly thus ren dered, but signifies literally, to remuse, transfirr onesult. Why did they wish him to bave? Partly, no loubt, because their proparty bad heen destroyed, and they feareal uther losses, parly also (soce alraady Theod. Maps, Jermue, in Cat.), beatuse their tolls.ipner was aroused by such an exhibition ot divine power, and ennselous of guilt they felt uneasy in his presence. Compare the foelings of Peter attor the miraculaus araught at lishes (Lukes: ), and eontrast the ennduct of the samaritan-of sivelat. (John 1:40.) While meekly retiring at the request of the frightened penple, he left them aflicient teachers in the men who hat beren dinpossessud (lukes: 38 r.); and he afterwards revisited their comatry. (1.5: 29.) - Thi- inirache forms the most instruetive and impresive intumer of demminiat prisession found in tha (xopels. The whole seene appears befure us with a vivid and terrible reality.

Ch. 9: 1. This sentence is tha end of the narrative beginning with s: 18, and should by all means have tornsed a part of the preceding

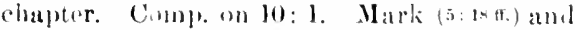
Lule (8:3*r.) relate that whan .Jesis had entered the boat, the man who hat been doliv(2red begred to go with him, hut was sulut back totell what God had done for him. (cimmp. on 8: 4.) Passed over, and came into his own city, viz., (ajeruamm. (seeson 4 : 1i.) ('hrys, remarks (cat.), " For Buthlehem lure him, Nazareth reareil him, Catperman wats his resiclence."

\section{HOMILETIOAL AND PRIOTICAL}

V. Igt: Theseribe: 1) Willing, (a) to ane (ept the teschings of Josus, (b) to sharo his fortunes. 2) Wirmenl, to comut the eost of following him; (comp. Lulie 14: 28-33: 3) Wront on, nutwithisumbing. So let us suppose he did, and so let usdo.- Ministersand chupdes ought to mote the Savionr's oxample in rean rel to this seribe, and dectaro platinly to all who propose to be his followers, what if i- they are undertaking. In dealing with a seribe, with him, they lesouglat him that be would depart from llecir borilers.

1 And he entered info a boat, and crossed over, and any p+r-son af superior eultivation and position, we ar. in danerer of ton ratily takiner for gramted that he molerstands the whole mater. Ryes: "Nothing has done more harme lo Christianity than the partice of tilling the ranks of' christ's aruy with every bulunterer who is willing to makir a little protiesion, and talk fluently ot hi. experience." strek: " Vushing was less atmenl at by unr Lurd than (1) have followers, nuless they wele gromuine and somml; lue is as fitr from desiring this as it would have beren casy to attain it." - V. 20. Jesus the wambloring misionary- V. 2l fo. Evouthestromeret natural feelings mu-t sometimes grive way to Cleristian duties. Even sacred matural duties may have to be diseregareled tor Chriat's salie. How much lessthen should any ardinary matters turn las away from spiritual thoughts or aletivitios. W11Eoplist.: "Wra must homer our parents, but

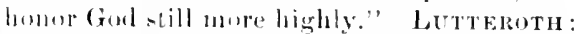

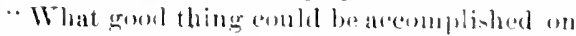

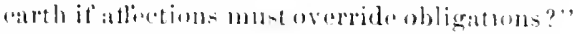
Hexlex: "An unwilling mind never latelis an excuse. Many are hindered from and in the

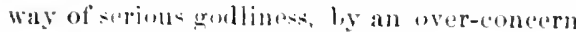
for their fandilies and relations."

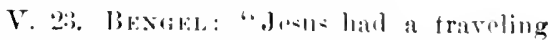
school; and in that selumel the disciples were much more solidly instruated thun it they had lived under a collego rouf without any anxiety and temptation." - V. "2l. Contrast Jisus and Iomah sleeping anid a storm. C'msYs.: "Their very alarm was a protitable oenenrrenere. that the miracle might apluar greater, and their remembrance of the prent be ren-

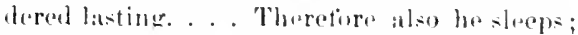
for had loe heon awatio when it happened, rither ther would mot have tiared, or they would not have besemeht him, or they would

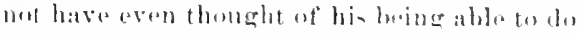

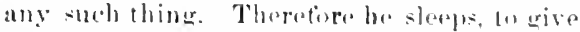
oreasion for thoir timblity, and to mater their perepeption of what was happening more distinet."-V. 26. Stilling the temputst. 1) Jesus

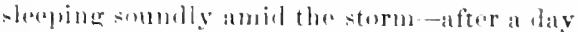
of great "xertion ard strain-the picture. 2) The disoiples atiad, through lauk of fath in

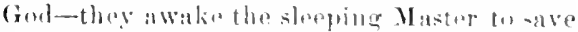
them. 3) He stills the tempest by a word 


\section{CH A P T E R I X}

2 And, behold, they brought to him a man sick of the palsy, lying on a bed: and Jesus seennt their failh said unto ihe siek of the palsy; son, be of good eheer; thy wins be formiven thee.
2 came into his own city. And behold, they brought to him in man sick ot the paisy, lying on a bed: and thesus sering their faith said unto the sick of the palsy, ison, be of good cheer; thy sins are forgiven.

I Gr. Child.

(eomp. Mark 4: 39), as by a word be had healed the centuriou's servant. $(8: 8,13$.$) 4)$ The disciples greatly wondering that the winds and the sea obey him; we no longer wonder, but we too must obey. $-A l l$ the sufterings and perils to which in God's providence we may be exposed, are trials oî our fiath. If we have strong faith we shall not yield to eraven fear. "With Christ in the vessel, I smile at the storm." This tempest doubtless proved a groat blessing to the diseiples in strengthening their faith; and our trials are among our greatest blessings, if they have a similar effect. - Not in the way of exegesis, but of illustration, we may say that there are storms in life, stormy passions in the soul, which only Christ can calm.-V. 27. Nicoll: "It is incomplete to say that the miraces justify beliet in Christ, and it is equally ineomplete to say that it is belief in Christ that makes miracles eredible. Christ comes betore usas a whole-his person and his work. It is impossible to separate the two, and we believe in the whole-that is, in both."

V. 29. Currs.: "Because the multitudes called lim man, the domons came proclaiming his Godhead, and they that heard not the scil swelling and subsiding, heard from the demons the same ery, as it, by its ealm, was loudly uttering." $-\mathrm{V}$. 31. Here wats very earnest asking, but we slould not call it prayer. And the thing asked was granted, as was Satan's request with respect to Job; yet it was not the prayer which God approves and accepts. Let us heware lest our supplieations be sometimes the mere utterance of selfish desire, and not the prayer of a trusting, loving, drvout spirit.-V.' 34. Luther: "The " mass of men would gladly hold to the gospel, if it did not tonch their kitehen and income. If Jesus gives them good things, they can very well endure him; but when be inflicts damage, as here, they say, 'Begone, Jesus, gospel, and all." " HaLL: "O saviour, thou hast just cause to be weary of us, even while we sure to hold thee; but when onee our wretched unthankfulness grows weary of thee, who can pity us to be pusislied with thy departure?"

9. 2-34. Further Miracles, with Call of Mattinew, and Discourse at MATTHEW'S FEAST.

The series of miricles (see on $8: 1.18$ ) is now continued by giving-

1. The Paralytic Healed, 9: 2-8; comp. Mark 2: 1-12; Luke 5: 17-26. The connection in Mark renders it probable that this miracle preceded the sermon on the Mount. We lave alrealy observed that Ifatthew is evidently bere not following the ebronological order, but grouping together certain speeimens of our Lord's actions and sayings in the way best caleulated to subserve his objeet, viz., to establish the Messiahship of Jesus, and exhibit the nature of the Messianic reign. We cammot always see the particular prineiple on which he groups. But in the present case Alexander has pointed out a natural relation between the events, which necounts for their being thrown together. shortly after the miracle of the two demoniaes ( $x: 28-34)$, oceurred the raising of the ruler: daughter (9:1-26), as we learn from Mark 5: 22 ; Luke 8: 41. But we see from 9:18 that the ruter came to Josus while he was talking with the Pharisees about fasting; and that (onversation oceurred (v. 14) directly after what he said to the Pharisees in reply to their complaints that he had associated with publieans and sinners, at Matthew's feast. (v. 10-13.) Now this fonst would naturally suggest to the divangelist's mind his own call to follow Jesus, which led to the feast given some time after the eall. (See on v. 10.) But the eall occurred (r.9) while Jesus was going away from the house at which he healed the paralytic; and this was a very important, a peculiarly instructive miracle, which it was desirable to introduce. So instead of taking 11 p at onee the raising of the ruler's daughter, Matthew first describes the healing of the paralytic (v, 2-x), and his own call, on that same day (v. 9); then passes (see on v. 10) to the feast he 
subsequently gave, and the fonversation whith rnstlet (v. 10-13,14-1i); and thas approaches the eatie of the ruler: daughter, and the other notable miracle connected therewith (v. 18-26i); afterwards appending two other miracles which torek plitce the same liay. (v. 27-36.32-34.) We may al-o pote (Lutterotl:) an ipterral relation betwern the complatint of the seribes in $v$. B, and that of the Pharises in v. 11, culminating in v. 34 ; and this may have atfieted the grouping. That the Evangelist's mind should thos have worked according to the natural laws of suggestion, is altogether compatible with the inspiration of his marative; for evory patrt of the Bible bears the impress of human thinking, only preserved by the spririt from error and guided into all truth, so that the inspired writer satys preceisely what God would have him saly.

The scence of this miracto was in Capernatum (Mark2:1,12), and quite probably alt Pecter's homer, which might well be our Lord's recognimed stopping place. Mark and Luke, ats is frequently the cuse, give fuller details than Mathew. Weiss holds that Matthew makes this aecur on the street, and thus eontliets with Mark; lout Matthew gives not the slightest hint of locality. What in the world is gained by mantututuring tiscreplancies?

2. And behold, see on $8: 2.204$. They bronght to him, literally, were bringing, a form of expression which not murely narrates the facet, but depicts it ats going onl. I mun sick of the palsy, a paralutir-sere on $4: 24$ : 8 : 1i. Lying on a bed. 'L ying' is the same word is ins: b, 14. The "lwal' wat doubthess a thin mattress, or a woll-waldod quilt, the imner material being wowl. It may have been plated in the present eatse on at slight frame of wourl, making it more comtortable and easerer to calrer ; lut it wats usually fine ordinary sleeping latil on the floor; while sometimes a more

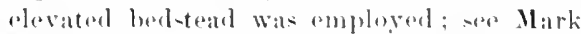
4:21, R. V., "under a bed." Wo learn trom Mark and lake that four men were bearing the paralytio on the bet, and that in comsequence of the erreat cond in and about the house where of and wats, they grot on the housetop, broke through the rowet, and het him down on his bed into the presence of Jeas. (comp.

The perfect might have been introluced by way of assimilation to Luke $5: 20$ (where there is noriation), or might have been abandoned because it is an unusual
Edersh.) Aud Jesus seeing their faith, that is, the taith of the bearers and the paralytic. He was more realy to work miracle for thus who hat fitith, (secte on v. 19, 28); and where forgiveness of sins was also involved. it Was indispensalple that the person concerned should have taith. (Cemp. on $8: 3$. ) 'sereing their fath in of enura a mere vividexpresion for pereesing, as when we say " I see your motive." The paine they hat taken (Mark and Lake) bowed their finth all the unce planly. son, be of good cheer. Literatly, be enconraged, child, or we should better imitate the simplicity and vigon' of the original by sayingr, "Couraere. child." "Child' is the literal rendering (marer. Rev. Ver., eomp. Darby. David-on), and is often used in colloquial English as an expresion of tamiliar atfection, thomgh not now - nited to an elevated style. Comp. "daurhter, v. 2z. Thy sius be-or, are-forgiven, als correctly rendered hy (om. Ver. in Luke (5-20.) The Greek varb is not imperative, but indieative, while the old Engli-b 'be' is used for either. The eommon Greek text has a perfect tenor, meaning have been forgiven, stand forgiven (so in Lake $i$ : 47 f.; 1 .lohn : : 12); Wresteott and Hort hale the preant tense, which would t'aluse the forrgivenese to be fonterivel of as just tlen taking place: it is not aing to decidrs which form is

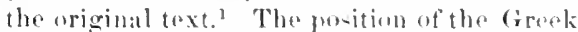
word: make 'forgiven' emphatie. No denbt nll prosent weremeh surprised, when instull

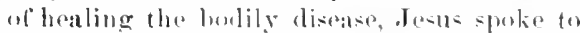
the man thes. It -eoms prebable that the disatse had in this tase resulted from some torm of disipation, such as not unfrequently produees paraly-io, (ompe. the man at the Pand of Botherdal (John 5: 14, lit.), "There bast heeome woll; do not sin any more, lest something worse happen to thee. It would not at all fiblow that all peculiar distabes and remarkable misfortuno result from some - peeial sinan idea previtent among the Jows, but distinctly ourroctod by our Lard. (John 9-3: Lake 13:2r.) Wr may not unreasomably think that the poor paralytie wat troubled and di-pirited. betallor he felt that his sad dienase wat the consequenere and the merited funishment of his sin; so the work ot Jesus, which surprised

form of the rerb. There is a similar difficulty in Mark : : 5 . 
3 And, behold, certain of the scribes said within themselves, This mart hasphemeth.

4 And lesus knowing their thoughts said, Wherefore think ye evil in your beark?

5 For whether is easier, to say, Thy sins be forgiven thee: or to say, Arise, and walk?

6 But that may know that the som of man hath power on earih to forgive sins, (then saith he to the sick of tho palsy, Arise, take up thy bed, and go unto thine house.
3 And, beholi, certain of the scribes said within then4 selves, This nan blasphemeth. And Jesus ${ }^{1} \mathrm{know}$ ing their thoughts said, Wheretore think yeevil in

5 your hearts". For whether is easier, to say, Thy 6 sins are forgiven: or to say, Arise, and walk? But that ye may know that the fon of man hath authority on earth to forgive sins then saith he to the sick of the palsy), Arise, and take up thy beal,

IJang ancient authorities read, seeing.

all the bystanders, would be to him precisely in place and full of comfort. Yet it would suffice to say (Schatf) that "the man's conscience was arouned through his sickness," without supposing the disease to have been caused by special sin.

3. And, behold, this too being remarkiable (comp. v. 2). As to the seribes, see on 2: 4 . Luke (5: 17, Bib. Un. ver.) mentions that there were present "Pharisees and teacher's of the law (the latter being substantially the same as 'scribes'), who had eome out of every viliage of Galilee and Jurlea ani Jerusalem." Here was quite a crowd of critical hearers. Said within themselves. Coup. on 3: 9. Blasphemeth. The Greek word, borrowed by us, signifies to speak injurionsly, or insultingly, to defame, slander, ete., as in Rom. $8: 8 ; 1$ Pet. 4: 4; Tit. 3: 2. From this it was applied to reviling God; saying anything insulting to God, anything impious. The Seribes held Jesus to be blaspheming. because he arrogated to himself" a power and right which belonged exeluwively to God, riz., that of forgiving sins. This is distinctly expressed by them, in the atditional words recorded by Mark and Luke, "Wlun can (is able to) forgive sins but God only?' He who elaimen a power peculiar to fod, spuke what was injurious and insulting to God. Yet it is not wive to find here a proof of our Lord's divinity ; for be sprakis as the sion of man, and speaks of authority given litin. (v. 6.8. comp. :, :15.)

1. Kn ow ing-properly, seeing-the ir thonghts, like sering their firith in s. 2.? Mark (2, x) has the axpresion percoivent in his spirit that they of reasument within themselves.' 'The faith of the parralytie and lis. bearers could be seen from their actions; but to see the unexpresied thonght of the soriberequired superhunas pereptions. Comp.

tObrious as is the meaning of this, sereral Is: in. cludiug B) and several early versions touk the trouble to chang: it to 'knowing'; this is ad pted of conrs. by
Luke 6: 8; 9: 47; Mark 12: 15; John 22: $24 \mathrm{f} ; 4: 29$. Wherefore think ye evil in your hearts? The 'heart,' according to Scripture use, is regarded as the seat of the thoughts as well as the affections. (See on $\mathbf{j}$ : 21.) Jesus replies not only with a mild rebuke, but with a proof that be was not blas. pheming.

5. For whether-or, which-is easier: It was as easy to say one as the other, viz., to suy it with effect. Euthym: "Buth were possibie for God, both impossible for man." In the ease of the healing they could test thr. reality of the power be clamed; and from this they ought to infer that be possessed the uther power also, seeing that he claincd to pussess it, and that one who could work a miracle ought to be believed. They hal already latd many proofs at Capernatum of his power to wurk miracles. We are often told at the present day that Jesus always relied on his teaching to convince men, and not at all on his miracles; but here he distinctly appeals to miracles as establishing the truth of his teachingrs.

6. The sou of man, our Lord's fivorite derignation of himeelf, see on 8: 20. Power. The word thus rendered in much used throughout the $\mathrm{N}$. T. It signifies primarily, permi-rim (licenee, privilege), then authority, (dominion, rule, etc.), and this sometimes suggests ability and puwer. The word very often convers two of these ideas at once, at privilege and power (Jobn 1: 12), authority and prowel. (John 19:10.) Comp. on $7: 29 ; 28: 18$. The Rur. Ver. has everwhere else in Matt. renderw 'authority" and it would have been better to duso here, a- is done by the Ameriean Reviers, Davidson, and Noyes. In this fraware it is meant that Jesus has authority to forgive -ins, and the power which sturh au-

IV II. (who cannot forsake B), and is unwisely followed by lies. Versiun. How can we acconnt for a change of 'knowing' into 'secing '? 
7 Aml he arose, and deparled to his hmop.

8 but when tho multumbes saw it, how matrelled, and ghoritied cind, which had given such puwer unte men.

9 And as Jesus passed forth irom thence, he saw a

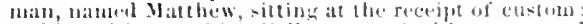
and he sailh unlo hin, follow tat. And be arose, and followell lins.
F and gountw thy house. And he arose, and deparled $x$ to his housc. jout when the multitudes saw it, they were afrate, and glorified fod, who had given such antherity molo men.

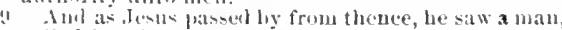
callod Math hew, sitting at the phace of toll: and be stith moln him, follow me. And he arose, and followel him. thority carries with it; this power is alluded to by the phrise. "Who can (Mark $2: 5$, Luke $5: 21$ ), and "Which i.s enteser (r.5, Bib, Vu. Yer.). Thes word "authority" is in this palange so placed as to be emphatic, "the son of' man hath authority, ete. Ansl while they naturally thought of torgivenes of sins as performed only by ford in heaven. he will show them that the som of man hath autherity on earth to forgive sins. Comp. the autherity to judge, John 5: 2-. He does nut procered to tell the Seribes what he will le to prove his antherity. but turns to the paralytic and lets then set. Take up thy bed. Being slleh as dencribet on v. 2, a man could easily take it up and

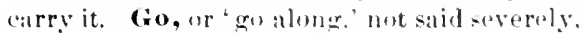
as in $4: 10$, but kindly, as in 8: 13; the wold taking ealor trom the anmention.

7f. What a mentent of suspense for all the beboldors-some bepinge, others fenriner, that the man would inderel slow himalf th be heabled. What a thrill mast hate parsed thromeh the crowal, at be arome and went offe How the seribes mot have been abatiod and confomeded. The paralytic went away "erluri-

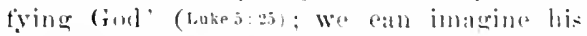
feelings of joy and gratitule, when he finud himelf carrying the bet whinh hall carried him, treading the anth in vigur and loralth again, yea, and with his sim-all forgiven. The

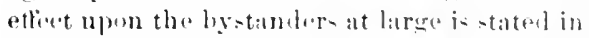
v. 8. But when the multitude- the ereneds -saw it. 'Crewdi' is the same ward at in 5: 1. They marvelled-hetter, feapel-this. and not 'wondered,' heing pretty cortininly the eorreet reading of the text.' They foit that alarm and printul mneatiness which is nut to be awakened in the bromon of sintul man by ansthing that seems to bring (rod nearer to him. (Luke $3: 8$; comps above on $4: 34$.) But this alarm quickly pasend into protice, and thes glorifed fod,which hat givenstheh power unto men. (Compe. Luliej: 26.) Regard-

\footnotetext{
1Superficial students and coprists would fail to see the deep meaning of 'fuard' in thin case, and change it to the more obrious term 'wundered,' so the inter-
}

ing Jesus as only a man, it was right that they should grive the glory to God. (5: 16.) And they probably did not consider this authority amel power as peculiar to him, but as bestowed on men, and possible for others also. It was trure in a semee which camnet have entered inter their thoughts, that what was given to J J su- wa: giveri to mankind.

Befire proceseding to firther miracles, the Evangelist narrates-

II. THE ('AlL OF MATTHE, AND CONVERATION AT A Feast HE GaVk, 9: :-17. These are also described in Hark 2: 13-22; Luke 5: :2-i:3.

9. Ind as Jesus passed forth from thence. Mark (2:13) shows that this oceurred immediately at fer the hraling of the paralytic,

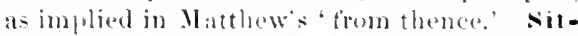
tiugat the reecipt of enstom-custom-house - iso tramslated in liheims) probably the place firr receiving toll- on the fi-hing and trade of the lake. The Romans laid taxes, at the syrian kings hat dome befure them. on almost averything. csee detalils in Edersh.) Matthew. Luke calls him 'Levi,' and Mark 'Levi, the son of Alphens.' It hatl hecenne rery common for a dew to bear twe sames and probably the first reaters of the ditlonat Gowels would readily underotand that Levi, the son of $\mathrm{Alph}$ (us, was also ealled Matthew. (The name Itathation, Mattai, might mant simply "ureen. Jike Nathan; or cle might be a contraction of Mattijah, "gift of .Juhevah, like Ionathatn. Nethaniah.) It world be natural that Mattlew shenld give anly the name ly which he was know ats an apmetle. which 11 ark and Luke aloogive in their list, of the apo-tles (Nork 3:14; Luke 6:15), and should aroid, as Patul diel, the name assaciated witl his former life. sume areue that this llate thew was not the Erangeliat. sinere he is spuken of in the third person; but it has always heen common, in ancient and modern times for nal probahitity here concurs with the testimony of the early MSs, and rersious. 
10 And it. came to pass, as Jesus sat at meat in the 1 house, behold, many publicans and sinuers came and sat down with him and his diseiples.
And it came to pass, as he ${ }^{1}$ sat at meat in the house, behold, many publicans and sinners cane

1 Gr, reclined: and so always.

writers thus to speak of themselves; and the apostle. John, in his Gospel, employs elaborate circumlocutions to avoid even mentioning bis own nane. Luke here tells us (uke 5:27) that Iatthew was a publiann, which is implied in the narratives of Matthew and Mark, and stated by Matthew in the list. (10:3) As to the publicans, see on $5: 46$; and as to Mattlew, - ee further on 10: 3 . And he arose and followed him. Luke says (5:2\%, Bib. Un. ver. 'And leaving all, he arose, etc. Matthew dres not mention this, because it would have been speaking in his own praise, which the Evangelists never do. Comp. on v. 10.) We can account tor lis immediately leaving all and following Jesus by the reasonable supposition that at the place of toll by the lake-side lue luad often seen and heard him, and had gradually become prepared in mind to whey such a call. It is even possible that he had been following Jesus before, and only now attached himself permatnently to lim (comp. on $4: 18 \mathrm{ff}$.). At the same time we may be sure there was something deeply impressive in the saviour's tone and look as hespoke thesimple words. (Comp. John 18: 6.) Observe that while all of the Twelre seem to have been men in humble life, Iatthew belonged to a class greatly despised. The Talmud (E)lersh.) distinguishes customhouse officials from other tax-gatherers, and speaks of them with peculiar hate, probably because their extortions were more frequent and more manifest. This publican Matthew, and the nutorious persecutur Sanl, were as unlikely, human!y spaking, to beenue apostles of Christas any men that could befomd. Yet such has been the work of soveroign grace in every age of Christianity.

10. We have now the account of somb conversation that arose while. Jesus and his disciples were eating at Mattlew's house, in conpany with many publicans and sinners. It is clear from v. 14 and Luke 5: 3:3 that the inquiry about fasting and the Saviour's reply nceurred during this meal; and from v. 18, that the ruler's ripuest to conte and raise his daughter was made while Jesus was speaking in response to that inquiry. But from Mark
$5: 22$ f., and Luke $8: 41 \mathrm{f}$, we see that the raising of the ruler's daughter took place after our Lurd's return from Gadala, and thus at a much later period than the healing of the paralytic and the call of Mathow. We therefore conelude that the feast was atually given by Mathew a considerable time atter his call, and that it is merely introduced by him, and also by Mark and Luke, in enr.nection with the call, because it was natural to bring the two together, thereby completing at once all that had any persomal relation to this apostle. It thus appears that all three put the case of Jairus daughter in its actual chronological position, and all three bring together the call and the feast, althoigh they were really separated by a considerable interval; the difference is, that Mark and Luke tell of the paralytic and the call at the early period when they oceurred, adding the feast by anticipation, and then some time afterwats introduce the healiug of Jairus' daughter, which we know immediately followed the feast; while Matthew puts the feast in its real chronological connection with the application of Jairus, and just before the feast introduces the call which had oceurred earlier) and the healing of the paralytic, which preceded the call. (Comp. on v. 2.) Any one who will take the trouble thoroughly to grasp the tacts, will see that this view removes all the diffieulty attendant upon harmonizing the three Gospels at this point, a thing which has often been declared impossible. We noed not feel bound, nor imagine ourselyes able, to remove all such discrepancies, but it is surely worth while to do so when practicable. If the nervous harmonizers stanl at one extreme, the scoruful despisers of harmonizing tertainly stand at the other.

And it came to pass, the same word as in 1:2*; $5: 18 ; 6: 10 ; 7: 28 ; 8: 19$. A $\leq$ Jesus sat at meat, ete, better, whle he was reclining in the house, comp. on 8: 11, where the Greek word is similar and substantially equivalent. Matthew omits tumention whose house it was; probably he omitted it through modesty (comp. on v. 9), or perhaps 'the louse' seemed enough in bis vivid recollec- 
11 Ant when the Phariseses saw it, lhey said unto his disciples, Why eateth your mastel with publicaus and siunters"

12 But whon Jesus heard that, he said unto lhem, They that be whole need uot a physician, but lies that are sick.
11 arm sal down with Jesus and his disciples. I11] when the l'barises sat it, they sabl telo his disciples, Why eated your Jister with the publicant

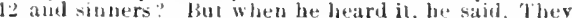
that are " whole have no need of a physiciau, bus

I 1)r, Teacher...2 Gr. strong

tion; though it is implied in the connection; Mark (2: 15) and Lnke (5: 2y) dintinctly state that it was Levi's house, and Lukesay-that "Levi made a great teast literally reception') in his house.' This would indicate that he posiesend some means; he seems to have sacrified a somewhat luerative position in orter to follow Jusus. Meyer's attempt to make 'the house' here meian Jusus' awn homse, and thus to hring Matherw into contliet with Mark ant Luke, is struined and uneallell for. Even Krim and Wriss understand it to bo Matthow's house. Behold, see on $8: 2$, "2). Iany publicaus nud sinucrs came and sat down, or, were reclining. Is to the publicans, see on $5: 46$. The . J w- were accustemed to call those persons "simners: who lived in open violation at the moral or ceremonial law; and they shrank from eontalet with all such as polluting. Matthew s previous assuciation latd brought him inlo enneetion mot only with publicans, but with all lhose other men, who, discegarding mally of the provaling religious observanews, and towling themselves to be ohjects of pepular dislike. naturally thocked tougeher. Iakes axpression as to the number present in still stronger, 'a great erowd.' Mark (2:15) mentions that these 'followed' Jests, as if of their own aceorl. "This is nut incensintent with the ideat that Matthew inviles them in, while it implien that the feast was a sort of public aflair, which agrees with the fact that the l'hariseds appear to have pressed in as spectutors. (v. 11.) Matthew dombtless wished to slonw resplexet to his Taicher by inviting a numbrous enmpany to meet him. perhaps asking in every one who followed . Jesus toward his house. It the same time he must have had some eherished friends anonger these despised men, somes whom he linew to have better stutf in them than was genterally sllplestal, and to lave been driven hy popular noglect and scorn into assoedation with abandoned persons: and be would hope that they might be henefited by being in company with .Jw1 and hearing what he said. The example deserves imitation.
Imagine the character of the gemeral conversation at this great entertainment. We shomld not sllpores that the presence or the words of . Jeolls ehilled the gruests into a dead -tilluess; that he showerl a latek of sympathy with the eommon concerns and teelings of mankind. He was not jorod, haughty, and forbideling. like many of the Rabbis, but was meek and lowly, lind amel gentle, and everything about him lendeal to attract mon rather than repel. Whatever he spoke of, it would be in a -pirit marked by fidulity to truth, and yet by lelicate consideration for the toselings. of uthers. And when it was appropriate to introluce di-tinetively religious topices, we can ses with what ease and aptues he would loring them in, from striking examples in Luke 14: $7,12,15,16$, and Jolun 4: 1+1, Itj.

11. It is flatin that these Pharisees were not thrmatres graests at the toust, for in that ease thry wombl have been doing the very thing they complainal ot in testas. Probably they pressed inte the holine before the teast ended, in order to hear what fesus would be saying. In Juke $7:$ : $t$ ti tl: no surprise is "xpresed at the woman's antering the diningromm, and no objeclion made by the host. Pharisers, see un $: 7$. Why rateth your master for your tateher, didaskalos, see on si: 19), with (the) poblicans and sinners? Thet two nouns with lut ono article present the two Classes as forming but ane group. Aceorliog to the prevaling . Jewish itleas, a Rabhi, of all men, "unght eartully to avoid all interentures with such per-ons." There was not omly the sucial objection to "kepping low enmpany" but the (onstant aread of coremonial pullution, from eoming in erontate with persons. likely to be ceremonially unelean (Mark 7 b): and alos that fereling so natural to man, whirh says. "Nitand back; 1 am holier than thum. (1-a.65:5.) Aecordingly, our Lart wat truquently met with the oljection here male to his courso. (11-19; Luke 15:2ff.)

12 f. He sioid, the correct text omitting 'Jusus" and "to them.' The di-ciples toll] their Teacher of the question which had been 
13 Bnt go ye and learn what that meaneth, I will bave mercy, and not sacrifice: for I am not come to call the righteous, but simuers to reventance.
13 they that are sick. But go ye and learn what this meanth, I desire merey, and not sacritice: for I came not to call the righteous, but sinners. asked. They were themselves as yet very imperfectly freed from the erroneous Jewish concentions of the Messiah's work, and would porblily find it difficult to explain why Jesus should wrste such a course. It was cunning in the Pharisees to ask them, il hope of turning them away from their Teacher. It appears from the connection, and is distinetly stated by Luke (5:30,31), that his reply was adlressed especially to the Pharisees, with whom the question had started. This reply embraces three points: (1) an argument from analogy; (2) an appeal to Seripture; (3) an express declaration that his mission was to men as sinners, and so he was now acting accordingly. In like nanuer Paul, 1 Cor. 9: 7, presents first an argument from the analogy of men's common modes of action, and afterwards an argument from sicripture.-(1) 'They that be whole, or are strony, stout, well, comp. the connection of the English words hrule, health, whole. Luke 5: 31 has literally, "they that are in health.' IBut they that are sick, or ill, the same expression as in 4: 24; 8: 16. The order of the Greek words puts an empllasis on need not. The foree of the illustration is manifest; the physician goes among the sick, and why should not the teacher of salvation go among sinners? Here is a beson needed in every age, for we are too apt to hold ourselves aloof from the vile and disrejutable, when kind and pationt efforts might win some of them to better things. At the same time we must, like the physician, take great pains to avoid the comtagion of the discases we seek to cure. Aud if our geord is evil spoken of, as happened here to our Lord, we should be eareful not to afford any just aecasion or exeuse for such reproach. (2) The second point of his reply is an alpual to Siripture. But go ye and learm. The Rabbis froquently amployed the samo formula, " wo ye and learn," indicating that one nrels further reflection or information wn the subjoct in hand. This was a severe rebuke to Sicrilues (Lukes: 3n) and Pharisees, who assumed and were popularly supposed to be particnlarly versed in seripture. I,earn what that meaneth (literally is), $i$. p., the following saying. The passage is referred to as familiar to them, while get they were quite ignurant of its real meaning. The old Test. thromgh. ont, when rightly understood, agreed with the teachings of Jests. I will have (wish, desire) merey, and not sacrifice, quoted aceording to the Hebrew. (Hos. 6:6.) The Hebrew worl includes the ideas of kindnes: ard compassion toward men, and of piety towards God. So piety and pity are originally the same word. Hoseats connection shows that the word was by him taken in the widest sense, but the single idea of kindness or mercy is all that is here necessary to the eonnection. The absolute statement 'and not sacrifice,' is not intended to be taken literally, but as a strong expression of proference for mercy. (Comp. Lukw 14: 12.) The idea is, I wi-h kindly fecling and conduct toward others, especially toward the needy and suffering, rather than the extermalof $r e^{2}$ igion-of which sacrifice was then the most important. So the Sept. translates, I wish. mercy ratler than sacrifice. Or the passage might be expreseded, I wish kindnes. and $I$ do not want sacrifice without this. The rendering 'I will have mercy,' which Com. Ver. took from Great Bible and Geneva, is very apt to mislead, beeause to fave merry now usually means to exercise it.-The were externals of religion are offensive to God, where its spirit and lifeare absent. The Pharisees were extremely particular to avoid that external, ceremonial pollution which they might incur by mixing with the fublicans and sinners, but were not anxious to show them kindness or do them good. Notice that it is Inthew only that records this argument drawn from the Old Test., just as he most frequently refers to the prophecies fulfilled in the person of Jesus; this course being natural for one who wrote especially for Jewish realers. Wee the same passage quoted again in 12: 7. (3) I am not come (see on 5: 17), to call the righteons, but sinners. The words 'unto repentanee' are not properly a part of the trit of Matthew, but they are genuine in the parmllel passage of Iake, and so were netually spoken on this ocasion. Such udditions to one Gospel from a paralle] passage in anothor, ate often fonnd in Msis. and versions. This third point of uur Lord's reply is that his 
14 Then came to him the dincigles uf Joln, sayimg,

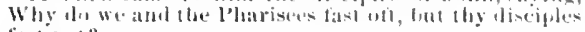
lasi inut?

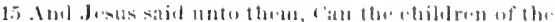

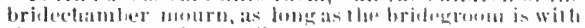

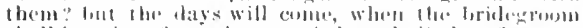
slatl be taken tronis them, and them shall they lant.

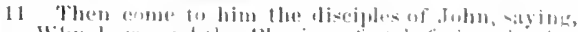

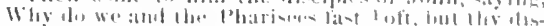

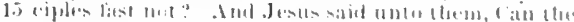

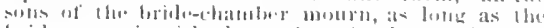

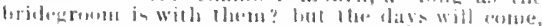

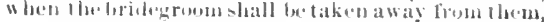

\section{Strue ancient atuoritaes umit, uft.}

conduct in assuciation with the very wielied

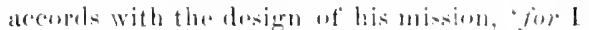
calme mot, r.te. The word tramsated reght-

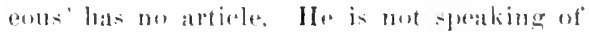

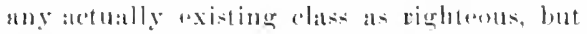

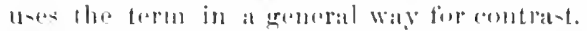
(Comp. Lulie 15: i.) There is eomutiont to thro

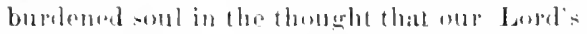
mission was to mon at sinnors, even to the mo-t vile.

14. The inquiry ahmut fistiog, and

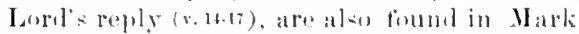

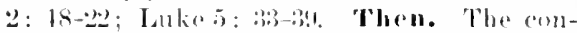
nection in buke (5: 33) also indieates that this comversation immerliately tollowed the pres

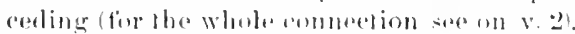

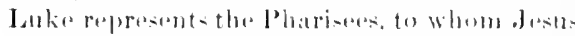

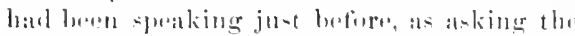

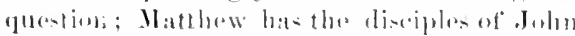
akking him, and Ilark $(2: 12)$ silys that both eame amel asked, almal thus sllegersts a way in which mamy similar "dincrepancius" maly be replatined. The quastioners los mot veluture

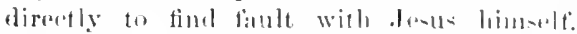
(C) I11). ․ 11.) Who are thes disciples ot

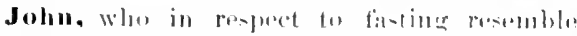
the lobarisese rabler than tho disciplas of

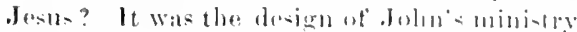
(comm, on :3: 1) to bring men to beliere an Josus as anning, and to follow him whol

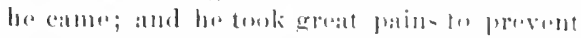

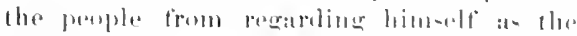

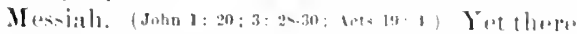
were sume who, failing to folluw ont llobil

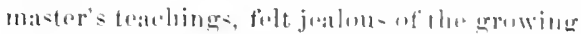

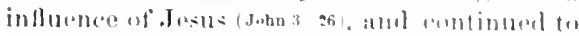

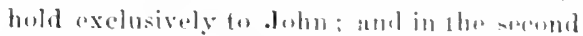

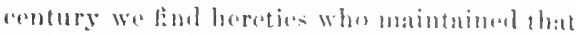

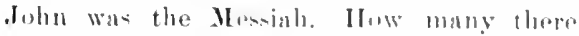
were at this timo who lispt thomalses alout from . Jesus, and were simply disejples of John, and what were their procise views, we

1 The worl rendered 'oft, literally 'much,' is wanting in $\mathbf{l} x$ and a few eursives, and hener omitled by risch. and WII. One caunot realily levile whether it was omitled to agree with Mark or insertel to agree

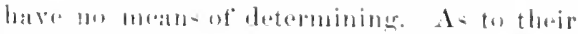

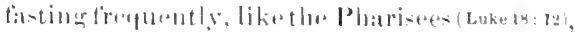

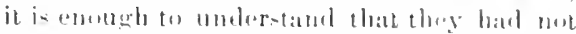

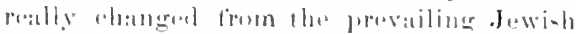

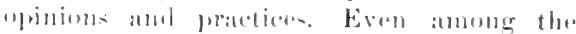

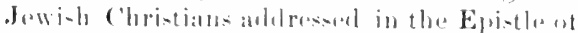

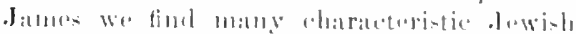

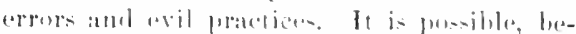

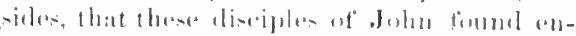
couraleremont to falsting in that self-denying

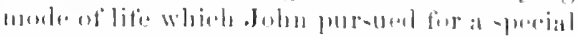

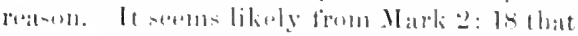

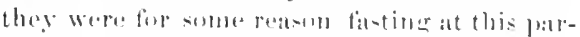
ticolate times it may have heren one of their

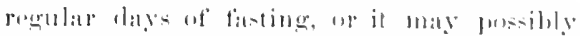

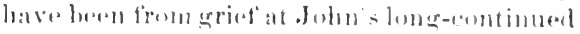
imprisemment." fremere "The disciples uf Juhn ware artainly to blame, in alumuiatriner hian whom they linew to have heren pror-

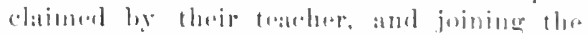

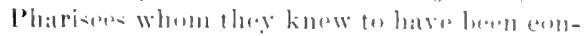

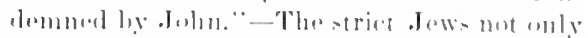

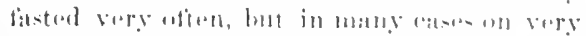

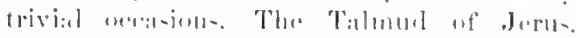

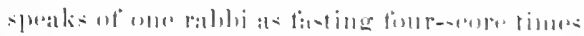

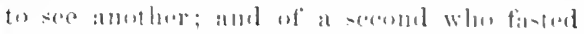

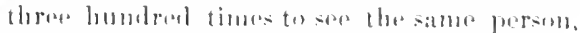

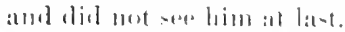

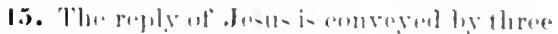

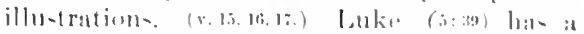
fimlth. Whe ehildan (smps) af the briderhamber. Thho torm 'sull is comployed, at

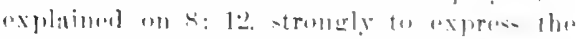

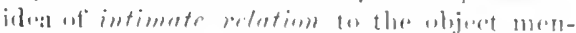

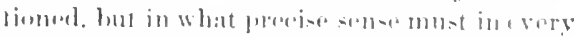

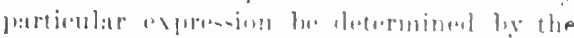

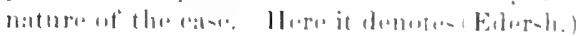

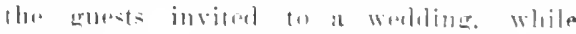

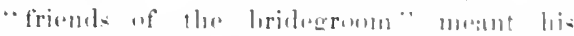

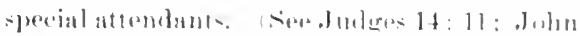

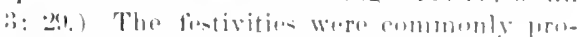

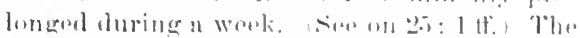

with loke. There is mo important tifferemes, as Matthew's axpresion willoul "uft' nalurally itulicates that they were in the habit of fasting. 
16 No man putteth a piece of new cloth unto an old garment; lor that which is put in to fill it up taketh irom the garment, and the rent is made norse.
16 amd then will they fast. And no wan putteth a piece of undressed clolh upon an old garment; for that which should fill it up taketh from the garment, word rendered cau is so placed as to be emphatic: can it be, in the nature of things? And the Greek has the peeuliar particle which denotes that a negative answer is taken for granted. The Talmud deelares that the bridegroum, his personal friends, and the sons of the bride-chamber, were free from the obligation to dwell in booths during the Feast of Tabornacles-these being unsuited to their festivitios; and were not expected to attend to the stated prayers. This shows how natural and probablin, according to the prevailing ideas and u-ages, was our Lord's illustration. Already in prophory had the Messiah been spoken of as a bridegroum (Ps.45.ete.); and John the Baptist had employed a figure drawn from the nuptial ceremonies as setting forth his own relation to. Jesus (Johu $3: 29$ ); so that in answering John's disciples this inage was all the more appopriate. But the days will come when the bridegroom shall be taken away from them-and then shall tbey fast. The term 'will come' is so placed as to be emphatic. For "when" read wheneer, whioh will indicate that the time of his being taken away is uncertain; this is the first instance recorded in Matthew of our Lord's alluding to his death. Fating is naturally and poperly an expression of grief, and therefore unnatural and unsuitable at a time of great joy. Surly a time was this when the disciples were delighting in their Teacher's presence. But there was coming a time when it would be natural for them to grieve, and therefore alumpriate to fast. The immediate reforenee is to the griof which would be felt by his disciples at the time of his drath. A fter his resurrection, ascension, and glorious cxaltation, their sormow was turued intojoy again. (John 16:22 ff.; Acts 2: 32-36; 3: 13 ff., etc.) Yet often afterwards, and often ever sinee, have his followers grieved over his absente and longed for his coming again; st that the time for fasting still eontinues. liy this illustration our loord teaches that fasting is not to be regardolor obicered as an arhitrary, "positive" institution, but as a thiog having watural grounds, and to be practiered or not, areoreding to tho dictates of natural feeling as growing out of the eircumstances in which we find ourselves. In some situations it is appropriate and may be made beneficial ; in others, it is out of place. We have noevidence that Jesus ever fasted humself, except in the quite extraordinary case of the forty days (for $17: 21$ is a spu. rious passage); but we know that the apostles and other Christians of their time fasted upon special vecasion. (Acts 13:2; 14:23;2 Cor. 11:27.) The principlè here laid down cuts at the root of fasting as a regulated observance, leaving it to be done or omitted, not indeed aceording to accidental or momentary impulse, but according as it is most suitable under the circumstances and likely to do good. (Comp.on 6: 16-18.)

16 f. Regulated fasting, though enjoined by Moses only on the occasion of the Day of Atomement (Luke 16:29), yet was now frequently. practiced among the Jews, and quite in aceord. ance with the distinctive spririt of the Old Dispensation. But it did not suit the spirit of the gospel; and our Lord shows, by two homely aud striking illustrations, bow incongruous and injurious would be the connection with the new of what was peeuliar to the old. Luke (5.36) calls this a 'parable,' $i$. $є$., eomparison for the purpose of illustration. The parables of the Gospel are usually in the form of narrative, but not necessarily. (See on 13: 3.) No man putteth, etc.,-literally, patches, a patch of an unfulled piece (i. e., fragment of (+loth) upon an old garment. The word rendered garment is here naturally taken in the general sanse, and not to denote simply the outer garment. $(5: 10 ; 9: 20$.) What is meant is not simply now cloth, for that is ofter used for patching, but eloth wheh has not been emmpletely dressed. A part of the proeess of preparing woulen eloth for use eonsists in shrinking it, and a patch of 'untulled' eloth, not duly shrunk, would contraet the first time it should become wet, and as the older and weakereloth all around must thrn give way, the result would be a worse ront. We must remember that Jewish garments of that day were usually all wool; and if unfulled, wonld shrink almost like our flanmel. Malk's statement of the emmparison (2:21) is almost identical with this. Luke (5:36) gives it in quite a different form, though 
17 Neither do men put new wine into ohl botlles: else llue bolles hrak, ami lle wint runneth anl, and tlit bolles perish: bul loey pul new wint indo new bottles, and both are presterved.
17 and a wors rent is made. Sither alomen put ntw

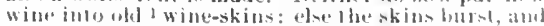
Lhe wine is spillnel, and lle skins persh: lon they jul mew wine inle lresh wine-skins, and bull are preserved.

I That is, skins used as butel.

the gemeral purport is the same. Neitherdo men put, hiterally, they, the usual impersollat expression, see min $5: 11$. Into old bottlos-or, skins. The Greek word signifies properly and axelusively skins for enotaning liquids, such an the oriontals, ancient and mollorn, have latrowy employed. The stiu is usually that of a goat or kid, whied is tough and light. The houd and leet of the animal boing removed, the skin is stripped oft whole. It is then sometime- tammed in a peculiar way

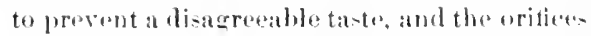
are tied In, leaving ande log or the neek as the opening. The hairy side is of enurese ontward. These skins are habitually usad for transporting liquids, sueh as wine, water, milk, ail, and are admilably adatysted te that

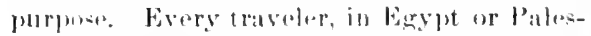
time, often sers them, and sometimes drinks watep from them. They arte mantiomed hy Homer and other chasinal writers, and in variuls falesages of the (bla Test. Buth in

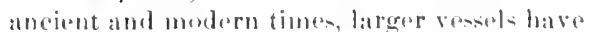
sometimes been proparoul of the skin al the

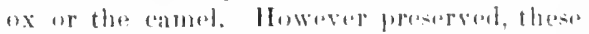

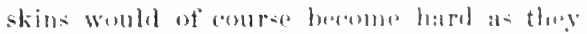
grew old, liable to a rack and bur-t, thomath the fiermentation of new wine. (c)mp. Ps. 11!1: 8:); Job, 32: 19.) It is a mistalio to suph-

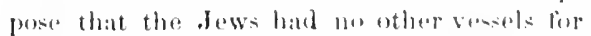

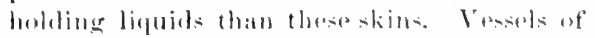

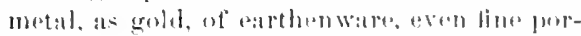
celatin, of stome, and alabatare, alld ut variouty colored glass, were is nas among the

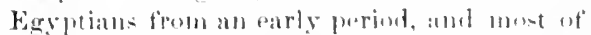

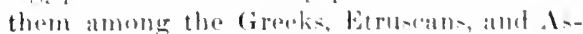

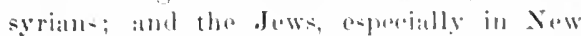
Tent. times, womld no doubt implort and nate

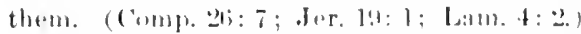
This second illustration is to the same roflect as that in $v$. 16 ; just as wo often tind a pair of paraliber, in chap. 19, and alsowheres. Bath mo drawn, as is usual iu our larles comparisoms, from matters of , (a)tumom observation and experience. The "spiritualizing" as to what the "skins' represolut, amb what the "wiue'-what the "enarment' stamele for, and what the "patch," is wholly unwarranted.

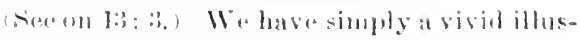
tration af the greloral teuth that the enmbinatiom of the Uhe and the Sew bi-prensatiuns would be not manely ansuitable hut injurious, temeling to sletioat, rather than top promoted the aims of the Mnesiania Di-penstion. And in the second ane there is added the positive atatement, but they put new wimeintonew bottles, ete., howing (Meyer)that a naw lile neado new forme. Whils the principhe hare illustrated was introkluerel with reatrel to fantimer, it is obvimbly of wirler applieation, extending to everything in which the two dispelastions sharacteristically dittor; aldet the ereat mass of the Chrietian worlel, from an waly period, has sally axhibited the "vil results of theregareling this principle. They reneld, wotwithstanding this and numerous other warmings, fommet Levitical rites with christanity. The simple preateher and

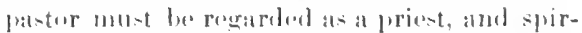
itual bienoines mu-t degend on his mediation, as if it were mot true that all (Yhristians are

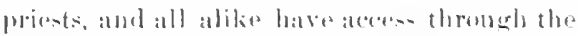
and Mertiator. 'The simple m+mento of the

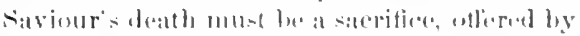

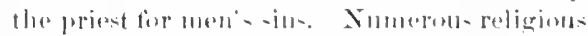

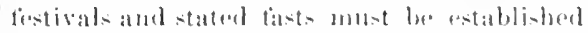
amb anjoinnel, tending tom materoligion a thing

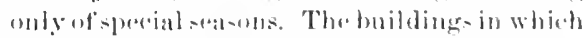
christians merot to worship most lie conse-

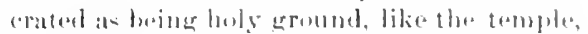
and sulemdid pites. in initation of the temples worship, mu-t lead anew's mind-awat from the -ianple and sublime spirituality of that

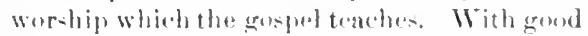
motives, mo thelit. on the gart of many, was this jumble of Indaisen amel choistianity introdured, and with grond montives de many lostain it: but mone the lose is it the very kind of

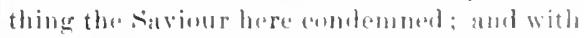

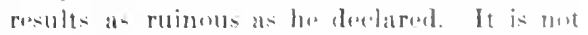
stralleg that (thrysatom and his followers

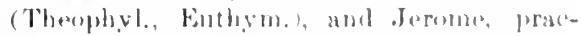
tivinas Judaized f'hristianity, were matble to understand this par-atere.

Returning now to the series of miracles, Mnthew grives- 
18 While he spakt these things unto them, behold, there came a eertain ruler, and worshipled him, saying, Ny taughter is even now dead: bui come and lay thy hand ujou her, and slar silall live.

is And Jestas arose, and tollowed him, and so did his disciples.

20 And, behole, a woman, which was diseased with an issue of blowel twolve years, came behind him, and touched lhe liem of lis garment:
19 While he spake these things unto them, behold, there came ${ }^{l}$ a ruler, atud worshipped him, saying, Ny daughter is even now dead: but eome and lay

19 thy hand npom her, and she sliall live. And Jesus arost, and tollowed him, and so did his disciples. 20 And belold, a woman, who had an issue of blool twolve years, came behind him, and touehed the

$1 \mathrm{Gr}$, one ruler.

HI. The RULer's Daughter, AND THE WOMAN WITH A Flow of BloOD, v. 18-26;

This is found also in Mark (5: 22-43) and Luke (8: 41-56), who as in many other cases give valrious details which Matthew omits. For the general connection, see on v. :2.

While he spake (mas srying) these things mo them, with emphasis on " these things." It is thus plain that the application of the ruler, which led to these two muackes, wat made while Jesus was in the act of speaking to "John's diseiples and the Pharisees (eom). on v. 14) These miracles must therefore have taken place at Capernaum. Behold, sometling rematiable. A certain ruler, or', 'one ruler' (margin Rev. Ver.), as in 8: 19. The Greek text is here greatly contused, but there is little doubt that the true reading is that of the Riv. Ver. The term 'ruler' is ambiguous, and might denote a member of the sanhedrin, as Nieodemus is called a "ruker of the Jews' (John3:1); but Mark (5:2z) says he was 'one of the rulers of the synagogue.' There wereserral of these, having authority over the conduct of public worship in the symagogue (Acts: 15), and a certain influenee rather than anthority urer the social relations and personal conduct of the perple (comp. on 4: 23). We see therofore that it was a man of importance who made this applieation. Luke (8: 41) gives his mane, Jaims; in Old Test. Jair. Came. The common Greak text would make it rame in, viz., to the scono of the preceding (omversation, probably Matthew's residence; but the more probable reading (as in W H.) would mean 'rame near,' 'approarbed.' Worshipped him, bowed d.ww before him as an expression of protound respect (comp. 8: :2). My daughter is even now dead. Luke ( $*$ : 4 , Bis. Un. ver.) in giving the substance of what Jairus said, las it 'wats dying.' Mark (5: 23. Rew. ver.) hats, 'My little daughter is at the point of death.' And then Mark and Julie inform us that while Jesus was on his way to the ruler's house, and atter the healing of the woman, messengers came meeting hin to tell the rul(r that his daughter was now dead; and that Jesus told him not to fear, etc. Matthew makes no mention of this mersige, and we conclude (Calvin) that dexigning a very briet account, he has condensed the incidents so as to present at the outset what was actually true before.Jesus reached the humse. For a similar case of condensing see on $8: 5$. IBnt come and lay thy hand mpon her. Tairus probably thought it nectssary that Jesus should be present and touch the person to be healed, as the nobleman in the same town thought (Jolum:47,48); the centurion of that town $(8: 8)$ had a juster vid"w.

19. In Mark (5:24) and Luke (A:42) we are told that a great crowd thronged around Jesus as he was going, and that Jens afterwards inquired, when in the midst of the erowd, as to who touched him (comp. on v. (2)2).

20-22. On the way to the ruler's bouse oceurred another miracle. And, behold, a fresl wonder. A woman ... with au issue of blood twelve years. We know nothing as to the particular nature of the hemorrhage, but tha most abvious supposition is probably eorrect. We learn from Mark (5:26) and Luke (8:43) that she had been subjected to a variety of methods of treatment by numerous physicians, spending her entire estate in paying them, but instead of receiving benefit, had been growing worse-a chronic, aggravated, and unmanageable case. Sitrauss finds an unveracious element in the domble oceurrence ot the number twelve in this nalrative (the woman has suffored twelve years, and the maiden was twolve vears old, Mark 5: 42 ); some of our allegorizers would find in it a decp spiritual meaning-wlich is the sillier notion? Came, ste., or coming to him from behind, partly, no doubt, through gen(ral timidits, partly from a reluctance to have public attention called to her peculiar affic- 
23 And when Jesus came into the ruler's house, and saw the minst rels and the people making a noist,

24 lle sidi unfo them, (ijve place: for the maid is not dead, hut sleepeth. And they laughed him to scom.

25 But when the pesple wre put torth, he went in, and took her by the hand, and the maid arose.
23 And when Jesus eame into the ruler's house, and saw the flute-players, and the crowd making a 24 tumult, he said, lije place: for the damsel is not dead, bat sleepeth. Ind they laurbed him to scorn. 25 But when the crowh was put forth, he entered in, and louk ber by the hand; and the damsel arose. was snceesful. Sire the same expression tised in Luke $7: 50 ; 17: 19 ; 18: 42$. Was made whole (healed) from that hour. The healing took place at the moment of the touch; what is here said is that from that time forward shewas no more sick, but well-not only delivered, lout preserved. So in $15: 28 ; 17: 18$. Eusebins ("Hist." VII. 17) gives a tradition that this woman's name was Veronica.

23-26. This resumes the narrative of $v .18 \mathrm{f}$. We learn from Mark (5:3i) and Lnke (8:51) that lesus sutfered no one to go into the house with himsave Peter and James and John, and the parents of the girl. The other twoucasions on which he took these three disciples only, viz., the Transfiguration and Gethsemane, were singularly solemn and momentous. What was therecorresponding in this case? It wasthe first instance of aur Lord's rasing the dead. And saw the minstrels, ete, ratherin Rev. Ver., the flute players (6mmp). Rev. 18: 22), and the crowe making atumult, the same Greek word as iu Mark 5: 39; Aets 17:5; 20: 10. This last expression is confined in the original to the crowd, so that a eomma is needed after 'flute players.' It was the custom in the East and still is, for the relatives and special friends of the dying person to gather romud the couch, and the moment the breath ceasod thay would break ont into lond cries, with every exclamation and sign of the most passionate grief; and unable treontinue this thomselves, they would hire professional mourners, especially women, who would keep up the lond, wailing ery throughout the day and night. (Comp. Jor. 9: 17; 16: 6f.; Ezek. 24: 17; Amos is: 16; 2 Chrou. 25: 25.) Persons of wealth might afford to hiremusiciansalso; and Jairus being a man of consideration, a ruber of the synagogue, we find that the flute players bave arrived, and although but a few minutes after. the child's decense, alrandy there is a crowd present, making a tumultuous noise of lam(ntation. All these things are witnessed by travelers in Egypt or Palestine at the present day.

24. Is not dead, but sleepeth. Jesus speaks with reference to what he intends to do. She is going to rise up presently as one who had been asleep. so that her death will be, in the result, no death; it will only be as it she wore sleejuing. Likewise in John 11: 11, he speaks of Lazarus as sleefing, beeause he was going to awake him out of sleep. Thus there was no oecision for the noisy mourning, and the preparations for a funeral; and the crowd must withdraw. Langhed him to scorn. This might only mean that anybody could see she was dead (Luke 8:53), and it seemed silly to think otherwise. But there in Cajernaum, where he had wrought many miracles, it may be that they supposed he would try to heal hor, and thought the attempt absurd, as she was unquestionably dead, and it was too late. It is not likely they thought he was proposing to bring the dead to life, which he had never done. Their seornful laughter shows that the people were by no means swift to believe in his miraculous powers and his divine mission; and thus renders the wondering acknowledgment, repeatelly extorted from them by facts, an evidence all the more valuable and satisfactory.

25. But when the people were put forth, or, thenst out, the word implying some con-traint or urgency. Ife was as yet in the more ptablic reception room of the dwelling. IIaving expelled the crowd, he (with the parents and his three followers (Lukes: 50 ), went in, viz., into the inner room where tho body was lying. Took her by the hand. Touching the deat body, like touching the leper (8:3), or being toucled by the woman with a flow of blood, would have the effeet, aceording to the law, of producing the highest degree of ceremonial mucleanness; but in all these eases Jesus, instead of receiving pollution through the touch, imparted cleansing. Mark (5:41) and Luke (8:54) relate that in addition to grasping her hand he spoke, and bade her arise. Also that he charged her parents much, not to tell what had happoned (comp. on 8: 4), notwithstinding which we find here that the fame thereof went abroad into all that land, $i$. e., Galilee, or the parts of Galilee adjacent to Capernaum. 


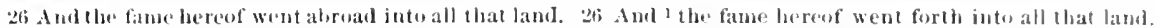

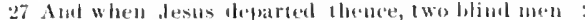

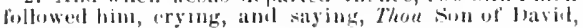
halve merey on $1 \mathrm{~s}$.

2x And whell be was comme inte the lonese, the blind

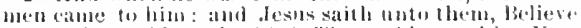
ye that 1 and able to do this? They said unto bin, lea, i. irit.

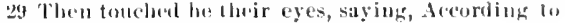

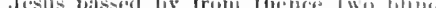
neu followed him, crying ont, and saying, 11:ate 28 merey on 11 , llaw som in fravil. Ami when he was

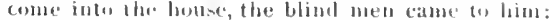
and Jesus saith unto then, Paliove ye that 1 and

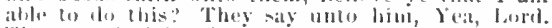

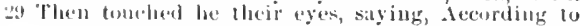

I tir this fictuet.

llar woman, for one reasm, was required to toll; Jairus, for anuther, was forbichen to tell. It caumot be that oresus expected the matter I remain wholly mbloown; lo probably wisherl to prevent their speaking of it at once and genembly, as they would lave done, because in that rase there wesuld have bean tous much excitement proluced, by the series of pxtracolinary mirales then aceurring in immediate suecession. (compr. an r. 28.) Stifr: "l'luren awakonings from death the sjeirit las caused to be recorded for ns, though of hers may well have taken plane; and these indered, in a remarkable and signiticant progression .... the maislen is here dead upon her bed, the

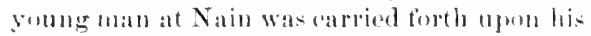
bier, Latatrushad lain tomerays in his grave."

The sorios of miraches in (ole. 9, and the whole group of (al) sand !), ands whth-

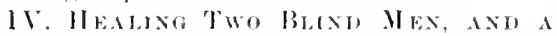

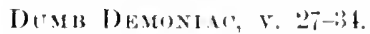

These miricles are not reorrded by the other livinumlists.

27-31. Heding the blind men. And whon Jesles departed thence-uets pessing along thence-the same expression as in 8.4 . It shows that the following miracles ocenred immodiately atter the preceding. Followed him, in the purely literal sense, wentalong bohindhin. They may have been sitting beside the rond when he jussed by, as in Luke J8: 35-37. Have merey, or, hare pity. The word really includes both ideas, and the lafter is the one bereprominent. (Seron 5: 7.) Bysaying, sun of David, they dealare their beliof that he is the Mes-

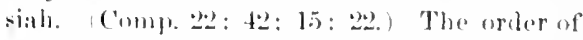
the Greok shows that their first thomght was firr morey on themalves-regre maturally. They had probably heard of . lestos miracles, perhajes of the two womderful works just wrought. If one inguires why they should believe him to be Masinh, while others did not, we can omly reply by asking why there is a similar difference now. The Gospels frequently mention blind persons henled.
(11:5:12:22:15:30;20, 30:21:14; Mark *:22: Jobu 5:3;9:1.) Blindnose is much mure enumon in the bitst

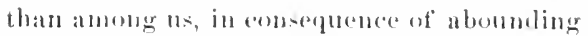

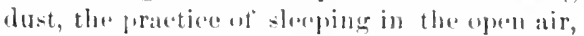
the sudden change from darkened louses to dazzling light without, and the fitet that their head-elress does not provect the ryes.

28. Into the house, viz., the house to which he returnol from that at the ruler. (v.2s.) It may have bern Matthew's lususes (v. 10), or Peter's (N: 14), or some otbrer which Instes mate his nital platere of aboule at

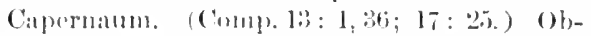
serve that in Capernatum ofetors all that is narrated in v. 2-:3t, as well as in 8: 5-2.2. Is

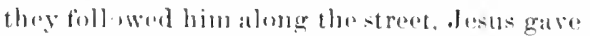
them an answer or notice; lut when he hat entered the house, they approached and ho spole to them. This failure to metioe llom at first was dembelese designted (1) to develop

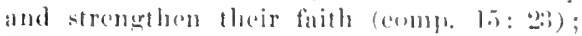
(2) to avoid the excitement which another jublic miracle just thor might have produced among the people, alroarly stirred ly the healine of the woman, and by the rapidly sfrataling news of the rasing of Jairus' daughter to life. (Cimpe on $\%$ 2-ti.) The fuestion, Believe ye that I am able? developeel inter greater chearnose the faith they bad alroaly shown by following and asking. In thoir answer. Lard is probably no more than a very respectful form of aldress. (see on \&: 2.) Jests was more roaly to work miracles where there was faitl in him. (Cump. an v. 2), 22, and 18: is.) But it is tor) much to say that he mever wromerlit miracles without fath: instance tho widews wh at Nain, and Malchus ear. Ohservethat his question wa-simply whether they helieved that he could heal them; his willinguens remained to be serm. (Cump). (n)

29. Tunching the eyes of the hlind (compl. 20-34), was u natural and kindly ate like taking the hand ot one proatrate with fever. (s: 15.) According to your finth be it-let 
30 And their eves were opened; and Tesus straitly charged them, saying, see thet no uan know it.

31 But they, when liey were departed, spread abroad his fambe in all that (enuitry.

32 As they went out, behishd, they brought to him a lumb man, posmesset with a devil.

3*) And whtn the devil waseast out, the dumbspake: and lh, multitules mavelled, saying, It was never so seen in Israt.

3t lßut llye l'harisees said, Ile easteth out devils through lie prince ot the devils.

1 Or, sternly...20r, In.

it happer--nuto you. (Comp. on 8: 13). An ofd Groman writer says that faith is like a hucket by which we draw from the inexbatustible fountain of God's merey and gondness, to which otherwise we cannot penetrate; and Calvin tompares it to a purse, which may itselt be worthless, but filled with money makes the mann ricls.

30. And their eyes were opened. We have no means of judging whether this physical bleswing was attended with the pardon of their sins. (Comp. on 8: 3.) The fact that they som atter disobeyed Christ's explicit and emphatic command renders it improbable that they believed unto salvation, though not imporible. And Jesus straitly (stemly) charged them, an muchasical, but matural sense of tho (rresk word, found also in Mark 1: 43. The expression implies that he would be sorimsty displeased if they disobeyed. As to the probable reasons for this, comp. on 8 : 4 ; and add here that they were virtually calling him Mresiah, which might excite popular fanaticism. (16:20: John 6:15.) He may latse spoken with greater severity of manner, bealuse a similar injunetion in previous cases hatd been diwpgatuded; ret it was dispegarded agalin in this case. Spread abroad his fame iil all that comutry, as in v. 26 . The Com. Ver., with its passion for variety, must neods give 'land' in v. 20, and 'country' leere, though thr. Creek has the same word and in the anme connectim, and though the earlier Eng. versions transiate it alike in both places. some have sought to excuse the disoluedience of the two men on the ground that it was very natural, and was no doubt sineerely dosigned to do him homor. But still it wats a

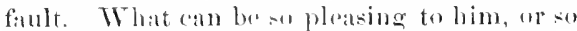
conducive to his glory, ats simple, unquestioning, luxing obediener?

1 IV H. braket this rerse, as of douht ful genuineness. But the omly ardence for onitting is that of l', two cornes of the old latin, and two latin Fathers of the fourth century, evidence exelusively "Western," and
50 your faith be it done unto you. And th opened. Amul Jesus 1 strictly charged

31 see that no man know it. But they w spreat abroad his fame in all that lane 32 And as they went forth, hebold ther :3 to him a dumb man possessed with a when the flemon was cast out, the dumt lish o: ke: and the multitules warvellid, saying, lt ... a . ver

34 so seen in lsrael. But the l'harisees said, 2 By the prince of the deumos easteth he out demons.

32-34. Healing a dumb demoniac. This is not related by the other Evangelists. And as they weut (were going) ont, namely, out of the house in which they had been healed. (v. 2४.) 'They' is slightly emphatic, standing in contrast to the next person who came to be hoaled. Behold, calling attention to what follows as wonkerful. They brought to him, i. e., some persons bronght; impersonal or indefinite, as in 5: $11 ; 9: 17$, and often. A dumb man possessed with a devil, a dememiac, sce on $8: 28,31$. Comp. Mark 9: 25 for a similar case. Mark $7: 32$ mentions a deaf man who speke with difficulty, and says nothing of demoniacal influence. Inatt. 12: 22 gives a demoniac who was both blind and dumb. And the multitudes, crourds, as in $5: 1 ; 9: 8$, and often. Marvelled, etc. IIondered, saying, It never at any time appeared thus in Israt; there was never such a thing seen before, in all the wonderful history of the nation. (Comp. Mark 2: 12; John 9: 32.) Probably thejp wonder refered not merely to this last ense of the dumb demoniar, but to the series of miracles that day wronght, and, it would seem, in quick succesion-the woman, the daughter of . Jairus, the two blind men, and now the dumb man. The Evangelists never stop to say themsolves that the miracles of Josus were womblerful. To them these things were not astoni-hing now as they looked back from the time of writing their narratives, for it was a fact long familiar to their minds that he who wrought them wat divine; and so they calmly tell the story of mirace after miracle, without any exclaunation or remark. But it was appropriate to nention, as they often do, the wonder felt by the persons witnessing a miracle, because this was one of the evidences of its manifest reality. T. $34 .^{1}$ But the Pharisees said, strictly "were saying,'

quite menre. This often arhitrary "Western" type of text might easily have omitted the sentence, from the notion that sueh a thing occurret but once and that its true place is in $12: 24$. 
viz. while the penple were axpessing their wonder. Through, literally 'in' (margin of' Rev. Ver. l, i. e., in union with, by puwer derived frun, the prince of the devifs, demons. This insulting charge was probubly made on the present oceation in the absence of .l estls, but made afterwards in his presence; see on 12: 20. The Pharisees; secons: $: 7$. They h:dl been finding fault with oesu- in connection with all the preceding matters for undertaling to forerive sin ( $\mathrm{V} .3)$, fur alsocia-ting with pullicans and sinners (v. 11), and for not farting (v. 1t), and now their opposition grows yet more hitter and boll, when they vesture upon the aceasation of union with sitall. The erewels, for their part, wondered at the unpuralleled event, but the Phariseres tried to explain it away, by however bianelese and blasphemous a supporition. So alon in 12: 2:? fo. They wree not willing to ateknowlenge the truth about Jesus miracles, for it would diminish their own con-ideration among the people: and so they struek out indaly after some cixplanation or other.

Thu- and the remarkable series of miractes which Matthew hats arouped (chat). 8 and 9), as speeimens of our Lard's wonderful works. (Comp. on 8: 1).

\section{HOMLETICAL ANI PRACTICAL.}

Ch. 9: 2-8. Siekness and sins: 1) Sime kinds of sickness proced directly from sin, and are it penalty. 2) Forgivents of sin is for more important than ande ot sickness. 3) He who could by a word heal the severest sickness can nlso formive sin. 4) The Usual condition of mirateulous healing wats fatith, and fath is the indi-pensible comdition of

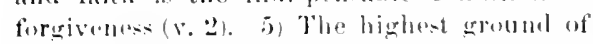
cherefuluess and gratitude is to have mor sins forgiven (v. 3).-V. 2. Fath and healing. 1)

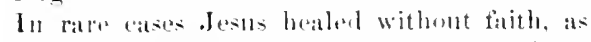
Malchus. 2) sometimes upon the foith of othere, at the nobleman (John 4-5o), the centuron ( $8: 10)$, the syrophonician. (15:2x) B) Usually upou thr fatith of the sullerer, v. 2.2, 28, and often. 4) Here upon the fath both of the sullerer and of his friends. - V. 3. II ExkY: "If we have the comfort of our reenciliation to God, with the comfort of our reencery from siekness, this makes it a merey indeed to us. as to Hezekiah. Isa. $38: 17 . "-V .4$ f. C'nRrs.
"Jeaus here does two things superbumanrecing theughto, and torgiving sins." - V. to. C'nkrs: "1) Pront of the forgiberness by healing. 2) Prouf of the healing, by arrying the bed." - V. S. Comp. the enferet prenduced at Citrmel. (1 king, 19. 33.) Hevry: "Others" moreites should be our praises."

V.9-11. Natthew. 1 Abandoning a lucrative employment to follow Jeslls in poverty. 2) Turning from a worblly necupation to follow deso in spirituality. :) Bringing his former wieked compunions to beat J Jesus, if perchance they will follow him tow. 4) Rising from deppod fubliean to aputle and evin-

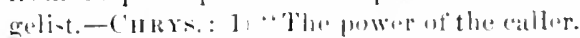
2) The obedience of the called." - probibly preparenl hofine hand, sut still at his old

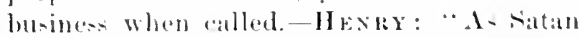
chooses to come. with his temptations, to those that are idle, so Christ chooses to come, with his calls, to those that are enuplogel." -V. Il. Jeans eating with publicans and sinmers. 1) social intercourse atloreds a great opportunity for doirg people gowd. 2) The worst men must he treated with respect, if we would win them to prety ; and the worst ment have in them something to bet pe-pected. (H.I.L: "] de not find where. Jente was ever bithlen to

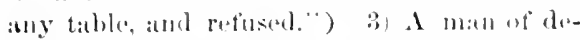
-pired calling maly berome a Chri-tian, and an eminent minister. 4 It may be law ful to atsocolate with very wieked pereple. when we can be confident of doing them gornd, and are duly guarded anainst reeding iojury.-

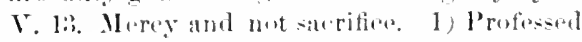
teachers of Secipture may greatly mi-take it: meaning. 2) The externals of religion atre mateceptable to Goml, without its true spirit. (2) The spirit of ('hrintianity tealehes a kindly pity for exen the grosily wirked. Ju-n seemed to be transgresing the law of extro mony; the Platrianes really were trathearess ing the law uf merey. H) The greatent kindnuse we can do to wieked peoples is to lead them to be truly pioms. 5) In arder tor romeh the most dearaded with Christian intluencers. we must trat them with eourtery and respent.

V. 14. Ilexry: "False and formal professors often excel others in outwall atets of devotion, and even of mortitieation. . . It is common for vain protessors to natke themalves a stmedard in religion, hy which to try and measure persons and thing, ats if all who 
35 And Jesus went ahout all the cities and villages, teaching in their synagogues, and preaching the guspel if the kingdom, and liealing every sickness and every disease anoug the people.

diflered from them were so fin in the wrong; as if all that did less than they, did too little, and all that did more than they, did too much." - V. 15. Fasting is proper only when it laus a natural basis in some actual grief.V. $16 \mathrm{f}^{2}$. Christianity and Judaism are in many respects ineougruous; let us not Judaize our Christinnity.

V.・18-21. Parental grief and persomal suffering both leading to Jesus.- $T$. 20-22. The timid sufferer's faith. 1) Follows the failure of all natural efforts (Mark 5: 26) ; 2) Overeomes timidity and shame; 3) Presses through an unfriendly throng; 4) Brings healing instantly and pormanently ; 5) Gains the Saviour's approval; 6) Bears her away lappy.-V. 23 26. The ruler's daughter. 1) The sorrowing, but believing father (r.18). 2) The noisy mourners, loudly proclaiming her dead. 3) The silent chamber (comp. Mark 5; 40), and the young life restored. 4) The supernatural healing, followed immediately by giving natural food. (Mark 5: 43.) Comp. John 6: 12. 5) The restored lite devoted, let us bope, to the good of man, and the glory of God.

I. 27. HeNRY: "It becomes those that are under the same afliction, to eoneur in the same prayers for relief. Fellow-sufferers should be joint petitioners. In Christ there is enougl for all." - $\mathrm{r}$. 28. LutuFR: "Christ is rejuiced to see our faith persistent, unwearied, stiff-necked." - T. 29. Henry : "They who apply themselves to Jesus Chrixt shall be dealt with aceording to their faith; not aceording to their fancies, not according to their professions, but aceording to tlupir fuith." - T. $30 \mathrm{f}$. We often fiil to speali fur.Jesus when we ought, but sometimes fail to be silent when we ought.

V. 2-34. Striking examples of belief in Jesus, and of unbelief. (1) Of belief. (a) The paralytic, v. 2; (b) The publiean, v. 9; (c) The ruler of the synagogue, v. 18 ; (d) The long-afflicted woman, v. $21 \mathrm{f}$; (e) The two blind men, v. 28. (2) Of unbelief. (a) The seribes aceusing him of blaspheny, v. 3; (b) The Pharisees eomplaining that he eats with publieans and sinners, v, 11; (c) The disciples of John, witl their skeptical inquiry about fasting, v. 14; (d) The crowd at Jairus'
3. And Jesus went about all the cities and the villages, teaching in their synagogues, and preaching the gospel of the kingdom, and healing all

house laughing scornfully, v. 24; (e) The Pharisees charging league with Satan, v. $3 t$.

$9: 35-10: 15$. MISsion of THE Twelve.

Our Lord here undertakes another eircuit of Galilce, similar to that deseribed in $4: 23$ ff., and in connection with it he now sends out the Twelve to engage in the same work, viz, to make the same proclamation of the near approach of the Messianic roign (e:mp. 10:7 with 4: 17), and to work similar miracles of healing. $(10: 1,8$ ) Before seriding forth the Twelve, our Lord addressed them a long discourse (10:5-42), giving them instuuetion not only for this mission, but for all their subsequent labors in his name; after which discourse he went to his work (11:1), and they to theirs. (Mark 6: $12 \mathrm{f}$; Luke $9: 6$.)--Some prefer to consider this as not the record of a distinct journey, but simply a return to the generul statement of 4: 23. The idea would thus be, that baving given a grand specimen of our Lurd's teaching (ch.5-7), and a group of specimens of his miraeles (ch. 8 and 9 ), the Evangelist now repeats the general deseription of his journeying, teaching and houling (simeterms in $9: 85$ as in 4: 23), and presently branches off again to describe the mission ot the Twelve. But it seems more likely that this was a seeond and distinct journey. Indeed, Luke appear's to give a third journey (Luke $8: 1-3$ ), which a Harmony would make intermediate between the two in Matthew. -Our present section ineludes so much of the address to the Twelve as is given by Mark and Luke also. The remainder (v.16-42) is given by Matthew only.

I. 9: 35 to 10: 1. Jusus Is MOVED To SENI OUT THE Twelve. While engaged in a eircuit of Galilee; he is moved with compassion at the spiritual destitution of the people, and begins to prepare the Twolve for going out as teachers. The portion in $v$.5.38 is found in Matthew alone, exeept that Mark (6:6) says simply, "And he went round about the villages teiching.'

35. Same as 4 : "23, "xeept that for "went about a!l Galilee' we here have more particularly, went abont all the cities and (the) villages, referring still to Galilee, as the con- 
36) But when he saw the malitudes, he was mowed

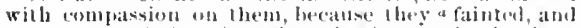

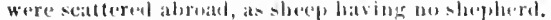

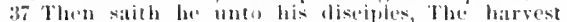

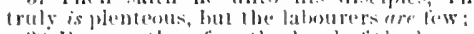

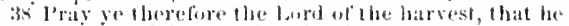
will semd finth labenrers ifalo his harvest.

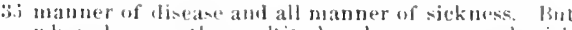
H hen lie sitw the mulizuldes, hes was noverl with

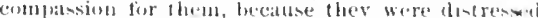

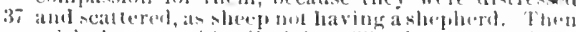

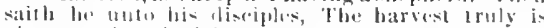

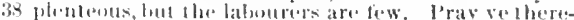
fure the larel of the harvest, that he seint fortl labeurers inla this harvest.

a or, were tired and lay doen

nection and the rircumbtances show. AII is so plated in the Greek as an be eonfined to the rities; and he conlel not have visited all the villages. Josephus say- there were in Galilee. not less than two humbeal and four aitjes and

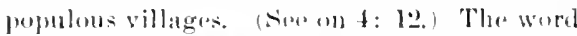
rendered villages dellutes propere a lown without walls, as opposed fo a torestiod town. The largor platers would of eourse all be tortified. Wre lealon then that onr Lorrl maklea thorough cirouit, guing into all the large [owns, and very generally inte the sualler places also. He dial not gil only where he could have a very large comgregation. For every sickucs and erery disease-i. e. every kind, not necessarily every calse-and for the other terms, sin on $4: 2$ : $)$. Imong the people, com. Greek loxt, i= omitted on orerwhelming evidemee. Ilore again, a- in $8: 10$ and 4: 2:?. wo must panso and alwell on the strong general sutement, or we shall nut adefuately conceive af the immense extent of our Lurd's worli as a Ilealur.

316. IBut when lo saw llo mullitudescroueds-ats in 5: 1. Is thele lis empasion led to a houg adrlresson tha Mount, so here it leals him to send out the Twelve, that hbeg. might aid in the so mulel needed work of teaching and healing. Similarly attor the roturn of the Twelve. (Mark 6-34) In the joraent ease, ats in 5: 1, we unelerstand that what follows touk place at some nuassignal timo in the course of the ciremit just leseribur.

Because they faimed, best text, were distressed, or "harasiod," "worried, remelered "tromble' in Nark i: 3.5: luke s: 4!. The evidenese tior this Greoti worel rather tham

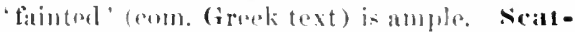
cered, literally, 'thrown, 'hurled,' might mean prostrate (so Davil-e,d), lying down, as being worn out and umable to go fonrwalle ar might mean east off, neglecterl; the groneral comeeption remains the same, that of a thock worried and sutlering for lack of a sheplerd': care. In the Eat, where sheop wanler freds in wild, unenclosed regions, so as to require constant attention, this image is very striking.

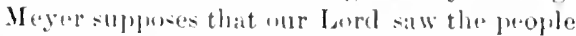
to be worn ant with folluwing him in long journegs and that this suggested to hin thes image of a tlowk tirol anw ; lut the supusstion sem- quite improbable. (Majes). The propele ware ereatly in need of stiritual instruction and guifanere, for those who profesent to be their shepherds were not laithtul and safo guiles. (sie the same axpression in Num. ำ : 17, and comp. 1 lings 20: 17; Jur. 5): 1i; Ezok, 31: 5; Yech. 10: 2.)

37, 38. Jusecks to awaken at rimilar (ompission in his followers. Disciples, sese on 5: 1. There were probibly other alieriples present, besides the Twolve (10:1), and the exhortation to lray was atdressed to them all, lut only the Pwelve were at that timesent fiurtl; at a later periul, srexenty others. (toke 10: 1.) Tho fignos af romping a liarsest ha had

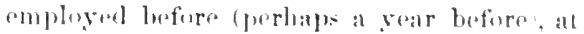
Jaculis woll (dohut:35 fr.), and will use again when semling ont the seventy. (ruke so 2.) Truly represonts tle (iroek word (men) explaiued an 3: 11, which denotes merely that this enatus is set in erontrast with what tollows. The irlea is sutfieiently exprened in Engisls by an emplatic utterance of 'harvost' and "laborers'; it wa so rendered hy 'Tyn. and

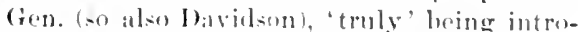
duced by Grate Bible. Whe harvest sienifies, not (as somes explain) the elext, these who will actually bo saved, but men in gen"ral, who muless gatlered and saserl will perish like wheat that is not reaped.-This compassion for prophing men will naturally

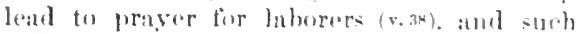
anpasion and fralyer will furm the but preparation for gotiog forth to be baburelsour-

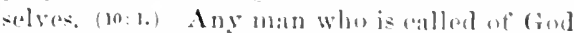
to dovole himself to proalching the gromel will have folt somothing, onght to have fiolt mulh, of this pitying lowe tor his perishing tellow mon. and wiil have praved murly for their resene; and those angagend in that work should be careful to maintuin, us 


\section{CH A P T E R X}

NI) when he bad called unto him his twetve diseiA pes, he gave them power a against unelean spirits, to cast them out, and to beal all manner of sickness and all manner ot displise.

"Now the names of the twelve apostles are these; The first, simon, who is called Peter, and Andrew his brother: James the som of Zehedec, and John his brotber
1 And he ealled unto him his twelve disciples, and gave them authority over unelean spirits, to east them out, and to heal all manner of disease and all manner of sictiness.

2 Now the names of the twelve apostles are these: The first, sinon, who is called Peter, and Andrew his brother; James the som of Zebedee, and John his

a Or, over.

long as they live, this same pity and prayer. And not only preachers, but all Christians, should feel as Jesus felt, and should regularly and habitually pray this prayer. Send forth is literally east out, 'throw out,' or 'thrust out,' the same word that is used in v. $32 \mathrm{f}$., in $10: 1$, and above in v. 25 (where see note). Comp. its use in Mark 1: 12; James 2: 25. It always implies urgency, haste, constraint, or some such idea, and here means that the laborers should be sent out promptly, pushed into their work. Beza: "For we are all very tardy, especially in such matters." This same word is retained when our Lord speaks to the seventy. (Luke 10:2.) ${ }^{1}$ Such laborers as the Lord of the harvest does put forth, we may endeavol, with his blessing, to train for the better performance of their work (see on 10: 1); but they must be his laborers, not ours, called into the work, and urged to the performance of it, by himself.

10: 1. Having led the disciples to feel intarest in perishing throngs of men, and encouraged them to pray for laborers, lesus now bids them go forth to lahor themselves. We ought carefully to observe the slow and gradnal process by which our Lord prepared the 'lwalve for their great and important life-work. Ficst, he called various individualstobe his disciples, as, for example, those in John 1 : :55-51; these went with him for a time, but afterwarks returned to their homos and their secular employments. Next, he called some to attach themselves permanently to him, as above in 4: 18-2\%, stating at the time his intention to make them fishers of men. Atter a while, he selected from the general mass of his followers the Tivelve, who were to be specially near to him, and to be trained for special duties; delivering to them, inmediately after their selection (see on 5: 1), a great discourse on the true nature of that $M$ essianic rejgn which they were to aid in bringing about. And now, at a still later period, when they have been long bearing his discourses to the people, talking with him familiarly in private, and witnessing his nultiplied miracles, he sends them forth, two and two, to preach and heal; but not yet to work independently of him, for the only to go before and prepare the way for his coming. After a season spent in such personal labors, they will return, and renain long with him, receiving furtherinstruction, which they will mole carnestly desire and more fully appreciate, from their attempts at actual preaching. And finally, after his ascension, they will be ready, with the Holy spirit as their abiding Instructor, to go aud disciple all nations. Ifter all this training they could do nothing without the spirit; yet, though they were to have the Spirit, they must also have this training-doing what they could, meanwhile, to roap the great and perishing harvent, but devoting themselves mainly to preparation for wirler nsefulness in the coming years.

With v. 1-15 comp. Mark 6: 7-11; Luke 9: 1-5. Disciples, secon 5: 1.-Power, authority, which in such a case would eary with it the power, see on 9: 6. As to demoniacal possessions, see on 8: 28. These spirits are called nuclean, because of their own wickedness, and perbaps because their plesence was a pollution to the person possessed (comp. on 12: $49 \mathrm{fl}$ ) ; and this served to distinguish them from good or pure spirits. Sometimes ther are called 'evil spirits.' All manmer of, etc., errory disease and erery infirmity, (comp. 1): $: 3 ; 4: 23$.

II. 2-4. List of the Twelve. Mathew has not mentioned the selfiction ot the Twelve, which took place before this. (Nark $3: 13$; Luke $6: 13$, comp. on 5:1.) At the time when he wrote, the twelve apostles wore well known, and he spealis of then aceordingly: "histwelve disciples,' 'the twelve apostes.' The number twelve was probably chosen with reference to 


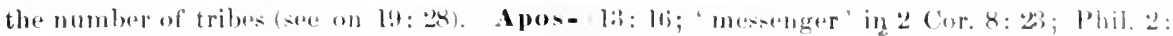

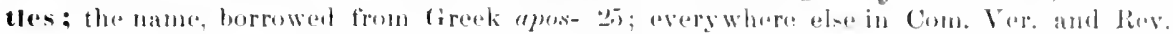

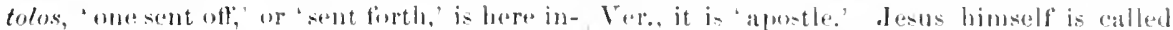

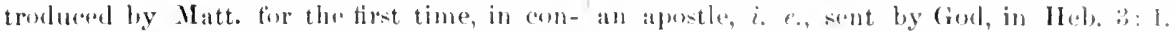
nection with the aedaton on which they ware Our worel missionery, derived from the Lattin, first actually sent furth (v. 5) to labor. But likewian mignifies "und sent.'

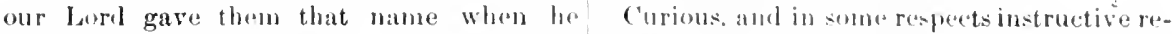
selected the Twelve (see Luke fi: lis). Tha sult., maty be obtained from a conparison of worl is translated 'one that is sent' in John the tuur liss of the 'Twelve.

\begin{tabular}{|c|c|c|c|}
\hline Matthew lt): $2 \mathrm{f}$. & Mark 3: lif. & Julief: $14 \mathrm{f}$ & Aets $1: 13 \mathrm{f}$. \\
\hline 1 Simmon Peter. & simon Peter. & simnn I'eter. & Simon P'eter. \\
\hline 2 Anilrew. & Jatures. & Androw. & Jaunes. \\
\hline$\because$ Jamos. & Johm. & Ianurs. & Juhn. \\
\hline $4 . J(1) 11$. & Androw. & Julı. & Androw. \\
\hline 5 Philip. & Philip. & l'hilip. & Philip. \\
\hline (i Bartholomew. & Bartholomew. & Bartholomew. & Thombas. \\
\hline 7 'l'huाuas. & Mattherw. & Matthew: & Bartholomew. \\
\hline 8 Matthew. & Thomas. & Thomats. & Matthru. \\
\hline $\begin{array}{l}9 . \text { Inmes the son of } \\
\text { Alphers. }\end{array}$ & $\begin{array}{l}\text { James the son of } \\
\text { Alphens. }\end{array}$ & $\begin{array}{l}\text { Jamestlueson of } \\
\text { Alpbers. }\end{array}$ & $\begin{array}{l}\text { James the son of } \\
\text { Alplieus }\end{array}$ \\
\hline 10 Thaddius. & Thatdens. & simonthe Zealut. & siumon the Zealut. \\
\hline $\begin{array}{l}\text { 11 Simon the } \\
\text { Camatmite. }\end{array}$ & $\begin{array}{l}\text { Simom the } \\
\text { Camannite. }\end{array}$ & $\begin{array}{l}\text { Judisthelorothar } \\
\text { of James. }\end{array}$ & $\begin{array}{l}\text { Judas the bruther } \\
\text { of . James. }\end{array}$ \\
\hline 12 Jublas Ineriot. & Jular Iscariot. & Judis lscariot. & (Vac'ant). \\
\hline
\end{tabular}

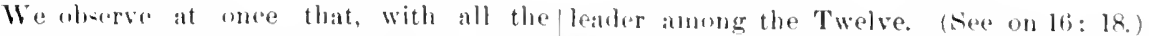
variety in the oreter of suecesion, Fimon As regards the remaining members of the limst.

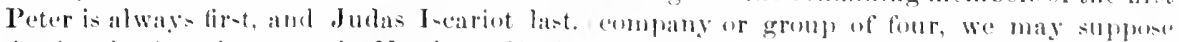
Agaim, the first six manes in Mathew, Mark, that Matthes and Luke put Mubrow arext to.

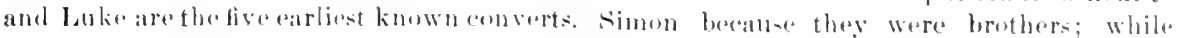

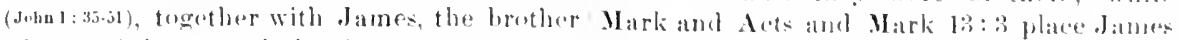
of ene of them; and the firet tiole in all the and John next to simom, breatuse there threes

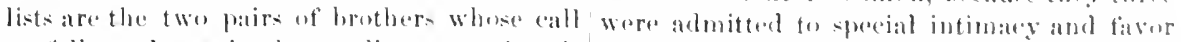

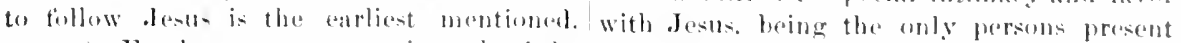

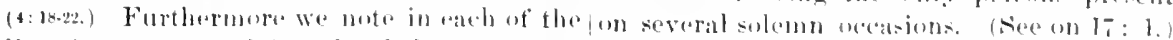

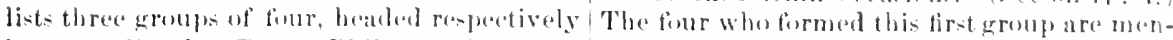
in every list ly Poter. Philip, and James, tiuned ju Nark l:3: $:$ as making private in-

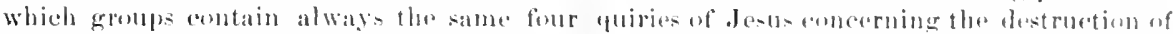

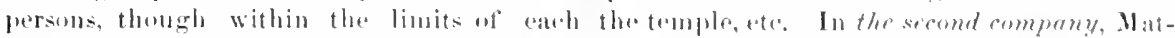

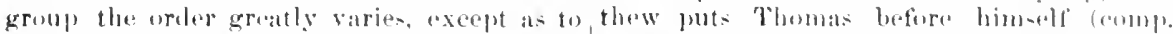

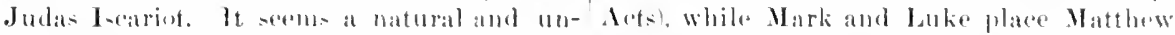
averelable inferenee that the Twelve were in first. Aftar Philip. Matthew, Mark and Inke some senee divided into thres companies of put Bartholomew, probably the same as Na-

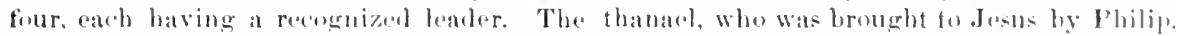

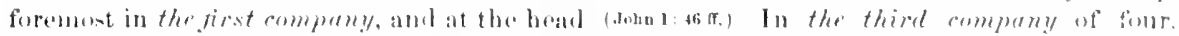

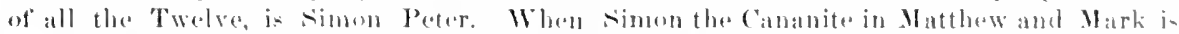

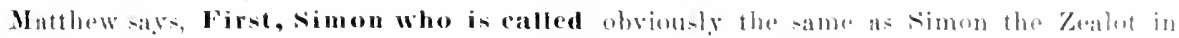

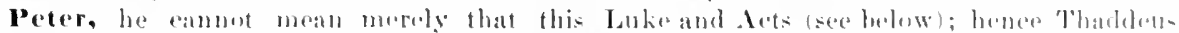

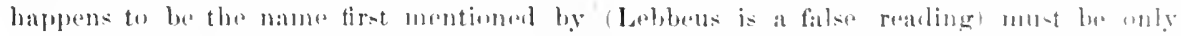

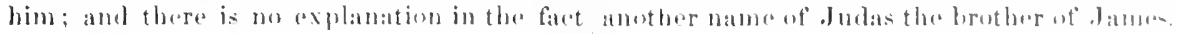
that thone are mentioned fir-t whe first eame He might naturally be put next to his brother. to.Jesus; for them Indew and probably John, as by Matthew and Mark; or Lukce arder

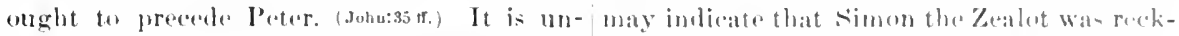
questionable that simon leter was a sort of uned the more important personage. Ubserve 
that there are among the Twelve three pairs of brothers-Simon and Andrew, Janes and John, James the son of Alpheus, and Judas the brother of James (though this last may be 'son,' see below); also that Matthew and Luke give the list in couples, and Mark (6:7) says they were sent forth 'by two and two,' and these couples would easily lead to the grouping into fours. It would be natural that in different journeyings the couples should somewhat vary, and this might perhaps account for the different order of names in the several groups of four.

Simon who is called Peter. Simon was a Gresk name, but in the New Test. is pretty certainly a contration of Simeon, which form is given in Acts 15:14, and by some authorities in 2 Peter 1: 1. Simeon signitied hearing. (Gen. 29: 33.) Simon was a native of Bethsaida (Jotu 1:44), a town on the Sea of Galitee, described below on 11: 2I. His father's name was Jonah or John (see on 16: 17). He and lis brother Andrew were fishermen on the Lake of Galilee. Andrew, and probably Simon also, was a disciple of John the Baptist, before coming to know Jesus. (John $1: 35$ fr.) Jesus gave to Simon when he first approached hin, the surname of Cephas (Jihn $1: 43$ ), which in the Aramaic language spoken by them, signified a rock or stone (Kepha, Greek form Kephas), and which was translated into the Greek Petros, signifying the same thing; hence Latin Petrus, English Peter. The Aramaic Cephas is always used by Paul ( 1 cor. fasl. correct text), and nowbere else in N. T. (except John 1:43.) After following Jesus for some time, Simon appears to have returned to his business as a fisherman, and was subsequently prominent among those allod to be regular attendants. (Siee on $4: 18 \mathrm{ff}$.) The principal events of his subsequent life are given in $8: 14 \mathrm{ff} ; 14: 28 \mathrm{ft} ; 16: 16 ; 16,22 \mathrm{ff}$ : John 13 : fiff.; Matt. 26: $89 ; 26: 69 \mathrm{ff}$; John 2I : 15 ff.; then in Acts $1: 15 ; 2: 14 ; 4: 8 ; 5: 8 ; 8: 14 \mathrm{ff}$; 10: $1 \mathrm{ff} ;$; $12: 9 \mathrm{ff} ; 15: 7$. He was an ardent and impulsive man, of great force of character, and extremely self-omficlent. Sad experience, througl the sperial influeness of the sprit, wrought a great change in him, though still, the last time he appears distinctly in the N. T. history, we discern the same impulsiveness and readiness to change, as of yore. (Gal. 2: 11.) He seems to have been at Babylon, where there were many Jęws, at the time of writing his First Epistle. (1 Petter $5: 13$.) The traditions concerning his later life are very uncertain, and so as to all the apostles except John. As regards Peter"s position of leader. among the Twelve, see on 16:18 f.

Andrew. The name is Greek, signifying 'manly.' The facts concerning his pareutage, residence, occupation, and ealy discipleship, have been mentioned in connection with Peter. The only uther cases in which he appears are John 6: 8; 12: 22; Mark 13: 3. The traditions concerning him are wholly unreliable. Yet he is important to us, not only as one of the inspired apostles, but as the means of bringing to Jesus his own brother simon. All the usefulness of Simon Peter is, in one sense, due to the brother who told him of Jesus. And so, many a one in every age, little known himselt, and ot no marked influence otherwise, has been among the great benefactors of mankind, by bringing to Jesus some other person who proved widely uselul.

James. . and John. James was probably the elder, as he is usually mentioned first, while John is sometimes put foremost, (Luke 9: $2 \times$; Acts 12:2), probably because nore prominent, and because alone surviving when the books were written. James is originally the same nama as Jacob, 'supplanter,' being written in the (xreek, Iacobos, Latin, Iacobus, then Jacopus, daconus, and so James. John is the Hebrew Johanan, 'Jehovalu graciously gave, see on 3: 1. Their father, Zebedce, was a fisherman on the Lake of Galilee $(4: 21)$, but apparently a man of some property, as he employed hired servants (Mark 1:20), and as his wife was one of the women who contributed to the support of Jesus and his disciples (27:55 f.; Luke 8:3), and probably al man of good social position, as we find John familiarly acquininted at the house of the high priest. (John 18:15 t.) From their mother Salome (see on 27 : 5i) was perhaps in herited the ambition (see on 20:20), and perhaps also the ardor, intensity, vehemence, and warm affection, which eharacterized her sons. These qualities of theirs were doubtless the ground of the name Boanerges. 'sons of thunder,' which Jesus gave to the two brothers. (Mark 3: 17.) John appears to have been a disciple of John the Baptist, it being almost certain that he was the unnamed diseiple of John 1: 35-41. 
3 l'hitip, and Barholonew; Thomas, and Hatthew lhe publican; James the son of Alphus, and lebbeus, whose surmame was Thableus;
3 brother; Philip, and Barlholomew; Thomas, and Alallew the publican; James the son of Alphatus,
We have no account of any call of James, until the time when the two brothers, with simon and Andraw, ware called to become our Lord's constant tolluwers (1. 21); Johu at least was probably with Jesus during the previous labors recorded in bis Gospel. (chap.:-4.) The peculiar temperament of the brothers appears in Mark 4; :38 fl.; Luke 9: 52 $\mathrm{tl}$; Matt. 20: $20 \mathrm{H}$. Afur this last event, we hear nothing of Jamrs, save as present at Gethsomane, and incluted in the list ot $\mathrm{A}$ ets 1 : 13, wntil the time when Herol Igrippa I. put him to (leath (Acts1::2), the tir-t martyr anong the apostles.

John, howevor, appors quite frequently, usually in immediate asocelation with leter, between whom and himself there was probably a special friend-hije. Together they were sent to prepure for the Paschal siupper (luke 22: 2), at which John was allowed to lem on Jesu, breast, "the disciple whom desus loved." Together thoy (and Iames) witnessed the agony in the garlan, and both followed to the triat. (Johu is: 15.) At the arose, John only of the 'Twelle seense to have been present, drawn by his ardent atlection, and perlaps relying to some extent on his aequatintance with the high-priest for safoty; and there lie received the mother of his dying trient as one of his own family. Peter and John were also

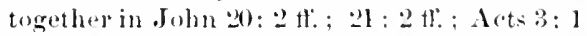
tt.; 8: 14; (Bal. 22: I. From Rivv. 1: 9 we lenrn that at some time lae was in exile on the [slaud ot Paturos. There seems little doubt that he spent many years in "A-ia," $i$. $r$, P'reonsular Asia, partieularly about Ephesus, and there wrote his inspired works. Sereral early tratitions in regarel to him are pleasing and probably true particulaty the story of his reclaiming the young robber, of his kirpoing a tame bird, of" his sayoing, "Little "hildren, lowe one another," and af his leaving a house beeanse a noted talse teacher was there. Jobn as diseiplined by gratee, exhibits one of tho noblest typos of human ebaracter. The love with which his Epintes abound has in it nothing efleminate. He strongly eroldemns and severely demouncos the prevaling errors and evils. He is not merely antemplative, but intensely practical; insisting that
Christian love must show itself in holiness and usafuluess, or it is naught. Still velienent, uncompromising, and outspoken, the hoving and beloved old man has not ceased to be the "Son if "Thuncler" ; but the vaulting anbition which onee aspired to be next to royilty in a worldly kinglom, now seeks to overcome the world, to bear testimony to tho touth, to purify the ehurehes, and glority ciod.

3. Philip. 'The mame is Greek, nignifying "lover of horsas." Philip, lik" l'eler and Andrew, was a native of Bethsaida Buba 1.55), and one of thone who left the baptist at the Jordan to tollow Jestls, his friend Nathanal, or Bartholomew, boing also bronght to Jasus through his influence. (Juha $1: 4$ f.) The only recorded incidents of his life are given in

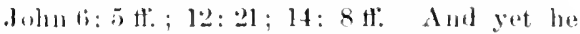
was apparently one ot the leaders mmong the Twelve, always standing at the head of the second group of four. The tratitions toul(eloling him are quite unreliable. He must of course he di-tinguished from Inilip the Evangrelist, of whom we raad in the A.ts. The name Bartholomew is Bar Tolmai, 'on of Tolmai, and Tolmai (porhaps "plowman') is an O. T. name. having in the sopt. of Joshua 15: 14 the form Tholami, and in Joseplate "Ant," 20. 1, 1, the form Thubomeus. Natbanael denestos 'Gorl-given,' like 'Themlore. etc. Fom John 21 : 2 wa naturally sllpose Nathanael to have bren one of the Twelve; and as it was Philip who brought

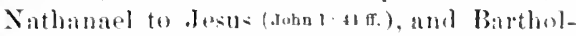
omew stands immediately atter Philip in low catalogues of Matthew, Mark, and Luke, wo conclude that $\mathrm{N}$ athamal and Barthalomew were the same persoll. Tho only fact known in his history is that ho was a mative of Cama. (Joha21:2.) The tralitions eoneerning him art of little or no value. But he stands out in eonspienous lustro form the tribute of Jeslls when he first npproghehed him, "Bohold, an lsatele indeed, in whom is no guile" ! foln 1: 4.) Thomns. This nandu signifying "twin" was sometimes trannlated into the Greek Ditymus (John H: 16), which means the

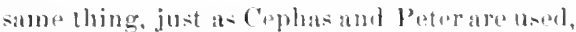
or Messiah and Chri-t. The incident griven 
of his life are in $\operatorname{John} 11: 16 ; 14: 4 \mathrm{f} ; 20: 24 \mathrm{ff}$. He does not deserve to be called "doubting Thonias," in the usual sense of the phrase; he was desponding, slow to believe what he ardently desired (as he bad been ready to believe the worst, John 11: 16), but when convinced, uttering the noblest confession in the Gospels. (Johu 20:28.) The traditions concerning him are uncertain. As to Mathew, see 011 9: 9. It is a trait of humility that he speaks of himself as Mathew, the publican: reealling the disereditable business which he had formerly followed, while the other eatalogues make no such allusion. Eusebius says ("Hist." iii. 24, (i) that "Matthew, after first preaching to the Hebrews, when he was about to go also to other nations, eommitted to writing in his native tongue the Gospel according to him, thus supplying the place of his presence." Papias, who wrote about A. D. 130, says: "Matthew composed in the Hebrew language the oracles, and every one interpreted them as he was able." The term "oracles" might mean simply discourses, or might have a more general sense, including narrative, as in $\mathrm{Pom} .3: 2$. The relation of this Helrew (Aramaic) writing to our Greek Gospel we have scarcely the means of determining. See the works on Canon and on Introduction.--The later history of Matthew is known; the traditions are unreliable.

rmes the son of Alpheus. If we adopt ach more probable viow that this Janes $\therefore$ atistinet from "James the brother of the Lord" (see on 13:55), we are left with scarcely any knowledge of this eminent apostle, the leader in the third grompof four. His father's name was Alpheus or Halpheus. which was also the name of Matthew's father. (Mark 2: 14.) Clopas (John 19:25) might be another form of the same name, but we cannot say that it was the same person. As to whether James was the brother of Judas Thaddeus, see below.
The copious accounts sometimes given of him result from identifying him with James the brother of the Lord. Thaddeus. This alone is the name in Matt. and Mark, according to the correct text. ${ }^{1}$ We have seen from comparing the catalogue that Thaddeus must be only another name of '.Judas the brother of James, as given in Luke and Acts. II was thus known as Judas the beloved, or darling. In Luke and Acts he is distinguished from Judas I searjot by calling him 'Judas of James,' or 'James's Judas, a form of expression whieh is quite common in Greek, and which usually adds the father of the person described, but sometimes another connection, such as busband, son, brother, or even friend. (see Winer, p. 190 [297].) An eminent example is that of the early Christian writer Eusebius, who, after the death of his friend Pamphilus, always ealled himself Eusebius of Pamphilus. If nothing were known to the contrary, we shouid naturally translate "Judas son of James,' as is done by the Peshito and Thebaic versions, and by our Rev. Yer. (Luke 6: 16; Acts 1: 13.) Comp. Bishop Lightfoot on Gal., l. 256. But as the Epistle of Jude begins 'Judas. aservant of Jesus Christ and brother of James' (where brother is expressed in the Greek), we seem entirely warranted in using that fact to solve the ambiguity of Luke's expression 'Judas of James,' and understanding it to mean the brother of James; yet it is inpossible to determine the question with eertainty, for we eammot even be eertain that the Epistle was written by the apostle Judas. The only ineident in the life of Judas Thaddeus is given in John 14: 22. The traditions concerning him are worthless.

Simon the Camanite, or Cananaean. The name simon being very common, this apostle is distinguished from simon Peter and others by the surname Camanaean, which in Aramaic would signify the same thing as the
1 It is given by $B \times 5,2$ cursives, the two Egyptian versions, the Latin Vulgate, and several eopies of the old latin. Lebbeus alone is gisen by $\mathrm{I}$, some Latin doctments, and llesychius, and so is a feebly supported "Western" reading. (D and some copies of the Obl Jatin make the same change in Mark 3: 18.) From these two easily arose "conflate" readings, "Jebbeus who was surnamed Thaddeus," "Thaddens who was surnamed Lebbeus," ete. The name Thaddeus is usually derived from the A ramaie thar, the female breast, Heb. shat, and would thus signify cherished in the bosom, 'beloved.' Now, Jerome says that Lebbeus (which obvionsly comes from leb, heart) signifies corculum, sweetheart, darling. We ean easily understand how the "Western" documents, so given to arbitrary ebanges, might change the unfamiliar Thaddeus to a word of similar meaning formed upon a very familiar root. Thus all the phenomena are accounted for, and Thaddeus alone stands as the name in Matt., as well as in Mark. The perplexity of several reeent writers has arisen from taking Lebheust to menn hearty, courageous, orerlooking Jerome's definition. 
4 -incon the (anataite, and Judas Iscariot, who alsit bel rayed him.

\pm and 'Thuddats; Simon the l Cananaan, and Judas 10r. Zealut. See Luke 1. Is; Actsi. 13.

Greck worl Zelotes given in Luke and Aets vi\%, 'Zatult.' 'Thirty yoats later that this. us we tind from ousephus \& "War," f, :3, !),

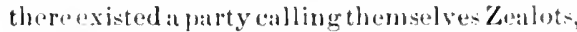
as being very zealous for the national religion and institutions. (Comp. Acts 21 : 20); Rom. 10: 2.) Ther were aceustoned to punish witherut trial, to "lymeh" any Jew who seemed to thom a trititor ar violatol of the law, tinding precedent and sanction in the case of Phinchas. (Num.25: 7.) This practice, as must always halpun when it is onntinued, lad finally to gross abuses and horrid cruelties, and the Zatalots hat no small part in the ruin of the nation. It is likely that the party al-

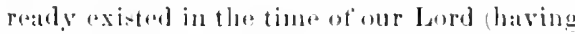
(o)medown from . Indas the (ralileatu). (Acts $5: 25)$, though on a much smaller stale than aterwares, and that Simum hat at one time betongud to it, and thus andyuterel his surname, Zelotes or ('amanaman. lt is guite a mistake to eonfoumd this with (anamite, which in Groek is materially ditferent 15 22); the mistake is found ats atrly at tireat Bible, "simon of Camatn," (so in Baseters Jexapla, hoth in Matt. and Mark. Bishun I,ightfoot [liev.] serens to be mintatien in arribing the duble "to the Bishop's Bible.) Ot this aponta"s history we kuow nothing at all. The fiat that he

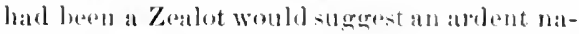

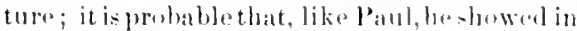
loing grood the same tiory zeal he had sloww in doingevil.

Judas Iscariot has the sime surnimme in John 12: 4; 13: 2. Mis finthel was callerl Simon Iscariot. (John 6: 71 : 13: 24, correctere.) Judats

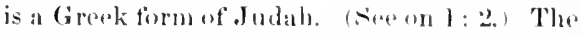
surname lscariot is Ish-lispioth, "man ot Kerioth, a town in the tribe of .Julah (Josh. 15:15); it is spelled Isatrioth in the better Greek text of Mark 3: 19; Luke it: 10, so Ish-Tob, 'man of 'Tinb' or 'men of 'Tob' is in the siept., Istob, and in Josephus lstobus. The fact that his father had tho same surname? quite excludes Lightemets finciful rymologies from Latio scortea, a leatlern apron, heeause he arriol the bag, or from Inbrow astiara, strangling. All the other disciples appear to have been Galileans (though that is not certain), und this ditference might have some etleret on .Juda in proventing full sympathy with the others. We know mothing ot his early history or his adall to be at a-ciple. It wat mot mbly a matter af divine torekunwledge that he would betray his Teacluer -ats all thing-atre-but was di-tinetly foreseren

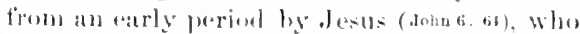
in his human mind wa- mot onmi-eient. (24: 36.$)$ That a geroon in whom this was foresosen

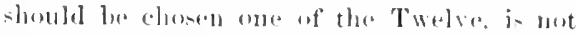

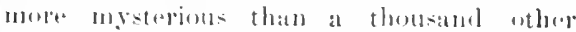
things which are done in the providenere of thesame Jard. Wirss: "The other disciples, tore, Wele not without great weaktusens atud faults ut elatareter, which were certainly mo

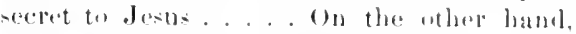
Judas must have pusesentel special anduwmants, for Jasts to consider it desirabla to secure him as a disciple." Ilis talent fior husiness, with the care ot the anmmon tund, serms tor have develuped a roinous avarion. eren in the very eompany of Jeslls. II shows us that the greatent outward privileges may be of no avail, and maly even lw prerereal into a corso; and ho exemplities the gradual progress, the terrible puwer, and tha awful result-. of corentousness lt mal very woll bes that in the beginning he wa- -ineere

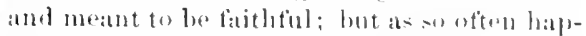

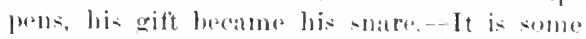
reliot to our distress when we sore mon in high places of christian usetulases at the present day falling utterly away, to remember that it was so at the beginning. (2)en anoung anr Lard's chosen Twolye. Judas must latse wrouelat miracles liku the otluers (compl. 7 :

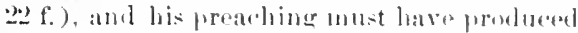
etfects like theirs, or the ditlierenesentul hive beom notiered lyg him and them. In like manner now, a bat mall sometimes preatehess and God converts somlo through his in-trumenttillity; and these, when he atterwarlo turus ont to have besen all the while a bate man at heart. may well mourn for him. hut nead have no fears as to the precoma-ness af thas truths lie prodatimed, or seruplas at to the validity of the ordinances he aldministere+t. Is to the motives of Judar in the betratral,

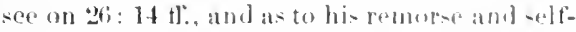
destruetion, sec on 27: 3̈ll. Betrayed, is 
5 These twelve Jesus sent forth, and commanded them, saying, fio not into the way ot the Gentiles, and iuto any city of the samaritans einter ye not:
5 Iscariot, who also Thetrayed him. These twelve Jesus sent forth, and eharyed them, saying,

Go not into any way of the Genliles, and enter not

$10 \mathrm{r}$, delivered him up; aud so always.

literally, delivered up (margin Rev. Ver.), the same word as in v. $17,19,21$, above in 5: 25, and often, It is a part of the eluaracteristic moderation of the Evangelists that never, "xrept in Luke 6: 16, do they apply to Judas the harsh words betray and traitor, which have beeme so fixed in our usage. Comp. on 17 : 2.2.

III. 5-15. I sstructions To THE 'TWELVE. The remainder of chap. 10 eontains the charge given to the Twelve on sending them out. (Comp. on 9: 35.) The earlior portion of this (s. 5.15), is also briefly reported hy Mark (6: 8.11$)$, and Luke $(9: 3-3)$. The re-t (v. 16-42) is found in Matthew only. (Nee below on $v$. 16.) A charge closely resembling the earlie part of this diseourse was also given to the seventy, when sent out sonne time later. (Luke $10: 1.16$. )

$5 \mathrm{f}$. 'These twelve Jesus sent forth; in Greek the verb from which comes apostolos, 'one sent otf.' (See on v. 2.) We learn from Mark (6:7) that he sent then 'two and two.' This arrangement may possibly lave lreen siggested by the fact that there were among the Twelve two or three pais of brothers see on $v .2 f^{*}$ ), but it had also some important advantages, both as rogurds the apostles themselves, and as to their work. The two served as company for each other, preventing the loneliness which the apostle Paul took so much pains to avoid on his journeys. They eould also relieve eateli other in proabing. which, in the opon air, and to the erowets gathered by their miracles, would be laborious, as our Lord himself found it. And then the testinony of the two witnesses ancerning the teachings and miraces of the Groat Prophet who was toming after them, would be more impressive ameong the people than that of one alone. Thes seventy also were sent forth two and two. (Luke 10: 1.) Comp. Ecol. 4: !-12; Luka 7 : 19.-Jow long these journeyings aud labor of the six pairs of apostles continued, we have no means of ascertaining; one would conjeeture a fow weeks. Way of the cientiles, like 'the removal of Bahylon' (eomp. on I: 11), and 'the way of the tree of lite,' (Gen. $3: 24$, realily signifies a way leading to the Gentiles (so rendered by Tyndale), a road to Gentile comntries. (Comp. also Jer. 2: 18; Acts 2: 28; 16: 17.) In traveling on the southern border of Galilee, they would of course come near some Samaritan towns; thus we see that the language is atuite precise-Do not enter a eity of the Sumaritans, do not go off into a road to the Gentiles.

Samaritans. SAMARIa was the district lying between . Judea and Galilee. The dislike between the Jews and the Samaritans had its begimings as far back as the earliest times of Israel in the jealousy existing between the tribes of Judab and Ephraim, which finally led to the division into two linglons. When the people of the Northern Kingdom who cane to be called samaritans from the capital city, Samaria, $1 \mathrm{Kings} \mathrm{16:24),}$ were carried into eaptivity by the Assyrians, the comntry was partly oceupied by Mesopmtamian colonists, who were idolaters. These gradually coalesed with the dregs of the Israclites who had been left in the land, and with the fugitives who returned from surmunding countries, into a half-lieathen nation, attempting to unite idolatry with the worship of Jehovalo. When the people of the southern Kingdom, the Jews, returned from their captirity in Babylon, and undertook to reluild the temple at Jerusalem, the Samaritans proffered to help them; and being repulsed, as not of pure Israclitish descent, they then did all in their power to hinder the building of the temple, and the fortification of the eity. A brother of the Jewish highrriest, having married a Samaritan woman, and being unwilling to put her away as required, went over to the tiamaritans, and was made priest in a temple built for him on Ilomt Gerizim (.Jos. "Int.," 11, 8, 2), whieh the Samaritans from that time began to contend was the proper place for the worship of Jelovah, rather than .Jerusalem. (John4:20.) These eauses naturally led to bitter hatred between Jews and Samaritans, and they were constantly attempting to injure and insult each otber, while under the dominion of the Greek kings of Syria. John Hyrcanus conquered the Samaritans, destroying their tem- 
6 But go rather to the lost sheep of the lumse of Isracl.

7 And as ye go, preach, saying, The kiugdom of leaven is at hand. finto any aily of the Sablarians: but gon rather lo 7 the las sheep of the houst of lorach. And as ye go, preach, saying, The kingdom of leaven is an hand. ple and eapital (ubout 13. c. 105). Pompey established their independence? (13. C, 63:3). At the time of on Lord's publie ministry, Juktea and samaria were governed by the same Reman procurator, but ats distinct administritive distriets; and the batred between the two nations, cherished through centuries, and combining all the clements of race jealonisy, religious rivalry, politiend hutility, add numerons old grudues, hill become so intense that the world hat probably never seen its parallal. The theory of om ene witurs that the samaritans were of purny heathen origin, wouldi suppose that the entire pepulation of the Nonthern penple was depurted hy the 1 sy ri:m-al thing oxt remeny improbable; would remler the fromuent clatm of the samaritans to be Jows an alberdity; and would make it

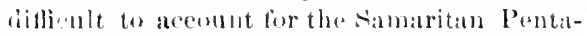
tench, and the simaritan expectation of Mrssials. Fur the simaritans, like the Jews, expereted the 31 essiath (dohn $8: 25,29$, and something like a year before this mi-nion of the Twelve our Lorl's preaching among them at syehar

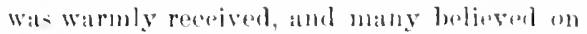
him. (Jola : $: 39.42$.) Somm time aftor this mission he aloo went twiace through simatria, and spuke atud acted kindly towath them. (Luke9: 51 15.; 17: 11 Ir.) Why, then, might not the Twelve ger inter their eitios"? It is conough tor reply that

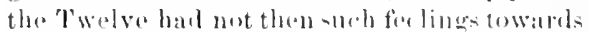
that people as would qualify them to do gond there. The propusial of James and John to eall down fire from lawaron upon as samaritan villatore (take 9:52 fr.) show that there wombla have been bitter entroveraies, with the oll national hate exer ready to bust out. (compl. Bruce, "Tralining of the Twelve.") In .hets 1: 8 , samaria is expresily included in the tield of their apponinted libors after the nasension. (comp. Aet: 8 ; i. i.)

6. To the lost sheep, ete. comp. on 9 : 36; and se the sane figure employel in I ial. 53: 6; . Jer. 50: 6; Ezek. 34: 5. Our Lurd coinfined his own peronal labors almost encirely to the Jews; he declitres, in 15: 2t, that his mission was "to the ios sheop of the house of Israel,' the same expression as here; though at a later period lie says that he hats 'othershewp which are not of thi-fold.' (soun 10: 16.) It was a part uf the peculiar privileges of the Juwinh nation that the gospel hould be first pratiched to them (Luke 24:47: Acts 13: 16; Rom. 1 i6); yet Jesus tilepuently intimated that thene exclu-iveprivilogosonid not la-tal ways. (*:11; 10:14;:2:43;22:9;24:14.) By+entining his labors and those of the Twelve to thom hes avereled exeiting their frejudires, and thusdeprived them at asen the poor excose for rejecting him which they wouhl have fomnd in his preaching fredely among tha Gentiles and

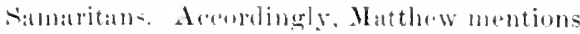
this limitation, while Mark and luke de not. Even at a later period, Paul formel it almost impusible to convinesesme Jewish christians that the finntilas were to be almitted as the privileges of the gonpel, without beroming lews. And then had the reign of Messials been prextaimed to the (iontiles bedire it had boen wolented by many. Jews. the formur miglat have made it a very phan-ible ol,jection to the new religion that it was not holieverl in at home, where it was bet understoml. Furthermore, as regards this misoisn of the fwelve, they were as yed too ignorant themselves ot the true nature of Mrsialls kingdom to undertake its propateation anong thes Gentilas; they womld lave introluesel the current Jowish errors an the sulpiet. Siome yours later, when hbeirown cour-o of andy inseluction was ampleted, nuel tios spirit was come, they ware prepured to prome " "pepentunee and remiasion of sins. . Into all the mations." (Luke2t: A. Bes.Vur. For the present they eoubl prepatre the dews amonge whom they went tore the proaching of Jentle and what they said womld not stemgthen, but so tar as it went wuld rather correct the pupular

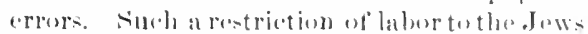
is not atdresonel to the sereventy (Luke 10: I tr.), but it is really invelvel in the statement that

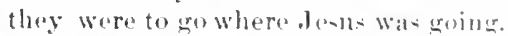

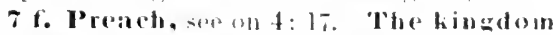
of heaven is at hand, sere om : : : 2. This wits the same annowneement that John the Batrtist had mate, mol with which Je-us hinstelf had begun bis ministry in (ialilee icmup. is 4: 1\%); so tile Soventy likewise. Luke ،n: s, 
8 lleal the sick, cleanse the lepors, raise the tlead, cast out devils: freely ye have reecived, freely give.

9 a Provide neither gold, nor silver, nor brass in your purses ;
8 Heal the sick, raise the dead, cleanse the lepers, cast 9 out demons: freely ye received, freely give. (jet you
Heal the sick, cleanse the lepers, raise the dead, cast ont devils-demons. The Greek las no article. The original means, Iteal sick, i.e., persons, etc. They were not commanded to heal all the sick they met with. Probably they restricted their miracles, as Jesus himself usually did, to those who showed desire and faith. The seventy alsowere eommanded to heal the sick, in every city which received them. (Luke 10:9.) As to leprosy, see on 8: 2; and upon demoniacal possessions, see on 8: 28-31. The elause raise dead, $i$. e., persous, is nut certainly genuine, but nost probably." Freely (or, gratis) ye have received, ireely (or, gratis) give. The word which Tyn., ctc., and Conn. Ver. here render 'freely' really signifies 'as a gitt,' and is exatly rendered yratis, by the Latin versions and Rheins. It is not opuosed to the idea of giving or receiving in a stingy way, or on a sunall scale, but to the idea of giving or reeriving for pary. Observe the force of the word, as thus explained, in Rom. 3: 24; 2 Gor. 11: 7; Rev. 21:6; 22: 17. (Comp. Isa. 55: 1.) The Jewish exoreisers who pretended to cast out demons were no doubt aceustomed to have pay; and physieians of course took nay for healing the sick. The Twelve could easily have obtained money, in large sums, for the cures they were empowered to jerform. We might think it strange that they should need to be told not to do so; but they had as yet very imperfect conceptions of the nature of Christ's work, and not merely might Judas Iscariut have been glad enough to drive a brisk trade in miraculous healing for pay, but otluers of them might have seen no impropriety in receiving compensation tor conferring such inportant benofits. Jesus tells them they received gratis, and must give gratis. They had not purehased the power of miraculous healing-as Simon Magus wished to do, (Acts 8: 18)- nor obtained it by long and expensive study, and habrious practice; it was received as a gift, and must be exercised in like manner. The miracles were really credentials for their teaching, as well as indications of divine benevolenee, and should be used accordingly. As to teaching, we find Mieah (3:11) naking it a reproach that the heads of Israel "judge for rewald, priests teach for hire, and prophets divine for money," some of the later Jewish writers maintained very earnestly, though often on fanciful grounds, and though many rabbis acted quite otherwise, that a min ought not to teach the law for pay, but gratuitously -just as suerutes and Plato held with reference to philosophy.

9 f. While they were thus to work their miracles, and tach the people, without pay, they must, on the other hand, look to those among whom they went for food and clothing (v.9 f.), and for a hospitable reception. (v. 11-15.) They must neither seek for gain (r.8), nor be anxious about thoir livelihood, but laying aside both selfish aims and personal cares, devote themselves to their appointed task. He therefore dircets them to lay in no money, whether gold, silver, or copper, no provisionbag, nor statt, nor extra clothing, nor even

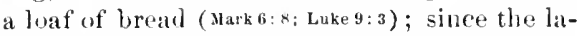
borer is worthy of his sustenance. Our Lord is not giving an exact list of objects to be dispensed with, but is only illustrating the principle; and so (Luttoroth) it is not strange that the other Gospels give the details somewhat differently.

Provide neitler gold, ete., or, as in Rev. Ver., Get you no gold, nor silver, nor comper, in your girdles. The expression involves a climax-not gold, nor yet silver, nor even copper. Mark ( $6: 8)$ mentions only copper; Luke (9:3) only silver. 'Brass,' as in Com. Ver., a mixture of copper and zinc, is not
It is omitted by all later uncials, and more than one hundred and fifty cursives, by the Thrbaic and Armenian, some syriac and Ethiopic colices, and some Fathers. The eoneurrenec of $B$ and $\boldsymbol{N}$ with ('and $D$, supurted by the other versions, some fifteen eursives and varions Fathers, requires us to retain the reading.
The words may have been omitted beeause no other passage of the fiospels aseribes to the apostles this power. Plumptre thinks they were inserted hecause of sueh later instauces as Acts $9: 40 ; 20: 9 \mathrm{fr}$. The words are retained by Lachm., Tisch., Treg., W Hl., and Weiss. 
10) Nor serip for your journey, neilher lwo eoats, neillar -hoes, hor yel a staves: for the workmin is worthy of his meat.

a Gr. a staff....litir. girdles.

beliesoed to hate been in noe amorner the ancitents; they madecoins, and a great variety

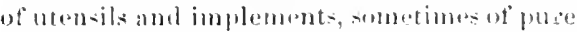
copp r, but more frepuently at brumze, a mixtore of eopper and tin. and it is this that is eommonly meant in serifture by the worel

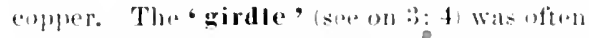
ot line matrerials and remant workmanship, and male bollow as as to (atry money. The word rendered 'purse' in Luke 10:4, is different, and demotes a small pusch. like our purse. No serip, etc., or, no bag fiof the roud, (traveling bitg, or latver-acke, the word signifying a leatler big or wallet. nsed fin arrying provisions when tritreling. The English word "scrip' Whs folmerly used in that sabe, but is now ols-olete. Iwo coats, the word streaning the imner garment or lomg

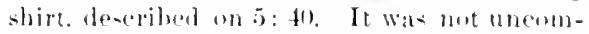
masn to woir two of them at ander, but wat unneresary; and so. Juhn the Batptisl luke 3: 11 direced him who hatl two to rive to him who hal none. In sotting ont on at journey it is latural to asoume additional or thicker alothingr and eventhis is here probibited. (conop. Mark ti: !.) Or it may mean that Iloy must

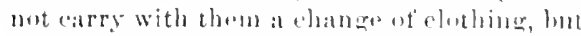
trut tu obtainine it when nexdeal. Neither

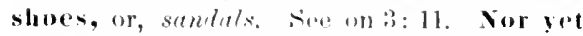
staves-bettop-mor stugf. 'The singular is the best supporial readines of the cirask toxt. Mark (b: 4), he charged theln to take abol hiog for their journey salo a statl only, would nont neeessurily eomtliet with II attluew. The one forbiti thrm to promere at stall tior the purpuse, the other allew: thom to atery with

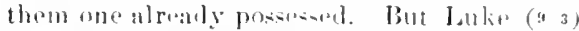
use-tho sime Greek term a- Mark, ther mu-t not carry al statl, and we have to fill back apon the prineipte stated aluse: there are

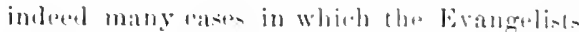

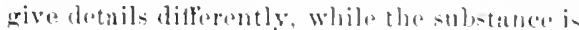

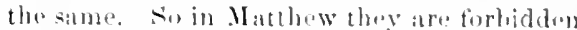
to procelue sandals, while Marli has it, 'but to go shod witl sandals.' Theses soles af leather or raw hide, bound under the feet, womld rery soon wear out in traveliner, and one setting out on a long padestrian journey would naturally wish to lay in a supply of them; but the
11) no gold, nor silver, nor brass in your l furnes: no

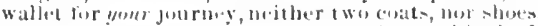

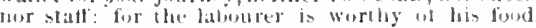

disciples mun-t go with these they had on. (umble an to the seventy Lakes 10: 4. We miglit takefior granted that these -pecific diretions were designed mily for the existing

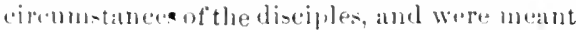

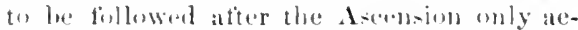
eording lo the principles involved, nol aceordjore to the barticular details. Sill more alearly is that sem in the direcetions of $v$. 11 tl., which are mante-tly fonmded upun the peruliar unages of Griental hompilalits. Ard this viem is established beyoul controversy ly Luke 22: : :5 tf., where under litlerent cir-

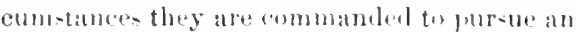

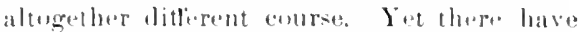
not besh watnting sume to (ns)tend, and exen persums fanalieal enulgh to atlempt carrying the idea into protedice, that mini-ters now, and especially foreigrn missionaries, shomld always gotiorlhinthewayeredirected. But our Luml himselt and the Twelrow wh hion solnelimes had unoner, which Julas catried in a purat (Juhn 12:6), and expended from time to time in supplying their wants and in relieving the jurs. (John 13:29.) For the worlimnu is worthy of his moatmor-sustenaner, this heing the exact meaning of the worl-whatever is

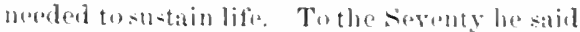
( home 10:i), "fur the lalurer is worthy of his lise, and this is the torm in whind Pabl quotes the soring. (1 Tim.s in) Ari-tutl, sitys, "I -laves hire is his sll-lenaller." (13)1), Num. 14: 娄.) It wa a very uselese variation for

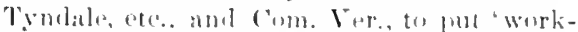
man" here, when tho same word is romblerent 'Jaburers' ju-t abura in 9: 97 t. amd alon in thr eorresponding passiges of Luke and 1 Tim. Our Lurd here diatinetly sots forth

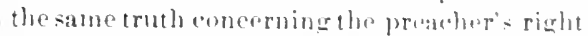
to have his wants suppliod hy tho-d anomes

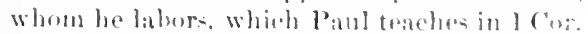
9, and 1 Tim. $5: 17 \mathrm{f}$. sume luink the menuing here to be that as Gud - laluerer-thev hat a right to export that he would erive them :ustemance, ly his providunee; but that viow dows not well slit the connection hore or in

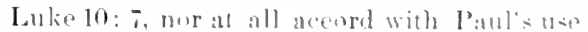
of thasaving in 1 Tim. Sen nlso | ('ur. o: 14 , which seems to reter to this passage, it wo 
11 And into whatsoever city or town ye shall enter, inquire who in is is worthy; and there abide till ye go thence.

I' And when ye come into a house, salute it.

1.3 And if the house bo worthy let your peace come upon it: but if it be uot worthy, lel your peace returu to youl.

it And whosoever shall not receive you, nor hear your words, when ye depart out of that house or eity, shake ofi't lie anst of your feet.

there understanel 'the Lord' to mean, as so often in the Epistles, the Lord Jesus.

II-13. What soever city or tow (village), see on 9: 35. Nearly all the people were gathered into cities or villages, it being unusual to live alonz in the country, and indeed unsate, from the unsettled condition of affairs and the prevalence of robbers; in fact, travelers in Palestine bave to pursue a similar course now. Inquire, search out, or 'ascertain by investigation,' a stronger term than 'enquire.' Who in it is worthy, $i$. e., a man of piety and hospitality, sueh as would make a fit assoriate and a willing host. And there abide till ye go hence, viz., furth from the city. In adrlessing the Seventy (Luke $10: 7$ ), he adds 'go not from house to house.' The chief oljoct of this injunction seens to have been to make them feel perfectly easy about the burden of entertaining them; they must not even trouble themselves to change their stoppingplace in a town, with a view to divite the burden. They had a right to a support, and must go without fear to a suitable place ant stay there. It would not prove a reul burdin to entertain two men on a burried journey, and they would of eourse not go to stay with a fanily which they learned was very porr. We can see another advantage of this course in that thoy could give themselves more uninterruptedly to their public labors. Thomson says ( Tol. ii., 407), that at the present day, "when a stranger arrives in a village or an encampucut, the neiglibors, one after another, usually invite him to eat with them. There is a strict etiquette about it, involving much ostentation and hyporisy, and a failure in the due observance of such hospitality is frequently resented, and often leads to alienations and fouds amongst neighbors." - The apostles found in carrying ont the directions here given, that they lacked nothing-all their wants weresupplied. (Luke 22: 35.) Iuto a (the) house, $i$. e., the one selected aceording to his direction. Salute it. The form of salutation would be readily understood, and
11 And into whatsoever city or village ye shall enter, search oul who in it is worthy; and there abide till 12 ye go forth. And as ye enler into the louse, salute $13 \mathrm{it}$. And if the lumst be worthy, let your peace come upon it: but if it be not worthy, lat your peace re14 turn to you. And whosever shall not receive you, nor hear your words, as ye go forth out of that bouse or that city, shake off the dust of your feet.

was stated to the Seventy (Luse 10:5), "Peace be to this house." This was the common sahutation among the Jews, e.g., Luke 24: 36 ; John 20: 19, 21, 26; 1 Sim. 25: 6; Psa. 122: 7,8. The Hebrew word employet, shatom, signified originally wholeness, soundness, and hence health, welf:re, prosperity, well-being in general; and then peace, as oppused to war, because this so greatly eonduces to prosperity and welfare in gentral. As a salutation, the term was thus an invocation of good of every kind, a benediction, a wish that one might he blessed in every respect. It is important to observe this hreadth of meaning in the term, when studying various passages, such as Jolin 14: 27 ; James 2: 16, and the opening and closing salutations of sereral of the Epistles. The same word, salaam, is now used by the Arabs. If the house be worthy, i. e., of your abiding in it, as in r. 11. The 'mphasis in the Groek is on 'be,' and if the house be worthy, as you were inforned. (v.11.)-If it be not worthy, let your peace return to you, without having accomplished anything. (Comp. Isa. 45:28; 55: 11.) The explanation offered by many, that he says the benediction would come back and do good to themselves, does not appear to be warranted by the usage of similar expressions, although the idea which would thus be conveyed, is itself just and Scriptural.

\section{4 f. Ont of that house or (that) city.} He refers at the sume time to the case of an individual refusing them hospitality, and of a community refusing to hear their message. Thry would turn away from an individual, shaking off the dust of their feet, if he refused to recrive or hear, but would not necessarily abandon the whole eommunity for his sake: But if a city refused to receive or hear, then they would turn away from that city, shaking off the dust of their feet. These two directions are blended in one sentence. Who. soever is singular here, plural in Luke 9: 5 . Shaking off the dust, ete., denoted that they wanted nothing whatever to do with them, 
comonting them vilu, and all that pertained to them pulluting. We tind l'anl doing this in I.t: 1:3: $51 ; 18: 0$. The Talmul reprosents it

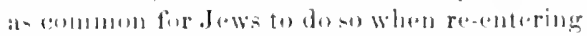
the IInly Laml trom a lieathon country. Similar is thranciont and momlern () riontal (2u-toun

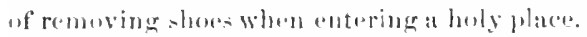

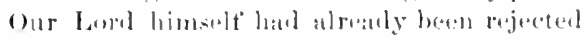

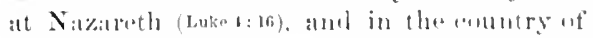

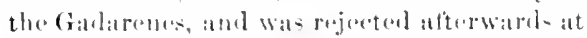
a Situaritan villatere (1.ukea: 52); indered, in gon-

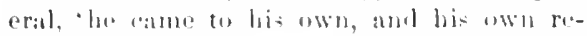

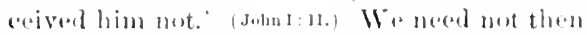

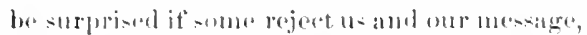

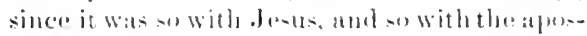

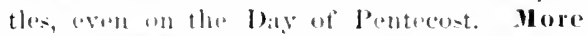
tolerabledior the tand of sudous and (io-

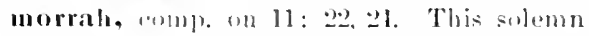
utteranew is here griver by Mathew amly. the corresumbling -entouce in Mark ti: 11 buing an unquestionably spurious though arly arddition to the text, surh as we so oftom timl mate in paralled patanges.

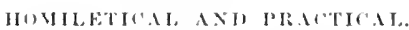

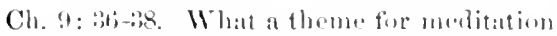

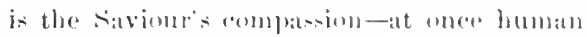

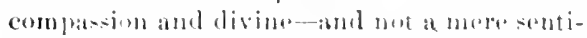

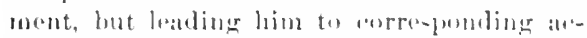

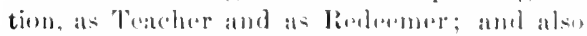

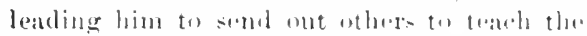
way of salvation. Every ens mow who is truly rent forth of Guel to spend lis lite in proclaming salvation is mally a truit ot the Savionr: amplation for the prishing. -

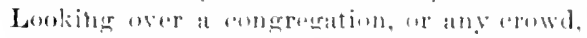

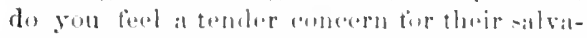
tion? 'thimline of tha millims who are perishinge in our own and other latuls, do you long for thoir salvation and pray for it?

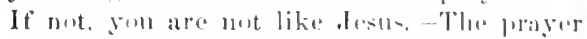
for laburers meght muede oftener to firm at part ot" onr public and private-11pplitotions.

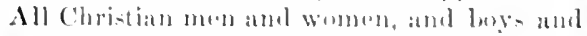
girls, omght to forel that they hatio a werk to do in gatheriug the great harven af sulals, that wares wide and jerishine orer all the

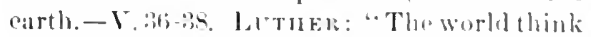
nothiner more trifling and despical, than the mini-tersof the word, or laburersin the Jurd" harvest; but that is like rejoicing over their own entles misfortune."

9: 36 to $10: 5$. Origin und development of a

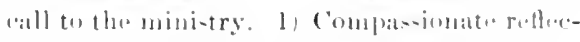
tion upun the perishing endition at men, 8.

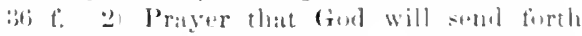
laburer, s.:3. 3) ('omviction that wo ulur-

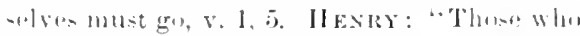
alo to be minjeturs mught, l) to live near to chri-t: 2 to be taught by him." - l. l.

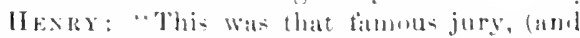
to make it at grame jury, l'atul was adoled to it) that was impaneled to inguire betwers the ling at king and the budy at mankind; atud in this chajerer they have their charare riven them ly hin to whom all julemment

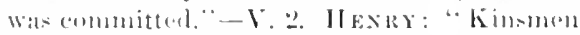

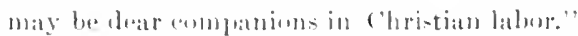

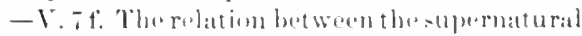

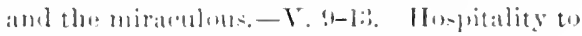

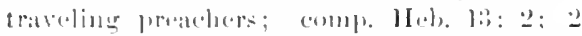

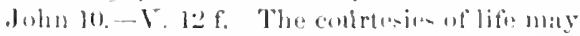
be the vehichos at tomporal and spiritual bles.

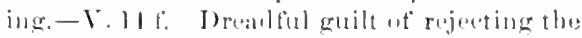

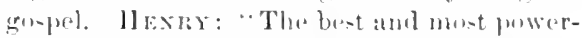

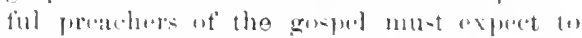
mere with some who will mot so much at grive theles the hatring. nor show them any token of refuet." - It nuty be sugereted that in ser-

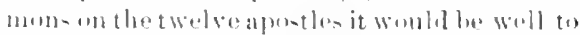

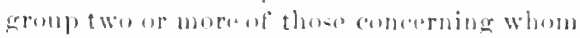

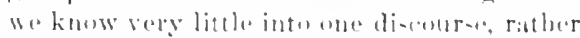
than $11-1$ -

10:16-11:1. Fintien INetrintoseto THE: TWE.,

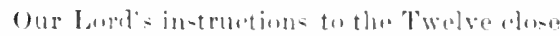
in Mark (i) 11) and Jukne a: is) at this point.

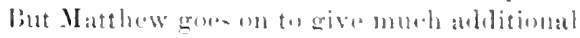
matter-fulien on the sames aceatom, Theres

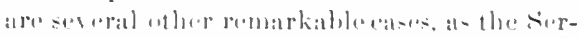
man on the Mimmt, the disentle in ehe 18,

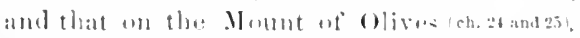
in which Matthew griven mueh morn than

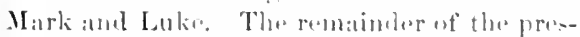
(ont aldrese (andsists of waruing-as t) (a)ming persections, direndins how to act when persecuted, and reasums why thry shomld nut

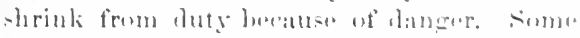
of these warnings and areetion- lowk heyomel this briof mi-cion in fialilue amel wn to thoir

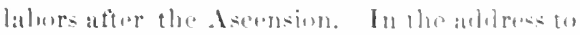

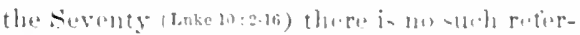
cance to futures time. It wat natural that he

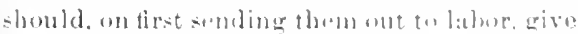
directions which would the of -irvice to them throughout their appointert ceenr=L: Brucc: 
15 Verily l say unto you, It shall the more tolerable for the land of forlani and fomorrah in the day of judgment, than for that city.

t6 Behold, 1 send you forth as sheep in the midst of wolves: he ye therefore wise as seruents, and harmless as doves.
15 Verily I say unto you, It shall be more tolerable for the land of soitum and (iomorrah in the lay of judgnent, than for that eity.

16 Bebold, 1 rend you forth as sheep in the midst of wolves: be ye therefore wise as serpents, and 'larm-

101. simple.

-It was his way on solemn occasions, to speak as a forphet, who in the present saw the tiuturw, and from small beginnings looked forwarl to great ultimate issues. This Galilean mission, though humble and limited eompared with the great undertaking of after years, was rually a solemn event. It was the beginning ot that vast work for which the Twelve had been chosen, which embraced the world in its scope, and aimed at setting up on the earth the kinerdom of God." The parts most peculiar to that journey apply in principle (Edershein) to us and to all time; the parts which pointed to the remotest future applied in principle to the immediate journey about Galilee. These eonsiderations form a sufficient reply to those who insist that Matthew has here put together matters actually spoken on different oceasions at a later period. Mark and Luke give some similar sayings in the diseourse on the $\mathbf{I}$ ount of Olives, and Matthew there omits them. It was natural that if similar things weresid in different diseourses an Evangelist should give them in one ease and omit them in ansther: and it was perfectly natural that Jesus should say similar things on different occasions. On this point comp. at the beginning of (ll. 5. In applying the present iliscourse to ourelres, allowanee must be made for the difference of situation. We do not work miracles. and are not inspired; the opposition we meet is rather moral than physical ; we often go to foreign emutries.

1. 16-23. THeY Mest Be ON THeir

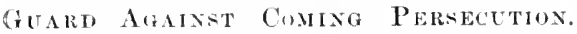
We have hore the general intimation and counsel of $v$. 16; warnings as to the persecutions which awaited them (v. 17 f.), with directions as to the defence ot thenselves when brought before the tribunals (v.19f.); further statements eonecrning proeestions and hatred ( $\therefore .21$.) ; and the direction to Hee from any town in which they wore persecuted into the nexit.

16. They are going forth into the midst of perils, and must therefore exercise a blended prudence and simplicity. These ideas are beatifully and strikingly expressed ly figures. Behold, I send you forth. "Behold' calls special attention to what follows. 'I' is expressed in the Greek, and therefor. in some sense emphatie. The idea perhaps is that they are not going out like sheep wandering into dangers, without the knowledge of their shepherd; he himself sends them forth into the midst of these perils; and lience both a reason why they should strive to eome off safe, and an eneouragement to hope they would sueceed. He sends them forth as sheep, weak and defenceless, and not only in a region where there was danger of wolves, but in the midst of wolves-the language is very strong. To the seventy (Luke 10:3) it is still stronger; they are 'lambs.' Herodotus speaks of leaving a man as a sheep among wolves. Be ye therefore wise (prulent) as serpents, aud harmless (simple) as doves. 'Be' is more exactly 'become.' get to be, implying that they are not so now. 'Therefore' may be taken as an inference not merely from the fact that they would be as sheep in the nidst of wolves, but atso from the fact that he sent them as sheep in the midst of wolves; there is a duty to themselves and a duty to him. 'Wise, more exuctly 'pruaent' (comp. on $7: 24)$; Latin versions prudentes or astuti. Fierpents show great caution and skill in avoiding danger. The Egyptian hieroglyphics use the serpent as the symbol of wixdom. We may under-tand that they were to be prudent in the recognition of danger, and in the ehoiee of means for oplosing or escaping it-in general as to their behaviour when in danger. But sueh prudent rogard for self-preservation is very apt to be aceompanied, in men as in serpents, with the tricks of low cunning. This is furbidden by the other injunction. The word rendered "harmless, better 'simple" (margin Rev. Ver.) signifies literally ummixed, and hence purs (as pure wine, pure gold), uneorrupted, and so ruileless, sincere. The Latin versions all have simplices: the Peshito, a word denoting whole-minded, upright, sincere; Chrys. ex- 
17 But heware of men: for they will deliver yol up, to the conacils, and they will scourge you in their synagougues;
17 less als deses, but leware of ment for they nill dediver you up lo councils, ald in their synagogues plains by simpleand artles. The Euglioh noe of "simples deres nut efuite clearly express the idea, but it is exactly hit by thes substantive 'simpliceity. The other propmend deroivation, without horms, and so 'laarmless, aclopted by King lamen, is highly improblable. The Greok word is uand alow in l'hil. 2: l.', and

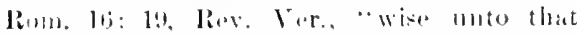
which is erood, and simple unto that which i= evil." In our putsage the worl is translated simple" in Wye. and liheims, MeClel-

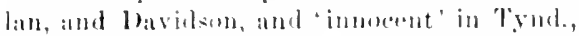
Great B., and Gerbeval. Tliey were not to deserve injury, or attord any pretest for it;

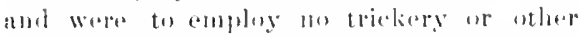
imbroper matus at escaping from dangere. They must combine prodencer and simplieity. It the dove alune ware talien as model, they might becomme silly (110\%, 7:11); if the serpent alone, they would become trieliy. (ciens:3.) Stire: "sio that thy wislom - lasll never degenerate inte emoning, mor thy simplieity into ignoranceorimprudence." I'lete: "Knowlesleres without justice shonld be called cumning rather than wislum." lf wa areto

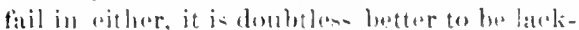
ing un Christian frudence than in ('hristian simplicity. But the injunction is to remblina botls in due proportion; and the examples at

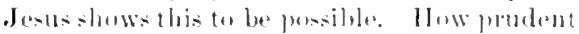
ho was, com-tantly taking pains to avolel danerer till his hour llats andue, alld at the same time? losw innocellt, eruiledens, and pure.

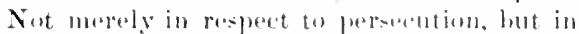
all the dangers to ourselves and nur work whele throner about Clori-tian laburers, we lave (e) simplieity. In a late ofwish rommmentary

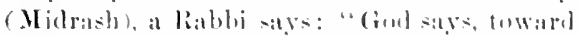

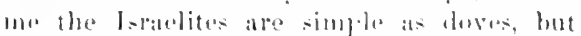

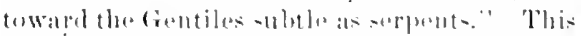

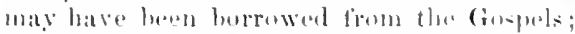
wo know that the later Jows horrowed from evary diricotiun.

17 f. With r. 17-2.2 (a)mp. similar thing: sail to the four disciples in the erreat disenterse onthe Mount of O)lives (Mark 13:9-13) L, whe 21 : 1:-19); there Ilatt. does mot recordthem. But beware of men, i. e.. of munkind ju general, spoken of as hustile to them, like "the world" in John
15: 18; 17: 14. They were few, and men weres

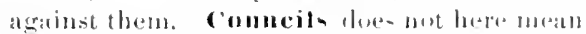

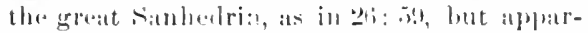

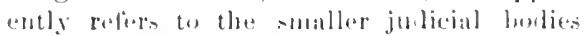
which existed in revery eity and village, as in

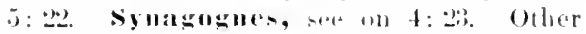

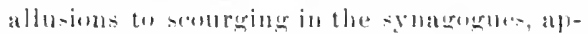

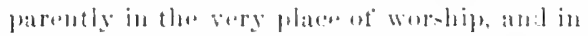

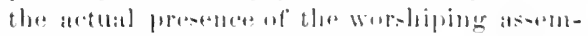

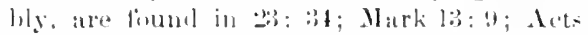

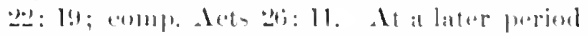
it is sald that, an whe orearion, the dews sumg a

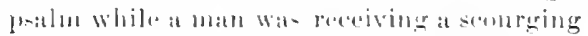
in the symateroue; atud Maimonides says that the fromeigal jublue would read pasenges of sieripture throughent the semering. The

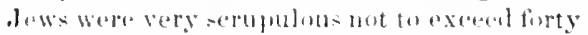

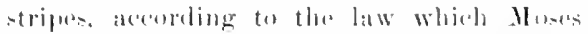

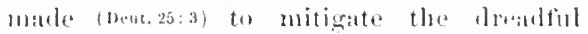

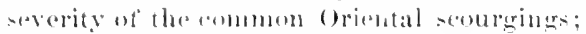

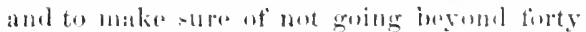

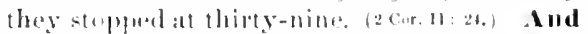
ye shall he hrought eren) hefore gaveruors and tiong for my satie. This is intro-

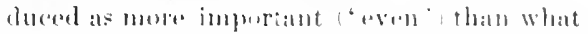

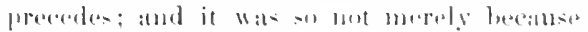

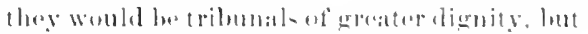

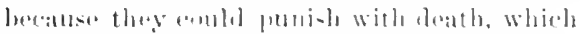
the dewish tribumalsat that timeandeld and de. It was als a rellatialle thing that they ware to be brought, not andy hefores the relieguse

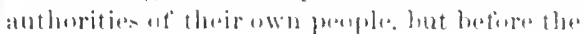

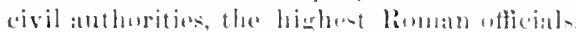

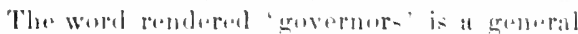
torm, which would indude mereral kinds of

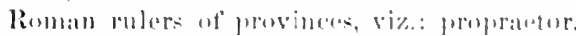
promen-ul llike sererius l'aulus and (ialliol,

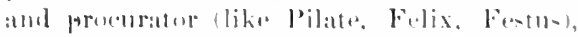

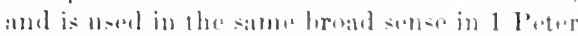

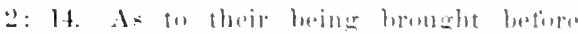

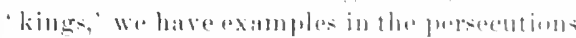

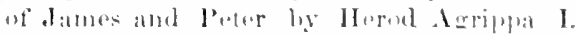

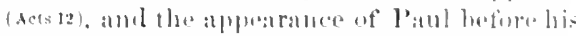

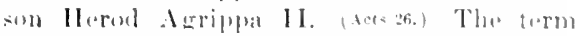

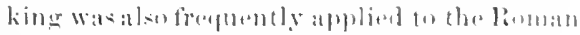
imperator or empuror (1 Poterz: 1.3 r.). and in that

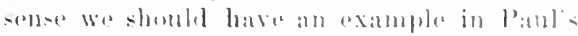
trials before Nero. For a testimeny arain-e (to) them and agaius to the cintilen. The Greek might mean 'against them' (Com. 
18 And ye shall be brought before governors and kings for iny sake, for a testimoly against them and the inentiles.

19 But when they deliver sou up, take no thought how or what ye shall speak: for it shall be given you in that same hour what ye shall s]rak.

20 for it is not ye that speak, but the spirit of your Fathtr which speaketh in $y(u)$.

21 And the brother shall deliver up the brother to death, and the tather the ehild: and the children shall rise 11$)$ against their parents, and cause them to be put to deall.
18 they will seourge you; yea and before governors and kings shall ye be brought for my sake, for a 19 lentimony to them and to the Gentiles. But when they leliver you up, be not anxions how or what ye sliall speak: tor it shall be given you in that low

20 what ye shall speak. For it is lot ye that speak, but the sipirlt of your Father that speakell in yo!

21 And brother slabl deliver up brother to death, and the father his chilel: and ehildren shall rise ul against parents, and 1 eause them to be put to death.

1 Or, put them to death.

Ver.), but the other is a more natural meaning, and better suits the connection. 'To them' may mean the rulers just mentioned, as distinguished from the nation at large; or it more probably means the Jews, spoken of as 'they,' 'them ;' as in v. 17, in $11: 1$, and uften. The idea wouk thus be that the design of Providenee in suffering the disciples to be fromght before these tribunals was, that they might bear witness to rulers and people-or, more probably, to Jews and Gentiles (Phn. 1:13; 2 Tim. 4: 17; - - of the truths they were going forth to proelaim. (Comp. a similar expression in $8: 4 ; 24: 14$.) All this we camnot understand as referring simply to their brief journey about Galilee, during whieh they would perhaps encounter some persecution (see on $\mathrm{v}$. 23), but were exrtainly not brought before governors and kings. It must therefore be undorstoed as glaneing forward to persecutions they would suffer in future days, while prosecuting that mission as Christ's apostles, of which this journey would be the first stage. (Comp. on v. 16.) How plainly our Lord spoke to his followers of the perils and persecutions which awaited them in duing bis work. He would have them eount the cost. And they diel not slırink from his service, though warmel what it would cost them, being doubtless sustained by their own devotion, and by such promises as those of $x .19$ and 22.

19) f. When thus called before the anthorities for trial, they need not be anxiously considering as to the defence they shall make, the testimony they are to bear, for it shall be eommunicated to them by the Dirine Spirit (v. 19), who indeed will be speaking in them as his instruments. (v.2n.) Comp. the similarpromise on the Mount of Olives (Mark 13:11; Luke:1: 14 f.), and unanotheroecasion. (Luke 12:12.) Take no thought, be not anrious, or 'do not anxiously cunsider.' See on 6: 25. They would be more likely to feel anxious what they should saly, becalıse it was conmon to make very elaborate addresses and affecting appeals; and before the Roman tribunals, even to employ counsel, such is Tertullus (Acts 24:1), who would understand Roman law and judicial methods, and could deliver high-wrought orations. Knowing that importanee was attaebed to such addresses, and conscious of inexperience in Roman legal procedure, the disciples might naturally feel, when they were delivered up, great solicitude; and this would be increased by the fact that they were called to present, not only a defense of themselves, but a testimony for Jesus. There was thus great eomfort for them in the promise here given. As speeimens of the addresses made by some of them under sueb circumstances, we have the speeches of Peter and stiphen before the sanhedrin, and of Paul before Felix, Festus, and Agrippa. How or what ye shall speali. 'Ifow' suggests the general plan and delivery of their defence, and 'what' suggests the subjeet matter. Comp. 'mouth and wisdom' in Luke 21: 15; and comp. Luke 12: 12.

20. For it is not ye that speak, etc. With the form of expression comp. Gen. 45: 8 , "It was not you that sent me hither, but God," and so Exod. 16: 8. Your Father, see on 6:9. This was clearly a promise of special inspiration, in the highest sense and degree (eomp. Ex. 4: 12). To apply it to uninspired preachers of to-day, is unwarranted and absurd. They may expect, and should earnestly seek, the gracious aids of the Holy spirit in their previons reflections and in their actual preaching; but they have no right whaterer to expect inspiration. This promise of inspiratiori was repeated by our Lord in the promise of the Comforter (John ch.14 to 16); and that assures us that in their writings also the npostles were iuspired.

2 I f. Not only will the public authorities 
22 And ve shall he hatul of all men for ms name's bate: but he loat endurell to the end shall be saved.

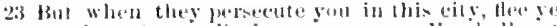
inta allother; lor velily I sily ilule you, lo shall not hate forle oser the eities of lsrael. tilf the sull of man lec enile.

ine d sposed to persecute them. but mon will deliver to the tribunal - their own dearest kinfroll for being Christians, and will put them to death, and the hatred against them will bre universal ; yet lot them andure to the end, and thas shall bie saved. Sien a similar palseige in Mark I3: I: fo and Luke 21 : 16-19, as - inken on the Mount of Olives, and part of it is in this case given by II attliew al-0. (24:9.13.) And the children shall rise 11 against their parents, and, literally, put them to dereth, (see margin of Rav. Ver). This doubthese means, will put then to death through the instrumentality of the anthorities. But Rive Ver. onght hatrlly to hate followed com. Ver. in giving a mere interpretation a place in the text, and throwing into the margin the correct translation of Tym. and his suceesours, and of Iavidson, Nuyes, Darby. The dreadful etlects of religious bigotry, as here predieted, and as so often witnessed in the world's history, should impress us with the immense fower and importanee of the roligions prineiple in man; just as when a train of carrum-ofl the tratek, or a dynamite tampory axplodes, we see all the more clearly from the

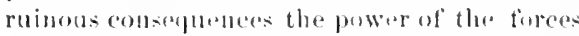
in question, and the impurtanerout their heing moperly" directed and antrolled. Fer the motive to such prer-orentions hats ustailly been, not opposition for it own salke to the roligrion persecuted, but allatehment to another roligion wilh which it wat thourht to interfore. But be linat endureth to the end, shall be saved. It seems proper loere, as is manifestly neersiry in the disconse on the Momnt of Olives (24:13: M:ark 13:13) to umberstand the assuranese as baving at twotedd application: first, he that enclures to the end of the prerere eutions and other evil-in que-tion shall at last be silved, deliverad, from these avils; lut also more widely be that allures to the end of life s trials shall be saved, in the nsual sintse of attaining eternal life. The propriety of understamling a twofold allu-ion in such

1 The "Western" documents, with Origen and the Armenian version adol ". I $\mathrm{ml}$ if out of this they persecute yon, flee into the other" (so W II. margin), whieh

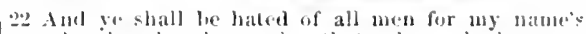
sake : bat las thal endurath to the end, llat same 23 shall he savel. lint when they persoente you in

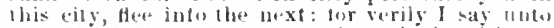

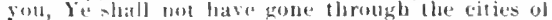
Is rael, till the sull of man te come.

passages, or making a varied applieation of them, will be disels-end at the beginning of eh.

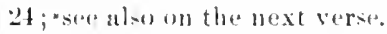

23. Fied ye into another, or the other, i. r.. into the next. The particular eity in whicle they are persectuted, and the one next in order are coneroved of as forming a pair,

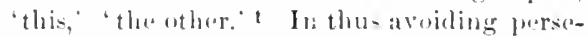
cation they would be "prublent as the serprente' (v. 16); so Paul and Barnabas ateted in gong from dntioch in l'isidia tol conium, ete. (Acts ch. 13 utul 1t) For verily I say IInto gou, -ee on 5: 18. Some faney that thisexpresion

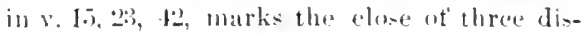
tinct sections of the discoures f lut this is suppusing a very artificial the of the phrate. and

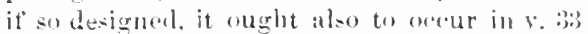
and 3.j. Ie shall not have gone over (or, finish) the cities of Isalel, till the son of man be come. 'Not' is at strong negative, tran-lated 'in nowise' in Jolun fi: : : and Heb. 13: 5, and in Mattlew 5: 20; 10: 42, atc 'Finish' (so rendered hy Tyn. (ion., Rheins. and matrin of Com. Yer.), in the semse of visiting them all. They must not stay in one

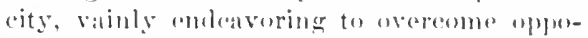
sition and porsecution, but hase the the next; for there were mure eitien than they wonald be able to visit befure the son of man shomlst. come. It is quite diffeult to determine the meaning of thic lat expression, at hare omployed. It hat buen suppored tor men: (1) Till he eome and rejoin the twe tre at the (and of this journey. (2) Till he make his appearance at the Mesiah, distinetly fresent limself as sucly. (3) Till he enme spiritually to console and support. (John 16.23.) (4) Till he (one to put an and to the lewish instiutulions at the destruction of Jerusilem. (i) Till ho come to judge the world. The firest -..11-e might at the mutset strike one as natmpal and geod, and it would be possible that he should return from tho mare general viow of their coming latwo and peroentions. to spente of the partieular journeg than betire tham: as or oruited. 
24 The disciple is not above his master, nor the serv- 2 ant above bis lord.

in the discourse on the Mount of Olives he sometimes returns from the secont topic to the first. In the mission of the Seventy (Luke 10:1, R. v.), it is said that he sent them before his fince into every city and place, whither he himself was about to come. It is ratural to suppose that he was going to follow the Twolve also; and indeed he must have done so, sinee their work was confined to Galilee (see on v. 5), and he himself went about all the cities of Galilee. When the objection is made that it is hardly probable they were persceuted during this journey, one may reply that Jesus himself was persecuted at Nazareth, and seriously threatened with death at various other places. The greatest difficulty in the way of understanding the expression in this sense is that the language seems too claborate and solemn for so simple an idea. He does not say "for you will not finish the cities of Galilee till I eome," but employs the solemn phrase "till the som of man come,' and prefices it by 'verily I say to you,' using alko the more genral term Israel. The second sense projured is not supported by any similar use of the phrase elsewhere, and does not seem very appropriate to the connection. There was indeed no broadly marked epoeh at which the appeared as the Messiah, and the occasional intimations of his Mrssiahship eommenced long befure the delivery of this diseourse. The third sense is that of Chrys. and his followers, of Beza, Maldonatus; while Calvin and Bleek understand similarly his coming in the mision of the IIoly Spirit. But the time of his spiritual eoming would be a very rague chronologieal epueh; and Jusus certainly seems to be speaking of sume personal coming. The fourth sense is atecepted by many recent writers. In 16: 28 , 'the son of man coming unguestionably refers to the destruction of Jerusatem. The idea here would thus he that they would not peach all the Jews with their ministry before the overthrow of the Jewish institutions; and henee they must not wate time in remaining where they wre perseauterl. But in the diseonrse on the Muant of Oiives (ch. 24 and 25 ), the coming to destroy .J salem and the coming at the end of the world are constantly associated, and sometimes hoth referred to in the same expression. So, also, in $16: 27 \mathrm{f}$. It would, therefore, seem natural to combine with this fourth the fifth sunse. On no oceasion would there be greater propriety in employing the obseure language and perspeetive view of prophecy than here. He wishes to give counsel which shall apply not only to this journey, but to their labors after the Ascension, and perlatis even to the labors of his followers in all ages; and to intimate that in earh of those periods there would be more to do than they could complete before the season in question would end. It may, therefore, be that the phrase was intended to include in some obseure fashion the first, fourth, and fifth senses. It was manitestly impossible that the Twelve should at that time understand any distinct referente to the coming to destroy Jerusalem; indeed it is not probable that they understond when be spoke of it on the Momnt of Olives. It was necessary, therefore as so often in $O$. T. and N. T. prophecies, to employ language which would refer to each of these at the same time; which would be understood at once as regarded the present journey, and would afterwards be viewed in its broader meaning when needed. (Comp. on v. 22, and at the beginning uf ch. 24.) The notion of Origen, that Seripture has everywhere a twofold, or "ven threcofold, sense, is now justly rejected; our present danger is that of rejecting along with it the unquestionable fatet that seripture dors sometimes use language referring at once to a nearer and a remoter esent.

II. 24-33. Excourdgentaxt to the PerAEcuted. The key-mote is here "fear nut, which oceurs three times, in $\mathrm{v} .20,28,81$.

21 f. They need not think strange, or complain that they were guing to be persucuted; this would only he shatring the fate of their Tencher and Minter, The disciple is not above his master (teacher, ) nor the servant above his lord (muster), (see margin Rev. Ver.) For 'disciple' see on $5: 1$; for 'te:teher' (didldskalos), and 'master' (kurios), on 8: 19; itnd for 'slatve' (doulos), on s: ti. This saying is also given by Luke (6:40), as used in the Sermon on the Mount; by John (13: 16), as em- 


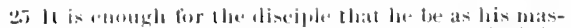

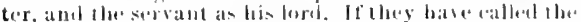
master of the hans lieelgetoub, how intuh more shall they call them of his bouseloblal:

24i linar them now theretore: lor there is mothing

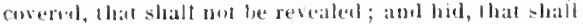
uch be kmown.

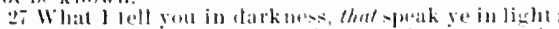
and what ve hear in lhe ear, that preach ye upon lha. loustelop.

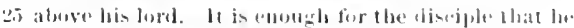

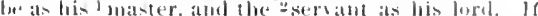

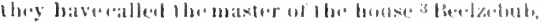

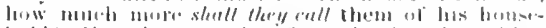

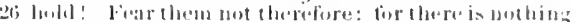

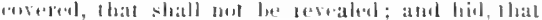
27 shall wol lo known. What I roll you intle datkwess, sreak ye ju the light: and whal ye hear in the tar,

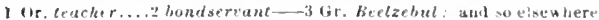

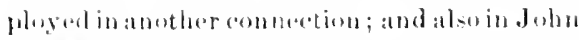
15: 2', where the applieation is marh the satue as here. The saying, "It is emonele for

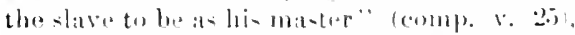
ocenrs repuateilly in the later Juwinh writing-, and was perlatpe prowerbial when used by

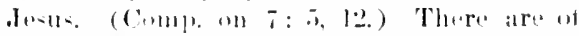

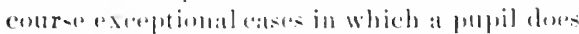
have a better lot than his teacher, or exen a

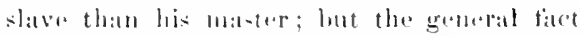

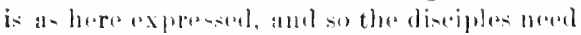
nut be surpriset at hearing that they would

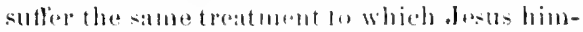

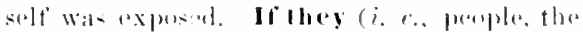
imperenal uso) ealled the master of the

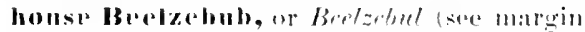

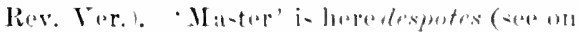
$8:$ 1:1), which we burrow its despent. The

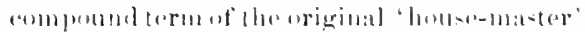

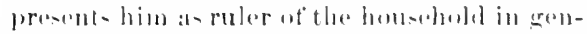
eral: a malls atulhorily asel bis wite and

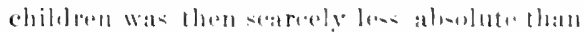

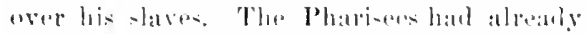

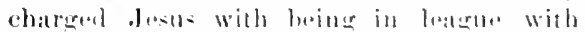

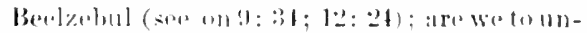
derstand here that they had actually applied the mente to J J necessitate this sllpu-ition, hut wo know they

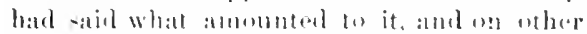

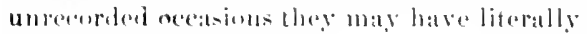
callerl him ly that name.

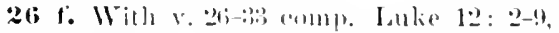
where -ub-tantially the satue lhings are said

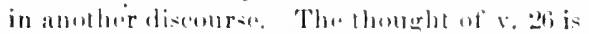
also fermul in Lake s: 17, at introduced in yet andher commertion. The injunetion,

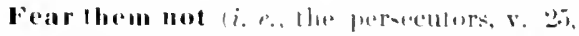

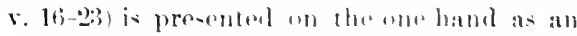

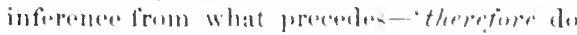
not fear, vi\%, beamen it they "plowes and persecute you, it is nolhing more than your

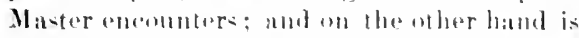
supported by the as-uralle that the truthe they benr forth are destined, in spite of all op- perition, to be male known-for there in molling covered that shall uot he revealed (e) menerered); and hid thal shall nol be

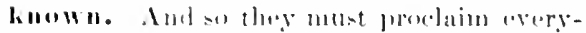
thing boldly and poblicly, even what he taturlat them in his privale instruction. (r.,27.)

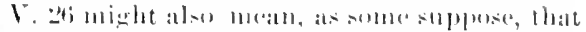

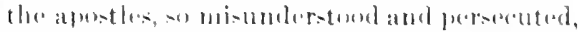

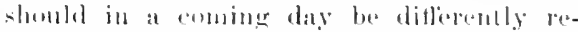
grarded. all math then pereceiving that they were the hemetactors af their time; but the obluer xiew better suit the connection. The

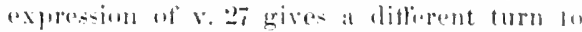
the iciea thatl that foumd in Lukn le: : but it

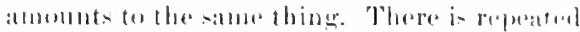
mention in lhe Talmul of Jewi-h teatcher-ar

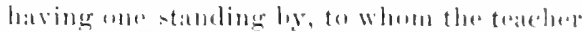
would whi-per something. and who would

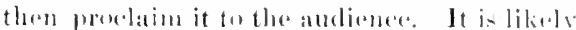

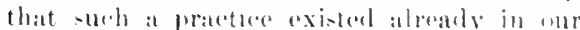
Luml a time. and it mas be that be here al ludes to it, net at metuing that he literally did this, but as a ligurative and strikine way of eaving that they were to kesel mothing batek through tiatr, hat even his privale in-l ructionto them were to be proclatimed in the ment public: manuer. Cpon the hometop. The ronets of the homses were that, and surrommlat by a narrow battlement. It wats commonon and still in for persons to waik on the rente and thi- would baturally afford an olevated samd

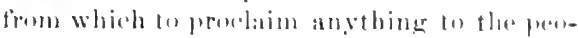

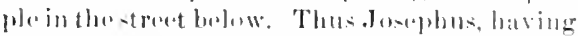
taken refuere in a butese trom a nuble in Tarichaea, "went mp un the rouf, and wilh his rightat land quieding the moruar, sail," we ("War.,"2. 2l, 5.) The Talunud repremente at religions ofticial as preselaining from at holl-elop, with the somul of a trumples, the

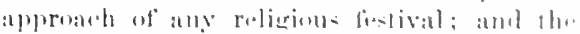

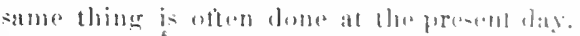

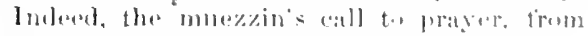
the minaret of the mustlue, is the same surt of thing. 
28 And fear not them which kill the boty, but are not able to kill the soul: but ratber fear hin which is able to destroy both soul and body in hell.

29 A re not two sparrows sold fior a a farlhing? and one of them shall nol fall on the ground without your Father.

30 But the very ladirs of your head are all numbered.

31 Fear ye not therefore, ye are of more value than uany sparrows.

$3:$ Whosoter therefore shall confess ne before men,
25 proclaim upon the housetops. And be not afraid of Ihem that kill the body, but are not able to kill the soul: but ralher fea lim who is able to destroy 29 boll soul and body in 1 hell. Are not two sparrow sold for a penny? and not one of them shall fall 30 on the ground witlout your Father: but the very 31 hairs of your head are all numbered. Fear nol thelefore; ye are of more value than many suarrows. 32 Every one therefore who shall confess ine beture a It is in value half-penny farthing in the original, as being the tenth part of the Roman penny. Sue $\mathrm{ch}$. 18: 28.-1 Gr. Gehenna.

28. Let them not fear men, but fear God. The idea of some that the phrase IIm which is able to destroy both soul and body in hell, means Satan, is wholly unwarmated and unsuitable. God is able to destroy; he does not wish that any should perish. (2 Pet. $3: 9$.) Jesus does not say that God will kill the soul, but, aroiding that term, says he will destroy both soul and body. For 'destroy' need not mean annihilation, but only ruin, perdition, the destruction of all that makes existence desirable. Hell is gehenna, see on 5: 22, and comp. on 5: 29. Fear is matural to man; and our Lord does not say we must root it out and bave no fear, but that the less fear must give way to the greater. The gospel does not teach stoicism or self-abnegation, but appeals to the human mind according to its aetual constitution. Comp. the appeal to a higher self-interest in 5: 29, and to hope and fear in v. $82 \mathrm{f}$. below. In proportion as one has a true fear of God he will feel no fear of man. It was a saying of Cul. Gardiner, "I fear God, therefore there is none else that I need fear." And not only with reference to persecution or any open opposition, but to a coneern for approbation or blame, loes the thought of this nassage apply. How mueh more inportant that we shondd aroid God's displeasure, than that of our follow-men. Comp. Luke 12: $4 \mathrm{f} ;$; James 4: 12. The thollght oecurs often in Jewish writings. In 2 Maeeabees $6: 26, "$ For even if for the present I shall be delivered from the vengeance of men, yet neither while living nor after dying shall I escape the hands of the Almighty." In 4 Mace. 13: 14, "Let "s not fear him who thinks to kill the body; for great is the danger to the soul, consisting in eterual torment to those who transgress the eommand. ment of God." Philo says, "For men reckon the extreme penalty to be death; but in the divine eourt of justice this is searcely the beginning." And the Midrash on Numbers (Wet.): "He who causes a man to sin is worse than he who slays him: beeause he who slays, slays him in this world, and he has part in the world to conse; but be who eauses him to sin, slays him both in this world and in that which is to come."

29-31. Let them not only dread God's displeasure (v.28), but trust in his protection; ho who cares for the least objects, will not fail to care for them. Comp. 6: $26 \mathrm{ff}$, and Luke 12: $6 \mathrm{f}$. (Sec above on v. 26.) The word rendered farthing, deuotes a Roman eopper or bronze coin, actually equal not to abont three farthings sterling (as in margin of Com. Ver.), or one and a half cents, but to about five-eighths of a cent (Edersh. I., 649), rnd trequently used to denote any trifing amount. Fall on the ground, viz., dead. Withont your Father, without his ageney or permission. On 'your Father,' eomp. onv. 20, and see on 6:9. The Midrash on Genesis says (Wet.), "A bird without heaven (God) is not taken, how mueh less so many souls of men." In v. 30 the position of the Greek words makes 'your' emphatic, and so with ' $y e$ ' ju v. 31. A single hair falling from the hoad seems to us a matter of the most tritling consequence (comp. 1 Sam. 14: 45); but every one of them is numbered by Gid. (Comp. Luke 21: 18; Aets 27: 34.) A late Jewish compilation (Wet.) represents God as saying, "Do I not number all the bairs of every ereature?" This was very likely borrowed from the New Test. Our Lord's line of argument here is in precisely the contrary direction to that which men often follow on this subject. They will say that no doubt God eontrols great matters, but that it is questionable whether his eare extends to such little things as the eoneerns of an individual man. Jesus says, God takes eare of the smallest and most trifling tljings, and therefore we may be sure he eares for a man, who is so muein more important.

32 f. Whosoever (every one) therefore ( $u$ ho) shall confess me. 'Therefore' presents 
him will I confess also betore my Father which is in heaver.

33) But whosever shall deny me belore men, him will I also deng before my lather which is is heaben.

31 Think not that 1 ann conne los sind peace on earth : I came nol to sesul peatere, bat a sword.

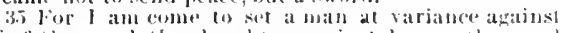
his finther, and the daughter against ber mother, and the daurhter in law against her mother in law.

3i And a man's foes shall be they ot his own honsehold.

I Gr. in him....2 (ir. cast. men, ${ }^{1}$ him will l also confess before my lather who

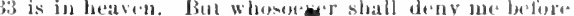
men, him will I also deny Gefore my Faber who is in heavell.

34 Think not that I caunc to 2 send peace on the earth

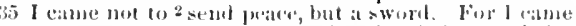
(1) sel a man at varialuce against his falloce, and the

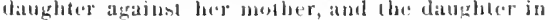
36 law against her mother in law: and a man's tors what tollows as an inference fron what precerles. Sinece God will protect, there is no $0 x-$ cose for shrinking trom duty throum foar of men, and therefiora he will contess only those who contess him. This atlecting statement stands last and highest in a climax of reasons for gring forward undeterred by the fear of men: first, the fact that if they are maltreated amd sandered, it is 110 more than their Master himselti suftered (veafs); secome, that the truths they procelaned are destined to be madis known, and thas no opposition will prerent it (v, 26r.); thied, that Ged's wrath is more to be dreaded than mants ( $x .2 x)$; fourth, that he who eares for trifling things will eertainly care for them (r.29-31): finally, that if we do not contess ('hrist bofore men he will not conters us betiore his Father in hearen. It is thus manitiost that the confession here enjoined mpon us does not comsint merely in a particular ceremony, or other single act, but denotes in general that w* culle out as his followers, and spenk and act as his, under all eircunstances and at all hatiarls. The term rendered eonfess' las been explainod an 7 : 23 , where it is rembleded "profess"; seos also l Tim. (; : 12. Observethat we have herea pere-

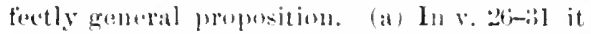

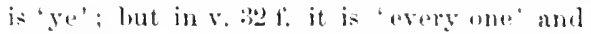
"whosuever.' (b) While thestatement is lore -pecially -luggested by the illoa of contussing Josus when persecuted, when bromght lueforo tribunals (v. 1n), fot the language is general, und doubloss infonded to inclube every kind of enntession during the whole conrse uf life. Many who have wnec publiely confessed ('larist, ambl are numbural with his people, wten fial to eonfess him aflerwards in word or deed. It is of course pussible that one shombl show bad judgmont and bad taste in amoune-

1'Confess in me' (margin liev. Ver.), i. e., "make confession in my case' is an imitation in the cireek of an Aramaic 'xpression, ant easily returns to it in the Peshito. So 'in him will I also confess.' It signities to ing himselt" a Christian where there is no occasion for it; bat for every person who does this unsasmably, there are very many who shrink from such an arowal whom it ought tes be made, and still more fail to comfess by the actions which "speak loucler than words." Will I contess, aleknuwlelge us mine. (Comp. $7: 2: 3$.$) What a quention it is, whether$ we are going to be contersed or denied by Ients, betore his Father in hearen. Hare again, as in $7:$ : 2o) f., ull Lurd speak frecly of his coming exalution as Westah; but it is likely thent the disciples at first malerstend it all of elevation and hrmor in a temporal kingdom. With v. :22 f., compr. Lake 1:2: 7 i. (Nove abure on r. 26.) Is to deny, compl. (1) 16 : 24.

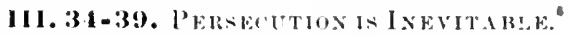
Let mo one be surprised at lourning that so much porsecontion in to be encountered by the Twelve and by Christ's folluwers in gencral : for it was the ubjeet of Christ's mission to introduce principles which would be sure to

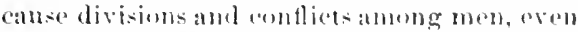
within the bosom of tamilies. Ilis religion was su wholly opposed to the spirit of the? world, that steh a roult was inevitable.

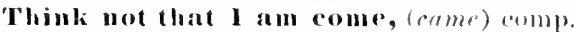
(1) 5: 17. If ere agnin, as so often, he Com. Ver. (but herefollowing Tyn., Great B., and Gen.), introduces an unneesisary variation in

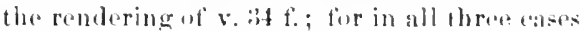
the (ireek has the same form, 'I 'ame.' Onr Lurl here, as in 5: 17, spealis of himself as having come among mon on a special mission. The bews wre acoustomed to bleody eontliets lutwont their politico-religious maties, thes Pharisees and saddueces, and (Lightit.) bestwest the followers of Ifillal and shammai, hut they wore likely to think Messiah's roign

make confession in the ease of, in the mattor of, the fursen stated. Similar is sept. 1 siam. 16:9, and comp I Jolin $4: 9,16$. 
37 He that loveth father or mother more than me is not worthy of me: and he that loveth son or daughter more that we is not worthy of ne.

3 And he that taketh not his cross, and followeth aliter me, is not wortliy of me.

39 He that fimleth his life shall lowe it: and he that loseth his life for my sake shall fimd it.

40) He that reveiveth you recelseth me; and he that reteiveth me receiveth him that sent me.
37 shall be they of his own household, lle that lovetl father or mother more than me is not worthy of me: and he that foveth soll or datughter noore thas 3. me is not worthy of me. Aut be that d all not take his cross and follow after me, is not worthy of

39 me. IJe that I findeth his lite shall lose it: aud he that 2 loseth bis lile for my sake shall find it.

40) He that receiveth you jeceiveth ne, and he that receiveth ne receiveth him that sent me lle that

I Or, found...201', lost.

would be a reign of peace, for so the prophets hat predicted; the diseiples of Christ were especially apt to think so, if they then knew of the angelic somg at his birth. The guspel foes tend to bring men into peate with each other, but only in proportion as they are hrought into peace with God. So as to the prophecies; men will beat their swords into plow-shares, only when men ground the arms of their rebetlion against Goel. Till then the enemies of God will be enemies of his porple, and often bitter enemiss. To send (ur cast as margin of li. T.) a sword upou the carth, is a natural image; and this led to the llse of the same term with peace, 'to cast feace apon the earth'; connp. Luke 12: 4!, 'to (enst) send fire upon the earth.' When lue says that he came to east a sword, etc., to divide the nearest relatives, etc., we understand that he came for the jurpose of doing a work which would inevitably leat to this; not that these evils were what he wished for. The langluage of $v$. 3. $f$. resembles that of Miah $7: 0 j$, where the prophet is deseribing the porfidionsnes and general wickedness which existed in the reign of Alaz. It is not hree quoted as a ploblucy, but the same ideas and similar oxpresions are introduced, and describe a similar state of things. T. Bo brings up again the ideas of $v .21$ above. Plumptre thinks the satements may have been suggested ly aeculpresces among our Lord's followars. "Had Zebedee Jonked with displeasure on the calling of his two soms? .

Were the brothren of the Lord, who as yet believed mot, as the foes of a matl's own homaloold?" With v. $44 \mathrm{f}$. comp. Lake l: 51-5in, whele like sentiments and expressions are found introluced on another occusion.

In such a state of divisom even in familis, the true follower of ('larist must not hositate Better to give up the nearest kindred (v.37), takf cross on shothlder (v.3x), and be content to lose life itself ( $\because 39)$, than to forsake Christ. The question whether one loves father or mother more than Christ, is put to the test in any ause in which the wishes of parents stand opposed to the known will of Christ. As to the duty of keepingall natural aflections subordinate to our love for the saviour, comp. on 8: 22; 19: 24. Is not worthy of me. Un another oecasion (Luke 14:26), he uses still stronger expressions: "If any man cometh unto me, and hateth not hiafather and mother ... he camnot be my disciple.' As to r. is f., see on 16: $24 \mathrm{f}$. . where the same solemm truths are repeated in a tufferent connection. The peculiar and striking expresion of $v$. $3 !$ was also repeated on two other occasions. (Luke 17:33; John I2: 25.) As to our Lord's frequent repetition of striking sayiugrs, seo at the beginning of ch. 5. Theapostles would readily understand the image of $v$, 38 , sines crucifixion was a common puniohment for high crime (eomp. on $16: 24$ ), but they did not yet know that Jesus was to be crucitied, and so this, like many other sayings of his, was not fully understoud by them until later. The terin find was obviously suggested by the contrast to lose; he who hy yielding to persecution and failing to confess Christ has aroided the loss of his life (the matural life), shall lose his life (spiritual and eternal life); and he who has loot (margin Rev. Ver.) his natural life for Christ's sake, shall find lite eterual (comp. (on 16: 25). As to such uses of a word in two different senses in the same sentence, comp. on $8: 2$.

IV. 10-42. THOSE WHo DO Not P'ERsereTF, BtT RECEIVE AND AID THEM, SHALI. BE REWARDED. Having said so mueh about the unkind tratment his followers will otten receive, Jesus returns to speak of those who will trant them kindly, and of the reward whicl such shall obtain. To receive them will be receiving him who sent them, yea, the Father who sent him. (Comp. a similar thought in 18:5, and again in John 18: 20.) IReceiveth is here meant especially of receiving into one's house (v. 14), which would not 


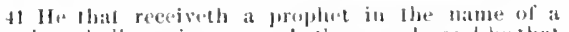
prophet shall receive a propher's rewall: and hathat

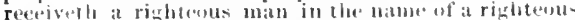

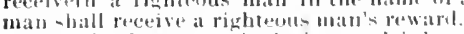

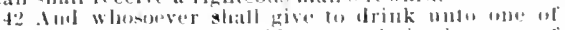

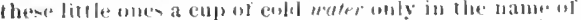
a di-ciple, verily i say unto you, he shall 1 uo wise lose his rewaril.
11 receivell a prophlut in the name of a prophes shall

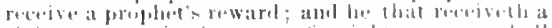

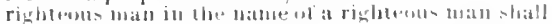

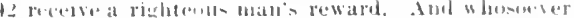

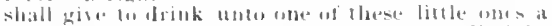

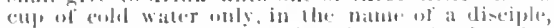
verily I say unto you, lat shall in no wise lase has rewail. only be an act of repect to the Lurd's servant, but would les helping him in his work.

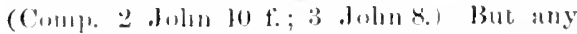

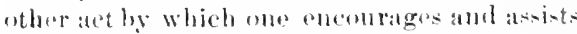
a servant ist the Lend in his work, is of the same elase, and shall in like manner be rewareled; even if it be merely grivins a cale at conl water to ane af the humblest disciples becatu-s loe is a disoiple, it shall nisuredly have a reward. 'Receiveth' may perhaps also include the untion of listaning to their messiane aud accepting it as truth. 110 said to the sieverity (Juke 10:16), "Ite that heatreth yous. hearoth we; and he that rejecteth yous, rojecteth ma, ete: Yet the notion of huspitality and locle apprars at least to be tlece prominont ase in the present distentere, as is shown by the ennehuling thought of the series. v. 42.) He that rereiveth a prophet (a persun spealing by divino inspiration, see (n) $7:$ es in the name of a prophet, with reference to the mand at a prophet. $i$. p. wat of regarel for the faet that he heals the nause

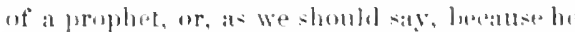

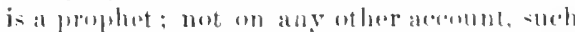

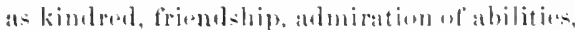
etce, but becall-a he is a prophol: and not simply linem the hope of reward. firr that would not bo doing it beatuse he is a pophet. (Compl. Isulie 14: 14.) Nhall receive a proplotes rewaril, the Mla-ianice, stermal roward. Sineo he treats kindly amb helps tho prophet beatuso he is a prophet, heshall get in enereity the same surt of powarl as if he had bornh himself an inspirenl teacher. Jereatuse he has besen hetping an inspirel teacher to du

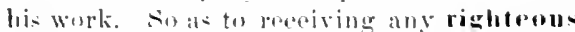
mau. Prophets aud righteous men are in like mannor united in 1:3: 17; :3: : have amomg us no inspired teachers: but every member of a chureh. in st fal as ho enrouragos and assists his pastor, takes part in the pastor's labors, and shall in like propurtion have the sort of etermal roward which pustors have; so in regard to missionaries, and nll Christian workers. As to tuture rewarls. comp. on $6: 1,19$. The sentiment of $r$. $4^{2}$ is aloc grivon in Mark 9: 4l, as repeatud on a ditferenterea-ion. One of theselitte ones

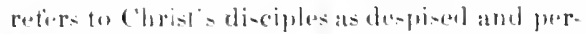

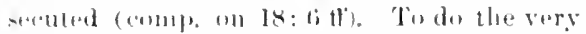
sualleot kindreas w the very humblest di-eiple

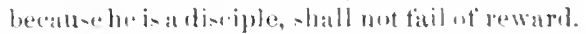

V. Ch. II: I. IIflye Fixisllell Ix-

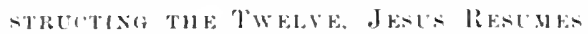
IIs OWX LAdzors. With thi- comeluding

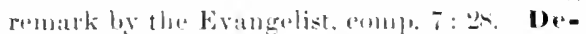
parted thenee. It was somuwhere in fraliles (comp. an ! : :3in). but there is no intimation as totheprecion loneality. Iov teachand preach in their ceitids. Ho did mot liv any meato send forth the Twelve in oreler to rediese himselt: lut immoliately ret nut to contimon his uwn laburs. 'P'pateh' is the common wort keresse, "xplatimel on 4: 17. Inthrir citirs, means not the eities of the disciplen. theneh they alre the jersons just mentioned. but wt tho porpule, the dows (emone. 10: 18). This

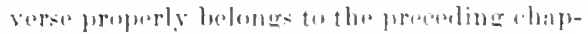
tar. and should have bean inclumblin is. $V$.

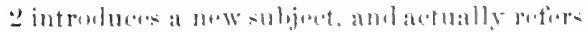
to a ditlirent periost. Is to the truefledet awkwalues of and division ints chaptors.

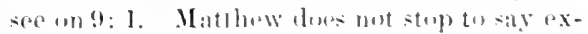
pressly that las Twelve also went forth as they were hidden. but leaven that to be taken fur grautal. Mark (6:12 r.). amil Tuke (9.6), state that they went furth, prasthing rofentance and worling mirandum- ourese as the

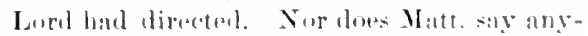
thinguf thoir returnand repurt. which is mentimed by Malk 16: 3an aud Lube (9:101; sete below an $14: 1: ?$.

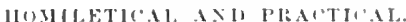

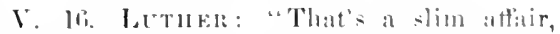

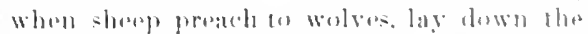

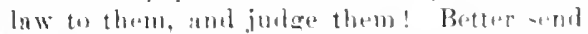
lions But this comese to bian al Pab sayc acor.2:51, that your fitith should rut stand in the windom at men, hot in the puwer of (rod."-Christian Prudune nond simplicity.

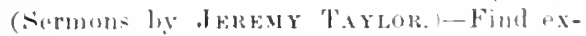
anples of combined prudence and simplicity 
in the life of Paul and in the life of Jesus. 1 GrRnard (Lange): "Have a serpent's eye and a dove's heart." Cinrys.: "These things have had an aceomplishment, and men becane prudent as serpents and simple as dover ; not being of another nature, but of the same with us. Let not then any one account Christ's injunctions impracticable. For be, beyond all others, knows the nature of things; lue knows that fierceness is not qurnehed by tierceness, but by gentleness." Broce: "Happy they who ean be both; but it" we cannot, let us at leat be doves. The dove must come before the serpent in our estem, and in the development of our character. If we invert this order, as too many do, and begin by being prudent to admiration, the higluer virtue will not only be postporred, but sacrificed the dove will be devoured by the serpent." $-V$. 19. Cinrys.: "It is no small consolation, that they aresuffering these things both for Christ, and for the Gentiles' enuviction." LANGE: "The dangers of care for oratorical finery in preaching. 1) It springs from anxiety, and restrains the spiritual life. 2) It manitests itself by excitement and excess, and alulterates the spiritual life. 3) It leads to weariness or self-seeking, and destroys the spiritual life." -Ditference between inspiration, and the spiritual help which may now be expecterl. - V. 21. Christinnity a awakening batred and as promoting love.V. 2.2. Unpoprularity is not always alarming. It may be easier to persevere amid the world's fruwns than its smiles.

V. 26. Two reasons why the Cluristian worker should not teir. 1) He need not be discouraged by roviling and assault, whieh even profect innoence and perfect prudence did not escape. (v. 24f.) 2) He may be eneouragad ly the asurance that the gospol must and will be made known. (v.26f.) HExRY: "l'here is nu part of Christ's gowel that needs, uprin any aceount, to be concealed; the whole coumsel of (rod must be revalled. (Acts 20:27.) In never so mixed a multitude, let it be painly and fully delivered." $-\mathrm{V}$. 28-31. Two reasons why we must do our duty notwithatauling opposition. 1) If through fear of man we shrink from duty, God will punish 11s. 2) If amid all oppesition we perevere, God will care for us. - V. 82 f. Confession and denial. 1) We are ull eonstantly doing one or the other. 2) There are many ways of confessing Christ, and many of denying him. 3) There are present bencits in confessing him, and present losses in denying him. 4) Life-long confession will bring eternal reward, life-long denial, etermal ruin. LUTHER: "What a great difference. 1) The confessors, we and Christ; 2) The place, eartl and heaven; 3) The hearers, wretehed men and God and the angels."

V. 34-36. When Christianity divides families and produces wars, this is not the fault of Christianity, but of human nature. Lutuer: "If our gospel were received in pence, it would not be the true gospel." II Exry: "They mistake the design of the gospel, who think their profession of it will secure them from, for it will certainly expose them to, trouble in this world. Christ has dealt fairly and taithfully with us in telling us the worst we can meet with in his service; and he would have us deal so with ourselves, in sitting down and counting the eost." - V. 37. Not that we should love kindred less, but Christ more.V. 38. William PenN: "No crose, no crown."-V. $38 \mathrm{f}$. We ought to be radaly to die for Christ; a fortiori, we ought to be living for lim. But "men are ready to argue for Christianity, reacly to fight for it, even to die for it, anything rather than live for it." - The great paradox-losing by finding, finding by losing. Contradictions in theory may often be completely reconciled in prictice. - V. 40-4. Helping the great workers. 1) We caunot all be prophets or apostles, missionaries, evangelists, eloquent preachers, ete. 2) But the greatest workers need help, and the lowliest can give it. 3) Thus sharing the blessed work, we shall share the blessed reward.

V. 24-42. Tuonas: "Encouragements to evangelical labor. 1) The cause for which the truc evangelist suffers is most honorable, v. 2.2. 2) The example he has is most glorious, v. 24. 3) The success of the cause is most certain, v. 26 f. 4) The providential care ot God over him is positively guaranteed, v, wh31. 5) His reward will be most glorious at last, v. 82 $\mathrm{f}$. 6) If actuated by the right spirit, be will find the greatest trials the greatest blowings, v. $38 \mathrm{f}$. 7) His interests are thoroughly identified with those of Christ, v. 40 , 42." 


\section{('II A P'TER XI.}

SI it came to pass, when Jesus hat made an ent if $A$ emomatudiag his I welve disciples, be deparled thence to leateh and lo prach in their vities.

2 Now when Jehn ham beard in the prison the works of Christ, he sent I wo of his disciples,
1 Ant if ame to pass, when Jesus hal nable an end of commanting his I welve di:ciplion, he departed thence lo teath and preach in their cities. 2 Sow when John heard in the prison the works of

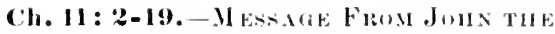

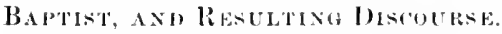

Javing given a groneral aceount of our Lerel's juncueys abunt Galilee, with some junpurtant specimens of his teaching and bis miracles (comp). on $8: 1)$, and having added an aceount of his somding ant the Twelse, with unch preparatory instruction, Matthew now alvances to other topies. Betore introducing examples of the Pariables (ch. 13), he mentions a romarliable message irom John the Baptist, aut our Lard's discourse thereupon (11:2-30), and then grives instances of arowed upposition to him on the part of the Pharisees. (ch. r.) Tho paragraph noted above (n:2-19) inelulles so much of the discontse occasionel ly Juluts mesisgo as relates to John himerelt. This is aloo given, and with unusually little difference of phraseologge, by Luke (7: 1 s.35); and from the eonnection of his narlattive it appears probuble (anmy). Iake $7: 1,11$, 18, that this message from Jolun wats semt shortly alter the delivery ot the seresum on the Ilount. Whe have heretotere seden that the arrangement of Matthaw, in chapters it to 13 , is not ehromologital but topucal, a eourse not unemonomly jursued by histurians and biographis:

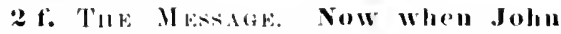
had heard in the prison. As to Juln's early life and ministry, seg an: : $1 \mathrm{tl}$. It has been stated in $4: 1: 3$, that ho wat "delivered up,' in the way familiar to Mathew's first reaters, and ntterwarls doseribed. (14:3 f $\left.\mathrm{f}_{2}\right)$ IIe hat now born antined in the cat les of

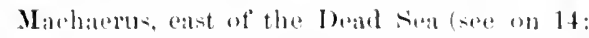
3), for probably not lase than twolve months, during which time Jasus has been pursuing his ministry in Galilee. Jolun was nllowed some intreourse with his followers (v.2: luke 7: 14), who brought him ateounts of what was goring on in the outer world. Yot this year of imprionment must have been for him a dreary time. He had indered been aceustomal to comparative sulitude for yours "in the deserts" (Luke I 80 ); lut at that time lito was betore him with its high hopes, und he doubt- less fele himsedt to be preparing for a great mission, the nature of which was gradually growing elearer to his mind. Then fane some aighteen montho at public habors, doring which he was attembled by vant crowels, aud his ardent natule most have reveled in the high exeitement of his work. And now he is shut up, ha, at "son at the wildemess," in ane of the dearle, dark, and frieghtiully lust dungeons of Machaterus, deprived of fresh air ant bulily texerise, of cherertul numeal emplogment and epportunity to do gounl, and dependent tor any future apportunitien an the caprifent" a watk ling and a cruel wombin. I. Elijah sometines got sally allt of heart, - John, who in many lospects closely resembled him (sis: on $: 3: 4$ ), would be likely to grow desponding, in this seatsm of entorecel illeness and ancertain langer. (Comp. the

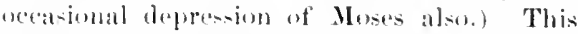
state of things may aceount for the proplexity which John's monesere of enepuiry serems to in-

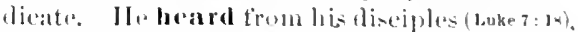
Who would lasurn the report, cirmlated thoughout the eountry (tuke 7-17), und somo: of whom had at leat on one occasion hearel J

'The worlis of (the) Clurist. Mathew's narrative lisually empluys our Larel's proper

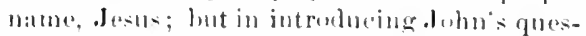
tion whetlor Jasts was the Jesolah, ho implies the an-wer by alling him the clerist,

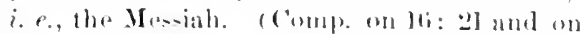
1: 1.) Fur the impurtanes of the article, "the Christ, seo an 2: t. His 'works' signify his genoral aetivity (which would inclute teaching), but espeially his miracles. This serems to be suegentrol by the answer (r.te), which points to the things they bhatr and sere, to his miracles and the eroud tilliugs he prosehed. Likewias 'all those thinge' in Luke 7: 18, would maturally include not merely the two miracles which there inmedie ately precele, lut someaneount at his remarkable teathings, as in the sarmon wn the Mount, which hat just reaurrel. Even in John, who usmally employs the tern "Works" 
3 Aud said unto him, Art thou he that should come, or do we look for anot tere"?
3 the Christ, he sent hy his disciples, and said unto tim, Art lhou he that cometh, or look we for another? to mean miracles (John $5: 36 ; 10: 38$, etc.), in $9: 4$, 'work the works of him that sent me' can hardly be restrieted to miraculous works. Sent two of (properly by) his disciples (comp. Rev. 1: 1), was in many manuscripts and versions altered into 'sent two of his disciples' (simply changing dia to duo), so as to be like Luke $7:$ 1\%. The true reading in Matt. 'by' or 'through' implies all the more strongly that John sent the message of enguiry for his own satisfaction. We still know from Luke (7:19) that the number of messengers was two; they would be company for each other in the journey of some eighty miles, and might supplement and eonfirm each other's statements upon returning. (Comp. on 10:5.) For the word disciples, see un 5: 1; as to the position of the thiseiples of John at this period, see on $9: 14$.

Art thon he that should come, or the coming (one)? 'Thou' is expressed in the original and at the head of the sentence, so as to be strongly emphatic; and to this corresponds the empluatic position in the Greak of another. 'The eoming (one)' had become at familiar designation of the Messiah (3:11;21: $9 ; 23: 39 ;$ John 6:14;11:27:Heh. 10:37), having probahly beer derived from Psa. 118: 26; Matt. 8: $1 \mathrm{f}$, ete. I,ook we, or nore probably, 'are we to look,' as in Noyes and Darby, or 'shall we look' as in Tymdale and Geneva. The Grapk subjunctive has in this word the same form as the indicative, and so the term is ambignous. The Latin varsions take it as indicative, and this probably influenced the Common Verson, following Great Bible and Rheims. The Peshito is ambingous, but the Memplitie is distinetly subjunctive. The majority of leading commentators take it as suljunctive (see Meyer, Weiss). The plural, 'are wa to look, means persons in general who eluerished the Mesianic hope. The form of John's question secms naturally to imply (Weiss) that he had regarled Jesus as the Messiah, and that he wished to karn whether he should still think so. The whole tone of the narrative, even more in Luke than Matthew, naturally suggests that John asked at least in part on his own acemut, to remove diflicultios in his own mind. So already Urigen (Cremer): "John's question was not for his own sake alone, but also for the ake of those who weresent." Tertullian also three times intinates that John himself was in doubt whether Jusus was the Messiah. So among recent writer, Neander, Meyer, Bleek, Ewald, Keim, Reuss, Godet, Plumptre, schati, etc.

But many have thought it wholly inconsistent with John's position and previous tentimony to suppose that he now felt personally the slightest doubt; and so they hold that he sent simply for the satisfaction of his disciples. So Chrys. (and his lollowers), with Cyril, Aug., and Jerome, followed by Luther, Calvin, and Beza, by Bengel, Maldonatus, and many others. Now, it is always desirable to accept the plain, straightforward meaning of a lassage, muless there be insuperable difficulties in the way of so doing. Any one who did not know John's previous utterances would certainly understand Matt, and Luke as here implying that he sent to Jesus for his own sake as well as that of his diseiples. It is very diffieult to believe that John would s'ist in hisown name ('are we to look for another?') and Jesus send back the answer to him personally ('Go your way and tell John'), when it was all merely for effect upon the minds of John's followers. Theophyl, aetually says that John "affects to inquire," and Euthym., "in pretence inquiring." The only rouson for adopting such an interpretation is the suppusition that . Hohn cannot have been in doubt after his known previous testimony. But while John knew hinself to be the harbinger of Jesus (John $1: 23$ ) and also to be the latrbinger of the Masiah ( $\left.J_{014 n}: 28\right)$, as indeed had been understum by his father Zachariah (Luke 1: 67-79), still it was conceivable that Jesus might possibly not be the Messiah. Among the various confused ideas which the Jews had developed from imperfectly understond Messianie prophecies, the notion was entertained by some that a succession of great personages womld arise. Elijah, they generally believed, would return to life; some thought that Jeremiah also would return, and perhaps others of the great propluets; then there was the prophet predicted in Deut. 18: 15, who was not universally identified with the Messiah. (See John 1: 20 f.; 7: 40 f.; Matt. 16: 14; 
4 Jesus answered and sad unto thun fio and slow

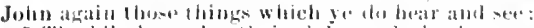

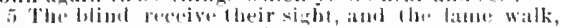

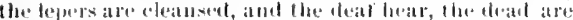
raised up, and the poor have the gispel freachell to ibeul.

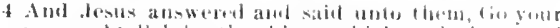

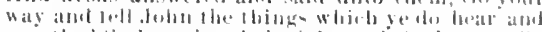

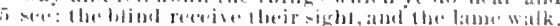

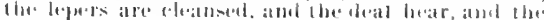

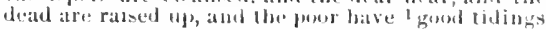

Luke 9: 19.) Sume thought it very likely that these would come in quick suece-sion, to herald with all the grater fumptheappmats

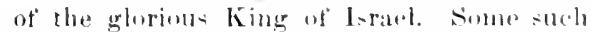
notion is astainly involved in the quation. "Art thouthe (embing (one), or ale we to lowk for another?' Now, John would naturally share the eurrent Jowish ideas (at the apmetlos diel at that time), oxeept so tiar as they were corrected by the special revelatioms given to him. These rovelations, aceorling to the whole history and manitist law of Gord's communications to mon, extromed only to the trutho neresary fin his own station and appointed work. Theres is theresture nothing surprising, and notbing derugatory to .John, in the idea that andil the de-pondent and perplexed thoughts of a weary prisomer, he began sometimes to question whether he-ols wats himselt the Mesiali, or moly a seromel and greater forerunner. Points which latep revolations have made olear enomeh to as, may casily have perplesed him. Wr meal nut suppome that leat any time wholly las his persuansion that .Jpous was the Mesiah, hut only that he

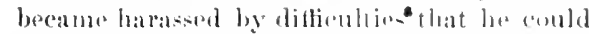

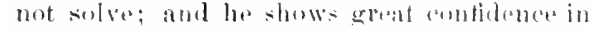
Josu- by referring the whole puedionte him.

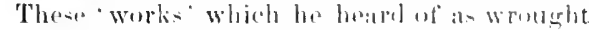
by bosus were very romarkablo. But how strange it was that the erreat workir. to whom

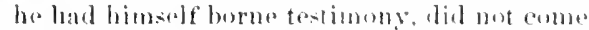
ont puldiely in the Mrsianio wharactere and have himselt erownel, alld peisen at the Anointer ling: how strandu that, with the powor of working such astomi-hiner milateles. he should leave? his derental servant and berald to languish so long in this mojust indprisummont, ent off from the work in which

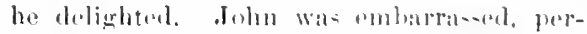
plexed-perhaps ( Köhler. Mrrines) impatient -he knew uot what to think. and was weary of wating-he would sond and ask Je-n- himself; and while the answer aleared ap bis own perplexity, as he hopod womld be the case. and perliaps aroused. Iesus to promptis netion, it might at the same time help lim in

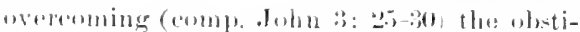

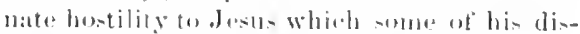

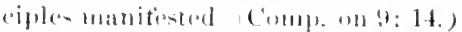

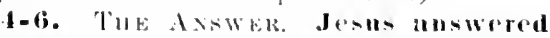
nud said muto them. It is of andrec ins-

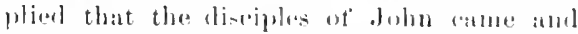

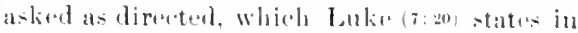

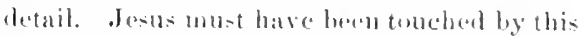

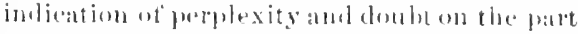
ot his imprisoned temerumber. Fiunlel: "Sml sturely at mo moment of thene years diul the whole preture of all hio tiortunes in the many(a) loper pant sinee his tirst neeting with the

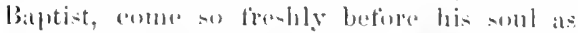
mow." (an and shcw Johu asmiu, calry lnate the mesatge to Jolin. A Arain in the Com. Ver. i-cerrect, but alyt te mislead, as it

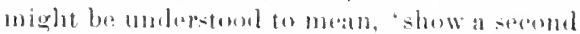
time. 'rhose things which ye do boar and sece, the teachines and miracles whidl be proweds to mention. Luke (7:21) stales

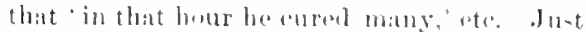

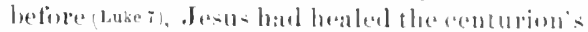
servint and hrought to litis the soln of the

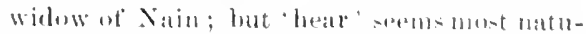
malle to retere not to the resort they hast

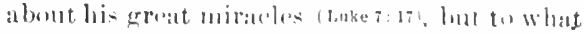

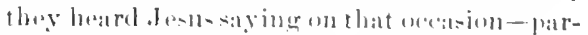
ticularly to the tace that ho was proclatiming

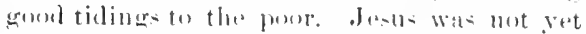

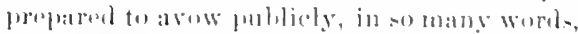

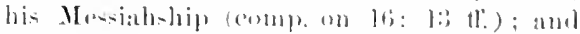

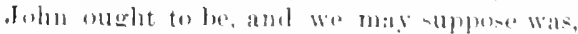

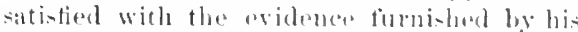
worling such miracles, and loringing such

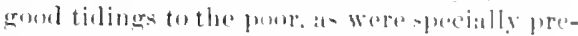
dieted in commetion with the Meniah.

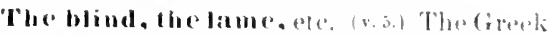

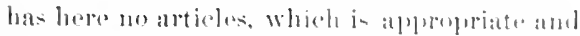
rxplessive, lut cannot le indated in the Fing-

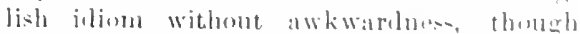

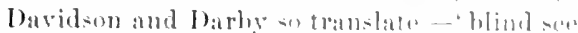

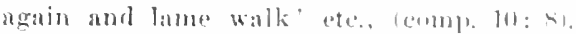

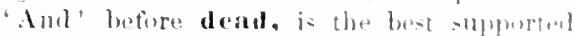
readiog: it was probubly amitted in orelor

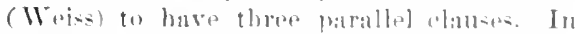
Ist. $35: 5 \mathrm{t}$. We read, "Then the eyes of the 
6 And blessed is he, whosoever shall not be offended in me.

blind shatl be opened, and the ears of the deaf shall be unstopyed; then shall the lame man leap as an bart, and the tongue of the dumb sing." (Rev. Ver.) Here was then a literal fultillment of a prophecy which referred also to the spiritual healing Jesus came to accomplish. In addition to the things thus predicted, Jesus was cleansing lepors, yea, and raising doad persons. The message of John came shortly after. Jesus had raised to life the sonl of the widow at $\mathrm{N}$ ain (Luke $7: 11.18$ ); and the raising of Jairus: daughter may have been, as the Harmonists think, some time earlier. Only a few specimens of our Lord's miracles are described, and it may well be that other cases of raising the dead occurred, but were not recorded. The poor have the gospel (good tidings) preached to them doubtless refers to Isa. 61:1, where Messiah is deseribed as commissioned to "bring good tidings to the lowly." This last word in the Hebrew signifies those who are oppressed and afflicted, and bear it with meekness-persons lowly in condition and in spirit. For all such Messiah had good tidings (comp. on 5: 3 ). The Sept. renders by 'poor,' and that word is retained, as sufficiently expressing the foree of the Hebrew, both in this passage of Matt. and Luke, and in Luke 4: 18. For the Greek word rendered 'have good tidings preached to them,' see on 4: 17. It here means more than what we express by "preach the gospel," signifying more generally the tidings of blessings to be enjoyed by them through Messiah's rejgn. The masses of mankind, poor and ignorant and suffering, received little attention from the heathen philosophers or from the Jewish rabbis. The latter often spoke of them with the greatest contempt, literally: "But this crowd (rabble), who know not the law, are aceursed" (John 7:49); and they delightrd tostigmatize them as "country folks," ancient culture being almost entirely confined to cities. It was thus the more remarliable that Jesus brought tidings of gond to the poor, to the suffering, despised, and lowly.

This appeal to his 'works,' as testifying in his behalf, was repeatedly made by our Lord towards the elose of his ministry (John 10: $39 ; 14$ : 11: 15:24); and indeed had already been made, at a period probably earlier than this message
6 preached to them. And blessed is he, whosoever

of John the Baptist. (John 5: 36.) These miracles and good tidings for the lowly, showing that Jesus of Nazareth was the predicted Messiah, still stand as an evilence of Christianity. The Emperor Julian (Wet.) says scornfully, that "Jesus wrought nothing worthy of report, unless somebody thinks that to heal the lane and blind, and to relieve demoniacs, in the villages of Bethsaida and Bethany, were among the greatest works." And blessed (hrppy, same word as in 5: $3 \mathrm{ff}$.) is he, whosocver shall not be offended ( find no occasion of stumbling) in me. See the same image in Isa. 8: 14. For the word meaning 'to be made to stumble,' or 'to find occasion of stumbling,' see on 5: 29 ; it has here the second meaning there given-whoever does not find in me an obstacle to believing, and hence reject me. Jesus was doing and saying things predicted of Messiah. But the Jews stumbled at his failure to dn various other things which they expected in Messiab, and so most of them rejected him. (Comp. 19: 57; 26: 31.) John was now perplexed by the same things; and Jesus declares, 'Happy is he who shall not stumble at me.' The form of expression delieately suggests a warning, that he who does thus stumble will be anything else than bappy. - This saying is clearly a part of what they were to report to. John, and this best aceords with the idea that the reply was meant for John's own benefit also, and not merely for his disciples. Were John's perplexities and dombts relieved by the answer sent? We are not told, hut eireumstances suggest that they were (Keim). Juhn's disciples, after his death, went and told Jesus (14:12) ; and subsequently we find Jesus speaking of John in a tone of high commendation $(17: 12 ; 21: 25,32)$, as indeed he proceeds to do on the present occasion, thereby showing his confidence that John is right at heart.

7-15. Testinony of Jises to HIs ForeRUNNER. John had repeatedly borne testimony to .Jesus (John I: 15, 26 f., 29-51, 35 f.; 3: 26-30), and now when he is cut off from usefulness by imprisonment, Jesus bears testimony to him. John's disciples are sufficiently devoted to him; so Jesus speaks this commendation when they are out of hearing, for the benefit of the people at large. This was grateful to 
7 Anel as they demarted, Jestus began to say unto l he

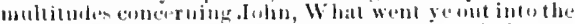

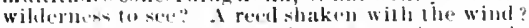

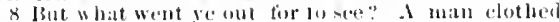
in sott raiment: lebuld, they that wear soft clothing are in kings: humses.

9 But what went ye unt for to see"? A proplect? yea, ! sal untw you, amel more than a prophet.

lit lor llas is he, et whom it is wrilfen, lichold, I send wy messenger beliore thy face, which shall prepare thy way betore thee.
7 shall timl none oecasion of stumbling in me. And as these went their way, Jestes leegan 6 say und the

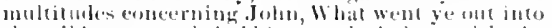

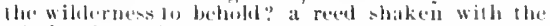

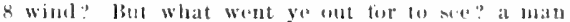
elothed ju suti raiment? [Bebold, lliey llat war

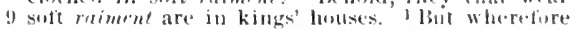

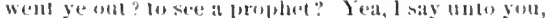
11) and moch more than at prophet. This in lie, wt whom it is witlell,

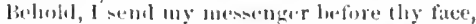
Who shall prelare thy way before thees.

1 Mang ancient authorities read. Wut what went ye out to see? a prophet

the people, anoug whom fohn wis highly esteenert. (2n:2ro) Began to say. While the unesiengers were going, Jesus bengin the disconrse which continued after they had disuppentrerl. Unto the multitudes (frowds, so aloo luke $7: 24$ ), see on 5 : 1 . Into the wilderuess, see on $3: 1$. To see, to behold, look at, as a speetacle; the word ixplatined on 6: 1. It serms to he implied that they went toromuch an if to lrok at a sort of show. (In v. 8 f. it is 'to see,' the common and simple worl.) Doubtles those who went out to see and hear dohn were much intlueneed by corjusty. But what was tlie object of this curiou gatying? Was it a reed shalien with the wind? Some understand Jesus to be asking whother they went merely to see an ordinary, natural objoct. But the phrase shaken, or "tonsed by the wind," and the use of the singular, "a reed," much more anturally slugesests that this is a symbol of ficlileness. Thery disl not go wit to see a fiekle douhter, and they most nost think he is really afickle dumbter now. The furplexities and difleulties indieated by his me-sige were not of the surt due to ineon-tancy, or to any weakness of character. Nor was it comp. on 3: 4) to see a man in soft raiment, elegant clothing, such as courtiers wore; John had refused to play comrtier, ats all the people knew, and hal gone to prison tor it. We learu from Jewish writors (Just, in Plumptre) that in the earty days of Hurod the Great, some Scribes who attached themselves to him, baid aside their msual phain dress, and wore the gorgeous raiment of eourtiers. But John was no wenkling, no self-secker.

' 'Rament,' though implied, is not expressed in the earliest authorities, and was probably adilin from Lake $7: 25$; so it is here properly placed in ilalics by Rev. Ver.

ZThis as given in B. $\boldsymbol{X}$., and others, would be easily altered to make it like $v, 7$ f, and Luke $7: 26$.

' $F()^{\prime}$ ' of the common Greek text is wanting in
These introductory quentions lear up to the great cluestion, which, in the correct text, 2 has a slightly altered form. What went yo out for to see, ete-liev. Ver, But wherefore went ye out? to sen a prophet? We learn from 21 : 26, that the masses of the propte nniversally regarded John as a prophet; and the tiact that there hatl been wo prophet for so many weary centuries invested him with a heightened interest. Jesus says he was indered "prophet, and something exceedingly more than a prophet (the word remberel "more" is nenter gender; comp. 12: 6, 41). He was indeed an inspired man who came to sprak for God (see on $\overline{7}:$ 22), like the prophet of aarlier days. He was also something more than a groplet, for he was the fulfillonent of prepleey (r.10), and he had a nuique and singuhrly dignified position, us the immediate forerumer of Messiah, thering in his glorious reign. Euthym. "The lierilds that murch near the king are greater than the others. . And John not merely saw the predieted one, but also baptized lim." Morison: "He not only said, He will come: he said. Ho has come; and the we is." (Onr Lord was here in finct exalting hisown mision by ('xalting that of John. The penplo should hasken to him, to whom this more than prophet had testificed.

10. 3'This is he of whom it is written, has been written, and now stands on reeord (see on 2: 5). The quntation is from Mal. 3: 1, and the literal rentering of tho Helorw is. "Behold I sond my messenger, and he shall prepare the way before my fice." There Jahovh sprakis as if coming himelt, namely.

several of the earliest authorilies. We can eavily explain its invertion, hut not its onission, for it expresses the real argumentative relation betwon the sentences. So we eonchde that it was mot originally in the text. In many such cases, the helter we like a particular rosding, the more certainly it is to be regarded as a laterinsertion. 
11 Verily I say unto you, Among them that are born of women there hath not risell at greater lian. John lle baplint: notwithstanting, he that is heast in the kingdom of hearen is greater thath he.
11 Verily 1 sar unto vou, Among them that are bors of women there hatli mot arjsen a greater than John the biptist: yet he that is l but lite in the kingdon

I Gr, lesser

in the eoming of Messinh. In the application / place.

Chrys. understands that it means bere made, Jahovah addresses Mesiah, as if Jesus, as 'less' than Jihn, "less in age, and, sending a mesenger before lim. This is only bringing out more elarly an idea really involved in the prophecy, as the N. T. writer have in various cases done, with an obvious propriety (comp. on 2: 6). The prophecy is fuoted with exatbly the satue variation of expresion, in Luke $7: 27$, and in Mark 1:2, and the anne variation is implied in the evident ruference to this passage in Luke 1:76. The most natural explanation is that in this form it was commonly given in the oral apostolical teaching. The supposition of quotation by the Evangelist from an orat Aramaic synagogue version (Toy), seems to bave no clear and adequate ground, here or elsewhere. As to the image involred, that of sending forward a messenger to prepare the way for a journey, see on :3: :3, Where a similar patsage is quoted from Isaiah.

11. Verily I say unto you, see on $5: 18$. Among those . . born of women, comp. Job 14: 1; Gial. 4: 4. A greater. Luke (7:24) has it 'a greater prophet.' The expression obviously refers principally to his exilted position, and also, perbaps, to his faitlufil devotion to its duties. No person had oecupied a position of higher privilege than John the Batptist, involving clearer views of truth, or grester honor in the sight of God. Nevertheless he that is least, literally, less, viz. than all others (ommp. Mark 4: 31), and so equivalent to 'he that is least.' Similar expressins and found in 18: 1 ; Luke 20 : 24, ate. and in the serpt. of .Judg. 6: 1.5, where Gideon says, "I am thr leant in iny father's houre." The Old Latin and Vulg. (ats well as the Memphitic) render 'less, and so all the Eng. Ver. before that of King. Jannes, which may here (as so ofton) have followed Bera, who renders 'least.' The Peshito also transiates ats if it wera a superbative. The renduring of the Rar. Ver. 'but little, dues not commend itself at partieularly good, for the Greek either means 'least' or 'lewe'; the oreasimal rendring of the comparative, somewhat little, rather little, ete., secms to be here quite out of aceording to the opinion of the multitude," which is excesively fur-fetehed. To refer the kingdom of heaven here to the future life, as many do, is entirely unsuitable. We must understand that the lowest subject of the Messianie reign is in a position of greater privilege and dignity (comp. Zech. 12: 8) than the great forerunner; or, else, perhaps (Calvin), that the lowest of all the teachers instrueted by the Messiah himself was superior as a teacher to the forerunner.

In any case this expression implies that John was not in the kingdom of hoaven. The inference is utten drawn that he belonged entirely to the Old Testament Dispensation. It is frequently asserted, and by many taken for granted, that the kingdom of heaven began on the Day of Pentecost following our Lord's Ascension, and so John had no connection with it except to predict its approach. But if this be so, where did the ministry of Jesus himself belong, the early part of whieh ran parallel to that of John, and embodied the same announcement (4:17; Mark I: 15)? If John's teaching and baptizing are to be set off as essentially different in kind from Christian teatching and Christian baptism, these beginning only on the Day of Penteenst, then we have the strange contradiction that Christ himself, as a teacher and baptizer (John3:22: 4:1 f.), did not belong to the Christian Dispensation. Morenver, in v. 12, and also in Luke 16: 16, our Lord speaks of the kingdom of heaven as already in actual existence, and counts John among the preachers of the kingflom of heaven, as distinct from those who merely predicted it. (Comp. Luke 17: 21; 10: 23 f.; Matt. 13: 16.) If some argue that John's baptism was not regarded by the apostles as Christian baptism, from the single and peculiar ease of re-baptism in Acts 19: $1 \mathrm{ff}$, it may be answered that those persons were re-bilptized because it was evident that when they previously received bajtism (frobahly from some ignorant disciple of John), it had been without knowing what they were 
12 And from the daty of Juhn the liajtint until now

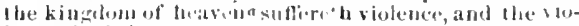
lent take it ly force.
12 of heaven is groater than he. Anul from the daysut

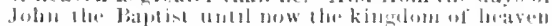
sullereth violence, amb wen of siolence take it by

a Ur, is goten by force, and they that threst men.

sbout, without ander-tandiner the fundat mental truthe at the Messianic reign, as annomneed by John hinsoll: As this isolated case ean be acounutul for in this way, and indeed in varions otlere ways, it is quite unwarrantable to make it the prost of a radieal distinetion betwexn Christian baptisn and the baptien admini-tered by Juhn and hy Christ liminsale.

How then are we to anceive of Jolun's position? In somesense lue belongs to the kingdom of Messiah, the Chri-tian Disjensation, his work constituting its introductory statge; and yet his position is inferior in dignity and privilege to the leant in that kinglom. Wis work may be compared in a landing-place in a stairway; the highost stop of the lower flight, or the lowest step of tho upper flight, or, whenever you choose so to regard it, higher than the highest of ono, lower than the lowest of the other. Or (Clirys.), it may be compared to the bour betwern dawn and sunrisaphrt of the day, yet less light that the first moment alter the sun is artually risun. The begimning of John's mini-try was the dawn of the Mesianie reign, whose light gradually inereased throughout the ministry of .l esus; the Dily of Pentereast was its sulurises. when it appeared in full-urbed beanty and hrightuese; its moonticle glory is yet to exmose. In this passage, then, Johnos position is lictinguished from that of one living when the Now Dispensation slunuld lue fully astablishad; while in other passiges he is spoken of at himsalt belonging to that Dispensation, in its opening stace. His position was so peeuliar, that it could be variumb regarded, aceording to the point at view in rach ralse.

12. 'lhis is comnected especially with the former elatuse of $v$. 11. The impurtace of Juhn is shown by a reference to the grait excitement his ministry had prouluenel amomer the proplor (eomp. Josephus, "Ant.," 18, 5, 2y), and which still continued, at the time when our Loril was spealing. From the dats of Johu the Baptist noms from the times when John was engagod in anctive labors, which chosed with his imprisomment. These labors had probably continued about ajghtecon months, and from six to twelve moluths hial alapaed sinee their alose. Cutil now shown that the work in guestion was still groing on, but without at all implying that it would now

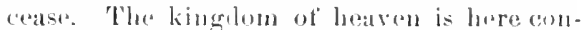
exived of as nut simply near, but in actual existence, and as having begun to axist with

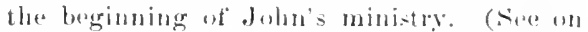
v. 11.) The kingdom of heaven sutlereth violence, ur, 'is taken by violenee.' (1):uvid-

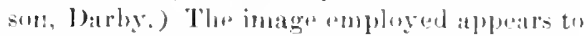
be wet precisely that of -torming a ciry (z Mace. it +1 ), but l lat of invaling and soiziner a lingd:ju. Liafore the time of John many were expecting the establishment of the Messiande kinglom, but in croneral were quictly waiting, without any armest efforts to prepare for it, and share its lolessings. John's ministry awakened atl atger "xpectation of its immesdiate appearatues, and men were arou-ed to press into it, like invaders pressing into a country and taking posecsinn. Our Lord docroibed this state of things by the same -triking intage an a later aceasion. (Luke 16. 3ti.) It is alpropriate and eminently desimble that both individuals and communitios shouid become gratly arousad an tha subject of $\mathrm{re}^{3}-$ ligion, and be derply in armest about it, so as to rexemble, in their pursuit of salvation, the resolution and irrosistible forew with whieh an invadiug army preseses into a moutry. How it torces its way alomg-every obstacle?

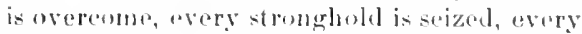
opposing how is lorokenand seattered-mothing can withstand its confuering advance. of course the applieation of this is to spiritual "uergr, and it gives nur warrant fior riolent hodily exareisus, axcopt in su far a- these may sometimes naturally rewalt trom uneweroliable teelings of soud; hat it does show the propricty of impassioned aromestmess and indumitable resolution in the rentranes upon, and pursuit of, a Christian lito (Comp. $7:$ 1\%; Lulio l:?: 21: Pliil. 3: 12 tl:, ate.) 'The' perim in qurestion was the tirst of those setsons ot woldesproal roligions excitument which have rofunterlly marked the proures of Christian history. Claristianity wa horn in a croat re-

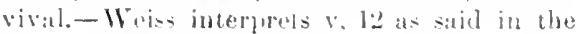


13 for all the prophets and the law prophesied until 13 force. For all the prophets and the law prophesied John. 14 until Jolu. And if ye are willing to receive 1 it, this

14 And if ye will receive it, this is Elias, which was for to eome.

is He that hath cars to hear, let him hear.

$10 r$, him...2 Some ancient nuthorities onit to hear.

way of eensure, viz., that John had introduced a hasty and stormy way of entering the kingdom of henven, opposed to the quiet and gentle introduction of it in which Jesus was angaged. This is ingenious, but it ill suits the following connection, and the whole tone of our Lord's testimony to John.

13-15. This reference to Elijah is not given by Luke, who on the other hand makes at th is point some remarks (1uke $7: 29 \mathrm{f}$.) not made by Matthew. For gives a reason for the statement of v. 12. This great religious movement, men pressing with eagerness and violence into the kingdom of heaven, he has just deelared to have existed from the days of John the Baptisı; for, mutil John, until his time, the prophets and the law (see on 5: 17; prophets here mentioned firt, doubtless because predietion was a less prominent element of the law) prophesied of the Messianie reign; but this period of prophecy ended with the coming of the new Elijah, in the person of John, who was at onee the last predieter of the kingrlom of heaven, and the first preacher of it; and now the good news of the reign of Messiah is made known (Luke 16:16), and men are pressing into it with violence. Athanasins: "Up to John the kaw; from him the gesper." (Comp. on v. 12.) And if ye will (are willing to) receive, $i$. e., most naturally 'to recuive it,' possibly 'to receive him' (margin Rer. Ver. and Geneva). They might be slow to reeeive it, because it conflicted with the mopular notion that Elijah in his own propor person woukd alpuear to anoint the Messiah (Justin Martyr, Trypho 8, 49); and becanse too, of John's prosent helpless captivity, which they might fancy (xod would not permit in the ease of one sunt hy him on a great mission. This is Elias-be, and no other, the original being emphatie, as in $1: 21$

1 'To hear,' after 'ears,' shoubl prefty certainly be omilted (as in liev. Ver. marr.), following $\mathrm{B} \mathbf{1}, 8,2, \mathrm{k}$; as also in $13: 9$, following $1: \times 1$, and some copies of Odel Ialin; and in 13:43, following $\mathbf{N}$ (first band) 13 , some copies of old Latin, and some of Vulgate. The fact seems clearly to be that Matt, in all three catses gives gimply 'be that bath ears, let him hear,' while Mark and elsewhere. As to reasons for giving the Old Test. form of the name, Elijah, rather than Elias, see on 1: 2. Which was for (thut is) to come, or 'that is going to eome.' This was the expression used among the Jews encerning the expected enming of Elijah, and our Lord retains it, as the familiar phrase, though the coming had now taken place (so also in $17: 11$ ). The prediction of Mal. 4:5, "Bohold, I will send you Elijah the prophet," ete., was generally understood by the Jews to mean that Elijah would come to life again, and many of the modern Jews have that expectation still. Jesus means that John had come "in the spirit and power of Elijah" (Luke 1:17), a similar man, and to a similar work; and this is all that the prophecy meant. (Comp. on 3: 4; 17:10 ff.) John himself was asked (John 2:21) whether he was Elijals, and answered ' $\mathrm{No}$ '; but he was answering in the sense of their question-he was not Elijah eome to life again. IIe that hath ears! let him hear. As Elijal was to be forerunner of the Messiah, and as John the forermner of Jesus was Elijah, it followed that Jesus was the Messiah-if they had ears, and were willing to receive it. This peculiar phrase, 'he that hath ears,' ete, was repeatedly used by our Lord, especially after saying something whieh was infportant, and also likely through ignorance or prejudice not to be understood (eomp. on 13: 9, 43; 24: 15); and it is still used in the last words he has spoken on the earth, the messages to the seven churches. (Rev. 2:7, 11. 17, 29; 3:6, 13, 22.) We ean seareely conceive how diffieult it was for the Jews to aecent the assertion that the prophecy of Elijah's coming was fulfilled in John the Baptist. And we have aluandant need to fear lest we ourselves lack ears to brar, lack the spiritual perception and sympathy,

(4.9.23) and Luke $(8 ; 8 ; 14: 35)$ give without variation 'he that hath ears io hear, let him hear'; and that Matlluew's expression early began to be changen into the fuller form. (Comp. liev. Ver. of $13: 9,43$.) It is notewortly that in all three cases $B$ has the correct text, while its companions vary. 
I6 But whereuntoshall I liken this grumalion? It is like undu childron silling in the matkels, and catling unlo their fellows,

I7 And saviug, W" have pipel ungu you, and re have tos danced: We have mourtied unto yon, and ye hate nol lanedierl.

the catreler and willingness of follow truth, the readiness to let the Bible menn what it wishes to mean, which are necessary to a thorungh under-tinding of Seripture.

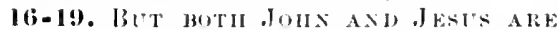
ReJkeTto. The thotaght of this patsige was naturally suggested by the reception which many bad given to the grat Forerunner, the new Elijall, and to Jesus himself. John was unsurpianed in the dignity of his position, the greatness of his work: he whom ol hon heralded wats greater still; yot buth were rejected. They had different, eron opposite, peculiarities and modes of lite; but that willful and un reaseonable generation rejocted atch of them, thus showing a determined and invincible opposition to the havenly wisdom which both were seeking to inculeate, and whicli was justified and vindicated by its effeets in all who received it.

$16 \mathrm{f}$. But whereunto shall I liken this generation? Their ennduet was sostrange, in its ineomsistent amd willful opposition to the truth, that he was at at los to find anything like it for an illustration. (Compl. Mark $\$:$ : 30 ; Luke 1:3: 18, 20; Latm. 2: : 13; and the rabbis have a similar formula.) In salying this generation, he does not math all without exception, but refers to the gemeral tome of pmb. live sentiment, and e-precially to the leading men, the suribes and I'harises who gavel lhat tone. Luke (7: 29) in form: 11- that of the persons present on that oecalsion the mass of the people and the publialus justified crol having received John's laphtism; hut the Phari-

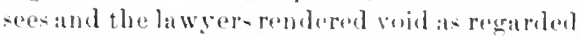
themselves the comm-els of (rod, not hatring heen binptized ly. John. (Our lared was net yet prepared to make upen diecrinuination monng the Jews, and demennore the seribes and Pharisees by name, at he diel at a haler period. (Chap 23.) It is like mnto ehilthr'n, "te. There is a certain eolloquial inmesont-

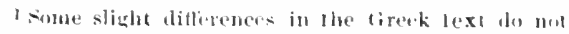
affect the substantial nuesuing. "Wh" call . . . and say' is heyond question the correct text. It is diflicult 10 decile between 'their follows' (hetnirois) and "the others' (heterois), like Juke $7:$ : :2, 'one another.' The earliest aut aorities for the most part give heterois, but
16 levar, lel him isear. But whereunlo shall l Jiken this generation? It is like nulo children silting in the

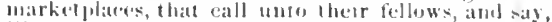

t7 We priped unto you, and yedid nol danee; we wailedé,

nes- in the expresion, which onght not to occasion any diflieulty. IIte does not mean that the men of this ganeration eorresund di-tinctively (o) the childron whe speali, which would make Jolun and himadf an-wer to the parties complatinen of ; but in general, the eonduet of this generation correnends to the case of children sitting in the market-place, some ot them saying toethers, ete. So in 13: 4.5, the kingrom of heaven is said to be like a merchant, rte., but it is not meant that the lingelon restubles the perend, but that in at

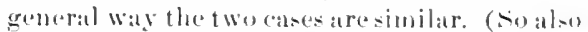

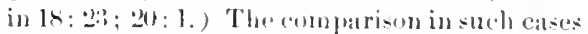
is made somewhat loosely, and is to be understond according to the mature of the cases. There is thus no newed at all for the various artificial explanations by which some able expositors ats Meyer, Ewald, Keim, IV eiss, Plumptre), try to work out the view that John and Jesus are the persoms called to, and complained of, for mot doing as the prepple wished. The simple and abvols applieation in the coutratry direction is much more natural and appropriate.' In the marketsmerelestpleces. The word hemotes a publis -quare, ur place of mublic resort in a town. such us the Grentis ealled Agora (the word here used). the Romans called formm, and we eall place or square. In Oriental eities this plate

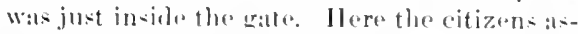
sembled. the juluese sat, luxiness was trinsacted, and marliets were opened 19en. 19:1: Ruth 4:1: Prov.31:23. pte.); atud here, as a matter of course, lenaters wombl lounge $P_{* \mathbf{a} .69}$ 12), and loys womld gather to play. The children. $i$. P. buys, are reprosented as imitatiner, in their playe the practice of their ellurs at melry-makiugs or funerals. We have piped unto you, the instrument indended somewhat rosmbling a flagentet. We have mournod. (ur, maled), i. r., sing the fumbril wail or dirge (1)avidom and Xojes transiate

the ather would he more easily elonged indo this by assimilation an luke. The two worls are prote nouncerl axactly alikoin Vodern tircek, and probably were when our oldesl copies were male. 'To gon' is rightly omithed in the secoud elanse. 
18 For John came neither eatiug nor drinking, and they say, Ho hath a devil.

19 The son of uan came ealing and drinking, and they say, bithld a man glatumous and a winebibter, a friend of publicans and simmers. But wistom is justified of her (abildren. is and ye did not mourn. Jor John eaue neither eating inr drinking, and they say, He hath a demon. 19 "The con of wan came ealing and srinking, ant they sar, behold, a glutomous man, and a wintebibter, a frieml of publicans and sinners! And wisdom 2 is justitied by her 3 works.

I Gr, beat the breast...2 or, vas....3 Maụ ancíent authorities read, children: a* iu Luke vii. 35.

'sang a dirge'), such as hired moumers were accustomed to sing at a funeral. (Comp. on 9: 2\%.) Lamented, literally, 'beat gourselves, beat the breast, as the publican smote his breast. (Luke 18:13.) The boys had tried their comrades with notes of joy and with notes of grief, and met no response to either. Stier: "I cannot but be noted that the Lord, nihil humani a se alienum putans [deeming nothing human without interest to himself], as he trok notice of the rending of mended garments (9:16), and the domestie concerns of the children in their beds (Luken:7), so atso observes the children's play in the market place, and finds in everthing the material for the analogies of his wise teaching." Who is not moved at the thought of the saviour standing sometines in the marketplace, with the busy throng around, and watching the boys at their play? This is the only place in the Bible (Nicholson) where any game of children is described.

$18 \mathrm{f}$. Our Lord then applies the illustration. For, presents this as a proof of the previous statement. The rase of this generation does resemble that of the ehildren, for they treat John and Jesus exactly as the children's comrades treated them. Johu came neither catiug nor drinking, $i$. e., as other mon do (Luke 7: 3:' 'ating no bread nor drinking wine'); not sharing with men in general in their modes of life, but living apsut aml abstonionsly. (Comp. on B: 4.) He hath a devil-elemon. Sire on $8: 28,31$. As an now would say, be is derauged. It is natural that such an expresion should boentue com-

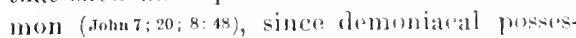
sons were often forsud in conjunetion with nerutal derangement, whother as cansing it or becanse persons were thereby remblared more suitable to be thus pussesied. Inomuniacs would sometimes go into a wild region. and live on som ford an they could procure

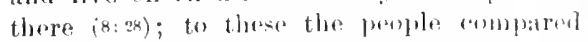
John. Though "willing to rejujer for a seat-

1 "Works' in B. (1st hand) S. 124, Yremphitie, the Peshito and Ilarklean Syriac, the Tithiopic, amel some son in his light," as "the lamp that burneth and shineth" (Joha 5: 35. Rev, Ver.), they were now rejecting his witness to Jesus and ridiculing his mode of life, saying, "He has a demon." On the other hand, Jesus lived anong men, eating and drinking as they did. He was atcustomed to drink wine, as was common, almost universal-those light and pore wines which abounded in that country, and which, taken in moderate quantity, and mixed with a double quantity of water according to custom, would stimulate about as much as our tea and cotfee. He went to the houses of Pharisee and Publican, of serupulous observers of the law and open tran-greseors of it, and shared their customary food and drink. And immediately they cried, Behold a gintouous man, and a wine-bibber : The Greek word here used for man implies in such connections a certain contempt, as we sometimes use 'a person.' A friend of publicans and sinuers. The emploas is mot on 'friend,' but, as the Greek order shows, separately on 'publicans' and 'sinners.' Beeause be ate pleasant food like others, and with no special abstemiousness, they called him a glutton. Because he sometimes drank wine as uthers did, he was a wine-bibber; one who drank latbitually and to excess. Because lo treated bad men with civility and kindness, carnestly seeking to do them good, he himself also was bad. (Comp. Luke 15: 1, 2, and see above on 4: 11.) So they talked. bohn was not enough like other people-a crazy sort uf man. Jesus was too much like othor people. Nothing conld please them. The son of man, see on $8: 20$. Publicans and simuers, comp. on 5: th.

Now, what shall be the comsolation of those religious teachers who see that, do as they may, men will find fault with their conduct, and rejoet their mossage? That in whieh Jisus touk comfort. But wisdom is justified of her children. 'Works' is elearly the

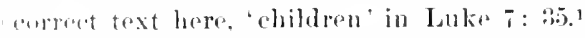


Thoush the people in grencral rejected the true widem, yet she was juslitied, shewn to be reglut, both in duhn's way of living and teaching and in that of . Jastle, hy her worksthe eremeral attects of the trow wiskem in these who recoive and pratetice is, and in particulas these mirandus- worlis which proved Jents to be the II sisiah. (1.2, t.) There is thas an, great sulusantial difference between juntitied by her works, at affeceling these who recelve her, and seren in them, and justitied by all laer rhildren' (Luke 8 : 35), recognized and a1)preciated by all of kindred -pirit to hore, all the truly wise. (Comp. the expresion ju-tihed God a lit!le betore, in Lake $7:$ :29.) The pecoliaritios of John and of Jesus were in

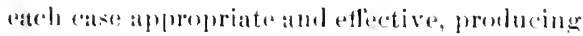
such works at the truly wire mu-t pecognize to be the legitimate allowe ot wischm. John's mode of lite was suilable to the steru rebuken and warninge ho came to proclatim (see on

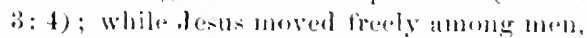
and conformed himsolf pleatsantly to their way of living, as representing especially the kind invitations and joytul lidings of the enomel. Buth mothods were blamed by the penple at larege, but both were justitiod by their esfects. and both were from (ionl. And as ats the the p.cenliarities of temperaunent, modes of lite, and metheds of worling. "n the part of pe-

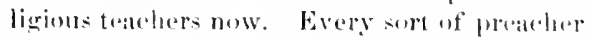
will be finnd foult with by the ungendly world; but every truly dovent and wise preaterer will be justified by the etlects of his ministry.

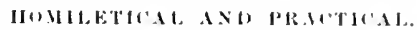

r. 2 fo. The stern law that exereise is necessary te bealth. bedily, mental, and spiritual, enferces itself eren in a rase of involuntary idloness. - V. 2-16. In ('hristianity divine? 1) Rousons for inquiring. (a) Chrietianity, ats al power in the world, lats to be secounted for.

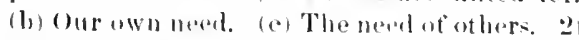
Evielenes. (a) The enterecof christianity are benefiente to bedy and soul. (b) They corre-

we ehanged inte 'thiltren,' 10 antorm to lake. The transcriptionat process of asoimilaling parallel passiges, which sooften exhibits itsell, is bere furlber betrayal hy the fact that some cursises insert all from hake, and that $\mathfrak{N}$ (alonet in luke changes 'children' to 'works.' It we suppose 'children' (1) have heren the original reating in buh truspels, it is very ditticult to account for the cbange luere into 'works.' We might spond to the 0 . T. predichions ats to its charaeter

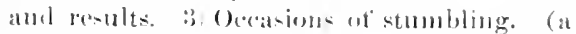
slow progerenofe christianity in the world. (b) lts highee benetits are not seen and temperal, but - piritual and reternal. (c) Many faithtial workers som to linil, and are left to suttior (like Johns. Hapny he whe earnestly presses the inquiry, wisely appreciates the eonvineing evidences, and rises aloove all the obstaleles. Compr. l'eter (16:16if.). Marthal (Johnal1:2i). Thomas (Joba 20.28 f.). - r. b. stumbling at Jeale. Calvix: "Every man builds fir himself a heap of stumbling-stones, because men atre malignantly andiens to keepe alent from Clarint." Plouldere: "llow tenderly our leord dealt with the impaticnee implied in John's quantiom. A waming was needed, but it was griven in the firm of a bestitude which it was still open to him to elaim and make his own."

V. 7-9. II Exily : "They who attend on the word will be called to an alecount, what their intentions and what their improventents were. We think when the sermon in done the care is over; nu, then the greatest of the care begins."

V. 11. John the Baptist. 1) The dignity and importance of his work as a foremumer. 2) IIis Iransitional relation to the kinglenn of hearen. :3) In what respects the humblest christian now is more fincored than ouhnoV. 11-15. John the Bitutist. 1) Coming : 15 the elimax of propherey, and the new Elijah. 2) Mno than a prophet, and tantirpasiod amoner matilind, v, 3, I1. 3) Bubluging to the Ilesianie rejern, yel not enjoying its highest privileges. v. 11. 4) Awalioning that Grat Revival, in which ebrintianity wat born. v. 12.-V. H. Comparison of Jehu and Elijah. 1) In ontwarl circunntamees and mode of lifie. 2) In temper and spirit. :3) In work. (a) Evils to be corrected ; (b) oppursition ascountered; (e) goonl dene.

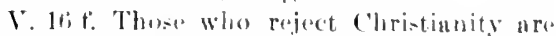
without exelle; for it singe joyous st rains :mbl mourafil strains. presents a bright sicle to fancy that apo, 'from, her whildren, Inokes strange, atud that "works" was suggested ly vo 2, and by tbes appeal in v. 1 f., but this would he a verye pour explatoatiun, whild as goud as any of that others that have luen

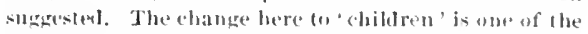
many "arly "Western" alleralious, being found in D), (1) myriac, and ()ld Latil. 
20 Then began he to upbraid the cilies wh'rein most of his mighty works were done, because they repented not:
20 Then began he 10 upbraid the cilits wherein most of his langhty works were dout, because they re-

1 Gr. povers.

.win and a dark side to warm, ealls to repentance and weleomes to faith, offers heaven and threatens hell - and they find finult still.r. $18 \mathrm{l}$. We often see precisely the same spirit manifested now. Let a minister, or wher active Christian, be grave and serious, and people will at once eomplain of him as sour or dull; let him be cheerful, and they will saly, "Entirely too much levity." If he is careful about his affairs, they charge that he is worldly, too fond of money; if he silently allows himself to be eheated, rather than seem to stickle for peeuniary interests, they say eompassionately, "Very good sort of man, very-but doesn't know mueh about business -hasn't muth common sense." And, alas! it still continues true that many will quite elisregard the intrinsic value of the truths proclaimed, and will treat them with respect or neglect, according as they faney or not the Jabits and manners of the preacher. HeNRY : "It is some comfort to faithful ministers, when they see little success of their labors, that it is no new thing for the best preatehers and best preaching in the world to come short of the desired end."-Christianity and social life. 1) In some respects antagonizing social usages. 2) In other respeets conforming to sociall usages. 3) In both eases otten misjudged and rejected. 4) In all enses justified by its 1'ruits."

20 - 30. UPBratDing TIIE IMPENITENT Cities, and INVITINa the Heavy LADEN.

The remander of the discourse given by Matthew as oceasioned by the mestage from John the Biptist (11:2), comsists of' two main divisions. $-\mathrm{Y}$. 20-24 is given also by Luke 16: $12+15)$ ns spoken with reference to the mission of the seventy. (Com]. Matt. 10: 15.)As to v. 25-50, see on $x$. 25. Some resont eommentators coolly take for granted that Matt. has wrongly located a pascige roally belonging whore it is given by huke. But it is perfectly natural that a religious teacher, going from places to plare, slumald repeat fuvorite thoughts. (Comp. at beginning of eh. 5.) The present passage is as appropriately comnerted in Matt. as in Lukr.- V. 20. Then would naturally mean immedi- ately or soon after what precedes, but is sometimes used quite generally. (Sice on 3: 13.) The same is true of the stronger expression in v. 25, 'on that oceasion,' 'at that season.' (Comp. on 12: 1.) It is easy here to trace an internal connection. The thought of the unreasonable conduct of the people towards John and himself (v.16-19) would naturally suggest the kindred fact that even the eities in which the greater part of his miracles oceurred, were still refusing to repent. (v. 20-24.) (See further as to the comneetion on v. 25.) Began is perhaps nothing more than a touch of that eircumstantiality of description for which the Hebrew style is remarkable. (Comp. on 5: 2.) So probally in 16: 22: while in other cases we can see that 'begin' adds something to the sense; as in $11: 7 ; 16: 21 ; 24: 49 ; 26: 22,37,74$. To upbraid, rendered 'repronch' in 5: $11 ; 2 \overline{-}$ : 44. This strong term, and the language of the following verses, shows that he felt not only pitying grief, but also indignation. It was not mere childish folly, -as some might perhans lave thought from v. 16, - it was a wicked and shameful thing. that they so acted. Stier: "Gracious as is the son al man in his exhibition of himself as the friend of publicans and sinners (11:19), he can also insist upon repentance, and threaten judgments upon the impenitent as severely as John himsolf; yea, more vigorously and severely than he, since he is himselt the Judge." Wherein most of his mighty works were done, or 'occurred,' the word explained on $1: 22 ; 5: 18 ; 6: 9$, ete. Mighty works, or miracles, (see on 12: 38), literally powers, works of power, and hence rendered by Com. Ver. 'mighty works.' But Tyndale and his followers here translated it 'miraeles' (v. 20, 21, 23), and that word ought to be restored, as in Bible [n. Ver., and Noyes. Repented, see on 3: 2. Our Lord's main object, in working his numerous and striking miracles, was to convince men of his divine mision, and thus induce them to repent, that they mimht become subjects of the II essinnic reign. If they did not repent, they had witnessed his miracles in ruin, yea, with aggravated guilt, 
21 Woe unto thes, Chorazin! woe unto thee, Bathsatia: for if the mikhly works, which were lone in

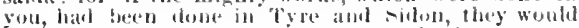
have repented long ago in sackelulh and ashes.
21 pentul not. Woe unlo thes, Clorazin! woe und Lhee, belhadidat for if the 1 mighty works had been done in fyre and silon which were done in you. lisey would have lepented long ago in sackelolh and

I Gir. pover.

so that they were more blameworthy than the most wieked heathen. Bengel: "Every hearerof the New Test. is either much happier (v.11), or much more wretehed than the mest who lived before Christ'scoming." "Ilost of his miracles' may mean only a majority of those whichoceurred in that partuf the commtry. We have no record of any miracles wrought at Chorazin or Bothsaida, though we read of many at Caprernaum (see an v, 2:3). The great mass of the miraclos are umoticel excopt by some such gencral expression as this (comp. on 4: 21; 8: 16; and sos John 20: :0). That II atthew and Luke should reeord this saying without having described any miracles as wrought at Bethsaida or Chorazin, is really a proot (Plumptre) that the words are genuine, for the $\mathrm{y}$ would not have been jutroduced into a pre-existing narrative without examining whether any niracles had been relerred to those places.

21 f. Examples of the npbrading. Woe unto thee. See in $23: 139 \mathrm{tl}^{\circ}$. Choraziu, not meritioned elsewhere in Noll 'Tost., save thet similar pastage in Lake lo: 1:. Eusebiusamd Jerome tall us that it was now dererted, and two Roman miles from Capermanm. It the latter be placed at Tel Ilum, as is of late the almost moveral opinion (see on 4: lï), then there can be little doubt that Churazin is the extensive ruin called kerazeh, which is up among the hills, two miles from T'al IInm; and the Arabic name would be the singular form, corresponding to Chulazin, as Iramaie plural. Sio Wilsen, Guérin, Megarvey. Bethsaida probably siguilies "homsot of fishing,' English tis-town, indicating that it began at a fi-hing-etation. There seene to bave beren two places of thut name om or near the Lalke ot Galiles. The well-known Buthiada Julias, near towhich the fivathonsand woreforl. wason the northeasternsileot tho lako; in fact an the eastern bank of the River .lurdan, some distance above its momth (sero (1) 14: 13). The? Bethsaida here and most irequently montioned, the native place of Andrew and Peter aud of Philip (John 1:46: 12:26), was in the land of Gennesaret (Mark 6:45.53), on tle northwestern side. uf the lake. (See on 14:34.) This fact serm, to ineclude the otherwise platusible suggention ot I)r. 'l'homson ("Lamil and Book"), that Bethsaida was erigrinally on beth sides oft the Jurdan, and that the astern part, being (as we know) greatly tavoral by the tetraroh Philip, gradually drew arorythime away trom the wostern part, which thus entirely disappeared. 'The puestion of its exatet lecation depends on the extent at the land of Gennesaret, and may never be settled. But there is new little dusbe that there were two town. of this mane on opposite sides of the lake or the river-a thing very natural upon a lake so abounding in ti-h, and in districts saldom under the sance rule. Observethat Juhn le: 21, "Bethsaida of' (ralilee," seems elearly to indicate that there was another Bethsaida from which this nooded to be distinguished. Betore Relaud suggestal this idea (Palestina, A. 1). 171t), the allusions to Bethsaida wre a vexed puestion, and no denbt gave rise to many charges ot hopeless "discrepuney" between the fruspels.

Tyre and sidon were doubtless chosen becatuse they lay clase by, lual loug hoom famous for the splomidil wirkedness which st ofter marlis eommoreial contros, and were intimately assombated with the Batal worship which had wrouglat such evil in Israel. Their wickedness was often denouneed by the prophets. Juel, Amos, Isalah, Jeremiah, and jaticularly that at Tyre by Fizkiel, ch. 2h

\section{IRepented in sackeloth and ashes,} as the people of Nineveh actually dill at the preaching of Jomah. (Jomah $3: 5 \mathrm{fr}$ ) Tho sack(a)th so often mentioned in sieripture was roughly weven frem the slowt hair of chunels, eattle, ete, and was worn as an expression of great ariet-sometimes instead of the ordinary garmente (Joana $\cdot 6)$, ofluner umber them, next to the flesh (2 kluga 6:30), and lowsely girt uroumd thr watint. (2sam. 3:31: Juel 1.x.) Sinmetimes the polson spread it under him and sat on it (ras on: 5), or lily on it at night. (1 kingo $21: 22$ ) (As to the similar comrse garments of hair, habitually worn by Elijah and somt other prophets. seen : : : 4.) On ocessions of extraodinary mourning they often addod ashes, which were sometimes put on the hend 
22 But I say unto you, It shail be nore colerable for Tyre and sulon at the lab of jublgument, than for you.

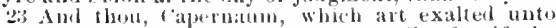

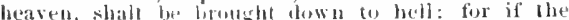
mighty works, which have heen thene in loce, had been done in sodom, it would have resuaned until this day.
22' ashes, Howlueit I say unto you, it slatl he noore colerable for 'lyre and siton in the day ol judguent, "3 than tor you. And tion, 1 apernatum, shalt ifou be exalled unto heaven? Ibou shalt lgo down nuto Harles: tor it tlie 2 mighty works hall betendont in solom which were done in thee, it woubd bave re-

1 Mang ancient anthorities read, be brought doun...2 (is. powers.

(2) Sum. 13:19: Lam.2:10), and at other times the monrmer sat in ashes (Jouab $3: 6$ ), lay in them (Esther 4:3), even wallowed hilnself in them. (Jer. 6:26; Nic. 1: 10.) Accorlingly Job says (42:6), "I abloor myself and lepent in dust and ashes," and Danie! prayed long (9:3), "with tasting and sackiclotls and aslies." (Comsp. above on $6: 16$.) It should be remarked that these and various other modes of manifesting grief among tho Inraclites such as rending the gaments, tearing the hair, ete.), were not a matter of divine apprintment, but were natural to the impassioned Oriental character, and are still customary anong Eastem nations.

22 . Bnt I say unto you. 'The connecting word rendered 'but' or 'nerertheless' (Tyndale and followers) senus to imply some such idea as this: "It is true that Tyre and silon did not have the opportunity of witnessing these miracles, and you may thus regard yourselves as peculiarly favored; but it shall be mometoherable even for them in the day of julgment than for sou; therefore be not proud of your privilere, but tremble at your responibility and guilt." The words 'Tyre and sidon are so placed in the Frate $^{2} \mathrm{ks}$ to be emphatic. The 'woe' denounced against Chorazin and Bethadela seems to eombine the ideas of temporal calanity to the cities, and future punislonent to indivirluals, as in 3: 10-12; but v. 2.) scens to show ( forlet) that the latter idea is the prevailing one. Day of judguent. This phrase appears in Matt. 10: 15; 11: 22, 21; 12: 86; 2 let. 2: 9; $3: 7$; 1.John 4: 17, and eomp. A ct- 17: :31; Judo f. It is aleo ealled the day of Goul, of the Lord, of ('larist. the last day, the day of wratl, that d:y (7:22:1 Thess: $5: 4$ ), and (simplye the day (1reb. 10-25), alsothe judgment (1: +1 r.). Ile who here foretells the decisions of the day of julderment will himsolf be the King and .Judge. (7:22;25:34.)

This declaration of Jesus was no doubt startling to the Jews, accustomed to think themselves safe for eternity beause thry were Abrabaul's descendants, and to look down with eontempt upon all Gentiles. And to us, in general, there is here brouglit out the great truth that men's lot in the world to conse will have degrees proportioned to their advantages in this world. (Comp. on 12: $41 ; 23: 1: 3$, and cousult Luke 12: $47 \mathrm{t}$.) This truth throws some rays of light athwart the dark, sad ques-

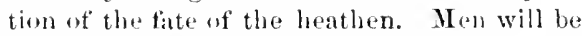
judged and punished aceording to their opportunities of knowing truth and duty. The heathen will not be condemned for rejecting Jesus if they had no opportunity to know of him; but anly for disregarding their own conscience (Rom. 2: 14-16), the light of external nature (Rom. 1:20 8.), and any true religious ideas which may in whaterever way have reached them. On the otber hand, those who know of Jesus, and live surrounded by Christian influences. and yet will not refent, incur an unspealiable aggravation of guilt and jusishment. But the expression 'more tolerable, or more endurable, easier to bear, is general and indefinite, and does not warrant any attempt to determine prectise degrees of punishment.

$\mathbf{2 3} \mathbf{f}$. The same thing is herestid, and in yet stronger terms, of Capernamm, which was a more prosperous eity than Chorazin or Bethsaidi, and more favored with the saviour's residence, miraches, and teaching. Stier: "To the two cities, two others are first opposed; and thrnome city to the one." Capernaum, see on 4: 13. Numerous miracles (Plumptre) have been deseribed as occurring at Capernaum (besides the allusion in Luke $4: 22)$ : the noblewan's son (John 1: 16.54); thedemoniac in the synagogue (Mak I: $23-2 *)$; with Peter'swife snother. and montion of a multitude of other bealings (8: 14-17); the paralytic borne by four $(9: 2.8)$; Jairus danghter and the woman with the issue of blood, togrother with the two blind men and the dumb demoniac $(9: 18-33)$; and the centurion's servant. (8: 5-13.) Which art, etc., rither, shalt thou be piralted unto heaven? thou shalt go down unto Hades.' In the ques-

I'Slatt thou be exalted' is the realing of $13 \times$ (' I I and most of the early versions. It could easily change, (which represent all three pre-Syriau types of text), by a slight alteration of two lireek words, iuto "that 
24 But I say unto you, That it shall be mone tolerabla. for the latnd of solum in the day of judgment, that for thee.

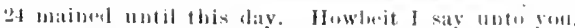

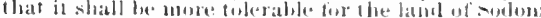
in the daty of jutguneat, than lior thet. tion a Greok particle is llsed which implies that the answer must be negative. Calpernatum, abraty properous, was cherishing, like Babylun (1sa. 4: 13), arrogant lupes of $11 n-$ limiteal prospority m tuture. But thisexpectation is dellsive. Tha rendt, as in the cast

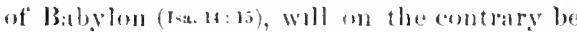
uttor de-truetion, as the prasles of privileges

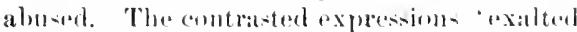
to leastell' and 'bromght down to Hates.' seem hero to incieate thet temperal prosererty and destruction of the cits, as they d, in the passage of Isaiah fiom which the imagery is derived. This dostruction might have boun obsiatal. Cajurnaum might have eomtinumed to axint and prosper if it had listened to the mirale-working Teaclror, and repented, as even the wielind sodotn would havedente. Wre

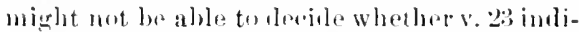
eated, besilestompural de-trotetion of the aity, the funmer punishment of individuals; but this thought is hrought ont clearly in r. 24 .

Hell. The Gropk word Hates, whieh efy-

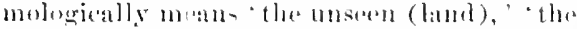
invisihle (world), is in aceordanes with its chasical use, and with that of the Heb. Shot,

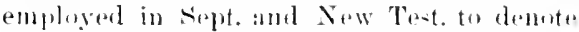

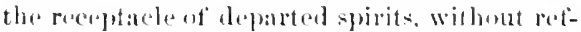

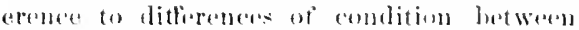

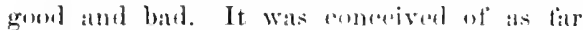

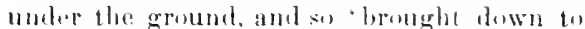
Sheol' (Mades) was antrasted with 'oxalted

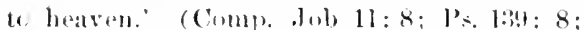
Amme b: 2; Rom. 10: 4, 7.) sinme have propored to render it 'the mulerworld' (Bible.
Un. Irer, Noyes), which, though imaluepuale,

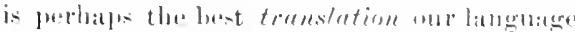

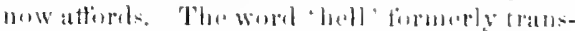
bated sheneland Hales, for it originally sierni-

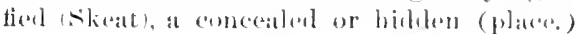

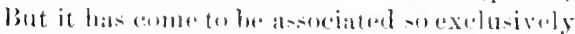
with the idea of tollument, that Riev. Ver.

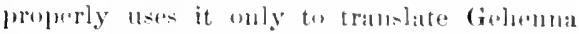

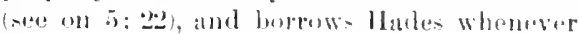

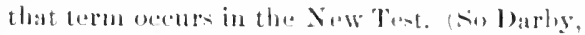

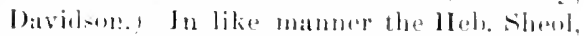
substantially equiralent to lladies, is lompowed

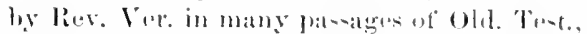
and ought by all meatus (as by Amer: linvisers,

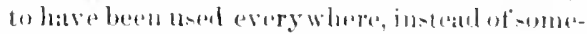

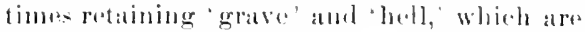
buth mislendiug. Ilater is unel in some pasatemas of the New Test. Where the enmmetim does not suggent any idea rother of halphiness ur misery-it is simply the alude of the the-

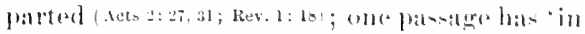
Ilathos, hoing in tormont.' (Jake th: 23.) It is

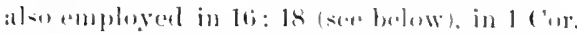
15: 5is (emmmon tirenk text, hat the correct

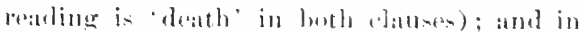

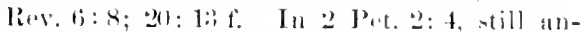

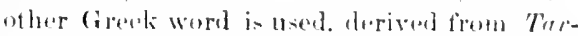
tarus, and signitying. like Gehentas, the juace of tarmint.

21. Sodom was astill mopecomspitenous ex-

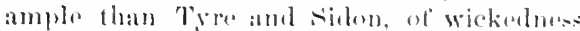
and punishment. All the worlel kusws how it wis steldenly and andmpletely destroyed. Its indescribableabuminations and its tereilole damm have alwage thrilled man with horror wast exaltod'; and the former being an unexpected curn of "xpresion, the latter is likely to have been preterred by andinary (o)pliats, while really the sharp and stortling interrogation is much after the matner of the lireal leacher. Thus benh intrinsic and transeriptional probaloility eoneur with the labling doctlments in supporting the furmer realing. The case is sulis antially the same in lake $10: 15,-1$ Whether the secull taluste shall real "go down' or ' In brought down, is a ditlicult putstion. The external evidence for the former comprises mbly the "Wrestern" Iochments and 13. In Luke 111: 15, it has only part of the ustal "Westeru" groulu with B. Sow the Rev, Thist. eneludes that this reading is right in Matthew and wrong in luke, which would acemut for the plomomena thus far stated; white W 11. as usual follow B, and reat 'go down' in both passazes. But the imatgery

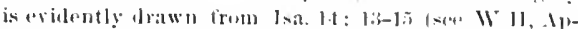

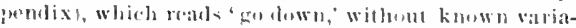
tion. It is lhen a very natural suppesilion that the "Western" deruments, whidh make so many arloitrary

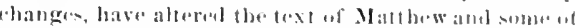

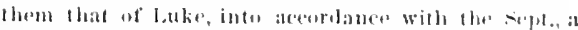

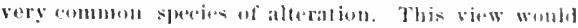

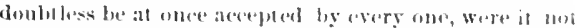

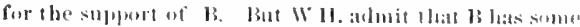
merely "Wistern" restinge in the Jipistles of l'aul.

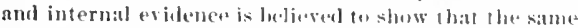

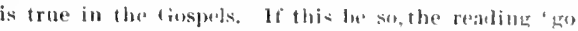
(bown' shonlel probally be rejecterd both in Malloew and in fuke, as a "Western" alteration. Internal evidenct is in this case nut clear on either side. 
25 At that time Jesus answerd and said, I thank ther, th fither, lond of heaven and eath, becaluse thou hast hidl these things from the wise and prodent, and hast resealed lhem unin bathes.
25 At that season Jesus answered and said, I thank thet, (1) lialler, Lord of heaven and earth, that thou didst hide these things from the wise and under-

10r. praise.

whenever it las been mentioned. And yet Solom wonl have repented, and remained through two thuusinel years till our Saviour's diy, hat it-peopie sten the mirates which tomk place in Capernatum. (Comp. Ezck. 16: 48.) Is this a mere loyperbole, like the precept to tarn the other chesk, of to go two miles with the impresing ofticer? We are hardly warranted in saring so. If then one should ask why the mes-enger Jehoval, who stayed behind with Alraham, did not go with the two alfgels to Sodum, work miracles, teach repentance, and save it firm destruction, we may see two things to reply. (1) We may an-wer as Paul does in Pom. 9: 18-20, that Goul is sovereign, doing what he pleases, and always doing right. (2) We may observe that the divine joln reguired that the fremanent alpearince of the sim of God should take place only among the Jews, and only "when the tulurso at time was comene" (Gall. 4:4), and this divine plan, whether we can see it or not, was dombtless best for total humanity, and for the moral government of the universe. Whon the time came, many of the Jaws had heen havened by disregurding previons divine influmbes, so that they were sower to believe ('hrist, with all his mighty miracles, than wicked heathen eities would liave been. (Complo. Juhn 1: 11-13.) The land of sodom, the district belonging to the eity, and not simply the city itselt. (Comn. 4: $15 ;$ Act= $7: 11$.$) I say unto you...$ thau for thee. In r. 2.2, ateh clatuse has the plurat, which mu-t then refer to the poople of the two cities; therefore the opening plural lore probably lofers to the people of calpernanm, and not generally to the hearers of the discourse. If we snppors the diecoulse to

J The word knires is not aldenuately tramslated by 'time, for it alenotes the exact tima, the fixed time, the appropriate time, gecasion, olpurtunity, scasm. The fom. Vor, remlars 'season' in various places, including $21: 41 ; 24: 15 ;$ luke $13: 1$ (where the phrase is simitar to this of Matt.); Aets 1: 7; 24: 25; (ial. 4; : ! : and 'opportunity' in fial. 6: 16; 1leb. 11: 15. It slould be rendered 'season' in many of lw'rs, ineluding 1": 1; $1: 3$ : $30: 14: 1 ; 21: 34$, and 'opportunity' in keseral, as Ephes. 5: 16; Col. 4: 5, 'buyiug up the unportunity" have been delivered at Catjernaum or in the plain of Gennesaret-which is probable, but the print eamnot be determined-then the hearers were mainly people of those three cities, and that would aceount for the ambiguity of the expression. 'Thee' of course means Capernaum, but with reference to the ecermal destiny of its indiviclual inhabitants. For but (honbeit), more tolerable, and day of judgment, see on v. 22. stier: "We read of no enmity or persecution to which he was subjected in Capernatum; but the careless reecption of his word and works was yet worse, and more eondemnable than any eruption of malice would have been; it bespoke that sothful, deal, impassive indifference, for which nothing more eould be done."

25 f. The remaining division of the discourse given by Matthew as oecasioned by the message firom John (emp). on v. 2and v. 20), viz., v. 25-30, consists of two distinct portions. T. 25-27 is also given by Luke (10:21 f.), as spoken immediately after the return of the Seventy : v. 28-50 is found in Matt. only, but is closely comnected with the end of $v .2 \pi$.

At that time, 'on that oecasion' (comp. 12: 1; 14: 1). This answers to 'then' in $v$. 20. and connects all with the message from John the Baptist. (11:2.) Our Lord lias been speaking of the mnreasomable and determined rejection of both. John and bimself by the Jews (v.16-19), and the inpenitence of even the cities in which most of his miracles vecurred. (v.20-24.) Tet these Jews, especially the religious teachers and other leading men, were wise and intelligent, well aufuinted with many aspects of religious truth. It seemod strange that they should fail to com-

(Rev. Ver. margin). But there are some cases in which nejther scason nor opportunity, nor any other term will suit the connetion, and we bave to lose the perdliar color of the Greek word and eoutent ontselves witl remliring 'time,' as in s: 24); $16: 3$ (spurinus); 26: 1s: yet in every case the (ireek word hats its own distinctive moaning, thomgl we eannot express it. The Rev. Ver. has trauslated it by 'season' in many more places than com. Ver., but uight have done so in ser. eral others, as $13: 30$. 
26 Even so, Fatier: for so it seemed good in thy sight.
26 slanding, and didst reveal them unto babes: Yoa, Falber, fior so il was well-pheasing in liby sight.

I Or. that.

prehend and appreciate Christ's traluings, which were understom and rewived by the lowly and comparatively ignorant. This is the proint to which he mow addrenses himself. Ife not only subuits to this stitte of things, but he reougnizes the propriety of it, and gives thanks for it. Answered. By a peenliar IJeb. jeliom, this word is often used in the seriptures where there is no previous question, nor even any thing that has been said by another. Yot in probably all cases, we can see something in the foregoing connection to which the worls arre in some sense a response, or which formed thenecasion for their being spoken (comp. 17:4; 24; :63; 28: 5). In response to, or as suggested by, the sat truths just uttered (v. 16-19, v. 20.24), Jesus states the comforting thoughts which follow. I thank thee. The word originally signities to make open or full eonfessim or ackmowledgment, as above in $3: 6$; derivatively, like a moresponding Heb. word, and somewhat like our phrase "to make acknowledgmonts," it signifies to thatuk and hence to praise. (Rom. 1t:9.) Tho enrly and the recent Eng. versions are bere ubout equally divided between proise and thank. The icleasem-to be, "I fully recognize the propriety of thy course, I rejuiee over it (comsult Luke 10: 21), and praise thee for it." OFather. We find a similar dircet address to his Father in fohn 11: 41; 12: 28; Luke 20:34. The added form of address. Lord of heaven and earth, is impresively appropriate. It is the sovereign of the universe that does this; whos shall hesitate to alcknowledge that what he does is right? Our Lord here sets us the example of empleying in prayer sueh namesof find, and phrases de. seriptive of him, as are alperepriate to the epeecial subject of the prilyor, or of each particular portion of it -a thing manifently proper and important, but often neglected. That thon hast hid these things, ijo, the things taught by .Jests, as for example, the teachings of this disconrse. From the wiss and prudent-umberstamlin! or "intelligent.' 'Prulent 'was a good trunslation in the Latin und enrly English versions (tbough Genera gave "mon of under-bnting'), but in modern English it is too restricted in meaning (see also in Acts 19: 7; 1 Cor. 1:19). Bible Lnion Ver. and Noyes give discerning'; Davidion retaits 'prudent.' The Greek his no artiele, "from wise and intelligent (prrsons'), emmy. on 9: $19 ; 11: 5$. The expression is general, hut here aplolins especially to the seribes and Pharisees, ant other religious tatchers (eomp). an 11: 16i. The reference is of contre to wislom and intelligence misused, perverted threngh prite, separated from a childikespirit. Unto babes, literally, infants, these who cammet sjuats (comp. lion. 2: 20). This surely does not, as sone imagine, designate simply the apostles, but the disciples of Josts in general. Tlune who were not wise and intelligont, but had a child's simplicity amd humble docility, understond and delighted in the teachings of Jests (eomp. Pat. 19: 7 : 116: 6; John 7: 48 fo: 1 (or. 1: 26 tf. ). Wo often now witnes the sane state of things. Intelligent and reflecting men "frectuently overlook the simple beatuty and perfect fitmess of the plan of salvation, which in plain enough to those who are eonscionsly and confesedly weak, and who gladly reoeive the Lord's teachings without eavil or difficulty. The gasper is so intenseply pratetieal that it ean be underetmed at the outeret only by persone willing to recave it, and will be thoronghly known mly in propurtion as it is truly boved. Here, as everywhere, we see the alaptation of the gexpel to mankind. Not all men ean become wire and intelligent, hut all may, by the grate of liod, become babes (comp. $1 \mathrm{Cor}$. : 18). The most useful Christians will be those who are "wise and intelligent," and are also babes-intellectual aml cultivatul ats posible, but chaldike in spirit. And when the wise and intelligent fail to discerer the -ignificance and ralue of ('hri-t = teachings, it is not the fault of their intellingence, but of this lack of a right spirit. Patrl sily " not man!y wise after the flesh (1 corr. $1: 26$ ) : there hase always been some. Obrervethat of as makes acknowladgment to the Father buth for hioling these things from the ome clase, amb for revenling them to the other. Wrata mat that the latter is the chief subjoet of thanksuring. yot the former is here the immediate oceatsion of 
27 All things are delifered unte me of my lather: and uo man knowelh th+ son, hut lloe father; neither knoweth any man the latther, save the fon, alud he to

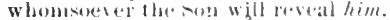

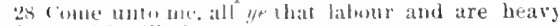
laden, and 1 will give you rest.
27 All things have bern delivered untw me of wy Father and norine knoweth thesin, savel be father; neither loth any kuww the lather, save the son, and he to 28 whomlstever the sis willeth to reveal him. (onte unto mes, all ye thal labour and are heary laden. introducing the topic. Mryer justly says that both lonpoitions form the ground of the thankseriving and puise, being two sides ot one great truth. Sio in Rom. 6:17, which is often complared with this pasinges.

()ur Lord taters into no explanations of Gods sovereign dealines with men. He simply adds, Even so (or yea) Father, for so it secmed good (1)r, was well-pleasing) in thy sight. (Comp. Eph. 1: 5, 9; Phil. 2: 19.) 'Well-pleasing, as in 3: 17; Luke 2: 14 (Rev, text). If with some at the ablest expunitors and Rev. Ver. naregin, we render 'that instead of 'tor' (the origrinal word meaning either according to the connection), the sense is substantially the same: "Yea, Father, (I thank and praise thee) that so it was well-pleasing in thy sight.' Notice that this $\mathrm{i}_{\mathrm{s}}$ not, as often quoted, an expression of mere resignation. Oul Lard acknowludges the proprioty of the sovereign. Father's course. and prasen him for it. Whatever pleases God ought turplease us.

27. Having reforred to the fact that not the wise and intelligent, but babes, umlerstand his toachings, Jestes now prosants himselt as Tratchere; Aeclaring that anly he ean give a trun knowledge of the Father (v.27), and inviting all to come and hatru from him (v.2x-30). All things were delivered to me of (by) my Father. At some past timas, not specitivel, say when he entered upon his earth!y mixion-rer, perhates, whes the eovenant ot reflemption was tormet in eternity (comple an 3: 17)-all things were (onmenterel to him, vi\%, all that fertains to the instruction we now in

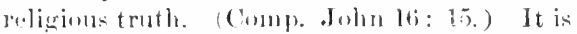
aunther and dintince fact thut all authority in heavell and earth was given to him as the

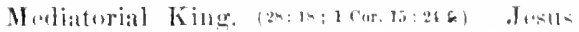
in the anthorizal instructor in the kunwl-

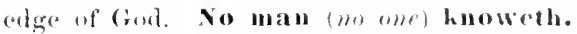
The verb is amponuneled with a proposition. so as to matal 'knows fully, as in 7 : 16; and]

Ilere the tireck nominative with the articto is clearly used in aldress, and equivalent to the voeative in v. 25. This was a eommun colloyral usage in lireek, seen often (Buttmann, p. 140) in Aristophanes and the , so Davidson lone translates. Luke in the sinilar passage (10:22) bas the uneompounded verb 'know' On the one hand, no one really and thoroughly knows the son except the Father, so that he must not be considered a mere ordinary buman teacher, and so that we need not womder if the wise and intelligent of arth faic, in their proudly speenlative and merely theoretical study, to comprohend and appreciats his teachings. (Comp. "reveal' here and in v. 25.) On the other hand, no we knows the Father, with that real knowledge which is ofrrual life (John 17: 3), except the Son, and he to whomsoever the son will (willeth to) reveal him. In old English 'will reveal' exprosied the jolea, but that phrase has beconne a simple finture, and the Greok must now be tranklated 'willeth tor, 'is pleased to, ur the like. (See especially Jubn 7: 17; 1 Tim. 2: 4; 2 I'et. 8: 9.) All their wisdum and intelligence will not avail to gain a true knowledge of the Father, unless the Sun chooses to reveal him to them. To him, then, let all (a)me. (Comp). John 8: 1s; 10: 15; 14: 9; 16: 15.) Heim: "This self-enelosed world of the Father and the son opens itself to the lower world, to men, only by its own free act, because it wills to open itself and to admit to companionship whom it will." Jerome: "It is one thing to know by equality of nature, and another by the condescension of him who reveals." On anvither occasion also (Luke $10: 2: 2$ ) he alds to his thanksgiving that the Father had hid these things, ete., the same statement as here, "All things ware delivered,' etr.; which shows that the two ideas are very closely related. Tha son approves the Father's will as to hiding and rovealing, and the Father has authorized him tor revalu or not, aceording to his will. (Wriss) Neyel says that this statement (v.27) "bears the stanmp of superhmman conscionsness." Only here (with luke 10: 2:) and in Marli 1:: :20 with perhaps Matt. 2t: 30$)$ do

lialontes of Plato; and aceoringly it apjears frequently in bihlieal Greck, which rests on a colloquial hasis; important examples are John $20: 28 ; 1$ Ieb. 1: 8 . 
29 Takisy yoke upon you, and learn of me: for 1

the throe first forsels eontain the expresion

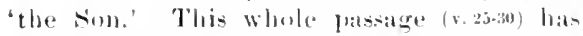
often besen remarked upon as reasmbling the Gospel of John, anel allegents to us that erreat ma-s of similar sayings of . Jesu- which anly the Futurth fospel eontains. Juhn's mental and spipitual constitution pecoliaty titted him to be the nomlium, of comsmumicating to

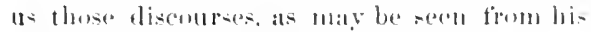
empleying in his Epristes a syle which sl elorely reacubles them. But sieh passigess ats this show that that class of ideas and expresions was not formign the the other Gos-

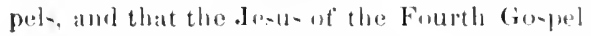

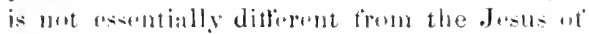
the ather throe.

2x-30. He staudi ats the freat Teacher, whe alone can give true, suving knowledere of God (v, zi), whone toatchings, while hid tron the wiseand intelligent, are revealed to babes. (v.z.) Thaugh rejected by many (v. 200-2t), and cron slandered and reviled (r.16-19), still he stamble, in the fulluese of his winderm, and the gentleness of his lore, and invites all the toiling and burdenred to enone to hint, to wear the easy yoke of his instruetion, and tom shall timel rest tor their souls, Notion how tire invitation follows immodiately apmenthe tatemont that mo amo knows tle Father but the

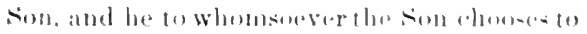
reveal hin. Tohismind therowas no centritdietion betweensolereign, electing grace, and the free invitations at the garpel. come noto me. literally. hithere to mer. the word in

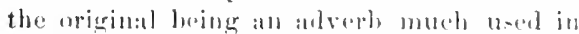
animated invitatiom. (C)mp. 4: 1!1; 1:4: 21 ;

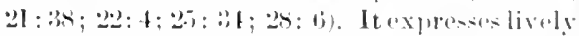
intreret an the part of the spealiers and invites

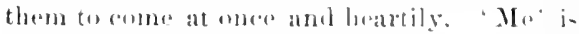
oot emplatic, as the opigimal suows the point is, I alone can grive knowluedere ot the Father; comer to me, and recesive my instruetion. All, together with the whole. connection, sugresets a goneral andienes (Wois); aud it wre understatud all since 11: 22 to be and diseonurso, than we linow that

The tieneva version has 'all ye that are weary and laden' (instead of Tymales "Hat labor and are lulen'); thi-lienesa rendering is still eommun in religious speeds and writing, having been perpetuated by

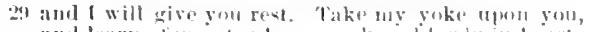

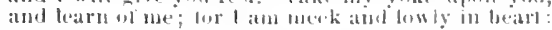

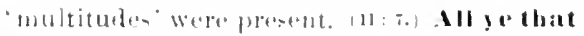

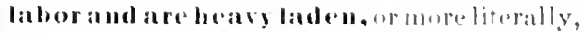

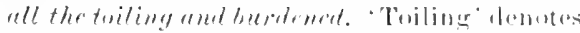

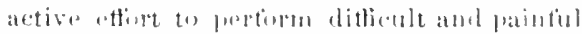

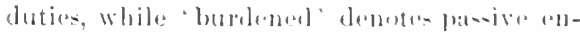

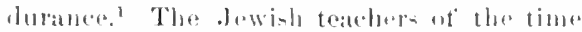
promiated res an cendition of minute atten-

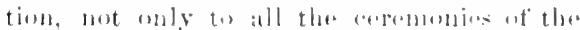
writt:a law, but alon to all the tratitions at

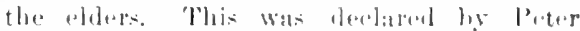

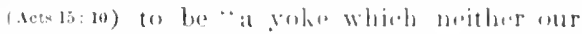

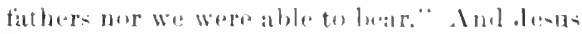

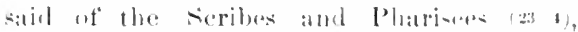

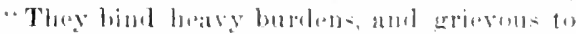

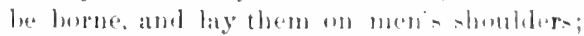
but thry themalves will not mose them with

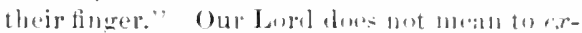

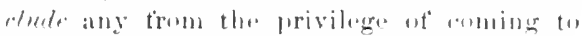

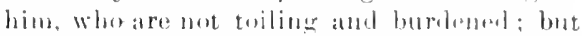
no ons wonld are to learn troln hin who did

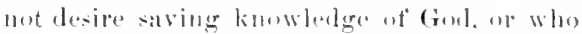

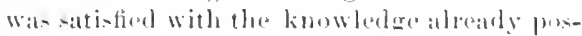
sessod, and he addreses his invitation to thoses who in thr nature of the easo would be likely to aceept it. The mont natural temblemer with

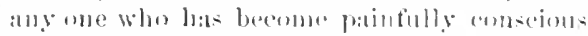
of sin, is to soek Gull - tiaver ly his awn doings and sutleringr. And will gave you rest. The mpiginal maken 'I' empluatio; he

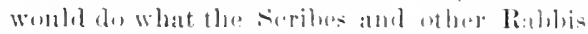
did not do. The great ditfierenew lutwern Jests and other poligriens twaners is that he

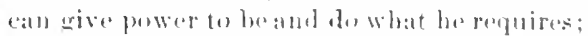
we fiml ret not simply in the superiurity of

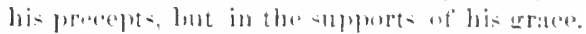

Take my yoke upon you, and learu of (from) ma. Amone the Juws:a pupil whosub-

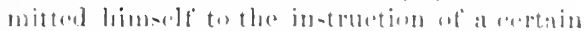

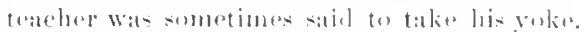

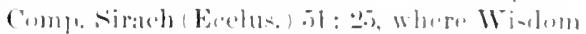

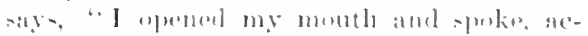

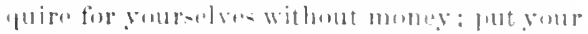

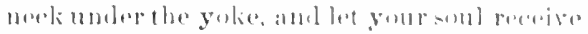
instruction . . . . se witle rome ryethat I toiled a little. and fimul tior my-relt munh

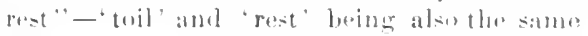

Iraditional use, added doubllese hy a hymu of which one verse legins, "(inue, ye weary, heavy-latho" (By John Harl, wrillew in 175\%.) 
an meek and lowly in beart : and ye shall find rest unto your sotuls.

30 for uny roke is easy, and my burden is light.
30 and ye shall find rest unto your souls. For my yoke is easy, and my burden is light. words as hore. Comp. also sirath 6: 24. The later. Jawish writers trequently speak of taking or rajucting the yolin of the law, the yoke of the kingrim of heaven. (Comp. Atets 15: 10.) 'Take my yoke upon you' is therefore only a figurative way of saying, Beeone my fupils (disciples), submit yourselves to my instruction; which is then stated again in unfigurative terms, 'and learn from me.' To interpret this last as meaning simply, learn from my eximple, is not natural to the expression, nor appropriate to the connection. For I am meek and lowly in heart. 'Meck' as opposed to the haughty and harsh teachers to whon they were aecustomed. (Comp. James 1:5.) 'Luwly (or 'humble') in heart,' not proud and repulsive, and not anbitions of domination over the minds of mon. Accustomed to haughtiness and pride in their touchers (Johu 1:49), his hearers might be show to come to him; and he condescends to assure them that he is meek and humble, and they need not shrink from him. Remember also that some teachers may be outwardly meeli and humble without being so in heart. Stier: "I am meek in heart, although I spoke words of such stern condemnation, $v$. 20,24 . . . . I tum lowly in heart, notwithstanding that I have borne witness to myself as the Son of the Fatlor, v. 25-27." Here also, as in v. 26 , it is possible to render 'that" instead of 'for,' learn from me that $I$ am meek, ete. So the Peshito, and possibly (though less naturally) the Latin vercions; and so Augu-tine interpreted, with many Latin followers. (See Aquinas, Malelonatus.) This, however, is an artificial interpretation, and not suitable to the eonnection-which n akes it all the more natural that Matthew A rnold should reeeive it. Ind ye shall find rest unto (for) yoursouls. Thisexpression is drawn fiom Jer. 6: 16, according to the 11eb., not the Sept. Romember that our Lemel used two expressions from the Psalurs whrn on the cross (Matt. 2r:46; Luke 23:46), and made three quotations from Deut. during the Temptation. (Matt.4:4f.) All religions profess to give rest for the spirit-Christianity alone can truly fulfill the promise. Others may give a kind of repose, but it is that of self- righteousness, or other self-delusion.-Christianity affords a well-founded and lasting repose, as to our guilt, our imability to gain God's favor, and our sinfulness of mature. How Jesus will do this, he dres not here sct fortls; indeed it could be fully understood only after. his atoning death and ascension, and the special coming of the Itoly spirit, and so the complete explanation of it was left for the inspired writings of his aprostles (e.g., Rom. 5: $1 \mathrm{tt} . ; 8: 1 \mathrm{ft}$ ) From them we know that our guilt may be caneelled through the Saviour's atomement, that we may be accepted into God's faror through his perfert rightonsuess, that the dominion of sin within us an be broken by his regenerating spirit, and by degrees completely destroyed by that spirit's sanetifying grace. Even the painful consciousness of remaining tendencies to sin need not prevent a eertain repose of spirit, since we have the assurance of God's word that in the truly regenerate and believing soul these tendencies shall at last be completly overcome. Yet, even now the Saviour's invitation and promise, in the unexplained and concrete form, brings rest and joy to many a trusting heart. A loving reliance on the personal Jesus, a loving submission to his authority, and obedience to his commandments, is the very essence of Christian piety.

For my yoke is easy, and my burden is light. There is no particular emphasis on 'my'; the contrast with other teachers has been sufficiently indicated before, and is not here expressed. 'For' presents this as a reason for what precedes, in general, but especially for the promise just given: "Ye shall find rest for your souls, for my yolie is easy." etc. The word rendered 'easy' means agrecable and serviceable-a volie that does not gall the neck, nor eramp so as to hinder the drawing. The Latin version and Peshito rendar by words signifying sweet, pleasant, and Davidson 'good.' He requires of his pupils only what is possible to do and bear, so that they will aetually find rest, and not be vainly secking it. Still we must really take his yoke upon us-must receive his instructions, and submit to his directions-must set 
ourselves to de what be bid; us, whether it semins likely to be pleating or painful. Ho not mly teaches what to do, but and give us strength to do it. And in propurtion as we do really submit, and conform and tru-t, we shall find his reguirments "not grievous" (1 Johu5:3), but helpitul and pleasule If Christes roke ever galls the neck, it is brouse we du not work steadily in it. lecenstine: "This burlon is not tho weight upon one that is laklen, but the wing of one that is about to fly." And it it ever foels like a weight and an incombranee, that is when the soul has soiled this hoavenly flumage with the mireote earth. It is true thit tho morality enjoined by . Jesus was mores spiritual, and this in ono sense more severe than that taught by the seribes and Pharisees (comp. 5): $17 \mathrm{tf}$ ), but a morality depending on a multiturle of minute out ward observalles and imperfectly known traditions must neecsarily be hirdonsome, while spiritual morality grows inereasingly easy to the spiritually minded. Observe that our Lord's invitation is supported, not only by the great promise, yo shall tind rest for your souls, but by two encumarements; one, the persmal character of the 'Teachor, "meek and humble in heart'; the other, the fact that his rowuirments are not severe aud mpressive: "my golie is easy, and my burden is light.'

The most exactly parallel application of this invitation now, is to persoms whorainly strive in other than gospel ways to obtain silvation and find rost; as, for (ximulele, ly atl upright and charituble life, or liy the diligent observanee of religious ceremunies-toiling to make the exterior of their life enrect in the sight of men and aceoptable to God, whilo within, the pollution of sin is not removed, the power uf sin is unbrolicn, the guilty eonscience (an find no true reliet; st al lot) to those whouretrying to obtain rest th rough false religions, or perversions of the true roligion. or any of the forms of would-be philosophic infidelity, 111 sueh persons, if derply earnest in thrir fuest, are nsturedly "twiling and burdencel." Oh, that they frould listen to the Great Teacher! But the invitation may be naturally and reasonably extended to all who desive religions repose in the knowledgo of God. Jesus, nnd heonly, mu give it, and he has left a standing invitation: "Come to. and poor in spirit. (5:3.) 2) Not all (an be me, take me as your roligious Teacher, and ye shall tind rest fir your souls.' - When we enore to Josus now, that is mot a borlily removal forn one place to nouther; tor be is present whonovor and wherever we seck him. But the obiect in eoming, the fording with which we eome, may be the same now as when he was on earth. Whenever we wallt anything from Je-us, let 11 - draw ueal to him in heart, and ask him for it as it bodily presint.

IIO) HLETIOAL, ANH IRAOTIOA.

V. 20). Gosped-hardenud! Hown: "Ite bregan to proach to then lomg beture (t: 17), but he did not begrin to uphraid till now. Rough and unpleasing methods must not be talien, till gentler means have first berom used." - T. 22. Mecting the heathen on the day of judernent. 1) The d(n)m of all will be proclatimed as a thing unalterably determined. 2) Mn will be judged acourding to their opportumities in this life: and the condemnation of the impenitent from Christian countries will be un-peakibly more terrible than that of the heathen. B) Thon should wo not aroid sendingtle gaspel to the heatlon? Nisy, for on that principle wo onglat to ke(s) our own chiddecn ignorant of the gospel.

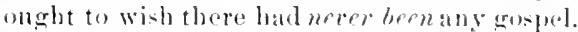
4) Will not the heathen pour nyom 11: doserved mploradings heanuse we loft them in ignoranere of the ouly true ford, and Jesus ('hrist whom he sout (Jihn 17:3)?

V. 25. Mankind aroprone to find fault with Goul's mode of prowedure in every respect. All rulers are blamed; and the only perfect ruler is blamed most of all. The pions heart should symputhize with this utterance of Jesus, and make acknowlodgment to the Father that he is right in all hi-doings. But this dues not mean that we ire to be indifferent to the fite of an fellow-mon. This sante Jesuswept wer ruined Jem-alem. Gregory TIE (Brkat (dquinas): “In which words wr have a lowem of humility. that we should nut rashly presume to discuss the enum-als at heaven concerning the tulling of sulte and the rejection of uthers: -howing that that can not be unrighteous which is willod hy llim that is righteous." - The guspel affurul to all. 1) Not all can be rich. but all may he four. 


\section{CHAPTER X II.}

T that time Jesis ment on the sahhath day through A lhe eorne and his disciples were at himgered, and hegan to pluck the cars of corn, and to eat.
I At lliat season Jesits went on the sabbith day through the corntields; and his dinciples were ain hungered, and liegan to pluck ears of corn, alud io wise and intelligent. but all may be babes. :3) Nomese (an commend linself to God by his natural goud worlis, but any one may believe in Christ, and gain the gift of the Inoly spirit. - V. $25-30$. Sovereignty and Invitation. 1) Thr: sorroign Father reveals the son only to the lowly. 2) The sovereign son reveals the Father ouly to such as lie chooses. 3) All who noed and desire the rest-giving knowledge of the Father are invited to learn tion this sovereign, yet meck and lowly 'Tuacher.- T. 27-30. Full knuwledge of God. 1) It an be had oniy through the Son of (iml. 2) It is conferred by the sion upon such only as he willuth. 3) He willeth to confer it upon all who will come and take him as religins Teacher. 4) He is a gentle Teacher, and his requirements are easy and pleasant. 5) To aecont his taching will bring rest to the sul.-V. 27 f. True linowledge of God, and true rest in God.-V. 28. AlexAnter: "Inviting men to come to him. nut in the way of sperulation, but of penitent sulmission, mot as philosophers to be enlightened, but as sinners to besaved. There is exquisite beanty in thjs sudalen but not latrsh transition from the mosteries of the Gudbead to the miseries of man. Tha Sin is the Revealer of the Father, mot to stimulate or gratify a mere scientific andu-its as to the mule of the divine exist(Noce, but to bring the Godhoad into saving "wntaret witlı the sin-sick, ruined soml." MtI. ANemTION (in Morer): "In this all thou -houlilet incelude thyself also, and not think that thou dout not holong therein; thou sfouldst seek no othor list of them that aro God's." I,TtIFR: "Ther are words of majesty whon lu, says, I will give you rest. No angel, lot alome a man, would undertake to promise that." -- V. $28-80$. The Grout lovitation. 1) The arotle Tracher. 2) Tlar ats

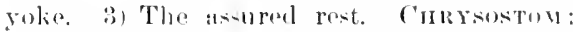
"Christ did not mention the grateins thing onle, and then hold his peace, nor the paintul things only, but sot down both. Tluss la. both spake of a pote, and callod it easy; louth named a burelen, and added that it was light; that thou shouldst neither flee from thrm as toilsome, nor despise them ns orer easy."
Hilary: "And what is tasier than his yulie, what lighter than his burden? Ta become praisewortly, to alstain from wickedness, to ehouse the good and refuse the evil, to love all and hate none, to gain eternal things and not be taken wilh things present, to be nuwiling to bring unon another what yourself would find hard to rndure."-To be toiling and burdened does not anfer the right to come to Clirist, but should produce the disposition to come. Some persons eome truly to Christ without any long and conseions triling to save themedves otherwise; such porsons are not specially adduessed in this particular invitation, lut are amply invited elsowhere.V. 29. We are treed from the yoke of sin by taking the yolie of Christ. Hexry : "The way of duty is the way of rest." Augletixe: "Thou hast made us for thyself, and our hant is restless until it rests in thee." $-T^{r}$. 30 . HENRY: "It is a yolie that is lined with love." Augustine: "All things are light to fore." LUTIER: "Christ"s burden is light because he helps us to bear it, and when it becomestoo heavy for us he puts himself under the loat with us. The world thinks it heary and unbearable; but not so, for one has a good comrade. You two ean easily bear a load, though one by limeclf camnot."

Ch. 12: 1-21, Jests is ACCesel of BREAKING TIE SAABRITI.

Pursuing his tratmont of suceessive topies. compected wibh our Lorel's life and labors ('om1). (m 11: 2), the Evingelist nuw spealis (ch. 12) of the opposition be aneounterel. This subject lias heen several times already hriefly alluted te $(9: 3,11,14,34 ; 10: 25 ; 11: 19)$, but is here treated at lougth, various instances of opposition being stated, with our Lord's reply in eacle (ater. First, we have two instances of thrir charging him with violating the sabbatl, viz., because the disciples plucked ears of grain on the sabbath ( $\times 1-x)$, and beeane he hoaled the withered hand on the sabbath. (v.9-13.) At this, the indignation of the Pharisees heramo so viulent that it was mocessiry for Jesus to withdraw, in which withdrawal 
the Evangelist points out the fulfilment of another prophecy. (v.m-2u) Yext, we hava their charge that he cast out elemons ly league with Beelzebub. (versis) Then, the demand for a "sign." (v.3s-4.) And tinally, an instunce ot opposition even from lis nearest relatives. (r. $46-50$ ) The fiact that these last cases (v.2\%-30) oceurred on the same day on which lie afterwards spolie the grout series of Parables in eh. 1:3 (ses on 18: 1), may aecount for Mattbews introducing the whole subject of oppontion just at this point of his treatise. Our present section comprises the two aleensations of violating the Sabbath and the inmediate eom-equences. IV shall see that this belong-much earlier in the history than the remaining instances.

1. 1-8. The Disciples Piuck Ears of

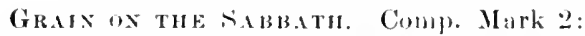
23-28; Luke ti: 1-.;. At that time (season), the same expresion in circek as in $11: 25$. It dues nut noxessarily show that what follows took place on the samm day with what precedes, but only that it belongs to tlat same general period of time. (Comp) on 3: 1, and eontrat 13: 1.) At that period, viz., while Jesus Was ongaged in journering about Galilee, teachiner and healing (-20 on $4: 23$ and 4 : 35), aceurriel the events nuw to be narrated. The oreler of Nark, who is w-mally ehronolugi[al, supported by that of Luke, placestluse tirst instaneres of opposition in the early latet of the Galilean mini-ery, betere the siornen on the Monnt. The standing grain hows the time of year, between Passuver ind l'entecost." A. it thessollowed a Pasover, the plue-tion arises to which of the Pasisurers mentioned in the Fourth Gospel we must rofor it. Now, it canmot have been that of Jobn 2: 18, after which .Je-ts tarried in Inlea (John $3: 22$ ), with so extensive results of his ministry (John t 1) as to require at lea-t several montlis. To place it just atter the P'a-surer of John 6 : 4, a y+ar beforo the crucifixion (Folershech.35), is to elis:regard altegether tha order of Mark amel Luke, for this sulpowes that Mark 2: 23 f. follows llark ij: : 11 tf., and Luke fo: 1 ff. fol-

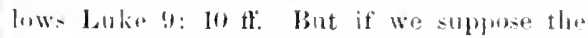
fea-t of Juhm 5: I to be a Patsover, (as most of the ILarmonies dor, all tits exactly. This is long enoughafter the beginning at our Lords ministry fire the hortility to have bucoune alent" these instance of "pposition on the gromud of sabbath-breaking in Galilee correspond to onte during the just preceding Patserver in oleru-alem (Jola s: lie), in both eases awakening a lesire to funt him to deatle (Joho 5: 14: Matt.12:10; and the oreler of Mark and Lulie is conserved. Of enurse it is pussible that the Pasieser liere in question slould be one not mentioned in the Fourth (romel; but the other suppostion is far mure probable.

Through the corn (or, giatiffiplds), literally, through the somen (places), which Tyndale and his followers renderel "through the eorn,' while in Marli2: :23 and Lalie $6: 1$, they make it "(o)ru-tiolds, though the Greak is the same. The word 'enru, in various European languages, is applied to bread-stutis in general, aspecially tu that most used in the particular nation, whotler wheat, barley, rye, or oats. In Eugland it means esperially wheat, while in America is has beennoconfined to maize, which onr English ancesturs called Imlian arm. Bosides this and the parallel passiges, we tind Tyndale and fol.

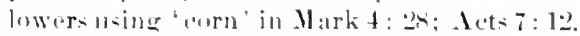
where the direski hats the common werd for "wheat. so tram-lated lig them all in Matt. 3: 12; 1: : 25. and wherever else in Xew Tot. it oceurs. In . Foln 1:3: "2t " (Com. Ver.) means a grain of wheat (Rev. Ver.), as in barley eorn. Why Rev. Ver.

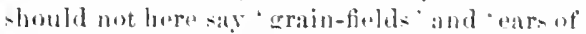
grain" (Nuyes, Bible I'n, Vier, and "wheat' in Marli 4: 2x; I.t-7: 12, is hard to tell. Amonin the Jews the lands of different owners were nut ustally separated by tences, but anly ly stones sot up at inturvals a landuarks (Deue. 19-11). and the rouds Wrese nut distinct from the fivlals, as commonly among $11-$, but ran riglit through them, as singthern planta-
I In lake 6: 1 W II. and Fer. Ver. omit 'secondfirst, but tanseriptional probability is very strungly

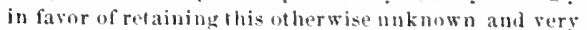
obseure componnd worl. Meyer's thery of is orinin, adopted by $\mathbf{W}$ II., is possible, lut far from probable. The question of ila guminenos is quite hard to solve, and its disenssion belongs to a commentary on Luke; fortunalely, is is of no historieal importance, for the stamling grain sulticiently suss the time of year, The most probable interpresation of the 'secondtirst Sabbath' makes it mean the tirst subliath after the second day of the lassover festival. when the sheaf of grain was presented, aflur which dis the new harvest conld be eaten. (Ler. 23:5-15.) 
2 Bnt when the Pharisees saw it, they said unto him, Behold, hy disciples do that which is jot law tul to do upou the sibbuth day.

:3 But he said unio them, Have ye not read what bavid diul, when he was a hugered, and they that were with bim ;
2 eat. But the Pharisees, when they saw it, said unto him, Behold, thy disciples do that which it is not 3 lawtul to do uponthe sibbatls. But he said unto liem, llave it not read what bavid did, when be was an bungerel, and they that were with him; tation paths often do, so that the grain grew ul) to the edge of the patl (comlu). on 18:4); the sane thing is seen in Palestine to-day. Disciples, see on 5: 1. Began to pluek the ears of corn (grain), either wheat or barley, frobably the latter, if it was just after the Passover. Luke 6: 1 adds, "rubbing the in their liands, a thing familiar to every one who has been much in harvent tields. Hegan to pluck, and presently the Pluarisees interfered, and tried to stu it.

2. These Pharives (com1). on:3: 7) were making a short Sabbath day's journey, about one thousind yards, througl the same grain-fichds. Behold, calling lus attention tosomething important. Thy disciples do that (aredoing). Mark (2:24) makes it a question addressed to him, and Luke $(6: 2)$ a question addressed to the disciples. In many cases the Evangelists do not undertake to give the exaet language employed, but only the substance of it (comp. on $3: 17$ ). Which is not lawful todo npon the sabbath. It was expressly permitted to dothic in general (Deut. 23: 25), and such thing: are still common in Palestine, but the Jew: maintained that it should never be clone on the subberth. For that day they numbered each distinct act that could be called work as a separate sin, requiring a separate sin-offering; to plurek the ears was one act, to rub out the. grains was a secom (eomp. Eder-h., (ch. 3in). As to tle numerous and often ab-urd Rabbinical regulations for the Sabbath, see Edersh. Appendix 17, Geikie, 4h. 88.

3 f. Our Lord's reply to this eensure of the disciples and himself contains, as here reportel, tour distinct arguments, v.: $1 ., v, 5 \mathrm{t}$. , v. 7 , and v. $8 . \quad A$ fifth arerument is given in this eomnection by Mark $2: 27$, a sixth below in v. $11 \mathrm{f}$, a serenth (probably just heforo at Jerusalem) in John $5: 17$, and an eightl (much later) in John $7: 2.20$. The lir-t argument is an appeal to history, viz., to the conduct of David (1 sam. 21: 1.6), which these J'harisees would admit to lave been justifiable. The point of the argument is, that necessity wouid justify a departure from the strict law us to things consecrated. And they that were with him may be connected either with 'did,' or with 'was hungry, and there is no substantial difterence. The participation of David's followers is unmistaliably indicated in 1 sam. 2I : 4 f.; our Lord brings it out clearly in order to make the case more obviously parallel to that of himself and his followers. The house of God, meaning the tabernacle. (Ex. 23:19; Judg. 18:31; 1 Sam. 1:7,24; 3: 15; 2 Sam. 12: 20; Ps. 5: ?; comp. 2 Cor.5:1.) Shewbread, literally, loaves of the setting-out, loaves that were set out, the common soptuagint'expression, in Heb. usually 'bread of the ficce, $i$. e., placed before the face of Jehovah. For the law about this, see Lev. 24: 5-9. Twelve very large loaves of bread were placed on a small table (at a later period, two tables, 1 Chron.s: 16$)$, which sat on the right side of the holy place to one entering. When the sabbath came, new loaves were substituted, and the old ones eaten, there in the holy place, by the priests, the descondants of Aaron-for this oftering was to be regarded as peculiarly sacred. (Lev, 24:9.) David was fleeing southward from Gibeah, saul having determined to slay him, and canse to Nob, just nortl of Jerusalem, where the tabernacle then was. Having left in great haste, withont food, he deceived the high-priest by saying that the king had sent him on a seeret and urgent mis-ion, and thereby induced him, as there was no other bread on hand, to loring some of the shew-lotses, which hatd been removed from the table, but not yet enten. It seems likely, from 1 Sam. 21: 5f., thougl: not certain, that the bread had been changed on that day, which was therefore the Sabuath. This woruld give additional appositeness to the illustration, but the point of the argument does not depend on it. Our Lord makes no allusion to the deception practiced by David, which any one would agree was wrong. The sole point he makes is, that for David and his attendants (buke 6:4) to eat the hallowed bread was justifiable, on the ground of necessity-n view in which all his hearers would concur. Kimehi, a celebrated Jewish commentator of the thirteenth century, on $1 \mathrm{Sam}, 21: 5$, muin- 
4 llow be enterel into the loouse of cind, and did eat the shewhreal, which was rol lawtil lor hin lo wat, neither for them which were with him, hit only for the priests:"

is or have ve net read in the law how that on the

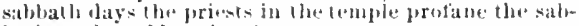
balli, and are? blameless:

i Bull Iay unte you, That in this place is one grealer than the ariule.

7 litl it ge had known what this meanelh, 1 will have meres, alld mol siteritien, ye would not have condemued the guiltless.
+ hrow he enterest into the house of rigl, and bicl ant Ihe shewbrabl, which il was ong lawtul for him to

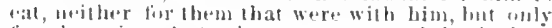

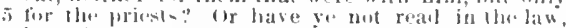

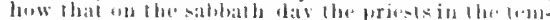

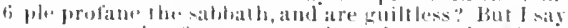

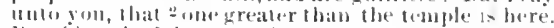

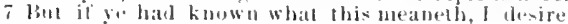
merey, imb not satritiea, ye would not bave eon-

I Some ancieut :utborithes reut, they did eat....2 Gr. a greater thing.

tains that in ease of hunger the sluew-breat might be eaten by thase who were not priests; not moly that which had been rembued from the table, but that which was upun it; yea, even when there was nome ta put in it roum. Anel it the law abust the hallowed breat wiglat be sot aside by neessity, so might the law about the ballowed day. The disciples really noeded toud. Ifark (2: 2i) here recorol. our Lord's alding the reneral principle, "The sabbath was male for man. and not man for the sabbath.' It cance into existrence fint the benefit of mankind, and so it may he temporarily set aside by any imperative necessity. (Comp. 2 Matce. $5:$ 1!).)

5 f. A secomel ground of justifieation for the disciples wats drawn. not from satered history, but froms the late. (Num. 2x: 3, 10, 14, 19.)

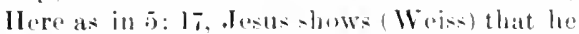
is not abregating or violation the law, for ho justities his controe out of thr law itselt. (Br, introduciug another argument, as in $7:$ : 1 . llave ye not read, a in $v,:$ ( (m)1np. v. T); 19: 4; 21 : 1ti, ete., reproalus them will ignorance of Seripture. Temple is hore the general term hieron, 'sicerod (placer), incluting the whole comserated enclome-buildings, courts, and all (see $101 \mathrm{4}$ : 5), thus applying requally well to the taberuacle and lo the Temple. The priest- wore dirented to oflior certain sucritices in the sacrul phace on the. sithbath-more, in fact, than on uther days-

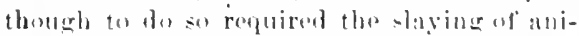

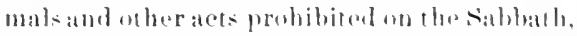
and which moler any ather circumstamers would "protitue the sibbuth. Thi-was light. becituse the temple with its - merifiees Was w ligher importance than the sabbath, and

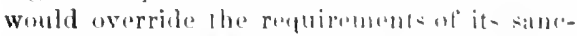
tity. Blameless, or, gmiltless, buth in $x$. and $v$. 7 , or else 'blameless' in buth, the? Geeck word being the same in beoth veres. nud the rerbal connection being of some im- portance. Our fard aremes that the same principle applies tes the ratse in hathd, and still

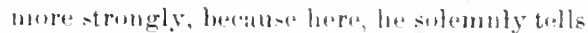
thesn, is onc-or, something-greater than the temple. The correct reating makes the Greek word mot masculine, "a gruater man), but neuter, 'a grater (thing).' comly, v. 41, and 11: 9. This paruliar form of expression may have been intembed to render the satement lese distincetly oftensiveto lowish projudices, but it unquetionably assurts is supurior dignity and importunce connected, in whatever way, with himand his mision. The temple Was superior to the Sabbath, and there was that here which was superior to the temple; much more, then, might the usual law of the sabbath be set asdoe withunt blane, when it becane neces-nry fur his disciples in his service. This argument would be best appreciated by drwish rouders, and is griven by Matlbew unly. On a latur vocasion, our Lord drow a similar aremuent from ciramicision. (.lohn 7: :20 fo) The principle he lyere lays down would slow the propriets, evere uporr granuds af Olal 'Test. latw, ot all sed active exertions on the siablath at ale really necessary in attouding upon and eanducting roligious wor-hip. (V. \& goesturthes still.)

7. A third perint in the defones is drawn

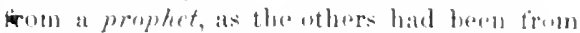
hiotory and law. This neatio is givan he

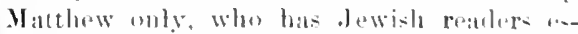
perially in mind. But if ye had hunwn what this meaneth-literally-what is, i. a.

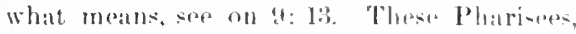
many of them serilues, dicl klluw what the pas-age was in its worde. hul dial not know

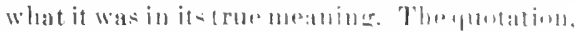

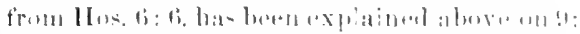

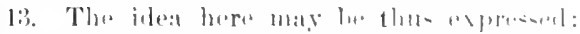

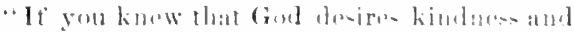
gerod-will tor mell, rather than sacritice, vou 
8 For the Son of man is Lord even of the sabbath day. would not bave condemned the guiltess." is implied that it they ratly knew the meaning of the passage, they would have acted accorling to it. ()nly those who are willing to obey scripture, filly e'snprehend its spiritual instruction (comp). Juhn $7: 17$ ). The disciples are 'guiltless,' just as the priests in the temple are, bealuse they are busy in eonnection with something even greater than the temple. And if these Pharises were disposed, acoording to the prophet's words, to treat their follow-men kindly and fairly, rather than to make piety eonsist exclusively in outward observances, they would not have condemned them (comp. $23: 23)$.

8. This gives a fourth defence of the diseiplos, in the shape of a reason for deelaring them 'guiltless.' Artingunder their Master's authority, they bad a right to do what would not usually be proper on the sabbath, for he is Lord of the Sabbath. (Nven is genuine in Mark and Luke, but not in Matt.) This tatement carries higher the idea of v. 6 . There be declared the presence of something superior to the temple, and a fortiori, to the Sabluth; here he says that the Mrsiah is Lor' of the sabbath, having full authority to (antrol and regulate it as he may see proper. In both cases it is implied that the sparker is the verson referred to, but it is not distinetly stated, because tho tine for publicly taking such a position bas not yet come. The son of man, see on $8: 20$. If the inspired aposthes of Jesus afterwards changed the day to be obscrved, and absolvad Christians from all particular Mosaie as well as traclitional pules concorning the manner of obsorving it, they wore not going heyoud tha athoritative eontrol over thesabhath which their Mastor himself hat clained.

As a sioth point, our Lord now shows (x. 9-13) that it is alsi proper to dienart firom the striet observance of the sabbath, when requisite to the relief of a suffering tialow-man, or even at suffering brute. Thusetwo instancess have locl to the familiar saying, lorived trom the Wratminster Catrohism, that we may do wh the Sabbath "worke of mecessity and norey." Anotber exumple of healing on the sabbath had oceurred, apparently just betion, bacling to a seventh argument (John5:9,17); and yet
8 demned the guiltless. For the son of man is lord of the sabbath. t othel instances are reeorded in Mark 1: "2l, 29 f.; Luke 13: 10 ft.; 14:3; John 9: 14 ff. This frequent departure from what the Jews thought to be proper on the sabbath, with the pains here taken to explain and defend his course, was doubtless designed by our Lord as a part of his general undertaking to teach them a more spiritual interpretation and observanee of the law (comp). on 5: 17-21). In order to this he showed, by word and deed, the error and folly of that rigid formalism with which they insisted so much on the minute and litural obscrvance of all its outward requirements, regardless of its true spirit and real design. He has bere said nothing at all calculated to impair the sanetity of the sabbath. On the contray, as "the exception proves the rule," his argument that there are peculiar cireumstancesin which itsobservance shotuld be set aside, neersarily involves the irlea that in general it should be observed. The sabbath seems to have been enjoined upon our first parents as som as they were ereated; it and the institution of marriage form the only relies that remain to us of the unfallen lite in Paralise. The command to hallow it was included among the Ten Commandments, the moral law which is of perpetual abligation. The very term "Remember the sabbath-day to keep it holy" (Ex.20: ४), seems to treat it as not something new, but an already existing institution; and it appears from the listory ot the first fall of manna (Ex. 16:5,22-30) that the people were previously aequainted with the sabbath and that some ot them were disposed to forget or neglect it. Recent researcli shows that the Babylonians before the time of Abrabam observed a week of seven days, ending with a rest day which they strictly kept, and which the Assyrian writers eall by the name Sabbath. With this agrees the week reportedly mentioned in Genesis, and it is now tom late to say that the sabhatlowas unknown till the lawgiving at Mount sinai. In the furthor legislation which folfownd the giving of the Ten Commandments, to the general idea of hablowing the day, is aldeal the prohibition of work on the sabluth, under penalty of death. (Ex.31:14;35:2.) To Parry this ont moriffectually, they were prohibited to kindle a tiro on that day (Fx. 35:3), 
9 Aud when he was departed thence, he wenl into their syliagogue:

10 And, belwhl, there wax a man whieh bal his haml

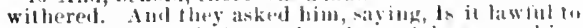
heal on the sahbalh days? thal they might aceuse him.
9 And be departed thence, and went inlo their symat(1) gague: and hebold, a wan having a withervil hatud Aul they asked him, saying, Is it lawful to heal on probably in order to provent robking, just as a duthle supply of mauna fell un the sixth day, and none on the sevoluth. 'This regulattion abont making a fire being forgutten or contromed by me of the prople, whe was found gathering sticks on the sabbath, be was, ly divine direction, stuned to death (Num. 15:32-36): an which areal:ion it wasprovided that the peoples should watr a fringe an the garment, with a riband at bhus sece abuse on 9: 24), tu remind them fontinually at the

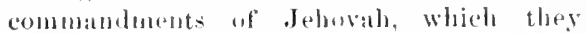
seemed so prome to forgret. ( Numb, 15:3i+11.) Now these particulat regulations, being a part ut the rivil and ererenumial law ot the Jewish people, ceased to be ohligatury when the matural gave way to the spiritual linel, through the work of Chri-t. But tiansabhath still remained, as it exinted brefore l-ram, and was even from the foration a day appointer by

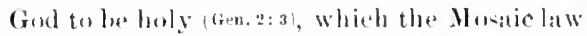
reconguizod at the untset, in reminding the

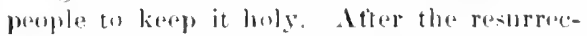
tion of C'hrist an additional signiticance was given tutheday, as representing nut only "the (ompletion of God"s work of cration," but alos "the triumplatut completion of the still more glorions werli of Rolemprtion." (Boyer,

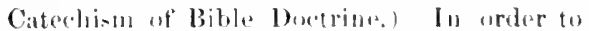
this, tho day appeats to have herall changed by the apostles from the seventlo to the tirst day of the week, as that on which Christ rose. (John 20: 19, 26; Acts 20: 7: 1 (or. 16:2: Kev, 1:11.) This addorl signifiance and change at day did not uffect the prepertual obligarion to keep boly the Sishloull. But Christianty, frue to its spiritual character, gives no particular procepts ats to the mode ot ubereing the day, and leaves us to perturm the luty of kerping it. holy insuch methuds an an emlightesed rouscience nuy desan mos enturmable to its twofuld signituranere and its gumeral desigut. Comp. below. "LInnilatical and Prationl."

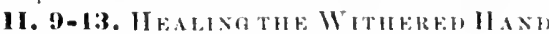

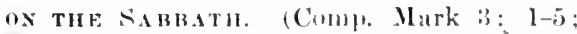
Luke (i: (i-lt) And when he was die parted thonec, he went into theirsyngogue. We slould most muturully infer, had
We Mattlew" marrative alone, that this incident tomli place on the same sabbath us the preceding. But luke f: Gsas, 'm another Sabbatl'; and nothing in Matthew's statement necessarily eontlicts with this. The connection in Mark 3 : 7 appours to show that the place was in fialilue, but it callunt be more exilelly deturmined. "Their synagugese. monas the synagingue of the pouple in that

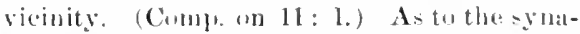
gogues, sw otl 4: 2.3. A man which had, etc. Maring a withered hand is the best suppurted ranling. Lake adds $(6-6)$ that it was his right hand. We camnot dotermine the jrecise hature of theatfection which catured his hand to wither. Jerome mentions that the so-called "Gospel" of the Nizarenes callod him a stome-nason-which, though only at tradition, womld illustrate for us the importonce of his riglit land. And they asked him. Lulie states that they were the seribus and Pharisees. IIs and Mark omly mention that they watched him to see whether low would loal on the sabbath; Matthew dows not omtradict them, but simply adds that they an-ked hine whether it was lawtil. That they might acense him, probubly before the

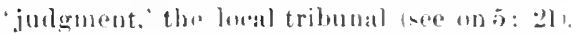
The lator Jowish writings show much discussion as to the propriety of healing on the siabbith. All a aresed that it onglat to be dome. where lifw was in langer sece Wet, Wün., or Eslersh.), but tlay af' pourese diffira l much or the quention what diseans emuld be endusd"rod as andangerins litu. The Talmud gives a hont of diroctions for different atsos, with many ubsurd dietimetiens; r. $/$. " (bust who las a sore throut must unt erargle with ail; but he mate swalluw oil (tur fimd), and if that eare-him, all rierht." ()ne Rahbi taught that " man miglit take a purgative drink, if he towk it for pleasure, but must unt take it tor the purpuse al healing. The law hat said nothing nbont lealiner disease on the sinbluab, lout matry Rabbis tomeli the gromol that it was "work." (tix.31-14.) Tymelale and folluwers, including our come. Ver. latue on the sabbatla days, in v. 10 and 12, but the plural form 
11 And he said unto them, What man sliall there be among you, that shall have one shen' $P$, and if it fall into a pit on the sabbath day, will he not laty hold on it, and lith it out?

12 How much then is a man betler than a sheep? Wherefore it is law ful in do wetl on the sahbath days. 13 Then saith be to the man, - Iretch forth thine hand. Aud he siretehed it forth; and it was restored whole, like as the other.

1 it Then the Pharises went out, aud $a$ held a couneil agaiust him, how they might destroy him.
11 the sabbath day? that they might aecuse him. And he said unto lhem, Whal man shall there be of yon that shall have oue sheep, and it this fall into a pit on the sabbath dicy, will he not lay hold on it, and 12 lift it out? How much then is a man of more value than a sheep! Wherefore it is lawfu! to do good on

13 the sabbath day. 'Fhen sajd he to the man, sit reteh forth thy hand. And he stretched it forth; and it

14 was restored whole, as the ol her. But the Pluarisees went out, and took counsel against bim, how they

a Or, took counsel.

of the Greek word is frequently used (Grimm) in the singular sense, as they all translate in v. 11.

$11 \mathrm{f}$. He appeals not as in the folmer instance, to the history, the law, or the prophets, but to the eourse pursued by the people themselves in other matters. This argument is here given by Matthew only, but similar arguments are given by Luke $(13: 15 ; 14: 5)$, as atterwards used on other occasions. Mark mentions (3:3) that Jesus told the man to stand up in the midst, probably that the bystanders might look at him with sympathy, and thus justly ajpreciate the propriety of lealing him. To awaken healthy feeling, is sometimes the best remedy for unreasonable prejudice. One sheep woukd be a matter of no great eonsequence, and yet even this the owner would lift out of a pit on the Sabbath day. In the Talmud some Rabbis maintained that it was enough when a beast fell into a pit to give it food; others said, put something under it to lie on, and if by means of this it chimbs out, all right; others sail, take it out with the intention of killing it, even though afterwards you ehange your mind and preserve it. $T$ o such silly pasions were men driven, by the attempt to convert morality into a mere system of rules. Jesus appeals to enmmon sense, askiug whether any one present would fail in such a case to preserve his property. Edersh.: "There comld be no doubt, at any rate, that even if the [traditional] la w was, at the time of Christ, as stringent as in the Talmud, a man would have formd some deviee by which to reeover his sheep." The old Roman religious law providen that on the sacred days an ox might be drawn out of a pit. A man better-of more volur-than a sheep, see a like argument in $4: 26$, and in 10: 29-31. Wherefore, or, 'so that,' a general inference from what preseles. It is lawful. The word law does nul enter into the Greek expression (see atso in v. 30), which means simply it is allowable, or permissible. To do well $(g \circ o d)$ on the Sabbath. Com. Ver. 'to do well,' looks literal, but really gives a different sense. Wyclif used 'to do good,' Tyn., Cran., Gen., Rheims, 'to do a good deed.' In Mark and Luke be first puts this as a question, 'Is it lawful on the Sabbath to do good, or to do harm,' intimating that by delaying to heal the man he would be inflicting an injury. They made no answer, and he 'looked round about on them with anger, being grieved at the hardening of their heart.' (M:rk 3:5.) They could not reply to his arguments, nor deny that he was right, and yet would not give up their fieree opposition. And so he looked upon then with mingled indignation and grief.

13. And it was restored in the act of stretching it forth. Whole, healthy, sound, well. Even from their own point of view the Pharisees must have found it difficult to call this brealing the Sabbath, for Jesus used no remedy, performed no action, simply spoke a word, and the man merely stretehed forth his hand. They had hoped to make a strong case against $J$ esus, and being silenced by his argument and baffled by his action, they were all the more angry, 'filled with madness,' (Luke 6:11.)

14-21. Plot to Destroy Jesus, a ND His Witudrawal. For the plot eomp. Mark 3: 6; Luke 6: 11; the eonsequent withdrawal is deseribed by Mark (3: 7.72) with his charneteristic fullness of detai]. Held a conncil, rather, took counsel, against him, as the sume phrase is rendered by Com. Ter. iu 22 : 15 , and elsewhere, and a similar one in Mark $3: 6$, and as all English versions before King James rendered here. Mark tells us lhat the Pharisees drew into this consulation the Herodians, who were their own enemies. (Comp. on 22: 16.) Remembering that this was before the sermon on the Mount (see on v. 1 and v. 15), and probably almost two 
15 But when Jesus knew it, be withlrew hiustif from thence: and greal multiolus followed lime ambl he healeat rhem all

16 Ant charged them that they shoubl not make him known:

17 That it might he fullilled which was spoken by batias the prophit, saying,

vears before the Crucitixion, we pereoive that the emmity of the leading oews had alrealy gune very far. A similar aflort to slay him in Jerusalem and upon tlae same chatge of

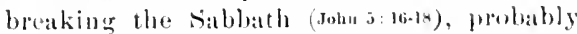
belungs in the hi-tory shorlly butere this etlint in Galilee. (sive an v. 1.) The two mosements may have arisen independently, or emisandes may bave beren sent from Jerusalem, as wat dene a year lattr. (15:1.) Their pretended reason for plottiog his destruction Was that he rialated the sabbath, and so was contemned to death by the law (w. 31: 1t: $25: 2$ ); the true reason seens to have been their jealon-y of his growing eredit among the people, and toar that he would impair their own inHuenee. What a reproale upon human nature, to see men maintainimg that it was a mortal sin to heal disease on the sabbath, and get foully plotting on that same sacred day, how thes might destroy the innoeent 'Peacher and Healer.

15. Learning that -lah was their intention, mur Lurel retired from that neighlorhome, and when croweds gathered to him in his new pusition besilte the Lake of tialilee, he hraled them all, and chatged them mot to make him

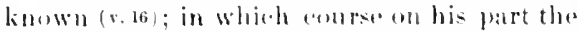
Evangelist pointsout the fultillment of another prophecy. (v.17-21.) Already in 4: 12 we hav. seen him withdraw from some place to a vold persecution; and there will be similar instances hereatider. (14:13;15:21:16:3.) flerander: "The rutrat hefore his mumies was prompted not by fear, but by that wise discretion which was constantly emploged in the selertion and the use of the nuessary mans for the promotion of the grate end which he cume to acemplish. As it entered into the divine plan that his grat atuning work should be preceled by a prophetic ministry of several vears' duration, the de-ign of which was to indectrinate the people in the mature ot his kingdom, to preptare the way for its orection, and to train the men by whom it should be organized, it formeel no small part at his work to ebeck and regulate the progresis of events, so as not to precipitate the cousum-
1.) might destroy bim. And desus perceiving it with-

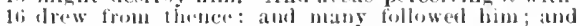

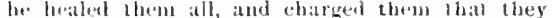
17 shomld mol make himknown: that it might be lulfilled which was spekcen through lsaiah lhe prophet, salyillg,

malion, but to secure and complete the re"fui-ite preparatury preecen." The hour was not yet cone, fior the sion of mon to be delivereal into the hamle of simners. (26:5.) He never slirank toon doiner gowal becausis of the: knowledge that it would provole onposition; lo simply transforred his branefient laborsto anotler seceice a he directed the disciples to do (10: 23 ). And great multitudes-or, many followed him. This was arly strengthened by somecopyint-intethe familiar phrase, 'many rmods, "1r 'great crowds,' ns in 4: 25, and often. Ind he healed them all. Another reneral and comprebensive statement of his great work (comly. an t: 20; $8: 16 ; 9:: 35)$. It this periud, as appears from a comparison of 12: 15 with Mark $3: 7-12$, and Luke 6: 11-21, the siermon on the Monut was delivered. Wo have already seen (on 4: 12, and $8: 1$ ), that in all this purtion of his Gospel, Natihew departs form the arder of time, and grams his materials according to the relation of topies, ats is often done hy historical writers. And (he) eharaed them, the Greels word implying threats of displeasture it they should disobey him. Forsome general reasons why he n-11:ally prohibited persons healed from lalking about it, sese on $8: 4$. In additional and previal reasul is lere given, viz., that it might be fulfilled which was spoken by (thromgh) Esaias the prophet. For these phrisas, emmle on $1: 2,2$, and $4: 14$. It was the divine lesign in his teanebing thus guietly and unostrutationsy, that this prophesy might be tultillel. The connection, thresefure, looks colecially to that part of the propheey whieh is contatined in $v$. $19 \mathrm{t}$.. hut the Erangelist cites a latrere prortion. because the remaindor also found a tulfilluent in Jesus. The Jews expectod the Mesiah to be a erreat endueror. Whose Warlike exploits would attract universal attention; and as the charace

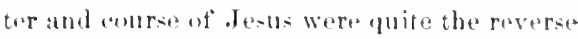
of all this, it was important for Mathew's purpose of convinging the Jews that he wa- Massiah, to puint ant that his action in this respect was in aceordanos with a Mesiande presliotion -all the more, as the current sedet. tramslation 
18 Bebold, my servant, whon I bave chosen; my belored, in whom ny sioul is well pleased: I will put my spirif ujon bim, and he shall shew judgment to the cientiles.

19 IIe shall not strive, nor cry; neither shall any man bear his voice in the streels.
18 Buhold, ny servant whom I have chosen;

Iy beloved in whom $\mathrm{my}$ soul is well pleased: I will pul uy -joirit upón him,

And he shall declare judgment to the Gentiles.

19 He shall not strive, nor cry aloud;

Feither shall any one hear his voice in the streets. had so interpolated the passage, as to turn away attention from its proper Messianic application (see on v. 18). This quotation, from Isil. 42: 1-1, is made by Matthew alone, being the seventh prophecy he cites, as fulfilled in Jesus (comy. on 8: 17), besides the two with reterence to John the Bitptist $(3: 3 ; 11: 10)$. It is guite tharacteristic of the two first Gospels, that while $\mathbf{M a t t h e w}$ alone gives the prophecy, Mark (3:7-12) gives much more copious details of the withdrawal and the healings.

18-21. This interesting quotation is partly from the sept., but with various alterations, for the sake of elose conformity to the Hebrew, or to bring out more clearly the Messianie applieation. Isia. 42: 1-4 may be literally translated from the Ilohrew as follows: "Behold my servant, whom I will sustain; my chosen (one) in whom my soul delights. I put my Spirit upon him; he will bring forth judgment to the Gentiles. He will not cry ont, he will not lift up (his voice), he will not callse lis voice to be lyeard abruad (or, "out of rlours'). A bruised reed he will not break, and a dinn wick he will not quench. He will hring forth judgment unto truth. He will not grow dim [like the wick, i. e., become feeb]e, faint], nor be bruken [like the reed, i. e., bruken down, disheartened], till he set judgment in the earth; and for his law (or, 'iustruction ) distant coasts shall wait." Now comp. Matthew. Behold my servant. The 'scrvant of Jehovah,' in Isa. eh. 42: 19, is primarily Israel. But here, as in Hos. 11: 1, and elsewhere, there is a typical relation between Fsract and Messiah (comp. abese on 2: 15); and the 'servant of Jehovah' also means Messial. Some of Isaiah's expressions refer equally well to either, Israel ur MLssiah; in others, a I I a . 52: 1:, and ch. 5:), the reference to Is ral seems to sink out of sight, and to our eye there appears nothing but Messiah. (Cump). at the beginning of thap. 24.) The sept. translators, understanding Isa. $4_{2}: 1$ of Istat, inserted the name, "Jacub, my servant.

Israel my choser." The Greek worl here rendered 'servant' in Matthew and sept.. is pais (see on $8: 6$ ), which might of itself menu either 'child' (Tyndale, Cran.), or 'serrant' (Geneva, Com. Ver.); but the Hebrew, here and elsewhere in Isa., is ebed, which unanbiguously means 'servant.' In like manner the question is settled as to Acts $3: 13,26 ; 4$ : 27,30 , by the manifest reference to this portion of Isa. Whom I have chosen, while the Heb. has 'will sustain.' Matthew may have purposely used the term 'have chosen' from Isa. 43: $10 ; 44: 1$, as better bringing ont the IIessianic reterence in the term 'servant of the Lord.' It was certainly lawful for an inspired writer to express more clearly in his quotation an idea that was really present in the prophets language. (Comp. on 2: 6.) God will sustain this servant of his, because he has chosen him, to perform an important work. So as to my beloved, instead of Heb. 'my chosen.' The expression is well pleased reminds us of the words spoken from heaven at the baptism and the transfiguration, which probably alluded to this passage of Isa. (See above on $3: 17$.$) I will put my spirit upou$ him, $i$. e., in a special, remarkable degrce. (Com. Isa. 61: 1; Luke 4: 18; John 3: 34, and see above on $3: 16$.) And he shall shew (will declare) judgment to the Gentiles. 'Announce" or 'Aleclare' (as in Heb. 2: 12) interprets the general term 'bring forth' of the Hebrew. 'Juigment' exactly translates the Heb. word. It might have been understood as meauing justice and rectitude in general. (23: 23; Luke 11; 42.) But it is better to talie it, in the prophecy and here, as denoting the whole body of what God declares to be just and right. (Comp. Isa. 51: 4.) Strive, or 'wrangle, may have been chosen by Matthew to contrast Jesus with the scribes, who were constantly disputing and wrangling: perhaps also (Plumptre) to contrast him with "false prophets and leaders of revolt, such as "Judas of Galilee had been." In the streets, gives greater distinctness to the Hebrew phrase; he would not talk in public places, in a way designed to attract attention. (Comp. 6:5.) If on such an vecasion as John 7:37. Jesus 'stood and cried out' in the temple court, it was not through ostentation, but for 
20 A bruised reed shall he not break, and smoking fax shall be mol quench, till be semt forth judguent unfo victory.

21 I 1 din his nane shall the fitentiles trist.
20 A bruined renl shall he not bresk,

Aul smokiug llax shall lie wol fuench,

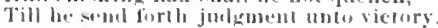

21 Ind in lis mane shall the fientiles hove. the gard of those by whom he would make himselt beard. A bruised reed shall he not break, emmpletely break, brouk oft. And smoking flax (a wick), literally, smoking linen. The lamp wick was uslually a strip ot linen; when there was but little ail. it would burn dimly and smoke. Instrad at" being a latrsh comqueror and momarch, Jer-iah would be gentle and kind; persons bowed duwn with conscous manthines, ferble as if verging toward spiritual extinction, he would not overwhelm and destroy, but would console and strengthen. Till he send-or bringforth judgment unto vietory. The prophory is quoted in a condensed form. The play upon workts in the IImbrew, He will not grow dim (like the wick), nur be broken (like the real), could not be made fully intolligible in a translation withunt todions circumlocutim, and as that clause was not important to the present fulfillment at the propherer, Matthew ants it. He then enmbines, to sume extent, the two brief' clauses, "he will bring forth julgment unto truth (i. e. truthfully. thoroughly, so that the whole truth about it should be kmown), and "until he set judguent in the earth (i. e.. astablish it), in each of whiels chanses thr beading term is .juelgment, i. e.e Gord's righteress requilenents. The result is this expres-ion, "till he send forth julgment unto vietory, i. e., victoriutusly. which includes the two motions of its being fully manifuted and tully established. The Evalugulist thus nooids complexity, and compries the whole in one simple expression. 'senel forth' is literally thrust forth, cast nbroid, the worl explained on :1: 85 : and its notion of furcible action tits the following term victory. Messiah will weremme all wbslacles and epponition, and victorinusly pro-

I There is an intimate conmection bed ween the illeas of hope and trust, thutgh really quite distinct, and the worts are often confonndert in pupular spesects. Tynflale, Cran., fich., and King .Iames thof Wyes, nur communly Rheims) seem to have lhought 'hope' often an inaleduate translation of the corresponding lir.word, so that they commonly remler by 'I rust ' tas here), and

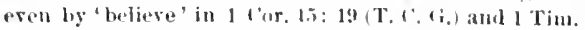
4: 10. (T. C.) The nom they all remularly translate 'bope, excepl 'trust' in '2 ('or. 3: 12 (1'. C. (i.), and in clain and e-tablioh Gorl's word. And in his name shall the cientiles trust, or hopes (Compl. Rom, 15: 12.) Here the Evangeli-t follow- tha sepl. which was sutficiently atecurate tor his furpose (eorn]). un: : : :3); naty, which states more clatrly than the: Heb. expresions a motion specially appropriate to the goopel, and which the llob. really con-

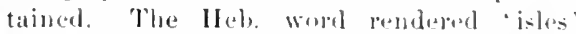
or 'coants' is trequently used for distant lands in general (1.a. 41:1,5;49:1:51.5), si) that nalions, or fientilus (reet on 4: 1.5), is insuch a case ryajualent to it. The llab. "shall wait tor his law' meant shall conficlently expect or hope for his in-truction. (I*a. 1 jo Prov. 1: 8: 4: 2: i:2.) (Compr. Toy an (2uatations.) The serpt. substituted "mante" and Matt. retained it, sinces "hope in his name andounted to much the same thing as wait for lis instruction, looth denoting dependence all him. Alformeter: "As the first part of the proplecy wate eited as an iutruluction, so this la-t part was added lo give romodness and completenes to the whols fuotation. At the sime time these supplementary expressions, although not what the author meant e-predially to quote, serve the incielental but impurtant pulpuse of sugereting. in the language of a propher, the "xtent at the Mescinh" suis-ion ami the ultimate conversion ot the Gentiles." Where Malt. departs from bolls Heb. and siopt. it is surely guite as atsy to refier the clanges to the illopiral Evanerelist himsalt, as to a hiputhetical oral Aramaic versinn used

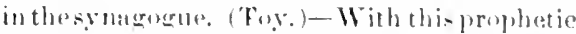
description at Mesiah, compl, what .J

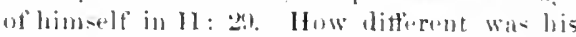
quirt course of life troms the turbulent violenee

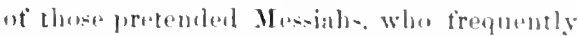
in:olvel the nation in enentusion and distress

Heh. 10: 23, whert Cum, Ver. actually has 'failh,

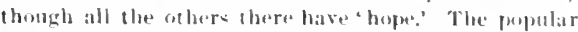
phrase "profession of taillo" is perhaps foumded on this erronems I ranslation of lleb. 1t: 23. In like manner 11 'et, 3: 15 is often quated 'a reason of the faith that is in you, Ilouluh it is really 'bupe.' The lower. fer. has rendered boll moun and verl, ly 'hope' in all e:mes, smmilimes " set your hepu, or the like. Fxamine expobally Luke 24: 21; John 5: $45 ; 1$ Tinu. 6: 17; I Ieb. $10: 23 ; 1$ I'et, 3:5. 
HOMILETISA, AND PRACTICAL.

In the chritian world at the present day, we may fond two (xtremes in respect to the observance of the sabbath, as well as to many other things. Sume act as if the Musaic regulations for the manner of observing the Sabbatll were still in force, and so they are exensivaly strict, and unwisely serupulous. Others imagine that when the eivil and ceremonial law arased to be binding, the sabbath al wo e eatard to be obligatory, and so they come to bold very loose notions as to abstaining from ordinary employments on the Lord's Day. One class incline to condemn all enjorment on the Siabath, at boure or abroad; the other rlase atre in danger of maling it a day of more idleness and festivity. Sime make modi-tinction betwoen the Jewish Sabbath and the Christian; ot bers, in urging that the Lord's Day is whully different from the Jewish Sabbath, forget that it is nevertheless the same as the primeval sabbath, withonly an arditional siguificance and a change in the tay of the week. It is a day "ballowed" by divine apjuintmont-distinguished from uther days, ancl set alpart to siered uses; a daty of rest from ordinary toik, bodily and mental, of worship and other distinctively religious emphyments. In an age when reading occupies s) large a nart uf eivilized lite, it would certianly seen important to abstain on the Lord's Daty from secular reading, expecially since we haveso rich a store of properly religious literature. In deciding how far to deny oursolves exorcise, suciety, table luxuries, and the like, we must have regard both to the objects of the day, to our own bodily, mental, and spiritual health, and to the influence of our example. As regardschildren, it is extremely important to afford them interesting and apfuropriate employment, and pleasant frod, so that they may not find the day wearienne and disagreeable. In genderal it should be remembures that most of us are far more likely to be tou lax than tom stringent, that we gravitate mueh nore poworfully towards celtindulgence than self-rtenial.

V. 2. HeNRY: "It is no now thing for the" most harmless and innoent atctions of ("lrrist's diseiples to be avil spolken of and petlented ryon at unlawtul epereially by thase whotare zeatous for theirown inventions and impritions." - Y. 5. Henry: "Ignorance of the
Is. ful 1. se who take upon them to others.' -V. 8. Christ is Lord of the Sak wh and the Christian Sabbath is the Lord's $11 . \mathrm{w}$ Rev. 1: 10.

$V^{r} \cdot 1-8$. The ceremonial and the moral elements of Christian piety. 1) Ceremony must yield to necessity, v. $3 \mathrm{f} .2$ ) Worship is superior to any sneredness of place or time, $v$. 5 f., comp. John 4: 21. 3) Kindly and just judgment of others is more acceptable to God than are ceremonial observances, $v, 7,4)$ Christ is above all ceremonies, v. 8. -V. 9-14. Baffled disputants. 1) They seek to entrap the Teacher with a question, v. 10.2 ) They are unable to answer his argument, v. $11 \mathrm{f}$, comp. Matt. 8: 6. 3) They can find no fatult with his action, v, 13. 4) Therefore they plot to kill him.-V. 13. Goder: "Like every call addressed to fitith, this command contained a promise of the strength neeessary to aceomplish it, provided the will to obey was there. He must make the attempt, depending on the word of Jesus, and divine power will alceompany the effiort." THeophyl. "Many now atso bave their hands withered-that is, not compassionating and not communicating; but whenever they bear the gospel word, they stretch torth their hands to give."-V. 15. Tukopuyc. "Plunging into danger is not pleasing to God."

V. $19 \mathrm{f}$. The quiet and gentle character here asseribed to Messials by the prophet, eorresponds to what Jesussaid of himself, meek and lowly and rest-giving, 11: 29,-V, 18-20, A prophetie pieture of the Saviour. 1) A chosen and beloved servant of God, v. 18. 2) Speeially endued with the Spirit of God, v. 18. 3) Quiet in teaching, and eompassionate to the timid and distressed, v. $19 \mathrm{f}$. 4) Destined to be vietorions in proclaming God's righteousness, and winning the nations to himself, v. $18,20,21$.

22-37.-The Blaspineny Against the SPIRIT.

In the course of those labors in Galilee of which the Evangelist has just given a general arcount (v.15p), there oceurret the events narrated in the remainder of ch. 12, followed by other events un the same day. (see on 13:1.) This was a gurod deal later than the two Sabbaths of $v$ 1-1\%. Between that time and this, the Sermon on the Mount was delivered. (See 
2.-2 Then was brought unto him one possescol will at devil, blind, and humb: and ho healed him, insomuch that ibe blind and dumb butb - gake and saw.

23. Anul all the penple were amazed, and siad, Is not this the son of Inavill?

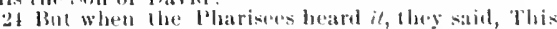

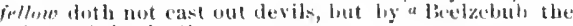
prince of the devils.
2.2 Then was brotught unto him lone pusesesed with a

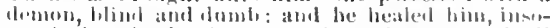
2:3 much that lhe lumb mat spate and saw. Iiul all

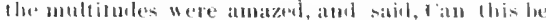

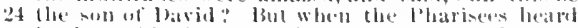
it, they said, This man doth nut cast wat dewons,

a ist. Benzelsul, and sov. $27 \ldots 2$ (br, a demonine.

(1) v. 15, and comp. Mark:3: 19.) ('omsulting

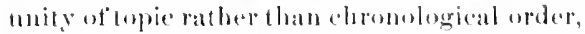
Mathew throws together these several instances of opposition to .hesus. Our present section treats of the blasphemons aceusation; the other anes of opposition will follow. Luke 11: 14-2:; describes a similar blamplamons aceosation, probably belomging to thes mini-ery in Judea mot Pereat, during the six unnths preceding the crucitixion. (Wieseler, (ilitri.)

Then, not necentaly on the same day as the precediug, but some time more generally, at the same perios (ses on:i: 1:3; 11: 201); hore it moans, at the time when he was engaged in the labor's of v. 1ijt. One possesseal, ete., (a demoniac) blind amd dumb, see m 8 : "), whers it has been remarked that rarious buelily aflectims were frofunently commected with the demoniacal posensions, whether as callst or effict. Insomucli, ate., so thet the lumb man spalis and sam is the aroreat toxt.' Aud all the people (erowils), same world as in 5: 1, and often. Jeshs was in a house, and the throng was so great that he and his disciples eould not even eat hrealal. (Marka. 20.) Is (omit not) this the son of David? moaning the Messiah, see on $9: 27$. The Giresk has all interrogative particlo whieh unifurmly implies that a negation answer is axpented, as in $7: 16 ; 11: 23$, and it is guito erroments to remeler 'Is not this, ette, at in Tyndale, ('ran., Gen., and in all the recent eetitions of com. Ver., while the two antiont folitions, A. 1 . lilland Hil3, give it without the 'mot' ; found

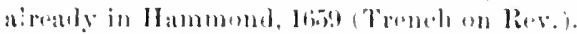
It is true that sometimes the spatater may intemel to intimate that perhajes tho answer ought to be attirmutive, as here and in .John

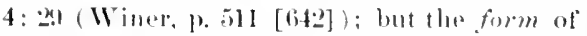
expresion is otherwise, and it ought to bo translated aceomlingly. Collowninl Euglish.

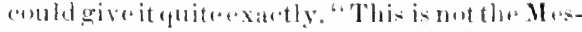
sialı, is it?" Engr.lev. grive" Isthis," Anu. Rev., "Can this lx. tha sun of I Itvid," as in Julı

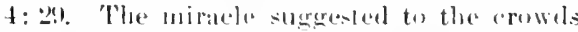
the idea that Je-n= might be thes Mesiah ; ret surely, they would loink, it atumot be -1 , since he does mot atperar and atel at Memolah will do, viz., at a mighty complueror and splemdiel monareh. Oherenethat the mirale sllgerested the pussibility that lue was lhe Mros-

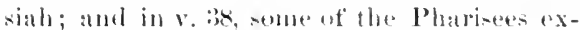
press their wish to ses a "sirn trom him, atter it had been intimated (v. 2u) that he was the

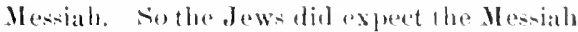
to work miracles, though Maimonides twelfth cent.) dectares that no miracles are to beexpected from tha Messiah, perhapm departing firom the oldir view in order to seeure an ar-

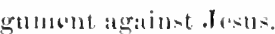

\section{But when the Pharisecs heard it.} Mark (3:2a) deseribes them mone partioularly as "theseribes that ("ande down forme Jertasa-

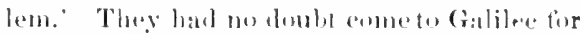
the purpose ot observinge the mirales and teaching of deste, and somking to prevent the perple from believine on him. (Campe on 1 .

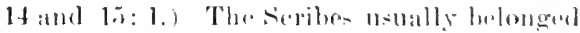

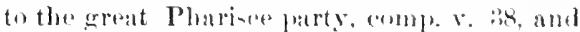
swan 2: : The The men set ahout thair work very viguremely. They satw that if his mir-

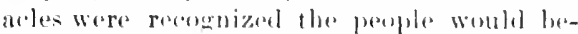
lieve that he was sent frum forl (sohns:2), and then all his tearhiners mu-t be recosived as trute, and all his rolaims atunited as just. They eomld not question the roulity of the healing. nor ascribe it to mere human aneney; they therefore resurted to thes nbentel idea of a leagua with siatan, though . Fests was ratly destruging Silan's Work. "Iland il, vi\%., the inquiry nalle momeng the enwels. This fellow doth not cast out devits the demons), hut by (im) Beclzebul, the prince

monts: while old Latin (most copiest and latin Villgate omit luth torme, ambl reml simply "so that he spatie" and sow.' Those variafions are instructive wo the student. The tirsl readiug accounts tor all the others
Memph., Eth. This was eamily altrered into"the bulind and domb man,' as in most docements and coumum 'Text, or 'the dumb and blind man,' as in many docu- 
25 And .Jesus knew their thoughts, and said unto them, byery kinglom fivided agaiust itself is brought the'm, Every kinglom divined agalus itself is brong itself shall not slaud:
25 lut 1 by Beelzebub the prinee of the demons. And knowing their thoughts he said nuto them, Every kinglon divided agaiust issetf is brumght to desolation; and every eity or house djvided against jtelf

1 Or, in.

of the devils (demons). "This' corre ponds to the inquiry of $\mathrm{x}$. 2:3: there is nothing to authorize the contomptuous term 'fellow' of Com. Ver. 'Demons,' and not 'devils,' see on 8: 3. 'In' ratlier than 'by.' see on 9: 34;

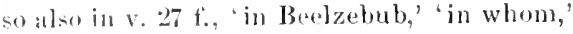
'in the spriritot' Gud' (so Wyelif and Pheims in all these expressions), every where lenoting intimate mnion. 'Berelzebul' is unquestionably the proper form af the lame, though it might not be worth while now to attenpt a clange in the popular usage. The name was frobal,y derived from Bat-zebub, the Flygord at Ekron $(2$ kings $1: 2,3,6.16)$, but there is donbt as to the reason for changing the last letter, and for applying the name to satan. (v.26.) This application to satan is not found in theold Jewish writings, and only in Matt. 10: 25; 12: 24, 27; Mark 3: 22; Luke 11: 1519, all referring to the blasphemous aceusation. Flies are often so terrible a plague in the East that we need not besurprised to find one of tho forms under which Baal was worshiped to be B:al-zabub, Baal of the fly, or Lord of the fly; Sept. makes it Banl-fly. So one of the Greek titles of Zeus (Jupitor) was "be who drives off the flies." It would be very natural for the later Jews to express their abborrence of this Philistine iclol by using his namo for satan. The change of the last letter may have beon meroly euphonie, as Bath-omandeb (the strait at the entrance of the Red Sea) is often writton Babcl-mandel, and Belial is sometimes written Beliar; but more likely the dhange was designed to give a new meaning, which might be, aceorling to different etymotogies, (1) "Lorl of dung" -as we know the Jews were fond of contempturusly purning tupon the names of idols: or (2) “ Lurd of the house," whirh would agres with the image of v. 29. This name for siatan was sufficiently eommon to be readily understoul, as alpueatrs from Mark 3: 22, 'he has Berlorbul,' like 'he las

1 so in all Greek MSS. and most of the early versions. Beelzebub is found in the oll and Vulgate syriae, the Vulgate Latin, and one or two eopics of the Mld Latin. The syriac would naturally take the IItorew form from a demon,' and from our Lord's using it in his reply, v. 27. For the other names, satan and Devil, sce on 4: 1. 'Prince' is literally 'ruler, a general term; we do not know the preeise nature of his authority over the demous, but everything indicates that it is absolute. Satan is also ealled 'prince of this world' ( John $12: 31$; $14: 30 ; 16: 11)$, and 'prince of the power of the air.' (Eph.2:2.) In 9: 34, Matt. has already stated that the Pharisces had reeourse to this absurd eharge, on occasion of a similar miracle of healing; but he did not there pause to tell how .Jesus refuted and solemnly rebuked it. Luke 11: 15 $\mathrm{fl}$. gives what is probably a third instanee in another part of the country; it was very natural that the same class of malignant enemies, involved in the same logieal difficulty, should attempt the same blasphemous explanation.

25 f. His reply divides itself into v. $25 \mathrm{f}$. (with which v. 29 is closely connected), v. $27 \mathrm{f}$, v. $30, v .91$ f., and v. $33-37$. And Jesus knew their thoughts and said, comp. on 9: 4. 'Jesus' was an early addition to the text, being thought necessary for clearness. Such insertions of the name frequently vecur. The Seribes and Pharisees appear to have made the blasphemous charge in a low tone to those around them, so that Jesus might not hear. They were at some little distance from him, in another part of the principal room or court of the house (Mark $3: 19$ ), for Mark (3:23) says he 'called them unto him' and replied to the charge. They were disposed to suggest their slanderous and insulting aceusations in an underland way, and he chose to reply openly. Mark says he spoke to them "in comparisons,' literally 'parables, see on I3: 3. Our Lord in his pitying condescension first argues calmly against their insulting charge, hefore proceeding to declare their awtul guilt in making it. He does this, we may suppose, partly to leave the blasphemers not even a seeming excuse, and partly to pre-

2 Kings 1: $2 \mathrm{H}$, and Jerome likewise probably hormwed it from the Helorew. The Latin Vulgate made this form familiar to Christendom. Notice that the uurgin of Com. Version says, Cireek Beelzebul. 
26) Amb if Satan cast out tiatan, lie is divided agaiust himself; how hall then his kingdom sland?

27 And if I by a fectzelonb cast oul revils, by whom do your ebildren cast them out? llerefore they shall be your jullges.
26) shall not slandl: and if satan castell ont salan, lo is divided against hinsell; how then shall his king-

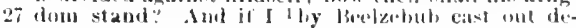
moms, lby whom dis your sous east them out? llace-

a Beclzibul, -1 or, in.

vent the bystanders from imagining for a moment that there was any gromnd for the charge (eomp. (m v. 30). His argament from analogy does nut mean that every case of intermal strife or civil war will destroy a State, but that such is the tendeney, and rery such act, so far as it goes, contributes to that end. And obsorve that it this charge was aceepted as applying to a single case of castiug out a demon, it must be muderstoud as extending to all cases; the whole work of .J asus in cilsting out demons must be ascribeal to this cause, and throughout his antire ministry be would be having the helpot satan in hreaking down Satan's powr. That wise "prince of" the demons" is too "umning to pursue so suicidal a course. Ind if satan cast out satan. For the prince of the demons to cast ant his subjects would be virtually casting out himselt, since they were doing his work. Those person- who so dislilio the remolaring 'deliver us from the evil one' (6.13, kev. ver.) ought to notiere that here and often. Iesus distinetly recoguizes satan as persomal.

27 t. Comdeseendiner. an he did with reference to the sibbath ( $12: 3$ a.), to present the argument in a variety of ways, our lard here gives it a bew and startline turn, bising what Jogicialls call argnmentum ad hominem, an appeal to their awn cas. Vour children (sons) moans those who had bown instructed by the l'harisees, like "soms of the propluets" in 2 King 2': 3; comp. the use of 'tithor' for a reverod teather in 2:3: 9: 1 (ur. 4: 15, and 'disciples' of the l'harisoes in 22. 10 . Exoreists would naturally belong to the Pharisee party, for no siadilueres would proteses the expulsion of demons, sine that party did not beliese an spirits, ovil or gond. Tu malio "your solls" moan ('hrist's own apostles, as Chrys. and other Fathers, and some modern writers do, seems unwarramted and absurd, leaving tise argument without force. It doubtless arose trom un mowillinguess to admit that the fewish exoreist- did really east ont demons, and a failure to observe that our Lord does not affirm that they did, but only argues from the point of view of the blas- phemors. Ihe appeals to the case of their own followers to silonee them, without then stopluing to examine the question whether their pretended expul-ions were reat. (l'aul uses the same kind at argument in 1 Cor, 1.): 24. ) It was very (common, about the timeof'un

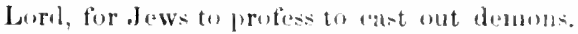
Curious aceounts of the mothoms they empliged, such as the use of a remarkitble rent, with incantations, which they pretended were handed down from solomon, are griven by Josepluus, “Ant.," 8, 2, 万, “W: conp. Tobit 8: 2; Justin Martyr, Trypho, ch. 85. In Aets 19: 13 wa real of strolling Jewish exorci-t - who thought there must be some magical charm in the name of Jestls which Paul named when working miracles, and tried to use it themsulves. Therefore they shall be your judges ("they" bring emphatic, as in 5: 4 tf. ; (omp. on $1: 21)$, $i$. e.. shall convict you either of lwing yourselves in langue with Beelabul, or ot unreasomable and wicked condurt in nerusing another of league with him for doing what they claim to do. But if I cast out drvils (demons) by the spirit of God, assumest that bedoes; and he has just shown that the contrary supposition womld cbarge satan with sleor tolly, and would involve the acrasers in solf-eondemustion. The chiotemphasis of the sentonere (atecording to the correct reading of the (irrek) is on the words 'by the spirit of God'; but 'I' is also emplintic, and suggests a enotrist betwern his eise and theirs. "singt has in the ciresk no urticle, but is molde detinite by the appenderl genitive, since there is but one spirit of (rod. 'Then is in the similar pastage of' Luke (11:20) rendered ly (ann. Vie "no doubt - -amother wt the numarous unmeressary valiations. Sio 'untor you' hore in Cemo. Ver. and 'mpon you' in Luke, are for the sume Greck prepusition. 'I'tren the kingdom of' God is (or hus) come nuto you. Mattbew here has 'kingrom of Gud' instead of his usual 'kinglom of hegren' (see on $3: 2)$, probably becallse of the rorbal commoc. tion here between 'spirit of Gol' amol 'kingdom of Gud.' The word rendored 
2's But if I cast out devils ly the spirit of God, then the kinglom of ciod is erme tinto you.

2!) or else, how can one enter inlo a strong man's homse, and smil lis gonds, excejt he tirst bind the sl rong natn" and then he will spoil his lombe.

30 Ifethat is tot with mo is against me; and be that gatherelh not with me seattereth abroal.
8 fore shall they be your judges. But if I l by the spirit of cod cast out demons, then is the kingdom 29 of liod come upon you. Or how cau one enter into the house of the strong $m a n$, and spoil his goods, except he first bind the slrong man? and bien he 30 will sjoil his bouse. He that is, not with ne is against mo; and he that gathereth nol with me

10 r. in.

'has comse' usually signifies to anticipate, to be leforehand, and so to come unexpectedly; and some urge such a sense here-bas already arrived, when you simply thought it would come before long-has taken you unawares. But the word apmars in the later Greek usage to have somelimes moant -imply come, arrive, etc. (1 Thess. 2: 16; kom. $9: 31$; Phil. 3: 16.) The idea then is, the kingdom of God, the Messianic Dispensation, has made its appearance in your presence. (Comp. Luke 17: 20 f.) Here again, as in 5: $17 ; 7: 21-23 ; 12$ : 8, our Lord strongly intimates that he is the Messial, yet without distinctly dechring it. The full conviction ammonnced by the apostles in 16: 16 seems to have been then recently arrived at. But that conclusion would not preclude, it would rather pro-suppose, a previous stage of perplexed inquiry, like that of John the Baptist (11:3), and is not fundamentally inconsistent with an early flush of delighted persuasion when some of them first met him, as recorded by John (1:41.49.) There is thus no such contraliction hetween. Juhn and the Synopties on this puint as some have imagined. Nor is it strange that Jesus should oceasionally intimate his Messiaship long before he thought proper publicly to avow it. But what as to the force of the argument in this passage? How did it follow, that if he was calsting out the demoms by the sirit of God, then the kingdom of God had arrived? The miracles of Jems did not directly prove him to be the Messiah, hut they proved it indirectly. This comstant divine assistance in working his great series of mirandes showed that he must have a divine mission, and attested all his elains as just; hut he claimed to be the II essiah, as he las bofore intimated and intimates here; therefore the miracles proved him to be the Messiab. So Paul says he was slown to be the fon of Gol by the resurration from the deast. (Rum. 1: 4.) Besides, in castingout domons, he was to that cxtent destroying the kingdom of Sitan ( $\because .26)$, and in so far establishing the correlative kingdom of God. (Comp. v. 29.)
29. This connects itself closeiy with the thought of v. 25 f. Or, to look at the matter in another way. (Comp. 7: 9; 12:5.) Else in Com. Ver. (fillowing Cranmer, Gen.) has no representative in the original. How can one enter, etc. This is a genera] truth, with an obvious application to the matter in hand. Jesus was taking away from Satan a part of his property, in delivering the demoniacs, and this could nut be unless he were at varianee with siatan, and strong enough to bind him. The word translated goods means utensils, implements (as those for cooking, eating, sleeping), and would suggest that the demoniacs were the instruments of Satan. Spoil, or 'plunder,' at the end of the sentence, represents a compound word, 'thoroughly plunder.'

30. Here again, as in the preceding verses, our Lord speaks in apophthegms (Mark 3:23), each sentence containing a distinct truth, expressed in general terms. It naturally fillows that nocomnection between these is outwardly indicated, and we are left to see for ourselves the internal connection of the thoughts. (Comp. at the berginning of (.h. 7.) The Scribes said that our Lord was in league with satan, but in reality he is opposing and overthrowing Satan's power, binding him, as it were, and plundering his house. In this great and deadly struggle, there can be no neutrality. No man can be friends with both sides, nor be indifferent to both. It is probable that many of those present were thinking they woukd not take sides between. Jesus and the blaspheming Scribes. To them, in the flrst place, this saying would come home; but it is general, and applicable to all times, and all varieties of character and conduct. The sentence contains two parallel and practieally equivalent mombers--the Hebrew paratlelism. (Comp. on 4: 16.) The image in the second member is from gathering grain in harvest, as in $3: 12 ; 6: 26$; John 4: 36 . Men often faney that they are by no mems opjosing Christ's service, though not engnged in it; that thry are friendly to religion in others, though not personally religious. But in the 
31 Wherefore I say untw you, All manner of sin and blasphemy shall be forciven unto men: but the blasphemy agrinst the dowy tibnet shall not be forgiven iIto int'll.

3: And whoserer speaketh a word against the son of man 31 shall be forgiven bim: but whoserersyatketh against the lloly t, hose, it thall not be forgiven him, neither in this world, neiller in the uorld to come.
31 satteruh. Therefore I say unto gou, Every sin and blasplieny shall be forgiven untio men; but the basphemy anasol the spirit shatl mol be forziven.

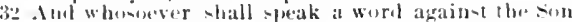
of stan, it shall he forgiven him; hul whosever shall speak against th. Holy spirit, it shall nol be forgitem him, neither in this l workd, nor in that nature of the ease, this is impossible. Stier: "Neutrality bere is no neutrality, but a remaning on the sile of the entemy" indolence here is no mere indolence, lout apposition; the morely not believing and not wbeying is still resistance and rejection." The gorpel is of such a nature, an to its oflers and its claims, that it cannot tolerate inditlerene. It it deserves our respect, it deserves our entire and hearty reception. If we aro not vieleling Christ our whole heart. we are really yielding him nothing. Profiesel nentrality. with real hostility of heart, may even he more offensive to him, and is sometimse more injurisus in its influerean, than avowed opluwition. -In Mark 9: 40; Luke !) 50 there is an expression which at first seems to contralict this, viz., 'He that is not arainat us is for us.' But $=0$ fur i- this from being the ease that breth saying: (Alexunder) "may be "xemplitied in the experience of the very same promes. For example, Nicodemus, by refu-ingto take part with the sanhedrin again-t our Lord, ah bough he did ant renture to esponse his catu-e proved himself to be upon his sille (John : :50 fo): hat if he had continued the same coure when the crisis had arrived, be would enually have proved himede to be against him." Compl. the apparently contradictury saying of Prov. 26; 4 f.; Gal. 6: 2, 5; Rom. 3: 28, an related to Junes: $2: 24$.

$31 \mathrm{f}$. Our Lord now solemuly declares that a blasphemy against the IInly spirit is the only unpardunable sin; and it is distinetly implied that their aceusation, hat he eant out demon by the help of Bectrobul, wat a basphemy against the Holy spirit, and so was pat forgiveness. Therefure, ri\%, on account of all that he ha-been saying. froms. 25 onward. It was manifest from such analugies that their charge of league with Beelze- bul was ahsurd; and they must have known that it wats not trufe and that the miracle was really wrought hy livine purer. Jeslls saly it was wought by the spirit of God, and so their accusation was not merely an insult to a unan, but a blasplemy against the spirit of God. For this reason he solemnly tells them that sueb blaspheng will never be forgivon. And we (an sue Eder-h.) that their malignant hortility to the kingdom of hearen, as allwaring in a form so contrary to what they experted and would have been willing to reougnime, here reached an acme of virulenes from which they went straight on to procure his leath. I say unto you, see on $5:$ is. NII manner of sill. Erery sin is the exact translation. With the general truth that every sin shall be forgiven unto men, lie enunects the speedic term and blasphemy, to leatrn nu doubt that every blatphemy tur a we wh a every other sin) will be foreriven; and thus brings out all the more strongly the sube axception, but the blasplemy against the Holy disol (xprit shall not be forgiven. This promise of firgivenes for erory -in and bh-phangy is of course to be limited by the conditionstof repentanee, ete., elsewhere lais down in seripture, and understoul in such a catse without being stated. (Comp. on $7: 7 f$ ) Blasphemy' bas been explained on $9:$ : as signifying in general injuriun on insulting spealingr. and so with regard to (rod, spealing impiousty. Blasphomy was comeidered among the Jews a very great unfince. ( $* 6.65$.$) In x .92$ we limb the general expression spealeth against. Here.the guilt of what the Plarisoes have lono is shown by another contratst. The son of man, we on 8: 20. Our Lurd had not distinetly claimed to be more than man. To speak againat him persmally, regarding him simply as a man
1 The marginal realing in Rev, Ver. (not in Amer. Revisers) 'Into you men' has no support but $B$, a single curslve, and a pasiage in Athanasius. It mat mot he strange that $W \mathrm{H}$. should cllng to $B$ and put this in the margin; lut it is strange that the reviors shmuld follow when internal evidence vields nohing tecisive.

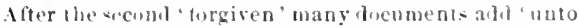
men'as in Com. lexi, and some add 'upto them. 
33 Either make the tree cond, and his fruil good; or else make the tree corrupt, and his fruit corrupt; for the tree is known by his iruil.
33 which is to come. Either make the tree good, and its fruit good; or make the tree corrupt, and its fruit (e. g. 11: 19), did not involve as great guilt as to speak againat the Ioly siprit, whose influenees filled lais louman spirit see on $3: 16$; 4: 1), and gave to him, as a man, the power of working miracles. (v.28.) In the phrase, but whosoever speaketh against the Ioly Ghost, spirit, 'the word 'holy' is so placed in the Greek as to be emphatic. They said, "II lath an unclean spirit' (Mark $3: 30$; while in truth he was full of the Holy spirit. ( Yot threre is no propriety in inserting the worl 'holy' in v, 31, as in Com. Ver.) Their charge of league with Beclzebul was therefure not simply a slander against the man, Jesus of Nazareth, nor simply an insult to the sion of man, the Messiah, but was a blasphemy agaimsthe Holy spirit. And it will not do to say that he was merely warning then against a possibility; for he is surely speaking of the blasphemy they have uttered, as blasphemy against the Holy Spirit. (Comp. v. 28.) It must be observed that the Holy Spirit, the sipirit of God (* $2 *)$, here represents the Divinity in general. There is liere no allusion to the peculiar gracious office and work of thesplint in calling, renewing, and sanctifying the sonl; it is the spirit of God as giving power to workmiracles. (Comp. Acts: 4; 8: 14-19, (to.) Thrse Pharisess arcribe to the influence and aid of Satan what was manifestly and unmistaliably wrought by divine power; and this was not merely an insult to a man, lut was a malienant insult to God. Similar, in this particular respect, was the sin of Alanias and Sapphira, who undertouk to practien a deception, not merely upon the aysutles, but 11 mon the Huly Spirit, who was well known to give them supornatura] knowlalgr. (Acta5-aff.) Panl had biasphened Jesus of Nazareth, and yet was forgiben, because be "did it innorantly, in mobeliet." (1Tim.1:13.) He did not then believe that Jesus spoke by the spirit of fond, and therefure Was not hlaspheming the Holy spirit. Afterwards he learned and taught that the spirit of God is "the sipirit of Chri-t." (Rom. . : 9.)
The conditions, then, under which this unpardonablesin of blaspluemy against the Spirit of God is committed, are (1) that there shall be a work manifestly supernatural, unmistakably the work of God and not of man, and (2) that one shall, in determined and malignant opposition, insultingly ascribe to Satan this which he knows to be the work of God. Now, are these conditions ever fulfilled, except in an age of miracles? Can any other divine work, as, for instance, the conversion of a friend, or a general revival of spirituality, be so unquestionably and unmistakably the work of God, that a person ascribing it to Satan is guilty, not merely of sin, but of that flagrant and deeply malignant blasphemy against God which is unpardonable? This is the question to be decided; and it can hardly be decided in the affirmative. As miracles continued throughout the apostolic age, this blasphemy against the spirit may very naturally be understond to be meant by that "sin unte death" which 'John implies (1 Jolu 5: 16) cannot be forgiven. Indead, wa seem compelled so to understand it, since on Lord here suys that the blasphemy against th. spirit is the only form of sin that will not be forgiven. The current plirase, "the sin against the Holy Ghost," is not found in suripture, and has been formed by combining Johlis expression with the passage before us. And the familiar idea of "sinning away one's day" of grace" ought not to be confounded with the blasphemy here poken of. It has already been remarlied that this blasphomy does not at all refer to the gracious work ot the spirit in ealling and regenerating, but manifestly and simply to his miraculous worl. Through neglect of this distinetion, persons often pass form speaking of blasphemy against the spirit to discussing what is called "resisting the Spirit," without being aware that these are quite different things. Even the passage in 1. John cannot refer to a person who has resisted the spirit till his influences are withdrawn, for no one else could decide that a mun was in that condition, while the apostle

1 The Rev. Ver, here changes 'Ghost' to'Spirit' as nec- It would have been much better had the revisersereryesary in order to agree wilh 'Spirit' in $v .25$ and 31 , where wade (his change. (Comp. on 1: 18.) 
34 (1) generation of vipers, bow call ve, leille evil,

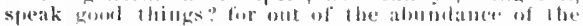
heart the mouth siteikith.

intimates that the "sin unto death" ath b." definitely known to others, sines he will not sily that one who has emmmitted it -hall he

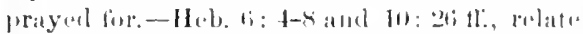

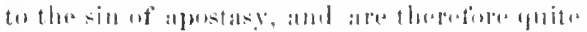

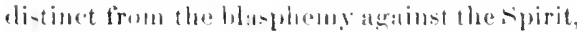
though witen routiomeled with it.

Noither in this world, noither in tho world to come. This is simply a strong atul expameled declaration that it will neren lus forgriven. 'Wurlel' is leere not hesmess the phy

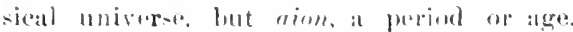

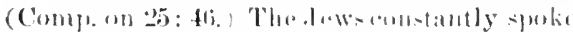

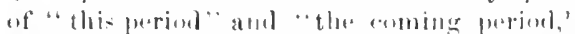

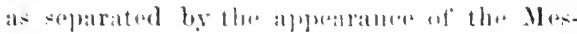

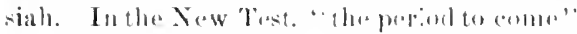
is usually anderived at as following the

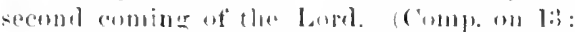
2.). Weise: "Xoithrer in this worlel-jereinel,

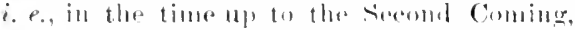
uor in the future worlalegeriul, which berins

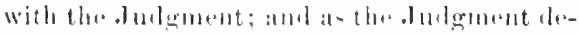

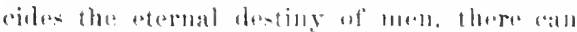

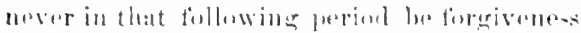
of the sin which at the duterment was astal)-

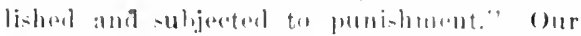
Loril's axpresion might in itsolt imply that sollo sins not forgivell in this worll will be

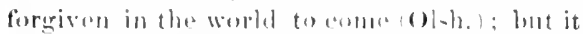
does mot neecesarily, nor usen verye maturally

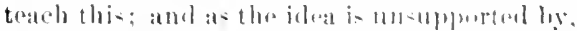

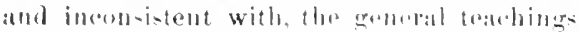

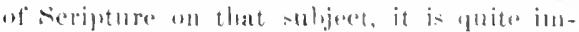
propere to basese intortant a losetrind al that

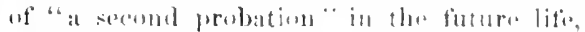

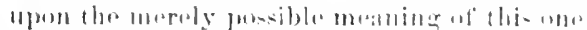

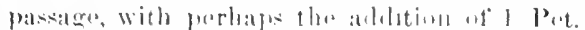

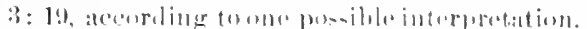

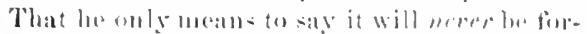

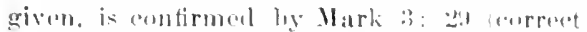

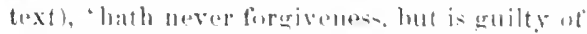
an etermal sin.' (ther sins maly he hluthal

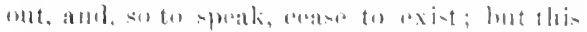

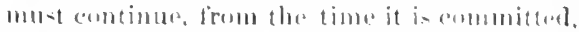
nlways rxistion, an arerlasting sin. Thu

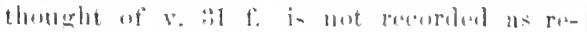
preated on the simbilar oceasion at lable l]:

I What is the propriets of satying Wheiss dlat the

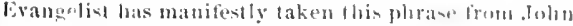
the Baplist's discourse? What objection can there be

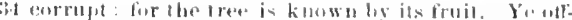

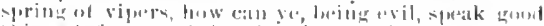

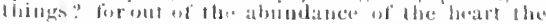

14, 20, but an yot anothror areasion, bukt 12. 10 .

3:3-35. It mierht lw-atid that here was only

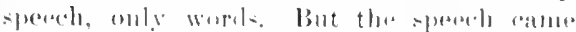

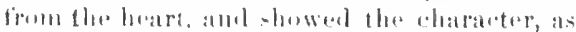

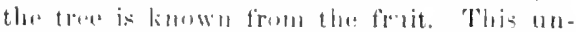

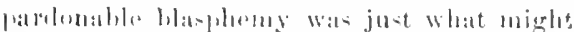

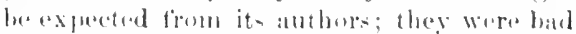

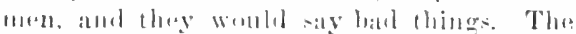

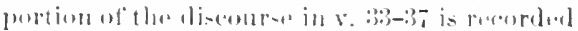

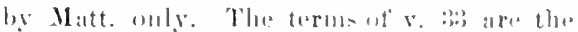

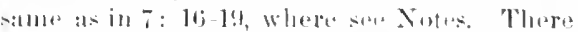

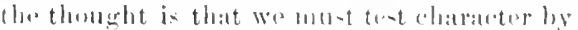

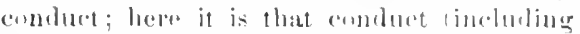

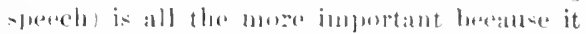

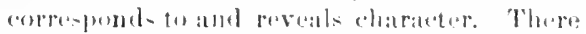

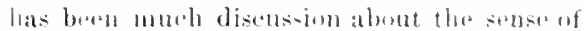
malie, shror "Xplating it as signifying 'ro-

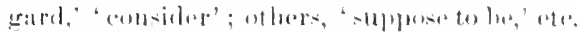
The ideas semeto he that the froit will be like the troe, and if you make the trop gerol you make its frat eroul. The worl "make" is thus anderstuml in its moinary stust. IIis,

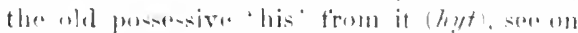
21: 22, molern its. (Aemenation oftsprimg) of vipers. the same axpresion as in $?: 7.1$

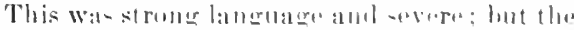
lowing saviour dirl net shrink fim the

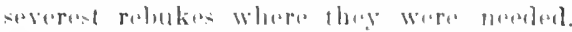

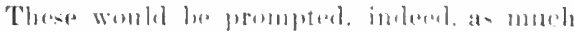
by lose to simners, as by imdienation ut thoir

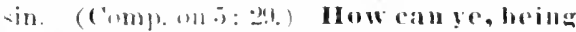
rvil, spoili good things? How is if jussible, in the nitture at things, that yot should?

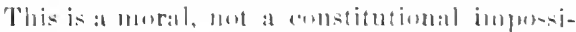
bility. For out of the abumdance of the

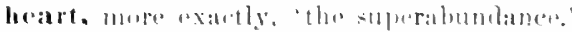

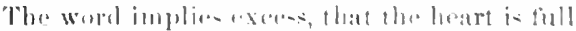
and more th:tu tull; the month gurnkis what

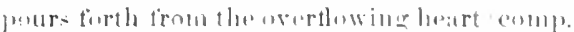

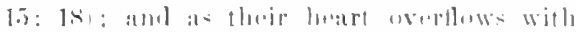

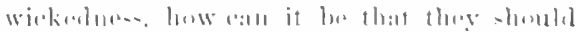

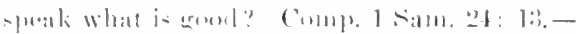

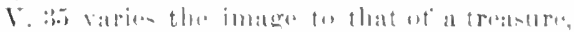

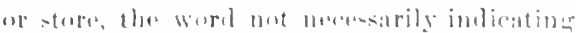

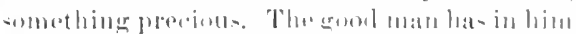

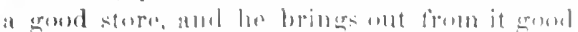

10 helineing that Jesus usint the same phrase? such alhtrary dieta are far from giving real sllumet ba 1 beary. 
3.5 A good man out of the good treasure of the heart bringeth forth good things: and an evil man out of the evil ireasure bringeth torth evil things.

36 I3uc I say unto you, 'l'haterery idte word that men shatl speak, they slitll give accomil ibereot in the day of judguent.

$3 i$ lour hy thy words lhou slualt be justified, and by thy words inoi shalt be condemned.
35 mouth speaketh. The good man out of his good Ireasure bringeth forth good things: and the evil Hatu otll of his evil treasure liringeth forth evil

36 thiugs. And l say unlo you, that every jole word that men shall sjeak, they shall give accont thereot 37 in the day of judgment. For by thy words thou shalt be justified, and by thy words thou shalt be condemned. things. This of course means the store of his inner man, heart, and so the woml "beart" was early added, in some quarters (as Old Syriac version), by way of explatation, being siggested by v. 34, and passed into many later documents and the Com. text. Bringeth forth is literally casts out, throws out, the word explained on $4: 38$, and here perhaps implying that the evil things ara as it were, involuntarily thrown out, "as a fountain doth its waters, by a natural and necessary ebullition" (Barrow). The fact that men speak good or evil aceorling to their mature, by no means frees thesu from guilt. This ought to be understrod from genaral principles; but our Lord leaves no room for uncertainty on the suljeet, for he proceeds to declare that words, even idle words, must be answered for.

36 f. IB ut (and) I say unto you, solemnly introducing an inportant saying (as in v. 31 ), see on 5: 18. Though they spoke so heedlessly the most blaspluemous words, and donbtless thought, as men are apt to do, that what one says is of littit importance, yet he assurestlem that men shall give account for every idle word. 'Idle' exactly renders the original term, which signities 'not working, and hence inefficiont, useless, ete.words not intended to produce any efleet. In the day of judgment, sees on $11: 22$. In v. 37 , by thy words, is literilly out of thy words, as a thing proceeding from their words, a result or consequence of them. Of course he dous not moan that it will proceed from their works alone; every one admits the fact as to actions, and worki an here the subject of remark. The repotition of "hy thy words" makes the statemont mole waighty and impressive. Word-are impurtant lieamoe they roval (baracter ( $(3,3,: 5)$, and breause they powerfully affect others. The only sin declared to be umpardonable is a sin of speech (v. 31 r.) ; and, on the other hand, " if any man offend notin speech, thesame is a perfect man. and able also to briclle the whole budy." (James 3:2.) Speoch is indered oije of the grand distinetions of human beings, and a mighty power for good or evil. But this passage must not be understood as condemning all light pleasantries of eonversation; it simply declares that the idlest nothings we ever ntter are $i n-$ cluded within the range of accountability to God. We must therefore see to it that our pleasantries are not essentially untruthful, that they are free from malice and impurity -in a word, that they are innocent and helpful. (Comp. o11 5:37.)

\section{HONILETICAL AND PRACTICAL.}

V. 23. 1)ifferent effects produced by the vutward evidenees of Christianity. 1) Many half convineed that it is divine, hut mainly inelined to reject it, v. 28 . 2) some persuading themselves and others that it is not divine, that its efferts are to be otherwise explained, v. 24. 3) Some trying to play neutrat, v. 30. 4) Some requiring further evidence, suited to their wwn notion, v. 38. 5) Some rejoicing to believe and ready to obey, v. $49 \mathrm{f} .-\mathrm{V} .24$. Anything to explain away the divine power of Christianity; anything, thungh it be absurd, insulting, blasphemous. $-\mathrm{V} .25 \mathrm{f}$. The furces of evil in the world do not act at hazald. nor by blind fate, but are directed by a lofty and shrewd inteligenee.V. 26. Satan and his kingdom. 1) There is a personal spirit of evil. 2) He has a kingdom. 3) The demons are his subjects, and are striving to make men his subjects forever. 4) Jesus opposes and shakes Satan's kingdom. (Comp. Lnke 10: 17-19.)-V. 30. We nust be definituly Christ's friends, or we are definitely his enemirs. Vinet, "Gospel Studies," preaches from this text on "The Intolerance of Christianity," and from Luke 9: 50 on "The Tolerunee of Christianity." - V. 31. Gladly, in several recorded cases, the savjour said, "Thy sins are furgiven thee." Sorrowfully he says that this sin "shall not be forgiven." - V. 33. Henry: "Unless the heart be transformad, the lite will never be thoroughly reformed."-V. B4. A heart overfull of wil, a mouth overflowing with evil.V. 37. CHRrs.: "Wherefore not the slan- 
3s Then cerlain of the seribes and of the fluarisees answered, saying, Master, we would seo a sign from thee.
38 Then certain of the seribes and Pharisees answered him, saying, I Master, we would see a sign

105, Teacher

dered, but the sanderers, have need to he andions and totremble. Fur the former are not constrined to answer for themselves, touching the evil things which are said of them, but the latter for the avil they have spoken; and ovor these impends the whole clanger."-V. 36 t. speech. 1) It is a peculiarity of human beings, and a groat power in louman life. 2) It reveals character, $v .35$. B) We are accontable not only for purposely wirked, but tor jdle speech, v. it). 4l sipeech will help to detromine our etermal future. DOmormoe: "Disconrso tomding to inmeent mirth, to exhilarate the spirits, is not idle discourstr as the time spent in necessary recreattion is not idle time."

38-.j0. Two OtIER Cases of OpposiTION TO .J ESUS.

Thase two instanees of opposition belong together ( 146$)$, and elearly seem to have followed immediately upm the bhasplinemos necusation. The word then (v.3x) does not certainly prove this (comp. v. 22), lut there is an obvious internal comnection; and notice that in Mark (3:31) the emming of the mother and brethren immediately follows the blasphemous aceusation, and the house

I There are three fireek woris used in the Niw Tesi. lo denote what we commonly and lonsely call "miracles,"

1. Trros signifies somelling portentous, suited io excite astonishment or alarm. The New 'lest, has it ouly in the plurat, and always in eonuedion with 'signs.' It is uniformly translated in fim. Ver. 'womlers.' (Comp. 24: 24.) 2. Junumis strictly signifies puwer, whether physical or moral, whether natural, acquired, or bestuwed, and is olten tratuslated 'pworer, (e., $/ ., 2.2: 29 ; 24: 29),: 26: 61$, and in liev. Ver. $11: 2.1$ It is ia com. Ver, tramslater 'murate' in Mark 1: 39 ;

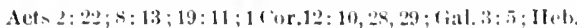
$\because: 4$. Of these passages Rev. Ver. gives 'mighty work' in Mark 9: 39: Aers :2: 22, "pwwers' in Jheh, 2: 1, and retatiss 'miracle' in th" rest, always putting 'pwwer' in the matrin, fro Com. Ver. gives 'wonderful works' in 7:22 (liv. Ver. 'mighty works'), and 'mienty works'

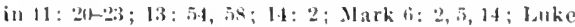
1): 13; 19: 37, which liev. Ver. retains, "xecpt that in Mark 6: It it elanges fo 'puwers, as in . Matt. 14: 2. A nul yel in all these places exept 71 ark $6: 2$ it wals already remlered 'miracles' by Tyndalc, rran., licn, and Rheims. So Nores, except in llatk fi: 14. This eonfusion might be almost entirely corrected hy uniformly and the multitude correspond. (Mark $3.20 ; 3$ 3I I.)

1. 38-42, TUE RORIBES ANI PJARISEE⿱ Ask A Firis. Comp. Luke 11: 29-322, which probably rofers to a subsenuent oreasion, in Judea or l'eren. (Sereabure on v.2.)

38. Answered. This was their response to the sevare and solemn words he had just sputien. (v.3.37.) Certain of the scribes aud Platisees (eomp). un b. 24) did mot encour with those he had reproved in aseribing his miracles to Betzohul (eomp. Luke 11: 15t:), but they intimated that the miracles he had wought were insufficiont to sati-ty them ot his divine misom, and as he hat impliedly claimed to be the Mexsiah (ve ex) they" would like to se him present a sign'suehas they would admit to be nnmistaknble. Their lallguage was respeetful, hitt their design was biad, as appurse from our Lord's reply; and Lulie deelares on the similar oceision that they did it 'tempting him.' (Luke 11: 26.) Teacher, didaskatos, see on 8: 19. We would (wish to) see, as in lit: 24 .

All we are here told is that they asked to see a "sigri". Iake (11:16) says that on the similar accision they sought of him a sign

rendering this word 'miracle' wher'er it denules a deed of supernallural power: since our word niracle, although in its Latin origin signifying a womder, is mow regularly userl in llie general sense of a sujeruatural deed. 3. Semerom, a 'sigu,' that by whoh something is signified or known, is used of things mot supernatural

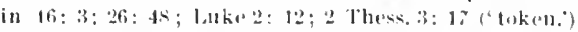
In all ofler passiges it deuotes some more or less dislinety supernatural event. It is usually translated 'sign.' But rom. Ver. has 'mirncle' in luke $2: 3: x$; Iohn 2: 11, 23; 3:2; 4:54; 6: 2, 14, 26; 7:31:9:16; 10: $41: 11: 17 ; 12: 14,37$; Aets $1: 16,22 ; 10: s ; 8: 6 ;$ 1.7: 12 ; linv. 13: 14; 16:11; 19: 201; and 'wonder' in Rev, 12: 1, 3; 13: 13. In all these prasagera lies. V.r. has given 'sign,' execpl luke 23: s; Acts 4: 16, 22, where it retains "mirate', placeing "sign' in the margin. In these last eases mirate seems in linglish a betler word, but the oflerer would sutfice, and Reve. Ver. has aften sacritiond much more than this fo preserve uniformity of rendering. The bible roion litevising remlers nufiomly the lirst word ly 'wobster.' the

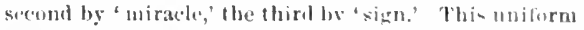
rendering would make the important subject of nitacles in llate New Tost. alpureciably platuer to the Linglish reader. 
:3) But he answerul and suid unto them, An evil and alulterous generation seektib arter a sign; and there shall no sign be given to it, but the sign of the prophes Jolias :

to For as Jonas wat throf daysaud lble nights in the whale's belly; so shall the son of man be threedass ard three nights in the heart of the earth.
39 from thee. But he answered and said unto them, An eril amb alulteruns generation secketh after a sign; and there shall no sign be given to it but the 40 sign of . Fonh the prisphet: for as. Tonah was three days and three nixhts in the belly of the l whale so shall the son of man be three days and three

Gr. sea monster.

from heaven.' And on another oceasion (Matt. 16:1), it is likewise 'a sign from heaven.' Mones gave manna from braven, Joshua made the sun and moon stand still, Samuel ratused thunder and hail in time of barvest, Elijah brought down fire fiom heaven, and rain at his worl, lsaial spealing for Jehovalı) bade $A$ haz ask for a sign, "either in the dopth, or in the height above." Somesuch sign as these the Seribes and Pharisees probably wanted. They may lave taken literally the predietion of Jocl :2: 30 . (Acts: 19.) Comp. below on 24: 30 .

39, 40. An evil and adulterons generation, viz., one which has forsaken Jehovah, and demamls a sign sueh as itself may dictate. 'Adulterous,' when thus figuratively employed, is usually applied in Old Test. to idolatry (Isa. $57: 3$; Vzek. 16: 15: Hosea 3: 1, etc.), but it is applicable also to any sin by which the nation forsonk her divine husband. (ump. James 4: 4, Rev. Vur.) The Jews had never beon generally idolatrous since their reofurn from the Babylonian eaptivits, but they were God-forsaking and wicked. And there shall no sign be given to it. Our Lorl wromght many mirarles, and these actually wereand anglat to have been considered, -igns of his divine miscion, as Nirolemus

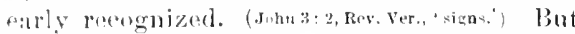
when with a blonding of jolle curiosity and molelict, they asked him to furnish a special "sien" (and of the procise linel that sutere their fancy), he would not do it. Solikewise in Li: 4, also at Nazareth (Juke t: 2.3 ff.), and hefore

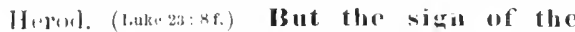

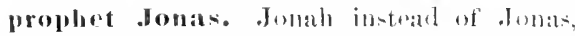
aenen $1: 2$. Wor as Jouas was threv lays and three wights in the whildes bolly,

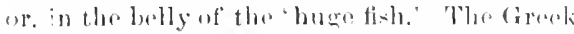

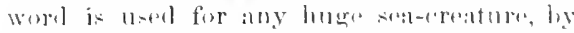

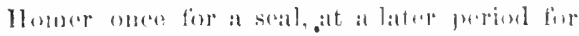
the whale, the shatr, the dog-fi-h, wote. The Hohrew simply says a grout fish, and tho

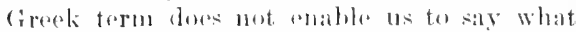
kind of tish it was. It wastranslated "whale" because that is the largest of the huge creaturw denoted by the Greek word; but the pendering was unfortunate, for the whale has not a throat sufficiently large to swallow a man, and this fact has given rise to some sneers from skrptics of the lower grade. The sharli or the dog-fish aould readily swallow a man, and whtio luman budies bave sometimes boen found in the stomach of fishes of this kind, The prophet's preservation was obviously miraculous; but it is useless to make the mere doglutition a miracle, when the language does not really so iudicate. So shall the son of man, $i$. $e$, the MLesiah, sce on $8: 20$. In the heart of the earth. This expression was probably used with reference to that of Jonah 2: 2 , 'heart of the suas'; comp. Dent. 4: 11, "unto the heart of heaven,' Psit. 16: 2, 'in the heart of the sens,' (all these passages in Rey. Ter. and margin of Com. Ver.) The reference is to our Lorl's interment, and the pasiges compared show that there is no propriety in insisting, as many do, that the language is too - srong for that simple idea, and must therefore be rofered to what is called his "elescent into Hades." Three days and three nights. S'ee Jonah $1: 17$. Our Lord was actually in the grave less than thirty-six loours, but it benan before the close of Friday, and closed on the morning of Sundas, and acourding to the mode of eomnting time amomg the Jews, this would he reckoned three days, both the first and the last day being alwaysineluded. (Compon 17: 1, and

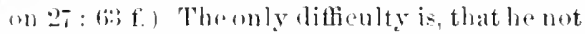
merely says "three days," but "three days and thres nigluts." when he spent anly two nights in the tomb. But the Jews reckomed the night and lay as togrther constituting one periont, and a part of this perion was

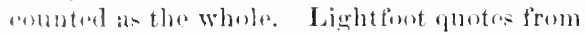
that oremalem T'almul two Rablicas saging, "A day and a night make an Onah, and a part of an Onah is as the whole." There was no way to "xpmess in Greok this period of twenty-four hours, except by day and night 
41 The un'm of Nineveh hall riso in jubsurent will this genesation, and shall comdenun il: becanse the'g repented at lh. preaching ot Jomas; atul, behold, a greater than douas is here.
4) nights in the heart of the earth. The men of Nitivils shall staml up in the judgment with his ganeraljou, and shall coudenall it: lor they ropented at (or night and day ) at here, or l,y the late and

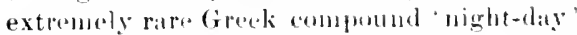
(zulechthemerone) ued in 2 Cor. $11: 25$. It wits nutural to chomes bere the fiomer phrase (even if we suppose the other kauwn to Matthaw), in order to state more strongly the similarity of the two canes. We fiud a parallel use in 1 siom. :30: 12 t., where it is tirst said that the Equptian had eaten mobing "three days and threenights," and then. "Iny mats-

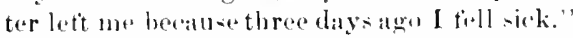
So also in E-ther 4: $16 ; 5: 1$. Some have inferred frem this pariage of Ilatthew that .Je-tis must have remained seventy-two thil hours in the grate; but onme of the axpresions ased in spealing of his re-urrection alsolutely fophid this. See on 25:63. The only sign which hombl be given to that wirkid generation was "the sign of fonth the prophet, a sign risembling the miracle which oceured in the ase ent lomah, viz, the resurrestion of Jest aftur being three days in the tomb. Jombin aniraculous deliveratue from the belly of the fish would naturally he made linuwn by lim to the Ninevites, in aceounting tor the \%all with which he prerelatined his mesiage (ecomp). Lulke 11 : 30; "Jumblh wits a sign to the Ninevite. ), and would contribute to thair reception of his messide. And so the restr-

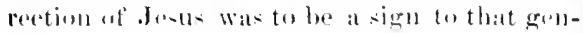

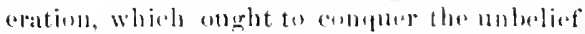
of the must perverse, and did conpuner in

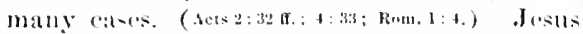
makes a similar obecure allukin to his resurrection in Juhn 2: 20, in which otas also he hat boent askiod for a 'sign.' John: $2: 1,1$

11. By a natural association of isleals, nur Lord pasie- lo say that the men ot "lhis gente- "ration areating much more wiekedly that did the Ninerites. It was a sublimespecelacle: when tha whole population of that vist lonathon city, the proul king, the mobles and all, down th the very humblent, repented at the preaching of donah. (Jouth $3:$ a-10.) This repentanere, both in the griet, the reformation, and the praver for forgiveness, wat have been genuine, tor otherwiec frod would not have regarded it, nor would leas have alpprealed to it lacere. Suberguent generations relapsed into idelatry. but so it eften was with Isratel. Shall rise, mure literally, stand up, and Rev. Ver. su renders, in order toleave rowm for the idea of standing up to bear witness. als in Matthew 14: 50. But this is the common term for the resurpectom, more eommon than the literal 'be raiced of v. t2, and dues not probably mean anything ase in the prosent catse. In (the) judgment, see on $11: 2.2$. With this generation, $i . a$ atlong with, in emulany with. And shall comdemo it, show its guilt and desert of eondemnation, by the antrat between it conduct and thoir own. (Comp. 11: 2.24. Repented, the vert correspunding to metrmoir (sere an 8 : 2), denoting not merely regret, hut change of mind. Tymdile, Cratu.. Gen.. "annended." At the preaching, ur proclamation, the word heing derived trom the rech lerusso, explatined on $4: 17$. Thes

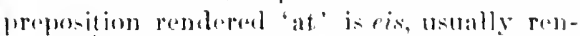
dered 'into' or 'unto, and often demolinger design or aim. It eannot possibly have that sense here, for cortainly the Ninerites did not repent in oreler thent Jomals nighlit preach. It alearly introduces the aceation or eremed

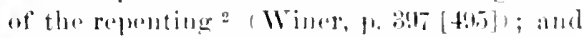

count is alone anthentic: lut low is amply refurel ly

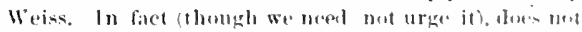
lake's uwn language really rest on the requmblanep

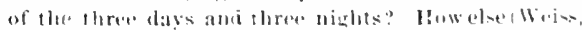

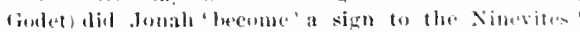
:tul why else does lesus say in lokke that the son of

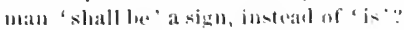

"The (uhi latin given here in some of its forms the" word-fur-wurl translation in predicationem, while uther furms and the vulgats latse in predicalione. The leshito has 'in,' $i$. e., ou the ground of.

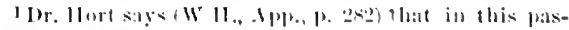

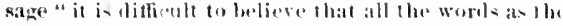

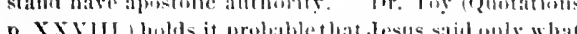
is recorrleal ill buke 11 : 30 , and the rest ill Mittlum was added hy "the ural tratitim." Why not then refer to another similar patsige, yark \&: 12, "1'beres stall no sign he gisen unte this grateration," and eonrelude that

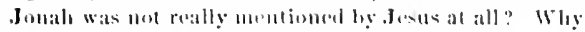

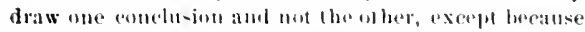

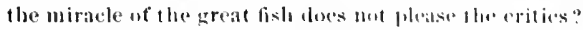
Bleek attempts an argument to prove lbat lake's ac-
} 
42 The queen of the south shall rise 111 in the jutgment with this generation, and shall condeniu it: tor she came from the utermost parts of the arth b hear the wislom of solomon; and, hebold, a greater than solonum is liere.

43 When the unclean spiril is gone ont of a mau, he walketh hrough dry places, seeking rest, and tindelh none.
42 the preaching of Jomah; and, behold, ${ }^{1}$ a greater than Jomah is here. The queen of the south shall rise up in lloe judguent with this generation, and shall condem in; tor the came from the ends of the earth to hear the wisdom of solomon; amel behold,

4: I a greater than solomon is here. Bul the unchean spirit, when 2 he is gone olll of the wan, passet through waterless places, seeking rest, and findeth

$1 \mathrm{Gr}$ more than...2 Or, it.

so) it may pussibly have the same force in i): 11 and Act 2: 38. And behold, calling attention to something important. A greater -or morp-than Jouah is here. The word is neuter, not 'a grenter (man),' but '(something) more.' (Comp. on 11: 9; 12:6.) If more than Jomah was here, then the men of this generation were under greater obligation (1) repent than the Ninevites, and all the more guilty for not repenting. Some records of buried Nineveh have been recently exhumed, and the world eagerly ronds their strangely recovered history; let us not forget that the Ninevites of Jonalh's day will rise up in the judgment and condemu all those of every age who hear the preaching of the gospen and will not repent. Heiss: "If Juhn already was more than a prophet (11 9), why should not the mightier one to whom he pointed (3: us) be beymond eomparison more than Jomab?" Whorever the gospel of Jesus is rally preached, the same thing holds true; for the gospul, when spoken by the humblest follower of Christ, has higher elaims to be believod and heeded than had the solemn warning of Jomah. This reply of our Lorul somewhat resembles that made at Nazareth. (1,nk.4:23 f.) In both cases miricles were do manded, and in both the answer rebuked the arrogance of their claim ly showing that God hat sometines blessed Gentiles mather than Juw:.

12. Another historical intanee is ardad, to show still further the wiekerluses of this genaration. They notonly refused to beed the call to repentance made by a more than prophet. but they slighted the wistom taught by a more than solomon. 'The guren of the somth, atled in I lings 10: 1-10 "the queen

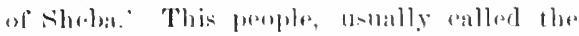

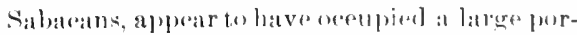

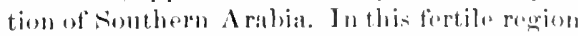
they grew riels hy ngrienlture anel trate, espacially the great trad. with Inclia, from which comntry they lorought spiees, prodions stones, ete., to supply the Western nations.
Hence came that abundance of costly articles which astonislied the court of Solomon. In Joel 3: 8 the Sabacans are called "a nation far off," and so in Jer. 6: 20, Sheba is "a far country." This corresponds with our Lurd's expression, came from the uttermost parts (the ends) of the earth (comp). Deut. 28: 49), which, according to the knowledge of the time, would be 10 exaggeration as applied to the southern extremity of the A rabian peninsula. 'Ends' is literal (so Wye., and Rheims), and simpler than 'uttermost parts' (Tyndale and followers). There wore few books in the days of this queen, and the only way to get the full benefit of some fimmous man's wisdom was to visit and converse with him. In our day of multiplied literature. thoughtful comversation on inportant topics is tou little practiced. A greater (more) than Solomon is here, as in v. 41. It must have startled the Jews very much to find Jesus quietly intimating that he was smperior, not only to the prophet Jonah, but to Solomon, the magnificent monarch, the revered sage. In the case of a mere man, and a man wise and humble, such a elaim would seem stringe. Shall not the delicate woman, whotook this long and trying journey to hoar the wisdom of Solomon, condemri us in the day of judgment, who have the history and writings of Solomon, the life and sayings of Jesus, recorded in a book which is any hour within our reach-if we neglect to seek its treasures of wistom?

II. 13-45.-JESUA ILLUSTRATES THE Consequexces of Neglectixg His TeachIxas. Fu un the similar oceasion of Luke 11 : 24-26. The illustration was doubtless suggested by the healing of a demoniac (12:22) which had led to the foregoing discours: Plumptio thinks this parable "eomes in nhruptly." But the wieked conduet of "this generation' in disregarding him who is more than Jomah or Solomon (v.41s.) is aceountod for by the parable, whieh is distinetly applied to them (r.45) and gives to our Lorl's inme- 
4 'Then loe saith, I will return into wy louses from whence l eame out; and when lite is come, he fimelli it emply, swell, and garmishal.

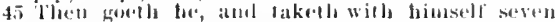

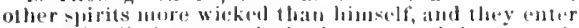
in and awell there: and the last state of llat math is worse llan the lirst. liven so blatl it be also unto llais wicked gentratiou.

$10 r$, il...20r, itsety.

diate heareri a new watring. This view is made clearer by the proper reading 'but' in v. 4:3. For when, ate., reall, but the neclean sparit. when he is gone ont of the mene, the spirit and the man, meaning a suppened or ideal indivilual, taken ats representative of what nlways lapprons in such at ease. For 'melean' see on 10: I and 8: 288. He, or it, ats in margin uf Rex. Ver., the Groek word fur "spirit' being neater, and so the pirsnoun being neuter. (so in $v$. It and fis.) Through dry (waterless) places, the litural tran-lation. It was a prevaling Jewish idea that evil spirits apecially frequented deart

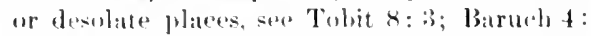
3.). And it need and beremsiderefl merely ats a Jowish notion, fur it is favored by the inagery of this patsinge amd of liev. 18: : 2 . It the evil spirits that infest the earth are sometimes unt oecenpind in posessing or tempting men, what spots woukl seem to be a more appropriate abode for them thatu parched and desolate places? As to demoniacal pusesessions, see on 8: 28. That demons dicl sometimes re-enter, attor lueing tast ont, is impliod by lark ! : "o-j, "Como out of him and enter ne more intu him." The house denotes the man whom he hat pussesed or aecupied. Epon returning, the spurit finds the house moorecupied, swegt, and adurmed-just reasly for nu wecupant; which, ate said of the matn, demotes that after lowing delivered from the unclean spirit ha does not reaplo his mind and beart with other and botter things, but lives in a state of readinass for repusession. This lunguago distinety indimates that the poseibility of demoniancal pusasions depended (ut least in some instancese on the mortal and spiritual eomelition of the per-un, al we wh an his physigal and mental health. Tha buelean sprit, finding wo rost in all his wanderinge, no spot where ho ean bes centent quietly to

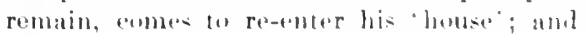

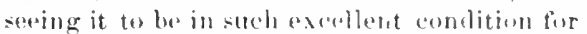
oecupation, he goves after others 10 share it with him. Seven other spirits, the com-
$4 t$ it not. Then ${ }^{1}$ he saith, I will return inter my house

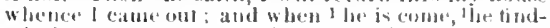

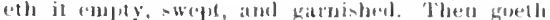

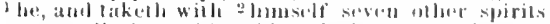

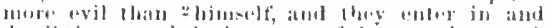

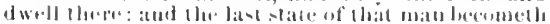
worme Ilatil llat tist. Even so shall it ln also unlo llikevil generation. mon, wit-rencurring mumber (comp. Lakes: 2 and a muele greatter number in Mark is: 9. More wiched. There sesm then to be thegrees of wickeduns animg the drmoms; just

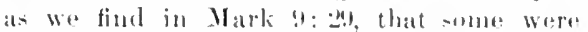
harder to ratst olit Lhan wethers. And the lant state (things) of that mun is (or, beemeses) worse than the first (things), $i$. a, his latet fortunes or eondition. Sumbe propuse to tiake the pasage as a propely hepolhetichl illustration, derived from foummon fincies and modes of expression, and not implying that = = and at thing exer really happlens ats at dispusesesion and repussenton. Whe have seent on $8: 28$ that the demontaleal pusessions must be taken as real, there being greater difficultios about any other view. And so here. Tho illustration is an ideal instaner, as the forms of axpresions show, but it corresponds to and repressents ralities. Even so shall it be also moto this wicked generntion, fomp. v. 39; 16: 4; 24:81. Our Lurd distinctly applies his illustration to the. Jewish nation ot his awn gerieration. The di-porsosion may pofer to the remarkalule abanderment al

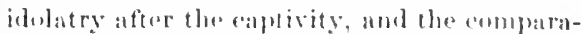
tively improved roligious and mornl andition of the perple. Then the empry, swept. and garnished stage might deseribe the refiacal to aeenpy themsalves with the spiritmal and salulary teachings of Jeus. Or. the dispussession may refer to the great impresoinm mall by John and Je-1s (11:12), which in

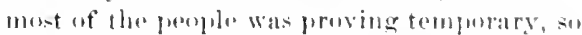
that in finally rejecting the Menianic reign they worlt locenme more completely than arer thro sulgeets of siatan, and in torty yours

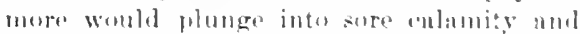
rain. Varion additional applientions of the illu-tration might he mates. an in others of and Lord's parables: hut stch applieations are of

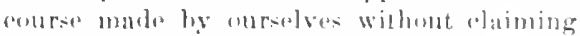
that they were contemplated he dets.

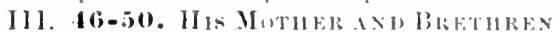

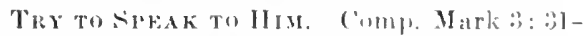
35) luke 8: 19-21. It wis not enough that 
4t; While the get talked to the paple, behold, his mother and his brethren stoul wilnoul, desiring to speak with him.

47 'Th(a) (ostesaid wn(s) him, Pehold, thy mother and tiog brothrenstaml withent, clesiring tosgeat with thee. is lsut ha answered and said unto him lbat lold him, Who is my nother". and who are my brethren?
46 While he was get speaking to the multitudes, behold his mother and his brethren stond without, 47 secking to speak to him. I And one said unto him, behold, ihy muller and thy brethren stand wilhout

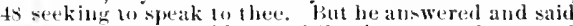
unto him that told him, Who is my mother: aud

1 Some ancient ituthorities omit ser, 47.

the loaling men atuong lis own people whom hre (atule t1) salve (Johu 1:11) rejected hion with blaphenies; but it was a fart of the cruel

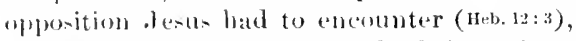
that onme of his nearest kindred for a long tinu misunderstond him, so that his brethren talunted him (Johu $7: 3-5$ ), and on the present "carion "his friends" even said he was insane, and wi-hed to stop his teaching by force. (Nark. 3:21.) By combining this aecount with that of Mark $(3: 20,21,31)$ we see that Je-us and the Twolve eame into a honse, where a crowd arsembled, so that they could not so much as "at breat, and that" his friends" (Nark:3:21), upon hearing of it went forth to seize him, saying that he was 'beside himselt.' The peculiar expression in Mark does not eontain the term 'firents, but signifies those that were of his family, or his comutry, or his marty, rete. It camnot here mean the apustles, for they were with him in the hons.; and ats "his motherand his brethren" presently reach the houne (sark $3: 31$ ) desiring to spwak with hion, it is natural to understand that they are meant by the plirase, valuely rendered, "his friends. (omp. Fritz. and Mey. (on Mark), Grimm, Wincr, ate. Meantime, in the house, he lualed a demoniace and then ocenered the liaphernous aceosation and the disourse forbwing. While he was yet spealing, hi mother and lirethren arrived at the house, and finding it difficult to enter because of the

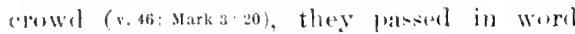
that they wore without, and weres serking to

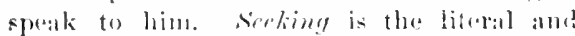
pardet transtation, and so Wre and Rheims. white Tymble and his followers inproperty rondered it hy desiring, which tails to indiaite that eflorte were made. IIis brethren, ses on 1:3: n. () any viaw they were near

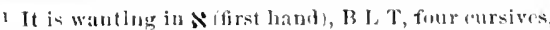
old Syrite, and two colpies of the (1) hatin. There is obvious ground tor supposing it to have leesh inserted bore from the cquivalent statemsent which oesul- withont variation in Mark $3: 82$; Luke no reason why jt slonld have been onitted, it originally relatives, which is sufficient for the present patsage. Bible Com.: "From the mention of his mother and his brethren only, it has been conjectured, with some probability, that Joseph was now dead." T. 47 must pretty certainly be omitted, having beren bought in here from Mark and Luke to explain the phrase "him that told him' in v. 48. There is evidently no los of substantial meaning.Are we to understand that Mary wished to seize him, and thouglit him beside himselt"? She mont surely bave remembered what Gabriel had told ber, and simeon and Anna had said; how can she have questioned that be was the Mesiah, and was to sit on tile throme of his fither David? Did she merely give way to the influence of the 'brethren, or did she in fact, as many prefer to think, go along from no smompthy with their views or intentions, but in arder to interpose between Jetus and their violenee? Some suppowe that they were only concerned abont his health, from hearing that he was so thronged as to have no opportunity of taking food, and was still speaking on with solemn vehemence and (on-uming ze:al; but this would hardly have matre them venture to 'seize' him. (Mark 3:21.) Our Lord's reply here seems to intimate that she, as well as the brethren, was nnwarrantably interfering with his work, at he had gently robuked her for doing on a former wecasion. (John2:4.) Porlank Vary sometimes hecame preplexed, as John the Baptist appeare to have been (se on 11: 2), by her son's pursuing a conreso widely different from what she, in common with other Jews, exprected of the Irsiah; and in this frame of mind she rould more rasily be prevailed on by the "bethren to accompany them, without fully haring either their view or their purpose.

present, save a possible offence at the repetition of th. same words, as in $v .46$; but that is a peenliarity of If harew styla, tom commun in the Bible to bave prorokel critical exeision. It is omitted in Weiss and II 11. 


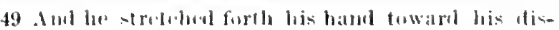
eiples, and said, behold my mother and my hrothron:

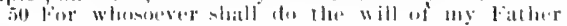
which is in heatren, the same is my hrother, and sister, alld menther.

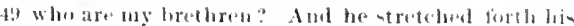

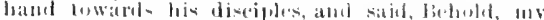

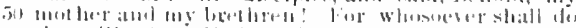

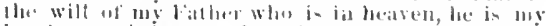
broller, and sister, and nuther.
The porson who told . Iesus naturally thought that he wonlet eon-isler the clatimsof his mother

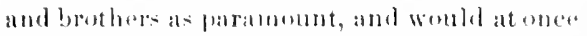
goforth, or callor throm to be almitted. But he know huw hi-brothers misundersemel him, and was aware that their motive at present was nut frimelly. It $-x^{2} m s$ to be inplied that

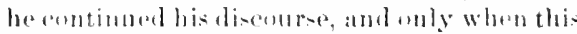
was fini-hod, and the crowel was diepersing.

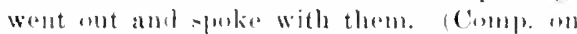
13: 1.) Ilowerer that may be, he touk the oceasion to make a most affereting declatation of his here fur his lineiples-for all who do the will of his Father in heaven. What hesad was atelersed aprebally to the person who spolie to him (v, t*); lutt akso (Mark $3: 34$ : Luke $8: 21$ ) to the persubs present in general. IL stretched forth his hand towards his disciples (comll. Mark 2 : 34 , the word here probibly inclublinge uther disciples as well ats the Twelve (see an j: l). 'The same literally $H^{\prime}$ is my brother, with emplatis on 'be,' as in 1: 201. And sister. ()ur Iorel lund "sisters' in the sultie sense in which ho had brothors, probably in the mont natural

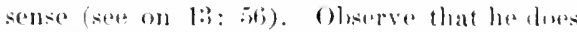
not siy hrothor, or si-ter, or mother (1 Tim. s: 2 ).

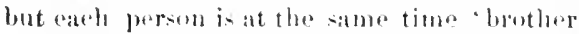
and sister and mother. as mubh belubed as all these combined. Simmohat similarly Anderomalhesals to her hushand, "Hector, thom art to mo tiather, and revered muther, and

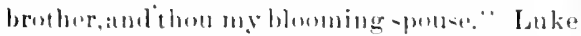
(8: 21) only gives the enenomal sentiment in thes briefest form. And $=1$, no lfumbt, many a

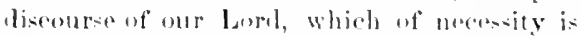
very liriefly reperted to 11 , was in the actual delivery full wi such poisted interrogation and inpresive ropetition as we have lore in Matthrw and in Mark.

\section{IIOMILETICAL, AXI PRACTIC.AL.}

V. $38 \mathrm{f}$. Men wforn demand further evidence of ("hristianity when they hatrabundant evidence but for their lotermination nut to believe. Therere is a moral probation involved in bolieving or rejecting tha gapel.

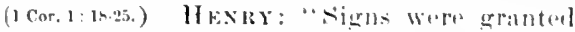
to those who desired them for the ementim-

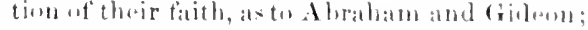

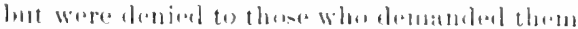

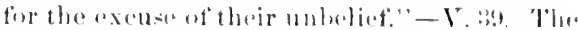

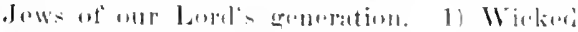

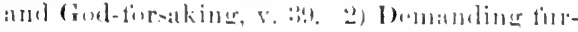
ther evidesece atmiel all hi- toachinge and mira-

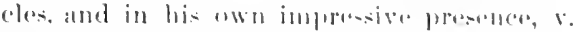

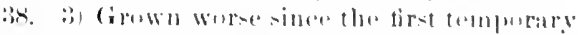
eftect of his ministry, v. 4.) 4), (on their way

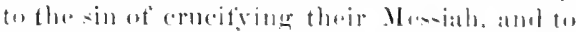
national calamity and lantruction, 5) bes-

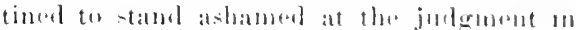
the presence of fientiles whom they despisol,

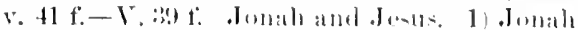
a great prophot, and, Josta- murethan Jumals. 2) The sign ot" Jamah, and th" siern at' Ja-11s" resurrection. :3) The preaching af lomah, amel

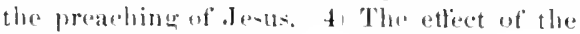
ameand of the onth.

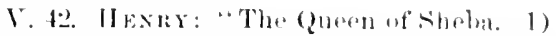
she hat no invitation to siolomon. mor promises ot luing welentued; hut wo atre invitul tu

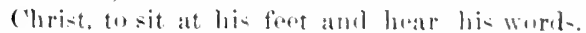
2) Solommon wats but a wise man; hut ('hri-t is

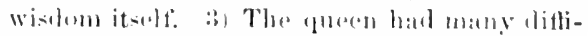

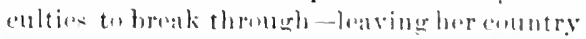

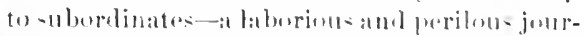

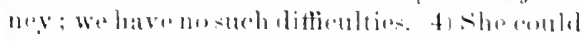

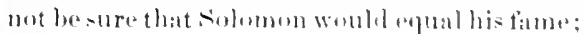
but we commeto Christ upm nos steb unerertain-

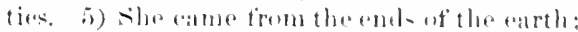

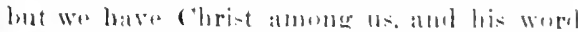

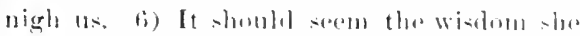

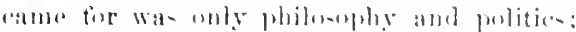
but the wislem that is to lwe hat with chriet

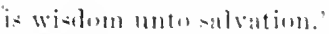

V. lis-4.). Whenever a nation or an indivielual attempts a returmation, the areil prinei-

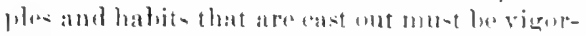

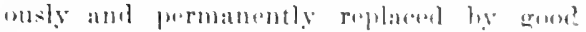
principles and halit-, or the evil will roturn and he worsen thath reser.

V. 4h. dante ambl his muther. I) Trainuerl

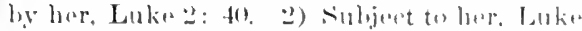

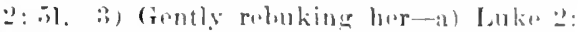

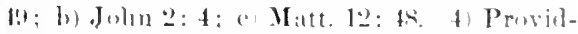
ing for her, Juhn l!!: 20tif. i) Lewiur all tru.

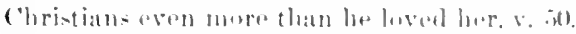
Euersuers: "For lad lie not enterent inte, 


\section{CHA P'TE R X III.}

THIE same day went Jesus fut of the bouse, and sat I by the stad side.

2 Sim him, so fhat he wenl into a ship, and sal; and the whole mullitude sloud on the shore.
1 On that day went Jesus out of the huuse, and sat 2 by the sea side. And there were gathered unto him great multitudes, so that he entered into a boat, and arthly kinship solely for the sake of the highrer spiritual relationshi] which be was about to found? Thus it was not that Christ set lightly by his mother, hut that he confoumed not the moans with the end, nor yet surrendored the spirit for the letter of the law "f love." Bexgel: "Ile does not eontemn the mother, but he puts the Father first." Corks.: "If she is nothing protited by being his mother, were it not fin piety in ber, hardly will any one the be saved by his kindred. For there is one unly nobleness, to do the will of Goul. This kind of noble birth is better than the other, and more real."

\section{FIRST GREAT GROUP OF PARABLES.}

Ch. 13: 1-23.-The Parable of the SOWER.

The Parable of the Sower, and apparently all those in eh. 18, were delivered on the same day ( $(x-1)$ with the discourse occasioned by the blatphemy against the spirit. (see on 12 : 2.2. 38.) J fous went forth trom the house in which the bharphemons aceusation had ocurred, and at beside the Lake of Gaiilee, and there spoke the parables of $v$. 1-35, viz, the siower, the Tares, the Mu-tard-ceed, and the Latren. Then leaving the crowds and entering the house $(\mathrm{r} .36)$, he adderl the parables of the Hid Treasure, the Presions Pearl, and the Net. (v.36-53.) On the evening of that same day (M:rk $4: 35)$ he went alerose the bake to the district of Gatara, stilling the tempest on the way. and there healed the two demoniansincidents which Matthew's mule of gromping topially has led bial to introluce in an

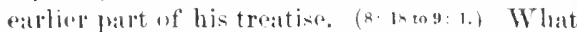
a busy day was this! beginning and ending with miracles, and tilled with remarkable disaoure. And our loord felt to the fuil, in his human nature, all that beslily and mental fatigue and prostration which such labors

1 It is probahly safer to follow the text 'into a boat," rather than the common cires text, whithollght to have been translated 'into the bubal' lat the anticle may have been omited hy Alexamdrian correctors (s B C I, Z, some cursives), because no boat has been must moduce. Seizing upon every opportunity of doing men good, excited by a consuming zeal, yearning in unutterable pity over the perishing, oppressed by responsibilities such at no other was ever called to feel, and barassed by the must unjust and insulting aceusations, he toiled on through the day, and at evening was so tired that be slept soundly on the cushion amid all the tossing of the waves and roal of the storm. Another example of a very busy day is pointed ont in 14: 39 ; a third was the day of the Passion; and dombtless there were many others, it being only oerasionally that the brief narratives of the Evangelists give us any complete view of his oeeupation throughout the day. With this section eomp. Mark 4: 1-25; Luke 8: 4-18.

1 f. The house, see 12: 46, and coinp. Mark 3: 20. Sat, the usual posture of a Jewish teacher when giving instruction. (Comp. 5: 1.) By the sea side, the Lake of Gatilee. (See on 4: 18.) Great multitudes, or 'many crowds' the same expression as in 4: 25; 12: 15 , and often. These crowds so thronged around him that he conld not be seen as he sit, and could not himself have any commanding view of those be addressed. When be entered the boat, probably swinging by its cable or its anchor some feet from the shore, and all the crowds stood upon the sloping and sandy beach, the sitnation was a bealutiful one for agreeable and impressive speaking. Much less probable is Plumptre's view, that he entered a boat to prevent a "hostile attack." The preeise point on the lake shore annot be determined, but it was probably in the Plain of Gennesaret. Ship, or boat, ${ }^{1}$ ax in Latin versions. Wye, and Rheims, rather than 'ship' as in Tyn. and followers. (Comp. on 4: 21.) stood on the shore, beach, the exact word for the Greek, which denotes a pebbly or sandy shore, such ats the Plain of Gennesarot exhihits.

reently mentioned in the narrative. So in $8: 23$ the article is onitted by $\mathbf{N}$, (second hand) B $\mathrm{C}$, some eursives. We conld explain the article ly referring to Wark 3: 9, and supposing that the boat there ordered hat been kept for the use of the little company. 
3 Aml lue spake many things unto them in parables, saying, behold, a sower went torth to sow;
3 sat; and all the muthitude stoul on the heach. And he spate w lew many loings in parables. saying,
3. He spake many things unto them in parables. The nature, dreign, aud jroper interpretation of our Lend's parables is a subject of great importince.

1. The (ireek word which we borrow in the form parable signitien a comparinon, conveying literilly the mution of putting things site by side, wheroby their resmblance will be

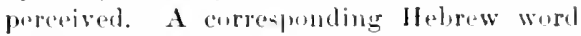
(moshal) is employed in the Uld Test. to denote (1) an illu-trative comparison (k.zek. 17:2: 24:3) ; (2) a sententious silyingor apophthegm, such as frequintly involves a comparion (Prov.1:1,6; 26:7,9; Fccl. 12;9); (3) a current, (1ften repeated saying of this kind, a proverb (1sam. 10:12; 24:13; Ezet. 12:22; 1.:2:3. etc.) ; (4) ally high wrought expression, done into parallel clauses like a comparison, as wa common in Habrew poretry (Nam. 23:7, 14; Joh 27:1; 29. 1: I*1. 14 4; Mle. 2:4; Het. 2:- ) (5) an obscure and derp saying (P.a.49:4; $7 x: 2)$, since pithy comparisons frequently require $m$ uch reflection in order to get their full meaning. It was matural that the New Test. writers should empluy the Greek word with a somewhat similar latitude of application. Alecordingly wo find it denoting (a) an illustrative comparison without the form

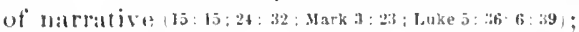
(b) an illu-trative complarian in the form of narrative, which is the common use in the first threa Gonets, and has anearioned the penular restriction of the term to our Loral's marative illu-trations; (e) a marrative illustration mot involving a comparion, als the Rich Foul, the Phariaes and Publiean, the Goulsiamaritan, the Rich IIII and Layarus; (d) a proverb (bnket: 23), corre-ponding to which we tinel that in John 10: is another word, which strictly denotes a proverb, is applifed to an illustration eomplarison; (10) a profomble or

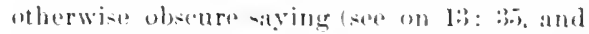

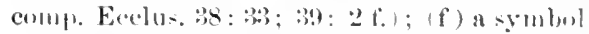
or image not axpresand in languaga at all. (Hel. 9. 9: 11:19.) Commonly, then, in Matherw, Mark, and Luke, (Jolun thes mot employ it). the word we borrow as farable denotes an illustration, most freduently in the form of narrative, and usually, in acerorlance with the origin of the term, involving a comparien, though sometimes, as in (e), it is only an exumple of the matter in hand, n take in peint.
The puphas restriction of the term to narrattive illu-tration-, is unfortunatu, for thele is no esential difference between these and ather illu-trative complarisols. (see 1)rummond, "Parabolic Teatching of our Lorel.", Some of the narrative parablen are very brief, as in

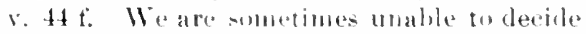
whether the natrative is real or thetitions. But in the hatter "are the story is alway presible, while fables areoften impusible, representing berlets and treess an epeating, ete. The dis-

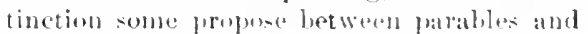
allegures is prerarions. Is not the parable of the Prodigal sim an allegory?

2. Our Lurd": Adsign in employing these charateristic illustrations mu-t be enolsidered at manifold. (1) Like all other teather-, he illu-trates moral and spiritual truth ly (o)mparison of thinge physical and social, the material for this abuunding in actual anabgies betwern the two splieres af exintence. Sinch teaching by illustrative stories and ot ber eomparions has from the arlient time-been partieularly ammon in the Eant; a few examples

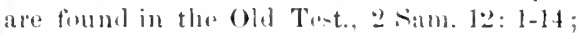

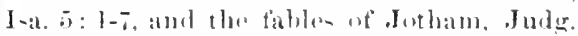
4: 8 , aml of . Forl, 2, sam. 14: 5-7: and it appeate from the Talmud that a like method was common among the . Jewi-b teachers in the time of Christ, as for example (Gill) one-third of Rablbi Meir's distourose consi-ted of parat

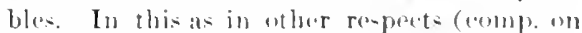

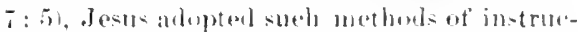
tion as were natural to men in general, ant fomiliar to the ofes in particular. From the rheturial puint of view un Lurd' - illustrations are marked by exquisite simplicity and elogance. at we wh a the profoumlest wisdom. Yot while of uneyusled exopllenee. they do not differ in kind, but only in degrese, from uninopired illustrations. and must he interpreted on the sande general minciples. (2) The parablase alsu servesl to put truthse at first hut imperfectly understend. inte a compant and purtabla form, in which they anuld be as-ily rememberest, till ther shomld afterwards enome to be molerstomal more thoroughly. (:) They enabled the Great Teateluer to state truth- likily to erive offence, in areh a firm that the enquiring and spiritually dispoed conld understand, while 
(aviler would nut see their point so as to be prematurely exeited to violent hostility, and thus, while instructing seme in hi- miscellaneous atudience, he was not, in respect to others, casting peirls betore swine. Sometimes, tro, a mans ascent might thus be gained to a principle before his prejudices were arouved, as Nathan dealt with David. (2 satw. 12.14.) (1) In so tar as parables were obecure to peroms lacking in lively interest and spiritual sympathy, our Lord employed then ati a judgment upon the willfully blind. This, though not $t$. be reekoned his only reason for using them so frequently from this time torward, is the one which he states when questioned abut the matter on the present oecolsinn. (Sice on v. 10-17.) Henry: "A marable, like the pillar of eloud and fire, turns a dark side towards Egyptians, which confounds them, but a bright side towards Is ratestes, which comtorts them. . . . A parable is a slell that keeps good fruit for the diligent, but keeps it from the slothful." Calderurnel: "There is a complete contrast between the view taken in modern times of our Lard's parables, and that taken by the atudiences to which they were first delivered. Even those who are averse to aeept Bible teaching lave an admirati on of thee gospel parables; ret to those who heard them, they were the most popplexing parts of Christ's dineoures." This is partly beeause the meaning of the parables has become comparatively phain, and partly beature many skeptics now admire the (xoments recarded only as literature.

3. In the intermetation of parables, we have the guidance of our Lord himself, who bas fully interproted thr parables of the Suwer and the Tares and, to sume extent, that of the Net. Remember that our method must aply to all of his illustrations, and not merely to the narrative, to which in popular usage the tarm parable is rentricted. There are four things to be dume. (1) We must make sure of understanding the language of the parable itself, and its varions allusions to physical phenomena or social usages. Thus matuy fat to molerstand the wayside and the rocky ground; the treasure hirl in a fiedd; the patch of unfulled cloth upon an old gatrment, and the wineskins (a- 16f f); the double invitation to a supper (buk.14.16 f), etce (2) We must ascertain what subject our Lord liere designed to illustrate. Sometimes he himself states it, either before or after the parable, or else the Evangelist mentions it in recording the parable; in other cases, the connection, if carefully observed, will suffieiently indicate it, there being few instances, if any, in which we are left to infer the subject simply from the tenor of the parable itself: (3) We must consider in what light the parable presents this subject. Here it is important to regard the parable as a whole, ju-t as we do any other illustration, and not begin by attempting to assign the meaning of particular items, without having con-idered the general drift. Let it be taken for granted that the Great Teacher used illustrations on common-sense prineiples. (4) Then it remans to determine bow fiar the details may be understood as separately significant. In this we can have no general rule to guicle ns, but must study the guidance rur Lord has given in his interpretations, exereise sound judgment, and endeavor to avoid both extremes. The tendeney has usually been towards the extreme of giving a separate spiritual meaning to every detail. I et Augustine already rebuked this by the remark that it is only the ploughshare that cuts the earth, while the other parts of the plough are also neeessary, and, indeed, indispensable. That wlich is the mere filling ont of the story, the mere drapery of the image, must be let alone. On the other hand, it should be remembered that our Lord has carried out his three interpretations in much detail, and we must not reduce the parable to a bare trunk, stripped of all its foliage. In some cases the resemblance or analogy is more complete than in others, and the points of contat more numerous. There may even he point in the illustration quite the reverse of the thing illustrated, as when our Loril's eoming is compared to that of a thief in the night, where there is, of course, uo resemblance exeept as to the unexpectedness of the emming; and so at to the unjust steward (ruke 16), whose conduet, while manitostly dishonest, is employed to illustrate the importance of prudent foresight and preparation for the future. Alexander: "As the sane illustration may legitimately mean more to one man than to another, in proportion to the strength of their imaginative fueulties, it 
4 And when he sowed, somes seats fell by the waysille, and the finwls tame and devoured themi up:

is some fill upoll stony places, where lhey latal not much earlh: and forthwilh ligey spruag ul, lecaldse they hall nollecponess of earlh:

6 And when the sum wat up, they were seoreled; and becallse lhey had no roul, lhas withered atway.

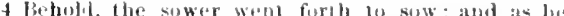
sowed, somereseds ledl by the way sille, and the hirds

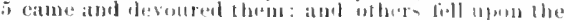

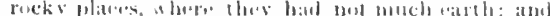

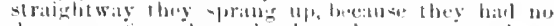

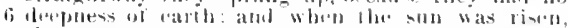
they were seorched; and because lhey hat nu roul, is highly important that, in attempling to de-

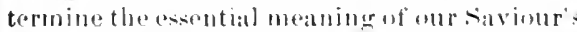
barables, wo slould not comlinumd what they may posibly be malo to maan, with what they must mean tuattain thoir purpone." Te may lawfully rmploy some detail of a parable,

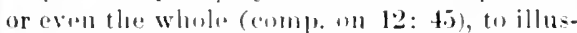
trate some oflere truth than that to which he applied it; but it must be lome arowerly upen onr awn authority. In groncral, the details of a parable must nuver be pressed into teaching what is contrarg to the platin, unfigurative toaching ot the seriptures at large.

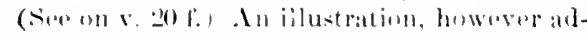
miralble, can moly present its subject in certain aspects.

4. There are three loading groups of our Lord's parables. A amol many isolated par-

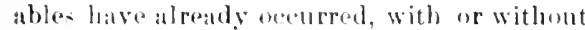
the furm of larrative, as (a) the wise and

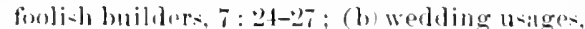

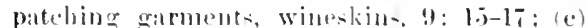
childrun at play. 11: 16-19: (d) the blind

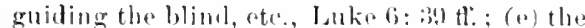
two slebtors, Julio $;: 41 \mathrm{tl}$; (f) the evil -pirit returning. Matt. ]:2: 4:3 45; and it may bo abservel that most of those sporalide paralbles refer to the recontion griven to Christ o teach-

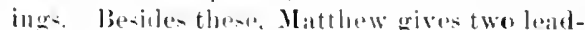

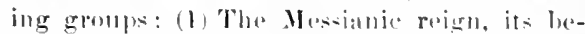
ginnings and growth, $\cdot$ h. l:3; given abuut the middle of anr Lard's ministry (2) The Messiunies roigu, its prongress and consummantion; givom ju-t at the alosts of the ministry. (3) Brtweent losetwo grolles in areler at time, we find a thirel group, given los lalke. ch. l:319, someste which relate to the Mratanderoign, but most of them to individual experionets.

The sevin parables of ch. l: a aru probalbly

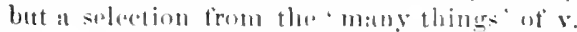
3. Mark 4: 20;-20 gives anuther, nut mumtionerl by Matthew, and the latleruatge ot . Mark 4: 3:3 implies that thero were many others Like all our Lard's illustrations, the paralules of this first gromp wop drawn trom fambiliat soureos-firom agriemaltum, fishing, and mer. chandise, from the proparation ot" breal, and the finding of hill treisure. this last aloo being in the Eats a fiumiliar idrat.

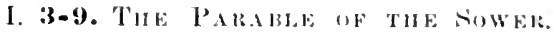
Found also in Mark 4: :3-!1; Luke 8: 5-s.

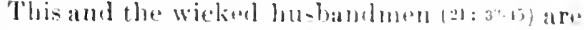
the only parablas recoriled by all three, Matthew, Mark, and Lake. II may andine? ourselves bere to explanation ot the story

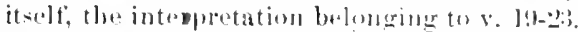
(soe Notes theres) Behold, callines attention to something important. Mark (4:3) pretixes - Ilarlien. I (the) sower went forth to sow, the definite artiele heing employel to designate an ideal individual, who represents a class (commo. on los 43 ), ats it in a fable we should say, "the firmer went wht to louk at his crops." The expresion showsthat this is not given as the narrative of a partictular, actual accurence. Tyndale amet Crinumer give "the sower; King James follownd fienera. Some isfeds) fell by the watyde. The ruals passol right thrumgh the cultivitent lands sece on 12: 1), ambl ats lat sowed the wheat or barley, some of the grains womld fall on the beaten wrentud of the post or path.

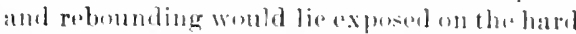

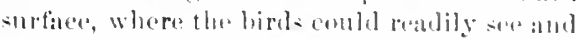
devour them. (Luke 8: 5 protixus tromblu muler fint.') It is still ('ommonn in the East

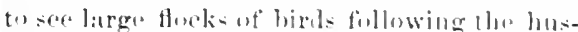
bandman as lu, ons his what, and eagerly pieking up every grain that lats mut sluk ont

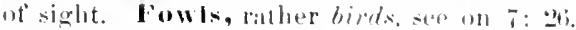
Some (others) fotl upou stoug, or the fucley (placest. Palestime is a lime-tome eomatry (comple 7 : 24), and one will find places "here a bromel, that, limestume rock line just beneatle thesurfice. with a thin labrouf atreth upun it. (Comp. Lulie s: ei, lin, the rueli.")

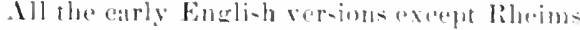

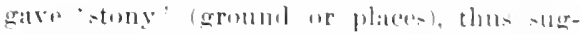
grestinga soil aboumbling in lon-e -tones, which

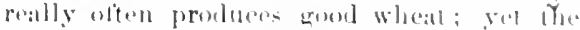
Greek word wak pain and ummiatakille, frome

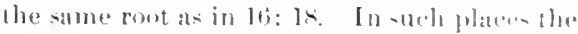

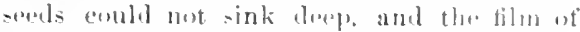
"arth being readily heated becathse at the 
7 And some fell amoug thorms, and the thorns sprung up, aud cboked then:

8 but ofher till intu good ground, and brought forth fruit, some a hundredtild, some sixtytold, some ibirtytollt.

y Who hatb ears to lear, let him hear.

10 And lle disciples came, aud said unto him, Why speakest llom untolbem in partables?

11 Ile answerel and said unl" them, Because it is given unto you to kunw the mysteries of the kingdom of hearen, but to then it is not given.
7 they withered away. And others fell upon the thorus; and the horus grew ul, and choked them: 8 and others fell upon the good ground, and yielded fruit, some a humdredfold, some sixts, some thirty. 9 He that hath ears, l lel him hear.

10 And the disciples came, and said unto hin, Whs 11 speakest thom unte them in parables? And he answered and said unto them, Cnus yon it is given to know the uysteries of the kingdom of heaven, but

1 Some ancient authorities add here, aud in ver. 43. to hear: as in Mark iv. $y$; Luke riji. 8.

underlying rock, they would eome up sooner than clsewhere, and at first would look uncommonly flourishing; but not being able to send roots deep into moist earth (eomp. Luke $8: 6$, when the hut, dry wather came. the stallis would soon wither, and show that the fair promise of a crop there had all been deceptive. Comp. the "grass upon the housetops," Ps. 129: 6 f. Amolng-or upon thethorns, there being in his ficld sume place or places specially infested with these. Persons accustomed to observe wheat-fields will remember to have seen spots where a fow scattered and spindling stalks were struggling for life among the rank briers. Into-or upon the-good ground, free from underlying rock, and from thorns, and plowed deep. Even this would produce more in some spots than in others, aceording to the richness of the soil and its preparation. A erop of even thirty measures to one of seed is quite a good yield. The richer euntries of the East produce very heavy crop (e.g. Gen. 26: 12), and some portions of Galilee have always been singularly fruitful. (Comp. on $4: 12$.) Various classical writers speak of crops as large as a bundred to one, and even two hundred or more, in very rich soil. The point of the whole story is that the same seed prolueed no wheat, little wheat, or much wheat, all according to the character and preparation of the soil. Who hath ears to hear, let him hear (see on $11: 15$ ), would suggest to any attentive hearer that the story was meant to ennvey spiritual instruetion, and that not all were likely to mnderstand it.

II. IO-17.-REASUNA FOR NPEARINA IN Parables, Comp. Mark 4: 10-12; Luke 8: $9 \mathrm{f}$. And the disciples came and said nnto him. They had probahly been scattered among the crowds on the shore, and they now approalebed the boat (v.2), and perhaps entered it, or else Jesus drew off from the erowd for a time, during which oeeurred this conversation with the diseiples, and after- wards resumed his discourse to the same or similar crowds. Certain it is that the reasons were given aluart from the people, for Mark (1: 10) explicitlysays, 'And when he was alome, etc. It is also plain that several of the succeeding parables were addressed to 'the (rowds.' (see on v. 36.) These facts can be accounted for on either of the above suppusitions. The 'diseiples' here are not merely the Twelve, for Murk (4:10) says, "They that were about him, with the twelve.' Others, therefore, of his constant companions shared the privilege of this conversation. The disciples did not see just what was meant by this story of the sower (Luke 8:9; Mark 4:13), though they saw that it was intended as a compar. ison ur parable to illustrate some religious truth. And as parables in general were apt to be obseure unless the application was given, they wondered why the Teacher was employing them. Remember (Goebel) that he introduced the story of the sower without pretace, and elosed it without applieation, simply intimating that it required attention. In parables, is plural, while, as far as we know, only one parable had been spoken on this oeeasion. But the plural might be used as designating the method of instruction in general. (Comp. Mark 4: 11.) We romember also, that he had previously given seattered parables, though not without indicating the application.

It need not be supposed that our Lord meant to give what follows as his sole reason for employing parables in general. (Comp. on v. 3.) Wo can see a speeial fitness in his dwelling on this reason upon the present ocasion, for it was the day on which the Seribes blasphemously aceused him of lengue with Beelzebul (see on 12:24 and 13:1); and he was now surrounded by great and excited erowds, whose enthusiasm be knew was largely superficial and short-lived-roekyground hearers. Not very long after this 
12 for whisever hath, to him shatl be given, and be

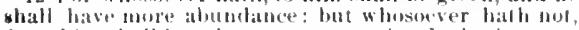
from him shatl be taken away even thall he hallt.
12 to them it is nol given. for whomerver ball, w him shall lie given, and ho shall have abundauce. but whosever bath not, frum him thall be taked
(14:34.36), ha. batel to dispel illusions among fallationl tollower-by the searehing aliscourse:

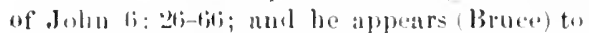
be in the parable of the sower commeneing this work of warning and diserimination; so alsu on at third and much lator ateasion. (1.uke14 25.35.) (rodet: "The desiern of .lasus is tirst al all to show that be is uot decerived by the sight of this crowd, which is apparently so attentive; then to put his aliseiples on their guard against the expertations whith such a harge (m) onurse might ereate in their minds; lastly, aml more than all, to warn his hearers of the perils which throitened the holy impressions they were then "xperiencing." Thero is also in not a few of these latrables, particularly in the sower, the mu-tard seed, and the laven, consolation tior olows luinsalt in refierenees to the eomparatively smal] numbor of true converts he whs thus far making. (Comp. John 6: :37.) Breanse it is given mnto you, literilly, 'has been gieen,' and so standi as your establithed privilege. To know the mysteries of the kimglom of heaven, i.e., of the Messinuic reign, see on 3: 2. The word 'mystery' dors not oceur elsewhere in the Gospels ("xiept in Mark 4: 11 antl Luke 8: 10, parallel to this passitge), nor in the Aets. but is enommon in the Epistles ot Paul and the lievelation. The Greeli worel musterion signitios smmething into which one is initiated, something hidelun or secert, and known only to the indiated. It anght lu a very simple thing in itselt, bat it was at sopet. Yot sime of the duetrines bebonging to the "Elemsinian mystepies" and other secret assoejations of (ireak, Eiryte ete, were raslly profoumbl, and ditlioult of comprehension, and so the word hats gralually come to sugeret the idea of something incomprohensible, though we still sometimes apply it to things which are morely harel to find ont. But in the Now Test. use. it uniformly demotes that which we could not know unless revented, whuther it be in its own mature simple or profommel. Paul's favorite application of it is to the great fact that the Gentiles were to share in the salvation of the gospel on equal terms with the Jews, a fict always before kept in silence and secreer, but nuw manifested by fiml, and to

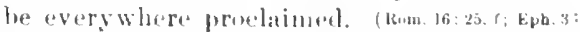
4-6; Col. 1:26 f.; $1 \mathrm{Tm} .3: 16$.$) Our Lorrl is in this$ series af parables setting forth views a to the true nature of the Messianie kincrann-surel as its partial accoptance among men, its - anall beginming-and gratual sprand, it-allewing the wicked to live on in tho worlel mingled with its subjects artil the end-which the maso of the Jews were mot spiritual-minded enouerh w) comprobend, nor humble enough to recoive. So he presents these views in the form of parables, which woule, with the help of his explanations, make then clear to his diseiples, but wombl leave them mysteries (seerets) to the unspiritual and unbelieving multitude, "Seerets' is here the translation of 'Tynelale, Cran., and fien. Observe that these pallables earry on the work of instruetion begun in the Sermm on the Ilomint, as to the nature ot the Mesianie reign. Ilere, as well as there, we mu-t frequently recall the popular . Iewiob errori in regard to the character of that roign -errors from which the disciples themolves were not entirely free-in order to see the precise aim and point of the di-eourm. This is especially true in the purables of the Tares and the Net, and in those uf the Mustaril-seed and the Leaven. The phrase "mysteries of the kinglom, recorded by all three Fivan-

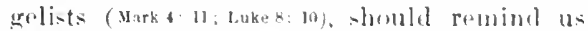
(Alexander) that this group of parables relate especially to the Messianic reien; while in so doing, they of course involve indivitual eluarneter ind testing.

We must not suppose that Jesus meant, like some of the frock philosuphers, whave cortain (exoterite) ductrine tor the massas, and eertain others esoterite) which werte enfined ti) a select fow. The reverse is eloarly -hown by what he and-in Mark and Jukle atter ax-

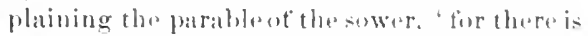
nothing hill silve that it shoulhl hemanitested,

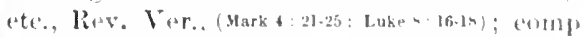
above on 10 : : 27 , and below on r. 52. In 6.126 ., he declares that he withlubls sonte truth: from the autride crowd (Mark \& I1) betall-e of their willful hlindnes. Sump previuns knowledge ot his teachings conecrning the Me-dunic reigu was necesary in order to un- 
13) Therelore-poak I lo thom in parables: lifcuse

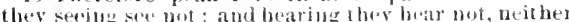
do ilery morterstanch.

14 And in them is fultilled the jowphey of Esaias, which silib, Bit hearing se sball heat, alid shall not nnekersaand; anil seding ye shall see, and shall uot perceive:
13 away cren that which he hath. Therefore speak I to them in parahles; beealse seejng they see not, and hearing the ${ }^{2}$ bear not, nether do they under-

it sland. And trito them is fultilled the prophecy of Isaiah, which sailh,

By hearing ye sull hear, and sluall in nowise unlerstand;

And sceing ye shall see, and shall in no wise perceive: derstand the hidden truths he was now revealing: not (as Mryor and Bleck stringely interpot r. 21 previons knowledge of the mysteriss of the kinglom, but of his other teachings as to the kinglom. Situch knowlodgethe unbelieving and careles had falled to obtain or refused to receive. They saw and gut dich not see (v. 13$), i$. e., did not see the rat and full meaning of his teachings. 'They were already beenming "gospelahar dened." 'Therefore (v 13) or more strongly, (on this accouret, refers to the general principle just stated, that he who has not shall lose even what he has; and the leason is then further presunted in anothor form by what follows, becanse they secing see not, etc. On this aceount he talloht in the form of comparisons, which would be intelligible and impressive to chose prepareel to Inderstand, but unintelligible to those who by their willtul igmorance, neglect, and opposition, were unprepared. In Matk (4:12) and Luke ( $\$ .10$ ) it is stated as the divine purpose, "that sering they may not seax, etc. This statement and Matthew's do wot eonflect with ateh other. That which was a natural re-ult ot their character was also a divine julgurent tupon them. It was not mbly foreecen that they would not understand these things, but dasigned that they should not, as a punishmont deserved by their charaeter and comblust. These parple were not ignolunt through liak of s,purtunity for gaining knowledgr, but ware willlully negligent, and esen malignantly hoste to the truth and the Teacher. (12.4.) It we shink sensitively from the ideat that tha" "Lord ot hearen and eath" reveals to sume and hides firom others, we are stratugely out ut sympathy with the feelings of .Josus and of l'aul, who foumd in this idrat not only actasion of rasignation, but of adoration and joy. (1):25 f.; Rom, 9: $1 \mathrm{kff}$; 31:30:36.) Nornead we supjunethat anr Lard's abjecet in using parables was only to withlobl truth from the hardened at a judemont, for the shortest way to do thi- womlel liave been (chrys.) to say nothing to them at all. His marables gave them -till the opportunity to understand, if not too much hardened to do so, and were even calculated to excite their curiosity, awaken their attention, and lodgesometling in their mind, the spiritual moaning of which they might afterwards comprehend, if any of them shrould come to have a better disposition. "For the stubborn and the frivohous, this is still the only language which in a happy noment can soften and awaken then. After they have once heard it as a parable, the figure sticlis to them, the mirror is ever turned towards them, and they annot but look into it at some time or other.'

The saying of $r$. 12 is repeated in 25: 29; the word more, which in Com. Ver. here uselessly precedes abumance, is there not introduced. In Lulis 8: 18 (Mark 4:25) we find this same general principle given as a reason for taking heed how they hear. Perhapsour Lord stated it both at the point given by Matthew and also in his further remarks atter the explanation of the parable. If this seensinprobable, we must conclude that the saying Was transposed either by Matthew, or by Mark and Luke, to a different commection from that in which it was spoken. As no writer eould tell everything, and some relation of topics must be observed in the grouping, it would be inevitable that such tratuspositions of partieular remarks should sometimes oecur.

14 f. And in them, or unto them aceording to the correct Greek text), so as to uffect them, as applying to then. Is tulfilled, present tensw, is being fulfilld. Is in so many other anses, it in Matthew mly who reports the citation of this propheey. Mark ( $1: 12)$ and Luke (4: 10) simply represent our Lord a: using expresions derived from the prophecy. Esaias, or Isurah, see on 1:2. The citation is from Isa. 6: a f., and exactly follows the sept., which departs from the Heb. in only one important farticular. The proplet is dirested to rebuke the people for their insensibility to God's cause; and though that eriminal insensibility would be increased by his 


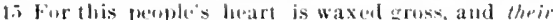

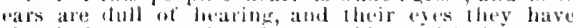

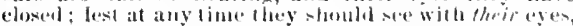

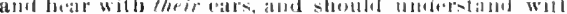
thrif forat, and shoulel be entrerted, and I shoutd heal Ilevil.

[i But b]:ssul are your eyes, for lluy se: and your ears, finc lliey hear.
1.5 For this [renple"s heart is waxtel grosen

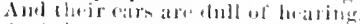

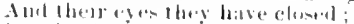

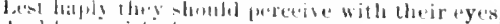

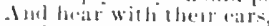

Aul mulrestabel will their heart,

And shoblil turn aritio,

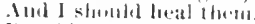

16. Ibut lidessed are your ryes, for they see; and your

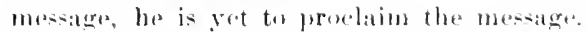
Acorelinerly he is and (in the Hab.), "Make the heart of this penple tat, and make theje ear-alull and thejerea dim. lest," ete. This

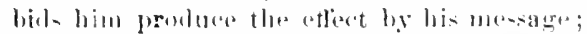

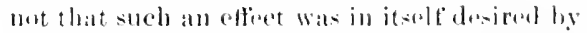

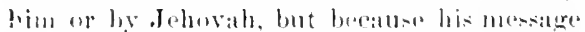

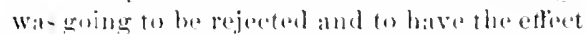

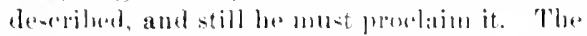

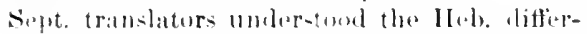
ently, and renderenl, "Fur this peopleses heare

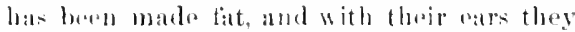
hax hand heavily, and their egesthey have rlasml." ete. This, as -ntlieiently expressing

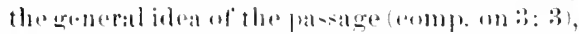
is retained by Matt. hore, and also by Luke

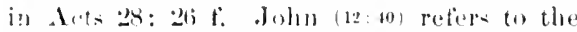
sime fassige, and puts it. He hath hlinded their ayes and he harilenes thrir hourt, ete.,

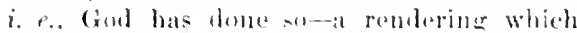

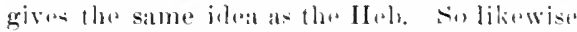

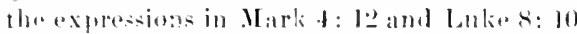

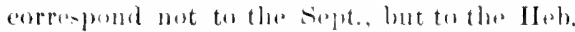
Thu insensibility of the pomble may be vari-

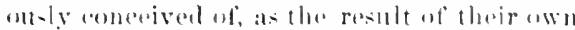
willul opposition, or as a julgmont alroaly

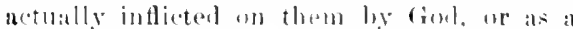
jultrment which would tollew their rejoretion

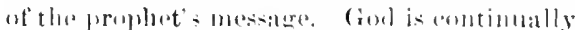
punishing men lug that whieh is the matural re-ult of their own misenoluet in violating

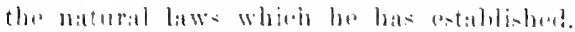

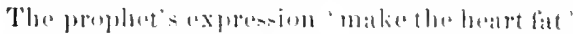
involves the image of a beatre andeleperel in

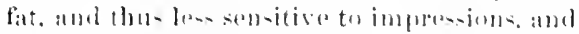
lese lively in its mosement, with a resultimg dullues of the serloces, so that it strikingly

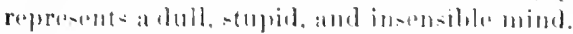

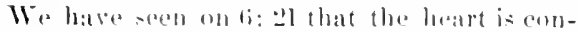
stantly usal in sierigture ats the seat of both iutellimenter, sem-ibility, and will. "Fat as to intellacet," "fat as to muler-tanding," are

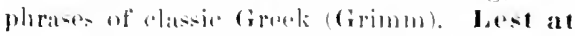
any time. Lest haply, or "le-t perbape, is a more probable rondering. The plaraso expresses, wot the design of the peoplo, as sume litvesoleght to "xplain it, hut the divine pur-

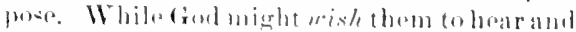

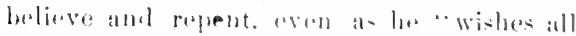

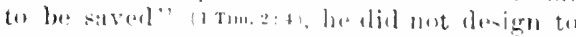

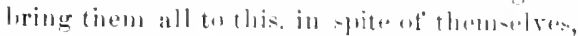

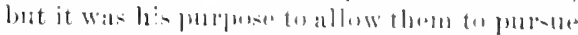

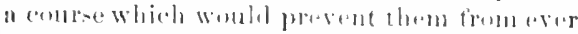

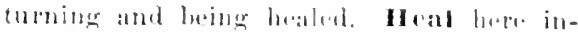

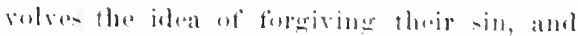
restoring them to spiritual hathlo and the faror at God. The multiplieation of similar and equivalent elanses in the guestere is lont the anomon paralleliom at llobrew puetry (kose an 4: lis. Turn amain. Sis Tyulale 'tuln.' and Gieneval return.' The Gresk word is thesameat in 12: 44, "I will return intu my house' This is muted bettre thatu thr frassive

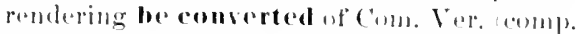

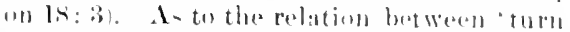
and 'rement, seon :3: :2. A likeim-en-ibility to that which the prophet wanld andentuter

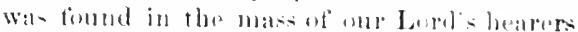
(c)mll. John 1:2: f(1), and in the . Jus who

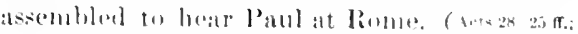

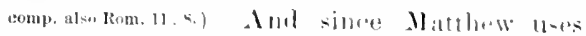

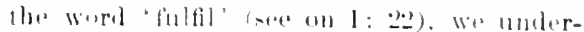

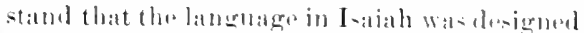

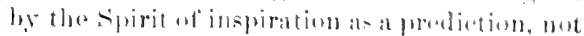

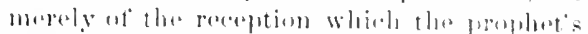

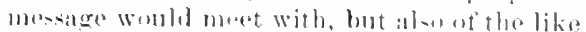

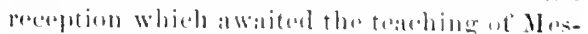

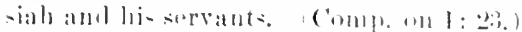

It;. With this eriminat insollsiblity uf

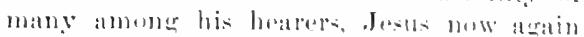

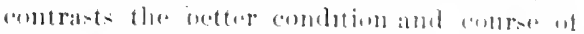
his diseiples, as aluse in v. 11 t. The torme

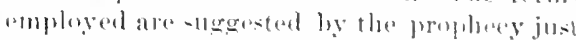

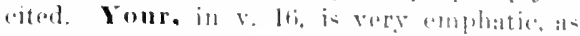
shown ly the justion in cirolk. lint in the verbs, they sec and they he'ar at ve li, and ye secamid ye hear at $v$. 17, the promoum is nest expressed in the Greek, and tharotion is

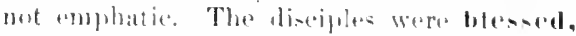

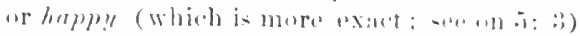
in the finet that they sam and latal : liar the things they wituessed were those to which 
17 For verily I say unto you, That many prophets ind rightends men bive lesired io seethese things which ve sece, and hatve not sextn them; and bo heatr those things which ye hear. and have not heard thrm.

is Ifour ye theredore the parable of l the sower.

19 When any ome hareth lho wort of l be kingdom, and undersandelh if met, then cometh the wickid one, and catchell away that which was sowh in his hearl. 'This is he which received secd hy Ihe way side.
17 ears, for they hear. For verily I say unto you, that many prophets and righteous nimen desired lo see the things which re see, and saw them not: aud to hear 18 lhe things which ye hear, and heard then not. Hear 19 then ye lie barable of the siwer. When any one heareth the word of the kingelom, and linderstandell it nol, then cometh the evil one, and slatcheth away that which hath been sown in his heart. Ithis many prophets and righteous men (see on 10: 41) bad looked forward with longing. but in vain. llero again (comp. on 12: 28) . lesus distinctly intimates that lie is the Messial. Feeing and hearing are here to be understood both ot the senses and of the spirit; they saw the miracles and heard the teatelings of Jesus, and they understood and approciated their spiritual meaning. In Lnke 10: 2of., we find similar language used on a ditferent accasion. It belongs to a class of rayiugs likely to be repeated. (Comlu), at the beginning of eh. 5.) This congratulation was not confined to the livelve, tor others also wore present. (See in v. 10.) Olshausen: "Mll the Jonging desires of the pious throughout the old Test. centrea in the Messiah. To behold hims was the loftiest object of old Test. hope. This hlessing was granted to the diseiples, and all their happiness, all their glory, consisted in this, that they ware illumined by the radianee of the sun of righteousness. The suecial grace thus vouchsafea is brought to thoir remembrance hy Clarist, not to exalt them above the old Tret. saints, but to lay tbem low before the J_ori."

III. 18-23. INTERPRETATION OF TIE Paralie of the Giower. Comp. Mark 4: 14-24; Luke 8: 11-18, Onr Lord's anthoritative 'xplanation of this parable and that of the Tares, furnishes us a morbol for the interpretation of his parables in general (eomp. on $v$. 3), - a brautiful modium botween excesive meagrourse and axossivo minutrness. Hear ye therefore, bottre, then ye, with strong emphasis on 'yo,' as distinguished from the beedless and lardenod. Jus to whom he gave no explanation. 'Then' prosents this as a conseruence of the principles just before laid down.

The idea of this jurable as a whole is, that as the same grain yollarl variuldy, aceording to the eharacter and preparation of the soil which received it, so the same word of trutli produces various affects aceording to the way in which it is reeeived. No analogy be- tween plysical and spiritual things can ever be perfect. The soil was not responsible if it was trampled, or rocky, or thorny; but men are acountable for haring the word improperly. This point the parable does not lunan to touch, confining itself to the general idea above stated, and opening a way for the exhortation, 'take heed therefore low ye hear.' (Luke $s:$ 1s, comp. Mark 4:24.) The word of the kingdom, is the word which tells of the nature and requirements of the Messianic reign. (Sice on :3: 2.) Luke (s:11) has "word of Gol?, and Mark (1:15) simply 'word.' Comp. 'gospel of the kingaom' in 4: 22; 9 : 3.); 24: 14. This 'word of the kingdom' means especially our Lord's own teachings; and so in 'understamdeth it not' the refurence is inmediately to his own hear'rs. Yet it will not do to say that 'the sower' distinctively represents Christ; it is any one who makes known the word of the kingdom, as our Lord intimates in Mark 4: 14, "the sower sows the word, characterizing him not as a certain person, but as the one why dues a ecrtain work.

Cuderstandeth it not. Arnot suggesti that in English as in Groek, we may express both the material and the moral failure by one term. 'does not tale it in.' Truth that is not understood, at last in some measure, can do mon no good. There is here reference to the tate of those described in v. 11-13; see the same word 'understand' in v. 13. The people were hardened into indifference, and some of them evon into malignant opposition to the work, and henee they did not understand it. Christianity is so eninently practical a thing that one will not truly understand it unless be is willing to receive it. Paseal: "In other things, a man must know in order to love; in religion he must love in orare to know." Whenever through inattention, lack of spiritual sympatly, unwillingness to recive, or opposition, men fail to 'understand' the word, it cannet benefit them. It lies for a moment on the surface of the mind, till by some one of 


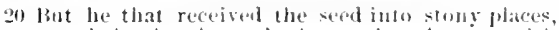
the sime is lo. Ihat heareth the worl, and anon with joy receiverth it:

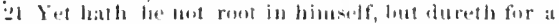

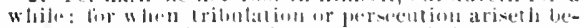
eause of the worel, hy and by he is otlended.

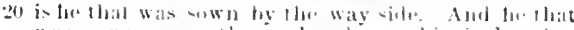

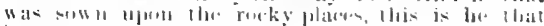

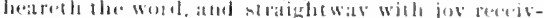

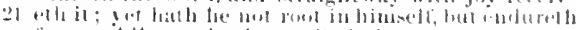
for a while; and whin tribulation or perseculdul

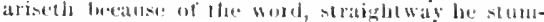

the thumsand evil inthuenees which satan and his suburlinates employ, it is camerht alval.

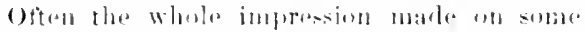

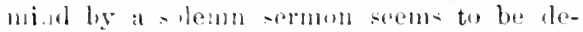
stroged thu in-tant theservice is mer, by an idle jest of at trifling eomrade. The wieked,

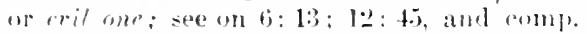

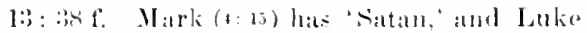
(k: 12) 'the devil. It i- illo to profes-tititio in the: teaching at Jestls. alld question the existence and frermality of sitan. Simateheth aurey better romeler-ilue Grask than cateheth

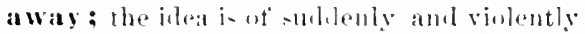
sazingand arrying uft. Sown in his heart, the seat of intolligence athd will, as woll ats of

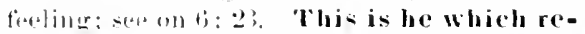
erived seed. of was somn-by the waside, connl. on $v$. 4. It mierht seom to us moro matural that the diflerent clases of hearershould be popresental by difterent kinds of sail; but war Lord malie the soud that tidl in the ditliarent platere represtent them, which

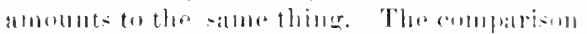

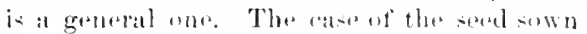

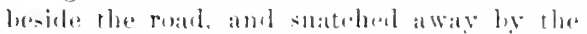
himle, correpomets the the cate of the liearele who does not molderetand the worl, wete ; and our larel aroids circumbention log simbly

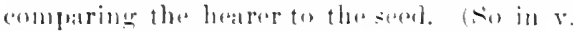

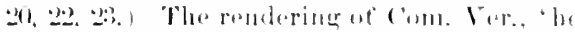

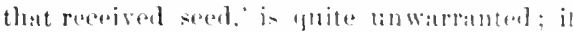
was dorived from (rammer, whilo Tyon. latel translated enrrectly; ambl in Marle t: It, ls.

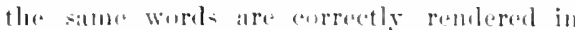
Com, Ver., "they whiell ares sown." simm have proposed to rendire here "this is that

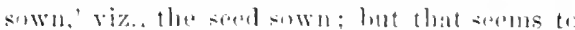

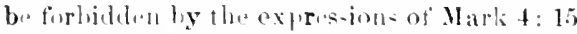

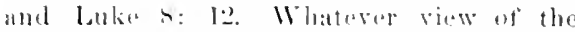
phrasoologg he aldopted. thes general moaning remains the sallt, and is ols

20 f. Into stony, upon the rerky (places):

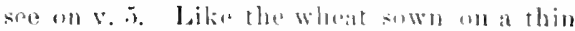

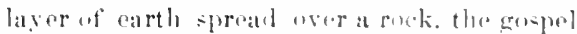
will probluce sombe impresion on such pursoll

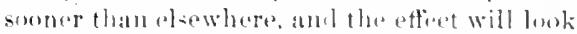
estremely gromising for a times so that prople think this person will suon be a Christian, or

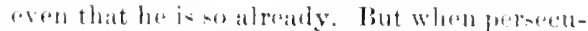
tion or any - erere teot uf principle oceurs, it

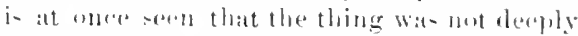

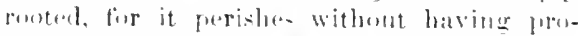

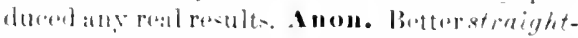

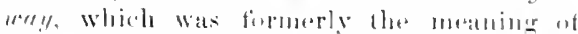

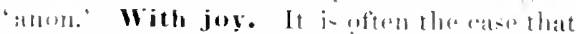
stuperfirejal and tran-jout roligions impresione

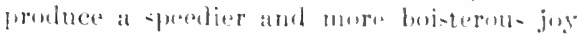

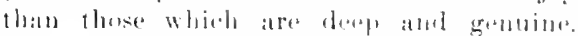

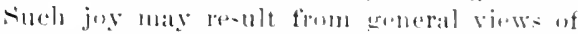

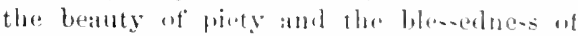

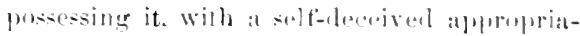

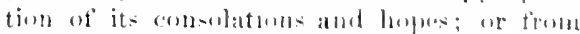
the excitemont of natural fecling hy touehing allu-ions amd forvid apleals; or timu mere. sympathy with kimbed and foimbl-: ar oven

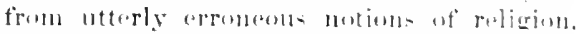
with the olation of solf-rightentasturs and

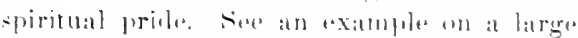

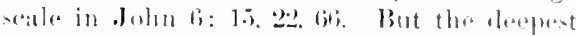

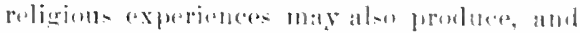
sught to probluce, a true and abudiuer jus. But dureth for a while, literally is tom-

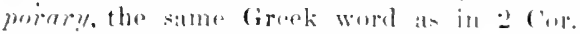
I: Is. "the things whieh are soen are tem-

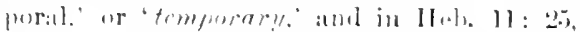
literally" "to latase tempurary ajogenent af

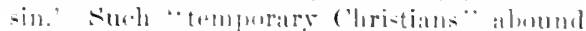
in times of extrandinary revival. For, litarally, aml. whou tribulation or presecution. The rom. Ver. mont unwarrantalily tram-lated "for when' followine 'Trmblale.

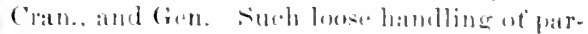

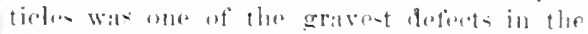
learning of that ane. "Tribulation" is a morr general term. 'prerserention' a miore particulat one. Stat the former alan in 21: !) 21. 2!. Tho remote asescialion of thi- Latin worl with

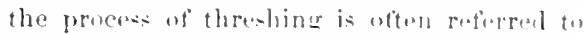
by preachers. but the fireck warel has mo slloh assuciation. It moans simply prosentr.

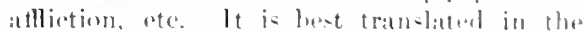
Siw Test. samblimese ly tribulation. and

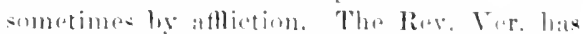

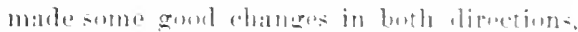

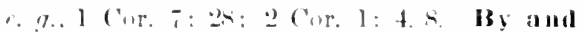
by, proporly atmaighteay, the situle Greek 
22 He also that receivod seed among the thorns is the that heareth the word; alld the ("a re of this world, allt the deceitfuluess af riclies, ehoke the wort, and be besmineth unfruitful.

23 but he that received sect into the grond ground is the that heareth the word, and undersambeth it; which

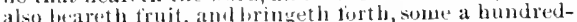
fold, some sixty, somelliorty.
22 bleth. And he that was sown among the thorns this is be that foerath the wort; anit the eare of the lworda, and the deceitfulness of riches, choke 23 the worl, and he becometh unfruitful. ind he

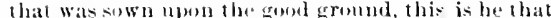
heareth the word, and ubderstandeth it; who serily beareth fruit, and bringeth forib, sowe a hunctredfold, some sixty, nome thirly.

1 or, age.

word as in v. 20 and $v .5$. The person described immediately receives the word with joy, and when trouble enmes, immediately he stumbles. This is a prominent feature in the characterization; but Com. Ver. has, as a often, obscured the verbal comnection by suploying three diflerent terms, forthwith, 'anon,' 'by and by. IIe is offended, or stumbleth, or 'is mide to stumble.' Tyndale and Cran. give 'falleth;' it was Gen. that hare introduced the unlucky rendering 'is attended.' The word has been explained on 5: 2y, and has liere the second sense there riven; the man finds an obstacle to progress, and abandoms the gonpol he had apparently recaived. (Comp). 24: 10.) Luke (s:13) has "all equivalent expression, 'fall away.' Only when grain is producad dors a crop of wheat amount to anything; only pernatnent piety is real piety.

2:2. Anong the thorns, comp. on v. 7 . That heareth the word. No further expression is here appended, sueh as "understunds' (v. 19, 29), or 'with joy roceives it' $(v, 20)$, but it is simply said 'hear-' the connection showing that the improssion at first made is afterwards destroyed. The care of this world. The correct Groek text omits this, as also in v. 40. Fur 'care' we could hardly $11 \div 0^{2}$ "anxioty' in this ulace, as in '2 Cor. $11: 28$, 'anxiety for all the churehes, and as the verl, is transtated 'beanxions' in $6: 25$ (ses $N$ otes): but "worldly anxicties" will "xactly oxpress the idea eonveroul. "The world" as in 13:

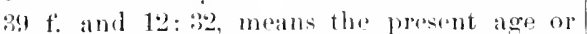
world-period, will ail its aflars; monp. 2 Tim. 4: 10, "having losed this prosent world," abd see on 25: 4h. The deceitlulucss of riches is a stronger expression than simply deceitful riches; it presents deocitfuluess not morely as a quality of riches, but as hero the prominent thought; eomp. "the uncertaints

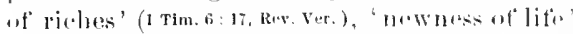
(Rom.6:14); also Heb. :3: 1:3; 2 Thess. 2) 10 . Riches deceive mon in many ways: as tor the ineans of acquiring them, making things look honest that are not so; as to the reasons why we desire them, and tha objects for which we intend to use them, ate. Some professed Chriatians imagine that they are so absorbed in the pursuit of gain, and so reluetant to give much at present, simply from a desire to be able to da great things hereafter; when the true reason is that they love wealth. And we must remember that riches often as grievulus deceive and distract those who vainly seek, as those who obtain them. "They that desirots be rich" (1 Tim.6: 9. Rev. ver.), may get the evil consequences without getting the wealth. Luke (8:14) adds a third point, "and pleasures of this life." Unfruitful. As fruit-hearing is the test, they are thus shown to have no real piety. Alas! how often men seem deeply stirred, by the word of the gospel, and perhaps resolve that they will give heed to the message, perhaps for a while seem diligently to do so, but worldly anxieties, especially about wealth, and worldly desires (Mark 4: 19), and worldly ploasures (Luke $8: 14$ ), soon get complete possesion of themind, and all the seeming good effoct is gone, leaving the soui a very thicket of thorns, Bruce: "It may beasked who has a chance of bringing forth fruit unto perfection, for what character is free from thorns? But the question is not, who is free fron evil desires, or from temptation to inordinate affection, but what attitude you assume towards these."

23. Into-upon-the good ground, comp. on v. 8. Fond gromnd here stands in eoutrast wilh the three other kinds of ground, and so (Grebol) is conceived of as a soil sott, deep, and clean. Understaudeth, see on v. 19. Also-better revily, not the word commonly rendered verily, but another, which is hard to ronder, but ealls attention to this person, marks him out as distinetively the one who performs the action ; all the others fail, this is the one that beals truit. ('omp. Meyer, and Multan in Winel, p. 578.) some a hundred-fold, ete. Even at those whotruly understand and receive the word, some exhibit 
better results that where rial: "The fruits of grace in believers ate of the same puality, yet not of the same quantity." That which yieldo a lesis alumblant harrest is still called good erround, sereing that it does produce at real repe. So the sersant who matle a goot use of but two talents was a good and fathful servant. (25:23,) Yet we should all dexireand strive to be not merely of these who bring forth, but of thoe who bring torth a hundredfold. Ambition is a worthy and moble thing, when it aims at eminent usetuluese, rises abuve envy and jealons, and suburelinateeverything te the erlory of crocl. It hat been remarked that this latet elates is distinctly contrastenl with artels of the others: they "understand, in opposition th the first class ; they "loold it fast in at geod heart' (touke 15 ), in oplpuition to thesecend alas; they lbring forth fruit with patience" (Lake s: 15 ) in opposition to the third clats. Yet in this last ease the eomparison is searcoly ju-t; for the thimel elatso dirl not bring torth fruit at all, as is sleown by the 'mufruitful' of' llatthew and Mark, and by Luke's (2xpresion (8. 14) bring no fruit to perfection.

The illustration calumet touch at all puints. It takes no acesunt of the fart that the condition of the spiritual soil may be altered by divine grace-that the trampled ground (an

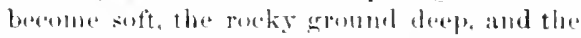
tharns be ronted ant. The inspired teachers in geoleral enstraight forwald with the subject in hamb, and towatel-the print in view, without pau-ing at every steple to guard agatinst misalpreben-ion, or to introluce rotated truth-; otherwis their discourse would gain no momentum, ant extrt no foror. other

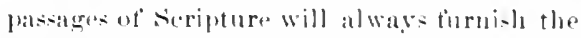
meatus of preventines misipprehention or of completing the viow. But, taken within the limits of it - design, this parable is strikingry comprehomoire. All these who hatre the werd to ne rabl profit may without straining be referred to one of the three deseses first griven; and the fourth ala enmprehonds various grades of actual fruit tulness.

HUMILETIALAXH PRACTICAI,

V. 2. The most -piritual preathing must net neglect to soek helpful ontward conditions. Our houses of worshipshould be socom-trueted that the people may clearly see and easily hear the preatcher. Marbe costly and hatudaume builelings are in thene respect- an extremely defective an to la an abunination. If the

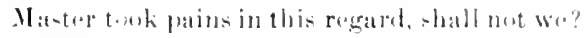
JkRoste: "A crowd jo of matuy minde, and a) he spealis to them in many larables, that ascele might receive appropriate instruetion. He did nut speak anepthing in parables. but many things-mingling the perspreuons with the obretre, that ly what they underetand they may be arourat tor seet knowlonder of what they do neot underetand."-V. !. H, that hath ears. I) Many will not hear - piritual truthorven with the outward and 2) None ean hear spiritual truth understambingly, anless they have some desire for spiritual profit. :3) Whover sees solne meaning in spiritual teatehing should eatruestly secek to know more thorouglily. 4) the religion teacher must net be diseouraged by the fatilur.

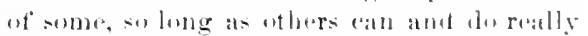
bear. Conge: "Even though tho lat lies more than such as reecive the word. yet they were not to despond. For this was the detwe exen with their Lard. and he whe fully firelinew that these things should be, did not thesitt from sorwing.

V. 11. C'melitions of gatining a drep know). elge of Chritianity 1) A real desere te

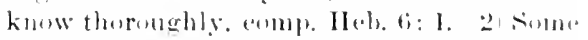
exi-ting linowledere as a preparation for lainning more, v. 11, 12. 1ti. 3) Ealmest exlliert to under-tand what is seren anel leard. v. I:3. fl Practical contormity tothe knowledge al reatly sained. eamp. John $7: 17$. Christianity i- intensedy pratial-knowing and doing mu-t alvance hanel in hand.-V. 11-1:?. Truth is not withhold form any ly arbitrary divime allot ment. but at the penalty of proviun areclent and hostility (12:24); comp. liom. 1: 28 . Currs: "It wa- a voluntary and self-ehomert blinelume: therefore he sat mot. simply, they see not, but sereing they see not; for thay saiw

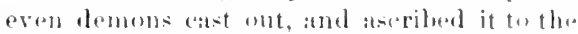

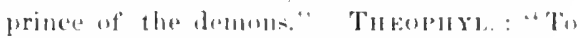
give them plain totehing would have heron to cast pearls loefore swine." V. It $t$. A ! iceture of many who rejpet (roul's wort. i) slight attention.and no real under-tabding. v. 14. 2 (allse of this in dull torpure ot theught and foreling. $v$. 1.j a. B) Filloct in preventine them trom turning and beine saved, v. 15 b. - V. 17. THFornYL. : In 
24 Another parable put ho forth uno them, saying, "2 The kingdom of hoaven is fikened nuto a man which suwed groul seed in his field: 2t Another parable set he heforethem, saying, The kiugdom of leaven is likened unte a man that two respects the apmotes exeelled the prophets, in seeing bodily, and in better understanding spiritually."

T. 18-23. Evon if preatebing were in itself perfect, it would have a very different etfect upon diticrent clatses of hearer's. Onr work cannot loe fairly tested by its actual results, but rather by its tendencies, aims, and adaptations. Yet a religious teacher should earnestly seek for tangible results, both in winning and in building up.-Curys.: "Mark this, I pray thee, that the way of destruction is not one inly, but there are difforing ones, and wide apart from one another. Let us not soothe ourselves upon our not perishing in all these ways, but let it be our grief in whichever way we are perishing." - V. 19. The gospel not understood. I. Causes. (1) Indifference and inattention to it. (2) Prejudices which exclude it. (3) Desire to do things it forbids. (4) Insensibility through previous neglect. II. Conserfuences. (1) It does not reach the deeper atfections. (2) It gives no impulse to the will. (3) It never touclus the lite. (4) It

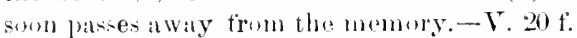
The temporary Christian, 1) Ilow he receives the gos jol ; al promptly, b) joyfully, c) with rich apparent effects upon lite. 2) How be abandons the gonpel; a) certainly before long, b) an som as ever serious trial comes, e) without any permanent benofit to character or life.-Y. 22. Cirkrs. "There is a way, it thon wilt, to ebeck this evil grosth, and to make the right ase of our wealth. Therefore he sitil not 'the world,' but "the care of the world ; nor "riches, but 'the deceitfulness of riches.' Let us not, then, blame the t!nings, but the corrept mind. For it is possible to be rich and wot to be deceived ; and to be in the world, and not to be choked with its eares." ORIGEN: "The apostle's 'anxiety for all the churches' is ront "anxiety about the worll." "-V. treat the gospel. 1) II and it, 2) mulcratand and receive it, 3 ) atet it ont.

24-13. The Tares, the Metarari-ken, TII LEAVEN.

After explaining the paralble of the sower, our Lurd proceeds to utter several other pairables. The first three of these were clearly spoken on the same ocearion as that of the Sower; fir the 'multitudes' of v. 24 and 36 seem to be platinly the same as thone of $\mathrm{v} .2$; and the 'house' of r. 36 the same as that of $v, 1$; the language of $v .51$ and 54 makes it probable that the other three also were spoken on the same vecasion. Mark (4:26-29) has at this point another parable drawn from sowing seed, which forms a sort of pair with that of the Sower. Here then are eight parables, in four pairs, since that of the Net closely remembles that of the Tares. Keim urges that the parables of the Mustard-seed and the Lenven, asserting the victorions extension of the kingdom of hearan throughout the world, could not have been delivered in the same breath with the sower and the Tares, which are "resigned and molaneholy." But why may mot the Great Teather have naturally introluced more hopeful views for needed relief to his own minel and to his hearers? Such quick reactions of strong feeling easily occur. There is thus here no accasion for rejecting Mitthew'surder.

I. 24-30. THe PARABLe of the Tares Givex. Put he forth unto, or set before, them, an image derived from setting ford before persons, as the word is naed in MInk 8: 6; Aets 16: :34; 1 Cor. 10: 2-. (Comp. v.31.) Jerome carries ont the image, comparing the diflepent parables to different artieles of tord, suited to one guest or another. 'Them' loere means not the disciples only (v. 20), but the peoplo in general again. (v.34.36.) As to the parable of the Tares (which is given by Matthew only), we must notice here the illustration itselt, reserving its interpretation tim the Notes on v. 3i-4\%.

The kingdom of heaven is likened, literally, wes likened. This kingdem or' reign has been already legun, and so the resembince may be spoken of as existing in the past. Or, we may understand it in the sense that the lingdem of heaven was likened, became like, and so is now like. Nicholson understands it to mean that some such parable as this already existed; and so in 18: 2: and 22: : 2. But the phratse does not at all require such a supposition, and while Jesus used some current ideas and expressions, there is 


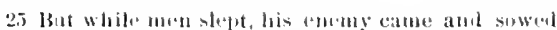
tares almullg the whoth, and went his way.

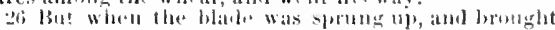

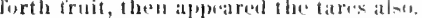

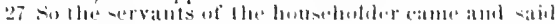

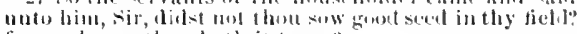
from whince then hath it tares:

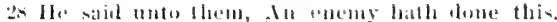

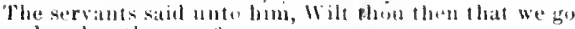
and gather theth ul,?

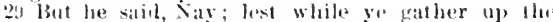
tares, yo rout upalso ilie wheat with ihem.

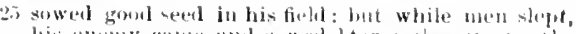

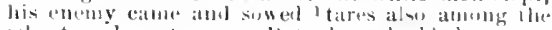

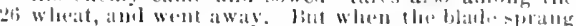

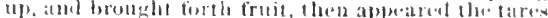

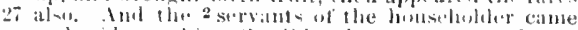

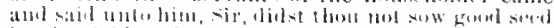

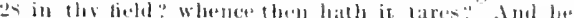

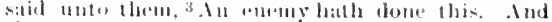

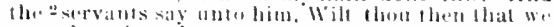

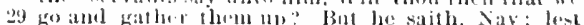
haply white ge gathel ap the tares, ye rout ij, the

$10 \mathrm{r}$, darnet....2 Gr. bondsertants.... Vir. A math that in anenemy

in reanom elsewhere to suppose that he hurrowed an entire illustration; and this jarable

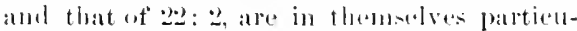
lar'y unlikely to have been griven by any previns teacher, heing su ntterly at variance with curlent Jowish thought and feeling. The future tense is useal, shall be like (liliened), in $7: 21,29 ;$; $11: 16 ;$ 25: 1 ; and the present tense in 11: 1li; 1:3: :31-.52; 201: 1 . Juto a man. Tin, Meniania reien (3:2) resambles not simply the man who sowerl, but the parable as a whole; the ammparison is simply aflirmed, horeandolsowhere, with referenere te the leading persollage of the story, al. the object it is natural to mention filst. (ompler. r4, 45, 47; 18: 23; 2): 1; 25: 1 .

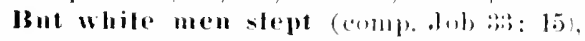
vi\%, at night, when there was nome to abscrve. There is morefolemedo any particular mon as negligently slexprings; it is simply meant that the emeny solected an olpertunity fior secently doing an injury. The word ren-

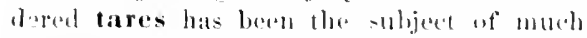
disculssion, but it is pretty gantelatly alderal that it demotes darmel, a platut ut the same family as wheat, and not realily distingui-bul foum it in the tarly stages. Julome, who

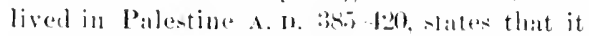
wn- puito dithenlt to di-tiogra-h them unt

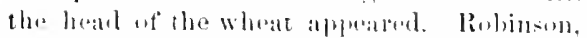

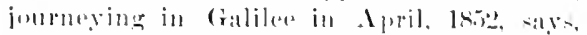
"Our path now lay througle tiolds of whe:at of the most luxuriant errowts: timer than which I had not befiore sesen in this or

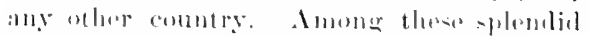

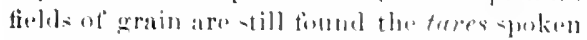
at in the Sew Testament. Is tererilued to me, they are not to be di-lingui-hed fimm the wheat until the ear appoars. The sopel rosambles wheat in form; but is smaller and black. In Buirut pultery are ted upen this sowe and it is kept for sal to for that purpure. When this is not separated from the wheat. freall made trom the flour often catuses dizziness to those whos eat at" it. All this corrow

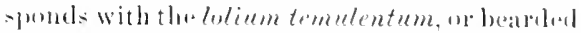

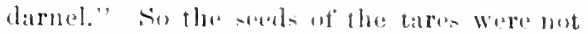

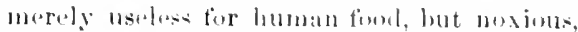

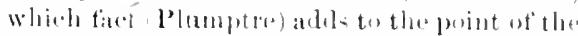

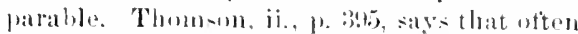
"the routs of the two plants are so intertwined that it is impur.ible to separate them without plueking up hoth." The notion that the tarm were a derentelute wheat, and by (eltivation ental be male to becente whost again, has besen very pleasing to smonninds,

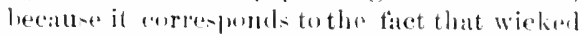
mon are fallonalud may be restored. Fined a motion as do darmel appears in the Talmud, and is cotertained by sumb persons in Pale..

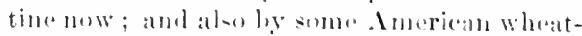
errowels as to what they eall "eheat." But (Thomson) it is not supmorted ly aderpuate evidence and the fancy may be abastodoned without rearet, for it would intruluee an illog quite apart ferm the design of the parable. Among the Wheat, in the Grask a strong expresion, all throutel the midst of tho wheat -making theseparation particoularly diffirult. And went his way aten?. so that no whe knew what he hat dome. 'lohis pratetice of sowiner noxions souts in an en+my's wlutat-

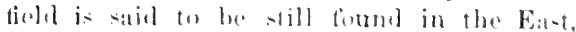

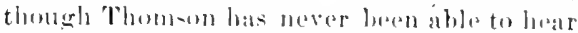
of an instames. - and is nut unkmown in other countrixs. The blade, the word remelered gracin in : at); 11: 14. And brought forth fruit, not lere the ripes grain, but the heals wotaining the grain, whoh would show thas

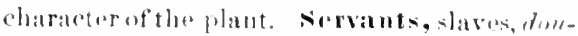

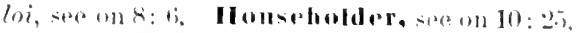

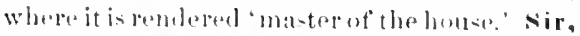

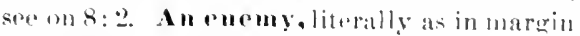
Res. Ver., a man that is atm ememy. 'That

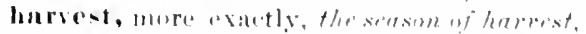
secon $11:$ :. . Cather together and gather 
30 Let both grow together until the harvest: and in the time ot harvest I will say to the reapers, cather ye torelher tirst the lares, and hind then in bundes wo burn them: but gat ber the wheat into my barn.

31 Anotber parable put be forth unto them, saying, The kingem of heaterl is like to a grain of mustard secel, which a man look, and sowerl ju his tixld:

$33^{2}$ Which inderel is tha least of all seeds: but when it is grown, if is the greatest amoug h+rbs, and beemeth a $\mathrm{tre}^{3}$, so that the birds of the air come and lodige in the tratuches thereol.
:30 wheat wilh them. Let both grow together until the harvest; and in the time of the barrest, l will say t1) the realects, fiather up forst tho tares, and lind them in bualies to burn them: but gatber the wheat into $\mathrm{me}$ birn.

31 Anothor parable sot he betore them, saying, The kingdom of heaven is jike unto a grain of mostari seer], which a man took, and sowed in lis tisld:

32 which incleed is less than all seels; lout when it is grown, it is greater than the herbs, and becometh a tree, so that the birts of the heaven come and lodge in the branches thereof: in v. 30 renresent different works, but amounting to the sane thing; the first might be tratuslated 'colleet.' Into my barn, rendered 'uramer' in 3: 12.

We might suppose that so many different farables spoken on the same occasion would continse the minds of the hearers, and thus firil to be understom or remembered. But only a part at them were spolien to the people at large (v. 36), and these not in inmediate succession. (v. 10: Mark 4: 30.)

II. 31-33. Parables OF TIIE MUstardSEED AND THE LEAVEN. The former is fonnd also in Mark 4: Bu-3:2; and botl: in Luke 13: 18-2l, as spoken on a later occasion. Some eritics wonder why other parables were introduced between the parable of the Tares and the interpretation of it. Do not these, in correcting a common Jewish error, help to prepatre the mind tou understanding the important correetion and instruction given by the parable of the Tares? Jutteroth suggests that tho disciples, after the rehuke of Matrk $\mathbf{4}$ : 13 , delayed asking the interprotation to see if they combl think it ont; a notion which may not be wholly fancifiul. Probably they ad ser the meaning of the parables of the Mustarel-sed and the Istown, which is comparatively obvious, and so did not ask an interprotation of them. (v.36.) It will he fomld introesting to romplare the four suceesive parab]es derived foum the growth of seala, viz.. the Sower, the Tares, the seed srowing of itself (Mark 4: :66-29), the MInstarrl-suded.

Pint forth, ete. Siet hefore them. see on v. 24. The kingdom of heaven, the Messianic reign, see on $3: 2$. A grain of mustard-secd. This is most likely the eommon mustard, which in the hot exuntries of the Fast is sometimes found eight or ten fert high. Thomson: "I havesen it on the riall plains of $A$ kkar as tall as the horse and hik ricker." Hackett ("Illustrations of Seripture") saw stalks seven and nine feet high, and before his eyes a bird came and perched on a lranch and sung. (Comp. Chark.) Thomson, ii., p. 16.', mentions one that was more than twelve feet high. Some expressions in the Talmud go beyond this, but Edersheim accotints fur them as exaggerations. Maldomatus (sixteenth century) speaks of seeing great mustard-plants in Spatin, with numeruts birds sitting on the branches and eagerly devouring the seeds. Meyer and others think that a tree is mant, now ealled salradora Persica, which abounds on the shores of the Sea of Galilue. It grows twenty-five feet high, but has a small seed of pungent taste, used for the same purposes as mustard. But if a real troe were meant. it would be nseless to say that it "is greater than the herbs, and becomes a tree." So we must understand the real mustard-plant. Field, the Greek dem noting a piece of eultivated ground, whether large or small. Less than all seeds is equivalent to a superlative (as in $11: 11$ ). Greatest among - literally greater than the - herbs must be taken strictly as a comparative; it rises above its own class uf plants, and becomes a troe. The hirds of the air, or heren. see on 6: 26. Lodge, or'make their labitations,' see on 8: 20, and comp. I)an. 4: 12: Psa. 104: 12. The branches thereof, rather its branches, see on $6: 34$. The mustard-seed seems to have been proverbially lled to reprosent anything very small (comp. 17: 20; Lnke 17: (b), as we find it so used (Lightf., Edersh.) in the Rabhinical writers. A Buddhist writing suys (Lutteroth): "Meru, the greatest of momntains, never bows before a mustard-plant." Our Lord is of course not asserting it as a scientific fact, that this is smaller than all other seeds in the world, bu: is spraking popularly, this being the swallest that his hearers were accustomed to sow, or the smallest that produced a large plant.

No interpretation of this marable is given, but its application is plain from the nature of 


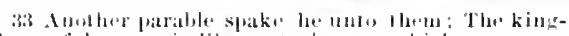

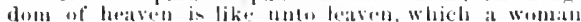
tonk, and hid in three a measures of meal, till the whole. was learened.

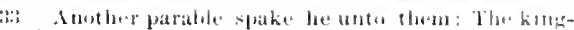

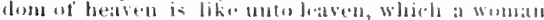

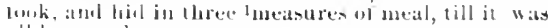
all leasinad.

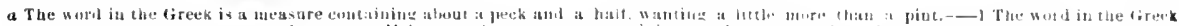

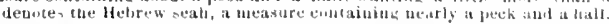

the cate. It represents the groweth of christianity in the workl, from small beginninge. to vast dimen-ions at lat. Some muler-tamb

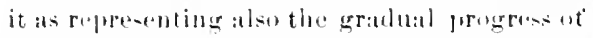
pioty in the individuat; but the uso of the fhria. 'kingdom of heaven throughout this series of parables, and in the (iospels at large. aplears to contine the view to the dirmer thought. The dieciples and otior Jews, clinging to the nution of at vist and splendid earlhly kinglom, would think it very strange that Mes-ials: reigh -hould beegin as quietly, and on -11 smatl it scale ; and in this patrable, and that of the Leaven, onr Lord wishes to imfress it upon them that thengh smatl in it:

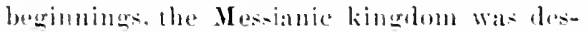
tined to attain a vat extent. If the disciples

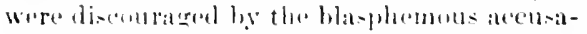
tion of that morning, and hy the parables of thesower and thre Titres, which indieated that

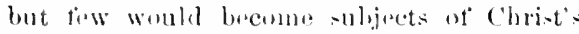
reign, these other two would re-atsurethem.

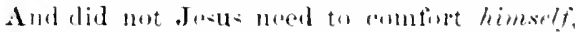
amid sueh - wall beginnings and sow progresis? We ser the ariginal riremonstances under whieh the parable wass guken well respredured now, at the first introlumbion of Christianity into some erout heathen nations. Not only the heathen themenelves, but irreligion salors, merehants. and tratolere form our cow country, often sneer at the ide:a that

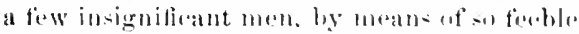
athing a-preaching. should px peet to change a mighty people. Fet it is tront imilar small begiming: that there ba* eradually grown up the ('hri-tianity and the civilization on' Eurome and Amprial at the present time. Some pxpusiture, following certain Fathers, find great significance in the sharp, pungent qualities of the mustard-seed as illustrating the fiect that Clristianity, though small, would prove very efficacints and impresive; but this is quit. beside the point if the parable: and even if uny one should regird the ideit as in it-elf worth notice, he must aceept it as merely a fance, and not as a part of the sariours teaching. Nor are we to find any distinct spiritunl meaning in the birds lodging in the branehes, which simply -hows in at vivid way

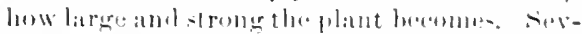
eral pasiages of the old Tost. represent an ax-

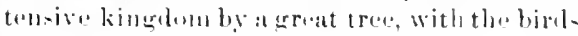
dwelling among it. branchus, Eask. I7: 2n24; :31::3-14; 1): $11,4: 16 \mathrm{Ht}$.

33. The farable of the Laven is griven

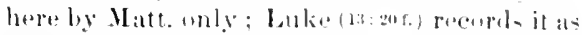

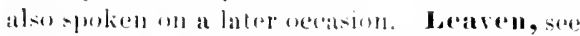
on lit: (i. Mald, rather what we now rall

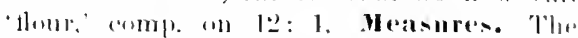

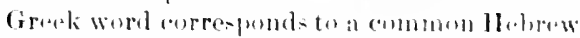
meature of things dry, ealled sereh, holding

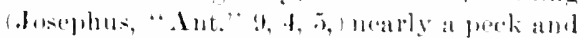
a halt (merergine; at that "there hetatures" womld be rather more that our bu-bed : but the size varied in different batt-al Palestinte. (Eder-h.) It contributes to the vivilue.. if the parabolie narmative, that it does not morety say " a large fluatity." hut names smore patr-

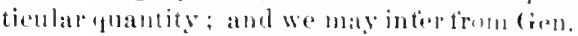

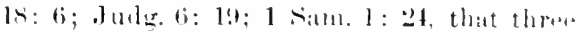
seahs (melual to ome whiah) was a quantity

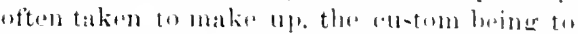

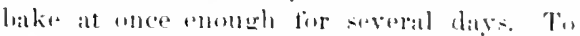
timl al sleneis - piritual meaning in the mumber three, wonlal seem to u- ridiculans: pot some great men ammere the Fithers, and sime fatu-

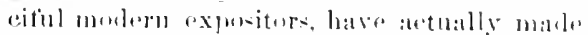
it signify Jews. Grenks and samaritans; ur

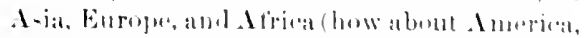

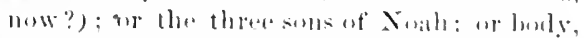
sonl. and spirit, ete. Sir with the ittumpte to give separate sienificane to the woman, when it wat a maller of enstre to spenk of a

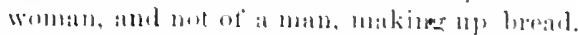
If the woman here demotes "the ehureh." what is demoted by the man in vo :31 ?-The

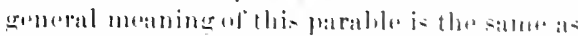
that of the frocesding. A small bit of leatroll, ampletery hidden from vien in the erent

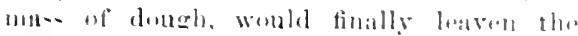
whole; and so chri-lianity with its - wall

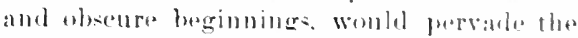
whole race of mankind. Thure in a like gradual progeres of piety in the individust, but that does not serem to lere the point here in view. A slight but jut distinction ba-been 
34 All these things spake Jesus unto the multitude in parables; and without a parable spake be not unto thenl:

:55 That it mimht be fullilled which was spoken by

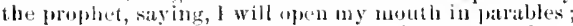
I will nted things which have liedn bept secret from the foundation of tise worla.
34 All these things spake Jesus in parables unto the multitudes; and without a parable spake be uothing 35 unto them: that it might be filltilled which was spoken through the prophet, saying,

I will oven my mouth in vatralstes;

I will nter things hidden from the foundation ${ }^{3}$ of the world.

1 Many ancient authorities onit, of the urorld.

pointal out between this parable and that of the (irain of Mustard. That represents the expan-ion of the Christian community into vast dimensions; this the assimilating diffusion of Christianity through the vast mass of humanity ; the one is extensive, the other intensive. - Befiate leaven is trequently used in seripture ats the symbol ol things corrupting and pernicious (16:6; Luke 12:1; Ga1. 5: 9; 1 Cor. 5: 6; and often in old Tent.), and nowlere but here used in a goul sense, some have strangely tried to interpret it here as denoting the corruptions which should arise in eonnection with Christianity. But 'an there be only one possilnte figurative use of an object? The lion represents Satan, and also the Saviour; but no one would fancy in the sante sense. (Comp. on 3: 11.)

III. 31 f. A PREDtCTION OF SPEAKING IN Parables. NII these llings, with no special emphasio on 'all.' Cnto the multitudes, or cronds (see 1:): 2), and not merely to

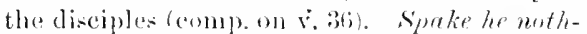
ing is the correct Greek text, instead of spalie he not, which is takon from the parallel pasistge of Mark. ( +34 ) It mu-t be meant simply that on this ocasion he sair nothing to them "xaept in parables; we know that on other oecasions, atterwards as well as betore, he frequently spoke to the poople in unparabolic languages. 'Sipake' is in Greek an imperfect, describing lis practice on that weeatsion. - Here again, as in so many ofler instances, Matt. pallsws to point out the fultill-

1 'Throngh lsatah the prophet' is the reading of $N$ (first hand), several imjortant cursives, one coldex of the Ethiopic; it in puoted in the chementine homilies (lafter part of seenul sentury), and satid by Eusebins

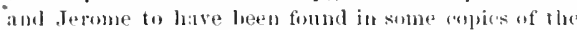
firspel. Jerome states that burplyy ry eited it as showing the igunrance of .tatthew. Tranceriptional probatbility would at once favor this, for it is easy to suppose sonbrous an error to have been corrected by eopyists (comp. 27: 9; Mark 1:2). On the other lanu, no prophet being named, some one might have felt movel to insert the name of the greatest prophet. It is also possible that some reader, observing the actual sonree of the quntation, misht have inserted $A$ saplu; and that then (ats Euseb. and Jerome surgest) others, not having heart ment in Jesus of an Old Test. mediction. That it might be fulfilled, see on 1: 22. This expression requires us to understand a real fulfillment of a real prediction-unless that idea could be shown to be in the given case impussible-and a fulfilment designedly brought abont in the course of providence. It is difficult, in the present instanee, to discern the prophetic relation, but it is not impossible. By the prophet, more exactly through, comp. on 2: 5. The quotation is from Psal. 78: 2. Minl of the Psalms are prophetic. and the Palmist David is expresty called a mophet. (Acts: 200 ) The writer of this I'salm is given by the heading as Astph, and he in 2 Chron. 29: 80 is called the seer, equiralent to prophet. (I sam.9:9.) The Psalm relates the history of Israt, and points out its lessons; but Israel was typical of the Messiah (see above on 2: 15), and so the passage might contain a prophetic reference to him, which the inspired Evangelist informs us it did contaiu. He states it as a part of the divine purpose, in our Lord's adoption of the parabolic method of instruction, that there should be a fultillment of that prophetic saying. Unless we can show that there was no such prophetie relation, we must certainly alecept the Evangelist's statement. I will utter. The Greek word means to beleh, to vomit, to pour out coptons speech, and this last corresponds to the Hebrew. From the fonndation of the world.2 The IIebrew has a plirase usually signifying 'from antiquity' and thus natu-

of sueh a proplict, should change it to the somewhat siublar naue faitah. With these contlieting transcriptional probabilities, and external evidence so slender, it secms right to fatl back on the int rinsic improbability (apat from all theorics of inspiration) that an inteligent writer like Matt, and a speeiat student of proplieey, woulif commit so manifest an error. 'Isaiah' is reat by Tisch. (following $\mathbf{N}$ ) and by W II, mergin; and strongly favored by Hort in Appendix.

2 'Of' the world' should probably be omitted, with $\mathbf{N}$ (secund hand) B, two cursives, ohd syriac, some copies of old Latin, and some Fathers. 'From the foundation' wonld really mean this, and 'of the world' would be eatsily added by copyists from 25: 34, where there is no variation of the reading. 
36 Then Jesus stul ltw multitule away, and went

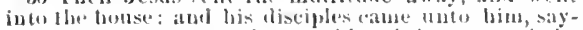
ing, freclare unto us the pitrable of the bares of the fich.

37 Jle answerel and sail ung then, Ite that soweth the good seed is the fou of man:

rully alply ying in the Psibnist's use to the early history of the nation lat sicpt. "from the begimning'); but the phatae also signitio

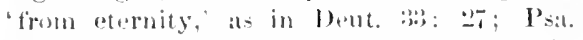
5.5: 19, and in the prophetice applieation might perhaps be mulerstond in thith semse, to which the Evangeliet's expression is equivalent. (Cimp. mn $1:$ : 2:3.)

IV. 36-13. INTERPRETATION OF TIE

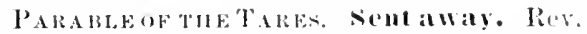
Vir. renders, he leit. Whe multitude, the crowels, as in 5: ]. 'Tleseor mimilar crowdshal lesart the parables of the siower, the Tares, the Mu-taret-aeed and the Lanken, though mot the explanation of the first (s.e an l:3: 10); also the other parable sived ly Marli (1:2060). Now the disciples alone alde to heat the explatnation of the parable of the Tares, and also to hear the thres other batrolyles that follow. Ilis disciples wareprobihly not merely the

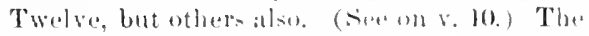
name Josus at the beginning of v. :3i), does mot alyotar in many af the he-t anthorition, and

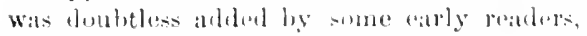

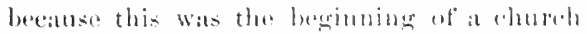

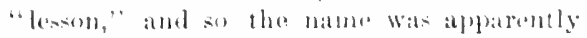
neroled. The same thing has happemed in

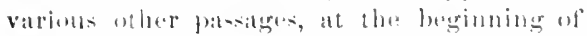

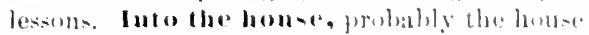
montumed in 1:3: 1, which mal have been

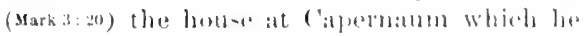
usually oceupied, vi\%.. that ut simm Peter. (Compl on 4: 1:3 and \&: If.) Declare, re

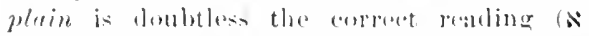
first hand, B, erigen, having bern changed to make it agrew wh lis: J.). The parable wi the tares of the tielel. This derejention show, that the dieciples had sojzed the most

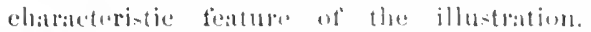
Answered and said, withut nut rhem. an unneressary addition of many doxuments. For "xplanation of the trems and allu-ioms of

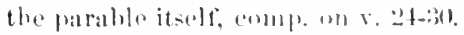

'The Jows, including and Iomets disciples, would matarally thind, with their routal notions of Masiali's reign, that he womld promptly destrog all those who dial not submit to his anthority, as wa eommon with Orien-
:30 Then be left the multitules, and womt into the fumse: atul his dinciples eame unto him, sayimg, lixplain unlo us the patrable of the lateent the fichl. 37 And lete answerel and salid, lle that sowell the groud

tal complerors, as Darid himsell was linown to hase dome. Their views and foreling-are illu-trited by the wish of . Janes and .lohn to eall down tire from heaven and (e) somaritan village, for refu-ing to receive

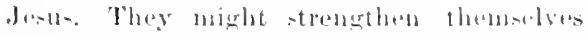
II eiss) in this vien by supposing that the

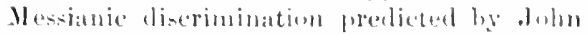
the Bapti-t (a- 10-12) would be the fir-t pat of the Mesianic work, and would be performed

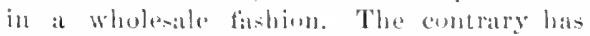
al ready" been intimated by the fatratele at the suwer, and by those we the Mustatri-send and the Leaven, all -busing that the Masolande "neration would be sratual, and wpon imliviluals. And it is distimely set forth by the proent jarable, whiels deelaren that while the Iessiah dests mot at ander dentroy those who rotuse him allegiance, but sulliors rightens and wielede to live on terether in the world, and intertwined in the relations af life (ve29),

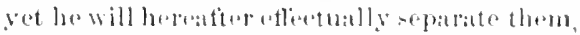

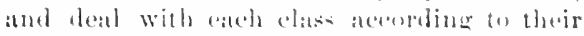
descrts. The Mesiande discrinination is to take place nut at the berimning, hut at the tomel of the prosent dispensation, when the wa-

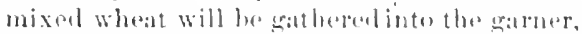

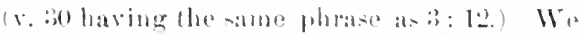
have seen (on $3: 2$ ) that the word remelerent

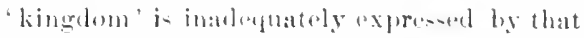

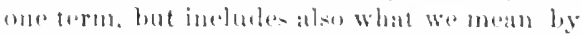

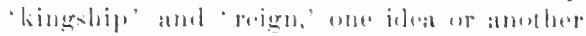

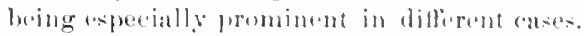
IIere the kingdom of hesven (ve 21) denotes expecially the Mesianie reign, and the parables sets forth some thing that will oceder in the world in enoneretion with that reign. But overlooking these facts, and thinking always uf the kingelem an implying an oreanization of subjerets, the christian world has largubly fallen into the habit af eonfonudinat the kiner-

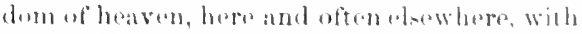
what is profularly atled "the vinible

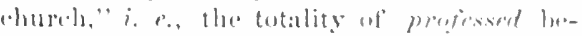

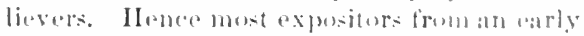

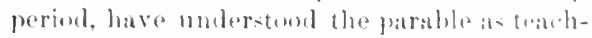
ine that in "the chareh" wa must have" righteous and wieked together. The tendency 
to understand it in this way was strengthened by Conntantines anlophion ot chrisianity as a plank in his political platterme, loadjug to what in molern limes wa (*all a Chureh Esablislunent, in which all are held as

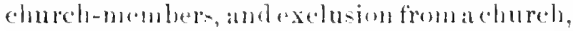
such at the Xil Test. soluetimes enjuin

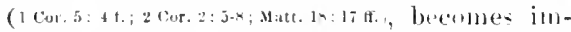
pur.ible. Nith a third callse attected the interprelation. When the Donatists undertark to exenmmunicate all persoms known to be evil, and in the ease of traditores, who hat given up enpies at serijuture to be burned during the peracentions, were unwilling rerer to vestore them to the church ennnetion, Augustine wrote arainst their views a great number of tratises, in which he comstantly alprated to this palable, as showing that good and evil persons nust dwell together in the chorch. He says the Domatist hishope would reple, "It does not refere to the ehureh; the Lurl said, the field is the world. not, the field

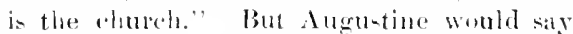
that the world here means the church. They compraded that the worhd is always used in a loul somse, quotiog many teatimanies from Sierifture, as "It any man hove the world." etr. (1 Johng: r.s.) But he replierl with 2 Cor. 5: 19, "Goul was in (hri-t, reconcoiling the world unto himsolf" ; "and ax-luredly" (saye Aler.), " (rod reconeiles to himself mothing but the chureh." On ane acearion Ales. actually states it as a sign of the ehurch that it contains avil and goun mixed together. The influebes of the enreat Lation thendogian thus male it a commonplace of Christian con-

The first statoment of this interprotation we hase

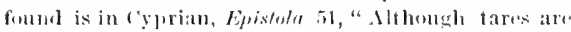

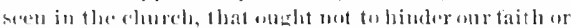

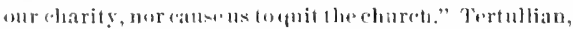

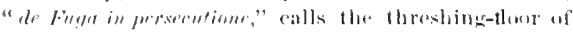

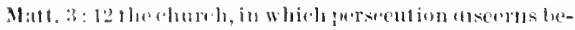

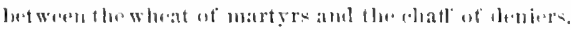

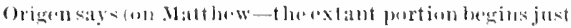

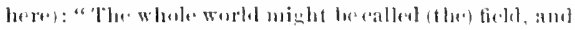
not the rherele of (iont only : for in all the world the sim of man sownd gond soenl, and the evil me the tares." Irenews, iv, fib, refers the parable to the intreduction of evil anumer men ly satan. Ilrrmas, "Ximil." iii., iv.,

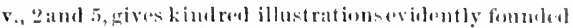
an this parable, asiug the phrase, "The ficla is the

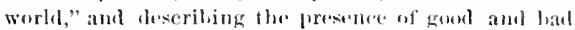
men toutllace in the worll. The application to the (burch was known to Origen, lat apparently owel it: wite aceptance to Cyprian, who did so much to de- trovers and exposition that the parable of the Tares deseribes the church as containing gmol and bad, and teathes that chureh disciJine munt not attempt to have it otherwise. Ill the commentators at the time ot the Reformation, and alnost all since that time, have been connected with some State Chureh, and would readily alopt the eurrent interpretation, beeause it accorded with their education and surroudings. But this cannot be a correct view ot the parable, for our Lord's interpretation, as the Domatists urged, expressly dectares, "The field is the world." It is very true tlat in any church there are likely to be manbers who are not true Cloristians, and whom it is often ditticult for us to deteret; but Augustines interpretation would make the parable teach that when detected, and elearly known, wr must not exclude them. Now the point of the paralile is not that obriously wicked men are to live on as reognized subjeets of Christ's kingdom, regarded as a definite organization- $i$. $e$, as nembers of his (-hurches-but that he suffers them, under or during his reign, to live on in the world, instead of being at once destroyed, as the Jews expected. This would explain to the diseiples. for example, why he who could work miracles had that morning allowed himselt to be insulted and blasphemed, and latel only given a solemn warning instead of blasting with in-tant destruction. It would also give another reason why the Messianie wrot was moving slowly. One reason already given was that many receive the "word of the kingdum' inproperly (parable of the sower);

velul the ehurch illea. II saying is repeatedly quated hy Augustine, as high authority from a martyr. Augustine's numernus treat ises and letters against the lonatists nearly all appeal to this parable, but his fullest statements are in the "Breviculus Collationis cum Intutistis, and the "Ad Donatistes post Collationem." (1ptatus, whine itea of the chureh appears to precede that of Angmstine and fo have heen developed indepundently of Cyprian, says, "de Schismate Jonutistermm," vii., 2), "The field is the whole world, in which isthe church"-a mure reasomable conection than that of Augusline-Ciregory Naz. in several hymus speaks of sowing tares on arth and in the soul, hut does not refier to the ehureh. ('hrysostom (on Matthew) understamb the clureh, arguing that the present world also in f'hrist's, and takes the lares to mean herotics, an idea hinted at in basil also.-lt woult be well if some spe. eialist in Chureh Hist. woult fully work out the history of the early interpretation of this parable. 


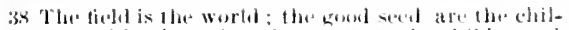
dreat of the kinglom; lout the tares ate the children ot the wickinl allo;

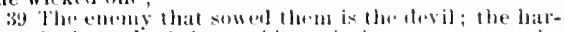
vest is the end of lle world; and the reapers are the aijgets.

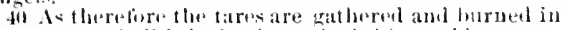
the tire; so sball it be in the emal ot this world, 3t seet is the son of man; and the fiell is llw worll ;

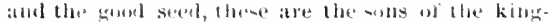

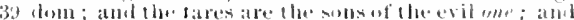
the enesty that suwed them in the thest; and the

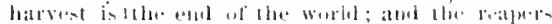

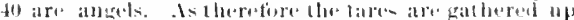
and hurned with tire; se shatl it be in libe end ut

$1(T$, the consummation of the age.

now another rateon is that while the son of man sows wheat in the worlet, the deril, in the satue field (the world), sews talles. all in amonin the wheat.

The mistaken riew of this parable abuve condemmod tiuds apjurent support in the

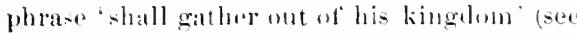
onv. 4l), and in the parableste the Xet. (s. $47 \mathrm{ft}$ )

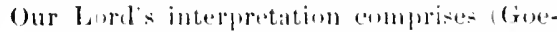
bel) two di-tinct parts. In v. :3-3;! a nuantug

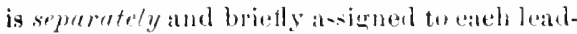
ing object and peram in the story. In r. 4043 , the timal stace of the suritual situation meant to be illustrated is virjelly described by a seriess aiferents.

37-39. The son of man, $i r$ the Mesnial, see on $8: 20$. The ficlal is the worlal, hert the pommon Greek term kosmos, having as broad and grenural a -ense a- our Enerli-b term worlel. ()ur Lorel's prersmal ministry wis restricted to Palostine, though ineluling some crentiles; but his work was to be afterwald extemled into "all the worlde (Mark if 15 ).

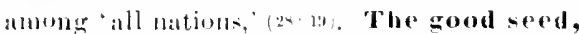

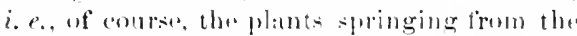
seced. The ehildren (sons) at the kingdom (eomp. on $8: 12$ ), thuse win have a ricrlit to the privileges at the Messianie roirn. ale if they were its very allipring. But in s: 1:2 the

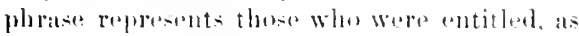
it were, by hirth, to the Mestianie privileses (viz., the bews), but many of whem womlel bo cast out: while here it is those who ale truly the suljeets of Mnsiah by the wew hirth (comp, 2) : 4:3). Auel so the children txons)

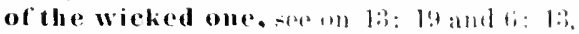
are those who ats elsoly resemble siatan, and ure as completely under his androl, as is the

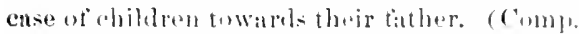

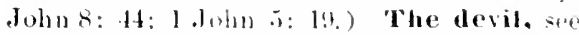
on 4: 1. Evil in the homan race uwe its origin to sittals. As to the reasms why Giml permitted its original appearance in the universe, speculation has scarealy proven satisfuctory. and seripure is silent. Somm argue that the parable must refer to "the church,"

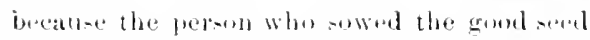
is the Mesiah, and tha enemy suweel afterwerds; while in the werld there had beentemot the evil ane long before the savionr's appuring. But no illu-tration can throw light in all direetions. This parable mull of entese describe tares as sown after wheat. fior uther-

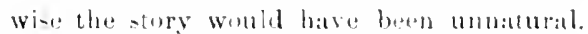

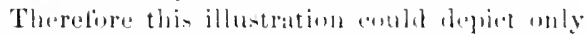
the present and fature relation- of goud and eril in the world, and could not loing within its horizon the pat history of the humatu race. The end of the worlal. The timeli for 'world' is not the same a- in v. :3, but the salue at in v. 2.2 and l:2: :3: whill, according to Jowish a-age, frefuently temotus the present period, the existing entition of

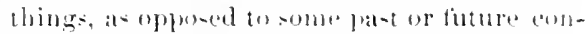
dition of things. The worl translated 'end' demotes completion or en-lummation (as in

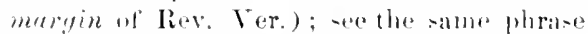
in 24: 3 ; 20: 20), and children at this worlal'

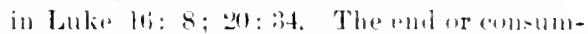
mation of the present periond or -tate wi thinges

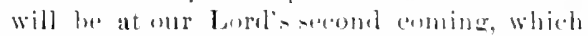
will upen the nuw and elermal perind. Ind the reapers are the angels, sest 611 18: 11. The Greek has here men article with 'angels ;

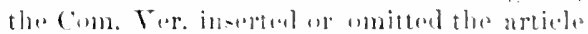

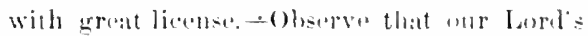
interpretation takes mo alecentut of the men whoslept (really meaning people in eromeral. and not implying blame, see $10 \mathrm{r}$ s. 25), nor of the servats who repurted what had happened; many (enmasentaters are not controt. with this and propuse varions interputations. whing eannot be expected tor rewardattention. (Comply as to the interpretation wf paralides on $13: 3$.

10-43. Burnel with fire is a mure prolbiblo. tratuslation thatn in the fire Ty"ndale and tollowers, the firm being attener in-trumental than lesative. (Comp, 3: 12.) In the end ot this (properly the wortat the worl 'this' being an unwarrinted adilition. as in v. ..2. 'The sou of man ... his mugels... 
41 The. son of man shall send forth his angels, and they sloull yather mal ot his kimglom all thiugs that offend, and ihem which do iuipuily; a
41 the worli. The fon of man shall send forth his angels, aud they shatl gather out of his kingdom

a)1. scandals.

his kingdom, sugeresting the exalted dignity to which he shall attain who was once despisod and rajected. (Comp) an $7: 21 ; 10: 92 ;$ 12: $8 ; 25:: 1$ ff.) The angels, who now desipe to lonk into tlee things of silvation (1 Pet : 12), who rejuice over one siunor that roponteth (1.uk 1.5: 7), who are all ministering spirits, sent forth to do service tur the sake at thos who are to inherit salvation (Heb. 1:14), will then lave assignod them the solemn task of sopurating the wicked from anong the just, ard consigning them to destruction. (Comp. 2.5: 3l.) Aud they shall aather out of his kiugdom. Observe that this points forward to the time of the final judgment. The Messianic dominion will then be regarded as virtually fxtending over the whole world, like God's muivorsal kingship or reign (Psa. 2z: 27 f.); the kingship of the world will be our Lord's and his Clurist's (Rev.11: 15); the kingdom predicted by Danial will be about to complete its destiny, and fill the whole earth. (Dan. 2:35.) All that will then be necessary to render this Messianic roign aetually universal will be to gathor the wiolsed out of the world, and as the worle will then by anticipation be his linglom, it is said that the angals "will gather out of his kinglum,' etc. (Comp. a somewhat similar view in Meyer.) It does not follow from this antiripative explossion that the wivked are now within his kinglom regarlat as an organization apart from the world. observe that the problem of interprotation her" is to reconcile the plorase "they slatl sathor out of his kingdom, with the cloar statoment of $v$. 3s, "the fund is the worlel.' If wounderstand 'lits kinglom' in this eave to mean what is callul "the visible church" thromglumt its history, then we must eillorunder-tand 'the world' in somestrained, ummatural suse, or we must utterly confound the visiblo rhureh with the world: and upon any such intrepretation the inovitable result will be that the pat-iage prohilits exclusion from a church, which as wo have seen, is olse. where distinety enjuined. In some way, then, the phrase "gather out of his kingdom

As when Augustine (sec above) says (he world means the church; or when Calvin says the world is (reign, dominion, etc.)' must be interpreted "ts not meaning "the visible church." or else we bring s'cripture into apparently hopeless conflict with itself. It might be enongh to say that in one sense all the world is under the Messiah's dominion, but not in the sense that all men are really his subjects. With 'gatler out of his kingdom' compare in tho kindred parable ( $v$ 49), 'the angels shall come forth, and sever the wicked from anong the righteous.' In the present 'age, or state of things, the subjects of Christ's kinglom or reign are mingled in all social and other relations with the wicked. To separate them now, and destroy the wicked-as the Jews might naturally expect of Messiall-to make now the Messinnic dis('rimination (3:10-12), would be to hreak up the whole framework of soeiety. But let no one imagine that this mingling will always continue; the tine is appronching when the wicked will be gathered out from anong Messialis subjects. They were never onewere always, in fact, as distinct as wheat and tares; hut they were closely united in the world, their roots intertwined, and they are to he completely soparated only when human society as a whole is broken up. This is all meant not as a reason why we should refrain from putting a wicked man out of a church, but as a roison why God refrains from putting him out of the world. We repeat that if the parable did refer to the presenee of unrenewed persons in a church, then it would clearly forbid any exclusion from a churcha diffirulty, upon that view, which has never been satisfactorily explained. It is idle to say that the parable only forbids very rigid discipline. By confining our view to the natural and obvious meaning of the parable, we free ourselves from all those eonfused and conflicting notions on the supposed relation of its teachings to chureh discipline, which lave almost buried, boneath a mass of unprofitable discussion, this beautiful and affecting parable of nur Lord.

All things that offend, that cause stumby syedoche, the whole for a part, the world thus denoting the church. 
42 And nhalt cast thom into a furnace of tire; there shall be walling and gnashiug of terob.

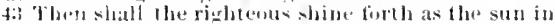
the kinglon of their lather. Who hath ears to hear, let limillear.
4.) all things that canse stumbling, and them that do iniguily, and shatl east them inte the turnate of fire: lhare shall twe the werping and graslsing of

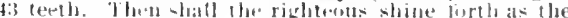
sun in the kingihm of their fiaher. He that hath ears, let him hicar. bling, soe on 5: 29. The idea here may be, all those who cause mon tu sin in general, or sperifically, all those who catuse nen to doubt and fuestion the reality of Christ's reign, from his allowing such peroms to liveon in the worlıl. And them which do iniquity teomp. 7 : 2:3), this bainer and moregeneral "xpresion being athed to the tienrature and more explicit on. preveding-all the stumblingblocks, and in genoral, those that do iniquity. The phraseolegy was perlages sugeresed by Zeph. $1::$. Into a (the) finnace of fire,

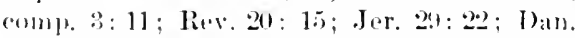

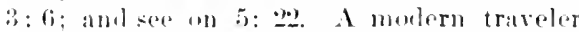
speak= of furnaces for punishment in Persia.

"The finsusee, the definite plate of future funi-hment. There shall be the weeping and guashing of teeth (eomp). (n) \&: 12). departe from the image of com-uming the tares, to introduee another thought of laorror, and heighten the terrible pieture. The use of rarions images for finture punishment shenld prevent a crude literaliom, and talls in with the impertant teaching that there will br degroes of punishment. (Luk.12 it) But the images munt be anderstoud as roporsenting something real. Remss, with his ratimalistic frexiom, ju-tly remarks that the furmase and the grnashing of teeth stand in the sume position as the shining glory of the riglaterts

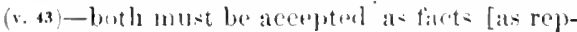
rosentiug pealitiess, or else buth alike referred to the more popular beliets at the time; wne eannot acerept the Bibledeseriptions at heaven us representing realities, and rejoct those of lacll.-Xaspiritual meaning is to be derived frum 'gatlur. 11 , first' in v. 30, $n$ - if sheming that the righteots are to witnes the deotruction of the wielied. Our Lerrel lowesut introluce the word "first' intu $r$, tl, and in the similar allu-ion of $v$. 48 the ureler $i$ revereel. simply following, in each case, the olswous proprioty of the figure. In like mannor some expo-iturs gravely discuss the spiritual meaning of binding in bundlus, when the author of the parable has entirelyomitted it from his exposition. Shine forth as the sum, in purity and glory; comp. Dmn. 12: 3 , "shall shine as tha lorightnes of the firmament. . as the stars for rver and erer." 'The rightcous are "plowed to 'those that do inipuity.' in v. 41. At present, they are often ohecure and unnoticed andel the arout mas uf mankind, impertietly anpreciated and little homared hy the world at large; hot llem, ownpletely di-limet and torever selarate from the wicked. they shall shine forlh as the sun.

In the kinglom of their rather, the eonsummate and eternal state of the Mesianic kinglone or reign (se on :3: :2), when ('brint "shall deliver up the kingelom to foul, oven the Father... that fiol maybeall in all." (1 Cor.15:24.2-k. v.) He that lath ears to hear, let him hear, "alling sulemn atuntin, seon 11: 15. - We loarn here that gomel and bad will both be fenum interminglod in the worlel until the eonsummation of thr proent age, at the second eoming of Clirist; which secms quite contrary to the notion at a provious millennium during which all mon withmut proption will be fatululese Christian. (')mp. Inkis ls: s.

\section{IIOUIJ.TICAI, ANED PRAF'TICAI.,}

Y. $31 \mathrm{f}$. The sow progress of cluristianity. 1) Slow becanse not a casce of mamblacture, but of growth. 2) slow besature in an unfriendly soil and clime an exotice :3) slow through the tault of those who ought to tund

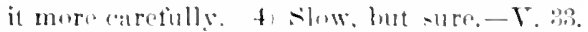
The gralual diffusion of ('lristianity. 1) Through dittoront spheres of life, spirimal, moral, social, pulitical. 2) Through slecessive ages nt hi-tury. (i) Thromel varius

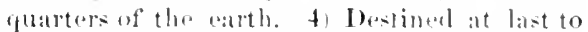
be univeral, in every-ense. - V. 3t. J Fromr: "Even lo-dal. the nultitudas hear in parables; the disciples ask the savjune at humu."

Y.3-4:3. The rightens and the wicked 1) Dwelling in the same worlit. 2) liombel together in politiral, social, and family life. (v. 29.) 3) blessed with the same entworil mereies. (v. 25.) \& Sometimes confummlul hy superficinl ob-ervers, but easily distinguished through their fruit. ( .26.$)$ 5) sure to he separated in the great coming dus, a) without 
41 Again, the kinglom of hoaven is like unto I reasur. hid in a fiold: the which whon a man hath foumb he hideth, and for joy thereol geteth and selleth all that he hath, and hoyeth ibat field.
41 The kinglom of heaven is like unte a treastre hroklen in the field; which a man founl, and his; and in his joy he goeth aud selleth all t. at he bath, and buyeth that tield. chance of error, b) without possibility of reuninn. (c) so that the one class shall hurn in unquemalable fire, and the other shall shine in $111-u l l i n$ perity and undimmed glory for"vel.-V. 38 . The sons of the kingdom. Alior: "For their sakes the world is presarrol now, alle for their sakes it will be destroverl when tles set time is come. The darmel is fermitted to grow in its seasom, and in harrest is ast into the fire-hoth for the salie ot the wheat. Because Christ loves his own, ho permit- the wicked to run their course in tiane: Wut because Christ loves his own, let will separate the wicked from the good at last." - $\mathrm{V}^{\top}$. betong orierinally to the constitution of man, nor has God his Maker introduced it. Our casc is ard. indeed; for we learn that an enemy whom wo cammot overome is over lying in wat. seeking how he may devour us, But what would our case hate been, if evil, instead of lineing injected ly an enemy from without, had heon of the esspuce of the ereature or the aret of the C'reaton"?

Tuoms: " Tho mixture of the gond and ball in this world is ot sorvice, (1) It is of

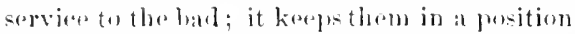
of infuromenent. (2) It is of service to the gomel: looly waracter is strengthesed and perferetred loy asutact with palpable evil.' PARKEI: "Lut Ms remit mer ase to the barvet. Do nut be answring the tiol and the alemy now, ald thus wasting oplortumities which onerht to be usefully empluged in endravoring to do enorl, lut wait ti]l the barvet. Then liall all afualities he tested, thon shall erery man lasen his proper place and standing lusture Giol."

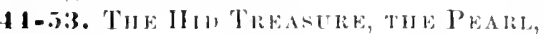
TIF: N I I:T.

These threa rematiniag parables of the gremp are fiomslin Mattlew anly.

1. 11. THE P'RABLE OH THE HIJ TREAsire. The worl again with whinh C'sm. Vor. begins is wanting hore in many of tla

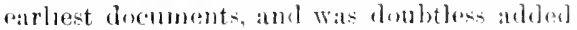
trom v, 45, 47, where the reading does mot vary. This leaves it meertain whether tlee three following parables were sjoken on the same occasion as the Sower and the Tares. They may have been given at some other time and place, and reenrded here by way of topical grouping, as is done with the miracles in eh. 8 and !. But the presumption in favor of the Evangelist's order is strengthened by the language of $v$. 51 and $v$. 53, and by the fact that the Tares and the Net form a pair like the other jairs of this chapter.

The kingdom of heaven, the Messianic reign, secon $3: 2$. Is like, so in v. 45 and v. 47. Some, beginning with Origen, have insisted on the fact that in these three eases the word parable is not used, as it is in v. $3,24,: 31,83$, and that these are similitudes but not parables. But cortainly a parable is one kind of similiturle; and the plirase 'is like' is employed in stating the parable in v. 24, 31, 33. See also $18: 29 ; 20: 1$, where unquestionable jarables aro not called by that name, aud are introduced by this same phrase. And the point sexms to be settled by $v .53$, "had finished these parables.' 'Treasure hid in a (the)

ficld, $i$. e., the eultivated land, the open country as opposed to the city. Palestine had passed through many revolutions, and liad always been exposed to raids from wandoring tribes aromol, and in many distriets to plunder from robbers at home. A ceordingly it was common, as is thr case in all unsottled (enntries, for ane who apprehended robbery or thievers (25:25), or whu was setting otf to a distant comntry, to bury his money, jewelry, plate and the like, in the earth. It thecwner was killed in battle, or died in tle far country, no one might know where his treasures were hid; and it became the usage that lidden valualibs for which no owner appeared -hould ledone to the ownel of the land. Theseareh for -llcli treasures is alluded to in .Jub. : : : 21; Prov. 2: 4, and often in Greek and Roman writers, and is ommmon now in palestine. Thomson, ii., p. 640: "There are many person- diegriner for hid treasure all wver the country, and nut a tew spend their last farthing in thenestrorts." Wearetold that in the bast men of wealth have been known to divide their 
45 Agan, the kinglom of heaven is like unto a merchantmatn, secting goodly pearls:

estate inte three parts, one invested in trate, a secomel part in jewels easily liept about the person, and the remainder buried in the earth -a satel eondition of atliairs for the prosperity of a nation. An instance of hiding treasure oceurred during the War of Sereesion in a Soutl Calolina village, wherethe writer livet. A sbermaker. apon the approated of hostile tronge, hid tive lomelred flollars in gold, and told his wife and a frient that he had done so, but withont revealing the place, supposed to have been in some aldjoming forest. In a few days he dird after a brief illuess, ant his widow was quite mublute to reeserer ble money, which years benee some man may find "hidden in the tield" whem he is at work. Fomm, hideth, or and hid, $i$. e. hial it again. For joy, literally from his joy, or less probably "from joy thereot:" (matrgin R. V.). Goeth, the word explakined on t: lo, which perhaps here implies eager alul basty goring. Notice the vivid change to the historieal present"found and hid . . . . goresotl ind sells . . . . buys" It in sometimes salil that this man's conrse wats dishonest, as he ought to have rovealed his disersery to the awner; if the calse be so underitomd. we must periember that an illustration maty hold exomel als to the thing illustrated even when the literal ant is inmoral, as in the aise of the unrighteons

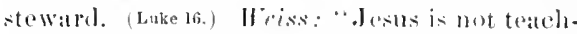
ing how moll ought to alet in such al case, but is nalleating a ease ont of ordinary life," as : :11 illustration. But is there really any propriety in ealling the man di-lenest? If he paid what the land was worth on other aceounts, had he not a perfect right to get the benetit himself of his gond fortune, or his skill, in liseovering the treasure? The trinsaction of the parable was contirely in areordance with Jewish law, though the apparently similar ease puoted hy Wet., Meyer, and many others from the Talmul, proves af filure when the connection is kmown. (belorsheim.)

The general idea which the parable illustrates seems to be this. If a man fully discovers and appreciates the advantages of Christ's serviee, he will be so anxious to make those blessings his own as to salerifiee my and everything that may be necosary for that purpose. (Comp. on $v$. $45 \mathrm{f}$.) It seems idle to
4.) Azain, the kingdom of heaven is like unto a man

seek any spereis -piritual meaning in the res hiding, or in the field, as that it means" "the? chureh," or the seriptures (O)rigen), or Christ, becaltse of (obl. 2: 3. To run therugh the Bible with a comerordintere, and wherever there is mention: of a troature or al field connecet it with this illostration, is a process fatal to sisumed interpretation and unworthy of soluer -ener.

II. 15 f. PARABHe OF THE PEAR, UL Great Pleree. The gemeral meaning of this parable in evidently the same with that of the preceding. It is very natural fing any toateher to give two illuatrations of the same truth. and was experially so fir a Jewloh tealeher. since the more elevated llaberw style tends always to parallelisms. A merehantman. The Greek worl denotes not a mere slopp. keeper, but one who travels to provene what he sells. Coodly pearls, or 'fine,' 'beatutiful.' Ile dues not want ordinary pearls, but such ats ale tiue; so when he fiuds an extremely tine one, le will appreselate and dosire it. One framing sueh an illustration now would doubtless speale of diamonds, lout in ancient times these were rery rare, and no merchint would have mate it his business to teall in them. One pearl of great price. Pliuy tulls w- Bru(o), that Cleopaterats two

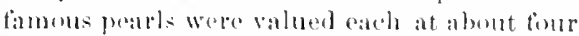

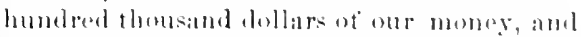
the purchating power of money was then toun ur fifteen times ats great ats now. It wats like finding a diamond worth millions. Sold all that he hade not simply all bis pearls, lut all his possessions, at the (ireek shows. and even the English in r. 4t. of enurse he regarded the pearl as worth much more than he gave; it was making a good invertment 'Andel' is liturally has suld, which gires vivituess-yout see the thing going on, als in 'talketh.' (Rev. 5: i. Rev. Ver.) Sol this answers in some mesoure to the historieal present of $v$. 44. The Mishna has a stery of a man who gave his whole forture for a purarl.

In like manmer, to be a suljoet of Ml exsiah's reign is so precious a privilege, that a man might willingly salerifice evorything olse to obtain it whatever pleasures, homors. phoses sions, or attaimments it is necesary to give un he might willingly abandon-whatever efforts 
46. Who, when he har found one joarl of great price, went and sold all hat he nal, amel hought it.

47 Agaill, tho kingalen of heaven in like unto a net, that was cast iuto the seat, and gathereat ot every kind:
46 that is a merchant serking goodly pearls: and Jaring found one pearl of great price, he weut and sold all that be lad, and bomert it.

47 Again, the kinglon at lowven is like unto a net, that was east info the sea, and gatlered of every

$10 \mathrm{Tr}$, drag-net

are requisite be might make-in order to secura that which is worth so mueh. The Jows thought the Messianic hlessings would (o)me as a mere gritt of (xod, without sacrifice or seckines; and Jous corrects their error. Yet ho does not mo:an, any more than in what has side to the rich young nuan (19:21), that all his followors must actually abandon every arthly poscession or pursuit; nay, piety may "ven (ontribute to the attainment of whatever olse is best worth latring in lifo. $(6: 33 ; 1 \mathrm{Tim}$. 4.4.) But he means that they should be willing to do so; and that his true tollowers aetually will, whenever in his Providence it is markad out as their duty to him. Comp. Moses (1ucb, 11:24 ff.), and Paul. (Phil.3:7f.)

There is a certain difference between this parable and the preceling, in that this inplies a provious seflimg. The gospel presconts itsalf to one man while otherwise oceupied (so with several of the disciples, we know), and attracto his attrution by its manifest value; anothor, while seeking spiritual wisdom, or the highest good of life (Pa.4-fir.), pereeives the areper to bet the trur wisdom, the supreme gond. (Phil. 3:s.) The man who finds a treasure lie had not somght las the joy of surprise; he who bas searched and triven, the joy of suc(ass. Obsorve also) (Bruce) that the tratsure represcouts piety as prartically useful, the pourl ats beautiful and beautifying. $-A$ las! how many tail to appreciate the value of this pearl, "rons when it is hold up before thoir eyes; fluey cannot thiuk it so valuable; they will not aretully axamine, or they apply folse tests. And how many, erern whon arowedly soareling for religions truth and comfort. will buy, reven at great eost, somus imitation-poarl, that is roally worth] ess.

III, 17-50. PARABLEOF TII NET, This is to the same general effect at: that of thr. Tares. (11:21,37.) Why it was suparated from its companion, whilo the other pairs stand together, we cammot toll, muless it was for the purpose of bringing in again, at the close of the series, the solemn allusion to the final judgment. Wejss thinks the again shows it to be the second of a pair, as in v. 45; but the comparison of 'another parable' in v. 24, 31 , 33, will refute this notion, leaving us to understand that wo have in v. 45 and v. 47 the second and third of a gromp. A net, sagene, a drag-net or suine (molern English form of the Greek word), drawn up on the bareh. In 4: 18 ff.; Luke 5: 4 ff., the words do not determine the kind of net, lut the circumstances show that it was there a dip-net, let down into derp water, and drawn ap into the boat. Gathered of every kind, not probably species and thus symbulizing the ditferent races of mankind, Theophyl., M(yej), but every kind as to value, both the useful and the useless. 'The bad, literally the putrid or spoilt, strietly denoting those which were dead before they were caught, and thus unfit for use; but probably designed also to include those which were worthless on any account. See the same word in $7: 17 ; 12: 33$.

The application here is in almost axactiy the same words (v.4y f.) as in v. 40-42. It is confined to the one point that at "the end of the world' or 'consummation of the age,' a sepa. ration will be made between good and bad, with tho terrible destruetion (punishment) of the bad; and it is implied that such a separation will not be made until then. This is clearly the lesson of the parable, and our Lord's intepreation suggests no other. It we attempt, on our own authority, not on his, to make religious application of precerting points of the parable, we must be cautious, and must assurelly avoid deriving from its supposed analogies any idea in conflict with the flatin and unfigurative teaching of other pastages of Seripture. (Comp. on 13: 3.) Now if we say, as many do, that the net represents "the visible ehurch," then it is implied that good and bad must remain together in the church, withont possibility of soparating or distinguishing them in any single case, till the Siecond Coming of Christ. The parable of the Tares, upon a similar interprotation, would make church discipline wrong, because injurious; that of the Net would unake it entirsly impossible. But church discipline is enjoined in Scripture, as all Chris. 
44 Which, whon it was full, they drew to shore, and sat down, and patlered the goud into vescels, but cant lle ball away.

49. Soshall it he at the end ot the world: the angels shatl

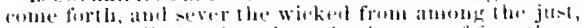

5) And siall atal then into the furnace of fire: thele shatl be waline atul groashing of teell.

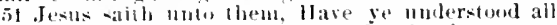
these things: They say unlo him, gea, larel.

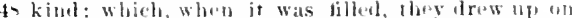

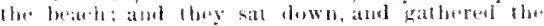

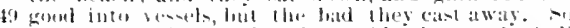

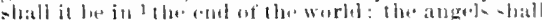

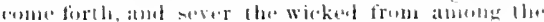

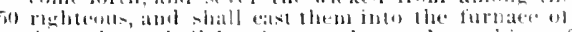
fire: lowe re hall be the wecting and gllashing of linth.

it IIaveye understoud all these things? They say

I (1), the corsummation of the uge.

tian- recognize; shall we aecept an interporetation of meroly lomman arigin, upon which the parable squarely antradicte these injunctions? And soe wat inconeruities the interpretition will involve (Arnot). (1) The anerele must he entirely distinet from those who manage "the clumeh" ; hut the persons separating the goud aud had fishes are not distincet frem those who draw the net. (2) Augustine. and numerum molern advocates of an Established church, wrge upun Sonconformists that it is wrong to yuit the church hecause of there being some bad tish in the net; while the ti-les, goud or bat, remain in the not only becallse they camot brakk out. And so as to other points.

"But is it not cxpresoly said," one might insist, "that the kinglom of heaven is like a net; and as the net gathers of crary lind, mast mot this mean that the kinglom of baraen will contain within its limits, at least its appurent and reeognized limits, buth gromed and hat?" Answer. (a) The word rendered 'kinglom' meanz alon what wo express by 'reign' (see on 1:3:37t.) ; in this sumse the jala would here be not of a definite organization of persons, but of a general state of things, of what happens under the roign of Messiah; and this sento ought to be hore proferred because it rolieves us of the hopeless difliculties involved in the other viuw. (b) The opening verbal comparison of the seperal parables is not uniform and essential to the menuing, but incidental and varving. Inv. 45 the kinglom of hearen is like a man seeking pearls, lut in v. It it is ampured, not to the tiuder, but to the thing fomel. In $v .21$ it is like the owner of the tielel, i. e. the Mossiah (v. Ba ) but in v. 47 it is compared not to the owner of the net, but to the net. Sin in 20: : 2 , the kingdom af beaven is likened to the kine who gave a marriago feast for his son, but in 25: 1 it is likened, not to the bridegromm, but to the virgins who droired to attend the feast. These and other examples show that our Lord does not in each case carefully as- sert a special relation between the Messianic reignand this or that particular uhjert in the parable, but moans to say that something is true of the Mes-ianic reign which resembles the case of the parable; and instead ot speaking in vagueterms ot gemeral eomparion las in 2.5: 14). he often sets out ly saying that "the kingrom of heaven is like" some learding person ar ohject of the strry, or some feature that readily presents itsedf at the hegimming. (Comp. on II: Iti.) In this yarable, then, we are not at liberty to lay any stress upon the complarison of the kinguman of heaven to the net itself. The comparism is to the whole story; and its particular point is given by our Lurd himself in v. 4t $\mathrm{f}$.

One might incline to suppose a reforence heretothe moniritual crowds who were following Jesus, many rekoning themselves his disciples, though they were not; and then an application miglat be proposed to similar hangerson at the present day. But fatal lu this is the fact that ofesus did take pains, not long after tho jarable was spoken. to make such persuss ses the spirituality of true dieipleship, s) that they coased following him. (Jobn 6: 66.)

Nay, the moaning is simply that Mesialt will not at once separate and destroy those perons who refued to become his subjels but will sutfer them to live on in the world during the gradual development of his rejen, until his Second (omine. and then the separation and puni-loment will take place. The phrases of v. f!t f. havelwen explained in the kindred passige, v. 40-42. The "furnace of fire" is an image not suggested by this parable, but by burning the tates.

some have found a mystical signification in the firet that this group eontains seren parabhes (the mystical number), which they ("empare with the soven letters of liev. eh, 2 and 2 , and suppose to represent seven epoehs in the history of Christianity. Apart from other grounds of otyection to this funcy (eomp. Guebel), it should be enough here to remember 
52 Then said lie unto them, Therefort pvery scribe which is instructed unto the kingdom of heaven, is like unto a man the is a householder, which bringel forth out of his treasule things new abd oh.

5.) Aud it cilme lo pass, that when .Jesus had finished these paraliles, be departed thence.

that Mark (4: 26 f.) gives an eighth parable spoken on the same occasion, and that these eight fall inte four pairs.

IV. 51-53. Conclusion OF THE DIscourse. Fonnd in Matthew only. Jesus saith wnto them is a spurious adrition, and so is cord, after yea. The simple yea or yes without addition was not impolite. (17: 23: acts $22: 2 \pi$.) Have ye understood or did you understand-all these things? The emphasis is not so much on 'all' as on 'these things' (so in v. 34). They had not understoud the parables of the sowor and the Tares without explanation; but guided by his interpratation of those $t w o$, they saw the meaning of the subsequent parables, though it is probalile they often saw but dimly at first. Morison: "Not that we are to suppose they understond the things to their summits and their depths. Who even yot has thus exhausted or comprehended them? But they saw light streaming through them. It was light from loaven; it would increase." Therelore, on this account, a strong axpression. (Alford wrong, following Euthym.) Sinos you have understond these new views of the Messianic reign, it follows that you, and every Seribe who like you has become a lisciple to that reirn, will have good store of truthe to teach, of new things as well as old. If the diseiples had not understood, it eonld mot have been at that time said that such a store of variod instrustion would be possessed by thrm and other teathers under the Now bispensution. scribe, see on 2: 4 . 'That is instructed, or, has bern diseipled, see on 28: 1\%. Wo greatly need a verb to distiple for both passares, and for :27:57; Aets 3 4: 2], as we need a verh fo shrpherel in $2: 0$; John 21: 16, etce Jiscipled unto the lingdom of heaven, would be aceording to the corport Groek toxt. The Suribes held themselves ats the diseiples of Moses (23:2: Johng:28); the Christian seribe (23:31) has hereme a disciple to the Messianie Dispensation, which takes him as a pupil, and teaelues him its lossons. If the Messianic roign had turned out only what the Jews expected, its Seribes would not have
52 unto him, Yea. And be sain unto them, Therofore every scribe who hath heen made a disciple to the kiugdom of heaven is like unto a man that is a linseholder, who bringeth forth out of his treastire things new and ohl.

53 And it came 10 pass, when Jesus had finished

been able to produce any new trutbs abont it. The Greek might mean, though less naturally, 'discipled for the kingdom of heaven,' for its benefit or service; the expression seemed obscure, and so was altered in some documents to 'in the kingdom,' and in mony to 'unto the lingdom,' meaning in order to, or in respect to (as in (com. Ver.). Householder, as in 1:: 27; 10: 25. 'Treasure, 'treasury,' or here lather store-house, the term not being eonfined to a place of deposit for valuables (comp. on 12: 35). Bringeth forth is literally throws out, 'flings out,' as explained in 1: 88 , the word appearing always to imply vigorous if not violent action. A man with ample stores flings out garments or articles of finod in profusion, some reeently acquired. others long on liand, each class having its peculiar value. A good housekeeper would make frequent alditions to his stores, while earefully preserving the old. The Jewish sicribes gloried in teaching only old things, but the Christian sicribe learned such new lessons as these parables have just been giving, and so could fling out things new and old. He would now have (Meyer) the fulfillment of many old prophecies, the explanation and now extension $(5: 17)$ ot many precepts, the more correct understanding of the old Mrsianic hope. The expression uaturally suggest tuus the Old and the New Testaments, but that can hardy be regarded as here meant by onr Lord. Purhaps he did also mean that the ('hristian Seribe must initate his example in employing new methods of teaching (as parables, ete.) He here plainly slows that he lid not design for the disciples to keep to themselves what had for the present been taught torthem alone. (Comp. 13: 10-13.)

5:3. This closes the aceount of this series of farables. (Comp. 11: 1.) The chapter ouglit to have ended here, thus possessing a beautiful unity. The remaining verses lave nothing to do with the group of parables, either in time, place, or topic. The other group of parables given by Matthew will be found near the alose of our Jurd's publie ministry, in chapters $18,20,21,2 \cdot 2$, and 25 . 
IJOMILETICAL AXD PRAETICAI.

V. 44. The hit treasure. 1) P'iety is a treasure. 2) One shenld determine to make it truly and thoroughly his own. :3) 11 e should be ready to paty the cost of procuring it, however great. if Well may he rejoice at the tirst view of it, and still nore in it- secured posession.-V, 4t. The pearl of great priee. 1) Piety is the most precious of all poseessions, the summum bomum, or supreme good of lite. 2) To obtain piety, we ought willingly to make all necesary sacrifices and exertions. 3) Piety is worth far more than it eosts. Cuns: "And much as he that has the pearl knows indeed himself that he is rich, but ot hers often know not that he is holding it in his hand (fin there is no corporeal bulk); just so alow with the gorpel: they that have hold of it know that they are rich, but the unbelievers, not knowing of this treasure, are in ignorance also of our wealth."

V. 5l f. Hexry: "It is gend for us, when we have real or heard the word, to examine ourselves, or to be examined, whethor we have unterstood it or not." - The (ionet seribe. 1) Ite is a disciple to the $M$ essianis reign, (a) learning its lessons, (b) obeying its laws. 2) Hebrings furth things new and ohl. (a) From Ohel Tert. and New Test. (h) From former teachers and from his own thiuking. (e) In old methods and in new methods. ORIGex: "The enverse must holl, whoever dors not bring forth trom his trensury new things :ud old, is not a seribe aliseipled to the kingdom of heitven. Therefore ve must diligentiy study notonly the Gospels, Epistles, and I prealypic. but also the law and the prophets." Conzs: "Let us then hear, as many of us as negleet the reading of the scriptures, to what harm we are subjecting ourselves, to what poverty. Fur where are we to apply ourselves to the real practice of virtue, who do not so much as know the very laws aceording to which our practice should be gruided?

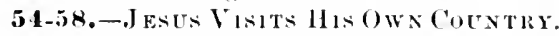

This visit of our Lord to his own country is also given in $\mathbf{M a r k} 6$ : 1-6. It must have been a different, thengh, in some respeets, similar visit to Nazareth that is reeortel in Luke 4: 16-31, and oecurred at the very beginning of his ministry in Galilee (Luke 4: 31 coinciding in time with Matt. 4: 13). The visit described by Mutt. and Luke appears to huve been about a year later. Many reeent eommentators argule, or take for granted, that the two events wre really one, and then dispute as to which oecupies the more correet chronological pesition. But the stromg probability that both Mark and Lake have follo,wed the chromologiend order, as they so commonly do (at leant in the early part of Luke), is here turther strengthened by the great fitlerence of "ircumstances in the two casers. In Luke, the synagegue atellese so angers the congregation that they rise nu and attempt to kili him; for this there seems to be no rewm in II atthew and Inark. In Luke, Jesus is expected to work mirackes, and openly declares that he will not; in the other ease he works a few miractes, and wonkers at the unbeliel which prevents his doing more. It was natural that Jesus should give the aequantanees of his early life a second ehance to bear, and when they did not believe, he might very naturally repeat the saying which was so readily suggented, and an strikingly appropriate (v. .); Luke 4: 24). It is thus easier to aceount for the similarity of the two narratives, if distinct, than fur their differences, if reterring tes the same event. But somecrities always tatke for granted that two similar events or fircourses must have been really the saume. A little experiente as miswionary preachers in: "ity and eountry, especially il as field-preachars or street-preatehers, or in general, als "evangelist-" would have taught them how natural it is to grive many similar points of instruction at different times and phates. Comp. at the beginning of eh. 5. and on lis: 88.) It is imponible to say wih oertainty whether we have here two events or one; but the probability seems strongly in faror of the former view. It is supperted by Meyer, Ewald. Wieseler, and many others.

Matthew does not here mention, theugh bis expressionsdonot exelude, varions oeenrrences whieh Mark's order shows to have eome between the series of parables and this visit. viz., the passage of the lake and healing of two demoniacs, the feast given by Matthew. the raising of Jairus' daughter, ete. These Matt., aecording to his topient metherl of grouping (in ch. 5-13), has introduced (atrlier. (8: 18 to $9: 34$ : see on $8: 18$ and on 13: 1.) Some skeptical expositors insist that his expressions do exclude any intervening events. 
54 And when be was forme into hisewn feoutry he

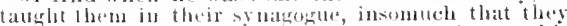

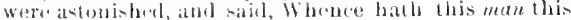
wistom, alsd these mighty works:?

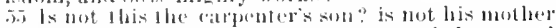
called bary? and his lrethren, Ja:ues, and Joses, and simon, ami l Imlat:
It these parables, lae deported thence. And coming julo his own country he taught them in lheir sylatgouste, insommele that they were antomished, and sitid, Whence hat lo this man this wistom, and these jij 1 mighty works? lo not this the 'arpenter's sou? is now his mother called Mary? and his brethren,

1 in. powers.

They reat it an one sentence: "Ho departed therace, and eoming inte his own country, tatught," ete. 'The Grobls might mean this, but aven so, must we necessirily understand that ho wont wif the same day, stopped nowhere on the route, and neither sate nor dial anytling from the close of the parables loside the lake till he reached the synagogue at Nazareth? It will surely be agreed that whe day may have intrervened, if no more; and it so happens that ond day with the preeeling night womld suftice for all the events mentioned by Mark as aceuring in the meantimes. It is wearisome to lollow out such alaberate attempts to make much of "dis("repanorios."

In Iatthew this rejection at $\mathrm{N}$ azareth eomplotes the aceount of opposition pneountered hy .le-11s (ch. 12 and 13); and the patrabolie teaching which was accasioned by this opposition is preceded by the interterenes of his kindred (12: $16 \mathrm{ff}$ ), and followed by the rejection at his (2:arly homile.

5.1. His own country must here mean the listrict of Nazareoth, and mot (ialilee in gren-

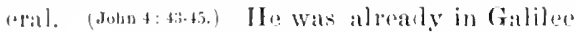
when las gave the parables. He is here in a fartienlar aity or village, having one detinite syougugue. Tho people know his brothers by

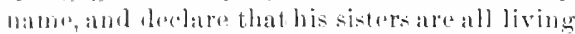

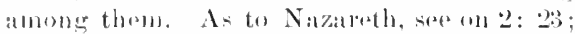

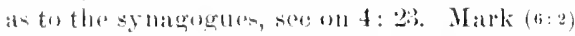
says that this tarehing was on the siablath,

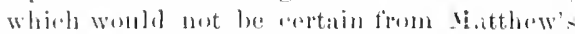
areount, sinese they met in the synagogue also on Momalay and 'Thuritay. And these miglity works, of "miracles, the word bujng

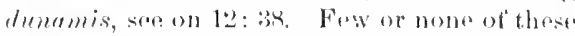
were wrouglit at Nazareth $(v, 5 s)$, but they hat hearl of them, and doubtlest sume Na\%aremes had witnessed them at other points. Notien that with alt their nnbeliof and hostility thery hial not question the reality of his miracles. (Counl. on 12:24.)

5.5 f. Is uot this the carpenter's sou? Jesus was of rourse considered anong the
Nazarenes to be the son af" Joseph, "and that impression was wistly permitted, because the iklea of the heavenly origin ot' Jesus could be of use only tu believers." (Olshausen.) The word rendered 'onrpenter' means in general artitirer, but usually denotes a worlier in woot. Mark (6:3) las it, 'Is not this the earpenter"' showing that Jesus had limself wought at his reputed father's trale. Justin Martyr, who was ratred in simaria, affirms in his dialugne with Trypho the Jew (an. sx), written about $A$. D. 150, that Jesus was a malere of plows and yolies-atradition which may well enough be true. In laboring as a mechanie we must not fail to see that he set -us an example. Bolonging to a poor fanily, he ate not the breal of inleness, but with all the great work that lay beforo lim, and already must have began to press mpon head and heart, he deroted himalf to bonest toil. It was the wine custom at the Jews that even when walloy their sons must be tanght some trate; as Panl learned tent-making, and lived to find it pxtremely useful. No doubt the Saviour worked diligently, a model to mehanics of mever slighting work, anch of always merting engagements. And no doubt he cherished all the day long so devout a spirit a to make these homely toils a jart of the lite of priety.

\section{And his hrethren . . and his sisters.} It seems impossible to determine with certainty whether we are to understand brothers in the striet sense, or half-brothers, or more lowsly, near kinsmen. Each of thess riews has been carnestly supported from an early time. LAm jarticularly goud diseussions of the whole suhject in Bishop Lightfoot on Gialatians, smith's "l)ict. Bible," Amer. Ed., Art. "Brothers of the Lord," Sichaff in Lange on Matt., and in "Churoh History" 2l ed., Andrew's "Life of Christ.") The three theorios are well describuel by siehaff as the brother-theory, held by many Protestants, the half-bother-thror? provaling in the Greek chured, und the cousin-theory, prevaling in 
the churela of Rome. 1. The mon abvions view is that the 'brotlers' were surh in the ordinily' sense, ans of "Joseph and Mary. In favor of this we have the natural though not

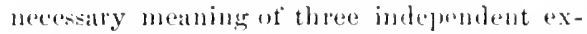
bresions. (a) 'l'he word 'brother' naturally meaths this, and ought to keso taken in any ease moless the contraly ean be there shown. It is used not once, but many times. And ob-rove that here we have al $=0$ 'sistors.' Morewer, it is not here lesus followess whosprali of his brothers and his sisters, but the mulyelieving and bostile Nazarenes, who are not likely to have emploged the term in any nommetural or num-lual sense. In their mouths 'his brothers' and 'all his siotres' aumot have meant lese than rhildren of Joserph, if not of Joseph and Mary. They eould

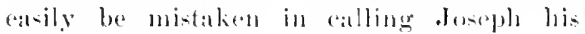

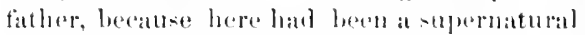
firct of which they were not informed; but how enold they low mi-taken as to his brotiors atod sintels"? (b) The phlane "kllew her not until (1:25), whild not neressarly meaning that aftere the birth of heresth they heed torgethere ia the ordimary relations of husband anel wife. naturally neatsis that, and it is lighly unnatural to understand it otherwise.

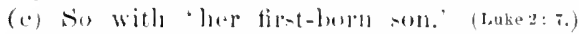
The special laws at to a fir-t-lown soll wight porsibly lead to the une at this expresion, thongh no othere ahildren followed. But this would have been less natural fior unf wher wrote long atterwatrels, ats Inkite did. IIrre then are three indepundent startements, each of which attords a cloar and - rome probubility, and the combination of the three atterels a very high, in talt an orerwholuing probatbility. And how strange it womld lonk for each of the four kitugelists, and P'and (Johu $i$ :

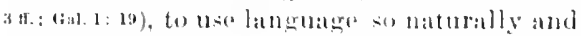
indeitably sugge-ting that Mary bore other children, if this wa- untrue, and a very objectiunalsle illas.

Theol,jertions to this view aro(1) sentiment. This pervades the Rumanist and Greale Christian world, and extemble to many l'rotestants. But it is Hentiment without seriptural support, and out of latrmony with the general tone of seripture in rearard to marriage. Thut Jesus should be born of a virgin bad an obvious propriety in showing that his birth was supermatural, and helping to put him. ontside the line of transmitted depravity amd grailt; bet nothing in regated to him or his work would be athered by his mother's afterwarls beariug ebildren to hap hushand. (2) This view would make James his brother an "apostle withunt being ons of the 'lwelse, ore (ial. 1: 19, and eomlly. Acts 9: 27. liut the phrase in Gal. 1: 1! (lows not certainly mean that Janue was all ajustle (sou meregin, liev.

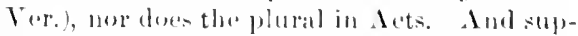
posing that to be montst, we mast obselve that

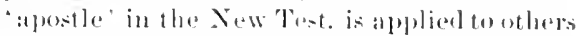
thitn the Twelve; lnarly sil in Acts 14: 14, "the apostles, Barmabat and l'aul," perbayso also in 1 (oor. 4: 5 f.; ; Rom. 16: 7; l llhess. $2: 6$; and the "false aputles" of "2 Cor. 11: 1:3; Rey. 2: :- would have beon simply ridiruled it only the 'Twelve. had ever been alled by

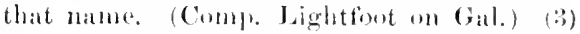
It would soem strange that Josus on the coros shomld commit his mother to a friend, when she had soms. But this would hold against the other theorien also, and even morret rongerly againet the ensin-thenry, fin then two of hex mephews wereanumethe Twedve.

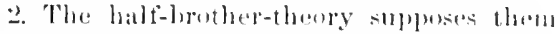
to be soms anel daughters of obseph by a former marriage. This leaves romm fier the sentiment as to Mary's perpertaal virginity, amel the last objexetion to the fermel viow atlerets thic in a less deoree. It might nlso help to aceome for the fact that "the brothers" were inclined to as

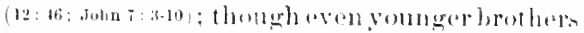

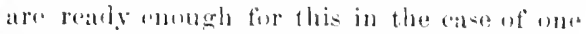
whom they regard as a religious rollhusiast. (Mark 3: 21.) - The objections to this theory are (1) It is a mere suppusition. (2) In this arise,

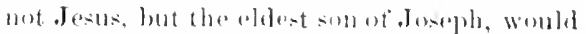
lisve been legal heir to the threne of [):aviel. (i) The brothersand sisters were, on this view.

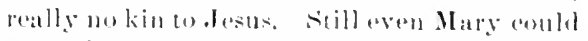
sity to him, "thy tiather and l" (luke 2 ar), and Luke could sprati of his parents. (ruke 2: 11.) (4) Wr must thus melerstand 'first-loorn son' in an imporobable semace (an above).

3. The (onsin-thary makes them the sons and daughteres of Mary"s sister Mary. That the term brother wan sometimes used in this lonse sense may be seron form Gen. 13: 8 ; 14: 16; 29: 1:2; $31: 23 ;$ Job 19: 18, and as as cially .Job. 42: 11, whort sistor- at well as brothers are mentioned, and aplourently mean- 
56 Aud hissisters, are they not all with us? Whence lhen hath this man all thest l hiness?

5) And they were offeudnd in hin. But Jesus said

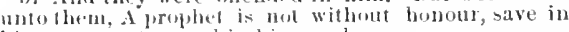
his own country, and in his own hotise.
56 James, and Joseph, and simon, and Judas? And his sisters, ale they not all with us? Whence then 57 hath this man all these things" Aud they were loffended in hint. But Jesus said nuto them, $A$ frophet is not without bonour, save in his own

IOr. caused to stumble.

ing relatives in general. And such a use of lleterus is still found among Oriental nations. 'This theory strjposes that (?) lous (John 19:25) was the sume ats Alphens; it makes James the lerel's brothor the same as James the son of Alpheus, and thus ome of the Twelve, and 'Judas of James' (whether brother or son), anotler of the Twelve. This also leaves remen for the sentiment involved, and aceounts for (ial. 1: 19 (see above). Olijections. sixmonths before the erucifixion "his brothers aid not helieve on hion" (John $7: 5$ ), when acenrling to this theory two of the four brothers had long been annong the Twelve. (2) Any natural etyuology of Clomas would be very ditherent from Chalphai, Ilpheus, (B) There would thus be two sisters of the same name. 'The notion of some that one was ealled Marian, and the other Maria, is quite set aside by the actual readings of the aneient doruments. (4) It would be strange that these young men, even those who were not belicrels in Josus, should be mentioned so often with his mother whan their own mother was alive. (j) And why should he entrust his mother to John, when atuong his twelve disciples werotwo en lacr nephews and familial assuciates? I pun the "brother-theory" we may rastily suppose that lis brothers were still at the timeot the erucitixion not believers. as had heen the (atses six months before (Juhn : : 5);

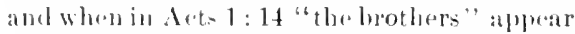
with Mary ammong the disciples, we may suppose that the jian Lord's appearance to . James (1 cor. 1.: 7), rolded all doubts with him and the other brothers. These suppositions sopm not Inmateral, and they aecomit tos our lurets eommitting his mothor to . Iolun, when letr soln were not get in sympatiy with him.

The question can never he setelded; lout the probabilities are very deridally in taver of the first viow, that these were sons and danghtere of . Toseph and Mary. Thus tho great alad unspeakably important institution of marriage is duly loonored, and Jesus, the firstborn son of Mary, is in no sonse dishomored.

Whenee then hath this man all these things? The astonishment of the Nara- renes was well-founded. (Comp. also . lohn 7: 15.) And it Jesus is thought of as a mere man, their question remains to this day unanswered and umanswerable. In the little tountry of I'alestine, in its least refined district, in a petty and secluded town, whose inhabitants were violent and in bad repute among theil neighbors (see on 2: 2\%), aruse a young meehanic, whose teachings, though ended by an early death, surpased all the windom of Fudia and the Chaldeans, of Egypt and Greece; and who, in the few vears of his eareer as a teacher, founded "an empire of love," which has spread wider than any empire of earth, and seems destined to last and to grow in all coming time. Whence then had this man all these things? Thore is but one answer. He was a teacher sent from God; he was, then, atecording to his own express declaration, God's Only-begotten Ston; yea, he was all that Thomas calied him-for he himself eommended the saving-" my Lord and my God." sine Young's "Christ of History" and Suhaff"s "Person of Christ."

57. Offended in him, or, caresed to stumble, as in $11: 6$, and secon $5: 29$. They found in him obstares to behieving. They stumbled at his humble origin, and lack of traning in the Rabbinieal selsools, and in their blind mubeliaf ther would not listen to his wisdom nor hrod his miracles. but rejected him without further inquiry or reflection. As he had had ner chance to become so wise, they concluded that his wisclom was not real. They ought to have san that it was real, and thence coneluded that it was divine. A prophet is not withont honor, ete. It was natural that the same objection s!muld be made by the peopla at on his former visit, and that he shonld quoto the same proverb in reply. (1,uke 4:22,24.) The fospel of John (4:45) applies this saying of our Lord to a different occasion, probably as axplaining why lue went back to his ow (ountry of Galilee, where his labors would not be likely to produce so much undesirable excitement as they had begun to do in Judea am siamaria. In any ordinary matters, a man will be more kindly received among his 
5x. Ind lat ditl not matug mighly works there because of theis intselieti.

5.t country, and in his own luane. And he dind and

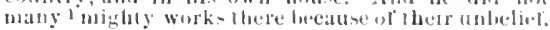

('II A P'T E li I I

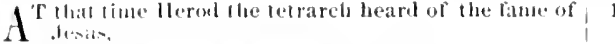

At that season llederl the ted ratroh hearel the report

1 Gir, pouers.

kindrodand early friends than el-awhere; but not when he appears as greatly theje sllperior, and protioses, or is popmlarly reportenl, to possess extmandinary powers. 'They think of him at he ased to be, and are sow to believe

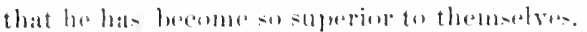

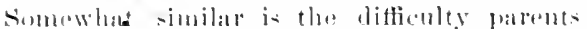
often hase in believing that their ahilinen are grown and can do mature wark-they karp remombering them as children. Olservethat

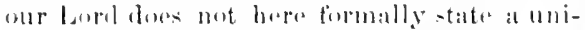

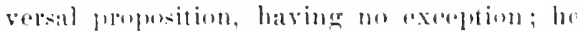

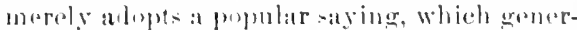
ally holls trur. In his own house. Mark

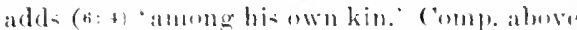

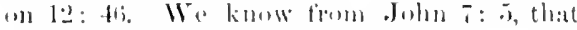
'his brethres' diel mot yet besliere an him.

Ex. The persple diat not attemple any vio-

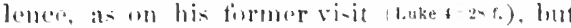

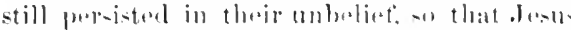

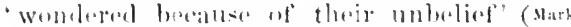

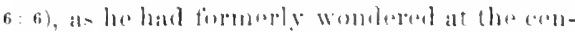

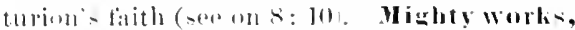

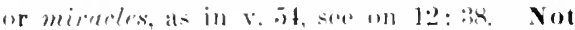
many. The fow mirales which he did work there eonsistenl (Warketis) in healiner a fiew sick

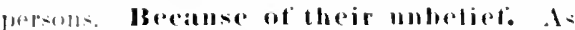
a general thing. he did not work mirates in

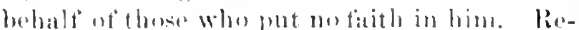
ligious benetit to the people, which wa- alwale his ultimateobject, wasimponibhe where thery

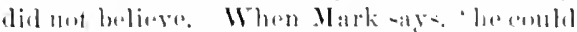

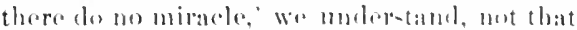

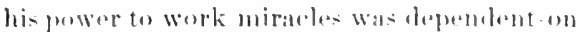
mon's fath for be sumetimes healod withent theje tatith or knowledge, 1.: g-: lake 22: il), hut that he (e)tuld not lo it in eonsi-temery wh his deigrn, without riolating the plan of his

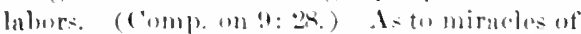

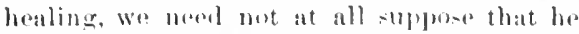
refused to beal any who atare to him; the unbelief which provented him trom working the miracles prevented the prople from sorking them.

\section{HOMULETCAL AYII PRACTICIL.}

V. 5t-58. A prophet in his own country. 1) Jesus strives to benefit the obseure and un- promi-ing anomunity armong whom he hat

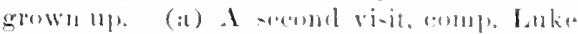

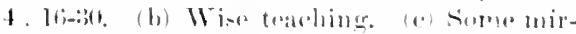
acles of hating (anmp. Mark li: D), motwitle

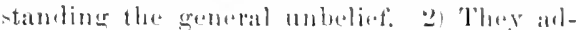
mipe bis wise teachinge and rightly think it

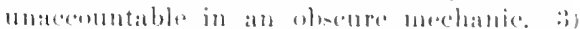

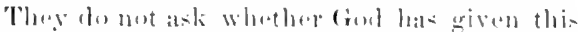
wislom, whether it is Mentamis tomehioner (comple lukes 4: 18-2l), lut stumble at his knum lark of Rabbinical trainind amel

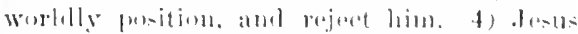

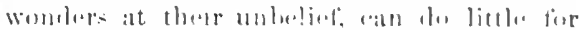

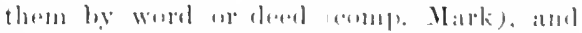
turns -all

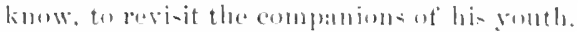
- V. it. "Whanee hath this man this wis-

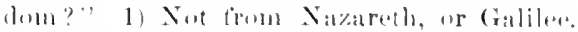

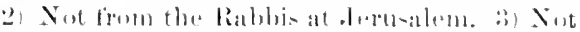

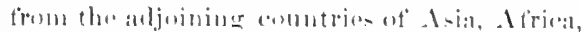

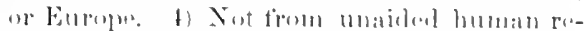

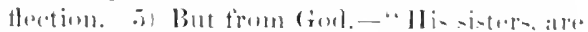

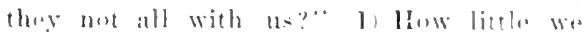

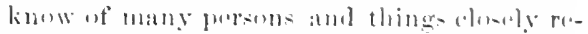

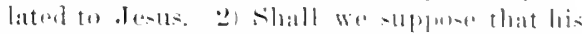
sisters shared the muludiet al his hrothers

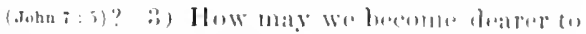

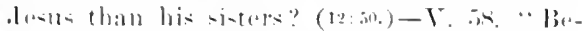

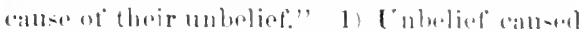
the fall of man. 2) Inbeliest resteded the?

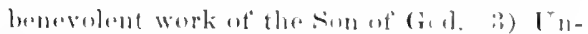

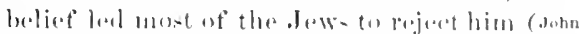

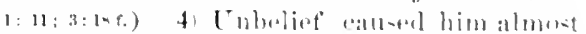

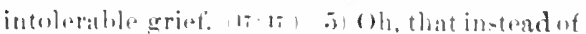

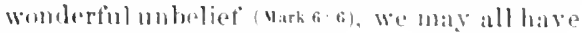
wonderful fuith. s:u, s: $\omega_{0}$ )

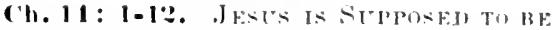

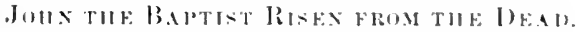

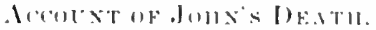

Thus lar, Matthew" narrative of mur I,url: ministry in Galilor, commencing with 4: 1: bas to a grent extent di-regareled the orter of time, and followel an arrangement a: :oreling to topies, hetter suital to his obigent of proseing to the Jews that Jests is the Mrsiah, and explaning the true mature of the Mesianic 
reign. ((omp) on 4: 12;8: $1 ; 9: 85 ; 11: 2$; 12: 1.) From this point onwall, he follows the orler of time, with a few slight variations in ch. 2l and 20. made fur the pulpose of convenience in the erroupinger.

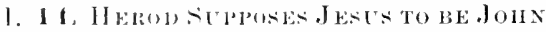

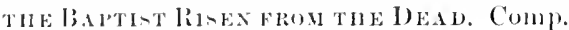
Ilarli i: 14-16; Lulie 9: T-!).

At that time (stasom), indefinite ats in 12:

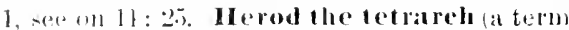

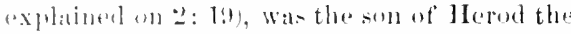
(ireat (nese on $2:$ I), and one of the three munng whom he divided his dominions. The Totratedes mother was a sianaritan; he was di-tinguished trom the numeroldsuther Herols by the name Antipar, a contration of Antipater. He and his brother Arehelats (2:22) had spent their youth at Rome. His tetrarehy

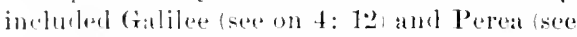
on 1!): 1), the region atas of the Joretan, form the siat of Galileetuthe northeren part of the I) and sieal. Is Totratroh of Galilee, he had beron the civil ruler at Jesus almont form the tirst, and John's bitptizing in P'ereal (John l:2s) put hine alog in Herenl's puwer. He had now boen roling alont thirty-two yeatrs. His first wifi wat the latughter of 1 retats (2 cor. 11:32), kinger of the Nabuthatan Arabs, whose capital wis the fitmens Potrat, and whose dendinions aljoined Perat on the south, the fortress of

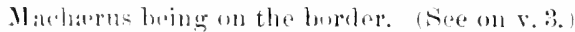

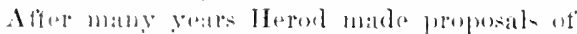

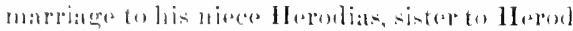

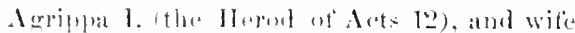

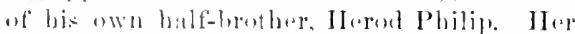

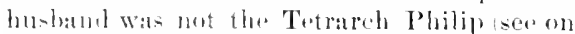
2): 20), whe marrial lare tholughter (sese on v. li, hut wat another son af If

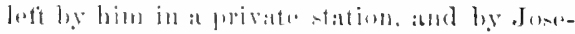
phus (alled simply Horul. ("Ant." T7, 1, 2); 18, 5. 1 amd 4.) The simplo and natalal sip-

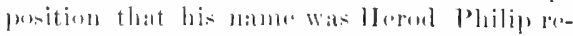

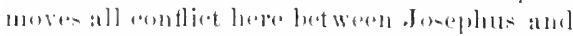

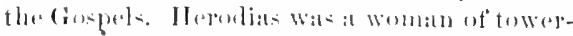
ing ambition, and readily aceopted, if imberel

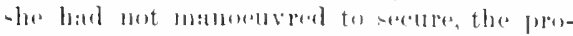

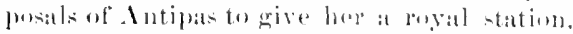

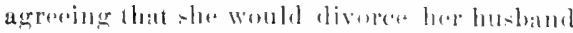
(comp), Mark 10: 12), whilo lu, must divorere his Arah wife. Althomerh acera-tenned to in-

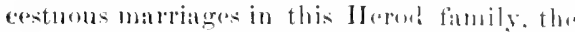
people must have been greatly antraced at the Tetrareh's taking the wife of his still living brother, to whom she laad borne a child. Hence the eftort he appears to have made to get the famous John the Baptist to endorse the marriage, which would have had a jowertiul effect on the popular mind. The injured daughter of Aretas escaped to her father; and some years later, disputes having arisen about boundaries, he was led by the double motive of revenge and interest to make war upon Herod. The latter's army was defeated and destroyed, and he was saved from ruin by the interference of the Rimmans. Josephus ("Ant." 18, 5, 2) states that some of the Jews thouglit the destruteon of the army a judgment from fiod for IIerod's treatment of John the Bapti-t, whom

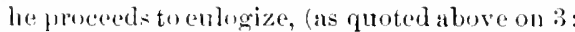
2), and saysthat Iterod put him to death from fear that his great influence might lead to a rebellion. This account in Josephus becomes nore intelligible through the facts given in the Gospels. Herod Antipas was not naturally a cruel man, but selt'-indulgent and unserupulous. There were miny other wicked deeds for which.Juhn folt bonnd to reprove lim(Lute $3: 19$ ), be-ides the shameful marriage. Like most weak rulers he attempited to use cunning, and Jesus afterwards enlled him a "fox." (bake s:31f.) -The three Ilerods called by that mame in the Now Test. may be readily distinguished by remembering that "Horod the Grat murdered the infints, Herod Antipas boheaded John the Baptist, and Herol Ierinua killed James and imprisoned Peter." But we know fiom. Josephus that many others of the fambily bore the name of the great formder. Thus each of the Philips mentioned above was named Heror Philip, and the Ioripla before whom Paul spoke was called Hopod Agrippa, like his father who slew Janice.

I Leard of the fame of (R. V. report con(n)ming) Jesus, comp. on 4:24. Iheroul usually resiled duriug bis latter years at Tiburias, town on thes. W. shore of the sea of Galike, from which it was sometimes called Lake Tiberias (see on 4: 12, 18). We have noaceount of otar Lord's ever visiting this town, and perhatps hestayed a way to avoid exeiting the bostility of Herod, who might be jealous of one beginning to be popularly regarded as King of the dews. But histrachingsand miracles bad spread the report of him far and wide, till it 


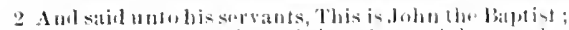
he is risul from thetleat ; aml therefure might wodks aderlew corlh themselvas in him.

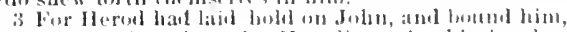
and yut him in prison tor llerodias sitke, his brollet libilip's wift.

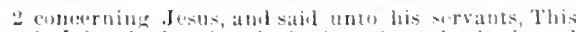

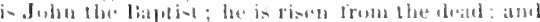

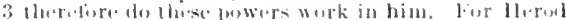

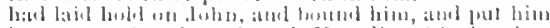
in prosin for the sake of llerodiats, his brother penetrated even the precinets of the conts The reesnt mis-ion of the Twelve (eb. 10) hat probably contributed to this, for both in Mrark (6: 11) and luko (9:7) the statement follows immediately upon the areount ot that mision, which would naturally malie a great sirall over the country. Ilerenl patd hitle attention to religions movements amomer his suljects, or he would have hearl ot .Jesus carlier; tior it hat now beren erelatinly one and a halt, and probably two and a balf yours (seo on l丷: 1 ) since our Lorel's baptiom, and for at year or more he hat been activels al work in fialilee, teaching and working a grast ntumber of mirareles. But it was in aceortanes with the luxurious and rather slethtul characere of the Tetrarch, that he should be thus igmoratet. It may be (Edersho), that as Tiberias hat beron recently huilt (Jos. "Ant." 18, 2, :3), ha wats still spending much of bis times at othor placess, which womld partly aceount fire his ienurance; yet raliles was at any rate the most important pant of his dominions.

2. Ind said unto his servants. 'Tlyes

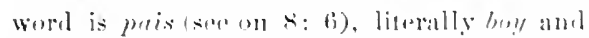
themes 'sersant, and otion applitel to the offlicers of an oriental court (ien. wa:20: 1 s.sus 16

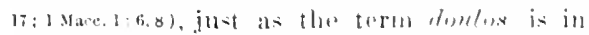

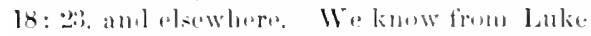
8: :3, that "Juamma the wite of" chiuza,

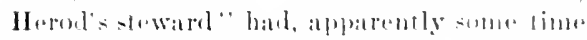

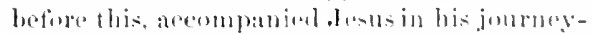
ings, and ministerel to him and his tollowers from her proptely. It womld stem mors likely that "Manaen (IItahem) the fosker-

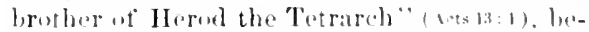
camo" a Christian at a later puriond. This is Johuthe IBaptist, seon $3: 1$. IIr is risen from the doad. with empliasis on bo" (comple un 1: 2l), implying that this romarkable puran at whom they hearel was not aly-

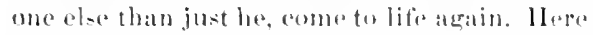
is a display of philosophizing, and a tourd of guilty conscience. 'From the deat,' $i$. A. from among the dead. From Mark s: li, compared with Matt. 16: 6, many lase inferred (even Plumptre) that II rod was a sidducee, but without sufficient ground. It is not likely that ha intelligently and haartily adrepted the relierions views of either party,

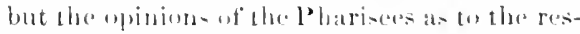

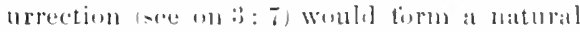
basis in his mind tor the notion herenglened. This notion did mot originate with I larend, lout was one of the conflicting aphions which he heard uf ats expresind atrong the perples.

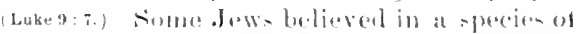

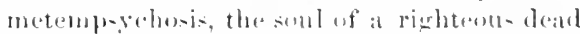
man antering a $110 \mathrm{w}$ benly borm tor the purpere Juspluts " War." "2, s, 14). But in regard to Elijab, Jakmiah, athd the famous prophestin general, it was believed that one of them mierlit -imbly ande to life arain, the same in soul and body. (Luke $9: x, 19$.$) llarod$

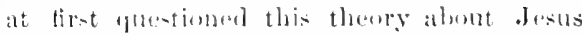
(Lukes.9, but aflorwards andephed it (v. 2: sark 6: 1t), and innisted on it ats the only correct view. (Marktian) He mas presibly have eon-

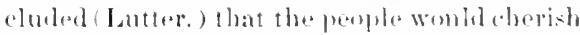

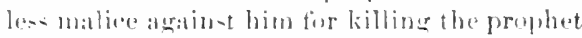
now that he wats reotoreal to thems. At at later period we find this notion still

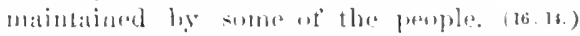

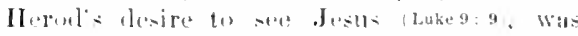
ferhapk pally that he might atale this quesdim, but parly arose from more enrionity to

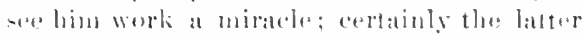

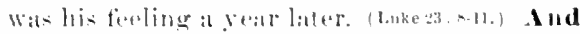

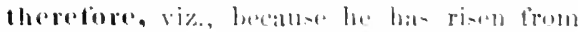

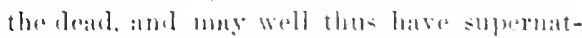
ural pusers, which he did not betiors puseses.

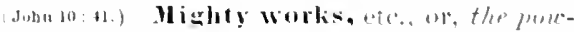

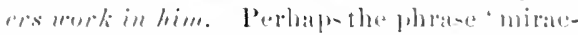

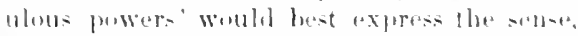

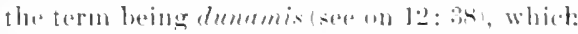

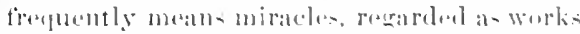

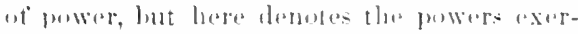

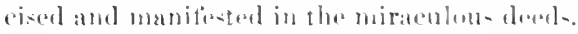
shew forth-work, exert themselves, eperatis. problece their etliect. In him, ats the seat of their residerene and exereis.

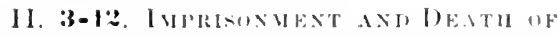

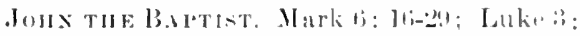
19t: IItthew amel Mark here stup to tell about Ilerod's putting bohn to death; and as introductory to that, they tell of his imprison- 
ment, which oecurres probably more than a yeatr carliur (see un 4: 12\%. Luke closes the paratlel fatage (9-7-9) without describing the deatla of .John; but in ending his aceount of John's anty preatehing, he had already mentioned in andrance that IJerend cast John into primon. (Luliez:19f) This return to a sulyect in me ('ane, and anticipation of it in another, are both conformed to the fitnes of things in historical narrative, which requires that the evento to he narrated shall not always be strung along in the oreler of their actual werurrence, but grouped aceording to natural primciples, or else the story will not be interexting and impresolve. Wark bere gives, as is characteristic of his (ropel, more minute and vivid detaits than the other Evangelists. lI rod had latd hold on John, literally, laid leold, the writur just stating the ocenrrenee hi-torially, and leaving the reader to sere for himelt the obvious fact that this was anteredent to what he las just before narrated. 1

Bound him and put him in prison. The place of his imprisonment and death, as we latrn from Josplute ( Ant.," 18, 5, 2), was Marrenus, alout soven miles from the Dead Sano on the X. E sile. Some writers wish to

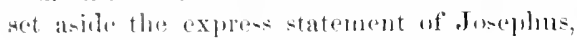
and loceat's the natrative at some other print; lut their alreumests and of very littlestrength. Macharelue was firet fortified by one of the

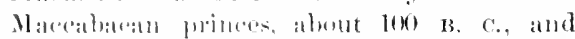

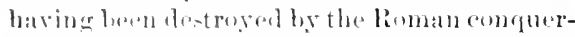
ors, wa- robult and rory stromely fortified by Hoped the cireat. The siles ancient deseription of the plave (Jus. "War," 7, 6) has recently beren -trikingly andimed by the only full merkern dererifition. (Tristran, "Land of

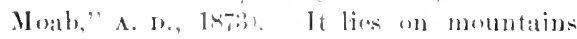

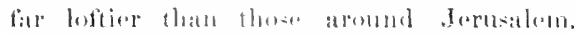

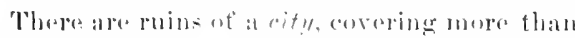
a suluare mile. lityond a valley rises a long flat ridere, more than a mile loing and quite difficult of aceess, all of which was minle a stroug fortress. From this ridge rises a high, conieal hill, the top of which is ne hundred yards in diameter, and which was fortified as an impregnable citadel. In this eitadel, besides a very deep well, and a very large and deep eemented eistern, are now found "two dungeons, one of them deep and its sides scarcely broken in," which bave "small holes still visibie in the masonry, where staples of wood and iron had once besn fixed. One of these must surely have been the prison-house of John the Baptist." (Tristram.) On this high ridge Herod the Great built an extensive and beantiful palace. The vicinity of the fortress and city was remarkable for mineral fountains, bitter and sweet, hot and (w)ld, whose mingled water. formed laths, good for various diseases, espereially for stronthening the nerves. The most celebrated of these were in the valley just north of Hachierus, called the callirrtus ('fair-tluw'), to which Herod the Great was carried not long before his death. There were also neighboring mines of sulphur and alum. Altugether, Inacherus was a delightful -11 mmer residence for the rulers, as wel! as a strong fortress on the boundary between Perea and Arabia. It had for a short time been subject to King Aretas (Jos., "Ant.," $18,5,1$ in the (rreek), but was now again held by Herod, who when visiting Perea would naturally lie attracted by the mountain palace and the luxurions baths. We may suppose that on some former vi-it he summoned John, who did much of his preaching on the eastern bank of the Jordan, to come to Macharus and give an opinion about his marriage, and there left him in prison. In that remote and hopelesis inprisomment, in one of those deep and dirk dungeons which were so cold in winter and so hot in summer, the great Baptizer languished (see on 11: 2) for probably more than a pear, until the court eame again. He was allowed oreasional risits from his followers, who brought him news of what was going on in the land-among other things of the works of .J esus (11:2)-and who fnally bore his headless body to the tomb.

\section{For Herodias, sake, his brother Phil-}

I This is a very common use of the tireck atorist tense. In English it may lo more natural and perspieusus to use the pluperfect, hut it is grammatically a very mislealing practice to say that the anrist is usel] for the pluperfect. (Comp. Butm., P. 2011.) One of the commonest and gravest errors in studying the gram. mar of foreign languages is to make a half conjeetural translation, and then reason back from our own linguage to the meaning of the origiual; or to explain some itliom of the original by the formally different idiom which is uor substantial equiralent. 
4 Fur John said unto hin, it is not lawlul for thee Io have hel.

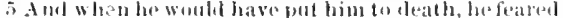

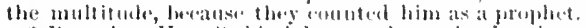

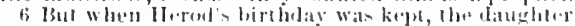

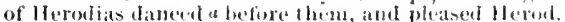

4 Jhilips wife. Jor John said unto him, 11 is mot

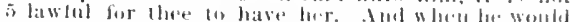

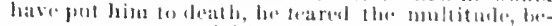

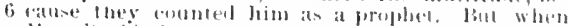

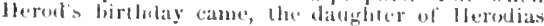

a lir. in the mides.

ip's wife, see un v. 1. For Johur said nuto him. The cireok varb i- in the imperfect tonse, and this is carefully reprocluenel by the O)l Latin and the Vulate, the Mom. phitice, and the l'eshito. Matr also (6:18) hats the same temse. It can hardly bre here tatien as the mere descriptive imperferet, but sorems to mean that John saje it repeatedly, ats may also he hinted by the tronse af " being reprowed in Lule :3: 19. Wo are not intormed how Iohn ame to grive Ilemel hi-judgment, but it is likely that the Testraceh sent fore John, heping that he would be over-awed when standing in his presenere, and so womble ferl bound to sleak fitvorably at the marriagewhich would have a salutary etlect in allaying the popular disemfent. But bohn stoul before lim, alparently serelal times, "in the spirit and puwer af Elijah" belore Ahab

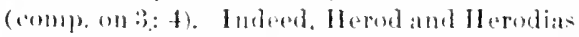
strilingly resembles Ahab and forebel. In

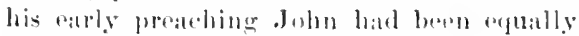

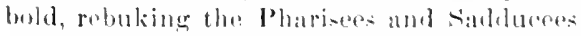

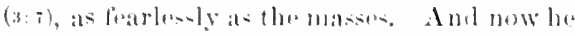
repreves Horeat, not merely for the marriage.

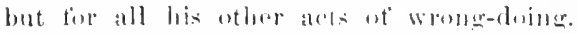

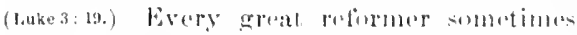
tinds it necessary to lue very lonld amel ant-

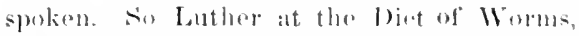
and Knox before Maly stutrt; amb he who was "meek and lowly" to the toiling and burdened, was stern and severe towards the hyperitical seribes and Phariseseren when he knew they ware plotting to kill him. and would eventually succosed. It is not Inwful, strictly it is not permissble: thom art not at liberty, viz., hecause the law of Mones forbado such a marriage. (Ler. 14:16:2) al.). The law required the marriage of a deceased and childless hrother's wife, but here the brother was still living and hat a daughtor. The ground of condemnation stated (oomp. Mark li: 18), is not that she was his niere, though that tous was forbielden by the law (am implied in Jes. 18: 12 f.), but his brother's witio. Nominally, she hat divoreed her former husband; but while the Jewish usages of that time allowed a man to divorechis wife for almost any anuse

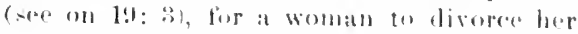
hasband omentioned only in Mark 10: 12) Was a Romatn eustom, which they lorla in great ablurrence. Jos. says ("Avt." 14, 3. b) that "boing minded to eontonnd har enuntry"s in-titutions," she malethis marriares

5. IId leared the multitule (or erourd), hecause they counted him as a prophet

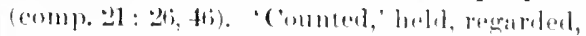
is in the impertiet tense, giving thrir habitual way of regareling him. 'Propher,' sece on

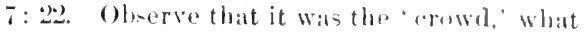
we call "the masses," that held this efrinion; the dewi-lo religione rulers were duite tom jealous to tolerate steh an idoat (21:25-27,32). Mark says b: 19) literally that " II combias hatel

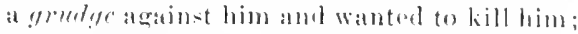
and she could not ; for Ilerod finted folu, kluwing him to he a righlente and holy man, and lent him safe. Ind upon luearing him

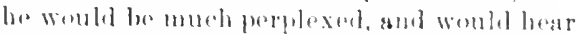
him gladly." All the verlis atre here in the

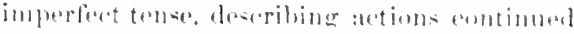
or repeated frome time to lime. The alpharent

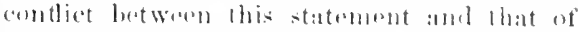
Matthem mag he explatined in varioms ways.

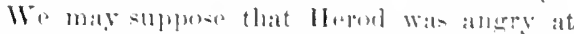
tirst, when John condemmul his mapriage, and censural all his wivkedness and wathted to kill him, but fearing the matses, impris-

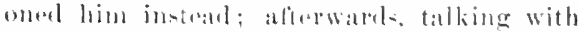
Juhn, and hi= wrath having emoled, he rame to tiol as Mark lescribes, and se continued during his jmprimmment. ()r it may lwe that while aremerally fasurable to Juhn, amd disposed to" "keop him sate" from the wrath uf Herolias, he somotimes folt inclined to relel to her solieitations, hut was then restratinal by liats of the erowd. It some platin that Hepodias wate watoluing for a chanes to compase Iohuts destruction, from the axpresion of Mark (6:21), "and whrna conbenient day was come."

(5) f. Iut when Irerod's birthday was liept, or came. The eurrect Greek text (as in Tisch. nud W II.) has a very peculinr con- 
struction, lut without difference in the substantial moaning. The term 'birthday' was alos sometimes applied to the anniversary of a ling'sarecsiom (Edersh.), hut Wieseler's exterded aroument firr so understanding it here is quite imeonchusive. It is easy to suppose that when Jirod's birthday approached he wat sojurning at Machatus, aceompanied by loading military and rivil officials ot his diminions. (Markfi:t.) The daughter of

Ilerodias, viz., ot her former marrige (see (o) $v .1$ ), was named salome (Jos. "Ant." 18, $5,+1 ;$ and alor alphirently sometimes called Hurulias, as refuired by the reading of the earlient and bestuanuscriptsin Markb: 22, "his daughter Ilerolias' ( IV II. and margin liev. Vor.), ank supported by Origen's expression here, "thedance of IIerodias." It is very easy to believe that be-ikles the namesalone, which was anumam in the family (borne by Herod the: (xeeat's sinter), slie nug have also been callud by her mothers name, even as $\therefore$ many inen of the timily were called Mered. This girl subsequently maried her uncle, l'hilip the Trotruch (Jos., "Ant.." 18 , 5; (omp). on. v. 1 and on 2 : 20 ), but the marriage did not last longe, as Philip died "in the twontieth year af" the reign of "Tiberias" (Jos. "Ant.," 18, 4, (i), say 1. D. 3, or 3t. Toim has, tor the sake of his theories rovived the old motion that the arucifixion oceured in A. I). 81, and the dath of . John only a far montlos arlier; but Meyer lomarks that the girl's dancing is quite appropriats for A. D. 2!), hut not for A. I). 84, when she had been for some time married, perhaps was a widow.

Danced before them, or in the midst; $i$. e., of the batnqueting-hall, or of the emopany, and so in full view of all; it is a phrase frequantly need in Greak to demote publicity. WV aunot roulily detormine just bow far this arct was indecorous on loer part. In all Eastern countries. women being kept in great sechuson, it hat always boen considered axtremely improper tor a fimale te danee in public. It is very common to liere dancing- women to exhibit at entertainments (e. g., the Hindoo nautch-girls), but the business is highly disreputable, and it is commonly taken for granted that they are women ot bad character. True, Jewish women lived in less sechusion than in other Eastern nations, and there are instances of their taking part by songs and dancing in public rejoicings (e.g., 1 Sam. 18: 6); but this was eonsidered a religious art (comp. Exod. 15: 20; 2 Sam. 6: 21), and quite a different thing from taking the place of daneing-girls at a teast. The Romans, too, had their dancing-girls at entertainments, but regarded it as a disreputable calling. A Latin inscription says, "It was disgraceful both to danee, and for a virgin to come into the banqueting-hall to men who had dranli freely." Cornelius Nrpos: "We know that arcording to our manners, dancing is even fut among vices." Creero: "Hardly any man dances when sober (uiless perchince he is crazy), whether it be in solitude or at a moderate and decorms feast" ; and he mentions a Greek father who was amazed at the proposition of a drunken guest that he should send for his daughter to eome in. On the whole, one nust reach the conclusion that if a respectable. Jewish maiden came in to dance at a feast, it would be very surprising to the guests, and could latrdly fail to be rogarded as very unbecoming. It was therefore a bold step which Herodias took, in sending hor daughter to dance before Ilerod and his grandees. Nould they he shocked by the immodest exposure of a princess, or would they he fascinated by the novel speetacle of a high-born and charming girl going thruigh the voluptuous movements of an Oriental dance? The experiment succeeded. She pleased IIerod, and all the company. (Mark 6:22.) No doubt rapturous expressions of admiration burst from the lips of the halfdrunken revelers. It is common for dancinggirls to receive presents, proportioned to the admiration their performanee has excited; and salome night maturally expect to re-
The eonstruction is unusual lims not mexampled (Ielf. ?699). The locative case grwes the time of the primeinal action, dancel ton Ilorod's hirlhelay, when it nceurred.' (Comp. the Iocative in Mark 6: 21.) This need not be called a case ahsolute, though it eorresponds to the latin "ablative (Jeative) alsolute;" and the Greek "genitive absolute" is itself also not really abso- lute, not cut loose from the rest of the construction, but gives some crent 0 action is specificall circumstances. It locative expressiol fimiliar genitive ce MSS, and the comm Ito which the principal for the iudication of its iatural that the unusual be here elsanged to the , as we find ic in many text. 
7 Hhorempun ho promisal with an oath to give her wliatsenerer she woulal alsk.

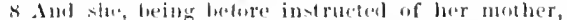

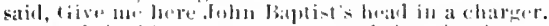

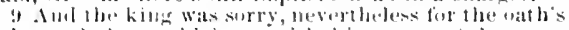
sake, anel thetu which sal wilh him at meat, he collmanded il lo be given her.
F danced in the midet, and foleasel IJ

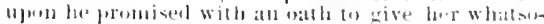

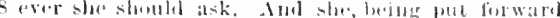

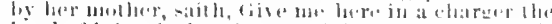

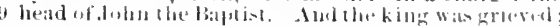

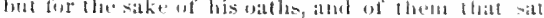

ceive sume present on the "Tetritrch's lirthday. Aneordingly, IIrend, anxims to express his enratifiotion, and also to play the manniticent betere this grand assembly. promined with an oath to give her whatsoever sloe wonld asli. Horevelfietal, petty ruler as los was, and not properly a king at all, to indate the grandilerpuenue of the great l'ersian monarehs (F-ther $3,3,6 ; 7: 2)$, and. with drunken dignity. swore to give her what she asked, "untu the hate ot my kingelom."

\section{(31ark 6: 23.)}

8. And she, being before instructed

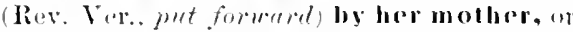

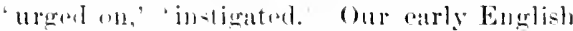
versions, following the Vulgate, mintramlated into' heinge before instrueted, and thus created an apmarent antlet with Mark, who says (6. 21$)$ that she went ant and incluired of her mother what she should ask. It is pathetic to think how many Bible students have puz\%led over this mamufatured dittienity". Wo eatn instgine the satisfatem with which Herodias heard how woll hele hold aheme hat

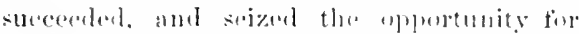
wreaking lore vengandue. The girl sympa-

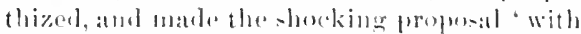
hitste" (Mark bi:s), or more axatly with zeall, eagurly. Give mo here. Markadd= furthwith.' l'robulbly salume and bor mothor foured Alat II roul would whomere his mint it they wated till he was soler. In a reharerer, more exally, "pun a dish, or 'plattere (se) translaterl in Luko 11: 391), and signifying a

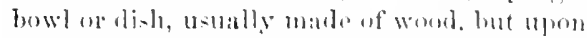

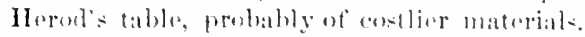
The Latin versiens loce hates disens, fiom which we lorrow disk and dish. Mire and Rhojus havo dish, 'Tyn., ('ran., and (ivm.,

\footnotetext{
The rablering 'before instructed is not omly unneessary, hut quite willomb warrant. The verb probihazo can mean iustrut at all only hy laking pro in the sonse of forwall, onwarl, to carry forware, to lead on; and so it hav wo be taken in all the kllown uses wl tlu verb. Ididell and seott give 'to teach beforehand' as the meaning in Ileut. $6: 7$, lut the proper meaning there as chown by the eonnection of the sert, and lletrew, ix simply tesch. There is no authorily at all in tircek
}

"platter"; King James intrudumed "chatrorer, which wat tomererly usal in linglish for at latere dish. It is much better to na- the

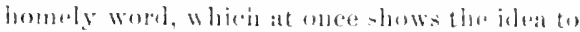

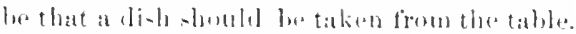

Johu Baptist's head. This de-ignation of Jolul was revilently fambiliar te all, fire it waand by salone and by llemol, by and Iard, and the Evangeliats gencrally, and ly Jusiphus (sin: an 3: 1).

9-11. The ling. It was flute ermumonte te ("all at tetrareh kiag, a- a matter al cornpli-

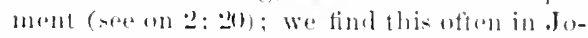
sphus, at well an in the Xew "Tent. Indeed the Greek torm was olton alpplied with grat. latitudeto any surepeign rular, from the Rarman imperator (1 Tise.2:2: 1 pet.2:1i) down to

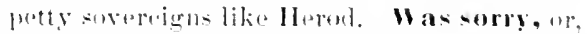
greiced. The thing whld he wrong. and als unpopular. (v. 5.) but his witir ruled him, as (1) many other aceasions. There is nu gered

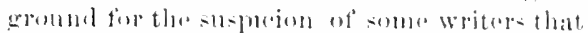
Herod himedt planued all this thing. in order to have an exrllae before the perple for -laying

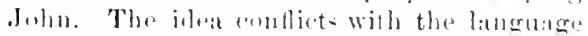

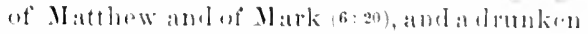

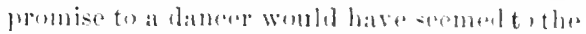

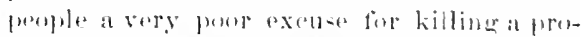
phot. For the oath"s salie-Riev. Ver.. his arthes. while above in r. 7 it was "with an

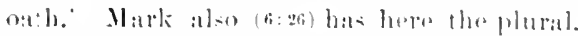
II" may comelude that llapel had soveral times repested his tipey promion to the eriel. with variols suths. Aud them whieh -at with him at meat, more exildty, reclimel with him, the astlal pusture at table sep an an: 11). IIt wat sujurstition - aluout his antho as many very wicked men artand wa a-hamod not to kene the promiso he hat so frepuently

usage, for the sense 'instruet leforchand,' and the etymology forbicls it. The natural meanime of uret forwayd, induee to a eertain esters. firimu, Mcyer

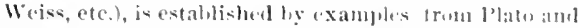
Xemophon. The Memplitic and beshibs here retuder 'instructed," 'taught, Wost copjes of the (1)d latin and the velgate, lave pramonite: but several copies (sabatier, Bianchini) have simply monilu, or docta. 
to And lesent, and beluaded John in the prian.

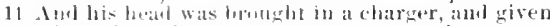

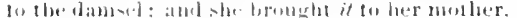

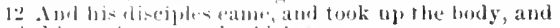
buried it, and wont and bold bests.
10 at meat with hin, he commanded it to bo given; 11 and he sent, and beheaded.John in the prison. And his heal was hrough in a charger, and given to the 12 damst; and she bromble it to her mother. Ant his disciples eame, and lonk up the conpse, and huried hin; and they went and told Jesus. matrle, and so solumuly anfirmed befure the a-soubled dignitaries. But a grosty wicked yomise is butter bolion than lient, especially whell ne ous will rably lose therelyy As to the gemeral subject of oath-, see on j: 33-87.

The girl wated for lore reward, and the king sont 'immenliately. (Markb:27) some areru*that thi-term. with 'here' in v. 8, and - srajerhtwa 'in Malk 6: 25. cammot be taken literally, lecanse the suectack would have spoled all festive anjoymant; hut they have foreroten how Iferonlias ancestor, Aloxander Jinnacus, while holding a feast with his conanbinrs, chmmanded eight hundred robels to h.ronfied in full view, and their wives and ahiluren to be slain betore their eyes. Jo. "Ant.," 1:, 1t,2.) A grout feant u-ually began alumt the elue of the day, and so it was probally lato at night when the executionory came and awolis. John and hurredly belorafod him. Iftor his weary imprisomment of more thath a Feare the Balptizer was now sudlenly cut oft. but hi= work was enderd: lor bat rente as the herald of the Mesianice reiern, and that reigh was now being estalin lished: the answer of .Jusle to his messago [11:20. hat dumbtlon aluared his perplexities and removed lingeringalublets ; therewatsothion more to live for, and to die was anin. Nor is if anything very alradful to dir sude donly. if mo has lived the life of fath. This

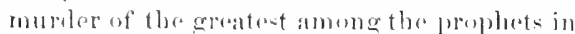
lis dungand was in itself hardly so blocking a sight, as the renderomder in the banquoting

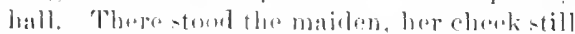
fluhbel with har reant axprtion, while the gue-ts sutght to drown their painful amotions in wine, and the oxrentioner hastened on his cruel errand. When the dish was brought, with tho hloeding hand upon it, nud doubt she took it daintily in her hamels, lat a drole of bloud should stain her gala drese, and tripmed away to her mother, as it bearing hor some choree dish of forml from the kiness table. It was not uncommon to bring the head of one who had beon slain to the pormon whor orered it. as a sure proof that the sommand had been obeyed. When the hend of Ciceros was brought to Fulvia, the wife of Antony, she spat apon it, and drawing out the tongue that had so eloquently opposed and condemmed Antony, she pierced it with her hair-pin, with bitter gibes. Jarome refers to this incident, and says that Herodias did likewise with the head af John. We know not his autlority for the assertion, but the darling desire of the Herod family seems to have been to ape the worst follies and cruelties of the Roman nobility.

Antijas and his family are not mentioned again by Matthew, but he appears in Luke 13: 31 t. and 23: 7-12. Sone ten years later, when Herodias' seapegrace brother Agripla (the Herod of Acts 12) had, through the friendship of the Emperor Caligula, been apprinted king over the former tetrarchy of l'hilip, this ambitiou woman wasconsumed with envy,and gave her hu-band no rest until, in spite of his love of ane and his caution, be went with her to Rome, to see if he could not also be formally declared king. But Agriplus sent lotter's to the Emperor, aceusing Antipas of treasumble corrosumlence with the Parthians, upon which he was depored from office and hanished to Gaul or Fpain Ios. "Ant.." 18, 7,2 ; " War," 2, 9, 6i), whence he never returned. The Emperor aftired Herodias ler treedom and bor private property for herbrother"sake, but she doclared that she loved her husband for well to forsake lion in his misfortunes; whereupon she was banished with him. One fancies it was not that she loved her husband more. but her brother less; and it may have been a trick to excite the young Emperor's sympathies.

12. 'There wore still men who regarded themselves as distinetively John's disciples. See on 9: 14.) But eventhose who adhered to him most tenacionsly knew well how eonstantly he had pointed them to Jesus; and tho report of the two sent by John on a mission of inquiry (11:2) must have made its impression on them. We may therefore suppose that most of them now attached themselves tw Jusus. Somp, however, continued to regura John as the Messiah. Thirty years after thio 
we mest persuls at Ephesus, "knowing only

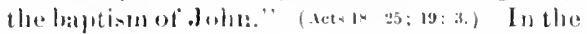
second century we tind a petty Gunstic soret who held Johnt the the Mesiah. The (irent

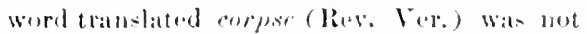
very often used, and was altered by many apyiste into the somenhat similar worl meaning body (com. Ver. ), likewise in Mark 1.5: 4.5); and so buried him was altered intu buried it. (Comp. on :4: 204.)

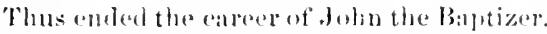

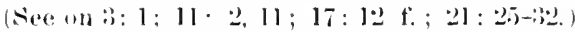

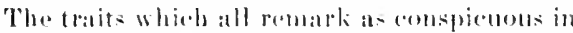
his charictor are solt-dental, comrage, and

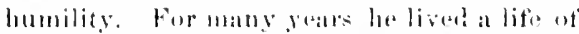
great havdship and lomelimese. that he might be letter titted tior his work as a retormer. As to his eourage in spealing the truth, see on v. 4 llis humbity, in eonstantly turning nway attention from him-alf to amother (John I 23, 36), and his rejoicing to see that other

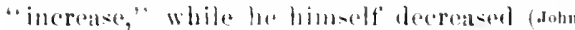
3:30), was so genulute and thorough that it serems to us a matterot' (e)turse in his character. Belfeay" (in litto): "In lloe splember of Christs arate amol truth John was haply to be darkened, and in sureli fame he was enotent for

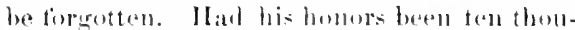
sand timos brighter than they were, he wombl have loid them all at ('hriet s teet. John in his ministry was not like the erening star -sinkine inte the dar'sues of night, but lika the mornines star-lo-t to our view in the

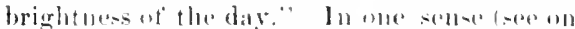
11: 11), Juhn w:1- rally the first ('hristian martyr-an homor $11+11: 1$ l! sosigned tostephen.

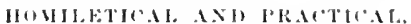

V. $1 \mathrm{f}$. Harol the Thetrareh's fir-t knowl-

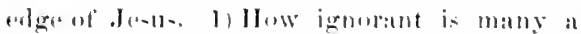
ruler ot the erat moral and religrions mose-

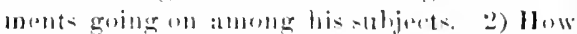

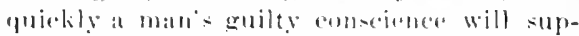
puse any startling aront to he connected with

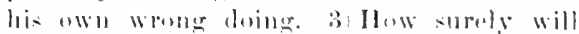
superetition mi-interporet the slyermatumbl. 4) IIow strongly lows ane crime tompt to the commision at" anuthor.-V. 6. HAl.: "I meet daughter for sueh a muther. It is not so frequently soon that the child follows the

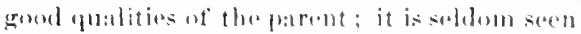
that it follow- not the aril. What with tratduction, what with education, it werestrange it we should miss any of our parent's mislispexitions."-V.8. IJerodian fearful revenge.

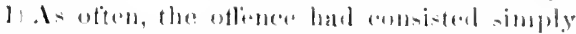
in telling the truth, v. 4. 2 Deliay had madi the desire of roventere trrow ticree, y. 5; Mark 6: 19 t: :3) The lomering tior revenge

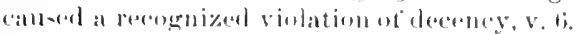
4) The domand fire revenge was mate with air-

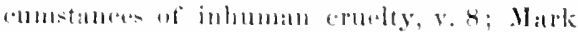

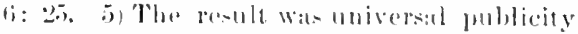
at to the orjginal arime, widropreal pupular

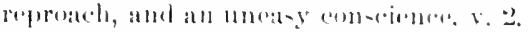

V.9. Thes downwarl progroses of wrongloing. 11 rielding to la-t and ambition, Herol tormis an unlawiul marriagt. 2) Inar-y througle popular eosuphaint, he tries to

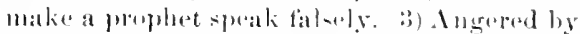
the prophet's refusil, he inpleisons, and wishes he emalel dare to kill him. 4 Won ly the

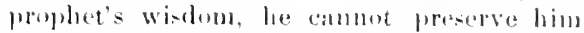
from the wiles of his wite. Mark ij: 19 t. i) Wild with almolien revelry, he makes a foulish promise. tis shoeked and grioved at

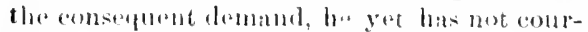

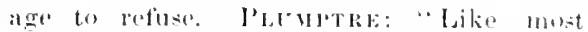

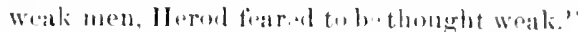

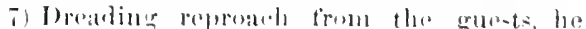
exposes himaste the their nter enotempt; for

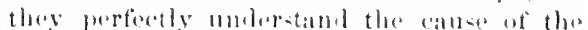

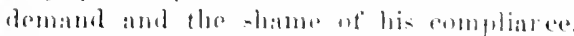

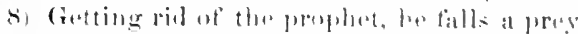

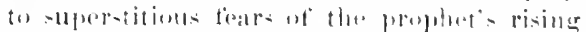

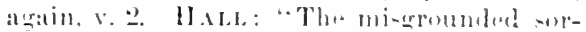

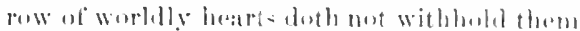

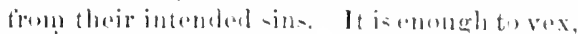

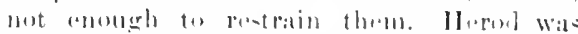

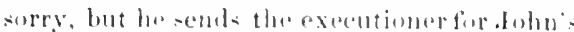

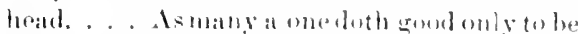

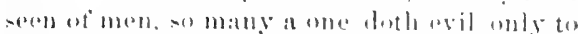
sotisfy the humor and opinion of others." V. 11. I remarkable death. 1) Sublan and

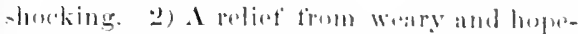

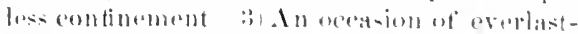
iner diegrace to those whe intliced it. 1) To

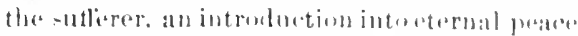

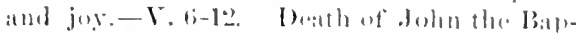
tist. l) In immolut purformanes ehatming

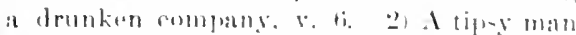

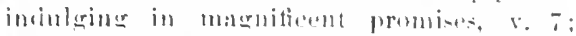
Markfi: 2:). 3) A malignant womall soing

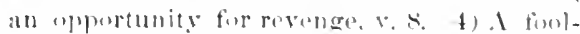

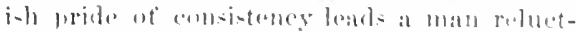

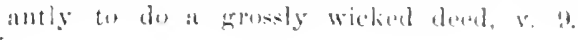


1:3 When Jesus heard of if, he departed thence by ship imo a deserr place ajort: and when the people hatd leard theresy, they followed him on foot out of the cities.
13 Now when Jesus heard it, he withdrew from thence in a boat, to a desert place apart: and when the multiludes heard thereof, they followed him on

I Or, by land

5 Alter wary waiting, a sudden death, v. $10 \mathrm{f}$. -V. 12. IlExry: "When allything ats us at any time, it is onr duty and privilege to make Christ aequainted with it. . . Jobn had lones since directed his disciples to Christ, and turned them over to him, but they could not lave their old mater while loe lived; therefore lie is removed that they may goto Je-us. It is better to be drawn to Christ by want and loss than not to come to him at a!l.'

I:3-36. Jeste FeEda THe Five ThouAANI, AND WALKS UPON THE WATER.

We have hore three closely related events: feeling the multitude, walking on the water, healing the sick in the Plain of Gennesaret.

I. 13-21. IN A IESERT PLACE IIE FEEDS TuE MULTitedo. Reorded also in Mark 6: 20-14; Juke 9: 10-17; John 6: 1-14. This is the first time in the course of Matthew's Go: pel that John las alpuatred as parallel. The arlier rhaptere of Juhn, as indeal the soreater part of his Gospere, treat of events and discourses which the othur Evalugelists have not describul. In the present case, John wisbes to recorml the great discourse on the lorad of life (John 6: z2.71), and he the pefore drescrilies the miracle which oceasioned it. When Jesus hearl of it, he departed, as in $2: 2.2$. What has heard may have heren rither the deatle of Joln (v.12), or the fact that Ileroul considerad

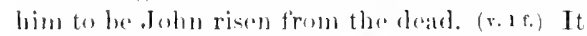
may oven lis that ho heared buth reports at the same time. At any rate, the crund morder of .J hu showerl what II Irod was capable of, and made it obvions!y prubleme for .Jesus to withrow from hi, dombinions, espeeially low, whren the mision of the 'Twolve had spread throughout radiles the axpoctation that the roign of Mesiah was alonet to rommence, whieh the poople gerserally would understand to mean an arthly kingrbom, astablished by a ereat enduerom wh, womb trample down the Jopolian dynaty, the Romans and all. ('omp. onr Lorel's cseape in infanry from the mombroms jealousy of Il'rod's father, cxeitol ly a single inquiry after one born king of the Juws. (?: I f.) By erossing to the nortbeast of the lake, Jesus would reach a very retired and thinly settled region, belonging to the tetrarchy of Philip, who was a comparatively good ruler (see on 2: 20), and to whose dominions he retired several times afterwards. (15:29;16:13.) On a former occasion (12:15) we have seen Josus withdrawing from the persecution of the Plarisces, as he will again do in 15: 21. On the evening of this day (v.22) we shall find him abandoning lis thosen place of retirement, to check the fanaticism of the masses. In fact, our Lord now enters upon a series of withdrawals, to avoid Ferod, or the Pharisees, or his fanatical followers. In the present ease there was a still further reason (Mark 6: 30 f.: Luke 9:10), viz., to seek a place of rest for the twelve apostles, who had just returned from their novel, laborious, and very exeiting mission throughout Galilee. It must have been highly exciting to the apostles to find that they eould work miracles. and to proclaim with conthusiasm the noar ajproach of the Messianic reign. (10:7r.) After such a strain for several weeks or months, they surely needed rest for bolly and mind; and our Lord has hero set us the example of paying regard to the eonditions of health and rigor, in proposing an excursion into the eountry for rest. (Mark6:31.) The believe it has never hern noticed that the season of these suecessive withdrawals was late spring and summer from the Pasovor to near the Fuast of Tabernacles); and that from the hot shores of the lake, far lower than the surface of the Iediterranean, he retired in each ease to a monntain region-across the lake, to Tyre, to Isecapolis, to Cesarea Pbilippi. II is plan for escaping notice and obtaining rest was on this first oceasion defeated, as heretotore in John 4: $6 \mathrm{ff}$., and hereafter in Mark $7: 24 \mathrm{f}$.

13. Hy ship, Rev. Yer. in a boat, cmull. on $4: 21$. Into a desert place, a thinly inluabited regjon (see on 3: 1), withont large towns, but containing villages. ( $(5.15$.$) Luke (9: 10) shows$ that the region visited pertained to a eity called liethsada, which must be distinct from the Bethsaida of 11: 21 (see note there), for the 


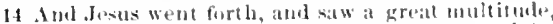
and was moverl will eompision toward them, and he healed their sick.

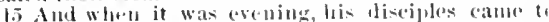

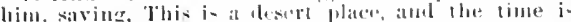

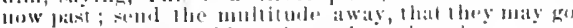
jutu the villages, and hoy lowmolves victuals.

disciples recrosid the sime enening to buth-

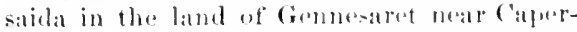

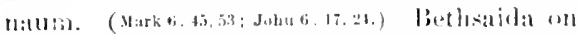
the eastern side of the Jorilan, a mile or more nbove its mouth, was rebult and aldorned by Philip the Tetruredi (Ju, " tat.." $14,2,1)$, under the new llame of Julias, in homor of Julia, daughter of Aueruetus; and there Philip wat atterwilds bured. From the mouth of the Jurelan a plain extends alung the rastern -hore of the lake for some three and a halt miles. gradually narrowing at the lake curves towards the mountain. This platu, whike not equal to that of trenmesaret on the other side. is mainly liertile, and war under caroful cultivation: but at its southern and the monntain comes so neat the lake at to make a very retired lewality ; and on the lower part of the momtain sides are beatiful grasey slopes, which an-wer to all the conditions of the nalrrative before us. The people hes. Var. multitules). . followed him on foot.

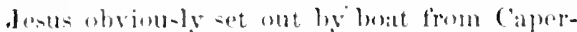
natum, or ane plares in its vicinity. The excited erowds of proples sooring that the buat wa- eroug eastward, acemethe burthern bart of the lake, hurriod aloug the shore and

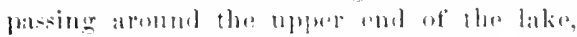
reachal the ande lowality which the buat wat secking. Xay, so earerly did they rum that at least somes of them "ontwent" Jeste and

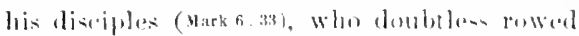
slowly, at their object who rest, and who pus-

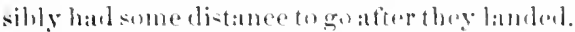
Out of the citios. From in the exalet trats.

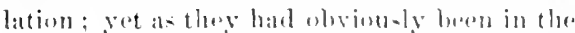
aties, all the versions from Tyn. to k. James

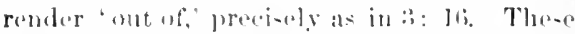

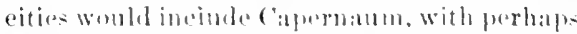
Clyorazin and the western bethendatand of

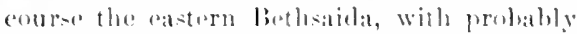
others unkmown to uc. The crowd wis very likely atumentad hy perwus from firther north on their way to the Paseoverer (Joher fo. 1), who andel bo eit-ily oxeited by talk about the Messianie reign. The Jordan hats a ford about two miles above its mouth; there may liave been a bridge, though we have no knowledge

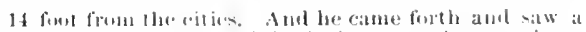

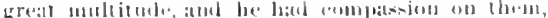

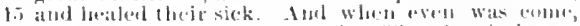

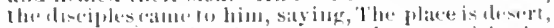

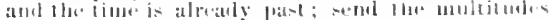

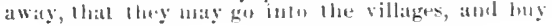

of it: and there womld certatuly be many bonts, belonging to the impurtant city of Bethaticla Iulia, which could eross the narrow river atrain and atgain in at short time.

11. And Jesus went (or, came) forth.

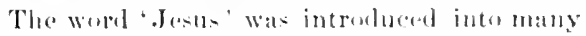
copres becatue this wat the beginning at at

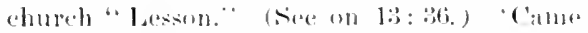
firth naturally means ont of the bont. Hort. Introduction. \% lise, think- that this would catues 'followed' in 1 attloew and Luke to contralint "outwent them" in Mark. But it is easey to understand that the crowd set int from (alperuatum after the buat started, and thus were following, and yet that some of them reached the other side before the boat alrived. of course 'allue forth' might mean from come nowk in the mountain, but there is noth-

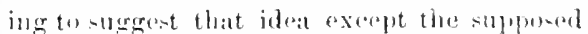
contraliction. fohn saly (6.3. R. . .), that he "went up inte the mountair,' viz., the mountain range which skirts the atastern side of the lake. Climbing loisurely the mountain-olde. amel at length sitting dewn with his disoiple. for rest. he foumd the crowd about him eontimally increating. Thumen they were di-turbing his retipement and repose, he did not repule or turn aw ay from them, but received them. (Luke9.11.) Mored with compassion

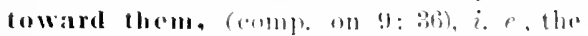
prople in gralcral, though with special refer(mese to their sick. This last word, meaning literally. 'without etrength,' is not found

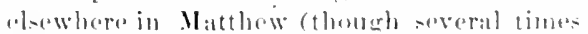
in Mark), but is suhetantially anuivalent to

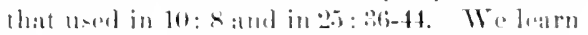

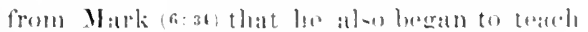
them many things. and from Lukp (9: n1) that

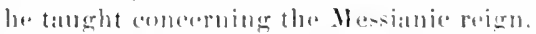

15-1R. And when it wasevening. The fow-were arenstumed to distinguish betwerst the fir-t eroning and the somml avening. Iu-t what the distinetion was has not been wertanly determined Eoler-hol; it is commonly steprosed that the first was from about : I'. v. to sunsed, the second from sunsed on inte the night. In v. 2: throsond oventing is meant; but here in $x .15$ it is the first evening; comp. 
16 But Jesus said unto them, They need not depart; give ye lhenil it) tat.

17 Aml they say unto him, WVe haw here but tive batres, and twe tisties.

is liesaid, Bring then hither to me.

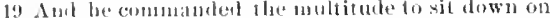
the grass, and lomk the five loaves, alld lhe awo tishes

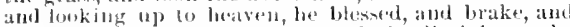
gave the loaves to his distiples, and the diveiples to the wullitude.
16 themselves foorl. But Jesus said unto them, The have no need to go away; give ye them io cai. 17 Alat they say unta him, It have bert: but dive 1. loaves, and two tislirs. And he sad, Bring then 19 hither to nue. And he commanded the multitudes I4 lsit down on the graxs; and be took the five loaves, and the two fishes, and lowking up to heaven, be blessed, and brake and gave the loaves to the

1 Gr. recline.

Luke 9: 12, "and the day began to decline" (Bible: Union Ver). The disciples were here simply the Twolve. (Luke 9:12.) This is a desert place, see on v. 1:. The time is now past. The Greek expression is peculiar, and may mean either 'the time' as in Wye. and ling James, or 'the day' as in Tyn. For the origin and uses of the Greek word, seo Lid. and Seott and Grimm. Some have renclered, "The hour (fior taking ford) is past," but this can barlly be correct. May go into the villages, surall, unwallad towns (see on 4: as), such as might well axist in the neighboring plain, and on the lower slopes of the mountain. Mark adels 'fields' or 'farms'; and Huke ineludes the idea of finting lodging at well as food. They did spend the night in that rogion. Give ye them to eat, with amplansis on 'ye' as the (areek shows. Mark (6. 57) adds that the disciples asked if they must eno away amb buy the value of two hun dred denario in loaves. This would bo about thirty dollars, and with a purrbasing pewer al least tentiones as great as 110w. It is not interded to intimate that the disciples had so

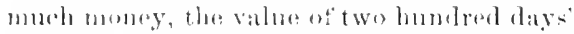
labor (2: : 2), lut rather the eomtrary. Mark and buke and otlere alotails, not in enotlied with Matthew. But Juhn (6:59) alprears at first sight to repreant the matter quite difforently. There, losus himself introluses the

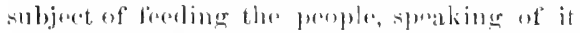

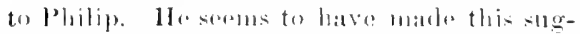

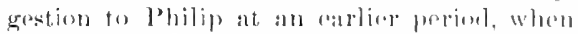

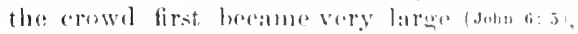
and loft it to work upon his mimd, in opelopto "prover hime (eompr. an 4: 1), vize als to whether he wombl havesule fath in the miracululs powers of Josut as to thiuk ut his ferding this vact arombl by a miracle. Philip

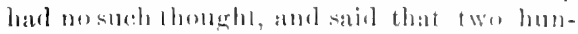
dred denarios' worlh of lo:aves would not suffice; but Andrew, who was stamling loy, spoke of the boy with lise tive bitrey loaves and two fishes. (Jum 6:9.) Later in the atter- noun, we may suppose, the Twelve came tr Jesus, as narrated by Matthew, Mark, and Luke. Haring heard of the conversation with Pbilip, they naturally mention (Mark 6: 37) the same large and round sum that be bad spolien of ; and the lad s supply of food some of the Twolve had by this time purchased or engaged. In this or some similar way, the apparent discrepancies may be recomeiled. The lonves were probubly round, flat cakes, not large (uake 11: 5), but resembling what in many parts of this country are called "boeakes." Fish formed an important part of the food of the people living around the lalie. John $(6: 9,13)$ secums to take pains to say that the loaves were of barley, cheap and coarse bread. Jesus made no sumptuous foast with deilucies, but gave them homely and wholesome food.

19-21. And he commanded the multitudesto sit down, or, recline, the usual posture in cating. secon 8: 11. The other Evangelists show that he gave this command through the disciples; what he did through theas he dicl himerelf (complon on $8: 5)$. It was a pleasint seasom of the yaar, just before the Pascover (Juhn 6:4), which was nearly the same time as onr Eastor. On the grass. Tuhn (6:11) says there was much grass in the place, and Mark (6: 39$)$, that it was green. Mark alsu says that he bade them recline "by conpanies' or banqueting parties, - "and they reclimod gardon-beds, garden-beds, by hundreds aml by fifties." Five thomsand men, reclining in this orderly arrangement along the greon sope of the momutain, must bave sproul over an extensive space, probably sevral acres, and ats the attermoon sun shume on their hright-hand oriental garments, they lonked like beds in a flower-garden. And yondar at one end of the area, with eyes uplifted toward heaven, stands the Wonderworker, who is about to fred this vast crowd with the forolonves atul two tishes now held on his liands. Nor was this arrangement 
20 And they did all eat, alul were filled ; and they

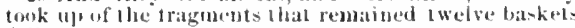
fill!.

2l A met lleve that hat fallen were about tive thousand men, hesile wouren and ebildren.

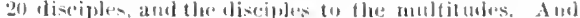
they dud all eat, atmi wero filled : and they torek up,

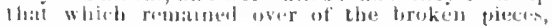

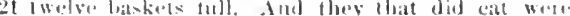

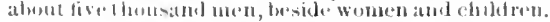

merely heautiful, but also useful. It rendered thromirate manifest, since all could see that their supply came from Joms, and that he hatel anly the five loaves and lwo fi-bes. It prevented selfish cowoting; for so the feoble, including the women and children, had an equal elature to be supplied, and the apustles

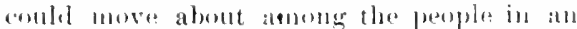
orelerly nanner, and turnish all alike. Tho

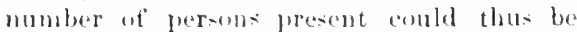

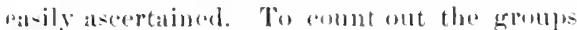
of lifty and a hendred, and armane them in

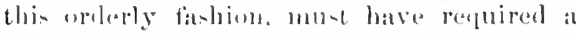

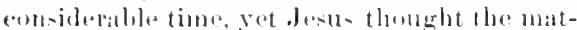

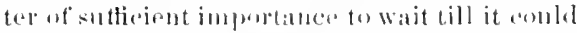
be deme. Jle blessed, maly mean either

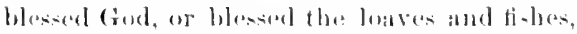

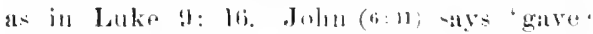
thanks, Rev. Vor. Tho same variety of phrase aceurs in the paralled miracele to this

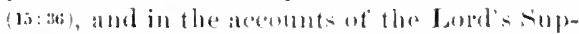

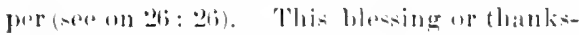
griving seems to have entreponded will the grace before eallong. which was m-tomatry among the Jew a a it is amongus. And were

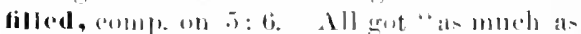

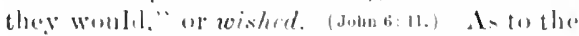
merle in which the foud wits multiplied, we eam form no comerption; and it is inlle t1) sperolate eoneerning a matlor so distimetly *upernatural. Observe los resulily. our bord returns from the supernatural

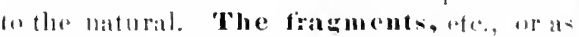
in linv. Vir.. What remained over of the broken pirees. The litst Givek term is formed mpon 'brolise in $Y$. I:t. and denotes not ermub malde by eaters. but a sur-

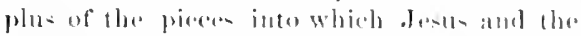

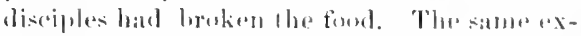

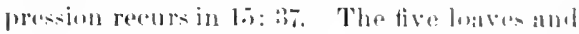

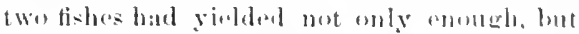
much to spotre. Twelve baskets dill. The Greek word is kophimes, lorrowent in Latin cophimes, and in Engli-h anentlu; Wye luere resulers 'cofyns.' It was probably atl oblong balaket of moderate size. A quite littirent Greek word is used in 15: $1:$ : : and the distinetion is mantained in 16: !) 10. We foarn from the satirical allusions in Juvcual (III.
14) that the dews of that age in Italy were in the habit of carrying a basket in travelius, probathly in order to keep at supply of surb foud as they coubleat without ceremonial defilement; aceordingly wa are nut surprised to find batsets here, even when the ownels hat

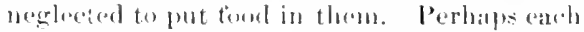
of the Twelve took a batsere and filleed it, which would aleenunt for the number of haskets montiomed. Thls conmmand to satve the

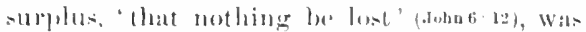
suited to teatelo eeconomy. It must be mitnitiont that we bave no right to waste anything, however ample anr resenrece, when we see him who is the Lord of all, ju-t atter multiplying al litte fered infora vast quantity, now earofiully salving the mplus pieces of contrse bitrley breal and fi-h. Thus also the disciples hant constanuly before theme for some ditys at leat, a memente of the axtratordinary misaele they had witnessed. Lacking in spiritual slacoptibility, atad living andid a sucees-ion of

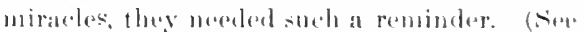
Mark ti: 52; Matt. Hi: !t.) Beside women and efildrell. The number of thene was polsubly small in proportion to the ment for

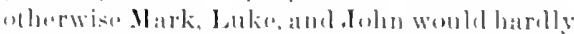

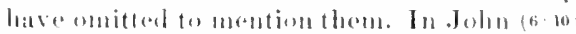
there is peribly an allusion to theme " Malk the perpla recline. . . ot the men reclined." The former torm is the ganeral one. which might include women atul childron. Perhaps only the men were conuted ont in groupses the women and childeren loving apalt to them-

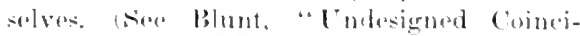
(lomerso," in Mil). (ommm.)

() rigen, followed by dopome and many Fithers, rune wild in allegerizing the breat,

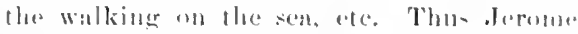
says flor lad with five lospen and two tiohes

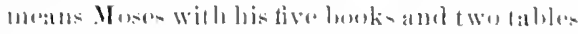
of the law: and (Irigen, that the reclining by bundrods demetes consereration tor the Divine Enity (the loundred heing a satered number. and reclining by fiftips demotes remision of sin, through a myetieal allusion to the dubilem and the Penterest. Such dreadful stutl' trom strpasingly giftoul men onght to be a warning us to the perits of allegorizing. Some eminent 
2*2 And straightway Iosus constranel his disciples 2

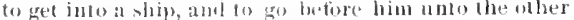
side, whilo he stont the multitudes atway.

2:) Ami whon he himl sont the multitules away, he want up in(1) a monntain ilpart (1) pray: and when the evening was eome, bo was l here alone.
2. And straightway he constrained the di: poler into the fust, and lo go betore him othor side, till he shombl semel the multitu 28 And arter lie hal seul the wultitudes went uf into the motutain apart to pray : recont rationaliots make equally ludierous

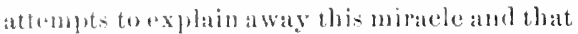
of walking on the waves. If these litelike marratives, griven in sucli vivid detail by all tind (rospels, could bo comsidrerel to ropresent mupre lecronds, than the Gospels would be nowhope worthy of endidence.

This great wirale of feeding the multiture could not tail to make a profound impresion; and the poople who witnessed it took it as showing beyome question that "this is of a truth the prophet that enmeth into the workd" (John 6: It, kev. ver.), i. e., probably the prophet

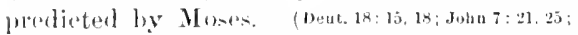
7: 10; Aets 3. 22: $7: 37$.) The Jews did unt all identify 'the proplet' with Mesciah; but the fersum here comerermed evidently did, for they were on the point of coming and seizing Jostes to malke hima kinger. (John6:15.) It was probably their droign to cary hin with them to. Jerusalem to the approaching Passover, and there proclaim him the anointed king, whether he expsanted or mot. Perbays they wrere all the more disposod at this time to rise atginst IIerod aud tho liomans, fom indigna-

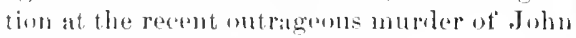
the Baptist. (Jax, "Mat.," 14, 5, 2.)

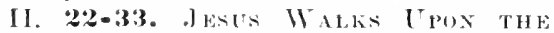
WATER. Fomml aloo in Malk fo: 45-5;

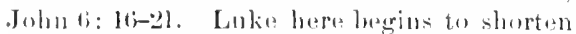

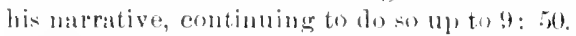
Jaslls, or le, constrained. Hurs again, as in v. 14, the word Jands was interpolated by

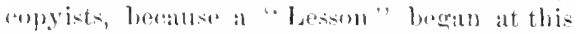
point. 'Constrainol' is more axinctly ren-

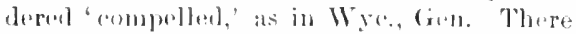

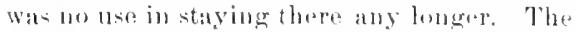
hoperef rest was gome, and the fame of this sroat miracle would only increase the popular

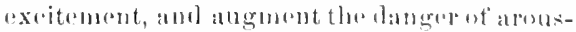

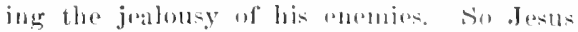
determines to return to the wast sile of the lake, whre we shall tind him the mext day bus healing thesick (v.34), and toachingin thesynagogue. (John 6:24, 59.) Shortlyatterhe will with- draw in a different direction, to the borlers of Phenicia (15:21); compe ahove onv. 1:3. For the prenent he wisbes to be alone; so he proceeds to break up the vast gathering, and legins by separating the disciples from the people and himself. They were natmeally slow to leave the scene of so astumislping a mirale. It is also likely that they sympathized not a little with tho pojular disposition to enerese Jesus inte assuming the erown and sceptre of Messiah. (John 6: 15.) Possibly, too, they saw indications of the (moning adverse wind, and drouded such a storm as that of $8: 23$. Whatever was the caune of their reluetanes, Jeslls 'ampelled them, of' course by enruestly enjoining it. Unto the other side. Mark (6:45) add- 'to Bethsaida," and Jolnn (6:17, Rev. ver.) says they "were groing over the seal untu Capernamo'; see above on r. 13. It would seem strange to be compelled to leare the sacral spot, the interested crowds, the Mastor himsell: So we, tom, must often do what the Lord in his providenee and his word clearly requires, "ven when it seems to us a strange and painful course. While he sent, ate; liev. Ver., mone ancurately, till he shomld dismiss the multitules. 'This loe pobalby dirl by going about among them, saying that lo should do nothing more that day, and requesting them to disperse. They moticed, however, that he did not go with the dis(ip)es, aml having now no oceasion for anxiety about firod, they spent the night in that vicinity. (John6:2y.) IIe went mp into a (the) monntain, on the east of the lake. (Juhn 6. as see ahove on v. 14.) We may snppose that ho had come down towards the shore to ser the lis.iples off, and now 'departed again' (John 6: 15) fothe monntuin, and went up into a highor and more secluded portion. Hepe in the mountain solitude and mild spring air be enttinued the greater part of the night (v, 25) in prayor. Jesus not only proyed rogularly and froquently (Nark 1: 35 : luke 5: 16:11:1), but when any special exigeney in his life arose he spent
1 'Till he should dismiss' is the meressary remering of heos and the subjunctive. so liheims. "While he
IIsmissud, Tyu. and followers, would represent heos and the indicative. 
24 But the slip, was nuw in the millst of the sea tosent with wases: for the wind wis cout rary.

25.5 And in the fourth wateh of the night jesus went unto them, walking on lhe se:il.

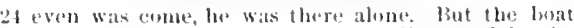
lats tow in the midht of the sead, dist resatel by the 2.5 waves; for the witul was entutary. Aml ill the tourth walch of the night le came unge them, walk-

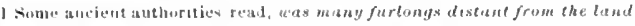

much time in special prafer; t. g., when he was about to select the twolve aporstles (luke s: 12), and in the aromy of (iollsemante. 'The ac aision for protracted prager in the present instance alppears to have bern that tho strongen proulat desire to mako bim a king, turether with the jealousy of llerenl and of the Pharisess, increased the difliealey of his position, and made him dewly find ha need of his Folher's dipection and-npyurt. Through this fanatical clowd. Satan Wats arain uffering him worlelly dominion upon endition of pursuing

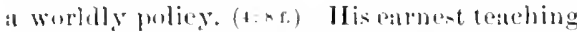
throutulut the day as to the Mentanie reign

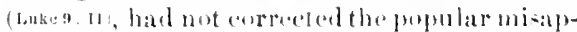

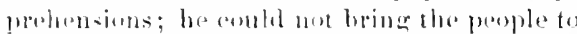
his viows. comld nut anform to thoir views;

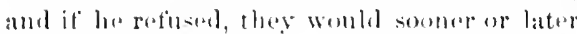
turu agatist him, and eneonrage the pulers to elestroy hint.

21 f. It serms likely from tho $u=0$ of' 'even-

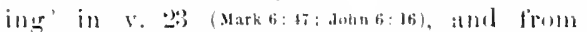
ether expressions of Julin, that already in thr atrly jart of the night the disciples laad seme ant inte the midet at the lake, and there entimucel to be hatrased by the firee oppoing wind nutil toward morning. The ship (boat) was now in the midst of the

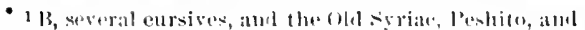
Jerusalem syriac, the Armentan, and semule ot ler versions read the boat was many forlonge dintant from the land' (so W If. and margin lies. Ver.). The quess-

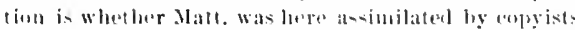

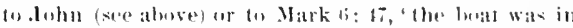

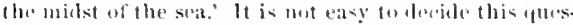

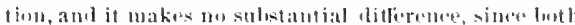

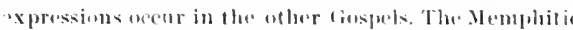
rorson was certainly conturmed tu duhn, for it read "about twenty-five furlongs."

"0) Wareh $27,18 \pi 1$, lle writer and a friend went in a loat from Tubarigh (Tiberias) to the probable place

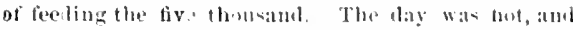
the batumen reluetant to aros. When within at mile

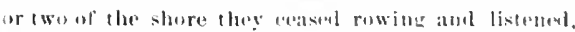
ant the leater salil, "Bat, sir, hat," l'aimt in tha' distanee, on the western sille, we hetard the souml of wiml, rushing down the ravines. The botmen then besan for row with all their might, lut before wo rearebel hand the lake was moh rutlled. We wort some half a mile d) the nearer slopes, linding beantiful grassy spots, one sea. John (6 19) says they had gone "about five and twenty or thirty furlongs, firm three to threw and a half miles (the stadion lueing less than wur furlongen, when threy siw Josuc walking, ele ${ }^{1}$ From the probable place of teraling lle five lhousand acros to Capormanm (Fel IJum), is abuut fint and a halt miles. The attempte of somu crities to malie out an errer bere, by insisting that "the millst ma-e mean the mathematical middle, is simply purpile. Fossed, literally, tortuled, at in to b, 2.1. While the Coms. Vor. hats here "tosecal," and in Markti: th "toiliner, it trans]ater the -ame wort 'tormented in 8 : 6. 2!) For the wind was eontrary. Johll arlels that it was a 'great wind.' It might seem that this - tatement shows they had sats, eoncrary to what has bern said on 4 : 221 but Malk says they were "toiling' (or thistressed) in rowing, for the wind was contratry, telt,

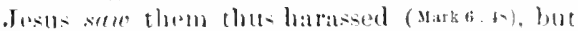
for a long time did not gon to thems. Whan they were in the former slorm $(8,24)$, he was

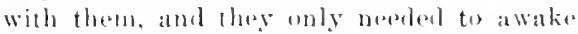
him; hut nuw ho had compelled them w start, and had remaimed as boler. Thus their

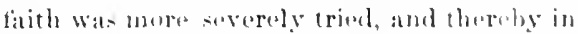
the end increa-ed. Inthe tourth wateh ot

in particular, well-suitud to be the seene of the mirack, and when we poturmed timul the lake perfecty horious. From nom till nearly sumst this eontinued; aven when the wind arased, the hillows substhel wry showly. Mbat the boat was pushel ont from its harlos in a

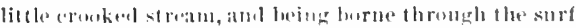
on the slumblete of the men, we entered it and at

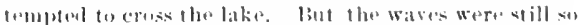
fierce that we comlel make ne healway atainst them.

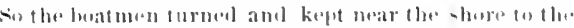
month of the Jorktan. Bursting through a wall ob water cansel by the lake-wases eppoing the current,

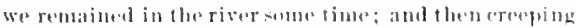
arousl the western shore, with the wases still trobble-

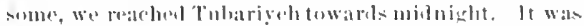
the sumb stason of the year, a lew days before baster, and ha' same western winl was "contrary"; but fortumately for us it bea jtelf ant in lle daytinte, while we were ashore. Mur rube boat, with its nuskillenl boatmen, conlal not pumilsy have lived if we had met the storm in the mithe of the lake. 
26 And when tho disciples saw him walking on the seat, they wert iroubled, saying, It is a spirit; and they criesl ont for loar.

"27 lut strughtwaty . Insts spake unto them, saying,

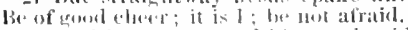

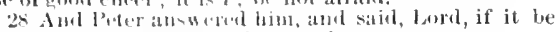
thou, bid tor come miln thee on the watcr.

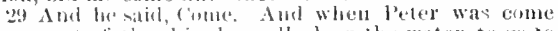
slown ant ot the ship, he walked on lhe water, to go to

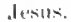

Bu but when he saw the wind boisteruns, he was afraid: and lesginuiug to siok, he cried, siying, lord, sareme.

:3 Iul imumediately Iesus stretched forth his hand, atrl "ausht him, and said unlo him, $O$ thou of little fath, whorefore didst thut doubt?
26 ing "1pon the sea. And when the distiples saw him walking on the sea, they were troubled, saying, it is 27 an alparition; and they erjed wut for fear. But stratghlwa Jesus spake llutu them, savilig, Be of 28 good chere; it is 1 ; be not afrail. And Peter answerd him and said, lori, if it be llom, hid me come 29 unto thes upon the waters. Aud be said, come. Aud leter went down trous the boal, and walked 30 upon the waters, 1 to come to Jesus. jut whente silw the wint, 2 he was atraid a a beginning to

i) sisk, he crienl out, saying, loril, save me. And inuediately lesus stretched forth his hand, and took

I Some ancieut authortien rend, and cume. 2 Many ancient authorities ald, strong.

the might. The ancient Hebrews divided the night, probably the period from sunset to sumrise, into three watches (Judg. 7 : 19; Lam. 2: 19; Ex. 14: 24: 1 sam. 11:11.) 'The (rreelis appear to have lual the same division. But after Pumpey's concuest, B. C. Ain, the l lews gradually allopted the Roman tashion of four watelles (eomp. Matk 13: :5, and ree Wieseler, "Nynopsis," J. ;it). At this satson of the yeatr, soon after llee verual expinox (ann 6:4), the "fourth watrh' would be from about thee to six arlack. Wrative nomeans of determining mare exactly the time of Jasus eoming. Jamo went (litrally, he came) unto them.

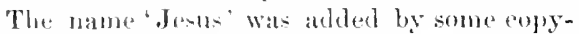
ist., tomake thes statement plainer. lo like manumer the anmmon Greek text has 'eame' rlatugerl to 'wont away.' Mark adds, 'and Je womld latere paraed by them. Literally, misterel to pasis. This might perbaps be un-

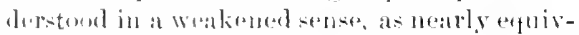

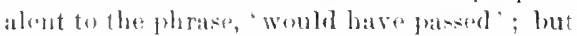

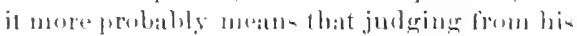

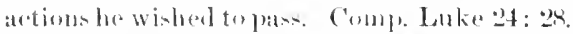

26 f. Whan the disciples saw him. They all saw hiul (Mark 6.50); and noar the bout (3unn * 19.) It is a spirit, an apparition is the

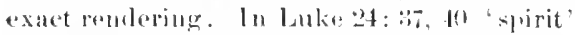

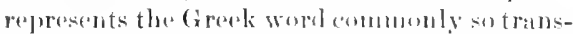

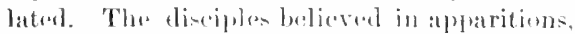
as dirl all the Jews foxerpt the siadduroes), and ats all nations a

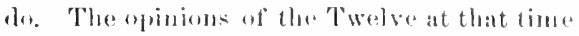
have no authority for us, sueve they ladel many

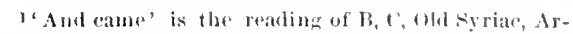
menian, Chrysostom. It is the mere diffeult reading,

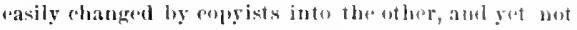

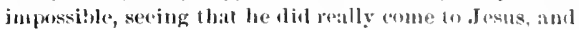
was within aru's length when he hegan to sink. in $r$. 30 'strong' is not found in $N, B$ (first haud), 33, . Mem- erroneous motions from which only the subse. quent inspiration of the Comforter telivered them. He of good cheer, Tyn and followers, is move exattly 'courage, as in $9: 2,22$; weak fath mald them eowardly, see on 8: 20. Jesus spolie straightway, in his kind desire to tree then at onee from their fear. It 1 I. They womble reognize his voice.

28-3I. This incident is recorded by Matthew only. Lord, if it be (is) thou. The form of expresion implies that he takes for granted it is the Lord. Instead of "Lord" wo. might translate 'Master,' (Tyn., Cran.), see on 8: 19. Fering Jesus thus walking on the water, Peter immediately felt the desire nat. ural to bold spririts to do anything which they see others do; and under a sudden impulse of confidente in J esus-mingleel, no doult, with his usual self-eonfidente-he proposed and undertuok to walk upon the water himself. We must ronamber that the Twelve, on their reeent mision, had been empowered to work milates. (1): s.) Perhaps also he was prompted by the desire to get near his loved teacher as soon as posible, as in John 21 : 7 . . Hesus consentrd to his toming. Peter would thus learn "needal lesson in the only way in which such confident spirits will learn, viz., fion experiente. Walked on the water, literally, "raters, the plural being an imitation of the llebrew word for water, which is used only in the plural; so in 1 . 28; Mark 9: 22; John : : 23. To go to Jesus. The marginal reading of Rev. Ver., 'and came to Jesus,' 1 is

phitie. The addition of this word would be rery natllrally suggested, and yet if it had been originally present we can sec no reason why any copyist should have wished its omission. Therefore we may decjde that it did not belong.to,the original-text. 
32. And when they werw come into the ship, the wind cerasiol.

3:3 'Plen they that ware in the ship rame and worshipped him, satying, of a truth thou art the son of limi.

3) And when they were gone over, they came intu the lanil of fiennesaret.
32 hold of him, and saith unto him, olbon wh little faith,

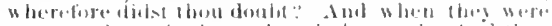

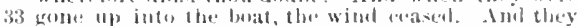
llat ware in the lasat wor-hipled hall, salyillg, of

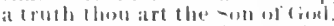

ist Ind when they hall crosed over, they cande to the very likely correct; it would make the lesson more striking, to leater and to us, for thus his frith fated when his task wats almost finished. Whou he saw the wille. Buisterous, ur strome, is an mowarerated addition. O thou of little faith, see on ti: 30 and $8: 26$. Ho dues not say 'of' no fatho' And he dores not

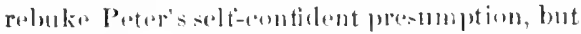
his weakness of tath, just as in 8 : 10, he enthments the centuriun' fith rather than his

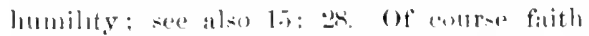
womld bave no netural puwer to kerel, him from sinking, as it wentel in swimming, broatur he was pertorming a slpermatural alet;

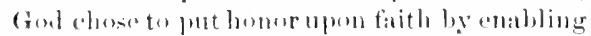
him to de this, alo longe is he did not doubt. Peater munt have folt a wholesome shame and th contusion at the result of his belle attement, but the other diseiples hate no time to notien it, nor

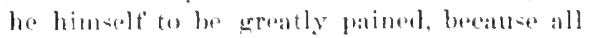
were engromed with almiration for the won-

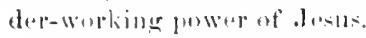

32 f. Nul when they wore come into the ship. Crome ne, representsts the correcet

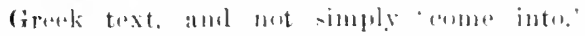
John says (6: 2y) "Ther were willing therefore

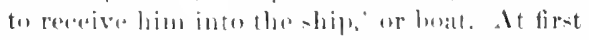
they hat teapel him ats at alparition; but

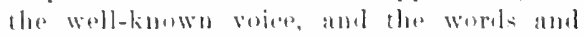

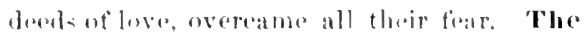
wiol ceased, and the buat which hat been for one on the lake. Was inmediately at the land. (Juhnt: 21.) These things mathrally made a ereat impression on their minds. Thary that were ill the -hip (hent) is a genceral expresion, and might incluse mot meredy the Twelle, but other persons whe aicked in managing the bont: as in $8:$ : 27 . Came and worshipped him. It is difficult to determine whether their workip or prostration (eomp. on 2: 2), was sim!ly reverener to a natu, "r real worship as to the Deity. And so as to the phrase thou art the son of God, which hert ocenrs for the first time in Matthew.
It serme eleas that by this designation the

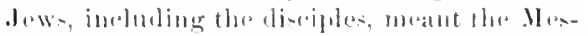

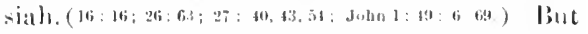
they alpuar to have had very vague dileats an to the perport of the expres-ion. The Ilight

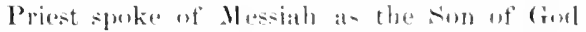

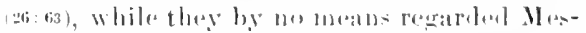

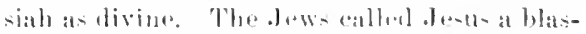

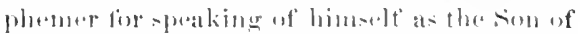
(iod) (John 10:33; 19:5), lut they calleed many thinge batepherny in which there wats no nssumption of divinity. (Comp. an 4: :3.) This

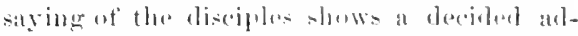
vance on that of $8: 2-2$, lout we mol-t mot press it into meaning all that ue shoult meatu by

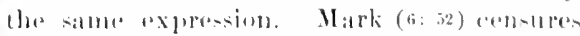
their astenishment at this mirates forr which the miralde of the loaves would have preparoul theon if theeir minds hat not been stapide and

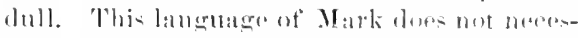
sarily forbid the sllpusition that they were

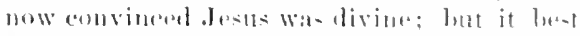
falls in with the idea that they wereat a lower stantjuint.

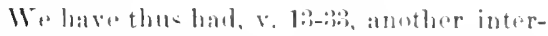

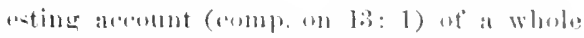

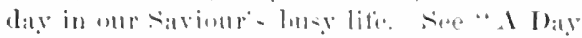
in the Litie of Julle of Xatareth," in Way-

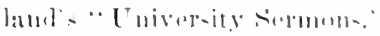

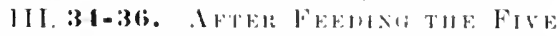

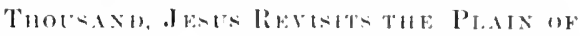

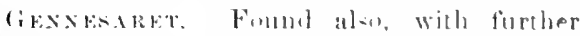
letails, in Markti: ris-o, When they were sone oxer, the same warlis in !) 1. They came iule the land, ell. The gemeral statement is first matr. "they came into ur mpens the land, eatue to shrers, atme this is follewed by the more particular statement

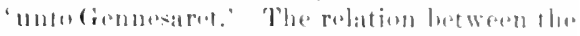

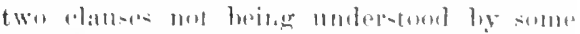

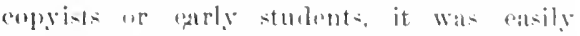
changed into "they eame unto the land of. Gennesaret, as in thr common Greek text and the (om. Ver-ion. Gennestret was the name

1 The prefixed term " "ame" or teming ' of the eommon fireek toxt is wanting in sume of the earliest docis. ments, and we can more readily explain its jusertion

than its omission; so it is not probably a part of the text. 
35 And when the men of that place had knowledge: of lim, they sent out into all that (w)ul ry round abotit, and brotught usto liful all that wore cliseased;

36 And hesolugh lim that they wight only toueh the hem of his garment: and as inany as towehed were marle pertecify whole.
35 land, unto Gennesaret. And when the min of that bace knew him, tley sent into all that region round about, aul brought unto him all that were sick; 36 and they besought bim that they might only tomeh the horder of lis garment: and as many as ionched were male whole. of a plain lying on the northwest side of the lake, about three and a half miles long, and at mme pintsover two mileswide. It is glowingly deacribed by Jostphus ("War," 3, 10,8) as of unrivaled beatuty, fertility, and variety of products; amd modern tratrolurs find his statements jo justified, it we malie allowance for the present wretched cultivation and paucity of inhabitants. Stanley: "Nolen than four springs pour finth their almost full grown rivers through the plain; the richuess of the soil displays itselt in magniticent wheat fields; whilst along the shore rises a thick jungle of thorn and oleander, abounding in birds of brilliant color- and varions forms." The soil is a dark loum, very rieh; and by irrigation will produce three crops a year. We know of no large city in this plain. Capernaum was pretty certainly at Tel IIum, further north (see on 4:19); and Chorazin was probably at Keraseh, u], in the hills (see on 11: 21). Whether the considerable ruins in the northern angle of the plain represent the western Bethsatida, so uften mentioned with Capernatum and Chorazin, we eannot dotermine. At the southern angle of the plain are a few huts

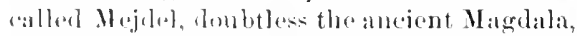
the home of Mary Magdalene. From this remarkable plain the sira or Lake of cialile was sometimes eallel Lake of Gennesaret. (Lukes: 1.) Had kuowledge of (i. e., knem) him, or reconized him. Mark adds 'straightway; they might woll recognime him at onee, for hes hat labored mueh in that vicinity. All that country round about, at il $3: 5$. Nll that were discased, or ill, the same phrase as in 4 : 24. That they might touch, a mon-tinal use of the (ireek

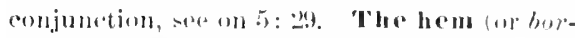
(te) of his garment, see on at: 20 ft. Thu

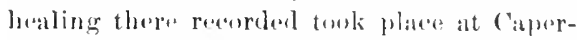
natum not long before, and probably ancolltaged the persons here mantioned. Were made perlectly whole, literally, were thoroughly sared (healed), a compund of the verb used in !): 21. Mark (6:54 fi.) givess further details, showing Jesus as entering int, cities, villages, and country places, and 'very- where healing the sick, which probably oceapied several lays. Weiss thinks it incredible that there were now so many sick to be healed in the region of Jesus' common residence. But he had been absent some time, on the journey about Galilee (11:1), and the season of malarial fevers had come. For previous instances of a general statement concerning unmerous miracles of healing, see $4: 23 \mathrm{f}$.; $8: 16 ; 9: 85$.

On the morning after the five thousand were fed, they eame acruss in borrowed boats to Capernaum, and crowded into the symgogue, where Jesus was teathing. To this idle and gaping crowd, delighted at getting plenty to eat without working. he addressed the grent disconl'se of John $6: 26-59$.

\section{HOMILETICAL AND PRACTICAL.}

V. $13 \mathrm{f}$. Jesus here an example. 1) $\mathrm{I}_{1}$ prudently withdrawing from danger. 2) In seeking bodily and mental rest for himself and his disciples, comp. Mark 6: 31. 3) In relinquishing needed rest in order to do wen good, v. 14, comp. John 4: $6 \mathrm{ff}$.- V. 14-21. Feeding the mutitude. 1) A lessm in compission, v. $14 \mathrm{f}$. 2) A lesson in obedience, $r$. 16-18. 3) A lesson in order, v. 19. 4) A leson in economy, v. 20. 5) A lesion as to the hamony of the uatural and the supernatural, v. $20 \mathrm{f} .-\mathrm{V} .19$. HALL: "That an homor wats this to thy servants, that as thou wert Mediator betwixt thy Father and men, so thou wouldst have them, in some beneficial (measion, mediate betwixt men and thee."V. 2\%. Oceasional seasons of retirement for limg-emtinued prayer, whether to a private alpartment, ur to the solitude of nature, are much needed in this luturied age. There is something very impressive in the still depths of a furest, or the recesses of a mountain, as a serne of solitary prayer. "The groves were Cond's first temples"; and the noblest houses of worship cannot so powerfully appeal to our feelings of devotion. Curys. "The wilderness is the mother of quiet; it is a calm and a harkm. delivering us from all turmoils."

V. 24. II ENRY: "Though troubles and diffi- 


\section{CHAPTE XV}

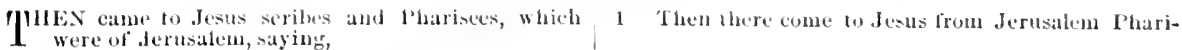

cultien may disturb us in aur duty, they must not drive us from it; but through the miclot of them we must press forwad." $-\mathrm{V}$. 2.: "Mlan" : extremity is Ged's ophortunity." V. 20. II Exs : " Most af our danger from ontwarel troubles arises from the oceasion

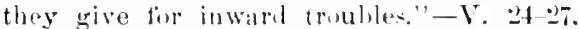
Danger and deliverance. 1) Parilous-trugghles long-continued make us dereply fied onr neded of help. 2) Apronathing delivarance sometimes wears all alarming atepet, vo 24, 3) Divine encouragendent is given "stratightWily," ju-t at semen at it i really beet for us, v. 27. 4) In life's worst trials, to reconnize

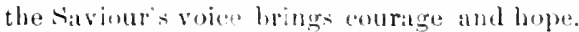
b) Storm and strugerle make us enjoy more the calum that follows, and applectiate more highly the Lord who delivers us ( 1 . : $: 2$ fo.).V. 28-31. Walking the walves. 1) The in-

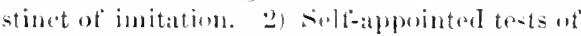
divine presence and power. 3) Solt-eontidenee often anrously blamled with antialence in the Lord. 4) There is frectuently strength

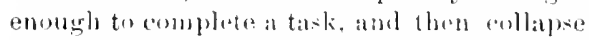

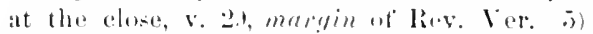
Haply the man whore (a)

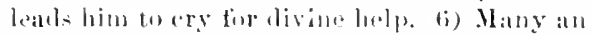

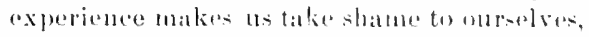

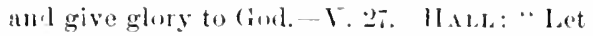
heaven be hut ats one seroll, and let it be writen all over with tiflese they eamnot ox-

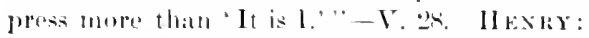

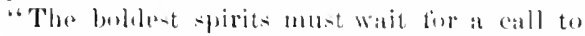
hazardous enterprises, and we munt not rashly

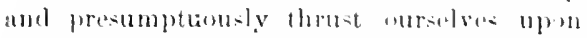
them."-V. :30. II ExRY: "Lureking at dith-

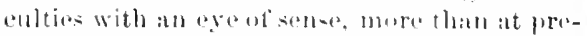
cepts and promises with an eye of fathlo, is at the bottom of all one indivilual teatr. both as

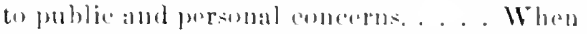
fath is watk, prager should be strong." - $\mathrm{V}$. 31. II rexr: "Our doubts and fond would soon vanish before a strict inguiry into the callse of them." - Y. 8.. Il ExRY: "Thume that have got the knowledgo of christ themselves should do all they ean to brime others aequainted with him too. Wo aln no bettor testify our love for our eountry than by pro- moting and propagating in it the knowle ? ge of' C'hrist."

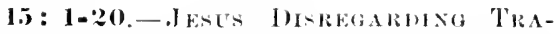

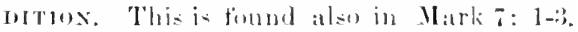
When the great miracle of tededing the dive

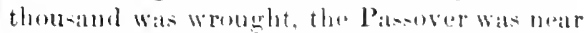
(sos on 14: 1!); which, aceoreling lo the view commonly held (see on 12: 1), wate the thiml l'a-sover of our Lord's publie minintry, and ane yeatr betore it elese. To thi- liat year belong half the whapters and andilfiably

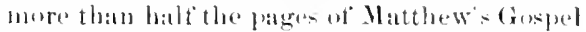
alld a still larger proportion ef the (xispels of Mark. Lake, and lohn. Jesus failed to gan to

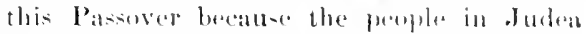
woresecking to kill him (a-mentioned atherwinds, John $7:$ 1), but continum] his laburs in ralilene, ats deseribul in greneral torms in 14: 3.; t: The partienlar indidut here recorded world seent to have occurred some little time after the Patisver, als it would not be natural for Inarienes to leave Jerusaldem -heretly hafore the feat. The seene of this exenrenee was somenhere in cialilese,

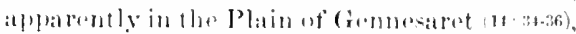
and probslyly at Capremalum, his a-1lal phee uf' abrele. The fault-finding inquiry by the

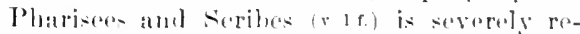
torted 10 mon them (v.3-9), and then ats-wored by a mos impurtant anderal prinejple, to which the spestial attention of all present is

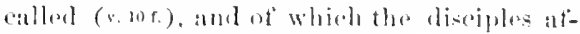
torwards seek an "xplanation in privitu. ( $x .12 \cdot 20$.

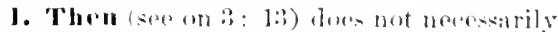
meatn at the times juret bertures mentioned (11: $3-36)$. lout is naturally sn talien, noles there be prowet to the enentrary, which is not here the citer. Seribes and Pharisees, the

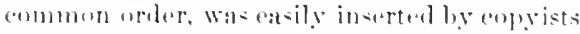

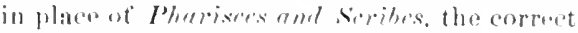
text. Come from ferusalem. Wias, in like manner, chatiged to wheh were of Jernsalem, hy inserting an apparently nembed artiele. Jerustem wat the seat of the grate schorls ats wall als of the temple worship, and the most eminent men wero congregated 
2 Why dothy disciples tratusiress the tratition of the elifers:" for they wash not their lands when they eat bread.

there; these prosons wore theretiore regarded in Galihe with spetal reverenee. Theiroljeet in enming may have been partly to satisty eurio-ity about, Jesus, excited by aceount given at the Pasoover, and partly to prevent him tronn gatuing too much influmee in Galilee. It is not mulikely that they were sent as a dreutation to observe Jesus, as afterwark in Lulie 11 : it, and still later in Matt. 2.): 15; compl. 12: 24 (n:ak 3: 22), and the deputationsont to Juhn the Baptist. (Jobn J: 19, 24.) A.to the Pharises, see or: $3: 7$; and as to the Scribes, on 22: :3. Thry begin by censuring, nert . hesu-himelt, but the diseiples. (Comp. (1) !t: 14.) On probably a later oceasion Jeils him-elt excited the same complaint. (Luke 11: 38.)

2. The tradition of the elders. The word remlered 'tradition' signities that which is pased along, or griven from one to another. It is sometimes applied by Paul to teaching: handel ner ly hin to the churehes for their olservaluce. ( 2 Thess 2: 15; 3:6; 1 Cor.11:2.) But here and in fial. 1: 14; Col. 2: 8, it denotes things lambled down trom generation to genreation, which is what we mean by the similar Iatin worl tradition. It is a favorite evasion of Roman Catholie controsersialists to conforma tlase two senses of the torm. The Worl 'aldere' hero mestos not officials, but the men of former times. (Heh, 1) : 2, and comp. satt. 5: :1.) Thr immonse mass of traditions which

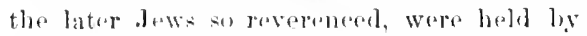
then to comsist pitlly of oral haw given ly Moses in andelition to the written law-which they supposed to be referred to in Doute 4: 14; partly ot derisins male from time to time by the juderes a dout. 17: affo, and which berame proededent and authority ; and partly op the explanations and opinions of eminent teachers, given individually or sometimes loy the vote of asemblies. These aral traditioncontimmed to acemmulate after the time of Christ till they were writen down in the Mishna and its commentaries. (keo on: : T.) They wore highly astromed by all of the nation, exeret the sidduceres. Indeed some reckoned them more impurtant than the writ-
2 sees and serihes, saying, Why do thy disciples transgress the tradition of the elders? for they wash not ten law. The Talmud of Jerusalem silys, "The words of the Seribes are more lovely than the words of the law; for the words of the law are weighty and light, but the words of the Seribes are all weighty." And the Talmud somewhere declares that it is areater crinc to "transgress the words of the school "f Hillel" than the law. So again: "My son, attend to the words of the seribes, more than to the words of the law." In this ats in so many reopects Judaism has colored the Christianity at the Chureh of Pome, which teaches the observance of numerous traditions protessedly coming from early times, and some of them fiom the apostles, though these often diresty vinlate the spirit, and cven the letter, of seripture. Among Protestants also there is sometines greater solicitude for the observanee of custom thin of Seripture; and more emphasis laid on "the rule of the church" than on the law of God. They wash not their hauds. It is worth while to distinguish several Greek words which our English Versions render 'Wash.' (1) Nipto, ued only of washing some part of the body, as the face, hands, feet; found in $6: 17 ; 15: 2$ (Mars $7: 3$ ); 27: 2t (compound); John 9:7, 15; 13: 5, 14; 1 Tim. 5: 10. (2) Brecho, to wet, moisten, sprukle, and hence communly to rin; found in Luke $7: 38,44$. (3) Piuno, used repecially of washing elothes and the like; found in Luke 5: 2; Rev. 7: 14. (4) Lamo, to batbe, or wash the whole body; formd in Johin 1: 10 , "he that is bathed (lome), needeth not save to wash (nipto) his foet;" also in Acts 9: $37 ; 16: 33 ; 22: 16$ (compound); 1 Cor. 6: 11 (compound); Heb. 10: 2.); 2 Pet. 2: 2*2; Rev. 1: 5, and a noun derived from it in Eph. 5: 24; Tit. 3:5. (5) Baptizo, to immerse, dip (sce on 3:6), is rondered wash in Mark 7:4; Lnke 11: 38, and a nomn derived from it in Mark $7: 4 ; \mathrm{H} \mathrm{b}$. 1): 10, in all which places the jdeat is that of immersion. Mark, who wrote especially for Gontile readers, here paused ( $i: 3 \mathrm{f}$ ) to give details about the scrupulous and elaborate purifications of the singular Jewish people.

This ceremonial hand-washing before cat- 
3 But he answered and said untothem, Why do yo also transgress the commanducht of (ionl by your tritdition?

4 For find colmunmlenl, saying, llomour thy father

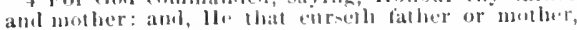
lat hion die the death.

if Jut resay, ll homerer shall say on his lather or his

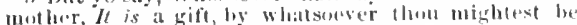
proliterl by me;
3 thrir hambs when they at hreal. And he auswered

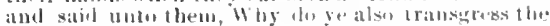

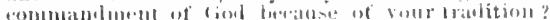

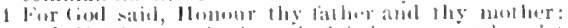

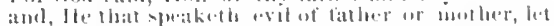

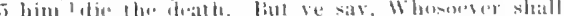
saly lo hiv tather or his rigother, That wherewitl

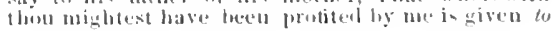

I 1 s, surely fie.

ing, the Rabbis tried to suppurt hy Les: 15: 11. It very matmially arome, along with the similar wabing aftur the meal, foum the finct that the ancients habitually ate with their tingers. It a later prorod a third washing

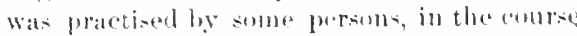
of the meal. The Mishon (Burachuth \&, 1) mentions a difterence betwen llillel and Shammat ats to whether one null, wath the hames betione or after filling the glatsise. The Talmud shows that hamd-wathing wats reckoned a matter of high importance. Somes

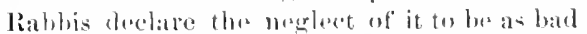

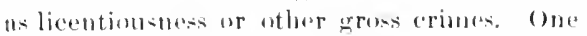
satid. "It is betler to go four miles to water than to incur guilt by neghecting hamb-washing " ; and a story is told of the f:mmun Rabbi Akibat that when imprisomed, and having his allewanee of water realuederl, he lowk what litthe there wase to wash hi hamble betiore patting, insteanl of driuking it, saying that he had rather die thate lransereses ibe inetitutions of his intersters.

3-6. Bofore procending to the ereat perinciphe (r. 11) involval in his justifiation obl the disciples for neeglect of the hamel-wathine, net

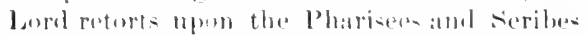

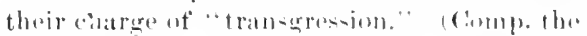
ad hominm areument in 1:2: 20 .) Why do

(Lev.ch. 15.) In general, the Hebrew terms lo not show bow this wanhime of sessels, we. was to be parformul, but in laev. 11: 32 they must lw "put intu water";

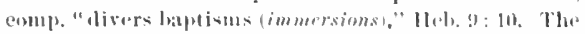
serupulous later Jewsoften alopteil this must thormugh purification even when not required loy tha law kae

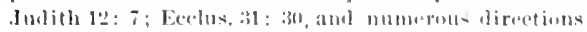
in the Talmudi. With this ateres Wark's datement that when they eome "trom the market platere. exeept they immerse, they ent not," which may mean immerse their lanks for thormugh washing, as distinguished from the simpoler morles of washing hamb carefully described in the Talmul, hut more probably moans immerse themselves. so in Mishna Chagiga, 2, 5, two recent Iowish authorities dither as to whether "iipping" means washing the hamls hy dipulug them (Winsche, and so Edersh.), or taking a hath (chelow, ye also iranseress, and that nut a more traditim of men, hut the commandment of cood by (becenes of ) your tradition? 'By your tratdion does net entrotly remder the Greak. They had sad the tradition of the alers, but he says simply your tralition; no matter what was it migin, they were now making it the oceasion of transeressing the law ot fout. This charge lat formes by an eximple, not rommented with hamb-washing or ather morications, hut drawn from a tuost sacred duty, as ackmowledged by mankind,

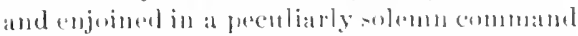

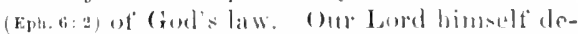
elareel (10:37: luke 14:26) that his sorvice is aboser

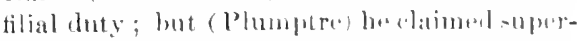
natural anthority, wheh the seribes did nut claim. For trenl stid, the true realing, was

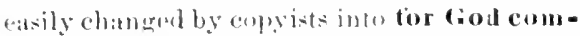
manded, saying, lineater "the communtudment hat ju-t herall mentionerl. The first

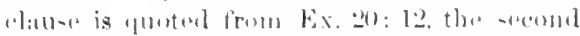
form kix. 21: 17, luoth taken from the septe.

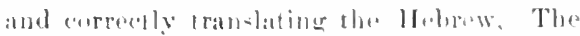
second was intromberal to show that this commmand which they prometicatly am almllat wats

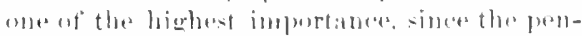

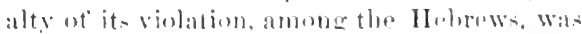
to be doath without firil. ('omp. veryestrong

tr. of Talm. Iorus.). Those who eannot lwasu that

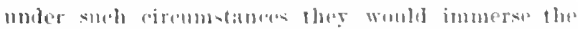
whole persen might rabl IIerodutus JI., ti, who says

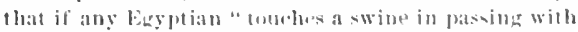

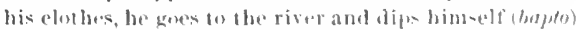
from it." some "irly chri-tian stulente or enpyiste,

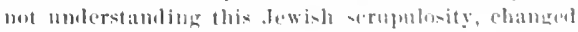

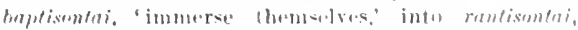
"sprinklethomsolves:" for though foumd in $\mathbf{N}$ B, nine eursives, and the late Fathor buthym., thi- is aloviunsly a ecorrection to avoiu a ditticulty, as is also the molimion

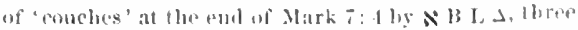
cursives, Mtuph. IIow ean any out aceount for lhe insertion of 'conehes, and the wangen of "sprinkie' (1) 'immerse'?-The question here is not al tralitional usage or the mere mode of performing a eremuny, but of the principle of strict obelievee to a livine command. 
6 A wel honour not his fither or his mother, he shall

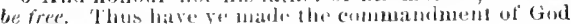
of youre etfect lis vour tratition.
6 God; he shall not honour his father. And ye have made void the 2 word of God because of your tra-

I sone ancient anthoritics ald, or his mother. I Sone ancient authorities read, law.

language on the subject in Deut. 27: 16; P'ruv. $20: 20 ;: 30: 17$. IIe that curseth; speralieth reil of, or 'reviles,' is the exact rondering; "aroses wenld be a different Greck word. 'Tho Mrblew means primarily 'bulittle, 'Malke light at,' and derivatively "enrse" fis the command is very broad. Let him die the death, or better, let him wurely die (margin liav. Ver.), the form of "xpresion being mueh used in the Olel Test., and oftener demoting the cortainty than the severity of the punishment. The conncetion here shows that we mant honor parents not merely in our tealiugs but ly anr atets; see similar uses of "homor" in l'rov. :3: 9; 1 Tim.

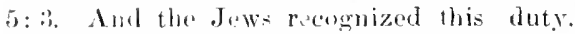
Eerlus. : $8: 8$, "IIomur thy liather and mother both in word and deed" ; Trlm. Jerus.: "A som is lonnel to nowrish his father, you, to beg for hin." 'The case heresupposed is ot a needy larent, requiring holy from the som, which be refures an grounds justified by tradition. But yo say, 're' hrong expressed in the original, and thus strongly comphatic. It is a bad position for men to orenys, when what they say in climerotly opposed to what crod says. By whatsoever (ar that wheremith) thon mightest. be (hane been) profited by me, is a general expresion, covering all sorts of casce. and is ofton fornd in the Talmol (Lf., Edersh.) in comuretion with this some sulject. Is a gift, or probals 'lot it be a gift,' the Greck having

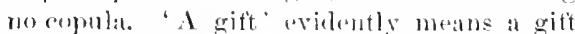
to God, and Ilark (7:11) prosents the II ob. word Corban, which the Tallowel shows they

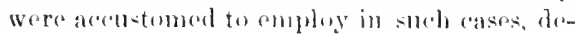

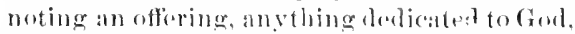
or demated for the n-w of the temple. The Peshito has the samo worr in Matt., and it is used in Matt. 27: fito denote the 'treasury, the agreregate of all such ufliorings. If a man's father or unother wanted any article form him -it might be food or elothing, or what nothe could just say, ('orbau, it is a gift, a thing consecrated to God (comp. 1,v, 25: (4, 16), and he was then, according to the traditionts] rules, not only at liberty to withhold it from his parent, but solemuly bound to doso. The Mishma ("Vows," 9, 1) tells of a former dif- cussion as to whether a vow could be set aside through regard for farents, and all but one Rabbi declared in the negative. The Jews reached this conchusion hy arguing that vows, as they had respect to God, were more important than things pertaining to men; and lience that devoting a thing to God was sufficiont to sot aside the highest abligation, even that to one's jarents. II re was a correct principle, creatly abosed in the application. We learn from the Talnut, which has copjous directions on this subject, that a man was not bound, after saying Corban, actually to dediate the article in the tomple, hut might kees it indefinitoly for his own use, of might give it to some other person, only not to the one had in mind when he made the vow. Corbun might therotore be said just for the nonce, as an excuse for withbotding; and with people at 'momey-loving' as the Plarisees (Luke 16:14), the license thus offered would often be sumelully abused. Even more; it appears from the Talmod that a man might not merely say Corlats: with roference to any particular object, but might say it once lor all, as applying to everything which he possessed, and that one word spolion in passion or groed, would make it impossible that he shomld ever do anything for the person in question, though it were his parent. We are told of a son in Bathhorom wha had taken such a vow agatinst his father, and afterwards wishing to supply the futher's neod, domated his own house and (linner to a friend on eondition that his father should share tho dinner; but the friend immediately dactared the house and manl sacred to houvon, and so the scheme failed. Mishma ("Vows," 5, 6). The lalmud mentions various ingenious expedients fur evading Corban and nther vows, when one afterwards clanged his mind. Several Fathers statothat a Jewish creditor could constrain an wgly debtor by suying "what you owe me is Corban," and so it had to be paid, as a debt to God. From all this we see how monstrous were the practices to which our Lord was referring. It is lamentable to think that they have been rivaled by trachings of moderu Jesuits.

There is some difficulty as to the Greek text 
7 fo hypocrites, well did lisaias prophesy of $y$ m, sayiung,

and the meaning in the latter part of $v$. 5 and v. 6. The best supported text mont naturally vields the manning given by Rev. Ver., (see Ifoultum in Winer, p. Fin); vi\%., you, acenreling to vour tratition, virtually say that when he hat one fiol all male this var he is not to hemor his father. 'The 'nut' is at strong doubled merative. It" "and be retained, then something munt he silently supplient. But it

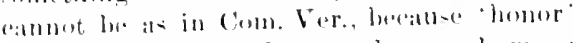
is certainly tuture. It mun be sommbuw so: whoevor silys to his father or his mother, that whrerowith thou wightime have beren

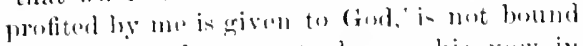
fye the law, lut must obereve his vow in

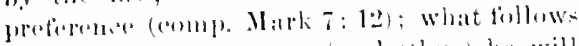

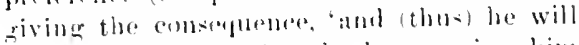
not humbe his fotlore, as the haw rexuires him to to. The general thought is the same upom lonth interpretations. IIave ge made void God's authoritative word, and not merely

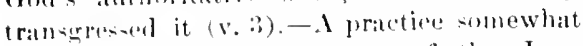
similate to this corbun vow of the Jows formerly exined in the samblede lstamls. Bernes: "The ehiefs and priests hat the power of devoting anyluing to the service ot

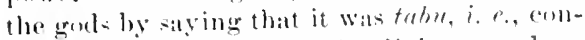
secrated to the serviere at religion; and nus matter who ham boen the owner, it eould then be appropriated to no other use." From this Polynosian usage remes ans word tabou, to

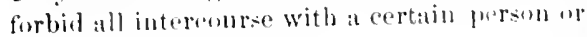
use of a cortitin thing.

\section{7-9. IIypocrites, sec in 6: 2. They}

1 Aml' is omitted by $\times 13, \mathrm{C}, 1$, sume other manuscripts, and several sersions. The groment for hesitation is that 'amo' is the diffinll realing. But lho verh "homor" should clearly the tufure tomse, as grven by nearly the sitne autloritios, amb not subinuctive, as if the eommon lireck toxt. The futurn indicative aftur on mo is unclassieal, though not 11 mommon in later fireck, and would thus lo readily ehaned ly copyists into the rosular chasieal sulijumetion, as in many other

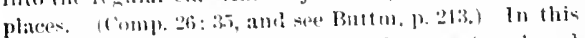
way 'homr' "ame into the same form at 'say, and then it might "asily oeen to a enplist that these mugt to be combeted hy 'and," whosoeser shall say ... and shall mot homor.' Thus the text of the oldest authoritios aecounts for the other rudings. 'Or his mother' $(x, 6)$ is omitted hy $\wedge$ B, $\Gamma$, and old syriac. The adition of this elause would he instintly suggested ly the furegroing phrases $(s,+f)$, white we cannot imagine
7 dition. Ye hyperites, well thet Isaath pophey of you, saying,

male grout protineo of devotion to Giod, amb insisted strenuously on the externals of his service, while at heart they did not love him, and were even realy to set ande hicexpress commands for the salie of their traditims. The persens patrecularly adshemed ware from Jerusalem (s.1), and an arly lialobi is related to have said that "there are ten parts of byperisy in the world, nine at erustem, and one in the wholn world." 'This serms to be the tirnt instane af onr larel's openly

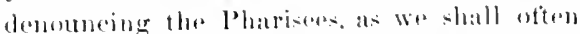

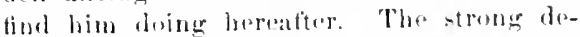
nunciatious ot Luke, ch. J1 and 12, are much

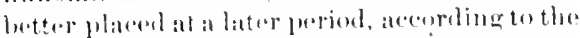
barmonj-ticarrangement ot 11 ieselere tollowed by 'linchemort"s "symopis" and Clark's "Ilam." (Comp. on la: 2.2.) Well, $i$. finely, alptly, with admirable appropriateness, (comple 1: : 14.) Yet our Lamd does not simply say that he timels the words at lsaiah to hixeontemporarias exartly applicable to these persoms, and him-elf malies the application, hut he siys, Well did Lsaias (Istiale)prophesy conceruing you. Isaiah spoke directly to themen af hisowntime, but his woml-werentso

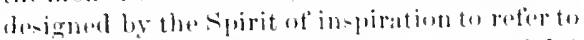
thecontenpurarient Mesiah. Far "Isaiah." in-trat at the rhangent Gerek form E-itias,

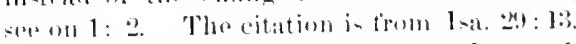
The worls in eolnmon Grenk text, draweth nigh nuto me with their month, nud are not genuine bope, hut wre added trom. the sept. ${ }^{2}$ Matt. quates from the seret. as he

any reason for its omisojon if originally present. In like manture "the worl' read hy B, I), amb al correcter of $x$ and hy matny early rersions and some fathers would easily be changed to ' the eommamburent, to suil

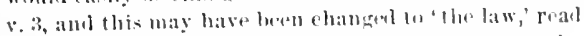

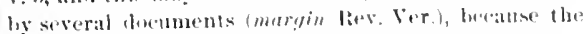

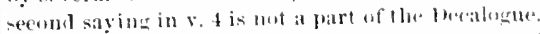

- They are winting in nearly all the eitrly versiens, in the eartiost fireek manmoripts, and in many l'atrive lie eitations. To enlarge a quotation by tringing in something more from the sill, wate a very emomom and natural muld of altering the copies. The clanse connot have been omitted in Malt. by way uf asquilat tion to Mark. for that would have led rather to its jusertion in Mark, areoriting tothe eustom of the eoplyists. Some llss, of the selut omit this clause, perhaps ly way of accommedation to the Gospels. 
8 This people drawoth nigh unter me with their

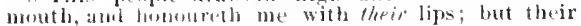
heart is far lrom nes.

9 liat in vain they do worslipl me, teaching for doc-

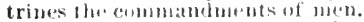

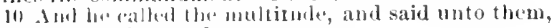
Hear, and understand:
8 This perple honoureth me with their lips; But lheir boart is far trom me.

9 but in vain do they worshi], me

Teaching ax their ductrines the precepts of men. 10 And be called to him the multitude, and said unto oftene-t does, and hore in v. 9 departs considerably from the Heb., whieh reads, "and their tear towards ma jo the rommandment of nun, (a thing) taught," i. e., their piety is merely a lesom they have lasmed from men, and nust a thing learned from and conformed to the worl ot Gorl. For this the regut. has, "Inat in vain do they worship me, teathing precepts it men and teachings." (As to the difference between Heb. und sept., compr. Toy.) Iatt. and Mark ( $7:$ 7) have slightly modified the singt. int; "teavluing teachings (which are) precepts af men.' This not only improves the vhraseology ot the sept., but brings out the prophet's thought mere elearly than worald be donte by a literal tran-lation of the IItob., for Inaiab neans to distinguinh between a worship of (iod that in taught ly nete, and that which is arcording to the teaching of God's word As to puoting rept. instead of IIeb., see (11) $3: 3 ;$ and as to verbal changes to bring out the salue more platinly, amp. on $2: 6$. For the difierent worls rembered teaching, see on $7: 28$. Instead of commandments, Rirv. Ver. hore uses 'precepts' las in Tyn., Cran., finn.), lueause the Greek word is somewhat difterent from that of $v$., , though substantially cquiralent. In rain, i. e.. it is not aceoptable to frod, nor profitable for themselves. So at the present day many persums claim a divine anthority fur ideas and fracetiees which are simply ot lumman urigin

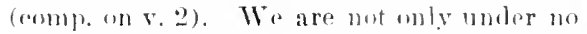
obligation to conform to these. lut it is our duty to oppose thom wherever they end to the violation or neglect of God's rommandmants. It must aloo be remembered that anr common buman nature is very prome to he intent upou the furms of religion and nowleot its spirit; to homor God with the lipk, while the heart is far from him.

$10 \mathrm{f}$. When he rotorted their question upon themselves (v, 3), it was not for the purpuse of avoiding an answor, and he now publicly proelaims a principle which goes to the lirart of the matter. Called (unto him) the multitude, or crovod, the muss of the people, as dis- tinguished from the Plarisees and Sicribes, who had pressed up around hin. He wished all to hear what he was about to say; and in fact the erowel were more likely to receive it than the others, being less prejudiced and sophisticated. Hear, and understand. It wats something important, and demanded attentive eonsideration. The disciples presently called it a "palable" (1. 15), yet he was not now employing obscure expressions as a juc gment $(13: 13)$, lut with great desire that all (Mark $7: 14$ ) should mnderstand. And they must not merely hear, but understand; fur he will not recite dreisions and opinions of the ancients, as the seribes rid, but will speak by his own authority ( $i: 29)$, directly to the understanding and conscienee of the perple. Defileth a (the) man, i. e., the man concerned in any particular case. So in the seeond elause, and in v. 18, 20. Tyn., Cran., and Gen. give the article in v. 11 and 18 , but not in v. 20 ; King Jannes gives it anly in v. 18. The word rendered 'defileth' is literally, males common. Some kinds of food were specially sot apart. as alune proper for God's ehosen people, and were thus in a eertain sense sacred, all uther things being 'eommon' (Actso:34) ; for an Isralite to partake of these forbidden thing would destroy lis exclusiveness, make him common. Honce 'to make common' atome to mesun to dofile, pollute. This saying of Jesus was to the Jews in the highest degree surprising, paraduxical, revolutionary (eomp. 12: 8). They saw at onee that it applied not merely to hand washing, lut to the whole matter of elean and unclean food, and this seamed to them one of the most vital parts of tha law. So they knew not what to make us the saying, "Not what goes into the mouth difiles the man, but what comes ont of it." The Pharisees stumbled at such a saying. could not admit the rivine mission of one who uttered it ( $x, 12)$, and even the disciplas failed to understand it. (r.15f.) Ceremmially, varions things did defile by entering the mouth; hut this was only designed to represent the idea of moral pollution, while the great mass 
11 Sol that which gonth into the month deffleth a man; hut that which comedh out of the mouth, this detileill a man.

1.2 Then touse his disciples, aud silul unto him,

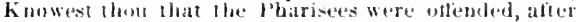
they hraml this maying:"

lif lout he anowered and said, Every plant, whieh my heavenls faller hath not planled, shall be ronted up.

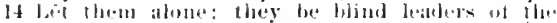
blime. Ant it the blind leall the blind, bonh shall lall into tlue tlitels.

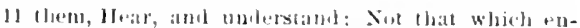
rereth into the momb detileth thes mall; but that

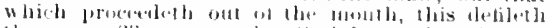

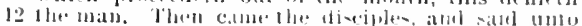

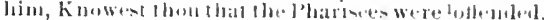

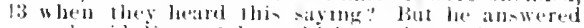

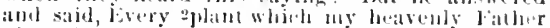

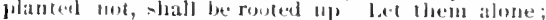

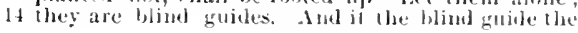

1 Gr. cansed to stumble...2 (ir. plunting.

of the Juws however serupulums about the reprosentative purity, were careless of the inWarel purity. Our Lerel therefore, by this saying directs attention to the internal and real impurity. Herr, as with reference to the Sabbith (12:1 ff.), and to su many puints in the Fermon on the Monnt, he is linding the peorple to lener amb more spiritual views of the morality which the law designod to teach. und thus nut abrogating or correcting, but 'completing' the law. (5:17.) Hi- teachiugs: did priburethe way for laying aside the ceremonies at the law, but this only by developing it into something higher. Accordingly, lae dues not abrogate the Masnic directions about unelean forol, hut lays down a general principle allulying to the point in hand (v. 20), and really corering the whole matter, though not now turther appliod. Many thing-taught in principle by Jestse, were to be tully devel"peel ly hi- inspired tiblowers, as men shomld becomispepared to mulerstand them. ('mmp. 1 Cor. 10: :1 : Rom. It: 1t tf. ; 1 Tim. 4: 4; Tit. 1: 15. Busides eduating the Israclites to the appreciation ot moral purity, the law about

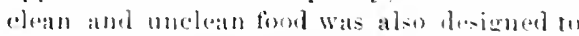
keep the chomen perples separate from ather mations, anal $\rightarrow$ Peter was tauglat to su it asilu when the time came for jereaching freels aunong the fintiles. (ros $10: 9$ er.)

12-11. This is fonmd in Mallhw mbly. It npleates that the conversation aceurrol ater Jesls and hi-immoliate followers hal relired

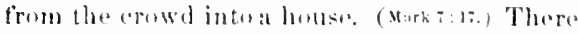
had thus bern a little interval since thesolye of $v, 11$ was uttered, and the disciples had hearel how the Pharisess were talking about it. They fiolt that the orinions of these distinguishoel men from Jarusidesu (r. 1) were veryimpurtant? Kmowest thou. It serencel likely that hodid not, or hes wembl he ha-tening to explain and thus recover the sympathy uf such imburtant hearers. Here otfeuded sce on $5: 2 y)$, made to stumble, finding an obstacle their believing reception af . Tasu? teachings (ats in $11:$ ij). When they heard this (the) saying, mut that of v. B-? ( Fritz. and whers), but the great saying af v, 11, aldresied to the erowd, but heard by the l'harisets alo (Mry., lilexk, Wuis, and athers'. The Platrisedes doubtless declated the sayingr to be in elirect reprosition to the law abont clean and anclean find. The disciples them-

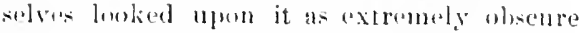
and strange ( $\quad 15$. and sympathizad not a little with the prejulices involved. Our Lerrd's reply is tothe plecet that it mattors not what -uch men think, whose anthority in morely human, and who are as blind as the multituile they lead. Every plant, ate. Every deretrine which diel not come from fiol, which is of merely human orieriu (v. 9), will lose its infuence and cease to be believerl. My heasculy Father, suse all di: 9. Jet them aloue,

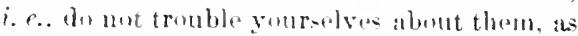
to what there teach. or wherbar they apurove my teachinge. The Great Tiacher did not ex-

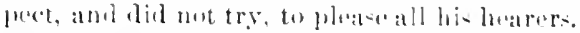

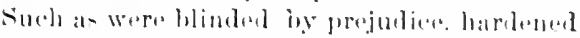

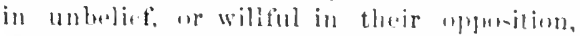

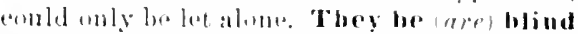

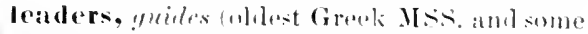

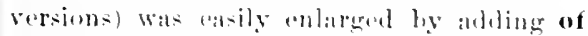
the hlind from lhe immediatuly fillowing exprusion. Guiles (Rhuims) is a more

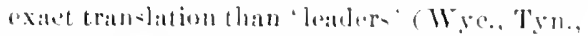
and follower- If the hind lead (ynide) the blind. Buth Grok worl-are singular

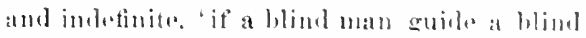
man, 'Int the drefinite firm makes at -mentlor English exprosion. It seme likely from

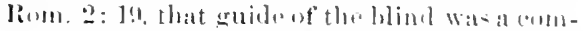
mon derignation of the Rabhis. Both shall (will) tall iuto the diteh (a pit, the silmo

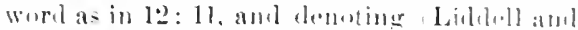

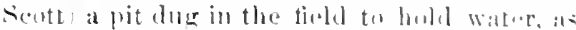

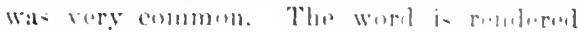
"pit' by Tyn., Cran., Gen., and Cinn. Vier., in 
15 Then answered l'eter and said unto him, leetare unto lis this parable.

16) Amb lesus satid, Are ye also yet without understamling "?

${ }_{1 \rightarrow}$ In wot ye yetunderstam, that whatsoever entereth in al the nowth goxth juld lhe letly, and is cast out intul lu. dralusht:"

Is but thone things which proced out of the mouth come forth iron the leart; and they defile the man.

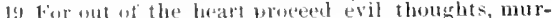
ders, atuleeres, fornieations, thefts, false wituess, blasphemies;
12: 11. but here they all adouted 'diteh,' probably from supposing the image to be that of the ditch beside a road. But the word does mot mo:an ditull, and the image is that of blind persons walking in the open field, and falling into a pit-a much more serinus calanity. This saring has the air of a proverb, such as sur lard repeatedly employed (see on $7: 5$ ), and it had already been used by him in the Semon on the Mount. (Lukeb:39.) Various simular sayings are found in classienl writers. (IV ct.)

15. Then answered Peter, not a speeifie reply to what Jesus had just said, but in a general sense a respone, keeping up the eonversition. (See on $11: 25$. ) Peter's expression, deelare unto us, shows by the plural that he speaks for all, and Jesus in reply says 'ye. (Comp. Mark 7: 17.) Peter is therefore spokesman for the Twelve, as he so often is. (sice on 16: 18.) This (the) parable; herecopyists readily changed 'the' into 'this.' The word bere dinotes an obsure expression. (Ser on 13: 13.) The roferenee is not to the figurative saying of' $v$. 14, ealled in Lake fi: a a parablu, but to v. 11, alrearly spoken of in $v, 12$ as 'the say'ing.' This is plin from on Lurd's reply, and confirmed by the eonuection in Mark $7: 15-17$, who has mot given the intermediate mattor of Matthew $y$. 1:) t.. and with whom 'the garable' must necessarily refor to the great saying.

16-20. And Jesus (strictly he) said, the enpyist. inserting 'J Jesls, as in 11: 14 and often. Are ye also, as woll ats the masese and the Pharisees. Yet. The Groek bas at strong word, not alsewhere used in the New Test. but which in later Grees has coren yet an a well-established meming; 'svon yet,' alter " all the instruction you have reseived, eompe. 16: 9; Hob.5: 12. He haul net givenany instruction that we know of on this particular subject, but his teachings in eh. 5 and ch. 13. and his general influenee, ought to have prepared
15 bind, both shall fall into a pit. And Peter answered and said nnto him, Declare unto us the 16 parable. And he said, Are ye also even yet without

17 underslandins": Peleeive ve not, that whatsuever garth into the mouth pasiseth into the helly, and is 18 cast out into the lraught? But the things which proceded ont of the mouth come forth ont of the 19 heart; and they defile the man. For out of the heart come forth evil thoughts, murders, adulteries.

them to take spiritual views of things. In $v$. 17 , do ye not yet understand (or pereeive), was strengthened by copyists by introducing 'yet,' beealuse of the expression in v. 1ti, and jerhaps with a reminiscense of 16:9. 'Perceive' ('Tyn., Gen.) is here better than 'understand' (Wyc., Cran., Rheims, Com. Ter.), in order to distinsuish from the different Greek word used in v. 10 and 16. The Jews had come very largely to eonfound eeremonial witl moral defilement. To eorreet this confusion of ideas, our Lord points out that articles of food eannot really pollute, beeause they pass through the body and out of it, and do not 'enter the beart' (Mark 7:19), camnot affret the spiritual nature; but the sinful things which are uttered through the mouth, and proeed from the heart, constitute a real pillution. Comp. on v. 11. Into the belly. The Greek signifies the whole hollow, or internal eavity of the body, including stomach and other viscera; and the English word formerly had a similar latitude of meaning. Into the dranght 2 kiugs $10: 27)$, sink, or privy (Rheims), literally, place for sitting apart. Mark adds ( 7 -19) that by this saying Jesus cheminsed all articles of fond, i. e., dechared them to be clean. (Acts 10:15.) With v. 18 comp. on 12: 34 t". In v. 19 our Lord dues not contine limself absolutely to sueh things as are spoken, in order to keep up the eontrasted image, but passes to the more general notion of whatever comes forth from the heart, has its origin from within us. There is, therefore, no ocasion for inquiring, as some do, how spcech has to do with all the forms of $\sin$ here mentioned. II ark (7: 1x-23) does not mention the mouth, but (m)ly the more general idea of entering and wning forth from the man, the heart. We bave seen on 6: 21 and elsewhere, that the heart was eonecived of by the Hebrews, and is spoken of by the Bible, as the seat of thought and rolition as well as of emotion. After the general phrase evil thonghts, our Lord speci- 
20 These are the thims which defile a man: hut lo eat will unwashen bands defileth not a man.

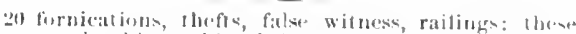
are the things which detil. Itw man: but lo eat with unwablen Jinds dielitell not the man.

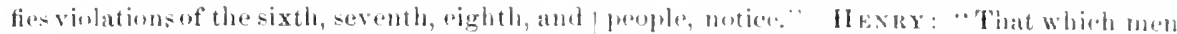
ninth Commandments in ordor. Natrk atds sonse other mins not mentioned by llatt. The. plural forms which Matt. has throrughout (even 'folso witnesings') remind us ot' the null erolls installews and hitlerent variceties ot there severil sins. Blasphemies (see on (1: : is); a litural translation of the (reek is in leve. Ver. 'rationge, In English wecentine it to raling again-t Cod. Philo Judaeus paratphrasiug I'lute, says that through the mouth

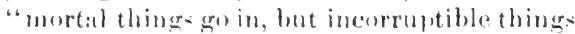
come ont. For loy it anter foud and drink, the corluptible bouly"s eorruptible nourishment; but through the month words come forth, the jummortal soul's immortal laws, through which the natural life is gorermed." "20. 'This hrst sums

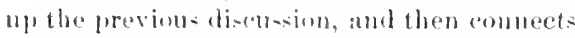
it all with the stiting point in v. 1. ()ur Lord has now not mily denomeded the Phariseesas hy porerites (v, i), bat holdly antagonized their cardiand tence of the authority of tradition. The contlict must insevitably wax lieree, aud he som begins to withlraw from their virulent opposition, and the famaticism of his frieuds.

IIOHILETISA ANA RRACTOAL.

V. 3-fi. Two appositions. 1) 1[uman tratdition reveres divine enmmandunent (a)

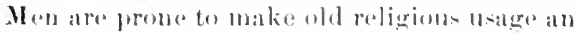
authority. It can chim respect, but not obrelience. (b) Wen ottern come to take more interot in lonerestablishenl llsage than in the express tealeliner of revalution-this through jersonal asociations and thromerl controversial heat. (e) II In sometimespracetically alter a divine commandunent to make it harmonize with establisherl (4lstoun; the siaviur represent= this a a grave sin. (y. fi.) 2) (eremontal serviens mereses morai duties. (a) Hunatu nature naturally tencls to be more interested in the externat than-in the moral

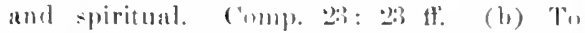
neghest a high moral duty lier tles salie of a mere religious usigen is to disurace our rerigion.-V. 4. Honoring parontz. 1) Humor thom in your thoughts. ¿ Homor them in vour speoch, ․ 4. latterpart. 3) Homor them in your actions, v. $5 \mathrm{f}$-BkxakL: "Yonng say, eren groat men, and leamed men, and men in anthurity. must be examined by that

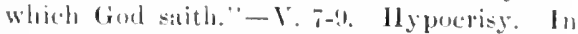
the days of Isatal, and of .Jesllo, and in our days. 1) Two forms of liymerioy. (a) Roligions talk without redigrouscharatere (1.8.)

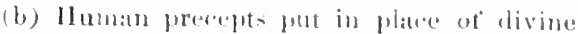

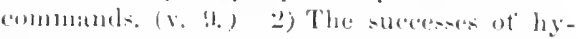
prerisy. (a) It maly decerive men-enther persoms-eren the livpuerite him-elt: (b) It never derecires Gud-it is " in vain," (v. 3). - V. Iot: I'reaching te the people. I The combinom preople are often more ready to rearive new religions ideas than the teaching

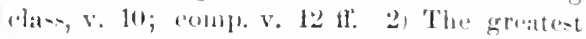
ol rolierious teachers had to ank special attention when giving straluge and unpalatable instruction, v. IO. (3) Even he was imprertiectly understomd by smone (v16), and fiumd falult with by others. (v.12) 4) Jet the common perple lieard him ofladly (Mark 12:35), and all that the Father galve him eame unto him. (John6:sa) H Hexky: "Not only sedulars, lut "ren the multitude, the ordinary jesple, must apply their minds to muderstamel the words ot Christ. . . There is need ot a great intertion of mind and chatruessof un-

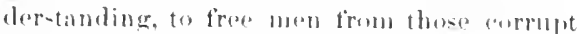
principles and protices which they lawe heen freal up in and lomer accustomed to; for in that asse the umberstanding is commmomly liribed and hiased by projuctice." - V. 11. Many silyings of .Jents that wore revolutionary at the timso are now Christian commomplaess-this tact is a gromud for rojoicing. - V. 11. P'ollution. 1) Ceremonial dietile-

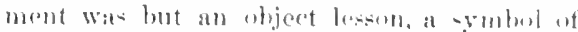
polluted eluaracter; and se ceremonial purity ot mulal purity. 2) Evil thoughts amb absires arise from at polluted nature, and their axpresion in spreceh or action follutes the whale heing, $v$. 18 i. 3 Evil envirmunant endangers charactor, but pure characere cau

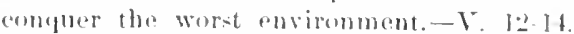
Blinet guides. 1 Jomgestablished religrints tenchers may meet new truth with blind prejuliee, $s, 12$. 2) Highly popular relierious teachings may have no divins approval or suppurt, v. 1\%. 3) Gratly homored 
21 Then , Jesus went thence, and departed into the

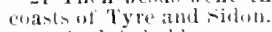

the Ind, beheld, a womain of Camaan came sut of the same cousts, and cried unte bim, saying, Have mercy

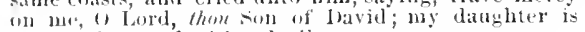
grievmisly vexed with a devil.

raligious instructors may be but the blind gruiling the blind, v. 14. 4) Plausible objeetrons firm distinguished sources must sometimes be quite disregarled, v. $1:$. Cunrs. "It is a gleat evil merely to be bind, but for a man to be in such a case and have nome to lead him, nay, to oceupy the place of a guide, is a double aud triple groumb of censure. For if it be a dangereols thing for the blind man not to have a guide, much more so that he should even desirs to be guide to another." - r. 16. Ignorance of Christian truth is blameworthy, 1) in any one who has opportunity to know, 2) especially in a Christian, B) most of all in one who has long been a Christian, and hat had superior alrantages for learning.- Y. 20. OrIaEN: "It is not eating with unwashed hands, but, if one may use so bold an expresion, it is eating with an unwashed heart, that defiles a man." Cinrss. "Even in the churels we see such a custom prevailing amonget the generality, and men giving diligence to a (o)me in elean garments, and to have their lands wasked; but low to present a chean solul to Goul. they make mareount."

21-38. Jestis WITHDRAWS TO PHOENHAL.

The story of the Syen-Phorenician woman is femud also in Mark 7: 24-80, in the sande combertion as bere. Iuke hastens through this lout of the history, omitting varions thingse and statine others vary briefly.

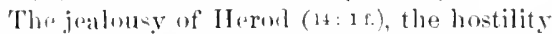
of t?e l'hariseses (12:11;15:1, 23: also $4: 12$; Johe $4: 1-3$, and the fanatical notions of the masses (Johnf. 15), still required that Jesus shombl withelraw from Galilese, ats lorestofores in 14: 1:3. Thenee, probably from capormamm. II" nuw set ont in a diffirent directiom, towarls the nortlowest, into Phorenicial, thus gerting beyond the juristietion of II, roul, at in 14: 13, and hereatiel in v. 29. and 14: 5.

Doparted, withdrom, same word as in "2: 1"2, $20 ; 4: 12 ; 12: 15 ; 14: 13$. Into the coasts (Rev. Ver. ports) of 'Tyre and sidon, $i$. the parts of the mountry, the pegion, botonging to those cities; so the samr word in 2: 2:-2 ; 16: 13; Mark 8: 10; Aets 2: 10; 19:1; 20: 2.
21 And Jesus went ont thence, and withdrew into 2.2 the parts of Tyre and sidon. And, behold, a Canaduitish womin rame out from those lorders, and cried, saying, Have mercy on me, () Lord, tholl son of liavd; ny datugher is grievomsly rexed with a

'Coa-ta,' i. e., borclers (see on 2: 16), is here an utterly erroneous translation of $\mathrm{Wyc}$, Tyn., and followers, due to the generally received notion that our Lord never went beyond the bounds of Palestine; the word 'parts ' never means 'borders.' still, the term looks indefinite, and Mark $7: 24$ says 'borders,' as Matthew also dues in v. 22; so it might scem not certain that.Jesus went farther than to the bounaries of Phoenicia. But while 'burters' often denotes the territory inclosed therely, 'parts' camnot mean simply the boundary. And the question is settled by Mark $7: 31$ (eorrect text), "And again he went out from the borders of Tyre, and came through sidon to the sea of Galider.' (see below on v. 29.) It is then certain that our Lord went into the heathen eountry of Phoenicia, the nearest part of which was about thirty miles from Capernaum. This does not eonfliet with the fact that his mission was exclusively to the Jews (v. 24), for be did not go thore to exercice his ministry (Mark $7: 24$ ), and as soon as he had been induced to work a miracle which would attract attention and gather erowds, he went away again. He entrod into a house (Marki, and wished to stay there in salusion, just as Elijah had done in the luouse of a widow at Zaroplath, or sarepta, in the same comntry of Phuenicia. (I kings 17: $9 \mathrm{ff}$; l.uke 4: esi.) He pobably also desired bodily and menta] rost for the tisciples and himsalf, as on the first withelrawal not long before. (Nark $\mathrm{i}: 31$.) A. to Tyre and sidon, see on 11: 21. The two cities together denote the country of Phomicia. II was probably at firt in the solthem part belonging to Tyre, and afterwark weat northward through the sidon districet. (Mark $7: 31$ ) We learn from Mark 3: 8; Luke fi: 17, that multitudes from the region of Tyre and sidon lad attended on our Lord's ministry at an early period. It was a refreshing change for him and his disciples, in the lat wather of April or May, to leave the arep bawin of the lake, so far bulow the level ot the Maditeranean, and visit the mountain recrion of Phoenicia. (Comp. on 14: 13.)

:2.: Aud belold, calling attention to 
23 Bal he answered Jur not a word. Aud lifin dirciples bante and bosotgint him, saying, send her away; fur stue crieth iffer us.

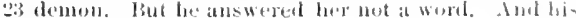
disciples came and besought him, saying, fend lacr what follows as rellarkiable. I woman of

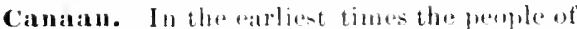
Phoendeia atespoken ot as Camanites (Jumg. 1:3e), i. e., ats belonging to the ereat tribe which oceupired all the low land-, and whichatterwards anve its name of Canatan to the whole land. It is porbable that the Jews antinued to apply this name to all the inhahitants of Phoceniciat, thenert mang of the later inhabitants may have heen of ditherent orierin. 'To

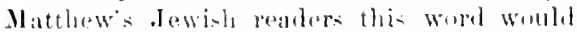
show that she wati a fientile. Ilark, having Gentile readers mainly in view, says (7:26) that sho was a Cirobk, i. e., a frentile, and also that she was a sipmphenician ly races a tem probably used by way of distinction trom the Libyphornicians or C'arthaginians. Came ont of the same coasts, $i$. e., that region un torritury, as in 2: 16; 1: 19;8: 3.4. This moans that she eane, not trom Galilee. but from the montry of 'Yyer, to the place where Jeste was. Jlany writers, aven lloiss and Edrer-h., understand that she came out of Phomeda into Galilee, which they suplese Je-ns hat not yot lett; but this ariass trom the persistenas of the old notion that he did mot rally anter Phomiria. Ealor-h. imangines

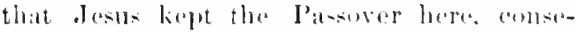
quently in a Jawiols house; but his ahromeloginal sclocme is at this and some other points quitu fincelel. Cried nuta him, saying, the correct text units "anto him.' The word demotes lond crying. Crieth alter us, v. en, $i$. e., bethind $u$, implies tlatt she was following them along as they wallinel. It is easy to stlpwose that while stayeder at the lumse (sark $7: 28$ ), Jents and his diseiples were ono day taking a walk, and that she having hourd alunt him (Marki:as), folluwed behiml and eried alomel as they went an. Tisch.

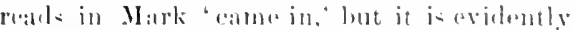

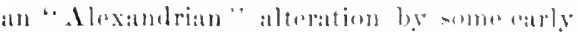
critice whot thought tho sethe of tha intaryow

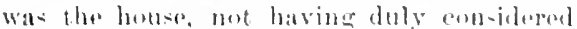
Mathew, IIave merey on me, the worr inchuling also the idea of pits, which is here

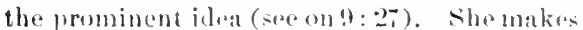
her chitd's ease her own. Lord, see on $8: 0$. It is not clear whothor this was an expression of high respect, or possibly of worship. she belifved hime toe the Mesiath, as sibun by

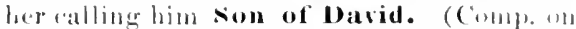
!): 27.) 'Thouerh a heathen, and living 111 a heathen eroutry, she was yet near the land ot Is rarl, tamiliar with the true religion, and like the woman at Karephatl, a worshiper

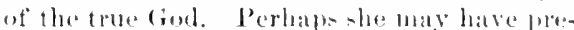

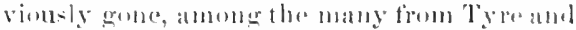
sidon (Mark 3: *, and attended the ministry of

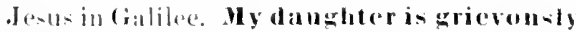
vesed with a devil. "Budly demomiand" would be a literal rendering, though the (ims. Vere grives a more tamiliar Euglish axpresion.

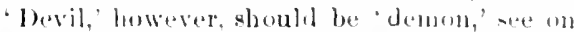
ri: :31: as to demoniacal ponsentions, see on

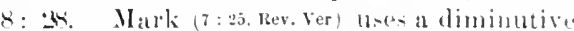
term, meanimer "little datughter, which sluws that she was al elilk.

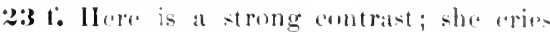

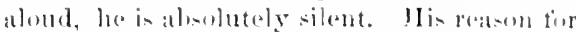

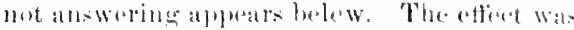
fo develuple strengthen, and mandest her taith (eomp) an !): 28. It is often st) now: it with

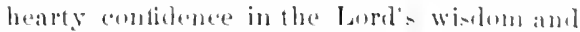
merey wo entinue to ask, we slall at hast res

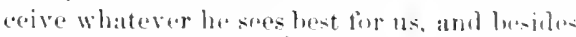
may be informed in piety by the dolaly. The

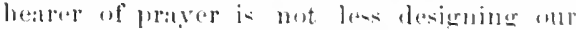
good whon he withboldsor defers than when be "hatro while we are yot speaking." II disciplos, probaloly the Twerle, did not 11 lerstamel the wisdorn and lowe of this aplatrent mentioct. Thay were probalily hall tomehed and halt annuyed by her lond alut

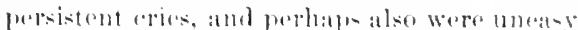
lat shes subld d law attention to tbens. When

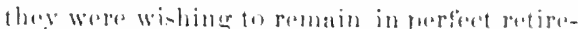

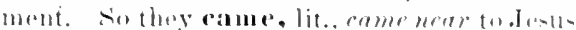
and hegered him to semel her a way, becalls

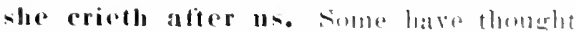
they wished hild simply to ureler her attis as trenhlesomo and likely to attract to thath the

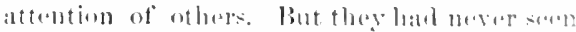
him dismiss a suppliant in any ofluor way than ly doing what was askind: and that they de. sired him to grant her requent is malde plain lis his answer. which is a roason why heshollit not erant it. ()lererethat this was an an-wor to

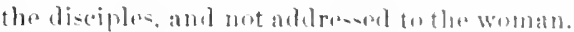
It is not clear that sle heard it; for the state- 
24 But he answered and sail, I am not seint but unto the leme shetel of the hutse of lsmat.

is Ther rame she and worshipled him, saying, Lord, help me.

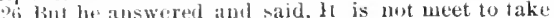
the childrev's bread, and to cast it to dogs.
24 away for she crieth after us. But he answered and said, J was not stut but unlo the lost she'p of the 25 humse of Isritel. Bul she cane and worshipped him, 26 saying, Lord, liejp me. And he answered and said, It is not meet to take the children's 1 bread and cast

$10 \mathrm{r}$, toaf

ment iu v. 25, "came and worshipled him, implies that she had besn following at some littla distance, as dues also the loud rrying of v. 2.' f. I am (or was) not sent (Rheims), like 'I cante' in 5: 17, leferring indetinitely an the time when the Father sent him forth to his mission in the world ; he had no commission to go to any uthers, even as he had given the disciples none. (10:ti.) Jesus here and el-ewhere speaks of hinselt as suburdinate to the Father, with reference to his official position and work as the God-man, the Mediator (comp. on 11:27); this dues not entlict with the iclea that as the Eternal son he is very Gud, and equal with the Father. (John 1: 1; Rom. 9:5.) Bnt (ol except) nnto the Iost shep of the homse of Israel, see on $10: 0$. He dumbtless bealed Gentile sick when brought to him in the land of Israel ( $4: 24 \mathrm{f}$; $15: 30 \mathrm{f}$; ("retainly in 8: 5 1l.); but now he had gone into a fentile conntry, and must aroid entoring 11 on a guneral ministry there. 1Jis ministry in Israel propared the way for a blessing to the Gentiles. (Rom. 15:k-10.) When his work was finished, then the apostles would be his "witurses, both in Jerusalem, and in all Jurlea and samaria, and unto the nttermost patesot the "arth." (Acts 1:8.) It would have (ondlixted with the nature and design of ('hriot's misoion, had ho anticipated this work of the apustlis, though he alluded to it as a bart of lis own work. (John 10:16.) The tewisle mind required slow preparation las the history in Acts plainly shows for the idea that Gentiles ware to share forely tha benufite ot" the Mesiande reign; and the Jews would have besu irritated and utterly repelled (Inttrenth), if their Messiah hat at once begun a grout work among the frentiles. Jasts was indued to make an "xo(p)tion to the rule by this woman's errat faith amd humble importunity, as the prophets bad

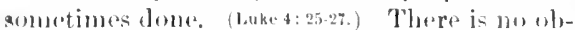
jection to supmesing him wreleome ly im-

1 Wye., Cran., cien., have 'for' Mheims "xactly 'for . also.' Tyu. gave 'nevertheless, and so fom. Vir. 'yet.' All but Rheims orerlook the 'also.' B. and portunity. But, in fact, this was hardly an exception, for her great faith brouglit her in some sense within the limits of his mission. (Gal. 3: 7.) Notice that v. 23 f. is found in Matt. mly, who wrote especially for Jews, and desired to. show that Jesus was the Messiah. Mark's Gentile realers would not at first have understoud such a saying as v. 24, and would have been rapelled by it.

25-27. The woman herself now comes. Worshipped him, bowing before him, probably prostrating herself, but not probably as to a Deity (4mp) on 2) 2;8:2). The Greek imperfect tense (correct text) not only states that she did this, but describes her as so doing. Jesus puts before her the same idea he had just stated to the disciples, that the Messinnic benefits were designed for the Jews, and purposely employs harsh expressions which will develop ber faith and bumility. He had poredueed a similar effect in the centurion by an "pposite course. (8:7.) The Jaws looked upon thrmselves as God's 'children'; and spoke comtemptumsly of the Gentiles as 'dogs,' unchan and vile. (Comp. on $7:$ (i.) The Gentiles around were accustomed to this, and therefore the expression here was nut altugether so offensive and painful as it would seem to us. sothe Mohammedans call c'hristians infidel Arogs. It is not meet, or gond, proper (katom), plea-ing to the sense of propriety. IVye., Rlyeims, Tyn., Gen., say 'good'; Cran. gave 'mete.' The woman's reuly not only shows a high degree of faith and humility, but aloo does credit to her shew wness and prompt intelligence-perhaps stimulated by maternal affection and soliciturle-for she gives the harshly expressed rofusal an admirable turn in her favor. Truth (or yes) Mord, yet $(f o r)$ the dogs eat of the crumbs. She dow nut present an idea opposed to what he had siil. as the incorrect rendering of Com. Ver., 'rot,' would indieate, but a confirmation of it. Tes, Lord, it is not proper to take the chiletren's

Jeshito onit the 'for,' apparently breause the meaning was not perceisenl. In Mark $7: 28$ it is also onitted liy several other Mss. and versions, probably for the samo 


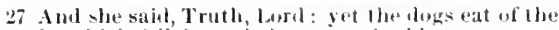
crumbe which fall from their masiers' table.

2s Thell hesusanswered alld sitid untu her, () wontan,

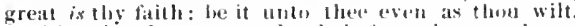
And her diughler was mate whole from thal very hour.

breall and throw it to the dugs, for the dege tow eat of the crumbs that fall trom their master's table; theyalso have their luwly phate", "mulur the tabie" (Mark), and their lowly portion. The Jewish people, she is aware, have a special mission in the world, and sperial privileges; and of these they need not bedrerived by her roquest, for a de-pratal Gemtile also may have an humble share of Me-sianic hessing. IIe i- not now healing any in Israel, and the chosen perple will hose no Mesianie gomel by this ons act of pity for her. (Comp. Matel., Wein) Luther: "Was not that a master strule? She snares Chri-tin his own words." In Mark, what omr Lurd had said to her is introrluced by the words, - Let the ehildron first be tilled; implying that atterwards the dogs might get something. This furnishorl all the more natural aceasion for the turn she give to her reply. The (ireok term in $v$.

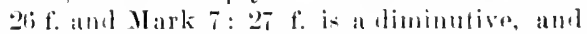
laals us to think of sualler thers, allowal to run tresly about the lonse atul wmer the table. The dininutive must hase been intentimally nowd heren, for it is foumd newhero alse in the Groes bible, while the common worl oceurs five times in Now Tist., and thirty-three times in sirpt. Everywhere in the Bible dogs are spoline of as abjects ut dislike. In Tobit 5: 16, a ling is a enmpontion. athing very rarely the cass in the East. where elogs run wild. It is hardly propere to supposes that "little dings" is heres at term of nflection; and Weiss' notion ut lap-elogs, the children's pets, is a strange analhornism.This heroine of faith is an raturple to all persons who al spesitually sosking Christ. Sume after awhile grow elespondent, and even frettul, as it badly trated, in that they de not

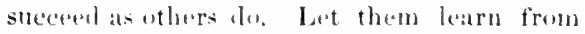
her humbla perseveranten.

28. 0 woman, mure expresive than simply 'woman.' Careat is thy faith. The world is ever atmiring and laudiug gratnes. but it is great intellect or innurination, errent

reason. Why should it have been insertent if nul originally present in either (iospel? Huw then shonld $11 \mathrm{H}$. liracket 'fer' in Matt.? Y't it mag be spurious in Mark.
27 it to tha dogs, But she said, Yoa, Lord: for even the doge atl of the erumbs which fall from their

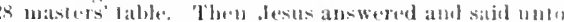
bor, () wollati, greal is lhy failh: be it dome num

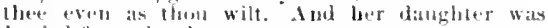
lavaleal from that hour.

ambition or tores of eluaracter, beallty or andiability, groat learniog or diseoverios, pus-

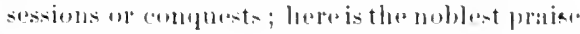
for the truet ereallums. The centurion's fath likewise exeitul tle wouder of Jests fee ons: 10), and he tom was a heathen. Be it unto there, ur let it come to puss for thee; thr same phrats as in 8: lis and bi: 10. The expresion in Ilark 7 : 2! tory have immediately folluwed that given in Matt. Is thon wilt. Treneh: "IIe who at first seremed as though he weruled have lenied her the -llathest bom, now opens to her the full treatsurehollse of his grace. and bids her to help herself, to carry atwa what she will. Ma had shown to her for awhile, lik". Jus'sh to his brethren, thes aspeet ot surerity: hut, like Josteph, he conlel not maintain it long-or rather he: would lost maintain it an instant longer than was noedful, anel after that woral of hers, that mighty word of an undoulting fath, it was needtul no more." Our Lamb dues not speak of her humility, themeh so remarkable, for that was

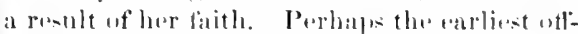
spring of Imbulitef is prishe ( $\mathrm{Tim}, 3 \cdot 6)$, while fitith at onee grives hirth to humility ; and in

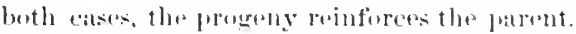
So, tow, her fath had lol to perseverance-. perseverance which may be complared with that of Jacul, in wertling with thr situte

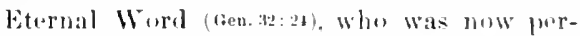
manently incarmarre ats J J

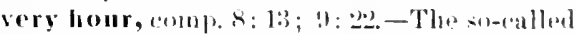
Clementine homilies (ment of seond rentury), in telling this story, all the womtan .Ju-lat, and her daughter Burnice, which namos may have beren either invented or tratitional.

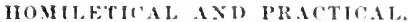

V. 2l. Jesus withdrawing. 11 From what? (a) From the jatomsy af Harod. (b) From the manhinations at the Jewish rulers. ((*) From the fantical desigus ot sume who counted themselves his followers, 2) In what

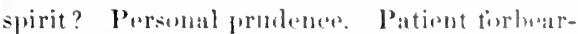

The (ireok worl means in Finglish pither "also" (luo), or 'eveu, acenting to the connection. 
29 And Jesus departed from thenee, and came nigh unto the sea of cialilee; and went up into a mountain, and sit down there.

30 Amd great mulilules cume unto him, having with them these that were lance, blind, domb, maimed, and

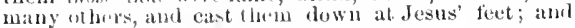
he healed them:

anter. :i) still evergwhere dring good, 1t: 1t; 15: :4-:30; 17:18. 4) At last, when his hour is colnt, he will withdraw no longer, Juhn 12: 2: - I . 2. -28. The Camaanitish woman. 1 Believes in the Jewish Messial, v. 22. 2) Humbly submits to be harshly spolien to by him, v. 24. B) Fibrewdly eorverts refiusal into a new plat, v. 27. 4) Gains her eause, and wins the highest possible commendation. v. 26.- - 28. (xreat faith. 1) Seen in a heatlen; compare eenturion. (8:10.) 2) Attonded hy great humility (eomp). Luke 18: 13), and producing areat perseverance. (Comp. Luke 18: 7). 3) Reeognized and rewardect by him who knows the heart. John 2: 24 f.- V. 2.2. A mother making her child's ease her own. $-1.2 \%$. Disciples seming kincler than their Lord. Il ENR : "There may be love in Christ's heart while there are frowns in his face." - V.24. 1HALI: "WVe need no other rule of life than the intention of our several stations; and if he that was God would take no further sone to himself than the limits of his commission, how much doth it concern us frail men to kerel, within eompatss." $-\mathrm{T}$. 25. Cinles. "She was the more instant. But it is not so with us; rather, when we fail to obtain, we desist; whereas it eught to make us thr mure urgent." TnEopiry. " Consider that "ven if holy mon pray for us, as the aposthes did for her, ret wa onrselves, praying tor oursulve, acemplish more." - V. 27. Mattermal she fownesturning the saviour's argumont agranst him. HENRY: "Unbelief' is apt to draw dismal enclusions evon from

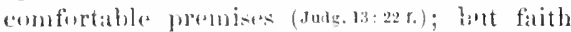
ean find encouragenent oren in that which

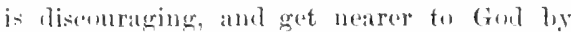
taking hold on that hand which is stretehed out to push it away." to be overcome, by intercession, by persmal entreaty, by argument.

15:29 to 16: 1.-.J EATS FEDHS THE FOER THOUSAND, NOETHEAST OF THE FAKE, AND RETURNA TO GALILER.

'This is found also in Mark 7 : :31 to $8:$ :?\% And Jesus departed from thener. Wi have no means of knowing how long ho
And Jesus deplarled thenee, and came nigh unto the sea of (ialilee; and he went up into the woun3) tain, and sat there. And there came noto him great mulitudes, having with them the lame, blind, dumb, maimed, and many others, and they east

staved in the conntry of Tyre; certainly not very long. for all the journeys of eh. 15 to 18 oceupied less than six months. (See on 15: 1, and on 19: 1.) Mark (7:31) says, in the eorrect text, that, 'he went out from the bolders of 'Tyre, and came through Siclon unto the sea of Gallee, through the midst of the borders of Decapolis.' This shows that in learing the teritory of Tyre he went northwark thrugh the territury of Sidon, or through the ejty itself, the expression being in the case ambiguous. We have no information conerrning the jest of his sojourn in Phoenicia. Next, he must have jassed eastward across the Jordan, and then southward, until, going through the district of the Ten Cities, Decapolis (see on 4: 25), he came to the shores of the lake, somewhere on its sumbeatern border. (For description of the Lake of Galilee, see (1) 4: 18.) This region also was out of Herod's jurisdiction, like those to which he hat previousky withdrawn. (1t:13; 15:22.) The desire to kecp ont of Herod's territory at that time may have caused him to take the circuit just described, instead of going direct from Tyre through Galilee and crossing the lake. Ile apprars not to have stopped in the neighborhood of Cesarea Philippi, probably through desire to revisit the environs of the lake; but soom the malignant attack of the l'harisees and sadducees will make him go away again. (16:4.) He was now in the vicinity of Gadara Lone wf the Ten Cities), the same rogion in whieh he had healed the two dimoniacs, and mitfered the legion of evil spirits to dastroy the swine. (n: 2s fo) This time his ministry produces a greater impression, perhaps through the testimony of the restored demoniac. (Luke s: 39.) P(rsoms from Decapolis had followed him long before. (4:25.) And went up into a (the) monutain, the mountain runge rumning along east of the lake. (Comp. Jolm 6: 3.) The momutain of Matt. 5: 1 was on the westorn side of the lake. The nore northern part of this easterly range was the place of feeling the Five Thousand (see on 1t: 13), and now a similar miracle is wrought on its wore soutlern part. And sat down there, 
3] Invinuch that the multilude womlered, when they -aw the dumb to spuate, the mained to les whole, the lame on walk, amd bihe bitud to see: and they glorilied the tionl ot larat.

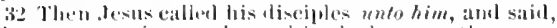

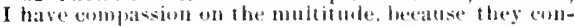
tinue with me now three bass, and hats nothing to eat: amd I will not send then away tasting, lest they laint in lhe way.

3:3 Ind his disciples say unto him, Whonos shombl we have on much bread in the wildermess, as to till sir great amultitule".

34 Ame .I hav" ye" And thes satil, Sivell, and a few litte tishes. is Amb he commanded ine multicule to sit down on the grouml.
31 them down at his teet: ame the bealed them: imse much that the multitule womblemel, when they saw tha damle sleaking, the matmed whole, and the latue walking, and the blind seoing: and they ghorlied

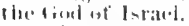

32 And Iroms talled onte him his disciples, aml sail,

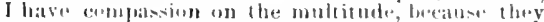

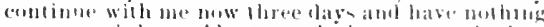

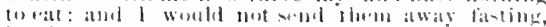

33 lest haply they fitut in the war. And the disciples

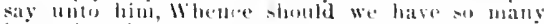

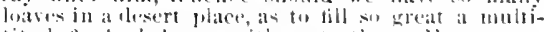
3.t titule? Imel bests satio unte them, Jow many

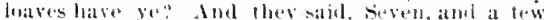

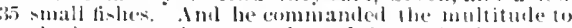
sit down un the grommi; and he weth the rovels the uinal posture ot a teacher. (Ner on 5: 1.)

$30 \mathrm{f}$. Hore, seated on a point in the mommtain rande, forobably in view of the lake, he wroteght many miracles of healing, and again fed the multitudes. In this ense a large purojortion of those juesent inust have been Gentiles, as the Ten Cities wore more a Gentile than a Jowish district. He must have spent at least several days in this region, since it requiret sume time for his presence to become genorally known, and the Funr Thousand had been 'three days' (r.32) in eloseattendanceon his ministry. Cacat multitudes, literally, many cromels, as in so many other batsages. We have here another general aceount of numerous miracles. (Cuml. 4: 28; 8: 16; 9: $35 ; 12: 15$ f.) One of those wrought nt this time and plate was the healing ot a deat and dumb man, deserilud by Mark alone. (7:32.3\%.) The urder of the words lame, blime, ete. (v.30), varies greatly in ditlierent documents, having doubtless beeli atloeted by is :3l: but this is a matter of no enmsequenee. The word rendered maimed signities cronlied, bent, contracterl; it is sometimes applied to catses of mutilation, the lose of some part of the body (1x: x), which is the meaning of mer word maimed, but is not often surecel, and probubly the bost English word here would be erippled.' Intehus' ear (26:51) is the mble recordad instanee of anr Lerel's miraculensly restoring a miscing part of the buly. And manv others. The kinds of disemses were so numerous that theyoould not all he named. Matthew appears to havesolected these nssociated with prodictions of Mesiah. (soe on 11: 5.)
Cast them down ut his feet, implies nut carresesness. Jut hury and bustle and the erowd ut' applianuts. "His tect" was ravily changud ly copyrist-into "the feet of Jesus." (Comp. on 14: 14. $)^{1}$ The dumb to speali: sperking, ete., is the literal translation. (rio Wye.) And they slorilied the God of Israef. In $4: s$ it is simply ' und they glorified (ionl.' But it Was matural to mention that these heathen people grorificel the Gisd of [s rated.'

32-38. Comp. on the similar feeding we the Five Thomsind, 14: 15-21. I have compassion, as in !1: 3i. Three days. They hat mo doubt butught some fond with them. which was now exhatested. They showed great zeal to see and hear and be liealed, remaining so long in the thinly inbabited region. Feropiner on the ground two nights in the upen air, living on the foul lirmerht with them, and slow to loave whon jit was gone. And I will not (ur am not willing to) send them away fastiug. ('l womld not.' Rev. Ver.. is hardly an improvemont upmon 'I will not' : it removes a possiblo ambiguity, hut se(ons to sugerest a condition.) Soma of them ware from a distance. (Markn:3.) Ilis (the) disciples (v.33), 'his" leving easily alded from v. 32. Som meh bread, literally, somany luaves, for the cireek is plural. In the wilderness, or a desert mlace, $n$ wild eountry with few inhahitants, soe on 14: 13 and 3: 1. (Only a region containing latrare towno comla at short motion furnish fous for senels a toultitule, and this wild country was a gend many miles from the nearest citios of Ibatumelis. A fow litte tishes. The diminutivetorn emphasizes the

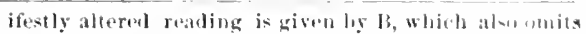

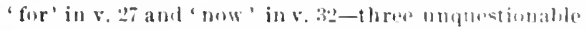
errors in eluse cunnection. In like manner the enrrect realing is, 'the multiutu' in v. 2.5 , but " the multitudes'

in v. 36, and much confusion arose in che copies.
1 'The multitule' (v, 31) is ehanged in must dectlments into 'the multiudes, evilently lecause the participle rendered 'when they saw' is plural (following a simgular " noun of multitude"), and heeanse "great multitudes' have been mentioned in v, 30. This man- 
36 Aml he took the seven loaves and the fistlex, and gave thantis and brake them, and gave to his diseiples, and the disciples to tive multitude.

37 Aml hicy did all eal, and were filled: and they touk "If of the linkel mont that was lett seven baskets tiull.

: Ind thes that dich at were four thousand men, besjde wonent and children.
36 loaves and the fishes; and he gave thanks and brake, and gave to the disciples, and the disciples to the 37 malitules. And they did alt eat, and were filled: and they took up that which remained orer of the

38 liroken pieces, seven baskets full. And they that did eat were four thousand men, beside women and tact that the supply was meagre; in v. 36 it is the common word for 'fishes.' Here again the ferplat are commanded to recline on the ground, and probably in companies and rows ats betiol't (yark 6:39 f), thusgh nothing is here said of it. Seven baskets full. In this case the number of baskets curresponds to the munber of loaves; in the previous ease (14:20) tothe number of apostles. Euthym: "Showing that it is easy for hin to do as he wishes." In Mark $8: 19$ t. on Lord seems to treat it as a matter of importance that such a quantity of brokin pieces remained in each case. Beside women and children, mentioned by Matt. only, as lutere in $14: 21$.

This miracle is recorded hoth by Mathew and Mark, and the former miraculous feeding by all fintr of the Evangelists. And shortly aflel $(16: 9)$, We find it recorded both by Matt. and Mark that wur Lurd referred to the two miraclus as seprately teaching the same lesson. This comelusively shows that strikingly similar events did oceur in our Lord's history, athing to be remembered with reference to the two visits to Nazareth, the two instanees of cleansing the temple, the two women who anointirl. Jesus, the parable of the pounds and that of the talents, ate, where it hapuens that the two events or diseourses are recorded only by differont Evangelists; and some expositors jump to the enclusion that they are nothing but varying and eonflieting aceounts of the same matter. If the feeding of five thomsand with five loaves bad been recorded only by one forpel. and that of four thoutand with

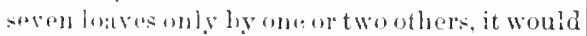
latye buen most contidently asserted that these were the same miracle. Let us neither be nervolts harmonizers. nor earer to assumet that harmonizing is impossible. It is worth ohsorving how natural in these two miracles are tha points of agrosment, and how striking are some of the differences. It was natural that the situation should in both ases be the wild country, where sufficient food could not lo obtained from ordinary sources; that the kind of food multiplicd should be that which
Was common on the shores of the lake; that Jesus should 'bless' or 'give thanks' before breaking the bread, according to custom, and should distribute the food by the help of the disciples, a matter of obvious convenience and propricty. On the other hand, the precise locality in the wild country is different in the two cases; there is now, in the parched summer, no mention of reclining on the grass, as Mathew, Mark, and John, all mention in the former case, when it was spring; the supply of food is here greater than before, while the number of persons is smaller; the people here have remained three days; in the other case only one day. There is also a slight, but quite remarkable difference as to the word rendered 'basket.' This is kophinos in all four Gospels in the first miracle, and spuris (or sphuris) in both Gospels here; and in the subsequent mention of these miracles (16:9 f.; Mark $8: 19 \%$ ) it is again in both Gospels kophinos with reference to the first, and spuris with reference to the second miracle. We do not know the precise difference between the two words, but the careful observance of the distinction throughout, strikingly shows how entirely distinct the two miracles were. Origen and Chrys. suppose that the spuris was somewhat large, and this seems confirmed by its use in lowering Paul from the wall of Damascus (Acts $9: 25)$, while the kophonos appears to have been a small provision basket, such as a Jew an a jourrey commonly carried with him (see on 14: 20). The disciples may have now had these large baskets because they had been making a long jouruey.

The strange thing about this second miracle is the fact that the apostles do not recur (v. 33) to the former miraculous feeling, which tork place but a short time before. Many critics lave thought this utterly inexplicable, and on this ground have denied the reality of the serond miracle, though explicitly and repuatedly affirmed. But let us remember. Our Lord had sternly rebuked the crowd who sharad in the previous feeding for following him the next day with the hope of being fed 
39 And he sent away the multitude, and took ship, 39 ehidren. Amb he sent away the multilules, and and come into the cousts of llagdala.

entered intu the heat, and came inte the borderse Magadiul.

\section{C'II A P T E T X I I}

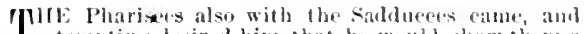
1 tempting drosired bim that be would sluew them a sign from heaven.

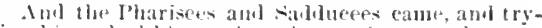
ing him asked him to show thetul it sign trom heaven. again (John b: 26), and hat been mule displeatsed

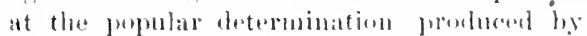
that miratelo to make houl a kiole. Naly, he bal hurpied the disciples themselves mowillingly away. partly, it is probable, headuse they sympatlized with this populat dowign. (side on 14: 22) Inthisstate at thingsthe thisciples might maturally lonbt whether he would relueat a miracle whinh had heen tormerly attemled by sueh unde-irable results, aud might at any rate fere erreat dedicacy about slogersting the ideat that he should at so. (Comp. Math 9: 32, "Wrere afraid to ask him.”) but as som at he iutiuntes such all intention, by asking hom mang loaves they have, they express nostuprise nor denbt, but go on to carry out the details.

And he sent away the multiludes, sop on 14: 2.) t. Ind took ship, liturally, ontered inte the boat, see on t: 21. The bout which

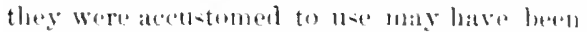
brought tom Capernanus, while they were staying here on thes. E. sille. Inta the coa-ts o1 Masdala, or borteles of Mengeden.

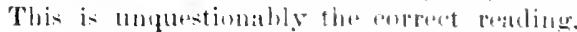

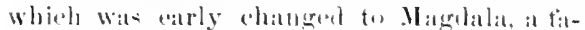

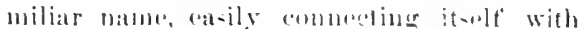

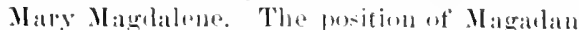
is ankluown, as is that of Dalumanuthat. (Markx: 10.) "They appuatr to have heses on the

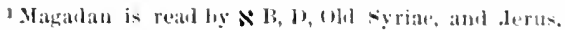

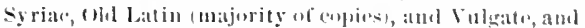

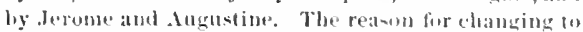
Matudala is obvious, while we can intugine rat reasuld for a change in the ofmosite dipection to an noknown

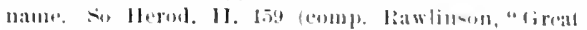
Empires," 111. 4\$ n.) changes Mogidno into Magrholon, a natlural direek form of Magelala. Axmoning 'tower, this word would very realily besmes the natue of a

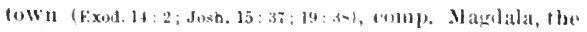
present cenpital of Alyssinia. There is now a blater called Mejdel comtaining a few huts), on the western shore of the Lake of tial., which was probahly the lome of Mary. The Heb. Migrlol, Aram. Magdala, Arab. Megelel (g, sofi), are exactly chatacteristio forms for the three languages. Magdalan, foumd in t., Memph., ele., seems to have been an infermoliate "Mlexambian" alteration of Magalatu, and Magdala the "syrian"
}

western side of the latie, luing reached by buat freme the other siele, atud especially

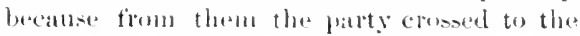
nortleatsteln side. (16:5; Mark n: 13.)

Ch. 16: 1. That which fillow-uecurred at Itagidall, somewhere on the western side of the halie. The Pharisees also, with the sadducese. IIere, an ia $3:$ T. there is but one

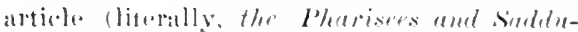

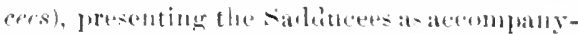

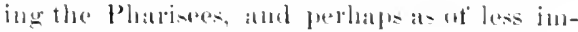
furtance; solsu in lo: ti, 11 t'. 'The somblu-

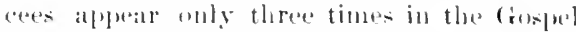
history; (l) witnes.ing the baptism ot Johu,

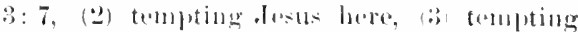
him, not at the some time with the Pharisos. but sepallately, in 2.2: 2:1. (Mark 12:10; Luke:20:27.)

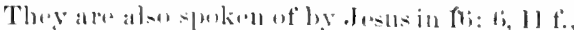
and areanentioned nowhere elso in the (rospels. Only a tow works betiore, and not more than

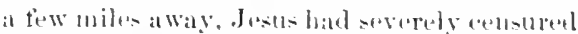
the Plutriseres as hrpererites ant violators of

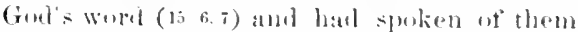

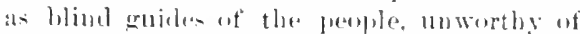

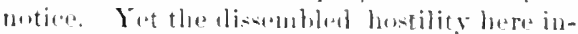
dieated wa- ant tiptawakened liv that rensure, for they hath ahrouly acemord him ot being in

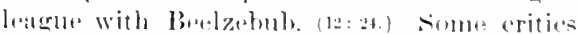
think it increalible that siadelueress should?

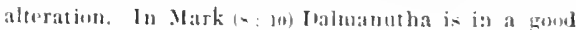
many drements changed to Magalan, and in a few to. Magdala. Caspari womld irleutify Magalan ame balmanutha with a Ifady and town far durn the Iortan valley. But in both limspels the party cambe by buat to those places, and presetotly gor from thesu by bent "on the other sile" (mortheastern side): huw ean these expreseions suit places some twelve to lwenty

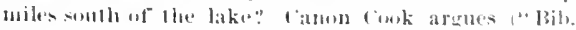

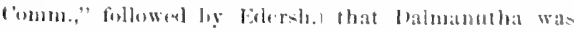

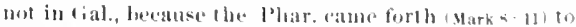

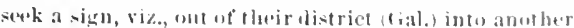
district. But it mure naturally me:ans, ont of their

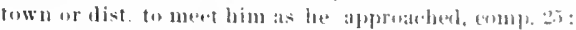

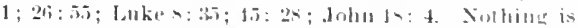

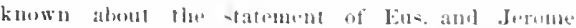

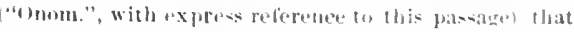
"there is now the listrict of Magedane near sorasil." 
2 Hu answered and sitid unto them, When it is evening, ge saly, It will he faj weathur: for the sky is reot.

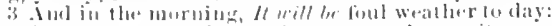
for the $+k y$ in ret] and lowering. "y hypucrites, ye

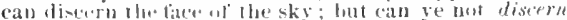
the signe ot the limes:

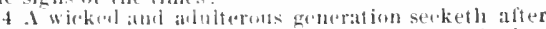
a sign: and there shall no sign be given unte it, but

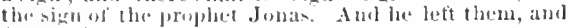
(le)taricit.
2 But he answored and said unto them, 1 When it is evening yes ar, It will be fair weather: for the 3 heaven is red. And in the morning, It will be fonl weather tomay : tor the beaven is red and lowering. le know how to discern the face of the beraven 4 but ye cammot discern the sigus of the times. An evil and adultejous generation seeketh after a sign; and there shall no sign be given unto it, but the sign of Jouah. And he left them, and departed.

1 The following words, to the ral of ver. 3 , are onitted by some of the most ancient and otjer impartaut authorities.

have enme with J'barisees. But they were temporatrily noniten by common hostility to Ja-n. (impl. Jerol and Pilate, Lulie 23: 12, and J'saln 2: 2. 'Tempting (American linvicers would remer 'trying him'), terting him (comp). on $4: 1,7$, with the hope that lie will not stand the test, will not be able 10. Nhow the sign; compl. 19: 8 ; 22.2: 18, 35. The scribus and Pbaristes hat arked a sign from lim in 12: Bx, and were refised. Now the loariens and sadeluess make a similar demand specifically tol" a 'sign tiom hosven' (so) also Mark $8: 11$ ), and get (v. t) exactly the silue retural as bretere. (12: 39.) They might bu thinking of steh signs as whon Moses gave

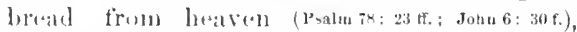
Jownat made the slln and moon stand still, Sianuml hrought thumler and rain in time of

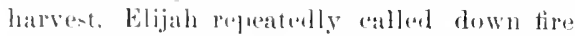
foom heaven, and at loainh's worl the shadow

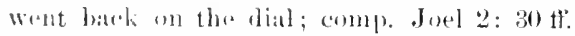

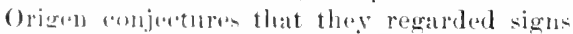

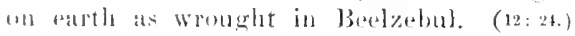
Probably nome Jows really rexpeted exlestial

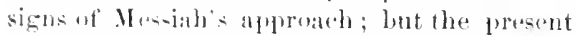
replust wate male from bad motives. Jeatis promi-el "arrat signs from hraven" in con-

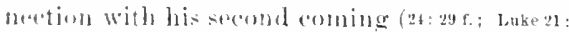
11. $25 ;$ comp. Rex, 15:1), and prealidted that the fatse C'hrist- would show great signs. (24:24.)

a f. 'lhis bassagre (except the opening words, Ho answered and said nuto thens), is duite erortanly non a purt of Matt. It is

J Wanting it $\mathbf{N} \mathbf{R}, \mathrm{V}, \mathrm{X}, \mathrm{V}$, and a duzen cursives, in old

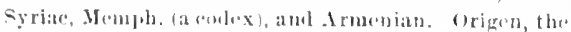

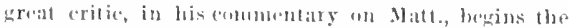

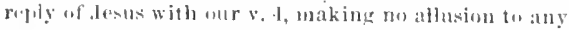
surle fratsage as that in puestion. Jerome says, "This is nut fouml in the majority of copies." Noludy, ortholux or heretic, (collit have hal any objection in

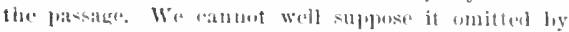
assimiluton to Wark (Meyer), for the congists usublly ascinilated hy inserting. Mnrion lancise it omitted

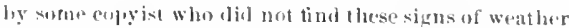
lobding good in his lecality; but this essevtially im- wanting in a number of the earliest documents (Ms's, versions and Fathers) ${ }^{1}$ no reason can le imagined for its omission, and it may readily have come from Luke 12:5t-56, where the closing and principal expression is substantially the same, and the differenee consists simply in using other signs of the weather. As the passinge is retained by Rev. Ver., we mention that Wet. cites from Greek and Roman writers, these and various other signs "if the weather; and that these signs inold good in England and in our comntry, being expressed by the saying, "Red sky at night is the shepherd's delight; Red sky in the morning is the shepherd's warning," which probably came to us from England. The signs of the times (seasoms) would be the various indieations then observable that the Messianie poch was at hand, indieations in the civil and roligius condition of Islatel, the fulfilment of Messianic propheeies, and the miracles wrollght by Jesus and his followers. The other terms of the passage as inserted in Matt. call for no explanation. Even of the doeuments containing the passage, several of the best omit hypocrites (v.3), evidently drawn from Luke 12: 56.

1. This repeats his former reply to a similar demand, 12: 38-40, and so on probably a later orasion, Luke 11: 29 f. Some eritics cannot bulieve that Iesus would several times repeat the sane thing; but see Int. to ch. 5. Of the prophet Jonas, or, Jonah. To Jonah was

Irulable notion will not account for its absence in so many documents from difterent parts of the worid. There is no difficulty in supposing it to have come from Luk" (where all documents have the corresponding passagn), whin we abserve that the main statement is the simm, and only the particular signs of the weather have iscen altered hy the memory of the student who first placed it on the margin of Matt, whence it would creep into the text. It is therefore quite unnecessary to supfore (Hort) a sejarate saying of Jesus preserved by tradition. 
5 And when his diseiples were come to the other side, the's hat forgollen lo lake lirtad.

6 Then Jesus said umb them, lake heed and beware of the leaven of the l'harisees and of the sidducetes.
5 And the disciples cant to the other sile, and for-

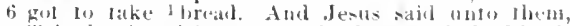
'Take heed and heware ol the leaven of the l'hari-

I ir. loizes.

easily alded "the prophet (common Graek text) from 12: 3!. Mark (x: 12) records umly the general refusal to give a sign, withollt mentioning the exerption, the sign of Jomal, nnd states that in replying ho "sighed decply in his spirit." .Jesus is berimning to tinel it bard to endure such perverse and malignant oplusition (eomp. 17: 17). Lett them and departed (eoml, 21: 17). Bengel: "Just severity." One of our lourd"s reatsons for previously withkrawing from fialilee hat been the hostility of the Platiseres (see on 15: 21). So now again he witharaws to the neighlorhood of Cesarea Philippi, the revion fitrthest removed from Jorusalom and its hyporitical and malignant parties (15:1). It is mot likely that he remained at Magadan longer than a day or two.

\section{HOMLETICAL AND PR.ATECAL.}

T. 20-31. New fields and new labors; comp. Acts lo: :34. - V. 32). livite: "It is a elurious and striking fact that of all the foelings expressed byour Lord upon eath, there is nome so often mentionel as compassiun. His joy, his sorrow, his thankfulues, his andere, lits wonder, his zeal, are all accasionally recoreled. but nome of these fordings aneso frequently montimed as compasion." II ExR': "Our Lord Jesu=kexps an aceount how long his followers continue their attrublance on him, and takes notion of the difliculty they sustain in it. (Rev. 2: 2.)" - V. 33. IIExkY: "Forgetting former experience leaves us muler furesut donlets."-Ch. 16: 1. Orfar:s: "Oftem now:also we soe perans who hold the most discorelant opinions in philesephyor othermatters, seoming to harmonize that they may mock at amo war aqainst.Jesus Christ in hisdisciples." - V. 1, 4. Signs, 1) Even our Jort's arly signs eonvineed Niendemusndul his triends. (John 3:2.) 2) The many signs of the noxt two rears did not satisfy malignant opposers (v.1), and were even aseribed by them to Berlzebul. (12:24.) 3) Captious demands for spereial signs ho atways rofised. (vit; comp. Luket:2n) 4) Even the sign of . Jomah $(v, 4)$, when it eame in his resurrection, while w enclusive proof, was rejected

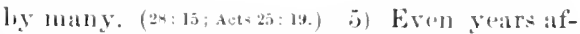
terwards the lews demambel fresh signs, but the 'alled' found Christ crucitied the pewer (1) God. (1 Cor. $1: 2 y$ ar.)

16:5-20. JESIS WITIIDRAWS TU THF

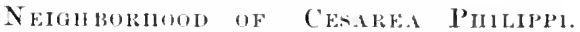
Peter's Gradt Confentox.

This is tound also in Mark 8: 13)-30, and the latter part in Luke ! : Is-2) Luke has palsed over everything since the foeding of the five thousambl. and hera also is very brief. This is the last amel most inportant of our Lord's four withelrawals from Galilee during the last six monthe ot his ministry in that region (comp. 14: 1:); 15: 21, 29), and will continueto $17: 2$ :

I. 5-12. CONVERATION OX THE WAY. To the other side, of the lake, as in $8: 18-20 ;$ 14: 22, always muning the eastern side. Mark presontly mentions (o:22) that they (amme to) Bethatala (riz., Julias), and at'terwarls went to Cosarea Philippi. Sothe first point reachad by boat wats on the nortleastern side of the lake. Forgotten: rather forgot ( 11 ye, Rheims), is the literal translation, natural here in English and still moreso in Greek. It jorubalbly means that they torgot in preparing the bost, and on reaching the other sille liecame a ware of the forgetting; or it may mean that upun landing they forgent to supply them-alves tor the journey. To talie bread-or lortra-except a single one (Mark), which amounted to mothing. The seven grout baskets of linuments from the miracke were probably given to the multitucle for future

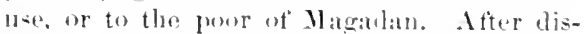
avering their negligence and destitution, the dieciplestelt an anduyance which led them to asingular lumbler. Jesusmeantime was thinkingot the Phariseesandsiahlucers, from wlose obeturacy and malignity ho hat just witharawn. (16:4) Thesegreat politico-roligious jurties see on 3: 7) haul immense influence. The disciples had been reared to respect them, and s).Jesus takesuecasion tugivea warningagainst their teachings and intlunce. The leaven of the Pharicees and of the sadunces. Mark has (s:15) "the leaven of" the Phar., and 


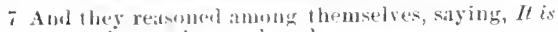

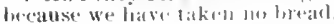

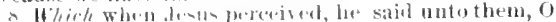
re of lifle faith, why radson ye among yourselves,

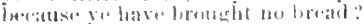

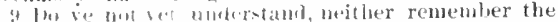

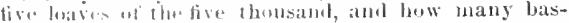
kits y tork 110 :

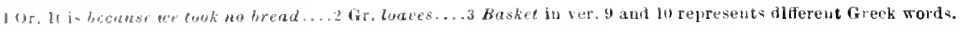

the leaven of Herol." Some have "inferred" that Hural Intipas was a sadducee, notwithstambling in 14: 22 he exprestad belief that John the biaptist was risen trom the dead. But Ilark las also omitted the sarducess in x: 11, as to asking a sign from heaven, and indoud anoutions them anly in 12: 18. This fact will acount tir his omitting them here. We thus undirstand that besides the Platr, and

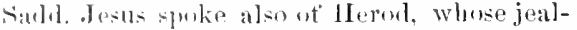
m1: $(14: 2)$ bad been one callse of his repeatally withdrawing from Galilee, even as now aratio he is going to the dominions of the trotrali lhilip. Matk's expression indicates the loaron ot Herud as di-tinet from that of the Phar. Intthew by not repeating 'leaven,' amb by haviner mbly ontarticle (see on 16: 1), mererasts something common to the Phar. and Sindl. mot nacossarily some common tenet or sporafir teathing, but a eommon hurtful tendoncr. It is therofore ille to say that Jesus is hore represented as confounding the rival vartios. Nor is tolis bussage in eonfliet with 20: :? for mmall of what the Suribes and Plar. talught was corport, and projer to be observed.

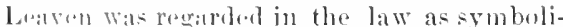
(ally impure (Exod. $34: 25:$ Lerit.2:11), amd henec tho firure in ] (orr. 5: (if. and liepe; see also Ialie 10: 1, whape it is used in a lifforont combertion, amb probably on a later ascasion. The di-cijles were in no nowed tor fignrative and spritual mrabings of words (momp. John 4: 10 1l:; 6: 24). They tomk it all literally, slymo-ing that the Master had observed their lack of brand, and was antioning thom not to furreliase any lobres made with the kind af leavere nand log the Phar. and siadel. This sormas to tho moderm minel a strange and atmont impossible noston; hut it was just suell at mattro as the Rablis made much at. The Tatmud (ontains disolesions as tu whother it was right to use Gonti]" leaven. (Lightf. $)^{1}$ sothe

1 Keim erolly suts aside the story, saying, "This gross and altogether ineoncoivalue misumdersanding enuld not have vecurred." One might have thought that such seses and sadducees And they reasoned among 8 themselves, saying, 1 We took no 2 bread. And Jesus perceiving it said, () ye of little faith, why reason ye amoug yourselves, because ye have noi 2 bread 9 In ye not yet perecive, neither remember the five Jaties of the five thousand, and how many 2 baskets

disciples reproach themselves. Because we have taken no bread (loaves), is an abrupt phrase natural to persons disconcerted. The word rendered in Com. Ver. (and Rev. Ver. maryin) 'because' is very often the mere 'that' after a verb of saying, which in English is not used when the exact words are quoted. It is best so to understand here (Rev. Ver.) but the marginal rendering is quite possible, and is preferred by Meyer.

8-1\%. The Master rebukes them for supposing that he was concerning himself about kindsof food. A few weeks or months before, he had said (15:1), "Not that which enteretb into the mouth defileth the man" ; how then could br be bying stress on a particular kind of leaven? And the repeated miractes of feeding vast multitudes from a very little food, and leaving a läge surplus, ought certainly to have showed them that the mere lack of brearl would cause him no concern. Only becallec they were of little faith $(6: 30 ; 8: 26 ; 14: 31)$ dict they imagine such a thing. Mark gives still sharper expressions. Notice the eonnectiom here between fath and spiritual perception. (v.sf.) With stronger faith in him they womd have been lifted above temporal andioty, and in better eondition to understand his spiritual instructions. Ye have (v. 8) waseasily clanged into 've touk' (rendered by Com. Ver. "ve have brought'), to make it like v. 7. Not yet, comp. 15: 16; and Mark 6: 52. Understand-(or perceive), v. 9-11 (Tyn., Gen.,) as in 15: 17 ; in v. 8 it refresents another word, which is awkward, but in this ease cannot well be helped, for the literal 'knowing' or 'having known' would be misunderstond. In v. 11 the text in Rev. Ver., which is that of the earliest documents, seemed abrupt, and was varionsly changed, finally, into the form given in Com. Ter. In the true text, after rebuking them for failing

arrogant and superficial criticism could not have oc curred, in the ease of an able, learned, and earnest mas. 
I0 Nither the seven loaves of the four thousand,

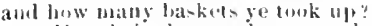

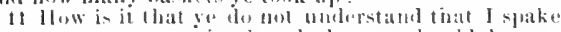

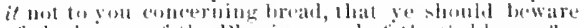

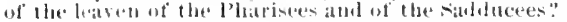

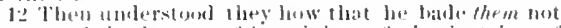
beware of the leaten of breald, hul of lle doetrine of

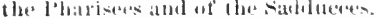

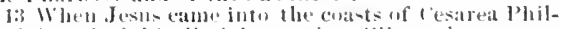

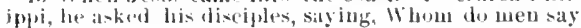
that 1 , the sinll of nian, ans
10 ye tromk up." Neither the sevent loaves of the four

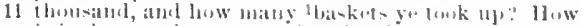

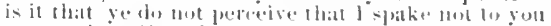

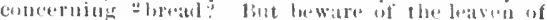

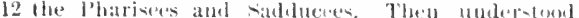

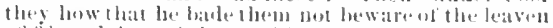

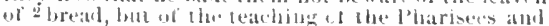
andilucions

13 Now when Jests cant. into lhw jats of fiesiren

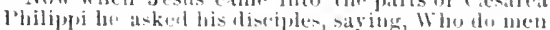

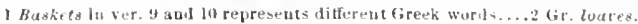

to forceive, he repeats the eounsel, in arder that they might now look at it and understand; and so they did. Inderstood ( $x, 12)$, as in 15: 10, 11. Doctrime-literally tearhing

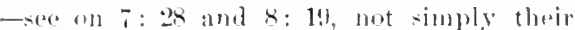
dugnas, as ' lusetrine' would now sugeest, but the whole spirit and tromaner of their teach-

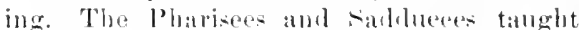
illats concerning relierious truth and duty in genclat, and in particulat concerning the Mesianje rejgen, whieh to the apostles would be misleabling and corrupting. Horod repressenten a certain tyme of polition-peligions fpinion, areepted by the Horolians, which would also lesequte misleating for prochamers of the spiritual Mosianic roign. This warning, while - llggated hy thes rearat demand of the Phariseses and saduluevest th: 1), was a preparation for tha groat approatehing iustruetion comecrning Mesials's tme mixion.

Aftor erosing the lake Je-n= camo to Bethsatila (-opon 14: 18), and there las alud a blind man: a very interesting case reorded by Mark alones. (s: 22.6.$)$

II, 13-20. P'HER's GRE.T ('ONFESION.

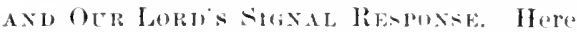
Luka comos in (a: in), thomels both be and Mark a lee lipief, and fail to give the response. The narrative in Matt. and Manle gues right on, and there is no reason to gurotion the comtinuity of evouts. Into the coasts (parts.) Wyelithere had "partis,' but Tyu. introluced the croments 'coasts, see un 1.): 21. Mark (x:2i) has the more dofinito expresion the villages wi Cesarea lhilipuif ; he was tarrying in the subturban villages. Cesarea Philippi was at the nothero end of Palestine, being near Inall ("from I)an to Beersheba"). It lay beside the astern and least cupious ot the two chinf springs of the Jumlan; at the other spring. two and a half miles west was 1)all below the junction of their stroans there comps in nnother, not mentioned by Josejhus, which has flowed many miles forme fitr uy the shom of Horuten, and is really the remotent surece of the river. The town wa- in an elevaterl phain, and thoursand one humbred and fifty totat aluve aho level of the Melliterraneam, and netar the fint of Monnt Hormon, which risen seven or ejult

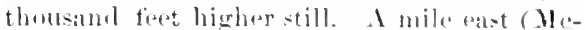

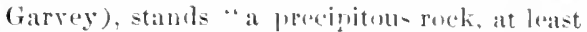
a thomsand foet above the town, " epowned ly a singularly strong firtress, latiug from luture the time of Christ, and in its luestent diunensions from the siariecens and the Crusaders. Stanley and others imagine that our forrl was lud hy this to use the phrise, "on this rock I will huild my chureh." The plain or terrace on which the city stuod is very basutiful. Porter: "It is ewered with atk and olivistrees, having green glades and elumpsof latwthorn and myetle." Maur travelurs speak of encamping under noble shates tros ju-t north of the town. Tristerm (in Ellersh.): "Every" where there is a wild medley af casearles. molberry-trews, fier-trexs, lashing torrutes, festomens vines, bubhling fumtains. roseds. and mins, and the mingled musie of hirels and waters." The fields between and around the somrees of the furdan are very fertile, producing brealotutt: and rice; and (Koim) "in summer the whole distriet is a $x^{2}$ in of thowers. whence tho beses gather a rieh harves." .Iosephus ("Ant.," $15,11,3)$ callsthe tountain Panion, showing that the Girecks hore wor-hiped Pan, whase worblip wats ufterl areaciated with caves and grottus: and there nre Greek inseriptims on the fuce of the clitf to the same eflect. Probably the Phorniacians had here workiped une of the forms at Batl, tor Rotinsun arertes that here was the town

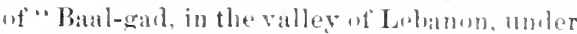
Wount Hormon." (Jush.11:17.) Hurme the Great built, near the fountain, a tomplu. nf white marble, in honor of Atgu-tus. J'hilip. the tetrarch see on $2: 20$ and $11:$ is, enlarged the town and called it Cesarea, in lonor of 


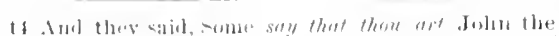

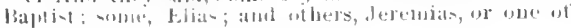
lla. !ruplates.
14 say that the ion of wan is? And they said, Some suy, John the Baptist; some, Elijah; and others,

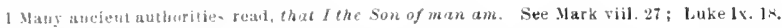

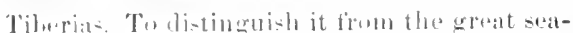

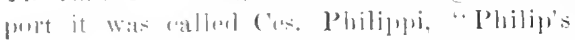

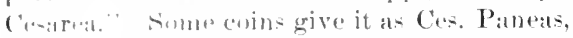
a Inam diriral from lan, and this survives

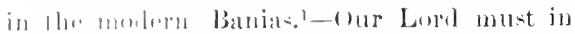
his youtl have alten gated at Ilermon from

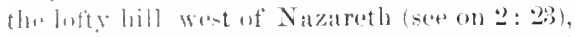
and-o chringr his minjotry must have loolied at tha - mow-chal line ut Lebanom from the Lakliz of (ialilon." It was doubtles a great

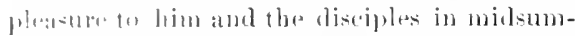
nore to leave the hot shores of the lake, far

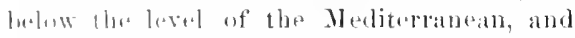

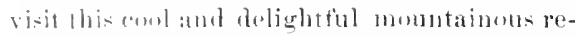

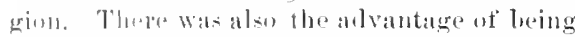
in the dominims of labip as in 14: 1:3; 15. 29. Who was a (omplatratively just ruler, aml hat no - neb aceasion tior suspictous jeal-

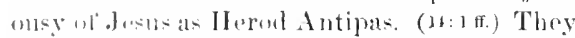

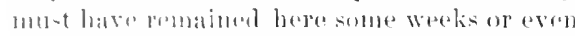

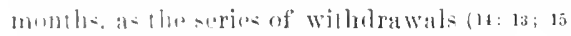

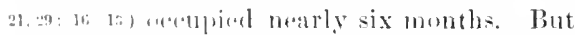
tho matter rearelied in connection with this

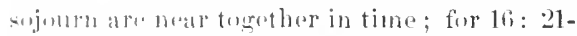

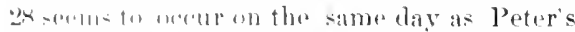

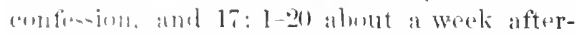
wark. From lit: lis it is natural to suppose that all thi-ank flaceshortly afture he leached that resion, and the lest of the time remains a bliuli.

Thro inhalitants of Cesorar Plibipli and virinity were larerely hoathen, and while

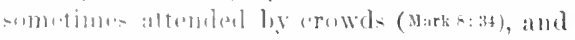

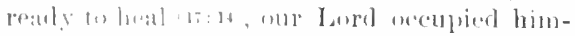
sulf mainly with the prisate instrustion of the

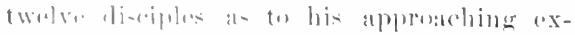

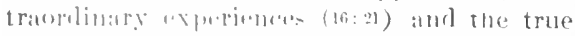

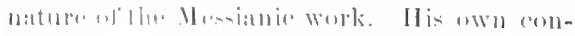
tremplatios uf hi- alpromehing rejection and

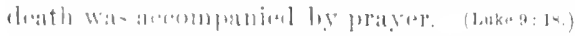

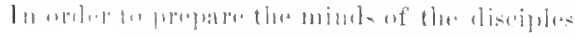

for these new views of the Massianic mission, he draws from them the cunfession that be is the Messiah, which Peter makes as spokesman. (v.1:-15.) This oceurred 'on the roal' (Mark: 27), probaloly trom one village to another; he lad withdrawn a little, and was alone with his dixsiples (Lukes: 19); afterwards he would naturally return to the road, atid luere came in eminct with a great number of whel persons. (Mark $x: 34$ ) In drawing out the confession, he killtully begins with an inquirs as to popular opinion concerning him, aud then alvances to ask their own opinion. The former was important as to any bope uf immediategeneral uswfulness; the latter tar more impurtant as to the whole future of the Messianie movement. Whom (who) do men say. 'Whom' all the early English versions) is a sort of attraction of the relative into the ease that would be required by the nearest word, 'say.' This use of the relative is also found in Sliakespeare, but abundoned in modern Englisls. That I, the son of man, ant This should read 'the sion of man is.' The change aruse from asoimilation to Mark and Luke. The phrase "the son of man' (see on 8: 20, and eomp. Jubn 12: 23) really implied that he Was the Mesiah, lut did not distinetly affirm it. lle bad already declared that the son of man was Lord of the Sabbath (12:- ), that he had anthority on earth to forgive sins $(9: 6)$, that heshall send forth his angels for the final harvest. (1: 11 .) He had also (Lutteruth) often spoken of God as his Father. (Jotn 3 : 13-14:5:25.27: Matt. $7: 21 ; 10: 32 ; 11: 27 ; 15: 13$. )

11. Popmlar opinion varied. Johu the Baptist, see on : : 1. This would suppose Juhn to have risen from the dead, as llerod Antipasthomght. (14:2.) Elias, instead of the Ifulpow tirm Elijuh, sea on 1 : 2. The Jews vary aromolly rapeeted Elijah to come to

\footnotetext{
chomb as it rame rolling up the Jumlan valley and oser the southoru (and of the lake, till it hung aluve us like a mighty pall. Jomking nurthwarl wo saw a winderful foly uf jagred lightuings alout the upper end of the lake, am then far in the north there gleamed out upun us the long ine of ledanom, with its snows indeseribably hrillinm in the evening sun. It was one of lhe sights of a lifetime.

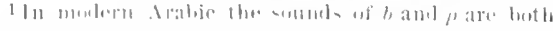

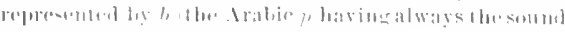

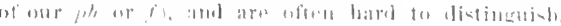

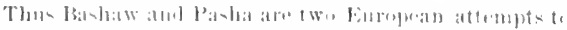

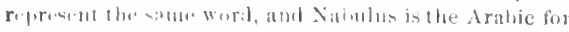
Sirapulio, lingli-la Xaples.

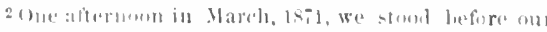
lent noar 'Juharjyeh (Tiberias), and watched a black
} 
1.5 He* sath unto them, But whom say ye that I ams."

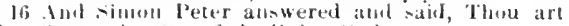
the ('hrost, the son of the living (ind.

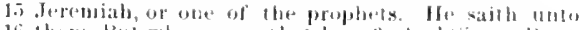

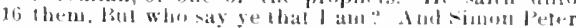
alsweret and said, "jhou are the chri. l, lae son of life again (soe an 11: 14), many suppusing he

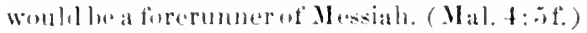
- Ind these who held that Ieste Was Elijal, probalaly thought that he was a fincrumuel of Masiah. Indothers, Jeremias (dromiah). 'Others' is liere a different Greek wort from

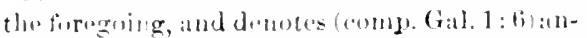
otherelation kind of persons, $i$. P., persuns who turmol away from the pormalar axpectation of Elijah. Jeremiah was in the timeot onr Larel greatly vemrated amomg the Jows. They had a legend that he apyeared in a vision to. Iudats

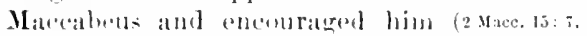
13ff.); alst that whon the temple was destroyed, . Ieremiah hill the tabermatele, the ark, and the altar of incerson in a eare of Monut Pisgah, and promised that they should omo day be restureal (2 sace. 2: Af.) ; amb a verylate Jesish writer says, that .Joremial would himselt"

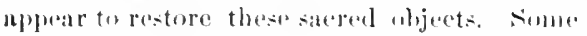
Rallhinial writers hold deromiall to be the

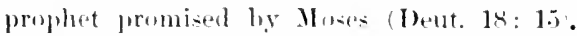
We now think of Isaiah ats the great projhet, beratuse he is so often epunterl in the Sew Test. ns predicting the Mesoliah; But the .Jurs in the time of Christ leteknneal Elijah and .Jeremiah as foremost. Or one of the prophets. Thele was great eenfision of opinion ats to the

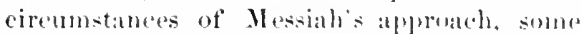
thinking there would be as series of furerunners (sem an 11:3). The last alass here mentioned were disposed to be nom-enmmittal as to jelontifying . Iesus with any partioular ancient prophet, but thought he must he some one of them. Tomany minds, mow that belief in 11 resurecetion had become virid, the idea of some furmer reverol prophlot re-ajepearing was more natural and aredilole than that of a new prophet; yet sump counted Juhn the Batptist a prophet (14:5: 11:9), and

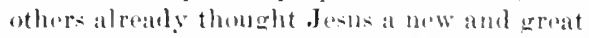
prophet (luke i: 16. Juhn 6i.14), als many did at a

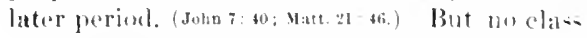

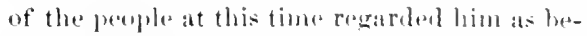
ing the Mesiah. Ilww eould thry. Whon in their view Messiah was to be a splendid conquelor and king?

$15 \mathrm{f}$. But whom (Rev. Ver., $w^{\circ} / \mathrm{h}$ ) say ye that I am? Observe 'ye, plural. and by position in the Greek exceedingly emplatic- in contrast with the liseordatht puphlat ppin-

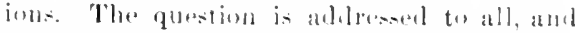
Peter answers as their spokestuate, just as he

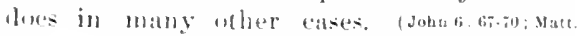

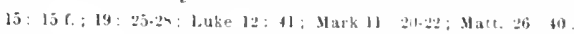
Acts $2: 37 f ; 5: 29$ etc $)$ ("trys.: "Preter, tho pror

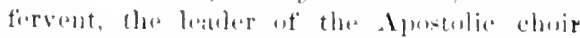

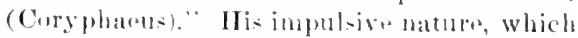
sometimes hrought him intotroulule (14:29:26:51) helped to fit Peter for this po-t of spokesmath, and a brotter rualifiotion was his strong faith

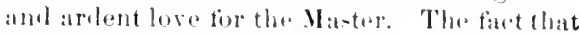
the rothers remained silont and latt him to speak does nut show that nome of them tully

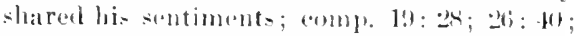
ete. Thou art the Christ, as in v. 2 . The aurly Eng. versions, including the tirst and

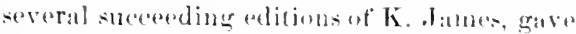
'C'hrist' without the article; it is nent aseertained whon the artiele was intrumluenel intur the (omo. Vele. It has also the article in the

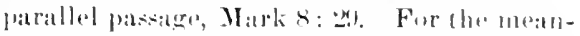

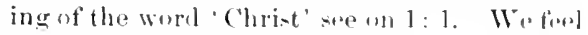
the furee ef it bettor in this and many passitges of the linspels. by using the llubrew word Masiah (s+e on et: f). Therst is axprosend in the Grenk, and theretore emplatice The son of the living fiod is a very seblemu expression. The god- of the healhon were

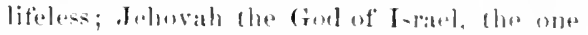
true Gind, was liring. Sil Paul at lystra (teda1t 15 R. v.): "that ye should shoulel turn from these raine things unter tho living God." Mark (s 29) rexures simply "thme art tho" Clurist (.Messiah)"; Luliet (9:00) "the Clorist (.Mesiah) of (rol. - The maliest disiples uf Jans, inchuling simm Pelar, at ander eoncluded that he was the Mes-iah. Jatul 11.49.) but he procerslod to atet ss dittielently from what they had been reared to expeet of Mesiah, that they wombl naturally herome greatly proplexed about his Masiahship, eren as . Inhn felt in his prison (-nen on 11: 3 ).

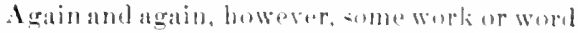
womld persuale them afre-h. Thus in $7:$ : he deelares, "Nany will sily to me in that day, Lard, I, red," ete. In 11 : 5t, he refers the messangers uf . Iuln to his Mesianic miracles and preaching to the pour. In 14: 33 the persuns in the boat sily, "of a 
17 And Jestringwered ind sairl unto him, Plessed art llwi, simon Bar-jonat: for flesh and blowd hath not

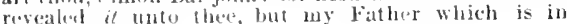
heavtll.

truth thom art the son of God." In John 6: lit. R. V., Peater suys (as spokesman): "What have beliovel and know that thon art the Iloly onu of (roul." (This last the copyists "hatugul into" "thou art the Christ, the son of the living foud," by ascimilation to our passage of Matthiw.) Now, two or three years later than their first early persuasion, they have bereme established in the convietion, though so in conflet with their life-long concoptins, that their Master is the Messiah. - We thus ses that there is 130 eontradiction, uch as many erities have alleged, between the satements of Matt., Mark., and Luke at this print, and that of John 1: 41. Nor do we raal that he had ever distinctly told the disciplas that he was the Messiah, though he harl said so to the woman ot Samaria. (John 4: 26. 24.) I fiow months later, the noble Martha, who focejors scant justice in many pulpits, made the same confession for which Peter is hereso commendend. (John $11: 2 \pi$ ) We under-tand the importanes of this confession when wo bar a Jow of the jresent time anmounce his now-fondel convietion that ofeus of Nazareth is the Messiah.-Does this confession of Promerepresont the savionr as divine? Sot neconsorily, if it stoud alone without any later ravelation. (Comp. on 14:38.) But sul)sefunt apostolic teahing, guided by the lloly singit, amploys kindreal plurases to set finth lis divinity, which may therefore be reanded as implieitly entained in the lan-

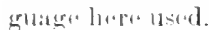

17. This response, v. 17-19, is griven loy Matt. anly. (our luerl serms to speak juytully. Ilore at last the diseiphes have reached the

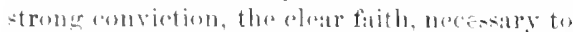

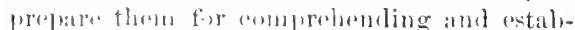
li-himer his spiritual Masiania reign. Bbessed,

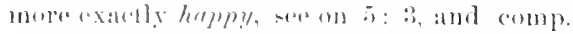

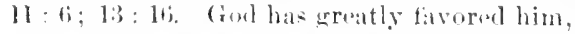

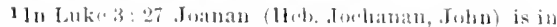
variens duenuents writton .luman, and in $3: 30$. lonam

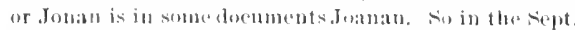
Joanan frefuently appears as doman. Pluerefore it is fluito pessible that in Matt. Jona is only a contraction

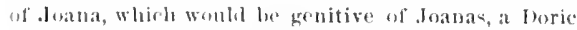

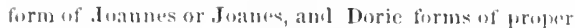
names are common in the New Test.; thus Bar-joua
17 the living rod. And Jesus answered aud said unto him, Blessed art thon, sinon Bar-Jonah: for thesh and bluod hath not revealed it unto thee, but my

in loringing him to this perception and conviction, and so he is a happy man. Why does Josus say this to simon Peter alone, and not to all those whose opinion he had asked, and for whom Peter had spoken? Partly, no doult, because he wishes to refer in what follows to the meaning of the name Peter, and partly beealuse Peter is to have a eertain leadership in the founding of the kingdom, and so what is about to be said will apply especially, though by no meansex. elusively, to lim. Simon Bar-jona. The Hebrew Ben (Benjamin, Benhadad, etc.), and the Aramaic Bar, signifies 'son'; e. g., BarJesus, Barabbas (27:16), Bartholomew (10:3), Bartimens, Barmabas, ete. Comp. John-son, Robin-son, ete., and kindred terms in many languages. The word Bar-jomah (Bar-jona in Com. Ver. is the Greek form) does not oceur elsewhere in the New Testament; in John 1: 42; 21: 15, we find (R. T.) 'Simon, son of'.John,' and there is reason to suppose that Jos a in Matt. is a contraction of Joana, which would be a genitive case, meaning 'of John,'I so that Bariona means not son of Jonal, but son of .John. Flesh and blood, viz., humanty, on its feeble corporeal side, as distinguished from the incorporeal or spiritual side, which is relatively strong (Bleek). The phrase is found first in Ecelus. 14: 18; 17:31; it oceurs repeatedly in New Test. (Gal.1:16; Eph.6:12; Heh. 2:14, etc.), and is very eommon in the Talmud. The old Test. makes a similar use of 'flesh.' (Gen. 6:3, etc.) Revealed. No one around had the fixed emnviction that Jesus was the Messiah; Peter and the disciples for whom he spoke had not derived that convietion from any human teaching, nor from their own unaided reflection. Iy Father whieh is in heaven, see on 6: 9. None but the Father knows the Sion. (11:27.) Tu lift them out of all the perplexed conceptions due to their education and

world be son of Jolun. In John $1: 42 ; 21: 15$, the true text has foanm, the Attic gebitive, which was early ehanged by some copyists to . Fona fhrough assimilation (1) Matt. Bisbop Lightfrot (on Rev., p. 133) gives a quotation showing that the "Gospel of the Ilebrews" cxplaned Bar-iona as a Jewish name, meaning son of Julun. 
If And I say atso muto theere That thon art Peler, aml opm this rock I will build my church; and the gates of hell shall not prevail acainst it.

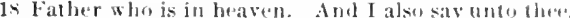
that loow arl lefer, and upon this" ruck I wil build ony ehureh; and the gales of llades shall wol

I Gr. Petros. 2 fir. Petra.

tonvimment, and fix them in the couriction that ons without soutre or army or aven homen, is the Messiah, roquired revelation from the Father (comp. Juhn $6: 4 t)$.

$18 \mathrm{f}$. Ilere are four main prints to be considered, 1) the rock, 2) the church, (3) the gates of Hades, (4) the keys of the kinglom, and the power to bind and lowse. And I say also noto thee, as thut last just said sumethine to ne which is so inportant. Wejss and others understand, "as the Fathar lats given thee this great revelation, I alsu give there a great distiuetion." But thus to contrast his gitts with the Father's would be quite foreign to the tone of our Lort's diseourses; anel the emphatic position of 'unto thee' (in the Gr.) firbids such a view. That thou art Peter, 'thou' heing expressed in the Greck, and therefore empiatic. This is not for the fir-t time giring him the nambe, as some destructive eritios hold in oreler to make out a contratiction between Matthew and John, but lotumlly implies that he has it already. (10:2.) Ile who long before gave the surname (Johu 1: 12 now refers to it as significant. C\%rys: "sere throughout all, his own authority; I say unto thee, I will build the church, I will give the key.s."

A. Upon this rock. As letermeans rock, the natural interprotation is that "upon this rock means upon thee. No other explanation would probably at the present day be at tempoterl, but for the fact that the obvions meaniner has been ahused hy Paprists to the support of their theory. But wo must not allow the abuse of a truth to turn us awat from its use; nor must the convenionce of roligins controversy detemine onr interpretation of seripture teaching. The athor interpretations which have been proposet are. that the rack is Peter's eonfession (or bis fath), and that the rock is Christ.

Now apart flom the lanmish perversion, certain other oljections are made to the matural interpretation. Sime loble that suteh a play upon worels, "thou art lioek, and on this roek," is unworthy of our Lurel. But there is a play upon workls, molerstand as you may. It is an even more far-fetched and harsh play mon werds if wo moderstand the rock to be Christ; and a very teeble and almost unmonuing phay ulum worets if therock is Peter's eonfesion. Nor is there any real objection to sllpuming patromomasia. Fuch expressions are very rommon in () let Test. (6. g., (inell. 17: 7; 82: 28), and in Now Test., especially in

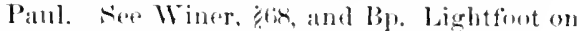
Revision (in seluat' on Ri(v. p. X V. fl.).

'The fact that 'roek' olsewhere in sieripture is often applied to God and mever to man ( Worksw. Alex.), may he ottiset by the fiact that our Lord himselt gave this man the mane roek (Johu b: fa), and here takes plains to tall him by that mane, which ho dues nowhere else save in Luke 20: 34 ; and forhalls erent the exception is signifieant, for low ws then prediction the shameful fall so nuwortly of one whon he lodel naned rock. Late. Jewish writings (Wün.) speale of Mbrallan as the rock, or of the patriarehs as the recks, on which ford latd the fumbation of the world.

Many insist on the distinction loetweren the two Greck worels, thon art Petros, and om this petra, hoteling that if the rock hat menant Peter, either petros we petra womlel have laenen used both times, and that petoos signifies a selarate stoue or a fragment brolien ott, while peter is the massive rock. But this distinetion is almost entirely eonfined to poetry, the common prose word instemd of peteos lesing lithos; nor is the distinction nuiformly observed (see Lid. and seott). It is worthy of motice, too, that ousus himsolf is ealled lithos in 1 l'et. 2: 5) Al. Again if petros hat leen nsed both times in the Greek, it would have meant, "thom art Peoter, and on this leoter," without distinctly showing the platy upon words; and it womld not have been natural for Matthew to write, "thou art petre (feminime), when he has been ennstantly writing the apostle's nane Finon Petros (maseuline). But the main ab-wer here is that our loord mmbubtrelly spoke Aranaie, which has no known moans of making such a distinction. The l'slito (We-tern Alamaic) ronders, "Thou art kipho, ant on this lipho." The Eastern Aramaie, spoken in Palestine in the tiuc of christ, 
must necessarily havo said in like manuer. "Thum at kephe, and an this licpher." (comp. Buxtorf.) Bura callud atrention to the fibet that it is so likewiots in French :

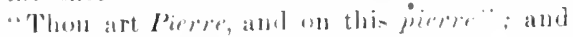

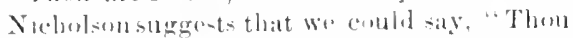

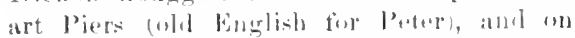

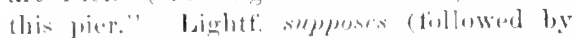

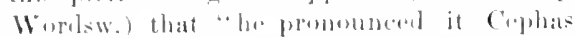

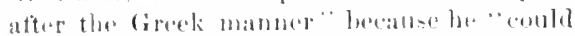

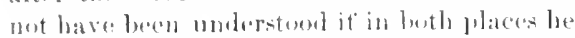

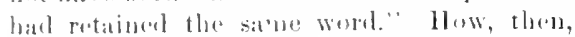
lats the leshito been underatome? Edershe finds the words jetes and peten horrowed in

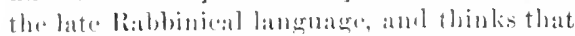
desus, while sprating Aranalic, maty have burroweal these (ireole werels laere. But this is grosely improbible, and the slege-tion looks like a desperate tepedient; nor has he shown that the late Rabbic themedres make

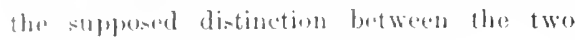
words.

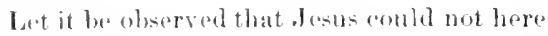
mean himself by the rock, ansictently with the iragere, because he is the buileter. To say, "I will Znild, . . . I am the rock an which I will build," would be a vergenofusal inage. The sngerestion ot solne: ('x positor- that in say-

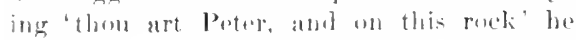
fointrul at limself, involves an artifiedality which to some minds is repolsive. Tlu" attampte to show that the themonstrative, "on

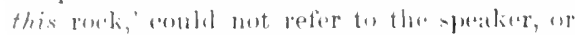
rould not retier to the persen addresced, are alikefutil.

But the great olojection on the part of many to the nattrat interporetation is the alyatrent

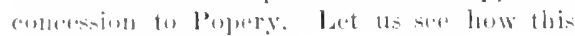
matter stamds.

flue aarly Fathers, whos arefor as anly very

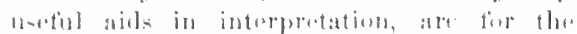

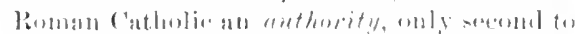

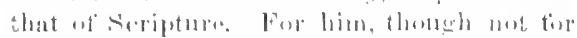

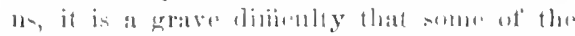

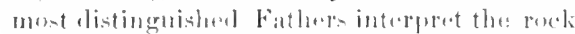

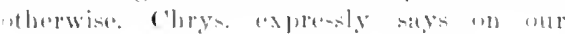

\footnotetext{
1 some of her fathere were uneertais, and hase inter-

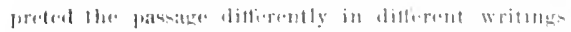

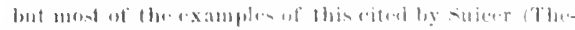

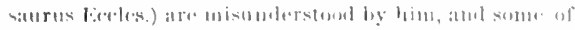

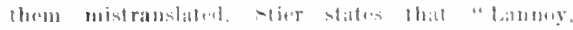

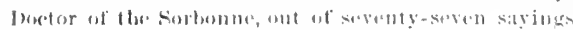
of the most famous church fottersand thureh writers,
}

Jassage. "(9) rhis rock; that is, on the faith of lis contessiml." He often elsewhere gives the sane interprotation and never any other. Onee heremarks, "He did not say upon Peter, for it Wa- 1 ot 11 men man, but upon his faith." Ialdonatus would have trouble in applying to thi- "xprosinn his "reverent" interpretatim that thow Fathers who say the church was built on the faith and eonfession of Peter really meant on Peter, becaluse of his faith and contesinn. Chrysostom's explanation is al $=1$ given by his contemporaries Gregory of Nysia and Isidareaf Pelusium, and the Latin Father IJilary, and by the later Greeli Fathers Theodorot, Theophanes, Theophylart, John of Jamasens. Probably these Fathers were all awale of a tendency to pervert the more natural inter]eretation which made Peter the ruck (that of Origen, Cyprian, Basil, Gregory Saz., Ambrose, Jerume, Cyril Alex., ete.), intu a sujpurt for the growing elaims of the Roman Bishop, Augustine in his "Rotractatiuns" (1.21) say sthat in an early work against the Donatists he stated that the church was founded un Peter as on a roek; but that very afton sine he has interpreted the language as moaning that the ruck was Christ; and that Sinmon contessing him as all the chureh does was therefore called Peter. He adds that the roader may choose which of these opinions is more probables We repeat that Clurys., Augustine, and the rest, are notable anthorities for the lisman Catholic, and grievously in the way of his building on the natural interpretation of the paratge.

But grant that the rock is Peter, and considur what the Roman Catholie will then have (1) show in order to establish the chaims of the Pajuary.

1. IL must show that Peter alone was to be the fommler of christianity. Of this there is mo aritene but the obviously figurative exformolon lefore us. Against it (n) we find variols oxpress declarations, especially Ephes. $2:$ : (1), "Built mpon the foundation of the aposthes and prophets," ete. (b) The history in

hat foumd umly serentcen which explain Peter himself as lhe rock. furty-four on the contrary understand the firlh, ant sixtren (torist hinself." But such numbricat utitements ean lw. but little relied on, muless one could have the cititions and know something of their sources. 
Acts and the Epistles is also opposed to this notion; especially in Arts ch. 1., where Peter does not at all acet splarately ar apjear to be

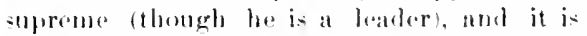

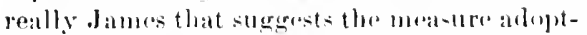
al by the brethren; also in (ial. ch. Z. where Peter is one of the there pillars. James lecing named first, ant where Peter is mulliely rebuled by Paul for acting eontrary to his ow convictions. Think of a Romish hishop rebuking the Popre to his fatce "before all." (a) The promise as to binding and lonsing heme male to Peter, is marle in 18: 18 at to the action of all the apmetes or any ehureh. A partly similar promice is mate in John 20): 2.- fe to the ten apostles and othere (as sheww by the (omplatrisun of Luke). (d) This saying is omitted by Vark and Luke, though they give what precerles and what follows it. Now aceording to the Rommint view the have omited the very heart of the gassage, and woll-nigh the mot inpertant thing Je-n-ever saicl. Thus II. J. Coleridge: "This contessim of st. Peter, and the magniticent hlessing which it drew trom on Lord. may be sald to be the very enentral point of our Lorde ministry. All betore it leats up to it, and all that follows it in some sertore takes its color from it." And yet Itak and Luke have both eomeright up to this trancerenlently impurtant saying, and then pased it by, giving the work which in Ilateluw immodiat oly tollow. The arement from silenee mutet always be eurefully used, but this is erratuly a very etroug ease.

2. He must show that Petrer not anly wathe sole fomender of Claristianity. but that he was vieregerent of foud and the sovereign of all Christians. So seripture testitios this at all, unlese the present paresage does and the whole tome of the New Testament is argatis-t it. Nor do the Fathers who mularstamb the rock to be Peter indieate the notion of hi- having and such position or power as the morlern Popere

3. II man-t show that this supposed atu-

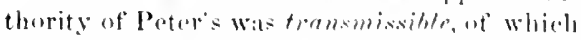
there is no partiele of eridenese in the New Test. : and it is stranerely inconsistent with the very image of a rormet-atome, or foumblation reck, to suppose it frequently removed and a new ane substituted.

4. 11 omos show that lentor lived and died at Rome, which is probably true but not eer- tain: and that he was, rather than Patul, the head of tho ahureh at Rome, of which there

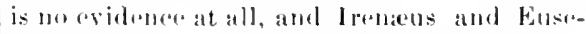
biu- agre. in making Lime first bishop of that church.

$\therefore$ He must show that Pater's mulumed transmi-iblo atuthurity was actually transmitsed to the learling oflicial of the churels at Rome. of this there is mo evidence but eomparatively latu tratition. And against it is the generat history of the earlient churehes, in which the chureh at Remele. g., in Clement's

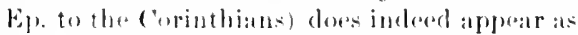
influential a naturat thing from it heing in the jumerial cityl, but there is not the slightest indication that it was sujpreme, or had any sorereienty, recentized or clatimed. Anel why should a special ofliere or authority be transmitted to a chureh oflicial at Rome rather than at Antiond or Jurunalem? Notion tow (Glang, "Exaere. Studies"), that on the Patjal thenry the great apustle John wite, alter the death of Poter, completely subject to the bishop of liome.

The Protentant rebuctance to admit that the rock means Peter really plays into the bauds of the Romi-h eontroversialists. It falcorsthe impresion then concending that point would he eanceding all that the Romanist chaimwhen, a- we haveseen. the hopeless burlen of his aremment eomesaterwards. Nuw totake Peter as the rock is erertainly the ment natural and obione meaning. And to make this the life or death isture is an grive the Romanist at seriens polemialal advantage. In general, it is a great principle in Biblieal inferpretation to take the mo-t whe ions meaning of any flarase. unleses it would thus yold a somechomplesely in confliat with the unambigunds teaching of other patsagers.

Ton underetand that Peeter is hero the rock is

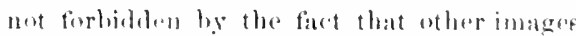
are drawn from the same souree. ln 1 corr. $\therefore$ : $11 \mathrm{tf}$, Paul speak of himself at Matstur-

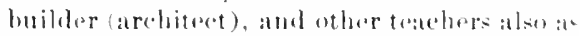
builders. Cleriet being the only foundation. In Eph. a: 1:1 th. he makes the apu-tlen and

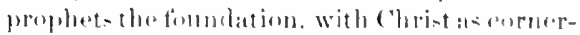
stone. Sis in Reve.21: 14 the Hames of the twelve apostles are engraved on the twolve foundations of the eity walls, whish matries

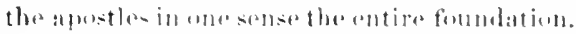
In 1 leter 2: 4 ff. all Christiansare living stonc's 
built up intuaspiritual house, with fhri-t as the

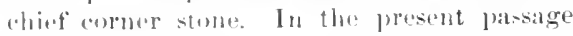
Chri-t is the lonilder, and the aposthes are the

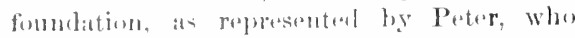

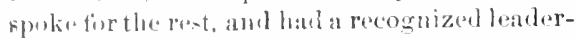

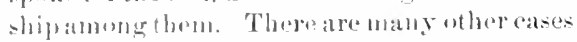
of an inater variously appliad. In v. 19, Peter is promisol the lieys, while in liev. 1: 18; 8 : 7 , fesus hat the keys. So in $5: 14$, Christians ane the liglit at the world, while in John 9:5 ('hrist is the light of the world.-That Peter

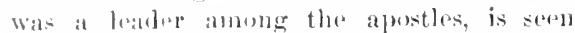
allowly fond his standing at tho houd in each of the tour lists. (See on 10:2.) He ayprats as mankelly prominent in Acts $1: 1.5 \mathrm{tr} ; 2$ :

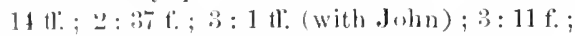
$4: 8+1$; $4: 1$ : (with .lohu) ; 5: 8, 15, 29; 8: 11 (with , lohu). (Observo aspecially the desiglution of l'etur to receive a speeial revelation anct take special action conerming the Gentiles. I (1.t 10): ! 18.; $11: 17 ; 15: 7$; also the promimencout l'reter and lames in the deeision 1) fl the fonterence at Jerusatem (Aets $15: 7$ ff.), Where Paul silys that James, Cephas, and lohn wer" leputed to be pillars (tal.2:9), an arehitectumal image somewhat akin to that which here makes the apestles the foumbation. Notion in particular that Peter was hader in (omberting mally Jows om the great Day of lenterent, and was also the first instrument in the enversion of Grontiles who had not boxemon, lews. In all this there is nothing at all to -lonw that his leadership amolnter to supromaty, but in fatet, mush to the contrary.

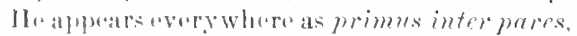
the tirst almong pejuals. The disciples after this time dispuld who shall he greatest. (18:1: bukez:at) ln so doing thoy artainly did met umberstand that derter was greatest, nur dial Inems intimate that in replying. II.

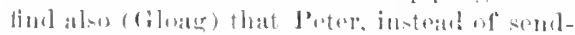

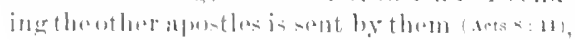

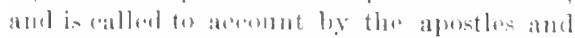

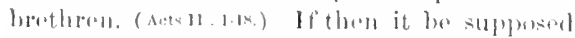

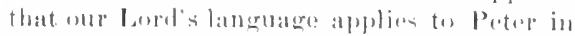

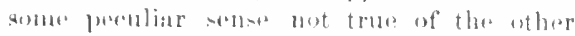
apostles, still it ranmot possible mean that

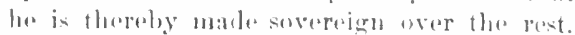

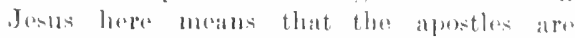
the fomblation on which he will build his chureh, and leoter is mentionel in partivular beeauss of his signitionut namo, appropriate churacter, spokesumaship, on this oceasion, and recognized leadership in general. That the rock heje means Peter is held ammog Plotestant expositors by Bengel, Ooldridge, Macknight, Fritzsche, Block, Irever, De Wette, Alford, stier, Keim, Grimm, Weiss, Geikie, Farrar, Mansel, Glong.

B. I will build. The image is that of a huuse, as seen also in 'gates' and 'keys.' T⿰, build an assembly was a combination of images easy to the Jewish mind, beeause the comyregration of Israel was often also ealled the house of Israel. The word church is used also in 18: 17, but nowhere else in the Gospols, and the disenssions comnected with it helong chiefly to the Acts and Epistles. The Greek word ektalesia signified primarily the assembly of eitizens in a self-governed State, being derived fiom ekfaleo, to eall out; i. e., out trom their homes or places of business, to summon, as we speak of ealling wut the militia. The popular notion that it meant to eall ont in the sense of separation from others, is a mistake. In a secondary senso fiklesia denoted any popular assembly (Ats 19:29.) This Greele term seems to have been applied directly to an actual eongregation or assembly of Christians, what we now eall a local ehureb, as in 18: 17, and usually in the Acts and Epistles, sometimes to an (appmrent!y) informal, unorganized meeting. (Rom. 16:5; Col. 1: 15; Philem. 2.) But in the Septuagint it is often used to translate the Hebrew qahol (forexamule, Deut. 18: 6; 28: 1 ff. ; Judg. 21 : 8 ; Psa. 20: :2n, ete.), which is also derived from a root meaning to eall, to convoke, and so simities a convoution, a eongregation, assembly. This and another Hebrew word of equivalent meaning are used in all parts of the old Test. to denote the congregation of Israt (comp. Aets $7: 38 ;$ Heb. 2; 10). In the. Now Tust. the spiritual Israt, never actually axiombled, is sometimes coneeived of as un ideal eongregation or assembly, and this is denotrol lyy the word ekklesia. So in Eph. 1 : :2.2, and often throughout that Epistle, in Col. 1: 14, 24; Heb. 12: 23, ote. This seems to be the meaning here. All real Christians are eoncoived of as an ideal congregation or assembly, and this is here deseribed as a house or demple, huilt upon leter (and the other aposthes, as in Fph. 2: 19-20, it is a temple "huilt upon the foundation of the apostles nnd pro- 
phets." There is a third une of the trin whlesin, wilely dithised throughout Christendom, in which it is made te denote the aggregate of all formally profiessing Christians, or all chtward organizations of Claristialls, or else some one outwarl organization which is alone recogrmoen log the perens axing the term ats being really "thre chereh." This aggrerate of professed Christians is in molern prarlance ealloll "the visible chureh," as distingui-hed from "the invisible ehureh," which demotes as aboye, the ideal atsembly of real christians. But the word is not uned in the Now Tent. to denote a congregation, actual or imaginary, of all profeseded Chrietians. unle- it he in dets 9: 31 (colreet text), and in 1 Tim. :3: 1.5. In the former the word probably denotes the original church at dernalem, whone members were by the persocution widely seattered throughout Judea and Galilee and siamaria, and lacld mertings wherever they wore, but still belongerl to the one original organization. When Paul wrote to the Galatians, nearly twenty yours later, these sepalate meetings had been oremized into distinet churehes;

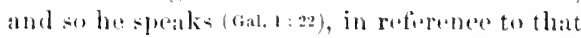
same period of "the ehurehes of duelea which were in Christ." In 1 Tim. 3: 15, "the chureh" is naturally the particular locell church with which ond is commected. If these two passages be not reliend on fir the purpuse, there i nu Now Te-t. autherity dir the sense of "the visible church," and therefore the word omght not to be so muderstend here. Is to the Englinh word 'churel, sers on $18: 17$.

C. 'The gates of hell, or IInte's. Tha

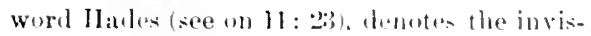
ible world, the abode of the departed. The

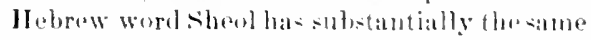
meaning. Fiseh was also the original stomse of the Eungish word hell, the hidhen or unsern

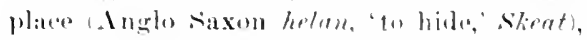
which was therefore in early English a correct tran-lation of Ifales and sheol. But it hos gradually eome to demete exclusicely the place of torment. as se many other words have beenome restricted to the brad sollise, and is now only a translation of (ixhennal face on 5: 2.2), while Ilades hat to be burrowed in Rev. Vor. of New Test. In Com. Ver. of Old Test., Slleol Wis tratuslated aither 'hell,' 'the grave,' or 'the pit.' In Rev.
Ver. the IIebrew shool has berall ofter burrowed, amb this ought assuredly to have

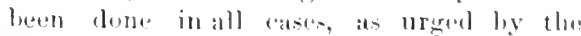
American Reviaers. Neither Ifalles mor sheol cover benotes alintinetively the plitere of

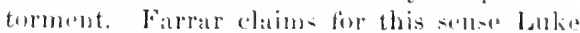

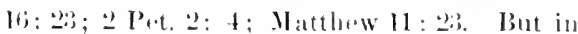

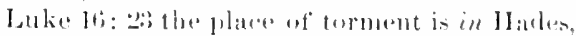

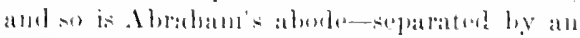
impatosable gulf, lut within -ight and hearing.

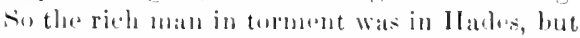

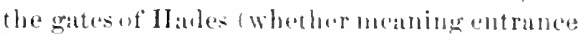
or prower) (anduret be distinctively the gates of the place of torment, the abule of satan. In 2 Pet. :- I the term IIntes is not ureed, Fout a verb derived from the (irenk word Thetures, which wats in Gronk llsage exchusively a plater of torment; and this word oceurs nowhere else in the Greek Bithle. In Matt. 11: 2:?

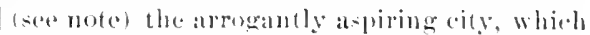
Aroans of reaching lasisent is to be bought

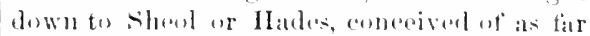
undergroumd, i. e., to utter destruction; : :11.] the idea of future torment does not evelu buter inte the eemonetions. Tlaere is nowhere nuy warrant for understanding Ilames an- lesunting distinetively the place of torment, the alwele of Satan; it is the cibuldeof the debartend, and throngh its gates pates all who die. To argue

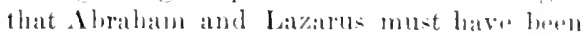
in hearen, and therefore wholly sepharated

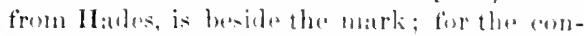

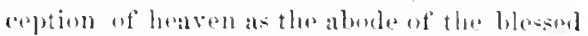
is entirely distincet from that of IJanles, amd the two eatumt be enonbined inter ono local imane.

The 'gates of slead' (IIames) are spoken

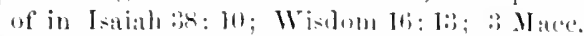

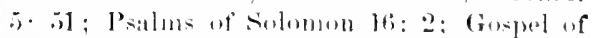

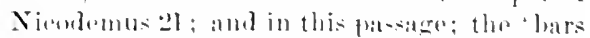

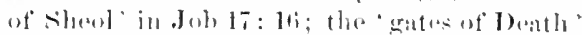

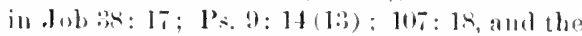

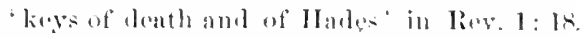

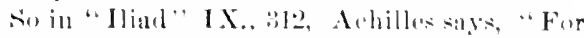
hateful to me. like the gates of Itades. is the man who hiles one thing in his breast and

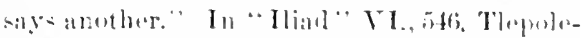

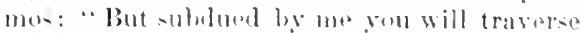

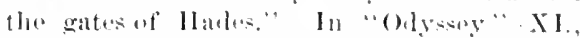
27. "But she went to the alunde of the strong gate-kenter, Itades" (the deity presinting ower

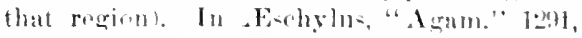
Clytemnestra addresses the gates of II andes, 
and prays that sle nay have a speedy and "asy loith. In Euriprides, "IJecuba" 1 , IIeculna says, "I comme, leaving the hidingplace of the lead and the gates of darkness, where II alder dwells anart trom the gods." It will besorall that in all the jassages from Holvew writings, and most ot those from Cironk writings, the gates of IIades are passed though by the lying. In the passage from

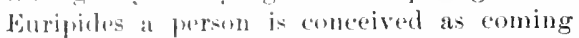
back through the grates of II atdes, and there a b $^{2}$ some ofther passiges of Greek authors to the same etfert. It would be posible, though mot lunst natural, se to understand Rev. 1: 18.

Prevail against, or 'overeome, literally, be strong agrimst, 'be too strong for' The freste word is found also in Luke 23: 23, and is an intensive enmpound of that used in Acts 1!: 16. It might in the (ireck grammatieally rotily the rock or to the church; the connevtion shows platinly that the latter is meant, hut there is no sulstantial difference. Fome ahlo commentators understand "shall not surpas it instrength," without the notion of "unflict; but this is contrary to the etymology

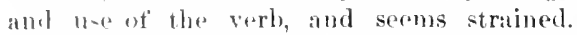
bratuse 'gater' has in Groek no aticle, Wriss takes it to moan 'IIades-gates,' i. e., grates of that rass or kind shall not surpass it instrusth. Hat the indefinite word gates is mate dofinite by apponding Hades, this being a dofinite and singlo locality-a use ot tha ap[under genitive that is quite common in the New Test. (Tiuner, 125 [15i5], Buttmann, ox, $11 \mathrm{is} .1$

"Tho gatos of llates shall mot provail against

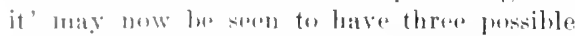
sullse. (a) It mont maturally means, aceorelto the llohrew uses that the gates at Ilates shall not - wallow upt the roureh. All earthly

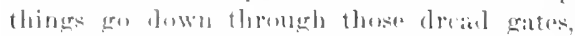

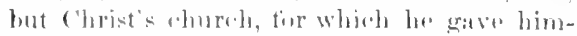
gonf, will maver andes to exist; themes will always bo ('hristians in tho world. This was a butal prodiction for a homeless teateher, with

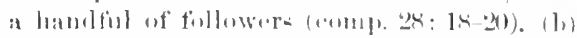

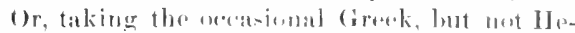

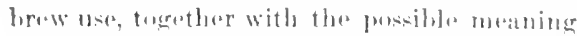
ot live. 1: 18, wo shall have the samse, thes

JThis matter of the alpunder genitive, mpen which Wincrand Butt. make many distincelions, may he rom

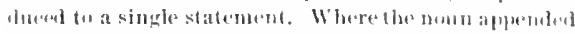
In the genitive is in its nature bo related to the ather gates of Hades shall not prevent my people from rising again (Meyer.) (c) 'Gates' may be taken, though it is an unusual sense, as a symbol of power, because strong gates completed the fortifications of a city (Gen.22; 17; $\left.\mathbf{P}_{\mathrm{sa}} .127: 5\right)$, or because judges often sat, kings administered justice, and garrisons gathered, in the gates. Comp. "the Sublime Porte," and the European use of "Court," as connected witl the court-yard of a palace. Then the expression would mean, the power of Hades shall not be too strong for my chureh, a sense loosely equivalent to (a.) Iet this is harsh; for while 'gates' might well represent defensive power, it is hardly congruous to take them as representing aggressive power. As to the widespread notion that it means the power of Satan, there is no authority whatever for so understanding 'the gates of Hades.' Satan rules over one part of Hades; but how can he control, or be represented by, the gates of Hades, through which the blessed pass in dying, as well as the wicked? This notion has been diffused through Christendom from two causes. The eonception of heaven as the abode of the blest rapidly supplanted the idea of the blest as dwelling in Hades, and Hades came to be thonght of only in the bad sense. Accordingly the Latin term infernus (inferni, inferna, interi), which originally meant substantially the same as Hades, gradually breane restrieted in Christian usage to the place of torment (Italian inferno, French, enfer, English adjective, infernal), just as has happonel with the English word hell. Thus in the Vulg. portae inferorum (inferi), like' gater of hel]' in modern English, roadily cane to suggest the power of Satan. The other cause is that this notion suited the conception of Christ's 'church' as a visible organization, which the power of Satan vainly strives to nerthrow. (d) Ewald thinks of the gates of Hades as opening to let monsters issue from them (R+r.9:1 fr.), and these monsters shall not overoume the whureh; but this is far-fetehed and lighly unnatural.

The passage then seems to mean either, my church shall not he swallowed up in the gates of' llarles (or possibly shall not be overeome

noun that the complex idea becomes definite, then the swaker or writer may, if he chooses, omit the article whth the tirm nomn, and yet expect the phrase to be understord as detioite. 
19 And I will give unto thee the keys of the kingdom of havern: and whalsuever tison shall time on earth - hall be bound in heaven: and whalseever tholl shalt loust on earth shall be loused in heavers.
19 prevail arainst il. I will give unlo the the kess of the kinglom of heaten: and whal-onele them-hall

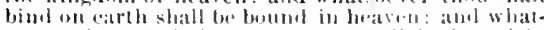
sogver thad shath loose' on earlh shall be loust in

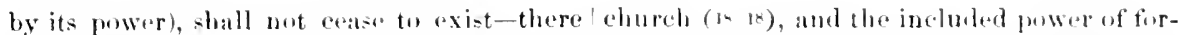
shall always be Christians in the world: or, my people shall rise again. The former is mach the more probable meaning, branse it follows the general Helorew usage. Then the question will turn simply on the word church (sombove), whether it means an outwarl oreanization of profesend Christians (or the ageregate of matuy such orematizations), or means an ideal assembly of all true Christians.

(1). I will give mb the the keys of the giviug sins was given to the ton apmetlon and others. (Johnzo: z3.) As to the "kingelom of

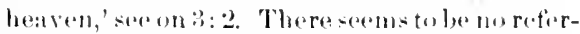

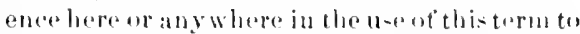
an whtward organization of De-iah's sulujuct-. His rojorn is a spiritual reign. anul athmisson intuhiskingalon is:-pritualanlmis-ion. Patur

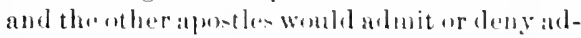
mission, as threr would forgive sins or retain them, by deaching the spiritual comditions of admission or forgiventestame by their inspired power at diecerning and declating n kingdom of heaven. 'That eopyists shomld prefix and was very natural. It tirst sight it seems to be required, though upern choser examination the statement is samen to be more expressive without it, as a parallel to' I will build.' The image here ehanges, in purt. There is still a house, but he who was before the foundation of the house now receives the lieys. Alexanler: "The abrlipt transition may lue ureged at an objection to lle supposition that the rock of $v$. lo is Poter. It is certainly no natural asouredation of idase that the keys of the building should be given to thr. rockun which it rosts. Fot it is quite as incongroous for the rock to giterthe keys as to receive them." II who hat the keys of a city or palace dotermined whether any given person should enter or be shut ont. (Rer.9:1t.; zo. 1-3.) This would sugerest a renoral anthority and comtrol, varying in axtent aecording to the nature ut the case. Thore sinus to be allasion herete the high steward of the palace of I)avid, Ist. 202: 15, 22, and in Rive. 1: 18; $3: 7$, a similar but spiritual finction is asoribed to Jesus himself. Thu Talmud makes like nse of thr phrase. Comp. nls+ in Lulie 11: "Te towk nway the key of knowlenler; ye entered not in vourselves. and them that wore

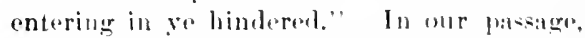
however the rock may be under-tomel. all must agree that aur Iarel grives the lieysto Peter, $i$. e., the power of arlmitting ( $e^{2} . q$, Acts 11: 17), or llonying almision (o. \% Acts 8: 21), into the Messinnie kingrlon. Yet it is not given to him in any "xulusive smse. for the clasely connected power of binding und loosing was not long nfter given to any

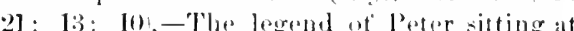
the gate with the keys a-sume-that the kingdom ot heaven here denotes heavon as the abole of the ble-t. It corresponds to, and perhape grew ont ot, a l'almudie legend that Abraham sits at the dour of Gohemas. and will let no eiremeneised parson gar down.

Bind and loose, in the Talmudaud other Rabhinieal writings (Lightt., Wet.. Wün., Eelor-h.), signify to interperet and apply the law and traditimsom any - Hhjede with strirtness or with lavity. and hemes in general to forlider or allow. The striat selhool of shatmmai is reprosentod as bindiner many things which the selowe of Hillal lowsed. Comp. wh

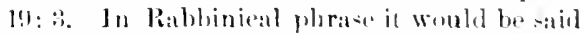
that in Arls 15: 10 leter anderated lowing what the Jubazers whished to himl. Diml. Sice. tell (1. 2-) of an image of Isis with the inseription, "I, lsis, am the quoen of all the labl. and whatever I shall bind no our

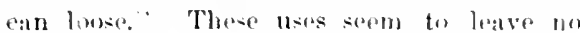
loubt as to the meaning ot the torms here. ()ur Turd lovelaresthat whatever Peter sould forbid ar allow. shomld thelare to bo wrong or righl. Womld lo sonctioned hy divine atu-

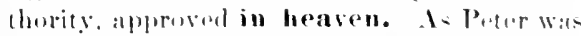
the-poke-man at all the apo-tla- wa -homld naturally understand that the samo would be

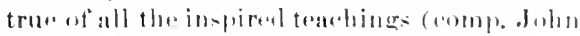

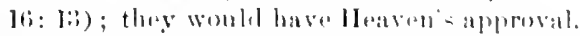
And this included torgiving or relatuing sim (dohe 20:23), whieh was promisod to the apustes and onthers present. (comp. Lake.) similar in that case is the expresson "loused u- from 
20 Then charesed he his Jiscipdes that they should

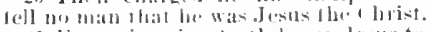

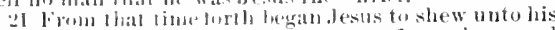

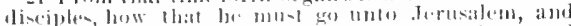

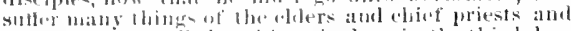
seribes, and be kille l, and be ratiol agato the third day.
20 hearen. Then charged he the disciples that they should tedl no man that he was the christ.

21 From that time hegan 1 Jesus to shew unto his disciples, how that he must go nuto Jernsalem, and sullitr miny things of the elders and chief priests and scribes, and be killed, and the third day be

1 Some ancient athorities read, Jesus Christ.

mor sus, Rer, 1:5 (norret text), and the

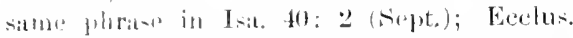
25: 2. ln $18: 18$ exactly the same promise at to binding and lomeing is made to all the per-

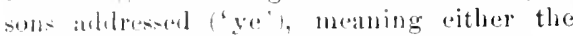

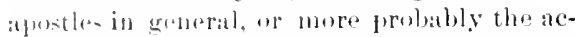
tion at any alurels. From the abuse ot 16 :

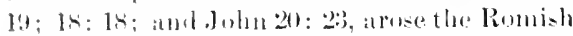
dactrine ot priasly alsolution, whieh some Joutustat presta-ions retain in a modified form. Mini-ter maly teach the conditions of forgivenos, hut they have no inspired power of direroitus a person's -piritual condition, and their decelatiations of abselution are of no valua bryourl stating the conditions.

20. 'Then charged he his (the) disciples. "Ilis" wate aldal by copyists, as in v. 5. The plaral blawe that they shared the conviction which loterasthoir spokesman had expressed. 'That he was Jesus the Christ.' 'Jesus' wa-innertal liy apyists. Until their own view at his Mle-ianic worli ware greatly eor redoul, as the Mater at ance logan to do (16:21), any statroment by them that he was Ma...iah would have lome harm rather than guml. It would have lorought hine prematurny into "pon antagoniom to the Jewish rubers, and might have awakelued the fanatirism of the massus, who would taka it for grantal that tha Moriab must collect an army line renqueleme, and this would have

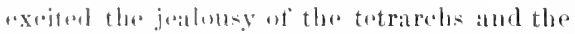
linman forvermment. (complo on $14: 22$ and

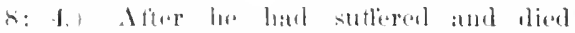

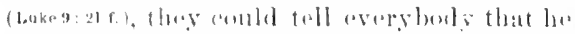

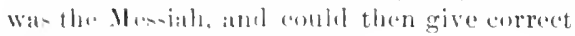
ikleats of thr. Il s-ianie work.

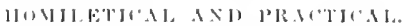

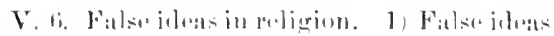

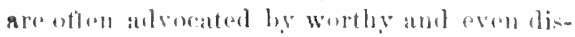

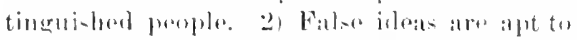

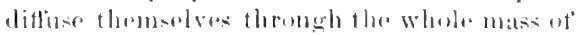
alls' roligime thinking. 3) Falso idwas will inceitably atlinet roligions character and lite. 1) Theratione wa mu-t heware of anbuting the religious errors of eniment and ahnirable
persuns.-The leaven of error in high places of prosition and culture. 1) The leaven of the Pluarises represents for us ritualism, formalism, lypporisy. 2) The leaven of the Sadduces represents skeptieism, "rationalism," "liberalism." 3) The leaven of the II erodians, saculari-n and the subordination of religion t" politics-V.9. HENaY: "We are therefore perplexed witl present eares and distrust, because we do not duly remember our former experiences of divine power and goodness."

V. 18-17. Opinions about Jesus. 1) What men think of .Jesus is a matter of great imfortance for their own good, and therefore of grout encern to him, v. 13. 2) Mten are uften very ingenious in devising other theories in omarr to avoid a view of Jestus which oflends their projudices, v. 14. 3) Those who wish to know the truth about Jesus must be raty to break, if necessary, with popular opinion, v. 15 . 4) The only true view of Iesus regarts him as the Divine Redeemer, v. 16. 5) Thoroughly correet views of Jesus are drawn only from revelation, v. 17. II ExRY: "It is possible for men to have good thonghts of Christ and yet not right ones, a high "1rinion of him and yet not high enough." - V. 17. OrIgEN: "If we say as Peter did, "Thou art the Christ, the son of the living God," not flesh and blood laving revealed it to 11s, hut light laving shone in our heart from tha Fathorin heaven, then we also becomesuch as Peter was, latpy like him and for thesane rouson."--V. 18. Christ building his cluureh. 1) Tho spiritual church of Christ inchudes all roul ('hristiuns. 2) ('hrist himself builds his "hurel, using his apostles as foundation, and all who helieve on him through their word (John 17:20) as matrials. 3) Christ guanatees that his suiritual chureh shall never eease to (xist-throw will always be true Christians on airti.

16 : 21-28. Jesus Begixs to Foretell IIIS DEATII.

'This is also found in Mark 8: 31 to 9: 1; Lukie y: :2)-27. It is closely comneeted with 
22 Then Peter took bim, amb began to rebukt him, saying, be it far from thee, loord: Ihis shall not be unto there
2.2 raisid up. And Peter lowk him, and lngath to row buke hiul, saying, be it far from thes, ford: llit

$10 \mathrm{r}$ ford have merey on thee.

Peter's great confesion, and from the commeetion in luke (9:21 f.) may have besoll spoken immediately after. The place is in the noighborboud ot Cesarea Philippi. (16:13.)

21. From that time forth began. Being now fully convineod that he was the Mesiah, the disciplas must be restrained from endeavoring to carry out the ar arronems notions of the Messianie roigru, and conld be taught mores eorrect ideas withont destroying their fath. But tho instruction here beonn had to be enentinued foun time to time. (17:9, 22: $\mathrm{r} ; 20: \mathrm{f} \times \mathrm{f}, ;=6$ 2, 12.31 f.; comp. John 12: 23 ft.) Filled with the poprtlar Iewish conceptions, it required frepuent repetition to make real to their mimes the amazing thought that the Messiah wat to be put to death. Imberel, they were inplespared after all; their houes were crushed by his death, and they foreot his promise of rising - again. This point, at which he begins distinetly to foretell his daath, eonstituted a new epoch (Mryer) in onr Lant's ministry, like that of $4: 17$, where the same explession is used, 'from that timo began.' 'This important epoch is eomsidelaluly more than six months, probahly eight or nine months, hefore the erueifixion. It must not fir a moment be supposed that fesus mly now hesan himnelf to foresee his sttferiugs and diath. (soe . Wohn 2: 1!) 3: 11; Matt. 9: 15; 10: 36; 12: 40. Jesus, should, a in the margin of Rav. Ver., be 'Jesus Christ.' 'lhis phrase weeurs nowhere else in the Gospels "xerpt in the beginning of MIatt. (1:1, 1*) and Mark (1:1), and in Johiz 17: 3 . It is here very approprinte in opening a now section of the (iospel. and when the diseiples have just tormally recognimed lesus as the ('hrist.' The designation 'tho christ' has been alroady applied by" Matt. to.Jeans in H: 22; 10: 20). How that, obselete; we say "that. II0 must, ats noressary to earry ant his mission and aeeomplish his work (26:5t: luke26:6: duhn 3:14.) (Bo nutu Jerusalem. This is mentional here by Matthew alone; comp. at the transfiguration, Luke 9: 31. Jesus is now at the errentest dis- tance from Jerusalem that was posible in Palestine. At Jorusalen the oppunition to him was most hitter, thrulger the conservation of learuing and of oflice. (Jobull-4) Those who had assaled hine mose tiererely in Galileat came from Jeru-aluan. (M:trk:3:22; Matt. 15:1.) Ho stayed away from the last proeseling l'axsover because the Jews at ofrusalen sought to kill him. (Jobri:1.) From thistimesuthethought of groing to Jerusalem and fatoing all that awaits him, is prominent in his mind. What is to betall him cannot haplenen elsewhere, Luke 1:3: 20; compl. Also, Matt. 20: 18, and the parables in Malk and lulie. And sulfer many things. Stu abo Mark and Luke. This general explesein was natural in the distance; but shortly before the crucitixion he made more sperilie statements, 201: 19; Mark 10:3t. Ot the elders amb chief priests and seribes, the tluee clat-ses whleh constituted the sambetrin, seron of : 59 . One article for the three momns indicatestheir close comnetion. Mink and Iuke ald, 'be rejeeted by the elelers, etc. Ind be killed. The Jews expected the Mesiah to conquer and reign; thero is no intination in their interbiblical or later writings of ans other persuavion, for $2(4)$ Estras $7: 28 \mathrm{f}$. is evidently a Christian intorpulation, and, indred, the original work is pobably post-Christian. 'Whe third atay, so Luke; Mark's "aftur three

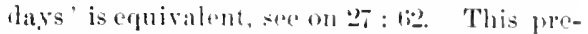
dietion of rising the thied day had bean obsorely given to his enemies, Juhn 2: 19; Iatt. 12: fo, and is now distinctly given to the disejples, and repeated un two suberpuent

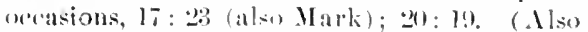
Ilark noll Luke.) He nlse predirts his resurrection withont mentioning the threw tass in IT: : with Malk): 221;: :3 (with Mark.) Mark (s: 32 ) alds, "Ind he make the saying openly' as opposed to the provious obsenre expersions. The disciples evidently acold not take in the illea that he was to ring anain. They believed in a resurreetion at the hast day (John I : 24), but that could not lu meant 
28 But lae turned, ankl said unto l'eter, fiet thee lie-

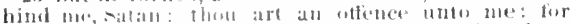

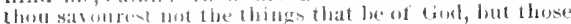
that be of wath.
23 slall never be unto thee. But he turned, and said unto leler, fiet thee behind we, Satan: thou art a stumblingluck untome: for thot mindest not the lore, for how then shomld he do the work of

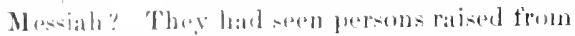

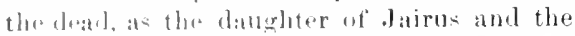
soll of the widnw of $\mathrm{Nath}$; but this was done by dosus, and whor was to raise him? The only wat in which they eoulil conceive of a persons : emming to hife agaju was that some miracle-worker shoulel bring him to life. They umbersood clearly the statement of Jesin that he Was to die; the horror of that thomerte would incerase their eonfu-ion of mind, and so they did not see what his resurrection enule mean (complo on 17: 9), probably thinling it munt be figurative, and thus of littlo persomal intresest to them in conneretion with the thouglat of his death. This state of thing apjeatrs sufficiently to account for thoir finiling to remember those prodictions whon his deatl and resurrection oceurred.

2:2 f'. Poter was probably elated by the commendation and promises of 16: 17-19, anol his native ardur and solf-eomfidences

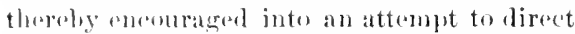
thw Mator's combluet. Took him, literally, torth him to himself; so also Hark. He drow Jeat aside (chrys), to make a personal and forivate remonstratere. ('mm). at a later

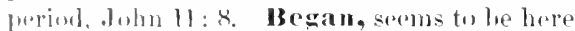

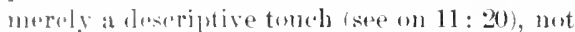
montine (as in $x$. 2l) that he atterwards did

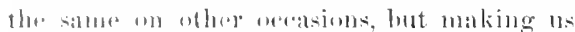

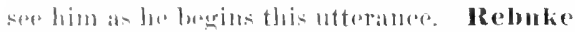
implies dietinetly that ofests is in the wromeng

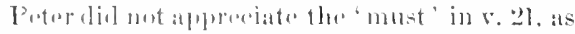

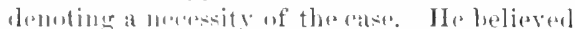

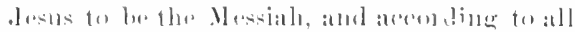

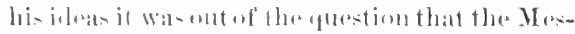

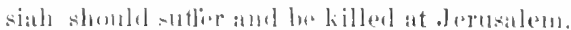

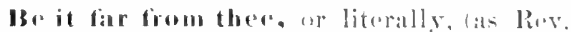

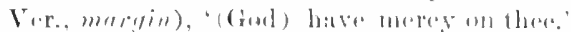

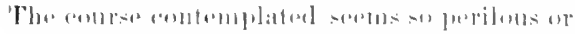

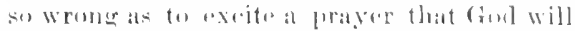
ferenorejtisl and prevent it. Sotice that the

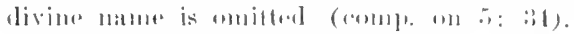

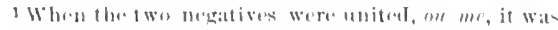
naturat that the followion weth should be in the sub-

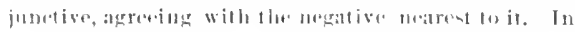
lator (including Biblical) (ireck, the subjunctive, which
Suth an expression if lightly made would he profuue, but might be properly used on arlequate oceasion. It is not found elsewhere in New Test., but several times in sept.; in 1 Chrol. 11: 19, David says (Sept.), "God be mereiful tome! that I should do this," Heb. "a frofune thing to me from my God," equivalent to Eng. "God forbid." Comp. also 1 Mace. 2: 21. Tyndale and Cran. render 'favor thyself;' Gen., 'look to thyself;' Com. Ier., margin, 'pity thyself,' supposing (Jerome) the Greek to mean, "(Be) mereiful to thyself;' but the Heb. and sept. seem to forbid this view. The Pabbis have (Elersh.) an equivalent phrase, 'merey to thee.' Comp. also Paul's farorite expression, me genoito, 'may it not be, rendered 'far be it,' 'Gud forbid.' 'This shall not be unto theo, 'not' hring the dombled and very strong negative, ${ }^{1}$ as in 5: $58 ; 10: 42 ; 15: 5 ; 18: 3 ; 26$ : 29, 3.), and often. 'Never' in Rev. Ver., 's nof an exact translation, for it introduces an alditional idea, as does 'in no wise, v. 28; Holn 6: 37 ; the Greek being simply a strong negation. So Jult. 749, obs. 4. Peter is sure that this ought not to be, and is persuaded that Josus will follow his advice, and so it certainly will not he. But he turued and said, might mean turned sharply upon him (Alex.), or turned away from him (Mey., Weiss); Mark, 'turning and seeing his disciples, decides for the latter. As Peter had rebuked him, s) he now severely rebukes Peter (Mark $8: 33$ ), calling hin 'Siatan,' and using the same plorase of repulsion and abhorence that he usol to Satan himselt in 4: 10. The ardent diceple was playing the tempter's part, in finct lefeating Satan's temptation, in trying w restrain the son of God (comp. 16: 16 with $4: 8,(j)$ from going forward in his appropriate and appointel patti. So a fow months earlier (Jumsi.7of.), our Lurd had ealled Judas Iscariot a 'devi]' (riabolos), i.e., a Satan. (See un t: 1.) Totranslata siatun ly 'adversary' as tho moninghero(Mald.), is forbidden by the

ly its douluful affirmation suggests futurity, is often replacel by the future indinative; thus hime and on me

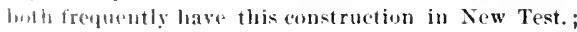
and en several times. (omp). $15: 5 ; 18: 19 ; 26: 35$. 
24 Then said Jesus unto his disciples, If any man will conse after me, Jithim deny himself, and late up his cross, and follow me.

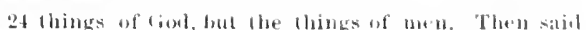
Josus untu his disciples, hi any man would come atier me, let him desy bimseli, and lake up bis fiet that in New Test. it is always a proper name.-Alats! the rock, Cephas, hats become a stone of stumbling; he who had just mate the divinely-taught conteswon (11: : 17), is now Satan, tempting him whom he had eonfesent. Thou art un offence ("stumbling bluck) unto me (see on 5: :29), meaning either an ob-tacle to gring firward in duty (Mey., Alex.), or more jrobably, a suare, a temptation to dis wrong. (Krim.) Thon savourest (mindest) rejurento at very expressive Groek word nsoul often by laul, but nowhere alse in New Test. salve liere and Aets $28: 20$, for which we lack an exart equivalent. (a) Its lealling use is most neatly expresined by 'think' and 'minl.' Thus in 1 Cor. 13: 11, "I thought als a child"; Acts $28: 22$, "to hear of thee what thou thinke-t, what is thy type of religions thought; Romans 12: 16, and Phil. 2: : 2, 'be of the sume mind,' think the sime thing, (or the one thing.) In all sach catses it suggests one's eharacteristie way of thinking. (b) In other uses it means to direct the mind towards, or set the mind on, some elject. Thus in Col. 3: "2, R. Y., "Set your mind on the things abose"; liom. $8: 5-\overline{7}$, "Thery that are after the Hesh mind the things of the flesh,' ete. In our pissilge, (amd Mark

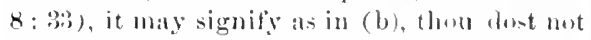
direet thy mind towats the affirirs (plans, interents. ete.) of God, luat then of men, (so Phil. :3: 9) ; or better, as in (a), thou dow not think Godes thoughts, but men's; thou last not Grel's way of thinking, but that of men. Comp. 1sa. B.s: 8, "For wy thulghts are not your thoughts," ete. Aceording to Gend's purpowes and predictions it wis neepsary that the Son of God should sutler and die before entering inte his glory, Luke 24 : 20; I Peter 1: 11. 'Savourest,' in the common and early Eng. versions, was always a defeetive transution, derived from the Vulgate sapitis, Fremeh snower and samer (Fing. savour), meaning think or kusw.

24. Then would not make us sure that it followed immerliately (ommp. on $3: 13$ ), but Mark lenves no aubt: 'And he called moto him the multitude with bis diseiples, and snid unto them, ete. This also shows that the notable suying which follows was addressed, mot to the dincifules only, hut to a great thamer

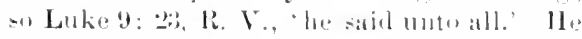
has come away form the place at which he

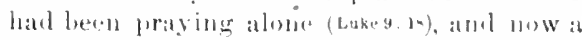
erowel is near; but as to per-ons or loncality wo have no infermation. If any man. Not only is Jenus himsele determined to go for ward in a path which leals tor suthering and death, undeterred by Peter's remomatrance. and not anly mu-t his twelwe disciples be willing to follow in sach a path, but this holds true of any and every one whe withes to be his follower at all. Will (or wishers to) come after me. "Will comes' is ambigumus, and at the present day ahment cortain to be misanderstend; "would enule" gives a slight eolor not present in the original (cornp, on 15: : 32 ). A, he designs to go forward like a man bealing his eross to the place of (oncifixion, so any one who wishes to come along behind him must do likewise. There is here no sabstm-

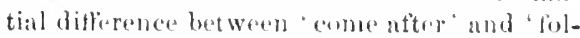
low.' The familiar ue ot the phrase deny himself almo 'take us his crose, the frequent application of them ter petty actions and sufferings, has gradually enfeabled their mear:ing in our eonception, and it recyuires an effort to return to their original foree. The phrases (ii) to deny a statement, and (b) to ding a request (both elassical), bave an obrioms meaning; (e) to deny a person (a sonse fiund only in New Thist.), is to deny that we have the relations to him which others are suppose ing, or which circumstances might scem to indicate (10:33; 26:34), or else to deny that one is what be claims to be, and hence to roject him (Acty 3:16; 7:35); and there nre variols other shades of meaning. In some of these unes the Greak las the simple rert, ns here in Lake; other have it compranded with : prepustion, as here in Matthew and Mark, giving a slightly increased foren. (d) To deny all object or prictice is to refued, roject, or renounce it : as denying implety and worldly desires.' (Ti, 2: 12. Rev. Ver., comp. 2 Tim, 3:5.) (1) Ti

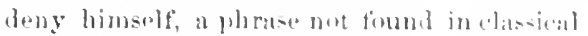
Greek, but characteristic of Chri-tianity, might seem to eombert itself in meining with (b); as a man denies a begerar. sin he denies himseli; i. $e$, retuses to grant his 
2.5 For whuscever will save his life shall lose it: and

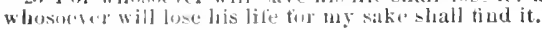

25 cross, and follow me. For whosoever would save his lift shatl lose it: and whosoever sliall lose his own refuests (chrys, Mey.) This is the sense, but much werkened, in which the exproniom is now widely used. But deres it mot. ats here u-ed ly our Lard, rather comnect itnelf with (e), meaning that a man remonncer him-elt"? As the Jew demicd the Mesiah (Aces: 16), so his tollower denies self, will not haveselt for his ruler el hisaim. Ile dotermines not to live according to hisown inclinations, but to do and bear whatever may

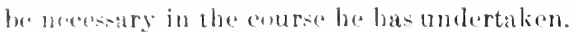
He mu-t rombe to live not tor plasure, but unctuluses; not for inclination, hut duty ; not âr selt, bat tir Goul. (Comb). Rom. 1t: 7-9; 15: 2 t.) Tyolale, Crin., Gen., translate "forsake himblt.' And take up his cross. The orws had long been familiar with the puni-humen of erucifixion, which was usod in Eisgit and all Western Asia, and from an ataly tiane in Italy. More than a hundred yatr lufore an Lord's ministry, King Alaxandre . Jumens erueified eight hundred robols at dorusalom, while he was feasting in public (Jns. "Aut.," 13, 14, 2), and evenundor Anti-

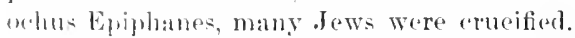

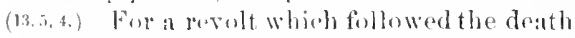
of If resel the Great, the proconsial Tarus rerucifiol two thousand Jows. And yet a J "wisld lathlit of to-day has said that the say-

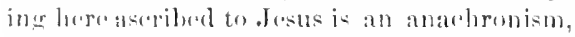
for the disejples comble not bave understood an allusion to (ross-burating till alter his erucifixion. It wa- entomintomakethecondemned

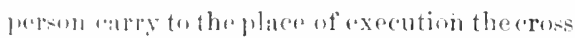
(on which ho w:as to suffir (comp. on $27: 82)$ : and $s$ the disciples would roadily understand the Master's allusion. Mr wasemeng forwater like ons marching to arucitixion. appointed to sulloring and lath ; and ang one who

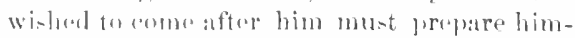
solf for the same experiones. The disciplos

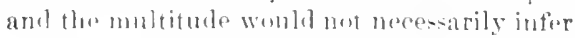

Io rire $k$ and lattin, in HAb. and in Eng. there are

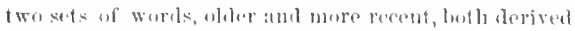
frum routs sisnifying to breathe: (iי) psegethe, animt (animus), woplesh, soul, (b) pmenmen, spiritus, ruarh, ghos\%. The latter sut are derived from rents still used in the stur. language, fur exen to chost correspumls gust. Tlue former sot are from rewts low longer uced in

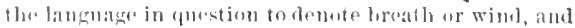
smme of them found at all only in kindred languages. from this that he was to be crucitied. It was not till a tew days before its occurrence that ho foretold the procise mode of his death. (20: 19.) They would understand that he was like a person gring to be crucitied, and they also must herudy forsuffering and death. Chrys: "IIe saith also how far one ought to renounce mesolf, that is, unto deatl, and that a reproachful death." Jerome: "And follow their tencher morientium animo." Jesus used the same impressive image on two other aceasions. (10: 38: 1.uke 14:27: in Mark $10: 21$, it is spurious.) It was plain enough at the time, and after lie was himself actually crucified it became all the more vivid and sulemn, as was the case with many other pirts of his teachings. Luke 9: '29 adds 'daily.' Every day must his follower comsent and detemine afresh to go forward through suffering and even unto death. Chrys: "Bear about this death continually, and day by day be realy for slaughter." Follow, comp. on 4: 19. There they were to follow with an especial view to instruction; here they must follow in a path of suffering, follow even to Aying; comp. John 12: 29-26. 'Follow' is aloo used in Com. Ver. for another word, which Rev. Ver. more exactly renders by 'initate, (1 Thess. 1:6;2:14;2 Thess. 3:7,9;1 Cor. 4:16 11: 1; Eph. 5: 1: lleh, 6: 12:13:7;3 John 11), thus hringing out more distinctly the great duty of imituting Christ.

25. Notice the repeated for (v, 25, 26, 27), each sonteneesumplying that which precedes with a prosfor a motive. In v. 25 our Jord passes from bodily to spiritual life, from temporal to etornal life. There is a similar transition in 'Teave the lead to bury their own dead,' 8 : 20; comp. Juhn 4: 10; 6: 27. He also passes in v. 25 f., from the vital prineiple of the lody to the immortal prineiple. The English word 'soul' 1 was formerly used for both of these,

Thus psyche corresponds to psucho, "to eonl," lis blowing thu-breath, etc. Inima (animms) corresponds to fireek ammos, 'wind,' Sanskrit an, 'to breatle,' Latin an-helo, 'to gasp, breathe with difficulty. Fephesh answers to Arahic nerphers, 'tolireathe.' Soul, Anglo-saxonsawul sawl, saul, fiothic saiwala, is evidently from a rout sav or sva, corresponding (Toy) to sauskrit root su, and joulahly to samskrit suka, wind. It is tlus plain that the tirst set of terms are older. These were long used 
26 For what is a man profitod, it lie shall gain the whole world, and lıse his own sonl? or what shatl a man give in exchange for his soml?

27 For the son of nat shall wome in the glory of his Father with his atenels; and then he shall rewaril every man accololing w his works.

and so in our earlier ranslations of sieripture, but is in othor English usage now ennfind to the immortal principle. Thus any pusible translation of lbe present passitre into eurpent English is necessurily defective. The (am. Ver, by eluanging to' 'sulul' in v. 2ti, conceals the elosererlal annection between the two sentences. The Rev. Ver., ly retaining the samo word 'lifo' in both, makes it less plain

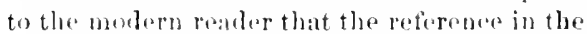
second sentonce is to the spiritual and oternal life. Yot the latter translation is certainly best, tor it only requires the reater to olserve a transition which the Groek artually makes.

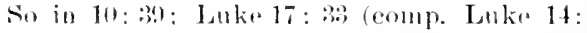
26); John 1:2: 2.); and a kindreel ideat in Acts 14: 2.); 2 Tim. 3: 12. Will save, or wishes to seme, as in v. 24. Whosenerer wishes to save his bulile, temporal life sall lose his spiritual, otormal lifi. Formysalie. Mark, 'for my silie and the gospel's.'

26. What shall a man be profited, read ly the rarliest documents, waseasily changed by eopyists into what is a man prolited, by assimilation to Luke; in Mark also the dueuments vary muel between present and future. Either point of viow is obviously possible. And lose (Rev. Ver., forfeit). Tha Groek verb is derived from the nom rendereel 'loss" as oppessed to 'gain' in Phil. $: 3: 7$, and is itsolt" used in Phil. 3: 8, "I have sutlered the loss ot" all things. It frequently dellotes a fine or forfoit L Likle and seott), and so fremeva hore, 'be condemoned to pay his soul'; hut tha image herois more probably that of protit and loss in business eprerations, whereano subtracts the total lose from the total gain tuse what profit he has made. The difficulty of trauslating the word in this sense as distinguished from the other word "Jose" just before, may 2is he for my sake shall tims it. For what shatl a mall he grotiled, it he shall gain the whele werlel, ame fortift his life" or what shall a math give in tex-

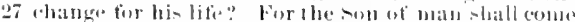
in the glory of his liabrer with his atugels; alul

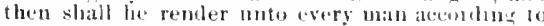

have partly influenced the Ravisers inte preferring the othet sense. Luke !l: 2.) gives buth teruss, "and luse or fortioit his awn self." And notiec that luke has "himsell" in-tual of "lis life" ; for a mall to lowe his life, in the highest semare of that term, is to lose himself.

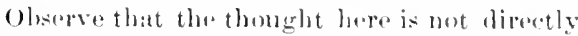
of what we all the lose or perelition ot a soml. Thu gain and lose in the great busines- transaction are compared, and the man's own bife in the spiritual and eremal sonse is the loss; what then will be the profit? In earthly busimess, howerer, one may sometimes prosper afterwatek and purchast back the property be has lost; hut what shall a man give in exchange for his suml (lifel, so as to purelatse it backe? Bengel: "The world low not suffiee." The noun antellegma demotes that which by excluange talios the place of something else, whether as sllb-titute (Feclus, 6: 15 : 26: 11), (1) as a rancom (Isa. 43:3); lupe it is more generally a purchasing exuivalent.

27. Weseethat this great balanoing of aeeoluts is mot a moro timure of specech, but will artually aceur. The Son of man, sere un 8 : 20. This eonstantly suggests that ho is the Mossiall (eomp. on 16: 19), and indicutes that he is to be the final jullese as in $7: 2.2$, and horaftor in 25:31, 2t. Shatl come, not the mere future teuse, but a strung expression like 'is going to combr, 'is aluste to emone, and in the Greok made emphatie ly its position at the head of the sentroner he is reming. and there is no mistake abunt it. This is leslieved tor be the first distincet intimation of his second coming. In the grory of his Fa* ther. In the same glory mond which his litther dwolls. Comp. 24; : it. This ghorye hat with his Father hefore the world was (Jehn 17:5); he hat voluntarily left it to come

when no clear distiuction was made hetween the rital be united, or there was a quick transition frum the one

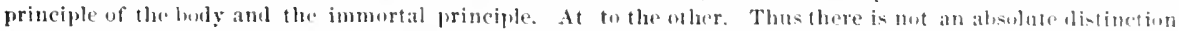

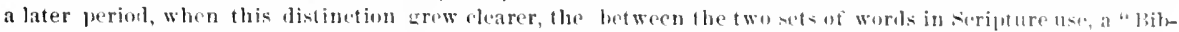

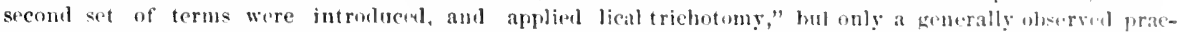

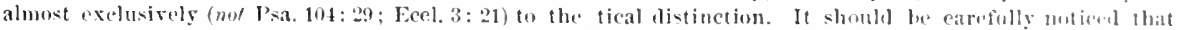
spiritual, immortal principle, while the older terms. 'soul' vers often in old Test. and smetimes in New though now chiefly restrieted to the rital prineiple of Test. denntes only the vital prineiple of the herly. the boly, continued to be often used in the other sense whether jt means the other, or mean loth tugether, is also, and were necessary when the two sevses were to a question fur consideration in every case. 
2s Verily I say unto fon, There he somp standing here, which shail not listo of death, lill they see the son of uatu coming in bis kingdom.
28 his ldeds. Terily I say unto you, There are some of them that stathd here, who shall in no wise taste of death, lild they see the son of man coming in his kinglom.

1 Gr. doing.

on his prosent lowly mission (Phis 2:6 ts.), but lowould return to sharo it again, and in that glory ho would hereatter come. With his angel- 13:41;24:31:25:31). luke (9:26) has an pxpresion which implies that their encompassing ghory will enhance his glory. As to the anculs, secon 18: 10. Accordiug to his decds, on, mure exactly, action, pratice, comrse of lite. (col. 3 : 9 bax the same woral.) 'The exprosion som to be suggested by Psa. 62: 12: l'roy. 24: 12, funtere in Rom. "2: b; (amp. line. 20: 12, and as to the thourht, 2 (a), 5: 10. The fact of this coming retribution shows the jupurtance of saving the suml; but thore is special reforenee to the thought ot rewarel tor fring and suffering in his service (v."te). Mark 8: 38 and Luke 9: 26, give the alditional point that when he ommes he will he a-bamed of overy one that has been ashamed ot him. Matthrow has before recorlul this thought as uttered on a different accasion 10: 33), and so he omits it here.

28. Ilis coming is not only certain, hat near. Verily 1 say unto you, as in 5: 18, introduring a very important utteranee. II is coning will ocurur before some of those present will die. There be, old English where we wow say "thereare. Some (of those) stand. ing here, who werenot only the Twelve, but a ('lowr. (Mank:34.) It is implied that not many of them would live to witness what is moralt: and this showe that it was not aur event very upar at land. Shall not, the

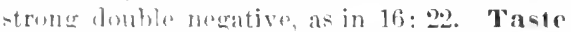
of death. The image is that of a bitter eup

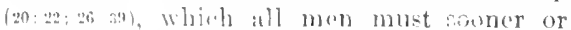
tatar tantu of, and i- very commuon in Jewish

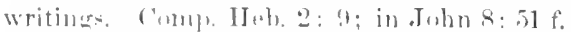

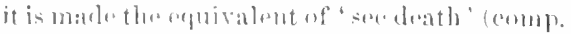

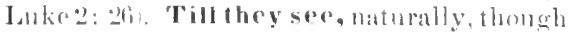
not nexsarily (comp. on $1: 25)$, implies that after the cominer in question they will taste of drath; and in for far an argument againet moler-tanding our lurd' final eoming to he moant. The som of man coming in his hiugdom, or kingship, royalty-coining as king (seo on 3: "2). So in the robber's prayer (1.uke $23: 42$ ), and comp. as to the thougint, Luke
21:31. In Mark 9: 1; Luke 9: 27, only the coming of the kingdon is mentioned; but that implies the eoming of the Messianic King, which Matt. expresses. How could Jesus say that he would come as Messianie King in the lifetime of some then present? Certain rationalizing expositors at once say that Jesus expected his final coming to judgment to talie plice within that period. The language would roadily hear that sense, espeeially in such close connection with v. 27 ; can it fairly have anv other sense? Since the Fathers of the thind century a good many have referred it simply to the Transfiguration, in whieh Jesus appeared as the glorious king. But (a) this is a very unnatural and enfeebled sense of 'coming in his kingdom; ' (b) it oceurred within a week, during the lifetime not simply of 'some, but of proluably all those present; and these objectionsare fatal to that riew. Manyotherseontent themselves with understanding a general reference to the establishment of the spiritual reign of Messiah; some say on the Day of Pentecost (Act:2), though that oceurred within less than a year and so conflicts with 'some;' others say throughout the following generation or the century. The most reasonable explanation, especially when we comp. eh. 24 , is to understand a reference to the destruction of .Jerusalem, forty years afterwards. This providentially lifted the Messianie reign to a new stage. It put an end to the sacrifices and the whole temple ritual, and thus tiught the Jewish Christians that these need be no longer observed, and to a great extont stopped the mouths of the Julaizers who rave Paul so mul trouble. The withdrawal of the Christians from Jerusalem before its destruction aceasioned an alienation between them and tho. Jewish people at large. In general, the destruction of Jerusalem made Christianity stand out as no longer even in appearance a mere phase or mode of Judaism, but an indopendent and miversal religion. (Comp. Br. Lightfoot on Galatians, p. $300 \mathrm{ff}$.) Tha sudden transition from the final coming for judgment (v.27) to this nearer coming at the destruction of Jerusalem, is repeatedly 


\section{CHATER X T T I I}

1 No after six days lesus taketh teler, lames, and I Inhm his hrolder, and bringeth them up into a high motuntalin itport,

parallelod in eh. $2 t$; and the very jhrate of v. 24 by 2t: $: 4 t$, “This generation shall not pase away, till all these things be ateomplished." l'menter: "That sleh words -lomld have heon remoled and published by the Evaluegoli-ts is a probt either that thes accepteal that interprotation, if they worta after the de-truetion of berusalem, or if we assume that they were led liy them to lowk lior the "enel af all things' as neat at laud, that they wrote beforet the gereselation of them who stout by had faswed away; and so the very

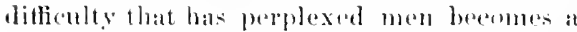
prowe wit the ary date of the there Gospels that contain the reened."

\section{HOUILETIII, AND PRICTIUA.}

V. 20 f. The imperfectly instrueted belicrer. 1$)$ Prejudien often prevents his nnlerstanding the plain teachinge of pevelation. 2) Conceit often leads hin lo set his own juder-

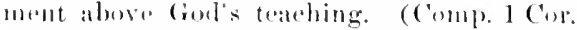
t: b.) :3) Proumptuons ignoranes uften dabkes him hindor the eatuse he tries to help. 4 Strongth of will and waruth of heart often

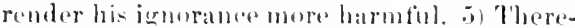
fire his home-t upinioms anel woll-meant adviee must sometimes he utterdy rejected by whers. (i) Further instruction and experimene maly make him a pillar in the rhuleh.

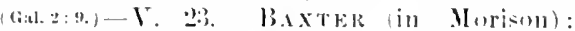
- (iond men ofteines do the derils work, though they linow it not." - There has always beon a temdeney, and enpecially in an day, to deroble puestiens ot roligious truth and duty trous the human rather than the divine point ot view. The Bible is judered exclusively from its eomtormity to haman reason and its melaptation to human wants. Well-meaning persons try to build up churelues or to furthar publir moralits, hy following the dietates of wortsly polies. But tothink Gol's thoughts, to lowk at things so far as we may from his standpoint, is in religion the only wistom and satery-C'urss.: "If the chief" aposte, even hedoro he had learnt all distinctly, was alled situth for feeling this, what excuso and they have, who after so

I We here sadly take leave of Arhion . llaxander, the foremost of American commenlators, whose work

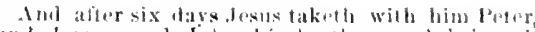

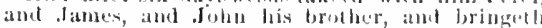

abundant proot deny the mystrery of the ('ros? ?

V. ett. Fullowing Chri-t. 1 Mathod. (a) In selti-rentunciation. (b) In cron-hearing. 2) Intiver. (a) The lose in following loin is but temporal, thegain is spiritual and remonal. (b) Tlat las in refusing to fisllow hinn is remectiles torever. (e) The love of ('hrist ("for my sake") grives patience in loss, and alds hrightmess to gain. ('ulars. "It any man will. I foree not, I comples not, but anch one 1 make loml of his own choled. . But he that leares the hearer to chroses attrats him more. For southing is a mightior thing

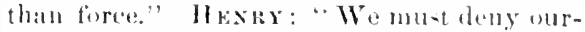
selves alsolutely; we mu-t not almire our own shadow, nor gratify onr awn lommor; we must not lean to on own under-tanding, nor sork our wwh things, nor be our own pml." - V. "25. ("IIRYs. "On that sidr. salvation and destruetion, and an this sille satrat tion and destruction, but how greatly the one

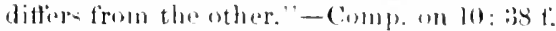

V. 26. Earth's groutest bu-iness transation. 1) Tho erreatrit fossible earthly gabin, aceompanied by the groatent posible atorthly lose. 2) Thas lows is uterly past remoly, and will soun render the sain utterly uspless: In this lind at busines we are all engiged, and onght to an-ult an true prolit. (comp.

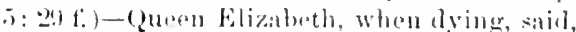
"Milions of momere fior an incle ot time." she had the momer, hut eomld not malie the

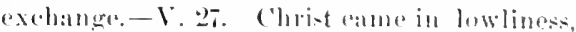
de-prised and rojoseted (1:a.53), in the formo of a servint (Phil 2: i), to live almong men and die to ature for them: ho will eomenerain in erlory, and take his pesplole to belobld his glory (dohn 18:24), and to sharo it. (13it. 3:21.)

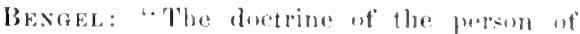
("lirist (16: 16) is immoliatoly libllowed by the dectrine of the crose (v.21), and this by the doetrine of glory." (s. 27.)

C'. 17: 1-13.-THE TIAXSFIOtRATIOx. This is describul also in Mark a: 2-13; luke !: 28-3ti. The seone at' the 'Transtigu- 
"Aml was transtigured before them: and his face divishine as the sun, and his rament was white as the light.
2 them up into a high mountain apart: and he was transfigured before them: and his face did shine is the sun, and his garments becante white as the ration is popmlarly sumposed to have been Momnt 'Tabur, in Lower cialifee. This opinion is axprested in the fomrth century, and

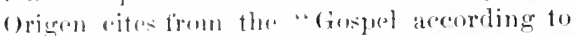
tha Hohrews" a basiage which probably relates to the Transtierumation, and woukl show that some held this riow in the sefend cennury. Yat the tralition is almost cortainly incorrect. The conversation (16:21-2x) which preanted the Tramsticuration by six days was vary alosely anmertud see on v. 21) with Pefor"s grout confesion, and this ocenren in the district of Costrea Phitiphi. It is of eourse pessible that in these six days . Jesus shombl

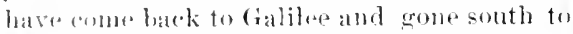
Monnt 'Tatur, but we know that he was at this period kerping away firm qalilee for mally injportant reatoms (eomp). on 16: 5). Mormever, we find in Mark that from the place of the Transfignation they went forth

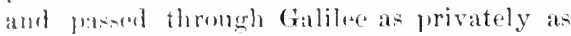

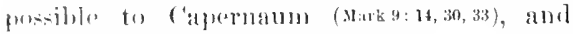
thenes went towarls Jemsalem. Ath this laves the hymothesis of a hasty jomroyey to Talme and bark violently improbable. Besides, Robinsm hols shown that there was a fortifiol rity on .IImet Tabor at that time, which most have rendered its narrow and romulacl smmuit anything elso than a place of solusion. In riow of these farts nearly all rosent writers anese that the Transfigura-

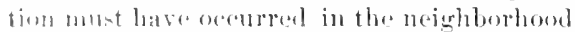
ut ('warra Philiphi.

1. Iuto a hish mountaiu, might he any one

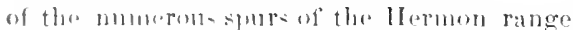
in the virinity of the rity. We ean hardly suppume and of the thene highest peatis of

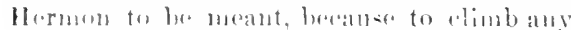
onde of than on font and return is a tatigning

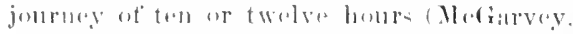

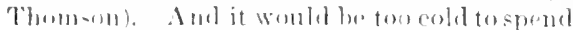
a nieht there without sheler. Comblor found it rerycold in atent. After six days. so

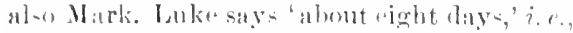
abont a werk, which Wis aften walled eight days, countiner both the first and the latst (sect (on l:2: 40), just as in the French amd German labguager at werok is tropuently ealled "eight days," and a fortnight "fifteen days." It
Matthew and Iark say 'six days' and Luke 'about a week,' there is certainly no conflict. It is not well tosuppose (Chrys., Jerome) that Matthow and Mark give only the intervening days, while Lulie adds the tirst and hast, for this is sulposing them to reckon in a way quite umatural for IIeb. or Greek usage, and such artificial harmonistie hypotheses are to be depreated. The real point to be abserved is that alt three Fvangelists deelare the Cransfiguration to have oceurred mly a fow days atter the predietion that Josus nust sutiel and be killed. Jesus taketh with him, as in $2: 19 ; 4: 5 ; 12 ; 4)$. Peter, James, and Jobn, alone wore also admitted to see the raising of Jairus daughter (Mark5.37), and to be near the Master in Gethsemane. (26:3i.) They betonged to the first group of four among tho 'Twelve see on 10: 2), and were evidently received to a peeuliar intimary. The convietion wrought in their minds by what they witnessed would impart itself to alt, through their tome and general influenee. Apart. Sinch an wnoarthly, almost hoarenly seene must have no unsymathizing spectators. Lulie says (9:28, Rev. vere) that he "wont up into the monstain to play" (compl above on 14: 29), and that the wonderful ehange of appearanee took place as he was praying. We lave screral times found mention of special -ensons of prayer at great erises of our Iord's history. (luke $3: 21$; Mark $1: 35$; Luke $6: 12$; Matt. 14:23.) As the three disciples were oppressed with slem during the scene (Luke), and his return to the othor disciplos was 'on the next day' (Luke 9:37), it sinms elenr that the 'Transfiguration oceurred at might. The shining of our Lord's fite and garments, and the bright roud, would thas be more manifest, and the whole sorne more striking.

2. Ind was transfigured, literally, his form wasclenged, meaning however, so far as we fan see, merty a ehange in his appearance. IBofore them, within their full riew, so that they ental beat witness. His facedid shiue as the sun, compl. as partially similar, Exod. A4: $2 y$; Acts $6: 15$. And his raiment, or, garments, was-or, became-white as the 


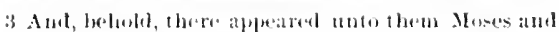
Eliats talkiug with hill.

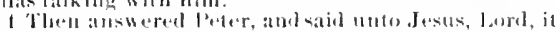

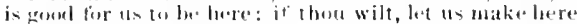

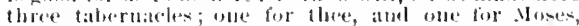
and one tor lilias.

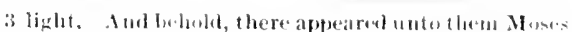

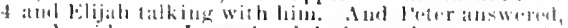

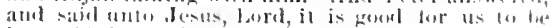

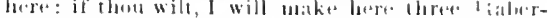
placles; one for thec, and one lise Moses, and ane lor

$10 \mathrm{r}$, booths.

light; Mark, Ris. Ver., "glittering, exceedinsy whito,' Luke, white and dazzling, (eomp). Matt. 28: :3). All this was at temporary atud partial anticipaldom not the grory that

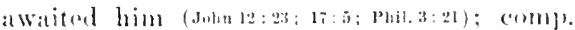
his apprarance to ond of these three dinciples in P:at1110)- (Rev, 1:13-16.)

$3 \mathrm{f}$. There aro here (foldet) three di-tinct points: the persomal glerification of besus (x. 2), llec alperaranee and conversation of Mases and Elijah (v.3e), the theophamy and divine voles ( $x .5)$. Moses, and Elias,

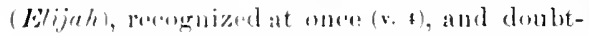
less by intuition, at a bate of the -lupermatural

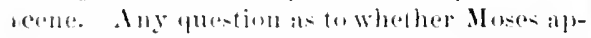

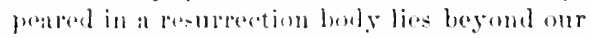
knowledge and is idle. "The law and the proplese wore until John; from that time the kiuglom of ciod i- preatehed." (buke 1ti-16.; Thus the Mesiante reigne is dintinguished fiom the diepensation of the law and the

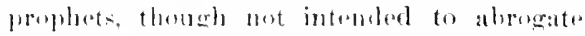
them. (5: 18.) Aceordinely wa find the toundor of the law, and the ereat reforming fore-

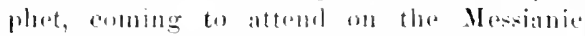
king: and as they disaphear, a heavenly verierealle on mento hear hint. The liablits freqhently spouk of Mowe and Elijah together ; and a writeref several eenturies after christ sags they were to cometogether in the lays of the Meriah. Talling with him. luke-ays (9:31), "spake of his lecease which he should aceomplish at , Jormalem," the announcement of which, a fow days before, had sustarterlamel pained the disciples. I"lemptem: "It is sienificant that the werd for "Ireceatso"

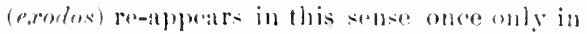
the Now Te-ot.e and then in elose commeretion with a reference to the Transtiguration. (:Peter : 15.)" J1 is not cleatr whother the diseiples heard this anoersation; at any rate it was partly deagmed tiol the savinurs own benefit, that he might hesupmorted in view of the sutherings and lath to which his mind

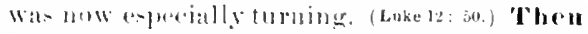
answered Peeter, not an answere to semething

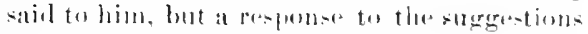
of the situation, an uttriatrea called fiorth by the impresion mate on his mind. (cimple th 11 : 25.) Loral. Mark has Rabli, and Lake

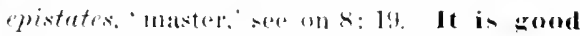
for us to be here. Full at' strange, hewildered. but delightiul teelings, Peter wanted to

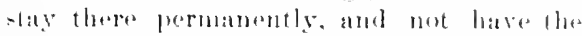

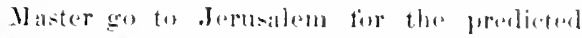

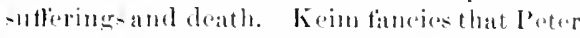
wished to smombon the other disciples and the people from every direction to witures this opening manifutation of the Mesianie erlory

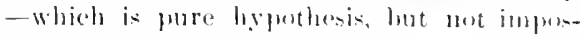
sible. Meyer and Weise imagion that Peter moans, "It is a geosl thing that we are heres." so als to take the neces-ary stepes. The Groek will bear lhis sen-e, hut the trone of the balrittive will mot.--It was indered gond to lw lhore. but they andel but stay. Duwn anain must Jasts amel his disciple gu, amid human surrow and sin (17:15), down to witnese distrese-

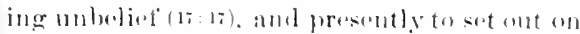

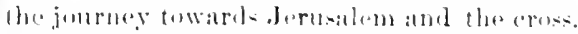
A- Masesand Elijah were pateting from J Jous (Ialia), Peler propered te deatan them by making three tabernacles, or 'buntho,

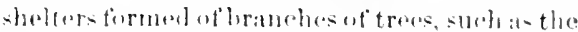

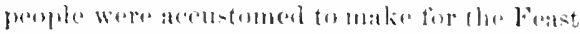
of Taberualede at Jurusalem. In thesetheir glorinu- larel and his heavonly visitor-might abiale in comfort; as for the di-ciples fhemselves, they endal remoin withomt shelerer,

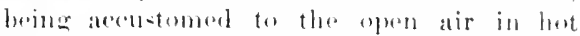
weather, even at night. Thi was a strange

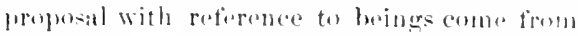

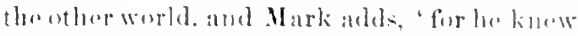
net what to answer: torthey were for loseamos) sorely afraid. I will make, is real by tha arliest manuseripts. and was easily chatuerel

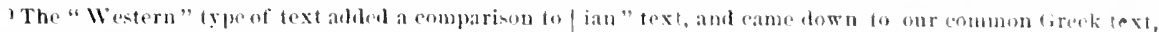

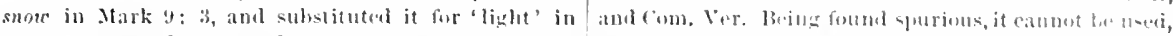
Matt. It was doubless derived from $28: a$; banill as by stanley, incousidering the duestion of locality. 7: 9. This adition in Mark was adopted in the "syl- 


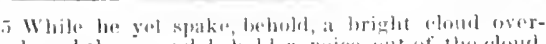

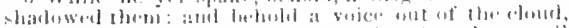

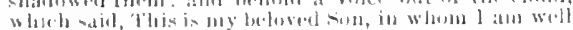
[H, and luar yolitu.

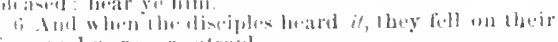

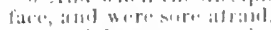

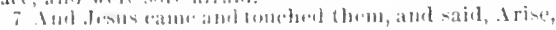
ant he nut atrail.

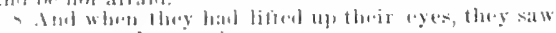

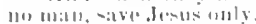

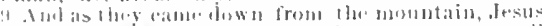

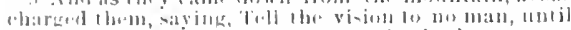

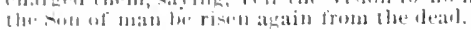

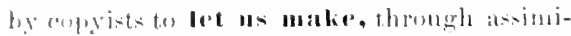
latim to Mark ant Isuke. It aceorels with

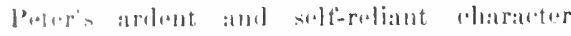
(16) 2.2) that he should jerejuse to make them himilt.

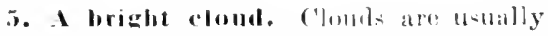
latk, hut this was a cond full of light (same worl ats in li: 2.), which in the night most

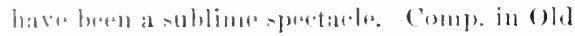
Trat. theophanies, Extul, :3:3: t]; l lings 8: 61. The thres dinciples seem to bave beren

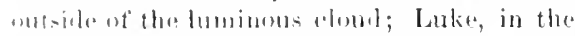

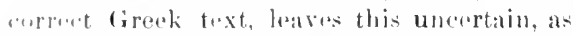
Mall. loes; lut a roice ont of the clumd slerenels that those who heard it were with-

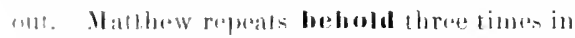

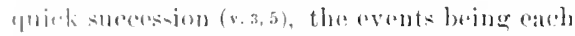
bery romarkahle. (O) two othel oecasions at

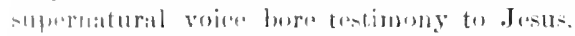

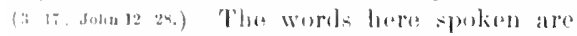

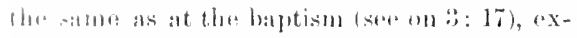

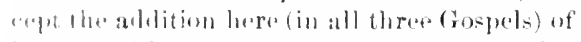
hear ye him, a solome $1: a l l$ to listen to his luabiuge and sulmit to his anthority. The

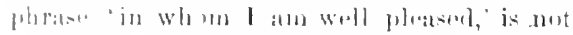

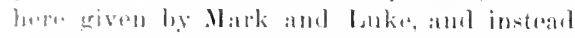

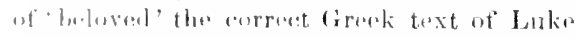

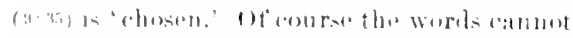
bave berns suken in all these forms; an mu-

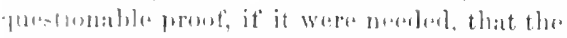

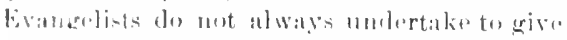

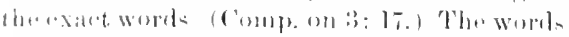

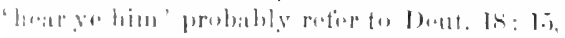

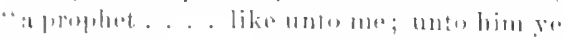

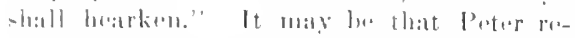

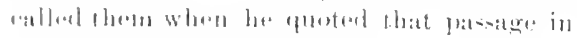

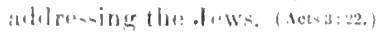

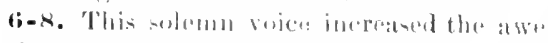
and corpor with whioh the diengules were

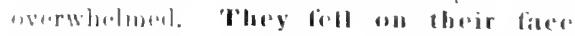

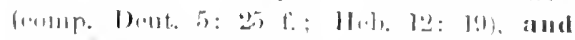

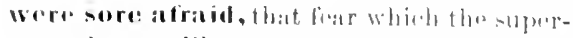

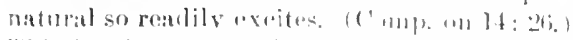

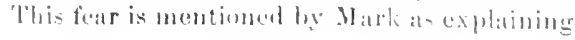

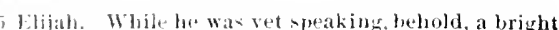

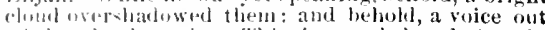

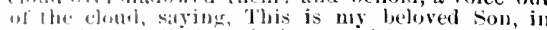
di whun l an well pletsenl; hear ye him. And when the lisedph hearl it, lhey lell on their face, and

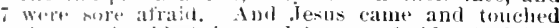

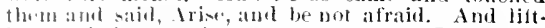
s illg ul lheir eyta, they saw no one, save Jesus unly.

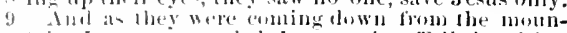
tain, Justs commsumed them, sayiug, Tell the vision to no 1uan, until the son of man lie risen from the

Prters mental contusion and strange proposition: l,y Luke, at folt when they saw Jesus with More and Elijalı, pntering the cloud; by Mall., as filt whes they heard the voice wut ut the cloud. We readily understand that it was felt throughout, and might be empharized at various points with equal propriety. And Jesus came and tomched them, as the angel fouched Ditniel. (Dan. 8: 1s; 10: 18.) (One can almost see the kindly saviour stomping to tometh each of the plostrate forms, si) as to arouse them to attention, and saying, Arise, and be mot atraid. They looked up (Mark, "suddenly') - the luminous cloud was gone, and with it the bright forms of Noser and Elijah-they saw no man for no (me) ave Jesus only. This means simply that the others wre gone and Jesus was alone; the wondertul scene was ended. It is quite unwarrantable to "accommodate" the words as a text in the way sometimes adoptial-tru-t . Jesus only, obey Jesus only, take. Jesus only as pophet, priest, and king -all corrot in themselves, but by no means heretanght.

\section{As they came (were coming) down from} the momntain, nure exactly, ont of the mementere. Pespl. who live near a mountain constantly say, "he is gone up in the mountain," "when he emmes down out of the muntain" ; he is nut in the earth composing the momtain, but is in the mountain as a loinlity. The evilenee is overwhelmingly in tavor of,$k$, 'out of.' in Matt., and probably w in Mark 9: !) it was changed by copyists

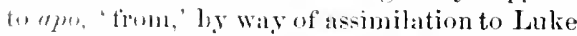
(a 3i), just as it was rhanged in Mark 1: 10 by an-imilatian to Matt. 3 : 11 ; (see note). This direcent in the summer morning must have loxen allommpanied ly delightful reflectuons on what thry had witnrsacel. Here was new and womblem comtionation ot their faith that Je-11- Wal the Mtesiah. They would naturally wish to meak of it to the other disciples and 
10 Aml lis disciplen askenl him, signiug, Why then say the scribes that Elias must dir-t equite?

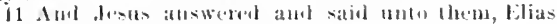
troly shall first coms, atoh restore all things.

all the pooples and were doubtless surprised and disilpuinted when Jesus not anly sial to them, lut charged theur, 'Tell the vision, or sight (acts: 31 , the word meaning simply smmething seen, to no mall, more wartly, to no one, mutil the sun of man, the Jessiah (sos on $x: 20)$, be risen from the deal. Ile is repeating what he had sad a week bestorre (16:21), that he mus tie and rise again. but they de nut unelerstand. Mark silys (9. 10), "They kept the saying, questioning tom, with another what the rising trom the deat slould meand. 'Ther were fimmiliar with the

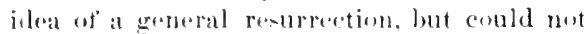
sre how the .lleniah wat to be killed and comato lifis arain (sere un lo: 21). Threg dombthess smprosed it mast mean something fienrative, and never thomeht at molerstanding it literally. Thes athere tiseoples woulel

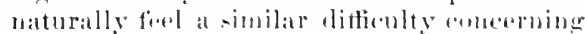
the predietion as made bestine and repeaterel atterwarls (17:23:2,:19); hut some of thesu mentiomed that sueh a predietion had lexen made, and when the molers heard of it, thes

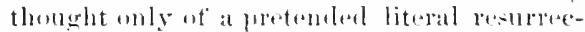
tion, which they endeaterest to prevent. (2i: (33 f.)

In comsidering tho desien of the Transfig-

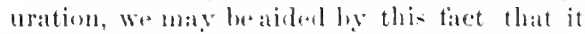

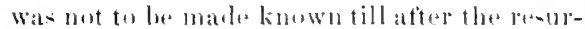

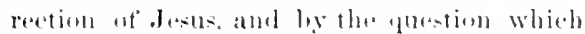

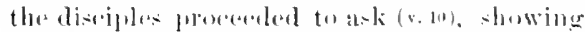
a deep enomietion that he was the Mesiah. The womderful serene was suited to tix this beliof so firmly in the minds of these three leading disciples that it wombl not heshaken

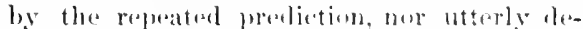
strover hy the heart-pending reality, ot his irnominions eleath. Ilenertorth, nu disap-

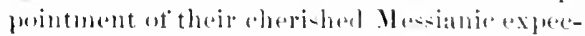
tations, no humbliation insfoud of lomor, and

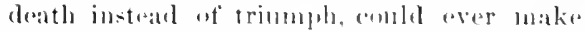
them dentet that he whome they had seren in such a form af glowy, and receiving such testimont, was indepel the Mesiah. Evell when leter so mournfully foll. ho did unt utterly lase this eomvietion, aven at dests salal the night before, "I mates supplication for there, that thy faith fail nut. (Lake 22: $32, \mathrm{kr}$ ) This unounquerable conviction on the part of the three
10 deacl. And his disciples asked him, satying, Why

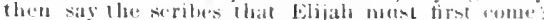

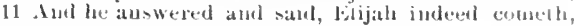

foremont disciples would keep the rest alke tremo waverine, though they eould not be told what hasel exererreel. Whern their lipewere mosaled, we may he sure that they delighted

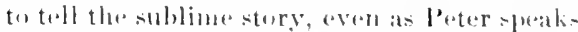
of it in glowing term in his lats fiphtle.

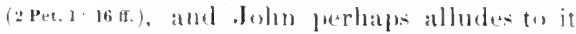

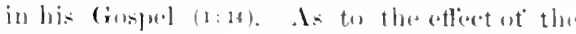

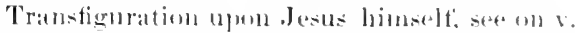
3. But why eomlel it nent be tollel until attor his resteresetion? He latel forbidelenthe diseiples to tell any ane that he was the Mr...iath

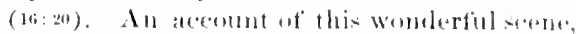
it given to the penple in general, with there

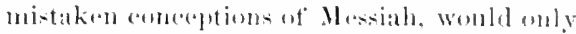
have exeited tamaticism and precipitated the

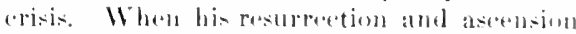
latel pent an enel to the thoueht of a mere temjural kingelom, and the minds of believers had been lifted un to a just conception ot their exilted lewel. then the story comble be appuredated, and would flogoud and not latrm.

10-I3. His aisciples, viz., the threes. (Mark 9.2.). Why then? There is $1101 \%$ mo demble that he is the Messiah. Why them, say the seribes that Elias ( Elijah) must first come? The thomerht af Elijah had hasn sugerested by lis appearance on the Monut.

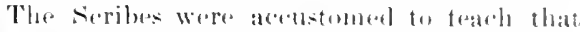

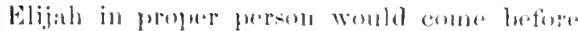
the Mesiah, and prepare the way for lim lo a new work of reformation-thus interperetion literally the prodiction of Mal. $4: 5$ (compl. m li: 14). Simmeof the Jews ledel that Eilijah would anoint the Masiah. But bere is Ma...

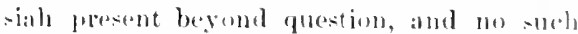
premaratory ministry ot Elijah has ocenrred. They ate him therefore to explain why the seribes say that Filijah must enme betione tla.

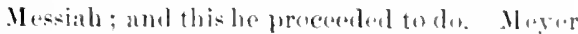
and others mppose. with tar le.s proluthility. that the disciples took thi-aplearance of $\mathrm{E}$ ilijah un the mount to bethe prodicted coming, and wereomly proplexed that Elijath had nut reme first. but atter the Mrsiah had appuatred. Ind Jesus (he) answered and said. Tha. worls 'Jesus" and ter them' are not part of the correct text; nor is "first. inv. 11. thoment genuine in v. 10. Elias (Flijah) truly shall come. 'Indeed, or 'truly, expresies con- 


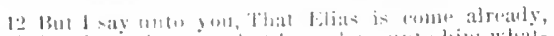

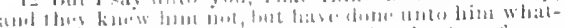

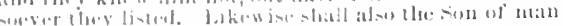
millier 11 l lin.u.

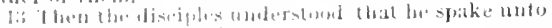

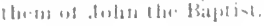

trat with something to bollow, at in $9: 37$.

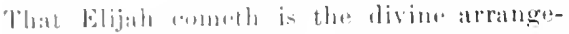

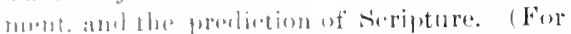

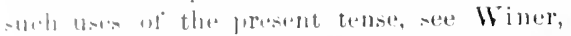

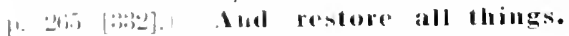
II

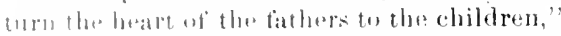
$10 .$, vi\%, as a proparation lor the great day ut the larel. This "Shall turu' is translated 111 the siret. 'shall restore,' and hence doubt-

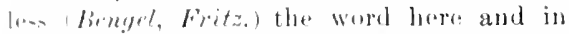
Mark (9 12). Elijah will stlect a preparatory returluation, anmp. Luke I: 17, '(1) make ready fir the Lurel a people prepared. (Our Lord mant - to say that so the prodiction stands. The linturetense dows not apletar to mean, as f'hrys and others have imagiaed, that there wato lo solne other enming ot Elijals still lump whon wur Lolul was speaking. Elias lighh is come already, (m)mp. 11: 14. Whatroever they listed, og wishede the ohl

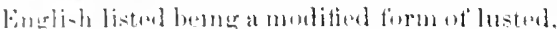

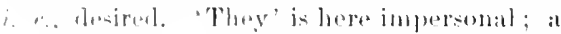

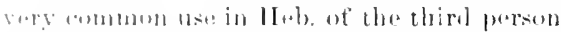
plural, likes the Euge. 'they say.' The reter-

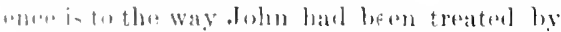

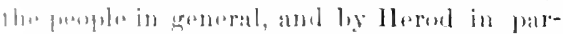
lirolatr. Inhu was not Elijab reapleatring in

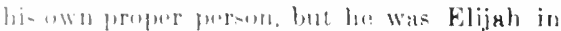

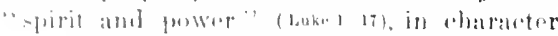

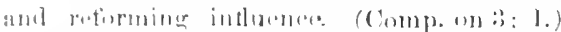

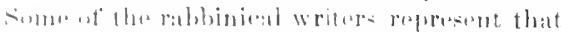
Elijah will hring lask the ark, the put of

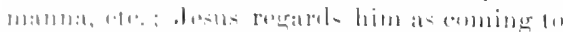

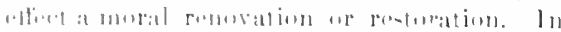

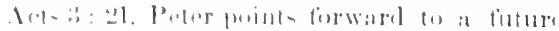

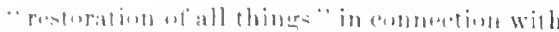

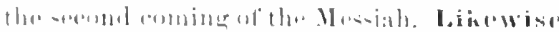

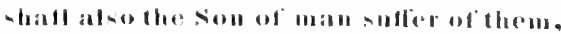

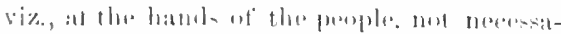

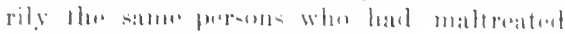

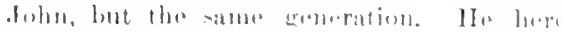

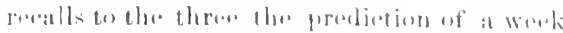

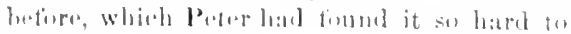
lin:tir.

H1).

V. I 8. The Transfiguration. 1) The gho-
12 and sha]l restore all hings: hut I say unlo you, hat Elijab is osume already, and they knew him not, fut diclute fin whatsoner they listed. Fiven so shall 13) tly. stoud the aliscijles trat he spate unto them of Joln the liajtint.

rious appearance. 2) The holy visitants. 8) The Fathers volice. 4) The effect upon the disciples. 5) The lessous for us; (a) as to the saviumr's glory, (b) his authority, (c) our serviceot him. - V. M. II ALL: "A strangenpportunity ! in his highest exaltation to speak of his sufferings; when his head shone with glory, to tell him low it must bleed with thoms; when his face shone like the sun, to tell him it must be spit upon; when his garments glistenerl with that celestial brightness, to toll him they mu-t be stripped and divided; when he waseen between two saints, to tell him how he munt be seen betweon two male-

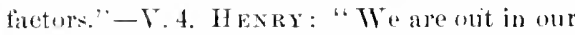
aim, if we look for a heaven here upon earth. It is not for strangers and pilgrims to talk of building. Whaturer tabernacles we propose to maketo ourselves in this world, we must alway remember to ask Christ's leave. "- $\mathbf{I}$. 5. JIear him. 1) As completer of the law. (i): 17.) 2) A last and greatest of God's mesiengers. (H(t), 1: 1 f.) 3) As the suffering siviour. (16: 21.) 4) As destined to be the timal Judge. (16; 27.)-V. 6. HExkY : "Through the infirmits of the flesh, we often firgluen ourselves with that wherewith we slonld enewrage ourselves."-V.8. Cilrsis. : "It' we will, we also shall behold Christ, not as they then on the mount, but in far greater brightnos. For then, to spare his disciples, he diecurerel so much only of his brightness as they were able to bear; hereafter he shall come in the very gloy of the Father, not with Moss and Elijah only, but with the infinite host of the anguls, not having a eloud orer his head, hut aven lowron itself being folded up so that all men shall see him sitting, and he will make answers to then by himselt, "Come, yohlencel of my Father,' 'Depart flom ne, ye ("IIr)ind."

V.9. Tall the vision to no one. 1) It is a lifficult and important duty sometimes to keep silanewhere we hum to speak. 2) Somp points of relieginetruthare best withheld from persons mot proparial la understand. 3) Delay in tellinder sometiun propares us to tel] more intelligentey and impressively. 
It And when they wore cume to the multitule, llure lallt' fo Jim a rertain man, knceling down to him, aml silyin:,

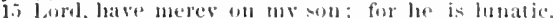

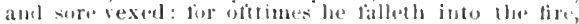
atnd ult into the waler.

li Aml l brought him to thy disciples, and liney eonlil mol enre him.

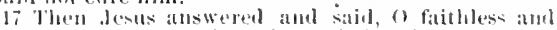

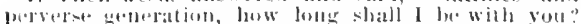
luw Joug shall I suller you? bring him hinher to me
14 And when they wrerente the moltifule, there

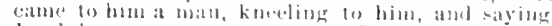

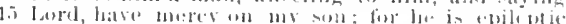

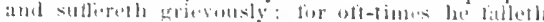

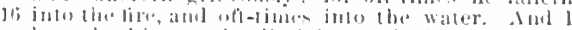

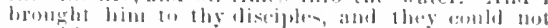

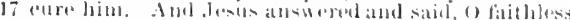

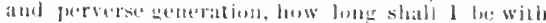
you: how dotng shall I bear with you:" bring hiu
I 1-20 (21/. JESE IIEALS THE EHLEPTI" BOY.

Mark here gives (9:14-29) matny vivid details not firand in Matthew or Luke (9: $: 3$ - 43 ).

14-16. And when they, vi\%, Je-11s, with Peter and James and .Jolus (1i:1,9), were come to the muttitude. The place wats near the foot of the Menut of Transtiguration (Luke 9:3i), aml so pretty cortainly in the neigh-

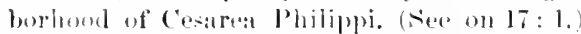
The great picture by hatfinclle, sizing upon the elose connection betweren the Transtigurattion and this serene, has taken the artistic license of representing them as antempurrancous, the Mater in ghory on the Munnt, the nine disciples sanly attentuting w heal the

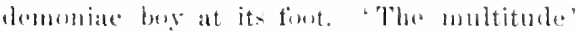
weresurrounding the nine disciples (Mitrk), and 'were gratly allatarl, probathly at the sudelen appearance of . Iesur after a night's uncexplaned absence, and atter this latilure of his followers. Sonse think there wats still at light in his countenance, as when Moses desecended with daz\%ling fiace. But this would hase excited a corbusity whish he and the three conlel nut eratity. (18:9.) Ilark adds that the muttitude ran to hin and saluted

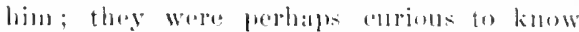
where he had been, and were doubless atarer

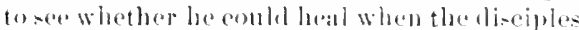

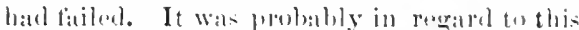
proint that "seribes" were apeolioning with

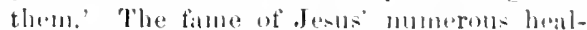
ingre in Galilese had long age sorwad far and wide. (t: 2 t.) A man, linecling to him, in humility and reverenece, not in worship. Ionde sese on s: 2. It is not eleatl whit aureunt of reverenes the word here expresess.

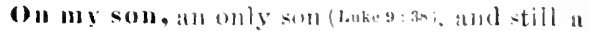

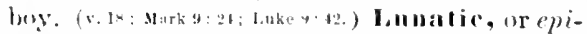
leptid, als in 4: 24t the worl does not aecur mewhere in New Tout. The symptems deseribed, and mure fully and vivilly in Mark (9: 1<20), are these of epilepsy ; and the boy had been so atlected from childhood (Mark). The epilepsy was in this cal-e connecterd (v. 14) with

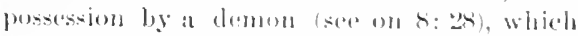
might cither have andion the bolily ailment, or taken reca-ion theretrum. In llark (9:17) it is called 'a doub-pript, indiating that the demoniacal ponsessien ball cansed the hild to be clumb. I brought him to thy disciples, the nine who bid been lest belind, and they eould not cure him. IIark anul Luke, "alst it ont.'

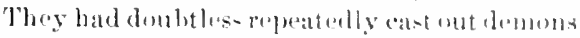

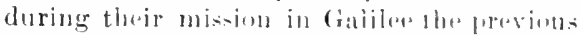
winter or spring (10:1.4), and they mieht have done so now but for watknesos of tath. (v, 20).

18 t. O faithleos (unbelirimg) aud perverse generalion. 'T'he terms are burowed from 1)ert. :32: 5,20 ; (comp. Phil. 2: 15. They

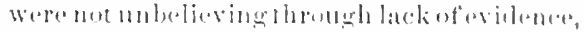
but through pererese nexplect or rejoetion of

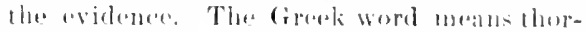
onghly twisted, crowked, ate. and so deres the

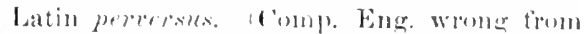

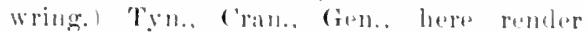

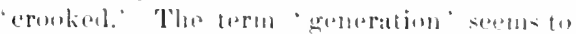
be uned generally, nut meaning specotiteally the disciples or the seribes ate. at varous writers have stppomet. The titther, the nine disciples, the crowd, the sereribe (Bava:14),

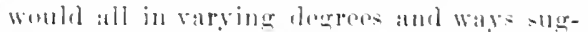

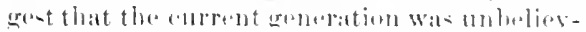
ingand pervere. Sozwingli, Bengel, bwald.

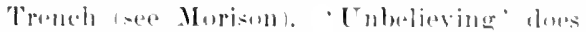
not nesersatrily mean that no whe in thes generation belierod at all ; the disciplens hat

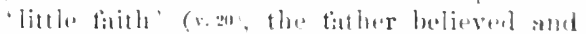
did not believe. This prevalemere of jerretree unbelief mate it paintul a live amil-uxbs a generation, and te sutfer, or hees with. them.

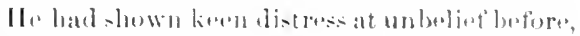

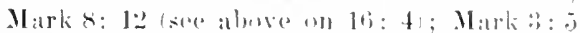

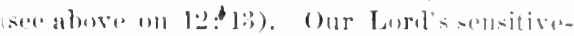

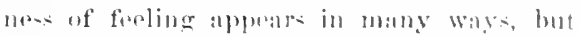

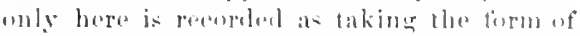

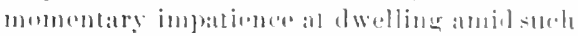
an environment it ma-1 hase been all the more distressing from the contrast with the 


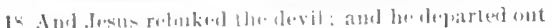

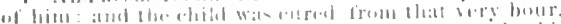

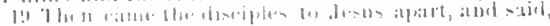
II liy (c)

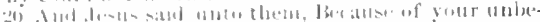

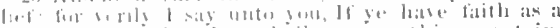

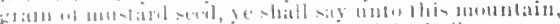

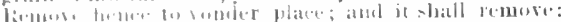

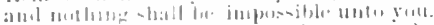

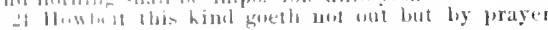
atIIt lik-11116.
It hither wo me. And Jesus robuked him: and the delum went ont from himt ant the buy wascured from that hour. Then came the hiseblits lo Jexis

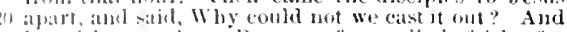

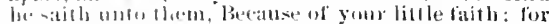
verily l sily unte youl, li ve bave faith as a grain ol muslate seol, ye shall say unts this mommain, Rewove berueto yomble place; and it shall remove; and nuthiug shall be impossible unto you.l

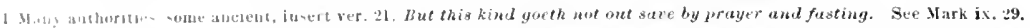

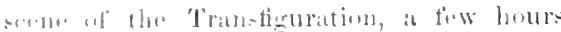

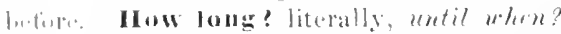

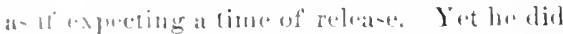
lual w iah lhat gencration for yet many mouths (-te an l!t: 1), athd did on this areasion, amid all the thateartroing and intolerable unbelief, fontuletly reogrnize and blesin a fath that was

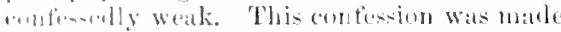

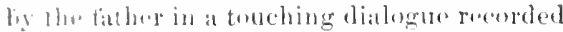
k, Itark. (9) 20 Bringhimbithertame.

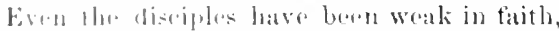
and What clege onght to have dome must be

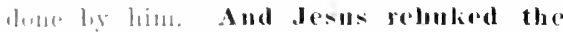
devil, Herally, him, the dermoniate, which of

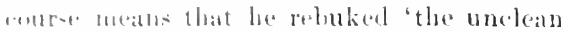
spirit Mats and Luke, ; the rebuke doubtl... relatled to lii- unlawful and maligualut

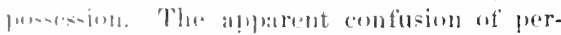

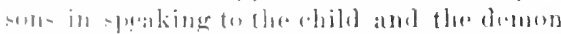
1- malural an the a-nomption of a real demon-

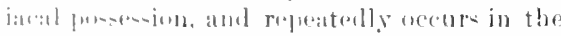

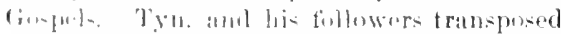

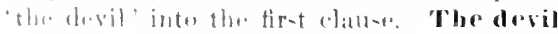

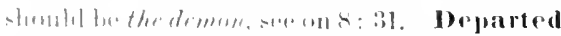

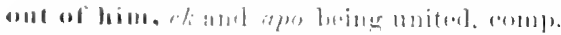

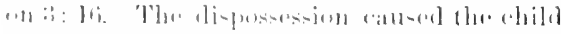

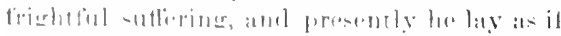

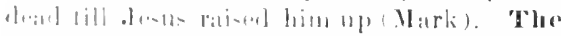

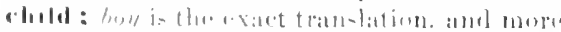

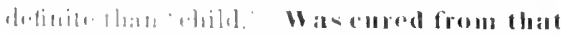

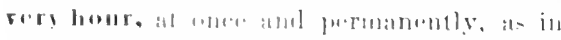

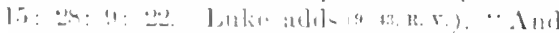

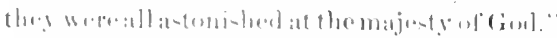

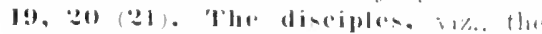

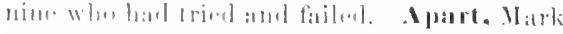

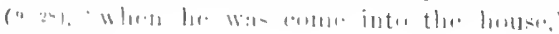

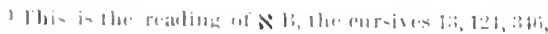

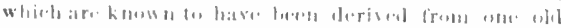

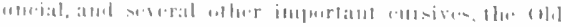

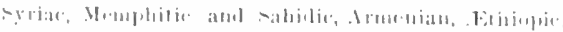

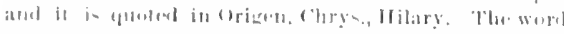

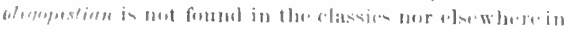

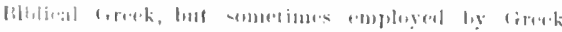

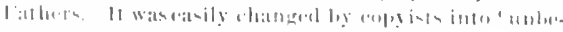

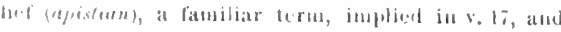

apparently that in which he and they had been sojumining. Why could not we cast him (it) out? 'we' being expressed in the Greek, and thus cmphatic; he had anthorized them to (ant out demons $(10: 1-x)$, and we cannot doubt they had done so. (Comp. the Seventy, Luke 10:17). Because of your nubelief, cur. w'xt, little faith." comp. 'ye ot' little faith" in $6: 80 ; 8: 26 ; 14: 21 ; 11$ : 8 . Tothis correymols the answer given in Mark. "This kind can conne out by nothing save by protger, viz., at incrusing their fath and spriritual puwer. For gives a pront of the precerling satement. Your failure must have been on account of ruar weakness of faith, for a very minute faith can work a very grait miracle. As a grain of mustard reed, often used for anything very small (see m $18: 81)$; their faith must therefore have been extrumely minute, being less than this. Cuto this monntain. He probably pointed to the mountain on whiels he hat the night leefore been trau-figured; so in 21 : 21 it is the Mount of olives. This faith that eould remose momution (oomp). Lulie 17: b; Matt. 21:21 f.; Mark 11: 23; 1 (or. 1:2:2) was properand possible only in those to whom it wats granted to work miracles. For us to attrmpt -lwh a thing is folly. Aud nothing shall he impossible unto you is of course an exagerated expresion, such as all men us. am all understand, and answers to what he hall just lafolu suid to the futher (Mark $9: 23$ ). "All tlinges are pursible to him that belinveth:" "omp. also Phil. 4: 13.

2I. 'This vare is spllious," having been sending all lirs mone in accordance wilh what follows. let in fant frown has never acensed the disciples af hatring wo fath, hut repeatedly of having litle fith (ofinoprigtui). 'l'his fatet is nol likely wo have neeurred 11. engins, while the other considerations are obvious. "It is wating in $\mathbb{N}$ (f) hat hatu B, two copies of the (1) latlin, lue (1), and derusalem syriae, sahidic, and atop! of Mmphitis, and Ethiepic. The insertion by colyists fom allother (iospel is natural and very com- 
an Ind while they aboda in (iablee, Jests sadd unto them, 'The sin of mat slatl be hetrayed into the hands of men:

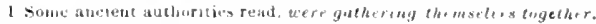

added by eoprists from Mark 9: : 2.t. Already,

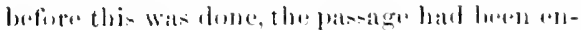

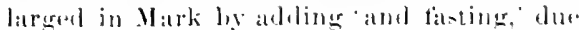
to the aseretiedsm among the carly Chri-tians. A -inilar allition of "fitting "was made by

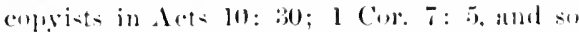
(atme inte the commonn text. The word fint-

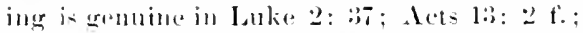
14: 2.?. For onr Lord's iustruction at to filsting. :

The events of lii: 1:3 to 17: : 1 oceurrol within a shore time, atplarently litte more than a

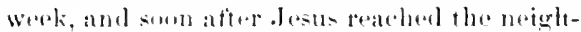

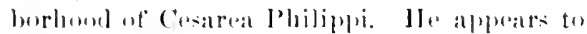

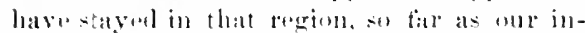
formation enables n- to judge, soveral weeks, perh:tps two or theer monthe leomple on 16: 3:), hut there is ne record of further sayings or doings.

\section{IONILETICAI, ANI) JRAGTCAL,}

V. $14 \mathrm{f}$. I fithers pomalkable experience. 1) The distresing ralamity. 2) The dislestrening fitilure. :3) The strugreling titith. (stark.2.24) t) The great bles-ing.-V. It.

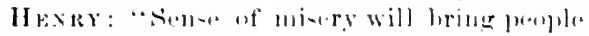
to their kness. . . Parents are doubly

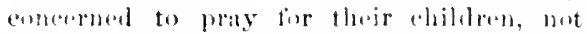
moly thee that are work and anmot, but math more that are wirkenl and will not, prat for themselves."-V. 17. The saviutr grioving

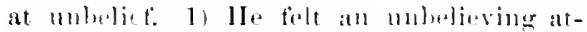

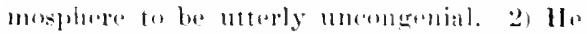

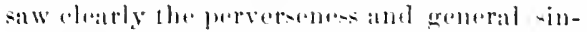

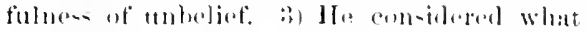
brsinge men were mis-ing through unbeliet.

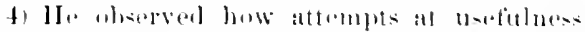

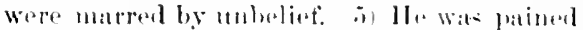

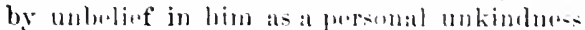

non, while we cannot imagine any reason for the ombsion ut the pasage if originally prentent in Matt.,

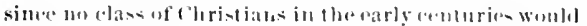

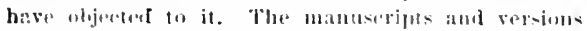
whiel contain il have much verbal vatiolim, a com-

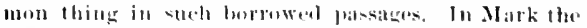
sentenep is fonmol in all linenmuthts, but the words and

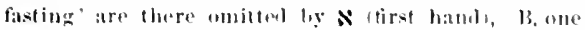

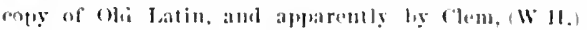

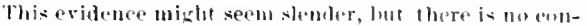
exivatio reason for the omiasion of the words ly copy-

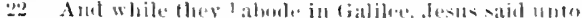
llem, The -on of man shall be bejivered up inlu,

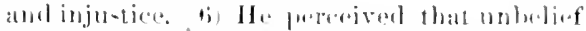
is nbstinate and hatrd to compluer.-V, 13.

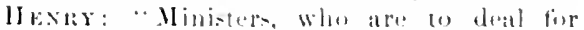

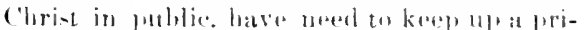
vate commonnion with him, that they maty hewatil the follie and intirmition at Lleir publie purformances and ingure into the catree of them."-V. 23. Lithl. liath. 1) It pe-

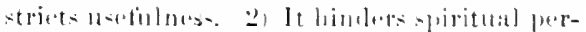

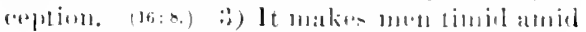

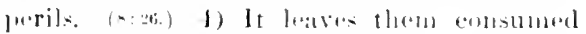

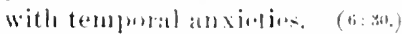

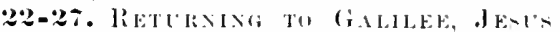
AGAIX FUIETHLLL IIS JEATH. HE PAYS THE Thampe Thx.

Here are two matters.

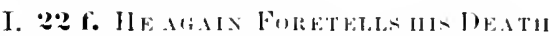

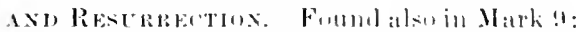

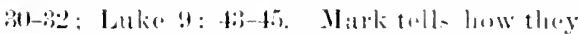
lott the flace of healing the denomiac bus, near tho Mnout of Trandiguration, atud patsend thromerle Galilee. And while they

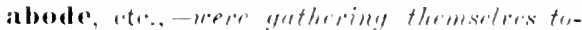

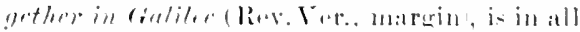
probahility thetrue text ${ }^{1}$ Jt implienthat they

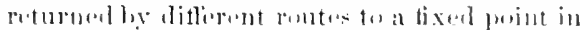

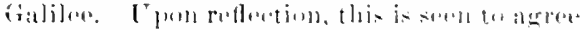

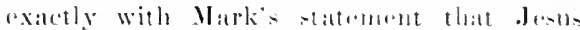

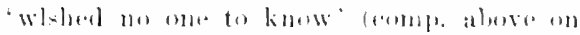
lli: if of the jourmey througl cialitee, for at matural "xpedient to this and would be the siparation of the Twolve inta areral parties.

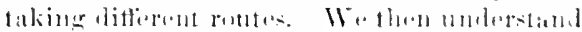

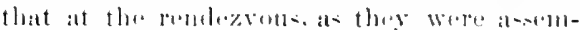
bliner, Je-the mathe the statement that follows. Mark's 'tor' (4: 31 , perlatu indientes (d)finti)

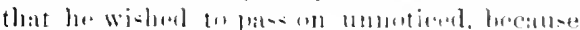

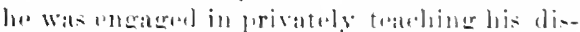
ciples almat his alpwoteding alath. ar it

ists or students, while Iheir inserting is explatined bs

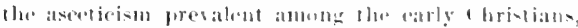

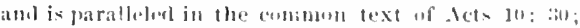

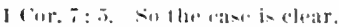

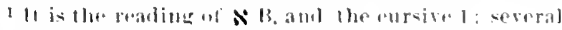
early versions show confusion and uncertaint? in their

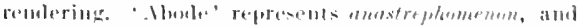

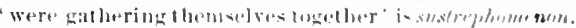

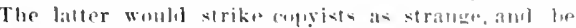

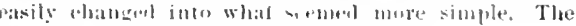
ease is not certain, lut highly jorubable. 
2:3 Aml they -hall kilt him, amd the third day he

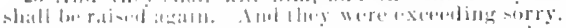

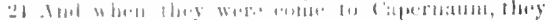

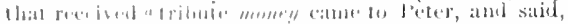

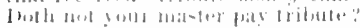

$2 \%$ the lanuls of men; and they shall kill him, and the thimlday he shall he raised up. And they were exceeiling sorry.

2t Amb whon lhor were come to Capernam, they that received the lhall-shekel came to l'eter, and

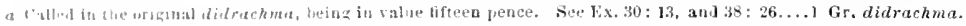

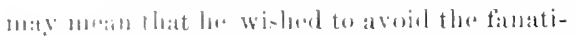
anl molnitule, who, at his last reeorded vi-it

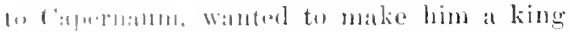

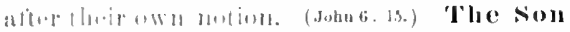

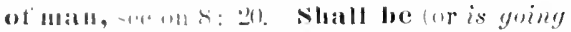

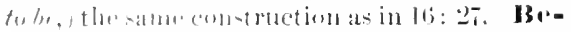

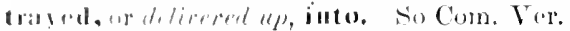
rierluly in Mati and luke, though rendering

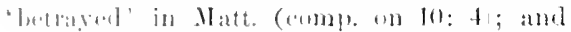
wa. -hall liml -imalar inome-isteney throughout

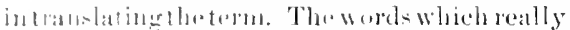
nuall 'butrar' and 'traitor' oceur only in

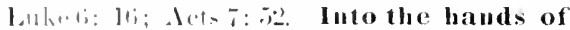

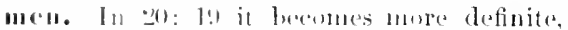

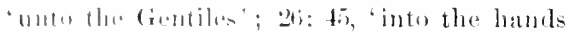

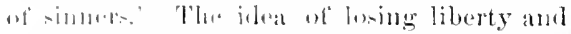

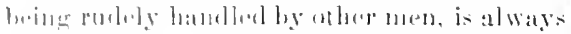
in itelf pantul. This being delivered into

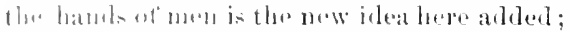

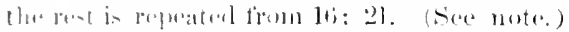

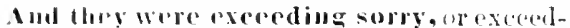

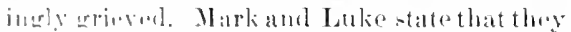

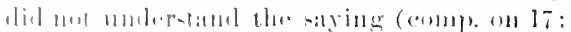

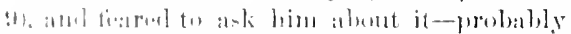
will that forliner whileh ofion restrains per-

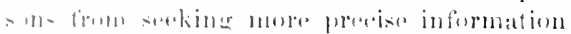

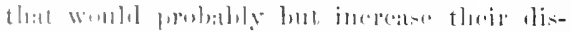

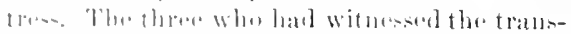

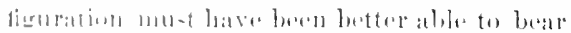

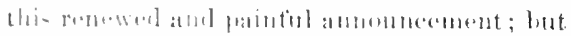

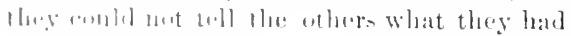

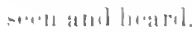

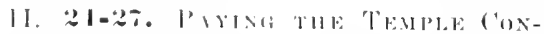

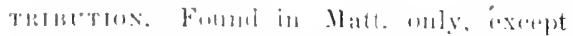

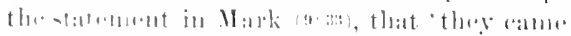

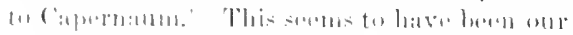

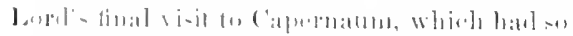

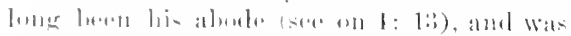

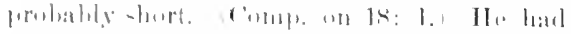

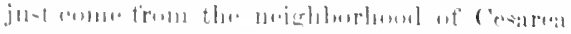

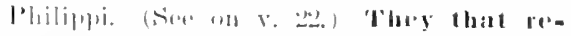

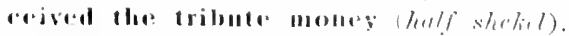

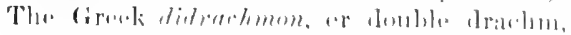

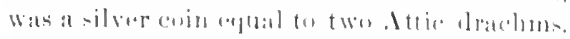
aml in the timen at the Now Thet. and

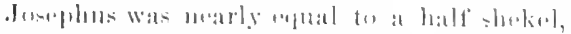
ar somothing are re thirty cents. "Triluste

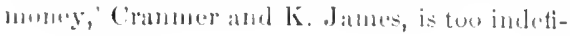

nite; 'poll money,' Tyn., Gen., fails to suggest that it was a specific poll-tax for the templo. It is better in such cases to une the difinite term of the original, and let this become matter of explanation. But as the Greek didrachin or donlle drachm is unfamiliar, it is couvenient to use the half shekel, the IInhrw shelol being familiar to us from Old 'Trest, Moses directed (Exod.30: II t5.) that whencier thr perple were numbered, every male over twruty years old should give a half shalin, rich and poor alike, for the support of the tabermache. Upon this Josials based his lamand for a special contribution to repair the temple. (2chr.21:6.) After the return from thr eaptivity, Nobemiah and his followers "marle ordinances"-not as being required liy tlie law of Nuses, but as a voluntary agrewant-to bay exery your the third part of a heliol (they were poor then), in order to pruvidesterifices, ste., fin the temple. (Neh. $10: 32$ f.) In thr. Mi-hma, a here in Matt., we mect with a well known contribution of a half shekel. Thr. Rabhis had krpt Nehemiah's plan of naking it annual, but had returned to the sum which the law of Moses required for the ncarional gift, and doubthess held that they werebut earrying out the law. The Mishna lat-a separate treatise on this subject. Priests, women, thillrem, and slaves, were exempt, but might give it the wished. The Jews in labestine were (xpected (Edorsh.) to give hefore the time of the Pasoover; those in foreigu anutries were allowed till Pentecost ur exwh Taberuacles, and there was a special chost in the tomple for contributions due the previnus yaur. Commisioners were wnt thromgh Palestine to enllect-'they that rereivel the halt shekel, distinct from the pullicans who obllected the government tax; in fimpign countries the money was depustud loy the leading.Jews in some fortified (ity till it could be escorted to Jermsalem. (in.." sut.." Is 9, 1.) ("icero states that gold was, very year, in the name of the Jews, exported lipun Italy and all the provinees to Jemsalem, and commonds Flaceus for prohibiting this expurtation from Asia, $i$. e., the region of 
25. The sath, lis. And when he was conde into lht house, desus prevelulel him, sayims, What thinkisl thes, simmo? of whum do the king- of the arth lake

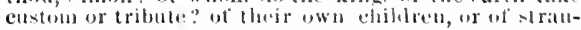
gers:"

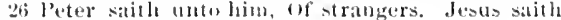
unto him, liben are the children tree.

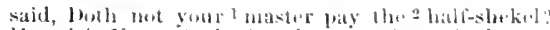

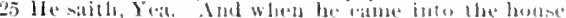

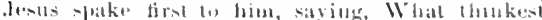

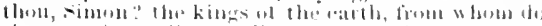

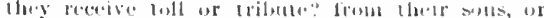

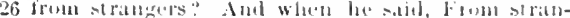

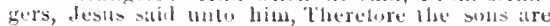

which Ephe-11- was the chiot eity. (Cicero,

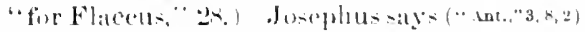
that the gith in Exol. $\$ 0: 11$ was trom men butween twenty and tifty years old, whirh statement makre it likesy that the atse was thes limited in his times. Which were these of thr. New Tistament. Alter Titus destroyed Jortusilem, Vepatsian derereed that the Jews everywhere"should bring two drachnsevely vear for the temple of .lupitar ('ippitulinus, a

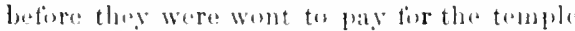

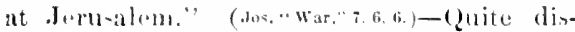
tinct term this yourly hatt sheliel. which wat required by ellstoms. if not by the law, were the voluntary antributions male at the templo, which valed indetinitely in amonnt. (Mark 12 a.) Entiroly listinct al-o was the tax (20:18) to the Roman grovermanent in Judeat and sambria, which two distriets formed at the time of our Iord's ministry a Iisman province.

It is not at all olear with what design the collector- a-kad the efurstion, but most likely in a reproachtul tone, as it he was -linhting a duty reesuruizal by all devout Jew. Doth

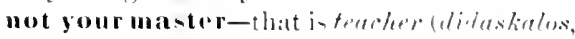

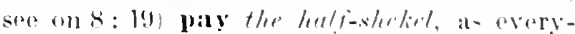

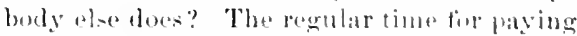
was in the spromer. while it wats now mat the

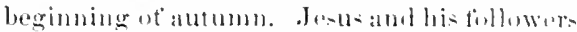

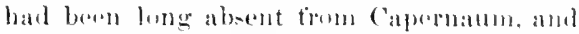

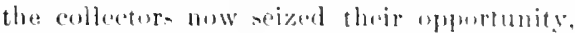

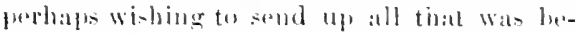
hind to the lobat at Tabernatelus.

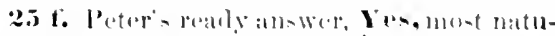
rally =llegests that Josu- had find in provious

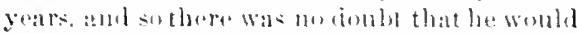
fay now. The tiace that Iatt. recerdethis inexdent wilhout any axplanation as totho nature and design of the contribution, is ane of the

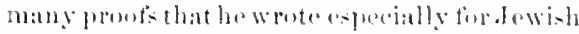
readers, fowhon the materer would be familiar. Into the homse, frobahly the housen

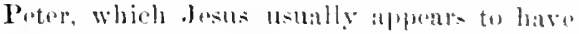
made his place of abode at Caneruaum. (comp). un $1: 13 ; 8: 14$. Jesus prevented,that is, spalie first to, him, salying. The Groeli

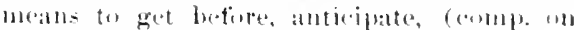

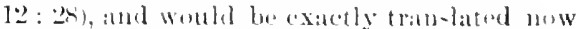
ly 'anticipated hill, sayiug.' 'Ty. and (iols.

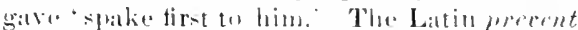
urierinally to combe befoles ) Was introduced by ( 'ran. and liheius, and at that time wits a

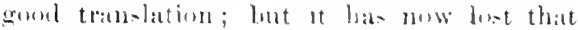
meaninge in Ener. and acomired a ditlopent semse, which makes it very mi-leatiner, (e. \%.,

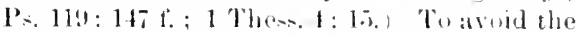
word 'anticipate, which is not need in k. Inume, the Riev. Ver. hat returued to spale tirst to him, a rather inaleguate rendering.

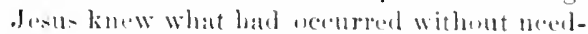
ing to betold. (Cumb. Juhn l: fic). Custom (rather toll), or tribute. The first Greok

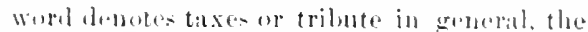
second is the Latin word crnses, which, from moanine a pegi-tration for the fulpuses of taxation, might nallually in the provineos be applinel to the pull-tax; its sollow lode and in 2.2: 17. Ot their own children (stmm), or of strangers? The litter torm

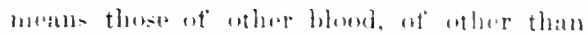
the royal findily. Then are the children

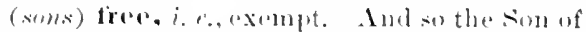

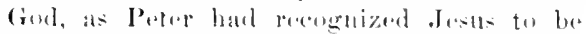
(16: 16), anglet to be exempted trom payeing tax

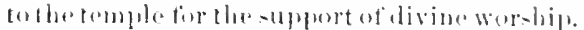

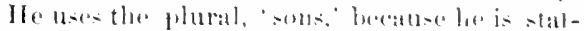

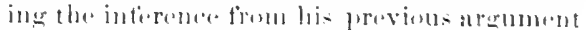

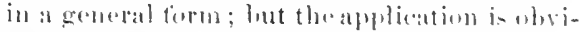

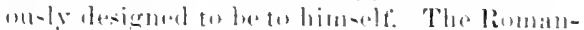

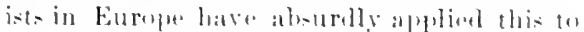

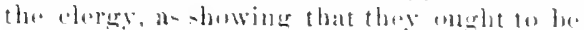
pxompted trone taxation, at any rate when it

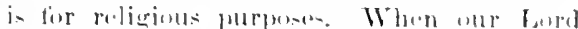

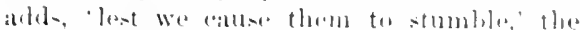

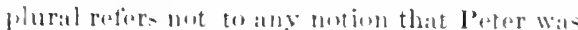
axempt, but tor the fact that P'etele at well as himselt had not patid ; and he promenls a direet has I'eter may paly both tior the Miser and himself: 


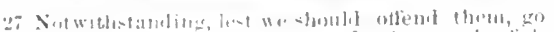

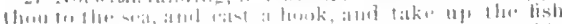

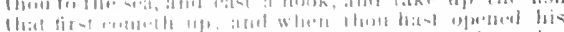

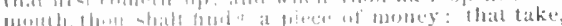

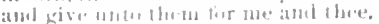

27 tree, Rut, lest we eause them to stumble, go thou (1) Ihe seal, and cast a howk, and take up the fish lhat first cometh thp; aud when thou hast upened his nomblin, thou shalt find a ${ }^{1}$ shekel: that take, and give unto them for me and thee.

\section{( II I P TER X VIII.}

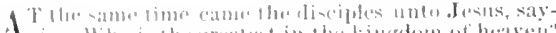

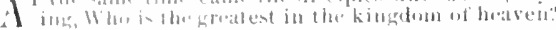

I In liat hun came the disciples unto Jesus, saying, Who l ben is 2 greatest in the kingdom of heaven?

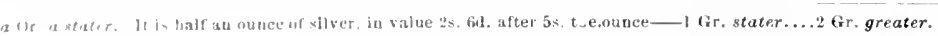

27. 1., we we homldoffend them, ar hettrer,

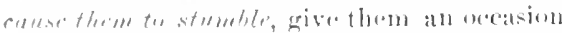

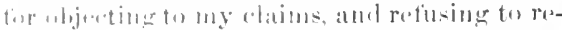

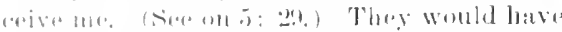
said that ho dis nut kesplo the law, did not por-

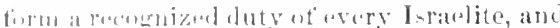

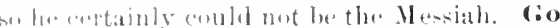
than to Hhe mate. The propestion is that

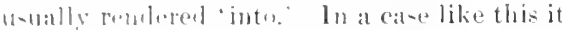
signilies intorlue locality represented in a genrorl way hy th" s"a, which would include it -hures. Whearo not at liberty te understand

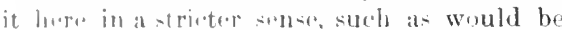

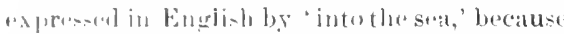

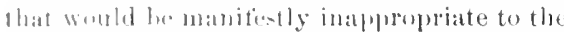
action which P'otor was to wrotorm, viz.

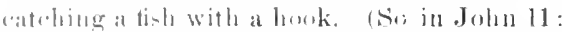

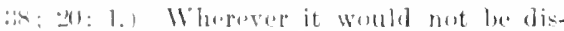

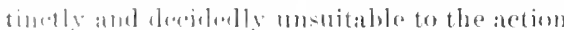
in equestion, fhe natural and commones serse of

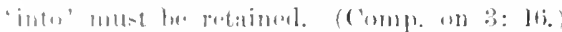

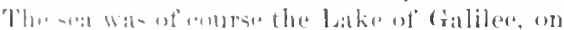
which ('atpromum wa-situated. (4:13.) Thou shatt find a piene of money, (a shelerl,

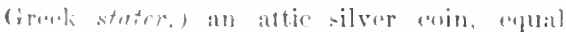

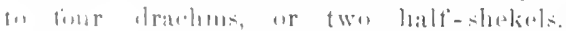
lor mo and thee. is -trictly. insteal of me. and there, the motion beringe of $"$ sulatifution. Which Was the original and

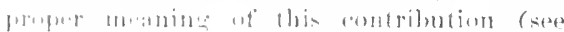

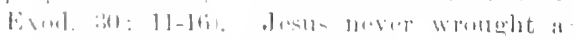

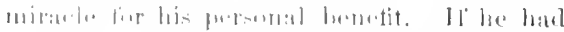

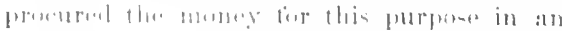

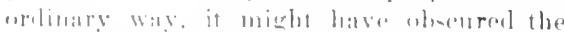

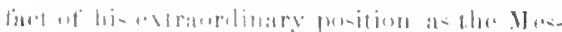

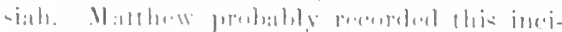

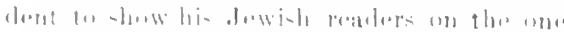

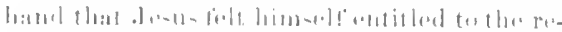

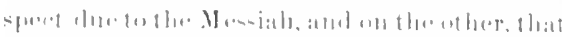

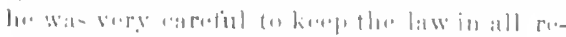

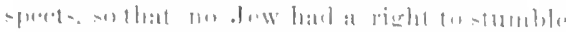

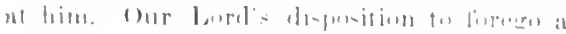

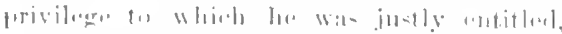

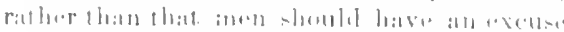
for misipprohending him, was imilated ly
Paul (J cor. \$), and stankls before us all as a lart of the example of Christ. A hook. Fin-hooksare mentioned elsewhere in the bible unly in Isa. 19:8; Amos 4:2; Hab. 1: 15; Jub 41 : 1, rete, and are not now used in the Latke of Galiloe. Peter had previonsly had experience of a miracle in catching fishes. (Luke 5: 4 ff.) Commentaturs compare here the story of the ring of Polyerates (Herod. III., $3(1-42)$

\section{HOMLETICAL AND PRACTICAL.}

V. 24-27. Jests giving for the support of the temple. 1) He takes pains to avoid being mistuderstomd; (a) speaking so as to prevent Peter from misunderstanding him; (b) acting so as to provont the Jews. 2) While avowing himself the Sim of God, he performs every duty uf a gond man (eomple : : 15), including that of taking part in religious contributions. It relinquishes an avowed claim to exemption, lest his enrse should injure others. Comp. 1 Cor. \& : $13 ; 9: 12,22$.

Ch. IR: I-I 1. TIIE NubJects of gul

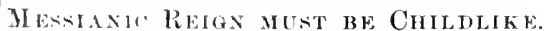

Wrare alproalching the elose of our Jurd's mini-try in (ialilee. (19:1.) Convinced that their Master is the Messiah $(16: 16)$, the diseiples begrin to tispute which of them shall have the highest wfice in the Messianic kingdom, which they conceive of as secular rather than spirifual. They hring him this question, and ly says at once that only ly being childlike "an they have any place at all in the Messisula kinglom; it follows that the childlike ought to be roopived for Christ's sake, and that any une incurs great guilt who eauses liom to sin (v.5.9); and they must not be 1] depisol. for the saviour and the Father are

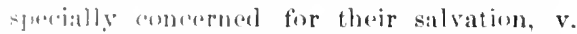

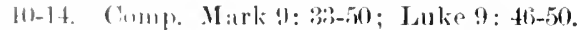

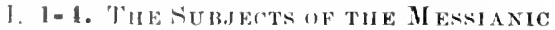

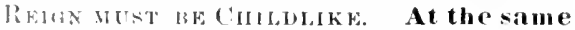
time, or in that hour, is best taken strictly 
2 Anl gesus callect a little chitd unto thim, and set him in lhe? minlst of thesu.

(10:19;:6:45), but may mo:an mores gonorally, at

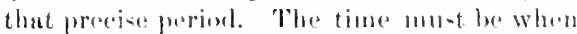
Jesus was in the houre at Citfermatum (17: :5: Mark 9:33), and prorhats while l'eter was gumb to fint the shokel. Came the disciples unto Jesus, saying. Luke, in his very brief' aceount, spealis only at' besus as saxing the reasoning of their henrl. Mark saysthey had "dispoted one with another in the way"

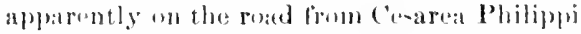
to (apernanm (emmp). on $17: 22$ ), and that

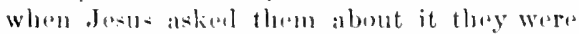
silent. Not kmowine all the cireumstances. we nead not he mervemsly anxiote to harmonizes these alcesunts; but it is not dificult to suppore that they eame introlung to ask him the quention, but lositated; that perceiving their tlumglit (Lules) he inquired, and they were at first silent ( Mark), hut at length spoke(Mitl.). Who, literally, whothen, who in the state of things present to their minds, implies some porious oceurrence or ambersation which led to the inquiry, and this may be the eonver-ntion to which Mark refors.

Is greatest in the linglom of heaven, $i . e$.

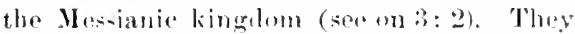
were thinking of it as a temporal kinglom, in whieh there would of eonrso be higher and lowerefticials. 'Createst' is literislly 'areater,'

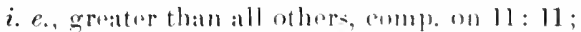

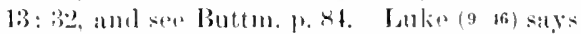
that the point in theirthonehts was "which of them should be greatest ; but lhey asked the question in a morn general form. Nuties that the tispute chesely fullows a prediction

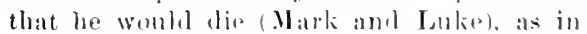
similar cases afterwaril- (20:20: 1.uke 22:24.) Convineed that he wats the Me-sials (16:16). and sut moler-tanding bow be comble literally rise again (so(e 11$)$ 17: 9), their minds

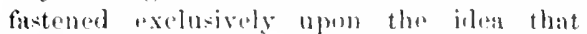
somehow or othor he was about to set up a Mresianic lingdom. (16.24) And though he land recently drelared it imposible to follow him sive in self-renuniation (16:21), they wore intent on selt-aggrandizement.

1 The simple Grek verb strepho is everywlere else In New Test., correctly translatud by tom. Ver. 'turn.' The compound epistrepho it renders 'eonvert' in 13: 15 (with Mark 4: 12; dobn 12: 40; Acta2s:27); Luke 22: 32; Acts 3: 19; .lauses 5: 19 1. All the precelling Eugtish versions had given 'contert' in Luke, Jobn,

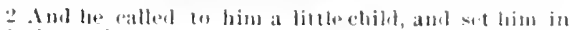

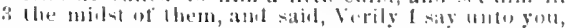

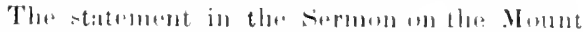

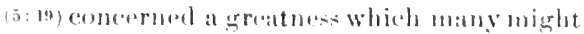

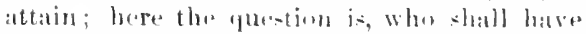
the single highent plater. ()ur Iard lial

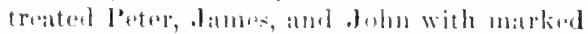
di-linetion, in permitting them alone to witnoes the Transtignration. (17:1.) Forlidalon

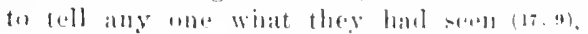
they would maturally saly an to the atlere disriples when askesl whome they and the Master

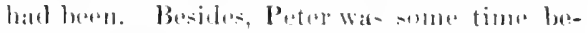

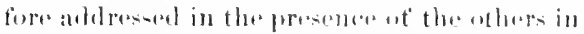
a manner which eaves him sperial prominence. (16:17 t5.) Ane? just now Jeros hats direeted that l'uter's temple-entributions shall br paid along with his awn through a spredial miracke, takiner monticent the ol brers. Abesut six monthe later, wo shall find bances and John, with thoir nuture as -pukesuman, acetually requesting that they may have the two higher placen in tho kingdons (:0::0), and the

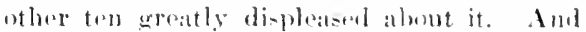
the dispute will he renewed aven on the nirht before the arucifixion. In to the probible grounds for individual claims of presmi-

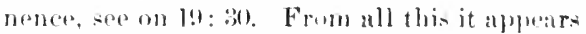
that we here rench a turning-point, the elis. ciples beginning a contuntion which will be rimewed mututhe end.

2-1. A little child. The henter was probably that of Petor (17:25). and so the child may have hern lenter's child. Called moto him, shrues a rhilel able to walk; it rould sit by his side (Lukm), yet was small emough to he maturally talien in his arma (Mark), and su yollug at to he ape propriately a pattern, to athord an alject-lose

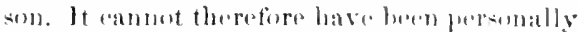
a believere (r.a). A late tratition makes this child Igmatius, martyrol alunt A. H. 11.5, but it is wiflosut antlurity, aul avidently arone from a fanciful misinterpretation of cerfain phrases in his lottors. Verily I say unto yon, indieating something very important, see on 5: IS. Except ye lue converted. ar tern, viz.. from gour present sintiul amhi-

Jabues, Acts 24: 27; in the uther passagras, lyo, and one or lwis uf his followers gave the Anelomiaxin 'turn.' (Comp. on 13: 15 and : 3: 2.) "Turn' in in the"

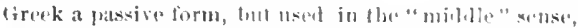
equisalent to the English andive intrancitive: on it is properly trauslated "turn,' and not "be lurnet " 


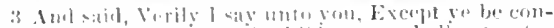

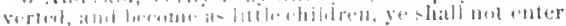

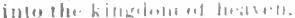

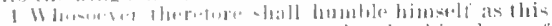

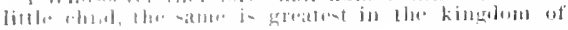
latiblith.

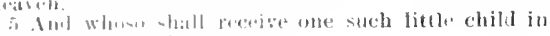

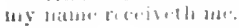

Except ge turn, an l becone as little children, ye shall in no wise conter inlo the kinglon of fueaven? 1 II hosener therefire shall humble hinself as Itis littl. ('hild, the same is lhe 1 greatest in the kingdom jof heaved. And whoso shall receive one such litle

I Gr, greater.

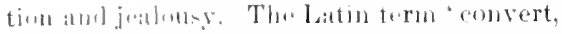

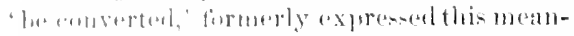

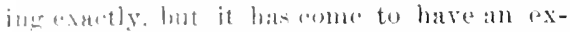

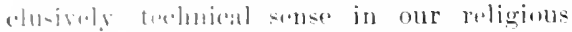
nistere, whinh makes it quite misluading in

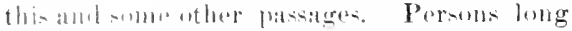

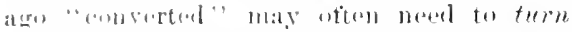
from sume wromg protice or dispestion. And hecome as litte ehildren. Lilie other illu-trations. this must not low rigor111-ly promete Littla children are by no

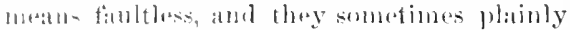
slow any and jealomsy. But we naturally rogumb a liftle child us a pattern (i. e. eomballed with ablalt-) of tember atfections, com-

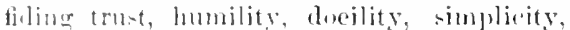

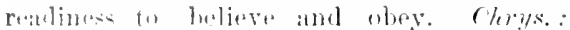
"Buth foum anve the little child is jure, and from bajuglory, and from longing for the

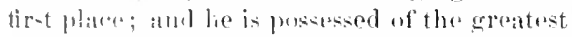
of virtus, simplieity, and whatever is artless and huls. . . And therhild which he

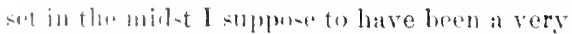
Follus ethild indered, free from all these pas-

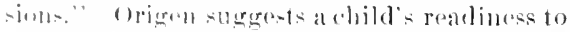

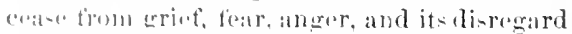
ot somal li-timeliom ammone its playmates.

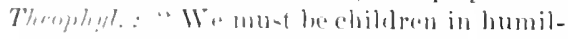

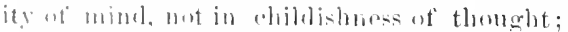
in luing withunt eril, not in being withont wh-n" Jo shall not, simply the strong

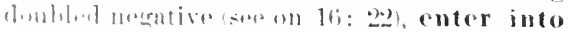

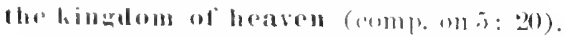
While thege are dieputing wheh is to have

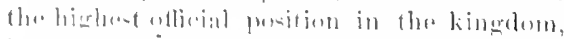

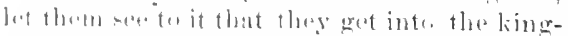
Jim at all. This interpertation of the olyectlanom i- muitterl here ly Mark and Iuke. who hewerer give the-ame thought as spolien

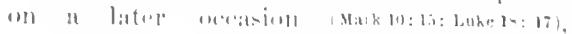

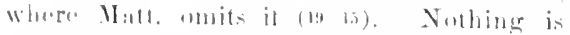
more natural than that an Wrighty n sentence

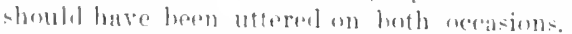

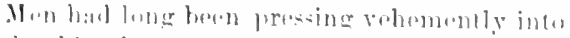

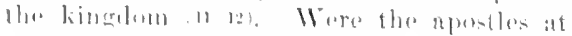
this moment still cutimely ant of it, still ans- renewed (Jomo $3: 3$ ), essentially destitute of saving faith? They would deeide this question by turning from their worldly anbition and jealomsy, and becoming childlike. Judas, for example, did not doso (John 12: 4.6), for lue was not at child uf (iukl, but a 'devil.' (John6 - iof.) Whosoever therefore. Since in general, they must rexemble little ehildren in urder to enter the kingdom, it follows that whosuever shall humble himself as this litte child is humble, will be the greatest in the kingdom. Inmility is thus presented as the frincipal thing in a child to be imitated by Mesiahs suljouts, and in that the disciples hakl just shown thomselves partieularly lacking. (Observe that the question was particular. 'who'; the answer is general, whosoever.' 'Shall humble' is the sime root as 'lowly' in 11: 29); eomp. 23: 12 'As this little child' humbles limself, would be grammatically possible, but is forbidden ly the connoction. The same is (the) greatest, with tho article, because a definite person ((十)II) V. 1).

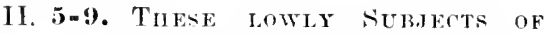
Mesilal shoted be hingly Recerved, AxH SHULD NOT BE LED Ixto SIN. This is a linetrol truth, suggested by the use of the littlu rhile as an olject lesson. In my name, literally, upon my name (as in 24:5; Acts 2: 38), ('hrist's namo being the gromnd of the ropeption-receiring not on the ground of di-tinction, wealth, personal agreeableness, ete., but on the ground of Christ's name. (comp. on $28: 19$.$) One sueh little ehild.$ Si) Mark, 'one of sucl little clibldren.' These expresions do not refer to the litral elild, but to the chiddike believer. (comp. v. fi.) (lirys.: "Br a little child here, he mean: thomen that are thus simple and lowly, and alijort and eontemptible in the judgment of the eommon sort." If we bear in mind the frepuent association in Seripture language of luwly spirit and lowly lot $(5: 3)$, it will seem likaly that this latter ilea enters here, as it cortainly cives in $v$. 10 . The reference in 
fi Rut whoso shall oflend and of three little moses which helieve in me, it were trotur tor him that a mill-

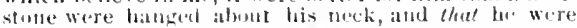
drowned in the rlophts of the siat. f child in my nane roceivell mo: but whus shall

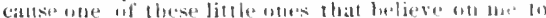

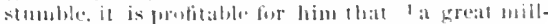
some shoulil be hanged abuat his neck, abd thot lie

1 Gr. a mill-stone turned by an ase.

Mathew and Mark then, is platinly to the

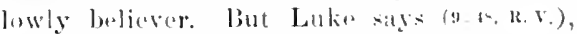
- whasever shall reecive this little child in my name.' Lukes account is very brief, minting the serings of our $x$ : : and $r$. 1 .

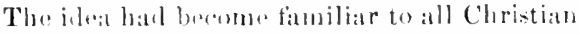
minle that olews ueed a little child for an ubject-les-on, and so it is likedy that Lulie In "ant "this litthe child ' representatively, the lowly heliever whe is like this child. Oosterzere (Lamee): "It in selterevdent that the axpresion is alphlicable. mot to the ehild in itoelt, but to the chibla a trpe of childlike minds." The wasl interpertation is to this offect. If, bowerer. we unleratand receiving this litte child itolf, thre idea will still be to receive it, not for its wan calie, but 'in my name, and thus as the sartions pattern (Woiss) of what his dieciples onght to be and that involves an honest desire to be what the pattern propeses. The di-ciplde were in a jealous inend, not dispered to be lowly themselves, wor to treat the lowly with lindine.. Jesus teatehes that his followers, thomgh they puses no earthly gramelemr, nu place of poweratul pridm, should be recervent in his name; that te receive the lowliet Christian in chariuter and ondition -yea, torecesion at little chibl as hi-appointed pattern of semels lowly character-wouled be receiving Chrint himself'; and Mark and Luke ahd, "whosueror shall receive me receiveth bim thit sent me. (Comp. on lo: tol i.; 25: 40.) Reeriving bere sem- to denote. not

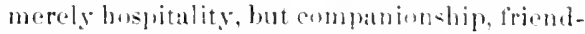
ship, ete. There who are not [eromally or socinlly attractive may be heartily reseived as Christ's representatives. Obrerve 'one, to receive aven a single such persun in to receive Chriat.

(if. It this point, as recurded by Mark (9:34) and Lulie (9:49). John interrupted our Lord. The idea of receiving in his name

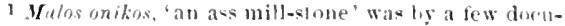
ments here, aml by many in llark, wanged to lithos mulikgs, 'a mill-stone,' through assinulation to Iake 17:2, where alos many documente changert in mulos onikos, like Mathew anil Mark. Such examples show the habits of cuprists. - For the noufiual use of hina -llgerested at resent oceateion on which Juhn

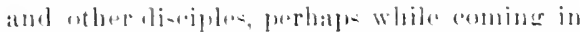

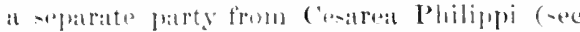

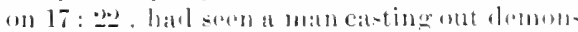

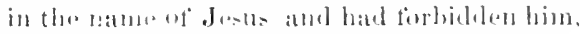
beratese le did not join then in tollowing Je-1ls alout. The Master" = beatutiful alud instructive reply (with which comp. almee

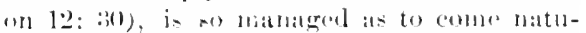
rally back to the suliject be hatd just terached upon before the interruption (comp. Mark 9: tl with 4:). Perhalp Matthew's reatum for muitting the incilent wit his anxiety to preserve the continuty of the dis-

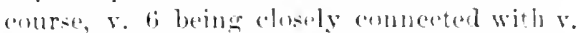
5. In s. it the thought was of revereing one -uch little child; here it is that of cansing such a une to sin; afterwarls the diecouree pares by natural association of ideas to vilrious persols and things that cause men to sin (จ. .9 ), finslly returning (s. n f.) to another thought concorning childlike believers. One of these little ones which believe in me (see also in Mark $9: 42$ ). shows that the reforence $\mathrm{i}$ - cortainly not to uneonecions infuntbut to childlike loblesers; this would serom to settle the que-tion as tor $r$. 5 and $v$. $l 0$. Comparatively young children are sumetimes believers. hut infauts cannot be (comp. Bezal. Offend-or, centse to stmmble, or to sin, see on i: :29. It were better (ur is profituble) for him, viz., in eomparian with the fate that a wait= him. So nn a later oreeasion. roke 1a:2.) A mill-ctone. The ordinary mill-etune. turned by hand $(2+4)$, wa complatitively small: lowo it is Rev. Vor.. matrerin) 'a millstono turnod ly an as:, whicls would lye quite large, and this makes the expresion very strong. Fqually strong are the phrace drowned, sunti. tor the very buttom, anl in the depth of the sea, fir from the shore. where the seal is deep. Druwning was a pan-

and the subjunctive, "that... should be hancel, sue on 5: 2o. Merer's allemp to make hind lase express purpose, only showsthe imponilitity of matntaining the ground that in the New Test. it alway has that sense. 


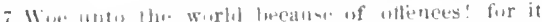

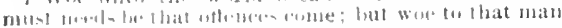

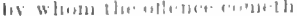

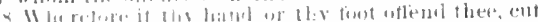

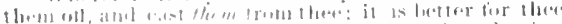

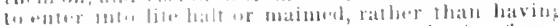

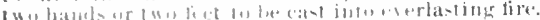

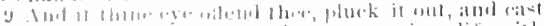

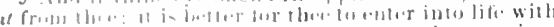

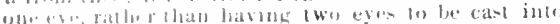
bitilin

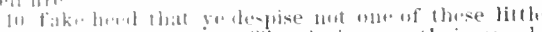

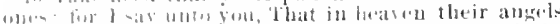

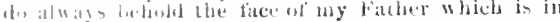
litation.
7 should tresunk in the depth of the sea. Woe unto I ht. worlol hecaust ot' oceasions of stumbling: for it must needs lie that the oecasions come; but woe to s lhat man through whom the occasion cometh! And if l hy hand or tiry font causteth thec to stumble, cut it 111 , and cast it trom then: it is goor for thee to (nter into lile maimed or halt, lather than basing two hands or two teet to be casi into the eternal fire.

9 Aud it thiu" eye rausetin thee to stumble, pluck it out, atul cast it from thee: it is guod for thee to 'uler intolice with oue eve, ratluer than having two

10 "yes (o) be ca-t into the lieh of fire. See that ye despise but one ot these little ones; for I say unto

I Gi. Gehenna of flre

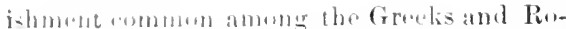

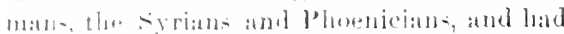

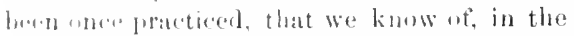
Lalie ont (ialilaw, in the early Jart of Herod's

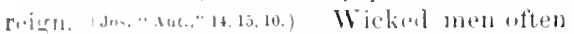
thimli it erpeat sport to imfluce a Chri-tian to

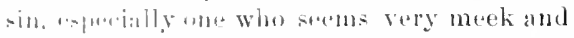
groute. Ji lowy ath make him violently angry, or lond him into expende levity, to say

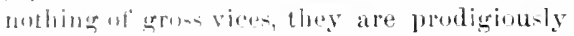
atmusal and erratifed. Fueh perams ought to

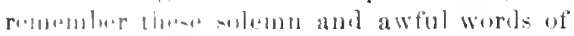
the campisimate savinur. Woe nnto the world beciume of offences, of occasions of

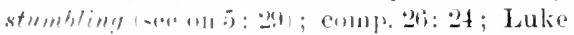
17: 1. Thenphol.: In his philatuthropy he lament- war the world, as destined to be Aamatered hy Hastumbling-bluselis. But why mal ratlor hrelp? Wratu-wer, that lamenting

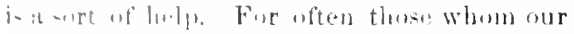

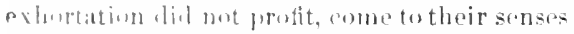
whell we laturent wrethem." For it must

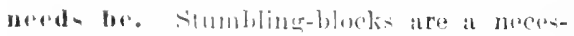
ary lart uf a -tate at prubation and eorreot-

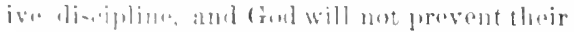

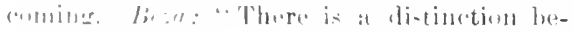

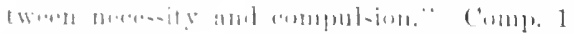

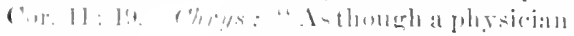

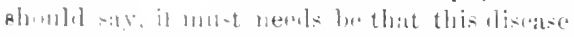

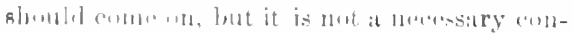

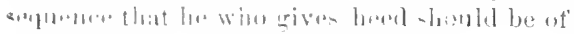

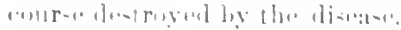

$\times$ f. Havine flamn thu eruilt of rotusing lowly clorintiand to - tumble, he aldrerts do

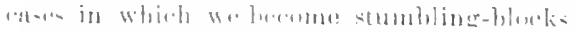

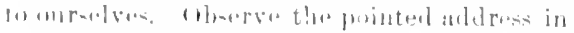

the seeond prrson singular, thy, etc.; comp. v. 15 tf., and see on 1: : 2. For v. $8 \mathrm{f}$. see on 5 : 29 f., which is substantially the same. Cut it off, is the correct Greek text, easily changed to cut them off. Mark $9: 48-50$ adds some kindred solemn thoughts.

III, 10-14. These Lowly CHRINTIANs MUST yot BE DEspised. The idea of childlike or lowly character is here connected by a natural suggestion with that of lowly station, Junble circumstances. The same assuciation of ideas is seen in $5: 3$ and $11: 5$, and probably above in v. 5. Little oues here denote, not little children, but childlike believers, as in v. 2, 6; so the Fathers, so Calvin and Beza, and nearly all nodern commentators.1 Men are very apt to despise Christians on the ground that they include so large a pruportion of persums in humble life, poor, and often ignorant ( $\mathrm{cor}, 1: 26 \mathrm{fr}$ ); and their very humility, though one of the loveliest of all human dispusitions; is regarded by many proud. ungodly jouple as nothing but mean spiritedness. To prevent despising a single one of these little ones, lowly in character and lot, our Lord calls special attention to the rason which follows.

I say unto you, see on 5: 18. However humbl. in the estimation of worldly men, helievers have angels as their attendants, sent forth to serve Gorl for their benefit leb. 1:14t, and then angels of theirs enjoy in heaven the highe-t diendey and consideration, like pernus admital to the very prosence of a monatrch, and allowed, not once, but continually, to buhold his face. The sechusion in whols

\footnotetext{
Jew low distinguished from those of Christians?" Does nut this involve the notion that infants dying unbapti\%ular. but: To find the very apostle of justification hy fith saying that a little chill becomes a believer liy being baptized, is humiliating aud disheartening.

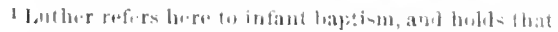

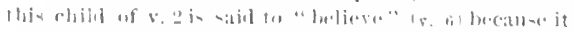

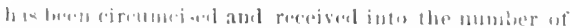

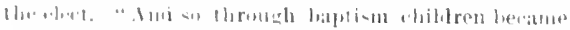
letievers. How edse conlid the ehildren of turts and
} 
11 For the sion of man is comet to save that which wats lost.

Orimatal momareh- live mate this image very expresive; see 1 Kings 10: 8 : 22 King25: 19; Exth. 1: 14; Tub. 12: 15: Luke 1: 19. and comple abowe on $5: x$. surely they who have as their attendants thene ligh and honored ministers ut the eourt of heavell, ato not to be derpised, whatever may be their earthly eondition.

There is in this no sufficient warrant fire the popular notion of " gruardian ang(rls," one angul e-pecially asoigated to each individual; it is simply said of bedievers as a chass that there are angels whicla are their angels; but there is nothing here or ekewhere to show that one angel has special charge of one believer. Janiol and Zechariah spok of the angel of a particular (e) untry, as the angel of Persia, the angel of Greecer we know mothing beyonel the fact thus revealoel, nothing as to the nature or rextent of the protection or infuence implied. But the Jews were not satisfied with this idoa of mational influedee or guareliamship, and adraneed to the notion of a guardian angel for anclo individual, as in the beautilul story of Tubit, and in the Rabbinical writings. Comp. tle Groek fincy of a guiding and protecting daimon, a s suken of by siocrates, and e-pecially by Epictetus ll. 14). The disciplas who were praying for Peter during his imprisomment, when tlangir insisted that he was at the gate, sprang to the comelusion that he had just been put to death and this was "his ungel" (Actat: 15), ate(e) reling to a notion that a man's guardian angel was apt to apprar to friends just after his death, witlı his form and voice. But the views of these di-eiples wero erronemus an many subjects, and are not an anthurity for us monless sandioned ly inspiration. It rannot be perstively asserted that the jideat of guarlian angels is an error, but there is 110) S(eripture which proses it true, amd passages which merely might be understond that way do not suffice for the batsis of a doetrine. (O) the other hatud it would appear that not suftioiont importanee is popularly attached to the ageney of athgels with reforeme to Christians in goneral. Ther are reprosented as Goul's me-sengers (both the Ilcbrow and Greek works signifying meseenger), and his agents in both ordinary und extraordinary yon, that in he:ten their angels de alwas bulathl

matters with roference to the budien and the

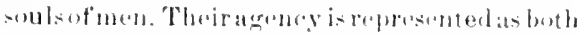
concourrieg with, and antrolibur, the atetion of physieal caluses. They minister to froml onbecially for the benelit of them that shail inlerit salvion (11+b) 1: 31, whele "mininter for theme really meant this, lut i= popmlanly misumelersond as meanime ninister to them). 'They protoret the humant servant of

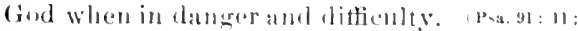

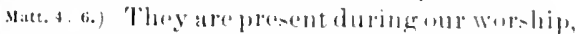
and we are anjoinded to prearerve dacoruma

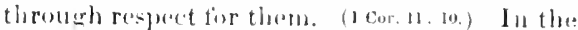
judgument they will be agents in separating the rightems from the wicked. (1: $11,24: 31$ ) They ean doubtless reach and atteset our minds in the same way at is lome by satall and his subordinates, all ot whom alpuar to bes merely lallenallgels; but like lotumantestelers, they can intluence the mind to spiritual groud only ly the lielp of the Iluly sipirit, while our fallen nature oflers itself readily the the inHuence of the fallen angols. While aroiding all meros sentimental tancies about the angels, and arorything that appreaches to

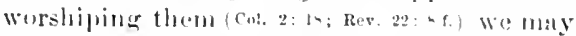
well fecel for them a pernotial gratitude amb affection, as follow-servants of fiod amel axalted friends to ourselyes. The (andonom motion that human heings may beeome anguls atter death, is utterly unsoripturat. The redesmed in slory will "juder angels," involving superiority wer them. (1 cor.6.3.)

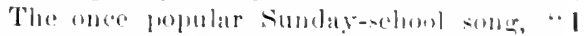
want to be an angue," is quite misluadiug. It may be added that the word "andernl or 'mestengor' has some other applications in seripture, as to prophets (I:a, 1 13: Mas. s: 11, t1? priests (Yal, 2: i), and to the comminiojuer of fiol put in charge of a partieular churels. (Res. 1:20:2:1, etc.)

11) 12-11. There can be wo louht that v

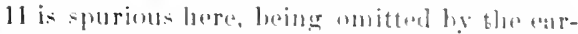

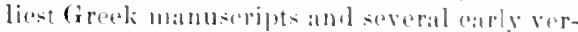
sions and Fathers, and manitiotly burrowed

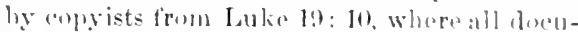

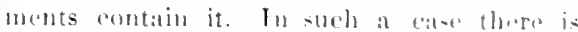
uothing lost to seripture as a whole. (hur Lord here gives a further rason why no one should despise his believiner littla onces. (r. 10,14.) One of them maly serme to man ats 
12 Inw lhink y." if a math hast a hundred shesp,

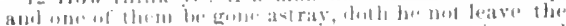

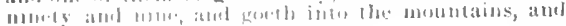
ankell that whieh in guthe astraty?
12 the face of my fatber who is in heaven. 1 How lhink ye? if any nan have a hundred sheep, and one of them loe gone astray, doth be not leave the' ninety and nine, and go buto the montains, and

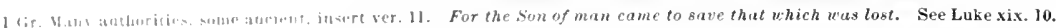

muimpurtant at a single -horep gene astray from a latret thek: hut the kindly shepherd

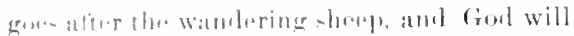

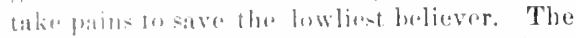
salue fortalublic illu-tration was amployed on

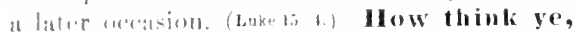
or, whet do you think? II" aplpeals to their awn- - $11-12$ at proprioty and judgument of probubility, ande, 1 Corr. 11 : 1:. And goeth into the monntains. "lohe (iresk of the common taxt is ambiguon-, and might mean "dofle lar mot leave the ninety amd nine apon fles montutails and go and serk'; and more

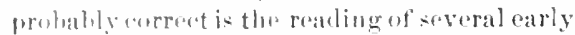
flemmonts will lue not leave the ninety and

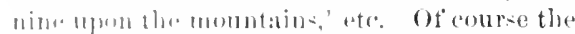
suliatantial senos is the samm. Betwoen the rauliug your Father and 'my Father' (lire. Vir. marefin), it is ditlieult to decide, as the latter, though strongly attested, may have (u) frum v. 10; the liflerence in meaning womld he light. That inv. 14 represents "freculiar (irack anntruction, explained on $5: x_{1}$ oburse 'ome of thresp little ones, as in $x .12,10,1 ; .5$. The appliation of the pasathle in r. 14 wenlet be inexplieable if "little mu. meant intints as distinguished from

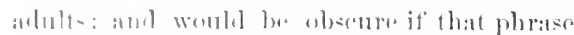
meant-imply buliever- regarled as humble in

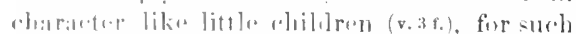

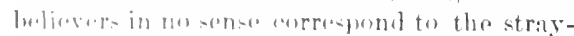
ing -hane. lint whan there lats besen intro-

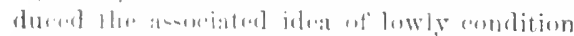

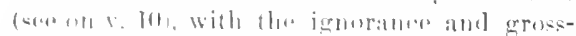

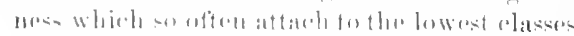

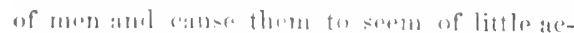

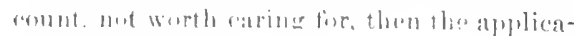
tion linerenter platis.

IIU)I.FTH

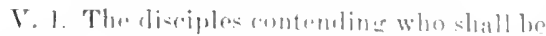
gramate 1) This shows that these wore like

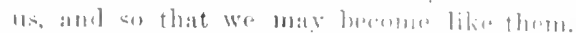

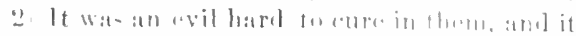

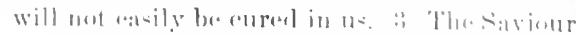

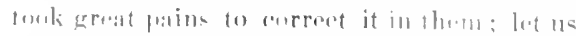

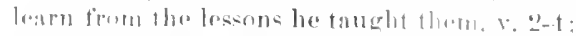
Luke 18: 14; Matt. 20: 21-20; 1,uke 20: 24-
27 ; John 21 : 15.-V. 2-4. Our Lord's objectlessons. (Comp. the old prophets and Aets 21: 11.) 1) The scourge of cords, John 2: 15, comp. Matt. $21: 12$. 2) The little ehild, v. 2, comp. 19: 13, 15. 3) The barren fig-trese, 21: $18 \mathrm{t}$. 4) Washing the diseiples' fect, John 13: 8ft. 5) Batptism. (j) The bread and wine.Christians must be childlike. 1) Not in mind and speech, 1 Cor. 14: 20; 13: 11. 2) In humility and freedom from jealousy, comp. 1 Cor. 14: 201. 3) In teachableness and submission to divine authority, comp. Eph. 6: 1. Vixet (in Lutter.): "While in the world the teacher says to the child, behave like a man, Jesus Christ says to the man, behave like a child." IIENRY : "Humility is a lesson so hardly learned that we have need by all ways and means to bo tauglit it. When we look upon a little elifid, we should be put in mind of the use christ made of a child."-V. 4. Our Lord's lessons in humility. 1) Precepts, $20: 215 \mathrm{f}$; 28: 12. 2) Illustrations, Luke 14: 7-11; 18:9-14. 3) Object-lessons, v. 2-4; John $13: 3 \mathrm{ff}$. 1) His own clatacter and example, 11: 29; Phil. "2: 8. Cinrs. : "Where envy is and love at' glory, there even sincere friendship has nostrength. Fur as those of the same craft cannot love one another with a perfect and genuine love, so is it with rivals in honor also, and with them that long for the same worlaly objects."

V. 6. Leading Christians to sin. 1) Why wickod men do this. Foramusement, through (ontompt (v. 10), to quiet their own consciences, to promote their own sinful aims. 2) How wioked men do this. By intentional aximple, by protendad triendship by argument, by flattery, by ridicule, by sudden temptation of the senses, ete. 3) Wherein lipe tho guilt of doing this. (a) It shows delight in sin, and makes one a willing helper of' Siatan. (b) It slows hatred of holiness, and "porn hostility to Gorl. (e) It is doing the uroutrest possible unkindnoss and injustice to a fellow-creaturo. (d) It reacts upon one's wwn soul to produce a yet more aggravated wicliedness. Thus may we partially see the ground for the saviour's awful warning. 
I.3 And if so loe that he finel it, verily I say untw vou,

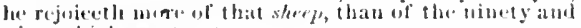
nine which went not aslaty.

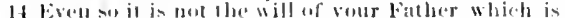
in beaten, that nace of thes. litte ones shomld perish.

1.5 IIorenver if tly hother shall trespas against

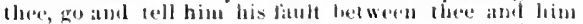
alome: if he shall lear thee, thou latst gained thy brother.
J:3 seck that whiche guetle astrats Aud if sor he that

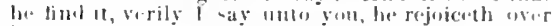

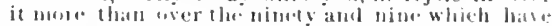

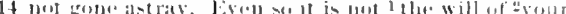

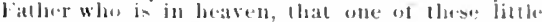
(1) monlal jerials.

I.j And il thy hrolher sin 3 against there, go, hatw him lis lault lexwers the and bim alone: if he

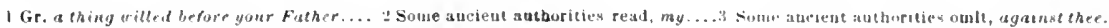

Comp. 25: 15. - 10. Doppisinge ('hrisians. 1) Why ('hristians are oftend deptisel. Matuy uf them are ignorant; most are pour; they eschew lashiomable viees; they will not defend their lomor ly brate foree; their sorion-ness and be ea-ily rilliculeel ; their lumility can he rogareled as nutan spiritrelur.s; their grouduess ran he represunted as hyporri-y; their faules attrate attention by contrast with general amol condust; they ofturn incur reproach throngh unwise action when thoir intentions are good col. 1.5). 2) Why ('hriatian-ought not to be lentised. They are at leat trying to do what all onght to be doing ; many of them are without repronels and abuve stl-picion, and silue are the axellent of the oarth; they render groat serviow to so)ciety (5-138) ; all real ('hri-tian- are childroll of find, who sends angels from his own prosence to care for them; they will finally become froe from all fault, and grlorioms forever (v. 14). Curse. "Sor hy low manythinges ho is urginer the care of anr moan hrethron. siay not then, storle a me is a biacksuith, a shomaker, a ploughman, a find-and so despise him."

18:1.5-3.5. HOW THDE.L WITH A BROTHER WHO IAS WRONIERU TS.

This is found lure in Matthew only, thoterh soment the expersions are paralloled on other oceasions in lake. The dinciplas having

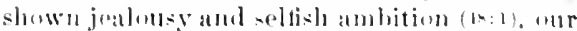
Lord uread mosn them humility and mutual kiubluss, and printed out the erreat wirkelness of eatusing the humblest ('leristian to sin.

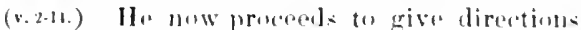

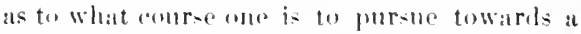
follow-christian who hats sinned. This is dividul into fwo parts. (1) reforts to win batek stich a hrother, v. 1.5-21; (2) readiuess to for- give grent and often repreated offenees, s. $21-35$.

1. 15-20. EFFORTS TO IIIN Bark A BRUTHER WIO UAS SINxEl, It thy brother shatl trespass, or sin. The addition in the common text actinst thee, is wanting in -everal at the carlier ducuments, and was elouletess lerouglit in hy (o)yists from v. 2l, ju-l as in Lnke 17: $: 3$, it was inserted trom the noxt verse. In this genural form the elirections of lle jasisan apply to all attempts to win hatek a hrother

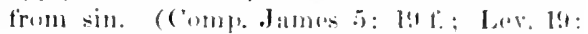
17.) To act quietly, and if posible privaldy. is hardly less important in other casese dlatu when the sill was agatiot nurselves. Sill. the following context suerests frersonat ofloneds. and that is still more plainly the caso in Juke

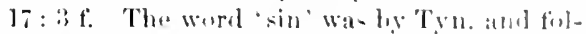

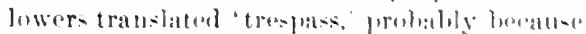
that word is ased in 6: 14; and they tran-late it likewise in Lake 17: : f. Notian "th" brother.' the fulluwing precepto lesiner fir individual action (v. 15-17), after which horeturess

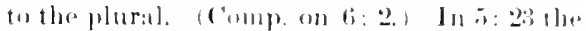
injuror is aderesed; here it is the injurenl.

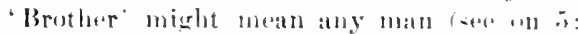
w2), but here means a hruther (christian, a shewn lis the reforestee to the choreh in b. 17. Cio nud telf (shom) him his finte 'And' after 'gen' is omitted liy tho arrecet text. The word monthe gre right aholles. as in 4: 11; 5: 24; 13: 44, ete. Show him his fatult is, more strictly, conviot him of his fatult, as in Johns: 46; 16: s; Jame-2: : T. Th convinces a man that he las errenl, esporially that he has wronged the person addresing him. is a ditliende and dolicate tals. Soms wion andusels were griven in lecelus. 1!1: 1:-17. A famotus Rabbi of lator times satd (Wün. '. I

I Wutiug in N B, three eursives, Thebaic, Origen, Cyril, Basil. Internal considerations seem to sette the question. The worls were easily introluced from $x$. 21, and agree well with the connection. We cannot

conceive of a reason for tlueir omicsion if ariginally present. Sil we must regard them as a spuriuus aldition. In Lake $17: 3$ the ducuments which und are much more numerous. 
lii But if he will nol hoar then, then takes with tlews,

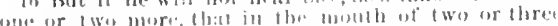

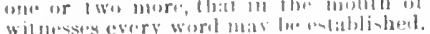

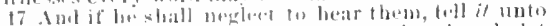

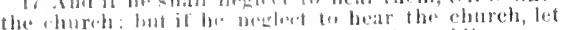

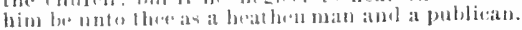

16 hear thee, thou hast gained thy brother. But if he hear the nit, take with thee one or is wo more, that at the mouth of two witnesses or three every word

17 may be established. And it he refuse to hear them, tell it und the 1 church: and if he refusc po bear the lehurch also, let him be unto thee as the Gen- womder whaluer there is any one in these

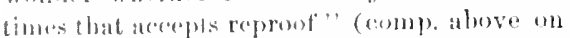
7: t). Anothrer replied, "I wonder whether" any one nowalays knows how to grive adunonition." Hotween thee and hin alone. Thus the injurer would be more likely to anklonwledge his fault than if approached in (o)mpany, so as to arotlse his pride; and thus the dibieulty if sottled need nover be known it all. 'Wou hast sained thy brother, miglit matn only gained him for thyselt, but probably means also (Ewald, Meger, Meins)

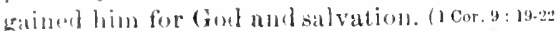
1 leeter 3: 1.). In, al at, the mouth of two or three: witurssos. Il woulal seem to us more natural to say 'two ol three witnesses, but "two witheses ar throe, is the cireole order, and so in 2 Cor. li, : 1, both corresponding to 1)114. $17: 6 ; 19$ : 15. (ompl). Joln 8: 17; 110l. 10: 2x. There is nenthing to forbid the 'une ar two more' from also helping to (unvinter binn. But wible these ar witnesies he

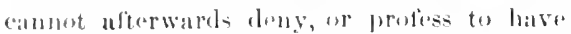
torgeten, what he hanl comereded. And if the matter has at last to come before the ehumel, these witmoses cath declatre what basen in the private intorview.

1\%. (boly ax a thirl stap, when the two more private allorts hate fitiled, must he tell

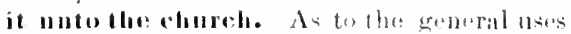

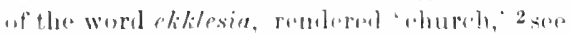
on lli: 28. In the plosent passage it rannent

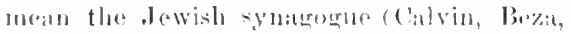

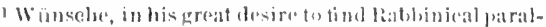

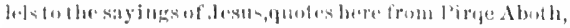
"He that bas won many for gouml, threngh !:al no sin

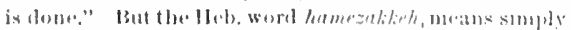
'he that makes pure, willunt any molion of winning

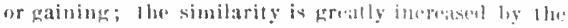

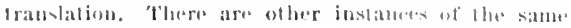
sort in his useful collection.

2The English worl rhureh comes trom the tirect:

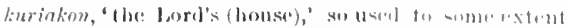

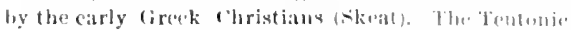
tribes, when comverted to chrietianity, andendel this circok word for the house of worshipe, ats it is finmel

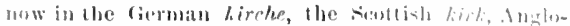
saxon cyrice, cirice, circe, from which eones th. Ling-
Fritz.) ; for it is impossible that r. 18-20 should have been spoken with reference to a Jewish symagogue. It must here moin one of two things. (1) It may be the ludy of Christ's disciples existing at the time he sreaks, including the apostles. (v. Ix.) It seems to be intimated by this passage, together witls 16: 18, that as the end of his ministry approached, Jesus began to regarel and speak of his followers as a sort of conmunity or asoociation, a thing which womld in itself appeir not unmaturil. The twelve apustles seem to have been gromped in eumpanies of four (see on 10:2). Yot we ean hardly suppose that they aline constituted the rkthlosin here spoken ot, since there is no elear amalogy for ayplying the term to them, and since $r$. $14 \mathrm{f}$. refers, br common consent, to any gathring of believers, and not simply to a gathering of apostles. $\mathbf{C}$ pon this view, then, the word must denote a general community, including the apostles. The exact constitution of this stlplonsed community eannot be determined. Some would liken it moreto the Jewish synagogues, others to the churches loseribod in Paul's Epistles; neither sike ean prove its point. (2) The wood 'entureh' may be used by anticipation for on: of the churehes founded by the apostles. It might he taken for granted from the general analogy of the synagogues, that there would fus sume sort of assembly or congregation to which thr person addressed in these instruc-

lish rhurh. The use of the word was gratually extended to th" assmbly meeting at the ehurch, an extensim similar, though in the opposite clirection, to that which has taken place in the words synagugue, parish,

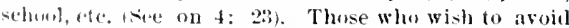
tho confusion which arises from applying the same woral to tho bulding and the assembly, would be keepille noarer to the history, at least, if they applical the tam church only to the building. The (ireek Christiaths thamselves are not known to have ever nsed furializn for the assembly, and in modern (ireek ehliksin is the only word in both senses. From this through the datin form ecelesia, came the French eglisf, our word ecclesiastical, etc. 
tR Verily l say anto yoll, Whatsuesor ve shill bind on earth shall be hound in hearral and what-oever ye shall lowe on earth slall lee lomed in heaven.

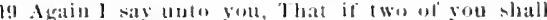
merece un earth an touching any thing that ther slatt ask, it shall be done for them of my father which is in heaven.

tions would belong. Perlatps the two idras might be combined; "the church' might nowall at the nomment the existine low-ely organized community of Christ's followers, then atter the I) ay at Pentecost the one organi\%ad assombly at . Jorusalem, and still later the lual anembly with which the persus in ques-

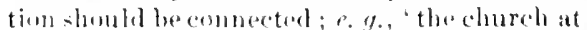
Curinth,' 1 Cor. i: 12. This question is nt no great importane fin the interuretation of the basiage before us, whatever interest it may posces in genoral ecclesiastical theory. Tyndale, Cran., and fren., correctly translatod the word by 'comeregation'; Wye and liboins arave 'church;' and this was ono of "the old ecelesiatical works" which, by di-

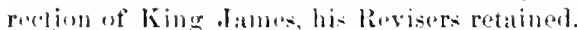
The Rev. Ver. of 1sit has plated 'eongrogation' here in the margin, probably through recognition of the fact that the matuing of the original is in this atas somewhat undefined; for the word conerregation has beenme gradually moditiod in manture hy $11-$ ange, and can no homeraboin general empluyed as the equivalent of chureh. Let bim be nuto thee, ote. The Rev. Ver. propurly tramslates, as the Gentile and the puliern, whe with whum you hase no communion or assowiation, Rom.

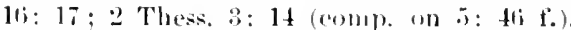
This does not distinctly teach what we call excommunication, but contains the germs of that which Paul afterwards clearly taught. (1 Cor. $5: 3.5 \cdot$ )

18. Whatsoever ye shall bind an earth. IIe is directly addrening the dinciples alone (avi), probably only the Twelve: but he has just montioued the artion of a church, and so the reterence heresenus to he mot to apostolic action, hut to church action (Bleck, Koim). Whatrver Christ's poople, asombled in their organized congregation or elureh, may deeida, is ratifial in heaven, $i$. e. by Godunless, of course, the decisimn be in itself wrong. The point is that the ebureb has God's aubority to deride. The reference here is especially to the sottlement of a ditficulty between bretluren, but the statement is

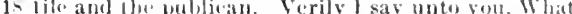
things soever yo shall bind on earth shall be butut

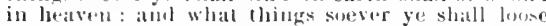

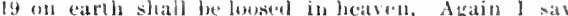
unte you, lhall il two ol yoll shall athree oflearth as rouching anything lhat they shall isk, it shall be

ageneral one. The power some time befiore givento Petar (16.19), is now rearly given to others; the only question being whether it is to the aposthes or te a chureh.

19 f. This is closely annected with the prereding. The chureh axpreses the view, mat of an individual, but a nuaber ot Christians conemrring in an opinion, and sn is more likaly to have the divine approval. Ho now adds that any petition in which two Christians unite, will be granterl by God. Agree. The Eroek word sumphone is used primari\}y of musical instruments that make the saine sound, then of harmony, symphony, where. the sounds agree, though net inentical, throb ot agreement in gencral. Origen on this passage pevels in the fincy of symphong in prayer. But it is doubtul whether more is loce intemded than the general idea of agreoing. On carih, as in v. 18. Tul pray "on earth." the "Father who is in heaven" answers. As touching, or simply 'about,' 'concerning. Auything that they shall ask, not simply any drecision that a church shall make (v.s), but any petition which even two shall atgree

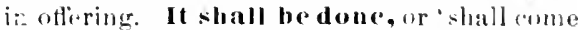
to pass, 'Lake place, see on b: 10. My Fathor which is in heaven, as in 18: 10; lı. gives his assurance concerning his Father see un fi: (b). This promise is of course understood as limited, (momp. on $7: 7$. The work- in my name' aro naturally reflected backe trom v. 20 upen tha foregoing promise by the eonnecting 'tor,' so that we have hereatio inplied anticipation of .John li: 23. Men are more influenced hy themited request wi many persons than by the request of ane; and this holds of requess to forl. It applies nl-o not merely to a large assembly, but to oven two wr three, when gathered in tho saviour"s name, and agreeing in their petition. In my

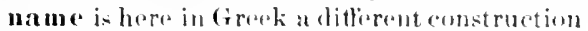
from 1s: 5 , but without substantial ditlerenow

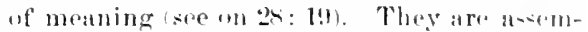
bled with retiorence to Christ, and not to - ome uhlor person ar ubject-assembled aceorting to his teaching, in relianee on him as their 


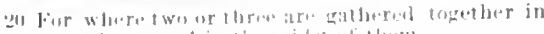

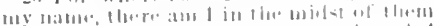

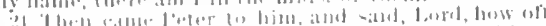

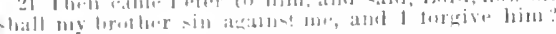
[1] - a.

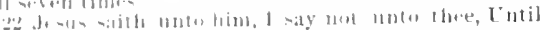

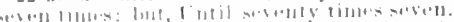

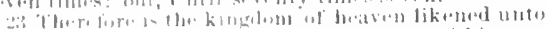

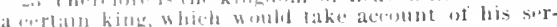
i.111:.
201 Anne for them of wy kather who is in beaven. For where iwo or inree are gathered tugether in my name, laere anu I in the nimbl of then.

21 'Then came l'eler, and said to him, Lord, how oft shall my hrother sin against ne, and I torgive him?

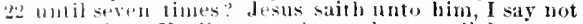
nutक there, Entil seven times; but, unti] seventy 2:) limes strell, Therefore is the $k$ inglom of heavell likened unte a cerlain kiug, who would make a reck-

I 10r, sexenty times and seten.

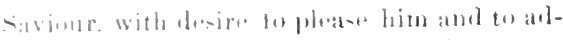

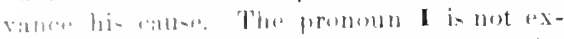

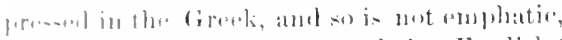

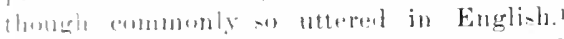
The puint in non that I am there, but that I

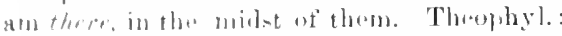

Fhore. nul far away to be sent attor and watitul tior, hut there." ()ur horel here ditine? y prists torwarel to at time when he will lwe arporeally absent but spiritually present.

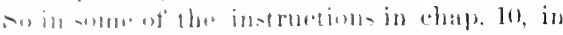

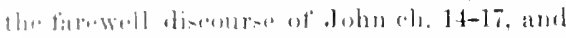

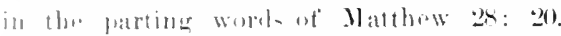
Notire that the language is perteretly general. It inn longer 'two w you, but in general "Hwe or theres"; it in not "there l shall be," lust

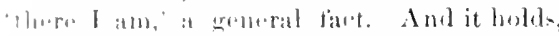
met merely af a larewe anoenbly. but of the

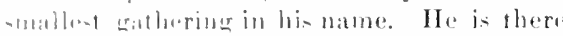
forive anthority to their action as a ehureh 19, ly making it his arfion, and to gire

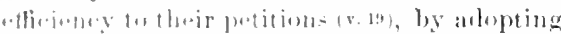

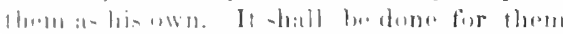

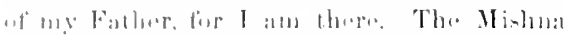

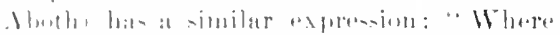

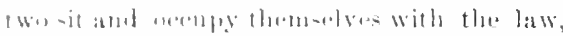

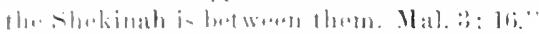

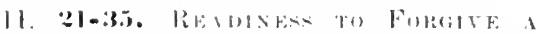

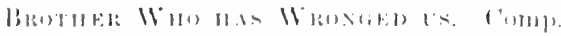

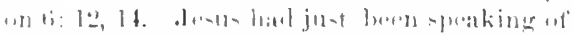

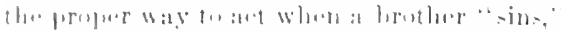

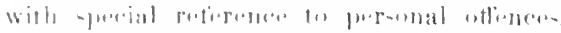

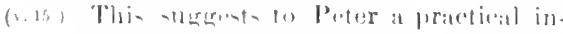

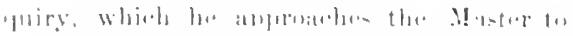

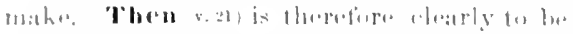

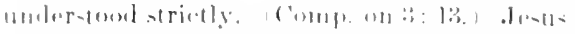

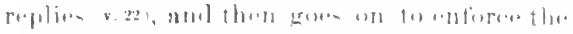

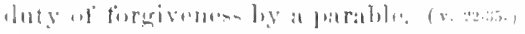

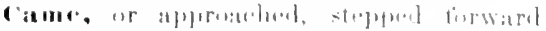

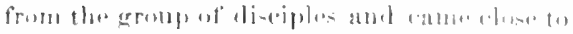

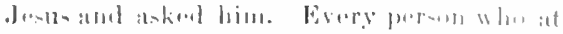

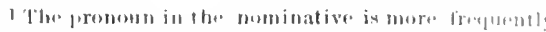

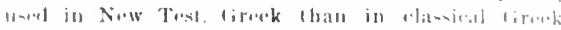

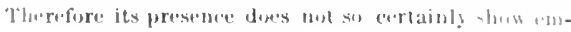

tempts to exereise a forgiving spirit towards thone who do him wrong, will sometimes have oceasion to feel that Peters question was a fractical one. We bring ourselyes up from a sense of duty, to the point of forgiving; bebold! very soun the same man eommits an equal or greater wrong; and so, perhaps, again and aguin. Huw long are we bound to let this go on? How oft shall my brother sin against me, and I forgive him? The former clause is simply the basi- of the latter; su in the muth discursed passage, Rum. 6: 17, aml so perhaps in Luke 24: 18. Tyndale, Cran., Cien., render, how oft shall I forgive my lowthre, if he sin against we?' This exproses the thought, but takes unnecessury librertien with the phrase. Uutil seven times? Ife probably thought this a very high number. Chrys: "Peter supused he wa-sying something great." The Talmud of Babylon says, "When a man sins against another, they forgive him unce, they forgive him an arend time, they forgive him a third time, but the fourth time they do not forgive him "seven," among its many uses, was sumetimes a round number, Ler. 26: 21; 1).nt. 24: 25; I'sa. 7!: 12; Prov. 24: 16, ete. Su wur Lurd, when -peaking of this subject on a sulwequent oecusion, says, Sieven times in lhe day." (Luke 17:4.) Seventy times seven in thr matural mmaning of the (iroek But it men! math (Rov. Ver. margin) 'seventy-seven fines, which some of the best expusitors prefin (O)ien, Bengel, Ewald, Keim Meyer), loneance precisoly the same expression is finmal in llo sept. translation of Gon, $4: 24$, where the Ifehrew an signily nothing ets? than 'reventy-aren times.' Comp. Moulton in 11 incer, :14, n. Either way it is a general expresion, which prantionlly removes all limit the the retitions of forgireness. (Theo-

phasin, lut its absonee does even more certainly (if fHoible, than is: edamical firek, show that there is no 'mpluanis (comp) John 11:21, 3:2). 
24 . And when lue had lexgun to reckon, ane was brought unto him, which wwed him tenthosisal a tatunts:

2; But forasmuch as be had not to gats, his lord commandml him an be sold, and his wite, and chuldren, and all that be had, and pay aseme (1) be lable.

26; The servant the relure fell down, and o wershipperl him, saying, lasd, have patience with we, and I will loviv llet+all.

if Then the lord of that servant was moved with compansioll, and loosed him, and forgale lian the deb.

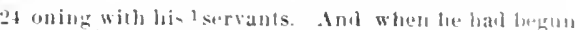

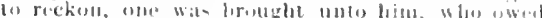

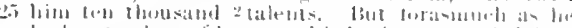

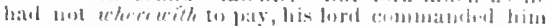

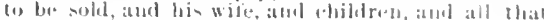

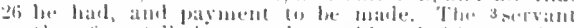

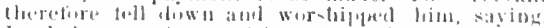

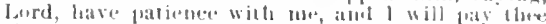

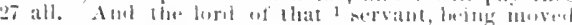

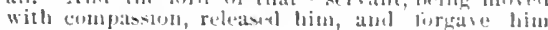

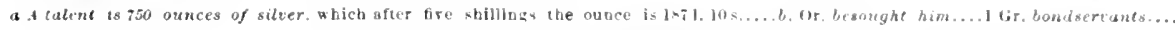

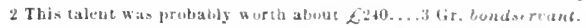

phyl.) Ot courseall this reats on thes supposition that we believe the man sincerely lepents. (Lukeri: f.) Otherwise we are nut bunnd

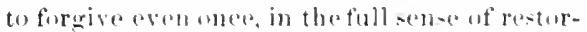

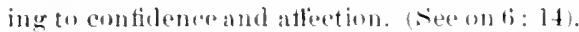

2:3. 'Therefore. Sinee the Itsiab requires his followers to torerive, and nu matter how often (vels), therefiof the Messianie roigu resembles the stury alout to be told; under that reign men will he severely dealt with it they reftus to forgive (v. 35). The kingdour of hearen, secoll $\because: 2$. Is likened, or has bere likenct, sere on 18: 201. lno a ertail kine, literally, to a man, a lina. The atotion of the l)vine King is illustratul by that of a hunoun king. Would take aceonut, wished

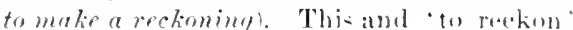
in v. 24 are kindred expresiuns, and ought not to have been difterently remelered. besides. 'take acounnt of,' is misleading, the idea being tos sottle acentunts with. His sersants, litorally slates (doulus), seco on $8:$ ti. It lats always loentermunom in the East to eall the court "fllicials the slaves of the king.-They are as dependent an his arbitrary will as a slave un his master, and with

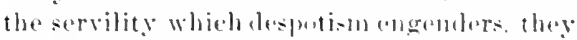

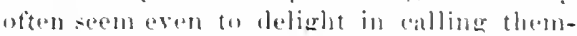
selves by that name. This wored demles is similarly us+d in 23: 2 tl.. and in 1 Kingrs 1 : ti; the more (enmmons worel in that semes is

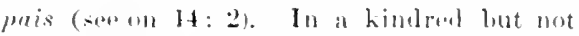
degrabling spriritual sense l'anl delierhts to eall himself at doutes of . Iesus ('hrist, and so lanes, Petor, Jude. In the parables, tlerefore, flo kinars 'servants are the ereat oflicers of govermbunt, who lecesival his rever nues and attended to their disbur-emont. It Was quite posible in ond of the areat oriontal lespotisus for a trasurer, or the satrap ut a province, to embezzle as much a- twelvo millions of dollars. Our lorel purposely sup-

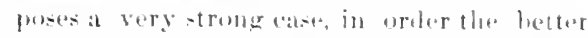
to illustrate the vas elsplarity leqween what fiml forerives to ul, alld what we alle collled to timrerive to others.

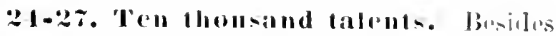
the diflerences betweren a talent at silver and of erolel, the [rold talent varied erroatly in

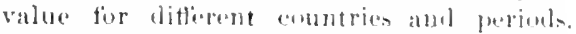

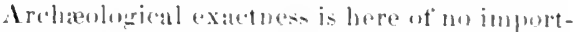

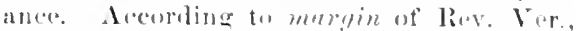
the tenthousant talont- would amount to mear twelve million alollars. Wr mat me hom vast

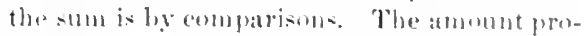
vided by loviel tur luilding the temple wats

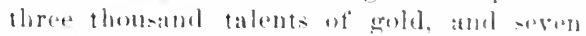
thotisand of silver, amd the princes sare orer

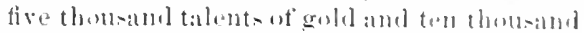

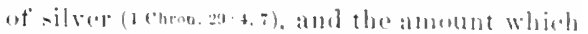
Haman wfiereel the Kine of Persia, fior tha

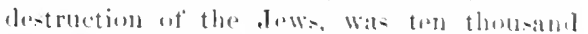
talent- uf silver. (Fother 3-9.) It is mut luecessary to suppose that the parablo narrates a histurieat tiut. Lut such things did happenth. ('om]. on $1: \%$ : :.) To be sold, and his wife ame rhildren, and all that he had. It is still (onmmon in oriental combleses to inflict all this upun at man of the highest station. The law of Mares allewerel a mall

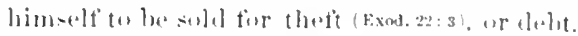
(1.er. 25: 39: 2kugst 1.) Worshipped, the prostration hefure a monareh, ses an 2 : 11: the Greak has here the iumpertiont tensed describing him as (menged in this lowly homagr. The math only askal for indularence. and he wombl fay. Perhaje he really hoped to do so: tir men whon ine into vast foublulent "purations are usually of very saluguime temperamulut.

Loosed (relensel) him, and torarac him

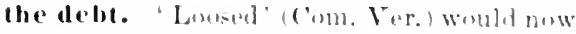

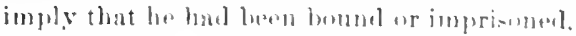
a thiog nest indicated nor probable; los was

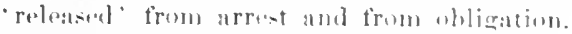
"The elebt is here morte exactly (liev". Ver., 


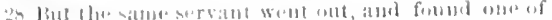

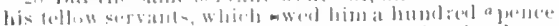

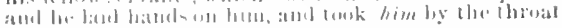

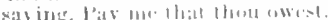

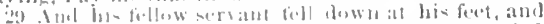

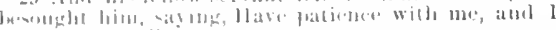
will [mas Hon all.

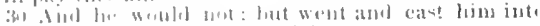

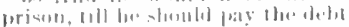

31 - Whe his fi-llow s.rvants saw what was dome

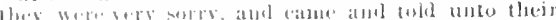
loril all th:al 11 :L dulle

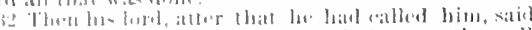

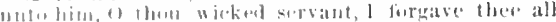

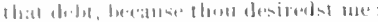

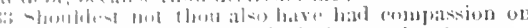

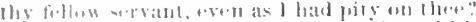

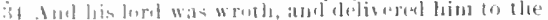
lurmollerr, lill he slould pag all that was due undo liin.

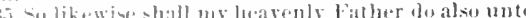

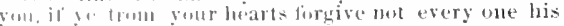

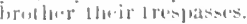

on that deht. But that 2 serrant, went out, abd found 1) 110 of his follow-servants, wlu owed hion a lun. dreal shillimes: and he baik hold on him, and rook himby the throat, sayiug, l’ay what thou owest.

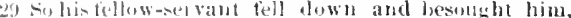
sasing. Ilave pationce with me, and l will yas lhee.

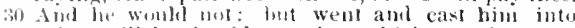
31 prisem, till ho should pay lhat which was dae. Sis

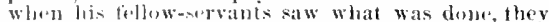

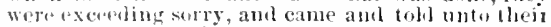
32 lorel all that was doute. Then his lord eilfod him untu lius, iusl sititl unto him, Thou wickod stervant, l lingare thes all that debt, beame thom loei3 semelitest me: shomldest mot thon also have hav urery on thy tellow-seryant, even as I had wercy

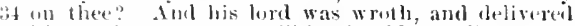
lime to the tormentiss, till he should pay all that was

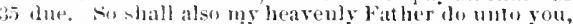
if ye lorgive not every one his brother from jour licirts.

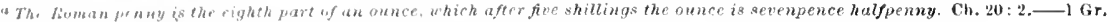

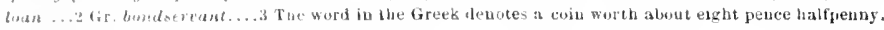

mergin) the hatus. In his ensupasionate

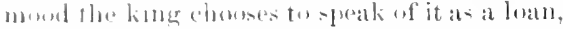

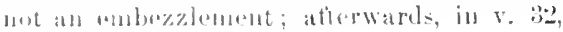
it is liturally "lobt.

28-30. Onr of his follow-servants.

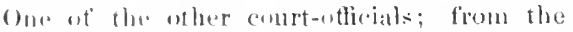
smallnes of llat aldet we should think of him a-an infirior oflicer. I husalreal penee, or

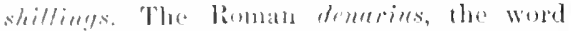

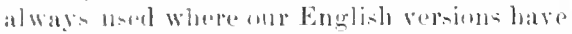

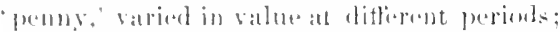

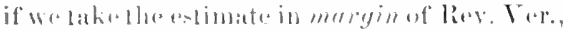

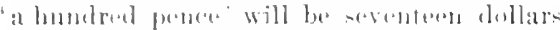
of ent momity. Sere, then, the dirparity of the lwa debts-twolve million dollats, sesenteen dehars. (1) we could get the effect of pombl numbers ly suging ton millim dollars and

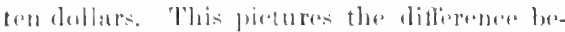
tween the gruilt of onr sin against form and that of a follow-luan's sins argatu-1 u- Took him loy the throat, ar mole lilerally, went to choling him. Paty that thou owestap ar

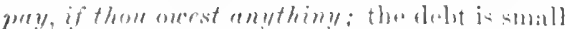

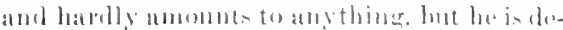
torminell to hatre it. The Romaln law ellowerel

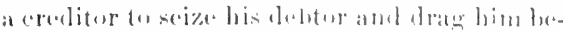

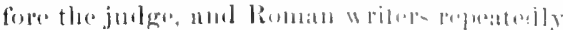

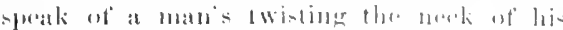
dobfor till the blood flowal foum month and metrits. Fell down merell: at his liont

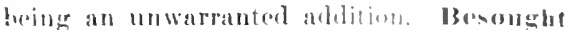
and would mot (v. 29r.) atro in lipale in lhe imperfort tellse, implying romsinmen antreats

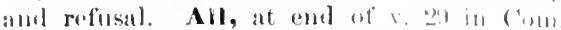

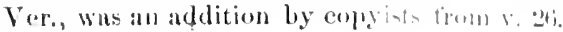

The similarity of the plea to that which had just aniled tur himself failed to touch the erealitor's heart.

31-35. His fellow-servants, wher courtofficials, high and low, saw what was done, what touk place. (see on 6: 10.) Told is in the Grewk a very strong word, signifying that they gave a refor and complete aceount. Lis Iord, ete. . . said, $O$ thon wicked servant. (thrys. " When he owad ten thousand talents lye did not call him wicked nor uploral him. lint hat compation on him; but when regarling his fellow-servant he was unforgiving, thon he says, wicked servant." Shouldst not thou also have had compassion (merey)... even as I had pity (merey) (v. 3:), lhe same (ireek word in both cases, and not that of $r, 27$, but that of $17: 15 ; 5: 7$. 'Tormentors (v.34), not simply 'jailers, as Tyn., Cran., Gen, but strictly 'turturers'; he was to be not now sold into slavery (v.25), lut imprisoned, and from time to time torturel. This fearful punishment suggests the forments of (xehema: comp. 8: 2t; Luke 16, 2:2, 23; Rev. 14: 101. ; 20: 10. So... unto you. The comparison of sins to delots was a familiar idea to the Jewinh mind. (Nee on (4: 12.) From your hearts comes in at the "hone with empluasis. Their trespasses is a 11-4.lun addition by copyists, and so is muto him, and of v. 34. Nobody would bave cared (1) omit (ather phrase if originally present, yet lust are wanting in a number of the tritient locumonts. Forgive, see on $6: 12$; "hearls, secen 6: 2hl 


\section{A P'TER IIX} A Nll it eame (n pass, that when Jesus had finished into the coasis of Judea leyoud Jordan:

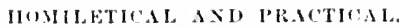

V. If $\mathrm{ft}^{\mathrm{B}}$ IInW to deal with a brother who hats wrongerl yoth. 1) Do not awitit his coming, but go right aw wo him. 2) Make loving. wire, and repeated eftorts to gain him. by perenal interview, by the help of other brethren, by the help of the ehureh. :3) $A=$ soon (bake ti: 3) and ats often as be repents forgive him (b. 2l f.); and when tempted to be untergiving. remember how much is forgiren

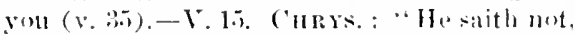
'accu+e, mor 'charge him, nor" demand sati-fuetion, but 'toll him of his fault." Atg.: (in Arf): "But why do you enrrect your neighlore? If you do it trom self-love, you do nauglit; it soul do it from love of him, rou do most riglutly." Hexry: "We should think no pains too much to take for the pecovering of a sinmer to repentanes" $-\mathrm{V}$. 16 . ('in rs.: "Tlu physician, in like "manner, when he sees the malady abstinate, doth not give ule nor grow imprationr, but then makes the more peparation." $-V .1 ! 9$ f. Cnited Christian prayer. 1) The proyer of many, even of two, is more likely to be for right objects. 2) The sympathy" af eommon $\mathrm{suppli-}$ eation pronotes earmestnes. : The tavinur himself is in the midet, makinger it his prover to) his Father. ('routs: "For it is not the number of these combing tongether. but it is the pewer of their piety that will he ethectual." Hexry: "If there be no liberty and opportunity for latge and numerone inembline, then it is the will of Giml that two or theree should gatles together. When we eamnet do what we wonld in religion, wo must do as we "an, and (ind will acepht $11=$."

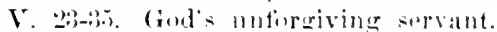

God forcios him an immense debt.) Io refleses to firgegies his fellow-servint some comparatively tritling debt. B) (rol will flush him with terrible severity. All turns upon the "if" of' $x$. :35; a true servant of' (iod will take warning and forgive. - V. 32. Cunrs, "Let us hearken, the anvetuls, firr even to 11 is is the word spoking. Let 115 luearken also, the mereiless and the cruel, for not $t$, others are we cruel. but to our-

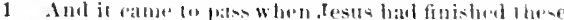

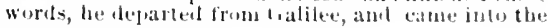

selves. . . Let us nut thrust thes sworid

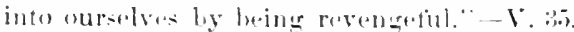
Forgivenesen 1) Who mut tiorerive? Evers ond.' 2) Why mu-t we toruive? a) bit in itself that they whe with to be firmiven should be willing to firrerive. (h) Clearly

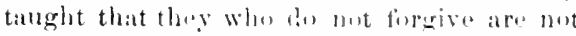
forciven; this parable and bi: 14; Jatue 2: l:3. (e) A sreatt privilese that we an thu

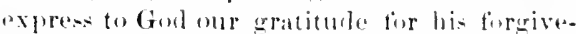

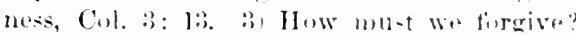
-From the heart." - Broce: "obvinuly Je-1ls hats now sense of incongruity hetwern the Fatherbord of Gend and the - tratnge work of stern jutement on the unmereinibl. Neither wat there roum for such a fereling. Thet be-

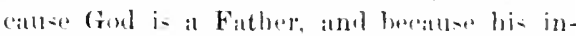
must apite is love he mu-t abhor a spirit an uttery alien trom his own. It is anly what we shomblexpect, that under the erovermment of a erateinus forl the spirit of mereilessues should have judgment without meres."

Ch. 19: 1-12. DEPARTER FroM (iAlt-

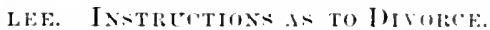

The greater part of thisesetion is timut also in Mark 10: 3-1.2. Our Lurd now latres Galileos and comes into Peroas. Matthew and Mark make no mention nt anything interveninger and a little later buth bring us a the triumphal antry and the tinat litsover. But Lake, after emompleting his aceount, parallel to Mathew and Mark, of the ministry in Galilue describer Je-11: $19: 51-56)$ at groing from Gablese not inte Perea, but thrueh sinmaria on the Way to bermithm With this agrese Juhn's areount (i: 2.10) ot his groing in sereret from Galiles to . Jornsilem to attend the

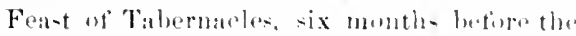
final P'asisver. Then Luke gues on in 10: 1

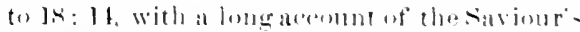

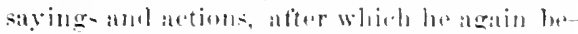
comos parallel (18. 15) with Matt. (19 13) and Mark (10:13), and so continuesto the and. Wr have berelofore noticed that Lulie erreatly condensed his narrative of the serias at with-

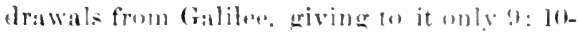
50, while Ilatt. gives 14: 13 to 18: 35 , and 


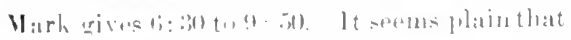

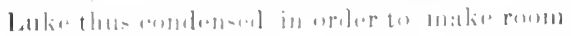

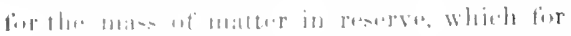

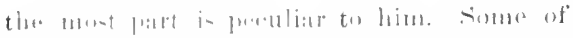

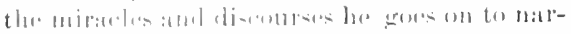

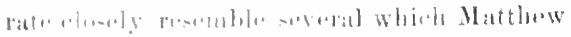
and لlath erave durine the mini-try ingali-

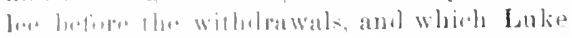

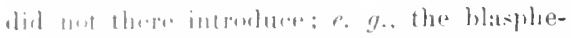

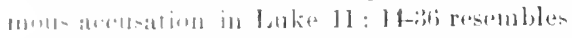

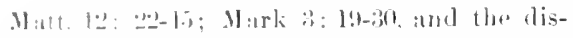

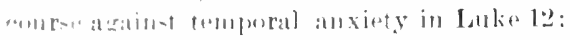

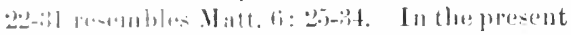

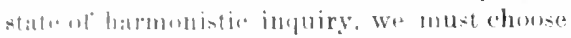

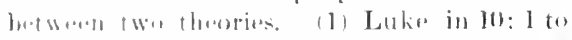

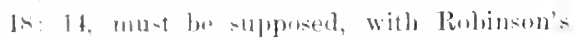
Ilarumbly and others, to grive a lowaly ar-

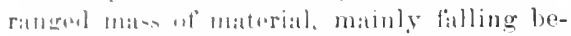

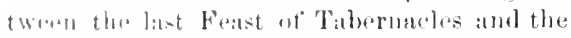

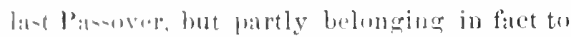
tha mini-try in (ialilan, where similar matters were reven by Mathew and Mark. This

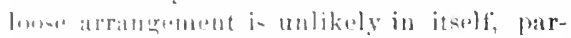

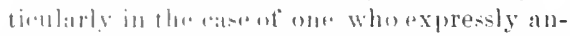

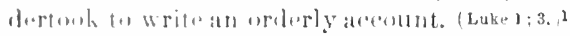

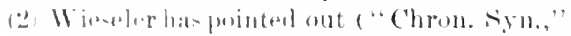
talluwal by Tincledulust"s "sirn. Evang.," Ellientl " I Eentures on life of Chri-t," G. II. Clark" "llarmumy at the Gospols") that Lulin in this lares section three times spealis

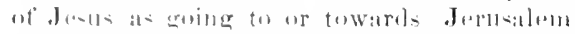

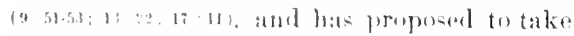

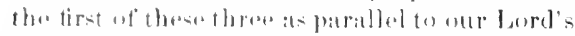

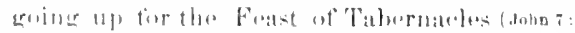

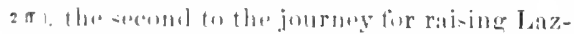

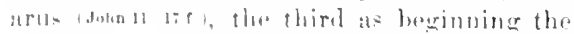

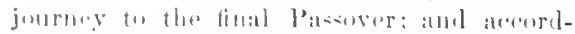
inely to arrangen all this wetion of Lalin, ate

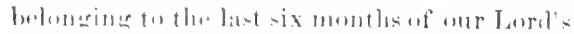

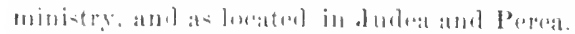

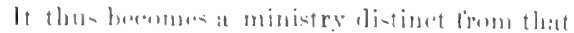
in tialilue marratul hy Matthew, Mark, and

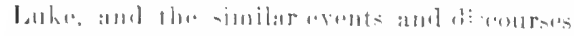

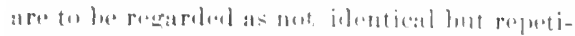

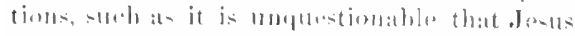

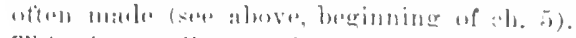
This view. well wrought ont in (1)ark" Ilar-

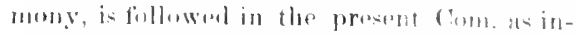
volvine towar diflicultion than any ather, amel

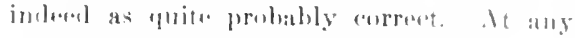

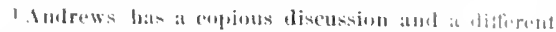

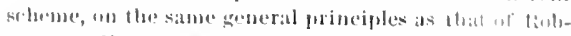
moven. Farrar also (eh. 12) gives an indepmitent
}

rat", it is clear, from the comparison with Lukeame. Joln, that Matthew and Mark pass woel nourly ail the last six mouths of our Lurd's ministry, just as both they and Luke pased over that early ministry of probably as grout length in Judea which is recorded by Whin (soe above on 4: 12). Mathew and Mark have in lact confined themselves entirely to the ministry in Galilee and vieinty, exceptethe tinal Passover and a few incidents an the journey thereto.

1 f. Jesus goes from Galilee into Perea, and exercises lis ministry. Departed is not simpiy 'wunt away' but 'removed,' a rare word und in New Test. only here and in 13: 5i3. It must not be here pressed to prove a permanent removal, for in 13: 53 there was only a temporary removal across the lake. The statement that he departed from Galilee when he liad finished these sayings, would most naturally mean that be left immediately upon empleting the discourse of eh. 18; emult, the same phrase in 7: 28;11: 1; 13: 5. We should then take this departure as larallel -to that of Luke 9: $51 \mathrm{ft}$, viz., to attend the Feast ot 'Tab., and the gap of nearly six months would have to fall between the two aljacent words 'departed' and 'came.' Wieseler holds that this departure was parallel to Luke 17: 1], where Jesus returus from Fulea through Samaria and a portion of Galilee, and probably joins the pilgrims on the way from Galilee through Perea to Jerusalem. In this way 'departed' is followed naturally by "eume, but "when he had finished these sarings' has to be understurd loosely. Mark's "xprosion (10:1) ngrees best with Wieseler's virw. IIowever much was to be omitted, we could not expeet a brak in the uarrative; see remarks introductury to 4: 12. It is well to observe that nothing in the interpretation of what fillows will depend upon this nice question of ehomology and harmony.

Matthew's account of the ministry in Galilee has continued since 4: 12. That ministry appears (1) have lasted, if we take the feast of Juln 5: I to be a passover, nearly two years, the last six months, however, being nearly all spent in tho series of withdrawals to adjoining districts. (1t: 13 to 17: 20.) Matthew oceupies him-

sebeme, which will reward examination. A full discussion, or even statement, of the various theories would here be out of place. 
2 And great multitudes followed him; and he healed them there.

3) The l'harises's also came unto him, lempling him, and saying unfo him, Is it lawful for a man to pul away his wife for every catuse?
2 burders of Jurted beyond dortan: and great mul-

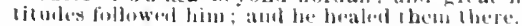

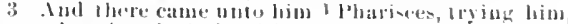
ind saying, ls it lawful fur a mun lo jut at aby bis

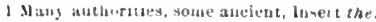

self especially with teachings concerning the kinglom of houven, while most of the parables given in Luke ch. 1:3 to 18 reter only to individual piety, and would thus not come into Malthew's platr.

Intothe coasts of Judea. Borders rather than '(roats, sece on 2): 16; 10: 20. Heyoud Jordan. The Greek anstruction is peculiar, but makes 'beyomal Jordin' state the routo by which he cance into the borders ot Jullual. Mark (10: 1, correctent) hias 'into the horders of' Judea and beroud Jordan. Copyists and early"sudents saw that this differed solmewhat from Matt., and so sume motted Mals's

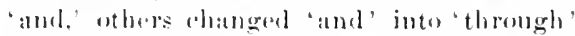
(cim. Ver.). IIark's expresiun tluus gives a twofoll designation of the region into which he calle, viz., the bordise of Judeat, and Pereat. Matt. might seen to luate the following matters in Juldoa, aticer Jeous lad passod through lerea; Mark refers them indefinitely to both distriets; the llammony seer 20: 17, 20, pretty clearly places the earlicr

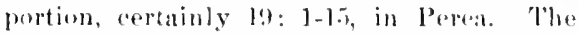

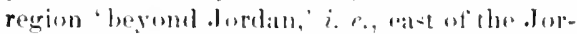
ditn (see on 4: 2.5), from its mouth to nut thes Lake of Galiles. Was in the lioman peroul olten callod the bryomel distriet), "the Pereat, the Groek werel fier leyomel lesing

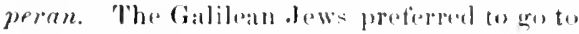

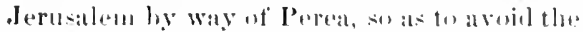
unfriendly sinmaritmus (Inke9:52s.); thomel the direct rotute through simalia was smometimes takell (eomp. Insepluss. "Litio," .02). Perea inclubed the clominions of silom and

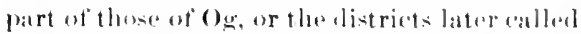
Giloal and part of Bashan. Tlate Romans separated Decapolis (sen on $4: 25)$ from this

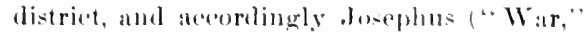
$3,3, ;)$ silys that Perea extouded from Machaerli: to lella (nearly opposite the plain of Estraten amd Bethshoun!. It Wats divided into a rougleer and very luantitul nurtherm portion, and a southern portion, which latter eomprised the plain immediately ast of the lower Jordan, and the higla table-land beyomel. So far niwe ean judge, our lard hereaplears in Southern Perea, on his way to Jericho and
Jem-alem. (20:29;21:1.) Many plates of this

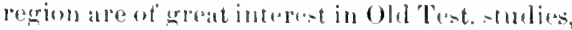
but mone alpwat distinctly in the New Tot.

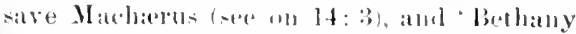
beyomd Jordan, "lhe place where. Johin was at first balptizing (Jobul:zar.: 10:so), and this last spot caumen be determined (eomple on

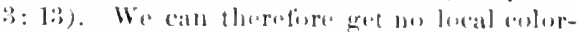

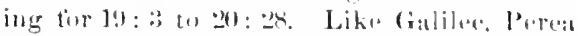
hate so fow Jews in the time of . Jubas Mareat-

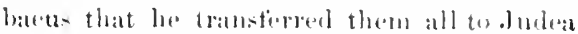
for sate kerping (1 Mace. 5 23. bi); but daring lhe reign at Ilerosl the Great the. Jewish pendula-

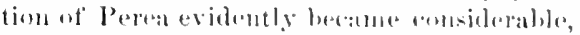

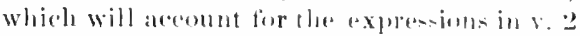
and .Juhn 10: 41-42; and this district wat an

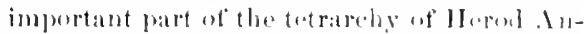

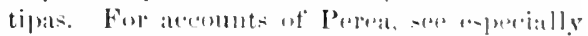
sehultz in llerzog, Art. "I'aläslina." 4);

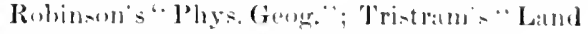
ul Mral," ; Merrill: "Eant of the Jurdan" ; but all are quite imenmylete.

Great multitudes, ser on $4:$ : 20 . Ilfore, as

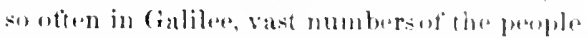
throngand crowel aroumel hime. Jt is prob-

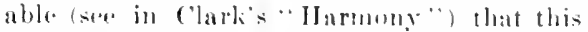

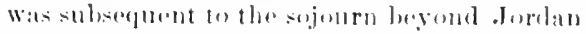
montional in .ohn 10: 41, f2, when "many

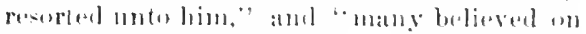

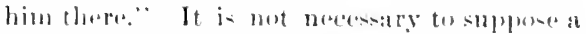
comsiderablestay in that regrion at this time.

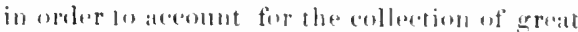
crowds, for thay probshloly ansiated in part of persin- journeving to lerusilem for the l'asiover. And he healed them there, as bo had otion done in Gililoe. "Thom" of oolurse means not all of the crowal. but sueh ats needrul healing. Mark says (10:1), 'ame as he was woll, lex tatught them atgin. Tlets the Galileam ministry is reprodured in leren -erowels, healiner. teaching. And here i-another instanes of at eneneral statement, whireh

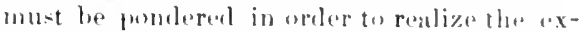

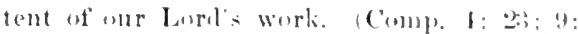
$3: 3 ; 14: 14 ; 11 ;: 30.1$

3. An impuiry as to divoree. Distingui-h

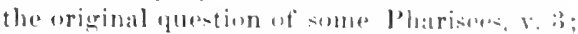
the answer, r. 4-6; an objection and his reply, 
V. 7-4: a lombtion remark ly the disciples and hi- relly, $\because$, l1-1:. Mark's repurt (10.2-12)

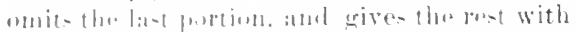

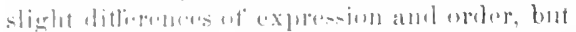

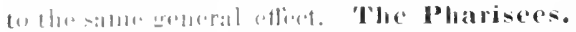

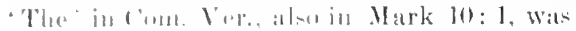

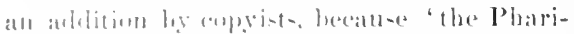

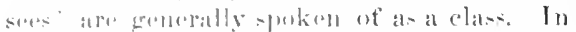
like manmer, muto him aftur sayingand molo them in $x$ \& a are wathting in the tatrliest and hust dormmonts, and were very easily

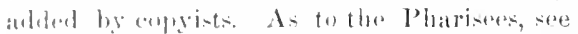

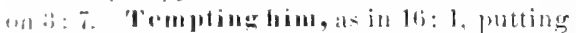
hime to the toot, (Amer. lievisers putered "trying hime" and loppiner he would say

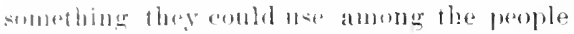
to his projulines, by represuting his teathing rither an-intolerably severe, or ats wanting in fidelity or the law of Muses. Perbates they

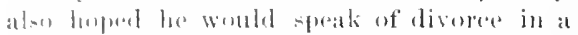

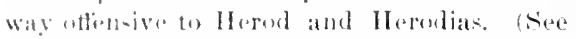
on 1 1: : The plate wate nut very far from Macharar, amb they might have remembered

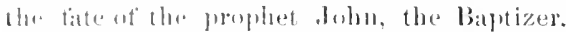

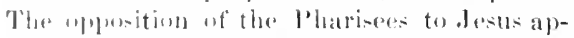

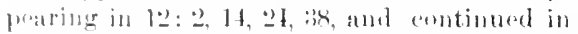
15: 1 and 1t: 1, is hepe renewed sowate the roul uf his ministry, and will be maintatued

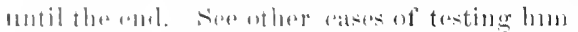

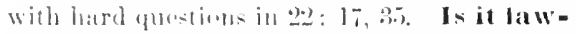

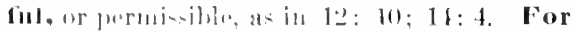
a man is maturally slugerested, and so was

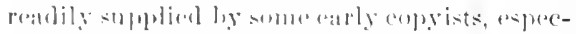

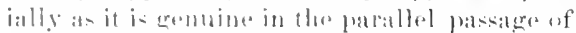

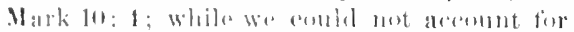

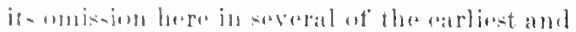

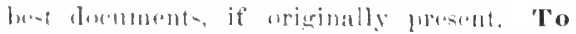
ful away his wife was balderstoul as involv-

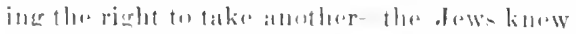

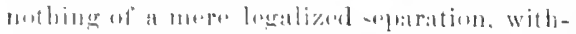

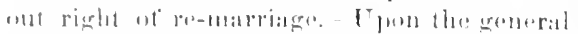

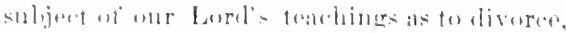

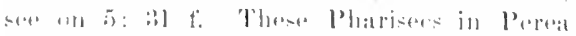

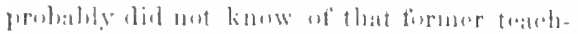

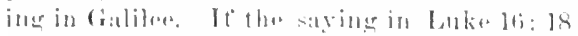

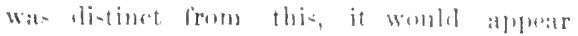

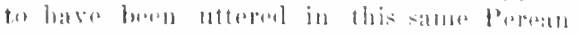

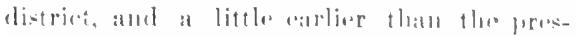

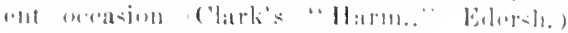

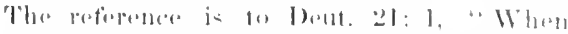
a taan taketh a wite, and anarioth her, thesl

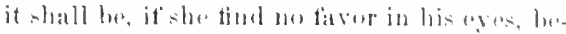
cause be hath tound some unseemly thing in her, that he shall write her a bill of divorcemint," ete. The euphemistie Heb. phrase translated 'some unsecmly thing,' has always heen alsenre. It is literally (as in margin of Com. Ver.), 'some matter of nakedness, and apमars to moan derivatively, something indecent, shameful, disgraceful, hateful. The Rabbis disputed much as to its exact meaning and limitations. The Mishna has a whole trantise on divoree, Gittin, but chiefly occupied with minute directions as to the prepalattion of the documsent and conditions of its validity. Tha lat paragraph reads: "The schonl of Shammai says, no one shall put away a wife unlese there has been fomnd in her sumothiug dingraepful (a phrase exactly correspumling to that of Deut. 24: 1), as written, "becatuse he bath tound something unseemly in lif ${ }^{\prime}$; the sehool of Hillel says, even if she has hurnt his food, as written, 'because ho lath found something unseamly in her'; Rabli Akiba says, even if he find another unde leautiful than she is, as written, "if she find no fitror in his eyes." Maimonides explains (Note in surenh. Mi-hna) that the school of Shammat rests on the term "unseemly" ; the schonl of Hillel on the term "nomething." Rabbi Akiba took the phrase be quotes to mean in respect to beauty. 1has: with what perverse ingenuity men quibhle to make the Bible mean what suits thrir wishes. We ser the folly of this practice in othars, but are all in great danger of doing likewise. Observe that in the Mishna the sebool of Shammai use simply the general phrase, something disgraecful or unseemly, as in the law. A late Midrash on Numb. 5: 80. yuofed in Wet., and two pasages in the Talmud mentioned by Edersh., state that the sabui of Shammai reeognized no ground but undhatity. It is worth inquiry whether this Was anyhing morothan an incorreet interpretation afterwards put upon the latrguage of the Mishna. Josephus, who was a Pharis.'s gives ("Aut.,"4,8, 29) a paraphrase of thr hav which uses essentially thesame plurase an here: "If'me wishes to be divorced from his whio for any caluses whatsover and many surh (ankes might happen among mankind), lot him give assuranee in writing that he will newrumre live with her," ete. It is evident that in rur Lord's eyes the expression 'something unserenly' might extend to other faults 
4 Amb ho answered amb a ad unto llem, llave ye not

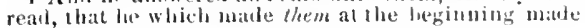
thenti atalis andel fillate.

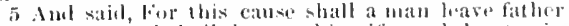
and molluer, and shall chavelohis wife: and the I wain shatl los: one thell:

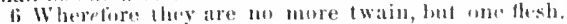

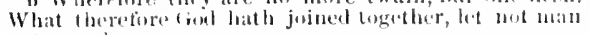
put asmucler.

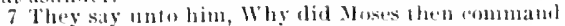
to give a writing of tiverceutent, and to pul her awaly?

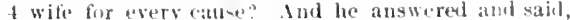
llase ge not reat, llat he whol malle the them

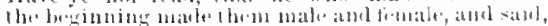

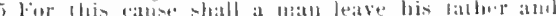

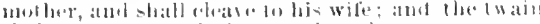

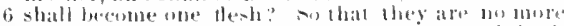

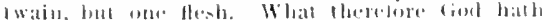
7 joincel torether, let not matu put asmuder. 'They say unto lim, Why lien did Moses command to give

i noue nucient authentle- rend, created.

besides unchatily, for otherwse there wombl have been no oreanon fire what he says in $v$. 8. The Pharisens, ly holding up betiore bim the Ilillel view in its mos extreme form, probabiy hoped to drive him to talis the Shammai viow, which was extremoly numbyular. He lul not sile with either parly, but (as in 22.2: 201) cut intu the hourt of the matter, reaching a fundamental and decisive princifile.

1-6. Reply to the Plaarisees. Ilave ye not read, complo on 12: ?. The seribes and Pharisees buastrel of their ateinaintance with the law, aml he rouroabes them with ignorance of it. Ilo makes first at referenee to fion. 1: 27. and then : ffuntion from Gen. 2: 24. 'That he which made them. "Creatred' (Rev. Ver. margin) is probably hero the currot roating, altored into "mate. to agres with seret., with the liond here immediately following, and with Marli 10: 6; but there is

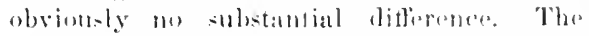
word: maleand female have in the fireek un emphatic position. From the beginniner, the race inclueled the two sexps, and these wereto bre unitol in marriage. Iud satid,

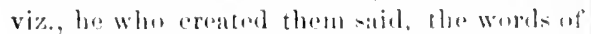
Alam in that exalted moml beiner tatien at expressing the will of the creatur. Latare father and mother. Even the impurtant filial relation will give way home higher seill. The twain is griven ly the sopt. and sryeral other versions of Old fort. and amly expresses empluatioally what the lleb. implines. shablo (or become) one thesh. "Themion at" soul is expressed, and theresiore inemollied.ly

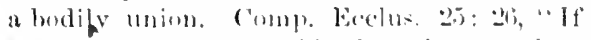
she ges not as thom womldst have hare ent her off frum thy theh," hreak the ludily union:

It is found in R, several cursives of singular exeellence, Irminian, (brigen (hree limes), and s'veral other Falhers. It is much eacier lo suppose a change to suit the Sept., the followiug word here and Marb,

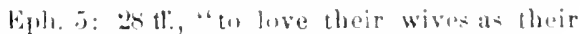

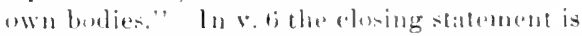
repreated for emplisisis. Ind there and Lorel fraws the entalu-ion that the two thus matert into one anglit nut to be separated. Joined together is literally yoliel togethere all als in

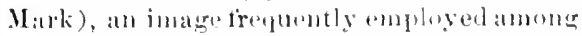
the Greclis for marriagr. (Combl. O Coteli: 11; Lov. 1!: 1!t.) 'lyo., Cran., (x+m., Jere remder "enupled.' Leet not man. Thenphyl.: "sluwwing what an interval there is brewnell Goel who joined together, amel man who puts asunder." Our Lorel has thus haid lown a broad general rula that the bome of marriage ought nover to be broken. A liste atter $(x, 9)$ le mentions, as if incidentally, an exerption to this rule, abunt which there was no differenee of oponion anomglis hearers, and which is in fact whly apparently an pxerption, braluse in that rise the esential bond has beent lirulines.

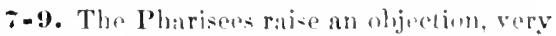
naturatly sugemeted, and anr lome poplies. Moses in Dout. 2t: 1 hat dertaimly allowal divoree, and they held that he had aemmomoled

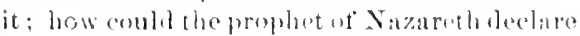
that divores wats eontrary lo the nature and

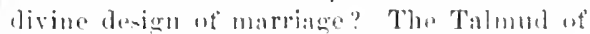
Ierusalem even represents it ats a prombiar privilege ot Israel, mot shared by the Gentiles, A writius ot divorerment. Thesime phrise is remelered bill of dimerement in (a)m.

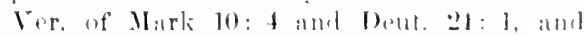
there ought to have heen mo ditforine in translation. The firesk is stightly ditfirerot abue in as: M. Moses... stillered you. Josls spualis of the law in Deute as emminer trom Moses. It is very haral to recomede this With the fashiomable theories ats to a latre dater

than an opposite change fo - nit the [I(d), which means 'created, for copyists and students of the text-forming periud seldom knew Heb. 


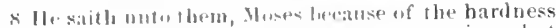

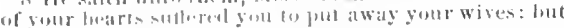

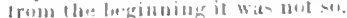

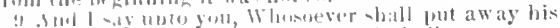

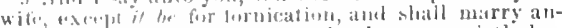
wiluer coumileth alultary : amel whosis marrieth her

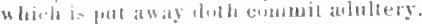

S a lill of divorcement, and to put her away? He saith unt" them, Moses for your hardness of heart sutfered you to put away your wives: but from the 9 fecinning it lath not beell so. And I say unto you, Whosover shall put away his wife, lexcept for fornication, and shall marry another, committeth

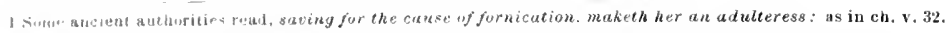

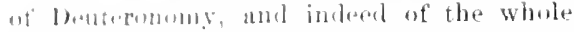

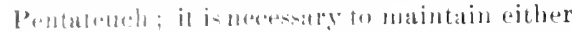
that , J1- - wat - mi-laken, ant this as to the

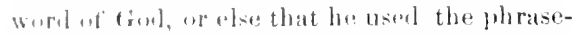
oluge "f his time in a highly misleading fa-hiun. Matry similar expresimen of his are

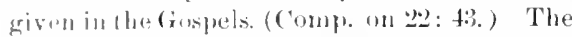
Platri-nes had said that Muras commmanded; oll loreit's reply puts it. 'sutfered.' But in

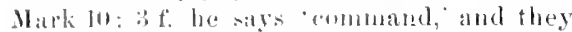
an-wer "utliar. Wia learu then that the law did not require the weongod hushand to jut ally his unfaithful wife; he might forgive her

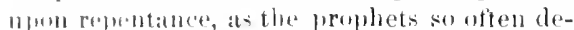
ralex lahorah willing to do with his unfaithful sponse, Isaul, The kaw suffered him to put awaty his wife, and commended him inso doing to grive the formal writing. Because af the harduess of your hearts. The fropmition (pros) trunslated 'because, signition 'lowking to,' 'considuring,' 'having regarl to. It was wiso not to attempt too much in these rivil ragulations for such a people. livalembar that the Mocate regulations at to marriag and divored wera vivil enaetments, though reating on an ethical hasis. Thenation of enaluripaterl saves whom Mases brought ant of Eiryen barl na lanlit tallen intu groat laxity anderoming marriage, ats slaves alwaly du, alul lo wath wise anough to kllow lbat it would be a slow and difficult task to lift thom uy to a high statucard of unrality in this inpurtant repuect. Fot he blocel serjoms potrictions mpen the exi-ting

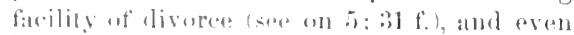
in this mattor .Josus Was unly "(onspleting"

1 Tho roaling of margin liev. Ver. is evilently drawn from is 32. The tirst part saving . . fornication'

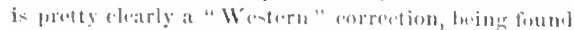

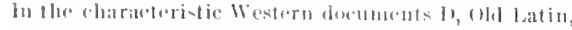

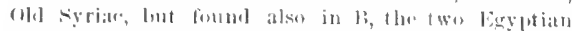
versions, Grigen, liasil. Wr H. lave placed it in their margin, and so it is in margin of liev. Ver. But is not this an instance of a "Western" alteration fomm in 13, the, like 27: 2s'? The next clatuse, "nukell her

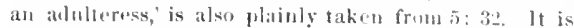
not given ly $[$, elc., but is given by $\mathrm{I}$, with $\mathrm{C}$ (1) the law by going further in the same direetion (comp. on 5: 17). 'Hardness of heart' (Rom.2:5; Eeckus, 15: 10) denotes not merely lack of proper fecling, as we use the phrase, but lack of proper perceptions and will (comp. on 6: 2l). The Israelites who received the law were not qualified for elevated ethieal perceptions, dispositions, or eondact, and would fiercely break over a severe enactment; and their deseendants were still too much of the same character. But the Messiah proposes to lift them higher; and $\mathrm{inth}_{\text {th }}$ matter tor return to the ariginal divine design of marriage. Our Lord thus recognizes that the practical direction of the law of Moses in this particular respect fell short of perfection. But we must observe that he does not declare the Old Test. as a whole to be imperfect even in this respect, but simply goes back to its earliest teaching on the subject, its great fundamental principles. Mal. 2: 14-16 speaks of divorces as offensive to Jehovah; but the Rabbis quibbled, smme saying that this only forbade a man's futting away his first wife. And I say unto you, solemnly ealling their attention (comp). on 5: 18). Mark 10: 10 shows that this was said 'in the bouse'-we know not what house-where the diseiples renewed the conversation. Matthew joins it withont break to the foregoing, and it was really a mart of the discourse on divoree. Our Lord grives his own authoritative statement on the sulject, applying the prineiple of v. 6 , and declares that divoree is not only not allowable 'for every cause' (v.3), but not allowable at all-except of course for unehastity.' See the

hand), $N, t$ wo eursives, and one or two mixed Latin copies, Memphilic, Origen, Aug. Here again B and Memphitie are elearly wrong, though not in this ease "Western." The last elause 'and he that marrieth,' etc., is doubtful. It would be easily inserted from $5: 32$, lut it is here omittel ouly by the "Western" group with L and some other MSS, the Egrptian versions and (trigen, most of which are elearly wrong just above; and its omission might have originally been aceidental, throngh the similar ending of this elause to the foregring. The conlusion arising in the text of two such 
10 His aliscipless say tmto him, If the caste of the nan be so with his wile, it is mol gooit to marry.

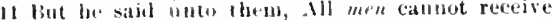
this saying, save thry to whom it is given. adulters: land he that marrieth ber when she is 10 put awa commillell andultery. The disciples aty unto hom, li llee case of the man is se with his wile,

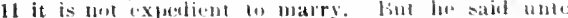
theos, All nes cannol receive this sayng, but they

I The following worals, to the end of the verse, ale omithed by some aucret authorities.

lealing terme explained above on the similar statement of is: :3:. That was nade in Galileer, and we are nuw in southern Pereat, a year or two later. It seemsetrange to modern reaclers that the highly important exception ene loord makes is so slightly mentioned, luth here (v.9) and in 5: :3, and that in Mark and Luke (on a somewhat earlier oreatsin, 16: 18) it is not rexerelal at all. The explanation is that allong the Jews there was no question on this point. Thestrirtes schonl of liabbis, that of shanmati, allowel divorea for unchastity, if mot for other di-graceful acts. Sis this mattor ald not model to be awelt on, hardly needeol to be mentionel, as it would butaken for erratud by all partien. But the question is uaturally

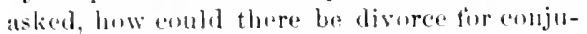
git unfichfulness, when the law punislued that oflence with death"? It is evident that the law was not regariled as compelling the husbaud to bring forth his adulterous wite for the death penalty. Joreph wa-mineled to put Mary away privately, and was prevented only by learning foum the angel that lereondition involved no goilt. (1: 1:0 f.) In the doubtless true stors, thangh nut belonging to sieripture, of the alulterom - woman brouert beforo J esu= (John 8:311), tha seribes and P'harisos: are reprenented as "tempting him" (just as here) with the question whether the law is to be enfirreed in her ease, and he dore not say that it mu-t he. And in the Talmud it is perfectly plain that the Juws did divore fir adultery instead of stoning. and uo one thought of eondemning it.

In Mark 10: 12 the statement is expressly dielared to hold of a woman also, who elivorces her husband. Everywhere in old Trst., and averwhere else in New Test. only the case of a man divoreing his wife is presented, the "ppusite ease being doubtless a very rare aecurrence in Oriental life. We might take for grantol that the same principles wombl apply to a woman divoreing her husaml, and this saying expressly enjoins such an application. It had bocome quite wotable parallel passages, is natural. It is not likely tnat the realing here has been affected by Mark 10: 11, commons for Romman woment to divorece their loushands and marry again, and this enstum laad begun to attect the otlicial anel tam-hionable cireles in Palestiue-as when Ilerullias clivoreed her hushams, Herod philip, to marry

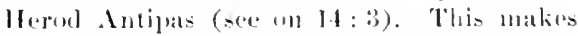
it natural that our Lord should once reter to that side of the question, aud that Mark's fospel should take pains to beport thesaying, as le wrote epereially for fientile, and perhaps especially tor lioman reablets.

10-1:. A renark by the elisciples and the Masters reply. The firet that this was "in the house (Mark), with only the disciples present, aceords well with the delieary ot the subject. This naise remark hows that avoll they shared largely the pojulat riews and foelings eoneerning marriagrand divaree and thought that as an indissolublemuion, marriage was to be avoided. Similar (Plumpures) is the view ot Mliton's "Doretrine and biseipline of Divoree." If the ease be so, and the form of expression implies fhat they aecept the supposition as true. The word

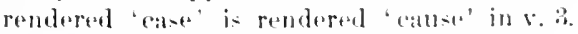

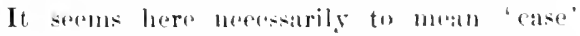
or 'matter, and this semse is veryenurally"

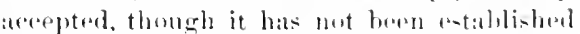
by other usage. The lation versions lase causa. Megers attempt to make it lore mean allso is nut suerastiul. It is not good (or erpedient) to marry, the term romberal 'it is profitables in 18: 10 ; 5 : 2y $\mathrm{f}$; sealso in 1 Cor. 1i: 12; 10: 2:3.

Our Lord's reply is that marriage is sometimes not expredient. All mon camust receive this saying, viz., the saying that it is not experlient to marry. What llope have said is true in some cases, mol for a sporial reason, quite different from the w11. intimatod by them. To understand this stying as his own saying, that marriage is imli-coluble, would make the sioviour contralict hi- ww argument, for he had argued from the divine purpose in the creation of man. "lieceive" does not hareman to ncepent a-trues, but the or the latter would hare been itself bikewise altered trom Matt. in some coples. 


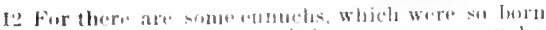

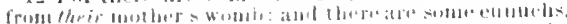

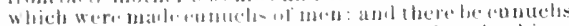

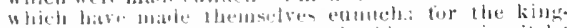

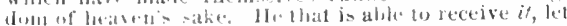
Lim retelle: $t$.
12 10 whom it is given. For there are eumuchs, that wert so born from their mother's womb: and there are ennuctsi, lhat were made elonuctis by men: and

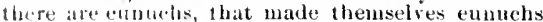
firr the hingdum of hearen's sake. He that is able to receive if, let him receje it.

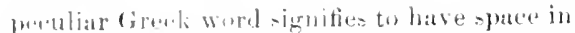
mar = matule for smothing-like a ressel holdimer an moll, comp. John 2]: 25-some-

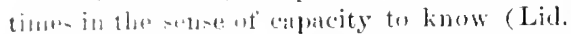
and seotl), hare in the solls of callacity to

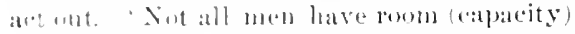
fior this satolug. The callacity depends on phyoblugical anotitution and gromeral tem-

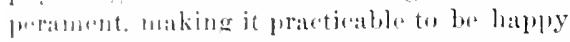

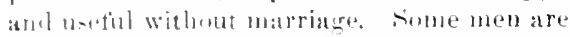
naturally dispualitied for marriage, and others have lnavl dinfualitied ly human aretion. Semp voluntarily abstain from marriage for lhe linglom of heaven's salie, fur the salis" of erreatur betuluess in proclaiming its truth and pronesting it- atabli-hunent. Some

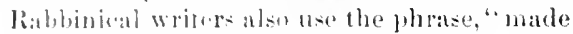

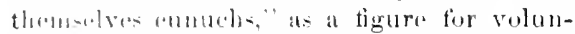
tary anel antire sexual abstinence. The fhrase was, and would atill bee, nafural enough

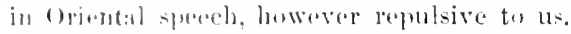
le womld probably nover bave been undersumel literally ly ang une, but for well-

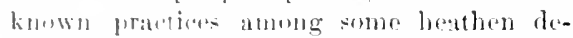
voture in 1-ia Minur and abewhere. Origen tomk it literally in hi- gonth and acted upon it. lont interprots it altegether suritually in

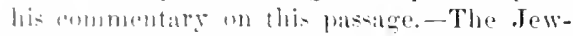

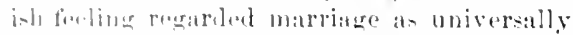

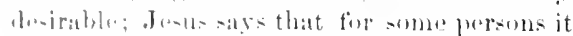

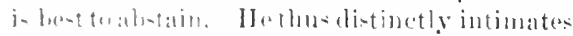
that wolihacy may erive erreat alvantaces in

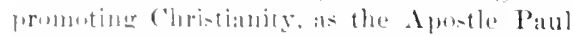

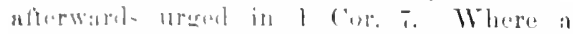

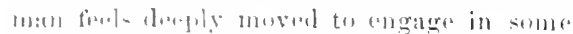
forme of religion- worle, with the prosecution wt which malrians wollel erregtly interfere,

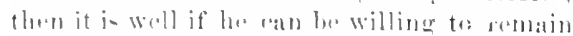

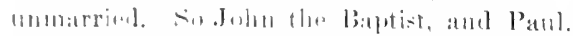

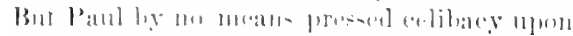

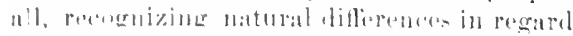

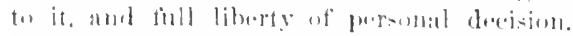

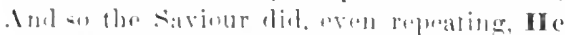

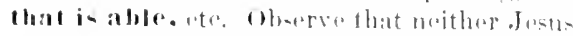
ane l'aul nur soripture anywhere fiscors the andic motion that marriagr is impure, or ase

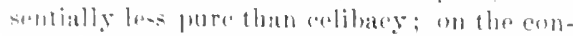
sury, "Let marriage he had in honor among all" (Heh. 13: + Rev. Ver.), and it was false teachers of thr worst type who were in hater times "forbidding to marry." (1 Tim.ti-3.) The question is not of a more or less holy state, but of greater or less usefulness, in promoting the kingdom ot heavin. Among the apostles to whom Jeall- said this, celihacy was not the rule, but the axeeption. Simon Peter was married (8:14), and when Palul wrote (1 Cor.9: off., r. v.), "the rest of the apostles," and "the brethren of the Lord," carried their wives with then in their missionary journeys. Paul himself remained unmarried for the sake of giving himself without hindranee to his work. (1 Cor 7:3: f.)-The Romisl rule of universal celibacy in the priesthood oecasioned a Protestant reaction to the upposite extreme. Protestant public opinion almost denands that a minister shall mary. Yet how much missionary work, in sarage or sickly (o)untries, or in home fields that cannot support a family, could be far better done by unmarried men. How many a young minister cuts short his preparatory studies, or prosecutes them amid great interruption and hindrance, or is obliged to begin pastoral work in too exacting a field, for the sake of an unnecessurity early marriage. Every one must decide for himself; but he should decide in view of life as a whole, and of the life to come.

\section{HOMILETICAI, AND PRACTICAL.}

V. 3. Tempting Jesus. 1) With hard questimn- Lnlio 11: 16; Matt. 16: 1; 19: 3; 20: 18, :3. 2) By efforts to restrain hin from coing forward to death, 16: 22 f., com]. John I2: 27 and Matt. 26:36 ff. 3) $\mathrm{B} y$ suggesting pritivesin, 4: 1-11.

V. 6. Fond and man as to marriage. 1) 111 the fundamental relations of socicty are hased an human nature as originally created. 2) Marriage was designed by the Creator to he a complete union of two into one, and indisolulile; the one sin that justifies divoree dous so lecoutue it has essentially broken the unim. B. Wherever man has violated God's lasign. by separating the married for reasons which do not break the essential bond, there 


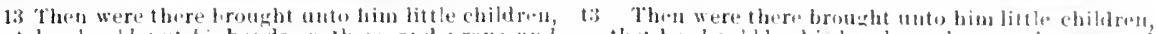
tinat he should pole his hitids on them, and pray: and line diaciples rebuked llem.

follow erroat and ever growiug evils. In such cases ro-marriage may serent to brovent alultery, but it is itsedt alultery (v. 4). 4) It is man" s highest wialour, interest, and dutybest for the parties concernod and best fior sorelety-tes follow fiod's law of marriage, strictly and fatithtully.

13-1.5. LITTLE ('IILDREN ARE BRQUCAHT TO JESU FOR HIS BLESAING.

Fonnd also in Hark 10: 1:3-16; Inke ls: 1.)-17. Luke here again beeomes parallel to Matthew and Mark, and continues so to the end, see above on 1!) 1. The places of this

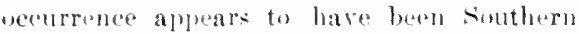
Pereat, in seme hutso (Nark 10:10), and the time a few days before the trimmphat entry, see on 1! : 1. I'hen is maturally, though not of nocossity (see on 3: 1:3), understoerl strie.lly, ats donuting the time of the foregoing conversation upen divoree. Mark has simply "ambl. Were there bromght. Wark has "they brought, impersonal, lika "thegsay": Luke. "they brought unte him their babes also,' which shows that the parents bromght them. They wereso mored hy his teatehingambl healing as not only to seek a preponal blessing, but a blessing upon their babes atso. Mark and Luke have the (xreck importeet tense, arseribing themb as ongated in hringing. And they hatre" robuked 'in thesatues tonse; while the parents were bringing and the disciples were rebuking, Iosels spolis. Inttle childrell, calle+l 'babis' in Iuke, and small enough to be naturally taken in anes arms (Mark). Theseterma torbiel anr umberstanding ehildron old enough trexereisotith. Put his hands on them, and pray. The Jew had always valuod the "blessinge" of a father, " proplact, a great rabhi, or other vamerable person. The Talumel ans they hrought their young ehilalren to the synagene tore this purpose. "Alter the fiather ut the child had laid his hand-on his child's hend, ho lend him to the elders, and by ane, amol they also blessed him, and prayed that he might grow up famous in the law, faithful in marriuge, and abundant in guol works." (Buxtort, in Geikie.) To lay hands on them, or (Marls and Luke) 'tunch them,' was the symbol of invoking a blessing upon them, and seemed to es-

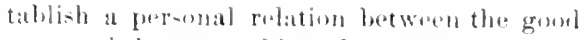

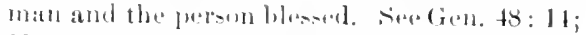
Numb. 27: 18; A(2to li: fj; li3: :3; (comll). Matt. 9: 1s, 201. They catme to. Justs at at rabbi or a prophet; and he disl what they desired, touk the chililren in hisarms and blessed them (eompr. IIark 10: 16!. And the disciples rebuked them. This in Matt. might mean rebuked the chilitren ore rebulitul those who brought them; in Mark and Julie it is clearly the latter, whleh is obvinu-ly alpure priate. Jasus bad just ber.n sjualing of a highly important pratetial topric. viz., tho. perpriety of eliveree, and the expediency at matriage. The disciples lawl renewed the subjeret after leaving the Phariseres (Natk 10;10), and tho Master wats pursuing it m private. Perhale ( Wit.) they were just thinling at other yluestions to ask on the suljeet. Thery dill nut watnt the privaley th Messiah the King

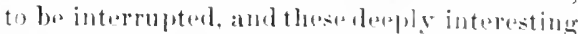

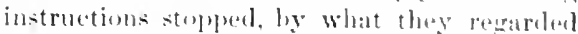

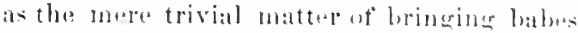
fer the teachers blessing. ('ismp. 201: 31; 2

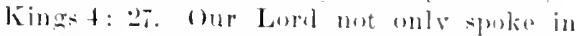
oflesition to their rebuke, but (Marli) "was moved with indignation, "a strong word, the same as in 20: 24; 26:8. Why was he so indiernant? IIs warmly loved inf:unt chil-

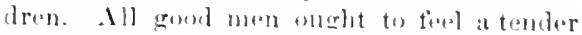
affection for them, and it seemed that the disciplos were in this resperet lefiedent. This vory scene has so talught the ('hristian world to love infatut children that it is litlicult for us to realize the alpurent focling at the disciples. They thought the infants and their parents IInworthy of tha Mosialis notien; and he wis indignant at such a concerention of childhond and of him. Inrencer. while they were as:moved at the intormption of valued instruse tion, they were forgetting that some months

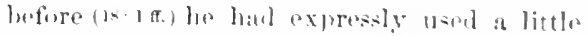
child as an ubjert-lo-son to give tham ateserved rebulie for their selfi-h ambition and joatons strife. This was ane ont the losens they most needed, and from that tims forth they anght never to hares loolied at a little chilel without recalling the losson and laying it to heart afresh. But no. They have forgotten the lesson, and behold little children 
11 lant dews salu, sutter little children, and forlin thetil rol, lo eome unto me: fir of sucls is the kingdom of heiven.
11 the disciplos rebuked them. But Jesus sajd, Sutfer the little children, and forbid them nol, to come unio ne: tor 1 to such belongeth the kingdom of

Ior, of such is.

without beine reminked. In a day or two

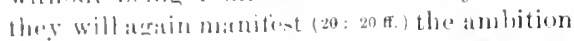
ami juallousy he hall ased that illustration to

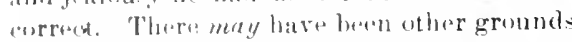
line the Master's indignation, and some of

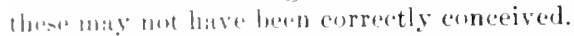

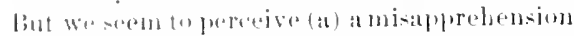
of him. for he touderly loved little ehildren; (b) a lafint in throir awn character, in that phey dial not love theme as he dul; (c) a griev-

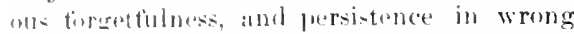
disfustions lie had taken steh pains to corroret and it may also be that (d) he was displan-al at their as-uming the right to decide whoslunld approach him, withont waiting to know his wishes. More than ance before he has sharply repreveel them tor not understanding or not romembering his instructions.

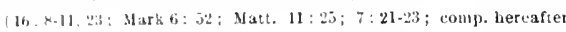

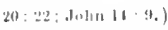

1. The repetition, suffer and forbid not, is highly cmphatie. It was vividly rememlerend, tior Matthew, Mark, and Luke gave the sinne works, with a slight difference (1) "urler. 'sutfier' is andist tonse, expressing the simples action without the notion of continuanes; 'torlide is present tensa, 'do not lo lorbiblime', or 'do not make a

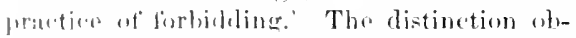
taim in Matthew, Mark, and Luke; and the diflerence was folt. fir the manuserjpt $I)$ has

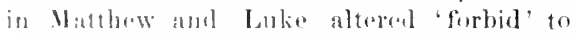
acriat. To come unto me is a general ex-

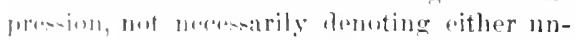

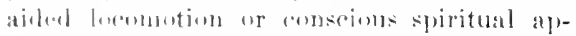
prostels, buth ot which are here tiorbidelen by the terms 'hales and 'were hrought.' The

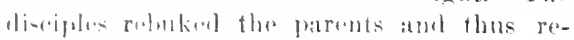

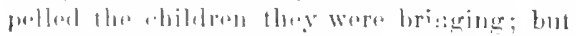

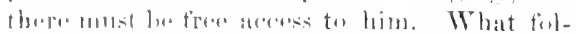

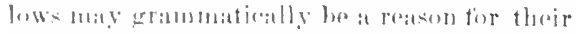

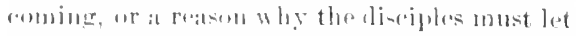

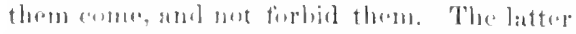

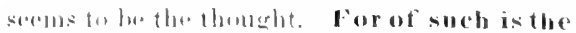

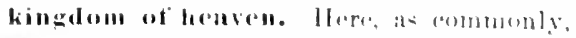
Matthew has the Jewish phatase kingelom at hraven, Mark and huke, 'kinglem of (boll'

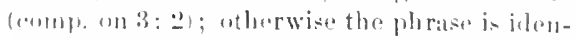
tucul in all three. Fur of surb is, the Amer.
Revisers give 'to such betongeth,' comp. 5: 3, 10; Luke 4: 20; James 2: 5. (So Meyer, (irimm, Jelf.) But the difference is not important. 'Such' evidently means childlike persoms, as he had previously taught in $18: 3$. The only question is whether it also means children. To understand it in both senses at the sane time is very diffeult. Morison argues that it means simply and exclusively childeen such as these, and not childlike adults at all. There is plenty of warrant in usage for" so understanding the word 'such'; but does not the eonnection here in Mark and Luke absolutely require the sense of childlike persons? They both add, "whosoever shall not receive the kinglom of God as a little child, he shall in no wise enter therein.' This is exactly what Jesus said on a former oceasion (18:3), when, as almost all commentators agree, he was using the little child anly as an illustration. Morison's position is therefore mntenable in this case. 'Such' certainly means childlike persons, and apparently does not mean children at all. So the Memphitic, "for persons of this sort, theirs is the kingdom of heaven." And the Peshito takes great pains, "for those who are like them, theirs is the kingdom of hearen." All the Greek commentaturs explain it ameaning the childike, mone of them mentioning chils:an as inclucled, and several expressly stating the contrury. Nor does any Greek commentator, so far as we an find, mention infant baptism in connection with the passage, though they all practiced that rite. Origen speaks only of the childlike; and so Cy.il: "The new-bosn child is a srmbol of innocence; for the bube is as it were a new ereature. . . . Christ does not wish us to lue without intelligence when he says. For to such belongs (or, of such is) the kingdom of heaven, but to be infints in evil, and in intelligence perfect (full-grown)." (Hrys.: "Toarhing them (the disciples) to be lowly, and to trample under foot worldy Iride, he receives them, and takes them in his itrus, and to such as them promises the kingrom; which kind of thing he said before "lso," i. e., in 18: 3 f. Theophyl.: "He did not say 'these,' but 'such,' $i$. $e$, the simple, 
the guileless, the innocent." Euthym. " $I I 0$ did not say to these helosigs the kingelom of heuven, but 'to sleh, tho- who imitate the simplicity of there." Inom. takes tla werason to exhort parents to bring their children incessantly th the prieste, that they may put their handsonthom and pray for them. Evan the great latin ecommentatur, Jesemer fintluwed by Bode+1, lells us: "He signiticuntly said 'such,' not "these', in arder to show that not age reigns, fut clatracter, and that the rewarel is promiseel to those who should have. similar innocenceand simplicity." But Tertulli:uand Augu-tine do nexution, not this clause hut that which prevereles, in eonncetion with infint bapti-n. Tortullion (on Baptism, 18) advises delay of loaptism till there has been fropor instruction, "elelay necording to each ones condition and di-position and even age; and especially as to the little ones. . . . The Lurd does indeed say, "Forbid them not to come untw me. Let them come, then, while they aregrowing up; let then come while they are learuing, whole they are loeing tateght whither to come; let them be made Christians when they have beamene ableto know christ. Why does the immoent are latseten to remission of sins?" He luere shows, as throughout the treatise, that haptism is regarded by him and those he arldreseres, as securing remisoion and makiug persons ("hristians. Sin Cyprian ("Ep. 11) Fidus") and ()rigen (an Rom. ch. 5 and IIomily 14 on Lukc ch. 2.) give as the reanom for infant bateism that the infants mase rereive remisoin of original sin, that the defilement of sin may he walled away through water and the spirit, cte.. hut neither of them montions this fatsage, nor does Origen mention infant baptisn in his intropretation of this passage. Hesays on Rom, ), "The chureh recoived it as a tradition from the apueties, togivabalptism tolittle onesalso." fuenestine ("Norm. 17t") says: "Noome passes from the

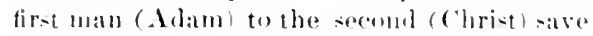
through the sactimunt ot baptism. In litale children born and not yot baptized, belobl Allan; in little chilelen lore and baptized and therefore born agaiu, behold Chrint.

What is it that thoul sayest, little childron

1 Maldonatus: "The Cairinists [i.e., Reformed] have no other costmony ly which bo prove that infants ought to the haplized, than that Christ says. 'Sutler the little ones to come to me.' For that strongest and have no sin at all, not even origrial sin? What is it that thom sagnest, but that thry

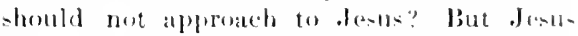

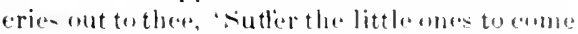
to me.." Ang. very frequently grives the same reason for infant baptism, constantly and veloenently asaniling the l'olagian- witl the arerument that there is no propriety in infaut baptiom unles infant: are moler the gruilt of origimal sin, but we lave found no other instance in which lae ansuciates with it this bas-age. Calvin say- "huth ebildren and thase who are like themo." Alfodeder (oll Marli): "More sati-fietory is Calvins (*xplanation of the sentenew an referring both to eloildren (i. e.. to believing eluildren) and to thue who are like them in thrir childlike "iualities." Butbelering children are in the same position as believing adults; so this ivirtually admitting that there is here no reterence to infants who are incaluable of belief. Alesandere adds, "The application of this pas-sage to infaut haptism, althougle seorufully rejected as absurd hy its oplynents, is entirm1 le legitimate, mot as an argument. Wut as an illustration of the spirit of the C'hristian $-y+$ tem with respeet to childien." Benefel siys: "Grant that such as are like infants are meant, then much more infants themselves. whore such, have the lingdom of Goul, and shoulal and can receive it by rominer tor Christ." And he aroually thinlis it helpe the matter to add: "Many of thuae who were then infints, afterwarels when arewn up bolieved on "hrist Jesus." Weyer: "Not little children, but men of a childilis dispusition,

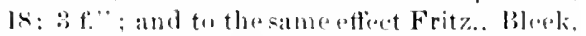
Lutter., Kém, Gomet. (J/sh. "Of that roference to infant baptism which it is steommon tos sees in this narrativa, there is elearly not the slightert trane to he foumd. The sioniomr sots the dildren before the abutles as symbols of spiritual regenemation, and af the simple childlike fereling therein imparted."

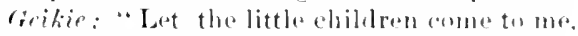
and do not forbid them, for the kinglom of hatren is given mnly to such as have a childlike spirit and nature like thrirs."

Tostam up. (a) There is nut eroul croumd

clearest testimung hy which the whreh has always

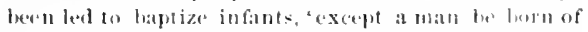
water and of the sirit he cannot entor into the kinedom of God,' they interpret not of baptism but of 
1is Ind he laid his hambs on the:es, and departed thence.

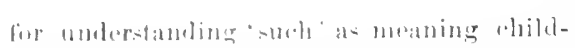

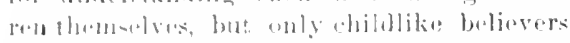

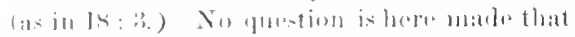

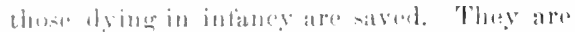
sibul thengh the atomemont af ('hrist and Ho. work of the Sprit, but this most buld tous of all alike, without reforence to an areroundy, amb no matter whether their

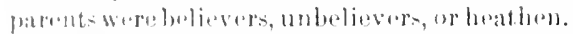
The Mrenanie kjugelom is always spoken of in comonetion with, and serems naturally to

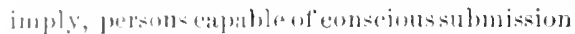

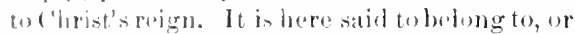
(o) llsistot, thechildlikr, and (acesolingto Mark amiluk(a)not?ers. 19'such'incluclesinfants, it inclules all istants, not only buse dying in inforrey, amb those that live and beeome believers, but thoss that live a lite of sin and are finally lust; in what sort of sense does the Masianid kinglon belong to (or consist of )

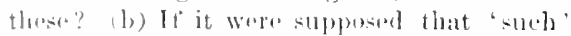
dous inchude literal children, it womld nest follow thet infonts oustut to be baptizod. There is

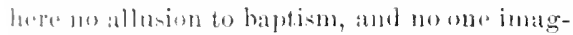

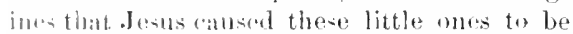
baptizal. Wre know that at one period Jesus wat baptizing (thromerh his disciples) very

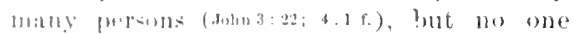
forestions llatt thry ware baptizad as poniturt

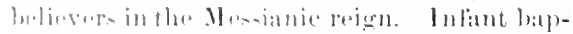

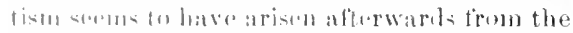

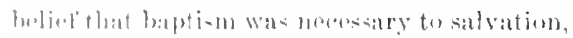

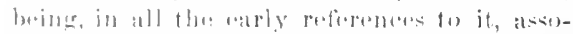
riatul witle that baliet, and whly as an atter-

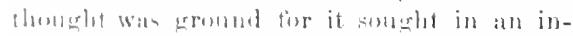

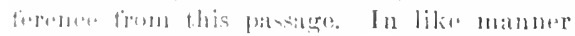

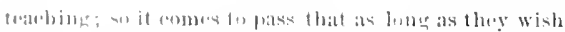

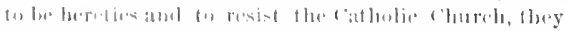

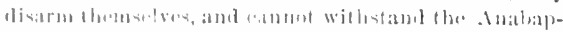

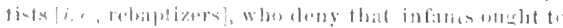

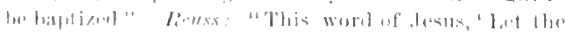

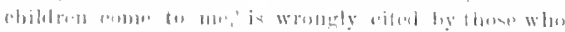

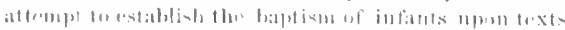

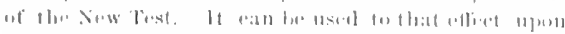

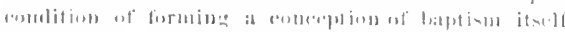

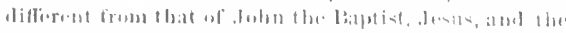

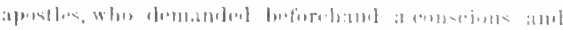

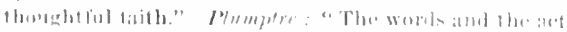

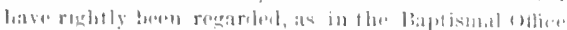

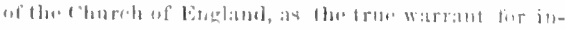

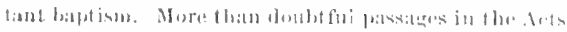

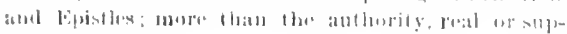

15 heaven. And lue laid his hands on them, and repirted thence.

Zwingli, in his entroversies with the Anabaption-, introbluced the argument from the Abrahanic (rovenant.

1.j. Laid his hands on them, ff eourse with the aceolupanying prilyer (v. 13) that they might be blesed. Mark adds that he 'tosk them in his arms.' apparently from the arms of thuse who brought them, 'and blessed them, laying his hamis upon them'; he must then have been seated-we have seen that he wat probably in a house. His blessing them means that ho prayod (v.13) that they nught be hleswed. Wre eamuet possibly know what results forlowed to the infints from this benediction. He prapol that his eruejfiers might be forgiven, and they wore-if they repented and believel. Aud departed thence. Mark I1: 17 may merhaps indicate that he left sooner than was expected. Was it beeause of his indignation at the diseiples?

\section{HOMILETIAAL ANI PRACTICAI.}

V. 13-15. Jems and infant children. 1) Jesus tenderly loves infant children (eomp. Mark 10: 16), for he has the same feelings now as when on eurth. (Heb. 13:s.) 2) It is right fur parents continually to seek the blessing of Jesui upon their infunt children. 3) It is a groat mistake and a great fault to take no intere-t in intants; they who do so are quite unilie. Josu-, and forget one of his most impressive lessmi. (omp. $18: 3$.$) 4) 111 \mathrm{fol}-$ lowers of . Jesus ought to be childlike, i.e., teachable, loving, free from selfis ambition and joubusy, rte.; not anly ought to be, but absututely must be childike. (Mark 10:15;

posed, of primitive antiquity; more than the legal fiction that they fulfit the condition of baptism linough their ynmsurs-they justify the Church of christ at litge in emmenting infants, as such, to the biessing of their lither. The blessing and the prayer of christ cannot be buatrad as a mere sympathizing compliatee with the foml wishes et the parents, and if infuts were ritpathe of spirituat bleswings then, why, it nay

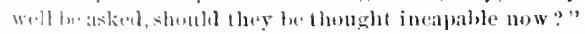
Si, "the true warrant for infant biptism" is found in at pastig, whith very many of the ahlest ancient and medorn writers who have practiced it declare to have no annection with the sulgeet.

11)r. 11. 11. Whitsitt, l'rot, of Ch. Itist., Louisville, kmows of no earlier use of this argument. 
16 Amd, lwhold, one (ane and said unlo him, fiom Master, what remel lhimer shall 1 do, that 1 maty have elurual lifit".

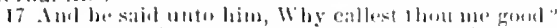

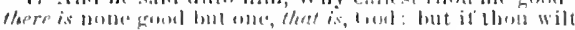
enter mote life, biep the commandusents.

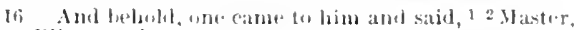

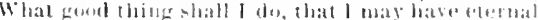

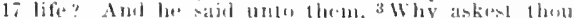

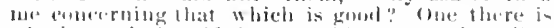

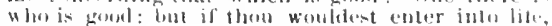

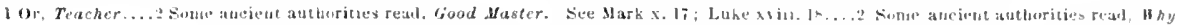

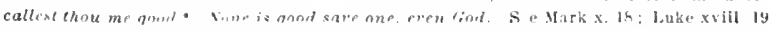

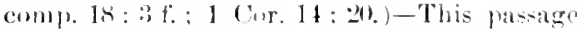
can hardly be used in addresing simdiy"

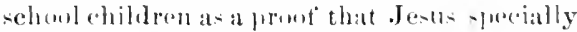

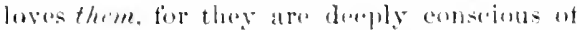
sin, and ollght to ank from ob:us a laew heart, forctereses and holp to live as his followers.

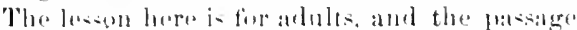
is oftens $\mathrm{s}$ mi-llsind as simply to promote in

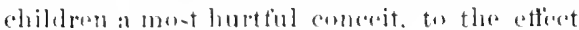
that they are greatly bettor than grewn perple.

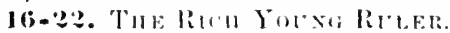

Fond also in Vark 10: 17-202; Luke 18: 16-?

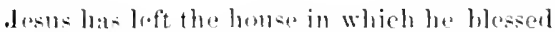
the baloe- (s. 15: Mark lit in). and is eroing forth

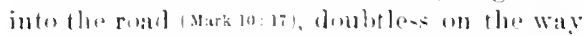

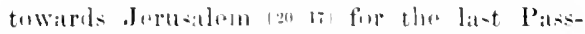
ever. The plate is till pretty certainly in sinuthern Pere:1. (19:1, 20. 29.)

16. One came. 'One may loe taken

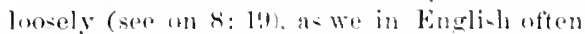

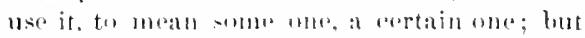
is porlang belter taken strietly-mot now :

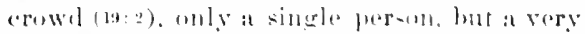
interesting and impurtant ase. Matthew

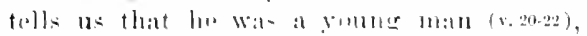
Luke that he wat at "ruler' (10.1n), unt preb)ably meaning nowe of the simbedrin tobn3.1),

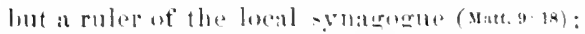
all threestate that he wate very walthy. The

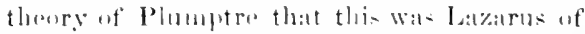
Buthang, rests entirely apun artain resemWhaneres, at wealth, high stameling, and the

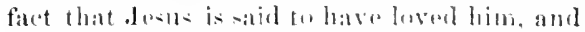
it must be rexardul as a pleatsant hemilotial fancy, rather than wen a probable

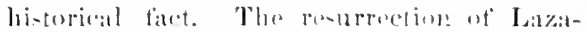
rus wa almus certainly before this time. For 'eame to him, Vark says vividly. Rev. Ver., "ran to hin, and kneeleal to

1 The other realines need not have been placed in the margin of liev. Vier. len there ean le nu question that they are wrollg. We ranont inateine any reasom for changing an easy realiog which agmel will llark and luke into an obscure une which slrikingly ditlers, him.' limding that Jous had left the house. and atger not to mi-s the deresed instruetion. he runs to avertalke him, and then knerels ini profouml reverence. God Master, $i$.

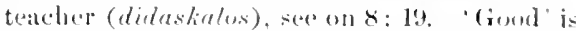
wanting in the earlient and best doenmemls. and was matulfesly brought in by apyist. from Mark and Lake. The same early dencluments, with matly others of great importance. read v. 17 as in Rov. Ver., which, enpecially as the meanine is not obvions, womld be roaldily changerl to agree with Mark and Lulie.' What good thing shatl I do? Ih has done many groud thiners, what elso? ( $(2,24)$ That 1 may have aternal life, (omul. on 2.): Hi. II is sinerety and derefly desiroms of graining it, a- he has shown by his conduct

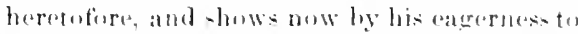
latarn from the Galilean teacher wher is passing by. ('ontrat the lawyer of Lake 10: 25, who equibloled. (v. 29.)

17. It is prosible (Aug) that Jesus used first the (xpresion in Mark and Iouka, and afterWardo that in Matt. (Lieve. Ver.) But thes Evangelists often report a siying in diflierent terms. (sere on : : 17.) Butle forms herexepresestruth, and they subantially agree. To eall him 'gromed ( Mark and lake). Was a sort uf thattery to che approached ouly as a Rabhi. which be rebukes at improper: only (iod is

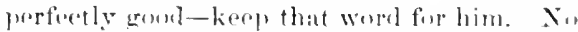
religions teacher womld really like to be aneosted als "a gond man." So here, to ask a teacher enncerning that which is gowe, what Enod thing shall be done. mull not lue will the notion that any mere human teateher is of limedf equalifiesl to grive the desired instrue-

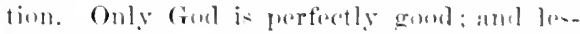
sons of gomlness are not lessons of merie human othieal widem. but of divine instruedime This is a surpar-ingly iumportant truth. Wrul

while the ehanec into assintation is presisty such at

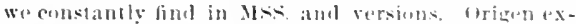

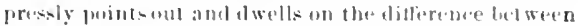
the text of Matt. aud that of Mark and lake. 


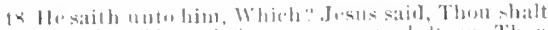

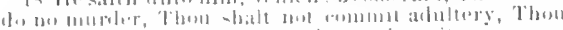

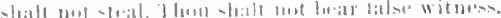

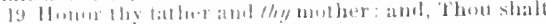

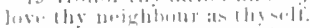

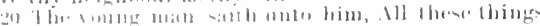

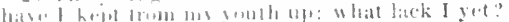

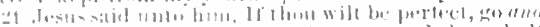

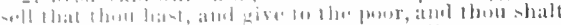

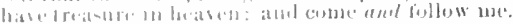

in every ate and enomtry are prome to think

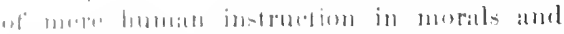

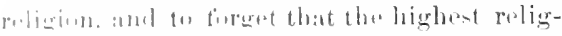

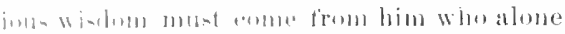

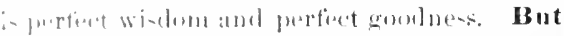

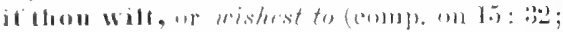
lii: 24), enter into lilie ( (e) lopet

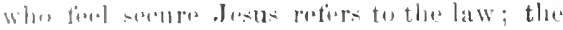

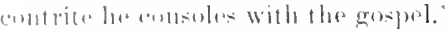

In t. Which, it striatly tramslated, would

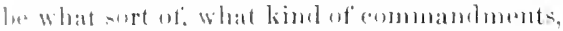

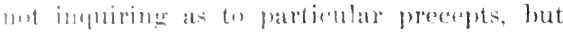

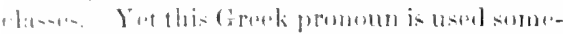
what Jwmely in New Jomt. atul may heremean -imply which. In Morlern Greele it has that matalline always. The ruler may have ex-

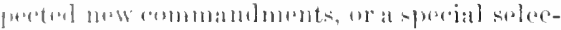
tinn foum those existing. Tlar Rablotis would have proceribed strikter attention tor tradi-

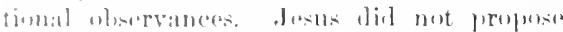

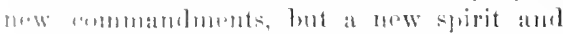

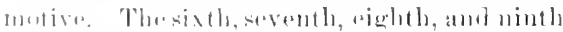

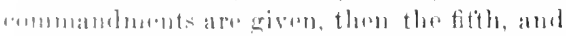

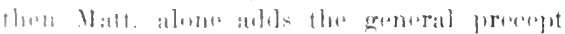

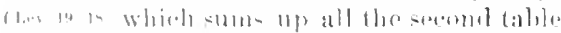

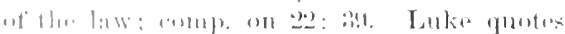

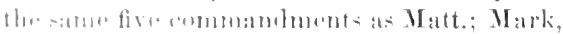

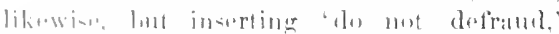

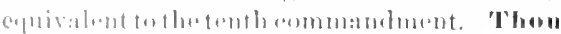
-liali do no murdar (lins. Yir., shalt met lill). Su alen (come. Ver. in 5: 20l Mark

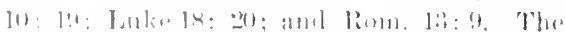

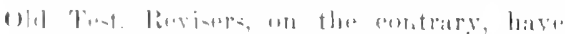

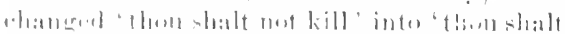

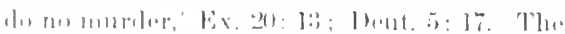

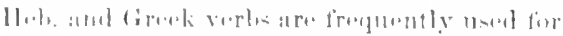

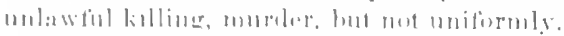

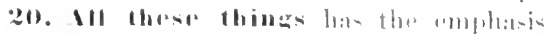

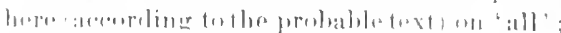

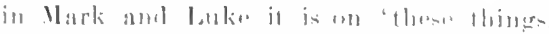

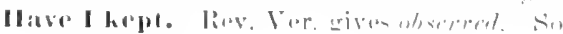

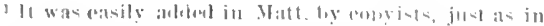

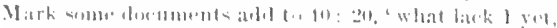
(which Mark really has just atter in athother shate) is his the eommandments. He saith unto him,

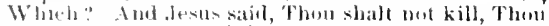
- halt bot conimit arlulery, Thou shalt not steal, Thom shalt not luar finlse wilness, llonour thy 19 fitther and thy mollore and, 'Thom shat love thy 20 mightout as thyolt. The roung man saith unto him, .1l] these things have fobserved: what lack I

21 sol". olesus sijul unto him, If thou wouldest be jerlixt, go, sell that thom hast, and give to the por, and thou shalt have treasure in heaven: and come,

'Tyn. and (iten. loere, and all early English vereions in Mark 10: 21), while all give "kept" for the same word in Luke 18: 21. Inv. 17 abrve, 'kejut represents a diflerent word. From my youth up is spurious in Matt., but gemuine in Mark amel Luke, and so was really said.' 'Tlie speaker was still a 'young man, but it is quitu common for young men to lowk laack to their youth, viz., boyhood, and as a very renute period. He must have bren sincero in his profession, and really blameless in ontward confurmity to law, for 'Jesus looking upon him loved him.' (sark.) What Lack I yet: Mark and Luke give as the herinning of the Saviour's reply, "One thing thou lackent.' So the question here must not be regarded as a mere self-righteous exprision. The only observance be had ever thumght ut was external and superficial; in regard to this, he had beon very eareful and correct. The latmud repeatedy mentions persons as laving kept the whole law, in me case "my holy onse, who havo kept the whole law, from Aleph to Tau," like Nlplua to Omega. The Great Tarcler does not stop for distinctions between the external and the spiritual which the youmg ruler would have found it diffeult to aprereciate, but cuts through all his seltdolu-ion and self-complacency by an extraordimaly trmand.

¿I. If thon wilt loe, wishest to be, as in v. 17. Prefect, so as to lack nothing, see on $\therefore$ : Ai. (xo, go alomg, go promptly, as in 4: 11); 5: 24; $13: 44 ; 18: 15$, sell that thou hast (compl. 1:) 46), at comprebennive expression, strengthened in Mark hy 'whatsoner,' in Luke by 'all.' To the poor. Hore again (see on $5: 8 ; 11: 5$ ) the notion of "begerars' is apute out of place; the wint giving is not always to begars. The Talmml ( Wot.) ppeaks of a rabbj as saying (1) solue (rentiles who sought instruction,

and to 11): '-1, 'if thou wi-hest to be perfect.' Such patent errors show the halits of copryists, and help us to uroup diremuents. 
22 But when lhe young man hearl that saying, he went a wa sorrowfol: for he had greal jussessions.
22: follow me. lint whet the young man heard the sayinta, he well away sorrowlut: for be wan ont lhat hid greal possessions.
"Siell all that you have, and moreuver gou onght to beenome proselytes." - This was al special te-t, racetly suited to the youmer ruler, as appears from his sorrowtul tailure to meet it. The primejule involved is supereme devotion to chrint. The test of this is ditterent tor ditlerent forple. Simme fand it harder to remonnce lappes of wordly homor and fitue for Chrint's sakr, than to remunce wealth; and fior others the liaril trial is to aloundon certain gratifications of the various appetites or at taste. Aliraham lift his mative eomutry at Geds remmand, but berame rich and fimmons. Moses gave ny the distinction anel

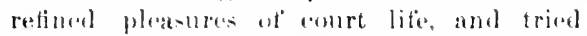
patiently to rule a clebatsed and intractable pepde. Elisha lift his moguerty at the eall of Gan through Elijah. Paul abandened his anbitious boje ut being a great rabhi. All

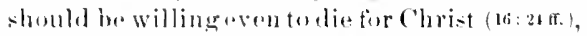
though mot many are aetually repuired to do so. The Romanists huild on this patsage their theory that for all jersoms and times rolumtary and alsolute purerty is a chiet moans of serering the highest spiritual attaimments. But there is no intimation that . I esus requires this of all his followers. Ile said bething of the kind to any but the Twelve, and a tew who, like them, wera allod to leave lome and travel about the country with him. Treasure in heavell, see on i: 20 . Ind come, fol-

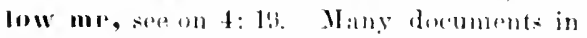
Mark, and one or two in Mattlow aclel taking up thy eross,' borrowed fiom Mark s : :3t; Intt. Hi: 21 .

22. He went away sorrowful. Wark prefixus 'his eountemance foll,' 'he lonked

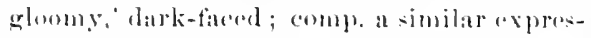
sion in Luke 24: 17 (eorreet toxt). It wat a painful distppointment; his talerer lonering and hope arave way to gloom-he combl mot give up his erreat jussesions. Among all nat tions, hut refredially among the Jewish higher clasis, the idea of falling from grout wealth to utter poverty womld be extremely painfin. Ile went away, and appoars mo more in the history. One womld ineline to the hopetiol persuasion that he afterwards beeame a true Christian, sineo Jesus loved him. But the story euds very sadly. Aud its lesson applies very closely to many whose 'possessinns' are by wo means "grout.

\section{HOMILETIOAL AND PRACTISAL.}

V. 17-21. W0 noed nonew anmonatuents, but a new motive, mlluemederotion ter ('brist.

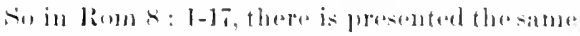
old law, hut a new revelation at toregiventes (v. 1), a new moral fores r. 2), a new motiva

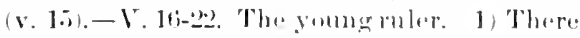
magt be nueh religions armestuess, and a lovable sinererity, withent true Chrietian piety.

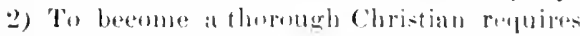
no new jrecepts, but a maw spirit. :3) A romplete Christian character and lite cammot exist without enmplete submision to (:brist. 4) The tusts af sllmbi-sion a christ will be very ditfirent in ditlirent canes, but must in werge case be squately met. (3) Turniug away from Christ with regret and grlommy sadues, is yet turning awas.-V. 17 (latter part). It them wisleen to anter into lite. 1) The wish. (a) None enter whodunot wi-h. (b) Xene who wish tor conter need fail. 2) The waly. (a) Thu commandments must be keje not anly antwarlly, but inwarlly, spiritually. (l) This ran he deme through help of Chei-t and of the uther comterter. (c) That holp is received (m)ly where there is supreme devotion to Chri-t.- It. Et). What lark l yet? 1 II" miglet serm to others to lack mothing: he hat

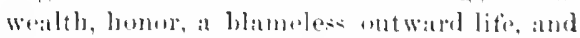
a derp sincerity and atuesturse. 2) Ilo is

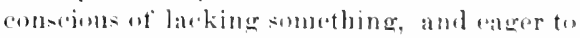
supply the lacke. B) Je really lateks everything ; for he has anly kept the commonand-

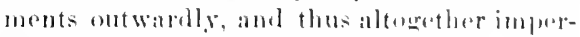

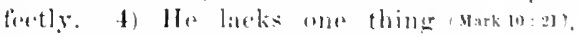
without which all is imalequate, and with which all will work toward perfection and etromal life: amel that one thing is supreme devotion to (hrist.- T. 2). Mr went hway sorrowful. 1) He went aw:y sorrowyl. -2) Ilo rent au*ay sirrowtul.

Ch. 19: :3-20: 16. IIRR FOR TII:

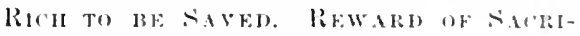
FICE FOR CHRISTS SAKE.

This seetion, "xerpet the parable, is fommd also in Mark 10: 2-3.31: Lakm 18: 21-30. In both it is immediately comeeted as here with 


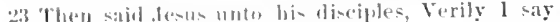

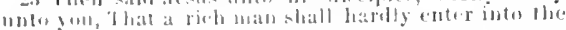

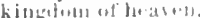

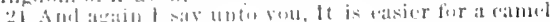

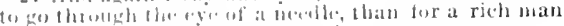
bi) (1)

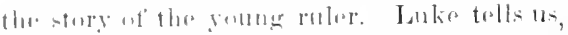

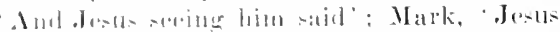

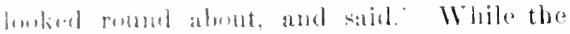
renuer man wallenl elmomily away, Jous Jonkel at him and at his liseiples, and spoke to them the erreat lentle which tiolluw. The

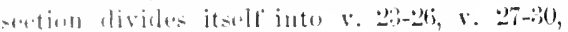
alid :31: 1-lli,

1. 23-26. HIIU fol: THE RICII TO IBE

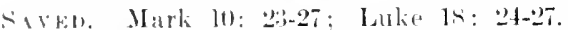
Verily I say nuto you, ralling slecial attontim, sene (1) $5: 14$. A rich man shall hardly enter. It is hated fire a riele mane (Rav. Ver.), was the lemelering of Tyudales and followers. "lohe comm. Ver. thomerli more literal, would now sllugest improbability rather than ditlimulty. The dew- inclined to think jt much

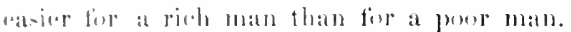

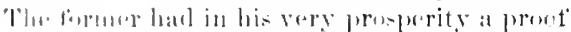
of the divino favor; ho was prime facie a

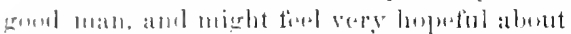

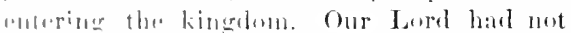

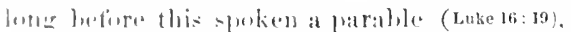
in which. contrary to what all Jews would

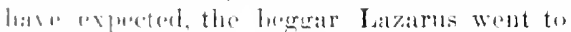

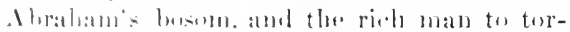

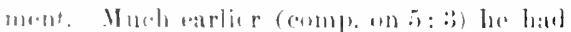

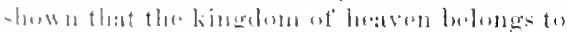

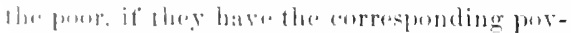
aly in mirit. línglom of hoaven, see on

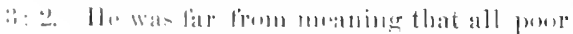

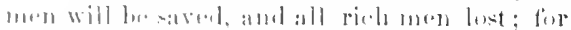

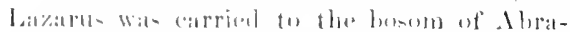

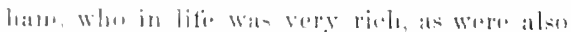

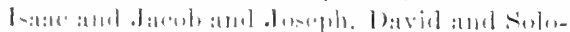

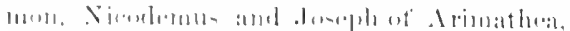

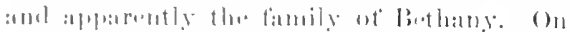

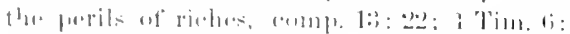

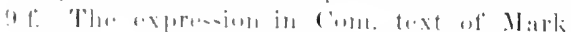

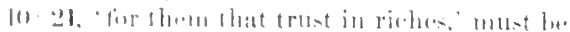

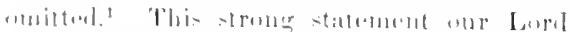

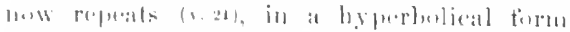

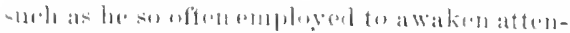

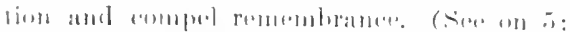

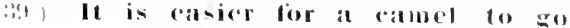

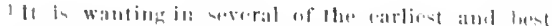

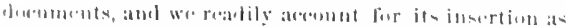
w ginally a marginal explatuation of a difliculty, am
23. Ind Jesus said unto his disciples, Verily I say unto rou, $1 \mathrm{t}$ is hard for tich nuals to entor into the $24 \mathrm{king}$ lom of heaven. And araill I say unto you, l is easier for a camel to go through a needle's eye,

through the eye of a needle. Sis also Mark and Luke. The camel was the largest beant familiar to the Jews, and the needle's rye was the smallest opening in any fantiliar bljret. So the expression denotes an impossibility, amb it was so understood by the disciples, and so treated by Jesus just after. (x. 26.) A little later (23:24), our Lold will again use the cand as the largest boast in another byprobolical expresion, "who strain out the guat and swallow the cames.' In the Talmud, fir an eleplant to go through a needle's eye is several times employed as an expression of imposibility, the Jews in foreign countries baving now become familiar with an animal arem larger than the camel. Onr Lurd may have leesu using a proverb (compl. on $7:: 3)$, but there is no prouf that sucls a saying was current in his time. Thu Koran (Sura VII, 38) burlows, as it often does, the saying of Jesus: "Those who say our signs aro lies and ar* tow big with pride for them, for these the domes of luaven shall not be "pen, and they hall not entel into Paradise until a camel sball pass into a needle's eye." The notion that the word means at cable, fumnel in Cyril on Luke, and in a scholium ancribed to Origen (Tisch.), and mentioned by Theophyl. aud Euthym. as lield by "some." was morely an attempt to solten the incougruity of the image; and the statement of thr late lexieographer suidas and a reluslium on Arjstophanes that kamolos is the animal, kamilos a thick cable, probably arose lonu that attrompt. (Lidall and seott.) The Momph. Lation, and Pesh. versions give ranuel. Origin understands the camel, and takes the loras" as a figure for the impossible; (c) ('brys. and forluwers. Jelome explains likewise, but adils that as Isaiah doclares (6olos) that the camels of Midian and Ephah (a) tore to Jorusalem with gifts, and though rurved and distorted they enter the gates of Intualin, so the rich ean enter the narrow gatt. ly laying aside their burlen of sins and

by way of correpondence to the next rerse, while we

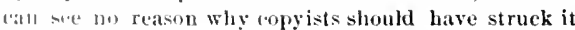
101. 
25 When his disciples heard it, the were exceedingly

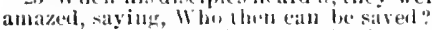

26 lint dests lebold them, and said unto thom, With men this is impossible: lut with ciml all things are persibli.

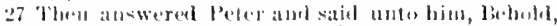
we hatve linsaken all, and fellowed thet: what shall we: have therefinge:

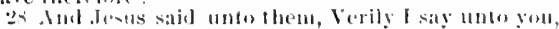
That ve which have lollowed me, in ihe reseneration when ihe sest ot man shall wit in thethrome of his glory, ye also shall-jt thont wedve thromes, jublying the twelie irilies of loritel.
25 thate for a rich matn to enter into the kingedum of

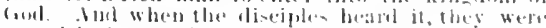

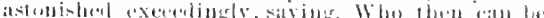

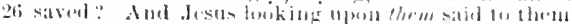

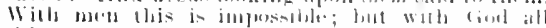

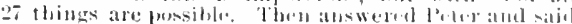

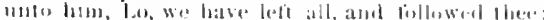

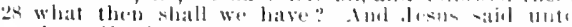

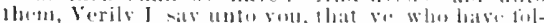

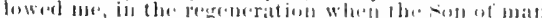

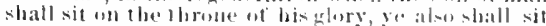
ujoun twelce thrones, judging the iwelle tribes af alt their budily doformity-which is moly his

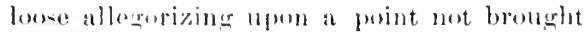
inte viow by the siaviour. I glonto An-rolum

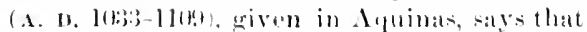
"al .Jerusalem there was a certain gate called

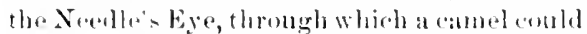
nut pase, save on its bended knees and atter its burken hat beren taken otti and so the

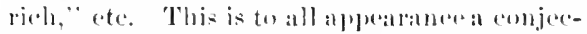
ture suggested fy Jerome's allegorizing remark. Laprl Nuerent many yearsago lefuoted in Morison, from líto) heard at Ilobrom al narrow entrance for fort-pasengers, ly thes sile of the larior erate, called " the ryent"a

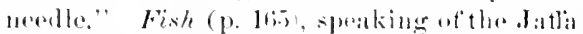
gate at Joruablem, says: "There is heres a

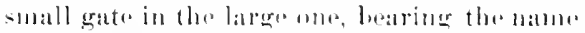
Sieclle's Eye. Mydraguman intomed me of thi-amd-aid it had alway-lexen - at called. I afterwards inquimel of a Christian orew, for thirty yours a resillent in fermsilem, who verified thestatement, and farther said that any little ante like that, in at larese moe. in

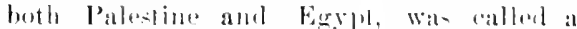

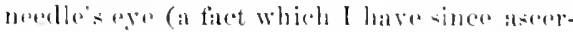
tained foum wher suluresst." sin tar an this

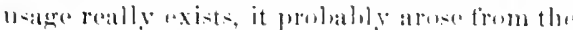
saving in the Now Thet., the 'Talmund and the Koran, togelhor with Juromus alleworizing

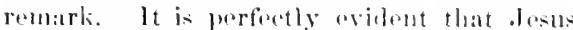

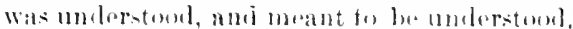
as stating an impositility; and a- tothe in(ongruity of the imatre, it is no gremiter than

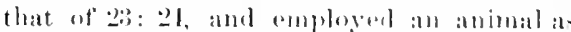
familiar to his hearers at the hupe is to us.

2.5 t: Tho disoiples were cuecediugly amareal, fio this was contrary to all lle no-

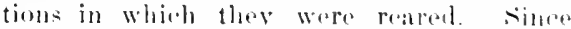
everyludy lublicved that a rich mala was shown by his wealth to hatre foul's fivor, and could securefiuther favor by his hemeficence. and sinee losus has deelared that it is practionlly impossible for a rich man to enter the Mosi- anic kinglum, thry bery naturally askell,

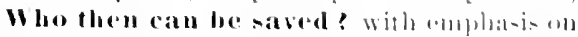

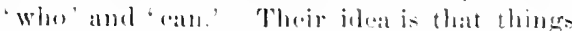
beille an the Maseter has mated (which is the

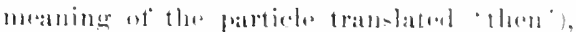

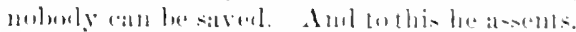

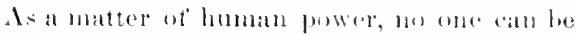
savel ; hut with God alt things aro pom-

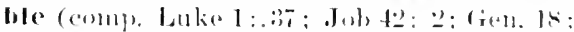
11), and thr divine ommipotence may save (even a rich min.

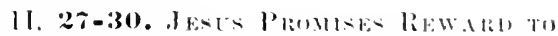

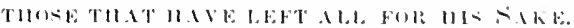

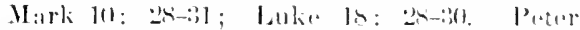

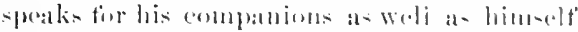

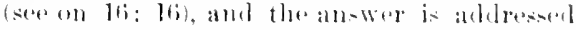

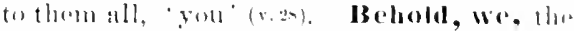

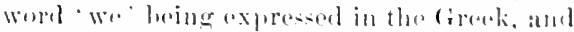

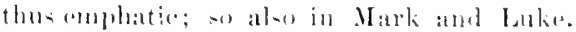

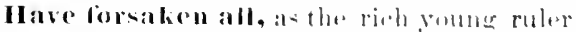

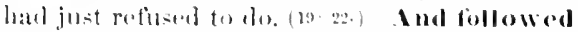

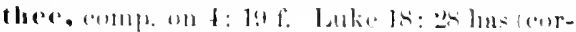
reet toxil 'hate loti nur awn, i. f.e propl-

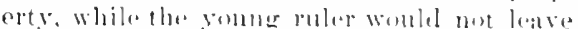

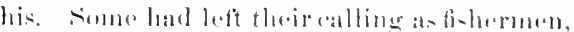

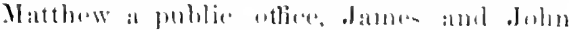

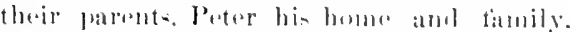
II hat shall we have therefore? withont

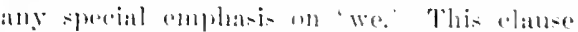

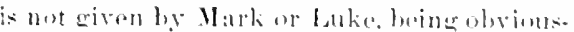

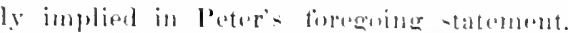

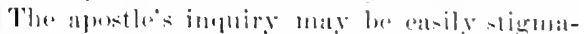

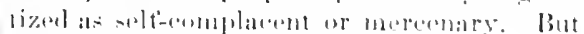

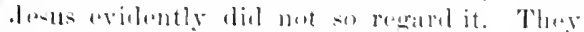

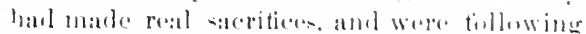
lim in worldly detitulim with di-nusl

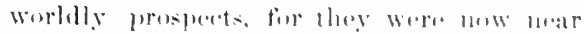
Jerusalem, where he womblil be rejected and

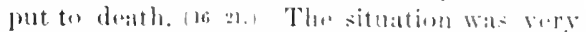

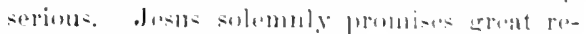

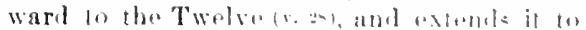
all who have loft anything tior his sake (1. : $:$ ) ; und then guards against all selfish and jealous 
at Ind every whe llat hith forsaken homses, or

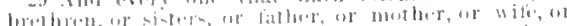

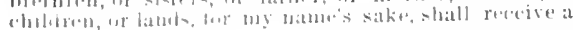

2y Israel. Aud eviry one lliat halh left houses, or brethren, or sisturs, or father, or ${ }^{1}$ mothar, or children, or lands, lor wy name's sake, shall rective ${ }^{2}-a$

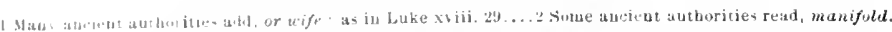

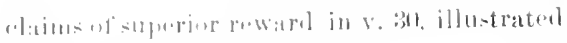

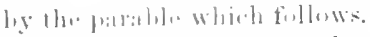

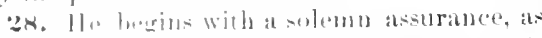

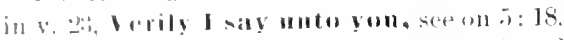

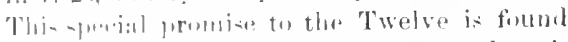
anly ill Matt., to whes dewish reaclers it wanl] lu wt - pacial interest. In the re-

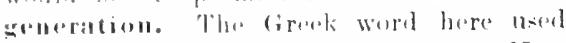

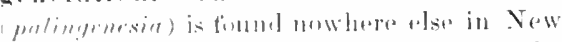

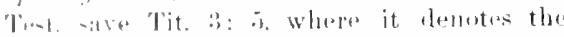
spririmal new himh. Hero it has a very dif-

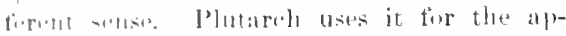

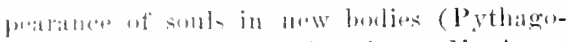
roinl dentrine of transmigration); M. Anto-

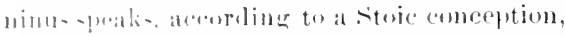

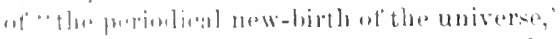

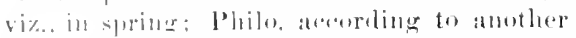

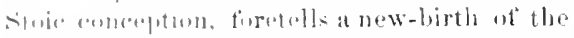

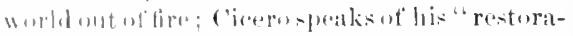
time to lienitios and homor" as "this newhimb of ond" ; and a late Platonint says. "linen]leation is a new hirth of knowlerlge."

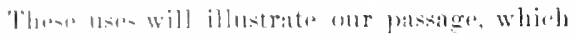

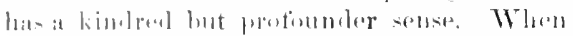

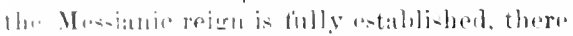
wil] he a

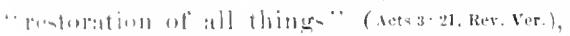

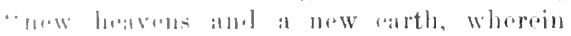

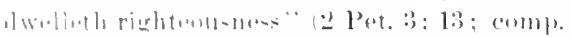

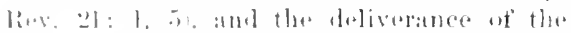
whole creallion from the bumblageof corruption

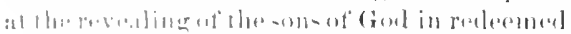

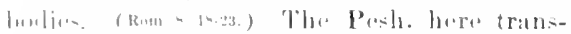

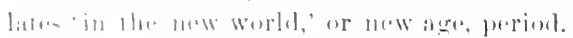

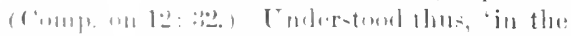

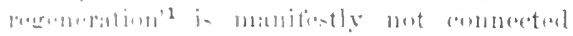

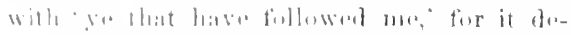

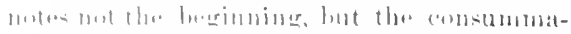

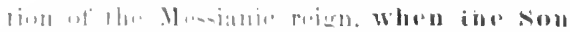

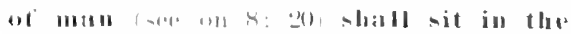

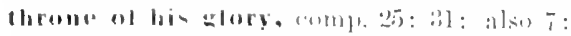

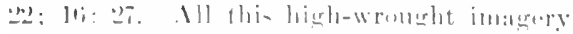

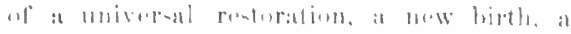

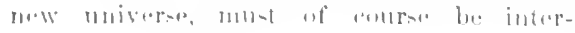

preted as imagery, and must not be so unlerstome as to exclude other facts of the future which are plainly revealed, as in 25: 4i. Ye also shall sit upon twelve thrones, is of course an image. It is idle to insist upon the exact number twelve (comp. Rev. 21: 12-14), and so to be troubled about the fact that while Matthias took the place of Judia, l'aul made thirtern apostles. Judging the twelve tribes of Israel certuinly does unt mean that only Jews will be judged, or that one apostle will judge one tribe. The Orientul king, and the Roman emperor, was alsu a judge, and when he sat on his throne in public, it was usually for the purpose of laeuring petitions or complaints and giving judgment. Sinch a momareh often lad persons scaterl near him (called by the Romans "asserome"), to ald him in judging; compr. Rev. 4: 4 ; "round about the throne were four and twenty thrones." To this position of dignity and honor will the Twolve be exalted at the cmommmation of the Messianic kingdom; (m)mp. 1 Cur, 6: 2, "the stints shall judge the world." Our Lord will use the same image again on the night before the crucifixion, Luke 202: 30.

29. Notonly the Twelve are to be rewarded, but every one that hath forsalien (left) anything for his sake; 'every one' is in tho ireok a very strong expression; every ane whoserer. The enumeration is substantially the sinne in Mark and Luke. But Luke, while condensing some of the other expressions, has also 'or wife,' and this, as so olten hispluned in parallel passages, crept early into many (o)pies of Matt, and Mark. Being mitted ly fewer earlier copies of Matt. than of Mark, the Rev. Ver. here plates it in the marrin. Though not belonging to either Matt. or Mark, we know from Luke that the werl was spoken. The list of oljects is not interdol in any ease to be complete; it mentions saveral prineipal things, and we undersubstmelal difference between this image and that of 17it. $3: 5$. ()ther terms describe the same spiritual prowes an a 'rentwing, (2 Cor. 4: 16; Rom. 12:2; Col. z 10: T11. A: 5; Eph. 4:23.) 
hundredfold, and shall inherit evertastiug tife.

:50 But many that are tirst shall let last; and the last shetl be tirst.
30 humbrotiold, and shall inherit cternat bese. lout many shall he last that are first; and first that ar lit:1. stand that the same is true of anything else. Houses may have been mentined first beealuse seme of the Twelve, as simon Peter, had loft homes; lands last, beenuse ranl estate among the Jow was sperially valuable property, not to be alienaterl, compr. Aets t: $31,37$. The mont exactly similar aise at the present time is seen in the foreign minsionary, or in a converted heathen, who is cast out by his kindret, and finds combernsation in the Christian atfention and kind offices of the other converts, and in the joy of sarving Christ, and hoping fior eternal life. More remotely similar is the case of a worldly young person in a Claristian land, who becomes converted, and tiorsilies worldly pleatures and companionship. Shall receive a hundredfold. It is doubttal whether we should reat this as in Vark, or 'manitold' (Rer. Ver., margine, as in Luke. The question is of no practical impurtanere. We might in reading Matt. thiok anly at rewalds after death. Mark 10: 30 says, "a loundredfold now in this time. . . and in the world to come eternal life"; and such a distinction surens to be in-

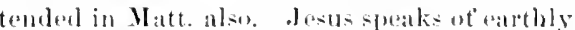
rewarels tirst, but does not mean literally similar things to those beft, but engivalent things -blessings temporal or spiritual, that will eompunsite many times aver for all that wats abantoned. The expresions cannot pusibly be cumlerstemel literally, beatuse that would be promizine in Mark a humbed mothers, and enomp. Luke.

30. But many that are first shall be last, ote. Thiscuigmatical saying is given al $\leqslant$ on by Mark 10: :3. In Matthew anc lacril proceeds to illustrate it hy a parable, at the cluses of which (20: 16) he repeats the sitying. In the? parable an emploger pays, aud aserts lis right to pay. the sitme wages to laturess who began later in the day, as an thene who began enrly. Then of esus is here spealine of the rewards that will be given his fillowrors, aml decelares that these will be given as a matter of sovereignty, without rowgnizing any (daim to precostence. So the immediate application of the sayilut the the Tre is probably to the order in which thay became disciples. In their disputes ats to which should have the

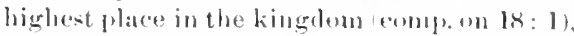
now shortly to be pencwed (20: 20), sume of the lisciples might maturally ures that the highest places shomlal be exiven to thase who tir-t followerl the Itastre. So litr as we kmow, these were John atud Androw, dext Andrews brothur simon, and porently Philipand Nit

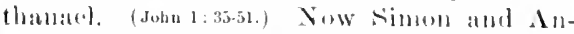
drew, John and his brother olumes, were afterwards tongether called to leatre other employments and folluw Jesus therse, are respeatedly mputioned together as heing in his complaty (Mark 1:39: 13:3), and com-titute the first four in every list of the 'Twelve (see on 10: 2). Peter, Janes, and John were alone with o exise during that night mon the mountain (18:1), of which they would give the other's no aceount (17:91, ats they had been on a former interesting areatsion. (Mark 5:35.) And presently .Janses and John will ask through their mother (20-20) for the two highest plates. These fitets make it not at all mmattural to suppuse that the order of time entereal inte

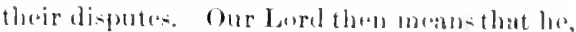
or the Father (20:23), will ant als he shall think properer (:0-15) in rospet to precenlenere, and meny who allared his service late will receive enciater rewarl thath others who rntered earlier; ho will rocosnize no clam on :uy stele grenond. A motithe instance would be the Apostle laul, But while immodiately designed to elocek dioputes an to this question of time, the principhe is sated esenerally and may have other applinations. It is presulposed throughout, at allowaly inrolved in 1!: 2es to, that Christ's servants will be ditlemently rewardod ; wa learn here that this rewart will not be reanlated by the mere out ward conditions of the time spent in his service, or the results atetually attained, but will be conterreal aceording to bis own judgment and supereign platsure. David, who meant to buidel, will be rewalded astruly, and it may be as richly, as solumon who built;

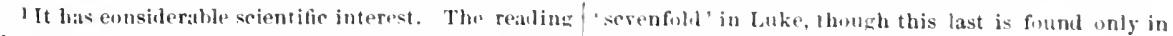
lscertainly "a hundrelfoll' in Mark no variation at the "Western" doeuments.

all), probahly 'manifold' in Matt., and quite possibly | 


\section{I P TER XX.}

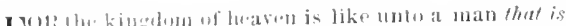

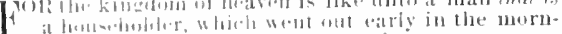

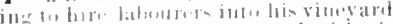

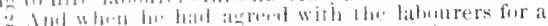

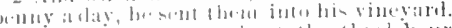

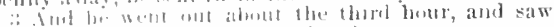

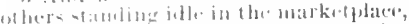

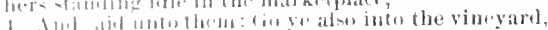
ats whathorer is right 1 witl give yoth. And they

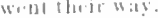

lonu b. Wut unt ahout the sixth and winth hour,

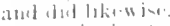

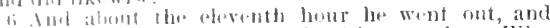

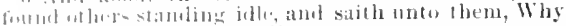
statud ye lore all the diay idle:
1 for the kingdom of heaven is like unto a man that was a houselubler, who went ont early in the 2 randing to hioe lalumrers into his vineyard. And

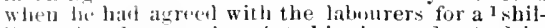

\$ line a day, he seut them into his vineyard. And he wellt out albul the third hour, and saw others stand-

4 ing in lhe narketplate idle; and to then he said, (in yoalso into the vineyard, and whatsoever j right

5 I will arive you. And thry went their way. Again he 6 went out abont the sixth and the ninth hour, and did likewise. And about the eleventh hom he went out, and found ollers standing; and be saith unto

I Stre marginal note on ch, xviii, $2 m$.

Iandes whe was marly gain, at truly as his hrother who livedest long. The aften re-

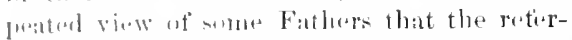

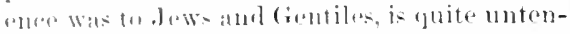
ahle. The ergual reward ot some who die "arly is set touth by a somewlat similar illutration in Talmud Jerus., Berach., ch.

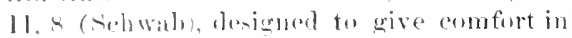
rearad to the eatrly diath of a rabbi. A king birel many laborers, and sering wne who workenl rematrkably well, towk him apart after (wo lostr-towalk with him to and fre. At

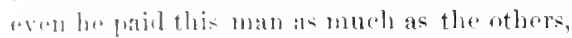
and when they amplatined, he sais, "This maln lit- done more in two hodes than gom in a wholw day. In like mannes the young rabhi kuew the law lister when he rlied at fle ase of twonty-edelet than any other

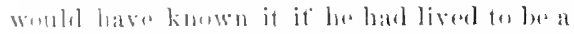

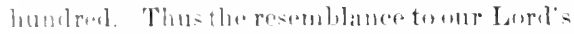
jllu-trition i- anly partiat, and the point of ilplication guite difterent, while in itsolf very plarintr.

III. (H. 20: 1-16;. PARARI, OF TIE

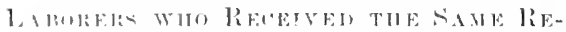

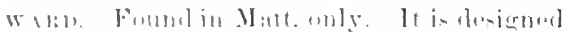

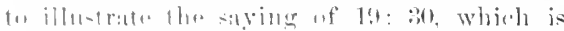

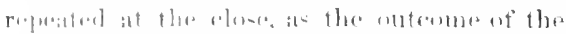

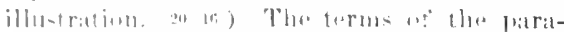

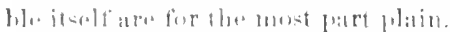

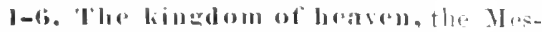

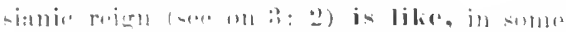

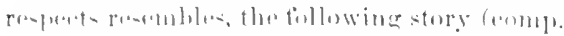

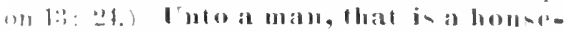

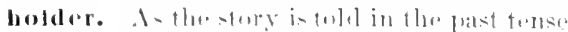

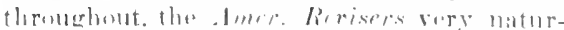
aly wish to iunert "that wats, rither that

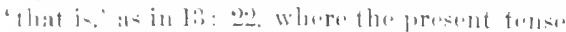
foilow- "Houschuldur," or homesmester, is the sime word as in 10: 25 (see note); $13: 27$, i2, and beluw in 21: $39 ; 24: 43$. He owns a home, and a vineyard. (s.8.) A penny, drmarims, aboutsevonteen cents, see on $18: 28$. This was the custrmary wages of a soldier or a lalurer: Plin. XXXIII, 3; Tac., "Ann." I, 17 ; Tub. $8:$ 14; Tammul. The third hour. The dews divided the das, from sunrise to sunset, into twolve parts. At the vornal and autumnal equinox these would be exactly as long as an hour with us, but at other seasoms would he longer or shorter. Tho sixth hour would always be noon, the third and ninth would correspond loosely to our 4 A. M. and $3 \mathrm{H}$. M.; tho eleventh hour loosely to an hour hefure sunsat. In the marketplace, ur public square, where people came tronther for business or cunversation. Go ye also, "ye" heing expressed in the Greek and thus emplatic. Whatsoever is right, no dofinitu bargain as with the first set. In the supposal actual oceurrence this might result from haste, or from the fact that they would now bo glad to find employment at all, and wombl trust the employer's justice without a Arfinitu arrangement. As to the illustration, this guint prepares for the result, and the feanliar application. About the cleventh hour. Horo 'hour' is mot expressed in the arrect fireck text, but maturally suggested. others stamina idle. The word 'idle' is here wanting in viry many of the earliest and but descuments. and was obviously drawn by copyists from v. 3 and the end of $v, 6$. Why wand ye here all the day idle? This is infer lsad homiletically as representing lereoms whos ure slothful in neglecting to work in Curist's vineysur. But such appliration ik nuwarranted, and alien to the tone of the parable. The reason given by these men 
7 They sily unto him, Becaluse no man hath hired as.

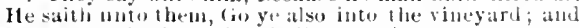
whatserer is right, that shadl ye receite.

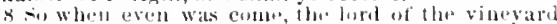
saitlo unto his steward, fall the latourers, and give laem the ir hire, beginuing loum the lats ante the dirst.

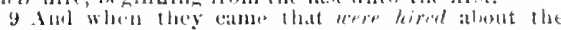

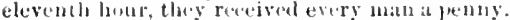

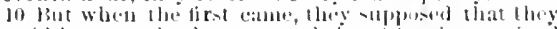
should have receiven mor"; and they hkewise received every inati a frentiy.

11 Anel when they hat received it, they monemured

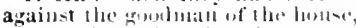

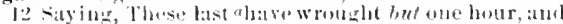

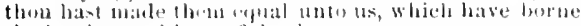
the buriled atul leath of the dity.

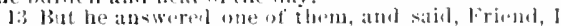

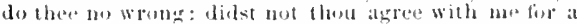
petury :

If Jiak" thet thine is, and gal thy way: I wall give

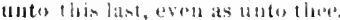

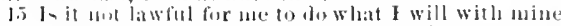

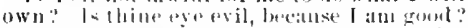

10; sit the liat shall be tirst, and the litot last: for

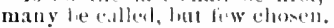

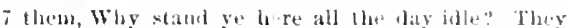

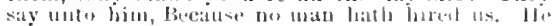

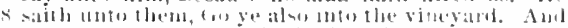

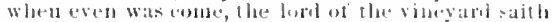

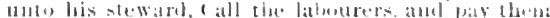

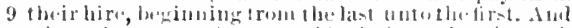

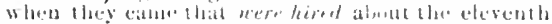

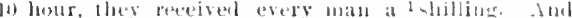

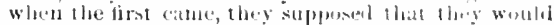

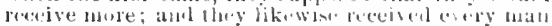

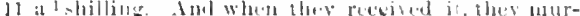

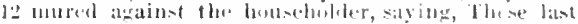

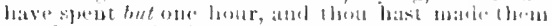

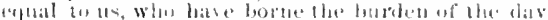

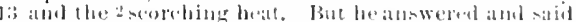

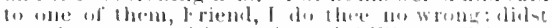

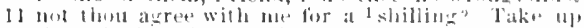
lbit whiels is thine, atul on thy way it is $11 y$ will to

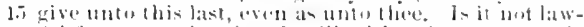

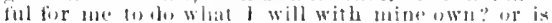

16 thine tye fril, ho"atiar I am goud" su the latst shatl be tirst, aud line dirst list. is treated as valiel, and they are paid for a fill day's wrork.

7. Go ye also, 'ye' emphatic, as in r.4.' Obviously this employer of labor acts very peculiarly. (Comup. Bruce) It is not neces-ssary+ to seek parallel ences, nor wise to plopose bis conras as a model in orelinary husinese (as Ruskin dues in "Cutu this last," the title being drawn from v. 12.) The thing is possihle. and the story is meant as an illustrittion of (xod's enures, who is other and higher chan than. (Isa. 55 : - f.) •

8-12. His steward, same word in Luke 8: :3; (a:al. 4: 2, is natural in the story of a preat amploger; what aroul is clune by say ing that the steward ropresents Christ? (C'mup. on 1:3: 8.) begimning from the last wats at spacial direetion given, in order that those hires catrling might see that all were paid alike.

11. Murmured, a strong word, more exactly, grembled. The Greale word, the Latio murmur, and the Engli-hermullw, are all anumatopoetic. The temse is impertect, descrebing the grumbling as in progress.

12. IIave wrought but one hour. Spent is the meaning, rather than 'wrought.' The beat, the samo worl at in Lalie 12: 5.5; James 1: 11. The Rov. Ver. remders 'senrehing heat in this $\mathrm{v}$. and Luke. and "sourehing wind" in Iames, and puts 'hot wind' in the margin of Matt. and Luke. The word means 'burner, and in applind sometime- to burniner heat in general, lut more frembently in seputuagint to the burning rist winel. (see Grimm.) The order of the words, "the bumben of the day and the scorebing heat, (kanesun), ats woll ats the more frequent use in that sell-e, rendurs it likely that the hot wind is here intended. Mere loat is so common in Palestine that it would searcely be worth remark: but the dry and soordhing bat win 1 is somothing terribed Even in Februaly (18:1) this dry an-t wind, having come aeros the derelt sinels and lost all its moisture, in an homs su frached the munth and nostrils as to make breathing painful and sperech difficult. The jorition of the articte in the cireck makes it impo-shble to render, "the burlen and beat of the day" (ars in Tyn. and followers.

13-16. Friend, or 'comrade, a familiar and kindly term, as in $11: 11 ;$; 22: $12 ; 20 ; 0$

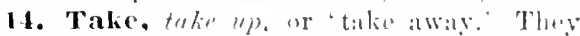
had received the paty, but perbape lad lad it down again, or stord holding it in the band. unwilling to $g_{0}$ ofl with it. I will give. The Rew. Ver., It is my will to gave, conreys the meaning well. The Greet jo exprensed in Enelish by "will to' or 'wish t1) $(15: 32 ; 16: 24: 19,17$, aleeording (1) the 11:ature of the case; montr. v. 1.); 1 Tims. 2: 4 ; Pet. 3: 9. 15. Is it not lawtirl, permissible. (see on 14:4) To do what I will with mine own? The savinur here illus-
The final clause in the pummon fireek text, and whatsuever is rimt loat ge shall receive; is wanting in the carliest and best documents. We can easily account for its inserlion from $r$. t, and canmin account for its unission if originally present; so there is no doubt that it is bere sputious. 
trates his somerognt! in the whole matter of rourding his follower. Or. Is thine eye

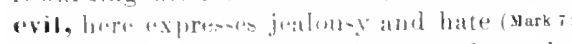

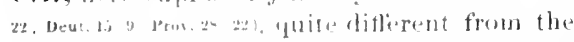
meanime in ti: $2 . ;$. Or is in the correct

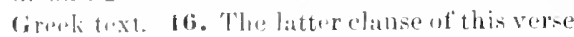
in the andoldont firesti text, for many be (refe) eatled, but feru chosen, is wanting

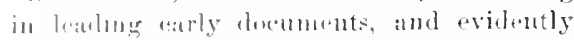
lirought in from in: 14 , where there is no

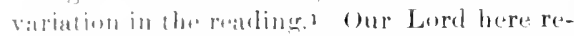

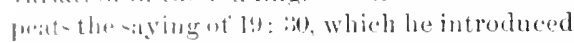
Hor faraloler ta illu-trate. It is very natural that it shomls le repanted in ageneral form, withont the restrictive 'many' of the first statement. Simne al,le writer- Meyer, Weis, others) urees that the parable and this statemont lable that in the con-momated Messituic limgrabu all will have an equal rewad. lint thi- is inemmeisent with the first statement, and with the listinet intination of 19 : zuff. that these will be difference of reward. The enorat thomght of the parable is that the ar-igumunt uf individual rewards will be at matter of divine sorereriguty, precisely as in

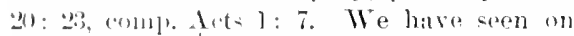
19: : the disoipla. hut a* a genoral prineiple may lue varum-iyaphliesl. It is vory true, as some commentaturs nege, and it may be properly realled here, that (xom will reward men more anewreliner to tim and spirit than to time spent or results alebieved: but the siviour dowe wot liere sily that, or distincetly imply it.

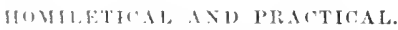

T.2: 2. Salvation of the rich. 1) It is

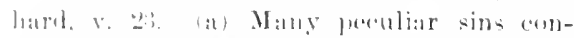

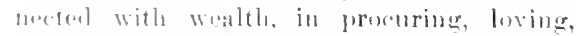

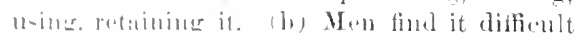
(e) withlraw the hoart from wealth (fis: 2t), and

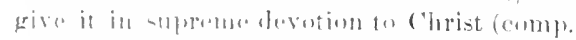
v. el to): amel without this there (an be no salvation. $\because 1 t$ i not mly harel, hut inspomilla. s. 21. 24; yeat, it is impossible for

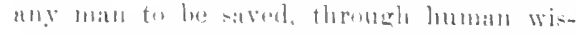

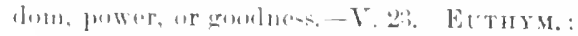

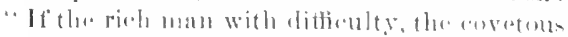
mat wot at all; tor it he that lowe not give his

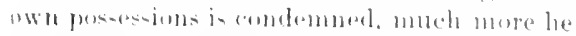

that also grasps the possessions of others." V. 25. Who then can be saved? IIENRY: "Considering the many difficulties that are in the way of stlvation, it is really strange that any are sived. When we think low good frod is, it may seem a wonder that so few are his; but when we think how bad man is, it is more a womder that so many are, and Christ will be eternally admired in them." -V. 27. Forsiking all. The all may not be muel, yot it is much to forsake all. Currs.: "The forsaling was done for the salie of following, and the following was rendered easier by the forsaking." - $r .27-30$. Forsaking and receiving. 1) Christ's servant must actually forsake many things, and be willing to forsake all things, for the sake of him and his work. 2) The negative forsaking must be accompanied by positive following. 3) He shall receive incomparably more than he has forsulien-both in time and in eternity. 4) The rawards received by different servants will be vory different in degree, v. 28. 5) But Christ himself must decide what ench me's ruwarl shall be, v. 30, comp. 20: 1-16; we must make no elaims and no complaints. - T. 28. They who follow Jesus in this world sall ragn with him in the better world. - V. 2"I. Crris: "He does not say that they shall have many fathers or mothers in place of one, or many fields in place of lew, but that all the aurthy things will be incomparably excolled ly the hearenly, and the things that are saved will be more valuable than those that ine lost," -Ch. 20: 1-16. 'The laborers in (tod's vineyard and their reward. 1) Unlike miny human employers, God cares as much for the good of the workers as for the amount of work done. 2) Gorl's service is not rejose in a "Castle of Indolence," but harel work in a rineytrel; self-denial and toil in promoting (1ur own piety and that of others. 3) God will roward his workors richly-in this life (19: 29, comp. Mirk 10: 30), and in the life to come. (v. 8; ch. 19: 21, 28.) 4) Ile will give to nome less than be had promised ( $v$. 19), but loe will give to some much more than he had promisurt; he will give as a sovereign (v. 15), and lis workers nust reeognize thut he does all things well. (v. 16, comp. 16: 30.)

combl he inserted, and can see no sufficient reason for its umission if origiually present.
1 It is wanting in $N$ B, L, Z, 3r, Thebaic, Mempluitic, and a corbe of the Elliopic. We see at once huw it 
17 And Thesus going up lo Jerusalem took the twolve

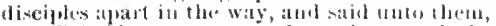

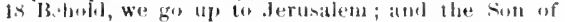

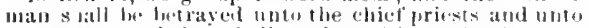
the seriln's, and they shatl condenst him to deatls,

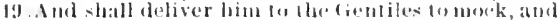
to seourge, and to crucily him: and the flurd day he shall rixe atsili.

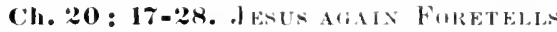

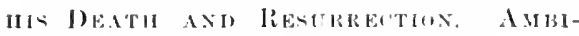

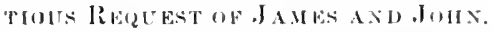

Fommdalso in 11 ate 10: $320-45 ;$ and (in part) in Islke 18: 31-8t. This pastage soems in Matt., Mark. atul Luke to dollow inumediately

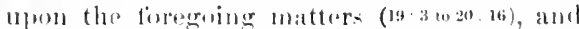
to precede by amly a few days the trimmolial entry. (21:1.) Tho phrase ' gaing up,' 'we gor

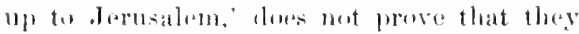
latd cerossed the river, and were now aseronding from its valley, as in Jalke 1!1: 28. Since Jerusalem was reatebed hy aseront buth from east and west, it liecanne costomary to spoak uf 'guing up" to Jerlsalem from all parts of the country, IAlie 2 : $\{2$; John $2: 1:\} ;, 5: 1$;

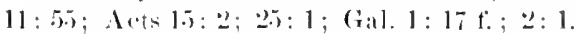
It is after this that olsus and his fullowers reach Jaricho, 24): 2!); Jark 10: fir. Thro scone is somewhat more likely to have been in Pereat. I loan between the river and Jaricho. which was anly a few miles; but tha guestion cammet be determimed, and deres not affect the exogesis. This section contains two parts, $v$. 17-19 and $v$. 291-28.

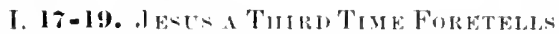

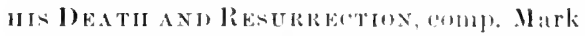
10: 32-:34; Luka 18: :31-84. 'The two precouding reeorded anosions were just betore and just atter the Trandiguration (16:21:17-22), und at least six months earlier than this. We camost judere whother he had spolion of it dstinetly in the moan time, hut there is in Iake I2: f!l fl., an indication that his own mind had hern all tho while torning towarels what awailol him, turning with a fenling of constraint and pros-lure, but mot of griet or discouragumont. Going up to Jerusalem.1 What follews was said in the way, on the road. Mark (10:3:) tells that his folluwers. hore neaning more than the Twolve, wore 'amazed' and 'afraid' as they walked nfter him along the road, probably beanase of what he had sadel about the difficulty of saving the
17 Aud ar Jesus wats guing up to derusalom, he laok

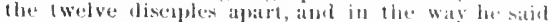

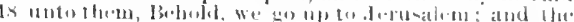

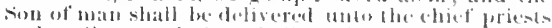

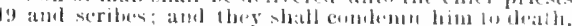

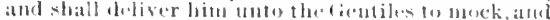

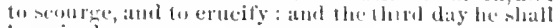
1). raisine

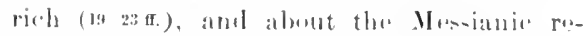

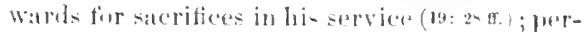

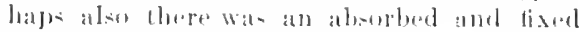
lomk in tha Mitsters fater as he prosed an lor lis terrible laptisus of suflepiner, that was mew, and filled them wilh wemter and alarme.

rouk the twelve disciples apart, froll the thoreng that ware alee(millanging him lo

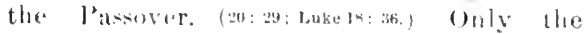
Twelve were in the least propared to muler-

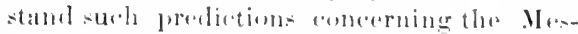
sials. Eren at Jorusilem, sommsix months

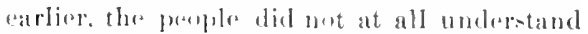
"Vet a litte while am I with you, and I Iso

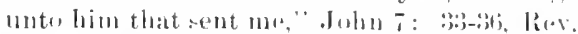
Ver. We go up to Jormalem, ule Origen remarks that l'aul exaclly initatul ('hrist when he went up to .Juru-alesu in full

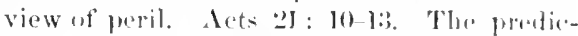
tion our Lared liare grives is substantially the

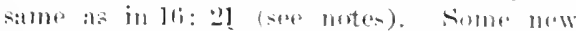
particulars ale now adoled, as is malural in the mearor approale to the ovent, and when thair minds have leen somewhal prefared ly the provius predietions. The šanhedrin will formally combemn him to death: and nut mbly will loe bo delivered into lle hands at

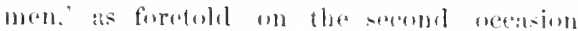
(17: 22, wh Mark and luke), lut delivered to the (ientiles (Matkand Lukenks), to mock, and to scourge, aud to erucify: Harli amd Lukir nud 'spit upun," and Juke genorally" that heshall he 'Shamedully troited.' Trondale, Cran., Gen., king . Inmes, all hore render the same worl, 'betravel' in $y^{*}$ lis and

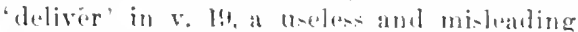
variation, emmp. on 17: 2, and 10: 4.-Xitill, after this renewed and detailed prodiction. the Twelve "under-toud numo at" these things." (Lake is:34.) It wat utterly contratry to all their ideas of Mesiah allul his Wurk: these things conld unt bo liturally true of the king-what diel it all moan? Xolion how Juke dwells upon their inability: "and this

I W II, adopt the realing 'was about in go up, from R, one eursive, Menulı., Thel., Pesl, Origen three limes). This might easily have been changed into.

'was going up' hy way of assinilation to v. 1h and in Mark and tuke, and so is frubalidy conrect. There is of course no substantial differenee. 


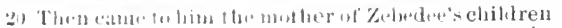

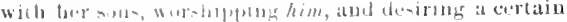

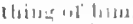

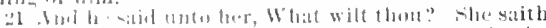

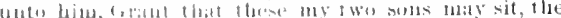

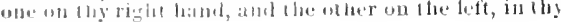
kingíluts.
20 Then eame to hin the mother of the sons of Zebediee with her sous, worshipling him, and asking a "1 certain thine ol him. And he said unto her, WV hat wonlder thou? She saith unto him, command that thest my lwo soms naty sit, one on thy right hand, savilue was hibl from them, and they per-

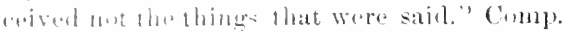
all 16: 21. Hannm: "This only jureses what " blimetion fower preconoeption and miseonantion have in hiding the simplest things whl in the simplest language-a blinding

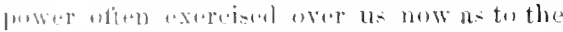
written. as it was then excreised oxar the aju-theas to their Master's spoken, words... flo.y had mate un their minds, on the best of evislener, flat he was the II lhay hanl thoir own motions of the Mesiahship. With lbesested sutlerings and such a

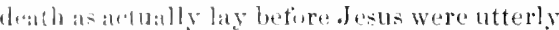
incmsistont. Ilis cxpressions, then, must be fierurative, ilstended, perhases, to represent shme sevele strggh with his adversaries, thenele which he hall to pats before hisking(1o)n wa-set upand auknewhedged.'

H. :0-2R. IULITIOUA REQUEsT OF THE JиTHEl: OF .IAMES AND JoHN. Mark 10: 35-4.). Juke deren not grive this, though parall.el to Mintt. amd Mark, just before and just nder; lut ha gires similar teaching on

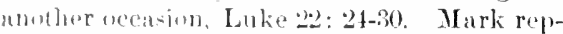
ront - Jamestaml Juhn as themselressaying, in almot "xact] identical worts, what Matt.

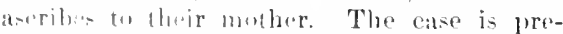

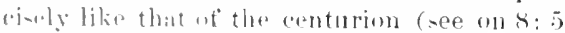

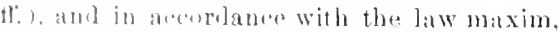

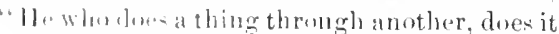

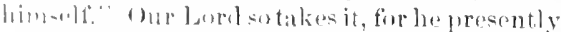

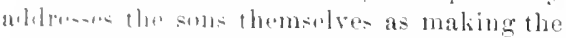

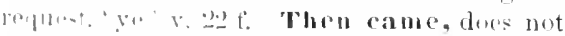

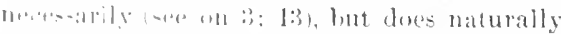

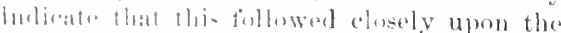

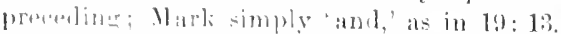

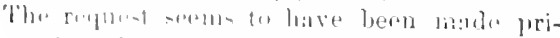
vatuly. when the ofher ton apostles wore not pronell, v.2. The mother ot Zehedees children with her sons. Trutale and fol-

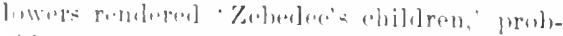

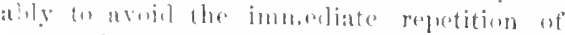

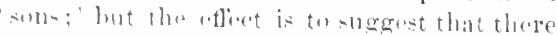

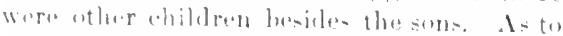

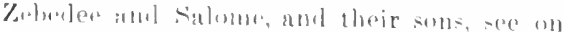

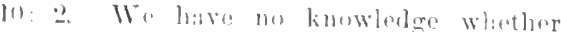
Zobedie was in the company, or was still hiv- ing. It is clear that the mother here shares the ambition of her sons, and so it is not unlikely that from her it was inherited. If, as many suppose (see on 27: 56), she was the sister of the saviour's mother, that would explain her boldness in persmally approaching him and preforring so grave a request. Comp. Bathsheba coming to David for Solomon, 1 Kings 1: $11 \mathrm{tf}$. Worshipping him here evidently moans paying homage as to a king, (comp. on 2: 2), for it is precisely as such that they approach him. 'Worshipping' and 'asling' are in the singular number, but it is implied that the sons united with her. A certain thing, or 'something,' Wye., Rheims, Bib. Union, and so Mleyer. Mark says they first wished him to momise that he would do whatsvever they should ask-which was presumptuous indeed. Grant-or command, that, for the Groek construction see on $5: 29$. She is thinking of the two highest places in an earthly kinglom. Could not the solemn prediction of his death and resurrection which he had just before made comeet their unspiritual conecption? Nay, even after the death and resulreetion had actually oceurred, the Twelve retained the same expectation. (Acts 1:6.) In fact the prediction seems on several other oceasions also to have been immediately followed by a dispute as to greatness in the lingdon; see on 18: 1, and hereafter 26: 2. (Luke 22:24.) They seem to have lost sight of the suffering and death, and fixed their minds only upon the thought that somehow or other the splendid Messinnic kingdom was aluut to be established; eomp. Luke just afterward (19:11), "they supposed that the kingrom of God was immediately to appear." Our Lurd had shortly before (Matt. 19:28), perhape the same day, spoken of himself as the Messiall who would 'in the regeneration sit on the throne of his arlory, and had promised that the Twelve should then occupy 'twelve thrones.' Salome and her sons seem to have fastened upon that thought. Why not risk that her two sons may sit on the two chief thrones? To place the most distinguished persons on the right and left of a sovereign or 
2. But Jesus answered aud said, le know not what ve ask. Are ye able to drink of line eup lisat 1 siall drink of, and to be baptized with the baptisn that I am haptized with? They say unto him, We are able.

2.3 And he saith unto them, losball drink indeed of my (rup, and be biptized with the baptism that I am hiphized with: but io sil on my right liatsd, and on $\mathrm{my}$ left, is not mine to grive, but it shall be given to then tor

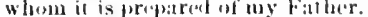

2t Ind when the tell hearel il, litey were moved witl indignation against lhe two brethen.

presiling persomate was common among the Groeks and liomant, as well as the Jews (VEet.), nud is practieed amone us at ballyuets, ate. As to the dignity of being on the right hand. eomep. Psa. 16: 11; 45: 1; 110:1;

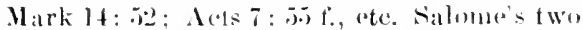
solls, with lootor, have alreaty been troatcel with special di-tinction at the raising of .Jairus' daughter and at the Transfiguration, and this might eneonrage their present high ambition. They had also shown a fiery and seltassertive nature in forbidling the man who followed not with them (Mark 9:3m), and in wishing to all down fire from hearen on the Sitmaritan village (luke $9: 54)$; comp. above on 10: $: 2$.

2:2 f. Our Lard traats the reafuest as that of the sons themonles. Ye know not what ye ask. Tuask that they might reign with him was asking that thry might sutter with him; comp. 2' 'Tim. 2: 12; Rov. 3: 21; Rom. 8: 17. The cup that I shall driuk, a familiar image for great suffering, as in 26: $: 99$; lohn 18: 11; I'sa. 75: 8; 1sa. 51: 17; Jer. 49: 12. Be baptized with the baptisu that an baptized, to be plunged in the same sutler-

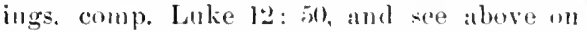
3: 6. This comos from Mark 10: 35, and was added to Matthrw here and in the next verse by inamy copies. We are ahle. This was exressive self-eonfidence, but mot mere arrogance. They were isuorant what the aly would contain, but sincere and resolute in their devotion, as ther afterwards showed. Probably (Aloxander) they thourht of having to fight for the Messianie kingdons, and the ardent spirit of the "Sions of 'Thumder" would swell at tles thoteght. Petere the other of the three ehosen disciples, male a like confident expression suon after. Lalke 22: :33. Onr Lerd's roply is not severe, hut kind. Drink indeed of my

It is liere wanting (in both verses) in $N \mathrm{BD} \mathrm{I}_{s} \mathrm{Z}$, two eursises, Old srriac, most copies of the Old Iatin, Vulgate, Iemph., Theb., Aeth.; and the difrerence be- 2y and one on thy leit hand, in lisy kingdous. But desus allswered and said, le know inot what ye isk Ale ve able ostriuk the eujpl hat I am alout holrithk" 23 They say unto him, We are able. Ile sath anto

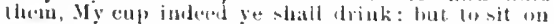
my right datul, and ofi my left latml is mol mine to

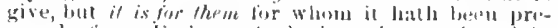
24 pared of my Father. And when the tea hrard if,

emp, the particle rendered 'truly' in $9: 87$ and thereexplainced, indicating that this statement is placed in contrast with something to folluw. Ye shall drink iudeed of my cup, - D but, ete. They were not apjointed to sutfor ats forafoumel montal anguina as the Matster, nor would theip suffering have any atoning character; but in his sorvice Jamas would die as the first apostolic martyr sets 12: 2), and Joln would as a living martyr suttap persacution (Rev. 1.9). and soretroublo in conflict with error Epistles of John). The legends that John was made to trink poison, and was phumerol in boiling oil, are likaly (Meyer) to lave freen suggrested by this saving. Not mine to give. Ifs thus litts thar minds away from the idea of a human sovereigu bestowing eartlaly lonors to that ot divine. gifts. Ite sperakis of himselt compl. John 14: 28) as otficially suborlinato to lla Fatluer in his office as the (rod-matn. the Maliator, in whiel he has doriverl all his anthority and power from the Father $(: 8: 1 *)$, and will at langth return it to him. (l cor. 15: ga) ('omp). 24: 36; Mark 13: 92. 'The English worl "but' might luere secm to mo:an "xoept " not mine to give except to those for whom it has been prepared," but the Groek word (alla) cannot have that sense. For whoul it

\section{is urepared of my rather. All the arrange-} ments of the Messianic kingelom have been already made by the Fatlure indeal made? "from the fomdation of the world," "2: :34, comp. Act= $1:$ T.

2f. When the teu heard it. Ther hal not been present at the time, hut hiard, upparently som after, what had necurrod. Hoved with indiguation against the two brethren, not 'against, hut comerning, about thoir whole course in the matter. Mark has the same expression. Their feeling is more easily aceounted for from the fact

ween Matthew and Mark is expressly mentimul by Origen. Sueh an enlarifenent of one Gospel froman- 


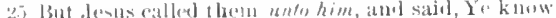

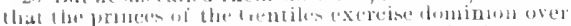

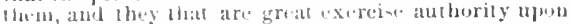
Ifenil,

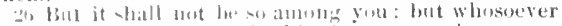

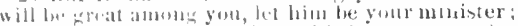

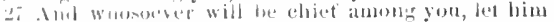
lie golite riatil:

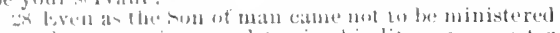

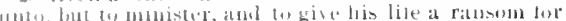
IIItII)
2.) they were moved with indisnation concernitis the twolirethrem. But Jesus called them unto him, and sidi, Ye know that the rulers of the Gentiles lond it

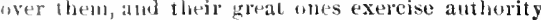

st over thesu. Not sushill it be auwne you: but whosover would become great among you shall be your 27 minister; and whomever woull be first antong you s shall he'youl zselvant: trell as the Son ot man came not to bi ministered unto, but to minister, and to give lis lifis a lassom for many.

IUr, servant...2 boudservant.

nuentionenl by atthew, that the request was a matle through salome. Here wan matenly an ambitious attempto gain the advantage over the lint, atul to firestall matters by at promise in allianse, but it maly latre seemed an unwortly thing to use a woman's pleat a all Ih. mure if she wat near of kin to the tuture sriorign. Somear the end, and they are still thinking of a worldly kingelom, and full of

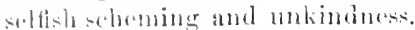

$25-3 x$. What at sorrowtul talsk for the loving sivionr, turement these anbitions and asperitics. Called them moto him. The lub hay hale berenstill with him, or all may

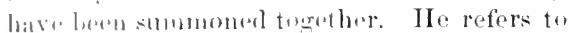
the fiuct that high places of authority and dominion helongeto worldly kingelome. It sball mot be so among yon, or more likely, not so "t is anmenty you. ${ }^{1}$ W ill be, or wishes to become; and os 'wishes to he.' For minister and

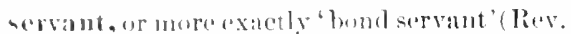
Vor. Matrgin), combe, in 8 : ti. Mlas! how meily lomman andition can uso those very worls and reot retain its awn spirit. The

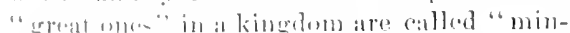

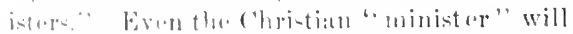

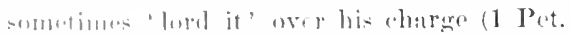

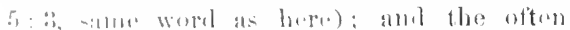

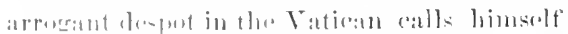
"lh" servatu of servants of the servants

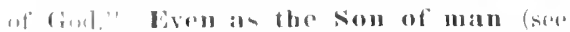

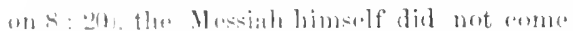

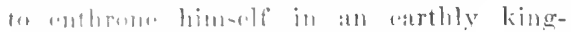

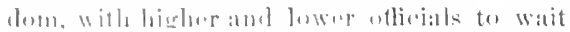
un him. Ilow difterent from all this his life

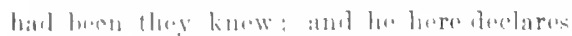
that such wis the purpuse of his eominer.

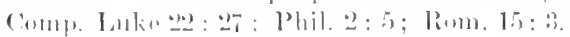

And new enomes a phrates of the higlaest

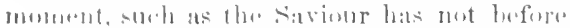

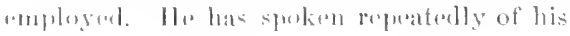

approaching death $(16: 21 ; 17: 22 ; 20: 19$; comp. Johu $7: 33)$, hat mow it is adled that his death will be redeoming and viamlous, and that this was the design of his esming. Mark 10:45 lats preciscly the same expression. This remarkable statement mu-t have been quite beyond the comprethenson of the diseiples, till atterwards brought to their remembance by the Itoly Spirit (John 14-26). His life, comp. on $16: 25$. A ransom (Groek lutrom). The Greek verh (luo) means to loose, release, e. g. a prisoner, Acts 22: 80 . Lutron (termination-trons is the means or instrument of roluasing, and this in the case of a captive is naturally a ritnsom. The word is often used in the elassies and the sept. (LirlInll and Sentt, Cremer) to denote a ransom in money, and in corresponding figurativesenses. So here Clorist's life is given as 'a ransom,' sorving to redeem men from ealptivity, from the power of sin and spirilual deatli. From this word lutron are formed the worlotranslated in the New Test. 'redeem' and 'redomption.' Our English word ransom is the French rangon, contracted from the Latin ralemptio, which we afterwards borrowed separately as redemption. The Old Latin and V'ulg. here render refemptionem; so Crammer and Rheims, 'a redemption for many.' The preposition rendered 'for' (anti) necessarily means 'instead of,' involving substitution, a vicarious death. The prepusition in Mark 14:24 and commonly cmployed by Paul in spreaking of christ's dath for 11, (comp. John $11: 51$ ) is huper, which means 'in buhalf of,' 'for the lunufit "ti," and derivatively 'instead of' wherover tha nature of the case suggests that illat, wherever performing an action for ons: - lomofit involves performing it in lis stuml. This derivative use of huper is frequent 
29. Ind as they departed trom Jericbo, a great multitude followed him.

enough in the (lissice, and that Paul often "molnys it to mean "instead of" is leyond all rea-1nable question. When objectors urge that that is only at secondary meanning of helper, and requer u- to prove otherwise that ('hrists death was viearious, then it in woll to remember that here (and so in Mark) Mha bre pesition is anti, which no one ean por.thly deny to have, and necossarily, the metuning

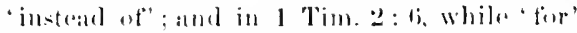
is hecper, this samere anti is poretixnel to luteren, "whe gave him-elf a substitutionury lausm for all." In 20 : 28 the preposition is peri, 'concerningr. For many, Christ's atoning dath made it compatible with the divine justiee that all should be saved if they would accept it un that ground; and in that sense he "gave himilt" a ramion tor all" (1 Tim. 2:6), "tasted death for "uory man" (Web. 2:9), eomp. 1 John 2: :2; but his death was never expected, nor divinely denigneel. actually to secure the salvation of all, and so in the sense of shecitie purpose he came "to give his

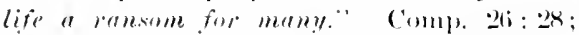

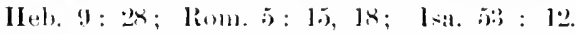
IIrrry: "sufhoient for all, etlietual for malny.

\section{HOSILETI'AL ANE PRATTCAL.}

V. 18. Orgate: "lt is not propor that we should al ways avoid perils, or always ad valuee to meet thens; ont muth he wise in ('hrist to

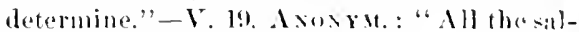
vation of men lies in the de:th of chri-t." -Four discourses; Josus predicting his passinn (see on lti: 201); Juls preparing for his

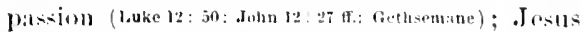
enduring bis pas-ion (Mnthew, Mark, Tonke rothn, comp. Iteb. 12:2); Je:us looking back I1pon his

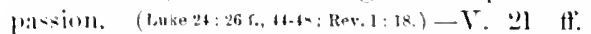
Currs. : Let no man be troubled at the apestles being in such an imperfect state. For
24

Aulas bey went out from tericlio, a great multi- not ret wat the erose accomplished, not rot the grace of the spririt given. But if then would-t learn their virtue, notsere them after these thinge, atud rese what mannerof menthey

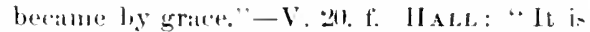
not dixemmendable in parents to serek the. preferment of their children, so it he by lallfal means, in at mederate moanure. Oh, the malluess of these parents that desire rathes to leave their chiblren great than gowel." $-\mathrm{r}$. 2.2. Ye know not what yeark. 1) Twa-k tor sperial qualities of mind and chatracter may be asking for the usually atlomdant faute and weakneses, and the con-entuent perils and distronses; puet, artist, oratur, financier.healuty, wit, strength of will, plimion, s:mgruinc temperatuest. 2) To an for worlaly woalth and bontur is asking for great foil and anxiety, asking to be enviod and evil suken of, asking often for disalpuintment and bitter sadness. 3) To ask aven for eminent roligiou* usofulness and reward is to ank tor great -uttiring, Col. 1: 24; 2 (orr. 11: 28; Rov. 1: 1; 2: 10; Rom. s: 17. Then let us alw:1yask in sulurdination to God's will, I John 5: $14 \mathrm{f}$. Alq.: "Give what thou hidet and bil what then wilt." IIExtr: "Wo know not what we ask, when wo ask for the glory of wearing the arown, and ank not for grace te liear the erose in our way to it." - V. 20t. Not so amomg youl. 1) In worldly kingdums ambition agerly secks for authority and dominion. -2) In ("hrist's lingdom the only greatness is usefulnose, the only dominion is serviere. 3) Our ling himself anme to bo a servant and a sarerifice. 4) Let these things be a cheek to roligious ambition, and a cure for religinus jealunsy.

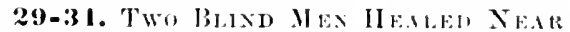
J ERtC.110.

Fonnd also in Mark 10: Hi-Tt: Luke 1s: 35-43. Our Lord and his disciples and the

\footnotetext{
Here the "Wistern" decuments, D, Old Syriae, most enpies of old Latin and some Latin Fal hers, add (leetals varying): "l3ut do yost seck out of little to increase and out of greater to be less. And when gon enter in and have been invited to line, do not rectine in the prominent places, lest a mere homorel llan thrm come, and the low ente and sald the the Move still lower, and thon shall be ashomed; hut if thon relim. thee, the host will say to thee, fiet up slill highrr, and this shall he useful to thee." The latter sunfouce is ohvisusly a mere tralitional erruption of Luke 11: I1. Thu former is likely enumgh lased on a true aring of our loril. For a collection of sayings aseribul to Jesus in early M-s, and Fathers, amd nut giren in Now Test., see Wesleott's "Introduction to study of

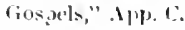
in the inferior place, and there come ouc iuferior to 


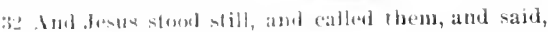
What will s. " that I shall do lunte yout"

3:: They sity untos him, Lord, that our eyes may be "1)

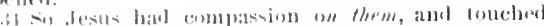

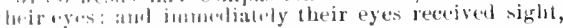
and thes followede him
32 un us, thom son of Iavid. And.Jesus stood still, and 32 catled flem, and sidid, Wh hat will ye that 1 should do unte rou" They say unto him, Lord, that onr eyes is may bo njened. And Jesus, being moved with comfasion, tonched their eyes: aut straightway they received their sight, and foltowed him.

\section{( I1 A P T E R X X I.}

S1) when they doew digh unto derusalem, and were

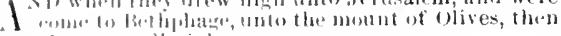

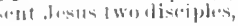

And when they drew nigh unto Jerusalem, and eame unto Bethjilage, unto the mount of Olives. muntlis hetire. (Jun:) Ir.) The multitude robulad roun. Jukr "they that wast belist". Wark simply 'many. Thos were

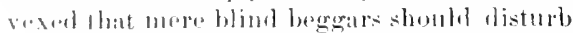
a proresson, and anday the principal persmatere from whom they may have beth eagerly

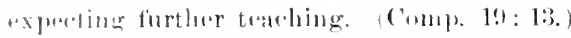
Buerars in the East are almont always offen-ive and ation di-erustimg, and it is hard to fesl

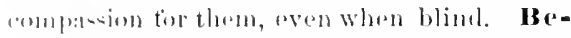
atu-1, or, that they should, lor the Greak

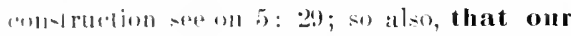
eym may be oprom. Hold their peace, :11 whl English phrase, the firose baing literally be silent. As there wore needy and hopmfal, opposition only simulated a burler

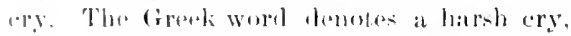

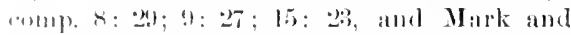
Lukr hawe the imperefet tense, describing a antimed reping.

3:2-31. Callod them. Mink gives vivil

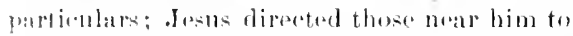

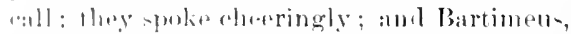

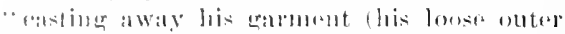

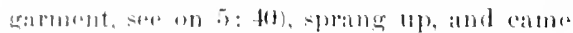

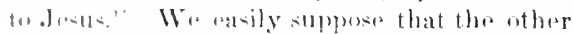
aldel lose notionalele hlime man followerl. In-ll- had compassion, ses tha Gromk word

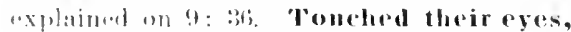
mol mantionml ly Mark or lake, at sign to

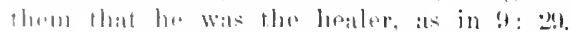

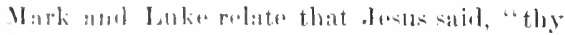
tath lath mate thas whole," saverl there,

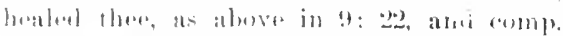

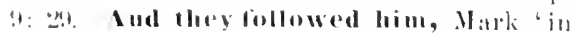

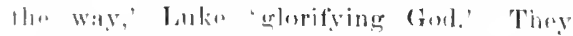

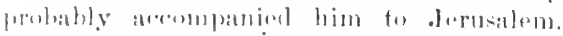

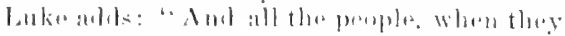

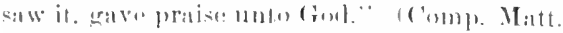

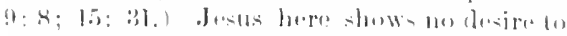
movent his miracles from hesoming enenerally

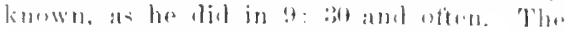

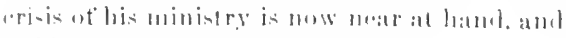
publicity will make nos ditlereneer.

\section{IOSILETICAL ANJ PRACTICAL.}

Y.:31. And the multitude rebuken them. 1) Men sometimes despise, as untit to be Cloristians, those whose case afterwards brings great glary to God. 2) Religious deeoram munt sometimes give way to intense earnestness. 3) Attempted lindrance becomos for earnest somls a stimulus to greater rxertions. 4) Christ's followers may hinder when Christ himself stands ready to hear. Currs.: "Seo how nut poverty, not blinelness, not their being unheard, not their being rebuked by thr multitude, nut anything else, impeded thrir excepling earnestuess." Atratsixe: "When any Christian has brgun to live rightly, to be fervent in good works and despise the world, in the very novelty of his worlis he suffers blame and contradiction from frigid Cloristians. But if he perseveres, and wreromes them by endurance, and does not fail in goml works, then they turn and begin to say, 'A great man, a holy man'-like that crowed that werewith the Lurd." - V. 34. The abjocts of Christ a eompassion. 1) They were very nealy. 2) They pleaded for pity. 3) Thry believed in his mission. 4) They persevered and grew more earnest. 5) They knew just what tley wanted. 6) They followed him in gratitude and devotion.

\section{Ch. 21: 1-11. The Triunphal Entry.}

Finnd also in Mark 11: 1-11; Luke 19: 294t; . lohn 12: 12-19. John has beretofore been lanallol to Matt. and Mark only at the ealy doparture from Jutea to Galilee (Matt. 4:12; John 1:1-1), and at the feeding of the Five Thousand. (Matt. 11-13.21: mhn6-1.14.) II appears to have coincided will Luke several times in the last. six months. (sioe above on 19: 1.) 1Iere he once more becomes parallel to the others, and will haso at the Bothany suppor, probably at the Painal monl, elearly at the betrayal, and at certain points of the Passion and Resurrec- 


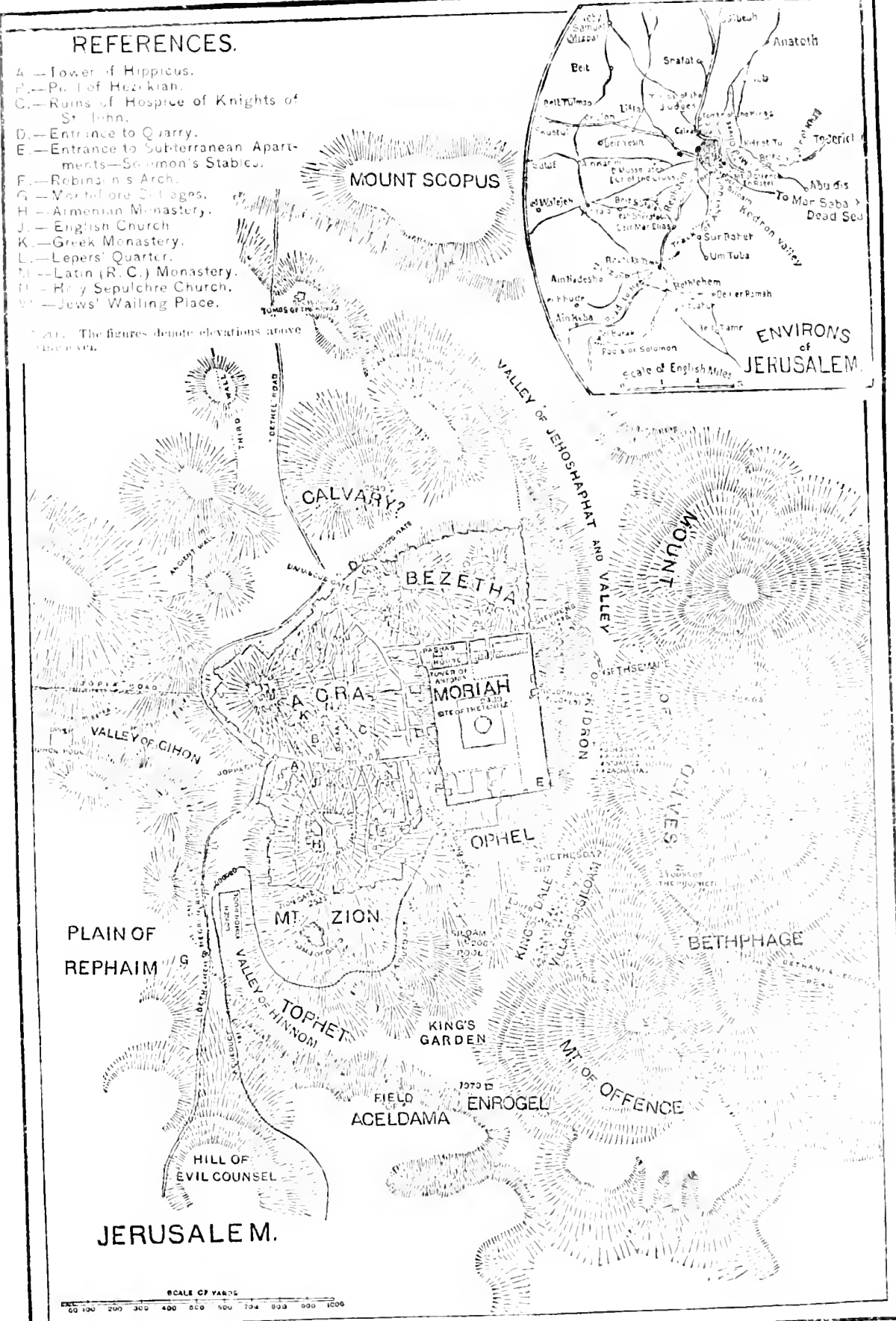


tion. Mathew, Iark, and Luke continue form this tiue as generally and as chosily prallel as they were during the ministry in Galikere.

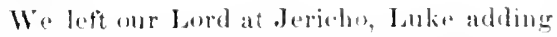
that ha" "went befure. going up to Jeru-atkm. (buke 19:24. B. r. ver.) Jle dumbtless climbed the Roman military roud, carrofully grated and palvel with hewn stone, which calue up trom

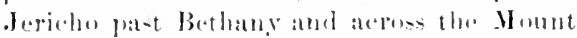
of Olives to derusalem, and portions of which are still celearly marked by patedues of pavement. There was modanger in this partieular journey that one would fall "ammo robbers." (luke 11. 3a kev. Ver.). Fince the multitud. formed a protedion; but there was usualiy such danger, and one cannot sately travel that

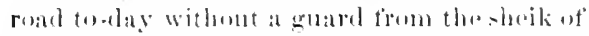
Lazariyole (Bethany). The distane frem

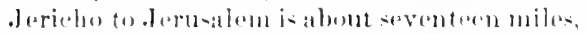
or filtern utiles to Bethang; the difterenere in elevation is some throe thensand teret. Mat thew boss not mention the arrival at bethany

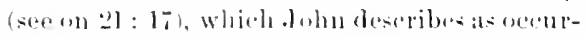

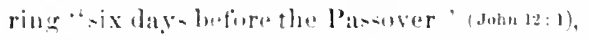
probably on Friday aftermon. Here Jeas

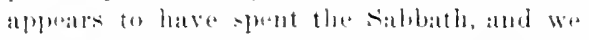

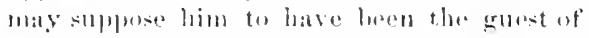
Marthat and Maly alud Lazarus. Jatring of bis atrivill. many J aws camm ayer from feru-

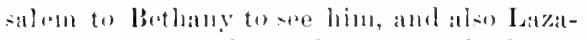
ris: whom he had rationd from the dead (Juhn 12:9); the time of the ir conting ma! hate been saturbly evening, or atrly next murning. Vark and Lako mention Bothang, in conteretion with Bethphaten, at meacheal befiore the triumplas entry. but give no details of a anjouru at bethang.

1-3. Ind when they drew nigh wute Jerusalem. The hills which firm the site if lerualem are really the somewhat lower bart of a spalew which endutly sloper from the

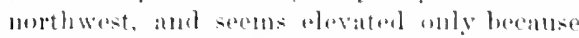
of the deep ravines which enomplates it on the atst and wet and south. Sien from a real mumntatu fire ar -ix miles distant in the northwest. J erusalem serems to be in a valley, with the high ridge of (1liver on the eastern and patrt of the mothern tide, and with another range of bills on the wost and south. seen from ollivet. the eity rises on an oppu-ite but lowor elevation, with a deep and narrow ravine lying between them. Seen from another deep ravine on the south, the hill of

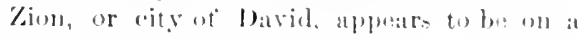
lofty and excectingly sterep hill, which Juab ambl his eomrade fouml it hard to climb and

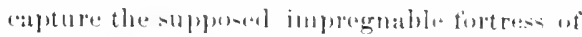

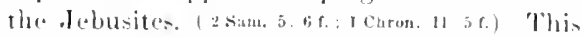
central space, which shpes narrowing down

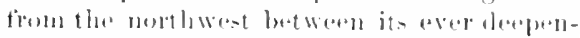
ing ravines, is preantly divided ly a sighter depresom, having the same diretion, intus smowhat separate ridges, the anstern ridges leing the temple bill, two hundreal firet lower

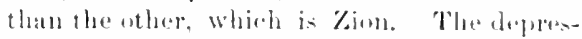
sion between them gratually derpern. con-

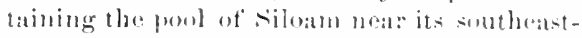

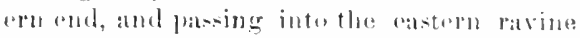
betian that forms a jumetion with tho other ravine which has conne lown on the wert and south of Zions. The nurthern part of the temple clesution, higher that the site of the temple itself, and outsile of the city, is loscontly with no small pmbabilaty ansidered

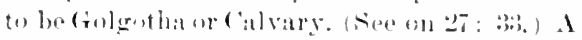
comsilerable spare borth and south of the tomple enclu-ure was aroupled by atwollings.

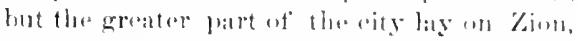
and in the deprenion soparation it foun the temple. The catern wall of the temple the

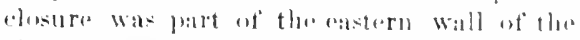

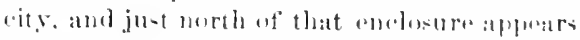
te bave been the principal eatsternentrames to

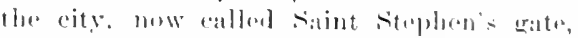
frem the tratition that stephen paresed through it to his martyrdom. Through this gatte,

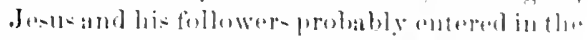

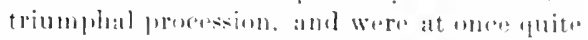
neat the merthern entrance to the omer court of the temple. And erery morning. als he

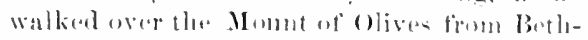
any, he wolld enter the aty ame the tomple the same way. In the northern and - hathwat part it the depres-ion betwen Zion and the tomple ridge wa- donbtlese, as now, the great northern gate of the rity. Out ut this it is mont likely that nur Loril was led to eru-

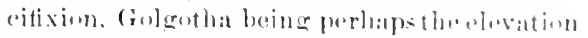
on the right aftur pasing the outer arate. Pi-

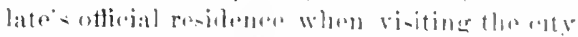
(27:2) Wats doubtlen on Zion, problably in

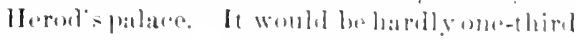
of a mile form that fllate to the morthern

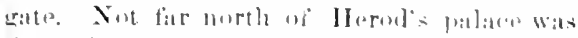
the principat Westorn gate. probably almat 


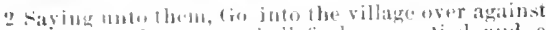

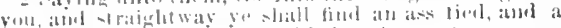

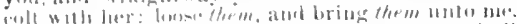

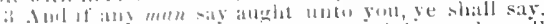

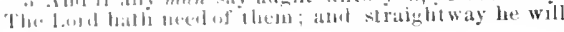
m.mil llacin.
2 Ihen Tesus sont 1 wo disciples, sayju undo them, Go inter the village that is over agahist you, and straightway yeshall tiud an ass tied, aud a colt will her: 3 lonse them, and bring them unto me. And is any one say aught unto yon, ye shall say, The lorel latb need of them; abil straightway he will semel them. the sime blate an the prosent gate leading to Juplu. "llow aity at that time dombtlessex-

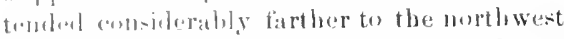
llan mow, lut the whole slate enclosed was

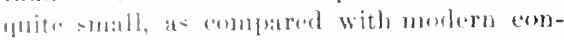

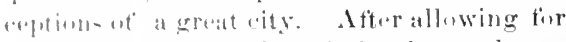

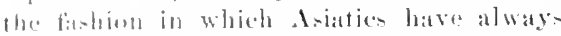
row bled logetber, as the chinese do now, it i- latal tus ore how the regular pupulation in the time of ('bri-t can have beren more than fwo or there humdred thousand. but vatst

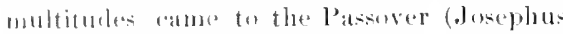

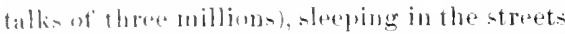
atul fublix plates, tenting in the surrounding filla. swatuing wror the -uburban villages like buthany tor several miles areund.

Were conc unto Bethphage. To menfint tlav village and the monntain showed on what sile they approatehed lerusalem, and

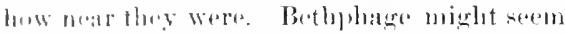
from tlue orter of Mark and Luke to have

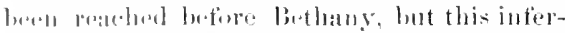
and in not neronary. The tratitional site is

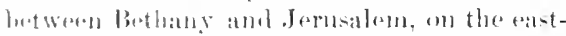

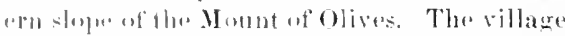

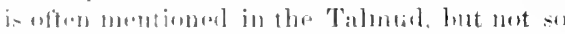
a- 10 stom its forcation, nor are there any

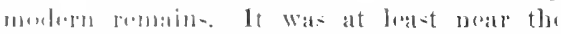
mometain on the arotem sile, and mont likely

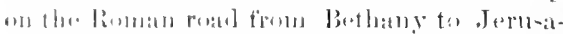

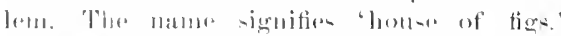

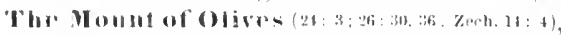
in A.t-1: 12 ' Hivet, i- a low momentain or

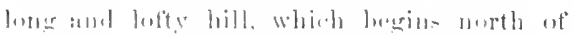

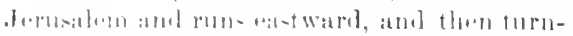

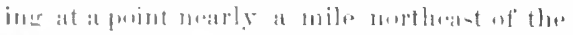

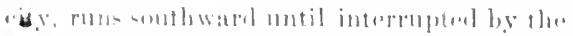

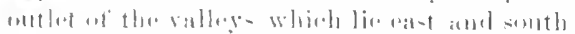

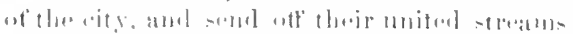

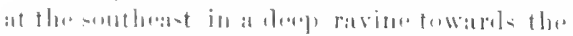

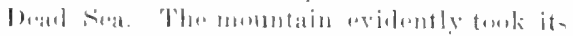

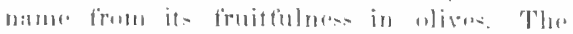

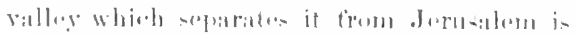

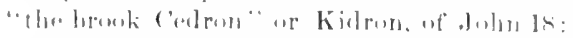

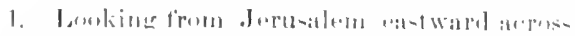

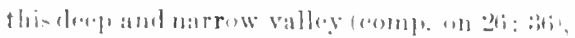

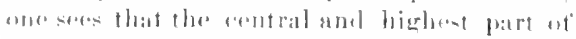

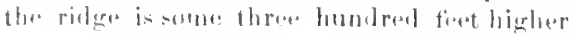

than the temple bill, and albout one hundred feet higher than the hill of $\mathrm{Zion}$; but that the summit line and face of the ridge are marked by three slight depressions, descendingsoas noarly to meet where they reach the valley of the Kidron. Ep the northern depression. asconding northeastward, went Davin in fleeing trom Absalom, "over the brook Kidron . . . up lyy the ascent of Mount Olivet.... past the top," and so along a route still distinguishable east of the mountain in that direction. (2Sam. 15:23;16:3) The central depresson runs nearly east and much steeper, almost straight across the mountain and so towards Bethany (sep (1) 21 : 17), and js the direct way for walking loatwen that suburb and the city. The sonthern depression ascends far southeastward, grioing a better grade and rossing at ansiderably the lowest part of the summitline; over this sap, and skillfully graded beyond it on the eastern slope of olivet, is the riding way from Jerusalem to Bethany, still elearly indicated by patehes of Roman pavement. Along this road came in the triumphai procession.

Then sent lesus two disciples (so also Iark and Iuke); we know not whieh two. but very likely l'eter and Johm, as hereater in Luke 20: 8. The village over against you is not certainly known, but was probably Bethphage, fronting them as from Bethany thry alproablod the eastern face of the Mount of olives. Straightway ye shall find: the description is quite definite. An ass tied and a colt with her. Mark, Luke, and John mention only a colt, which hete Was the more important of the two. (Comp. 11) 24: :30. The object was to have Messiah the King ride a young animal not previously lled. "whereon no man ever yet sat" (Mark and Luke), as a matter of special houor compl. Dont. 21:3; 1 Sam. 6: 7); and the mutber was jrobably led in front, to make the colt move quiotly. Processions often in"Hata led animals, besides those ridden. 'The I,ord hath need of them. We cannot tell whother this would be understood by the owners (Luke 19:33) as meaning that they were 
4 Mll his was dome, that it might be hidtled which

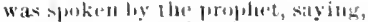

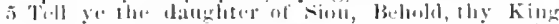

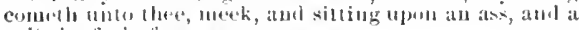
eolt the foal of at ass.
4 Xow this is come to pase, that it might bo fulfilled which was yniknth thrullgh tha" prophel, saying,

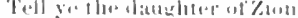

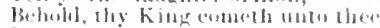

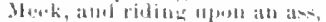

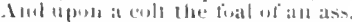

wanted tin the service of Jehovah, or detinitely for the Lurd Jesus: in lhe lalter cal-n we might sllppose owners who knew of Jesus,

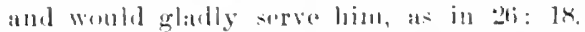
Dombthes the animals we restored that atternome at thore wise nu further use for them; it conth lwe easily done in recturning to bethany.

If. Ill this was done, ete-better at Rev. Ver., None this is comer to press (in the course of divine pureidence)-that it might be finflithd which was spoken by the

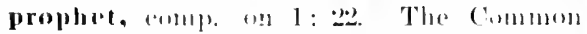
T'xit hat "all this, evidently altered by

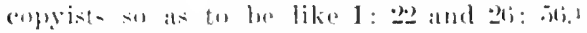

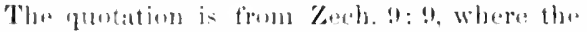

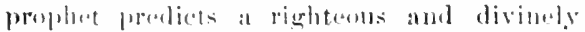

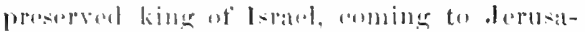

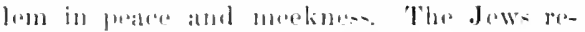

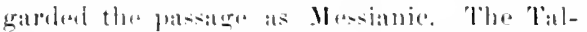

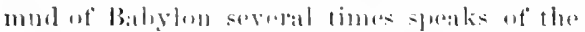

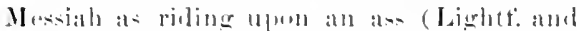

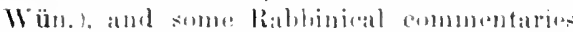

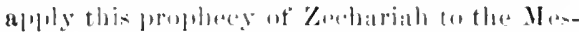

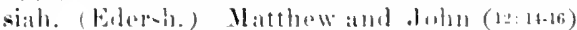

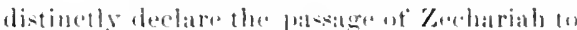

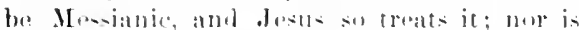

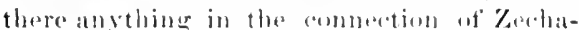

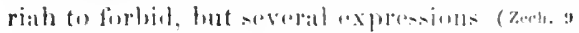

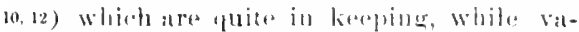

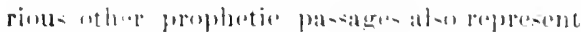
the .1 esolith under the tienure of a king of I-rute. The II obrew signifits (Twy), "Jic-

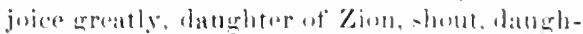

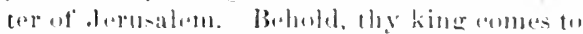
these ; just and satred is he, monk and riding

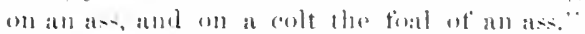
The siente ditliers but slimbty. Intthew

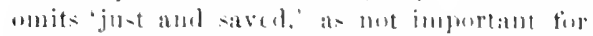
his purjuses and abridges and morlitien the

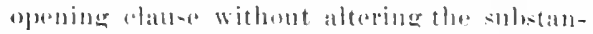

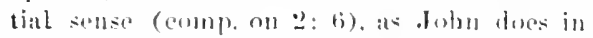
another way. Simme think that Matthew hats combined this pasige with lat. lie: 11 .

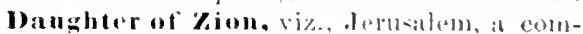

nom IJ lorew tigure by which a city was rept resented ats the oflepring of the leceality.

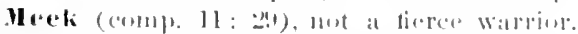

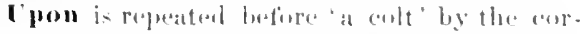
rece Greek text. In ve j, ase the secounl time?

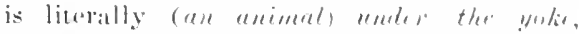

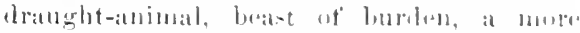

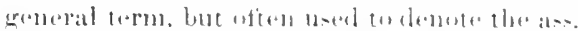

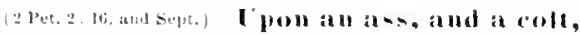
is a Hehrew parallediom of the perentiat lind

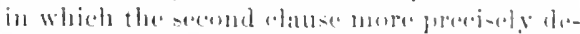
fince the first ; Rev. Ver. of Zachariah put it

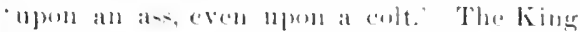

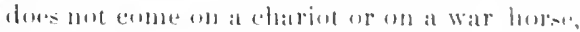
buet riling an ruters did in time of prian. (1 king, 1: :33; Jude, 5: 110: xum, 22: 2:3.) The tratincel mule and donkey of Eerpe and sirlat are very pleatant for ridinge and hate there an

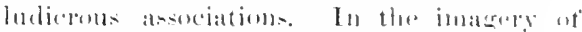

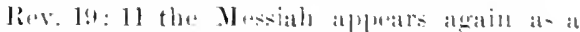

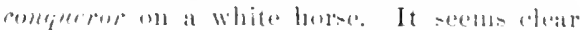

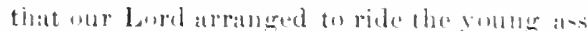
inter the city, as an intentional fultillment of

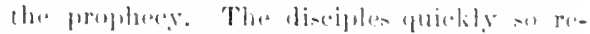

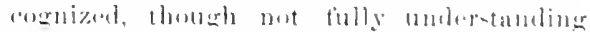

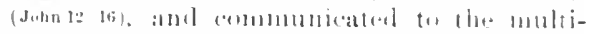
tude the ideat that this was at Mesianie entry

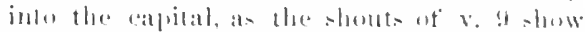

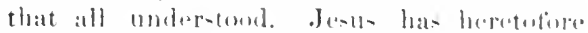

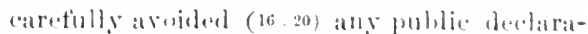
tion thate he is the Mariah, bereture it would

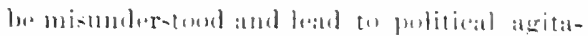

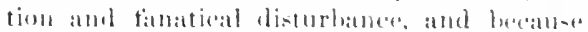
the disciples themectres were not ret sutliciantly instrueted an tw the true nature of that

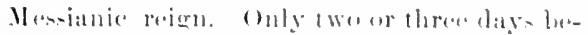

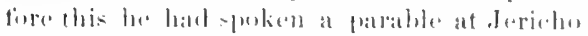

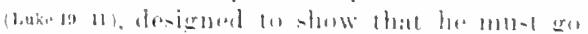

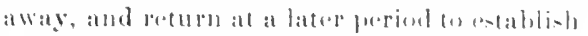

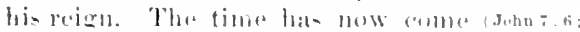
12: 23) for declaring that he is the king W.... siah. hut a luwly and paratial king. (cinup. 20 i : (i:i, is.)

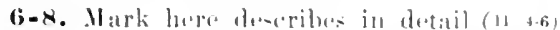
the findine of the animal aceording to tirese

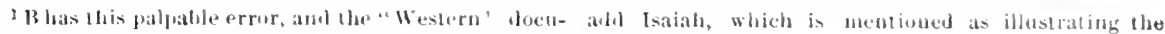
ments, with bany olhers, hate the correct text. To ways of colpgi-ts.

'prophet' a few copries add Zechariald, and two ur three /
} 
(i) And tho dinciphes went, and did as Jesus conunutiolecil thein:

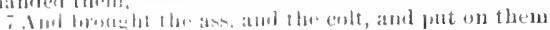

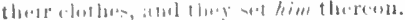

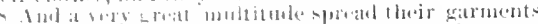

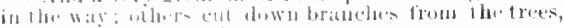

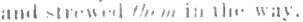

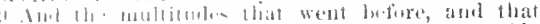

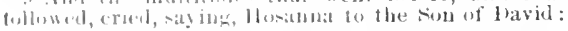

tions. Ind put an then their clothes (numbuts). In amimal to le ridelen hy a

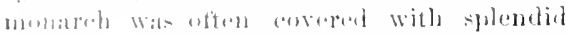
Wothe Isteking these, the diseiples touk off

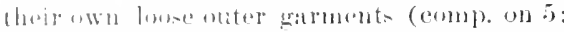
f16, and put them at hom-inge, nut anly on the (a)lt but en the mother ats alse, als that was to form jort of the procession. And they set; and he set is the text mot only of the lead-

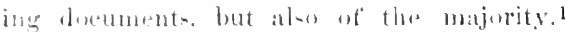
'Thereon, literally, on them, whieh naturally

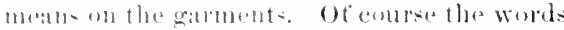

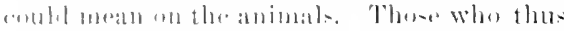

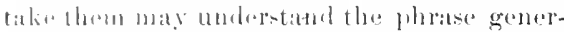
ally. like "the pustillien rede his huses

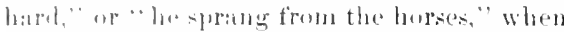

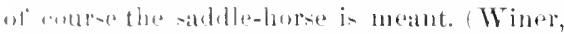

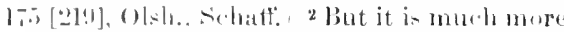

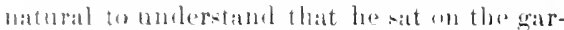

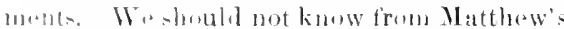
"xupe-ion on which of the two animals he

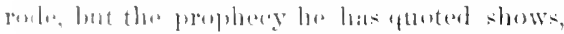

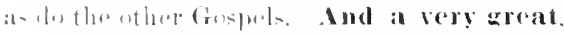
whe. Inel the most poret of the meltitule, is

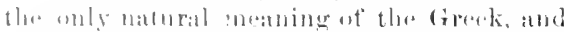

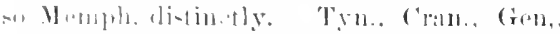

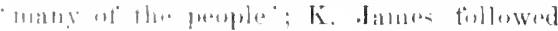
Rhaims. 'a very erreat multitude, which

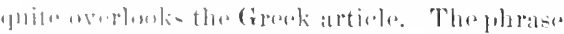

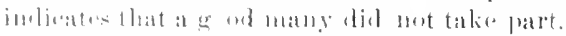

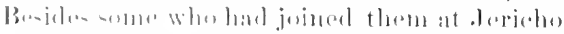

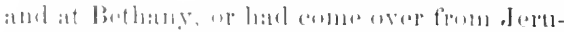

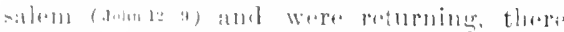

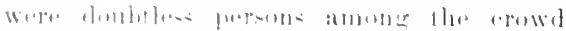

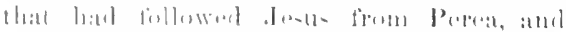

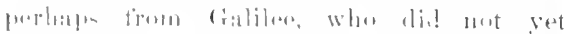

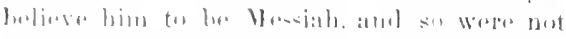

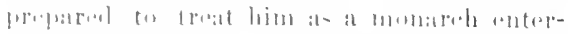

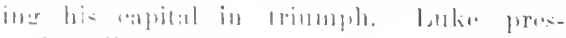

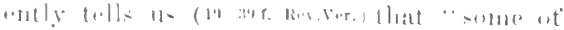

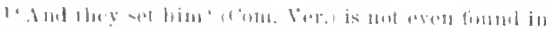

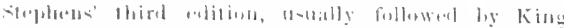

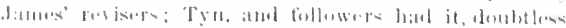

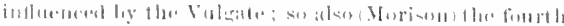

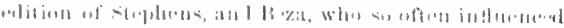
Kint Jatures man. Lake 19: prosion. fi Aud the disciples went, and did even as Jesus ay7 pointed them, and lrought the ass, and the colt, and put the them liteir garments; and he sat thereon. And the most part of the multitude sproad their garmentsinthe way and others cut branches from 9 the trees, and suread them in the way. And the multitules flat went before him, and that followed, crien, sayiug, hosanna to the son of Ilarid: Blessed is he that concth in the name of the Lord: Ilosanna

the Phariones from the multitude" spoke to Jesus and compulained of what was going on. spread their garments in the way, having no magnificent enpets to spread on the road over which the King was to ride, as was often done in trimmilat processions. Compr. 2 Kings 9: 13. Wetstein quotes, from rireok, Roman, and Jowish writers, accomts of carpets and graments spread under the fuet of some lomored one moving in a procession. Robinson tells of the Bethlehen yeasints as on a certain ucasion spreading their onter garments on the raid betore the horse of the British Comsul, and entreating his help against the exactions of the Turkish tax-gatherers. And others, must not be talien as metuing the rest of the multitude besides 'the most part'; but simply as an additional number of friendly persons who offered another mark of homer to the ling. This second elass is mentioned ly Mark also, though not by Luke. The tense of' the verb 'spread' changes in Matthew to the imperfect. and with that of "cut deseribse these persons as engaged in cutting and strewing. 'Thus three things were dune; the disoiples juced their garments on the animal, most of the erowd spread their garments on the rond, and some sprean boughs of tress. The trees are naturally conceived of as mainly olive-trees, which have ample and accossible branches, and from which the nountain took its name, but also fig-trees and others. Malk's expression sugenets rather lenves than boughs. The leaves were of enure the main object, and they ant in the rond only such smaller branches as would net embarlass locomotion for man and brast. Siowoseatter flowers.

\section{The multitudes that went hefore} and that followed, the honored King

astrauss and some others have chosen to insist that Itatt, represents lis Mastor at riding both the animals. In this abmally hyperitieal faney they were anticipatted ly tha "Western" docnments, whieh, with their lusual free hand]ing, "langed 'on them' (lroth times) to on it 'or 'on the colt.' 
dully olueved (

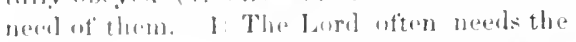
fropmerte af men. 2) The Lurd's ministers mu-t inform men of this maxl. :i) The Lord prontionsurese in attaining what is needed. - V. .). The peacefial King. 1) Ilis chatace ter is juaterul. 2) II is mothorls and sur-

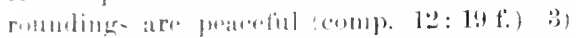

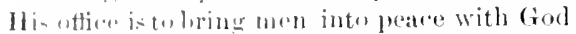
and with ranle otlurk. (Luke: 1s.) 4) His service maly arouse the hortility of the ungodly

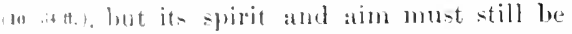

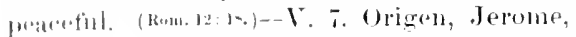
and other Fathers made the as represent the

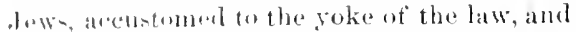
the colt the hithertes untaned Gentiles.

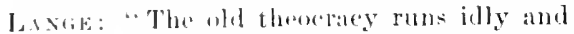

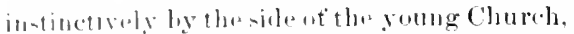
which has lecome the true bearer of the kingdub of ('hrist." It is somewhat dangerots to ulention thus concerits, ('vell as a warning, for

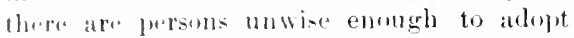

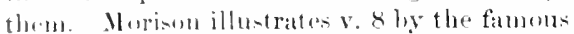

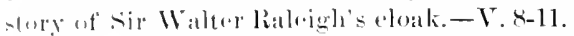
Pofular alphlaum. 1) It may be sincere even whan supurficial. 2) It need not he alespised

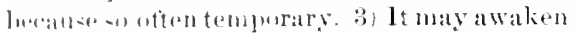
the attention of ofhers, and thos do goos! (r. J1) \& I1 must mat prevent sorrow orer lla, peri-hing. (Inke ly 11 f.) - V. 10. HALL:

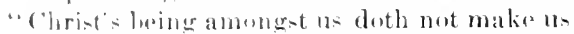
haplye. lut hi- waleonle. Every day may we latar lim in anr strects, and yet lo as new to

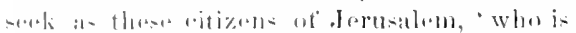

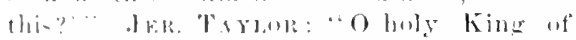
Youn, apronal, Ju-ne, he pleased to enter into my som witl trimull, trampling over all

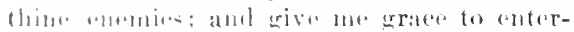
sain tho. with joy and aderation, Joppiner ott

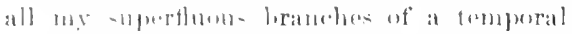

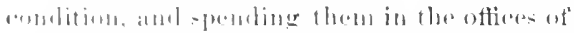

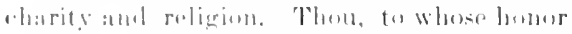

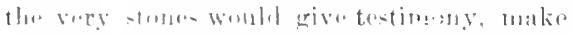

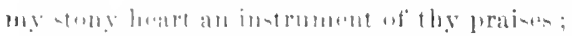

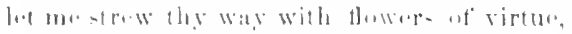

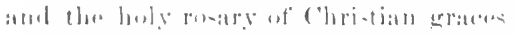

and lot u- at lat follow hors intor thy hestrenly J.ru-alem with jalus in our hamel- and juy

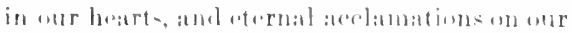

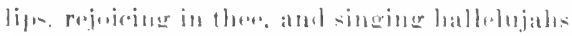

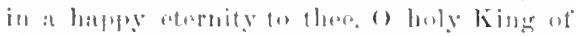

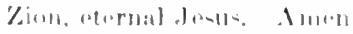

12-17. ('LEAXSING TUE TESTLE.
Found also in Mark 11 : 15-19; Luke 19: 4548. It appears from the order of Mark, who is nearly always chronolingical, that this did not accur on the day of the triumphal entry, but on the next day. Matthew, as so often before, has grouped topies, without stopping to indieate the time. Comp. o: $21: 20$.

Juhn (2: 13-22) has described a similar cleansing of the temple, at the first Passover of our Lord's ministry. Of course the destructive critics at once assume that these are only conflicting accounts of the same event. But we have seen (on 15: 38) that Jesus certainly did perform some very similar miracles, as he certainly repeated a number of sayings (see at beginuing of ch. 5). To malie the two eleansings the same is to treat either the Fourth Gospel, or all the other three, as grosily inaccurate in respect to historieal irder. Mattlow, as we have seen, sometimes "urangestopically rather than chronolugically. but su far as can be judged, the uthers are as chromologieal as historians usually are. Certainly thon we ought not to suppose that John has placed a striking event at the first of several passovers, and the other three have 1)aced it at the final passover, unless it be impossible, or extremely diffeult, to believe that the act was repeated. Now it is perteetly natural that the money-loving traders, who hat been temporarily triven out by a prophet's strorn rebuke, should quickly come back when he was gone. Their fatlers had often returned to idolatry and gross vices very soon after the reformation wrought by a prophet. Nobody linew that the prophet from Nazareth would interfere with them again. And what he had lone problueed no grout peeuniary loss, while the "ppurtunity for gain in this business was "2uticing. After all, they might say, we were worse scared than hurt. The propliet does not kill unr imprison, nor impose fines, and the temple anthorities make no objection; why not go in again? Nothing is more comun than for reform, even when accompanied by severe penalties, to need frequent renewal on the lart of civil as well as ecelesiastical authoritis. Fven the second cleansing doubtloss had only temporary results. The chief impurtance of the act lies in the assortion of jerellotir althority (21:23) and its reengnition ly all eneerned, and in the symbolical lessons. There is thus no difficulty at ull in supposing 
12 And Jesus went inte the temple of fiod, and carl ont all them that bought and solil in l he leriaple, and overthrew the tablas of the money ehatogers, atud the seats ot them that sold doves,
12 Amblesusenlired into the temple l of lind, and (a) out all them that sold and bothbl in thetemple: and overthrew lhe tables ot the nouey-changers, and

1 Jany ancient authoritles omit. of fiod.

a repetition of the cloansing. The first womld not be mentioned by Mutt., Mark, and Luke, because they grive no acount of that early Jutean ministry with which it was conneeted, and which John nurratez; and the second womla be omitted by Juhn, whe introdumet

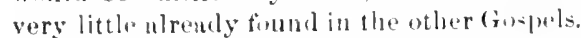
There are nnmerous atler ca-es in which one of the Gospls reourd- a certain event or tisconrso, and onds the pretition of it which we find in another (rospel. On this second oceatsion ot cleansing lewer letails are mentioned -nothing of ux+n and sheep, and nothing ats to a scollrore of eorts.

12. Jesus went into the temple. The additional of cod shomld probahly be omitted (Rev. Ver., margin), but the question is diffi(nlt and the substantial sense not altered.' Though ho had entered Jerusalem as the King Messiah, he did not seek the palace of Herod or the city uf Davia, but we find him every day teaching in the temple (luke 19:4i) ; for his IIestianie roign was t" be lirought nbout through spiritual instruction. 'Temple' is here hipon (see on 4 : 5), the goneral sacred enclosure. fests is mowhere sath to bave enterent the naos, tho sacred house, which none but priests were alluwel to anter. (Comp. on 2.7: 5.) The mered houle was situated on the lop ot a hill, anel surronnded by an amelosed spatce which, as

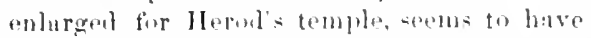
been about six hombrel feot square. The heuse on the stmmit was neat the western side of this space. The larea onter comrt. witl its groat watl and inner (a) onnales (soe on $4: 5)$, wa ensiderably lower down tho hill. Into this, as more remote from tha

lomiltel by $\times$ B L, severa] s!irsices, Memph, Theb.

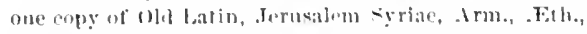
and sume falhers. It is not foumd in the parallel pansages of Mark and Luke, nor the similar pasaled of John (2: 11), hul that laet, ifolserved by ensy ists, wottd have leen a reason, as we may julge from thelr general pratetice, not for omitling it in Yatt., but fior inserting it in some of the others. The expresulon would not be intrinsiealy objetionable to any one, and so we eamont aceount for ils omission on that grount. Some anppose it to have been onitted because the phrase is rare. The saterod houst and the altar, it had beentl costumary bu allow the entrance of Gentiles, aml so it wats colled the Court of the comtiles. From this enturt went up grand steps, in two tlierlats whith a litnding betwe(n) them, an the north, an-t, amb -outh, to the next anchosure, ealled the Court of I-rael, and a jurtion of it separated at tho Cimet ot the Wumen. The wall at the top of the steprs had gramel gatus. one of which wats known ats "Beantitul" (Acts s:2), and wat perliaps the sames that Jo-ephu- glowingly deseribes in " War," 5, 5, 3. Along this wall were stmue pillats, bearing in Greok and Latin the inscription, "Let no Gontile enter here under pain of death" ("Mar," 5, 5, 2) ; une of these is said to have been found $n$ few years agu. drainstele, and gates ut the summit, to the eentral Court at the Priesta, lying east of the sacred houst, with an enclosing wall of only two feet in height. Just within this eaurt on the eastern sirfe stuod the great atar of burnt sacrificoprobably built on the large ruck which the Mobaminedans hare enelosel in the Monfue of Omar. Thus the workhiper enuld bring his sacrifio up the steps and pass it in to the privets, and coulal sece plainly whan it was lair on the altar (5: 2:3): and lowking beyond the altar (a)uld see into the enstern end of the sacred hem-e, where the priests entered at certain times to burn incelles. (lake 1-99.) As Gentiles were admitues intu the larem antor eourt, it was very assy fur Jewi-h trabers to enuelude that they might propuerly sell bore the animals to be wad in sacrifice. Wibarever purellased, thene animal- bat to be lowl througl the cotirt= up to the altar. I! that were lorought in for sale would, it wats homed,

Jew had litle uxe for such a phrame, wince for them "The temple" enuld mean only one thing. IBu the alditiun would not strike a copyist as utrange ur unnalural. And a similar phrase doen oceur, even in 20: il, and figuratively in 1 cur. 3: 16 ff.: 2 Thess. :2: 4: Int. :3 12, pte., and "remple of the Lord' in Inke' 1: a, the worlin all these caces being not hieron but num, which for our present murpose makes iftlle ditlirulds. The Internal evidence is indefisive, it seems wises in follow the doeuments which an geverally give the currect text. ('omp. II H., IP). 


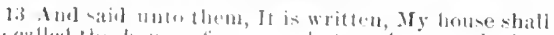

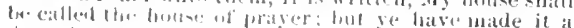
den of inders.
13 the seats of then lhat sold the dores; and he saith Iulu them, It is writen, My house shall be called a house of prayer: but ye make it a den of robbers.

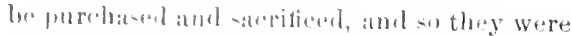

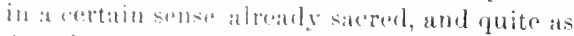

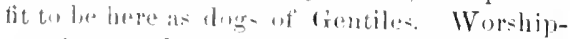
er from a dietance would enter the conts,

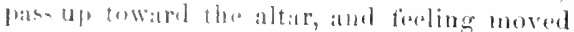

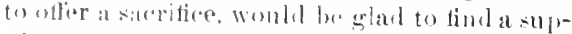
bly $\because 1$ convaniently natr. Lightfout says (finom the Talumal) that they alsosold "wind,

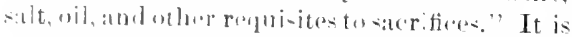
nattural that the praction of achottine tradurs, not mentioned in Ghal Tiat., shonld have

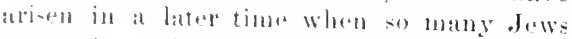

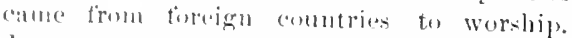

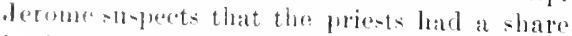
in the protic ; and probalbly ( Iorison) extortionate pricas were clatrged. At any rate we know they darived gain from all sacrifices and these would be nudtiplied by having the

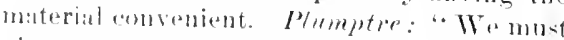

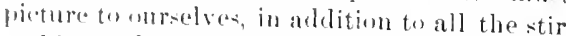
and buste insisparable fion such trafice the wranchling and bitur words and rackless ath which moresallily grow ont of it with such a forelele an the Jows. The history of Christian ehurelues ha- not hexu altogether without matrallols that wa:y lielp us to understand how sucle a lesereration came to be permitted. Thase who remamluer tha state of the great Caflealral of Iomkon, as painted in the lite-

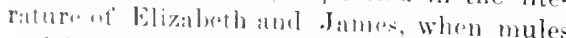
and lur-w lanlwn with market promluce wero led thromerls st. Paul's, as a matter of every-

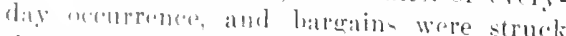
thera, and lowrerlaries plannor], and servauts limol. and proflierate assignations mate and

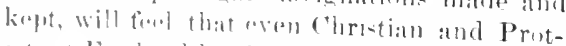
rotaut Fughand has laarelly the right to cast at

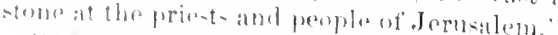

cant out. Wia lo not know whother as

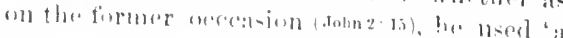

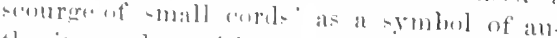
thority and jubismant. overthrew the lables of the money changers. Tho

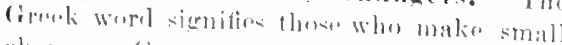

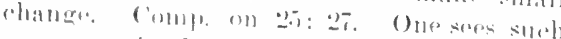

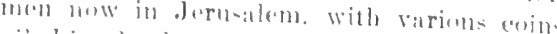
pilon in slemelur pillars on a table, reatre for asmall fromium to change foreign money intes swh as womld le mora current. In onr Lurl's time there was monch demand for thi- on the part of fureign .Jews, whom custom furbade to put any but Jewish coins into the treal-ury of the temple. (Mark 12:41.) As tho changr was thus needed in order to a sacred enotribution, ponple easily persuaded themsolves that it was proper to allow moneychanging for the special purpose to take place in the "nter court. That sold doves. Thest Wre appointad as saerifices in variuns cases. and allowed in others as substitules on the part wt the poor. (Luke2:24.) There is here (and se) Mark and Luke) no mention of oxen and shrep, as on the first occasion. It might lye inferred that the traders hat not again beeome bold enongh to bring in these, but the inference would be somewhat precarious, as the aroount maly have morely omitted them. Mark alds (11:16, Rev. ver.), "and he would not suffer that any man shomld carry a vessel through the temple." The word rendered 'vrsel' denotes all sorts of utensils and implements (comp. above on 12: 29, 'goods'). It had probably become common to go threugh the courts for a slort eut from the great eastern gate of the city towards the sonthern part of Zion, which was connected with the temple by arched bridges over the intervening ifepression.

13. It is written, in Isa. 56: 7. Lurke quotes as liore. Mark adds the prophot's concluding words, 'for all the nations,' which cary the emphasis in Isa., but are not necessary here. The meaning and application of this quotation are obvious. But ye make it, as in loaling carly documents, was easily ebunged to ye have made it, as in Lulie (and Mark). A den of thieves, or, rublers, as in 27: 38. They were worse than 'thirves,' they openly plundered, making moniy ont of the worship, in sight of the altar. The phrase is borrowed from Jer. 7 : 11, where the prophet reproaches the people with having a superstitious reverence for the temple and its services, and yet living so immorally that they seem practically to regard the temple as a den of robbers.' The Jews whom .Jesis repronched were reproducing (Toy) the superstitions reverence for the tem1) and the wickaluess that dishonored it. Un the former occusion (Jobn 2: 16), Jesus had 
14 And the blind and the lame came to bim in the temple: :and he he:aled theriu.

15 lul whon the chief priests and scribes saw the wondertul things that he ditl, and the childrete cryils

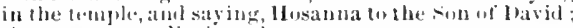
they were -ure displianed.

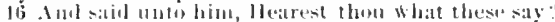

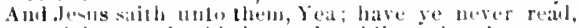
Gut of the mumb of babes and suchlings thou hatst jeerfected praise:

simply sail, "Make not my Father's homete a homer of merebuntive."-- What led the traders to obey? There must bave heen in our Lard a look and tone of superhunan anthority (21: 2:3; Joln la 5 r.) ; and then the trader: knew in their secere heart that they were doing wroller.

1. This is mentioned by Matt. only. Many aflicted promons were dombtles to be seen in thr tomple eourts, asking alms ( octs:2), or seeking consolation in worship. 'The miraculous healings, then and there,

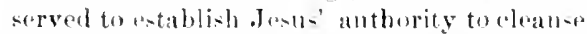
the temple, and in somesense (Wiss) reronsecrated the courts which had been profaned.

1.5 t. 'The chief priests and the scribes were prorhas representatives of the sinhe-

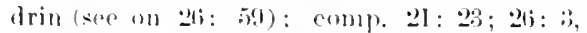
17; Vark 11: 18. saw the wonderiul things that he did, not terata. "prodigirs, llsually trandated 'wonders' (seen on 1:2: 38 ), but the guneral term which means axactly woudertul things. This doubtlens includes his eleansing the temple and his healing the blind and a lame. And the eluiltren cryiug ; thent were erying, Res. Ver., represents the Groek of the leating manu-crijpt. The worls are masuline, maning luys as in 2: 16, and whe the general torm ahildren it. ill 11: 16. It would naturally he boge rather than girls, for enmparatively fow "wen of grown women wont to the temple amid the

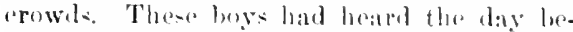
fore the cries of the triumphal procession. "Ifosanna to the sion of Davis: (21 - a), and readily understom it to mean the Messinh; now observing the anthority with which he

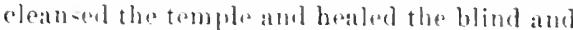
the lame, thay recalled that ery nud were loudly repeating it, even in the temple. The older poople who had said the same on the Mnunt of Olives and in the streets of the

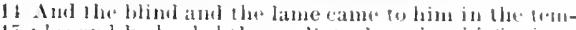

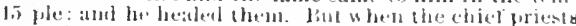

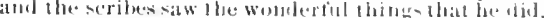
and the thildren that were cry ing in the leaple atol

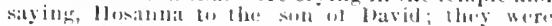

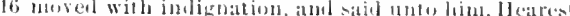

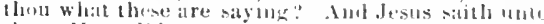

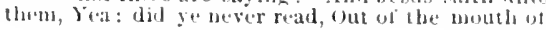

rity might haw shrunk from making the bold - proclamation in this mest public place and in the very face of their reliegens rulers; abildren are in such a cas: more aldelent and mure fiearluss. They were sore displeasede are mered with indignation, silne word ats in 211: 24. Throg ought to have heers led to carnest inquiry whether be whe thus ascerted anthority and wrought miracles and allowed himselft to be hailed a- lhe som of Datrid war indeed the Mestiall ; and his purification of the temple might well hase remimaled them of Mill. :3: 1-4. They rejected the ideal withent inquiry, and were indignant at the apparent caim. He wasaltegedher ditferent from their

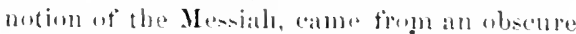

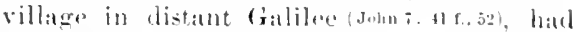
net asked the recogutition of the simbedrin. but sermed to be relying on mere popmlar recognition Johas: su) : and as the Ylesiah was of enture to he a revolutionist and civil ruler, his chaim and its pumbar sllpwort might provolie the Romans to crush out the " nation," and deprive llase Jewish offirials of their "walce." as sume of them had intimated not lone bes fore. (Johnll tis.) ILearest thou what these are sayinge They do net really domlot that he hears, but mean to intimate surprie that he does not stop a thing so impreprer ats to eall him Som of David. So during the triumphal froesesion (luke s: an), "-rme of the Pharisess from the multitule" onenly eallenl on him to robuke his diseiples for languades implyiner that he wat the lfesiab, hut he fere fused. (comple alwre an 21: 9.) It is idle for critices to suppose this a mereinaerurate repert of that former cater. tior the flace is ditlerent. the persons making the outery are here ahildren, and ho soviour's roply is also entirely different, and adapted to the te-timumy is children. The seribesemplaining may have

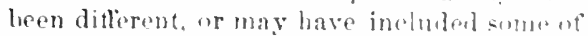
the same perans, now still further outragal

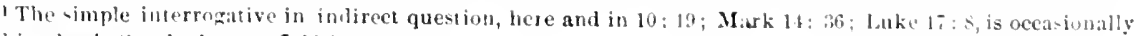
us : in cla-sic Cireck alsu, ste Jelf, żi, Obs. 2. 


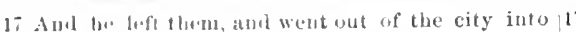

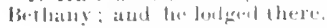

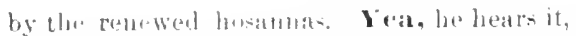
and finds it andigentimable and proper.

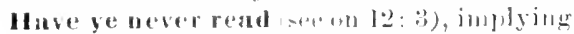

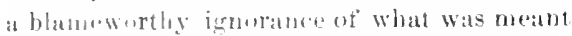
by a very fimiliar lasiage at those sacred is ritiller- 11 ith which sicribes werestlphosed to

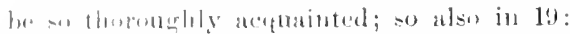

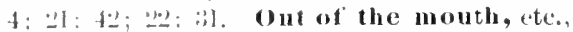
firm I'-ill o: 2) (3). Hubew, sut of the malli= ot babes and sucklings thou hast astalli-loul strunth. The siept. has "thou hat prepared prases'; in severat other pasaterin (Tily) it hate rendered the word for 'Erenerth' by "praisa. Matt. follows the sinu. an lie sis often does where it expresses the Ihol, rutlicintly fur his purpuse. (Comp. on i; : : and1 12: 11.) The treek word means 'prepared ar 'completely jerepared,' and so

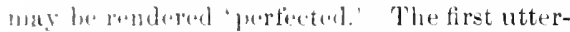
ances of vary boumes children, showing admiration al Gokl's works, and ready reeognition of hi- uxistence, are at strong testimony to his being and ghory, and ouglu, the Psalmist adds, ter silonerethe ("atemy and the avenger, all the "malieruant milers aguinst Gud." (Alexander on Pallus.) Surkling was sometimes contimurl among the Jowstill the ehild was three year ald (asace $7-27$, and such a enstom is still roported liy some travelers in the East. IIhat tho l'salmist dechred true of sueking luber was aloc and sill more true of these

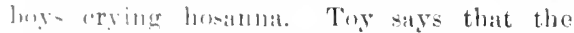
momine in which the words are here usodis "-wh-tantially the same as that of the Psalmint-iml hat -huwn these childrem a truth that llar latrumel mon dial nut see, and hat therely male tlener instruments of praise and

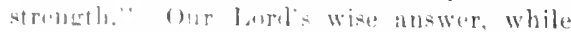
mot proveliner, fort failed to restrain, the pur-

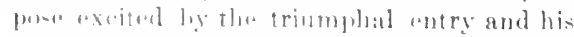

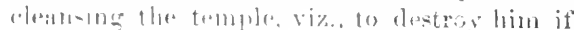

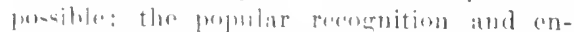

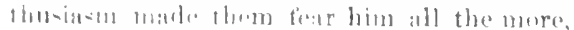

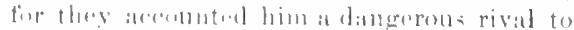
their ow ll go-ition at religions instructors and rulers. (Markb: In: lokela is 9 )

17. Ind he ledt theme, ete. Mark shome that lhis was not on the day of the triamblial ontry, but an the day fillowing. (Comp.

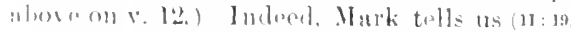
ker.ver.) that "every eveniug he went forth
7 babes and sucklings thou hist perfected praise? And le left I bem, and went lorth out of the cily lo bethany, and lodired there.

out of the eity" ; and Luke states in eonneetion with the next day that "every day he was teaching in the temple; and every night he went out and lodged in the momnt that is called the Mount of Olives." (Luke21:37, Rev. ver.) This natirally enough means Bethany, which lay on a spur of the mountain. Thus the statements agree, and show us what eourse he took on the three days of his publie appeatrance, probably the first, seeond, and third days of' the week; he cime "early in the morning " (Luke: : 38 ) to the temple and taught, and went out at night across the monntain to Bethany. Many who had come to the feast sought nightly lodgings in the surromnding villages. Jesus would go out to seck repose in the home of his friends (eomp. on $26: 6$ ), and probably also to avoid an attempt to arresthin, stch as was sucessfully made the first night he spent in the city. There is no oecasion to suppose, as some bave dome, that he and his followers camped out near Bethany. His friends in the village were apparently wealthy.

In leaving Jelusalem by the eistern gate (comp), on 21: 1), Jesus and his disciples would descend the steep declivity into the uarriw valley of the Kidron, and by a little bridge would cross over the dry bed of the stream, all covered with flat stones worn into rounded shapes by the torrents of the rainy scason. Realuing the foot of the Mount of Olives, they found near them a garden called Gerthemane (see on 26: 36), doubtless vecupienl by olive-trees and fig-trees, with probably flowers, and less probably vegetables. It stems to have been a place open to the public, and "Jesus oftimes resorted thither with his disciples" (John 18:2), perhaps stopping to rest under shade and among flowers lefore elimbing Olivet, or in the norning hefore entering the bot and crowded eity; for in April it is extremely hot in Jerusalem in the daytine, though ehilly towards morning. (John 1m:1m.) Up the central depression in the slope of the Mount of Olives (eminp. on 2I: I) the path is steep and toilsome, sometimes (lambering up ledges of line-tone rock, and gradually rising to a level with, and then abure, the ciry on the hills behind. At the summit, from which could be secu the long 
$18 \mathrm{Now}$ in the morning, as he returued into the cist, he lisugered.
Is Suw in the morning as be returned to the city, his interests. 4) Mhath mon wrongutherethrough

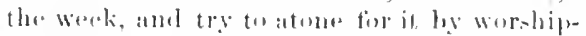

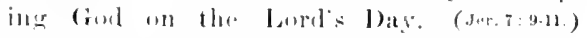

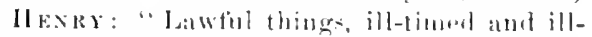
placel, mily bocomm sintul things. That

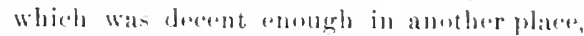
and not anly lawfol but landalide an aurther day, detiles the sametuary and profines the

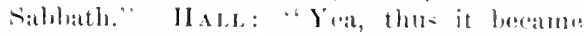

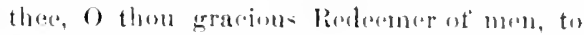
let the world see thom hast not lost thy ius=tive in thy merey; that there in mot moro lenity in thy formearances, than riende in thy just seserities; that thou canst thumbler as will as shine."-V. 1.) f. Childen erying in the temple. I) Wubld-be wize men uttan show folly log dospi-iner the young. 2) children sometimes see religious truth more (elaryly

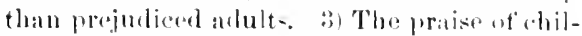
dere is theromerhly aceoptable to Goul. 4 Tho piedy of ehildren wenght to touch hard hearts, and silenoe maliguant opporers of the gropel.

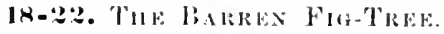

Fomnd also in Marli $11: 12-14$ and 2020 . If we had anly Matthew, wo should sllyme that all this cecelured the momind which fillowad tho triumphal entry and the cleansing uf the temple. But Matthew dues not at all antradice the fuller aceount of Mark, vi\%, that atter the trimmphal entry (probably on the

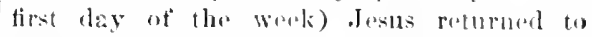
Bothany; the mext morning (Momday) an his

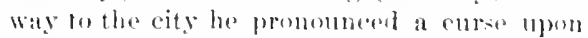

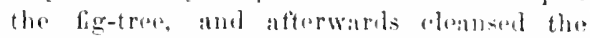
temple; and the following morning (Tuestay) the disejples exprosed their surprise that the trese had at wnee withered. Matthow has simply thrown together the whole nutter af the lig-trea, just as in narrating the ministry in Galilee he ofton arranges topically rather than ehromologrically.

18. Is be returned, or probilhly. npon returning. IIe hungerod. The first moil wats ustally taken about the midello of the firre-
I Aorist part. in $\mathbf{X}$ (first baud।, B (first hanıl), I, (fir)lowed by 'Tiech. and IV 1t.). 'tpoun returning' 'aftor returuing,' 'having returued.' 'This, as the ubre ditlicult realing, easily elianged ly copyisis into the other. has strong elatims to aluplion. 'tho immedialmy forlowing "by the roal" wombl show lhat the former expression ia metunt loos ly, llatt though he had reachet the city, he had not entered it. There is thus anly an apparent eontralietion leewen ihis amd Mark, "when the'! were come out from IBothany he was humery. It was less than Iwa milis from one plite to the ofber. Buttmann would leere trabslate "put oft" as it munns in luke i: : $\mathrm{f}$, thus making it "atter pulling off to the city.' But it cau liaraly be shown that the wurd has 
19 Arr when hesaw a figtree in the way, loe came fo

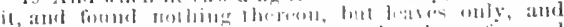

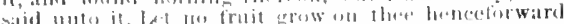
fir ever. And presenty the tig treet withered awa.
19 hungerel. And sceing 1 a fig tree ly the way side, be came lo it, amd found nothing lhereon, but leaves ouly : and he sath unto it, let there be no finit from thas henceforward for ever. And immediately the

\section{J Or, a single.}

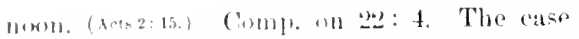

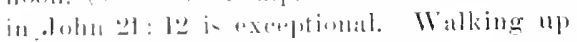
and down the sone monutain in the early morning air wolal naturally awaken alperelite, eserecially in one whe had aten moder-

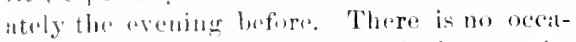
sion firr llar suppesition that he hat spent the night in suecial prater.

19. A lie-trese, or mone jormbably, in the

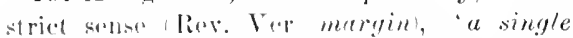

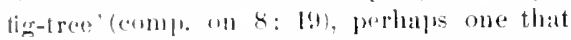

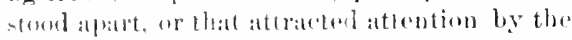

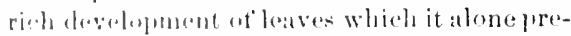
saltel. Pliny "Natural IIistory" XVI, f!

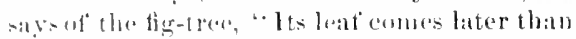

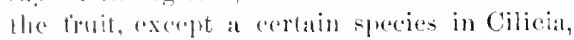
cyprus, alll cirecee." Tristram says " Nall. lli-t. of the billa") that in Palestine "the fruit uplears lufore the leaves." Inr. (thanbars (ins sichatl) denies this, bat the contlict ab reports is accounterl for liy the statement at 'Thomson ("land and buok"): "The figr often rome- with, or even betore, the latves."

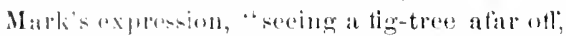
having laskes, he eame," shows that the pres-

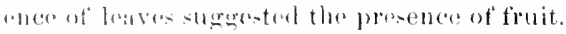
They had furhape atem new ligs in the deep

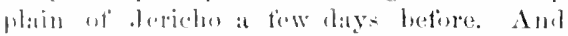
theregh "it was mor the saison of figs" (Mark 11 t: sere Ver.). Lero an the mountain, yet

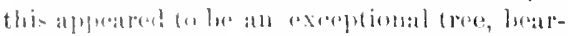

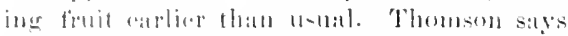

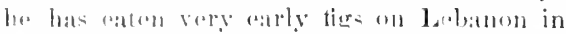
Max, and that finit are there a memth later

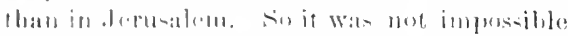
that in some warme nowk of the Mount of

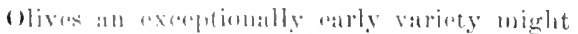

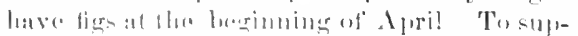

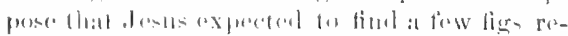

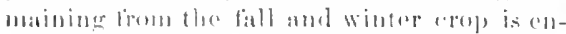
tirely an-uitalile. latsen would he no sign

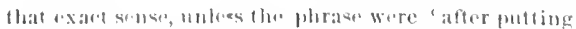

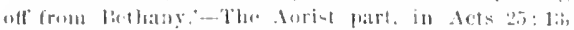

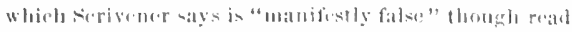

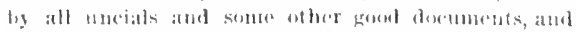
which Hort regards as an instamee of "prior corrmplume of the text, way ferhap le explained as meaning "I they canc down to cesarea by way of greeting to of such romaining fruit; there would be no occasion for finding fault, and no symbolical lesom. The artificial translation of Mark whiuh some have proposed, "for the season was not a gool one for figs," is withont warrant in grammat, and a mere expedient to acape a difficulty. - To take from a fruit tree beside tho roal, or even to pluck ears of grain in prssing, was entirely in accordance with law and custom, Dent. $23: 24 \mathrm{f}$., comp. above on 1:2: 1. See the thorough humanity of our Siviour-hungry from a mountain walk, seeking food from a tree beside the road, and distppointed in inot funding figs when there was sueh a show of leaves. His human mind, which hat grown in wisdom (Luke $2: 52$ ), which did not know the day and hour of his own second coming (Mark 13:32), was of necessity, as a finite mind, unable to contain all knowledge. IVe must beware of unchastened inferences from this fact that he did not linow sume things, remembering that in the mity of his peroon dwelt a divine as well as a hmman nature, and that the Holy spirit was given him without measure (John $3: 34$ ) ; but we must not leny or beclond the fact, when distincetly set forth. This is indeed a necessary part of a real incarnation, and we must aceept it as a mystery. Maldonatus holds that Jesus feigned to be hungry, and feigned to seek what he knew he would not find-which painfilly rominds us that the great commentator wa; a Jesuit. Let no fruit grow on thee henceforward forever. So Mark, and this is what Peter called a curse. (M:rk 11:21.) To suppose that .Jesus angrily uttered impreations aquinst the inanimate object is not only irreverent, but gratuitous and silly. (our Lord souglat illustration of religions truth from all sources; from food and water. patching clothes and bottling wine.

Fustus," sinee the eoning itself was a greetiug as well as the worts spoken an arriving. This woutd he like "You did woll in reminding me" (anamnesas), Plato. ('onp. Jesuw 25: :3; 26: 12; 27:4.) The present parl. wonld mean, "they eame down while saluting." Comp. on $2: 3: 21$, as to the geueral theory ot the aorist. 
20 Aud when the disciplus saw $i$, they marrelled,

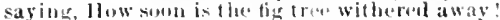

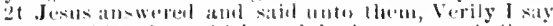
unto you, If y.hase tath, and dembt not, ye shall usit

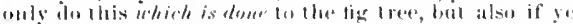
shail say unto this monntain, lie thou romoved, and in thot cast inte the seat it ahall he dutur.

sowine and reaping, and changes of weatler. birds and flowers, flants and besse an well als

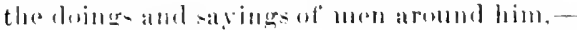

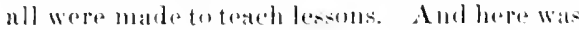
all olfwertunity for a very striking lesson. The

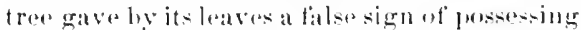
fruit, and on would strikingly represent fitse professionsonf piety without the enteets therent,

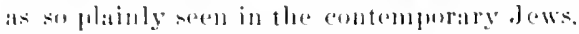
and alas! not in them alone. by the enree pronounesed it became a symbol and a warming to all who shomlel evor hear the gospol. That withereel tier-trese stands as one of the most conspienous objerets in salered history, an

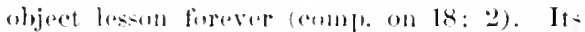
losion corresponded exaletly to that of a parable given some month: earlier (1,4ke 13:6-9), and eorrespunds generally to the lamentation over Jorusilen the day before (tuke 19. f2), to the cleaming of the temple which immeliatery followed, and to the long course of toaching on the next dity. (Nate 21 : 28 to $23: 39$.) There wats among the lows of the time great religiosis, and little roligion. Witnese the tralling in the temple. the hyperiey of the sieribes and Pharisees, their reforal on helieve John the

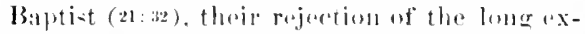

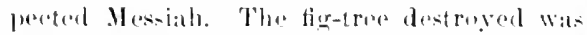
of extremely little value, ats it bure and fruit. It may be that standing 'on the roal' it was mot private property. The Talmend often di-tingrui-hes (Lighti.) botween the fruit of troes that grew in common-, and the fruit of treses that grew in gatrdens or fields. But that

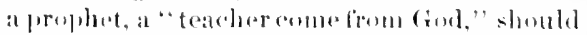
de-troy a piece af property of trifling valua fir the sake of teatelinge a great lesem, would

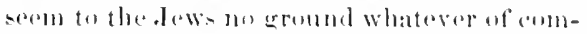
phant; mouh lese will it seemso so these who beliere in his divinty. (omp. the destrue

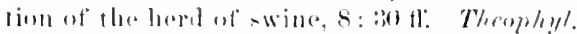
remallis that our Jord's other miracles were all benefieent, and lest it should he theoght

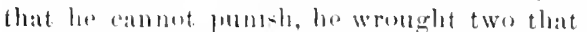
wore punitive: ret these were not upon men, lat unon the tree and the swine, and really meant kindne-stoward men; "lye withersthe tree that he may chasten men."

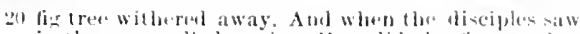
it, thay harvelletl, sityog, llow dial the tig tre. in-

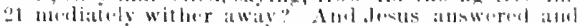

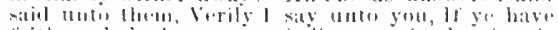

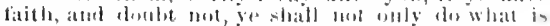

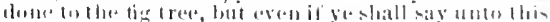

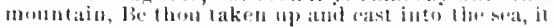

\section{ently (liev. Ver., immediately) the fig-tree} withered away, deres mot meressitrily meatu that the withering was completred in at moment. And when Mark (11:2n, Rev. Ver.) states that "in the morning they sitw the tig-trese withereel away from the prosts," he indiendes that the: "ithering han prestomsly oceolured. So there is no contradiction.

20. Ind when the disciples saw it, which we fearll from Mark Was the follewing merninge. Mathew dares not memtion the latpen af time, but deres not deny nor exelude it. How soon, ate. luettren, as in Rers. Ver.

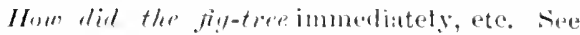

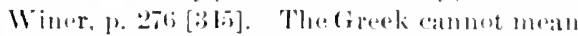
"how seron, for the word is 'immediatuly, just as in the preading vares. The disciples imguire how the inmediate witherian necourred. The porecess was justly characteri\%ed ats immediate, ats there hat beron anly twentyfour hours. and it was withered form the pors (Mark). The Master had not expresely sial that the troe should withere at once lut only that it should nevere bear truat. Wo learn

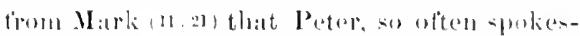
man, mentioned the matter to the Teateluer, but the answer was aldressed to them all.

$21 \mathrm{f}$. Onr Lated indirengly answers their folection by golline how they tow may work not only such a miracle, but more wobdertul ones, and may obtain in prayer all that they

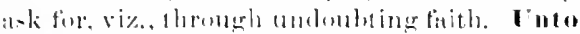
this momntain westld naturally be the Mount of Gliverse and bute the sea wenld lo the

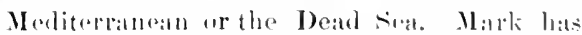

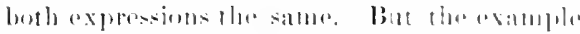
is evidenty presented, not as at thing likely or proper to be actually dome, but as an astreme cane of a concecivalle miracle (oomp. 1 corr. 19: 1) to illut mate more vivilly the miranufolle pasobilities presented to unwatrerinter

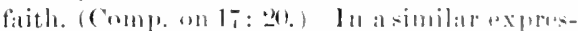

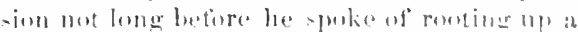

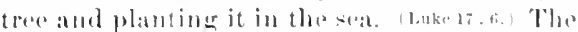

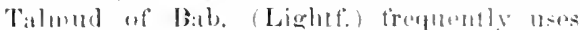
"ronter up of mountains" ats a tierure on de-

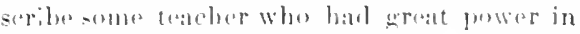
remuring difficuleies. - Christians of the pres- 
,2 tud all things, whatsoever ye shall ask in pratyor, beluobing, ye: shall rectur.

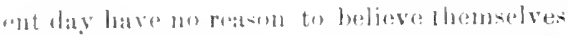

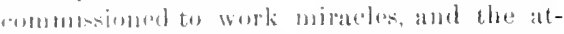

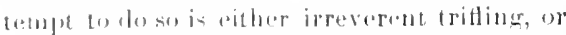

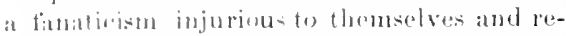
ful-iveto thomghloul abservers. Every true prater of christian faith is taughte ly the spirit of tiol (Romans $8: 261^{2}$ ), and he will

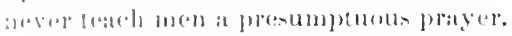

From the power which taith will grve them fo worli nairacles, our Lorel passes to its anore

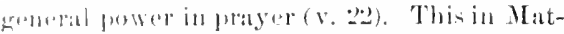

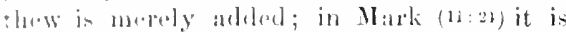
dereladed lo fibllow ats a conserquener from what

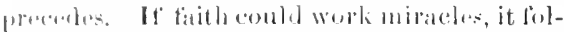
fuw-that linith can soence whaterer we pray for (a) ollp. Iames b: 16). Helieving, ye shall receive. Of course this promise has limitatims; we shall pereive what we ask, or someLhing which our Iloarenly Father knows to be better (comply, on $7: 7,11)$. Mark has a yet menerer and quite perenliar expresion, "be-

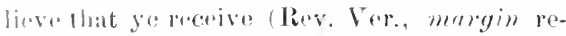

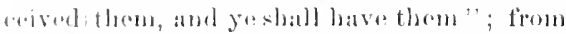
the time of asking aroun believing that your frayer was heatrd, that you virtually reenored whine your astiol, and you slatl have the

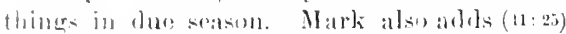
an injunction to forerive ontlurs when wo are praviug for Goll's torerivemes; whieh Mat thew mielat ande from having recorded it as alse given in conmention with the "Isord"s Prilyer." (6 11.)

\section{IUMIIETI'AI, AND PRARTIOAL.}

V. Int: Nathine late lanves. 1) Protission

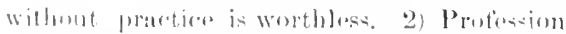

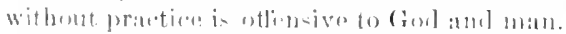

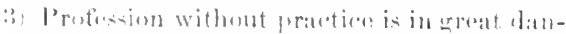

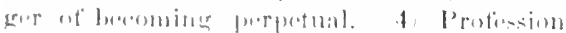

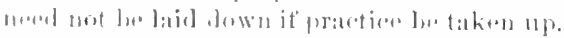

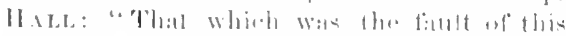

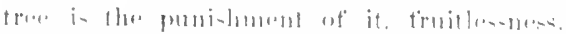

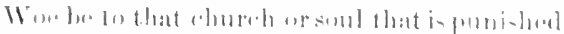

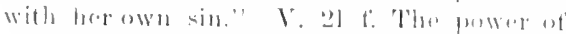

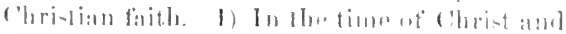

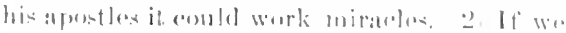

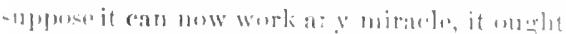

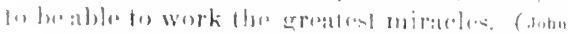

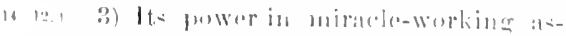

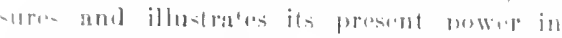
mayer (comp. James is: It t; ; Iake 111: 201).
$2: 2$ shaij be fone. And all things, whatsoever ye shall asti in prayer, believing, ye shall receive.

4) Wrannol be sure that miracles would now do groud, but we know that the prayer of faitl in every age brings tho richest blessings. 5) It enlances the privilege of prayer to believe that (forl will give what we ask, or what be sees to be better.

23-3:. Tine Rulers Question Cinrist's

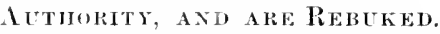

Funul aloo in Mark 11: 27-33; Luke 20: 1-s. It accured in the third day of our Lomd's apjearance in the temple, which was joubably Tuesday.

\section{3. 'The chief priests and the elders.} Iark, "the chief' priests and the suribes and the elders, representing the three classes whide composed the sanhedrin (see on 26: 5id); it is not neeesary to suppose a formal deputation. They had already begun seeking to dentruy him (Lukery: 47 f.), and even some timesooner. (Junn $11: 53$ ) As he was teaching. Su Luke, Rev. Ver.; Mark has 'as he was walking in the temple, probably in one of the beantifiul colomnates, as some months arlior in John 10: 23. To teach while walking about was very common with the Rabbis, as it was at Athens, where the followers of Aristotle were lrom this specially called Peripatrice. To stop a teacher and ask loim (fuestions. Was also conmonon. (22: 26, 23,35.) The conversation between our Lord and the rulers now groes on for a loner time in the temple enurt (21: 23 to 2:ats), the people thronging to hoar, their ustal lieen interest in rabbinical discussons being heightened by the triumphal entry and other reeent events. After that, he turne from the laftled rulers to address directly the menltitudes and his disciples (ch. 23), and towards crening speaks to the disciples (in) the Musut of Olives. (ch.2tani 25.) $\mathbf{B y}$ what authority (seoon 9: 6), more exactly, by whet sort of anthority; so also Mark and Luki. And who gave theethis anthority? The tirst puestion asks the nature of the authority, the serend asks its souree. Did he (atim prephetic authority (21: 11$)$, Mesianic anthurty (at:15), or what? Did he elaim auHhorty lous man, or from God? Aur.Jew Wa- allowal to talk publicly about religious flu-pintas (as in our social meetings.), but if lo joropumed to be a regular toicher (laabbi), he must be authorized by other Rabbis or by 


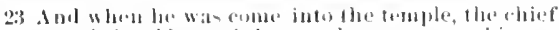

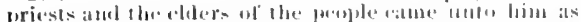

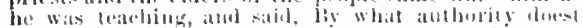

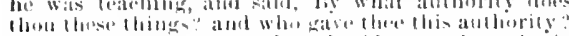

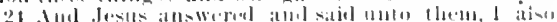
will ask you one thathe, which it 1"toll nue, I in like wise will tell you by what and lastiy I dollese thioge.

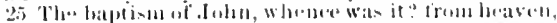

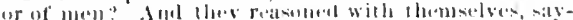

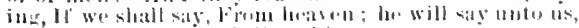

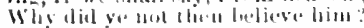

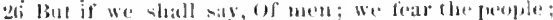

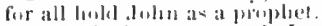

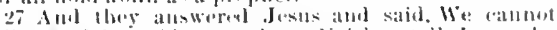

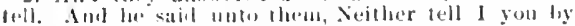

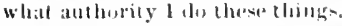

2:3 And when he wats cance into the lemple, the chind

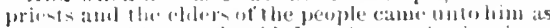

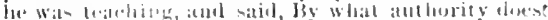

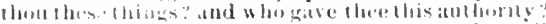

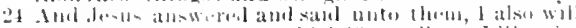

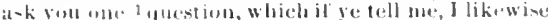

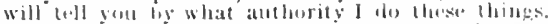

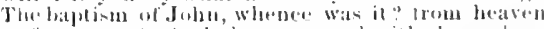

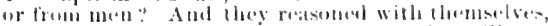

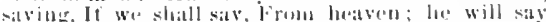

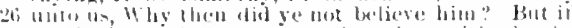

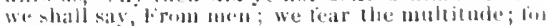

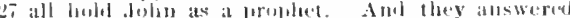

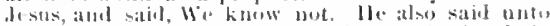
them, Nifhes tell I yeu by what anthorily I to

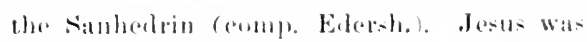
not only makine it his acempations to tratels,

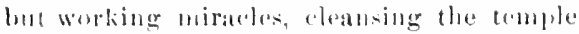

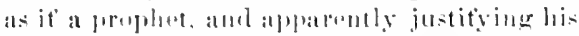
followers in gremeling him as the Mesiah. lt was proper fore the satuherlein lo inguire inte

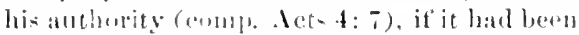

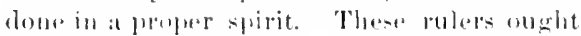

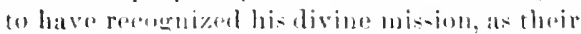

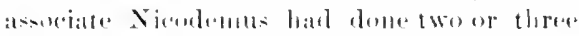

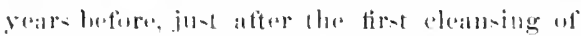

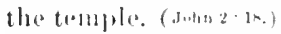

21-27. I . I atu-wers by aking throu a

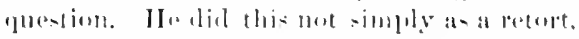

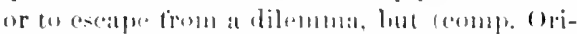

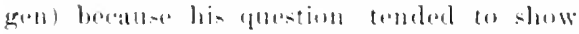

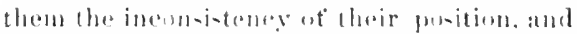

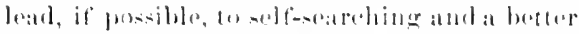

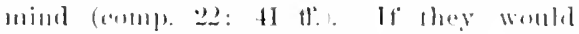

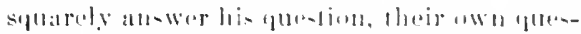

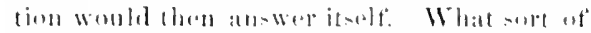

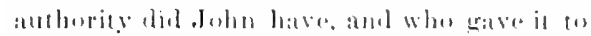

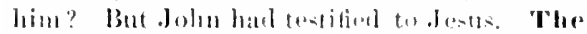
baptism of John. This ariking rita, flum

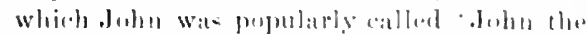

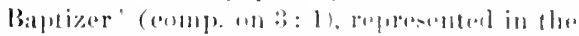
jepmlar miml his entime mini-ery, and our

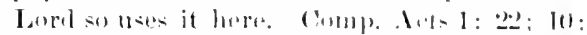
37: 13: 21. From heirro, wat the salle a-

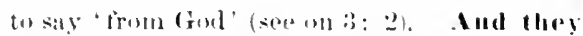
reasoned with themselves, maly moin eithor anome themsellose, ar in Lhoir awn minds. Theeir mubarramolunt in arenument

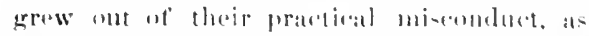
ofeen liappen-. Juhn' mini-try hat mate a great improsion (anmp. an : 2 : 5 , and the people had bory naturally reanenizol that it was from heavell, llat he wat a true prophet.

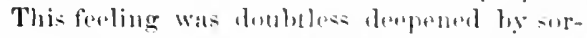
row at his untimely death, - w that fhe multiande would not now tolerate any exjerssion of floublas to his being a prophet. But the

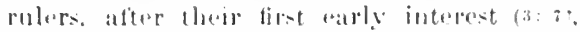
had tarmed away trom his ministry, and aleclined hi- lapplism (luke $\pi: 30$ ); landere their frement embarasiment. Why did ye 106 thou believe him? Juhn emostanlly tostified that the Mesianice reign was noar at hand, and flistinctly intimated to mestungels. from the rulers that the Ilasiah would very suob : 4 p)

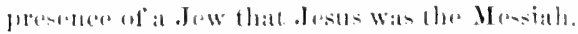

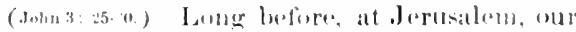

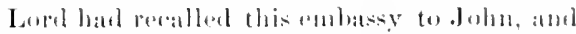

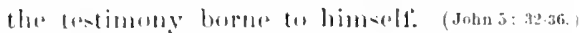

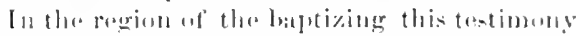

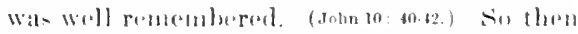
to rejoct him, whon by his atetioms and by pepular acelatim declared to be the Mesials,

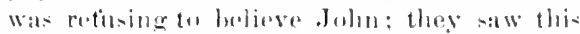
planly, and knew that it wemld les solil (v.32) Wre four the penples or multitule. Luhn adels, "All the perofle will stono us. For all hodd John as a prophet. Sir alon Ilak and Lake. Ilorud had loner fouroul to

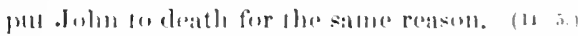

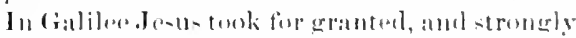

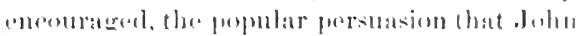
was a prophet. (s.2. 11 11: 7.) Wreanmot 10ll. Ho kmen not. is the litreal and exaret meanine. Sis 11 ye. and lilesims. It was

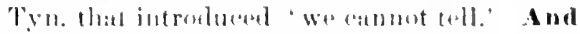
he, or he also, with a eortain emphasisun "l,

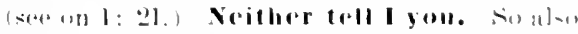

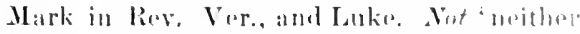

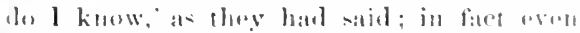

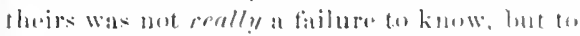

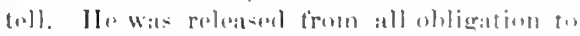

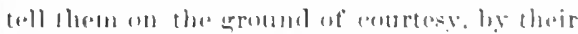
declining do answer his question. He did nut

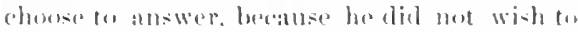
make distinct and public prochmation of his 
2. But what thisk ye" A rertain matn hatil two sums

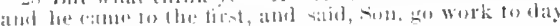
111 119 vincyatr.

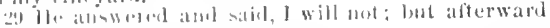

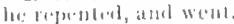

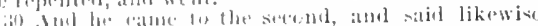

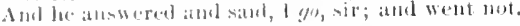

2x these things, But what think ve? A man hat two sorss; and lie eane lo the first, and sall, 1 son, go 29 work to-laty in the viney ard. And he answered and saicl, I will nol: lout altrowarl lue regented himself :30 aud went. And he eame to the seound, and sitid likewise. An 1 be answered and said, I $y o$, sil: and

$10 \mathrm{r}$, chiled.

Masiabship till dye moment of erisis eame

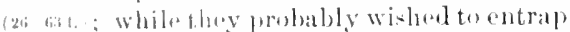
him intes some avowal for whind he eomld bes

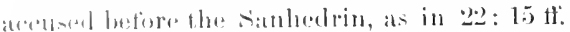

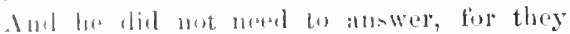

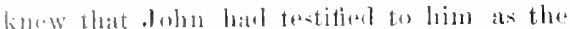
Messiali, and that he had suttered the people to greet bim as the som of bavid. The principls involvel in his refusal is the

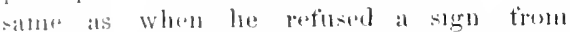

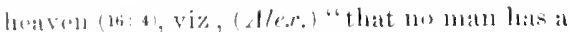
right to lemand a sluperthity of evidenese on any cuestion of belioter aluty, and that as the

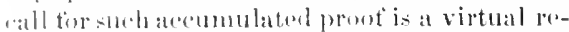
jortion of that previonsly griven, it is the law of that disine alminislations to refuse it even

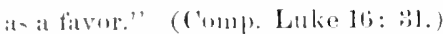

()ur Lism now rehulits the rubers by there latrables, the dirat and secomel being pointedly

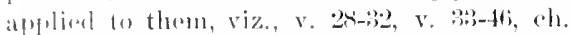
an: 1-1 T. The first and third are griven by

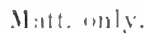

2x-30. 'Two sons, litrally, children.

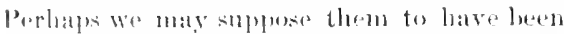
loge, to whom lho romeluet in the two castes

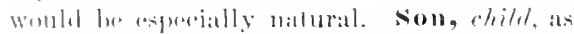

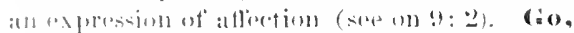

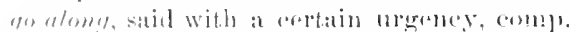

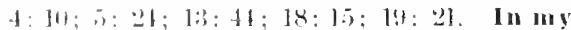

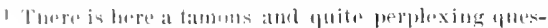

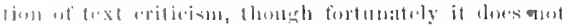

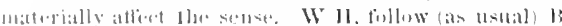

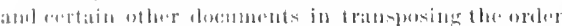

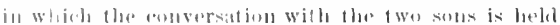

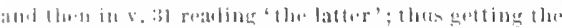

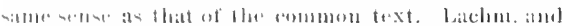

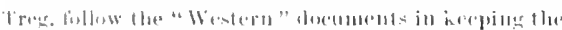

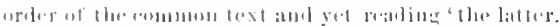

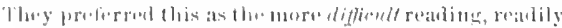

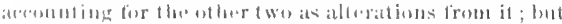

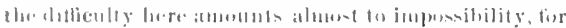

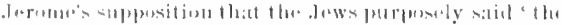

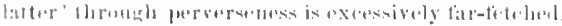

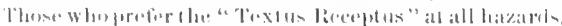

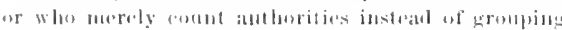

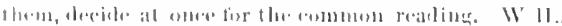

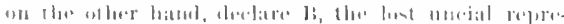

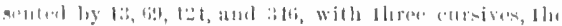

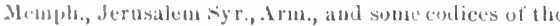

vincyard, the, nut 'my,' according to the best text. The finther speaks of it as pertaining to the fandily, nut as distinclively bis own. I will not, a rough and eurtanswer. Repented is the Giect word (metamelomai) which expresses regret, and may or may not be followed by ehange of purpose and conduct (eom). 27: 3); quite different from the word (metamieo) used to denote repentance unto lita. (see on 3: 2.) It is rendered repented himsell' in Cond. Ver. of $27: 3$, and it is better t" givo with Rev. Ver. the same rendering here: and in v. 32. In 2 Cor. 7: 8, 10, the miller English term "regret" is a suffieient translation. I go, sir, with empluasis on 'I. as it is expressed in the Gresk; a polite and wetrutions reply. Sin the Jewish rulers professed that they served God, while others did not. The same fanlt hat been illustrated that morning ly the fig-tree, which male great show ol leaves, but had no fruit. Some understand the 'I' as a Hebratistic expression wilhout enphasis, compuring Aets 9: 10; Judg. 13: 11; but those cases are mulike this, and aven in those loe ' $l$ ' is really emphatic.

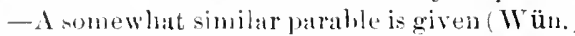
in the Minlash (Jewish commentary) on Exolus, mobably of the eleventh or twelfth century. A ling wished to rent out sone land; Eth., and some ratler late Fathers, to be "far the higher authority," which is surely for too strong a statment. It is not easy to say whether lo eommon realing or that of 13 will best account for the others. Prylitpe tha most satislactory conjecture would be that in solne "arly (opy of the "Western" type 'the latter' or. 'th' last' was substituted by a eopyisl's mistake, and propasited; and that then a correct or of the "Alexandrian" type forme such corrections we have already fonn in li) semoved the difficulty by transposing the orlar of the fwo conversations, a transposition further menmuendol to him by the faet that it puts first the soll who represents the rulers as opposed to publieans atmil harhots, and (upon the interpretation of origen and other fintluges the Iews as opposed to Gentiles, which miflet se'th the more natural order, and would eorrespond to the order of allusion in v. 32. This theory is antatuly mol nore thespun than that of WH. in the 1ppreste direstion. So lar as it goes it will tend to support the common text. 
\#1 Whether of them inain did the will of his father:

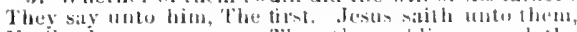

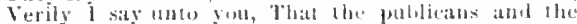

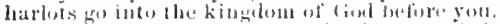

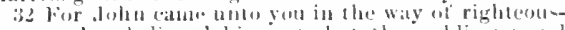

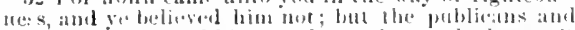

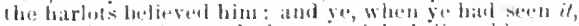
repented aot atferward, that ye mighe belicve him.
31 wont nut Whether of the fwain did the will of lais

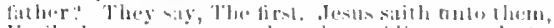

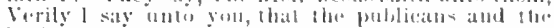

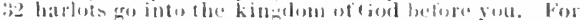

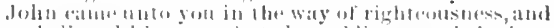

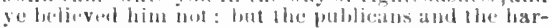

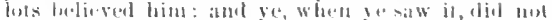
enell reput yourselves allerward, ilnat ye night beliete tim. s.verial farmers teelined; one unfertuek it, but diel not work the lanel; the king will be mest anery with the lant. J'his may have been an intation of that griven by osus.

31 t. Tha application is not las Origen and other Fathers explain) to Juws in contrat th Gentiles, as in the next batrable, lout expressly (v. 3a) to the Juwish rulers and outwitrdly corrrect perems, in contrat to somes whe had been eronsly wicked. Comp. Lulie's remarls

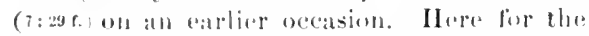
first time our Lemb makes all open, fersonal

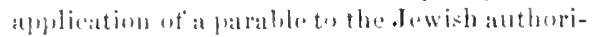
tie- Ste aleo in s. fir fl: The time hats rome fir speaking out unrearvedly to theme, and

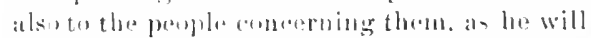
dolater in the day. (eh. wa) The publicans were vary unfululat, and often very wicked.

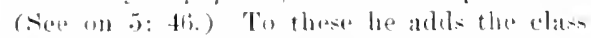
everrwhere most despied, and too often resgatried at beyout the reach of religions inthence. The "woman which was a sinner" of Luke $7:$ : $: 5$ furobably belonged to thi-class. Bruese: "Publicans and hatroto! why, the phra-e was proverbial to denote all that wak vile, lontherme, and alien to the feediugs of the pure, the respectable. and the patriotice

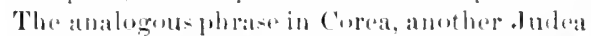

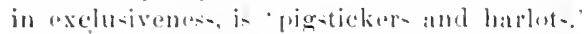

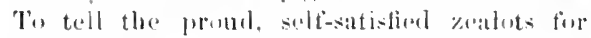

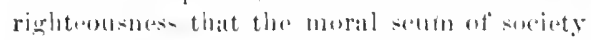
was neater the kingrom of fred than they. was to ofler them a mortal and unpariluablile in-ult." Verily I say unto you, molemnly calling attention, sere on $\therefore$ : is. Into the lingdom of ciod, the Mas-ianie kingrdun. see on 3: 2 and 11: 1:2. C:o before you (ats

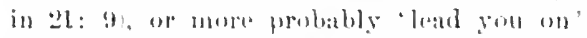

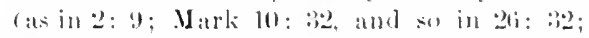
然: 7). You nut only do not leat them formward, a = you ought to de, but will mot even follow their leal. In the way ot righteon-

1" Not even, omle, rather than on, "not' (eom. text), is read by B, sereral cursives, the latin and syriac ver-

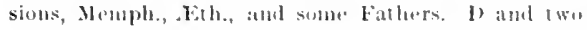
copics of the old Latio pul it repented afterward ness, and het in any way of sin-a man of righteons bechavior and righteous teathing.

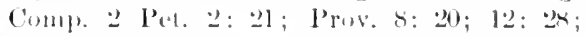

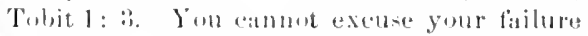
to believe him by impuguing his chatader or his instruetions. John showed no lack of

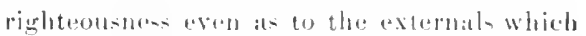

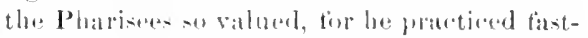
ing (9.11, n:1-1), and male formal payers. (luke 11:1.) Olsh, and biace serme to go tor far in making thi- lant the sole thought. And ye believed him not, (a)mp. on :3: 7. They linew Jesus would charge this npon them. (v.25) When ye had seen it, or sam, saw that soma of the vilest were believing . Juhn and entering thr. kingdom. Repented not, ete. Better, ats in Rex. Yror., Did not even

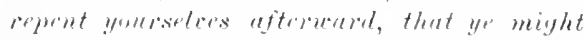
beliere hime. This does met mean that they did not repent of their sins in general (me-

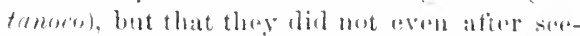
ing the eflect protuced in others, repent (metemertomeni) af their provious refusal te beliese John and anter the kinglom. The trema 'mpent rentrelyes' and 'alterward' ame in the application borrowed from tho piarable.

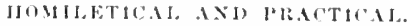

V. 21-2fi. A qunetion answered by a questions. 1 It is sometimes proper tis silenes candius inepury by ating questions in return.

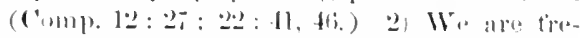
quently insolved in logionl and in pratical

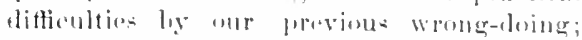
compre loilate. 3) One late no right to decide questions of truth and duty by considerations uf satery and popularity. f) Yet pulolie opinion is often wi-er than eniment mulers (com)

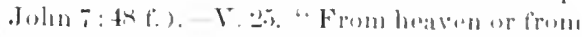
men." 1 Xo religrous tomehing is anthori-

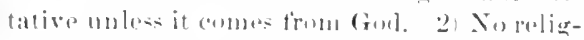

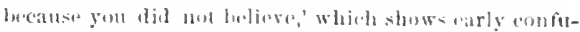
sion at to the lext. 'Don even' womkl be realily

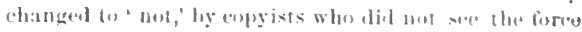
of the argument, and is au doubt tbe correct reading. 


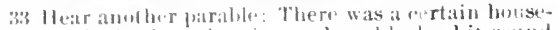

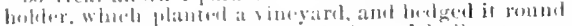

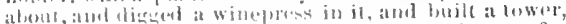

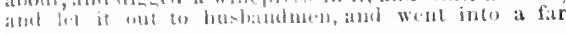
exalialig

"I viul when the fime of the fruil drew noar, he

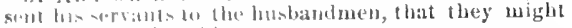

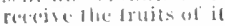

33) Ilear another parable: There was a man that was a lunselwhler, who planted a vineyard, and set a hedige aloont it, and digged a winepress in it, and built a tower, and let il wut to lusbandmen, and went it into anuther commry. And when line season of the fruits drew near, he sent his lserrants to the hus-

1 Gr. bondqurvants.

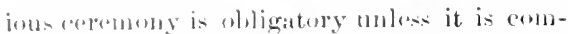

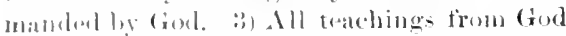
stombl be helieval, and all repermonies alpoincel by him shomal be practiced.-V.27. " M. know not." I) Men often shrink trom knowine, becatuse of a lurking tear that the

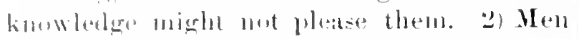
ofton freterde they do not know, becallse it would be ambatrasing to tell what they (b) know. (3) Man mightit otten gain, ly ateting up to what they linow, some blessed in-

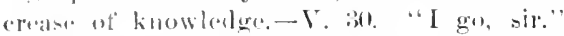
1) It is right to profess, if we also pratelice. 2) It is verong in profesoing to as-mus superi-

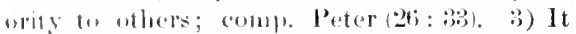
is abominable (1) proftess, and that lomelly, when one does not protice ; comple the fig-

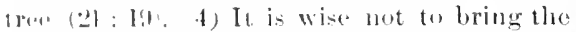

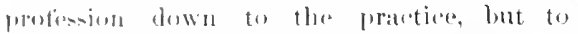
hrime the pratetion up to the profesion.V. 3 i. The dexent and the vile. 1) The vile whe bulieve Godes moseage and turn from their sin ale aceneted; the Prodigal

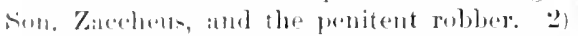

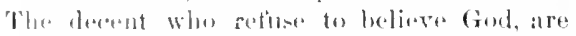

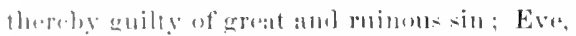
(itiallits. (iallio. :) The situed who were

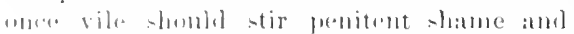

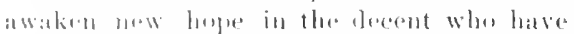

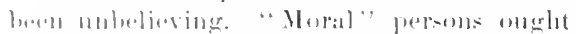

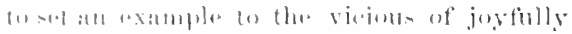

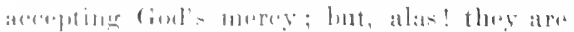

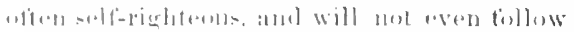

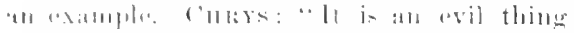

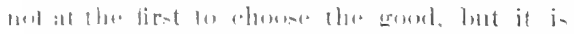

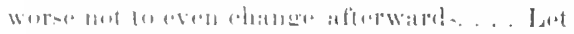

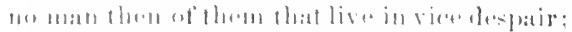

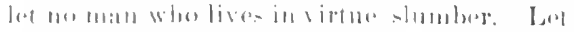

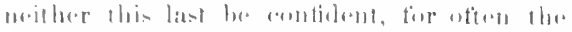
harlal will pare him hy: mor lat the other

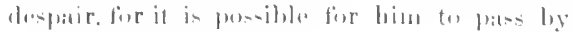
infll the fir-t

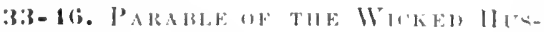
MIXII

Fonml also in Mark I:2: 1- I2; Iake 201: ! 1!).
$33 \mathrm{f}$. Hear another parable. Jesus addresest the Jewish rulers. (21:23.) Many of the people also were listening. (Luke:20:9.) He had not called v. 28-30 a parable, but all perceived that it was such. As to the term, and the general principles upon which our Lords paribolic discourses nust be interpreted, swe (1) $13: 8$. In explaining eertain points of the story itself, we may sometimes for conronience anticipate the application. The imagery lure recalls Psiln 80: 8-10, and expecially Isa. 5: 1-7. Bruef: "Our parable is but an ald theme worked up with new variations. Erory one who heard it knew what the vineyasd with its hedge, winepress, and tower signified, and whothe vine-dressers were, and who the servants sent for the fruits. These phrases betonged to the established religious dialect of Isratel" A certain houscholder, see on 10: 25. A tower, in whieh guards stay to protect the vineyard against robbery. Pulpit interpretation slould beware of separately "spiritualizing" the hedge, winepress, tower, etc. Origen here especially eautions against "torturing the parable," and then does it. These dotails simply show that the owner male all necessary arrangements, so that the vineyard whght to have yielded a good return (a)mp. Isa. 5: 4). Let it ont to husbandwen, the general term 'agriculturists,' here applica to one partieular department of agri"ilture. Went into a far conntry, literally (is our colloquial) moved away. Luke adds. 'firl a long time.' The time; season of thr fruits las in v. 41), not 'time,' see on 11: 2l. His servants, 'bond-servants (Rev Ver. margin), doulous, see un 8: 6; hore they act as the master's agents. Mark am] Luke mention only a single servant each time, hut Mark adds 'and many others.' 'To receive the fruits of it, or, his fruits. The irrek may mean either; the eomnection fisurs the latter, and so Mark and Luke. 'The ront was sometimes paid in money ( Edrorb.), lut in this case in a certain portion of the eroy, (see Mark 12: 2), which the agents 
3.) Inl the husbaulmoll touk his servants, and beat

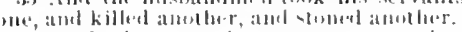

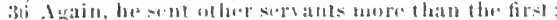

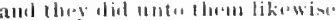

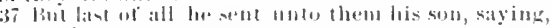
They will reverence mis soll.

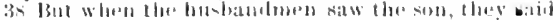

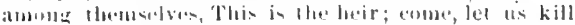

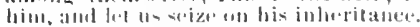

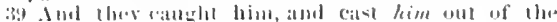
vimesal, and sewhim

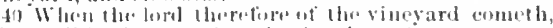

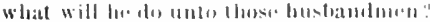

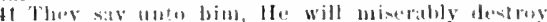
those wickol mon, and will led oul his vineyard molio

101, the fints ut it

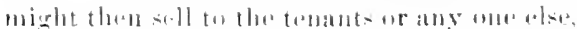
or might catroy away with throm. This is

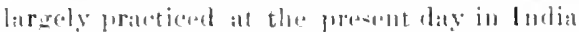
and in Italy, and to a considurable extent in this country.

35. Ind heat one, mure exatetly, seomeretel,

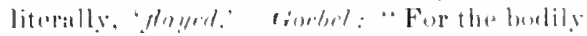
ill-tratment of the prophets. the eximple of

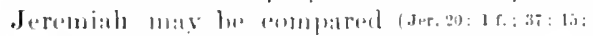

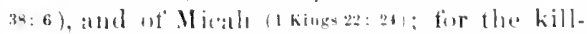
ing, the murile of the prophets in the time of

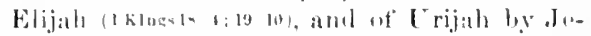

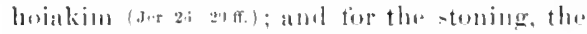

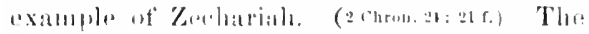
killing of the prophats alleotively is man-

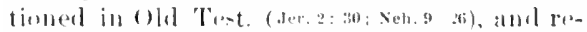

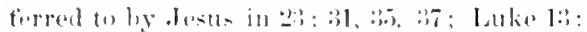

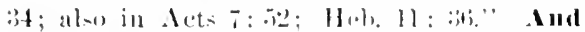
solled another mily wall follow killew,

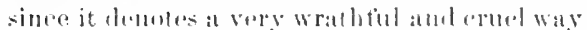

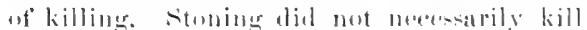

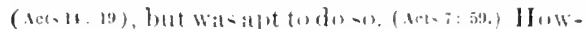

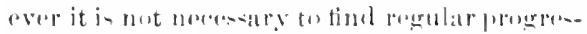

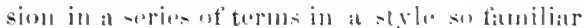
at that of the Gionels.

36 t. Renewed and mole urgent ralls.

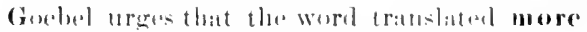

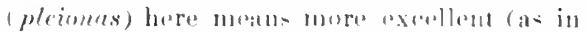

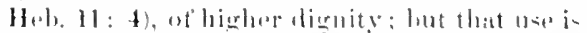

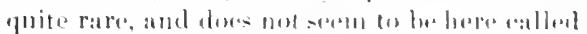

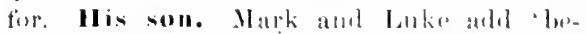

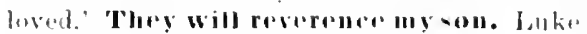
prefixes it may lon.' This inderentes a lomper

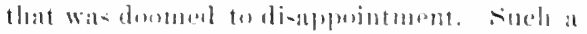

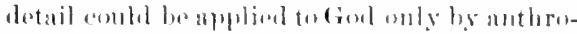

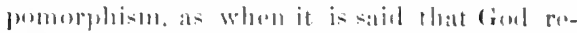

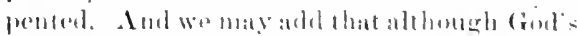
sum wa- sain, his misiond did ultimalely bring fruits from "other husbalummen."

38. Let us lill him, and let us seize an his inhrertance. Thi wis smmething nut likely to oceur in sueh a case, but entirely

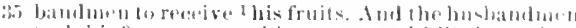

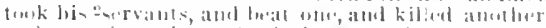

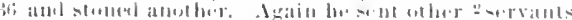

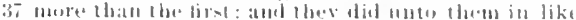

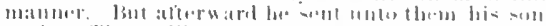

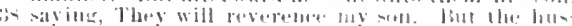

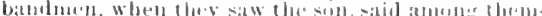

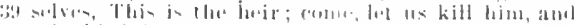

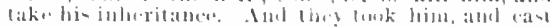

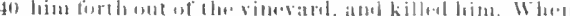

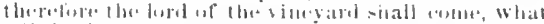

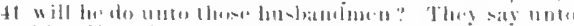

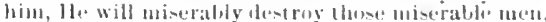

\section{2 (ir. bundservantu}

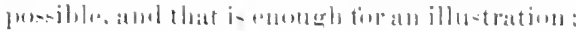

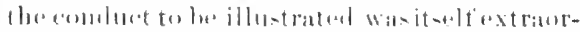

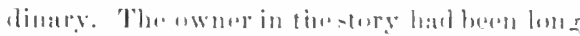

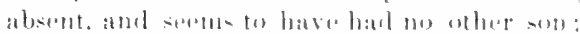

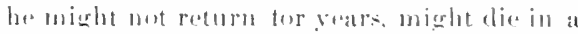

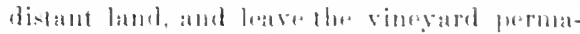

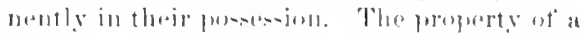

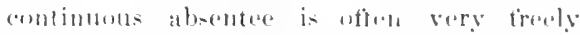

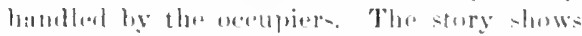
seriour defoets in local goveroment and ant-

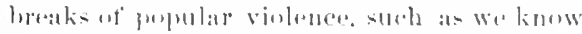

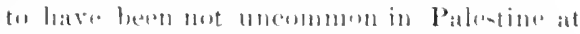

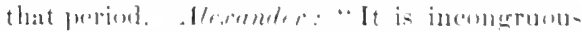

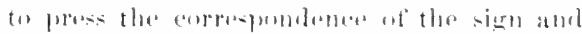
the thiner -ignitiol. altheuerb this proprestion

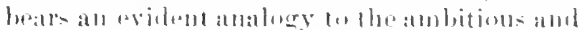

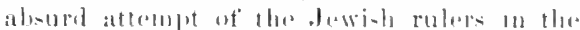

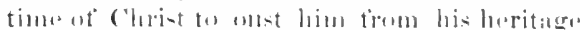

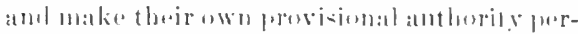

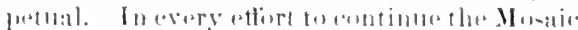

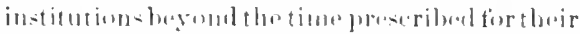
duration, the Jand have herell gruiles of the usurpation here projected by the lowband1116.11."

39. Ind east him ont of the vineyard.

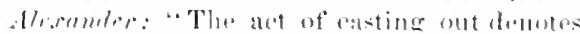

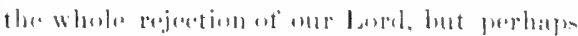

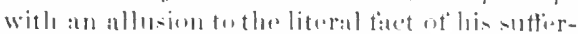

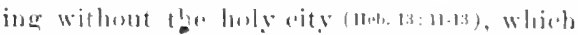

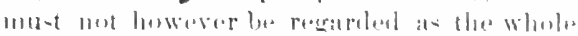

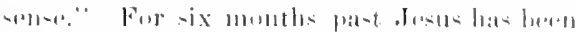

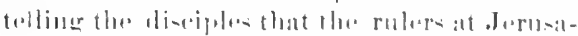

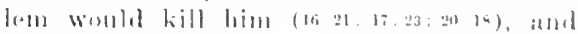

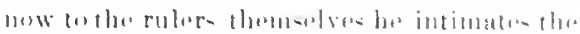

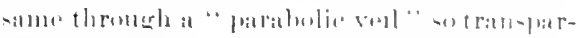

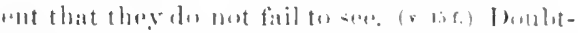

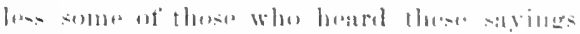

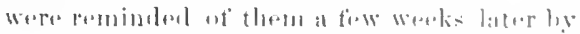

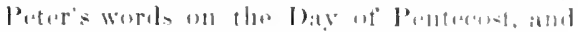
all the more were pricket in their heitet. ( 1014:2:21,37; 3. 16.)

11. He will Iniserably destroy those 
other hushandusen, which shall render him the fruits int thit it at:

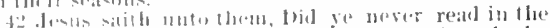

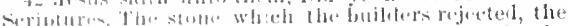

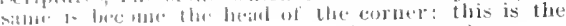

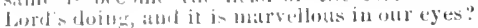

and will let out the vineyard unto other husband42 mell, that shall render him the fruits in their seasons. Jeslis satili anto them, Did ye never read in the seriptures,

The stoue that the luidiers rejeeted,

'The same' wat male the head ol' the corner:

This was from the lord,

And it is marvellows in our eses? wichol men. Tho Rev. Version preserves

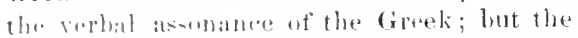

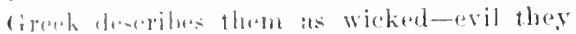
are ind weil sall be their tate. Instead of drawila unt thi- roply from the rulers, so as

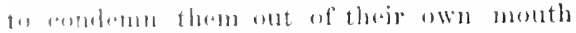
(a)m]. Dathan and bavid), wor Lork in Mark alul Luliv makes thestatement himselt. We

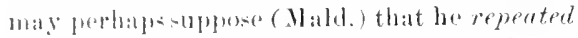

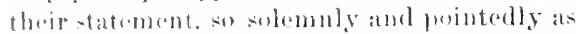
allonly to iorlicate that it meant them; thas

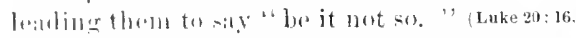
Rev Vet..marqiu. It any rate there is nosubstantial ditlirman (anmp. on $3: 17$ ). Crebel:

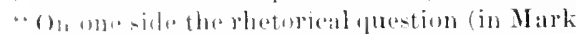
and Lulio) is still an alyeal to the assent of the has rere we the statement introduced by the yuetion; and ane the othere the arecentance ot

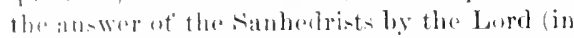
Matt.) is copuivalunt in sulstance to a statement of his awn of the same jurport." In drotroying the hushanduen, the owner acts as at-11 11 - 1 -

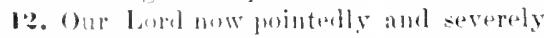
applies bis illustration to the Jewish rulers,

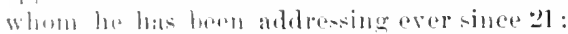

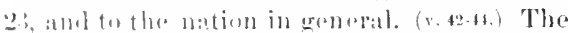

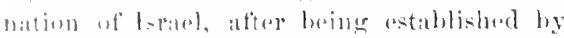
speral divine aret in the land of promise, and

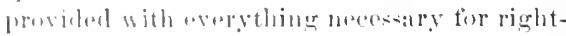

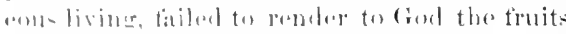

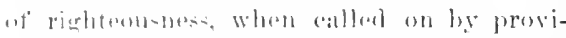

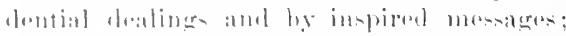
they have insultod and sometimes killed his:

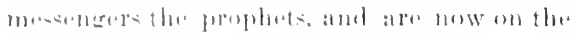

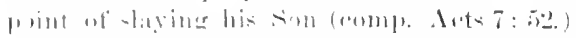
Fet this will mot and the matter. The ro-

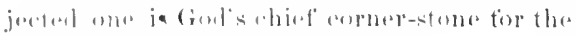

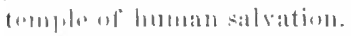

bul ge lower read in the seriptures? ats

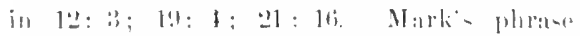

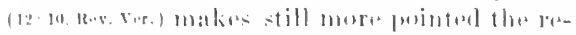

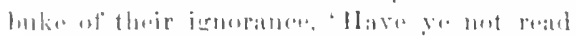

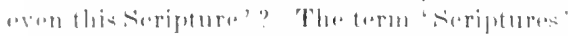

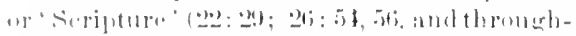

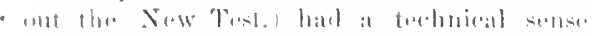
among the Jews of our Lord's time, just ats among us), donoting a certain well-known groull of sacred books We learn from Josephus and the Talmud, from Melito and (Origen (ses works on The Camon), that this group comprised exactly our Old Test., 1.either more nor less, and was recognized as definite and fixed. The Tulmud states, it is true, that in what must have been the latter part of our first century, some Rabbis questioned, on internal grounds, whether Eeclesiastes was sacred, amol some others as to Solomon's Song; but the final decision supported those bonkis, and there is no hint of any quesfion as to the other books-so that the exception provers the rule. Whan therefore Jesus and the apostles spoke of 'the seriptures' or "sicripture' as sacred and authoritative, they knew that their hearers would understand them to mean that well-known group of bouks; and they have thus stamped their seal upon the entire Olal Test.

() Lor Lorl's quotation is from Psa. 118: 20 f., just freceding the words borrowed in the hosannas of the multitude during the triumplaal entry (see on 21: 9). The quotation follows the H(d). and the Sept. withont any noticeable difference. Mark has the same. The second eomplet, 'This was from the Lord,' etc., is omitted by Luke, and also by Peter, whoquotes the parsage both in addressing the sanbedrin (Aots:11), and in his first Epistle. (2:7.) Comp.in general Isa. 28: 16. The stome which the builders rejected. A few miles aurthwest of . Jerusilem, on the Roman road to Gibeon, may now bo seen in an old quarry a tome set on end, say $8 \times 3 \times 2$ feet. As observed from the road it is a good stone, but wil riding around you find a great taw that lentroys its value. This stone was quaried and oftired. lont when litted up for inspection was rejocted by the builders, and there it tinds. Imagine such a rejected stome to broanue the ahiet corner stome in some grand luildiner. 'The tradition sometimes repented that -4 b a thing actually aceurred in building the temple, doubtless grew out of this jasige and is worthless. The corner stones 
43 Therefore say I unto you, The kingdonn of timl shatl le tatien from you, and given to at Itation bringing forth the fruits therotit.

4 . Ind whereverer shall fall on this stoue slatl be broken: hall on whomsover it shall tall, il will grind lim to pwoter.
4: Tlurefore say I unto you, The kiuglom of fiol shall

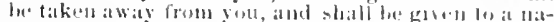

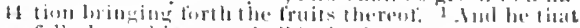

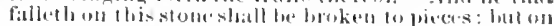
whomatever it shatl fall, if kill sealter him as dust.

I Some ancios anthorities ount ver. Al

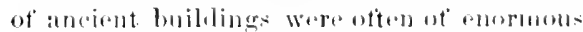

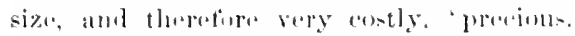

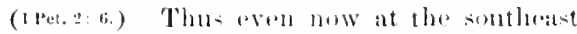
eorner at what was the temple areat is sem

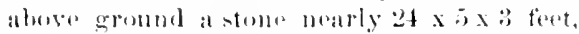

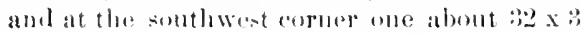
$\mathrm{x} 2$ ferot (awmpl. an $21: 1)$. The same is be come, or simply bieamer 'The head of the cormer dow not show clearly whether it stand: as the foumblation, or as the topmont stome, or alsewhrer. It serems to bo called 'hoal' simply from its prominerese and importanep. This was 2 from the Lord, is the literal translation. 'Tyudale's paraplorase, "'Ihis is the Lord's doing,' is very plotisiner. In the P'salun, the date of which is uncertain, but lobsulbly atter the eaptivity, Israpl seominto he: the stone, complaered, earried awat, and flung aside as of no nse, but divinely destimel to a tiuture of importance ame eraudeur. But thero is atyplobal resation botweren the history at I-rael and the Messiah

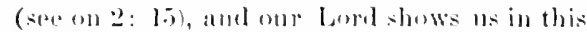
passage a prophlore at the same tinue of himsilet:

13. This is given by Matt. mnly, buing of special momont to his Jewish reaclers. Ilor

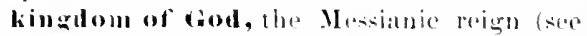
oll $: 2:$ 2), with its privileges and hemefits. shall be talien away from you. This war fultilled parly in the destrtation of . Jorusalom and of the Inwish siate, and partlyin the fact that most Jows through their moheliof" failet of the Mtresianiosalvation. And ariven to a nation shows distinctly that it was to be

It is very alubt fal whether the aurist passive of this verb is anywhere pereoptitsly different in loree from the atrist mildle.- "The stome" in tireck is all allecusattive, by at1 untisual, bul not unnatural nor wholly unexaliapele form of attration.

2"This' anl 'marvoluts" aro fominime in the tirezk,

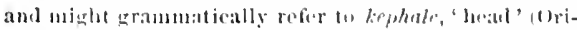
gen, Meyer); but Matt, anly follows the saph, and the feminine seems there a mere literal remblering of the

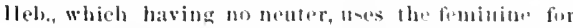
general itleas, so that "this means this thing or this oceurrence, as it would naturally le laken in lingli-h. There are other examples in sept., as 1'sat. 20: 1; 10: : taken away not merely from the .lowish

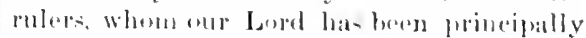

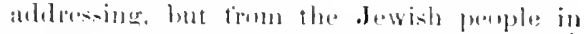

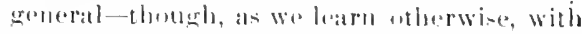
many individual exceptions, and with a prosprect in the fiar tinture (kom. ch. 11), which our

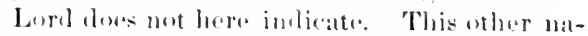
tion will ba the spritual I-latel, called by Proter "al July nation." (I Per.z.y.) ('omp). Acts 1:3: 1t; Is: 5 . Bringing forth the fruits thereof (om111). : : $x ; 7:$ 16 tr.),

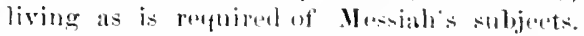
The image elatuges from that of paying the wwners share of the truits, to the more taubliar one ot prolueine the fruits. Or perhatps it is meant that the hashandmen were not only unwilliner to pay the aweres slater, but had fatided to make the vineyard duly productive.

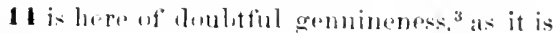

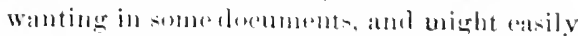

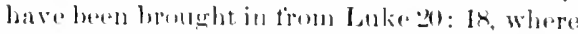
there is no variation at all, while, an the otluer

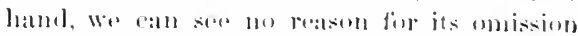
loele if original] y present. It is at ally rate a

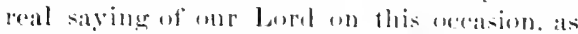

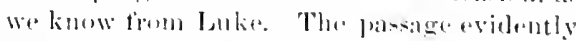
refers to Isit. \&: $14 \mathrm{f}$., which is borrowed in i Prot. 2: s. along with the quatation form Psil. 118. which has here just freceedeel. Broken,

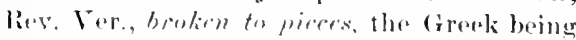

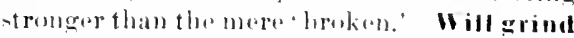
him to powder. Sis Tymale, fime, and lí. lanes. This would strike any ane at first sight as beiner what the inale calls for. But

9:119: 36; .lulp. 15:7. So our passate is understoml

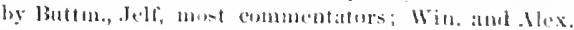
hesitate.

3 Wanting in 11, 33, acreral enplese of the old Lattu,

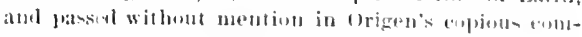

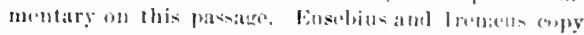

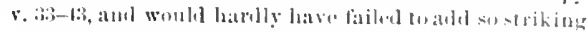

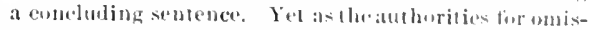
sion are tew, and represent nasinly the "Western" eroup, which hats se much arbitrary alle rattioll of the

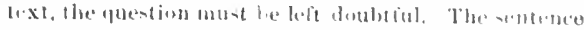

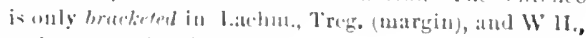
and see margin of liev. Ver. 


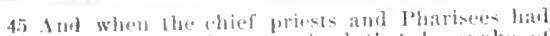

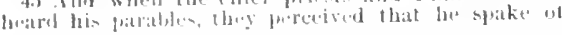
III $n$.

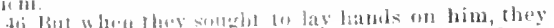

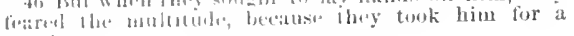
jeriphet.
1.) Amt when the chief priests and the Pharisees heard his forables, they perceived that he syake of them. 46) And whin they sought to lay hold on him, they fearel the multitudes, because they took hin for a propliet.

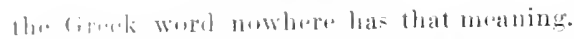

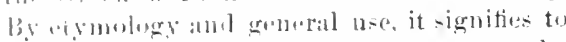

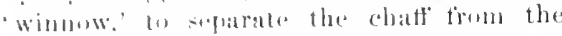
whent: and derivaturely to "aratter.' like

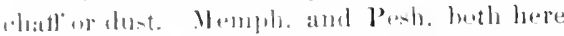

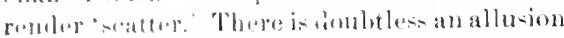

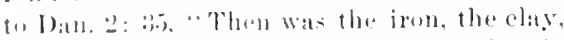
tho lian, the silver. and the grold broken in

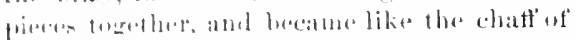

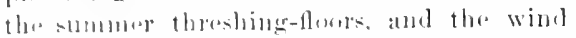

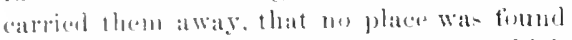

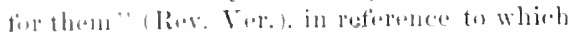

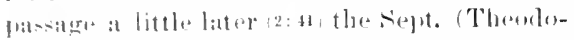

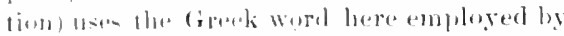

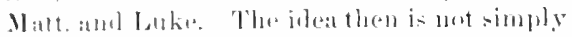
that ut arushing. but wl scattering into nethingrues. What then is the thumelot ot our

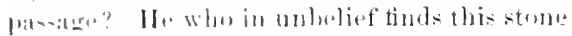

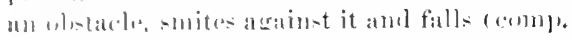
u1 Il: li; 5: :3!, will not anly be bruined by

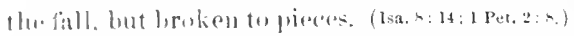

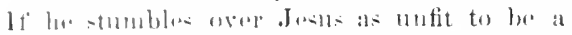

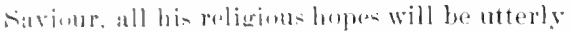

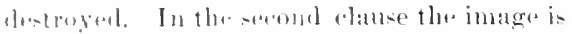

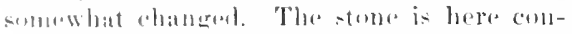

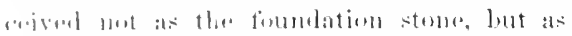

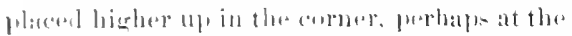

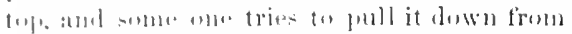

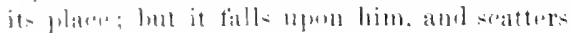

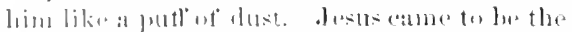

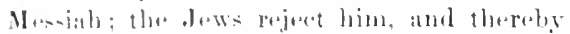

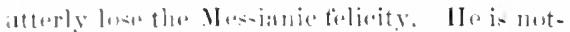

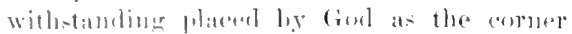

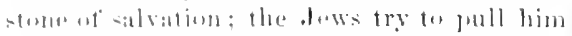

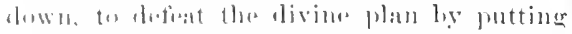

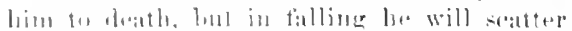

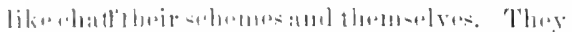

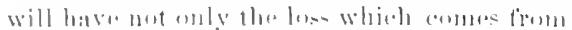

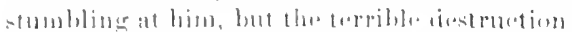

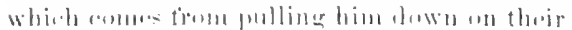

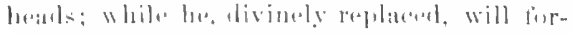

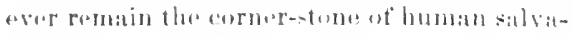
timin.

15f. "The chief" priests and Pharinges,

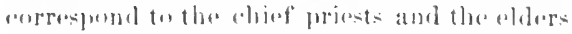

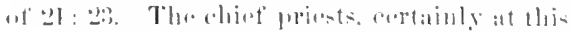

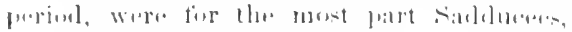

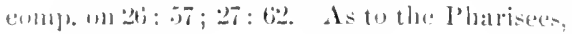

see on $8: 7$. Had heard his parables, this and that of $21: 28 \mathrm{ff}$, and perhaps others not recorded. Mark and Luke, laving only given this one, say 'parable.' That he spake of them, not of them as distinguished from the people at large, but especially of them ats being the leaders. (Comp. on v. 43.) When they sought. This would cover not merely actual efforts, but plans and wishes. The sim hedrin had some weeks beforeformed the purpuse to kill Jesus. (Johu 11:47-53.) They frared the multitudes, just as with reference t". John the Baptist. (21:26;14:5.) Took him for a prophet, the expression being, in tha (m)rect text, a little aifferent from that of $21: 26$.

\section{HOMILETICAL AND PRACTICAL.}

V. RT. Reverencing the son of God. 1) He diserves to be reverenced by all mankind. 2 lle amme to men, and his own chosen people (Jobn 1:11) rejected and killed him, v. 39. 3) He is nuw rejected and elishomored by many who onght mont to admire and revere him. 1) Ho is arucified afresh (neb.6:6) by some who lave profisied to show him reverence. 5) Yor, thumgl rojected and slain, he is risen and ascended and reigning, and multitudes do reverence and spre him. (j) In the great day every tongue will confess that he is Lord. (Phil. 2: 9-11.)-V. 41. Hexry : "Many ean anily forngusticate the dismal consequences of" "thar people's sins, that see not what will he th" encl of their own." - V. 42. "Did ye never loa 1 in the seriptures?" 1) If we had roud the Scriptures aright, they would solve for us many a now perplexing question of trutl and duty. 2) If we had read the Seriptures aright, we slould cleatly perceive that they condemn us. 3) If we had road the sirrifutures aright, we should see in them Imols Chriat the corner-stone of human salvation.-1. 4:. ORIGEs: "The kingdom of (iml is not given to any one that is reigned wer hy sin."-r. 44. Use and misuse of the ("orner-atone. 1) God gave his son to be the (o) rnel-stone of salvation to all who will accept hims. (1:a. 28: 16; 1 Pet. 2:6; Eph. 2:20.) 2) 


\section{P PER X X I I}

1) Jesus answered and spake ombo them again hy A parables, and sabl.

2 flie kinglom of heaven is like unto a corlain kimpt. which made a matriage fior his som,

Many stumble against that stome instaul of

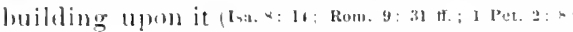
sate.11:6), and aro broken to pieces by tluc fall. (a) Some belinse mothing in the biblo. (h) others do not bolieve that e'hrist in the temurattion of salvation by his atomement. (e) otherthink the vicions may build an Christ. But they ean build on thementres. (3) ()n many that stons: will fill and utterly detroy them. (a) He will assotry by his providence theje plans of eple sition to his kimerame (b) $\mathrm{He}$

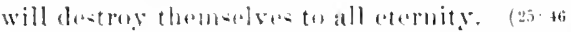

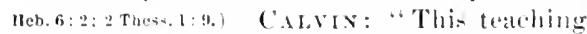
partly instruct $=1$ shat with temeler and thexible leart we may geently yielel anrselvesto be rulat over by ('hrist; partly also coufirma

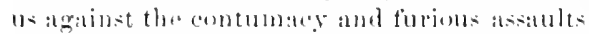
of the ungouly, for whom at lat-t a faarful emel

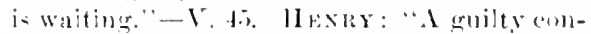

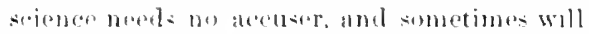
save a mini-ter the labur of say youg "Thou art theman.' Whenthoowhohear the repronfsot the wort preceive that it spatsis of them, if it do not do them somb it will cortainly do them hurt." - V. 4.) f. ('Al, IX: "The Fvangelists

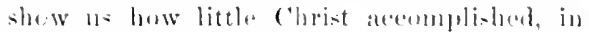
order that we may not womder it to-rlay the gospel does not eon-tratil all to obey gotl.

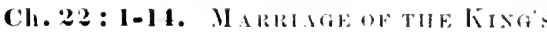
siox.

This is found in llatt. only, hut the first part reambles a parablu, given hy Luke an spokell somo timo earlier. (buke1s 16.28.) some eritics at onee atsome that only ane pat rable was given. But any matn whererer went to and fro as a preacher will kitow that to pepeot an iilustration to a new andiender with some mod-

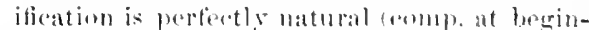
ning of eh. D). Su later in this sime laly, eh.

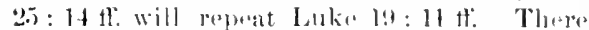
are examples in the Talmos of a like repetition and reworking of an illuntration be dif'ferent Rabbis, and why not this be done lus the same Rabbi? It has been helel that a parable cannot have beon suken at this point, between the rise of the ferlings deseribed in 21 : 4.) fond the comsultation of $2.2: 15$. But
1 And frestux anowerod and spake arain in parables

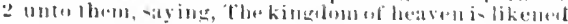
undo a certain bing, who nado a narriage feasl for

why mot? It respuired only a finw mimutes.

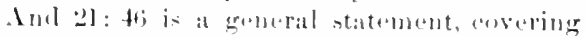

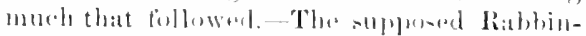

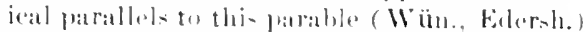
are in filet an little like it at net to be worth -tating. To dorive illu-tration from at fiast would be a matter of enduree.

1. Answered, wat to anything that had besul said, an tar an we kmow, but respumded to the

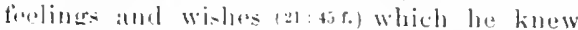
were entertainul. Ind spalie asain by parables. Ouly ane is given; there may hatre berall others, or this may have been regatrdent as compri-ing two $(2.10 \quad 11.13)$, wh the

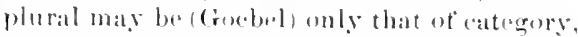
moaning that he spolie jarabolically. This parable is not exprembly aplial, like the two thregoing, beeanse the applic:ation i- now snt-

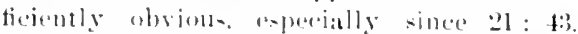
Breer: "The parable of the vine-dressers

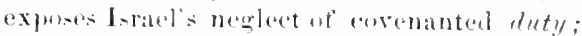
this, her contempt at God's andere. The two are nutually complementitry and present tugether at full riow of Istatel sin." For the term parable, and the general prineiplas of interjeretation, ses wil 13: :

2 f. 'The kingdom of heaven, see on :?: :2 Is like nuto, seon 13: 24. Unto a certain king. Note the leading differences between the present paratile and that of Lake 14: 1titl: There it was -imply a certain man. bere it is a king; there mepely a great supper, here at marringe feast for the king's son. Them lue

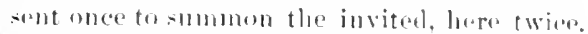
There they made excuse; here thery make light of it, abel some shamefully treat and kill the king's mesengers, and the king bestroy them and their city. Then in buth parablis other guests are invited wherever they caln he picked up. It thus alpumes that this later parable bring out much more elearly the wickedness of the Jus in not simply rejecting Gond's general insitations of lowe. but disbomoring his ton, and killing his servinte a and that difference "xatetly sut st the chanere of circumstanees. Very naturally the paralue in Luke is offenest used in our fulpits, an it denes not soli-tinctively relate to the cuncluct of the 


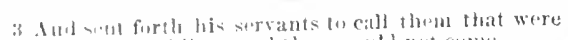

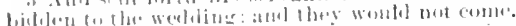

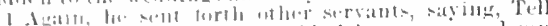

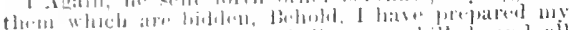

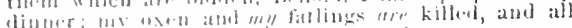

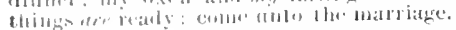

3 his son, and sent forth his I servants to call them thit were bidden to the marriage feast: and lhey 4 would not conte. Agatin he sent forth onher ${ }^{1}$ servants, sayiug, 'Teil them linat are biditen, Behold I trave made ready my dinner: my oxen and my

1 fir. boudsereuse.

Inwa. But this also, asprecially with tha addition uf 1 . 11-1:, is full of stolemn instruction firl all timrs. Made a marriage feast. sinnc rombre this simply "a feast, becamse gmmess 'matriage, is usad by the sidet. to

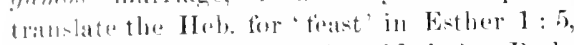
combl. 9: : 20) and it may be anderl that Pesh.

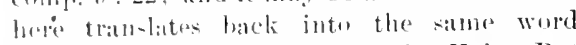
forat that is thare emploged in the IJeb. But a- there is mo wher known axample of such a

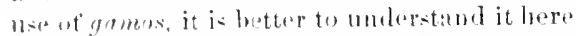
in the litrial and amomon sellor, especially

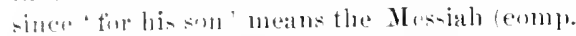

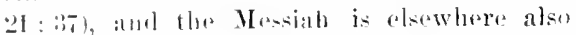
representul as a bridegrou) Rev :1 9. 9: E.p. 5:25:3e), just as in the prophets loral is atten the spouse of Jehovals. The Greak worl is here in the plural, (gumous),

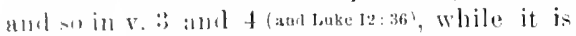

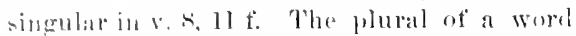
lemoting a fentival was oftem used to indicate it several fourts or stieses (Buttm, l? 23); comple ant worl nuptials. Wrelit here imilater the cireck plural, "made wedetings. In moleru lingli-li wo could say, "made a weddine. Hut the simerular is wanted tis the

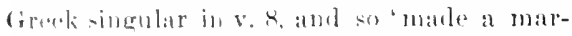

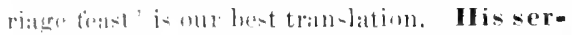
vauto, hitrally stares dombust, see on $8: 0$;

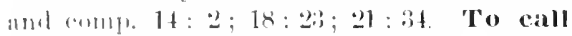
them that were bidden, literally, "to call the cotled. Thes guents wero invited in ad-

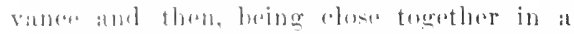

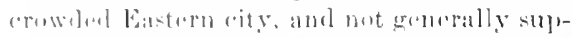

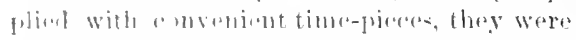
notifiml when the trats wat ratily. Comple

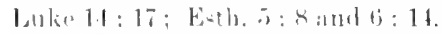

1. Igain lor sent forth othor servants. Tho kine kimbly renews the stummens, and

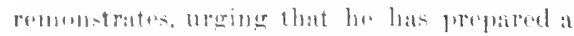

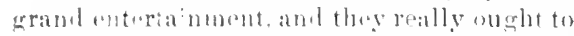

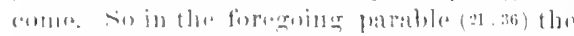

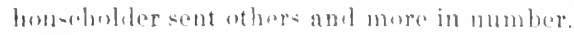
I have prepared, or, mate redely. the same Gruek root as "roady" ju-t balaw. My dinmer, aristom, fomnd alsu in Iakke 11 : :3, while dripnom, 'supunr, is found in 20 : 15 and often elsewhere in New Test, and both occur together in Luke 14: 12. The ariston seems to have been asually talien about the middle of the forenom, sometimes earlier or later; the deimeon at the close of the day, often after dark. Josephus ("Ant.," 5, 4,2) supposes that Eglon's guards (Juig. 3:24) were negligent ahout mideas, "both beeause of the heat and becaluse their attention was turned to dinner", (ariston). This would indicate that in Josephus own time the ariston was sometimes takin as late as noon; on the other band in John $21 \cdot 12,15$ it is taken shortly after dawn. Irambery (in Morison) says of the Turks at the present time, "There are only two meals driring the day, the smaller one between ten and abren oclock in the morning, and the sermol and larger one after smoset," Grimm, Plump., and others scem to be wrong in supposing that the Jews of our Lord's time took a separate and slight meal on pising, as the later Greeks did, and some among the later Romans. There is no evidence that the Jews had more than the two neats. (See smith's "Inict.," Art. "Ments.") In the time of Elizabeth and King .James, the principal meal in England was taken some time heforo mogn, and called 'dinner, and the slighter mal taken at the chose of the day was called 'supper.' Accordingly in the early English rersiuns aristom is rendered 'dinner, and deimme 'sulper,' which conforms to the time of day, but quite misrepresents the real imfurtance of the two meals. In modern city life the words breakfast and dimner, the formel wenring at 9 to 120 oclock, the batter at avrning. would eorrespond quite closely to arixtom and deipnom in the New Test., but it is ton latio to make a general change (see Rev. Ver, of . John $21: 12,15)$. The marriage finst mentioned in this parable is an aristom, curiot1sly resembling the English "woddinghreakfast," while the feast of Luke 14: 16 is a deipmon, as entertainments usually were. But hror the teast is either protracted, or more likwy detayed, until after night. (vis.) As nall gruosts had to be summoned and must 
5 But they made light of it, amb went their ways, whe to this farm, allother fo his merehimbise:

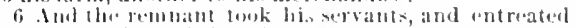
theme spitefitly, and stew them.

T But when the king hearet theregh he was woth : stod

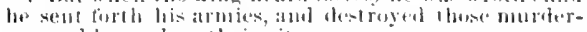
ers, atud hurned up lhoir cily.

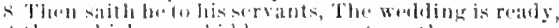
but they which weto bistalen were not worthy.

9 fie vellerefore inte the highwats, and ax many ax ye shall time, fid to the marriage.
5 fotlings are killed, and all thinges are reaty : come

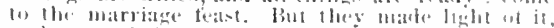

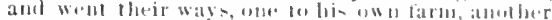

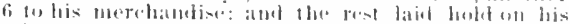
Iscratuls, altul entrated lhem shamefully, and killed

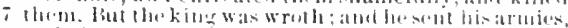

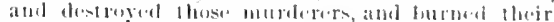

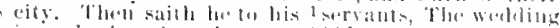

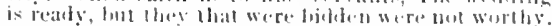

9 (in ge therefore toute the parting of abe highwals and as many as yo shall timf, bis to the natriage

1 (ir. bendierrants.

have time to astume feetive alparel, it might well he night bution the festival wats actually in prompesen, and the king anterad. Or the ariston mat have heren intended at a preliminary hanquet, while the marriage would wecur at nighte. (23-6.) In 1 ('or. 11: 20 , " the

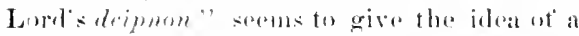
banquet to which the Lomd invites. Myoxen

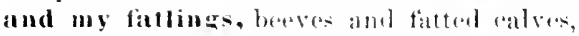
as in 2 sam 6: 13; 1 Kings 1: !. Wher Adunijah made a royal feats. Come is the same stromg and urerent word at: in $11:$ : 28.

5-7. They made light of it, a great insult (1) a king. Whoce invitation was the highed honor, and who was colehrating an oceasion of prealiar interost. Theos showed ontempt by geing oft to their arery-day employments. and these that rematined bused exen murderous hatred, a spirit of relellion against the ling and his soll. (Psa.2:212.) One to his farm. Hisment form, is the nat meaning of the (ireck: 1 he was caring exclusively for his "wn atlitir. Anotherto his merchandise, his moreantile lusiness. The remnant, rather. the rest, which is not only simples but a more cxact translation. Took, or, seized, a stronger terut than in 2 : : :5, :39. Entreated them spitefiully. Shamejully sos (raumer) is better than "spitefully" ; we might say simply 'insultal them. But the ling was wroth, a strong word. When . . heard thereot, is a spurious addition to the text. sent forth his armics. One word armies now alwars sngerets a large number of soldiers, which is not true of the freek word: Plump. proposs 'trons.' Destroyed those

1 Winer, Bulm, frimm, suppose that here and in 2.5: 14, and some wher pasciges illos toses its proper sense, and means not 'his own,' hut simply his. But none of the passages require lhis weakent sense, and therefore it is mut justifical.

"The term rendered "purtings is not found clsewhere in the New Test. The frequent sept, sense of oullet, womb answer liere, if the expression were

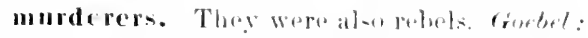
"The hitheres furareful image of" an insitation to a marrage fatst in now ahanged ints the warlike image of a military raid with fire and sword against murderous rotreln." And burned up their city, which maty be themglit of as among the suburhe of the "aprital where

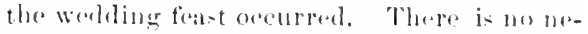
cosity torsuphesing that this orderwasereverel met betore the king ant forth to invite other

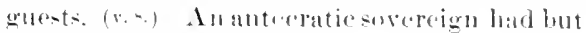
is give the order. and condel then turn his attention to other things.

\section{$8=10$. Into the highways.2 Lit. the port-} ingse of the higheroys. collorg., "the forks of the roads.' whare the roads batding ant from the city separated each inter two or more roads. There the comentry people coming in from dif-

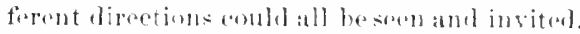
V. It has the simple term highurays, which is enough withut repeating the precise diresetion. It is merely oser-refinement to say

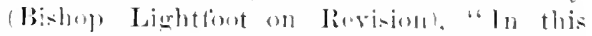
change of "xpression we serm to see a refurence to the imperfect work of the human agents as contrasted with the urgent and uncompromising terms of the commande" but eertainly the two phrases omerht to be kept distinet in the transhation, which was net done by Tymolile and followers and imperfectly done hy Wre. and Rherims. In Luke 14: 21 tf. the messongers werosent first inter the streets and lanes of the "itg and afterwards inter the roado outside; here only the batter are mentioned. Meyer aldy endicindes that the capital was the eity hurned, and nome lut

"dierodous of the streets," but nut when it is "dier"

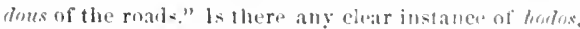
"way," "road,' being applienl to the street of a city" The preposilion dia lue ro has its jrequest foree in componond

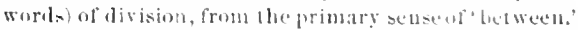

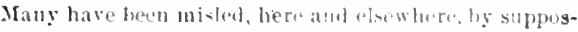
ing that dia must neeesarily mean " lhow lo, 


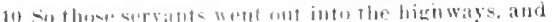

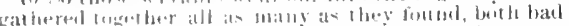

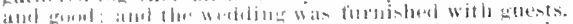

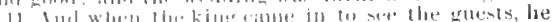

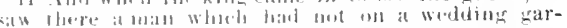
$111 \cdot 111$ :
10 feast. And those a servants went out into the highways, and gathered together all as many as they fonind, butli bad and grod: and the wedling was 11 tilled will gutess. Isul when the king came in to beholel the gucsts, he saw there a man who had not

1 Gr. bondererants.

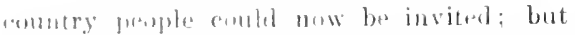

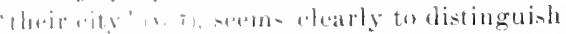
it trom the rity in which the king lived. As many a they fonnd, both bad and good.

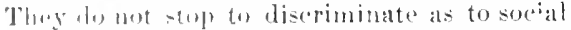

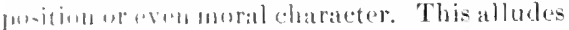
lo the liat that sume fery wicked persons would beconde Christians. The bad are mentionul first, so at to emplum-i\%e the king's aritee. And the weddiug, or, aceording to the mure probsible Gresk text, the bridal-hall was furmi-hed, filled. the literal and exact menniner. with gnests, with gejsons reclining, vi\%, at tables. Sien 1311 8: 11.

The meaning uf the parable up to this point is jolur. The benetits and deliubts of the Masianie poind are represented under the imate of a matriage feast ju honor of God's

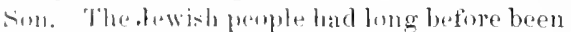
invited to enjoy tine foust. Gorl had sent his sorvant- tho propless form time to time (we maty imelude. Julun the Batptist), to call them (1) the wekling. But many had been utterly imdifferont. caring anly for their worldly pursuits: and solue hall insulterl and stain hio monenerer: These murelurege frobl will most

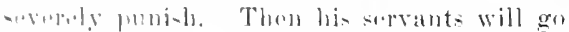

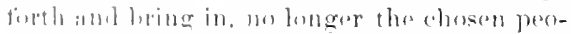
low arierinally imligatel, Jut Gentiles, includ-

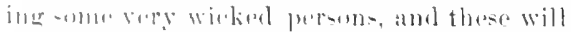

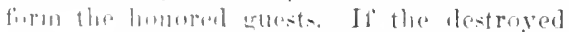

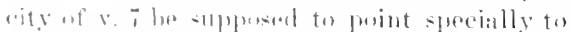

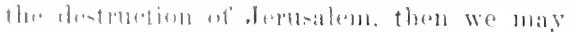

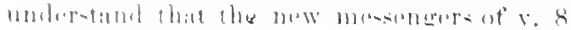

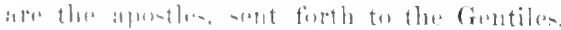

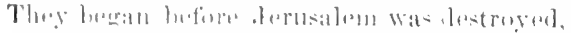

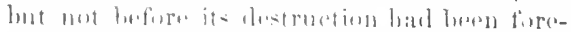

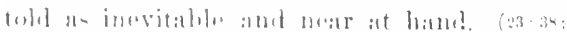

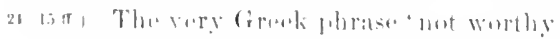

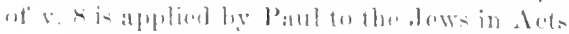

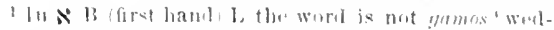

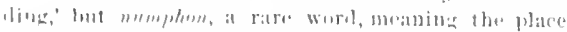

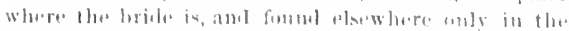

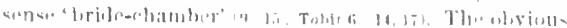

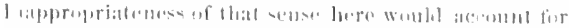

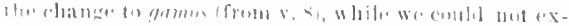

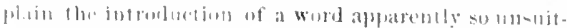
able Fymblesically it cull asily signily "bridal 1i: 46, and rendered 'unwortly.' 'Thus ncolect and outrage on the part of the Jewish nation will not prevent the Messiah from having a people (John 6:37), nor mankind from enjoying the Me-sianic benefits, the forast of salvation. This parable, therefore, repeats the idea of the foreguing that the Jews will be severely punished for slighting and slaying God's mesengers, but brings out more fully the tl.ought that others will enjoy the benefits they have lost. (Comp. 21: 41 with $21:$ 7-10.) Jesus here still louks sadly at the past and present, but also lonks hopefully to the future.

11-13 presunt a new feature of the parable, baving notling like it in Juke 14: 16-24. $\mathrm{V}$. 10 makes the transition from the main parable to this further lesson, as is shown (Gocbel) by the phrase 'those servants,' whereas 'the servants. would have been matural in a mere conclusion of the fisperuing narrative. The kings divections were carried out, and the bridal hall filled with persons reclining at the banquet; but they were not all suffered to enjur the feast. When the king came in to see the guests, rather behold, not simply "to see,' but to look at them us a pleasing spectacle. $(6 \cdot 1: 11: 7$.$) This is not the forenom meal$ originally intended or begun with, for it is now night. (vin) A mau. He represents a principle (Bruce), and therefore a class; comp. the ane slotlutul servint in 25: 24. Had not on a wedding sarmeut, a dress suitable for attending a wedding. We do not know of any sperific wolding lress, as distinguished from that appropriate to other testive oceasions; but tho guestio must come properly arrayed. Oriental monarchs now frequently present -ome alount article of apparel to a visitor; and haner jt has been widlely supposed by cummentators that in this case the king had

hall, tha place of the wetding hanquet, and so be entirely alpripriale. Jet the mere fact that 'was filled,' sugrim a roum (comp. Luke 14: 23) would not account ting an harge from the sufficiently suitalle term gamos fer all apparently yuite nosuitalule word. Tisch., W H. anul Wim reat numphon, and Treg. (who had not $\boldsymbol{X}$ ) placel it in his margin. 
12) And las kith unlo him, friend, huw eames lholl in hithor not havinge a weding garment? And he was spertehlens.

13 Then saich lle kins to the servals, bind him hamd and fout, and take lom away, and cast him into ontele

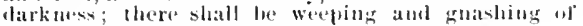
lieelli.

14 fir many are called, but liew are chomen.

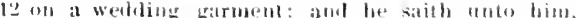

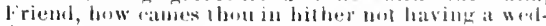

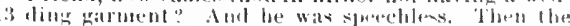

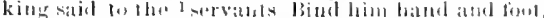

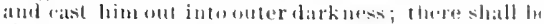

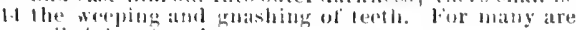
ealled, bul lew choselt. furnished suitable appatel, and this man had refused or neglecterl to jut it on. But the

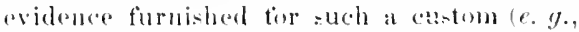
ly Trench) is mot alleyunte; and if the? supposition be here made, it must be gremeled on the necessity of the case. These is, hewernr, mo intination that tho man was porer. This is wot a charitable feast to the foos (Luke H: 13), but a eranel entretainment in lomor at the king s sum. I forenoun banquet was origimally proposedand it is now night, sothat there has been ample time tor preparation. We may then suppowe rither that the man ought not to have eorme in at all if umable to drese himself properly, ar that he might havesolught leelp iroun the ling moler the peculiar circumstances if he had folt a proper anxiety to he attireal worthily of the aceasion. At any rate, his presence without proper dress was tacitly almitted by himsele to be quite inexrusable, and was regurded by the king as a tharant insult, deserving the severest punishment. No light is gatuel by stupwing a reterenees to Zeph. I: it.., Where the imagery is quitedifterently used. Frieud, oremrabe, see on 21): 1:;. And he was specehless. 'This shows that he felt himselt to be rotirely without cxeuse: he fully knew what was proper, and it was not heyend his raich. Onr molpit interpretation bad better holal tast to this fact and not distract attemtion by discouseing the guretion whother wadding garments

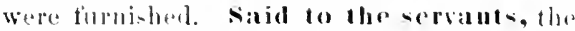
attondants diakmols, see on 8 : li). inchuding biher hosides his slaves (v.3.6); Rhoins 'witers. Hind him hand and foot, atud cast him. The insorted words talie him. away aml, are wantiog in the best manuseripts and noarly all early remsions, allel thougl

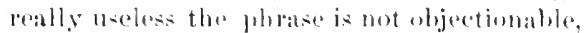
-1) that it is clearly all adtition of the eoperj.sk. The binding would prevent his return to the bridal hall, and wombl leave him helpless in the datriness. Into (the) outer darliness (nee on 8: 12), which would be oppressively dark by the contra-t of the brillianty lighted maliace.

What now is the application? Those who

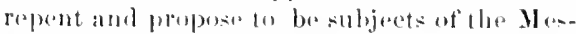

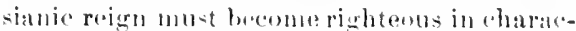
ter and lifeor they camont onjoy its benefits. (5:2n: 110b. 12:34) It is not mough for a man to plase himente in outward relation to the

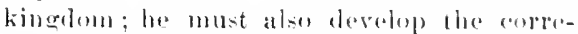
spouding eharacter and rombluct. There have always been porson. who desired thetemporal and etermal advantages which Clari-tianity nffurs, withont caringe to ba and to do what it requires. l'bose who aceept God's buanty in the eropere the sabution that is not hy worls but aceording to his merey, must "be (atroful to maintain gool works" (Tlus:a:4-s) ; otherwise they insult frod, and diserace the last of salvation, amb will not be allowed to shatren it-yea, will hoseverely punished. Thr le. son here tameht is this seen to be uf the erratest importanen. But tobring in the Panline conecption of imputed rightenteness. and under-tand the parable to teach that wa must "put on the wolding-garmont of christ's righteousness," is altogether unt af plare, and turus attention away from the real losson.

To leave no doubt as to what is meant by 'the outer darkness.' our Lord adds, thore -hall be the weeping and gnashing of teeth (sce on 8: 12), the well known signs of wretehedness in Gehenna, the place of eternal punishment. (13:12; 25:3n.46, crmp on 5:32, 1 This chase canmot be taken as spoken by the king, and is easily understood as an addition mate by mr Lord, like that which immedintely follows.

I. For many are called, but few are chosen. This is n generil faret adrled as alc(omuting for the particular fout de-criber in tho parable (mestice "for"). Many aro called

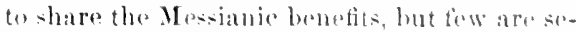
lectod aetually to attain them: a hare portion of the called utterly refusing to aceept, 
15 Then wonl lhe thatisees, and lonk counsel how llsey might entingle thim in his latk.

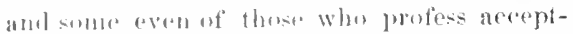

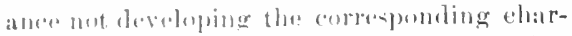
acter moll liti. This selection ot the actually

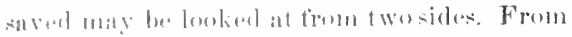
the divion sille, we sow that the seripteres [ated all aternal election at ment to etermal

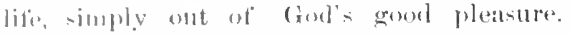
Frem the haman side, we sere that these persells altatil the lolesings of salvation through ("hrist who aceopt the gospel invitation and ohere the gaspen eommandments. It is dombtfinl whother our minds can ambine both sides in an single view, but we must not for that reason aleny rithere of them to be tereseThis ralletese is unwarrantably borrowed by many derements (and the common text) as all adklition to 20 : 10.

\section{HOMILEIICA AND PRAETHCAL}

V. 万. "Tluey ustulw light of it." 1) Many mom ankmoledge no obligation to honor the sim of (ionl. 2) They take no pleasure in enoteruplating his chatrater and showing him

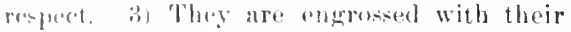
own worldly pomesems and pursuits, and sare lor wothing that he oflers. 4) They thus Anerive themselves of the highest bencetit, and ntler him the grosesst insult. - T. 7. IINRY: "Chri-t will hate a kingelom in the world, thenem wany rejoret the errites and resist the

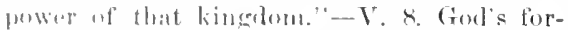
lowratere and wrath. 1) Ha is not rupelled by refinst. hut limally ureses the invitation, v. 4. 2) II. rhastism thuse who insult him and ont-

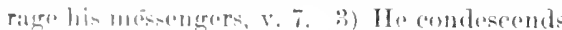
[a call matal wholl the world womld have thomerte untit for ench an bonor, v. S-I0.

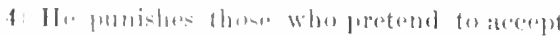
him imsalion, lut dishunar him hy atter in-

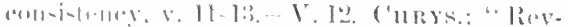

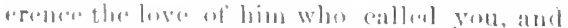

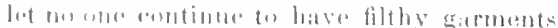

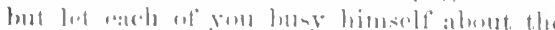

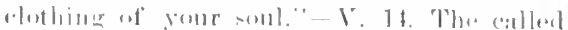

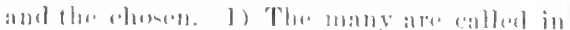

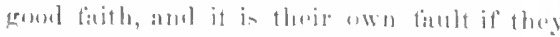
du net have part in the fisast. 2) There alde

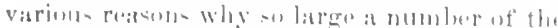

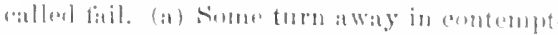

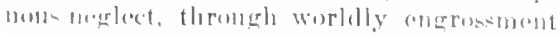
s. h. (b) Some hate lim who calls and out-
15 Then went the Pharisees, and took counsel how rage even those who bring the call, v. 6. (c) Some profess to aceept it, but take no pains to have the corresponding eharacter and conduct, v. 11 f. 3 The tew who are chosen give prouf of it by aceepting the call and behaving aceordingly. 4) These enjoy the feast of salvation, glatly honor the som of God, and lumbly ascribe all to suvereign grace. JERome: "He sums up all these parables in a brief sentenee, to the effect that in working the vinevard, and in building the house, and in the marriage feast, not the beginning but the end is the great matter."

15-16. (QUESTION AND ANSWER IN THE TEMI'LE.

This is found also in Mark 12: 13-37; Luke 211: $2(0-41$.

It was customary fur any one who desired it to ask questions of a Rabbi in public, even interrupting him at pleasure. The Talmud gives many examples, and sometimes the Rabbi replied witl further interrogation. So with the Athenian philosophers, especially Socrates, who reduced quentioning to a science. The lending priests and Seribes felt themselves pointedly assailed by Jesus in the three parables just given, especially in 21 : 28-32, 40-45. It was determined upon consultation to attaek the Nazarene with hard questious before the multitude, hoping to extract from him some answer that would offond popular prejudice or provake the Ruman anthorities, and at any rate hoping to show that he was not greatly superior to other Rabbis. Accordingly, three quastions were successively proposed by represontative porsons, the tirst by Pharisees and Horodians united, the second by sudducees, the third by a Lawyer. To all these Jesus made promint and wonderfully wise replies, and thos finished by asking them a question of the deepent importance, which tliey wore unalule to answer. These four instances of question and answer hang closely together in tho narrative, being all given in the sime oreler by Matthrew and Malrk, and all except the third given also by Luke. They ocenrred in the temple (ont, probubly on Thesday, threse days hotione the crueifixion.

I. 15-22. Tile Piharisens and HerojeAns Ask nbott Tribute to Cesar. Mark 1:2: 1:3-17; Luke 20: 20-26. Then does not 
16. And they sent ont unto him lleeir disciples wilh the Ilerodians, silying, Master, we know that thoul at

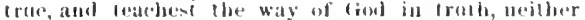
carrest lhou for any men: for thou regardes not the lierson of men. to they might ensuare him in his talk. And they semid

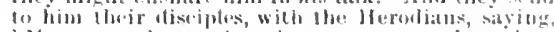
1 Matsler, we koow that lhou at trum, atud teichest the way of tient in troth, and carest mol for any one: mastearily (sor on 8: 18), hut dues naturally indicate that this wats on the same enceation ats the foregring (compe on 14: 1); Yark and Lukn bates simply "and.' Went, from where Jesu- was teaching, to some other fart of the temple eourts. The Phariseses, see on :? : Eutingle. This literally mesus, to catch in at sllare or tril). Wheir disciples, sar on in: I; the leading lialblus send some of their astute pupils, white they themselves stand alowet to watch the preult, and so are not eommitted to any suberpuent en-operation with the Herod farts. With the Ierodiaus. When Ar-

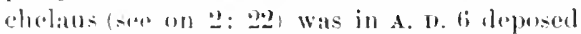
form the ethuarehate of Judeal and siamatria, and thoed di-trict - were placed under a Roman governor (side at and of chatp. 2y), the Jews were much divided in sontiment. Secularist: freforred the new arrangemont, ats giving sceurity to business and property; and with these the sidtlueses generally sympathized. Many Platriones bitterly oppored it on the ground that Jehovahs sueple ought not to be subject to heathen rulurs. Some presons insisted that anuther prime of the house of

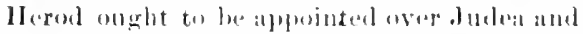

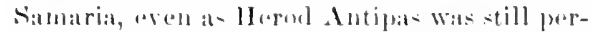
mitterl to rule anere Gialilene and Pere: ; : and it was doubthess hopred that somm prince of the fomily would one day regain all the dominione of IIerod tha (ireat, als was at lengeth

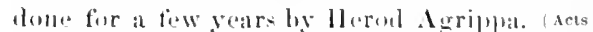
1:. r.) These persums graddually came to be kmw a : Herudian, $i$. e., partisans of 11 rod, comp. Pompuians, ("esalrians, Chriatians (Aets 11: 26), the Latin termination-anus heing unal to denote a follower uf a political leater. This perlitieal party probahly hanl the symfatlyy of the lo.s rigurou- l'hari-ees, als oflering the only atsilable alternative to direct laeathen rule; while the great borly of the Phariseres hated them, sines the II erod princes weres, atter all, only appointers anel umlurlone of the Romatne (comp). Simith's "Diet.") Is lioman govermors eontinued to rule over Judeat amel šamaria, the Herod party would gralually diminish, and aleorrolingly it is mentioned only here (with Mark
12: 13), and in Mark $3: t ;$; not at all in Jerece

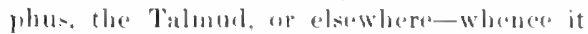
follows that the athose or any other theory of theirorigin wa-t bes partly (onnjectural. When IIerod $\mathbf{1}$ gripha became king of all Palestine in A. D. 11, the lingering supporters of lus family in Judat must have greatly rejoired, but all men by that time saw that no politieal position was longer poribible? except submision or hostility to the fomans, and so it is natural that we should hear no more of at lierod party. When the Pharisess united IIerodians with themselves in the effort to ensuare Jesus, it was obviously through the cohesive power of a semmon jealoust towards une popularly regarded as the Me--iah; for if recougnized ats such, they were stre be would werthrow the II erod hamily everywhere, and dopree the present Jewish affecials. On the earlier necasion in Gililes, nearly two yearo before this, aceording to mont harmonists (Mark 3: bi), the Herodians could be relied on to excite Ilerol Antipas against Jens; laere. they represent Roman sympathies, sinee on the Rumams all II erolian bopes now resilly depremeded. Luki (20.20. R. v. dees not mention Pharienes or Il rerodians, but says that the seribes and the chiet priestsont "sples, or in

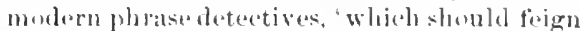
themselves to he juet - whinlagrees with their attempt at Hattery in Natt. - and wished to find an excuse for delivering him (1) the goveruor, i. $f$, I'ilate-a dexign bere repres sented by the Ilerodians. Master, or Teroher didastialost, sete on $8: 19$. We kuow, without emphasis on 'wo.' They salil it in a tar diflerent spirit from Nierdemus (doha: a: 2); what they said was really true, but lhey meant it only as flattery. By this muthery they would embliten the teacher to sporak wut againet the Ruman rule, fir thes will knew in alvanes that only through the Romins could they complitss his death. The way of cod, the way in which crol would hawe men walk; this would inclate the question whether the peoplo of God onght to do so and so. Thou regardest not the person of men. This is one of several Greek phrases 
17 'lell us therefore, What thinkest thou"

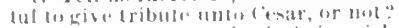

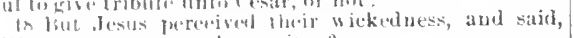

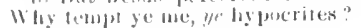

Is it law- 17 for thou regardest not the person of men. Tell us therefure, whist lhiukest liun" Is it law ful to give

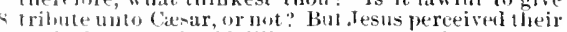
wickeduess, and said, Why try ye me, ye byporites?

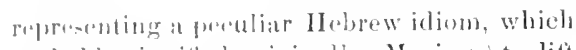
forobably signifiol originaldy (.Morions) to lift

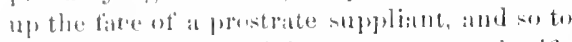

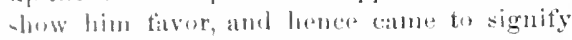
regand for a person in the ganel sense, or in the bial senses regareling the frerson rather than the justice of the cause; in Hebrew and Cirenk the term 'tiare' was derivatively used line person. The llatterers meant that Jasts would follow principhe and truth without finar or favor. (Compl. Gal. 2. d; Rom. 2: 11.)

17. Is it lawful, or permissible, allowalle isee on 11:4); there is no direct references to law, whether lewish or Roman. Or not; they wish him to saly yesor no, ats when lawyoretry to corner a witness. Tribute. The Latin worl census is borrowed in the Greed of Intt. and Mark, while Luke has the gen"ral term 'tribute.' (tonsus in Latin signifies a reseistration of prepons and porperty las we burrow it in English), and hence a $\operatorname{tax}$ on either. But hero it signities smuply a poll-tax

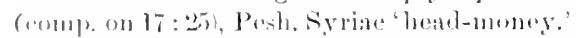
(1) coure the prindiple wat the sande, whether the question enomerned pell-tax or trilute in general; the former lowehed the puresent, and Wa- at it is amoner as, a mattor of grealler pepular interest and anmplaint. Cenas is

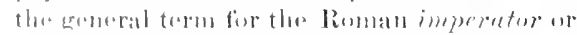

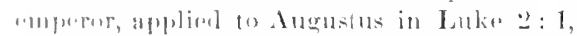

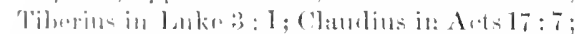

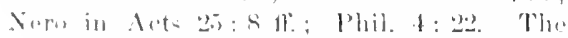

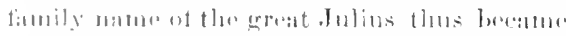

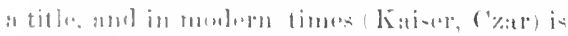

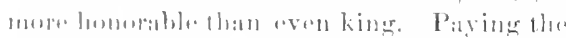

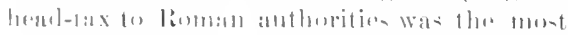

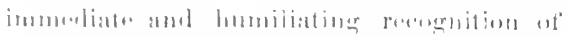

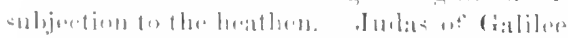

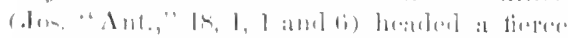

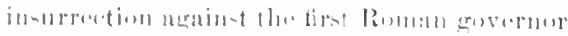

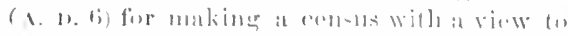

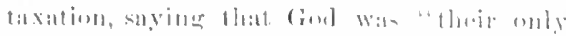

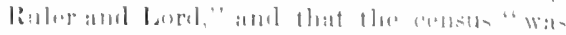

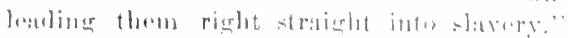

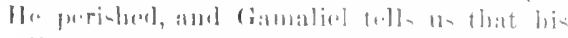

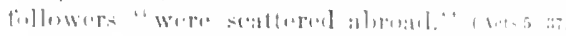

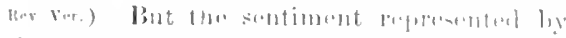
that movement still burned in many bosons.
Josephus say's that Judas the Galilean was "the founder of a fourth philosophy," whose followers agreed in all other things with the Pharisess, lut were tanaties for liberty, and that this led to the insurrection (in A. D. (66) which ended in the destruction of Jerusalem. At that later period they were called Zealots, and it is supposed that simon the Zealot $(10: 4)$ latd bitonged to the party, and also perhaps barabbas. (27:17.) We may therefore be sure that among the casily excited crowds who tilled the temple courts when Jesus was anked this question, there were many who regarded paying the poll-tax as the very ladge of slavery to the heathen, and as treason against Jebovah, the theocratic king of Israel.

\section{8-2:2. Jesus perceired their wicked-} ness, or as we should say, their villainy. With smoth, flattering words they came, asking a question which they thouglit would prove a hopeless dilemma. He was desired to sity either yes or no. If he said yes, the Pharisees would loudly proclaim, through all the temple courts aud every day, that the Nizarene said it was proper to pay tribute to (awar, which showed that all motion of his leing the King Messiall must be ridienlous and that in fact he was neither patriotic nor prims. It he said no, the IIerodians would go straight to Pilate. The Romans cared nothing for questions pertaining to the religion of at -1 liject nattion (comp). Acts 25: 18-20), and intertioed very little with local affairs, providrol awass the preople kept the peace and mad the taxes. So contident were the Jewish mulers that this plea would be effectual before l'ilate that three diars later with flagrant filselunel they treld him, "We found this man furliduling to givetribute to Casar, and saying that he himself is Christ, a king" (tuke $23: 2$. w.r. Ter. Why tempt ye me, testing him with had questions, in hope of drawing him t1) saly something injurious to himself. (Comp). (1n 16: 1 and 19: :3, Ye hypocrites (see on (i: : and 1.5:7); they wore pretending grent aduiration for lim as a teacher, and pretend-

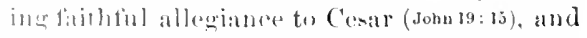
pretemeling a lofty patriotism and piety. Jesus 
19. Sluew now the tribute money. And llacy brought unto him a a penuy.

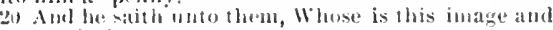
${ }^{b}$ superseriplion:"

2f l'he sily unlo him, (')

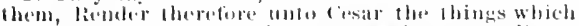

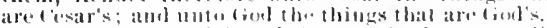

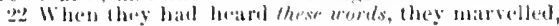
amil lett hist, and went lluir way.
19 shew me the tributa mones. Amb they hrought

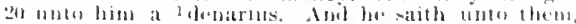

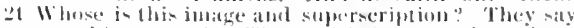

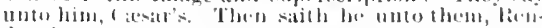

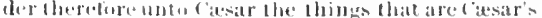

22 and unlofind the thinge that are camls. And whor they hetert it they marvelled, amd left him, and weill Iheir way.

a Iu value sevenpence half penny : ch. 20 : 2...b 0 b inseription.-1 see marginal note on ch. xviii. $2 \mathrm{k}$

showed them by this term (Benged) that he was indard 'true, and ready to spreali mut. Nhew me the tribute money, the enin uned in paying the poll-tax. It wats matural that the Romban eoin -lonuld he eommonly used in

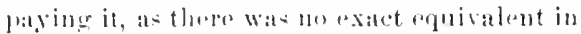
other abins. Hobrew shokels, ete. from the

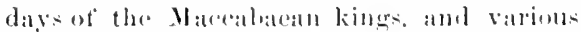

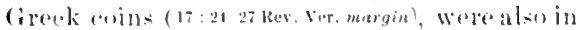
as. The llemel family and the procematers

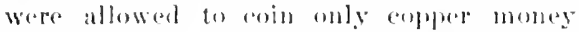

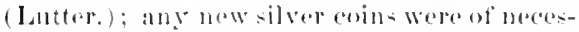

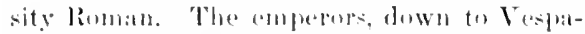

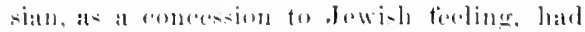
forins mate der that provines without the heatl of the emperor (limetim). which would

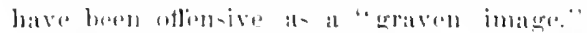

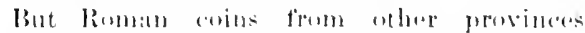

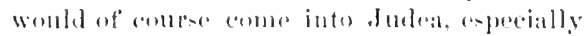

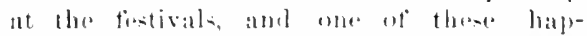
frelled (: a we saly) to be hamlend to Jeslls. A ponuy, froprely 'a demarius, a lioman

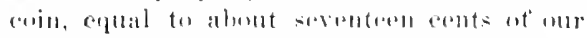

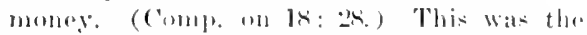
priece of a day" - labur in the parable (20): 2), and the daily wages of a lioman soldier (out of which he paid for his tionel), alld seroms nlso to have been the proll-tax at thi- time. luase and superseription, or 'insejpiption.' The formel translation miglat sugeret andething writton abere the imatere. Wherents the Greck word meatus anly somed)ing writhell (or erravend) an the anith. Morizom.) Mally

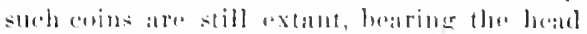

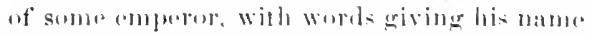

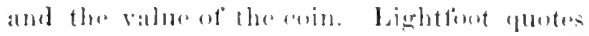
from the Tathmod that " if a kinge roin is

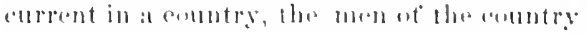

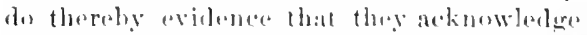

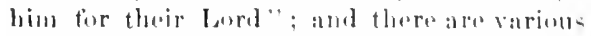

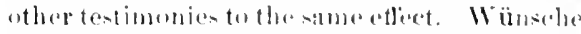
tries to show the existence ot ath experetation that the Mesials Wombl deslare the Roman coins uncurrent, whicle expectation would be an interesting illu-tration of this passage it

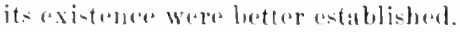

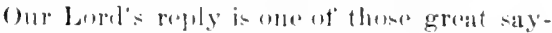
ingeof his which cut intothe heart of thing (comp. 15: 11; Mark 22: 27), clearing U1, ditficulties that had long perplexed many homest

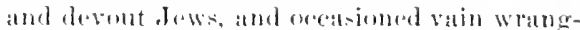

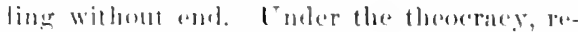
lierious dutien and rovil dutien were lueth dutive to the sane bivine lauler, and men hat litule.

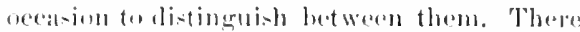

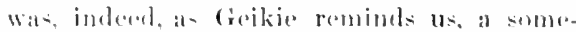
what similar confusion of relierion and civil

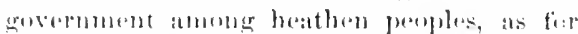
example the Roman emplepor was always chinet priat. Now, howerer, that the lewish divil ensernment was adminisered by houthert rulars, tho disinction between aival and relieriuls duties wase of ereat importance, but the

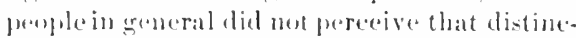
tion. Tosms loulds up the eoin, which bre

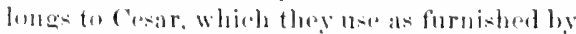
him, and thus vividly shows that theme aro duties to the avil ruler which are di timet

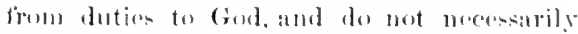

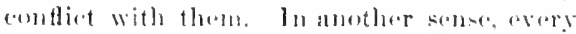
duty to ofher men or to ourselves is at the.

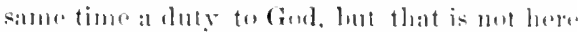
tho print. l'aul afferwards axpresed the savinur's teaching on the subject in definite prevelt, when writing to Cluristians at the

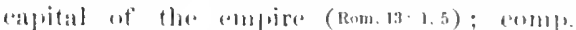
1 Pet, : : 1:-17. This was allother case ot all

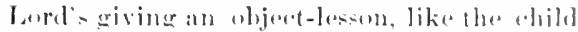
(ix: 2). the tigetres (21-1:4), the fort-washing. Remder as in li: 27; 21: 41. litorally arien

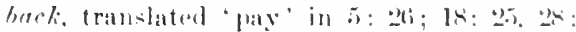

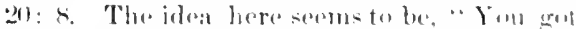
this from ('estr, fuy it batek to him." ("111:) :

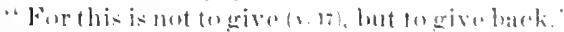

'rhe things whichare cear"s. nent merely the tax, but all that citizrms awe the aivil government, one mattor here slerestimer all. The things that are cied's, not simply the 


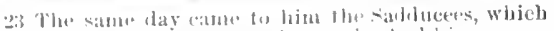

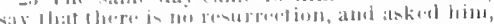

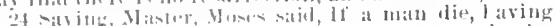

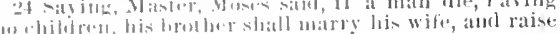

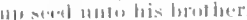

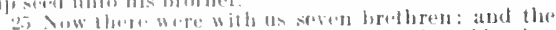

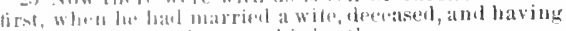

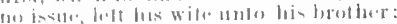

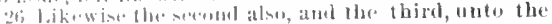
ancindillt

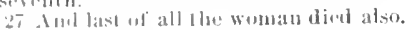

23. On that day there came to bim saddueees, 1 who say lhat thele is no resurrection: and they asked 24 him, saying, " Ilaster, Most's sald, li a man die, hating no children, his bother 3 shall marry his wite, amd 25 raise up sect muto his hrother. Now there were with us seven brethren: and the first married and deceased, and having no seed left his wile unto lis brotiel. 26 in like maner the second also, and the third, unl, 27 the strenlh. And afier them all the woman died.

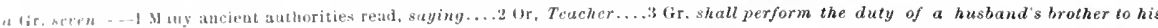
wife. Compare Deut. xxv. 5.....4 Gr. seven.

Lemple revernom, but all eeremomial and moral

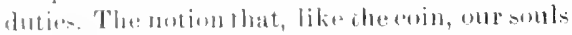
arestanled with the image of Gind, and must therofore bu giolded to his service (Tert., (origell, and many), is a nexp laney. They marrolled. With all their hustility they (o)uld met help secong that he had not only astamed form the dilemma (eompl. Suke 20: 2li), but had wond.rofully clrared 11] an intfurtant question. Iet when there was time (1) thet, they (o) deld not tail to pereeive that

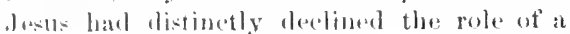
fulitiol and revolutionaly II wombl gralually alienate foum him the fmpular hrapt. (compl. Wejes, "Life.")

II. 233-33:3. T11E SADDLClES ASK AS To

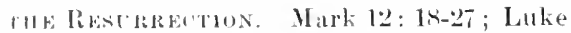
211: 27-41). This is a recond hard question

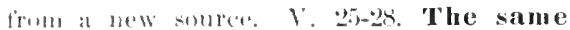

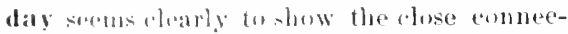
tion with what propertes; Mark and Luke masio lave simply 'and.' 'The sadducees

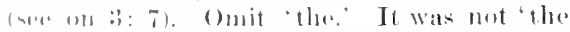

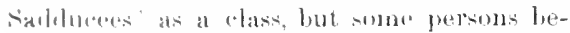
loberian to that party. Which saty. The

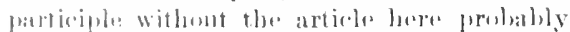

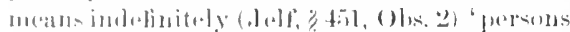

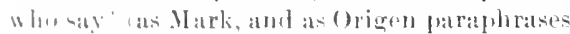
Ilatt. whil, with the artiole it wombl

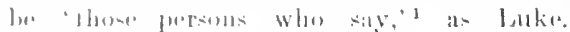
'lhat there is no resildrection, not only

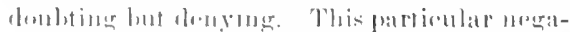

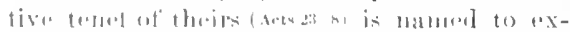
plain what follows. It must have heren wall

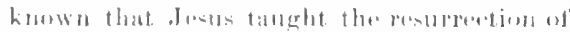

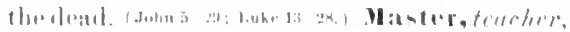

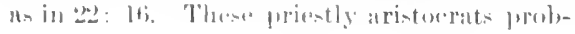

ably fult contemptuons; but they were gentlemen, and must be eivil; one seens to detect a tance of polishal seoffing in their attack. Moses said, in Deut. 25: $5 \mathrm{f}$. The quotation is eundensed bnt withont important alteration. Mark and Luke have "his brother shall take his wife, etc., as in septuagint. Matt., writing especially for Jewish ratders, takes pains to transiate more exactly the Jlebrew, as sept. does in Gen. 38:8. The Jebrew lats a peculiar verly representing this peenliar law, yebamate yibbemah, 'lier lusband's brother shall husband"s brother her,' shall act the part or perform the duty of a husband s brother to her. (See margin of Rev. Ter. in Matt.) From the late Latin levir, 'brother-in-law, this preeept of $\mathrm{Dent}$ is eommonly called the levilate law. A like usage rxists now in Aribia, the Cancasus, and elsewhere (Smith's "I)ict." Art. "Marriage"). It was an whl custum (Gen.38: *), which Moses did notabolish, lut regulated and restricted, as he did with divorce (see on 5: 52) and blond revenge. No atetual case is recorded in old Test., but the custom is alluded to in Roth 1: 11-13, and a related pratice in Ruth 4: $1 \mathrm{ft}$. In our lurd's time the law was but little observet, as there was then less conceru about maintaining fomilies and family estates. The right of the husband's lorother to decline (Deut.25:7 ff.) is declared in the Mishna (Edersh.) to take preexdence of the olligution to perform, and there was a growing disposition to limet the pratice. The ase described here by the salducees need not be supposed to have actually uecurred. As in a parable, they toll the stury for illustration. Seven is natural in

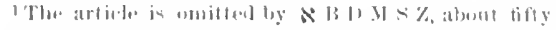

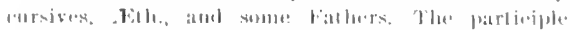

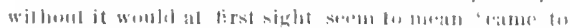
him, saying," whieh wambl be an imoletrums and im-

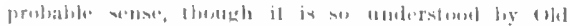

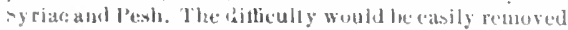

ly conyists thromgh the mere insertion of the article. The indetinte use of the protieiple after an indefinite Inum, 'sulducees, (persons) who say, though infreynent is anfuestionabie. So with the reading of W11. in $23: 24$ 
28 Therefore in the resurreetion, whose wife shall she he of the seven: for lley all hall her.

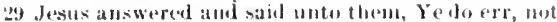
knewilg the beriptures, nor llat power uf liod.

31) For in the resurrection they meither marry, aor are given in uarriage, but are as the angels of fiod in hoiven.

31 But as entheliug the resurrection of the deald, hatre ye not read that which was spoken unto you by ciod, saying, 2s In the resurrection therefore whose wife shall shes be

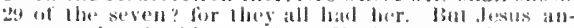

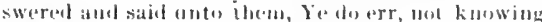

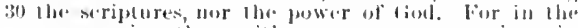
resurtection lisey neillar marry, nur are given in 31 marrigge, but are as angels' in lieaven. But ax touching the resurrection of the dead, have ye not

I Mang ancient atuthrities adil, of God

stlel a story as a round number. One inagines they had often nonplussed the Pharisecs with tho quantion, in the resurrection whose wife shall she he? The Pharisees gencrally held that the resuresetion life would be a nere reprobuction of this life, with all its relations and conditions restured and made permanent. The cahalistic book Solour, written late, but with much oarly material, says, "The woman whe has marriod two in this world is in the world to come restoreal to the former." Maimomiales (twelith enentury) taught that ehildren would be produced in the worlel to eome.

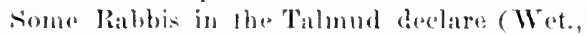
Wüu.) that in the world to come there would be no eating aud drinking, no trating, no marrige and produetion of children. But it is evident that the other oprinion generally previliled.

29 f. Ye do err. He speaks with kindness and decision. Notknowing the seriptures, nor the power of Gind. Bengel: "Tlus resurrection of the dead rests on the power ot God; and our faith in a resurration rests on the seriptures." These sidhluees were arecustemed to deny that the seriptures so taught, and foubtless also maintained, as skepties in all subseyuent times have done, that a resurretion ot the budy is imposible. But "the puwer of (ionl' can acomplinh it, and ilat not by merely resturing the conditiums of this life, but by exalting to a ditterent and higher typu of existence. For introulues the explanation of the diffieuly. In the resurroction, in the state of things represented thereng, in the risen lite. Ihey neithor marry, ete., viz, in the sense of eartlyy marriage, which under its physical atpects,

\footnotetext{
'Th" addition 'of Cod,' margin (Rev. Ver.) is wanting
}

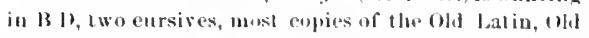
syria, Theb, Aru., and repuatedly in origen. We might regard this as a "Western" omission, followet lyy B. and origen (as does sometimes latppeat), but for the fact that one sees nothing to cause the omission. is mecosstrily an exclesice relation, so that a woman camout here be the wite of several men at the sime time. There is nothing in this statement to forlid the persuasion, olsewhere countenaneel in seripture, that the relatiens of earthly lifo will be remembered in the finture state, the persons recognized, anel specal allections cherishrel with elelight; and we can imagrne that exalled and spiritualized comjugal atlections laty then and there exist towards more persons than one. The jelea is hard to aceejut now, only becallse we do not realize how great clatinges of feeling will acompany existence in the gloritied body (1 Cor.15:41:Phil.3:21.) In henvan, the love of two that were stecessive husbands maly ho as little mutually exclusive as the have of two ahilden or two sisters. nut yet be intense, peculiar, and delightful. This is another of those syyings by which anr Lord at one stroke eut into the heart of some difficalty, and hail it opren. Comp. on v. 21 . But are as the antels in heaveu, vi\%, in heing exalted above merely plovical eomditions and relattions. Luke's axpression, "are equal untortho aneres, anounts to hle same ibiug. There is mothing at all hero to imply that the salnt: become angels (commp. on 18: 10). Our Jorrl at the sane time teathes that the siaddures are wrong in denying the rexistruce of andul-

31-33. Having explained how they arr through not linowing the power of Coul, he now shows thrip ignorance of the Seriptures on this subject. ( $v$ 29.) IIave ye uot read, comp. un 21: 42; 12: 3. Spoken unlo you hy cond. (rod spoke thus to Moses (Ex.3:6), and presently (3:15) bite him sprak likewise to tha children of Isracl. Maltherw
On the other hand, 'angels wi rod ' would be a nalural marginal mole tw explain 'angels in henven, and might then easily erep inle the text. Several of $1 \mathrm{~h}$. desenmenls which add the morls bere add them in bark also. 
32 I am the tion of Abraham, and the fiod of S saac,

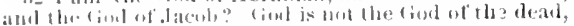
loil ol the living.

:33 lind when the multilute hearil this, they were aslonimbrel il bivelantrine.

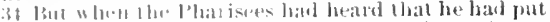

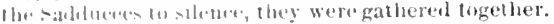

and Ifitli fuote fiom r. f, Luke from v. 15 . Luke-atys, 'aron Moses signifiod.' lt was infirroel frome this log Tist., ()rigen, Chrys.,

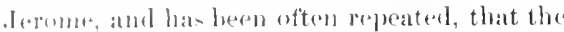

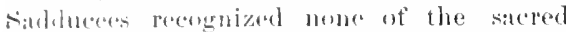
luolis as anthoritative exerept the Pontatenteh. liul thror is no prost of more than that they vilued tha lont. ware highly than the other lumlis. Whith wats true in some degree of all Ihe dews. Lulies expression is sufticiently acrecunder for ly the fact that aplarent proof nt the resurecetion wore familiar in the prosphets. Jerts meates to say, uet only bave the prephats slown it, but aven Moses. The Cood. 15. 32, i- in italios in Rer. Ver.; it is maturally undelotom to connplete the senae. 'The sathlueses denied a resurrection of the

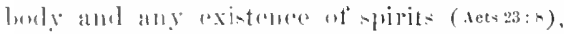
which position would exclude a separate immortality of the sulul, and so there is noweratsom do douht the statement of .Josephus (" IV:ar," 2, x, 11) that "they do away with the

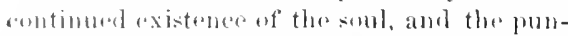

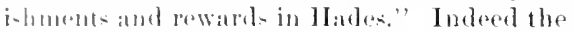
idea ut solutate immortality of the soull was lithle present to the: mind of the Palestinian

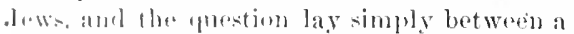

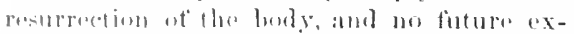

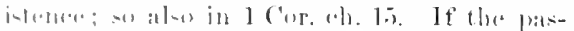
satere at lixasl. he takes in the superficial sullor, atl thjector miglit fairly deng that it

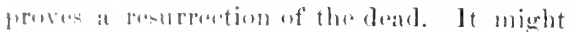
mean -imply, "I an ha who was the finl

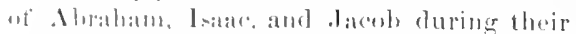
liti, amel this is a ploclege lhat I will be

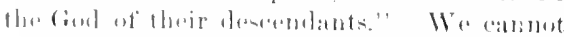

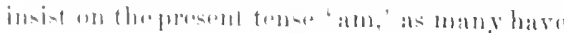

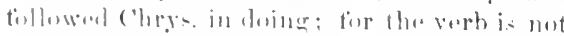

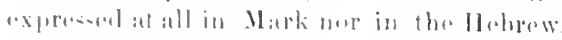

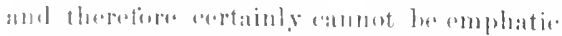

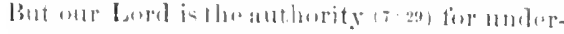

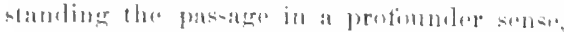
e.

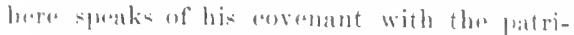

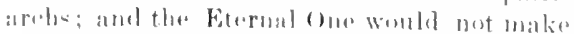

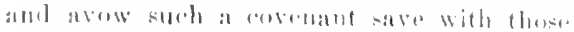

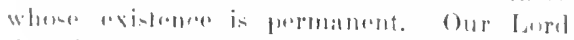

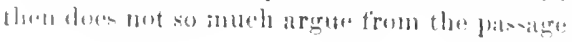

read that which was spoken unto you by God, say 32 ing, I an the fond of Abraham, and lhe find of lsaic, and the fiod ot Jacoh? God is not the Gou of the

33 drat, hut of the living. Aml when the multitudes freard it, they werc astonished at his teaching.

34 Bnt the Pharinees, when they heard that he had put the saduces to silence, gathered themsetves

in its obvious meaning, as authoritatively expound it in a deeper sense. To explain in this way the diffienlty which the passage repreacents is not entirely satisfactory, hut it is certainly more natural and reasonable, on the very lowet ground, than to suppose that Jesus failed to see the fallatey which would otherwise lurk in the argument. The Talmut (Wün.) tells of Rabbi Gamaliel not Paul's teacher, but a later Rabbi) as convincing some sadducee by arguing from "them' in Deut. 11:9, "in the kand which the Lord sware unto your fathers to give then" ; and of another Rabbi as proving the resurvection from Exod. 6:4, "to give them the land of Canatu," viz., (v.3) to Abraham, Isale, and Jacob. These do not involve the profinud thought of the pasage used by our Lord, and even these (Edersh.) may have been only pool imitations of his teathing. The multitudes... were astomished as in $4.22 ; 7: 28 ; 13: 54$, at his doctrine, lit. terching, see on $7: 28$. Luke says that some of the Seribes (not of the Saddueees) answered, "Teacher, thou hast well said."

The story of the woman taken in adultery (John $7: 53$ to $8: 11$ ), which ertainly does not belong where the common text gives it in John, is placed attur Luke 2l: 38 by the lost uncial represunted by the four eursives, 18, 69, 124 . 84ti. This would put it on the day of these several attacks uprom Jesus, which it strikingly resembles both in aim and in result. As the story is in all probability historieally true (nee Hovey on John), it may perlaps be suppused that the interview really oceurred on this day. Lange ("Life") and Ellientt would place it at the point we have now reached. Hirzig before the question of the siaddueres, Waiss before the question about trilute to ('esar; which latter view suits the phrite "early in the morning." (Johns: 1.)

III. 31-10. A Lawyer Asks Which is THE freat Commandext. Mark 12: 28-34. Luke dexes not give this, probably because he lan wiven a similar teaching in connection with the parahle of the Good Samaritan. solnc months carlier. (Luke 10: 25 ff.) 
as Then whe ol them, which wes a lawyer, askesl him a questim, templing him, and saying.

:3i Mater, which is the great eommandmont in the kaw :

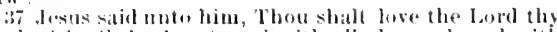
fiok with all thy leart, and with all thy soul, and with all thy mind. 3is touther. Ind ome of then, a lawyer, anked him a 36 question, trying hitu, Ilater, which is l he creat

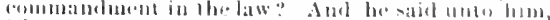

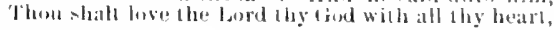

I Ur. Teacher.

31-36. The rivalry betweren the Phatrisedes

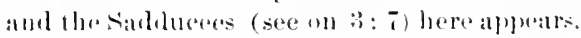
The formere, who hisul withdratwh (v.22), were

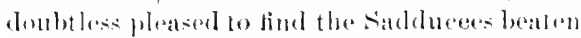
in alsument, their jerhaps colebrated and to the Pharises very perplexing question solved, and the deretrine of the resurrection more firmly establielod in the puptalemind; but all the morr was it important that they themselves should milie al further attack upous the Natalrenc, last his tollowers should think him viotorions over ali. When the Pharisees had heard. This mat retior to the leading Phariens who had put forward the juniors. (2: : 16.) Put the saddueces to silence. The pasive of the same verb is rendered "wats spreachlen' in 2.2: :2.) It signifies literally to musele (1 cors.9:9), then to silence. (1 Pet. 2. 15.) They were gathered together, aither for comsultation as to their next move (compr. v. 15), or to give the weight of a large attendance to the new enculury. One of them . . . a lawyer. Mark, 'one of the sirpiber. The

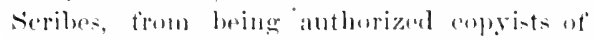

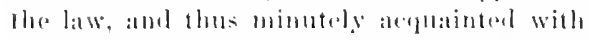

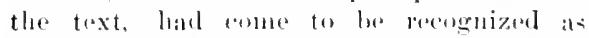
anthoritative expounders of its maning, (sere on 2: 4). In this calpsteity they were

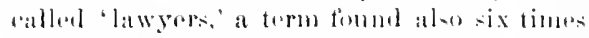
in Lake, and in Titns 3: l: and which ma!

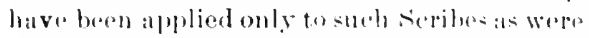
particalarly noted for their interpretallions of the law. Somse of them areted als formal

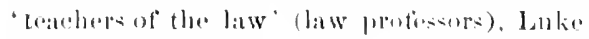

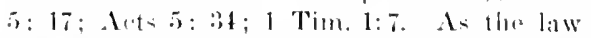

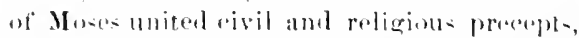
these latwers and be deneribed to the modern mind a half law wer, half thrologian, arorresponding to the original and prepor nese of the

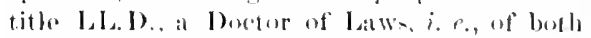
eivil law and eamon law. They w re looked up to ale erroat antheritios. But their aitations and interpretations of seripture-law were ofton belittled by petty quthbling, and were londed with references a former dorisions (oomp. on $7:$ : : : 1), both of these being vices not confined to the lawyers or thenlongians al any" one atre. Tempting him. (comp. un …: 18; 16: 1). Putting him to the tert, with the bopethat he would say something umpopular, (1) perbaps that le might be drawn intu at hitter and wrangling di-edl--ion. This the law-

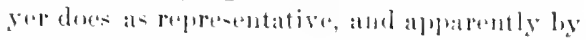

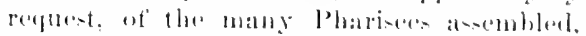
Mark shows (12.24), that the law yer himmlf hatel been tarorably imbmesed by our lond answer to the staddurere, and was a man inclined to true devouthes. The applaterat eonflict between this and Mattlew's statement is removed by the supureition ju-t mate. To understand 'tempting" here in the gand senese (Plumb. IIorison), is contrary to the ne:arly unition and rery treguent use of the word in the Sow Teat., and does nut harmonize with the tome of Matthew's nalrative. Which is the great commandment in the law? More literally this would be: What sort of commenelment is gremt in the lan? Andsleh

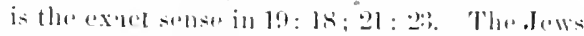

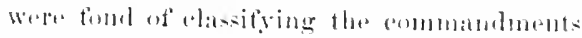

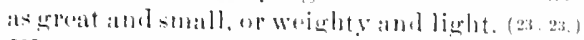
Winselye thinks that the ohjert of so doing

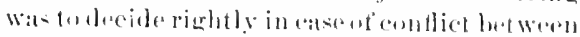
meveral precepte and prohibitions, since the

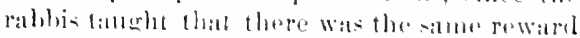

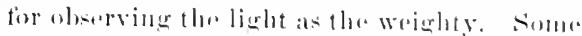
bold (Talmut ller.) that "Hhe worls of the

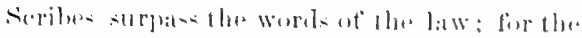
womb ot the law ate weighty and light, but the work of the serilue are all weighty."

The sperial hope in asking this question mat

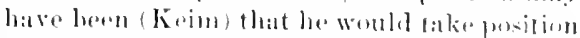

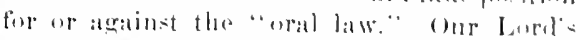

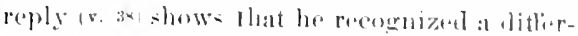
ence in the importanese of the commandeilients.

37 f. Jesns said. 'Jenus is wanting in some of the best documents, and was realily inserted ly enpyists (complo on 14: 14. With all thy heart, ete., literally, "in all, the love dwelling in lowe heart. (comp. an :3: H).

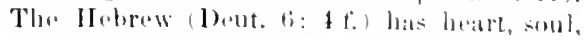




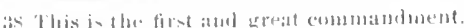

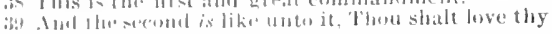

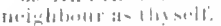

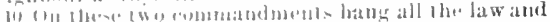
the poplats.

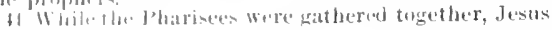
an-kid] $\{h+113$
34 and with all thy soul, and with all thy mind. This

39 is the greal and first commambunt. iAnd a second like whis it is this, lhou shalt love thy neighbour as 40 thyself. (I) these two conmandments hangeth the whole law, and the proplsets.

41 Now while the Pharisees nere gatbered together,

I (), Ant a secund is like unto it, Thou shatt love, etc.

miellt. Wh loworopeatodly olserved that in

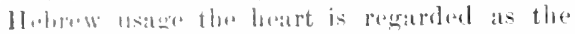
sout wt thomblatul volition, as well as emo-

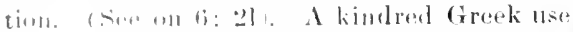

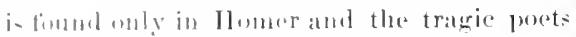

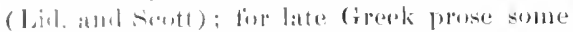

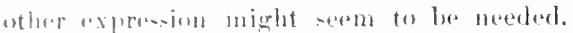

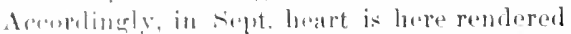

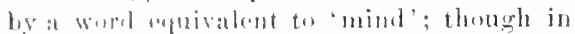
$\because$ Kinte 2:3: 205 it translates literally beart, mul. mirht, and 'luart, soul' in Dent.

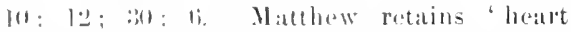
anel sulstitutes " mind" for the generol term

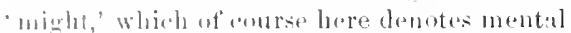

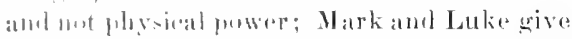
lubh 'migul' and 'might, and prosently Mark (12: an) has the seriluestating it as heart, undersabclinge, might. All these amount to the

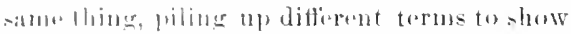
that all anr fiteultios and atteretions must be merlpiod with lave ta Joluwals. The first and great commanduent, ${ }^{1}$ groatest in innpurtame, and first in prosper order of state111.111.

39 6. Allorantwering the inumediate question, Ja-11: liaptarestates what is the secomd.

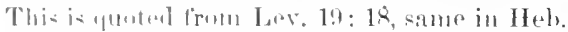
aril sion. Likg unto it, riz., like in na-

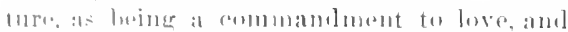

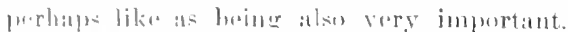
O) these two eommandments hang, ate.

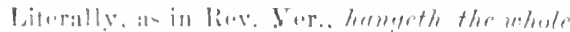

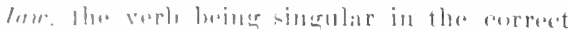

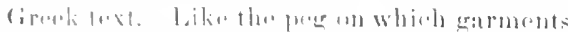

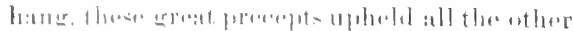

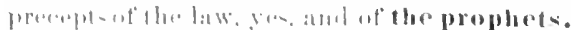

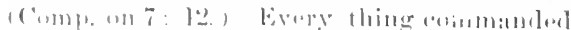

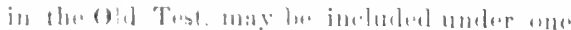

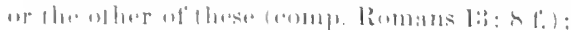

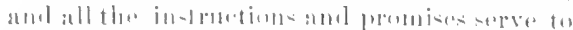

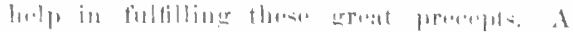

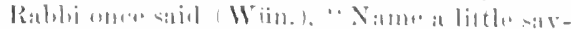

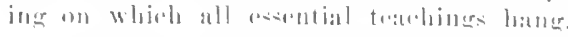

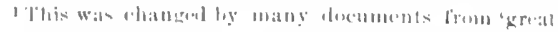

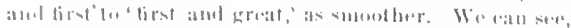

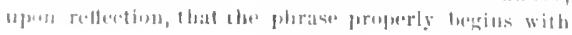

'In all thy ways acknowledge him.' (Prov. 3: 6.)" Plutarch says (Wet.): "Know thyself,' and 'Nothing in excess' ; for on these ballg all the others." We see from Luke 10: "27 that at least some of the "lawyers' were wont themselves to combine these two great commandments, as together telling what inust be done in order to "inherit eternal life" ; yet we may be sure they took a fitr less brond and spiritual view of them than Jesus took. The two are quoted from different books, but our Lord cleclares them similar, and places them in alose relation. Sone religinists incoline to dwell on the first and neglect the wher, smme unbelievers eulogize the second and care nothing for the first. But there is no earnest and intelligent love to God without love to our neighbor; and the love of our neighbor derives its fundamental and necessary sinction from love to God. The second procept cannot stand alone, even in theory. Why should I subdue egoism and lift altruism to a level with it? Certain skeptical philosophers say that natural sympathy by frequent vxercise hardens into altruism. But suppose this has not happlened with me; why should I trel it my duty to sacrifice my interest or inclination for the benefit of others? The true and only sufficient answer is, that suprome duty to God includes and authenticatas duty to man.-Mark tells us $(12: 32,34)$ that the seribe fully recognized the proprinty ot the answer, and the superjority of these groat etlijal duties to nll religious "remmoy; and seeing that he answered sensihly, Josus said, "Thou art not far trom the kingrlom of frod.'

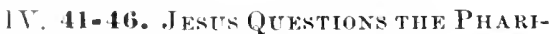
SFAs As TO DAvid's SuN AND Lord, Mark 12: 35-:35; Luke 20: 41-44. Having answered wll the questions so as to command the and. miration even of his enemies, our Lord finishes tho annersation by turning an the Pharisees

'Irrat,' landuse that was the point of the inquirs; but (20)y isla, like modern compositors, seldom bad time 10 rellect. 


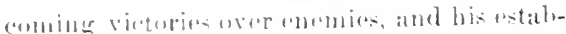
lishoment in the dientig of prie-t. 'There is

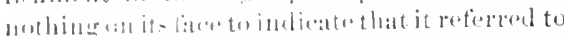

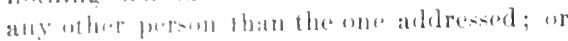

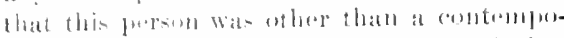

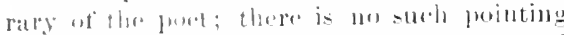

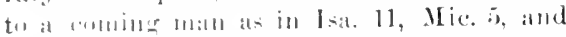

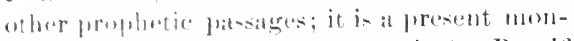

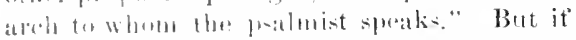

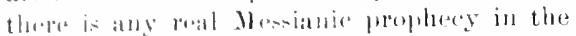

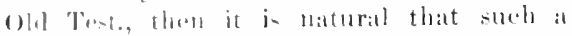

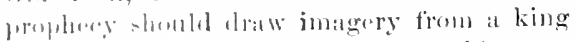

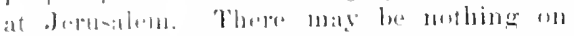

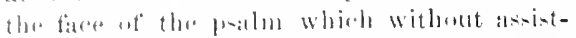

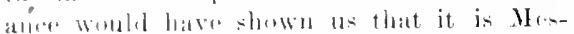
slation lant there is mothing to show that it is not, and the Fommler ut Christianty urformo the that it is Mesianje. A t to the

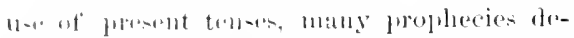

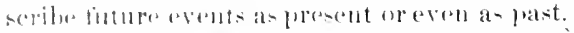

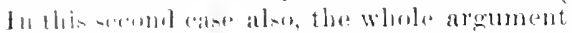

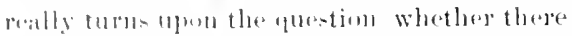
Was a supuruatural alounent in the teaching ot

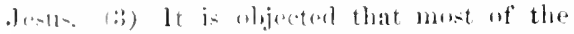

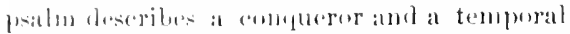

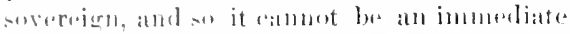

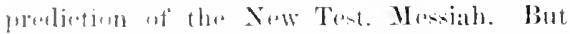

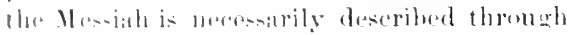
imatgen, and is in variome other propleseics (4)

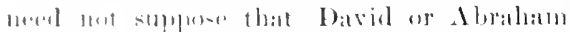

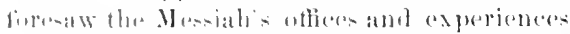

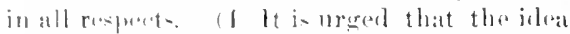

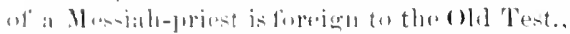

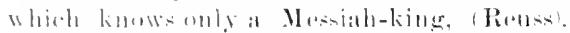

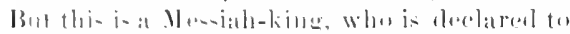

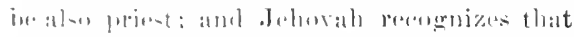

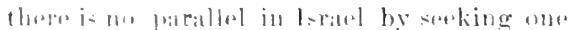

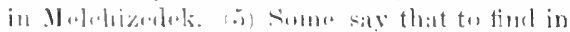

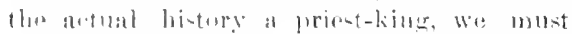

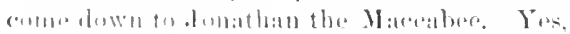

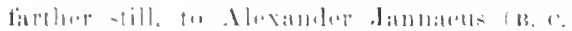

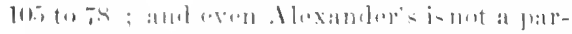

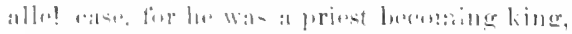

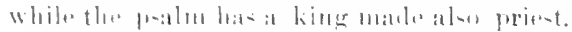

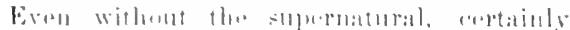

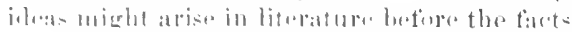

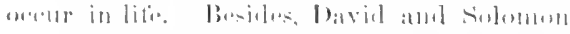

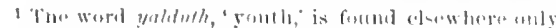

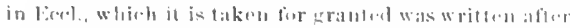

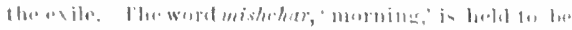

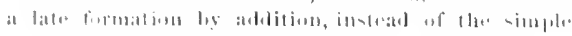

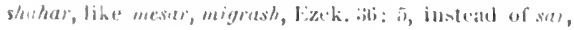

smotimes oflered sacrifice, assuming temporarily the functions of prient; and the psalm speak- of its ling ats a priest forever. So the irla: is not impossible or unintelligible for the mon of David's time. And thungh supernatual ponhecy manally drew its imagery from the actual, it certainly might male new and casy combinationsut existing oljects or ileas. (i) The language hats been held to show a far hater time than that of David. Some erities have laid stress om this argument and afterwarls silently abandoned it. Hitzig insists that two wards in the psalm clearly prove it to have been written atter the captivity.' But Ewald says: "As alao the language of the soler dow not oplune, it is to be regarded as (e)tiin that the king is I)avid; for king and kingulum appear her at the highest point of mblenes and glory." IIitzig's lroot's from language caunot he very strong, when Ewald hrubles them so nneremoniously aside. In fact, thes amount to practically nothing.

These are all the objections that are known to lave bem ardaced. Only the first and second batre any considerable force, and certaiuly they are very far from being conclusive. Fet these aro the grounds npon which some oven of peverent eritics take the position that . Jesus has here based an important argument mpon two downright errors. It is true that the knowledge of our Lord's human mind was limited (comp. on 21: 19); but that is a verg different thing from saying that it was rromeous, and that he used error as at moans of instructing and convincing others.

In (the) spirit. The Greek expression, if it stood alome, would be ambigurus, for it might ineill, as all the early English rersions bere rentrr. "in surit, viz., in his ownspirit (as in Juln 4: 2:3). But the term syirit soon be(ance among the (hristians equivalent to a proper mane, and su might be molerstood an lofinite without an article, meaning the Holy suirit (as in John $3: 5$ ). Now in the parallol patsilge of Mark (12:36 R.v.), it is "jol the July spirit, Wa cannot always determine throxat moaning of language from a parallel matagr. But here the connection is precisely

grosh. But the very word migrash is used as a noun in Num. and Jush. Aml mishlar, though found moly here, is a legular Iforen formation. not characteristically

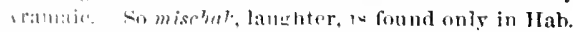

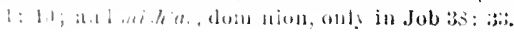


H The Ioro sad untomy Jard, sit thou an my right 4

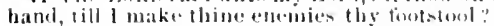

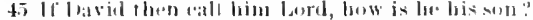

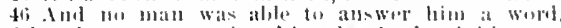
mejther alur-t any men lrom that day fortb ask hiul any more guestions.

the same, and so dlark's mxpresion may be takell ats defining that of Matt. Comp. "xactly the same Greek plobe in Rev. I: 111;

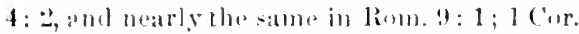
12: : As to the ide: here ennvered, comp. Acts 4: 2.): Ilsl), :3: 7 ('punting al palm), and lo: $15 ;$ allo 9: 8, where the spririt teachen through a 19 m. and 2 Pet. $1: 21$. These passages strongly nesert that the 11uly spirit

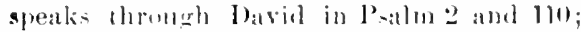
also that he spealis in Psalm 95 ame Jer. 31 : $33 ;$; and that he speralis through the propherts in eneneral. There is here no theory of intpiration; nothing taught as to the precise nature or modus operemedi of that influenes of the spirit under which 1)avidspoke. But it evilently means a sujernatural influence.

The soptuagint here exactly translates the Itomew, and is elonely followed in Luke, Acts, Jlebrews. But insteal of "as the footstonl of thy tinet, Matt. and Mark in the correct Greek text have simply 'underneath thy levet." which was reatily ehanged by copyists to agres with the sispt.' The Lord said unto my Lord. In the llobren: "J Jhovah ( Jahwehl saidl unte my loril.' The later Jows hat a superstitinus derat of promuluedeg the projur name ot the fiml of latael, and when they eame to it in realing would sulstitute.

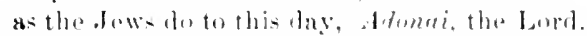
Aceordingly tho sepr. tiansiatera, who were

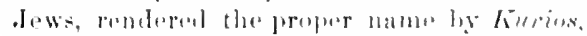

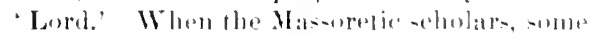
centuries attore ('luri-t, umblertank to write

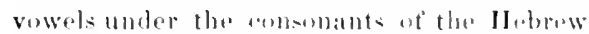
worls, they grave to the prepure name, thrh the rowels of the word .lemei which they were accu-tomed to sub-tilun, with a slight

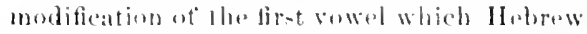

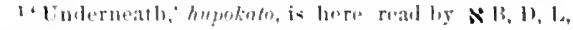

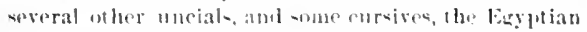
and other versions. ll was davily changed ly enpyists

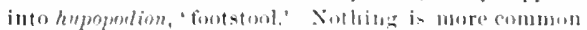
in the manuscripts of the Xew $\Gamma_{1}-1$. than to fiml a quotation alterel in conformity with the sept. In Mark hupoketo is given ly B, W, the Egyptian rersions, ate. Hupopolion is read with siluht varition in luke, and without any varbation in . Acts and llelorews. sig it is
The lacid said unto my lourd,

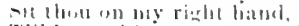

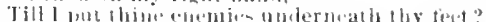

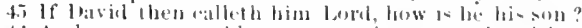

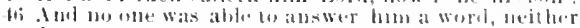
durst any man from that day forth ank him any more questimit.

u-age warmated. Thisha-led to the mustern

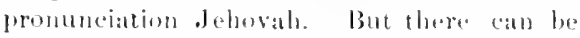
Ine deubl that the word was uriginalty piomoneced with other rowels ; and itsondul was

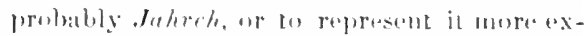
actly in English letters, Fahech. Our Enerlinh ver-ions of the Gla Tert. have alwass in like manner represented this bropur natue hy

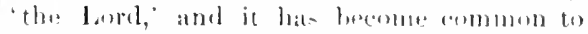
print the Lorl' in apritals in theses catsento distinguish it from delomer There would be great alvantage in -ubetituting ollowab, as preferred by American lievisers ste Appendix. as showing that a proput name is really meant: and the mere mattor of conrectly rep-

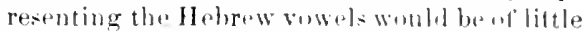
proctical impertance. The New Tent. writers.

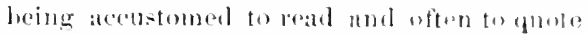
the septe, hase followed its prateter: and it is sometimes not ensy to determine whether kwrios means oluwah, wr simply Lurd in the mene general sense. sit thon on my right hand. This wat naturally the post of highest honor at the court, where one could be andreniently comsulled by the monareh in jurler-

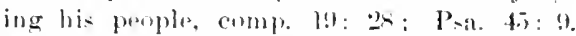
Malie thine enemies. ite. lueter a- Reve Ver. put thine enemies unternersth thy fort. Thi- is an image founded on the practies de-

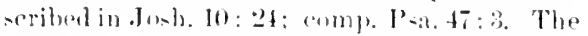
Ilesials will share the divine reign and con-

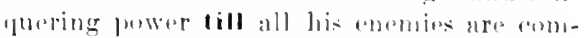
pletely sllyluted, and will then give batck hi= deleganed Itesianie dominion (an 1,4 , to the Father. (1 cors $15: 2 \mathrm{ma})$

The ruestion roperated and presed in $x .45$ was an eatch-tpuntion, such as the phar. and

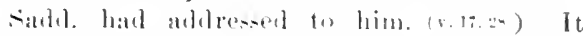

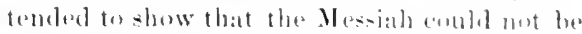

clear that 'unkerneath' is the trae realing in Matt. and pretty char in Mark,(kev. Ver. margin). This" undermeath is probahly a mere simplibeation, but mag have come (Tuy) from the sept. of l'sa, $8: 7$. Th, news

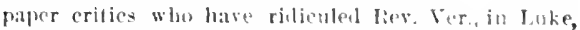
Acts, ete., for using such a polurase as foutetum of thy fent, did not know that they were ridiculing the originals. 
n incrotunpmral soveruigh, nor in fact a mere man.

16. Noman was able to answer him a word. (Cimpr. Luke 14: 6.) Aceording to their annerption ot the Messials the question wa- unam-waralib. It was afterwarlsanswered by and whow was at that time a young Platisir, lloush wa know not whether then studying in .lurusalem or allosent at Tarsus. This

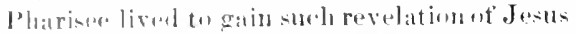
the Mariab, and such understanding of the Masianix seriptures, ns to pereeive that he wais " male horn) of thesped of l)avidaceordjug tor the flwh, and dextared to be the son of find with power, aceording to the spirit of hulines, hy the resurrontion of the dead.' (am. 1:36, crmp.9:5.) The faet that no oue durst from that day forth ask him any more questions is alsostated by Mark and Luke as the re-ult of this same series of questions and nuswer- Mark (12:34) makes the remark at the chese of thr lawyers question to Jesus, the lust question of his enemies; and Luke (a) 40 ; at the oluse of the anestion ly the sarlelueres, the last that he records. All the s.leret wistom and ingunuity of the learnod und ruling classos, in loth the great parties, hul lowenht thoir most puzaling questions to the young teachele from Nazareth, who had neveretudind in any of the seluouls (John $8: 15$ ff.), and lo not anly gave in every case an answer uf astonishing dopth and elearness which sent the wisost men away in wondering peflectiun. lut at leneth retorted by a question which mome enuld an-wer, and which seemed liainly to indieate that their views of the Mesiah were radioally detertive. Our Lord womt riglt on discour-ing, attarling the ruling

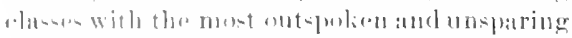
reverity ah. 23). lust they dared mot any more intrerupt or impuire. They were holpless in urerumont. and as nsual with foiled and angry disputants whe will not lo anvincerl, they hare no hoprebut in violences. At this point

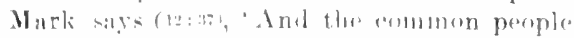
hearel him glally. The fuesplu whothrongerl the tomplo anert lond no pusition to lose, and

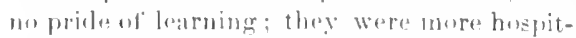

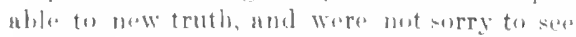
urromut rublis and prissty aristoerats put to shame.

III) II. HTCAL AXD PR.ATIEAL.

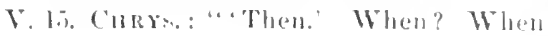

most of all they ought to have been moved to compunction, when they should have been amazed at his love to man, when they should have teared the things to come." $-V .16$. Jesus praiced by his enemies. 1) Aeute flatterers may show what reputation a person really desires. 2) What these fattering foes said of lesus we know from other sourees to have been thoroughly eorret; (a) he was true, (b) he taught the way of God in truth, (c) and without fear or fnvor. 3) There are other recorded instances of unwilling testimony to Jesus. 4) The day is eoming when every tongue shall eonfess that he is Isord (Phil. 2: 11.)-Alexander: "Such adulation (as was here offared to Jesus) has blinded the eyes and warped the judgment of its thousands and its tens of thousinds among human sages, and espeeially of those who glory in their insusceptibility of flattery." $-\mathrm{V} .17$. It is much to be desired that people shall often ask their religious teacher concerning questions of truth and duty. Fven when questions are asked with evil motives, as a test or a snare, it is well to eseape the snare by prudent answers (v. 46), and to silence the evil-fisposed (Tit. 1: 11 ), and better still to give answers that will elear up real diffieulties (v. 21), and enlighten the welldisposed. (v.22; Mark 12:7.) Human tempters may often be not merely overeome, but won to wiser judgments and kinder feelings. $-V$. 18. 'Jestis poreeived their wiekedness.' He knows to-day all that is in the hearts of those who are openly trying to injure his eause amb dishonor his name, and of those who hypocritieally protend to be his friends.-'Hypoerites. "IERomE: "It is the highest exeellance in one who replies to know the mind of the questioner."-T.21. Civil and religious luties. 1) It is a religious duty to pertorm all rall civil duties. 2) It is not a cirilduty to perform religious duties. Jaws as to Sablath observanee, ete. ean be based only on public health and moral welfare, and the right of worshipers to be undisturbed. 3) Careful obsarvace of the distinetion between eivil and religious duties is nefessary to freedom of eonscience, and greatly promotive of genuine piety. Here, as everywhere, liberty has its (a) barrassments and perils, but on the whole it is far host.-Civi] duties may still be binding when the ruler is persomally immoral and tyrantical; Cesarherewas Tiberius, and when 


\section{A P'TER X X III.}

TIIbx-patie Jesus to the multilude, and to his disciplest

Punl and Perer urged obedience it was to Ner". ('unys: "But thou when thou bearest, "romler unte Cesat the things which are Cesar's, know that ho is speaking mly ot those things whirb ares no detriment to godliness; sincer it it be any such thing as this, sueh a thing is no longer cesar's tribute, but the levil's."

V. 28 f. Skeptic; oftan have favorite catchquestions; hut supcrficial and ridieuling infuiries are much broter than silent negleet, and they -lomld usually be met with a kind and thoughtful answer, and may sometimes be mate the areasion of establishing positive truth. All skepticism as te Christian truth results in part from ignorance of the Bible, and of the divine attributes. $-V$. $29 \mathrm{tr}$. The resurraction ot the datal. 1) It is taught in the Bilde, (a) even in the l'entatench, (b) in the P'pophers, (c) in the Now Trest. (2Tim. 1:10.) 2) It puts areat homor upon the louman body. (Psa. 1:39:1t: Phll.3:21.) i) It gives vividness to our conceptions of eternal existence and lelieity, 4) It will exalt above mueh of the narrowness and exclasiveness of earthly relations and atfertions. Culs res: "since then the resurrection is like this, eome let us do all things that we may ohtain the dist homor. there."

V. 30. All eommandments ot God are in one semse efually binding, and the spirit of obedience is tented ly all; but sonne relate to matters intrinsically more important. Those commindments are greatest which are most spiritual, most opposed to selfishness, most comprehemsive. Duty to God is in itself the highest Hutr. and comprehends all other duties. - V.37. Lese is the attraction of gravitution in the moral nuiverse, binding moral erentures to each ot bor, anel all alike to Gorl. Loving God and knowing God are mutually dependent. Pascal remartis that in other things we must know in order to love; in religion we must love in order to know. Sourees froun which we may gain keowledere of Goll-from nature-trom human natureflom "the image of the invisihle Goil' ("God W:a: made flesh, that flesh might soe that God is fore")-fromi revelation in general-from

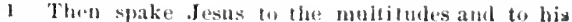
2 disciples, sayng, lhe teribes and lhe phari-ees sil observation of his providencer, and combutanion with his speirit. Renans lor loving (ionl. 1) Buratlos: he is (iont. 2) Becallse he is our

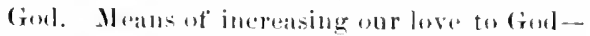
think of hin much-epeali of linu with reverence-coltivate delight in his worship-see him in lintory, anel in onr own life-obey his coumuamoments-strive to hring others to love him too.-- V. :39. - Thom shalt lovethy neighlor as thysill", 1) Why shonld I love my neighbor ats mysolt"? 2) Who is the neighbor I munt love as mysolf? 3) What is involved in loving my noighbor as ny-wle"?

V. 4.2.7. The Mesiah. 1) 'To aceount the Mesciale merely a man, is hopelessly inconsistent with seripture. 2) The J "wish Messiah is also the world's Mosiah, 3) The Mesiall reigns now on the right hand of Gend. 4) shall we live as the IIessiab's enemies, to be tramplod nuder fort, or as his loving suliject-. to in-

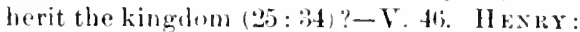
"Many are silenced that are nut saved, many convinced that are not converted."

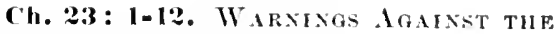 S(MIIBE AND J'HARISERS.}

I'artly foumd alon in Mark 1:2: $38 \mathrm{f}$; Luke 20): 45t. 'This di-conrse probathly belougs to Tuestay, three days before the crucifixion. The solemo intimations mades early in the? day that he knew the Jewi-h rulers would rejeet and kill him, and would be torribly punishod tor it (21:23 to 22: 14), were tollowed by the sharp efeetioning of $22: 15-16$; and now, having vanquishat bis opponents in question and answer, Jesus speaks ont plainly alunt the Seribes and Pliarioses, first warning the people again-t them (23:1-12), and thend donouncing upon them a series ot mourutul wees. (13-39.) Attorthat he will spenk no more in public, bot will louve the tomple, and give the final discourse to his diseiples on the Mount of Olives. (chap. 24 and 25 .) Nll theor discourses follow ench other in natural conneetios, and to all appearance were spoken on the same day. The attempts of smo crities (1) scutter them upon differont dirs=are arbitrary and useless. Of these wanings and woes 


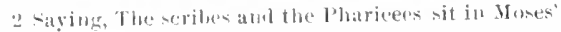
stiat:

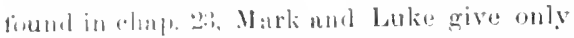
u very stuall portim.

I. Then naturally suggests, though it does

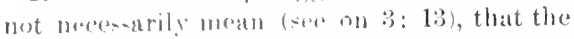
firlluwing wat an the sane day as the forregroing. 'To the multitude and to his disciplen. Ilim previous di-courses doring th." day wer. alllessed mainly te the ruler: and the fur-ens whe wane questioning -though in

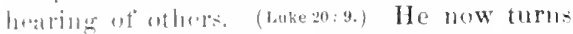
away trom these lauding persons and ad-

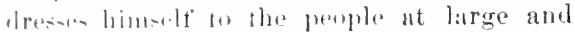
to his immoliate tohlowers, the latter being

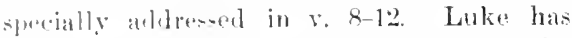
(20) 5. kes ver), "In the hearing of all the ponple ho said unto his di-ciples"; which lowes net materially differ. A year before

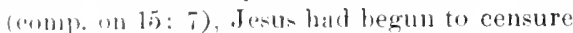
the ficribes and Pharisees with outspoken soverity; and within a few months, probably in lerea. Charly not at Jerusatem, he had desouncel woes nfon then and warned the perplo again-t them. (wake11:37-54.) Now he lans clae -inue thing at Jerusalem, in the fomple compt, during the great feast of the Pasiover ; and thrse denunciations form the nlmax and comelu-ion ot bis public dis(a)urese. It is matural that he should have thu s suken ont eatrier elsewhere than at doru-alran during the feast; nnd it is much mure rainsualile to suppose such a repetition

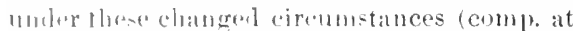
bogimning of (lith. 5), than to suppose that either Jukk or IIathew has utterly displaced threse momonteus trachings. Notire that Mark and Julis buth repurt at this some quarter small purtions at the dincourse given by Matthink,

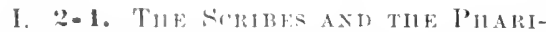
RER : M XUT PRACTHE WIIAT THEY TEACH.

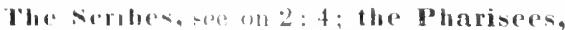

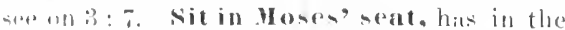

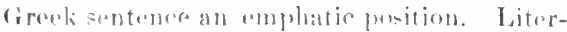
ally the verb is sat, 'huve salf, have tation a

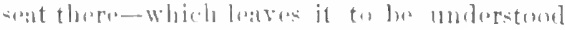

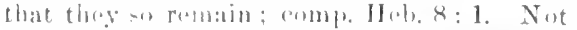

1 ll is wallug in soveral early versions and some

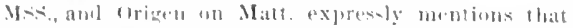
luke alds this lorm. It might he easily inserted low'te arom tenke, while on the other hand no sme conld have an reason for omitting it if orlginally preatu; so it is

3 in Moses' seat: all things therafore whatsuever

o11 $l_{y}$ the judge Exod.18:13) but in later times the teacher, u-ually spoke in a sitting posture. (5:1; 13:2; Luke 4:20; Acs 22:3.) The Greek term for "seat' is kathedra, and as borrowed into Latin gave the phrase "to speak ex cathedr"a," i. e., "from the spat" of an authoritative tracher. The liabbiniral writers speak of a Rabbi's successor as sitting in his soat; so we, as to a professm"s "chair," which work is our contracted form of cathedra (skieat). Our Lurd meins, then, that the scribes and Pharisees are in some sense successors of Muses, teachers of the law as he was. They chimed this, and to a certain extent the elaim was just, since most of their explanations were substantially conformed to seripture. The time had not come for turning away from their teachings to new and better teachers.

All therefore whatsoever they bid you is set in contrast to their works. He meant in ageneral way to commend their unstructions in religiousduty as correct, and then tocontrast strongly their practice as wrong. We know that he condenned the exaggerated importance they attached to their traditions $(15: 3,6)$, and their general spirit. (16:6.) The common Greek text has 'biel you observe, but the authority against adding 'observe' is ovelwheming. Observe and do, the verb heing in the tense of continued action-continually mberve. They say, and do not. So he had alreaty declared in Galilee $(15: 7.9)$, and buw reprats in Jerusalem on the nost public :ceasion, For they bind, yet rejresents the correct Grooli text. IIeavy burdems (comp. 11: 28), the strict requirements of tradition as fo ceremonial observances and the details of moral duty ; comp. Luke 11 : 4 ti. Peter sulstantially repreated this statement in Aots 13: 10. The inage is of binding fiugots of wool or bundles nt grain; the idea is of eombining numy separate precepts or requirements until together they make a heary lond.

The term remlered grievous to be borme does not bolong here, but was brought in by mpists from Luke $11: 46.1$ Will not move

doubless spurious in Matt. W H. place it in their margin hre, apparently because $B$ has il, and because the documents for oulting have an "Alexandrian" linik. 
3. All therefore whatsuever they hial you observe, that olserve and to; but do wot ye after their wolks: for they sily, and biente

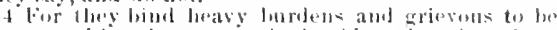

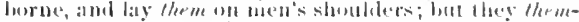

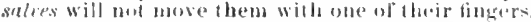

5 But all their workstluey do for lo hesen of ment

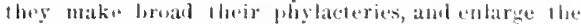

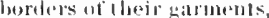

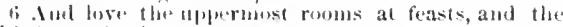
chief seats in the sylligugles,

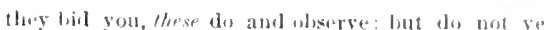

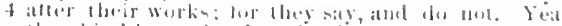

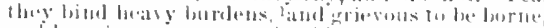

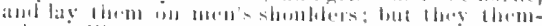

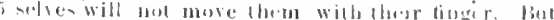

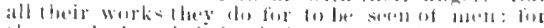

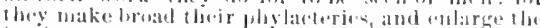

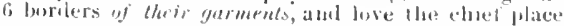

I Jang abcient auborities oult and grievous to be borne.

them with oue of their fingers does not mean that the hurdens are ansy to move, but that they will not make the slightert bxertion to meve them; far less will they take them (1) their slaculders.

1I. 7-7. THE S'RRIBEs AND THE PHARI-

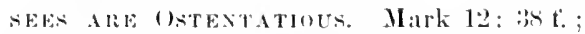
Lule :21: 4i;. To be seen of mem, "with a view to ho loulied at by men, the same phrase as in b: 1. 'The desire tor louman prais was, and often is, a sreat hindranes to believing in

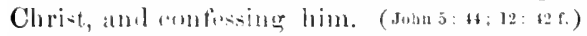
lor they male is the correct Gr. toxt, and introduces the pront of the foreguing. 'IJey make broad their phybetries. In Exol. 1:3: 14; J Jat. (i: s; 11: 18, it was said to Israce emoraning the teachings af the law,

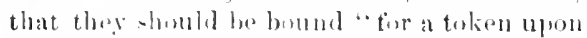
thine hamel. and fire frontlets hetween thine ryes." IIre an image seoms to be drawn from the old Ergptian pratice of wearing ammlots; the Israblites were to kerep the law always near thrm, always in mind. In the

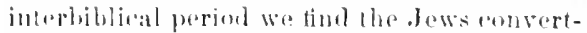
ing this figure into entwarel lact. Thry test

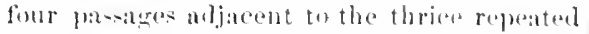
injunction, viz., Exoml. 13: 2-10, 11-17; Dent. b) 1 1; 11: 13-0, at.l writing thom on strips of parolment, encased the toldenl strips in minute leather buxes. These find lowes were

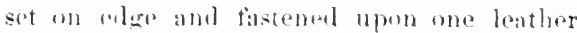
bisas, which was placed on the middle of the forchead, and belal thore by at stringe tiod romol tha heal with peenliar knots, which hall al my-tical meaning. Femr similarstrip were plateel in a smaller single lox, which was worn sh the palm of the hamd hy the side

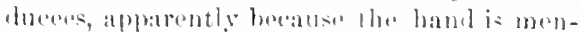
tioned in the tigurative injunction, but ly the Phariaess on the left arm near the heart. becallse of Deut. it: i, ". and these words . . shall be in (or "pon) thy heart." They placed the box an the bate arme as atear the heart as poscible, fastening it with a my tically kmoted string, and then arevering it wib the

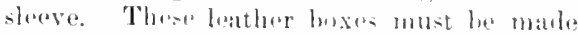
from the skin of a "clatu" animal, and enlored black. Phylaceries similar lu lluse thus dencribed by thr habhinical writers are? now worn hy the stricter of Jws, the delailo -lightly varving in diflerent eountries; and

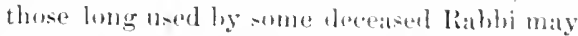

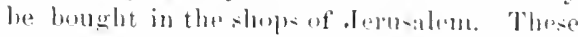
little boxes with their contents aro called by the Targum of (Onkelos and by tha Rabbini"al writers teplillin. "prayers," berallate put tom before praying (sere linxtorf); they were worn by men in goneral during public worship, but by the Pharisens worn antinte ally. Matthew's turus phylactery. formel nowhere else in the Grom biblo, simnitios

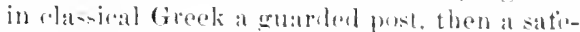
gruarel, linally an amulet, as eruardiug aleainst

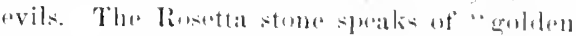
phylacteries" worn ly thr kings of Egypt. (Lid. and sientt.) The Rabbinieal writings show that many Jews reararded the phylacteries as anmolels; and it seme most likely

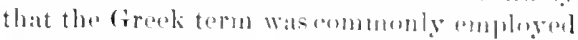

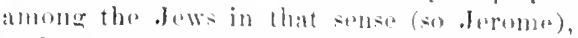
and Matt. meraly useal it becallose it was common. The torm might etymerlogically mean "a place tor enatrdinge the divine word scliötgen, sior). but lhere is mo ustge tirr that sonse. Justin Martyon talls Trypho (th.

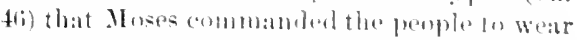
a phylactery. but dows not throw any lieght in

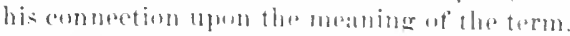
The Pesh. here translates ly tephillin, thes Rabblinical werd. The conneil of leatedient

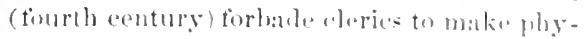
lacteries, declaringre (with a play nyon thos word) that they are prisons of their souls, and those who wearthem must be expollow from the rhureh. (suicer.) Clirys. compares lhe fiact that "matly of" our women now watr Gospels 
i And grentings in the markets, and to be called of ne+1, Rablit, lablit.

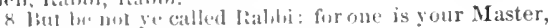
fen Clerist: aluil all go are l,rtilured.
7 at feasts, aud the chief seats in the synagogues, and the salutalious in the markctplaces, and to be called 8 of men, liabbi. But be unt ye called liabbi: for one hunefrom thairnecks." Simmemulern writers have maintaned that Moses intrinded these litural fromtlets and armbots to lue worn as al

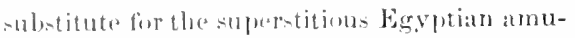
lat. Bhat linw could Moses tail to see that they wauld thomselves lo worn as amulets? Mis fiml no eviderese of their une until the latter fuat of the interbilolical preriud, and the genceral temdency to sermumlesity about extermals womld aleeount fior throir appearance at that time. The Karaite Jews (who arose in the reighth e'hristian erentury) have always molerstemel throe par-agesot the law as figurative, holding that the hand represents prerepte for action, and the head represents the menlal and mpiritual. Comp. l'rov. 3: 3; 6: "2l; E\%ti. 2ut: 17. Making their phylacteries mbustally loroud would show every rasual olmerver that the Phariones were remarkably pions. The hoad being bara, or covered only witla aloth, this cube of some two inches oil erory sibe, projecting firm the contre of the forelead, would attract erreat attention. En= lares the borders (of their garments). "Thase peruliar "lumblers" wore comman led to he worn (xum.15: $3 k$ ), and were worn by

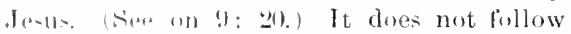
that ho wore the phylateries. Mathew's Jewioh ratar- womld at once understand 'enlarese the lorelers'; hut many eopyists

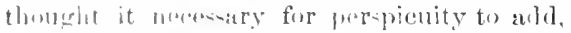
'of lluir gammonts, and this naturally erept. inte the (jommon text. Iave the uppermen rooms (or chief plape) at fease.

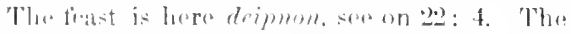

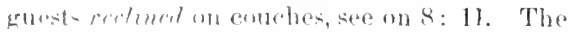
phare of highret honor for a guret apparently Waste recline just in tront of the host, so that llor lorat andel lor latid bark in the host's

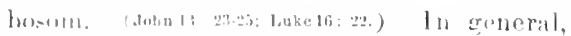

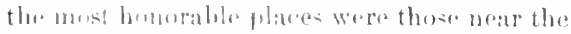

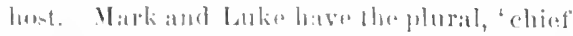
places ; all thres we the same firoek word, literally, ehief restiming-place. The old ron- dering, 'rooms,' really meant simply places, lut would now suggest apartments. "Uppermost' was prubably used here by Tyn., Cran., K. J., because of the phrase "come up higher" (Luke 1t: 10), and the Euglish expression, "the "pper end of the table." The chief seats in the synagogues were the front seats noarest to the place in which the rulls of the law were kept. For 'synagogues,' sue on 4: 2.3. And greetings (salutations) in the marlicts, tlat is, the marliet places. They were the general places of assembly, for men of all pursuits. Indeed, the Greak word denotes primarily a place of gathering or asscmbly, the thought of buying and selling being subordinate. The Asiatics have always attached grait importance to profoundly respectful salutations in public interesurse. Not in Paris, but ouly in China, could one find such elaburate courtesy as in an old-fashioned sheik who meets you in Palestine, as be tonches his lips and forchead and breast, each time bowing low, and saying, "Salaam to you!" Aud to be called of men, Rabbi, the common Jewish word for teachor. (S.ee on 8: 19.) It means, etymologically, 'great one' or 'superior,' like master from mag-ister, and somewhat like "His Excellency," "Your Ifighness," ate. The office and its title were much coveted among the Jews in the time of C'urist and afterwards. Statements of tater writers make it probable (Ferzog) that the use, or at any rate the frequent use, of the title began in the time of Hillel and shammai, in the generation preceding the Christian era. ${ }^{1}$

III. 8-12. C'IrIst's Disciples MUst Not

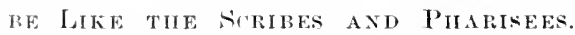
Jusur turns from his aceount of the inemsistent and ostentatious. Jewish teachers to warn his ilisciples (comp. v. 1) against doing likewise. Fom thinks it impossible that in an arlitresto the people (v. J) Jesus should have introunced aldmonitions to the disciples con-
1 The dimbling of Rabhi (enmmon reeck text) is

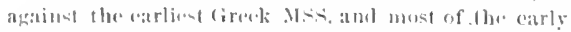

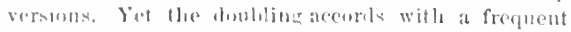

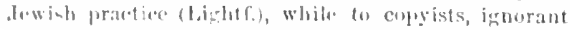
of that prastice, it wonlal be apt io secm supertluous;
So we cannot, with entire confidence, reject it. 'Even (the) Christ' (r. s), is no doubt spurious, added from v. 10; ats alsw 'teitcher' was here changed by some document (1) 'guide,' the word in v, 10. 
9 And eall no man your father upon the carth: for one is your fiather, which is in heaven.

10 Nebller be ye ealled masters: for one is your Masier, erenclirist.
9 is your teather, and all yeare brettren. And abll mo man your father an the aarth: for owe is your

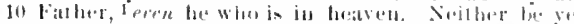
called maslers; for wle is your manter, cout the

I Gr. thr heavenly.

cerningtheir one Teacher the Mesiah, and slould thon have launched "woes" anain-t the Phari-ees, "as if he were speaking to them." lint what strange eritieison is here. With a hetarogeneons crowed thromging around him, nothing was more natural than that an impas-juned popmlar speaker shombl turn from one elass ot his hearers to almother. After v. 12 it might aven be suppesed that some of the ficribes and l'haricees, hearing in the ont-kirts of the thromg that he was waluing the people agaialt them, bad presesed their way throueh and were just then drawing near with loustile lowks, so as to furmish an innediate oceasion for his addressing thenll.

IBe not ye called Rabbi, with emphasis oll 'ye' as the (iresk indieates. Do not crave the honor of being re(o)gnizol as a religrious teacher. Jor one is your baster, teneher. The Rabbis wre imblendent, and any one of them mierlet found a distinet school. But Christians areall pupils in one schoml of Irets. and amoner thene is no diflerence of dignity. Sio Iernatius addressest the Ephesians (ch. 3) as his "sehoulmates." As liobbi i. equivalent to tha latin Doetor, 'tomoher,' sumo literalists urero that to call a minister "Docetur" is hrere detinituly prohilited. But the matter goos fitr denpor. What un Iard probilits is deserefor the distinetion involved in being recogntizod as at roligions touller. A man whoshows great elesire to be " invitud into the pulpit," or otherwise publicly treated an a minister, is cractly violating this counmand. The title of l)werer of Dirinity is often so eonferrod, so songht, so burne, and sometimes so drelineal, as to an!me undror thiti lend, but it is the spirit involved rather than the phrise that shombl ha eomelemmenl. lt would be bottor to have no distinctive titles, sorming to set one minister alsose others. for there really is langer of forgetting that all ye are hrethren. Yeat (schaff) "our addresing of hers by the u-nal titles is not forbidien; pride taking the furm of want of emutes annot find sholter here." The folly of mere vorbal and literali-tic interprotution is seren in the fiace that persons who vehemently declaim again-t the ase of " Ductor," as being probibital in v. \&, are oftend find at "alling some vellerable miniser "Father." which is antua!ly probilsited in 4 . 4. The. Jews

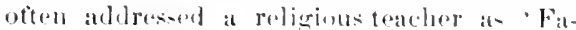

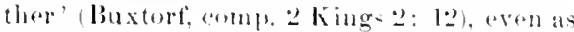
the "son- aft the prophets" and the "-ons:" of the Pharisoes weretheir pupils. (complo an

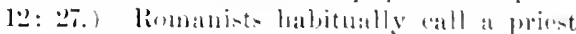
"Father," and the sovereiern frrimet they atl "IInly Father." Sis dbbot is derived trom abba, 'fatber, and l'ope is the sande worrl as the Euglish papa; in the Cirrek Chureh papras is applied in any joriost. In the Chureh of lingland a bishup is sometiones formally addressed ns "Right Revelend Father in Gud." While earnesty comdemuing all this, we do well ta remember that sitephen said, "Brethren and tathers, hatien" (Acts: 2 ); (umpl. also 1 Cor. 4: 15. One is yonr Jather, which is in heaven, more exactly ats by Aner. lievisers, even low whe is in heaven,' literally 'the heavenly (anc), comp. an 6: 1.

$10 \mathrm{ff}$. Master is here liathegotes. guide, instrutor. seesn 8 : 1!). Even the Christ,

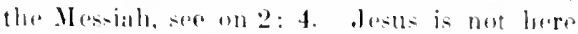
di-tinetly sayiner before the bustile hentrors that he is the Menialt. Mlis distiples st molerstuml him, but he did nut pulphely arow him-elf as anch until he apluared betire the sinnhedrin. (26.64.comp.on:t:16.) IJe that is greatest amoug you, ote, is repeited from 20: 24. 'Greatest' is locere literally 'greatere (than all ofluers?, as in 18: 1. Mnthis matter also there may be lond professons without the reality. One who with strift and ostentattious literalnes calls bimsell! " servalut of servants of the servants of (iol," yot claims to be sovereien of the Cloristian worlil. Whosoever shall exalt himself, secking to attract human notice aid praine. Shall be abased. The Greek has humbled.... humble; the early Fuglish versions. risept

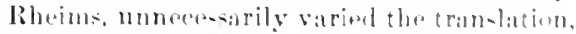
e. g., Com. Versien. Tha saying of v. I: had been given before. probably a werels or 
II Bull he that is ereatest among you shall be your servalit.

t: Ind whesesershall "xalt himself hall lw abased: and he that shall humble himsilf shall be exalled.
11 rlurist. Put he that is ${ }^{1}$ greatest among you shall 1'2 be vour 2 servant. And whosomver shall exalt himself thall he humbled; and whosoever shall humble himselt shall be exalted.

1 Gr. greater...20r, minister.

(wi) matier, in Peres, Luke 18: 14. It is very llallural that any saring uttered at a distance

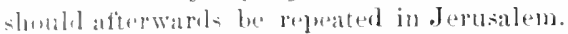
The lesen at humility isone peraliarly needing to lu aften repeated. In one furm or another, Juss bas taught it many times; (o)mp. on 18: 4; and comp. Prov. 15: :33; 29: 2.); Jamea 4: 6; 1 Pet. 5: 5. The Talmud ha--inilar sayingr, mpecialiy one (Wün.), "Whorer loumbles Jimnlt God exalts, and whorver "xalt- limmelt God liumbles," which maly haveben borrowed from the Gospels, or may have been built on Ezek. 21 : 26.

\section{IIOMILETICAL ANI) I'RACTICAL.}

r. 2-4. Toaching without practicing. 1) A vely faulty man may give teaching that is sirifurally arerect. 2) A man whoutterly noglont- his awn duty is often very sovere in lating down the luty of others. 3) Wemu-t uftull lisugard a teacher's evil example, and

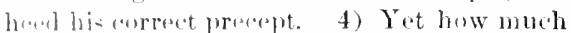
loster, for taicher and for hearess, when he that ays, also does. C'urys. " For what

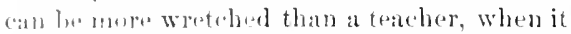
is the pleservalion of his di-coples not to give J

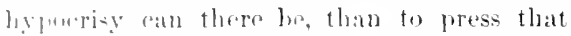

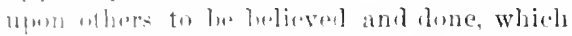

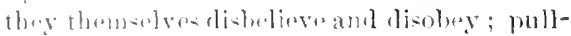
inter luw in their pratede what they build up in thrir probloines; whon in the pulpit,

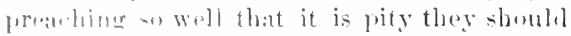

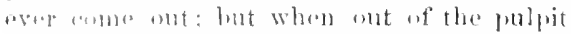
liviner -1$)$ ill that it is pity they -lonuld evor forme. in.,"

V. $\therefore$. I man"s aims deformine the meral

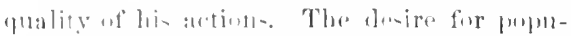

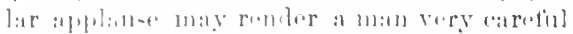

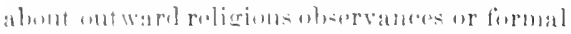

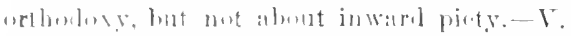

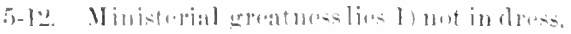

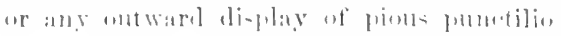

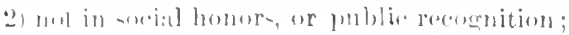

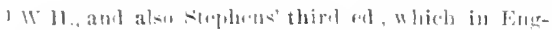

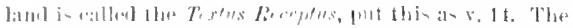

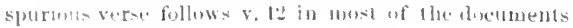

3 ) not in titles, or aduiring followers; but 4) in humble service of others.-T. $11 \mathrm{f}$. Humility. 1) Professed humility is often only envert pride. 2) Effort to be humble in hope of exaltation may impose on ourselves, and on many of our fellow-men, but cannot deceive (iod. 3) True humility has not time to think of self, because busy with serving others, by speech and action. 4) Genuiue humility will laad to exaltation, in God's own good time and way. (1 Pet. 5:6 f.)

13-39. WOES DENOUNCED UPON THF S'Cribes aNu PHARISEes.

This is given by Matthew only. Luke recorls several similar woes ( $11: 37.54)$, which aj)pear to liave been promounced some months eallier, compl above on 22: 1 and on 19: 1. Our Lord now ceases to address his disciples and the people in general (23:1), and turns back to the Scribes and Pharisees, pronumcing upon them a series of mournful Woes, v. 13, 15, 16-2.2, 23 f., 25 f., 27 f., 29-3t, closing with an apostrophe to Jerusalem, 3739. In each case some special form of wickedness is made the ground of this stern denunciation, and tho solemnly repreated address at the upening of the successive paragraphs gives them a rhythmical character, like strophes in an ole. Krim: "In the seven woes, the first place is given (first and second woes) to the fulgment against the foes of the kingdom of Gorl, whose proselyting zeal for their lost cause stands in sharp contrast to the hindrances to the progress of the kinglom of haven. The third and fourth woes denounce thoir false traching of the law; the fifth and sixth, the slownly efforts after purity by the "pure'; the seventh definitely reverts to the attitul. of tho. Pharisees towards the prophets -the annonncers and forerunners of Jesus - whor growes they build, and in doing so prove thomsolves to be the sons of those that murdienel the prophets.'

\section{13.1 TuEx SHut the Kingdom. Woe}

which contain it. The early Euglish versions proba. by fullowed the Vulgate in giving the other order. 
13 l3ut wow unto you, scribes and pharion, hy pur

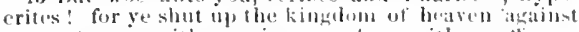
unen: hor yoneitheryo in pomseles, neithersuller ge them that are enterisin an gis in.

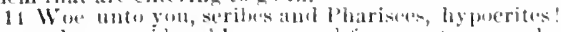
for yedevour wiolows lasuses, and for a prefonce make iong prayer: thereture ye shall geceive the greater dammation.

1.) Wue unto you, scribes and l'hariseres, lypucrites for ye exmpiss stal alul lamel lo make ome proselyte; and when lae is male, ye make him twofold more the child of ludi than yourselves.

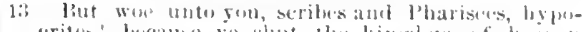

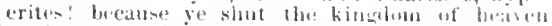

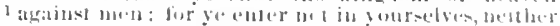
atslier se them that are (1)

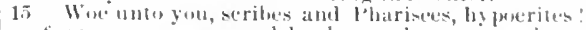

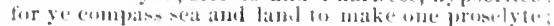

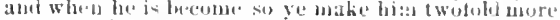
a son of bell than yeurselives.

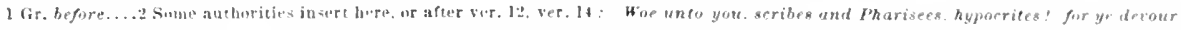

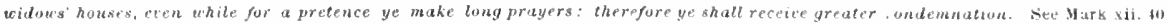
Luke גx. 4i....3 Gr. Gehenna.

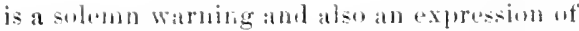
pity-alas for goul. (1x: T.) With thene e.ight 'wues' (the eighth given by Mark and Luke), comnl. six "woes' in Isa. ('h. 5, and five in

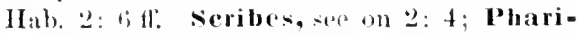
sees, see on : : 7; hypocrites, see un ti: :2; kingdom ot heavell, secen on: "̈. Our Lorel implies that the: Mesianic reign has alpealy begun, at he did even in 11: I2. Fe shut. Theoe roliginus teachers ollght to hives set men in general the aximplo of promptly and joyfully entering the . Iesianic kingarom, but they actually frevented of bers frome contering. Amainst men, literally beforemen Rev. Ver. margine, and so all English versinds before K. James. The image is at the prople at

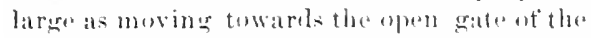
kingelons, and wn the point of enterines but

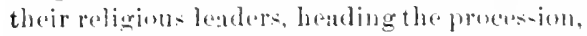

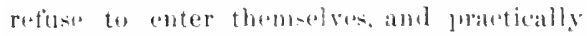
shut the gate in the penples face. (compe on 10; 1!.) They do this hy denying that the kinerdom of heaven is at hand. and striving to turn the puptular mind aw!y from the rising persuasiun that Jesus is the Mesulah (2t:9.15. 4if.), and from entering the Mosianice kingdom through penitent tith. They paraded themselves as leaders of the peoples while really ( IV eiss) they were misteaters.

1. This verse of ('om. Ver. is lere spuri-

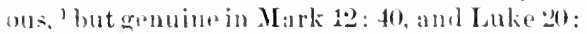
$4 \overrightarrow{7}$, sit that it wats aetually spoken on this ofereatsim, though not imeluded in Matthew"s report. Widuws, heing without a male representative in business, havealways been in A-ia spereially

\footnotetext{
It is wanting in tho earliest and hest cireek mantuseripts, ant reveralariy ver-ions, is ovidently unkmown here tultigen, and Eus, and Jerome, and was oluviously brousht in from Mark and Luke. lieing writen on the matrin of Hatt. by some student, and known ly subseruent cupgists to be a real saying of Jewis, it
}

exposed to fratud and other wromer. (Cimnje. Luke Is: : ; Aets b: 1 ; James 1: 2.7.) Toseize their property, eren their homes, is in other parts ot the world also a commonn practies of men who onmosend themiches loy "making lone prayers" (eompl. b: 7) as extraurdinarily devout, and threfore trustworthy. The ex-

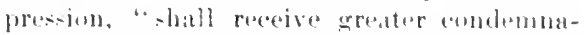
tion," suerests degrees in future punishument, a subject of very great pratetical imprortance. Soe lle Commentaries om Mark and Lulie.

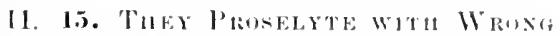

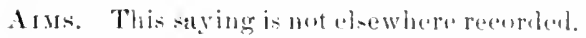
Woe unto you, ete., see un v. 13. IIyo-

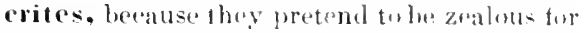
the promotion of the true religion and for the religions benefil of men, when lhey are really aiming mly to multiply partisuls, and aro making them not better, lut worse. Ve enme pass sca and laud, literally, the divy (lomed), as souften in Old Test. The hypurbulieal exprosion shows how zealous and atetive they weroinureler that weren a single Gentile mierlet luecombe a Jew. An inferenting axamplente groelyting eren beyomel the Tigris, a few

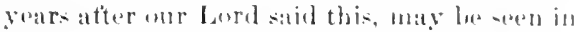

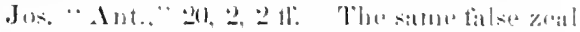
appearel afterward-in the Judaizers whe fird-

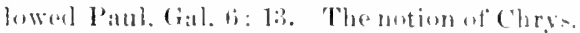

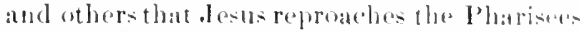
with thasmall results at their immensearelivity, is quite foreiern tuthe emmection. Its is sleaking not of suall resulls, hut of hat risults. 'Tu make ome proselyte. This worl is fomml essewhere in New 'Test. an? in

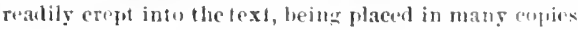
affor v. 12, lut in some after v. 13. Euth introluction

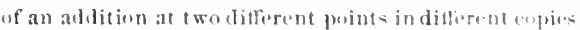
is mot jufrepuent. and shers light on the treatment of parallel passages ly students and copyists. 


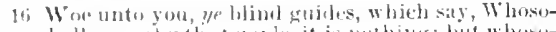

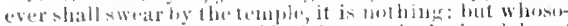

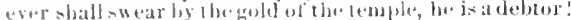

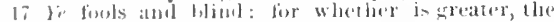

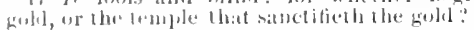

l) (t) sauctuery: as m ver.

A(ct-2: 10): (1):5) 13: f: but very often in Sirfl. It signitied originally an immigrant, a

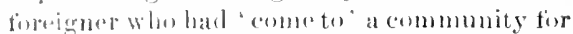
the purpose of dwelling there; this is its comanm lle in s'pl., English 'stranger.' By an " (us trancition it demoted a Gentile who berane a lew, which is its ue in Now Test. What is involved in 'makw' ome proselyte? Twe envine him that Jehovah the God of l.ratel is the only true God (Deuto $6: 4$ f.), and imlure him to be rireumeised and set out to kesp the law of Moser. (Exml. 12: 48.) Thome who were anvinesel, but unwilling to submit to this mpopular rite (Jos. "Ant.," 20, 2, 4). wre called "proselytes of the gate," as if not fully entering the city and becoming citizons, lut merely sitting in the gate; the others were called "proselytes of righteousness," rightens proselyten, who dis their whole luty. Alter the ceremony of arcumcision, the proselyle must of course give himself a therough puritication, as he would atter any other thorough defilement, before alproaching the altar with a saleritice. In later times, atter the lastruetion of the temple by Titus,

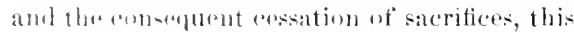
purtication of the preselyte was the final act, ancl eamo to be thon regarded as a spoedal rite, which by modern writurs is alled "prosolyte

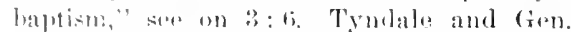
bave here "to bring one into your beliod," which is not a batel paraphatase. A pieture of a real proselyte te the true tith is guen in 1 Pot. 1:2-1. Talmor Bab. says that a

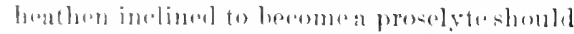

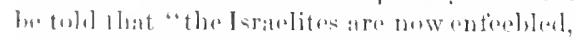

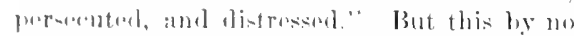
man- proves, as Wün. and othars atome, llat the Juws were never much given to proselyt ing. The attompl in later conturies to shorek the inflax of promelyber by speaking of the

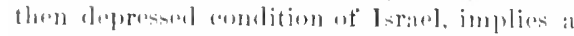

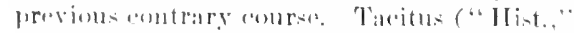

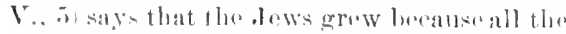
woret men lapt their nalional roligions and

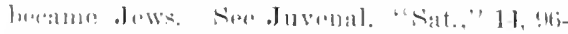

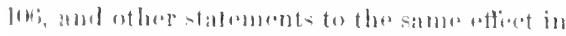
Wot., and comp). Edersh. And when he is
11. Wue unto you, re hlind guides, who say, Whosoever shall swear by the ' temple, it is nothing; but whosiverer sh:1l silear by the gold of the l teinple,

17 lus is a deluor. Ye fouls and bijud: for whether is greater, the gold, or the ${ }^{1}$ temple that hath sanctified

made, Rev. Ver., he is become so, or 'is become (a proselyte), as in $4: 13 ; 13: 82 ; 18: 3$; "made" was here a bad rendering of the Greek word, as it contiounds this term with the term 'make' that precedes and follows; it was an imitation of the Vulgate. The child, $a$ son (Wyelif') is the exact translation, as in $5: 9$ Rev. Ver. and 8: 12, ete. Hell is here Gehenu, the place of torment, see on $5: 22$. 'A son of hell' would be one having a hellish character, as a child is apt to resemble the parent (comp. on 8:12), and so suited to dwell in hell. This, then, was the ground of the woe; not that they zealously made proselytes, which was entirely proper if rightly done, but that they made them bad men like themselves, yea, doubly as had. These proselytes retained the escential faults of the heatheri, and took on the faults of the Pharisees. So some of" our "civilized" Indians are still savages, with the vices of civilization, and comp. the hathen converts made by sone lesuit misuionaries. In these proselytes the goud was more superticial than in the Pharisees-who often retained some roots of ald convictions-while the hypocrisy was not less derep. Pupils in error aud vice frequently surpass their tenchers. Very likely also some became proselytes for the sake of gain. Tet not all the proelytes of the time came under the eondemnation here uttered, f'or some of them were anong the early convertsof the apostles. (Acts $2: 10 ; 6: 5 ; 10: 2 ; 13: 43,50 ; 16: 14 ; 17: 4.17 ; 18: 7$.) other proselytes would naturally be very bitter against Christianity ; and Justin Martrr, after quoting this passage, says to Trypho (ch. 122), "But the proselytes nut only do not believe, but twofold more than you they batpheme against his name." Pruselytesare often mentioned in the Talmud with suspicion or contempt. I'lump.: "The popular Jewjoh fireling about them was like the popular ('hristian feeling about a eonverted Jew. Proselytes were regariled as the leprosy of Itral, hindering the coming of the Messinh. It became a proverb that no one should tru-t it proselyte, even the twenty-fourth ereneration." 


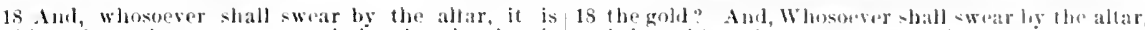
nolhigh: hot whosecver weareth by lbe gilt that is (1)

19 be fools and filind: lior whether is greater, the gift, or the altar that situctitioth lhe grift?

a) Whoso therelore balt swear ly the altar, sweareth hy it, and by all thiugs thereot:.

2I Turl whoro shall swear ly the temple, sweareth by it, and by him that dwelleth iherein.

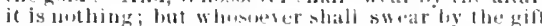

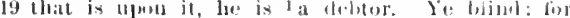
whether is greater, the gilt, on the altar that sancli-

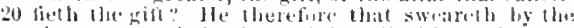

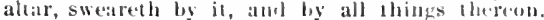
21 Amd he that sweiseth by the :iemple, swearedh hy it,

a Or, debtor, or bound.-1 Or, bound by his tath....? Ur, sunctuary: as in ver. $\mathbf{3 5}$.

I1I. 16-22. BY FoOLISII 1)ISTINTION: THEY FXCUSE THE VIOLATHON OF OATHS. This is tound in Matt. only. Is to the general subject of oaths, comp. on 5 : $333-35$. Ilere the Saviour eontines himselt to one point, viz., that the sieribes and Pharisees wickedly encourage the people to violate ouths, by making untenable and silly distinction; betwen cortain oaths as linding and certain athrers as not bindiag. Woe unto you, as in v. 1:. Y'e blind guides, see on li): 14. I relierious teacher who gives misleating instruction is strikingly represented ly a blimel guide. Our Lurd raes not in this eatse rall them hyperites, as in theother woos.

'The temple is here the naos, the sacreal house, see on 4: 5 . The oath by the temple would naturally be often u-ed, and so would be often violaterl, until anom dicl not teel very solemuly bound by it to speals the truth or keepan engagement. Then a new oath wat invented, by the gold of the temple, and this as being new was folt to be morobinding. 'This gotel would mean the and plates with which much of tles temple was eorered (Jos. "War," 5, 5, 3-6), and the trolden vessels of the tample (i, s, 3); probably also the eoin fiom contributions. Jus. states ( Ant.," 14, 7, 1) that (rassus touk from the tomple eight thousand tabents of gold. say ton million dollats. It is nothing. The Mishna on Vows (Nedarim, l, 3) speaks of rowing. "This saill be to me as the lamb, as the woul. as the tire, as the altar. as the temple. as .lerusalem;" and adts "Rabbi lebuda says, lt one says "Jerusalem" (i. e. not "as Jorusalem", he has said nothing." (Comp. Wün.) The seribes and Pharisees bad conformud to pupular custom and feeding by actually teaching that the old and common ath by the temple was not binding, but anly the now-tistrioned ath by the gold. The saviour shows this to be an absurd distinetion, since it was the temple that gave to this gold such sucredness a- to make it the natural subjeet matter of an vath.
So as to thre oled oath by the altar, and the new aath by the gift lhat is upon it. It was only the altar that made the gift a holy thinge, so as to render it natural that ment should swear by the gift. Ilo adds (s.20) that to swear by the altar inclueled swearing by the gift, tor the former suggested and involved the latter In like manner, the old and slighted aath 'by the temple' roally involved swearing by him that dwelleth therein, who grives to the temple jts sacrolness. The Jews would aroid literally taking in rain any name of Jehowah their fod, and whele swearing only by things assoeiated with hum, as the temple, heaven, ete. they inaginesl that they would not break the third commancment in violating such an oath. The Mishat on ()aths (Sliebucth, 4, 13) say's if one adjures others by beaven and by earth, they are not boumd; but they are busmol if he aljures them by a d. representing fonnai (Lord), or hy i, h,

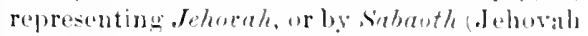
ot host-), or by any dirine attribute or divine natue. The Gemara on this passage of the Mishna explato (Wün.) that this i- because thesetrerns mus mean the divine leeine, while heaven and arth can be conceved ot as mere objects, without retirenee to thes Creator. This is exactly the notion that our I,ord beres condemos. Heaven and earth, when used in oaths, do suggest the Creatur. Sis the Mlshammodans will take many oaths without pretending to act aceordingly, but an outh lyु the koran they must keep. The Bobernian in "Quentin I)urward" glibly utters many profuse vaths, but when repuirol to sweir "by the throe kings at ("ulogne," and that with his face turued towards the east, ha forls boumel. Comp. above, "Ilom. ame Prace.", on

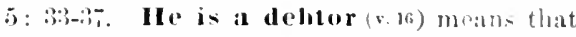
he owes what lae has thus solemnly declarol or promised, and must pay it - he is boumd by hisath (Rev. Ver. margin). Thesande Greek word is nsed in v. ls, lont Com. Ver., als so often, must needs vary the translation, and 
22. Int he that shall swear by heaven, ewearch by

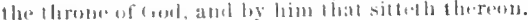

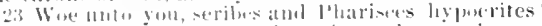
for yo pay lithe of mint and a anime and commin, and 2

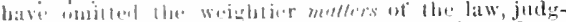
mont, num and fith ha these onght ye to have done,

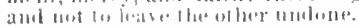

it fi bind subles, which strain at a gnat, and swallows at caturel.
22 and by him that dwelleth therein. Aur he that sweareth by the hearen, sweareth by the throne of fiokl, and bi him that sitteth thereon.

23 Woe unto yot, seribes and Pharisees, hyporrites! for ye the nint and 1 anise and cummin, and have left undone the weighiter matters of the law, justiee, and mercy, and failh: but these ye onghi to have lone, and not to have left the other undone.

21 le blind guides, who strain out the guat, and swallow the camel.

a Gr, anethon, dill,-1 Or, dill.

giveho is guily. 'That hath sauctitied, is in 1.17 the correct Groek text; in v. 19 it is that sanctifieth. The assimilation of the former to the lattor was a characteristic act of crpyists. Sio with the addition of "tools

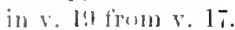

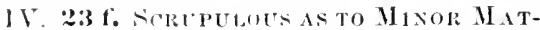

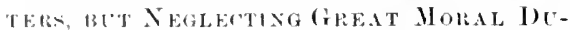
Tiks. Woe nnto you, rote. see on v. 13. The law repluired the Ioratelites th pay tithes of acrovaltural products, inclurting frujts (Lev, 2i:

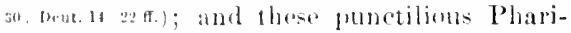
sese touk labius a titlo every product that was ralible and conlel br proserved. ('Talmunl.) ()ur Lord mentimus as specinens, mint and anise and cummin: on the formor aceasion he gare "mint and rue and

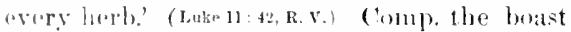
"I grive tifhos of all that l get." (Lake 18: 12, R. v. Simme ron gave tithes of what they

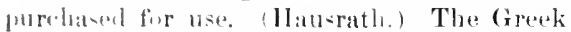

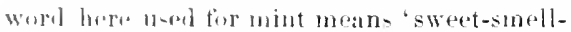
ing." thomerle the Groek also hat the word

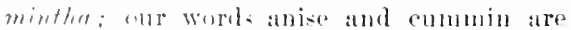
kormowel foun the Gresk. The lowes of mint and the senlo ol anise (or dill) were

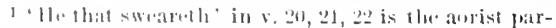

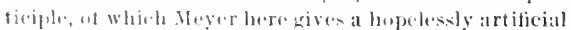
explanalin, and whith nome of the grammars treat sallifieterily it presente the simple netion of the

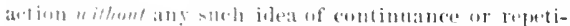

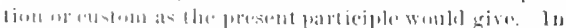

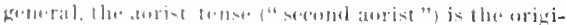

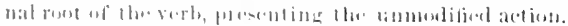

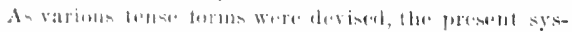

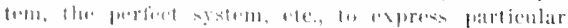

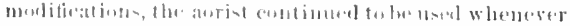

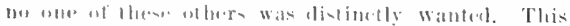

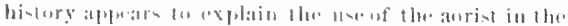

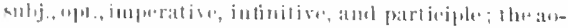

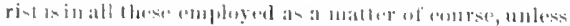

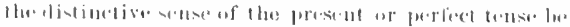

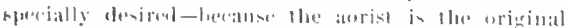

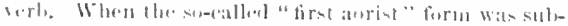

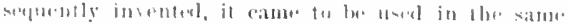

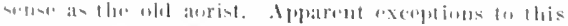
theory of the arist are betieved to be only aplarent. used both for flavoring food and as valuable carminative medicines; the seeds of cummin were used for the former purpose. Judgment, merey, and faith, $i$. e., good faith, fidelity (Rom. 3:3), the eommon elassical sense of the term. In Luke, it is 'judgment and the love of God.' Comp. Mic. 6: 8. The Aneriean Revises properly urge that not "judgment,' but 'justice, is the correct translation here and in Luke, though the Greek word is currectly rendered 'judgment' in v. 39 , and so rendered elsewhere. To render a Greek term everywhere by the same woud is very desirable, but not always practicable. The weightier matters of the law. We bave seen (on 22: 36) that the Rabbis called some commandments of the law weighty and otlers light. Jesus recognizes that such a distinction is legitimate, but draws the line very differently from their teachings, for he makes fundamental, ethieal, and spiritual duties (comp. Lulie) the woightier matters. Comp. 'one uf these feast commandments.' (5:19.) As to the suleriority of the ethical to the ceremonial, complo on $9: 11$ and 12: 7 . And not

It the aurist suljunctive is sometimes naturally translatel ly the latin future perfeet (as some would do in v. $1 i, 1$ s), this is merely suggested hy the nature of the case, just as when the aurist indieative is translated by the pluperfect. So when the aorist parijeiple denotes an ation antecedent to the time of the principal verb, this in moly through a suggested contrast to the present partieiplts, which would of neeessity give an action contemporaneous with that of the prineipal verb; and in a case like that befure us the suggestion of such a cuntrast is exeluder by the nature of the ease. Comp. on 21: 1s. In the indieative mood the aorist hears lhe same rolation to the imperlect that it bears in the other mouts to the present. It these views of the arist be "wrrest, there is no iceasion for the various artificial detinitions of that tense which are given ly many granmarians and eommentators, -In v. 21 the aorist participle for "Awelleth', given by many documents and wlitors, is probably an alteration of the eopyists to wake it correspund out wardly to the tense of 'sweareth.' 
25 Woe unlo you, seriles and l'harisens, hyporices!

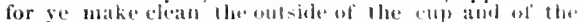
plalier, but within thes are full of extorlion and excess.

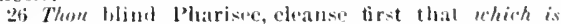
within lla cul and platler, lhat the outside of them may be clean also.

to leave the other undone. The wh Enelish plural use of 'other' here creates momentary difticulty, as if referring to a singular, and them is no propriety in retaining it. Our Ianl beautifully anlapt his two expressions. They worestrict as to the slightest externals, and left undone the ethical; he salys that the ethieal duties onght to be dene, and the others not to be neglected. So Lake 11: 4: and conple above on l: 7 . He does not forbid the tithing of herhe, but sets in strong contrast with this scrupulesity their neglect of great momal dulies. Yo blind guides, ats in v. Hi, lataling the people utterly attray by false teathing and boul bxample. The image

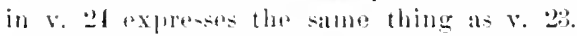
The lalland speaks (Wet.) of straining wine in order to remurer minute anclean creatures. (1.ex. 11: 11.13.) Thr Buldhi-ts in (rylon strain their wine for a similar reasun. Grats sip at wine, ant on may fall, into it. Trench (on Rev.) tellsof a soldier in Morocen who alwatys placed the eml of his turban ower the rassel from which he dratnli water, avowedly for the purpore of straining out the guats, "whose larvar swarm in the water of that woutry."

The guat and the camel are put in enutlatet as extrenes in regated to size; the latter is obviously a strong haperbule, for the camed wits the larment animal fantiliarly known to the Jews. (comp. on 1!: 24.) ()herre that

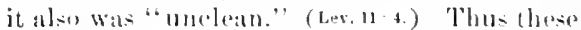
perams carefully strain out tho smallest ereature, and swallow the latrenet ; they arto very scrupulous about the minutent matters of ceremonial obserranes, and then nestect the highent ethical duties enjoind by the law. The translation strain al is generally supposed to have been a more mi-print, in the origrinal edition of $K$. Itumes version, for 'strain out,' which had ben given by 'lyn., Cran., aml Gen. The Greek means

1 This was nol undersomel, and mang mamucripts have 'extorlion and iniguity, and several loading early versions have "pxiortiun aud uncleanness"; loth are obviously alonges to remove the dilliculy, and, for once, the simplification did not pass into the Textus
25 Woe unto you, scribes and Jharimen, Jypueriqu:

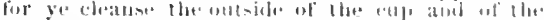

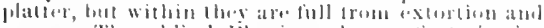

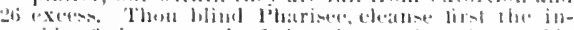

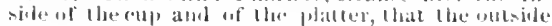
thereal maty becone clean alow.

'thoroughly filter,' theroughly strain, applied to wine in Amos ti: 1, and lare to that which is remused by tillering wime. Alford thinkis that the K. J. revisers purpuely gator 'strain at,' meadning 'stratin (thre wille) at the

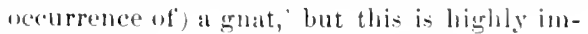
probible.

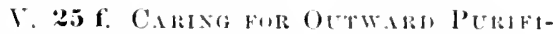
"atur Rathel THAX fol: The MoRAlitr. Comp. What Luke gives (11:34 tr.), ats sprien some time earlier. Woe unto you, ate., ste an $\mathrm{v}$. $1: i$. Of all the re"quirements of the law, purifieation wat that on which the Platriapes reene to have latid most stress; comp. on 15:2. There is luere: regular progresion, (nathe, tithes, purifications. They were careful almut not only the aletual cleaning, but the ceremonial cleaning of the cup and the platter, Mark $7: t$. Platter is in the Greels a rare werd, denoting a sidedish, seme delicatey sed on the side-talle, and only hamber to the gute-t, and derivatively the dinh used for such datinties. Full of from lies. Ver.) extortion and eacess,

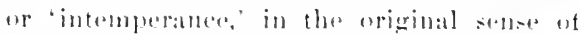
that tem. The enetents of the ("up) and di-b, namely the wine and liond, are the product of exturtion, and the eup and dish are filled in couserfuence of droire for excess in eating and drinking. The innge seement to clunge slinhtly, the full cup and platter loeding due in one sense to extortion, and in inuther twexcess. ${ }^{1}$ Thou bhod Pharisee, not new reproatehent as blindly leading others antray (v. 16, 21), hut as blindly going atstray liminelf. Cleanse first that which is within. Let the comtents of the eup and dish ba the fruit of lonest industry amel not of exlortion, and be used temprerately and not in exeres; then

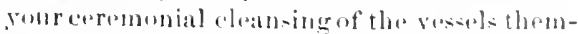
selves, will be real, and aceptable to froll. Comp. on t: 8. May be clean; Rev. Ver.

liecepolus, So, also, some themments omit the propesi-

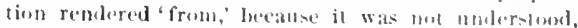
and the carly English versions fail to tramslate it, giving simply 'full of,' which is correct in Luke 11: 39 , and below in 5,27 . 
27 Wre unt you, scribes and Jlatrises, hypoerites!

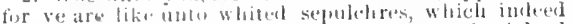

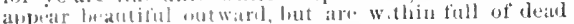

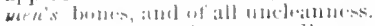

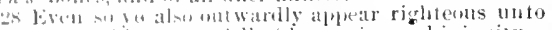

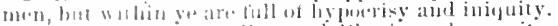

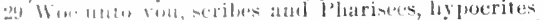

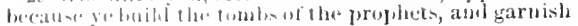

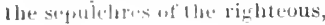

27 Wo unio rou, scribes and Pharisees, hvpocrites! for ye are jibe unto whited sepmldires, which outwarily appear beautilul, but iuwardly are tull of

of dezel men's lones, and of all uncleanness Even so ye also outvirily ajpear righteous unto nen, but inwarlly ye are liull of hyporisy and iniquity.

29 Wre unto yul, seribes and Pliarisees, lypoerites! for ye build the sepulehres of the prophets, and moly beome clem is the pasct meaning of the Cicuris aml suits the connecetion.

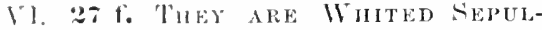
(11:Es. ('mmp. Luke 11:44. The transition fino outwall and inward purity of vesecels to molwarl and inwart persomal purity, is naturill and immeliate. Woe unto yon, ete. serem $1,1:$. Whited sepulehres. Tombs ot tha bother class aluot Jerusalem were ares, or artiticial chambers eut in the linesome rowli. (28: ait.) Tho fxterior of these was whitrwallal, mainly to prevent persons from tomehing them unawares and thus beroming unclaall Num. 19 16), but also for agreeable alp-

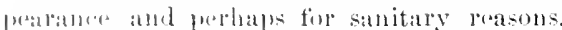
Thr. Mishat sates (shekalim 1, 1) that on the

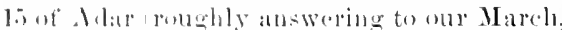

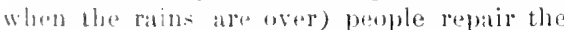
rouls, and puldie baths and otler public werks, and whinasth the tombs. The Jeru-

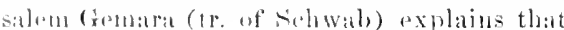
thi-i- lonatian the rain may have washed att the lime. The Talmud also represonts (lierhti.) that sometimes thro whitenod the whele lomb, in other cases made on it the tigner at a lume or bumes, and ald that

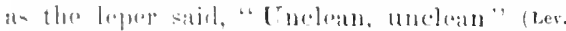

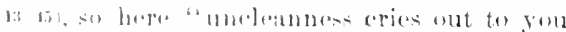

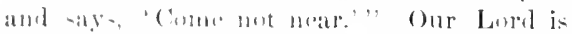

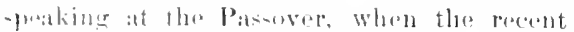
Whitoning wolld low very noticeable. Which appear beatiful outward, not simply through the whitewa-hing. lut arehitestural

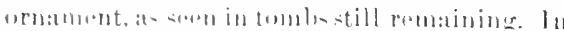

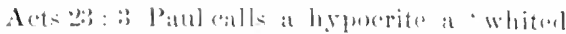
wall. Imol of all umeleanores in dolivale

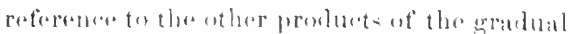

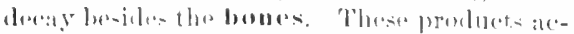

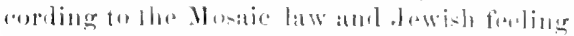

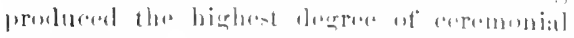

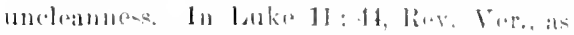

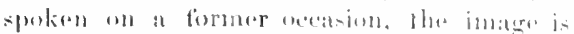
somewhat dislierent, 'ye nre as the tomlss which appera not. and the mon that walk orer thens know it mot.' It is likely th:it the masses of the pouple buriod in the groumal, at we commonly do, and as is done with most of the Jews now dying at Jerusalem; while the sepulchres in the rocks would correspond to our vaults and tombs above ground, though much oftener employed. The different Greek terms in Matthew and Luke do not suggest any practical distinction, for that of Luke is the sume as the second term below in v. 29, and as in.Juln 11: 28. In v. 28, iniquity is more exactly lavessness, anomia, violation of law, asin $7: 23 ; 13: 41 ; 24: 12$. Thisword is not used by the other Gospels, but was a natural term firr a gospel addressed especially to Jews and for Paul, while Jobn particularly needs it in 1 John 3: 4. Adikia, 'iniquity, or 'injustice, is not used by Matthew, but several times by Luke, Paul, and others, and Matthew bas its aljective in 5: 45, and its verb in 20 : 1:) Are full hele represents a different word from that of $v$. 25 and $2 \pi$, but our language eannot conveniently express the difference, and it has no practical importance.

VII. 29-36. THey Resemble THeir WICKED ANCESTORS. WHO SLEW THE Propinks. Comp. Luke 11: 47-51, probably spoken some montlss earlier, see on $23: 1$. Woe unto you, etc., see on v. 13. There is no practically impurtant difference between the sepulchres and the tombs. The word rendered garmish, means literally, adorn, 'ornament, as in 12: 44; comp. 25: 7. The prophets, - - the righteous. (Comp. 10: $41 ; 13 ; 17$ ). In 1 Mace. 13:27-30, is lescribed a grand tomb which Simon the Ilacoubee built for his father and brothers. Inepluns tells us ("Ant.," 16, :7, 1) how IInod louilt a marble momument over the tombs of Darid and Solomon, to atone for his altemyt to plunder them. It is very doubttial whother the elaborate structures on the lowar slopo of Olivet, somtheast of the aity, which are now called "tombs of the profluets," have any proper claim to that name; hut thryappear to date from the time of the Ifrouls (Robinson, Thomson), and may thus give an idea of the tombs referred to. One of 
in That mon you may when all the rightoous hlowd

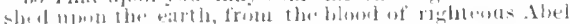

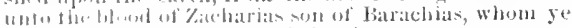
slew betweru the womple and the altar.
35 cily lo city : that "pon you may cume all the rightenus hlooi shed on the eath, from the bluml of ibel the righteous unto the bhend of Zachariah son of barachiah, whom ye slew between the sanctuary resolative (Joha:3:2), as having plenary atuthority in the whole mattere at humalu salva-

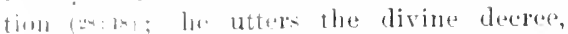
which in the -imilar passonge of Luke (11: 49)

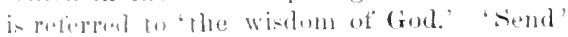
in the propent fon-e, becaluse the mission is arrallent and on the point of beginning. $\| \%$ refine, or therfore, because they are like theip tathars, allal will treat ford's mesongers a-their fathers did, he sends them mesongers

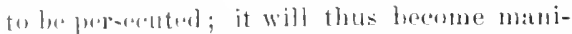
dietly right that threy should be held guilty for therr andesters sin and their own. (v, 35.) fioll of couredes not wi-h nen to sin, but hotosts thenl, so ats to show to themselves and older-thoir real character, and vindicate the justinot their punishment. Wise men, and scrilus atre. Jowish teluns, uned because of what fureceder ( $x, 2$ and $23: 2,7$ ), "wine men' being a (a)monn alprellation ot the Rabbis. Jut they may bo fultillod in apostlos and evangelintsulso (cos) $19: 50)$. The astinction be twese thens should not here be insisted on. Tha derow to send, and their tratment of the frorons sont, maly inchule all the divine moseligers lo that erelieration, from John the bitplist to the destruetion of Jerusalem. (x, :si: :4:34) Jusus intimates his knowledge that thry will not only kill him (21:38), but

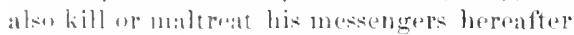

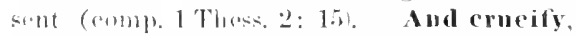

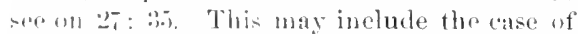
deste himalti lt is a tradition that Peter Was reruejtal, and Simeon, a brother of Jesur. sume of them shall ye scourge in your symarogues, as he had already foretold to his finluwars. (19 17.) And persecute them from city to city, ommp. 10: 28; Acts : :

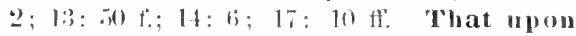
you may come is the livine purpenes, not

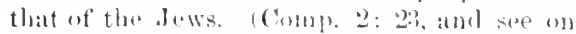

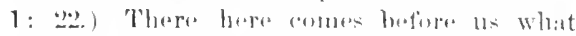

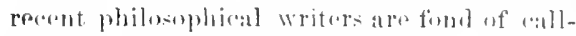

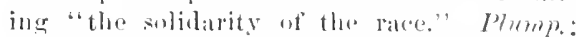
" Ilen make the gruilt of past ateres thes own,

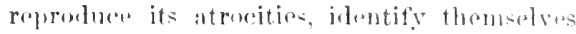
with it; and so, what swoms at first an athitrary decree, risiting on the childronthe sins of the fithers, becomes in stach cates at rightems judgment. If they repent, they cut off the terrible entail of sin and punishment; but if they haden themserves in their evil, they inherit the delayed punishment of their fithrers sins as well as of their own." The Jewish multitude afterward voluntarils tonk upon thejuselves and their children the blowd ot Jesus. (25:25.) Notice here the solemn threefold repetition of 'blood.' shed is prisent tense; the totality of the righteous bland is conceived as in the process of being shad, the whole past and present tirown together.

Zacharias, the son of Barachias. There is here a well-known difficulty, which various theories have attempted to remove. (1) some think that the prophet Zechariah is meant, who was son of Berechiah (Zech. 1: 1) ; but we lare no aecount of his being slain. (2) some Fathers supposed Zathariah the fatherof John tho Baptist to be meant, and had traditional struies of his being killed for asserting the perpetual virginity of the mother of Jesus; but all this is without historical foundation, excessively improhable, and very likely suggested by the present allusion. (3) Aug. and some otbers liave supposed that our Lord is medicting the death ef Zachariah son of Baruch, killed in the temple during the subsequent siego of Jerusalem, as described by Joselus. ("Mar," 4, 5, 4.) But tbetemple is there only hiom, which means the general onclosure, Baruch is quite a ditferent name flom Barachiah, and our Lond is evidently spaking of things already past ('ye slew'), while this erout was forty rears later. (4) In 2 ('hron. 24: 20-2.2, we read that a priest named Zachariali was stoned "in the eourt of the house of Jehovah." II dying words are "fuits in aceordance with the reference our Lorel here makes, "Johovah look upon it and rertuire it," and correspond to the other case if Abel's blood. (ren.4: 10.) In the ancient Hulrew grouping of the books, as in Hebrew Bhlor now, the Chronieles seem to have stood at the end; so that from Abed to this Zachapial, would include all the cases from berinning tu end of the sacred borks. All these ciroum-tances fit exactly. Both l Je Jerusalem 
Bu loholil, yomr heruse is left moto you desolate.

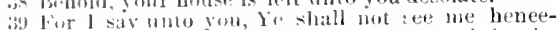
forlh, tull ye altall ray, Blensod is he that cometh in the nasue at live loril.
38 and ye would not! Behold, your house is left unio 39 yet idesolate! For I say unto you, Ye sliall not see me henetiorth, lill ye shall say, Blessed is he that cometh in the name of the Lord.

I Some ancient authorities omit desolute.

Othres would suppose that he spealis of the frofuent divine wish in jast generations. As a hen gathereth her chickens. This beatulful complarion is the omly pasage of

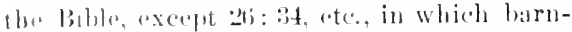
Fard timlis are axpesty mentioned, but see probable allusion in l'sa. $17: 8$; $91: 4$; Jer.

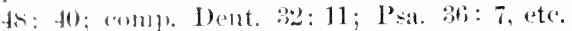
Wilkinson says they are not represented in the old ligrytian paintings. Yet they are now axtranely common in both countries, and mu-t hatro leen on from arly times. Them wa- - imply mu acasion for more froquent reterence to thems. Proselytes are spoken ol in tho' Jalusud ( Wün.) ats taking slielter moder the wines of the shechinalh. How often would I. . and ye would not. 'I' and "ye' are not separately axplessed in the Ciredi, and so ranmot be talico as emphatic. The redirence here is to the divine wish and

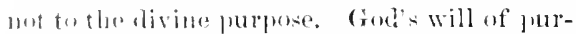

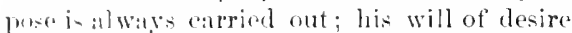
aften tats, because the frese will of men will not yola: emone. on b: l1). Your house is Iett, prosent tense, is now hoing lett.' The cill, which is the house ol dwelling of thes prople, is now in process of bering left deso-

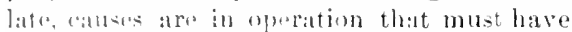
thi- ronlt. Finm think that 'house', means the eromperather than the city. For introdares the pront that this jureses of leaving them dresolate is groiner on, viz., in the fact that the Mrsiah who has so ottun wished to gather and sive, is now on tho point of turning away. Yo shall not see me henceforth. Atiertherestracetion he was not seoen by the

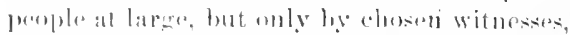

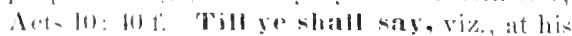

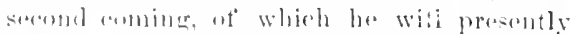
spork tully to bis disciples (ch. 2t and 25) it the trimusphal rottry (21:9t somes said this. hut

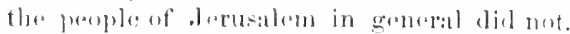
At the secomel amuing all will sinerroly.

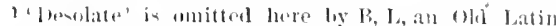
oppy, and a quotation in origen. In lanke 13: 35 it is omitud ly most doements, ant its chiof supports are there" Western." It seems pretty chetr that the woril is spurious in loke and genuine in Natt., as this sup-
}

though some most unwillingly and sady, reconnize him as the Messiah, that cometh in the llame of the Lord, 24: $30 \mathrm{f}$., comp. Rev. 1:7; Phil. 2: 9-11. From Rom. 11: 25 ff. we may bope that among those whothen joyfully recognize him will be many Jews.

\section{I1OMILETICAL AND PRACTICAL.}

V. 14. Origen: "Two faults. 1) They do not thenselves enter the kingdom. 2) They do not suffer those that are trying to enter. These two sins are naturally inseparable; he who commits the one camnot refrain from commiting the other; be who refrains from the one is sure to refrain from the other also." - What an evil thing it is by our teaching to shut the gate of salvation in mon's faees; what a blessed thing to open the gate, and lead men to enter.-V. 15. False religious teaching is very apt to make the pupils worse than the tacher; 1 ) more extreme in upinion; 2) more sure they are light; 3) more mulesitating in action ; 4) more une laritable to those whothink otherwise.-Ortaen : "To the son of Gehenna, Christ's teaching gives the right to become the elild of God." (John 1:1:)-T. 16-2.2. Wiscrimination is an indispensable clement of somnd judgment, in the sphere of thought or of action; but false distinctions are onecit the eommonest means of self-decention. - The fact that oaths wear out is not a reason for inventing new ones, but for retraining firm onths, save when med on extraordinary oceasions and in a reverent spirit; complon 5: : A. - V. 17. The Saviour atlls these men "fools, not withstanding what he said in 5: 2.2. He intullibly knows them to be fouls, and he says it with perteetly right aims and feclings.

T. 29. The centre of gravity, even in the Musaic system, lay in the ethical and not in the reremmial, and still more is that the case with Christianity ; but even apparently slight matters of extemal observanee, if divinely

position aeeounts for all the phenomena. W II. omit it in llatt. also, plateing it in the margin. But we have fouml various instances in whieh $B$, with some other doemueuts, must be regarded as wrong. 


\section{CIIAPTER X XIV.}

Al) Jesus wenl omt, aml departed from lhe lemple: $A$ and his disciples catme lo him for lo shew lim lae buildiugs of the temple.

enjoined, should by no means be neerleceted. -

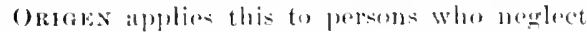
wholesome intruction, and are only for rhetorical ornaturent; comp. I Cor. 1: 17.-V. 2f. Blind guides. Corters. "For if for at blind man not to think he need a gathle be extreme nisery and wretchedness; when he

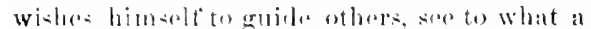

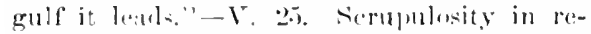
ligions aeremonial atumet ateme for extortion in business or for indulgande ot appetite to

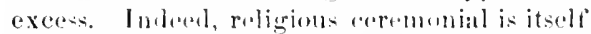
unatereptable to tiod when performed by the immoral. 1 Tim. 2: 8 ; Proy. 15:8; 21:27.-

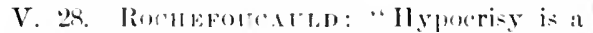

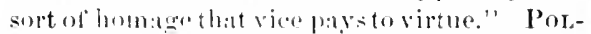
LOK: "ll" wits a man wh" stole the livery of the court of hestren to serve the devil in." -

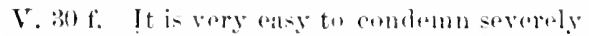
the miscomitur af others, while seretly guilty of escentially the sumes in. But "(rod is not mecked," (ial. 6: 7. Hexir: "The deceitfulness of sinners' hearta appears very much in this, that while they gor down the stream of the sins of their own day, they fincy they should have swam angato-t the stream of the sims of former diags: that if they hath had other peoples's oppertanities they would bare improved them more lathlu!ly ; it they had been in other peoples temptitions. they womld have resistal them more vigomelng; when yet they improve not the oppertunitios they have, nor resist the temptations they are in." -V. :32. Filling up the measure. 1) In one

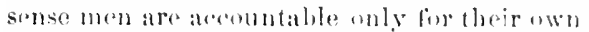
sins; "the soul that simmoth it shall die." Ezek. 1s: 4. 2) Yet all mensuther the consequences at the wrong fing of others-ancetors, precent lindred, rulers, neighbors. B) Human wickerlnese geses on increasing in line of deseent or of uther relation till there eomes at time of reckening, till the full meisure of guilt werthws in destrution. whe only eseape is in really turning from the sin of wickas ancestors, so as to interrupt the tran:misson of wickedness and guilt; yea, in turnine from all sin to the sin-hatiug and sin-pardoning Ged.
1 Ind, lesus want oul from the lample, allu wat going on ltis way and his disciples came lo loim lo

21: 1-36. DESTRUCTON OF JERUSATEM

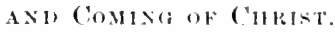

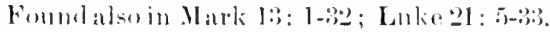

Our Lural' last publer disedurso has now been endrel. Tho day is probahly Thesdaty of

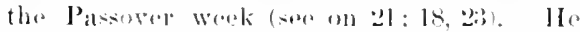

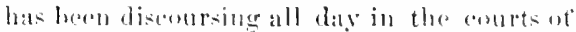
the templn, ambl betere turning al wa he draws in-truction form the widow's tonching gitt to the sacred treasury. (Nark 12: H: Luke:21 1,) IJ then latres the temple, and somms noper to hatre entered it again. In this tinal departure it was very natural that his thenghts should dwell on the impermling destrution of the temple and the aity. Moresurer. at there is no sufficient reason for depating from Matthews order (comp. on e:? : 1. 1:3), weses that ho harl just before prodicted the destruction of . Jerusilem and his own future coming.

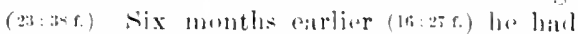
derelared that he would come aterin in the erlory of his Father, as the sovereien .Judere of mankind; and that some then present would live to sor him "erming in his kingdom." We therefound it neecesary tounderstand that the proticular coming to which this

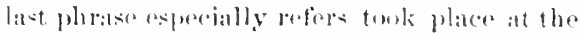
destruetion of Jerusilam. which made Christianty ampletely and manitestly distinet from Judaiom, and extallisherl the Mresianie kingdom in its permanent present state. The prealiation thon hriefly made by and Lord is now more fiblly unfolded. It fir-t declates in leaving the tomple that it is goving to be amplotely destroyed (r.lft): and then, sitting oll the Jomnt of (ylives, lar gives the great discourse of eh. 2t and 25.

This disentersertainly foretalls in the out -

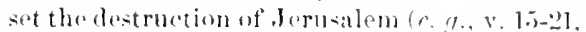
v. 34) ; and in the conclusion artainly forttells the final eoming of anr Lord, with thes general judgment of mankind and the resulting permanent atate of the gond and the bad

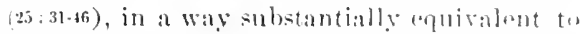
the predictive deacription atterwards ariven

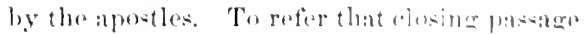

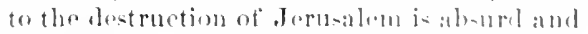
imparible. So then the disconrse begrins 
with the dentretion of the temble and aty, and mol- with the tinal anding to julgment: buw Jum it make the transition trom the borm.r. to the latter tupice? Every attempt to

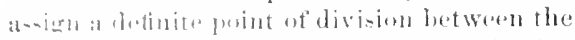

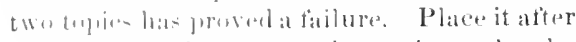
v. 2he sibyine that we to that point only the tirrmer topic is meant, and after that proint

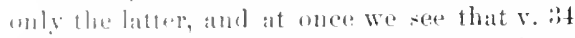

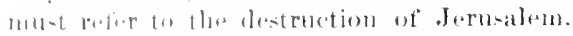

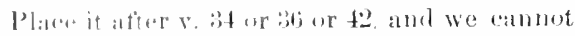

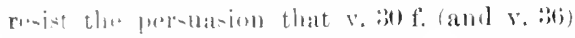
mu-t refore the flual coming for judgment

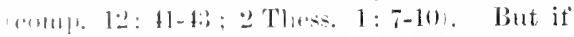

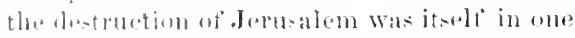
semer a comile of the I ard, why may we not sulpose that the transition from this to the final combing is gradual? Then mueh in 24 : :-3it maly be tation a- referring both to the former atmil the latter tope, while some of the (xprumin- maty retior exclusively the the one or thu othere. In $24: 37$ to $25: 13$ the earlier

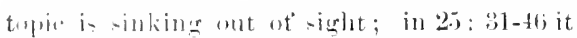
ba- comblutaly disalperared, and nothing is in view hut the final combing to julgment. (Lake and Mark atro paraled only as far as 2t: 4.2.)

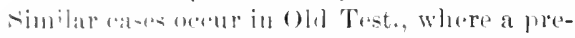

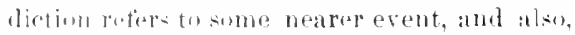
ly tyoneal rolation, to a kintred event in the

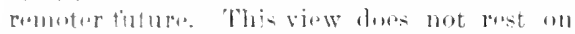
the "rud" motion of a "double sense" in

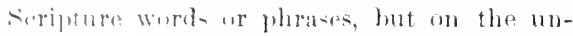

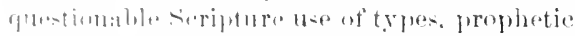

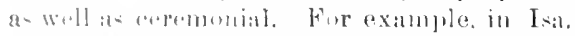

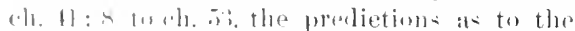

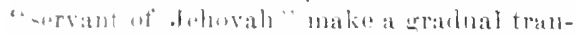
sition lom laraes to the Mesialle the former

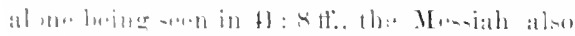

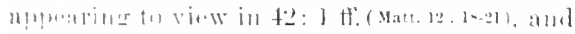

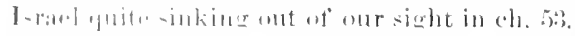

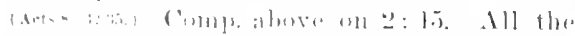

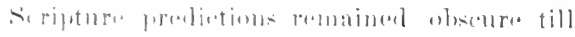

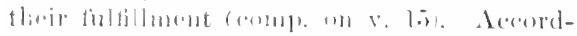

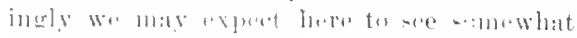
elearly the folltillanent in the destruction of

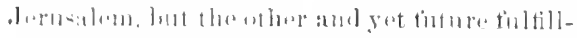

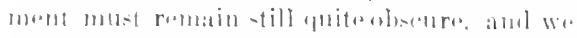

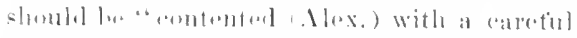

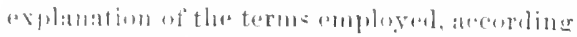

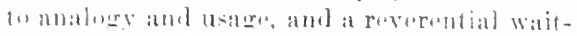
ing fin ulterior disclowere ly the light of divine provicence shining on the word." Sime zealous students of prophery have brought reproach on the seripture by their lack of moderation and reserve in the interpretation. It should be frankly conceded that grave difficulties attend the interpretation of this discourse in any of the methods that have been suggested. The view above leseribed is believed to involve fewer difficulties, and to yield better results, than any other thenry.

$1 \mathrm{f}$. 'The temple is here hieron, the general saered enclosure, see on 4:5. Jesus went into the Court of the Gentiles and the Court of Isratel, but never into the eentral building (noos) and the surrounding Court of the Priests. (Comp. on 221: 12.) The elause 'from the tomple' stands in the Greek (correct text) ${ }^{1}$ between the participle rendered 'went out' and the verl, 'was going, and could be connected with the latter, is in Com. Ver., but is more naturally eonnected with the former, as in Rev. Ver. The preposition 'from? makes the temple the print of departure; the other expression, 'going out,' shows distinetly that he had heen in the temple, which would be latin from the nature of the ease. (Comp. on 8 : 1ti.) Wus going on his wal (Rev. Ver.), doubtless returning towards Bethany, whence be had come that morning $21: 17 \mathrm{r}$; Luke $21: 37)$; and the disciples interrupted his progress to show him the buildings of the temple (hiem). In Mark (13:2) they are exprosely called 'great buildings,' and in Mark and Luke special attention is directed to the vast "tones" employed. Jusephus says ("Ant,," 15, 11, 3) that Herod built the sanetuary (mos) of stones that were "white and -trong," probably meaning a hurd variety of white limestone still much used in Palestine, and that they were about twenty-five cubits fong, ciglit in height, and twelve in breadth, or in onr fiset about forty by twelve by twenty, which is even larger than the stones wow found in tha southern angles of Herod the Great's unter wall. (See un 21: 42.) In "War," 5, 5, 6, Jowphus even says that some of the -tones were forty-five cubits long (eighty-five firet). Doubtless the immer walis also, and pillars of the colonnades (see on $21: 12$ ), presompol very large and 'beautiful' stones.

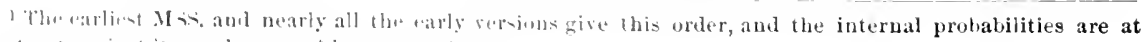
beast wot atritiont it; s.s there need be no question. 
"And Jesus sajul unto them, see ye mot all thes.o

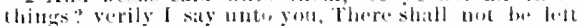

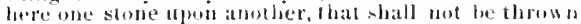
down.

3 Aul as hir sat toun the monut at olives, the disciples calme nula him pirately, satying, Tell us, whin

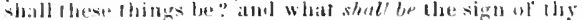
entuing, athd of fhe end of the world?

(1,uke 21, 5, Bib. Vu. ver) It is douldtiul whether any uther pile of sicred buildings on earth lats bean so valst or to eomtemporaties so imposing as Ilerod's temple. Talmud bab. sars: "Ho that never sill the temple of II rod, never saw a fine building." Julie's

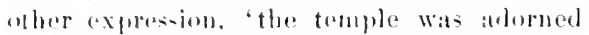
with hoilutilul -tonces and otterings' (Bib. In.

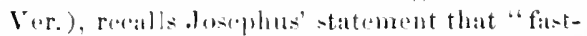

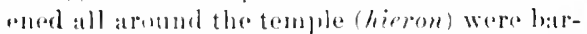
baric spoils, and all thres King Herod oflered 11p, arldine whaterer be touk from the Aratbians alkir." (comple. liev. 21: 20.) There were douldedes also many votive tablets, and wher batutiful objects uffered by the people,

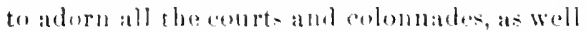
as thr contral satereal huileling. Tareitus says ("Hist.," V., 8, 12\%, that if was "a tomple of

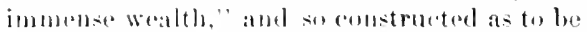
"an expellent fortress." (our Lord secmeto have been enutside of' the tomple when his attention was alteal loy the disciples, lout this lares not show that they were observing only the stoues of the outre wall, for the central building rose high above tho ander acourt and its wall, and wats vi-jhle to a ereat distaner.

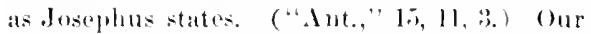
lend's language in $r$. 2 shows that he is roforring to the entire strueture. Ind Jesns said, cote. But he ansurered and said, is tha rorrect (ireek text. The subseruent insertion at the name 'olesus' is a thing of trepuent ace "urrence in the manuseripts, eomps, w11 11: 11 . see ye not all these things? This eallowl their attention to the vast and solid mass af buildinge, by way of proparation tor the statemont that all would he overthrown, a thing which then semed in the hirhest degree unlikely ; indeed. we know that Titus fully moint to proserve it. (Jos. "War," i, 4.) Thre shall not be left hereone stone npon another. So also in Mark and Lule. Some stickle at the tiotet that several stones of llerul's onter wall now remain in situ, $e$. $q$. at the Jewe place of wailine, and at the sulutheast and solithwest corners; indeed, at at the southeast curnor the recent Euglish ex-

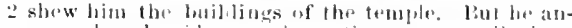

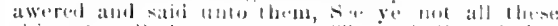

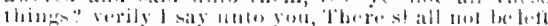

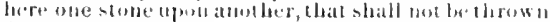
down.

3 Anil at lu, sat on the monnt of thives, the disci-

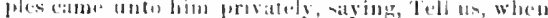
shall these things bes" and libal shall bet the sigh ot

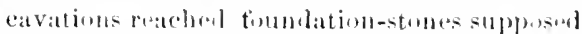

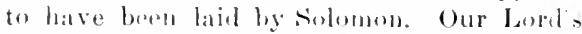
laluguage is of eour-e pepular, and surle an

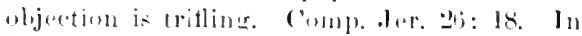
fiet, it i- wouderful how literally the predicfion was fulfilled, lor very seldom was a great

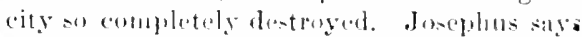
("War," $7,1,1$ ) that 'litus finally ordered the whole eity and the sanetuary to bo razol to its fommbations, except throe towers and pitrt of the western wall, and that all the rest "it the eits wall "Was so eompletely leveled with the gramal that therewas no honcer anything to lead those who visited the spot to believe that it had ever been inhalited."

3. Going on towards Betbany, our Lord climbs tho stepp bate of the Homet of Oloces sere on $21: 1,17$. Malf way up the walling path ane is alut to forel tired on a bot altremone at the time of the Passover, and to salt himselt an some ledge of limestune rock to rest. There he find-himself "overatgatinst (Mark) the site of the temple, at abuet the same ireight alose tha ravine of the liedron. Our Lomel may have sat hero, or perhaps on the summit, where he would look down upon the whole eity. The place at which some days before lie "saw the eity and wept oxer it" (tuke 19: 11. Rer. Ver.), wat alunt halt' a miles further south, on the riding road from Bothany. The time was now towarts night, and the avening sun kindlat the white stone and andet of the temple buildines into splendor. The disciples. Mark says (13:3), Prer and James and Jolu and Amdrew, whowere? the tirst company of the Twelve soe above on 10: 2), and three of whom had bon with the Lord on the Monnt of 'Transtiguration. (17.1.) This fact might havo bed these particular ulise ciples to suppose that he womld tedl them what he would not toll the rest of the Twelse: and IIathew's general exprocion mient ho easily restrietent to the four mentioned by Mark. Or it nua be, as Euthym. sluerests, that "they all came to learn. lint tour asked, as lanving greater fredum of acers." Privatedy, so also Mark, as opposed w the public 
4 And Jisus answere] and said nnto them, Take beel that no man daceive you.
4 thy ${ }^{1}$ coming, and of ${ }^{2}$ the end of the world? And Jesus answered and said unto them, Take heed ibat

I Gr.presence...2 Or, the consummation of the age.

disconrses he hatd been giving all day in the temple. J dews would ot course refrain from apeaking plainly in pullice ot his future eoming as the Mesciah, when he hat not yot publuely decelared himselte to the the Messiah. And it would have been dangerous (Mald.)

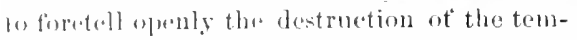
ple (ompl. John 2: 20), which in the ease of Stephon was reckoned blasphemy. (Acts 6:1: 8 .) When shall these things be? So Mark and Lulis. Tho prodiction that the entire temple wenld lot thrown down reminded them of previnus prendictions that he would come

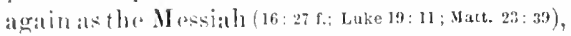
for they might well suppose such an utter destruction would acenr only in eonnection with the estallishment of the Messianic kingdom, which many. Jews helieved would be attomked by mighty changes. So the disciples privaldely inguire ats the the time of his pronised coming, and the sign of it. The sign of thy eoming, (parousia), presenee (Rev. Vor. margin), as in 2 Cor. 10: 10, or 'arrival' ats in the phrase 'by the eoming of Tilu-. 22 Cor. 7: 6 ; the ifea is of not morely atriving lut then romaining present, The worl sugerets (Ewald]) that. Jesus will come and stay with his penple. This peculiar term is used fur the seerond onming of Christ four times in the elhaptere ( ally by otumes, Paul, Peter; also in 1 John

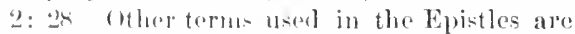
manitiotation, revelation, appearing, coming, day. The werd 'thy' has a rertain emphasis in the (iverek. II has sulken of the Messieth's omming $(23 \cdot 39: 16: 24)$; they are satisfed that this means his comping. And of the end of the world, or, as the Groek exactly means,

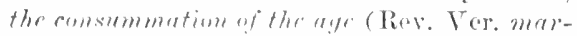
gin), ero on l:3: : ence to any sueb idra as that of the destruetion of the: material universe (kosmess), lut only the consumbation and tormination of the present aiom, ager, or state of things. A common lowish comereption was that the apr- pearing of the Messiah would close 'this age, and introduce 'the coming age'-these phrases often oceurring in the Talmud. The disciples would easily transform the conception inte that of a future appearnnce of their Master as the Messiah. Jesus had taught them that at "the consummation of the age, the ond of the present state of things, the Messialh would destroy the wicked $(13: 41,49)$, and they were now fully convinced that he himself was the Messiah. Thus it was natural for them to ask these questions. It is not wise to distinguish sharply between the three clauses as it representing three entirely separate prints. Evidently the disciples did mot scparate between his future coming and the and of the present period; nor has the Saviour done so in his reply. They also then supposed that the destruction of the temple would coincide with his coming and the end of the age; the reply did not elearly show that they would in fact be far apart, but it left the way open for what bas in this respect turned out to be the ease. The phrases 'coming' and 'consummation of the age' would be readily intelligible to the Jewish readers contemplated by Matt., but not to Gentiles; and aceordingly Mark and Juke have simply 'and what is the sign when all these things are going to be completed' (Luke 'to come to patss'). ${ }^{1}$

The Sayiour's reply, so far as inelued in our present section, divides itself into v. 4-14, $15-28,29-31,82-36$; and this last is very closely comnected with what follows in the next section. Olscrve that the whole discourse is evidently de-igned, not to satisfy curiosity alout the future, but to save from misenception, restrain impatience, and stimulate to u(crpetual watchfulness $(24,42)$ and fait!fulness. (25: $14 \mathrm{fr}$ )

1. 1-11. Misleaning Signs. Foundalso in Mark 13:5-13; Luke.21:8-19. Alexander: "The divine wisdom of the Saviour and his knowlertge of the perils which beset his followers

\footnotetext{
I Wänelo bere quotes a gool deal from the Talmud, | that would really help in understanding this discourse. and wher Rabiuical writings, as to presages of the As to the widedifference between the Rabbinical conWessiali's coming (i. e. what we catl lis first coming), coptions of "the last things," and those of the New and diecriplinns of the Messianic time, hut nothing Test, see Elersh. Il, 434, 445.
} 
5 for many shall conte in my name, saying, $f$ am Christ : ambl shall deceive many.

6 And yeshall leatr of wars amel rumours of wars: see that ye in not tromblat : tor alt these things must conse to jass, lout the emal is not yol.

are strikingly axemplified in this preliminary warning against error and delusion, this exposure of false signs betore giving a description of the true. This method of procending is the more remarkable becallse the eutse sugerested hy tanatical exeitement is the very oppositr, and even wise men who devete themselvesto such inquiries are too prome to low exulusively at what is positive in Christ's instructions, without heeding this prelininary admonition, or even observing that his purpose in this first palt of his disenurse is not to tell what are but what are not the premonitions of the grait eatastrople to which he here refers, whatever it may be."

(a) Falso Mesiahs and other false teachers, v. 4 t.; also in Mark and Lule. Mauy shall comsin my name (secon 18: 5), hore means more that reliance on him, for they would elaim to be what he really was. (Compr. 23-25 and . Ter. 14: 14.) We have no aceount of any one who elaimed to be the Messiab between this time and tho destruction of Jerusalem. Yet there may very well have beensuch persons. As the Jews expeeted the Messials to be a political deliverer, it was very natural that men whoset up for political deliverers should pretend tu be the Messiah; but as Josephus had interpreted the Messianic predictions as fulfilled in Vespasian, and knew that any popular expectation of a mative ruler would be highly unacerptable to the Romans, he would be likely to pass war sueh claims without mention. Christ, the rhrist. with tha article. (Nee on 2: 4.) Coms. Ver. itself gives the article in $24: 6 \%$.

(b) Wars, fumines, earthquakes, affecting the world at large, v. fi-8; so also Mark and Lukr, the latter expanding. These extraordinary oceurrenees would beeome a fiulse sign
5 no man latal you astray. For many shall conu. in my natur, saying, I and the Christ; and shall latul 6) many as raty. And yo sliall hoar of wars and raumurs of wars: sece that ge be nol troubled: for these things

by heing misinterpreted, as such events utten are. Wars amel rumors of wars, which latter may turn out unreal. Buth raal wars and such rumors were abumdant befores A. I". 70, as well asoften since. Famines (Aete) $1: 2 n$ ) are uften mentioner in Old. Test. and are still frequent in l'alestine; carth(pualies also frepuently oceur, and there are many sigus of former volcanic activity. We real in das. and Tacitus of various famines and earthquakes in Palestine during the years precending the destruction of Jerusalen. Persons cariug to trace them out may refer to Alford or "Bihl, Comm." IRe not trombled. Iake, 'tarritied.' Alferender: "As it these commonmotions would mecesarily imply the imminence of some great catastroplie, or at the final comsummation. The necessity ot this caution, wot to the first disciples merely, hut to their suecessors, is abundantly apparent from the well-known filet that pious men in "vely age have been continually falling intu the mistalie of looking on national eommotions and collisions as decisive proof that the world is near its end. The meaning is not that such changes may not be immediately suecerderl by the greatest ehange of all, hint only that they are no sign of it, and ought not to he so regarded." ror all these things (rather, they) 2 must come to pass, the latter torm as in 5: 18. Why "must," or "must needs?" (Rov. Ver.) We might simply sily (Meyer) that it was necessary aceorling to the divine purpese. the theught of which might emsole the disciples, as it did tho saviour. (26:54.) But does not the axpression mean that in the preparation tior the complete reign of the Mfsisiah, conflict is Imavoidinlile, not simply individual and domestic varianee (10:34 ff.), lut confliet of the races and mations,

things, a few 'all these lhings;' the curliest MSS, and sevoral early versions are wilhout any such exprossion and the various plirases mentioned are olviously alditions made by students or copyists. In 8,7 "and pestilences' is adod by many docunents, but wanliug in the carliest Mss., and plainly inserted from Luke $21: 11$. 
7 lor uation shall rise against nation, and kjagdem ugatust kibghom: and there shall be lamines, and peslilences, and callingakes, in divers places.

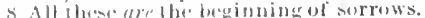

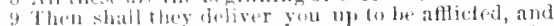
shall kill you: ami ye shall be hated of all mations lor my namb's sake,

10 tuel hon sball many be oflindef, and shall betray one amother, and sall hate one another.

if And many talst prophets shall rise and shall ilecetive mittiy.

12 And incause iniguily shall abound, the love of uhany shall wax colll.

as atterwards depieted in the visions of Joln in l'atmos? Meyer sees in v, ij l., "the first, fir ofl' indirect prognostius of the second advent, like the roll ot distant thunder." With the iusagrey of v. 7 comp). that of Isa. 19: 2. $111 \%$ \&, the beginning of sorrows, or, travail, and not the end, the consummation. "Travail" is in the Greek a plural, meaning the pains of labor, the birth-prangs (1 Thess. $5: 3$, and often in ()ld 'Test.); then any severe pangs (Acts:24) These things will not be merely the beginning of distrosses, but of Jabor-pains (compl. Rom. 8: 22) ; and the rend of these will be the appoaranee of a bettersate of things (comp. "the regeneration," 19: "2.) Eolersh: "Jewish writings speak very frequently of the so-called "sorrows of the Massial, [the word monuing lalor-pains.] These were partly those of the Messiah, and furtly- perbaps chiefiy - those coming on Isran and the world previous to, and connected with, the coming of the Messiah." The jar"ficulars montioned vary greatly, and the deseriptions arequite lanciful. but they may eronerally bevharaterized as markinga period of iuternal corrupution and of outwale distress, experially of famine and war, of which dhe land of l'alestine was to be the serone, and in which the ferple of Israel wore to be the wher sutherers; yet none of them refers tu Ates)lalion of the ('ity and Temple as one at the 'signs' or 'sorrows' of the Mesialt.

(a) Things dimetly affereting the Cloristians

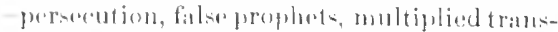

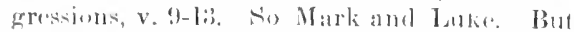
they here alse give a preslietion that 1 he dis-

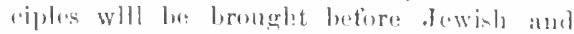
heathen tribunals, with fwelectition and

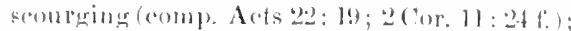
and that they will he tauent by inspiration

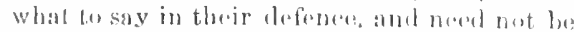
anxims in alvanee on that print. (comple. Arts 4: 8-li,) Matthew has criven a similar passige in the diseourse to the Twelve on send-
7 must neads come to pass: but the end is not yet, for vation shall rise agaiust nation, and kingom against kingdom: and there shall be famiues and 8 carthquakes in divers places. liut all these things 9 ate the beginming of Iravail. 'Then shall they deliver you ul unto tribulation, aud shall kill you: 10 and ye shall be hated of all the nations for my name's sake. And then sliall manr stmmble, and shal teliver up one another, and shall hate one another. 11 And many false prophets shall arise, and shall lead 12 many astrity, Ind becaus iniquity sluall be multi-

ing them out (see 10: 17-22), and therefore (we may suppose) does not repeat it here. To he afllicted, better, as Rev. Ver., to tribulation, soe the word explained on 13: 21. For instances of perecution, see Aets $4: 1 ; 7: 59$; 12: 1 ; Rev. 2: 10,12 . Ye shall be hated of all nations. Comp. "as concerning this sect, it is known to us that everywhere it is spolien against." (Acrses:22.R.r.) Tacitus ("Annals" XV. 4t) speaks of the Christians as "a kind of men hated for their acts of wickedness." And then shall many be ofCended (stumble), comp). 13: 21,57, and see the term explatined on 5: 29. Shall betray (ur detiver $u p$ ) one another, represents a peculiarly painful feature of the situation in times of scvere persecution. Tacitus in spealiing of the persecution of Christians by Nero in A. D. (4t, says, "At first those who confessed were seized, afterwards upon their information a great multitude." And shall hate one another. Remember how Paul was hated by the Judaizers, and by various parties at Corinth.

$11 \mathrm{f}$. is tound in Matt. only. There shall be not more!y perserution but false tenching. (Comb). Acts 20: 29 f.; 2 Pet. 2: 1; 1 John 4: 1.) False prophets, comp. v. 24; $7: 15$; 2 Pot. 2: 1. Shall deceive, or lead astiay, many. the sane term as in v. $4 f$. Iniquity, more exactly trunsoression of law, see on 23: 2. Sh. Shall abound, or be multiplied, as this worit is everywhere else rendered. 'The love of (the) many, the general mass, exeepting a t'ew incliviluals. (Comp. Winer.) 'Love' here pubably means loveto Christ and to his people. "The groat increase of the violation of God's kaw among the wicked will gradually tome down and elill the zeal and love of the great mans uf profusied subjects of the Messiah. 'Th" Epistlo to the Hubrews seems ained at stell a tondeney, and similar periods have often "xisted in Christian history. Tyndale and followers greatly enfeebled this state- 
13 Bint he that sha!l endure unto the end, the same shall bes satverl.

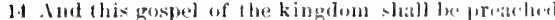
in all fhe world fol a witncistubatl nallons; and [lien shall the ent comr.

1.; When ve therefore shall seo the alomination of desolation, sjoken at be l baniol the prophet, stand in the holy plice, (whoso readith, Iot him understatul :)

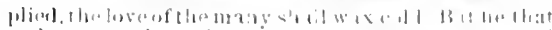

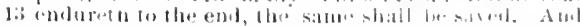

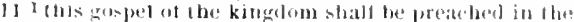
whole: world for a lestimony unto ahl the ualiens; aml then khall ihe end comes.

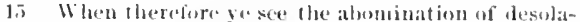
tion, which was spoken of through lontel the pro. phet, statiog in 3 the holy place (let him thas read-

I Or. these good tidings....2 $\mathrm{Gr}$. inhabifed carth...3 $1 \mathrm{r}$. a holy place.

ment by neglecting the article, and making it 'the love of many.'

13. He that shall endure unto the end, that through life endures parsecution (v.9-11) without flinching, and with muliplied transgresson all around him matutains wam Christian lore (v- re); compl. Rev. 2: 10. Or'unto the and mav mean not threugh life, but unto the ond of these trials. Luke gives (:1:19) the lindred and romatrkible axpression, "in your patienee yeshall win yoursouls" (eorrect text and translation), implying that men may gain possession of their own spiritual nature through patient endurance of the ills of lite.

(d) A corrective to the falke signs, v, 14; Mark 1:3: 10. Nothwithstandiven the perowe cution from without and the talse teaching and diminished love within, the gospel will be averywhere preabed; then, and not till thril, will the end rome. This gospel of the lingdom, the good tidings (Rev. Ver. mergin) that the llesianic kingelom or rejgn is near (sen on 4: 23; 3: 2), which the sityjour was aud long bal been engaged in proclaming. Comp. the hearinning of our Lord's preaching in Galilee, Mark 1:15. Preached, kerusso, see on 4: 17. In all the world, more exactly, in the whole inhabited (earth), as in Rev. Ver. margin. This term, oikonmene, is repeatedly used in Luke (and Acts), not elsewhere in the Gospels. From it enmes the modern Popish phrase, "an aenmenical council," one whose membere gather trom all the inhabited arth. This statement, that the gospel shall be preached in the whole inhabited earth, and the following expression for a wituess unto nll (thr) nations, eonld be regarded as a hyperbolical prediction of what was fultilled before the destruetion ot Jerusallem, even as Paul wrote to the Colossians (about A. I. 63), concerning "the gospel which ye beard, which was preached in all cration under heaven." (Col.1:23, Rev. Ter.) It will evidently be fultilled much more thoroughly before the seeond eoming of ('brist ; yet Paul's phrase, and the apparent primary ref- erence bere to A. 1), 70 as 'the end, should restrain theorizors from insisting that the secoud coming of Clarist cammot take place until this has been fulfilled with literal eompleteness. For a wituess, or, testimony, inorder that testimony maty be othered them concerning the Ilessiah and his salvation, such at they may beliese if they will.

II. 15-28. ONE GREAT SEIGN AT J J HEV

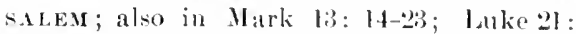
20-24. In v. 15-20 the saviour states what they must do unon the aecurrence of this sign, and in v. 2:3-28 warns against mislending pretensions and propusitions.

(a) The sign, and what they must do, v. 1522. When ye therefore shall see. What interence is expressed by "therefore"? Ha" has saill that the end is coming (v.14! and that those who endure to the end shall he saverl (v. 1.3); when therefore they soe al erertilin sigm, let them promptly flee, in orderto sive themselves. (

V. 13i., apparently refers both to the destruction of Jerusalem and to the final coming of christ; an inference from it in the former sense is that which here follows. The abourination of desolation. The Greek construction makes it the abomination characterized by desolation, which might he as a tolien or at a cause of desolattion. This vague plurase is further elescribul by adling spoken of by (throuth) Danicl the prophet, vi\%. spoken of by (xorl thromgh the prophet, (omp. 21: 4, and see on 1: 2:2: 2: 5. This addition is wanting in the correcet text of Mark (13:14), having been adddut in the common text from litt. It is staterl in D:niiel (9:26 r.). that 'the anointerl one.' the Mes. siah, 'shall be cut uff,' and 'the prople of the prinee that shall eome, shall destroy the aity and the sanctuary. . . and ho shall camse the sacrifice and the meat-otfering to coase: and upon the wing of abominations shall come one that maketh desolate.' or cmarain. Rev. Ver. "upon the pinnacle of" abominattiuns shall be one that makech desolate.' In 
16. Then let them which be in Judea flec inte the imuntatus:

this last sernse it was under-tood by the sept., which renders 'Ipmen the temple (hieron) (shall be the abunination of the desolations.' In I)an. 11: ;il and f2: 11 the sept. has 'abumination of lesolation,' as here. The writur at 1 Mace. (1:54) applied this phrase (1) the luathon altar which in the time of Antiochun Fipiplanos was set upun the altar of l.hovah. It is evident that our Lord interfrets the prenliction in Daniel as referring to thr. Mnsiah, and to that destruction of the eity and the tomple which he is now foretelling; and his interprotation is authoritative for us. What this predicted abomination of desolation" would be, was an obscure question. Many a prediction of human aetion was noessiarily obsoure till the fulfillmunt eame, borase otherwise it would have so influruced believers as to fulfili itself, and would have thus failed to be valid as a superhuman prediction to strengthen faith in him whosys) ke it. (John it: 29.) Our Lord cites thisobseme expression without explaining it, simply mointing out that it demands attention from the reat]er of lonicl-let him that readeth understand-and inplying that if really molerstood it hats tha roforence he is indi"ating. Some suppose the parenthetio remarli (1) he that of Mathluw, aldressing the reader "ot the fiospel; but this is made improbable hy the faret that Mark geves the same parenthe-is repbotim, for although Mark (in tlue (oorroct tiext) does not mention Daniel, yet the peretiale and well-known phrase would suggest. its sontres in that beok. Inke (21: 20), probably breamse the phrase was obsenre and diffienlt, paraphrans it by an expression for perthaps reports an alditimal "xpression, (2ompl. Luke 19: f2), which suegests to us the

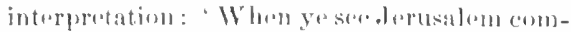
pasine with armies, then know that the desesJation thereof is noar.' Isterally, it is 'bejom emeireled loy armies, when you see the pro-

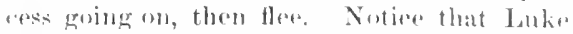
rotains the term 'dexolation.' Now we cannest

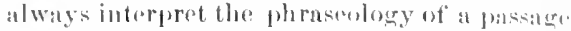
from that of a parallol pastage, but thero is always a strong probability that their moning is substantially the same. It is porsible

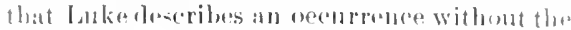
city, and Matthew, some concurrent desecrat-
16 eth muderstand), then let them that are in Judra fee

tion of the temple, represented by the abomination of desolation. But it is much more likely that "the abomination of desolation, standing in the holy place' means some object conneeted with the Roman army under Titus that encircled and captured Jerusalem, which ohject foretokened speedy desolation. The Ruman military standard, with its eagle of silver or bronze, and under that an imperial bust which the soldiers were accustomed to worship, standing anywhere in the holy city (4:5) would be a violation of the seeond commandment, would be abominable in the eyes of all devout Jews, would in itself desolate the holy place, according to their feeling, and would foretoken a yet more complete desolation. Holy place cannot well mean dirtinctively the temple in this ease, for when the Roman standards stood in the temple it was toro late for fleeing to the mountain. One or two years before the Saviour thus spoke, Pilate had outraged the Jews by bringing into Jerusalem by niglat such military standards, having on them the emperor's bust, and only npon vehement and protracted entreaty did lue consent to remove them (.Jos. "Ant.," 38 , 3, 1). The masculine participle for "standing' used by Mark (13:14, correct text) might reter to the empreror whose bust the standard bore or to the gemeral whose authority it represented. The term 'abomination' is oftenest used in ()ld Test. as denoting idols, or oljects connected with idolatry. The horror of eivil war in the temple (Jos. "War," 4, 9, $11 \mathrm{f}$.) would not so well aecount for this phrase, nor eorrespond to the connection in Danjel. Somme prefer simply to understand the Roman puwer, as abominable and desolating.

16. Then. The signs previously mentioned will not show that the end is near; but when this sign is seen, then the followers of Christ numst at mee leave Jerusalem and the entire district of "Judea. Flee into the mountaius secus to be a general phrase, not denoting any fartiular mountains. In the Maceabean time the Jews had become familiar with the iden of hiding in ravines and eaves of the mountains. Euselius states " Hist." III., 5, 2f.) that at the time of the siege by Titus the apostlu bad gone to preach the gospel to all the nations, and that the people (laity) of the 
17 het him which is on the housetop not eome down to tate allylhing olut of his house:

Is Xeither let him which is in the tield return back to take his chothes.

is . lul wot molo them that are with child, and to them that give suck in those days:

20) l3at pray ye that yum thight be not in the winter, meitlece wit the sabuatli day:

ehurels in Jerusiatem, in aceorlance with a certain divine communiteition given by revelattion bofore the war, removed and dwett in a vits of Perea latued Pullat. Epriphanius bas a similar statcoment. Merrill, "East of the Jordan," leaves no retiomable dumbt that Robinson wats right in identifying Pellat with the ruins callecl Faln'l, lying just across the Jordan valley eatstward trom Bethshean, in a beantiful and healthy situation. The ruins indieate an important eity. Epiphanius says that when Ifadran rebuilt Jerusalem, ehanging it: name to Flia (A. D. 135), the (hristians a serond time withdrew to Pella. It is not elear from Euschins at what precise time the Christians withdrew trom Jerusalem; it maty lave bran (sor Plump. ant Edersh. thiuk) in A. D. tis, hut it sems to have oecurred after Titus took command, which followed the death of Galbil, A. D. bit (see Jos. "War," 4, 9, 2). During the siege, in A, 1. 70, Titus allowed many Jews to withdraw from the eity ("War," 5, 10, l), and the (hristians may bave loft then. Such an abandomment of Jerusalem was not uaprecedented, for atter the atlitir of Cestius, in $A$. Is tif, "many of" the distinguished Jow left the city, as if swiuming from a sinking ship)" ("War," ", 2()$, 1)$.

$17 \mathrm{f}$. The flight is to be prompt, immediate. The top of an Oriental house is llat, with only slant emough to earry otl the rain, and with a battlement or parapet to prevent persons from falling. (beut. 22:8.) This rouf is usually renehed by steps from the inner eourt. (Mark $2: 4$.) In al (ity, where the homses adjoin, one might go along the rows from hense to boune without

1 Literally' to take ancmy the things that are out of his house, an ahrevialet exyression for "lo take out of the house the lluings that are in it." This is amboubtedly the currect reating here. Thi' singular 'Earment' (or 'cloak") is real by all the earliest Jsix. and many others, and by nearly all the eariy versions; this must out weinh the probability of assimilation to Yark 1:3: 16.

2 It was a great merey to the sonthern people that the eml of the civil War (Isis) eame in April, when if the men hurried home and went immediately to work,

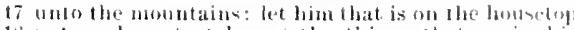
18 not go downto lake out the things lloat ale in his lonese: and bel him that is in lletichl not reluri 19 back to take his eloak. lint wot ullo them that are with child and lo them that give stuck in those days!

descenting to the court and the street. Josephus ("Ant.," 1:3, 5, :3) represents some Jowish soldiers at inelling a tumulturns rehellion in Antioneb by gring on the roufs of the palaces to cant down missiles upm the erowels in the streets, and then lraping from house to house and setting fire to the dwellings of the people. So here, he which is ou the housetop (e.g.. Acts 10:9) will find it the shortest way to escape from the doemed eity to pass from roof to roof, and inust not go down to talke anything out of his house. hu like mann'r, neither tet him which is in the ficld at work, and hats laid aside hisouter garment (5: :0), return to the phace where he latid it, but he must blese strighthway. Origen understands return to the eity, but that would take a long time, and the prohibition of it would not indieate great haste; besides that decorous persons would not leave the outer garment at home, but would wenr it in going from the city to the ficld. These are strong expressions-such as the Saviour frequently used, see on 5: $8 !-t$ to show that the dlight must be extrmely prompt, when the prelicted sign appeirs.

19-2:. Woe is here said compassionately, while in 2: 13 it wat denounced as at thing descrved. A flight so prompt and hasty must involve great hardship and diffeulty for deliente women, and for all it it should be in the winter.2 so the tranlitional law as to a sathbath day journey, that it shoult be not mure than two thousand cubits, about ten humbed ant fifty yards. would prove overwholmingly inconvenient, if the flight should neeur on the sabbath day. Some (Wün.) holel it

there was just time enougle to plant. eorn, tolnac(4), cuttou; this prevented disoribr and violonoe, ly emgaging all in hopeful industry. So some Rabbinionl writers (Wel.) speat of it as a spereial merey that the dlestrum-

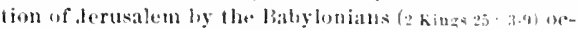
currel at a season of the year suitable for jumrutying and exposure. And, aceorling to Josephus, the army uf litus reached Jerusalem in April (A, 1), 70), and destroyed it in september. 
21 Fior then shall te great tritulation, such as was

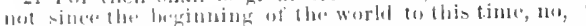

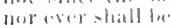

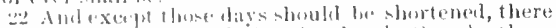

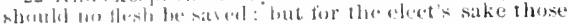

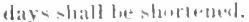

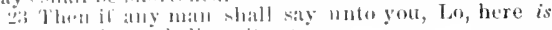
thist, of there? leeliere it not.

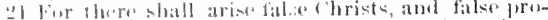
bhets, ancl shall shew great siens and womblers; insumunh llat, it it wore pussible, they shall deceive the very rolicet.

20 be lold, 1 have told you before.
20 And pray ye that your flight be not in the winter.

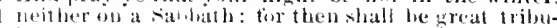
lation, stleth as hatb not been trom the beginmon of 2.2 the world until now, no, nor war shall be. And excout those days had been shortened, no flosh would

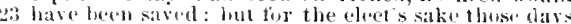
slabll be shortened. Then il any man shall say unio 24 you, la, here is lhe Christ, or Here; helieve if sot. for there shall arise falso forints and false prophets, and shatl shew ireat signs atul wonders; so as 2.) lead astray, it possible, even the elect. Behold, I lawtul to violate this when in perit of lite; and such a coursa our lard would certainly have approsed (complo an 12: $2 \mathrm{Hl}$.) ; but it would be to auy strict Jew a paintul and mularrasing necessity. Mureover (Messey, in "Bible ('ommo."), "it was no doubt considered wrong to assist the travoler, however urgent his errond, in his movements on the Siabuth day. All possible infodiments theretirre would be thrown in the way of the fugitives by those who were still zealous for the suposed repuirements of the baw." Our Loprl soms to imply that his Jewish followers will be still serupulous about the traditional momle of observing the sabbatl up to the dentruetion of . Jerusalen. It was indred this aveut that first mate the Jewish (thristians "learly understand the ceremenial law to be no louger binding (comp. on 16: 29). Pray yout your flight be not is a nom-final construction, see on $5:$ : $2 \%$.

21. For, reason for the injunction of v. f(i, which was expanded lyy v. 17-2(). 'This raston is that the suflierings attendit upen the destruction of derusillom, will bu withent parallel in past or future hislory. (cmup. on v. 29.) Wr migle regard this also as the hyperlublical language often uscel in prophery (commp. D): In. 12: 1; . Juel 2) I ; yet in this sase it mat betaken liter-

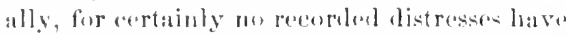
beren so vast, so prolomerat, so torribla, a

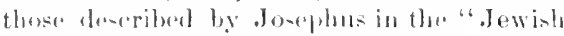
War," Wirare not - Mrprised to find him say-

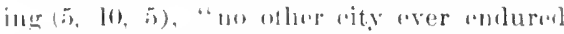
similar calamities, and no gencration "rol "xisted more prolifie in arime." ('ompl his

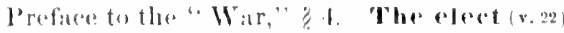

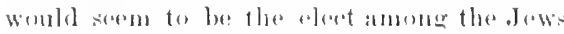

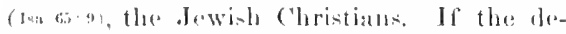
reruetion and desulation inflieted by the Romatu deriug the singe and overthrow of the eity, and afterwards at various points, had been continued much longer, they would have swept away all. Jews who were then Christians, and all who aftelwarls beeame Christiansyea, the whole. Jewish race. Shomld be shortened, ete., liev. Ver. Itad been shortened, no, flesh would hare beon saed, is the necessary meaning of the (rrek; 'saved' means the saving of the lifi, $9: 21 \mathrm{f}$, comp. on $1: 21$. Mark $13: 20$ refers the shortening expressly to Jehovah. That others should also be saved for the sake of saving the eleet, reminds of Gem. 18: 23 ff. Luke adis (:2 : 24, r. y.) "and they sluall be led away captive into all nations' (eomp. Jos. "War," Book 7), "and Jerusalem shall be trodren down by the Gentiles until the times of the Gentiles be fulfilled."

$W^{+}$e eannot say that $v$. $15-22$ does not at all refer to the times just preceding our Lorl's final coming; lut no sueh reference shows its.lit. The terms of 5 . 22 might readily be so understoud, but 'tlouse days' can hardly mean anything else than the days of the flight from Indea. (v. 16-20.)

(b) False pretensions which must then be eruarded against, v. 20-28; so Mark 13: 21-23; net in Luke.

2:3-25. Further cases of false Messiahs. (Cimp). v. 5.) A psendo-christ, one who filsely chimed to be Christ, must be distingruiklod from an anti-christ, an opposer of ('hrist (Epistles of' John); compare the somewhat similar designation in 2 Thess. 2: 4. shall shew great sigus and wonders, mimp, on 16: 1, and for the terms see on 12: :34. Shall deceive, or lead astray, same trom as in v. $4 \mathrm{f}$, , 11, and in 18: 12 f. (Comp). [)olt. 13: $1 \mathrm{ff}$; liev. 13: 1:) Aleramder: "This prodietion, in its strict sense, is anong the passages which seem to show that even real nuirulus are not sufficient of themselves to prove the truth of any doctrine, but only 


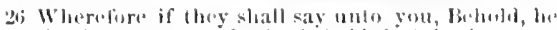
is in the lestrt; gonot forth: behold, he is in the secret chambers: leclieve it mot.

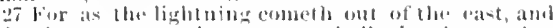
shineth 12yoll anlothe west; so shall also lhe combing

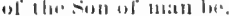

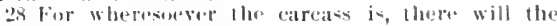
eagles ly. mathered tomethr.

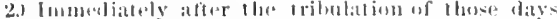
shall the siln be darkenesl, atmol the memn shall wot give lice light, and the stars shall fall from lietsen, and the powers at the hatavens shall be slatien:
20 have tobl you beforehaud. If thereform th.y shatl

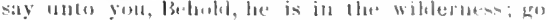

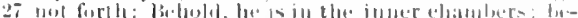

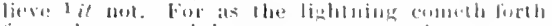

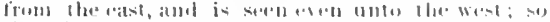

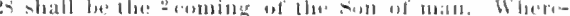

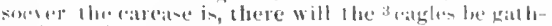
trict together.

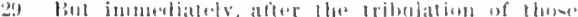

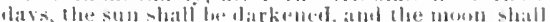
not give licr light, and the slats shall fall irmo

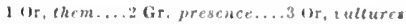

ome lart al a eomplex demonstration, nt onter sensible, rational, amd spiritual."

26 t. The thu. Mrssiah's appeariug will be sudden and visible to all. The desert or wilderuss (4: 1), and loe secret cinambers

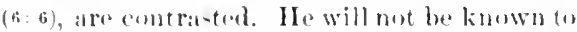
havealpearalolowhere, and will not be found by seareluing in the wild, thinly inhabitod regions, or in the private portions of sume city house; his appralling will he visiblo to all, as a thas of lierloning. (Comp. Luke 17: 28t.) The comine, (a)mp. an v. 8 . The Som of man, the Mresials, secon 8: 20. II rere the coming ut the sim of man' answers to 'thy eoming inv.

27 is alosely conneeted hy for with v. 26 , which last points to the lestruction of Jerusalem. Yot the language of $v .27$ seens specially alpuropriate to the tinal combing ; and it may perbatps be moleretoul ats referring to luth. (Comp. on v. :3.) Xlso is an inalequately supported addition in the common text. Ind shineth, or is sern, as in 6i: 5; not that the liehtning groes to the wort, as 'shimetle' miglit smgerest, but that its light is sean even that fiar. The thomght therefore?

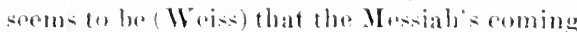
will lu alike visible to all, and so there will be no oceasion for some to tell others where he may beseroll.

28. ('mmp. Luke 17: 37, and the same image in Jub : : : : W. Wheresocver the carcass is, ${ }^{1 h}$ here will the cagles be gathered together. As the eate proper rarely foeds on earrion, the worl probably here demotesea anrion-kite, which Pliny classes with areles (firimm), or a ereat volture as larere as the eagle. which mow aboumls in Palorime. and is eallad eagle lyy the matives (Thommand, III,
2.21). The moaning af the saying as hore abplial serems to be, that things will ante lo biss when the aceasion tor themexists. Mhen

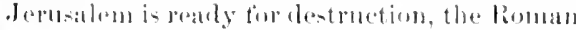
ander will gather and drestros it ; wen the

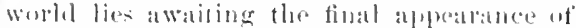

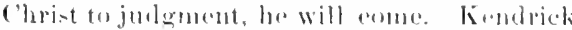
(in ()lsh.) enomiders, with less probubility.

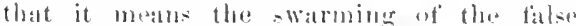

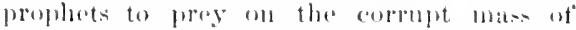

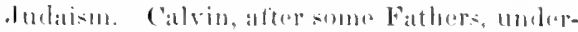

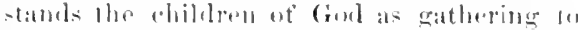
chriat and fording un him, an jobateml-ive in itsolf, and ont of latronomy with thro (antnection, in whiols ("Bible ('munn.") Christ (onnes not in erraes, but in jumerment: yet many lator writars lave nuwiody adopted this viow. It is latrlly pusihle, as formerly fintreied by some, that our lorel meant at allu-iontetho Roman raglas.

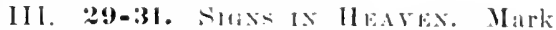

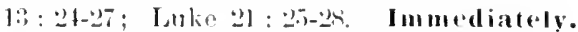
Tho phrats is not exatly immediatelyafter' the alseren 'immerliatoly' is commected with 'thestll shall he ditrkesued, ete. The sub-

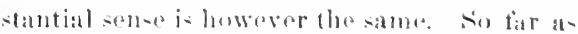

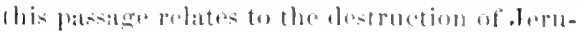
salem, wo naly supluse that the roonts is

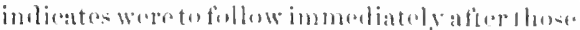

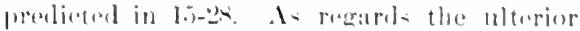

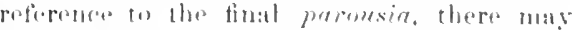

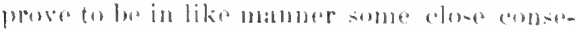
antion, lont moly the fultillment is likely te. -low. Itter the tribulatiou of those daty,

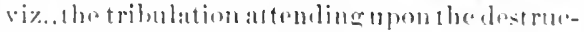
tion we Jermsalem, see esperially v. 2l. The

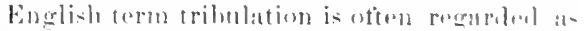

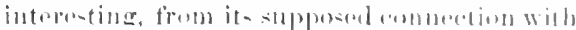
the Istlin tribulum, a threhing-aled with
1'For' is wantiug in the earlient Mst. amb most of the early versions, and would be rery asily inserted dy stiklents or copyists. The worif meining 'carcass,

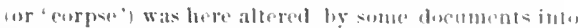
the sumewhat similar word monimg ' lunly, which luk. has in $17: 37$; eomp. alroveron $14: 12$. 


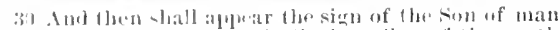
in lefallen: allul then : - ball all the tribes of the earth

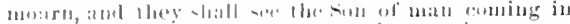

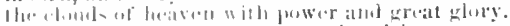

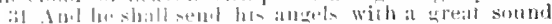

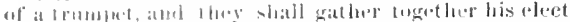
from the tour winds, irom one end of heaven to the others. heaven, and the powers of the heavens thall he 35) shaken: and then shall appear the sign of llie son of man in heaven: and then shall all the tribes of the earth nowrn, and they shall see the son of man coming on the clomis of beaven with power and 31 great glory. And be shall send forth his angels i will "a great sound of a trumpet, and they shall galler togrether his telet from the fuur winds, lrom one end at lieaven to the other.

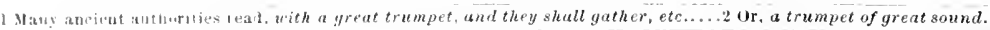

Shatp landle to beat the errain out of the straw.

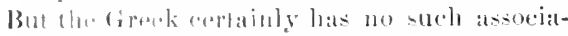
[im, and [11:ans -imply pressure, oppression,

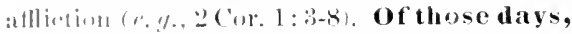
is natmpilly but not necesarily the same period a- 'tluse days' in $v$. 1!1 and o2.2. The snn shall he darkened, cete, eomp. tuel : : :31;

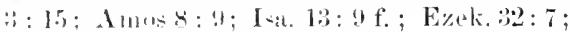
lirv. li: 1:2. Theer pasares ineline one to under-taml the expressions as a mere inatge. And so with the following exprowion, the stars shall fall, meaning not some statrs, but the stars genurully. Comp. 1sal. 34: 4. The powars of the heavens, the forees which lwell in the heavens and keep them stable; the shakiner of witich will disturb their stability (Mrerer). Lule condenses all this into theres shall bo signs in sun and moon and star-.' anel thon ards some other striling imaterye as "the roaring of the sea and the billuw:.' (Luke 21 : 25 r..r. ..) some Promillenujalin or Adrontist writers hold (IImua) that with v. 2ol begins the aceount of the introduetiun of Chrisl's feromal reign on eath, ex-

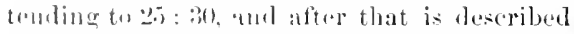
the eromeral judement at the end of the millounimm. But it is extremely doubtiul whotluer wa onght to introduce inter the

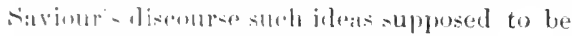
drawn from the dpesilype.

30. The sien of the son of man in heaven. The dums hat rewatedly aked fur such a sign

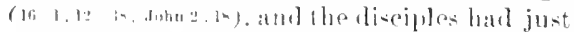

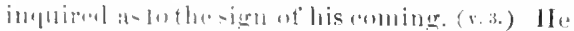

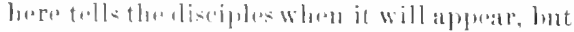

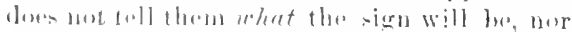

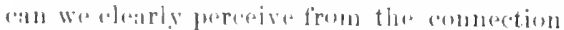
somm Futhers funciol that it meant the appeatrabere of a crose in llae sky, ats in the famens story of (ometantine ; but this is quite unwarranlol. It may be (lialsin) that the sien will be molhing wore than the saviour:

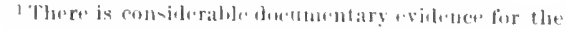

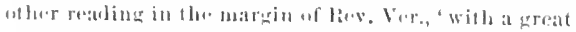

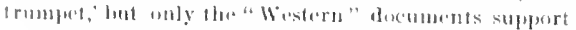
that in the margin of com. Ver., "with at trumpet, and own coming on the elouds, as just afterwards mentionerl, and as predicted in Din. 7: 13.

Then shall all the tribes of the earth mouru. (Comp. Zech. 12: 10, 12; Rev. 1:7.) Not simply the Jews shall mourn, but all men. This may have been true in some partial sense at the destruction of Jerusalem. Is it not probable that many Jews who had heard the apostles preach, or who had real the Gropel of Matt., did then remember the rejeeted Jesur, how he predicted all this cal:mity and ruin, how they voluntarily assmmed the guilt of bis blood $(27: 25)$, and did mourn bitterly? But the prediction will doubtless be completely fulfilled at the seennd coming of Christ. Coming in the clouds of heaven, etc. (Comp. 16: 27.) Com. Ver. obscures the variation of this expression in different passages. The Greek has 'on tho clouds' here, 20: 64; Rev. 14: 14-16; 'in clouds' (Mark 13: 26; Luke 21: 27); 'with the elouds' (Mark 14: 62; Rev. 1: 7; Dan. $7: 1 \%$.)

31. Send his augels (see on $13: 41$.) A great sound of a trumpet. With a trumpot of great somud (Rev. Ver., margin, i. e., with a loud-souncling trumpet (Buttm.), is the natural translation of the most probable text. ${ }^{1}$ It might possibly be translated as in Com. and Rev. Ver., hut not naturally, for so the word rendered trumpet would have in the Greek an emphatie position without any discernible reason (Weiss). The inage js drawn from a heralel sounding a loud trumpet to annomee the apponach of a monareh, or of his pepresentatives, and to assemble the perple that they may hear his eommands. From this saying laul probably derived the expressinns of 1 Cor. 15: 52. And they sha I gather together his eleet, ete. Notice how uften this term 'the eleet' is used ( $v, 22,24$, :i1), and so Mark in ench case. (Comp. above,

a greal voine (sound)', which is a manifest alleration. The ditference in any ease is unimportant, as a great trumpet would make a great sound. 


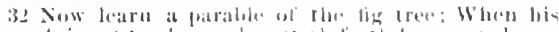

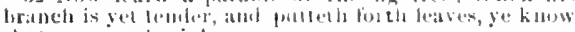
llout summer is nigh:

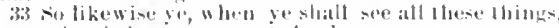

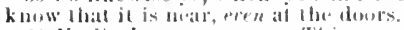

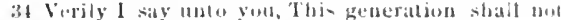
pats, till all these thimgs be fullilled.

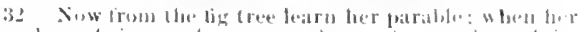

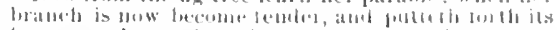

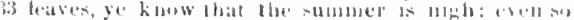

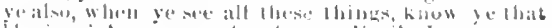

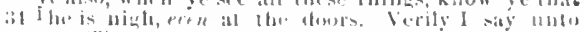

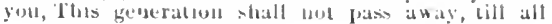

1 Ur. it.

22: 14.) From the fonr wiuds, a colnmon designation of what we now call the four peints of the complatss. From oue end of heaven to the otlier, a plorase drawn firm the old conception of the earth ats an oblong plain, bounded at each and by the sky, the borizon. Siueb familiar phrases are llated in Seripture as they are ammur us, withent becoming responsible for the eonfiormity ut" the concention they inrolve to the physical lact. The meaning is that the elect will be gathered from evere part at the parth in which they are forund.

lt is fractionlly imporsible to suppose that v. :30 if. relates simply to the lestruction of Jepusilesur. Is the lattur part of the discourse (25: 31.46) clearly refiers to the soeomd eoming ot

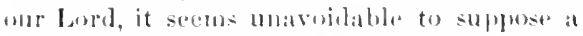
similar reperence here; aee also the corre-

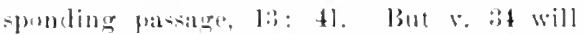
presently declate that 'all' the foregeing matter wall aecul aluring the exinting generatiun. Then a wa anmot helieverwith Meyer and others) that the saviour mistalienly ex-

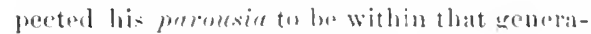

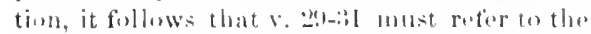
deatruction uf onrusilam. The dittienly is rolieved by understaubling a typienal realation brotween the destruction ot . Jerustalem and his final parousin, on the gromad ut which ralattion v. 2u-ibl rally points in some semse to both events. (Comp. above on r. 3.)

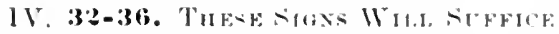

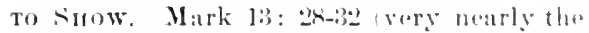

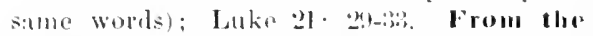
fic tree, placed tirst in the antencer, and thas: emplutic. The may have lowked at some tig treenear them, just as in the same vieinity he latd five days before usme a fige troe tur an abjeet-lesson. (21:20) But the article, "the fier treec' does not neeresarily inclicate a particular tree, hut may mean only that kind of erop. ar that elase of oligets. Learu a parabla" (Rev. Ver., her perable), or simply the latable, the ato whieh the fier trees hats to teach. Everything in nature has its nural analogeres J Jesus han sot us the example of

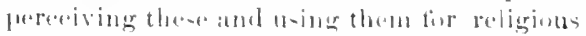
instrution. The word parable (are on l:?: :?)

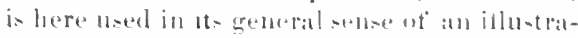

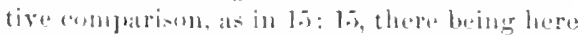

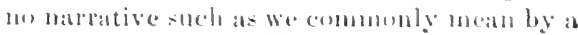
parable. When his branch ...... laves. The "his" is the alel pomessive uf "it, which was origrually 'hit," and is still often an promunuend by the vulgar. The possessive its was just beginuing to be used when the K. James version was madt, $1 \mathrm{t}$ is

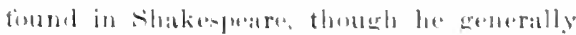

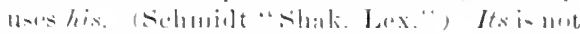

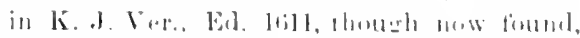

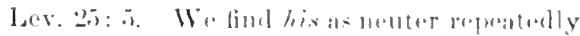

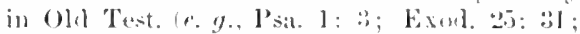
36: 17, ote. , and several time- in Sew Tot. (5. 13: Act 12 10:1 cor. 15:34) The paral!al farsileres in C'om. Vere of Mark has "hor libanch,' which Rev. Ver. ahopts here, jer-ondying tho tig tree an fominine like the (iroek), alud

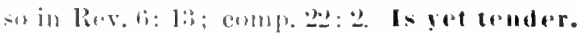
The liev. Vir., Is mom beceme temlere, grives

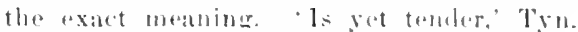
and followors sulegets that the temelermess is alumt toletare, when the Greak means that it

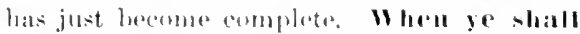
sec all these thiugs, probably those of $v$. 15 and $r .2 ! f$. Konow that it is mear. (r.31.)

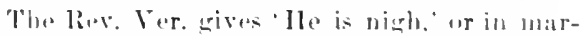
grin. "it is nigh," viz., lis emming (v.27), or "the kinglom of finl is nienh' (luke 21:31), all whviomsly amomuting to the samo thing. The 'he' i= mont naturally sugenested hy what pre-

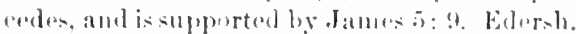
thinks" "jt call searewly hesupjused that ( 'hrist

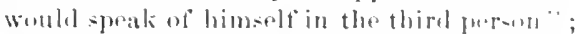

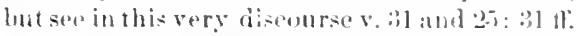

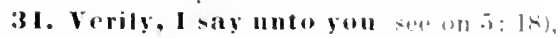

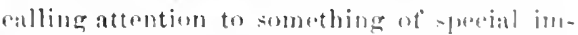

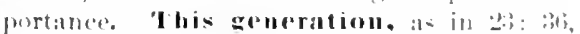

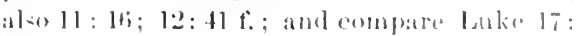

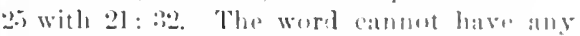
other meaning here than the olvioms one. The attempts to establish for it the sense of 


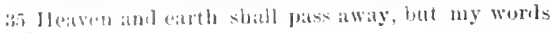

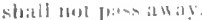

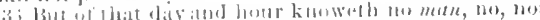

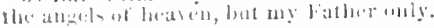

ij these thinas be accomplished. Heaven and earth sull fust away, fut ny wurds shall not pass away. 3i) but of that dily and hoir kuoweth no rule, not even the andulsotherven, neither the son, but the Father

1. Man anchoritie, sonte ancient, omit, witker the Son.

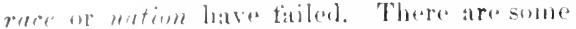

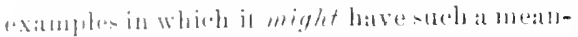
inge, hut moms in which it must, for in every

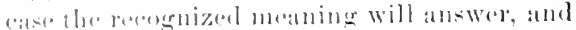

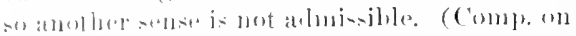

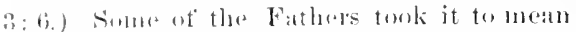

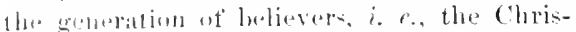
tians, ote., atter the lowse mammere of interproting into which many at thems so otten

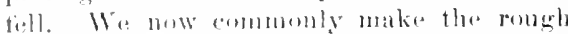

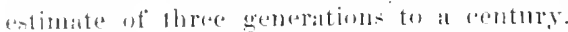
l'he yatr in whinl our I rerel said this was mont ponbahly A. 1). 80 , and if so, it was torty

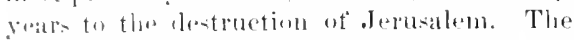
thomelot is thus the same as in 16: 28; and

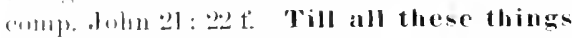
he filfilled, ar, mure exactly, talie plase,

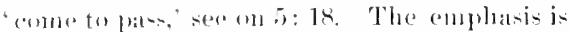
an "all, All the thing predieted in s. 4-31

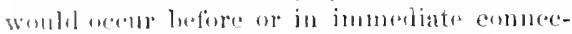
tion with the destruction of Jupusalem. But like "vouts might atgain oreme in entusection with another atul arrealer conting of the Lerrd. and surh sorom evidently to bo his meaning.

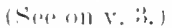

\subsection{Il caven aud earth shall pass away,}

1 Throlsh of little fuartical importanee, the ques-

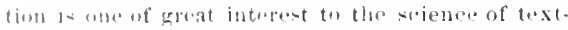

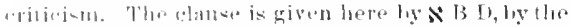

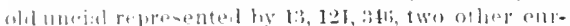

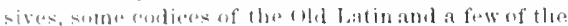

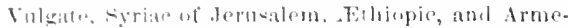

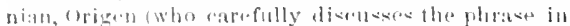

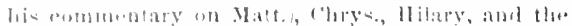
Antonymentefomm. Oll Malt. Xisw it B were absent form this li-t. the clathe would be inmoliately re-

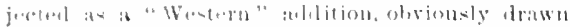

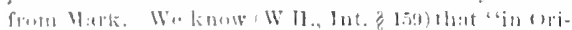

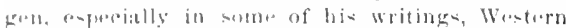

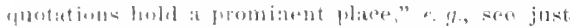

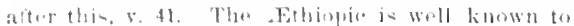
froment " 11 fotern" palings in many passages, and 1he Irmentab grives them in v. 2: 25: 1; Acts 8: 37;

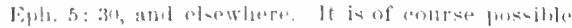
(Ti-eh. and W Il.) that the words were omitterl be.

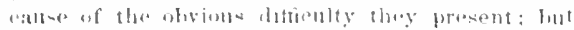
then why are they omited from llark hy nes dow-

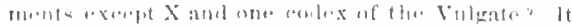

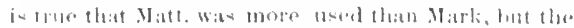

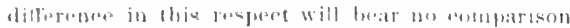
whth the immense ditlerence betwrelt the doeuments atc. sese on 5: 1!h, still further emphasizes the importance of what he is saying, which was intreduced by 'Terily, I say unto you.' It Was harel for tba disciples to believe that their Iaster would eome again and utterly destroy the templo and the holy eity (v.2 f.), and work such great ohanges as have been indieated by $v$. 2)- within that generation; and so he assorts it vory solemmly, eomp. Jolin 16:7. We loam alos in 2 Pet. $8: 7$ f. and elsewhere that heaven and earth will pass away; mot that they will ease to exist, but that they will he changed into something entirely new.

36. The prolietions he lats made will receive a folfilment within that generation (v.34), to be witnesid ly some then living (16:29); this much he solemnly declares, but the time lie will not more exactly state, for indered the prexise time no one knows but the Futher only. Of (comeriming) that day and hour. It is mere quibloling to say that sti]l we may ascertain tlie year and month. No, not the augels of heaven, comp. on 18: 10 . Tho Rev. Ver. gives 'weither the Son.' It is difficult to deride whether these words are here genuine. They are eertainly genuine in

for omission in Matt. and in Mark, even after we allow for the reacly arceptame likcly to he giren to a forth of text thit would remove a dittionlty. Viujous Fatlees spreak of the clause as wanting in Matt, and present in Mark, hut they do not resard that as lessoning the doetrinal difficuliy. On the other hand, nothing would he more natural than the inscrtion of the "lause in Matt. hy transeriptional as-imilation to Mati. Sucl assimilation of parallel parages oecurs oftener than ent he numbered; while altertion to avoid rfoetrinal diffienlty is a thing of very rare oceurrence. ILw then ean W H. maintain thut the umission "an be no less easily explained ly the dortrinal difficolty" than theirinsertion bw "assimi. lation tu Mark"? This seems to he ouly heenuse thry resard "the documentary evidenee in fare" of the rlatue as "overwhelming"; and it is malle cres. whelming hy the concurrence of $B$ with the other documents. Now it is true that a group rontaining R very eommonly presents the original text, as w II. have convinojngly shown in their genealogieal rlasification on the hasis of internal evidenee. But it is mot true that such a group presents overwhelm. ing evilence; for we have seen in this commentiry a good malny cases in which a group containing $B$ is 
: romitug of the son of man be.

tho worle. : Clerist romimands his people to preateh it lo all. (Comp. 2s: 39.) 4) Christ predicts that it will le preached to all. Are wo porsomally receiving it, and busy in pro(atiming it?

V. 16. HFARY: "In times of imminent peril and danger, it is not only lawtul but our

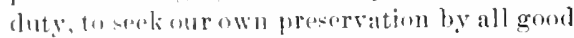
and homet means; and if frod opens a door of

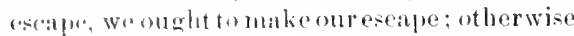

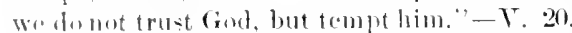
HEXkY: "Though tha easeot the borly is not to lo mainly ansulted, it ought to be duty considered: though wo must take what God sonds, and whon he sends it, ret wo may pray againet imenvenienses."- - 20. Fath is a "haractropistie of Christianity; but belief of truth involves stern refusal to believe in fulsehood. Hoxley: "There is not a greater pnemy to truo faith than rain credulity. The simple lolieveth every word, and rums

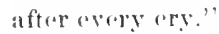

$V^{*}$. 3) f. The final and gtorious eoming of ('lerist. 1) lt will be sudden, v. 27. 2) It will be not in the form of a sorrant (Phis. 2: 7), but as tho loivine King, with power and great glory. 3) It will catses mourning to all who haverojected him. (Rer. 1: 7; Jleb, 6:6.) 4) It will briner all bi-scattored penple togethar in 1 mspualialdramdetrornal blosedness, comp. 2 Tim. $4: 8$. Hexily: "Eomnor ur later, all simers will he monrners; penitont sinners lowle to chri-t, and moem aftor a gemly sort; imponitout sinners shatl look unto hiun whom they have firereat, and though they laugh now,

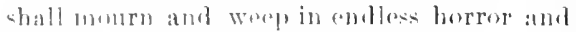

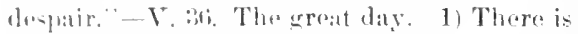
"lofinite day on which christ will come to

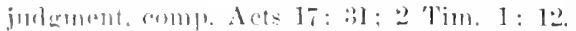
2) Tlu propice day i- wholly morevealed, and know anly to foul the Fathor: attempte to fix it loy ealembution are irle. B) Our great comern is to lere realy when that day comese, and w. shall dothis by comstant and watehful

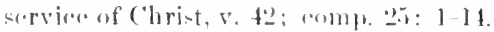

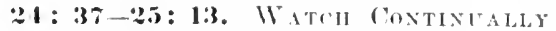
FoR THF CONIXg OF CHBIST.

Only the (arly part of this sertion bas at parallol in Mitk (13.33.35) and Lake (21:31.36); lut Lake has more extomsive parallels in "arlina dicourses. As to the general contents and the divisions of this discourse on the Mount of Olives, see at the beginning of chap. 24. From the point we have now reacled, the destruction of Jerusalem sinks rapidly out of view. The passage in $v .37-44$ might be understood as having also a primary reference to that event, regarded as a coming of Christ, but it contains no expression requiring to be so moderstood. Still less indication js there of such a reference in the two illustrations of v. 45-51 and 25: 1-13. But throughout this section everything naturally suggests that final coming of Christ to judgmont, which is alone brought to view in the closing jaraguph of the grat diseourse, 25: 31-46. There would be no profit in working out a possible allusion to the destruction of Jerusalem in some parts of this section, and we may confine ourselves to its obvious and supremely important teaching as regards preparation for the final coming. Our Lord first declares that his eoming will be unexpected, as illustrated by the coming of the flood and the coming of a thief, and bases on this an injunction to watehfuluess (v.3i-44); he then further illustrates the same fact and consequent duty by the supposed case of a good and a bad servant (v.45-51), and by the parable of the foolish and the wise virgins. (25:1-13.)

I. 37-44. Watri, for IIE Will, Conf, INexpertedur. Comp. Mark 13: $3:$ and Luke in the earlier diseourses he gives in 17: $26-;) ;$; and 12: 399 f.

(a) Illustration from the eoming of Noali's flomi.-37-39. But as, Rev. Ter., and as. But smme of the best dremments read 'for as, which would easily be ehanged by copyists because somewhat obsoure; it is therefore probably cosroct. (Lach., Treg., W H.) It daes not exactly give the reason why the day and hour is unkuown (24:36), but a confirmation of the statement that no one knows: men will not even be thinking of it when it arrives. Also is genuine in Luke 17: 26, but not hore, nor in v. 39. The coming. see on 24: :3. The Son of man, see on 8: 20. On a former oceasion our Lord had added another illustration to the sqme effect from the times of 1 ut, Iuke $17: 28-32$. Here, as often before, the question arises whether we shall suppose that Jesus used these illustrations only once, 
:3 Ior as in the datys that were before the flom they were rating and drinking, maldring and giving in

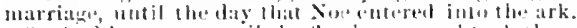

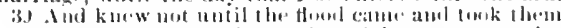

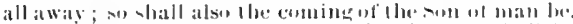

40 Thin shall fwo be ju the fielel; the wre shall loe

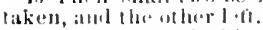

4t l'wo "emen shall be grimling at the mill; the une shall lastaken, and the uh+r lofi.

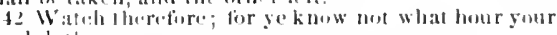
toril intiliente.
$3 x^{2}$ coming of the son of matn. Fir as in these days

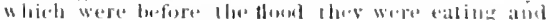

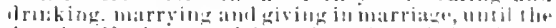

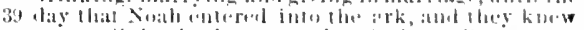

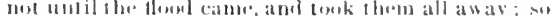

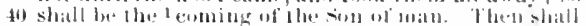

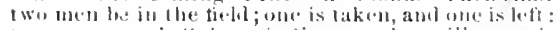
11 two women shall bre grimbing at the mill; ane jo 12 taken, ant ono is loft. Walch theretiore; lor ge and ome or wher Evangeli-t hats mate a dislocation; or that ho repuatrel. To one who has hat experience of itimelant preaching to pepular andiences, the suppe-ition that an illustration was repeated at sumb new place and timesems an fuerfietly natural that there is no recaton for the other hypothesis. - The comine uf (lisist will find mon in general busy with the ordinary pursuts of life, as in the time ot Sinh; only those who are prepared as ho was will eseape the sudden and unexperedel restruction. It follows that our Lord' - coming eartainly camnot be at the end of a thousand rears of universal and pertect pirety, for in that ase all would know the exact time, amb all womll be devoutly and eigerly exproting the event. Comp. Luke 18:s. Touk them all away, with empha-is on 'all.'

(b) l'ersons most intimatoly associated will be soparated ly lhat unexpected eoming. 40 f. Two (ment. The Groble has anly 'two.' but the coumected wombs are masculints as with the tullowing 'two' they are feminine.

In the ficld, in the cultivated district appertaining to sobno suppukenl rity. One shall be (lit., is) taken, takon along, perhaps by the alugels sont to gather tho eloct. (20:31.) The stme freek word is pombered reedive" in John 1.t: 8; for the ilsa, comply. 1 Thess. 4: 17. Tho Giresk ha: here thr present tense, whirh is more visid than the futurewouhl he. some undrerstand the term to mean taken along by thu hestruging agoneics altending

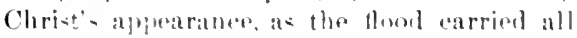
away. In eiller vinw of this plirise the main thought of the paseage remains the same; it shall he well with oneand ill with

This expression was interpolated into the text of Inke 17:36, and 1, $13017: 31$ was interpulated here, in both cases by the "Western" gromp of doeuments; the former interpolation passul into some "syrian" documents, and so intok. James and the Elzcrir, the Ter- the other, and there will be nu time then tir prepiring. Two womengrimdiug at the mill. This domestic habor is still frequently performed in Palestine by women, and was oberervel there by the present writer. Tha luwer millsture, say twolve inches in diam-

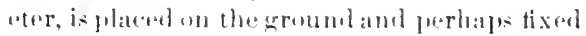
in it: the upure stome is turued by a pene near the wuter alge. One womath sits on the gromull (1sa.18:16). su as to lave the mill stealind butweren her linees, theother crouches un the oplusite sidu. Sinnetimes the stome is maneh laterer, and anch erourbes on une sirle. One pullithe preg towards her through hat a cirele, the other sojos it abover or below and (ompletes the circle; ur else both retain their hold. and one relaxes while the ather pull-. With the fres hand nne now and then juts a little grain into the central oriticas ot the ro. volving -tome. lon the jerky motion of the stone they kepe time by a low, wating chant. "The sotmet of the erinding" |Fecl 12:4) mat be only the rumbling and ringine noise male by the revelving stome, but more probatsly retiers to this chatet.2 The two women are apt. in the nature af thingse to be mother and daughter, or ulder and younger sistur, or friondly moiglobers, or slives in the same homse. Jet even these will lee sepurated by the Lard's second eoming. the prepared one being acelped, the wher having then mo time

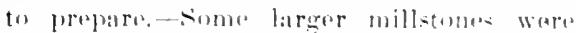
turned by an ass (1-:6), and athers ly water, Where this was arailable, as is now to be seople in many places. "The Fronk Antholuerg" (Wet.) has a statement that “in atucient times" women used to arind, ledors the art of griuding ly water was dincoverell- - I

tus Leceplus on the Continent, thongh not found in stcphens, the Tertus Rocephus in direat IBrituin.

2 [r. Iiolinson heari] no such chiul, lut we heard it at lil. Jil (iibeon). Iaborers of many kints all over the world have certain iries or songs to accompany amd relieve momotonous work. 
f: liut knew lhis, that if llar geomman of the house

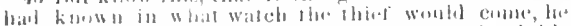

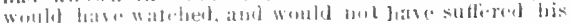

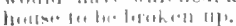

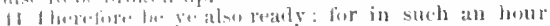

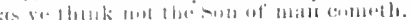

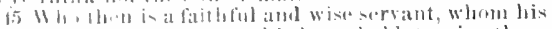

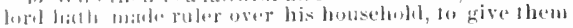

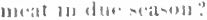

4i; know not on what day your Lord eometh. 1 Bu: know this, that it the master of Ihe house had known in what wateh the dhief was coning, he would have watched, and would not have suffered his house 41 to be "lorokt'l though. Therefore be yealso ready : for in an bunr that yelhink not the son of man

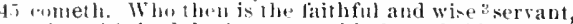
whon his lond hath set over his household, to give

1)r. But this ye know..... (tr. digged through....3 Gr. bondserrant.

thirl illu-tration of the same kind is griven in

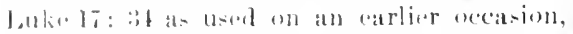

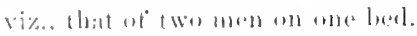

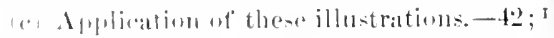
Mark I:S: :3: What honr. Rev. Ver., on what day. This is loul ly many of the best doeumente, and was anily relanged by copyists intu 'Houre, ly arsinilation tav. 4t. 'Thus of the twr warl- in v. 3ti, we have ane in v. 42 and the other in v. 4t, and again both in v.

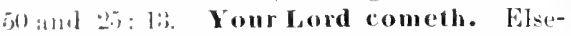
whele be alwats says the sion of man com-

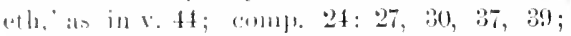
Luke 1:2: 40; 17: 24, 24, 30; 21: 30 . The expersin 'your lord emeth' connects itseltelusely with 'lois lorel' in the illustration that fursently follows, v. 4i-str, and so in Lulie. I'rolubly this expression led to the phlater "ont Ined eometh," which was so cormumom a saying anomer the early Cloristians

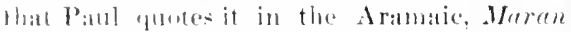

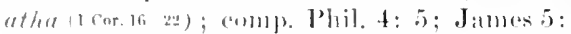

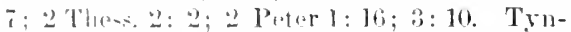

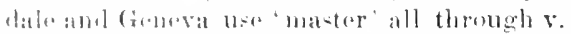

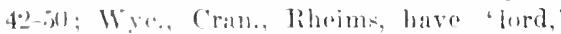

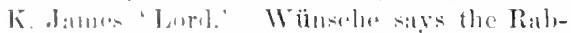

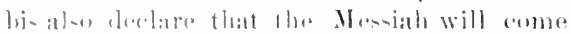

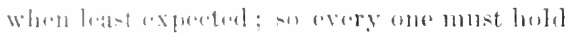
tim-all realy and ho who dows not, will loive himselt in hamo if hre is shut out. In-

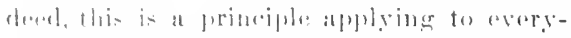

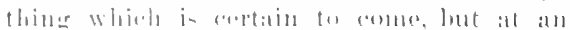

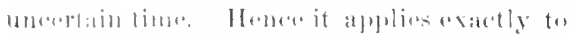

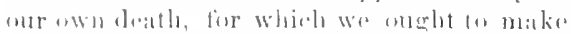

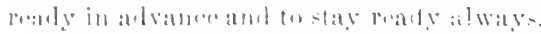

(d) I further illu-tration anel its applica-

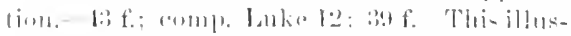

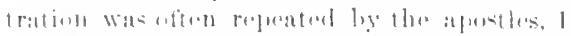

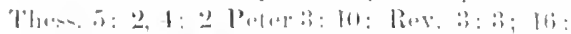

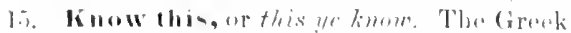

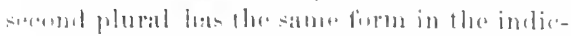
ative as in the imperative, henee aceasional anbiguities, as in John 5: 39; 14: 1. The grood man (master) of the house, see on 10: 25. In what watch. The night, from sunset to sunrise, was divided by the Jews in aurlier tines into three, but under the Romans into four periods called "watebes," colid). Mark 19: 35, and see above on 14: 25. Brolien up, literally digged through (Rev. Ver. margin), implying walls mule of mul or of sum-dried bricks, which are still common in many parts of the world, comp. on $6: 19$. Therefore (r.4t), the propriety of the injunetion being inferred from the foregoing illustration. Be, more exactly, berome, get ready; yealso, as the householder must do if lre would be ready whenever the thief comes. The son of man, as in v. 37,39 ; serestil $8: 20$.

II. 15-51. IET IIIS COMINa FIND you A GoOd SERVANT ANU Not AN Evil ONe. Mark 13: 34-87; Luke 21: 34-30; conly. an earlicr dicenurse in Luke 12: 35-38, 42-10.

15-17. Servant, doulos, slave, sce on 8: 6 . Wise is not the general Greal word, but moan mure exactly pudent, discreet, shrewd, etc.. with varying slaades of good and hat monning, as in $7: 24 ; 10: 16 ; 2.5: 2 \mathrm{ft}^{\circ}$; Lulie 16: 8 . It hore probab]y signifies prudent and judicions in the means and methods of faithfully soring thema-ter; or possibly, prodent in suber ing his own true interest l: tidelity (1) his master. Iousehold. The Greek Worel denetes the whole body of domesties. Theservat in question is the head strward. charered with thespecial ruty of regularly supe ] lying all the domesties with food; alongwith that lie exoreised a general control, observe, mude ruler, or set orer, and sometimes assmmel the risht lopmish (v.49). Meat, food, Whicl wis formerly the meaning of the Englim worl "neat.' In due season. To distributw the foul regularly and promptly was

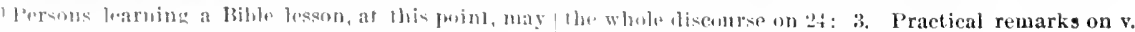

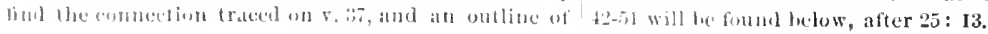


46 Bitsund is l hitt an reant, whom his lord when be eomelli shall fiul sit doiuge.

$\$ 7$ Verily 1 say wato you, Thal he shall make him ruler orer all his gomis.

It bul and if ihat evil servant shall say in his heart

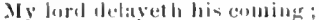

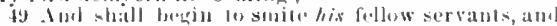
to eat atul ilriuk with the ilrumken;

in 'The lord of that struant shall comp in al lay whell he loukelh mot lor him, and ill an hour that he is nol awatro? $11 f^{*}$.

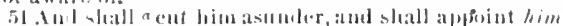

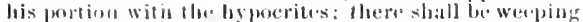
and gualsing wi terlli.

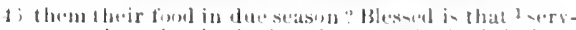

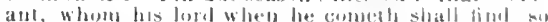

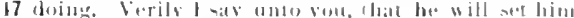

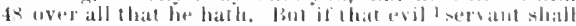
4) sily in hi- loart, My loral larriolls; and shall begio

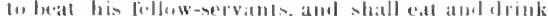

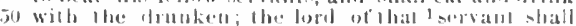
comes ill it 1]!y when h. expectell mot, aml in an

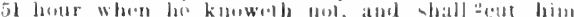
asmuler. alul appoint his purtion will tho lagme crites: Afuroshatl be the weeping awel grtashing of [e. [1]. an important point of gool manag+onent in at steward. IBlessed is more (xatetly hap)!y, as in 5: :3 tl: ; mother boatitule. His lord, when he cometh, frum some jomrnoy, or some oh hir place of resiltenes. Shall lind so doing, faithfully and judicions-ly supplying the domesties with toud, $i$. c. performing the special duties of his porition. Verily I say unto you, calline special attention, compl. an 5 : l8. Will make him ruler (or set him) over all his goods, over all his property of every kind, and not simply wer his body of dommsties. Comp. 25: 21; Iulie 19: 17, 2t; Our loord here puts homor mpom those who sarve him by comparing them, not tu a menial or ordinary slase, but to the intelligent, fathlul, anul trusted head-slave of the houscholi, like. Juseph in lotiphar's house.

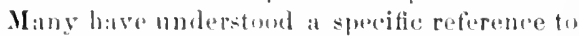
ministers, and from this notion has arisen a singular mixud foxt, widely eurrent in the? language uf alevotional moetings, "a workman that mealeeth net to be ashomed, rightly dividime the worel of truth, and giving to atoh

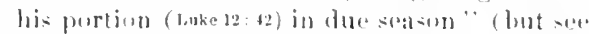

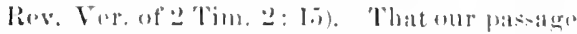
roally refiers to all Christians is emfirmol lo Mark 1: : : : " "And what I say untu youl l sily unto all, Watch." The pasiage maly bo alpplied to ministers a fortiori, as having all the ordinary responsibilitios of ('hristian litie and athers that are extramelimary.

18-51. With the filibful diligence and laiply rowart of the gasul hegul-sarvant (in

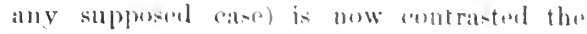
behavior and punishment of the hedal-servant in case be turne ant an evil alle. Evil is opposel both to fonithful and to prudent. (v.45.) But and it. Sis also in 'lyndale and all his filluwers. In Middle English and was usut in the sense ot" "it" (Slient), nfterwads distinguished from the enpulative and hy writing it an, as in silakespeares "an it pleate youl," "an thom lovest

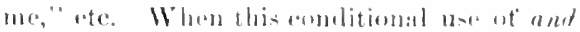
urew indistinct to the mimel it was strength-

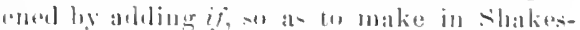

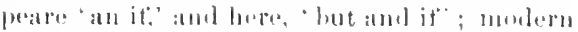
usage ampits the and, amal the old phratse "but and if nuw louks very strange. Compl. Lalie

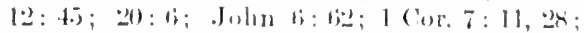

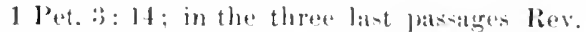
Ver. 110 woly retains 'and.' sluall say iu

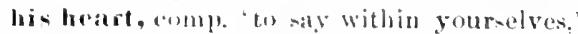
in 3: !?. Tho heart, at always in serigture, is heres the soit of thought us wall as ot ferelion, sere on ti: 21. Delayetla his comiun. Thro rieth axpresies the correet Greok trext. It. contained a delicate intionation to the disciples that Jestas was not enming anginina very suet time (onmp. on 25: 1!h. Shall bogin. coms. on 11: : All. And to, rither, shall cet and drint with the drunken, carousins at the

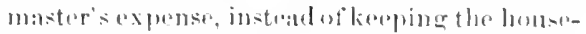
loble in oreler and exereisine a prodent aronomp. In a day, implios that he comes from somer distance; and in an hour, amplitios and maker more impressire, as so thllon in

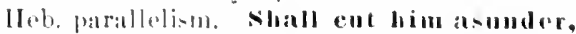
cut him in two. This is the exact matning ut the term, and no wher has any support from

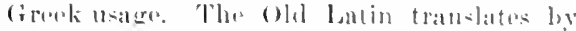
dirilet, 'will divile,' or findet. "will eleare"; Pesh. "will diviale'; and Memph. takes erreat pains, 'will divide him in lis mid-

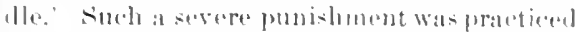

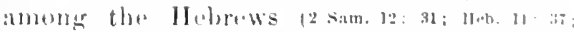

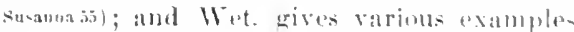
from Gireck and Rummu writers. Sumellink

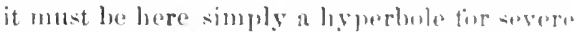

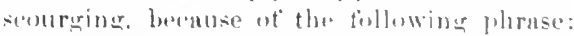
And appoint his portion with the lypocrites. This makes a slldlun transition from the illustration to the ihing illustrated. "Cut 


\section{CHA PTE R X X V.}

FHlis shall llu kingdom of beaven be likened unto

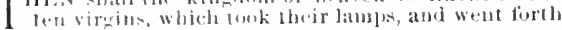
(1) neted the bridegrooms.
1 Then shall the kingdom of heaven be likened unto ten virgius, that look their lamps, and weut forth

l Ur, torches.

him in two' is the image, at severe temporat puni-huncut; "his fortion with the hyporritus is in eternity. That hyperites (see on bi: 2) are grom offensive in Gerd's sight, and mut luesererely pmished, was a thought tiamiliar to the minds of the disciples $(6: 2,5$, 36; $1.5 \cdot 7$ : 16: 3), and just freshemed through the dimcourse of that same day. ( $\because 3: 13: 29$.) The groul servant will be axalted to the high(st perition as sorsant can have $(x+4)$; the lad servant, who drank with the drunken, shall Awell with the hrpererites. Now if "aproint his portion makes a transition from the atrthly funishent to the punishment of hell (25: 4h, wis), ther. is no ocearion for objecting to the literal itnd only extabli-hed sense of " "ut lim in two, and no ground for the alternative remdring of Rev. Ver., margin. The weping and the guashing of teeth see on $8: 12.1$

Lukir having given a similar comparison tr. the groml and hat stewarl in an earline dis-

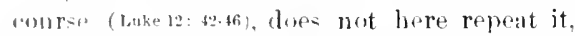
wor yet wholly pas it hy, hat sums up the thomeht in the comprohensive and impessive sontencen- if 21 : : $: 4 t-3)$.

II Ch. 25: 1-13. Parable Of THE TEN

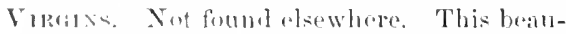
tifial paralle is a further illustration of the varimaly illutrated injumetion to "watch' (24-42.4, which is ropentoul at its clone (25: 13 ), in such a firm at to resalf also the great

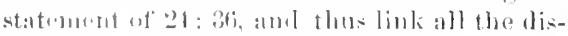
cour-e up to this point in the closest conneretion. (Mal lurel is -till sitting on the Manut of (olises late in the aftermonen of hise last daty of public ministry (sin on $21: 1$, : 3.)

1. 'Plan, viz, at the time of the savionr's roming :4 (2.46) The linglom of heaven, the Ifreianic Diepensation (see ont : : : : )

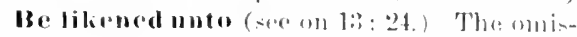
cion of "ertain tatitils, and the decire of interpresers to prepare tur this or that hemiletical appliation, have led to much difleremes of

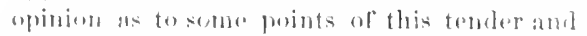
benutiful story. But seareely my of thene seriously affeet the main lesson of the parable, and they should not be allowed to vecupy much space in an expository sermon or Sunday-school lesson. It was the custom to hold weddings after nightfall. The bridegroom and some friends went to the house of the brirle, and after religious cermonies there he set forth towards his own abode in a grand procession, which was illuminated by torehes or lampin the hands of the participante, and often preceded by musicians. In the utterly dark street of an Asiatic eity, every one who goes forth at night is expected, and in modern . lerualem is strictly required by the authorities, to carry a light. (Comp. Psa. 119: 105.) other invited guests, who had not gone to the mide's home, could join the procession at any mint, and enter with it iato the bridegromm's residence, to share in the festivities. But without a burning lamp or toreh they could not march in the procession, and so could not enter the house. In order to join the procession conveniently, such persons might assemble beforehand at different points along the proposed route, and wait for the bridegoom's approach. Some recent commentators urge that the bridegroom must here be conceived as on his way to the bride's house, to fold the festivities there, since in the applieation Christ comes from heave to earth to estallish his kingdom; but it is useless for the sake of a painful literalism, to imagine a demature frem custom. In 1 Maec. 9: $89 \mathrm{only}$ the hridegroon is mentioned as coming forth, with a grand procession and muxicians; and rot just above (v.3i) we see that they were "bringing the bride." When the bridegroom came from a distance, the festivities were muctimes held at the residence of the bride, as in (xen. 2!r: 22, Tobit 8: 20 ff. In that aks, lowever, the virgins would not have lighted their lamps till news came that the hritlegroom was nuar, and after that the dehy on his part would be unnatural, whereas according to the common view, the delay of the wedling procession in setting out from the bricte's house is naturat enongh. In that ease, 
2 And five of them were wise, and fice uere foolish.

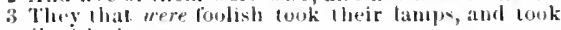
notil will them:

t But the wise touk ail in their vessels will their lanim.

5 While the bridegroom tarricd, they all slumbered and sileli.
2 to mect the toridegroom. Ant five of them wore 3 findish, and live were wist, fur the fomlish, whan

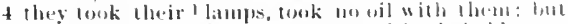

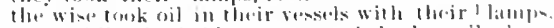
5 Now while the briflorrorom larried, lhey all slum- also, not the brislegroum, but the fither of the bride, would have decided whether the five slomblal be admitted. It serims tolerably evident from r. lo-le that the marriage feats is at the house af the bridegroum. Still, the general lessum remains the same in either view of this partieular. The "Western" type uf text has, with its usual free hamdling, made it read 'went forth to meet the bridegrom and the bride, in order that the text might distinctly eonfirm to custom. The bride i really not mentioned throughout

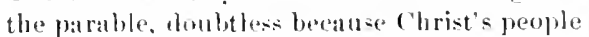
in this image are represented by the attendants.

The story in itself considered has curious points ot' naturalness and verisimilitude. Young girl- would be specially interested in a wedding. prominent in its ceremonies, and distressed at missing the fertivities. Bridal ceremmins are very alt to be delayed beyond the time appointerl. It is prident that great delay is lore suppured, for otherwise the maiden= would not lhemselye have been nrrayed and asombled on long beforeband as to lisve time fior all filling nelepp while they wailml.

Ten may be regardeel at merely a round number, sllficienty large to show interest in

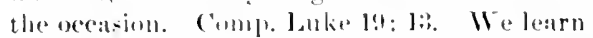
bowever from Lightorot that the Jews"delighted mightily in the number ten. A synagogue must have at lasist ten present; an order or ring of men enosisted unt lut of ten at the linat." Wün. adds that ton men must be present at a wedhling, in arder to utter the

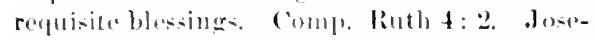

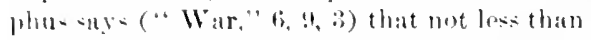
ten mul must asstmble to partake of a jaschal lamb. Morison reminds us how these unes of the number might be sllggested by the ten

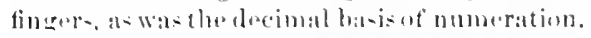

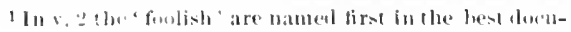
mente amb on in all Jinglish verainns hefore k. Iames,

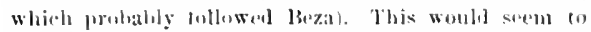
copyint: an unnatural orier, but really aceords with the whole tone of the forenoing passage, whicls makes
}

The word for lamps is diflirent from that of 5: 15, and regularly mealle a loreh \{John 18:3: Rev, n, 10), at11 we know that the Greeks and Romans emontmoly unol furches in marriage processions; but here it siens to demote a

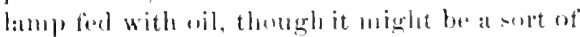
torch fed with oil (Rov. Ver. menrgin). In processinus, such a lamp wats borme on a wooden fole (Eder-h.); and was donbtless protered from the wind. probubly (as anw) by a covering of woed, or af eloth supported ly a wire frame cinnith" "l)iet."). There lamp

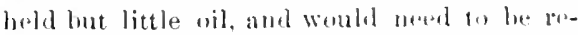
plenished. Is the lamp was indispm-n-athe, and the movements of a brielal fromessiont: were mbertain, prodent perans would carry with them vessels of oil, bat these were very unpleasant fior persons in fietive apparel to carry, and the improlent might conclube to risk it with the ail in their lamp. They would all ret down the lanns and leave them burning, becaluse they were andanty expecting the alproach of the propesion. If we anceive then an wating at the bride's homen, it wemld have been silly to lease the lamp burning, before the was any atmentucentent of the bridegreomis alproanch ; pecially as in that virw he womld be coming from a great distance. Goebel maintains that the fomli-h bad empty lanpe, the resicels being those which formed part of the lamp. This faney is deviset in nreler that the oil may man divine graed, withunt any hiteh in the interpretation; but it makes the forelish rirgins simpletons. Wise' is the worl meaning prudent, etce see on 24: t. Tarried is tho same word as in 24: 48, and cum "if' the linkof eonnection between the two illusmations: comp. also $2.5: 1 !$. Slumbered and sept is lit, nodded amd were slepping. Prorsons sitting up and overeome ly drow-ines- tirs nowl and presently begin to senp continumsty.

frominent the care of the unpreparet. The wathe

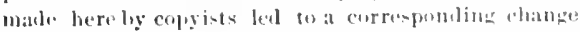
in 5.3 (almost dexactly the same duenuments, which properly reitls 'for the foulish,' introltacing a prouf of theis folly. 
6. And at midnight there was a cry mate, Bebold, the

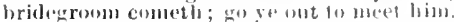

7 Then all those viruins arosen, and trimmer] their lamps.

s Aud lla forlish said und the wise, live us of your

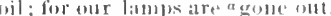

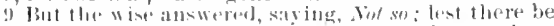

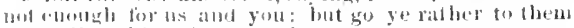
that sell, and buy for yourselses.

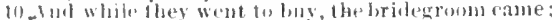

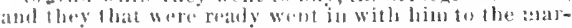
riage : aind the dowr was shut.

II Alferwarl eame also the other virgins, saying, Lort], Loril, "1pen lo $11 \mathrm{~s}$

12 lial ho answered and said, verily J say unto you, I know you not.
6 hered and slept. But at miduight there is a cry Bulold, the bridegrwom! come ye firth to mee him. Then al! those virgins arose, and trimmed their lamps. Aud the foolish said anto the wise, filve us of vour oil ; for our ${ }^{1}$ lamps are guing out. 9 Jut the wis answerefl, saying, Peratrentum there will not le: chough for us and you: go ve rather to 10 them that sell, and huy for yourselves. Ame while they wons away to huy, the bridegrom eame; and flis that were realy went in with him to the sur11 riage feast: and thwilowr was shut. Afterward come atso the other virgins, saying, Lord, Lord, opea to 12 us. But be answered and said, Verily I say unto

a Or, going out._-10r, torches.

Ga ve out, or come yt forth. The latter is more jurbably the meaning than 'go geout';

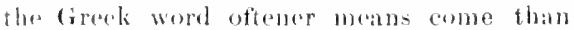
ga, which is neually exprosed in New Test. hy the worl used in $v$. 9, (amp. :3: $5 ; 20$ : :29; and tho: cry would naturally be mado by perans in thestrect who saw the procesoion approakhing, rather than by persons in the lomse; nor woutd the latter bave oetasion for making a loud, clangormus cry, such as the cipeck word denotes. There was a ery, or more litelally a cry has arisen, a vivid exprosion which transports us into the mirlst of thoserne. Behold, the hridegroom! like - Ballollat, the Lamb of Grod!' (John 1:36); lut many (a)pyists adder, as in comn. Ver., comptl. 'Trimmed is tha worel renderod "garnish' in 12: 44 and 2:3: 29, amd denotes adorning, beatutifyin; they poured in oil, trimmed and alrew up the wiek, wiped off the lamp, lial everything fluat would maks it beautiful and liriglic. Our lamps are going out, the Grovk having the present tonse and not tha

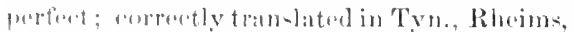
and marein of ('ome. Vir. Lest there be

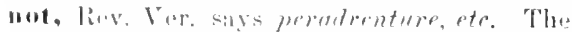

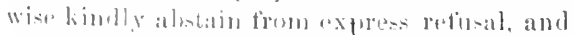

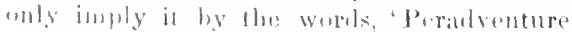

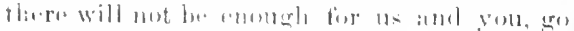

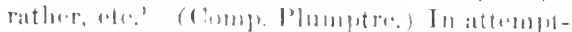

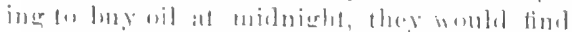

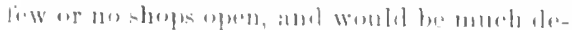

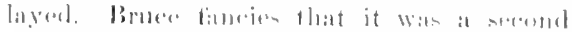
tolly to enatter ail, when if they latel hint re-

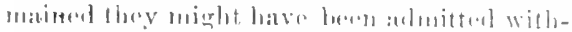

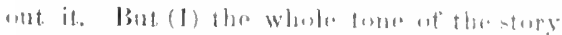

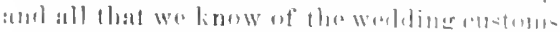

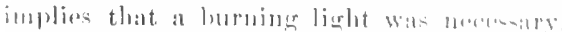

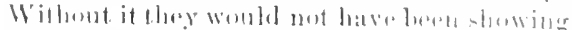

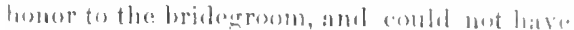
loren distinguisled at the dour from stranger- or other persons having no right to be admitted. (2) The adrice of the wise to go and buy must, on Bruce's view, be taken as cruel mokery, or possibly as dietated by the unretlecting selfishness of persons hurried and disconcerted; either of which would seem excessively incongrunus and improbable. To the marriage (feast), as in $22: 2 \mathrm{ft}$. The door was usually in the middle of one side of a house, leading by a passage under the seeond story to the innes court, upon which all the roms of the house opened. When this outer door was shut, all conneetion with the outside world was ent "uff: Persistent knocking, and loud contreaty addressed to the bridegroom personally, might at length bring him to the door. Verily I say unto you, a solemn assurance, comp. on $5: 18$. I know you not. They have no claim to be received as guests; he doos not even reergnize them as aequaintances (comply $7: 23)$.

The application of this beantiful parable is olovious, but is surpassingly tender and pathetie. It teaches the same lesson as 24:3742 , and $4:-51$, that the only way to be ready when. Jesus comes is to be ready always. The term 'virgins' must not be given a spiritual simnifinuce, as if denoting pure Christians; for five ot these represent persons not really ('hri-tians at all. The division intotwo halves must surely not be supposed to teach that at Hoe onning of Christ half the people in the world or in any community will be ready to mon+l him, and half not ready; it was simply the mose natural division of the round numlur, the being no special reason for dividing "therwior. 'The hridegroom tarried might sugent to the diweiples that their Lord would mul (mole immediately. (Comp. on 25: 19.) T"lu. fact that all the ten wero sleeping should not be made a reproach to true Christians. It 
13 Watch therefore: for ye kuow neither the day wor the hour wherein the sou of man eometh.
1:3 yut, I know you not. Watch therefore, for ye kum oul the day nor the hour. was mot wroug fior the virgins to shep under the circunstateres; they were neglecting no duty in se doing, porvided they had therouchly made ready for the bridegroumis coming. Th molderstand it as meaning that

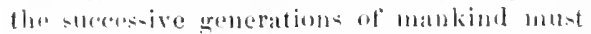
fall asloep in death (valdous Fathers and some modern writars, is wholly unwarranted and sepuse stranguly unsuitable. Whether lhe finlish vilerins atre to be compitered as representing "alumreh members." haere is mothing to show: they aro jersons who profess and home-ly think that they aro ('hrist's friends, and experet to moet him with joy. To take

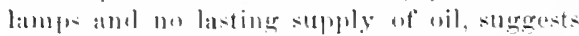
that smperpial and temporary interes in divine thiners which is so aften witnessed; comstr. Jlanas 6: 4. The hurriod and fruitless attempt, when the moment arrives, to make the preparation which seleght to have bern mate in atrantere is derply pathetice and touches a sally commoun fault in rogard en leadiuese for moefing clarist at his eoming, or

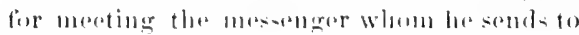
bear us away, aren deatle. Tha inability of the prodent virerins to help the fouldes in their costremily reminde n- that piety involvos personal eonditions and relations to C'hrist that are nut transtirable. I know you not. This will not he rejecting persons who ask to be saveal, but disowning morsons who elaim to have buan saved, to hatre beral reatly and wating for his amingr

To find somo sepalate spiritual manuing in the lasuph, the vestels, the ail, and the salloge

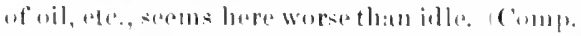

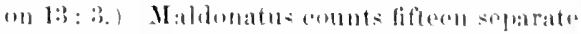

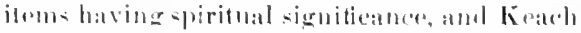

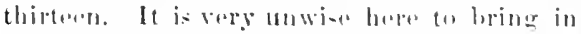

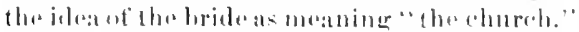
(tiphes:at) The bride is not montiomed in the

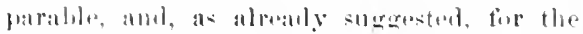

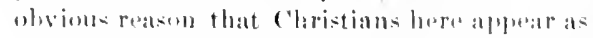
frients wating to join the procession. Bring in the liride as the ehureh, and you intruduce. inceitable anfuriun of idea thromerle a mixture of distince imagess. It anght to be "verywhere earefully rememberent that if " mixed metaphors" are laal for rhetoric, they nre worstior exegesis.

Wath therefore, for ye kuow neither the day nor the hourt repeats the sul-

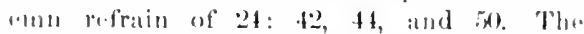

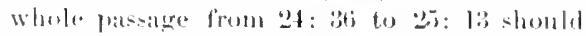
be raat in wombip as one, and this rio frain brought unt wilh special emphasis; ju-t as alle roads l'salms 42 and 43 , with the retratin of $42: 5,11$ and $43: 5$; or like the refrain in

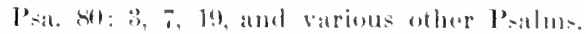
This is mut sayeing that the passige bestorents is.

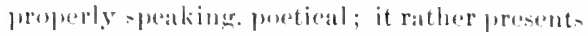
an uraterical repedition of the practical theme, after calch semarate illustration. "Watch Jees not here mean keop awake, as oplosed to the sheaping of v. 5 , but be so heeplitully expeetalut as not to be alught mupropared.

HOMILETICAL, AXD IRATTICAL.

("h. 24: $: 9-8,3$. The floul, as a picture of ('lorist's timal coming. I) Mro know not when it would he. and did mot really beliove

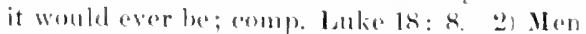

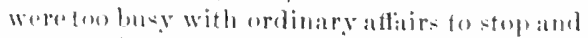
think alunt (iod's mereiful warning. (i) Mon

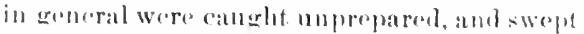
intadestaction. f) Thon men who believed and mate reaty foumd themsolves satio, and hall a blessed future- V. Ho l'. 'The most intimate associations of this life will in mank

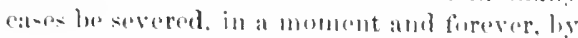
the enming of ('brist. Ind so death, theneri tor nome all eternal sleep. will be for many. alas! an cternal sefaration. - V. 42. The coming of and Larel. 1) Wraknow noll when he will eome-nexl not know-esnnol know

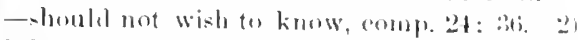

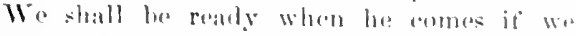

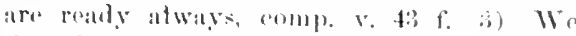
should wateh, mot in druad but in hopre, fur

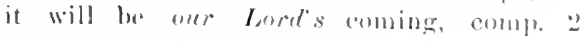

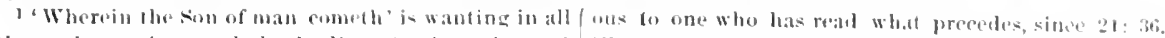

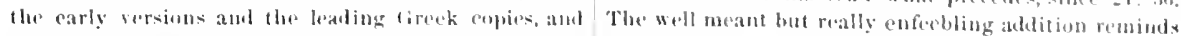

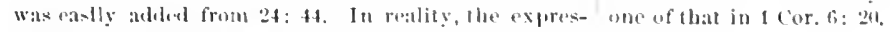


Tim. 14: 8; Titu, 2: 11-14 4) Thus are we buttur flepared to serve him when he does (2)1ua; (a) with patiance under trouble, comply. Jance $5: 7$; (l) with guntleness and torbeurance towards others, comple. Phil. 4: 5; (c) with all holy living and piety, compl. 2 Peter 3: 11 f. : (1) with etports to makeall men biliewise ready to mont him, comp. 24: 14. - V. 4517. I roul servantof (lorist. 1) IIe is aware lhal the respensililities of Christ's service refuire not only tathfulness, but prodence, dis-

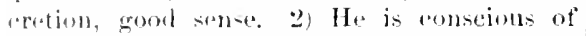
futios to his fohlow-men, and is exact and punetual in performing them, at being also dutios to Christ. 3) lle is always ready to meat clurist, because always bu-ily engaged in Christ's sarvice, 4) He will be rewarded for sorving thriat here by bettor opportunitios of serving him hereater. $-V$. 45-51. The gond and the bid servant eontrasted. All men are in whe or another sense Christ's servants, and will be held by him to account, "omp. 2 Cor. 5: 30. 1) The good servant is firithtul and wise; the bad servaut is unfaithtul ankl foulish. 2) The gorol servant is bus in saving ('hrist by benefiting others; the bitd atrount is nokind to otlers, and engrossed with salfish gratifieations. 3) The goon servant will waleosus the ford at any moment; the bat servant will be aught unawares. 4) 'l'he genel servalut will be exalted to highor homors alld wialer usefulness ; the bad servant will be torribly punisled, dwelling forever amid hyporlitas, and filled with bitter but vitin remperts.

2.: 1-1:3. The Ten Virgins. 1) The eoming

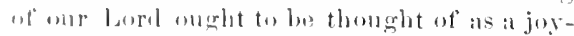
ful revent. 2) The time of his coming is an-

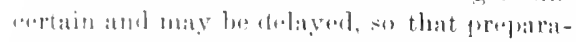

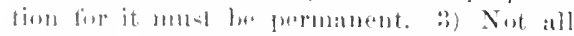
thome who eall thellowlyes his friends, and

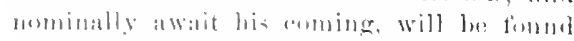
really ratily whath he (a)mes. t) Jlarrial at templo to make reaty thom. will proses at

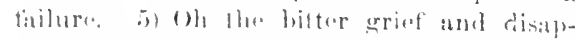

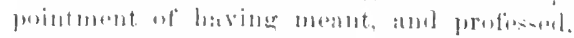

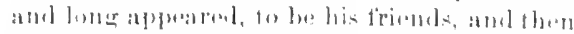

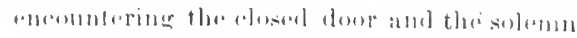

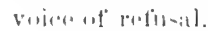

"No light had we: lor that we d" repent

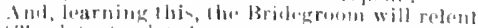

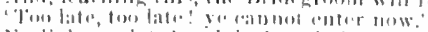

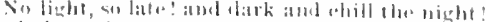

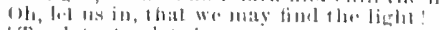

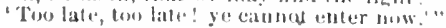

V.8. Hexry: "Those will see their need of grace beruater, when it should save them, who will not see their need of grace now, when it should sanetify and rule them." $-V$. 11. JErome: " What does it profit to invoke him with the voice whom by works you deny?" -Y. 1:. HENRY : "With regard to those that put off their great work to the latst, it is a thousamel to one that they lave not time to do it then. While the poor awakened sout ardresses itself, upun a siek-bed, to repentance and prayer, in awlul confusion, it seareely knows which end to begin at, or what to do first; and presently death comes, judgment comes, and the work is undone, and the poor sinner undone forever." - V. 13. We need not wonder at the freruent repetition, and fourfold illustration, of " Wateh, for ye know not," seeing that human nature is so prone to heedless soth or toproceupation with worldy aftairs. - All these exhortations to watch, and be ready, for the Lurd's eoming, will apply without material alteration to the duty of preparation for death, which will in an important sense summon us to meet Christ, and will leave fixed and permanent the relation in which we shall rise to neet him when hedoes come. (Jotn $5: 24$ f.)

14-30. Be ReAdr to GIVE Accoust AT TIIE Coming af Cintist.

This is found in Matt. only, though a quite similar parable is given by Luke (19:11-27), as suokell at Jericho, some five or six days arli*r. On that occasion it had a special design, to indiente that the consummatrd rejen of the Messial would hegin only at his peturn aftur an absence, and that then he wonld reward and punish men aceording to their bohavior during his absence; the illustration in that form exactly corresponded to the bistory of Arehelaus. (See above, at elose of (hap. 2.) Here thuse peenliar traits are droplud. and we have not a returning king, Jut simuly a master, who returns from a long fonrney to reward and punish. It must not ha interred that Jesus is here taking pains to avoil calling the Messiah a king, for he does so immoliately afterwards. (25:31.34.) Some "ritics at once take for granted that Jesus smlin only onc parable of this sort, and that aitlar Luke or Matt. bas reported inaceurably. But we have already remarked many times that - weh varied repetition on the part of a prealor who journeys about is perfectly 
14 Fur the kinglometherem is as a man travelliug imb

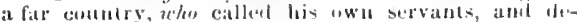

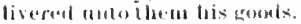

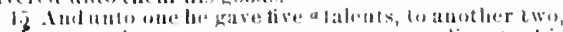

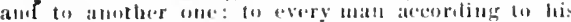
sevoral abitily; amd s ratglitway lank his journey.
14 For it is as when a man, going intw andher comu.

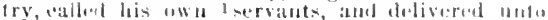

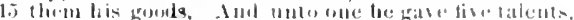

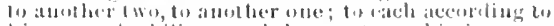

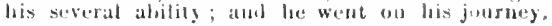

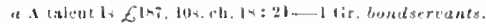

natural. Meger thinks it would be unmatulal that the simpler shomld be the iater form. It is ambing to wateh the eurront popensity to explain every thung as an evolution form the simple to the complex. Cortainly in preacleind it is very eommon to produce a comblox illustration anlapted to certain surroundings, and on a second lose in sonde other diseourse to make it simbler and more general. Fidersh. connts it ditidenlt to belieres that our Lord womla give a parable in the presence of his dicciples at Joricho, nul then, a fiew dias latrer, repuat it to the disciples in private; but

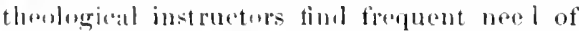
repeation to a clase in an alteren form what hatl heen said in a sermon not longr before.

11 f. For the kinglom of heaven is as a man, etc., (ireek, lit., for just as a man, cote. 'Tho other membere of the eompalioun is never finrually stated, but it is muderstuod without ditliculty. (Mur Laml has givell (sinee 21 : : a serias of illustrations to show the importance of watchiul preparation for his eoming -the days of Noal, one takitl and the other loft, the thiof coming unexpectedly, the hoatstewarel and his roturning master, clue fisolish and the prublut virgins. In the battor case he said express\}y (25:1) that the Messianic roign thail resemble the case of these virgins and the eoming loridegroon, so be here groes on without further stating the matror to be illu-trated. It is important to wateh (v.ris), for tha Mesiah's second comning is like the (ast: of a man, ote. See a similar expresion in Mark 13: :34. Travelling into a lar country, as in 2l: 3:; "look, or went on, his jenrney, v. 1.5, is the same Greek term. IIs own servauts, as in 22: ib, those that helonged to him, dewlous, slates (see on 8: (i). from whom he might reguire mat expert are for his interests. Trench: "silabe in antipuity were often artisans or were allowed otherwioe to thgage freely in buniures, puging. as it was forepuently arrangarl, a fixed yearly sum to their mater; or they hal money eommittod (1) them wherowith to trade on his neeount, or with which to enlarge their business, and bring in to his: a shales of therir protit.." X

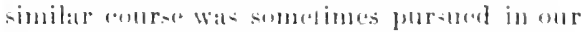
southerm states, duriug tlat existence of marry. Five talents. A talent of gold, see m 18: 24, womld be neal twolve lumbled doliars of onr moner, and with a purelatsing power at last ton times as errat. It was as it aneshomld now put stiog(n) in the hands of a

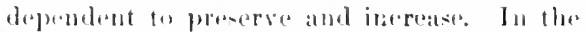

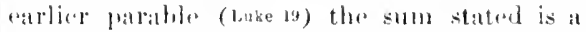
"mina," abunt st7, so that ten mina- would be one hundred and seventy", expal in purchasiner prower to say two thousand dollars. The slum- llosel in the two illu-trations are obvion-ly round numbers. As talents in tho: parable represent whatever Goul gives us to use and improve, and as beyond eompaleison the most impurtant of such gifts ale our mental puwers, su it has besome common in English fo call a man's montal powers his talents, and henew to speak of a man of tabent, or a talented man. A momer or loss similar use is fommd in German and Dutch, in French, spanish, and Italian, even in moderu lireck. To every man aceordius to his severat ability or 'his own a bility, viz., his caplacity lor freserving and increatsing the fumb- intrustad th him. Comp. Rom. 12: ti; 1 (irr. 12: 11: Ejuk, 4: 11. In the earior parablu this alintiotion was not made. but to each was given the same sum. (ruke 19:13.)

16-18. The trusted servints go to work. straghtway should most probahly be onnected with what lolluws, as in liev. Ver., rather than with what precedes, us in Com.

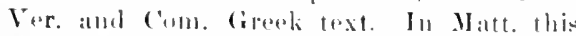
Greeli word ( Wriss) nlways connects with what follows it. The croud and faithfol sorrant (v.21), foeling his repomsibility, wont to work withut delay. Wo naturally sllppose that likewise, sild of the secortd selvant, ineludest thic fieature. Traded, literally uroked.

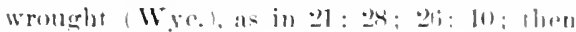
in a tochnienl sollseo, 'enguged in busimess.'

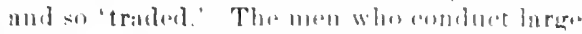
business operntions have towork indeed. Une 
16 Thell ho that hat reerived the five talents went and traled with the situe, and mats then other tive taletils.

17. And likewise he that letel recened two, be also

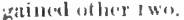

is but he that had received ond went and digged in the estrth, atud hid his lorel onemey.

19. Alter a lome time the lord of these servants cometh, and reckesuch with thems.

20 Aul an he that hat redeivel five talents eame am

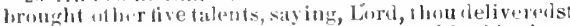
unto me tive lalents: helold, I have gained hesite them five titlents illore.

$2 t$ lli- lorel stid unto him, Well tone, thou good and

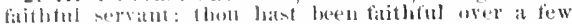
thinss, t wilt make the ruler over many things: enter thou inte the joy of thy lorid.

2. hle also thitl hal recerived twe talents came and said lerel then deliveralst unto me two talents: leeboht, I hase gatined two other talents beside thent.

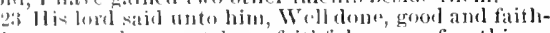
[ul sorvanl: thom has beren fathlal over a few things, I will mak, there ruder over many things: enter thou into blo. juy al ilıy lorel.
16. Siraighiway he that received the five lalents went and traded with llem, and made of hel dive talsuts. 17 lilike manner ho also that ieceired the on gained

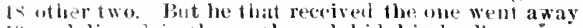
19 and digued in the earth, and hid his lorel's nubing. Now ather a long time lle lorel of those logrants

20 conteth, and maketh a reckoning will thenl. And he that received the divetulents came and bromght otluer five talenti, silying, Lord, thom deliveredst unte us dive laleuts: lo, l lave gained other five

2l talents. Ilis lord said into him, Wihl doue, good and fithtul eservaut: thom hast heen tathliul over a few thilles, I will set llee over many things: enter 2. thow into the juy of thy lord. And fie also that rereivel the two talents came and sald. Lord, thro luliverad-1 unto use two talents: lo, I have gained

29 other 1 wo talints. llis hor said unto him, Well dome, good and faitlful g servats; thou hast heen faithinl over a few things, I will set thee over many of the pupular delusions is shown in speaking of "the working classes," as if brain-work were not uften fitr more intense and severe than mire land-work. But the term "busimes men" preceeds on a like assmmption that mo enw etse is really busy. In the other farable (Luke 19-13-15) the Greek word nased an mutans directly 'ongage in business, which wate exprusised in Oll English by 'occupy'

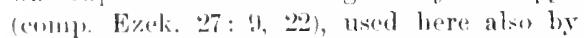
('ran, and liheims, while Tyn. and Gen. in Lule give 'buy and sell.' Made. It is hasd to decide whether we should read this word or 'singed,' which has numbeb better documentary evidences, but might eanily here rome from 8 17, 20, while 'made' is also found in lulie 19: 18, Reve. Ter. There is obvinusly me sulastantial ditlerince. For lord, meaning moster, sies on 8: 19.

19-23. The mater roturus and hemands

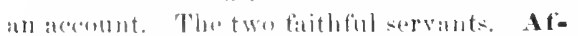
ter a long time. This wan nexestary in the

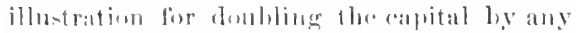
safe bu-ines. In the alpliration it intinates

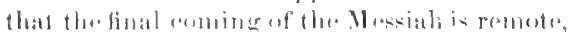
but still the phasese is antere indefinite. There whe mothing in it to slese that the comsing

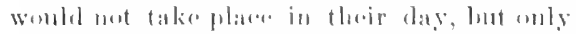

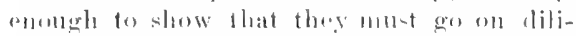

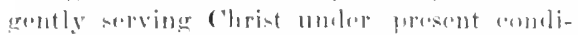

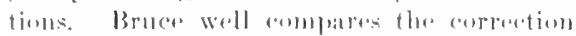

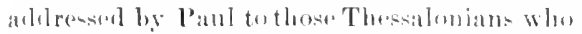

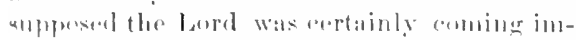
menliately, and infored that it was asedes to congagre any more in the ordinary duties of
Ilfe. (2Thess. 3: 10-12.) Well done is a good translation, fomd first in the Geneva version; but stress canmot be laid on 'done' in eontrast to the 'well doing' of Gal. 6: 9; for 'Ane' is not expressed in the Greek, but only implied in the word 'well.' . Tyndale and Cran. translate simply' 'well,' but this in molern English would be inadequate and anbignous. Over a few things . . . over many things, implies that the master had vast capital and many kiads of business to be managed. We cal hardly suppose here a enception remaining from the former parable, where a king was speaking (Luke 19: ii), for there the reward was to be made governor over ten cities; the two parables seem to be consistently distinet throughout. The joy of thy Lord is in the story the rejoicing and felicity consequent on the master's return to his home (comp. Luke 15: 20. tt.). But here the applieation quite overpasses the limits of the illustration. The noblest and purest sarthly delight could but dimly pieture the joy which will follow the saviour's final coming, tor all that have been good and faithful sorvants. a joy unspeakably heightened by the fact that they will share in it with him; (n)m), Ilal, 12: 2; Rum. 8: 17.

The rhythmical repetition in $\mathrm{v} .22 \mathrm{f}$, of $\mathrm{v}$. 20 f. reminds one of $7: 26 \mathrm{f}$, and of the parallinism which charapterizes the Old Test. poetry. But what is more important, it comunends and rewards the servant who has faithfully used the two talents in the same terms as the one who received the fivetalents. 


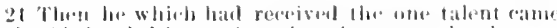

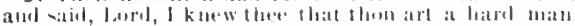

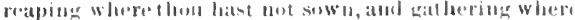

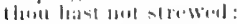

2) lud I was atioijel, and went and hid thy talent in the earlls: lo, there phom loast that is thithe

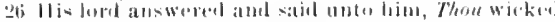

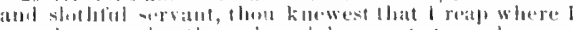

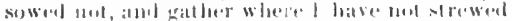

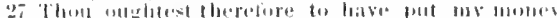

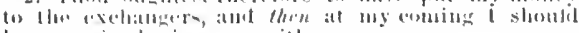
late lenteivil nille uw w wh ustry.

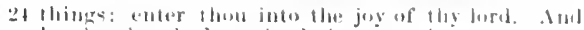

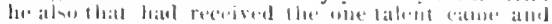

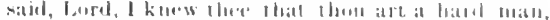

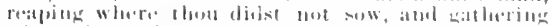

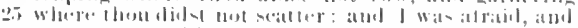

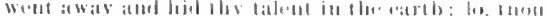

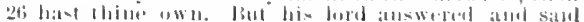

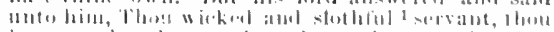

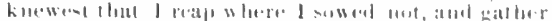

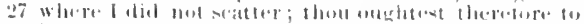
have put my money to the biakel's, and at my com-
There will dumbless be ditherent capateities for sharing in the jor af anr lard, hut tovery one will rojog to the full. In the other latrables

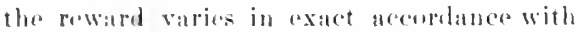
the frotit made mpon the original tratst, ten

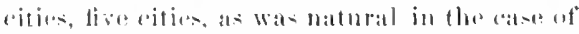

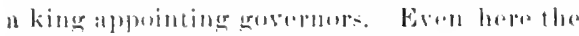

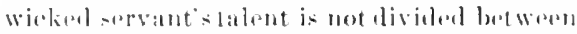
the two nthere, but griven to the first. In

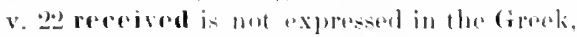

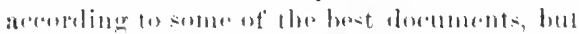
left lo he understoud; beside thent rests in interiur aviriencer.

21-30. Tha wiekenland stothful servant.

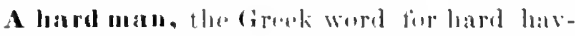

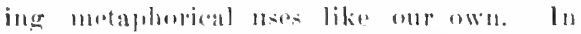

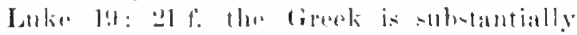

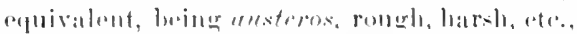
which we lurrow through the latio as all--

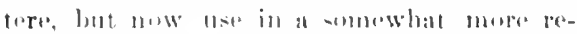

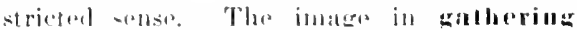
where thou bast not stewed, ur srattered, is mot ratetly the same ats in reaping where thou hast not sowu, but semils to nuean the eatlering at wheat that atter it was ent

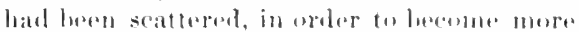

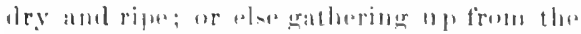
thresing-thur what atuther hat satterod

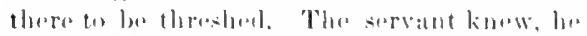
sajel, that his ma-ter was land and graspiog.

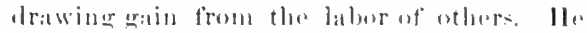

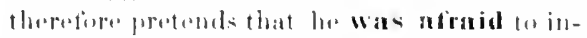

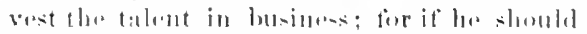

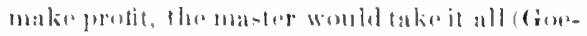
bel); amel it he shomlel lose the prinejpal. he would be harshly treated, sines ane who so

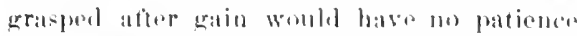

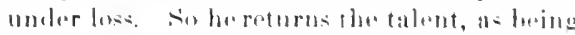
all that womld really have belomered to his master even it he had angaged in profitable busines. He lowe not recugnize his position and luty as a servant, ami tries to exell-e himselt by attacking his manters character

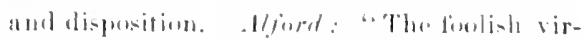

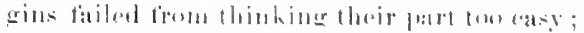

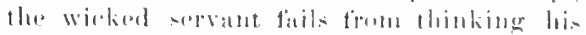
tun hard." Hid thy talent in the rarth.

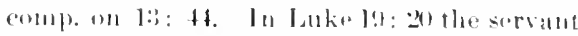

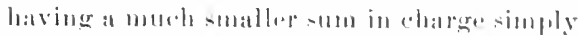

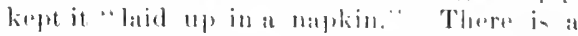
surt of suiterul fling in the worils lo, there thou hast that is thime wwu, ar then

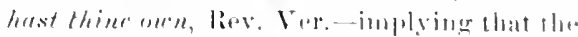
master bad nut right to experet more. Thou wicked and slothtul servant. Ite woked. ly mi-judged and stadered his master, amd tried to make llat an esense tiol his shothlil

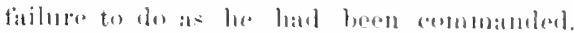

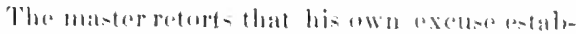

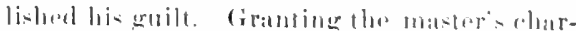

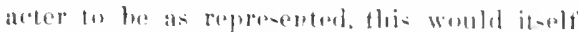
have indieated the propriety of at leat-t lend-

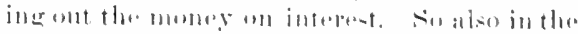
earlier parable, I,ukr l!1:09. Nxebangers, ur

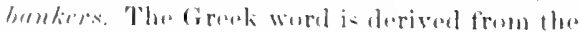

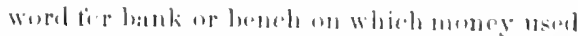

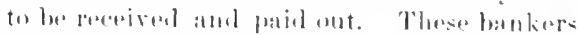

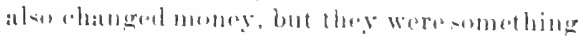
marh bighere than the smallechange men of

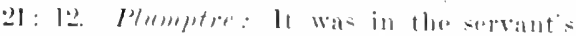
fowre "to take atrantage of the bankinge.

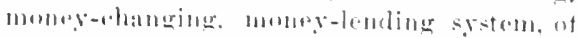

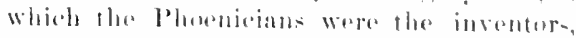
atid which at the time was in full operatem throughout the lioman Empire. The hanker.

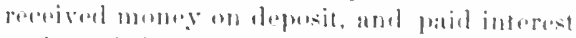

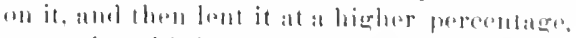
or enployed it in trade. or a a did the publi-

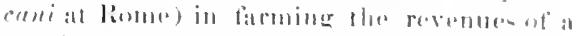
provinee. 'This wastheretione the natural resoluree, as investument in -lucks or complation

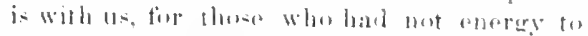

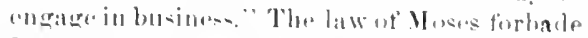

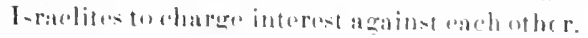

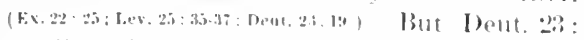
20 allowed them to lend upon interest to Gen- 
2s Take therefore tlow latent from hine, and give it

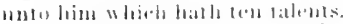

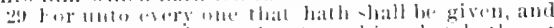

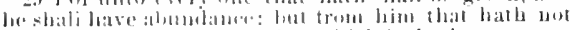
shall be talkoll al aty "voll that which he hath.

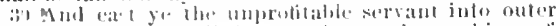
darkmos: there shall be werping and gruashing of lecthls.
28 ing I should have received back mine ow w wh interest. lake ge away therefore the talent from him, and give it dinto bin that hath the ten talents.

ge for unto every one that lath shall be given, and he shall have ahmolame: but from him that hath not,

30 crint that which lie hath shall be taken away. And (atst ye out the unprotituble 1 servant intu the outer darkness: there shatl be the weeping and gnashing of teell.

1)r, boulseriunt

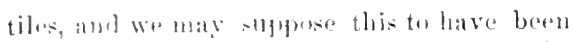
a rase of that sort, there boing here no indi('ation of nationality. Besides, the law was

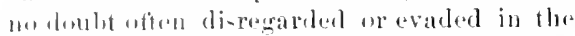
dealiuge of Jow-with anch other, as we find in the rimb ot Xollomiah. (Neh. 5: 10-1\%) ()ur Lord draws hi-illustrations trom the actual eamduet af men, sometimen fiom their wrong conduct ( $\because 1$. Luki 11i: $1 \mathrm{Hf}$; 1s: $1 \mathrm{ff}$ ). Csury, in ()lif Eneli-h llenoland simply what we now call intrepest, heine the sum fatid tor the exse of monery, Latin usula: but ly degrees eamo fo sirnily exurlitant interest. as so many worls have tionn evel practires acoulered an

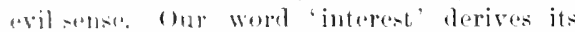

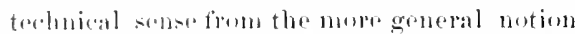
of protit. Tha Greok word here einploged

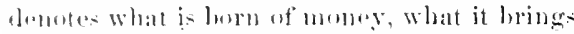
forth of pouluers. The translation omght to

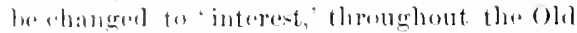
'Test. P'al. 1.i: 5 refers to the litw of Moses nluxe montioned, which is not binding upom (liristialls.

28. "Bih. ('ommo": "Fol's gifts are not left

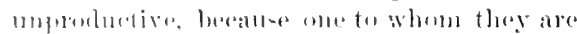
intrustal menlect- his duty. So fitr as such

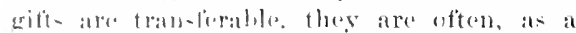

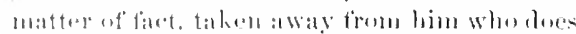
nat ns. them aright, alld griven to another.

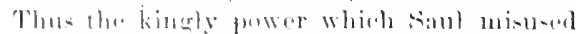
wa- taken trom him and given to Morid. 'Thun the kinglum of fiod was taken away from the fl.we and eriven to a nation bringinge liorth lise fruit- therent."

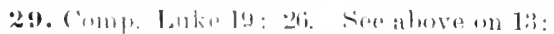

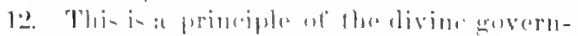
mont haviner manty applications.

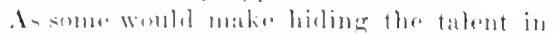

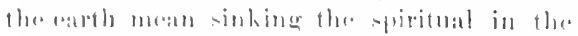

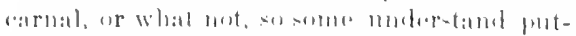

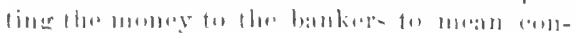

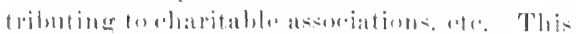

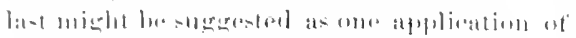

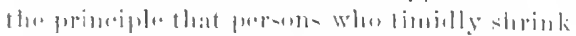

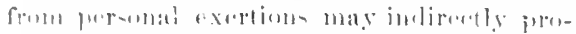
mule spiritual wolk; hut n single protetionl application of a general principle should not le put forward as an interpretation.

30. 'The mprofitable, or "unserviceable, in collounial plirase 'of no use'; before called 'wicked and slothiul.' If the man with one talint was blameworthy for making no inrease, much more (Bruce) would that have ajplied to perions laving two or five talents. Thu the guilt of uselessness holds true for high and low. Alas! how many professed Christians are utterly useless. Into (the) onter darkness, etc., (see on 22: 19), while the firituful servints share their master's joy in his brightly lighted abode; the ajplication of the image is to hell and heaven.

\section{HOMILETICALA AND PRACTICAL.}

V. 15. 'To each aceording to his ability.' 1) Inequalities of human condition necessarily revult from the inequalities of human (ladicter and conduct. 2) To have more of projerty or of other talents than ane can manage firr Goel's glory, would be a burden and not a privilege. 3) The way to get a larger portion is to make wise nse of what we law 4) The best reward in eternity, will be the ability and opportunity to do grander worli for Christ. 5) The fathful use of two talents will recoive as hearty eommendation as that of five; and the eup of juy will in each case be full. Vea, it would have been the same with the servant who received one talwht, hat he faithfully used it.-V'. 2l. "Enter thou intuthe joy of thy Lerd.' 1) A joy unalloged log sorrow. 2) A joy which is the rowarl af fathliful service. 3) A joy which comsists not in idle resting, but in higher and widur usefulness. 4) A joy shared with the laril himalt.-V. 23. Jewish comm. (Midlall) on Exodus (VTet.): "God nevar bemow great things on men till lo bas first trimel thum ly little things; e. !, Moses, bavid."-r. 2t. Galling Gud a hard master. 1) II'n are oftan hard masters, but that does not prove that frod is. 2) (fod gives to every servant some talent to improve-only in pro- 


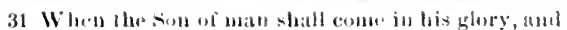
all the buly angets whli him, lhen shibl he sit upon lhe lorome of his glos!y :
:31 But when the ton of man shall come in hic glory

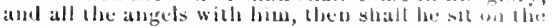

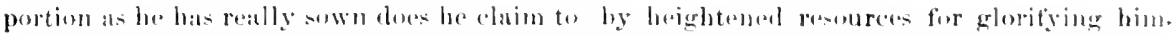

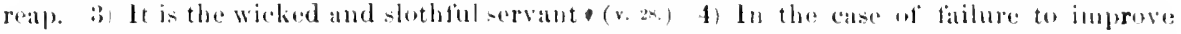
who complatins of having a hard mater. our talente, many or few, complanints against 4) Ton axcuse our lack of serviee by acell-inger him whom we onght to serve, is but alling insult to injury. 5) We may delude nurselves with flimsy excolses, but we cambet

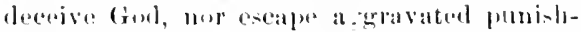
ment. $-V$. 2.5. The hid talent. I) It is " his lorid's money" (v.ls), entrusted for use and increatere, and the sorvant has mo right to hide it. 2) The reacen for hiding maly be profiesadly problent fear, but is really soth, disobediencerand andek of devotion to the mater's interests. 3) The risks ingolved in doing anything whatsoner, form nosuflicient reason for doing mothing. I) To return the hid talent is ued griving the manter his own, for he has at riglit to expenet incereter. Axos.: "One wher, peceivirig seed tosow, hats at seed-time not suwh it, infliets lows upon his master; altheugh he lass not lest the seed, yet there is a low in propurtion as there might have been gatio if he

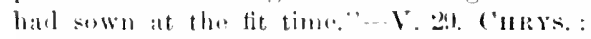
"He that hath at gift of" word and teaching to protit therelys, and useth it not, will lose the gift also; but he that grivelh diligrances, will gain to himenelt the gift in more aboulanere; evell at the other lowelle what he hatel received." - V. :30. Thu unportitable servant.

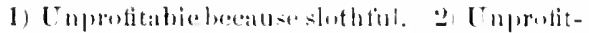
able, and therefore wickorl. :3 Tuprotitalile and inexcusible (v. 2br); it strinking from one way, he might hase heren lecthl in some other. \& ['nprotitable, and for thi encelely punished.

V. 1t-30. Parable of the T:alents. 1 Chrim tians should glatly recosnize that they are christ"s "own servants," and num bend evory energy to pomote his ame in the worlel. 2) christ commits to 11 as tallents to

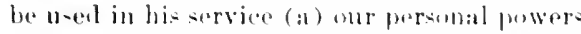
-of body-of intellect, imagination. pasion. taste, aromaience, will; (bi our attaimments:

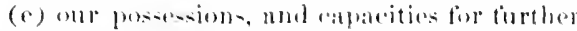
nequisition; (1) our intluenese, throngle family, social. and husiness relations. 8) When Christ enmes he will reward u- for the fathtul use of all these by almitting us into intimate and permanent interenurse with himself, and

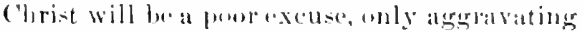

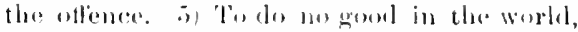
to lee simply lorelens and worthless, is to sin grievouly agatust Christ; and only by inces-

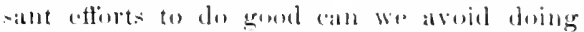
pesitive evel. (i) The umpretitable servant will be punished by taling away hin meglected

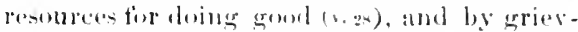
olls and abjeling sullioring. (v. 30.)

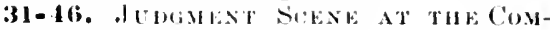

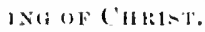

The other binepels have uothing at all paratlel to this onlemuly leatutiful pisitge. Matthew has in varioge other in-tances givesu

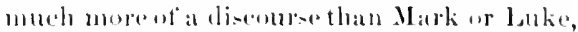

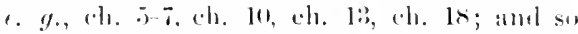
here eh. Dis all pecouliar to Matt., execpt that

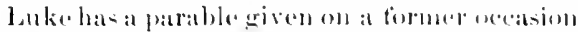

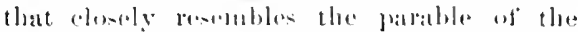
lialents. The peferenese the destruetion of Itrusalem, with whieh this great discourse beran, hals now pasedel ont of sight, and we think only of the tinal coming of ('brist.

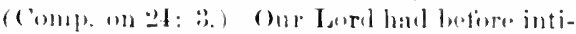

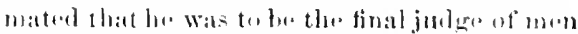

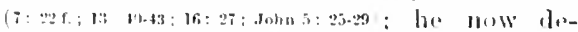
serilue the finture juelement secene in at way -trikingly apprepriate for the andelusion of his whole discourse on his combinge. (ch. et and 25.) Esperially atese is the connertion with the forengung parable of the Talents, in which the ma-ter returns to examine, and reward y punish. - Some expusitors here intro-

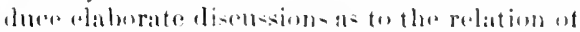
this judgment to the "thomsamel veatrs" of

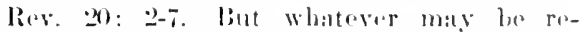
srarded as the meaning of that obrewre and highly figurative statement in the visions of latmos, it seems ont of place to bring in the matter here. where there is no distimet romm. and uo oreasion whatever, for its introluetion. -The pasiage olwion-ly divitles its de intar. :31-39, :34-40, 41-4i, and th. lliosed: "It will heighten onrestimation of the womllerfil - - bh-

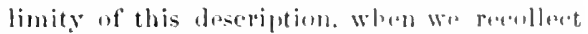
that it was spoken by the Lord only three days before his sufferings." 
32 And hefore him shall tee salhered all nations: and he shall sepalate them one from awother, as a sheplierd dividith his sheep trom the gonte:

31-33. All man sathered and dirided. When, Rise. Virr, But when. It is very doubthal whether the Groek particle ought hereto lue translated "but, or 'nuw, or to remain untranslatul. This depends on the relation of what follows to what procedes, which the fartic lo ifolt lowes not at all dotermine. (On] if lla tollowing pasage stands in somo solt of oppostien to the foregoing, do we projerly lender" "but, atherwise the Greek term is anly a particle of transition, which we remeler by "110, ar 'and, or often leave quite untritlolated. This prassage does not seen clearly oplused to the parable of the "Talents, for tluat also, ats we have seen, presents an examination followed by reward and punishment. It would therefore seem lettcre to lave the larticle untrinslated, as in Com. Ver. The son of man, the Messiah, as so often in this discourace (34:27,30,37,39,44), and previously see on $8: 20$. Nowhare in the discourse does Joslas strat this will be himself, but he is answering thequestion of the disciples, "what shall he thesign of thy coming? (2t:3); and indefed lie lat long encouraged the disejples in the beliof that he was the Messial. Shall come il his glory, emmp. 16: 27 , "in the glory of

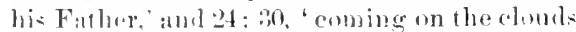
of hoaven with puwer and great glory. We bava little furthere information as to the nature of this "glory. Just helow is unfontioned "the' throme of his glury: and Panl speaks of "flaming fire" (2 The $1: 8)$, and "the trump of

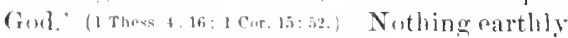
conld turnish tha images for an ardoquat, deseription. Ind all the holvangels with him, like the splombled retinue of a king, ammpl. 18: H1: 16: 27. No longer will he be a lommeless wanderer, with a loumblul of fol-

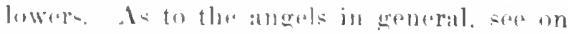
18: 10. "Ilaly" (come. Vor.) is a spurions artdition. Sit mpon the throme, is a king (v. 34): comple. 1!t: 2x. The lews, including the Twelve, experetert the Mrasials to sit on a ilorom of tompmral dominion. Our Luret lure shows the diveiples that at his second coming low will sit on a throne of judgmont,

It $\mathrm{i}$ wantiog in the earliest uncials, and in nearly

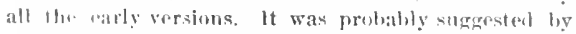
way of cuntrast 10 'the devil and his angels,' in v. 41 ,
32 throne of his glory: and before him shall be gathered all the matious: and he shall separate them one trim another, as the slepherd separateth the sheep

making awards for eternity. He sits now already on the throne of mediatorial authority (2s:1x), spipitually conquering and ruling. (1 Cor. $15: 25 ;$ Heb. 12:2.)

All (the) natious. Not only Jews, but Gentiles, not only some nations, but all. The ancients all inelined to think that every nation must of eourse bave its own deities; but there is mly one God for all nations, and (n) yne Mediator and final Juelge (comp). 1 Tim. 2: 5). Though his personal misvion was exclusively to the lost sheep of the house of Israel (15::4), yet he was destiued tu draw all men unto him (John 12:32), and the proclamation of his work was to be made to all nations. (28: 19.) Bengel: "All the angels, all the nations; how rast an assembly." Some commontatators sulpose that it means only the Gentiles, who are most frequently meaut by 'the nations.' Plumptre finds a striking distribution: the parable of the Virgins refers to all Christians; that of the Talents to those "that bold any office or ministry in the church" ; and this passage to the heathen. But the parable of the Talents does not admit of the froposed limitation; and here, certainly the blessed for whom the kingdom is prepared are Christians. Others, even Meyer, morstand that this judgment relates to Christians ouly; but that is made lighly improbable by "all the nations,' and seems impossible in view of 'depart accursed'-strange Cluristians! As (the) shepherd, in any particular case, like 'the sower,' 'the good man,' ete. (12.35; $13: 3$.$) Divideth, or separateth (Rheims),$ same word as in preeding clatuse. Com. Ver. follows Tyn., 'divideth, an impropervariation of the translation, ecmp. on v. 46. From the goats. Tho Greek word properly means 'kids' (Rev. Ver. margin), as in "Thom never gavest me a kid, Lulie 15: 29. The Latin and Peshito versions latve the distinctive terms for kids; Jerome expressly mentions that it is not goats but kils, and Anon. labors to show why the torm kids is moreappropriate. The difference is of course quite unimportant. sheep and goats are often found in one flock (fen. $30: 32$ f.),

(1) liy "the laril my fod shall come, and all the boly ones with lhee," Zech, 14:5, Rev. Ver. 
ant lor I was a bungortul, and ye gave me meab: I was thirsty, and yet gave une diuk: 1 was a stoungr, anel ye touk mat ifi:

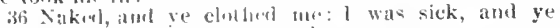

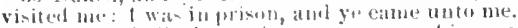

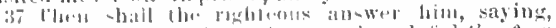

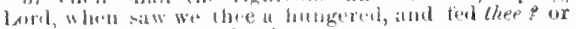
thirsis, amilatiol the driuk:"

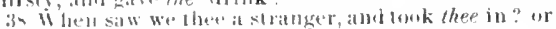

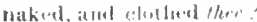

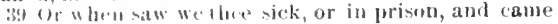
antut the?:

til Iml lla King shall answer and say unto them, Verily l sid anto you, lualmuch an ye have doue it unte unt at lhe least of these my brelhren, ye have done il unle met.

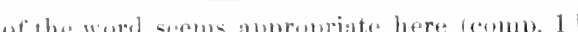
('or. 15: 5n: Gal. 5: :21), and not the moditied

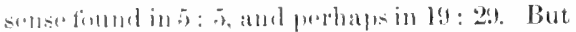
thishreh-hiph prosen to exist hy their maniferting a christian charactor and lealing a ('hristian life (2 peter 1: 10) ; and paldicularly, as here sut furth, hy their kinduess to Clurist's yeople. The lingdom is leve the Mossianic linerblum (soum 3: 2) in its perfacted hearenly stite. Prepared, not meroly destinel, but malle reaty (Mcyer); comp. John 14: 2; H.h. 11: lli; James 2: 5. Peter adds (1 Pet. $1: 11.1$ that it is preserroul for the lears, and thry aro eruarial for the inleritance, so that noither shall fail of the other. The eternal fire also is 'prepured.'(v.41.) From the foundation of the world, comp. Juhn 17: 14: 1 l'ot. 1: 20; Eph. 1:4, and above in $1: ;: 3 \pi$. For introluess the prosf that they are hiseserl of the Father, and ontitled ter inherit thokingulom, viz., that they have renArresl norvien to the king's brethren. and thus virtually to hint. Ie took me in. The

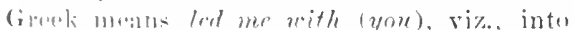
Four Jenters Grimm. Nalied, imperfectly

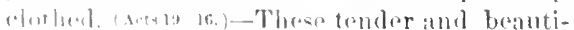

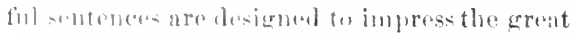

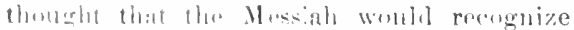

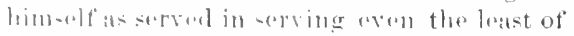

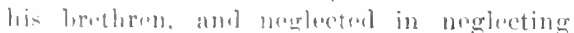
them. " thuerhe for which the way ha-

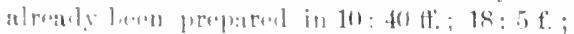

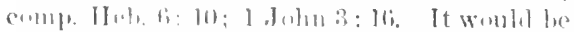

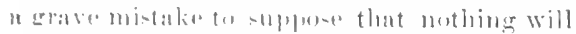

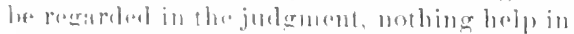
suermininer a toun's finturo, lut the simple

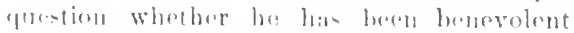
townrt-suthering christians; wo nre taught einwhere that rateh will "roceive the things done iu the lowly, neeordiron to what he hath

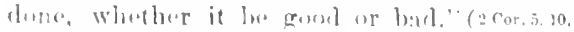
Rev. ver. It is alsu n mistake to infer that only
35 pard for you from the fonudation of the world: for I was an hungred, and ye gave me meat: I was 36 thirsty, and ye gav ine drink: I was a stranger, and ye towk me in: naked, and ye cluthed nte: I was sick, and ye visited me: I was in prison, and ye 37 cante unto me. Then shall the righteols answer lin, saying, lord, when saw we thee an hungred,

38 and fed thee". or athirst, and gave thee drink? And when saw we thee a stranger, and tonk thee in? or 39 nikerl, am clothed thee? And when saw we thee 4i) sick, or in prisun, and came unto thee? And the King shall answer and say unto them, Verily I sily unto you, Inasmuch as re ditl it unlo one of these my brethren, even these least, ye did it moto we.

actions will enter into the judgment. The essence of the passage is that the aetions in question will be accepted as indicuting personal relation to Christ; and it is really personal relation to Clorist, as aeted out in the life, that will fix eternal destiny. All this directly applies only to those who hare liad some linowledgenf Christ's brethren and of him; the heathen who have had no such knowledge will be condemned for neglecting the light of nuture, and the law of conscience. (kon, 1-18 ff. 2 :12-16.)-Observe then that our Lord is not expressly speaking of bencrolence to the pour and suffering in general, but of kindness to his poor and suffering 'brethren' for his sake. Tet he himself liealed and fed many who were not truly his; and we are initating and homoring lim if for his sale we minister to any and all who are needy or distressed-provided always we ministre wisely in a truly helpful way, and not so as to promote professional beggary or other impusition, nor the sulf-eoneeit of eriminals in priwn, ete.

37-39. The righteous answer in no solf-depreeiation, but in simple sineerity and humilily; they have not persomally seen the suviour (1 Pet. 1:8), and how (Mald.) can they have rendered him any personal service? They will, when actually bromght to judgment, think and feel otherwise only in propurtion as they have understood and remombered the lesson here given.

40. Verily, I say unto you, alling solemn attention. (Comp. on 5: 18.) With this reply ut the king we may well empare $6: 4$, Rev. Ver. "that thine alms may be in secret; and thy Father, whioh seeth in secret, shnll recomjense thro." He knows and remembers eyery uret of mollest charity, and is ronely $t$, accept it as done to himself. One of the least of these, or, cern these least. Many of Christ's followers were poor and of little apparent 
41 Thand shall lese say also untu them on the loft hand,

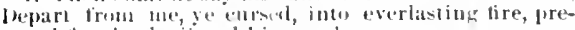
patieal for th. levil and his angels:

4. For I was a hutuered, and ve save me no luteat

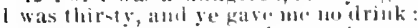

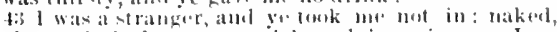

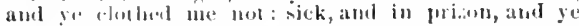
visiltil $111 \mathrm{t}^{\circ}$ nut.

4 Jhon shall tlay also atumer him, saying, laril,

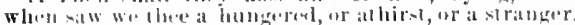

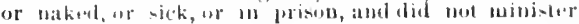
intur inee?

4.5 lhell shall bo answer them, saying, verily 1 saty

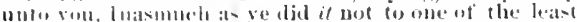

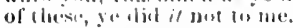

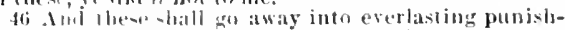

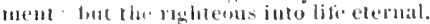

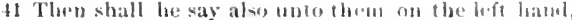

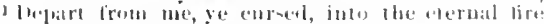

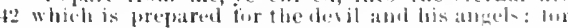

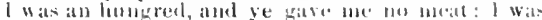

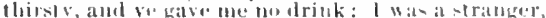

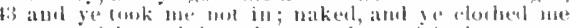

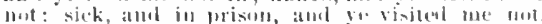

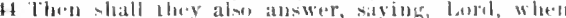

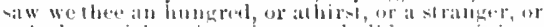

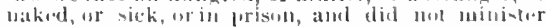

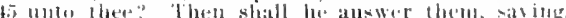
Verily l siy mmo you, Inasmueh ats ge did it mel

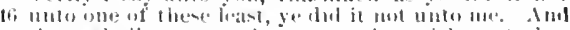

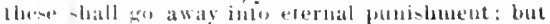
the righteous into cicerual life. importance; inly a fiw were otherwise.

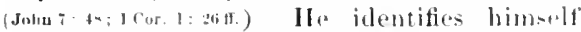
not morely with the distinguishad, but witl thrse whom non would lightly atrem. Morisom: "IVhen the .Iulgen, as it Ware, points to these bis loruthren, and then refers to the lenst ot there, it is mot nerelful that we shomlel sulppose that they ats: diflirent from "the sherep."

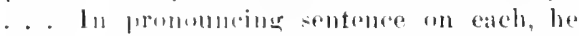

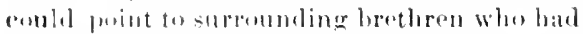

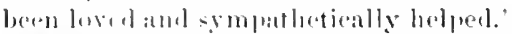

11-1.). These un the left hand. Depart from Ine, substantially the same expression ns in $7: 2: 3$; hut the acldol worels are here moreawtul. The garticiple pouldered cursed lackis the article in some ut the earliest mel

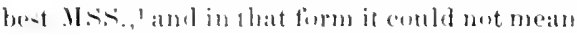
yecursol, lut depart arouserel, depart troml me under a eurse' (liev. Ver. maregin), the

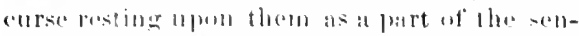
tence. Liverlasting, or, the etermal, tire, the Groble baving the article; that eterual fire which wate a fausliar thought tothe mimls rif

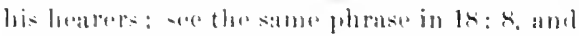

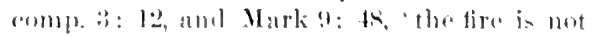

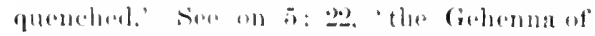

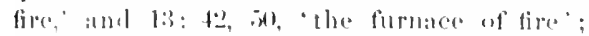

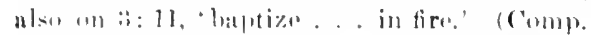

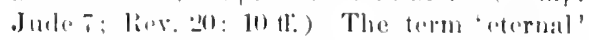

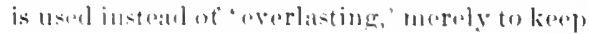
the tritustation uniform. ision an $r$ ti.) Whothere cornal junishmont involves any phy-ioal realizy correspombling to fire, wo

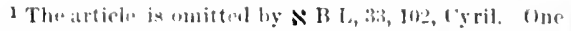

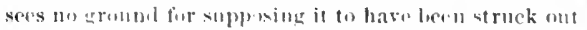
a* an ". Mexamelian" correction fench as these duenmente soumetimesgivel, sines the realing wilh the arlicles is geroul and unulbjectionalibe, eorresponding exactly in "come, ge blesed." liut we can sre ulvious reasons for the inserfiom of the article by colyists, buth because know uot; there will he something at had ats fire, and danhthes worse. for mo eat thly indage

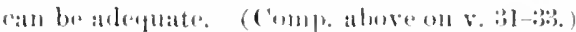
For the devile that is, sutan (soe on 4: 1.)

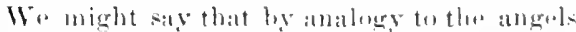
of find, Satan's atholdants and lowpers, the

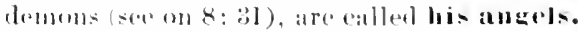
But aure than that appears to be true. Tho

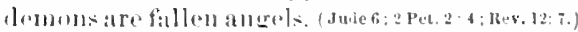
Wa must lueware of confounding what litalu we know from sioripture anderning these

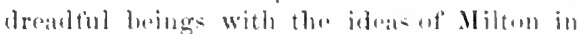
Paralise La-t, or with pupular tratitions and murerytales. (Complo an l: l.) Nuticenterigen ) that while it is the lingelom preparol for

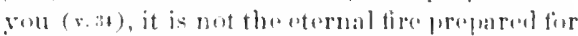

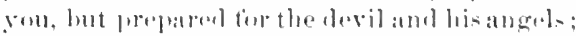
the wicked wo to -hare the drealful dement

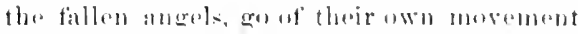
into that whieh was propared for withers. And they are not said to 'inherit the eternal tire. but incure the punishonent through eomecious sin and through rajertion ot the silviour.

42-15. This answers to 3.i-fl, with the beantiful Hobrew circumstantiality and paral-

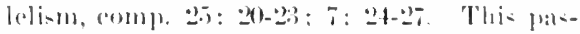
sige presonts a nutable excmplification ut wins of omixxim.

46. We tind here a remarkable instance of that unneeresary and unwarrantud variation in eransation which so ubumds in the varsime from Tymale to King James. Th, Grook here mpplies the simo adjective to pun-

of a certain obsenrity without it, and from the llesire

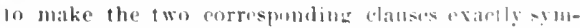

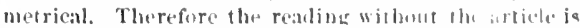
quile probahly correct. Its dintinctive mantint, though one lhat might not realily occur to a courist. is thoroughty appropriate. 
ishmont and life. The Jatin and other early versions translated hoth hy the same word, and Wye and linciuss, following the Latin Vularate, render "erenlating in both cases; hut Tyu. and tollowers, "forlasting pain. .

lite ratornal.' Thr English language, as being

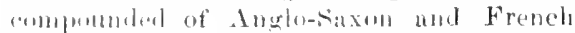
(Latio), has an extraudiuary number of woml- mearly symongmons; and this fact has probalily firtered a passion for variety of "xplension. As a mare quentions of English bitrature, the early versions lome no doubt anincel a certain leatuty of style by

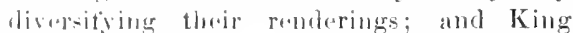
Jallus trallatators, in their "Aldress to the lieader," have expressly defended themselves and their predecessors for this practice. But thay have themplosiously obscured the verbal (")mbertion throughunt many a passage and betwern diflerent bassages. The eareful student af the Engli-h Bible, using Concordance and Riferences for eomparing Seripture with seriptule, has been misled $n$ thousand times, aither imagining two passages to eontain the same II ebrew or Greek word when theg do not. because the Engli-h has the same worl. or failing to learn, often in highly important cases, thut two massages do eontain the same word in the original. boenuse the English bu- remelored diffisently. It is of course imponsible to translate the same Hebrew or Grock worl in trery cusa by the same English werd: lut whorevor his can bo done with due regarel to the mosuing, it is a grave fault to meglant it maroly eror the salia of gratifying a "artain fartidion tasta in English style. Amoner the maty examples of this fault which orenr in the Commun Version of Matt., s.w. 5: 1. 1: ; 14: 24; 18: 38; 19:20; 20:20;

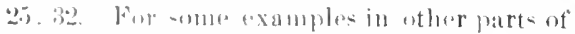

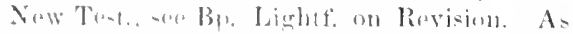

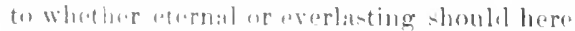

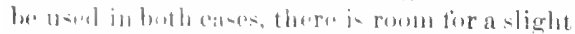

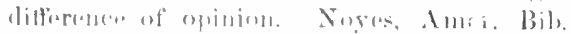

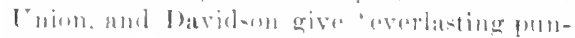

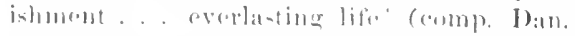
12: 2): Darlı, "otermal puni-hmont. . life

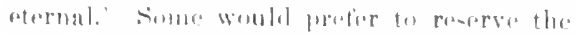

term 'etrual' for that which is without beginning as well as without end; but that word is necessary in several passages of the New Test. to denote duration that is simply without end. Upon the whole, the Revisers are believed to have acted wisely in uniformly rendering this Greek word by eternal; thare is a sligit fose in somo passages, but an important gain upon the whole. It is difficult to estimate how much would have been gained for the English speaking world in the exact apprehension of the present important massage, if the punishment and the life had boen through all these centuries described, in English as in the Greek, not merely by substantially equivar lent works, but by uxactly the same word.

Eterual punishment . . life eternal. It will at once be taken for granted, by any umprejudiced and docile mind, that the punishment of the ricked will last as long as the life of the righteous; it is to the last degree improbable that the Great Teacher would have used an expression so incritably suggesting a great doctrinche did not mean to teach; those who deny the doetrine must establish here a difference of meaning, and with an overwhelming presumption against them. Attempts to set aside the obvious meaning havo been made in sereral ways. (a) It is pointed out that the etymology of the term aionios, 'eternal,' has not been clearly ascertained. But it is now past question (Curtius, Lid. and Seott, Cremer, skeat) that atom, originally aiwon, las the same root as aiei and afi, "always'; the same as the Latin apr-um, from which eame a v)-ternus, borrowed by us in the form etermal: the same as the Guthic aius, aime, the Gurman ew-ig, 'everlasting,' 'eter11al, and the English ev-er in everlasting, forever, ete. And the words aim and rionios in the Greek a woll as in the other languages mentionul certainly have the use in question, whatevor may have been the primary semso of the rout. You cannot persuade tuose who soak English that tho meaning of everlating is doubthul, simply heeause phibologers have not leteruined the primary sense of the rout (r. (b) It is nreed that aion and atonios are

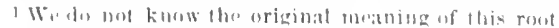
niu, or N, whedfuer 11 meant primarily unlimiled siura-

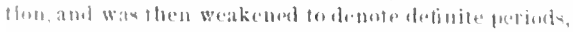

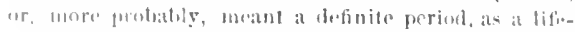
time, an agc, and was then extended to denote an in- dafinite period, or mulimited duration. But there is no question that the fireet words furmed upon the root do often actually denote unlinited duration; e. g., eis ton niom, 'forever, 'ap'aionos, 'from everlasting, etc., and aronios", as often applied to God. 
in the sept. frequenty applied-following the II el, word olam, - to thing, tinite, an " the everla-ting liblls," "all orilinance forerer." certainly, ju-t at in English we saly" "t" have and to held, untw him and his heirs forrerer," or saly" "there is everlatsting tromble in that chureh." In the one cate we use a nathral and pertectly intelligible hyperbule. in the other tha pusase-ion or the law really is of unlimited duration, in a sense well nuderstomel, and not restriated save by the nature of things. Any treme that could possibly be empleyed to deserilo funce puni-hmelit as anlimited would bo arfually subject to such processes of "explaining atway." (c) It is affirmed by some that while aionins here means etrerual, that is a wholly different illat from everlasting or entles. They say that eternal life, as in John :3: 36. Rev. Ver.; 5: 89; 17: :, lev. Vor., does not me:un 'endless life,' but simply the kind of lite whin is lived in eternity, tior it really begins in this life whencerer one beenues a Chriotian; and so they inter that 'oternal puni-hment' means simply punishoment sutlered in eternity and not noensitrily andless punishment. But 'eternal life' does in all the eases primarily and distinety derote the future and endless life, and it is simply an added thomght that tho bediever becomes already in this world a partakerof its spipitual sesence-this alled thenelit not at all exiluding ur puthing out of view the primary senac. Of course then the inference as to etermal punishment falls away. Others tum attention to the Jlolorew plirase "this 'olem,' and 'the coming 'olem.' lsece above on

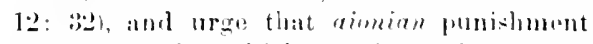
means only that which prertains an the coming aim (a)tem), atge or period. after the day of jutement, withom alyige that it is to be onetles: punishment. But the forrent those of awi-h plarases, whether as and hy the Rabbis or in New' Th-t., turnod on "this' and "the coming, which terms are wanting in the phrase aiminn puni-hment. ${ }^{2}$ Thuts nune of these at- tempts have act aside or really weakened the

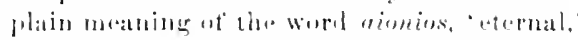
at-here destribing buth the punishment and the lite. Wentent and 11 ort suppose the ex-

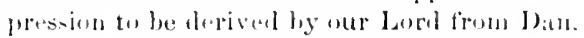

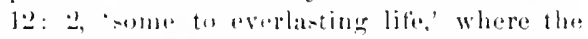
lireck hat exitetly the same phrase as here, "and some tu shame and everlasting contempt, where the adjectivo is the simme.

The term kolasis, pendered punishment: demotes primarily pruning (a tree, vino), and henere checking, chasti-ement, astigation, puntiment. Arintete says that this word is diflerent form timere, vindieation, vengeance, revenge, "for puni-bment is tor the silke of the sutherer, but revenges for that of the person inflictiner it, in oreder that he maty be sattiated" ; and Plato join= kolasis with admonition, as opposed to irrational vengeathes (Trench "Syn."). So kolasis is the milder term, implying the absence of vengefulnesa. It is therefore maturally emploged here to denote punishment inflieted by (rod, and so also in 1 Jolm $4: 18$, not 'torment' ('om. Ver., but 'punishment' Rev. Vere, and the verhin 2 Pet. $2: 0$; while the soverer term timorin is used only in 1I0b. 10: 29, for the punishment of very igoravated sin. liat that the distinetion matle by the philosephers was mot abserlute, that kolesis really meant penal intlietion. is seen from the lls of the rorb in . Icts $4: 23$, "finding nothing how they mierht punish them," complared with Paul's llse of the stronger term timeren in .let: 2.2: $5 ; 21 ;: 11$, to describe the presecutions he bat intlieted on the Christians: also from such elassig phrases as "punish (koldzin) with death" and from the conjunction of the two words kolazein timerias (Lid. and seott). It is thereforo vain to say that the u-n of this term here forbids us to understand the punishment as penalty, and without end.

With this pasester anrese the general teachings of seripture on the suliject, ineluding even some corresponling expresions, as 'into

Thus we see that the term 'entless" enuld the aplained aw: in the same fashom.

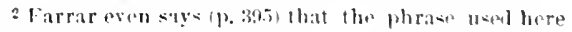
by the Peshitu syriale means the punishument of the

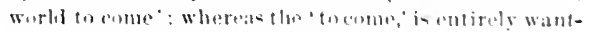

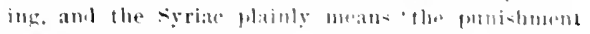
lhat io furever, usige the same phrase an the Hebrew

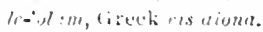

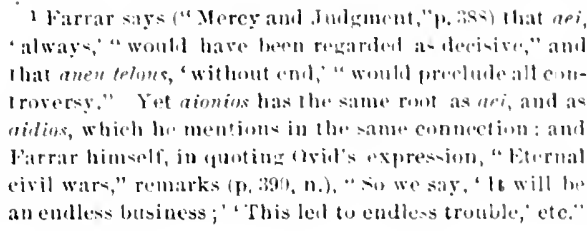


the eternat fire, $x, 41$, liev. Ver. (comp. Jude i), 'inte the uncquenchable fire, Mark 9: 43,

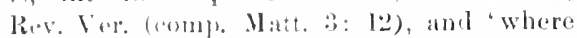
their worms dieth not, and the tire is not quenched, Mark !): tr. This last phrase iobviously derived from 1sal bit: 24, but it dores mot follow that our lerd means by it only what the forphet had in view, for it is nol "s unotation. but a mere use of the prophet': terme. Compla also John $3: 36$, Rev. Vir., "11. that leeliweth on the som hath etermal life; but he that bulieveth mot the Son shall not see life, but the wrath of God abideth on him," where the last phrases distinctly inclicate a jenalty without end; also

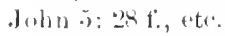

But certain more general objections are hronght againt the obvious maning of our Lurd's language.

(1) It is said (Furrar) that the Jews in our buril's time dis not bedieve Golumm to be a place of eternal punishment, and that his hatrers would understand him acoording to the common viow, unhes he stated the contrary. But this is an ineorreet statement, see Siinshe, Forsheim (App. XIX.), and the Talmudic palsages quoted in surenh. Mishna, V.,. 2, p. 314. There make it manifest that the ureat Jewish schools athout the time of our Lurd did both believe in Gehenna as a plice of furpotual punishment for some persoms. Ant the striour hure teaches that such will be the are with the persuns of whom he is speakine. ${ }^{1}$

2. I metaphycical aljection is sometimes

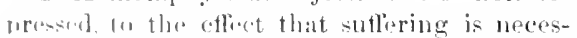
sitrily destructive, and so the suflerer must smorer a later conse to exist. But this is not prosen. Ancl surely hue who coused to exist could kinep in exintence. This is the most

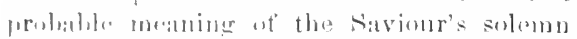

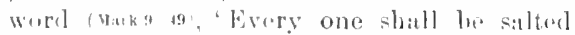
with fire. Fire is nowally destructive, lut lhi- unquenthalle fire will aret like salt, presserving instrand of destroying. So kenle,
"Christian Year, Fifth Sunday in Lent," says of the Jewish race in their present condition:

$$
\begin{aligned}
& \text { "Salted with fire, they seem to show } \\
& \text { How spirits lost in tondless woe } \\
& \text { May undeeaying live. } \\
& \text { Ob, sickening thought! get hold it fast } \\
& \text { Long ats this glittcring world shall last, } \\
& \text { Or sin at heart survive." }
\end{aligned}
$$

(3) There are also "moral arguments" alleged to show that the Saviour cannot have incant to teach eternal punishment. (a) Some maintain that it is inconsistent with the goodness of God. Thus John Foster said it was useless to oecupy oneself with the discussion of toxts, since the matter is decided by a great moral argument. But il we have a revelation from God, it is certainly our chief source of instruction concerning things unseen and eternal, and such lofty superiority to the discussion of texts is quite out of place. God is certainly a better judge than we are, as to what is consistent with his goodness. Perhaps we have not an adequate sense of the evil of sin, nur a full appreciation of the claims of justice. Perhaps the hunanity for which our age is distinguished, has with many run into a sentimental humanitarianism, which weakly shrinlis from the iden of suffering, and does not sympathize with stern moral indignation against wrong. Farrar argues that the doctrine of endless punishment los converted many men into infidels. But many have also declared themselves driven off by the doctrine of atomement, or that of regeneration, or of the divinity of Christ. Paul did not cease to preach the cross because to the Jews it was a stumbling-block. (b) Others say it is ineonsistent with the justice of God to punish all alike, when their actual wrong-doing has been so different, and their advantages likewise so different. But it is expressiy taught that the eternit punisbment will not be the sime for all. "That each may reeeive . . accurding to that he hath done." (2 Cor. 5: 10.) "It

\footnotetext{
1 The shome of shommat lade there woutd be three rasuses on the day of julgurent, the perfectly right-

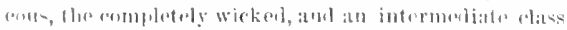

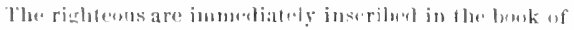
life; the "ompletely wioket "are inseribel and inmen

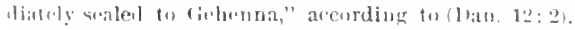

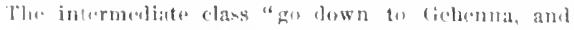
mudu, and afterwards asecul," aeesrding to (Zach, 13:

9). The sehoul of Hillel held that in God's great merey the intermediate elass do not go down. of the thoroughly wickol, some go down aud are punished twelve month; and are then destroyed. But heretics, informers, Ejpitureans, persuns who deny the resurreetion on the dearl, and persons who eause many to sin, like Jero hoan, "gn down to Gehenna and are there punished unto ages of ages."
} 
shall bo more, tolemble for Tyre and sidon, in the elay of juelgment, than for you." (Matt. 11: 2), Rive Fer) E-foreially netioe Lulie 12: fi f.. Rev. Ver.: "Aud that servant, which knew his Lord: will, and made not reaty, nor did aceording to his will, shall be beaten with many stripes; but he that knew not, and did things worthy of stripes, shall be beater with fow stripes." "This teaching lats been in many cases grievoumly overlooked. Taking inaces literally, men havefancied that the 'Cichenna of tire' $(5: 22)$ will be the same place and the same degree of punishment for all. But the above passatges and many others show that there will be differences. The degrexs of punishment must, in the nature of things, he exeredingly varions, and the extremes of punishment must be as remote as tho eatst is from the west. All inherited proclivities. "taints uf blowl," all difference of envirunment, every privilege and every disadvantace, will be taken into alecount. It is the Jivine. Juder that will apportion punishmont, with perferet knowledge and perfect justice and pertoet gouduess. This grout fiat, that therowill bo degrees in future punishmont-as woll as in future rowards-ought to be more prominent in religions in-truction. It grives some relief in contemplating the awfinl fite of those who perish. It might save many from goine away into Enivorsalism ; and othere from droming of " a second probation" in eternity, for which the seriptures give no warrant (comp. on 12: 22 ) ; and yot others form unjustly assaling and rejecting, to their own ruin, the gospel of salvation.

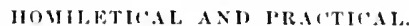

V. "3. Sepatrition of the righteous and the wickeal. 1) A necessury separation: (n) neeessary to the vindiuation of God's justice: (b) necessary to the bicsedures af the righteous ; (c) mocesary to the punishmont of the wicked. 2 An acourateseparation-mo mi-takes; selfdedusion. hypocring. strangely mingled eharacters, mothing will provent tho assignment of

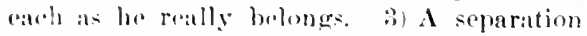
loaling to new eompanionships-the righteons with the saviour and all the angols-tho wickinl with the devil and his angels. 4) $\mathrm{A}$ separation without hope of reunion, v. 46 ;
Luke 16: 26, - V. 35-40. Charity. 1) Vurietio

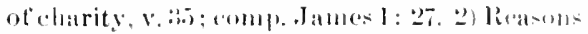
for clatrity ; (a) for the sake of humanity; th

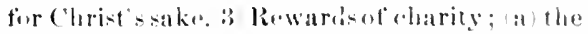
joy al doing stervice to the soviour; (h) the kingelon prepareel. $-\mathrm{V}$. 40. Clorist inluntifiol with christians. 1) Through them men maty learn concerning him, and be eonvinead a tes the divinity of his religion. 2) Inward muien with Chriet shomld be exporesock, and thus strengtenesl, by all outwarel muion with his forple. 3) Benofits eomferred on his perople as sueh (eomp. 10: [2), will be acknowlenleral and rewarded as henefits to himselt. 4) I'ukindness to Chri-tians as such is insulting rejection of chriat.-V, t2. Sims of' onti-xioll. 1) The negleet of any duty is in itsolt' a grout sin. 2) The omis-ion of right-doing turns all our active powers towards the eomminion of wrong. - V. 40. Letriles: "Whaever thon is mineled to de works of compassion to ('luri-tians, becanse le believes lee has in christ a faithful Redermer whe reconciles him to fiod; or himself sutfirs the oppostion of the devil and the world because of his taith-let him be cheerful and joyous, for he has already received the joyous soutence, comes yo blessed." Ciajux: "Mlenever we foul slothful about lebping the wroteded, let the Son of God eome hefore anr cyes: to roluse him anything is a dreatful sateriluge."-V. f5. Lather : "What shall berectue of thome who not only give nothing to C'hriet's ponr, but by framd and extortion rob thom of what they lave?" Calvix: "I Let ludievers be admonisled for as wreed promises to incite us to zeal in living well, so also threatemings to kerey us in solicitude and fear." $-V$. Bl-th. The judgment secue. 1) The duderemer a homeless wandorer, now enthromed in glory-

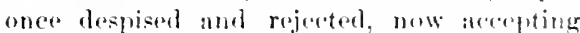
or rejecting-once suljected to murighteons judgment, now judging the world in righteousness. (Acesi: 31.) 2) Thar gromuds at this judgment-the conduct of men to wath other, as revealing tlacir relation to (ion); (a) benefiting Christs brothren is aceoplend by Christ as persomal service to lim: (b) negleeting them is regarded ly him as frersonal neglect. 3) The results of this judgment-eternal punishment-eterual life. 


\section{('HA P T R X X V}

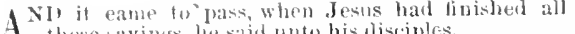
A thase sayings, he sald unto his discijples,

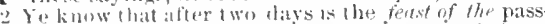

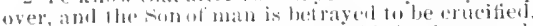

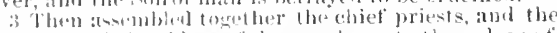

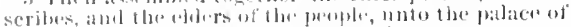

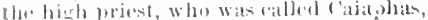

1 And conalifed duat they might lake Jesus by subally, and kill him.

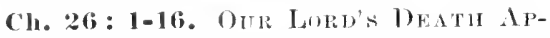

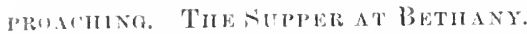

Funul also in Mark 14: 1-11; Luke 22: 1-6; John l:2: :-86.

Ihere besins what is commonly called the history ot ond Lord's Passion. This is nurrated by all tisur Hangelists, but the matter griven in the formeth (tospel is tor the most fout distinat from that sriven in the other. In Matt. Eti: 1-Hi arerything is prepenation. Josus prepares the diseiples tor" the speedy

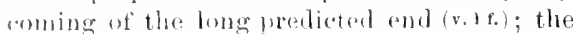
rulers lay theil plans (3f.); the anointing prefrares Jous for burial (6-13); Juclas arrange to doliver him up (1t.16); Jesus further prefares the disciples, warns the betrayer, amb institutes a memorial of himself for the future (17-30); ho then warns throm of the appurachelsiner trial to their own fulelity (31-35); and linally ho prepares himsolt by sulitary prayer fol all that aw wits hims. (36-46.)

()ar Lord has mow endect his taaching in the

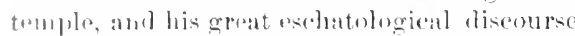

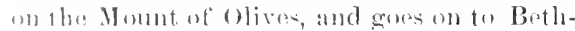
any (ver) to spend the night as nsual. He

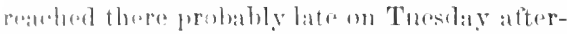
mentl, or if it was after sumset, then in the first

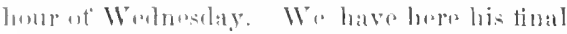

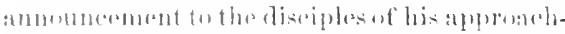
ins death, with sumb alcesunt of the plans of the dowish rulars tor killing tim, v. 1-5; then

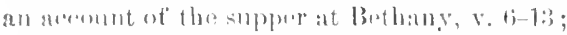
and timally of Judat' alrangement to deliver

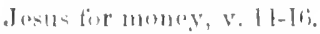

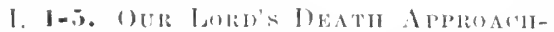

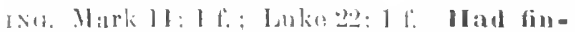
ished all these say iness, mathing tho dis-

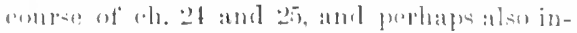

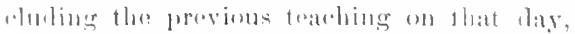

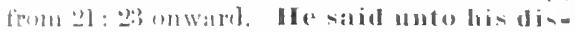

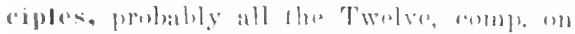

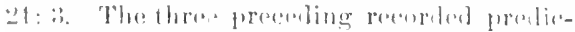
tions of his death ale in 16: 2l (comply. 17: 91;
1 And it came to pass, when Jesus had fonishod all 2 these wolds, he said unto his disciples, re know that after two days the massover comelh, and the 3 son of man is delivered up to be erueified. Then were gathereal together the chief priests, and the elikers of the jeoplo, unto 1le, erurt of the high

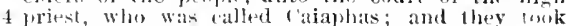
counsel together that they might take, iesus by sul)-

17: 22 f.; 20: 18 f. The passover, sec on 26: 19. Is, cometh, occurs, the word exllained on 1: 2*, and very often used; tike prosent tense signifies that the passover so occurs accorling to the custom and the law, as the diseiples fnow. Affer two lays (so Mark 14: 1) must mean less than forty-eight honls, or it would have been called three days (comp. on 27: (ii); the festival began on Thurstay afternoon with the slaying of the lamb. The worls may be naturally regarded as uttered after sunset on what we should eall Tuesday, but aceording to the Jewish reckoningr, the beginning of Wednesday. (see above.) The sou of man, the Messinh, see on $8: 20$. Is betrayed, strictly, delivered up (see on 10:4; 17: 2.2), stated in the present tense beatuse it is near and sure to oceur. His enemies are planning it, and he is preparing for it. Aceorlingly, the Latin versions iranslate by the future, and so did all English versions hefore $\mathbf{L}$. James. This woull from the construetion of the sentence be more naturaly understond as a part of what the diseiples 'know, but may be simply apponded to it. They knew that he was to he crueified, and at Jerusalen (20: 1 1 r), but we are not informed of their knowing that it would he at the Passover. To be crucified, see on 27: 35. IIe does not in this ease add that ho will he raised again, as he did in all the previous anmonnerments of his doath. Wis it boraume his death would correspond to the paschal offuring (1 cor. 5:7), or because the shadow of the crose was mow on him, and his thouglits went no further?

3-5. Then naturally, though not mecessarily (sop on $9: 1 \%)$, means at the precise time wi what precoldes, The night following his grmit soriss ot ascourses in the temple

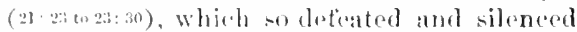
the Jowi-b tewehers, would have been the natural time tor this plottins; sre $21: 45 \mathrm{f}$. 
5 l3ut lary said, Not on the feast ray, lest the re be an

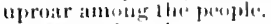

fi Ninw when hesus was in Bethang, in the lounse of simon the leper,

The chiet priests and the elders were two at the elases' comstiuting the sanhedrin, see on 20; : $\overline{7}$; also ats to the high pricet who was called caiaphas. There is dombt whether wo shoulel translate the patace, or the conet, $i$. $c$., the inner court at the high priest's otlieial residence, as in 26 : ti9, Reve Vels, or whethor it means in general the residruece palace, as remdered in this place ly Grimm, Keim, Weiss, and se in 2ti: is, and as often noed in latro Groek. It is perinaps botter, with Rev. Ver., to use 'enult in all three passages, there being no substantial ditference. And consulted, touk counesel tor gether (comp. 1'sit. 2: 2; Acts 4: 2t it.), apparently not in an otheial meeting, lunt only an informal ensultation. They had

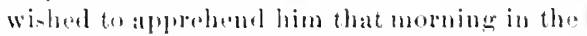
femple enute, but "feared the multudes

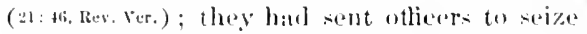
him at the foust af 'Tabernacles, six months before, but tho otheres ware awed by his tratchinger. Johu $7: 32,45$ at.) Now they proprose to tale Jesus by subtitty. Com. Ver. ressders the crieck word by "guile" in Jolun 1 : t7, aud ly a still distopent worl "cratt" in the patrallel passage of Mark 14: 1. We'iss: "Thus the rulers were obliged to resint to secrecy. It is wot likely that they ever thought of asiasination, for Jusus was so constantly sulromuded ly his diseiples that sueh a deed must have been discovered, ated the odium of it would latve elune to the supreme Comneil. The resuect entertained for him ly his fislluwers emald unly recoive a fatal blow by a public and shametul execution carriod through with all the forms of instice; and it he were once sately in continemom, ways and means for therexeration would som be fonmel." Sut during the forst, which listed seven days. The romdering ot Com. Ver., on the feast-day, is a mi-take. The rulers say nothing ats to the sacreduess ot the ocension, but are only eonecruml lest thexe be an uproar anomer the people. Of this there was always sperial dauerer when vast crowds wore assembled for a great fe-tival (eomp. Mark

1 The Com. text inserte also the "scribes, but this term is wathing in the earliest M.s. and versjous, and
5 tilty, and kill him. But they said, Not duriug lle.

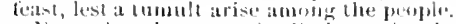

6 Now when desus was in bethany, in the house of

12: 12); and l'ilate hatd taught them that a lopmlar tumult conld beconte with him the vecation of savage eruelties. 'The sulsefuent propusition of Juelas ( $v 13$ ) led them to change their plan, anel talie the risk; and sothe saviour's death camon at leant a week earlier than they had caleulated, and at the time he portdieted. (v.2.)

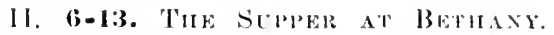
Malk 14: 23-9; Jolnu 12: 2-8. Bethany, see un 21: 17. As to the time, no one of the lhree acenuts gives any derisise statement. 'Mark anrees with Mate. in mentioniug the supper immediately atter the con-ultation of the authorities ats te serizing Jesis; and Marlis marative runs on without any brakt, so that it womld be very dillienlt to remove his paragraph about the supper tos ath earlicerehromologrical position. Lulie does net speale ot thet slypere, perhates becallise he had described a somewhat similar anointing in falilee (Luke $;: 36-59$ ), lout lie gives immediately attix the ansolestion the proposition male to the authorities by . Judas, which in Matt. and Mark followsin the sitme orter, with the sup-

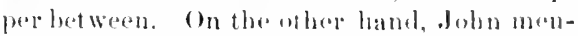
tians the supuer just aftertellingof our Lord's arrival at Bothany lefore the triumplat entry. which whuld place it threeor four days aralier. Either Johu, or Matt.and Mark. must besupposed to have given the "vent ouc of its chronological position. Several considerations support the opinion that it oceurred where Matt. and Mark mention it. (a) The rebule of . Jesus to a sueresestionabout the poror which really (atme from Jutas (John!?.1) would be the natural oceasion of his decidiner to earry out the design which may have beon previonsly meditated, viz. to deliver the Instore to the autlueritios: and this acreos with the order of Matt. Mark, and Luke. (b) The outsmken indication that our Lurdts death ix at hand (v. 12), agrees grently botter with a time following his intimations in 21 : : : $\mathrm{t}^{2}$ : and 23: 89, his escluatological discourso in (eh. 24 and 25, and his definite prediction here in 26 : 2 , than with a time precoling the trimmplosl

was evidently interpolated by copyists from Mark and Luke. 
- Chere came nuto him a woman having an alabaster bes of very prodens cintenent, and poured it on his heall, as he sall at meat.
7 Fimon the leper, there came unto him a woman having 1 an alabaster cruse of exceding precjous ointurent, and she poured it upon his head, as he sat

1 Or. a flask.

entry. (1.) This al-t) better acounts for the idest that the lovent womath was preparing him beforehaml tom burial. (d) We can see

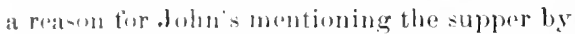
antiripation, vi\%, beealuse be has just spoken of Bethany, and he will spoak of it no more. () n ll, othel biat, Mark at loat has mentionul Bethany before the trimmphal entry Mark 11 1), and we see no reason why he slomld have disfocated the stipper. John is in gentral more chromologiaal than Matt., as some have here urgerl, but nut more so than Mark; heres Matt. and Mark exactly agroe, and (1) a ("artain axtent Lukealso. John's exprosims, 12: 2, 12, would naturally suggost that the suppere acenrred at the perint ot time at which he sparks of it, but they do not at all repuire that viow. The great majority of rowent writers follow John's order, usually without giving reasons. On the other side aro liobinson, (but Riddle otherwixe), Hackett, (i. IV. Clark, Meclellan, Geikie, and othrors. It jimposilile to settle the question, but the event sorems to fit much better into the situation frosonted hy Matt. and Mark. The notion of Origan and Ghrys. that there wore two dithome tousts of Bethany, with a similar anointing and antverstion, only three or four day apart, is wat of the quation. The asstempiom of many that the anointing in Gali-

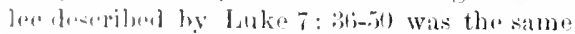
as thic, will not brat investigation. The only point- of resomblamore are (a) anointing by a Woman, (b) at a tiats, (e) in the hunse of simon. But Inka is areely ahromological in

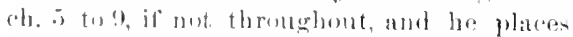
his amointimer at a mush arber fims, anel not at Irerusalen, lut in Gitilen. Phere the wa-

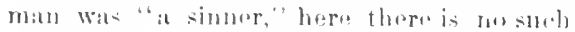
intimation, and in John's andount it is the

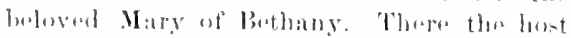

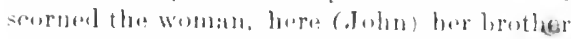
is wne ot the errests, and luer sistor aseinting the family. "Therewo find nothing whaterer answering to the enemplaint of the diseiples and the Sovimur's roluke, justifieation, and womAerfiul promiso; and on the other land we

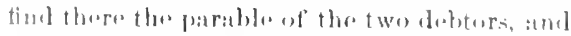
a very diflierent assuranee to the womati. The distinct allusion $t$, his death is possible only here, and there is nothing to alcount for Luke's removing thestury so far away in time and place. An anointing might certainly take place more than once, being a very natural way, according to their customs, of exhibiting reverential affection. (ruke $\mathbf{i}: 46$.) The Talmud of Bab. reports it (Wün.) as a custom in Babylon at a wedding for women to pour fragrant wil upon the heads of the rablis present. A feast where the guests reclined on couches, was a very natural oceasion for anointing the feet. The name simon was very common. Thus the differences between the two cases are many and serious, while the few points of resemblance are easily accounted for. This question is important; for to suppose that Luke had transported this story to Galilee, and so long liefore, would cut us oft from all reliance upon his chronological order, and to suppose that the other (xuspels have transfirmed the event in Galilee into the so different occurrence they here describe, would make the whole history unreliable. As to the oceurrence of similar events in various cases, comp. above on $13 ; 54 ; 15: 38 ; 21: 12$.

In the house of sinon the leper, (so) also Mark), who is not otherwise known. Doubtless his leprosy had been healed (consp. (1) 8: 2), either by matural causes or by the Saviour's superuatural work, and he merely retained a distinetive name he had long borme; comp. Mattlew the jublican, Simon the zealut. It would bave been a violation of the law of Moses for Jesus and his diseiples to recline at table with an unbealed leper. A woman. Matt. and Mark give no name. John statere that the woman who anointed was Mary. that Luzarus was one of the guests, and Martha "served," i. e., took part with the women of the houscluold in preparing and furesenting the ford. It seems elearly not trut, as even Meyer holds, that John repres'nts this supper as given by the well-known fimily: for in that case the expressions nsed in rogarel to Lazarus and Martha would be quitr unsuitable. The notion that simon was the dereasad tather of this fanily is idle. The sisters here present the same difference of 
Q But when his lisciples saw it, they hat indignation, saying, Towhat purpure is lhis waste?
8 al meal. But when this dionples saw it, they hat

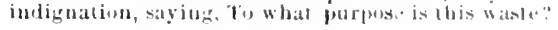

character at wen Luke first mentions tham (luke 10 34-12), and at the ratioing at Layarum (Johack. 11), tha alle. Showing love ly bu-tling activity, the other dolighting in unpractical and lobicatemanifestations at atleretim. Trum Clori-tian pioty does mot altor untes tumdamontal type of character. but brines out its

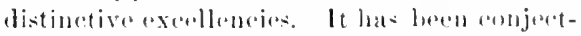
ured that thes sepere af lake about Lazalus, and of Matt. and Mark about the whole family, was atusol by the jualous hatrod of the ofwish rulers, win might have revived

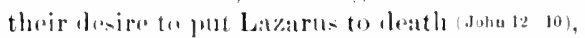

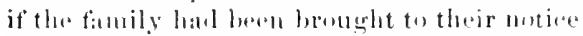
in the orat amel written aleenuts griven by the

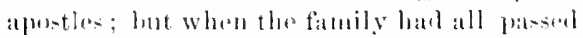
away, and the Iowish state hath been destroyerl, John enthl speak of them without

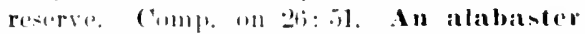
box, ur erese. Simme kind-of alabaster are of delicate and richly varied hues, and are ex-

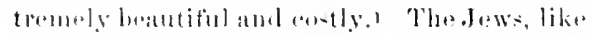
all the other coivilizen ancient peoples, mates mucls use of tratgrant ointment, often ralu. and of groat priere; and the na-ks which contained it were of errout variety at to material and shapu. John says this llask contained "a promd, viz., of twelve annees. It was, with its enutents, a tasteriut and andly olyeet, such as a woman womblelelight in possesing. Very preciosu wintment. Mark aut lolus tell the kimd of ointment, wing the samr torms. But ane of the torms is at uncortain meaniug, as statud in metrgin liov. Ver. "t Mark 14: :, "Gr. pistie nord," pistic

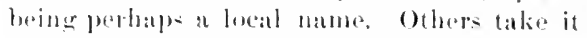
to noran encumime; others, liquid. Yert this uncertainty does not afteet the substantial meaniner it was uintment of extranrlinary

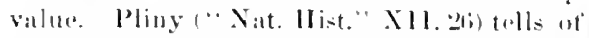
many kimb of procims natrel. Ind poured it on his head. Mark says, Rov. Vier. 'she brake the eruse and punred it. The task, or cruas, probably had a tong neek amd a small mouth, fo freverut evaporation, and the prom cime ointment was omlinarily extracted in small fuatuties. Beiner a thick, viscill man,

biuilas definms alubustron "an oil-vessel having wn

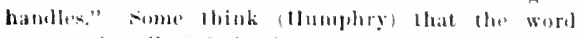
meant primarily a llats without hamdles (tester) atrd was it could not be made to How treely through

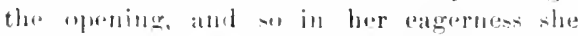

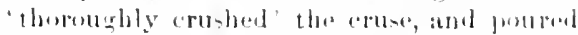

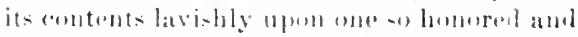
loved. A thin thisk at delicates alatrastel

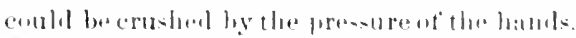
Is he sat at meat, lit. as he reclimed, - -6. an

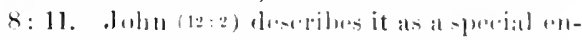

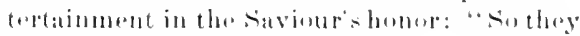
male him a -1apuer there." . lohn malies the" aplatrently confletiog statement that she

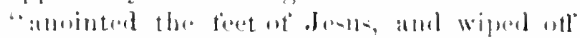
his feret with her hair." To amoint the load

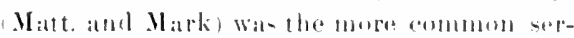
viee of friend-hipe ur homer, but II aly went furthrer and anointed avell hi-feret. It is plain

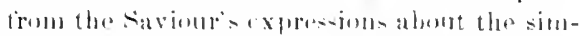

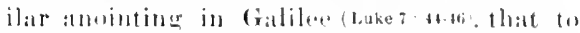

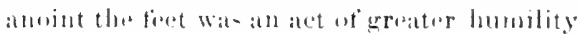

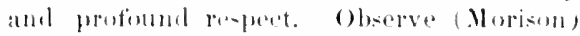
that Matt. amel Mark simply say "fumbat ujurn Jis heall, without insolting 'it'; se there is no ditlentey in supusing that she.

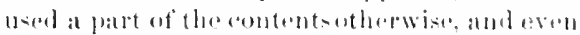

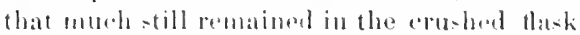

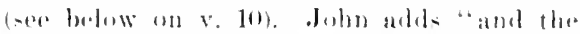
house was tillenl with the werer of the sint-

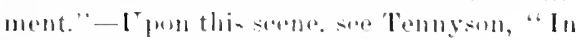
Mommriam," xxxi., xxxit.

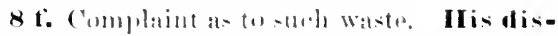

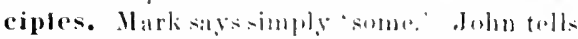
us that Jublas lecarint said, "Why was mat

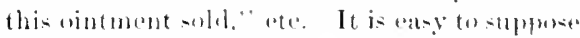
that Judas liest stad this, and athers at the

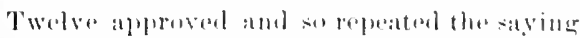

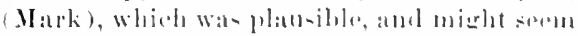

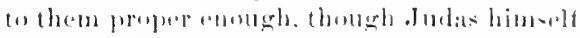
hat sugerested thas idea through very uta-

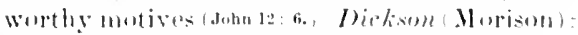
OOne murmurer may inferet a whole rempany." Pling remarlis that indulgence in costly porfumes is more luxurious than in genss and galments. hereatuse the former pere

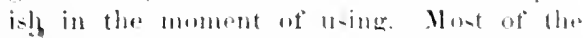
aluetles had little familiarity with sued anstly luxuries, and the waste mient serem to theim frightenl. The word ointment in mot fore-

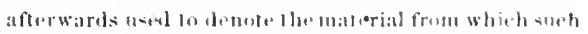
Hasks wre ollen male. Hence the rencleriug a "llask' in margin Iiev. Vir. 
9 bor this ointment might have been sold for much,

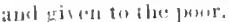

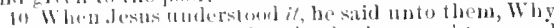
erouble ge the womats: fin she hath wrought a good witk lifin me.

11 lor yohe hlo puor always with you; but me ye hater mol alwats.

l' lest in thil she hath ported this vintuent on my brly, she did it for my burtal.
9 For this ointment might bave been sold for much, 10 and given to lhe poor. But Jesus pereejving it, said untri them, Why truble ye the woman? for she

11 hath wrought a goul work upon ne. For ye luave tho poor alway with you; but me ye bave not al12 ways. For in lat she ${ }^{1}$ poured this oiutuent mpon

I Gr. cast.

"at in the eorrect (irenk text of r. 9, but is naturallysugrested. Might have been sold for much. John: "for three humdred denaries'; Mark: 'for above three houdred denarien. 'The lioman denary, about seventern (ents fee on 18: 28), was the common price of

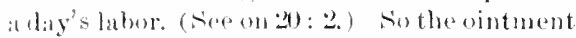
was worth more than three humdred ditys lat-

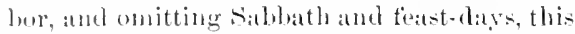
wruld be a year ot laber. Pling (XIII, 4), says that some unguent rost more that four humblod demaries a pound. Ife see at once that the sioters must have leeen woulthy. A porr youmg woman coubl not have possessed at thak of prefumery worth a man's labor tor" at whole veats; or if hy inheritatuce or extraorlimary gritt postessing it, she would bave hat no riglst to expend so large as stm in an ute.rly umpratical rxpresion of atlection. Thr inference that theg were rich is supported bey the tiact that many at the bews exume ont from . Terusalem to this suburbatr villatere to andort the sisers after their brother's death (folun $11 \cdot 39)$; and it explains the properiety of Mary"s lowion Martlat "to serve alouse" (bake 10: 111). which worrlal bave bean wrong if

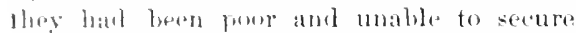

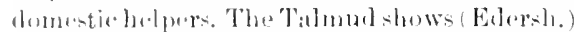
that watley dewish women often spent large sums fior perfiumery. Aud given to tho poor, without article (in acolecet text) to pum

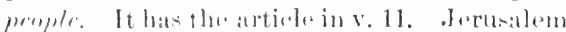

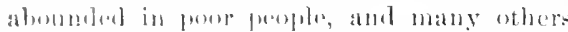

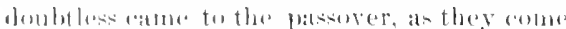

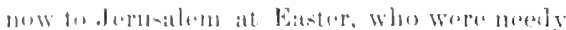

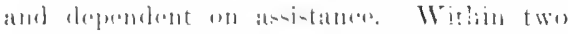

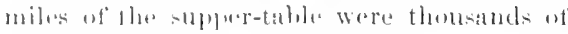
tho ratly jumr.

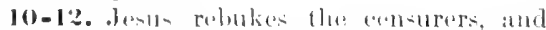

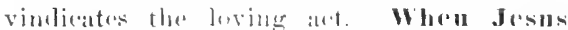

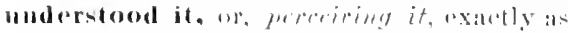
in J6: 8 , lieve Ver. The complatints land

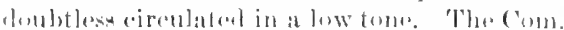
lir. lats grivell an wufortunate rentering, for it would sugerst that a comsiderable time in- tervened, and the Greek does not. Why trouble ye the woman? The Groek expression is quite strong; see in Mark also, and in Luke 11: 7 ; Gal. 6: 17. She bath wrought a good work upon me, is presently explained by saying, she did it, ete., (as in Rev. Ver.) did it to prepare me for burial. so Mark, Rev. Ver.: "she hath anointed my body aforehand forthe lurying.' John (12:7), Rev. Ver., aceording to the correct text and most natural transhation, has, 'Sutfer her to keep it against the day of my burying, which may mean that she bad been interruptod, and mueh of the ently ointment still remained in the broken flask. See another fussible triuslation in maryin of Rev. Ver. of Johu. Ye have the poor always with you. And Mark adds, 'and whensoever ye will ye may do them good.' (Comp. Deut. 15: 11.) Hut me ye have not always, i. e., in botily presence; he would be with his people spiritually. (28: 20; John 14:2l-23.) Extraordinary oeensions may justify extrordinary expenditures. WVe may suppose (Keim) that at an earlier priod he would have declined the proposed service, and directed attention to the pour. But openings for ministry to the pour would never easse; while their opportunity for personal services to him would soon be at an end. And this apparenty useless and wasteful service possessed in fact a special significance and timeliness in connection with that foreseen death which was now so near. (r.2.) It was an interesting, gratifying, comfurtiug token of affection, as a sort of anticipation (Mark) of the usual anointing when preparing a budy for inferment; comp. the large quantity of eusty spices brought by Nieodemus for the actual interment. (John 19;39.) To moive this loving proparation might help the havium to look forward with less pain to the suffering and shame which awaited him. It is not necessary to conclude that Mary so dosignul her action; hut it is very naturis to sulpuse she did, as they were all thinking 
13 Vurily t say unlo you, Wherestever this gospel

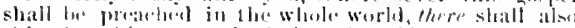
this, that this womalu hath dome, be tolel for a memorial wi hiner.

If Tlum and of the I welve, (alled Julas Iscariul, went unto 1he chitet priest:-

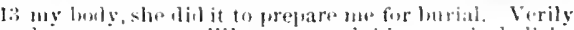

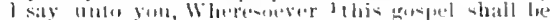
preached in the whole werlel, lhat al-w which this

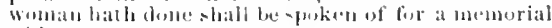
ai liar.

14 Then one of the twolve, who was ealled Judas I -

1 (1), these gord tidint.

muele of his intimations that he worsld som an die; at any rate, he soresecepted it, alud that must latro breet an unspealiable juy to luer. "Shle hatle dome what she combl" (stark 1t:a); and she finds lhat she had railly dome something extrounely grateful to the Master. she

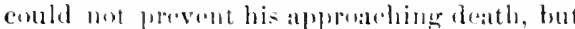

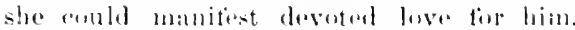
Feninine intuilions, kindled by intense allex-

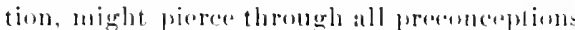
and acerot it ats a tardul reality that the Mes-

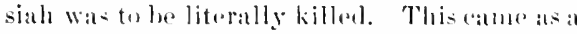
new and startling : amonnerment to her, without time fior the mystiall interperetations which the disciples apyear to have platerel mpon it. (sive on 16: 2l.) Wlatteror titly manifiots, and ly reacetion strenglhens, deverut atlecetion -true roliginus sontiment-is in itself aceeptable to christ and usetul to us ; for thesesontiments are a newesidy part ot developed and symmetrical christian charateter. Norsolumld

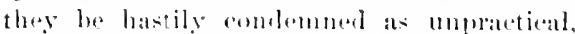
for they stimulate to enerespondius action. This anjuratical grift, and the saviomr's com-

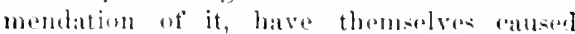
rivher gitte to the puor in atl anes than the whole wealth of Jellsalem would lave

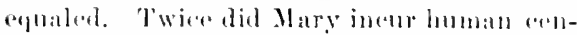

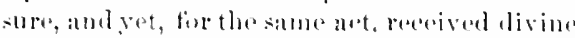
commendation. (lukelo: 40.) Pourel, in v. l:, is not the oretimary word of $r$. T. hut means

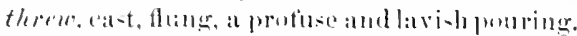

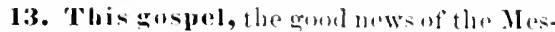

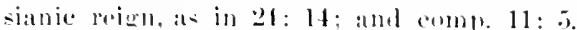
In the whole world. He here anticipates

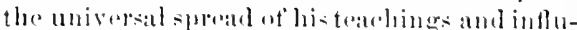

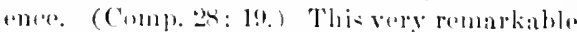
promise conereming the woman was alroaly in process af follilluent when oblun wrote his Gospel, probalily sixty yours aftorwards; for lae di-tinemishes this Bethany from the one

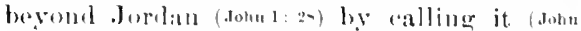

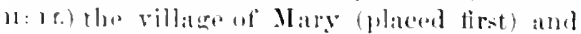
her sistor Martha; and then makesall lofinite and elear ly adding. "it was that In wy who anointer the I, rrel with ointment." ate. IIo has not yet in his Gospel told the story at the anointine, but he assumes that it is familiar to all ("hri-tian reaters. (Hrys.: "For les!

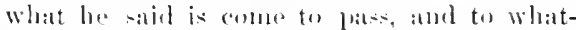
evor late of the oarth thou mayest go, thou

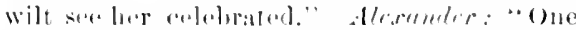

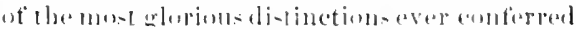
upon a morlal, a distinctiun which in-tatu uf

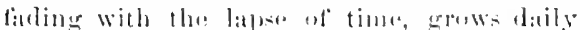
lybighter, and to which, as alle has well ald,

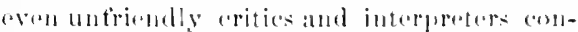
trihute, as it wore, anainst their will and in the

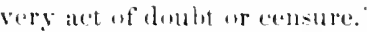

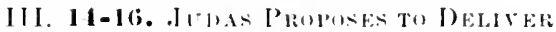

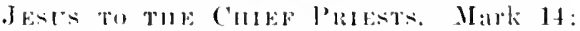

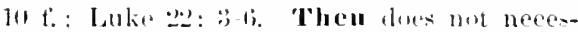
sivily (xos on : : 1:3), lut does naturally indieate flat what follows in the narrative ocecurred immodiately atter what prexedes. Markand Lake luave simply sade 'and,' lut place the tmater in the same combection as

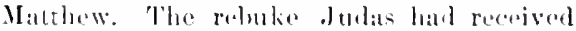
(see on v. (i), may have bromelat to al arisis

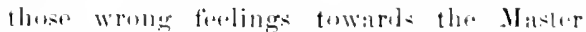

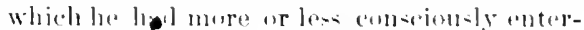
tained for a lomer time. (Johns: one.) Fivell atere this, when he had made the hareatiu, and Was aw:ating an opportmuits, sitan rosk still

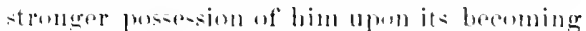
manifiet that .J ostls understemel him. (John $1: 1:$ :-7.)

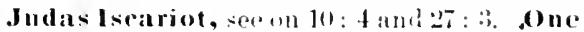
of the twelve is a phrase givon ly all fintr

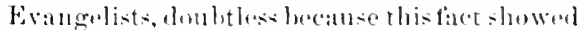

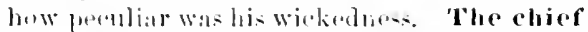
prients, ser on 2 : 4 What will yon, we. What are you willing ter gire mo, is the exilt translabtion. This was apresed in ula Enerlish by what will you grive mo, lut that is now undurstued as a mere tuture temsta an in the following worls. Aud l will dobiver lim, the Gorek making the 'I' emphalie. lle knows they wish to get Jasts in their loanels, and he will gratify them it lhey ares willing to give anough. "loliver is lume enrrectly translated in ('om. Vor sos orn 10): 4; 17: 2.2), lut in v. 11, aml in Marli and

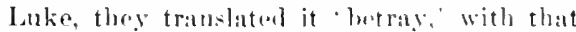
pasion for variety in rendering whicle marks 
15 Aud sitil unte them, Mbat wilt ve give mo, and will helver him unte you? Anl they cosenanted with hiut tor thirty proes ot silver.

li . In] foum that time he sought orportunity to beIraty him.

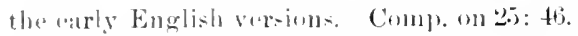
They coselanded with hime Ret. Ter., wighel untw him. Thr word means literally plotent in the thalener), and is used fior weighing unory in the classices and the seretuagint, $\therefore$ \%, Zeeli. 11: 12, "sin thry weighed for my hime thinty peres of silver." The worel in Matt. might be transiated, "apponinterl unto him, or 'cormanted with him, and these were preforred by the arly Hnglish versions becaturs Mark sags they promised, Luke '(o) sonanterl, to grive him noney. But Mark atud Luke usis of her torms, and there can be little doubt that Matt. is relerring to Zechariali. Coins hate certainly bren in use from the tine of Simun the Maceabee, B. c. 140 (1.Mace 15:6); but it may have been still not uncommon to wergh the coins, being of varialle valus, ant this especially on the part of religions luncetionarius, who usually retain Hollu-toms. Matthew's expression dises not renpiret us to nulerstand that they paid it at the moment of his proposition, but that they paid it in alvance. Some have plausibly slereastoel that this sum was anly ealuest monery, and more was to follow. A traitor is shlum tru-ted with his entire reward in atvaluas. Tha thirty pieces of silver were pooblaly slakels, worth in our lowl's time sementime oyer sixty cente, (a)mp. on 17 : 2y. Thirty shekels was appointoll liy the law as damages for tho killine of a slave by an ox.

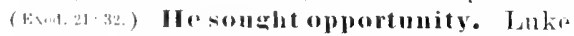
alal- "withmet a throme." This plan Judas sillinlly areried ont, finfliner him at night,

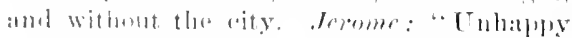
Indas! tho low ho thought ha hat incoured by the fusting ont of the ointurent, he wishes

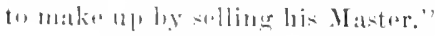

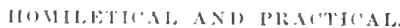

('h. 20;. 1. Jlexry: "Sin christ's withesses

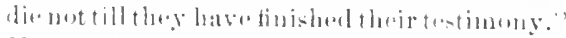

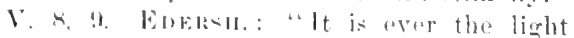

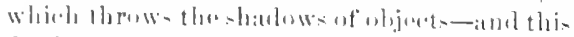

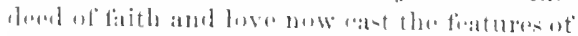

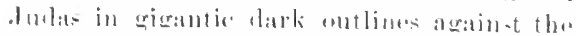

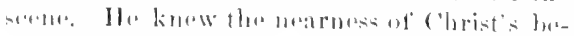
trayal, and hated the more; she linew uit thes
1. cariot, went unto the chief priests, and said, What are ye willing to give me, and I will deliver him unto you? And liney weiglued unto lim thirty 16 pinces ut silver. Ami from that time he somglit opportunity to deliver him unto them.

nearness of his precinus death, and loved the mure." IIENRx : "It is no new thing for bad affections to shelter themselves under specious eovers; for people to shift off works of piety under color of works of charity."

V. 10. "Why trouble ye the woman?"

A woman's love will sometimes be wiser than a man's judgment. 2) A devout heart will often build better than it knew. 3) An act plausibly eensured at the moment may be destined to everlasting henor. Henry : "It is a great trouble to good people to have their gond works eensured and misconstrued; and it is a thing that Jesus Christ takes very ill." A good work. 1) A good work, though due to the unaided promptings of a loring heart. 2) A good work, though severely censured by some gorod men. 3) A good work, though wholly unpractical. 4) A good work, though moler ordinary circumstances it would have been wasteful and wrong. 5) A good work, which gined the Sariour's apporal, and will be honored for evermore. - It has been remarkin that the only two persons .Jesus is recorded as enmmenting for their gifts were women, one porr, the other rieh.-V. 11. Jesus and the poor. 1) By helping the por we may always honor Jesus. 2) By honoring Jesus we do always help the poor-Charity to the poor. 1) Charity is not our only duty. 2) Charity must not be made an excuse for neglecting other duties. 3) Charity is greatly promoted by loving devotion to Jesus. $-\mathrm{T}$. 14-16. Currs: "Hearken, all ye coretous, and beware of the ealamity. For if he that was with Christ, and wrought signs, and had the benefit of so much instruction, because he was not freed from this disease, was sunk into such a gulf; how much more strall ye, who to uot so much as listen to the Seriptures, who are comstantly riveted to the things present, become an easy prey to this ealamity, uniess yr have the allantage of constant care." I. 1\%. Bishop Hall: "It' Judas were christ's tomostic, yet he was Mammon's servant; he could not but hate the Master whom he formarly prolessed to serve, whilo ho railly sorvid that master which he professed to hate." II ENkY : "The greater pro- 


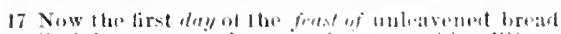

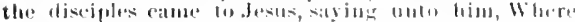

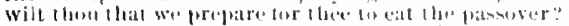

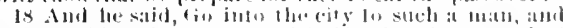

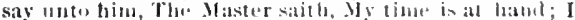

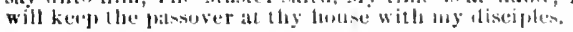

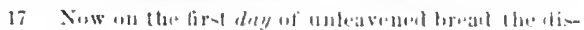

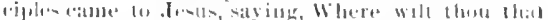

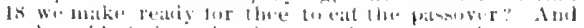

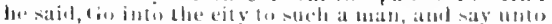

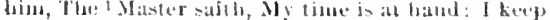

\section{$10 \mathrm{r}$, Tetrhe}

fesion men make of rendiginn, and the more they are coupluyed in the study and service ot

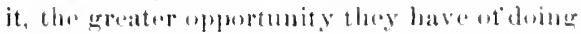
mischiet, if their hearts be not right with Ciml.'

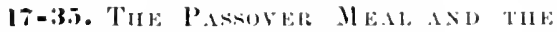

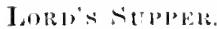

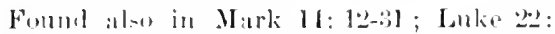
7-8:9; comp. Jorlan 1:3: l to ls: l. Mark is here quite (elosely parallel to Matthew; lalise adels a good deal. John introducestace fiectwashine, and the great falrewell discoutrat,

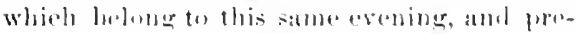
sent several not very distinct posints of contaret

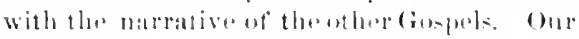

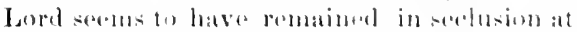

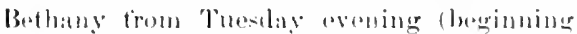

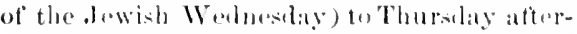

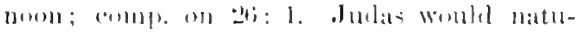

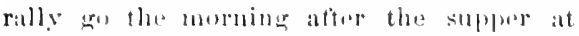

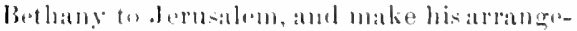
mont with the rulers. Josustays alway from

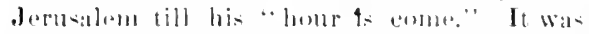

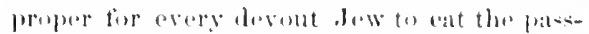

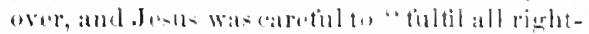

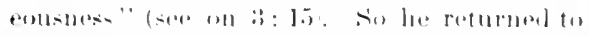

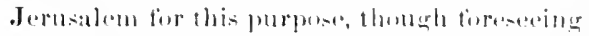

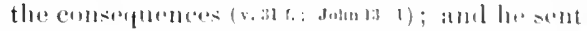

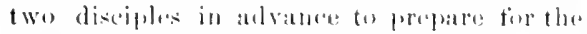
forat. This secetion may be divided intos.

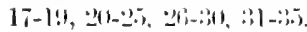

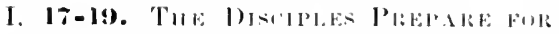

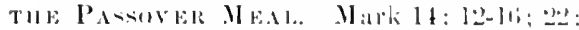
7-l3. Ou the liret day of moleavenod breall. Marli abls, Rove Vur., "when thes

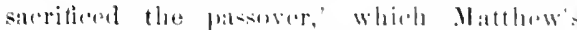

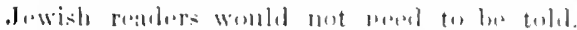

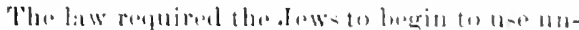
leavemed breatel with the fifterenth aly at the

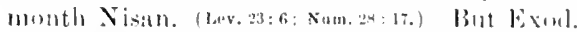

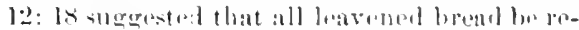

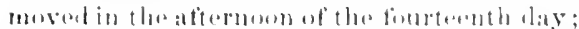

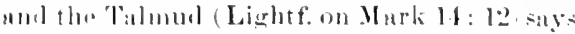

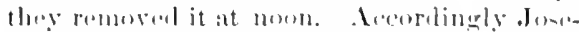

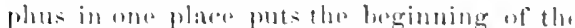

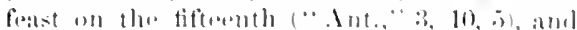
in another place on the fourteenth (" 11 ar,"

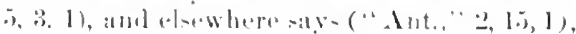

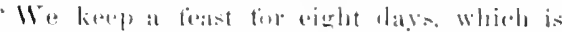

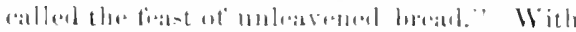

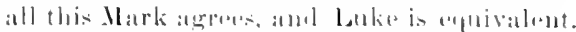

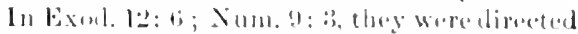
to kill the lamble betweels the two esoning

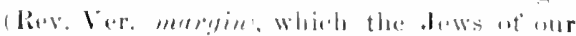

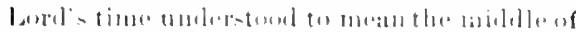

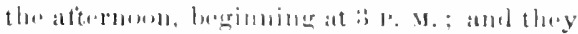

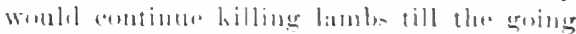

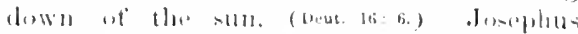

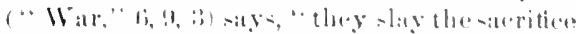

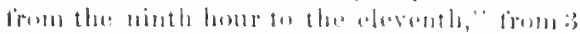

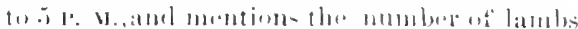

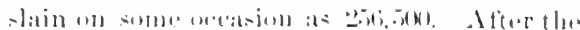

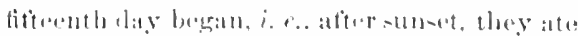

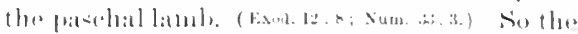
lisciples porbably wort totherity about mom,

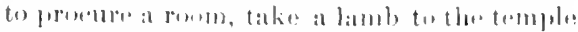

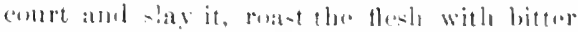

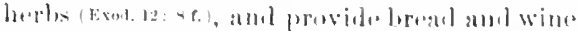
fire themal. 'The disciplescande lo Jesus,

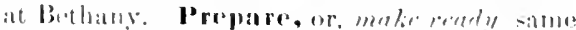
firenk waplas in v. l!) It mas rerv well be

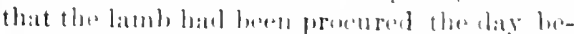
firre, an was armmons what they impuire

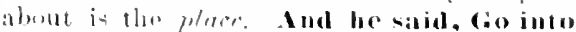

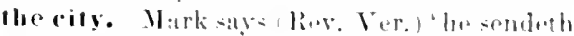
two of his disciples and sath untethem. (io)

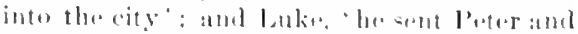
John," wha trom this tima atre fireterently

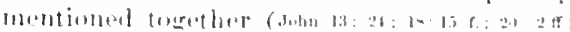

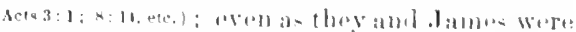

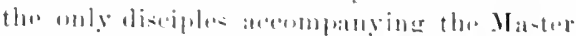

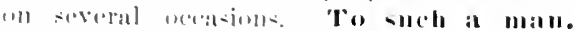

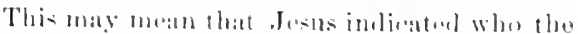

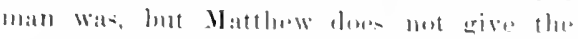

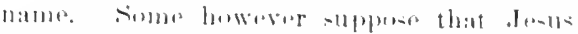

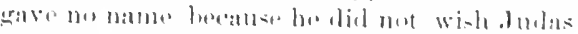

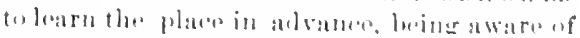

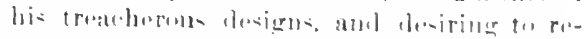
main unintorrupteol till a later lomer. With

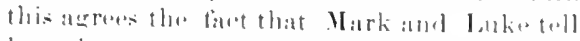

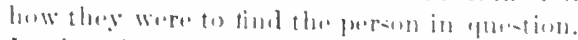
In the reity they will mest a man lueving a pitelorer water. and folluwiner him lonme? they must deliver a mensige to the gromlman 
19 And the disciples dirl as Jesus harl appointed th m; and they made really the pasosver.
19 the passoner at thy house with my disciples. And the dirciples did as Jesus appoigted them; and they of the house, substantially the same as that recouded by Iatthes. All this would sem to insolve suprotural linowledge, like the prophetie direction in 1 s:an. 10: 1-8; but -mene think that J ente had arranged with the hrumbuller tin such signs. The Master sath, show - that this man would prove to be a disciple of Jews, it mot in the full sense, yet the sil far that he would ghadly render him this serviers; comp. Nicodemus and Joseph of Arimathea, and comple above on 니 : :3. 'Mas-

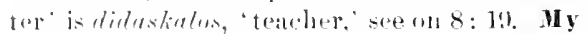
time, finires, wet time, special time, seasom, see on 11 : a- moaning hare the time of his death: compl the use of "bour' in John le: ㄴ: : 17: 1, and often. I will heep, ar, I leep, the present tenses indicating an intention about to be carried out. It thy house, hat in the firese an empluatic pusition. The

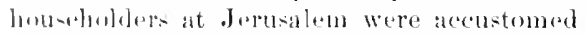
to recerive into their houses without charge such fimily group as wished to eat the paschal lamb (Edersh. and ot isers); but they

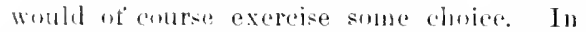
Mark our Lurd athis. "And he will himselt" how son a large upper room turnished and resty" ; the hrowholder would show respect ly goning himselt, the rom would be large, and in all respects prepares for une. It is sill comsumon in oriental houses to have the frimeipal romon in the second story (compl. A10 - 1: 1:3). Ind they made ready the pasoover, as described abrue; and at oven Ju-1ts (anme and ate it. (r. 20.) So also Mark and Lulin.

Thu- Matt., Itark, and Luke distinetly state that oluts ate the parchal meal, and that

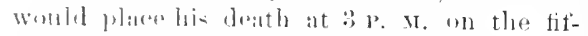
twollh of Ninall. But there are sereral pats-

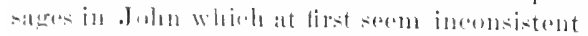

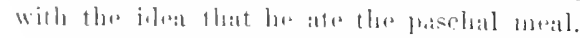

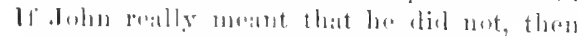

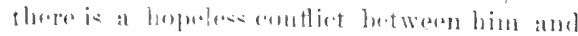

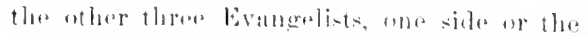

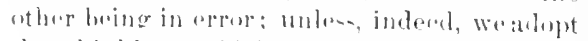
tha highly artilicial supposition of somb writers that Matt, Mark, ame Luka rofior to an anticipation of the paschal meal twentyfour hours in advance. But this we cannot do; for besides the difficulty of supposing that the Saviour. would thus violate the law in the act of observing it, who can believe that the temple authorities would have knowingly allowed the slaving of the paschal lamb before the time, of that Peter and John would have slain it chandestinely? A number of recent writer contend or assume that John's language does forbid cur believing that Jesus ate the passsover. M[ot of these writers, it should be observed, are quits willing to recognize errors in the Seriptures as tomatters of fact; and some of them are anxious to point out such errors ujon every pusible accusion. Others of us are very unwilling to admit the existence of such error, and earuestly strive to remove the appearance of contradiction in the sacred writers, whenever it can be finirly done. Neither side in such a case can claim superior exemption from the influence of theoretical preporessions; and it becomes every writer to state his views with due respect for those who differ with him.

There are five passages of the Fourth Gospel which have been regarded as showing that Jesus did not eat the passover. (Comp. especinlly Rubinson's "Harm., "Clark's "Harm.," Andrews, Milligan.) Dothese passages really thus teach? (1) John 13: 1, Rev. Ver.,"Befure the feast of the pissover, when .J esusknew, "ete. This is held to show that the supper described in Joln 13 occurred betore the pasehal supper, and comserquently twenty-four hours before it. But ubserve that 13: 2 is not 'supper being ended,' but (in the correct text) 'during supper.' Then may we not understand that 'before the feast' refers to the feet-washing, which accurred atter they had reclined for supper, but before they actually partook of the funt? Is not this more probable than that Matt., Mark, and Luke are in downright "rone? (2) John 13:27, "That thou doest. du puickly." It is adled that some thought this mant, "Buy what things we have need of fiol the feast," Pev. Yer. But if the pas-

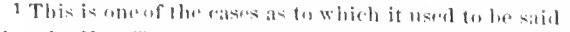

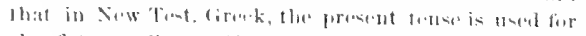
the listure. Compe $26 ; 2,45 ;$, lohn $10: 52 ; 11: 17$. AC- cordingly, Tyndale and followers here render "I wili
kep:" liut nome now talks about present for future. sie 11 juer and Buttmann. 


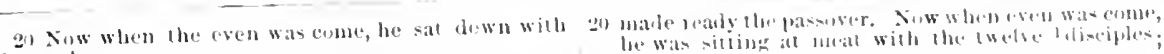
the twetre.

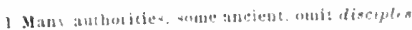

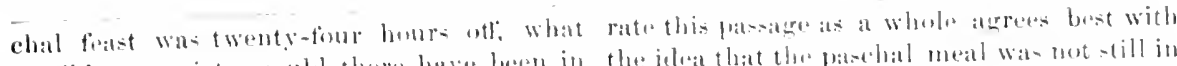
possible proprioty would there have beren in ha-tenius ant that night to matie purehasefor it? It is moneh tatsier to strpluse that they

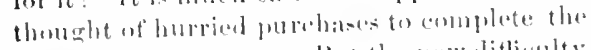

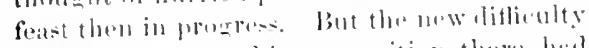

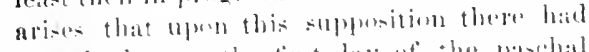
alrealy heran the tirst day af the parehal fe-tival, and this being a bely day, purelateres womld not have heen lawful. Sinw the Mishna. "sahbath, "2.), 2 , syly that if the day before the patenser be at siabliath, thet may buy a lamb, evou louving his garmont in pledere, and then sectle after the featst. From this Ealur-b. and wher fatrly areme that if a purehase at something meded for the feast could be made aren on the siabluth, much

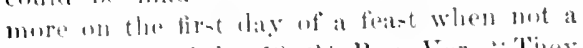

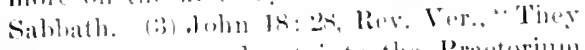

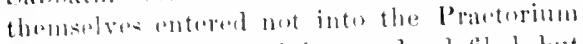

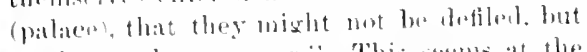
might wat the pasiswer." 'This serme alt the first glanes di-tinetly to show that the patsebal

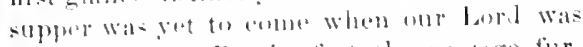
befire l'ilate. But in fallet the patsige fiurnishes an aremument in the other dienetion. lit this hat buen the morning betiors tho pas

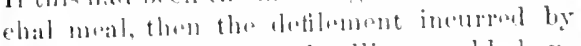
entering at Gentilas atwelliner could hatre

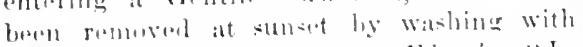

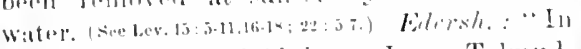

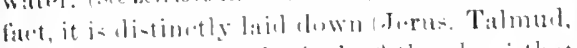

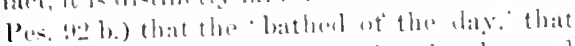

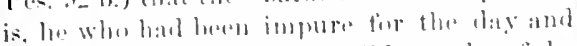
had hatheal in the evenimar. did partake of the Paschal supper, and an instame is relatmel Pes. sid b.), when sume soldiers who haml

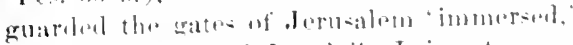

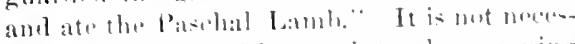
sary to explain with ertainty the meatuing

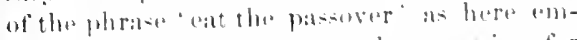

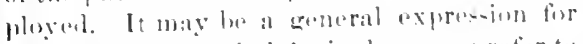

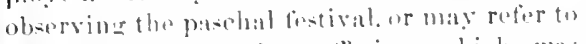

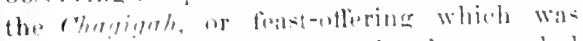
offerol on the mormine we the first panchal

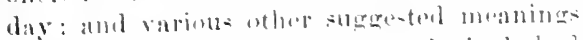
are pusible. If the pasenerer fortival lated alyealy conmmeneoul. the ruler would wi-h

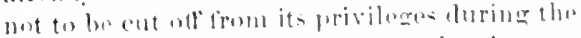
day nyon which they hat entered. At any the jelwa that the pasehat meal was mot-till in the future. (1, Juhn 1:1: 1), "Sow it wa-the

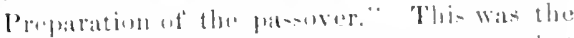

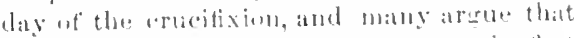
the day ut the eruatixion was not on the fir-t dity ut the pasthal foutival, as Mate, Mark.

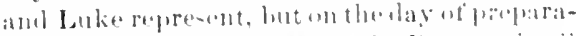

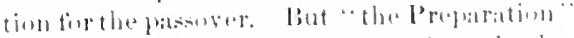

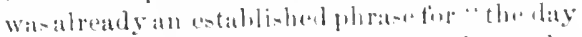
lofure the sabbath," as di-tibetly =humn by

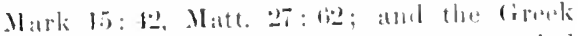

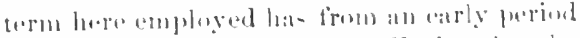

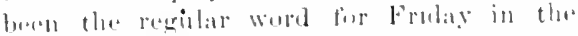

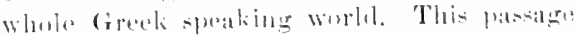
of Juhn mat thelefore easily mean that it wat

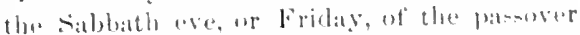

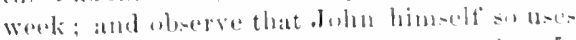

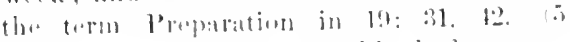

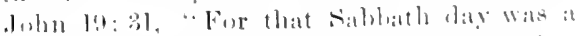

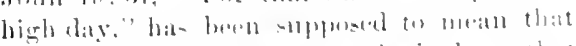
the first day of that fasener fiestival on that

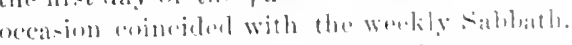

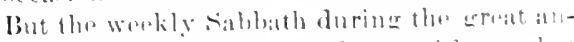
mual fertival would have henen without that

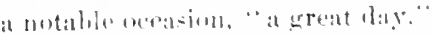

It thes appeats that monder of these five pat salere alt all requiras us to muderetand that

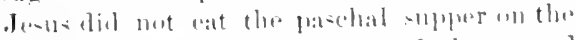

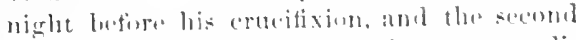
and third di-tinctly teme in the eontraty direction. Gratit that the first impresojum pros-

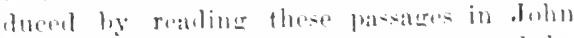
womld he as elaimml: grant that some wet the

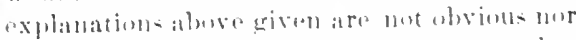

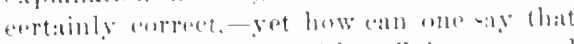

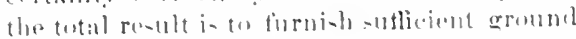

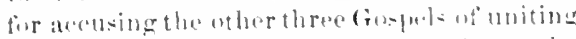
in alefinite arrer? Amone the writers who

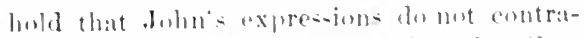

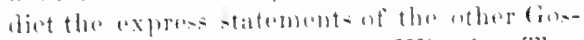
pol-are Rutinsun. Androws. Wiecler. Thu-

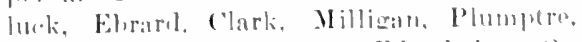

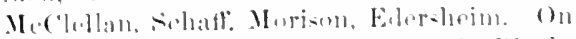

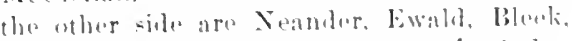

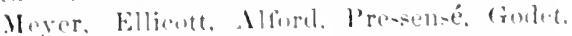
Farrar, Miseterte. Misiss.

II. 20-25. WHILF Fatige THF PUS-

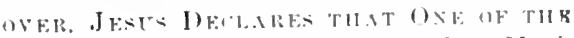

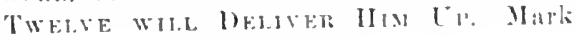


21 And as they dir eat, he said, Verily I say unto you, 21 and as they were eating, he said, Verily I say unto that one of you shall betray we.

14: 18-21; Luke 22: :21-2\%; John 1: : 21-30. When the even was come, after sumset (see on v. 17); no particular lour ot the evening wis fixed by the law or by custum. He sat down, etc., hev. Ter., he was sitting at ment. reclining, as in $26: 7$, see on $8: 11$. It was originally directed (Exos.12:11) that the passorer should be eaten in a standing posture, "with your loins girited, your shoes on your foet, aud your staff in your hand; and yeshall eat it in haste," reprenenting the ciroumstances of its first observance. This postule and haste luad been disusel, probably beeause the cireumstances no longer semed to call for it. The Talmud of Jerusalem says, "It is the nanner of servants to eat standing, but now let them (the Israrlites) wat reclining, that they may be known to have pasied ont of slavery into liberty." We have to conchude that the matters of posture and haste really were of no importance, and so Jesus eonformed to custom. Reclining at table at all was an indolent practice, but it was not neeessarily wrong; and in this, as in dress and virious other matters, Jesus was eontent to follow austom. With the twelve disciples. 'Disciples' was omitted by some early and many later documents, probably by way of assimilation to Mark 14: 17; the word is inplied it lot expressed. Twelve made a party of about the usual size. Josephus says ("War" 6, 9, 3), that thecompany partaking of a machal lamb consisted of not less than ten men, and sometimes reached twenty. It was mocessury to have a good many, in order to comsume the entire lamb. (Fxod. $12: 4,43-46$.) On the several steps in the observance of the Passover, as described in the Rabbinical writinga, seu Lightf., Moyer, and a highly interesting acount in Erlersheim. It is not certain how far this round of observances already existed in the time of Christ. Nor do thry throw any clear light on our Lord's appointment of brend and wine. Though instituted on the occasion of the paschal meal, and out of its materials, the Christian ceremony is in no way dependent, for its meaning, importanee, or proper observance, upon the Jewish ceremony. - Luke reports (22:14-16), our Lord's expressions of gratifieation in eating the passover with his disciples. He aiso states
(Luke $22: 23-30$, R. v.), that "there arose a eontention among them, which of them is accounted to be gratest," as above in 18: 1; Mark9: 34. Our Lord rebukes this spirit, in terms similar, first (Luke $22: 2 ;:-27$ ) to that uttered after the ambitious request of James and John, Matt. 20: 25-27; Mark 10:42-41, and secondly (Luke 22:30), to that recorded by Matt. alone in 19: 28. It is thus possible that Luke, who has no record of those sayings, gives here what was spoken then. But it is much more likely thit on a new nceasion. Jesus relukes the same fault in similar terms, as we lave often found lim doing (comp. on $21: 12$ ). The contention as to who was greatest might have been suggested in this case by questions of precedence at table, about which Orientals andevon Europeans show an outspoken solicitude which in Ameriea we ean hardly imagine. The Mishna ("Sabbath" 23,2 ) speaks of drawing lots to determine the place at table, even among the members of a family. Lulie passes at once from the opening paschal eup to tell of our Lord's institution of the memorial bread and wine; then narrates the alusion to Judas, the contention among the diseiples, and so arrives at the warning to Peter. This contention also suggests a very natural oceasion for the feet-washing of Joln 13: 1-17, as another object-lesson in lumility, answering exactly to that of Matt. 18: "2. As they were eating (v. 21 and 26 ), two things veeurred: Jesus (a) foretold that one of them would deliver him up, and (b) established the ordinance of bread and wine.

21 f. The strong expression betray me, seems to be necessary to our fecling throughout this passage (r. $21,23,24)$, partly because we are accustomed to it; yet the Greek really means simply deliver me up, precisely as in Rev. Ver., 26: 2, 15 f. The Evangelists speak with compassionate moderation of .Judas, comp. on 17: 22. Began is not mere Hebrew eireumstantiality (eomp. on 11: 20), but suggests that the process of inquiry was continued by one after another. Lord, is it I? with an interrogative particle in the Greek which strongly implies expectation of a negative answer, as in $7: 9$ f.; 9: 15: 11: 23 R. $Y$. The nearest English equivalent would be, 'It is not $I, I s$ it?' 
2.) Amb they were "xcending sorrowful, and began

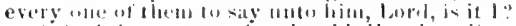

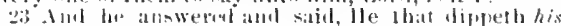

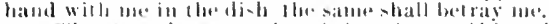

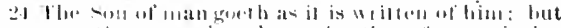

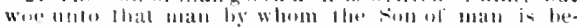

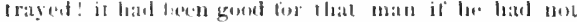
beren lints.

25 Than dulas, which levraved him, answered amel

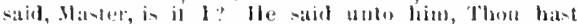
salial.

1 Gr. for him if that man.

Jerome: "The oleven, believing the Manter" more than themelves, and fearing their uwn Weakutes, sally atk abmut a sin ot which they hat nu (') 11 Ilc that dippeth, or dippred (Rev. Ver.). his haud with me in the dish (so also Maris), might seem only ugeneral dercription.

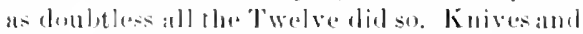

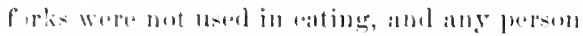
walle help him-ell from the dish lufore him.

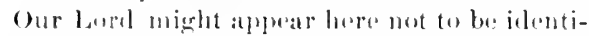
fying oulas, lut moroly showing the anormity of his wfiences: the man that ate form the same dish with me will deliver me up. (c)m1, I'sil. H: 4; Juhn l:): 18.) 'Ile that

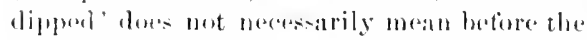
timent spraking, but just as well before that of dulivering 110 . Sha it dese mot materially difler foum 'lee that lippreth' in Mark 14: '20,

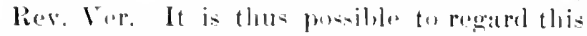
salying as diflerent form the identiticition de-

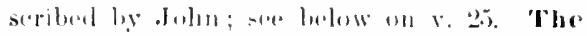
Son of man, our Lard'semmon desirmation

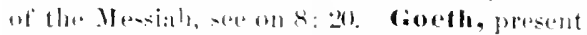
tense luevalus the goring is cortain and unal at latuel; so with is betraged. Is it is writ10.1 of him. apparently not a referenee to any particular prediction, hut to the general teruor uf Meniande propheres, vi\%, that he

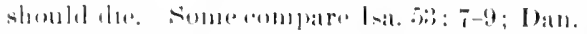

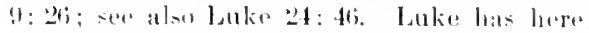
(22:2: Res. ver. "as it hath heon dotermined, viz. in the divine pulpure. I'/ump.: "It was

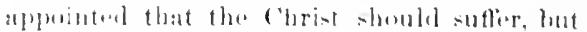
that alyointment did not make mon lese frese anents, nor alimini-ls the groilt of tratelery or injustier. Som, in like manner, as if tallerht b.

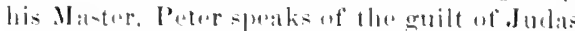
in $\Lambda$ els : : bi-ls, and of that of the priests and siribes in tet 4: $27,28 . "$ Wor 11010 ma!" "xprese not only wratl 1:2:13 t.), but at the -ame time compla-siun (24 18.) $\mathbf{3 5} \mathbf{y}$, or through, whom, tlep porson through whose ation a thing eomes to pass. It does not seem proper

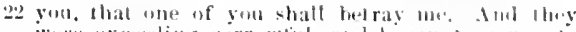

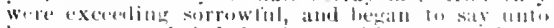

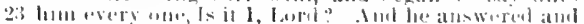

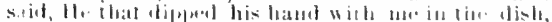

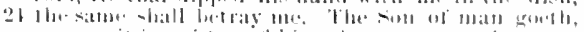

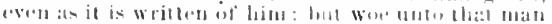

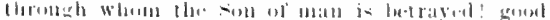

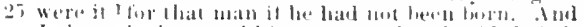
Julas, whoburated him, answeredilud said, is il 1 ,

to fiml here (with Winer) a hint that .Judus Was mores the instrument of uther men. He alpeatrs to liave acted of his own motion.

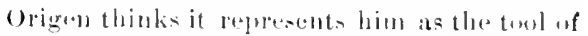
satall. Betrayed, deliereel up). (sixe an v 21.) It hat been good fior that man, etce This is a pumblar "xpresion. If he had never

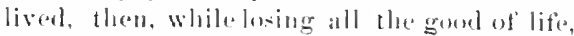
lue would have escapuel thes dratelful guilt he is incurriner, and the lorrors of future retributiun. Fur hind life wasuot "woth living."

25. Judas, som an 27: :3. Amswred. He had mot trean directly adetresedel, lut he telt himself concermeal in the porinted sayoings just utteped. (v.21-21.) A- all the others were alsk-

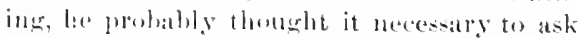
alow, lest silenes should hetray him. Master, is it I? with the same interrogative maticles at in 6 . 2), implying the expectation of at

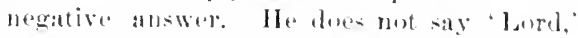
like the others, hut literally, Rabbi, and so in

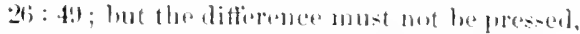

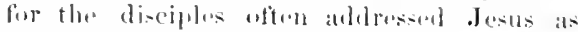

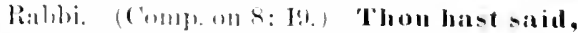
i. e. hast said what is true. This was a corllmon form of atlirmative reply, fommd also in 26: tit. and mecurring in the 'lalmul. It here solomuly rouels the sugerestion ot a negative al) swor, and treats his questiond as a virteal entession (Intter.) This is the momont represented in Lembarilo Da Vinei's fresen of the

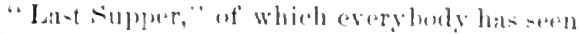
some rongraving; Judas has just recoived the aflirmative answer. Of (entrese we mu-t met

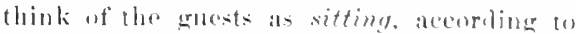
that pieture, for we know that thes renliued. soe an ingeniums releresentalion of the probable serene. with a plan of the table in Eileroh. II., 4th. This question of .Jullas and the answer in Matt. (not finmel in Mark ar Lukn) is reourded in torms so general as not tos show whother the answor wats alsu kmown to others. John has a full neeount of apparently the sime matter, diflering in form, but not in sub- 
26 And as tlees were eating, Jesus took ireal, and a blassul it and bialse il and gave it to the dreiples, and said, Trake, talt ; this is my lody.
26 Rabhi? IJ saith moto him, Thon hast sair. And as they were eatting, Jesus touk 1 hreart, and blossed, and brike il; and be gave to the disc ples, and said,

a Mang Greek copies have, Gave thanks. Sue Mark 6: H1._- Or, a loaf.

stance, from Matthew's stmmary statement. He says the disciples were at a loss whom Josus was praking about, and that Peter beckonex te. John, who was reclining in the hosom of Jeshs, to inquire who it was. Then Jesus replied, apparently in a how tome, that it was he fur whom he would dip a sop and give it to him; and presently he dipped, and gave it to Jukls, who immediately went out into the night. In connection with this sign t) Juhn, our Lord may bave given an oral answer to the fuestion just asked by Judas, as in Matt. : or the facts may be hamonized in other ways.

Acording to the order in Matt. and Mark, . Mrlas went out before the memorial of bread and wine was instituted. Luke seems to place things otherwise; but we have seen that he appars to ralate the institution of the braad and wine immodiately after mentioning the first pasclual cup (Luke 22:17-20), and then to return to sonak of the false disciple; if so, Luke durs nut trach that .Judas was present at thr institution, and partook of the loaf and the enp. The case is not certain, but this is the most natural way of eomlining the aceounts. So thele is no propriety in understamiing that here a tlagrantly wieked person was knowingly admitted to take part in the orlinaner.

III. 26-30. THE LORD's StPPER, Mn'k 14: 2:-20; Luke 2.2: 19, 20; 1 Cor. 11 ; 23-25. John gives jo arount of the in-titution of the Lord's Supuer. Paul says, "I have received of the Lord, aml julging from his similar expresions alsewhere, we understand him to mean by lirect revelation, which womld malie this an imlependent areount. It resembles that of his eompranion Luke. and Matt. and Mark form another pair. The places is an upper loom in the house of some friend (v. 18), and the time apparently some hours after sunset, on the evening betiore the crucifixion. As they were eatiug, comp. v. 21 ; this is the second thing described as occurring in the course of the meal; so Mark 14: 18, 2.2. Jesus took bread, or a loaf (Rev. Ver. margin); the common Greek text has an article, but wrongly. The word is singular in all four accounts. It is sometimes employed collectively for bread in general $(4: 4 ; 6: 11 ; 15: 2,26)$, but more commonly for a loat or cake of bread $(4: 3 ; 12: 4 ; 14: 17,19 ; 15: 33 \mathrm{ff} ; 16: 5 \cdot 12)$, and plobably so here. This is more likely to have been what we should call a cake than a loaf (see Smith's "Dict.," Bread); strch flat cakes the Jews at .Jerusalem now eat at the passover. It was unleavened, of course, as required by the litw at the passover (Exod. 12: 15; 13:3, 7 ; Deut. 16: 3); but our Lord makes no reference to this, and it is not wise to insist on uxing only muleavened bread in the Lord's Supper. And blessed, naturally means blessed the lonf, that being the object of the preceding and the two following verbs. Luke and Panl, however, have 'gave thanks, viz., to God, as below, v. $27 ;{ }^{1}$ and so some would bere understand it to mean blessed God, But in Luke 9: 16 it is distinctly 'he blessed them, viz., the loaves and fishes. This shows that the idea of blessing the loaf is not repugnant to seripture, and as the connection naturally indieates that jdea here, it should be preferrod. Compl. I Cor. 10: 16, "The cup of blesing which we bless." To bless a loaf is of courso to involie God's blessing upon it, to ask that God will make it a means of hlessing to those who partake. And bralie it. Hence the observance of this ordinanee came to be described as "the broaking of bread.' (Acts 2: 42,46:20:7; comp. 1 Cor.
IIf indent W I1, are not right in holding that all in luk", alter "buly, being abant in the "Western" group of clocuments, is really an interpubation from Paul; alud that $r .17 \mathrm{f}$. is Lulie's account of our Lord's wiving the cup, the order of the elin and the loaf bring simply transposet. The question of text is rery diffi. calt, int the arguments tor exelusion seen to grow num one with ronewol eonsideration. The onission of that portion of Luke would, howerer, take away nothing from the total information possessed by us, as it is all given in Paul.

2 The realline 'gave thanks,' in 5.2 , mentioned in margin Com. Ver, is suplorted only hy later documents; the earliest uneials, and nearly every one of the rarly rersions, give thessed,' and the ehange to the other is at onee explatined as an assimilation to $\mathrm{v}, 27$, and to Luke and Paul. 
10: 16.) And gave, is acoordingtothenow probabletirese trext in the imperdect tease, which mery moan that lae went an eriviner, himalt

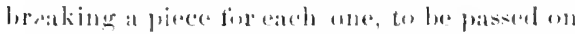

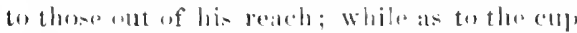

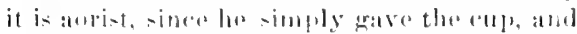
they fat-sed it to aitele other. But the impereforet in such a case might anly describe him as

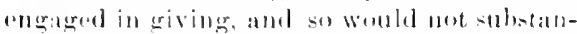
tially diflie from the andist. rake, eat. Mark has simply' 'take'; Luke and P'aul in lire. Ver. have moithor. 'This is my body.

"This" is neater, while the masembine would

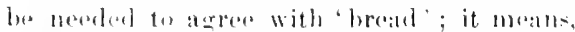

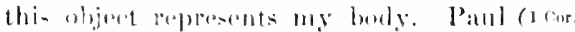

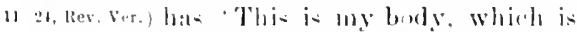
for youl, where 'lopken' wascarly inserted,

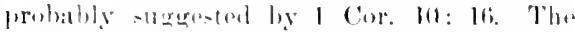

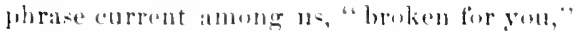

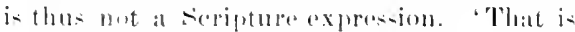

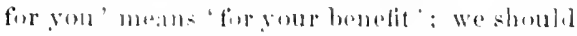
Jovingly take what represcots the buly that in for ur. Ialie, liov. Ver., has "this is my borly which is given fur forl, which amounts tu the same thing. Mirise: "Not as a lark fatality wore they tes rearal the doath which he wa- now to mest, but as the way ly which find wombl make them sharers in his areatent

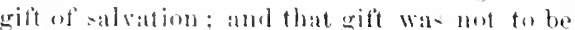

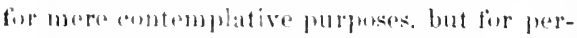
shal alpropriation."

Fond ditherent vioms as to the meaning of tho phrate. 'this is my body, mow provail in the Christian worlel. 'Two of them take the "xpression liforally, tho others tiguratively. (1) Transtah-tantiation, which represents the

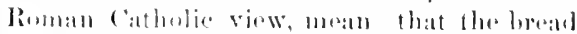

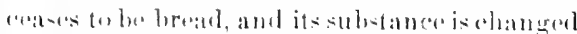

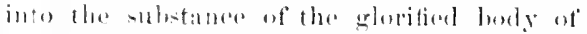
christ. This notion aros fiom embining

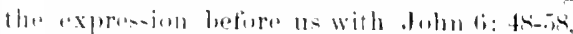

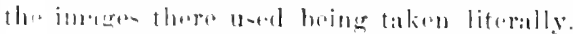

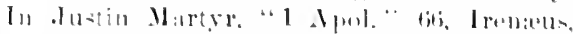

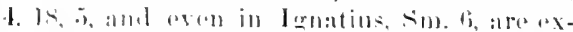

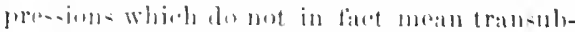

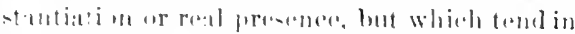

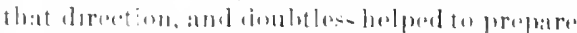

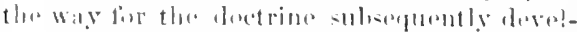
"puel. 'Jhoreis nothinget the sort in the "I)i-

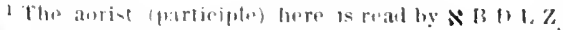
sume impertitht chrsives, and the Itemplitice, strols

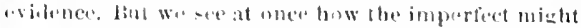
h.weleen ebanged intocorrespondence with the arotint

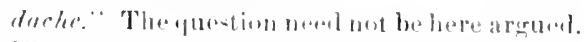

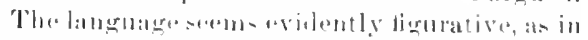

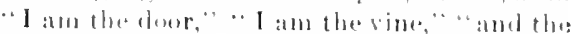

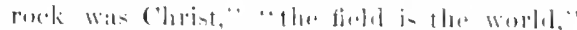

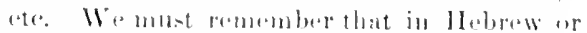

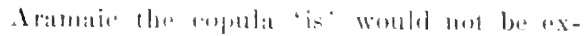
presalel at all. (2) (om-ub-atutiation, the? term inventud by Lather, and still used hy

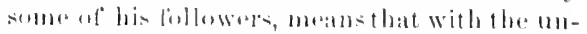

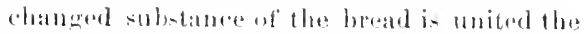
substanes of the glopified benly of chriat. Luther: "What is mow thes siterambut of the altall" Answer: It is the true lonly amb

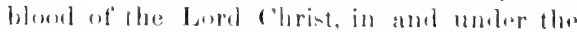
breat and wint, which we christans are

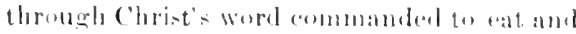
todrink. . Int hew tho huly is in tho loreat,

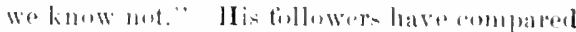
it to imon, witls heat supuralded, or more me coutly to irom mandetizal. But tho whole. netion is olvionsly a mere makeshift of per-

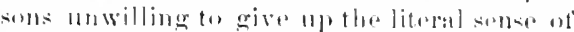
"is, and the my-tical notion of e thrist" seal

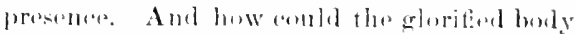
he invisibly dwolling in the hreat, and the

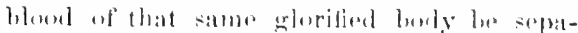
rately alwelling in the wine? They andel bo symblized separately, but how endel they

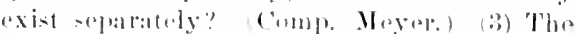

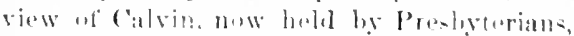
Methoulists, and many Ejiscopalians, appuats to be that to the partakine of the loreate is at fached ly divine appointement a special spiritnal bloning, which is roerived ly all who take the breat in fitith, and which tatumb bo latel without takinger it. Ilencere they stome-

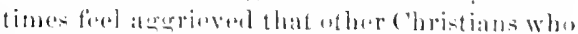
do not invite them to patralio of the loreat and

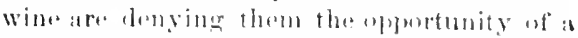

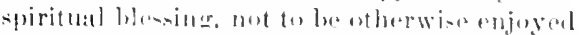
at that times. Somme High churehmen liate resereled from the calvinian viow and maintain the "liest l'reatenes" of christ in the sircandent. without undertaking to oxplain in what way or in what solse it axi-ts. 1, The? vitw of Zwingli, now almost univerally held by baptists. is that the borat is simply appointed as the symbel or memente. Whinl wo takeju remembramen of the savionr: boty,

of $r .27$, and of the maridluk as lolbe loit in Mark and

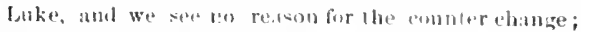
therefore the imperfect is probably correct. 
27 And lie took the enp, and gave thanks, and gave if to them, saying, Urink ye all if it:

as lor this is my blom of the new te-timent, which is shed tor many lor lue remission of sims.
27 Take, eat ; this is my lody. And be took ${ }^{1}$ a enp, 2k and gave thanks, and gave to them, saying, Drink yeall of it; for this is my blood of the acovenant,

I Sortue ancint authurities reud the cup.....2 Many ancient authorities insert new.

and that the natural effect of such a memento or symbol in vividly reminding of the Savionr, and kindling gratefial affection toward him, is blessed to the devout participant. A menento of the departed may be a very simple thing, and yut deeply move the heart. B.t the blessing thus receeived is not supposed to be asentially different in kind from other spiritual blessing o. or to be associated by nere divine appoiutment with this partienlar means of grace. Hence no spiritual loss is necessarily infleted by fitiling to invite to this reremony persons who have made a credible orai profession of faith, but have not yet subinitted to the prerequisite ceremony.

27. Took the cup: $a c u p$, is the eorreet text in Matthew and Mark, while it is the cup' in Luke and Paul. There was a cup on the table for drinking wine accorling to the custom of the paschal meal; 'a cup' does not saly there were others. The paschal wine was usually mixed with a double quantity of water (Edersh.). Gave thauls. From the Greek word thus translated comes 'the Eucharist,' $i . e$. , 'the'I haukgivung, as a plarase for taking the broud and wine. It is used ly I guatius and the "Didache" to denote the taking of bread and wine in comuction with an agape, or "lovefeast' (mule 12), just as Paul seems to use his phrase 'the Lurl's supper.' (1 Cor.11:20.) But the commection with a regular meal in common

1'Covenant, without 'new' in N B L Z, 3:, 102, Thehaie, Cyril; in Mark, N B (: D l, Theb. and Nemph., and $\mathrm{k}$ of the Old Latin. We see at onee that the "ne' might have been interpolated in Matt. and Mark from luke atul Paul (and comp. 5.29 ), while we see no reason why it shoull have been omitfed if originally pres. ent. Sio the internal wilenee supports this important group of dencuments. Notice the constant correspondence in this narrative between Matt. and Mark, and betwern luke and l'aul.

2 The word diuthele signifies both eovenant, an arrangement helween (dir) I wo parties, and testament, an arrangement of things at intervals (dirt), each in its proper place, a disposition of one's affics. The former is clearly the sense in most passiges of the New Test. lut the two isleas are blented in 1ICh. 9: 15-20, because the n'w covenant was made in and througl Christ's death, and its benefits are, as it were, an inberitane from hin. This sense of testament early took hold of is not made a duty by Paul, nor the connection witl the passover by our Lord. What he directs is not to eat the passover, or to eat a supper, not to eat in the evening, or at a table, or in a reclining posture, but to eat bread and drink wine. Protestants unite in deelaiming against the liomish practice of withholding the wine form the laity, brause the Saviour enjoined both the eating and the drinking; and exactly what the saviour enjoined we should do. So as to baytism, there is no command to baptize "in living water," as the "IDidache" dechares preferable, or in any particular place, time, cireumstances, or manner; the thing enjoined is to baptize (28: 19), viz., in water (3:11), and we should insist on mothing but water and the baptizing. (Comp. on 3: 6.) Drink ye all of it. It would seem unnecessury to say that this means all of you, and not all of it, as the Greek places beyond question; yet some have misunderstood. Mark records, wot the command, but the performance, "and they all drank of it.' Nor, what follows heing a reason for drinking. 'This is my blood, $i$. $e_{\text {, }}$ this wine represents my blood, like "this is my' body.' Of the new covenaut: the correct reading here, ${ }^{1}$ and in $\mathbf{M}$ ark, does not entain "new." It was added by copyists from Lulie and Paul. (Comp. Jer. 31: 31: Heb. 8: 8. $)^{2}$ Moses at Mount Sinai" took the book of the

the Christian mind. The Old Latin and Vulgate versions everywhere translate dittheke by testumentum, which in many passages is thagrantly inappropriate (as luke 1: 72; Acts $3: 25 ; 11 \mathrm{eb} .8: 8$ ete.), and nowhere needed exeept in Ilel, 9: $16 \mathrm{f}$. The old Covenant and the New Covenant thus gave names to the two great divisuns of the Bible under the form of Old Test. and New Test., which names eanuot now be slaken oll, though Covenant would be fur more expressive. The domination of this illea made it bard for early linglisb Iranslations to lreak away tron the rendering "testament. Wye. and Rheims of eourse follow the Vulgate, and give lestament everywhere. Tyu., Cran., Gen., and K. I., all give testament in the four passages pertainiur to the lotd's supper, in 2 Cor. 3: 6, 14, and througliout lleb. $9: 15-20$ (Gen. has eovenant in $9: 15$ only); and all give eovenant in luke $1: 72$; Lets $3: 25 ; 7 ; s$; Rom. 0 : 1; 11:27; Tyn. and Cran. have testament, but Gen. and K. J. covenant, in Gal. 3 : 15, 17 ; Eph. $2: 12$; Heb. $8: 6-$ 
29 lint I sily unlo you, I will mol drink hrenceforll of

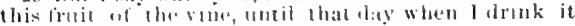
new with you in ou fathers killatour.

covenant and read in the andience of the people," and they promised to obey. Then he "touk the bleod" of oxen ju-t stain, "and sprinkled it on the people, atul said, Bebold

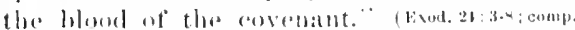

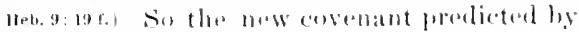
Ier. : : : 31-3.5 is abeut to be ratified ly the

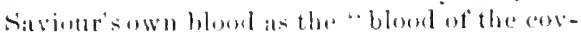

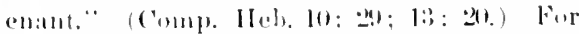

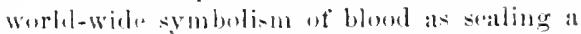
covenant and its participation ats demoting vital unime exe Trumbull: "The Blenel Covenant," mpunally p. 201-28ti. Which is sheal, proesilt lense (in Vlarkalso), expressing what is neitl and andin, on the point of taking place like is delivered, '2li: 2., Rave. Ver. and I keen, 2ti: ls, liev. Ver. For many, so Mark. In Luke, if r. 20 be genu-

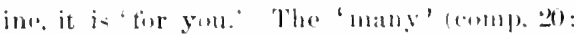
24) is simply a gencral expresion (probibly

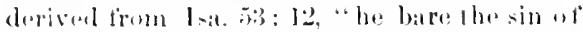

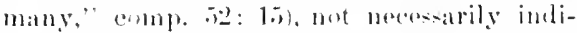
rating that some are amitted. In one semse, Ja

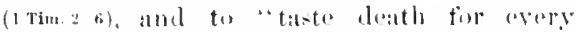

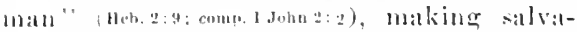
tion objectively per.ible for all; in another

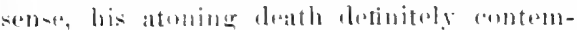
Hated the salvation of lare ellect. Finthym. mulerstame that whereate the blome of the

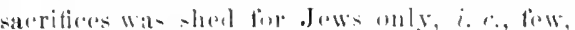

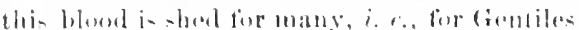
alse. The preponition bere rombered "fore meatu: "concerning' (peri), and so for the benefit of.' as in John 11; : 26; 17: !), 20; Hols. 5: :?; 11: 11. Thi- preperstion would nut of itself - Meresest the ideat at substitution. That

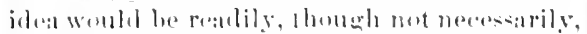

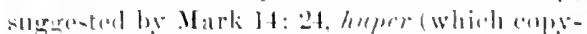

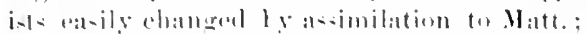

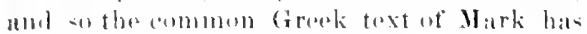
peril: and subetitution is nesensarily the

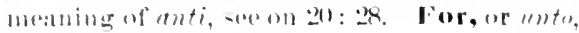

24 which is shoul for msur unlo remission af sins liu

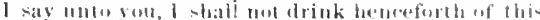

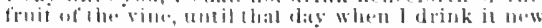
with you in my lather's kistrilum.

remission of sims, in oreler that sins maty be remittol. (net, 9:22.) This is the nitural ams must probable mandung of the prepustion and its cane, and is lowe entimely appropriate.

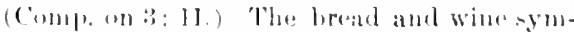
belize objectionly the siarene's bedy and hlumd ; mar wating and drinking these symbol-

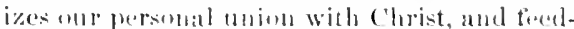
ing our sprotual nature upun him; and our cloing this tengether with others will, from the nature of the atse, like any other action in anmmen, promete ('hri-tian fellowship and mity where these aheally exist. Yet this latet is a submelinate and indelental ellixet of

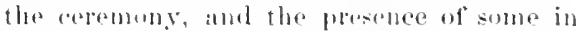
whese pioty we lack entefiderese slootd not prevententeatiog the loreal and drinking the wine in remombrance of christ. The Lord' supper is efterl called "the Communion," through a mismderstanting of 1 Cor. 10: ]6, whare the word commonion really means "partieipation," as in Rov. Yer. margin. This wrong namo for the ordinanes has otten

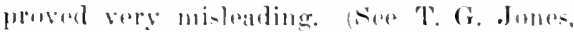
"The (ireat Mismemer," Nathville. Temn.l Fuw have arer questiend that the apostles

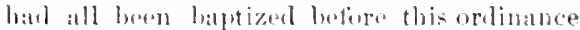
was establisherd; some uree that being the

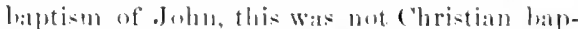
tism, and so they onrionsly infor that chris-

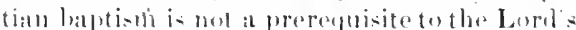
suppere but if ouhn's baptiom watsessentinlly distinet from ('bristian bantiom, then how do to the hatiom alministered be Christ him-

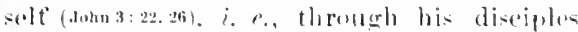
(fon 4:1 f.), at the -ime time with .John, and upon the salne genteral teaching (Mark 1:15)? It the baptisul perfirmed by ("hri-t was not Christian bupti-m, then what wiss it? (Comp. on $11: 11.1$

29. I will not drink, sluuld be. "I shall not drink.' ne pretierred hy Amer. lieverers. This frote of the vine. (One of the prayers

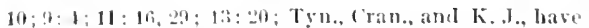

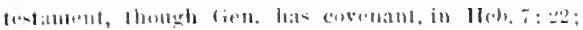

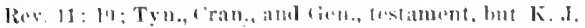

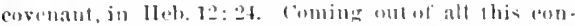
fusion, lsib. In., Soves, Jarly, lowidsun, and lies ver. give covenant everswbere excell in llob. 9: i6 f.

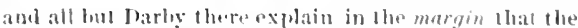

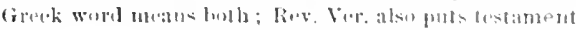

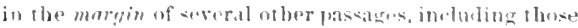

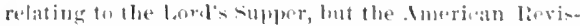
"res righty desirel to mat this marginal alturnativa remlering. 
30) And when they had sung a hymm, they went out 30 into the mount of (lives.

And when they harl sung a bymn, they went out undo the monnt of Olives.

a or, psalm.

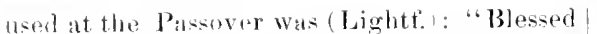
art thou, Jehovah our God, who hast created the truit of the vine." Orink it new with you in my Father's kingdom. Ha has cradually suceepded in making it plain to them that he will not establish a temporal kingdom, such as the Jews expeeted the Messiah to found. We is going to die, will soon latve them. But there will be a future kinglom of God, not a temporal but a spiritual kinglom, in which all things will be new (Rev. 21:5.) In that new kingdom, founded on the New Covenant, he will meet them again, and drink with them a new kind of wine (Lutter.) This ean hardly be nnderstood otherwize than as a figure, even by those who expoot a quasi-temporal reign of our Lord at Jerusalem after his second coming. (Comp. Juke 2.) 16, 30.) In lis present state of submission and suffering, our Lord does not speak of his own kingdom (as in 16: 28; 25: 31 , :34), but of his Father's kingdom, in which he, as thr sion, will rejoice with his friends. Yes, and all who shall have believed on him through the word of the apostles, will be with him there. (John 17.20.24.) Matthew and Mark have not stated that the taking of the bread and wine was established by Jesus as a pelunanent institution. But Paul makes it clear by rowroling the words, "this do ye, as oft as ye srink it, in remembranee of me," and adding, "For as often as ye eat this brear, and drink this (up, ye shew the Lurd's death till he come." And we see the apostles praticing it. in $\Lambda$ (.ts 2: $42 ; 20: 7$.

30. When they had sung a hymu, literally, if our idiom would allow, after hymning. The Greek wured humnos was properly a song of praise; and with this agrees the hept. and New Test. use of the word, Acts 10: 25; 1Iel, 2: 12. WVolearn from the Talmud that the ofews were acoustomed in comnertion with the pasobal meal to sing P'salms 119 to 118 , which Psalms they called "the erroat Hallol" (praise); it was sung in two parts, 11:), 114, and 115 to 118 ; the singing here was probally the seeond of thrse pouts, or possibly listi, which the Jews now sing at thr close of the passover meal. It is interesting to read these
Psalns in this comnection, remembering that Jesus himself took part in the singing. The psalnus were written in the Hebrew form of poetry, viz., parallel clauses; to trinslate them into metre, which is the ordinary English form of poetry, is therefore appropriate. The term 'Jymm' must not be here taken in our common sense as diffrring from a psalm, nor is there any radical distinction between the two in Col. $3: 16 ;$ Eph. 5: 19. The music was a very simple chant; something probably quite similar may now be heard in an oldfashioned (not "reformed") Jewish synagogue. They went out, viz., out of the homse and the city. There was light in many dwellings, and novement in the streets, till long after midnight, at which hour the feast was required to end. - Before leaving the house, our Lord must be supposed to have given the great farewell discourse, and the prayer of Jolun ch. 14-17. It is not unlikely that ch. 14 was spoken bofore singing the latter part of the great $H_{a l l}{ }^{2}$; then Jesus said, "Arise, let us go bence" (John 14:31), and after making arrangements for leaving the room, they sung the psalms, and he went on with th. 15, 16, and the sweet and solemn lrayer of ch. 17, after which we read (John 18: 1. Rev. Ver.), "When Jesus had spoken these work, he went forth with his diseiples over the brook Kidron, where was a garden," and hither. Judas eame, with the soldiers and officials. This answers to the prosent sentence of Mitt., and the parallels in Mark and Luke. Into the monnt of Olives, see on 21: 1. They would naturally go through the eastern gate norb of the temple area, which is now called St. Stephen's Gate; then down the steep declivity into the valley, presently (")ssing the bed of "the brook Kidron," probably on a low bridge as now, and in rot many steps further would reach the foot of the monntain. It was late, porhaps midnight or later ; but the city gates were open all night during the great feasts. The paschal full mom shone upon them from exactly overlread, lighting up the bottom of the deep ravine.

IV. 31-35. OUR Lord Foretells the 


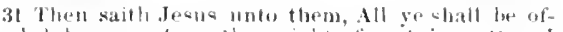

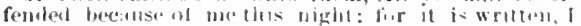

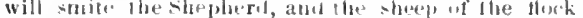

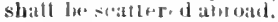

32 lint atles 1 am riven again, I will gul lefore you intoriatilece.
31 Then sitils Jesus unto them, All ge slatl lu l we

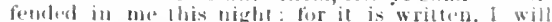

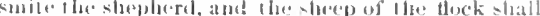
32 le scallered ahruad. Hat aller I and raised ne, I will

I Gr. cizurd to stumble.

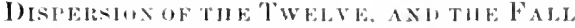

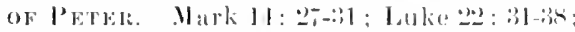

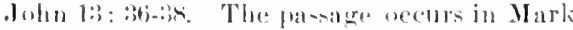
in the same orelue as hores lut neitherof them compuls us to under-tanel that the warning was given after louving the romm. That reeordod hy dolus is distimotly phaned ly him

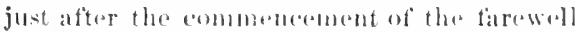
address-for that addran rablly begins with Iolan dis: :31. Luke sarma alos to put the

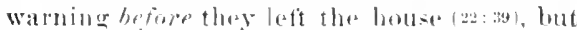
his oreler in 22. : 2l-3s is, as we have seen. fretty chearly mot ahromolengical. It is more ditticult to slypuse the roport in .Jehn to be out of its chromelogical position than thosent Matt. and Mark. ('Jark's "IIarmi." suppueces two distret warnings, that griven in Luke and Iabn oceurring before they left the hamas. and that of Matt. and Malk atter they wont unt. This is an improbuble supposition, though

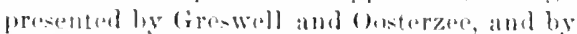

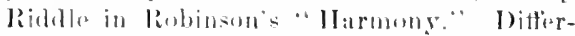
mot at are the terus ampluyed in Juke, we more naturally under-tand the warning as the alue in all four (rospels, for jts repertition during the same orening is hielly improbsble. It is therefore hest to slypuse. with most harmoni-ts, that Matt. and Mark have here introduced the warning a little later than it = elumolegical pusitim, in order to aroid

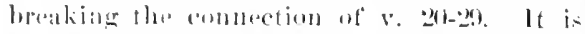
likely that more was said thatl any of the Gospols grive, or all of theme tegether: at in the sermon on the Mannt, and ation. III ye shall be ollended hecande of (in) me, or shall find in me aceresem of stmmbling as in 11: 6, and so on 5: 23. They will find in

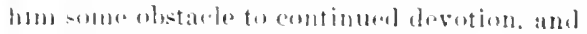
so will turn away and hossles him. This uisht. II dists during more than six months repeatedly toretold that he shomld bes put to

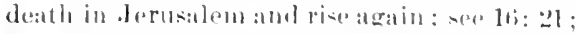

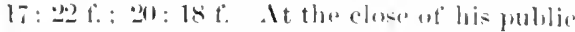
teaching. he dealared that he shomlal at the

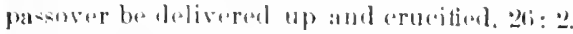
Now he is pertectly refinite as to the tine. For it is written, stands on record, a com- monf formula of reference to the old 'Tist seriptures, as in 2: $5 ; 4: 4$, ete. Neither our lurel nor the Evangelist silys that this was fulfilled in the pressut aceurrences, and it migit he enougle to understand that our Lord marely burrows the language to indicate that lar will he killed, and the disciples will leave him and lisperse. sithl, his introducing the

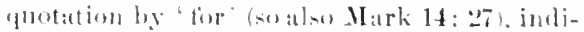
catces it as froving or as recfuiringe that which he has just forotold ; and it is entirely pussible toumlemetand Zech. li3: 7 as roally print-

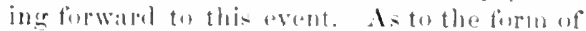
the efuntation Matt. and Mark follow the Webrew. "xe(3)t in changiner "smite" cincrular into"I will smite'; while the seret. B and

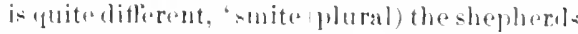
and draw forlh the steon.' This is a clear case of Mattlews following the Mebrew rather than the sept. (Comp. on $3: 8$.$) T.$ take the passage as roferrillg to the Mesial,

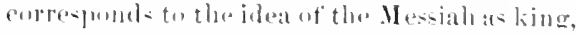
since kings were often described as bhepherdThen the flock will here ha I-race, and the prediction is that Israce will be souttered, the tirst stage of which wat the seattaring of the Twelse whon the shophera was smitten. It is, howerers, diflicult to annert Zuch. 1:3: i. thus understoul, with what there precedas

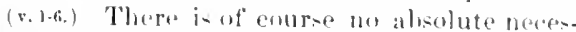

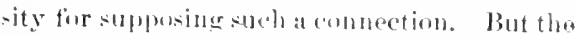
idea mag be that in the eoming time (s.2 2t.). ialalatry and false prophesto shall cease whill was true ju-t before the amoing of ('hrist). and yet there shall be erreat wickednem, and the shepherel shall lue smitten and Isacl

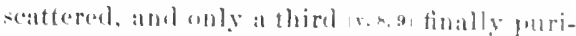
fied and saved. Many writers insist that th. idea of a shepheres here must be essemgially likethat of Zech., chatp. 11, sethat this is a bat shepherd, i. e., a bad linge of Isracel, whom

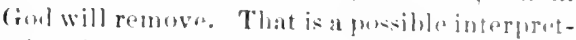

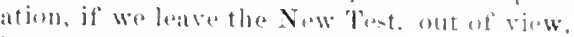
but not at all a nocessary ane.

3:. Atter 1 am risen arain, or raised up. Ile has in revery (aise. except 2t: 2, promisad that witer being killed the would rise again. 
33 Peter answertul and sild unto him, Though all men shall be offended because of thee, yet will $I$ never be offingled.

3t Jesus said unto hin, Verily 1 say unto thee, That this mighl, belore the cock crow, thou shalt deny we inrice.

35 Petel said unto him, Thougl I shoull dje with the yet will J not deny thee. Likewist also said all the di-ciples.
33 go hetore you into (ialjlet. But Peter answered and aid unto him, It all shall be 1 offended in thee, 34 I will never be loffended. Jesus said unlo him, Verily I say unto thee, that this night, before the 35 cock crow, ihou shalt deny me thrice. Jeter saith unlo him, Even if 1 must die with thec, yet will I not deny thee. Likewise also sajd all the disciples.

1 Gr. caused to stumble.

I will go before you into Galilee, liter:1ly, will lead you for ward, see on 21 : 21 ; possibly with reference to the figure of a shepherd here just preceding. So Mark, and below, $28: 7$. II is chicf appearance to then was to be in Galileo (28:16), which had been the principal tield of his ministry.

3:3-35. 'Though all.... I never. The peculiar Greek construction (two indicative futures) implies the assumption that all will. llere is the beginning of that self-confidence which led stop by step to Peter's dreadful fall. And here is tibe distinet assumption that he loves tho Master" "more than these" (John $21: 15$ ), indeed more than any one whatsoever loved him. When bitter experience had ehastened him, hr mads no more complaricons, but said only, "Thou knowest that I love thee." Verily I say unto thee, ealling attention to something solemnly important (see on 5:18). This night, as in v. 3 . Before the cock crow. Mark (14:30.72) has before the cock crow twice.' The coek was apt to erow aloout midnight, and again a fow bours later. The stecond corwing was the ane more apt to be observed as indleating the alpuoach of morning; and so this alone is mantioned by Matt., Luke, and John. Aleramer: "The differ"unce is the same as that betwen saying - before the ball ring ' and 'before the second bell rings' (for church or thimer), the referwee in both axpressions being to the last and most important signal, to which the first is only a preliminary." Thr minute recollection of this reference to th" first euck-crowing also would be natural in Peter, and there are many things in the sereond (xospes] to support the very atarly tradition that Mark wrote

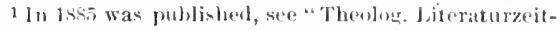
ung," 13 Jume, a papyrus frament in tirsek, brought from Egypt to Vienn:t, which forms a shorter parallel to v. 31-34, and Mark 14:27-30. As completed and transJated, it reats, "[And aftur] eatine, as they were going furth: I will smite the [shopherd and the] sherp wall be scattered. Upon Peter's [saying], teven if all, no[t $I$, he down what he heard Peter say. (Comp. 1 Pet. 5: 13.) Some have made a dificulty of the fact that ome passage of the Mishna forbids rearing fowls in Jerusalem, because the worms they serateb up would be Levitically defiling. But Wün. and Edersh. show that the cock-crow is repeatedly mentioned in the Talmud, and produce from it a story of a enck stoned to death in Jerusalem because it bad killed a child. S'o the Rabbinical rule did not exist in the time of Christ, or else was not strictly observed. Palestine seems particularly well suited to fuwls, and they are very numerous there now. Deny, see on 16: 24. Even if I must die, is the exact translation; that of Com. Ver., 'Thomgh I shomld die, is indequate. Peter is so extremaly selt-confident through consciousness of real and honest attachment, that even the Master's own warning eannot make him think it possible that lie would do sach a thing. And eneumraged by his ardor and positiveness the other disciples make similar assurances. Comp. the proposal of Thomas some weeks before (John 11:16), "Let us also go, that we may die with him." We have mo reason to believe that any of the ten did formally deny their Lord, though they all left him and fled, Peter and Jobn presently returning. ( $26: 56$.) All four of the accounts of the warning to Peter include the cock-crowing and 'deny me thrice. But in Luke and John the contident expressions of Peter are called forth by sayings of our Lord quite different f'rom each other, and from that recorded by Matthew and Mark. In John, Peter wishes to go with the Master now, and asserts that he has no foar of perils: "I will

sait to him], the eock will crow twice, and thou first (i. . before that) wilt thrice deny me." IIarnack thinks this shorter account is from a gospel earlier than Matl. and Mark. But it is casier to suppose, wilh Warfield amd Iort, that this is a mere abridgement of the gow pu. story, given from menory in some homily or prac tical treatise. Tbe reasons cannot be here presented. 


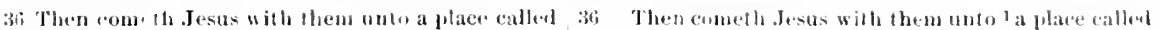

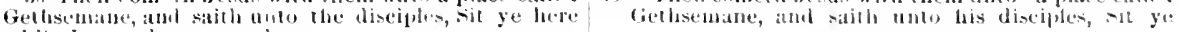
while I go alud pray youder.

I (it. an enclosed picce of ground.

lay down my life for thy salie." In Luke. Jesu- spealis of Satants alsiug fur the disciples that be might sift them; he surs ha has made special suppliation for P’oter. and adels un injunction that atter turuing agrain he mu-t stablish his brothrem. Peter repels the implication that he will go wromg ated haveto turn, saving, "Lerd, with there 1 atm reatly to gun both to prion and to doitlo," Riev. Vier. In aach caico, onr Jord replies by substantially the same warning as in Mattlew and llark.

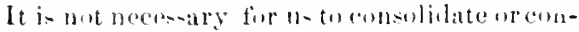

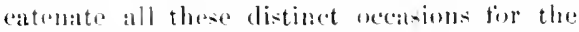
watringe Probably the eonreleation was more extended than any of the natratives would indicate. Ind a fix mis-ing proints of information might harmonizeall the alceonets.

\section{IIOMELETI IL ANL PRACTICAL.}

V. 17-19. The oxteruals of religions servioe. 1 'They should he observed with forethomerht and propriety. 2) They are a proper sulijere of reatues fior the Jarel's guidance.

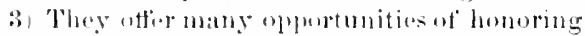
the leord with wir substance, v. Js, 4) Yet,

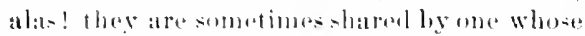
leart is sot on worldlinas and wiclicolntes, v.

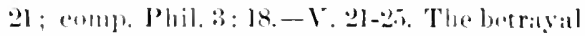
foretald. 1 Com-oin-mess of grond intentions cammot always save us from feat of erommittillg grout sill, ง. 2.2; 1 ( our. 10: 1:2. 2) 'The most affecting assoliations amd solemon warm-

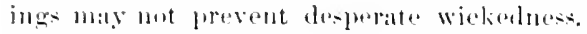
3) Ono whos heart is set on the darlitst crime may sombetimes talk calumly atmd with aflectoed molety, v. 25. 4) A bad man may be unintoutionaliy acemplesthing sume exaltod pur-

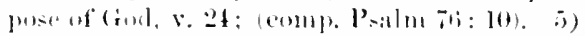
'The faret that an evil action is everruled for remel does not lesen its guilt and penalty, s.

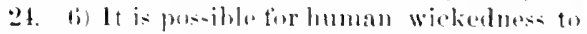

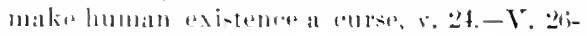
26. The bread and wine. I) Jutus has hidelen

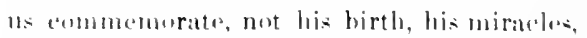
lisis trimphal entry, lout his death. 2) IIis leath sealed a eovenant of salvation (comp. Hul, !: 1!t:, making atomement for sin, amd purchasing forgiveness for simmers. B) To ant and drink these simpla emblems of his body and blond shoulal awalion grateful remem-

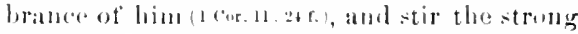
desire to live for him whendital for ns.-V.

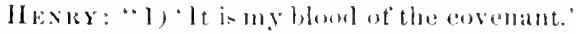
2) It is shod for matuy. :3) Euto remision of -ins." - V. :3). II Exhis: "Throe areoften leant sate that are man serello."

36-56. THE \GNY IX GETHSEMANE ANU,

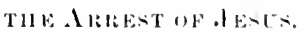

Foundalsoin Mark 14: :"2-52; Luke 202: :3!5:); Jolun is: 1-l:. The tima of this section is betweramidnierbtand morning. Girthemant is lenerealled a place, Rer. Ver., mergin, an

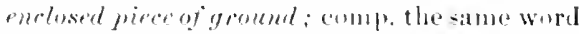
in John 9: 5. The mane firthemane motus "ail-jores. But the platere was not simply an vil-prese, for .Juhu call- it a garden or oreharol, probably containing fruit treses and flowers, as woll as veretaliles. Gothoemande is now shown as a small anclesure lying ju-t where? the three rosd acens the llount ot Olives branch ofl at its base (s+e on :I: 1), and between the eentral and soluthern roads, buth uf which land to bethany. This enclosure is of smorewhat lem than an aure, and contains several very ald olive trons, bolking at a distance hilie large ald aphle trous. These identical tree-appear to low traced back for many centuries. but they canmot have exi-ted iu

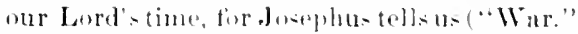
b, 1. 1), that the Romats. in oreler to build their mounds about the walls, ent down all the trees for ten or twelve milas around the city, sothat the romion that had bernso bratutifil with trees and Lardins (paradises) was now desolate on reery -irle, and a pitiable. monrutul spectatele. And even befire this

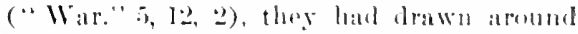
tho city a wall which is drencribed as paseiner

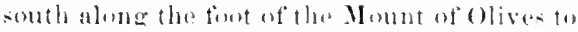

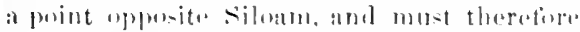
lowve pased "xactly whore the prosent enclosure stamels. The roal (iethsemante wats probalily quite nour this enclosed place. As "Jeslls oft-times resorted thither with his discijoles," so thit Jubla "kindu the place" (Johu is.2), we maturally tlink at it as near the Wiy to and from liathany. If hot is sulall public garden or purk, it was owned by a 
37 And he took with him Peter and the two sous of Zebedce, and besan to be sorrowful and rery heary.

38 'linen saith le unto liem, My soul is exceeding sorrowful, cven unto death: tardy ye here, and watch with me.

39 And the went a little further, and foll on his face, and praycol, saying, o my lather, it it be possible, led this cup patss trom mo: nevertheless, not as I will, l, as thore wilt. here, while I go yonder and pray. And he took with hin Peter and the two soms of Zebedee, and began to be sorrow ful ank sore troubled. 'Then sath he unto then, My soul is exceeding sorrowtul, evan unto death: abide ye here, and watch with ne And he went forward a little, and fill on his lace, and prayed, saying, 0 my $l$ inher, it it be possible, let this cup pass away from we: uevertheless, not publicespirited man who allowed visitors to enter at will, partioularly luring the great festivals, or else hy some triend of Jesus, like thes own's of the louse in which he had eaten the passover. - In 1871, a party of Americans went forth from Jurusalenu one night at Easter to visit Gethscmane. Passing through what is traditionally called St. Stephen's Gates, we wont aloug a winding path fat down the steep descent into the narrow valley at the Kidron (which has there no water "xcept in the raing season), and crosing, were almost inmediately at the modern stome wall which encloses the old olve trees. The paschal full moon for us too shone bright on the scenes. It was late at night, and all was still; and at several different points we linered, a little company from a distant land, and one or another of us prayed with chokisd utterance, for we knew that we could not be for from the spot at which the Naviour kneeled down, and fell prostrate, and prayed in his agony.

This suction divides itself into two parts, the Agony and the Arrest.

I. 36-16. The AgONY IN GeTHSEMANE. Mark 14: 32-42; Luke 22: 40-40. Johu does not reeorit this, but he records (Alf.) a somewhat similar utterance on the previous day, John 12: 28-39, and other passiges whinh reveal mental suffering, John 1:3:21; 16:32. Sit ye here, aplarently antside of the enchanre. Peter and the two sous of Zebedee. These three bolong to the first group of four anong the "Twelve (see on 10: 2); they alone had acoompanion. Jusus when he raisod dairus' daughter tor lito, and up unter the Mount of 'Transfiguration. Began, and continued for some time (sece on 11: 20$)$. Very heavy; sore troubled is a butter translation than 'very heavy. Mark ha-thesame poulliar Greek term. My soul is exeecdiug sorrowtio. The phrase, which resimbles Psil. $41(42): 6$ in Sept., can only droste a rail human mind; comp. Jobn 12: 27. The ancient fancy which some are trying to rovive, that in the Incarnation the divine nature took the place and fulfilled the functions of a human soul, is incompatible, not only with this scene and the temptation of $4: 1 \mathrm{ft}$., but with the whole history of Jesus. Th hatever anthroponorphic expressions may be necessauily used in sperking of God, it is evident that the divine nature could not, inany proper sanse of the term, suffer agony. How his human soul could suffer apart frem his divine nature, is a part of the mystery of the Incarnation, like his temptation, his increasing in wisdom (Luke 2:52), and his not knowing the day nor the hour. (Mark 13:32.) Nor is it wise to make trichotumist distinctions botween 'suul' here and 'spirit' in r. 41 ; see on $16: 25$. Even unto death. ('omp. Isa. $88: 1$. The time is now nearer than on the reasion deseribed in John 12:27, and his suffering is more intense. Alford: "Our Lorl's whole inmost life must have been one of continued trouble of spipit-he was a man of sorrows, and acquainted with grief-but there was an extremity of anguish now, reaching even to the unnost limit of endurance, so that it seemed that more would be death itself." 'Tarry ye here. Il bat brought the three to some point removed from the other eight. And wateh with me. The jdea seems to be that they were to guard his season of exceeding and deadly sorrow firom intrusion, and also to give him the support of knowing that sympathetie firiends were elose by. In any season of extrandinary sorrow. one likes to be much alome, and yet to have some dear friuds near, so that he may goto them when the craving for sympathy becomes uppermost. Alford: "He does not say pray with me, for in that work the Mediator must be alone."

39-41. He withdraws the first time. He went a litle further. Luke says "about a stome's cast,' say fifty yards. This might be from the eight disciples, as Luke does not montion the special three; but from comparing his whole connection we sce that it more likely means the three. Jesus doubtless sought the most secluder spot in the enclo- 
fll Aml he amouth unto the tistiples, and timdeth

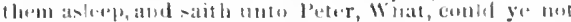

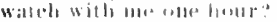

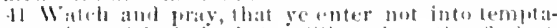

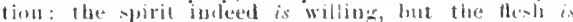
weiali.
4) ac I will, but as thom wilt. Int he cometh unto the

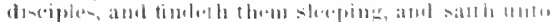

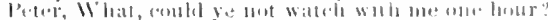

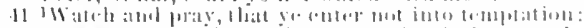
the spirit indeed is willing, but the thesh is weak.

J Or. Wutch ye, and pray that ye enter not

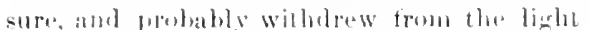

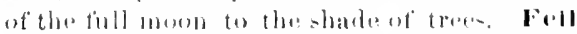

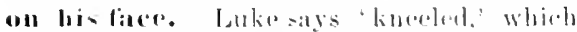
would wattrally be followed, in an agony of distren, hy complete prombation, And

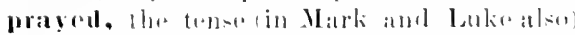

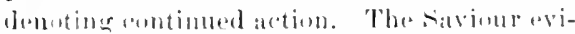

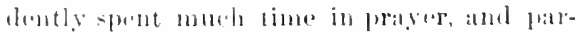

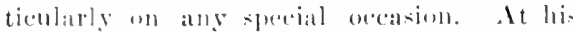

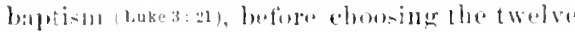

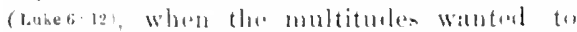
Inalio him king Mate. 1t:2s; Johuti lis), when the disciple. were just luxwming sottiotied that he

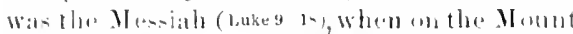

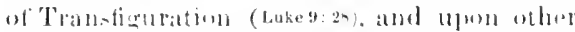

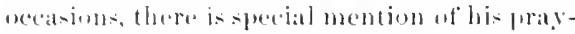
inger, sometimes for many hemrs, even a whold

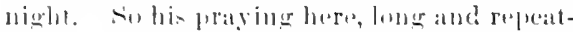
elly, is monew thiner in his experiencer. (), my father. Mark gives the Iramaic word dbha,

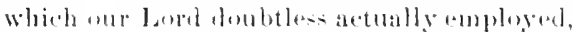
atmel then anlsk the Gropli woml. making Ahba, Father'; so Paul in Rom. s: 1.\%. II

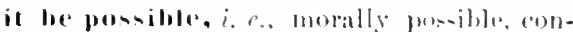
sistent with the Father's purpure of satring

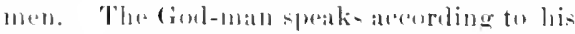
sutheriog louman uature, reforring all wh the

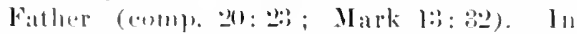

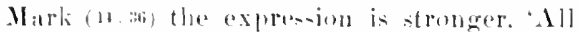

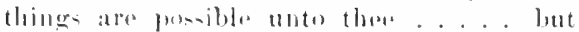
what them wilt -herefers it to the Fithleres will. This cup, at ammoll intage for greit

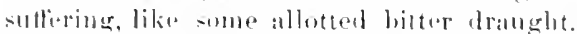
sien an 201: 22. Let this cup pass from mo. (i) Mark, lint Luke, in the enommon and Hobably" arepet text, "If thon art willing ter

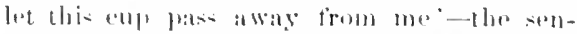

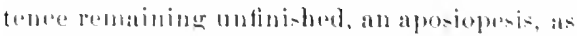

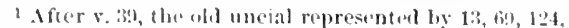
sume firek letionaries, and the syriae of dermalem introbue the aromut of the hlouly sweat and the. angel's appearing, taken from Luke go: 13 r., and, of collrse, not anduine here. 1 mumber of important doeHubents omit that paksage from leuke. But the omision ran le more batily acconnted for than the insertion. All the cinotic bereties of the secome century would dislike the passage intensely, and many orthodox peo-

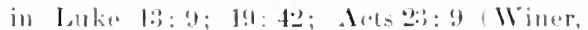

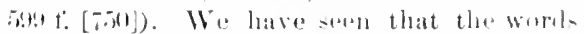

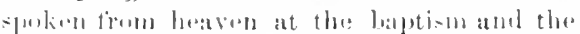

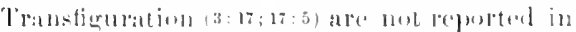

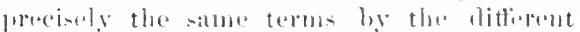

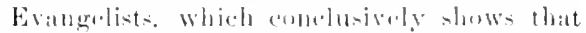

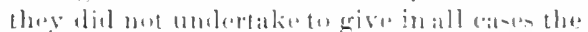

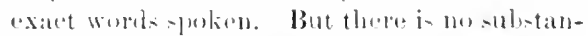
tial dillieleres Not as I will, but as tholt

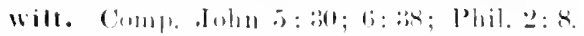

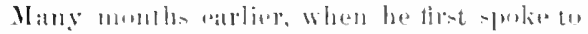
lhe disciples at his mpleraching death, he in-

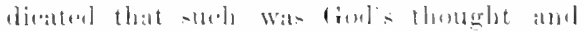
purpuse. (16. 23.) He cometh untothe disciples, the thloes And dindeth them

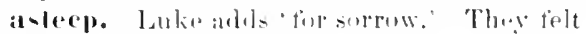

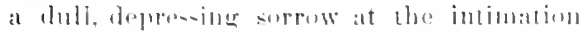

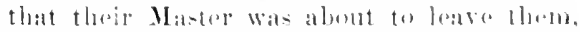

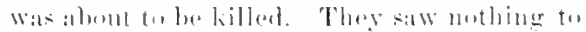
be dome ly thementres, and enold not realizes

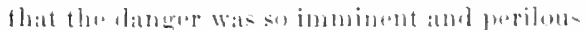

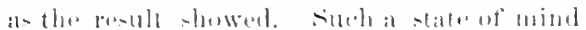

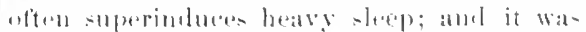
now lame pat midnight. These same thros

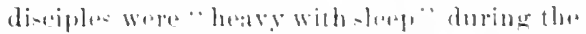
'Tran-figuration. (lukes 32.) Ind saith unto

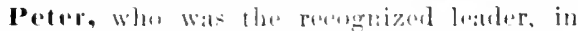

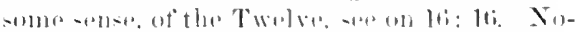

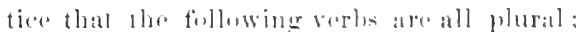

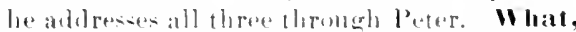
could ye out, is a goud linglish oquiralent to the peculiar phrase of the criginat, "Wore ye

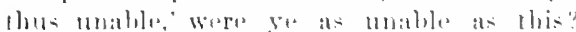
Watch with me one hour. The "xpreniol

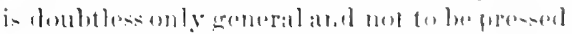

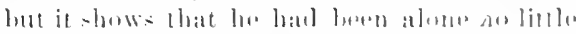
time. "Wateh' refiels primarily to litepriner

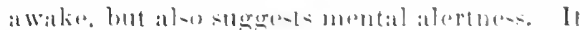

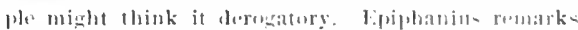

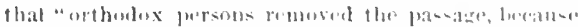

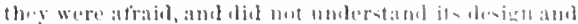
setrenes impromese" We think, therelure, that it

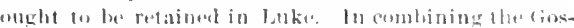
pels, this passage is more naturilly tonnected with the lirst stavon of prager, than with the secont or llited, when his aguny seems tu have been less severe. 
42 Ite went away again the second time. and prayed, 42 Again a seond time he went away and prayed, saysavill, () my lather, if this cup may not pass away from the, except I lrink it, thy will lie done.

bereame a favorite tern with tles apostles; (1) 11 ). 24: 42; 25: 13; 1 Thess. $5: 6 ; 1$ Cor. 16: 1:3 liom. 13: 11; Col. 4: 2; 1 Peter 5: 8. That ye enter not, may be conneseded with both 'wateh and pray, or with only 'pray, as in Riv. Vere margin, and so Origen "On Prayer," page 5.7. Migur), Chrys., Theophyl., Euthyn. In Luke '22: 40 it is simply "pray that yo conter not, ate.; and in 22: 46 Rev. Ver., 'pise and pray lest ye enter into', the latter connection is much the more natural of tlae two. 'Temptation, compl. on 4: 1. Observe that it is not merely "that you may overenme temptation," of "that vou may bo supported under temptation," hut "that you mal wot enome into temptation," may aroid luing tempited. Comp. on 6: 18, and see Luke 2) : :31. The Cons. Var., through oversight or in it passion for variety (sece on 25: 4(j), tramslates lyy 'lest ve enter' in Mark and Iulie. In the following elause it gives in Mark, 'thespirit truly is reaty,' but in Matt. where tho Greok has exactly the same words, it transiates, the spirit indeed is willing, the word 'indead' being nsed to translate the Greek wort men, a particle which moroly indicates that to its clause something (1) will prosently be lorought in contrast; complo on :3: 11 or 9: $97^{\circ}$ The emphasis is on 'spirit,' not at all on 'indered.' This is given as a gencral proposition, suggested by their casc. The flesh means not simply the body as opposed to the mind, luat the body as representing onr sinfulness, heingsonsed beranse bulily sins aro patent; while thaspirit reprosunts whit is better in us, reurarded as yorodued hy divine influanee. Comp. a similar antra-t botweon body and spirit, or flesly and spirit, frequently aecurring in Paul's Epistles. 'This statrment was not added by way of excuse, as some have imaginat, but of warning and ineentive. The fact that while the spirit is willing the flesh is weak forms ronson why we should watchfully and praverlully strive to ke(d) ont of tomptation, lest it take advan-

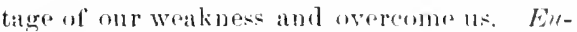

1 If eonnected with both terms, the dependent datuse is final; if taken only with 'pray, it. is non-final, sore 011 5: 29, Grigen, chrys, ete. use the infinitive (and so luke 22 : 40), which is the classical coustruction to con- thym. " Do not look to the soul's readiness and be bold, but look to the flesh's weakness and be humble.

42-14. He withdraws the second and third times. He went away again the second time. When wne is in very bitter grief, and, after being for some while alone, eomes back to his fieuds, it is matural, especially if they do not secun very sympathetie, that presently a great wave of sorrow should come afresh over his soul, and he must again seek to bear it alone. It this cup may not pass away. Correct text omits 'cups.' The Rev. Ver. hus more literally camnot. 'May not' is a quite different and feebler expression, the question being not merely as to the permissible, but the possible, as in v. 39. Mark (Rev. Ver.) says, 'and prayed, saying the same words.' They are, as given by Matt., substanstantially the some as the first time, and yot we mote a certain progress. He does not now begin by asking that the cup may pass away, and afterwards attain resignation; he begins with the assumption that it eamnot be otherwise (whieh the Greek phrase inplies), and at once expresses resignation. The third time, Mathew also has, "saying the same words. This was very different from the "vain repetitiuns" condemned in 6: 7. Imprasioned feeling sometimes makes repetition natural.

Thy will be done, the same phrase as in the model prayer, 6: 10. Asleep agaiu. Alas! not even from ardent Peter, and the impassioned "discipla whom .Jesus loved," could he find sympathy in this terrible time. Mark adds (Bib. Un. Vor.), 'and they knew not what to answer him.' Their minds were confused at the thought of the Messiah dying, of the miracle-worker slin, of the Mister forsaking the disciples, and this inereased their dull irowsiness. Luke does not mention his withlrawing three separate times, but makes one general statement (Luke $22: 40 \cdot 46$ ), substuutially equivalent to the more detailed narrative of Matthew and Mark. Agaun. The Greek worl for this (palin) oecurs twice in $\mathrm{r}, 44$, ac-

ver the idea often expressed in 'later' Greek by hiua non-final; and the infinitive in this connection could not be taken with "watch." 


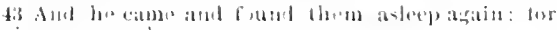

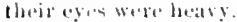

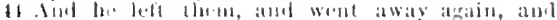

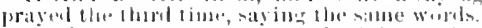

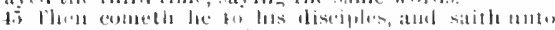

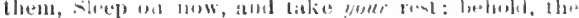

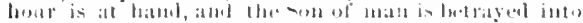
the hamblat simules.

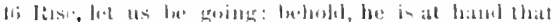
dult !n+liay int.

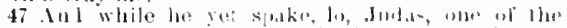

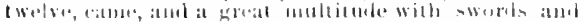

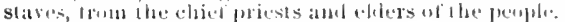

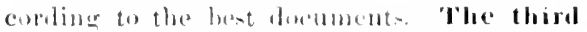

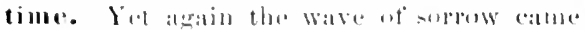
rolling arer his -oul. It must hater heon somethine awtul and wrelwhelming, it .Jans

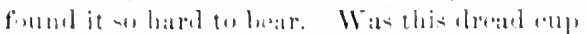

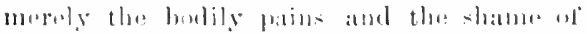

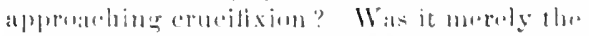

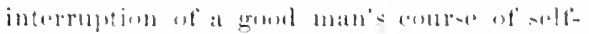

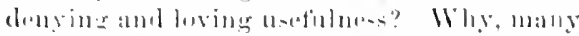

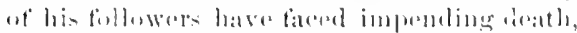
evert at the -talis, withent under proying that

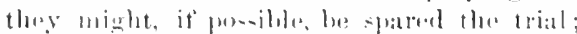

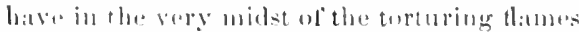

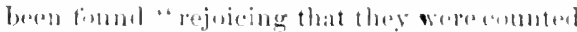

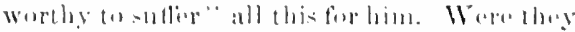

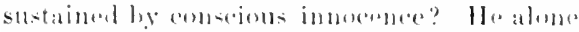

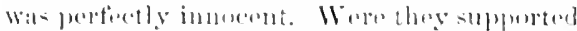

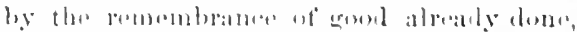

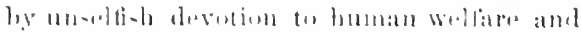
to (ionl's elory, by the indwelling sipirt? In

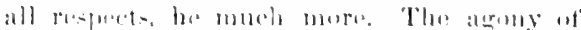

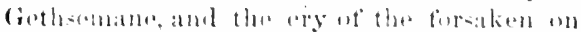

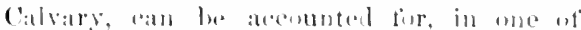

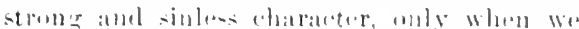

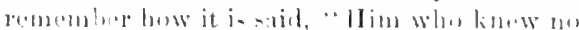

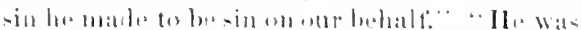

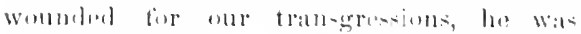

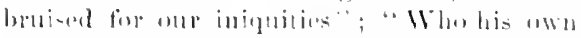

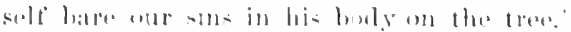

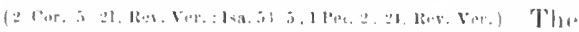

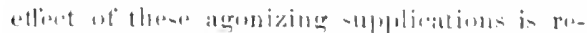

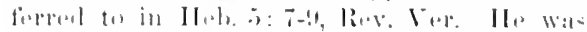

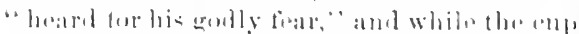

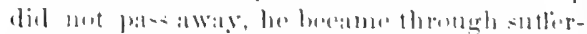

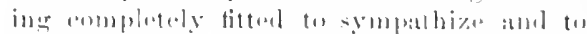

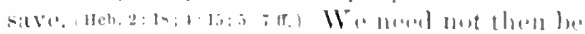

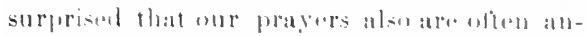
swrerel ley erantine, mol what we at first askel, lut somothing letter.

15 t. II in tinal ritum.

Nhech on $110 \mathrm{m,}$

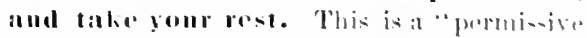

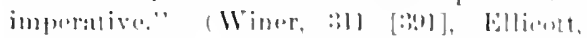

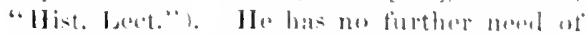
their keeping an ake; his struggrles in the suti-

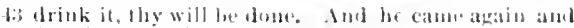

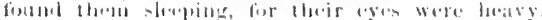

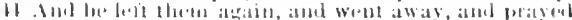

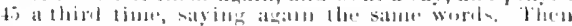

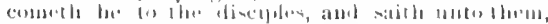

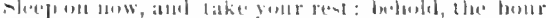

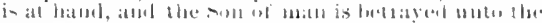

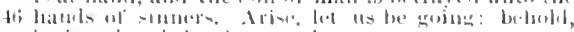

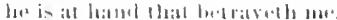

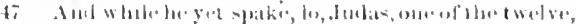

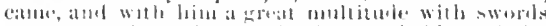

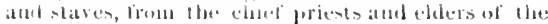

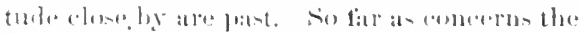

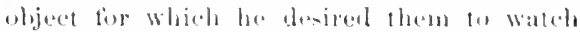

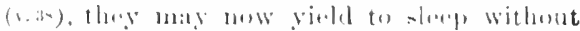

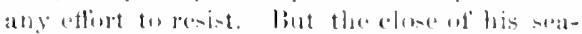
son of strugerle in promptly followed by the

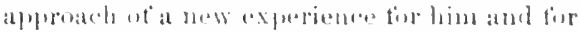
thems. It maly be (llackelt) that ju-t aftor

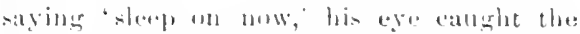
of

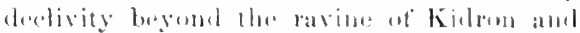

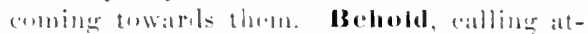

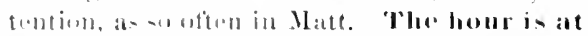

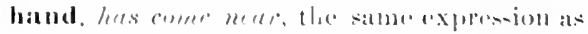

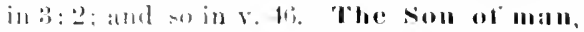
the Mesiath, sece on st: 20 . Is bellatyed,

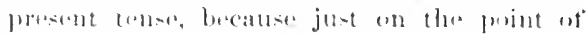

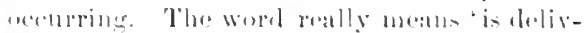

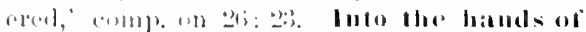
simers. 'Tha fircek has ne arliele, but

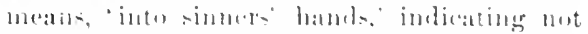

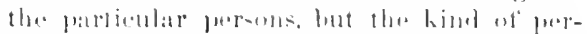

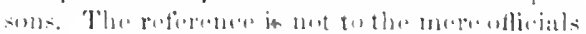

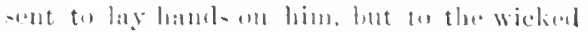
atuthoritus, the sanherlin. Rise, tot us be

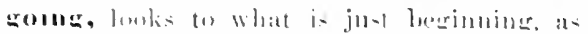

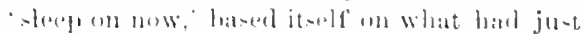

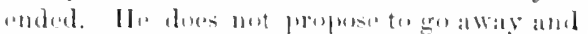

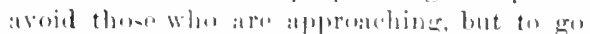

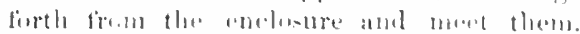

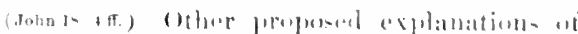

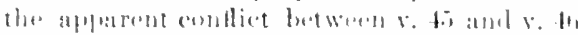

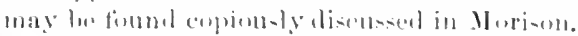

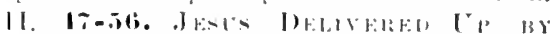

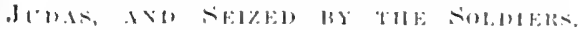

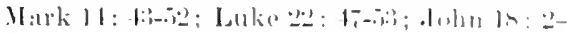

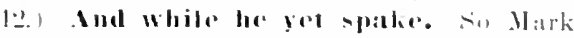

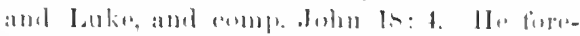

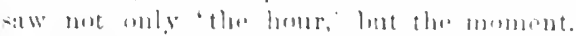

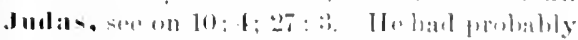

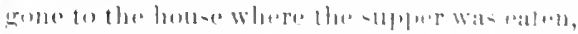

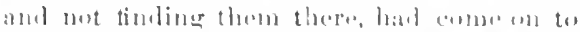

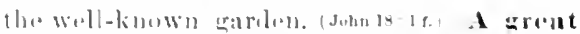
multilude, with swords and taves. Sin Mark. Juhn (liev. Vele. maryin), says that 
4. Nuw the that betrayed him gave then a sign, saying, Whomsorver 1 shatl kiss, that same is be; hold him fast.

49) Anct forthwith he came to .tesus, and said, IIail, Master ; and kissul him.

in And fosls sid untu him, Friend, wherefore art thou come" Then came they, and lad hamds on Jesus, and lowk him.
48 veople. Now he that betrayed him gave them a sinn, saving, Whomsoever 1 shall $\mathrm{k}$ iss, that is he: 49 take him. And straightway he came 6 Jesus, and 5) sad, llail, labbi; and l kissed him. Ind Jesus sajd unto him, Friend, do lhat for which thou art come. Then they came and laid hands on Jesus, and took

$1 \mathrm{Gr}$, kissed him much.

Judas reweived the cohort 'of soldiers, which, it full, would le several hundred men, and the extrene solicitude of the Jewish rulers lost the Galilean crowds attending the fenst should rescue olesus might well account for so latre a force; but the work may be used generally for a 'band ' of men. The articlesuggeste the particular cobort or band then garrisoning the temple. It was commanded ly a chiliarch, or military tribune, a rank higher than our exolonel. (John 1s: 12: comp. Acts $21: 31$ ef.) Edersh. suggests that so large a foree and so high an officer commanding would hardly have been furnished without the knowledge of P'ilate, and this miglit aceount for the anxions dreatm of Pilation wife. (27:10) It was e.mmon to strengthen the garrison of the Gastle of Antonia at the time of the great feast: in order to restrain the throngs in the eity and in the temple (onluts (Act:21:sl fr.), just at the Turks do now at Easter. This 'band' cannot have been Jewish solkiers, for the Romans would not have allowed borlies of armed natives in what was now a regular Roman provinec. The 'great multitude' may have included many followers through curiosity, as people were moving about through the whole of the masover night. Whatever was the numbar of soldier, there wats at any rate a military fores to support the officials sent to make the arrest, which was not the case at the attempt of six months earlier. (John $7:$ 3.:.) Besides the wealune. Tohn says the party had "lanterus and torches.' The inoon wats full, for the passover came at the midde of the month, and the month began with the new mom, but the officials might expeet to have oreasion for sarch in dark places, and for asured identifieation From the rhief priests and elders. Mark alds, the Scribes, thus showing more plainly that the sauhellin is meant, see mo $24: 59$. We learn fresently from Luke 22: 52 that some of theme clignitaries were themselves among the multimals. So there were soldiers (John), temple? officials (Luke, John), at least one servant of the high-priest (Matt., Mark, Luke), and some of the chief-priests and elders (Luke); altogether 'a great multitude' (Mitt., Mark, Luke).

48-50. Jesus is pointexl out and seized. Gave them a sign, gave it when they set mat tongether. All the better instinets of human nature revolt at the treatererous disciple's ki.s. The kiss was a common form of salutation, but only between friends. And Judas seems to have pretended a vory marked friendliness; for both Matt. and Mark; in saying 'and kissed him' (v.49), do not use the simple verb as before, but compound it with a preposition, so as to mean kissed frequently, eagerly, watrmly. (Rev. Ver, morgin.) There is the same change from the simple to the eompound verb in Luke $7: 45$ f, where the latter denotes warm affection; comp. also the prodigall's father (Luke 15:20), and Paul's friends. (Acts $20: 37$.) The distinction is recognized by ITeyer, Ellicott, Grimm, Alfurd, Morison, Edersh. Comp. Prov. 2̄: 6, Rev. Ver. "The kisses of an enemy are profuse." Hold him fast, take him, the same word as in v. 4, 50. and 5., and the translation ought not tobevaried. Our Lord is deseribed by John as coming voluntarily forward to the multitude and avowing hinself to be the person they were seeking; and this while Judas was standing with them. We may perhaps suppose that Jutis, to fulfill his contract and atm his reward, stepped forward notwithstanding and gave the appointed sign. And the accasion for this may have been afforded by the fact that the multitude, overawed by the calm majesty of the sariour as he avowed himself, "went backward and fell to the ground." (Jotin $1 * 6$.) Noreover, the Roman officer might not know but that some other porson was pretending to be the one whom he somght, and would naturally wat for the sign ngred upon. Master, or Rabbi. This term was often used by the disciples in addressing .Jesus, eomp. on 8: 19. Friend is not the common Greek term, but signities compan- 
5) Aml, helsold, one of them which wero with Jests stretchol gut hi: haml, and irew his sworil, amb stuck

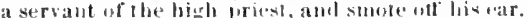

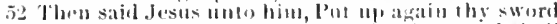
into his place: lor atl they that tale the sword slatl perish with the swort.

5:i Thinkist thom lhat I cambut now firat to ny lather, and las shall presently give me mine tuail twelve legrions at angels:"
51 line. And belould, whe of them that were with . Thans stleteliel ant his latul, and dow his sworl, and

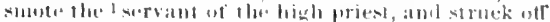

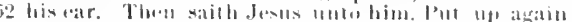
thy sworet imto ils plater: for all ton+y that lake the

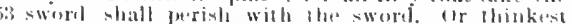

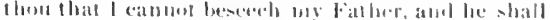

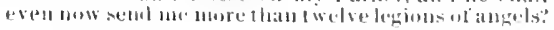

1 Or, tondservant.

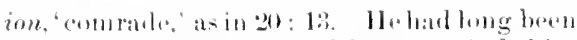

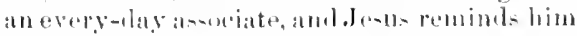
of this finct. (I), that) for wheh than art come. This is the naturit meaning wi the Greek, ant not, Wherefore art thou come?

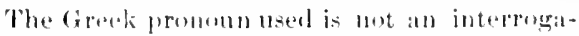
tive, fut a rolative, which as very often in

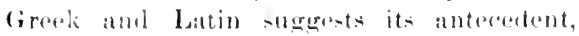
"(thate) for which than art acome. We then hase: to suphly a verb, which might be "toll'

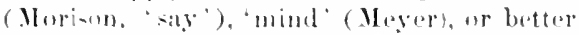
"do." (Euthym.) 'This anenels with the say-

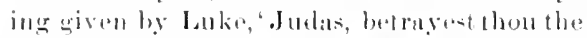
son nt man will a kis.?" and with Jolu

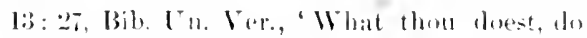

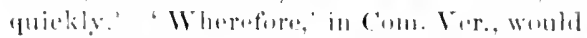
imply that .Josus dial not linow, and would seom tor contliet with Isuke. "( What is that) fior which thon ale come, is also at posible

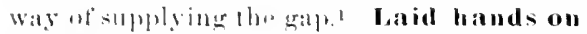

Jesus ant tooli him. 'Tlar himbiner Jubn 1s.12) seems to have mererred a little later, when they wren about to leat him away.

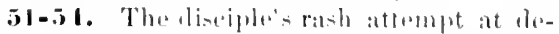
force. One is the numbral, not-imply some

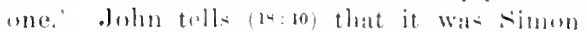
Peter, ant erives also the namo of the man

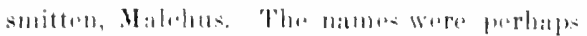

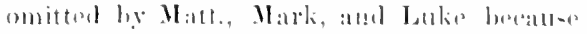
Peter was still living whon they wede. and

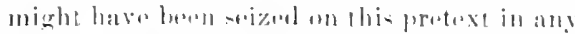

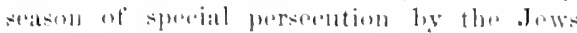
(cosup. A(1-2]: 25$)$ : while whon Juhn wrote.

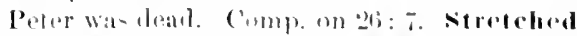
but his band and arew his morde dratil.

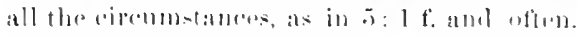

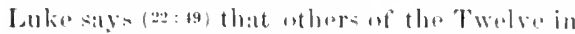
sompalty with leper united with him in a-king, Larl, slall we smitw wilh the sworl?" And ome of them (rash Peror) dis mut wat

1 Winer, Battm., and lirimm, and manr commentators, take the promoun as aseal interrengatively, being intluenced ly a tealitional interpretation from the Vulqate). But lhere are no clear examples af sneh a use of he relative has comp. Neyer, and it is highly im- for the answer, but smote. A (the) servant of the bigh priest. The woret is elenten, "slave, see ans sid. But a save of the high-

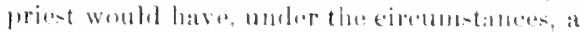

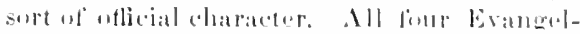
ists montionthio, fir it was an important ropcumstance, ereatly incerasing the purit of

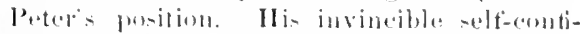

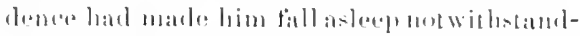
ing the Mater's warnings. Now, suldenly awakenime, he saw tha Hew comber laying hamb-am the Master, and with a sudblen im-

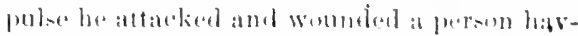
ing offioial imporince. Smoteoll his ear,

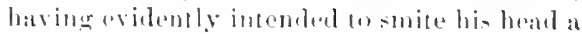
deaclly hlow. Peter (amos very near (Alt.) beiner lika Palublat and his followers, "who,

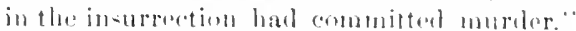

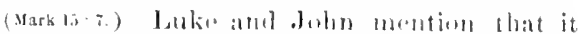

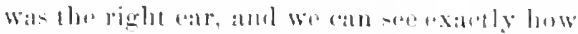
the blow misod. IReturuthysword into his

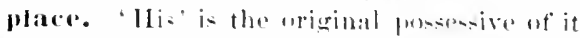

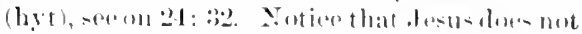
bid him throw away theswerel. Ill theythat tale the sworle ete. fimp. liev. 1:): 10. chrisf's follower-are nut to carry an his work

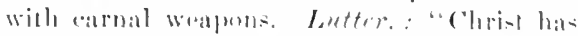
motherswarel than the sworel at his momth.

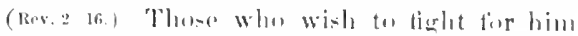
mu-t in like manmer liare mo uther." Evon

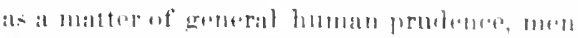

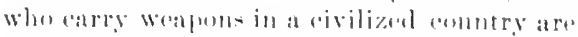
an the whole in mone greater dinger than mon who do mot. Thimkest thome ote., lil..

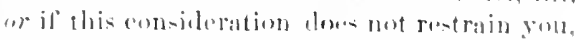

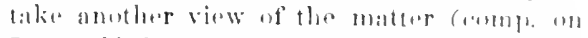

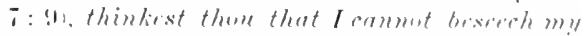
Fether, is the exatet translation, nut simply

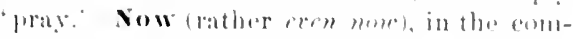

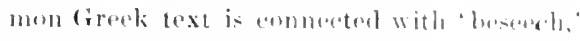

probable in itcelt. The examples onllectoul ly Moulton in his Winer, 207 fo, are all readily explatided as relative wilh the antecedent understoud, or ax attracted relative. 
54 But how then shall the Seriptures be fulfilled, that thus it 111!!st be?

5.) In that same hour said Jesus to the multitudes Are ye eone out as arainst a thief with sworks and stalestor totake me? I sit daily with youleaebing in the temple, and ye latd no hold ein me.

26) Put all this was done, that the ceriptures of the mopleets minlu be tulibled. Then all the disciples forsook him, andl tled. 5t IIow then should the seriptures be fulfilled, that 55 thus it must he?" In that hour said Jesus to the multitudes, Are ye come out as against a robber with swords and staies to seize ne? I sat daily In the 5 tomple teaehing, and ye took me not. lint all this is come to lass, that the seriptures of the prophet might be fultilled. Then all the diseiples left him, and thed. but in $N$ B I, and most of the early versions it is comnected with 'shall send' as in Rev. Trer. Give, or supply, furnish. twelve legions of angels. Nore thaı To protect twalve men (himsuf and the eleven), lie might have twelve legions and more of defendurs. If a cohort semned formidable, lue might lave legious. A tull Roman legion at that day contained some six thomsand men. ot enurse the expression is guneral, a romd number, and stated strongly. He is nothelplesty subuitting through lack of strength and ot protection (comp. 2 Kings $6:$ 17), but is voluntarly yielding himself to those who design putting him to death. IIe could easily avoill all that is coming, hut how then shall the scriptures be finfilled, that thus it must be? viz., that the Messiah must be demisad and rejected, must suffer and die (compl. Luke 24: 25 f.). 'The Scriptures,' a trelnuinal torm amomg the Jews, denoting the colloritum of hooks which we ail] the old Toktament, see on 21: f2. Only Matt. gives hare tho loforence to prophecy, a matter in which lo took peenliar interest, as writing especially for Jowish readers; but Mark also g.ves the parallel to v. 5it. John (1s: 11) recorls another exprossion in harmony with v. 5.254, "The cup which 11 y Father has given me, lall] I not drink it"? Just after, or just hefore, thus speaking to Peter, he spolie also (Luke22:51) to the persols who were arresting him, "suffor ye thus far" ; sutter thr rosistance of the mistaken lut well-meaning followre to go thus tar without punishing him. Thro inmodiately hasling the ear by a miraculous tumeh, he indured them to let the rash clisciplualuno.

5.5 f. Ilaving rebukul the disciple, and conciliatrel the jursoms immerliately engaged in arrestiug hin, Jesus now turns to the multitudes that throngoul around. Luke shows (22:52) that amoug thom wero chiof priests and captains of the tomple and elders, who might maturally amough, in their extrume solicitude, come along to see that the perilous arrest was surely and safely made. In that same hour (comp. 18: 1), viz., at the time when they were engaged in arresting him; but it is not easy to see why this more emphatic expression is used instead of the simple 'thon.' Perliaps the following words were well known among the Christians to have bcen spoken by Jesus, and Matt. means to say that this was the time of their utterance. Mark and Luke have a simple 'and.' Are ye come ont as against a thief, etc. Better as in Rev. Ier., as if ayainst a robber are ye come aut with swords and stares to seize me? Not a 'thief,' but the quite different Greek worl meaning 'robber," see on 27: 38. A thief would try to escape by flight, a robber was likely to resist, and they must foring waipons to apprehend him. 'S'eize' is in the Greek a stronger term than that of $v .48,50$, and end of 55 ; Mark makes exactly the same distinction. Jesus roproaches the multitudes with coming against him as it a man of violence. There had been abundant opportunity of arresting him without difficulty. I sat, imporfect tense, continued or hatitual aetion. This posture, which was common for a leacher (5:1), would have made it easy to seize him, and also indicated quiet innocence. Waily, for several days of the preceding week; possibly it points buck also to earlier periods of teaching at Jerusalem, recorded only in the Fumrth Gospel. Witl you, is wanting insome of the lest documents. In the temple, hioron, the general sared enclosure and edifiees (sce on 4: 5); he taught in the Court af the Gentiles and the Court of Israel; not being of the tribe of Levi, we may he sure ho never entered the naos, nor the Court of the Priests. And ye Jaid no holal on me. IIe thus reminds them that he had given no oceasion for their treating him as riolent and dangerous, nor tor their arresting him at all. IBut all this was done, is come to pass (comp. on 1: 22), still the Saviour's words, as elearly shown ly Mark 14: 49. In the conrse of Providence this plotting and arrest- 
ing hath all taken place, that the seriptures might be fultilled: thollgh the hu-

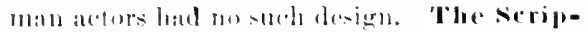

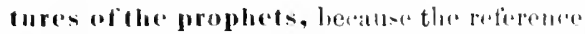
is enerially to the predictive purtion of

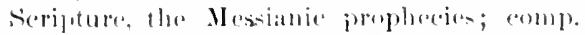

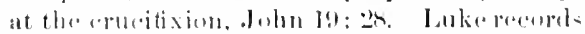
the additimal silyoge, in hapmony with that given lacese. "But this is your hour, and the

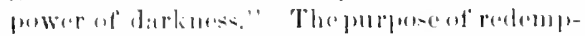
tion mew premitted that great wrong. which was to be womelertully overuled for good. llen all the disciples forsook him and fled. In jurleing them, we mut remember that the Ilanter had forbidho all resistance, and hat dietinetly saitl he wat about to latse them. Dlark add- (16:518) an alecount of a certain roung man who left his solitary garment when he was seized by the capters, amel fled. The mention of this slight incident may

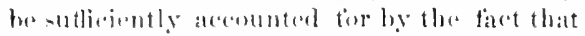
it shew: hes great was the terrere teit hy the follower of thells. Some think, howerer,

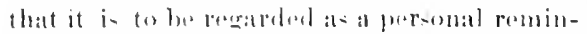
iscenese, the venth lwing Mark himselt,

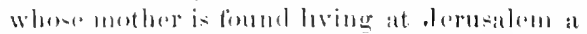
do\%n yours later ( $\Lambda$ at: $12: 12)$; and it is suggrested (Woin. Edrots.) that the youth had followed trobs and the disciples from the hosew in which they had aten the pat-soser. and an that the homplable homaloblder was dlatk's father. There is rery slight gromucl fir this conjecture, ar for the notion that it

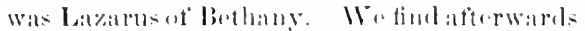
that Perter and John andet hatre speentily re-

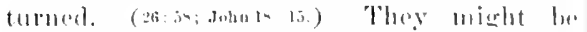
rogarded as axernioms to the genoral state-

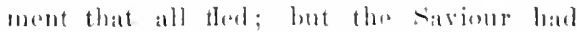
also made a gemeral prediction (26-31, k. v.),

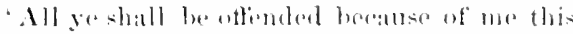
night. - Sos the olliecials and the soldiers bed

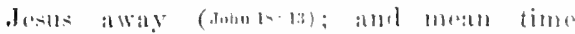

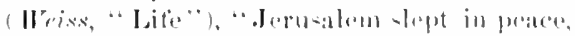
and dis wot know what had halph.ne.l."

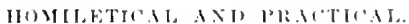

V. 37. The theres dieciples in fietlesmane. 1) How have to realize the sirnitionure of great crises in life. 2) How implepteret is all human sympathy with the Divine Redermer. 3) II down the willing should be in sll timesof special trial. b) Ihow great the privilege of praying that we may

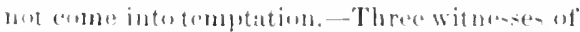

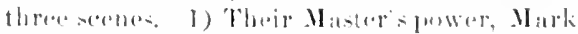

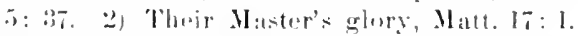

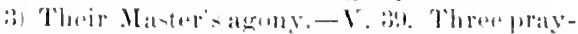

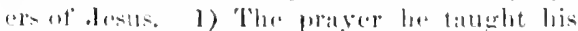

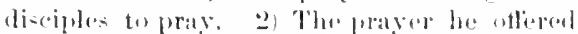
in bethalf of his disciplese, follon 17 . 3) The prayer he mate in his nwn linhalt. Al.Foru: "All contlice of the holy soll is proyer ; all its strugroles are (ontinued ("olumunion with (iod. When Alinhans faith wats to be put ta -n soreat trial, lorestys, "I and the lakd will go youder and urowhip.' (Our lord calmost on the somes sout) unites in himself (stiep) ats the friest and rietim, Abrahames fath

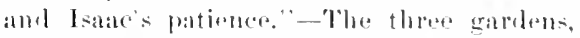
Elen, fetheanane, Parabies. The till of man in Eelen made necessary the aguny of man's savenr in Gothemathe, and this madro fusible the almi-nim of man inte the Para-

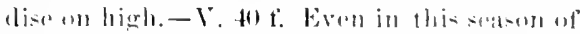

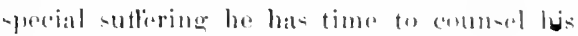
disciphes ; so an the crose he prates for his murlerers, provides for his mother, and an-

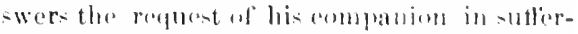
ing.-V. 11. Sataty as regarels tomptation.

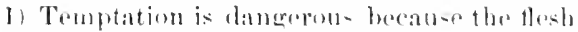
is wak. 2) Onr only real saldoty is in apredind temptation. (3) In order to thic, let us be watehful and prayerhil.-V. to. Pressexse: "Not thy will hut mine be done, chanered Paradioe into a desert; not my will but thine

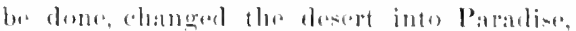

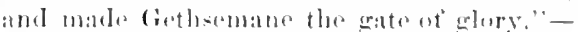

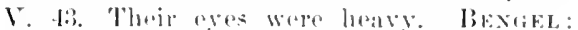
"Sincle sothenluese ofter bulds the proms when it is loist becominer."-V. 1.) fo liest and arise. It is oftenthe the that when and

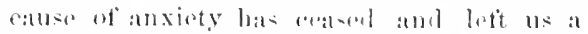
moment's pert, in the next moment whe new

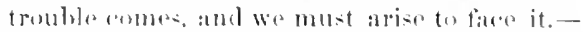

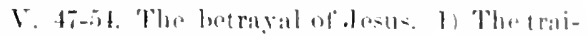
tor's kiss, and the siviour's calm respmese.

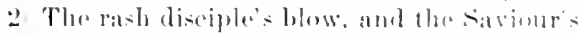
mikd rebulise. i) The siviour's determinit-

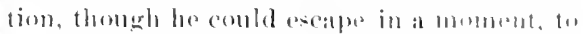
fultill the seripturesand work out the world's salvation.

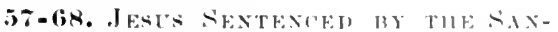
HEITIX.

This is fonnd also in Mark It: rin-fin; Luke 2.2.) : it, (6:-6.5); Joln 18: 120-14, 191-24. 
57 And they that had laid lold on Jesus led him 57 away to Catapias the high priest, where the seribes and the clders were issermbled.
57 And they that had taken Jesus led him away to the house of Cuidphas the high priest, where the Calaphas A. 1) 18-36. The son Eleazar eame The trial of our Lurd may be divided int two main parts, the Jewish and the lioman trial. Each of these must be subdivided. (1) The olewish trial compleises (a) The oxamination betole Annas, John 18: 12-14, 19-23; (b) The sintenco by an informal session of the sambedrin, Matt. 26: 57-68; Mark 14:59(i.); (c) The formal trial before the sanhedrin, which sonds him to Pilate for sentenee, Matt. 27: 1 t.; Luke 20: Giti-7l. (2) The Roman trial inchudes (a) The first examination before Pilate, 27: 11-14; John 18: 28-88; (h) The reference to Herod, Luke 28: 6-12; (c) The tinal alpurance before Pilate, 27 : $15-81$; John 18: 39-1!: 16. It is moticeable that John gives a good deal as to the Roman trial that is not found in the other Gospels, particularly as to Pilate's private inquiries. Mark continues to resomble Matt. Luke has some matter not found in the others.

Our present section contains the trial before an informal session of the Sanhedrin. It may be divided into v. 57 f.; 59-63a; 68b6if; $67 \mathrm{f}$.

I. 57 f. Josus is buought before Caiaphas and the Suribes and Elders. Peter follows and lookson. (Mark 14:53 f.; Luke 22: 54; John 18: 15, 24.) They that had Iaid hold on Jesus, at Gethsenane. Led him away to Caiaphas, the high priest. The appended "where' implies that this means to the house of Caiaphas, and that is distinctly stated in Luke. Caiaphas was the son-in-law of Anmas, Ananus, or Hanan, who had long before heon higl priest himself, and among the numerous changes of the time, was suecoeded hy five soms and this son-in-law toos, "Ant.," 18, 2, 1 f.; 20, 4, 1.) The fimily were all cadducees (Jos., Talmud), and were specially odious to the Pharisees, the "homso of Anmas" berming a by-word (Tabmud). Josiph Caiaphas was deposed shortly atter Pilate lost the proenratorship, A. D. 36 ("Ant." 18, 4, 2f.) The tims when he was mate high priest depends on an obsen re statoment of .Jos. "Ant.," 18, 2, 2.) His expressoms leave hardly moro than folle years betwen Annas and Caiaphas. Either Amuas officiatrerl about A. D. 7-21, and then Caiaphas A. I. 25-36, or Annas A. D. 7-14, and then between Annas and Caiaphas; Jonathan and 'Theophilus' (Keim) A. D. $36 \mathrm{f}$. ; Mathias A. D. 42 f. ; Annas, junior ("Ant.," 20,9, 1) 1. . 68. This makes the last a different person from the high priest Ananias of Acts 23: 2; 24: 1, A D. 68. The character of Caiaphas appears from John 11: 49-52, and from the trial of Jesus, to have been shrewd, selt-seeliing, and unserupulous. Where the seribes and the elders were assembled. Mark mentions also (14:53, 'all the chict priests,' and these are expressly mentioned just atter by Matthew, v. 59. These were the three classes composing the Sunhedrin (see on v. 59.) Instead of 'were assembled' (Com. Ver.), it is better to translate were gathered together, for the former would indicate a formal session of the sanhedrin, while the Greak term is neutral on that point. Mark's phrase is simply 'there come together with him,' and the fact scems to be that this was an informal gathering before dawn, whereas, a formal session could not be held till 'morning was eome.' (27:1.)

It was apparently while the dignitaries were gatheringat that unseasonable hour, that Jesus was first questioned by Anmas. (Jchn 1w:12-14.) Annas and Caiaphas were both regarded as high priests (Luke $3: 2$ ), the former still in popular estimation holding the office as long as he lived, while the latter only was recognized by the Romans. So in 1 Kings 4: 4. Zalok and Abiathar are mentioned as priests, it having been stated in 2: 35 that the ling put Zadok in the room of Abiathar. An action would be valid in the eyes of both the parple and the Romans if known to have the approval of both Caiphas and Anuas. This was easior from the fact that Caiaphas was son-inlaw to Annas; and the supposition (Euthym. and varions recent writers that Annas at this time lived with Cajaphas in the high priest : official residence, each having his own reception roon, will aecount for all the statements in the several frospels. It is also a plausible conjecture (Wieseler, Ewald), that Annas may have heon at this period prosident ( $\mathrm{Nasi}$ ) of the simbedrin. Johu distiuetly states that they "led him to Anuas first; for ho was 


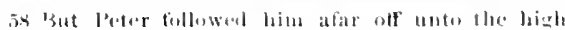

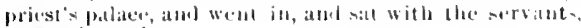
10 see tlie chil.

fathor-in-law to Caimplias, who wat hiert

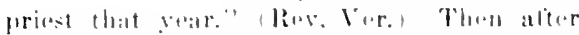

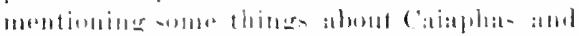
about l'etar. Juhn states that "ethe hight

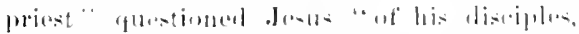

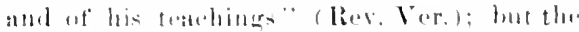

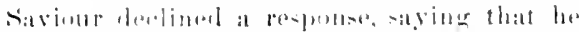

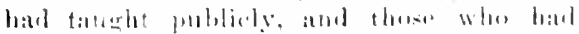

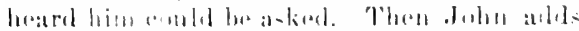

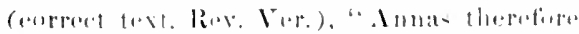

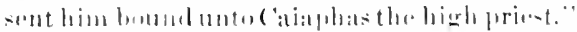

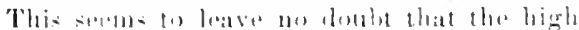

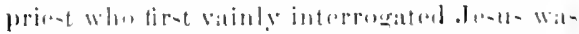

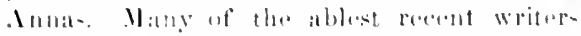

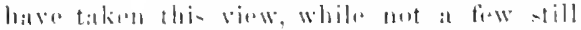

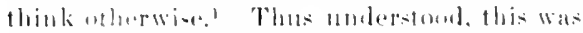

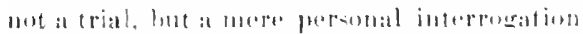

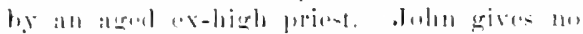

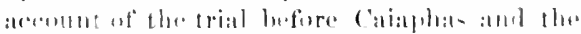

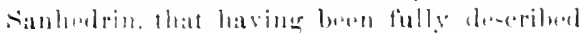

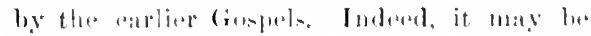

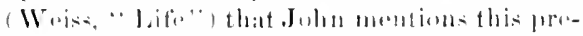

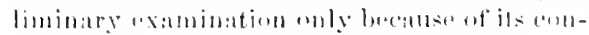

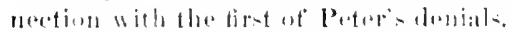

But Peter followed him alier oth, riz.,

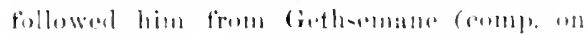

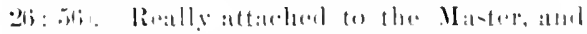

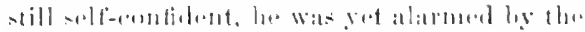

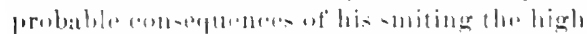

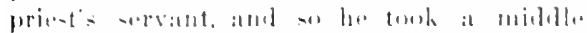

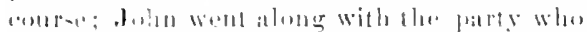

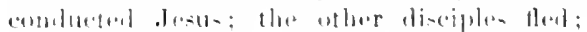

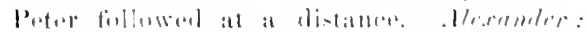

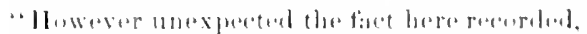

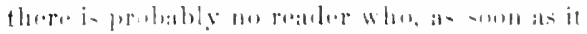

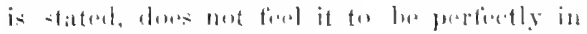

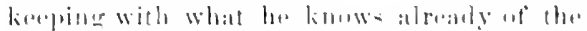

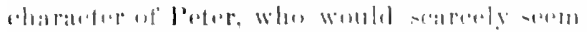

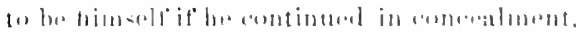

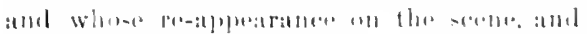

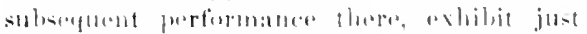

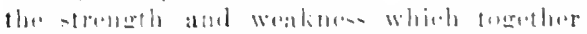

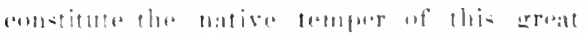

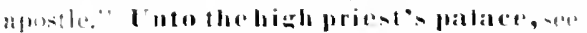

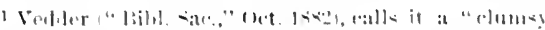

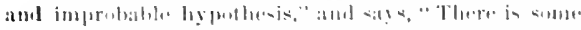

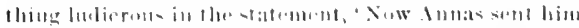

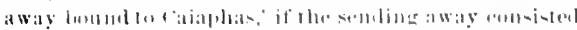

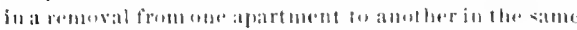
Jislse." Ban be liats lail an unwarranted stress upon

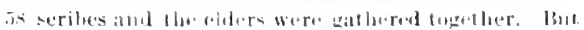

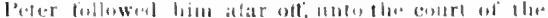

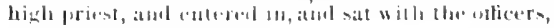

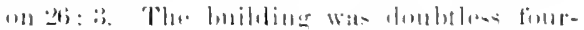

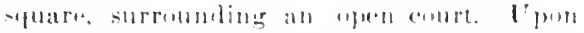

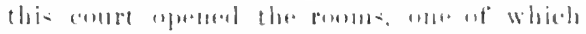

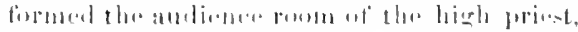

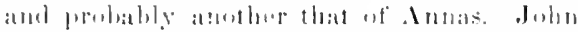

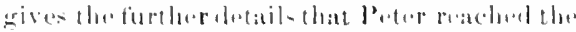

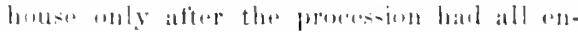

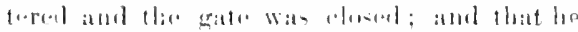

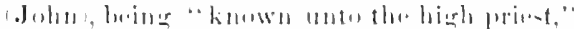

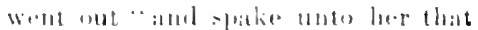

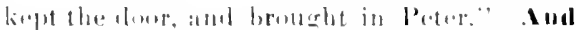

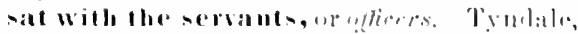

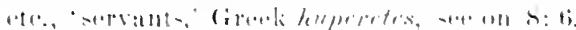

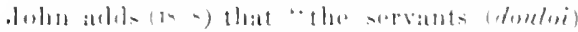

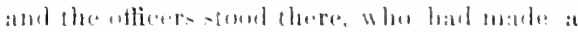

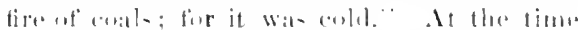

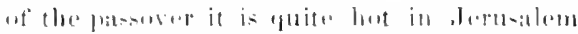

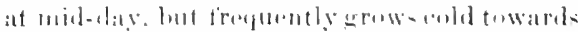
muruing. A- tuthe finct that IItt. -ily- sat,

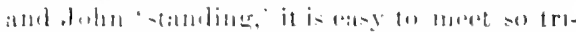

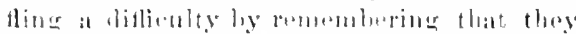

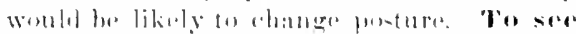

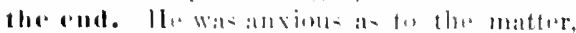

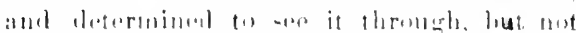

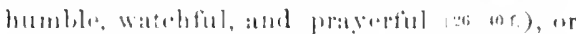

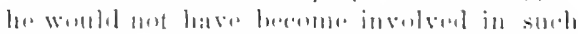

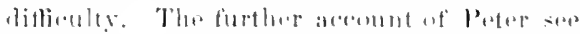

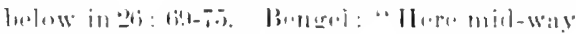
hotwath (a)

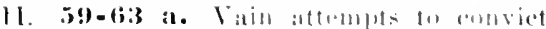

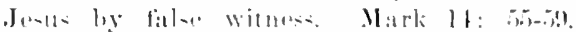
Lulir due not mention this infinrmal gathere

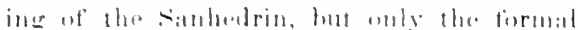

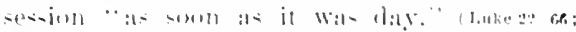

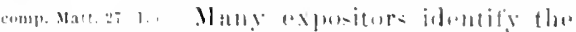

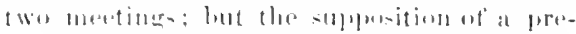

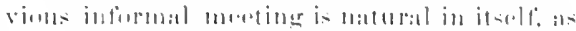

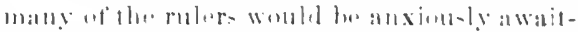

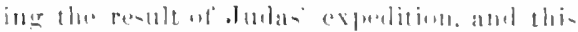

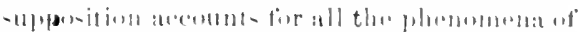

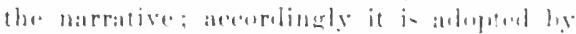

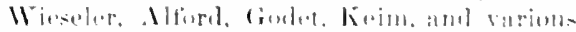

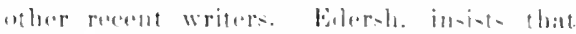

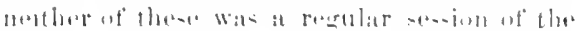

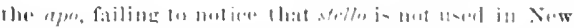

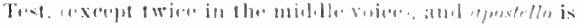

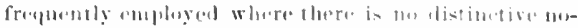

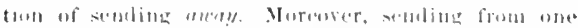

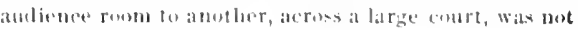
a trilling remusill. 
59 Now the chief priests, and elders, and all the coun.il, sought false witness against Jesus, to put him to dialli ;

(i) but fonnd mome: yea, though many false witnesses cante, yef found they nome. At the last came two talse witnesies,
59 to see the end. Now the chief priests and the whole council sought false witness against Jesus, that they 60 might put him to death; and they tound it not,
Sanholrin, and there was no formal eondenmation of Jesus by that body; but hisline of argument is far from convincing. Geikie adopts the same view from the Jewish writer Just. Chictpriests,andelders, and all the conncil,orstuhedrin. The phrase suggests that the rhiof priests formed a jart of the sanbedrin, and that this was a full meeting. While no exception is here mentioned, we know from Luke (23:50 f., R. v.) that Joseph of Arimathea "had not consented to their counsel and deed," and we infer the same as to Nieodenus from the accounts in .John. It would not be an improbable supposition that the rulers lad avoided informing Nicolemus of this meeting (comp). Iohn $7: 5(1-52)$. I quomum of the Sanhedrin was twenty three (IR.), but this was "all the sauhedrin," a very full meeting.

The sambedrin was in the time of our Lord the highest court of the . Jews. Our knowledge of its constitution and functions is but frammontary. It arose during the Greek or the Naceabiean poriod. The very lame is a mere II ebrew spelling of the Greeti sumedrion ('sitting togethor'), the h of hedra, lost in the Groek componnd, boing restorod in tho translitration, as has frequently happened. The Mishna supposes that the subhodrin was a survival of the council of serenty formed by Mos ( have continined seventy members, or adding one for Moses, then seventy-one. It is probable that this was the number, but we cannot certainly dotermine. The ennstitution of the borly is not described by the Talmud, but the Now Thet. shows (27:1: Nark 15:1; luke 20:66) that it consistod of ehiof priest, ellers, and seribes, though we kuow not in what proportions, nor what sort of ehlers were included. As to the chiof pricsts and the soribes, sore in 2: 4. The chicf priests are usually montioned first, and would naturally be the ming soetion of the body. They were for the most lart Sadelucres, while the seribes were probubly all Pharisies. The presileney of the body scems to have been elective, but the high priest was commonly the person reeted. The sinheArin tried (Se!ürer) all the more important secular and religious, civil and crimina! causes, the less important being tried by inferior local tribuuals. It seems highly probable, though not certain (see the difficulties well stated by Vedder, p. 666 fi.), that the Sanhedrin's death-sentence could at this period be executed only by the procurator's permision. In John 13: 81, the Jews say to Pilate, "It is not lawful fior us to put any inan to death." Someargue that the Romans had taken away this power when Judea first became a provinee, as they are known to have done in some other proviness. The Jerus. Talmud says (Sanlı. i, 1; vii, 2), "Forty years before the destruction of the temple, judgments upon life and doath were taken away from Isacl." This date is probably glven (Febürer) in a round number, as wats natural three bundred years later. 'The crueifixion was probably in the forty-first year before the destruction of the temple. The stoming of stephen was a tumultuary proceeling, and probably aceurred at a time whon there was no proeurator. The regular place of meeting of the sanhedrin was at a hall either in or noar the temple area (Jos. and the Mishna differ). It is stated in the Talmud that forty years before the destruction of the temple the Sanhedrin ceased to meet in its hall, and met in shops; these may have been in the outer court of the temple, which the sariour more than once cleansed. At any rate, a special mesting at the higl priest's residence would not be surprising in such an emergeney as the trial of Jesus, when in various ways they were departing from custom. Moreover, it may lave been only the infiormal meeting that was ield at the high priest's house; the formal session of 27 : 1, may have been at their hall-notice esecially 'led him away' in Luke 22: 66 (Rev. Ver., correct toxt).

somsht false wituess, imperfect tense, doscribing them as engaged in sceking. 'To, or, that they might, put him to death. They must have snfficiont evidence for senteneing lim to death, in order that they might gain the Roman governor's authority to execute 


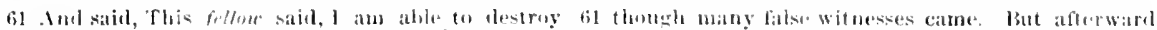

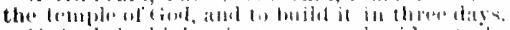

6i2. And the high priest arose, and sail tuto hum, An-

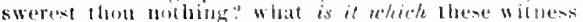
atgainst thee:?

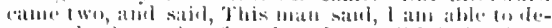

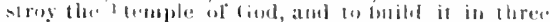

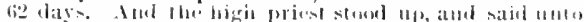
lobin, Alsweres thol nothing: what is it which

1 Or, sunctuary avin ch. Xxiii. 35 ; xxvii. 5.

the sontonee. Though many false wit-

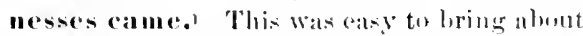

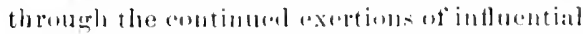

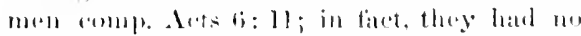
dould been tar some fime lountiug 111 witnosites. (26: tr.) Anywheres in Isiat, not to

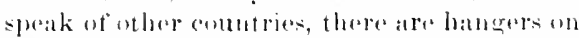
about the courts reatly to sell testimony.

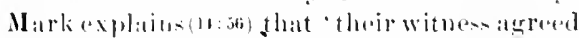

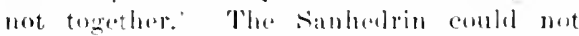
aflorel to discegared tha melinary torms of

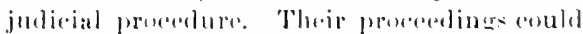

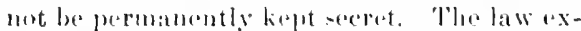

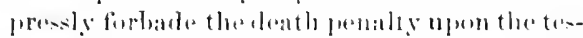
timully of:a single witmes. ( Num. $35: 30$; Deut. 1i;6.)

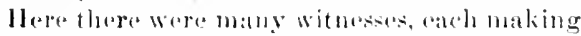
a separate acelusation, but not two to the samb connt. It is vain to enenjecture what were the varions and comtlicting talse testimenies. At tho Inst (afterard) eame two. The Com. text alds "talse witmoses, trom the preanling rerse. We might sppose that these two acread in theip testimuny; but Mark (14:53.

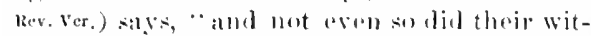
ness agres togelluer," probably meaning that

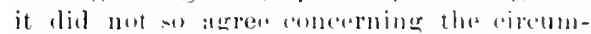
stances and torment thes alleged statroment as

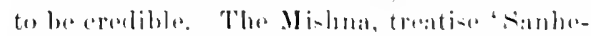

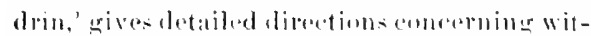

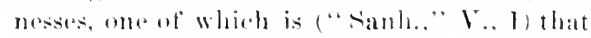

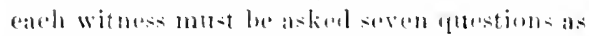
to the nlleged othenes, viz., in what period ot sevell years (a)tunting from the sabbatieal

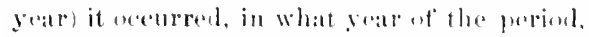
in what momth, das of the amomth, day of the week, hour af the day, and at whit place; and the limita are inclicated within which two

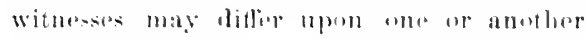
question, withut invaliusting their testi-

The common text here presents an infureting ex-

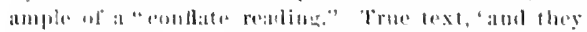

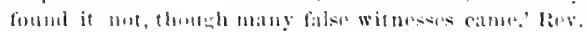

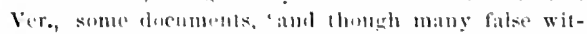

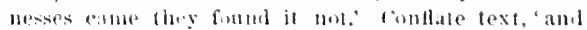
ling formol it nut, amd though many fitse witueses came they foumd it not.' Iny ludy" eth son that the last was formed by combining the ol her lwo; and there mums. (Cump. Wünsele, or "The C'riminal

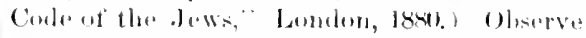
that in Mark (14:in) the witnesies lleclatre, " "ile heard him say," ate., with remplasis on "we"; and so they andul be roptaireal to give time and place. We at comess de nest know how fiar tleses strict lulles were actually ab-

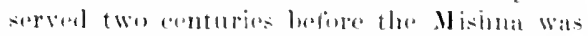
writen dewn. But while the sanherlrin was

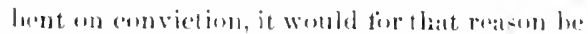

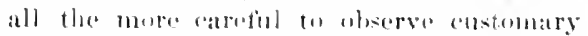
forms. Notice that thereserens to have berom

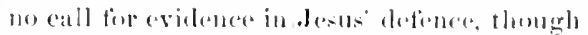

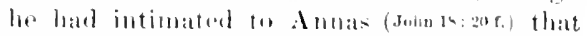

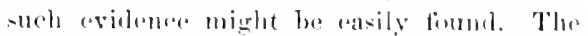

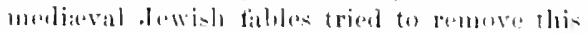

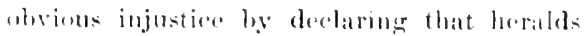

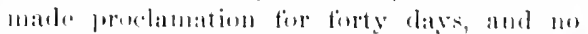

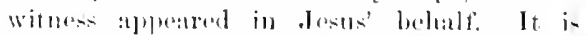

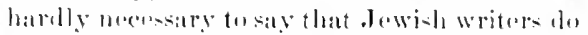
not nuw elatim any resperet for these tables, though some of them try to softent the gruilt af the sanderelrin. This tellow (ratlere man) said. The Groble tur "this' does not in itsolf (arry such emtempt as Tyudale, ete., axprosul by 'follow. I am able to dostroy. Mark hats 'I will dentroy, sulstantially "quivalent: and se as to the othareslight dit-

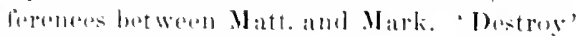
is Jifurally, "pull down, sambe word as in हो:

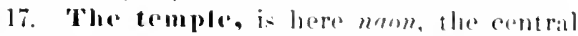

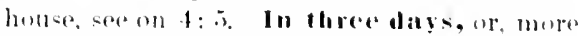
correcetly, after theer deys, literally" "witls ati

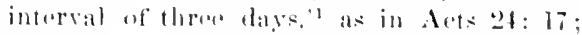
fial. 2: 1. This alleged statement was ari-

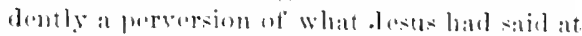
the tirst pa-suser af his ministry (John': 19), "Inotroy this tomple, and in throe lays I will ritise it up." He did not even sulgest

are many such reatinge in the common tireck text

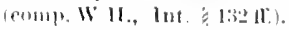

2 Jeyer amel many are hore misled by laking din in

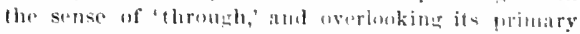

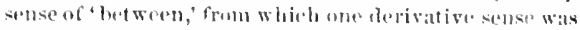
that of interval. In: 2 : 11 and Jolu 2: 19 the phrase employed literally means "in three days." 
63. But Jesus held his peace. And the high priest answered and sadl unto him, I aljure the by the living find, that lhou tell us whelles thom lie the 'hrist, the fon ut liod.

the idea of himself destroving the temple, which the Jews would naturally call impious; and we know, as the sanhedrin might have latrued from him if they had desired, that he meant the expression in a merely figurative sons:. But we find the sane conception still elurished anomg the Jews in Acts $6: 14$. It might be (Edersh.) a good pretext to use with Pilate, that Jesus would encourage pupular violence against public and sacred buildings. The Egrptian of Acts 21: 98 promised his followers that from the Mount of Olives they would see the walls of Jerusalen tall at his command, and could march in. But this eould hardly be seriously treated as a ground for sentence of death; so the high priest agerly urges Jesus to answer the accusation, hoping that thus he will somehow eriminate himself. This eagrorness is indicated by the fiact that lue arose, or stood up, Mark likewise, and also by the second question, what is it, ate., by which he seeks to arouse the acensed juts attention and response. It is much nore natural to understand the Greek as two questions than as me. But Jesus hold his poace, literally, was silent, eomp. Isa: 5:3: 7. He knew that no explanation or solif-defences would be heerled, that his condemmation and sentonce was a foregone conclusion; comp. on 27: 14. Ho was fully premared for the foreseen result ( $26: 42)$, and now awaited it in ealm silence. Origen remarks that the utter failure, notwithstanding diligront effort, to find anytling against. Jesus: shows that his life was nost pure and wholly irreprohensible.

II1. 6:3b-66. Tesus is condemued upon his own testimony. Mark 14: (30)-6it. Luke, who gives no aceount of the informal merting, presently introduess mum the same matter into his aceount of the formal susion held "as soon as it was day." (Lake 22: (66.71.) It is very improbable that this was all repated in the formal session (Clark's "Hitrmuy"), and very easy tounderstand that Luke has thrown all the examination together, while some wortions of it would very likely be repeaterl.
63 thes? witness against thee? But Jesus held his peace. And the high priest said tato him, I adjuse thee by the living crod, that thou tell us wheber
The only matter of great practical importance was that Jesus was condemned by the Sanhedrin, and upon his own confession.-Finding that the false testimony does not suffice for at conviction, and that the accused will not discus it, the high priest essays a buld struke. IIe demands a catogorical answer, ujon oath, to the question whether Jesus is the Messiah. And the high priest answered and said unto him. The Com. text seems to be here riglot in its reading.' The 'answered' neans responded to the situation presented by the persistent silence of Jesus (comp. on 11 : 25). I adjure thee, means exactly' I put thee on oath.' Soe the same Greels term in Gen. 24: :, 'I will make thee swear by the Lord, and comp. Lev. 5: 1 (Rev. Ver.), where it is declared to be a sin if we who has witnessed a matter "beareth the voice of aljuration" and does not tell what he knows. Comp. also 1 Kings 22: 16. The high priest used the most solemn form of oath. by the living God. If one answered after such an adjuration, he answered on oath; the mere ceremony of putting on oath is conventional, as in some parts of our country men take an oath by pointing to heaven, in other parts by kissing the Bible. So thru Jesus spoke on oath before a court of justiee, which shows conclusively that he dil not mean to eondemm all such waths when he said, "Swear not at all" (see on 5: 34); that he spoke of caths familiarly used in comversation. That thou tell us. The peculiar Greek construction is explained on 5: 2!. Whether thon be the Christ, the $\mathbf{I}$ (essiah, see on $2: 4$. II (Mark and Luke also) K. Jannes rightly inserted the article, though Tyn., Cran., Gen., hall simply 'Chri-t,' as K. J. has in many uther places. Luke here gives only 'tlie Christ"; Mark adds 'the Som of the Blessad'; Matt., the Son of God. It is evident form John 19: 7 that 'the Son of God' was molerstood to mean the Mrsiah, and that chaining to be the Non of God was considered blas. phemy. But it does not follow that the Jews mon or muderstood the plurase as denoting di- 


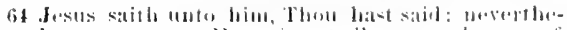

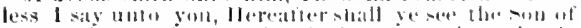
math sillitge on the right hatal ol power, and combing in

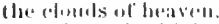

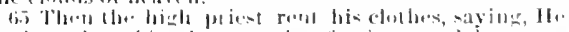

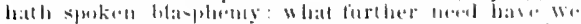

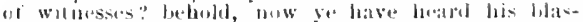
flictily.

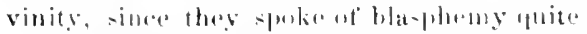

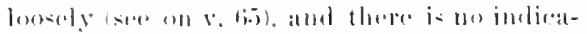

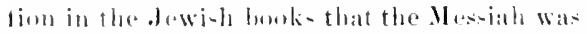
(2)

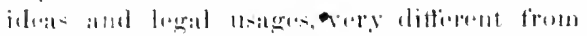
those provitiling in mant oflere countries, it

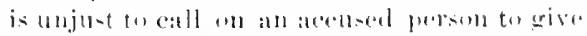

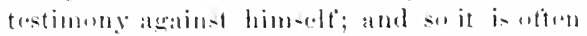
silil that the high prient dealt mujusty in callime ond J J providere that in some rases of Hurertainty

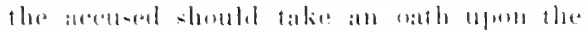

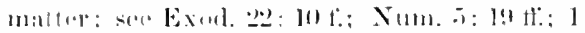
lines: 81 t. Thas the high prient scourse Was mot formally illenal, themeh in spirit atul intellt it wits mojust. It is at late antuing to

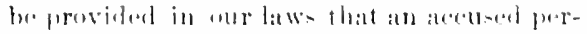
son may tortity in his awn hehalt, hot eatumet

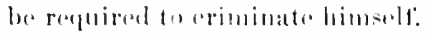

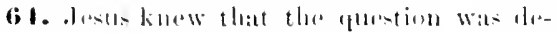

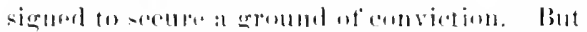
lar was mo demerele silent. Now that the erioi-

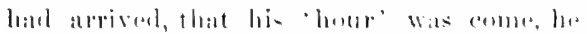

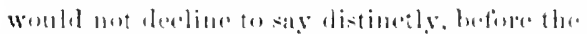

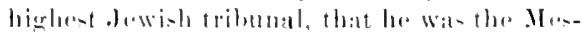
sials. Ha hatel long urearl the tisciples to "toll no mith that he was .Jestl the ('hrist,"

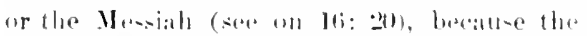

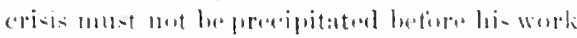

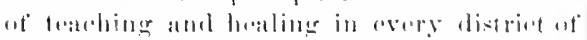

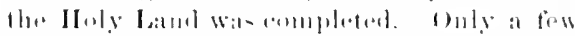

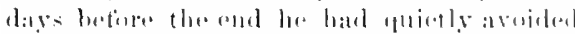

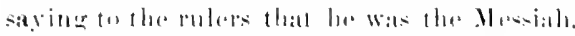

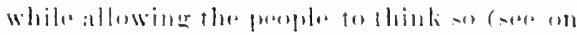

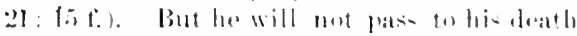

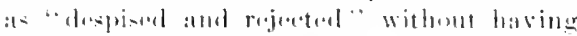

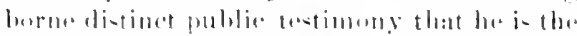

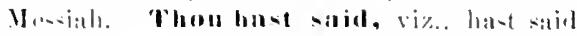
what is trum. a firmula of atlirmativa answrer

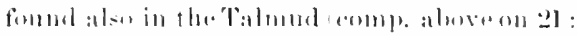
4t.). In Mark it is directly I am.' In Iakk

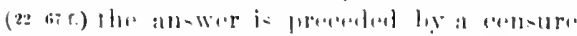

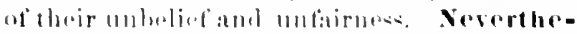

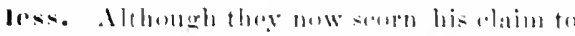

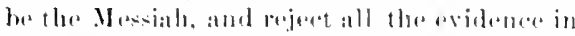
his teabings and his works, vet threy will henceforth see his Messiahship indubitably

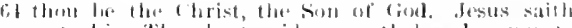

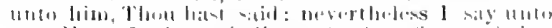

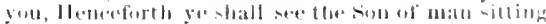

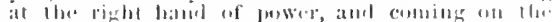

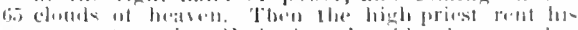

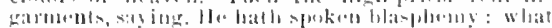
furlher medi haw we of wilnesses" behold, nuw ye

manifieted. IIerrater, henefforth is the

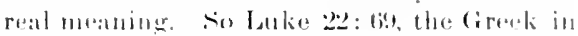
buth ranes lueing literally 'from now.' 'T'he.

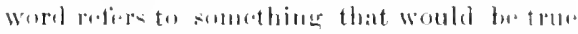
onward from the timente - peaking. The sar-

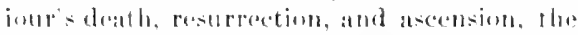
miracles wromelit lig his apostles amb othor

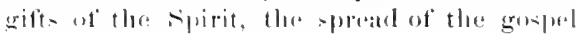

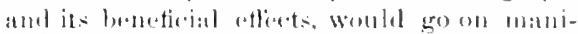
lieting him to he the Mresiah, sitting on the right haud of power: and fimally they

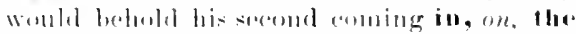

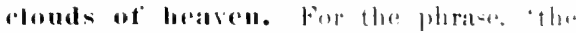

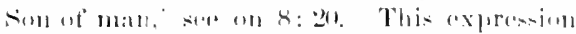
would remind the rulars at b:11. $7: 13$, B. thi-titlo. Inste hud lomer virtually alaimed to

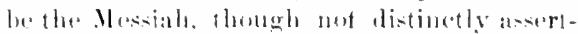
ing it in pultie. 'Puwer' (a) Mark amel

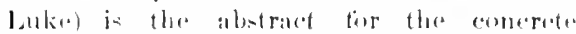
(Mryer); Talmud and Midrash (iill, Wiin.

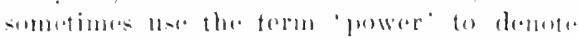

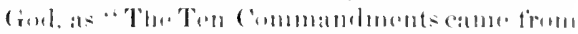

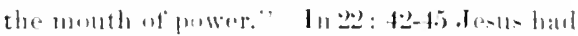

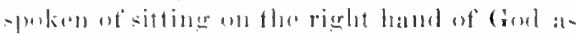

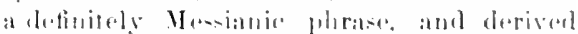

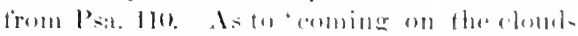

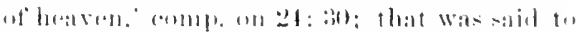

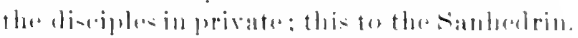

6.j 1. The high prirst has areomplistued

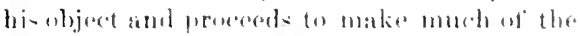

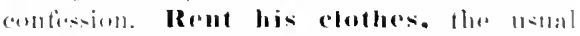
expression of griof, horror (ets it 11 ), or ather violent and lowesutrallables emation. Tha rustom, which existod also amoug the rarly

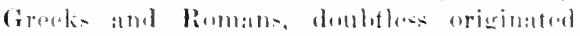
(Bonered in the fat that aveited remention11terl a

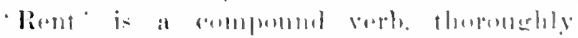

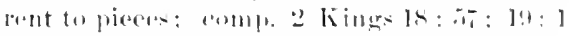
Mark has the more seedice term which dro

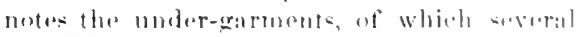

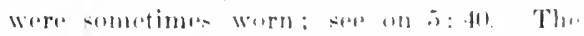

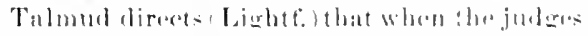
in a case of havplume remel their garment-.

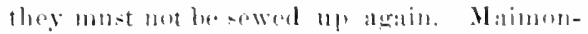
ides shows that at latast in his time prenthiexpression of uneontrollable emotion was 
66 What think ye? They answered and said, He is guilty of dealls.

67 'Then dinl they spit in his face, and buffered him; and others suote him wil b the palns of their hands,
66 have hearl the liaspheny: what think ye? They 67 answered and sadid, lle is 1 worthy of death. Then did they spil in his face and buffet hins: and solme smote him? ? whll the fralms of their hands, saying,

J Gr, liable to....2 Or, with rods.

formulated by custom; a man rent all garmente axeept the inuremost and outermost; and fent firom the front of the neck downwarks to the length of a hand. 'The high priest was forbidden in the law (bev. 10:16;21:10) to rend his clothos; but this was in mourning for the dead, becanse such mourning unfitted him tor the portormance of ofticial duties, and it was not understood as probibiting the practice om other occasions; see cxamples in 1 Maccabees $11: 71$; Jos. "War," 2, 15, 4. He hath spoken blaspheny. It is not entirely clear, but serms probable, that the high priest here understood the phrase the son ot' God' as chaming divinity; eomp. Luke 23:70. At any rate Jesus had distinetly claimed it in the adred womls about sitting at the right hand of power, ate. In John 5: 18, R. V., he was aceused of "making himselt equal with (rod," bacase he "said Gorl was his Father," and in John 10: 50, for saying "I ant my Father aro ane," the Jews sought to stone him, "because that thot, being a man, makest thyselt' (xod." It is very harel to determine how much the Jews really meant hy these charges, as acrusatory expressions are ajet to be stronger than would be uned in calm declaration. Noristhe question important to us, since the saviour left mo dombt as to the meaning of his answer, and tha New Test. as a whole teaches that Jesus Christ is tlyt fom of God in the highest amd fullest sense. And certainly, if Jums had only been a homan teacher, he would surely now have axplainsel himself to that affect What think ye? This was the regular fropla phrase for putting any question to the vote. They answered and said. They took no formal vote, bat decided hy acelamation. IIe is suilty of drath, wr liable to death (Rov. Ver. marain), as in 5: 2l f., "in dauger of.' So Tyn., Cran., Gous., 'worthy to dir';

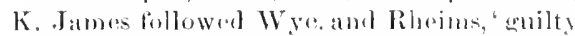
of death,' ('omp). Num, :35::31. 'The salue terun is here nsed in Mark. Death was that legal punishment of blasplueny. (tev. 24 16.)The Mishnar requires ("Ainh," v, 5) that where a vote would condemn to death, the matter must be postponed to the next day, when after the night's reflection any of those who voted to conclemn may change, but not contrariwise. If this rule existed in the traditional law at the time of our Lord, we can inage the sanhedrin evarting it by construing that they had virtually voted to condemn Jesus some time betore (John $11: 45.53$ ), or that the meeting atter dawn (2z:1) was virtually another session, with a portion of night for reflection -which would have been a device quite after their fa-bion. It is, huwever, probalsle, as Edersh. and sehürer remarli, that these were largely ideal regulations, exprensing what the Rabbis thought ought to be done, and by no means strictly followed.

IV. 67 f. Jesus spit upon, buffeted, and mocked. Mark 14: 6.; ; Luke 22: 63-6.5. Olserve that white Luke has tramsfersed the examination and condemnation to the regular sesnion after dawn. lue puts this outrage and mocking first, in thr. same order as Matt. and Mark. Then did they spit in his face. This would most naturally mean the members of the sinhedrin, mentioned in the preceding santence, but might mean (comp. 27: 2) the subordinate officials who had Jesus in custody, and so Lulie has it $(22: 63)$, "the men that held Jesus." Mark's statement (14:65, Rev. Ver.) "some began to spit on hins. . . the officers received him with blows of their hands," explains that some members of the sanhedrin joined the subordinates in these outrages. (Comp. Acts 7: 57: 2::2.) They would be oncouraged (Keim) by finding trat they eould with inpunity smite him whose roported mirales had often made them tremble. Buffoted him, smote him with the fist. So Tym., Cran., 'buffeted hym wyth fistes. Smote him with the palms of their hands, as in $5: 30$, and so Latin Versions, Memph., and Gothie; m perhaps (Rev. Ver.morgin), smote lim with rods,' as Geneva. The same two torms oefur in Mark 14:65. lulie says (22. Bs B. U. ver.) they "mockel him, beating him." Prophesy, meaning, suak by divine impiration, not necessurily, nor even most eommonly in seripture, involving a predie- 
68 saying, Irophesy unto us, flow Christ, Who is he that sube thes"

tion. Here, with hi- fitere coverod (Luke sud Mark).

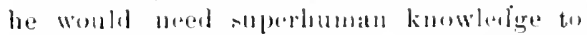
tell whosmote him, and such linowledge the Mesiall mierlet be "xpectad to have. Mitt. alomet gives the tameting aldress, thou Chriet, or simply "Clorist." Lulio adds, liov.

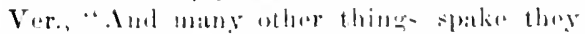
again-t him, roviling him." IIne the Jers

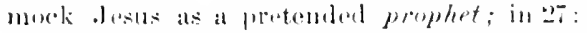
27 11., the. Rementes will mock him ats a protemded kin!. Inid all these insults of word and loed ha was sti]l silunt. Compr. 1 Peoter 2: 23 .

\section{HOMII, HTITI, AND PRATTINAL.}

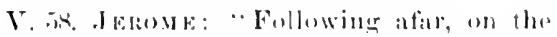

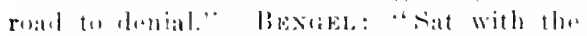

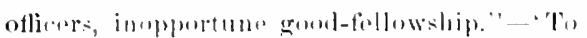

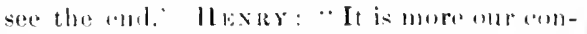
cern to prepare tor the end, whatever it may be, than eurionsly to empuire what the and will lor. The avent is Gorls, but the duty is

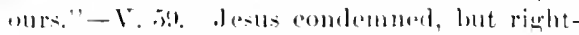

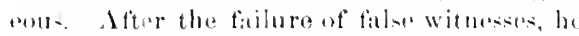

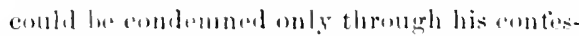
sion of what shomld latre lume at reatson fir reverencing him. The traitor contresed him

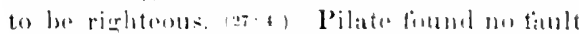

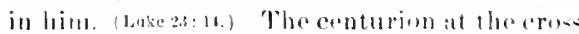

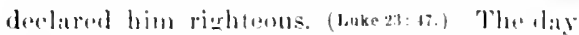

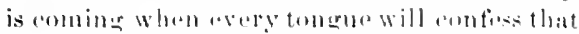

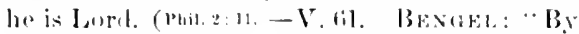

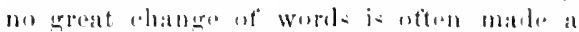
groat alulummy. learn form this passage to despise the uttore

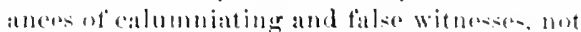
holding then worthy af reply ur of resistanen.

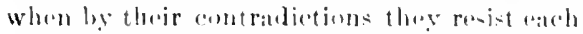
other. It is a erreater thing to maintain a

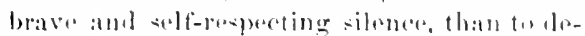

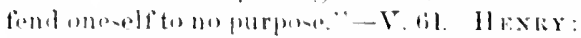
- Ile thus andesed hilaselt, for axilmple and encoldriterement to his finluwers. when they are called on it, to andese himi hefore moil, whatever hazarels they mun by it,"-le dit. HALE: "t) sariour, this is not the last timo

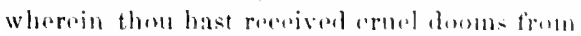
them that protisolanruine and holiness. What wonder is it, it thy weals members sutler that which was endureal by su perfect an beadd."
68 Prophlesy unto us, hou Christ: who is he that struck lifer:"

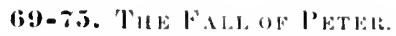

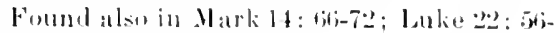

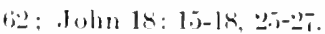

Petrer's three lental-ot his Lord avidenty aceureed during the progress at the . fewish trial, which secons to liave lasted two lours or

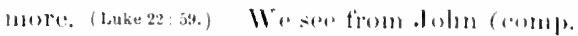

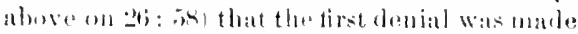
while Antas wa- questioning Jusus: and it is clatr forsen enmparing all the natratives that the second and thire were male while

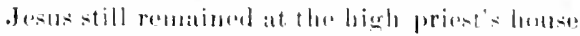
and l'eter in the coult. and probubly during the trial hy the informal mesting uf thes śan-

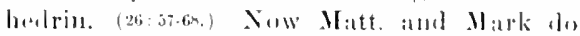
not record therexamination by Ammas: aldentlingly they mly mention at the ontoret that

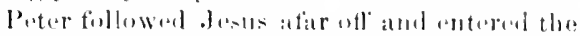
light priestis enurt, and then, after Harration the trial ly the intormal mostinge they de-

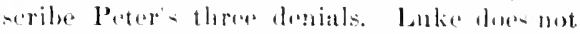
give either the examination by Aumbers the infurmal trial; ateordingly, ate seme as he hringe Peter into the high priest's enurt, he at

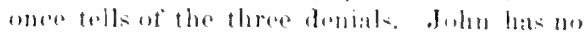
aceount of the . Iewisle trial exerpt the ratuination lo Annas; so ho gives the lirst dersial

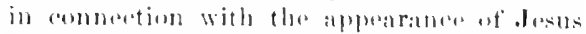
lefiore Annat, and then, after narrating thes interrogition and telling how dunas sent

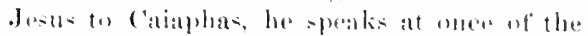
seromd and third denials. Thus the apparent di-locatim at this natrative in the several

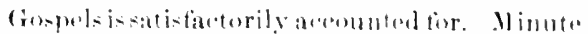

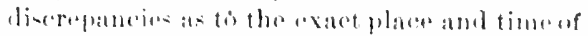
the ditlerent dental noed not supprise as. The

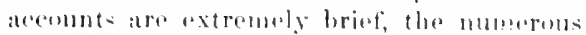
persems in the enurt llere moving almolt atsl

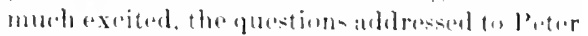

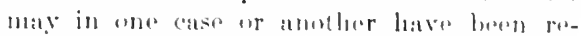

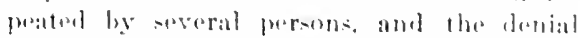

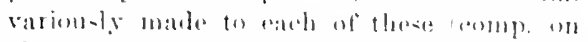
-beeran in v. 74), while yes there were three? distimet and separate derials, at indiented in each of the Gospels. It is mot reven mesesestry to stlpowe that they all grive the thren in the

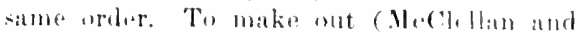
sume others) five or six sepurate lleleials, aldd thereloy harmomize the details, is to diverere from the saviour" sexpress prediction, "Alum 
69 Nuw Peter sat without in the palate: and a damsel vane unto him, saying, Thou also wast with Jesus of Galilee.

fu But lue denied before them alt, saying, I know not what thou sayent

71 And when he was gone ont intothe porch, another maid saw him, and said unto them ihat were there, This fellou was atso with Jesus of Nazareth.

72 Aud again ledenied with an vath, I do not know the man.

73 Anl after a while tame unto bim they that stond by, ami sidid to l'eter, surely thou also art one of them ; for thy speed bewrayeth thee.

shalt dony me thrice," and to disregard the stress baid by all four narratives upou three denials. Surely murh more is lost than gained by sueh painful harmonizing.

First Denial. 69 t. Peter sat withont in the palace, of court, viz., in the court of the high priest's house (26:58); "without' is saifl in contrast witl the audience room in which Jesus was appearing before the anthorities. Petel was not in this romm, but out in the open air of tile court; and this was "benoath, on a lower level than the andience romm. A damsel, viz., maul-servant; and literally, 'one maid,' as distinguished from "another, in v. 71. So, Mark 14: 66, 'one ot the maids of the high priest.' Came unto him, as he sat in the conrt, beside the fire of chareoal; so Mark and Luke. John says l.hat the maid, who was the doorkeeper, and who was indureel by .hobn to arlmit Peter, asked him the question; and this might seem in conflict with the other accounts. But John's briof statement does not necessarily mean that she asked him at the moment of arbitting him. She would very naturally alose tha door and return to the fire herself, and might then ask the question. With Jrsus of calilee, a very natural pxpression in tho high priest's servant, fooling everything at Jerusalem to bu immeasurably suprriortethe provines. Mark, B, $\mathrm{I}^{\top}$., with, Jesus. the Nayarele, and so Matt. in v. 71, Rev. Ver. We have often seon that the Evangelist do not uncertalie in all cast's to give the exact wolds spoken; wo are conerened only with any such discrepancy of statement as might

It is not certain that 'ome' rver heomes in Now Text, a mere indefinite article; the most likely examples in Matt. are 8: 19; 21: 19, (Iuv. Ver. mampin). In the present passage the latin versions and fisthic bave 'one', Memph. 'a,' l'esh. aunbiguous. Fönsch holls that wmos is sometimes a nure inclefinite articho; hut many of his examples are elearly foreed, and wone of them (including this passage) seem eonclusive.
Now Peter was sitfing without in the conrt: and a maid cane uno him, saying, Thon also wast with 7) Jesus the Gablitan. But ke lenied betore them all, il saying, I know not what thou sayest. And when be was goue out into the poreh, another maid saw lim, and saith unto them that were there, Thic man 72 also was with Jesus the Nazarene. And arsin he 73 denied with an oatb, 1 know not the man. And after a litte while they that stool by came and sail to Peter, of a truth ihou also art one of them; for thy

seem to impair credibility. I know not what thou sayest. So Mark; Luke 'I know liim uot' ; in John she asks if he is one of this man's diseiples, and he answers 'I am not.' There is here no substantial conflict.

We must remember Peter's situation. Over-confidence in himself, notwithstanding the Master's warning (26:33*35), luad led to lack of watchfulness (26: $10 \mathrm{f}$ ) ; suddenly awaking, he committed a rasb aetion (51), which be might very reasonably fear would be avenged if he were discovered; so when suddenly asked, he was startled, frightened, and bastily denied. Then low wa depper in trouble than evor. We are not called to extenuate his conduct, but only to observe that it was peyohologically not umatural.

Sierons Denial. 71 f. When he was gome ont into the porch, the open gateway passing under the middle of one side of the house into the court; Mark calls it "the fore"aurt.' Luke gives at this point no note of place. John gives the second denial as made while Peter was standing and warming himself. Possibly the first and second denials are hy him given in reverse order. Observe that he here says generally 'they said,' while Matt. has 'another' (feminine), Mark 'the majd,' Luke 'another' (masculine), $i$. $\epsilon_{\text {, }}$ another perion. The terms of address and denial slightly differ as before.

Thimi, I) enial. 73 f. And after a while. Mark says 'a little after,' while Luke says more definitely, "alout the space of one bour "ufter. Camethey that stood by, and said to Peter. Sio ju effect Mark, but Luke says.

2 The statement in Com. text of Mark at this point, "and the coek erew, is probably spurions, as it is wanting in $\times$ P I, one Evang., Memph., and one eoly of the (Old Latin, and might be very naturally plaeed on the margin here (and creep into the text), as explaining 'twjes' in Nark 14: 30, 72, and "the seeond time' in 72 . See a very interesting discussion in W H., Ill $_{\text {. }}$ 8323. 


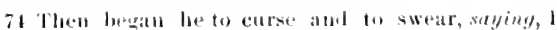
know not the matr. Aut inumetialely the cock clew.

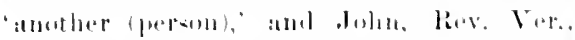

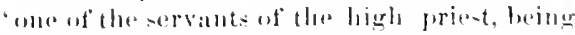

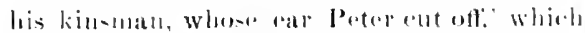
would be a spesially alarming tact, esperially

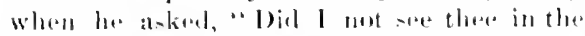

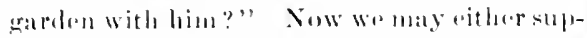

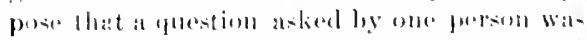
taken me and repeated hy atluers, which would

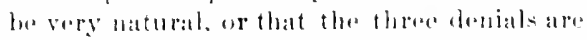
given in aldierent orelor lig the several Gospols. Matl. and Mark lave (a) a maid in the coute (b) another maid in the entut. (e) the by-tanders, apparently in the ermut. Iulde his: (a) a maid as he sat ley the tire, (b) all-

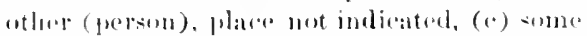
other (fersom). place in the courl, as-indicated

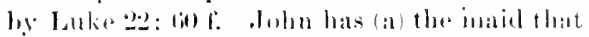

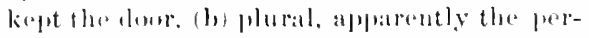
solls with whom he was standing and watro-

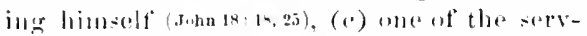
ants of the hiegle prien, plare not indienterl. It may hethat lohn has mentioned theserent denial lirst, becallse sugerested then ly his ace-

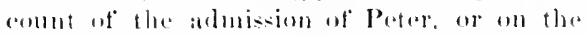
uther hamel. that Matt. and Mark have. chanered tho order. Inhris (h) agrees at to the plural with the (c) of IIatt. and Mark. The vanum another perom and "sume other jersoll at Luke.treat the detilis as comparatively unimpurtant. We nored nut insist un any latereular theory for "xactly harmoniziner the seroral statements. There is nothing is

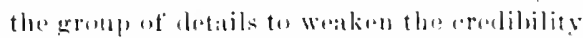
of the narlatives, lent their oredent independence strenerthens their croblibility. ats persons

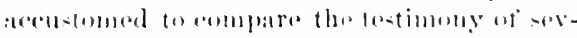
rill witurses will romlily sere; and wo may be content to metice whe or anomber posible

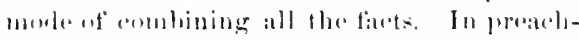

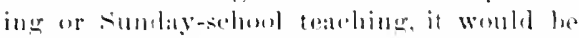

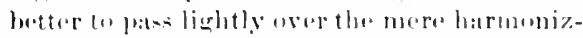
ing of detaile, and ilwall on the eremeral tare which are the satme in all the (Fopels and which yeld lessens of ser great importames.

Thalilean peenliarities of spech are repeatedly men-

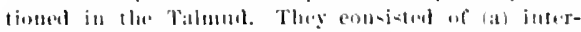

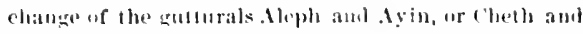
Ayiu, which rautue be illustrated from our language; (b) Intorehanereot the palasals Kaph and equph, a lithe

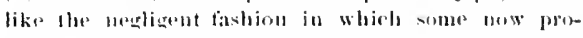
noumce quole, quota, quorum, as if writlen with a $k$;

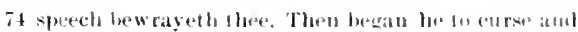

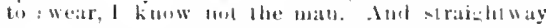

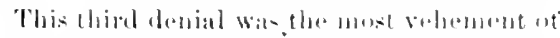

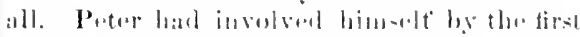

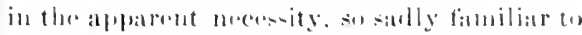

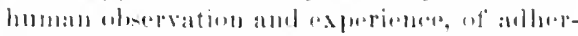

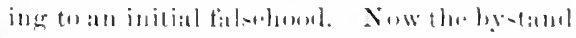
er iun-ist and areme. Nurely, of "tenth, $i$.

thou also art our at them. There are $=11$ ro of it. For thy sperent bewayeth there,

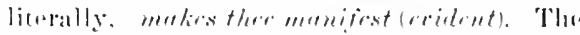

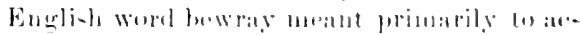

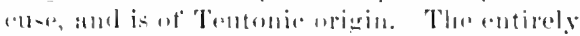

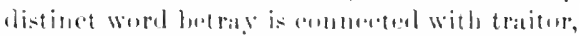

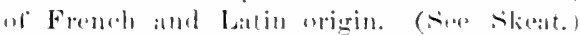

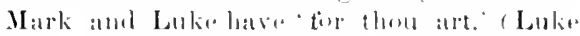

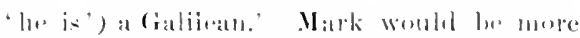

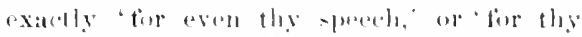

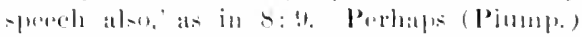

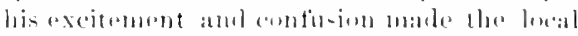

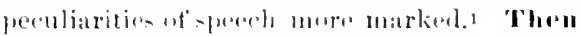

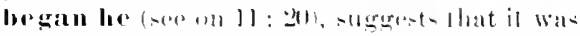

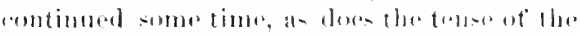

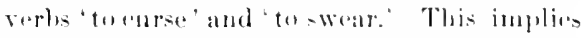

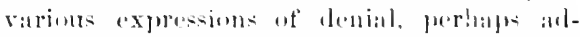

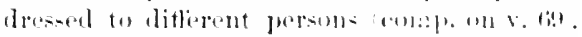

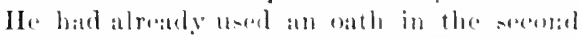

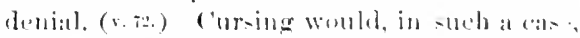

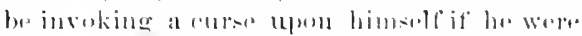

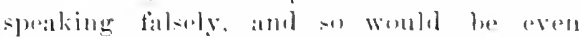

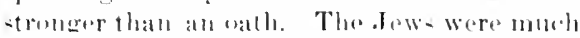

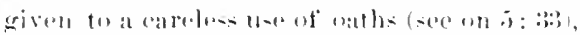
and it may lue as Alexamber supposes, that

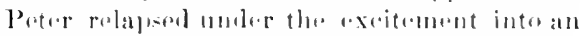
arly habit. which he hat al andened through

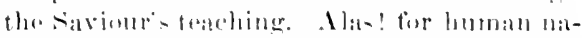

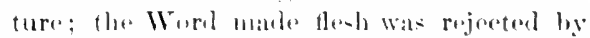

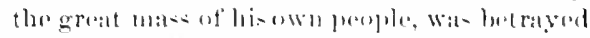

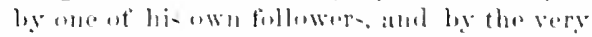
leanler at them wis bisoly deniod, again and again. with wath- and curses. Sere l cor, ]H: 12. Ind immoliately, on stionithtwen, the cock crew. Marli, Iiev. Vor., ame .Iuln Rav. Ver. "straightway": lukn"immenlialmy. while he yot spake, The Gireck momn liks no article: it doses not meansome frorlicular

(c) intretange of s or sh and th, like our li-p, and the

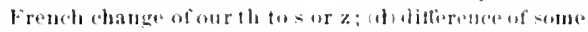

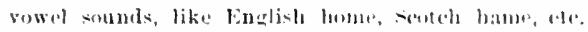
Examplesare given trom the Talmul in Wetstoin, linx-

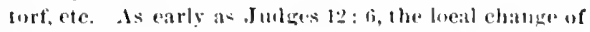
shibholeth to sibboleth was marked and invariable. 


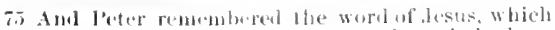

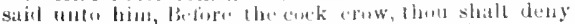

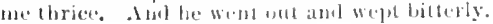

5.) lhe cock erew. And Peter remembered the word which Jusus han satid, Before the eock crow, lhou shalt deny me thrice. And he went out, and wejt bitterly. fowl, and our Enirlish article omby demotes the woit lonwh sien of combing day. Mark,

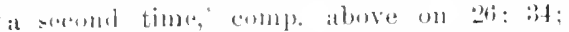

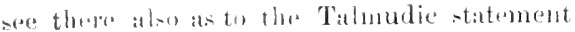

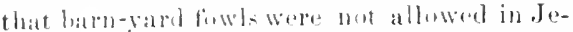
lu-itlut. And Peter remembered. Isuke

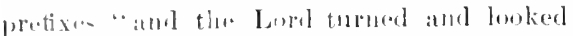

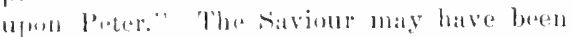

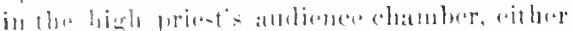

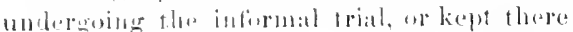

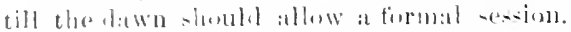

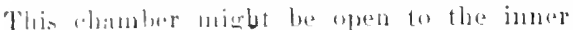
and : and the lights in the renoll, and the fire in the antlot. Wenthl natie the pitying Master andi the fillen disciple visilhe to each other.

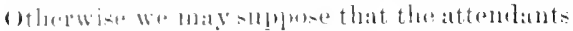

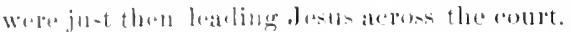
sis. Ilrs. Browninge two somnets, "The

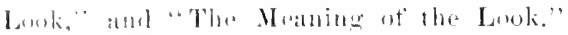
Ind ho went ont, into the erreat entrances

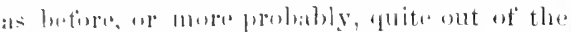
buililing. It surh a moment one Mould natmrally lone to boalome. Ind wept bitterly.

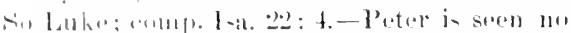

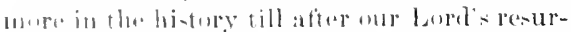

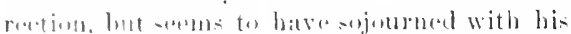

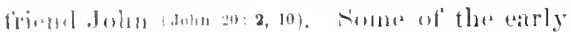

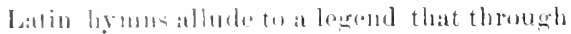

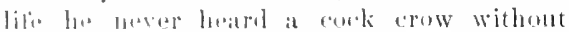
Wepeping.

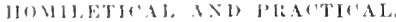

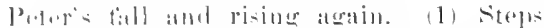

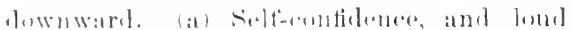

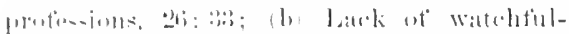

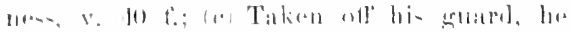

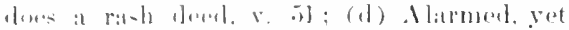

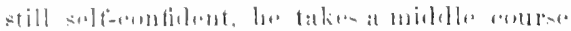

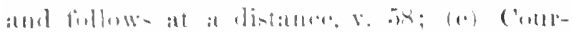

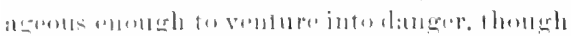

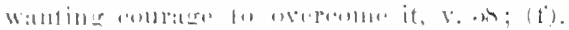

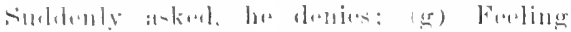

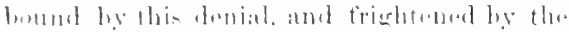

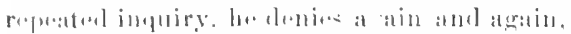

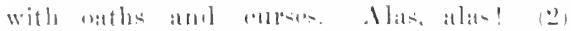
('lisuling ujuated, through (bol's belp. (a)

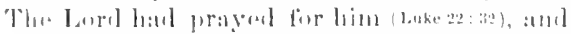

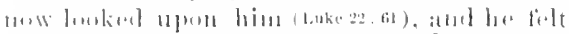

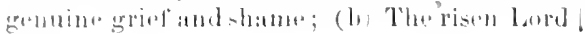

apjeared to him alone (Luke 24:34), a most touching occasion of confession and forgivenes; (c) The Lord afterwards delicutely reminled him of his lond professions, and while no longer claiming superiority toothers, he earnesty avowed his love, John 21 : 15 $\mathrm{ff}^{2}$; (d) Helped by the l'entecostal spirit, he boldly confened Christ before the sanhedrin and the nation, Acts $4: 10$.

('ALYIN: "The fiall of Peter is a mirror of buman infinity, and a memomble example of Got's gumducss and compassion. Peter acted incomsilerataly in entoring the high priest s court. It was proper to follow the Master, but he had been warned of his eoming detection, and he ought to have avrided the recasion. Oftro thus under the appearance of virtue du beliterers fling themselves into temptation. Conacious weakness slonld not hinderus from going whithersover Gul calls 11:; but it nuglat to restrain lashnessand stimulate tuprayer." - V. G. Calvix: "He who lats thrown away the fear of God, may tremble at the fill ot a leaf. . The more minent one is, the more should he be careful; because lie camnot fall from his high place wirhunt danaging others." - T. 70. WEess ("Life"): "When Peter vowed so confidently that he would gu with his Master to death, he wasthinking, nodoubt, of a solemn testimony to him for whom he was realy to sacrifice everything. But a great deed of homisn is often easier than loyalty in small thiner." - T. 74. Contrist Peter in his great anfession (16: 16), wishing to stay on the Mount of Trausfiguation (17: 4), andmaking urrand promises only a few hours before this

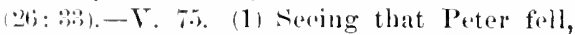
let him that thinketh he standeth take heed lest lie fall, I ('or. 10:12. (2) seeing that Petor was forgiven and became so useful, let him that knows he has fallen rise up in earuast repantanue. Lutrikr: "No article of the ('rund is su hard to believe as this: I beline in thr forgireness of sins. But look at l'ate. If I emuld paint a portrait of Peter, 1 Ifmld write on every luair of his head forgriveness of sins." 


\section{I P'TER X X VII}

Wllte the morning was come, all the chiel priests

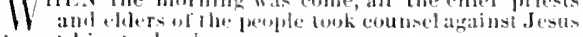
to put him todeath:

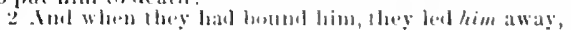
and ileliverat him lo lontius l'ilate tho" gevernor.

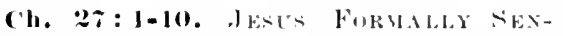

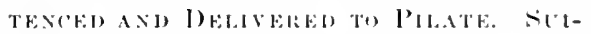
etles of . ITHAS.

'This section divides itselt' into, v. $1 \mathrm{f}$, anel $\mathrm{v}: 3-10$.

I. J $\mathrm{f}$. The formal meeting of the Sanbe-

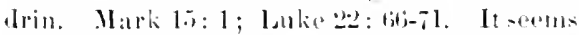
greatly lest to sulpmer, as we have been doiner, that whila the real trial and condem-

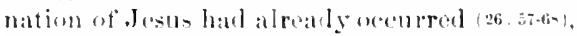
a formal session of the sianhedrin was hald after daybreali, when the morming was come. Sir Mark in the mmoning, and Lulio

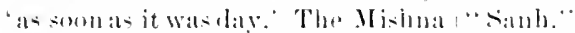

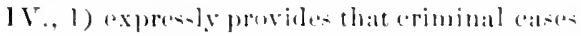
call be derelded anly in the day time, and that while n sentement atepuittal may be made. the same day, a sentence ot comdemuation must be postjumed to the next day. We Wave seen (on 2ti: titi) how the latter provision might have bets evalded, but the finmer seems to have been here regareled. boilig in tact bardieg to evale. Lake has not deseribul the intormal meting and sontenere but he lats just before mentioned the indignitios affored to bests, which we linuw lirom Matt. and Mark to have gidluwed that sentenere It is natural that Lulex, in deeribing the formal sesion should imelule sume thing- that ace-

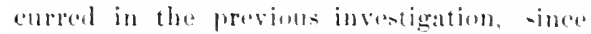

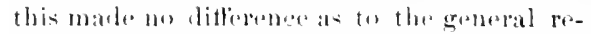

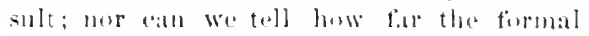
merting would reputelt the proserses of the

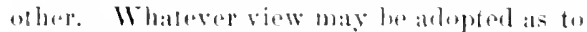

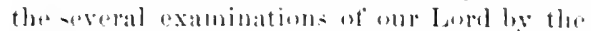

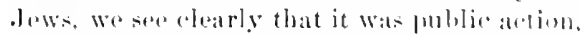
un the part of the highest national authorities.

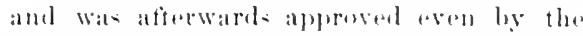

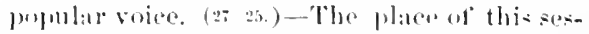
sion may have been the high priests resi-

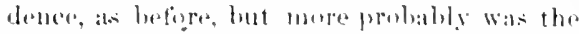
regulat hall for meetings of the sanhedrin

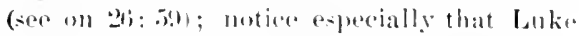

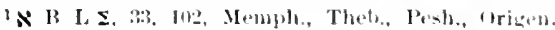
Wo might suppose Pontius struck out loese beesule wating in the other timspels or inserted becase fatmiliar to the early Christiaus; but then why not like-

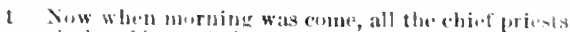

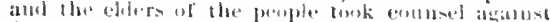

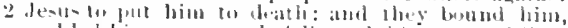

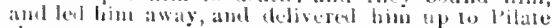
the gevertior.

22) : lib -ays." they lad him intertbeir counceil," thesimliedriu.

Fools comusel against desus to put him to death. They hat alrealy voted that he

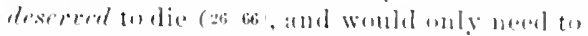

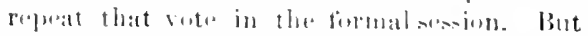
there wat a lorther flacetion as to hew they contal actually fut him to drall, ats the Rumans had taken fom the simblutrin lsoe an 2ti: E.t) the right to infliet capital punishment, and thi- comble be malliged only

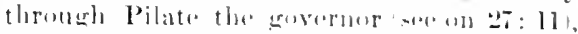

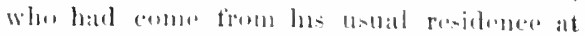

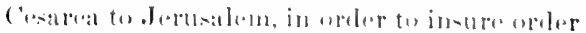

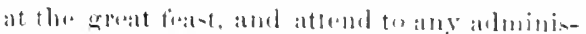
trative poins that mierht acome up. Ther forobahly then atereed to malie hefore Pilate the aceositions they actually did malin, riz.,

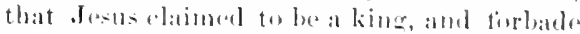

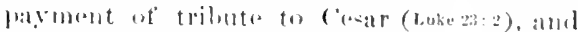

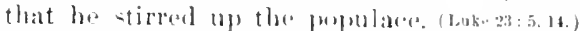

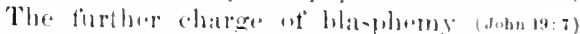
tboy womld hole] in reserve. The (inm, text

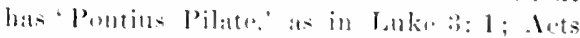
4: 27; 1 Tim. li: l: ; lut Pilate alone is

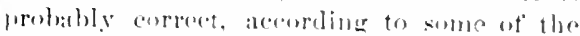

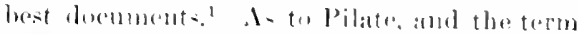
"governor.' see on

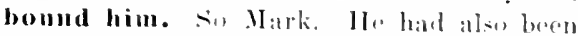

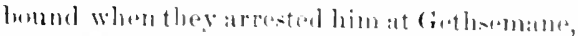

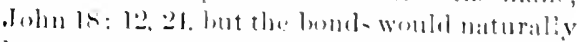

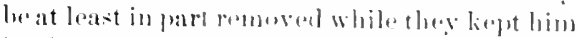

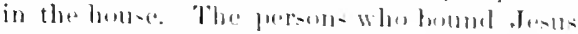

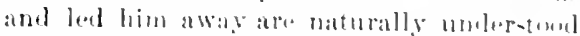

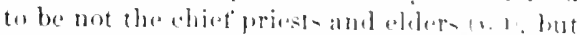
the officials who did their lidelines The

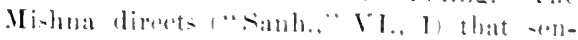
forles shall bu followed by lealing away to "xecution, while the contert rematin in wasin

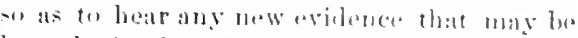

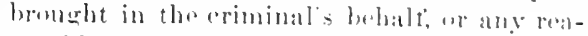
sonable appeal he maty make, whila in the wale, fior a new trial. but here "the wholo wise insert il in Mark, Luke, aml Julu! lil lac ab-

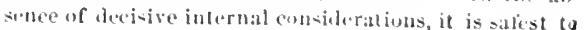
lollow documents so geverally right. 
3 Tlun olulits, which han betraved him, when low saw

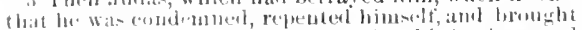

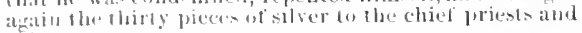
inlers,

1. Filine I have simped in that I have hetraged the

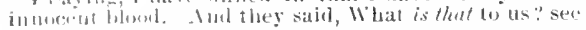
thom to therl.

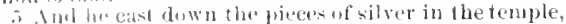

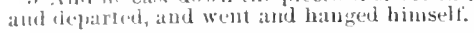

3 Then luias, who betrayed hin, whon he saw that he wat comdemmed, repented himati, and brought back the thirly pieces of silver to the chict priest

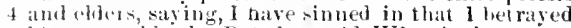
innocent blook. But they said, What is that tois? 5 see thou to it. Andi he cast down the pieees of silver into the sanetuary, and departed; and he went aw ay

1 Many ancient authoritie- read, rightcous.

compante of them rose uh, and hrought hum bufores Pilate." (Luke 23-1, Rev. Ver.) Ho was not yet on the way to "xeculiom, and they need mot king the simbedrin in session.

Il. 3-10. This sal fiate of .Judas. Not finmel in the other frospels, but comp. Acts 1 : $16 ;-19$.

(a) Judar roturned the money and hanged himsolt. ( $(x, s)$ Judas, which had betrayed him, see (m) 10: t as to his marlier history. When he saw that he was comdemmed, vi\%, that dests was andernued by the sambedrin. Perbape he liferally saw the procession

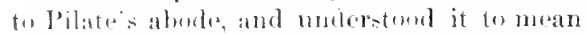
that the filnholrin lad comdemued him. This mut have ocenred hefore the erucifixim, at andy the comdemation is mentioned. It is mont natural to follow Matthew': orelor, platemer it betore the trial by Pilate. Yet llat in not a necossary riew, since Matt.

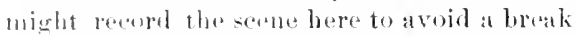
ill the subsequent narrative. The rlofef priats and alders ia goneral went with the

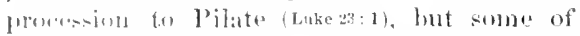
thom may latro gone at once to the Court of

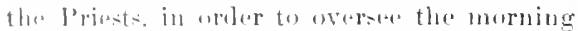

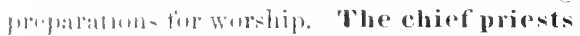
and elders are muntimnol in v. 3 , with me

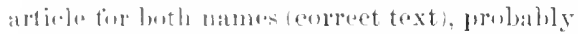

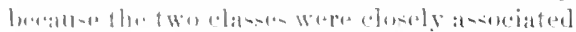

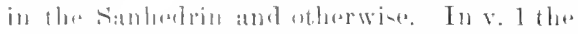

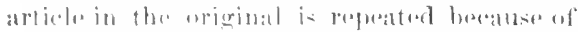

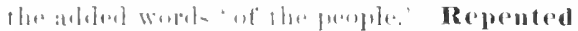

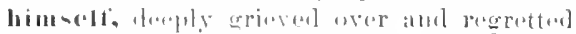

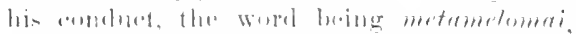

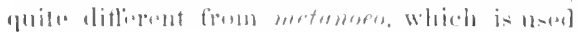

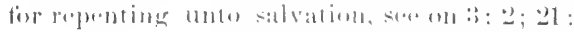

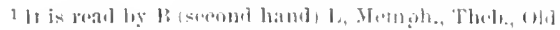

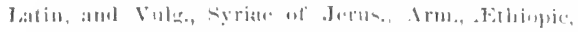

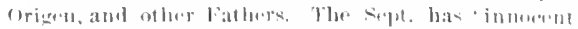

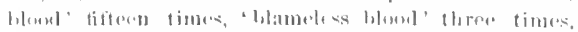

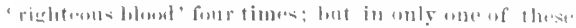

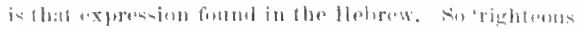

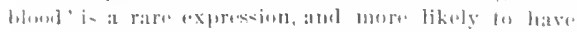
Inen changed inles the combon 'imnocent bloud ' than
2.). Bronght again the thirty pieces of -ilver, see on 26: 15. In that I have betrayed, delivered "p, as in v. 2, see on $10: 4$ and 17: 2.). Imnocent blood. The liev. Ver., margin, 'righterus blond' 1 is probalsy correct, but there is 110 inportant difference. The riply of the rulers was scornful. Comp. Icts 18: 15). In the temple, Rev. Ver., into the sanctuary. But the Com. text, 'in the sanctuary is more probably correct. ${ }^{2}$ The sanctuary is noss, the central building or temple propere see on 4 : 5 and $21: 12$. Some have attempted to entablish an occasional loose use uf mos for the whole sacred enelosure, but withut success. Not being a pricst, so tiur as we have any ratoun to helieve, Judas had no right to cuter this building, or aven the Court of the Priesto that surromaled it. He must have felt doperate and reckless, so that be ru-hed into the Court of the Priests, or into the lunilding itself, and flung the coins ringing on the flur of the sanetuiry. If we read 'into,' le must at any rate bave entered the court, which was equally forbidden. Aud went and hanged himself. See the same word in 2 sam. 17: 2:; Tobit : : 10. As to the further statements in Acts 1: $18 \mathrm{f}$., see below.

In comnection with what hat been said of Judas in 10:4; $26: 14,24$, it may be remarked that wur Lord gave Judas a position for which he appears to have been by nature specially tittel. That is for any man the best providential assignment, and can anly turn wut otherwine through his own grievous fault. (Comp. Edurbs.) Sume snodern erities and literary men. in view uf Judas' remorse and suicide, have tried tu comstruct for him a noble char-

contrariwise. In New Test. 'righleous blood' is found only in Matt. $28: 55$; 'imureent blood' not at all.

2"In" might easily he changed lo"iuto," uy persous who know that Indas had mo right to enter the sanethary. It is probably an "Alexandrian" alteration, luing found in $\mathbf{N}$, origen, Eus.: and $\mathbf{W} \mathbf{H}$. would doubless ealt it such but for its being found also in $B$. 
9 Thrn was fultilled that which was spoken by Jer-

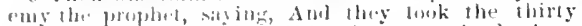
freces on silver, the frice of lime that was valued, whom the $y$ of the chilitren of torael clid value;
9 Then was fulfilled that which was spoken through deremiah the jrophl, sayiug, And they took the thirly pieces of silver, the price of him that was priced, 2 whom ertain of the children of Israel did

10r. I took...2 (15, whom they priced on the part of the sons of Israel.

te lacite it on the north. Comp. Robinson, "Bihl. lies.," and a striking eleneription in II arekete' "Illustratiom at Seripture." Unto lhis day, hows that this Gospel was written a gund many years atter the crueifixion; it would be much mole natural in A. D. 60 than in A. I). (1).

Tha acenut in Act- 1 : 18 l. differs in varions prints trom that here given, (1) Matt.

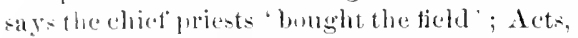
"this man purehaved (acquired) a field.' The lattor in a high wrought expresion, portectly intalligible - all that he acquired by his treatelury was a field. The money bought hima herial-place; that was to him the serle financial outcome of the iniquitous transaction. (2) Natt. silys he "hanged himselt"; Acts, "falling lieadlong, he lurrot asunder in the mid-t, and all his buwels gushod out.'

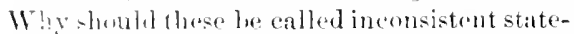
mont-? suplume that he hanged himself in the potters fiold-probably an unenchosed spot, fresur which potter"s clay had often be+en ohtainat, lik" a brickstril, and therefore not costly ; and suppose that the rope, or a limb wf a tros, lorolis; and the statenents are all

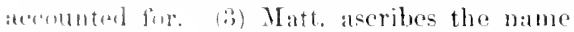
finlel of lolusel to the fitct that it was benght

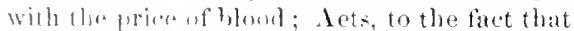

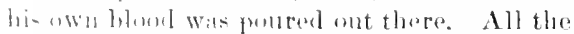

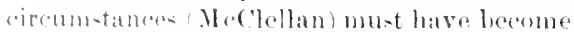
kanwe to the Cluristians, who resided at Jople-

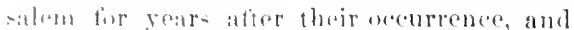
wombl loxel a jainful interest in the entire.

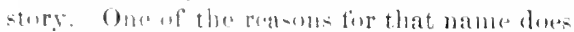
notexelundethenher. - Theseseveral explan:ifiom areatifielal, but nut highly so, alud are

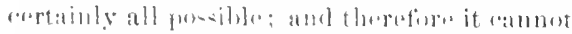

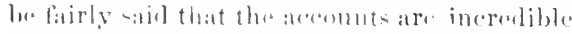
besume eontralietury. nor that the writers

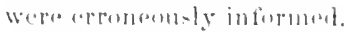

9. 'Then was fulfillod. For the trom "fulfilloul, sor on 1: 22; and for the filurato 'Alun was fulfilled,' instabd of' 'that it might

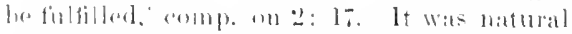

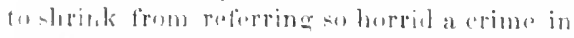

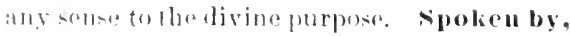
theough, Jeredniah, viz., "by God through
Joremiah, ree on 1: 2.2; 2: 17. Price... was valued ... did value. Thesame word is und throughout in the Greck; the repetition being painfully impressive. Com. Ver. must ot' necesity vary the tracslation, 'price,' 'valued,' 'did value'; but it did better than Tyı,, Crau,, Gen., whieh had "price," 'valued,' 'buught.

The promlesey is eviclently derived from Zeeh. 11 : 19, and yet is here referred to Jeremial. There can be no doubt as to the text. Augustine alraidy remarks that the tew (Latin) copies which omitted the name (as also Poshito does), or substituted Zechariah, warevidently trying to remove a difficulty. This difliculty has baen the subject of inmense discussion. The prineipal theories are as follows: (1) Error on the jurt of Matthew. This is apparently a very easy solution of Luther, Boma, ete., and is popular now with many, even Keil and Wright (on Zechariali). But some have surdy failed to eunsider the consequences involved in such an admission. Persons who earnestly seek another solution, or who admit they cannot find one and are quietly reeognizing an unsolved difticulty, may be just as honest and truth-loving as those who with reckless bravery cut the knot. (2) Origen and Eus. suggested, and many have repeated, that it might be a mistake of an original copyist, which is of course a mere asimmption, hat quite as likely as a mistake of the Evangelist. Morison ingeniously compares "strain at a gnat" in 23: 24, which appears to have been a slip of the pen or a typographical error in the original edition uf King .l:mos. (3) The notion Origen, Jerome, Ewald, and others), that it was taken from some Aporerybal writing ascribed to Jeromial, is arbitriry and luardly worth dis(1)sing. (4) Mode suggested, followed by Turpic, Wright, and others, that Joremiah may havoleen the author of Zeeb. ch. 9-11. This would paltly fall in with the recent theory as to a divided authorship of that book; but the theory bolds, for internal reasons, that the author must have belonged to the time of Mieah and Isaiah. Mede's view is 
barely possible. Murison woll says that it

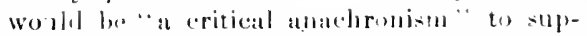
pese $\mathbf{l}$ atthew indicating in this tashion the (a) Jusite nuthorship ot the bouk. (5) hight-

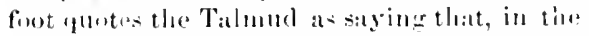
aneitent order of the prophetice boeks, obremiah-tuml first. Sn huthinlis Matthew has quoted firoun the general prophetice eollection $a=t l_{1}$ l, wk at Jeromiall; comple the Psalms ot Dovid, the l'roverbs of solommon. This iverv intanious. But nusimilar fuotation is

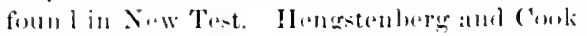
("Bil. ('omme") notice the litet that only" Jereaniah, Isaliall. alld l)anied are fursted by th nome in the (inspeds, Zech. being several

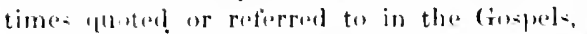
and many times in New Trast., lut never mamual. (i) Jengstenberg thinks that as the later prophets often reproduce atelior predietions. so Zech. Was here really reproduciner

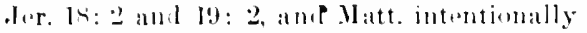

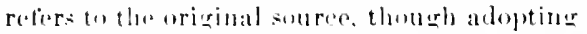
maimly the latere torm. "This theory is ahly

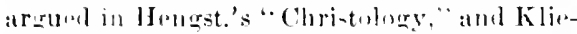
foth has a sinilar though distinet thenry (sos Wright. Basides thes above-mentioned tiact

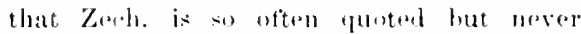

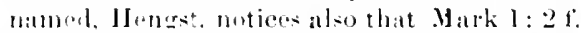

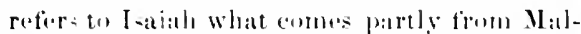
achi, triving the alder and greater ploplowt arelit for the whole, the two predictions bring akin.-On the whole this last seems the most nualy satistactory thenry: hut somo af the other aro prsible, eveli plam-ible. If not (puiterentent with any of these explanatims. We lasd bettrer lase the question at it stand: rouncubering bum slight an unkmown circumstance might solve it in a mommont, and how must a ones edelerated difficulty has been elated up in the gradual prenceses of

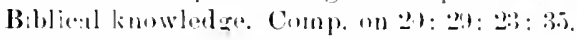

In Zeebariah 11: 13 the prophet in vi-iun is a repreastative of Johusah atetion as shepherd af l-rat. The Hork so mi-bulatra that the shepherd ealle for his wages to eluit. The people (tholk) - bow him anntempt by valuing him at thirty shekels. the priecenf at slare. Jahowah siys to the shepherel, "Fling it to the peter, the arlerious priee at whjeh I was priend by them." 'The prophet ands. "And I touk the thirty pieces of silver, and I flung it. in the homse of Jehovah, to the motter." In like manner, Jesus is contemptuously valued by the representatives of I-race at thirty - hok-

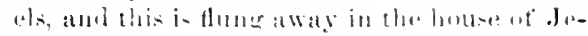
lariali, and gine- to a putter tior the purchate of his lield. The two casts are -indilar iutermally as wall as in striking extertal puinte, and the Fiangrolist deelatres them to have a

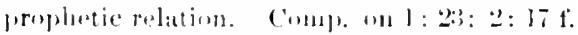

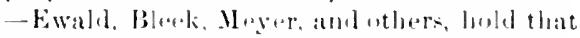

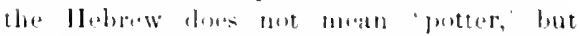

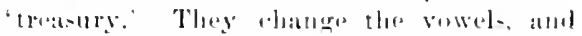
make an mulinown worde and think that thi:

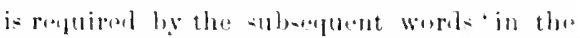

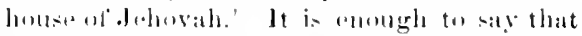

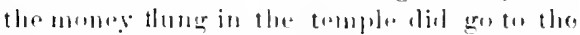

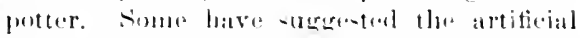

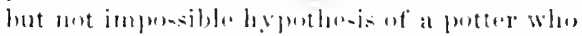

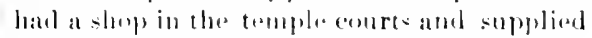
the temple, and whon anoml the pieces ot land that was bonght.

As to the firm of the quatation, Matt. here leaves the siept. and maken comsiclubles chaneres in the expressing at the Melorew. but only such as bring ant more releally the

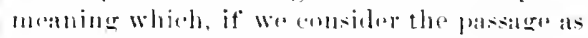
propletice is really conseged by the llebrew. Cimplo (1) : : 6.

\section{HOMILETICAL ANH PRACTICAL}

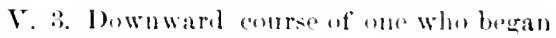
as a teatcher and an aposte. 1) Avarice, 2) Thievery, John l:z: b. :3) Betrayal, f) lismorse, 5) sujedele, fi) IIis awn plater, flet= I : 25.-Peter and Juelas. 1) They buth, and

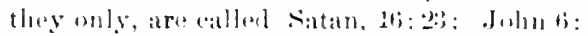
70. 2) They both, and they anly, turmed openly again-t the Mater at the end. 3) They buth surrownd leeply. hut in one it was remorse, in the onthrer it $11: a=$ lammble amil love

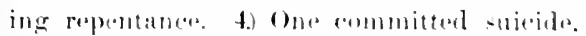
theother fiomd forgiveness and lived a long life of $11-12$ fulues.-Ilow the tratur was treated. 1) Easurly waleomed. and promptly paicl, 24: 15, 22, solemmly warnmel, but in vain, 20: 24. 3) biligently a-sisted. 24: 47;

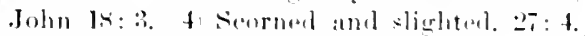
5) The price of his treablery male a monument of his ignoming forever.

V. 4. "I lase simmel." simergum has a

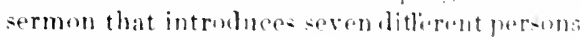
in Seripture, each soring, "1 hares sinned." "What is that to us?" It was reatly mueh to them; for it" Judal - hanl betrayed a rierliterus man, they had eondemned him. They could 


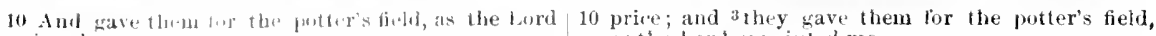
apprinted ine.

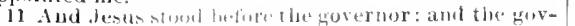

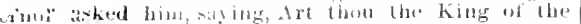

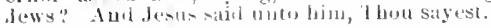
as the Loril alpribiled me.

11 Nuw iesus soud belote the governor: and the governor asked him, saying, Art thou the King of I some ancient autlorities real, I gate.

mot shitt thrir grailt upon Judas, as Pilate

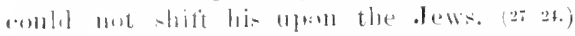
Il kx : : "It is tolly for us to think that the sine ot otlere aro molling to us, expecially

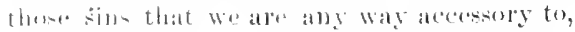

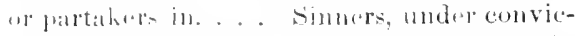
tiens, will lind their olel compantoms in sin

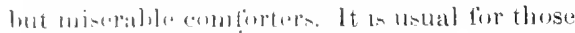
that love the troisen wo bate the tratitor."

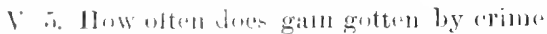

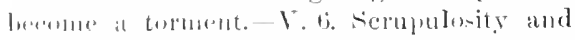
injuntione I) They would pity the price, but wall not put the price of bland in the troasury. 2) They would wat enter the gorerumes

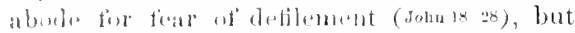
they would manemere and lie to make the

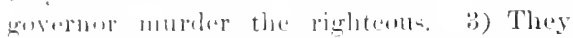

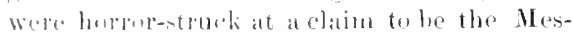

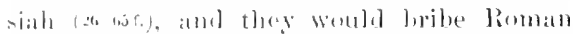

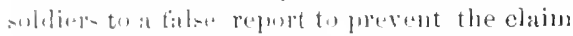

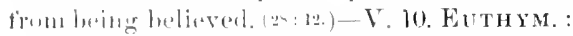

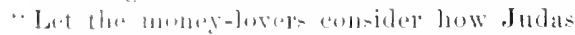
lowmmitten the sin. 2) atid not enjoy the

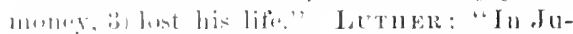
Aas we sae two things: how sin at tirst easily lipe in, but allurwards makes sucele a horrible atil.

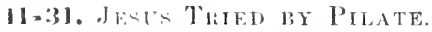

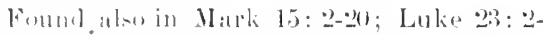
25; John lit: 2s-19: 16. Iduke lore grives a

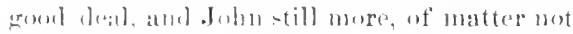
[omml in Malt. and Mark; while Matt. Jats twe remakatule points not found in the uther. viz., v. 1!tand v. $24 \mathrm{f}$. This section in Matt, divile inta v. 11-14, 15-18, 19,:20.23,

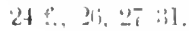

l. 11-11. Jilate timle no grounds of comlemmatim. Ind lesis stood before the wowernor, vi\%.. Pilate. (27:2.) The time

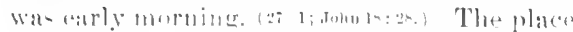

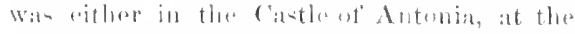
mothwa-t antme of the temple area, or at the

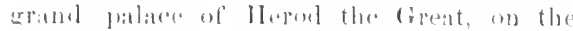

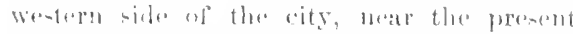

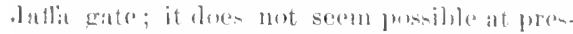

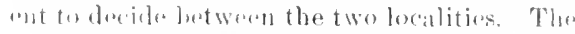

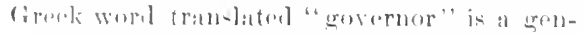
ral torm signityinglabder, rulor, goveruor in general, as in 10:18; 1 Peter 2: 14, and frequently applied to a Roman procurator, as througlyut this and the following chapters, and in Acts ch. 24-26; so sometimes in Josephus.

When Archelans was banished in A. D. 6 (comp. above, end of (l). 2), Judea and samaria were made a Roman provinee, governed by a procurator, who resided at Cesarea as the political eapital, and visited Jerusatem upon orasion, especially at the time of the great foasts. The sixth procurator, A. D. 26强, was Pontius Pilatus, who, besides New Tost. and Jos., is mentioned by Tacitus ("Ann.," F, 44), "Christus, in the reign of Tiberius, was executed by the proeurator Pontius Pilatus." TVe know nothing of Pilate's history luefore entering ujun office. In the probably four years he had now been holding it, he had made himself very odions to the Jews, by dirregarding their religions convietions and feelings. We find mention of firur instances, all apparently belonging to this early priod. (a) In removing his army from Cesilvea to Jerusalem for winter quarters, he sent in by night some ensigns bearing busts of Cesur, while former governors lad used other ensigns in entering Jerusalem, out of regard for Jewish feeling against graven images. Multitudes of the people went to Cesalea and continued for five days and nights their incessant entreaties for the removal ot these images, which he refused hecause it would serm an insult to Cusar. On the sixth lavic let in soldiers threatening the suppliants with slaughter; but they prostrated llomselyes and bared their throats before the drawn swords, saying that they would gladly dio ratles than allow transgression of the law ; so he yielded, and ordered back the inagtes (Jus., "Int.," 18, 3, 1; "War," 2, 9, 2-4). (b) Plilo, in urging upon Caius CaJigula the "xample of Tiberius, tells that Pilate once oflered up in the palace of Herod som. gulden shields, without figures, but inscribut, and after long obstinately refusing the whtreation of the people, received orders from Tiberius at Ronie to remove them. 
12 And wh il he was acened of the chief priests and elilers, lie answered undinis.

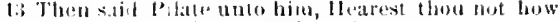
many things thes winten atuinst thee?

Siar thit curious work, writum soon ntter

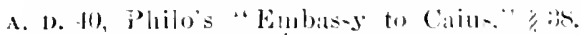

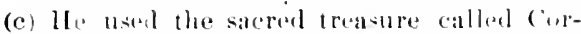

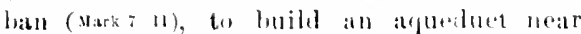
tilty miles lomer. On his return 10 Jerusalem the peaple rathered alout his tribumal with lumb elamors, and le sent amome them soldiers, whu beat theme savalgely with - tatres, killiner many, while others were trodelun tw leath in the tlight; and so in that a $\cdot a-c$ he tri-

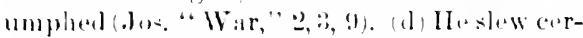
lain Galileans while angagen in otturing sateritioes at the temple, suthat theil bloml minshes with the blowel of their sacritioes-to Jowisir feeling a horrible eomblination uf

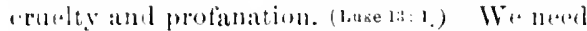
not wollder that los. hats an aceorunt ot 1his. for Philo spealis of Pilates "-arecessiva muclers without trial," declaring that he

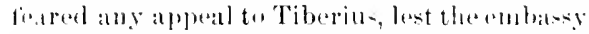

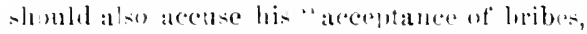
plunderings, nutrages. and wanton insults, continual and most grievous eluclty," and elaracterizing him as "umbondiner. selfwilled, harsh, and malignant." Thene fiucts and statements will prepare us to molerstand the relotions of the accusers and the justge in the trial at" Insus before pilate. It should be abled tiat six yoars later the procumsul ut syria. Wha was the procurator's superior,

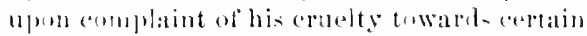

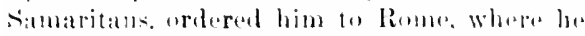
arrived atter the death at Tiberius ("Int." ls. 4, l $l$. Euscbius says ("Ili-t." 11, 7), llat "in the time of Caius (.1. D. :37-4l, Pilate tiall intose great mi-fortunes that he commit-

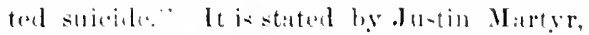
Frertultian, and Eu-eh., that Pilate made ats otlieial repert to liberius ancorniner his trial

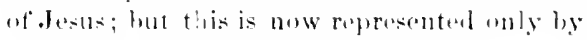
manurstionably spurjuls writings.

Johit relates low Pilate rame ont form the preterium, heean-e the rulers were unwilling

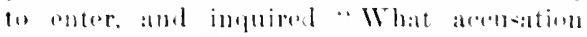

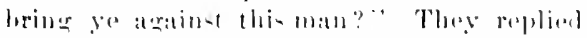

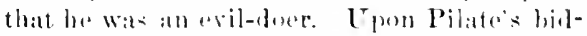
ding then take him and julder him than-

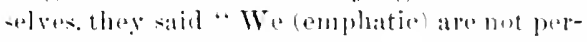
mitted to put any one to death" ; and so

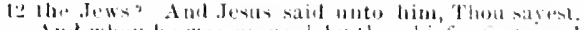

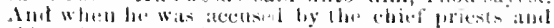

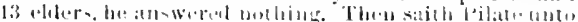

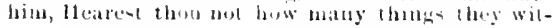

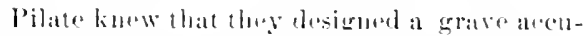

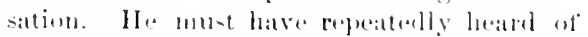

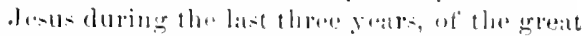
croweds that tollowed hims and the reported miracles, but also that he sermed to have nes pelitical atms. Lake (Rev. Vire) tulls that

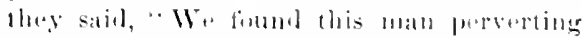
nur natiun, and forbibding to give trilute to Cesar, and saying that he himedt is christ, al

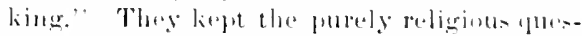

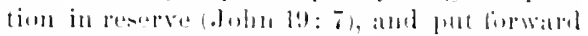

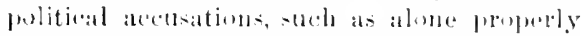

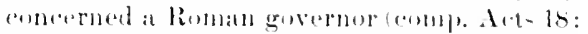

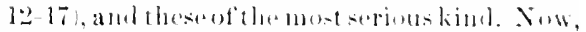

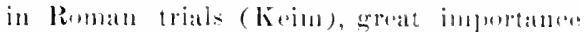

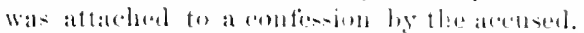
Aceorlingly, l'ilate a-kol the you-tian griven ly Ilatt., Mark, and Lukre, amel Iolin, Irt thou the ling of the dews? Thi-in Matt. and Mark repuires something said ly the Jew as aceountion fior ic, which Juhn and

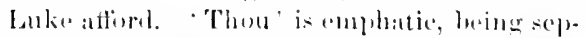
aratuly expresonel in the Giark. Thon say-

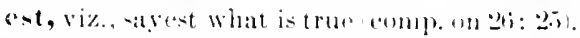
John shows that this que-tion and answer were speken in privite within the preterium

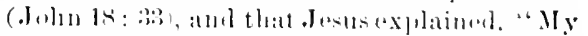
lingdum is mot of this world." Me hatresen

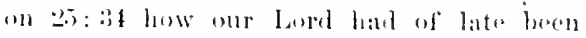
speaking of himselt to the diseiples as ling,

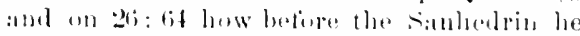

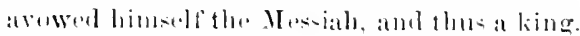
It is probaloly to this contission that he was the king of tha fows that laul refeles in l Tim. li: l:, liev. Vur.: "('lupst .Juslls, who before Pontins Pilate witnessed the gumbenfin-inn."

Whou he was aceused, ur, while le wils being acensel. IBy the chief priests and elders, tirst amts speiblines. amel then anuther.

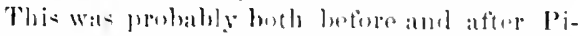
lates private interview with him. ro nover. ur, not reren to one worel, is the litoril tran-laltion. Pilates romomstrantese r. l:3) aypurars to have bern kindly musut. Ther mter-ilenens

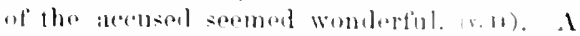
Roman writur says, " Silener is a kind af entr-

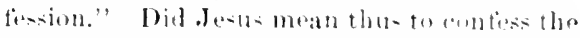
charge as true? Tleere was something about 
1. And be answerel him to never a worl: jusonuch llat the goverisor hiatrielled greatly.

15 Now at thet lotst the guvernor was wout to release

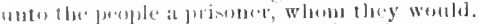

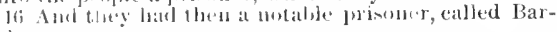
atbliats.

17 Therafore whon they were gatherel together, Jjbate saiblund them, Whour will ye that I release unto you?" Batabbas, or Jisus which in called ('lurist?
14 ress against thee? Anr he gave bim no answer, not (') en lis one word: insonuch that the governor mar15 valled grealy. Now at llateast the governor was wonl (1) release anto the multicule one prisoner, lf whom they would. And they had then a notable 17 prisontr, called larabbas. When therefore they weregathered together, Jilatisaju untothem, Whom will ye that I release unto you? Barahbas, or Jesus

lor, a Seast.

bim which disinclined the governor to think so. How many things. The Greek may mean eifher luow many or how great, inderel may include loth-what a mass of things. Can we see reatoms fir this remarkable siloner, lefore the Roman as well as the Jewinh tribumal (26:63)? (1) II, has alrualdy beell comdemned by the Sambedrin for blasphemy.

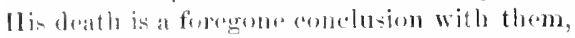
and Pilate is fettered by his own past woughaing, and must yield to their wishes. It will (h) no gond to speak; it wonld be casting peatls hefore swine. The only charge that nereterl axplanation to l'ilate he did explain to him in privale. (2) The crisis of his minisIry has arroed, his 'hour' is now come. For two year a he bas prulenly avoided axciting the ber-tility of his comemies, and the fanatirisun of his friends. But there is no occasion for forther dedeying the inevitable collision. II" hat finished his work of teaching, his life of lommiliation, and thr hom is come that he

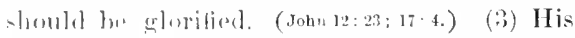
dratl, is not only inevitalile, but neressary. and lo now voluntarily submits to it. (Johu 110. 17 :) (1) prayer to the Father might stop, it, lint los will not so) praty. (ono 12: 27:

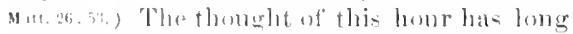
beom a burtoroto his soul (buke $12: 50$ ), and last night its approach (a)t him a long and fainful struerelo in thrs enadern; hut mow he is

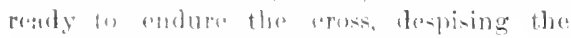
sianare, for the joy that is set before him. (mes. 1:2.)

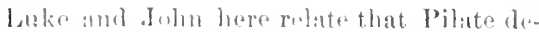

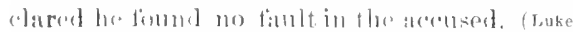

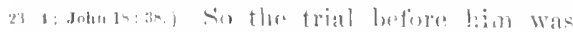
Ibus far a fallore. But tha Jwwislo rulors

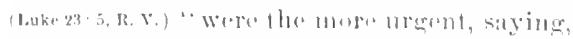

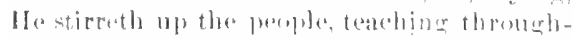
ant all .Inlea, ambl beginniug from Galiles evell unte this place." Thus Pilate learneel

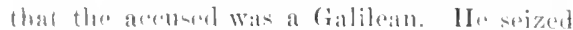
upun this facet as atlierling a prosperet of an estape foun this unpleasant trial, and at the same time of enciliating Herod Antipas, the tetrareh of Galilee, with whom he had been at (mmity. So he sent Jesus to Herod, who had cometo. Jerusalem for the forst. (Luke $23: 7 \cdot 12$.) This formed the seoond stage in the Roman trial. But while le suceeded in comciliating Herod, the governor failed to escape the responsibilaty of thr investigation. Jesus was utterly silent before Iferod also, and was sent back, nothing having heen aceomplished.

11. 15-18. Pibate attempits to release Jesus. Mark 15-6-10; Luke 28: 1:-16; John 18: $39 \mathrm{f}$. summoning the rulers and the people, the procuratur declared (Luke) that he, and likewise Herol, had found no fault in this man concerning thr matters of accusation. So he pripused a sort of eompromise, "I will therefore chastisohim, and release him." II hoped that this amount of punishment might satisty the hostility of the aceusers. At that feast, Rev. Ver., the feast, frast by feast, whenever at feast accurod; but the reforence is probably to the passover, and not all the feasts. The goveruor was wont to release nuto the people, multitude. This was more likely a Roman than a .Tewish custom, but its origin is quite unknown. Despots have often found some reluse of prisoners to be popular with the many. A, one, prisoner. This is clearly a numeral, and not an indefinite article, emp. on 26: 69. They had, viz., the governor and those associated with him in such matters. Barabbas. The insurrection against the liomans when a procurator was first appointed bat lelt some popular robbers, who were regarded as patriots (romp. on 22: 17). It is not unlikely that. Barabbas was one of those. He was not only "a robber" (John 18:40), but had excited an insurrection in the city, during which he and his followers had committed murler. (mark b: 7; Luke $23: 14$.) These facts vecomut for Mathew's (alling him a notable prisoner, or 'a prisomer of mark.' It is also prolathe lhat the two robbers erueified with Jesus were Barabbas' followers, so that the 
13 for he knew that for ans they had dielivered liius.

t) When lue wats set dow on the juclememt suat, his

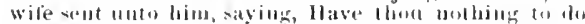

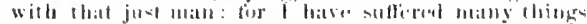

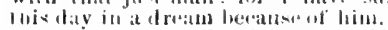

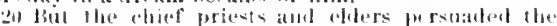

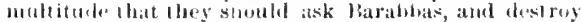
Ji'sis:

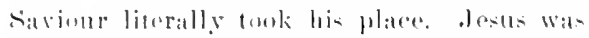

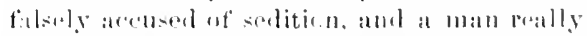

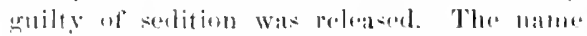

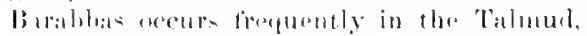

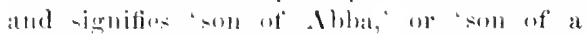

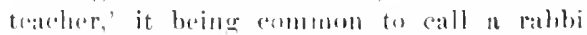

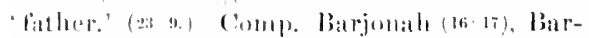

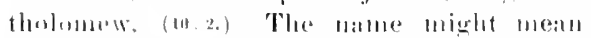
simply 'son of his father, hut not soprobahly.

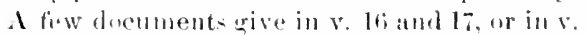

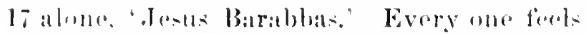
this to be an interesting reading, but the aridenes is ton slight to warrant areepting it, as i- deme by Fritz. Mreser, Firrar, and otloers. Tregelles has - hown how it might have arison through a mistake in copying; seos also Tiselo. ame IV $11 .$, Apr. Whom will ye that 1 release unto you? Jolin alsostatres, and Luke implies, that Pilate sugerested the releaso ot

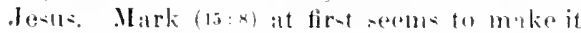
("omes from the prople. But ha only thates that the thronging multitude at that perint reminded Pilate of the (1)-tom, at vers natural

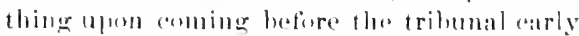
an the tirst day of the fortst, and Pilate tombli up the inleat and askeal whether they wished

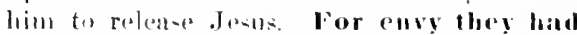
deliverod biu. Mark anofully distinguislas

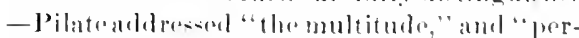
cerived that for colly the chief prients hat delivoroll him up," li. V. Thoir jentall-y alros" from the taur that a person alaiming to be the Mesiah would intertare with their pomblatery and puser. Pilate might wall anongh sllpfore that the multitude wouth have lithle symbitliy with this fexling. Or Iesus. which is ralled Chrise. Wr Msually timl 'tha ('hoint, the Mersiah, sise on "2: 4: hut here. as in 1: 1, 16; and probably in 16: 201, it is simply '(Heriot, a foroper namo.

111. 19. Mrestge from Pilates witi. This

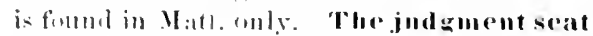
Was at sperial relaic, often earrienl abont by a Ruman otticial of rank, and plateed as a seat of justice in front of his tent or house. upon an elabated 'pavement, teselated or mosaic.

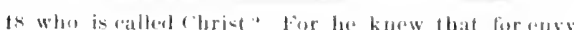

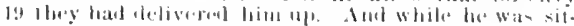

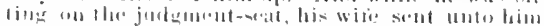

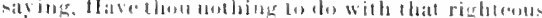

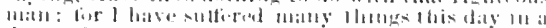

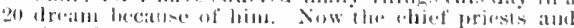
the elders perstated the multitulesthat they -hould

The Romans were estentations of pulblivity in trials, as opponsed to sereret invertigations.

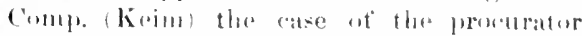

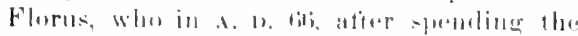

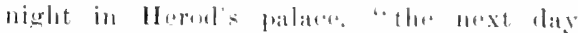

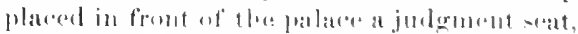

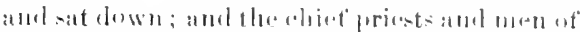
powerandall that was most dinfinguishod int the

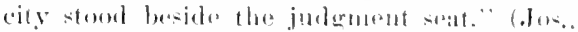

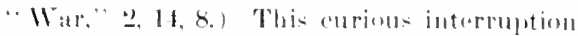
from leilates wite anve time fore the rulere to

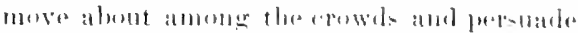
them to atsk lior Barabbar. (v.20.) lt is sug-

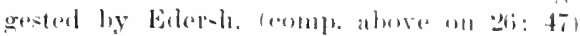

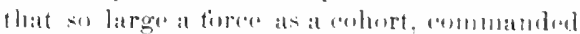

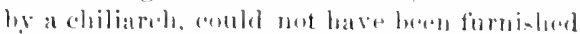

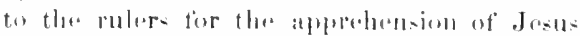

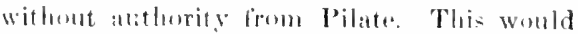
areount for the fact that Pilate's wifie know what Wa- going on, and folt distressol and anxious. IIare thon mothiog to do with that just man: the sume Groek comstruction

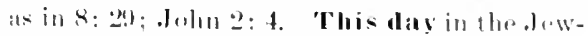
ish sintse, loegrinning at sullest. There is mothiner hore to imeliente a divine influences in

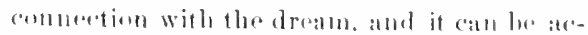

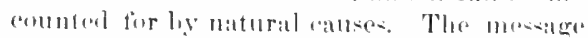
would naturally incrase the govermor's re-

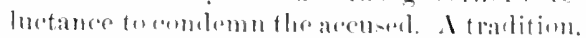
with but slight support, gives to Pilates wifo

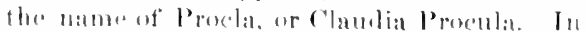
like mannere the two ruhbers. fle contarion,

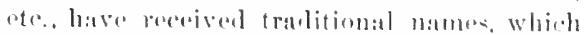

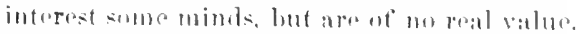
In 1. D. 21, it was propused in the Romatn sonater that mo prosincial magistrate shombl

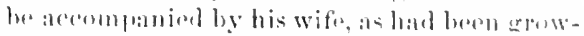
ing commons: but the motion failesl. Tareitus

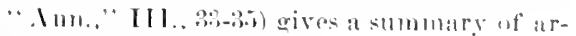
gumouts an both sides.

IV. 20-23. The people chouse Barablias rather than Jusus. Mark 1iv: |1-11: Iulie

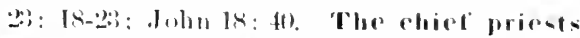
and elalers bursunded the multitude. while Pilato was mellpied with the masiane from his wife. Sotice thit great throngs of 
"1 The governor answered and sail nuto them, Wholher of the twain will gethat l rotease unto gou: lliey -itid, liatrabbials.

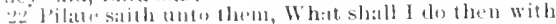

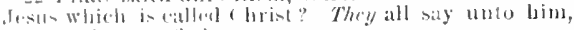
let lime be cructicel.

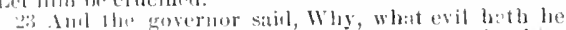

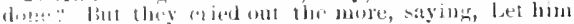
he elmiciticisl.

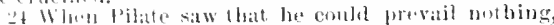

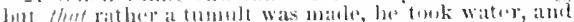

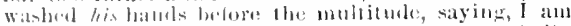

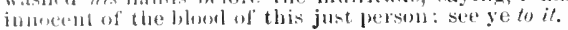

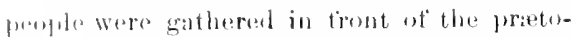

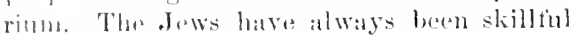
polifirians. The popular geal abut Jesus ats the Mteriall had evidently cembled, and probably hecallow now for five days since the trimuiphal entry be had dome nothing towards a-tilbishing himself as king. The wily dematangume combl say that the highest court hat triat lease, and fomml him an impostor and at blasphemer, whe deserved to die, and they larperl Pilate wostd arueity him. It Barabhas was asereiated with patriotic traditions, ats Wre hatre supposed (on v. lli), it was easy to areite popular gomel-will towaris him. Comp. the moturn Greek robbere ander Turkinh rule. Mark, Rov. Vop., says, "the ofief priests stirren[ up the multiturle," astrong term, indi-

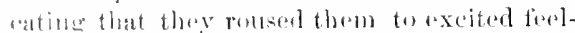

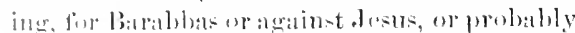
louth. Prowlated that they shomblask', is a

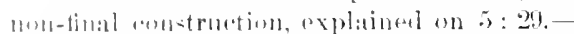

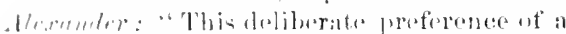

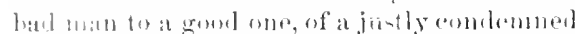
sriminal to one whom aven l'ilate reenenizen?

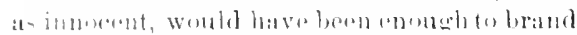
the anduluet of the prinsts with infiny. Bute

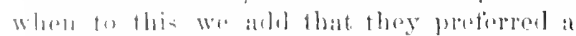

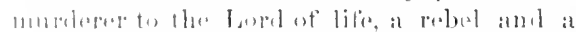

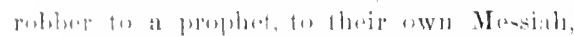

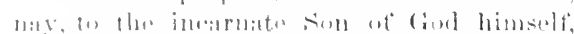

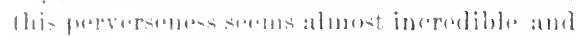

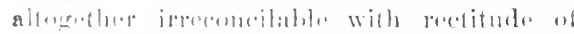

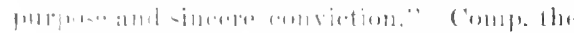

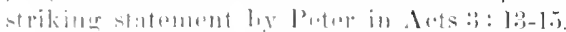

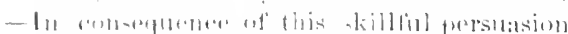

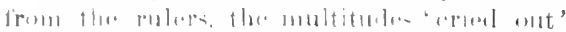

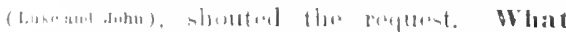
shall f de then with drolls which is called

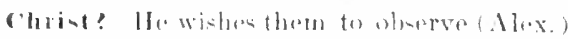

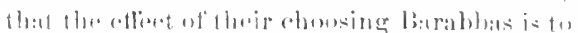

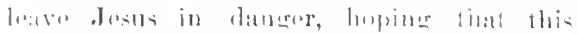

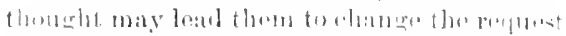
They all sily unto him, lat him lo, crol

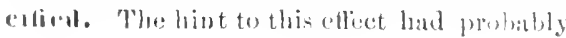

2] ask for Burabias, and destroy . Tesus. But the goveran answered atud said unti them, Whether of the wain sill ve that I releise unto you? And thry

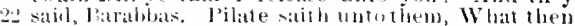
shall b do unto Josus w ho is called ('hrist" They 23 all say, het him te crucified. And he said, 17 hy, what ivil hath be lone:" biut tlify eriel ont ex2t eevlingly, siline, Let him lus crucitied, sowhen J'ilte saw that he previluted molhing, but rather that a tmmult mas ari-ing, he took water, and washed his hauds before the wultitude, saying, I am inno-

been given the crowd by the rulers. They could thu make his death ignominions, so as to break his hold on popularalmiration; and could also have an excuse for saying in future, if (omplatined of, that it was not their act but that of the Romans-as some Jews anximsis maintain now. They knew not that under an overruting Providence they were bringing absut a form of death most suitable to atonement, as involving "shedding of blowd," and eatusing wounds that would be marks of incentifiation after resurrection, without the distrening mutilations caused by stoning. 1s to the trm. 'crueified,' see on $16: 24$, and $27: 35$. Why, what evil hath he done? Pilate had no liking for the rulers, and undrrotemel their joulunsy of Jesus. (r.18) And where his own intorests or passions were not involvel. he hat some sentiment of Roman justice. So he remonstrates with the crowd. Luke tells us that he declared, "I find no callse of death in him." B. U. Ver, and a second time properend (Luke $23: 16.22$ ), as a sort of (c)mpromise that might satisfy the enemies of Joils, "I will therefore chustise him and let him go." All this, als (lirys. says, was weak and unmanly contuct; see below on v. 24. But they cried ont the more, or crecedincly. An excitol throng is often more boisterun in propurtion as it has less rason. (C)mp. Acts 19: : :

21. Pilate tries to shift the responsibility, and the people assume it. This is reorded ly. Matt. mly. - Saw that he conld prevail nothing, that he did no good by his suggestions. Why was the man of power thess powerbes? Why comld he not say, Fint jusfitin, met instum? Let justice be dene, if the heranessall. II was avidently very anxious to averid condemulng the innocent, for he marde in all six distinct efforts to ascape the ditlublity : (1) somling Jesus to Herod; (2) surgenting that he might be releasd aceording to the euntom; (3) proposing to compro- 


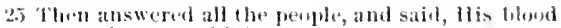
be on 11s, alld olt our chifutretl.

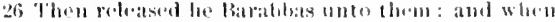
he had scourged Jesus, he dolivered him lo lie crucilied.

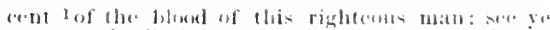

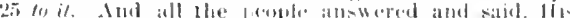

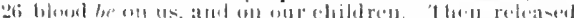

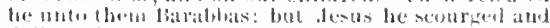
delivered to be criscitied.

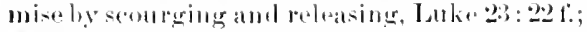
(4) wathing his hamel and disclaiming responsibility ; (i) propusing to tiorn the case eser to the dowish rulers, Jolun l!: li; (6) appealing and remonstratine before he promouncer

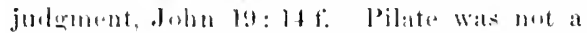
man of heroige smonlel, lut low was "solt-willed and olretinate." Why romld he not dor what he se greatly desired? He was antameled by his awn previolls wrong-rloingr. sere onv v. 11 . He had mate rulers and poople hate him thoroughly, se that they would he erlad of an exelles for reporting him to Tiberius; and he kurw that the suspreions and jealous and peror wobla beslow to pase wer lloe charene

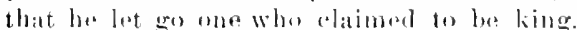
Pilate was weak mow becallore ha had formorly been wieked. Like many a pulitieian, hi. record was in the way of his comsoimen. I tumule was made, ore, mas arisimg. The Romans derired two thiress in the provinces, tribute and peace. A suceseftul grovernor was one who kept averything guiet, and pupular tomult was erreatly di-likiod, as being troublesomeand expensive, if not dangerens. Waslued his laands before the multitude. The law of Mases had direrted this ereremony in a

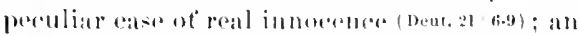

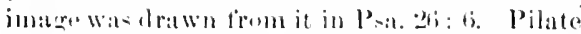

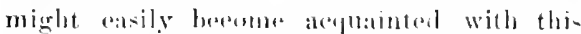
fowish relotom, whiels was in itself a verv natural symbul. Inubcent of the blood of this just persou, ar rightenes man. Tha shortor text ot margin liav. Vore is quite probably correcet, innoreant of this blenel ; there is ma important difleromos. for l'ilate

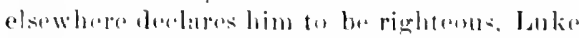
2:3: 11; John 19: 4. But the erovertorer was

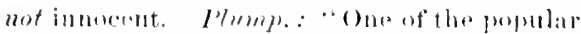
pestsof his ewn timn and eountry misht have taurbt him tho nullity ot sueh a formal ablution-

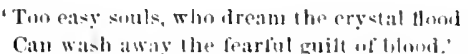
(rid, "Fitst.' ii. 4i."

And he bimself felt that lie was not inno- cont, for it was afterwarls that he mate the

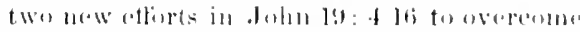

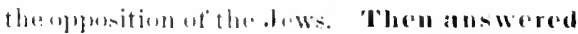
all the people. Nint simply some; it was a generalery. Il is blowd be on us and on our chideren. Jeremer: "A fine inheritanere the

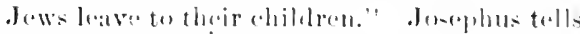

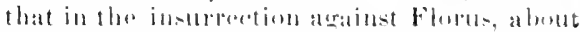

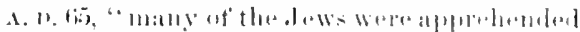

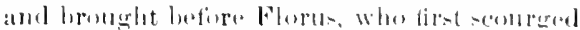

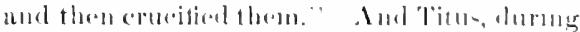

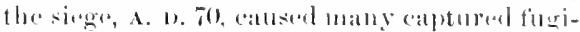
tives somelimes five homdred a day, le be

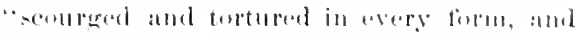

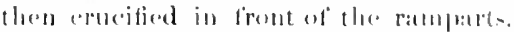

Ind aremeat was theje number that the loe was

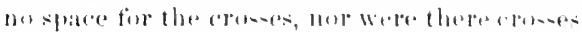
for the londies." ("War," $2,14.91 ;, 11.1$.

VI. 26. Jesus delivereal to be ermeilinel.

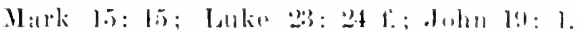

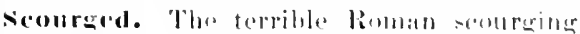
carriol with it inte the provinees the Latiu word. which is here borrowed into the lirene of Matt. and Mark, and su into the sirliac

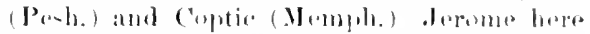

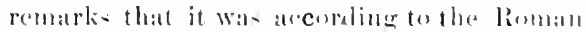
laws that ond who is erouglied shall tirs las

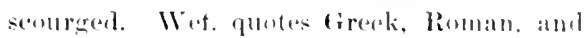

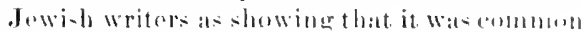

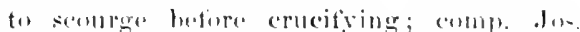
above. l'bo sullierer was striplend and boumel (1) a pollar er post. lemeling fiorward so as lo expese his hack aomplotely ; the heary whip

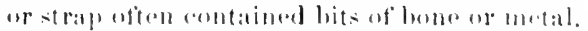
and tore the quiveriner tlah into ond handy

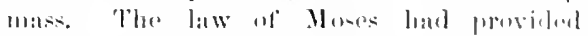

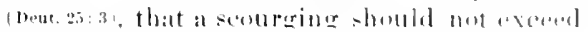

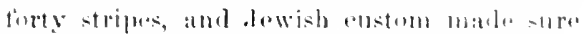

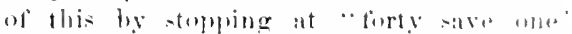
(20or.11 21); but the liomin scourerers were restrietrel liy nothing lint - reoleth and inclina

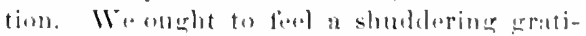

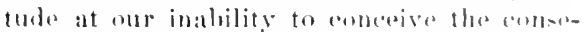
furences of this ermel inflution. Delivered, tu some of his soldiers. (*2i.)

VII. 27-31. Jesus mocked hy the soldiers, 
27 Then the soldiers of the governor touk Jesus into the acoumon ball, and gathered wutw hisu the whole b.ind of soldips.

's In] the's stripped him, and put on him a starlet rolis.

29 And when they had platted a erown of thorns, they put if nom his heal, and a reed in his right band: atud they buwed the kn obefore him, and nucked him, saying, Ilail, ling ot tle dew-!

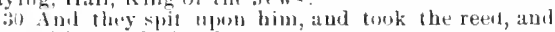
smote him wn the hrail.

31 Amel aftur thit thry hal mockid him, they tomk tho 1obe: off from him, anil put his ow rament on him, alal led him away to crucify him.
27 Then the soldiers of the governor touk Jesus into the l'retorium, aud gatbered unto hius the whole $2 x$ rbaud. And they ${ }^{3}$ stripjed him, and put on him a 29 searlet robe. Arid they plaited a crown of thorns and put it noon his head, and a reed in his right hand; and they kneted lown betore nim, and 30 mucked him, saying, 1Iat, King of the Jews! And they spat upon him, and touk the reed and simote

31 himi on the head. Aml when they had mocked him, they tonk off trom him the robe, and put on him his garments, and led him away to clucify him.

a 1\%. gorernor's house._- I Or, palace...20r, cohort....3 Some ancient anthorities read, clothed.

and lod away to be erneified. Mark 15: 162); Iohn 19: 2-16. The soldiers of the governor, the Roman soldiers in immediate ntemelame. Threse were seldom Italian (Ace10 1 , but drawn trom all parts of the entpire. They may in this case have been syrians, or may have been Gromaths. Took Jesls into the common hall. In Rev. Vur., palace was used by English Revisers. This is mot the word rendered 'palate' in

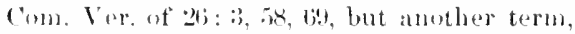
the Roman proturium (bormwed in the Greek), drouting the pretor's tent or abode, the gen-

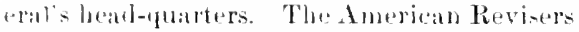
wirely preferest to render prepterium. The trial and the ecourging had taken flace in front of the proptorium, in a broad opeen spare where the judgment seat was placesl and the rowds assembled. The mocking that follows accurred within the pratorium, and afterWark-tles sufferer was again led out ?y Pilate,

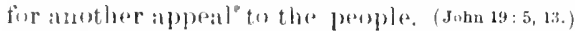
And quthered unto him this whole band, ir 'cohort' (morgin, Rev. Ver.), comp. on 24: 47. The rxpression (Meyer) is of conre puphas, wot necosingily inplying that every soldier of the cobert was present; but it was a large number. And they stripped him. There ath be little dould that this is the correcet text; that of mergin, Res. Ver. (aliffering

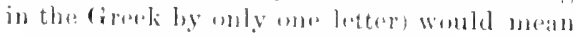
that baving previnty stripped him foi the secourging (dets 16-22), they now replatedes his garmeste and then put rousd him the searlet cloali. I scarlet robe. Ilark and John, 'purpie.' The anciente did not so arefully

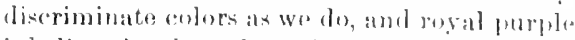
is believal to latve inclueled all tints from sliyblue to erimsin. The term lare rendered robe' denotes a short real aloak worn by Ruman military and eivil officials. The soldiers would maturally take this ats at mocking -ubstitute for a ling's purple robe; indeed, a Roman emperor might wear it. A crown of thorns. So Mark and John. The crown woułd simply be a garland. The plant employed eamnot certainly be determined, but was most probably the nubk of the Arabs, "a tree which is formd in all the warmer parts of Palestine, and about Jerusalem. . . The flexible boughs are tough, and well suited to form a garland, and the thoms are numerous and sharp" (Tristram, "Nat. II ist."). The thorus were of course unpleasant to the brow. but not excessively painful, and were probably uned more in derision than in ertelty. A reed in his right hand, as a mock seeptre. Hail, King of the Jews! The Jews had mored him as a pretended prophet (26:65); hare the Romans mock him as a pretended king. Spit upon him (Mark likewise), as the Jews had done in their mocking. (26:67.) And took the reed and smote him on the head. So Mark. The tense of 'smote' is imperfect, a continued smiting, and so in Mark as to the spitting atso. Then restoring his own garments, they led him away to crucity him. So Mark, Luke, John. Juhn interposes an account not given by the other Evangelist, of a renewed effort made by Pilate once and again, to excite popular com. passion and change the result. But the wily Jewish rulps knew bis weak point and their advantage, and said (John19: 12), "It tibou let this man go, thou art not Cesar's friend: whosuever makith himalf a king speaketh against Cear." We have seen (on v. 24) why Pilate telt helpless in presence of this thought. And so his last efforts had failed.

IOMILETICAL, AND PRACTICAL.

V. 11 f. IIENRY: "Many oppose Christ's loly religim, upon a mistake of the nature of it ; they dress it up in false colors, and they 


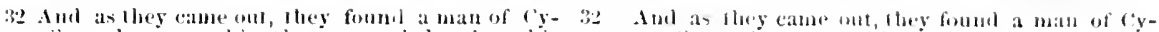

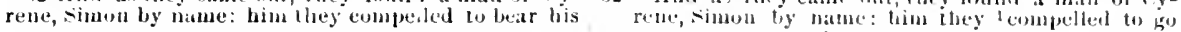
crosis.

1 Gir. impressed.

fight against it." (irifretu: "Sio always a true hoart will speak out boldly, indillorent to eircum-tances, - will not endeavor to clip and fear and file the furm ot its, luterances, in order to avoid eollision with miseonewetion and prejudice." - V. 14. There is a time to speak and a time to be silent. - V. 19. H Fxry: "It is an instance of true love to our trimeds and rolations to do what we and to liepe then froma -iu." $-V^{+}$. 2). Balrabbas. 1) The smll ot" a religious teather sometimes becomes rery wickial. 2) Parple often clowse some evil person or thing in prefirence to Christ. B) A man guilty amd condenned may escape lath because of ('hrist's dying in his places. -V. 2.2. Slas! for the tiekle multitude who shout "II paseral cry out, "Crurity him." The ror pop-

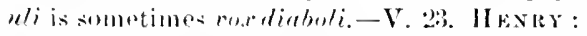
"The Lord fesus sutfirerd as an evil-doer, yot noithor lis judere nor his prosecuturs eould find that he had dome any evil." - V. 25. Cinters: "Passion and wicked desir" suther mot men to see anythimg of what is right. For be it that ye curse yourselves; why do you draw lown the curse upon vuur children also?" ('Alwix: "There" is no doubt that the .Jews folt serure in levoting themselves, supposiner throir eause to be just in the sight of God; but ineonsiderate zeal drives them hoadlong to ent ofle trom themselves all hope of pardon tior thair wickedness. Hance we learn how anxionsly in all judements we

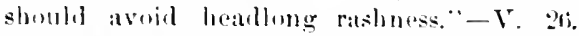
Lesinn from the case of Pilate. 1) Skeptiristu and superstition often ero trigether"What is truth?" and tho dram. 2) 'skepticism will sometimes turn awa from the richast surees of instruetion and the amplast

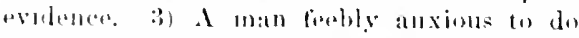
right may be sorely embarrasiod by previons wrone doiner. 4) A man cannot makea derision and evalde the reponsibility of it. 5) Others may voluntarily sharea man' a guilt, and not lighton it. - The greatest of all instaners of crod's bringing aond out of eril is the fact that becallite of Iudas, Caiapliar. Pilate, and Barabois, the Divine Radeener
Wa: lifted up that he might draw all men unto himstil:

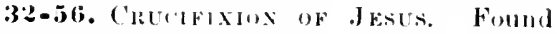
ato in Mark 15: 21-11; Lule 2:3: 24-4!1; John J!1: 17-3;. In their accormts ot the crucitixim, Matt. ambl Mark nust nearly agree in the -election and orfer of the material, as they have bean loing since 19: 1 . luke gives much that they do not eontain, and John s narrative is natrly all alditional to the ather three. Matthew's atecount di-

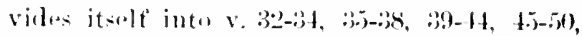
51-56. - The time of the crucifixion was beyond question from abeselt ! A. I. to : P. M., and

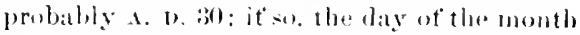
was probably April 7 (Wicaler, 1. 3is, Clatk's "IIarm." p. 29)l). As to the place,

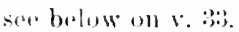

I. 32-34. IIr is led a the place of erucifixion, aml rofuses the stupufying draught. Ind as they came ont, not wut of the prietorium, but ant of the city, as shown ly the statement of Mark and Iuke that Simon was "oming out of the conntry." It was customary and, natural to gu orit of the city for

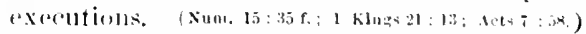
A man of Cyrene. ('yremt was an wh Greck settlement on the east of Africat,

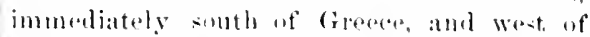
Mlexambria. being a places of much trable. it contained many Jows; the seeond Book of Marualuese (2.23) was originally written by and Jason of Cyrent. Thereity is montioned in . 1.t: 2: 10: 6: 9; 11: 20); 13: I,

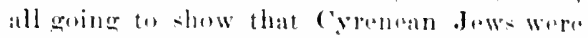
numerous ; and oftenson in Jerusilen and vicinity. Simon hy name. The name shows that hr was a Jew. IIak alds, "the" bather wt Alexandoramd liutus:" who inust for some reasill liare been well known anomer the Christians at tha time when Mark wrote. Wa eannot say whother this was the Rufus of liom. 16: 18, the name leeing very (oommon. Mark and Luliestate that sionon was " eoming out of the country," just entering the eity as the proession went out of the gate; there was no objuetion to jourueging on the feast-sabbath (see on $v .39$ ). 
:3is Anl when th:y were come untw a place called (iv)lonthat, that is to say, a plocee of at skull,
33 with them, that ine might licar his eross. And when they were come unt at place called Golgotha, lbat is

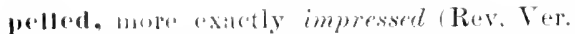
matein), a menulial worl empluged by Mark also, and explatind alrove on 5: 11. To bear

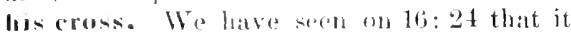
wis anstomary to malie the oundenuned carry his erom to the place at erucitixiou. Meyer show- flat this was u-ually tha mpright pust,

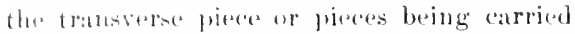

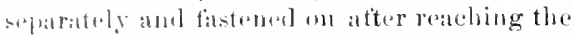
flater in anmo in-tanters (Keim) the alectesed lane the transverse portion, perhape in rares

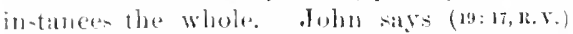
that . besle went ant, bearing the cross for himarle. Sio we must suppose that the burden provel ton great for one who land spent at serplas and troubled night, including the slypuer and farewell disentre, the acong in Gollsemane, the alprebension and series of trials, thre repeatrel mockings and terrible konatu seourging; and when he fell under the furden or wallied too slowly for their enterniences, the soldiers used their puwer of implenting the first stout man they met. luke siys thry "laid on him the cross, to lnate it atter dests." Sumethink this means that Fimun walkal behind Jesus, bearing one and of tha piones of timber: but the more obvious viow is probubly corroet. -On the way,

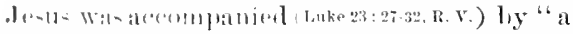

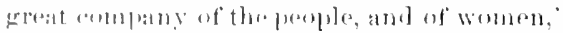
who werelowatiog himp and in temeler com-

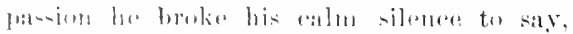

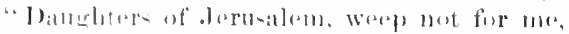

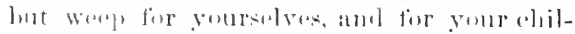
lrom," and went on with an intination of

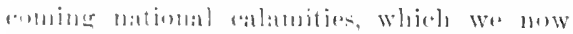

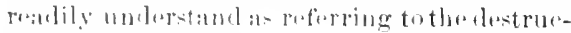

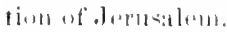

Into a place callod couleothat that is ta -ay, I place of a sliull, ln libbrew gulfoleth is "skull, "from a rout mosning tor roll, indiantiner the erlolublar timm of a sliull.

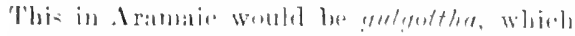
is fommel in flus syrias of Jermsalene, and

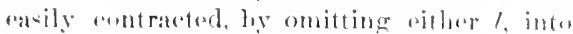

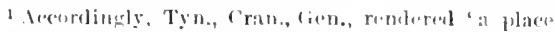
of deal men's skulls, thenuth the birek is singular, "a

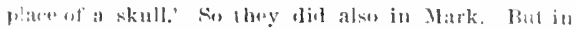
luke (2:3: :3;) this rendering was imposible, and so fley fell back upon the latin translation celcaria, gugoltha (Syriat Pesh., and Itark.), or golgotha, the form found in most documents. Thus the word means simply skull, and so Luke (2:3: 83 , kev.Ver.) salys, "unto the plitee which is called The sliull," while Matt., Mark, and Jolun liave literally "skull-place. The notion was early sugge-ted (Jeronde) that this denoted a burial-ground, or a place of execution, marked by a skull or skulls lying on the surfice. But the Jewish law did not allow bones to remain unburied, and this would have been carefully observed near the eity. So it must have been (Cyri] of Jerus.) a round hill or rock, somewhat resembling a skull in shape. Mark, Iuke, and John all lave the Greek definite article, "unto the place, indicating that it was linown by this nimue. It is conmon among us to eall a roumled mountain-top ur hill-top a head, as "Conar's Head" in the lilue Ridge; comp. hearlland.

It was suggested in the last century (Herzog), and has been fitirly established by Rolinson ("Bibliual Researches") and others, that this camnot have been the platee discoverel at the request of Helena, the mother of Comstantine, and now eovered by "the Chureh of the Holy sejulchre." Golgotha was "without (or outside) the gate" (1leb.13:12), while "nigh to the city" (John 19:20); lut the Churell of the $1[\mathrm{~s}] \mathrm{y}$ sepulchre is far within any probable position of the eity wall at the time of the crucifixion. The reverence many feel fir whatever has been believed for fifteen humbrod yours has caused earnest resistance (1) this conclusium, but in vain; see results uf recont English explorations in Conder. I,

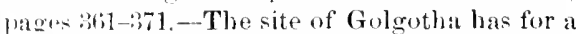
seneration and more been apparently quite unknown. But Thenius, A. D. 1849, ard inclemeluntly Fisher Irowe, pamplilet on "The True Nite of Calvary" (New Tork, landals, 1871), suggested a theory which hat of late been adopted by many. The merthernextension of the T'emple Hill, beyond

which meant skull, and gave us Calviry. Tertullian aldialy began to treat this caluario as the name of a Hate. Thome mentions the notion of some that Adam Was huried in fingotha, and cinrist's hood dropped up $\because n$ his tomb; and says the people liked to hear it. 
34 Thos gitre hum vimegar lo diuk migerel will gall: and when he liat lasted theregf, he would not drink.

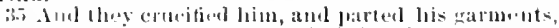

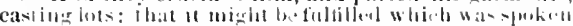

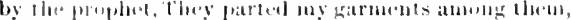
aidd upon hy vesture did they cast lots.

the will-, lias inte a roumled hill resimbling the top of at slull. and some sixty fieet above the Jevel uf the surpoumling ground. A cut acro... the ridge to proteret the wall from being

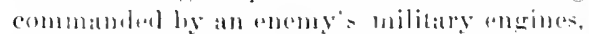
gires to this roumded hill it perpendiculat southern tiones in which is the entraner to a

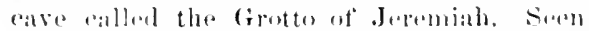
from the Menut of Olives and enther print of gorol riew, this hill looks strikingly like al skull, with a great cyeless sorket. The cht aceses the ridge must have berell ancient, from military meensty, and the eave is probably ancient wo. The theory is that this hill was Golgetha or Calvary. The site firlfills all the conditions $\quad l i$ is ontside the great nerthern gate, and near. The hill rises beside, and its summit is in full riew of the great northern

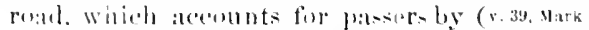
1.5:23): alld the Romans werte aecustomed to erucify in a complionous place, to malke the lesent more notalib. It is in a recione alowndine in ameient tombs, which account fur Jusph's gatrlen ard tomb. And this site aceosunt for the tradition of a hill, "Mount (alvary," which istraced back to the timrth contury. A lewish tratition puints to this hill at "the blace of stoning." i. e., the reurular place fur rexeeulinus. And a Christian tratition makes it the sene of stephent: deatle aftopwards by tmelition locillal olsewheres. - This theory was aldepted by the late Bishon (x)bat of Jerusalem, by (iomeral

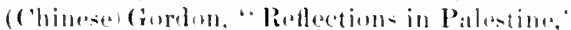

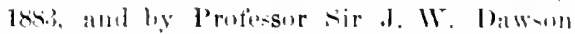

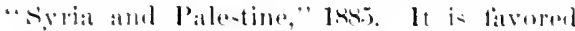

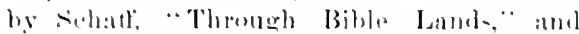

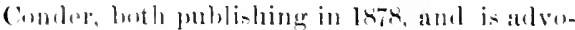
'ated ly Ealer-h. Dr. Selah Marrill, Amor. comsul at oleru-., in "Amburer lioview,"

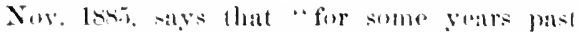
there bas heros a growing convietion" to this eflied and that "hunderels of christian toupists visit the plater arery year, and forw of them gor and uncomvinend that buth the aremententam the strong probability are in favor of" this view

Gave him vinegar (or wine) to drinl, 24t to aly, The plate of a -kull, they gate him wine ho

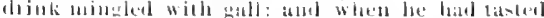

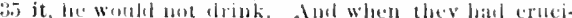

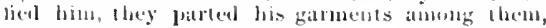

millgled with gall. Mark, "wine mingled with myrrh,' 'The eurrede lext in Mittluew

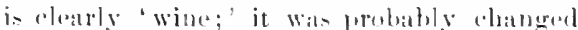
in matry decument- to agrme with r. th beterw;

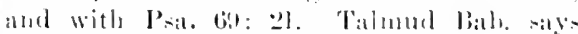

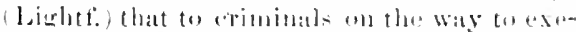
ention was griven at dink comsisting of winn mixed with a bit of fratulincenase to sumpty them, atud that aceording to tratition, the mohle women of Jerusalem furmislaed this at their awn expense. This maty be contrected

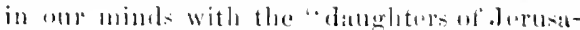

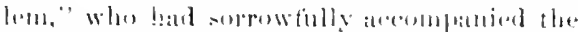

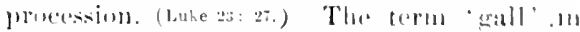

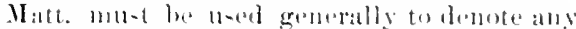

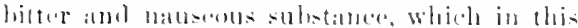

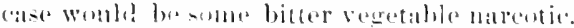
It would frem lieim, Plump.), that Matt-

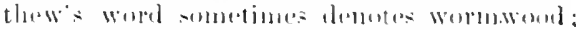

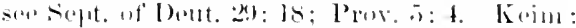
"Tlae drink mierht have been prepsired form

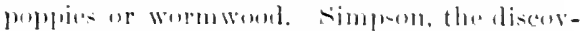
erer of ehlopeform. thoughe of hashish. the

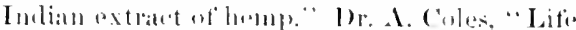

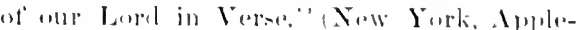
(uil), sugerestsmandraterural, mambrake, "which

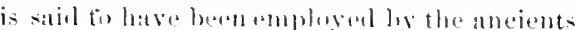

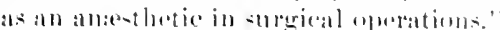

11. 3,j-3x. II, is armedifiel between two

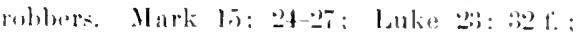
Juhn 19: lis an. And they crucitied him.

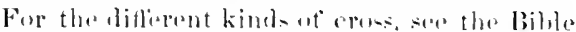

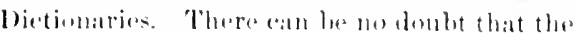
sitviours a less wat of the shape with which we are familar, an mprient best with re trans-

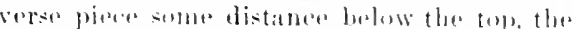
inseription being platerel "athere his heate." But the erous wat net so high a- the ordinary representation, the jerson beine $11-11: 11$ y but

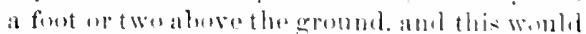
esperially be the ase in lallentine, wheretimher wits searee. Thar hamel-were nitilesl to the transverse bean. This ometimes extemelel nerose the funt at rieht anterle: int in wher

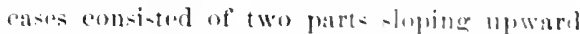
firm the post, se that the lumly atemest te hathe hy the hathels thengh it was really enpported by a projecting jerg. The fect were 
39 Atul sitiog down they watched bim there;

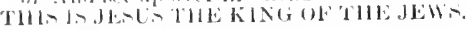

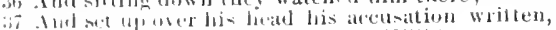

:36 casting lots: and they sat and watched bim there. 37 And they sel up over his bead his accusation writ-

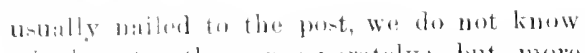

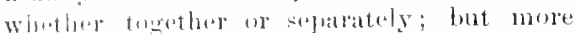

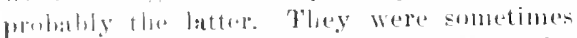

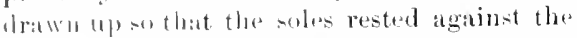

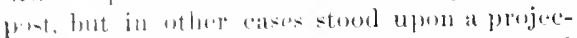
timb. It lias heren maintaimed ly Paulus and

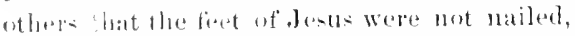

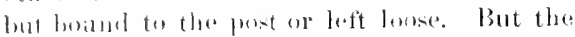

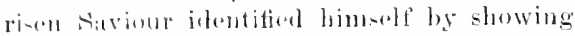

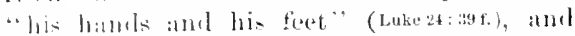
certails supposed ancient evidence that ally

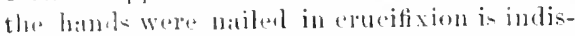
tituet, and far out-weighed by coutrary state-

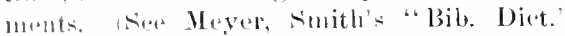
Anur. (1). "Crucifixim)," or Keim). It (an)not he determined whether the sutferer wat

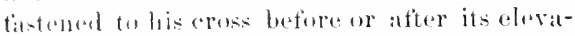

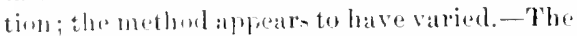
physinal sutforing pronduced by coucitixion wab-fiatrul. The contrationed and immovable pusture of the berly and arms would grad-

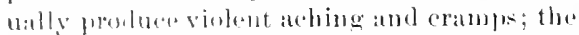
pinereed limbe becanes inflamed. problueing feres and thirst; the circulation of the blowel being hindeled, it githered in the head and luncs anding great distress; the body would erratually grow stitt, and the vital purers

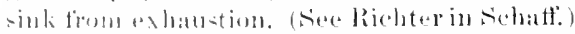

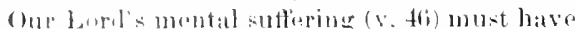
l,apll ereatio still; but we should not underrater the physinat.

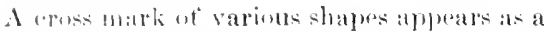

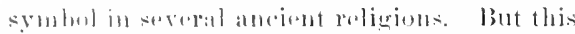
hat rally unthing to do with Christianty,

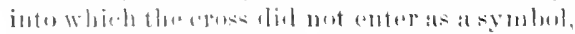

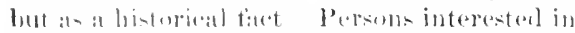

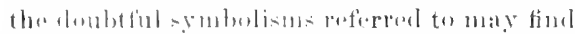

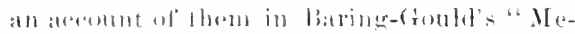

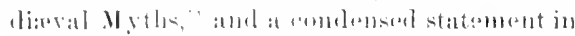

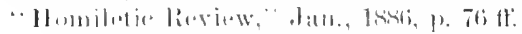

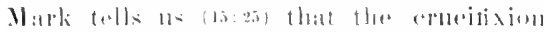

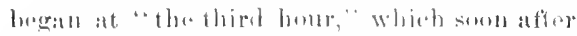

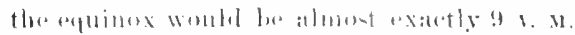

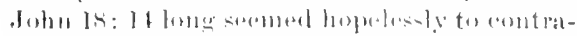
dict this, by say ing "it was alunt the sictl home" when Pilate was ourling the-1rial. But

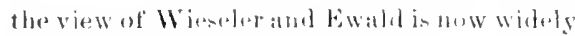

adopted, that the Fourth Gospel counts the lonurs as we do, making the sixth hour is $\mathbf{\text { A. M., }}$ and we conld ansily suppose that the preparations emsumed the intervening three lours. This view is strenuously opposed by Farrar (Aply. to "Life of Christ"), but he is an-wered by MeClellan, f. 737 ff.; see also Westcott on John. All the passages of John in which liwurs of the day are mentioned may be readily understond in this way, and it seems to be necesary for John 20 : 19, when eompared with Luke $24: 29,36 .-$ At this point Luke mentions (2:3::at) that d wos said, "Father, forgive them; for they know not what they do." Evory one feeds that these must be words of Jeens, and they are most frobibly genuine as a part of Luke's Gospel, though it is hard to aceount for their absence from some important early documents.

And parted his garments among them, casting lots. John explatins in detail that they "made four parts, to every sollier a part," there being a quaternion or grous of finur soldiers detailed to crueify and guard each frisoner (comp). Acts 12: 4), who naturatiy took his elothing as their perunisite. Hohn also ands that his "coat, or tmice, the mulergarment (see above on 5: 40), "was without seam, woven from the top throughnot," apparently a costly gament, and no dunbt a gift of atfection, and that being unwilling to "rend" this, they cast lots for it; and that this oceured in the course of providince "that the serripture might be fulfilled (a)mp. above on $1: 22$ ), which saith, They parted my garments among them, and upou my vesture did they cast lots. This furtation from Psa. 2\%: I8 was introdued by some aly lists inte Matt., heing given in $\therefore 35$ by ducuments of no great rabe. Jewish foeling remuired (Mishna, sinnh., VI, 3) that the person of one stripped when about to les stomed should not be left wholly exposed; and though the Roman eustom for crucitixion was otherwioe, we may perhaps suppose that Juwish finding was in this ease regarded.

And they set "p over his head his acen-

to he remered like a pluperfect, 'hat set up,' because they think the inseription must have been put up be- 
40 Anm sal ime, Thou that riestroyest the temple, and

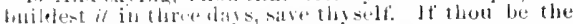

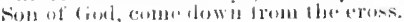

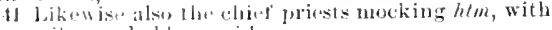
tla" serithes alud chlers, said,

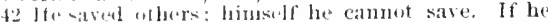
be tlac King ot Jsabl, Jet him now eomedown from the cross, alut we will heline hisu.

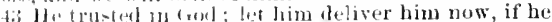
will have hin: for he sajd, I am the som of God.
19 sayng, Thom that destroyest the lemple, and bujlesi it in three days, save llssit: it hou art flesun 41 of fird, come down trom the cross. In like namer also the chici priests mocking him, with the scribe42 atul "lelers, sair], He sated others; 2 himsell he canmot sive. He is the King of Isracl; let hin now eome down from the cross, and we will helieve on $43 \mathrm{him}$. He trustoth on Gut: let him deliver lim now, if he desireth him: for he said, I am the son of God.

J Or. sanctuary...2 Or. can he not save himself:

northem roal. Some have inferred that this mult lave loeen a working day, and not the fir-t lay of the passerer, which would be a siablith: but Elloll. siys that "traveling, whith was forbidelen on sabhaths, was not prohibled on toustalays," adding that "this is distinctly stated in the Talmud." Reviled him. Thr freck word is horrowed as 'blasphemel in a: 3 ; 26 : 6.). and rxphaned above on 12: :31. Com. Ver. tramslated it 'raiked on him' in the parallel pasaigus, Mall 15: 20, Luke 2:3: :3. Thouthat destrorst the temple, ete. This alcelusation (ces on 20 : bil) the ruler had probably spread while preading the corwels to prefer barabbit. Silte thyself. The woml is used lsets (n) 1:21। buth of bulily and spiritual saving. If thon be the som of cod, as in $4: 2,6$. The form of "xpresion assumes that he is the Sum of Goml, but their whole tone and manner slomed lhat they mant the contrary. It is not clase that the . Jaws understoud this ex-

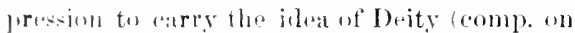
2t: (ii, ) t they artainly understond that one whor a-sumed it ramed stperuatural power.

(b) The chiof priests . . With the scrihrs and plders. Of these three clases

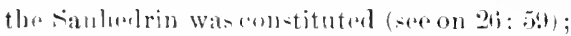

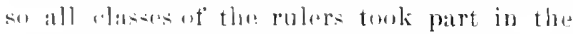
mowking. Mhile the othor mokers all ad-

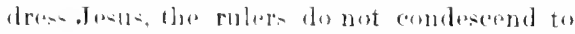
sponk fo him. but sprak contemptumbly about him in hi- prosener. Notice Mark 15: :3, R. V.. "numkine him amonethemselve";

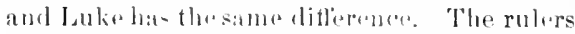
make threw distinet taunts. 1) He saved othors, probably refors to lumbily bealinge.

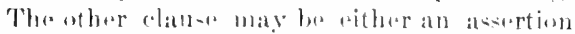
or a question (marrill. Rex. Yor.), as the Gerek in this alase nt expressions makes mo

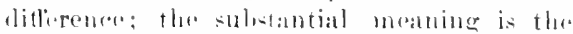
sonder ather way. (2) If he be the ling of
Israel. This is said in irony, derision. He had that moming claimed before them to be the Mesial (20:63 f.), and the Messial was of course to be king; the inscription also dedared him to be the King of Israel. Euthym.: "For as they could not cluange the inscription, they try to prove it false." The irony not being understool, 'if' was inserted, like v. 40 , and passed into most documents, but is wanting in some of the rarliest and best. I And we will believe him, or, on him. They would bave done no such thing. He had wrouglit miracleseven more wonderful, and upon learning it they were only the more determined to kill him. (John $11: 4-53$.) Our Lord never responded to any demand for signs of his minsim. (3) He trusted in cod, properly perfect tense, has placed histrust on God and kesps it there. 'Trusted,' past tense, Con. Ver., is an erroneous translation; "on" here and in v. 42 is the literal meaning of the Greek preposition. The similar words of Psa. 22:8 probibly oecurred to the rulers thromgh general "familiarity as expressing their thouglit-a surt of unconscious Messianie quotation (comp. below on v. 4b), like the momscious Messianic prediction of Caiaphas in John 11: $51 \mathrm{f}$ - Ealersh.: "These jeers cast contempt on the fur grat facts in the Life and Wurk of Jesus, which were also the molerbying ideas of the Messianie Kingdom: the new relationship of Isracl's religion and temple ("thon that destroyest the temple and buililest it in three days') ; the new relationship to tho Father through the Messiah, the sim of God ("if Thou art the son of God' R. V.); the new all-sufficient help brought to buly andsoul in salvation ("Hesaved others"); and finally, the new relationship to Israel in the fulfillment and perecting of its mission through its King ("He is the King of Israel, R. T. .,."

I Wanting in N B 1) L, 33, 102, Theb. If originally present there would have been no objection to it. 


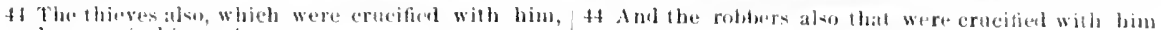

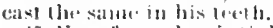

15 Now from the nixth hour there was tarkness over to alf the land unto the moth hour.

(10) Lulke states (23,3is that "the solliliers th also mockent him." offiting him the som wine they were atrinking. At a later periond, this wat - griven him in kindluess, (Jolun 19: 29.)

1) Whe thieves also: better ats in Rev.

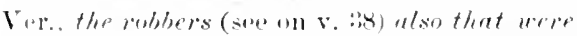
crecifiat with hime cest "prom home the sump

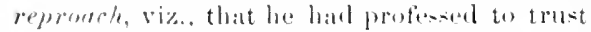
in find and elatimed to be the son of Gosl, and yot was not now delivered. Cant the same in histeeth, is a vigulous imilare of Com. Vir., lut not presented by the crreekl: llark makins at similar statement, "they that were erureitied with him reproneled him. But in Luke we lind a striking differences.

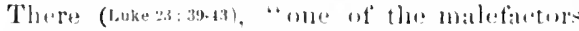
ratied on him," at: pretenting to be the llessiah, while the other bellesed that he were the Ifeniah: yea, more diecerning than the Twelle he believerd that thengh now despied

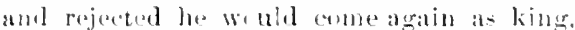

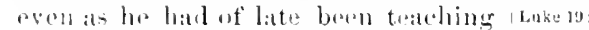
11 r.: M:te. $25 \cdot 31: 16: 28)$, and in humble petition atid, "desus, remember mo when then comat in thy kingdum," li. V. How he learnod s) much, and anderstomel sus well, we do not kunw; but the savionr, who math no pespunace totatunt and revilingr. from Whatsonever soured, allswered the first worl of petition, and promiand more than he batul

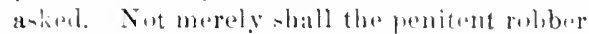

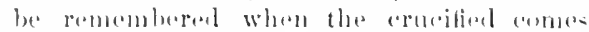
atrain a-king, but "To-d lay -halt thun be with me in Paraliee." -Now the quention halaben

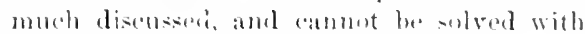

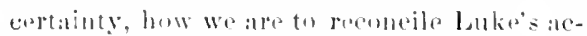
count with that of Matt, and IIrk, The prevaling viow is that both the robber at

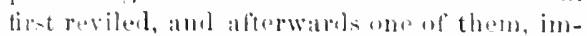

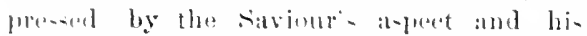

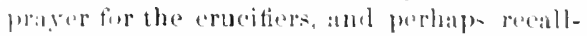

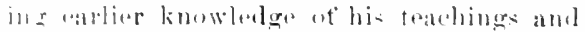

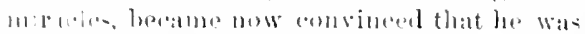
inlent the Me-niah. This makes it all the more wemlertill that he -henld underetand so

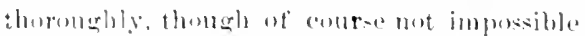
umber special divine influener. But II att. and llak may be molertwol, with matny expositurs, as merely including in general

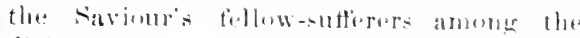
dithorent dase of revilers, without distingubling between the two, which wombl hatre requited a full aterount of at matter they

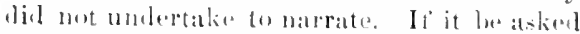
how they could omit this, the salue pluestion ariogs ats the the giving only ante of the andon worts on the erome and so in mally other caros. In this viow the pentent roliher may hatve become a beliexter in Joens as the Messiah on some darlier day, since his erimes get

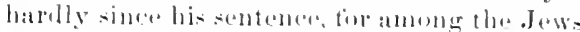

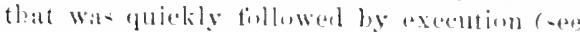

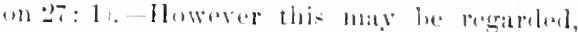
we mu-t remmber the gemeral and impressire fillet that dents wat revilend by many

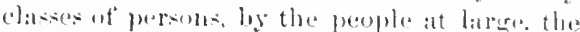
rulies (all seretions of the sinhedrin), the mbliers and aren partieipation in -tulering dich not pevent reviling. This mocking and maling probably began yhen he wal tir-t lifted on the crom, and continued from time to time. Oberve that all the verto here.

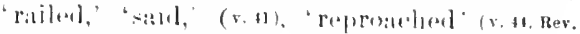
ver. , are in the Grokk imperfect temst, demot-

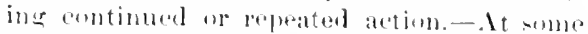
point during the dirst thee henrs ocentred the

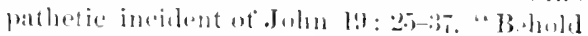
thy" som," and "Behohl thy mother." Thu= the savienes sulke three times that we know of during the tirst halt" of the correitixime.

IV. 1.5-50. Ho cries out in the darlinese, ant dies. Itark 15: :3:3 35; Luke 2:3: 1t-46; John 19: :2x-80. From the sixth hour. . .

unto the ninth hour eomp. on 2 (1): : from

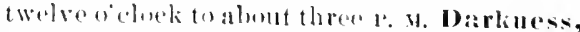

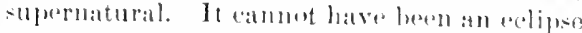

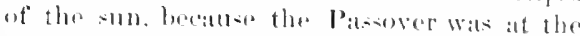
midille of the month, and the month alwaye began with the new monn. so that the mem Was now full, i. f., on the opmesite side at the "arth from the sun. Thus all the loner disens-

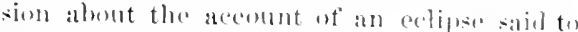
hase been given by Plilegun, a writur of the second century is beside the mark, for this wat not an eelipe. "The surl's light failine,

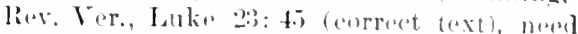
mot man what is technically callund an echipen. but -imply states that the sun falled, without 
4; And about iht ninih bour. Tesus criex with a loud

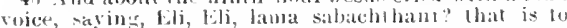

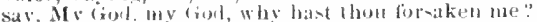

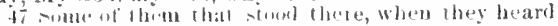
that, sidel, This mon calleth tor Elias.
46 all the land until the ninth hour. And about the ninth hour Jesus criel with a loud voice, saving, kit, Eli, lama sabacht hani:" that is, Ily liod, my (iod, 472 why hast thon forsalien me:" And some of them that stuol there, when they heard it, sail, This man

I Or. earth...2 $0 \mathrm{r}$, why diast thou fursuke me?

iurliating tho aruse. Alt men fael alarmed ly any sublen and errat darknes. The Rab-

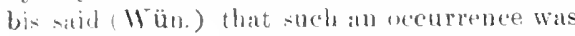
a bad sign tiop the world, alld was to be ex-

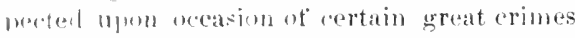
or mi-fortumes. Wretstuin has many pastages fiom frack and Latin authors showing a similar fincling. Over all the land, viz., of Patertims. The word might muan 'earth' (metrgin Rev. Ver.), (om) on s: 5 ; but it was diak, naturally, "val balf the sarth, and a miraculous darkneso over all the enlightaneel batt is imporobable, seeing that sis barge a fropertion wi the perams involved would mot kmow its motuing, and so it would be a II- less mirale. The suprematural darkness

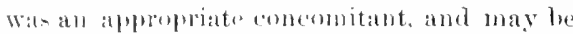
renaleded as a sert of symbol of the Saviour's mental suthering, which at last found explession in his loul ery. Through nearly all this freimd liesesems to have continued silent. Ite must have been enduling a dark sorrow, a arushing griof, even greator than in Gethsemand, waing that ha spratis here in morr in-

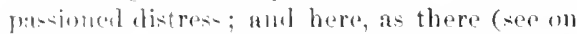
20; 44, it can be axplatined only by tha fact

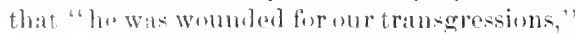
wa- "maklo sin tor us," "grave his lifo a ransmb for many" (womp. on 20 : 28). Cried will a loud voice, showing groat suffering. Eli, Fli, lama sabachthani. The original work- ale griven, beatur. Eli, explains the

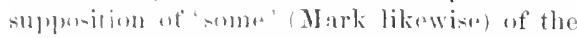
lystanturs, that ho was ablling for Elijals. That fir-t word are hore given in the Irabrow, hise the Psalm, hut hy Mark in the Aramaic Elui, which Jusus haul duhtotlasespolion. The last ward is revan by both in the Araisatic (so in tho Taroum, Bustorf, the IInbew haviug

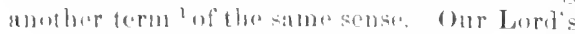

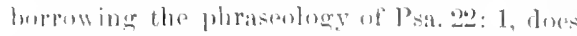

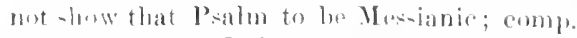
hi-horowine in Luke 23: flitom Psa. Al: 5, ancl lis answermer ateh of Satan's three sporial demplations by guoting from beut. chap. 6-8. Still, as Psalm 2:2: 13, was a Messianie proplicey (Jobn 19:24), we may suppose that 22: 1 Was de-igned by the Spirit of inspiration to brased by the Messiah on the cross. It is commmonly said that Psa. 2.2 was not regarded by the Jews as Messianic. Elersh. (App. IX) gives two references to it $(5,7,15)$ as applied to the Messiah in a collection made in the thirteenth century, but believed to consist of ancient material. Tertullian thought that Psa. 2n "contains the whole passion of Christ." Why hast thon forsaken me? A more literal translation would be, IFhy didst thon forsalip me (margin kev. Ver.), but it would amount to the same thing. 'Why' is not hre 'for what cause, but 'to what end'; yet the distinction must not be pressed (comn). $9: 4$. If the question be asked in what sense "thr. Fathor forsook the son, the answer is that we rally do not know. In himself the Savionr was still well-pleasing to the Father, in voluntarily laying down his life that he night take it again (John 10:17f.); it must lave been as our substitute, because he "bare our sins in his mon body on the tree," that he was forsaken. If it be asked how he could feel himsulf to be forsaken, we must remember that a human soul as well as a liuman body was here suffering, a human soul thinking and feeling within homan limitations (Mark 13:32), not psycholugically unlike the action of other devout souls when in some great and overwhelung surpus. Comp. W. N. Clarke on Mark 15: 84. Hanne: "It was the sensible comfort only of the divine presence and faror that was for the time withdrawn; the felt inflowings of the divine love that were fur the time ehecked. But what a time of agony must that bave heen to him who knew, as none other could, what it was to bask in the light of his Futher's counterance; who felt, as none other could, that his faror indeed was life! On us-so liftle lowe know or feel what it is to be foralim by God-the thought of it, or sense of it, may maka but a slight impression, produce

1 II hruw 'azhthami, which some "llestern" ducmments have endeavored to reproduce here by changing intu zopleheni and sinilar forme; so also in Mark. 
4. Ind stragluway one of them rati, and lomk at

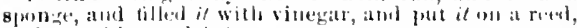
an.l gave lian lo Iriuli.

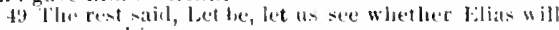
enime 10 silve lim

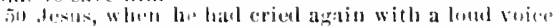

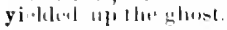

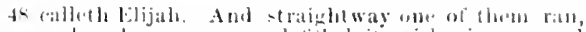

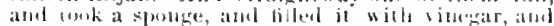

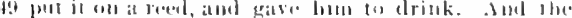

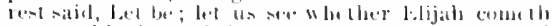

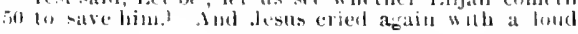

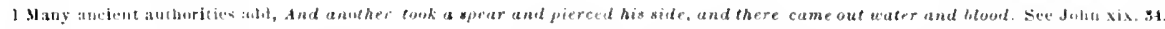

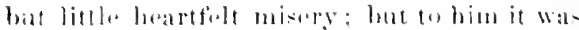

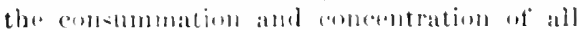
were bevond which there was and enduld be no decper aneruish tior thesout.

Whis mall calleth for slias, or Elijeh. The errand lierure which Elijah mate in the histors, and the promise of his aming in Mal.

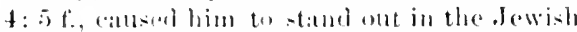
mind as the greatuet of the prophets. Thero

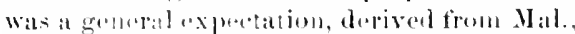
that he womld work varions womders (comble.

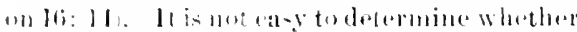
this utteranes was a mocking misrepresenta-

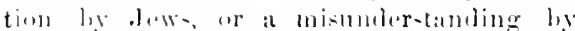

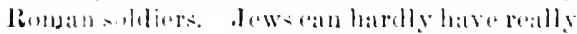

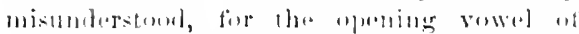
E i hat lo the ()riental war a vely diflerent sommel from that at Elijah. Suldiers, it lomen resident in Palestine, might have becomm acpuaintel with tho pepmlar expectatums concorning Elijab. Eave him to drink, is

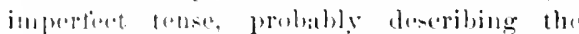
kimbly soldier an repeatedy applying the

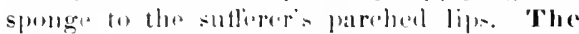
rest sate impertient tense, describing them as contereel in sagilly. Bengel: "Altur the

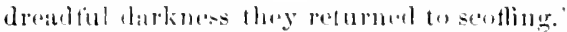

Let be, let thing-stay as thes are; do not grive him any aid or comfort - re if Elijah will hear his prayer; fir it'su, all bis walls

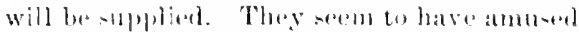
themelves with the thought that this fres

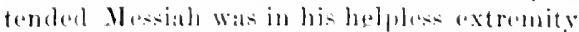

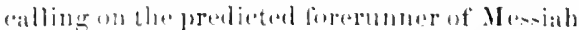
(1) enue and help him. Whether silas, or lijah. will come, or is moming. Is to sirlling Elijah, insteal of Elias, see on 1 : 2.

1 The :aldition in margin liev. Yer., 'And anotber fouk a purar and pitered his sich, and there came out water and blowl, musl le rearded a- an insertion from

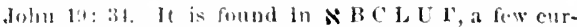
sires, and lass important versions, Chrys., Cy rit. Thus only shus, as we have scen in several other cases (comp. on 21: 3: hthat $\mathbf{N}$ B, even with other support,

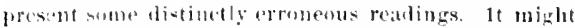
Ire argend that the worils were onitted because they r"pre-ent the pierting ats preceling the saviour's

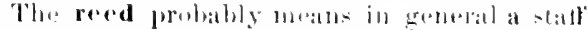
for walkingr. Whiels we in like malmere all a eane. From John l!1: 20, it alpurats to have leeen made from a salle of hysere; and Toro Iram ("Nat. Ili-t.") says that the catpel,

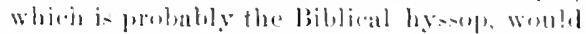
furnish a stalk three or tisur lewt in lenerb.

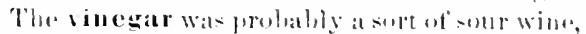
thougle vinegar ilselt (no doulut aliluted wilh

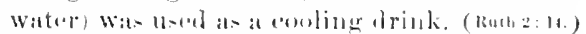

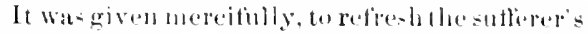

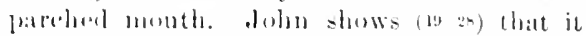

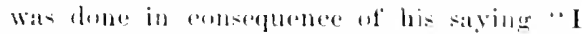
thils.". IJ" had retused the slupelinger draterhe at the buginninger but asked tore thi.

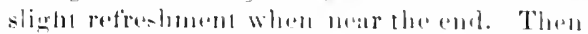
ha utteral a third word (.lohn), "It is tinjoluel," and fimally a fourth Lakes, "lothor, inte thy hand- I commend my spirit." so

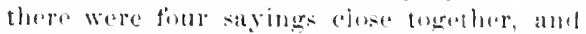
near the end; amb with the there ntered luriug the first three homers wat find in all

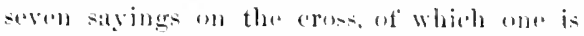
recorded by Matt. and Mark only, three by Luke anly, three ly Juhn only.

Cricd anain with a lond voice, Mark likewise. This seems to denote great bodily

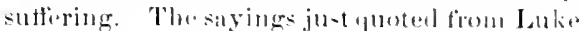

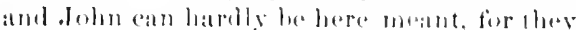

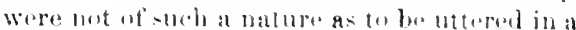
lomd roiee: it must latre berna a ery of pain or distress. This grant matery in the monnent of dying was not a nallural result of mene death liy erucitixion, which wemld promber gralual "xhatustion. Taken in comberiom with tho blond and water hrought forth by the soldier's spear (John in as), it hals berin

death, wheroas . John makes it follow: hut that ditlierence would onls lave been a reasun fur romeving the

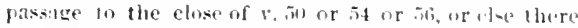
"ould hare heen sume tampering will the pusition of the passage in . Inhu, which is not the cate. The bas sage of Juhn was 11 riften by some stude gin of Mat from nemory, and by a eopri-t an $k$ wardly introduced into the text. No eritio wuld question this, but for the perstasion of some that $13 \times \mathbf{C} L$ "can do no wrong." 
51 And, behold, the vail of the temple was rent in

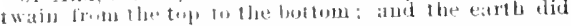

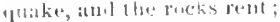

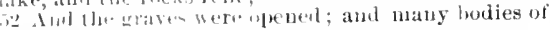

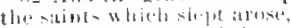

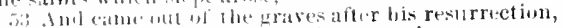

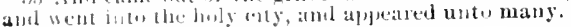

5t voice, and yolited up his spirit. And behold, the veil of the $i$ (rmple was rent in twain from the top to 5. the bottom; amb the earth id quake; and the rock: were reul; and the tonds were opened; ant many

5.3 bolite of th" saims that har fallen aslece, were rased ; and ensuing forth out of the tomitis aiter lis resurraction they entered into the holy city and thought to show that our Lord dient from a hurbling of the heart. This is atgued with

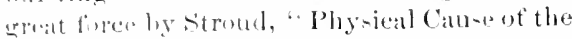
1).ath of ('hrist," republisbed in New York,

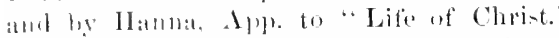
Tha que-tion jumanes a certain kind of intere-t. but atomot be suttleel. Let u- leware of

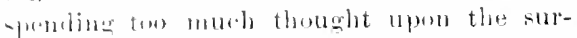
poundines and phrsicat eontitions of nur Lared's death. 'The great matter is that he "dind for anr sins," "tasted death tor every man." - Yidaled up the ghost (spirit). 'The clo-ine repiration seems a natural indication of lecting the immaterial in us, which is otemet rathel s,irit, go forth from the body "anto (iont who wave it." 'Gave 11]) the ghro-t wa- gurl in old Engli-h, but we donot nuw une "erhont in that soluses.

50-5.5. Portunts following his deatb, and

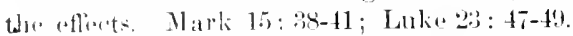
The vall of the temple (mats, see un $4: 5)$ ), wat a richly wromght and heave cartain.which

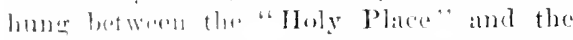

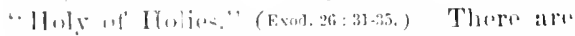
some 'Talmonlie state monts to the etheret that this vall was domble in thr seomml temple,

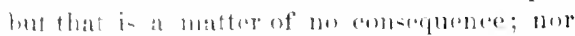
latre wo anythinge to do here with an outrer

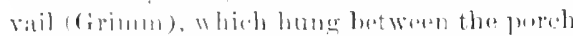

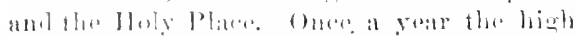

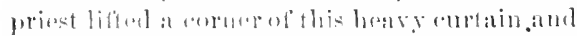

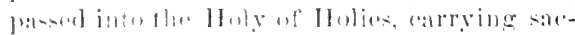

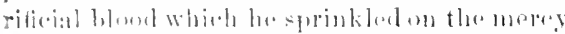

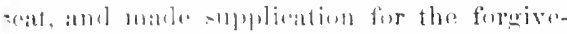

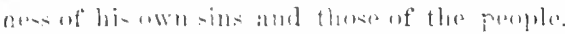

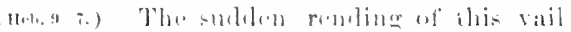
from the top to the bottom Malk liknwion, showing llout it was not lome by humbul

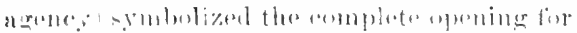

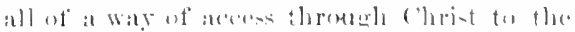

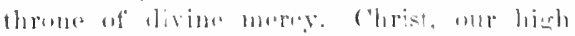
priest, hil= entered hle true Huly at Holios in

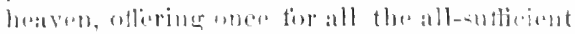

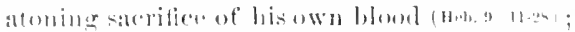
and now in his mane we maty losk without dreitl upon the very throne of God, and come with bullness to the throme of grace. (neb. $4: 16$ : 10:1\%.) - The other portent is mentioned by Matt. only. Earthquakes are eommon in Palestine, and this carthquake need not be thought supernatural. The earthquakemight naturally rend pocks and open tomlis-not graves likewurs, but tombs in the rock. (Comp. on 27: 61.) But the rising of the read was of course supermatulal. Notice that they were hodies of the saints. The clause after his resurretion is ambiguous, as it mathe connected with what precedes or what follows. It is mors naturally eonnected with what follows; then we molerstand that they rose at the time of Christ's diath, when the earthquake "proed the tombs, but appeareel only after he alpeared. It may be that they appeatred only to believers, who knew that Jesus had risen. The eonjecture of Plump. concorning this matter is of some juterest. He holds thit the tombs opened by the atrthquake were near Jerusalem, and as the term "saints" was alurost from the first applied to Clristians, he thinks that these saints were believers in Jeats who hat died before his crucitixion. On this supposition, we see some renson for their appearing to Christion friends and kindred, in order to show that they were not slut out from a share in the kingdom. ('omp. 1 Thess. 4: 18f.) "Thestatrment that they did not appear tillafter our Lord's resurrection, is from this point of view signifieant. The discijules were thus tanght to lowk on that resurrection, not as an isolated phenomenon; but as the "first fruits of the rietury over A.ath (1 cor. 15:20), in which not they themsedve only, but those also whom they had fordi and lust were to bo sharers." - The holy (city, comb). wh 4:5.

Our Lumd's denth is deseribed as specially impresing threcelasses of persons. (a) The limman ewenturim, or as we shmuld say, (at)tain (sox (1) 8: 5), and also his soldiers who conducted the erucifixion, were convinced that 
54 Nins when lle centurion, and they that were with

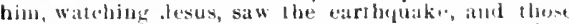
things that wrre tone, they leared greally, saying, Truly, litio was the vin of limi.

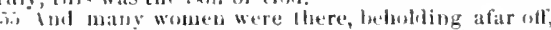

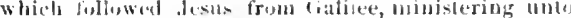
him:

j; Ammen whinh was Mary Magiatene, and Mary

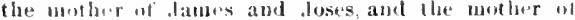

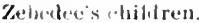

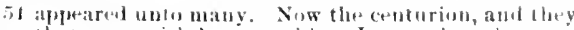

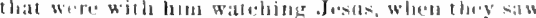

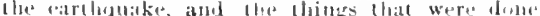

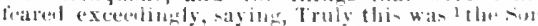

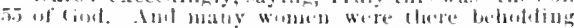

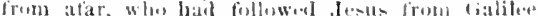

it) minisloring tuto him: anwolg when was Mary

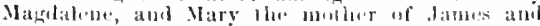

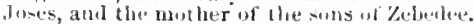

1 Or, a son of fod

Jesn: was what he chaimed to be. When ... they saw the earthinalie, and those thing- that were douc, were trling plare (correct text), ar coming to pass (comble on 1:22, alpatently referring to the longecon-

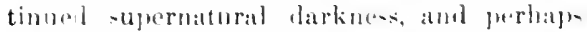
alsu to the siviour's aspect and expressions, they fented experdingly. (Rev. V+r.) Well they might fadr; for they hatl beren engaged in puttiog to an igmominims desth une who, a- they now folt stere, was not it remimal, not an impu-wr mor a fantic, but truly the Son ol cod. Was, becation his litio had ended. Mark has tho same expresiuna-Matt. Lake gives " ('ertainly this was a rienteous man." If $-1, h_{1}, W_{a}=$ what he alaimed to be, and he had chaimed to be the sinn of froml. So tho ditference is moly applarent, and in falct we may in this ate sulpuse that he nsed both expresoinn. The Grevk might mean "as som of Goul, and sompe suppose that the herathen conturiun thomght mly ut ane among many domiends. But this creek phraso is bery

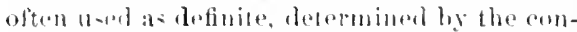
neretion, and here it is eas to to suppense that he? had borrowed the phrase from the Jews, and

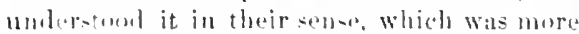

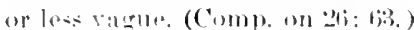

(b) * Ill the multitudes that eammetogether to this sieht," the throlles of dewish spredattor- (boke t3. Ax, Res. Ver.), "returnal-mitingthoir brata-ts," satistied that a great wromer had herm dones, and fiaring abat they would sutter tor it.

(1.) Maur of his own folluwers buheld hi. death, with the derpest erriet. Many women. But lulit mentions alio) men-"all his ate-

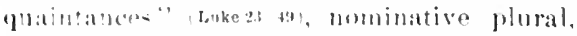
manculint. Boholdiug afar ofl, thrment timidity, and throueh deliesey. The only womm of his following who enmenear the cross were his mother and hor sistor. Mary the witi uf Clupas. and Mary Magdalene. (Johnig-23. Ministering wuto him. They per-mally bunght and prepured food; and they alsil furnished money whorewith to porchatso found and] to jaty for anoking it-all thi- heines sllegentid by the torm and cireumstances, comple. Lulies: 2 t:

Mary Magdalene, i. e., from Migulala,

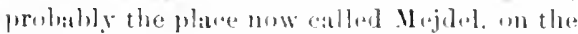

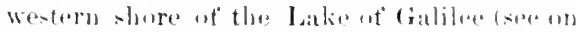
1.5: :3e, whare the (enrreet text is Matualan.) Mary Magdalene has reserived seant justien in Chrietian liturature and art. Thu hotreatlic.

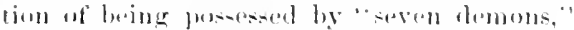

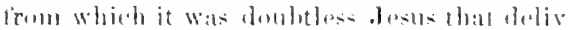
ered her, does not jorove that she hat been ex-

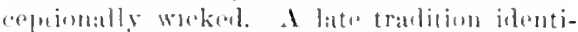
fied her with the "woman that was a sinerer,"

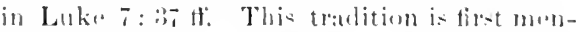

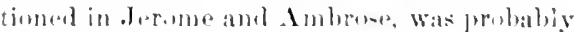
nenthing hut an inferenee from the sovere dre moniacal pousesion, and wats nevor repoiven in the Gireok Chureh. The illentification is

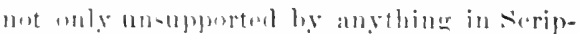
ture, but remberel hierhly improbuble by llos way in which lake ju-t aftorwats mentiuna

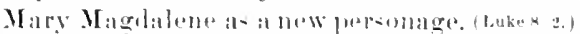

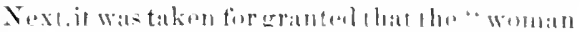

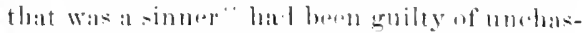
tity, and upmon l his fommdation only, thishighly. improbable tralition, and this uncertain

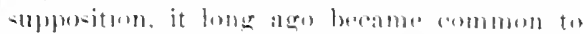

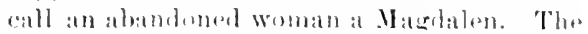

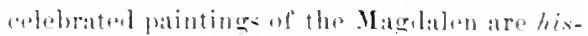
torically an ahominaliom, and roligiensly quile* hortul. There is at brodien a paintine "of the scollowl of "Titian." which represent- her as a woman at millle age once very batutitul. with deop lines of -utlinerine in her fare hot mere it atl a look of gentenese, peaces, and anutlerable gratitude. This comereption in his-

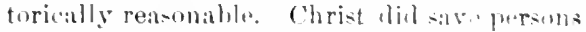
af the clase to which she is uswally refirroul (21:32, and will save sueh fersoms-zill it they ropent and believe him: hut that is nu reasun for involving this speosal friemel of his in modeserved dishonor. The usage abunt Mary 
canumet now be wholly corrected, bat it may ho persomally avoided. With this listof three womon, "Itary Magdalene, and Mary the motler of , lames aud Joses, and the mother 1) tha soms of Zebedee, 'eomp. Mark's three (15:4), Rev. Ver.;16:1), "Mary Magrlalene, and II ary the motler of Iannes the Little, and uf . foses, and salome." This leares little loubt that the mother of Zebedee's soms was Salome. Xrain, in John (19:25), the womm prosent are " his mother, and his mother's sister, Mary the wife of (lopats, and Mary Magdalem." Ilere his mother's sister might be Mary the witi of Clopas. But it is not tikely that two sisters would be named Mary; and if wo mmlerstand that here are fomr distinct purouns, then they tall into two groups, the fir-t gromp, being two unnamed persons, the soroul two naned persons-and this rhythmiloal form of statement ( W esteott on .John) resembles the style of the Fourth Gospel. Now it is gramally agreed that .John's "Mary the wife "f Clopas" is the same as "Mary the methere of . Iames the Little and of .loses" in Mark and Matt. (Complom 10: 3.) Leave a-jete then the mother of Jesus in John's list, with Mary Magdalene, who is the same in all, aml it becomos highly probable that salome, the nienthre of Zeberlees soms, was the sister of our Lurdis mother. This theory belps to aceount tor the prominonee of . Janes and John, ard for tha ambition repuest ot their mother in 20:20. 'Then also Johu's omjssion of his mothar's mano would be (Westentt) exactly like his anstant omission of his own name. These levout and loving women, and (Luke) some mon with them, saw for themselves that the Mastor really died, and where he was buricel. (v61.)

\section{IIOUILETICAL AND PRACTICAL}

Sermons and herotimal books often give nverwrouglet deseriptions of the erueifixion. The faeling axeiterl by contemplating it ought to he natural and genuine, and not galvanized. It is bettor to initate the reserve

1 Rerent hymn looks have:

"Munt Jesus lwar the cross a one." ete.

Harine in youth lowal it sune with "simon" insteal, wr have long been sati-tied, on prineiples of fext criticiom, that this was the original form, A findul who has given much attention to hymmolocy, recumly stated that the stanza in the aborequoted and simplicity of the Evangelists, maling our narration and deseription quiet and inelaborate. Any other course is injudicious, in questionable taste, and really irreverent.

V. 32. Simon of Cyrene. 1) A man sharing undeserved reproach. 2) A mau rendering involuntary service to Christ. 3) Yet, let us hope, learuing to walk voluntarily after Christ, bearing his own cross (16:24), as we know that his twosoms did. (Mark 15:21.) CALvIN : "In the sight of men, this task brought him to the lowest degradation; but God turned it into the highest honor."

\section{"Shall simon bear thy cross alone, Ami other saints be free? \\ Each saint of thine shall find his own, And there is one for me." 1}

V. 33. Because of Gethsemane and Golgotha, we sinners may hope for Paradise.V. 35. SHAKESl'EARE:

"In those holy fields

Over whose acres walked those blessed feet, Which fourteen hundred years ago were naited, For our advantage, on the litter cross."

V. 40. "Save thyself." How easily he could have done so! But his object was still to save others (v. 41); be was dying that men might live. $-\mathrm{V}$. 42. Euthy. "And he would have come down, it it had been true that they would believe. Like them are many now who propose their own conditions of belining, but really would not believe on any condition." CaLvix: "It is too eommon with the impious to measure the power of God by present appearances, so that whatever he does not do, they think he camnot do." V. 46 1) He is my God, yet he has forsaken me. 2) He has forsaken me, yet he is my God.MPS. BRow

"Yea, onee Immanuet's orphancd cry his universe hath shaken.

It went up single, echoless, 'My God, I am forsaken!' It went up from the Holy's lips amid his lost creation, That, of the lost, no son should use those words of desolation."

\section{47. Hexry: "It is no new thing for the}

form is taken from the "Penitential Cries" of Rev. Thomas shepled, of Braintree, Essex, England, publi-hed in 1692. The hymn in its now common shape has borruwed only this one stanza from the originat. It is credited in some collections to Prof. G. N. Allen, 185.2 , who wrote the familiar tune, and may hare made the changes and the additions. 
5i When the eren was conc, there cante a rich man of Irimathea, mamed Joseph, who also himstl was Jesils' alisciple:

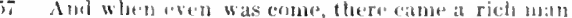
from Arimathea, naned Joseph, whe also himate most pinde devotions at the best men to be

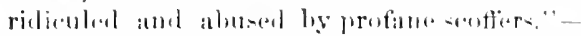
V. so. Itis. TAYlon: "O holy and imma(d1-

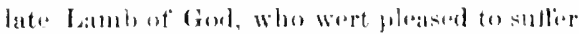

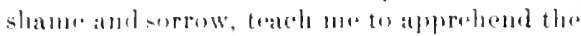

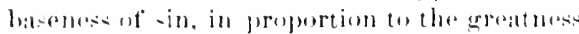
of those a al:mities whieh my sin made it neeessary for There to sutfire, that 1 mal hate the

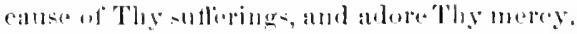
und indate 'Thy aharity and ropy ant 'Thy patience and homility. and love The perem to the uttermont extent and degreses of my at atfections." - Through the cross at ('hrist may

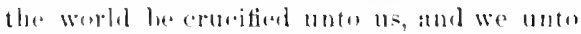

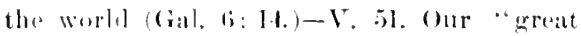
llierh lereet, Je-us the fion of foud," lais passed through the vall of the heavens into the trues salletuary, and there ever lives to intereede; lot us thereforre enme with loldenes.

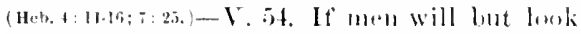
camdidly at the life and death, the teachings: and elaims ot .lesus ('hrist, must they not acknowlenles him to bes more than a meres

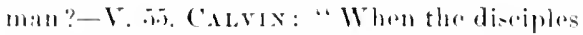
hat fled hither and thither. Yet solne women

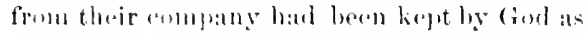
witue-ses; more brightly then slone ont their piety towardis the Master."

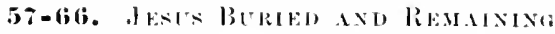
IN THE. ToMn.

Fonud alst in Mark 15: 42-47; Luke 2:?: 50-.;it; Joln 3!t: :31-t:2.

Boforethe interment comos the proposition of the .hews (sono) to break the lears of the

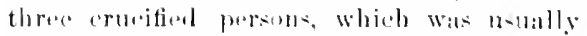
Lollowed (Eder-h.) by giving them a deatlistruke. The object at the propusition was that they might die and he remosed hefore sun-et, whentherententshath of the l'aserver weok womld herin. The soldiers wore sur-

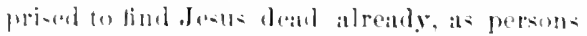
ustatly romaimed alive on a cross more that twety-tine lusurs, and sumetimes even fir three ditgs; and one at them piereed his side. wiele a prear, bringiug wut bleod and witer. John appeats to this as seon hy himselt, probnbly bueanse it proved that Jesus had a real buman burle in appunition to the Dorectic

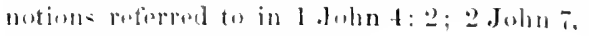
and that be was really dead.
1. 5\%-61. The lutial. Luthe": "From this comelusion of the history of our Lard's mation we sees what the death of our dear

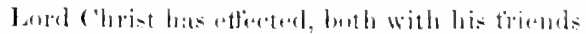
and his anemies. The amemies becomen unquire and toartial, and evidenty tall deeper intes sin. But thess who lovethe land christ.

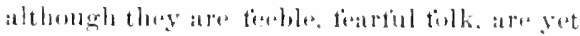
through the deathof ('hrist com-oled nut countidelit, and venture now npwe what lueline

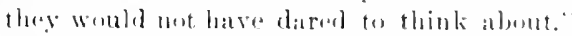
IV a seethat the Father, who alpleared to have "torsalien" Christ, is rxercisiner al sperial provilence orer his death and intarmont, with reference tor his spesely resurrection. His homes were mot loroken likw thowe at the robluers, nor his boxly flumer inte a public ro"eptatele, but while "numbered with tritungresure" he" "was with the riell in his diath"

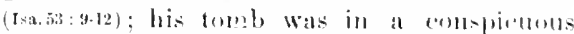

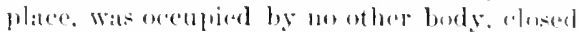
with the guvermment seal and guarded by Roman soldiers-When the even was come, towatrds sunset. whicle at that siatum womld beabut fie. I. A rich man of Arimathea, a flace not otherwise known. The name is obvionsty formed upun liamah, "high place, dual liomathatio, the mante at several eitien in lale-tine. Lulie says it 11 as " a r.ity

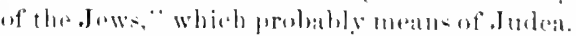

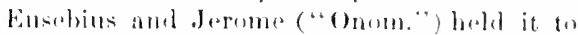
ho the Ramathaim of 1 sian. 1: 1, which was Sammol's hirth-phace, apparently at fow milas

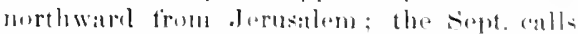
this plater Armathatim, ambl Jos. ( 'Int.," it, 11. 2) Armatha. The fitet that Juseph wats riab explatins his owning ermunds natr the city, amb aloo adde imprortance to the marlis of resperet be paid to Jesess. Matrk arel Lulie siy lo was "a coumeillor," i. e. a member ul the sanhedrio, and Luke ablols “a gaod man and a rightedus-he had not comsentede to

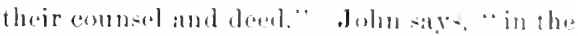
phace where he was eruedied threre wate at garilen, and in the gardun it now tomb." Howph may hasestomi in hic galuder. which prorlatpe ocempied a slope of the hill on whose

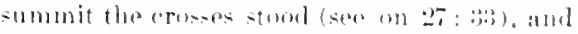
his eve filliner on the unecenpied tomble he determined upon hiscourse. Who also him. 
Fs Ile went to Pilate, and begrea the ludy of .Tesus. Then pilate commonaliel the budy lo be delicered.

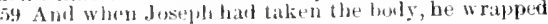
it in a chean linen clobh,

(i) And lad it in his uwn new tomb, which he had hew out in lhe rock: and ht polled a great stone to the door of the sepulchre, and dejsaried.
58 was Jesus' disciple: this man went to Pilate, and askel tor the budy of Jesus. Then Pilate com59 nuaded it to be given up. And Joseph took lhe 6it body, and wraner it in a elean linen eloth, and laid it in his own new tomb, which he had bewn out in the rock: and he rolled a great stone to the door of sell was Jesus' disciple (comp. on 5:1), Iohn alding "but seeretly, for lear of the Jews." He the more reatily became a disriple beciluse (Mark) he was "looking for the kingrom of Goll." Went to Pilate, Mark alding "boldly." It required courage to offire so much homor tu one whom his assuciates of the Fambedrin har sentenced for blasphemy, and whe had died an ignominions death. He had shrunk from dectaring himsalf a dis.jple, but nuw, when all the world had turned againt Jesus, he came ont holdly. As the execution was by the Roman authorities, their permisson was maturally required in order to talie eharge ot the iody. Tho Pumans often left the brulies of rrupified persons on the eross iill they decayed or ware devoured by birds of prey, ju-t as in England and the Ameriean colonirs borlies used to be hung in ehains; but tha law al Moses raguired that a dead boty fumennatros should not romain over night, as it would defitetholamd. (Jut. 21:23,) Jos. says ("War," 4, 5, 2), "The lews are so attentive to the pites of sepulure as to take down even thore who have molorgone the sentence of crucitixion, and inter thom before sunset." Brerered. Asked is the exact meaning, mot

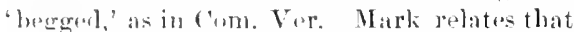

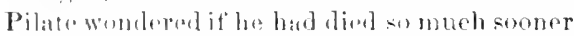
than was commom with the remeifiod, and sont tw ask the resturion in "harer. This message (thomel the distance was small), and the va-

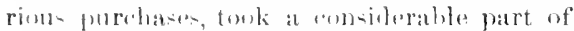
the time lutwerenthere and six o'eleck, and

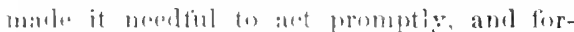
tmmatr thit "lhe tomb was nigh at hand" (. Iohn). commanded tho body to be dolivered, mot maniring momer, a was so arm-

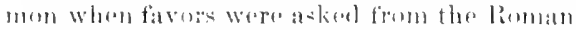

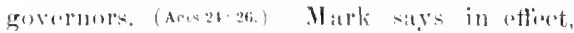
"marle a prosent of the corpese to dereple,

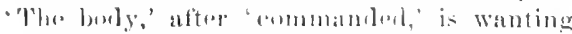

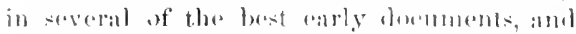

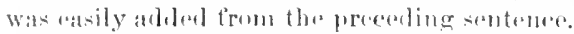
- Il was, perhaps. some lithle comblort to b'ilate, to see respect shown the remains of one whom he had so reluetantly yielded to an undeserved punishment.

'rook the body, Mark and Luke 'took down,' which was the "dcseent from the Cross," su often represented in pictures. They of eourse washed off the stains of blond. Wrapped it in a clean liuen cloth, which Mark mentions his purchasing. John aclels, "There eame also Nicodemus, he who at the first came to hin by night, bringing a mixture of myrr and aloes, about a hundred punnd weight." The hundred pounds (probably of twelve oz. each) could be easily borne by two servants. In the funeral procession of Herud the Great, five hundred amestics and freedmen bore spices (Jos. "Ant," 17, 8, 3; "War," 1, 3\%, 9\% A rabhinical writing says (Wet. on John) that at the funeral of Gamalio the elder, a proselyte burned more than eighty pounds of balsam.-Nicodemus doubtles recalled with deep emotion, as he aided in taking down the body, what Jesus hat said in their conversation of three yrars before (John 3:-14): "As Moses lifted up tho serpent in the wilderness, even so must the son of man be lifted up." - The linen cloth, in eomsequenee of their haste, was probably not torn into many narrow strips, as in the case of Jazarus (Jobu $11: 44)$, but into severat pieces, and these are called eloths (piural) in John 19: 40; 20: 5-7; Luke 24: 12. There was ako a napkin. or as we should say, handkerchief (roun:0: i), probably put under the chin and tied over the head, so as to keep the features in position (eomp. John 11; 44). In his own new tomb. It was a special honor to occupy a new tomb, tike riding the ass's (wi)t, "whereon no man ever yet sat," see ahove on 2I: 2; and all the nore that it was the tomb of a walthy member of the sanbecirin. Comp. Isa. Sis: 9. Which he had hewn out in the rock (Mark and Juke likewise), a better kind of tomb than a cave (Jom $11: 3 x$ ), less subject to dripping water, and to dreay of the walls. The roek tombs now fomnd around Jerusalem usually present a number ol recesses in the walts, each large 
61 And there was Mary Magdatene, atm the other

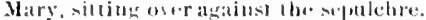

tiz Now the next disy, that fillowed the day of the preparatlon, the chiet priess atud l'harisee's eame logether ntaln l'ilate,

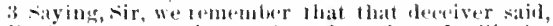
while he was yet alve, After threedilys I will rige 2uatin.

emougle toluld one lody. Rolled a great stouc, tom latre to lift; compl. Mark 16: :3,

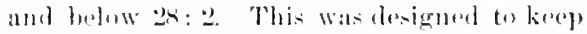
out lowste and birdsot prere, and petty thieres. The Talmud (keim) often mentions the golal. 'roll-some,' in describiner interments. ()m. laree tomb now exi-ts, halt a milo of se north of the rity, which has a circular stome, like a mill-tone on orlere, rut from the solit rosek, with the rhammol in which it revolves (sor

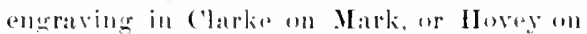
Jahn), and originally finruished with a secret fitenoing. doubtless in the hupe of kecping out robloces. who might phumber the spices,

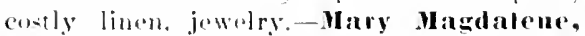
and the ather Hury, sitting over against

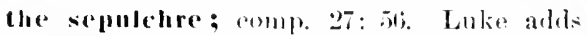
that they "boheda the tumb, and low lijs borly was laid," so that they knew whither to

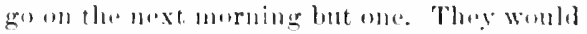
naturally line at some distanes $(27.55)$ whilu the budy was preparing for the tomb, and thas might not know how amply Sicomlemus had anticipated them is proviting spicos; or,

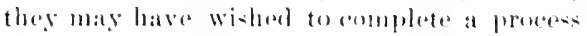
which they knew had been hatily preffirmed.

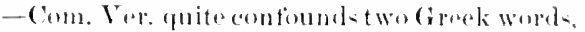
both signifying a tomb). The ditlerence is at" mo great practical importanere, hut they anght to be kept distinet. as in liev. Vor., which

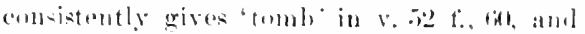

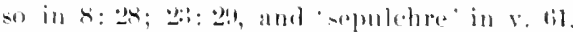

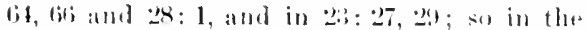
othor (inspels.

II. (;:-60. The sepulahre sealded and gualeloel. 'This is malrated hy . Matt. alome. Neal day, coter Rer. Ver., the monerom,

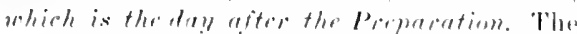
J'requation 11-4ally meant the day of propa-

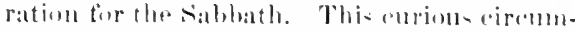

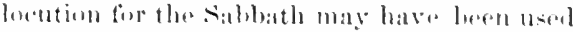

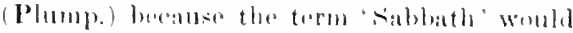

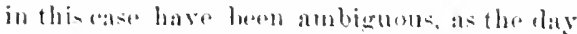

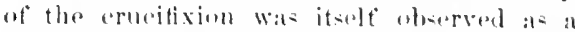
sabbalh, heine the first day of a fount. The chiet priests and Phariseres. The chjef uriests were ut this time mostly sid-

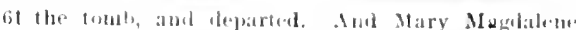
was there, aud the wher Mary, sitimén over atzams thi: semeletion.

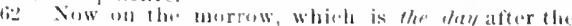

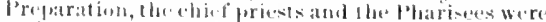

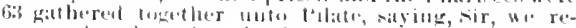

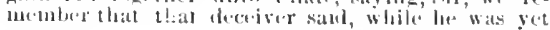

dineses. and so the ewo jarties were unitiog

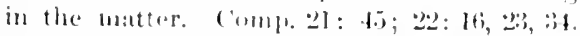
We remember, liturally, we remembered, at

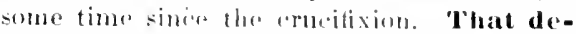

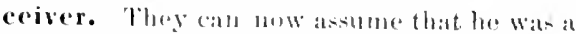

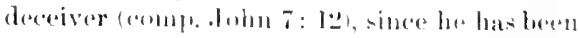

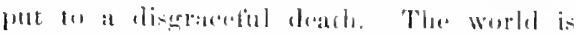
mule dispused to judge character by circumstancos and wutward results. After threes days l will rise again. "The prosent tense

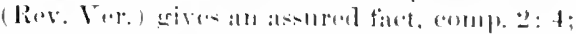

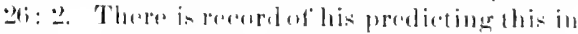

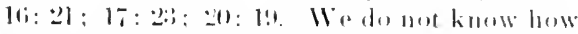

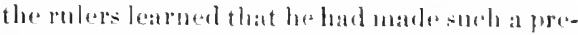

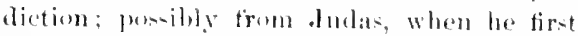

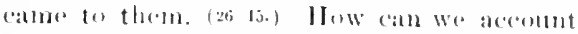

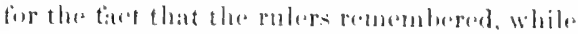
the disciples sarm to haves fingetten thes "rodictions? It is probalble that the latter rearated the whole idea wf the Mlessiabts luting killat and rising agrim as sumbthiner figurative. Peter. James, and . Iolun, Foting Girected to toll nu man of the "Translignration "save whor tha sion of man should have rime again frome the dead, "wrere aleenstomed (1) "fuestion whe with anuther what the risine linom the de:al should mean." (sark g gr.) They andel not helieve that the glorions Kint Iesials womla lue literally killed arel hiterally

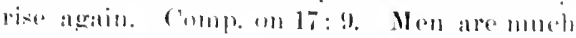
di-gused to " interpret suiritually" when the

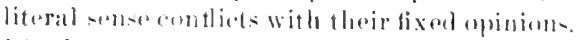

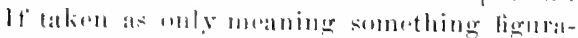
tive, the prediction womlel he moro roulily foremente, till the literat fultillmant hromerlit it to mind. Sis the murels said to the wombon

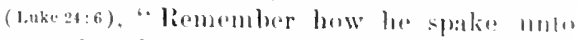
vout when he was yed in tralilers. salying that the fion wi man most. . the third thy rion agrin." Tha rulers, on the wher lomm, when ther hearel of such a prodiction, womlel think "ff it only in a literal sense, and so they rementurered it.

Ater three days has boen insisted an by some as -luming, here and in Mark 9: 31

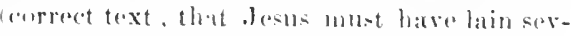
enty-two hours in the tomb, which they sup- 
6) Command therefor" that the stoutchre be made sure until the thint daty, lent his disciples comse by

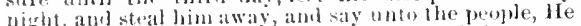

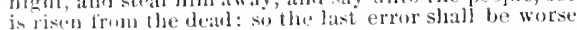
lhath the tirst.

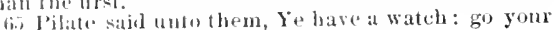
wat, makes ot ats sure als ye call.

bitis they went, and male the stpulchre sure, sealing tletestine. aud setting a watub.
64 alive, After three days I rise agais. Command therofore that the sepulchre be made sure until the third day, lest haply his discijhes eome and steal lim away, and say ninto the people, lie is risen from

65 the dead: and the last error will be worse than the first. I'ilate'said unto them, I le lave a guard: go, $602^{2}$ make it as sure as ye eatn. So they went, and nude the sejulehresure, sealing the stone, the guard being with thint.

I 1), Take a guard...2 Gr. make it sure, as ye know.

juse to be confirmed by "three days and three niglite in llatt. 12: 40. But the only natural way to understand 'after three days' in the mouth of diw, Greek, or Roman. would be (enim]. on 2t: 2) to count both the first and the last lay, so that it would mean any time on the third day. The phrase 'on the third day' is complonylin seven independent statements almut oll Loril's resurrection; (1) in $16: 21$ (:ul Luke 9: 22); (2) in 17: 2:3 (and Mark 9: 3 common text); (:3) it 201): 19) (aud lake 18:33); (4) in Luke 24: 7 ; (5) in Luke 24: 21; (6) in Luke 24: 46 ; (7) in 1 Cor. 15: 4. There is then an apparent conflict between these seven statements and Matt. 12: 40, while the other expression, 'alter three days, distinctly sides, aceording to known nsige, with the former, and is indeed parallel in Mark!): :31 (correct text) to the former in Matt. 16: 21; Lukı: 9: 22, and in Mark 10:34 to Matt. 20): 1! and Luke 18: $3:$; (amp. here also v. 64 with (is. Now 'the thim day, sooften used, cromot possibly mean afterseranty-two hours, while the singlestatement "throe dars and three nights" cen be the umlerstured as meaning three omehs or nightlay preriols of twenty-four hours, any part of such a period being counted, ateopling to the

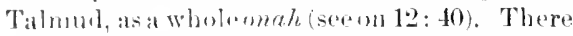
is therefore me propriety whatever in saying that mur Lurd remainesl in the graveserentytwo hours. Anl the narrations show that it was in fatet at very small portion of one day,

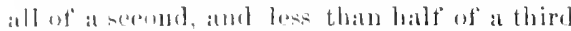
laty.-Lent his disciples come. By night is eriven in none of the earlinet mantereripts alld fow of the carly versions, and was obviuncly added from gx: $1 \%$. Yo have a wateh,

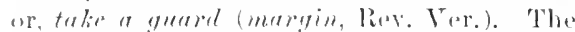

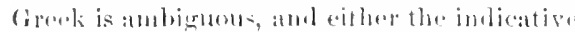
or the imperattive islea will sult the connection. the ferener being somewhat mole probable. Malie it as sureas ye call. As supe as ye kmen (low wo do), is a more literal translation (mergin, liev. Var.), and womld imelicats such meatures ats they underatoorl and antually proceeded to take. So they went, not prub- ably a sabbath day's journey, though in their present mood that would not have restrained them. Setting a watch, or as Rev. Ver., the guard being with them. The guard were present and united with the rulers in sealing the stone; and then of course remained to watch the sealed tomb. (Comp. 28: 11.) To break a seal fixed by government authority would be a high crime, bringing condign punishment. (Comp. Dan. 6: 17.) A cord was probably drawn across the stone which elosed the door, and its ends were fistened by seals to the walls. This labor was contrary to all the Jewish ideas of Sabbath oberratuce, and would be performed by the ehief priests and Pharises only in some extraordinary emergency, even as they had on the first day of the feas condemnel the saviour and secured his exerution. We may suppuse ("Bib. Comm.") that they had expected Pilate himself to take all these steps, and when he simply authorized them to do so. they could not draw back. It is difficult to suppose they did the scaling after sunset, when the sabbath was ended, for that would not be "on the morruw, (v. 62) after the erucifixion and internent.

\section{HOMILETICAL AND PRACTICAL}

T. 57. Joseph of Arimathea. 1) A member of the sanhedrin, who had refused to go with the eurrent. 2) A man of high official and social position, who at a erisis wats ready to risk all. 3) $A$ wealthy man, whom the goveruor would listen to, and who could offer the most honorable burial to the body of the crucified. 4) A man who leoked for the kingdem of God and knew it when he found it. i) A disciple of Christ, whose timidity we must not julge harshly, since lie came out so grandly at last. - Hexler: "Worldly wealth, though it is to many anobjection in religion's way, yet in ame services to be done for Christ it is an advantage and an opportunity, and it is woll for those who bave it, if withal they have al heart to toe it for God's glury.' 


\section{CHA P'TER X IVIII.}

I the end of the sabbalh, as it began lo dawn loward

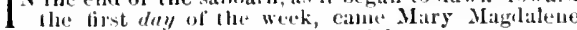
and the ofleer siary to sece the scepulches

"Resling from his work to-day, In the lomb the saviour laty; stitl he slept, from hesal to feet shrouled in the winling-sleet, Lying in the rock alone, llidilin by the seated slone.

"let me h"w thee, Lord, a shrine In this rocky herart of mine, Whare, in pure embalmed ecell, None but thum matever dwell.

" Myrrh and spiees will 1 bring, True allectints offering; Close lhe door from sight and sound of the busy wollel around: Aud in pattinu wateh remain T'ill ny Lord appear agaiu."

T. WIITEHEAD, 1812.

V. bil, forrs.: "Ther whos seized him when livinge are afoud of him when dead And yot if he had been a mere math, they hat roastu to have taken comrage. But that thes mirht learn, that when living also be endured of his will what he did endure; helueld, buth a veal, a steme, and a wateh, and they were not able to hold him."

Ch. 28: 1-1.j. The Reslriectios of J kess.

Found also in Mark 16: 1-11: Luke 24: 112; John 20): I-18. Comp. 1 ('or. 1.5: 1-8. 'The five natratives of our Lorel's re-urrection and aplearanees ditler much as to the detats but only in the way enmmon when there are sevoral independent and briof aceounts of the same suries of event-. If the narralives are

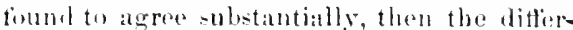

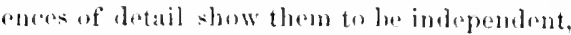
and really strenerthen their eroljbility. The detail in this case can all be harmomized by rasomable suppositions. If at some puint the only explanations thas tat otferen sorem artificial and strained. Wemust remomber that the total inlormation given on the subject is quito limited and yel embraces a great varioty of distinet matters, and it eonlel not be axpected that the relations between these wanlel he everywhere male prefeetly clear ; alou that the progress of researeh is in every generation clenring up some question that wats long con-
1 Now lal* on the sabbath day, as it began 10 daw toward the first dey of the week, eanne Mary Magrla-

sidered diflicult. Tho sacred writers de mot treat thoir Lurd's restrrection us a dunbthul point, needing to be etablished by their slatements, but as an unqumotionable fact. Each of throu gives such intornation eoncerning it as betars upon the droigu of lis particular writing. Thus in Matt. the arthquale eonnects itself with that ot $27: 51$; the report ot the guatrd bears upent a story eturrent allong the Jews; the prominenere given to Galilee accords witl the large space vecupied in this Guspel by the fialilean mini-try; and the Great Commassion shows the true natmre of the Mesianie reign, as spiritual, and destined to be muiversul.

'This secolon at' Matt. divides itself into $v$. $1-4,5-7,8-10,11-1 . j$.

I. I- C. Certain devout wouten tind the stome rollect awat from the sopulehre.-In the end, ete. 'The Rer. Ver. begins with now, the Groek de, the ustal particle ot transition. lt might hore be rendered 'but, expressing an ifposition between the precantions of the rulers and the events which lace tollow.

End of the sabbath, iRev. Vir., late or the Silbbeth day, as it bogan to dawn toward the first day of the weeli. Thisopening expresion is mot mis. to interprot. 'Isate on the sabbath day" is the wly natural and wellsupported meaning. But the Jewish satshath ended at sunset, while Matthew's aceount. indicates, and tho oflore Gospels distinetly declare, that aur Lurd's lesurroetion aceurrob in the arly morming. The other expression, 'as it leggan to dawn.' might rofer to the buginning ot the new day after sunset, as it

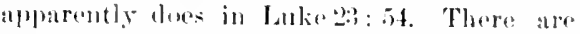
three ways in which Malthews opening phrase way be underetemd, so as not fo conthict wifh the other (rospels. (a) It may porhaje mean 'atter the sablantli, and many insiot that this ismade neopesary by what follows and by the other aceounts. It is not clearly made out. hut is maintained by suell anthorilies as Frit\%-ehe, Grimm, Godet, and others, that the Greek phrase an have this monning. (b) 'Iate on the sablath day" may jerhabs reckon the following night as a part of the 
2 And, lu. ludl, therea was a grutearthquake: for the

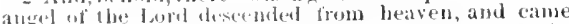

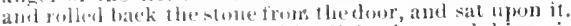

3 His enunfenanee was like Jightuing, and his raimout white an show

$t$. Dul tur lear of bim lle keepers did shate, aud becaume as dead not $h$.
2 lene and the other Mary to see the sepulehre. And behold, there was a great earthyuake; for an angel of thr lomil descended from hewen, and cane and

3 rolled away the stone, and sat uynn it. His appearance was as lightming, and his raiment whise as 4 suow: alt for fear of bin the walchers did quake,

a Or, had been.

Sidbiald, departing trom the Jewish usage. This interprention is given ly Moger, and vigorems]y stutol by Morison: "The difficulty valuishes if we sllypone that the method of adoline diurmally the uight to the day, rather thatl the day to the night, had got more or lom into eommon use anong the Jews, so, that there wre two ways at reckoming enmplete astromonical days; nammes, tiont by nightlays and semolly by dav-nights. Heve the Evangolist was thinking of day-night see next anuse), and lence "late in that day-night womld mean about the end of the night that fallumed the day uf the sabhatl." This explanation is posilble, lut is certainly strained. (1.) 'Late in the Fablath' may be taken in its molinaly souse of betione sumat, and we may Imbleratand, with MeClellam and Westeott on John, that Matt. here mentions a previous visit by the two women, quite distinct from tho risit of next morniner. This atso is possible, hut lifficult; for 'the women' of $v .5$

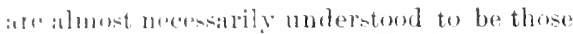
of $x$ J ; and altur soring the guad, if not the seal, on the previons visit, how could they axpert alusiasion into the tomb? Thus no onerof the oxplanations is easy, and entirely satisfartory; but as atoh of tham is possible, it will nent do to say that Matt. is here in ireme

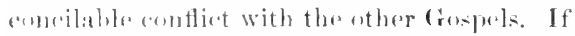

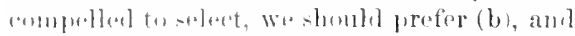

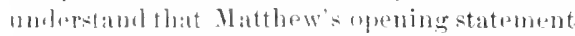
refier to the anoming dawn. Matr hate it. very anty an the tirnt day at the wesk.

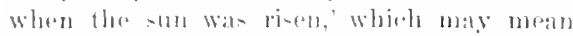

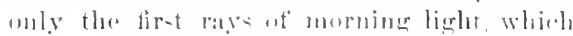

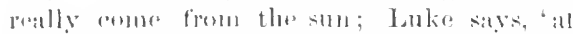
maly dawn' John 'while it was yot dark.'

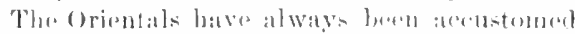
torarly rising. Tho gates wenlal low elosed at

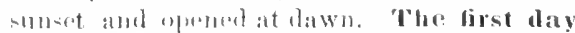

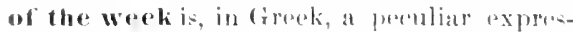

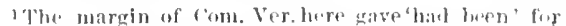

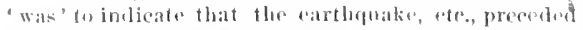

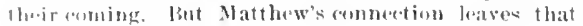
douturul. There should be great caution about trans- sion, answering to a well-known Rabbinical whalse (Lightt.), but there is no dombt as to its meaning. Came Mary Magdalene and the other Mary; the mother of James the Little and of Joses, 27: 5fi; Mark 15: 40. Mark ailds (16:1) Salome; Luke (24:10) adils Joinna (comp). Luke 8: 3), and indicate- that there wero yet others. There may have been two different yarties, that of Joanma and other coming later; so Westent, Edersh. To see the sepulchre. The verb means to belurld, as a spectacle; so in $27: 5,5$, and at kindred trom in 6: I. They designed also, it it should appear pricticable and approjriate, to 'amoint him' (Mars 16:1), and brought with them spices (Lako 24: 1) which they had provided the evening before, when the sabbath was past. (Mark.) As they went (Mark 16:3, Rev. Ver.), thry were concerned about the question, "Mho -hall roll us away the stone from the door of the tomb?" for they knew from olservation of the intorment that "it wasexceding great" (Mark 16:4, Rev. Yer., comp. Matt. 27:60), and a man's strength would be neeessary.

Aud behold. Matthew often thus introduces matter of srecial wonder; and liere it was jeculiarly apjropriate. The aecount in $v$ 2-4 is found in this Gospel only. The great arthquake is here distinctly supernatural, but that dues nut prove that the same wats true in 27:51.3 As to angels, see on 18: 1C. The comparison of the angel's appearance to lightuing and his raiment to suow, recalls the Tramsfiguration. The general term rendered "alpearance" (R. T.) was unwarlantably ristricted hy Tyn.and sucessors to the countenaner, yerhapi from eomparison of Dan. 10:5. 'The keepers, or wateliers, same word as in 27 : if. Shake, quale, same Greek ront as in tho word renderod 'earthquake.' Matthew's lameruge would allow, but does not require us to belirve, that the women saw the angel

lating tlue anrist $\mathrm{by}$ the pluperfer. It is only the conmelion in the ireik that shows one action to be prior to th. ofler, and the connection can show it in English. 
5. Aucl the angel answered and said unto the wothen, fear mot ge: fir I know that yeseck leslls, which was crucitionl:

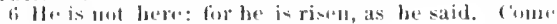
see the plites where the Lord ling.

roll at waty the stome; Mark shows the cortitratry, fir while dircusing, ne they appronteh, the quention whe shall roll it away, "lowhinge

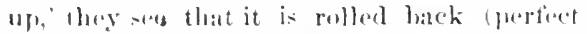

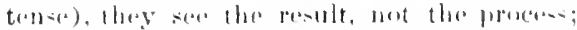

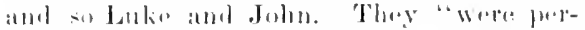

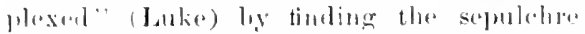

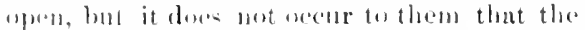

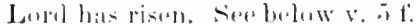

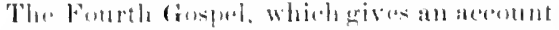

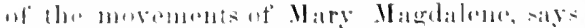
that -ereine the stome taken awily she ran to Petore and Jahn and stid, "Theg hatretalion

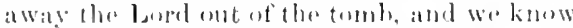
met where they hase latid him." (J)ereve

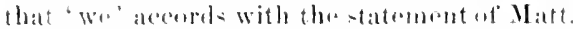

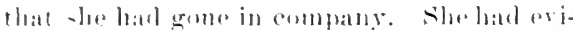
dently mo ideat that the Lorel hat rome to lite.

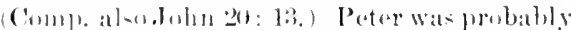

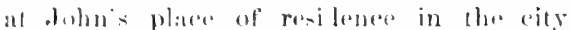
(Jolu 19.27.) Ther alporar to hate bern old

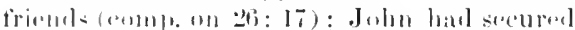
leoter's athision to the court of the hierh

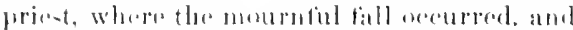

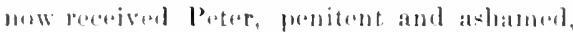

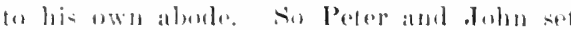

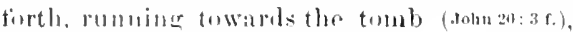
fiollowed he Vary Magdallone.

11. 5-7. An angel tells them that Jests in

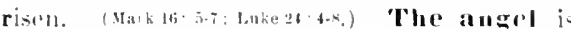
laere obvionsty the one that had rolled aw w the stone. Ilatk, who has not tohl how the stome wias rolled at way, saly's that "entring inte the tomb they sat a young math sittingon the right sille, arrayed in a white rolue." Rer. Vor. As this young man sild what Matt. acerilese to the angel, we unclerstand that hat

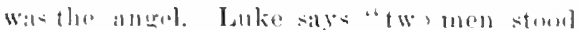

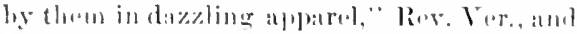
gave them the sime information. Simme understand that this was at a later puint and that is prosihle. But we lave hat several ine stancesenf one pursens mentionod in it matrat tive, and two pwrons in amother nalrative ot

The stune stanks withoul ablition in N B | , sors-

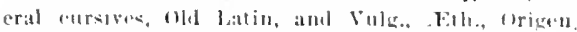

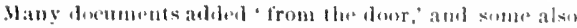
athlew "of the tombl, hy assimilation to . Iark 16:3.

21 is found whout 'the lord' in $\times 13,33,111$ ?

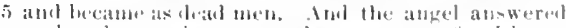

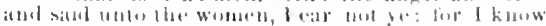

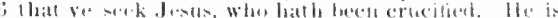

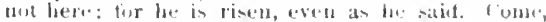

thes

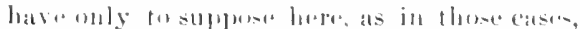
that ane of the two was morte eomspicuens athe

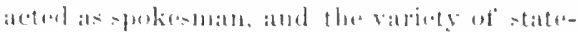

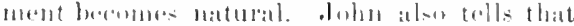
Mary Magelalene presontly saw "(wo) aldgels

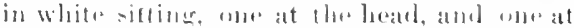

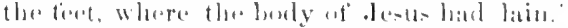

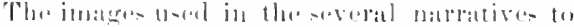

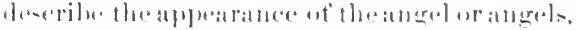

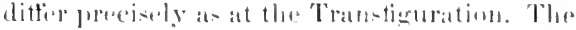
ditlinelet jusitions and pustures mentioned

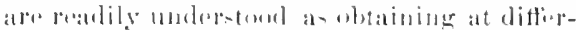

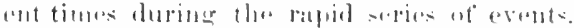

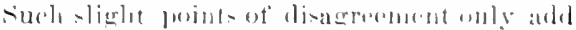
(1) the maturaluess and verisimiliturle of the totil remert.

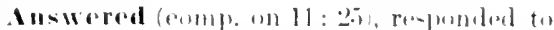

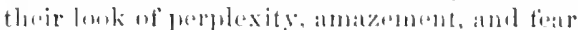

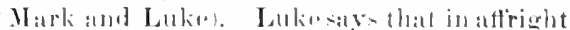

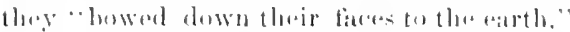
Rove Vier. Aud said nuto the women.

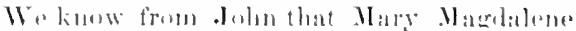
hat now lett, hat we have serent that salume and Ja:anda. and alyarently utlere. wero

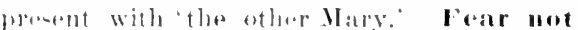

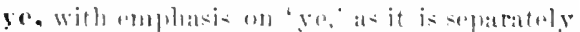

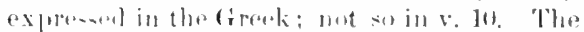
guarel mieght woll ho alarmed (r. 4), but theses

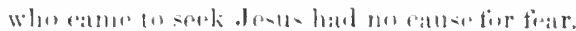

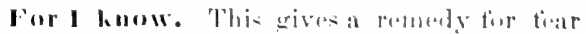

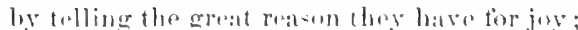
comily, $v$. Jeste, which was rucifica, arsimply "desus the ermeitid. Jor be is

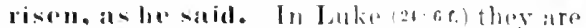
bidelen to romenther law when stili in fialibes he prodiceod that he womld be aruediond and rise atuin the thirel day. Coumese the place where the Iand lay. "Where he

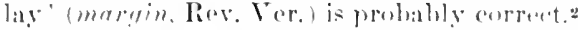

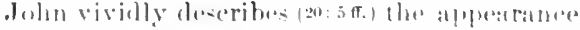

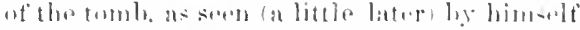
and Pener: and intimates that the orderly hi-pusition of thr limen clotho and the hand-

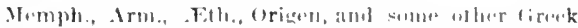

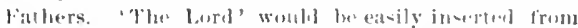
some - ondent"s marginal nute, hut was mot likels bo be moillel. "Flo" addition is what 15 H. call "Western ind syrian." 
7 And ge quickly, and tell his alisciples that he is risut trom the deat; : and, betuld, he goeth before you into datilee; there slall ye see him lo, I have told Yill

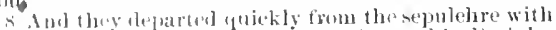
feats amb ureatl juy ; and did run to bring bis dineiples woril

! Ind as they went to telt his discipies, heludd, Jesus

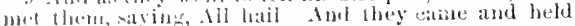
him loy lie fiet, and worsbiped him.
7 ste the place 1 where the Lord lis. And go quickly and tell his diseiples, tIe is risen from the deal; and lo, he gocth before you into fialilee; there shall ye 8 see him: lo, l have told you. And they departed quickly from the lomb with fear and great joy, and 9 ran (1) bring his dineiples word. Anu behohl, Jesus mist them, sayiur, Ill hail. And they eame and

1 Many ancient authrities read, where he lay.

lisphinf, showing that here was no work of

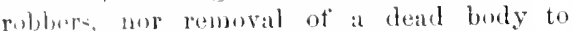
another tomb, cilu-ed hin to "believe," viz., that the Master wat alive again. This same impressive situation the women beheld. And go fuiclity, and toll his disciples. " (quidkly," so that they may thesomer bave (opyortunity to rise out of their distress and de-pair. And behold, sane word as 'beluld' in v. "2 and v. y. He goeth before yom into fallen, as Jesus hat promised in 20i: :32; and thesame verb is usal here as there, muaning the aroes betore and leads you, as a shruhrerl his fluck. (Joun 10:4.) The present trim ropresents the action as sure and near. 'There shall ye see him. This does nut neosesarily exclude the pussibility of their swoing hisi fopwlope, heforeor atter, and we know from Luke and John that they saw hin in, lallation and rieinity, both before going to Raliles and after returning. But the em-

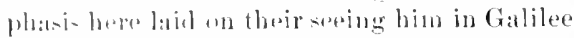
aceorels wall with the view (1+omsp). below on צ. lii, that m a rentain monntain in Galilee was to he tho glowt woweting, where mang dis-

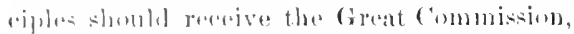
thes lifterencine this roming event from the appunaturas on that same day at . Ferusalem to a complatationly small number. Notice Lukn's statumant ar a. R. v.) that the women "told all thene thinge to the rleven, and to all

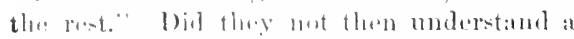
mescitge to "the disciples' as not ineroly to

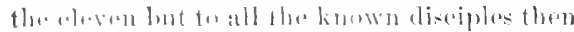

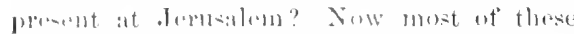

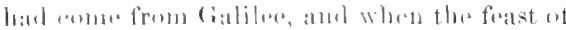
the la-sovere wato overe it would he natural that

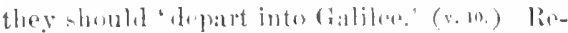

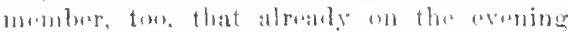

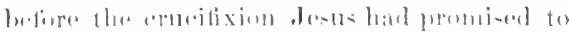

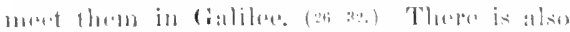

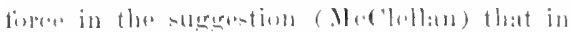

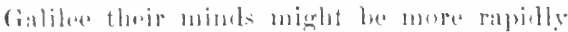
weanonl away foum the notion of a temperal kingdom, which partially reasserted itself afterwards whon they returned to Jerusalem before the ascension. (Acts 1:6.)-Lo, I have cold you. II (re Mark, who has agreed with Matt. almost word for word through several lines, has 'oven as be told you.' Some "IVestern" dreuments ehanged Mark to be like II at thew.

IV. 8-10. Jesus meets them as they hasten away. Mark 16; 8. Quickly, as the angel bade them, v. 7 ; and did run. The word sepulchre, Riv. Ter., tomb, changes from that of $v$. 1 (comp. on $27: 61)$, though there is no important difference in substantial meaning. With fear and great joy. The fear (v.5) has not cuased, but it has beeome mingled with irreat joy. Mark (16:8. R. v.) says strongly, "for trembling and astonishment had come upun them." He adds, "and they said nothing to any one; for they were afruid," $i$. $e$., thoy spoke to wo one they met on the way, being tor much occupied with the fear proluced by what had oecurred. To bring his disciptes word. The most of the disciples were not at the same place as Peter and John. It has been suggested that they proluably retired to Bethany, as they and the Master had been wont to do every (rening. (Luke: :37.) Josus met them saying, All hail. This is simply the common Greek salutation, rendored 'hail' in $26: 49 ; 27: 80$, and there is no rason for rendering it otherwise liere. The 'all' was introlued by Tyndale. The common trat prefixes 'as they went to tell his disciples, but this is a mere explanatory addition bromght in from the margin. IIeld loim, literally, seized or 'grasped, the action showing grat humility and veneration. This was not censured, and yet the Saviour said to Mary Magulalene (John 20: 17, Rev. Ver., margin), "Talip not bold on me; for I am not yet ascarbel unto thr Fa+" ar." The most probable יxplanation of supposed this । "arence is that Mary "Master's "spirit," 


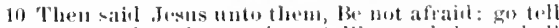
my brelnoen thal they go inlo falilet, and linere slatil they sere ture.

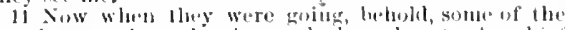

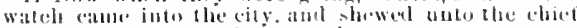
pritols all the lhings that were dinne.
10 touk lubl l wl his foet, and worshipend him. 'l'bon

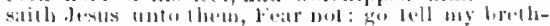

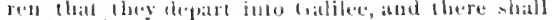

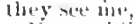

11 Now whil. laey were going, behold, some of the

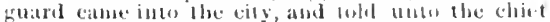

as the disciplesclid the same evening (Luke:2: 37 ), and was proposing to ta- the reality of the botily appraranee, which experiment lesus rebulied. Worshipped. lingorl: "Jesus betore his passion wats wolshipped by otluces lather than his disciples." (io tell my brethreu. It was special kinchess thus to sprak wi them (comlu). 12: 50; 25: 40; John 20: 17), when they were likely to feel special humiliation at the thought flat they laal all forraken him, and one of them demiend him. It was apparently tor the same purpose that the angel had expresty alded the name of Preler (Mark 16:7), lest the sadly fallen une should teatr to think that a nessigge to the disciples of .J ats a mossige to him.

Meantime Peter amol John arrived at the tranb, saw it empety, and leturned homes.

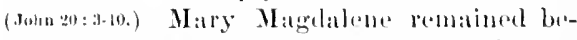
hime, standing without, worphing. And presently olesus appeared to her, in that aflectiong intariew which John deseribes in 201: 11-18. It the expression he alpheated tirst to Mary

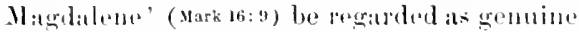
aml chromological, then it may be thought that as she departind to toll the di-ciples (John:t: 14), Jesus also departed, and overtork

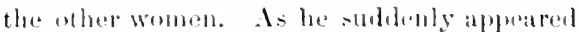

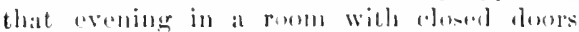

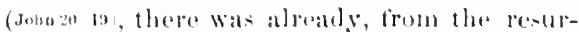
rection onward, sonething supelontural in his bodily andedion and mowemants, and so it may be that he overtouk them, thomegh they were

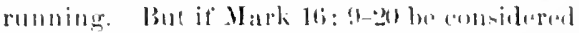

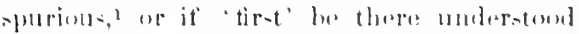
to mean simply the tir-e and the throe appar-

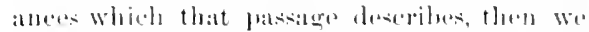
("an dispense with the suppo-ition just mads as tolocomotion, and suppose that Jesus "Inot"

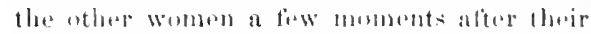
departure, mol then, returning to the tomb, appeareal lo Mary Maserlalane.

The question lats been timpluently discussed, why these angelic alpuatrances, and fir-t ap)-

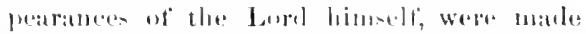

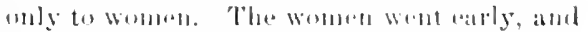

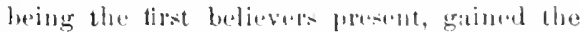

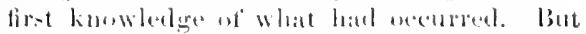

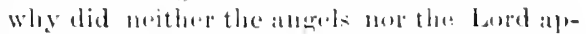

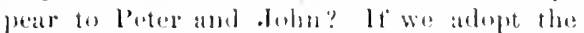

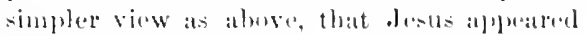

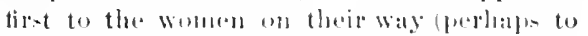

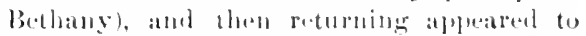
Mary Magdalene, it mights be enoligh $40 \leqslant-11$ pore that he did not reach the tomb till attor Peoter and Jobn lotit. Is to the angals, it wosuld be a quantion whathar the wortuen re-

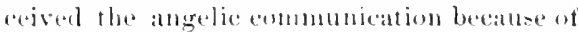
their faith, or mented it in urder to taith. John believerl, merely form ubserving the order that prevalud in the emply tomb; amb

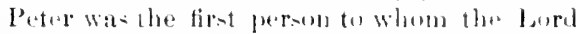
afterwards appeated in the entrse of the day. (1.uke24.34.)

V. 11-1.5. False repurt by some of the guard. This is fomml in Matt. (m) It Was batulat that he, rabher than the other Evangelists, shmold give it. localuse le wrote aspecially tor lows, atuemer whum this repurt latel sureal. (vis.) Whon they were going. The events ware excitiner, and nolumly dielayed. Some of the watch eatue into the

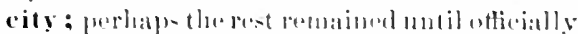
atuborizad to latre. And shemed unto the chiet priests. Thene hall takem thement to

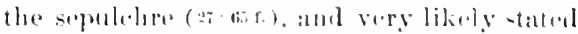
their foetr that tha disciphes at the buried ome

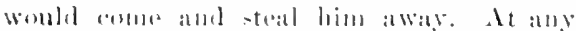

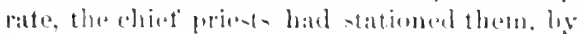
Pilates jermis-iom, and to the chief priests

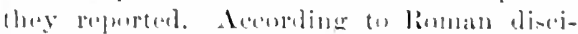
pline, they ware liable to vely severe puntsh-

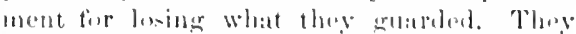

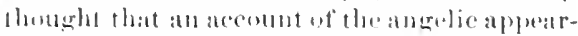

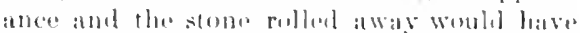
indlusnce wilh the Jewish anthorities. and :their crime as soldiers might smolnow he tim-

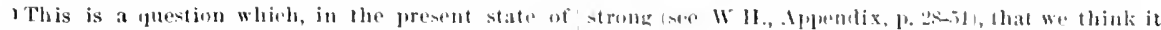

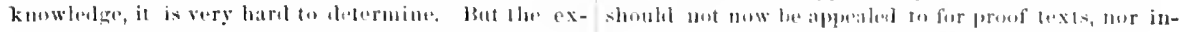

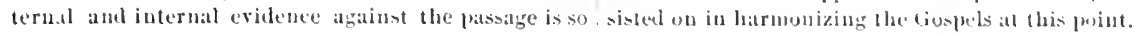


12 And whon thoy were arsoublad with the elders and hat taken counsel, they gave hates nowey unto the sililiers.

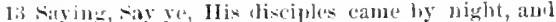
stole hin anal while wa slept.

tt And it this conte lo the governom's cars, we with

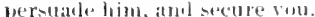

1i) tamght: and liti- saying is commonly repurted among the bews until this day.
12 prists all the things that were come to pass. And when liey ware itsenthled with the elders, and had tak+ll curinsel, they give barge noney unto ihe sol13 diers, sayum, say ye, llis flisciples came by night, 14 and sult him away white we slept. And it this lconte tothe governor's ears, we will persuade him, 15 and ridl you of cal's. bo they touk the monev, and did as they were taluht: and this sayiug wis spread abroal awoug the Jews, and continuth until this day. griven. Aceordingly, they told the dhice priests th all the things that wror eome to pass. The story must have excited great sumprise and alam, but it wrought no repentame. Alas! tor these bad men, they were now, like Pilate, so entangled by previous wickednes, that it seemed they must go firwarl. They hat stid, "Let him now conne down from the cross, and we will believe on him" (27:42; Rev. ver.); betholl, he hat donesomething still more wondertul, yet they dir not believe, no, nor make further impuiry, but simply bribe

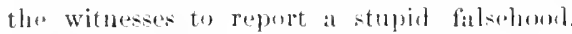

Larger money, or 'quite a numbre of silver (pirces), which wohld nont naturally mean shekels, 26: 15. His disciplos. . . stole him away while wo slept. Throtatment

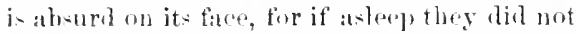
know it, and if onse of them linow, he could have awaked the others. It also eonfesses on their part a criminal breach of disejpline. 11 lhis come to the governor's ears; so Trn., ('ram, amb K. Itame. It mus more likely

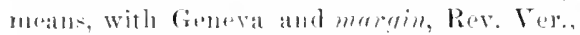

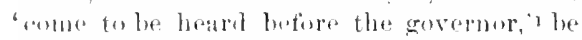

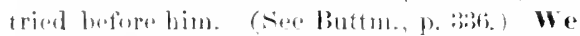
will persuade lom ('W' being amphatic), mot simply by aremunt and persmal influences, but by the anderideration they had just brought to bear upon the soldiers themselves. Wet. given several patesalges of la reck atuthors in which mention is male of persumeling men loy meatse of money. Philu expresely states (sopon $2-7: 11$ ) that Pilate was a hribetaker, a- wo know wat trme of Folix. (Aate2t:26.) And secore you, literally, and maler you to

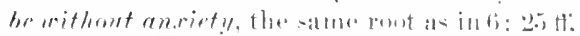
And did as they were tanght. The rulers.

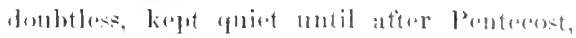
when the di-ciples began to derelare and to prove that J was wat rinen, and then masle the suldiers trell their latse story. Intil this day,

li has hore a "Western" realing, found in P D, ant Latin rersions, hupo insteat of epi, making it mean the time when Matt. wrote his Gospel, eomp. on 27:8. Justin Martyr says to the Jew Tryphn (ch. 108), "You (the Jews) selected men and sont them into all the world, prochaiming that a ecrtain atheistic and haless sect has arisen trom one Jesus, a Galilean deceiver. whum wo crucified, but his disciples stole him hy night from the tomb, and deceive men by suying that ho has risen from the dead and arcenderl intw heaven." The absurd and blasphemous modiaval Jewish legend ealled "Toldoth J J sulu" expands this allegation.

Attenuts atrestill made, by men whose theories eannot be otluewise maintained, to set aside the fact of our Lord's resurrection. No intelligent critie now holds that Jesus did not really die, or that he died, but his resurrection was a mere implusture on the part of his diseiples. The nuw common theory of unbelieving crities is that it was a rision, or, in some way, an illuxion, on their part. These men are not mere disintersted inquirers after truth, as they somotimbersert; they have to aceount for Christianity, ats baving in it, according to then, wothing supernatural, and yet as a great prwer in the world; as affording the noblest ethical teachings, and presenting the unrivaled character of Christ, and as unquestionably based by its propagators on belief in a risen sariour. Of courie, men so ingenious will make some plausible show of explaining awa the evidence, or flinging around the sllypet some appearance of doubt, as skillful lawgers know how to do with the wealiest cilse. Saran eximmination of their theories in Milligan, Lext. III, and brief and vigorons discunions in Gullut, Weiss ("Life"), and Eder-h.: ore also a rurious and powerful refutation of these skeptionl thenries by Keim, on erounds as rationalistie as their own.-The great filct stands. Wresteott ("Gospel of the R(es."): "It has been shown that the resur-

'be heard by the gevernor,' which was manifestly int.ruluerel tor simplitieation. 
rection is mot an indaterlevent in hi-tury. but at onde the end and the beginning of vast alurelopments of life and thomerht that it so the climax of" a long series ot divine dispen-ations which find in it their eomplement and axplat nation; that it has formed thes starting-pmint of all prosersive modern society, ever jorsentine italt in new lierhts. accurding to the immerliate: wallts of the age." 'Jhen atter restatiog the evidence, he ardsts, "Taking all the evislence trogether, it is nut tero much to saly that there is mo single historie incident better or more variously supported than the hitonrrectinn of ('hrist." Ind let it be rementberel how mueh this great fact carries with it. The l'ourection of ('hrist establishes the divine origin of his mis-ion and teachingr-; it gives frol's sanction to all his colaims, and he clatmed to be the Masiah, to speak by divine authority, to be one with fod. Rom. 1:4. Ilemen: "Jests han publicly peried his reputation as the Chrind at Gud, cuthe aecurrence of this avent. When challenged to give some sign in suplonrt of his preten-ions, it was to his thture resurrection trom the deat, and to it alome, that he appouled. (Juhn: : 20; Matr. 12 3*-41.) Nften, and that in torms incalpable of miseomstruetion, hat our lund foretolel his resurration. It carrierl thus along with it at triple proste of the divinity of one Iuret's mission. It was the fulfilluent of a propherey, ats wel] as the working ut a miracle; that miracle wrollegh, and that prophexy foltilled, in answer to a solemu and confident aymal made beforehame by christ to this event as the crowning te-timumy to his Me-nath-hij)."

\section{HONILETI:AL AND PRATTIAIE:}

5. 5. Feeking the Crucitiod, funding the Risen On.-T. T. "(ko quiekly." 1) Redigions excitment shomlil prompt to religions exertion. 2) Whele others are surrowing. We tell twice if we toll quickly, the news that will cheerthem.--"Lo, I have told youl." Inxry: "Jhose messengers from fiod that di-charge thrir trust fathtully, may talke the comfint of that. Whataver the suceess be. Aetz:20): $24 ; 1 . "$

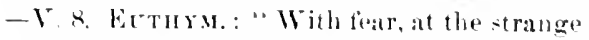
things they saw; with great joy, at the gorol news they learel." - I. I. It was while they were hasteming to honor the saviour and rejoice bis disciplor, that he met them.-T. 10. The saviour recognizes the importance of repetition in giving in-tfuntion. ( ('mpln, v. 7.)

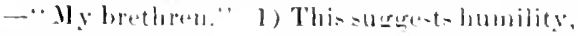

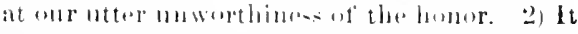

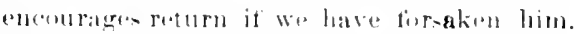

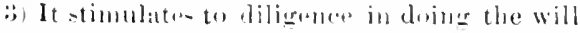

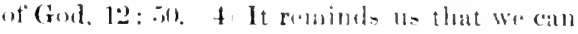

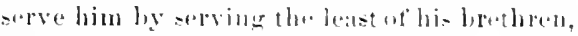

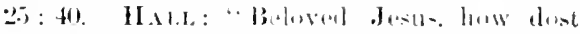
then raise the tithes of thy folluwers with thyselt! It tirst they werethy servants, then lieciples, a little heline thy diath they wors thy friendo; now, alter thy resterection, they

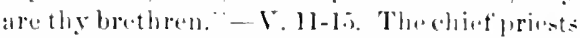
amd the goard. 1 So multiplieation ut evidence will enemeines thase whe als -tubbornly resolved not to believe. 2) Think of religious teachers itrving fiond by a purehased lie. 3) Bribery reduind further and hearier hribes;

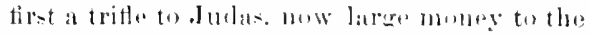
soldiers. and presently, perbats the gurermor. 4 I talneboul will be lomgr-lived it it -uits men s prejurlices. (v. 15.) i) Etturt-against the truth semetimes luelp it progren; the stal and the guard only malie it mole clear that the sariour rove tron the deal. $-\mathrm{t}$. 1:3. SAll will beljere ally story, howerer improbilde."

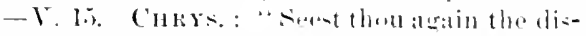

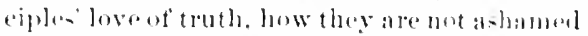

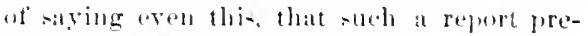
valilel arainst them."

The lesenrection of Chri-t is not omly a [illlar of Christian evidence. lnut has impoltant theologieal and pratetieal rebations. (a) It completed lis worle of atomement. and stamped

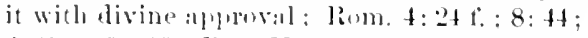
2 (ur. o: 15. lies. lere) Aceurelinely, to

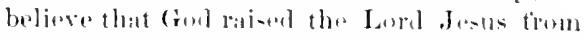

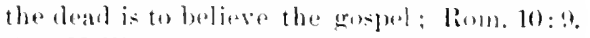
siee Milligan, "Leet." IS. (b) It is the

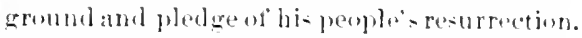
(1) of their spiritual resurrection, to walk in mentess ot'. life; Rom. ti: 4; Col. 2: 12 t.: :3: 1-4. See Wricott. "The (inepel of the Resurrection" ; Liddon, "Eater sermons."

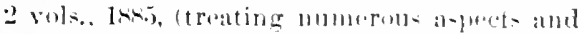

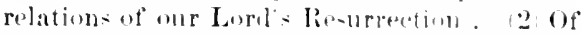
the resurrection of the lunly: 1 Cor. l.t: 20 ;

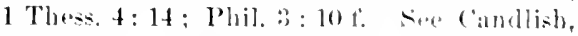
"Idife in a Risen saviour" leecturas on 1 Cor. 15); Lidelon. (c) It is represented in baptism: Rum. and (al. (as above). (d) It is celebrated on the Lord's Day. 
16 Then the cleven disciples went away intoralilee, 16 But the eleven disciples went into Galilee, unto into a montant where Jesus hasl appointed them. the mountain where Jesus had appointed them.

16-20. JERES APpeArs to the Disci-

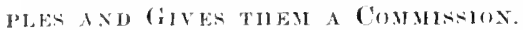

Foumlal also in Milrk 16: 9-20; Luke 24: 195.3 ; John 20 : 19 to 2.2: 2.); 1 Cor. $15: 1-8$. Combining the four Gonpels and Paul's acmunt we find recorded ten appearances of our bard between the renrretion and the aseension; comp. the Ilarmonies of Robinson and Clark, and that of Aneustine, III, $\% 83$; also Westertt on John, beginning of chatp. 20. (1) To the women; in Matt. (2) To Mary Mangdalene; in Jolun [and Mark]. (B) To Simon Peter; in Luke and Panl. (4) To the two going to Emmaus; in Luke [and Marli]. (5) Tor the apmotles, exeept Thomas; in Luke, John [and Mark]. - These five alyearances were on the disy of the pourrection, and at or near

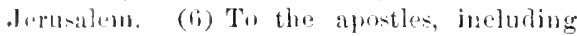
Towmats, a werk later at Jerusalem; in John and baul. (i) Toreven dirciples at the sea of Giliter ; in John. (s) To the apostles, and probably at the same time to abre five hundred lwatuen, on a mountain in Galilee; in Matt. and Paul. (o) To James; in Paul. (10) Tor the apostles, just beforo the aseonsion; in Luke; ( Leta) and Paul.-Then eomes the Arension; in Luke, Gospel and Aets land in Mark]. - Of thwe ten appearanees Matt. record- but two, viz., 1 and 8; Luke records four; John four; l'aul five; Mark (if' 16:9(l) be gronuinse), three. Thus the events following the resurrection are to besought much mure in the when natratives than in Matt. But the onp appearanes and eommission here given mat the regarded at of very great intarent amd impertince.

A to cur Lard's appearances in generil, cortilin puints may bue noted. (a) He appeared mulere a grat varioty of circumstanees; as to Hilese, times of day and night, nt:mber of

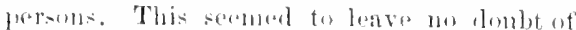
tlar fart that he hat riwen, and to make his followers thoroughly familiar with it. (b) He towk great pains to show that here wise a real buly, of "fluk and benes," nut "a spirit"; and that it was the same louly. with the marls

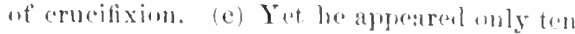
times that we know wef, in forty dalys. And he nexer remaned long in their company. Howats thus prepinge them to live withont him, See Hanna und Gejkic. (d) JIe ap- peared suddenly in a rom with elosed doors (John 20:26), so that somethmes he was not at first reeognized. (Luke $21 ; 16 ;$ Jolu $21: 4$.) With this agrees the expression of Mark 16:12, "in another (that is, in a changed) form." It would seem that his borly was already partially transformed, as it were begimning to be glorifed. This, with the foreguing, would prepare his followers for thinking of him aright atter his ascension; compr. Ellicott, Hanna. Yet he Was not, as some have thought, fully glorified, eompletely changed into a "spiritual body," at the resurrection, for he afterwards ate food. (e) He appeared ouly to his disciples, though once to above five hundred of these. (1) Perhaps they were alone alole to appreeiate the change in him: eomp. Westcott, "Gosp. of Res." ; Milligan, "Lect. I." (2) Had he appeared to others, we can see that the multitude would have blazed with fanatieiem, worse than ever; and the rulers would have furiously sought to slay him afresh, as they proposed with reference to Lazarus. (John 12: 10.) It was necessary to lift friend and foe to the thought of his spiritual work; and this would have leen dofeated by his bodily appearance to the multitudes at this time.

Then, or but, in opposition to what the soldiers and the rhief priests did, the eleven disciples carried out the Saviour's direction. The (rreek enuld be rendered "now," as a particle of transition, thongh the eonnection here indieates the other jolen of opposition; but 'then,' ats in Com. Ver., would suggest a notion fuite foreign to the Greek. The eleven disciples went. Matthew gives no means of judging how soon. Blit we see from John 20: 26 that it was more than a week after the resurrection. and trom Aets 1 : 3 that it was within forty days thereafter. It is commonly taken for granted that the eommissim of $v$. 1!) was given shortly before the ascension, and henee the arrangement of the Hamonies as above indieated. But this is ly mo means certain, for in John $20: 22 \mathrm{ff}$, we find a commission given on the very day of the resurrection, So we cunnot decide at what point in the four weeks proceding the ascension the appearance recorded by Mitt. occurred. And if Matthew's reeord seems to sugrgest that the disciples went promptly to 
17 And when lhey saw him, bey workipped him: 17 And when they saw him, they wor-hipped him: but but some donthed.

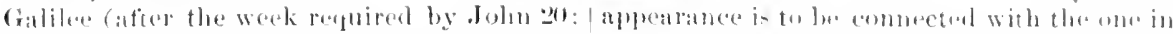

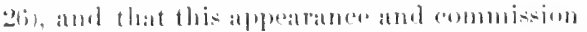
(alume not mally days atter their arrival in

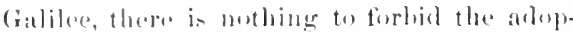

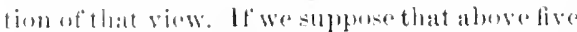

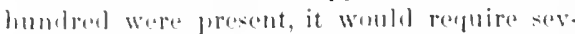

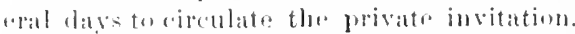

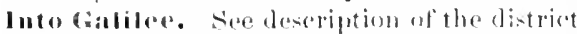

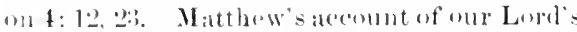

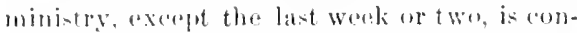
limal to the ministry in cialilee. (t:12.]n:33.) That is poublity the reasom why loe seized with rexlusive interest upem the direotion

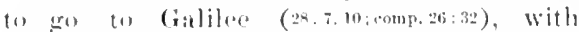
the alpuaralle and rommission which fol-

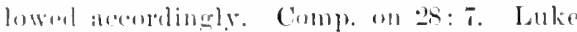

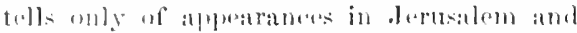

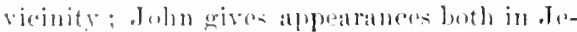
rusillem and in falilee. Whan it is said that llatt. appuars to exeluda all ather appearanees than those he has deseriledel, it maty bo answapul that from lake, eh. et. an, might maderetamel onr Lord's Asecnsinn on bave takin folaw on the day of the restrretion, while trom lalke's statement in 1 ('ts $1: 3$, wa linuw that finty days interverued.

Into a (the) usoutain where Jesus had appointed them. We hatre not beentold of "Inolutain, or other fartioular ulace in fali-

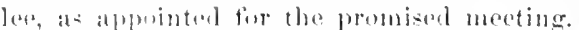
But Iatt. R. Y.) quaks af' it as= "the mountain, ond detinitely atpuinted or asignme: and there is nothing in theotherareonts to andlict witle this representation. Wo latio

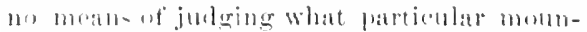
tain it was, and conjexture is idle. A vory late and vary silly tradition makes it moan

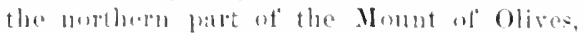

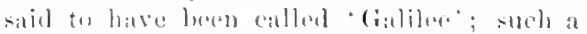

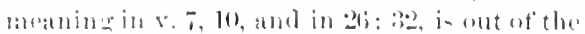
yluestion. The selection ot' a mountain, which

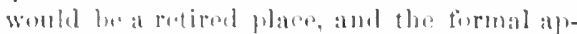

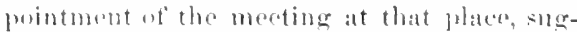
gents soumething moro thath a more menting with the aloven, sureh as we know from Jolu

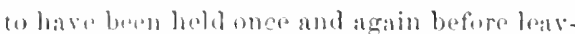

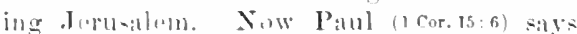
thit desia alppeared to" "above five handreal beothren at once," the greater part uf whom romatined as living witnosses some twentyseven yeats later. The supposition that this

Matt., forecounte fior the retired place and the

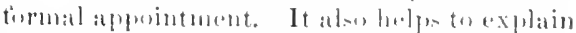
why this moting wate to be in lialilen, both

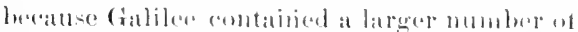

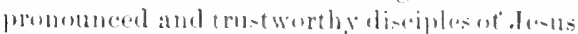

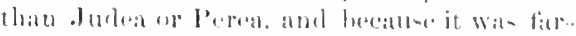
they foum the watehtiul joalom-y at the rulers

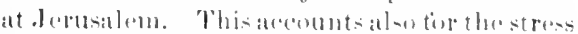

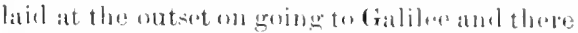

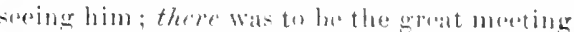
with many disciples, and the griong of the Creat (commision (

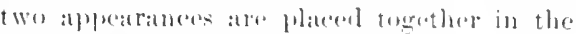

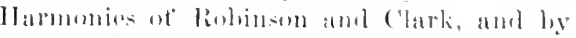
many very able recent expusiturs, inclubling Ellient, Godet, Wik. They worshipped him. This Was not morely homate (1) a king

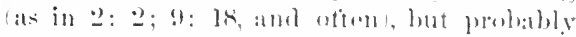
involverl the enduretion that ha was divine.

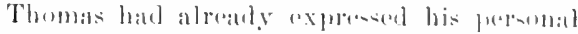

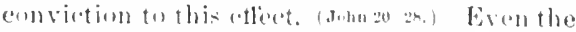

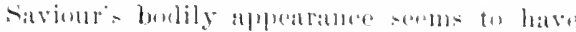

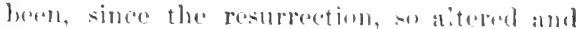
spiritualized sore alurel, that they fint more imblined than formerly to wor-hip lim, besilles the awe with which he was inverted by the faret of having rasuel himsulf foum the draul. (John 10:1s.) IB IIt some dombtrel. Tho peretrliar Gireok ronstruetion is the same as in

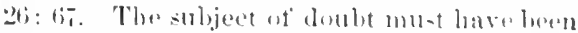

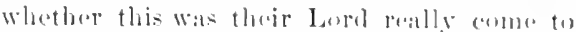
life. From Matt. alome we homlit naturally understand that the danbers were somace at the oleven, and this is in itseltentimly pusilole, even as at first they "disholinger for juy",

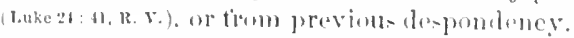

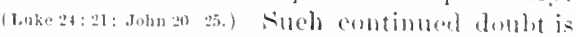
more intelligible if wo suppose this to have

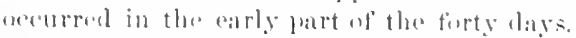
The aceomente all goto show that the apo-tlea wore liy no means swift to aecept the ereat and anazing fact of their Mastor" rebrece-

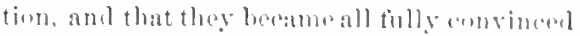
at last anly beanse of multiplied and varied "rideree-a fibet which makas their final comvietion and testimentr all the mores valualole to us. Jerome: "Their doubliting incruases our faith." It we suppore the "abuve tive hundral'" to have been prosent on thas same vecision, then 'some durbeded' may mean 


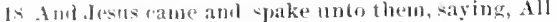

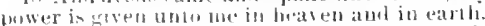

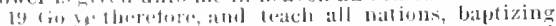
them in ilse names of the father, and of the forl, and of the lloly fitum :
Is solne doulied. And Jesus came to them, and spake whto them, saving, All anthority hath been given 19 unto ne in heiten and on earth. (io ge therefore, and nake diseiples of all the nati ns, biljtizing them into the nane of the Father and of the son and of some of thr. five hundred, though not of the

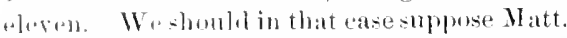
to he writing simply as an eye-witness, mentioning forsons whose presence his marrative has mol acentuntud for. Whuever the doubters were. wa may ferel contident that their doubto were remered lig the words that follow, and by the arom-jom and the l'enterostal gift. Some take tha plirace, and losus eame, as sugge-ting that he suddenly appeared at a distance, and the doubtimer continued only until ha anum luats. And spake noto them. We may well -unnose that he first said many other things. What is horegiven divides itself into three barts; (a) Thr asertion of anthority, v. 1s; (l) The commission, v. $19 \mathrm{f}$; (c) The promisin, $v 20 \mathrm{~b}$.

(a) 14. III power. Jesus claims universal atuhrits. Wp hase seen on 9:6 that the firesk worl denotes premisoion, privilege, rinht, authority, and it sometimes suggests the juw rer naturally attendant upon atuthor-

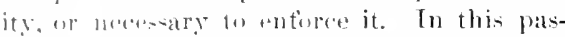

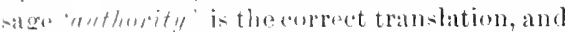

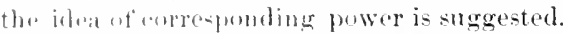
III powne (at thority) in heaven and in earth. airlently demotes eomplete and uni-

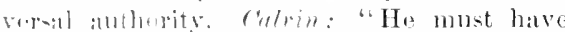
slpwome and truly livine dominion, who

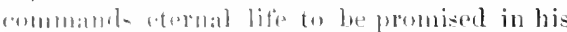

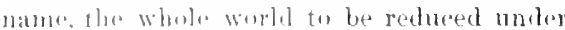
his swas, and a dustrine to be promulgated whinh i= $10-11$ hlue arery high thing and bring

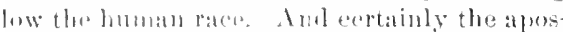

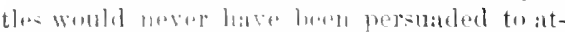

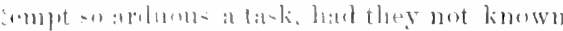

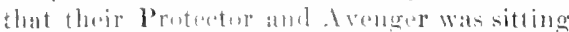

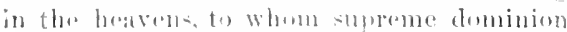

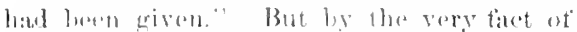

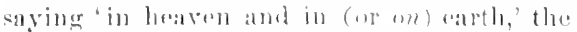
Sisiour showerl that he did not meall the

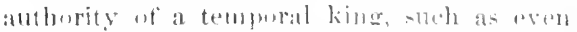
the disciples so persiotemely ludiesed that the Manah would lu. Io grinen, more liberally, wes giem, without suying whon, and louving

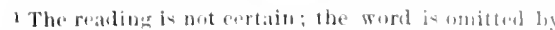
many documente, and maly bave been inserted (1) liring ont the relation between this aud the foreguing elatuse it to be malerstood that the authority thus given is still prssessed. We might suppose a referenee to the councils of eternity, but more likely the gitt was at his incarnation, as in 11: 27, Rev. Ver., "all things bave been delivered unto me ot my Father," and perbajs was consummated at his resurrection. Comp. in general Dan. 7: 13 f. 'The giver was God the Father; comp. especially Jolun 13: 3 and 17: 2, also, Matt. 9: 8; 20: 23; 21: 23; John $5: 27 ; 10: 4 \%$. We learn elsewhere that this authority given to the God-man, the Mediator, is a temporary gift. When he shall have subjected to himself all opposing authority among men, then he will deliver up this delegated authority of the King Messiah to God, eren the Father, and his special mediatorial dominion will be re-absorbed into the mnjersal and eternal dominion of God (1 Cor. 15: 24-28). It is on the basis of this mediatorial authority, in hearen and on earth, that tho siviour jssues his commission to his followers. Go ye therefore. This "therefore' ${ }^{\text {should }}$ never be overlooked when we think of the commission (comp). 'therefore, in Heb. 4: 16). It was a despised Galilean, a wandering and homeless teacher, that gave this audacions comnand; but it was a teacher just raised from the dead, and ondowed by God with universal authority. Hamma: "When Jesus said, 'Go, make disciples of atl nations', ho' announced in the simplest and lenst ustentatious way the most original, the broadest, the sublinest enterprise that ever human beings have been called upon to accomplish."

(b) $19 \mathrm{f}$. Jesus gives dircetion that all the natious shall be discipled unto hine and taught to lewp his commandments. If the "above fire hundred" were present (see above on v. 16i), then this commission was not adlressed to the Eleven only; and it is phin from lets 8: 2, 4, that the first Christians all set them-olves to carry it ont. Judaism in general vias not a misionary religion. It was willing fur Gentiles to come, as the prophets

But that relation exideutiy exisis, whether expressed liy a particle or not. 
hat predieted they would, but it hatd no thought of going. The later Jurlatism had descioped a zeal in proselyting, which in itseif would hate been comtechdable; but it proselyted to mere formaliom and hypucrisy ; (comp. on 2:3: 15). Christianty is esentially a misionary religion, analugons to the great compluering nations, the Romans, Enghtis, Rusians. It munt spreald, ly il law of itnature; it mat be active at the extremities, or it beeomen chilled at the heart; must he enlarging its circumterence, or its very centre tends to be detaced. We tearn from Latie (26: 4 ify) that they were nut to go immediately, but to tarry at Jerusilem for the promised gift of the Holy sipirits power. This "ame in a very short time, and yet they tarried lomer, apparently several yours: for the great Pentecost was probibly in A. D. 80, and the death of stephen in $A$. D. 83 or 37 . It required persectition at last to scatter them, and then tiey "went about preaching the word." (Acts 4: A. Rev. Ver.)

'Teach, Rev. Ver., make disciples of, or more exactly, disciple. We greatly need an English rerb 'discipte, tor this prasige, and for 1:2: 5: and $\Lambda$ cts $14: 21$. In Juhn 4: 1, the literal translation is 'makes disciples.' The Syriac (Pesh.) here exactly reproduces the Greek, by means of a callsative form, probably derised for the purpose, and gute distinct from 'teach' in v. 20. The Latin and the Coptic were unble to make the distinetion, and the Latin failure extended itselt to the early English and German transhations. some later Germams liave rendered make disciples of,' as in several reent English versims. The reth 'disciple' is fimmd once in Shak. ("Nll's Well," 1, 2, 28), once in spenser's "Fatry (queene," b. ir., e. 1), also in H:mmond (d. A. D. lotio) ; it is called obsolote by Wublor, but recomnized by Richardson, Wurcester, stormontli, ete. There may be doubt as yet about introrlucing it into a popular version, though employed here by Am. Bib. (n. and by l)ardson, hat it may be used in religious discourse with great alvantage. 'Teach,' in all early English versions, was a very imperfect transiation, confounding this term with that in v. 20, which really means 'teach.' To disciple a person to Christ is to bring him into the relation of pupil to tencher, "taking his yoke" of athoritative iustruction (1): 29), accepting what he says at true because he say it, and submitcing to his requirements as right berause he makes them. Towards a mere hunan and uninspired teacher we can properly fect and act thus only within narrow limits; but the cireat Teacher has perferet wirdum and unlimited autherity. We se then that Christ's intimated anthority ( $*$ I*) is ant only the basis ot our duty to disciple othere, but the basis of all true disciplestip. II is teacting and requiresments are pertectly wise and rightenole and gond, and we may sere this to-ome extent at the outset, and more and more an we go on in the diseiples life; but we aceept them at onces, and set abrit conforming to them. becalpe bes

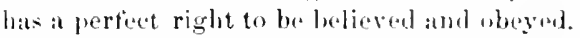
As to the noms 'disciple, see on is: 1. We know trom other sicriptures that in order to men's beeming true disciples to Christ, there is needed, not merely houlan instruetion and influnee, but a special work of the IInly spirit of (ind.

All (the) nations, the Greek having the alticle. Not merely the contigunas, or the kindred nations, wot merely the most cultivated, but all the nation. Inicoipleship to Christ is ponsible to all, necesary to all. Our Lord has already predicted that the good news shall be priached in the whole world (26:13), and that when be finally comes for judgment "hetore hin shall br gathered all the nations." (25-32) So in the latent (0)mmisson, given just before the asconsion, "and that repentance and remissinn of sins should be preached in lis name unto all the nations: begimning trom Jerusalem." (Luke at Si. R.v.) And if Mark 16: 9-20). R. V., be accepted as gentine, the commision there given reads, "Go ge into all the world, and preach the ganpel to the whole "rition." In Matt. 10: i, Rev. Ver., the Twelve were tintidden to go "into any way of the fintules"; but that was a temporary and limitul mission; the final and permanent mision mado them begin with the bew (tuke:s:45). but go intu every waty of the Gentiles, disciple all the nations. The idea of one religrion for all the world then seemed vary strange. Liditun (II, 247): "No existing religion conth aim wt, since the "xisting religions were luclieved to be merely the products of national instinets and aspirations; pach religion wiss fart of the 
furniture of a nation, or at most of a race. (ivlls, fooking out on Christianity in the serond contury of oin era, with the feelings of Gibbon ur of Voltaire, said that a man must he out "th his mind to think that Greeks and Barbarians, Romans and seythians. bondmen and fromen, could ever have one religion. Nevertheles this was the purpose of our Lord.

Baptizing them. See the term explained on :): It It hore the present participle, as is 'tarching' in the next elause. This contruetion might grammatically mean, if called forbs the matural relation between the actions, or by the eonnection here, or by the known rolations as alsewhere set forth, 'disciple by baptizing... by teaching'; and so many understamit. But the general teachings of scripture do not allow us to think that discipling ran be effected by a ceremony and asub-quent cunre of instruetion in Christ's preoepts. Wo must therefore understand that the presun particinlos give batptizing and teaching at in a general way concomitants of dis(ripling, the ceromony attending it prompt]y and one for all, the instruction in precepts breginning immediately, and continued without linit. from the nature of the case.

In the name, but into Rer. Ter.) is the most obvings and (ommonomet translation of the (ireck whrise (ris to omoma). The same jropueition and ease are found after baptize in 1 (口t. $x: 16 ; 19: 5 ; 1$ Cor. 1: 19, and (with

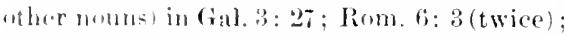
1 ('or. 10: 2; commb. aloo Matt. 10: $41 \mathrm{f}$; Is: 20. Now if we take this ofwious sense 'inte.' the question will arise whethor the ceremony actually brings the person into the name, jutn ('hrist, into l'aul, Moses, rete, or whether it only represents, symbolizes, tho relation thus indicatud. Those who berlieve in baptisusl regemeration, or in laptism as combtuting regencoration, will of course take the phraw in the former suse; others will under-tand that the oreremony and y represents the forsun's introluetion into tho name, into christ. In rither casethe idea denoted by 'into' soems to be a hichly important, and with those who beliove in haptismal regeneration, rete, an essential element in the signiti- eance of the ceremony. Now it is to be observed that Iuke in Acts, while twice using 'inte the nane' (eis to onoma) (as above eited), in 2: 38 has epi toi onomati (so also in Matt. 18:5; 24:5), 'upon the name, upon this as basis or ground of the eeremony, and in 10:48 en toi onomati, 'in the name, within the linits of it, with relation to it and it alone. If then the jdea attached to "into" be highly important, or even essential, how do we account for the fact that Luke uses these other expressions, which may with some effort be construed as equiralent, but will quite fail to indicate the important conception in question? It would seem elear that Luke, when recording the action of the apostles in earrying out the commission, did not regard the distinctive notion of 'into' as essential or highly important, or he would lot have used that phrase twice, and twice the other phrases. And those who insist on the most obvious translation of eis by 'into,' must beware of treating any particular interpretation of the expression as very important, in the presence of Luke's usage. The question may alsoarise whether it is zot better, with the great grammatical commentators Fritzsche and Meyer (comp. also Weiss) to understand eis to onoma as meaning in all these eases 'unto the mame,' with reference to the name, as that to which the ceremony is restricted. Then it becomes plain at onee that Luke's other phrases give substantially the same sense, and we see why he has varied the expression at will. This rendering is felt by all to be necessary in 1 Cor. 10: 2, 'baptized unto Moses,' which only Davidson ventures to translate 'into Moses.' Noyes suys 'into the name,' but 'to Moses'; Darby 'to the name' and 'unto Moses.' And in Gal. 3: 27; Rom. 6:3, 'unto' gives a thoroughly appropriate conception, 'baptized unto Christ, with distinct and exelusive roferenee to lim; $i$. e., the ceremory dues not refer to Moses, or to Paul, but to Christ. And note especially the appropriateness in liom. 6: 3, "all we who were baptized unto (hrist Jesus were buptized unto his death." ()ur baptism in referring to (hrist Jesus referred especially to his death. "We wre buried therefore with hin through the

1 'Thr aorist participle is read by $B$ I), without otber support, and iu obsious assimilation to the aorist par. liciple and vert, which precede. 
bapti-1n unto death," ote. We beliere then that it would be a deridud improvement to render baptize ris eserywhere by 'unte. It this le not denr. it would bo lens mi-leadiag to retatu the cu-tomatry batptismal formulat in the llatle, alld thus aroid stogesting a com-

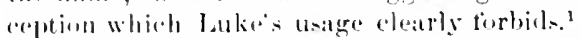
O) if 'inte' be empluyed ats the most obrion-

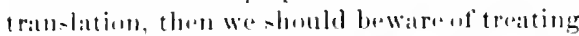
the di-tinctive motion it suggerts als esential or important, when Lulse has evidently not $\therefore$ (considereded

li Hebrew thought and freeling, the nome of (ionl wat peeduliarly silered, ats reprosenting bim. It must not be proken irreverently, and later Jewish forling axagererited thi- into a rule that the poples name Yahweh mu-t not he pronouncerl at atl. but ansethere word substituted. (Comp. on 2.2: H.) The name of (Fol mu-t not in all wath be taken in vatin.

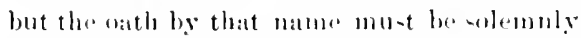
takina and sateredly kept. In numsermo parsatges of the (Old Testament, the name of (ionl solemnly repreanterl himedf ; tolueform any andion with express peference to his name gave tho action a silerent cluaracter. Ane so in the Now Testament use, "hallowed bre thy name, 'did we not prophey by thy name, 'in his name shat the (ientiles bope,' "where two or three are erathored together in my name, 'many shall comm in my name, ete. In such phrases a great variety of specitie idens will aries aceoplien to the liatural relations of the particular oljerets and actions, and the conneetion of the statement; but in all cises the natme is a sacered representatise of the persome. Thus 'baptizel unte the name of' l'aul' is an impressive Wily of -ilying 'baptized unto Paul,' like "baptizenl unto Mosos" ; 'baptized

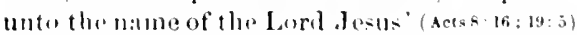
and baptiond on (in) the name of Jesus Clari-t' (1,es: $34: 10: 4$ ), are an impreseive equivalentfor 'baptized unto Christ' (Gal. $3: 2 \pi$; fom. 6:3); and 'baptize unto the name of the Father and of the Fon and of the Itoly sipit' is a solemn way of salying "unto the Father, and the soll, and the Holy spirit.'

Bapti-n then is lore mujoined as to bo prerformal with express reference to the IIoly
Trinity. Comp. 2 Cor. 13: 14. From this, no doubt, aroesthe quite arly practice of baptizing t! reetimes, a practice still maintaiued in the Greek chureh, and in Germany and Aueriea by the Tunkers or Dunkard-, and sone others. It is not an umutural conteplotion, and not in itself particularly objectionable, but it has no warrant in Scripture ; and indeed, the formof "xpres-ion hore remployed, 'unte, the nature' heing used only oncer, is distinctly untasorable to that practice. It slonid aloo be discouraged at temeling to exalt the eremonial element. While Now Test. Christianity hats the minimum of ceremony.

It is very natural that christians should averywhere employ in baptizing thi phases, 'unte (into, in) the name of' the Father and of the Sion and of the lloly spirit, and we see no reatoon for departing from it. liut it is of dembetiul proprioty to all this a lawe and to insist that baption would nut be "valial" without the $11=0$ of this particular phrate. Fur it must be remembered that baytize is nerwhere clas in the Now Test. anoriated with this partieular expreseinn. In let- and th" Epistles wo find anly the Lorel dosus: ar

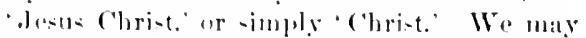
woll anougl under-tand that this is a compendionse expresion, which tonches the main print or peeculiarity of the great Christian purification. We conald not wionly inter from that lisage that it is improper or undorablow to employ the full expresion given by Inatt., but we are bound to muler-tand that it is not indispensible. There would he nothing gained in pratice by u-ing me of the sherer phases given in Areta and Paul, lust there is something gained in just conereption if wre abstain from regarding the expresion in Matt. ahaving the chatrater of a law, about which we shomld thon hace to suppose that lake and Piul had been strangely negligent. Plumptre fancies cafter Cyprian, "Ep. Ti:." e. 17. Is that it was anough tor derish con-

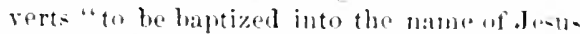
as the Mromiah," while heathen convert-, who "wore without ford in the world." and harl not knuwn the Father, weeded the other and fuller formula. But Patul has not ured it.
1 Tertulian giros in nomen, but the Latin versions in all forms, anl ummerous Iatin Falhers quoted hy sabatier, give in nomine. The Memphitic se ens to be equir- alont to in nomen; the -yriac candot well make the distinction. 
20 Tegehing them to ohserve all things whatsoever I have commanded you: and, lo, I am wilh you alway, even unto the enr of the world. Amen.
20 the Holy Spirit: teaching them to olserve all things whatsoever I comminded rou: and lo, I an with you ${ }^{1}$ alway, even unto $^{1}$ the end of the world.

I Gr, all the days...2 (or, consummation of the age.

and his converts were mainly heathen. $1-\mathrm{It}$ was probably this passage and the great benadietion of 2 Cor. 13: 14 that made the English Revisers unwilling to adopt the suggestion of their American assoeiates, and change 'Holy Ghost' into 'Iloly spirit' (eomp. on 1: 18). The former will, no doubt, long continue to be employed in certain phrases of devotion; but it would be a gain to mniformity and clearness of rendering, if the latter were every where used in the translations.

The design of Christian baptism seems to be indieated as threefold. (1) The element employed represents puritication; "arise, and be baptized, and wash away thy sins, ealling on his Hame." (Acts $22: 16$. R. v.) This meaning it has a in common with the Old Testament purifications of every kind, being a very impressive kind of purification, because "the putting "W wy of the filth of the flesh" (1 Pet3:21) is in this ease so complete. (2) The action performed symbolizes burial and resurrection, the actual burial and resurection of Christ, and the spiritual death and resurrection of the believer in union witlı Christ. (Rom. $6: 3 \mathrm{ff}$; (aal. 3:27.) (3) To have this ceremony performed upon ourselves in the name of Jesus 1hrist, or in the name of the Father and of the Som and of the Holy spirit, is a sort of anth of allegiance or pleage of devotion to him as our savionr, and our lood; we are not baptized unto Moses or unte Paul, but unto Christ, unto the 'Trinity. Hence it was at plessant fincy of the parly Latin Christians to) call baptiom a sacramontum, the Roman soldier's oath of absolute duvotion and obediancer to his gereral; though the word sacrat ment afterwards came to be gralually employed in applications and senses quito foreign to the New Testament.

Teaching them to observe all things whatsoever I have command ed you. Baytism is a mereceremonial and initial act of ubesdience to Christ, which should be followed hy a lifelong obedienees to all his commandment.

In the "Didurhe", h, 7, and in .Justin Martyr, "Afol. f," chap, fil, the formula of Matthew is girnu, as if a matter of conrse. There was no little dispute
The person who is diseipled and baptized is only started in a eourse of Christian living. Notice that it is not simply teaching them the eommandments of Christ, but teaching them to ubserve his commandments. They who disciple and baptize men must teach them the duty of obeying Christ in all things; and the Christian instructor has still fillen short of his task mnless those whom he is ealled to instruct have both learned what Christ's commandments are, and have learned to observe them. Notice also the emphatic and eomprehensive terms, 'all things whatsoever I have commanded you.' The risen Redeemer looks back upon his now finished work of teaching and speaks of it all in the past tense, as he already often did in the jrayer of John 17, on the night before the crueitixion. These completed commandments would be hereafter brought fully to the remembrance of the diseiples by the new Paraclete who would soon take the Saviour's place as their instructor and counsellor (John 14:16, 26), and this whole mass of saered instruction and duty, withont omission or alteration, they must teach those whom they disciple to observe. Liddon: "This is not the least noteworthy feature of our Lord's worls, that he does not foresee a time or circumstanees when any part of his teaching will breome antiquated or untrue, inappropriate ol needless."

How vast is the range of thought presented or suggested by this saying of our Lord. (1) Theology, the doctrine of the Trinity, and the Mediatorial authority of Christ. (2) Diseipleship, and the work of diseipling others. (3) The great missionary idea, "all the nations.' (4) The ceremonial element of Christianity. (5) (hristian ethics. (6) Christ's perpotual spiritual presence with those who sorve him. ( 7 ) Christ's final coming.

(c) 20 b. Jesus gives assuranee ot his perpetual spiritual presence with all engaged in discipling athers and in observing his commandments. Obedience to the Great Com-

among the Fathers as to whether baptism in the name "ff lesus woukl suther. See Ilerzog, "Taufe," 4). 
mission is hasel un his universal and eomplete authority (velu), and encouragud by the promine ot hi- unfiling and sustaining presence. And this reatrily aplies, not morely to the apusthes, hut to disciplas of every period. even to the end; amp. 18: 201. True Christian wolkers may bo desplised by skeptical philosephores and some protentions mene of science or men of letters; but history has shown that they are a puwere in the world, and that powere is explainod by the perpeteal frenenco at then Lold and Redeemer.

Nany things in this Gospel have been introdecerel by lo or behold, calling attention to what fiblows as woulertul; lut surely none more fitly than this its marvelous and blessed elosiug word. I is sopalately expresiced in the Grooli, and is therefore emphatic. Alway is liturally (mategin, Rov. Ver.), all the days; days of strength ambl of weakness, days of suecess ond of failure, of joy and ot sorlow, of youth and of age, lays of life and day of death-all the days. ( ( 1 mp. Westeott, "Revelation of the liisen Lord."') The end of the world is literally (morgin, Rev. V(r.), the consumenetion of the age, or of the world-

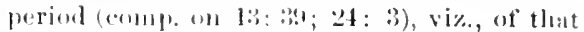
world-period which was introducid by the Mesialis coming, and will be amsummated hy his secoud anming. Then his spiritual presence will looense a visible presence, but noue thr less spiritual, sustuining, nud delighttul; then we shall see hin whom not having sern we love, and shall klow even as also wo were known.

Jesus, the very thought of thee With sweethess fills my breast; But w weeter fur thy fitce to see, And in thy presenee rest.

Maỵ erery beari confess thy name, And ever thee adore;

And seeking thee, itself intlame 'Tu seek thee more and more!

Grant me, while here on earth I stay, Thy love to feel and know:

And when from bence 1 pass away, To me thy glery show.

BERNARD UF CLAIRVAUX, TR, BY CABWAIL 



\section{INDEX I.}

\section{AUTHORA QUOTED OR REFERREI TO.}

Much space has been saved by giving only an author's name, fromently abbreviated.

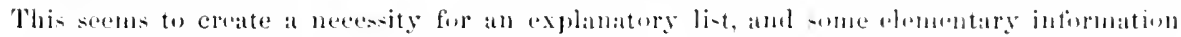
about anthors and the works quoted is alded fir the benetit of junjur sturlents, and of general readers anxious to know the anutry, age, and religiens poitions of the anthori-

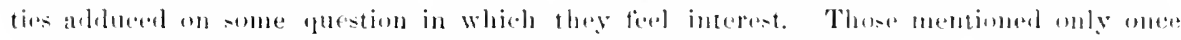
are there sufliciently described. and astully not inclueled in this list. The early christian athors are abled Fathers, without olserving the Romish dietinetion betwon fathers and writers. Whore no date is given, the author is supuesed to be still living (16wi).

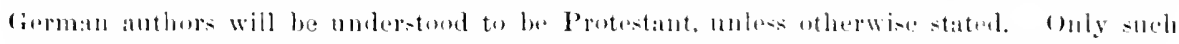
works of an author are montioned as have been puoted or referred to in the Commentary The titles are all given in English, and the original language mentioned where a work is not known to have been translated. The lowks of refierence empleged in making this

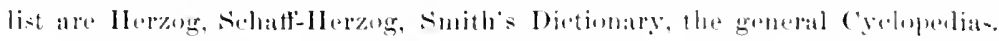

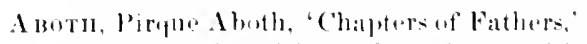
a stertion uf the Mishon. 'Tram-lation with moten by (c. Tilylur, "sityings of the Jewish Fathers."

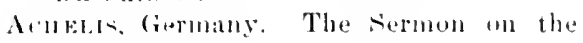
IImunt. 18is.

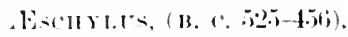

Airn., Ethiopic vorim of the New Test.; probilly matre in Fifth century.

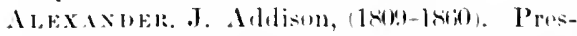
byterian 'Thoolugical P'rot. in P'rincentent. Commentaries an Mark, Mathew, Isaibl, Pialme.

"Araxanuma" text, see Westent and Horti Lutronluction.

Alr., Altiorl, Itrity, (1810-1851). I):an of Cinterhury. Greek Testament.

Ants. Ape. Ameritan Apendix to the Ravinel Euleli-h Verson of list. The levised text griven in this cimmentary is one confinmed to the preforences axprosent in that appertix.

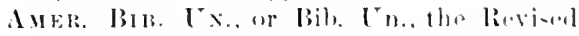

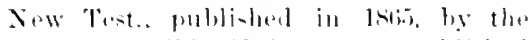
Ameriean Bible lnion: now published by the Anerican Baptist Pablication Society.

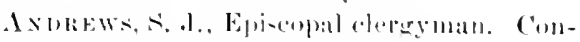
necticut. litis af our lurel.

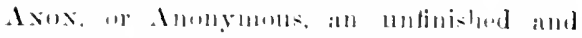
ammymoms Lattin ('ommontaly on llat -

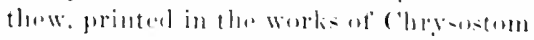
(Migne, vi.); ustally alled (1) Im- Imperterettum in Matt.

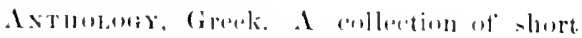

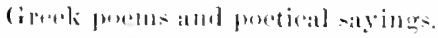

AxT, or Antoninu, II. Auretius (1. I). 1:1-1401. Roman Emproror. Meditatims.

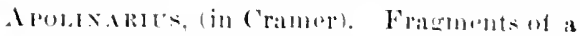
ciresk chlistian writer, probithly one who died . . 1. $3: 014$.

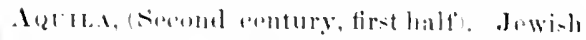

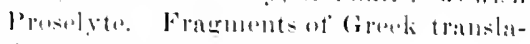
tiull at (1) the Test.

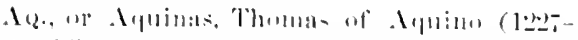

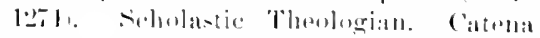
Aureat, al commentary un the (Bospuls,

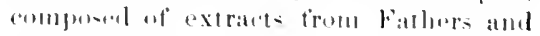
later writurs.

Aru., Arementall versind of the Now Tent, probably mate in Fifta antury.

Arsolab. Gromang. Roman catholice Commentary on Mathew (in Groman). 
Arxot, William (1808-1875). Sentland. Presbyterian minister. On the Parables.

Ava., "r Augustine (. . บ. 353-4:0). Latin Father. II armony of the Gispels. Sermon on the Hount (Trench's ed).

Bapt. Quarterly, Philadelphia, 1867-1877; Bapt. Qunterly Review, New York, from 1885.

Barnes, Alhert (1798-1870). Philadelphia. Presbyterian minister. Notes on the Gorpels.

Barthet, S. C. Congregational minister. President J artmouth College, New IIampshire. From Egyut to Palestine. 1879.

BEDA (674-735). England. Commentary on Matthew.

Broget, John Albr. (1687-1752). Germany. Guomon of the New Testament.

Bur. Comm., Bible Commentary, called in England spealier's Comm. On Mattlew, by Intusel, completed by the editor, Canon Corkt.

Ber. Un., or B. C., see Amer. Bib. Un.

B13. SAc:, Bibliotheca Sacra, Quarterly Review, formerly published at Andover, Mat..., now at Obertin, Ohio.

BraEk, Frindrich, (1795-18-19). Germany. Srnoptical Explanation of the three first Ginspels (in German). Introduction to the New Test.

BurTu, F. C., Churels of England. Thoughts on tha Lord's Prayer.

Boalmax, (r. l)., Philadelphia. Baptist Minister. The Mountain Instruction. The Moclel Prayer.

Boyes, J. P'., J'resilent sinth. Bapt. Theol. Sem., Louisville. A brief Cateehism of Bible boctrine.

Bruer, Alex. B., (B)asgow, Seotland. Presbyterian l'rof'. The Training of the Twelve. The Pamalolie Teaching of ebrist.

Be'tтm, or Buttmann, Alex. Germany. Grammar of Nuw Testament Greek.

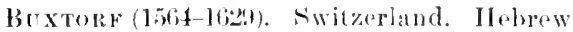
ancl Chaldee Lexicon (in Latin). Jewish siynagogne (in Latin).

Gaperwoon, II., Seotland. Prot. Momal Philosonlyy. The Parables of our Lard.

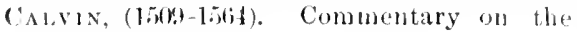
New Test.
Caspari, Ch. Edwd. Germany. Chronol. and Geograph. Introduction to the Life of Christ.

Chrse, or Chrysostom. (347-407). Greek Father. Homilies on Matt. The "followers" of Chrys, often mentioned with him, are Theophylact and Euthymius.

Cickro, (B. C. 106-43).

Clakk, G. W., New Jersey. Baptist minister. Hamony of the Gospels. Conmen. mentary on Matt. Both published by Amer. Bapt. Pub. Soc.

Clarke, W. N., Toronto, Canada. Prof. in Baptist College. Commentary on Mark., Amer. Bapt. P'ub. Soe.

Clem. Al., or Clement Alex. Clement of Alexandria (flourislsed about A. D. 200). Greek Father. Works partly translated from Greek.

Colmridge. II. J. English Jesuit. The lite of our Life.

Com. Ver. The Common English Version of the Bible, often unwarratably ealled "Authorized Version."

Conant, Thos. J., Brooklyn, Bapti-t Theolog. Prof. Revision of Matt., with Notes. On Baptizein. Amer. Bapt. Pub. Soe.

Coxder, Claude R., English Engineer, engaged in survey of Palestine. Tent Work in Palestine.

Corn. A Lap., see Lapide.

Covernale, (1489-15699). Church of England. English translation of the Bible (1585).

Cramer, Johu Authony, formerly Professor in Oxford. Catena of Greek Fathers to the New Test. (1844).

Crax., or Crammer (1469-1556). Arebbishop of Canterbury. An English translation of the Bible, see "Great Bible."

Cremer, Hermann. Germany. Biblicaltheological Lexicon of New Testament Greek. Steeond edition translated, third and fourth editions enlarged.

('ertils, George (1820-1885). Germany. Clanicical Prof. Prineiples of Greek Ety. mology.

Crpriax (Third century). Latin Father. Works.

I)ARBY, Joln Nelson (1801-1882). Chureh of England, afterwards leader among the Jymouth Brethren. A New Translation of the New Test. London. Morrish. 
Demalunds, a Greek Pythagorean philosopher, date unknown.

D) ELT\%(CI, Frati\% (born 1813). (iermany. "A Day at Calpernaum," 18 .

DF: WETTE $(17 \times(1-1849)$. Germany. Exegetieal IIand-bonk to New Test. (in German).

Dibacilf. The so-ealled Teaching of the Twelve Apostles, written in the seeond (antury (probably latter jatrt).

DoD.SIC., Diolorus Sirulus (tourished about ('hristian Era). Universal Ilistory (in (ireori).

Dö:tıxaer, I. Germany. "Old Catholic." The First Age of Christianity and the ('hureh.

Doray version, see Rbeims.

DYke;, I. Oswald. London. Presbyterian ministor. "The Minifesto of the King." (Sermon on the Momnt).

Errard, John Hen. Aug. (born 1818). Germany. Criticism of the Gospel History, $181: 2.18 .5 \%$.

Eer' Hoso. Anonymous work on Life of Christ. but written by Prof. J. R. Seeley, Londin.

Eords., Ecclesiatiens, Wisdom of Jesus the son of Sirach, a book of the Old Testa-

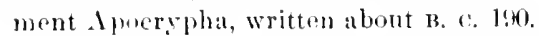

EDERsir, Elersheim, Altred. Chureh of England. Life and Times of Jesus the Messiah. Sketches of Jewish Social Life. The Temple.

Egrptiax Vhroions: (1) Memplu., or Memphitice, in Lower (Northern) Egypt. (2) Theb., or Thebatie, in L Uper (sonthern) Egrpt. Buth wereprobahly made late in the Seeond, or early in the Third century.

Elcicott, Chas. John. (1819). Bislop of Gloncester amb Bristol. Historieal Leetures on Life of Christ. On Revision. (ommentaries on Galatians to Philemon. New Test. Commentary for English Readers, edited by Ellientt, see Plumptre.

Epictatus (tlourished A. D. (10). Stoic Philosopher. Diseourses, ete.

2 Esidris, one of the Old Test. A procryphal books.

Euritides (B. c. 480-406).

Ers., Fusebius about A, D, 200-340). Greek Fither. Eeclesiastienal IIistory. Commentary on the Psalms.
Eustatules (died A. D. B3: Bishop of Antioch.

Eutury., Euthymius Zrgadenus (Twelfth rentury. Byzantine direk writer. Commentarits on the Four (isencls.

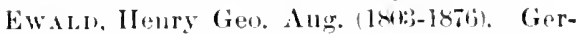
many. llistory of Christ and I! - Times. Three first Gospels. 1s30.

Expositor, The, monthly. London.

Falrbarrs, Patrick (180,i-187ti. Seotland. Preshyterian minister. Ilermenentical Iamual.

Farbitrx, A. M., England. Inderendent College principal. Sturlies in the Life of Christ.

Farkar, F. W.. C'hurch of England. Life of ('lirist. II Ierey and duldement.

Fisir, II. C. (18:41-18it). Xaw lerey. Bapt. minister. Bible Land- lllustrated.

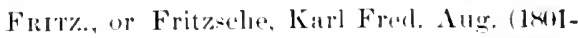
1846). (irmany. ('ommontaries on liatthew, 1826, and on Mark, 1830 (both in L:tin .

GeIgkr, Abrabam (I810-18i4). Germany. Jewish rabbi, Julatism and Its IIistory. sitdduceses and Plariores. (Both in German).

GeIkIE, ('. C'hurch of Englind. Life and Words of ('lurist.

Gex, or Geneva, an English version of the lible (15is).

Gide, Joln (16is-17i)). Tandom. Bapt. minister. Commentary on the Bible. Body of Divinity.

Glong, P. J., Siotland. Presb. minister. Exegutical studies.

Govet, Frederic (born 1812). Switzerland. commentaries on Luke and on John. Now Trestament stmies.

Gokber. (Bemany. The larables of Jesus.

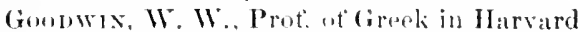
Eniversity. (ireele Momels and lenses.

Gothus, Verson of New Te-t., made in Fourth eentury.

Gakat Bunate an English reprion in a large volume (15ig), seentel enl. with prefiee by

- Crammor. and bence aftun ealled Cranmer's Bible

GrFa. Y.1\%, Gregury Xakianzen (A. D. 830sen). Greek Father. Works (in Greek and Latin). 
Girffith, Thomas. Chureh of England. sundies of the Divine Master.

Grimu, (. L. Wilibald (born 1807). Germanl. Lexicon of the Greek Test. (in Latiol, 21 ed., 1879. ('Phayer's Lexicon, 18si, transhates Grimm entire, and makes valuable alditions.)

Groters, Hugu (158:-1645). Holland. Anmotations num the old and New Testamonts (in Latin).

Giffix. France Description of Palestine (in Frencli). 7 volumes.

HALt, Bp. Hall (1.54-1650), Joseph Hall, Bishop of Norwich. Contemplations upm the New Testament.

Haxi, Wm. (1808-188*). Seotland. Presb. minister. Life of Christ.

H.ARIs, John (180)-1858). England. Indepembent minister. The Great Comnision. Mammon.

JISE, Karl Aug. (born 1800). Germany. Life ot . Jesus. (Fifth ed., 1865, in Germin.)

HA corati, Alolph (bom 18:- Germany. Hintory ot New Testament Times. $3 \mathrm{~d}$ (1), 18,

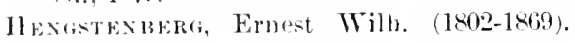
Germany. C'bristology of the old Testa1110.11.

Mrspr, Mattlaw (16ro-1714). Fugland. Ind.pendent ministar. Exposition of the () lid anid New Tertaments.

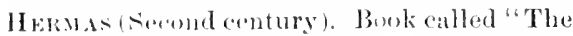
Flomphred"; among the su-callert Apostolic Fathers.

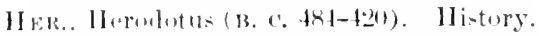

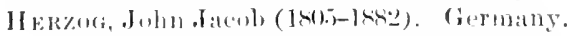
Thereloriend Furegelophedia (in (ierman).

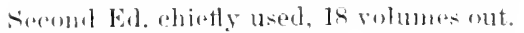

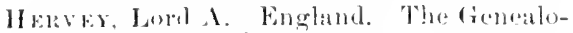

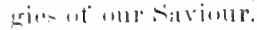

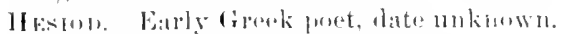

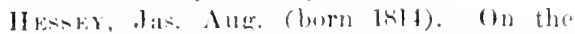

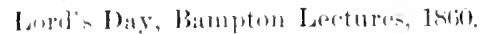

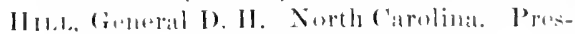
hetorian laymand. The siermons an the IIIIIt.

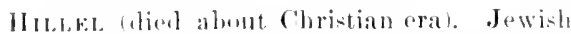
labbi. silvinge preserverl in Talmul.

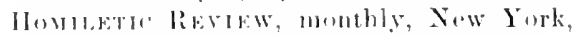

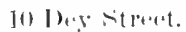

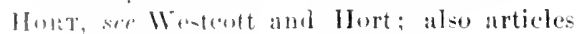
in poriodicals by F. J. A. llort.
Hover, A. Massachusetts. Baptist President Theological School. On John. 1885. On the sieriptural Law of Divoree. Both published by the Aner. Bapt. Pub. soc.

Humpiry, Win. Gilson (1815-1886). Church of England. Commentary on Rev. Ver. of New Test. (explaining changes).

Ignatios. Groek Father. Martyred about A. D. 110 (Bishop Lightfout). Seven Epistles.

ILI A L

IndePENDExt, THE, weekly religious paper, Now York.

IRENeUs (flourished Second century, latter half). Greek Father. "Against Heresies."

Irvixa, Edward (1792-1824). Seotland and England. Minister. Sernons on John the Baptist (in Works).

Jelf, W. E. Chureh of England. Greek Grammar, two volumes, fourth edition.

Jeroye (ahout A. D. P40-420). Latin Father. On Mathew. Lation Translation of Euscbius on Names of Places, sfe Eusebius.

JoNes, Tiberius G. Tirginia. Baptist minister. "The Great Mismoner" (Communion), Nashville, Tenn.

Joskpuls (born A. D. 37 or 38, died after A. D. 100). "Ant.", Antiquities (Ancient History of the Jews; "War," Mistory of the Jewish War; "Lifo," Autrobiograplyy; "ag. Ap.", Against Apion.

Julian (A. D. 831-36\%). Roman Emperor, called "the Apostate." Wurks (in (treek).

Justax, Martyr (flowrished seeond century, middle). Greek Father. Two Apolngies. Dialogue with Trypho.

KEBLE, John (1792-186i6). Clutureh of England. The Christian Yatr.

KEH, Karl Fried. (born 180\%). Gormany. ('omnentary on Jattlew (in (ierman).

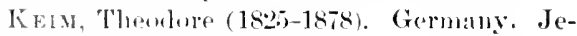
sut $11 f^{\circ} \mathrm{Nazatra.}$

K. I., or K. Janu, the English version made for King dantes, published 16il. The (and. Virs. as now printed, diffors in min!y slight drotiils.

livell (11)-1240). France. Jewisl Rabbi. 1f -brow Commentaries. 
Kertekr, I. A. Kentueliy. Baptist minister. On the Design of Batptionn. ('incinniti.

K1тT0, Jolu (1804-18is), Euglish Layman. Daiv. Bihle lllu-trations. Cyclopedia of Biblical Literature.

Köntkr. Germany. John the Baptist (in (ierman).

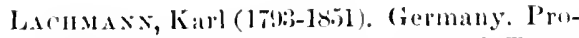
fessur of Plifology. Text of (ireck Testament. 18:31, :3 ed. 184i.

LAP.. or a Lappirle, Comelius a Lappide (1568-

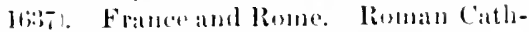
olice commentary on the (iospels.

Laxbor, Wilter siange (17i5-18lit). English II an of Ietters.

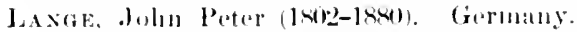
Commentaryon Mattlew. Lifie of ("lariat.

Late Vrastosis: (1) Mll Latin versind or versinn, mate first in second contury. and new of reviond rersins in sereral followiug centurios. (2) Latin Vulgate. mate at emo of Futhth eentury.

I. and $\mathrm{s}$., or Lid. and reott. II. G. Liddell and liohert sionte C'hureh of Eustand. (imeli-kuglish Lexicen, sixth and seventh eititions.

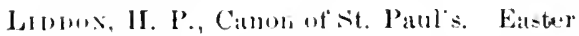
Sertuons.

LF., or Latitr., John Lirhtfont (1102-1675). Claureh of Einglatul. Worlis.

Bp. LnilltF., J. B. Lightfont, Bishop of Durhath. "Rer.", on a Fresh liavision of the English Xinw Testament. Commontaries on Galatians. Philipplatus, ('olossians; alo wh ('lement of lismes and on Innatius and Polycarp. Articles in Contempurary linejew.

Lorambr. G. C. Chicater. Baptiat minister. Jeste the World's sitviour.

Letuter, Itartin (1thi-lithi). Expmestion of the (inpols, collected from his works. ( In (iormin).

Letr., Latere. Lutteroth. IIenri. France. Expm-ition of the (bo-pel accorling to Matthew (in Fremelo).

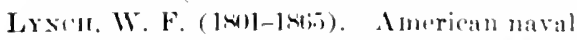
otlion. I. S. Expmelition to the River Jordatu and the Doad seat.

Macidaes, First, Seenold. Third, Fourth. Among the old Test. Apoeryphal books.

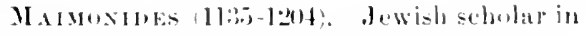

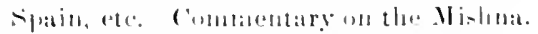

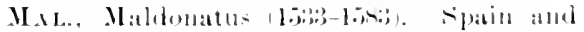
France. destit. Comburentally on the Four (insplets in Latin .

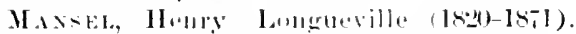
chureh of Fineland. Cimmonentary on (fatrt if) Matthew, in "Bibl. ('inmm."

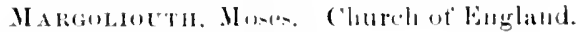
The Lord's l'rityer.

Malvorela. Engliob. Traveler in Pallestine alout labt.

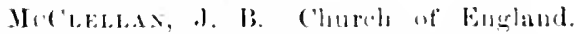

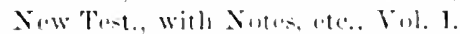

Mefrarvey, J. W. kinutucliy. limeiples, or Christians. Mlnister and l'rotessor. Latuds of the Bible.

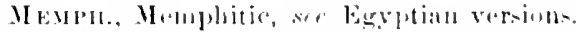

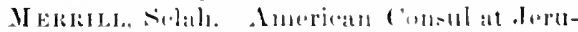
salen. Congregational minister. Cialilen in the Time of un land. biat of the Jurdati.

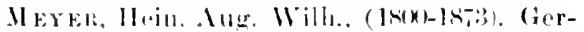

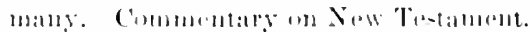

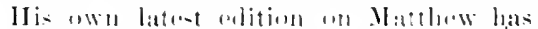

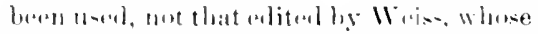

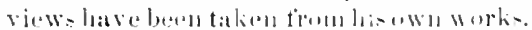

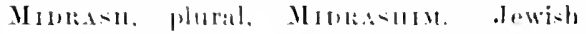
(ammentatries on sereral lemes of Old

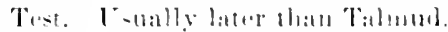

Male. W. II. Churels of Eurlanul. On the Ilythionl Interporetition of the (inepels.

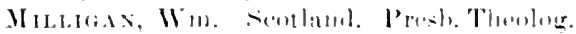
Prot: Articla in (intemplarary Roview

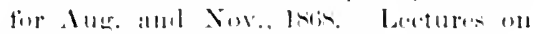

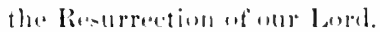

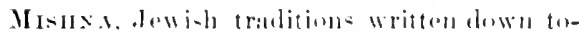

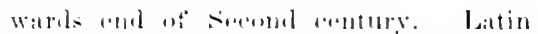
Tratu-tition by Surenhu-ins: Eneli-h tran-lattinso of some purtions ly barctaly, and hy siol:a and liaphalll.

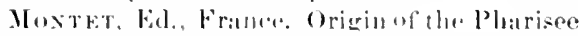

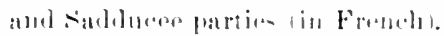

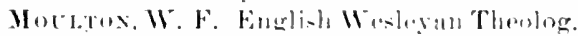
Prot: Tran-lition of Winere with enpions fimtunter.

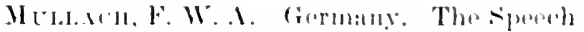
of the (mothrn) Cireak Common penple (in) German!

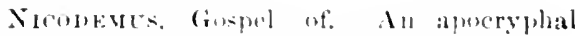
writing of the second or Third century. 
Nicol, Win. Robertson. Secotand. Presb. minister. Eulitor of the Expositor (1885). The Incarnate siviour.

Noyes, G. R. (17ak-1stis). Prot. in IIarvard [niversity. Unitarian. New Test. t]anslated (1sici).

ODYSEEY.

Olsil., or (ohshausen, Hermann (1796-1839). Germany. Commentary on New Test.

() Non.,Onomastieon, see Fusebius and Jerome. ()'татL:, (Furth eentury). Domatist. On the schism of the Domatists.

Oriakx, (about A. D., 18.5-about 254). Greek Father. On Matthew. On Luke. On Prayer. Other works, and extracts in Crilluel.

Paiker, Joseph. London. Independent ministr. "Tluese sayings of Mine." Inner Lifte of christ.

Pascal, Blaise (1623-1660). France. Roman Catlrolie (.Iansenist). Thoughts.

Prnu, Philo the Jew fan old man in A. D. 411). Aloxandria. Works.

Puree Alootil, see Aboth.

Plato (abeut B, C., $428-84_{7}$ ).

P'IXY (A. D., 2:-79). Natulal History.

Phetarril (fourished latter part of First century). (ireak. Parallel Lives. Morals, or Miscellaneons Writings.

Polaok. Rubert (17:M-18:7). Seotland. The Conrse ut' Time.

Porteus, B. (1731-1808). English Bishop. Works.

Psalus of fiolomon, so ealled, probably writtall about B. 4.45.

Pythagaras (xixth (exhtury B. c.). Greek phibsopher: Fraguents.

Qubankl, Pasquiar (10,4-1719). France. Ronuan Catholic. Now Testament, with moral reflowtions.

Quintelan (alment a. 1). 40-118). Roman writer on Rheturis.

RaBants (about Trtimalit. Fronel abbot. Quoted from Apuinit.

Rawlasson, Georer (horn about 1815).

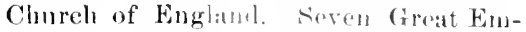
pilos.

Recovery of Jerusatil, see Warren and Wilson.
Reflectons. Practieal Reflectionson every verse of the Gospel. By an English Clergyman. 1881.

Reuss, Ed. Strastburg, Germany. Synopsis of the three first Gospels.

Rexnolos, H. R. England. Independent College President. On John the Baptist.

RiInIMs, a translation of the New Test. into English (1582), made from the Latin Vulgate by Roman Catholies at Rheims in France. The Old Test. in 1609, at Douay, called Douay Verion.

Rinule, M. B. Cunnecticat, Presb. Theologjeal Prof. New Editions of Robinson's IIarmonies.

Ritrer, Karl (1779-1859). Germany. On the Geography of Palestine.

Roblnson, Elward (17914-1863). New England and New Tork. Prosb. Theological Professor. Greek Harmony of the Gospels, and English Harmony (new editions by Ridale). Lexicom of $\mathrm{New}$ Test. Greek. Bıblical Researches in Egypt, Arabia Petraea, and the Holy Land. Physical Geography of Palestine.

Robisson, Thomas. England. The Evangelists and the Mishna (1859).

Rocinefoucatio (1619-1680). France. Moral Maxims (in French).

Röscen. Hermann. Germany. The Italie (Old Latin), and the Vulgate; a grammatical treatise (in German).

Rost and Paral. Germaing. Greek lexjcon (in German).

Ruskix, Jolnn (horn 1819). England. The Lord's Prayer. Other works.

Sculff, Philip. New York. Presb. Theolog. Prof. Commentary on Matthew. ComInnion to the Revised Test. Chureh History (seeond ed.) On the Person of ("hrist. On Revision (ineluding the treatises of Ellicott, Lightfoot, and Treneh). PCHNECKENGURGer, Matthias, Germany. llow old is the Jewi-h Proselyte Baptism? (in German). 1828.

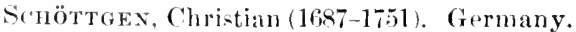
Hore Ebraicate et Talmulicae (Illustrations of the New. Test. from the Talmud). (1) Latin.)

Scmürkx, Emil, Germany. History of the Jewisli People in the Time of Christ. 
Sellwab, M. Freneh Jew, Talmud Jerusalem translated inte French, nearly finished ; inte Engrlisl, bergun.

Ścrivexre, F. II. A. Chureh of England. Introduction to the Criticism of the Now Test. (Third enl., improved).

SExEd (died 1, 1), 6.5). Romanstole. Works.

SEPCAGLT, the familiar Gerek tramslation of the old Test., mate hy different prorson- probably between 13. c. 250 and 1:30.

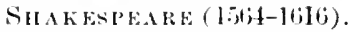

Sinacir, ser Eeclus.

SKEAт, W". W'. Prof. in Cambridge Lniversity, England. Etymological J)iet. of the English language.

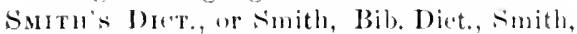
William. ('hurch of' England. bietionary of the Bible; American elition, enlarged by llackett and Abbet. Dict. Clar. Ant.. Dietionary Christian Antiquities.

Surtu, Phihp. Chureh ot England. Nomual of Xow Testament llistory.

Sputieor, ('. II. Fermons.

Staxfosi, Charles. (1823-1856). England. Baptist ministor. The Lord's Prayor.

Staxtey, A. P'. (181.)-1881). Dean of Westminster. Sinat and Palestine.

Steinveyer, F. L. Germany. The Miracles of $114 \times$ latrd.

stater, Rudulph. (1800-1850). Germany. Words of the Isord . Ifecus.

Strabo (flourished abent Christian Era). (keography (Roman Empire). (In (ireek).

suetoxil's (dlomished early part of second ente). Roman. The Twoly (amatr.

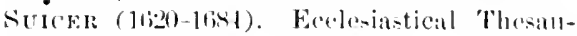
rus (in latin).

Subls (probibly Tenth century). A (ireck lexient.

Srymacits (soond century, latter balf). Samaritan, Jewish prokelite, or Indaizing Christian. Translated old Test. into Greali; tragments remein.

Srrace versions: (1) Old (cupetonian) Syriac, probably malle in second (ont. (2) Peshito, a rovision in the 'lhird eent. (:3) Hacklean, made in the sixth cent., and revised in the seventh. (4) Jerusalem syriac. Gospel "Lessms," of unknown date, but with an early form of text.

"SYriax" text. aleording to the thenry of Westeott and Hort, see their Introluction.
Theress (flourished absut A. D. lon). Roman. Amuals. History.

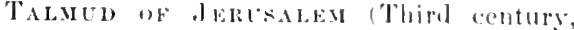
compare Mishon). (gunted from sillowal), or at resend hambl.

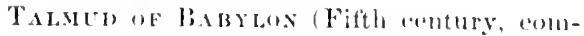

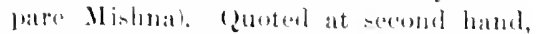
or from German translation by llänsclue.

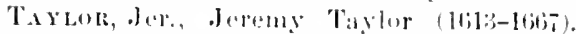
English Bislup. lifie of cluri-t.

Texirates. Alfred Lom (born 1sten. England.

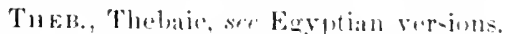

Theod. Mlops. Theodoleof Mopseretia (about

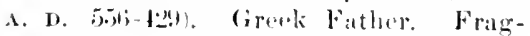
ments of ('omusentary on (inepels.

Theobotrox. (seenend century, middles.

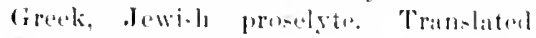
Old Tert. inter Greak: fragenents remain.

Theopura, Theophylact. (Eleventh centstury). Greack Commentatur. On the (aispels.

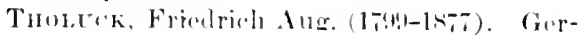
many. Thr siermon on the Momnt. Commentary 6 , lohn.

Thosas, D. Eingli-h Inelipendent minister. Ilomiletieal Commentary on Matthew.

Tuomsox, W. IJ. Amor. Probs minister and missonary to syriat. Some reforences to tiret ell., "land and linkl." Others to

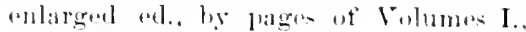
I1., 111.

Tisen., or Ti-chemderf, L. F. ('. (1s15 18-4).

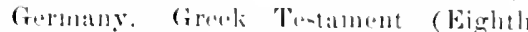
larger embition). Sirnopis Exandelica (Harmony of the (ins)els).

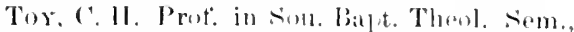
now in llatrard laversity. Juntations in the Now Testament. Articles in periodien:sls.

Trea, Treqelles sammol P. (181:-185i). Enerland. Plyumbth brotliren. Greeli New Test

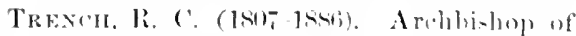
Dublin. On a Rovisinn. Srmonyma of the Now Te-t. Miriales of onr larel. Parables of onr larel. Stullies in the

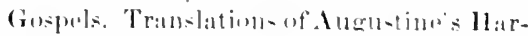

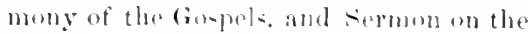
IIsunt.

Tristran. II. B. Chureh of England. Natural IJistory of the Bible. The Land of Joab. 
TyNdale, William (14kt-15,6). New Test. translatal inte Guglish (1,05).

"Yrese, (' Vireinia. Bathist minister. "The livine Epistle."

Terple, 1). II. Sutand. Prosb. minister. The () le Tet. in the New.

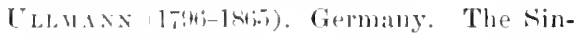
lemalless of dexur.

ItPIII, F. W. New York. The ITje Men.

VAN DE VELEE. Otheer in Duteh Navy. Yal ut the Holy Land, and aceompany-

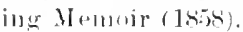

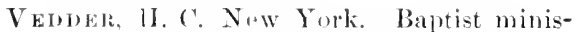
ter. Article on "The Trial of Christ," in Bibl. Sacril, Oet, 1882.

W arfiklo, Benj. P. P'mnsylinia. Presb. Theolog. Prot. Articles in periodicals.

Warrex. Englisl ('aptain of Engineers. Excavations at Jeru-alem (in "Pecovery of lerumaleme).

WaYLaxt, Frameis (1796-1865). Baptist. Prosilent Brown University. Tniversity Sermorns.

Wrist, Bemham. Cremany. Life of Jesus. The Mathew-(rospel (in German).

Wera masis, Julins (horn 184t). Germany. Pbarisose and sadduceos (in (iorman).

Westonte, B. F. (Mhurald of England. Commentary on John (in Bihle ('umm.). Introduction to sindy af tho Gospels. The Gosper at the Re-urrection. Rerelation

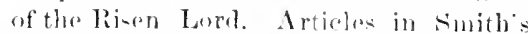
Jict. Bib. Sice also WII.

WV II., or Wroteott and llort. Chureh of England. tropek Testament, Irol. I, Grok text; Int. 2 Introluetion and Appenfix. Int. liy Ifurt.

"Westers" toxt, acoording to the theory of Westoott and llort, see their Jutroductimn.

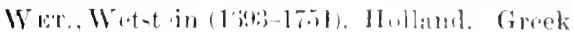
Test., with momerents atritets frem
Greek and Roman, and from Jewish writers. (In Latio and Greek).

Wi eserer, Karl. Germany. Cisronological syomsis of the Life of ('hrist.

Wilimass, Wm. R. (1801-1884). New York. Baptist minister. The Lord's Prayer.

Wruson. English Captain of Engineers. Surver of . Jerusalem and siea of Galilee. (I.u "Recovery of Jerusalem.")

Wis., or Wincr, Gen. Benediet. (1789-1858). Germany. Grammar of the New. Test. Diction; the refirences are to the pages of 'Thayer's translation, with those of Moul: tou's translation added in squarebrackets; whore no page is given, the student can find it by consulting Winer's Index of Passages. Bible Dietionary (in German).

Wisdon of solomon. An apocrypal bonk of the Old Test., witten at Mlexandria, probably not long before the Christian era.

Woosey, T. D. Congregational minister, formerly President of Tale College. On Divoree.

Worisw., or Worlsworth, Christopher (18071885). Bislop of Lincoln. The Holy Bible, with Notes.

Wrinilt, O. H. H. Churele of England. Zechariah and his prophecies. (Bamptou Lextures, 1879.)

Wïx, or Wünsche. Germany. Illuntration of the (xospels from Talmul and Midrashim (in (terman). One velume of German translation of Talmad of labylon. Wre., or Wyelif, In]n (about 1:817-1:84). Roman (atholic and Reformer. English translation of the Bible (1:380).

Youna EDward. (1684-176.1). Church of Engiand. Night Thoughts.

Zwixgl, (1484-1581). Switzerland. Works.

Information as to text-criticism may be had from any of the following: (1) More elaborate works. Scrivener's "Introduction to Tuxt-criticism of the New Test," third edition (conservative). Westeott and IJort's "Jutroluetion," in Vol. II (progressive). (2) Shorter works. Mitchell's "Critical Hand-bouk." Achatf"s "Companion to the Revised Version," or Schaff's "Introduction" to Westcott and Hurt, in Vul. 1 (Ameriean ed.) (3) For readers not acquainted with Greek, Serivener"s "Six Lectures." Milligan and Roberts, "The Words of the New Test." (progressive). 


\section{INDEX II.}

TOPICS DISCUSSED, TERHA EXPIAISED, PERSONA AXH PIACFA DESCRIBED, IN THE COM-

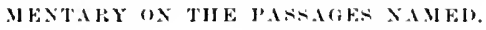

Al.Ms, (i: : 2 .

ANDREN, 10: :2.

Axials, and the Belief in Guardian Angels,

18: 10. Angels at the Tomb, 28:5, 10 .

ANSWER, $11: 25$.

AxXIFT, li: 25.5

Apostaks, the Twolve, 10: 2.

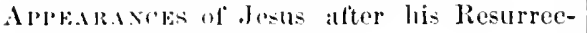
tion, 20: 16 .

Aproritos, 14: 2 ti.

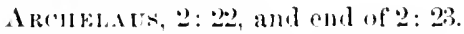

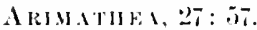

ArTuls, Indutinite, 8: 19.

A тrнoritr, :1: 6; 28: 18.

BA ВАВBв, 27: 116 .

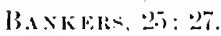

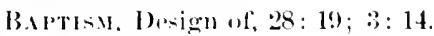

B.tpTst, The, : : 1 .

BAprow, : $: 6$; in Water, $: 3$ : 11 ; in the $110 l y$ (ihow and Fire, 3: I1; in (unto, into) the N:4111, 28: 1!.

BAR-.JuYA1, 16: 17.

B.1ктиноме世, 10:3.

[3E1), !1: : 2.

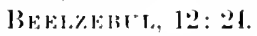

BETHAYY, 201: 17 .

BETHI.EHEบ, $2: 1$.

BнTHPHALE, 21: 1 .

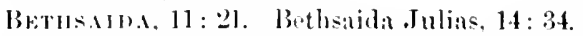

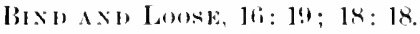

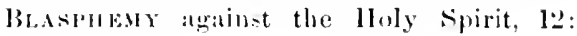
:31, :3:.

B1, Es:str, is: :?.

Boptlat skins, 9: 16.

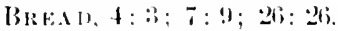

Berthlek of the Lord, 12: 4t; $13: 55$.

Bubsula, Temptation of, $t: 11$.

C.ESA $:, 202: 17$.

Cesarka P'underi, 16: 13.

Camplitas, $26: 57$.

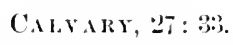

('An E. Through needle's rye, 19: 24.

(…… 15: $: 21$.

Caxisite, Properly Cananite, or Canan:1:311, 10:4.

Caperaten, $4: 13$.

('ElHISTY, 19: 11.

('extrom, s: :5.

('H ReF Plikets, 2: 4.

Cintu, ats :u Ohject-lesson, 18: 3. Christians must be Chilalike, 18:5, 10; 1:1:14.

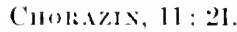

Curist, 1: 1; the Chri-t, : : 4 .

('IU⿴囗十, 16: 18; 18: 17. The English word Chureh, 18: 17.

('skixisat the Temple, $21: 12$.

('ORBAX, 15): 5.

('ons, 1: 1 .

('less, Take up, 16:24; $27: 32$.

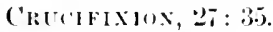

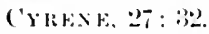

D.MNITION, 23):39.

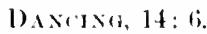

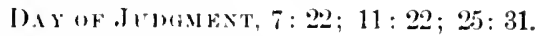

D) F(C)

IDEFII. 15: 11.

DEGikes of Future Punishment, 11: 22; 12: $41 ; 2: 3: 13 ; 25: 46$.

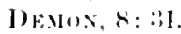

Denoride, Domonineal Posessons, 8: 31; $1: 2: 4: 3$

Devil, t: 1. Ilurtul andeptions of him, 4: 1 (Hom. and P'ract.). Posnessed with Davils, ser Demomiate.

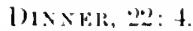

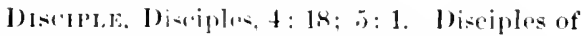
Iohn, 9: 14. Tordiacizle, :28: 19.

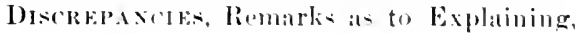
$1: 12,17 ; 2: 23: 3: 17 ; 4: 12 ; 0: 10,14$; 20): $29 ; ; 2: 3: 35 ;: 27: 9$

Drokee, Ј: 31, 32; $19: 3,9$. 
1)

1)oris, $7: 4 ; 15: 20$.

Deve, Ruprenting the II oly sipirit, 3: 16.

1) REA.IS, 1 : :29.

EArLAS, 24: 28.

E(i)

ELIJA1I, $11: 14 ; 17: 11 ; 27: 47$.

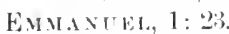

ENEYIES, LAve of, 5: 44.

ER., ("friatian, 2: 16, 1\%.

ESEEXEA, :3: 7 .

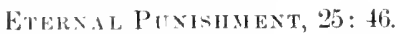

EVENING, 14: 15.

EVERLASTIX, 25: 46.

Evir, or the Evil (one), $5: 37 ; 6: 13$.

Farthixi, 5: 20\%.

Fintera OF Jests, 4:2. Conditions of our Fating with l'ropriety, 6: $17 ; 9): 15$.

FATHER, 15: 1 .

Fentixi the Meltitude, 14: 19-21: 15; $32-38$.

Fia T'ree, barren, $21: 19$.

Firstiolix SON, 1 : 25.

Foul, :2: '2.

Forgaterese, 6 ; 12 .

FORNITATOX, is: :32.

Fourters, Three sets of Names, 1: 17.

FUtril, $1: 2 \% ;: 5: 17$.

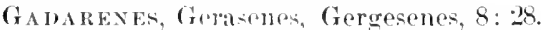

GALILEE, 4: 12, 2:). Fien of Galitue, 4: 18. Our Lurd making Cipcuits of (ialilee, 4: 2⿱口. Gatitean Poculiaritios of speceh, 20: 7.) On thr Mountain in Gatilee, 28: 16.

GakMexts, Jowisl, 5: 40; $27: 95$.

GEUENA, 5: "20.

Gexentomes, 1: 1. Gronealogies of Christ in Mathew and Luke, 1: 17.

Geñesaret, Plain of, 14:34.

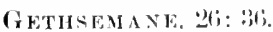

Gliost, and HoLy Gilost, $1: 18$.

(HIFTh, 2: 11.

Goldex RULE, $7: 12$.

Golgotila, 27: 32 ,

Gosper , 1: 1. Gospels, Relations of the Four, $2: 23$.

H AIES, $11: 28 ; 16: 18$.

II A PPY, 5: 3 .

Harmonizing the Gospel Narrative, see 1)iscrepancies.
HEALING, Extent of our Lord's, 4: 23.

Н ЕАлт, 6: :21.

II ELL, 5: 2.2; $11: 23 ; 16: 18$.

HEM OF GARUENT, 9: 19; 2: : 5.

IHEROD TIIE KING, 2: 1. II is Successors, 2: 20.

Herod ANTIPAs, 2: 20; 14: $1 \mathrm{ff} ; 16: 6$.

IHERODIAs, $14: 1,4,6,11$.

IEROUIANs, 2.2: 16 .

His, For Its, 24: 32 .

IMMANUEJ, $1: 23$.

1ncarnatuon, 1: 25 (Hom. and Pract.).

INTEREST, 25: 27.

J A MES THE SON OF Alpilets, 10: 3.

J A MES THE SHN OF ZEIBEDE, 10: 2.

Jenovat, Yahweh, 22: 44.

JEREMIAII, $16 ;: 14$.

JERIIIO, 201): :29.

JERUSA LEM, $21: 1 ; 23: 37 ; 24: 1$.

Jesus, The Nane, 1: 21. Youth of Jesus, at the end of $2: 23$.

JoHN TIIE APOSTLE, $10: 2$.

JOIN TIF BAPTIST, 3: 1 tf.; $4: 12 ; 9: 14 \mathrm{ff}$; $11: 2-19 ; 14: 1-13 ; 17: 10-13 ; 21: 25,32$.

JoHn's BAptisu. Its Relation to Christian Baptisın, 11: 11.

JONAII AND THE S'EA-MONATER, 12: 40.

Jorbas, 3: 6. Beyound Jordau, 4: 15. Region about Jordan, : 25 .

Josepu the Husbund of Mary, 1: 18; Find of chap. 2; $13: 55$.

Josfirir OF A RIMATIIEA, 27:57.

JUDAZING CHRISTANITY, 9: 17.

JUDAS OF GALILEE, 22: 17.

JUIAS INARIOT, 10:4;26:14; 27:3, ff.

JUUस 2 : 20 .

Kinapou, Kiugdom of Heaven, $3: 2 ; 6: 10$. Keys of the Kirgdom, 16: 19; Coming in His Kingdom, 16: 28 .

KNow, $7: 2 \%$.

-1. A MPS, 25: 1

LAWYER, :-2: 85.

I. EA VEN, 16: 6 .

LENTINA, $5: 42$.

LEPROSY, 8: 2.

LIFE, Soul, Spirit, 16: 25.

1,1LIES, fi: 28 .

linestone Rock in Galilee, $7: 24 ; 13: 5$.

LOCTST: $3: 4$.

LUst, 5: 28 . 
M A IIRRUS, $11: 2 ; 14: ?$.

II AGADAN, 15: :3!).

IAGDALA, 14:31.

М A (II, $2: 1$.

II AMMON, $6: 24$.

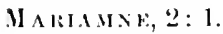

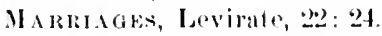

MAl: the Wother of Iesus, $1: 18 ; 12: 14-50$.

MARY MAGDALRNE, 27: 5,6 .

VAsTEk, Diflierent worls su Tramblated, 8 : 19.

I А TTIL: $9: 9 ; 10: 3$.

II rastike, 1:3:

MILL-STOVE, 18: 6 ; $24: 41$.

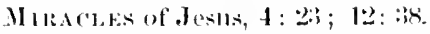

Houstax, the, 5: 1; 14:2: A High Mountain, 17: 1. The Mountains, 24: 16.

NUATARD, 1:3: :31.

MrSTERES, 13:11.

Nane of Ged, 28: 19.

Nanks, having Different Forms in (). T. and N. T., $1: 2$.

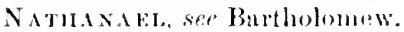

NА\%АะЕТн, 20 : 2:3; $1: 5: 51$.

Ners, Ditlerent Kinds, 1:: 17.

Non-kesistaxere, $5:$ :

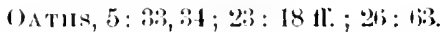

(1)FEX], 5: 29).

().1. LE, Mount of, $21: 1$.

PALESTIN, 2: 20.

PAkals. Meanings of the Word, our Lord's

Design in using P'arables, (Broup of Para-

bes, Interpretation of larables, 13: :

Pakalektast in Ilelorew Poetry, 1: 16.

Passoybes of Our Lord's Ministry, 12: 1.

P'ancas, Cottly, 13: t6.

Pexitexce, Penaner, : : 1 .

Peiserer, 5: 48 .

P'EREA, 1?: 1 .

P'F.TH, a Married Man, s: 1t; General ac-

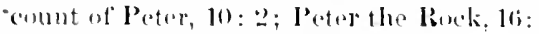

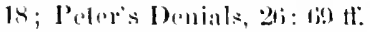

l'וl IIISERA, : $: 7 ; 16: 1$.

Plomer, the $\Lambda$ postlo, 10::8.

P'IIIIP, the Titr:areh, 2: 20 .

Pmoxici., 15: 21.

P'HYLACTHEIER, 2:?: 5.

PInate, 27:11, 21. Pilate's Wifo, 20 : 19 .

Plar upon Worl:, $8: 2 \cdot 2 ; 11 ;: 18,2.5$.

Pour, 5:3.

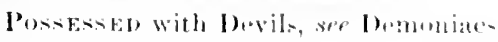

Pow

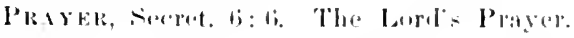
is: $: 3$.

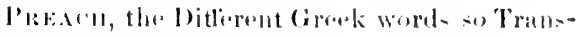
laterl, $4: 17$.

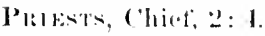

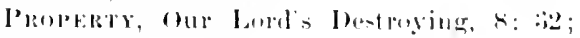
$21: 19$.

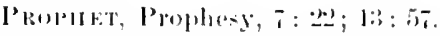

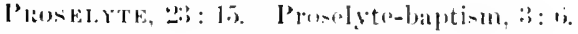

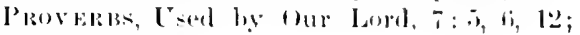
$1::: 3$.

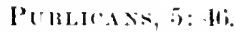

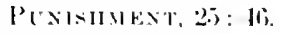

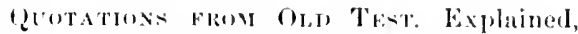
$1: 2: 3 ; 2: 5,15,17,2: 3 ;: 3:: 3 ; 4: 4,6,7$

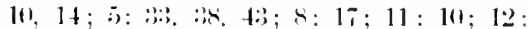
17, f1); 1:?: 14. :3; $15: 7 ; 1 ! 1: 7 ; 21: 4$,

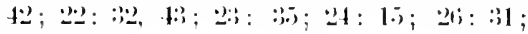
$27: 41$.

Rivison, 201: 24.

REGLXERTIOX, 1!7: 288.

REPEST, : : $1 ; 27:$ : :

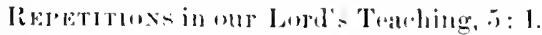

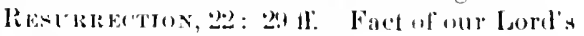
liesurrection. $28: 15$.

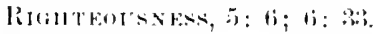

lioc'k, 14i: 18 .

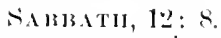

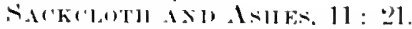

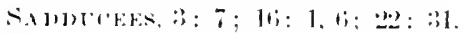

SAINT, 1: 1 .

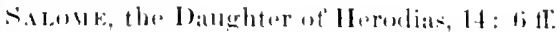

SAlome, Probably the Wifo of Zelodec, $27:$ int.

Sil.T, i: 1:;

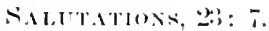

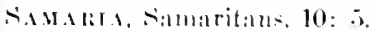

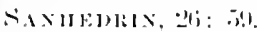

Siा 1 r. 1: 21 .

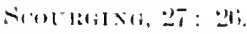

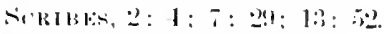

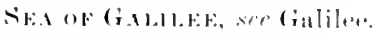

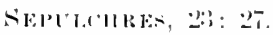

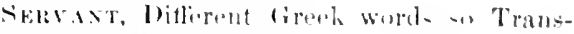
lated, $8: 1 ; ; 1$; : 2 .

SIIEB, 12: 4.2.

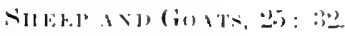

SIIEW

SIIII, 1: :2.2. 
SHAOX THE (ANAXITE, 10: ?.

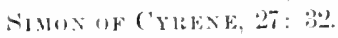

Sisux P'ETER, 10: 2.

SAXNERS, 4: 10.

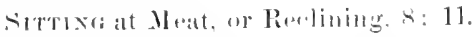

Solvon, $11: 24$.

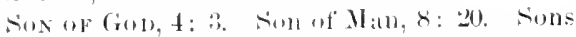
"if the Kingdons, $x:$ 12. Sions of the

Bricle-chamber, ?: 15.

SOLL, 16: 2\%.

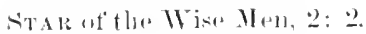

S'Tuxke, 21: 42; 24: 1 .

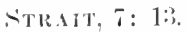

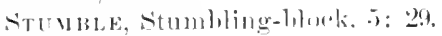

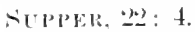

SYNAGurites, 4: 2:?.

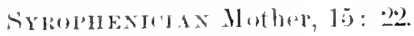

[А1.ЕलT, 18: 24; 2.5: 1.

TAREs, 13: 25.

TEATll, 20: 19.

Tenple, two Greak Worls or Truslated, 4:

5. The Temple ] encribel, 21: 1:2; 24: 1 . Veil of the Tenule, $2-5:$ il.

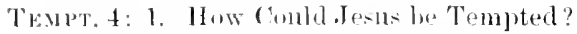

4: 1. Tempting Goul, 4: 7. Bring us Not intw Temptation, (;: 1:?

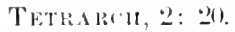

THAIJEAs, 10: :?.

Tuks, a Favorite Word with Mattlow, : 13. Thes, Which should bre 'Robber,' 27: 38. 'The P'onitent Thief' (roblex'. 2T: 44.

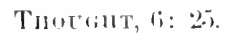

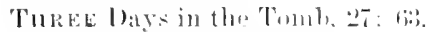

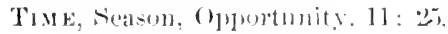

Tradition, 15: $2 \mathrm{f}$.

Transfiguratjon, its Design, 17: 4, 9.

Treastre, Hid, 1: : 44.

Tribulatiox, 13: 21.

TrIBITE-MONEY, 17: 24; 202: $17,19$.

Trituphas, ENTRi: $21: 4,6$.

Trust, and H(1)e, 12: 21.

TYre and sidom, 11: 21; 15: 21.

UxCLEAN Śpirits, $12: 4: 45$.

UXIERATANI, 13: 19.

TARJED Translation of the same Tord, 25: 46.

Tirilin, 1: 23, 25; 25: 1.

Vor'e From Heaven, 3: 17; 17: 5.

WAsit, 15: 2.

Wa'ruks of the Night, 14: 25.

W ATER, Baltize in, 3: 11.

WVDTINGS, 25: 1 .

Wilneriess of Judea, $3: 1 ; 4: 1$.

WINE, 11: 18.

WISE, 7: 24; 10: 16 .

Wise Men, see Magi.

WOEs, 20: 13.

Wosen Grinding, 24: 41.

Womex Named in the Gemealugy of Christ, $1: 3$.

Worı, End of, 13: 39; 24: $3 ; 28: 20$.

Yoke of a Teacher, $11: 29$.

ZaCJARiAf, Son of Barachiab, 23: 35.

ZEALOTs, At the end of $2: 23 ; 10: 3$. 


$$
\text { . }
$$


、

, 


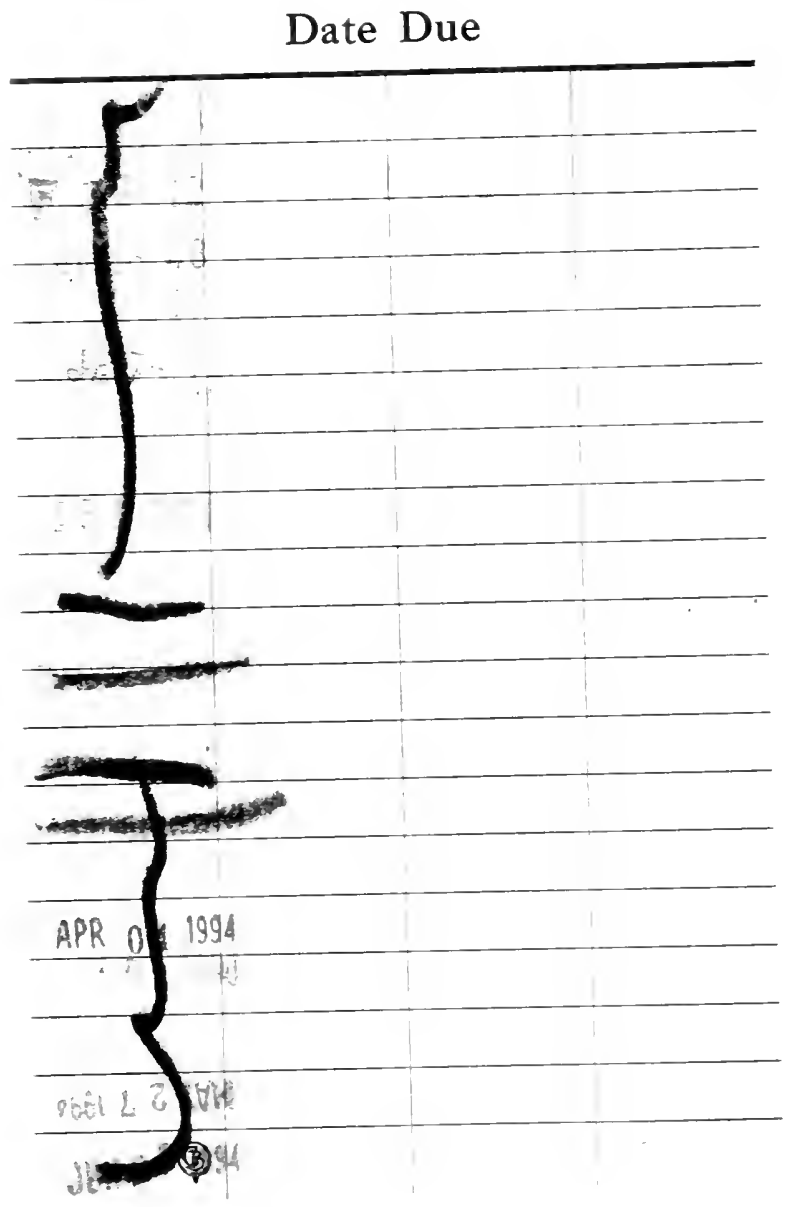





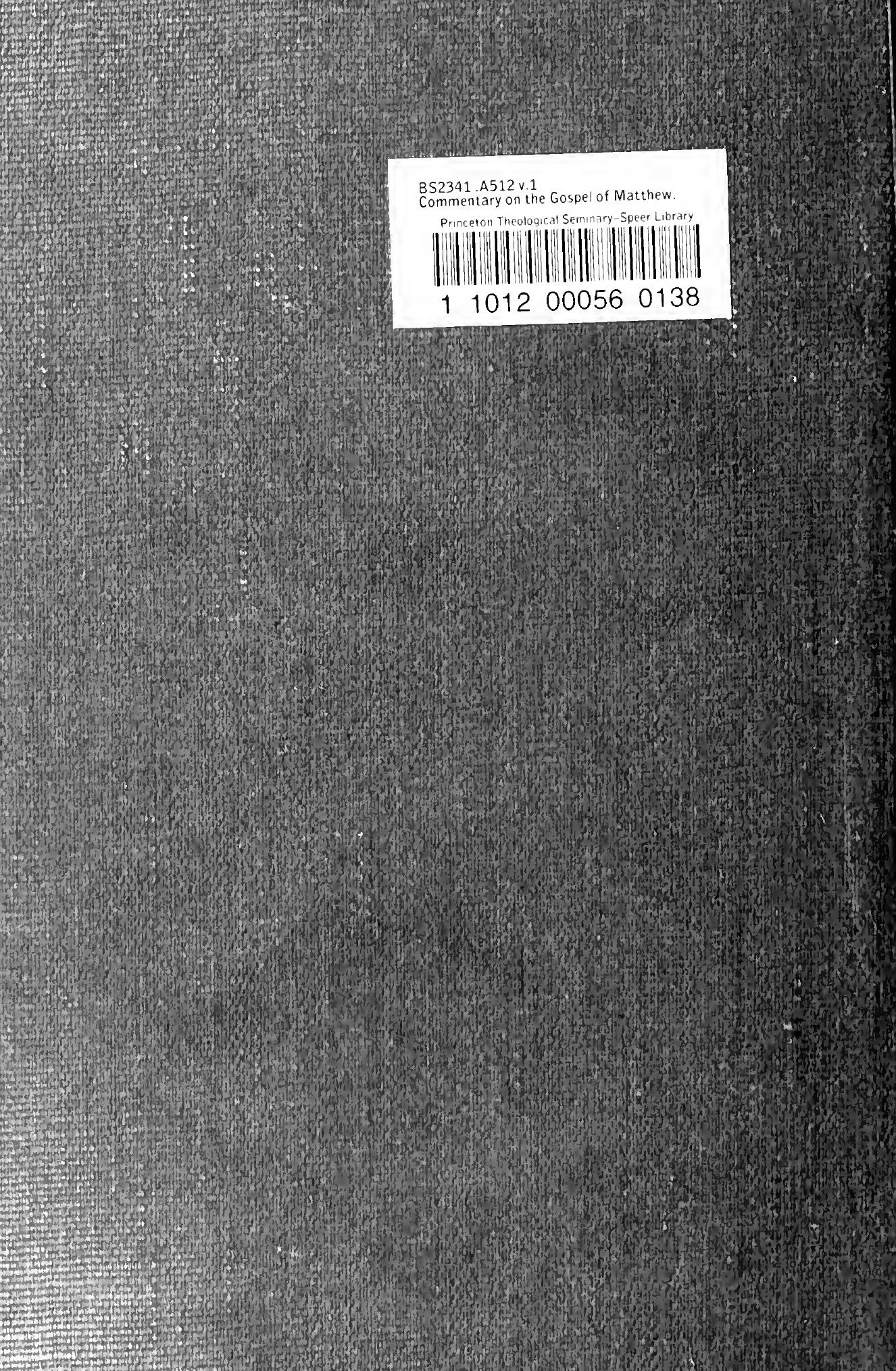

